




$$
\text { (51) S23B }
$$




\section{feldrludd für fürfer}

und

\section{für die, weldje es werden wollent.}

\section{Dr. Beorg Ludwig fartig}

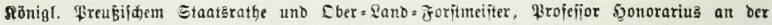

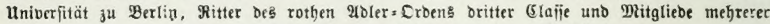

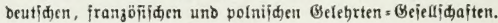

$\circ$

(Elfte, viclfad) vermehrte und berbeilerte 2(uflage.

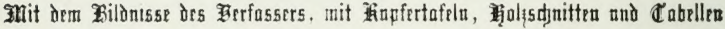

Rad) Des Verfaijcrs Tode herausgegeben

ron

Dr. Theodor finartig.

Eriter Band.

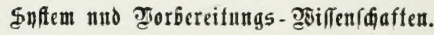

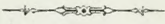

\section{Stuttgart.}

Berlag ber Э. (5. Eotta'ichen Bubhandlung. 


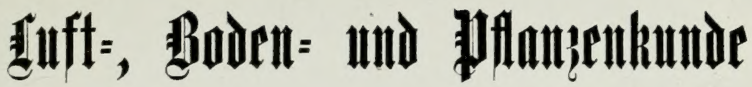

in ifrer 2 fnwentung auf

\section{For $\mathfrak{f} \mathfrak{w} \mathfrak{i} \mathfrak{r} \mathfrak{f} \mathfrak{j} \int \mathfrak{d} \mathfrak{a} \mathfrak{f} \mathfrak{f}$}

von

\section{Dr. Theodor faurtig}

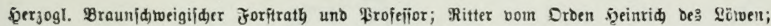

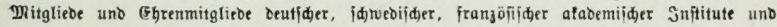
Gelebrten = Gieiellidaften.

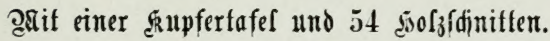
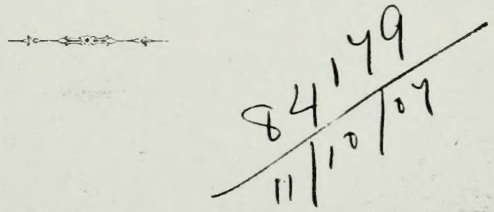

\section{Stuttgart.}

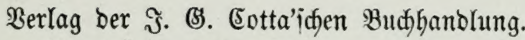




$$
\begin{aligned}
& S D \\
& 371 \\
& H 37 \\
& 1877
\end{aligned}
$$




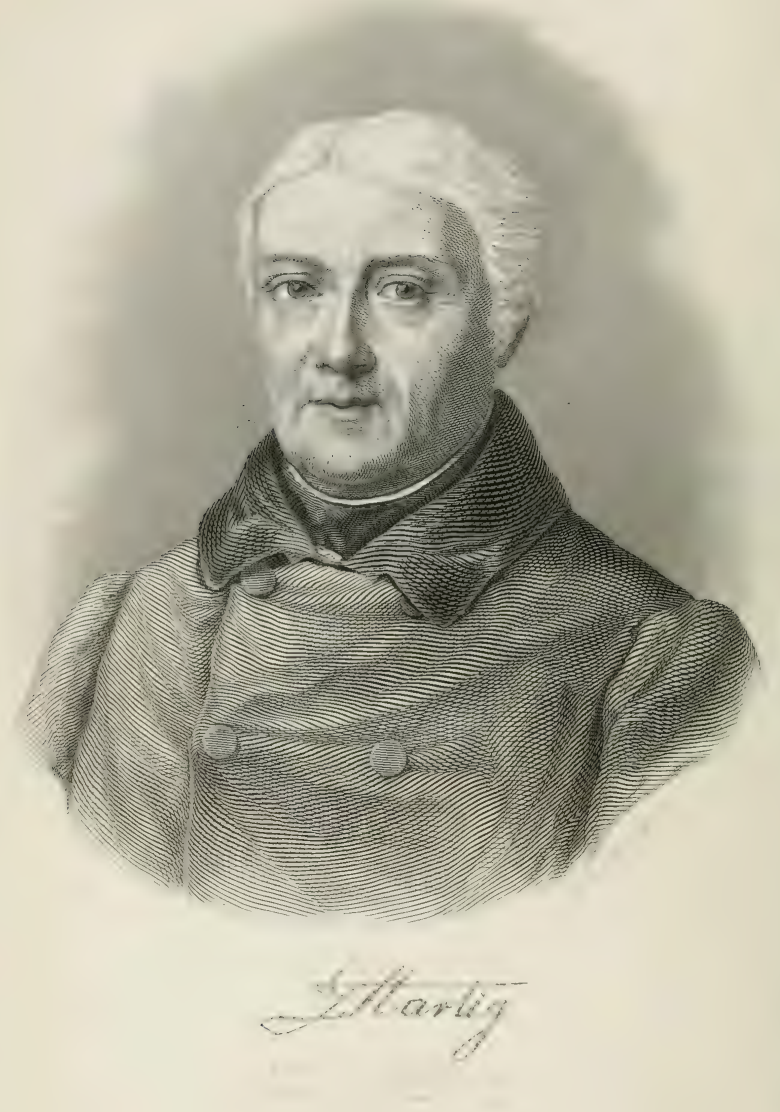




\section{Ulortede 3ur elften Aufluge.}

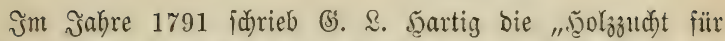
Förfter," ein Bud), bas bis z̧um Salyre 1806 in 8 2tuflagent fid verbreitete. Durd) Şinzufügung eintes eriften uno cines britten

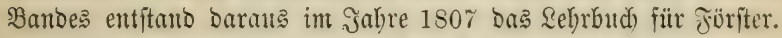

Edjon mehrere Jabre vor bem Tobc meines ßaters murbe

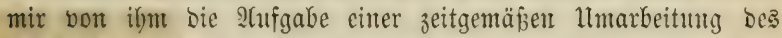
Sebroudeses, bas bejonbers in feintent eriten, foritnaturimififen= idjaftlidjen Banbe veraltet war. Som Jahre 1840 an habe idj)

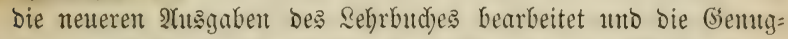

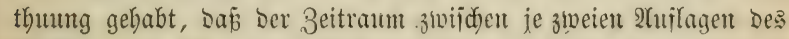
Berfes, Der fid mif 13 jabre verlängert hatte, vort 1840 ab

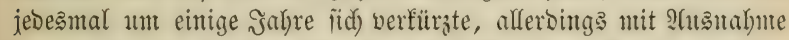

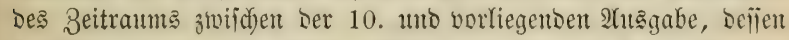

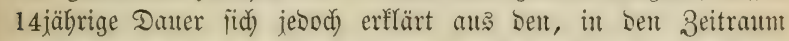

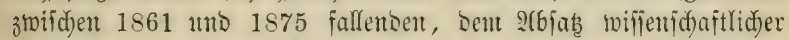
Merfe twentig günjtigen, friegerijdyen Ereignifient unt Dent Erid)einen

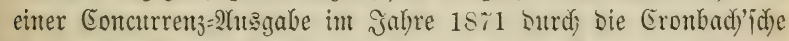

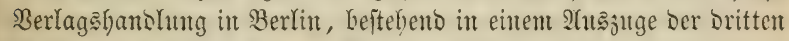
2fuflage Des Rebrbuctes, eriojienten im Jathre 1811!!

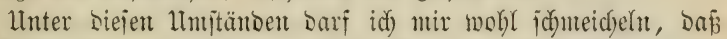
Die 2 bänbenungen, weldye Das Refbrbud) unter meiner Feber erlitt, in feinem Sejerfreife and hente nod) 2(nerfennung findet unb bitte

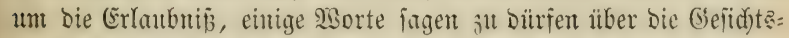
punfte, bie midy bei ber Umarbeitung Des $23 \mathrm{seffes}$ leiteter.

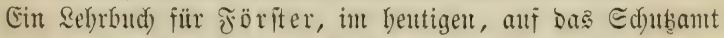

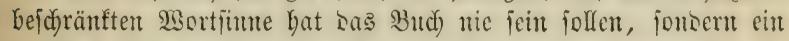
Sehrbud) für Den, mit ber Betriebsiülynung beauttragten forft= mann, bas gebt aus ber 2fulage fadon ber eriten 2Atägabe bes 


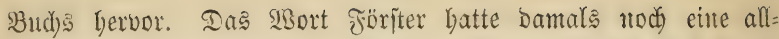
genteinere Bebentung und hat fie anker Beamtentreifen nod) heute.

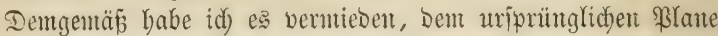
Des Serfafiers entgegen, Diejenigen Bweige ber gejammten Forit= wiffenjochat, mit Denen ber Betricbsbeamte nicht in täglicher Be=

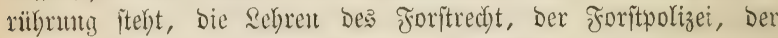
Etaatsforitivirthfid)aft Dem Sudde zu interniren, Dafielbe baburd

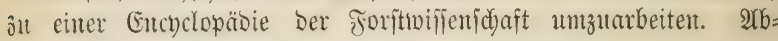

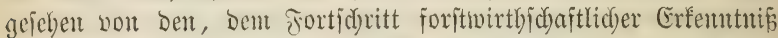

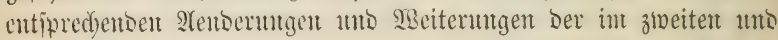

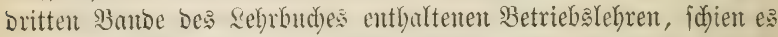

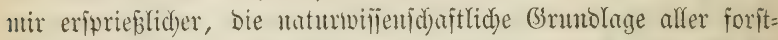

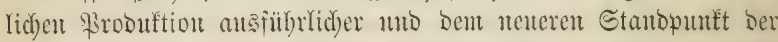

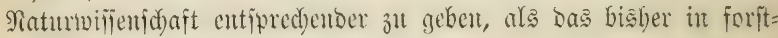
liçyen sebrbüchern geidyeben ift.

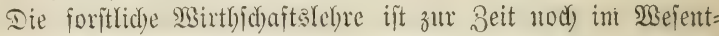
lid)en eine Erfabrutganifiend aft, anfgebaut feit F̧unerten von Salyen ans Erfabruntgen über Die Erfolge ber Berjüngutg uto

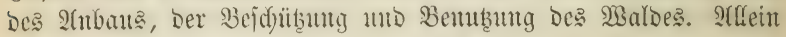
alle sieje Erfabrungşälse baften au Der Edfolle, fie geben unt feinte Eiduerbeit, Daf, unter andoren Etanoortâverbälntiffen, unter

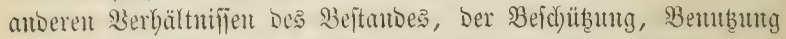
Dent als gut (Erfantutu nid)t cill nod) unerforid)tes Befleres zur Eeite itebt. Dief abjolut befte weroen wir un erfabren aus Der gentuteften Befanntichaft mit Dor शatur mierer 30̈glinge, mit Den Sebingurgen ifres (sebeibus, ans Den Beziebutuen, in Denen fie

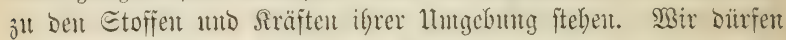
uns nidyt Damit begntügen, Das 23 ie Der Erfolge umierer Şanto=

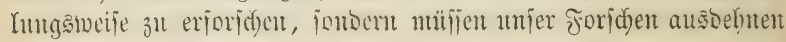
auf Das

Daj Dieje, meintem wifienj(baftlid)en Etreben zum Gruntoc

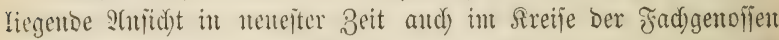

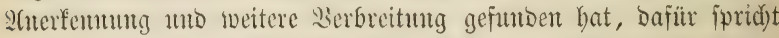

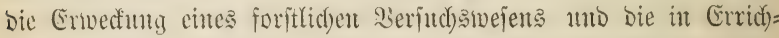

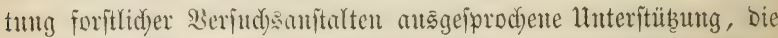
ify non Seiten Der Yeitenden Betriebsbebörden in erfrenlidyer Weife âl Ilyeil wirt.

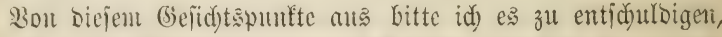

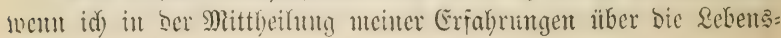




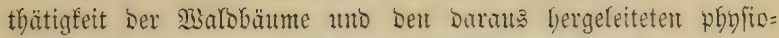

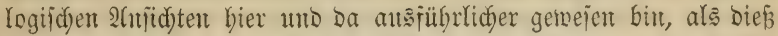
in einem Rebrbudde Der Foritwirthichait erwartet werben faut. (E)

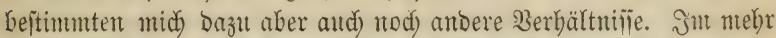

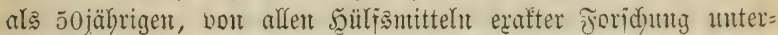

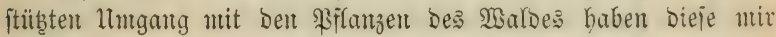
Mand)es vertrant, was bie Einjelpflanje des Gotanijd)en Bartens weber auf bem Mifroffoptijule nod im Raboratorium ju lebren bermag. Die Darauts Kervorgegangenten Erfabrungen uto 2fnithten habe idf in fleineren felbititändigen 9 (b)anblungen, theils in Beit= fudriften beröffentlidyt, Deren Bugänglidjéteit für Den Rejerf́reis Des

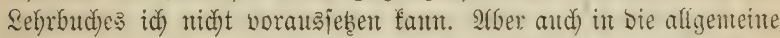

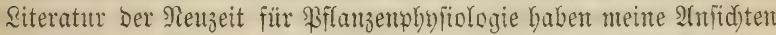

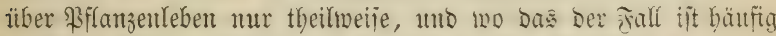
entiftellt, Eingung gefunben, Da Die meiften Derielben Den berr=

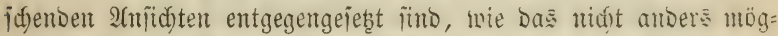

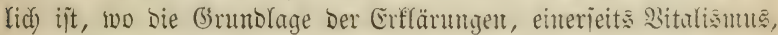

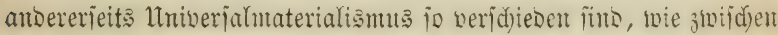
nix un meinen Mitarbeitern in Gebiet Der Piflanzenphyiologie, went einerjeits Der grfanje jelbit, andereriets Den Sebriäbent Der

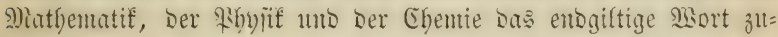

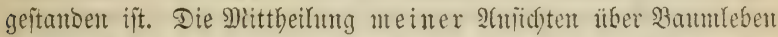

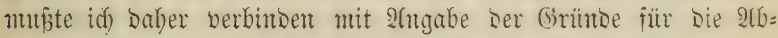

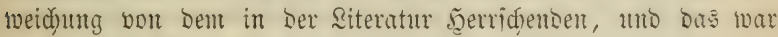
mit wenigen $\mathfrak{B}$ orten nidyt ausfübrbar.

Die feit fünfunbad)tjig Jahren Durd) ziwantig 2hiflagen ver:

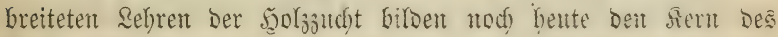
Butche?.

Eie jumb in פiejentlidfen Diejelben geblieben.

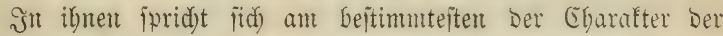
Sartig'id)en Echule aus, Den wir als einen phyitotratijd =confer=

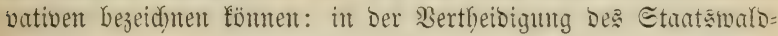

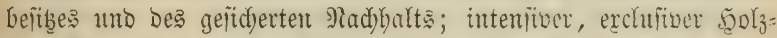
produftion; Des jodywalobetriebes; Der Dent hödjiten siatural= crtragsinerthe entiprechenton IImtriebszeit; in Der Erhaltung uno ซörberung Der Bobenfraft Durd) Eelbftverjüngutg; in Erzeugutg pflanzemrecher Beptänbe uno Deren Erziebung in fortbanternoent Beitands [d)

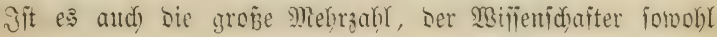




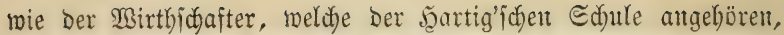
fo fteben bod) Derent Srunbiäbe feintesmegs unangefochten ba. Finter= feiț find es bie Bertbeibiger ber finanziellen Ŝntereffen bes gegen=

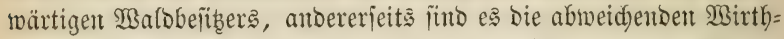

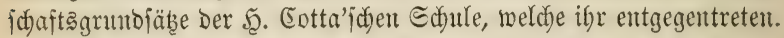

Für eine Uebertragung bes Staatsmalobeitzes in bas Eigen= thum Der ßrivaten, wie für bie (Selbmirtbidjaft in ben Wäldent trat unter ben Foritleuten zuerit $\mathfrak{B}$. Pfeil in bie Sdyrantent. In

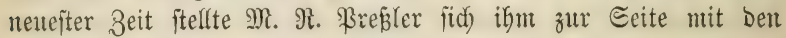
fdjärferen Waffen miffenfduaftlidjer Begrünoung. Bom mathe=

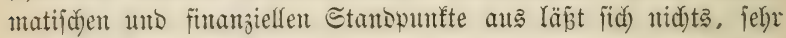

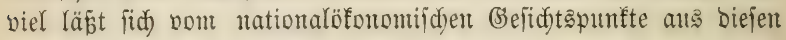
Grunbiäben entgegenitellen.

Wie unjere Bäume in Dentidjen Boden, jo Gaftet Das Bolfas= wohl mit taujenten jeiner Wurzeln in unjerer bentidyen, conier= vatiben Foritwirtbidaft. Man bebente fid wohl, ehe man biefe ihrem Boben entreifst und in einen Buftand veriebst, in Dem ihr (Sebeiken minbeftens zweifelhuift ijt. Man bebenfe fidc) wohl, ebe

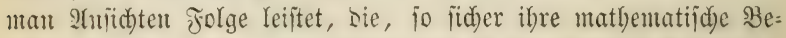
grünoutg iit, fo net uno verfübrerifd) fie ber lebenton Generation gegenübertreten, in anberen \&ändern fïch feineswegs jegenfpendeno erroiejen haben.

(Semif verbienten die gropen pecuniären Bortbeile Der 2ibald= veräuberung fowohl, wie Der Borgriffe it 2rbtriebs = ober aud

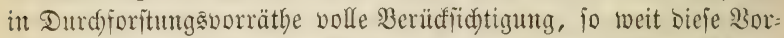
theile uidyt anf Roften Des Rettowerthes Derjentigen Gödjiten Boben= produftion erboben werben, bie Den bleibenden Bebürutiffen an Walsprobuften entipridft. Jeoe Uleberjudreitung Diejer Girenze räd)t

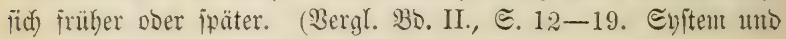
2Unleitung $\subseteq$. $76-83,152-155$.)

Man ijt mur alljujebr geneigt, Die abjolute $\mathfrak{B a b r b e i t , ~ w e l d y e ~}$

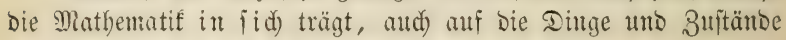
ju ubertragen, mit weldyen ïe in Berührung tritt.

Sn ber Rolitif bes Forithanbhalts wie in ber Der Stanten ift aber 2.2 nidyt immer $=4$.

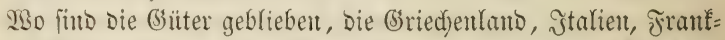
reid) mögliderweije ants ibrer Entwaloung gezogen baben fömuten? હidjer wäre bie Bevölferung biejer Zänber hente Durd) fie nid t

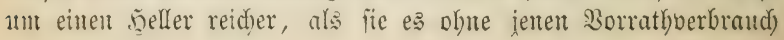


jein würbe. Wir aber bauen nod) beute unfere $\mathfrak{B o b n u n g e n , ~ w o i r ~}$ ermärmen uns förperlich uto geiftig nod) heute an Der gepflegten Nadjfommenjodaft jenter Wälder, in benten unjere Borfabren Den Un uno bas Elf jagten.

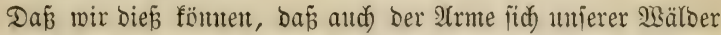
erfireut fam, bas berbanfen wir unjeren guten, alten, conjervativen

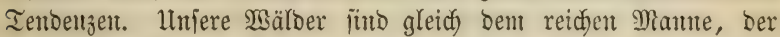
von jeinen lleberffuffe unentgeltlid) abgeben fant und reidj(id) abgibt, ohne jelbit zu barben; ber ben mageren Jahren \$̧Garaonis getroft entgegenjeken fanu, im Betwubtiein wohlgefüllter Epeidher.

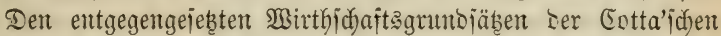
Edutte bin id jelbit entgegengetreten, mit Dem Beitreben phufio= logijoder Begrünoung Der Rebrjäbe meines : Baters. Das Etrebent, in mir felbit zur Rlarfeit zu gelangen in Betref̈ Der, zwifhen Eotta uno . Đartig bejtebenoen Controverjen, führte miḑ ju tiefer eingreifenton phyfiologijonen Stubien, Denen id) aud meine Bumadj: foridumgen hinzuzäble.

Bin id̄ auf Dem Mege ber Foridunt zu Ergebnifien gelangt, Die mir bie Beofadytungsrejultate meines Baters beitätigten, fo ijt Das bem Eohnte allerbings einte grobe Frente gemejent.

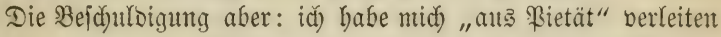

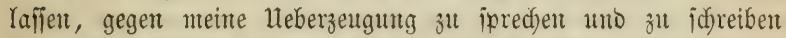
(j. Die Recenfion Der vorigen Aluflage Des Qebrbudes in Der Forit: unD Jagozeitung) mun ich aufs beftimmtejte zurüafmeifen.

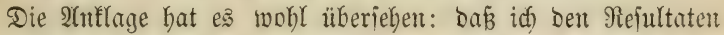
meinter Forfadung ftets Die mifjenjichaftliden Faftoren beigerïgt babe. ज̂t Der Sebre bon ber pflanzlidyen Indoivioualität; nom übermie= genten Cinfuffe Des Stammzahlfaftors anf Die : Mafientrobuftion Der Flächen; vom bejodränften Einflufie ber Belaubung auf Die 3umad)sgröße Der Bäume 2c. ijt Dief überall bis in bie flemiten Einzelheiten geid eben.

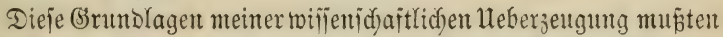
meinte Gegner ale irrig nad)weijen, ebe fie zu einer Inflage idjritten, Deren Edfwere fie wohl nidjt eriwogen babent.

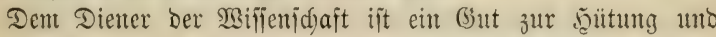
Siflege anwertraut, bas fodwerer wiegt als alles Gold mo Eilber.

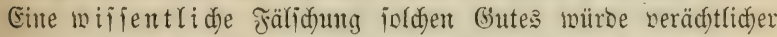
utb ftrafbarer fein als bie Beruntreung jebes anderent, Dent Dienter anbertrauten fremben Eigentbums. 
Dem Dritten Bande batte id bereits in Der vorigen 2uflage

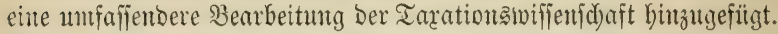
Mantòes bavon ift in biejer 2Ufflage berbefiert unto verbollitändigt.

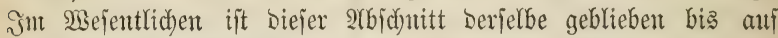
Die Berlegutg aน̉ bem oritten in ben ziveiten Band, wofür bie Sehre vom Foritidus aus bem joweiten in Den britten Band ver=

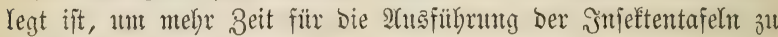
gewintuen.

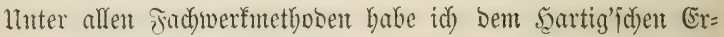
tragsfadjwerfe Den Sorzug zugeiprodyen. Damit man nidjt aud bier wieser unzeitige Sietät mix zum Borwntrf madbe, babe id

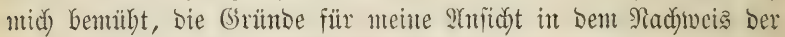
Durd)greifenten Folgerid)tigfeit Des 3 3erfubrens Darzulegen.

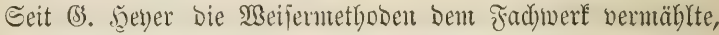
baben eritere mebr und mebr ifre wirthidaftlidye Bebentung ver=

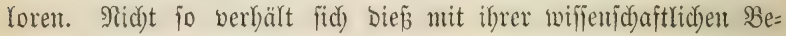
Dentung. 2(le aebruttel babe id fie betbebalten.

Die Iebre vou ber Forftbentbung habe, ich) focjon für bie vorige

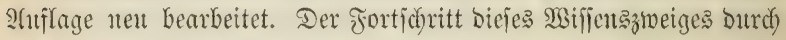

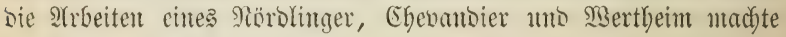
Dię̧ nothrwentig.

9hein Sobn Mobert hat bie llmarbeitnty Der, Den Edylum bes

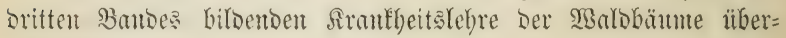
nommen.

\section{Der Sernuggeber.}

Branuffmeig, Den 15. December 1875. 


\section{Ditlialt bes erften Ḋantoes.}

Einleitung uno Gyftem Der Forftwiffenfd)a ft

Erfter Saapttbeir.

Siaturgefdidte ber Solzpflanzen

\section{Erite 2fotffeilung.}

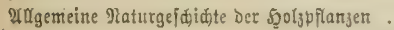

\section{sirfer Dibrduritt.}

Suft und \$flanzen in ifren Wedfelroirtungen

Erftes Rapitel. Bom Stoffgehalte det \&uft.

1. 'Die atmofphärijo $B u f t$

2. Die Roblenjäure

3. Die freudjtigteit

4. Suftitaub uno Salglöjungen

5. Umonniat uno Salpeterfäure

Btoeites Rapitet. 23om Rlima

1. Die 23 ärme

2. Daß Sidnt

3. Die f̧euntigtéit

4. Beregung unt Ruhe Der Buft

5. Rlimatijace (Bejammtunteridiede

a. Silima meeresgleidier Ebenen

b. Rüftentlima

c. Silima Der Syodiebenen

d. Thaltlima

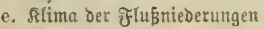

f. Bebitgallima

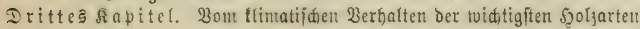

Siteratur 
III. 2̧on Den Єtrulturberbältniffen Der Bebirgßarten . . . . . . . 68

IV. Bon den Bebirgajormen . . . . . . . . . . . . 73

3reite S̊apite1. Bom Boden . . . . . . . . . . . 73

I. Bon ber Entftelyung Dę Bodeng _. . . . . . . . . . . . 73

II. 'Bon den Beftandtheilen dę Bodens _. . . . . . . . . . . 76

A. Bon ben mineratificjen Beftanotheilen . . . . . . . . . 76

1. Erben . . . . . . . . . . . . 76

a. Riejelerde . . . . . . . . . . . . 76

b. Thonerde . . . . . . . . . . . . . . 78

c. Ralterbe . . . . . . . . . . . . . . 80

d. Talferbe . . . . . . . . . . . . . . . . . 83

2. Salze . . . . . . . . . . . . . 83

3. Säuren . . . . . . . . . . . . . . . . 85

4. Metalle . . . . . . . . . . . . . . . . . 85

B. Bedentung Der mineralijden Bodenbeftandtheile in Bejug auf Pflanzen= wuds

C.

D. Bom $\mathfrak{B a f f e r}$ und von Der $\mathbb{R}$ uft $\quad . \quad$. . . . . . . . . . . 95

Drittes Rapite1. 2on Beurtheilung Der Bodenbeimaffenlyeit und Bodengüte 97

1. Won Der Interfud)ung bes Booens nad) feinen Beftandtheilen uno \&age= rungşberbältniffén . . . . . . . . . . . . 98

2. Bon Der Beurtheilung dę̧ Bodens nad äuß̄eren אiennzeiden . . . . 105

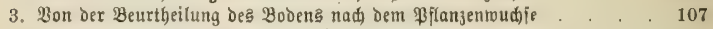

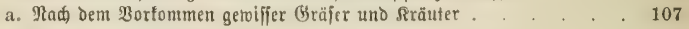

b. Rad) Dem \$̧oljwudie . . . . . . . . . . . . . 109

Biertes Sapitel. Bom Berbatten des Bodens jum \$ृolzmudje . . . 115

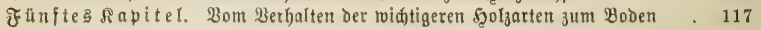

Siteratur . . . . . . . . . . 123

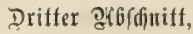

Bon den Planzen . . . . . . . . . . . . . . . 124

(5xite己 Rapitel. Morplologifde Betradtung oer Seolyplanzen . . . . . 128

A. Der aufiteigende Stod . . . . . . . . . . 130

1. Bon ben 2(d)jengebilden (5̧auptadfen) . . . . . . . . . 131

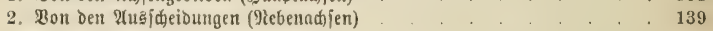

a. Die Blattauşcheioung . . . . . . . . . . . 140

b. Die Rnojpenansjdjeioung _ . . . . . 143

1. Sangiprö́tnofpen 146

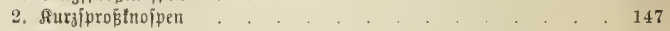

3. Berborgeniproß̈łnofpen . . . . . . . . . 150

4. Rugeliproß̈łnojpen . . . . . . . . . . . . . . 153

c. Die 2usideidungen in Der Inofpe . . . . . . . . . . 154

B. Der abfteigende Stc d. . . . . . . . . . . . 157

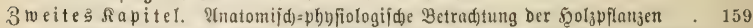

A. Entitebung uno Iuझbiloung deక Pflanzenfeims innerbalb Deß Samentorns 159

1. Daร Pflanzenti und dos Reimiädden . . . . . . . . . . 159

2. Die Befrudtung . . . . . . . . . . . 160

3. Der befrudtete Belltern und defien (Entividelung zur urzelfe des pflanj=

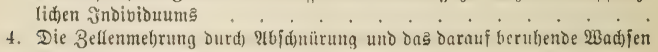
Dę ஒflanjenteims . . . . . . . . . . . . 169

5. Die f̧ajerbildung und fajermełrung . . . . . . . . . 173

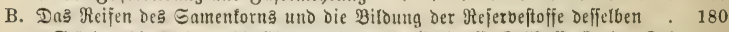

Stärtemehl, Slebermebl, (Shlorophyllmehl, (Gerbftoff, Belfftoff. Butfer, Del 182

C. Die Samenrube . . . . . . . . . 184

D. Die Reimung . . . . . . . . . . . 186

E. Die 24ubiloung Deङ Reims zur einjährigen Pflanje . . . . . . 191 
2. Ernöhrung

b. 23ad引thum . . . . . 199

c. Die Beffenfeftigung . . . . . . . . . . . . 202

1. Die einfade Bellwanoung . . . . . . . . . . . . . . 203

a. Die হipfel = uno ₹ipjeltanalbiloung . . . . . . . . . 205

b. Die Epiralfajerbiloung . . . . . . . . . . . . . 208

2. Die zufammengeféste Bellmand . . . . . . . . . . 210

a. Die Finjđađtelungstwände uno deren Spiralfaltung . . . . . 210

b. Die Rernboljfajer . . . . . . . . . . . . . 213

d. Wantlungen Der Elementarorgane . . . . . . . . . . 214

I. Die Bellentwandlung . . . . . . . . . . . . . . 214

a. 3ิm Marle . . . . . . . . . . . . . . . 215

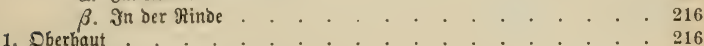

2. Spaltôñüen . . . . . . . . . . . . . . . 216

3. Şaате unঠ Drụ̈en . . . . . . . . . . . . . . . 219

4. Sorfgewebe . . . . . . . . . . . . . . 220

5. Senticellen . . . . . . . . . . . . . . . . 223

6. Blattnatbelort . . . . . . . . . . . . . . . 224

7. Seimgetwebe . . . . . . . . . . . . . . 224

8. Brine Rinde . . . . . . . . . . . . . . . . . 224

9. Lebenşaftgefăß̈e . . . . . . . . . . . . . . . 226

10. Terpentin $=$ un๖ đdjleimbälter . . . . . . . . . . . . 226

II. Die faferwanঠlung . . . . . . . . . . . . . . 227

a. Elementarorgane aus Derroajung mehrerer đ̛ajerjellen . . . 227

1. Solz = und Siebröbren . . . . . . . . . . 227

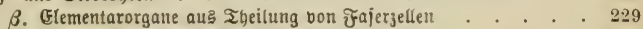

2. \$rimäre unঠ fecundäre Marfftrablen . . . . . . . . . . . 229

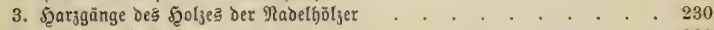

4. 5ृolzparendigm . . . . . . . . . . . . . . 230

5. Belfajern $\%$ Elementarorgane aus Bellenbiloung innerbalb der fajern . : $: 230$

6. Sryftallammerjafern . . . . . . . . . . . . . . . 231

7. Baftbündelfajern . . . . . . . . . . . . . . . . 231

e. Oronung der (Elementarorgane zи ङyitemen . . . . . . . 232

1. Das Enftem des Mart = und Rindegervebez . . . . . . . . . 233

2. Das Syftem der Dartitrahten . . . . . . . . . . . . . . . 233

3. Das fafergewebe : . . . . . . . . . . . . . 236

a. Solztörper . . . . . . . . . . . . . 237

b. Bajttörper . . . . . . . . . . . 242

f. Abreidungen bon 23oritebendem im Baue der Blattiftele und der Blätter 245

g. Abtweidungen von Borftehendem im Baue ber Burzel ... . : . 246

h. Die Rejerbeftofife... . . . . . . . . . . 249

i. Die Seltete . . . . . . . . . . . . 250

k. Die $\mathfrak{B i n t e r t u k e ~ . ~ . ~ . ~ . ~ . ~ . ~ . ~ . ~ . ~ . ~ . ~ . ~ . ~ . ~ . ~ . ~} 251$

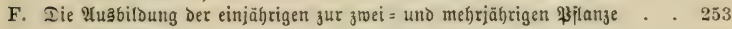

a. Ernăhrung . . . . . . . . . . . . 253

1. Die früfpperiode der Begetation, Reimungaperiode . . . . . . . 255

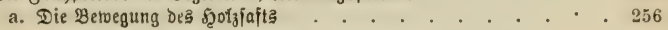

b: Das Bluten der 5ol3pflanze . . . . . . . . . . . 264

c. Die Sojung der Referbeftofie зu fecundärem Bildungßjafte . . . 268

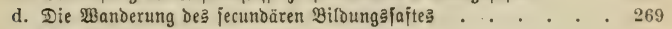

2. Der Begetationj̧ommer . . . . . . . . . . . 276

3. Der $\mathfrak{B}$ getationgherbit . . . . . . . . . . . . . . . . 279

4. Der Begetationzrointer . . . . . . . . . . . . . 281

b. Bađకtbum . . . . . . . . . . . . . 282

G. Reproductionzerjळeinungen . . . . . . . . . . . . . 293

1. Die Heberwallung . . . . . . . . . . . . . . . . 294 
2. Die Bełleibung

3. 2roventiblnojpen

4. Tloventiotwurzelis

5. Wurzelbrut

6. Stredten und Beagen

H. Sirantheit und ₹od

Siteratur

303

304

305

306

\section{3weite 9rbtheilung.}

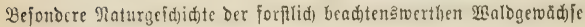

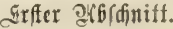

Enftem und (Eharafterifitif

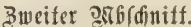

Befäreibung Der widitigeren Forftculturpflanzen .

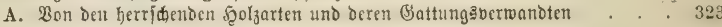

(Erftes Rapitel. Die Nadelbölzer

Fidule

Tanne

Särdic

Riefern

Btweite $\mathfrak{R}$ apitel. Die fübdenblumigen Bäume . . . . . . . . 336

(5id)en

Buden

Birfen

Erlen .

B. Bonden untergeoroneten Solzarten......... . . 350

Dritts $R$ R pitel. Raftanien

Sornbaum

jopfenbudie

ธूajeln

Happeln

Weiden

Bicrtes Rapitel. Fiden . . . . . . . . . . . . . . . . . . . . . . . . . . . . . . . . . . . . . . . . . . . . . . .

Filnftes Rapite!. HImen . . . . . . . . . . . . . . 361

Scd)tes Rapitel. Rpfolfrïdtige Solzpilantzen.

5ुagedorne

9Mipeln

Xepiel.

(5)berejogen

Siebentes Rapitel. Mandelfrubtige Solzpflanzen.

Pffatumen

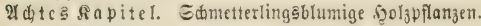

Cdiotendorn

Meuntes Rapitel. Mhorm

\section{Drifter ơfgf(f)ift.}

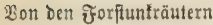

Erfte S Rapitel. Won Den boijigen Forjtunträutern 


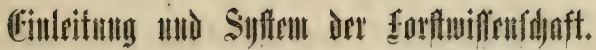

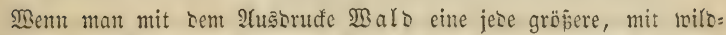

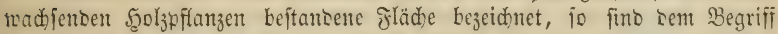
vou Jor ft jethon engere Grenzen gefteçt, inocm man mur biejenigen Mälocr

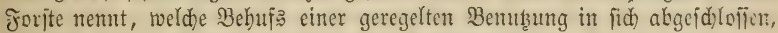
begrenzt fino, uno nad) gemiffen Regeln kehantelt uno benutb̧t werbent.

Die Gejanmtheit biefer, für bie Behantlung, Befobü̧̧ung uno Be: nuţung Der Malsungen norbantenen Borfdriftent uno Regeln, in ein Selln: gebäube vereint, bilbet bie For ftiviffenid) a ft.

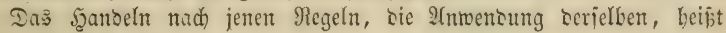
Jorit wirthicaft.

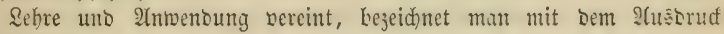
Joritmejen.

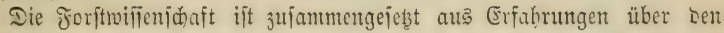

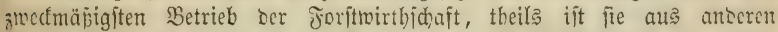

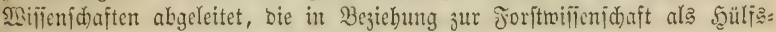
uno Nebenwitienidaften baftehent.

Şiernad zerfällt bie Jorftriflenjabaft in orei Şaunttbeils:

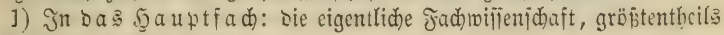

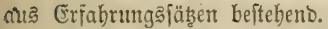

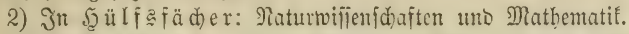

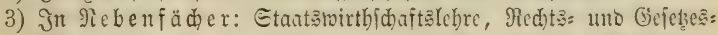

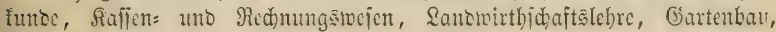
รagd uno Fifderei, Baufutio.

Das Şa uptfach zerfällt in folgenbe gejonderte Sebren:

\section{Fefoldte, Siteratur, Statiftif.}

Dieje Drei Sehryweige greifen io vicleitig in einander, sajp fie fid)

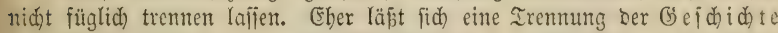

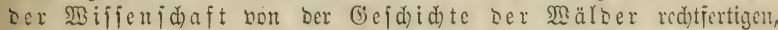
went man in Eritere, in bie Darftcllung Des Enttwiłlungsgnnges Dor Wiñenjolaft bon ibrem Entfteben bis zum heutigen Etanopunfte, sic

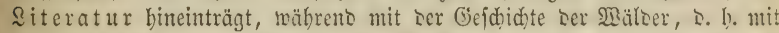

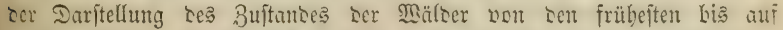
heutige Beiten, bie Forftitatiftif, s. h. Die Echre bom gegentürtigen

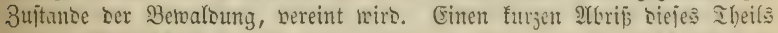

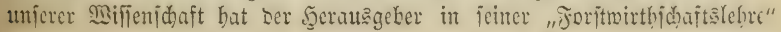
gegetert. 


\section{2. $\mathfrak{B a l}$ z $u d t$}

lehrt uns bic Şerftellung uno Errhaltung eines Malojuftantes, surd) weld)en bem Boben Der bödjitmöglide Marloertrag nadbaltig abgewonnen wirb.

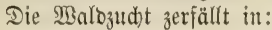

a) Betriebslehre - Sebre von ber Behanolung ganzer : Bäloer; Sebre von ben Malobeftänben in ifrer gegenfeitigen Bejiebung uno BBechielmirfung.

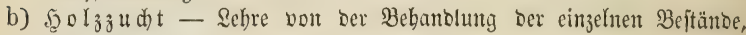

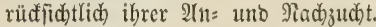

Solzzucht - Nad)zucht ber Beitänoc.

Seolzanbau - 2trzudut ber Beftände.

\section{3. $\mathfrak{B}$ alo benubung.}

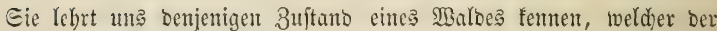
Dertlid)feit gemäß bas höd)fte (Sirfommen nadbbaltig zu getwäbren vermag

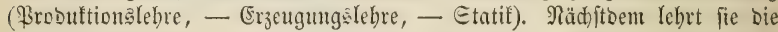
vortheilhaftepte Ât ber 3ugutmad)ung, Iransport, 2Aufbewabrung und

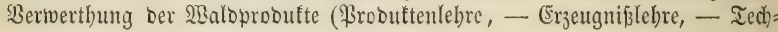
nologie).

\section{Maldiid)erung.}

Die Sebre von ber Eid)erftcllung Deక জsalbeigentbum unto feiner Brobufte zerfällt in:

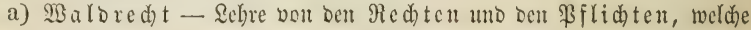

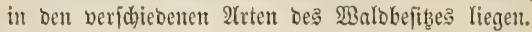

b) Malopolizei - Sehre nou ben Berorbutngen, welde von ber Gtaatsgenalt zu erlajien fino, um bas böd)jte $2 \mathfrak{B a l b}=$ (Eintontmen ber Nation zu erzielen.

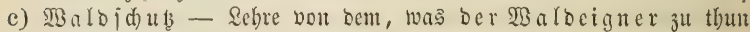
voer zut veranlafien hat, um fein (Eigenthum uno befien Benub̨ung ğu fidcent.

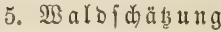

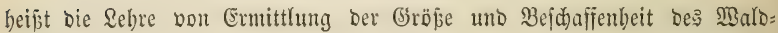
vermïgen?

\section{Walbvertwaltung.}

Sehre vom Befchäftäbetriebe in ber $\mathfrak{B a l b m i r t b i d j a f t . ~}$

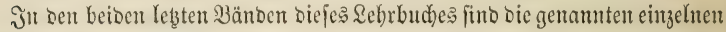

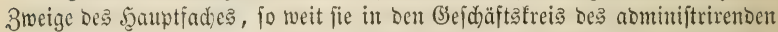
Forftbeamten eingreifen, vorgetragen. Der vorliegente erfte Banb beid)äftigt fich

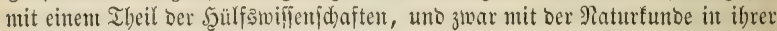
?(nwentoung auf Forjtivirthid)aft, wohin aud) nod bas $25^{\text {fte }}$ Sapitel bcs ziveiten

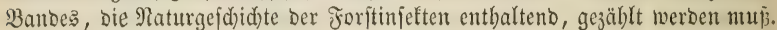

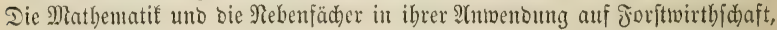

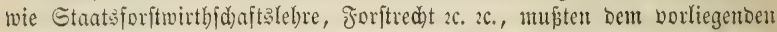
Berfi ausgejdloffen bleiben, wern es nidjt bud gefteigertent Breis bem wentiger bemittelten Forftmann unjugänglid) werben follte. 


\section{Errfer Šmtpttheif.}





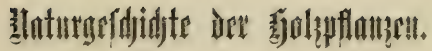

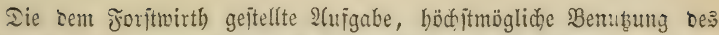
Malobobens burch bie Inzud) bon Scolzpflanjen, madjt bie Sebteren zum

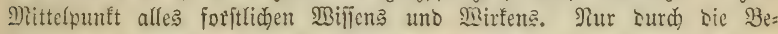
jiebungen, in benen bie übrigen Dinge zur Şolzpflanze, ju beren sisadjen und Gebeiben, 3u beren Ernte und Benub̧ung ftehen, erbalten fie für ben Forftwirth bejonbere Bebeutung. Eturm, Sdince uno Regen, Giejteine,

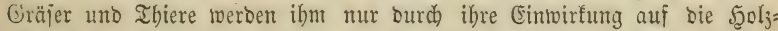

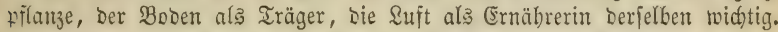

Damit fino nun bie Girenzen einer auf Jorjtrirtbjefaft angewanoten Maturtunbe bejeidnet. Eine forftliche Raturfunbe foll fich nur mit ben: jenigen Naturförpern bejwäftigen, bie mit Der Şolzpĩlanze in Bejielung Ttehen; jie joll an bicjen mur biejenigen Berübrung?spuntte bejonbers bes

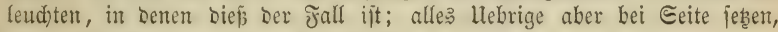
um bas Widjtigere nidjt zu verbunfeln.

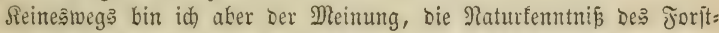
manns jolle fid auf bieje, in bie forftlidge $\Re$ a turfunbe aufjunchmen=

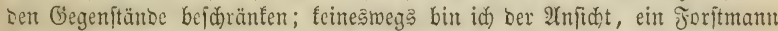

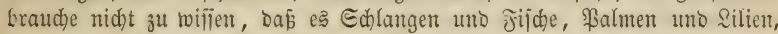
Siupfer und Binn in ber Mgelt gebe. Bon jebem gebilbeten Mante tvirb beutiger Beit allgemeine Raturfenntnif geforbert, um wie biel

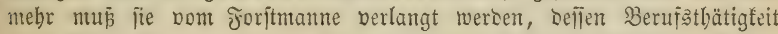
einen jteten llmgang mit Der Natur forbert, Dem ohne allgemeine Ratur=

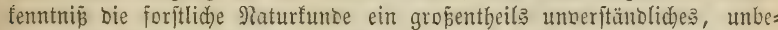

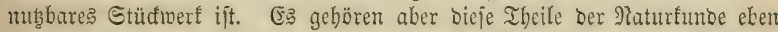
io menig in ben Rreis unjerer Jorftwifienjwaft, wie Religion

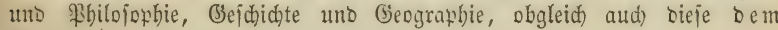
Wijfen Des Forftmannes nicht fremo fein bürfer.

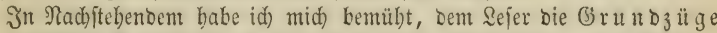

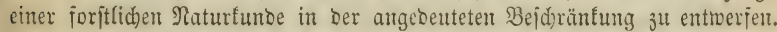

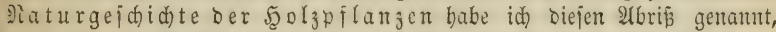
weil alfer übrigen Naturförper nur in ifrer \$3ejiehung zur Şclzpflanze gc: bacht werben joll. Mit bemjelben Red)te, mit Dam bie 2ebre bon Der

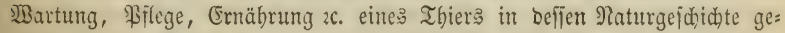
bört, fam auch bie Sehre bon ber Eintwirfung bes Bobens, ber \&ujt ac.

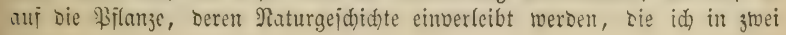




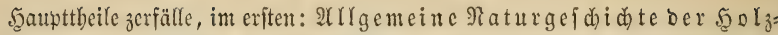
wflanzen, başienige zufammenftellent, was bie forftliden Sulturnflanzen

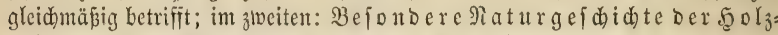
pflanzen, bie Eigentbümlidfeiten jober $\mathfrak{A}$ rt gejonbert berworbebent.

\section{Erite 2Ubtheilung.}

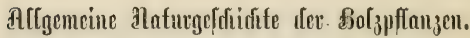

Die Pflanze feimt und murzelt im Boben, fintot in ihm Plabrung, Stanoort uno Scaltung; fie erhebt ibren belaubten Etamm über bie Dber: fläd)e Des Bobents, unto tritt mit ber \&uft in innige \$erübrung uno Siedjels

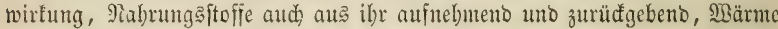
uno Sidst, io nöthig für ibr Seben uno Gedeiben, emıfangeno. \&uft

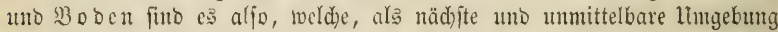
scr Pffanze, auf bie verfdjiebenartigfte Weeife förberno ober hinberno auf

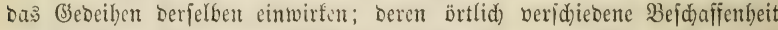
uno Buftänoe, Menge uno Bejchaffenbeit Der pflanzliden Erzeugniffe unjeres Erofërpers beftimment.

Dem Forfmanne, tweldem Die 2lufgabe geftellt ift, feinem 30oent Den

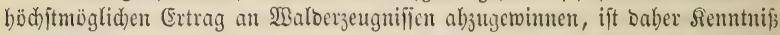

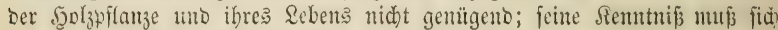
in Demfelben Grabe auf bie Bebingungen ibres Gebeibens, auf bie fie un= gebente Suft uno ben Boben erftreden. Jd) werbe baber in Nadfolgendem auerft von Der \&uft uto Deren Eimwirfung auf Das \$ftanzenleben, Dam vont 3oden in gleider WBeife, cublid) von ber Matur Der \$flanje felbjt ipredjen.

(El)e id) aber ju bicjen (Einzeltheilen meiner Darftellung mid inentoe,

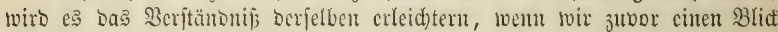
auf bie gegenfeitigen Bezichungen werfen, in benten bie 5̧olzpflanze, Der Boben, bie suft zu cinanoer fteben.

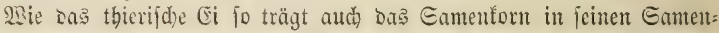
lappen ober im Gamentweiß cinen Borrath bereits berarbeiteter Billoungs: ftofic in fich, Der gentügent ijt, Die junge Bfflunze bis zu cinem 3uftanbe heranzubilben, in bem fie fäbig ift, Rohjtoffe ber (Enäbrung nidgt allein von aufen ber in fid) aufzunebuten, fonbern folde aud zu organifdem Bilbutgs:ftoff umjumandeln un burd) befien Berivenbung auf bas eigene

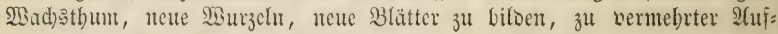

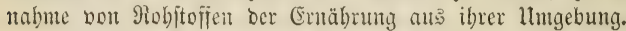

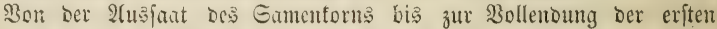
Blätter ift Daber Die Sfflanje non Den Robjtoffen Der Ernäbrung in \&uft 4no Boben unabbängig, es fino aber einige berjelben aud für ben Seimung Suft zur Siudbiloung Der feften Mejervejtoffe bes Gamenforns in fluifigen 


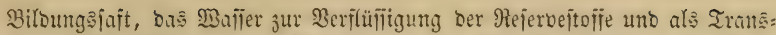
portmittel berfelfen als ben Eamenlappen ober bem Eamenteif in sen Reint.

Mit bem entididen Berbrand Der im Eamentorn, Dem אeim bon Der Mutterpflanze mitgegebenen Rejerbejtofie, bie einer weiteren Rerarbeitung

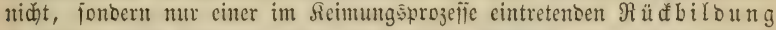

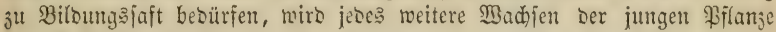
von Robjtofien ber Ernäbrung abbängiy, bie von ber jungen Pflanze ourd:

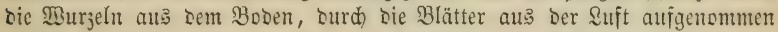

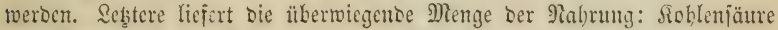

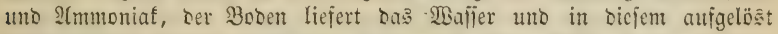

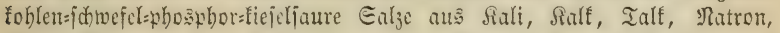
Oifen, Mangan, freie Soblenjäure, freies 2tmmoniat, wabrideinlich audh atmoipbärijde Suft. Dicje terreftrijden Räbritoffe, nadbem fie von ben $\mathfrak{B}$ Burzeln auw bem Boben mit $\mathfrak{A} u s$ wa hl anfgenommen murben, werben

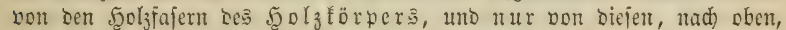

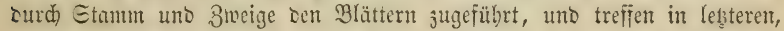

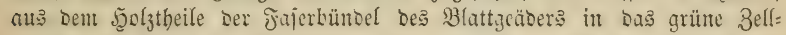
geivebe der Blätter ausgeidieson, bier mit Dent surdh die Blätter un=

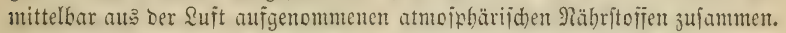
Sn ben Blättern vereint, wersen sie terreftrijhen uno bie atmojphärija,en Pobjtoffe Der Crnährung unter Sidft: unb Märmetwirfung in bem Bellgetwebe

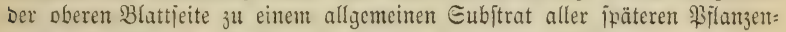
ftoffe, zu bem was id Bildungafaft nenne, verarbeitet.

Sisie im contrafen Bündeffreife ber \$urjel, Des Etammes uno ber

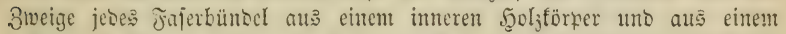

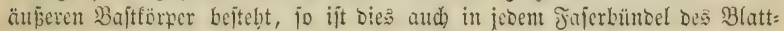

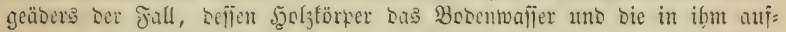
gelös̆ten terrejtrifáen Siohitofie sem verarbeitenden Sellgemebe ber Blätter

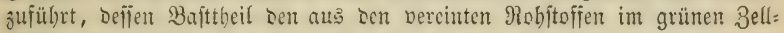
getwebe Der Blätter bereiteten Bilsungåajt Den Blattjellen mieber entjieht

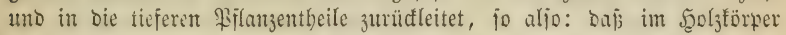
nur eine auffteigente, im Baftërner nur eine abwäts jintenoe fortbe:

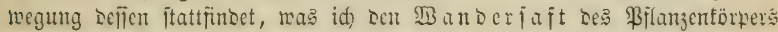
neme, jum llnterjhicse von bonjenigen 3 elliäften, beren nachbarlicher

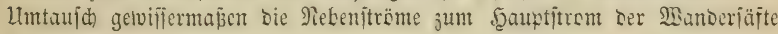
bilbet:

Ier in Den Blättern Lereitete, in Don Baftfajern rüăichreitenoe Bifoungäaft wirb mun bulfin geleitet uno findet ba jeine Serwentung, wo meift fejte ?leubiloungen ans ibm hernorgeben jollen. Dicje Reubifoungen fino entweder fermanente neer tranittorijde. 3u Erifteren gehören alle Das פisad)

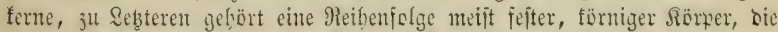

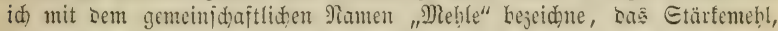
Slebermehl, ઉ̉erbmehl, Grünmebl, Jarbmehl.

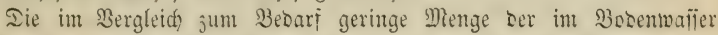

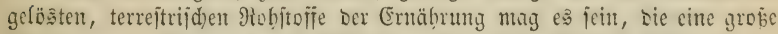

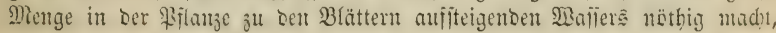


von Der Die größte MRenge von Den Blättern unberänbert aber in Dunfform ber $\mathfrak{A}$ nbenluft wieber zurüdgegeben roiro.

Ier in ben Blättern au Robjtoffen Der Ermäbrung bereitete, int Bajte zu' Den tieferen PFlanjentbeilcn zurüdfebrenbe Biloungşaft, angelangt

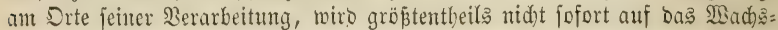
thum Der Biflanze, auf Bellemmebrung, fonoern auf Biloung pon Re ferbe=

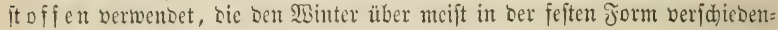
artiger Melble, bod) aud) als 3uder, (Summi, Ed)leim in beftimmten Bĭlanzenzellen ruhen.

Diejer alljäbrlid) fich wiederbolenbe Zujtano ber Winterrube unjerer Malokäume mit feinem Reidthum an Rejerbemeblen ift Dem reifen Ganten= forme zu bergleiden, wäbrent Der Dauer Der Samestube. Wie Dort füb

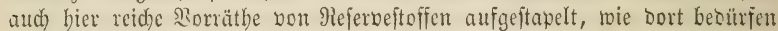
aud) Gier bie Rejerbeftofie einer tweiteren Berarbeitung in oen Blättem nid)t, fonoern nu einer Burüdfübrung in Den Biloungşaft, aub Dem fie intjtanden; wie Der Gamentube Die Reimung, fo folgt ber Wintermbe bes Baumes alljäbrlic) bic Jrübjabrtbätigfeit mit ifrur WBieberauflöjung ber Bejerbeftoije, mit ibrex Eprofintug uno Meubilsung Der Belaubung.

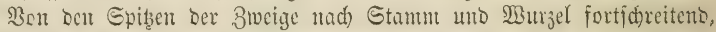

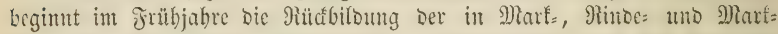

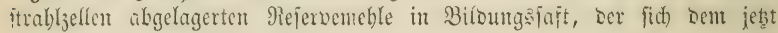
wieber aufitcigenben Robjaft beimengt und mit sicjen in bie Sinospen uno in bie aus ibnen fid entwidelnocn, blattbilbenban neucn Triebe empor:

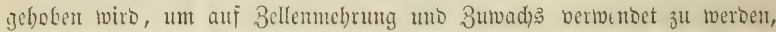
cbne einer meiteren 3 erarbeitung in Blättern ju bebüricn, die Dem Baume in fcinem isintertleibe feblen uno, wie bic Iricbe, an bencu fie fid) bilden,

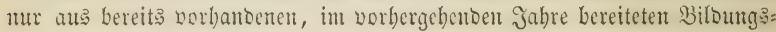
iäften ertoad) jen tömter.

WBie dic Hejervejtofic Des Gamtentorn' Den über Den Samenlappen jumachienden Theile oer Seimpiflanje, jo müfien auch bie Referbcftofflöfungen Des älteren Baumes sen Jrübjabretricken beffelben surd das aufiteigenise Bobentwajer in aufiteigender Ridstung zugefübrt werden, um das Material für Den Sängezumads: der neucn Jabrestriebe zu liefern, eร gefdiebt die:

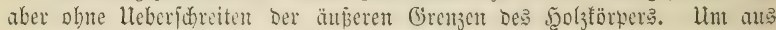
Den frolj in Den Bajtörper gelungen uno aud bier ju Peubiloungen fid geitalten zu fïmen, mülien die im auffeigenten Robjafte gelösten Rejerne

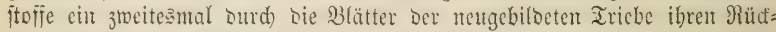
weg Durd) Den Baftërzer antreten, un erft jełst, alfo im jweiten Jabre mad) cer Bereitung Des primären Biloung jafts in Den vorjäbrigen Blättern, al: jefunbärer Bildungsjaft im Bajtörper rüdjobeitub, Denjenigen Drtent jugefübrt zu werben, an Denen Pleubiloungen ftattfinten follen, jeţt gröpten= theils berwentet auf Reubiloung bon Bellen ber Rinbe, vou Jafern auf

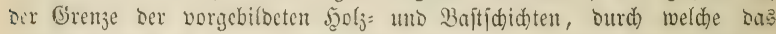
Didemad) vermittelt wirb.

Der Baum mădyt aljo in jeben Jubre ourd Bermentung von Biloung ftoffen, Die im vorbergebenben Jahre butd) feine Belaubung auts Den PRol)= 


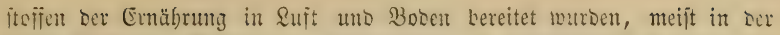
jejten Jorm von DRehltörpern überwintern, int aufiteigenoen Rohjafte De:

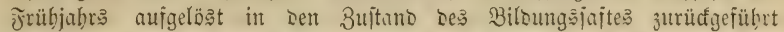

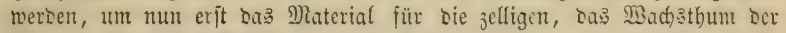

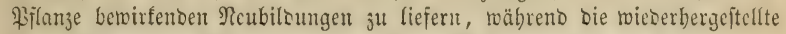
Belaubung neuen Bilounggiaft bereitet für bie Bereitung neuer Rejerveftojie.

Nidut jeser Boben enthält in Bereid) Der \$rlanjentumeln alle bem

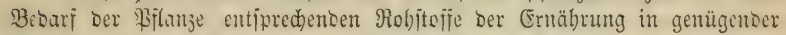
Menge. Jm Berbälnif̧ zum Bebarf älterer Beftänbe an \$boșthor, Edmejel, Ricjel, Ialf, Ralf, Sali, bejonbers in reiden Eamenjahren, ijt sic Menge biejer Etofie im Boden oft eine perjobinbeno geringe, und e? bebarf einer 2 ufipeiderung Derjelben in Der \$flanje jelbit, um bieje aud)

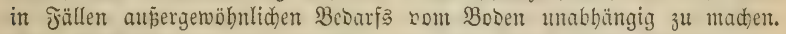
Tieje Aufpeidherung bollzieht fids in Der That imterbalb Der Neubifoungen an Bellitoff jowobl wie an Rejerbeftoffen, bie, in Jällen gefteigerten Be= Darfs ibren Ueberidus an jenen Gtofïen Den Wanberjäften abgeben unD erneut in Circulation ferien.

Etehen Boden uno 2Amoffbäre jur Bilanje in Bezichung theils als

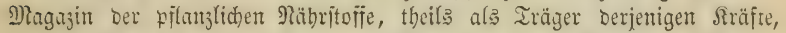

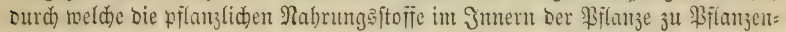
jtofi berarbeitet werben, bes Sidts uno Der siärme, jo fteben andererjeits

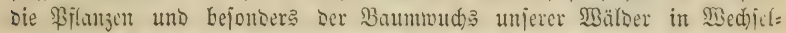
wirkung zu Boben unb Atmtophäre burd) bie R̂taft, mit ber fie bie vorüber:

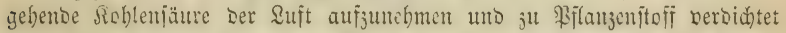

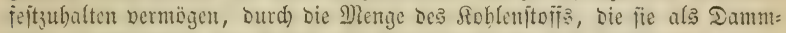
erse uto Gtallmijt Dem Boben, als Sioblenjäure Der 2ujt jurücfigeben, Durd) Den Cinflü auf Bobenbilouny und an Betwegung in ocr Rage Des gebilbeten

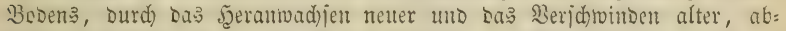
gejtorbener Betrurzelung, surd sen Einflü ses Blattichinte: auf Bosen

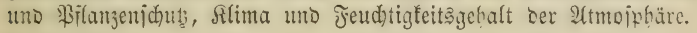

\section{Griter $\mathfrak{A b j u n t i t . ~}$}

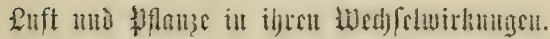

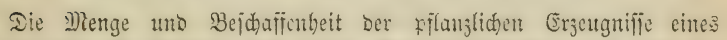
Stanborts ift abbängig son Deflen Bobenbejdafienbeit unb bon six

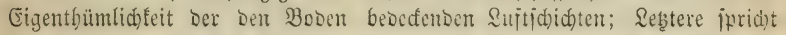

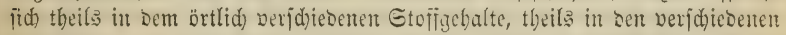

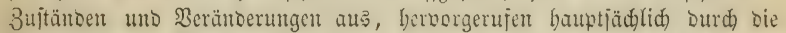
Eintoirtung Der Märme. BBir mülien Daber juerjt Den Etoffgebalt ser

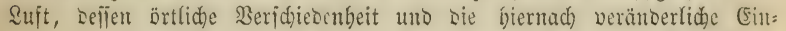
wirfung auf Das Pflanzenleben temen lernen, Den fid) Dann Dic Betrad)tung

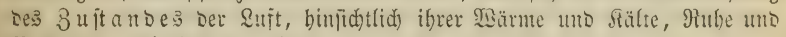
Betvegung, fllarbeit uno Irübe zc. anjụlieñt. 


\section{Siffes siapiter.}

\section{Bout Stofigeíalte ber $\mathfrak{Q} \mathfrak{u}$ t.}

Itnjer (Eroball wiro von einer $9^{2} / 3$ geograpbijde Meilen bohen Edid)t

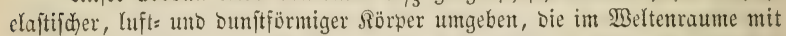

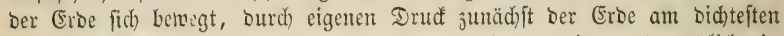
ijt, nad) oben allmählig bünter uno ausgebehnter wiro uno enbliç) in

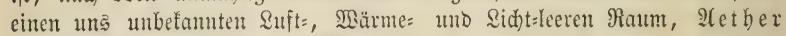
genannt, übergebt.

Dieje Ed)idtung luft= uno Dunfförmiger Sïrper nemnen wir Den Dunftereis, bie Atmofphäre unferer Eroe. Die Beftantbeile Der= felben find:

1) atmofphärifde \&uft, beftehent aus eincm biemenge von 21 Raumtheilen (23 Gewidttbeile) Rebensluft (Eauerftoffgas) uno 79 Raum=

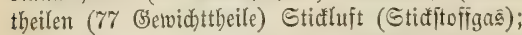

2) foblenfaure \&uft 0,000315 bis 0,000713 Raumtbeile, 0,000470 bis 0,001083 (jelvidttheile Der atmofphärifden \&nft.

3) Maffer in bent beridjicbenften Zuftänben, von bent feft in Şagel= forne bis zum Kuffförmigen Buftanbe.

4) Jefte Rïrper, bejonocrs Salze.

5) Âmmoniat.

\section{Dic atmojphärijoje $2 u f t$.}

Shre Beftuntbeile: 21 Ibeile Sebenßuit uno 79 Iheile Eticfuft, finto überall bicjelten uno in Demjelben Maje gementgt, man mitg bie 2 uft

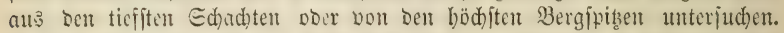
Dagegen berringert $i$ id) bie Did)tigfeit ber Suit aufwärts, proportional bent auf ibr laftenoen Drufi Der böheren Euftididsten, io Daj 4000 Meter über ser Mecreșläd) in einem Cubifmeter Raum un balb fo vich \&uft, 12,000 Mieter über bem Micere mur Der ad)te Thcil, 25,000 Meter über Dem

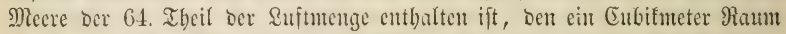
in meeresgleicher Ebente fajt, bir rromal weniger als bas $23 a f l e r$ wiegt.

Die Berbinoung Der beiben \&uftarten ift feine demifabe, fontern mu

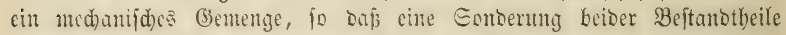
obne domifde Edeisung möglid ift. Diefe Abfonderung ocs Eanerftofïs

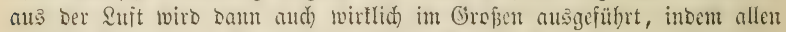

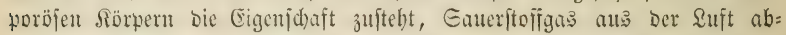
jufdeion uno einjujangen, obue fid) bantit demifi) zu verbinben (baber nicht mit Srboation 3 verwedjeclu). $3 u$ bicfen foröjen Sïrpern gebört auch) Der Soven, Der, wie twir fpäter fehent merden, dic Jäbigfeit ser Sauerftoffabicheidutg in hohem Girabe befiţt.

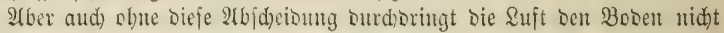
alfeit uno füllt befien Piäume aus, es finoet aud cint täglider \&uftwedjel it jebom Bobent baburch ftatt: ba is it bem, Dutch Särmeftrablung am Mlorgen

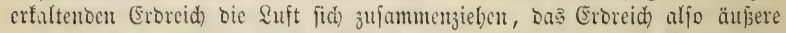
Suft in fich aufuchment muई. Dit fteigenber Ermärmung to bosens am 
Tage finbet bie auझुgesehnte Bobenluft in ihm nidht mehr ben nöthigen

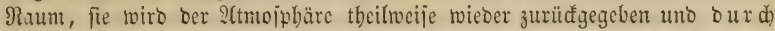

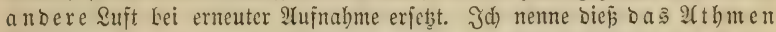

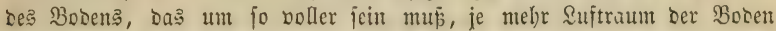
entbält uno je gröper bie täglide Differenz feiner Ientperatur ift. Daj; bierourd bie Berjeţung Der organijhen Bejtanotheile Des Bobens unt bie raj(h)ere Berbunftung Der Bobenfeud)tigfeit geförbert werbe, bebarf faum

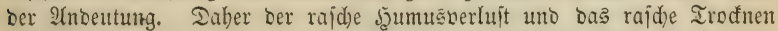

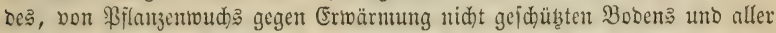
leidhten, luftreidjen Bobentarter. Daber bie Erfolge Der Bodenloderung, Durd)

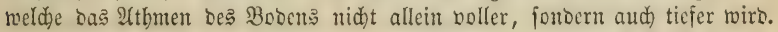

Der vom Boden aus Der Suft aufgenommene Saueritofi ifit mu in

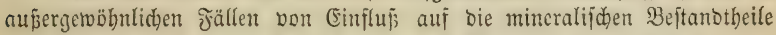
Defielben, Da bieje grö́tentheils Srybe, o. h. Sörper find, dic fich mit dem ibnen зuftänoigen Mirimum non Eauerfoff bereits verbumben haben. Ia: bingegen vernittelt ber atmojphärijde Eaueritoif, im Boben twie überall, bie fortichreitende \$ermejung ber abgeitorbenten organijden Etofie, inoem

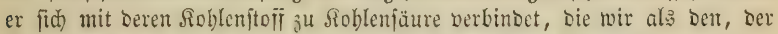

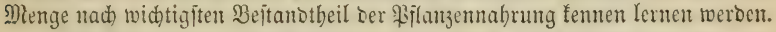

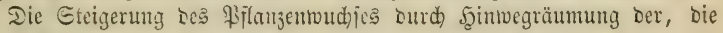
Eauerftoffeinjaugung binternden limitätbe, die Erfolge ber Bobenauf:

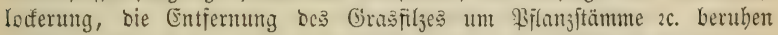
gröftentbeils auf Der geffeigerten Wirfung Des Gaueritofï im Boben uno beweijen Die Plotflwendigfeit Deflelben. Eミs geht aber nur ein Theil Der von bem Boben eingejogenen Rebengluft, als Sohlenjäure, in Die Fiflanze

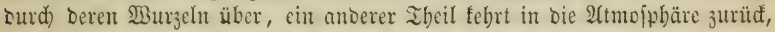
indem er, an ben Soblenjtoif bes Bobens demijh gebunten, mit biejent verflüdtigt. Diejer leştere I Iheil ift größ̈er ober fleiner, je nadjoem ber ¿uftwedjel in uno über Dem Boben ftärfer ober geringer ijt. Jm lid)ten Etanbe Der Wälder, im aufgelocferten $B_{0 D e n}$ ift $\mathrm{cr}$ am gröften; twir fehen unter joldjen $\mathfrak{S}_{\mathrm{erbältni}}$ en ftarfe Dammerbejobidten in furjer Beit wer:

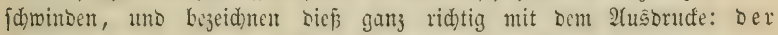

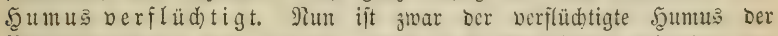
\$rlanjenernährung nid)t verloren, inoem er bie Ittmojphäre befrudtet uno

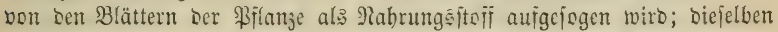
Serbältnifie aber, welde feine Berflüótigung betwirften, rajder Suftmedjel, finto aud bie Urjache, Daj or nidst, ober sod) nur theiflueije senjelben Bilanzen, Deren Emährunģraume im Boben er entzggen wurbe, jonbern anderen, weit entfernten (Belvädffen zu Bute fommt.

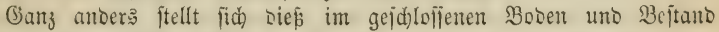

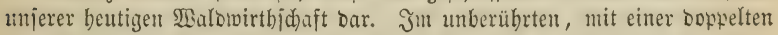
Saubichichte bededten Boben, ift ber Suftmechjel gemüpigt; Daber jehen wir hier Die Berjeţung Der Єtreu зu Scumus langiam vorid)reiten, Den

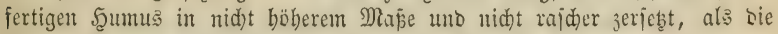
\$ilanze Sodennabrung bedarf. (E亏 viro ferner aud) Der berfiüdtigenoe Theil Der Bodenfuddibarteit in Dem gejdloilenen Biftanoe jurüdgehalten,

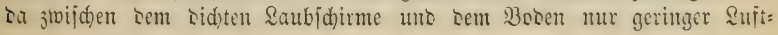


mediel jtatt findet. Sie Lem unteriroifchen Ernährungšraume einer \$Flanje entifiegene Bobenfrudthartict wirb biefer baber nidgt entzogen, jonbern ber= bleibt in ibrem oberibifiden Ernäfrungäraum, bis fie von ben Blättem Defīelben (Bemäd)jes aufgenommen wirb.

Go wirft alfo unjer $2 B a$ lo mit feincu aejolofienen Beftänben auf ein Bleiben Dex Bfflanjentubrung a Drte; er twiro Daburd felbit:

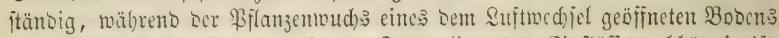
uno Beftandes von fremben, in Der Jerne licgenden Einfluffen abbängig ift.

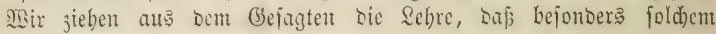
Boben, Ler an uno für fid) sem \&uftwed)jel in böberen (Sraben zugänglich iit, wie Der Eano Des Mtecreşbodns, ferner foldem Walsboden, Der ciner Onbüujung und Bebectung von Dammerbe zur Erbaltung feiner Feudtigteit

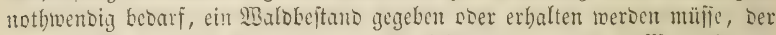

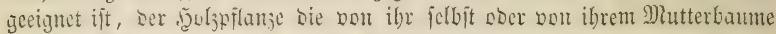

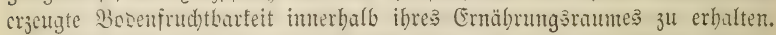

Piäjitsom mirft bic atmoinfärijd) \&uft aud) über $5 \mathrm{~cm}$ Boben mäd)tig anf bas Pfianzenteben ein; ibr 3utritt zur Pflanze ift jogar Bebingung

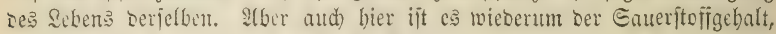
melder mirteno auftritt; Der Etidjtoif erjdeint nur in iofern widhtig, als e: Die allyuträftige Wirfung bes Eanterftofḟ abftumpft; er ift Berbüntung

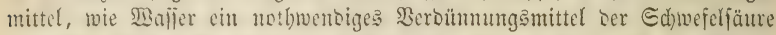

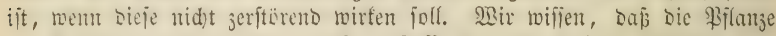
jur Sadatzeit uno im Edatten Eaueritofigas aus ber Suft abjocioet uno

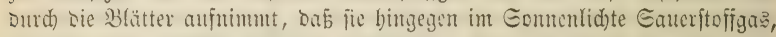
uns zmar im reinften Buftanoe ausbaud)t. Dagegen jocint $e_{5}$, als biente

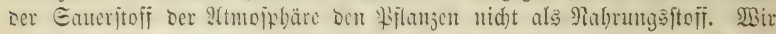

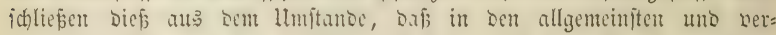
breitetiten Biflangeniteifen Der Gaueritofi jum SBafferitoffe in bemielbon

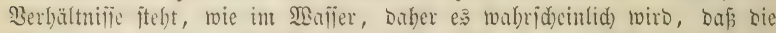

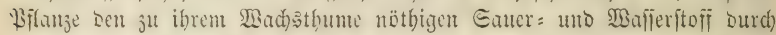

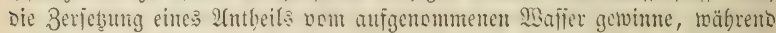
Der won Den Blätten im Sid)te auŝgeid)iebene Eaneritofi aus ber $3 e r=$ legutg Der Sohlenjüure berftummt. Seocufalls ijt saourd) crwiejen, ouj

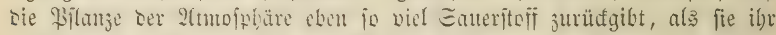
entjicht. Ia fich jwei \$olumtbeile Gaueritoif uno ein \$olumtbeil Sioblen=

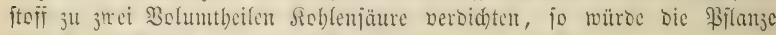

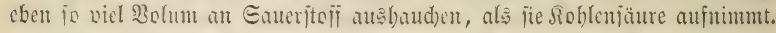

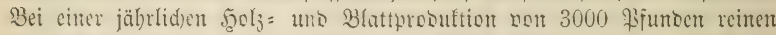

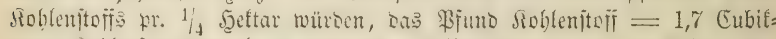

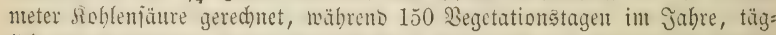
(id) 144 Cubifmeter reines Eantritofigas von cines gut beftanoencen beftar WülDes in bie 2tmolphäre übergeben.

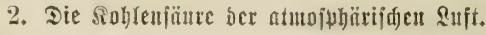

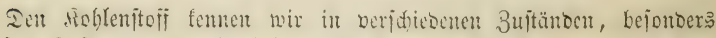

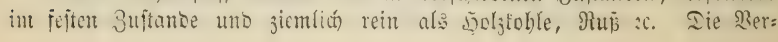




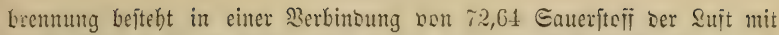

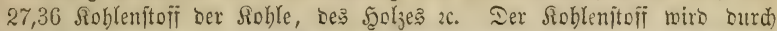
Daț Berbremen nidht vernidjtet, nidjt einmal verringert, fonbern nerliert nur feine fefte form uno wirb zu ciner Suft, bie wir foblenfauce nemen (tohlenjaures (Sas). Die foblenfaure \&uft, 1,5 mal fablwerer als bic amofphärifde \&uft, mengt fich mit ber atmofphärifjen \&uft uno ijt io lange ein Beftandtheil berjelben, biz fie entweser burd bie Blätter, ocer

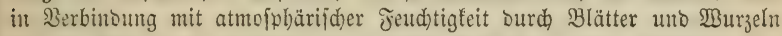

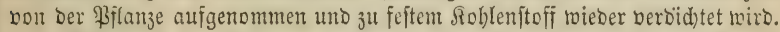

Die Durd bie ßerbrennung in bie Suft übergebenoe Sioblenitofïmalle

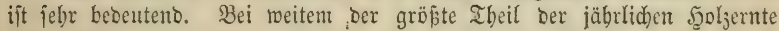
wiro früber ober fłäter berbrant; Ë̈nten wir nun annelmen, baj jäbrlid) im Iurdjidnitte eben io viel $\mathrm{S}_{0} \mathrm{l} l_{3}$ geerntet uno beinabe eben fo viel ner:

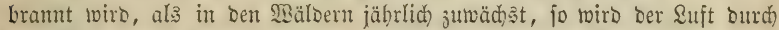

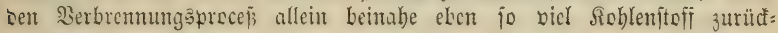
gegeben, als bie $\mathfrak{W a ̈ l b e r}$ ihr cutnełnen.

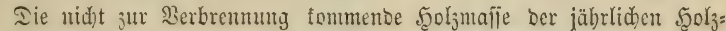
ernte mus früher ober fräter ibren Soblenftofigebalt ebenfalls, werigitens

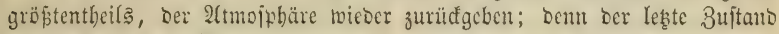
Des rerfaulenten Pflanjentörpers ijt ebenjalle Der luftï̈rmige, uno mur serjenize Theil Des Sohlenitoff: Der gefammten \$Flanjemprobuftion eines Sanoes, me!djer meber berbramnt wirb, noch berfault, fonbern bor feiner

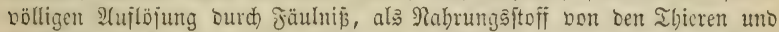
Sladtrflanjen ${ }^{1}$ aufgenommen wiro, ift ber \&uft io lange entzogen, bis bie

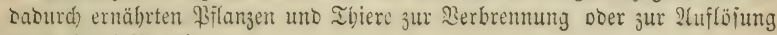
Durch) Jäuluíp gelangen.

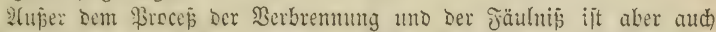

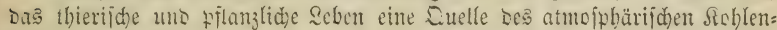
itrff: Sou Thieren cingeatlimete, von Sohlenjäure freie Suft, entbält nad) bem 2(usatbmen $S-81 / 2$ Froc. Soblenjäure; bie \$flanjen athmen zur

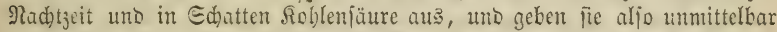

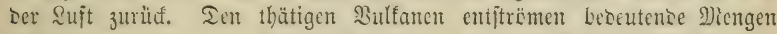
tohlenjaure Suft; das Euelfwaffer berliert jeinen Siohlenjäuregebalt boi längerer Berübrung mit Der \&ujt uno Der Sioblenftofi ice Etcin = uno

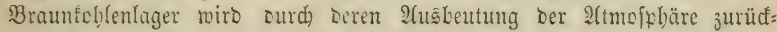
gegeben. In Menge finbet fich ser Rohlenitoif an Mineralien gebunoen;

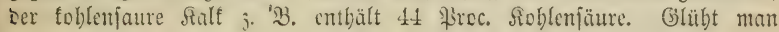

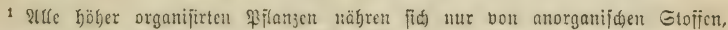

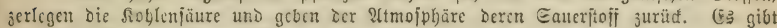

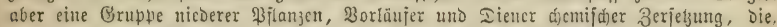

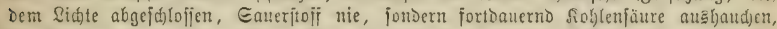
Die fie Dem todten organijden förper unmittelbar entjiehen. (Eg gebören Dabin Dic

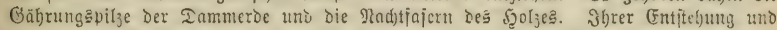

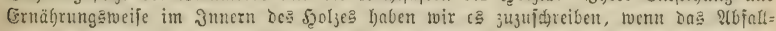

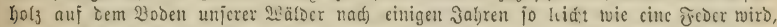

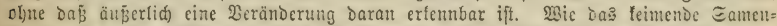

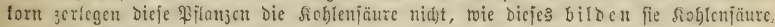

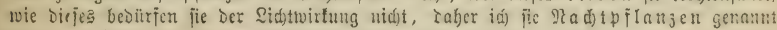
babe, im Gegenjabe zu ben foblenjäre jerlegenden \&idtpflanjen. 


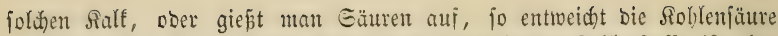
in Suftgeftalt. Eo grop bie Menge des mineralijden Roblenitofïs ift, bat jie bennod) für bas Bflanzenteben nur untergeorbnete Bebeutung, da ber Roblenftofi nom (Sejtein nut burd) aujergewöbnliche Ercignije getrennt wiro.

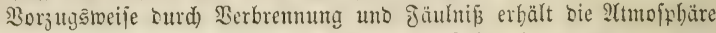
ifren Soblenitoffgebalt, berjelben als foblenjantre \&uft beigemengt uno jwar auf jeden Raumtbeil atmojphärijhe Suft nabe $3-7$ Bebntaufendtbeile foblenfaure Suft. Gauinure fand Den Soblenjäuregebalt ber Suft im

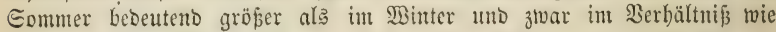
7,13 зи 4,79. Man follte meinen, es müpte biej entgegengejest fich ber: halten, da Der Gommer die 3eit Des Serbrauds burd) Die \$flanzen ift, in \$inter gröpere Mengen Sioblenfäure burd) die Serbrennung gebildot werben. Die int Sommer thätigere Jäulnif uno ßerwejung fonn bon obigent wobl faum das Gegengemicht fenn, uno müfien dicjer Differenz wobl nod) andere unbefannte lirjad)en zum (Srunbe liegen, wobin vielleicht bie gröfere Didjte Der Minterluft gebört - Ziebig berednet Das (Gervidjt Des in ber 2Atmofphäre entbaltenen Roblenjtofïs auf 2800 Billionen Brunbe,

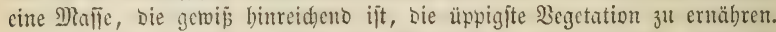

Edjon Eauffure batte bie Bermutbung ausgefprod)en, daj bie Biflange cinen Theil ibres Roblenftoffes aus bem Roblenfüuregebalt Der Suft bejöge. Da bieje Bermutlung jebod) mu auf Dem Borbanoenfern Der Sioblenfäure in Der ¿uft rubete, blicb die ältere 2tnfid)t einer Crnäbrung

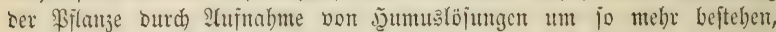
als Eaujure jelbjt Dicjelbe Durd) sirefte Serjude nadjgetoiejen ou haben

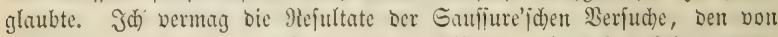

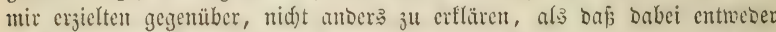
Berlçung ober Sirantbeit Der Betwurgelung ftattgefunden babe, ober bab ber beobadtete Berlujt an .̧umutslöfung aus cinter Berlegung Derjellen in Sioblenjäure berborgegangen war. Der won mir juerft gelicferte birefte Betweis, Daf நumuslöjungen non unverlesten, gefunben sisurjeln cbent fo wenig wie andere Sojungen organifd)er Stoffe (Jarbjto $\bar{f}=$

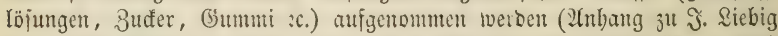
Drganijobe (Ebemie, 1. 24ül.) fand nod) in Ed)leioen (Sirunojüge II. p. 469)

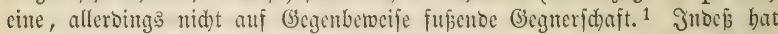

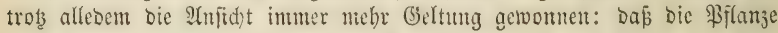

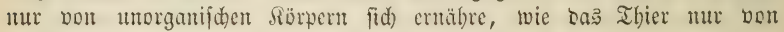
organifichen Rörpern fid) zu ernäbren bermag.

Wenn wir beute cine Jläde feuditen, anşgewajónenen Dünenjandes ntit Riefern anbauen, fo finten fid) nad einigen Decennien auf ibr, nidht alfein im 5olzbeftande, jombern aud in einer reiden 5umusjojid)t be= bentente Roblenftoffmaffen angejammelt, obgleich alljäbrlich bie Berfebung

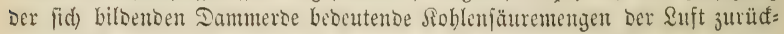
gegeben bat. Diefe ganje, io bebeutenbe Sioblenftofimafie fann mur bem Jioblenfäuregebalte ser 2(tmojphäre entmommen fenn. Es ift bief in

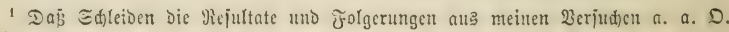
in jeiner łolemif ganj entiftellt wicoergegeben bat, jeigt ber einfadje Dergleid) aud bent Intundigen. 


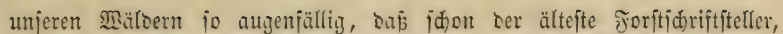

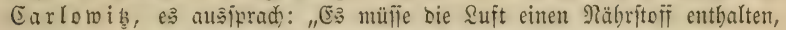
Der bie Duintelienz aller Elemente fey."

Jerner: toem unjere Mälder nur oud ben Blattabfall und burd)

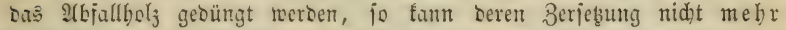
Roblenitofi bem நूoljbeltande liefern als jur jäbrlichen Wiecererjeugung ciner gleid) groben Nenge bor Blättern uno Abjallhola notbinenoig ijt.

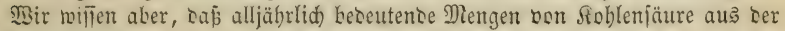
Dammerdejdidt in sie 2tmojphäre jurüafgehen. Dieje und bie ganje

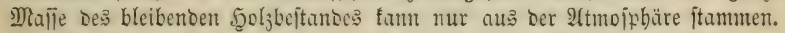

Mū man biể jugeben, jo blicbe inmer nod) Der Eintwand: baj; aud) bie atmojphärijde fohlenjüure erjt in ben Boben aufgenonmen verben mübte, um aus biejem burd) bie Fiflanjentvurzeln aufgefogen zu twerden. (E⿱ weder twirb bie nom Boden aus ber Itmojphäre abjorbirte Soblenjäure nur mit bem Bobentmafier aufgenommen - ob rein ober in Berbinoung

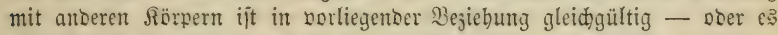

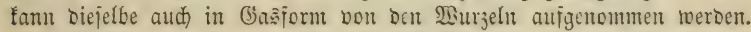

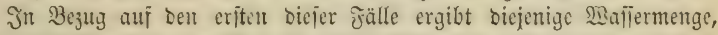

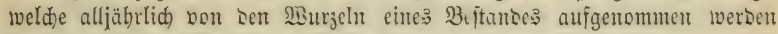
fann uno Deren Gebalt an Roblenjäure, sas möglidhe Duantum oer

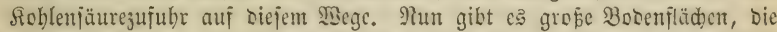
ibre Jeudtigteit mur Dem jüfrliden Regen, Edynee unt Thau verbanten.

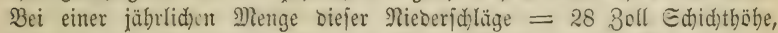
bei einem Sioblenjäuregebalte Dis Bodentwajier: $=2,5$ Solumprocen:

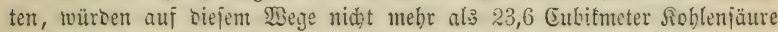

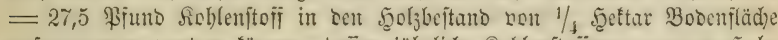

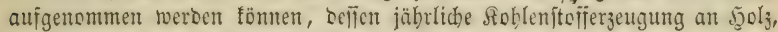
Saub und Jrüdten möglidgermeije 5000 Pfunbe betragen fann. Dap bie im Bodentwaijer enthaltene Sohlenjäure von ben Pflanjentwurzeln wirfliá),

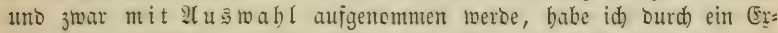
periment umittelbar erriejen (尺iebig org. Chem. 1. 2lufl. Є. 194); allein aus 3orftehendem erbellet, Da

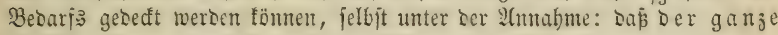
jäbrlidje Regennieberfall non Den Biflanzenturzeln aufgenommen werbe,

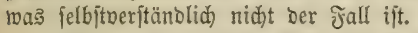

Ier zmeite möglidge Fall, Die 24unahme nid)t bem Bobentwajier bei= gentengter, vom Boben auß ber Suft abjorbirter Siohlenjäure burd) bie Burjeln, liegt außer Dem Bereidhe ber Beobad)tung. Sie faun wenigften:

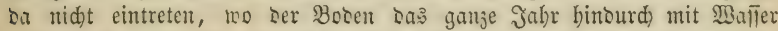
gejättigt ijt. Es ijt biej Der Fall in Boben vieler unjerer Erlenbrüde uno Tiseibentheeger. Die Sohlenjäure fun bier nur Durd) sas Maljer ben

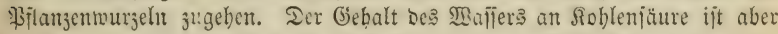

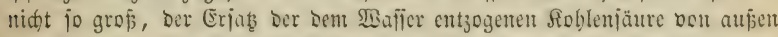
ber gebt nidid jo rajo von Statten, baj jid bieraus bie mädtige fioblen= jtofiproduftion aud siejer siäloer ableiten liejec. S) Sülīen wir aber für

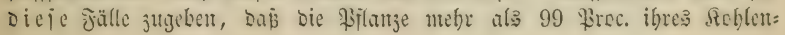


ftoffibcoarfy Durch bie Blätter ummittelbar Der ?(tmojphäre entnefme, fo ijt burd)an fein Gruno vorbanten, biés Bermögen nicht aud) Den übrigen Pflanjen auf anberem Standorte zuzufdoreibent.

MSie bie Alufnabme ber atmojphärif(d)en Siohlenfäure burd) bie Blätter

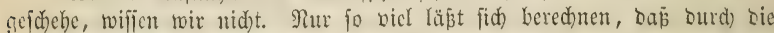
ftete Bewegung ber \&uft Dent üppigften \$Flanjenmudie eine genügende Dienge

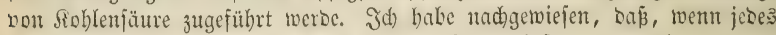
3latt eines $1 /$ seftar grofen, 60jäbrigen \&ärd)enbejtanbes, wäbreno ciner jübrliden 2lbjorptionşoit bon $10.120=1200$ Stunsen, in jeber 3eit= fofutse cine Die gefammte Blattoberflädye umgebente Suftididyt von

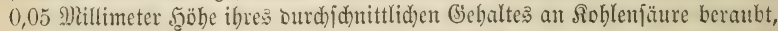
Dir in Derfelben Beit burd \&uftredjecl erfeţt miro, baburd allein 5000 Bfunbe Soblenftoff aufgentommen merben tömen.

Wie bas Maffer ber Eroe uno ber Ruft, fo ift anch ber atmo:

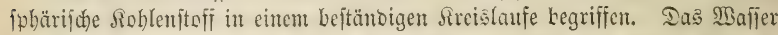
Ser (Froe verounftet, geht in bie \&uft über, fammelt fich in ber Suft zu \$olten, wirb six Eroc in Regen, Ednee 2c. wievergegeben, uno weilt

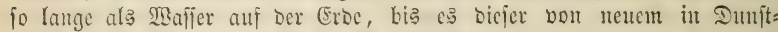
geftalt entwoicht. Eo aud) Der Siohlenftoff ber Suft; cr wiro von bent Biflungen eingeathmet uno veroid)tet fid) in ihnen zu feftem Sioblenitsfi, weilt als folder fo lange anf ber Croe, bis cr Durd) Sierbremung, Sier= wefunis ic. mieber flüdtig unt Der Snft twiebergegeben wiro, aus ber ibn Die ßflanze von neuem wieber auffaugt uno feftbält.

Sn biejem gropien Sireislaufe Des atmofphärifden foblenftoffes fpiclt Daber bie, cinem Etofimedjel 1 nidht untermorfene fiflanje eine widstige

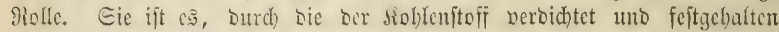
wird. Durd) welde Eserfjeuge bieß gcidebe, ift in ber Bflanjenlebre

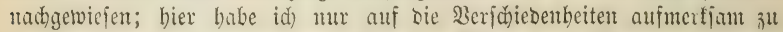

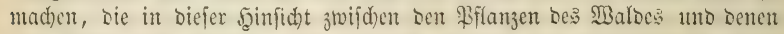

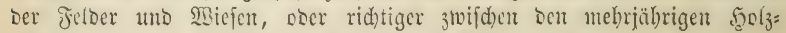
طflanjen uno ben einjäbrigen Gräjern uno fräutern ftattfinoet.

Iir befte 2Heterboben wirb nit ber Beit unfrudtbar, ment ifut nid)t mentigtens ocr gröfere Iheil feiner jührliden Erzengung im Dunge wieber:

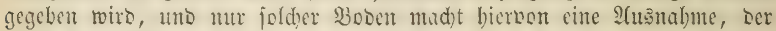

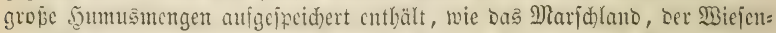

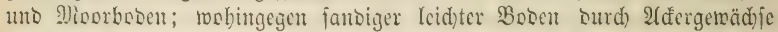
wenizer soblenftofi erjeugt, als or zur (Erbaltung feiner fruddbarfeit fordert, uns buber cines 3ujdujes non fremben Grumbitüten bocorf (Malditreunuţung), wenn er fundbar bleiben foll. Ganj anbers berbält

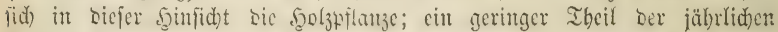
sioblenftofierzengung cines Beftandes, fdyon allein ber jährlid) Saubabfall Der siefer genügt, um folbft sent unfuditbarjten 230 ben, oer reinen Eams:

1 Mbgejehen bon ben voribergeh)enden Folgen Der Maftung wirb bas a

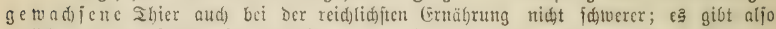

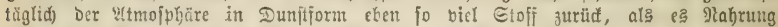

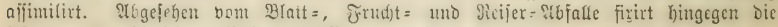

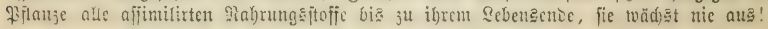




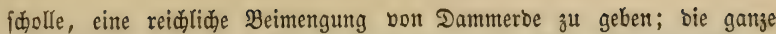

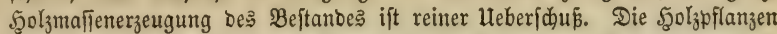

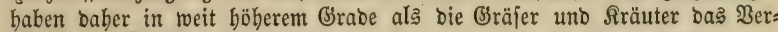
mögen, Den Sohlenitoff ber Ruft ३u firiren; bie \$ెeftänoe ber Mäloer fino eine örtliche 2(nbäufung ungeheurer Rohlenitofimafien, 1 uno wirten bas

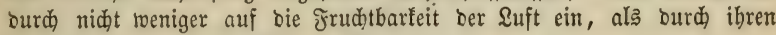
Einflup auf bie ₹eudhtigfeit ber 2Atmofphäre.

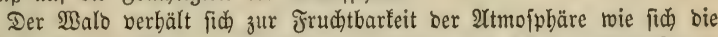
Gefteinbroden Des Bobens zu Defien Feudtigfeit, wie fiळ bas Sumpfmoos

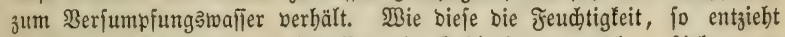
er ben wedjfelnben Suftmafien bie Rohlenjäure, näbrt fid bom Borübergehenten uno gibt feiner llmgebung nachbaltig ben reidliden

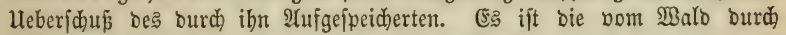
Defien Blatttbätigteit aufgenommene Roblenitoffmafie jo groß , baj, trobs ber Jirirung groper Mengen zum bleibenden Malobeftande, Dennod) täglid uno ftünolid) grope Nengen ber \&uft wieber zurïđgegeben werben, burch Blattaus[aceibung fowohl wie burd) Berwejung ber Dammerbe.

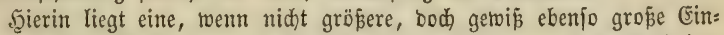

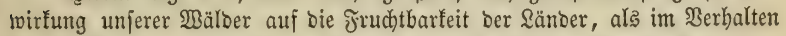
Der Wälber zur Jeứtigtigeit. In tvafierarmen \&änbern nag bie Bebeutung Der Betwalbung in lesterer Rücficht ebenjo roidtig fegn; für unjer, reid)= lid) mit anbern Jeudhtigfeitsquellen gejegnetes, von Meeren bieljeitig um=

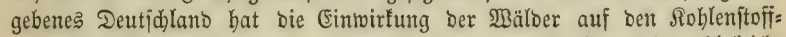

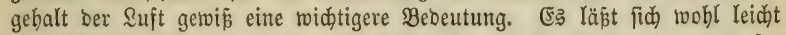
ourdidgauen, Daßs ein groper, in viełen Theilen Deutiblanbs ber gröpte Theil ber jäbrlichen $\mathscr{U}$ (déererzentgung, nidht allein burd) bie Streuabgabe, in viel höberem Brabe burd jenen mäd)tigen Einflū ber Mälber auf bie

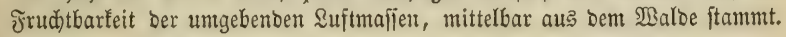

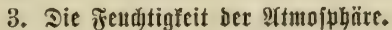

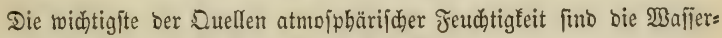
fläden, bie nafient uno feuchten Rörper ber Erbe.

Wajier verbunjtet, ๖. ho ę verbindet fid mit freier Märme, wenn Diejer ber 3utritt geftattet ijt, uno nimmt in biefer Berbinoung \&uftgeftalt

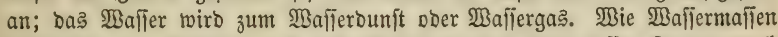
berounften, fo entweidht aud) Dab Bafjer feudter ober naffer Sïrper burd) Berbinoung mit $\mathfrak{B a ̈ r m e ; ~ D e r ~ S o ̈ r p e r ~ t r o d i n t . ~}$

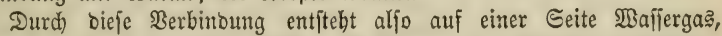

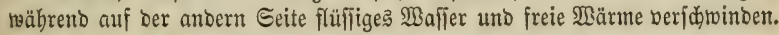

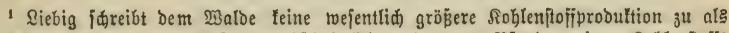

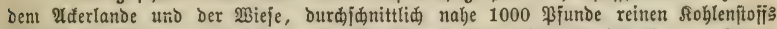

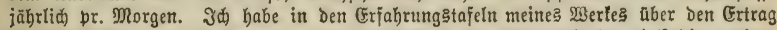

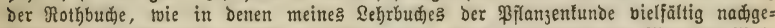

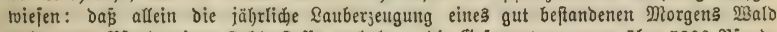
nahe 2000 Piund reinen Sidhtenftoffs enthalten, Die Bejammterjeugung über 5000 PFunde fteigen tönne. 


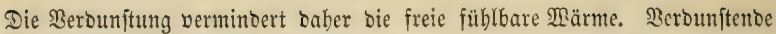
Wafierflächen erniebrigen bie Sufträrme.

Die Berbunitung geht um fo rafder von ftatten, je gröfer bie Dher:

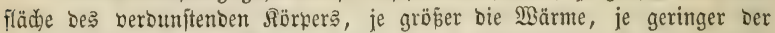
Suftorud ift, und je rajder bie \&uft über bem berounjtenden Rörper wedjelt.

2ud) Thiere uno Bflanzen find burd) Berounftung eine beadtens:

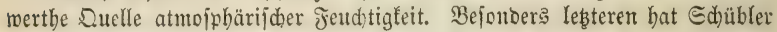

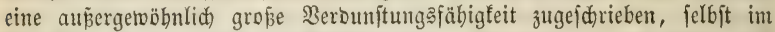

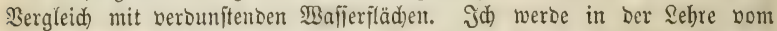

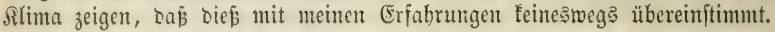

Das, biejen Duellen entipringenbe WBafjergas geht in bie, ben ber= Dunftentoen Siörper umgebenen \&uftidididten über uno fättigt biefelben bi३ $\jmath^{u}$ Dem ifnen eigenthünlichen, Durch ifre $\mathfrak{B a ̈ r m e}$ beftimmten Grade mit Jeudtigfeit. Sit bie ben verbunitenoen Rörper umgebende \&uft mit Waffer= gas bollftänoig gefättigt, fo bört bie \$erbunjtung auf; fie roiro baher Durd) Suftmedjel beförbert, wenn baDurd) bie mit Jeudótigteit gefättigte \&uft burd) trodene erfeţt wirb.

Ein Eubifmeter ¿uft, mit פinnjerbampf gejättigt, enthält bei $-10^{n}$ 3 Grm., bei $0^{0} 5,4$ Grm., bei $+10^{0} 1005 \mathrm{rm}$., bei $+20^{\circ} 17$ (5rm. Waffer. Jn freier Suft tritt bie Gättigung mit $\mathfrak{B} a$ ffiergas jeodd) nur örtlid) be=

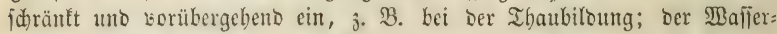

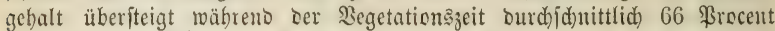

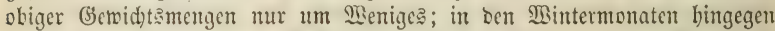
fteigt ber an jid, geringere Waflergebalt bis auf 86 \$rec. jeines Maximum. Jm Enmmer uno in ser (Ebene enthält bie Suft Daher mehr Waffer als im $\mathfrak{B i n t e r}$ uto auf bergen. Die $\mathfrak{B i n t e r}=$ unto Bergluft ift aber relatio feudter, in jo fern fie bent an fid) geringeren Maximum bes $\mathfrak{Z}_{\text {affergebalte }}$ (Dem Thaupunfte) näber ftebt.

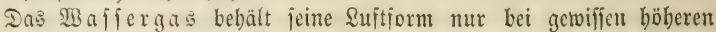
Märmegraben; Afblitblung vermandelt cs in 2 safferbampf. Die Blajen, welde fid) im fodjenden Waffer biloen, fint Maffergas; bießs behält feine Suftjorm noch auper bem $\mathbb{R} a f j e r$ in ser Räbe Defielben uno berwandelt fid erft in einiger Entfermung bou Der fodjenoen $\mathfrak{B a f f e r f l a ̈ d ) e ~ i n ~ f i d d t b a r e n ~}$ Dampf; leitet man einen fälteren \&uftitrom über Die Fläd) be to fodenben

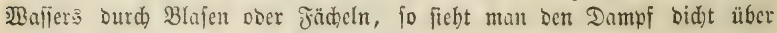
Der Dberfläche bes $\mathfrak{B a f f e r s}$ fid bilden.

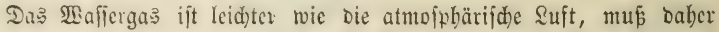

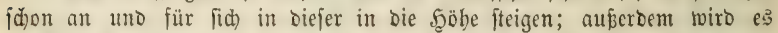

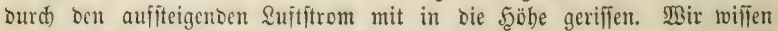

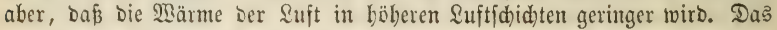

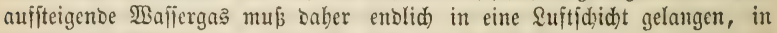

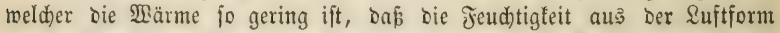
in bie Dampfform übergeht. Dannf keftebt auß Bafferbläaḑen, bie fo flein uno leidht finto, baj̄ fie fid) in ber Suft fadwebeno erbalten. Die

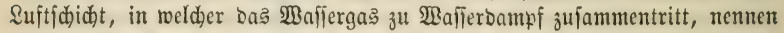
wir bie $\mathfrak{B}$ olfenregion, ber angebäufte Wafjerbampf erfdeint uns als Bolfe. Befintet man fich auf hohen Bergen innerbalb einer $\mathfrak{B D}_{\text {olfe, fo }}$ 


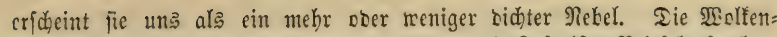
region ift höber, je märmer uno je trođener bie \&uft ift. Bei fehr feud)ter

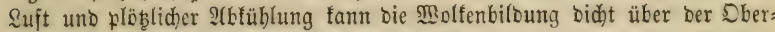

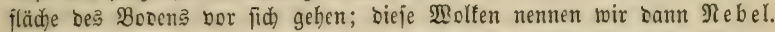

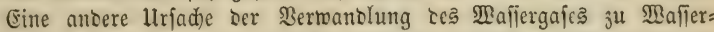
bampf roiro bie \$ermifdjung ungleid) ermärmter, mit Feudtigfeit gejättigter Enftiftröme, bie jebesmmal einen Rieberidlag zur folge hat, weil bei ber

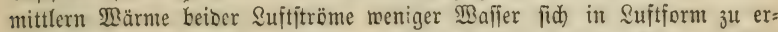
balten bermag, als bei ber bişher getrennten Märme beiber Etröme. IUi

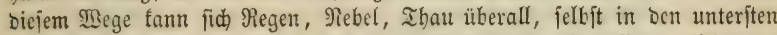

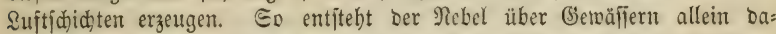

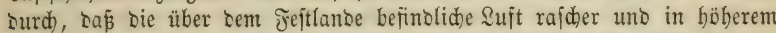
(3rabe abgefüblt wirb, als bie über bem Getwäffer liegenden Suftididaten, uno bon allen Seiten borthin ftrömt. Befrorenter $\mathfrak{B a f l e}_{\text {erbampf }}$ ift $\Re$ e if unD Duft.

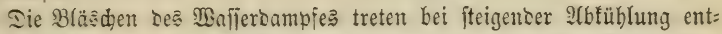
reber ju Ed) nee, soer ju Regentropien, ober ju 5gagelförmern, ober (fir a upeln jujammen, merben baburd) ip fdmer, báp fie fid in Der ¿uft nidht metr ju erbalten bermögen, uno fallen auf bie Erbe jurücf.

Mie ber Rohlenjtoff, jo ijt aud bie Jeuchtigteit Der 2 ttmojpbäre uno Der Froe einem beftändigen Rreialaufe untermorfen; aud bitr ijt bie \$flanze, jeDod) nur für einen Theil Der circulirenঠen Jeu(t)tigfeit, Durd)gangätörper. Die Nothmendigfeit Des Rreiझlaufs beioer Etofife läpt fidh jebr leidt er=

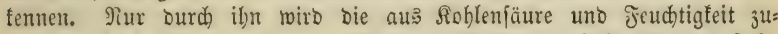
jammengejeb̧te Pflanzentrabrung alleitig bertbeilt; wo \&ujt ift uno \&uft=

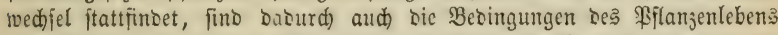
gegeben; mur Durd Den Sreislauf Der luftförmigen Pflanjemnabrung uno ourdy beren alljeitige Berbreitung von ihren Duellen aus vermag ber Jels, Der unfru(b)tbare Eand fid) mit Pflanzen zu bebeden; Der Bflanzentwd jebes von Dammerbe freien Bobens ift lebiglid bon ber, burd ten Rreia:

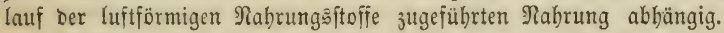

Bejtätigen fortgefeb̨te Ilnterjudungen bie neueren Beobad)tungen über

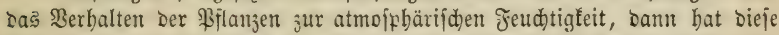
nur in io fern einen bireften Einjlup auf bas \$filanjenleben, als fie ben (3rab Der $\mathfrak{B a j p e r b e r o u n f t u n g ~ D u r d ) ~ b i e ~ B l a ̈ t t e r , ~ m i t h i n ~ a u d ) ~ D e n ~ B e b a r f ~}$

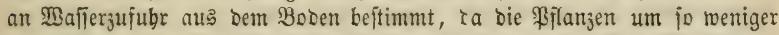

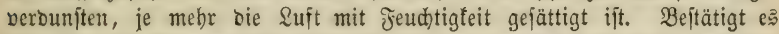

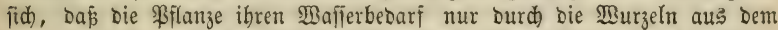

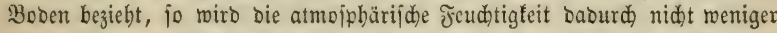
widhtig für bą Pfllanzenleben, ba fie bie widhtigfte, in vielen fällen bie

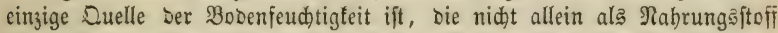
Der Pflanze bient, Der fie Den Sauerftoffi= uno $\mathfrak{B a j i e r j t o f f b e d a r f ~ l i e f e r t ~}$

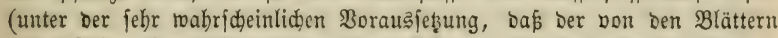
unter Sidftwirfung abgejdiebene Sauerftofi auß ber 3erlegung ber foblen=

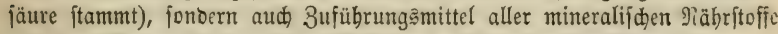

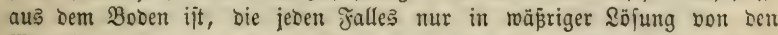
Burzeln aufgenommen werben fönnen, wenn aud, neueften Beobadtungen 


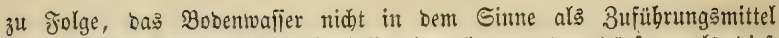
mineralifder Bobenbeftandtheile follte betradtet merben bürfen, als bié bisher gefdah. (E⿱

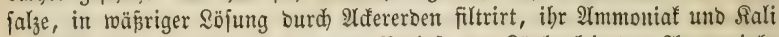

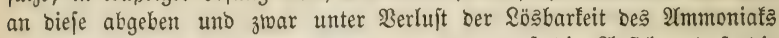

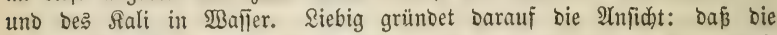
Bflanzentwurzeln es fenen, weldje burdh einen nod) unerforjdyten aft organi: idher Ihätigfeit über ibre eigenen Brrenzen hinaus wirfjam, bie Sößlidłteit

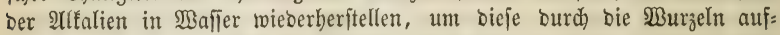

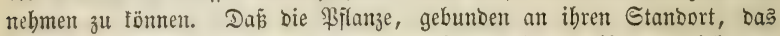

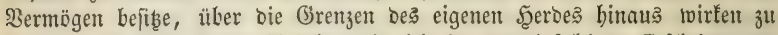
fönnen, ift aud meine Infididt, bie id in mamnigfaltigen Erfideinungen

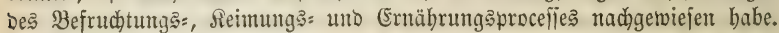

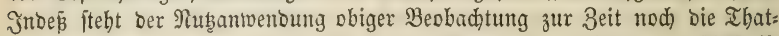
fache entgegen: baß bie forgfältigften, aud auf (Erforid)ung ber ftidfoffif= Galtigen Beítandtheile bes Bobens gerid̄teten 2(naltyjen, eine jentem (Experiment entiprechende 2(nbäufung von Alfalien nid)t nadıeifen. Bei Dem bes

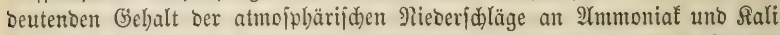
(ভeite 21, 22) müpte in cintem, längere 3eit in ßrad)e liegenten ßoben, in Boben unjerer Balbblöß̈n, Der Siebweibe entzogener, pflanzenarmer Eulturflächen, fđon nad) wenigen Jahren eine Duantität von 2Ammoniał uno Rali fid anjammeln, bie ber Beobadtung in mehr als "Spuren" fid ergeben würbe. Jerner mū man fragen: wem bie 2̂dererbe bas zuge= fübrte $\mathfrak{A}$ mmmoniat fo energija) binbet, woher rübrt bann ber ammoniafalijace Gerud) frijōer Garten= uno Dammerbe, ber bod) auf ein ftetes (Entweiden

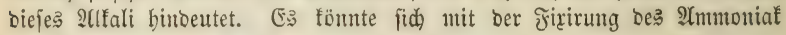
im Boben ebenjo verbalten wie mit ber Unlöslid) feit bes Şumus, bie nur in ber Digerirflajose bes Raboratoriums wirflid) bejteht, won ber ber Bobent

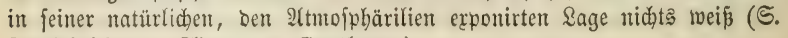
Feuditigfeit bes Rlima uno (Enäbrung).

\section{Suftitaub uno Salzröjungen.}

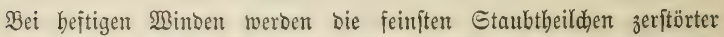
organijder Rörper in bie \&uft gehoben und erbalten fid barin, vom \&uft= ftrome getragen, Yängere ober fürzere 3eit. Mit Der Berounjtung Des Maffers geben ferner geringe Mengen aufgelö̧ter Ealze mit bem Waffergas in Die Suft uno werben fo ein Beftandtheil bes $\mathfrak{B a f j e r b u n f t e s ~ b e r ~} \mathfrak{B o l f e n =}$ region. Serbidytet fich biejer zu Regen, Edanee, Şagel 2c., fo fallen mit biefem aud) jente Gubjtanzen auf bie Erooberfläd) zurüd.

Die atmojphärifden Nieberjaläge beftehen baher nie auß burd)aus reinem $\mathfrak{B a f f e r , ~ j o n b e r n ~ e n t h a l t e n ~ f t e t s ~ e i n e , ~ w e n n ~ a u d ~ g e r i n g e ~ M e n g e ~}$ frember Stoffe, bie in neuerer 3eit am genaueften bon . Bertels ge: mefien uno beftimmt murben (Yournal für praftifabe Ehemie XXVI. ธ. 89-96. 1842).

Unter $\mathfrak{A}$ mahme einer 0,9 Meter betragenoen Şöhe fämmtlid̄er atmo:

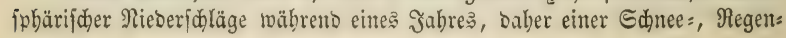


unb Thaumenge vont nahe fünf Millionen $\mathfrak{P}$ funbe jährlich auf $1 / 4$ Şeftar, fanb Bertels im Durdjidnitte aus monatlidy wieberbolten Unterjuđungen wäbrent eine? Jabreక

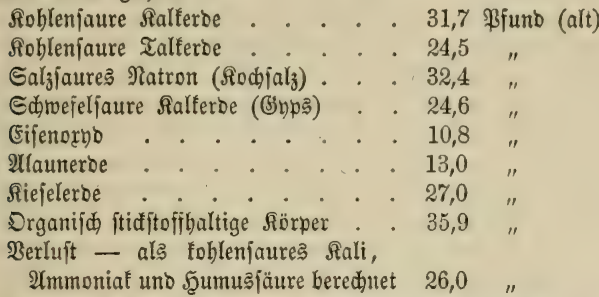

Summa 215,9 \$fund $=202$ Pfund neu fefte Rüufitänoe in ber Menge bes jährlidjen atmojphärifden Rieberjoblages auf $1 / 4$. Scettar, worunter 150 Pfuno Salze, Erben uno Metallorboe. 1

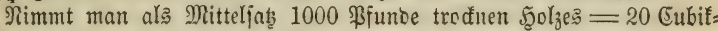

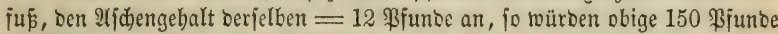
an Salzen 2c. für eine jäbrliche 5̧olzproduttion von 8,5 (Eubifmeter pro

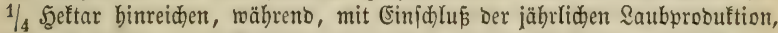
felbft in vollfommnen $\mathfrak{B e f t a ̈ n d e n ~ f e l t e n ~ m e b r ~ a l s ~ b i e ~ M a f f e ~ v o n ~} 3$ Eubifmeter

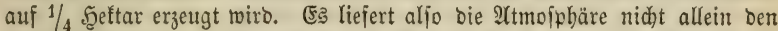
nöthigen Sohlenitofi, Gauerftofi und $\mathfrak{B a j i e r f t o f f , ~ f o n b e r n ~ a u d ~ b i n r e i d e n t o e ~}$

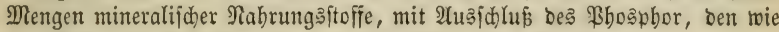

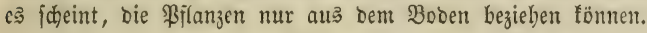

\section{2(mmoniaf แnঠ Salpeterfüure.}

In einer bewalbeten (3egeno Der $\mathfrak{B}$ ogejen unterjuchte Bouningault wäbreno ber Monate Juli bis November ben (behalt ber atmofphärifden

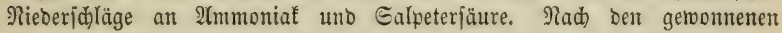
Rejultaten geben, bei einer Regenmenge von 0,62 Meter Edjidtböbe, Dem

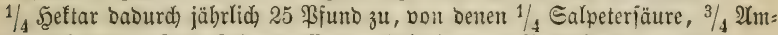

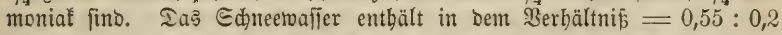

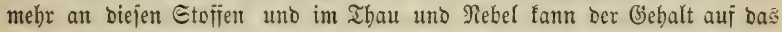

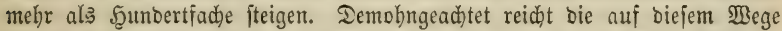

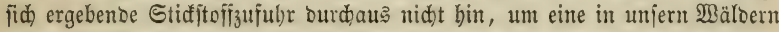
zeitweife fehr bebeutenbe Stiditoffprobuftion zu ergeben. In fehr reidhen

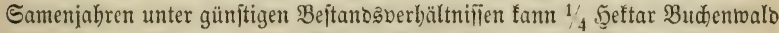

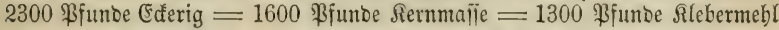
mit 9,5 \$roc. Etidjtofi = 123 \$funbe Etidjtofi erzeugen. Jene 25 Pfunbe Galpeterjäure uno $2(m m o n i a f$ Decfen aljo nur einen fehr fleinen Ibeil bes Bebarfs, zumal ba bon ihnen ohne 3weifel ein groper Iheil niăt zur 2Alf= nabme in bie $\mathfrak{B f l a n z e}$ gelangt.

1 Gtwas abrweideno bierbon fino bie Rejultate Der Interjudjungen Barral'sి. (Er

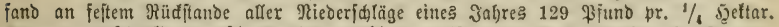
Darunter $55 \%$ Gnps, $7 \%$ Siodjals, $38 \%$ organifde, in Alether löstidje Eubftanj. 


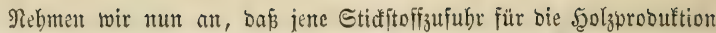

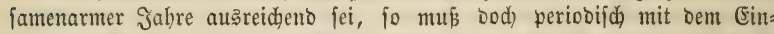

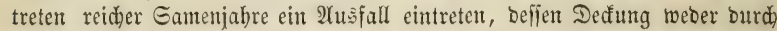
Den jäbrliden Blattabfall, nod) ourd bie abjterbenden I Ifierleiber ber Dammerbejuidjt erfolgen fann, da beibe jährlich reproducirt werben, Daber

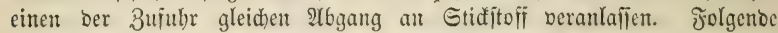
Syypothefen ftehen in Bezutg auf bie Duellen bes Mlehrverbrautches nabe gleidberechtigt tebeneinanoer: bedententer Irnmoniafgebalt Der bygrofcopif

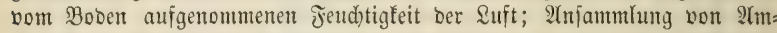
moniaf im Boben aus vorhergegangenten längeren 3eitrăument bes Minder= verbiaud)

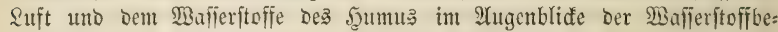
freiung. Der erften Senpotheje feblt zur Beit nod) jebe beftätigende That=

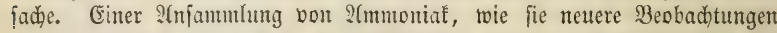

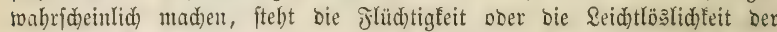

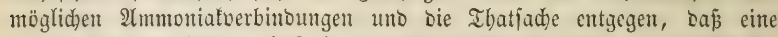

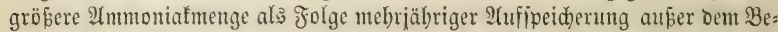
reidge unferer Erfahnungen liegt, ba

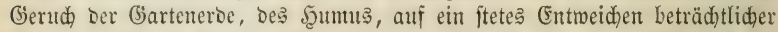

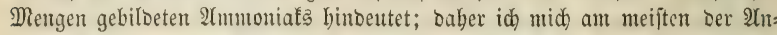
nabme binneige, einer ?tmmoniaf = uno Galpeterfäurebiloung im Şoben felbit.

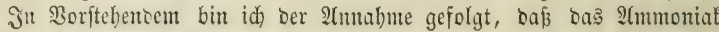
ber 2tmojphäre dem Boden zugehen müñe, um ans biejem von ben

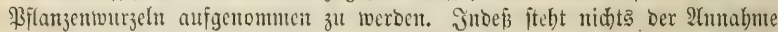

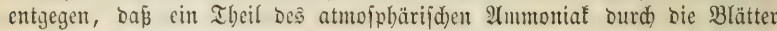
bireft der 2ltmoiphäre entnommen werbe. Miüfen toir zugeben: daj bief

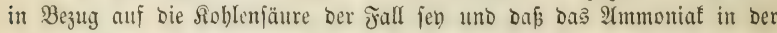
Sttmofphäre in Berbinoung mit ber Soblenfätre gas̆förmig vorfounmt, io liegt bie S(nutabme cintes gleidzeitigen Bejugez beiber als foblenfaures

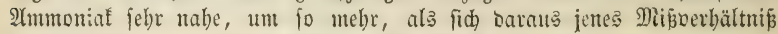
зıijden 3ufubr uno \$erbraud) am einfadjften erflären würoe.

Jn Bezug auf Den Uriprung Des Ealpeterjäuregehalț ber 2 tmofphäre

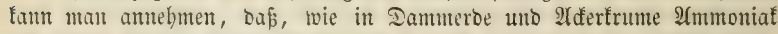
fid) bildon faut aus Dem SBafferftoff ber fid jerjeksenton organifichen Gub= ftanz uno ben Stiđfitofi Der \&uft, Ealpeteriäure ummittelbar in ber \&uft entftehen fömte ourd atmofphärifiche Eleftricität aus sem Gauerftoff bes zerlegten Bafiers uno Dem Etidftofi ber atmofpärifoben \&uit.

\section{马ెweites E̊apitef.}

\section{Som Sirima.}

Slima nennen wir bie örtlid beridiebene Eigentbümlidfeit Des Dunftfreifes unferer (Erbe, nad) befien Märme uno Jeud)tigfeitsmenge,

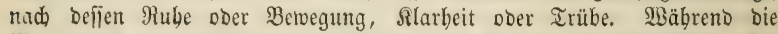

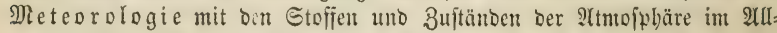
gemeinen fich beidäftigt, bat es bie $\mathfrak{R}$ limatologie mit ben bierin ört= 
lidh beftebenton Berfojiebenheiten zu thun. Man fönnte fie aud 2 Itmo= iphärograpbie nennen.

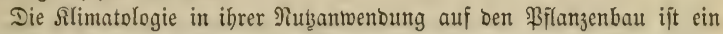
bejobräntter Ibeil Der allgemeinen Rlimatologie, inbem mand)e flintatifden 3uftänoe unferen Prlanzenbau überbaupt nidht berübren ober in ibrem Ein=

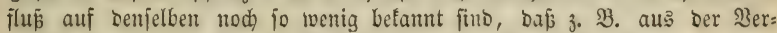

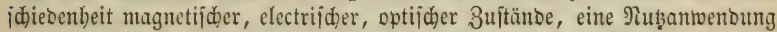

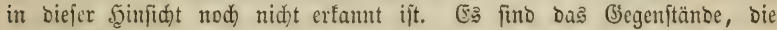
Der Wifienifhaft angebören, bie aber in $\mathfrak{B}$ ejug auf bie unz norliegenten 3reffe jur Beit nod) uno jo lange auper S(d)t bleiben fömen, bis eine Nubannenoung auj unjeren \$iflanjenbau gefunben ift. Wir mülīen in ber Be= färänfung hier jogar nod) weiter gehen unt alle auperbalb ber (brengen Mittel=

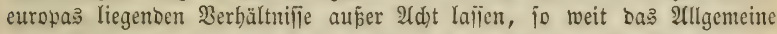
uno Ferne nid)t einer Erflärung Deş Befonoeren uno Şeintifajen bienjtbar ift.

Die, einer Dertlid)teit eigenthümlid\}e Bcidaffenheit oer 2 tmofphäre ift von

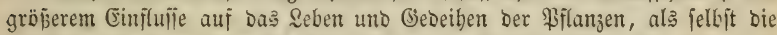

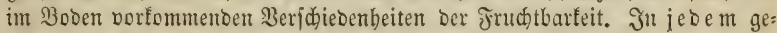
nügeno jeudten Boben fömen wir jebe Bflanzenart ergieben, menn bie

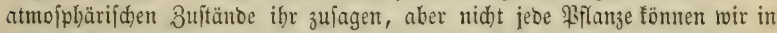
jebem Slima erzieben, jelbit nidht unter ben ihr günjtigiten Bobenverbältnijien.

Es gibt feinen Boben, Der nidjt bie zur Errnäbrung Der Bifanjen

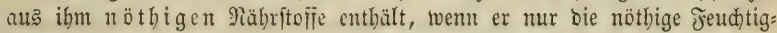
feit, Sodferbeit uno Tiefe befiţt. Dagegen gibt es Suftitriche genug, bie,

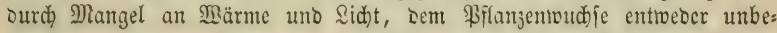
Dingt, ober Dod) in Bejug auf viele \$iflanzenarten fich abichliễen. Märme und Sidht fino bie widigtigiten Bebingungen Des Gedeihens Der Bflanzen.

\section{Dic $\mathfrak{B u ̈ r m t e . ~}$}

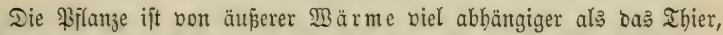

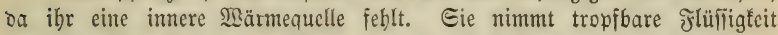

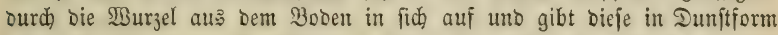

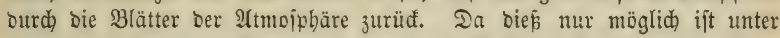

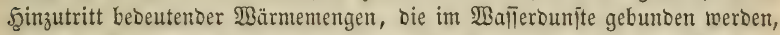
ba bieje $\mathfrak{B a ̈ r m e m e n g e n ~ n u r ~ a u s ~ D e r ~ U m g e b u n g ~ b e r ~ P f l a n j e ~ e n t n o m m e n ~}$

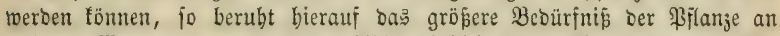

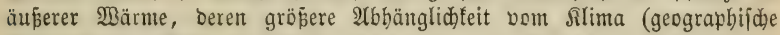
Berbreitung). Wiro bie \$ilanje währent ber \$egetationszeit non aupen ber nidht in Dem Maje erroürmt als ibre Berbunftung biés exforbert,

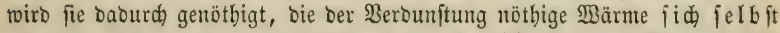
zu entnehmen, dann erfaltet fie biersurd rajd in bobem (3rabe, felbit bis zum Jrofttobe bei einer Temperatur, bie auf bas thierifde Seben ganz chne nadbtheiligen Einflus ijt. Darin, in ber Eelbiterfaltung surळ organij̄e Э̧erbunftung uno nid)t in einer unerwiejenen, überwiegenden Wärmeftrablung

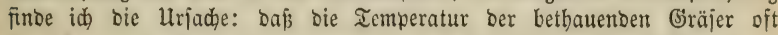
$5-6^{0}$ unter bie Temperatur ber umgebenden Suftididenten binabjintt; baraus erflärt es fid, wenn bie lebendigen Eäfte felbjt ber zarteften \$flanjentbeile 
auch) in ber grösten Sonnenbibe fübl bleiben, wenn an ben beifeften

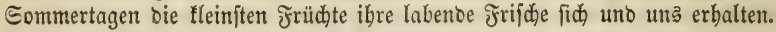
Daber wirfen alle in bie Begetationszzeit fallenden, wenn aud geringen Jrüb) = uno Spätfrötte fo nadłtheilig auf bả \$flanzenleben ein, wäbreno auserbalb biefer, im Spätherbjt uno im Binter, bie Säfte jelbit zärtlider

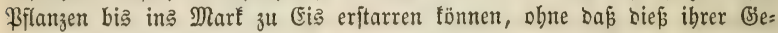
funbbeit nadtheilig wiro. Went gewiffe Pflanzen ber heifen Bone in unjerem Slima fijon bei $4-5^{0}$ Märme erfrieren, andere \$flanzen beffelben Baterlantes meniger empfindlich finb, fo bermag id) eine Erflärung bierfür

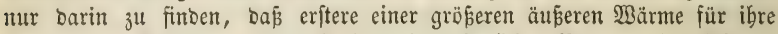
Berbunftung bedürfen. Das Ridftgedeiben füblidjer Pflanzen im fälteren

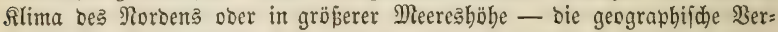

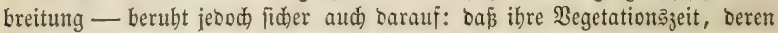
Infang uno Enoe, ber Wärmevertheilung im nörbliden Nlima nid)t ent= fpridht, in Beiträume fällt, Detten bie nöthige Wärme fehlt. Das $21 c c l i=$ matifiren ber Bflanzen mag vorzugstoeife wobl in einer 2 er: änberung ber Begetationstermine beruben.

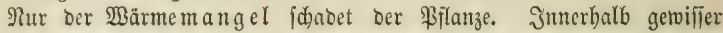

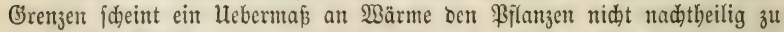
jebn. Die Bletjderweiben gebeiben redt gut, felbft in ber warmen Suft unjerer Treibhäujer.

Die $\mathfrak{M a} \mathfrak{r}$ me ift zugleidh ber twidtigite Faftor aller anberen ver=

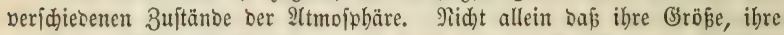

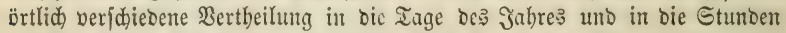
Des Tages an fidh einen mejentlichen Einfluṕ auf bas \$illanzenleben auts

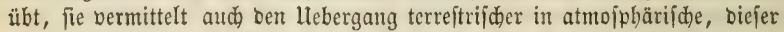
in terreftrijhe Fendigtigeit, fie ift ebenjo bie Urjadje jeber \&uftbetwegung uno baburd ber Mijd)ung uno 2 Utagleidung warmer uno falter, trodner uno feudter, Elarer uno getrübter \&uftmajier.

Die einzige beadtensmerthe Duelle atmoiphärifher. 2 Bäme ift bie Sonne.

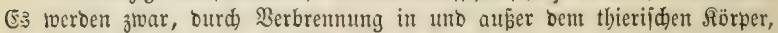
an fid) nid)t unbedeutento Wärmemengen frei, allein im Bergleid zur Gonnentwärme ift beren Menge ood) cine verid)minoent fleine. $\mathfrak{A} u d$ muf, beim fteten Wedjel in bor Bufammenfeß̧ung brennbarer Rörper ber Erobe, auj ber anberen Seite eine $\mathbb{B a ̈ r m e m e n g e ~ g e b u n t o n ~ w e r b e n , ~ b i e ~ b e r ~ M e n g e ~}$

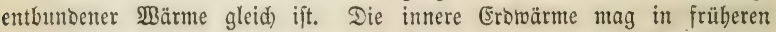

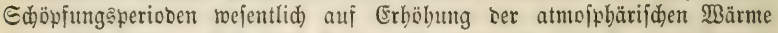
mitgetrirft baber. Daß bießs beute nid)t mehr ber frall ift, geht baraus hervor: Daß bie Bobentoärme bỉ zul ciner Ticje bon 22 Meter abivärta, Den Iemperaturbifferenzen ber 2ttmofphäre, wenn audh langfam uno er= mäbigt folgt, in jener Tiefe fortbauerno eine, ber burdjidnittlid jäbrlichen

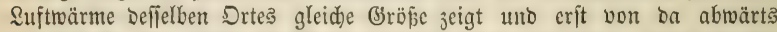
um $10 \Re$. mit jeben 31 Deter gröferer Tiefe zunimmt. Das follechte

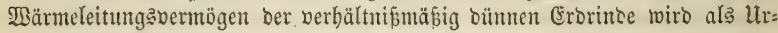

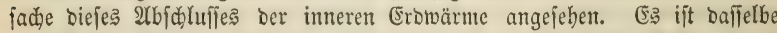

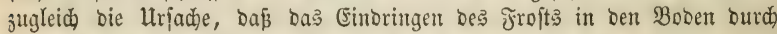
Bebecfen beffelben mit Saub, Stroh, Mifit zc. berbinbert ober gentäpigt, wiro 


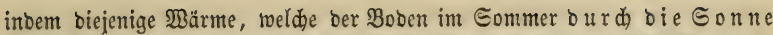
erbalten hat, baburd bis tief in ben Minter binein in ihm zurüđgehalten wirb.

Sit $e^{3}$ aber bie Sonme allein, weldher bie 2 tmopphäre, ber Boben uno Dus Pilanzenleben ben nöthigen Bebarf an Wärme berbantt, jo mú bie Menge berfelben zunäbjit abbängig jẹn von ber Beitoauer bcr Sonnentwirfung, vom

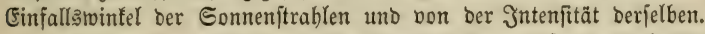

Ter gröbte Iheil ber Eonnenwärme wiro erft ba entbunden uno wirffam, wo ber Sonnenitrabl ben Eroförper trifft. Dhne Unterbredung gibt ber Eroförper bie empfangene Wärme an bie ifn einbüllenben \&uft= fäichten $a b$. Die 3unahnte jeiner Erroürmung bängt baher bavon $a b$, bá

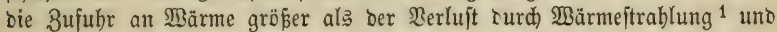
Seitung ift. Bon Eonnenuntergang bis Eonnenaufgang feblt bie Bufubr

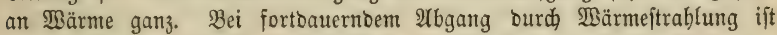

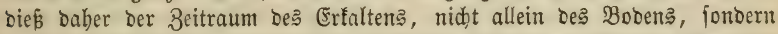
auch ber Suffididten, bie ihre vom Boben empfangene Wärme fehr rafd) an ben falten Şimmelşraum abgeben. Die niebrigfte Temperatur mus an Enoe biejer \$eriode bes Morgens furz bor unt nad) Eomenaufgang ftatt= finben. Je höher bie Sonne gejtiegen ift, um fo mebr erwärmt fie ben

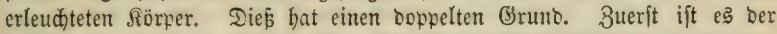

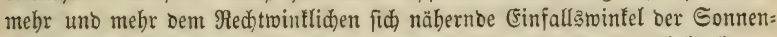
jtrablen, mit ऽem eine gröfere Єumme von Wärmejtrablen ben beleudjteten Rörper trifft, bie ihr Marimum beim hödiften Eonnenjtande erlangt. So: Dann gibt aber aud ber Eonnenitrabl, ehe er Den Eroförper trifft, zlwifden $1 / 3$ uno $1 / 2$ feiner Bärme an bie Dïnjte ber \&uftididden ab, bie er burd)= bringen núf, ehe er ju ben feften Rörpern ber Frobe gelangt. Je niebriger

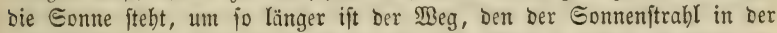
Utmojphäre zu Durdwantern bat, um jo mebr Märme gibt er an Dieje ab. mit $\iota \mathrm{m}$ jo geringerer Intenjität ber $\mathfrak{B a ̈ r m e}$ trifït er bie Rörper ber Eroe.

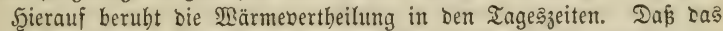
Marimum ber Märme nid̆t in bie Mittagsftunbe, jonbern etwaß über zmei Etunden ipäter eintritt, liegt in bem bis babin fortbauernben Uekergetwidyt

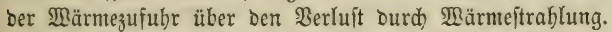

Wie befant berfolgt bie Gome in ifrem ideinbaren Sauf um

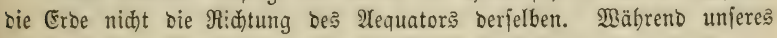

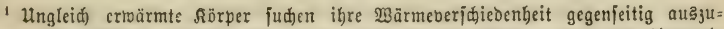
gleiden. Undurdjiatige 3rija)enförper leiten bierbei bie Wärme ourd fid) binourd, indem fie fid) felbjt baburd) erroärmen (gcleitete $\mathfrak{B a ̈ r m e ) . ~ D u r d j i d f t i g e ~ 3 r i f d e n t o ̈ r p e r ~}$

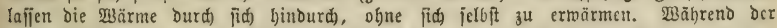

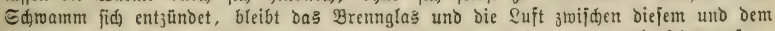

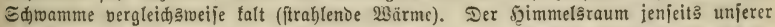

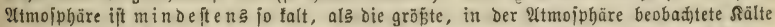

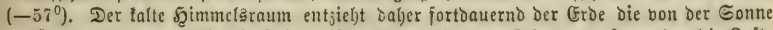

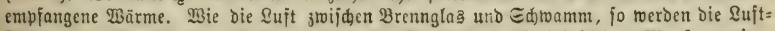

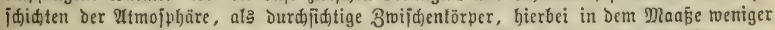

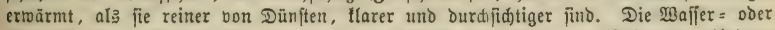

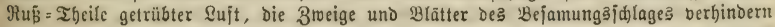
niđ)t unnittelfar bie Wärmeftraflung, aber fie nelmen bie firahlende wärme bes Boden in jid auf, erloärmen von fid) aus bie fie umgebende Suft und verringern baourd bie

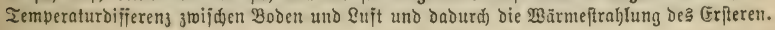


Winters ift fie mehr ber jüblidjen Erobälfte, während unjeres Sommers ift fie mebr ber nörbliden Erobälfte zugewentet. In Folge beffen joheint uns bie Sonne im Sommer böher am Simmelagetwölbe binauf zu fteigen als im 2 Binter; ibre Strablen treffen uns im Sommer fentredter als im Winter uno geben auf bem fürzeren Weg burd) bie 2Utmofphăre meniger Bärme an leb̧tere ab. Die ungleiche Bertheilung ber Sonnentwärme in bie Jabreşzeiten hat baher biefelben Urfad)en roie bie Märmeunterfajicoe zwifden Gonnentaugang uno Untergang eines Iages. (Es tritt bierz̆ aber nod) bie Yängere Dauer ber Sonnembirfung in ben furzuädtigen Sommer: tagen, Die ber $\mathfrak{B a ̈ r m e z u f u l g r ~ e i n ~ b e b e u t e n d e s ~ H e b e r g e n v i d h t ~ u ̈ b e r ~ b i e ~} \mathfrak{B} a ̈ r m e=$ ftrablung gibt. Das Hebergetwidt ber Sommertage über bie Sommentäd)te fteigert fid mit größerer (Entfernung vom Slequator unb biejem llmitande ift es

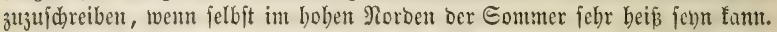

Dieferben Urfachen liegen aud ber Bärmeabriabme zum Grunte,

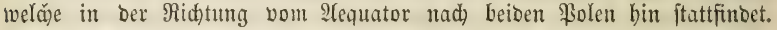
Эe weiter ein Drt vom Aequator entfernt liegt, um fo fabräger treffen ibn

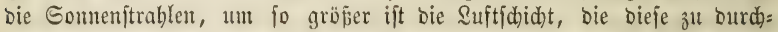
laufen haben, che fie ben Erbtörper treffen. Ohne ftörenbe Einfluiffe würbe

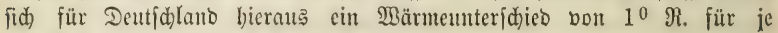
30 Meilen meribianer Rid)tung ergeben.

Bis baher lafien fidh bie einem Drte eigentbümlidjen Temperatur:

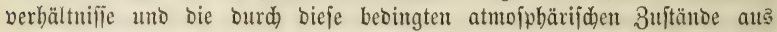
feiner geographifonen Lage, aus feiner Stellung zut Gonne herleiten. Die atmojphärifchen 3uftänbe, wie fie hiernad) cinem Drte eigen fenn müpten, wemn fie nidgt bout anderen, bie Sonnentwirfung mobificirenten Berbält: nifīen abgeänoert wären, bezeidhnet man als befien geographifd)es ober jolares Slima. Solder, bie Somtenwirfung abändernoen Berbältnifie gibt es aber fo viele unto fo einflupreiche, dap vielleidyt nirgends lare Rlima in ber Birflidfeit beftebt. Dahin gebören

a) Die veridjedene (Erhebung Der Drte über bie Meereşfläd)e.

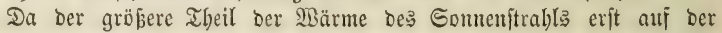
(Erbe entbunden wirb, erleiben aud bie, biejer zunädjt liegenten Suft= jichidten bie gröpte Erroärmunt; fie behnen fid in Folge belien alt?, werben Yeidter uno mülīen burd) bie überliegenten fälteren Suftidjidten in bie Szöbe fteigen. Daburd bermintort fid) aber ber auf ihnen laftente

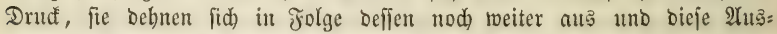

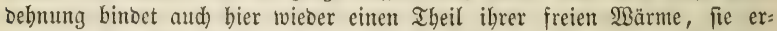

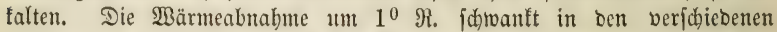

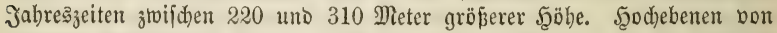

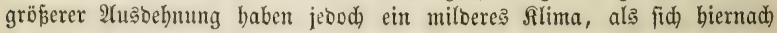
ergeben würbe, da bie Sonnenjtrablen nad) einem fürzeren Wege burdy bie Euftidjidten ibren Booen treffen; ifolirte Bergginfel baben ein rauberes Slima, da fie bie empfangene $\mathfrak{B a ̈ m}$ rafd an bie fie umgebentoen \&uft=

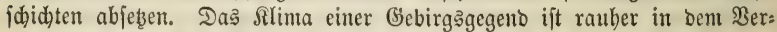

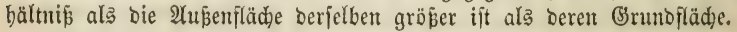

b) Die Lage uno Entfernung gröferer $\mathfrak{B a f f e r m a f i e n . ~}$

Durd bie Berbunftung riro $\mathfrak{B a ̈ r m e}$ gebunoen uno ben bie $\mathfrak{B a f 1}$ er: 
fläđ)e überlagemben \&uftichidjten entzogen. Heber bem Kenadbarten Jeft=

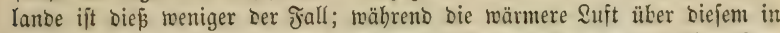

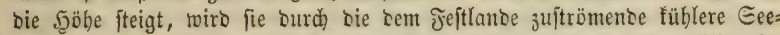

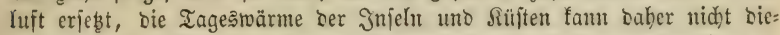
jentige Scöbe erreidjen wie bie Des Bimnenlantoes. Dabingegen erfaltet zur

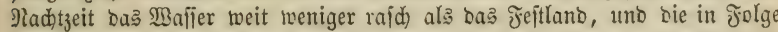
Defien wärmere Geeluft erieb̨t im Sireialaufe bie ber Gee zuftrömente fältere Sanoluft, woburd, wie bic gröpere Errwärmung fo aud bie gröfere Ertaltung ber Ranbluft berbindert wirb.

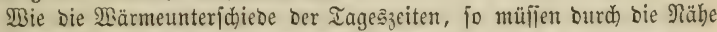

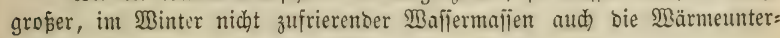

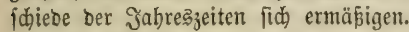

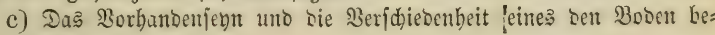
bectenden ßilanzentwudjés.

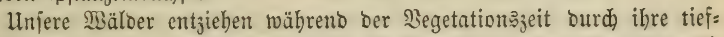
greifente Betwurzelung Dem Boben grobe $\mathfrak{B a f f e r m e n g e n ~ u n o ~ g e b e n ~ f i e ~ b u r c h ) ~}$

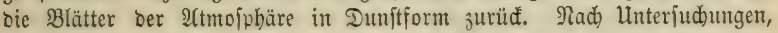
bie id in berwidjenemt Eommer ausgeführt babe, berounjtet ein 20jäbriger,

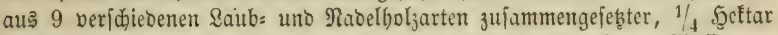

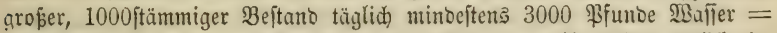

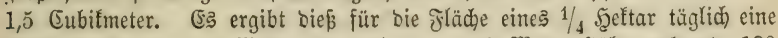

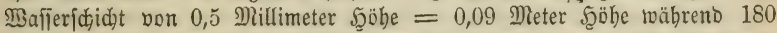

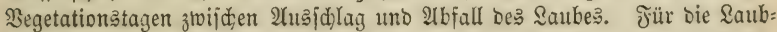

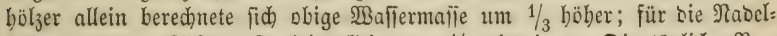

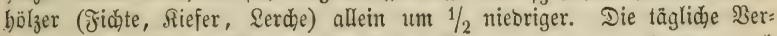

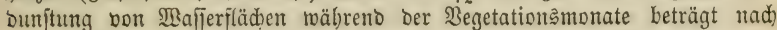
Eđübler nabe 12 Eubifjoll per Duabratiun, Daher 2,2 Millimeter Edjid)t=

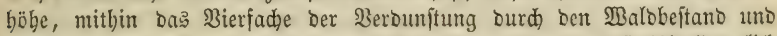
jelb/t bie Berbunjtung bes Bobens in Derjelben Beit $=7$ Eubitzoll täglid) vom Duabratfu仿 $=1,1$ Millimeter Edidthöbe ${ }^{1}$ überfteigt bie Berbunftung

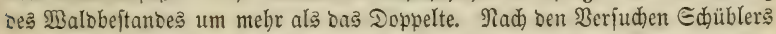
ijt bie Berounftung einer Rajenfläche um bas 2-3fad)e größjer als bie

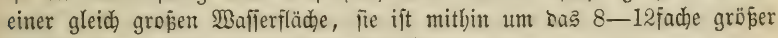

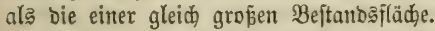

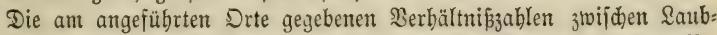

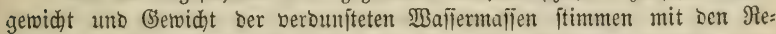
jultaten meiner Unterjudungen nidht überein. Mähreno Єdü̈bler bie

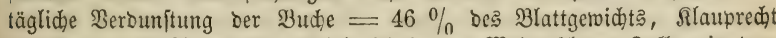
Diejelbe $=36 \%$ angibt, erbielt id in ber Mebrzabl ber fälle ein Dent

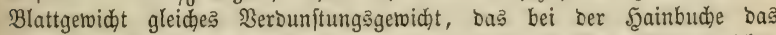

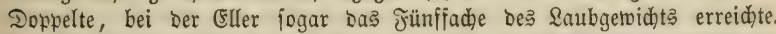
(5: liegt biejer Unterjaieb wobl Darin, baj bie Nerbunjtung überbaupt

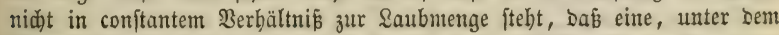
Bebarf belaubte \$flanje ben \&aubmangel burd reidjlidere Berounjtung auts Den borbandenen. Blättern erjeb̨t, eine über ben Bebarf belaubte Pflanje

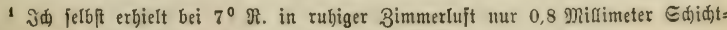
böhe bes aus nafiem Boden tägliđ berdunftenden Majīerక. 
bingegen burd) jebes 3 latt weniger verbunftet. (Es fteht bieß in gutem Einklange mit ber bon mir nadgetwiefenen Thatjadje: baj eine, über einen gewifien Bebarf gefteigerte Belaubung feines̆megs von einer bem entfpredenoen 3uwadjserhöhung begleitet ift.

2uf Grundlage ber Rejultate meiner Unteriudyungen würbe ben betwalbeten Fläden eine geringere Berbunitung als ben $\mathfrak{B a f l e r f a ̈ d}_{\text {en }}$ uno Freilagen eigen fenn, ba audi ber bom Saubjdirme unb yon bem $a b=$ gefallenen Saube vor rajdem Suftwedjel gejdübzte Boben obne 3reifel

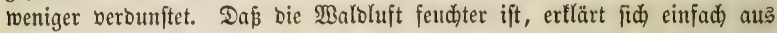

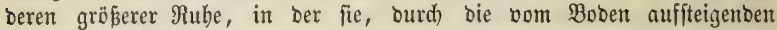
Dünfte, mehr ober weniger mit Feuditigfeit gefättigt ift, woburd) ebenfalla

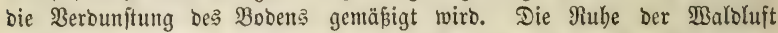

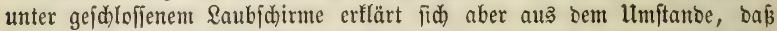
bier bie Gomentwärme nidht auf Dem Boben, jonbern über biefem, im

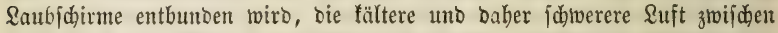

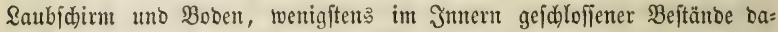
Durd) nur wenig beunrubigt wirb. Daher bas Raujden uno flüftern in Den $\mathfrak{B i p f e l n}$ Der Bätme aud bei rubiger Suft im Freien uno unter Dem Saubfairme.

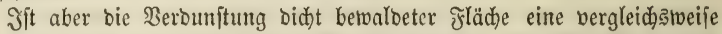
geringe, fo mirb bier aud weniger $\mathfrak{B a ̈ r m e}$ gebunden, bie Betwaloung múp

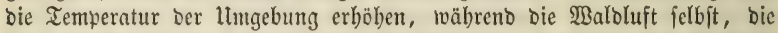
Suft unter Dem Saubjhirme, hei Tage wentiger erwärmt, zur Nadizeit

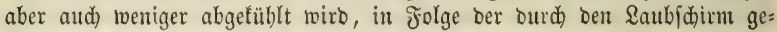

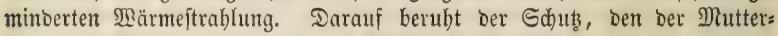

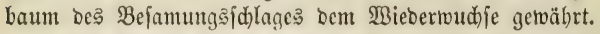

Der herborftechente Einfluई Der Betwalbung auf ben Duelfenteidythum Der Ränber erflärt fid aus Borftebendem febr einfad). Der geringe Majjerbebarf ber Misalobäume hat zur Folge: daßj bie ganze, ben Boben

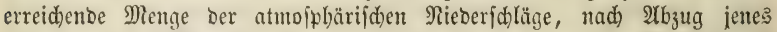
Bedarfs in sie Bobentiefe binabfintt, ba bie feude rubige Walduft ibr Berbuniten in böhcre (Srabe ermäßigt. ${ }^{1}$

$\mathfrak{B}_{\mathrm{c} n}$ bie fommergrünen Raubholzwäloer in fofern günjtiget in biejer

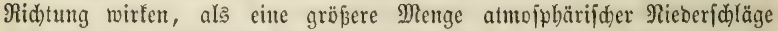
währent bes Yaublofen 3uftandes ben Boben zu erreichen vermag, gleid)t

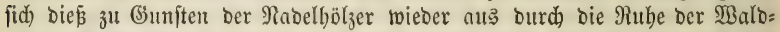

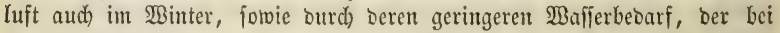
ver Fidste $=1 / 2$, bei Der Särdye $=1 / 4$, bei ber Riefer $=1 / 7$ Deß

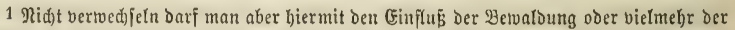

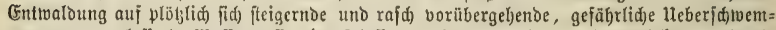

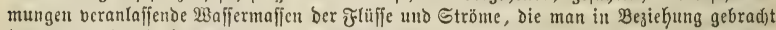

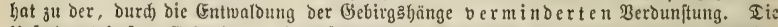

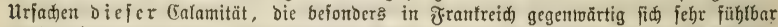

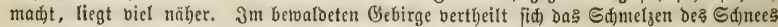
auf cinen viel lä̈tgeren Beitraum Durd) Den ভđaub, ben ihm ber Raubjđirm gegen bie

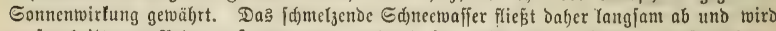
grofentbeiţ vom Boben aufgenommen, twährend im unbelvaldeten Gebirge grofe Sdnnee=

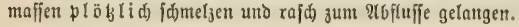


Mafierbebarfs ber Şainbuđje utb Eller ift, bie unter ben \&aubb̈̈lzern bie grö̈̈te $\mathfrak{B a f l e r m e n g e ~ v e r o u n f t e n . ~ D e r ~ M a f l e r b e b a r f ~ b e r ~ \$ a p p e l ~ u n o ~ B i r f e ~}$ ergab fid $=2 / 3$, Der ber $\Re$ othbuche $=1 / 2$, Der ber (Eid)e $=1 / 3$ jentes

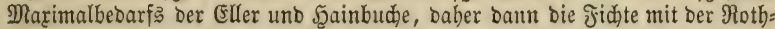

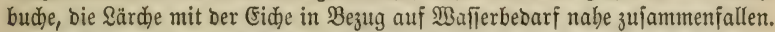

Die Thatjadhe, bas Entwaloung in gewiijen Fällen Berjumpfung

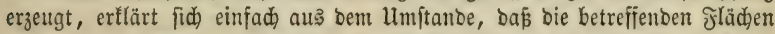
Sumpf jenn würben, audi wenn fie nie betwalbet getwejen wären, bap bie bişherige Berwaloung ourd taujenbe lebendiger ßumpwerfzeuge bie ü ber:

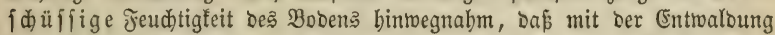

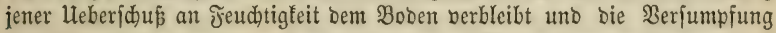

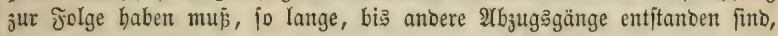
bie fid nidjt jelten nad) mebreren Jabren von felbjt bilden, rabrjdeinlid,

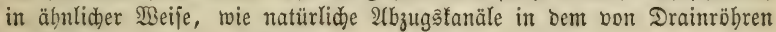
Durdjogenen (Froreid entifteben.

Eteigert Der Duellenreidtham eines Bobens ben Şandel uno Gemerb:

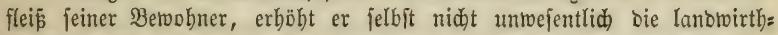

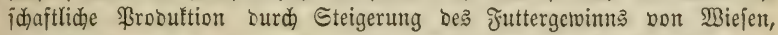

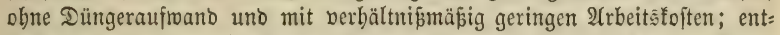
fpringt einerfeits ber Quellenreidthum, anbererjeits ber Edub gegen Ueber= fadwemmungen uno Berjanbungen Der fłüfie unt Etröme twejentlich ber Bewaldung bes Landes und zwar eines folden, Deren Sronenichlup eine

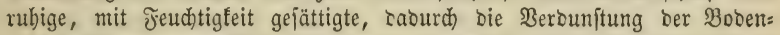

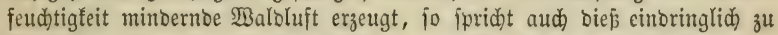

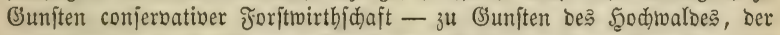
Sुeritellung uno Erbaltung vollen Fronenifhluijes in einem Umtriebe, bis

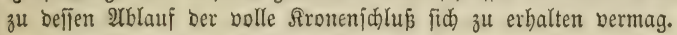

d) Die exponirte ober gefdüß̨te Sage.

Die Unebenbeiten ber Erboberfläde, beren Beptaltung uno bie Lage

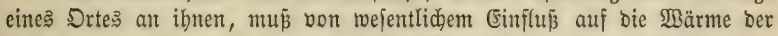
Suft fenn, weil von leb̧terer ber Einfallsmintel ber Eomenftrablen $a b=$ băngig ift, ferner weil bie gebirgige Erboberfläd)e nidłt mehr Wärme

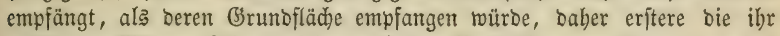

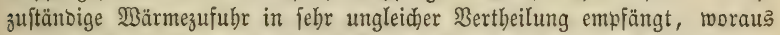
notbwenbig eine eben fo ungleide (Erwärmung ber benadbarten \&uftidjidten

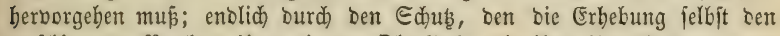
beridjiebenten \$unften ibrer eigenen Oberfläd)e twie ibrer Umgebungen gegen herrichende \&uftifrömungen und beren eigentbümliçer Märme ooer Sälte, Feuchtigfeit Doer Trođenbeit gewäbrt.

Die ungleidje Erroärmung unebener Erobberfläden hat zur frolge, Daj̃ an ben früber uno in höherem Grabe erwärmten Drten bas ßilanzen=

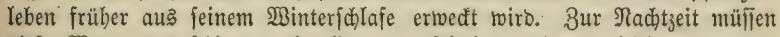

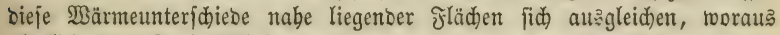
plößzlidye uno ftarfe Erfaltungen bervorgehen, bie bem vorzeitlid) erwectent \$Flanzenleben oft töbtlid finto. ${ }^{1}$ Jn unebenen $\mathfrak{B a ̈ l b e r n ~ f i n o ~ f e b r ~ b a ̈ u f i g ~}$

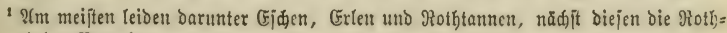
budje uno ber Bergahorn. 
bejmbere Froftthäler, Frofthänge, Jroftitrid)e Bejdäbigungen

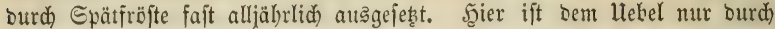
Ánbau folder Selzarten abzubelfen, bie erit fpät im Jrübjubr zu treiben

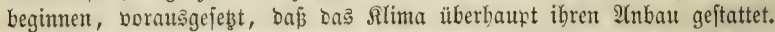

(5: mag biefs genügen um Darzuthun, mie bielfältig uno mächtig bie Berbältniffe fino, weld)e ben Eharafter bes geographifd)en Sllima in Bezug auf befien Temperatur veränbern. Die burd) bas 3 ufammentwirfen aller

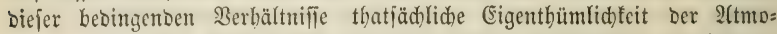
fphäre cines Drtes heift befien phbiffalifdes, befier beffen reales-

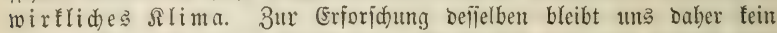

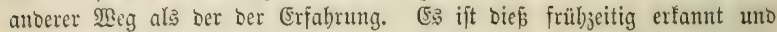
ičon feit längerer Beit fino an bielen Buntten Der (Erooberf(äche zablreid)e Beobad)tungen in biefer sinficht angeftellt unt verzeidnet toorben. In Bez̆ty auf Die $\mathfrak{B a ̈ r m e}$ bat man aus bent Minimum uno Maximum ber Tageșoäme bie burdjidnittlid)en Iagestemperaturen, ants bicfen bie monat=

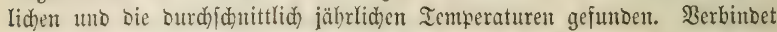
man auf eitter Rarte biejenigen Drte Durd) eine fortlautfonde Sinie, Derent Durdjfdnittlid) jäbrlid)e SBärmemenge biefelbe ift, fo nemut man biefe Sinien Siforthermen. Conftruirt man folde Sinien nad ben Beobad =

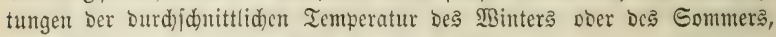
fo beipen biefe Sinien Sfodimenen uno Jiotheren.

Die mittlere Salrestemperatur fann für bas füblidhe Deutidlano =

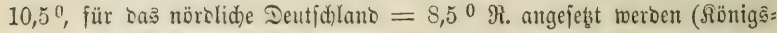
berg $\left.=6,5^{\circ}\right)$.

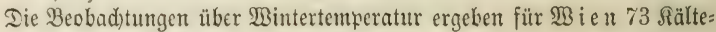
tage ${ }^{1}$ mit burdj(d)nittlich $-2,1^{0}$ Sälte, 112 2 ärmetage mit Dutrdjajnitt=

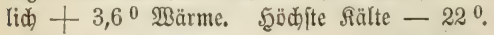

Jür $\Re$ arlgrube

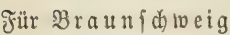

Jür Berlin

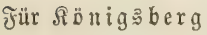

22 Rältctage burdjobnittlic $-0,70$. 128 23 ärmetage Ђöd)fite Rälte 20 Sältetuge 160 Bärmetage

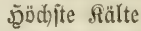

92 Rältetage

85 Wärmetage Söchite $\Re a l t e$

108 Rältetage

89 Bärmetage

Jjödjte Rälte
$+2,7 \%$ $-270$ $-1,8 \%$ $+3,70^{\circ}$ $-27 \%$ $-1,50$ $+3,50$. $-30 \%$ $-2,80$ $+3,80$ - $34 \%$.

Die תältetage fallen nidjt zufammen, fontern fie vertheilen fich in

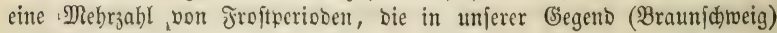
burdifdnittlid folgendermaken liegen.

(Etwas nad) Der Mitte Des Geptember tritt nid)t felten eine erfte Rälte ein, bei Der gegen Eomenaufgang bie Temperatur unter $-1^{0}$ fintt

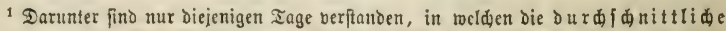
Tagestemperatur unter 0 iff, nid̆t aud bit jogar größere 3 abl berjentigen $\mathfrak{I} a g e$, an benent

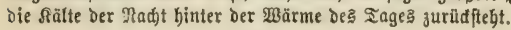


(Reif), währeno bie Mittagänärme nod) $13-15^{0}$ beträgt. Seltner gegen

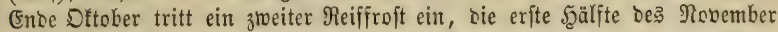
bringt ben eriten Ednee, felten hobe Rältegrabe $\left(1812-15^{\circ}\right)$ bie Tages= rörme pflegt 50 jelten зu überiteigen. Der December ift vergleid)șmeije milde uno erit gegen (Enoe bes Mlonats bleibt bas Thermometer aud am Tage unter 0 . Bis baher famm man bie in 2(bjäţen eintretenden fröifte als $\mathfrak{g}$ rübfrö fte bezeidinen.

2lnfang Januar tritt Die erjte $\mathfrak{B i n t e r f a ̆ l t e ~ m i t ~}-10$ biß $-15^{0}$ ein, ermäpigt fid gegen bie Mitte Des Monats uno fteigt bie Märme in Der leţten Şälfte bellelben nidyt felten über $+5^{0}$. Die zweite Minter= fälte, felten über $-4^{0}$ fteigent, tritt 2 nfang Jebruar ein, bie britte: Mitte Februar mit -4 bis -70 , nad) einer furzen Märmeperiobe. Gegen bas Ente bes Februar fteigt bic Wärme nidit felten auf +10 bis $+15^{\circ}$. J̧r folgt 2 Anfangs März eine bierte, Ende Märs cine fünfte Winterfälte, eriftere zwijchen -1 uno $-9^{0}$ [d)wanfent, leţtere felten

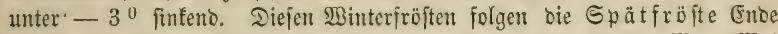

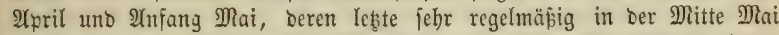

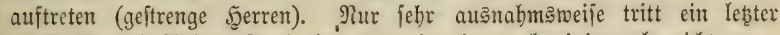
Reiffroft nad) 2(njang Juni ein, ber mir aber bod) einigemale nid)t uner= heblidjen Edaben gebradtht hat.

Bejonbers ber leb̆te Sinterfroft Enbe $\mathfrak{M a ̈ r}$, bei bem bie burdjidnitt= liche Tageŝtwärme bäufig $8-10^{0}$ erreid)t unt bas \$filanzenleben erwedt

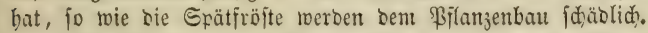

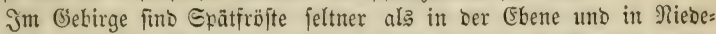
rungen, Da Dort bie Begetation fräter uno erft bam erwecft wirb, went im Fladlante bie Periobe ser Epätfröfte bereits vorüber ift, bon too $a b$ bie 2 ärme ber Ruft bes benad)barten Flad)lanbes eine bebeutende Tempe= raturerniebrigung ber Bebirgaluft verbinbert.

Rach Den Wärmeeffecten untericheiden wir innerbalb Der SBrenzen Ieutid)lanos

\section{Beintlima}

Pittlere ฐabresె= temperatur.

Sopfen: uno Dlaištlima Wintergetreibetlima

Sommergetreibetlima (brenze ber Aderfultur Brrenze dee Walobaus Sdnneegrenze $7-8^{\circ} "$

$6-70^{\prime \prime}$

$5-6^{\circ}$

$4-5^{0}$

$3-4^{0} "$

$2,70^{\prime \prime \prime}$

$$
\begin{gathered}
\text { 9obenbearbeitung } 9= \\
\text { zeit. }
\end{gathered}
$$

9 Monate

8 "

7.

$6 \quad$ unter 6

(5马 ift eine folge geringcrer $\mathfrak{B a ̈ r m e ~ b o ̈ h e r e r ~ \& u f t j o b i c h t e n , ~ w e n n , ~ i m ~}$

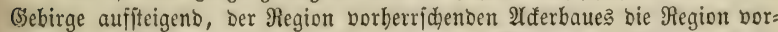

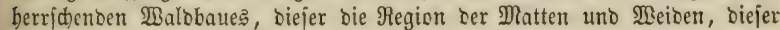
Die Region des etvigen Єannees und Eifes folgt; wenn innerbalb bes

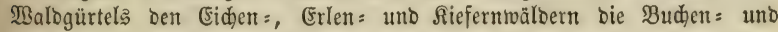
Bergahorne, biejen bie Fideten uno Tannen, biejen bie Zwerg = uno Zirbel= fiefern, mit ber Alfpeneller uno ben Allpentweiben, biefen bas Fogmäen=

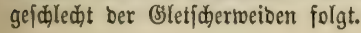


Es ift ebenfo eine Folge geringerer Wäme, wenn Sapplano nur 500, Dänemarf 1034, Deutficland 2000, granfreid) 3500, Europa über: baupt 7000 berjobiebene $\mathfrak{A}$ rten $B$ lüthepflanzen trägt, eine Mannigfaltigfeit

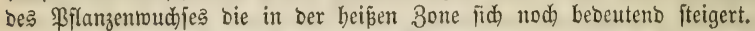

Die größere Mamnigfaltigfeit im Bflanzenwudje jüblicker Slimate hat

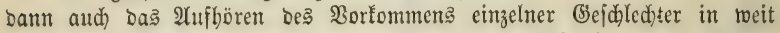

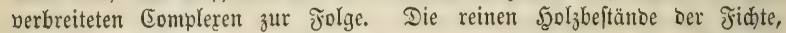
Riefer, B̈udhe fommen jüblid) bem 48 ften Breitegrabe nur nodh in Siebirgen vor, wenn fie uidét fünftlid in ber Gbene angebaut wurben.

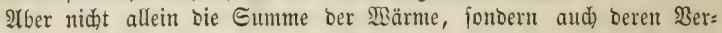
theilung in bie Jabreszeiten bat einen meientliden Einflus auf ben Bflanjen= wuch). Unter bem 2Hequator baben alle Jabreşjeiten faft gleidhe Iemperatur, bie Begetation fam baher bas ganje Jabr ungeftört vor fich gehen, uno

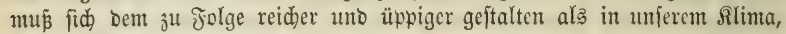

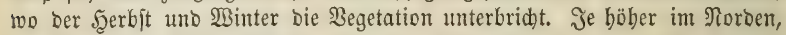
um fo mehr verfürst fïh bie 3eit bes \$flanzentwudjes, um fo geringer würbe bas Rejultat berfelben fein, wenn nid)t bie foblenftoffipeichernoe Rraft unferer geidhlofienten f̧odjwäloer ein (Segengewid)t Darbötc.

Heber bie geographifhe Berbreitung unferer forftliden Sulturpflanzen

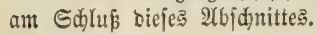

\section{2ณฉี ฉiđut,}

cin treuer Begleiter ber Märme uno aus Derjelben Duefle fließ̄ento, ift

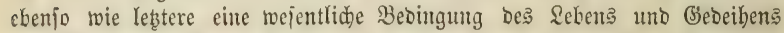

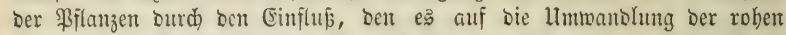

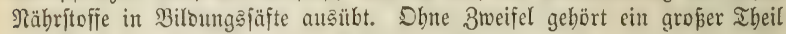

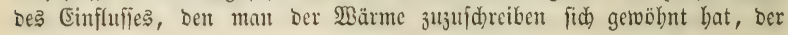
gleidzeitigen 乏id)twirfung an.

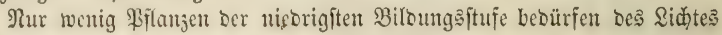

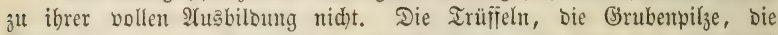

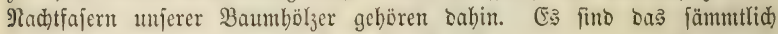
Pflanzen, bie von organifdem Gtoffe fid ernäbren, einer Berlegung unorganijder Soblenjäure Daber nid)t bebürfen. Daffelbe ift ber frall bei allen höher entmidelten Biflanzen in sen frübeften Stabien ibres Reben?. Der Rein entwidelt fich im Eamentorne aus organijyem Etofie, ben ifm bie Mlutterpflanze in ben Eamenlappen oder im Eantenweis mitgegeben bat. Im Reinungsprocelle bebarf Daber bie \$flanje ber Sidtuirfung nidjt. Das

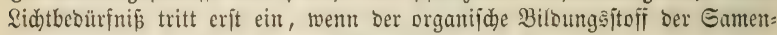
lappen verbraudit ijt uno neue Biloungäjäfte aub ber Berlegung von außen aufgenonmener Soblenjäure, aufgenommenen TRafiers bereitet weroen müfien. Da bie 3erlegung Der Roblenfäure Gauerftoffabjacibung jur Folge hat, fo fällt Der 3eitpuntt cintretenden ¿idtbedürfnifies mit bem Beginn ber Eauer: ftoffabjcheioung zujammen. 1

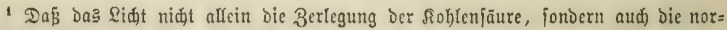
male $\mathfrak{B}$ erbunftung bermittle, habe id) Durd) bas nadjolgende (Erperiment ermiejen. Junge Pilanzen vom söwenzabn, in cinem Blumentopfe unter Glasglode wachjens, iditeden 
Wie wir im phyfiologifdyen Theile fehen werben, wieberholt fich in

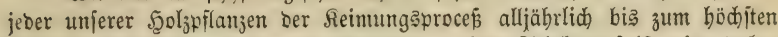

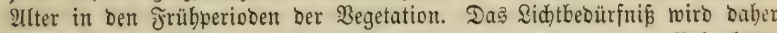
in biejen ein geringeres fein als fpäterhin, menn bie erneuete Belaubung

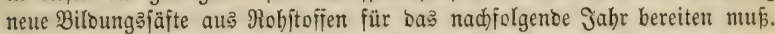

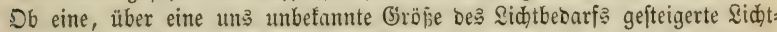

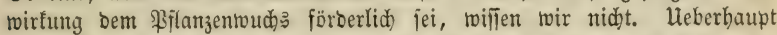
treten bier ber Beobadhtung aupergetwöbnliche Sgitnoernifie entgegen, Da, bei

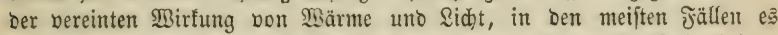
unmöglidy ift, benjenigen SAntbeil an Errolge, weldjer ser sidbtwirfutg

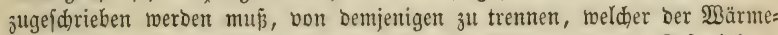

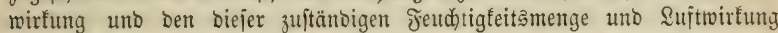
angehört. $\Xi_{0}$ jehen wir jiemtide allgemein umjere Şoljpflanzen an ben

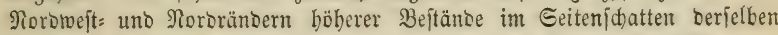

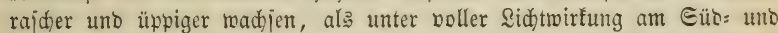
Eüoweftranbe; ob biē aber eine Folge Der geringeren Sidttwirfung, ob ę Jolge eitrer ober ber anderen ber fie kegleitenden atmoiphärijhen ober

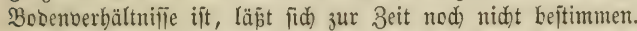

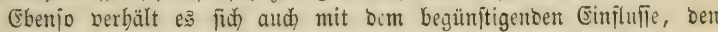

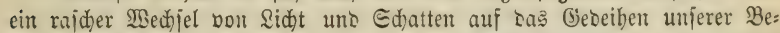

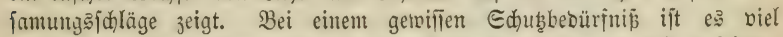
weniger ber Bejdattungägrab als bie Bejdattungäbauer berielben fläd,e, auf meldher bie $\mathfrak{B}$ irfung des Mutterbaum (Ërforidung nod) ein weites Jelo offen. (5) leudetet aber ein, Dap bei ber zur Beit nod bejtebenden Unfiderbeit in Erfenntnif ber Mirfungen,

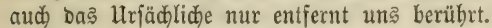

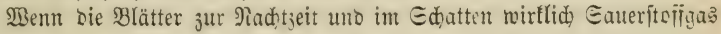

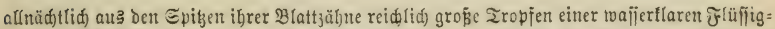

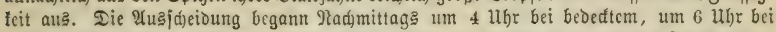
beiterem Şimmel, nie früber und ofne Unteridjied Der Iemperatur und Des হtmperatur=

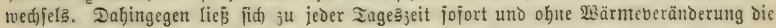

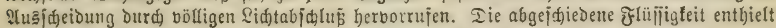
geringe Mengen einer juđerattigen, frnjtafiiirenden Eubitanj und cinen flebrigen, nidit

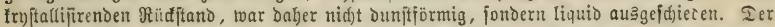

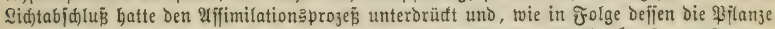

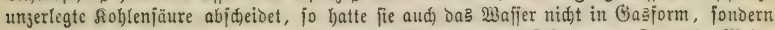
in feinem urjprünglidjen 21ggregałłujtande auşgejdieden (Bot. Beit. 1855, Є. 911). Meine neueften photometrijden 2 (rbeiten haben ergeben, Das̄ Die hödjte Sidgtwirfung mit Der

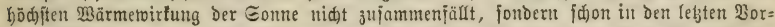
mittaggftunden eintritt. (Gs ijt bas jowoht bei beiterem als bei bedecttem frimmel, im

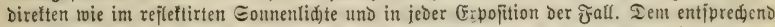

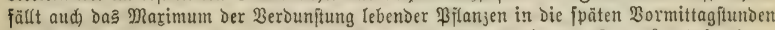

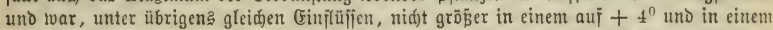

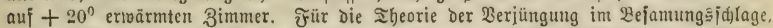

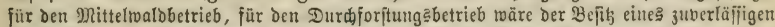

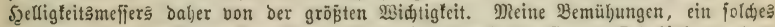
3nftrument bon praftijder Braudbarfeit für unjere Brede ju erfinmen, fino bigher an bem

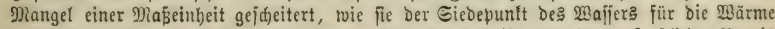
barbietet. Heber einen \$botometer, ber wenigitens ben meiften ber in ber foritlidien Praria

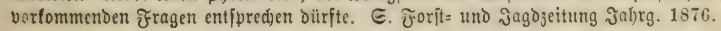




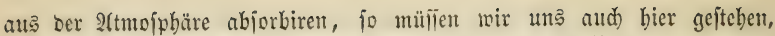

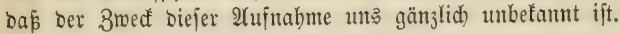

\section{Die J̈eudutigfeit.}

Das rajd) Eritarfen burd) Bodentürre welf getwordener Pflanzen

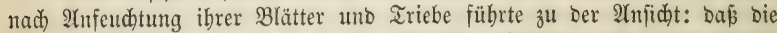
Bflanje Jeudutigleit aud) Durd) bie Blätter aufnehme. Ungers birette Berjude haben Dief minbeftens fehr zweifelhaft gemadyt. Dbgleid mande Thatiaden Dagegen zu fpred)en fdycinen (i. im phyfiol. Theile: Auffteigen bes Eaft

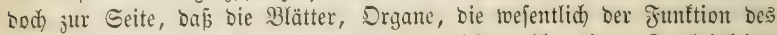

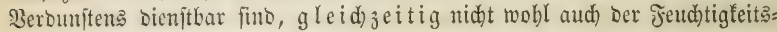
aufnabme bienen föntent.

Nehmen wir an, baj bie Pflumze Durdh ihre überirbifden Theile Jenchtigfeit aus ber 2 (tmofphäre nidgt bejiehe, fo hat bie atmojphärifde Jendtigfeit mur in fo fern einten bireften Einflup auf bie Pifmze, als fie ben (Srab Der Berbunftung beftimmt. Meine neueren Berfuche ergabent,

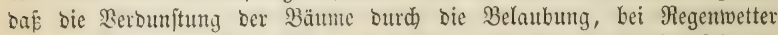

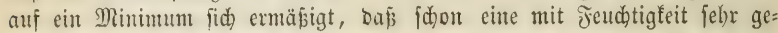
fa)wängerte \&uft biejelbe in hohem Gribe crmäßigt. Eine mit ber Sd)nitt=

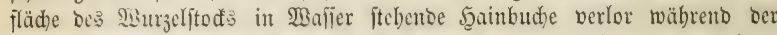
erften beiben Piegentage faum merflich an Gervicht, wäbreno am britten Iage, nadjoem bie Suft flar mo rein geworden mar, bic täglide $\mathfrak{J}_{\mathrm{er}}$ Dunftung über 5 ßjumbe betrug. Daß cine häufiger eintretente Ednnälerung ber Berbunftung güntig auf Den Buwad)s wirfe, ift faum anjumebmen, ba bie ftälfere Berbunftung eine nothuncnoige Jolge lebhaftercr 3ufubr bon

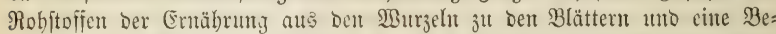
bingung ser 2fifimilation Derjelben ift, ba man baher wohl antehmen barf, bas ber verringerten 2 erbumftung aud) eine verringerte 2(ijimilation jur Seite itehe. Dem Einwande, daj dic naffen Jahre Den Şoljzuwad)

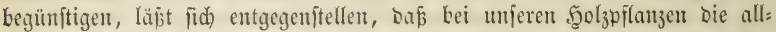
jälorlid) bereitete Menge von Biloungaftoffen erft in nädjitfolgenoen Jabre

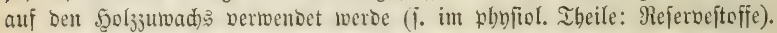

Dabingegen hat bie atmofphärifde Jeud)tigteit inoireft einen mädbtigen

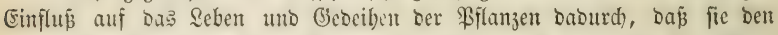
Boden fpeist, aus Dem dic \$flanjen jebenfalls ben bei weitem gröpten

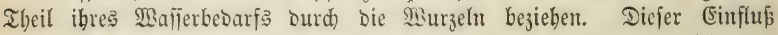
muß cin um fo gröperer fein, je abbängiger bie Bobenfeuthtigfeit von

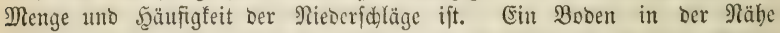
gröperer Șafjerbecfen wirb von biejen aus getränft, ein quelliger Boden erbält feine MBajierzufubr aus ber Tiefe; Dajielbe ift Der fall bei ben fo= genannt "f d) wib̨enden" Bobcuarten; Der Sumpf: und Wiejenboden bewabrt bem Pflanzentudde Die in Beiten reid)lid)en Regens überidülīig empfangene Jeudtigteit. Die tiefgründigen Sandlager Des Meereąboden bingegen, ber genteigte Boden Der Borberge und Gebirgäbänge, Der flachgrünoige ßoben über unburdlafiendem Untergrumbe oder über einer Unterlage, wilde bie 
Feuchtigfeit Yeidht aujuimmt uno ableitet, fino tweit abbängiger non ber

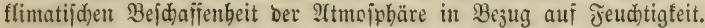

Der Boben empfängt jeine Feudtigfeit aus ber $\mathfrak{A}$ tmofphäre auf żvei=

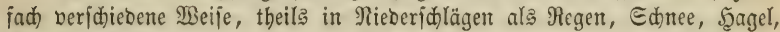
Thau, theils entzieht er fie ber Suft burd) feine hngrojcopijde (Figenidhaft; leb̧teres um fo energifcher, je reicher er an mildom .̧umus ift. In beiben

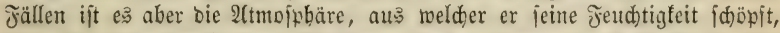
bie nidht allein burḍ ifren Reidthum baran, fonbern and surd bie 21rt uno Meife, wie fie biejen sem Boben abtritt, bebeutungänoll für das Ģe= beifen ber ßilanzen wiro.

2H einer Reibe eigener Beriude über bie fngrojcopifde Mallerauf:

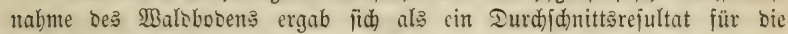

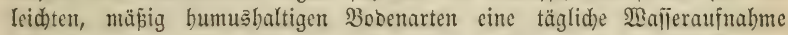
völlig getrodneten Bobens aus mit Feưhtigfeit gejättigter \&uft $=58$ Gramm pro Dunoratmeter. Allerbing: febr willfürlid) ali $1 / 4$ biejes Betrages er=

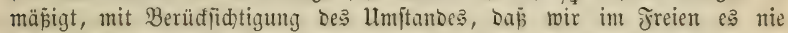
mit wirflid) trodinem Boben zu thun haben, die 9(bjorption bes feudten Bobens eine viel geringere ijt, berbleiben 14 Gramm, bie weiter um $1 / 4$

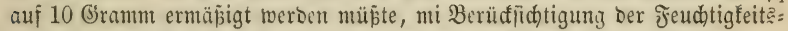

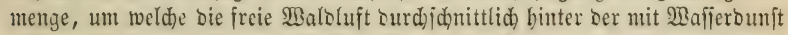
völlig gejättigten Suft jurüăfleibt. Son biejer Bajis aus mürbe ber Boben binten 180 Begetationstagen 1800 Gramm hngrojcopijches Mafier abjorbiren,

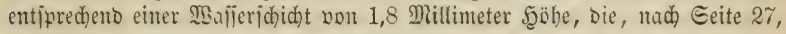

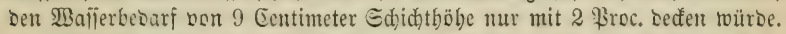

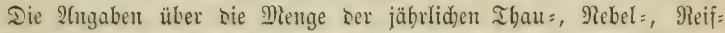
nieseridläge fino feht fdiwantent uno liegen 3 wijden $2-3$ uno $15 \%$ de:

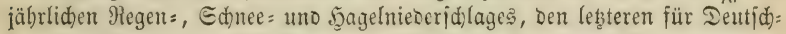
Lano surdidjnittlid) auf 62 Centimeter Edjidthöbe beredunet. Pimmt man im Mittel bie Eumme allen 3uganges $=68$ Centimeter Edjidthöhe an, jo werben

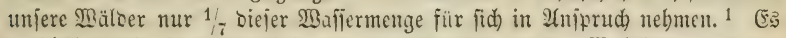

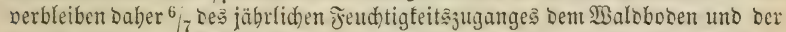

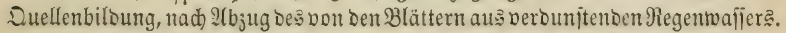

Die Jeudhtigfeit bes Sllima iji abbängig von ser Menge, von ber Befdaffenbeit, von ber Bertheilung uno Sage Der Jeudtigteitąquellen. Jiur

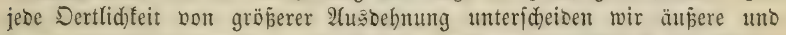

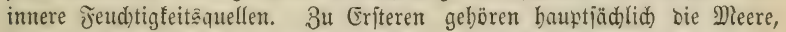

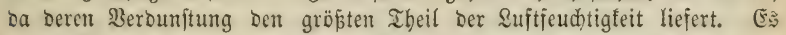
gehört bahin aber aud) ber von Eüben unz zuflefende \&uftiftrom, Delīen Jeuchtigfeit, in Folge fortictreitenter 2(btüblung, in unjeren Breiten jum

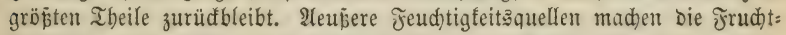

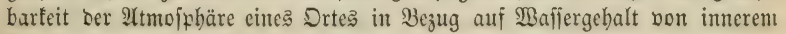

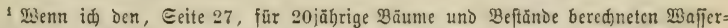

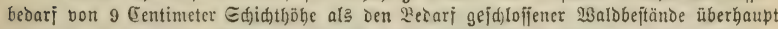

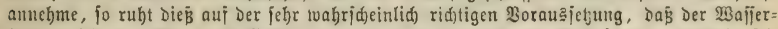

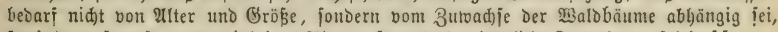

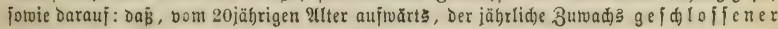
Wa I b beft äu be feiner bebeuten ben Steigerumg untermorfen ift. 
Quellenreichthum unabbängiger, wenn bie Sage befielben zu exfteren eine

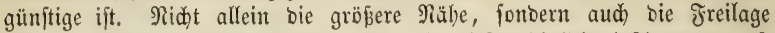

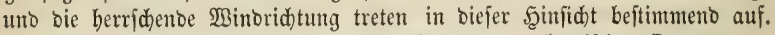

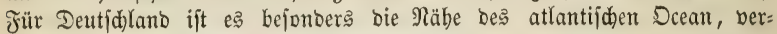
butben mit ber vorberrideno fübweftliden und wejtliden \&uftiftrömung, aus ber ibm, im Bergleid mit ben weftlid)er gelegenen \&ändern, ein feuchtę Sllima erwäd)at. Selbit imerbalb Der Grenzen Deutjollands treten bier nod) wefentlide Unteridiebe herbor. Die Ebenen bes nöroliden Theiles empfangen bie feudte Seehuft mit ihrem ganzen Wafjergebalte, ber in ben,

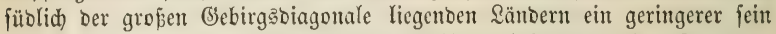
muा Suftmaffen, in höbere, fältere Suftiodid)ten emporgebrängt, einen beträd)t=

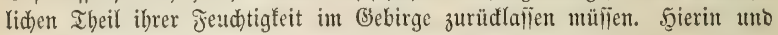
nidht, ober bod bei reitem weniger in ber Bewaldung ber Gebirge ift es

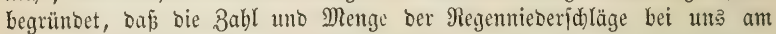
Norbweft: bis Sübmeftrante ber Bebirge eine gröfere ift als in ber Ebene.

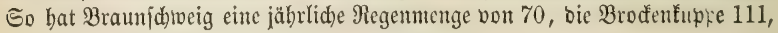
Sohegeis 86, Erfurt hingegen mur 33 Eentineter.

2tber felbft in ber Ebene ift bie 2tonabme bes Regennieberfalles mit größserer Entfermung vom Meere, jelbjt auf furze Etrecten cine beträd)tlid)e. Die Regenmenge Braunjemeigs bon 70 fintt fobon bis Berlin auf 51 Centi=

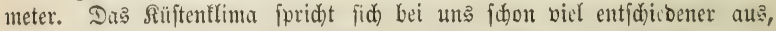
Dem wäbreno in Berliu faft jährlid) trifflidger Mein uno \$firfidue reifen, verben fold)e bei uns mur in jebre günjtigen Jahren fodmathaft.

Ment aud) bie (sebirgsluft an fid) eine bon 2 afferbünftent reinere ijt, fo

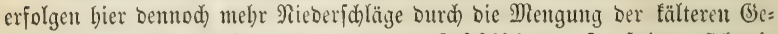
birgaluft mit ben andringenton wärmeren Suftidichten. Eo fteigert fich bie

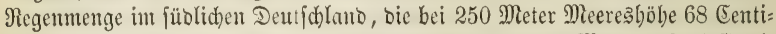
meter beträgt, bei 340 Meter auf 65 Eentimeter, bei 600 Meter auf 94 Centis meter. Die Regenmenge Der Broctenfuppe beträgt 111 Centimeter, wibreno fie in Braunjejweig nur 70 Eentimeter ijt.

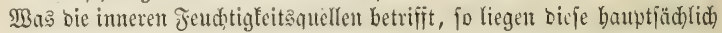

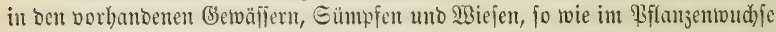
Deß Ranbes, beibe, wie wir gejehen baben, fid) gegenjeitig beoingino unt unter fid) cinen, bem größeren untergeoroneten, Rreislauf atmofphärijher uno

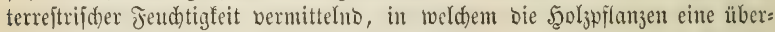

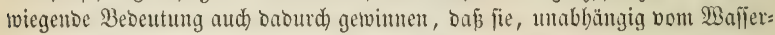
gekalte ber oberften Bobenjdidten, burd ibre in bie Iiefe hinabiteigende $\mathfrak{e}_{e}$

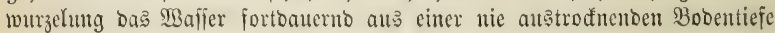
emporbeben uno ber 2(tmofphäre zunüfgeben, für ifre Umgebutg baber, mebr als ber 2Aderboden und das Weibelanto, ju einer nad) baltigen Duelle atmojphärijder Jenthtigfeit and) in Beiten anbaltenter Sciz̧e unt Dürre werbetr.

Wärme, Sidyt uno Jeudtigfit zufammenwirfeno, beftimmen ben Be= ginu uno Den ßerlauf Der jäbrlid)en Begetationserjocinungen. ${ }^{1}$ (Ein

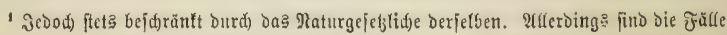

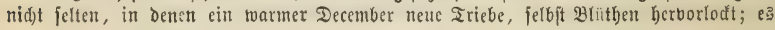


fonniger uno warmer März erwedt bie Bflanzen nidł zu erneuter Thätig= feit, wenn ber Märme nidht Jeudhtigfeit gefellt ift; bie Sno spen regen fid) nidit, wäbreno nad bem eriten warmen Regen ber $\mathfrak{W a l b}_{\text {fid }}$ oft in einer

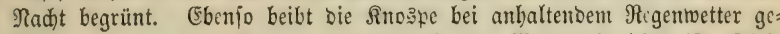

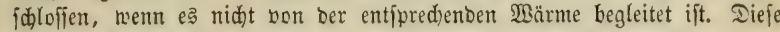

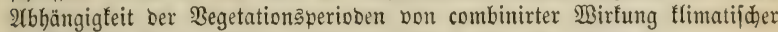

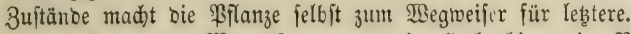

Heberall, am Meeresttrante uno im Sodgebirge, im Norben unb im Eüben Deutichlands bejeidnet bie Blüthejeit ber Şajel benjenigen Termin,

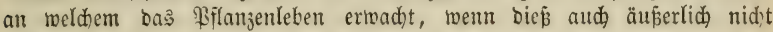

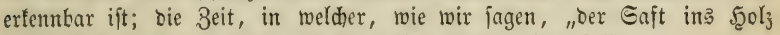

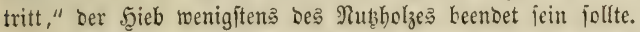

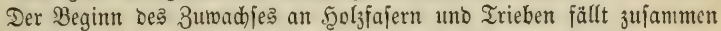

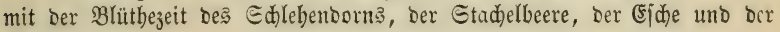
Balbanemone.

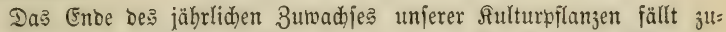
jammen mit bem Ed) hus ber Beizenernte, mit boller Reife Der Bflaumen,

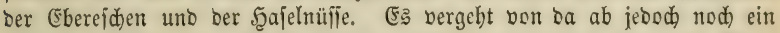
14 tägiger Zeitraum, ehe bie zuleţt gebilbeten Şolzfajern ihre volle Waan= Dungştärfe uno F̌eftigfeit erlangen.

Der 3eitraum bes 3uradjes an ben überirbifden Baumtheilen ift

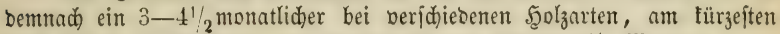
beim 2 horn (3 Monate), am längiten bei ber Riefer $\left(4 \frac{1}{2}\right.$ Monate).

Die Reubiloung von Rejerbeftoffen beginnt in ben unterirbifden Baumtheilen mit ber Blüthezeit be: Scaibefrauts, fteigt jebr langiam au i= wärts, fo baß fie in Den äußseriten 3weigipizen erit mit ber Blüthezeit Der Şerbitzeitloje (Colchicum autumnale) zufammenfällt. Eie enbet überalt erft mit bem 2 bfalle bes \&aubes.

ธ. bierüber meine Mittbeilungen in Der Forit= un๖ Jngojeitung 1856 ธ. 361,1857 ธ. 281 .

\section{Betwegung und Ruhe ber Ruft.}

Die Eriftenz organijden \&ebens auf unjerem Eroförper berubt wejent= lich auf einer fortbauernben Betwegung ber \&uft uno Mengung ibrer $\mathfrak{B}_{e}=$

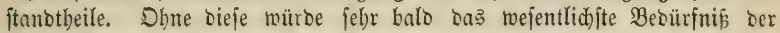
Bflanze, bas 2 affer bem Boden entzogen fein, bie Pflanze uno mit ihr Das. Thier müpte fich an bie niebrigen llfer ber groß̧en Meeresbeden zurüd: zieben, würbe aber in ihrer Fortbauer aud) bier febr balo gefäbrbet fein

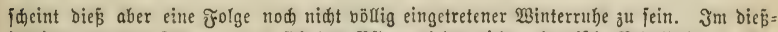

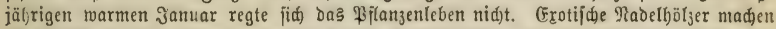
im Szerbite bäufig nod) einen jweiten Irieb mit (Endfinospe, ber aber jefre furrj und frautig bleibt, Deffen Mabeln faum $1 / 4$ der normalen Sänge erreiden. Im falthauje überwintert,

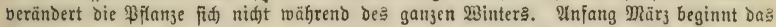

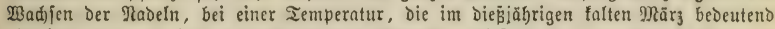
nieiriger war, als in ben vorhergehenden Ponater. Sieferzapfen, ben ganisen $\mathbb{B}$ inter in trodner varmer 3 immerluft aufbetwabrt, offnen jiđ erit im früljiabre, wenn ihre 3 e it getommen ift. 
Durd) Mangel an Erjah ber verbraudten Soblenfäure, bes verbraudjten Gaueritofifs. Alle bieje bem Reben nöthigen Stoffe, Jeud)tigleit, Sioblen= fäure, Stidjtofi, Gauerftoff fino balo Beitanotbeife ber atmofpärifden \&uft,

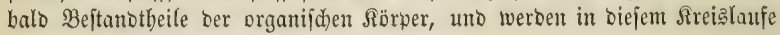
mur burd) bie Bewegung Der \&uft erbalten.

Die Bewegung Der \&uft entipringt veridebenten Urjaden. Die Erbe

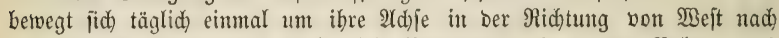
Dit, un๖ bie 2 tmojphäre theilt bieje Bewegung, bie an ben $\mathfrak{B o l e n}=0$ unter bem Alequator am größtent ift. Went uno wo bie 2Atmofphäre gleid raid) mit ber (Erboberfläthe fidc) rotireno betwegt, ba bejteht 2 Binoftille, ab= gefeben von anoeren bieje ftörenten Urjaden. In unjeren Breiten rotiren aber bie fire bedectenten Theile ber 2 tmofphäre, aus Urjachen, bie weiterbin erörtert finto, unter Umitäuben $\mathfrak{r} a \mathfrak{j}$ d)er ober langlamer, als

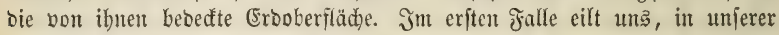
nad) Diten geridteten Rotationabewegung, ber Molfenzug voran (Weit=

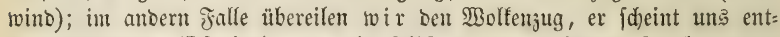
gegenjufommen (Ditwint), ba wir felbjt unjere rotirente fortbetwegung nid)t empfinten. Der Effeft ift natürlid) berielbe, ob wir in eine andere Snftididut uns berfezen, ob eine andere Suftididgt zu uns gelangt, bie frübere berorängeno.

Eine zweite Urjache Der Ruftbetwegung ift bie Erroärmung bes Ero: förpers burd bie Eoume.

Wie wir bereit gefeben haben, wiro ber gröpere Theil ber Sommen= rärme erit auf ber Erobberfläh) entbunden. Die baburd ftärfer erwärmten unterften \&uftidjidten fteigen burd) bie fälteren überliegenten \&uftidjiḑten aufwärs; ę entiftebt ein aufíteigender \&uftiftrom, ber burd) bie tiefer finfenoen tälteren \&uftidjid)ten eriebst uno unterbalten wiro, ber einen fteten Shechjel ber oberen uno unteren \&uftichidten, ber Iemperatur uno Jeudhtigfeit berfelben im Befolge bat.

Unglei he Errwärmung benad)barter fläd)en bes Eroförpers hat, im Gropen twie im Rleinten, einen Srciâlauf Der Ruitmalien zur Folge. Die böher ertwärmte \&uft anţer bem Edatten eine’ Baumes fteigt aufmärts, uno twiro burd) bie fühlere Sdhattenluft des Baumes erfebt, bie ifrerfeit’ wieber (Erfab finbet burch) Das 3uftrömen ber erroärmten aufgejtiegenen \&uft in ben Edattenraum. Daber rülbrt bie füblenoe \&uftbetwegung im Sdhatten

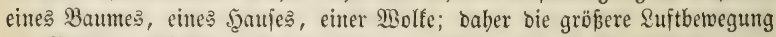
am Rande gefdloflener Walobeftänbe, am Ufer größerer Wafferfläden.

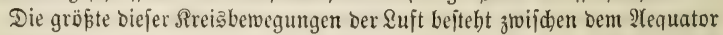
utno ben ßolen. Die unter Dem Aequator im hödjiten (brabe crmärmte \&uft fteigt aufwärts uno veranlaß̧t ein 3ujtrömen ber fälteren \$olarlujt in ben unteren \&uftididten zum Erials ber aufgeftiegenen 2lequatorialluft, wäh= reno eritere burd bie auf ibrem $\mathfrak{B} e g e$ zu ben \$olen allmäblig fid) ab= füblende $\mathfrak{A}$ equatorialluft ber böberen \&uffid)idften fortoauerno erfeßzt wirb. Der urfprünglich in Den höberan Suftidbidten über bem Bolarjtrom in

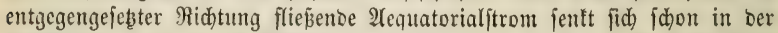
gemäpigten 3one burd) 2(błüblung fo tief, baß er bier nidht mebr über, fontern neben bem bon Norben nad) Eüsen geridteten Polarftrome ber: 
Lauft. Diefe Sufthewegung fann in voller Sraft nur auf ber von ber Eonne beleudteten Erobälfte ftattfinoen, Daber bie Rube uno Etille ber গaditluft, wo biefe nidht burd anbere lurjadjen geftört wirb.

Die 21tmojphäre zeigt alio gleidyseitig eine boppelte Bemegung: Die rotirende, von $\mathfrak{S e f t}_{\mathrm{s}}$ nad Sit geridtet, uno bie meribiane, bon Norb nady

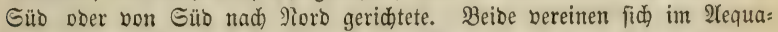
torialiftrome zu einer aus ভübofeft nady Norboft, im ßolariftrome zu einer

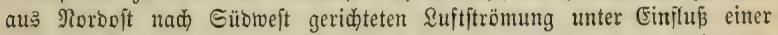

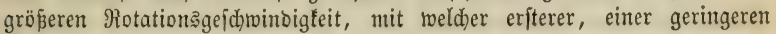
Rotationsgejdrwinbigteit, mit welder leb̧terer in unjerer 3one anlangt. 3wifhen beiben Scauptridtungen bes MBinbes folgen fid bie, Der Zeitbauer

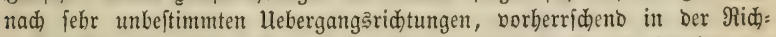

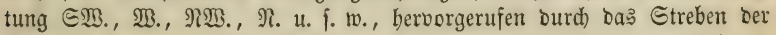
beioen, in entgegengejebter Midhtung nebentinanber verlaufenoen, meribianen ¿uftittröme fị gegenfeitig zu verbrängen.

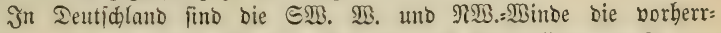

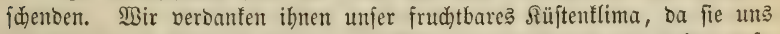

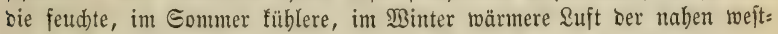
liden Deereşlähen zufübren, währeno bie trodene \&uft Der entgegen=

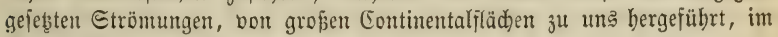
Winter fälter, im Sommer toärmer ift.

Birtliche Stürme, von einer Şeftigfeit, bie bem Beftante unjerer Wäloer B̧cfabren bringt, finto meijt lofaler Entítebung, am bäufigften wabr= iđeinlid) berbeigefübrt burch plöblide $\mathfrak{3}$ erbidtung grofer Mengen $\mathfrak{B a f j e r =}$ Dampfes, bie jur Jolge hat, Daßj bie Dem Drte ber \$erbidtung benad)= burten Enftidjidten mit grofer (semalt alljeitig auf biejen einbringent. Gtürme biejer Entftehung fö̈nten baher bon jeber Şimmelagegeno her bie Bäloer angreifen uno bie üblidhe Şiebsridhtung von Dit nad) SBeft idüb̧t Die Buftände gegen Den Angriff Der Stürme mur bebingt.

\section{Slimatifije (jejammtuntcriajiebe.}

Mach) ber vereinten Fintwirfung ber einzelnen, in Boritehendem erör: terten Faftoren flimatifder 3 uftänbe unjerer 2 tmojphäre lafien fid nad: folgenbe Sauptgruppen biejer 3ujtänbe unteridheiben:

\section{a. Slima meereggleider Ëbenen.}

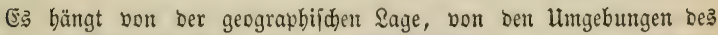
Sanoes, ber Bobenbebedung uno Bodenbejdaffenheit ab. Cine allgemeine

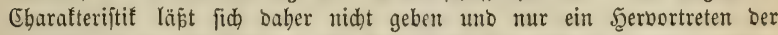

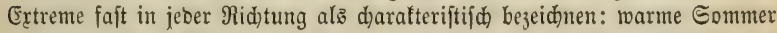
uno Iage, talte Binter uno Päß)te, anbaltenoe Feudtigleit, wechjelno mit

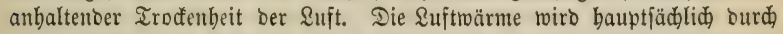

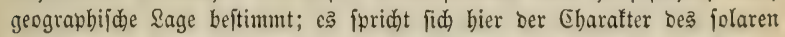
Яlima am beftimmteften aus. Die Strömungen ber \&uft finto bödfft ver= änoerlid, ba bie bejtimmenoen Hrjaden meijt in weiter ferne licgen. Mirflidbe Stürme gebören zu ben jeltemeren Eridheinungen. 
Der Feudtegrab Der Almojphäre, fofern er von äuperen Feudtes quellen abbängig ift, wiro burḍ bie Lage ber Ebene зu ben ftänbigen Strömungen ber 2 tmofphäre bejtinmt. (So erbält unjer Deutjdlano

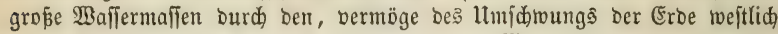
abgelentten Bolarftrom, weldher fich über ben Meeresfläd)en mit Feudtig= feit jättigte. Beiter p̈jtlich gelegene Sänber werben von bemielben Strome weniger befeudtet, ba er fdon früher einen Theil feiner Jeudtigfeit ver=

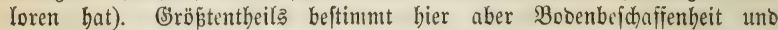
Pilanjentudes ben Jeudtegrab ber Suft; Bodenbejdaffentrit, je nadjom

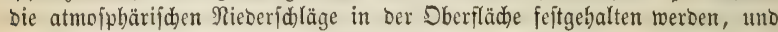
einer erneuiten unmittelbaren Berbunftung unterworfen find, ober in bic Tiefe finfen uno ber Berbunftung entzogen werben; Bflanzentudda, inoem mit größerır Bflanzenmenge ber 2Utmofphäre eine größere Menge Jeud)tig= feit nadbaltig zurüffgegeben wirb.

\section{b. Siütenflima.}

Die mittlere Rufträrme beş ganzen Gabres muß burd bie ftarfe Ber: Dunftung ber benadbarten Baffermaffen eine geringere fein. Dahingegen bleibt bie \&uftwärme gleidmmäpiger, bie (sctreme fehlen, fie werben im Sommer burd) Berburftung, im Winter burd) bie märmeren $\mathfrak{B a f j e r f l a ̈ d e n ~}$ abgeftumpft. Daher fennt ber Englänoer faum bie Mäntel, bie in Stalient uno Epanien зur Minterşzeit unentbebrlid) find. In Jrlant gebeiht in gleiđer Breite mit Rönigaberg bie $\mathbb{P}_{\text {yrthe wie in }}$ Hortugal, aber es reift fein $\mathfrak{B e i n}$, Der in Röniģberg nod) gezogen wirb. (Ebenjo gleiden fid aud) Die Temperaturent bes Iages aus.

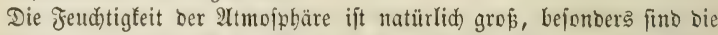
feineren atmofphärifकen Nicberid)läge häufig. Die Etrömungen fino heftig,

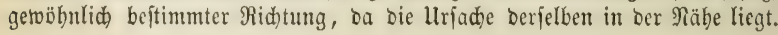

\section{c. SIIma Der 5̧odebenen.}

Die Märme bängt im Allgemeinen von ber Erbebung über bem Meereşpicgel ab und nimmt mit biejer relativ zu, ba ber $\mathfrak{B e g}$, ben bie Sonnenjtrablen in ber 2 tmojphäre ju burdlaufen haben, ebe fie ben (Erb: förper treffen, ein fürzerer ift uno in biefem Berbältniß́ wentiger $\mathbb{B} a ̈ r m e$ an bie \&uft von ihnen unmittelbar abgegeben wirb. In gleicher Şöhe ift

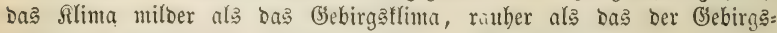
thäler, bie \&uft trodner, häufig treten aber Nleberidläge ein.

\section{d. Thalflima.}

Da bie $\mathfrak{B a ̈ r m e \jmath u f u b r ~ n i d ) t ~ g r o ̈ p e r ~ i f t , ~ a l s ~ f i e ~ b e r ~ ( G r u m b f l a ̈ d ) e ~ b e ß ~}$ Thales zugeben würbe, fo mirb bie Dberfläde bes Thales in bemjelben

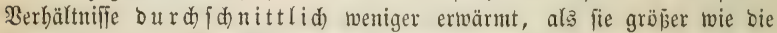
(Brunbflädse ift. Die Wärme ber Sommerjeiten ift aber eine erböbte, ba burd) bie fenfredt auf bie Berghänge fallenton Somenftrablen eine größere Märmerrenge entbunben tviro. Itı fo weniger $\mathfrak{B}$ ärme empfängt bie 
Die Ebene beftimmt. Nur in Gebirgathälern fteigen bie weidhen Saubhölzer bisweilen böber binauf.

Diejen Şölzern folgt bie Eidhe, fie geht im Şarze, in Bejtäntoen nid̆t bis zu 350 Meter. Die Miothbuthe, Weiptanne, Sgornbaum uno Eid)e gehen über 700 Meter, bie Fichte, Särdhe, Birfe, Eberefde, 2Hhorn, Merftweide, bis 1000 Meter.

Sm Riejengebirge fteigen die meiften biejer Sgälzer 350 Meter, in ben fübbeutiden Gsebirgen gegen 700 Meter höher als am ந̧arze.

24ud in Beziehung anf Die Bertheilung Der Bärme äufert bie Ex= hebung über Dem Meeresfpiegel ähnlidhe Eridjeinungen, wie bie Entfernung vom 2equator. Die \$ertbeilung wiro ungleid)mäpiger, Die Jabreşwärme bereint fid getwifiermatien in einen inmer tïrzeren Zeitraum. Se melhr man fid erbebt, um fo melyr fdinintet ber in umfern Ebenen fo beftimmt

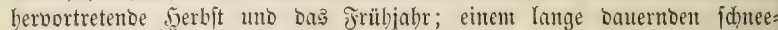
reiden Binter folgt fajt unmittelbar ber furze beise Eommer, biefent ein im Allgenteinen furzer, gegen bie Dauer bes Jrübjubres aber langer, ge= mäß̋igt falter uno beiterer Şerbft.

Der Feud)tigfeitşgebalt ber (Bebirgsatntophäre ift an uno für fid geringer als in tieferen \&uffidjidten, fteht aber feinem relativen Marimum näher, jo Dá̉ eine geringe Märmeabnahme Pieberidlüge zur Folge hat.

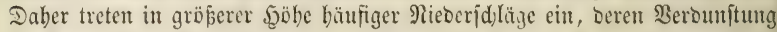
bie 2Atmoiphäre büufiger, aber vorübergebeno jättigt. Daber bann auth) bie

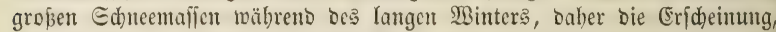
Dap im Bebirge jeltener die hohen Brabe Der Minterfälte hervortreten, wie fie ber (Sbene eigenthümlid) finto.

Strömungen wegen Mangel an Ed) bä bäufig, beftig, meift ftäntiger Ridutung uno in ibr Durd) ben Merlauf Der Bebirgajüge beftimmt.

Uebrigens hat im Gebirge bie Reigung Der Saänge nach veridiebenten Şintmelsgegenton einen jehr wejentliden (Sinfluß auf Das Rlima.

Die Ditfeite ift falt, ba bie Gome nur ocs Morgents und Bor= mittagß, wanl fie nod) nidht Den hüd)ften (5rab Der Errwärmbarfeit erreid)t hat, auf Den Boden cinwirft; fie ift trođen: Da bie fie treffenden $\mathfrak{B i n b e}$ über großse Santoftrecten geweht uno Dort ibre Jendtigfeit abgejebst babent. Die Strömungen fino felten bon bejonberer Şeftigfeit.

Die Begetation erwadyt fpät, reéballb von Epätfröften wenig zu befürdhten iit; mehre idasen im Sgerbite bie rauben trodinen Ditwinbe, went bie Saamentilanzen uno jungen Soben nod) nid)t gebörig verbolzt finto Daber fäe unto pflanje man bier im Jrübjabre uno väble im Rieberwaloe Den Minterbieb.

Da bie trodenen Ditminoe bie \$Flanzen uno Den Boben zu berftärfter Ylu引bünftung anreizen, io muß bei ber Serjüngung Der Dithänge ber Boben möglidjt gefdübzt erbalten werben; wiorigenfalls berfelbe bie ber:

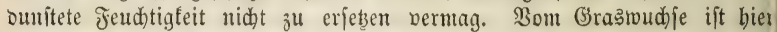
veniger žlt befürdten als in anoeren Jreilagen, ba bei ber Sidteintvirfuntg weldhe ber (Srastwud) forbert, eine bemfelben entgegenftehende Trođenbei rrzeugt mirb. (Bei Ditminben fliegt Der meifte Gaame $\mathfrak{a b}$, befonder ber bel

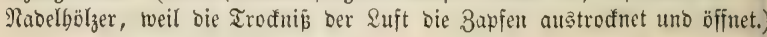


Die $\mathfrak{B}_{\mathrm{e}}$ it jeite erbält bie fenfredjten Somenjtrablen zwar erjt bann,

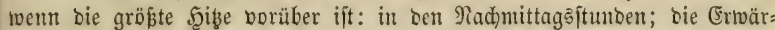
mung Des Bobens twirb aber Daburd) gefteigert, Dap fie zul einer 3eit ftatt= finbet, in welcher bie umgebenbe \&uft bereits erwärmt ijt. Daber trodnet bie Meftfeite bei anbauernoen trodinen Winden in böherem Grabe aus als bie Dfteite; ba aber Deutid)lano bejonters Gäufig von anbauernben feuduten MBeftrinden beimgejud)t ift, fo tviro jener Nadjtheil mejentlid geniloert; bäufige Rieberialläge erbalten ben \$3oben feudt, uno Das Slima erbält baburd) eine bem \$flanjentwudje jebr zujagende Bejdaffenbeit.

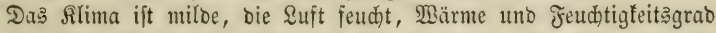
bef̈änbig, bohe Grabe Der Rälte uno SBärme feltent. Der Bilanzentwuch: leibet Daher felten von Früh)= ober Spätfröiten. Deîto nachtheiliger werbent

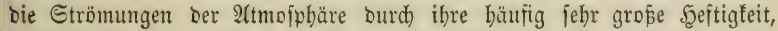

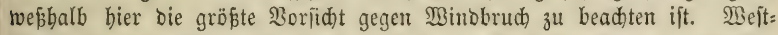
bänge fino bem $\mathfrak{B}$ inobrud) jeood) nidt in bem (brabe ausgejeb̧t, wie Güb= twejt= und Norbojthänge, Da ber Wino, wem er in geraber Midhtung bie

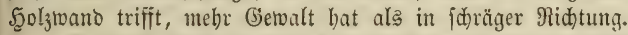

Die Edlagitellung famn hier bebeutento lidhter fein als an ber Ditjeite,

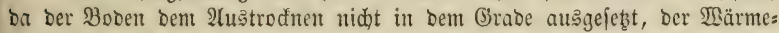

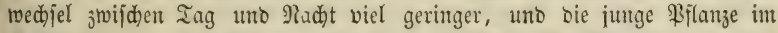
(Sebirge von gropen Ed)neemafien lange geịüß̨t ift. Nur ber mitunter

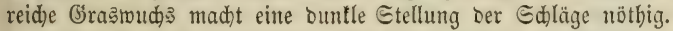

Die Norbjeite erbält erit fpät am Tage bie Eome, und beren

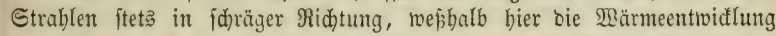
ant geringften ift. Der Jeudjtigfeitsgrad Der Suft ift all uno für fid toe=

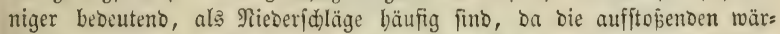
meren \&uftitröme bier ibre Jeudtigfeit zurüdlafien. Son Winbbrud ijt nidht viel z̆l fürdten. Megen Der geringen (Erwärmung Durd) bie f(d)räg einfallenten Somtenftrablen ift bie Dififerenz ber Tages= uno Radttempe: ratur wentiger bebeuteno, baher bie jungen Biflanjen feltener bon Späts

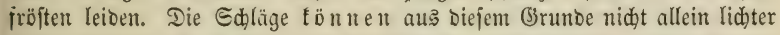

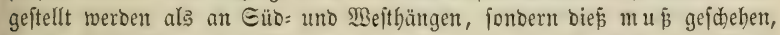

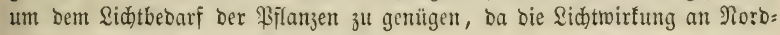
bängen eine viel geringere ijt.

Die $\subseteq$ üb feite ift für bie Bigetation bie ungünjtigite. Die Eome wirft Den ganzen Tag über. Die Strahlen fallen zur Mittagşzet, wem Die Sonne am hödjten fteht, redtwintlig auf ben Boben, entwiđéfn bie

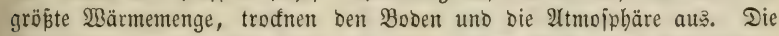
Begetation ermad) jebr früh uno leibet baber bäufig von Spätfröften,

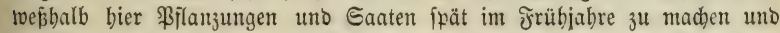

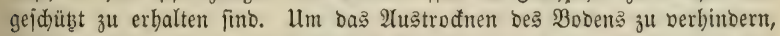
muß berjelbe unter Bejobattung erbalten werben; Daber ift eine buntlere Edjlagitellung uno allmäblige 2luslidhtung ratbjam; notbmendig wiro fie, twenn Das Thal, meldyent ber Sübbang angebört, nach Weften geöfinet ift, in weld)em fall $e^{2}$ von heftigen unto anbauternden Strömen heingejudt wirb. 


\title{
Drittes Enapited.
}

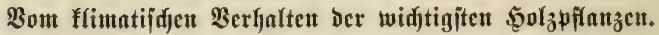

\author{
Die Birfen.
}

Betula pubescens (alba Lin.) iit unter unjern Waldbäumen un= ftreitig biejenige Şoljart, weldhe ber geringiten Märme bebarf, baher aud bie gröpte Berbreitung hat. Mir finoen fie von ber nörolidjiten Spize

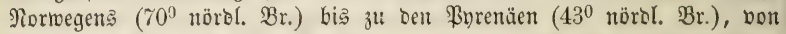

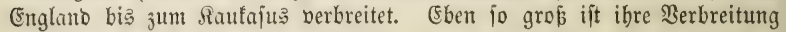

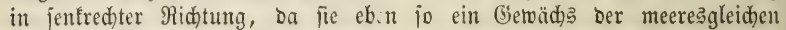
Nieberungen wie boher Gebirgstämme ijt. Sange bauernbe beife Sommer funo ihrem (Sebeihen nid)t günftig, saher fie bann, sbgleid) in nöroliden und mittleren Deutidland nod) cin (Gewäd) ber Rieberungen, fdon im jüblichen Deutichlano jid) in bie (bebirge zurüdżiebt. Surze, mäpig warme, nidbt zu nafle Sommer fino ibr am zuträglidjitu; jelbjt trodne $\mathfrak{B}$ itterung ift ihr günjtiger als anbaltende siaffe, wenn fich binlänglide Jeudotigteit im Bobert vorfindet. Atudh bie ganz junge Bftanje leibet wenig unb felten von Froft, häufiger burdh anbaltente Düre. Im Gebirge gebeibt bie Birfe an bejten an ben fübleren uno feudteren 2 (bento = uno Mitternacht= jeiten. In auşzebreiteten reinen Beftänoen finden wir B. pubescens in

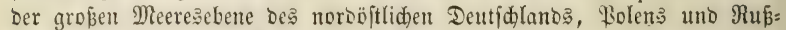
lants, wie üher ganl Rorwegen, Edweden, Fimulant uno Rapplano ver: breitet; in Den beutiden Gebirgen tritt fie mebr bereinzelt in llntermtengung mit anberen 5 gl $_{3}$ arten auf. B. verrucosa bingegen ift eine biel loeniger weit berbreitete, vorzugstweije Deutid)lano uno jwar bent meeresgleidhen (Ebenen angehörenoe, nid)t fo hod) als B. pubescens in bie Gebirge bin= auffiteigenbe $50 l$ zart.

Ein äbulides Berbalten mie B. pubescens zeigt bie Eberefde, bejonbers in ibrer Berbreitung in fenfredter Ridtung; Dabingegen geht fie bei reitem nidt io bod nörolid.

Entgegengeleșt geht bie 3 itterpappel beinabe cben fo reit nady Rorben binauf als bie Birfe, bleibt aber bei uns im Gebirge febr früh̆ zurüd.

\section{Die $\& a ̈ r d y$.}

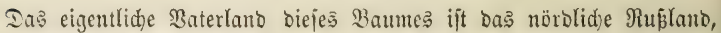
Eibirien uno das norböftlide Afien, wo er bis zutr Baumgrenze fïh ver: breiten joll. Rädjftbem eridjeint er nod in Den Rarpatben unb in ben Edweizer Alpen auf natürlidem Stantoorte, uno zwar bis zu Derfelben söbe wie bie gidjte aufíteigent, aber mehr vereinzelt, felten in reinen Beftänoen. In Deutidjlano ift er feit einem balben Jahrbunbert häufiger angebaut, bleibt aber hier febre früh, meift fichon mit bem 50ften Jahre,

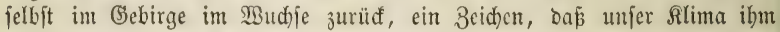
nid)t zufagt. Demungeadtet zeigt bie Särdje bier auf günftigem Stanborte

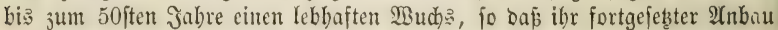
in llntermengung zu empfeblen ift. Sm Gebirge gebeibt fie am beften an Den gemäpigt feudten Norbbängen, uno an ben $2 B e f t$ feiten, wenn diefe 


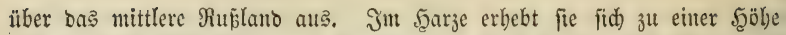
bon mehr als 700 Meter, im Riefengebirge fteigt fie um 300 Meter, in Den füboeutichen B̈ebirgen um 700 Meter böher. Jul G̈ebirge liebt bie

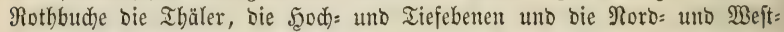
bänge, gejoüz̧te Sagen mebr als Freilagen, in ber Ebene finden wir fie von vorzüglichem Budfe in sen Nieberungen bes flupbodens und auf

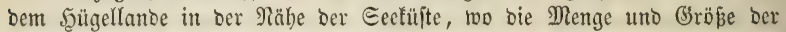

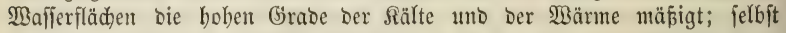

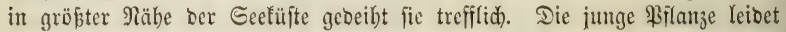
viel uno lange von Spätfröften, bejonbers an Mittag= uno Morgenfeiten, wo Der Pflanzentwuds früb erwad)t uno Der llebergang ber geringen \&uftwärme Des Morgents, zu ber hohen bes Tages rajder erfolgt. Daher fino junge

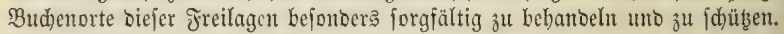

\section{Der $\mathfrak{S} \mathfrak{D} \mathfrak{i} \mathfrak{b} a \mathfrak{m}$}

bat mit ber Rothbude ziemlid) glcides Sorfommen, sod) verbreitet er fid nörolid) nidyt über Deutid)lano binaus, uno aud) im (Gebirge bleibt er

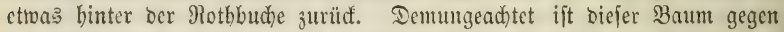
atmofphärif(he (Sinwirfung weit weniger empfinolich. Beringere Bärme unb höhere Jeudtegrabe fagen zwar aud ifm beffer zu, bod) fehen wir ihn felbft in fübliden Freilagen, bie ser Jiothbude nid)t melbr zujagen, nod) ganz gut gebeihen; aud) gegen Exätfröfte ift felbft bie ganz junge Pflanze weniger empfinblid), uno fiton in wenigen Эabrent Dem Froftidjaben gänz= lid) entwadjen, fo baj felbit bie ftärfften Rältegrabe unjerç Slima ibr

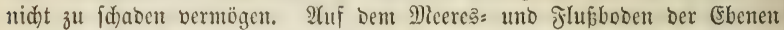

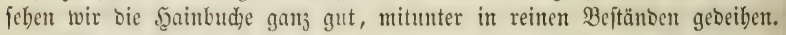

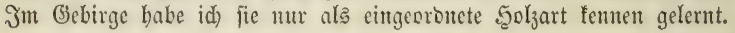

\section{Die Eేide}

ift über ganई Deutid)lanto verbreitet, int शorben vielleid)t bäufiger alą im Eüben. Sm Gebirge fteigt fie mit ber Rotbbudde gleidh hod unt berlangt befonders cinen böberen Jendategrad ber Suft, wefibalb fie bie Süb= uno Difthänge meioet uno mehr in Ihälem, an gefdübzten Norb: uno Wefthängen,

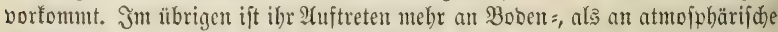
刃erbältniifie gebunben. Die jungen \$filanjen leioen bäufig non Epätfröften.

\section{Die \&inde}

verbreitet fid zwar weiter nörblich wie bie beiben vorgenannten Fुolzarten, gebt aber nidft fo hods in bie Jebirge binauf unt ziebt bie Rieberungen, Ibäler unto gejchüb̧ten \&agen ben Frcilagen vor. Gegen Rälte ift fie aud in ber Jugent ziemlid, unempfinolich, wentiger gegen Siţe uno lange bauernoe Trodenheit ber \&uft. Hleberall fommt fie nur unter andere \&aubbölzer gemengt bor.

Die $\mathfrak{B}$ eiftanne.

Ĵn angagebebnteren Bejtänoen erftređt fie fid) nid)t weit über bie nöro: lidfe G̈ebirgas̆linie Deutidjlands binaus, und nur am Fupe ber Subeten 
unmittelbare Rähe der Seefüfte mehr als bie Rothbuche. Die junge Pflanze, weldye idon im eriten Sabre eben fo tief, auf loferem Boben tiefer in bie

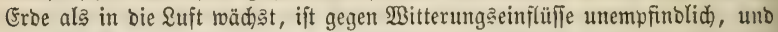
nur ber Saame bedurf, fomohl wäbretto bes Winters als wäbrent uno nad) bem fieimen, bes Єd)ubes burd) eine (Frobeffe ober burd) Raub.

\section{Die $u \mathfrak{r}$ men}

finto in noch höherem Grare als bie Eidje an bie Ebene und an bie Bor= berge gebunten: hier finoen fie fid jluar burd) ganj Deutidlano, jebod) größtentbeil’ einzeln uno mur in flupniederungen, z. B. Der Elbe, in

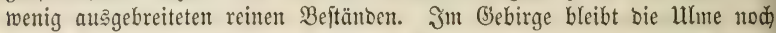
binter ber (Sid)e zurüd, und finbet fid bier ftets nur einzeln mehr an ben marmen Süohängen uno an freilagen, als in entgegengelę̧ten Berbältniffen. Эhr vorjüglidjiter Stantoort ift ber frudbtbare flupboben uno bie flachen mul= benförmigen Thäler ber Borberge. Die junge \$fflanze leibet nicht unter Epätfröften, wohl aber unter Jrübfröften uno ftarfer Minterfälte, funn bei unt jebod) ganz im ofreien erzogen werben.

\section{Die rotbe Erle}

iff über ganz Europa bi zum $60^{\circ}$ nörol. Br. verbreitet, wobingegen fie in ben Gebirgen fehr zurüdbleibt. Jim Şarze fommt fie fdon bei 500 Deter nur nod fiummerlid) fort, in ben fübbeutiden Bebirgen foll fie fid faum bis zu $1 / 3$ Der Edjneegrenze erbeben. Jnmerbalb biefer Grenzen ift ihr Borfomment weit mebr von Bcbenverbältnifīen, als vom Slima abhängig, in Folge befien fie bejonbers bäufig uno in grofent reinten Beftänoen, in Den Brüden bes nörblid)en Deutjd)lants, vorzugsmeife bie Eeefüfte bes gleitent, heimija ift. Daß Seeflima jagt ihr überbaupt jebr zu, uno fie zeigt bier, jogar im ausgemajd)enen Eande ber Dünen, einen guten $\mathfrak{B u d}_{\text {jas. }}$

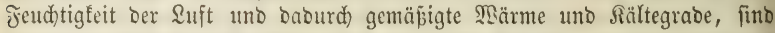
ibr un fo nöthiger, Da nid)t allein bie junge Bflanze, fondern felbit bas

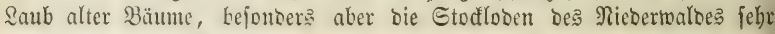
unter Spätfröften leioen.

\section{Die norbifde Ex re}

ijt in Deutid)lanto nur fünflid) angebaut, geoeiht aber im Slima Noros

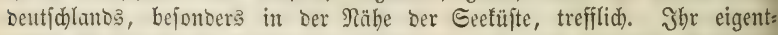
lidjes Naterlanto ijt Rorwejen, Edjweben uno bas nörbliche Ruplant; einzeln fonmt fie aud in ben Edweizeralpen bor unb hat fid bon ba aนล in Den, biefen entfpringenden Flupnieberungen verbreitet. Dap fie ein trodneres, wärmeres flima forbert als bie rothe (Erle, fann id) nid)t

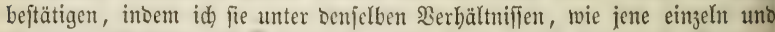
in reinen Beftänben betwirthjadaftet, überall in gleid) freubigem Bebeiben beobadtet babe.

\section{Die $\mathfrak{R}$ iefer.}

Shre geogruphijche Berbreitung ift febr groß̄, bon ben \$ryrenäen biŝ

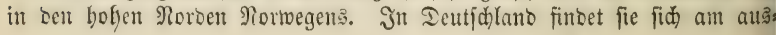




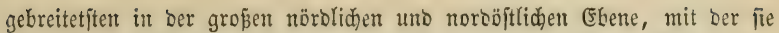

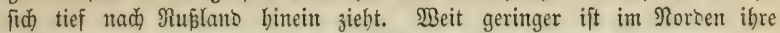

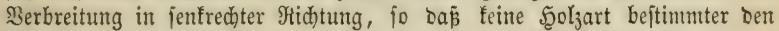

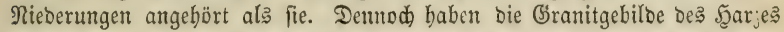
in früheren Beiten Rieferbejtänbe getragen, twie bie mäđtigen Etämme betweifen, weldhe man nodh jeb̧t in Den Torfbrüdhen unter bem Broden findet. Im füblic)en Deutichlanto wiro die Siefer (Sebirgabaum. Im Murgthal babe id fie bis zum Samme ber weftlidben Bergbänge in gejolofienen $B e=$ ftänoen aufiteigeno gefunden. Unter allen Şoljarten berträgt fie bas trodenfte unb wärmite Rilima, wie biép ben Santoflädjen beș Meereşbobens eigenthümlid ift, Da ibre fehr tief ftreidhenten Wurzeln bie Bosenfeudhtig= feit aud aus groper Tiefe an jid) jieben. ?(ber aud Jeudjtigfeit uno ge:

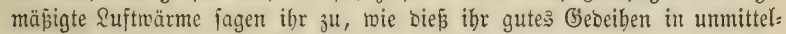
barer Eeenäbe betweișt. Wenn fie baber felten uno nur einzeln in Ges: birgen auftritt, fo liegt Diep mebr im Boben als in atmofphärifden $\mathfrak{B} e r=$

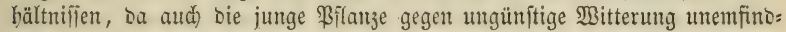
lid) ift. Mehr als bie übrigen Nabelhölzer leibet bie Sitefer wegen ber vollen Belaubung uno ber Brüdigfeit ifrer Afefte unter Duft= uno Gdneebrud..

\section{Siferatur.}

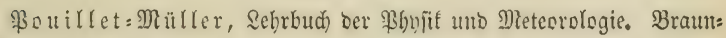
ichlocig. 1842.

Do we, meteorologifde linterjudungen. Berlin. 1837.

Sdübler, Ģrunbjäbce der Meteorologie. 1821.

2. (3). Şever, forjtlide Bobentunoe uno Rlimatologie. Erlangen. 1856. Gebr auşübrlid uno Scauptwerf.

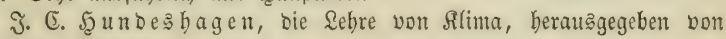

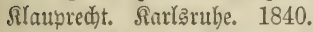

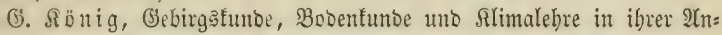

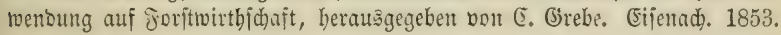

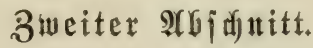

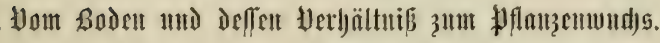

Unter bem 2 (s) fteht man bie oberfte locere Erofdidjte bes feftlandes unferer Erbe, fo weit

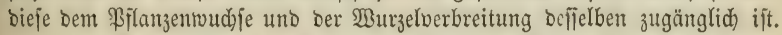

Die Bodenfunde foll uns bie Bejiehung fenten lehren, in benten Der Şoden zu ben ठ̉etwädjen jteht.

In biefer Rid)tung, als integrirender Beftandtheil ber Prlanjentunte,

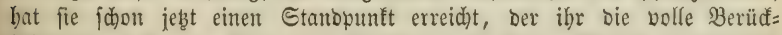
fid)tigung aud) bon Seiten bes forftmannes fid)ert. 2Anbers verhält fid

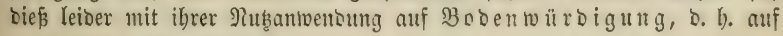

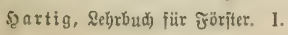




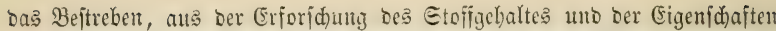

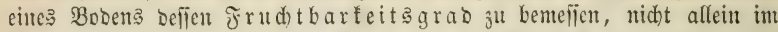

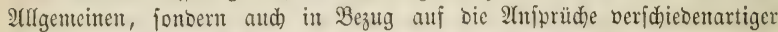
Rulturpflanjen; nidht allein in Bøzug auf bie Duntität, fontoen audi in Bejug auf Die Duantität Derjelben. In Diejer Ridutung bat un? bie Bobenfunbe bis beute nod wenig mţbare Früdte getragen. Die Utrache

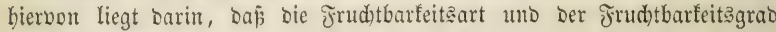
cines Stanoorts nidjt allein bon Beidaffentheit unt (Eigenidaften bes

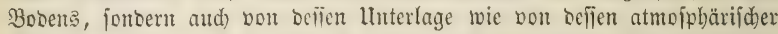
Bebedung abhängig fint, baß in beiben, wie in Boben felbit Fruddbar= feitsfaftoren entbalten funb, bie wir theila gar nid)t mefien fömen, ibrer Beränberlid)feit Doer IInjugänglid)fit wegen, für sie anterertheils ein bem Pflanjenbebarf entipred)enter 决aftab nod nid)t gefunben ift. (ङ. meine "Euntroverien Der Forftwirthid)aft". Braumidueig. 1853. G. 30.)

Es märe aber shne 3 weifel jul weit gegangen, mollte man "bas Befte als bes Guten gröpter feino" allein gelten lafieno, all' uno jeoe unmittel=

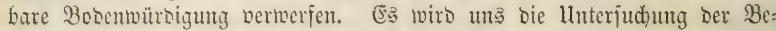

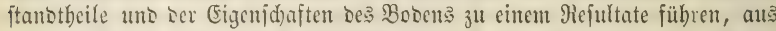

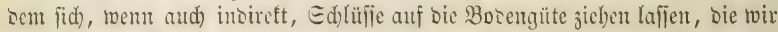

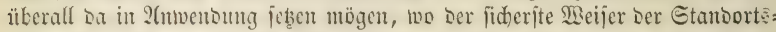
güte fehlt: bas in unjeren mehrjährigen, normal ermadjenen Sgoljbeftänben un! vorliegente Rejultat mehrjäbriger Probuttinn beffelben Etanborts.

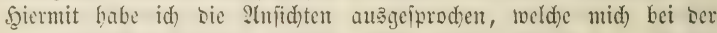

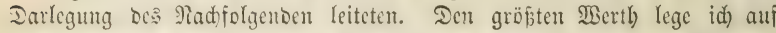

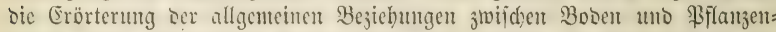
muds, Der allgemeinen Besingungen, bon benen bie Frud)tbarfeit bes

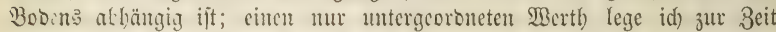
nod) auf alle umittelbare Mefinutg ber Bobenfraft, Daber aud) auf fpeciellere

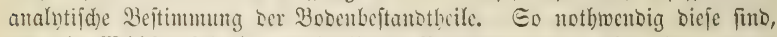
um Die S⿱ wärtigen Gtanofunft ju erbeben, ftehen jie Dod) Den bier borliegenten

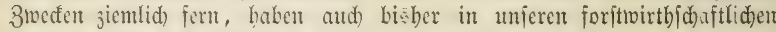
Erperten nid)t viel mebr als ormamentale Bebcutung gehabt.

Injere boljpflanjen ftchen, bei ibrem erften 2 uftreten, vom Boben jiemlid) unabbängig Da. Der feimente Eaame bedarf nidut unbebingt bes Eroreid)3. Die meiften Eämereien jehen wir bei entipred)enter Märme

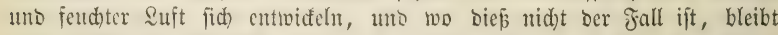
Doch bic 2frt ber Besectung gleid)gültig, twem nur ein bem Sieimen günftiger

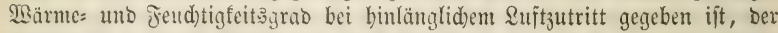
allerbings in bielen Fällen mur surd) Beocctung unt burd bejondere Eigen= fduften ber Decfe gejichert werben faun.

Erft went bem feimenden Eaamenforne bie junge ßjlanze entiproffen ift, tritt ber Boben zu ihr in? mebrfad)e Beziehung. Buerft gewälort er

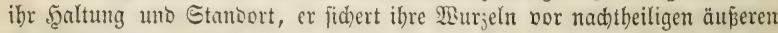

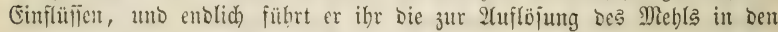
Saamenlappen nöthige รeudtigłeit วัu.

Эit meiterbin sic vom Mutterftamme Dem Saamentorne mitgegebenc 
Nabrungsimenge ber Saamenlappen verzehrt, hat fidh in Jolge befien ber Sieim Des Eaamenţ zur freien, felbitftänbigen Siflanje entwidelt, bant ge: wäbrt ibr ber Boben nid)t allein Şaltung, Ed)ut uno Feuditigfeit, jonbern er führt ihr, in leb̨terer aufgelöst, aud bic mineralifd)en Mabrungsftoffe 3u. Ier Bo¿en erbält bann für die ganje Scbenzbauer ber \$filanze eine

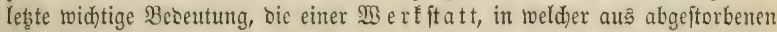
pflangliden uno thierijaben Stoffen, io wie aus bem mineralijhen Beftanoe Des Bobens felbit, Biflanjennabrung bereitet wird; er ift eine 3 orrath fammer, in welder fich bie unterirbifd)e Pilanjennabrung anbäuft uno im Ernäbrungşraume ber Wiflanje jeitgebalten unb aufgefpeid)ert mirb.

Die \$eridięenheit Des Bodens, nad ber er Den \$flanjent it gröserer

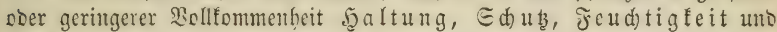
Rabrung ju gewähren vermag, ift unendlid gro $\tilde{\beta}$, uno nidst allein in jeiner Beichafienbeit, jonem aud in ber feiner Grenjen, ber Boben= unterlage, wie in ser ifn bectenten 2 tmoiphäre begrünbet. Mir

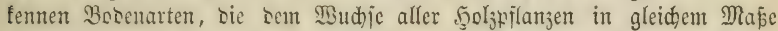

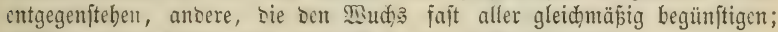

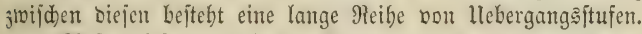

SGuper biejer unbebingten Bobengüte erfentun wir aber aud mod eine Febingte; Kesingt, criftens: Durch) bie Natur ber Pflanze, reldhe auf bem

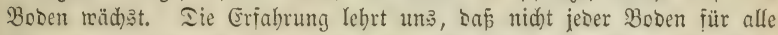

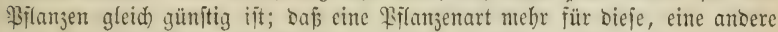
mebr für jene Bodonbejduffenteit beftimmt exfdeint. Eo fasm der befte Erlenboden für tie Budje ber fobledtefte fein, guter Buchenboden Dem

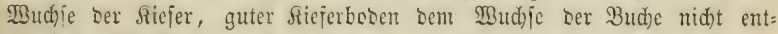

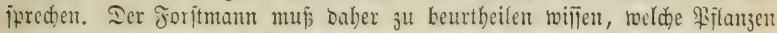
einer borliegenten Sertlidfeit mebr soer minoer entfpreden, burd) welde er biejemt oder jenem Boben sen bödiften Ertrag abzugewinnen bofien Darf, uno tajul bebarf er einter fientnī̄ bes Bobens unt feiner Eigen= ihaften. Er bebarf biejer Renntnis ferner, um bie Bemirthidhaftung ber

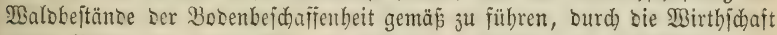
guten Booen it feiner Güte ju crbalten, jd)led)ten ju berbeffern. $\Theta_{0}$ forbert 3. B. eine Bobenart Edjub uno Edirm vom Mutterbeftanbe, anbere ertragen, nod) anbere forbern Riditung uno Suftwedjel.

Bebingt ift bie Bovengüte ferner nad) Der Berfhiebenbeit Deş Rlima. Ein uno berielbe Boben fann im rauken feudten fllima frudtbar jein, Der in heiper fomiger Sage, in trodner $\& u f t$ böd)it unfrud)tbar fein mürbe, unto ungefefrt. Bebingt ift fie endlich Dutrch Dic Bejdaffenbeit ibrer un= teren Begrenjung; Derjelbe Eanbboben, melder in geringer Erböbung über

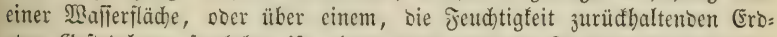
Doer Befteinlager frudtbar ift, fann unter anderen \&agerungşberbältnifien bie bödjten Grabe Der Unfruchtbarteit tragen.

Die Büte eines Bobens miro baber nidht allein von ber Bejdaffenbcit

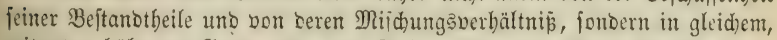
mitunter böherent Brabe von der Tiefe, Sage und Bejdajienbeit feiner

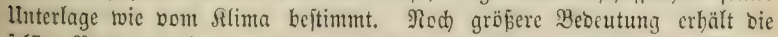
Felige Bodenunterlage da, mo ber fie bedecfente Boben aus ibrer Seritörung 


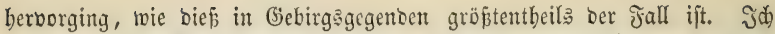
merbe baher in Nadfolgendem zuerit non Der Bobenunterlage uno beren Einflū́ auf bie Bobenbejdaffenheit, Dann bon Der Bodenunterlage al's Bobenbilber, uno zuleb̧t vom Boben felbit fpred)en.

\section{Erftes Eapitel.}

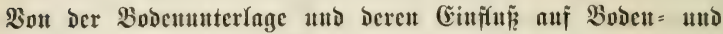 \&iff(a)}

\section{Entitehung Der Ģebirgaarten.}

Eo weit wir in bas Jinnere unferer Eroe eingeirungen funb, befteht

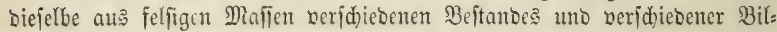
Dung. Sn Der 3ujammenfügung eines Ibeiles bicjer Felsfohidhten erfennt man beutlid, Daf ifre Mafje, früber im \$isafjer aufgelöst, fidh aus biejem niebergejd)lagen bat. (E: jeidnen fid bicje Jetsmafien burd) ein, nur in

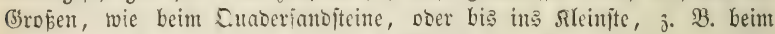
Thonfdiefer hervortretendis fojicfriges befüge ibrer Beftuntheile aus. Ein anderer Theil Der Felfon läp̧t cben fo bentlid) erfennen, Daf er, wie jener Durd) Wanjer, einft burd Jeuer flüilig war, uno jeine jebsige Jejtigfeit mit Dem Beridjwinoen ber fdmelzenten Seize erhielt.

2นเ bem verfdebituen Beftunte, ber Sagerungsridtung, uno aus auf= gefunbenen thierijden uno pflanjliden, berfteinten Sörpern im Innern Der

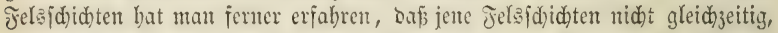
jonbern in mebreren, Durch) lange Beiträume getrennten \$erioben fich bildotent.

Man ift bered)tigt anjunebmen, Daj unjer Erotörper, nod) lange Beit nad) iem 3 ufammentreten feiner Etofie aus bem IIeltenraume, fid im

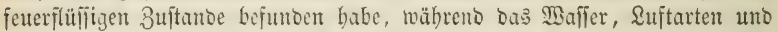
anbere, bei groper 5ił̧e flüdtig: Beftantheile Der Eroe, Durch bie vom Eroball auştrablento Şişe in Iunftorm aufgelöst, einte weit entfernte Wolfenididgt biloete.

AH ber feuerflüfïgen, Durd, Den Unid)wung abgerutbeten (Erofugel mupten bie leibhtejten Metalle, bie ber Eroen uno 2rlfalien, bie Dberflädhe

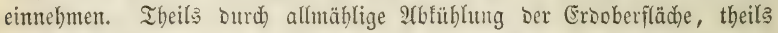
Durd) Berbinoung ber Metalliftofie mit Dem Saueritofie Der 21tmojphäre ent=

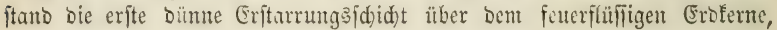

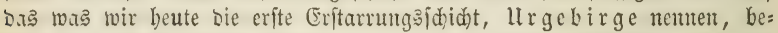
fteheno aus fryftallinifo förnigen, berfteinerungsleeren felsarten: (5) ис und Gilimmeridiefer, Ialf = unt Ebloritjiefer.

Jn Jolge junehmenter 2 (bfühlung Der (Erboberfläh) unb vermintorter

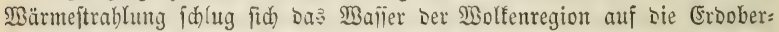

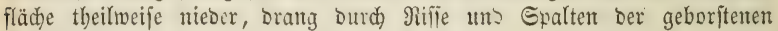
Erorinbe zur inmeren, feuerflüifigen Miafie uno veranlapte unterirbifa)e Dampfbilinung, Durd) Deren Riäfte Die nod) Dünte Erorinbe theils gehoben, theils gefenft wurbe. Jn ben Senfungen fammutte fid bas $\mathfrak{B a n j e r , ~} e^{3}$ entitand Der Gsegenją̧ zwijd)en Meer und Feftlanto. 
Durd, mädtige ltmmälyungen bicjer $\mathscr{A} r t$ war ein groper Theil ber Urgebirgșmajien zertrümmert uno aufgelöst morben. Mieberjoblag auß bent Meerwaller bilbete geididtete Beiteine: bas llebergangagcbirge,

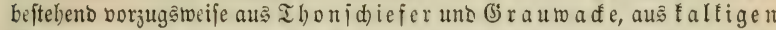
(b) e ft e in en, roie Marmor uno Iolomit; untergeoronet Riejeljwiefer, Duarz=

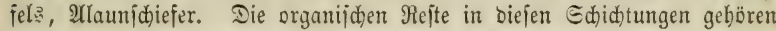
überwiegent Meereşbetwohnern an unt zwor nur nieserer Biltung: Rorallen, Sdaalthiere, Srebje, Denen aber eime reiche Bilanjen= Begetation vorber:

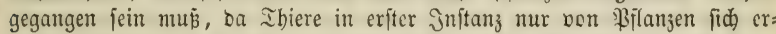

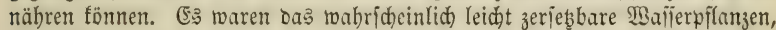
Deren Ueberrefte in Den geringen Diengen von Grapbiten uno Antbraciten

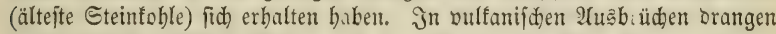

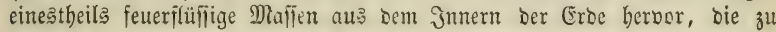
fryftallinifo förnigen Gijteinen, 3u Grani ten uno Syent ten eritarrten,

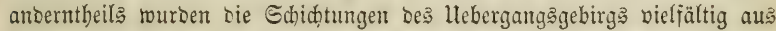
ifrer uriprünglid) borijontalen Sage verrüdt, gehoben ober verjenft; ein Theil Des früberen Feftlandes jenfte fid) uno wurbe žum neuen Meereşbette, ein Theil bes früheren Meeres̄bettes wurbe erhoben uno Jeftlano.

Nad) siejer erften Ummäljung trat auf bem Jejtlanbe eine Periobe ungemein üppigen $\mathfrak{B}$ tanjenwudfes ein, Dellen llntergang, in Folge einer żmeiten Ummälzung, mäd)tige Eteinfohlenlayer ihr Entîtehen verbanten. Die Flora bejtano bauptiäd)lid) aus Farrenfräutern, Encabeen uno $\mathfrak{A r a u f a r i e n =}$ ähnlichen Nabelföljern, feltmer aus monocotnlen Bflanzen. Edjaalthiere und Jifide im SBafier, jelten gefuntene Jnjeften bes Jeftlandes, bildeten bie Fauna. Dieje ztweite, im 2tllgemeinen von Denjelben Erjdeinungen uno Errfolgen begleitete llmtwäljung lieferte bie plutonijden Bebilde ber (3) rünfteine unb bie neptunijhen ber $\subseteq$ teinfoblenformation: Roblen= fantofteine, Bergfalf uno Edjieferthone, wedjelno mit Eteinfohlenlagern.

Jolge einer britten llmwälzung ift bie, Das Eteinfohlengebirge über= lagernoe 3 ed fteinformation, befteheno aus ben gefdidteten Gebirgs= arten bes Rothen und $\mathfrak{B}$ eifen= Iodtliegenden, bes $\mathfrak{A} u p f e r=$

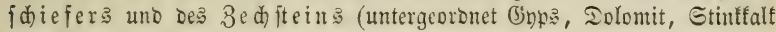
uno Rogenitein), geboben uno Durdbrocten bon Porphyren. Drganije Refte finden fid hier jefr wenige uno mu joldhe bon Meerberwobnern.

Der Bedfiteinformation folgte bie formation ber Irias (Ealj= gebirye); зu unterit bunter Eanojtein, bann Mujdelfalf, Dann Reuper; Salfe als Muidelfalf mit untergeoroneten Sagern bon Dolomit, Sbpps, Steinjaly, Scornftein, Settentoble (leb̧tere jelten uno in wenig mäd)tigen Qagen auf Der (Srenze zwifhen Mujhelfalt uno Reuper) uno Sager von Thon uno Mergel.

Die Эuraformation befteht porberricheno aus Ralfiteinen uno Eantiteinen; untergeoronet Dolomit, Mergel uno Ihon.

Das Rreidegcbirge bejteht aus Drei untergeoroneten formationen:

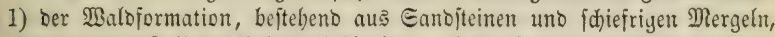
untergeorbmet Salf uno Edivarjtohlenlager; 2) Der Duaberjanditeinformation: Quaberfanditein, Ralk= uno Mergellager; 3) Rreibeformation: Rreibe uno Rreibemergel, untergeorbnet Mergel, Sanbjtein. 
Dieje Reihe beutlid gejdiebener Frormationen fann man, wom Sohlen:

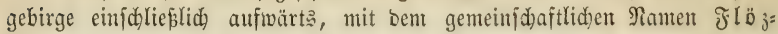
gebirge bezeidynen.

Die Jormation bes 3edjtein, ber Trias uno Des Jura enthalten an organifjen Mejten faft nur Meerbewohner, fehr wentige Sanopilanzen. Es:

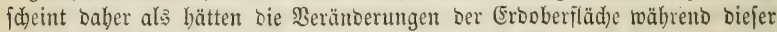

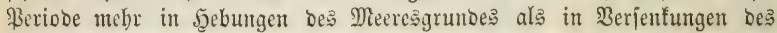

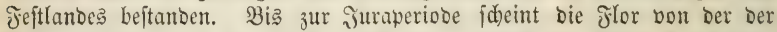

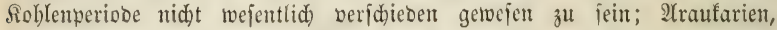

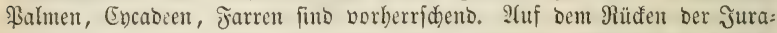
formation bingegen erbielt bie flor einen Durdjaus abreidjenten Typus. Siabelbörger ähnlid) unjerer (Gattungen Pinus uno Abies fino vorberridento, großßblättrige Saubbölzer (Credneria) häufig, einzeln treten fod)on bie in tertiären Jormationen fo berbreiteten ?abelhölzer aus ber Familie ber ( prefien auf. 1 Die Heberrefte biejer Begetation finton fid theils in ben bberen Edidaten Des Jura, vorzugatweife ater in Den Soblenlagern ber unteren Sreibejdidsten.

Grünftein=Eruptionen fanben von Der Zeriobe Der Graumadenformation bis zur Billoung Des bunten Eantofteins, Borphyr:Eruptionen von Der Biloung Des foblengebirgs bis in bie Juraperiobe lintein ftatt.

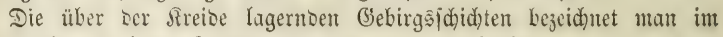
Ganzen als tertiäre Formationen uno unterfdeiot

1) Die Molafeformation: a) untere Braunfoflenformation, be= ftehento aus Gantiteinen, Edieferthonen, Gant: uno Ihoulagent, wedfelno mit Brauntoblenlagern; b) Grrobtalfformation: Ralffteine, Ibon, Mergel, Eandlager; c) Eüpivalierfalf; falf mit Eüpivailer=Condyblien, Mergel, Sano uno Brauntoblenlager.

2) Dilubialformation: Atblagerungen von Sano, Sebm, Thon, Mergel, gemengt mit Gejdieben norbifder Gebirgäarten (meift Granitfint: linge), untergeoronet Sitod)enbreccie uno Bohnerj; gebiloet Durd) eine lebte, allgemeiner berbreitete Ummälzung uno Şebung.

3) Arluvialgebilbc: Siçs:, Ganb=, Sehnt, Thon= uno (seröll= Arblagerungen, Salftufie, Einter, Rafentifen, Iorflager, entftanden feit ber Bollenoung bes Diltwium uno nod) beute fid fortbiloent burd) $2(n=$ idmenmungen von fitilien oder Geelt aus, burd) 2(bją̧ aus Duell= ober Eumpfwafier.

Den ßerioben ber Molaffe uno des Dilluium gehören bie vulfani= fohen Eruptionen bes Bajalt, ber Alllubialperiobe bie \&ava ergüfie an.

Eine äuserft reidje flor Der fireibeperiobe ift in Den Gebilden ber tertiären Formationten, befonoers in ber Molaileformation erbalten. $\mathfrak{B}_{\mathrm{or}}=$ berrfacto, wenigitens im nöroliden uno mittlen Deutid)lano, ijt bie Jamilie Der Enprefien, Dod) Deutet Bicles Darauf bin, Daßs unjere Braut= foblenlager borzugșiveife aus ITreibhol $_{3}$, vielleid)t aut fehr entfernten Giegen= Den ftammeno, entitanden fino, uno daj bie flor bes jeftlandes unjerer Sängen nid)t wejentlid) von Der jeşt lebenden veridjieden war. Nod) vor

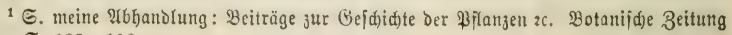
1848. ङ. $122-190$
} 
Surzent habe idh ein entidieben ber Molaileformation angehörentes Braut=

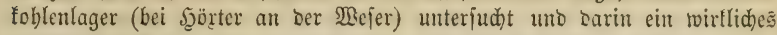
antebilubiane Iorflager gefunben, wie bie heutigen aus Sphagnum,

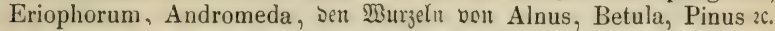
bejtebento. Die 3apfen Der Pinus=2trt fino unverfennbar folde oer Pinus Pumilio und Abies excelsa beutiger flor, neben benten ein ber Abies alba äbulicher 3ałfen einer auşgeftorbenen Fidhte Abies brachyptera m. porfommt. Sbot. 3tg. 1858 G. 378.

Die erften Sanotbierrefte finoen fid) in Der Grobtalfformation; bie obere Braunfohlenformation uno Die Diluvialgebiloe fino reid Daran; Der Menid) aber wurbe erft nad) Der Bollendung bes Diluvium geidaffen, uno

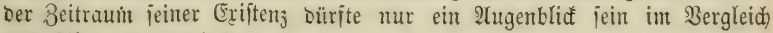
зum 2ulter bes Eroballs.

\section{Bom Beftaltbe ber Felsarten.}

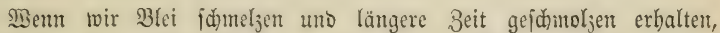

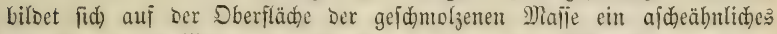

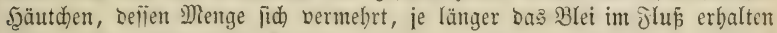

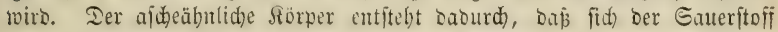
Der \&uft mit Dem Blei verbinbet. Diefer Berwandlung in ersige Rörper fint alle Metalle unterworfon, wenn fie fid längere Beit mit Saueritoff in Berührung befinten; bei Den uneden Metallen erfolgt bie \$erbinoung raider, bei ben eblen Metallen langiamer.

Sommen joldhe Metallaiden ober Metalloxyde mit Gäuren in $\mathfrak{B}_{e}=$ rübrung, io verbinoen fie fid) mit ifnen 3 Ut Ealzen uno erbalten als jold)e beftimmte Sirgitallformen. Die Grumblage Des falfę z. 23. ift ein Mletall; in Berührung mit Eauerftoff berbrent bafielbe zu Ralferbe (im (hemijd)en Eimme); tritt Soblenjäure ober Ed)wefeliäure zur Ralferbe, io bilbet fid im erftern Falle Soulf, im lețtern Jalle Gups. Lnter Butritt

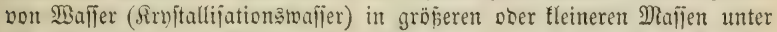
fid) Doer mit anderen Sörpern felt perbuntoen, nennen wir foldhe med)anifdye

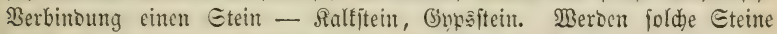
Durch irgento cine medhanijhe Urjache in feine Theile zertritmmert, ober fant uriprünglid) eine Bereinigung zu fejten Mafien nid)t ftatt, ober ver= lieren fie ifren 3ujammenthang Durd) Beridjminden ober Beränberung eine Bindemittels, jo nent man diế ebenfalls Erbe - Salferde, Ginpserbe aber im agronomijden Sinne.

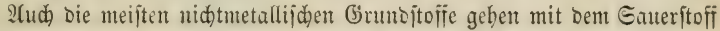
Berbindungen ein, bie Säuren genannt werbent. Der Roblenftoff liefert bie Soblenfäure, der Edivifel die Ediwejeliäure, ber \$hosphor die \$hos: whorjäure, fluor bie filujpäure, Etidjtoff bie Ealpeterjäure, Ricjel bie Riejeljäure, Mafierjtofi Da马 Baijer. Die Gäuren bilden ben zweiten Be: ftandtheil ber Galze und gehen auj oieje \$Beife in bie 3ujammenjebung Der B̈efteine und Desె Bodent ein.

Eo grof́ bie 3abl ber in ben Mineralien berbundenen einfacben Rörwer

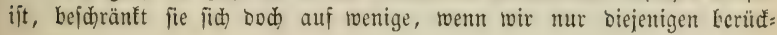


fidtigen, bie wegen ber 2Ullgemeinheit uno Menge ibres Norfonmens in Bezug auf ben Boben uno auf Bilanjenleben von bejonberer $\mathfrak{B i d}$ tigfeit fint.

Unter ben nidtmetallifden Grumbitoffen fino es Der Saueritoff, ber Wajieritofi, ber Etidftoff, Der Sohlenitofi, Riejel, Eblor, Bhosphor und Sdywefel, unter den metallifanen Errunditofien fint es Ealcium, Magnium, Slluminium, Ralium, Ratrium, Eifen uno Mangan, bie Den Saantbeitand ber Gsebirge unt Des biefellben bedecfenden Bodens bilden.

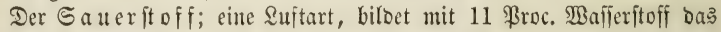
Baffer, mit 26 \$roc. Stifftoff bie Salpeterjäure, mit 27,65 \$roc. Sohlenftofi bie Solhlenjä ure, mit 48 Froc. Siejel bie Riefeliäure, mit 47 ßroc. Ehlor bie Ehlorjäure, mit 44 Broc. Bhoßphor die Bhos: phorjäure, mit 40 Broc. Sdivefel bie Sd) wefeljäure, mit 72 Proc. Ealcium bie Salferde, mit 61 Broc. Magnefium bie Ialferbe, mit 69 ßroc. Âtuminium die $\mathfrak{I}$ bonerde, mit 83 Broc. Salium das Rali,

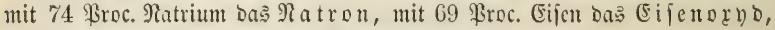
mit 70 Procint Mangan ba: Manganox̧y.

Der $\mathfrak{B a f f e r f t o f f}$, gleidfalls eine Suftart, biloet mit 89 Broc. Gauerftoff bas 2 a ajfer, mit 97,26 \$roc. (Ehlor Die Ehlorwafierftoff: ¡äure (Ealzäure), mit 17,46 Proc. Eticfitnif bas 24 moniat.

Der Sti cf ft off: Der rein, im gaşförmigen 3uftanto, mit 21 Bolum= procenten ober 23,1 Getvidtprocenten Eaueritofi ge men gt, bie atmojphärifde

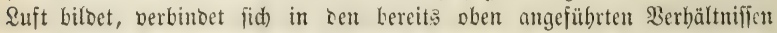
mit $\mathfrak{W a f f e r f t o f f}$ uno mit Gaueritofi zu $\mathfrak{2}$ mmoniat uno Salpeterfäure.

Der $\Omega \circ b l e n j$ iff; ein nid)tmetallijder feiter Sörper, im reinen 3uftanoe nur als Diamant uno Pieipblei befaunt, faft rein in ben älteften Edwmarztoblen (2fnthraciten), mebr ober meniger verumreinigt bie Ed)warz=, Braun= uno Golztoblen biloento, fintoet fidh) in größter Mlenge mit 72,35

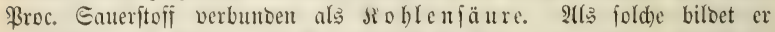
einen ftänbigen 2(ntheil ber 2(tmofphäre (j. Seite 10). Siebig bered)nete feine Menge barin auf 2800 Billionen Wfmbe und meint, baßs bieß mełr jei als bie ganje Malle ber lebentoen uno vortucttlid)en Pilanzen betrage.

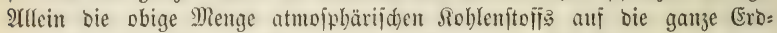
oberfläd)e gleid)mäßig vertheilt, lwüroc bod) mur cinte Sdjid)t bon faum einer Sinie Diffe betragen, umb biej ift getwip weniger als bie Summe alles bor= uno jeb̧tweltliden begetabilifden Roblenjtoffs, bejonders wenn man bazu die Menge bes in faft allen Slöz= und Iertiärformationen berbreiteten Bitumen red)net. Sußseroem finbet fid bie Rohlenfäure in ungebeuren Mafien mit Metalloxiben verbunben. Jeber Siubifjuj toblenfautrer Ralt $=165$ Fifutbe enthält 73 Pfuno Soblenfäure uno barin 21 PFunde reinen Roblenftoff.

Der Sohlenftoff berbinbet fid ferner mit 24,62 \$roc. Mafferftoffgas ju leidtem Roblenwafieritoffgas (Sumpfluft, jdlagende Better, feuriger Edwaben 2c.) mit 14,04 \$roc. Mafferftoffigas bas (d) twere Roblentwafferftoffgas (ölbildentes (bas) bildento.

Riefel (Silicium) ift ein nidtmetallijhes, duntelbrautes, foblent= ftoffäbnlides ßulver, bas in Der Matur nid)t rein vorfommt, in Defto größeren Majen aber in Berbinoung mit 52 \$roc. Saueriftoff als $\Re$ ie $j \mathrm{el}=$ fäure, bie einen Beftanbtheil ber meiften Minteralien ausmad)t. Die 


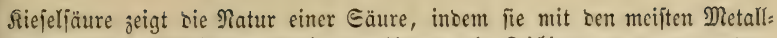
proben fich zu fiejelfauren Galjen verbinbet, bie Silicate genannt werbent. Die Berbinbungen ber Riefelfäure mit ber Thonerbe fino am verbreitetften als Jeloipath, Ihon, sehm, Forzellanerbe 2 ., aud bie meiten Suarze müifen als Eilicate betradtet weroen uno jelbjt ber Bergfrnjtall enthält nod Spuren bon Thonerde.

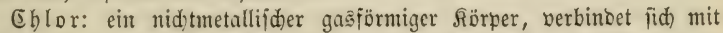
53 Proc. Gaueritofi zu Ebforiäure, mit 2,i4 \$roc. Walleritoif zu Ealjiäure, auberbem wie ber Gaueritofi mit ben meiften ber übrigen Elemente. Die \$erbinoung ju Ealjäure ijt jeboch bie einjige agronomija

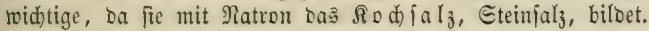

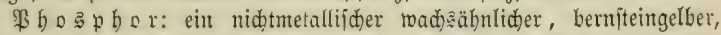
Durdjideinenber, leid)t entzünolider Siörper, berbinbet jidy mit 56 \&roc. Gaueritofi зu Bhosphorfäure, bie bejonoers in Berbinoung mit Ralf, Talf unb (Fijencrno cinen nid)t unbedeutenoen $\mathscr{A}$ ntheil bes Bejtanoes ber (jebirgsarten und Yđererben bildet, aus biejen burd) bie Piflanzen aufge= nommen wirb, mit ber Pillanzennabrung in ben thierifden Rörper über: geht, Deren Sinoden vorzugameije aus phosphorjaurem salf bejtehen.

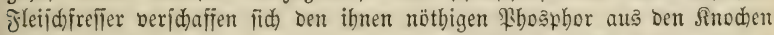
uno Snnrpeln anoerer Ibiere. Die übrigen zablreid)en Berbinoungen Deङ Phoâhor haben feine herboritedente agronomiide Bebeutung.

Sdinefel: ein nidtmetallijher, feiter, bellgelber, leidht brennbarer Rörper bilset mit 60 \$roc. Gaueritofi bie Edbrefelfäure, mit 5,84 \$roc.

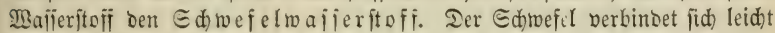

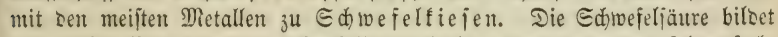
mit vielen Metall=Drnoen jumefeljaure Ealie, von benen ber $i$ d wefel= ja ure Ralf (Ginps) bas im Boben berbreitetifte ift.

Ealciun: ein filberiveiñes Metall, perbinbet fid mit 28,09 Broc. Eaueritofi ju $\mathcal{S}$ alferbe (gebrannter Ralf). Ralferbe mit 43,71 Proc.

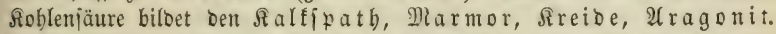
Durch Glüben wiro bie Sohlenjäure auşgetrieben uno falferbe wieberher= geitellt. Bergfalf, Mujdelfalf, Jurafalf zc. Futo bie unreineren Formen beß fohlenjauren Ralfs burd) Şinjutritt von Thon, Ialf, Eijen zc.

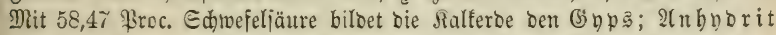
genannt, went das Sunftallwafier fchlt. Durd) Brennen läpt fith bie Ed)wefeliäure nidht auझtreiben rie beim Ralfe bie Sohlenjäure, wohl aber

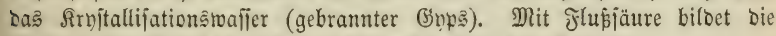

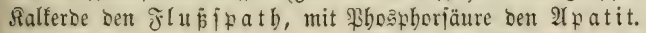

Magni um: ebenfalls ein fitberweipes Metall, berbinbet fid mit 38,71 \$roc. Eaueritofif zu Magnefia (Talfer be). Mit 65,98 Edwefel:

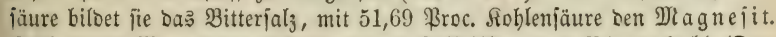
Rohlenjaure Magnejia uno fohlenfaurer Ralf bilden ben $\mathfrak{B}$ itterfalf $(D S=$ $10 \mathrm{mit})$. Mit Riejelfäure in verjobiebenen Berbältnifjen verbunben fommt bie Ialferbe in ber Natur am bäufigiten vor als (jemengtheile ber horn: blenbeartigen uno augitijen Gejteine, im Serpentin, Epeffitein, Meer= iđ̆aum, Slivin, ßifrosmmin.

Ifluminium: ein filberäbnlides Retall bilbet mit 31 Procent 
Sauerftoff bie Thonerbe, cin weißes geidmad̆lojes ßulver. 2Hm reinjten

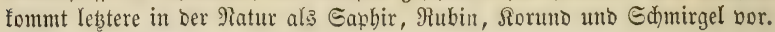

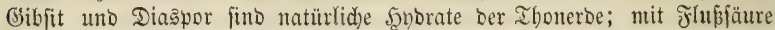
bilbet fie ben Iopas uno Prfnit; nit Ed)wefelfäure Den 2 (funtuit uno bie

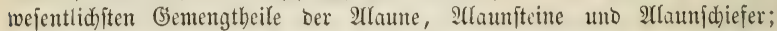
mit Bhoß̧phorjäure ben $\mathfrak{B a w e l l i t . ~} 2(m$ bäufigften und in ben gröften Maflen fonmt bie Ihonerbe in Berbintoung mit Siefeljäure (al’ Silicate perjobiebener 3ujammenjeł̧ung) vor; mebr noer tweniger rein als Enanit, 2lgalmatolitb, Forzellanerbe uno I bou, in Berbinoung mit fiefeljaurem Sali ober Ratron bie Reihe Der Jelbipathe, in Berbinoung mit fiefel= faurem Salfe bie Reibe Der Beolithe bildent.

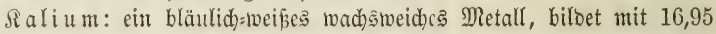

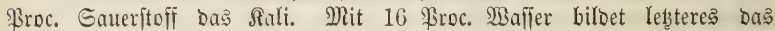
Salibubrat (2feb̧tali); mit 31,91 Froc. Soblenjäure dą foblenjaure Sali, wejentlidjiter Bejtanotbeil ocr Fotajd); mit 53,44 Proc. Salpeterjäure ben Galpeter. In ber Tlatur futbet ç fich ant häufigften uno in ben ber=

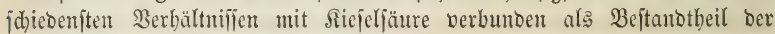
Salifelofpathe.

Ratrium: cin filberweifes wad)shartes Metall, werbindet fid mit 25,58 \$roc. Gaueritoff zu शiatron; leb̧teres mit 22,35 \$roc. M3affer zu

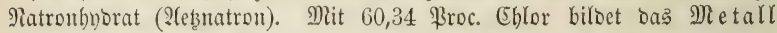

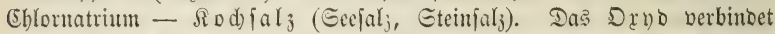

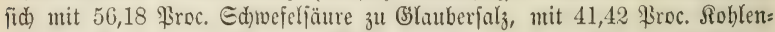

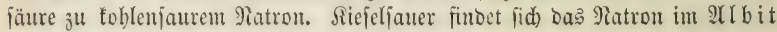
ober Natroufelofpath, im S(nalzim, Rephelin, Eläolith, Mefotnp, Sobalith, \$etalit uno Epodumen.

Eifen: ein befannter metallifd)er Rörper, finoct fid in ber Natur

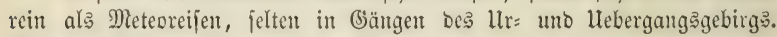
Mit 22,77 Broc. Sauerftofi = Eifenorboul. Dießs leb̧tere fommt mit Soblenjäure verbunben vor: als Epatheifenitein, Ephärofiberit, Ihon= eifenjtein; als Şubrat = Brauneifenftein. Mit 30,66 Broc. Gaueritofi $=$ Eifenoxbo als Eifonglanj (Eifenglimmer), Rotbeifeniftein (ङ્lastopf, Bhutfein), (Eifenrabm, Eifenod)er, rother Ihoneifenftein (9iothel); mit 28,22 Broc. Gauterfoffi $=$ Eifenoryouloryo $=$ Magneteifen. Mit 54,26 \$roc.

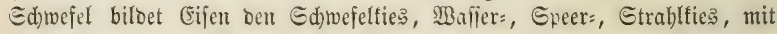

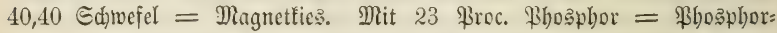
eifen, ein wejentlider Beftanotheil bes Rajeneifenifteins. Jm Boben fommt Das Eifen allgemein in grö̈̈ren ober geringeren Mengen, theils als Drboul, theils als Sryo vor.

Mangan: ein grauweifes, bem Ssufeifen äbulides Metall, ver: binbet fich mit 22,43 \$roc. Saueritofi zu Mangannorybul, mit 30,25 \$roc. Sauerftofi zu Manganorto, mit 36,64 Proc. Saueritoff zu Manganjuper: Druxb (Braunftein). In vielen Giebirgsarten uno in ben meiften Bobenarten fommt es als Drvo uno Dryoul bor, uno gebt von bort loie bas Eifen in ben pflangliden uno thierijden Rörper über.

2(u Den in Borbergehenden aufgefübrten einfachen Stoffen unt Deren genamnten nädjiten Berbinbungen ift mun ber bei weitem größte Theil Des 


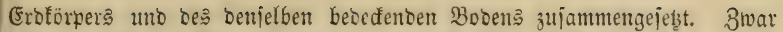
gibt es nod) eine Menge anoerer einfader Etoffe uno Nerbintungen, allein

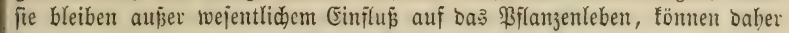
bier mit Etilljoblweigen übergangen werben.

\section{Ginfarade Gepiteine}

nennen mir biejenigen Berbinoungen Der aufgejührten Elemente, bie in fid)

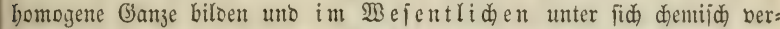
bunben fino, injofern fie dem Ẽroförper als einem (banzen angebören uno burdh Menidenhände nod) unveränoert fino. Dahin gefören:

1) Duars: bejteheno aus Siejelerbe, jehr wentig Ihonerbe, Eijen:

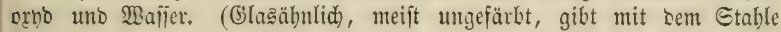
Junfen.)

2) Jeloipath: 60 Siejelerbe, 17 Thonerse, 17 Sali ober Satron Doer Ralf. (Werlenutter= oder forzellanglänjend, fleijojfarbig, grünlid, meişlich.) Der Jelofpath beist Drthoflaz: bei vorberrichenocm fali=

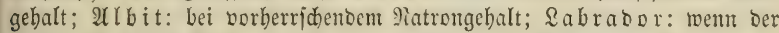

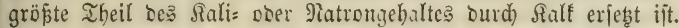

3) Ģl immer: 46 Siejclerbe, 31 Thonerbe, 9 Rali= poer Talferie, 9 Eijenorbo, Das Uebrige Flufiüure umb Maljer. (Blättrig, meid), me= tallifids=illber: ober gologlänzend.)

4) Ialf: 62 Siejelerbe, 1,5 Thonerbe, 27 Ialferbe, 3,5 Eijenoryb uno 6 Baffer. (Eehr weid), meißßlid) ins grünlide, fettiges 2(nfüblen.)

5) $\mathfrak{A}$ u git: 54 Riejelerbe, 21 fnhlemjaurer Ralf, 12 Ialferbe, 10 Eijen: Dxybul. (Borberridend f̧ivarz, glänzent, hart.)

6) 5ूornblende: 60 Siejelerbe ( $\tilde{T}, 5$ I fonerbe), 12 fohlenjaurer Ralf, 28 Ialferbe (19 Eifenornbul). (Worberrideno ¡đjwarz, glänzeno hart.)

7) Dolomit: 54 foblenjaurer Ralf, 46 foblenjaurer Talf. (iseid, brauşt mit Eäuren, tweiß bis grau uno gelblid grau.)

8) Ğıps: idfwefelfaurer Ralt. (WBeid, braust nid)t mit Eäuren;

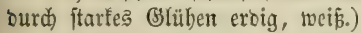

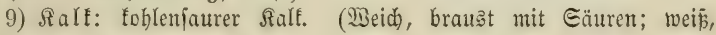
grau, gelblidgrau.)

10) Eifen: Eijenorbo ober (Eijenorboul (graphitgrau, rojtroth).

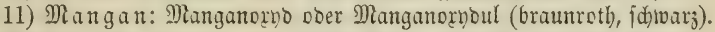
Jreilid) gibt es nod) eine grofe Menge anberer einfad)er (befteine;

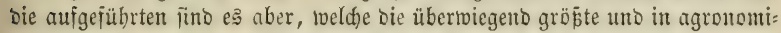

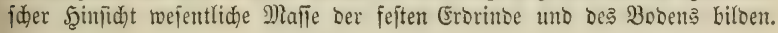

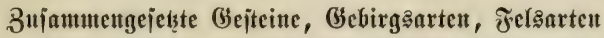

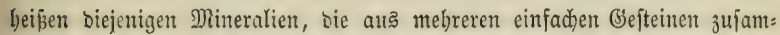
mengejebt fino. Man red)net zu Den Feläarten aber aud biejenigen ein=

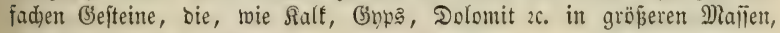
Bebirge bildento, auftreten.

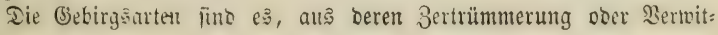


terung ber Boben fid gebilbet bat. Sie fino baher nidgt allein als Boben= unterlage, fonbern aud infofern widtig, als fid) aus ibrem Bejtande ভdlüfle auf bie Befdaffenbeit bes aus ifnen berborgegangenen Bobens zieber lafien, jebod) nur innerbalb gemiffer (srenzen, bei ber großßen Ber: fodiebenbeit bes quantitatioen Berbältniffes ber Gemengtheile, nid)t allein in ein uno berfelben (3ebirgsart, fonbern bäufig in ein uno bemfelben Felfen.

Eelbjt rem wir in einer Gebirgsart die Mnjienberlältniffe der Mengungätheile uno ben Bejtano ber leb̧teren aufz gentauefte fennen, läß̧t fid aus ibnen bod nid)t immer mit bolfer Siderbeit auf bie 2trt uno

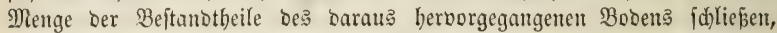
indem mährend ber Berivitterung bes Bejteins ober fäter, einzelne auf= lösbare ober löslich geworbene Beftanotheile beffelben, wie Silf, Ialf,

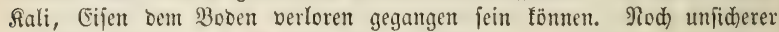
find bie Edlüfie auf Jrudtbarfeit bes Bobens, indem bieje, abgejeben bon ben äuferen bebingenten Einflüffen, nidft allein bon $\mathfrak{A}$ rt uno Mengen= עerbältnis, fonoern aud) bon Der Form uno 3ertbeilung Der Beitanotbeile abbängig ift. Derjelbe Riejelgebalt einesె Bobens, welder in jebr feinter

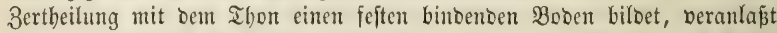
einen viel höbern Brao von Soderbeit, wem er in Sïrmern als Sant

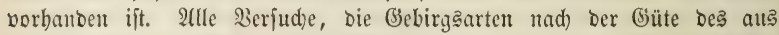
ihnen entitebenden Boden? zu claffificiren, fint baher mifglüaft uno toerbent ftets mişglïđen; mur innerbalb erweiterter (5renzen uno mur inbent man

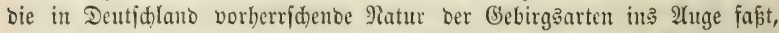

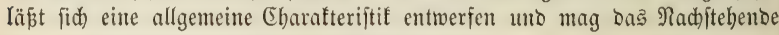
al’ ein $\mathfrak{B} e r\{u d$ biejer 2 rt betradtet merben.

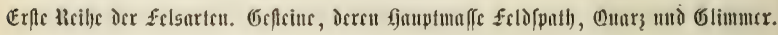

\section{Branit}

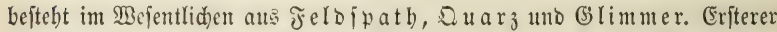
bilbet meift bie Saauptmaffe, ber GSlimmer ift in geringiter Menge bor= handen. Llebergänge in Gineis, SSlimmerfatefer, Snenit uno Diorit. Die Berwitterung fdreitet meift langiam vor, um fo langamer, je mebr Quarz vorbanten ift. Die meiften Brantite liefern cinen Boben, ber zu gleichen Theilen Ihonerde uno Riejelerbe, nit 5-10 ßroc. Eijenorbo, 2-6 \$roc. Rali entbält; Der geringe Ialfgebalt uno ber Bebalt an Rali verfdiwinden

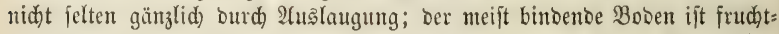

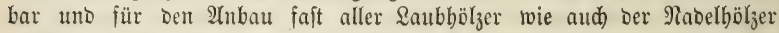
geeignet, büufig aber jebr flachgründig, Daber mebr für bie Şolzarten mit flader Bewurzelung geeignet. Jid)te uno Rotbbudbe gebeiben auf ihm am befter. Mande Srranite, bejonders febr grobtörnige, befitzen mitunter einen geringen 3ufammenbang ber einzelnen Beftanotbeile uno zerfallen

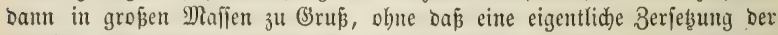
einzelnen Beftanotheile ftattfindet. Soldje Granite liefern einen jehr un= frudtbaren Boden, inbem aud bie allmäblig ourd) Bernitterung fid bil= bente Erofrume in bie Bjeröllidid)t binabgejdwemmt wirb. Aluf foldhem Boben ift befonders bie $2(n=$ uno $9 a d$ zud)t ber Beftänbe mit vielen Edjwierig= 
feiten verbunben, uno fann oit nur baburd betwirft twerben, baj man bie Saaten ober Pflanzungen in plaşweis aufgetragener Bodentrume voll= jieht. Epäter, wenn bie in aufgebradten Boben erzogenen Bflanjen io weit herangetwadjen fint, baj fie mit ibren $\mathfrak{B u r z}_{3} \mathrm{ln}$ bie Bobentrume auf

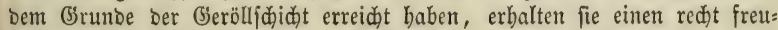

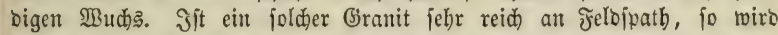
Ler zufaumengefdwemmte, fehr bindente Thonboden leidht zu einer bas

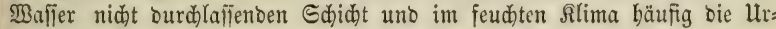

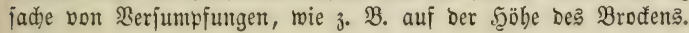

\section{Oீnci引.}

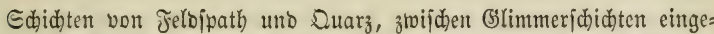

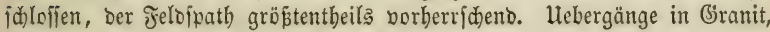

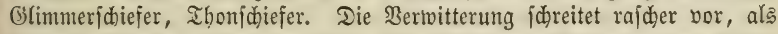

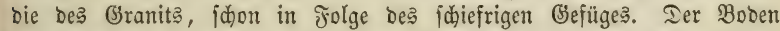
Deșienigen (sneijes, in weldem ber Felojpath vorherridt, fommt bem Boben Des feinförnigen Stranits gleid̄ uno zeigt mitunter nod) böbere Grabe ber Jrudutbarfeit, fकbon in Folge ber meift größ̈eren Bobentiefe uno Der günftigen Eintwirfung ber geidid)teten uno zerflüfteten Itnterlage auf

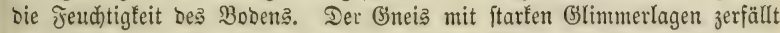

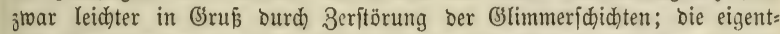
lide Berwitterung, bie Scerausbiloung einer Bobentrume wirb aber baburd nidht wejentlid) geförbert uno bie entítehenoen (srū̧lager wirfen auf bies jelbe MBeije, wie ber grobfömige lofe verbuntene Granit, nadtheilig auf Bobenbildung ein. Som Granitboden unterideibet fid) Der Gineisboden ferner burd einen feintörnigeren Gand.

3. Brimmeridsiefer.

(3)Cimmer uno Quarz im fđjefrigen, oft blättrigen Befüge. Der

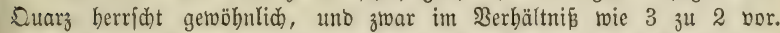
Uebergänge in Bnteis, Thonfidiefer, Şornblenbefdiefer. Die Berwitterung Des Gejteins forreitet um fo rajder vor, je größer fein Shlinmergehalt ift, gröptentheils leidhter uno rajder als (5ranit uno Bnneis.s. Der Boben felbjt ift mir unbefannt, uno bie 2Yngaben ber Sdriftitteller über feine Eigen=

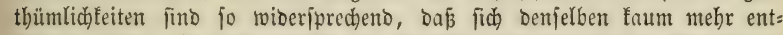

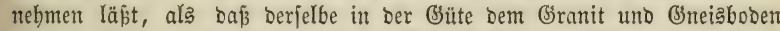

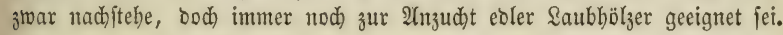

\section{Thonjdiefer}

ift im $\mathfrak{B}$ ejentlichen wie Granit uno Bneiß, aus Felbipath, Quars uno Cllimmer zufammengejebzt, zu weldhem meift nod ein geringer 2Yntheil von Talf fommt. Aflle Beftanotheile fino aber in hohem Grabe zerfleint uno fo innig gemengt, bafis fie bas blope 2luge nidht mebre zu unterideiben

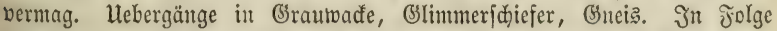

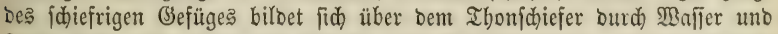
Jroft leidjt uno rajd) eine Sdjidyt lofer (Befteintrümmer, bie ber Bobent= 
biloung baburd jebr binberlich) ift, Dap bie fich bilbenbe (Frbfrume ourdy eigene Edwere und Durd) Regengüffe in Die Tiefe Der Trümmerjøidt binab=

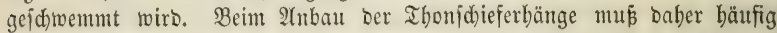
Daflelbe fulturberfabren in Inwendung treten, beflen id bereits beim Granit ermäbnt babe. Die Berwitterung idreitet übrigens rajder als bei ben vorgenamnten Sebirgsarten bor. Ibonfdiefer mit vorberrjdenbem Suarjgebalt geben einen fehr frudtbaren, trob des bedeutenden Gichalts an Siefelerbe (biß 80 \$roc.) Dennod) berbälnifmäfig binbenben Boben. Die Urfache liegt in ber jelor feinen Bertbeilung ber Riejelerbe. Thon= jhicfer mit vorberridentem Glimmer liefert einen leidhten, locferen, eben=

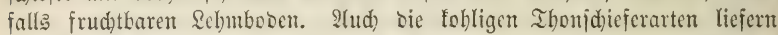
cinen guten Boben, Der aber, befonber: wenn er viele Giefteinbrofen ent= bält, Durch bie Eonme in bobent Grabe crwärmt wirb. Ia bas Giejtein

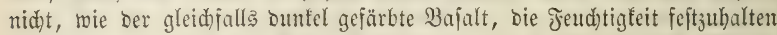
vermag, io trodnet Der Boben leid)t ans, inocm ifm von ben (Seftein= broden bie Jeudtigteit entzogen wiro. (53 mu; Daber ein fold)er Boben, bejonders an Eommerbängen, febr jorgfältig bebandelt werben. Der jorft= wirth hat barauf zu jehen, Daßs ber Boben Durd) fortwäbrente Betwaloung für immer ber ummittelbaren Eintwirfung ber Gonnenftrablen entzogen ift,

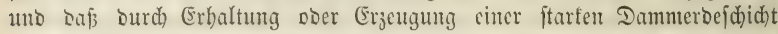
ibm Die Jeudtigfeit gefidert bleibt. Ihonjdiefer mit borherrid)endem Jelo= path und Ialfgebalte liefern cinen jebr binbenoen Boden, Der leidt Ber= jumprungen veranlapist.

\section{Grautwa de $e$.}

Gröbere ober fleinere Etüde von Suarj, Granit, Gilimmeridhiefer, Ihon= idjefer, (sneis, jelofteinporphnr, zujammengefittet ourd) eine jebr quarzreiche Ihonid)iefermaffe; theils im fömigen, theils fdiefrigen Gefüge (G) r a u va de $n=$ idiefer). Hebergänge auf Der cinen Geite in Ibonfdiefer, auf Der andern in Ganbftein. Berwitterung, bejonbers ber quarzreidyen förnigen Graubacte, fd)wer uno langfam; Ieidjter berwittert dic Graumade mit borberridbenben Irümmerjtüfen, am leidhtejtent ber (Sraumadenfdhiefer. Ier B̧oben ift gleid)= falls jebr berjobicon; Die Grauwade mit borberridfendem Binbemittel unb Duarjtrünmern liefert einen lofern, fiejigen, wegen feiner flad)grünbigfeit felten frudhtbaren Boben. Einen guten, janoigen Sebmbooen, jeood) jelten von grofer Iiefe, liefert bie törnige Grauvade mit groben Brudjitüden; Den beften uno meift tiefen, bincenben 30 on liefern bie meiften (Sraumadenjaj)iefer.

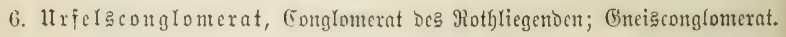

Duarz uno Gefteintrümmer von Grantit, Gsneis, Glimmerjdiefer, Thonfhiefer, Gornblente zc. in cinen Ieige theils thoniger, eijenfiüfijiger (rothes Tobtliegendes), theils mergeliger, fiefiger (weifes Tobtliegendes) Bejdaffenbeit. Mebergänge in Brambade, Jelojtein = Borphyr uno bunten Ganbitein. Rerbitterung, bejonbers Der Arten mit groben Irümmern und cijenjdülïigem thonigen Binbemittel, rajd) unb leidt; mandhe IArten mit vorherridenoem Bindemittel, bejonbers fiefiger Bejdafienbeit, vermittern 
ungemein fdwer. Der Boben bes rothen Tortliegentent ift an uno für (iid) jäwer uno binbend, ber meift beträdtlidue $2(n+$ theil unzerftörter Geftein=

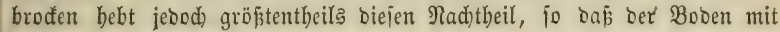
3u Den frudjtbarjten Dengungen gehören fant. Die Bobengüte redjelt

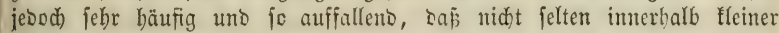
fläd)en bie größten 2(bftänoe hervortreten. Die harten Saubbölzer gebeihen in biejem Boben am bejten, und mit ihnen babe id ibn aud) gröfentbeils

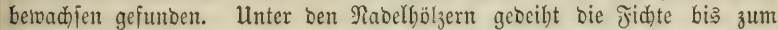
mittlern 2(lter trefflid, läp̈t aber früh im $\mathfrak{B}$ udje nady uno wiro balo rotbfuul. Birfe uno Sicfer follen fajt gar nidst auf biejem Boben fort= fommen. Siel weniger guten Boden liefert bą weipe Iobtliegende, Dod) babe id) herrliche Meī̄tamnenbeftände über Demjelben gejehen.

\section{Felofteinporplyr.}

Sörner uno Firvitalle von Felojpath uno Euary, untergeoronet Ǵlimmer, in einem thonigen Binbemittel liegeno, bieß leştere vorberrichent,

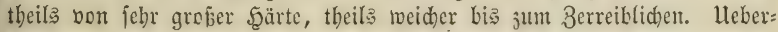
gänge in rotbes Iodtliegendes, in Iradhnte und Irapp= \$orphnre. Die

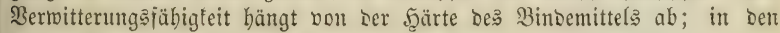
barten ßorphyren hält fich bief am längiten, bie Jeldfłathfruftalle ber= rwittern juerit, bie Berwitterung jobreitet Dann jefr langaam vor. Bor= phyre mit reid)erem Bintemittel zerfallen oft burd) Jroft in tiefe (Beröll= haufen obne eigentlide Wermitterung Der einzelnen Beftanbtheile, woourd)

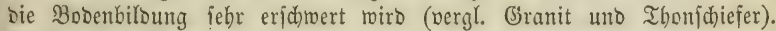
Der gebilbete Boben ift gröptentheils ein ftrenger magerer 2ehmboben von gleidjen Theilen Siejcl= uno Ihonerbe, un๖ fann zu ben mittelmäpigen Bobenarten gezählt werben. Iie sidfte gebeiht auf ihm am bejten. In Den Thälern jeigt er oft hohe Grabe ber Frudt)tharfeit, feltner an ben Şängen.

\section{Phondith.}

תlingitein, ein gleich)artiges (Bemenge von Jelbjtein uno Natrolith, vermittert leicht uno licfert cinen fruchtbaren aus annäberno 80 \$rocent Riejel= uno Ihonerbe, 8 Proc. Rali, 10 Broc. Natron, etwa? Ialf, Ralf uno Eijen bejtebenden Boben.

\section{Tradint.}

Trapp= Porphyr: eine felofpathartige Grunomajie, in ber firvftalle vou glafigem Feloipath liegen, berwittert jehr leidht uno licfert einen äuperit frudtbaren Boden bon 66 Siefelerbe, 20 Thonerde, 11-12 Sali uno 3-4 Eijenoryb.

3ucite lisilhs. Geffeitte, Deren fjauptbeffand felo(path) und fjornblenì.

\section{Snenit.}

Sabraborfeldpath uno f̧ornblende im innigen Biemenge, entweber mit vortwaltenoem Jelbjpath oder beibe zu gleiden Iheilen. Uebergänge einer:

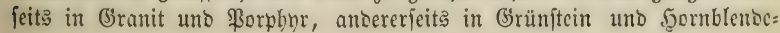


geitein. Die \$erwitterung fafreitet langiamer vor, als bie bes (Sranit

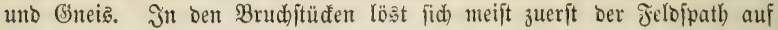
uno verwanbelt fid in Raolin. Das Rejultat ber 3eriebzung ift ein frucht= barer, fehr eifenfchüifiger \&ebmboben, in meldhem ber Thon zun Siejel meift in bem ßerbältnifie wie 1 zu 2 fteht. Daju tritt ein bis 10 Proc. fteigenter Ialfgebalt, 5-6 \$roc. Sali uno eben fo viel Eifent. Ein be: träd)tlicher Salfgebalt, bis 15 ßroc., tritt bejonbers ba binzu, wo ber Syenit mit Ralf wedficlt, ober biejen Durdjebt. Der Boben ijt Daber fruchtbar, aber jelten tiefgrünoig; Dem (Sranitboden ftebt er in Güte meift etras nad. Der $\mathfrak{B e i p b u c t ) e ~ f o l l ~ e r ~ b e j o n d e r s ~ z u j a g e n . ~}$

\section{Gேabbro.}

Ein förniges Gemenge von Rabraborfelofpath uto Emaragoit (Diallag), Doer von bid)tem Jelojpath (Gaufiurit) mit Bronjit ober mit Edjillerfpath, oft mit Strablitein verbunben uno in ein jerpentinäbnlides (Seftein über: geheno, berwittert Yeidft uno liefert einen tiefgrünbigen frudtbaren Boben, Der aber an Şarze (Bafte) megen jeiner Şöbe über Dent Meeresfpiegel ıur Fichtenbeftänoe trägt.

\section{Grïnjtein.}

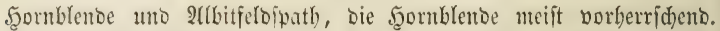
Sino beibe Beftuntheile Dentlid) uno förnig gefdieben, fo heißst bas (be= ftein Diorit; bilsen fie ein fheinbar gleidartiges uno Didtę bientenge,

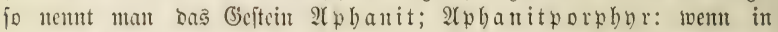
leţterem einzelne größjere Sornblenoe ooer ?llbitfrnftalle porphyrartig cin= gebettet liegen; $3 a r i o l i t$ ober Blatterftein, went bie Jeloipatbmajfen fugelförmig eingefprengt fino. Hebergänge felten in Bincis, bäufiger in 5gornfels oder in Gabbro. Berwitterung fo langfam wie beim Encuit, nur Der fcl)r grobförnige (Brünjtein berwittert rafcher. Der Boben trägt

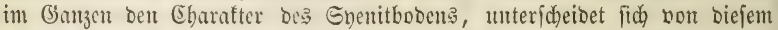

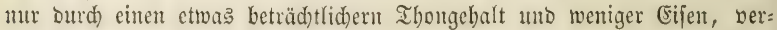
wittert zlwar langfam, ift aber jebr frud)tbar unt trägt am 5earz berrlide

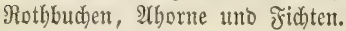

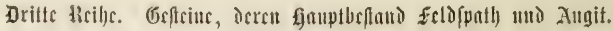

\section{3. $23 a j a\lfloor t$.}

Augit, Jelbipath nno Magnetcifen in innigen (Sintuge. Ueber:

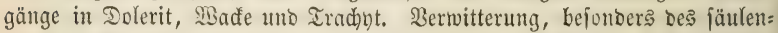
förmigen Bajalts, febr Yangjan uno mu an ber Dberfläd)e; rajdher zerfällt Der förnige Bajalt. Dą enoliche Rejultat ber Berjebsung ift ein ungemein fruchtbarer Boben, meift bejtehend aus 40-45 Siejelerbe, 14-16 Ihon= erbe, 8 Salferbe, twenig Ialf, aber bis über 20 Broc. Sifentrbo uno

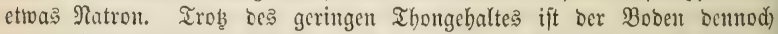
verbältnifmäpig binbenb burd) Die feine Bertbeilung ber Riejelerbe. 3u ber, Den 3 uammenfeb̧ungstbeilen faum entipredenton, groß̧en frud)t= barfeit trägt Das Berkalten Des Befteins und ber Dem Boben beigentengten 


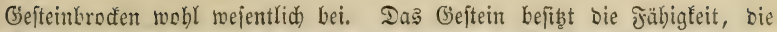
Dünjte Der \&uft an jid) zu zieben unb zu veroidten in hobem (jrabe, bält

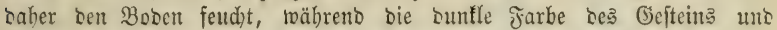
Bobens bie Märme ber Sonnenjtrahlen entbinbet uno Boben wie \&ujt crwärmt. Der Bajaltboden ift bejonbers ben \&aubhölzern günitig, bie (d) ह̈nften reinen S(hornbeftänoe neben ausggezeid)ueten Rothbudentorten babe id) bier gefunden; zwar ebenfalls jebr freubig wadjent, aber bennod) Dem

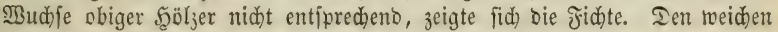
Saubbölzent uno ber Birfe foll ber Boben nid)t zujagen.

\section{Dolerit (Graujtein, f̛̈̈̈griinftein).}

Jelojpath, $\mathfrak{A}$ ugit uno Magneteijen in mehr oder weniger erfentmbarem (5entenge. Felofpath uno 2lugit meift žu gleiden Theilen. Hebergänge in Bafalt unb Wadfe. Serwitterung viel leid)ter als bie bes Bajalt. Boben= bildung uno Bobenbefduffenteit giemlidy biejelbe wie bei jenem.

\section{5. $\mathfrak{B}$ a if $\mathrm{e}$.}

Jelbfpath, 2fugit, Magneteifen, Ǵlimmer uno Şornblende im innigen Oientenge. Hebergänge in Bajalt uno Eifentbon. Berwitterung nod)

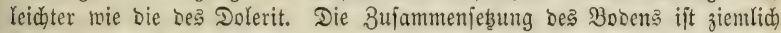
biefelbe wie bie beß Bajalt’, bod) ift ber (Eijen = und Thongehalt etra geringer, loogegen ber Gsebalt an Riejelerbe bis über 60 \$roc. Fteigt. Der Boden foll ebenfalls jebr frudtbar, befonders für bie $2(n j u d) t$ ber Saubs bölzer geeignet frin.

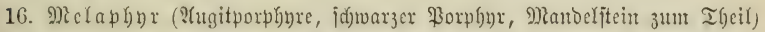

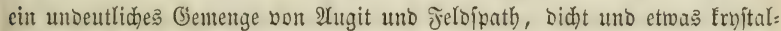
linifd), oft mit Mandeliteinjtruftur, vartwittert langiam, trägt aber am

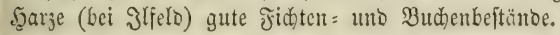

\section{Sava.}

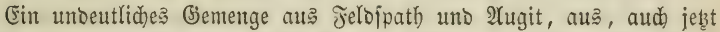

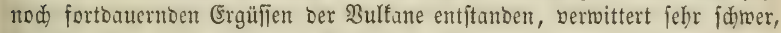
liefert aber endid einen fehr fruchtbaren Boben.

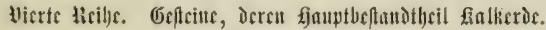

18. Ralfitein (bidjter Salf).

Soblenfaurer Ralf, Ibon, Sicjelerbe, Eijenornoul im bidenten Ġemenge. Hebergänge in förnigent Salfftein (Marmor) uto in Mergel. - Ner= witterung Des reineren Salffteins fehr fobwer und langfam, je gröper ber Thon = uno Eifengebalt, um fo rajher; befonders trägt bas, auf einer niebrigen Eäurungsftufe ftebento (Eifen Durd höhere Drboation mefentlid)

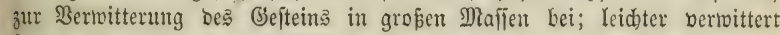
ferner ber fodiefrige uno vielfach zerffiuftete Salt als ber majiige, ba er in höberem Mafe von Der Jeud)tigfeit Durdobrungen wirb. Der Ihongebalt be? Ralfitein 
Der Raltboben ijt um io fruchtbarer, je gröfer ber Thongebalt. Der mit=

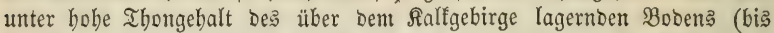
30 Proc. uno melyr) rübrt aber jelten von ber 3erjeb̧ung Des Salfgefteins her; bäufig ift bem Ralfgcbirge eine bis ins Slleinfte gebente Berflüftung eigentbümlid), burd) tie es mit einer Menge von 2(bern burd)zogen ift, weld)e meift mit Ihommafie ausgefüllt fin๖. Steigt in foldhen fällen ber

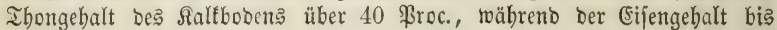
unter 2 Broc. binabjinft, fo zeigt er auperorbentlicje (5rabe ber Frudt= barfeit, und wirb mit bem Ramen $\mathfrak{S a j e l e r d e ~ b e z e i d n e t . ~ D i e ̂ ́ ~ i f t ~ f t e t 3 ~}$ ein = unto aufgeidwemmtes (Eroreid) (J̈lözboden $)^{1}$ uno nidat aus ber Ber=

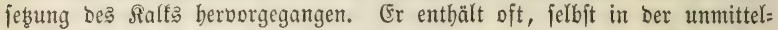
baren Berüfrung mit ben B̈efteinbroden feine Spuren bon Salf. $24 m$ jajönten gebeihen auf ihm die Prunus-, Pyrus- ano Sorbus-2Yrten.

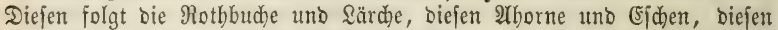
bie Fidhte unt (Eid)e. Dent weidjen Saubbölzern fagt er am wenigften zu. Die Riefer foll auf Salfboben ein fehr brüd)iges $5_{2} \mathrm{l}_{3}$ madjen und bort mehr als fonft von Edneebruf leiben. Je mehr im Ralfgeftein ber Thon:

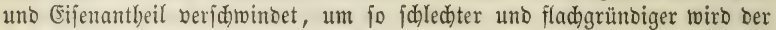
Boben. Der thonarme Salfboden ift trofen und warm, berliert bie Feud)= tigfeit lcicht burch Berbunftung, kefî̧t bas Bermögen, Die Dünfte ber 2ttmojphäre anzuziehen, nur in fehr geringem (srabe, faugt bie atmo:

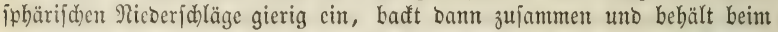

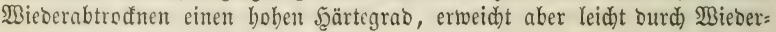
anfeudfung, viel leidter als Ihon = unt Rehmboden. Die Frudtbarfeit jolden Bobens roirb Iurd eine Dammerbejdjidt, bie ihn ftets feudst erbält, abgejeben von Der Frudtbarfeit ber Dammerbe jelbit, in bohem Esrade geförbert, baber bier mit Eorgfalt für ununterbrod)ene Betwaloung zu jorgen ijt.

\section{Sireide.}

Die Rreibe beftebt fajt nur aus foblenfaurer Salferbe; Der (Sebalt an Thon, Ricjel und Eijenntub ift wenigitens jo gering, baj er feinen wejent= lidjen Einflū auf Bobenbiloung hat. llebergänge in Mergeł. Berwitterung langiam, Dod) leid)t zerftörbar burch mechanifde Siäfte. 2(In uno für fich ift ber Sreibeboben unfrudbtbar uno mur in fehr feudjtem Slima gebeiben bie Ralfpflanzen, bejonders die Prunus-2Yten uno bie Rotbbuche nod) ganz gut. So tragen bie Sreibeberge Rilgens mittelmäßig gute Roth= buchenbeftänbe, Deren minber gute Bejafjefenbeit mir mebr in Beftanos:

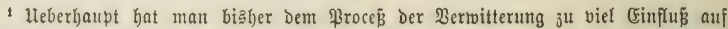
Bodenbiloung jugejdrieben. Jèer Berwitterungsboden gibt fid als fold)er Durd bas in ibm nod) in alfen (5raben ber Berivitterung bis jum feinften forne borfommende

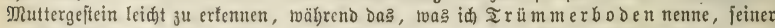
Scauptmaffe nach biel gleidförmiger zerfleint uno in geringer Tiefe burd ja)arffantige von

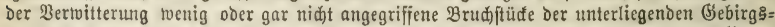
art ausgezeid)net ift. Sold)en Irümmerboden fand id. im Bebirge über Ihonjdiefer, (Braut=

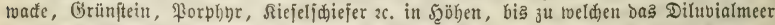
nid)t angefticgen ift, mitunter in bebeutenoer Iieje abgelagert. Man tönnte ign ale bejon= Dere? Formationgalied ber unterliegenden Giebirgsart betrachten. 


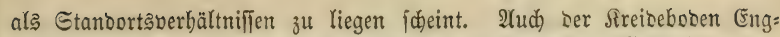
lanos foll theilweife einen üppigen Pflanzentwudjs zeigen. Man fann aus

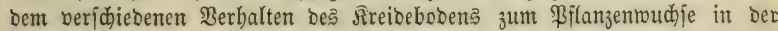
Eeenäbe und im Binnenlande (Ehampagne) mohl mit Recht ben Ed)

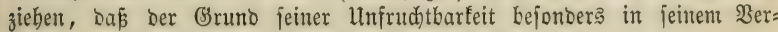
balten žur Jeudohtigfeit liege.

\section{0. $\Re$ alftuff (Dufftein).}

Eine locfere bis eroige, poröje Ralfmafle mit mehr ober meniger Riejelerbe, Thonerbe unb Eifen. Bermitterung rajd und leiḑt. Der

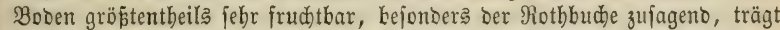

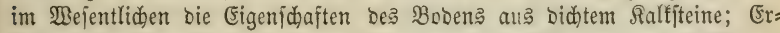
baltung ber Bewaloung uno ber Dammerbe wirb bejonbers auf Iuffboden mit geringem Ifongehalte notbiwenoig.

\section{Dolomit (Bitterfalf).}

Sörniger poröjer Salffitein, beftehent aus tohlenjaurem Salf mit 3-46 \$rcc. fohlenjaurem Ialf. Berwitterung leidit uno rajd. Der

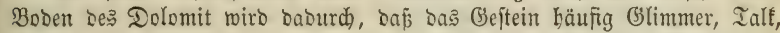

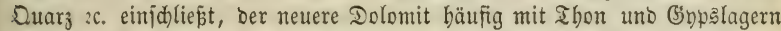
medjelt, ber Begetation, bejonoers barter \&aubböljer günftig; feine $\mathfrak{B e}_{\mathrm{e}}$ ftanotheile find meiftens 40 fohlenjaurer Ralt, 10 idmefeljaurer Ralf, 20-30 tohlenjaurer Talf, eben jo viel Thon, 8-10 Siejelerbe und ctroas Eijenorbo und Manganorboul.

\section{2. (5)p巨.}

Edhmefeljaurer Ralf, befteheno aus 33 Ralferbe, 46 Ed) 21 Bajler. Berwitterung jebr leid)t und rajd, ba bas G̉ejtein vont Regentwajier aufgelöst uno auझgetwajden wirb. Der reine Grnps gibt einen

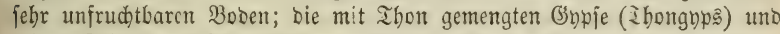
reines Geftein mit Thonidhidten wedjelno, bilden mitunter fehr frudtbaren Boben, auf meldjem bejonbers bie Rothbuche und bie 2thorne ganz gut gebeihen.

Sünfte kicihs. Sandftiuc.

Suarzförner von geringer Gröppe in einem thonigen, falfigen, mer: geligen, fiefigen, eijenjdütiligen Binbemittel. Bermitterung berjobieben nad) Beridiebenheit uno Menge bes Binbemittels; mit thonigem und eijen= jäüfïigem Binbemittel berwittern bie Sanbjteine am rajdeiten, um fo raicher, je größ̄er bie Menge beß Binbemittel’; mit tiefigem uno mergeligem Binbemittel am langiamiten. 24uch bie Bejdaffenbeit bes aus ben Eano= fteinen berborgehenoen Bobens ijt nach 2 (rt uno Menge bes Sitts uno nach ber CBröß̨e Der Quarzförner jehr beridieben.

23. Dex Thonjandjein

liefert einen meijt fehr fruchtbaren binbenden $T$ hon $=$ ober Sehmboben, bellen Thongebalt mitunter bis auf 30 Proc. fteigt, bejonbers Dann, went bas 
(3eftein aus febr feinen Duazłtönern bejtebt. Bei bemjelben Ihongehalt wiro ber Boben weniger bindent unt thonbaltig, je gröber bie Quarztörner finto, intem alabann bie Thontbeile burd) Regengüffe in bie Tiefe ge= fdomenumt werben, wo fie fid anbäufen uno ein bas $\mathfrak{B a}$ ajjer nidht burd)= lafientes Ihonlager bilden, weldyes, wenn es nidht tief unter ber Dber: flädhe bes Bobens jteht, häufig Beranlajïung zu Berjumpfungen wirb. Der Boben eines feintörnigen Ihonjantofteing ift für bie meiften Saubhölzer unto für bie siddte ausgezeidnet gut. Bejonbers foll er ber Eidje jebr entiprechen.

\section{Der Raltianditein.}

Áper bem Durd) bas Anfbraufen mit Säuren erfennbaren falfigen

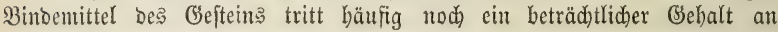
SSlinmer binzu, in weldem Falle Der Boben jebr frudtbar miro, aber alle bie Rachtbeile einer großsen Sodétheit zeigt. Er cignet fich bejonders für bie Budje unt \&ärdje; went er tiefgrüntig ift, aud für Fidhte uno Riefer.

\section{Der Mergelfandfein}

liefert cine ber frudtbariten Bodennifdungen, wenn bas entweber thon= mergelige ober falfmergelige Bintemittel in bittreichender Menge vorbanton ift. Die Duarzlörner Des Mergelfanbfteins fino gröptentbeils fein, Daber fid) Der Boben in feiner Mija)utg zu crbalten vermag. Bei gleider Sitt=

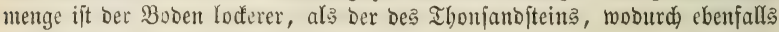
bie ₹rudthtbarfeit geförbert wiro.

\section{Dex Duarjandftein}

bejteht aus cinent fiejelerbigen, cijenfounffigen Binbemittel zwijd)en feinen abgerumbeten Duarzfömern. Das (Seftein barivittert fehr fidwer, und Der Daber meift febr fladje lockere Boben ift aud) Durd feine Bujammenfebungs:

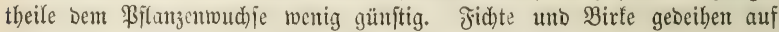
ibm nod) am beften; ber Riefer ift er felten tiefgrünbig genug.

Den Sagenungsverbältnifīen nad) unterjecibet man: Ouaberjand: ftein, buten Sanditein, Soblenjandtein 2 . Sebe biejer Arten fam fowohl Thon=, als Salt =, Mergel= ober Duarzantiftein fein.

Ier nidht berbundenen (jebirgarten, wie: Ibon, Mergel, Sand, werbe id im Berfolg gebenten.

\section{Bon Den Etrufturberbältuifen ber Ģebirgagrten.}

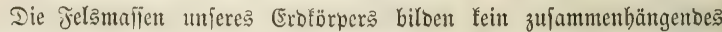
Gianze, fontern find, fowohl int Groken wie im Rleinen vielfad) zerflüftet uno zeripalten. Die Eigenthümlidffeiten ber B̈ebirgäarten in biefer Şin= fid)t find in fo fern bon mejentlidem Einflup auf bie Befdaffenbeit bes überliegenden Bobens uno founit auf ben ßifanjenwudjs, als bavon, bor= züglid) bei flad)er Bobendede, das Eingreifen ber \$flanzentwurzeln in ben

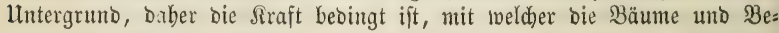
ftände Den Stürmen Trob̧ zu bieten vermögen; als ferner bie Erbaltung 
Doer 2rbleitung ber Bobenfendatigteit, uno enolid) bie rajdere ober lang: famere Berwitterung ber Felsmmajןen babon abbängig ift.

In Bezug auf Strufturrerbältnifīe, fo reit fie ben bejonberen 3rect meiner Mittbeilungen betreffen, treten zunädjit ztwei wejentlidbe Berjdiebent:

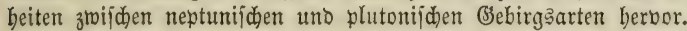

Die im heifflüffigen 3 uftante aus bem Jnnern ber Eroe hervor: brechenben, plutonifden Ergüije zogen fich, idgon zu fejten Mafien eritarrt, bei zunehmender 2(btühlung immer mehr zufammen, roodurd bielfältig bą̧

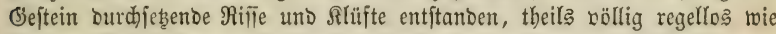
bei ben Brünfteinen, Borphyren, theils in beftimmten 2 (biftänten uno Ridhtungen wie beim Bajalt, einigermañen aud beim Granit, Eyenit $2 c$.

Die nektunifden (bebirgäarten baben fid gropentbeils nid̆t plöklid) aus bem Waīer niebergeid)lazen, fonbern allmäblig uno jojidtentweif. Bei biejer 2Ublagerung wechjelten nicht felten bie Beftantheile bes Rieber= id)lags mannigfaltig ab. Durd biefen Wedjel bes Beftanbes erbiclten fid bie einzelnen Edhidtungen im Rleinen wie im Brofen bis heute erfennbar.

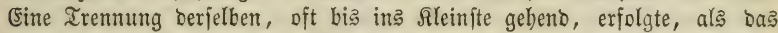
Gebiment= Şejtein, aus bem Meere emporgeboben, abtrodnete, in Folge befien bie gleidzeitig niebergejd)lagenen (Sebirgstheile fid in vertifaler Ridtung zufammenzogen. (Es entitano baburd) bie Edjieferung wie fie ber

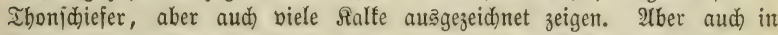

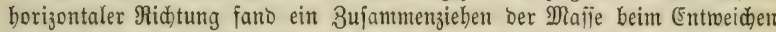

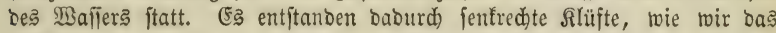

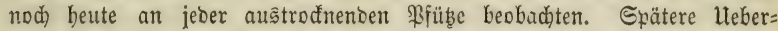
¡divenmungen baben bann nidht felten bie, zwifden bem (sejtein ent=

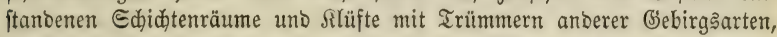
wie Sand, Lehm, Ihon 2c. ausgefüllt, Duth weldhe bie Iiefgrünoigfeit bes Bobens häufig erję̧t wirb.

Uriprünglid) muß̄ten alle Gebimentgeiteine eine borizontale Sage baben; erft fräter auftretente Rräfte, theils bis zum Heberwerfen gejteigerte Şebungen, theils Einjentungen Der gebiloeten Edjidten beranlafiento, änberten bie urjprünglidje \&age ber Edhidten refentlich, fo baj wir biefe gegentwärtig eben jo bäufig in geneigter, oft joyar jenfredter Etellung al’ in ber uriprünglid twagerechten Sage vorfinven.

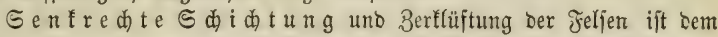

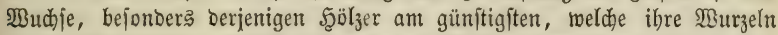
in bie Tiefe fenden. Gelbit $\mathfrak{F}_{0} l_{3} a r t e n$ mit flachlaufenber Betwurzelung ziehen

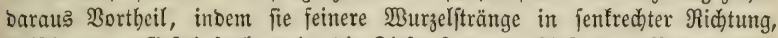

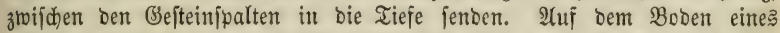
über 20 Meter tiefen Ralkfteinbruches jah idđ feine Burzeljtränge bes über Dem Brudje madjenten Budjenbeftandes, in ben mit binbenbem Ihon ges füllten Bejteinjpalten verbreitet. Bieht man in Betracht, ba $\bar{\beta}$ bie atmo:

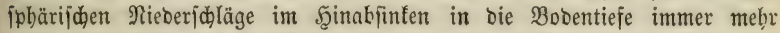
mineralifhe Söjungen in fich aufnebmen uno ben $\mathfrak{B u r z e l n}$ zur 2 (ufnabme barbieten, fo miro man erfennen: Daf bie ?lufnabme non Bobentwaffer auङ großer Tiefe überall einen günftigen Einflū auf bie Begetation außüben muß̧, wo fie nidht auf ein unterirbifdhes Becfen ftagnirenben Wajiers ftopent. 


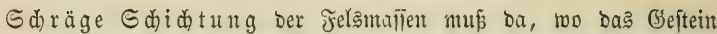

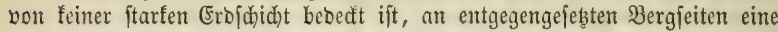
ganz verfojiebene Sintwirfung auf ben Bflanzentouds äupern. Diejenige Bergmano, bon melder aus fid bie Sdidjten fenfen, wirft auf ben Pilanzentwuds eben jo günjtig ein, als bie fentrechte Ridtung. Die ent= gegengefeß̨te Bergwant ift für alle Şolzpflanzen, für bie mit tiefgehender

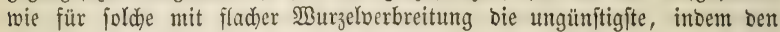
WBurzeln überall bie Gefteinfläde entgegentritt, beren Berbreitung baher bier allein auf bie Bobenfrume bejđhräntt iit.

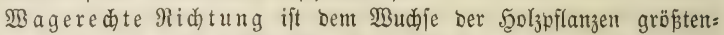
theils ungünftig; immer auf Bergebenen uno für Şolzarten mit tiefgebenber

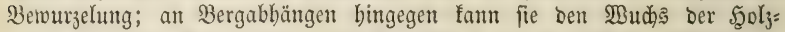
arten mit flader Betwurzelung mebr begüntigen als bie fentred)te Edjidung. Reid)lid)e 3erflüftung Der Sdjidten bebt bie Nadbtheile ber wageredten Sdiditung.

Eine nähere Beachtung biejer Berbältnifịe wiro in vielen Fällen bie

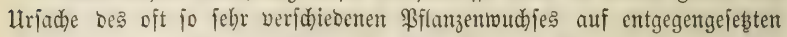
Bergbängen zu erfenten geben; fie fino für ben Gsebirgaforftwirth von

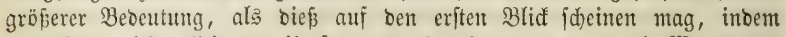
bon ibnen niđjt allein ber Umfang bes Ernäbrungşraumes, bie Menge uno Rad) baltigfeit ber Booenfeudte, fonoern aud bie fejte Şaltung ber \$äume abbängig ijt.

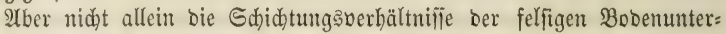
lage äupern cinen wojentlident Einflus auf Boben= uno Bflanzentwuds; in

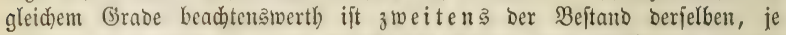
nadbem ar gecignet ift, Dem bedecfenden Boden feine Feudjtigfeit zu er: Galten, oder biejelbe abzuleiten uno in bie Tiefe zu fübren. Die Eigen=

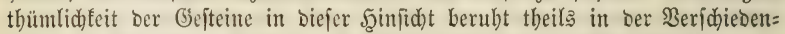
beit ifrer Struftur, theils in ber Meridiedenheit ibrer Beftantheile.

Maffige Jelfon leiten bie Feudtigfeit weniger $a \mathfrak{b}$, als gejojid)tete ober zerflüftete Jeljen; Derbe, frnftallinifje (bebirgäartent weniger als fojiefrige uno zujammengefittete; fefte Gefteine weniger als verwitterte; wagerechte

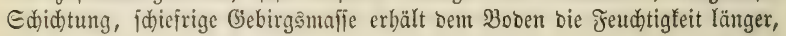
als jebe andere Ridytung.

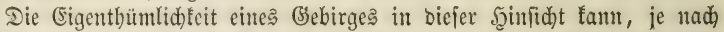

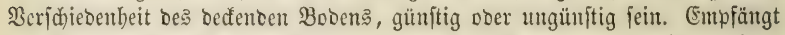
ein \$oden nid)t mebr Jeudtigteit als zur Şerftellung uno Erbaltung eines ben Bilanzen günitigent Jeudtegrabes erforberlid) ift, jo wiro eine ableitente Ilnterlage nad)tbeilig wirfen, bie unter anberen Berbältnifien bei überichüjīig

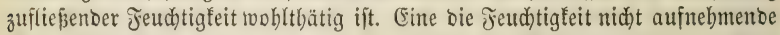
Öebirgäart fann aber auch auf Irodenbeit bes Bobens eintwirfen, wenn ber liżtere nämlid fo flad) uno ber Some ober bom \&uftrodffel fo aus:

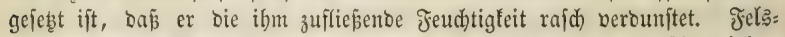
arten, bie bas $\mathfrak{B a j i e r}$ aujnehmen, fömnen in foldhen Fällen günitig wirfen, inbem fie bie cingejogene Jeudtigfeit an ben rajoh austrodnenden Boben wieber abgeben. Die Mirfung ein uno befielben Befteing ift ferner ver:

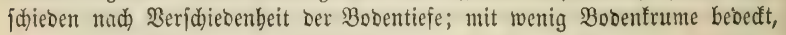




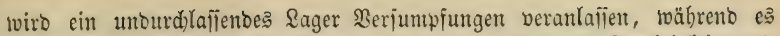

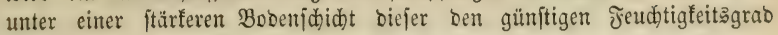
ertheilt.

Wir erfenten brittens cinen wejentliden Einflup ber Bobenunter=

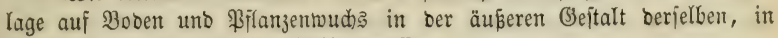
ber Lage uno Neigung Der Bebirgsmaffen.

Je gebirgiger, unebener bie Bocenunterlage und mit ihr ber Boben

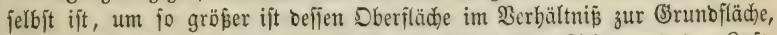

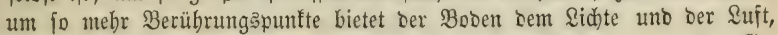

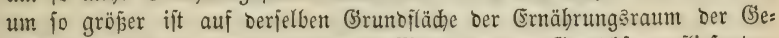

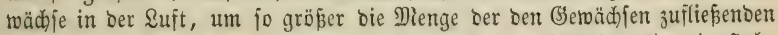
¿uftnabrung. Da nun, wie id) erwiejen habe (vergl. Seite 16), bie Scolz= pflanje in weit böherem (brabe fich aus ber \&uft, als aus bem Boben er:

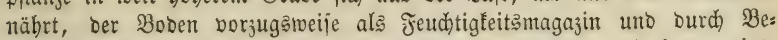
fruchtung oer \&uft auf bie Pflanzenernäbrung eintwirft, fo mutí eine geneigte

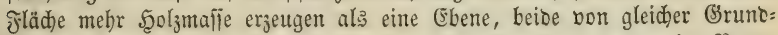
flädenausbehnung, um fo mehr, ba ald ber Ernäbrungstraum im Boden auf ber geneigten fläd,e ein gröserer ift.

Da bie Jnjolation einer gebirgigen Dertlidfleit ftets bie ibrer Ornuno:

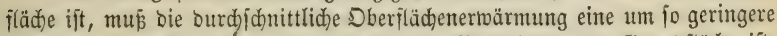

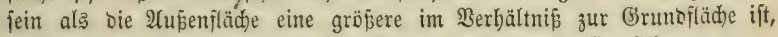
abgejehen von bem mobificirenden Einfluis veridiebener Erpojitionen.

Die Sage und Reigung ber Unterlage bat ferner einen wejentlident Einfluß auf Bobenbiloung. Bei einer Neigung von mebr als 40 Graben fino bie Feljen vont Croe uno Rajen entblöpt, nur fledten uno Moofe baften an ber fteilen Felswanto; bie burdh Bermitterung aus bem Jelfen gebilbete Erofrume bermag fid nidst zu erbalten, unt finft allein fidon Durd) ibre Edwere in bas Ihal binab, ober fammelt fich über Uneben= beiten und in Epaltungen ber Fels̈mände. Şier fiebeln fid bann zuerit bie höher gebiloeten \$illanzen an, uno wir jehen Berghänge horftweije mit

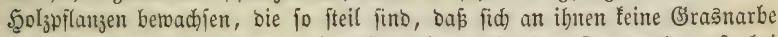
zu biloen vermag. Dhne Fुolzwuchs biloet fid eine Graßnarbe erit bei ciner Neigung von weniger als 30 Graben; der unbenarbte Boden be Ađerlanbę vermag iid) mur bei weniger als $20 \mathrm{Brab}$ Neigung zu erbalten, uno felbit bei 15 Grad riro ourd Regengüipe nod viel bes unbentarbten

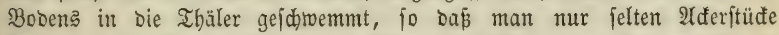

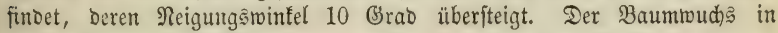
ununterbrodjenen Beftänoen geft gewöbnlid') nidjt über 30 Grabe binaus. Eine Reigung von 5 Braben ift für Ebaufieen uno Sanbitrafen fdon un= günjtig; Die fteilften Jabrwege überfteigen felten 15 Grad शeigung. Je geringer ber Reigungşwinfel, um jo mebr wiro bie Bobenbiloung geförbert; in Thälern vermebrt fich bie Boocnfrume nod) bebeutento burd) bie, bon Den bentadbarten Bergen ourd Regengülile abgejdinemmte Erbe, um fo mebr, je fteiler bie benadbarten Şänge finto.

Senfredt nent man einen Berghang bon 80-90 Graben, bei $40-80^{0}$ jäh, bei $25-40^{0}$ abjd) üliig, bei $15-25^{0}$ jteil, bei 10 bis $15^{0}$ lebn, bei $5-10^{0}$ anjeigend, unter $5^{0}$ geneigt. 


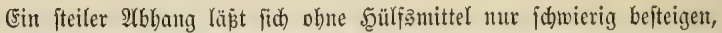
ein lebner Berg erfadeint bem 2Huge jodon febr fteil.

Durd) Kein Mittel wiro bie Dobenbiloung an Gebirgähängen mehr beföroert, als burd forgfältige Erbaltung ber Betwaloung. Der Forftmant

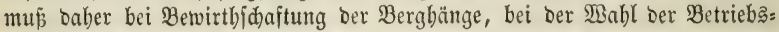
weifen uno bei ber Berjüngung Der Beftäntoe bejonders jorgfältig zu $\mathfrak{B e r f e}$ geher. Unvorfidatige Enttwaloung fteiler Berghänge fann biefe für immer

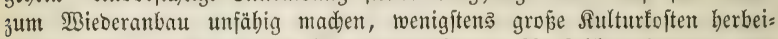

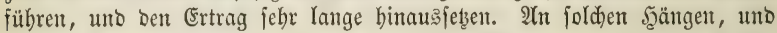
wenn fich ber Berjüngung burd natürlidłe Befaamung erfabrungs̄mäpig grope Edjwierigfeiten entgegenftellen, ift bie \$läntermirthid)aft ober aud ber Mittelwalbbetrieb mit vielem Sberholze an finer Stelle. Betrieb mit Meibebieh ift bier fehr nadtheilig.

Biertens beftimmt bie Tiefe Der Bobenunterlage ben unterirbijden

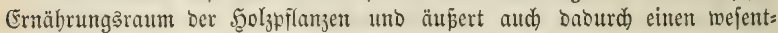

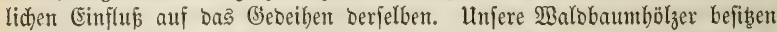
cine jehr veridjiebene $\mathfrak{B u r z e l b i l o u n g . ~ D i e ~} \mathfrak{B u r z e l n}$ ber Riefer, (Eid)e $2 c$. gehen in bie Tiefe, bie ber Buthe, Jid)te zc. Derbreiten fid mehr in ber

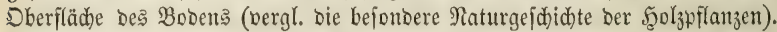
Erftere verlantgen baber zut ihrem freubigen (5ebeiben einent tieferen Bobent, leţtere begnügen fid) mit einter geringeren Iiefgrünoigfeit. WBir jehen erjtere auf f(ad)em Boben fümmerlid) wadjen unt in geringent after abjterben,

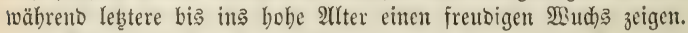

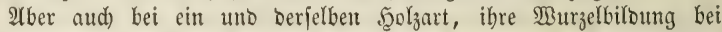
ungehinberter Entwiaflung mag bon eitner ober ber antoeren 2 rrt fein, bat bie \$odentiefe einen wejentliden Einflup auf Beftano uno Ertrag, intom von ibr, wentgitens theilweife, ber bid)te Stand ber Şolzpflanzen abbängig ift. Wie einem tiefen 2 (ferboben ein meit bid)terer Stant ber Getreibe= uno Der Futterpflanzen eigenthümlich) ift als bem flad)grünoigern, io ift auch Dem tiefen Balobobent eine gröpere Stammzabl, bid,terer Beftanto uno

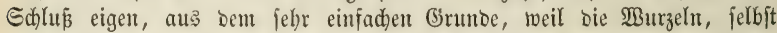
ber Şolzarten mit flacher Betwurzelung in bie Tiefe gebrängt werben und (iid) nidht in bem Grabe gegenjeitig befinbern, als wemt fie burdh oflad)=

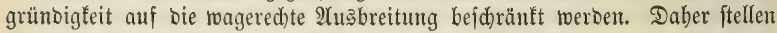
fid) auf flachem Boben bie Beftände weit früher lidst, fino baber lange nih̆t fo für bie Erzeugung langidhäftiger Baubölzer geeignet, als bie ge= brängteren Beftände des tiefen Bobens. Befonbers zu berü fifichtigen ift

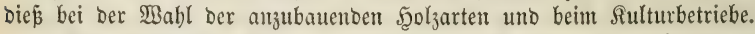

Der nad)tbeilige Einflup flad)grïnoigen Bobens auf Şolzarten mit tiefgebenber Betwurzelung tritt um fo jhärfer hervor, je älter bie Bäume

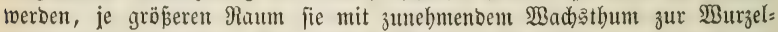
auลbreitung beoürfen. 2(uf flachem Boben mus baber Der Umtrieb ber Mälber ein fürzerer fein, als anf tiefgrünoigem $\mathfrak{B o b e n . ~ D i e j e l b e ~ S c o l z a r t ~}$ im Rieberwaldbetrieke bebandelt, faum oa nod einen bohen Ertrag ge: währen, wo jie im 5od)twalbe nur fümmerlid toäcbst.

(sin flader Boben wirft um fo weniger nad)theilig, je mebr bie inn

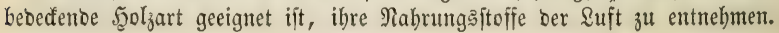


Shude, Jidute uno Riejer jteben bierin allen anbern Syoljartent voran, uno wenn bie lekgtere bem flachen Boben abholo ift, jo liegt siés allein in ihrer

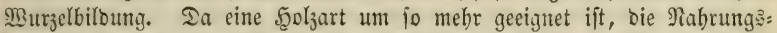
ftofie ber Suft aufzunebmen, je gröfer ibre Belaubung ift, fo müfjen wir auf flachem Boben bie Beftänbe in thunlidjit freiem Stande erziehen, um fie vom Boben möglidjft unabbängig zu madjen; ift jeboch ber flache Boben bem rafden 2Utstrodnen fehr unterworfen, fo barf bie freiftellung

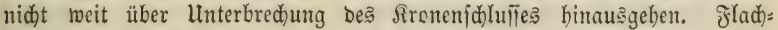
grünbigfeit mirft aud ba meniger nadtheilig, wo bie sujt bauterno uno

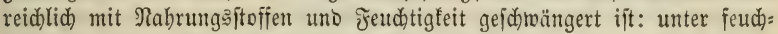
tem Slima in zujammenhängenben $\mathfrak{K a l b u n g e n ~} 2 c$.

\section{Bon ben Gebirgäormen.}

Iheils als Träger beక gebildeten Bobens, theils als Bobenbilber äupert bas fejte (Beftein aud burdh bie Form jeiner Dberflädje einen bes achtensmerthen Einflus auf ben Boben, infofern ebene uno wellige Dber: flächen bie Bobenbiloung uno bie Rage bę̧ gefildeten Bobent förben, ¡öroffe und zerrifīene Gebirgs̄formen ibnen entgegenfteben. E๖ übt aber aud einen beadtengwerthen Einflup auf bie Maijenerzengung gejd)lofiener Beftänoe, injofern bie größere Dberfläche melligen ober geneigten Bobens

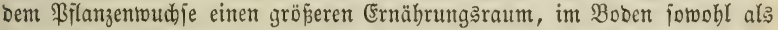
in ber $\mathcal{U}$ tmofphäre barbietet, Demzufolge bann aud bie Bflanzenzahl ber geneigten Fflädhe in Der That eine größ̄ere fein fann, alß bie ber 'ent=

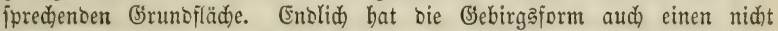

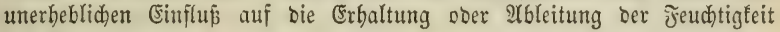
Des $\mathfrak{B}$ Dodens.

Eine andere Frage ift $\mathrm{es}, \mathrm{ob}$ und in wie weit man ben berfobiedenen

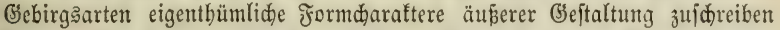
fönne. Es: ift Das vielfach gefchehen. Benn man Dem Sranit wellige Gebirgsformen, Dem Borphyr uno Duars fabrofife uno zerrifiene Frormen

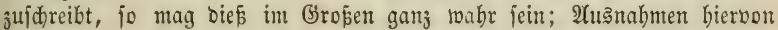
fint aber fo bäufig, baj fich eine allgemeine Bejiebung zur Bobentunde

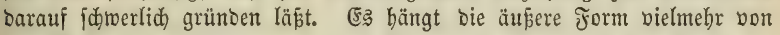
Der Mafle des Şebenten uno bez Gebobenen uno bon ber Fraft ber Szebung, als bom Material bes Sgebenben ober Behobenen ab. Echon

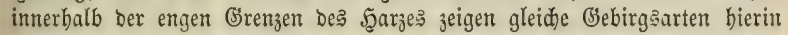
bie größ̈ten ßerjadiebenbeiten.

\section{3weites kapifel.}

\section{Bout Bodert.}

\section{Bon ber Entfebung beg Bobent.}

Der bie fejte Erorinbe bebecfente Boben ijt bierjachen Uriprungs. Ein Theil beffelben gehört einer frühen Biloungsperiobe, bejonber’̧ bem flöj= gebirge an. MBir fehen nämlidh zwifden Den felïgen Edjichtungen ber 
flözperiobe häufig mehr ober min๖er mädtige Sager non erbigem Ihon, Mergel, Sand auftreten. Dieje Gdidjtungen bilken nidht felten bie oberite Sage Der Formation, gehen in mefro ober minoer ausgebreiteten flächen zu Tage, ohne baj man fagen faum, bie Edjidhtung geböre ber leb̧ten

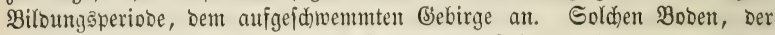
bejonbers bäufig über jüngeren Ralfgebirgen auftritt, wollen wir mit bem

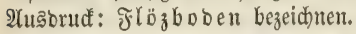

Ein gröferer Theil bes Erobodens berbantt ben lebten gropen Unmwälzungen unferer Erorinbe fein Entf̂tehen; er ift wie ber Flöjboben, ant uno für fich Boben uno zugleich Bebirgäformation, bie lek̨te ber ges

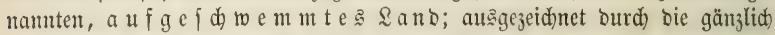
mangelnoe ober mur geringe \$erbinoung ber Sefteintheile zu feften zufammen= hängenoen Mafien; Ablagenutgen von Canto, Lehm, Thon, Mergel, Ğes fdjebe uno Gerölle veridiesentartiger Jelstrümmer. Diejen Boden finden wir

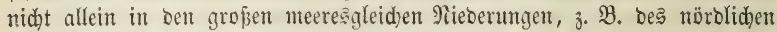

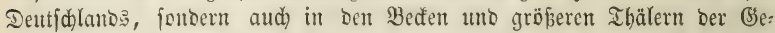
birgstänber, fowie in ben flufutieberungen berfelben verbreitet. Man fann ibn mit bem Namen Dilubialboden bejeidnen; in ben meiften Fäller:

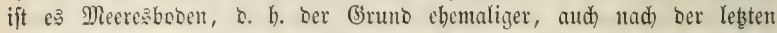
Ueberidwemunung nod) eine Beit lang zurüfigebliebener grofer Wafiermafien.

In äbulicher Beije, wie jener aủ ben Utwaffern abgejohiebene Boben, biloete fid) and fpäter uno biloct fid) nod) gegenwärtig ein aufgeid)mentmer

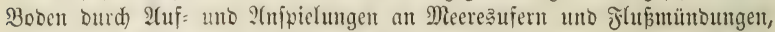
fowie burd) Mbjab aus ftehenden 2iaffern. Man nemt foldhen Boden, zum Unteridjiebe vom Diluvium: $\mathfrak{A} \mathfrak{l}$ uvialboden.

Ein lebeter Ibeil Des (Erobodens bat fich erfit nach ben lebeten Eroum: wälzungen, ohne Beihülfe ber veriebenben Rraft Des SBafiers, allein burd) Berwitterung Des Geftein Der früber nadten Feljen über biejen gebildet. Bir nemen ihn 3 erwitterungsboden, in den meiften Fällen ift es

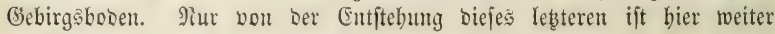
bie Rebe.

Die Bobenbiloung burd) Berwitterung roiro theils ourd demifiche, theil(s Durd) med)anifide Siräfte geföroert.

(Ehemifde Beriesung erleibet Der Fela burd) (Einwirfung bes Sauer:

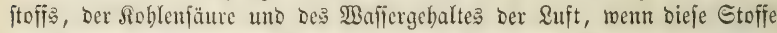
mit ben veridjiebenartigen Beftantotheilen ber Bejteine in Berübrung fonmten, in demifde Berbinoung mit ibnen treten, Daburch ibre Ratur verändern unto bie frübere innige 2 Serbintoung Der Gefteintbeile löjen.

Der Sauer ft off wirft borzugameife auf Den Bebalt ber Befteine an Metallen, inbem er bieje auf eine böhere Gäuerungştufe erbebt; unter

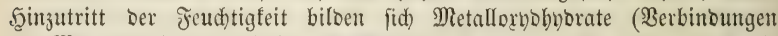
Der Metalle mit Samerftofi uno Majier), morauf, nidat allein burd bie 3eränberung Des Beftandes jelbjt, fondern aud burd) bie bamit berbun= Dene Nolumerweiterung ber reränoerten Metalle, Der frühere innige $3 \mathfrak{u}=$ jammentang biefer mit ben übrigen Gejteintbeilen zerftört wiro.

Die Roblenfäure ber \&uft und be马 Boben? wirft baburd) auf bie 3erftönmy Der Befteine ein, Dafs fie diefelben in Berbintoung mit 


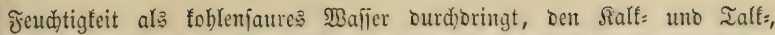
Sali= uno Natrongehalt berjelben in einen lösliden Zujtano verjeb̧t uno Dem Beftein bieje Bejtandtheile entrührt.

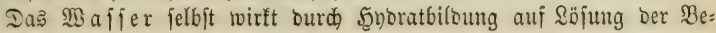
ftanotheile ein.

Fine widhtigere Rolle als bie d)emifajen fpielen bie medhanifden Srräfte bei ber Berwitterung Der B̈efteine. Das $\mathfrak{B}$ a f f e r wirft nidht allein Durd) 2 Auslaugen ber, bermitteljt demijder Sräfte in einen lößliden $3 u=$ ftano verjeb̧ten uno ber, an uno für fich) löslid)en (bejteintheile; ç zer= ftört vorzugsmeife ourd) feine ß̧erwandlung zu (Eis uno Der bamit ber=

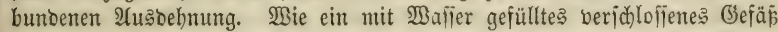

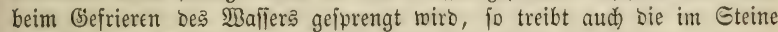
entbaltene Feudtigfeit beim Ģefrieren bie Gteintbeile auseinanber uno zer: ftört ben 3ujammenbang.

Sit auf bieje Meife bie äufere Gefteinfdid)t gelodert, berntag fie in Jolge Deflen eine größ̄ere Menge von Feud̆tigteit auj̧unehmen, fo treten

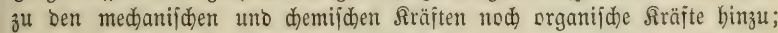

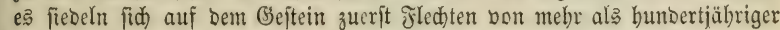
Sebenzoauer, Dann Moofe an, es bildet fid ein Ueberzug nieberer Pilanzen, Durd) melden bas Morid)reiten Der Berftörung in Folge ber verrintgerten Berbunftung, bes erhöhten Feuchtigteits̄grabes unb burd bie in bie feinften Deffinungen einoringenden Biflanzentourzeln bejoleunigt wirb. Inter ber

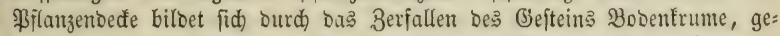
mengt mit ben Ueberreften ber abgeftorbenen Pflanzen, in roeldyen num

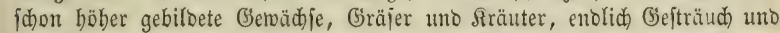
Bäume Scaltung uno Feudtigfeit finoen. Dic $\mathfrak{B}$ urzeln ber böher gebildeten Bjlanzen bringen mit ibren feinften Fajern in bie Giejteinfpalten uno förbern

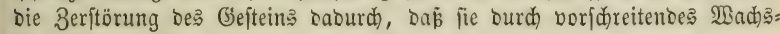
thum bie Epalten erweitern, auseinanberbrängen.

Der auf bieje \$eije in einer Reibe von Jabrhunderten gebiloete Ber= ritterungsboben bleibt mun entweber auf ber Etelle, wo er fid bildote,

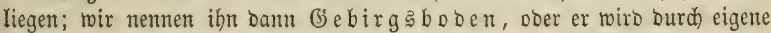

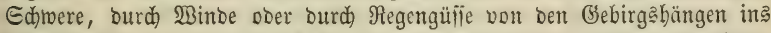
Ibal geführt, uno fammelt fich bier ̧̧u mehr ober minoer mäd)tigen Sdjidten:

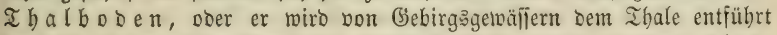
uno oft erit in weiter ferne von feinem Entitebungsoorte abgeję̧t: $\mathfrak{I} l u \tilde{s}=$ boden.

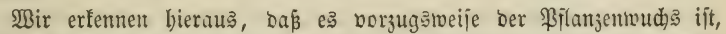
weldher bie Seerausbildung einer tragbaren Bobenfrume über bem verwit= ternoen Gejtein bollendet, baj es bejonbers die Scolzpilanzen fino, weldhe bierauf mädtig bintwirfen, inbem fie nidt allein bie Bobenbiloung förbern, jonoern aud ebenjo burd) ibre Betwurzelung als burd) ibren Laubidirm Den gebiloeten Boden feithalten uno in böberem (jrabe als alle übrigen G̈etwädje burd) Den reidjlidjen Blatt= uno Reijerabfall zu befrudjten ver=

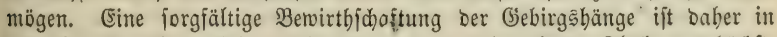

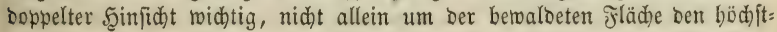
möglichen Ertrag abjugetwinnen, fonoern aud um bie tragbare Dberfläche 


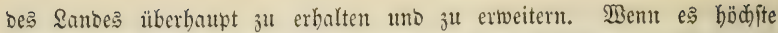
2lufgabe ber Foritwirtbichaft ift, זen Crtrag ber Mälder zu erböben, fo gehört babin nidt nimber die biewinnug bisher ertraglofer

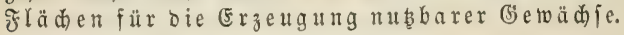

\section{Bon den Beftandtheilen des Bobens.}

Die Stoife, aus benen bic Bobentrume julammengejebct ift, finto theils

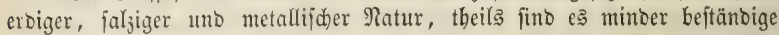

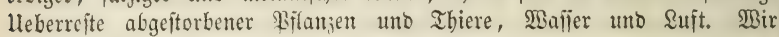
wollen bieje Bejtanotheile einzeln, ber Reike nad näber betradten.

\section{A. Wou icn mituralifden Beftantheilen Des Bodens.}

Sie mintralijent Bejtantheile bes Bodenß, uno unter biejen bie Eroent, biloen in ben meiften Fäflen sie Şauptmalie ber Bobenfrume. Non ihrer

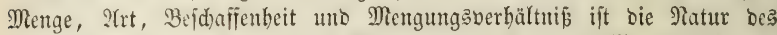

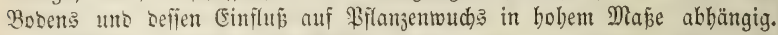

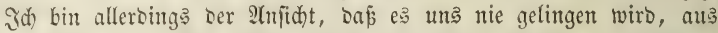

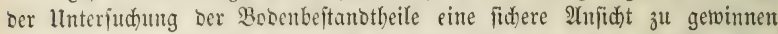
über bie einer getwifien Bobenart jufagente . Den Frudtbarfeitagrad oç Bobens in Bejug auf fie, uno jwar alts bem einfachent Brntmbe, meil auf bie Bobengüte, ober ridtiger auf bie Stano= orţgüte, auber ber Boonbefdaffenbeit eine grope Menge von Faftoren einwirfen, bie unjerer Foridung fid entweber gant entzieben ober in Raum

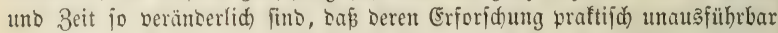
ift; bamit lvill id aber nidft gejagt baben, baj ber mineralifde Beftano

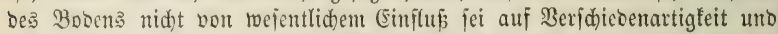
Gebeiben tes Bifantzentudbjes. WBir wollen baber zuerit bie Eigenidaften ber veridfiebenen Cinzeltheile näber betradten.

\section{Eroen.}

Den Sauptbejtanto bes Bobens biloet bie Riejel=, Thons, Ralf= uno Ialferbe. Alle übrigen Erben find ibrer Menge nad fo untergeoronet, bap fie in ber forjtfiden Bobenfunbe feine weitere Beadtung berbienen.

\section{a. Die Riejelerbe}

finbet fid) im Boben in breifader form; theila in demijder Berbinoung mit ber Ihonerbe als Ihon, theils in einem febr fein zertheilten 3uitande ałs Riejelitaub, entolid in größeren ober fleineren Quarzłörnern uno

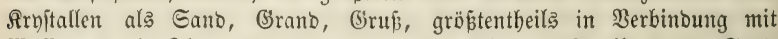
Baffer, wenig Ihon, mit (Sifen ober Soumusiäure. Je flarer ber Santo bes Bobens, um fo freier fint bie Rörner von Beintif(t)ung; eine mild $=$ weiß̧e Farbe crbält er häufig Durch anbängende faltttbeile, eine röthlide

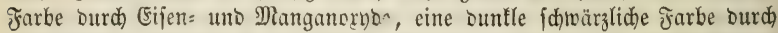
Şumustheile, bie mit ber Dberfädhe ber Duarzförner iunig, wabrfdeinlid demifid verbunben fino. 
balten zum Gauerftoff ber Ruft, baher bann bem Sand auch bie Sigen: fdaft, ben Sauteritoff anzuzieben, unter allen Eroarten an wenigften żl= ftebt, eine in jebem Falle nadtheilige Eigemidaft.

Endida baben wir nod) einer (Eigenid)aft bes fiejelreiden Bobens zul erwäbnen: Der langjamen 2Bieberabfüblung Deffelben. Die Erwärmbarfeit bes Sanbbobens burch Eintwirfung Der Sonne ift ziemlid) biefelbe wie bie aller übrigen Eroarten, nur bie bumfel gefärbten Bobenarten werben von Der Gonne in böherem Grabe erwärmt, und zu biejen gehört ber Sand: boben in Der Regel nidjt; Dabingegen hält er bie empfangene $\mathfrak{B a ̈ r m e ~ v i e l ~}$ Yänger fejt, fo baj j. B. Thonboden in ztwei Stunben eben fo viel Wärme berliert als Sanoboben in brei Stunben. Die Urjache liegt in ber glatten glänzenten Dberflädje Der Duarzfönter, inbem Sörper mit rauber Dber: fläde mebr und rafder bie Wärme burd) $\mathfrak{B a ̈ r m e f t r a b l u n g ~ v e r l i e r e n ~ a l s ~}$ glatte Fläc)en.

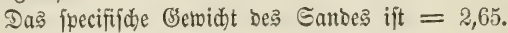

\section{b. Die Thonerbe.}

Der reine Thon ift eine demifde Berbinoung von Alauneroe uno Riejel= erbe in verjobiebenen Berbältnifien. Berzelius untericheibet brei Thonfilicate: 1teg Silicat 48,15 Riejelerbe, 51,85 2Ulaunerbe.

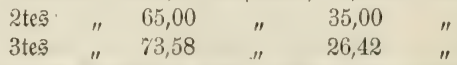

Tritt 3̆l bem Ihonfilicat eine gröfiere ober geringere Menge freier, ftaubartiger oder föniger Riejelerde uno Eijen, fo beipt das C̈emenge Lebm. Man unterideibet nach dem (Sebalte beß Thon an Riefelerbe fünf veridjiebene $\mathfrak{2}$ rten von $\mathfrak{L e b m :}$

1) mit Dreifad)em Riejelthon $=76$ Ihonfilicat uno 24 Riejelerbe

2) mit zweifachem " " $=68$ " 32 "

3) gleidatomiger $\mathrm{Rehm}=52 "$ " " 42 "

4) mit zweifadem ahontiejel $=35$ " " 65 " "

5) mit breifachem " $=26$ " "74"

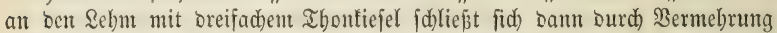
Dç Gandgebalt bon 5-10 \$roc. (Eifenorno gibt bent (Semenge eigentlid) erit ben Namen Sebm; ohne biefe ftellt es bie unreineren Töpferthone bar.

Der Thon bes Bobens ift in Maffer unauflöslid), foll aber mit

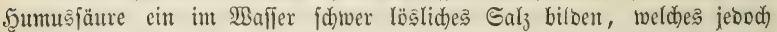
leidet in bafifden 3ujtanto übergeht uno Dann im $\mathfrak{B a f f e r}$ unlöslid) wiro.

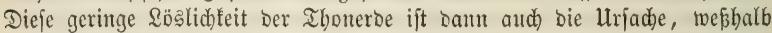
wir fie in bem Duellwaffer, wie in bon Pflanzen, in faum erfenbarer Menge, weit weniger wie bie Riejelerbe borfinben.

Der Thon wirft baher weniger burd) fein demifdes, als burd fein phyfitalifdes Berbalten auf Bobenbejdaffenbeit ein, uno äupert faft in 2Ullem eit ber Riejelerbe burdhaus entgegengeję̧es ßerbalten.

3uerft zeigt ber Thon bie hödjte (wie ber Sand bie geringfte) 3u= fammenthangsfraft uno übertrifft bierin alle übrigen Eroarten um bas 3ehn= fadje. Dieje (Eigenjadaft madjt ben reinen Ihonboben fehr unfrudb)tbar, inbem 


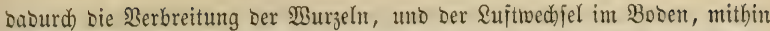
aud) bie (Entwifflung ber Bflanjennabrung aus bem Şumus beffelben gebinbert

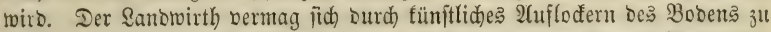
belfen; uns jtehen foldhe Mittel nidht 3u Gebot, uno ber ftrenge Thonboden bat baber für ben Jorftmirth weniger Wertl) als für ben Sanbwirth.

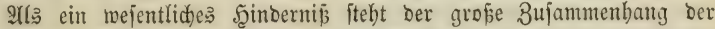
Thonerbe im bindenten Boben bei Dem Rulturbetriebe, bejonders beim Bflanggejdäft ba, indem ę nur im loceren Boben gelingt, bie $\mathfrak{W} u r z e l n$

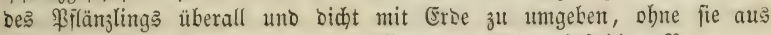
ibrer natürlichen \&age zu bringen. Man fann fid) auf foldyem Boben nur

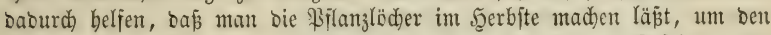

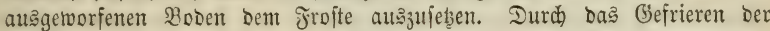
Bobenfeudhtigfeit werben bie Thontheildhen bes binbenben Bobens aus : cinanbergebrängt, verlieren ibren 3 ujammenbang uno liefern im Frübjabre eine lodere Bobenfrume.

2ber nidbt allein auf Die Rulturarbeiten hat Der größ̄ere Bujanmen= bang ber Bobentbeile wejentliden Einflup, jonbern aud) auf Wadsthum uno (jebeiben, bejonders ber 33üfdelpflanjungen, wie überhaupt aud ber bidteren Eaatfulturen. Sslüfliderweife fommen bie reineren Ihonformen nur felten,

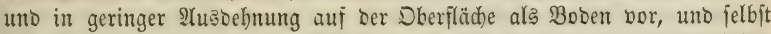
jehr binbende Bobenarten entbalten ben Thon in einer fehr beträdtliden Untermifdung mit Eant, Durd weldhe biejelben bohe Grabe ber Frudtst: barfeit erlangen, indem bann alle bie mohltbätigen (Eigenjwaften beక Thons hernorzutreten vermögen. Thoniger \$erwitterungsboben ift in ber Megel frudtbarer, als bie primitiven Thonlager, theils in Folge häufigerer Bei= mentgung bon (Sefteinbroden, theils Durd) gröberen (Sebalt aus nod) fort=

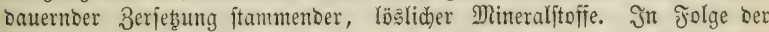
3ufammenhangsfraft bes Thons, jowie ber feinen 3ertheilung, ift ber \&uft= wedjel im Boben gering, woourd) allein fdon bemielben bie Jeudtigfeit

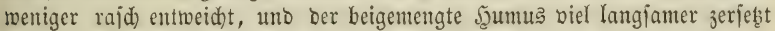
wirb als in loferen Bobenarten.

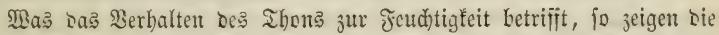

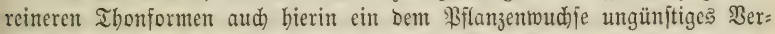

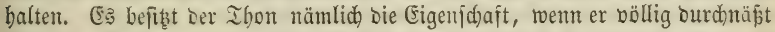

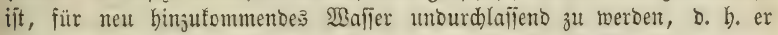
gibt bas aufgejogene $\mathfrak{B a f j e r}$ weder an bie unter ifm befindlichen Bobent ober

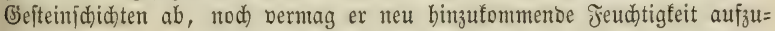
nehmen; fo baj leketere, wenn fie feinen 2tbflup finbet, fich -über ber Thon= jabidht anjanmeln unb Berjumpfungen beranlafien mup. Die meijten Sümpfe, Moore, Seen, Brüd)er des Meeresbobents berbanten einer unter ifr liegenten undurdhlafienden Thonichidht ifr Dajenn. Berjumpfung mú überall entjtehen, two sinem Boben auf eine ober bie anbere 2rat mehr Feudtigfeit zu= als abfliest uno nur burd) Berbunjtung zu entrocidjen bermag. (Finem fold)en Boben fann nur Durd) A(bzugg̈gräben ober burd) Unterbred)ung ber unburd)=

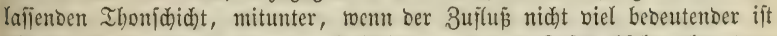
als bie ఇerbunftung, făon burd) Beförberung bes \&uftwedfels über bcm

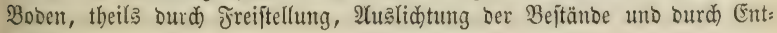


Fermung ber bie Serbunftung bindernben Bifanzenbede, Eumpfmooje 2 . geholfen werben. 2(ud) bieje nadtheilige (Figenid aft bes Ilyons wiro burd) Das f̧inzutreten bes Gandes zur Bodenmengung geboben. Die binbenten

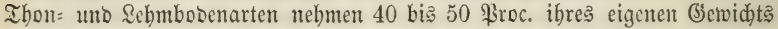
Maffer auf, wäbreno ber Ganto nur 25 \$roc. aufnimmt; Ralf=, $T$ alf: = uro

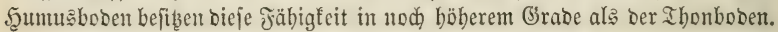

Der Thonboben nimmt aber nidht allein eine größpere Feud)tigteitßmenge auf wie ber Gant, er befizht aud in weit böherem Grabe als biefer bas Şermögen, bie Jeudutigteit ber \&ujt an fid zu ziehen, uno bie auf einem Doer Dem anoen $23 e g e$ empfangene Jeudtigfeit feitzubalten, nidjt jo rajo surdh Berbunftung zu verlieren. Er fteht in biefer Şinficht fowohl gegen ben Gano als gegen bie übrigen Bobenbeftandtheile in ziemlich gleidjem

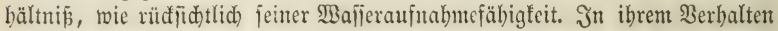
jur Jeudhtigleit ift baber bie Thonterbe bei nidjt zu grojen Uebergewidht

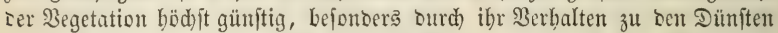
Der Suft, indom bamit zugleid) ber bohe Grab, in meldhem biefe (Froart ben Eauteritoff ber Suft an fid ziebt, verbunden ijt.

Die ber Thonerbe in jo hohem (Brnde zujtehente Fähigfeit, bie Dünfte

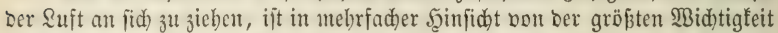
Durd) Den wohlthätigen (Eirflūs, ben fie auf bie Jeudhtigfeit bes Bobens fowohl, als auf bie Entwiaflung Der Bflanzennahrung im Boben aubäbt. Durd biefe Eigenjofaft vermag fid ber Ihonboben aud olne wirfliche शieber:

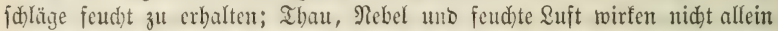
auf jeine Sherfläde, wie beim Ganbboben, fonbern gehen tiefer in ihn ein

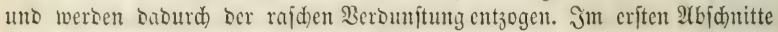

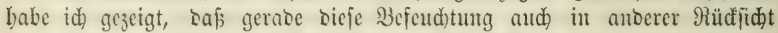
febr wohlthätig wirft burd) bie Mlenge scr Siohlenfäure, bie mit ben feineren

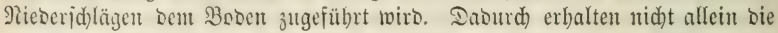

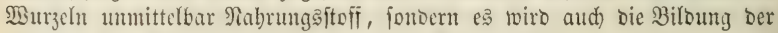
mineralifden Pilanzemuabrung in bohem (Srabe befördert.

Atud) in ihrem Serbalten jut Märme ftebt bie Thoneroe ber Riejelerbe

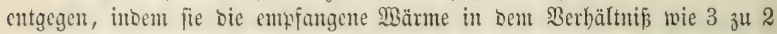
rafd)er verliert als biefe. Sierauf berulht theiltweife ber Unteriddies zwijhen bibigem, warmem unb faltem Boben, ber anorerjeits jebod) aud burd) Fendigteite = uno Bulammenhangsgrabe beoingt ift.

lleber on ßerbalten bejonoers ber Ihoneroe zu bem in ben atmojphä:

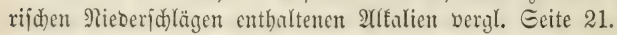

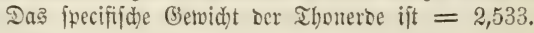

\section{c. Die firferde}

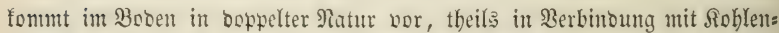

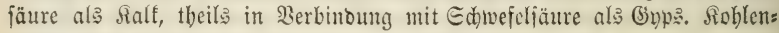
faurer Salf mit fohlenjaurem $\mathfrak{I} a l f=$ Dolomit.

Die fohlemiare Salfẹdo

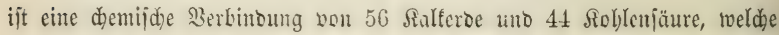
Yeţtere ourd) Glühen auşgetrieben merben fum (Ralfbremen), worauf ber 
Salf im äbenden 3uitande зurüableibt, bis er entweber ourd $\mathfrak{A}$ ujnabme ber

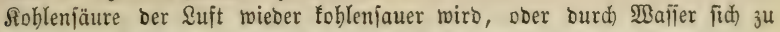

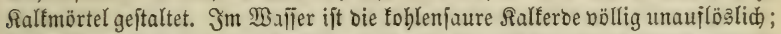
fie wirb es aber burd Berbinoung mit ber Scumuşäure bes Bobens, inocm

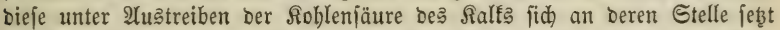
uno bumuşaure Ralferbe biloet, bie in 2000 Ibeilen faltem $\mathfrak{B a}$ afjer auflö引lid) ift. Die Ralferbe wirb ferner burd fohlenjäurehaltiges Waffer zu neutralem

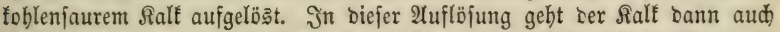

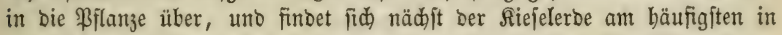

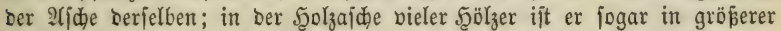
Menge als bie Riejelerbe enthalten. So fand Saujiure in ber 2 (jidje bes Fid)tentholzes auf (Sranitboden gewad)ien 46 ßroc., auf Salfboden 63 Proc., auf gemengtem Ralfboben 51 \$roc. Ralferbe, währeno bie Riejelerbe in ber

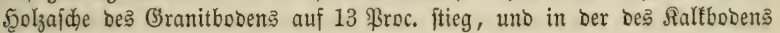
gänz̧lich fehlte.

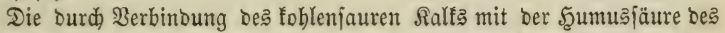
Bobens fich bilbente bumusa aure Salferbe, wirft baourd) wohlthätig auf bie

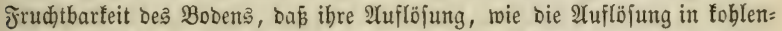
faurem Wafier, ben im Boben enthaltenen unauflösliden Scumu३ in einen lös:

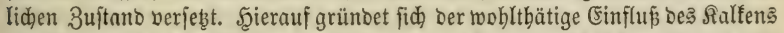
unt Mergelns joldher Biefen uno Felber, Die vielen unauflößlid)en Şumus ent= halten. Da bie Ralferbe fo grofie Mengen von Roblenjäure enthält, uno, rie wir wiilen, bie Roblenfäure in ibrer Berbinoung mit Wafjer ber wejentlide Theil Der Bflanzennabrung ift, fo fönnte man z̧um Şlauben verleitet werben: Der fohlenjaure Ralf wirfe ourd Albgabe feiner Soblenjäure näbreno auf bie

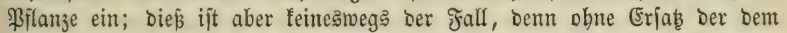

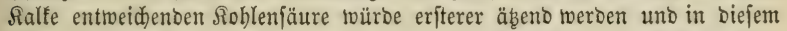
3uftanbe zerftörento auf bie \$flanzentwurzeln einwirfen; Die Cäure aber, weldhe bei ber llmwandolung bes foblenfauren in humuşauren Ralt an bie Etelle ber entweidjenten Rohlenjäure tritt, ift jelbft eine Duelle ber Pflanjen= nabrung, uno es wirb baber bcm Ernäbrungşraume ber \$flanze mindeftens eben fo viel, wenn nidst mehr, Nahrungştoff entzogen als er erbält, ourch bieje

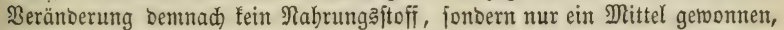

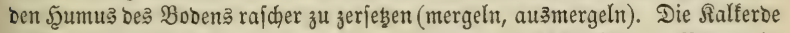
wirf̌t baher nidjt nähreno, fonbern mur reizeno, bie Ihätigfeit dę Bobens in

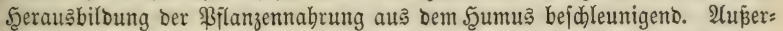
Dem ijt ber Ralf als widjtigftes 3ufübrungsmittel ber Edjwefelfäure uno ber \$hosphorjäure in bie \$Flanzentwurzeln von herborftechender Bebeutung.

In テ̃olge biejer Eigenjdaften Der Ralferbe nent man Den Ralfboben

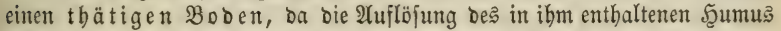
zur Bflanzennahrung jebr rajd vor fid geht. Soll ein Boben, ber viel

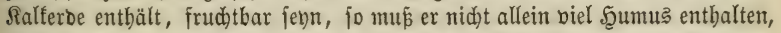

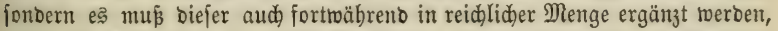
Daher über Ralfboden bie bidte Betbaloung eben fo forgfältig als über bem ločern Sanoboben 3 erhalten, uno für biejelbe eine \$̧olzart zu ertwäblen

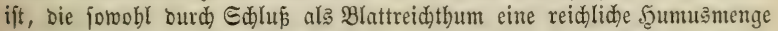
zu erzeugen vermag. Diejen $\mathfrak{A n f o r b e r u n g e n ~ e n t i p r i d t ~ b i e ~ \Re o t b b u c h e ~ u n o ~ b i e ~}$ 
Sdwarzfiefer am meiften, ber aud ibrer Natur nad ber Ralfboben bejonbers zujagento ift.

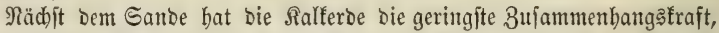
nidht viel höher als ber Sano, Daber fie einen loderen, leidten, ber $\mathfrak{B u r z e l =}$ verbreitung günjtigen, felbjt im nafien 3 ujtande twenig binbenten Boben bilbet. Die feinere Bertheilung ber Ralferbe ift aber bie Urfache, reßjhalb ber Suftivectjel im Boben geringer als im Sanoboben ift; wirb biejer burch cine reid)lid)e Beimengung von förnigem $\Re$ iefel beförbert, fo ift bie Ihätigleit Des Bobens nod) biel größ̄er ala obne dieje.

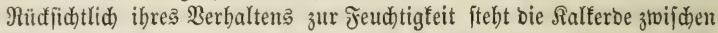
ber Siefel= und Thonerde, uno ift im reineren 3uftande in biejer Şinficht Der Begetation ungünftig. Sie faß̧t, je nadbem fie weniger ober mebr zertheilt ift, nur 25-40 \$roc. ibres eigenen (5ectwidtes an Maffer, berliert bie auf: gefogene Feud)tigteit febr raja) burd) $2(b z u g$ in bie tieferen Bobenjadidten Doer burd) Berbunjtung unt bejiţt baß Bermögen, Die Dünfte Der \&uft an ji(k) zu zieben, in febr geringem (5rabe. Die Ergebniffe riffenj(d)aftlidjer Unterfudungen fteben biermit vielfad) im Miberiprude (vergl. Edhübler I(grifulturdemie), was fid) wohl faum anders als burd bie grope $\mathfrak{B a f f e r}$ leitunģ̆fäbigfeit ber Ralferoe erflären läp̆t.

Bom Enntenlidte wirb bie Ralferbe, borzüglid) wohl wegen ibrer Tročenheit, nädjt ber Riejelerbe am meiften erwärmt, inbem im trodnen

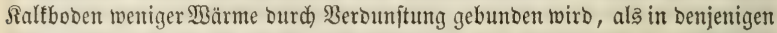
Bobenarten, Denen ein günjtigeres Berbalten zur Feudjtigfeit eigentbümlid̆ ift; Die Wieberabtühlung geht nidht viel rajher als bie bes Sandes bor fidd, baher ber Ralf cinen fogenanten hei Ben ober hibigen Boben bildet.

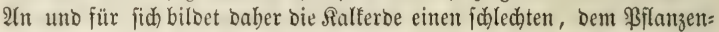
mudje menig günftigen, trodinen, warmen, meift bumusarmen Boben. Dic Mengung mit Thonerbe unb mit Scumus hebt jebod) biefe Mängel in bem Grab, Daf fid) aus ibr bie frudbtbarften Bobenarten herausftellen, wie bief 3. B. Der Fall ift, wenn bie Ralferbe mit 30-40 ßroc. \&ebm gemengt ift, Dod) bebt fdjon ein Rebmyehalt von 10 \$roc. Die nadtheiligen Eigenidhaften

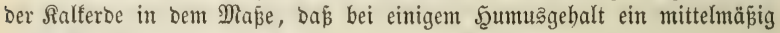
guter $\mathfrak{B a l}$ aboden erzeugt wirb.

\section{Mergel}

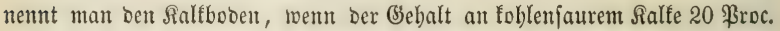
nid)t überfteigt, uno biefer ßalftheil mit Ihon uno Sano gemengt ift. Steigt ber Sanogehalt auf 60-70 Proc., fo nennt man bie Mengung fanbigen Mergel; fteigt ber Thongehalt auf 20-40 ßroc., fo heipt fie le hmiger, bei 50-60 $\mathfrak{B r o c}$. Thon thoniger Mergel. Die Mergelarten, bejonbers aber ber lebmige und ber thonige Mergel, biloen ein außerorbentlid frudtbareß Eroreid), inbem in ibnen bie (Erbarten in einem fo günjtigen ßerbältniffe gemengt finb, bas beren nadhtheilige Eigenidhaften gegenjeitig aufgehoben werben.

\section{Die idnefeliaure Ralferbe (Gupt)}

ijt für bie forftlidje Bobenfunbe von geringer Bebeutung, oa fie nur felten

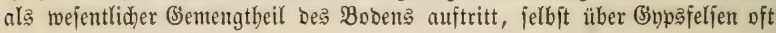


in nur geringen Mengen Dem Boben beigemengt ift, unt zwar wegen ifrer leidyten Röslidfeit im Maffer, in Folge beren ber Grnpasgehalt bes Bobens vom Regentafifer nad) uno nađ̆ aufgelöst uno ausgelaugt wiro. $\mathfrak{B O}_{0}$ ber (Snps in überwiegender Menge vorbanben ijt, zeigt er fich Der Begetation nidht förberlid, inbem er einen loceren, mageren unb beiß̄en Boben bilbet, ber bie Feudtigfeit in nidbt gröperer Menge als ber Duarzano aufzunebmen bermag, biejelbe fajt eben fo rafd) verliert uno fajt gar teine feuchtigfeit

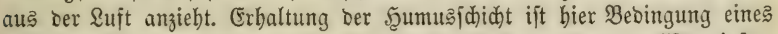

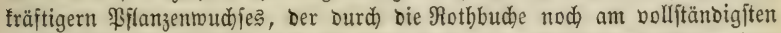

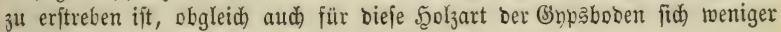
3uträglidh zeigt, als ber Salf.

\section{d. Die Talferbe}

findet fid im Boben in boppelter Serbinoung, entweber, wie ber Ralf in ßerbinoung mit Soblenjäure, ober wie ber Thon, in \$erbinbung mit Siejelerde

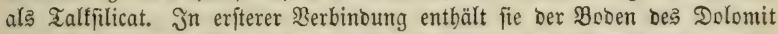
uno in geringerer Menge ber mandher Ralfiteine uno Mergel beigemengt;

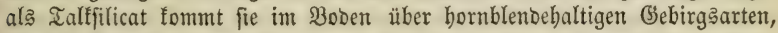
über Talt= uno Ebloritfchiefer vor. Bis zu 1/2 Froc., feltener bia 1 ßroc. Des Bobengemidts, findet fich bie Ialferbe fait in jedem Boben. In ihrem natürlichen Borfommen im Boben ift bie Talferbe im $\mathfrak{B a f f e r}$ unauflöslid,

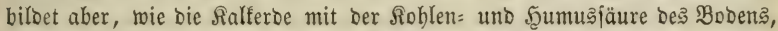
leid)t auflö̧liche Ealze, uno zeigt überbaupt in demijđer Şinficht ein ber Ralferbe äbnlides Berbalten.

Die Talferbe bat zwar zunädjit Der Ihonerbe bie größte 3ujammen: bangăfraft, jebod) mur ben 9 ten Theil ber bes Thones, baber fie als Loderungs:

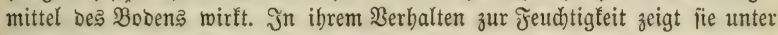
allen Erbarten bas günftigfte \$erbalten, inoem fie nidht allein bie größ̈te Waffermenge aufjunebmen bermag, jonbern bieje aud fefter erbält, als jelbjt Der Thon, unb bas Bermögen, Die Dünfte ber \&uft anzuziehen, im bödjiten (brabe befiz̧t. In gröferer Menge bürfte bie Talferbe bem Boben Daber nid)t

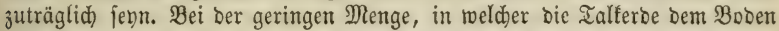
getwöbnlid) nur beigemengt ift, fönnen jene (sigenj daften nur wobltbätig wirfen,

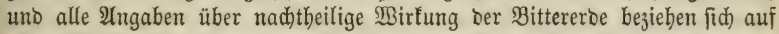
Deren Eigenjofaften im gebrannten 3ujtanoe. Die Dolomitifden Şohenzüge

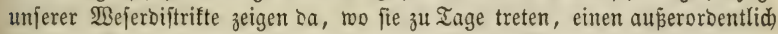
fräftigen Rothbuchenwuds uno fehr reidhaltigen Flor.

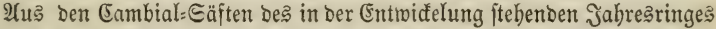
erbielt id) ourch) Bebanolung mit 2tmmoniaf forobl bei \&aubholz= als bei

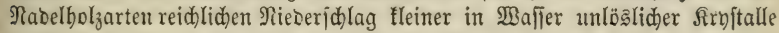
von phoşphorjaurer 2 mmoniafmagnefia obne Spuren von Ralf jelbft von Boben= arten bie reider an falf als an Talf raren. (5’ gewinnt baburd ber Talf Des Sobens bejondere Bebeutung für bie Ernährung Der Scolzpflanzen.

\section{Salze ber Alfalien und Der Metalle.}

$\mathscr{U}(\mathfrak{3}$ Bobenbeftandtheile find unter biefen mur

foblenfaures $\mathfrak{i a l i}$, 
foblenjaures uno falziaures Natron, foblenjaures, fdiwefeljaures uno phosphorfaures Eifen unt Mangan beadtenswerth.

Der Bebalt eines Bobens an Galzen überfteigt nur in außergetöhnlidjen

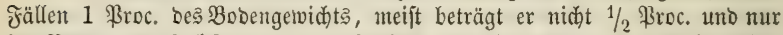
im Boben Der Salziteppen, Der Sectüfte, Der Hmgebung von Salzquellen, fo wie in manden Iorf= uno Sumpfboben tritt ein beträdtliḑer Salzgebalt auf, Der bem Wudje unjerer Walbbäume ftets binberlich ift.

Bemn, nad) Brandes Unterjudungen, jäbrlid) über 100 Pfunbe veridjiebenter, im Regentwajier aufgelöst enthaltenter Salze, auf bie Flädhe eines Morgens niebergeidhlagen werben, io läpt fich ber geringe Ealzgebalt

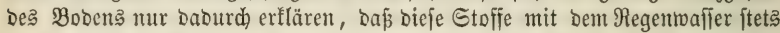

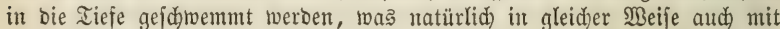
Den, Dem Boben eigenthüntid) angebörenden Galzen ber Fall ift. (Sin Boben ift baher um fo freier von jalzigen Beftandtheilen, je reidter er bem Waffer ben Durdygang uno ben $\mathfrak{A}$ (bzug in bie Iiefe geftattet; je binbenter, thonreidjer ein Boben ift, um jo gröper pflegt fein Salzgebalt ơu jebn (vergl. S. 22 über bie Firirung ber $\mathfrak{A}(f) a l i e t$ im $\mathfrak{B}$ oben).

YIm ungünftigiten auf ben Pflanjentudds wirfen bie Eifenfalze, bie fich, theils im Sumpf= unb Moorboben burd) Merbinbung bes barin häufig

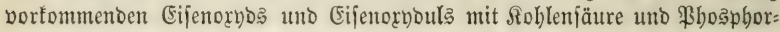
fäure, theils in fold)en Bobenarten entwicfeln, welde Edwwefeleifen (Ed)wefelfies)

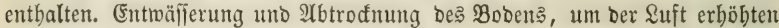
3utritt zu veridaffen, ift bas einzige Mittel, burd weldes ber Foritmann bie aus biejer Urjache entipringente Unfrudtbarteit eines Bodents zu beben vermag.

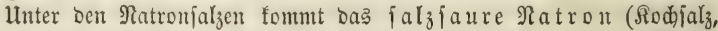

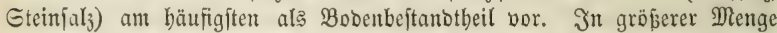

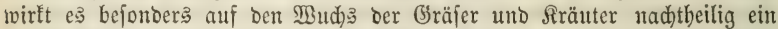

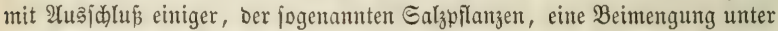
$1 / 2$ Froc. joll jeood günjtig wirten. Beniger nadbeilig fdeint biés Salz

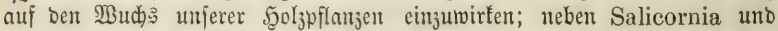

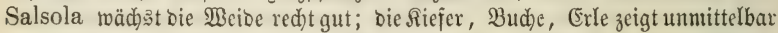
am Stranbe ber Ditjec auch ba, wo ber Boben faum über bem Mleeresjpiegel erboben ift, ein frentiges (Jebeiken, obgleid) bas bis zu 2 ßroc. falzhaltige 2Baffer nidht allein burd ben Boben, jonbern aud burd) bie \&uft ben \$ffanzen zugeführt wiro.

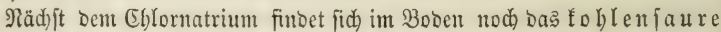
Natron ziemlid berbreitet, bod meift in febr geringer Menge uno, wie

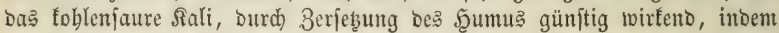
¿อ̉ die Bobenthätigfeit iteigert.

Widhtiger für uns ift bas f ohlenjaure $\Omega$ ali, inbem roir uns beffelben in einzelnen ₹ällen bebienen, um bie Bobentbätigfeit zu erböben, fo beim

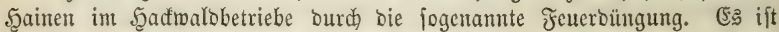
nämlid) Das Rali ein ganz allgemeenter Bejtandtheil ber \$flanzen, ber in ber

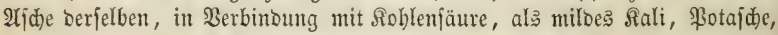

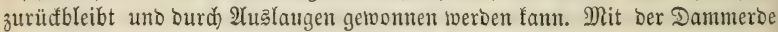

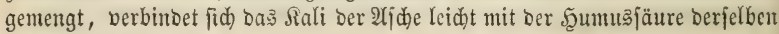




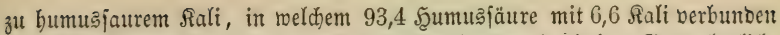

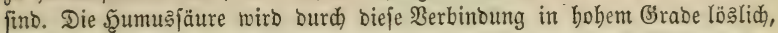
zerfeżt fich rajder zu Rohlenjäure uno beförbert baburd ben $\mathfrak{B} u d$ ja, aber natürlid mur vorübergeheno, wenn bie rafd) aufgelößten Şumu引theile nidgt erfeb̧t werben. Die Feuerbüngung befteht in nidjts 2 Inoerem, als baj man

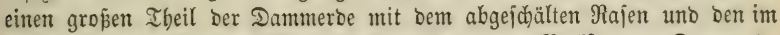

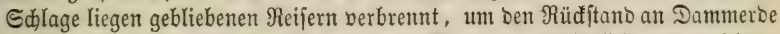

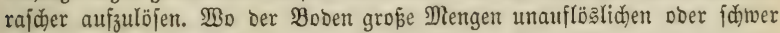
löslichen Şumus entbält, wie ber Torf=, Moor=, Eumpfboben, ober wo bie

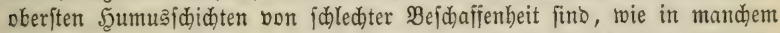
Şaibeboden, im Boben unter Ledum palustre, ba ift gewí̄ bie feuerbüngung nidht allein vorübergebeno von guter Wirfung; für ben gemöbnliden $\mathbb{N}_{B}$ ald: boben mit milbem löglidjen Balbhumus ift bie Feuerbüngung ftets böchit

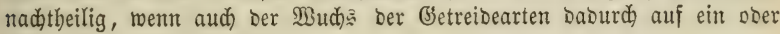
ztwei Jahre geförbert wirb.

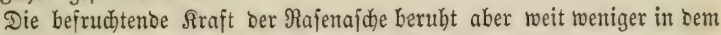

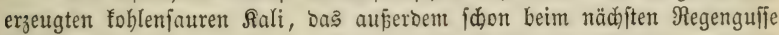
in bie Tiefe gejdinemut wirb, als in Dem Durdglühen bes Bobens, woburd) einestheils bie Eijen= uno Mangan=Drnbule in Drybe verwanbelt werben,

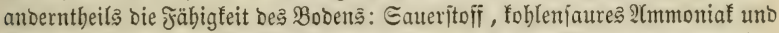
Feudtigfeit aus ber 2Atmojphäre anzujiehen, in hohem Grabe geiteigert wirb.

Der eigenthümlidhe Gebalt bes Bobens an Sali ift bejonders in ben aus Jelbipath uno B̈limmer baltenoen Bebirgsarten herborgegangenen $\mathfrak{B}_{\mathrm{c} D e n=}$

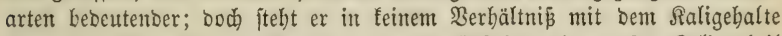

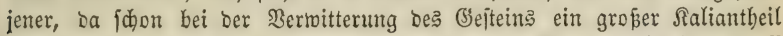
verfabininet; ben locfern Bobenarten, bejonbers bem Ganbe fehlt biejer Stoff mitunter gänzllich, überiteigt felten $1 / 2$ Proc.; im $\mathfrak{I}$ bon, Sebm, Salf uno Mergel fteigt er bismeilen bis auf 1 Proc. Die Wirfung bes bem Boben eigenen foblen= fauren Rali ift im 2Ullgemeinen natürlid) biejelbe, twie bie bes burd) bie Feuerbüngung erzeugten.

\section{Säuren}

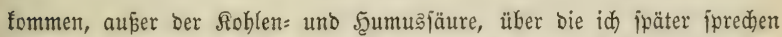
werbe, im Boben jebr felten obne Berbinoung mit einer Bafis, unt in ben jeltenen Fällen mur vorübergehend vor. 2(m bäufigiten tritt bie $S_{a} \mathfrak{l}_{3}\lceil a ̈ u r e$ in ibrer Berbinbung mit Natron, bie $\subseteq_{\text {dr wefel }}$ äu re in Berbinbung mit Ralferbe unb Eijen, bie \$hosphor $\{$ äure an Eijen gebunben auf. Heber bie Wirfung biejer Calze im Boben habe id fo eben bas bem forftmanne Widjtigere mitgetbeilt. Was man im getwöbnliden \&eben unter bem 24usorud: faurer Bo ben berfeht, bezieht fid auf bie Befdaffenheit bes Scumus und auf bas ßerbalten bes Bobens zum B̋raștoudfe, indem man Denjenigen Biejen= ober Brudboben jauer nemnt, Der feinte guten Juttergräjer, jonbern Binjen, Rieogräjer, Moofe 2c. erzeugt.

\section{Metalle.}

Das Borfommen ber Metalle im Boben ift jehr bejabräntt. $\mathfrak{A} \mathfrak{m}$ bäufigíten finbet fidh bas ङijen, in biel geringerer Menge Mangan 


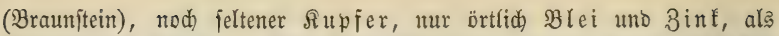
Bleierbe und Goalmei. Bon biejen Metallen berbient in ber forjtlichen Bobentunbe mur

\section{Das Eijen}

ciner näberen Beadtuntg. (E⿱ volfiänoig mit Saueritofi berbunben als Eifenoxyb uno als Eifen: oryoul (wenn Eifen ber Eimbirfung ber Suft ausgejebt ift, berbinbet

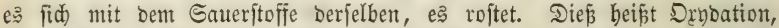
bie entftandene Berbinbung, wenn fie volfitändig ift: Drvo, wenn fie un= vollitänbig iit: Drybul). Mit demifd gebuntoenem $\mathfrak{B a f f e r}$ bilben biefe beiben Drybationsftufen $D \mathfrak{x y b y b r a t ~ ( E i f e n r o f t ) ~ u n o ~ D r y b u l h y o r a t . ~ H e b e r ~}$ bie Berbintoungen des Eijents mit Säuren zu Salzen habe id̆ bereits ge: iproden.

Das Eifen in bollfommen prybirten Buftande fann bem Boben in groper Menge beigementgt fein, ohne Daß $e^{3}$ einen nadtheiligen Einfluß äußert; im (segentbeil, es enthalten bie meijten befieren Bobenarten größs= tentheils biel Eifenoryo, uno man follte baraus faft auf eine günftige

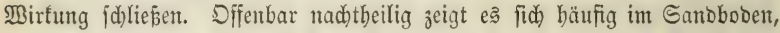
menn es bemfelben über 10 Proc. beigegeben iit; ę gibt dem Sanbboben alsbum eine juarfe, rothe Farbe (Juds;anb), bie wir allgemein als ein Beichen groperer Unfruddbarfeit femten. Selbit bie Riefer fünmert in einem fold)en Boben uno erreid)t tein hobes 2llter.

Das Eijenornoul joll fid häufiger als bas Drno nad)theilig zeigen, bodh feblt bier noch eine binlänglidje Reihe von Beobadatungen. (Es bildet fid aus bem Dryo burd) Abgabe von Sauerftoff an verwejende Bflanzentbeile

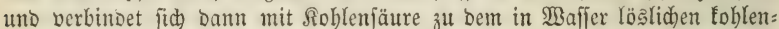
jauren Eifenoryoul. Sontnt die Söjung befielben mit Phosphorjäure in Beruibrung, fo bildet fie unter Sanerftoffaufnalme mit ber Säure bas phosphorjaure Eifenorbo, den Rajeneifenftein uno ben Murzelroft.

Bergl. meine Ilnterfud)ungen über Den (Einflu⿰ Der Säuren, Salze,

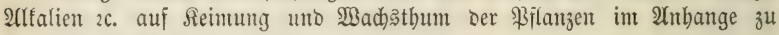
5̧artig forjtl. Eomberi.=2ericon.

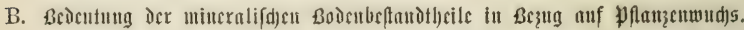

Der Boben foll Den Bilanzen Scaltung unb Etanoort gemäbren, zu= gleich) aber aud) einer möglidjit reidjen uno weit verbreiteten 13 urzelbiloung günitig fein. Eş foll berjelbe ferner Den $\mathfrak{B u r z e l n}$ zu jeber Zeit bie nötbige

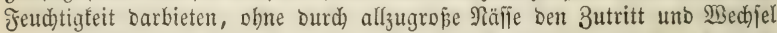
Der atmofphärifकen \&uft zu verbindern. Der Boben folf enolid auch Durd)

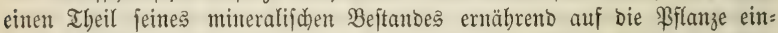
lvirfert, indem er ibr nadbbaltig uno in genügenber Menge biejenigen mine:

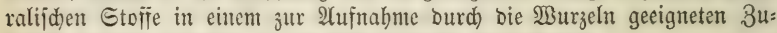
ftande zuführt, bie wir in ber Bflanzenajde twieberfinden.

Es ift hauptiädlid bie Edjwere uno bie 3ujanmenthangsfraft ber Bobentbeile, Denen bie Bflanze ibren Scalt im Boben verbantt. Sieringe Grabe berjelben fönnen erfeßzt jein Durd) gröpere Bobentiefe, fo wie burd) 


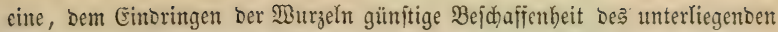
G̈efteins. Sobe Brabe Derjelben, wie fie Den reineren Ihonformen zuftehen,

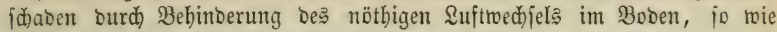
Durd Erfdwerung ber $\mathfrak{B u r z e l v e r b r e i t u n g . ~ N a b e ~ b e r w a n b t e ~ \$ i f l a n z e n ~ z e i g e n ~}$ jeodd) in Yeketerem ein febr veridicbentes Berhalten. Eo Durdjoringt bie MBeymoutbfiefer mit ihren Murzeln felbjt Den reinen Töpferthon, Der für bie Särche faft gänzlidì unzugänglid) ift.

Der żweiten 2nforberung genügt ein 30 ben in um fo böherem (5rabe, je mefr er bie burd) Regen uno Sdneetwafier empfangene Jendigtigleit im Bereiche Der \$flanzentwurzeln feftzubalten vermag, je mebr er befäbigt ift, Das Dampfï̈rmige Waijer Der \&uft anjuzieben. Die Urjade zu grofer Bobemnäjle liegt nie im Boben felbft, fondern in Defien Unterlage, wenn

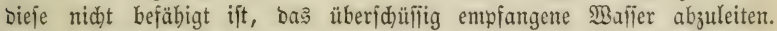
Aud bie Eigenjafaft ber Bobentrume, in 3eiten mangelnoer Mafierzufubr

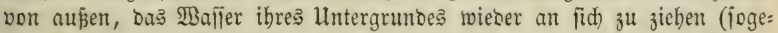
nannt "fdrwiß̨ender Boben"), eine Eigenidaft, bie vorzuggheife ben Boben= arten bon grobem Sorne zujtändig ift, berbient alle Beadtung.

Heber bas Berbalten ber verfdiedenen Bobenbejtanotheile in biejer Sinfid)t babe id bereits im \$orbergebenoen gejproden, es bleibt mir bier bie nähere (Frörterung Der Beziehungen, in Denen bie Bodenbeitanotheile

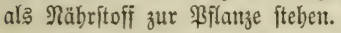

$\mathfrak{Z}$ uper ber Thonerbe finben wir in Den \$flanzenafjen alle minera: lijaten Bobenbeftanotheile wieber bor, theils rein, als Sefrete (Siejelerbe, fohlenfaurer Ralt); theil’s mit Bilanzenjäuren (Draljäure, Eiligiäure 2 .) verbunben uno in Intern ber Bellen zu Siryftallen auggeidieben (baupt=

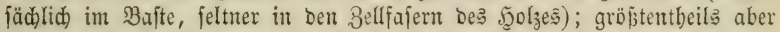
als bem 2 (uge nicht mehr erfennbarer Beftantotheil ber Bellwantoung felbit. Sn welder Serbinoung fie in Der Bellwanoung vorfommen, ob fie mit Dem Bellitoffe demifo berbunben, ob fie biefem nur beigemengt fino, wifien wir nicht, folgern aber aus ber 2Ullgemeinbeit ibres Norfommen im 3ell= ftoffe, fo twie aus ber günftigen \$Birfung auf ben \$flanzentwudbs, wenn

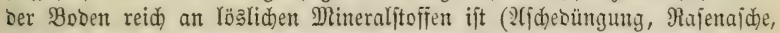
Grnpfen), baj fie eben fo nothwendig jur Bellenbiloung finto wie jeder anbere Bejtantboil Derfelben, Daßj fie nid)t allein F̈̈rberungsmittel uno Bebingung Der in ber Piflanje vorgehenten demifden Biloungen uno 3er:

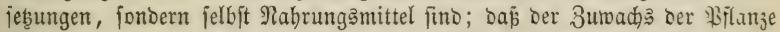
ebenjo an eine genügente $3 u f u b r$ mineralijober Stoffe, wie an bie ber

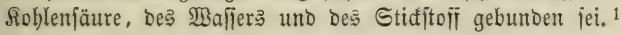

1 Inmittelbar nadj jeder Sidftitellung im Edluffe erwadjenter 3 äume tritt eine bedeu=

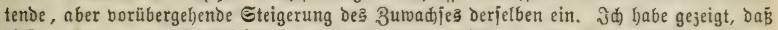

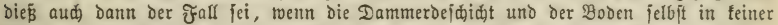
Weife eine Beränderung erleidet. Die Durd) die freiftellung vermebrte Blattmenge tann ebenfalls niat bie Urjade biejer 3uwadş̧teigerung fein, ba bieje fofort uno früber eintritt,

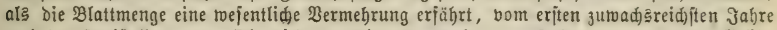

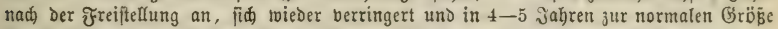

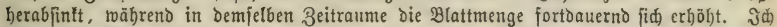

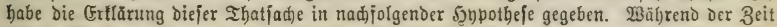

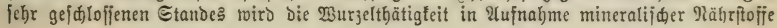


Diés als ridtig angenommen, fragt es fid immer nod), ob ber $\mathfrak{B e}=$ barf ber Bflanzen beftimmte mineraliface Bobenbeftandtheile in beftimmten Mengen erforbere, ober ob, in Ermangelung Des einen ober bes anderen Beftanotheils, burd Mebraufnabme vorbanbener, ber Bebarf in veridies

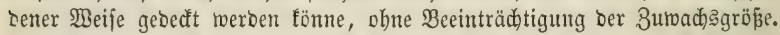

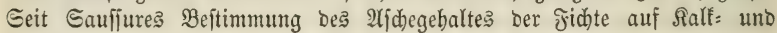
Branitboben (Eeite 81) bat fich lebetere 2 Anfidst immer mebr befejtigt und ift gegentuärtig bie herrichentoe.

In unjeren Wäloern gibt bie 3erjebung bes jäbrlicben Blattabfalles bem Boben eine Quantität mineralifher Stoffe zurüaf, bie bem Bebarf für jährlide Blatt=ßeproduftion genügt, nicht allein in Menge, fonoern auch in Bejdaffenbeit. Wir fönten baber biejen 2(ntheil bes Bebarf?

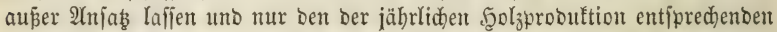
Bebarf in Redinung ftelfen. Trocenes Jidtenbolz entbält 1,7 Froc. Arfde; 3 Eubifmeter jäbrlicher Maffenerzeugung pro $1 /$ Sgettar $=3200$ Pfunt

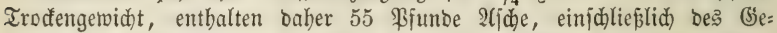

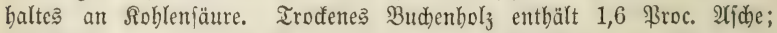
1,5 Cubifmeter jührlidjer Mafientrzengung $=2250$ Bfunbe Irodengemidjt enthalten baher 36 \$runbe 2 (j)

Bergleidjen wir hiermit bie Mengen von Ralf, Talf, Ratron, Riejel= erbe 2 ., bie nach ben Geite 21 mitgetbeilten Unterjuchungen alljäbrlich mit bent Regen= uno Ednneewaffer bem Boben zurüffgegeben werben, beren Menge Den jäbrlidyen Bebarf ber Bflanjen um bas Mehrfache überfteigt, jo roürbe bie mineralijde 3ujammenjeb̧ung bes Bobens felbjt, ohne Cin:

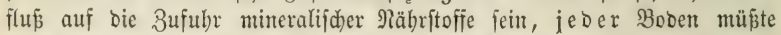
ben Bebarf an jolden ber Bflanze in überreider Menge liefern, um jo

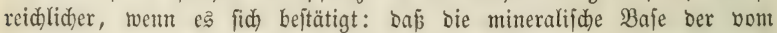

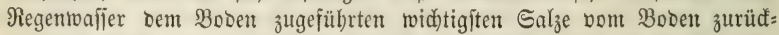
gehalten wirb, ganz abgejeben von Der Ibatjache, Daj es faum einen

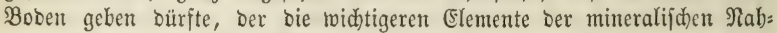
rung nicht in genügender Menge in fid) trägt.

Wenn es fich beftätigt, baj bie Bajen aud ber an fid in Bafjer

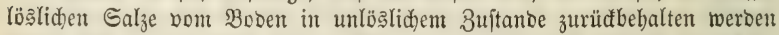
(Seite 22), Dann müfifen wir ben \$flanzentwurzeln bas \$erntögen zufprechen,

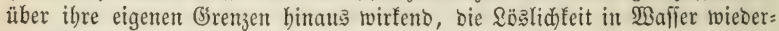
herzultellen, ba bie (Finfubr in bie \$flanze nur in räfirriger \&öjung möglid)

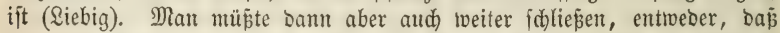

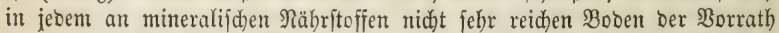

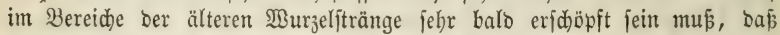

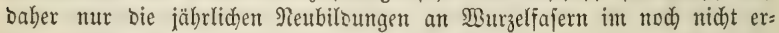

nidat in Demfelben Maß̃e verringert als bie Blattthätigfeit burd berminderte Blattmenge

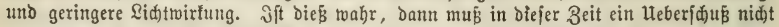

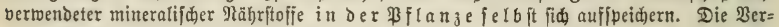
wenoung diejes Ueberidjuffes bei gefteigetter Sidtroirfung auj die Belaubung ift ę, weld)e

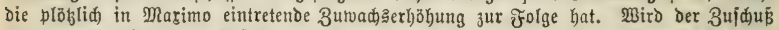
jur normalen jäbrliđen $3 u$ fuhr von Jahr zu jahr fleiner, fo finlt ber 3 utwadj in bem=

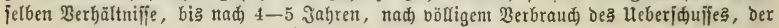

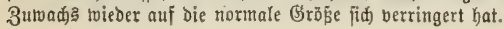




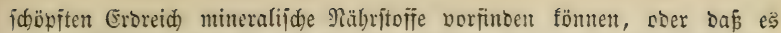
bie mineralijae 3ujuhr aus der 2tmojphäre jei, Durd weldhe ber bie

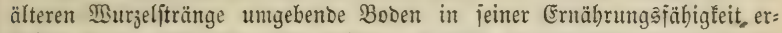
halten wirb. Eshe wir nidht wifien, ob mur bie jüngiten ober aud) bie älteren Murzeltheile zur 2Uufnabme von Bobennabrung geididft finto, läp̄t iid) in biejer jür bie Bobentunbe riddtigen Frage nidht cimmal eine $\mathfrak{B} e r=$ muthung ausiprecten.

\section{C. vom fjumus.}

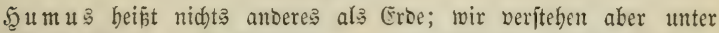
biejem 2 (uşbrude bie burd) Berwejung zu einer tobligen, lockern, ftruftur=

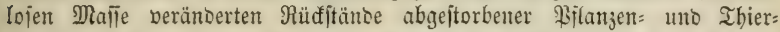
förper, weldhe in Untermijdung mit minera(ijchen Bejtanotheilen Łes Bobenz unto mit nod) nidyt böllig berwesten Prlanjentheilen bie Dammeroe un:

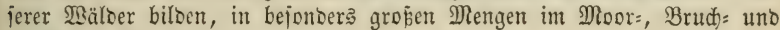
Torfboben enthalten fint.

Der jährliche Blatt= uno Reijer=26fall biloet Den Şauptbeitand beక

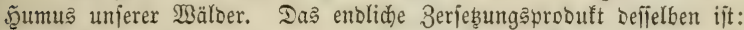

1) Sobleniäure: aus bem Gaueritofi Der Atmojphäre uno bem Roblenitofif ber Bilanzenfajer; ${ }^{1}$

2) Wajier: aus Dem Gaueritofi und Waijerftofi ber Bilanjenfajer;

3) 2 mmoniaf: aus bem Stiditoif uno einem Antheile Waileritoif Der Bifanzenfajer (unter llmitänoen: Salpeteriäure aus Stid: ftoifi uno Gaueritoifi);

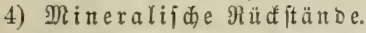

Die Pfilanjenfajer, in ihren Hebergangş̧uftänben aus bem uriprüng: liden in bieje Yeţten Bujtänoe, bilbet bie Dammerbe; ben zujammen=

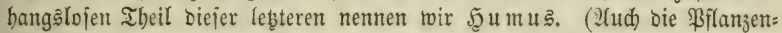

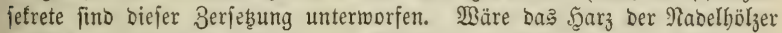
wirflid) unvertwesbar (Qiebig), bie Inbäufung belielben in ber Dammerbe unjerer $\mathfrak{B a ̈ l}$ ber müpte eine ungebeure jein.)

Der in alfalifichen \&augen lößliche Theil bes f̧umus, aus ber \&öjung

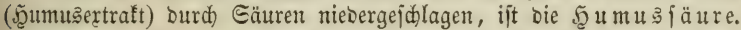

Die Berlegung ber Bflanzenfajer in ihre endliden Beftanotheile be:

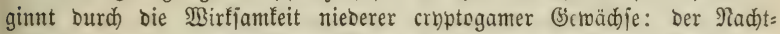

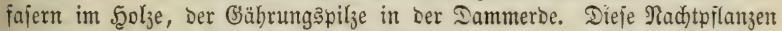
jino 3orläufer uno Diener ber demifden Berjeţung, inoem fie fid bom organifकen Stoffe unmittelbar ernäbren uno ihn gröptentheil’ Der 21tmo= iphäre jurüưgeben Durd fortbauernoe Sobleniäure:2Aßjicheioung. Der in

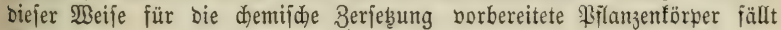

1 Siebig nimmt an: daj̄

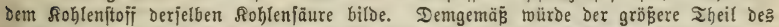
Sohlenftoif ber ßflanjenfajer ben jur Roblenjäurebildung nöthigen Gauerftoif nidht finden und als ein tohliger Rüđftand, Den Siebig Mo Der nemnt, jurüđbteiben. Tie Dammerde

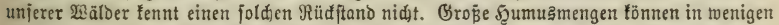

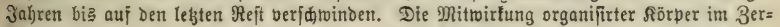

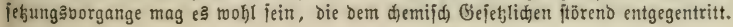


nun norzugaweife ber Wirfung Des Gauerftofís antheim, ber ihn unter be= günjtigenten Umitänben in wenigen Jahren bis auf bie 2lidebeftandtheile ju verflühtigen bermag, um fo rajder, je größer ber \&uftwedfel im $B$ boden burch tieferes uno volferes 2 (thment beffelben ift (Seite 11).

2(ber nid)t allein burd) Berlegung in bie flüd)tigen, binären Ber= binoungen ber Soblenfäure, Deక Waffer unt bes 2 (mmoniaf, berringert fich Die Menge bes Şunus in Der Dammerbe. Sin unter Umiftänben febr

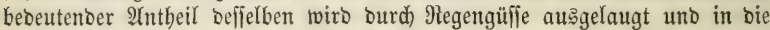

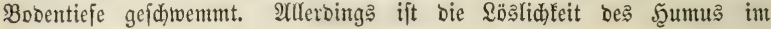
Waffer Der Digerirflafdhe eine fehr geringe, id) habe aber gezeigt (Jorit=

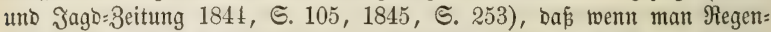

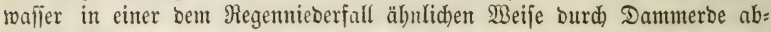

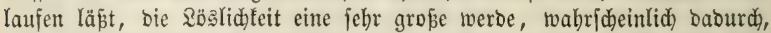

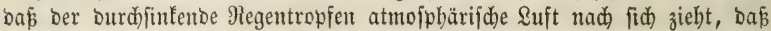
burd) Den vermebrten Sauerftoffzutritt eine rajdere Berlegung Des Şumus in Rohlenjäure berwirtt wiro, in Folge befien bas freigeworbene Rali und bas $\mathfrak{A}$ mmonial ber $\mathfrak{B f l a n z e n f a f e r , ~ w e l c h e s ~ a u s ~ b e n t ~}$

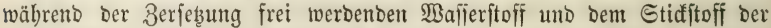

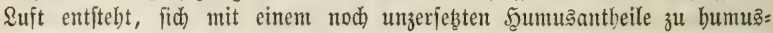
fauren, in Baffer leidjt löslichen Salzen verbinbet unb ausgelaugt wirb. Dem ift es bauptfäd)lid zuzufdrciben, went auf Blößen, Räumben uno

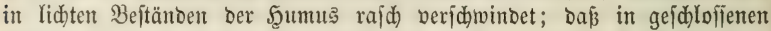
Beftänoen, beren bidłter Blattichirm ben größeren Iheil beక Regennieber= falles Dem Boben entzieht, bie Dammerbe in größeren Maffen fidb anbäuft.

Stagnirente Bodenfeud)tigfeit bingegen verzögert bie Berlegung, Ber=

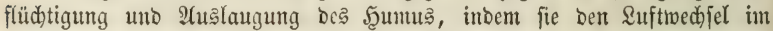
Boben verminbert. Bei gleidjem 3ugange an Scumus bilbenbem Material

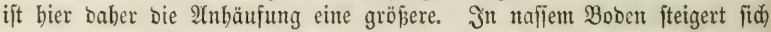
bieje zu belt bebeutenden Mengen, bie wir im Brudh, Mloor, Sumpf=,

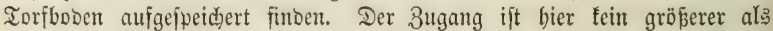
in unjerem $\mathfrak{B a l}_{\mathrm{D} b o b e n,}$ aber bie Berjeķung ift eine langiamere.

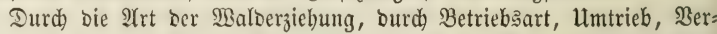
jüngungšs, Cultur=, Durdforftungşweife, Durd) bie $\mathfrak{B a b l}$ geeigneter $\mathfrak{S}_{2} \mathrm{I}_{2}=$ arten bermögen wir in mannigfaltiger $\mathfrak{B}$ Beife, nidft allein auf einen größeren 3ugang an humusbilbendem Material, fonbern aud, mas nod widtiget ift, auf minter rajde Berfeşung beffelben binzumirfen. Die Befrudtung

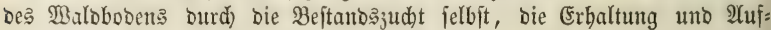
ipeidjerung bumojer Beftanbtheile bes Baldobobents ift eine Şauptaufgabe pfleglidjer Foritwirthjchaft. (ङ. Bo. II, Seite 60.) Seeritellung uno Er:

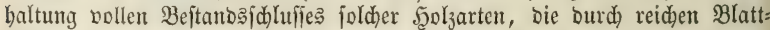

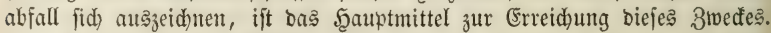

Die befrud)tente Birfung des Scumus im Boden berubt auf Ber: fichiebenem:

1) Bebeutung bes ફ̧umus als গähritofi.

Dá̉ gejunbe, unverleb̨te Bflanzenturzeln Şumuslöjungen nid t auf: nebmen, habe id bireft nad)gewiejen, zugleid) aber aud) gezeigt, baß Soblen= fäure nicht alfein mit bem Bobentwaffer aufgenommen, fonoern biefem ent= 


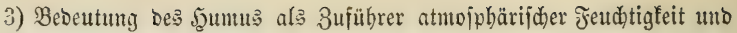
atmojphärijđ̄er Rährftoffe.

Unter allen Bodenbeftandtheilen bejibt ber Shunus am meiften bie

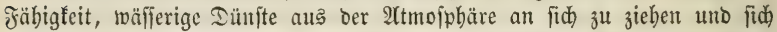
baburd) aud obne Sugang tropfenförmiger flüfitigfeit feudt zu erbalten.

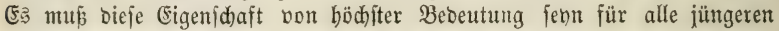
5ुolzpflanzen, Deren Bewurzelung nod) nidht bis zu eiter Bobentiefe binab: reidht, in ber iffr bie nöthige Feuchtigfeit unter allen Umitänben gefidjert ift. Mit Den Dünjten ber 2 (tmojpläre nimmt ber f̧umus zugleid) aber aut') foblenjaures 2 mmoniaf in fith auf uno befrudtet baburd) bas Eroreid. Db feine Saueritoff abjorbirende §raft mur auf bie d)emifiden Borgänge im Boben,

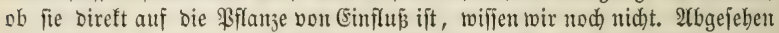

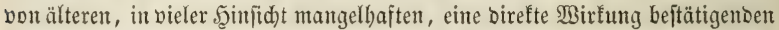

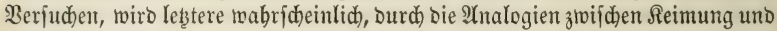

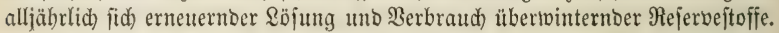

4) Bebeutung bes .5umus als Urjad)e einer inneren Bobenbetwegung.

Die Beriebung Des Şumus theils in löslidke, theils in gasförmige, Dem Boben entweichende Stoffe, unt jeine burd) ben Blattabfall alljäbrliche Enneuerung, mäffen eine fortbauernbe Beränberung in ben gegenjeitigen Sagerungşberbältniffen eines Ibeils bes in jeinem Bereide befindlid)en, anorganifichen Bobenbeftandes zur Folge baben. Durd) bie in größjere Boben=

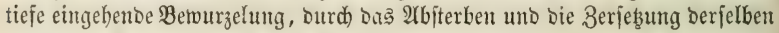
mit jebem Abtriebe, nach jeber Durdforftung, muk bie baraus hervorgehende innere Berwegung ber bleibenten Bobentheile aud) in größere Bobentiefe Ginabreiden. (Eine wid)tige Rolle ppielen bierbei bie annuellen Bflanzen Durdh

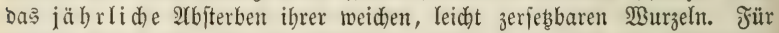

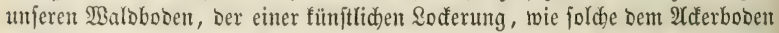
3u Theil wiro, in ber Regel nidht unterworfen ift, muईs bieje natürlide Soderung nidyt allein bon Bebeutung jebn, man barf audd antuehmen, bap jelbft im Bercidhe ber lebendigen uno thätigen Betwurjelung eine Seränberung in Den anlagernoen mineralifaden Bobentbeilen bierourd betwirft werbe; baf an bie Etelle ber eridöpften anbere Bobentbeile treten uno der abjorbirenoen Wurzelflëdhe fich barbieten.

5) Bebeutung beక Şนmus als Soderungsmittel.

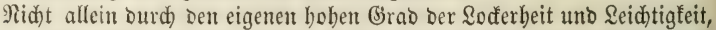
fonbern aud) burd) ben fortbauernben 2tbgang von Theilen feiner Maffe wirb

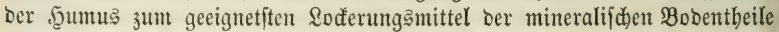
in ben oberen Sdfidtungen, in benen vorzugatweife bie zarten Thau= und

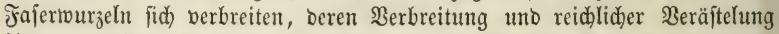
bier ber geringite Wiberitanto entgegentritt, bie bier zugleidh im Saboratorium

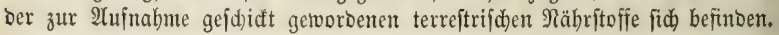

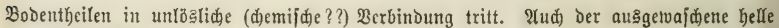

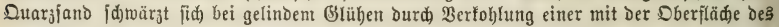

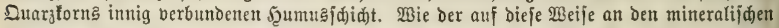

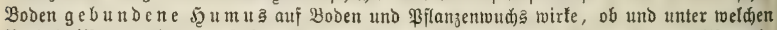

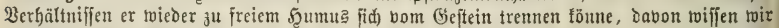

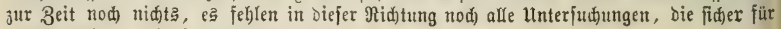
Die Bodenfunde roidtige Grgebnifie liefern rürden. 
6) Bebeutung bes 5ุumus als Bobenidub̧.

Bejonbers bie oberen, nod) unbollitändig zerjesten Echidhtungen ber Dammerbe vermindern nid)t aflein Den Euftivedjel, bie Sersunjtung oer Bobenfeudtigfeit uno bie ftärffere Ermärmung Des Bobens int Sommer, fie berbinoern aud bas tiefere (Finoringen Des frofts in ben Boben, indem bie, mit bem fohleçteften WBärmeleiter, mit Suft reidjlid gemengten Damm: erbejdidften biejenige Wärme bis tief in Den Winter hineit bem Boben erbalten, bie biejer ben Sommer über von aujen ber empfangen hat. Diefe ICftumpfung Der Iemperatur=Extreme im Boben ift fidher eine in hobem

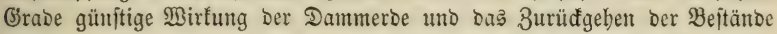
auf, Dem Gtreurechen unterivorfenen Boben entipringt borzugstweife Dem Mangel biejes Sđukzes.

Aber nidbt unter allen Hmitänden geht aus ber Berjeb̧ung ber Brlanzen=

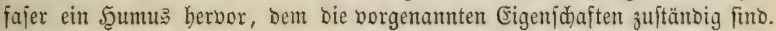

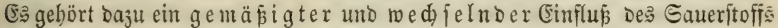

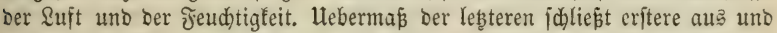

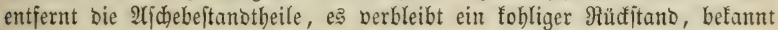
unter bem Mamen $\mathfrak{I}_{\mathrm{or}} \mathrm{f}$. Suntpf=, Mloor=, Brudboben fino Mittelbiloungen

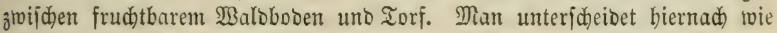
nad anberen Eigenidaften:

\section{Milder $\mathfrak{5} u \mathfrak{m}$ s $-\mathfrak{B}$ alobumus.}

Der miloe Şumus bilbet ben organifden Beftuno Der frudtbaren Dammerbe unjerer Bäloer, Der Idferffrume uno Der Bartenerbe. Durd)

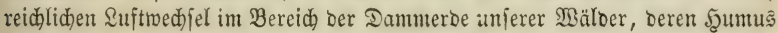
in rajder uno ununterbrod)ener Berjeł̧ung fteht, merben fortoauerno bie

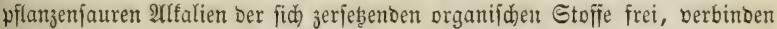

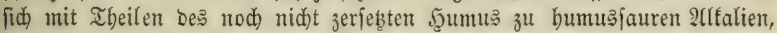

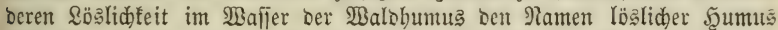

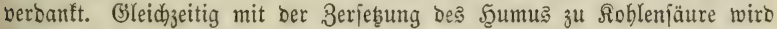
Wafierftoff frei, befien ßerbinoung mit Dem Sauerftoff ber \&uft im 2 Uugen=

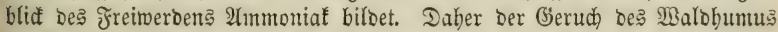

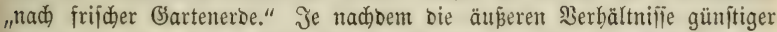
Doer ungünjtiger fino, enthält Der Malohumus weniger oder mehr Şumus̄:

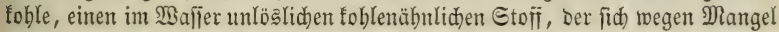
an Eaueritoff nod nid) зu fertiger Şumuşäure berausbiloen fonnte, allmäblig aber burch Berbinoung mit Gauerftoff in Şumus übergeht. Nid)t allein wegen feiner Söslidffeit ijt ber Maldbumus fo frudtbar, jonbern aud meil bie bereits gefdjilderten, bie Bobengüte in fo hokem Grabe förbernoen phofifichen Eigenfdyaften Des ફ̧umus bei biejer $\mathfrak{A}$ rt am idjürfiten hervortretelt. Eine Ulebergangabiloung zur folgenoen $\mathfrak{A}$ rt ift ber Wiejenboden.

\section{Saurer Şumus (Moorboden, Brudboben).}

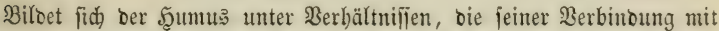

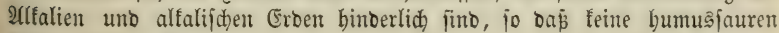

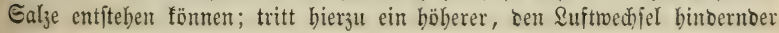




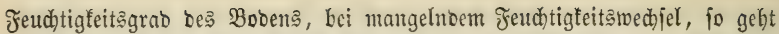

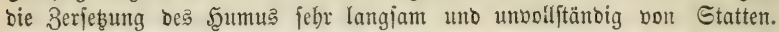

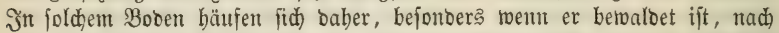

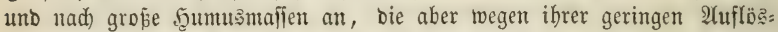

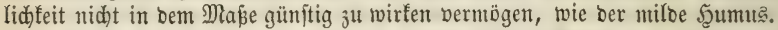
Nur wenige Şolzpflanzen gebeiben in einem jold)en Boben gut, bejonbers gebört ibm rie (Erle an; bod) aud) Efden, Birfen, (Eberefden twadjen bei nicht zu groper Mäjfe nod) recht gut.

\section{Robliger 5ூumus (Torfboben)}

entjteht aus ber Berfeb̧ung abgejtorbener Pfflanzen unter, burdh grope Näffe verbinbertem 3utritt Der Suft, in Folge beffen nidht in bem Make Saueritoff jum Sohlenftoff ber Bflanzenrefte treten faun, um vollfommene Şumuşäure

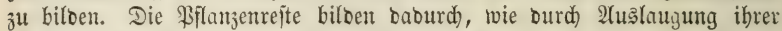
alfalijden Beitanotheile, einen mebr tobligen Rüfitano von jajwarzer, burd Eifenorno meijt bräunlicher ober röthlidjer Farbe, Der im $\mathbb{B a}$ ajer faft ganz unauflöslid ift, un fo mebr, ba biejem Şumus aud) bie nöthigen (Erben

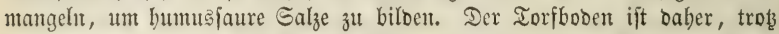
Des grofen (5ebaltes an F̧umus, jebr unfrudtbar uno fann nur burd) Entfernung ber Räfie uno burd) Mengung mit mineralijden Bobenbejtano: theilen, ober burdy Berbrenten ber oberften Sdidjten frudtbar gemad)t werben, iniem bas in ber 2 fidje ber Bflanzendecfe frei getworbente Rali mit bem nicht verbranten Şumus gemengt, วu bumuşaurem Rali fich verbinbet.

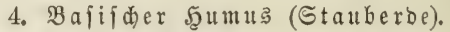

Bejonbers bäufig an fonnigen Freilagen ber Ralffteingebirge, in einem Boben, ber viel Salftheile entbält, bod' aud unter anberen, nod) nidjt

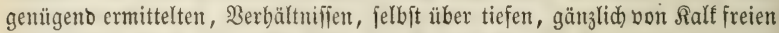
Eandlagern finbent wir nidht jelten eine Dammerbe, bie im troctuen 3 ujtanbe afdenäbulid ift uno fid fowohl ourd grope Unfrudtbarfeit als burd ihr Iluffrieren auszeidnet. İngefeudtet bläht fid bieje Stauberbe auf, nimmt

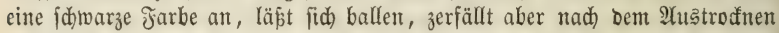
bon jelbjt wieber zu Staub; aud hat fie nidht bas fettige, fanfte 2Anfüblen ber frudtbaren Dammerbe, fondern ift rauber und magerer. Die Stauberbe nimut viel meniger $\mathfrak{B a f f e r}$ auf als ber milbe Scumus, uno trodinet febr rajd) wieber aus. Das $\mathfrak{B a f j e r}$ vertheilt fid nidyt jo fein, fonbern bleibt mehr in Iropfen beifammen, gefriert zu Sirvitallen uno betwirft baburd bas jogenannte 2Yuffrieren, weldjes allen Bobenarten, befonbers bem Boben mit

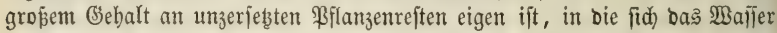
nid)t wertheilt, jonbern in tropfbar flüffiger Form verbleibt. Man fagt: bie Stauberbe entjtehe gröptentheils burd Ueberiättigung ber Scumuşäure mit einer ober ber andern Bafis; befonders jei ę bie Salferbe, weld)e in ifrer Berbindung mit f̧umusäure leidht ein bafifdes Sulz bilbe, wenn bie Sूumus= jäure beş fautren ober neutralen Galzes eine Berję̧ung erleioet. Daraus erfläre fid) bann audd, roarum man bie Stauberbe bejonbers über falfigem Boben

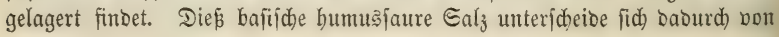


ben neutralen unb von ben jauren bumusfauren Ealzen febr beftimmt burd

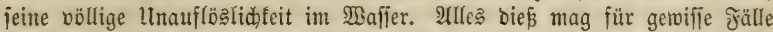
Des Borfommens ber Stauberbe wabr jein, auf bie mir befannten Jälle

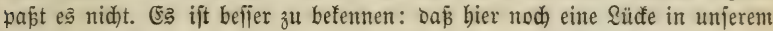
Wiilen bejteht.

Die Stauberde ift in bobem (srabe unfrudtbar und im Maldoirth= id)aft引betriebe nur burd) Erziehung gejdlofienter Bejtänbe zu verbefiern. Bei

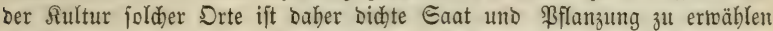
uno bie Efauberbe bon ben Saatpläzen binweģuidaffen, ba fic bejonders

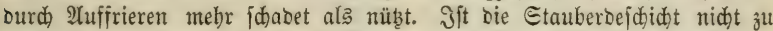
ftarf, fo genügt aud fichon eine Mengung berielben mit bem unterliegenden Boben, bie felbjt wohlthätig wirft, wenn ber Boben jehr binbend ijt. Sat jich Der an Stauberbe reiche Boben mit einer Sirasnarbe überzogen, fo hüte man fid̄, Dieje zu zerftören, fondern betwirfe bie Şolzfultur burd) Gaat in

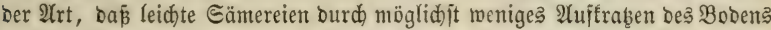
mit ber Erbe gemengt, fdhwere Єämereien, weldhe cine ftärfere Bebecfung forbern, bermitteljt bes Etens in bie Erbe gebradjt werbent.

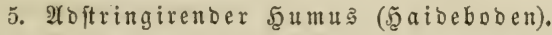

Biele unjerer Şolzpflanzen enthalten in ihrem Şolze uno in ben Blättern

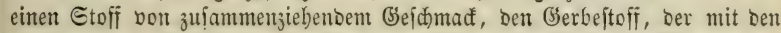
abgejtorbenen Theilen in Die DammerDe übergeht. Bei Der Bildoung De?

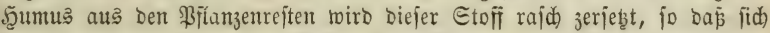
im Şนmนక aนริ Eiđhen uno Birfen taum Spuren babon finben; nur wenn eine Pflanze neben bem (S̈erbeftoff zugleich reid) an barjigen uno wad)zartigen Stoffen ift, wie bie Scaibefrautarten, ber Rienporit, bie Allpenrojen, ioll neben ben jebr langjam fid zerjebenden barzigen Bejtandtheilen aud Der Gjerbejtoff im Soben zurüđbleiben, indem ber mitunter bis auf 12 \$roc.

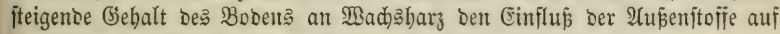

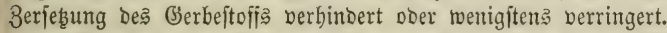

Dhne bejondere fultur wadjen im Scaibeboden - Ier Name ftammt

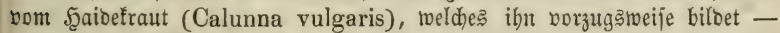
mur biejenigen \$flanzen gut, aus weldhen er entitano; Der Riefer uno, wenn jonjt ber Untergruno von guter Befchaffentheit ift, aud) Der (Eid)e unt Birfe

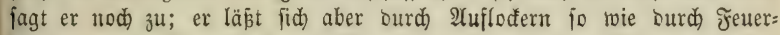
büngung rejentlidy berbefiern. Wenn man einen joldjen Boben nach bem Berbrennen bes 5̧aibefrauts uno ber oberiten, an unzerję̧ten ßílanzenfajern

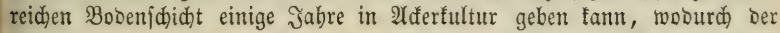

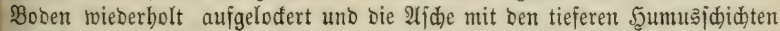
gemengt wirb, fo gerathen bejonbers Rieferjaaten trefflid uno zeigen aud im Berfolg einen guten $\mathfrak{W u d}$.

\section{D. עou Waffer uni von ocr fluft.}

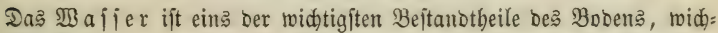

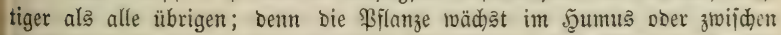
Felşpalten wurzelno, ohne eigentlidje Bobenfrume; fie wädst im Eroreid 
obne Şumus, aber bie günitigite Mengung beider iit unfrudtbar obne J̌eud)= tigfeit. Alle übrigen Bosenbejtanotheile wirfen günjtiger ober wentiger günftig, je nadoem fie fid berichieben in ihrem Berbalten zur Jeudhtigfeit zeigen.

Das Mafier im Boben wiro nidht allein als Nabrungştoff uno als ein

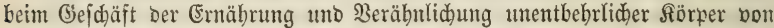
Den Wflanzentwurzeln aufgenommen, $\mathrm{e}$ bermittelt aud ben Lebergang ber minte= ralificen Bobennabrung in bie Bflanze, bie, wie wir wiffen, im $\mathfrak{B a f f e r}$ auf=

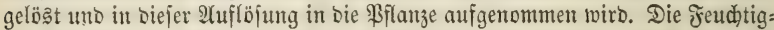
feit Des Bobens beförbert ferner bie Biloung Des Fुumus im Boben, fie berringert Deu zu gropen \&uftzutritt uno \&uftwedjel, trägt aljo wejentlid zur Erbaltung ber Bobenfrudhtbarfeit bei; fie ift $\mathrm{e} 3$, Durd weldhe hauptjächlid bie Berwitterung ber Gefteine eingeleitet uno bie Bobenfrume herauzgebilbet wiro.

Eo notbwendiy bie Bobenfeuchtigfeit für bie Pilanze ift, fo günftig ein

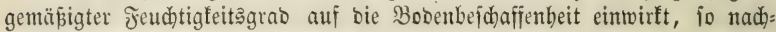
theilig werbelt zut bohe Grabe bes Waffergehalts, inbem baourdh bie Ruft aแs Dem Boden verbrängt, in Folge befien Die Entwidflung Der \$Flanzen= nabrung aus ben abgeftorbenen Biflanjen berbindert wirb (Torfboden, Sumpf:

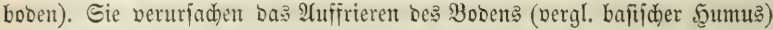

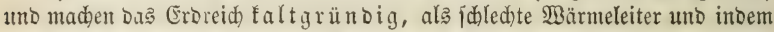
Durch bie ftarfe uno bejtänbige Berbunjtung Märme gebunben wiro.

Wir unterfdeiben zuerit feuden und nafien Boben. Jeudht ift ein (Froreid, wem bas Waffer in Der Menge vorbanten unt fo fein zertheilt

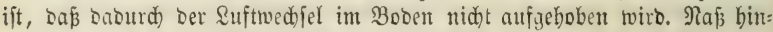
gegen nennt man ben Boben, wem alle 3rifidsenräume ber Bobenfrume nit SSafier erfüllt finto, bie \&uft baburd) gänzlid aus bem Boben berbrängt ift.

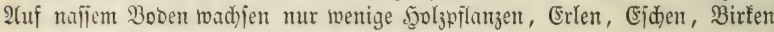
uno Weiden; ber feuthte jagt allen zu.

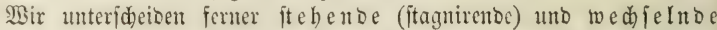
Bobenfendhtigfeit. Erftere ift foldhent Boben eigen, ber in ber ?ähbe von Seen,

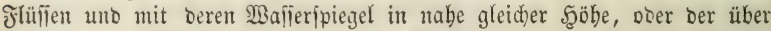

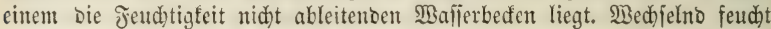
ift ber Boben, welder bas burd) Regen, Ednnee, Stauungen, Heberidhem= mungen erbaltent Balïer burd Berounjtung oder S(bflup leid)t wieber verliert. Stehello jeud tigfeit ift günjtiger als wedjelnoe, indem burdh lebetere Der Boben ausgelaugt unt jeiner näbrenten Bejtanttheile beraubt wirb;

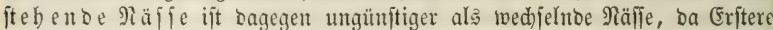

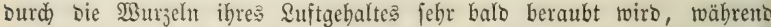
Seל̧tere mit Dem für bie Crnährung nötbigen \&uftgehalte in Der Umgebung ber $\mathfrak{B u r z e l n}$ fid erneuert.

Der Boben ift beftänoig ober unbeftänoig, feudt ober na b,

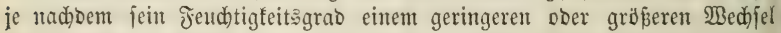
unterworfen ijt. Beftänbig feudhter Boben ift befier als unbeftänbig feudoter, beftänoig nafier Boben iff fidledter als unbeftänbig naffer Boben.

Der Boden ift grundeudt ober grunona tigleit aus Der Tiefe oder aus benad)barten (jetwäfiern ftammt; er ift luft:

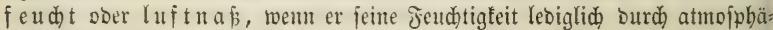

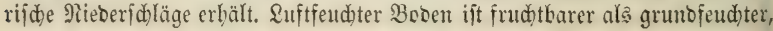




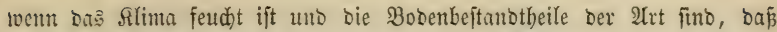
fid) bie Erofrume aud bei eintretender trodner Mitterung lange Beit feudht zu erbalten vermag, indem bas \&uftwaffer frudjtbarer ift alక bas (Eromafier; grunbfendedter Boben ijt bagegen im trodnen Silima uno bei Bobenbeftano: theilen bon geringer wafïerbintenber Rrnft frudtbarer, oa ihm bic feudhtigfeit in böherem Sirabe gefidert uno gleidförmiger ift.

Suftfeud)ter Boben fann wieberum ge fte $i n f e u d t$, erof $e$ ud $t$ ober

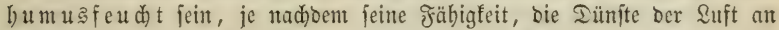

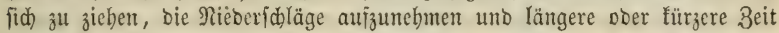
feftsubalten, in ber Befdaffenheit ber Bodemunterlage uno Der ben Boben beigemengten Gejteinbroden, Doer in ber Natur ber mineralijchen Boben= Leftandtheile ober in Dem Bebalt an Dammerbe begrïnbet ift. Heber baß Berbaltent Der Gebirgşarten, Der Bobenunterlage, der Groarten uno bes

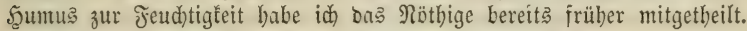

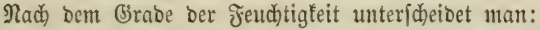

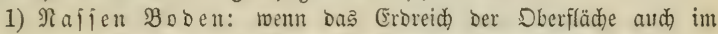

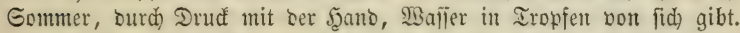

2) Jeudten Boben: wenn fich im Gommer eitem ber Oberfläde

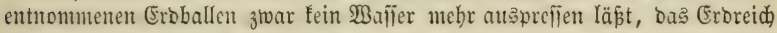
aber nie ïber 1 3oll tief troffen twiro, im Jrübjabre bie PFlanzlöber Bafier zichen.

3) Jrifden Boden: went ber 3̧oben aud im Eommer nie über

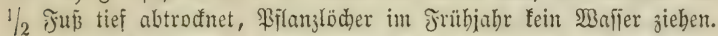

4) Irodinen Boben: trodnet im Eonmer ber Boden imerbalb

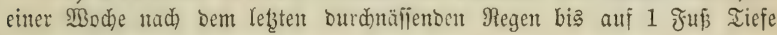
unb bariiber aus, fo nennt man ibn trocen.

5) Dü $\mathrm{rr}$ heipit ein Boden, wenn er fodon in einigen Iagen nad) bem

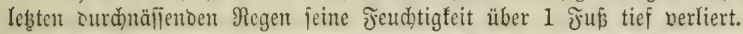

Derjelbe Booen zeigt einen verifhiebenen Jeudtigfeitsgebalt uno baburd)

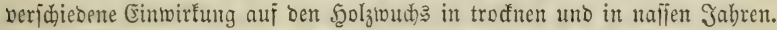

Heber don ¿uftgebalt bes Bobens uno über bie Birfung ber \&uft in Boben weije id) auf bas zurüd, was id im erften Sapitel bes erften Abidnittes über atmoiphäriłche \&uft bereitz mitgetheilt babe.

Nad) ben Unterfud)ungen $B_{0} \mathfrak{u} f i n g a \mathfrak{l}$ t

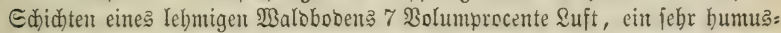
reid)er Boben bis 42 Molumiprocente. Sn biefer Ruft fand berjelbe bas 22-23fad)e Des Sohlenjäuregehaltes ber freien atmofphärijden \&uft. In

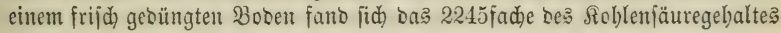
ber \&uft.

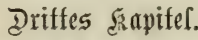

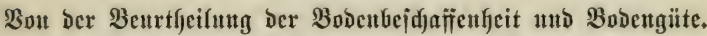

Die Befarfifenbeit uno Giute eines Bobens erfent man:

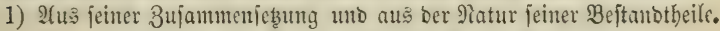

2) $\mathfrak{2}$ นร äuperen, in bie 2 (ugen fallenben Siennzeiden.

3) 2 (us bent ifn bebectenden \$ilanzentwudje.

5artig, sehroud) für föriter. 1. 
1. Bon Der Unterfudunges Boben nad feinen Beftand= tbeilen und Qagerungsverbältnifen.

MBenn ę fid) Darum hanbelt, die (Süte eines Bobens ober vielmebr eines Standorts, in Allgemeinen wie in $B e z u g$ auf einjelne (setwädffe, aus Der Bejd)affenbeit Des Bobens felbit zu erfenten, ein Berfabren, welches bei

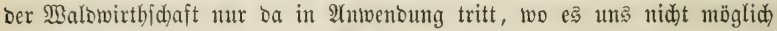

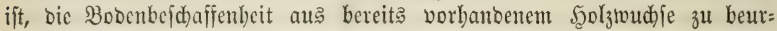
theilen, wie з. 2. auf großen Blößen, voer auf Sänbereien, bie von ber Iderwirthfd)aft Dem Waloe abgetreten werben uno umgefehrt, ober bei ßer= änberungen ber biaher gezogenten Syolzart, bann ift bei ben betreffenden Unteriuctungen Folgenbes zu beadten:

1) Die Befdaffenbeit Der Bodenunterlage, Deren (Einflup auf Jcud)= tigfeit beక B̊obents, auf Şaltung uno Stanoort ber Fflanzen unt auf 3ugäng=

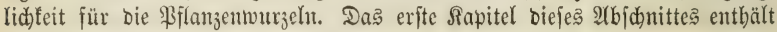
Die biefür nötbigen Fingerzeige.

2) Die Triefgrünoigfeit be Bo Bobent.

3) Der eigenthümliche Jeud)tigfeitşgrab.

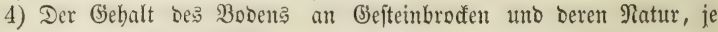
nad)oem fie gecignet find, Waffer aufzunebmen uno es allmählig bem aus= trodinenoen Boben zurü fługeben.

5) Sage, Erpofition, Neigung, Slina uno beren Einflup auf Boben: feud)tigfeit uno Bobenioärme. jelbit.

6) Die Natur uno bie Mengungsverbältniffe der Bobenbeftano bheile

Was bie unter $1-5$ angefübrten, auf bie Bodenfrudtbarfeit fehr einflufreiden Berbältnifije betrifit, fo beriveife id) auf bas, was in ben vorbergebenoen Rapiteln barüber bereits gefagt wurbe; Gier bejoäftigt uns nur bie Unterfuchung ber Bobenbeftandtheile.

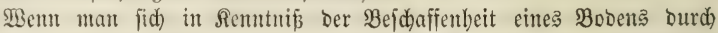

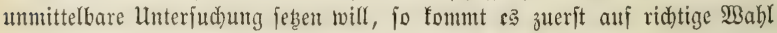
Der Srte au, bon weldjer bie zu unterfuchentoe Eroe genommen toirb. 3u= erft nuß man afle ungewöbnlid)en (Erböbungen uno Dertiefungen vermeiben,

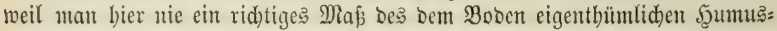

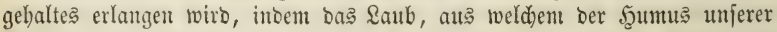
Tälder gröptentheils gebildet wirb, von erfteren $a b=$ uno in leb̨tere zu= fammen geweht wirb; ferner find joldhe Unebenbeiten alid bäufig burd)

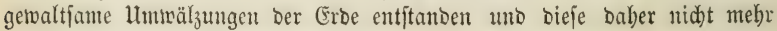
in ibrem riătigen Mengungäberbältniffe. Man wäble baher alfo eine ebene

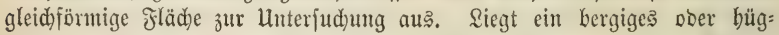
lides Terrain vor, jo müfien gefonoerte Unterfud)ungen auf bem Rüden, an Den Şäıgen unt in beł Thälern unternommen werdeıt.

2Ał ben für bie lunterfudhung ausgemäblten Stellen werben mun, too möglich bis zur Unterlage des Bobens, im tiefgrünbigen $\mathfrak{B}_{0}$ en bis 1 Meter tiefe Röder gegraben, uno eine Der Seitenwände mit bem Spaten idarf und fentrecht abgeftod)en. Şat man bierburd) ein Bilo Des Bobendourd)= fditnitts erlangt, fo notirt man fid) bie Befdaffenbeit Des Bobents, fo weit 


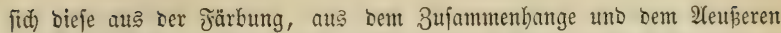

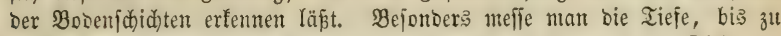

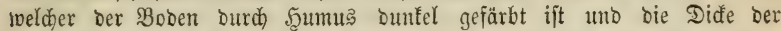
Durdi) Järbung 2c. fich als veridieben zu erfennen gebenten (Erofdidten,

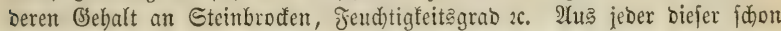
Dem 2luge fich als wejentlid) verfficben zu erfennen gebenden Edjidten soerben bann zur näbercu llnterjudchung einige Scänbe voll Erbe in Fapier gejhlagen uno auf biejem mit Bleiftift bie Tieje bemertt, in roeldjer bie Eroe lag.

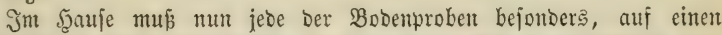
Bogen \$apier bünn ausgebreitet, fo lange liegen, bis fie vollfonmen luft= troden geworben ift, worüber, je nadibem bie Suft mehr ober meniger warm uno trocen ift, $2-3$ Iage vergehent. Die lufttrecfne Erbe wirb

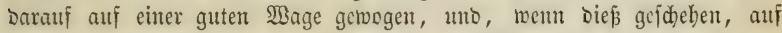
cinem Ieller ausgebreitet, auf Dem Dfen böllig ausgetrodinet uno nađh Dem Erfalten abermals gewogent. Der Gewichtorluft zeigt Die Grabe an, in welchent Der Boben bie Jentchtigteit zu binoen uno feftzubalten bermag; Dod) ift bieß Dörren ber (Erbe aud fdon Dephalb nöthig, um nidt Waffer mit in bie Rednung zu ziełen.

Die geoörte (Erbe wirb nun burd) gröbere und feinere Siebe ges trieben, um bie Gefteinbroden von ber Eroe, bie gröberen Erotheile, B̈ramb, (3ruis von ben feineren zu fonbern, worauf bas (Setwidt jeber biejer ge: fonberten Iheile ermittelt mirs. Şat man bie Gefteinbroden gejonbert, io wirb unterfudht, welder (Bebirgsart fie angehören, worauf fie nid)t weiter in Betrad)t fommen.

Die gröberen und feinteren Erotheile werben nun wieber zufammen=

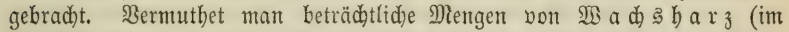
Saibeboden), fo wirb derfelbe mit ftarfem Spiritus übergofien, in weldem

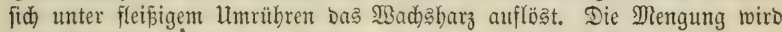
Darauf Durd) ungefeimtes Bapier filtrirt, in einer Edjale abgebampft, morauf bas Wadjhharz zurüableibt uno geroggen werben fann.

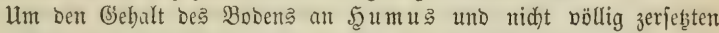
ßflanzenfajern zu bejtimmen, wirb ber Boben auf einer eifernen \$latte er: hiţt, fo baj alle freie Jeuchtigleit entweicht, bierauf gemogen uno in (Er: manglung eines hefilifd)en Ed)melytiegela in einem gereinigten eijernen Gieks=

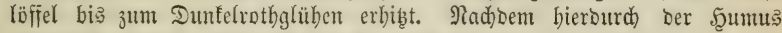
berbrannt und bie Erbe erfaltet ift, wird fie abermals getorgen und aus

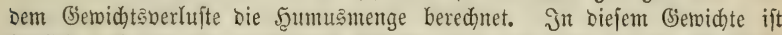
freilich auch bas ber unzerfebten Pflanzenfajer uno eines bor ber (s)lübbibe nid)t zu verflüd)tigenten Wafierantheifs enthalten, allein bas Rejultat wirb für unjere 3 we cfe bod binlänglid genau, um jo mebr, als ber f̧umus:

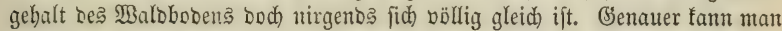
Den Scunusgebalt baburd) beftimunen, baj man bie Dammerbe mit einer

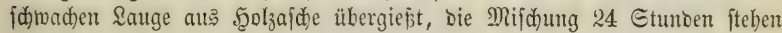
läpt, morauf fich bei mehrmaligem Umrül)ren bie Şumuşäure vollftändig

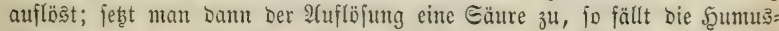
jäure in braunen Floden зu ßooen, bleibt anf bem Filtrirpapier zurïd, 
wirb getrodnet unt gewogen. Der (bebalt an nodh nicht zu Şumus zer=

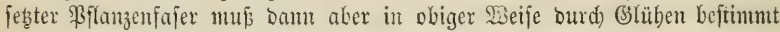
werben.

Der Silf = uno Iarfgefalt Des Bobents wirb beftinum, inbem man Den vorber geglüheten uno gemogenen 3̧oben mit verbünnter Effigjäure DDor mit fehr ftarfem 2 beinefifig übergiept, welder nad) mehrftünbigen (Er: märmen uno wieberboltem llumüfbren diefe Eroen auflöst. Şat man bie

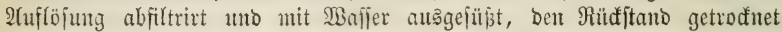
unt getwogen, io gibt ter (Sicwid)twerluft ben Salf = uno Ialferbegebalt Des Bobents an.

In Derfelben 2Beife wirb nad) (E)tfernug bes alf = und Ralf= gehaltes ber Gebalt an Sali, Eifen mo Manzan beftimunt, nu baj man anjtatt ber Effigiäure berbünute Salzjäure anventet.

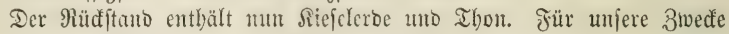

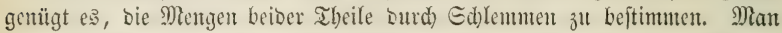

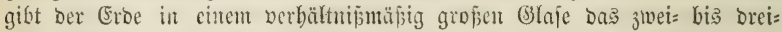

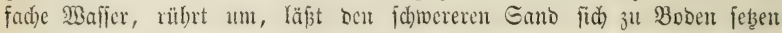

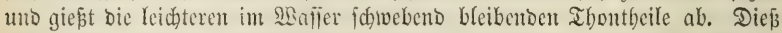
Edjlemmen muj fo oft vieberholt werben, als bas aufgegoffene Waffer fid) beim llmtrib)en bebenteno trübt. Das Sd) (enmunaffer wiro in cintent

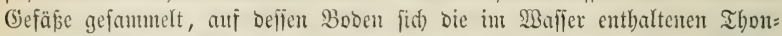
theile bei Yätgerer Rulbe nieberichlagen, worauf bas flar getworbene $\mathfrak{B a f f e r}$ abgegoffen, Der Rüfftano getrodinet uno gewogen wiro.

Ier auf biefe 93 eife vom Thon befreite Sand mirb gleidfalls ge= trodint und gewogen, ban anf cinem Bogen weifes \$apier ausgebreitet unD mit cincr Soupe unterfud)t; Dic glünzenben glabartigen Söner fino Duarjanto, metallglänzente Blättd)en uno Sd)uppen finto (Slimmer, rötb=

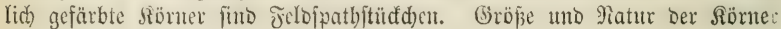
baben citen wefontlidyen Cinflup auf Die Befdhaffentheit des Bodens uno fint baber febr zu beadtent. ${ }^{1}$

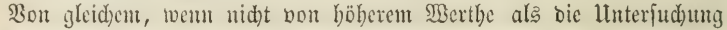

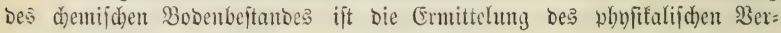
balteñ. Dabin gefört:

1) Die En theile. Jid) crmittle bicfelbe, inoem id) aus bent zu unteriudenten Boben Sitgeht von einem 3oll Durdjuteffer fnete, uno biefelbe nad) bölligem $2(b=$ troditen über Darauf gelegte Bretter fo lange mit (bewidbten belajte, bis

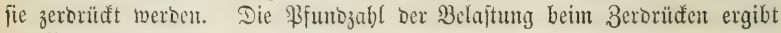

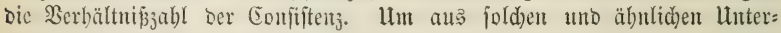

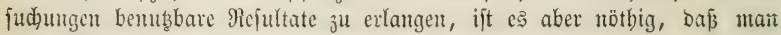
eine Melyzabl verfdjicbenartiger Bobenarten, barunter foldhe, welde bie

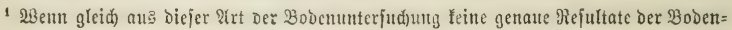

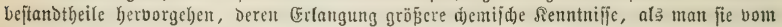

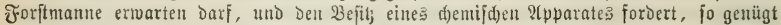
Die (Senauigfeit derfetben für unjere 3weife Dod) vollftündig. Wer fid eine genauere Rennt=

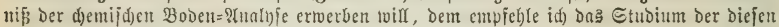

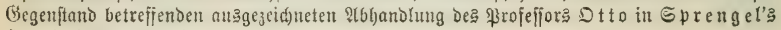
ŞandGud) Der BoDentunde 1837. G. 303-469. 


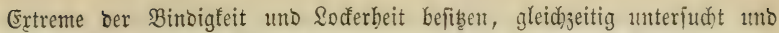
burdaus gleider Bebanolung unterwirit, um genauc Berbältui zahlen zu getwinnen. Eine Unterjudungareihe von nahe 100 verjobiebenent Bobenarten bes Şarzes uno Der Umgebungen bofielben lieferte mir folgento Scale:

3ufammenhangalos ift ein Boben, belien Sugefn nad bem $2(b=$ trodinen von felbjt mieber zerfallent, wie ber reine grobfömige S.unajano.

Sebr loder ift ein Boben, bellen fingeln $1-10$ Pijuno Gewid)t

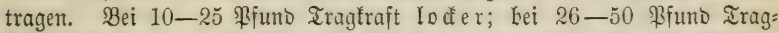
fraft faft bindig; bei 50-100 \$fund binbig; bei 100-160 Bfunben fehr binbig ober feft - bie reineren Ifonformen. Die Sugeln waren bieju auf Der heisen Dfenplatte ausgetrodnet

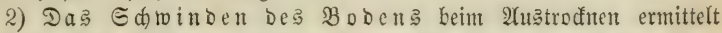

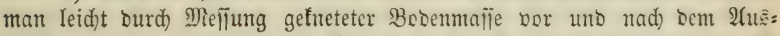
trodinen. Das mir befannte Marimum Der Iurdmelīerverringerung iit $=0,6$, bas anbere Extrem $=0$.

3) Die Feudtigfeitscapacität ermittelt man, inbem man eine Quantität Des zu unterjudenden Bobens auf einem warmen Dfen voll= ftänbig abtročnet, twiegt, barauf mit S⿱

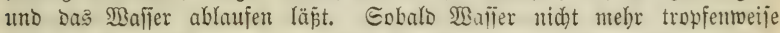
bom Silter abläuft, wiro ber najie Boben mieber gewogen uno aus ber Getwid)täbifferenz Die Menge Dis Maffers bejtinmt, bas er aufjunebmen

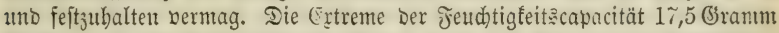
Waffer auf 18 Eubifcentimeter Boben zeigt bie Dammerbe, Etauberbe,

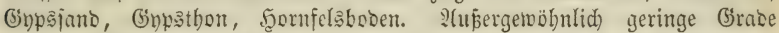

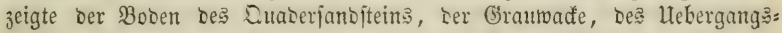
falfę und ber fandige Meeresboben mit 6-7 (5ramun 2 Baller auf 18 Cubif= centimeter, Der bei allen übrigen von mix unterjuchten Bobenarten 12-13 (rramm $\mathfrak{B a f j e r}$ anbält.

4) Die Scggroffopität. Der Boben wirb getrodnet, auf einen Teller ausgebreitet mit bem Ieller gemogen, ein fleines Echäldhen mit Baffer Darauf gefeķt, Dem Ieller eine pafiente Glas̉glode ober ein irbenes

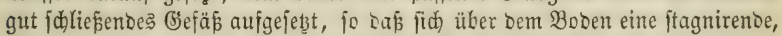
mit bem berbunjtenden $\mathfrak{B a j j e r}$ bes Єdäldhen gefättigte \&ujt bilbet, aus ber ber Boben bie Feudtigfeit einjaugt. Die bödjten Grabe ber Wanfer= auffaugung झ̈äbigkeit: $6-7$ (Sramm (Semid)tzunahme pro 0,1 Suabratmeter Dberflädje zeigte Dammerde, Iorfboben, Etauberde, Grypatthon=, Rreibc: mergel=, Granitfoden uno ber Trünmerboden bes (Elm über Mujchelfalf. Die geringiten Srabe: 0,07-0,14 (5ramm fro 0,1 Suabratmeter ber fandige

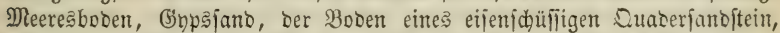
Berwitterung引boben über Marmor. G̈eringe Brade: 0,9-1,4 Gramm pro 0,1 Duabratmeter; einige Bobentarten Der Graumade, bes Ihonjujefer, Der

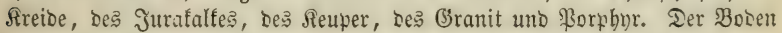
Der meiften Granite, Porphyre, Des Grrüntein, Deß Szornfels, Ihomidhiefer, Des bunten Ganofteine’ jeigten mittlere Grabe ber Şygroftopität.

5) 2(ud Das Bermögen Des Bodenz, Die Jeudtigfeit aus ber Iiefe an fid) zu jieben und baburd fid feudt ju erbalten, ift 


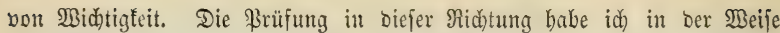
auşgefübrt, Daj id cinelt $1 / 2$ Meter bohen (Slascrlinder, auf befien 30 ben

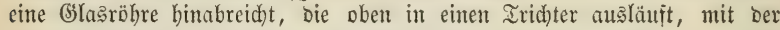
jul unterfudenben 3lobenart im Kufttrochinen 3ujtambe anfüllte, auf bie Bobenoberfläche ein Sdjälden nit Sdiwefeljäure jeb̨te unb bie Enlinber= münoung mit einem (ślaßtäfelden bebecéte. Säpt man bann burd) ben Iridter Wafier auf ben Boben bes Enlinders, fo gibt bie Söhbe uno bie

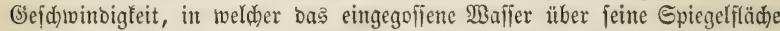

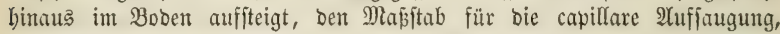

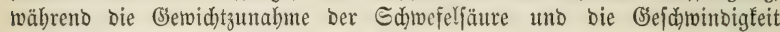

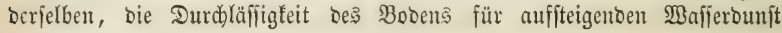
nadjweist.

Unterjud)ungen biefer 2 (rt fömnen natürlid) immer nur relative Re= fultate ergeben. Reiner Sant, reiner Ihon uno reiner Şumu ergeben in ber Regel bie Ertreme, auı Denen eine Gcala ju bilben ift, in weldhe Die Refultate ber gemengten Bobenarten einjutragen fint.

6) Die Sraft, mit welder Der 30 Den bie Fetdigfeit

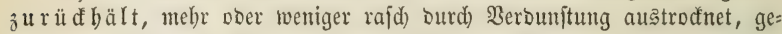
mệen Durch täglide $2 B a ̈ g u n g$ Der mit Waffer gejättigten, ber Bimmerluft

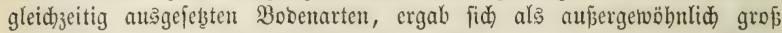

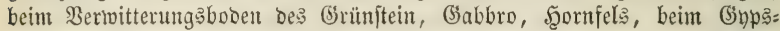

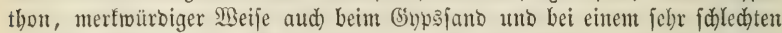
fantigen Sieferboden. Großß jeigte fie fid) beim Boben eines Jurafalfes, Seupers uno Thonjdiefers; gering bei bem Boben Der meiften Stranite, Thonichicfer, Marmor, Mujdelfalf, Sireibe unt (srautwade. Die bumus: reiden Bobentarten zeigten mur mittlere (Srabe biejer Eigenfidaft. ${ }^{1}$

Alle bieje phyjitalifden Eigenjofaften Des 3 boens berubent weit wentiger auf bem demifden Bejtande feiner Ibeile als auf Dem Berfleinerungagrabe Derfelben. Sano uno Ihon, bie in biefer Simficht in ber Regel bie beiben Ertreme barbieten, Dem Ilon Das Marimum, bem Gant Das Minimum Der Comftiftenz, oer $2 B a j$ eraufuahme, Der Şugroffopität zc. gehörento, zeigen cin nabe gleides Berbalten, wenn Der Santo in fo feine Theile zerrieben ijt, Dẩ fie Denen Des Thons bierin nahe ftehen. Die Beftimmung bes Berfleinerungsgrabes zu unterjud)enber Bobcuarten ift baber von Bidstig= feit, intem fid) Daraus, obne weitere birefte Unterfud)ungen, Sdhlüfie ziehen Yafjen auf die whyfifalifden Eigenjdaften berjelben. Das Jmitrument, weld)es id) mir für llnterfud)ungen biefer 2lut erfonmen babe, beftebt in

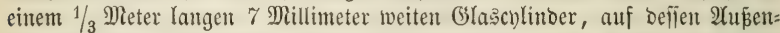
jeite eine bis 1 Millimeter gebento Iheilung bom glatten Boben aufiteigeno cingeäbst ober auf einem aufgeflebten \$apierftreifen mit 2 ngabe ber Eentim. uno Millimeter verzeichnet ijt. Jn biejer grabuirtent (Slaşröhre wiro ber ju

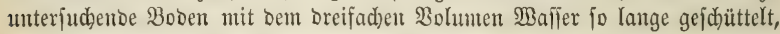
bis fid) alle Ibeile beffelben getrennt babent. Genfred)t feftgeftellt, läßst

1 (Eine nähere Darlegung meine

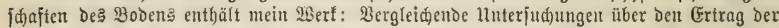

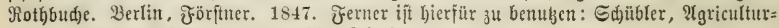
(5hemie, zroite Auflage, von Sirubjid. Seipzig. 1838. 
man ben Boben algbann fid jeken uno verzeidnet, mit Der $\mathcal{U}$ by in ber Szano, anfänglid̄ in Łïrzeften, jpäter in längeren 3citräumten, gleidłseitig

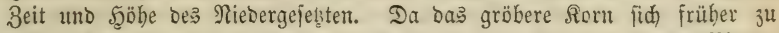
Boben jekst als Das feinere, fo erbält man im 3eitma ja bes Nicber=

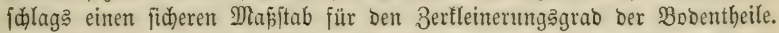

Jd) babe umfäglidhe Müben Darauf berwentet, in mep̧baren Eigen= thümlidfeeten Der veridjiebenen Bobenarten einen Majitab für birefte $\mathfrak{B}_{\mathrm{e}}$ ftimmung ber Bobengüte zu finten. Dieß̃ müroe ber Jall getwejen fein: wenu bie Grabe ein ober ber andern Eigenjdaft, twent .5ngroffopität, Conifitenz, Şumusgebalt, Ifongebalt 2c. mit bent (Sraben beobadteter \$ro: buftionstraft Des Bobens in gleidem Mlap̉e $a b=$ ober zunehmeno fid ergeben

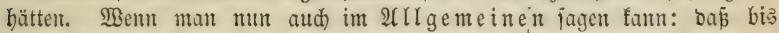

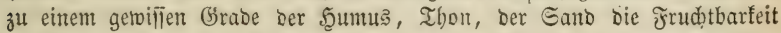

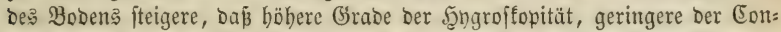
fijtenz $2 c$. mit zu Den Eigenifjaften eines guten Bobens gebören, fo ift jebe einzelne biejer Eigenidaften bod fo wentig majgebeno, baj eine birefte Beurtheilung Der Bodengüte zur Beit nod) unausiühbrbar ijt. Die ltrjadje

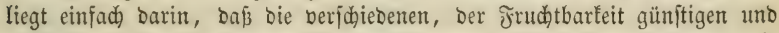
ungünjtigen (Figenidaften bes Bobens fid) gegenjeitig theils aufbeben, theils

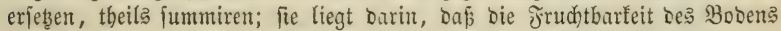
nid)t allein von Defien Beftantheilen uno Deren (Eigenfadaften, fonoern eben jo von einer Menge äuß̧erer, theilfweije ummę̧barer Zujtänbe abbängig ijt, von ber Bobenunterlage, vom Slima, von ber Bebectung mit \$ilanjen; barin, Dap bie Frudtbarfeit eines Gtunoorts überbaupt relativ uno für

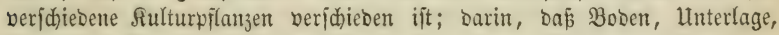

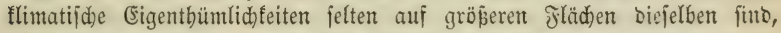
Dft in geringen Jernen ben grȫten 2 (bänderungen unterliegen; furz, meine Unterjudungen baben mid ju bem Rejultate geführt, nid)t allein baj wie man zu fagen pflegt - bein heutigen Etanopunft ber Bobentunbe eine Direfte Bobenwürbigung unausfübrbar jei, fondern daj biés wobl immer

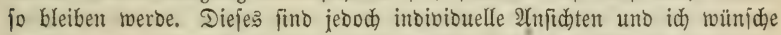
herzlid), Daß anDere Beobadyter güntigere Rejultate ibrer MIrbeiten erringen, als fie mir zu Theil geworben finto.

Demobngeachtet bedürfen wir einer Senntni ber Bobenbeftandtheile unt ibrer (Eigenidaften, wenn es audh nur zum Zroefe einter allgemeinen Begrifisbejtimmung ber berfdiebenen Bobenarten fein jollte, ohne Daraus Folgerungen auf bie Jrudtbarfeit zu ziehen, Deren allein fidjerer Maj̃ftab bie Rejultate verflofiener ßrobuttion find.

Nad) ber berjdiebenen 1 trt uno Menge ber Bejtuntheile unter= joheibet man:

1) Ibonbo.den: über 50 ßroc. Ihon, nidyt über 5 \$roc. Salf, nidft über 20 ßroc. Sนmนติ.

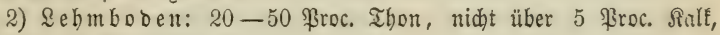
nicht über 20 ßroc. รุumut.

3) Mergelboden: 5-20 ßroc. Salk, nidjt über 50 ßroc. Ibon, nidt über 20 ßroc. Şumut.

4) Raltboden: über 20 ßroc. Ralt. 
5) Sandboden: vorkerrident Eand, nidat über 20 Proc. Ifon, nidht über 20 ßroc. Salf, nicht über 20 ßroc. Şumus.

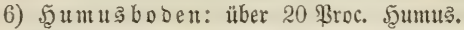

7) Eijenboden: über 15 Proc. Eifen uno Mangan=Drboe Doer Drvoule.

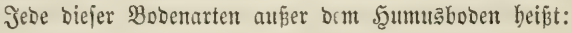

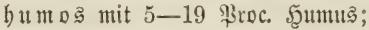

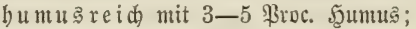

vermögento mit $1 \frac{1}{2}-3$ Broc. Şumts;

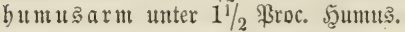

Itle Bobentarten auker Ralt uno Mergelboden beipen

falflos: mit $0-1 / 2$ Froc. Salt;

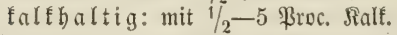

Eifenfdüffig beišt ein Boden, Der $5-15$ Broc. Eifen= ober Manganoryd enthält.

Der Thonboden heíst

jandig: wenn jein Gebalt an Siejelerbe nidgt in feiner Bertbeilung, fonbern in füblbaren Duarförnern befteht; $\mathfrak{f} a \mathfrak{l} f i g$ : went er mit Ralf= fteinbrocten untermengt ift; mergeli (d): wem er 4-5 \$roc. Fein zertheilten Ralf entbält.

Der Sebmboben heist

f a n b ig: wemt er $70-80$ Brec. Sanb enthät; mergelida, falfig: unter denfelben Berbältniffen wie Der Thonboden.

Der Mergelboden beipt

t $\mathfrak{b}$ o ni g: mit mebr als 50 Proc. Thon; $\mathfrak{l}$ e h m i g: mit $20-50$ \$roc. Thon; fandig: mit 60-70 \$roc. Eano; falfig: unter benjelben \$er: bältniffen wie ber Thonbodent.

Der Sandboden heif́t

fdhledt: bei mebr als 90 \$roc. Gant; lebmig: bei 80-90 \$roc. Sano; mergelid): mit 2-5 \$roc. Salf. YUuperbem unterideibet mant nad) bemt Beftanoe Der Sanofömer: Duarzjand, (5) limmerfand, Felbipatb=

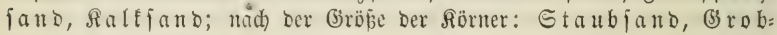

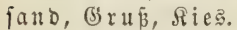

Der Eanbboden oder ber Sanbgehalt anberer Bobenarten beißst ft a ub ig: wenn bie 3ertbeilung fo fein ift, Das fie fidh bem (befühl nid)t mefr zu erfemen gibt; feinförnig: wenn ber Gano aแ feinen, aber nod) fübl= baren Rörnern beftebt; grobtörnig: rem bie Römer bie (3röß̧e Der

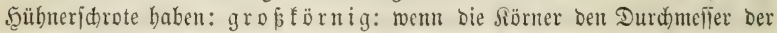
Edrote Nr. 3-1 baben; grandig ober fiejig: wem die Gröpe ber= jelben bie ber Rebpoften überfteigt.

Der $\mathfrak{R}$ altboden heipt

fanbig: mit 15-20 \$roc. Sano; $\mathfrak{l}$ ehmig: mit 30-40 Broc. Sebm (Sand uno Thon); thonig: mit 20-25 Broc. Thon.

Der $54 m u \xi b$ Den uno ber Eifenboden heinen thonig: mit melyr als 50 Proc. Thon; leh mig: mit 20-50 \$roc. \&ebm; fandig: mit 5-10 Froc. Rehm; mergelig: Kei $5-20$ Prec. Ralf; falfig: bei mehr als 20 Proc. Ralf. 
2Atperbem unterideibet man:

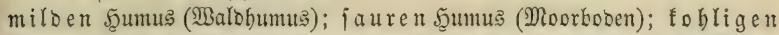

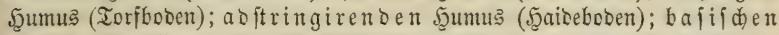

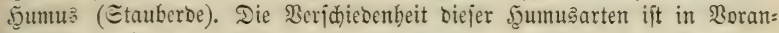
ftehen๖em erläutert.

Nach Dem Brade ber 3ujammenbangärait unteridheibet man

leide ten Boben: wohin alle Bobenarten mit vielem grobförnigen Gano Doer mit vielem f̧umus gehören;

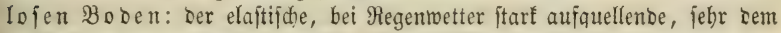
2tuffrieren auşgeję̧te entwäjīerte Torf $=$, Moor= uno Brudboben;

bindigen Boben: alle Bobenarten mit mittlerer Bufammenbangstraft, wie ber feintörnige lehmige Ganbboden, Der grobtörnige janoige \&ehm= boben, ber Ralf: uno Mergelboben;

¡光 weren Boben: hierher ber feinförnige Sehmboben uno ber Thonboden nit gröberem Sanogehalt;

วä Gen Boden: bierber ber Thonboden mit geringeren Mengen feinförnigen Ganbe?.

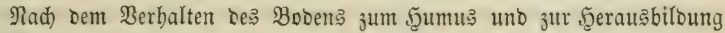
Der Bflanzennabrung aus ibm unterideibet man:

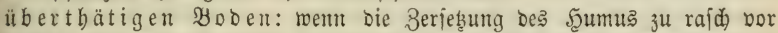
fid) geht, wie im trodnen luftreichen Ganoboben uno im Saltboben;

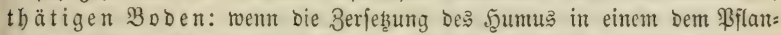
jentrudje, wie Der Erbaltung Der ßodenfrudtbarfeit günitigen Srabe vor fich geht, wie im lehmigen Gano, jantigen \&ehm, im Sebmmergel uno in ben gemäpigt feudten Bobenarten;

träger Boden: wenn wegen zu hohen Thongebaltes, ober wegen $3 u$

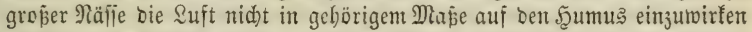
vernag, ober wenn wegen geringer Mengen Des leb̧teren ober wegen fejter dhemificher Berbinoung wenig \$ilanzennabrung mur langiam ent= widelt wirb. Scierber ber ftrenge Thonboden, alle nafie Bobenarten, ber Shaibeboben und bie Stauberbe;

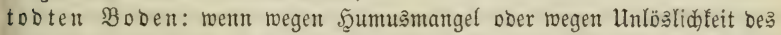

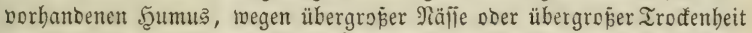
gar feine Rulturpflanzen Mabrung uno Etantort finben, wie im Tori= boben, in manchent (Serölleboben, im Fluganto $2 c$.

\section{Bon ber Beurtbeilung bes Bobens nad äu Rennzeiden.}

Bei ber Beurtbeilung eines Bodens nad äup̄eren Rennzeiden find zu=

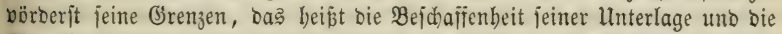

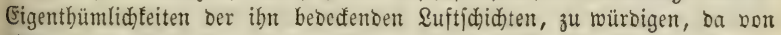

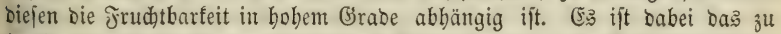

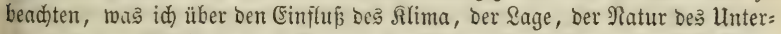

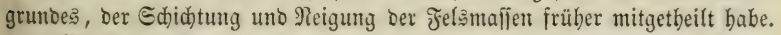

Nädjitbem ijt bie Tiefe ber Bobenjojicht zu erjoriden uno zu beurtbeilen, ob fie ber Berbreitung Der Pflanjentwurzeln genügt ober nictst; ob ntangelnoe 
Tiefe burd Die Bejdaffentheit bes Untergrunbes erję̧t wiro, uno twelden Einflup ber Grab Der Tiefgründigfeit auf Den Feudtigfeitsgrad bes Bobens aușübt.

Rädjt ber Tiefe bes Bobens ift ber Gebalt beffelben an Steinbrodét bödjit widtig, uno beffen Frudtbarfeit fowobl bon ber Menge, als von

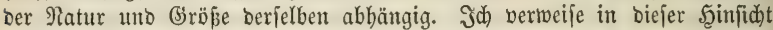

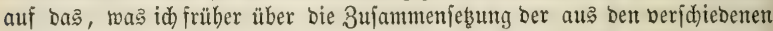
(Bebirgaarten burd) Berwitterung heroorgebenoen Bobenfrume, uno über baß Berbalten Der unjerjeķten Gejteine zur Feudigtigeit gejagt habe. In jebr vielen Fällen wiro ber (Sebirgaforftwirth fidon allein aus ber Befdaffenbeit Der felfigen Unterlage bes Bobenz, und aus ber Natur ber bem Boben beigemengten Befteinbroden ein amäherno rid̄tiges Urtheil über bie $\mathfrak{B} e=$

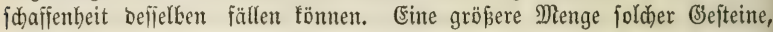

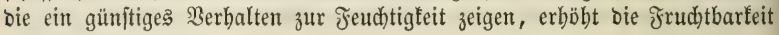
bes $\mathfrak{\text { Maldbobent. }}$

Den Thongehalt eines Bobens erfennt man an bem höheren $3 \mathfrak{Z}=$ fammentbang befielben, Durd) ein fettiges $2(n$ füblen, 2 (nnbängen an ber 3 unge, gieriges Einfautgen großer $\mathfrak{B a f f e r m e n g e n ~ u n t e r ~ E n t r i d f l u n g ~ e i n e s ~ e i g e n = ~}$ thümliden Ihongerudes, burd jebr langjame Bertheilung im $\mathfrak{B a f f e r}$ uno baburd) entiftebende Snetbarfeit, burd) eine graute, bei 3utritt bon (Sijenorno ins Röthliche übergehende Farbe; ferner burd langames 2Yustrodnen uno baburd) im $\mathfrak{B}$ oden entitebente Riffe unt Sprünge.

Den 2 ebmbooen erfennt man burd feinen geringeren 3 uammen=

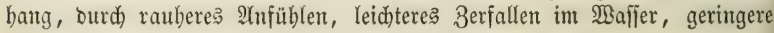
Rnetbarfeit uno eine meift höher röthlidye Färbung.

Den Mergel erfennt man burch ben gänzlichen Mangel ber Rntet= barteit uno fein rajd)es Berfallen im Bafjer; Durd) eine mebr ins (Braute bis (Sraumeipe ziebento Farbe, uno burd) fein 2̂Afbranjen, wenn ex mit Säuren übergoflen wiro, wozu man fid) getwöbnlid ber Salzäure bebient.

Den $\Omega$ alf erfennt man ebenfalla burd) beftiges $\mathscr{A}$ fubraujen mit Säuren, burdh Roderbeit uno eine bellere meipliche bis grautweipe Färbung, bie jebod) ebenfalls burd) (Eijen bäufig in Roth, ourd) bitumintëfe Stoffe in Sd)warz= grau übergeht; Durd) Mangel ber Snetbarfeit unt raubes aber feinförniges थnfü̉łlen.

Der Sand gibt fid) burd bie geringiten 3 ufammenbangsgrabe, burd

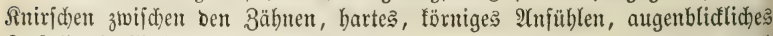

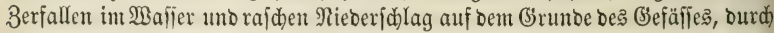
helle, glafige, glänzente, gelblid)weipe Jarbe zu erfennen, bie burd) (Fifen in

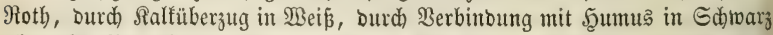
übergebt. Betrad)tung mit ber Soupe ijt hier fehr zu empfehlen, indem man burd) fie bie 3ufammenfelsung aus Duarz, Jelbjpath=, (Blimmers, Saltheilen uno beren Mentgenwerbältnifie am beften zu beurtbeilen bermag.

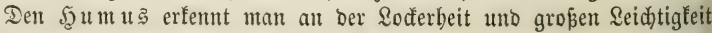
Des Bobens, an einem eigentlumlidjen (serud wie frifde Bartenerbe, an rafden 3erfallen bes Bodens im $\mathfrak{B a f f e r}$, weldyes burd bie leidten Scumus: theile lange Beit bunfel gefärbt roiro, unto an Der fobwärzlidłen Jarbe, bie nad) bem (słlüben verfdiminbet. 


\section{$\mathfrak{A}$ uf trodenem $\&$ ebmboben.}

Arctium Lappa, Chenopodium polyspermum, Lactuca scariola, Saxifraga granulata, Senecio viscosus, Avena tenuis, Bromus sterilis.

$\mathfrak{A} u f \mathfrak{f} f \boldsymbol{r u b}$ tbarem fandigem 2 ebmboben.

Spartium, Calunna, Genista, Ononis, Malva sylvestris.

$\mathfrak{A} u f$ gefdübtem Sanbboben mit wenig Fुนmus.

Vaccinium uno Arbutus, Fragaria, Veronica, Viola, Herniaria; bei fteter Feudtigfeit Farrentrüuter.

\section{$\mathfrak{A} u$ frodenem magerem Sambboen.}

Elymus arenarius, Arundo arenaria, Carex arenaria, Dianthus arenarius. Verbascum, Festuca bromoides, ovina uno glauca, Aira canescens unb praecox.

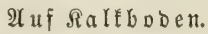

Tussilago Farfara, Digitalis purpurea, Rubus caesius, Hypericum montanum, Prunella vulgaris, Hedysarum onobrychis.

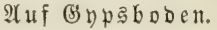

Gypsophila, Gymnostomum curvirostrum, Úreeolaria gypsacea. $\mathfrak{U} u \mathfrak{f} \mathrm{Sal}_{\mathfrak{z}} \mathfrak{b}$ oben.

Salicornea herbacea, Chenopodium maritimum, Plantago maritima, Arenaria marina, Glaux maritima.

\section{$\mathfrak{A} u f \mathfrak{B r u d b o d e n . ~}$} Scirpus.

Orchis, Parnassia, Hydrocotyle, Eriophorum, Juncus unb

\section{$\mathfrak{A} u$ I $⿻$ rfboden.}

Erica tetralix, Andromeda polifolia, Myrica Gale, Ledum palustre, Drosera rotundifolia, intermedia, Empetrum nigrum, Vaccinium uliginosum uno oxyeocess, Eriophorum=2laten, Holcus mollis.

Unter ben genannten Fflanzen fino jebod) nur febr roenige bobenjtet, ftreng genommen unr eitige Des Torfbodents, Des (3ryples, Des Galzbodens und Des Jluganbes. Das fino aber Bobenarten, beren Borfommen theil's

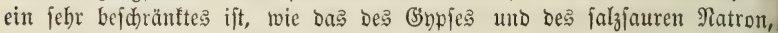
bie anderntheils an uno für fich jo fd)on unverfennbar fino, bá eine Beítim= mung ibrer Bejdafienbeit aus bent Bflanzentwulde feine praftifd)e Bebeutung

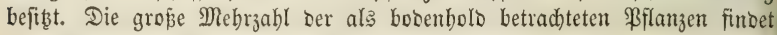
fid) allerbings bäufiger auf Dent ihnen zugeid)riebenten Bobenarten, berbreitet fid) aber von biejen aus aud) auf anbere Bobenarten, wenn fie in ber

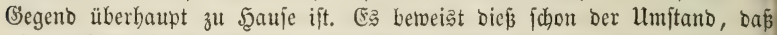
wir fie fänuntlid) in bempelben (barten bereinigen fönnen, obne ibnen eine

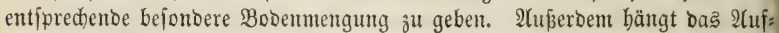

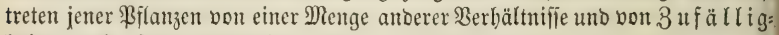
feiten ab, fo baj wir nid)t entfernt fajließen bürfen, baj, two Tussilago ober Gypsophila feblt, Der Boben $\mathfrak{e}$ in Salf= ober (Snpjoboden fei. Die Pothbudbe ift eine entidjieben falffolde Bflanje, ntan twitroe aber ebenfo irren, menn man überall unter ihr einen Raltboden vorauşeb̧en wollte. 
Seiber ift aber aud bie Attmendung biejer Beurtheilungameife, felbit auf Drte, bie mit Şolzbeftäntoen betradjen finto, unto auf Denten leine Beränberung ber bisherigen Betriabsıeife ftattfinden foll, febr bejdräntt. Sie jeb̨t nämlid boraus:

1) Daß̉ Der gegentwärtige Beftano inter normalen Berbältnifien heran:

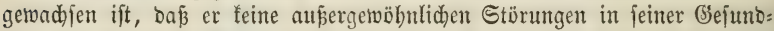
heit uno in feinem $\mathfrak{B u d j p e ~ b u r d ~ a ̈ u s e r e , ~ n i c h t ~ v o n ~ D e n ~ ( E i g e n t h u ̈ m l i d f e i t e n t ~}$ Des Stanoorte berrübrende Ereignifife erlitten babe. Ein Beftand, Der in Der Jugend bäufig vom Wilopret ober Bieb berbiffen wurbe, Der bis inక

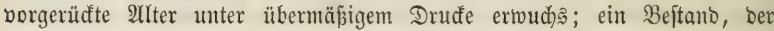
wieberbolt von Jnjeften, Jeuer, Diebjtahl heimgejudst murbe, ber einer übermäßigen Streunub̨ung unterworfen war, fann natürlid) feinen Beifer für bie Stanbortsgüte abgeben.

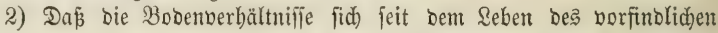
Beftandes nicht bebeuten beränbert baben. Bejonders bäufig ift bießs rüct=

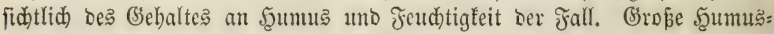
mengen, erzengt ourd gefd)loffenen Malbbejtanto unt bejdräntte ober gänz= (id) feblende Benuţung beffelben, fönnen aud) Dem unfrudtbarften Boben hohe Srabe ber Fruchtbarfeit ertbeilen; wiro burch geiteigerte Seburrfniffe uno erhöhte benubung die Şumusmenge uno mit biefer bie in vielen Fällen von ihr abbängige Feud)tigfeit Des Bobens berringert, fo trägt

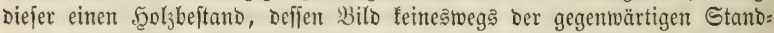
ortagüte entiprid)t. Natürlid) fann ebenio aud) eine Gteigerung Des Shumus=

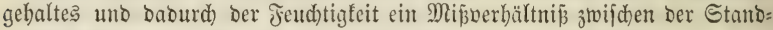
ortsgüte unto bem barauf vorfinolichen Beftandsbilbe berbeifübren.

2Hber felbjt beim Befteben biejer beiben Borausferzungen ift bie Beur=

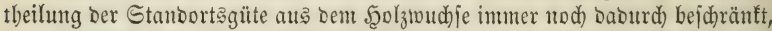
daß̃ biejelben Etanbortşberbältniffe eimen gantz berfadiedenen Einflup auf

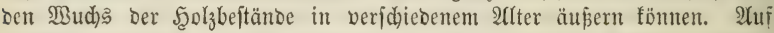

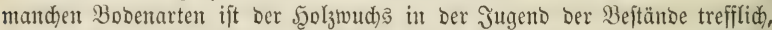

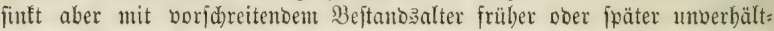

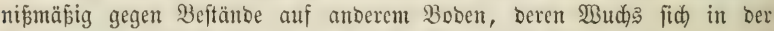
jugend weit weniger freutig zeigte. So föment wir baber unter obigen

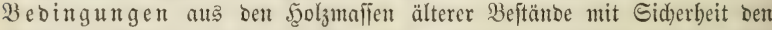
Brab ber Standortägüte bemelien, mit geringerer Sicherheit jüngere Drte hierz̆ benu(zen, wenigitens nidjt ohne Unterfud)ung Derjenigen Berbältniffe,

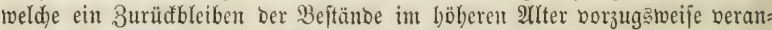
lafien: Fladgründigfeit bes Bobens uno flimatifaje Berbältniffe.

So bejdränft baber bie Bontitinung bes Baldbobents nad) Dem barauf

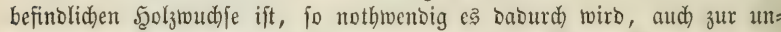

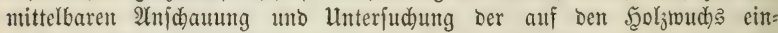
wirfenoen Standortşverbältniffe $3 u f(u d) t$ zu nebmen, findet fie bennod) eine

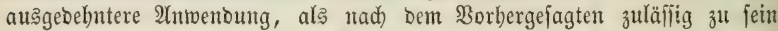
fdeint. Der Blict uno Das (sefübl bes erfahrenen Forftmannes wirb aud) ohne ftrenges Ânbalten an Die Rejultate ber verfloffenten Erzongung faft überall ein, wenigitens amnäherno, rid)tiges Urtbeil über Stanbortägüte

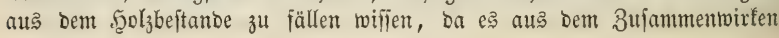


gar vieler, im Einzelnen unjđeinbarer, finnlicher Einbrüđe hervorgeht.

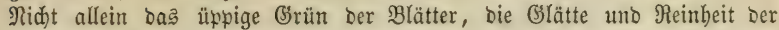
Etämme, bie volle Belaubung, fonbern audh Der Duft und bie \&uft, bie wir einatbmen, Sidjt uno Dunfel, SBärme uno Rühlung erzengen ein (ઉ̉efühl, weldes ben mit bem $\mathfrak{B a l b e}$ vertrauten forftmann oft ridotiger leitet, als eine rationelle Sombination aller äußeren Merfmale.

Bei ber Beurtbeilung einer Stanbortägüte nach bem barauf por= findliden Scolzroudje, infofern ber Beftand ben oben aufgeftellten Be= bingungen entipridit, es aljo zuläjitg ift, aus ber vorbanbenten Şoljmafie

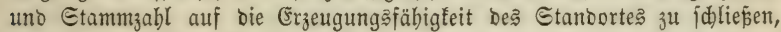

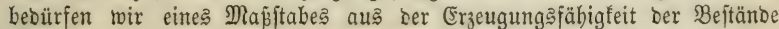
unter Den günjtigften, unter weniger günftigen un๖ unter ungünftigen Stanbortäberbältnifīen. Einen foldhen Maßjtab gewäbren unts bie (5. \&.

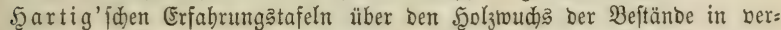
jobiebenem 2Ulter uno auf verjdiedenem Boben, ober vielmehr Stanborts: flaīen, ba in ihnen nidht allein bie vorgefunbene (Erzeugung, fonbern aud) eine Eharafteriftif ber unterjudten Bejtänbe in 2(ngabe ber Etammzabl, Der beridjiebenen Stammflafien uno Etammitärfen gegeben ift, beren wir für vorliegenden 3med notbmentig bedürfen. Эđ gebe Daher bieje Er: fabrungstafeln für unfere 3roede bearbeitet in folgenden Tabellen: ${ }^{1}$

1 Der rheintändifđe, ober magoburger, ober preupijde Morgen, ber ben nadfol= genden Iabellen zum Grrunde liegt, ijt $=0,255322$ Şettar. Ia Die Tabellen überall nur

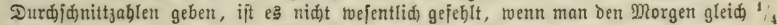

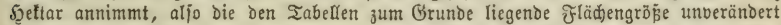

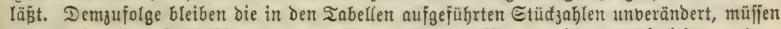
aber, wie bie auf Rubifmeter umgeredneten Grtragş3ifiern, mit 4 multiplicirt toerden, wenn man ben Ertrag eines Şettar twiffen will.

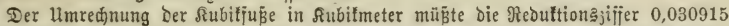
zum Grunbe gelegt jein. F̈̈̈r ben hier vorliegenden 3roef ift bie đbrunbung auf 0,031 zuläfïig, mit weld)er $3 a b$ r ber Ertrag in Subiffüen multipticirt ift, um ben Grtrag in

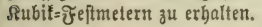


Iab. I.

(Eid)cuboirt (im Scodjwalbbetriebe).

\begin{tabular}{|c|c|c|c|c|c|c|c|c|c|c|c|}
\hline \multirow{3}{*}{$\begin{array}{l}\text { Pobent= } \\
\text { flaffe. }\end{array}$} & \multirow{3}{*}{ 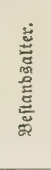 } & \multicolumn{8}{|c|}{ Solzbeftanb uad ber Durdforftung. } & \multirow{3}{*}{ 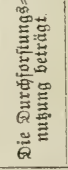 } & \multirow{3}{*}{ 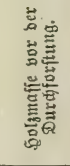 } \\
\hline & & \multicolumn{2}{|c|}{$\begin{array}{c}\text { Stämme } \\
\text { erjter Größe. }\end{array}$} & \multicolumn{2}{|c|}{$\begin{array}{c}\text { Stämme } \\
\text { 子tweiterG̈röße }\end{array}$} & \multicolumn{2}{|c|}{$\mid \begin{array}{c}\text { Etämme } \\
\text { oritter Grö̋̈e. }\end{array}$} & \multirow{2}{*}{ 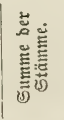 } & \multirow{2}{*}{ 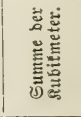 } & & \\
\hline & & $\begin{array}{l}\text { Stüht: } \\
\text { zaffl. }\end{array}$ & $\begin{array}{l}\text { Subit: } \\
\text { ingalt }\end{array}$ & $\begin{array}{l}\text { Stiud } \\
\text { zahl. }\end{array}$ & $\begin{array}{l}\text { Siubit= } \\
\text { intyalt. }\end{array}$ & $\begin{array}{l}\text { Stüdt= } \\
\text { zab̆l. }\end{array}$ & $\begin{array}{l}\text { Subif } \\
\text { intyalt. }\end{array}$ & & & & \\
\hline \multirow{9}{*}{ I. } & 3afire. & Stüđ. & situm. & Etüa. & subm. & Gtĩu. & stubm. & Etüđ. & suknt. & \$tt6m. & Siutm. \\
\hline & 40 & 400 & 0,04 & 800 & 0,01 & - & - & $\begin{array}{r}1200 \\
400\end{array}$ & $\begin{array}{l}60 \\
50\end{array}$ & $\overline{624}$ & 24,80 \\
\hline & $\begin{array}{l}00 \\
80\end{array}$ & $\begin{array}{l}200 \\
100\end{array}$ & $\begin{array}{l}0,19 \\
0,37\end{array}$ & $\begin{array}{l}200 \\
100\end{array}$ & $\begin{array}{l}0,06 \\
0,25\end{array}$ & 100 & 0,09 & 300 & 71,30 & 6,24 & $\begin{array}{l}55,80 \\
77,50\end{array}$ \\
\hline & 100 & 50 & 0,62 & 50 & 0,56 & 100 & 0,31 & 200 & 90,00 & 12,48 & 102,30 \\
\hline & 120 & 50 & 0,93 & 50 & 0,81 & 50 & 0,43 & 150 & 108,50 & 18,72 & 127,10 \\
\hline & 140 & 25 & 1,40 & 25 & 1,24 & 50 & 1,05 & 100 & 118,57 & 28,08 & 146,47 \\
\hline & 160 & 25 & 1,86 & 25 & 1,67 & 25 & 1,30 & 75 & 121,00 & 31,20 & 152,00 \\
\hline & 180 & 25 & 2,42 & 25 & 1,98 & - & - & 50 & 107,72 & 37,44 & 146,00 \\
\hline & 200 & 25 & 2,79 & 25 & 2,33 & - & - & 50 & 127,87 & - & 127,87 \\
\hline \multirow[b]{2}{*}{ 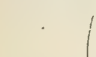 } & 40 & 400 & 0,03 & 800 & 0,01 & - & - & 1200 & 16,52 & - & 16,52 \\
\hline & 60 & 200 & 0,12 & 200 & 0,04 & - & - & 400 & 32,55 & 5,60 & 36,89 \\
\hline & 80 & 100 & 0,31 & 100 & 0,19 & 100 & 0,06 & 300 & 56,20 & 5,60 & 60,14 \\
\hline \multirow{6}{*}{ Mitter. } & 100 & 50 & 0,56 & 50 & 0,50 & 100 & 0,24 & 200 & 77,50 & 9,36 & 86,80 \\
\hline & 120 & 50 & 0,87 & 50 & 0,68 & 50 & 0,37 & 150 & 96,10 & 15,60 & 111,60 \\
\hline & 140 & 25 & 1,18 & 25 & 1,11 & 50 & 0,87 & 100 & 100,75 & 23,25 & 124,00 \\
\hline & 160 & 25 & 1,55 & 25 & 1,36 & 25 & 1,05 & 75 & 99,20 & 24,96 & 124,00 \\
\hline & 180 & 25 & 1,86 & 25 & 1,55 & - & - & 50 & 95,25 & 31,20 & 116,25 \\
\hline & 200 & 25 & 2,42 & 25 & 1,86 & - & - & 50 & 104,56 & - & 104,63 \\
\hline \multirow{5}{*}{ (cd)led)t. } & 40 & 150 & 0,03 & 250 & 0,02 & 1200 & - & 1600 & 15,10 & - & 15,10 \\
\hline & 60 & 150 & 0,09 & 250 & 0,03 & 200 & 0,02 & 600 & 57,00 & 2,17 & 27,87 \\
\hline & 80 & 50 & 0,24 & 100 & 0,15 & 250 & 0,06 & 400 & 43,40 & 4,65 & 48,05 \\
\hline & 100 & 50 & 0,37 & 100 & 0,22 & 150 & 0,08 & 300 & 51,92 & 6,93 & 59,00 \\
\hline & 120 & 50 & 0,56 & 100 & 0,31 & 150 & 0,11 & 300 & 75,14 & - & 75,14 \\
\hline \multicolumn{12}{|c|}{ Iab. II. } \\
\hline \multicolumn{12}{|c|}{ Budjruboisu (in Scodjwalobetriebe). } \\
\hline \multirow{5}{*}{ I. } & 40 & 300 & 0,0 & 300 & 0,03 & 600 & 0,01 & 120 & 37 & - & 37,20 \\
\hline & 60 & 150 & 0,24 & 150 & 0,09 & 100 & 0,04 & 400 & 54,93 & 6,51 & 61,53 \\
\hline & 80 & 100 & 0,45 & 50 & 0,13 & 150 & 0,10 & 300 & 75,18 & 6,24 & 81,37 \\
\hline & 100 & 50 & 0,74 & 50 & 0,26 & 50 & 0,43 & 150 & 90,00 & 18,72 & 108,50 \\
\hline & 120 & 60 & 1,12 & 50 & 0,39 & 50 & 0,50 & 150 & 127,10 & - & 127,10 \\
\hline \multirow{5}{*}{ פittel. } & 40 & 300 & 0,04 & 300 & 0,01 & 800 & 0,01 & 1400 & 24,80 & - & 24,80 \\
\hline & 60 & 150 & 0,19 & 150 & 0,06 & 200 & 0,02 & 500 & 40,30 & 5,60 & 44,64 \\
\hline & 80 & 50 & 0,38 & 100 & 0,24 & 150 & 0,10 & 300 & 57,35 & 6,24 & 63,50 \\
\hline & 100 & 50 & 0,62 & 50 & 0,48 & 50 & 0,31 & 150 & 71,30 & 16,28 & 85,58 \\
\hline & 120 & 50 & 0,93 & 50 & 0,72 & 50 & 0,43 & 150 & 105,40 & - & 105,40 \\
\hline \multirow{4}{*}{$\begin{array}{c}\text { III. } \\
\text { S(d)ledyt. }\end{array}$} & 40 & 150 & 0,04 & 300 & 0,02 & 1150 & 0,01 & 1600 & 22,81 & - & 22,84 \\
\hline & 60 & 150 & 0,12 & 300 & 0,04 & 150 & 0,01 & 600 & 34,10 & 2,20 & 36,27 \\
\hline & 80 & 50 & 0,24 & 100 & 0,16 & 250 & 0,06 & 400 & 43,40 & 4,65 & 48,05 \\
\hline & 100 & 50 & 0,36 & 100 & 0,22 & 150 & 0,08 & 400 & 59,68 & - & 59,68 \\
\hline
\end{tabular}


Iab. III.

Birkentoden (int Sodjwalbbetriebe).

\begin{tabular}{|c|c|c|c|c|c|c|c|c|c|c|c|}
\hline \multirow{3}{*}{$\begin{array}{l}\text { Boben= } \\
\text { flafie. }\end{array}$} & \multirow{3}{*}{ 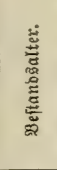 } & \multicolumn{8}{|c|}{ 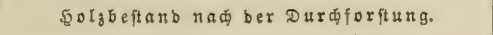 } & \multirow{3}{*}{ 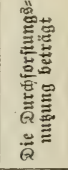 } & \multirow{3}{*}{ 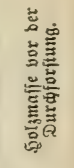 } \\
\hline & & \multicolumn{2}{|c|}{$\begin{array}{c}\text { Stämme } \\
\text { erjter Größ̈e. }\end{array}$} & \multicolumn{2}{|c|}{$\begin{array}{c}\text { Stämme } \\
\text { glveiter Srößse }\end{array}$} & \multicolumn{2}{|c|}{$\begin{array}{c}\text { Stämme } \\
\text { britter Đröß̄e. }\end{array}$} & \multirow{2}{*}{ 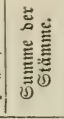 } & \multirow{2}{*}{ 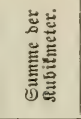 } & & \\
\hline & & $\begin{array}{l}\text { Stüut: } \\
\text { zaฤı. }\end{array}$ & $\begin{array}{l}\text { Subit: } \\
\text { inthalt. }\end{array}$ & $\mid \begin{array}{l}\text { Stü } t= \\
\text { zahl. }\end{array}$ & $\mid \begin{array}{l}\text { Subit }= \\
\text { infilt. }\end{array}$ & $\begin{array}{l}\text { Etü d= } \\
\text { zakุL. }\end{array}$ & $\begin{array}{l}\text { Subit: } \\
\text { infalt }\end{array}$ & & & & \\
\hline \multirow{4}{*}{ I. } & $3 a$ bre. & | 厄tüđ. & surm. & | Etüđ. & subm. & Stüd. & ftutm. & ธtนีđ. & siubm. & sukm. & \&ubm. 1 \\
\hline & 20 & 200 & 0,03 & 200 & 0.02 & 800 & 0,01 & 1200 & 15,50 & -- & 15,50 \\
\hline & 40 & 50 & 3,72 & 150 & 1,86 & 200 & 0,31 & 400 & 52,70 & 6,51 & 59,21 \\
\hline & 60 & 50 & 5,58 & 150 & 2,80 & 200 & 0,62 & 400 & 82,15 & - & 72,15 \\
\hline \multirow{3}{*}{$\begin{array}{c}\text { II. } \\
\text { Ditittel. }\end{array}$} & 20 & 200 & 0,08 & 200 & 0,01 & 800 & 0,01 & 1200 & 10,85 & - & 10,85 \\
\hline & 40 & 50 & 2,48 & 150 & 1,24 & 200 & 0,02 & 400 & 35,65 & 4,34 & 40,00 \\
\hline & 60 & 50 & 3,72 & 150 & 1,86 & 200 & 0,47 & 400 & 58,90 & - & 58,90 \\
\hline \multirow{3}{*}{$\begin{array}{l}\text { III. } \\
\text { edjlectyt. }\end{array}$} & 20 & 150 & 0,02 & 250 & 0,01 & 1000 & 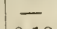 & 1400 & 8,12 & - & 8,12 \\
\hline & 40 & 50 & 1,86 & 150 & 0,93 & 200 & 0,12 & 400 & 26,35 & 2,17 & 28,52 \\
\hline & 60 & 50 & 3,72 & 150 & 1,24 & 200 & 0, s & 400 & 43,40 & & 43,40 \\
\hline \multicolumn{12}{|c|}{ Iab. IV. } \\
\hline \multirow{3}{*}{ Giut. } & 20 & $200 \mid$ & 0,03 & $|200|$ & $|0,02|$ & 800 & 0,01 & 1200 & 15,50 & - & 15,50 \\
\hline & 40 & 50 & $4,3 \pm$ & 150 & 2,17 & 200 & 0,04 & 400 & 62,60 & 6,51 & 70,06 \\
\hline & 60 & 50 & 6,20 & 150 & 3,10 & 200 & 0,06 & 400 & 90,00 & - & 90,00 \\
\hline \multirow{3}{*}{$\begin{array}{l}\text { II. } \\
\text { Dittel. }\end{array}$} & 20 & 200 & 0,02 & 200 & 0,01 & 800 & 0,01 & 1200 & 5 & - & 10,85 \\
\hline & 40 & 50 & 2,80 & 150 & 1,60 & 200 & 0,03 & 400 & 43,40 & 4,34 & 47,74 \\
\hline & 60 & 50 & 5,00 & 150 & 2,40 & 200 & 0,04 & 400 & 71,30 & - & 71,30 \\
\hline \multirow{3}{*}{$\begin{array}{l}\text { III. } \\
\text { S(d)leditt. }\end{array}$} & 20 & 150 & 0,02 & 250 & 0,01 & 1000 & 0,01 & 1400 & 10,00 & - & 10,00 \\
\hline & 40 & 50 & 2,17 & 150 & 1,20 & 200 & 0,02 & 400 & 34,10 & 2,17 & 36,27 \\
\hline & 60 & 50 & $|4,34|$ & $|150|$ & 1,60 & 200 & 0,0 & 400 & 51,15 & 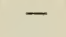 & 51,15 \\
\hline \multicolumn{12}{|c|}{$\begin{array}{l}\text { Iab. V. } \\
\text { efrrubodelt. }\end{array}$} \\
\hline \multirow{7}{*}{$\begin{array}{l}\text { I. } \\
\text { Gitt. }\end{array}$} & $20-25$ & 150 & 0,07 & 150 & 0,03 & 1300 & - & $1600 \mid$ & 23,00 & 14,88 & 37,85 \\
\hline & 0 & 150 & 2,48 & 150 & 0,09 & 500 & 0,02 & 800 & 54,30 & 6,24 & 62,50 \\
\hline & 60 & 50 & 6,20 & 100 & 3,41 & 150 & 1,20 & 300 & 81,28 & 10,24 & 91,91 \\
\hline & 80 & 50 & 9,30 & 100 & 5,00 & 50 & 2,48 & 200 & 108,50 & 16,43 & 124,93 \\
\hline & 1 & 50 & 12,40 & 50 & 6,82 & 50 & 5,58 & 150 & 124,00 & 16,43 & 140,43 \\
\hline & 120 & 50 & 15,50 & 50 & 9,30 & 50 & 6,20 & 150 & 160,58 & - & 160,58 \\
\hline & $20-25$ & 200 & 0,05 & 200 & 0,02 & 1400 & - & 1800 & 20,92 & 9,36 & 30,22 \\
\hline \multirow{5}{*}{$\begin{array}{l}\text { II. } \\
\text { Mittel. }\end{array}$} & 40 & 150 & 1,60 & 150 & 0,06 & 600 & 0,01 & 900 & 37,20 & 4,65 & 41,85 \\
\hline & 60 & 50 & 5,00 & 100 & 2,48 & 150 & 0,08 & 300 & 62,37 & 7,44 & 69,81 \\
\hline & 80 & 50 & 7,44 & $=100$ & 4,72 & 50 & 1,80 & 200 & 83,40 & 13,18 & 96,88 \\
\hline & 10 & 50 & 10,00 & 50 & 5,58 & 50 & 4,34 & 150 & 99,20 & 12,87 & 112,06 \\
\hline & 120 & 50 & 12,40 & 50 & 6,82 & 50 & 5,00 & 150 & 125,55 & 一 & 125,55 \\
\hline \multirow{5}{*}{$\begin{array}{l}\text { III. } \\
\text { ङdj)ledjt. }\end{array}$} & $20-25$ & 200 & 0,03 & 200 & 0,01 & 1400 & - & 1800 & 13,64 & 8,68 & 22,32 \\
\hline & 40 & 200 & 0,07 & 200 & 0,05 & 500 & 0,01 & 900 & 27,37 & 4,03 & 31,40 \\
\hline & 60 & 50 & 4,72 & 100 & 1,80 & 250 & 0,06 & 400 & 52,70 & 5,27 & 48,00 \\
\hline & 80 & 50 & 5,00 & 100 & 2,48 & - & - & 150 & 49,60 & 18,30 & 67,90 \\
\hline & 100 & 50 & 6,20 & 100 & 3,10 & - & - & 150 & 64,48 & - & 64,48 \\
\hline
\end{tabular}

5̧artig, হebrbud) für F̈örfter. I. 
Iab. VI.

fidjtenboidel.

\begin{tabular}{|c|c|c|c|c|c|c|c|c|c|c|c|}
\hline \multirow{3}{*}{$\begin{array}{l}\text { Boben = } \\
\text { Ilaffe. }\end{array}$} & \multirow{3}{*}{ 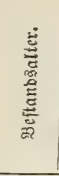 } & \multicolumn{8}{|c|}{ Sol zbeftanb na由 ber Durqforftung. } & \multirow{3}{*}{ 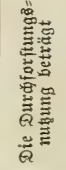 } & \multirow{3}{*}{ 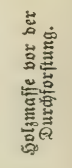 } \\
\hline & & \multicolumn{2}{|c|}{$\begin{array}{c}\text { Etämme } \\
\text { exfter Größ̈e. }\end{array}$} & \multicolumn{2}{|c|}{$\underset{\text { 3weiter@röß̆e }}{\text { Etämme }}$} & \multicolumn{2}{|c|}{$\begin{array}{c}\text { Etämme } \\
\text { britter Ǵrö̉e. }\end{array}$} & \multirow{2}{*}{ 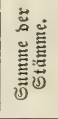 } & \multirow{2}{*}{ 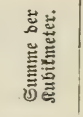 } & & \\
\hline & & $\begin{array}{l}\text { Stüd: } \\
\text { zabl. }\end{array}$ & $\begin{array}{l}\text { Subit }= \\
\text { infalt. }\end{array}$ & $\begin{array}{l}\text { Etü̈f: } \\
\text { saft. }\end{array}$ & $\left|\begin{array}{l}\text { Subif }= \\
\text { inf falt. }\end{array}\right|$ & $\begin{array}{l}\text { Stüit: } \\
\text { zahl. }\end{array}$ & $\begin{array}{l}\text { Subit: } \\
\text { inthalt. }\end{array}$ & & & & \\
\hline \multirow{9}{*}{ I. } & 3ahre. & Etüđ. & $8 \mathrm{ntm}$ & Gtüă: & stukm. & - Etüa̛t. & utem. & ena. & & subm. & \\
\hline & $25-30$ & 200 & 0,06 & 200 & & 1400 & & 1800 & & 15,60 & \\
\hline & 40 & 200 & 2,40 & & 1,20 & 400 & 0,0 & & & 9,36 & 102, \\
\hline & 60 & 100 & 5,58 & 10 & 4,34 & 200 & & & & 13,02 & 143 , \\
\hline & 80 & 100 & 9,92 & 100 & 6. & 100 & & 300 & & 17,36 & \\
\hline & 100 & 50 & 16, & 50 & 14, & 1 & 7 , & 200 & & 22,94 & \\
\hline & $1 \%$ & 50 & 21, & 50 & 18,60 & 100 & 9,30 & 200 & & . & 29 \\
\hline & $25-30$ & 200 & & 200 & & 1400 & - & 18 & & 11,78 & 27 \\
\hline & 40 & 200 & & 20 & & 400 & 0,02 & & & 7,75 & 63 \\
\hline \multirow{4}{*}{ II. } & 60 & 100 & 3,72 & 100 & 2,4 & 200 & 0,0 & 400 & & 6,51 & 87,11 \\
\hline & So & 100 & 7,44 & 100 & 4,3 & 100 & 1,4 & 300 & 131 & 8,68 & 140,43 \\
\hline & 100 & 50 & 12,40 & 50 & 10,5 & 100 & 5,5 & 200 & 170,50 & 13,02 & 183,52 \\
\hline & 120 & 50 & 17,05 & 50 & 14,2 & 100 & 6,82 & 200 & & - & 223,75 \\
\hline \multirow{5}{*}{$\begin{array}{l}\text { III. } \\
\text { ed)ledit. }\end{array}$} & 30 & 200 & 0 , & 200 & 0 & 14 & - & 18 & & 6,24 & 16 , \\
\hline & 40 & & & 20 & 0, & 60 & 0,01 & & & 4,65 & 38 \\
\hline & 60 & 100 & 2,40 & 100 & 1,6 & 400 & & 600 & & 2,17 & 64,17 \\
\hline & 80 & 50 & 5,5 & 50 & 4,9 & 100 & 2,4 & 200 & 77 & 13,02 & 90,52 \\
\hline & 100 & 50 & 8,68 & 50 & 6,20 & 100 & 3,10 & 200 & 105,40 & 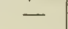 & 105,40 \\
\hline
\end{tabular}

Iab. VII.

Bòet (int Niebertwalobetriebe).

\begin{tabular}{|c|c|c|c|c|c|}
\hline \multirow[b]{2}{*}{ golzart. } & \multirow[b]{2}{*}{ Bodentiafie. } & \multicolumn{4}{|c|}{ umtriebszeit. } \\
\hline & & $6-8=$ & fä̧冖riger Dur & $\begin{array}{c}30= \\
\text { [1 }\end{array}$ & $40=$ \\
\hline \multirow{4}{*}{ Eidje } & I. gut & Subifmeter. & $\begin{array}{l}\text { Sintifmeter. } \\
1,0\end{array}$ & $\begin{array}{l}\text { Subifmeter. } \\
0,7\end{array}$ & $\begin{array}{l}\text { Subitmeter. } \\
0,7\end{array}$ \\
\hline & II. mittel & - & 0,6 & 0,5 & \\
\hline & III. f(d)ledflt & - & 0,5 & 0,4 & 0,4 \\
\hline & I. gut & - & 0,7 & 0,8 & \\
\hline \multirow{2}{*}{ Budfe } & II: mittel & - & 0,6 & 0,6 & 0,6 \\
\hline & III. idf)ledft & - & 0,5 & 0,5 & 0,5 \\
\hline \multirow{3}{*}{ 5ૃornbaum } & $\begin{array}{l}\text { I. gut } \\
\text { II. mitter }\end{array}$ & - & $\frac{1,2}{2}$ & 1,1 & - \\
\hline & III. (d) (ed)t & - & ? & 0,6 & - \\
\hline & I. gut & - & 1,0 & 0,7 & 0,6 \\
\hline \multirow{3}{*}{ Birfe } & II. nitttel & - & 0,6 & 0,5 & 0,4 \\
\hline & III. (jof)Iedft & - & 0,5 & 0,4 & 0,3 \\
\hline & I. gut & - & 1,5 & 1,7 & 1,5 \\
\hline \multirow{2}{*}{ Erle } & II. mittel & - & 1,1 & 1,2 & 1,1 \\
\hline & III. (d) Ied d)t & $\overline{58}$ & 0,7 & 1,0 & 0,8 \\
\hline \multirow{2}{*}{ Weibe } & $\begin{array}{l}\text { 1. gut } \\
\text { II. mittel }\end{array}$ & $\begin{array}{l}30 \\
33\end{array}$ & 34,2 & $=$ & 二 \\
\hline & III. fduledut & 22 & - & - & - \\
\hline \multirow{3}{*}{ 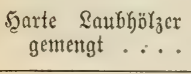 } & I. gut & - & 0,7 & 0,8 & 0,8 \\
\hline & II. mittel & - & 0,6 & 0,6 & 0,6 \\
\hline & III. (d)led)t & & 0,3 & 0,5 & 0,5 \\
\hline
\end{tabular}


In boritebenden Tabellen ift eine Durdforitung ohne Unterbred)ung Des Sronenjdlujies, nach ben int folgenden Şaupttheile alfgeftellten allge=

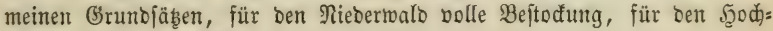
walb bolfommener Beftand angenommen.

Es würe biernad) ein (Eid)enboben gut genannt werben, wenn er auf $1 / 4$ Settar ober auf bem magbeb. Morgen bei vollem Beftande im 40 iften Sabre nad) Der Durdjorftung nod) 1200 Stämme mit 24,8 Rubit= meter entbält; er wärbe $j$ d le d) $^{t}$ genannt werben, wenn er bei vollem Bejtande von 400 Stämmen im 80ten Jahre 48 Rubifmeter enthält. Der

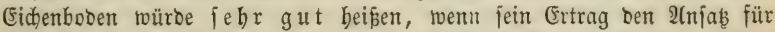
ben Ertrag bes guten Bobens um mehr als bie Şälfte Der Differenz zwifchen Dem Ertrage bes guten und mittlern Bodens, з. B. im Eidjen=?iebertwalde von 20jäbrigem $\mathfrak{U m}$ mriebe um mebr alઢ 0,15 Rubifmeter überfteigt; man

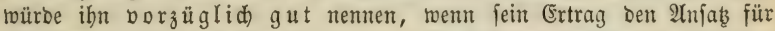
Den Ertrag bes guten Bobenక um bie volle Differenz żwifden bem Ertrage bes guten uno bes mittlern Bobens, im bezeidnneten falle um mehr als 0,31 Rubifmeter überfteigt. Ebenfo würbe ein Eidjen = RieberwalDbobent jehr $\{$ d ledt genant werben, wenn bei 20 jährigem umtriebe fein Er: trag um mehr als 0,08 fubifmeter, er würbe borzüglid fdhled) ge= nannt werben, wenn fein Crtrag um mebr als 0,15 Siubifmeter hinter

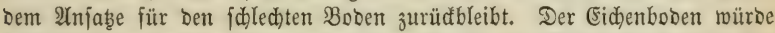
fajt $g$ ut zu nenten fein, wenn er mebr als bie Mittelzabl zwijden ber

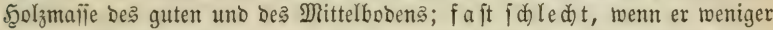
als bas Mittel zwifichen mittel uno fd)led)tem Boben an Solzmafie erzeugt.

(Es fommt bierbei natürlic) gar nidgt barauf an, ob bie in 2̂njał gebrad)ten Ertragsmaffen mirflid) Mittelzablen aus ben bisher gemadten uno nod) zu madenben Unterjudungen über ben . Solzgehalt ber Beptände

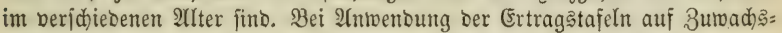
ermittelungen an gegenwärtig jungen Beftänben ift biés allerbings von

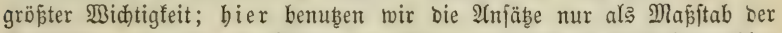
Bodengüte uno als ein Mittel, bie Grrabe Derjelben in Berbältnī̧̧ablen ausbrüđen zu fömnen.

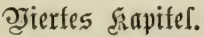

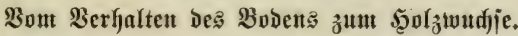

In Den vorkergebenden Sapiteln haben wir bie einzelnen Bobenbe: ftandtheile, ihre Bejdjaffenbeit uno Eigenidaften, bie Mirfung, weldje jeber einzelne auf bie übrigen Bejtandtheile, theils unmittelbar auf bas Bflanzen= leben ausübt, fo twie bie mannigfaltigen Einflülie ber unteren uno oberen Bobengrenze auf bie Natur bes Bobens uno befien Frudtbarteit femen gelernt; es bleibt uns bier nur nod) übrig, eine Ueberfidt bes Ganjen, eine Daritellung ber Bejammtwirfung aller Einzeltheile žu geben.

Beoingung ber Frudtbarfeit eines Bobens ijt:

1) Die Loderbeit Deß Giemenges, vorzugheife um ber \&uft 3utritt zu ben \$flanzentwurzeln uno zu benjenigen Bobenbeftanotheilen zu gewäbren, welde mur burdh 3utritt ber \&uft in einen 3uftano berjeb̧t 


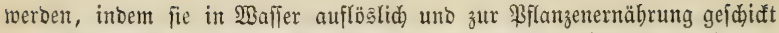
fint. Die, aud ber fräftigen $2 B$ urzelausbiloung uno $\mathfrak{B u r}$ jelverbreitung föroer= liche Sođerbeit deş Bobents hängt mur von einem günítigen Mlengungşver= Gältnifie Der bindenten unto ber loderen Bodenbejtanth theile ab; fie fann aber

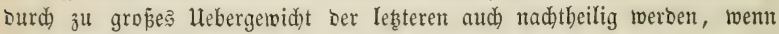

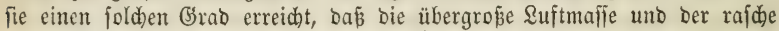
Quftwedjel im Boben ben 5ुumus ju rajd) verflüdtigt, bie Jeudtigleit in

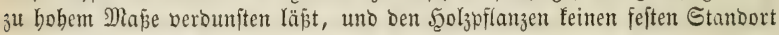
zu gewähren, wie fid felbjt nid)t in ibrer Lage zu erbaltent bermag (f̧lug: fanto, Sdamemmjant).

2) Die Tiefe ber Bodenfrunte, won welder forohl bie 2 us= Defnung bes unteriroifden Emäbrungs̆raumes ber ßiflanzen, wie aud bie

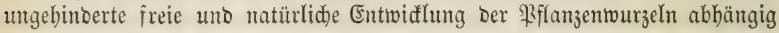
ift. Bejonbers roddtig wirb bie Bodentiefe für bas Gebeihen aller in febr gebrängtem Etanbe beifanmen wadjenten \$flanzen, ba bieje fich gegenfeitig in ber borizontalen Burzelverbreitung behinoern, wab um fo nad)theiliger

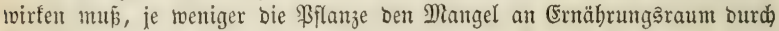
Eimbringen in bie Tiefe fid zu erfeţen bermag. (Enolid ift von ber Iiefe

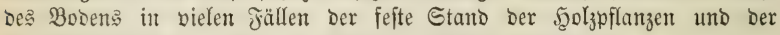

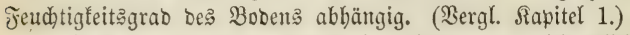

3) Ėin günftiger Feudtigfeit agrab, nidht allein nadh Menge

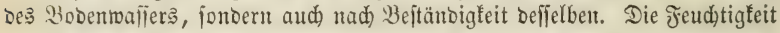

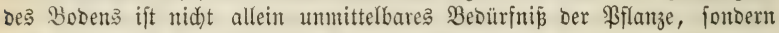
aud) nötbig jur Şeraußbiloung ber Bflanjemabrung, fie erhöht ferner ben 3ujammenbang Der Bobentbeile uno miloert ben zu gropen Suftzutritt uno ¿nftwedjel im Boden. Jn zu hohem Mape fdabet fie bejonbers ourdh

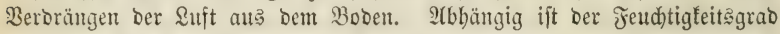
Des 3obens nidht allein bon ber Booenunterlage unt vom Rlima, fonoen

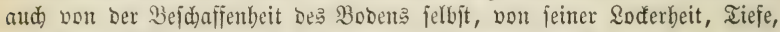

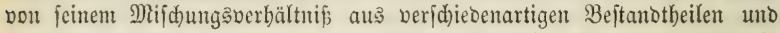
Deren uns bereits befanntem, abweidentoen Berbalten zur Jeudtigteit, fo wie von ber Bebecfung bes Bobens Durdh \$flanzentwudb.

¿oferbeit, Iiefe mo Jeudtigfeit fino bie brei Scauptfaftoren Der Jrud)tbarkeit unjeres $\mathfrak{B a l d b o b e n t s . ~ E i n ~ i n ~ g u ̈ n j t i g e m ~ ( 5 r a d e ~ l o d e r e r , ~ t i e f = ~}$

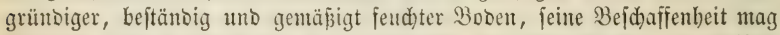

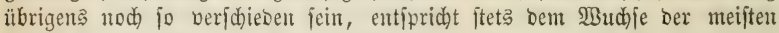

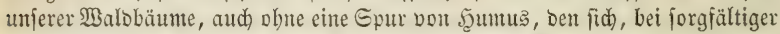
Wirtbjøaft, bie Beftänbe jelbjt in immer fteigender Menge erzengen, fo bafs felbjt Der ausgewajhene See = uno fluffano Durd ben 2Unbau geeigneter \$ुolzarten in wenig Decentien eine reid)(id)e Beimengung biefes Stoffes erbält.

Die Frudtbarfeit bes Bobents ift fermer abbängig

4) von ber $\mathfrak{i}$ atur und bem Mengungsorbältui ber mineralifon Beftandbeile des Bobens und vom Şumus= gehalte befielben. Beide, Die mineralijen Beftantheile uno ber Şumus,

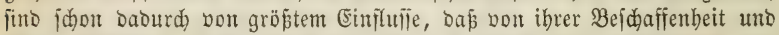

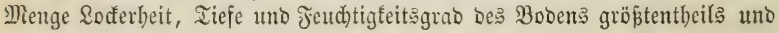

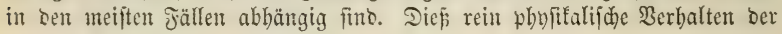




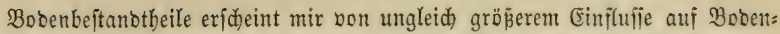

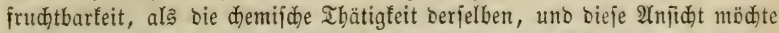
id, went allein vom Berbalten bes Bobens zum B̉ebeiben ber $\mathfrak{S}_{0} \mathfrak{l}_{3}=$

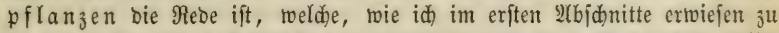
baben glaube, ibren Roblenftoff borzughtweife aus ber \&uft bezichen, jelbjt bis auf ben Şumus aušbehnen, defien in jeber Şinficht günifiges phnji= falifices Berbalten wir bereits fennen gelernt baben.

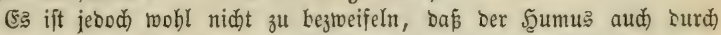
bie aus ifm fid) entroičelnde \$flanzennabrung zur frudtbarfeit bes Boben:

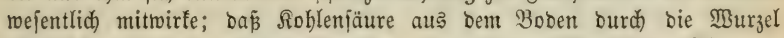
unmittelbar in bie झ̊flanze übergehe. Die Şerausbiloung ber Pflanzen= nabrung aus bem Scumus wiro aber, wie id gezeigt habe, ourd) demifde Berbinoung beflelben mit ben mineralijhen Bejtanotheilen des Bobens jut

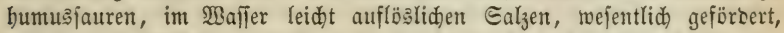

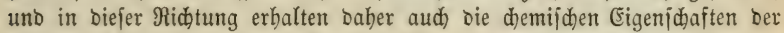
mineralijden Bobenbeftanotheile Einfluf auf bie Frudtbarfeit bes Bobens, indem fie bie Thätigfeit Des Bobenz, D. h. Die Rraft, mit welder ber Boben

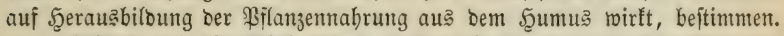

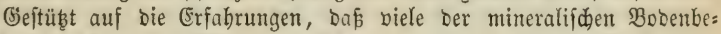
ftandtheile aud in Den Bftanzen gefunben werben, Daj bas \$orfommen mand)er Pfilanzen (bodemitete) an bas Borbandenjein gerwifiler Bobenbeftand: theile gebunden ift, hat man in neuejter Beit ben Gaķ aufgeitellt: Daj bieje in ber \$ilanzenajde fid fincenten, aus bem Boren aufgenommenen Mine:

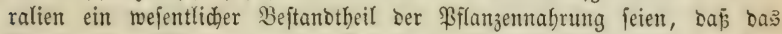

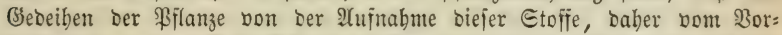

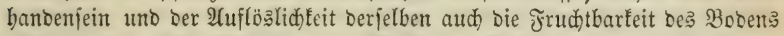
abbängig jei. Die 2Uufnabme ber Riejelerbe, Ralferbe 2 , aus bem Boben burd) bie $\mathfrak{B}$ urzeln ber Pflanze ijt nidjt in 2lbrebe zu ftellen, babingegen

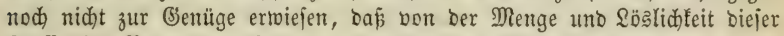
Stoffe im Boden das freubige Geedihen ber ßilanzen abhängig fei, im Giegentbeil ftehen biejer 2 nnahme nod) viele Erfahrungen entgegen, bejonder引

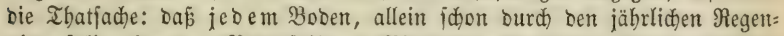
nieberfall, eine bem Bebürfniṕs ber \$ilanzen entipredjende Menge löslider

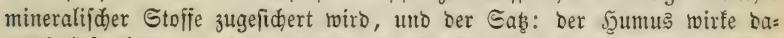
Durch befrudteno, Dā̧ er, Durch feine Berbinoung mit ben mineralifajen Beftandtheilen bes Bobens, bieje im $\mathfrak{B a}$ aijer auflöslid uno zum Hebergange

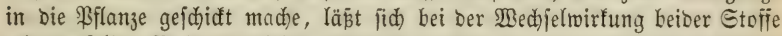
mit bemjelben Redts umgetebrt aufftellen, inbem man fagt: bie mineralifden Beftandtheile wirfen in ihrem demijonen Berbalten nur baburd befruditent, daß̄ fie ben รูนmน auflöfen.

\section{马illitftes şapifel.}

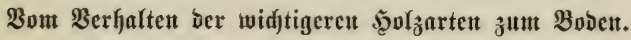

\section{Die $\Re$ ot b bude.}

Der ihr entipredjente Boden fann einen ziemliden Grab bes 3ujammen:

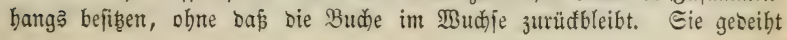


felbit auf Dem binbenderen Ihonboden, am beften allerbings auf Sebmboben, jelbft auf fanbigem $\mathrm{Sehm}$. Die reinen Ihonformen fino ihr idäblid, uno veranlaifen ein frübes 2Hbiterben. Gandboben wirb mur burd hohe Jeudte= grabe bes Untergrunoes und ftarfen Şumusgehalt für bie Rothbud)e taug: lich; mandbe tiefliegende Reviere an ber Seefüjte zeigen aber, bap fie unter obigen Bebingungen audi) bem Sanoboben nid)t abbolo ift (3ing ft, Darft zc.). Şanz bejonbers gut fagt Der Rotbbuche ber Trümmerboben über Ralfgebirgen zu. Unter ben Ģebirgäarten liefern außer ben lebm= haltigen Ralf: und Gyppsgefteinen bejonbers ber Bajalt uno bie befieren Granite einen guten Budenboben, ber audd aus vielen Sanbiteinarten, bejonbers benen mit gemengt thonigem und falfigem Binbemittel herbor= gebt (bunter Sanoftein und rotbes Iodtliegendes).

Şumusreidhthum bes Bobens ift ber Budhe mebr als allen übrigen Şolzarten nöthig, vorzugatweife auf (5runo ibrer flad)en $\mathfrak{B u r z e l v e r b r e i t u n g . ~}$ Der geidlofiente Stano ber Budhe, ifre reidje Belaubung, bas marfige Slatt, fichern Dem Boben bei wirthlidjer Bebandlung ber Beftänbe einen bimreicjenden f̧umuggebalt.

F̧obe Feudtigfeitsgrabe finto ber Budbe zuwiber. Wir feben fie felbft

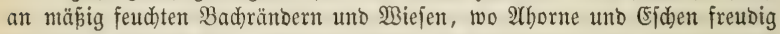
vegetiren, zurüdbleiben. Nur im locfern Gande verträgt fie einen böberen Feuthtigfeit $3 g$ gab.

Bei ber flad) verlaufenden Burzel nimmt bie Budje mit menig Boben= frume vorlieb, ood) ift fie nidht fo genugiam wie bie fidiste.

\section{Die (Eide.}

Berträgt eben fo bohe Eonfiftenzgrade als bie Rothbuche, begnügt fid aber mit leidjterem Boben als jente. Eandiger Sebmboden uno Yeh= miger Sanbboden, wie er im Meeresboben fid) bäufig finbet, im (b̉ebirgc

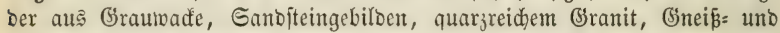
(Glimmerjobiefer herborgegangene Boben, jagen ber (Eiche zu, wenn ber Boben binlänglid) tiefgrünoig ift. Iiefgrünbigfeit bes Bodens ift eine Şauptbebingung ihrer fräftigen Begetation im Scod)walbe, baher fie bann

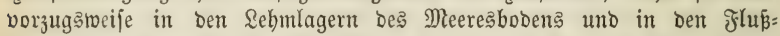
nieberungen heimifa) ijt. Im (5ebirge liebt bie (Eid)e bie welligen boben= reid)en Sorberge uno G̋ebirgathäler. Die Traubeneidje foll mit leidterem Boben borlieb nebmen als bie Stieleidje. 2(İ Sd)lagholz nebmen beibe

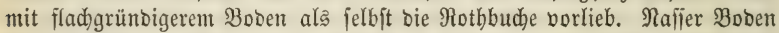
ift Der Eidhe im 2lllgemeinen zumiber, bod) fommen mitunter merfmüroige 2luşnabmen bor. Man trifft nicht jeltent riejenmäß̧ige (Eid)en im Brudd)= boben, oer allem 2trideine nady immer Brudboben war. 2Aud babe id junge (Eid)enanpflanzungen von ausergewöhnlid) freubigem $\mathfrak{B u d j e ~ i n ~ e i n e m ~}$ Brudboben zwifden Erlemitöeden gefunben, weldher auf 0,25 Meter Waljer zog.

Da bie Eiche menig Saub trägt, fidh im höheren 2 (lter licht ftellt, uno in bem ibr gewöhnlich geftellten bohen Umtriebe einer grökeren

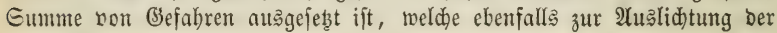


Beftünto mitwirfen, berbefiert fie belt Boben wenig, uno wiro baber ant beften im Gemenge mit anberen, ben 30 ben befiernben Scolzarten, nament= lid mit ber Rothbudje, erzogent.

\section{Die Birfe.}

Gedeift am beften auf einem lebmigen Ganoboben, bejonbers went Der Gano grobförnig - Brano - ift. Die bindenden Bobenarten fino ihr zumiber. Ëbenjo meibet fie ben Ralf, Den bunten Sanoftein uno bas rothe Tobtliegenoe, überhaupt alle Ganbfteinformen, bie reid an thonigem eifenjdülligem Binbemittel fino. Ganj vorzüglid) gebeibt fie auf ben bohen Etellen ber Brudgegenden uno an Den Rändern Der Brüde, zieft fich aud in ben nidjt allzu naijen Brudboben binein (B. pubescens), meioet aber bie গäfie uno ben fauren Sูumus.

Pajper Boben ifit ber Birfe zum freubigiten (Bebeiben nidst zuträglid, fie berlangt einen frifden, hödftents gemäßigt feudten Boden.

Eine Bobentiefe bon $1 / 2-2 / 3$ Meter genügt ber Birfe volfommen, da bie $2 B$ urzelmenge gering uno flad ausftreideno ift. Sie nimmt mit wenig f̧umus vorlieb, gebeift aber auf ganz humuझlofem Boben faj)ledst uno bermag Denjelben burds fid felbjt nidht zu verbeliern, indent ibre frühe \&idhtitellung eine überaus rajde 3erieb̧ung Des \&aubes jur Folge hat.

Dbjobn baher ber Standort bes freubigiten Shebeihens ber Birfe fehr bejdränft ift, fo jeben wir bennod ifrent Samen faft überall aufgeben,

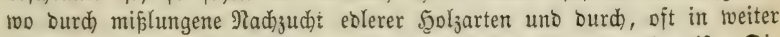

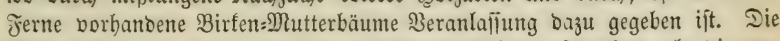
Birfe orängt fich bann bier ein, wädst im 2 fnfange freubiger als bie ver=

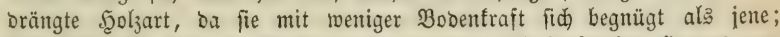

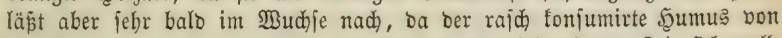
Der Birfe wenig Errał erbält, Deren ¿aub in jebr furzer Zeit fid boll= ftändig jerję̧t. Mit Reçt zählt man fie baher unter Umitänden ž ben "ร̌oritunfräutern".

\section{Die Erle.}

Jorbert geringe Eonfijtenj= uno hobe Jeudtigteitzgrabe bes Bodens. Bir finden fie baher vorzugstweije in bem burd grope şumusmengen ge: locerten Brudbboen, uno it folchem lodern Ganbe, Defien Oberfläd)

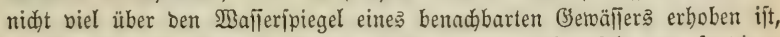

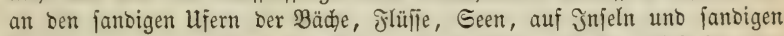
Infobemmungen zwifden ben Dünen ber Seelüfte, wo fie, felbjt im auss:

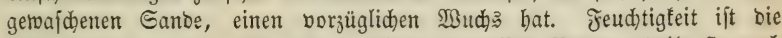
5auptbebingung ihrer Begetation; felbft auf nafiem Boben gebeibt fie nod jebr gut, befier als auf frifdem 30 ben.

Die $\mathfrak{B u r}_{3} \mathrm{ln}_{\mathrm{n}}$ ber Erle gehen wenig zur Seite, fonbern in vielen fleinen

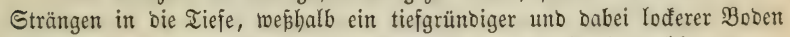
nöthig wirb. Da bie Erle im ganz naffen Boben gebeibt, in weld)em wegen Mangel an \&uftzutritt wenig \$illanzentahrung fich zu bilben bermag, da fie aud im ausgenajdenen Geejanbe freubig wäcst, fo fönnen wir Daraus folgern, dáp fie fid vorzugsweife aus der 2Atmofphäre ernäbre. 


\section{Die Meiben.}

Şauptbebingung ibres frentoigen (sebeibens ift Feudtigfeit, felbjt ఇäfie bes Bobens. In locferem Boben gebeihen fie beffer als int binbenton; ber geeignetite Stanbort fino bie fanbigen $\mathfrak{A n}$ jकlwemmungen ber Fluß̧ufer, bieje felbit, fo tvie bie Ufer ber Bäche, Seen, bie \$Biejen = unb Brudhränber.

Den troctenften Stanoort erträgt S. purpurea, daphnoides unb alba; auf Brudboben räds șt nod am beften S. pentandra; cinerea, aurita unb rosmarinifolia, ben binbentiten $\mathfrak{B}_{0 \text { ben }}$ verträgt $\mathrm{S}$. caprea; auf

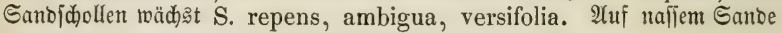
S. viminalis, acuminata, rubra ete.

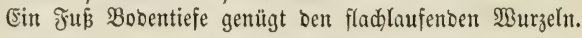

\section{Die Riefer.}

Şauptbebingungen ihrer Begetation fino Tiefgrünoigfeit und Sodererbeit Des Bodens. Rehmiger Sand uno fandiger Sehm fagen ihr befonders z̧u, Dod) gedeift fie auf bem fterilften Sanbboden, wenn fie in ber Jugeno bort nur im freien Stande angebaut wurbe. Der Boben fann in feiner Dberflädye troden fein, woun er mur in ber Iiefe frifd) ober fendht ift,

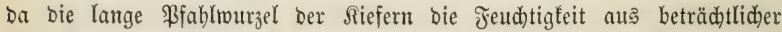

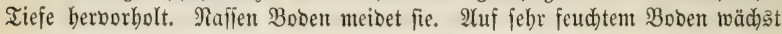
fie zwar, erreidyt aber bort früh ihre Saaubarfeit, uno liefert ein leid)tes

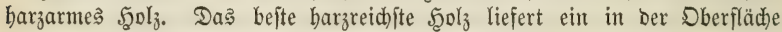
bis auf $1 / 3$ Meter trodner fandiger Sebmboben.

2Uf Raltboben joll bas $5_{2} 0 l_{z}$ jebr brüdjig werben.

2Huggezeidnet ift bie Riefer rüdfidtllid) ibres geringen Bebürfniffes an

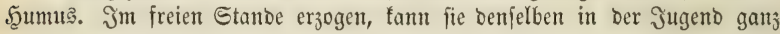
entbehren, fidh allein aus ber \&uft ernäbrent. Später, wenn bie jungent Drte in Sdluf fommen, verbeffern fie ben Boben burd) Nabelabfall in hohem Brabe.

\section{Die Fidte.}

Daß Borfommen Der Sidjte ift ein ztweifades. 3uerft uno baupt=

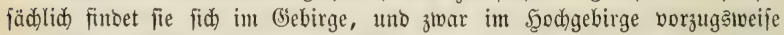
auf (3ranit, SSlimmeridjiefer uno (Bneißß, aud) bie Thonjdiefer uno (Brau= wade uno bie meiften Porphyre tragen gute Fid̦tenbeftänbe, wobingegen bie jüngeren Eonglomerate uno die Ralfe ihr weniger zulagen. Dod finbet

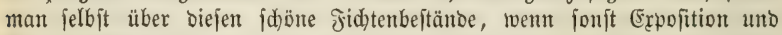
תlima günitig fint; ja, ganz ohne Boben begetirt bie Fidhte zwijd)en Stein: geröll, went bie 2tmofphäre nur feud)t ift. Dürre bes Bobents uno bes Rlima find ibr am nadtheiligiten; im trodinen Sande uno im feften thonigen Boben geoeiht fie nidt. Daber baben aud Steinbroden im Booen einen jo günjtigen (Einflußs auf ibre Begetation, ba burd) biefe ber Boben feudjt erbalten wirb. Die in ber Dberfläd)e bes Bobens fid berbreitende, weit ausftreidjenbe Bewurzelung begnügt fidh mit geringer Bobentiefe.

Benn Der natürlidge Standort ber Fidite im fübliden unb mittleren

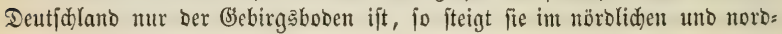


piftliden Deutid)lano, idfon in Ed)lefien, am redten Doerujer, in \$olen, Sitbauen uno Ditprensen in bie Ebenen Ginab, uno gebeift bort in bent

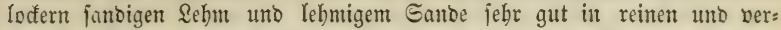
breiteten Beftänben; tročnen Eant uno binbenden naffen $\mathfrak{T h o n =}$ und 2 ehm= boben meibet fie aud bier.

\section{Die Beíntanne.}

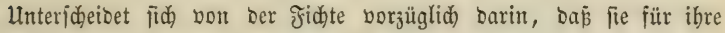
in bie Tiefe gehenden, nid) weit ausftreidjenten Seerzmurzeln einen tief=

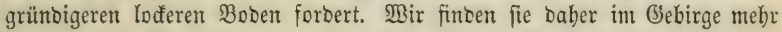
über foldhen Bebirgâformen, bie einen tieferen Boben liefern, bejonberß über ben Eonglomeraten, uno ben felofpatbreidjen Urgebirgsarten. 2Uud) Der Bajalt trägt trefflid̄e $\mathfrak{S}_{e}$ iß́tannen. Bei außreidjenter Bobentiefe fommt fie übrigens meift mit Der Rothtanne im Semenge vor, unt finbet fid in Ed) lefien mit biejer auth im Meeresboden. Im Gebirge geft fie nidht io hod als bie fidhte, und ift mehr im Süben Deutid)lands beimifa).

\section{Die \&ärøe.}

Forbert yor allem Tiefgründigfeit beక Bobens, ta fie eine ftarfe

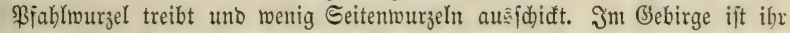
Der bejiere Fichtenboben, in Der (Fbente ber gute Rieferboben angemefien, bod) nimmt fie mit leidtem Rieferboben vorlieb, went biefer mur nidet arm an Şumus ift. Der Bocen fann in ber Dberfläd)e fogar troden fein, ba

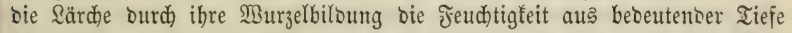
heraufbolt. Inter Den Giebirgsarten zeigt bie Särche eine entichiebene Bor= liebe für ten Ralf uno bie Conglomerate mit falfigem Binbemittel. 2Yud) auj buntem Ganoftein habe id ausggezeidnete Särchenbejtärioe gefunben. 2fư thonigem Boben läßst fie früh im $\mathfrak{B u d j e ~ n a d y . ~}$

Bon ben untergeoroneten Şoljarten hebent wir bier nod) folgente hernor:

\section{Die $\mathfrak{A b}$ orne.}

Der gemeine und Der Spib=2(born baben mit ber Rotbbuche ziemlid gleides Bodenbebürfnif́, bod) gehört zu ihrem freubigiten (3ebeiben ein tiefgrünbigerer Boben, ba fie eine ftarfe, wemn aud nidt febr lange Prabl= wurzel treiben. Die Tiefgrünoigleit ift aber niḑt fo nöthig als bei ber Eide, Riefer 2c., ba bie 2thorne, wem bie ßjabltwurzel ein Şinbernip findet, fehr ftarfe uno lange Eeitenwurzeln entwidéeln. Die fdönjten reinen 2 horn= beftände habe id auf Bajaltboben gefunden. 2(ud) auf Ralf, Thonj diefer und rothem Tobtliegendem wadjent fie gut. Jim Siebirge bleiben bie Athorne binter ber Budje zurüđ, uno gehen nidjt üher bie (Eidjengrenze binaus, befonders finden fie fid im Thalboden ber Bebirge.

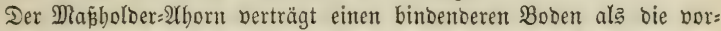
genannten 2 rten. Sein eigentlicker Stanbort fino bie fluñnieberungen; oort erreid er in Sd)lefien ein $\mathfrak{B}$ olum von 3-4 Enbifmeter, wäbreno er im 5öbenboben uno im Ģebirge meift nur als Straud erifter Grö̈ße vorfommt.

Die 2fhome verbeliern surd Saubabfall oen Boben mäpig, verlangen 
aber einen frudtbaren Boben, werben aljo fajon allein bephalb beffer in Untermengung mit ber Rotbbuche als in reinen Beftänden erzogen. .

\section{Die Efide.}

Feudjtigfeit ift Şauptbedingung ibrer Begetation; fie rächast fogar neben ber Erle in faft naffem Boben, bort aber weniger gut als auf Biess:

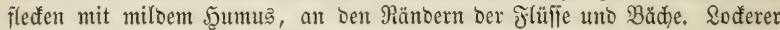
Boben ift ifr zujagender als fefter; auf leţterem gebeiht fie nur, wenn er Durd) Sुumus gelodert ift. Sie verlangt Frudhtbarfeit, verbefiert ben Boden aber nicht. Thalboben uno Flupboben zieht fie Dem Gsebirgs = uno Meeress= boben bor; Yekzterer barf aber nidht zu bintento fein. Neben einer ftarfen

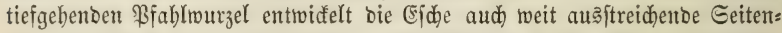

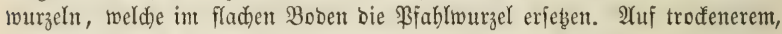
thonigen Boben ift Fr. pubescens ausgezeidnet rajdwüdfig.

\section{Die $\Re$ üfter.}

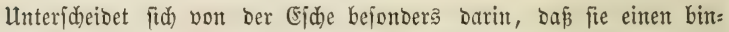
bentoren Boben liebt. Sie wädşt zmar ebenfalls im nafien Boben, liebt

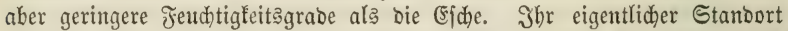
ift in ben Flupinieberungen mit binbendem Boben; man finbet fie jebod aud) im feudten bumuarreidyen Sant uno lebmigen Ganbboden, ja, fie fommt mitunter fogar mit ber (Erle gemeinj(daftlid) in ben nidft allzunaffen

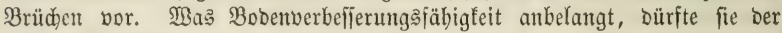

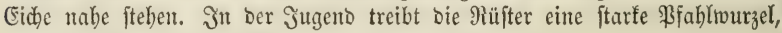
päter mebrere ftarfe tiefítreidento Seerjwurjeln.

Die Feloulme verträgt trodeneren Etandort als bie raube Ulme.

\section{Die Şainbude.}

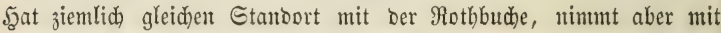
einem toeniger guten, troffencren, Yeidbtern, flad)eren uno bumusärmeren Boben vorlieb.

\section{Die Sinben.}

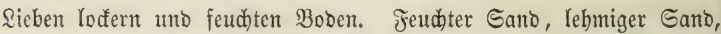
felbit nidjt ju naffer Brudboben fino ihr Etandort. Die Şerżourzel geft tief in ben Boben, ood) behilft fid bie Sinde aud auf fladgrünbigent Stanb= orte. 5ुumuąerzengung bebeuteno.

\section{Die $\mathfrak{B a p w e r n .}$}

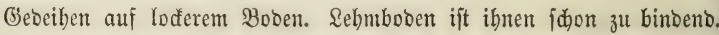
Der Bodent mú ferner in ber Dberfläche feudht fein, ba bie Wurzeln fehr flach berlaufent und bie freuchtigfeit nid)t aus ber Tiefe heraufholen fönnen. Trodenen uno binbentoen Boden verträgt nod) bie 3itterpappel. Sdwarz= uno Beippappel findet man fajt mur an fanbigen Ujern ber Seen, fłlüfle, Bäd)e. 


\section{Dritter $\mathfrak{A}$ (bjifutitt.}

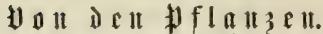

Den befdreibenden Raturwifienfidaften: ber Mineralogie, BD=

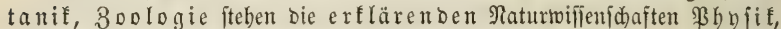
Chemie, Bhyfiologie zar Seite; erftere bie Befdaffenbeit en, lebtere

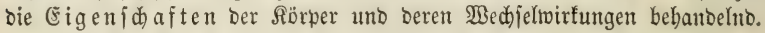

Die \$bbjif und bie Cbemie bejäaftigen fid mit ben (Eigenjajaften ber anorganifden, fowie berjenigen organifden Rörper, bie burh ben Iob beక Drganisntu: Der anorganifकen Rörpertwelt zurüdgegeben finb. Die ßby): fiologie bingegen bat biejenigen Eigenjdaften Des Drganifden zum Şegent=

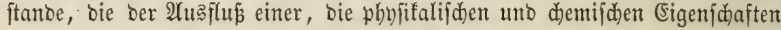
Der organifiten Materie beberridcenden \&ebenţ fraft 1 find.

In Der tobten Rörperwelt, Das torte Ibier, bie tobte Pflanze einge= (d) lofien, bejteht bas (s) D u $\mathrm{r}$ ( ) fid jelbjt fich zu betwegen, fid zu veränbern; jebe Betwegung, jebe Beränberung jeiner felbft, beruht auf Der Med)feltwirfung minoejtens ztoeier Sräfte: Die Büdjenfugel twürbe fortbauerno im Robre ruben, wenn nidjt Die treibende Rraft Des \$ulvers fie in Berwegung febte, fie mürbe in Frig= feit unveränbert bleiben, wenn nidjt ber Sauerftoff ber \&uft fie in Bleiajoche ummanbelte, dic Sitze fie jammölze, die Sdwere bes Sammers fie plattete.

Unter gleidsen äuberen Einflüfien find die Erfolge foldier

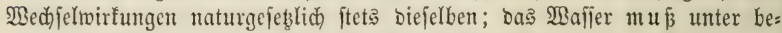
ftimmten Märntegraben in Dampf ober in Eis fich umbilben; loblenfauret Ralf $m u \tilde{\beta}$ unter Eintrirfung von Edrwefelfäure zu (s)ps fid umbanbeln; Waage, Thermometer uno Barometer, Das photographifche Bild, ber Iele: graphenorabt, Der Compais, die Dampfmajdine, die Epectralanalyje uno

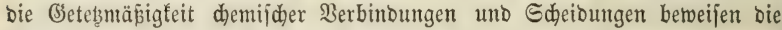
Unfeblbarfeit ber Bechfelmirfungen bes tobten Stoffs.

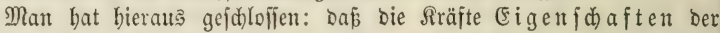
Materie uno bon lebsterer untrennbar fino; Daj es Stoffe obne bie ibnen

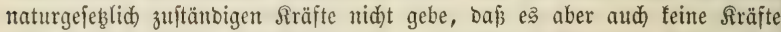
gebe obne ben ibnen zujtändigen Stofi - Dañ es feine förperloje Rräfte gebe.

Jn Befdräntung auf bie to bte Rörperwelt läpt fich) gegen bieje 2 In:

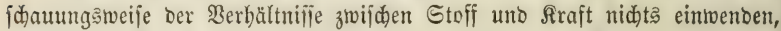
man fömte fie als wiffenfd)aftlid beredtigten Materialismus näber bezeidnen.

In neuerer 3eit ift man aber nod einen Edritt weiter gegangen, zur

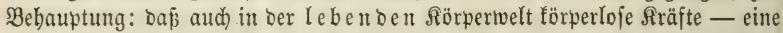

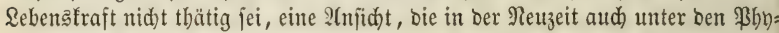
fiologen fajt alleinherrfbend getoorben ift, feit Siebig fie in bie \$braje fapste

\section{"Die Sebengftraft ijt ein \$opan?"}

\section{๖. h. ein Ding, bas nur in ber Einbiloung befteht.}

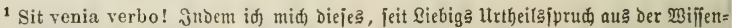
jafajt berbanuten 230 rtes bediene, halte id́) mid berpflidtet, nadjolgend bie Gründe aufjul=

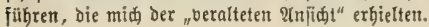


Jit bieje Anicht, bie id als Uniberfalmaterialismus bem wijienj(baftlid) beredtigten Materialismus gegenübergejtellt babe, beredtigt,

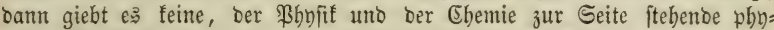

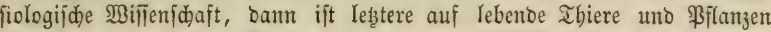
angewanote \$byfit und Chemie. Allein jene Bleidfitellung bes Sebenoigen uno bes Iobten in Bezug auf bie Berbältnilie zwij̄en Etofi uno Rraft ift eine rein willfürlide, Durd feine Ihatjache geredtfertigt uno wenn Riebig mit ber Natur ber lebenoen Pflanje näber befant gewejen wäre, würbe er jene, in ber Wiijenjhaft Epode madyente \$raje nidjt ausgejproden

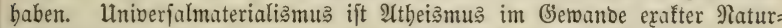

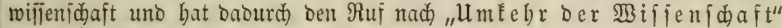

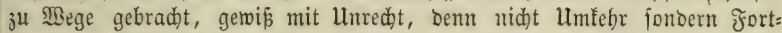

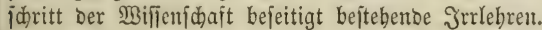

Man follte meinen, Dap eine Sehre, bie eben fo tief in bas bürger=

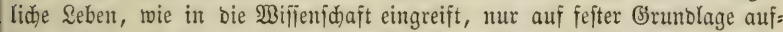
gebaut jein bürfe, begegnen bier aber ber größten Reidtfertigfeit. 2Ulle?

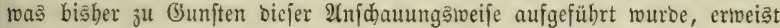
(iid) bei eingehenter Würbigung binfällig. Der bereḑtigte Materialis̄mus

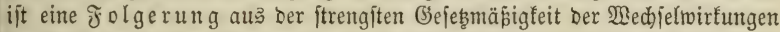

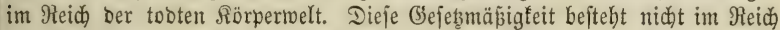

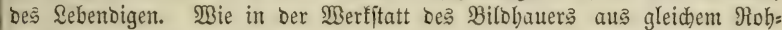
ftofie Berjobiebenartiges, aus beridiebenen Rohjtoffen (Sleidartiges unter

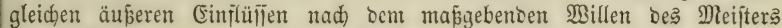
bergeftellt wirb, io audi in ber Merfftatt bes Sebendigen. Sumberte pon Thatjaḑen laffen jid für bieje Bebauptung anfübren. (o) eximere nutr an bie geidhledtliden Unterjojiede bei 3rillingageburten uno unter ben Gamenförnern aus Derfelben Jrudft, an bie Unteridiebe ber Jrudjt bes Edelreijes uno bes Wilolingaites auf Demielben Stamme in Etoffgebalt,

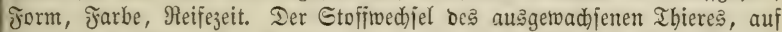
ben man fo übergrofes (Semid)t legte, daf man jelbit das Denfwermögen aus ifm herleiten mollte, ift ber lebenoen Pflanze fremo uno bas foblen= faure 2Ammoniaf zäblt eine größpere Menge von Elementen ala ber Szaupt= beftant bes Pflanzentörpers, ber Bellitoff.

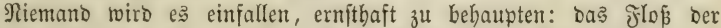
Eteinzeit habe burd) fich jelbit, burd) bie Sräfte feiner Bejtandtheile, fid

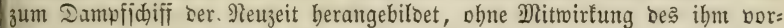

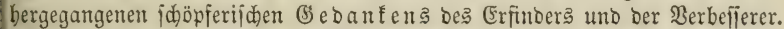

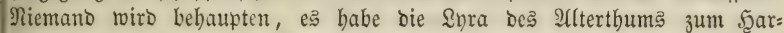
monion Der Jetbetzeit, Der Bogen zum Sinterlaber burd fich felbit fich ver: volltommet; Daß Şarmonion werbe im Serlauf "unbentbar langer" Beit= räume babin gelangen, wie bie Nadutigall fid felbit зu fpielen, bą Edjiff werbe bahin gelangen, fidh felbjt einem vorausbeftimmten Drte entgegen zu fteuen, ohne bie leitente 5̧and deక Eteuermants. Jebermann wirb ba= gegen zugeben, es jei bie bollendetite Majdine aus Menjwenbanto Rinber=

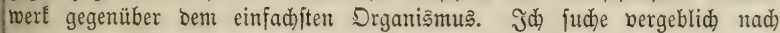
irgeno einer Beredtigung zur $\mathfrak{A}$ nnabme, das Sebendige ftebe allein unter

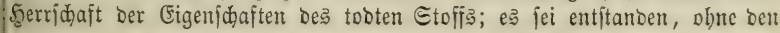




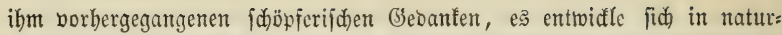
gefesblid) beftimmter $\mathfrak{B e i f e}$ aus Dem einfad)en, mifroffopifd fleinen Eiförper zum bollendeten Drganismus, ohne bie Mitwirfung einer Fübreridjaft, ohne weldye Der einfadjite Mechanismus feine ihm zuftänoigen Junftionen verfagt.

Die größ̄te Beweißłraft für bie Mitwirfung einer förperlofen Sonder= fraft in ber Merfftatt bes Sebentigen befibet für midh bie Thatjadje, baj in ber unzäblbaren Menge untergeoroneter Merfitätten, bie zujammen= genommen Den Gejammtorganismus bilben, bie veribiebenartigiten Arbeits= fräfte mit ben berfojiebenartigften Stoffen einem einbeitlidjen Biele bienftbar

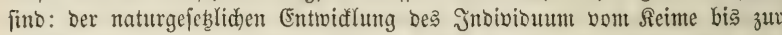
Blüthe. uno Frud tragenten Pflanze; ba ziehung zu einanoer ftehen, ber Reim nidjt ohne bie Samenlappen, bie

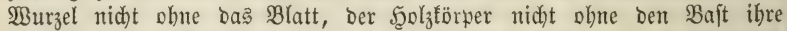
naturgefeblliden Berridhtungen zu bolljieben bermögen, wie bas Ihterreid nid)t obne ein ßflanzenreid, bas ßflanzenreich nidht ohne ein vorgebiloetes Eroreid), Thier, Bfilanze, Eroförper nidht ohne Sontenwirfung bejtehen fön=

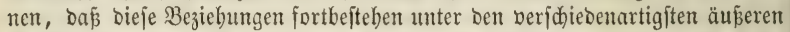
Einflüfien, vom Şodjommer zum Winter, in ber Meeresebene roie im Szod)= gebirge, im fruchtbaren, wie im unfrudtbaren Boben. Sid faun mir biefe

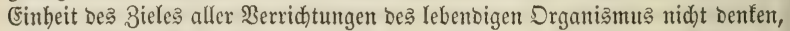
ohe bie Mitwirfung eiter fdaffenten, oronenden uno leitenton Rraft, bie nidht bie Eigenjd)aft cines cinzelnen Stoffa fein fann, eine förperlofe fein

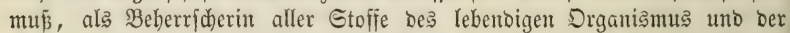
Sräfte Dellelben, renigitens liegt bis heute feine Erfabrung vor, Daßs Sum= mirung Der Rräfte Des Tobten Giftirung ober 2(bä̈berung ibrer Wedjel= wirfungen im Biefolge baben fömne.

Man faun bollfommen bamit einweritandon fein, baf aud im Se:

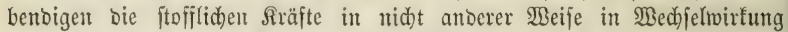

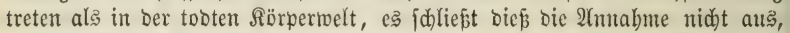

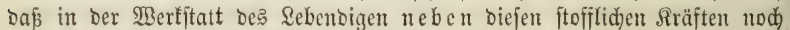
cine förperloje Sraft thätig ift, bie fid 3u Erifterer verbält wie ber $\mathfrak{B e r f}=$

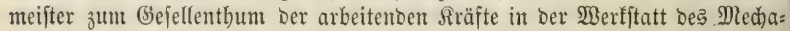
mifden, Der, ohne felbjt zu arbeiten, mur Dutrd Dronung uno Seitung ber

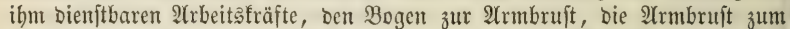
Jetergewehr umiduf. In biefem Sinne, Durd) bie Mitwirfung einer bie

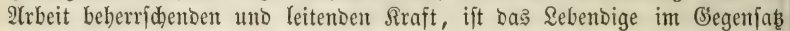

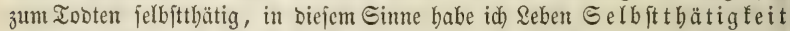
genamt, erfemubar burdh bie Unteridjiebe jwifden Sebenbem und Iobtem, wie Sidht, Wärme, Sdywertraft ebenfalls nur begreifbar fino burdh bie Unterfadiebe zwifden bellen uno bunfeln, warmen und falten, leidjten uno jdiwereren Rörpern.

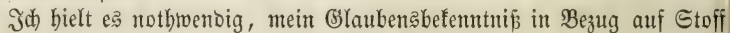
uno Rraft Des Rebendigen ben biologifden Betrad)tungen in Madfolgenoent bier voranzuftellen, um io nothwentiger als idd in ihm fait allein itebe. Dhne 3weifel hat Das Jorjhen nadh Dem Birfen ber ftofflichen fräfte im Rebentigen jeine volle Bered)tigung, es Darf aber nidht jum Ariom erboben, bie forfidung ber lebenden \$flanze entzogen uno in bie Rebrbüder ber 
Bhyif uno ber Shemie berlegt werben, wie bas beute vorherridento (bes braud ift, wenn wir in ber Erfenntnís bes Sebentigen boridgreiten wollen.

"Reben gab ihr bie Fabel, bie Edule bat fie entfeelet,

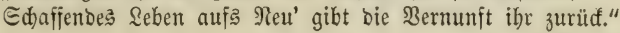

Sdiller.

Wie bie $\mathfrak{I} b a ̈ t i g f e i t$ einer $\mathfrak{u b r}$ erít erfannt merben fann, nachbem mant

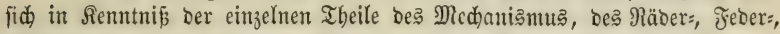
Rettentwerfs, ibrer 3ufammenftellung uno ibrer Berridjtungen gefebt bat, fo

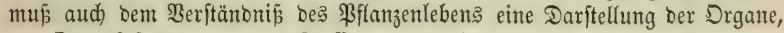
ber Drganiniteme und ber Stoffe vorausgehen ober zur Eeite ftehen, aus

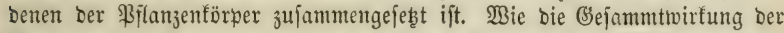
uhr auf Dem Inteinanbergreifen ber Einzeltwirfungen jener Majdjinentheile, io berubt bie Gefammtwirfung bes pflanjlicken Drganismmes, bie wir bas Pflanzenleben nenten, auf ber $\mathfrak{B}_{e d j e l w i r f u n g}$ veridiebentartiger Stoffe uno Sräfte in veridhiebenartigen, з廿 veridjiebenartigen Enjtemen gruppirten Elenten= tarorganten. Mag es immerhin Mand)em genügen, wenn er bas Iiden ber llbr bört, wenn er bie regelmäpige \$ెewegung beక Zeigers über bas Ziffer=

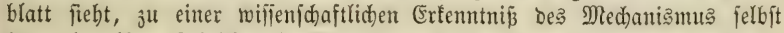
fann eine bierauf bejoräntte Betrad)tung nid)t fübren. Diefe twiffenfdaft= liche, aus ber Foridjung herborgegangene Erfentnif ift aber notbwentig, menn wir nid)t allen benjenigen Sinne morfen bleiben wollen, weld)e bie, bom Experiment niằt allfeitig geprüfte un๖ bewährte finnlidje Wabrnehmung (Beobad)tuntg) mit fid) führt. Die Beobadtung begnügt fich mit ber Wabrnebmung, fie zeigt, baj bie Sonne fide um bie Eroe betwegt, bie Forfdung prüft bie Beobadjtung

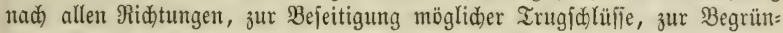
bung bes Raturgefebes.

Die Pflanzenphyfiologie ijt bie Brnundlage rationellen Pflanzenbaues.

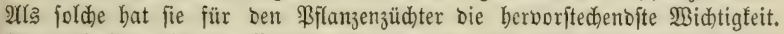
Die Şolzpflanze ift ber Mittelpunft, um ben fid) alles Ihun und Ireiben

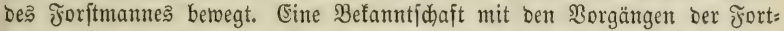

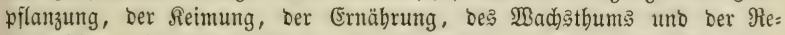
probuftion, eine Befanntid)aft nit ben Bebingungen bes ("̧edeibens ber Pflange ift ober follte boch bie Grundlage aller feiner, auf \$robuftion fid beziełenden Şandlungen fein. Freilich hat eine vieljährige Erfabrunty über bie Erfolge vorangegangener Betriebsopperationen eine \$rariis beక Betriebs geidaffen, in ber wir, aud) ohne näbere Renntniß bes \$flanzenlebens, bą

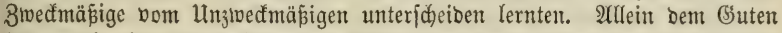
fanm nod ein uns unbefamites Beffere zur Seite ftehen uno dieß leb̨tere werben wir nur bann und um fo eher erforidjen, wenn wir unjerer Brartis eine Crrunblage uno einen \$rüfítein beigejellen, in ber wiffenjafaftlichen

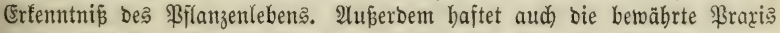
an ber Sdjolle. Was bier wahr unt ridjtig ift, fann bort falidi uno unt ridjtig fein. Die ridjtige Praries auf frember Sdholle werben wir ftets mur

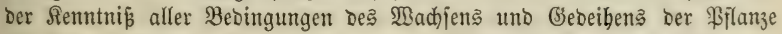

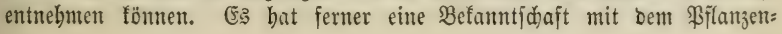




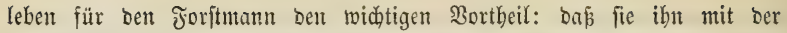

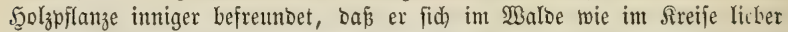
Freutnoe füblt; Daßs Snoppe uno Blatt, Blüthe unt Samentorn für ihn eine Epradhe geminten, bie ihn in ben einförmigiten Beruf̧gejdäften geiftig lebendig uno bewegt erhält. Der Sd)lenorian inftruirten Thuns wirb ba= burd) in ein geiftiges Sdaffen verwandelt, bas auf Den Sdaffenden felbit looblthätig zurüctwirft, indem es ifn ber Berbumpfung entżieht, bie fo

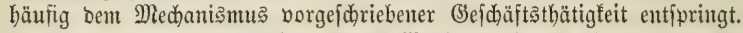

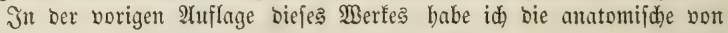
Der chemifden uno biologifden Betrad)tung ber Bflanze getrennt; in biejer neuen 2 ufflage bingegen ben ßerfud) gemad)t, Dieje (Eirzeltheile zu einer

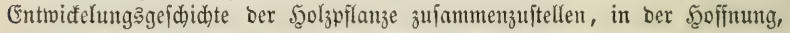

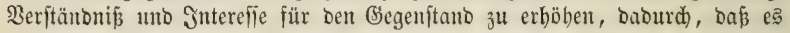
auf biefem Wege Yeidter wiro, bie gegenfeitigen Beziebungen ber Sinzel= theile uno (Einzelthätigfeiten Daržlftellen. Dem befieren Beritänonis hielt idh es ferner entfpredhend, in einem erften Sapitel biejenigen Ibeile bes Bflanzent= förpers einer morphologifden Betrad)tung zu untertwerfen, bie fdon bem un= bewaffneten 2 Age als unterichicoene Theile be \$flanzenförpers entgegentreten.

\section{Sirftes Gapitel.}

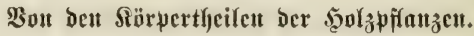

(9) Rorphologifiches.)

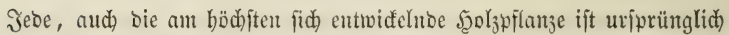

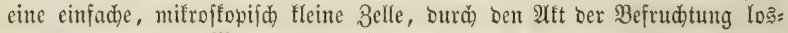
geriffent von einem Mutterförper gleid)er 2 frt unt zur felbittiäntoigen Fort= bilbung befäbigt.

Dieje im Reimfäddjen bes Santentorns lagembe llrzelfe bes pflantz= lidjen Jnbivibum vermebrt fid Durd) Gelbittheilung in Iodterzellen

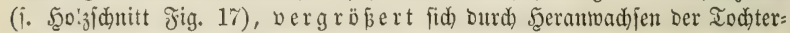
jellen zur Größe ber Mutterzelle ober barüber binaus.

Bieberbolt fid Diejer Borgang in Der Ridtung Derjelben urfprüng:

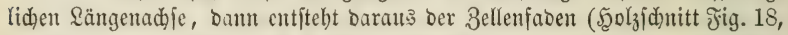

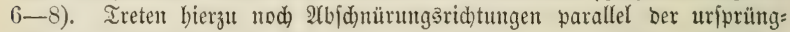
liden Sängenad)je, Dann geht baraus, unter ftetem Scerantwadjen ber Todjter= zellen zur Grö̈pe ber Mutterzelle, Der Bellentörper bervor ( รig. 10, 11).

Wie bie \$flanze fid aufbaut burd) Bellentheilung unt $\mathfrak{B a d}$ șthum Der Theilzellen zur (3röbe Der Mutterzellen, fo baut aud bie Einzelzelle fid

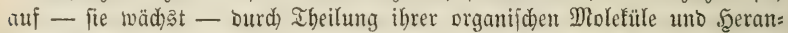

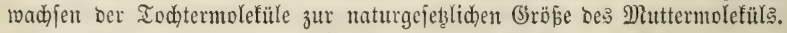
Mie bie Bejammtpflanze bas Material für ibr Wachjen Den Robftoffen Der fie umgebenden \&uft uno bes Bobens, fo entnimmt bie Einzelzelle bas

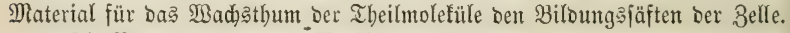

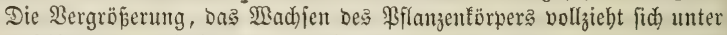
fehr beridiebenten Beftaltungen, theils veridicbener Sflanzenarten, theils 
veriducbener Sö̈rpertheile berielten Pflanzenart. Die erfte Urjade siejer gefess

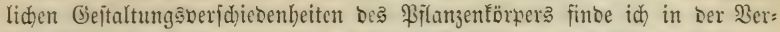

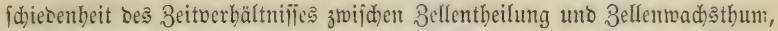

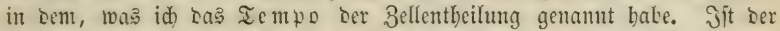

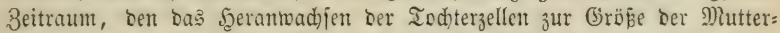
jelfen in Anjprud) nimmt, fürzer als ber Beitraum, in weld)em bie Thei= lungen mieberfebren, bann mur fann bie Iod)terzelle zur normalen B̧röß̈е ber Mntterzelle berantwadjen, wieberbolen fich bie Iteilungen in füržcren Beiträumen, sann erleisen bie Iodterzellen eine emente Theilung, che fie

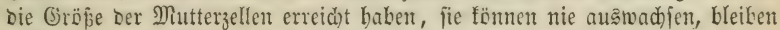
fleiner im Sergleid) zutr Mutterzelle als bie Theilung rajder fid wieber=

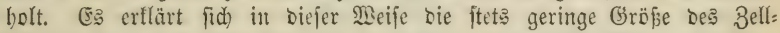

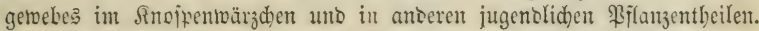

Denft man fid) in eiluem zelligen fiörper cin raidjeres Iempo ber

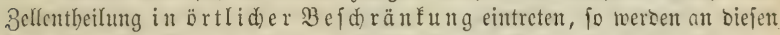
Drten Complere fleineren Bellgetwebes fid bilden (3. B. Şoljfanitt Fig. 53, a b).

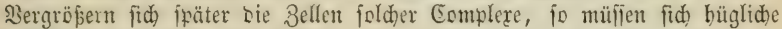
Erbebungen nad) $\mathscr{A}$ ufen bilton, ba in jeber anderen Ridtung ber zur Sergröberung nötbige Raum fehlt. SAuf Dieje SBeije entiteltt bie erite

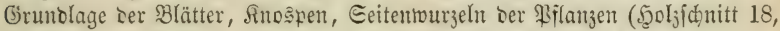
গig. 12, e d). 2(ui bie naturgejebslide Weridiebenbeit ber Drte, an Denen

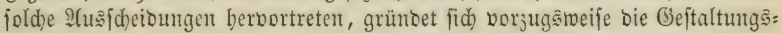

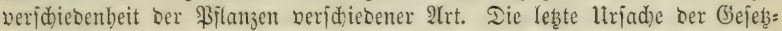
mäßjgfeit biejer Gejtaltungäberjobicbenbeiten wiro uns für immer verborgen bleiber.

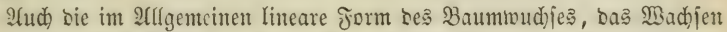

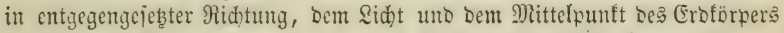

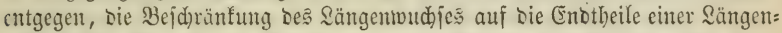
achje lafien fid auf bas Tempo ber Belfentbeilung zurüdfübren. Tie Thei=

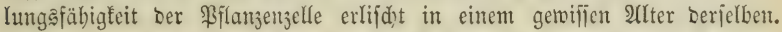
In ser Durd Ifeilung einer Mutterzelle uno burd) wicberbolte Ibeilung ihrer Iodterzelle entftandenen einfad)en Bellenreihe werben bie Mittelyeflen bie ältejten, bie Enozellent bie jüngften uno einer um jo lebhafteren Mehrung unterworfen, baher aud) um fo fleiner fein, je näber fie Den Endent bes Bellenfacens fteben, währeno in ber Mitte bes Bellenfabens bie Iheilungș=

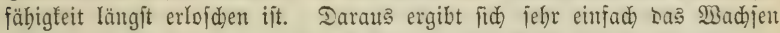

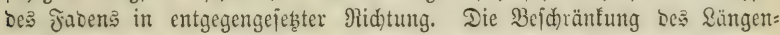
wudjes auf bie Enopunte Der Sängentadje, bie man auf bie zujammen= gejeb̧te Scolzpflanje übertragen fann, wenn man fid Den auf= und abitei= genden Etod berjelben, mutatis mutandis, zulammengejeb̧t benft aus vielen neben einanter liegenben Bellentreiben, beren Enozellen sas aufitei=

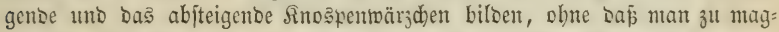
netija)er \$olarität oder bergleid)en 3uflud)t jut nebmen nötbig bat.

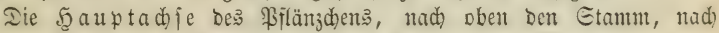
unten Die \$fabliwurzel bilbeno, zerfällt nad) ihrer Entwiaflungşrid)tung in

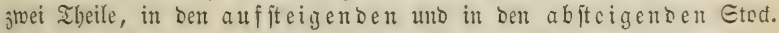

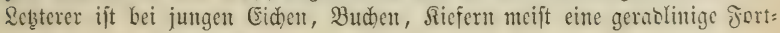




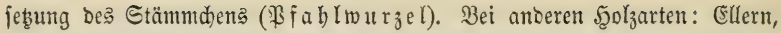
Jidten, Iannen zertheilt fid bie $\mathfrak{B}$ fablwurzel balo in mehrere, fdräg in

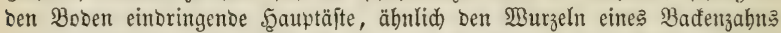

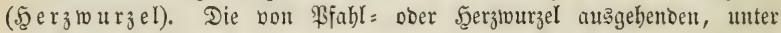
Der Bobenoberf(äb)e fortiftreicjenden, zu gröperer Stärfe herantwad)fenden

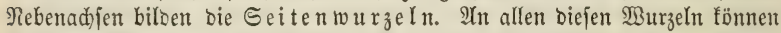
in jebem Altter junge Nebentadjen fid bilben, bie theiltweife nie zu bebeu= tender Stärfe herantwadjjen, alljährlid) furze, frautige Sprofien bildent;

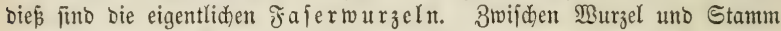

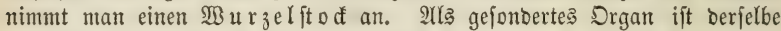

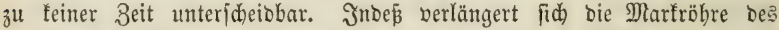
auffiteigenten Stodes mebr ober weniger weit in bie \$fahlmurzel hinab. Man fann benjenigen Theil berfelben, ser noch mit Marf auşgeftattet ift,

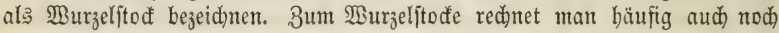
Denjenigen Theil Desె Stammes, an bem bie oberen Eeitentwurzeln, burdh excentrijhe Jabrringbildung, zum Theil über ben Boben binaus, in bie Şöbe geftiegen fino (Wurzelanlauf).

Man bat ferner bon einer zwifhen Surzel uno Stamm liegenden "inbifferenten Fläd)e" gejprodhen. Dieje Flädhe müp̈te ba liegen, wo bie crite Belle ber Pflanze bas eritemal zu zweien Todterzellen fid abgeidnürt bat. Für alle faäteren Zujtände ber Pflanze hat bie Phraje feinen Sinn, eben fo menig twie für einen ftabjörmigen Sirbitall, Der an feinen beioen Enopuntten burch Intabe neuer Theile fid verlängert.

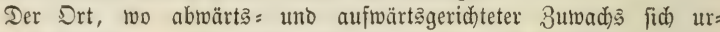
fprünglid) fdeiben - nid)t immer mit ber uriprünglid) inbifferenten Ouer: fläde zufammenfalleno, ift bei veridjiedenen \$flanzenarten verfdieden. Bei

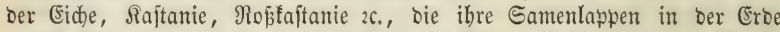
zurüđlafien, liegt er über biejen, bei ber Budie, Efdje, bei Den 2(born= arten liegt er unter ben Samenlappen. Tiefgefäeter Rabelboljame wäd) anfänglid) fnieförmig, aljo mit ztweien indifferenten Duerfläden aus bem Boben herbor.

Der auffteigende Stod bleibt entweber für immer einftänmig und entwickelt nur 3 weige, ober er beräftelt fid in gröperer soer geringerer 5ुöbe in eine aus $\mathfrak{A}$ eften uno 3 weigen zuammengejeţte Rrone. (5r:

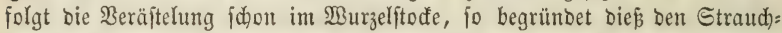

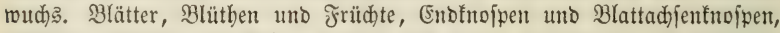
Ranten, Dornen, Stadyeln, Drüfen uno Şaare entftehen im normalen Berlaufe ber Entwidélung fteţ mur an Den jüngften Irieben ber Bezrweigung.

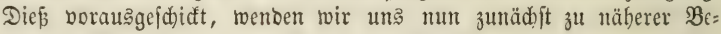
tradtung ber Rörpertheile bes aufitteigenden Stode?.

A. Der auffeigend Stodk.

Wir unterfheiben an ihm zunädyit

1) Ildiengebilbe - Etengel (Edaft), Itefte, 3weige und beren Entfnofpen;

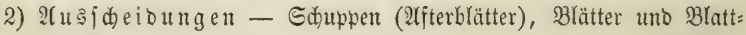
adjelftnofpen. 


\section{Bon ben $\mathfrak{A}$ diengebilben.}

Betradten wir, bermittelft einer guten Supe, ben mit eincm idjarfen Rajiermeijer geglätteten Dueridnitt eines einjäbrigen, fräftig gewadjenen

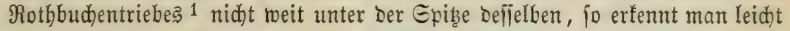
brei veridiebene Regionen, beren mittlere und äupere, aus einer grünlid̆ gefärbten, weidjen uno zelligen Subjtanz befteheno, bas $\mathfrak{M}$ a r $\mathfrak{f}$ unb bie $\Re$ in be ift, beibe gejdieben burdh eine concentrifche Edjidtung abroeidenter Färbung uno Struftur (รajeridjidt), bie ibrerjeits unterbrod)en ift burd) eine größere

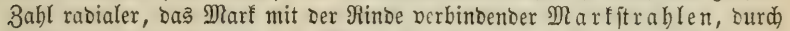

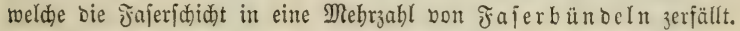

Die nebenjtebende frig. 1 jtellt ein Stüddhen eines einjäbrigen Rotbbudjentriebes in adt: maliger Sinearbergröferung bar. Eie zeigt oben bie freisförmige Queridnittfläd), ${ }^{2}$ in biejer Marf = und Rindezellgewebe getrennt burd) einen Rreis bon Jajerbündeln, bon benen ein jebes in einen äußeren Bafttörper uno in einen inneren Şolztörper zerfällt, twie dię bie einfache B̈renz= linie beiber anbeutet. Der feilförmige $\mathfrak{A}$ แ⿰氵 ¡dnitt an ber linfen Scite bes Triebftüd’s legt зum Theil ben rabialen ober biametralen \&ängen= idnitt frei und zeigt zwijden Marf und Rinbe ein Faferbüntol mit oreien borbeiftreidenoen Marfftrablen. Der vorbere tangentale Sängen: idnitt zeigt beiberfeits bas 3ellgewebe ber Rinde, bazwijhen bie gegenjeitige Beräjtelung ber Jajerbündel uno bie tremmenoen Marfitrabl= queridnitte.

テig. 1.

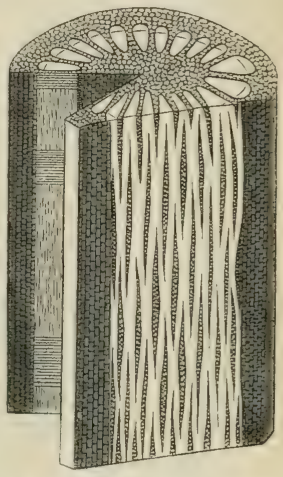

WBir mögen mun folde Sueridnitte aus ber Epibee ober aus ber Bajis Deß Triebes entmebmen, überall treten uns bie genannten brei Re=

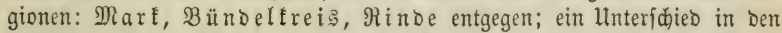
inneren, tieferen Theilen Des Edafts bejteht nur barin, daß̧ bie Fajer: bünbel nad Der Rinbe bin breiter werben und fid enger aneinanberlegent,

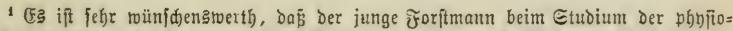

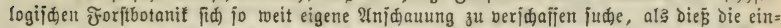

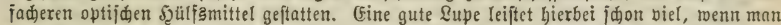

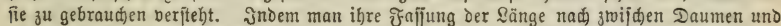

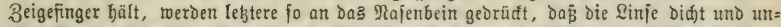

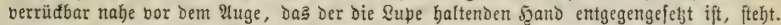
Der zu betradtende Begenjtand wird Dann in bie andere Sand genommen, und Dieje mit Der

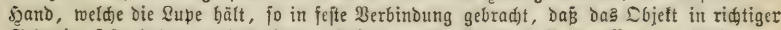
Eefreite feitgefalten werben tann. Feine bermittelit eines Rajirmeffers ju fertigenden

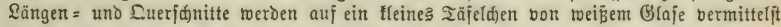
Wajfer feftgeflebt uno, gegen ben bellen Simmel gehalten, in vorerwähnter Weije betrađjtet.

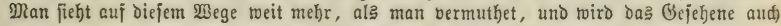
berftehen, wenn man es mit guten 2(bbildungen und (Ertlärungen vergleidłt.

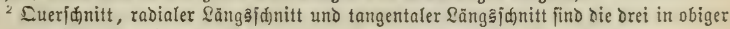

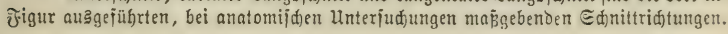


währento bem abiteigendent Etode (Wurzel) Das Mlarf fehlt unto ourd cin centrales Jaferbünoel erjebst ijt.

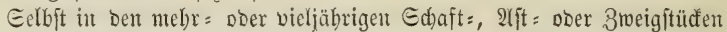
fintoen wir biejelben Drei Regionten wieber vor; Den Marfförner ziemlid) unveränbert, Den Fajerbündilfreis erweitert burd) Şinzutreten neuer ₹ajer:

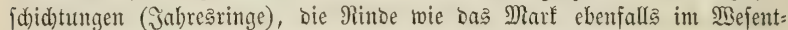
lidjen unveränbert, abgefehen von ber burd) bie 3̧ergröpermug ber Fajer:

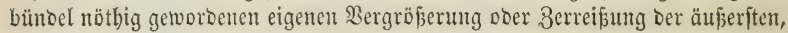
älteiften Rinbetbeile.

Diefelben Regionen wie Der Dueridnnitt zeigt uns aud ber rabiale

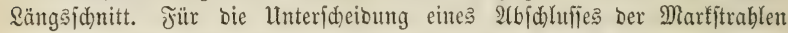
nad) Dben uno unten reid)t bas cinfad) Bergröferungg̈glas bier nid)t aus.

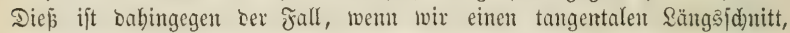
wie bie voroere fläche ber vorftehentoen Jigur, fo tief fübren, baf biefer

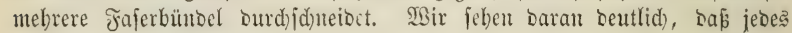
Der Bünoel nid)t vereinzelt vom Ciiffel bis zur Bafis bes Triebes hinab: Yäuft, fondern baß eine gegenjeitige \$eräftelung Derjelben ftattfinoet, im Bejentliden Darin beftebeno, Dara, in mebr ober weniger weiten 2rbitänben,

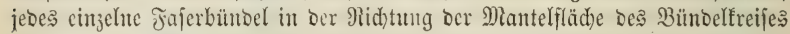

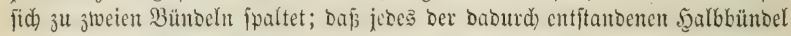
mit ben benad)barten f̧albbünbel ju einem (5anzbündel fid) bereint, bis eine crmeute (Sobeltheilung Des ungleid)=uriprünglid)en (heterogenen) Jajerbünoels Das gleid)=urjprünglifade (bontogene) Jaferbünoel wicber berftellt. Dieje fid) fortbauemb wieberbolente Babeltbeilung uno Micoervereinigung ocr Babel= theile jedes Jajerbüntels bat einen, im Iangentaljd)nitt fpindelförmigen Áfid)lu; des Marlftrablgewebes jur Jolge, wie bicjent bie vordere (tangentale) Sd)nittfläche ber voritelenden gig. 1 zh erfenmen gibt.

ซig. 2.

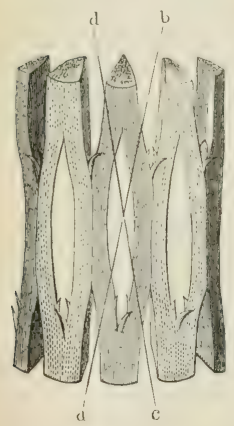

Die nebenftekenbe Fig. 2 mag bießs nod) näber

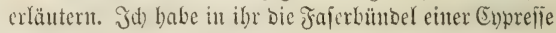
mit quirlförmiger Blattausfdeioung auseinanber uno in Die Ebente gelcgt, bie zu jeben Jajerbündel geljören= Den Ibeile abwedhielno burd) ganze uno burd) punttirte Sinien von einatioer unterichieben.

Diejer 2Anjidt entiprcchento wäre baber, abgejeben won bem als indivibulle Eigenjwaft nid)t felten auf: tretenden, gebrebten 23 ud) mandjer 50 lazplanzen, bie 2tufiteigung ber Fajerbünoel cine grablinige uno jent: red)te. Dießs beftätigt red)t überzengento bie $\mathfrak{A n a t o n i e}$ einjähriger Triebe ber Âtpenrante (Atragene alpina), won ber id) in ber nadjitebenton sig. 3 a bie oberften orei Snternobien ${ }^{1}$ mit ifren Sinofpen und Blattaus=

1 bei ben Gräjern, aber aud) bei mel)reren frautigen \$ftan=

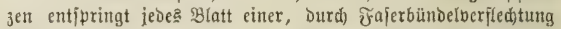
cutfitandenen, fnotigen Berbifung oes Etengela. Man nemt baber Das zrwijhen je zroei

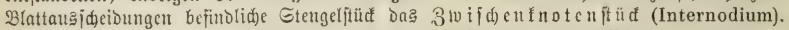

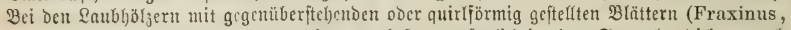

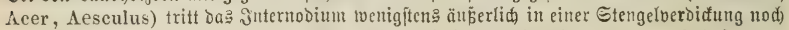

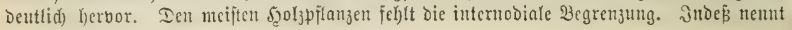


ideibungent gejeidunet babe. Rocht man Iriebe biejer 2 trt mebrere Tage hinourch, io läp̄t fich, mit einiger ßorjicht, Rinoe uno Baft fo vom Şol förper ber Fajerbünbel $a b=$ löjen, Daß̃ biejer unberleb̨t bleibt. Wäjoht man bann unter $\mathfrak{B a}$ ajer bas Marfge: webe mit einem feinen Pinfel aus, fo erbält man bą

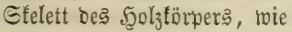
Dieß, vergrȫ̄ert, Jig. 3 b baritellt (wojelbjt jebod), des Raumes wegen, bie unteren Internodien im Berbältní̄ zur vergröß̄erten Breite etraa马 verfürzt gezeid)net werben mupten). In biejer รigur babe id, beijpielsweije nur am mittleren Jajerbünoel, bie bomogenen Strecten mit $\nabla$, bie Sabeltheile mit $V$, bie beterogenen Gtrecfen mit \| bezeidnet. Wie biefe Thei= lung uno 2 Bieberbereinigung ber getrennten Theile in Dueridnitten berfobiede= ner. Şöbe jid) zu erfennen gibt, zeigen Die Figuren $\mathrm{c}-\mathrm{g}$, entnommen benjenigen Stellen Des Triebes, bie in Fig. 3 b mit gleidem Bubditaben be= zeid)net fint. Jedes ber fed) Bünoel Des Dueridnittes c ijt in d z̆ brei Bündeln zer= ipalten, von benen Der mitt= lere zum Blatt auşjdecibet, je brei Mitteltbeile in einen

man Den Raum ztwij̄en ztweiell Blattausfacidungen aud ba nod) Internobium, too bie Blătter in einer ober in mebreren Spiral= linien bom Iriebe ausideiden ( $\mathrm{Fa}$ gus, Quercus, Pinus).

Die Summe alfer in cin uno Demijelben ふabre entwictelten $3 n=$ ternodien bildet Den Jahrestrieb.

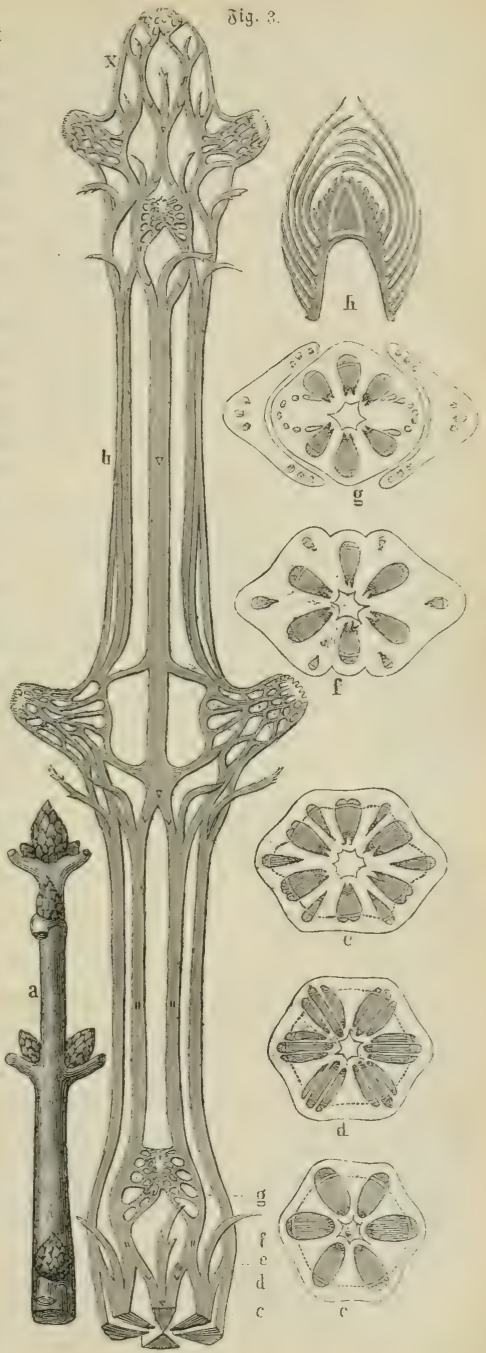


Blattítiel eingeheno, währento bie Seitentheile je zweier ఇadbarbünoel zu einem heterogenen Büntel zufammentreten (ef), worauf bant bie Beräfte= lung biejer zur Blattadjelfnojpe eintritt $(\mathrm{g})$, nadbem bie Mitteltbeile je oreier Bünoel zum Blattiftele uno Blatte fid emancipirt baben. (5) ift beadtensmerth, Dá⿱㇒㠯 bie Bujammenfę̧ung ber beterogenen Bündel an beren innerer Grenge ftets erfennbar bleibt, wie biep bie Queridnitte e $-g$ zeigen.

Wenn nut aud bie 24uffeigung jebes einzelnen Fajerbünols eine jent: red)te ijt, fo ftellen fid bod) bie, Durd) bie Beräftelung ber Fajerbünbel ent= ftehenden primitiben Marfitrabllücen ftets in eine um ben Trieb ver=

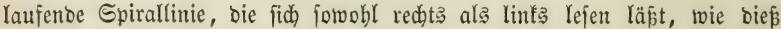
bie 乏inien a b uno e d in ber Fig. 2 anbenten. Jit bie 2tuffiteigung biejer

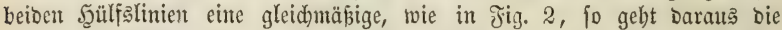
horizontale Sdjidjtoromung Der Marfitrabllüfen heroor, bie bann, wie wir fpäter fehen werben, bie gegenüberftänbige ober quirfförmige Blattftellung zur Folge hat; ijt hingegen bie 2luffteigung ber beiben Scülfslinien eine ungleidmäßjig fteile, wie in Jig. 6, Dam hat bieß eine fpiralige Dronung ber Blattitellung im Bsefolge.

Bie Jig. 3 zeigt, berfürzen fidh nad) Der Epize Des Iriebes bin bie Jnternobien immer mebr, die Jajerbünbel laufen endid in bie feinften,

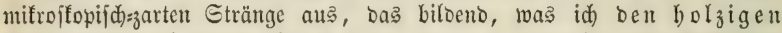
Snofpenfegel neme (Jig $3 \mathrm{~b}$ x), Der bie Srumblage Der Enofnope รig. 4. (Terminalfnoipe) deș Iriebes bilbet. Dic leb̨ten Bündełaus:

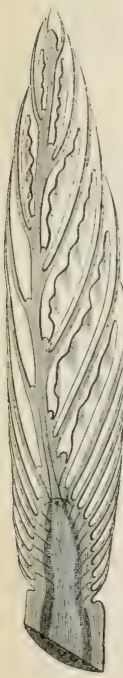
fideibungen bes Sinofpenfegels entrideln fich nidjt mebr zu 3lätten, fonbent zu Sinofpendecten, bie cin frautiges, ben fertigen Tricb frönentes Gebiloe einfobliefen, bas nidhts an= Deres ift, als ber vorgebildete, nädit jährige \&ängen= trieb in einem mebr ober weniger entwidfelten 3uftanbe.

Die bödjte Etufe ber Entwiđłlung De: nädjitiăbrigen Triebes bietet uns bie Rothbud)enfnofpe, von ber id neben= ftehent, Jig. 4, bic viermal vergrößerte 2(nfid)t eineş \&ängen= Durdjidnitts gebe. Der holzige Snofpenfegel, aljo Derjenige Theil ber Snofpe, ber noch bem diejjährigen \&ängentriebe

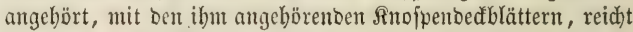
bis zu Dem mit * bezeid)neten ßunfte oer Marfröbre binauf.

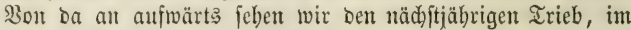
fleinen Masitabe zwar, aber mit allen ibm angebörenben

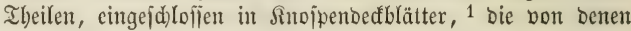

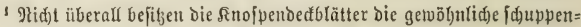
förmige, blattäbnliđe Gef̣talt. Bet Salix, Magnolia, Liriodendron, Platanus, Viburnum, Staphylea find bie Dedfen fappenförmig geid)loffen. gRan pflegt in ähnlid)en fällen dię̆ aus einer Berwađjung Der Blattränder herzuleiten, uno in ber That zeigt fid aud) eine bem entipredende תappen=

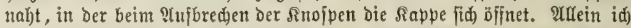
habe nad)gerviejen (bot. 3tg. 1855 ङ.223), Daß̄ die fiappenform Der S̨ülfen bei Salix und Magnolia uriprüngliđ ift, Daß̉ fie aug einer innern fappens förmigen Spaltung Des 3ellgetwebes herborgebe. Da, wo nie eitte Tren=

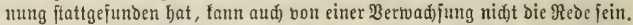

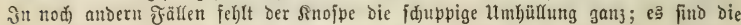
lebten, verfümmerten, aber normal entwifelten glätter, toeldhe an beren Stelfe treten. 
Des holjigen Sinofpentegels nidjt verfotieben fint. Wir feben ben \&ängen= trieb mit eben fo vielen $\mathfrak{B l a ̈ t t e r n ~ b e j e b ̧ t , ~ a ł ̧ ~ a m ~ n a ̈ d j t j a ̈ b r i g e n ~ T r i e b e ~ u ̈ b e r = ~}$ baupt entiftehen; wir jehen an ber Bajis bes Blattitiels, im Winfel zwifden ihr unto Dem Etengel fleine $\mathfrak{B a ̈ r}$ żden, bie im fommenden Jahre zu Blatt= adjelfnofpen fid aušbiloen, bie in ber Blüthefnofpe fdon in biejem Jahre

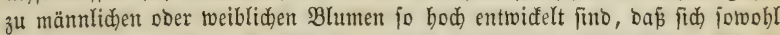
Die Staubfäben als bie Jrudtffnoten, felbjt bie Eier ber nädjitjährigen Blüthe

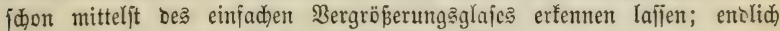
entipringt unter jebem Blatte ein Rnoppendeçblatt.

(Einen nid)t minber hoben Entwidflungäzuftano des näditjäbrigen Triebes

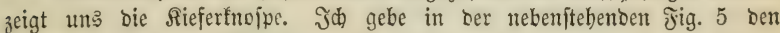
Qängenjonnitt einer Enofnojpe ber Sdhwarzfiefer in nur zweimaliger $\mathfrak{B}$ : gröperung, an beren unterer Duer:

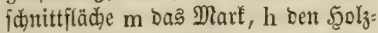
förper Des Rnofpentegels, b bie Baft=

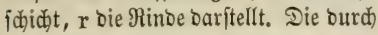
jenfredhte Stridje bezeidnete Er= ftredung Des holzigen Rnoipentegels reiăt bis zum eriten Dritttbeil ber Sinofpenlänge binauf uno feilt fid bort aus, während bie an ber inneren

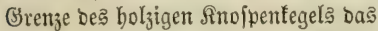
Mark begrenjenten, in ber 2 bbbil= Dung burd) bunflere Dueridnitte be= zeidneten Spiralfajern, umunterbro:

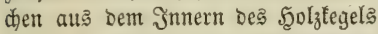
bia nahe zur Spişe bes nädjitjährigen Triebes auffteigen. 2leuperlid) ift ber holzige Inojpentegel burd bie Baft= idicht begrenzt, bie in ber Arbbiloung Durd) zartere Duerlinien bejeidnet ซig. 5. ซig. $7 . \quad$ ซig. 6. murbe. Dieje Bajticjidst jeķt fich ebenfalls ununterbrod)en nad) oben bin in Den näditijährigen Trieb fort, befteht bort aber aus ben Elementen eineß

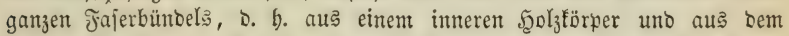

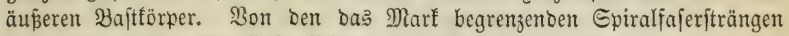

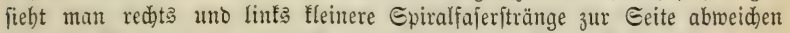
uno als Blattnero in jebes Snojpendecáblatt eingehen. Didyt über biejer einfadjen, zum Dectblatte gewenteten Bünbelabzlweigunt zeigen fid nod) żwei andere, zur Blattadjelfnojpe getwenbete Bündelwerzweigungen (₹ig. 7), bie id), Der geringen $\mathfrak{B}$ ergröperung wegen, in Fig. 5 nidht mit aufgenommen

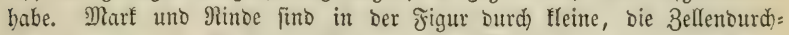
fantitte andeutende Sireife femntlid gemadht. Man fieht, wie in Der Epib̨e

So bei (Cornus, Evonymus, Viburnum (Lantana), Ligustrum, Frangula, Hippophäe, Anona, Halesia, Hamamalis, Fothergilla, Rhus, Clethra, Pterocarya. (E̋ jino Uinter=

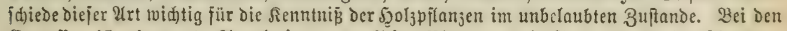

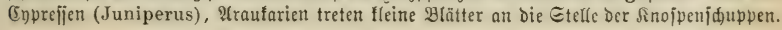




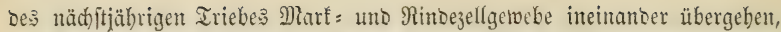

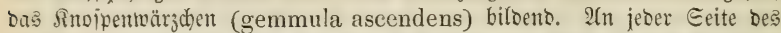

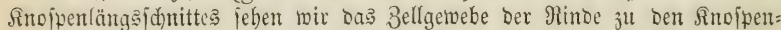
Dectblättern fid erweitern uno über ber Bajis eines jeben Dectblattes eine Blattadjelfnofpe böher entwicelt als bei ber Rotbbude, inbem, wie Jig. 7 Deutlicher zeigt, an ifnen, außer ber Grumolage bes fünftigen Nabelpaares, aud) Die baffelbe fünitig einjolliefenton Scheibeblätter bereits vorgebildoet jino. (Die weitere Entwiflung 3un Nabelbüfdel ift in ben Fiç. 12 a umb 9-11 Dargeftellt.) 2(ud) Gier fint, wie bei ber Rothbud)e, dieje Blatt= adjelfnoipen in ber Bläthefnofpe theifweife zur Blüthefnofpe fonon im Serbjte vor ber Blüthezeit höher entwidelt.

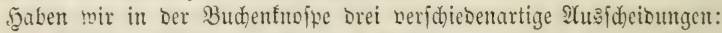
Sinojpendedblätter, Blätter uno Blattadfelfnojpen, fo treten bei ber Siefer mur lebtere uno Deçblätter auf.

Rod)t man möglidjt groje, frifhe sinopen ber Edwarzfiefer mebrere Tage binourd) in reinem 2Bailer, fo läpt fid Baft uno Pinde, mit ben Der leb̧teren anfängenoen Ibeilen, vont Jeblytörper ablöfen. Mtau crbält

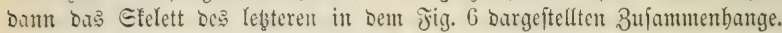
Der bort gezeid)nete Iheil entipridht bemjenigen Ibeile in Jig. 5, Der über * befindlid) ijt. Bäblung ber Mlarffitrabllüften uno Der an ber Bajis einer jeben Rüfe entjpringenten Blattausijheioungen ergibt: Daj bie Befanmtzahl

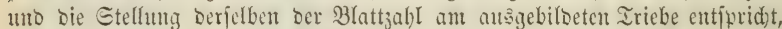
Daj baher aud bier alle Theile bes nädjitiäbrigen Iriebes jdyon in oer

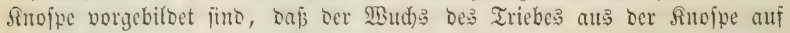
3mijdenbilsungen burd) Bellen = uno Jafertheilung, wie auf Bergrößerung Der bereits borbanoenen Elementarorgane berubt; eine Thatjadhe, bie nod) überjengenoer an Biflanzen mit moftündiger Blüthe (Adesculus, Acer, Cornus etc.) bervortritt, in beren Blütfofnofpen bic Blüthe ebcnfalls bereits vorgebiloet ift.

All ein Beifpiel geringerer Entwicflung Des näd)itjäfrigen Iriebes jeben wir in ber vorangejtellten Fig. 3, bei h bie Enofnojpe volt Atragene

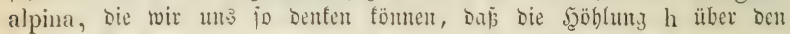
holzigen Sinopentegel $x$ ber Jig. b geitülpt ijt. Bwifhen ben, bem bol= jigen sindipentegel cntipringenden Sinoipenbedblättern felen wir Den \&ängen=

รig. $\cdot 8$.

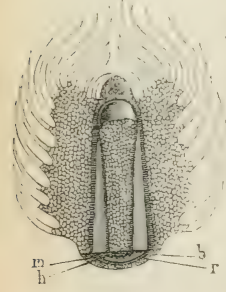

idnitt Des nädjitjäbrigen Triebes in Der form eine paratolribifchen Regels, bejtelento aus nod) äuḃerft zarten, fleinen Bellen, żwijden Denen ber Fajerbünoel: freis einen frübejtent cambialen 3uftano nod) nid)t überichritten bat, jo Daßs bas Mitrojtop ben Berlauf ber Jajerbünod mur ourd) bie bellere järbung zu erfenten vermag. Demumeradtet feben wir im $\mathfrak{H}$ : fange bes nädjitjährigen Triebes nid)t allein bie $\mathfrak{A}$ it: fänge ber nädjitjäbrigen $\mathfrak{B l a ̈ t t e r , ~ f o n b e r n ~ a u c h ) ~ n o c h ~}$ bie ibnen entipredentoen Blattadjelfnopent.

Diep leb̧tere ift nidyt mebr ber Fall in ber Fidutent= fnojpe, bon ber idj Jig. 8 einen Rängenjantitt gebe,

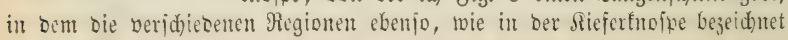




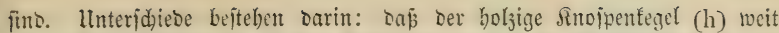
böber binaufreidt, als in oer Sieferfnopipe; D.rf Die Marfmalle nicht bis

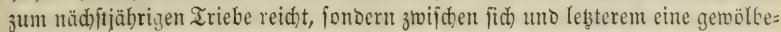

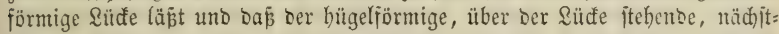
jäbrige Irieb ganz aus cambialen Bellen beftebt, bie fo tlein fino, Dafs fich berent äupere Begrenzung uno Jormunterjobiebe, jelbjt bei febr fturfer $\mathfrak{B}$ er: gröperung, faum erfemten lailen. Dem entiprecheno fino benn auth bie

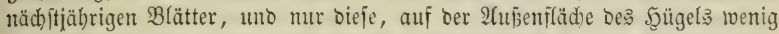
herbortretend, zeigen aber jøon jebst sie ipiralige Stellung, bie jie am nädhit= jäbrigen Iriebe eimnebmen, wovon man fid) burd) (ntichuppung eimer Fidten=

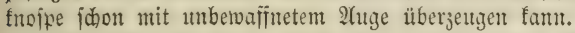

So jeben mir Denn, jelbit bei nabeverwanoten Bjlanjen (Riefer uno Jichte - Rotbbuche uno (Ëide), die anticipirte Biloung Des nächitjäbrigen Iriebes in Der Rnojpe auf jebr verichieben vorgejdrittener Entroidlungsitufe.

Ueberbliden wir bas Gejagte nun nod eimmal in Der Sïrze. Wir jeben, oufj ber aufiteigenbe Stod in jeinen 2Abjengebiloen aus einet cylin: brijden Bellgewebsmalle bejtebe, die, in einer inneren Mantelfläche, burd) eirten Rreis fid gegenfeitig beräftelnber Jajerbünbeln in Marf uno Rinbe gejdicben ijt, beibe unter fïh verbutoen Durd) bas, Die Beräftelungslücten Des Jajergemebes füllende Marfitrablgetwebe. In Der Epibe bes fertigen

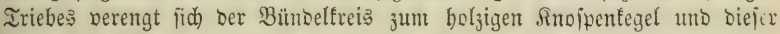
trägt über fich ein anticipirt entwicfeltes Gebilbe, sen nädjifjälbrigen, mebr Doer weniger weit ausgebilbeten \&ängentrieb, umgeben bon Rnoppenbed: blättern und mit diejen die Enofnofpe biloeno.

Yeite uno Breige entiteben, wie wir ifäter fehen werben, aus Blatt= adjelfnopen. WBie die Blattadjelfnofpe in ibrem Bunte yon ber Enofnoipe Des Echaftriebes nidht veridhieben ift (Jig. 3), fo unterideiben fich aud)

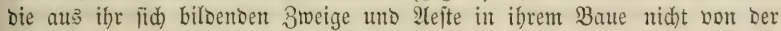

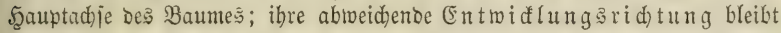
Der einjige Dauernoe Interfafied, uno jelbit bieje fann in bie Entroidfungs: ridfung Der Şauptadje fid) veränbern, wem leţtere abjtirbt ober getwaltjam berfürăt roiro.

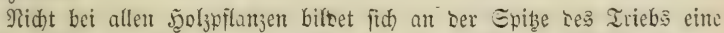
malyre Enofnope. Bei Den 5oljpilanjen mit enditänoiger Blüthe (Acer,

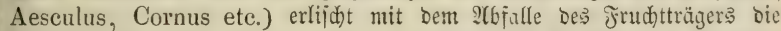
Jortjeb̧ung Derjelben Sängenahje für immer; eine Eeitentnojpe entwicfelt

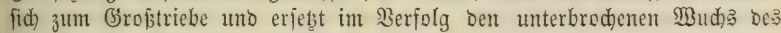
Sुamttriebs. 2(ud) allen ähten Dormäiten an Prunus spinosa, Crataegus, Pyrus, Ononis, Ulex, Genista, Catharticus, Hyppophäe fehlt dic Enofnoipe, das Marf gebt in Der Epibe biejer Triebe unbebect zu Iage. Bei Carpinus, Corylus, Betula, Salix, bei Platanus, Ulmus, Morus, bei Ailanthus, Catalpa, Paulownia, Rhus, Cephalanthus, bei Gymnoclades, Robinia, Cercis, bei Vitis, Ampelopsis, Periploca, Aristolochia, bei Syringa, Staphylea, Viburnum, Philadelphus, Laurus (Berjoirt), Calycanthus, bei Sambucus, Berberis, Lycium, Spiraea und bei bielen anderen Gtraudböljern verfümmert bie Endfnoppe regel: mäp̈ig; die lebsten Internobien bes Iriebes werben abgetworfen, oft, twic 
an ber Blattnarbe, mit beutlider Rifienbiloung (Tilia, 1 Ptelea, Ailanthus, Cereis, Gymnoclades, Direa) ober ohne Rilienbilloung wie mit bem Mefier abgeiänitten (Carpinus, Salix, Morus, Catalpa) ober ver= bunben mit einem tiefer binab eintretenten 2 biterben ber Iriebipibe (Robinia, Amorpha, Sambucus, Spiraea). Jn allen biefen fällen tritt bie näbjite Ydjelfnofpe an bie Stelle ber Enotnojpe, bie bei Syringa uno Staphylea ausెnabmsmeife noch zur 2tuabiloung fommt, Dann aber fehr verfümmert auftritt.

Man Darf es Daber nid)t flimatifden (Einflüfien zufdreiben, fondern

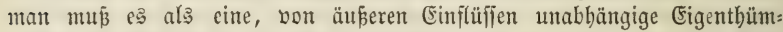
lidefeit ber Gattungen ober $\mathfrak{A}$ rten arjehen, baj bie oben genannten $\mathfrak{S g l}_{3}=$ arten ibre Jabrestriebe ourd) Terminalfnofpenbiloung nidjt zum 21bidlunfe bringen. Bei Robinia, Amorpha, Spiraea, Sambucus, an benen bie leksten Internodien bis zum Serbjte lebentig bleiben uno erit burd ben jroft getöbtet werben, fönnte man bie Erficeinung wobl aus bem 2 Uufbören Der Saftberwegung bei nod) unvollenbeter $\mathfrak{A}$ ubiloung ber Iriebipibe er: flären; ba bingegen, wo bie Entofnofpe fdon im Sommer an bem nod) fräftig madjenten Iriebe abortirt, two bidst unter ihr Geitenfnofpen zu bollfommener Entwidelung gelangen (Philadelphus, Syringa, Staphylea),

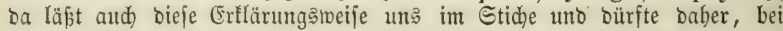
bem unvertentubaren 3ujammentange bes Urjäd)lid)en, auch auf Robinia ete. nidjt antwenobar fein.

Bei Den 1 mpelibeen finbet anperbem ein merfwürbiges Sdwanten in Der Entridefelung Der einzelnen Internobien Des Jahrestriebs ftatt. Mäbreno

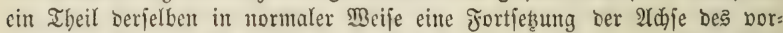
bandenen Stengelgliebes ift und an feiner Bapis Blatt uno Blattadjel= fnofpe trägt, entrvidelı fid, meift alternirento, anbere Stengelglieber au? Der Blattadjelfnofpe uno bie Scauptadje abortirt entweder, ober fie fdeibet

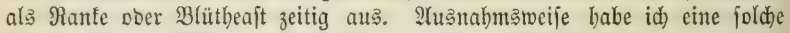
Fortjeb̧ung bes 21djengebiloes aus ber Blattadjeltnojpe aud an fräftigen

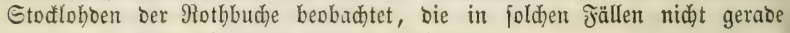
jondern an jeoer Blattbafis minflid verlaufen.

Bei wenig Şolzpflanzen bleibt bie uriprünglide Şauptadje bes Embrno für immer vorberrideno. Fid)te, Iame, Särdje gebören babin. Sdyon bei ben Siefern ift bas nut bis zum 80. bis 90. Jabre ber fall. Jn biefem alter bleibt bie Scauptadje in ibrer Entwidelung binter ber ber Nebenadjen zurüc, ę bilset fid baburd) eine mehr ober weniger fdjirm: förmige Sirone. Şei Den einheimif̧en \&aubholzbäumen tritt ein bleibendes

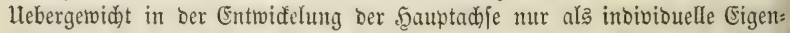

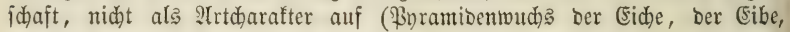

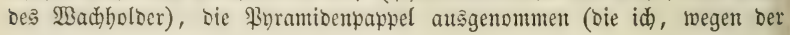

1 23ie an Blattnarben, fo fieht man fier an Der Enofnoppennarbe bie einjelnen Fajer= bïndel tlein und bon einander entfernt fteben. Der 2 (bidhth bes Triebes in der Enonarbe

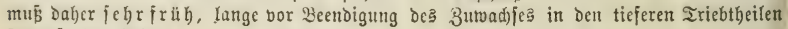
ftattgefunden baben.

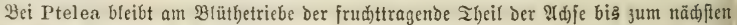

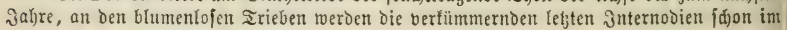
Jabre ber Triebbiloung abgejtōen! 


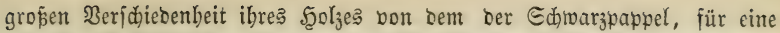
gute $2(r t$ balte). Der Birnbaum im Bergleid) zum 2 pfelbaume, ber Gü firidbaum im Bergleidh zum Eaurfiridbaum zeigen ebenfalls nod ein, lange 3eit bauembes Borberrfden ber Sauptadje. Die meiften Raubholy= bäume, im శreien uno obne äuseren 3rwang erwadjen, berlieren fojon bor Dem 50. bis 60. Jahre Das Uebergetwidt Der Scauptadje uno fajreiten zur Sronenbiloung, früber auf ungünftigem alङ auf günftigent Stanoorte. $2(m$ meiften ift biés ber Fall bei Weiben unb \$appeln, Fiden, Rothbudhen uno Scainbuchen, bie nur burd) ftete Erz̧iehung im Edhlū langidaftig er: balten werben, weniger bei Ejoben, 2Hbornen, Rätern, am wenigiten bei Birfen uno Erlen. Der Straudjwuḑ berubt auf einer Beräftelung fojon

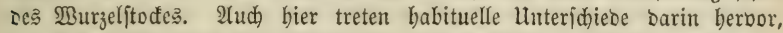

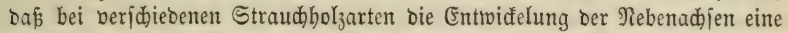
veridjiebene ift, theils bie Entwičelung Der Şauptadje überflügelno: Bletider=

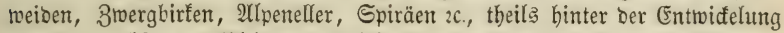

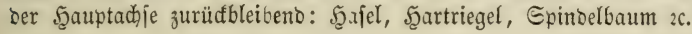

\section{Bon ben $\mathfrak{A}$ แฺd cibungen.}

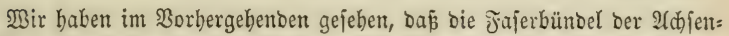
gebilìe unter fid einer gegenjeitigen Beräftelung unterworfen feien uno

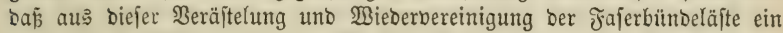

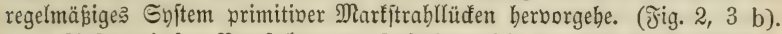

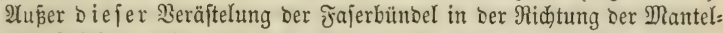
fläde bes Iriebes, tritt nun nod) eine, nad a úpen geriditete Ber= äftelung berjelben Fajerbünbel ein, Deren Uriprung ftets bas untere Enoe Der primitiven Marfiftrahllüđe ift.

Bereits Seite 133 habe id gezeigt uno burd, bie Figur 3, b-g

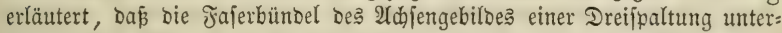
worfen feien (テ̛ig. 3, b d) uno bafis ber mittlere biejer brei Bünoeltheile

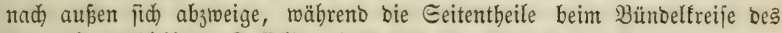
Gtengels verbleiben. Daflelbe zeigen unt bie figuren 2 uno 6 .

Bei ben meiften Mabelhölzern ift es nur ein Mitteltheil ber Fajer:

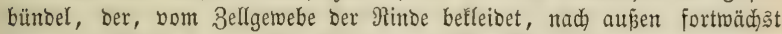
uno zum Blatte twiro. Jebe primitive Marfitrabllüfe liefert bier ein einnerviges Blatt (Fig. 2, 6, 9 c). Die 3ahl ber Blätter ober ber Blatt= fdeiden eines Iriebes entipridt Daher Der Bahl uriprünglider Marfftrabl=

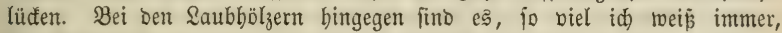

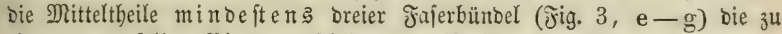
ein und bemielben Blatte ausjojeiben, meift fibon im Blattítiele einer er= neuten Theilung unterworfen (テ̌ig. 3, g), in Der Blattideibe fich gegen=

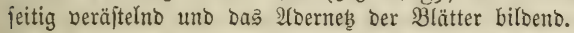

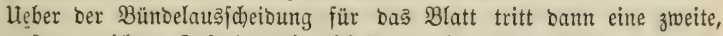

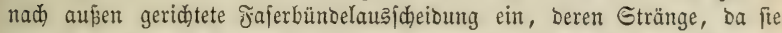
von zwei ober mebreren Faferbündeln ausgeben, fid jodon uriprünglid,

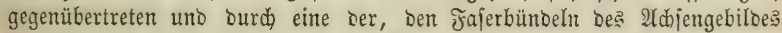
ähnlidhe ober gleid)e Weräftelung uno \$Biedervereinigung, einen felbititänbigen 
Faferbündelfreis bi(ben. Nirgends pprid)t fid) bießs fo flar unb überzengento aus, als im Efelett bes holjigen Rnoppentegels ber Blattadfelftrofpen von Atragene alpina, Das in Fig. 3 a viermal in ber Seitenanfid)t, zlweimal in ber 2fufficht bargeftellt ift. In ber That ift hier ber holjige Smofpen= fegel für bie Blattadjelfnojpe, von bem für bie Enofnojpe, im WBefent: liden nid)t berfdieden uno wir fönnen uns bie Crgänzungäfigur 3, ebenjo über jeocs Blattadjelfnofpenffelett, wie über bas (Enofnopenffelett $x$ ge: ftülpt Denten. Damit find bunn aud) alle Bebingungen einer, Der Fort=

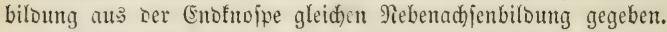

2fud) bierin einfad)er ift bie Bündelauşfheibung für bie Blattadjel=

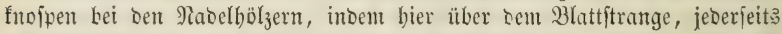

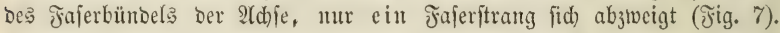
Gegenüberfteheno laufen beioe unveräftelt bis zur Blattadfelfnofpe uno geben

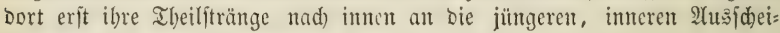
Dungelt $a b$.

Man tönnte hierans leid)t ju bor 2(nfid)t gelangen, es jei bie Bünbel=

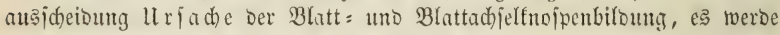

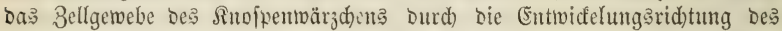
Fajergetwebes nad) aupen getrieben uno zur 31latt = uno Snofpenbiloung Disponirt. Dem widerjpridht die Thatfade: Daf im Embryo 3. 3. Der Riefer

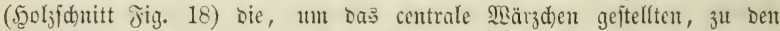
Blättern berunvadjenden zelliyen Saügel fdon ba jino, che nod eine Differen: zirung bos Bellgewebes in Bellen uno fajern eingetreten ift. Thud im näd)itjäbrigen Triebe ber Fid)tentnojpe (Jig. 8) fehon tvir bie Blätter fdjon über bie Sberiläd)e bes fleinten Sä̈gels bervortreten, che nodh cine 206 : jweigung von Jajerbündeln zu ibnen bemertbar ift. Dafielbe zeigt jebe

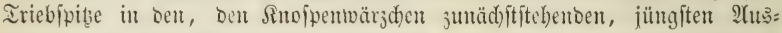
fdeibungen. Wir müfifen Daher annebmen, daj, wie bei ben Bellenpflantent

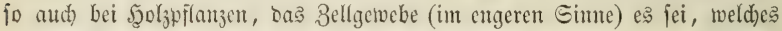
bie ber Prlanzenart eigentbümlidje Entwicelungşrid)tung uno formbiloung

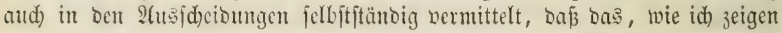
merbe, ans cinter ltntwandlung vorgebildetir Bellen entftehente Fafergetwebe aud) in jeiner (Entwidelungsrid)tung ber bes 3ellgewebes nad)folgt.

\section{a. Die Blattaugidecibung.}

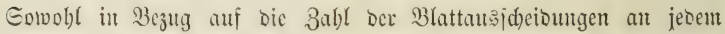

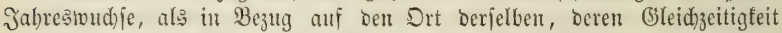
ober 2fufecutanderfolge, beren Beilenzahl unb Beilentichtung, zeigt fid bei verjdiebentn Bflanjengattungen cine berjdiebene, imterbalb getwiffer Brenzen mathematijd) Gejekzmäpigfeit, bie nidgt allein ein wejentliḑes Moment to: tanifher llnterfideioung entbält, fontoen baburd) auch bou ted)nifder $B e=$ Deutung ijt, baj von ber Blattitellung bie Rnoppenftelhung, von ber Rnofpen: ftellung bic 3weigitellung uno Beräftelunty, von Yeşterer ber Edhaftioud) uno vou biefent wieberum bic ted)nifde \$ermenobarfeit bes Baumes weientlich abbängt. (5s wirb baburd) gerechtfertigt jein, went id) auf biejen (Segen= ftano etwas näher eingehe.

Sd) on vorftchento habe id) ülber ben, burd) bie Sinien a b, ed in 
Den Jiguren 2 uno 6 angebeuteten Unteridjied geprochen, ber aus ber gleiden ober ungleiden ?fuffiteigung ber Epiralen berborgebt, in benen bie frimitiven Marfitrahllüden georonet fino; id) babe gejagt, Daf hierauf ber Unterfacied in ber gegenüberftehenoen ober quirlförmigen (Jig. 2), von ber

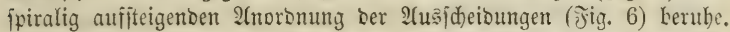

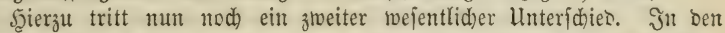
biahker betrad)teten fällen fehen wir ber Bafis einer jeben primitiven Marf=

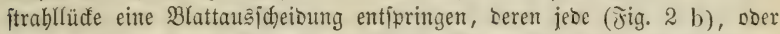
Deren mehrere vereint (J̧ig. 3) ein Blatt bilben. Die 3ahl Der Epiralen, Die man fowohl als lints wie als red)t getwunbene verfolgen fann (テ̛ig. 2, 6 , a b, ed) ijt in allen Fällen gleid) ber $3 a b l$ aller urfprünglichen Fajer: bünbel bes Bündelfreijes, aljo inmer eine mebrfad)e. 2l(ber nid)t bei allen Solzhflanjen liefert jebe Darffitrabllüfe eine S(usfideioung. Bei Der grofen Mehrzabl Der Saubbölzer bleibt bie grö̈te 3ahl Der Marfftrabllüđent ohne

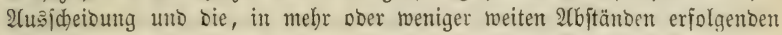
2łus̄ideibungen gehören bann entweber ein uno berjelben Epirale an, bie vorkerricheno bie redh getwumbene ift (c d), fo bei Quercus, Fagus, Salix etc., ober fie gehören mehreren Epiralen an, in meldhen fällen bie IHasfheioungen Derfelben, gegenüberiteheno, in gleiden Triebhöhen auftreten (Fraxinus, Acer, Aesculus). Bei Den Eacteen betbeiligen fid) alle

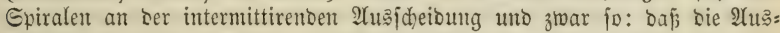
idjeibungen felbit entweber gerablinig auffeigento georbnet fino, jebe fol= gente einer amberen Spirale angehöreno (Cereus, Opuntia), ober in, Dap fie felbjt in eine Exiraflinie treten (Melocactus, Mamillaria), trot ber aud bier grablinigen uno fenfredten 2lufjteigung ${ }^{1}$ ber Jajerbünbel.

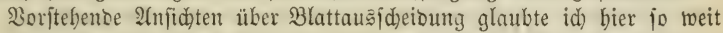
- barlegen zu mülīen, als fie mit ben in ber Botanif́ herridenden Meimungen $n i d$ int Einflange fteben. In allem Uebrigen fann id auf bas trefflide

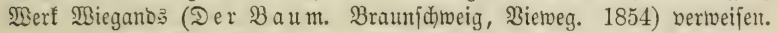

Ier vom Bündelfrẹife augggefdiebene Jaferftrang, bereinjelt veer mit mebreren Jajeriträngen ber 9lad)barbünbel bereint, bilbet auperhalb be? Idjjengebildes, umgeben von Rintosellen, in Der Regel zunäd)it einen fürzeren ober längeren Blattitiel, in weld)em fiad) bie burd I Iheilung meift

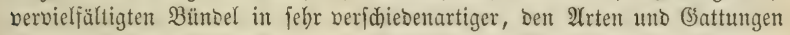
eigentbümlicher Weife gruppiren, felbjt bis jur Biloung eintes vollitändigen Bündelfreifes. Эđ̆ babe barüber in meiner Forftbotanif eine Reibenfolge von Beobadtungen mitgetbeilt. Lleberall entbalten bie Blattiticle alle Elemente ber Jajerbünoel Des Etammes, fowohl bes Ş⿻l一 = als bes Bajttheils berjelben.

Nidyt felten trennen fid fichon an ber Bafis ber Bündelausjojeioung für Das Blatt ein ober mehrere Bünbelitränge und gejtalten fich unter Doer neben Dem Blattitiele zu fojuppenartigen Bebiloen (Bracteen), wie in ber Bud)entnofpe テrig. 4, wojelbft fie als Snofpendedblätter auftreten, oder fie verben zu blattähnliçen Bildoungen, 2 f terblätter gentant. Mitunter 3. 3. bei ber Rothbud)e, berlaufen diefe Conderbünel weit bin unter ber

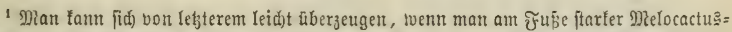

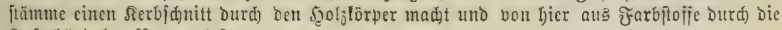
f̌ajerbündel aufiaugen läs̆t. 
Rinbe und geben siejer ein geripptes 2(eußere. Bei Calycanthus ver: grösern fie fich oft biele Jabre bintourch in ber Rinbe, ifolirt, burdh eigene

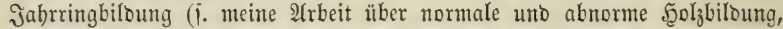
Bot. 3tg. 1859 S. 109).

Wie es ein = unb mebrjäbrige Pflanzen gibt, fo gibt es aud ein= uno mehrjäbrige Blätter, beren \&ebenß๖auer von Der Dauer bę intermebiären Sängenzuwadjes ber Blattwurzel (i. weiter unten) abbängig ift unb bis zu

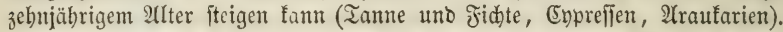
Die abgeftorbenen Blätter trennen fid) an ber Bafis bes Blattfitila vom 2lite, meift in Folge einer 3wijhenbiloung von Rorfzellgetwebe an viejer

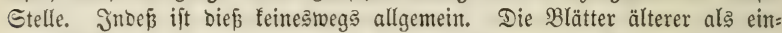
jäbriger Riefern 3. B. trennen fid nie von bem furzen Blattadjelfnojpen= ftamme, Dem fie angehören, fonbern fallen gleidzeitig mit biejem ab. Bei Taxodium und Glyptostrobus fallen bie entwidelten Seitenäfte mit ben

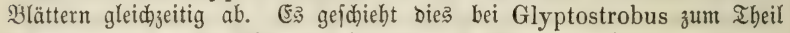

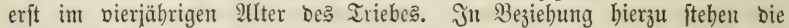
2Ubjprünge Der Fidjen uno ber Bappeln.

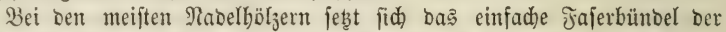
3lattausfcheidung burch Den furzen ober gänzlich fehlenden Blattfitiel un=

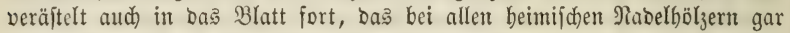
nidbt Doer wenig in bie Släd)e fidh erweitert. Bei ben meiften Saubböljern bingegen erweitert fid ber Blattfitiel zu einer mehr vber weniger ausge: breiteten fläde, in ber bie fajerbünbel, mannigfaltig veräftelt, enolid) in Den feimften Eträngen anaftomofireno in fid) jelbit zurüaffehren. ${ }^{1}$ Die ge:

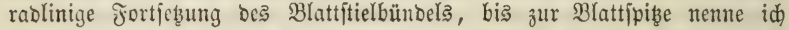
Den Blattfiel (Fagus, Quercus ete.). Bertheilt fid ber Blattfiel fidon an ber Blattbajis oder unfern biejer in mebrere geradinige Stränge, wie bei Aesculus, Acer, Viburnum, Ribes etc.; fo nenne id, im Begeniabs zum mittleren $\mathfrak{5} a \mathfrak{p t f i e l e , ~ D i e ~ f e i t l i c h e n ~ S t r a ̈ n g e : ~ \Re e b e n f i e l e . ~ D i e , ~}$

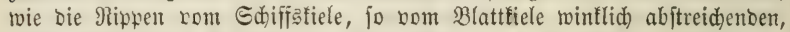

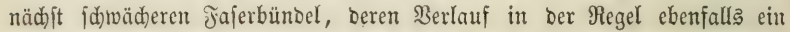
mehr ober weniger gerabliniger ijt, nente id bie Blattrippen, bie von

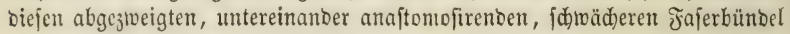
bingegen $\mathfrak{B l a t}$ t a bern (Blattmerben).

Mit bem, bei beridiebenen 50 lzarten beridiebenten Berlauf ber Fafer: bünbel Des Blattę, bängt bie, für bie Erfennung Der Pflanzen midtige Blattform zufammen; widhtiger in Bęug auf bie, erft fpät zur Blüthe uno Jrudtbiloung gelangenten Şolzpflanzen als für alle übrigen früh)= blübenden Gsemädhje.

Bom Einfaderen zum Bufammengejebsten fortfdreitent unteridheiben wir:

a) Einfade $B$ lätter.

1) Rrei引förmige, 2) elliptifde, 3) oblonge (ment bie Rang= jeiten ber (Ellipje ganz ober nabezu parallel geworben fint), 4) linear (wemt bie \&änge bes oblongen Blattes vielemal gröper als bie Breite ift),

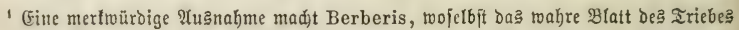
ala breizadiges, Dornäbnlid)es Gebilde auftritt, twäbretto bie Belaubung aus den untern I(usjideidungen ber Blattadjelfnojpen alljäbrlia fỉ erneuert. 
5) eiförmig (wonn bie Ellipie vor ber Bafis in (Eiform fich erweitert), 6) berfehrteiförmig (wenn bie eiförmige Erweiterung vor ber Blatt= ipize liegt). - - - i) lanzettförmig (aus elliptifder $\mathfrak{B} a j i$ la lang

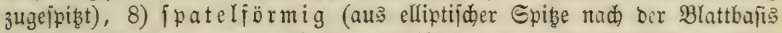
bin gerablinig berengt, 9) fpindelförmig (aus elliptifder Mitte nad) beiben Blattenden zugeipibt). _ - - 10) oreie fig, beltoio (aus antäberno gerabliniger Bafis breieđig zugeipibt), 11) berzförmig (aus einipringenbem Bajalwintel breiectig), 12) rbombija) (aus aus: jpringendem Bajalwintel breiectig), 13) feilförmig (aus fpib̧ent Bajal= binfel langgezogen breiedig mit abgeftuţtem Blattende), 14) nierenförmig (aus herzförmiger Bajis halbfreisförmig).

In Bejug auf ben Rano fino bie einfachen Blätter entweber $u \Perp$ getheilt (wem jeberfeits ber Rand eine gerabe ober bogig berlaufente

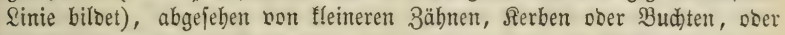
fie find burch wellige (Einjonitte $g e b u d t e t$, wenn bie Einbiegungen Den IUabiegungen ähnlid fino, ober fie fino gelappt, wenn bie $\mathscr{A} u s=$ uno Einbudtungen ungleid und jeitlid bis zur ફ̧älfte ober mehr bem Blattfiel genäbert fino; fie fint gefpalten, wem bie tiejen uno jpibinintligen Ein: fantitte nur vom Dberranbe bes Blattes ausgeben; fie fint getheilt, wenn oben folde Einjanitte bon allen Geiten in bie Blattidheibe einoringen.

Der Rano, fowohl ber ungetheilten als ber getheilten Blätter fam entweber ganjranbig ober gezähnt ober geferbt, gejägt jein. (jes= zabnt nenut man ben Rand, menn Durd jtumpfe Einjonitte Sähne gebiloet merben, bie fid weber nad) oben noch nad) unten neigen. (be jägt nemut

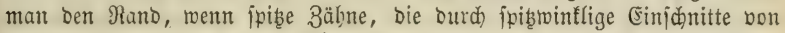
einanber getrennt find, Der \$lattipiz̨e fid zuneigen. Sino bie Cägezähne nid)t pits fondern abgerundet, io heipt bießs geferbt. Doppelt geferbt, gejägt, gezäbnt nennt man $e_{3}$, wenn bie gröferen Zäbne mit fleineren rieberum bejeţt finto.

b) 3 ufammengefeţte Blätter.

Sid)t überall erweitert fid ber Blattitiel in eine einjige Blatticheibe. Ridłt felten bilbet er eine Mehrzahl gejonoerter Blättchen, bie entweber,

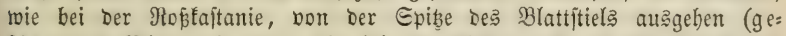
fiugerte Blätter) ober, wie bei ber (5ide, auch an ben Geiten bes

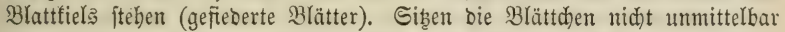
am Blattfiele, fonbern an Blattrippen, bie von ihm ausgehen, fo nemnt man biḗ ein boppelt gefiedertes Blatt. Säuft die Epibe bes Blatt= fitiels in ein 3latt aus, jo heißst das Gejammtblatt unpaarig gefiebert, im Begentheil: paarig gefiebert.

\section{b. Die Snoipenatujeidung.}

Den Uriprung Der Blattadjelfnofpen, aus einer warjigen Erhebung

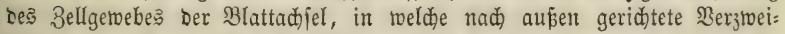
gungen ber Jajerbündel bes 2(djjengebildes bineinwadjen, Das Bellgetweke jelbit in Marf uno Rinde ideibeno uno baburd) ein neues 2ldjengebiltse conftituireno, baben wir fidon im Borbergehenten fenmen gelernt. Id)

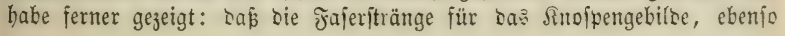


mie die für Das̉ Blattgebiloe, einer primitiven Marfftrabllü de entipringen:

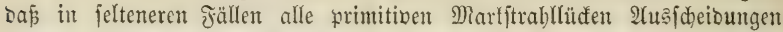
abgeben (ङig. 2, 3, 6); Daf aber überalf, wo eine Snofpenbünbelaus: id)eidung befteht, siejer eine Blattbündelauşideibung berjelben Marfitrabl= lücfe vorbergegangen ift, 1 twährento nidht immer ocr Blattbünodlauşfdeioung eine Snofpenbủnbelauŝfbeibung folgt.

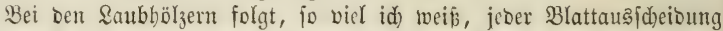

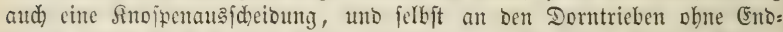
fnofipe treten fie mehr ober minoer reid)lid auf. Bei (Fid)e, Budde, A(born,

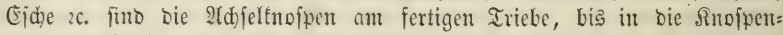
fdupten binab, fdon Dem unbewaffneten Ange crfennbar, went aud bic tiefer ftehenden in Der Entwidelung weniger weit vorgeforitten uno fleiner, oft fohr flein werben. 2ln Den jüngften Irieben alter Meiben, an fra: nifden flieser eridgeinen b.e unterften Blattadjeln auf ben erften Blid fteril, genaue, anatomifiche linterjuchung zeigt aber ood aud bier wenigftens bie 2tulage jur Sinofpe. B̉ei Tamnen, Jid)ten, Särdjent bingegen feblt bie

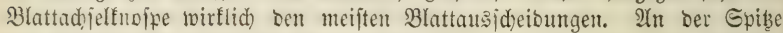
bes Jabreatriebs treten fie als Suirffnojpen, auperbem vereinzelt, jwif hen

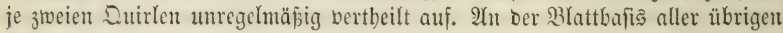
Slaseln ber Iannen 2 . habe id feine Esur von 2(d)jelfnofpen auffinoen fömกtr.

Jig. 9.

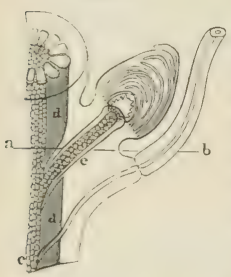

Die nebenftebenoe fitgur 9 gibt bie 2 Anjicht beß Sängenídnittes einer Geitentnofpe ber Fidute uno ber ifr angebörenden Blattausideioung, in Berbinoung

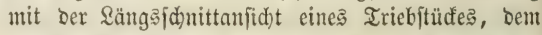
Die Sinofpe entipringt, vorzugameife zur (Erläuterutg bes 3ujammentanges bcs, Durd fleine Sreife bezeid)= neten Marfes in Trieb (c) uno Sinofpe, uno ber Durdbred)ung ber Scolzidididte int Triebe, Durd) ben Scolztörper Der Anofpe (e) Fowohl, wie bes Blatte

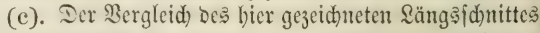
ber Geitentnofpe mit ber ausgeführteren Beidjung

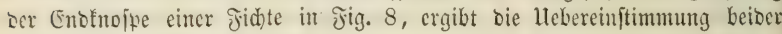
in allen wejentlid)en Theilen.

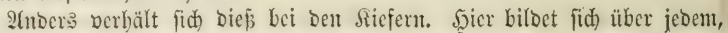
nur an Der einjährigen Bflanze zur normalen Entwidfelung fommenten, ein= fad)en Blatte DCS Trieles aud) cine Blattad)jelfnofpe; aber mur biejenigen Blattadjelfnofpen, weldhe zunädjt Der Enofnojpe fteben, entroideln fid zu normalen Iriebfnofpen (Duirffnojpen), beren Bau von sem ber Enofnofpe (J̈ig. 5) nidht veridjieben ift. Alle tieferen Blattadjelfnofpen bleiben auf

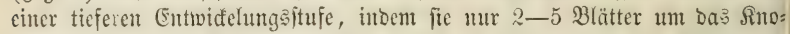

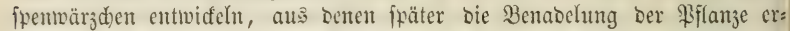

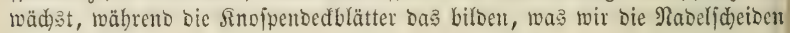
nemnert.

1 Iic jeitenftünoige B(iithenfuope bon Solanum dulcamara ift bie einzige mir be:

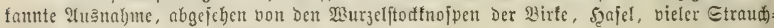

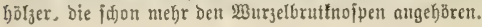


3um ßergleid mit Fig. 5 gebe id in nebenitehenter Fig. 10 ben \&ängen= burdjidnitt eines Triebjtüdes ber ge: meinen Riefer, vor Eintritt bes Nabel=

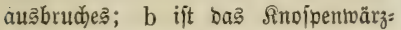
œen, a ift eine ber beioen bas $\mathfrak{B a ̈ r z}=$ den umitebenben fünftigen Nabeln, c fint bie Sinofpenbećcblätter, bie jpäter 3u ben Edheibeblättern bes Nabelpaares werben, e fino bie ädjten, einfachen Blätter bes Triebes, bie fpäter in ber punttirten Sinie abfallen unb am ferti= gen Triebe fid nur nod an ber Blatt= narbe ober ben wallförmigen Erhöbungen erfennen \afien, bie ben Irieb ber \&änge

Fig, 10.

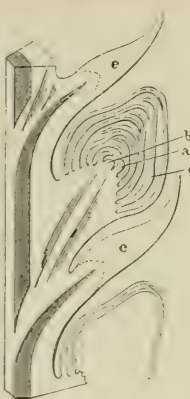

ซig. 11.

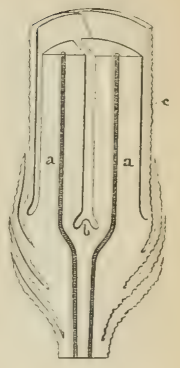
nach bebecten. In Fig. 11 gebe id Den unteren Theil eines, aus folder Rnojpe erwadjenen Nabelpaares im

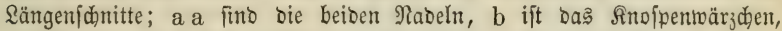
c fint bie zu ben Edheibeblättern umgewandelten Sinoipendeḉblätter. ${ }^{1}$

Bei einigen Saubbolzarten bildet fid unter ber Blattachjelfnofpe nod) eine $\mathfrak{U} \mathfrak{n}$ terfnofpe, $\mathfrak{s}$. $\mathfrak{B}$. Carpinus, Sambucus, Atragene, Juglans, oder es entwideln fid) über ber Blattadjeltnojpe eine ober zwei $D_{b e r=}$ fnoipen, 3. B. Lonicera, ober es biloet fid an jeber Geite ber Blatt= adjelfnope eine Geitenfnofpe, z. B. Salix, bie dann in ber Regel erít im zweiten ober britten Jahre äuperlich zum Boridein fommen.

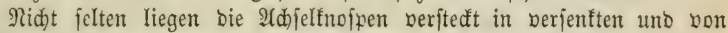

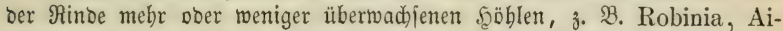
lanthus, Gymnoclades, Xanthoxylon, Philadelphus, Ptelea, Cephalantus. In anbern fällen treten fie ungemöbnlid weit bervor uno fint jogar Deutlid) geftielt bei Alnus, Cornus, Liriodendron, Anona, Sheperdia.

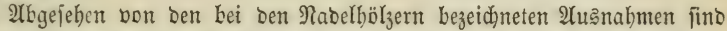
bie auggebiloten Blattadjfelfnofpen ifrem Baue nach bon Den Enofnofpen

1 In alfen einjäbrigen Siefern beftebt bie Belaubung nur aus ben einjađjen äd)ten

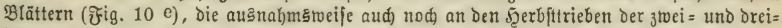
jäbrigen Siejern auftreten, bei P. Pinea bis jum 5. bis 6 . Jabre bie Belaubung bilden. Wäbrent ber ßeit einfad)er Belaubung bleiben Die Blattadjelfnojpen als jalafende Augen

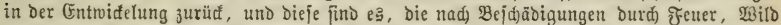

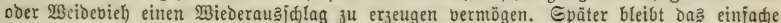

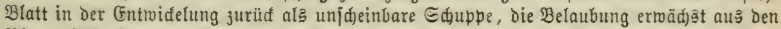
Blattadjelfnoipen, uno ba bieje mit Den Blättern nad) brei jabren abjaflen, fo erlija)t ba=

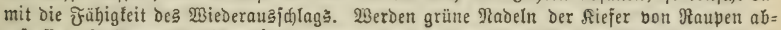

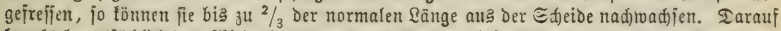

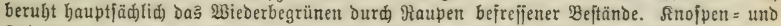

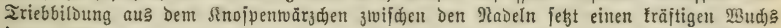

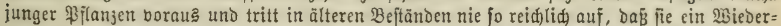
begrünen 3ur folge haben fann. Eie exjolgt bingegen regelmäpig aug den oberften 9label= büfdeln, wenn man im Jrübjabre benabelte Triebe bidft unter dem erften oder zweiten Luir! abidineidet. 
nidbt allein nidbt beridbieben, bäufiger nod) als bie lekgteren entbalten fie

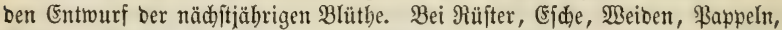
Siefern, Särd)en fino mur fie blüthebildeno, rähreno bei (Eid)en, Buchen,

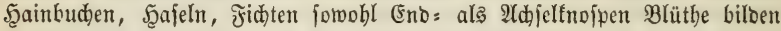

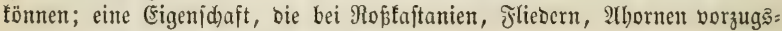
weije ben Enofnolpen zulfänbig ijt.

Dabingegen find bie Ydojelfnofpen in Bezug auf ibre meitere fort=

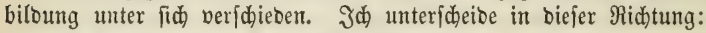

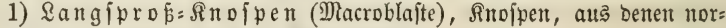
male Triebe, 3weige uno 2 tefte berborgehen.

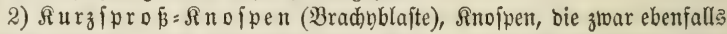
alljäbrlid) normale und belaubte Triebe bilben, Deren Triebe aber unge= wöbnlid furz bleiben unt im ungeftörten Berlauf bes $\mathfrak{B a d b a t h u m ! ~ n i e ~ z u ~}$

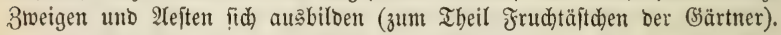

3) Berborgeniprof=snofpen (Sruptoblafte), Snofpen, bie viele Jabre binourch in $j i d$ unveränbert bleiben, bie aber alljährlid $u n t e r$ fid im neubinzutretenden $\mathfrak{S g l}_{3}=$ und $\mathfrak{B} a$ ftringe einen furzent Sängentrieb bilben und fid baburdh lebendig erbalten, bis Rrantheit ober Berleb̧ung Des Baumes fie zur Triebbildung nad) aupen veranlapt (zum Theil: fobla= fenbe 2(ugen ber Särtner; \$räbentibfnofpe in meinen früberen Sd)riften).

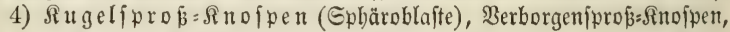

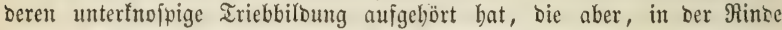

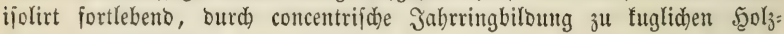
fnollen berantadijen.

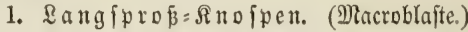

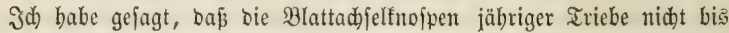
3u gleidem Brabe fid ausbiloen. Die oberen find ftets weiter in ber Ent: widelung vorgefdritten als bie unteren, fo baj bie unterften oft faum bem

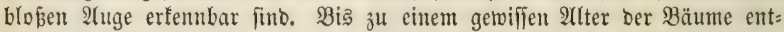
wideln fid) mur bie oberen, ausgebilbeten Seitentnofpen zu Irieben, alle übrigen zeigen äuferlid) gar feine Beränderung; bei Abornen, Ejकen, Beibenftofloloben finto fogar bie fälle nidjt felten, daj bis zum 2-3jäh̆= rigen 2flter Der Sflanze gar feine Blattadfeffnofpen zur Triebbiloung ge= langen, bejonbers wenn bie Bflanjen im Ed)lufie ftebon. Jnoep gelangen in ber Regel einzelne 2ldjelfnofpen fdon im einjäbrigen, ober bod) im jweijäbrigen 2Atter ber \$flanzen zur Triebbiloung uno entwideln fid ganı

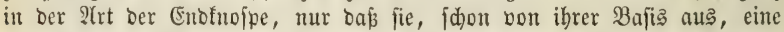
3ur 2 (d) je bes Stämmdents biagonale Ridłtung verfolgen uno im Sängen=

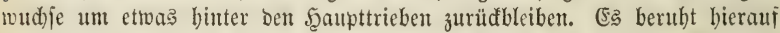
Die, fowohl bei verfdjebenen Baumarten, als bei ein und berjelben Baumart

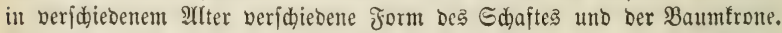
Die meiften Straudb) $l_{3}$ arten fino, wie bie Baumbölzer, in ben erften Jabren einftämmig uno ifr Straud)wuds entfteht erft im zweiten ober britten Jabre

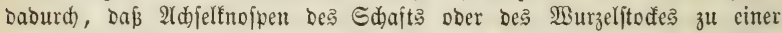

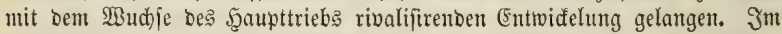

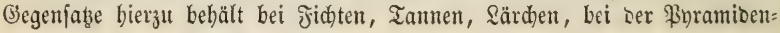


pappel, bei Der ßyramideneidje bie Şauptachje für immer Das Ulebergewidyt. Eine wirllide fironenbiloung tritt bier nie, fondern nur $B e z$ toeigung ein. 3mifden biefen beiben Ertremen ftehen bie verfahiebenartigiten 31wi= idenftufen, fowohl was bie form Der fronenbiloung, als bie Beit be马 Beginn berfelben betrifft. Bei ben Siefern, bei ber Rothbudbe, Der Erle zeigt Der Edaftrieb bis über bas mittlere Alter binaus ein entichiebentes Hebergemidht, worauf bann erjt bie Seitentriebe zu überwiegender Entwidé: lung gelangen uno eine mebr ober minber fajirmförmige Frone bilben, in Der Der Şaupttrieb entweber jebr berfürzt ift poer burd) mehrfache (Babel=

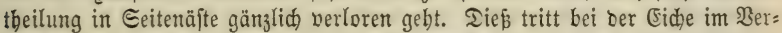
gleid) mit ser Buct,e uno Şainbude, bein Atpfelbaume im Bergleid mit bem Birnbaume, beim Feltaborn im \$ergleid) zum Bergahorn, bei ber Cauer= Firidhe im Bergleid) zur Eüptiridhe, aljo bei nahe verwanoten \$̧olzarten, unter

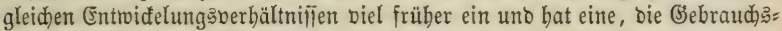

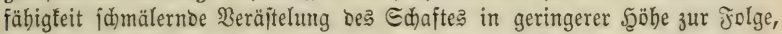
ber wir burd) Erziebung ber Fiflanzen in bidterem Etande, bejiehungsmeife Durd) Edoneitelung bis̄ zu einem getwifien (Brabe entgegentreten fönnen.

Aber aud bie Entwidelungsridjtung ber Eeitenjweige hat einen wejent:

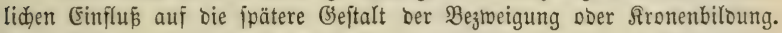
Abgefehen von Dem Einflü ber Sdhwere uno Des, ber tiejeren Bezmeigung

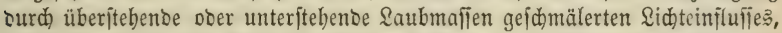
weldhe ben normalen 2 fftftand abänbern fönnen, abgejehen ferner bon in= Divi b uellen Eigenijaften ber Bäume (Jुängebirfe, Şängeejhe, ßyramioen= eide, Pramibentwadbolder 2c.) ${ }^{1}$ zeigen 3. B. Fidhte uno Tanne, Edwarz=

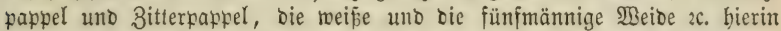
Die auffallenoften Unterjojiebe in ben fugel=, fuppel =, fđirm:, fegelförmigen Umrijīen Der Rrone, in ber rabialen, bejenförmigen, fparrigen 2(fittellung.

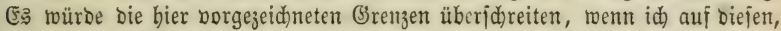
Dem Forftmanne jehr interefīanten Giegenjtano bier näber eingehen mollte, was idh um fo eher unterlajien faun, oa erft in neuerer Beit ber mor=

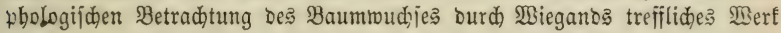

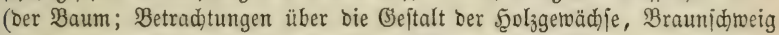
1854) eine umfantende Darftellung zu Theil geworben ijt.

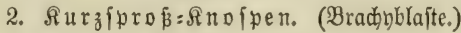

Bereits Eeite 145 babe id gezeigt, Dán die Belaubung ber Riefern, vom j̇meijährigen (bei Pinus Pinea vom 5-6jäbrigen) 2llter an aus Blatt= adjelfnofpen herborgehe, bie ein für allemal gleid)zeitig 2 ober 3 ober 5 Mabeln

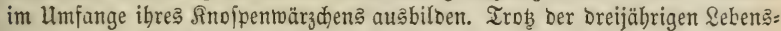
bauer biejer Blattbüjchel bleiben biejelben bis zu ihrem Iobe und Albjalle äuferlid unberänbert. $\mathfrak{D a}$ aber im britten wie im erjten Jabre bie, von einem eigenen Sुoljtörper eingeiकlofiene Marfröbre biejer Blattbüididel= fnofpen ununterbroden bis zur Marfröbre beڤ Adjengebiloes berläuft uno

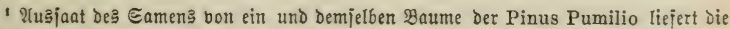
beridjicbenften Baumjormen, theils einfämmig gernbe auffteigende, theils aufgeridtete phramibal beafftete, theils nièerliegende Stämme. 


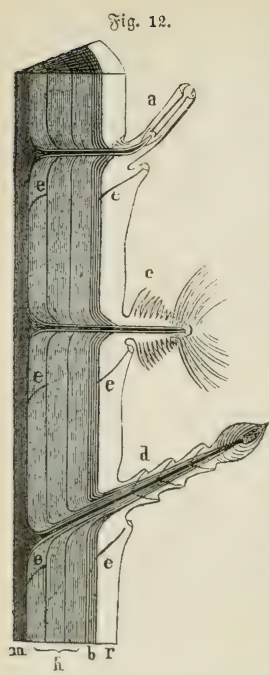

in bieje cinmünbet, tooran man fich burd \&ängen= idjnitte benabelter, oreijähriger Riefertriebe leiđht überzeugen fant (Fig. 12 a), fo hat im zweiten unb oritten Şolzringe bes Iriebes bie Blattbüidgelfnojpe alljäbrliç unter $j i$ d einen Sängentrieb von ber

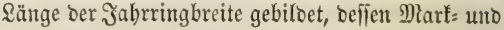

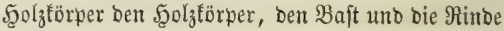
Des 2 (d) fengebiloes mebr ober wentiger $\mathrm{red}$ t w in $\mathrm{f}=$ lig Durdjęzt. Da biejer Rängenzumadjs nidjt in

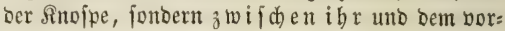
gebildeten \&ängentriebe Derjelben erfolgt, fo babe id) ibn ben interme biären, aud) unterrinoigen ¿ängenzuwadbs genannt.

J̛̀g. 12 zeigt Den \&ängenfiunitt ber Sä̆lfte eine s. oreijäbrigen Лiefertriebes mit Dem \&ängen=

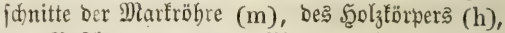
Der Bajtlagen (b), Der Pinte (r) ${ }^{1}$ uno eine? oreijäbrigen Nabelbüichelitummes burd) alle Jabres: lagen (a). Der Blattiftamm (e) iit Durd) bie nadgebiloeten $\mathfrak{g}_{0} l_{3}=$ uno Baftlagen nidht unter: brod)en. "2

Geben wir einen Sdyritt meiter, jo jeben wir in bem Blattbüijhelitanme Der Särd)e (Fig. 12 , c) ganz biejelbe Biloung innerbalb bes mehriährigen Iriebes. Es tritt aber cin wejentlid)er Unterfajied darin

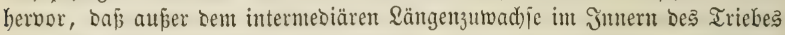

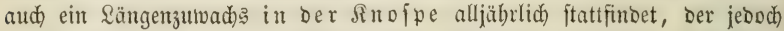
verfdrminbeno furz ift, auf feiter Spib̧e aber alljäbrlid) einen nabelreidjen

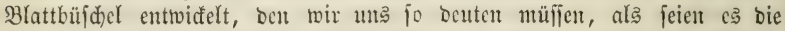

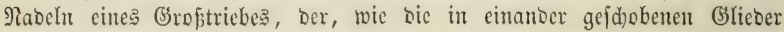
cines Jernrohrs, auf cine geringe Qänge verfürzt ift. Die mur cinjäbrige Sebenşbauer Der Mabeln hat überall eine Unterbred)ung ber Berbinbung

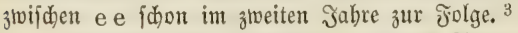

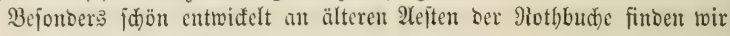

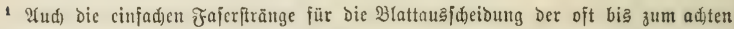
Jahre lebendig bleibenden fidsten = und Iamemnadeln erbalten fid, bis jum stadelabfalle

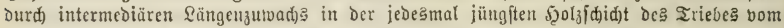

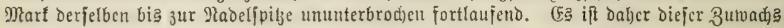
an Das Эorbanocnjein eine

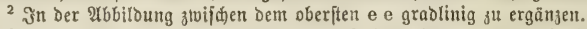

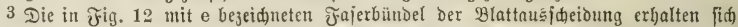
Durá) intermediären 3uwad) nur bis zum Blattabjalfe vom Mart bis zur Blattnarbe im

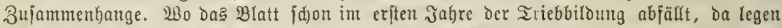

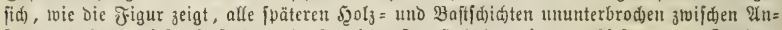

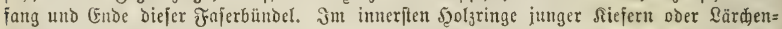

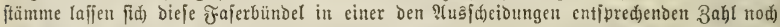

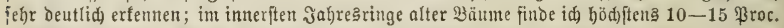

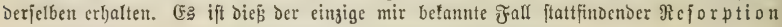
Der Den ફzolztörper radial butrdjetzenden Blatt = oder Sinojpenftämme. 
Die Saubholz=Dornäjte mit abortirenber Enofnofpe (Prunus spinosa,

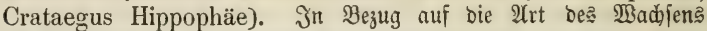

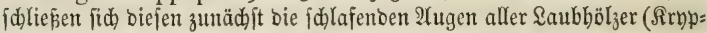
toblafte) uno bie Blätter aller $\mathfrak{P}$ flanzen mit mehrjäbriger Blattbauer an.

\section{Berborgenipropisnofpen. (Sirptoblafte.)}

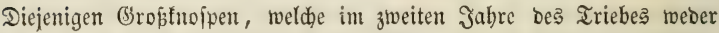

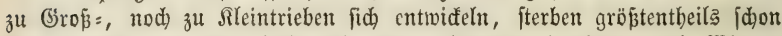
im zweiten Gabre uno fallen $a b$. (Ė erlifdjt bamit bie normale Wieber: auşj)lagfäbigteit tes Triebes an biefen $\mathfrak{B} u n f t e n$ für immer. Die viel fleineren 2lbjelfnoipen an ben unteren Theilen ber Triebe, ferner bie Unter=, Dber = uno Seitenfnoppen zeigen ein anoeres Berbalten. Im normalen, ungeftörten Berlaufe ber Enttwifflung ibres Trägers fommen fie żwar nidht 3ur Iriebbiloung, viele Jabre binourch erleiben fie weber äuperlich, nod) im Bereidhe ber Sinofpe jelbjt, irgento eine bemerfbare Beränberung beş: jenigen 3ujtantos, bis zu weld)em fie fid) am einjäbrigen Iriebe ausbildeten,

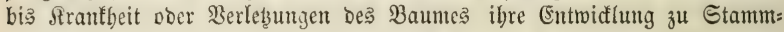

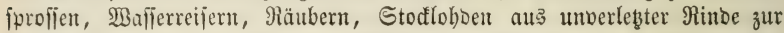

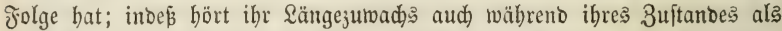

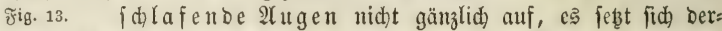
felbe aber nid)t in, fonbern unter ber Sinofpe fort, und

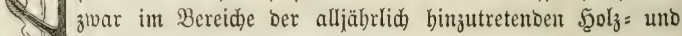

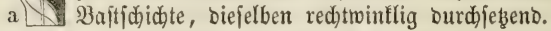

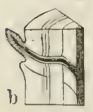

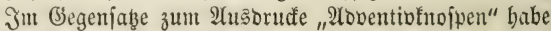
id) Diefe Snofpenarten früher ßräbentiofnojpen genannt. Des Einflanges wegen mit Den, Geite 146, 147 aufgeführten Benenumgen anderer Entroifllunģarten oer Blattadjelfnofpe

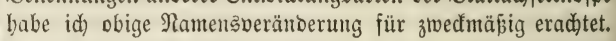
Die nebenftehenten Figuren 13 a-f geben bie Ent= viađlungşolge eine Sirtptoblajts bom einjährigen bis zum

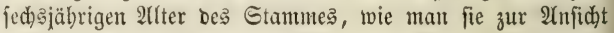

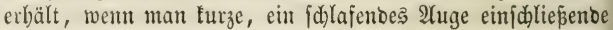
$2 \mathbb{B a l}_{3}$ enfitüe 1-6jäbriger Iriebe zu fleinen Sheiten fo aus= fpaltet, baß ber Sängşpalt ben Sinofpenjtamm in zwei Şälften tremut. ${ }^{1}$ Bon Der Marfröbre bes Triebę aus fieht man

(1)

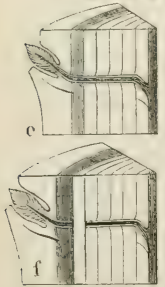

1 Jn alfen Figuren bildet bie bunfel gehaltene Marfröhre be马

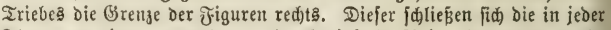
₹igur um einen vermebrten, ourd) einfadbe Sinien begrenjten Şolg= ringe an, benen bie gleidlaufigen, burch bidjter neben einander ftebende einfad)e Sinien bezeidjuten Jahreslagen beכ Baftę folgen, äupertid)

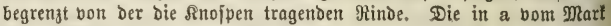
bis zur Blattnarbe unter dem Rnofpenjtamme ununterbrod)en verlaujende

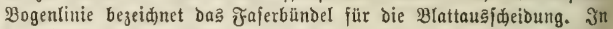

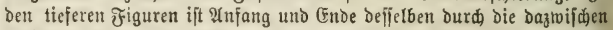

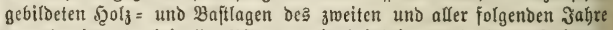
unterbrod)en, da bei affen Pflanzen mit einjäbriger Belaubung ein inter=

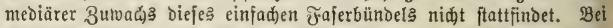
allen Pflanzen mit mebrjăbriger Belaubung findet aud bier biejer $3 u=$ twad) 


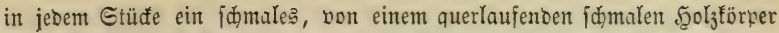
eingeidlojienes Mart bis in bie Snojpe binein berlaufen. Im einjährigen Triebe (a) verläuft biejer marflhaltige Rnoipenftamm gerablinig in färäger

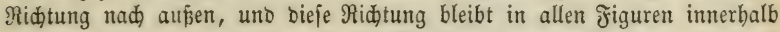

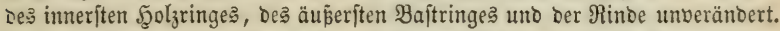
Die in jebem neu binzufommenten $\mathfrak{S g}_{3} \mathrm{l}_{3}=$ uno $\mathfrak{B a f t r i n g e}$ burd intermebiären 3urvaçs alljäbrlich entítehenden 3roijhenftüce, bie in Bezug auf bie sìnofpe als Sängentriebe betrachtet werben mülîen, entroiféln fid ftets in

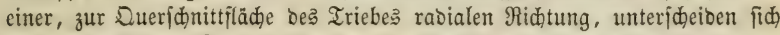

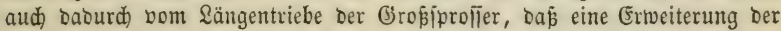

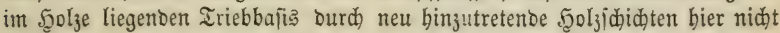

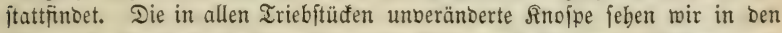
älteren Irieben mebr uno mebr in bie Rinbe verjentt ober, ridtiger, bon Diejer überwadjen, baber bie idlafenden 24ugen mit zunelymendem 2Ulter

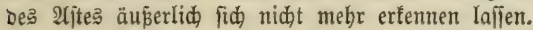

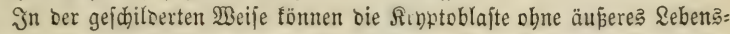
zeiden ${ }^{1} 10,20-100$ uno mehr Jahre hinourd burd intermediären $3 \mathfrak{3}=$ wachs fich lebendig erbalten; ibre Jortbauer als firnptoblajt ift aber ab= bängig bon ber Jortbauer bes intermebiären 3utwadjesె; bört biefer auf,

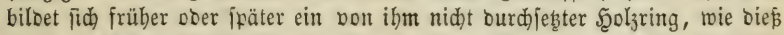
in Der jüngiten Sुolzidicht Der Fig. $13 \mathrm{f}$ ber Jall ijt, bann ftirbt bamit

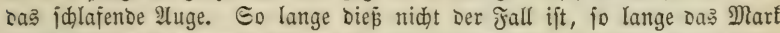
Der finofpe mit Dem Des Iriebes in ununterbrowenem 3ujanumenbange fteht, ruht bie Sinojpe jelbjt fortbauerno uno unveränoert unter normaler Ent= widlung Der \$iflanze; Rrantbeit, beionders Bipfeloüre, gewaltjame Ent= laubung ober 2 bbjeb überitebenoer Baumtheile erwedt fie aber zur Ihätig= teit. Jn Der form von $\mathfrak{B} a$ ajerreijern, Măubern, in ber Form von Etamm= oder Stodausjhlag jeben wir fie jef̧t zum Triebe herborbreden. Jeber a eines in ber Rinbe lebentig gebliebenen Rroptoblajt, uno bieje fino es, auf

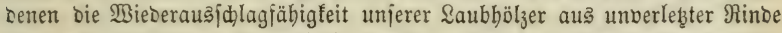
älter aļ einjäbriger Baumtheile berubt. Der ben Reprobuftions̄erjळei=

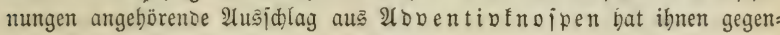
über nur eine untergeoronete $\mathfrak{B}$ ebeutung.

Der Wieberausidlag aus Irtyptoblaften berubt alio rarauf, baj eine viele Jabre binourd in $i$ id jolummernoe, aber unter $j i$ d fortwadjente

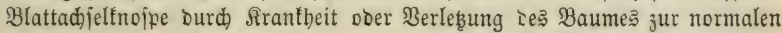
Iriebbiloung erwectt wirs. Fer in Der Sinojpe jelbjt liegente, von ben

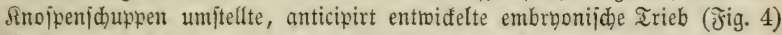
ift es, ber aus jeinem oft mehr als 100jäbrigen Ed)lummer erwedt wirb uno binfort fich ganj cbenjo fortbildet, wie bie Triebe aus jeber andern Snojpe.

Das Durdh unterrinoige Triebbiloung erbaltene, wenn aud ịdlummernoe

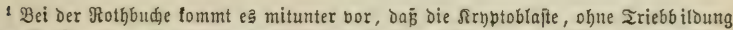

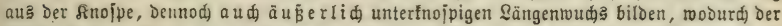

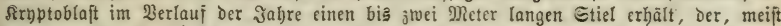

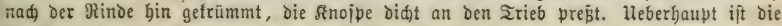

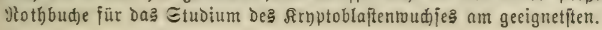




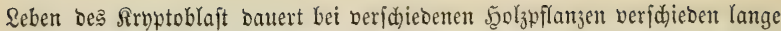
3eit. Bei ber Birfe fterben bie meiften Sruptoblajte fdon mit 10-12jäb)

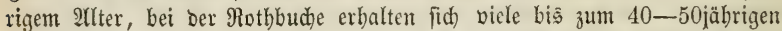
2Ulter; mebr als 100jäbrige Sinoen = ober (Sid)enftöde liefern nod) reid)lidjen

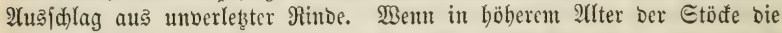

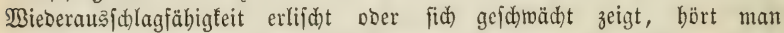
häufig die Erflärung, "ę fei bie Rinbe fo bart uno bid geworoen, Dẩ fie von ben Snopenfeimen nid)t mehr burdbroden werben fönne." Das Borjtebende ergibt Die Uızuläfifigfeit biefer Erflärung, ba bie fallafenden 2lugen, wenn aud bon ber Rinbe mehr ober weniger überwadjen, Dentod) ftets nad) aupen frei liegen, von einem Durdbbreden ber Rinbe baber gar

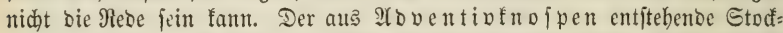
ausjidlag bilbet fich bingegen, wie id) fpäter zeigen werbe, ftets nux im

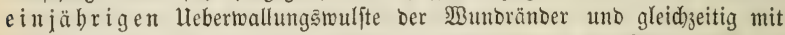
biejem, baber aud bier bon einem "su bif werben" Der Rinbe nidjt ge= fproden werben fann. Die Ihatfad)e einer mit jumebmendem 2Alter ber

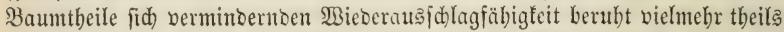
auf früber ober fpäter eintretendem SGbjterben ber Sirnptoblafte, theila auf abnebmenter \&ebenßfraft uno Entwidłlungşäbigfeit berjelben. 1

$\mathfrak{U}_{\mathfrak{H}}$ mebrbunbertjäbrigen (Eidjen fiebt man nid)t felten, in Jolge ein:

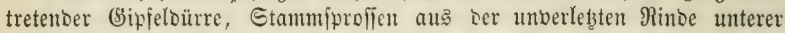
Edajttheile herborwadjen. (Es ift teinem 3meifel untermorfen, Daj bie Sinojpen, aus benen bieje Triebe herworgeben, fdon am einjäbrigen Triebe ber jungen Eidhe entitanden fino, daß fie aljo mebrere şunbert Jabre alt fein fönnen, obne in fich irgento eine Beränberung zu crleioen, aber aud)

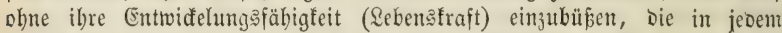

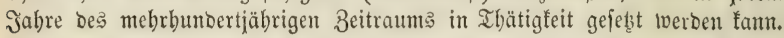
Währento biejer Yangen Beit ift bie fidlafende, ridtiger ideintobte Snofpe vollfommen gejund, alle Bebingungen normaler Fortbiloung zum Iriebe fint vorbanten, uno went bie Snofpe Demolngead)tet ihre ftoffliden 2 Trbeits:

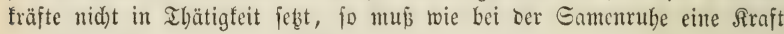
mitwirfeno fein, bie foldees verbindert.

Jm böheren Allter ber Sirbptoblajte tritt nidht felten bier unb ba

1 Obgleid nahe 20 Jalgre berlaujen find, feit id) bie bem Forfmanne jo twid)tige Sebre

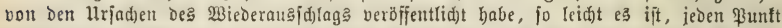

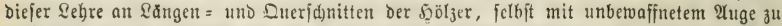
berfolgen, hat fie Dennod) bis jeft in ber wiffenfdaftlidjen Botanif nidat allein feine Aluf = nahme gefunden, fondern jelbft die neueren und neueften Sd)riftfteller über phyfiologifde Jorftbotanif erwähnen ihrer nicht. Die Sirnptoblafte oder \$räbentibfnojpen werben immer tod mit ben \&obentibtnofpen zujammengetoorfen, bon benen fie genetifd) himmelweit ber=

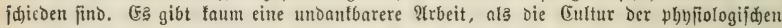

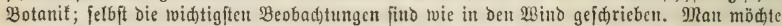

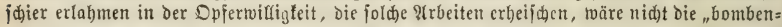

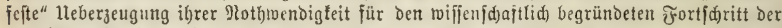

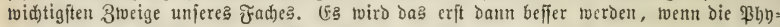
fiologen von ofad) fid Darauf einlaffen, die Rebenterjueinungen ber Pflanze an ber le ben ben Planje felbft, anjtatt in Den \&ebrbüdern ber Phbfit uno ber Chemie zu ftudien. Wie bie Sadhe heute betrieben wirb, Darf man nid)t ftaunen, wenn ber Phbjiologie borgetworfen twirb, fie jei hinter \$byjit und (Shemie tweit zuridgebliebent. 
cine Theilung ber Snojpe unt cine bierauj berubende Beräjtelung Deڤ unterrinbigen Rnojpenitammes eill. (ভ. Naturgeid). Der forftl. Eulturpfl. Taf. 8. Jig. 70.) (5马 berubt bierauf Die Majerbiloung am Jupe alter

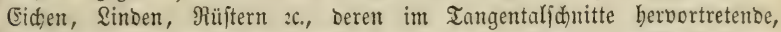
iogentannte Âgen nidht weiter fino als bie Dueridnitte ber Marfonlinber

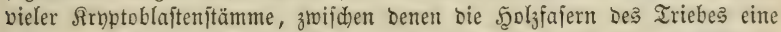
getwunbene Sage annehmen muiflen. Wie bie Beräftelung ber Brachbblafte

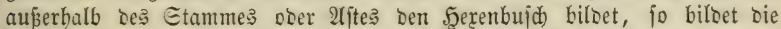
3erältelung ber Rroptoblafte innerbalb beక Etammes ben Majermudbs.

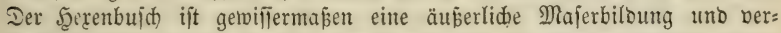
junnlidht red)t gut bie Sestere, wenn man fïb bie Räume zmifiden jeinen

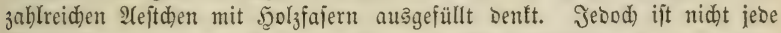
Majerbiloung an bas $\mathfrak{B}_{0}$ rbantonfein von Sirtptoblajteftämmen gebunben. Ein 15 Eentim. jtarfer Erbeuftamm meiner Eammlung zeigt febr fäb̈ne Majerbiloung aud ohne centrale Marfcnlinder. Diejer marffreie Majer:

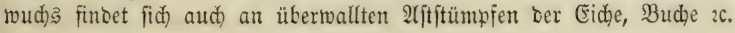

\section{4. $\Re$ ugelprof $=\Re$ nofpen.}

Şört ber unterrinbige ober intermediäre Rängenzumad)s Der frrypto: blafte auf, fo ftirbt in ber Regel aud) bie über ifm in ber Rinte liegende

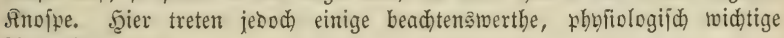
IUșahmen auf.

Wäbreno bei ben europäijđen Siejern die weibliche Blüthe unt Der baraus entiftehende 3arfen im Blüthejahre enoftänoig bleibt, wächst bei (allen?) Dreinabligen Riefern bie Iriebipiţe nod im Jabre ber Blüthe über bie jungen Bapfen binaus, io Daj biefe am fertigen Iriebe etwä über ber Mitte bes Triebes fteben. In Der llmgebung Der Zapfen fowobl, als ba wo bie männlichen $\mathfrak{B}$ lüthen fid entriçeln, bleibt bann eine nabelfreie 3one, in Der bie Blattadjelfnofpen nid)t z̆ur Blattbiloung vorịt)reiten, jondern im 3ujtande von Rirbptoblaften berbarren, Deren Borbandeniein bie breinabligen Siefern ibre, an älteren Etammtbeilen bäufig herbortreibenben Brad)blafte uno die baraus muthmajlid hergeleitete $\mathbb{B}$ ieder:

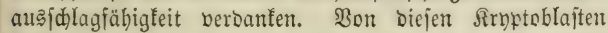
ichließ̧t fich mun ein groper Iheil nad unten zu einem boljigen Sinollen ab, Der, wie bie nebenjtebende Fig. 14

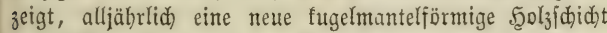
entwicelt. Dhne mit Dem Marf =, Şol3 = und Bafttörper bes Triebes in irgeno einer Fajerbünoelverbinoung zu jtehen, fübrt bieje Rnojpe im Rindezellgewebe gewifijermaß̄en ein parajitifdes Seben.

In ganł gleidjer Meije entifteben bie fugliden Snollen bis zu mebreren 3oll Iurdmefler, bie man jebr bäufig über bie Rinbe älterer Rotbbudben

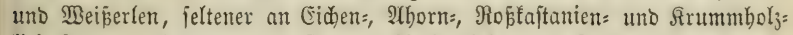
fieferitämmen herborrageno finbet. YUud) biés fino Sirnptoblajte, bie in Jolge aufbörenden intermediären 3uwadjes nicht abiterben, fondern nod) viele Jabre bindurd in ber Rinbe fortleben, alljäbrlid) eine fugelmantel: 


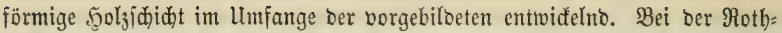
budhe finoet man nidjt felten Den Sirnptoblajt, bem ber Sphäroblajt feine Ent=

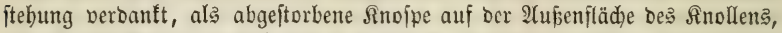

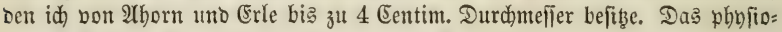

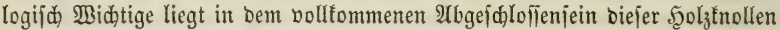

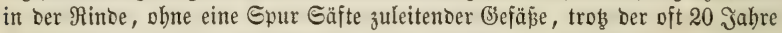

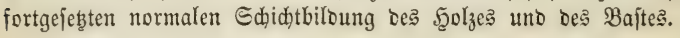

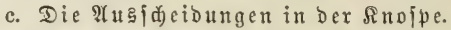

Dą̧ $\mathfrak{B e j e n ~ b e r ~ A n o i p e ~ ( i n ~ b c m ~ b i e r ~ v o r l i e g e n d e n ~ S i n n e ) ~ b a b e n ~ w i r ~}$ Darin erfannt, Daßs um ben anticipirt entwicfelten nädfitjäbrigen \&ängen= oder Blattadjeltrieb einer Sholzpflanze, auper ben mebr ober minoer hod entridđelten Blättern uno Blattadjelf́nofpen, in ber gropen Mehrzabl ber

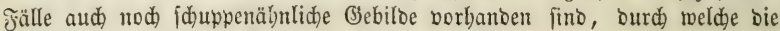
anticipirt entwidelten, frautigen Theile ben $\mathfrak{B i n t e r}$ über gegen bie nad)=

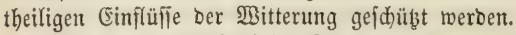

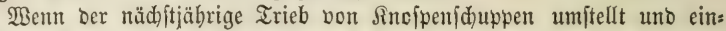

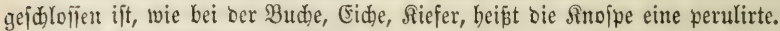

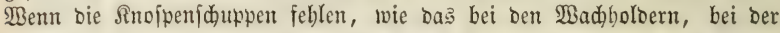

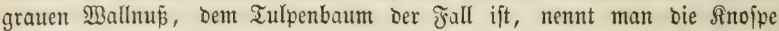
eine offene poer nadte.

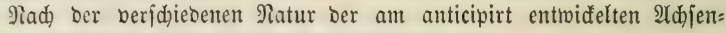
gebilde crfentubaren $\mathfrak{A}$

Iriebtnofpen, Blütbefnofpen, Blüthetriebfnofpen, Durzeltnofpen.

Iriebtuofpen fino folde Ento doer 2ldjelfnofpen, in benten alle

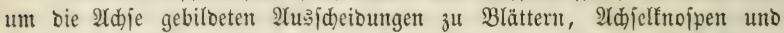
Sinofpeniduppen geftaltet fino (Jig. 4 Budentnojpe; Fig. 5 uno 8 Riefer= uno Fichtentnoppe). Sie liefern entweber blütheloj̣e \&ang= Doer Surztriebe ober verbarren längere ober fürzere Beit ober für immer im Buftante fóla= jenter 2Augen. Das anticipirt entwidelte $2(d)$ jengebiloe zeigt entweber mur

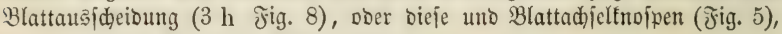

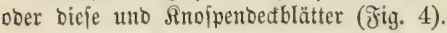

Blüthefnofpen find folde Sinofpen, in benen fid alle Theile bes

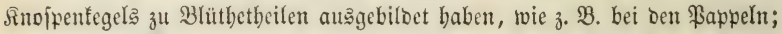

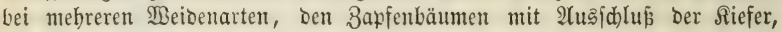
Den SSattungen Myrica, Clematis, Viscum, Daphne, Ulmus, Fraxinus, jum Theil Cornus, Cerasus, Lonicera etc. (5s erleiden hierbei bie

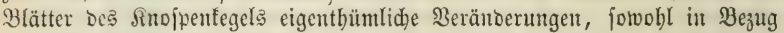
auf ibre Stellung, als in $\mathfrak{B e z}_{\mathrm{j}} \mathrm{g}$ auf ibre Bildoung. Jn ber bollfommenten 3witterblitthe veriväd) Blattfrantz bildet bie Blumenfrone, ein britter ben $S_{t a}$ bfaben= $\mathfrak{f} \mathfrak{r} \mathfrak{n} z$, ein vierter verwäd) ftändiger Rnoipenfranz entwidelt fid bei Siche, Budbe, Raftanie,

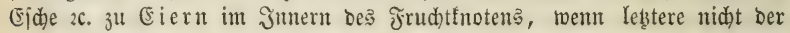

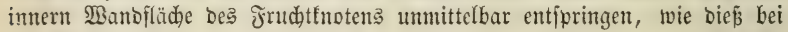
Den Gattungen Prunus, Pyrus, Robinia, Salix, Pinus ete. Der fall ift. 
Rebenftehento gebe id bie fdematijue Dar: ftellung einer volffommenen, normal gebauten 3rit= terblüthe, wenn man fičx beren $\mathcal{Y}(d) j e$ verlängert uno baburch bie beridiebenen Blattquirle von einanber getrennt uno in ibre einzelnen Blätter zerlegt benft (pon benen bie Figur jeood) nur je zwei baritellt). Der unterifte Blattquirl (1), befien Blätter meift unter einanber zu einem teldfiörmigen Drgane ber: wadien find, bilbet Den $\mathfrak{R} e l$ d) ber Blüthe; ber żweite Blattquirl, belīen Blätter bäufiger bereinzelt auftreten, bildet bie $\mathfrak{B} \mathfrak{l}$ umenfrone; biejer folgt ein $\mathfrak{B l a t t q u i r l}(3)$, befien Blattideibe in bie eno=

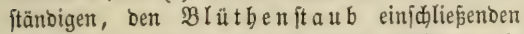
Staubbeutel berwandelt fino, wäbrend bic

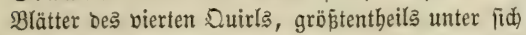
verwadjien, ein frugförmiges Drgan, ben $\mathfrak{F} r u$ d $t=$ fnoten biloen, an befien oberem offenem Ranbe Die Blätter in Den $\Re$ arbenarmen fíd trennen. Dą leşte innerbalb beక Jrudttnotent liegentoe,

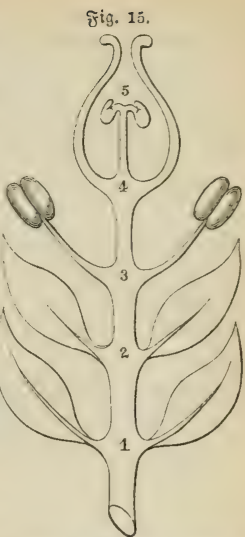
D. b. vom vierten Blattquirl überwadjene uno eingejohlofieme Internobium $(4-5)$ endet mit einem Rranze jeitenitändiger Sinofpengebiloe (5), 3. 3. Quercus, Corylus, Euphorbia etc., ben päter zum Eamen erradbienden Planzeneiern.

Nidht bei allen Pflanzen fint alle bieje 3 lüthentheile in einer Blume vereint, wie biés bei ben f́ronblumigen Sgolzpflanzen ber Fall ift (i. Das Evftem). Şäufig fehlt ber jweite Blattquirl, bie Blumentrone ganz - feldblumige 5olzpflanzen; nidt felten ift aud ber erfte Blattquirl bis auf eine ooer tonige ifolirte jouppenartige Drgane ber=

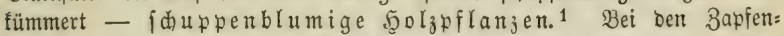
bäumen feblt bie frugförmige ßerwadjung Des vierten Blattquirla, Die Eier entipringen ber Bafis cines offenen orrudtblatte马. Bei vielen Saubbölzern

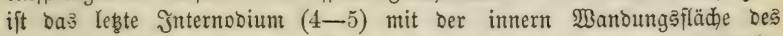
Fruchttnotens berwadjen, in Jolge Defien bie Eier (5) nidht adjenftänoig, jonoern wanoftändig auftreten. In nod) anderen fällen ift ber frrucht=

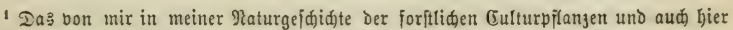

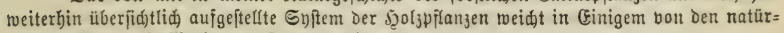

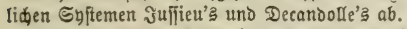

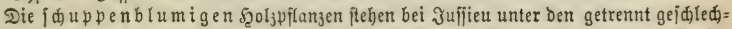
figen Dicotyledonen mit vielblätriger Blumenfrone; die leldblumigen Şol pflanzen ftehen theils ebenfalls bier (Urticeae), theils unter den fronblattlojen Dicoty= ledonen (Apetala Juss., Monochlamideae Dec.); bie fronblumigen 5 J lzpflanzen mit ein=

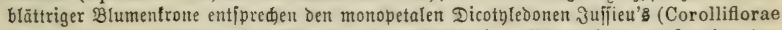

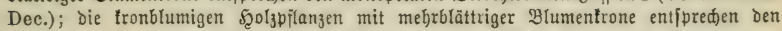
polypetalen Dicotyledonen Juffiteu's, Die Decandolle in Thalamiflorae und Calyciflorae

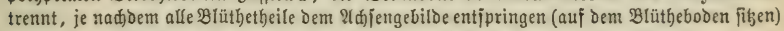
Doer Blumenfrone und Staubgejā̄e bem Reldrande injeritt find.

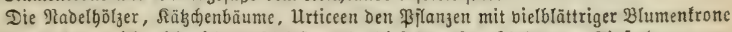

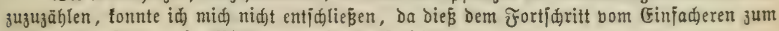
3ujammengejebsteren im Blüthebaue niđt entipridt. 
fnoten (4) jo tief in bas 2 djengebiloe binein verjentt, bā feine Bafis

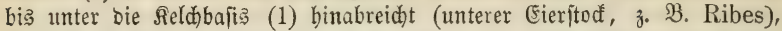
in weldhem Falle bie Jnjertion ter bajwijhen liegenden Blattquirle wejent= lid)e Beridiebentheiten zeigt. Man nennt fie eine oberftän bige (epiggne), menn ber Frudtffnoten ein unterer ift unb bie Staubgefäpe auf Dem oberen Theile beffelben fteben. Interfänoig heißst fie (bnpognn), went bie Staub= gefäß̈e unter einem freien Fruchtfnoten entipringen; um ftäno ig (perigbn), weln bie Staubyefäß̧e erft über Der Bafis eines freien Frudttnotens von Der Blumenfrone fid) trennen. Mandben Blüthen fehlt ber Frudchttnoten (männlid)e Blüthen), andern feblen die Staubfäben (meiblidje Blüthen). Beibe beifen getrent gejdledtig, im begenjab zul ben 3witter: blumen, in denen mäntidide uno weiblidge Blüthetheile bereint ent= halten finto.

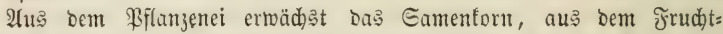

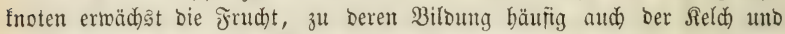
felbjt anbere accefiorifd)e Blumentheile herangejogen twerben. (Fid)el und Budhecern fint nidht Samentörner, ionbern es fino früd)te.

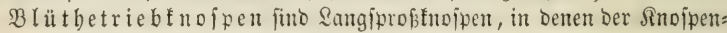
fegel bie Enofnojpe ober mehrere Blattadjelfnoipen zu Blüthen umgebildot enthält. Dabin gebören bie Blüthefnofpen der Riefern, Der Buche, Der Eidje, beren 2 (d)je fich) zu gewöbnlid)en Sangtrieben nomal entwidélt, mit Dem Unterfohiede, Das ein Theil ber Blattad) felfnoipen zu Blüthen

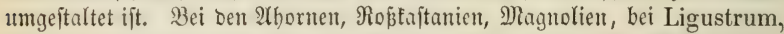
Viburnum, Sambucus ete. ift ę Der obere Theil Des Rnojpentegels felbft, ber fid) zur Blüthe ausbilbet, in Folge befien ber aus foldhen Snofpen berborgehende Trieb mit ber Eamenreife von oben herab bis ju Den unteren Blattadjelfnojpen abjtirbt, abgeftopen uno erfebet wiro burdh eine ober ztwei ber zunäd)jt jtekenden $\mathfrak{A} d$ felfnojpen.

MBurzelfuo ipeu. Obgleid) an auffeigenden Stode ber meiften

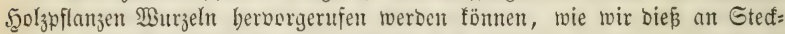
lingen uno abjentern feben, gejdiebt biés freiwillig uno im normalen

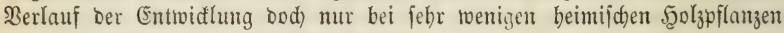
(Hedera, Cuscuta). $2 \mathfrak{l n}$ älteren Bflanzen von Potentilla frutiensa fanb id) Suftwurzeln am oberirbij(hen Stode in reid)lid)er Menge zmifhen ben

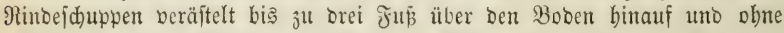

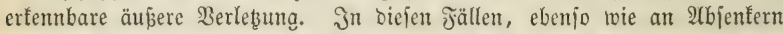

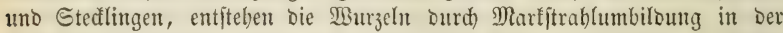

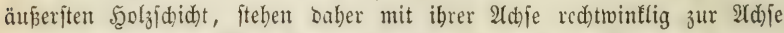
Des Iriebes, aus reldyem fie herborgehen, intem fie bie Baits uno Rindent= lagen burdbred)en uto in Der Regel eine Renticelle зum 2(usggangäpunfte erwäblen. Son einer eigentlichen Sinofpenbiloung fann bier nidgt bie Rebe fein, Da es bie nacte uno ungetbeilte fuppelförmige Wurzelipike ift, weldhe

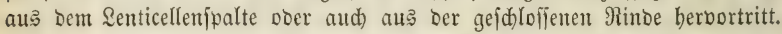
Da anticipirt entwidelte Biloungen an ber Murzelfpibe nidyt gebilbet werben, fehlen biejen aud) bie zum Ed)ube berjelben allein nöthigen Snofpen= beçblätter. 


\section{B. Der abftigeuid Stod.}

Die $\mathfrak{B} u r_{z} e l$, vom aufiteigenten Etode überall burd ben Mangel einer Marfröbre unterjdieben, zeigt zroar ebenfalls eine Berä|telung uno eine allmäblige Etärfeabnabme ber $\mathfrak{A}$ ejte nad) unten ober in ibrer feitliden $\mathfrak{B}$ er: breitung, allein es feblt bier niđt allein eine äuj̦ere Begrenzung ber Jabreš

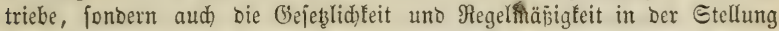

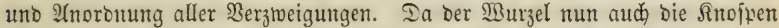
uno bie Slätter jeblen, fo berriḑt bier ein weit gröperes (Finfad) ber Bir= Dungen, als an oberirbijden Etoce. Wie wir fpäter feben werben, geht

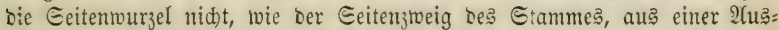
\{dxcioung von Fajerbünbeln bes Bündelfreife: herbor, fonbern es entwidelt fid) jeoe Eeitentourzel uriprünglich an ber Etelle eines Marfitrables ber

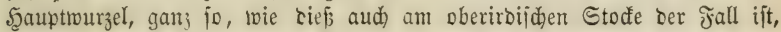
toen er Durch Gteden ober Xbjenfen zur Murzelbiloung getrieben twirb. Daber rübrt ç Denn auch, baf́ bie Bafte jeber Eeitentwurzel auf Der \&ängent= adhje ibrer Mutterwurzel uriprünglid) jentredt fteht, wäbrent alle 3weige bes auffiteigenden Etodés von biejem ober von ben Mutterztweigen in fadräg nad) oben geridhtetem Winfel ausgeben.

Ybgefeben von ber abnebmenden Etärfe Der Murzeläfte uno Wurzel= 3̆tweige, unterfbeiben tvir am abjteigenden Etode unjerer Scolzpflanzen, Deren Burzelbau im Bejentlichen ein febr übereinftimmentor uno einfadjer ijt, nur zwei berfdiebene $\mathfrak{A r t e n}$ bon Wurzeln: Iriebrourzel, burd) welde

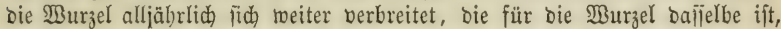
was bie aus Mafroblajten fid entridelnben Sangiprollen für ben aufiteigenden Etod futo uno: Jajertourzeln, die, obne merflide Didezunabme uno

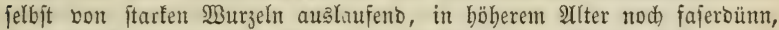
fic) reichlid) uno in furzen $\mathfrak{A b j t a ̈ n b e n ~ b e r a ̈ f t e l n ; ~ f e b r ~ f r u ̈ b ~ i m ~ J a b r e , ~ m e i f t ~}$ ¡đou im Jebruar, furze uno dicfe, bell gefärbte Rrautiprofien (Iaf. 1. テig. 12) treiben, Deren biđes Rinbezellgewebe im Eommer zufammenfällt, bertodnet uno braun wiro, woourd) Die Sirautiprolle zum bünniten Ende Der J̆ajerwurzel wirb, bis im fommenoen Jrübjabre an ibnen neue firaut= iprolie berborbachien. Dieje firautiprojie fino die Drgane, die man früber bie Blätter ber Burzel namute, meil man glaubte, bas fie, twie bie B!ätter alljäbrlich abgeworfen wurben. Das ijt aber nid)t ber Jall; fie beridwinben nur Daburd im Gommer ber Beobaditung, baß bas 3ujammenjdrumpfen ibres biden Rinbezellgetwebes bie fichtbaren Unteridjebe zwijden ibnen uno Den braunen Murzelfajern, benen fic aufitben, aufbebt.

Sinoppenartige Scüllen finden fid an ber 2 Burzel nirgends, toohl aber fino bie jüngiten Murgelipiţen einer periobijch fich wieberbolenben f̧äutung, eine: Ubiterbens uno 2(blöjens ber äuferften Bellenichichten unterworfen, Deren Rẹte längere ober fürzere Beit einen mübenartigen Ueberzug Der

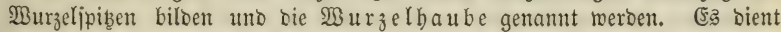
biejelbe obne 3meifel zum Edus biefer zarten Wurzeljpiben, ift aber aud) in fofern beadbtensmerth, als ibre enolide $\mathfrak{A}$ uflöjung bie Urjache ber $\mathfrak{U}$ =

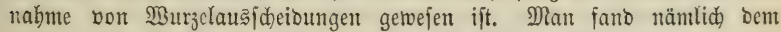

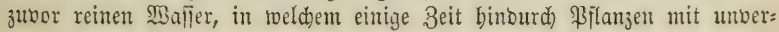




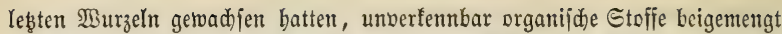

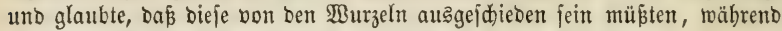
fie erweislid) aus ber Berję̧ung abgeftofiener Bellen berrübren.

Befonders $D a$, too bie feinften $\mathfrak{I r i e b}=$ und Fajertwurzeln nidht bidht von Erbe umgeben find, wadjen bie äuperften Bellenlagen ber $\mathfrak{B}_{\text {Brzel zu }}$ Şaaren aus (Taf. I. Fig. 13, 14), wie foldhe aud) an ben frautigen Theilen Des oberirbifden Stodes fid) biloen. Sie fino obne 3tweifel zur verftärften Einjaugung Dunftförmiger Flüffigfeit beftimmt, ba fie fich), in Berübrung

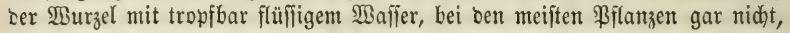
bei allen aber in um jo gröperer Menge bilden, je reidjer bie fie umgebente

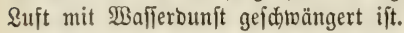

Wie am auffteigenten Stod bebingungsmeife Wurzeln fid bilben, fo fönnen am abjteigenoen Stode aud) Sinofpen entifteben, bie von ben Irieb: Enofpen bes erfteren nidht verfdieben fino. Mährenb aber am aufiteigenten Stocfe wohl feine Sholzart Ilbjenferberwurzelung berjagt, befizen nur wenige

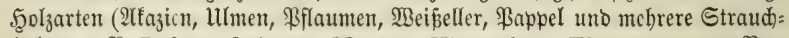

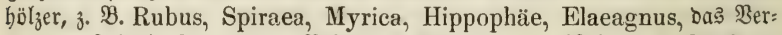
mögen, Triebtnofpen bes aufifteigenden Stodę am abfteigenden Stodfe zu bilben unb zu $\mathfrak{B} u \mathbf{r} z$ elbrut zu entrideln. Die Tricbfnoipe entitebt bam nid)t wie am auffteigenben Stode burd) ein vom Bünbelfreife ausjideibenoes Jajerbünbel, fonbern ebenfo wie bie Seitenwurzel, burd Marfiftrablumbiloung, mit bem Unterjdiebe, baj in ber 2(dje bes in Fajern umgebildeten Mart: ftrablgetwebes eine Martröbre, bie Bebingung oberirbifa)er Rnofpenbiloung, entitebt. Id) fomme bierauf zurüd bei ber Betradtung Der interen Dr= ganifation Des Baumes uno berweife einjtweilen auf ben bajelbit gegebenen

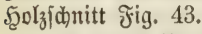

Trok ber Regellofigfeit in ber 2Anorbmung aller Seitenzrmeige ber Baum= murzsl, fint bennod) getwiffe llnterfdicbe in ber $\mathfrak{B}$ urzelbiloung veridjiebener

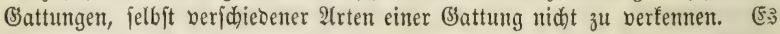
ift aber febr fafiwierig, ben bier ftatfinbenten Unteridjieben einen wiffen=

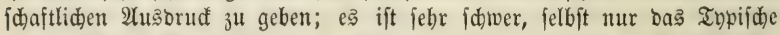
Der fpecifiid)en $2 B u r z e l b i l$ oung zu erfennen, nidjt allein ber natürliden Un= regelmäpigfeit in ber 2̂norbnung, fonbern auch) ber mannigfaltigen Störungen wegen, benen bie normale Entrwiflung im feften (Erbreide bäufig unterworfen ift. Man jebe nur, wie verjodieben bie Burzelbilbung berjelben f̧olzart auf flachem, auf tiefgrünbigcm uno in fteinigem Boben fid geftaltet, unb man wiro fehr balo bie Ulberzeugung getwinnen, Daß zur Zeit an eine miffenjđaftlidje Unterfdeioung ber Bewurzelung älterer Bäume nod) gar nidłt gebad)t twerben tann. Jür junge, in gleidhem, gelodertem Boben erzogene Scolzpflanzen, bie bem Forjtmann bäufiger in ibrer Integrität beim \$flanj=

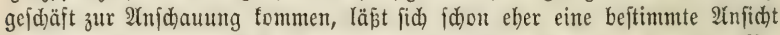

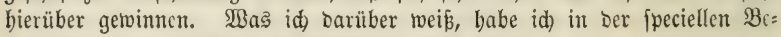
id)reibung ber forftlidjen (Eulturpflanzen mitgetbeilt.

Im inneren Baue unterideibet fid) Die $\mathfrak{B u r z e l}$ bom Stamme nur barin, Dá bie Martröhre burá) ein centrales gajerbünoel bertreten ift unb báp mit ber Sberhaut ber Burzel aud) bie Spaltbrüjen feblent. 


\section{马ెweites Sanpite!.}

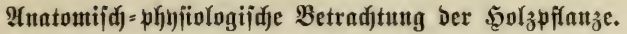

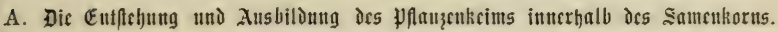

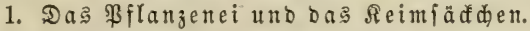

Ibgejeben von ber $\mathfrak{B e r v i e l f a ̈ l t i g u n g ~ e i n e r ~ S c o l z p f l a n z e ~ b u r d h ~}$

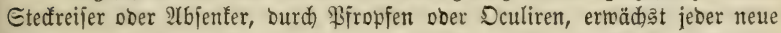
Baam aus einem Samenforn; bas Samenforn entftebt aus bem

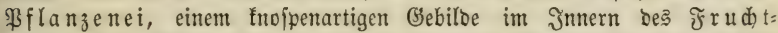

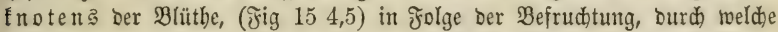
Der Reim einer neuen ßflanze (5mbrno), urfprünglich) ein einzelner Belffern,

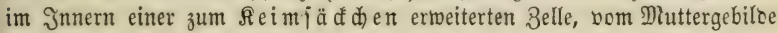
loşgerifien uno zur felbititänoigen fortbiloung als ein ber Mutterpflanze gleider Drganis̄mus befäbigt twirb.

Iaf. I. Jig. 18 zeight den \&ängenourdhidnitt einer weibliden Blüthe Der Eidhe in Deren früberen Entwidlungşzuftänten, beftebeno aus bem, von

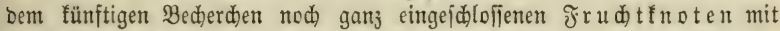

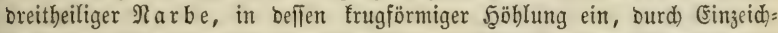
nung ber Bellen fenntlid) gemađter fiörper fpäter zu einem açienftänbigen

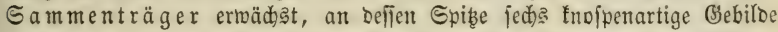
entiteben, von benen jebod) in Der Regel nur eines fid zum (Fie ausbilbet, twäbrenb bie übrigen berfümmern, ${ }^{1}$ biejenigen jeltenen fälle auझgenommen, in benen fich in ber (Eid)el ztoci, nod) jeltner brei getrente Camentörner vorfincen (in ber Manbel al: jogenannte "Bielliebd)en" kefannt).

Die Jortbiloung eines einzelnen biejer feds inopipenartigen Behilbe im Irudtinoten ber Eide zeigt Taf I. Jig. 19-21.

Urjprünglid find es einfache, aus fleinen, runblichen Bellen bejtebende,

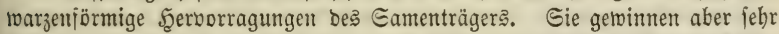
bals baburd eine fnoipenähnliđe form, baf, twähreno fie felbft fegelförmig fich ver: größern, an ibrer $\mathfrak{B a f i s ~ r i n g s h e r u m ~ e i n e ~ w a l l f o ̈ r m i g e ~ E r b o ̈ b u n g ~ a u s ~ u n t e r ~ f i d ~}$ vertoadjenen Blattwirteln fid) bil tet (Taf. I. Jig. 19), bie am Inojpentegel hinauf= wädşt, räbrend bäufig ein zroeiter Blattfranz am Grunbe beș eriten entiteht

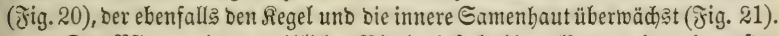

Das ßflanzenei der weiblidben Blüthe bejtebt bier aljo auseinent inneriten Crifegel und aus einem ober zroeien, benjelben feitlich umgebenben, am Grunbe untereinanber uno mit bem Segel berfdmolzenenzelligen f̧üllen, Die über ber Epibe

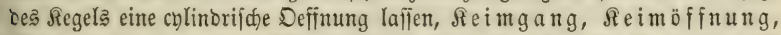
Micropyle genannt. Morphologijd ift Sebztere für die Rerntwarze bę

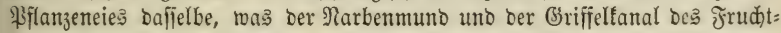
fnotent für Das \$flanzenei ift. Dieje wallförmigen Umbüllungen Des Regels

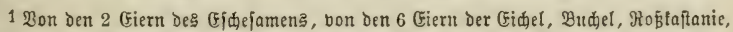
von Den 14 Giern Der Marone fommt in Der Regel nur ein Camentorn (bei Der Rośtaftanie

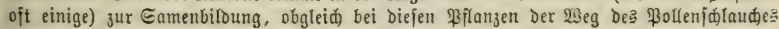

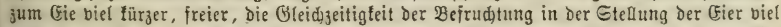
mel)r begünfigt ift, a!క z. B. bei Den Qeguminojen, beren (Eier Dennud in Der Regel fämmtlid) bejructet rerben. Wie bei ber beridiedenen Dauer der Gamentuhe beridiebener Eameneier,

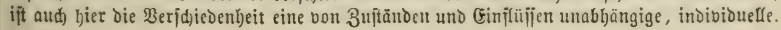




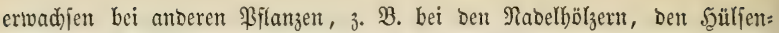

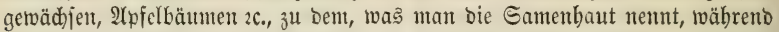
fie bei ber (Eid)el bie bünnen, braunen Şäutden bil'ben, weld)e, innerbalb Der aus bem Frudtftnoten erwadjenden, harten Edjale, Den Rern ber Eiddel überzieben.

Arle ferneren wefentlichen Beränberungen im Bflanzeneie gehen von sa ab im Regel bejielben vor fid. Sie bejtehen barin, dáp eine ein= jelne 3 elle beffelben, auf Roften ihrer Nadbarzellen uno unter fort:

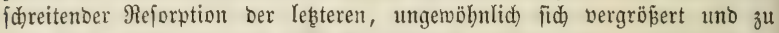

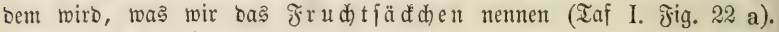
llrfprünglid) enthält bieje Belle, wie alle itbrigen, mur einen Zelffern, ber

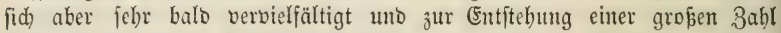
förniger und zelliger Siebilbe Seranlaffung wirs, Die Den Ptndoberaum bes

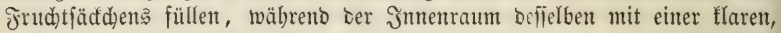
juđerbaltigen glüffigfeit erfüllt ift. (Эđ) werbe weiterbin erflären, wa引 unter Bellfern uno \$thdoberaum zu verftehen jei.)

\section{Die Befrudtung.}

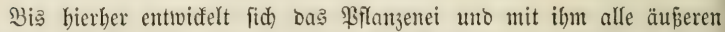
Theile Der Frud)t, obne 3utbun männlicher Befudtungämerfzeuge. Siele

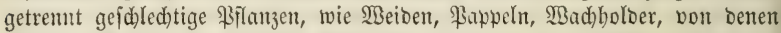
in einer Gegento nur weiblide Exemplare vorbanden finto, blübent nidht allein, fonbern fie tragen aud) Früd)te mit äuferlid) jdeinbar vollfommenem Samen. 2lber ber Eame ift in folden Fällen $t a \mathfrak{a} \mathfrak{b}$, b. $\mathfrak{h}$. ifm feblt ber wejentlidjite Beftandbeil: bie junge \$flanze im embryonifden 3uftande. ${ }^{1} \mathrm{llm}$ bieje berborzurufen, erideint, uad) allen fideren Beobadtungen zu

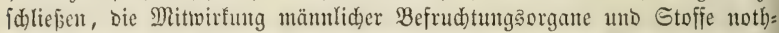

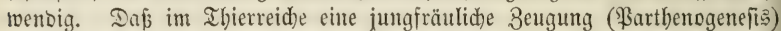

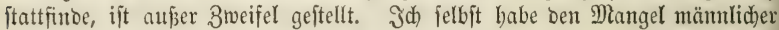
Ibiere aller 2 trten ber engeren Gattung Cynips außer 3roeifel geftellt. v. Siebolo bat bei einer Ed)metterlingsggattung (Psyche) Daffelbe nadgge: wiefen. Jn beiben Fällen finto männlide Befrud)tungştoffe im Rörper ber

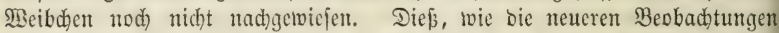

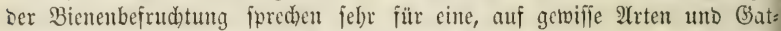
tungen bejobräntte, jungfräulidbe Zeugung. Neuere Beobachtungen an einer

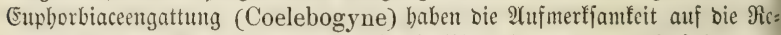
fultate früberer Beobad)tutgen am Scanf, Bingelfraut 2 . zurüdfgefübrt uno

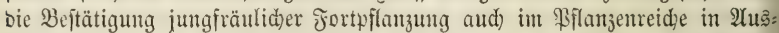
fid)t geitellt, gegen bie aber jobon jeb̧t fid Stimmen erboben haben, mit bem Nachiveife cines jehr verfteften Borfommen!s männlider Blütbentheile an weibliden \$flanzen. Einen Fall biejer $\mathfrak{A}$ (rt babe id felbft nadigetwiejen an

${ }^{1}$ Jृ offmcifter bat neuerding Beobad)tungen befaunt gemad)t, Denen zu Folge in fold)en Fällen aud) Dą (EnDopperm ber Sameneier nid)t jur (Entwidflung gelangt. Der

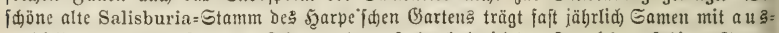
gebildetem (Endoipernt. G(jon mebrere Jahre habe id Den ftets feimunfähigen Gamen unterjud)t, aber nie aud) nur eine 2(nlage zur Reimbiloung aufgefunden. Jn einer Genoung Cembra= Gamen von mehreren Pfunden twaren alle fiörner reid) an (Enoojperm, feine $\mathrm{ent=}$ bielt einen Seim. 
Der weibliden Blume won Castanea (Maturgeid). ¿er forfitl. Cultur: pflanjen $\mathfrak{I a f} .25$, ร̃ig. 55).

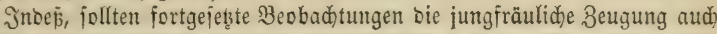
in Prilanzenreide bejtätigen, fo toirb jid) bieje, wie im Ihierreide, bod)

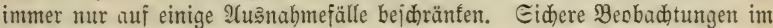

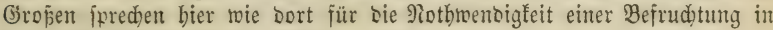
Der gropen Mebrzabl der Fälle.

Die Organe ber Bilanjenbefruditung fint bei ben Fुoljpilanjen bie Etaubfäben, beren zwei Iaf. I. Jig. 16 über a abgebilbet fino. 2Uf ocr Exibe cines mebr ober weniger berlängerten Etieles fteht ein meift jmeifummeriges, eiförmiges Ġebäuje, Єtaubbeutel gentunt, in befien

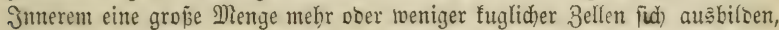
bie zur Beit noller Błüthe aus Den jïh öfintenden હtaubbeuteln ausgeptreut werben uno Blütheitaub (Pollen) beipen.

Jese eingelne \$ollenzelle befteht aus einer mebr ober weniger biden, oft jebr regelmäpigig uno zierlich mit Seiften uno Epişen bejescten ojt

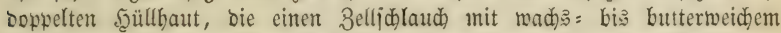

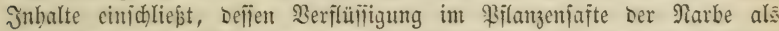
"mämnlid)e Eamenfiüinitgfeit" (Fovilla) betrachtet wiro. Jn Der äup̃eren Güllbaut kefinoen fid mebreve runbliche, mitunter ourd) eine Silappe ver:

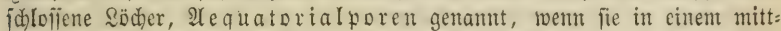
leren Gü̈rtel Der \$ollenzelle liegen. Iaf. I. Jig. 17 ftellt eine foldhe Follen= jelle von Corylus mit brei Foren bar. Tritt bie \$ollenzelle mit Mafier

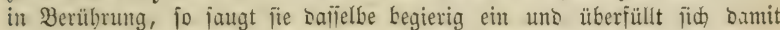

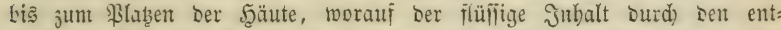
jtanbenten Ris mit (jetralt in bas umgebenoc Wafier fid) entleert. Die Bollenzelle wiro Daburd zur Berridjtung ibrer Junftion ungejhict, uno Diejem Umftante ijt es jujufdreiben, Daf anbaltenter Regen mälveno der

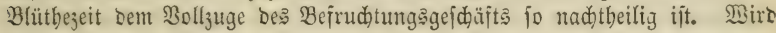
bingegen bie ßollenzelle im 2fusfallen noer ourd) Den Sino oder Durch

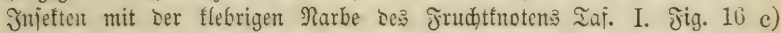
in Berübrunty gebrad)t, Dann mäd)st bie imtere Saut ber Wollenzelle id)laudförmig aue einer ber Foren herbor (Dajelbit ₹ig. 1i $)$, Durdbohrt Die Sherbaut Der Narbe uno wädst im $3 e l l g e$ webe bes (j) rif: jels, nie im ofinen fianale bejielben, bis zur frudtfnotenböble akwärts, Durdbohrt bort wieberum oie innere Dberbaut Der

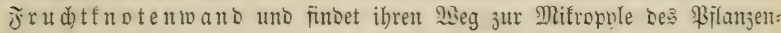
cię, um in biejer bis in Daß Bellgemebe bes Eifegels vorz̆loringen,

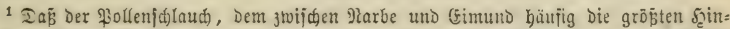

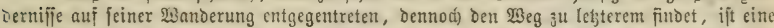

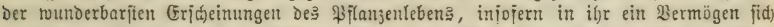
3u erfenten gibt, Das Dem thierijden Jnjitinftc nabe jteht. 2 ernünftig ijt jedes Thun

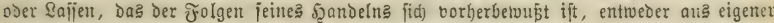
oder aus angelernter frember Crijahrung (Wijienjafaft). Iem injtinttio en Thun oder

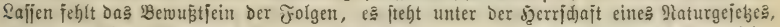

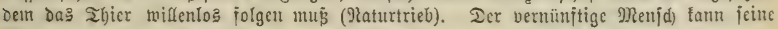

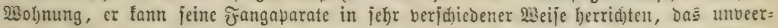

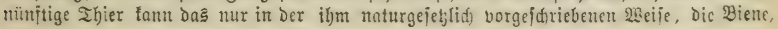




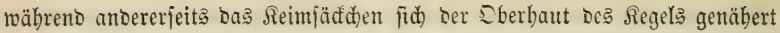
hat, fo Dấ bas Ende Des (bei Tulipa suaveol. mehrzellig geglieberten) Bollenjolauches uno die Spibe Dcs Embrnofactes jid) unmittelbar berühren. Iafel I. Jigur 22 zeigt bas \$flanzenei in biejem 3ujtande, a ben $\$$ fa)lauch), ber bei $d$ in bie Mifropnle eingegangen ift uno fid bem Reim:

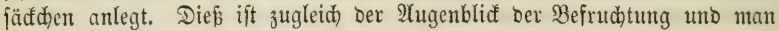

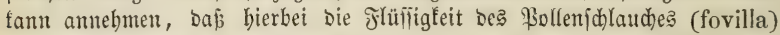
in Den (Embrbofacf übergebe, Daß bierburd) einer ber Bellferne beffelben in= bivibualifirt, ๖. h. zur jelbitftänbigen Fortbil'sung als Grundlage einer neuen \$flanze befäbigt merbe. Einer, bem entgegenftebenden 2 njicht, nad) welder

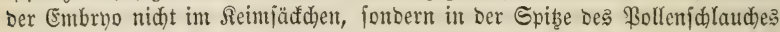
entfiteht, nad)ocm biejer jelbit in baß Reimjäc(d)en eingebrungen, ober viel= mehr bié̃ fappenförmig por fid) hergetrieben hat, nad) ber baher bi e Bollenzelle Den Bflanzenfeim biloet, bin id zuerft in meiner Sdyrift: "Theorie ber Befrudhtung. Braunjhiweig, Bietweg $1845^{\prime \prime}$ entgegengetreten.

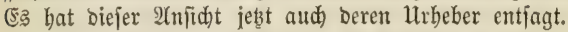

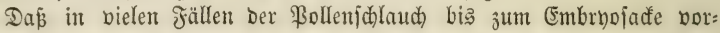
bringt, ifit feintem 3weifel unterworfen, dap biep aber immer uno bei allen Fflanzen notbmendig jei, um einte Befrudtung zu betwirfen, habe id in eben genannter Sdjrift in 3wcifel geftellt, geftititst auf eine Mehrzahl bon Beobad)tungen, in benten ber Bollenf(d)laud) nidht bis zum Eimunbe vor: bringen fann, ober, wo ftatt jeiner ein leitenbes Bellgetwebe anberen $\mathfrak{U r}$ : fprungs in bie Mifropyle eingeht (Campanula, Capsella, Passiflora).

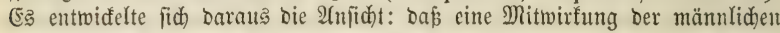

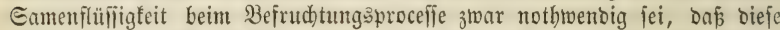
Flüiligfeit bem Reimfäctchen aber aud) burd) bas Bellgewebe Der Rarbe,

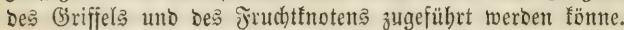

Sb bie männlid)e Samenflüfitigfeit im Reimjäcfdcen materiell ober nur bynamif ${ }^{1}$ wirfjam jei, bas ift einte offente Frage, zu beren Beantwortung wir wohl nie, weber bier nod) im Ihierreid)e gelangen werben. Wir fenten nur bas Rejultat ber Befrudtung, bie Jnoibioualifirung eines 3erfeerna und Defien Fortbiloung zum Ėbryo bes Samen= forns und zur Bflanze. (Es wirb Durd) Den 2(ft ber Befructung ein fleinfter Theil ber Mutterpflanje, einer Der Bellferne bes (Embryofactes, bon ber Mutterpflanje losgerifien - er hört auf Beftanotheil berielben zu fein,

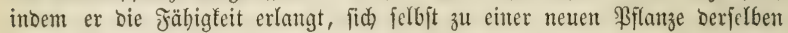

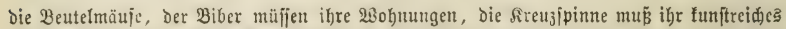

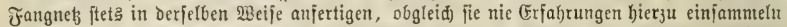

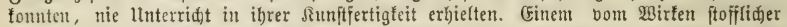
Siräfte unabbängigen Maturtriebe ift aud Die Copulation ber Spirogyren, baß Berfalten ber

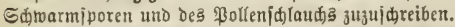

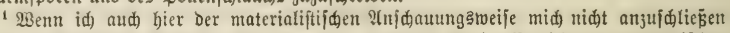
vermag, jo find meine Grtinde dafür folgende: Heberall, wo im Bereidje ber anorganija)en Platur zroei Riörper zu einem britten fid bereinen, ift Die Natur bes lefteren Durdaus ber=

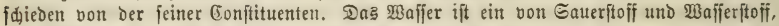
Der Ğyps ift ein bon Gdwefelfätre uno Salferbe ganz beridiebener fiörper. Im Befrud=

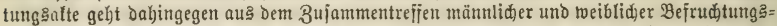
ftoffe ein ber Mutter twie Dem Bater gleider förper bervor. Dieß̃ jpridt meines (Er= ađtens entidieden gegen ben Chemismu! im Befrudtungsafte. 
2rt fortzubilden, went er auch nod) eine Beit lang - bis jutr Eamenreife - mit ber Mutterpflanje in organijchem 3ujammenbange bleibt uno von biejer ernährt twirb.

\section{Der befrudtete Bellfern und befien Entriớlung zur

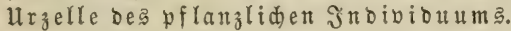

Bis zum Jahre 1842 unteridjed man in Der Biflanzenzelle nur bie ftarre Bellwanbung uno Deren flüffigen Jnhalt, Dem leb̧teren bie förnigen uno bläsెdenförmigen Sïrper beigemengt. Man betradtete bie fejte 3ell= want als eine bomogene, eierjhalenförmig gefdlofiene, burd) gejolsilene

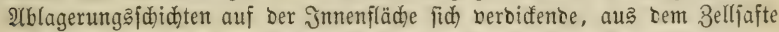

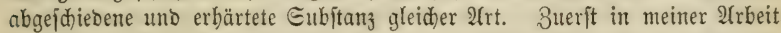
"Iheorie ber Befrudtung" madhte id auf ein fdlaudförmiges, zartbäutiges, ber inneren Bellnanoung bidt anliegenbes bebiloe aufmerffam, bas id juerit

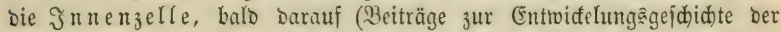

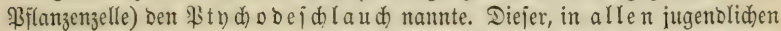
Bellen vorbandene, aber nur im Rinoezellgetwebe unt im Siebiajergetwebe

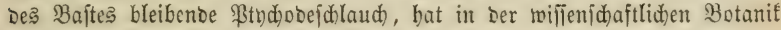

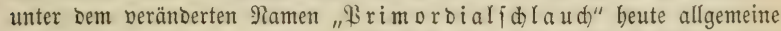
ATnerfennung gefunden, mit ber Befdräntung auf baß Borbanbenfein nur e iner Ed)laudbaut, währeno nad meinen Beobad, tungen ber $\Re$ tydyobejdlaud aus zroeien, ineinanbergeidachtelten; blafenförmig geid)loffenen Szäuten be=

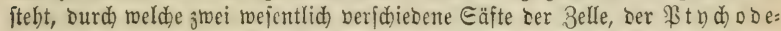
iaft uno ber $3 \mathrm{errjaft}$, Der 2 rt bon einander getrennt find, baf erfterer im Raume zwijd)en ben beiben Ed)laudbäuten entbaiten ift (j. ben nad)= folgenden Şolzid)nitt Fig. k), Dem Dann aud) Der Bellfern uno alle förnigen uno bläş)enförmigen Rörper ber Belle beigemengt fino, mäbreno ber jteţ wafierflare, oft gefärbte Belliaft Den Raum innerbalb ser inneriten Ed)laud)=

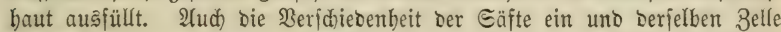

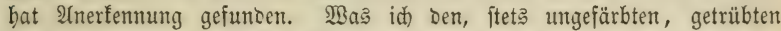

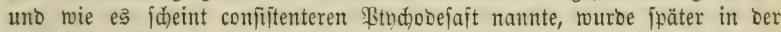

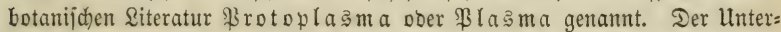

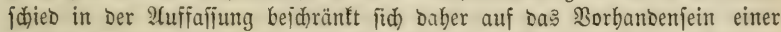

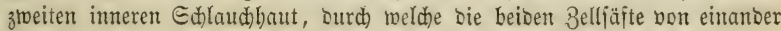
gefidieben fint.

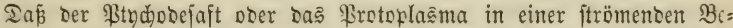
wegung fid befinde, erfennt man in bielen Fällen beutlid) an ber fort= bewegung Der, biejem Eafte allein beigemengten organifïten, feften förper. ${ }^{1}$ Befonbers fdjön fieft man biej in ben grofen Bellen ber 2Armleudter (Chara, Nitella); Der Cucurbitaceen; in Den fnollen bes Ranunculus Ficaria im Jrübjabre zur Blüthezeit; in Den Etaubfäbenbaaren ber Tradescantia virginica, in Deren Bellen ber Belliaft blau, ber \$tndoobejaft ungefärbt ift. $\mathfrak{B O}_{0}$ Der 3ellfern ein mandftänoiger ift, wie in Fig. $\mathrm{k}$ be nädjtfolgencen Şoljidjnittes, Da bejdränft fid bie Etrömung auf bie Ceiten=

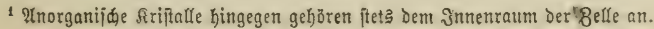


wänbe Der 3elle, an benten ber Gaft im Sreisłaufe anf uno abfteigt; ba bingegen wo Der Bellfern in Mittelpuntte Der 3elle fid) befinoet, wie in Jig. f, g, h (bajelbft), ba verlaufen auperbem Eaftítröme von ben Eeiten Der Belle aud nad) Dem Bellferne bin und zurüa, wie biép bie Rabien in $f, g, h$ andeuten.

গun follte man meinen: bieß alles jei unmöglid) ohne ein Enftem von Sd)laudbäutent uno Sanälen, in welden ber \$tndjobejaft vom Bellfafte

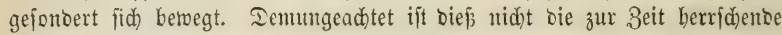
Anfid)t, es befteht vielmebr hartnäctig bie 2(nuahme: Brotoplasmma uno Bellaft, bie, wie id gezeigt habe, fofort fid miteinander mengen, toent fie gleidzeitig ocr burdidnitenen 3elle

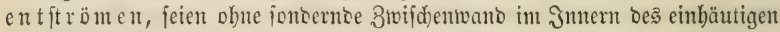
Frimbroialjallaudes burd) fid felbjt gejondert, etma unie Del uno Wafier fid) in Demielben Giefäpe gejonbert erhalten; Die Fortbemegung Deß ßroto: Wlașma jei eine felbfiftändige, is feien bie zarteften, bon allen Ceiten bem

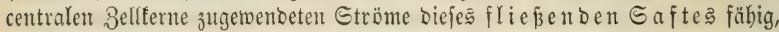
Den verbältnißßääßig großen uno fd)weren Bellfern in ber Mitte oer Belle,

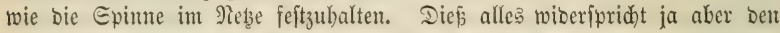

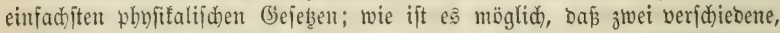

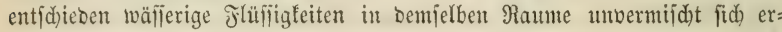
balten föment, bon benen bic eine auf= uno abftrïment in ber anberen fid betwegt; wie wäre es möglid, daj bie zarteften, rabialen Etröme biejer Jłüffigteit Den fd)weren Bellfern, ofte umgeben von einer gropen Menge anberer förniger siörper, im Mittilpuntte ber 3elle feftzubalten bermögen; wie will man bieje Syupotheje mit Der 2Amabme bercinen: es berube Der

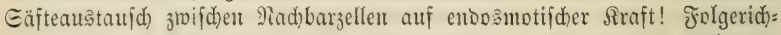
tigfeit ift Dent bod bas 2 senigite, was man in jolden Dingen berlangent Darf. Dlne 3weifel gibt es Erid)einungen im \&cben ter organifden Melt,

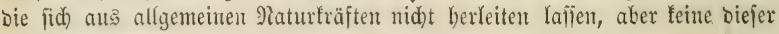

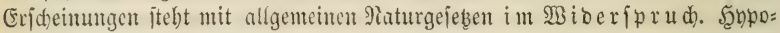
thetifde 2(nutabmen tönten wir in ber \$byfiologie leider nid)t entbehren;

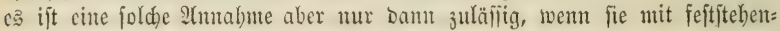

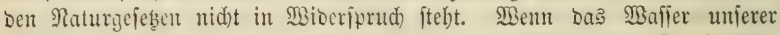
Bäd)e uno Jlülie mit beren Polliteinen beute beliebte cinen Epaziergantg burd) bie Suft зu maden, eз wäre Daڤ nid)t mirafulöjer als jene Gaft= ftrömung in ber Fflanjenzalte ofne einfoblicfiente Szautfläd)ent.

Ed)on in Dbigent liegt meines (Erad)ten's genügenbe Rechtfertigung,

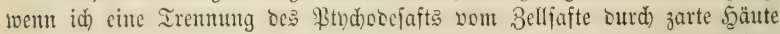
aud) ba antebme, wo folde optifd) nid)t má)weisbar fino. Dieje $\mathfrak{Y}$ nnabme

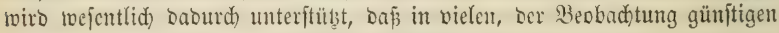
Sällen, bie trennembe Şaut wirflid erfembar ift.

Erit in neuter 3eit ift $\mathrm{es}$ mir geglült, Durd) Eintwirfung von Jarbitoffent auf Den Bellfern, Delïen Baau uno Diejenigen Beränocrungen

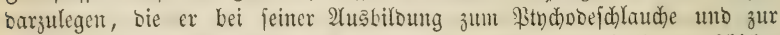

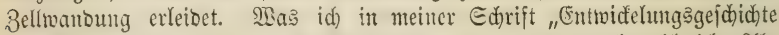
Des Pflanjenteims, Reipjig 185\%" bierüber gejagt mb burd) zablreide $\mathfrak{A}(b=$ bildongen belegt babe, will id) nadjiftehent in möglidjiter Rürze zufammenfaffen. 
Der 3 elffern (nucleus) ift ein joliber, mebr ober weniger fugel= förmiger, vorherrjoeno 0,02 $\mathfrak{R m t r}$. int Durdmeffer großer, mehr ober meniger

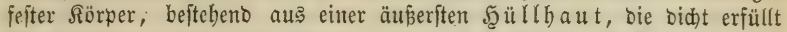
ift mit ciner grofen 3 ahl fleinerer, Durdh gegenleitigen Druf polyebrifder Rörnchen, Den $\mathcal{R}$ ernft offförperden (granula primitiva), unter benen ein Einjelnes (jelten Mehrere) Durdh bedeutentere Größe uno fdärfere Unt:

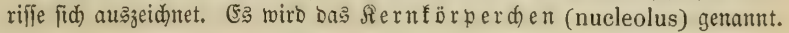

Æig. 16.

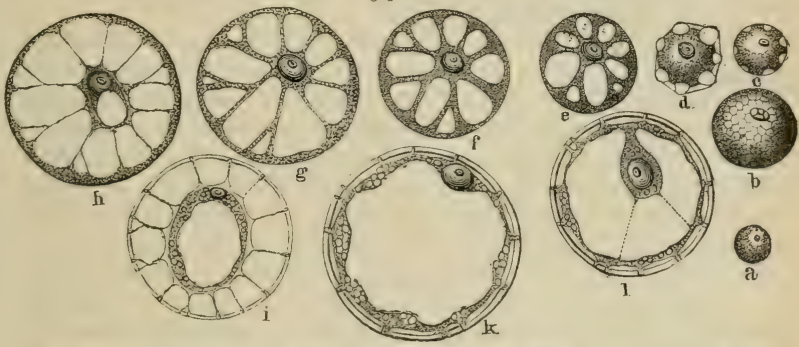

Die boritehenoe Fig. 16 jeigt bei a Den Sellfern mit jeinem Sern= förperdjen. Bei b jeben wir ibn in jtärferer ßergrößerung uno mit Rarmin= löjung bebantelt, woburd) bie 3ujammenjebung bes Inbaltes aus bid)t ge= brängten Rernitofffërperden an gröperen Bellfernen beutlid herbortritt.

Da too aus einem Belfferne bes Embryojades eine erite Belle entítehen foll, fiebt man einen Theil ber, bic Şülllbaut begrenzenoen Sernjtoffitörperd)en burd) Einjaugung bon flüffigteit zu fleinen Blääd)en fìd erweitern, bie

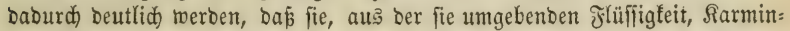
löfung nidht mehr aufnehmen, fonbern ungefärbt bleiben, währeno alle übrigen inneren Theile bes Belferns roth gefärbt werben. Sig. c uno d zeigen bieje Bläßdhen bes Zellterns in junehmender Brößpe, eingeid)loffen in bie erweiterte Fॄüllhaut beక Bellfernt.

Şaben bie, aus einzelnen Rernftoffftörpern Des primären Bellferns ent:

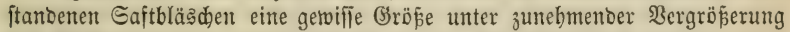
Des 3ellferns erlangt, bann beben fie bie gemeinjdaftlidje Şüllbaut Des Belleerns von Den übrigen Sernitoffförpern befielben $a b$ (d), es löst fid) baburd Der gegenjeitige 3ujammenhang aller übrigen Rernjtoffförperden. Nun vermehrt fich bie 3abl berjelben, burd, Theilung, bił zu molefularer

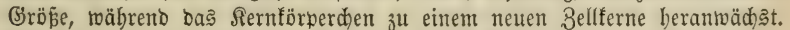

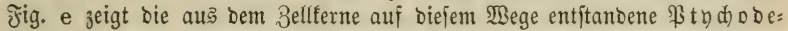
zelle, in weldher ber neue, aus bem Rernförperdien entftandene Bellfern von einer Menge gröperer uno fleinerer Gaftbläßchen (Bhyjalibe) umitellt ift, bie ihrerjeits bon ber uriprüngliden ermeiterten Süllbaut bes Bellfern's (a) 3ufammengebalten werben. Der Jnbalt ber Gaftbläsెhen ift walierflar und wirb in Rarminlöjung nidbt gefärbt. Der, Den fecunbären Bellfern uno bie Saftbläßdhen umgebenbe Eaft bingegen ift getrübt, färbt fich nod burch Rarminlöfung utb entbält grofie Mengen nolefularer Rörper, 
Die llrjadje feiner Trübung. Id babe biefen getrübten $\epsilon_{a f t} S_{d} l_{a} u d f a f t$ $(\Re t y d)$ D befaft) genannt, zum Unteridjebe vom wafierflaren Inbalte ber Saftbläs̄d)en, ben id) 3elliaft namnte.

Mit zutebmenter Größß̨e Der, Den jecunbären Belffern umlagernben Gaftbläsd) bilibet fid um eriteren eine 2 rt intracellularen, zartbäutigen Bellgewebes, woourd Der \$tndodejaft in Dic intercellularen Räume biejes Bellgetwebes, in bie Umgebung Des jecunbären Belfferns uno jur inneren

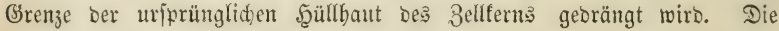
§ig. f zeigt biefen Entwidéelungşzuftant.

Weiterbin feben wir, wie Fig. $g$ unt $h$ andeutet, an Gtelle Des mit

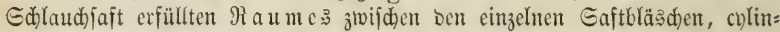
Drifde, mit Sd)laudjaft erfüllte $\Omega$ an äle, bic vom peripherifden Sdlaud): faft zu Der, Den centralen Belfern umgebenten Edlaudjaftmenge binzieben, unto man erfent mun in biełen Fällen bentlid) cine Jortberwegung be马

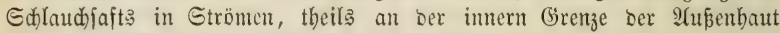
(Ptnd)oide), theils von biejer zum Sd)laudjafte ber Bellenmitte bingementet

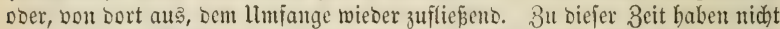
felten einzelue Molefule ies Ed)laudjafts zu Etärfemehl= ober (Eblorophyll=

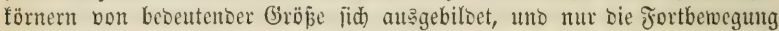
Diefer Rönd)en ift es, an Der man bie Bewegung bes Eafts erfenten unt Derfolgen fann, wie Denn and) Die bäutige Begrentung Der Sanäle, in ber Der Sd)laudfaft fid bewegt, mur in einjelntn, ber Beobad)tung günftigen Fällen birelt nadjweisbar ijt. 1

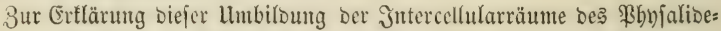
getvebes in Sanäle unt Sdlaudbäute nehute id) $n u n$ an: baf́, überall

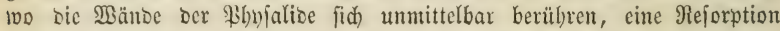
Derfelben cintrete, wäbrento alle miteinantoer nidht in Berübrung ftebenden, Durd) ßtndjobejaft von cinanber getrennten Şautfläd)en untereinanoer ber: wadjen. Daburd) würoen entftehen: 1) cin Den Bellfern einfdliepender zart=

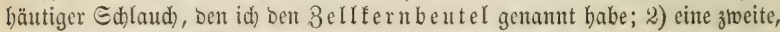

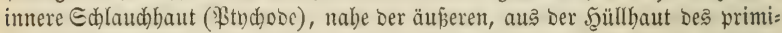
tiben Bellferns ftammentert $\Theta d$ laudhaut (Btnd)oibe), Durd weldhe ber periphe=

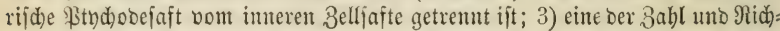
tung früherer Sintercellularräume Des \$byfalibegewebes entipredhente $2 \mathfrak{a n g a b l}$ rabial berlaufentber bäutiger Sanäle, Die einerfeits in ben Bellfernbeutel, anberer=

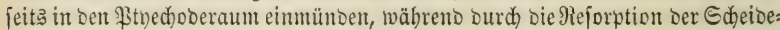

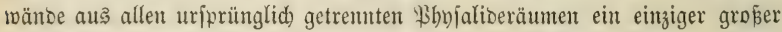
Bellraum cntitanden ift, erfüllt mit ben Safte aller früberen \$hyjalioeräume.

1 In ben grošen 3elfen Der (

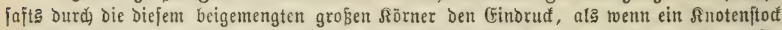

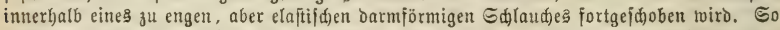

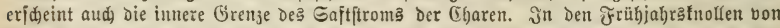

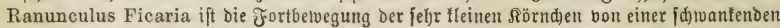

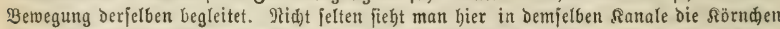

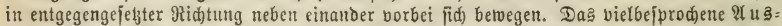

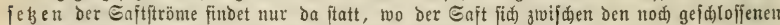

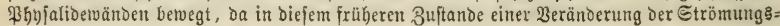

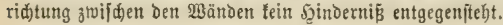


Diejer Annabime bient allerbings nidut viel mehr als bie Thatjache zur Etüke, ba $b a$, too in Der jugendlid)en Belle ein \$hnjalibegenebe (in ber

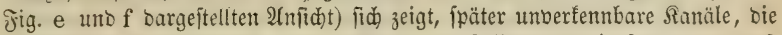

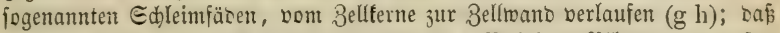

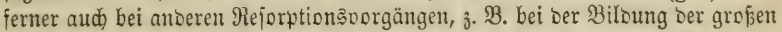
Söd)er in Den Duerwänoen ber Sgolzröhren, bieje fidh auf benjenigen Theil ber Manoung bejodräntt, ber mit oer Nad)barmanto in unmittelbarer Berührung

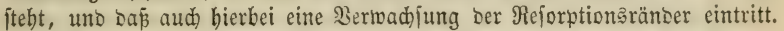

In Dem Fig. g bargeftellten 3ujtanbe hätte nun ber wejentliơjte, lebens: thätige Bejtandtheil Der \$iflanzenzelle feine $\mathfrak{B}_{0}$ llentoung erreidft. Wir haben Ia einen centralen Bellfern, eingeja)lofien in cinert zarthäutigen Bellfernbeutel, non Dem eine Mienge zartbäutiger Sanäle ausgehen, bie ben Belltraum rabial surdbieben uno unfern Der äuperen Bellhaut in eine innere Bellhaut ein=

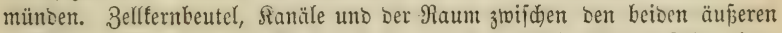
Bellbäuten (Ptndobe uno \$trydoibe) find mit bem Ed)laudjaft erfüllt, einer spafen, förnerbaltigen fouliligfeit, beren ftrömende fortberegung mit ver fortberegung bes Gafts von 3elle zu Zelle und burd) bie ganze Pflanze, febr wabrideeinlid in naber $\mathfrak{B} e=$

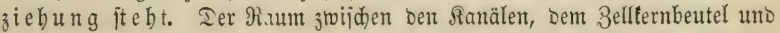

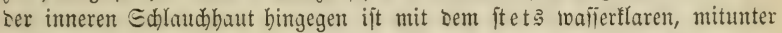
farbigen Belljafte crfüllt, in Dem eine Bemegung nidht erfennbar ift.

Diejer ganze 2tpparat bilDet Den wejentlidjiten, Yebensthätigen Bejtant: theil ber \$iflanzenjelle, jeine zarthäutige Beidaffenbeit würbe aber nid)t ge:

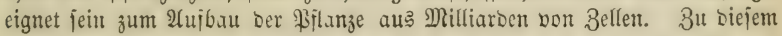

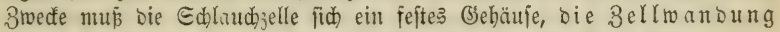

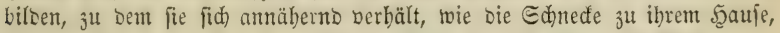

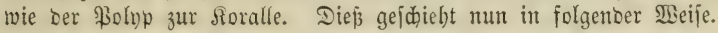

Der jecuntäre Berlfern, Den wir in Fig. g in ser Mitte Des Bellraums gelagert jeben, entwidélt jeţt aus einem feiner, Der f̧üllbaut anliegenden Sernftoffëbrperdhen ein ei nzel nes Gaftbläsdben (Monorbnjalio) in berjelben Meije, wie bie Enttvidelung einer Mebrzahl Lerjelben Durd) bie Figuren

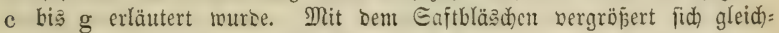

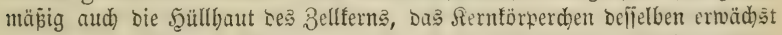
jll einem tertiären Bellferne, und die Rernftoffförperden bes fecunbären Bellferns treten auseinanter, entwicoeln fid) zu Etärfemebl=, Eblorophyll=, Silebermeblförnden uno vertheilen fidd in oer Flüfitgfeit eines neuen (jecun= rären) Ed)laud)raumes, Defien äupere Şülle bie ertweiterte Şüllhaut bes

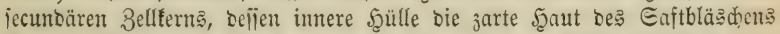

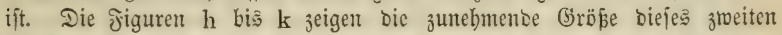

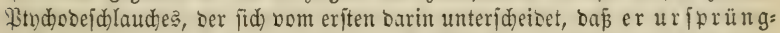
(i d) mur einen vom herantwadjenben Gaftbläşhen gebildeten Belliaftraum

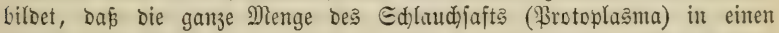

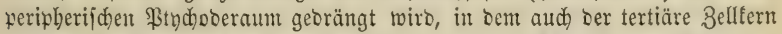
gelagert ift, ber babur d̆) nu zu einem wanbftänbigengeworben i jt. Die Urjadje ber veridfiebenten Etellung bes Bellferns liegt aljo barin, Dap bort mebrere, bier nur ein Gaftbläşchen aus Den fiernitofiftörpern bes 3ellferns unter ber Şüllfaut befllelben fid bilbeten. 


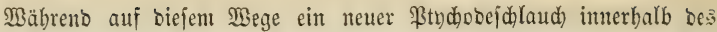

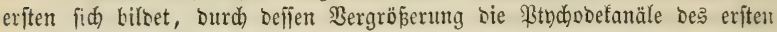
Sd)lauches, fid) zujammenziebent, nad) bem Umfange bes lebeteren gebrängt werben, erleibet ber Jnhalt bes eriten \$tydoderaumes barin eine Neränbe:

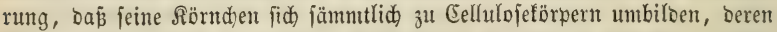
(5rößjezunabme uno grgenfeitige Berwadjung bie ftarren Edjidtungen ber

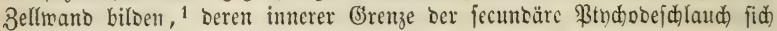
anlegt, gebrängt burch bas lebendige Streben ber Selfe, bie möglich größte Eäftemenge aus ihrer Umgebung in fid aufaunehmen (Turgescenz). Diejen 3uftano ber nun fertigen $\mathfrak{B a n d u n g}_{3}$ elle ftellt Fig. $\mathrm{k}$ bar. Wir feken ia,

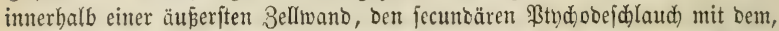
in ifm liegenden, tertiären Bellfern, auperbem in Ptydobefafte eine Menge

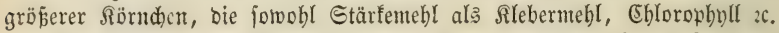

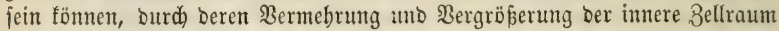
unb beffen Bellfaft endlid) ganz verorängt twirb, wo baun bieje, ourd) $4 \mathrm{~m}=$ biloung Der אernitoffförper bę fecundären Bellferne entitantenen Rörper bie ganze Belle erfüllen, nadjoem bie Şäute bes ifnen angehörenden \$tndjode:

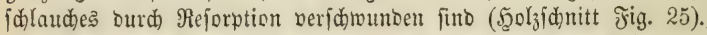

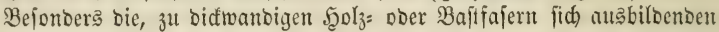

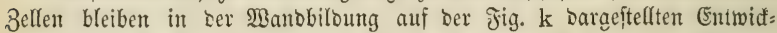
lungsitufe nidyt ftehen, fonoern es bilbet fid imerbalb oer erften Bellwand aus Dem fecumbären Ptndrobejdlaudje eine ztweite Bellwanbung, ganz in

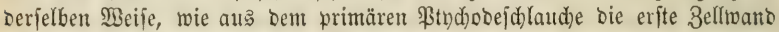
fich bilbet. $\mathfrak{B}_{0}$ bieß ber Jall ift, Da tritt ber wanbitäntoige Bellfern Durd) eine Einftülpung in ben imeren Bellraum, wie biế Jig. 1 barftellt, worauf

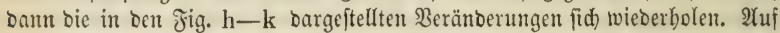

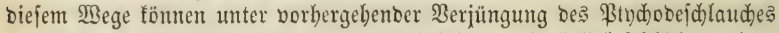

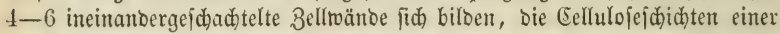
jeben, auß̌n uno imnen befleibet von ben bleibenden Sä̈uten bes \$tndjode:

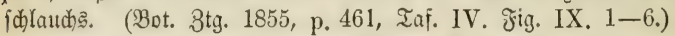

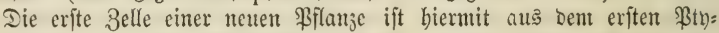
dodeidlaudhe, ber erfte Ptndjodeidlaud) ift aus bem criten Bellferne ent= ftanden uno biejer erfte Bellfern ift ein Nachtomme bes Bellferns berjenigen

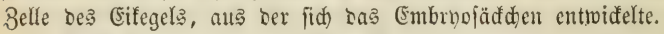

Dieje Ulzolle bes pflanzliden Inoivibuums untericheioet fich in nidjts Bejentlichem von jeber anberen Pflanzenzelle, uno ebenjo ift aud bie $2 \mathfrak{2 t}$ unto ber Berlauf ibrer 2łtäbilbung von 2frt uno Berlauf anderer Fälle

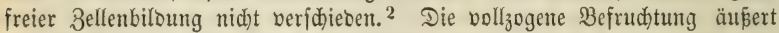
nur barin ibre Mirfung, bafs bie Utzelle, wenn audh nod bis zur Samen= reife ihre Fortbilloungsftoffe bon ber Mutterpflanze bejiehento, als ein in

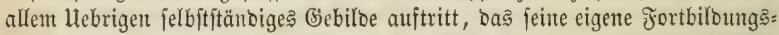
rid)tung berfolgt, entipredeno bemjenigen Biloungägange, ben bie Mutter=

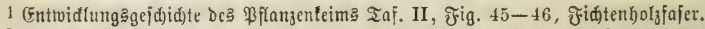

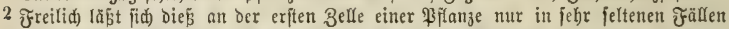

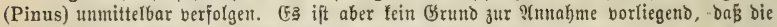

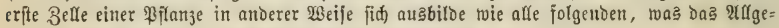
gemeine Des Bildung = und Rehrungäborganges betrifit. 
yilanje auf gleider Entwidflungşfufe in ibrer Jugeno Durchlaufen bat;

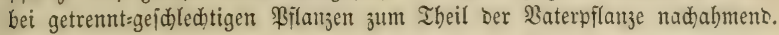

\section{Die 3elfenmehrung ourd) 2 bidnürung und bas barau beruhende $\mathfrak{B}$ adjen bes Bflanzenteims.}

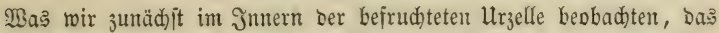
ijt bie Biloung neuter Bellen in ibrem Raume burd) 2(bjdnürung Des Pty=

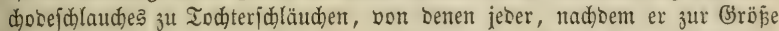
ber Mutterzelle herangetwadjen ift, nadjoem er zur Bellwand getworben und einen neuen \$rndyobejdlaud im Jnnern bes alten gebildet bat, einer er: neuten Theilung unterworfen ijt.

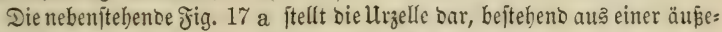
ren 3elltwanoung und aus bem \$itndiobejdlaude mit wanbftänbigem 3ellferne. Fig. b fehen wir

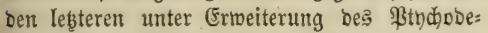
raums in ben Mittelpuntt ber Belle gerültt, eine Erweiterung, bie fich in Fig. c auf bie entgegen= gefeşte Seite fortgejeb̧t, förperlich betrad)tet über bie ganze mittlere Querfläche ber 3elle fich ber= breitet, uno baburd bie innere Sdlaudhaut 3̋ ztwei geidlofijenen, einbäutigen Zellräumen abgeidnürt bat. Der in ben Mittelpuntt ber Querfläche gerüđte Bellfern zeigt idon bie Sinie einer fünftigen 3meitheilung. Fig. d ift bieje 3tweitheilung eingetreten, morauf aud bie

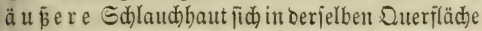
ringförmig einfaltet, bis bie in Jig. e bargeftellte

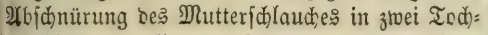
teridjläudje bollentot ift, beren jeber einen balbirten, fid ergänzenoen Bellfern im gejđlolie= nen Ptndyoderaume entbält. Nadbem jeber biejer P(t)djobejd)(äudje in vorbin gejdilberter $\mathfrak{B e i j e}$ einen neuen Btndobejollaud) mit wanojtänoigem Bellferne in feinem Jnneren auggebilbet bat (f), wäbrento oer erite \$indyodejdlaud) zur Bellwan= Dung erftarrt ift $(\mathrm{g})$, tritt in ben mun zu Mutter: gellen ausgebildeten Todjterzellen eine enteute 3.weitheilung zu Enfelzellen in gleicher Beije ein, bie bie urjprünglide $\mathfrak{M}$ utterzelle zu Iod)ter= jellen fid abidnürte uno entwidelte (h). Die

รig. 17.

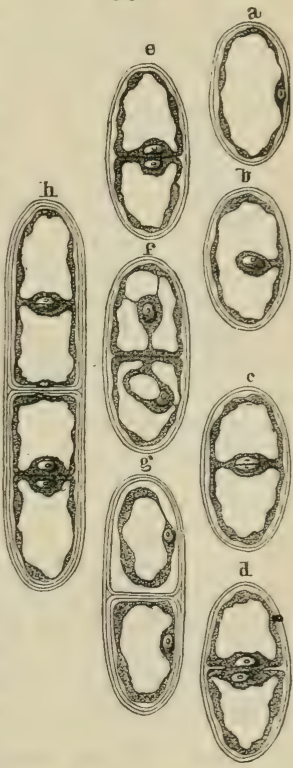
jweite 2lbjanürung erzengt Dann bier, bie britte adht, bie vierte fedjebn Bellen u. f. f. Nebmen wir nun an, baß bie auf 2(bjdnürung berubende

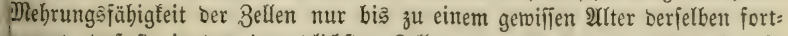
pauert, báp fie in ben jugenolidjpten Bellen am rajdhejten vor fid gehe, io nus enolid ber Sängenzuwad): in jeber Bellenreihe fich auf beren Enbjellen

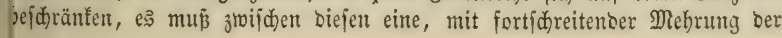


Enojellen wadhiende $3 a b l$ nidht mehr mebrutgäfähiger Bellen entiteben, beren nun eintretente Banboerbidung für bie jüngeren Enojellen einen feften 3rifhenftamm bildet, den Iräger des auf = uno abjteigenden \&ängen:

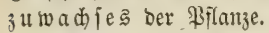

Neben biejer, Den \&ängenjutwach) bes \$ilanzentörpers vermittelntoen S(bid)nürung rechtrinflig zur Sängenad)fe ber Bellen, tritt mun aber nod) cime 2tbjdnürung parallel ber Sängenadje ein, burd) weldhe bie Zabl ber Bellenreiben fich bergröpert. Dieje Bermebrung oer Zellenreiben vermittelt Den Di đé

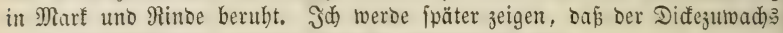
Durd Fajermebrung anberen (Bejeł̧en unterworfen ijt).

Denten wir uns nun bie Y(bid)nürung red)twintlig zur Sängenadje

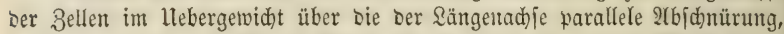
fo muß baburd) ber Pflanzentörper bie Form eines in bent Grabe lang:

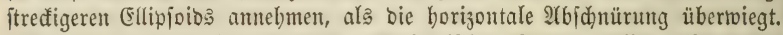
Mir erbalten einen langitređigen, ellipjoidijąen Rörper, Defien beid)räntter

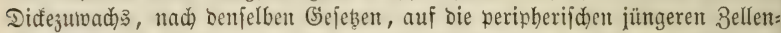

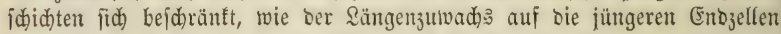
Der Sängentadje im auf= unto abfteigenden Sinofpentaärzchen.

2tı

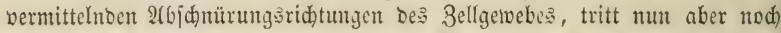

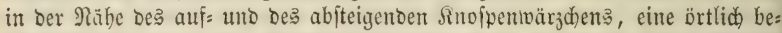
fdränfte Steigerung ber Bellenmebrung ein, Durdh weld)e bie zellige (Srunto: lage fünftiger $\mathfrak{B} l a ̈ t t e r$ uto $B$ lattadjelfnoppen hügelförmig ${ }^{1}$ über bie Dber=

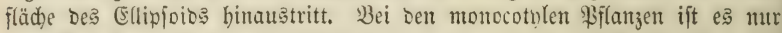

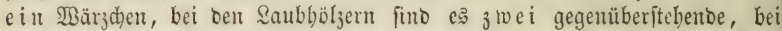
ben meiften Nabelföljern fino es viele foldher Blatthügel, weldhe fid gleich):

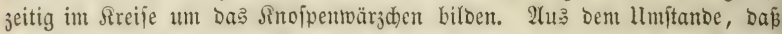
im Embrno uno in ber Samenfnope bie warzige Grunblage bes Blatte idon entitebt, ehe nod) cine Epur bon faferbünoeln nadbeisbar ift, aus

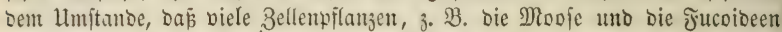
jefre entwidelte Blattformen ausbiloen, ohne bas ßorbanbenjein von fajer=

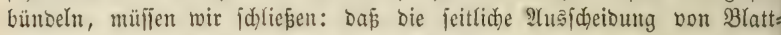

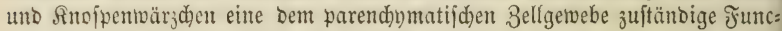
tion fei, Daf hier bie Jajerbiloung ber Bellenbiloung eben fo folge, wie

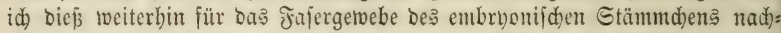
weifen werbe. (Es läpt fid) Daber Das Şeranwadjen des Embryo aus ber Urzelle, einjoblieflid) Der an ifm fid) bilbenben Blätter (unb Blattad)jel= tnojpenanlage), jebr tobl auf rein parendyntatijd)e Junctionen zurüdfübrent.

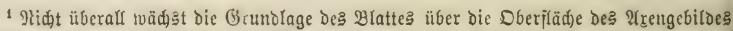

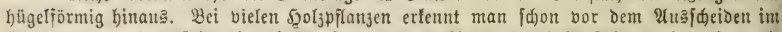
3ellgetvebe Der Triebfpiłge eine einjanneidende Gpaltbiloung Durd) (Entitebung einer Doppel= iđjiđ)t von fläđ)enförmig gcoroneten 3elfen, Die jpäter zur Epidermis einerjeiţ Der Blatt= jd)eibe, andererfeits Des Iriebez werden, nadjoem bie beiden Bellenjdidjten fid) getrennt

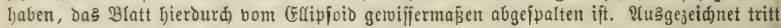
Dieje \&f bipaltung bejonders bei Magnolia und Liriodendron auf, twofelbft ibr bas Blatt entipringt uno eine fappenjörmige $\mathfrak{A}$ us jp alt $\mathrm{ung}$ folgt, Durd) weld)e alternireno bie nnoppenbülfen gebiloet werben. 


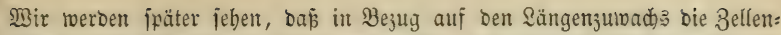

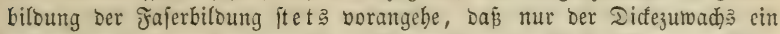
antoerer wiro, Durd) unmițtelbare Frijermehrung auf ber Brrenze zwiiden Sololy uno Bajt.

Die Utrzelle ber neuen Bilanje entrwifelt fich in ber Regel nidyt un= mittelbar zu bleibenden Theilen bes Embrno. In ber Regel bildet fie zu= nädjit einen, aus einer ober mehreren Bellenteiben bejtehenden, fabenförmigen Iräger, aus belīen Enozelle ber Enıbrno erroäđast.

Die untenitehende Jig. 18 (6-12) jeigt oie Entwiälungâfolge bes Embrno ser Riefer, wie id bieje Tafel 25 meiner Naturasididete ber forit= ซ̃ig. 18.
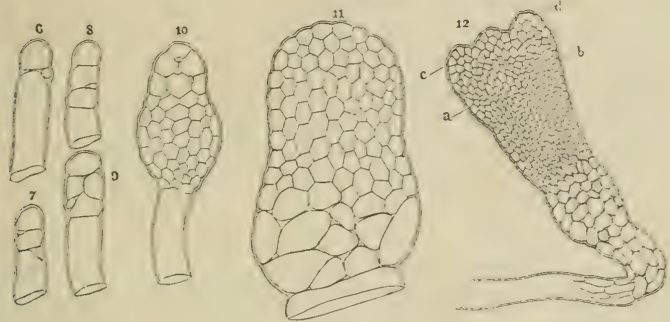

lidłen Culturpflanzen weiter ausgeführt habe. Ĵn ber Spibe Des bier aller= bings jecundären Irägers jeben wir in 6 eine erfte Belle abgeidnürt, bie in 7 uno 8 fid 3 utwei uno orei Bellen vermehrt bat. In 9 beginnt bie $2(b=$ idnürung paralfel ber ¿ängenad)ie, 10 uno 11 zeigen bie auj biejent Bege

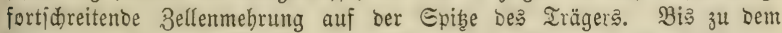

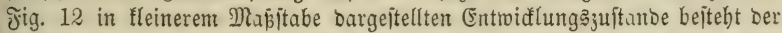
Embrno mur aus parendumatifonem 3ellyelvebe, obgleid) bie fünitigen eriften Nabeln als fleine Bellenbügel (c, d) im Ilmtreije bes centralen Snofpen= wärschens fidion beutlid erfentbar find.

Der Embrno bejtebt aljo anfänglidy au gleid)gebiloeten ober bod) gleid)werthigen Zellen; aus ciner Mehrzahl ber Sängenadjje paraflel liegender Reiben joldher Bellen, bie im Queridnnitte concentrijae Edidgten bilben

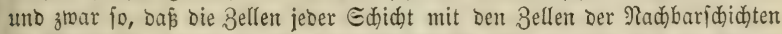
im Berbante Yiegen (i. Die Dueridnittiläche Jig. 1 uno a af. I. Jig. 2 i-k). Da bie Bellen jeber Reihe aud̆ im Sängenjantte mit Den Bellen ber Nađbarreihen im Berbande liegen (i. bie Sängenjanitte burd Marf

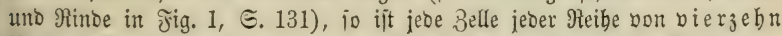
Nadbarzelfen begrenzt, von Denen zwei berjelben Bellenreibe, zwölf oen an=

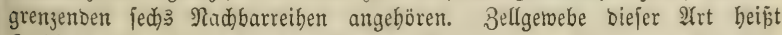
Berlgerebe im engeren Einne (Barendym). Eeiner meift bün=

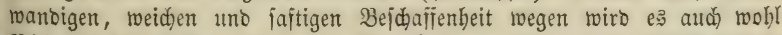
Bflanzenfleifd) genannt, im (begenjabe zu bem, aus berbbäutigeren

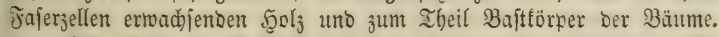

Die fibon am Embrno yor Der Eamenreife auftretenoen Blattaus: 
¡cheibungen erlangen bei beridhiebenen Pflanzentarten jebr beridbiebene Grabe

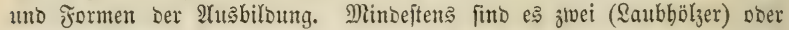

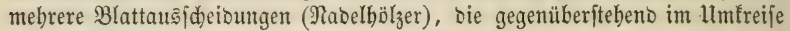
bes Snofpentwärzchens entfteben. Bei Den Rabelbölzern fommen nur dieje eriten Blattausfaheioungen im Samentorne zur 24usbiloung uno liefern ben

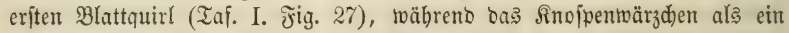

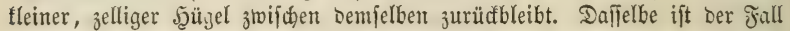
bei ber Rotbbuche, Sjhe, Rüfter 2 ., mojelbjt bie eirsigen beiben Blatt= außjheibungen ju Samenlappen fid berbiden. Bei ber Eidhe bingegen, wie bei ben meiften Reguminofen entwiffelt bas centrale ßnofpentwärzhen idon vor ber Samentreife nod) eine zweite, britte, oft fogar vierte Blatt= ausfcheibung, wie biép bie Entwiđflungşolge besె Embrno ber Eid)e Taf. I. テig. 23-26 erläutert. Fig. 24, 25 b, Fig. 26 a fino bie ju Eamen= lappen fich verbiffenten, erften Blattanşheibungen; Jig. 25 a ift bas aus Dem finofpentwärzhen berangebildete fieberden (plumula). Die 2laffe Des Embrno, fo meit wie die Marfmafie abwärt’ reidht, heipt bas Sten=

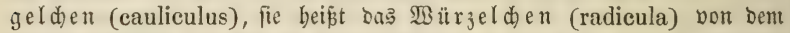
Bunfte abroarts, an bem bie Fajerbünel bes Stengels ju einem centralen Faferbünbel fid bereinen.

Benden wir ben Blicf nod einmal auf bie Jig. 17 a bis h zurüd, is jebn wir, bas jeber abgeidnürte Todterfallauch fidh jur Bellivanoung ausbilset, twähren

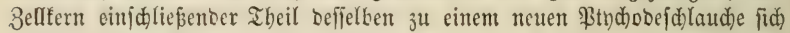

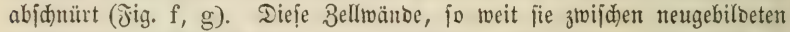
Bellwänben liegen, werben fpäter reforbirt. Im fertigen Bellgewebe ift eine, mebrere Bellen einfdliefente Belltwanbung nidft mehr aufafinden, wie biế Der Fall fein müßte, went eine Reforption nidjt ftattfänbe. Da= gegen erbält fidd) bie erfte Bellwanoung ber erften Mutterzelle, ourd) bie anliegenten 3ellen ernährt uno in fid felbjt fortwachieno, als gemeinjdaft=

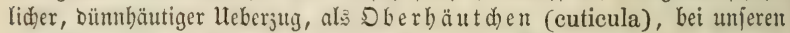

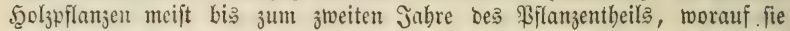

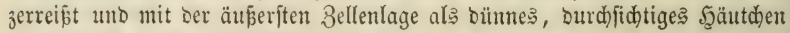
abgeworfen rird. 3meijäbrige Triebe bon Prunus ober Populus zeigen Dieß am bejten. Iie Cuticula ift aljo bie im Umfange Der Bflanze bis zu

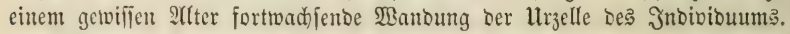

Rad) Der herridhenoen 2(nficht fino bie Dberbautjellen, b. h. bie äuferite

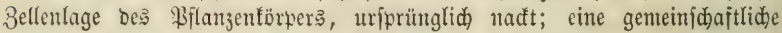
Oberbaut biloet fid) über ifnen erft fpäter burd) Gefretionen. (jd) vermag nicht, biejer $2 \mathfrak{n}$ fid)t mid) anzuld ließen.

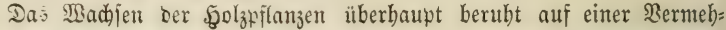
rung Der fie aufbautenben 3ellen. (5s berubt bie 3ellenmebrung, fo meit meine Beobadtungen reiden, allein auf einer Iheilung vorgebilbeter Bellen. Jebe 3elle, felbjt ber älteften Pflanze, ift baber ein burd) Theilung ent=

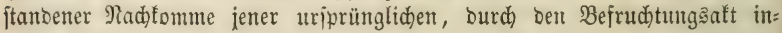
bivibualifirten llrzelle, bleikend und unabänderlid) begabt mit Deren fpecififden und inbiviouellen Ėigenjaften. Reine ber fünftliden Sermebrungäarten einer Mutterpflanze änoert irgento etwas an 


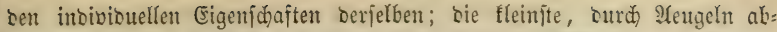

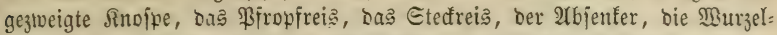

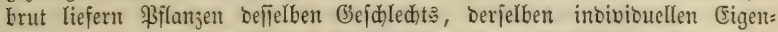

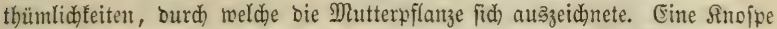
ber Blutbudue, Der Şängeidhe, Der Byramibeneidje liefert unfeblbar Blätter, Iriebe, 2Aejte, Etämme berjelben Biloung, auch menn fie auf Miloling=

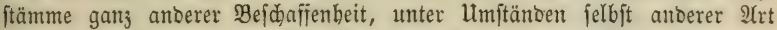
uno Gattung verję̧t murben: Glyptostrobus auf Taxodium, Pyrus auf Crataegus, Amygdalus auf Prunus), ofue baí baburd bie গatur de Bilolings veränbert wiro. ${ }^{1}$ Iaujenbe von Etedifeijern ber männlichen Meibe ober \$apwel liefern ftets wieber männlide Jnbivibuen. Ğanj anders

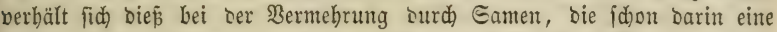

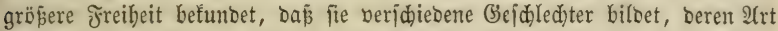

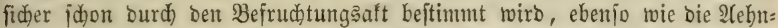
lid)teit Der 3ajtarbe mit Der Baterpflanze mur bem Befruchtungsafte ju=

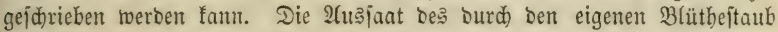
befruchteten Gamens ber Błutbuchen, Syramibeneiden 2c. ergibt meift nur wenige Siflanzen, in Denen fid bie inbibibuelle Albnormität ber vereinten Mutterpflanze fortgepflanzt bat. ${ }^{2}$

\section{Die Faferbiloung und Fafermebrung.}

Mir haben gejehen, daj ber \$flanjenfeim uriprünglid uno bis über Den Beginn Der Blattausjokibungen binaus nur aus parendinmatijd)m Zellgewebe bcittebe. Jrüher ober fpäter, jebod ftets lange vor eintretender Gamenreife, ment 3. 3. Das Riefermpflänzchen bis zu dem Geite 171,

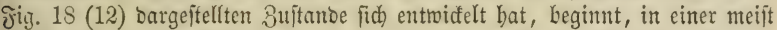
gleid) weit vom Mittelpunfte wie bom Umfange bes Sueridnnitts entfernten

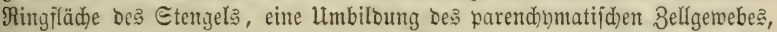
Deren Enbrefultat bie Pflanzenfafer ift, bon ber Pflanzenzelle in 2 fll=

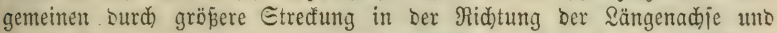
Durd) bie Brntppirung zu Bündeln unterifhieben, in benten fie, rabial ge= oromet, borijontale Edjidten bilon, bie unter fid̄ burdh bas Jneinanoer= greifen ber jabräg žugeipiz̨ten Enden jeber Fafer verbunden finto (Taf. I. テig. 5 e e).

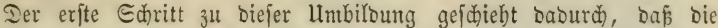

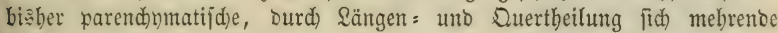
Belle, nunmebr eine Theilung in biagonaler $\Re i d$ tung erleibet, wie

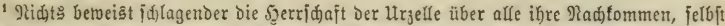

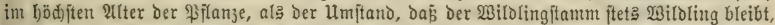

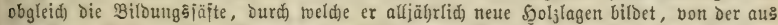

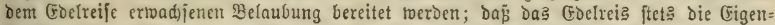

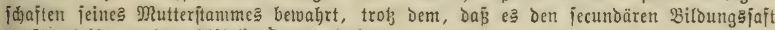

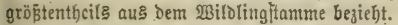

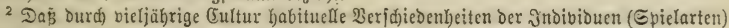
beroorgerufen werben fömnen, Die jid) Durd jedes Gamentorn fortp Flanzen, bejtätigen einige Irten Der Gattungen Brassica, Raphanus, Beta, Viola. Wieldes die phyjiologijde

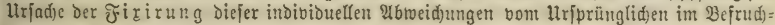
turgsalte fei, ift uns unbefannt. 
ซig. 19 ,

Dieß̉ bie nebenftehente fig. 19 a erläutert. Durd) \&ängen=

c wad)sthum biejer beiben Tod)terzellen in ber Ridutung ber

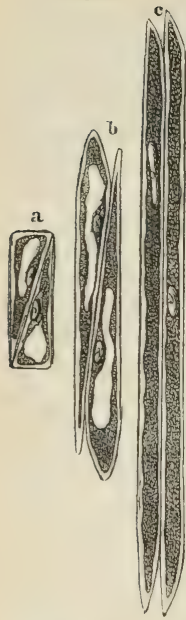
biagonalen 2Tbidnürungâfläche geht baraus bie Fajerform hervor, wie bieß bie folgenben Entwidłlungsifufen b c bar: ftellen.

Denft man fid, bom Mittelpuntte einer, Den Duer= ¡dnitt bes Stengeไs repräfentirențen Freișfläd)e aus, einen fleineren Sreis vom balben Durd)meffer Des gröferen be= id)rieben, fo beginnt bie Fajerbiloung in einzelnen, ans näberno gleid) weit bon einanber entfernten \$untten biefer inneren Sreislinie und jadreitet von biejen Funten aus in rabialer Ridjtung nad) aupen vor. (3)(eidzeitig mebrt fid) aber aud) von jeocm Funtte als bie 3ahl ber Jajerrabien baburd), baj an jeber Eeite beక borgebildeten Faferrabius ein neuer 3ellenrabius in bie Epaltung z̆แ zweien Fajer= rabien cingeht. Durdh Den jeitlichen 3uwadis an ₹ajer= rabien verengt fid ber Siaum zwifden je zrwei ber auf biefem Wege fich bildenten Jaferbündel, bis endlidh mur eitt ober einige Bellenrabien zmijhen ibnen übrig bleiben, bie nidht зu Fafern, jonbern zu Marfftrablzellen fid umbilben, ein Bellgemebe, beffen 2tnorbmung bon ber Dronung Des uriprünglichen Bellgetweles burchaus verfdieben ift, bas Daber ebenfalls nidyt als ein 9üuftanto ocs lebeteren betrachtet

werben barf.

Sn Der nadfolgenben Figur gebe id Die Entwidlungsfolge eines ein= zelnten Jajerbündels, wie fie fich in Suerfdnitten aus jungen finofpen Der Fig 20.

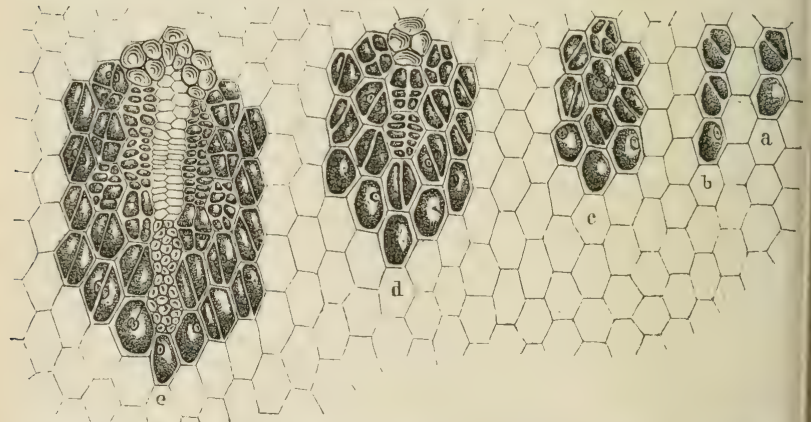

Eámarzficfer zu erfennen gibt, wenn man von ben oberiten, jüngiten zu Den tieferen, älteren Bilbungen binabiteigt. Im cambialen Bellgewebe a bis $\mathrm{e}^{1}$ feben wir über $a$, als erfte llmbildungsifufe, Den Beginn Der

1 Wie bief, Durd feine rabiale Sronung bom parendymatifan Bellgerobe unter=

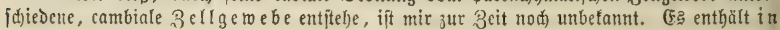




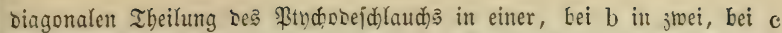

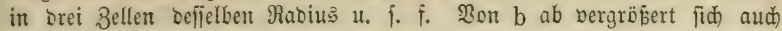
die Breite bes Fajerbündels baburd), bá, an jeber Eeite tes vorbergehent зи Fajein umgebilbeten Bellenrabius, ein neuer Bellenrabius in bie bias gonale Theilung eingeht, woourd) bie anfänglid breiten Siäume jwij(hen Den Fajerbüneln idmaler werbent. Der burd) bie Diagonaltbilung er= fembare Hebergang ser Cambialzellen in Jajerzellen unb bie barauf be= rubende Bergrößerung ber jungen Fajerkünbel iłt, wie bie Jiguren zeigen,

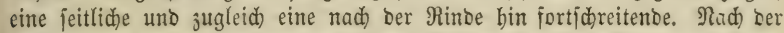
Idje bes Triebes bin fintet ein fortidritt in ber Umbiloung nidht ftatt, bie zuerit gebildeten Faferzellen bleiben bei ben meijten Syolzpflanjen für immer bie innerften bcs Bünoels, uno verwanbeln jid̆ febr früh, nad) fortgefebeter Theilung, in ähte Epiralfajeržellen, wie bié in ben Jig. d uno e Durd) eingezeidnete Bogenjtridje angebeutet ijt.

¿ङs entitehen aljo aนふ jebem Bellentabius ber rabial georoneten Bell= jajicht z̧mei fajerrabien. Die innerften, ältẹten biejer leţteren fino bann

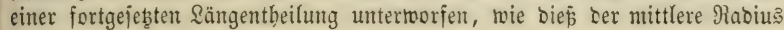
Des Bünbels d andeutet.

Dieje Jajern ineiter Theilung fint $e$ s, bie fid rabial oronen, beren

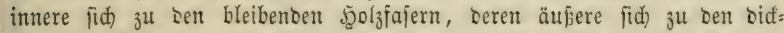
manbigen Baftfajern ausbilben, wie biér im mittYeren Rabius bes Büntel: e angebeutet ift, wofelbit bon e aus in ser zweiten unb britten Belle, bie

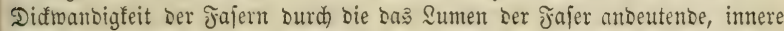
Bogenlinie bezeidnnet ijt.

Scaben bie Jajerbünoel jich biz ju bem Grabe in vorbejeidgneter $\mathfrak{B} e i j e$

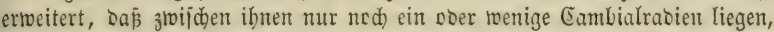
bann wertwandeln fich bie Bellen leterterer in Marfítrablzellen. Wie es zu=

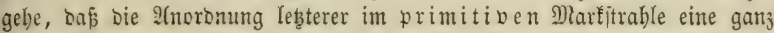
anbere ift, als bie ibrer Cambial=Plutterzellen, habe id ebenfalls nod nidht ergrünten fönnen, fo leid)t bie Biloung ber fecuntören Mlarfitrablen

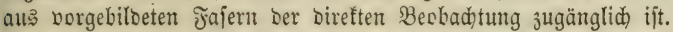

2(uf siejer Entricflungştufe angelangt, tritt mun eine febr merfwürbige Beränoerung in Den 3umadjerjdeinungen Des Jajerbünbels ein. Mie burd)

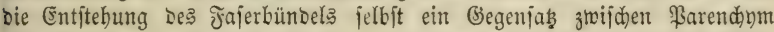
und ßrofendbum, jo tritt jeb̨t ein weiterer Gegenjabs in Jajerbünbel jelbjt,

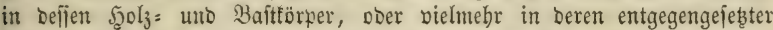
Entridflungşrid)tung hervor, ber eine beridiebenartige jortbilbung ber

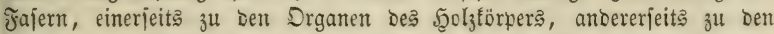

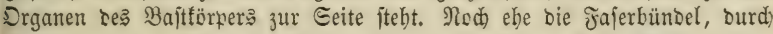
Umbiloung ber Bellen in Fajern, zum geidlofjenten Bünolftreife heran=

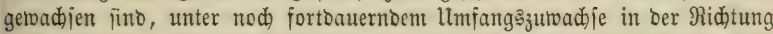

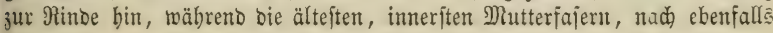

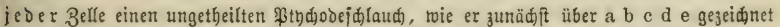
ift. Itm die Entriffelungşolge beutlid)er zu maden und bie einzelnen Entroifelungsftujen Der Fajerbündel juärjer von einander зu trennen, habe id ihn jedod) nur ba in bas, bie

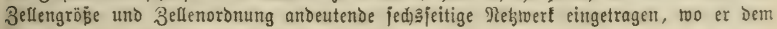
Fajerbünol angehörend betradtet werben tann. 


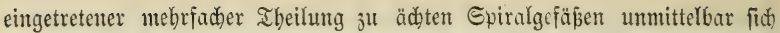

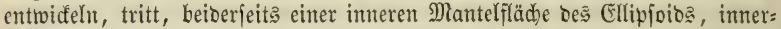
balb einer concentrifden Sreisfinie dę̧ Queridnittes, bie ungefähr bie Mitte oer Fajerbündel idjneidet, eine Differenjirung des 3uwachjes baourd ein, $b a \tilde{\beta}$ ur bie, biefer ioeellen Mantelfläde beiberfeits anliegenden fajerueines jeben fajerrabiusibre fähigfeit als Mutterzellen für jeben Jaferrabius behalten, währenb in allen hinter un bor ibnen belegenen Jajern biefelbe für immer erlifd. Hogefeben von einem nod furze Beit fortbauernoen Umfangåzuwadje, vergrößert fid bas Fajerbünoel von ba ab für immer nur von biefer inneren flähe aus uno ztwar ber 2 rtt, baj bie, biejer Grenzlinie ober (Srrenzfläche ${ }^{1}$ nad) bem Marfe bin zunädjit Yie=

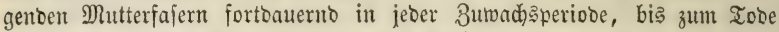
ber Pflanze, fterile Iodterfajern nad) bem Marfe bin burd) Eelkfttheilung

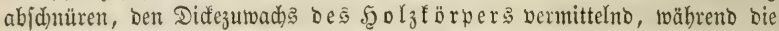
Derjelben (5renzfläche nad) ausen zutächjt liegenden Mutterfajern ebenjo

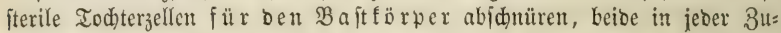
wadłperiode Dutrd) Sängstbeilung in tangentaler Rid)tung fo oft fich ver: Doppelno, als bie in jeber 3uwadsperinde (in jebem Jahre) fid bilbenten Jajerrabien ber $\mathfrak{S g l}_{3}=$ uno Baftichidhten Fajerzellen entbalten.

Man faun fid biejen, auf ber Brrenzlinie żwifhen Scolj uno Baft

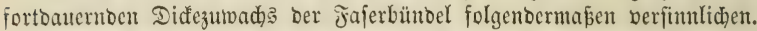

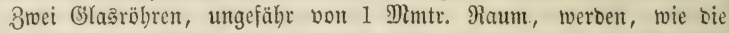
Rohre ciner Doppelflinte, mit einanber verbunten uno mit einem ihrer sffenten Doppelentoen redtwinflig oer Mitte einer żwei Jus langen, beiber:

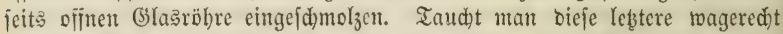
in cinen Irog mit Eeifenwaffer, hat fid biejclbe mit Eeifentwafier gefüllt, bläßt man baun ftofiveife \&uft in bic jenfrech)te Doppelröbre, fo geben von

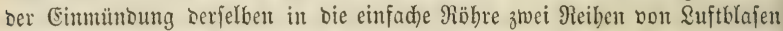

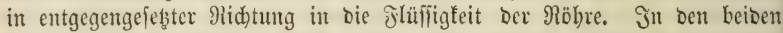

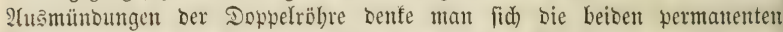
Mutterfajern cintes Jajerrabius, in ben beiben Suftblajenreiben benfe man (id) bic von ifnen in entgegengefebter Ridhtung ausigehenocn, fterilen Iod)ter= zellen Deffelben Rabius, bie nad) ber cinen Scite bin ausgefdiebenen zu

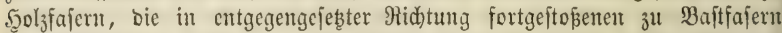
jid entwidelno. Dentt man fid ferner eine grope Menge fold)er 2 ppwarate

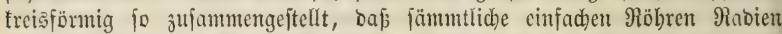
ciner uno berjelben Sreisfläde bildon, fo würbe bas gleid)zeitige Eintreten bon Suftblajenreihen in jämmtlide 2Ypparate, nad) bem Mittelpuntte biu bie Fajerrabien Des .̧olgförpers, nad dem lumfange bin die Fajerrabien Des Baftförpers conftituiren. Säpt man zu veridjiebenen Malen \&uftblajent= reiben in bie Glaseöbre eintreten, fo repräjentiren bieje ben 3umad)s an

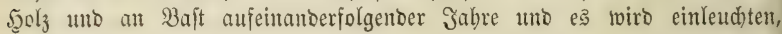

1 Die Lage Derjelben ift Eeite 131, Jig. 1 auf Der Duerid)nittflüd)e Der einzelnen Fajer= bündel Durd) eine innere Ifeilungslinie angcbeutet. Der zwijd)en ihr und Der Rinde liegende

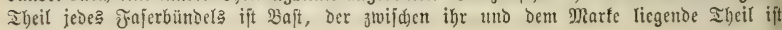
5jolytörper. 
Dap biefer nid̆t ftattfinden fönne, ohne eine, währento befielben fortbauernoe

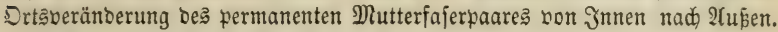

Die nebenjtehende Fig. 21, in weldher a bas in Scolz= unb Bafttörper getrente Jajerbünbl bes erften Jahres, b bajielbe Bünbel im ztweiten Jahre, c bafilelbe im britten Jabre u. f. f. barftellt, gewäbrt eine Ueberifht ber in jebem Jabre burd) 3rijden= bildung neuer $\mathfrak{S g l l}_{3}=$ uno Bajtlagen binju= tretenton Theile. In jebem Bünol fino bie Theile gleidzeitiger Entjtebung mit gleiden ₹ig. 21.

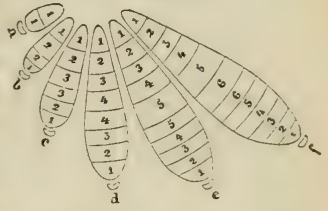
3iffern bezeidhnet, beren niebrigite ben älteften, Deren böbere ben jüngeren Ibeilen angebörent. UMm bie Biffern eintragen zu fönnen, fint bie Baftlagen berbält:

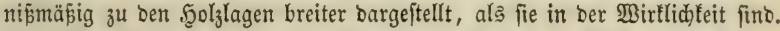

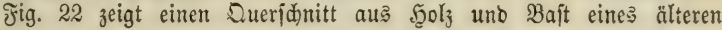
ชี่. 22.

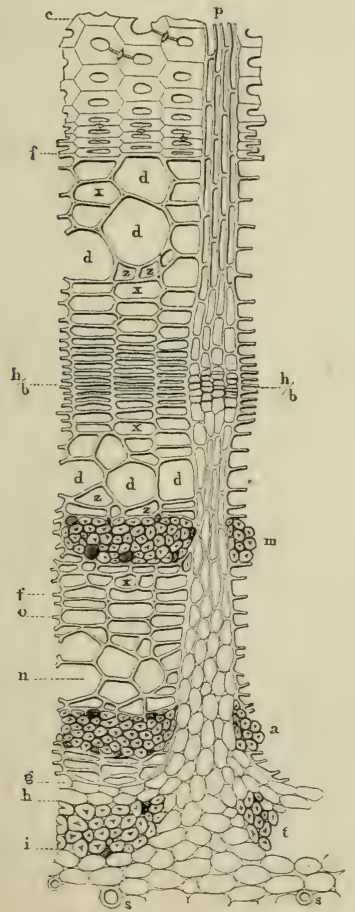

ซึig. 23.

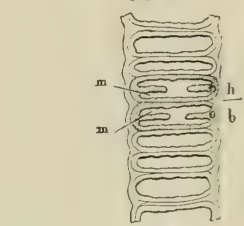

รีig. 24.

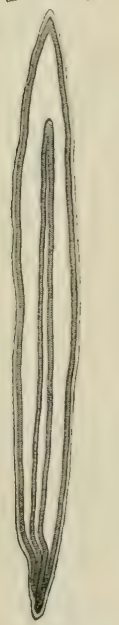

5̧artig, lebrbuch für ₹̈oriter. I. 
Eid)entriebes; $p$ ben aus bem älteren, fertigen Sgoljtörper $\mathrm{e}-\mathrm{f}$, in ben

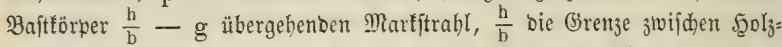
uno Bajttörper, bon ber aus eine neue, nod) unausgebildote 5ुoljidjidt $\frac{\mathrm{h}}{\mathrm{b}}-\mathrm{f}$ unt eine eben joldhe neue Bajtididat $\frac{\mathrm{h}}{\mathrm{b}}-\mathrm{m}$ gebilbet fint. ${ }^{1}$ Fig. 23 zeigt bie in $\frac{\mathrm{h}}{\mathrm{b}}$ liegenden beiben Mutterfajen $\mathrm{m} \mathrm{m}$ unb beren Thei=

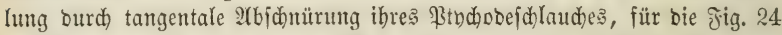
eine Sängenanfidst gibt, wenn aud) mur andeutend. Die mit zunebmenter

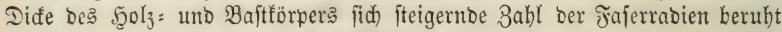
auf einer bon 3eit zu Beit nad) Bebari eintretenten \&ängentbeilung ber Mutterfajern in rabialer Ridtung. ${ }^{2}$

Das beiberfeits von Den beiden Mutterzellen $\frac{h}{b}$ aus fid entmidefnte, jugenolide, nod) zartwanbige Fafergetwebe ber jungen $5 \mathfrak{J}_{z}=$ unt Baftlagen ijt $e_{3}$, bas man cambium genannt bat, uriprünglid) von ber 2 (nficht auşgebento, baj baffelbe eine flüffige, formlofe, zmijosen bem im Frübjabre

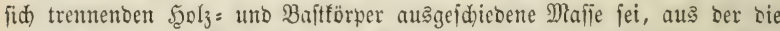
jungen Fafern wie Sirbftalle in Der Mutterlange fid frei entmičelten. Sine genauere Unterfuchung uno beffere Initrumente zeigten Dann, Das jente

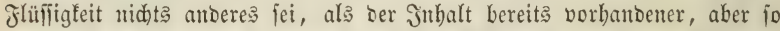

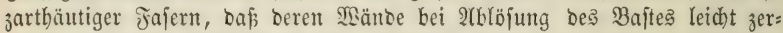
reif̄en uno ibren flüffigen Snbalt, gemengt mit ben zerriffenen Bellbäuten,

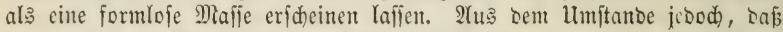
Die auf ber Baftfeite gebilbeten Fajern im Berfolg mur theilweife fid ber:

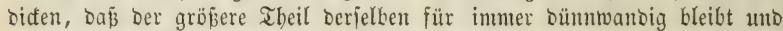
in cambialen 3uftante verbarrt, baher aud) in Winter unb üterbaupt zur 3eit rubender 3uwadjerfdcinungen als eine aus unfertigem Jajer:

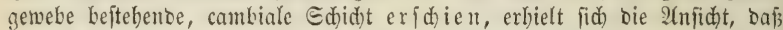

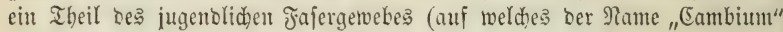
übertragen tourbe) im unfertigen 3 uftante übertwintere und im fommenten

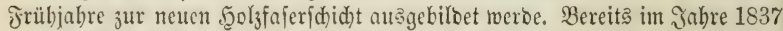

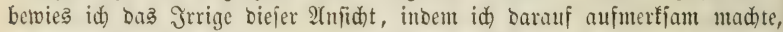

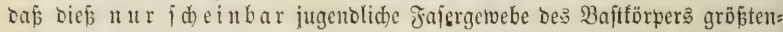
theils für immer büntwandig bleibe und vom jugentlicken Fajergewebe bes

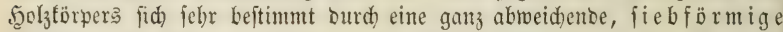
Iipfelung für immer unterjheioe (f. m. Jahreăberidte Iaf. I. Jig. 40-43). Erit in neuefter 3eit hat biefe Beobachtung anth in ber phyjiologifden Botantif Slufnabme uno 2tnerfenmung gefunden, jeood) obne bas bis jebt biejenigen nothwendigen (Enjequenzen weiter beiproden wurben, bie ich im Borbergehenten Dargelegt habe, betreffent Die Entwiaflung Des Jahrešringes

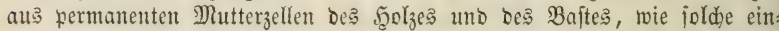
feitig aud) für das ebenfalls rabial georbnete Bellgemebe bes Sorf's befteft. Jèes einzelne Faferbünbel burd)läuft baher brei \$erioden eines ber:

1 Bergl. Taf. 1, Fig. 2 e f o.

2 Die Biloung iterifer Todyterselfen, bon einer permanenten Mutterjelfe aus, wieder= holt fid) im Sorfgetwebe und ift bort Der bireften Beobadtung weit leidter zugänglid). (S. Den

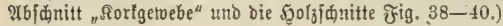




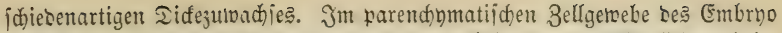

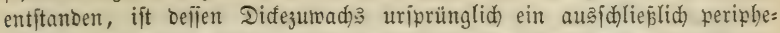

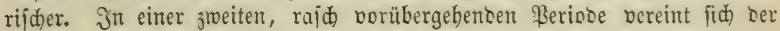

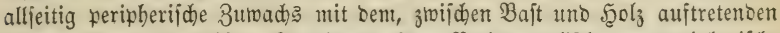
intermediären 3utwadje. In einer britten Periobe erlijatt ber peripheriface Buwadss in allen auper ben Enopunten Der \&ängenachfe Des Ellipjoio uno befien ßerä|telungen für immer uno nur ber intermebiäre 3uwaç引 ift $e_{3}$, ber fortan bie zunebmenoe Berbiaung bes Stamnes bermittelt.

Man verfinnlidgt fid biejes am leidteften, wenn man bie aufgeridoteten

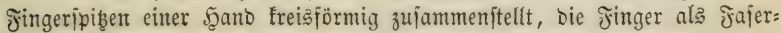
bündel betrad)tet, ben Raum zwifden ihnen als Marfgetwebe, eine fie

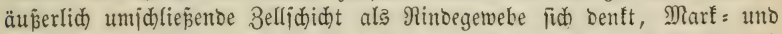
Rindegemebe verbunben burdh ein zwijhen ben fingern liegentes Marfítrabl= gewebe. Uleber Den aufgeridteten Jingeripiz̧en confluiren Marfitrahl = uno

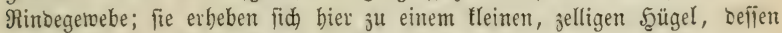
parendymatijde Bellen jtets jehr Elein bleiben, ba berent rajd) fid wieber= bolende, eine energiidje Belfenmehrung vermittelnde Theilung Der Sceraus: bildung voller Bellengröße entgegenjteht. Diejes, die Jajerbündel ooer

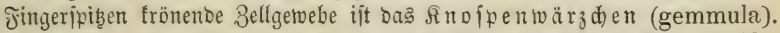
Sein rajdes, von Blatt = uno Inojpenauşd)eioung begleitetes (Emporwadjen bermittelt ben 2 ängenzutwad) bes Triebes, fo weit biejer nidjt auf Sergröß̄erung ber uriprünglid jehr fleinen Bellen berubt. Die Epiben Der Jajerbüntel (ooer Der Jinger) bingegen berlängern fid) nidht jelbftitäntig,

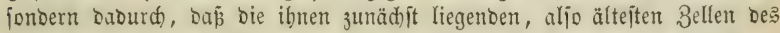

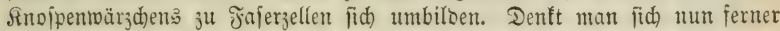
nom oberften Giliebe ber Finger abrärts siefe oser bie fajerbündel in

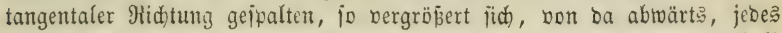
Jajerbünoel Durch eine auf Jufertheilung kerubenbe Jajermelyrung innerbalb

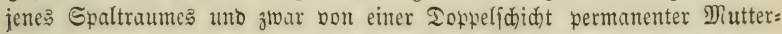

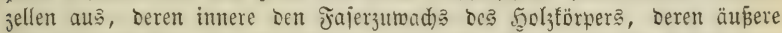
Den Jaferzumads Des Bajttörpers bermittelt. Bom sberften Fingergliebe

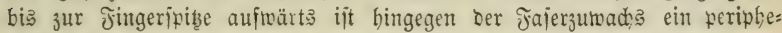
rijcher und berubt, wie über ber Bünoelfpibe, auf einer ltmbiloung von Bellen in Fajern.

Go meit meine (Erjabrung reidht, beid)räntt fid bie Entitehung neuer, unabbängiger Fajerbüntel int aujiteigenden Etocke auf jenen früben

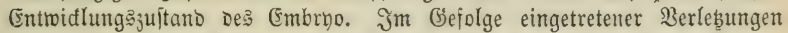
fönnen neue Jajerbünbel audd in älteren Biflanjen entiteben, wie ich biés

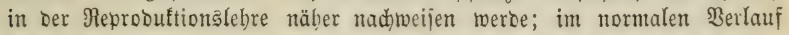

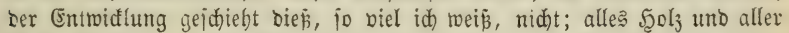
Bajt, jelbjt bes ältejten Baumeß, gehören entweber ber Bergröß̈erutg jener, im Embryo entitandener fajerbünbel an, ober fie ift, in Blattiftiel uno

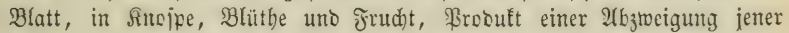
uriprüngliden Jujerbünbel. Die Beräjtelung bes abfteigen ben Etodes

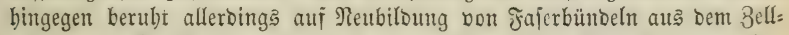
gewebe ber Marfjtrablen, Daher bann aud an alten Murzeltheilen, ohne

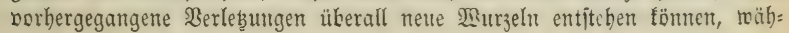


rent neue Triebe bes aufiteigenoen Stodes an biejem mur im frühejten

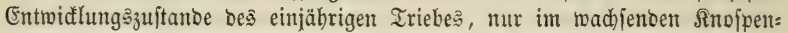
wärzḑen entfitehn.

\section{B. Das Ileifen Des Samenkorns und Dic Bildutg Der Kefrerueftoffe ieffelben.}

Der Embryo empfängt biş zur Samentreife feine Biloungŝtoffe im flüiligen 3uftande fortbauerno von ber Mutterpflanze. Bei ben meiften Soljoflanzen verwenbet er fie nidht allein auf Ballenbiloung für eigenes

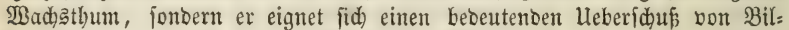
Dungäjäften an, Den er, zul Stärfemehl, Nlebermehl uno Del ungebildot,

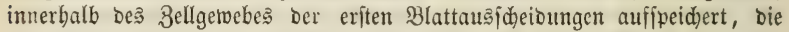
baburd oft unförmlid berbiatt werben (Eid)e, Raftanie, Manbel $2 c$. ), wie

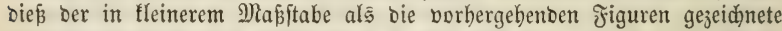
Sängendurchidhnitt einer (Fidpel (Taf. I. Jig. 26) zeigt, in ber a a bie zu Samenlappen verbidten eriften Blattauşdheibungen fino. Dief ift jebod

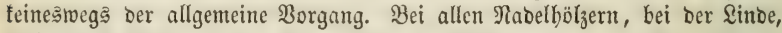

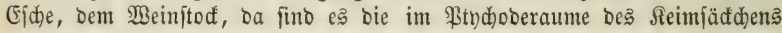
gelagerten Bellferne, bie hier zur Erzeugung eines Bellgewebes Beranlafīung werben, in bem fich bie für ben Reimunģ̧aft nöthigen Rejerbeftoffe ab: lagern, bie bann in einer ichlaudförmigen Edid)t ben Embrno umgeben. Taf. I. Jig. 27 zeigt Den \&ängendurdjidnitt bes Samentorns ber Riefer, befien im Jnturn liegender Embryo vom Samentweip ober Endofperm a a eingejdloffen ift, Das er, umgeben von ben Samenbäuten, beim Reimen mit über bie Erbe emporbebt, und bann erjt burd bie anliegenden Blätter auşaugt. Die eriten Blattauşd)eibungen ber Nabelbölzer, Der Sinbe, Der Sịhe, finto Daher von Den fwäter fid entwidelnoen Blättern bei weitem nidht fo beridieden, wie bie Samenlappen ber Eidje, Budje, Bobne zc. In now anberen fällen - idj bermag feine Şolzpilanje biejer $\mathfrak{A r t}$, fonbern, unter ben befannteren (setwädjen, mur die Bafferlilien (Nymphaea, Nuphar)

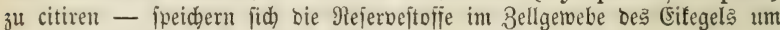
ben Embryojaft herum auf, das \$erifperm bildeno.

Sei es nun in ben Samenlappen bes Embrno felbit oder im Crnopiperm ober im ßeriperm, in allen Fällen fammelt fid) in ober um ben (Embryo gegen bas Enbe feiner 2 Uabiloung oder mit beramabender Samenreife eine

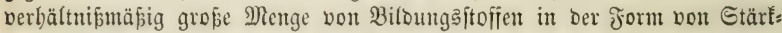
mehl, תlebermehl, (stünmehl ober (berbmehl, begleitet von Del uno anoeren, Der Menge nad) untergeoronteten Etoffen, Deren Biloung uno Umbiloung

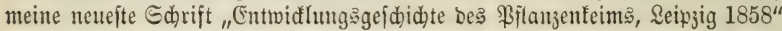
auşübrlich barftellt uno mit 2 bbildungen belegt. Der Borgang ift im Bejentliden und in ber Rürze folgender:

Bereits Seite 165, Jig. 16 babe id gezeigt, Daja, twem aus bem

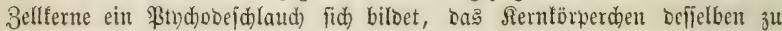

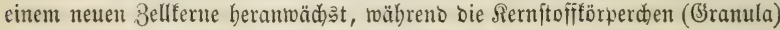
im Patydoberaume fid vertheilen uno fid bort ourd Selbittbeilung ber= mehren. Die Rernitofftörperden jebes erften \$tnd)obefd)laudhes werben auf bie Bellmantobiloung verwenbet, indem fie zwijdhen ben Ed)laudbbäuten zu 
Den Cellulojeididjten verwadjien. Dief ift mitunter aud nod ber Fall mit

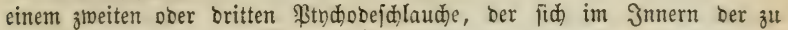

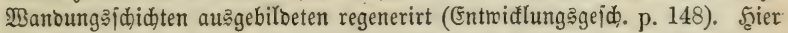
im Embrno ober in ber Umgebung beflelben ift $e^{2}$ aber in ber Regel jijon

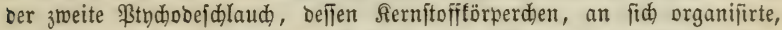

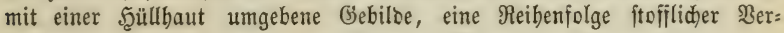
änberungen erleiben, bie bei veridjiebenen Pilanzen veridhieben jin๖.

In ber nebenitebenden 2 (bbiloung gebe id) bie Entriadungşolge ber förnigen Rejerbeftoffe in ben Samenlappen ber Reguminofen, im Eamen= weiß ber Ejche, ber Nabelhölzer zc., fo weit als ę nöthig ift, um eine allgemeine 2 nnidit zu belegen. Die fpecielleren Nad)= weijungen mannigfaltiger 2(broeidungen entbält meine

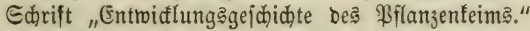
Der Bellenourdjidnitt a beijtebenter Fig. 25 zeigt innerbalb ber vou Tipfelfanälen ourdję̧ten, äup̌eren Bellwanoung ben Ptydobejdlauch $p$, etwas contra= hirt uno von ber inneren Mandung:̣läche, ber er im natürlidjen 3 uftande bidyt anliegt, bis auf einzelne Stellen abgelöst, an benen bie äนBere ફ̧aut mit ber Sd) lief̧baut der Tipfelfanäle nod in Berbinoung fteht (Die mitunter langen Ed)laudharme, Durch) bie ber fich zufammenziebende \$tndobejwlaud mit ber Eajlię̧baut ber Tipfelfanäle in Berbinoung bleibt, beuten auf eine Berwadjung ober Bertittung beiber Şäute). Jn ber burd Rörnden geringiter Bröße

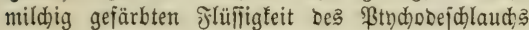
fiebt man bei $\mathrm{z}$ ben 3ellfern.

b zeigt nur injofern eine Beränberung, alङ

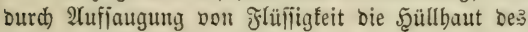
Bellterns fich bebeuteno erweitert hat. In Folge Defien fino die Granula des Bellferns auseinanter getreten uno liegen bier in ber Bellfernflüfitigfeit. Das Rernförperden bes Bellferns $\mathrm{z}$ hat fich zu einem neuen, nod) fehr fleinen Bellferne $\mathrm{z}^{\prime}$ aus: gebilbet.

3riiden b uno c liegt ein Entroidflungs: ftabium, in reldhem $z^{\prime}$ zur normalen (5röpe Des relativ primitiven Bellferns $(\mathrm{z}$ in a) herangetwadjien ift. Der Bellfern $z^{\prime}$, nadbem er ausgewadjien, er: leibet bann biejelben $\mathfrak{B}$ eränderungen $3 \mathfrak{u} \mathrm{z}^{\prime \prime}$ wie $\mathrm{z}$ зu $z^{\prime}$, ๖. h. Der aus Dem Rernförperden bes pri= mären Bellferns $\mathrm{z}$ entitantene fecundäre Bellfern $\mathrm{z}^{\prime}$ bat fein Rernförperchen zu einem tertiären Bellferme $\mathrm{z}^{\prime \prime}$ entriffelt, feine Gramula baben fid, wie oben, in aufgeiogenem \$tndobojafte ijolirt, währen bie Bramula bes primitiven Bellferns, unter fortbauern= Der (Erweiterung ber Şüllbaut beffelben, surd) fort:

ชิig. 25.

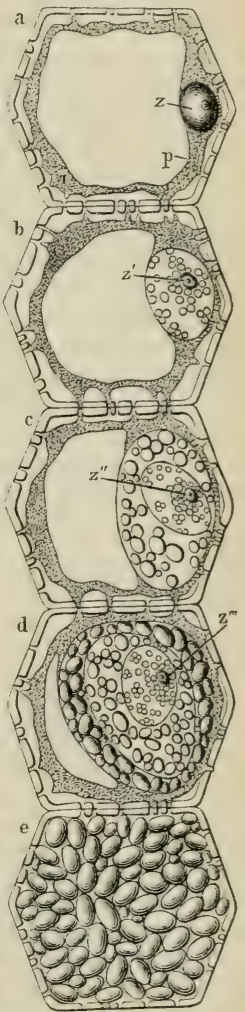


Dauernbe $\mathfrak{A}$ ufnahme von Bilbungäftoffen nid)t allein größer werben, fonben aud burd) Selbittbeilung fich bermebren.

Radjoem Das Rernförperd)en bes fecundären Bellferna $z^{\prime}$ zur normalen Größ̋e eines tertiären 3ellferns $z^{\prime \prime}$ berangewadjen ift, wieberholt fich in

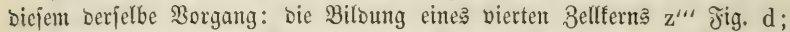

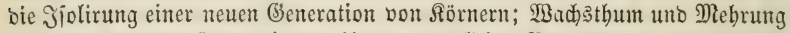

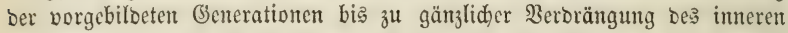
Bellraumes, wie biejes bie Jig. a bis d aufcinanberfolyent barftellen, bis enolid), unter Rejorption ber vorgebilbeten Scäute, bie ganze Belle mit förnigen Sörpern erfüllt ift (₹ig. e), um bie fid im parendyntatifdent 3ellgetwebe mur bie äupere Sdłlaudbaut erbält.

Dieje, Den Bellferne entfpringenten Rörner erleiben mun im Berlauf

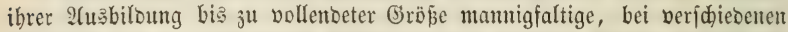
\$flanjen und in berjdiedenen \$flanzentheilen Derjelben Pflanze beridiedene Beränberungen, nid)t allein in Bejug auf Form, Billoung unt 3 ujammen= jekzung, fondern felbit in Bejug auf elementare Beptantheile.

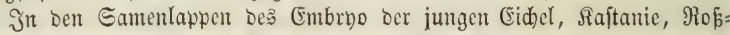
fajtanic verwantocln fid) bic Cramula unmittelbar in Stärfemebl (Amylon), cinen runbliden ober eiförmigen, mitunter burd) gegenfeitigen Drud polye=

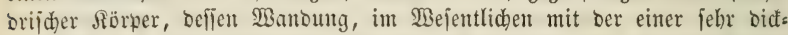
wanoigen Belle übereinjtimmento, aus $43 \frac{1}{2}$ Sohlenftofï, $491 / 2$ Eauerfofi uno 7 Bafierftoif beftef)t. Llnauf(öslid) in faltem $\mathfrak{B a f f e r}$ bilden bie Rörnchen in fod)entom Waifer burdh Afufquellung Den befannten Slcifter. Sie färben fid) Durd) Joolöjung inbigoblau, ipeidgern feine Farbitoffe, geben burd)

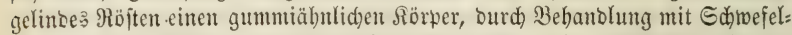
fäure uno in Seimungäproceffe bilden fie 3uter. Die voritebentoe Fig. 25 zeigt in e bie Formen bes Etärfentebla ber Eid)el; jur Unterfdeioung babe id) in ber nadjtehenden Fig. 26 bei b bie unregelmäfigeren formen ber Etärfe Deకె Şolzes Dargeftellt.

శึig. 26.

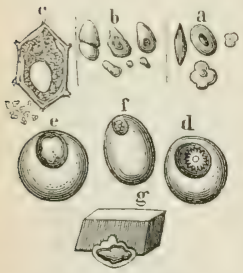

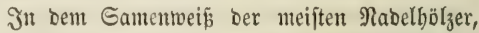
in bem von Fraxinus, Tilia, Vitis berwanbeln fid bie Granula unmittelbar in $\mathscr{R}$ lebermeblförnden (Aleuron), bem Stärfemebl in Form uno (sröß̈e ähnlide, ebenfalls hüllhäutige Sörper, in benen zu Den Beftandtheilen des Stärfentehls nod) 9 bis 10 Proc. Sticitofi, etwas Sdimefel (unt \$hosphor?)

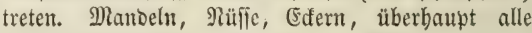
Ölreiden Sämereien enthalten nur Slebermebl, Das im $\mathfrak{B a f j e r}$ fid) Yeidht auflöst, in todenbem $\mathfrak{B a f i e r}$ feinen ßileifter biloet, Durd) jalpeterjaures Duedfilber roth, ¿urd) Joblöjung braungelb fid) färbt uno Jarben fpeidert. Eigen=

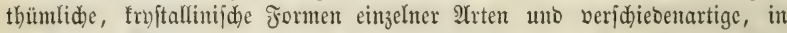

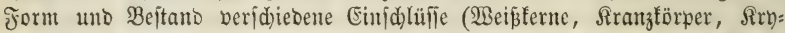

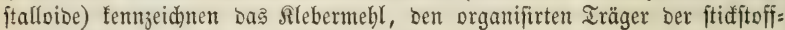
baltigen Beitandtheile des \$fllanzenreids.

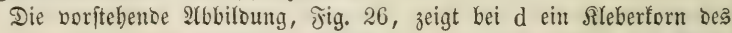

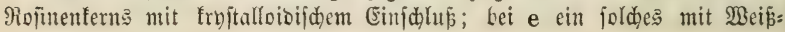


fern; bei $f$ ein Sleberforn ber Blidecfer mit Sranztörper; bei $g$ ein fry=

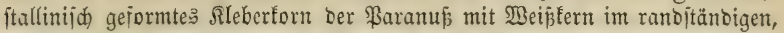
mur burdh bie beutelförmige Şüllbaut abgeidlofienen Innenraume.

In jebr vielen Eämereien ijt ber Embrno in feiner frühejten jugeno

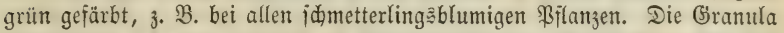

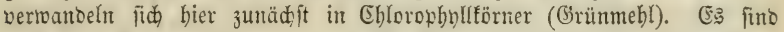
dieß ebenfalls runolidje soer ovale fefte fiörner, bie, uriprünglich) ungejärbt uno farbenpeidferno, fpäter eitte grüne Jarbe erbalten burch) 2(usbiloung cines, an cinem wadbälnlid)en Etoffe haftenden, grünen \$igments, von Dem Das fefte Rorn Dudborungen ift. Aflle grüngefärbten Bflanzentheile verbanten ibre färbung biejem Grünmehl, dejien fejte, gegen d)emijobe Reagentien bödjit inbifferente Grumblage in ihrer elementaren 3ujammen: jeţung nod unbefant ijt. Die voritelende Jigur zeigt bei a mebrere verjaicbene Formen biejer Sörner. Das mittlere biejer Rörner zeigt cinen

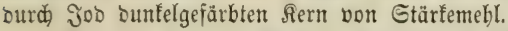

Nur bei menigen Bflanjen verharrt cin Theil der Eblorophyllförner Deš Embrno bis jur Eamenreife in biejem 3uftante (Tropaeolum, Acer), bei ben meijten verwantelt fid das Eblorophnllforn, entweder von einem oDer von mehreren \$unten auڤ, in Etärfemebl. In ben grünen Erbjen

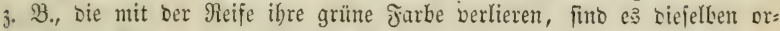
ganifitten Sörper, bie anfänglid als Chlorophyllförper, fpäter als Etärfe: mehlförner auftreten; id habe jogar nadgewiejen, baj bieje Stofiroand: lung in bielen fällen nod) weiter geft, $\delta a \tilde{a}, 3 . \mathfrak{B}$. in ben Gamentappen von Lupinus, Tropaeolum, Da: aus bem Chlorophylfforme entitundene

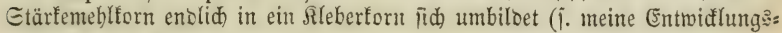
geididate bes \$illanzenteims).

Einzelne Bellen in ben Eamenlappen Der (Eidel entbalten aud G

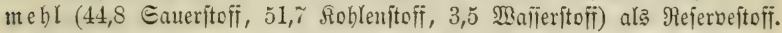
Mährent Des Binters enthält aud) Der Bajt Der Eide ben Gerbftofi in fefter Jorm, bäufig Deutlid) geförnelt. Er lagert hier in Den Eiebfajern uno in Den Marfitrabljellen Des Baftes uno wirb burd) (Eijend)lorio wie

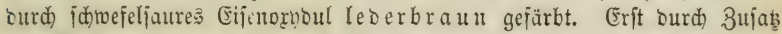

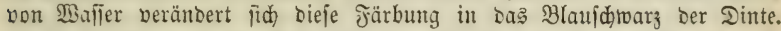

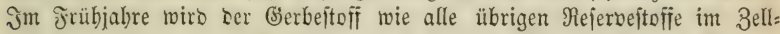

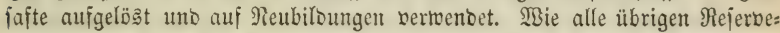
ftoffe, fammelt er fid im Eommer und Serbjte für bas nädjite Jabr wieber

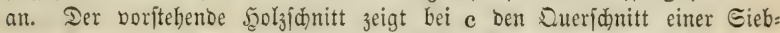
fajerzelle mit eingelagertent, geförneltem (5erbitoffe, son bem einzelne förnden

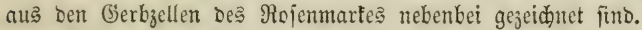

Währent Des Reimens der Eidjel löst jid ber Gierbitofi ebenfalls uno Durdboringt bie Stärfmeblförner, bie Dann bon Eijendjlorio fdrmarjblau gefärbt werbert.

3u Den Rejerveftofifen bes Gamentoms gehört ferner aud ber Bell= it off (Eelluloje) ber Bellwandoung felbit ( 45 Roblenitofi, 42 Eaueritofi, 6 Waijerftofi). Die mitunter fehr biffen 3ellmäntoe, 3. B. Der Gament=

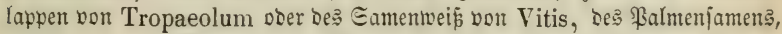
verid)winoen im Reimungşnrocelie entweber bis auf ben bäutigen Bejtano 
(Vitis) ober bis auf die Cambialmantoung (Tropaeolum) (i. Entridflungs:

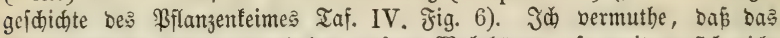

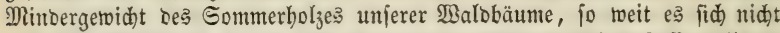
aus bem Berbraud Der in ihm abgelagerten förnigen Rejerveftoffe erflären läß̨t, auf ber \&öjung uno Berwenoung eines Theils ber Celluloje aud) bier berube.

3 ufer (48,8 Sauerftoff, 6,4 Bafieritofi, 44,8 Sohlenitofi) ift in Sämereien zwar nod) nidht nadgetwiejen, ber füpe Sejdmad mebrerer ber= felben beutet aber auf Das Borhanbenjein befielben hin. $U_{m}$ fo bäufiger

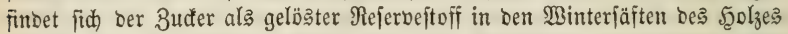
fowohl, als des Baftes. Beide finto eine Funogrube verifiebener nod) nict)t näber unterjudter 3uđerarten.

Frit bei ber mit heramtabenber Samenreife eintretenben Umbildung Des Stärfmehls in Alebermebl, imeiden fid fette Dele aub, bie im Samenforme Der Budbe, Der Scajel = uno Mallmüfife, ber Pflaumen=, 2Tepfel=,

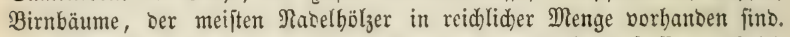

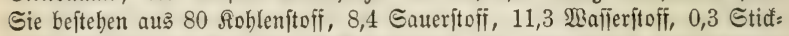

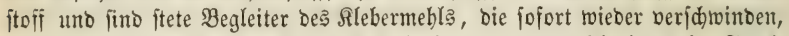
wenn leksteres im Reimungß̄procefie aufgelöst, ober rüđidreiteno in Stärt: mehl und Eblorophyll umgetwandelt wirb, wie twir biés an ben im Samen= forne ungefärbter Samenlappen ber Budhe, Des \$flaumenbaumes, ber Iffazie ieben, Die nad) Der Reimung in Sid)te mieder grün merben.

Die Stufe ber 2lusbiloung, jul welder bie junge Pflanze im Samen= forne bis zu beffen Reife boridhreitet, ift eine bei veridiebenen \$flanzen= geidledtern febr beridjiebene. In ber Entwidflung ber \$lumula am weiteften vorgejdritten zeigen fid bie Segumintojen, bie Fidłe uno bie Roṕfajtanie, bie erften Blattausfheioungen fino am meiteften entwiffelt bei ber Sinbe, Fide, ben Nabelbölzern. Jimmer aber ift bei unjeren Solzpflanjen der Embrno mit Eintritt ier Eamenreife in feiner Entwidlung fo weit gebiebelt, Daj er alle mejentlichen Elemente oer älteren Bflanze: Stamm, Blatt, Burzel uno Endfnoipe, Marf, Rinbe uno Jajerbünoelteis in fidi) vereint, wenn aud) alle biefe Theile nod) nid)t fo ausgebiloet fino, baj burd) fie eine vollfommene Gelbitftäntoigfeit ber fortbiloung eingetreten ift, bie erit bann erreidjt wirb, wenn in Reimungsprocefie die von ber Mutterpflanje

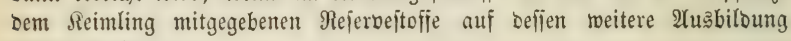
berwentet finto.

\section{Dic $\$ a m \in n r u b c$.}

Meift im Şerbite, oft fiton im Sommer ober Borjommer bes Blüthe= jahres (Ulme, ßappel, Weibe), jelten erft im Şerbjte bes zmeiten Jabres nach ber Blüthe (Riefer, Badbolber, Berreide uno viele norbamerifanifde (Eid)ent) erlangt ber Same feine Reife, bie fid Darin äupert, dá̧ eine meitere 3 ufuhr von Bildungsääten ber Mutternflanze nidjt mebr ftattfinbet uno baj ber Same, theils mit theils ohne bie frrubt abgeworfent wirb. Die Eichel, bie Budfecfer, bie Şajelnup, bą twas rir Same nennen: Der

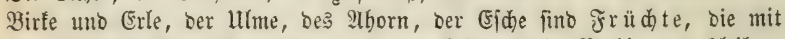
Dem eingejolofienen Samenforn bis zur Reimung in Serbinoung bleiben, 


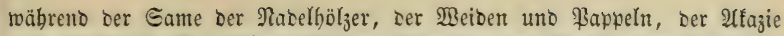

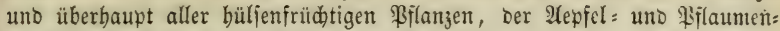
fame, aus bem Pflanjente uno beffen Umbüllungen allein gebiloet, Same im wifjenidaftliden Sinne bes $\mathfrak{B o r t e}$ fint.

Benn ber Same jeine Reife erlangt bat, tritt ein 3ujtano ber Rube aller vitalen Funttionen ein, Der bei veridiedenen \$flanzen beridieben lange 3eit bauert. $2(m$ fürzelten ift bieje Eamenrube, wenn man bier überhaupt won einer folden ipredjen fam, bei Bappeln unb Beiben. Frifd Dem Baume entnommenen \$appeljamen babe id) idfon nad 24 Stunoell zum Seimen gebradt, leiber vergehen bie meiften, oft alle Reimlinge eben io rajd wie fie gefommen fino uno ift es mir nod) nidjt geglüatt oie Urjadje biejer Eonberheit zu ergründen. Die (Sräjer feimen meijt nach 3-4 Tagen,

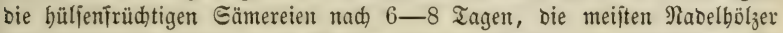

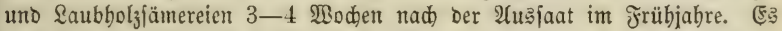
gibt aber unter ben Saubbölzern forohl wie unter ben Nabelhölzern $\mathfrak{A}$ rten,

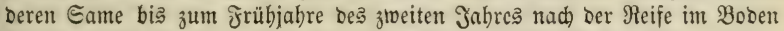

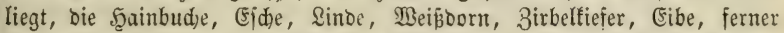
viele Straudhölzer wie Cornus, Vibrunum, Evonymus, Ligustrum, Hippophäe, Daphne, Solanum, Ilex, Ledum gehören babin. Eక ift dię̧ eine rumberbare Erjokeinung, bie weber aus ber Bejdaffenteit ber Eamenbüllen, nod im Baue ober Beftande ber inneren Gamentbeile eine Erflärung finbet. Der Same unjerer beimifden Ejche liegt mit feltenen

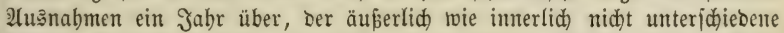
Eame Fraxinus pubescens, -gleidjeitig mit bem Samen unjerer (Ejde vom Baume genommen uno gleidzeitig eben jo rie biejer auj bemjelben

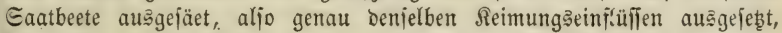
feimt idon im Jrübjabre nad) Der Serbitjaat. Der bifichaligite Nabel=

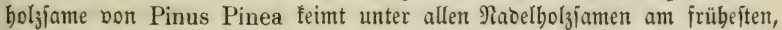
meift fdon nach adjt Tagen, ber ifm jehr äbnlidje aber weniger bicf=

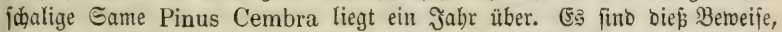
baj̧ bie veridiebente Dauer ber Samenrube, unabbängig von materiellen

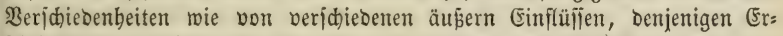
ideinungen angehört, bie wir nur aus einer im Drganismus in bivio ua= lifirten Eonderfraft berleitu fönnen, bie wir ala Lebengfraft barin

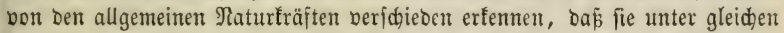

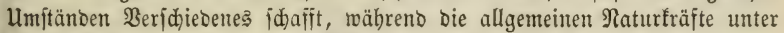

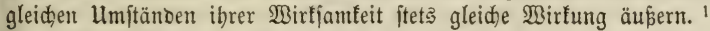

Die Eriftenz ber Gamentube erfennen wir in ber verfdiebenen Dauer berjelben bei beridjiebenen Gamenarten. Gelbjt bie ber Reimung

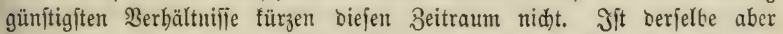

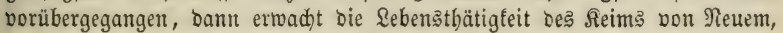
jeboch mur unter Bebingungen, bie ibrer Ermeçung günftig ift: unter Ein=

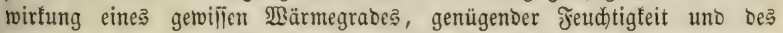
Gaueritoffis ber atmojphärijonen \&uft. Der 3utritt von Saueritofi ideint

1 In bie Reibe biejer, bie Eriftenj einer leitenden Sondertrajt betweijenden Sebens=

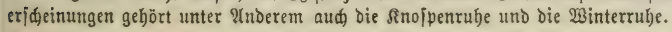


and wäbrento ber Gamentulbe notbrendig zu fein. शur fo erflärt fid bie

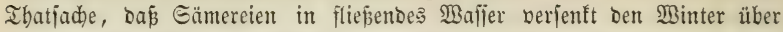
fich jebr gut erbalten, wäbreno fie in jtehenbem $\mathfrak{B a j p e r}$ unfeblbar abjterben uno berfauler.

Durd) Entziebung einer Der Reimungabbebingungen läpt fich bie Gamens rube ivillfürlid berlängern. 'Die niebere Iemperatur uno bie Irockenbeit Der \&uft in Den Ratafomben 2 egnpten hat ben Mumientweizen Jabrtaufende binourch in Der Samenrube erbalten. Die Ingaben, Dap̃ Der Same peine Reimfäbigteit nidht eingebüft babe, getwinnen immer nehr an Ślaubloür= bigfeit. Mein Bater bat aus minbeitens 30jäirigem Samen von Sarothamnus \$flanzen erzogen; Jreifaaten mit 11 jäbrigen Fid)tenfamen baben nod) einte grofe Menge \$flanzen geliefert; anbere Eamen, Eideln, Raftanien, Buchecfern, Šajelnülīe erbalten ihre Reimfäbigfeit mur bis zum Jrübjahre

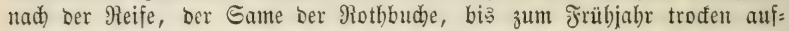
betwabrt, liegt mitunter bis zum zweiten frübjabre im Booen ebe er feimt.

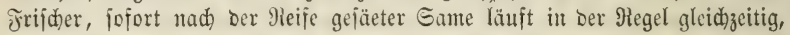
älterer Eame, befonders wem er troden aufbewahrt rurbe, feint oft febr

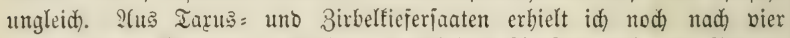
Jabren junge Bflanzen; aus eimer vorjäbrigen ?(usjaat auf bem Bretter= boben eines Epeiders aufbewabrter Eideln feimten ungefäbr ber britte Ibeil im Mai uno Juni, bie übrigen erit in ben folgenben Monaten biş

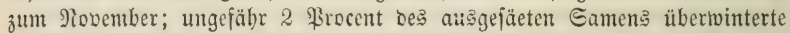
im Boben uno licferte erit im zweiten Jrübjabr gejunde, fräftige ßĩlanzen.

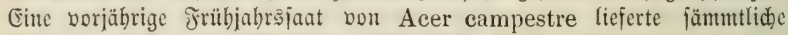

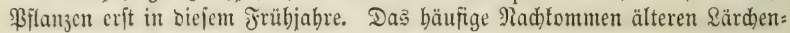

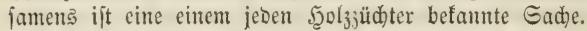

Dic Erfahrung hat aber gelebrt, baßj, je älter ber ausgefäete Eame

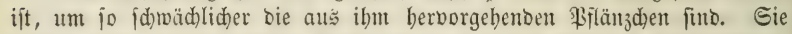
fönnen unter begünjtigenden Einflüīen зu gejunden Bflanzen berantwadjjen, erliegen aber weit Yeid)ter jeber ungünifigen (Finwirfung ber $\mathfrak{B i t t e r u n g}_{\text {uno }}$ Des Bobens; baber ę Daun als Pegel gilt, Den Samen fo balo wie möglid nach erfolgter Beife zu jäen, wo Dem nidht größßere Befabren entgegen=

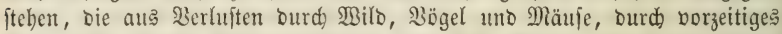
Reimen bei miloer 2 Sintertwitterung erwadjen fönnen, wenn ber Game längere Beit als nöthig im Booen liegen múp.

\section{Dif fifimung.}

Pad) 2(blanf ber gejeb̧liden Gamentube ift eine Märme von 10 bis 15 Graben, $c_{3}$ ift ein gemäßigter, Den 3utritt Des Gauerftoffis ber Altmo: iphäre nidht abjolliepenter Jend)tigfeitşgrad Bebingung oes Reimens,

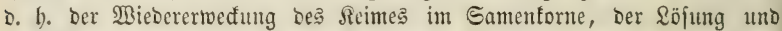

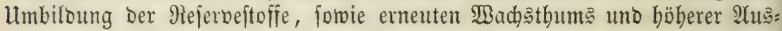
biloung Der bereits vorhandenen Drgane.

Dap Der 3utritt atmojphärifhen Gauerftofis Bebingung bes Seimens jei, habe id baburd ermiejen: baj id rajd feimente Eämereien in einer aud) Den Boben burdbringenden fünftliden 2 tmojphäre von foblenfaurem Gaje beliebig lange 3eit unter übrigens günfitigften Bebingungen vom feimten 
3urüđfbielt. Die berwenbeten Gämereien feimten fämmtlid) fofort, nadjoem Die Roblemiäure burdh atmojphärifhe \&uft erjebst worben war. (ङ马 batte

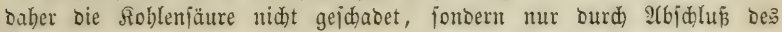
Gaueritofijs ber \&uft Die Reimung verbinbert. (Jorftl. Converi.:\&exifon, 2(nhang.)

Entfernung Der Sioblenjäure int Boben uno Begünjtigung beڤ Eauer: ftoffjutritts förbern baber Die Reimung. Soderung bes Reimbettes uno

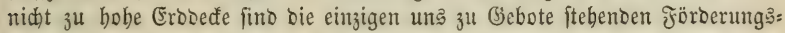
nittel, ba eine Serwentoung buntşfreien Bobens bent Gämlinge mebr fđ)aben, als bem feimenden Eamen nüken mürbe. Die Mirfung Des $\mathfrak{B}_{0} \mathrm{r}=$

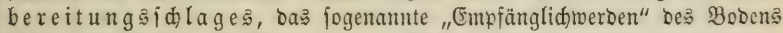

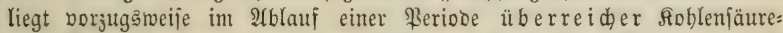

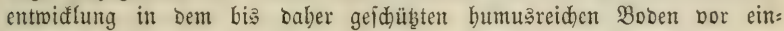
tretender Befamung.

Dagegen bedarf bie Seintung ber Sidhtrirfung nidht. Seb̨tere ijt überall mur ba notbwendig, wo $\Re$ ohftoffe ber Ernäbrung in organifden Bildungsitofi umgemandelt werben follen, wo aus ber anorganijhen Roblen=

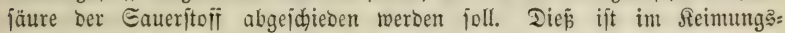
procelie nidht ber Fall, belien Enozweof es ijt, aus bereits vorbanbenen, non ber Mlutterpflanje bereiteten, aber in fejter form als Rejerbeftofie

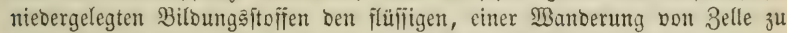
Belle fäbigen Bildungşaft wieder herzultellen. Daher wirb benn aud im Reimen fein Eaueritofi frei, jonbern ber aufgenommene Eaueritofi in Ber: binoung mit Siohlenitofi als Roblenjäure abgejdieðen.

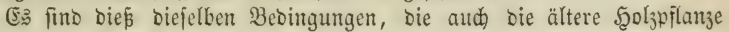
alliäbrlich) aus ihrer Winterrube wieber ertwecten, uno in Der That ift leb̧tere eine ber Gamenrube burdjaus analoge Erideinung im ßifanzenleben. Streng genommen ift ber Embryoim Eamenforne bie einjäbrige Pflanze, bie zur Reifezeit in die erfte Winterrube eingeht, Demjufolge bas, was twir bie einjährige \$flanje nennen, eigentlid die jmeijährige \$rlanze ift. WBir

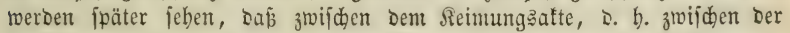
2luflöjung Der bem (Embrno von ber Mutterpĩlanze mitgegebenen Biloungsి: ftofie zur frortbiloung Des Seimpflänjobens uno ber Jrübjabrethätigfeit jeoer

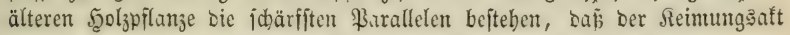

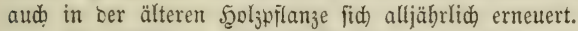

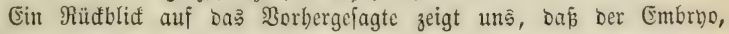
Das Reimpflänjuen im reifen Eamentorne, von einer gröperen ober ge:

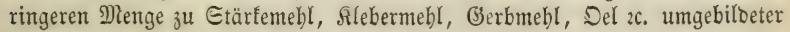
Rejerbejtoffe begleitet ift, bie, von ber Mutterpflanze bercitet, biejelbe $\mathfrak{B} e=$ Deutung für Den Bilanjenteim haben, wie Dotter und Ėimeif bes thierijden

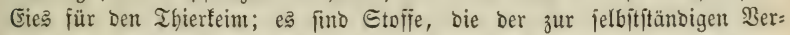

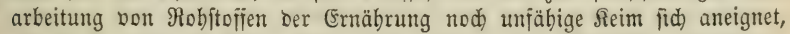

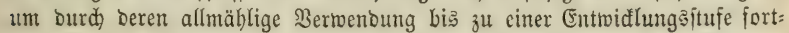

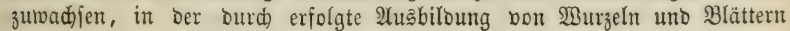
jetter 3ujtano jelbittätäniger Ernährung cingetreten ift. Dieje Aneignung bon Rejerbeftoffen tritt bei ber Mlebrzahl ber siflanzen jüon bor vollendeter Samenreife ein, fie gibt fich in ber Berbifung ber eriten Blattauझidheibungen 


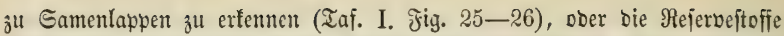
lagern fid in bem ben Reim einjaließ̄enten Samentweiṕ (Enopiperm) ab (Taf. I. Jig. 27 a Riefer) uno werben in biejem Falle erft währeno bes

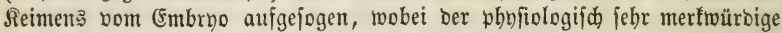
uno vieljagende Umitand eintritt: baj biefe 2Yuffaugung ju einer 3eit ge= idjieht, in ber ein organifaer Zufammenbang zrijchen Reim uno Samen= forn nidht mehr ftattfinbet. Man unterjudue ein Nabelfoly= Samentorn zur Beit, wenn es eben auts bem Boben emporgebobent ift uno man twiro in Den, Dae fieberdhen bebeđenden Gamenbäuten (Räppd)en) nod) Den faft vollen Giehalt an Samentweís wie im ungefeimten Samentorme borfinden. Einige Iage fpäter fino bavon nur nod) bie auțgejogenen Şäute zurüđ= geblieben, obgleid) währeno biejer ßeit bas gieberchen mur fappentartig vom

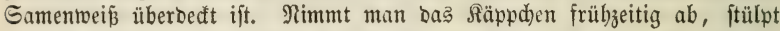

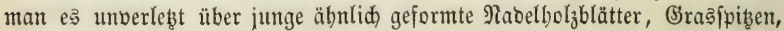
eben aufbrechende Saubbolytnofpen, ober über ein Stüdften Binofaben, burdh

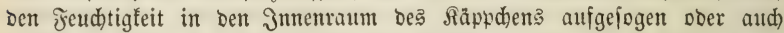
abgeleitet werben fann, waß fid) mit ber Rappe bes gropen Samena ber

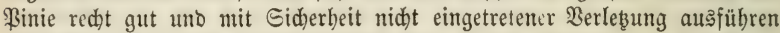

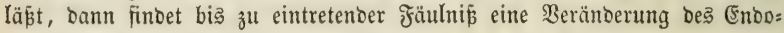

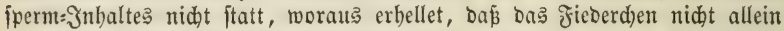
auffangeno wirft, fondern oa $\beta$ beffen $\mathfrak{B}$ irffamfeit über bie eigenen (3) renzen hinaus in bie Entopperm= Mafie binein fid eritreft, bie 4 m=

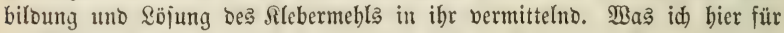

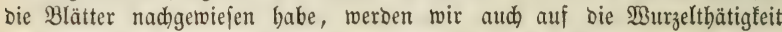

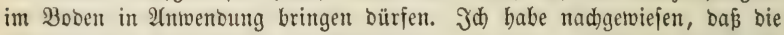
Burzeln bent Bobenwaffer bie Rohlenjäure entzichen. Eben fo werben fie aud) anbere gelöste Stoffe ibrer Umgebung mit 2 usmabl entnebmen fönnetr.

Die erite Beränberung, Die Der in ein günitige Reimbett, D. $\mathfrak{l}$. in eine Sage veriebste Same zu erfennen gibt, in weld)er ihm Wärme, Jeud) tigfeit uno atmoiphäriiche \&uft in geeignetem Grabe zutreten fönnen, ift ein bedeutentes $\mathscr{A}$ nidivellen ber Samenlappen ober ber Mandel folder

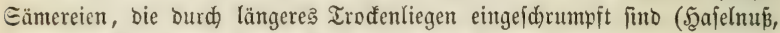

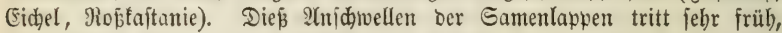
fdjon wenige Tage nad) ber ?(uşaat im Şerbjte ein uno ideint auf nteda= nifcher $\mathfrak{B a f j e r e i n f a u g u n g}$ zu beruben, wenigitens ftebt $\mathrm{e}$ sె mit feiner anderen erfentbarent Sebenserfoeinung im Zujammenbange, uno aud ber alte, feimungşunfähig getworone Same ift ibm unterworfen. Diep aufgefogene Waffer bält ber Eame aber febr feft uno wiro baburd) für längere 3eit=

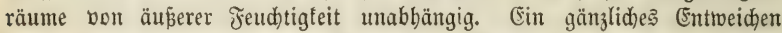
biejer einmal aufgenommenen Feudtigteit id)abet ber Reimfäbigfeit uno fann fie gänzlid) vernidten, wie wir biés im Grrofien am Erlenjamen feben, ber längere Beit auf bem Waffer gefdrwommen bat unb bann gefammelt uno getrodnet wurbe, wäbreno berjelbe Samte, naß auşgefäet, volltommen feimfäbig ift.

Db ziwifhen Dem 3eitpunfte bollenbeter Samentuhe und bem Beginn ber Reimung nod) ein Beitraum liege, läjpt fid nidht befitimmen. Da bie 
Gamenrube jelbjt fid nur aus ber ungleiden Dauer bei veridiebenen

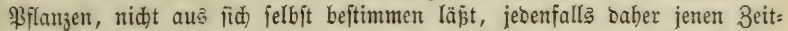

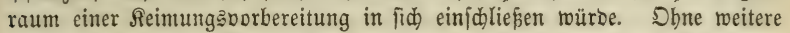
optifibe ober demijhe Fुülismittel erfennt man bie Seimung erft mit bem Servorbredhen Des Würzelchens aus Dem Gamentorne, bas in Der Regel an berielben Etelle erjolgt, bie aud zum Einoringen Des \$ollenidjlaudjes bient (Taf. I. Jig. 22 d), inbem biejer, bie Minfrophnle genannte bang aud wäbreno ber 2lusbiloung bes Gamentorns nidłt verwädbst, wenn er

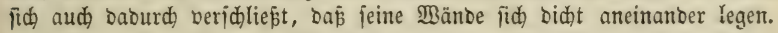

2ber ehe nod bas Mürzelden aus ber Reimöfïnung herboridaut, haben bie Rejervejtoffe ber Gamenlappen ober des Gamenweibes faton theil=

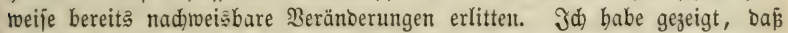

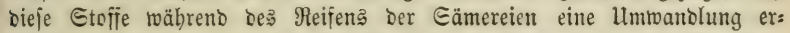
leiben, Der zu Jolge bie urfprüngliden Rernftoffiförperd)en bes Zellferns in Chlorophylffö̈nḑen, bieje in Stärfemehl, leb̨tereş bei ben ölhaltigen Gäme: reien in Fllebermebl umgetwanbelt werben, ¿a’ Den fiärfemehlfaltigen Eäme=

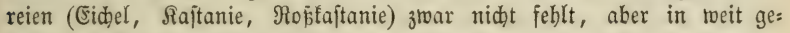
ringeren Mengen Beftantbeil Der Eamenlappen ijt. $\Im$ d) babe nun in

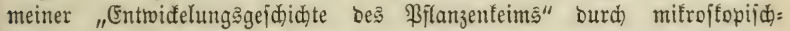
demifde Unterjudungen nadgetwiejen, ba niebergelegten Rejervejtoffe rüałwärts biejelben Umbilbungen rährento be३ Reimens crleiden, die fie wäbreno bes Reifens voridreiteno burdhliefen; bas Rlebermehl twirb wieber zum Stärfemehl, biejes wirb wieber zum Chlorophyll, bie Eamenlappen wieberum grünfärbent. Jm reifen ß3uden= famen fino bie Eamenlappen ungefärbt, ein Tröpfden Joblöjung färbt Dueridnitte baraus gelbbraun: fie entbalten nur Rlebermes)l; ift Der Game angeteimt, fo färbt Joblöjung bie Queridnitte blau - bas Rilebermehl bat fid in Etärfemehl umgebildet; baben die Eamenlappen im Sidjte fich entrwidelt, bann twerben fie grün: Das Etärfemebl bat fid in Chlorophnll

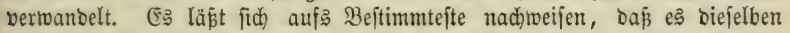

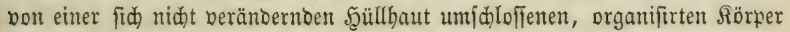
fint, bie burd) Ummandlung ihres In haltes biefe Beränoerungen vor= uno, rüđjdreiteno erleiben, eine Ihatjadje, ourd melde bie biaherigen

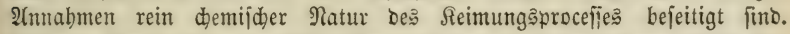

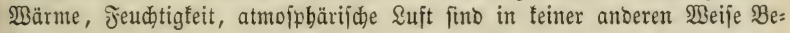

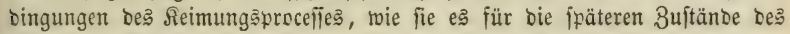
Bjlanzentwachsthums ebenfalls fino.

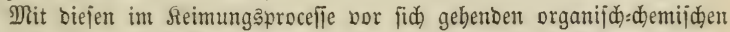
Umbiloungen uno Etofifmanolungen geht nun aber bie $\mathfrak{A} u f$ löjung eines

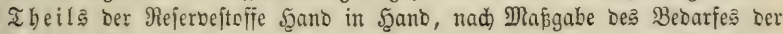
Reimlingpilanze, зu Deren eigenem Wad引thum. Eミ fteht bieje Afuflöjung aufa Beftimmtefte unter ber Şerridaft bes Reimlinga, bem jene Rejerveftoffe von ber Mutterpflanze mitgegeben wurben. Salten wir ben

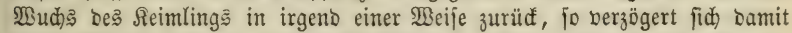

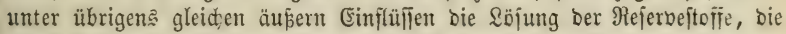
um fo rajoer fortidjreitet unt um fo früber vollenoet ift, je üppiger uno rajwer ber Seimling fid entroicelt. Mähreno in Demielben Gaatbette bie 
Samenlappen Der fräftig entwidelten Eiden, Rajtanien, Şajelnüffe längit auşgejogen finto, enthalten bie Gamenlappen ber Edywäd)linge ober burd)

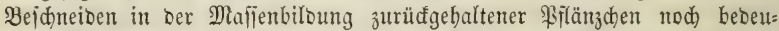
tende Mengen von Etärtemebl. Die im 3oben zurüdbleibenden Gamen= lappen biejer Bflanzen fino aber ficher ganz gleid)en äuß̈eren (sinflüfjen unterworfen. Thatjaden folder 2 (rt treten bent forftmann alliäbrlid in Menge entgegen, es fommt mur barauf an, baß er ben ridtigen Şonig Daraus zitehe. Gamenlappen ber (sid)e, auf bem Ranbe einer enghalfigen Flajđe liegent, bie $\mathfrak{B u r z e l n}$ im beftillirten $\mathfrak{B a f f e r}$ Deriflben, bą Etämm: den fümurerlid) wadjeno, habe id orei Jabre binourd) lebenoig uno mehl= baltig erbalten. Das Bflänzen batte ifnen nur jo viel Biloungşftoffe

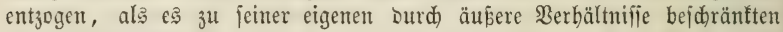

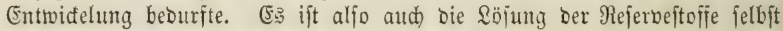
fein rein dhemifajer Borgang.

In ben an Stärfemehl reiden Gamenlappen ser (Eid)e, Rajtanie,

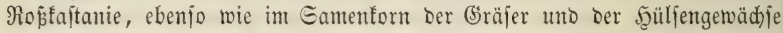
ift bie Bilbung von Etärfegummi unb 3ưđer bas nädfte Rejultat ber

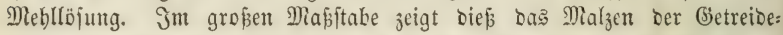
arten, uno aud bie Eidjel crbält im Reimen einen jüpliden (jejdmad", fo

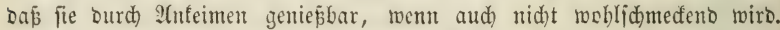
Das Deblforn ber (Eid)el reagirt Dan auf Eifendlorio mit blauer garbe. Welche Molle bei biejer \&öjung ein bỉ jeţt mut fünftlid) extrabirter Stoff bie Diaftaje jpielt, ob er in ber That ein nothmendiges, bie lumbilbung bermittelndes Jerment aud) in ber lebendigen Pilanze jei, läpt fid jur Beit nod nidft beftimmen.

Mie Die natürliche Qöjung Der Rejerbeftoffe ftärfemeblrcider Sänte: reien einen ftidftofifreien fruftallifationsfähigen Etofif ben $3 u d e r$ bildet, fo enthält bie natürlidbe Söjung Der flebermebltreiden Gämereien (Bud)e,

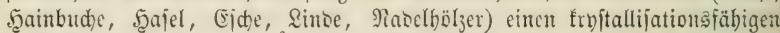
fticfifoffbaltigen Rörper, Der aus ber Mandel als $2(\mathrm{~m} v \mathrm{~g}$ barin betannt ift.

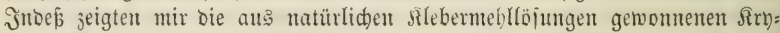
ftalle ood) mannid)faltige $2(6$ weid)ungen, theils gegenüber Dem fünftlid) alts bitteren $\mathfrak{M a n b e l n}$ Dargeftellten 2 (mugbalin, theil(s unter fid) aus verjoficbenen Eämereien; Daher idb bieje jtidjtofibaltigen, frojtallinif(d)en Rörper mit bem Sammelnamen 하

Der Delgebalt Des Eamentorn ftht mit Dem Rlebermehlgehalt in inniger Bejiebung. Ebenjo wie feinent Eamen bą R̊tebermehl gänjlid feblt, mangelt auch bas Del in feincm Eamen, e's tritt aber in unt io reidlid)erer Menge auf, je gröper Der Slebermeblgebalt ift, bie ölreidjiten

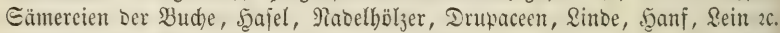
enthalten nur Rlebermebl. Daju gefellt fids Der Umitand, baj bas Del

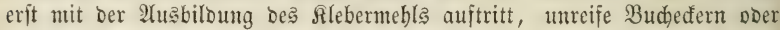
Şajelniilie entbalten fein Del. Ebenjo beridiwinbet aud bas Del jofort,

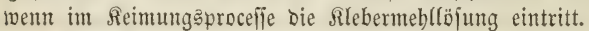

Daraus erbellet bie phnfiologifde Bebeutung Des Dels. Das Stärte: mebl ift gegen bie Eintwirfung wäfferiger Flüfiligteiten unempfindlid, ę

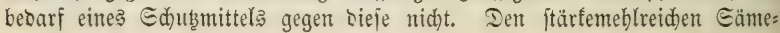




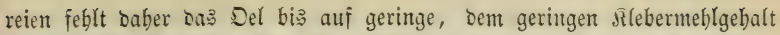
entipredjente Mengen. Daß Rlebermehl bingegen ijt gegen bie Eintvirfung

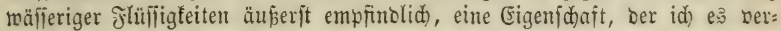

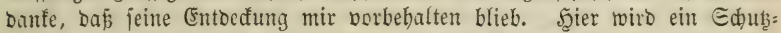

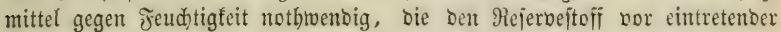

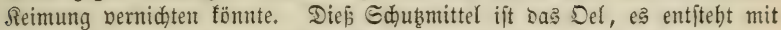

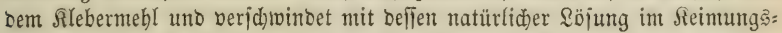
proceffe. Je tiejer mir in bie গatur ber Dinge blifen, um jo mebr oifen=

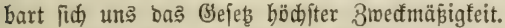

Diés alles zufanmengebalten beitebt auch ber Reimungsprocés au

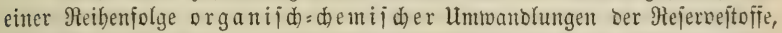
beren Enoztwed bie fuccefi ive Mieberherftellung berjenigen flüjigigen, einer \$Banberung von Belle zu Belle fäbigen Bilbungsitoffe ift, aus benen bie

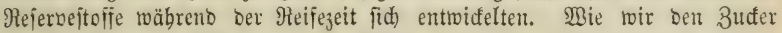
in fejter form barftellen, um ihn Jahre binourd) unveränbert aufbetwahren

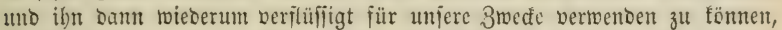
io vermandelt aud) Die \$ilanze ibre überiduffifigen uno für Den Bebarf Fpäterer Beiten nöthigen Biloungŝäfte in bie feften Etoffe Des Etärfemehl: und des Rlebermebls, in bas flüfilige, aber ber Berfebung nid)t unter= worfene Del. Das Meifen bes Gamentorns ift ber Aft organifoder Biloung,

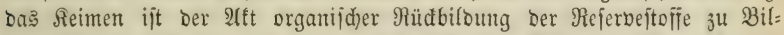

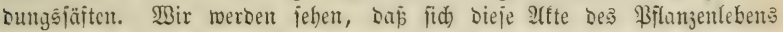
feineșegg auf Den jugendliden 3uftand Der Bflanjen uno auf Das Eamen=

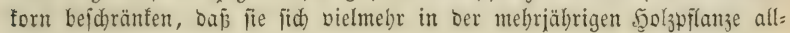
jäbrlid) etmeuern.

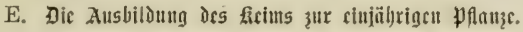

a. Eேrnäbrung.

\$ir verlię̧en Den Embrno im reijen Eamentorne auj einer (snt=

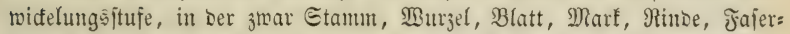
bündelfreis bereit sorbanden jind, alle bieje Theile aber mit jeltenen $\mathfrak{A}$ น: nabmen in einem nod) wentig entwidelten 3 ujtande fid) befincen. Int J̃olge Defien ijt ber (Embryo, went aud befäbigt Durd) Beflenmebrung, Bellent= radjsthum und Bellenfeitigung jich felbit weiter fort3ubilden, bod) nod)

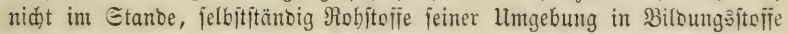
umzutwandeln, er wiro baburd) abjängig von ben ihm von ber Mutter= fflanje in Den Gamenlappen ober im Gamenweip mitgegebenen Rejerve:

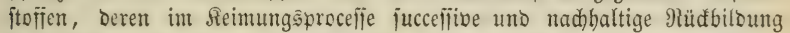
in Billoungsiäite ibm bie Etofie liefert, burd Deren Berwenoung er bis ju Demjentigen 3uftanoe fid) ausbilbet, in bem er jelbjt aus 33oben uno Ruft robe Pabrungsifoffe nidht allein aufjunebmen, fonbern bieje audh ju Bil= bungşäften umz̧arbeiten vermag.

Die (Enäbrung ๖er einjäbrigen Bflanje jerfällt saber in brei Periosen, in seren criter ber 3uwadbs allein aus Der Bertwendung Der Referveftoffe Des Eamentorna erfolgt, mäbreno in ber zmeiten \$eriose neue Bilounga: itoffe aus Robitoffen bereitet uno iofort verwentet wersen muifien. Эn 


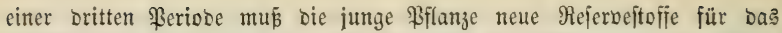

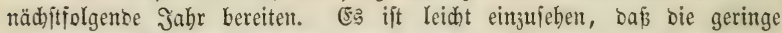
Menge Der Rejerbeftoffe Des Gamentorna Der Birfe, Erle, ßappel bą Dlaterial für bie 2Aasbiloung ser einjäbrigen Bflanje nid)t liefern tann.

Die erite ßeriobe ber Ernäbrung enbet bei beridbiebenen \$flanzen zu jebr verifiebener 3eit, am frübejten bei benjenigen, bie, wie bie Nabel= bölzer, wie Sinbe uno Ejake, ihre eriten Blattausfideioungen zu Gamen= lappen nidht berbifen, früber bei Denjenigen $\mathcal{L a u b b o ̈ l}_{3} \mathrm{ern}$, beren Gamen=

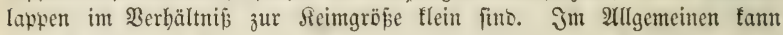
man fagen, baj fie vollentet ijt mit ber vollfommenen $\mathfrak{A}$ usbiloung ber criten normalen Blätter. Man faun fid biervon leidst uno in wenigen Sisoden überzengen, wenn man Boknen (Vicia) feimen läf̧t uno von Tag z̆ Iag einigen berfelben bie Eamenlappen abjuneibet. Man wirb bann finton, Daf vom Iage Les ßerluftes ab bie \$flänzd)en wohl nod etwaß höher werben, Daj aber beren Blätter auf Derjelben Entwiđelungsitufe fteben bleiben, baf nad) einigen $\mathfrak{B}$ oden biefe fowobl rie ber Stengel ab: fterben. Iritt ber Berlujt ber Eamenlappen erjt bann ein, went bie erften normalen Blätter entfaltet uno erftarft finto, bann bat berfelbe cinen ben

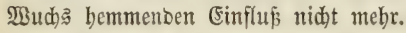

Säpt man Bobnen unter völligem Sidjtabidlufie feimen, bann wadjicn fie, went aud) f(d)mädtig uno bleidjüd)tig, bis zum Berbraud) ber Rejerbes ftoffe in normaler Weife, fterben alssant aber unfebltar ab. Zur felbit:

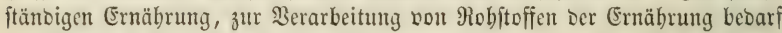
bie Pillanje Daber nidjt allein ber Belaubung, fondern aud) Der \&idstwirfung.

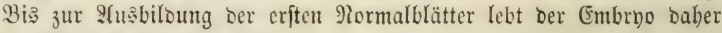
von ben Referbeftoffen ber Gamenlappen ober des Gamentweip. Da biefe Rejerveftoffe bereits verarbeiteter uno zrar von ber Mutterpflanje bereiteter

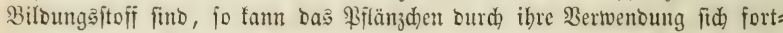
bildon, obne gleidyzeitig bie Jähigfeit einer Umbildung von Rohftoffen in Biloungsftoffe zu befiken. Bis babin gleid)t bie junge Samenpflanze in

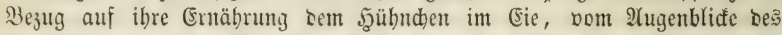
Bebrütens ab. Der Moment, in weld)em bie eriten Mormalblätter aušs gebiloet fino, entipridt Dem 24ustommen bes bühndens aus bem Eie. Erit von Diefem 2lugenblide ab vermag bie junge Bfianze Mobjtoffe ihrer Er: näbrung nidst allein aus ibrer llmgebung auijunebmen, fie ift nun aud)

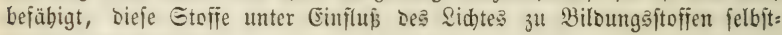
ftändig umżumandeln.

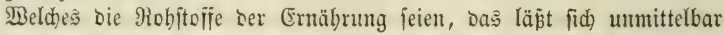
nidjt erfennen. SBir fönnen fie nur entnebmen aus ber demijden Unter: fuchung Der Beftandtheile Des Bflanzentörpers. Afle bic clementaren Stoffe, aus ber bie \$flanze zujammengeję̧t ift, müfïen von ibr alsె Rabrungştoff aufgenomment merben, freilich in ganj anderen Bujammenftellungen, als wir fie in ber Pflanze vorfinden. ${ }^{1}$

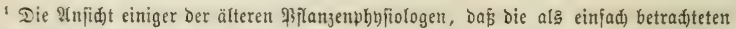
Etofie nid)ts anderes feien als fiorper, Deren toeitere 3 erlegung ber chemie bis iest nid)t gelungen ijt; bas mandie unter ibnen aus einfadjeren Etoffen zujammen= gefetjt feien, in Der Pflanje, Durd beren vitale firaft, aub lebteren gebildet werden fönnen; 


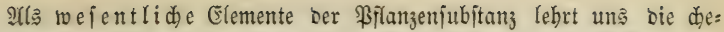

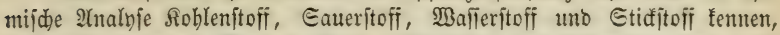
benen in geringen Mengen Riejel, \$̧hoßphor uno Ectwefel, Rali uno Natron, Ralf, Talf, Eijen unt Mangan beigegeben find. Die zuerit ges nannten Elemente fint im Boben uno in ber atmofphärifden \&uft ent=

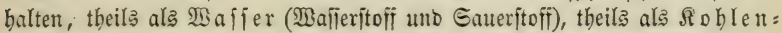
\{äure (roblenftofi uno Eaueritofit), theils als $\mathfrak{A}$ mmonial (Wafferitofi uno Etidjtofi), theile als Salpeteriäure (Eaueritoif uno Etiditofi). Die zuleb̧t genannten mineralifden Stoffe fino Beftandtheile bes Bobens

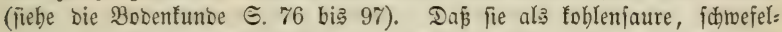
faure, whosphorfaure Galze im Bobentwaffer gelö3t, nur burd bie $\mathfrak{B u r z e l n}$ aus bem Boben bezogen werben fönnen, ijt Daher unzmeifelfaft. 2fuf Dem= jelben Mege fann bie \$flanze aud ifren ganjen Bebarf an Eaueritofi uno Wafferftofi burd Berlegung Des aufgenommenen Bobentwaffers bezieben. Niddt fo verbält es fid in Bejug auf Deren jäbrliden Bebarf an Roblen: ftofi. Die bas ganze Jabr binourd) in naffem Boben wadjente (Erle ober

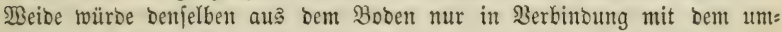
gebenten Bobentwaffer aufnebmen fönnen; fie würbe burd eine, bem

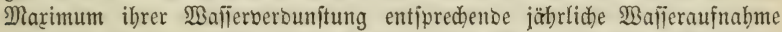
aus Dem Boben, felbjt unter $\mathfrak{A n n a b m e ~ d e s ~ M a r i m u m ~ v o n ~ R o b h l e n j a ̈ u r e s ~}$

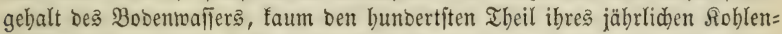

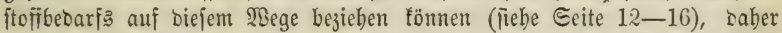

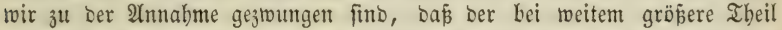
beక Rohlenftoff̈bebarfs Durd) bie Blätter unmittelbar ber atmofphärifchen Slift entnommen werbe. $S_{b}$ uno in wie weit biep auch in Bejug auf ben Etidjtoffibcoarf angenommen werben fann, ift eine offene Jrage. Dap ber: felbe gropentbeils burd) bie Murzeln aus bem Boben als fohlenfaure?

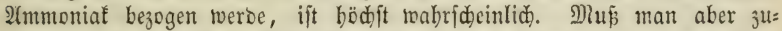
geben, Dap bie Blätter Sioblenfäure aus ber Suft entnebmen, fo liegt $e$ s nabe, bieß audy auf ben Eticfitofi in ber 3ujammenjeb̧ung zu foblenjaurem Atmmoniaf anzunebmen.

Wir find Daber zu ber Annahme berechtigt: Daß bie Pilanze surd ihre $\mathfrak{B u r z e l n}$ aus bem Boben $\mathfrak{W a f f e r}$ aufnehme, in weldem toblenjaures 2lmmoniał, fohlenfaure, fiejeljaure, fdwefelfaure, phosphorjautre, zum Theil aud) jalzfaure भiffalien, (Erb= und Metallorbbe aufgelöst enthalten fino,

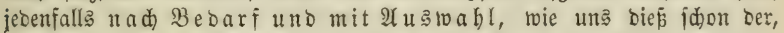
in Menge und Bejdafientheit verjojedene 2lidegebalt nebeneinanoer er: radjener, gleid grofier uno in gleidem Mailejumadje ftebender Riejern uno Buchen berweist. ${ }^{1}$

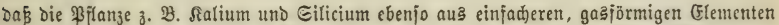

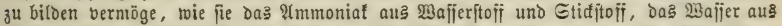
Wafferfofif und Gaueritofi mögliderweifc bilden fann, hat mit ben fortidyritten ber Chemie alle Eympathien berlorem.

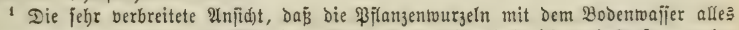
aufnebmen, twas in biefem volfiändig gelöst enthalten ift, habe iđ nad) ภrüften zu be=

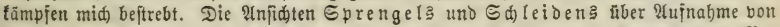

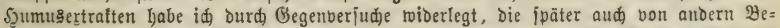

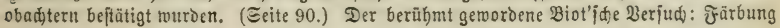


Dap bie von ben Burzeln aufgenonmene wäfiferige Bobennabrung ourd bie ganze \$flamze binourd) bis zu ben Blättern emporiteige, beweist uns

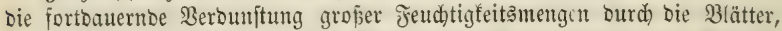

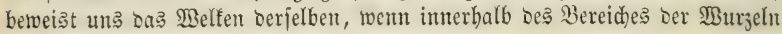
Der Boben außstrodnet. ${ }^{1}$

3u Den Blättenn cmporgeftiegen, müilen die aus dem Boden ent= nommenen rohen Nährftoffe nit ber, von Den Blättern aus ber Suft auf=

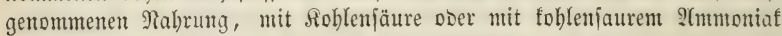
zujammentreffen. Diés 3 ujamentreffen veridiebenartiger, bis babiu unorganifder $\mathfrak{x}$ äbrtoffe mag es wohl hauptiäd: lid) fein, Durd weldes teren bisherige Berbintongen zerlegt unto neue, organifid: demifhe 3 ujammenftellungen Der Elemente herborgerufen werben, Deren Rejultat ein hinfort organifder Stofi, Der primitive Bilbung faft ift, Den wir als flüfitige, Der Wanterung von Belle zu Belle befäbigte Grunblage alfer fpäteren, aus llnwwandlung berjelben herborgebenton Bflan= zenftoffe betrad)ten müiffen.

Beldye Molle bei biefer erften Umbiloung ber Robftoffe bem Sonnen= lidbte zugetbeilt ift, muß burd) fortgejeçte Unterfuchutgen erit nod) fiderer als bisher ermittelt merben. Wir wifijen, dap̉ bie Blätter im Eomnenlidete reines Gauerftofigas abjheiben uno glauben baraus eine demijhe, ben

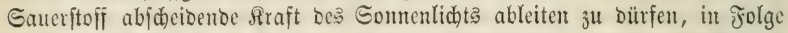
Deffen die Soblenfäure zerlegt uno eine Berbintong bes in ber Bfilanje 3urüctbleibenoen Sohlenftofis mit den Elementen bes Waffers bermittelt toerbe, wie wir joldee, als Enbrefultat einer langen Mcibe von Gtoffwant: Yungen bes Biloungsjafts, im Bellitoffe ber Pflanje ausgebilbet uno fixirt fchen. Allein twir wiffen aud, baj biefe Sateritofifabideibung mur unter

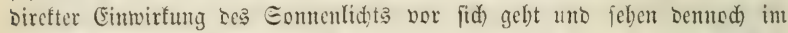

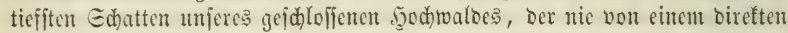
Gomenjtrabl erbellt miro, gemiffe \$flanjenarten, felbjt böberer Entwidelung, freubig begetiren uno ibr normales (stün ansbiloct. Jd) erintere nur an Diervillia eanadensis, Xanthorhyza, Hedera, Oxalis. Eintige unjerer Eulturpflanzen: bie Isciptame, bie (Eibe wadjen jogar entid)ieben rajder uno fräftiger, wenn fie burd) eine, jur Eeite befindide Edjublwano ber

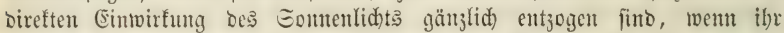

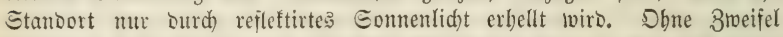

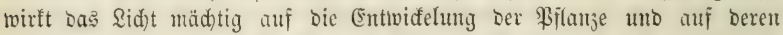

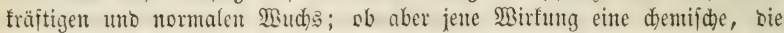
Ummandung ber Rohitoffe in organifden Biloungsijtoff bebingende fei, bas barf man, meine id), jur 3eit nod) nid)t mit Eiderbeit bebaupten, wäbreno meine neucften ßerịd)e mir einen überaus mädtigen (Einflus ber Sidtwirtung auf sie Energie ber Berounitung ergeben baben, bie, sa Das

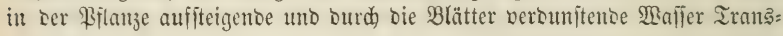

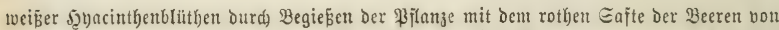

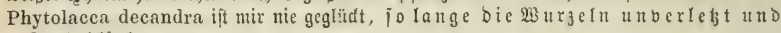
gejund blieben.

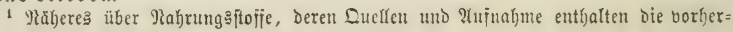
gebenden beiden Abjunitte Der Suft = uno Bodenfunde. 


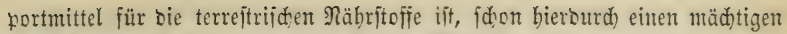

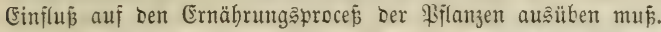

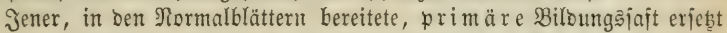
nun fortan Diejenigen fecundären Biloungşäfte Deß Reims, bie biejem

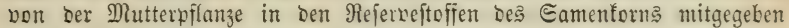
wurben. Bom Siebfajergetwebe ber Blattnerben, aus bem umgebenen Bell= getwebe bes Blattes aufgejogen, geht er Durch ben Bajt Des Blattjtiels in Den Baft ber 3weige, 2tefte uno bes Etammes zurüd uno fpeist von ba

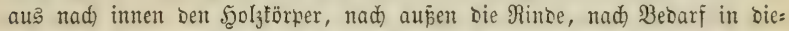
jenigen Bellen ober Fafern fid bertheileno, in benen entweber Bellenmehrung unb Bellentachsthum ober bie Afübiloung von Rejerbeftoffen (Ehlorofbnll= förner, Etärfemehl, Alebermehl, Jnulin ic.) Doer von Eccreten (Jarbjtoffe,

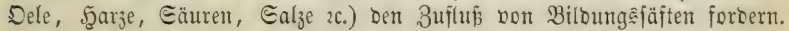
$\mathfrak{I} \mathfrak{m}$ Drte jeiner enolichen Berwenbung angelangt, iteht feine meitere $11 \mathrm{~m}=$ biloung unter ber Şerridaft berjenigen Belle, in welder er bas Enojiel

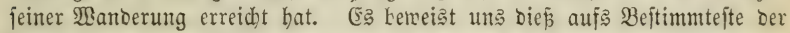

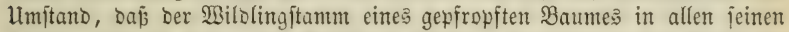

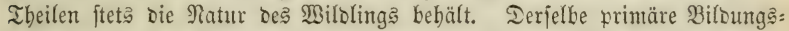

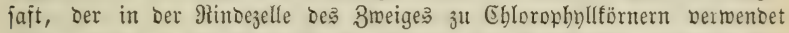

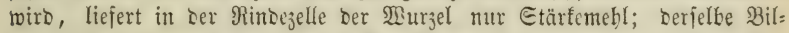
Dungsfaft wirb im Bellgemebe delielben Blumenblattes zu ben veridiedeniten

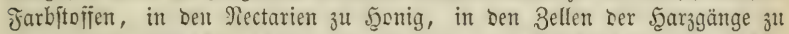

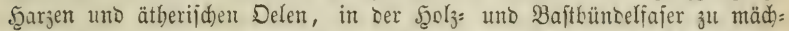

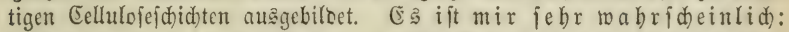

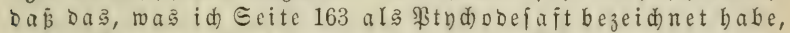

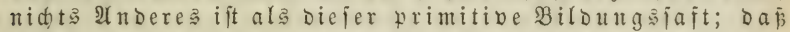
Die Betwegung Des Btydobefafte in Der einzelnen Belle (Seite 164) in Bejiebung itehe mit ber Bewegung bes pri= mären Bildungajaftz vou Zelle zu Zelle; Da pi Der Zellfern a us bem Biloungiafte refp. Ptrdodefafte bie zu feinem

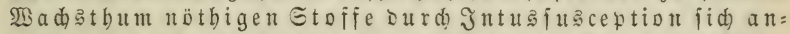
eigne; Dáp Der im Zellferne firirte unb zu Rernftofförper= den ausgebildete Ptrdobefaft von ba ab erfteine beridie:

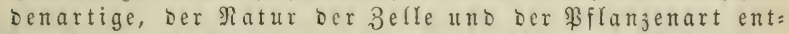
frredente umbiloung erleibet, theils zum Gafte der Phyialibe und bes Bellraumes, theils zu Eellulojeförnern und zu dem baraus ermadienden cellulojebande ber Bell. wand (E. 105), theilszut sen veridiesenen förnigen bebilden, z̆ Stärfemehl=, Slebermehl=, Chloropholltörnern ze. iid ausbiloeno (E. 180). Ia aber lectere, wie die 3ellmanoung jelbft, aud nad) ibrex (entitehung fid nod bebeutend ber: gröbern, io mülfen jie, wie ber Bellfern, bie Jäbigfeit be= jibgen, Bildungsiäfte in fid aufanebmen uno jid zu ber: äbnliden, mit bem lnteridiede jebod, das, abgejehen von ipäter mögliden Stoffrandlungen (E. 181), ber bom Etärfe: forne aufgenommene Biloungsiaft iid 3 U Etärfe, Der bon ber Bellmand aufgenommene Eaft fid zu Celfuloie un= 
mittelbar ausbildet, wäbrend die $S_{u b}$ it anz bes wadjenden und bes a jelbe zu fein foreint.

Der fid felbjt aus bem Remtörperden regenerirenoc ober ourd Thei= lung fid mebrente Bellfern ijt ber Schöpfer aller organifirten Bejtano= theile des ßrlanzentörpers; legtere befitzen aber bis zu ibrer Bollenoung bie Jähigfeit burd) Theilung fid zu mebren, burd) $\mathscr{A}$ ufnahme von Biloungs:

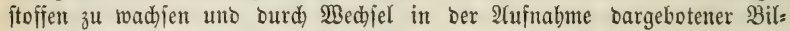
Dungsftoffe ibre Gubitanz zu verändern.

Erit im Saufe des berwidbenen Sommers ift es mir geglüdt, jenen primitioen Bilounģ̧aft fenten zu lernen. (5) war im Monat Juli, 1 als

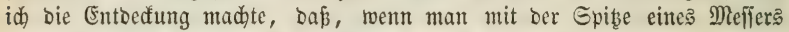

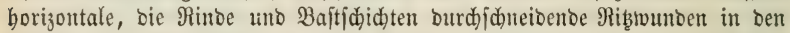
Gtamm von $\mathfrak{A b o r n f t a ̈ m m e n ~ o b e r ~} \mathscr{U}$ ejten 1-63ölliger Stärfe einfdnneibet,

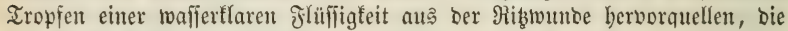
mit einem Binfel aufgefangen und gejammelt twerben fönmen. Später er: bielt id in gleid)er Weife ben Baftiaft aud) aus Motbbudben, Sainbudben,

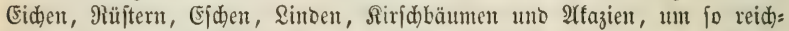
lidber, je fpäter im Jabre, bį zum erjten Jrübfroft. Surz bor bem Blatt= abfalle war ber Erguf fo reid)lid, baf id) von Rotbbudben, Scainbudben, Sinben, צfazien in wenigen Etunben über cinen Cubifzoll Jlüffigfeeit fam=

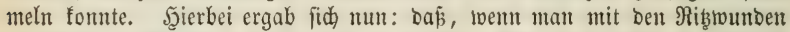
am Jupe des Reidel beginnt, jebe an berjelben Baumfeite höher angebradhte Wunbe gleidfalls Saft gibt; ribt man bingegen zuerit in Manneshöhe, bann liefern alle tiefer gefübrten Ribgtwuben feinen Gaft. ${ }^{2}$ Es beweist

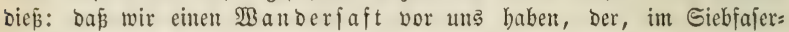

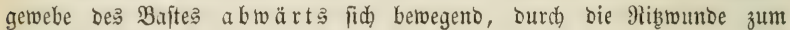

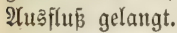

Filtrirt uno aufgefodst gibt Der Gdröpfiaft uur einen febr geringen

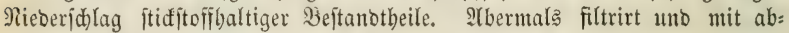
folutem arffobol bebandelt, färbt fid) ber Saft mildbiveiß uno liefert einen Pieberid)lag, Der, getrodnet, zu ciner grauen fpröben Malle erbärtet, o ie

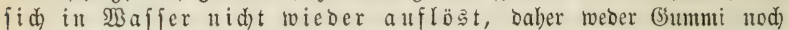

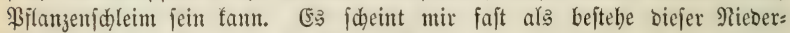
¡d)lag aus Den fleinjten, Durd) Das Jilter nid)t abgejdiedenen organifden Moleculen.

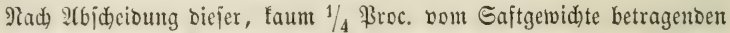

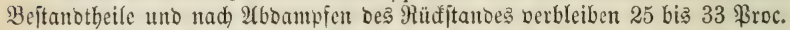

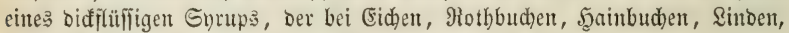
Atazien, Ejden, wie mir jueint jeiner ganzen Malle nad), zu Zuder aus:

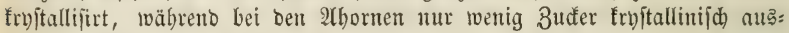

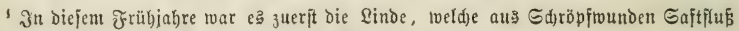
gab und ztwar fdon Mitte âpril bor bem 2 (nj dwellen der Rnojpe.

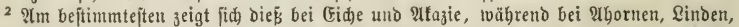

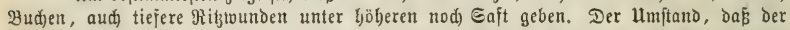

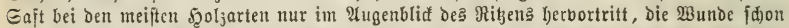
nat) Berfauf einer Minute feinen Eaft mehr ergibt, fann nur auf Turgešcenz ber ben Eaft

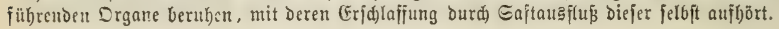


iheibet, ber grö̈ere Theil biejes Rüđjtanbes 3u einer wallerflaren, frröben Mañe von bödjt bitterem Gejdymađe eintrodnet. Ier I(hornjäröpfiait wirb im Dftober fo bifflüfilig, Daj er wie Riridgummi wenige Etumben nad) bem Şervorquellen tropfig erftarrt, wie biejes eine braune farbe in Der \&uft annehmeno (Extractioftoff - bittere (Ertracte ber älteren (Shemie).

Gerbjäure habe id nur im @d)röffiafte ber (Fidje uno ztwar auch bort mur in jo geringen $\mathfrak{M e n g e n ~ a u f g e f u n b e n , ~} \delta a \tilde{s}$ id) zur $\mathfrak{2}$ (nnabme geneigt bin:

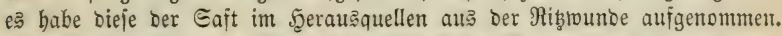

Jür ben Chemifer ijt ber Edröpffaft eine Junogrube ber veriđạiebent= jten Buderarten. Der Edröpfiait Der (Eiden eritarrt fait mit Der ફூülfte

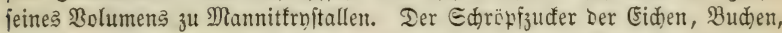

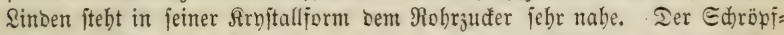
zucfer ber 2lfazie frnftallifirt aus ber alfoboligen \&öjung in iphärijden

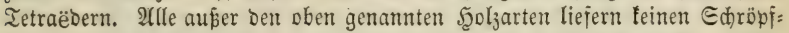
jaft; ba man aber aus ben genannten Sুolzarten Denfelben 3ưfer erbält,

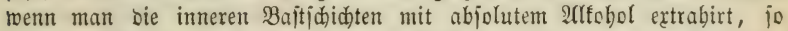

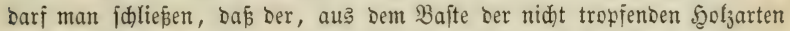

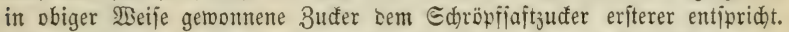
Eine Heberifidt ber auj biejem Mege Dargejtellten, in Der Frbitalliorm ver=

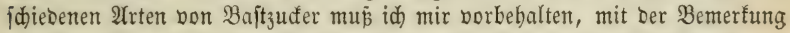

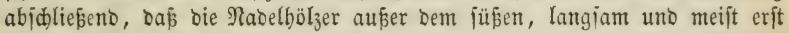
nad) Jabren fryftalliītrenden Buffer, im Baftjafte nod reidjlidje Mengen

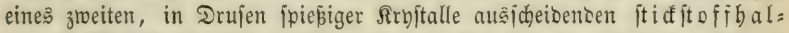

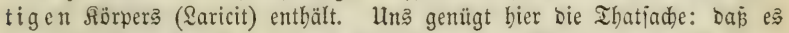

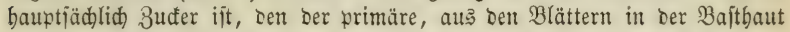

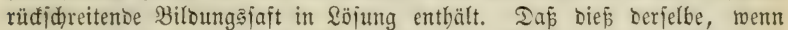
aud) etras peränberte Gaft ijt, weldhen bie Blattrippen und Blattiftele

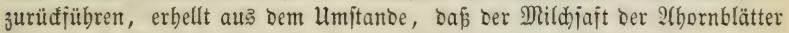
nach 3-4 Monaten ebenfalle froftallinij̧e formen erbält.

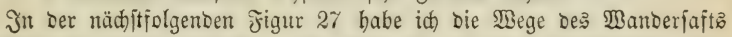

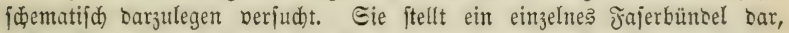
befien Burzelende bei $z$, Defien Innopenenbe bei w, befien Blattnerbenenbe bei $x$ gelegen ift. Die bunfle Şälfte diejes Jajerbünocla bedeutet den

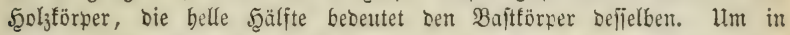
großem Map̧tabe zeidnen zu fönnen, babe id) neben Dem sajerbündel,

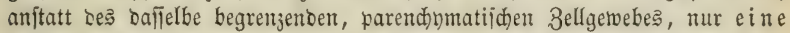
Belle als Repräjentant belielben für $\mathfrak{B u r z e l , ~ E t a m m ~ u n o ~ B l a t t ~ g e z e i d n e t , ~}$

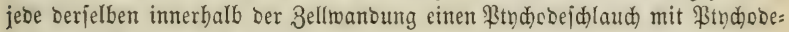
jaft uno 3ellfern enthalteno.

Die Rindejelle Der Burzel nimmt Das Bobenwaffer mit ben in ifm gelösten Galzen bon ausen in fid) auf (a), leitet es burd fid binourch uno gibt es, rabricheinlich unter Bermittlung be: Marfitrablgetwebes an

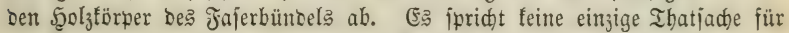

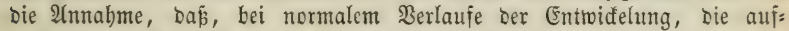
genommenen Robftoffe fdon in ber Murzelzelle in organifase Eäfte um=

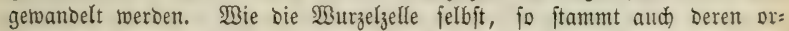

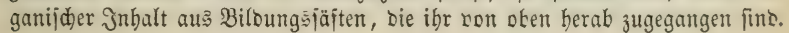




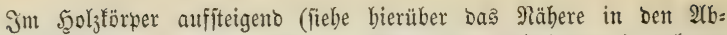

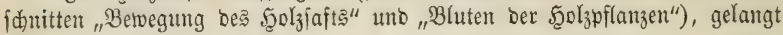

Fig. 27.

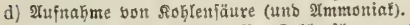

अuşideibung bon Saueritoff, foghlenjäure unb Bafiferounft.

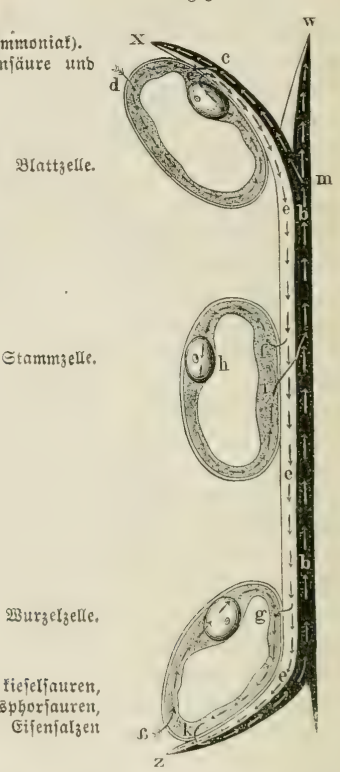

a) 2ufnahme toäfiriger \&öjungen vou fieielfauren, fohlenfauret, jowefelfauren, phos̄pborfauren, Hmmoniat $=$, $\mathfrak{A}$ li $=$, $\mathscr{R} a l f=$, Talf $=$, Eifenialzen unb von foblenfäure.

Der robe Fahrungşaft auf Dom, ourd) Wfeile angebeuteten Bege bb burd) Blattitiel, Blattfiel uno Kippen bis in bie Blätter $(x)$. Şier wirb er an bas, bie leitenoen Fajerbündel begrenzende Bellgewebe abgegeben (c) uno trifft in biejem mit ben aufgenommenen, atmojphärifden Räbrftoffen (d) zujamment. Die bent Sidjte zugängliďse Blattzelle ift mu ber Drt, an

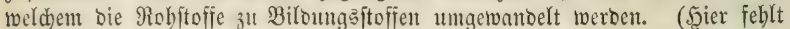
nod) jeoe birefte Beobadtung Des interen Borganges.) Dieje Biloungšs fäfte gibt mun bie Blattjelle nidht an bas Soljajergewebe, bon bem fie bie Robjtoffe empfangen, fonbern an bas Siebfajergetwebe ber Baftfojidten (e), in bem fie, abwärts fobreitento, in bie tieferen Bauntheile zuritd"= geben (ee). Aluf biejem Rüfwege geben bie Bajtididten nad) Bebarf

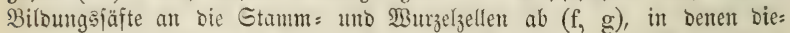

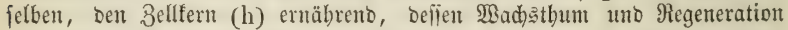

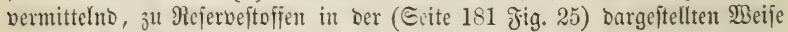
längere ober fürzere Beit fid fixirent.

Daj ber primitive Biloungajaft mur rüflaufeno uno in ber Duer= fläche Der Fajerbünoel fid) fortbewegen fönne, bafür werbe id) meiterbin bie 
nötbigen Beweije lieferm. (E) fragt fid mun: mie ber madhfenten Irieb= ipibe Die nöthigen Biloungâfäfte zugehen, wenn die unausgebiloeten Blätter

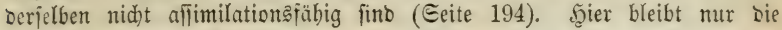

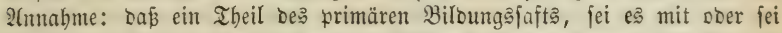
cล obue borbergegangene vixirung zu Rejerbeftofien in Etamm= uno \$Burzel= zelle, aus lesteren als jecunoärer Biloungsiaft an ben 5ूoljf̈̈rper Des Jajerbündels abgegeben werse (i, k), uno in lebsterem mit bem roben Şolzfafte gemtengt, bis in bie Triebipişe $(\mathrm{m}-\mathrm{w})$ aufiteige; Daj ber im

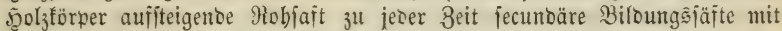
fid) nad) oben fübre uno burd) bieje die wadjenoe Iriebipike ernäbre. Mir werben fpäter jeben, baj biej ber $\mathfrak{W e g}$ ijt, auf weldem Den Irieben ber

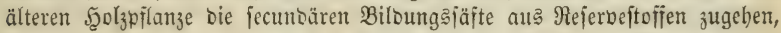

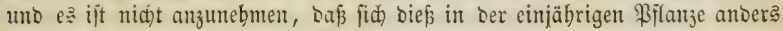
verbalte.

Demmad unterjadjece id): $\mathbb{B}$ a noerfäfte (Jajerjäfte) von Bell= fäftcn. Nur eritere geben eine bejtimmte Banberrid)tung zu erfennen. (5: gebören babin: 1) ber im £oljtörper aufiteigenbe, ftets mit jecundärem D. b. auङ wieber aufgelösten Rejervejtofien ftammendem Bildungsjafte ge= mengte Robjaft. 2) Der vom Bajtförper ben Blattabern aus Dem Blatt= geroebe extrabirte, im Baftörper abfteigende primäre Bilbungsiaft.

Bu Den Bellfäften bingegen zäble idh alle biejenigen Eäfte, die, ohne erfennbare Belogungäriatung von Den Wanberiäften ab uno im

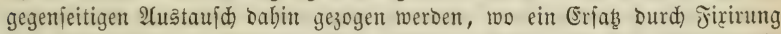
uno 3erbunjtung notbrentig wiro. Dabin gebören: Die vom Blattgervebe

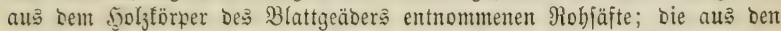
Blattjellen bom Bafttörper Des Blattgeäbers zu extrabirenoen Biloungs̄ääte; Die Cambial=, Mart=, Rinbejäfte; Die Marfjtrabl= uno Bellfajerjäfte; fur alle Piflanzenfäfte, bie nidht ben Manberjäften angebören, aber burd) bieje erjebst werben, wo ein Serbraud von Belliäten biep nöthig mad)t.

\section{b. $\mathfrak{W}$ ad) $\leftrightarrows$ th $u$ m.}

Im Ëmbryo ๖es Eamentorns fint jwoar äuberlid bas Etengelden

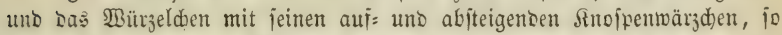
wie eine ober mebrere Blattausideibungen zll erfennen; $e^{2}$ fino innerlid Das Mark und die Rinbe Durch einen Jajerbündelfreis bereits gejdieden, aber bie Jajerbünbel fteben nod) auf einer febr nieorigen Entroidelungșituje. Man erfennt ztoar Deutlid) Die Den Jajern eigentbümliden Jormen uno Etellunģgejebse, bie cinzelnen Fajern fino aber nod) aujerorbentlid) flein, ibre Manoungen jebr Dünn uno obne crtennbare Epuren ciner Iipfelung. Den tieferen Etengeltheilen feblt jogar die zuerjt crfennbare Epiraljajer: biloung, die erit in Den böberen Ibeilen da beroortritt, too bie Blatt=

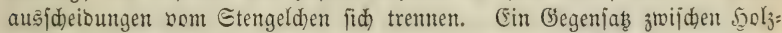
uno Bajtförper läjt fid) bier nod nid)t erfennen, Die Jajerbünbel fteben bier böbiten auf Der (Esite 174, Jig. 20 d) Dargeftellten Entroidelungsitnte.

Das Mahjen Der, aus Dem Eamentome beroorgegangenen Reimling: pflanze geht nad) benjelben Gejeben vor fid, bie wir bereit: Eeite 169 in 
Bejug auf bie Enttoidelung bes Embrno im Gamentorne fennen Yernten. (5s beruht wie überall auf Bellenmebrung Durd) Theilung ber vorgebildeten Mutterzellen in Todterzellen, fo wic auf ber Bergröperung Der, einer fort= gejeķten Theilung nid)t mehr unterworfenen Bellen ober Jajern, bį zu

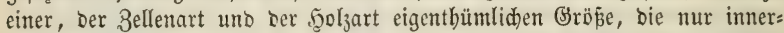

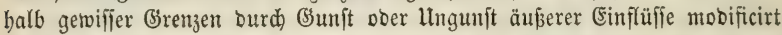

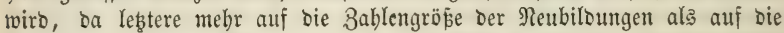
Gröpe Der einzelmen Elementarorgane von Einflup fino, bas rajdere voer minber rajde Madjen bermittelno.

Die $2 \mathfrak{u}$ sbiloung ber bem Gamentorn entitiegenen Seimpfilanze zur

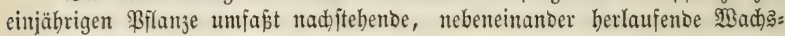
thumąvorgänge:

\section{A. ふ๋ ber รุauptadie.}

1) \&ängezutoads nad) oben uno nad unten, vorzugşweife in uno bid)t unter bem auf= uno bem abjteigenoen Inofpentwärzden beß Edaft=

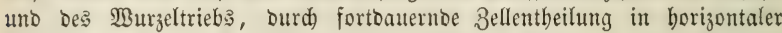
Ridstung io wie burdh Ltmbilbung ber Bellen in Jajern (Seite 174). In ben älteren Triebtbeilen Durd) Sängentwud) ber gebildeten 3ellen uno Fajern.

2) Diatezuเ und fortbauernoe Bellenmebrung nad) Becarf bes fid erweiternoen Raumes

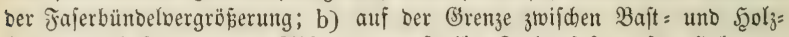

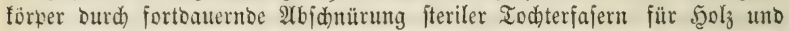
Baft, vom permanenten Mutterzellenpaare eines jeben fajerrabius aus (Seite 177).

\section{B. Bildung von Rebenadien.}

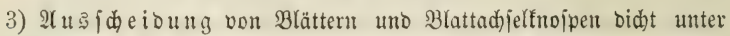
bent aufiteigenden Snoipentwärzchen uno nur bort (Eeite 171).

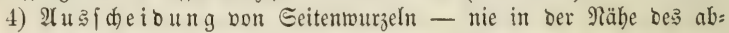

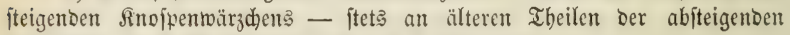
5auptad)je ourd Marfitrahlmetumorphoje (Seite 157).

\section{Inticipirte Bildungen.}

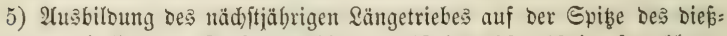
jährigen, umbüllt von Sinojpenbectblättern (Seite 133-135), forwohl an

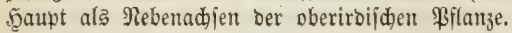

Waß̉ id) Seite 169 uno 171 in Bejug auf bie im Smofpentärzdon vor fid gehente Bellemmebrung und Faferbiloung zur Bermittelung Dę Sängenjumadję̧ gejagt babe, gilt ebento für ben eriften, wie für alle nad)= folgenden Jahrestriebe. WBas Den, in Den tiejeren Theilen bes twadjenten Triebes obne 3weifel ftattfintenden \&ängenzuwad) betrifit (Jabresberidte ธ. 107), io beruht biejer wabrideinlid nidst auf Belfenmebrung, fondern allein auf \&ängenzuwaḑs ber jobn vorbantenen, einzelnen Bellen uno

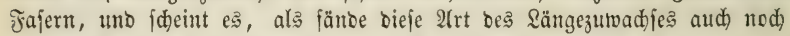

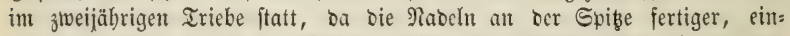
jäbriger Triebe, ふ3. $\mathfrak{B}$. Der Riefer, bidter beieinanber ftehen als an ber 
Epize Des zmeijährig geworbenen Triebes. ${ }^{1}$ Iabingegen fino alle älter als jweijäbrigent Iriebe einem Sängenjuwadjje niḑt mehr unterworfen.

Fin mejentlider Unterjajieo im Sängejutwad, jteigenten ๔todes finbet in jofern jtatt, als nur in exfterem, neben bem

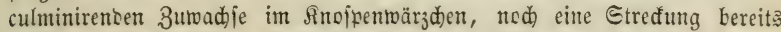
gebildeter Theile bis zur Bajis des Jahrestriebs binab ftattfinbet (i. meine

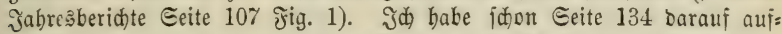
merffam gemad)t: Dás in vielen Inofpen alle Theile bes näcfitiäbrigen Triebes vorgebiloet jeien. Das in ber Budjentnojpe Fig. 4 liegento Blatt jehen wir am fertigen Triebe oft mehr als einen $\mathfrak{s} u \bar{s}$ über bie Rmoipen= bajis emporgehoben; es finoet bier baber eine Drt引beränderung bereits ges bilbeter Sfilanjentbeile ftatt, ber fid) in ber wiberftanoslojen \&uft fein Şinber= nißß entgegenftellt. Der, nod) in ber Snofłe liegente, nädjitjäbrige Trieb läpt fich vergleiden mit einem zujammen gejdobenen, auf bas Dbjectio ge=

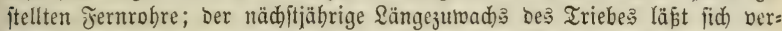
gleident mit einer Berlängerung Des Jernrobres, theils burd) terminale Reubiloungen unter ber Dberfläđhe bes Dculars, gleid)zeitig aber aud burch) von sben nad) unten abnebmento Berlängerung aller Şülien bę Jernrobr?

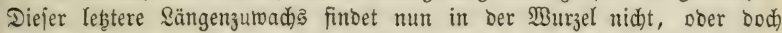
nur in jefr geringem, auf bie nod) unveräftelten, äuß̋riten $\mathfrak{B u r}_{3}$ ltriebe bejobräntem Maje ftatt. Der ftarre Boben, in toeldem bie zarten $\mathbb{B} u$ urjel= triebe fid entwicfeln, fteht einer folden Drtşberänberung bereits gebiloeter Bilanzentbeile entgegen; ber Sängezunadbs ift bier wejentlid) ein terminaler.

Mas ben Didezuwadjs burd) Bellentheilung betrifit, fo erreidst berjelbe im Marfgetwebe jebr früb jein Enbe, in Der Rinde bingegen bautert er fo lange fort, als bieje fid lebendig erbält; bei Rotbbudje, Scainbudje z. $\mathfrak{B}$. bis zum höditen 2llter ber Pilanze. Er erfolgt bier, fo lange ber Trieb (iid) nod) verlängert, burd borizontale Duertbeilung, burdh rabiale uno

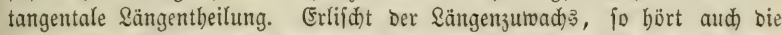
borizontale Theilung auf, tangentale uno rabiale Sängentbeilung bauern io lange, als bie grüne Rinoe fíd) nod perbift. Şört ber Dicfejutwact): ber= felben auf, bann finbet von ba $a b$ mur nod) rabiale Sängentheilung ftatt,

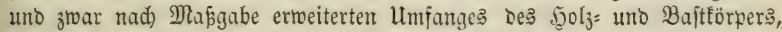
bis enolich bie Rinoe früher ober fpäter abjtirbt, reforbirt wirb ober ver= trodnet, aufreipt uno mit ben, gleidfalls auper Buwadbs tretenoen, äuperen Bajtlagen bie aufgerifiene Borfe billot.

Der Didȩ́utwad, Durd) Bellenmebrung ift aber ftets ein geringer im Sergleid zum Diffezunads der Pflanze Durd Jajermehrung. Dá und wie bieje innerbalb einer tangentalen Spaltfläche aller Fajerbünoel ftatt= finbe, nad) außen ben Bafttörper, nad innen ben 5ुolztörper verbičeno,

${ }^{1}$ Erotijae אiejern gehen niøt jelten mit einem Enotriebe in Den $\mathfrak{B i n t e r , ~ D e r ~ f a u m ~}$ ein Biertel feiner enoliden $\mathbb{Q} a ̈ n g e$ erreidft hat, an bem die 9ladeln nod) weit mehr binter ibrer enoliden Sänge zurüdgeblieben find, an benen aber bennod) bie (Enotnofpe im $\mathfrak{B}$ interfleide fteht. Im Ralthauje bleiben folde Sriebe ben Winter hindurd) un= verändert, und erit im fommenden frribjabre radjien fie trie die Sradeln jur normalen Sänge heran. Bci P. Taeda, inops etc. überîtehen foldje unjertige হriebe jogar im frreient

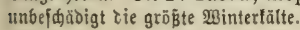


babe id̆ bereits Geite 177 auşübrlich erörtert, Geite 179 u. f. über bie,

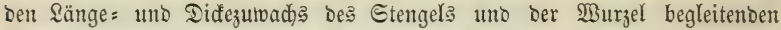
2łuşđ)eioungen von Blättern, Rnojpen uno Seitentwurzeln geiprochen.

\section{c. Die Bellenfeftigung.}

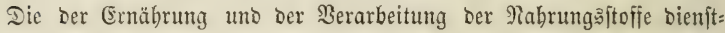
baren 3ellen, im $\mathfrak{B e f e n t l i d j e n ~ b i e ~ B e l l e n ~ b e r ~ R i n b e , ~ D e s ~ M a r f s ~ u n o ~ b e s ~}$ grünen Blattzellgetwebes, erlangen mur ausెnabmsıeije einen Ģrao ber Şärte, wie er nothwendig fein würbe, um unzählbare Zellenmenge zu größ̄eren łiflanzen zu vereinen. Die fogenamten Bellenpflanjen fino entweber von

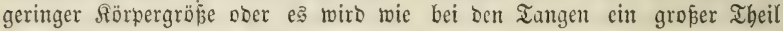

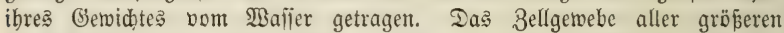

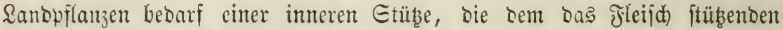
Snodhengerüft Der MBirbeltbiere verglidben toerben fann. Dieje Stübe bilbet fich jeoe Belle ourd) Sermandlung ifres erften \$tndhobefdylaudes in eine Bellwandong, es bilbet fie fid) bie (Sejammtpflanze burch Bilbung eines centralen, mit ber Bflanze felbjt fich vergröfernben Scolztörpers, befien Fafertwäntoe in böherem (Grabe fich verbiden burd) wieberbolte Bilbung in=

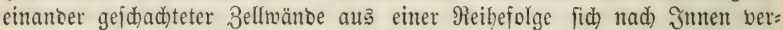

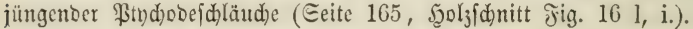

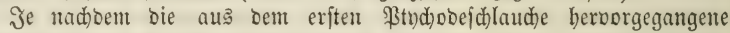
Bellwand allein bas Bellengebäuje bilbet, ober ein żmeiter, britter, bierter,

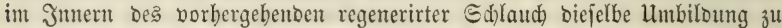

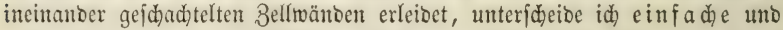

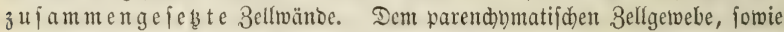
Dem Siebfajergemebe Des Baftes fino vorberridhento einfache Belltwänoe, Dem Fafergemebe Des Şolzes uno Der Baftbündel fino vorberridento zujamment= gejeß̨te Bellwänbe eigenthümlid.

Durd) bie bem 2 ufbau bes \$flanzenförners nothmendige ßerbidung ber Bellmänbe würoen aber bic lebenșthätigen Bejtandtheile benadbarter Bellen, es würben bie \$tnd)obejdläud)e bon einanber getrentut uno ber Gäteaustaujd) zwifden ihnen eridwert, vielleid)t ganz aufgehoben werben,

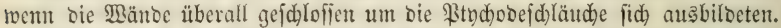

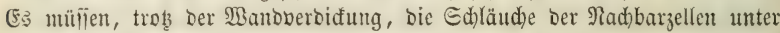
fid) in Berülyrung bleiben, wenigitens nidyt burd) Celfulofeidjidten überall

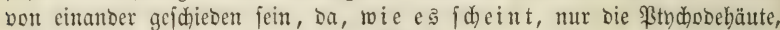
nid)t audb) bie (Eellulofejdidgten für Stliffigheiten uno (saje permeabel fino.

Fine biejem entipred)enbe, örtlid)e Befdräntung Der \$erbidung De Eellulofeantheils ber Bellivanoung tritt mun in Der That überall ein, wo eine Serbidung Der Zellwanoung itattfinbet. Gelbit ben fehr bünn= mandigen Bellen Des Marfes unt ber Minde fehlt fie nidft. Sie ift theils eine fanalförmige im $\mathfrak{I} i p f e l$ uno Tipfelfanale, theils eine fpiralige ober ringförmige im Spiral= ober $\Re$ inggefäpe.

Dieje Interidiebe in ber Entwiffelung Der Bellmantung fint $e$ s toir nadjolgeno näher betrachten wollen. 
1. Die einfade Berrmandung.

Mie id Geite 165 gezeigt habe, biloet fid bie erfte, äuperfte Bell=

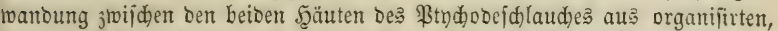

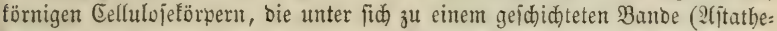

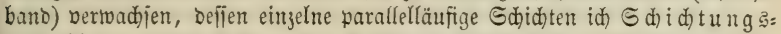
lamellen genant babe. Die Entfitehung biejer Eellulojejoichten aus ber Beribachjung von Ceflulofeförnern babe idh mehrfad) bireft nadjgemiejen

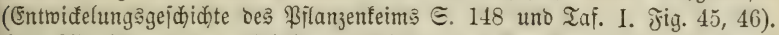

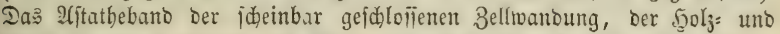
Bajtfajer, ber Eiebjajer, Der Marf= uno Rinbezelle ift in jo bidten fpira= ligen Binoungen um ben Innentraum ber Belle gelagert, baj bie Winoungs: ränber befielben fid berübren, eine iheinbar gejd)lofiene Wano bildeno.

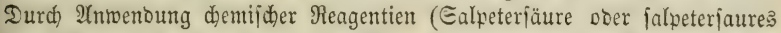
Ouedfilber) gelingt $e^{3}$ jebod, bie Minoungen auseinander treten zu lailien

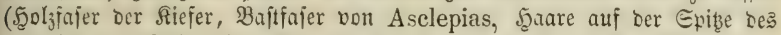

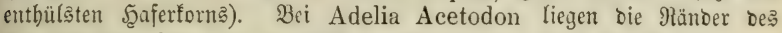

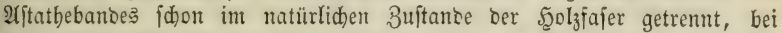
vielen Braunfoblenbölzen ift ourd) Eontraction des äftatbebantoes bie Irent= nung eingetreten (Taxites (?) Aikei). Гiер́ uno baङ ziemlid) allgemeine Borfommen eine

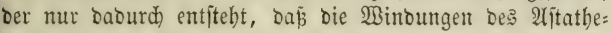
banbes ba auf furze Streden ausetnanber treten, to ein Tipfeltanal żifd,en ifnen binourdgeht, fpred)en für bie Allgemeinbeit biefer Struttur ber Belfmano.

Rebenjteheno gebe id) oie Arbiloung eines Єtüđes ber Riejernbolyfajer, an welchem, nad) Bebanolung Derjelben mit Salpeteriäure und 2Aether, bie Mindungen des 2 fftathebandes in ben unteren Theilen ber figur auseinander gezerrt fint, räbreno fie, in ben oberen Theilen mebr geloblofien, bort als färüg über den inneren Iipfelraum verlaufende Epalte erideinen. Durdh itärfere Finnirfung bon 2(ether auf bie mit Ealpeterfäure behanbelte $\mathfrak{S}_{\mathrm{o}} \mathrm{l}_{3}$ fajer löjen fid) bie einzelnen Edidhtungslamellen bes $\mathscr{X}$ jathebandes in \$rimitivfajern, biefe enolid) in \$rimitiofügelden auf, wie bief́ ber-unterfte

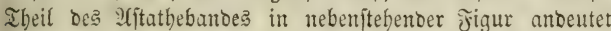
(i. über Beftuno unt Mirfung Der ershlofiven Baummolle, Braunidiweig 1847).

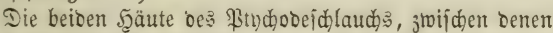
bas 2 (itathebant fich entroidelt, legen fich ber äuperen uno ber intmeren (5renje ber aus biejem gebildeten Gelluloferwanoung an, berwadjen mit berfelben uno bilden fortoauemo einen zmeiten, b) äut i gen Beftanotheil Der Bellwandung, bie äußsere uno innere Grenzhaut berielben, benen id'), ibrer Átammung wegen, ben=

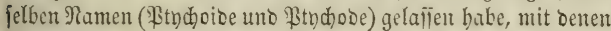

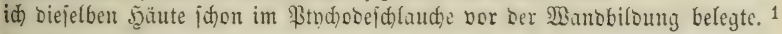

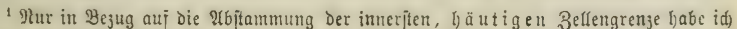

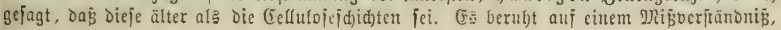




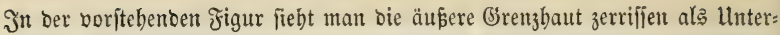
lage bes 2 fitathebanbes, bie innere Brenzhaut abgelöst uno zu einem bünnen Sc)lauche contrahirt, Bilder, wie man fie ourch Bebanolung bes Dbjects mit Sdjwefeliäure und Jodalfohol leid)t erbält.

Die Bellwanoung befteht baher aus zwei veridiebenen Beftandtheilen,

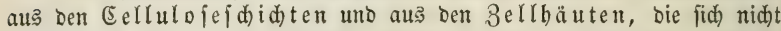
allein burd) bie, nur Den leb̧teren zuftänoige, granulirte Struttur, fonbern aud burd) ganz entgegengejeb̧tes Berbalten zu demifhen Reagentien von einanoer unterideiben. Die Eellulojejhidhten werben ourd) Sdjwefeliäure expanbirt, endlid) gelöst uno in 3ufer umgewantelt, bie Bellbäute bleiben unveränbert; leb̧tere werben burd) Salpeterjäure aufgelöst, bie Eelluloje=

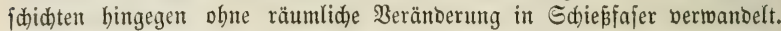
Supferorboammoniaf löst bie Cellulofejobidten und läßjt bie innere fowobl, wie bie äunere Bellhaut ungelöst. Man fann fid bavon leid)t überzengen, wenn man Baumwolle ober ifolirte Fafern bes Eidhen=, Buchen=, Riefern= bolzes unter Dedfglą mit biejer flüffigfeit in Berülhrung bringt.

Die Dicke, bis zu welder bie einfache Bellmantoung fid entridelt, ift cine jehr verfdiebene. Die Marf = unb Rinbezellen, bas Rorfgetwebe, bie Blatt= uno Frudtzellen, Dą Siebfajergewebe ber Baftjdidsten bleiben

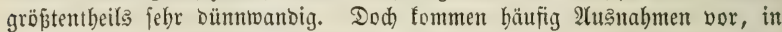

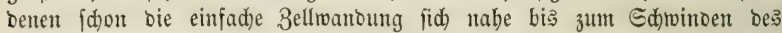
Innenraums Der Belle verbiát. Das Marf von Taxodium, bie Stein= zellen ber Birfenrinbe uno unedler Binen, die Siebfafern bon Camellia, Thea, Die Dberhaut = uno Eollendymzellen ber meiften Bflanzen, bie Beflen vieler Sämereien uno Samenbüllen Yiefern Beifpiele. Dabingegen beftehen

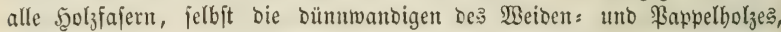

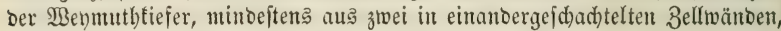
von benen bie äußere, bie id bie Cambialmandung genannt habe,

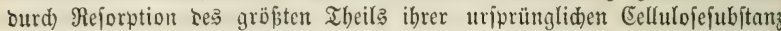
auf eitte febr geringe Diffe rebucirt ift. Id) fomme Darauf bei Betradstung ber zujanmengejebten Bellwanoung zurït, nadbem id) bie beridjiebenen Irten Der Durd)bredung einfacher Bellwänte oargelegt babe.

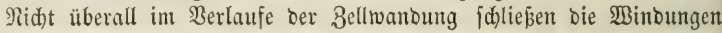
Des fpiralig gerollten 2 (jtathebanbes bid)t aneinanber. Mefre ober minder häufig, nad) beftimmten, ber Bellenart eigenten Stellungşgeję̧en, treten veridjieben grope uno beridicben geformte \&üfen im Eellulojeantheil ber Bantung auf, bie mur an ber äuperen Brenze ber Bellwanto burd ben bäutigen Bcitano Derfelben gefdloffen, nad) bem inneren Belfraume geöfinet uno mit ber inneren Bellhaut befleibet fino, bie fid) von ber inneren $\mathfrak{B a n}$ bungsgrenze aus in bie Rüden fortjebt, bis fie fidh am (srunbe ber Rüde mit ber äuß̉eren (3renzbaut zu einer, wie ç id)eint, einfaden Şaut ber=

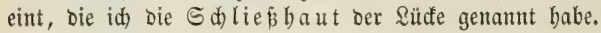

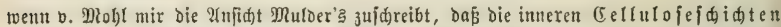

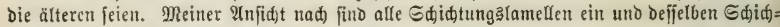
tung sompleres gleid)seitiger (Entftehung und nur in Bejug auf bie ineinander gejdachtelten Gdidgtungscomplere $z$ ujammengejebter 3 eltwände fann von einer bildungafolge bie Rede jein, wo dann felbfiverftändlid die inneren fteţ bie jüngeren fein müffen. 
Man Denfe fid) zwei leere Şanojoduhe jo gegenübergelegt, baf beren Singerjpiten fid) berübren, bie correfpondirenten Finger cine gerabe Sinie

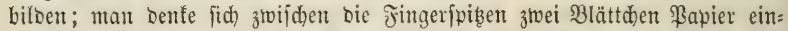
gefdoben, jeberjeits Den Raum zmifden ßapier uno Scanofdubleber mit einer bem \$apier gleidläufig geididteten Eubftanj erfüllt, fo verfinn= lid)t uns leţtere bie Eellulofejdidnten zweier nebentinanberliegenter Zell= ranoungen; bie beiden unnittelbar fid berübrenden \$apieritreifen ent=

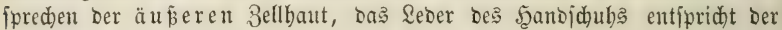
inneren Bellbaut, bie bom inneren Raum ber Belle (Şantoraum) in baß

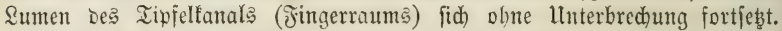
Dentt man fich mut Papier uno. Seber von gleider Subftanz uno bieje

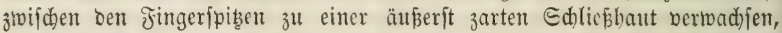
io hat man ein getrenes förperlides Bilo ber Belfwano uno ibrer fanal= förmigen Durd)bied)ungen, Das man fid) nod) Durd) Fig. 28 vervollitändigt,

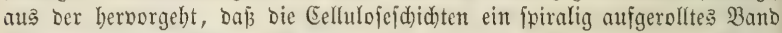

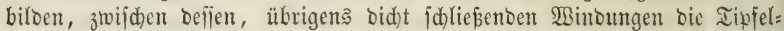
fanäle von innen nad) ausen berlaufen.

Die Correjpondenz der Tipfelfanäle benad)barter Zellwanoungen, bie

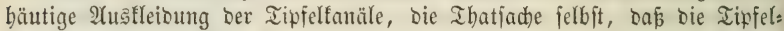
fanäle frei bon Sellulofeablagerung bleiben, aud) bei ben bödften (Sraben

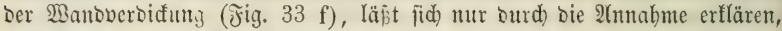

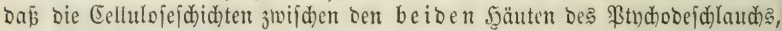
aljo in Ptndjoberaume, fid bilden; Dap fabn nor ber im Btndjoberaume

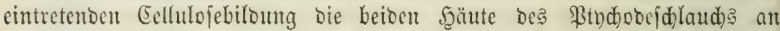
Denjenigen Etellen untereintander ž einer Şaut (Edhlię̧haut) verwadjen; an Denten fräter bie Tipfelfanäle fid bildoen, in Folge Deffen bic Eellulofe= bildung bann mut an benjenigen Etellen zmijd)en ben beiben Ptnd)obebäuten ftatfinoen fann, bie nid)t mit einanoer verwad)jen fino, fo beu Berwadjungafläden notbrentig ein cellulofefreier Sanal mit juncbmenter Dide Der Cellulofefdidaten fid

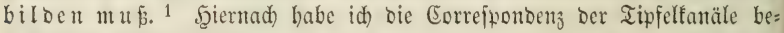
nadbarter Bellwanoungen aus einem, Der Copulation Der Spirogyren äbn= lid)en 3organge erflärt, in Der 2(nnabme, baj fithon in bem, nod) mit

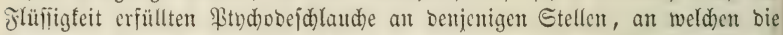

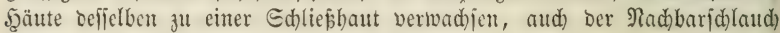
ju einer gleiden Berwadjung befimmt werbe.

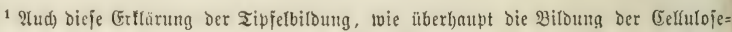

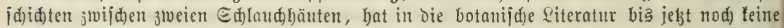

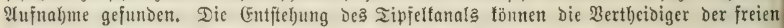

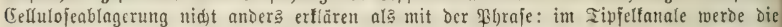

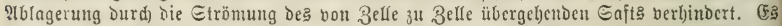

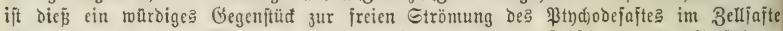

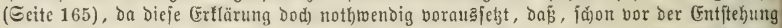
Deg Sipfelfanals in Bellfafte, eine Etrömung von Bellfaft nad) allen benjenigen \$unften Der primitioen Bellwano bin ftattfinden müßte, bon benen ipäter bie Tipfelfanäle

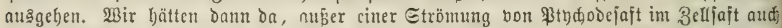

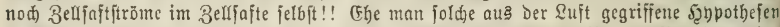

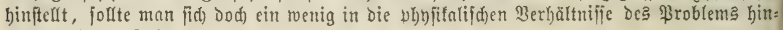
einzubenten berjuchen. 
Wie Jig. 29 jeigt, fino bie Tipfelfanäle nidjt immer von gleidjer Bilbung. Die phyfitologijde Bcbeutung ber bier borfommenten Beridieben: Geiten ift uns nod unbefannt; lebtere fino aber für bie Unterfideioung ver:

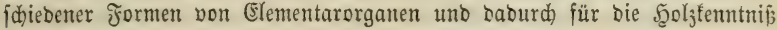
von $\mathfrak{B i c h t i g t e i t . ~}$

Эđ̆ unterideibe zunädjt gleidförmige uno ungleidförmige Tipfelung, je nad)bem bie, je zmeien bentacbarten Zellwänoen angebörenton, correfponbirenben Tiffelfanäle gleidggebildet (Fig. 29 a be) ober ungleid) fint (ร̌ig. $29 \mathrm{ed}$ ).

3ur gleidförmigen Tipfelung gehören

1) bie cylinorifde, wo, wie in a, bie Weite bes Ranals überall biefelbe ift, wenigitens eine merflid)e (Erweiterung befielben nad) aujen nidht

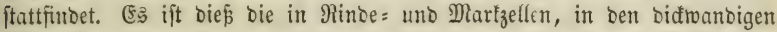

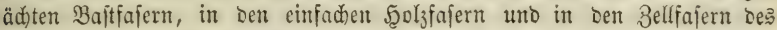
Selzförpers berridende Tipfelung;

2) Die ftempelförmige Iipfelung, roo, wie unter b, ber Tipfel= fanal am (Brumbe fid ftempelförnig erweitert. (Ẻ finbet fid bieje Biloung porzugşweije bei ben llebergangåbiloungen vom Spiralgefäp zur F̧olzröhre, feltener in biftwanbigen Marfzellen (Taxus);

3) bie fiebförmige Tipfelung (e), Darin von allen anbern Tipfel= bil’bungen beridjieben, Daf̧ bei ibr viele fleine Tipfelfanäle zu einem gemein= idaftliden Tipfel bereint fino. Alle primitiven Drgane Der Baftididenten zeigen biefe Bilbung.

3ur ungleidförmigen Tipfelung geb̆̈ren

4) Die linfenräumige Tipfelung (c). Der Tipfelfanal eriveitert

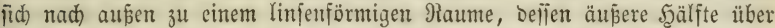
bie Bellengrenze binauatritt, wäbrenb ber correppondirente Tipfelfanal ber

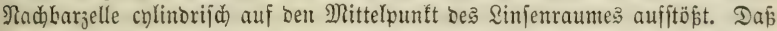
Der linfentäumige Tipfel einfeitig geöfinet ift, erfennt man, wenn man nidht

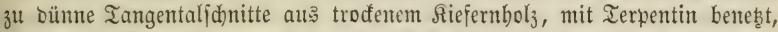
unter bem Mifroffop betrachtet. Tas Del bringt bann rajd in bie burd

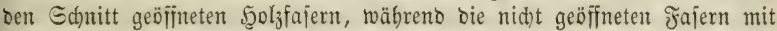
\&uft erfüllt und baburd) mit fd)warzem Innenraum erfdeinen, wie bieß bie mittlere ₹ajer ber nebenftebenben ₹igur barftellt. Man fieht Dam bie \&uft bes Jntentraums einjeitig ununterbrod)en in ben \&injent= raum verbreitet, wäbreno auf Der entgegengejesten Geite fie nu:

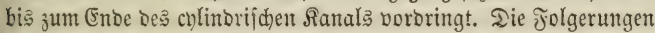
bieraus find febre einfach) uno betweisłräftig. Şintoert bie Integrität

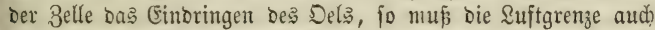

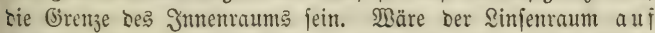

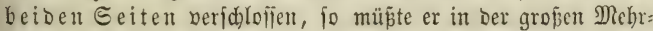
zahl ber Fälle bie \&uft betwahren, da inmer nur wenige Sinjen:

テig. 30.

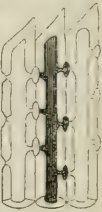

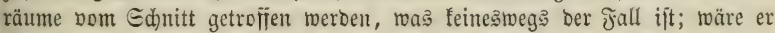
gar nidt berid)lofien, fo fömnten fid) aud) bie nid)t vom Edjnitte getroffenen Bellen nidht io lange frei vom Dele balten.

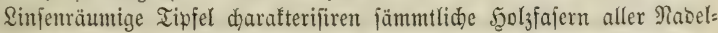

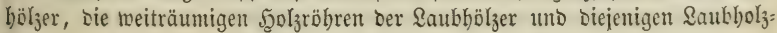




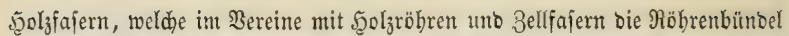
Des Şolztörpers bilden.

5) Die geftufte Iipfelung (d) findet fid) zwifden Sgolzröbren uno ben ifnen anliegenoen Marfftrablgellen uno unterideibet fich baburd),

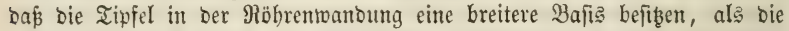
correfpondirenden Iipfel ber anliegenden Bellwanoung (z. B. (Eid)enthol $\mathfrak{z}_{3}$ ). 2udd) bie febr breiten Marfftrabltipfel ber mittleren Etodwerfe bon Pinus gebören bierber (Naturgejđ). Der forftl. Eulturpflanzen Taf. 34, Fig. 5). Fig. 31. In nebenitebenter Figur 31 jehen wir brei Tipfel ber Riefernboljfajer, wie foldje ba gebiloet fino, wo jie ben mittleren Stodwerfen ber Martiftrablen anliegen.

Alle bieje veridjiebenen Iipfelformen burdbrechen bie Eellu= lofefdid)ten ber Bellwantoung vollitänbig; bie Manoungsbife je zloeier benadbarter Bellen ijt baburd) örtlid) bis auf beren bäutigen Beftantbeil rebucirt; biefer leb̧tere, bie Ed)liephhaut zwiiden je zwei correfponbirenden Iipfelfaüälen, idjeint aber übcrall vorbanden uno

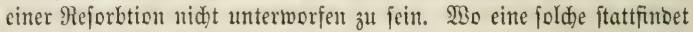
(3ellen ber Moosblätter, Qucrwäntoe ber Şolzröhren), ift fie als fold)e aud) leid)t erfennbar. Jeobe einzelne Belle ift baher trobes ber Tipfel ein in fich böllig gefd)lofiener Bebälter, sem Einoringen fejter Sörper unzıgänglid) uno bie im Tipfeltanal auftretende 28 anbveroüunung hat wohl feinen anderen 3wedt, als ben ber Gäfteleitung von Belle zu Belle, wabr: ¡deinlid) unter ber Îmabme, Daß mur bie Bellhäute, nidht bic Eellulojes jdidbten für Flülïigfeiten permeabel fino, wie wir jpäter febent werben, unter Mitwirfung Der auf Druff berubenden Iurgešcenj bes lebendigen \$flanzen:

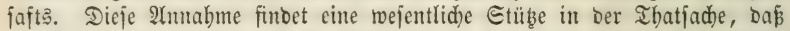
Da, wo in ber 3ellmanbung ein \$tnd)obefthlaudh nod) vorbanben ift, Derfelbe aud in bie Iipfelfanäle cingebt uno bort mit ber Gdyliephaut ber 3ell= wanbung verwadfen exideint.

\section{b. Die Epiralfajerbiloung.}

Eeite 205 babe idj) gejagt, es entiftebe die Iipfelbiloung aus ciner

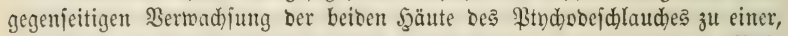

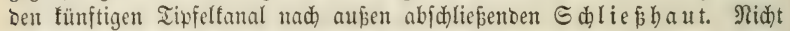
felten erweitern fid bie Iipfel im Umfange ber Bellen fo bebeuteno, baf Tie fajt bie ganze Breite berfelben einnehmen (Vitis, Magnolia, Cereus etc.). Oschen wir nod cinen Ed)ritt weiter: Denten wir uts ben Tipfel um ben ganzen llmfang Der Belle verlaufent uno ringförmig in fid zurüdfebreno,

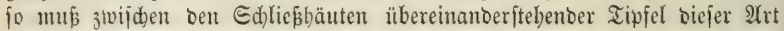
bie $\mathfrak{B a n b v e r b i đ u n g ~ D u r d ) ~ E e l l u l o f e b i l o u n g ~ e i n e ~ r i n g f o ̈ r m i g e ~ f e i n . ~ E r f o l g t ~}$ Die Berwadbjung jut Edjliç̧baut in einer ober in mebreren Epiralfiäden, fo mus aud) bic Cellulojebiloung żwijden biejen ôläd)en eine fpiralige Form annebmen. Daraus geben bie beioen Şauptiormen einer Zellenbiloung herbor, Die man Epiral= uno $\Re$ inggefäßze genannt bat, wäbrento man unter

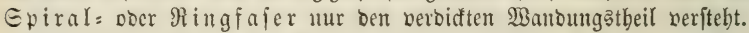

Die Epiralfajer = ober Ringfajerzelle unteridgeibet fid) oon ber Iipfel=

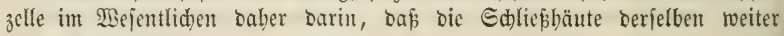


uno in eigenthümlicher Beije verbreilet funt. 3erreist man einen an Exiral=

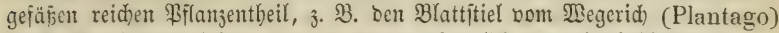

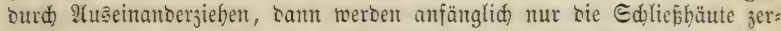
rifien, bie fpiralig aufgerollten Mantboerbifungen zieben fich zu filberbellen Jäben aus, an benten, beim शachlaijen ber zerrenben Sraft, bie einfadbe supe rcht gut bie uriprüngliche 2fujrollung nod) zu erfennen gibt.

Iie nebenftehenbe Figur 32 jeigt bie beioen ameinander: liegenten Enditüde zmeier Epiralgefäpe, in bie ich bie wejent= lidjften Seridjiesenheiten ber ipiraligen Wanobiloung einge: tragen habe. Bei a jehent mir febr breit gejogene Tipfel, Deren

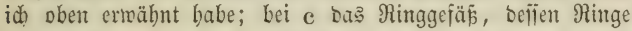
bie, mitunter in einer abrweideno färägen Ridjtung geftellt

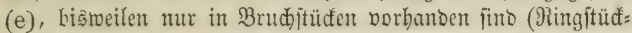

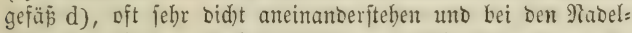
büljent zugleich) audd) linjentäumig getipfelt fino (Pinus f).

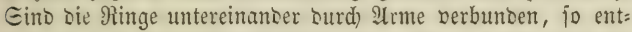
fiteht baraus bas Ireppengejǟj (b). Bei g iehen wir ein bicht getounbenes, bei h cin weitlüufig gemunomes Epirals gefüp mit boppelter Epirale. Werben bie Epiralfajem jehr breit, jo entifteht Daraus das banoförmige Epiralgefǟ, bas, wenn bie Bänter bid)t nebeneinanber liegen, ien Hebergant

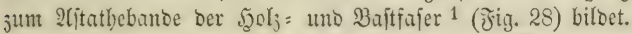
2urd) bie eingezeidneten Punftreihen habe id) Das 20 orbanden= fein ber bie Jajern verbindenten Edyliej̧äute uno jugltid beren feine Gramulirung angebeutet, die fie mit ben Säutten Les \$tydobejdlauds gemein baben uno saburd cbenfalls ifren ltrifrung verrathen, mährent jebe einzelne Eellulojejdid)t im unveränoerten 3 uftanbe Durd)au frufturlos erjecint.

In allen Etengeltheilen findet man bie ädhten Spiral= gefäpe nur zunäd)it sem Marfzellgewebe, Den fogenamnten Marfcylinber bildents. Son ba aus begleiten fie bie Fajer: bünbel des Blattitiels und Der Blattabern. In jebem jugent: lidenen fajerbüntel fint fie ftets bie zuerft jid fejtigenten 3cllen. Die, gegenüber ben fxäter jich entricfelnben 5ुolajajern uno

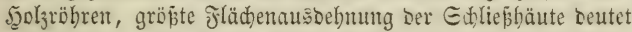
barauf bin, Daj fie in biejer Jrübperiobe eintent erböhten Säfteaustaulde bienjtbar finto.

Ridht jelten zeigt fich, bom Marfe nad ber Minbe bin, eine Reibenfolge in ber Entwidlung nom Unvollfommenteren

วig. 32 .

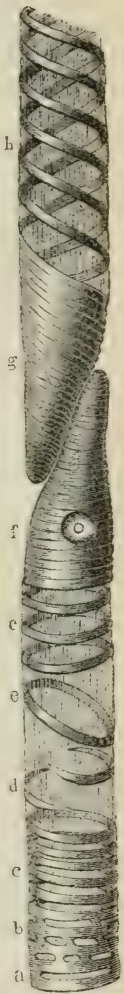

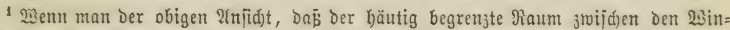

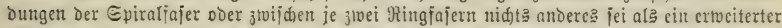
Tipfelraum, oasjenige zur Eeite ftelft, toas id) Geite 203-205 über bie 3ujammenjetjung ofr

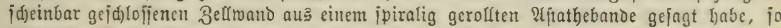

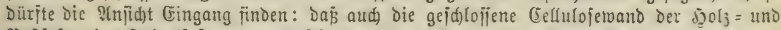

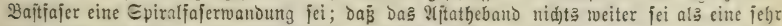

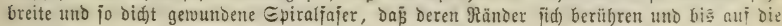
¿ipfelipalte unter fid mehr oder weniger innig beridjmelsen. 


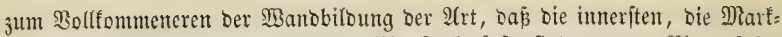

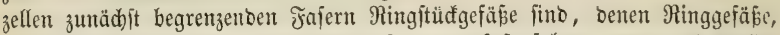
abrollbare Spiralgefäpe, banbförmige Treppengefäpe folgen, benen fidh entlid) bie getipfelten Şolzröbren anjd)liésen. Daraus bildete fid bie Sebre von ber Metamorphofe ber Spiralgefäpe, oft fo aufgefapt, als fänbe bier wirf=

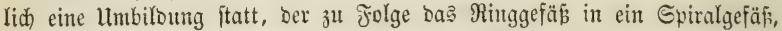
lebsteres in ein Treppengefäf fich berwandle. Man iit fogar nod) reiter

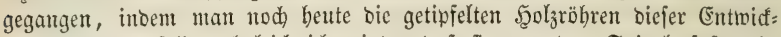

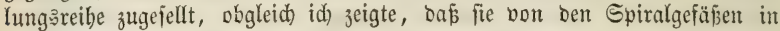
Der Biloung, im Bertommen, in ber Funtion uno in ber Ent fte bung weife burd)aus veridiedene Drgane feien. $2($ ber aud in ber Bejdränfung

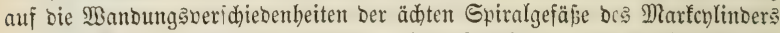

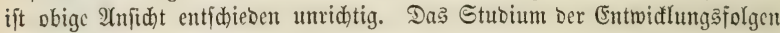

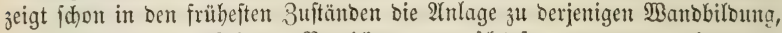
bie fpäter burd) gefteigerte Berbiçung nur fhärfer ausageprägt wirb; Da马

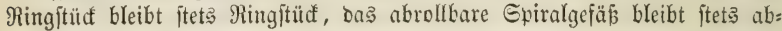
rollbares Epiralgefäp unto felbit in ben Entfermungen ber Ringe uno Epiral= winbungen tritt feine andere Beränberung ein als bie, weld)e Daß $\mathfrak{B} a$ ăfen Des Drgants mit fid bringt.

\section{Die sujammengejebte Befrtonoung.}

Mir haben bis zaher gejeben, wie ber burd Iheilung vervielfältigte

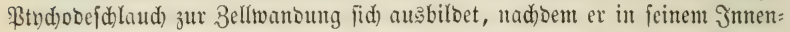
raume fid regenerirt hat (Seite $164-169$, Fig. 16, 17). Die meiften Bellen ber Rinoe und Des Marfes, or Dberbaut (jo lange bieje als joldhe befteht) uno Des (Eollendum, fo wie des Siebfafergetwebes verharren fü: immer auf biejer Entwidlungsftufe; bie einfache Bellwand unt ber barin gelagerte ßtndyodefdlaud̆ bilden bie bleibenden Bejtanotheile ber Bellen, Deren $\mathfrak{2}$ ubenwänbe fid) gegenjeitig verfitten.

Bellen mit einfad)er Waanoung fönten burd bebeutenoe Wanboerbifun?

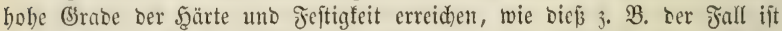
in Der Mindeborfe ber Buthe unto ber Birfe, in ben Früdten unebler Birn= forten, in vielen bolzigen Samenhüllen zc; in ber Regel bleibt aber Zell= getwebe biejer 2 (rt toeid) unt frautig, es bildot nid)t allein ben weidjeren, fonbern aud) Die, Durd) Jäulnif (Daceration) Ieidter zerftörbaren Bflanzen=

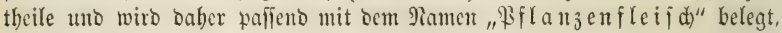
im Begenfabe zu ben im 2llfgemeinen fefteren uno Danerhafteren, bem

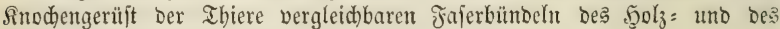
Bafttörpers Der Pllanzen.

Dicje größcre Sূärte, Bufammenbantgåfraft uno Dauer verbantt bas Jajergemebe Deక Şoljtörpers uno der Bajtfajerbüntel einer weiteren Ent: widfung ber einzelnen Zellen, beftehent:

a) in ber Biloung von (Einjdadtelungswänden,

b) in Der Berfernung.

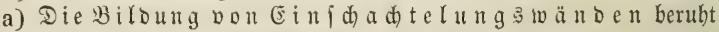
barauf, Daj ber jecunbäre Ptndyobefd)laud) im Intern ber einfadjen Bell= wanoung, wie vor ihm ber primäre Ptydhodejdflaud), zur Bellwantung fid) 


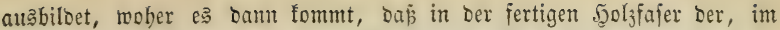
jugentidgen 3uitande aud) ifr nidht jeblende Pind)obeid)laud nidht mebr vorbanden ift.

Sierbei tritt nun ber beachtenstwerthe Umitand ein, dap̉ rie Ent= miałlung ber fecunoären Bellwantoung ber Solzfajer auf Sioften ber pri= mären Beffwanbung bor fich) gebt, fo baj, wenn Eritere bollftänbig au: gebilbet ift, Sebtere auf bie febr geringe Dide einer focheinbar bomogenen 3roijhenjubitanj rebucirt ift, bie id), zujammengenommen mit ber verbin= Denben Rittmaffe (Euitatbe), in meinen früberen botanijhen Edriften al: Suitathe bezeidinete.

In Der nebenitehenoen Fig. 33 gebe ich Die Entwid: lungsgejdichte ber Riefernbolzfajer in einer 2tneinanber: reibung bon Duerourdjidnitten, in Denen id, ber Deut= lidffeit regen, im $\mathfrak{B} e r b a ̈ l t n i \overline{5}$ zur Jajermeite die $\mathbb{B} a n=$ bungatheile bider gezeidnet babe wie jie twirflid) fino, ungefähr fo, wie man fie burd) Expanjion bermittelft Sđ̆vefeljäure zur $\mathfrak{A n j i d h t ~ e r b a ̈ l t . ~}$

fig. a zeigt die junge ફुolzfajer im Cambialzu= ftande. ङechs prismatif(h), mit Suft erfüllte Intercellu=

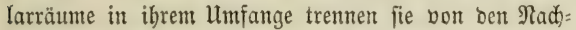
barfajern, won benen mur ein Theil ber Wanoung in bie Beidnung aufgenommen ift. Ëin linjenförmiger Tipfelraum ijt jobn jeşt vorbanden. Mit ber häutigen Begrenjung Des Sinjenraumes verbunoen, feben twir in

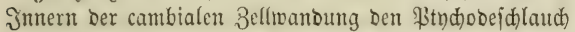
mit Belffern. Die Belle b zeigt nod ben vor ฐäften und Rörnern ftrobenden ßtndyodejalauch, die Cambial= manoung bat fich bereits berbünnt. Dieps ift ber $3 u=$ ftand, in bem iđ bie Biloung Des 2 (jtatbebanoes aus ben unter fid berwadienoen Eellulofeförpern bireft beobadtet babe (Entmidflungsgefo). Des Pilanjenfeims Taf. II. Jig. 45, 46). In $\mathrm{c}-\mathrm{f}$ ijt ber Btydodeidlaud

F̧ig. 35.

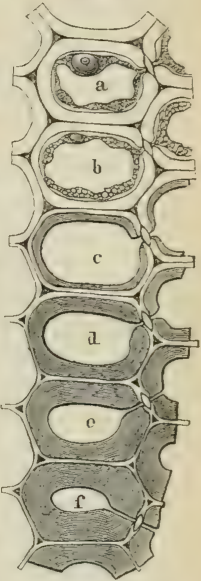
beridfrunden, b. h. er ift zur jecunbären Jajermanbung untgetvanbelt, bie primäre Bellmanoung ift Durd) Rebuction ju einer fheinbar homogenen 3roijdenjubjtanz verounnt, in Der die in a uno b beutlich erfennbaren, mittleren Irennungslinien nur nod) an Den comprimirten Intercellular:

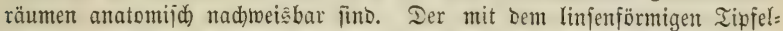
raume bieffeitig in offener Berbinoung ftebenoe, in Der Cambialwand ber:

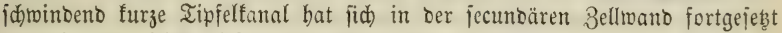
und eine ber Dide biejer entiprechende Ränge erreidbt.

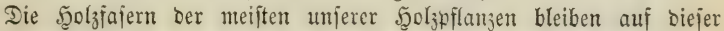
Entwidłungsifufe iteben. (Sinte auf eine ideinbar homogene 3mijd)enjubitanj rebucirte Cambialtwanoung uno eine mebr ober meniger mähtig entwidelte, jecunoäre Bellmand bilben beren Beftand, dem Jnnenraume feblt

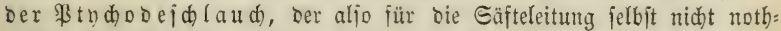
menoig ift, fich aber ba borbergebent regenerirt, too eine 2tblagerung bout organifitten Rejervejtofien itattfineen jolf. Dafis bie jecunbäre Bellwanbung 


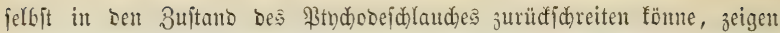

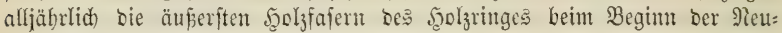
bilbungen.

Sn einigen Fällen regenerirt fid) ber \$tnchobefd)laud ein żweitesmal vor Billoung Der zwoiten Bellwanto, er entwidelt fich zu einer britten, Der

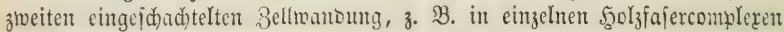
von Populus nigra, serotina. In Baftfajern wieberholt fid biejer $\mathfrak{B o r}=$ gang nod) öfter, fo dafis bie Bafffajer bes Walmentholzes rft aus $5-6$ in= einanber gejdad)telten Belfränten befteht, je be Derfelben aus bielen ber

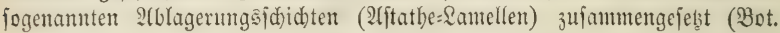
3eitg. 1855, Taf. IV., Jig. IX.).

Es ijt bemerfentwerth, Daj in jeber folgenoen rer eingeid)idjtelten

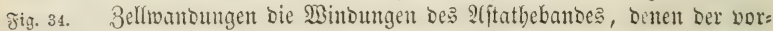

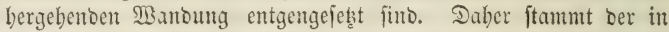

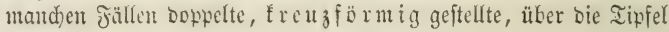
verlaufente Exalt, Dor befonters in Der Sold fajer von Pinus

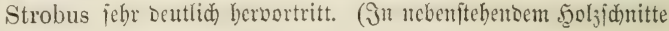
b. bie obere Figut a.)

Rebent Der Tipfelung, mitunter audh obne biefe, zeigt bie

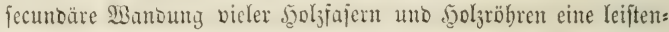
förmig herwortretente, friralig ober ringförnig um ben Эnmenraum

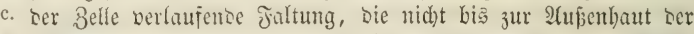

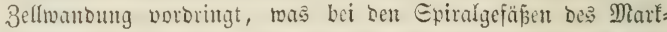
culinders ftets ber fall ijt. Jn ber nebenftebenden Fig. 34 gebe

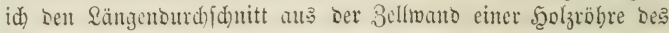
Sthornblattiticls. Die Einfaltung Der inneren Bellhaut bringt bier

ชีig. 35.

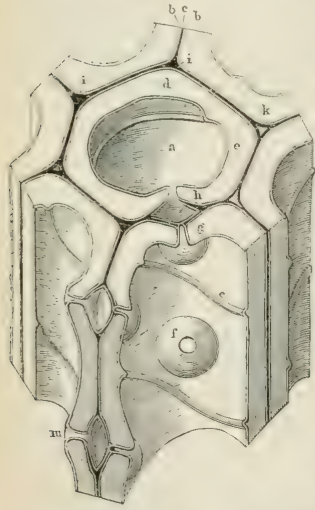
ungefäbr bis zur Mitte Der 2 andoungsoide cirt uno zeigt von obent nady unten zunebmente

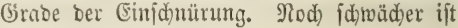
bie fpiralige ober ringförmige Faltung an ber Syolzajajer von Taxus, won ber idy in neben= ftebender Fig. 35 bie förperliche Darftellung eines furzen Stüddents derjelben gebe. a ift Der Intmentaum einer mittleten Jajer, bie von jeds Mad)barfajem umitellt ift, von weldyen leksteren jeooch nur bie angrenzenden Bellwan= Dungstheile gejeidunet finto, fo, als wären bieje

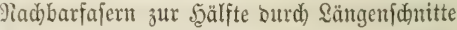
entfernt. e ift bie imnere (Srengbaut, b b jino bie äuperen Ģrenz̧bäute Der fecunbären Bellwanoung, d ift ber Eellulojeantheil ber: felben (2(jtathebant). Die tiefid)warz gezeid)= nete 3ivifhenjubitanz (c) bezeidjnet bie leber= rejte ber primitiven. Bellwanoung ( $f$. Die $5 r=$ flärung zu Fig. 33). f, g, h, m geben bie verfd)iebenten Infichten Der linjentäumigen Iipfel (i. Die Ertlärung ju Jig. 29 e); $\mathrm{k}$ ift ein offenter Intercelfutarraum, ber bei $\mathrm{i}$ mit cinem 
3ivijdentitte erfüllt ift. Ifn ber imteren Grenze ber Belfwanoungen jehen wir ipiralig verlaufente, leijtenförmige falten über bie Ekerfläte berwor: treten (e e), beren Erhebung nid)t mehr als $1 / 6$-1/5 Der Cellulojemanoungä: biđ̛̣e beträgt.

(Fine nod) zartere ipiralige faltung ๖er Jnnenfläche zeigen bi: Breit=

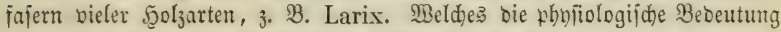
biejer Bildungen fei, ijt uns zur Beit nod) verborgen.

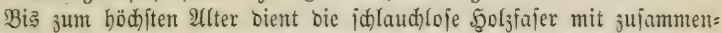
gejeb̧ter Bellmanto Der Eäiteleitung nach oben. $2(n$ im Minter gebautent Etöctent alter Bäume twiro im Jrübjahre jur 3eit des Gaftíteigens bas

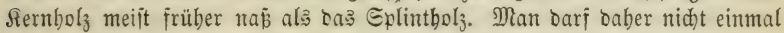
jagen, dáb lebुteres ber Eäfteleitung mehr als erfteres bienitbar jei.

b) Die Rernbolzfajer.

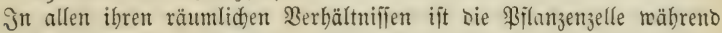
weniger Iage, hödjten mähreno weniger Mioden volltommen ausgebiloet.

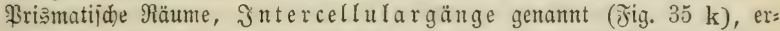
balten fid) bis babin sfïen, enthalten \&uft uno bienen als 2tbleitungägänge für bie von Den thätigen Piflanzenzellen abgeidiedenen Baje uno Dünjte. Sit bie Zelftwantung bollendet, io wirb ein, feiner Eubitanz nad) unbe= fanter Etofi burd) bie Bellwandung hinduch abgeidieden, in bie Jnter=

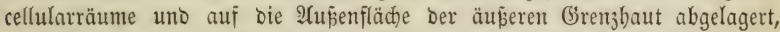
wojelbit er zu einer, bie einzelnen Bellen berfittenoen Mafie erftarrt, bie

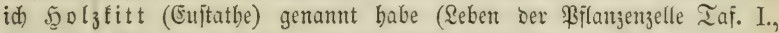
Jig. 45). Non da ab finbet, mehrere Jabre bindurd), Doer bis zum Rebens: ento Der 3elle, eine Beränoerung nidyt jtatt, weלer in (3rößezunabme nod) in Manbberbifung, nod) im Şinjutommen neuer Theile. Man nennt biế ben Eplintzujtano der 5olzjajer. Nur bie Jajerzellen bes Şolztörpers vieler Baumarten, nadbem fie eine längere ober fürzere Reibe bon Jabren im Eplintzuftande unberänoert verbarrten, geben baourd) in Den Sernbolzzuftanto über, Daßj fich in ifnen eine amorphe, idwarz, roth, braun, gologelb, violettblau gefärbte, in bohem Grabe inbifferente હubitanj anjammelt, bie id Xylod)rom genannt babe. Sie jüllt nidht allein bie interen Bell= räume mebr ober meniger, beim Ebenbolze 3. B. oft gänzlich aus, jonbern

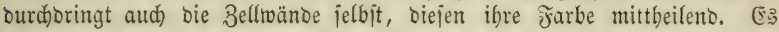
fäjien mir jogar in mebreren Fällen, als wern die Belltwänbe bierbei eine mertliche Berbiffung erlitten, bielleid)t burd) 3mijøenlagerung amorphen

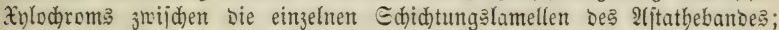

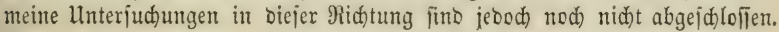
Nur jo biel bermag idj jobn jeb̧t mit Gidjerbeit anzugeben, Daß̧ alle

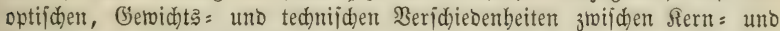
Splintbolz vorzugsweife auf ber $\mathfrak{A n j a m m l u n g}$ von .Enlodrom beruben, Delien ohne 3meifel veridiebenartige demifde 3ujammenjeb̧ung (id) erimnere nur

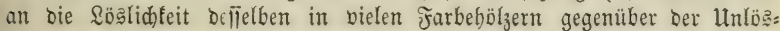
lidfeit im (Ebentjolze, Eidenholze :c.) bie Urjadje Der berjhiedenen Dauer beక Şolzes jein mag.

So biel idh meip, miro nod) beute von ben Botanifern bie Sernholy= jajer uno mit ibr baz $\mathcal{N e r n b o l}_{3}$ Der Bäume als ein abgejtorbener Rörper 
betradtet. Feine Ihatjache bered)tigt hierju. 2(lle Junctionelt ber Eplint=

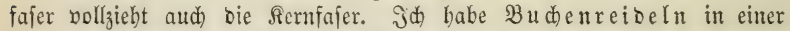

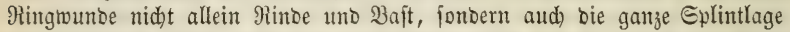

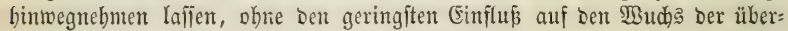
ftebenten Baumtbeile. Jn Der glübenditen Eonmerbibe blieb die Belau=

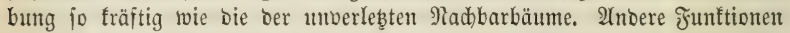
als bie ber Eafteleitung nach oben bat aber audh bie Eplintfajer nidyt. Die jäbrlidje Enreuerung uno Bieberauflöfung des Stärfmebls ber. Mart= ftrablent uto Bellfafern geht aus Dem Eplinte tief in bas Rernbolz hinein. Selbjt die fogenaunte "tobte Rinde alter Eiden ober Riefern balte ich

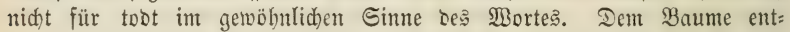
nommen uno berjelben Stelle wieber aufgetittet, verwittert fie in wenigen Jabren, wäbreno fie in ibrer natürlid)en \$erbinoung mit ben tieferen Baft=

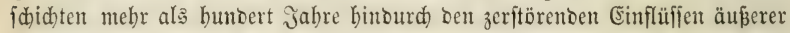
2lgentien wiDeritebt. Nur wenige F̧olzarten unter Denen mit gefärbtem Rern= holz fint ç, bei benten bic Siernholzfajer nid)t jäfteleitungşähig ift; Dahin gehören bie Iffazie, bie (Eidje, id) glaube aud bie Rüjter.

\section{d. Wanblungen ber Elementarorgane.}

Siele aber bei weitem nidht alle Elementarorgane, aus benten ber

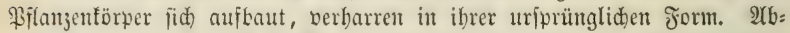
gejeben von ber bereits im \$orkergebenben betradteten, berjdjiebenartigen Enttwiflung ifrer Bellwanoung zu Tipfel=, Epiral=, Mingformen treten nod) cine Reihe anberweitiger Beränbernungen örtlid hervor, bie wir im Plad)folgenten betrad)ten wollen, ausgebeno vom erften Begenjabe zwifhen 3ellent und Fajern im Sinofpenwärzden, ba alle aufer bem Sinofpenioärzdent entittebenten Fajern primitiver Biloung fino.

3 ben protomorphen, ๖. h. зu Denjenigen Elementarorganen, bie in Derfelben form für immer verbarren, in Der fie uriprünglid) fich biloeten,

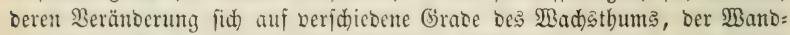
verbidung, Der Tipfel = ocer Epiralbiloung bejdränfen, gehören bie meiften Dart = und Rinbezellen, die Spiralgefäße des Marfcylinders (Eeite 206, Jig. 32), Die 5ुolzfafer (Jig. 41,2), bie Siebfajer (Jig. 41, 6) uno alle in ber Cambialjojid)t abgeidnürten, Den 3uwad) bereits gebilbeter Marfitrablent vermittefnoer Marfitrablzellen. 2Alle übrigen Elementarorgane futo metamorphifder Slatur, ๖. b. fie entiteben entrober aus 3ellentwanblung ooer aus ₹ajertwanblung.

\section{Die 3erlentonolung.}

Wir faben, wie bas uriprünglid parendymatijache Bellgewebe Des Embryo burd) Bellemmebrung madje (Eeite 171), weld)es bie Stellungägejeb̨e feien, nad) Denen es fid pronet (Geite 1r4), wir Yernten bie 2lusbiloung jeber einzelnen Belle ternen (Geite 165), uno faben bereits bie Gonberung befielben in einen Marf = uno in einen Mindeförper burd bas 3roifdentreten eine

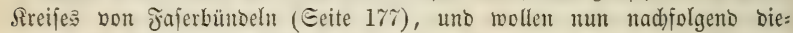
jenigen Beränberungen betradten, bie es im Berlauf feiner Jortbildoung erleidet. Weit bejoränfter als in ber Rinbe fino biefe 


\section{c. $\Im \mathfrak{m} \mathfrak{M a r f \mathfrak { e }}$}

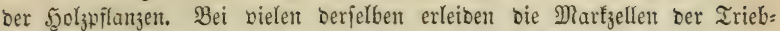

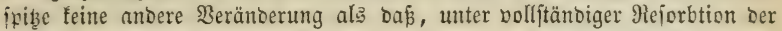
primären Bellwanoung, ber \$tndobeidlaud zu einer zmeiten Bellwant fid

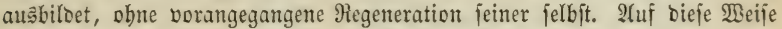
entitebt das inbaltloje, luftfübrenoe Marfgetwebe Des Follunber, ber (5iden,

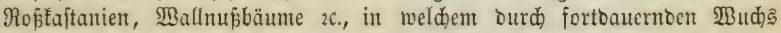
Des Triebes nad bereit’ erlofdenter Mebrungsfähigleit ber Bellen, nidht felten groß̧e Rücfen entfteben (Juglands, Rhus), Die bei üppigem $\mathfrak{W u d j e ~ m i t = ~}$ unter auf bas ganje Internobium fich eritrecten (Paulownia, Catalpa).

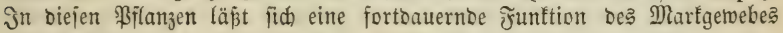
nicht erfenten, wie biés ber Fall ift bei Fagus, Quercus, Alnus etc., mojelbft aud im Marfe älterer Baumtheile eine jäbrlide Anjammlung unto Wieberauflöjung von Rejerveftoffen (Stärfemehl) ftattfinoet. Bei einer geringen Zahl bon Syolzpflanzen werbifen fich bie Mänoe ber Marzzellen bedeuteno, in reldent テ̈ăllen aud) bie rebucirte primäre Belltwant beutlid erfembar ift (Beiträge, テ̛ig. 12, f, g. Marfłzeller aus Tarcodium).

In ben meijten fällen kefteht bas Marf nur aus' parendumatifđem 3ellgemebe, uno nur bei menigen 5ुolzpflanzen gehen aus ibm burd)

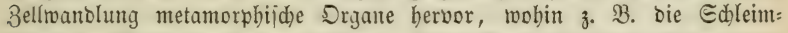

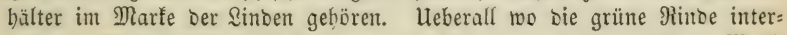

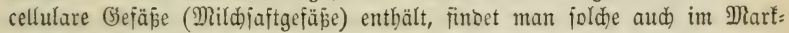
jellgetwe'se, io bei Den Euphorbien uno Mamillarien, uno felbjt two bie Rinoe Milç;aftgefäpe nicht enthält, finoen fich jold)e mitunter im Marfe (Robinia).

Man hat sem Marfe früber eine weit größ̄ere Bcoeutung unterlegt,

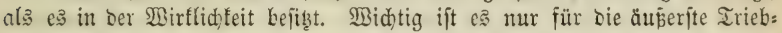
ipibe, ba too es mit bem Minoeparendym nod) confluirt uno aus il)m alle

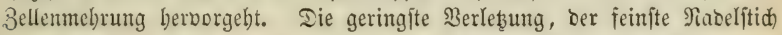
in biejem Drte hebt bie fortbiloung Des Iriebes in gerabe aufiteigender Richtung unbebingt auf.

Эd) fann nidht umbin, bier eines phnjiologijd jebr widtigen falles ju erwähnen, aus Dem hervorgeht, wie weit bie Möglidfeit einer 3ellen= wandlung gehe. Die Berleţung Der Epibee eine üppig radjenden Riejer: triebes hatte eine nad) Dem Marfe hingeridtete Heberwallung Des Ednitt=

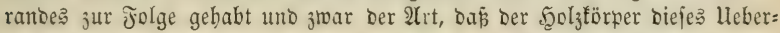

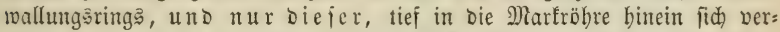
längerte, als menn man von einem Scanbjdubfinger bie Epiz̧e abjdneibet, umb Die obere Sälfte befielben in bie untere Şälfte bintein berjentt. Der Dueridnitt des Triebes jeigt Daburd), bis a uf 10 (Eentim. abrärts,

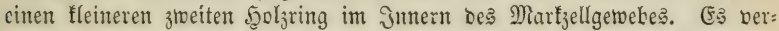
fteht fich bon felbjt, baj bier von cinem wirflichen Şineinwadhjen bes um=

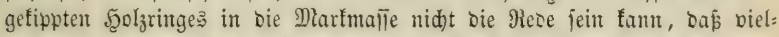
mehr eine culinorijhe Edidht vorgebilbeter Marfżellen, bom Ueberwallung:

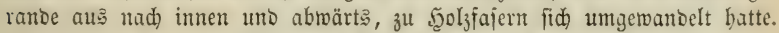
J゙) betwabre biejen merfwürbigen Irieb in meiner Eammlung phnfiologifder \&räparate. 


\section{$\beta$. In ber Rinde}

ijt bic Bellenwandlung nidht allein eine weit umfajientere, fonbern and) eine allgemeinere als im Marfe. Ës gehnen aus ifr bie Dberhaut mit ihren Spaltorüjen, Şaren, Drüfen, bas Rortzellgetwebe, baß \&eim= gewebe, Ierpentinbälter, Ed)leimbälter uno bie Mildafaft= gefäpe hervor, bie twir nadfolgeno näber betradten wollen.

\section{Die Dberfaut.}

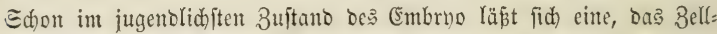
gewebe Deffelben umidhließende Dberbaut nachweifen. Bebanbelt man ben= jelben mit beroünnter Sdiwefeljäure, fo contrabirt fich nad̆ längerer 3cit bas Bellgemebe uno liegt ban in oer abgelösten Dberbaut wie in einer

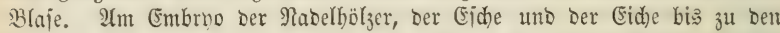
frühejten 3uftänden befielben verfolgt, bat jich mir barans bie $2 \mathfrak{A n f i d}$ t gebildot,

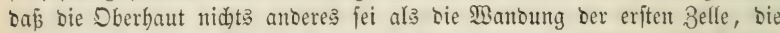
im Unrfange Der in ibr fid mebrenoen Iodterzellen fortwäd)st. (Eeite 169, รig. 17.)

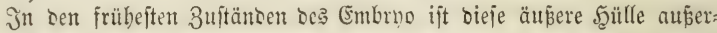
orbentlid zart uno idgeinbar eine einfache 5ुaut. Später verbifft fie fid oft bebeuteno und zeigt fich bam nidjt mebr einfach, fonbern rie jebe andere Belfwandung zujammengejetst aus ciner äuperen uno einter inmeren, zarten uno gramulirten (Grenshaut, swiiden benen eine geididstete, Der Eellulofe verwante Eubitunj ben übernviegenben Theil ber Wandungabife bilbet. Die Analogie Der Dberbaut uno ber Bellwantoung geft aber nod weiter. Mo unter ibr bie Epaltorïjen entfftehen, da rebucirt fid iur Bereidje bes

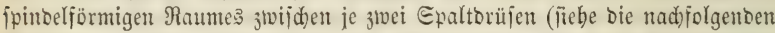
Figuren uno Deren Erläuterung) Die Dberhautbife auf Deren bäutigen $B e=$

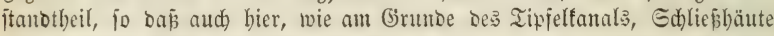
von geringer Dide entfteben, bie hier wie bort ben Durd)gang gas = und Dunitförmiger Stoffe vermitteln.

Die Dberbaut bält fidh mur bis ôu einem gemifien 2 (tter ber jüngeren Bilanzentheile lebenoig, im zweiten ober britten Jahre oer Stengeltheile unjerer 5oljpilanzen zerreipt fie uno löst fid in Säpkd)en ab, nad)bent in Den junädjt ibr anliegenden Bellen bas Rorfłellgewebe entitunden ift, Das

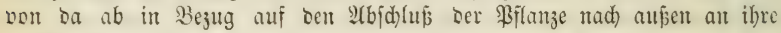
Stelle tritt.

\section{Die Epaltorüjen.}

Im jugendlidjten 3uftanto bes Embrno, am eben auşgeidiebenen Blatte

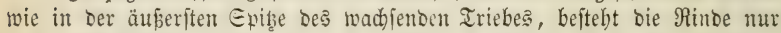
aus gleidggebildoten Bellen, beren äuserfte Lage befleibet ift mit Der einfachen, nirgends burdbrodenen Dberbaut, bie, wie id Seite 169 erörtert

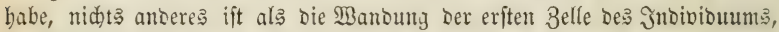
bie in fich jelbjt fortwäd)at, ernäbrt von ben igh anliegenden parendgnmati= iden Bellen.

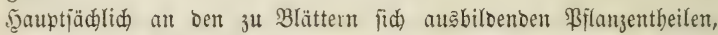
jeltner aud an Theilen bes Iriebes, entwideln fid bie jogenannten "Epalt= 
Fig. 37.

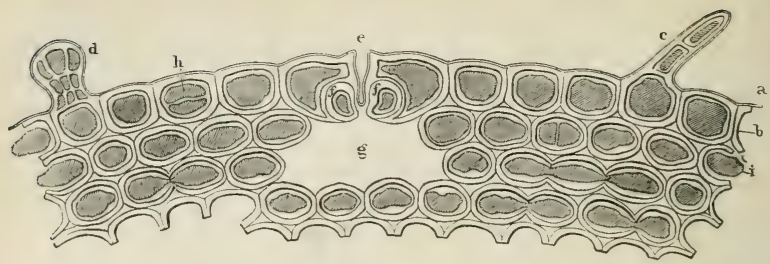

Die grofie 3abl, in Der Diefe Drgane auf ben Blättern Der meijten, böber gebildeten Bflanzen vortonmen, die grope Ucbereinftimmung im Baue Derielben, Die \&üde im Bellgewebe unter den Spaltorüjen, fichert Denjelben obne 3weifel bie 2fnerfennumg irgeno ciner übereinftimmenoen, phyfiologijden Junftion. Das 5̧ajken nad) Stulogien aus bem Ifierreide mad)te fie

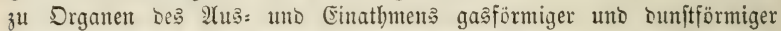
Stoffe, bemgemäb ibnen Dam aud ein periobija) wedblelnoes Deffnen uno Edliepen bes mittleren Spaltes jugeidrieben murbe, natürlich verbunben mit ber ?annabme eines unbebinderten, ๖. b. Durd Dberbaut nidht ber=

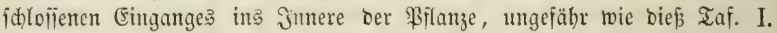
Jig. a b Daritellt, jo baf eine bimreidheno fleine Püde nidht allein in Die

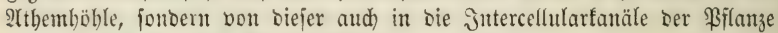
gelangen uno fpajieren fliegen fönnte.

Jnoes babe id foron feit langer 3eit ourd cine grope 3ahl bon (5x: perimenten nad)getwiejen, nidht allein baj bie Dberbaut uriprüuglid boll: fommen gejdlolien jei, baj fie fid) Durd) Bebantlung mit geeigneten Rea:

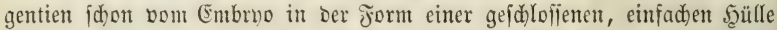
abbeben lafje, jonoern auch: Dafs bieje Integrität fid bis in bie fpätejten 3eiten oer lebendigen Dberbaut erbalte. Die meiften Mitarbeiter am Mifro= ffope baben bierauf gar feine Müdfidht genommen uno lebren nod) beute Die alte Inficht. Einige Derjelben baben zwar zugeftanton, daís die Dber: baut uriprünglid) nid) burdbroden fei, fie nebmen $a b e r$ an, baj mit Dem Entiteben Der Epaltorüfen eine Pejorbtion Der über bem Epalte lie: genben Sberbaut eintrete, ohne biejen Sorgang aud) nur Durd) einen ein: jigen, Direften Mad)wei ju belegen. Maceration von getod)ten Blättern abgelöster Sberbaut jeigt aber fo flar Die アidjteriftenz oon \&ödern, id babe theils in meiner Naturgefdid)te oer forftlichen Culturpflanzen (Taf. 27, 28,

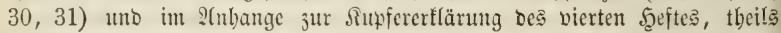
in Der Bot. Beitung 1853 S. 399 fo viele Belege Des Bejdlofienfeint ber Dberbaut beigebrad)t, Daf́ mir jelbît aud nid)t Der geringite Sneifel bierüber geblieben ift. ${ }^{1}$ S(ber aud) abgeieben von allen bireften Beobachtungen fteht

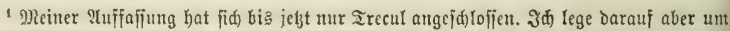
fo mehr Gervid)t, als Srecul olyne 3 weifel Der thätigfte und fdarfifidtigfte Phytotom unter

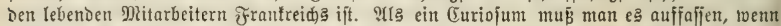
Srecul am Salufie feiner Mlittgeifungen (Annales des sciences naturelles 1855) jagt:

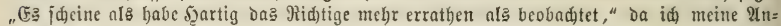
fid)ten überall mit Den Detaiflirtejten âbiloungen beftimmter fälle belegt babe. (Hyacinthus habe iđ̆ nirgends als Belegitūđ aufgeführt.) 


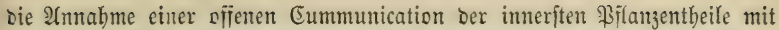
Der äuß̧eren 2(tmojphäre im Wioerfpruche zur Eorgfalt, mit Der bie \$flanze

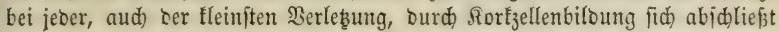
gegen Den freien 3utritt Der äußeren \&uft.

Meiner jejten Ueberzeugung gemäp ijt bie \$iflanze burd) bie, zmijd)en e uno g Fig. 37 mehr ober tweniger eingejentte Dberbaut überall nad) aupen bin abgeichlofien, fo lange nidht Sorfiellgetwebe an beren Stelle ge= treten ijt. Heber Dem Epaltraume ber Epaltorüjen ijt bie Dberhaut jebnch jebr zartbäutig uno id babe bie S(njid)t ausgejprodjen, baj, went fie jelbjt

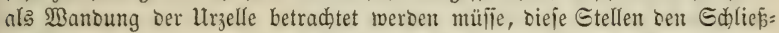
bautfilächen im Girunbe des Tipfelfanals jeber anderen Belle enfiprechen unt,

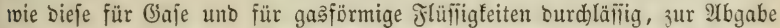

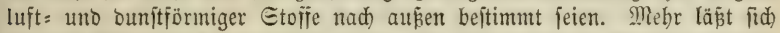
zur 3eit über bieje Drgane nid)t fagen, bie, bejonbers an Nabelfolzblättern jehr groß́, fdon Der Beobachtung mit Der einfachen \&upe zugänglid) finto. Bill man fie auf Saubboljblättern beutlid jeben, fo mus man lekgtere fo lange foden bis bie Sberbaut (mit ben äuperften Bellenid)idten) fid) ablöst,

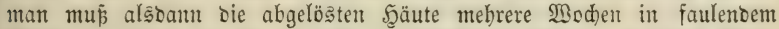

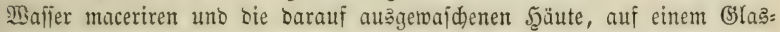
täfelden ausgebreitet uno gegen daş \&iđ)t gehalten mit ber \&upe betrachten; man wiro Dann erftaunen über sie groß̉e Zahl berjelben, bie biæ zu 600 auf bie Duubratlinie fteigt, wie über bie Regelmäpigłeit ihrer Biloung uno Utnoromung.

\section{Sุaare und Drüfen.}

Wie die Bellajern bes Şoljtörners Durdy Biloung tiner Reife bon

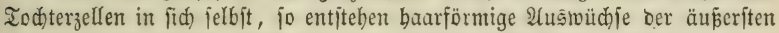
3ellenlagen burd) nad) aupen fortgefebte Todtergelfenbiloung, theils aus einer

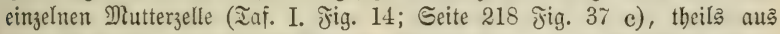
einer Mehrzahl netentinanderliegenter Mutterzellen, bie zu Demjelben Şaare

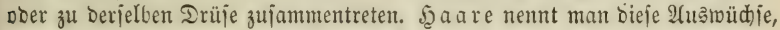
went all uno in ibnen eine Secretion aupergemöbnlicher Eubitanz nidft er: fennbar ijt; Drüjen nennt man jie, twenn Diéf Der Fall ift, wie z. $\mathfrak{B}$.

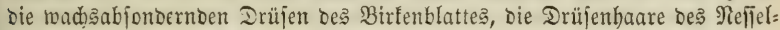
blattes. Die Etadicln an Trieben uno Blattftielen ber Roje, IAfazie, an Xanthoxylon, Aralia, Grossularia ete. finto vielzellige, verbolzte Şaare, Durd) Den Mangel von Jajerbünoeln unterjobieben bon ben Dornen an Gleditschia, Cratægus, Prunus ete., io wie von ben berfümmerten Dornblättem an Berberis. Die Şaare finto in Der Regel zugeipib̨t, Die

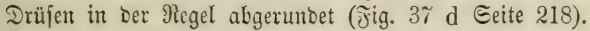

Scaare bilben fid fowobl an oberiroijden als an unterirsijden Pflanzen:

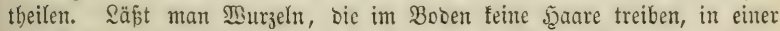
mit Bajierounft gejättigten Suft madjen, bann biloen fid) an beren Dber: fläd)e eine Menge langer Şaare. Şier liegt bie Bebeutung Der Scaare flar ausgefproden vor uns. Die Bilanje erweitert burch bie Bebaarung ihre

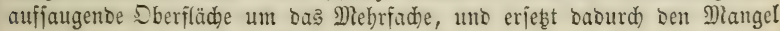
einer, leid)ter in grös̄eren Mengen aufnehmbaren, liquiben Jeud)tigfeit. $D b$ 
fid) Dieß̧ and) auf bie Bebaarung ber Blätter unt Iriebe antwenten Iafie, ift minoejtens jefre żweifelhaft getworben, jeit Unger nadgewiejen hat uno

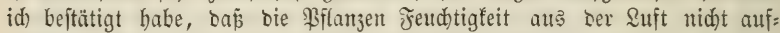
nehmen. 2tud) jint bie am: meiften auf Euftfeuthtigfeit angewiefenen Eacteen, Enphorbien, Erafiulaceen, meift haarloje Pflanzen. Ob bie Bebaarung mit

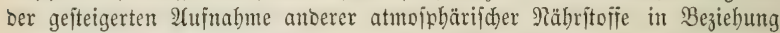
Ftebe, läpt fid vermuthen, aber burd) feine Thatiad)e berweijen. Die Triebe uno Blätter manther f̧olz̧flanzen fint an jungen Bflanjen uno Bflanzent= theilen ftarf bebaart, an alten Bflanzen bingegen unbefaart, z. $\mathfrak{B}$. Betula pubescens, excelsa.

Ebenjo wenig fennen wir sie Bebentung ber Drüjen. Allerbing: famt man bie von ihnen zum Theil ausgejhiebenten Etoffe Eracrete nenten,

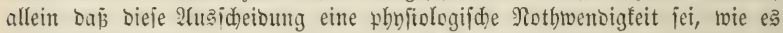
bie ber Thiere iit, Dá̉ jie mit irgento ciner ber allgemeinen \&ebensfunttionen in einem nothivenoigen 3 ujammenhange ftehe, bafür fehlt ung jebe that= iäd)liche Stübe.

\section{Das Sortgetwebe.}

Menn bie jungen Triebe ber Şolzpflanzen bollfommen ausgenadbjen fint, ober vielmehr an Denjenigen Theilen berjelben, bie eine bebentende Sergrößerung in bemjelben Jahre nid)t mebr erleiben, beginnt eine Spal=

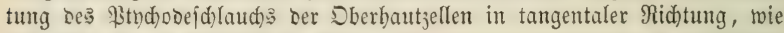
Diés Fig. 37 in Der Belfe h zeigt. Der innere Der Dadurd) gebildeten

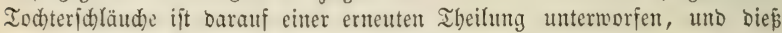

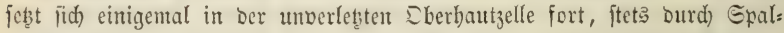
tung mur ber inneriten, permanenten Mutterzelle, während bie nad ank̄en

テig. 38.

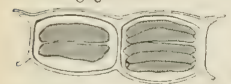

ซig. 40.

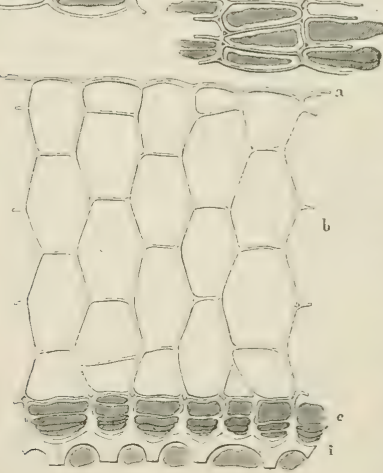
abgeidjürten Iodterzellen einer fortgejekstent Iheilung nidht mebr unterworfen finto; Jig. $38 \mathrm{mag}$ biés beranjuaulidjen. Diefem Borgange folgt bie Bildoung einer 3ellwantung in Umfange jebes Ptydyodeicllauches, gant in ber: jelben Beije, bie id Seite 165 uno 169 erörtert babe, worauf baun bie zwijden Den neu ges bilbeten Bellmänben liegende Bell= wanoung ber Dberbautzelle rejor: birt wirb. Jig. 39 zeigt bus, auf bieje Weife entfftandene, jugento: lidje Rorfgetwebe im Queridnitte Des Triebes aus Viburnum lantana. Der primtitioe \$tndjode= id)laud) ift in eine primitive Bellwanoung umgebildet, im Эn= nern lebterer bat jid ein neuer Ptydobejdlaud) gebiloet. 
Bäbreno siejer Sorgang an oer interften Grenze de今 entítanbenen

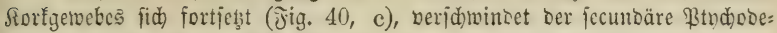

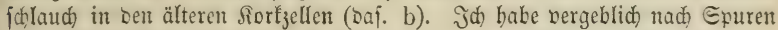

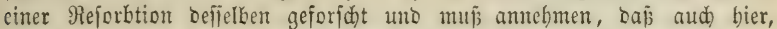

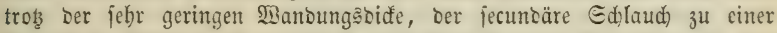
jecunbären Bellwano fich auşbilset, wabricheinlid) unter Rejorbtion Der pri= mären Bellwand.

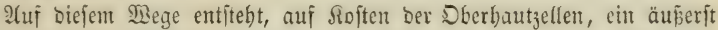

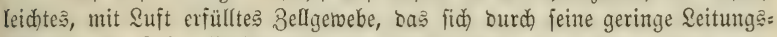
fähigfeit für Ruft, Maffersunjt uno früifigfeiten von jebem anberen Zell= gemebe unterideibet, uno baburdh 3u eintm tednifich widhtigen Material wirb

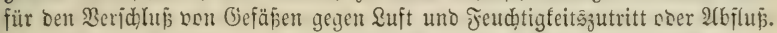

Bom Bellgewebe Der unterlicgenden grünen Pinde unterideiset fid) Das Siorfgewebe auj ben erften Bliđf burd) jeine rabiale Sellenorbunng, bie in criterent eine peripherijche, concentrijhe Reiben bilbento ijt (Jig. 3\%). Wie zwifden Solj: uno Bafttörper, io we r ben aud bier, je ood nur von einer permanenten Mluterjelle, fterile Iodterzellen nad) aufen in tangentaler $\Re i$ d tung abgefduürt, eb mieberbolt

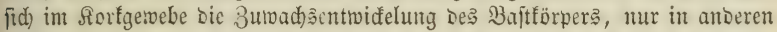
3ellenformen; es wieberholt fich ber 3uwadjęgang Des Soljtörpers in an= berer 3ellenform unt in entgegengefeţter Entwifelungşridtung.

Ias Rortgetocbe entitebt ftets all Roften Der Dberbautyellen, uno wem id) Iaf. I. Jig. 2 Siorfgerwebe 1 uno Dberbautzellen $\mathrm{m}$ jugleid, gezeichnet babe, jo geidab diejs nur ber 2(noeutung jelbjt wegen. Die

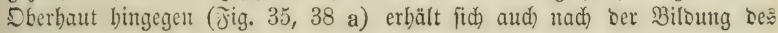
Sorfgewebes nod) einige 3eit unverleţt, zerreip̄t aber früher ober fpäter uno

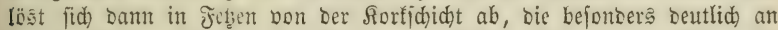

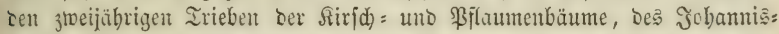
beeritrauds, ser Eilberpappeln zc. als fillbergraue Şäutchen fonon bem un= betwafineten 2 (uge erfenubar fino.

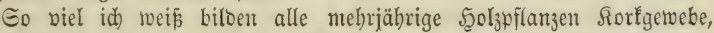
aber nidht bei allen feşt fid bieje Biloung aud in fräterer 3eit fort. Da

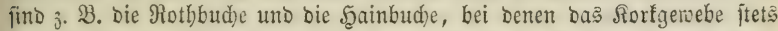

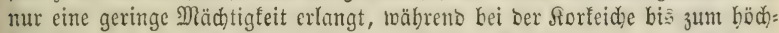
ften Alter, bei Der Siorfrüjter, bei Den Birten, Rirrdbbäumen, beim Ed)e: ball $6,10,15$ Jabre lang alljäbrlid̆ neue, wie bie Şoly= uno Bajtlagent

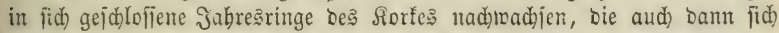
reprobuciren, wenn, wie biē bei Der forftreid)e geidieht, bie Rortjdidyten

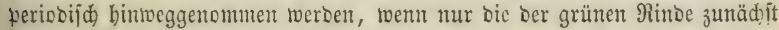

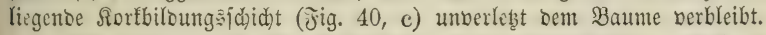

Bei Thamus ift bie Sorfbiloung 2 rteigentbümlidffeit. $\mathscr{2} u d$ bei

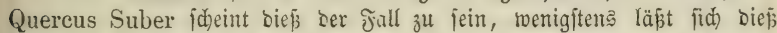
aus Der Gropartigfeit der Gewinnung bes Siorfes faliepent. Das ift

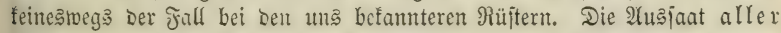
2trten liefert theils glattrindige \$ilanzen, theils foldhe, bie bis zu einem

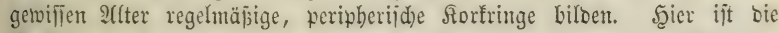
fiortbiloung baber entidieben nur eine inoiniouelle Eigenthümliḍteit ber 
Bflanzen. S?ur beim $\mathfrak{B}$ urjelftode bon Thamus, bei Betula, Cerasus, wabrideinlid) aud bei Suber barf man baher von einer Sorf́borfe als $\mathfrak{A}$ rtdjarafter fprecten.

$\mathfrak{I}_{\mathrm{m}}$ längiten Dauert bie peripherifde Sorfichidtenbiloung bei Betula

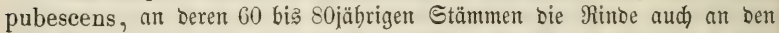
unterften Etammtheilen mur wenig aufreist. Bei Betula verrucosa bin= gegen tritt idon mit Dem 10. bis 12. Jabre an Den unteren Stammtbeilen eine ftärfere (Entwidflung ber grünen Rinde ein, Durd) weld)e bie reinen Rorflagen zerriffen uno getöbtet werben. IIn bie Stelle Der Sorfborfe tritt Dann eine tief gefpaltene, harte und fefte Rinoeborte. Sn ben böberen Baumtbeilen erbält fidh bingegen die weipe Rorfborfe bis zum bödjiten Alter beș Baume?.

IUper Diejer peripherijhen, tritt nun aber bei bielen Sुoljpflanzen nod) eine eingreifende Rortbiloung auf. Bon Den oberen Baum: theilen alter Siefern, vom Stamme der Platanen zc. (öjen fich alljährlid) Borfejtüfe von geringer Diffe ab. Dieje ideibenförmigen Borfeplatten befteben an Den bünnen Ränbern nur aus forfzellen, ber mittlere berbicte Theil bingegen bejteht ats Siebfajergewebe, bas beiberjeits bon Rorfzell= getwebe eingeidlofien ift, in leşteren, wie bas Gamentorn ber Ulme in feiner Slügelfrud)t liegeno. Interjudt man anf Dueridgnitten bie tiefere Stammborfe Der alten Siefer, fo findet man biefe aus eben foldhen idheiben= förmigen Rörpern zufammengejeţt, fo weit bie Bajtictichten braun gelobroen, auper Juntion getreten, relatio abgeftorben fino. Der llnteridies beftebt mur Darin, baj fie bier in ihrem 3ujammenbange verbarren, wäbreno fie jid) in Den oberen Baumtheilen periobijđ ablöjen, fo baj bort, felbjt bei böherem Altter bes 2 lites, bie Borfe nie fo bid wiro als an ben unteren Baumtheilen. Berfolgt man bie Eache mit Dem Miftroffope, io

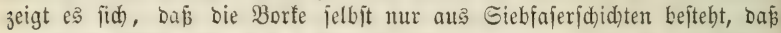
bie grüne Plinto uno was auperbalb berfelben beftano, längit abgeftorben uno abgeitopen wurben, ${ }^{1}$ baj aber, bon aupen nad) imten fortichreiteno

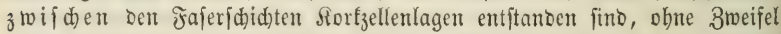
ourd) Untwanthung vorgebildeter Jajern in Sorfzellen, ftets auj Der Grenze 3̧wijden fungirenoem uno auper Junttion gejeştem Siebfajergewebe. Dieje 3rifhenbiloung vou Sorfjellidid)ten geidiebt, ganz aufer Hebereinftimmung mit Dem 2llter uno Dem Berlauf Der Bajtlagen, ältere uno jüngere Bajt= lagen Durdjiftreident, ungefähr io, als wenn man von einem cylinorijden

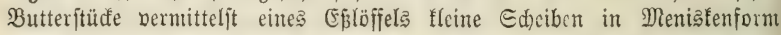
von aupen nad) innen abjdneibet un zıijden biejen Menisfen, nadjoem fie wieber in bie uriprüngliche Rage verjebt wurben, cine Forfzellidicht fich gelagert benft, beren jebe in ibrer mittleren Fläche zu ztwei, mit Den eingeidlofienen Deniaten in Berbinoung bleibende Єđjid̆ten zerfällt, wenn

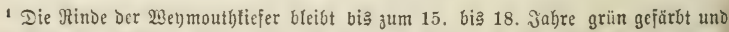
mit Der Oberlfaut betleidet; Dann seigen fid blutrothe Fledfe, bie fid) allmäblig vergröß̈ern

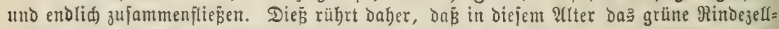

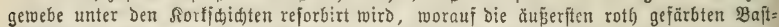
fajidten mit ben forfjelfen in Berübrung treten und ibre rotbe Farbe Durdjidjeinen Iaffer.

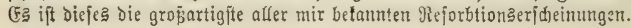


uno two ein joldher Menistus oon ber Borfe fich ablöst, wie diej bei Den Blatanen alljäbrlich ber Fall ijt, wäbreno in Der Jajerborfe ber Eichen, Eichen, Sinben 2c. Die Denisten in ibrem 3ujammenhange bleiben. Selbjt= verftänolid) feblt allen rinbebortigen Scolzarten (Rotbbuche, Sainbud)e, alte Birfenrinoe) Die Menißfenabidnürung, fie finbet jid) aber auch nidt bei allen

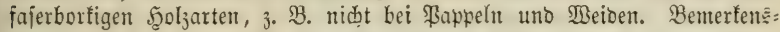

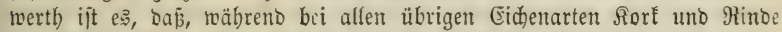
febr bald berloren gehen und Durch bie Jajerborfe erjebst werben, die Ent= widfelung Der Bajtlagen bei ber Sorteiche eine ungeröbnlich forwade uno träge ift, woher es fommt, oaj bier bie grüne Rince uno mit ibr bie forfbiloungşđididt fid lebendig erbalten.

\section{Senticelfent.}

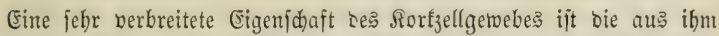
hervorgebende Senticellenbiloung. Bejonbers gros, uto fäon bent unberwafineten $\mathfrak{A}$ (uge erfennbar, fiebt man an ben jungen Irieben ber (5jd)en, Rutbbud)en, Erlen 2c. ovale, etwas herbortretenoe, in ber Mitte ber 尺änge

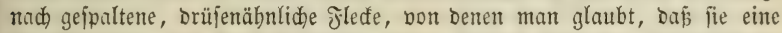
Durdjbredung Des Rorfzellgeroebes jeien, um Der \&uft Den unmittelbaren Butritt jum Rinbejellgetwebe zu erbalten, nadbem berjelbe, Durd Den Ber: luft Der Dberhaut und mit ibr ber "Spaltöfinungen", abgejolofien jein

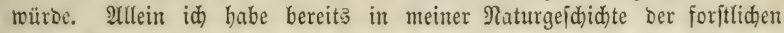
Eulturpflanjen ङ. 305 Jig. 1 uno 2 nadgetwiefen, Daj bie Senticelle feine vollfommene Durdbred)ung ber Rorfididbten mit fidh fübrt, fondern mur eine Berbünnung Der Edjidten veranlajit, indem mitten in Den Rortjobichten eine grobe Babl pilzäbnlidber Bellden entiteben, Deren Nermebrung unt

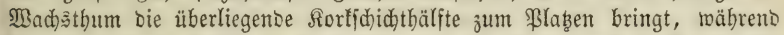
Die unterliegente Şälfte an ifrer Unterjeite fich fortbauerno burd 3umad)s verbidt uno ergänzt, bis in ber Ridhtung bellelben Rabius eine neue Bell: denbilbung Den erften Sorgang roieberbolt. Dieje auf berjelben Stelle fid) oft 6 bis smal wieberbolende Berreifung ber oberen Rorfjobidthälfte surd) freie Zelldenbiloung, bie fonjt in ber ganzen ßïlanje nidjt reiter vorfommt,

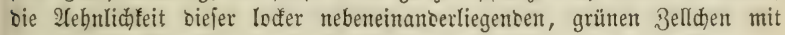
mandicn einzelligen Suftalgen, ijt allerbings ein jebr merfwürbiger Borgang. Die untere Rorfididhthälfte, bout Deren Biloungsjididyt aus fid regenerirent, verjentt fid beutelförmig oft tief in bas Rinbezellgervebe, allein eine böllige Durdbredung Der forfididyten finbet bierbei nie ftatt. Yudy bief ift ein Gegenftano, bon bem wir fagen müfien: Daj roir ibn zur 3eit nod) nidht

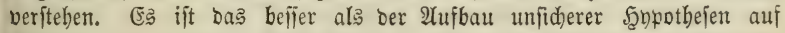
flüd)tige uno ungenaue Beobadtungen. Die an Steflingen ber Pappeln, Beiben, Erlen fid bilbenben Wurzeln, wäblen jebr bäufig bie Senticellen

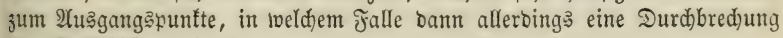
Der Rorfidichten eintritt.

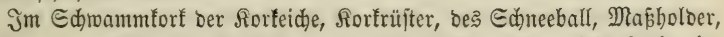
Siquibambar erlifat bie fortbiloung ber Senticellen jöon jebr früb; in Blätterforfe ber Birfen und Riridbbäume bingegen fetst fie fid burd) biele Jahreslagen bes Rorfes fort, gleidzeitig in ben älteren äup̧eren fiorflagen 
an $\mathscr{Y}$ (usbebnung gewinnent, wie bief bejonbers ber weife Birfenfort zu ex: fennen gibt, in Defien fid) ablöfenden Bänbern bie gelbbraunen, in Der Beri= pherie Des Gtammes verlängerten Etreifen, nidhts anderes als bergröperte Qenticellen fino.

\section{Blatmarbeforf.}

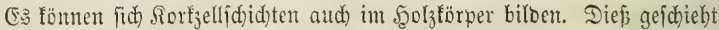
regetmäfjig, quer burd den ganzen Pflanzentheil binourd), ca, wo balo barauf Der obere Sfflangentheil abgeworfen werben foll, in oer Duerfläche aller Fräteren Blatmarben, in Der ber Enofnofpentarben ber Sinoe (Ptelea, Ailanthus etc.). Siorfbiloung ift ferner ein treuer Begleiter jeber Uleber: wallungzerficinung. Wer biefe berfolgt, ber wirb bald bie lleberzeugung getwinten, baj bie phofiologifde Bebeutung berfelben feine andere jei, als

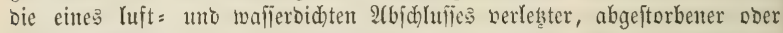
auper Junttion getretener Bflanzentbeile nad) aujen. Was ber fort für

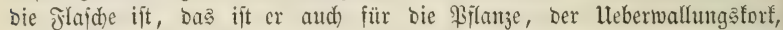

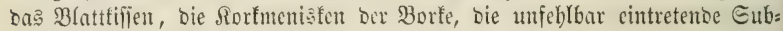
ftituirung Des Rorfes vor erfolgenoem Dberbautberfulte beuten fämmtlich) Darauf bint.

\section{Das Seingetobe (Collend)yma).}

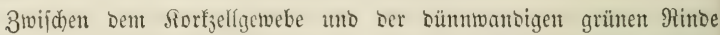
lagert bei ben meiften Jgolzpflanzen eine mebr ober weniger breite 3elfen= jhid)t mit jebr bidwandigen Bellen (Taf. 1. Jig. 2. k l), Deren Anoronung

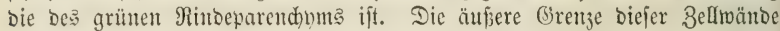
ift 10 jartbäutig, baf wenn man nid)t mit geeigneten Reagentien arbeitet, Dielelbe ber Beobad)tung leid)t entgebt, fo bafs es ideint, als jeien bie entfernt

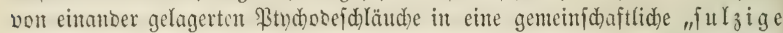

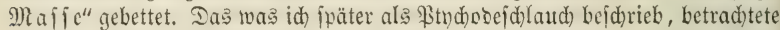
man bier als bie vollftünoige Belle felbjt, uno bielt jene, bie Bellen un= gebende "fulzige Maile" für eine benjelben gemeinjofatliche "S̃ntercellu

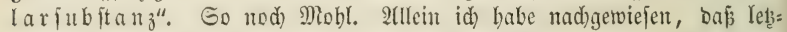
tere Belfwanoung jei, Daß́, wie überall, fo aud lier cine zarte Brenzhaut vorbanben fei (Naturgejdidbte ser forftlichen Eulturpflanzen Taf. 45 (37), Fig 3,4), bie in einigen Fällen allerbinge and ber forgfältigiten lunter= fud)ung fich entziebt. Mit jenten Beridytigungen fällt Dann die biefent Sellgetvebe, to twie jener vermeintliden Intercellulariubitanz früber unter: legte befondere Bebentung. Ein Itnteridjed Des Collendonn vom Bellgemebe

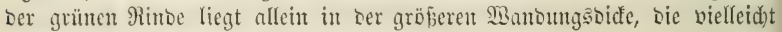
zur Rorfzellenbiloung in Beziebung fitebt.

\section{Die grünte Rinde ${ }^{1}$ (\$arendynta int engern Cinne).}

Dhue fódarfe Begrenzung, unter allmäbliger Berringerung bex Man= Dungöbidte geht Das Eollend)nu auf feiner Jnnengrenze allmäblig in bas Dünmantige Rinbezellgewebe üker, Dellen concentrii h) georbnete Reiben unter

1 Sbgleid) Das Bellgelvebe Derjelben nid)t 3 ben metamorphijden (Elementarorganen

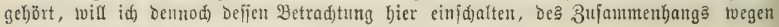
mit Bor $=$ und Plad)ftehendem. 


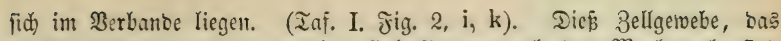
Siebfajergemebe uno in mand)en $50 l_{3}$ flanzen aud bas Marfyetwebe fino bie einzigen Drgane, in ocnen Der Btndobejdland bleibeno ijt. Jn Der

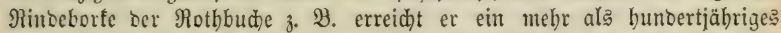
Alter, in 3elleern, Eblorophnd, $2(m b l o n$ alläbrlid) neue Rejerbiftoffe für

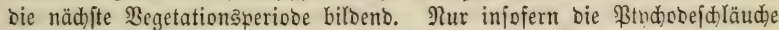
biejes Bellgewebes fid fortbauerno zu Tod)terzellen theilen, banit bas Rindes

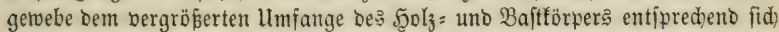

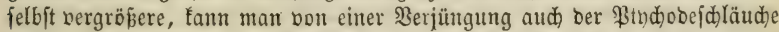

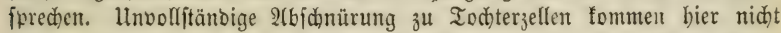

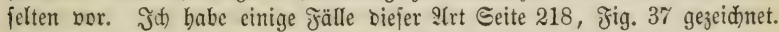

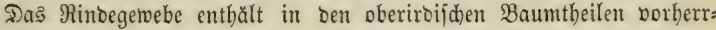
fajeno Chlorophyll, in ben unterirbifden Baumtheilen bingegen Stärfmebl, befien alljäbrliche $\mathfrak{A}$ njammlung und $\mathfrak{B i e b e r a u f l o ̈ j u n g ~ b e r ~ \Re i n b e ~ b e n ~ S h a r a f t e r ~}$ eines Magajins für Rejerbcitoffe ertheilt. In ben jüngeren Trieben bes auffeigenten Etodes geht aud) bas (Ehlorophyll hei gewifien Bflanzen periobijd in Etärfmebl uno fllebermebl über; allgemeiner ift biés ber fall in ber Rinbe älterer Iriebe. In wie meit aud bas wie es fideint permanente Chloropbyll ber jungen Iriebe als Rejerveftoff betrachtet werben bürfe, vermag id) zur 3eit nod) nidjt anzugeben.

Bei ben fleifdigen, blattlojen Eacteen, Euphorbien, 2lpocnneen erfüflt

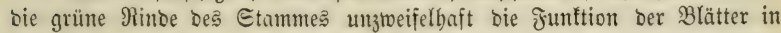
Afiimilation ber roben Nabrungsifofie. Das wiro man aud annebmen müfien für mebrere Sträudber, felbjt Bäume, benten vie Den Giattungen Ephedra, Gnetum, Casuarina eine Belaubung im engeren Sinne feblt; man wiro es ausbebnen tömnen auf einige andere $\mathfrak{B f l a n z e n , ~ a n ~ t e n e n , ~ m i e ~}$ bei einigen 2(rten Der Gaattungen Spartium, Genista, Ulex bie Belaubung

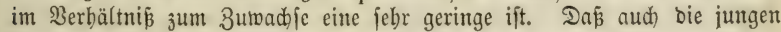

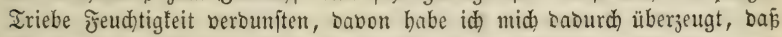

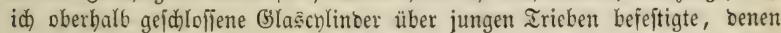
id) mebrere $\mathfrak{W}_{0}$ den vorber ibre Belaubung genommen batte. In ben frühen

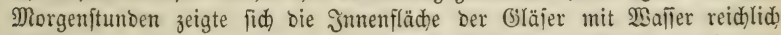
bejolagen. Daburd wiro es Dann wabrideinlid, baj ber Rinte, fo la nge biefe bem \&idte in böherem (jorabe zugänglid i it, bie afimi= lirende Junttion Der Blätter zuftänoig jei. Daß̧ bierbei bie tieferen Baaum= theile nid)t betheiligt fino, geht aus Dem einfachen Umitanoe hervor, Dá bei ber großen Mebrabl aller Scolzpflanjen bie Rinbe mit allen über ifhr liegenben Drganjididten idon frül gänglid) verloren geht, relativ abgeftorbene

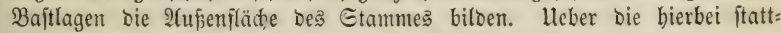
fincenoen Rejorbtionserideinungen babe idj idon geprodent.

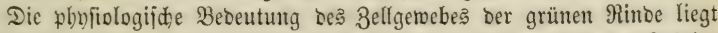
Daher vorzugsineife in Den jüngiten Iheilen ber nod wadjentoen Triebe. Das Rinbegewebe vertritt bier Die Etelle bes 3ellgetwebes ber Blätter, bie an

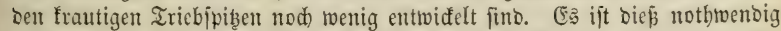
3ur förberung Des Rängenmudjes berjenigen Iriebe, für beren 3umad) bie Eumme Der aufgefpeid)erten Referbeftofie nidyt ausreidt, ba bie Mob)=

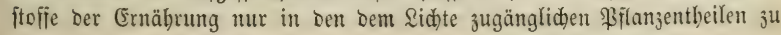

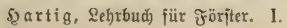


Biloungąfäften umgetwandelt merben fönnen uno ba, wie id fpäter burch eine Reibe von Beobadtungen nadjweifen werbe, primäre Biloungşäfte auts tieferen in böbere Baumtheile nidht aufiteigen fönnen.

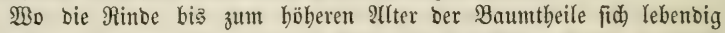
erbält, ba wirb fie, ebenfo wie bie Bajtlagen ber (sid)e, Riefer zc. Durd intermebiäre Sorfjdidhtenbiloung зи Menisłenjdjeiben abgejdnürt. $\mathfrak{A}$ 3ellborfe biefer 9 trt bejteht bie oft mebrere 30 ll bife, braune, riffige Borfe am Juke alter Stämme von B. verrucosa, in beren zelligem Theile einzelne Bellencomplere eine bebeutende Wanbverbifung erleiben und bas bilben, was id Steinzellen= Refter genaunt habe. Die barten, wcip= liden Rörper in ber Birfen:, Budjen=, Şainbudenrinbe ftammen baber, mit

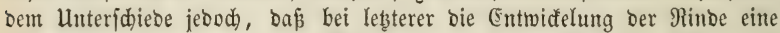
jebr geringe ijt, uno von ben Sorfididyten aus eine Menisfenabjdnürung nidst itattfinot.

Bei Der großen Mebrzahl ber Scolzpflanzen ftirbt mit ber Dberbaut, mit ben peripherijden Sorfidjidten uno Dem Eollendynm bie grüle Rinbe idhon früh. Die Borfe befteht bann nur aus ben ältejten Bajtlagen, z. $\mathfrak{Z}$. Quercus, Fraxinus, Populus, Pinus, Larix etc.

\section{9. ¿ebenక̧aftgefäве.}

2(ud) in ber grünen Rinbe entwifeln fid) verfdiedentartige, metamor= pliide (Elementarorgane, bie fid) eintheilen laffen in celfulare uno $u$ tri culare. Eritere geben aus vorgebiloeten Nindezellen herbor; für Seb̧tere - bie Lebensfaftgefäßze - läpt fid) diés zur Beit nod) nidyt mit Sidherbeit behaupten. (5s fino bief, mur wenigen Pflanzengruppen zuftän: bige, unter fid uno nadh ber Dberbaut zu veräjtelte, Durd Berwadjungent unter fich communicirende Elementarorgane (Seite 228, Jig. 41, 10), beren Ptydobefodlaud einen bidflüfitigen, theils ungefärbten, theils gefärbten Saft enthält, befien trodener Rücfitano bas Sautiduuf (Gummi elasticum) ift. 3uerjt in meinten Jahreảberid)ten 1837 babe idy gezeigt, baj ber Mildjaft Der Euphorbien nidht allein eine Menge Belferne, fonbern aud eigenthüm= lid) geformte Mehltörner entbält (Dajelbft Taf. I., f̧ig. 17-20); it meiner

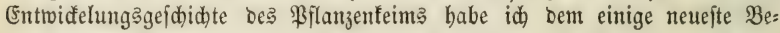
vbadtungen binzugefügt, betreffeno ben Inthalt bes Mildajafts von Pastinaca, Heracleum etc., aus benen meine 2(nficht fid mebr und mehr

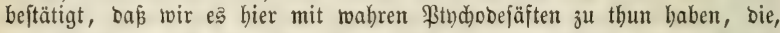
rie überall fo aud bier, einer ftrömenden Drtsveränterung innerbalb bes=

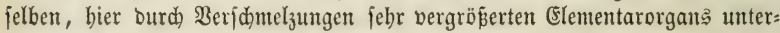
worfen find. Jnoés intereffiren uns biefe Drgane bier menig, da fie bei feiner unferer forftlidjen Rulturpflanzen vortommen, Dem bie Mildjäfte einiger 2lbornarten fint nidjt in Rebenşaftgefäpen, fondern in ben bier aușnahmsıeife unter fid veräftelten Siebröbren bes Baftę entbalten (Seite 228, Jig. 14, 5).

10. Terpentin $=$ unঠ Sđlleimhălter.

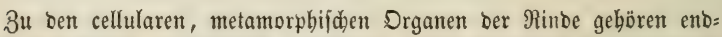
lid bie von vielen, concentrifd georoneten Bellen begrenzten Ierpentin= 
bälter ber Nabelhölzer, auf Queridnitten junger Triebe jobn bem un= bewafineten IUge erfennbar, ferner bie Shleimzellen uno Sdleim= bälter ber Sinben:, Ulmen:, Tamen=:inbe.

\section{Die Fajermanblung.}

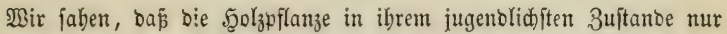
aนอ parendymatifdem 3ellgewebe bejtehe; baf aus einem Theile bieję 3ellgetwebes Durd biagonale 2 (bidnürung bas Fojergetwebe entittebe, in feiner bünoelmeifen Gruppirung Daß uriprünglide Bellgewebe in Marf uno Rinoe trenneno. Dießs jajergewebe bejteht urjprünglid aus gleidgebilbeten, langitredigen Faferzellen in ber Eeite 174, Jig. $19 \mathrm{e}$ Dargefteflten Form, nidht allein im entftebenden Jajerbündel des Pilanzenteims uno in befien

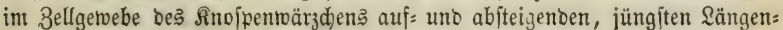
zuwads, jondern ebenjo aud in ien, ben Diffejuwad,s älterer Fajerbünoel bermittelnoen, jogenamnten Eambialjajidjten, mie uns bié̃ Geite 177,

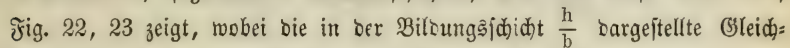
förmigfeit Dec Duerjonittfläden aller Fajern fid) aud in jeber anderen Sinfid̆t zu erfenten gibt. Alle die fpäter fo febr beridieben= artig geftalteten Elementarorgane bes $\mathfrak{g}_{0} l_{z}=$ und bes $B$ aft förpers fitto anfänglid gleidgebilbete, einfade Fajer: zellen. Biele berielben berbarren aud) fäter in biejer urjprüngliden Form unb beränbern fich) nur burd) Bergröperung, burd Berbidung ibrer Wanbungen uno Durch bie beridiebenartige 2fuabiloung zur Tipfel= Doer Epiralfajer, wie id bief Eeite 203-208 in ben Jiguren 28-35 Darftellte. 2lber nidht alle Drgane besె Fajergetwebes behalten ibre einfade, ur: iprünglide Form uno Biloung. Theils burd) Berjdmelzung einer $\mathfrak{D}$ (h)

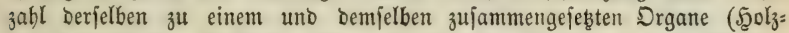
uno Siebröhren, Mildjaftgefäáe), theil(s burd) Bertbeilung urfprünglider Jaferzellen in eine Mehrzabl anberer Drgane (Şolzparend)om, fecunbäre Marfitrablen), theils ourch Bellenbiloung im Innern uriprünglider fajer= zellen (Zellfajern) entitehen beridiebene frormen metamorphijder Elementar= organe, bie wir in Nadjfolgendem näber betrad)ten roollen.

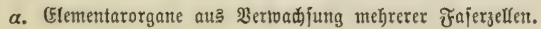

1) $\mathfrak{g}_{0} \mathfrak{l} \mathfrak{z}=$ un

Berfen wir zuerjt einen Blid auf Seite 177, Fig. 22, fo fehen wir über unb unter $\frac{h}{b}$ an bem Drte, von bem alle Reubiloungen bes Dides zumadjes von einem \$aare permanenter Miutterzellen ausgeben, beren burd 2tbjonürung gebilbete Todterzellen $z u$ jed 0 r 3 eit uno obne $\mathfrak{A} u s=$ nabme gleid) geformt uno gleid gebildet. Erit in einiger Entfernung von

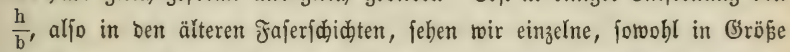

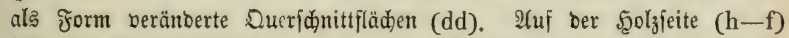

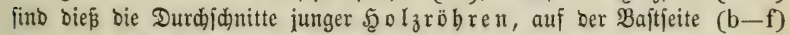
fino ę bie Durdidnitte junger Siebröbren.

Die nadjtehende Figur 41 zeigt bei 1 ein Stüa einer Syolzröhre, bei 


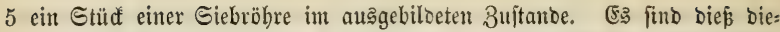
jenigen weiträumigen Drgane, weldhe man auf Duerfannitten bes (Fid)en= bolzes fdon mit unbewaffnetem 2 Huge als runbe Söd)er erfemten fant, bie

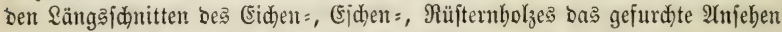
geben. Sie fommen nur in Den Saubbölzern, nie in Nabelbölzern vor

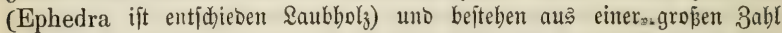

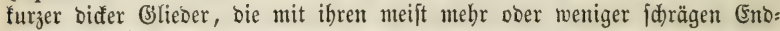
flädhen untereinanber berwadjent fino (bie Şolzröhre Fig. 1 zeigt brei größ̄ere

ซig. 41.

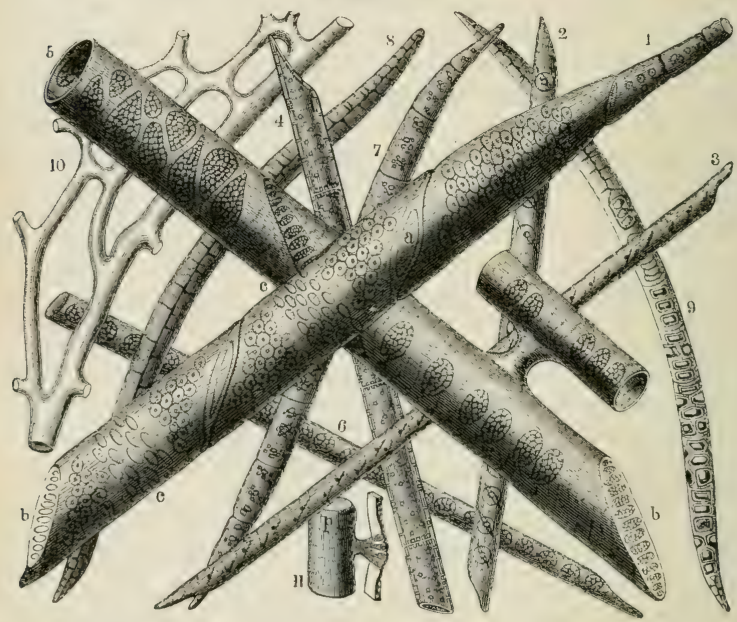

Mittelgliedar und brei fleinere Enoglieber, sie Eiebröbre fig. 5 jeigt mur 2 Mittelglieber) uno baburd eine gemeinidaftlidfe Röhre bilden, Dá bie

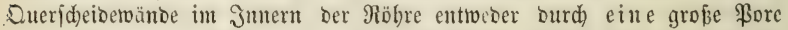
cinfad) (1 a) Doer burd) viele länglide Boren leiterförmig (1 b) burd)= brod)en finto. In Den 5odzröhren ift bie Tipfelung eine Yinfenräumige, uno nur Da, wo Marfiftrablen an bett Sgolzröhren vorbei ftreid)en, ift fie eine geftufte (c). 2An bon Giebröhren bingegen (Jig. 5) ift bie Iipfelung überall eine fitbförmige, fowohl an Den Geitcnivänoen als an ben oft jebr fdj)rägen

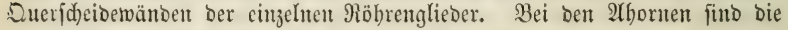
benachbarten Siebröbren burch Dueräpte untereinanber berbutben (Jig. 5); bei anderen Sgolzarten babe id) Dieje Berbindung nid)t auffinden tönten.

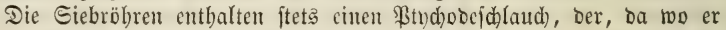
cinem Siebtipfel anliegt, an eben fo vielen (Einzelitellen ibm abbärirt, als Der componirte Tipfel äunerlid) Untertipfel erfemuen läpt. Der ibeale Durdjidnitt eines folden Iipfels Fig. 11 zeigt bie mehrarmigen 2Unbeftungs:

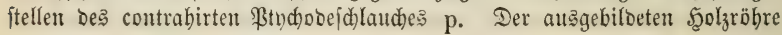


bingegen fehlt ber \$tndjobejdlaud. Wie in ber Şolzfajer, fo ift er aud hier in eine fecunoäre 3elltwano umgetwanbelt, bie febr bäufig neben ber Tipfelung aud fipiralförmig geftaltet ift.

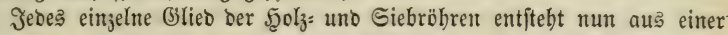
Mebrzabl unter einanber verwadjenber Fajerzellen, unter gleidzeitiger Re= jorbtion Der 3mijdentwände jeder einzelnen Fajerzelle. Ės liegt mir bierfür ein jehr volljtänbiges Material ber Bitweisfübrung vor. Einen Ibeil beš felben babe ich in ber Bot. Beitung 1854, Є. 57, Iaf. I. Fig. 1-25 publicirt.

Die Siebröbren find ftets mit Gäften erfüllt, bie bei ben 2 hbornen in unberfennbarer Strömung fid befinoen. Die ausgebildete Fुolzröbre bingegen, bei ber Eidje, Rüfter zc., im böheren 2llter mit fleinen zelligen Blajen erfüllt (Tillen), entbält meift nur $\mathfrak{L} u f t$, bei einigen Şolzarten (Gleditschia, Gymnoclades, Ailanthus) fübren fie einen bem Iragant=

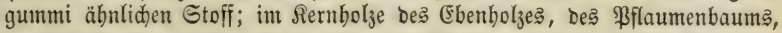
Der Cäjalpinie entbalten fie Denjelben Stoff, Der auch bie Bellmände burd)=

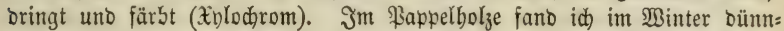

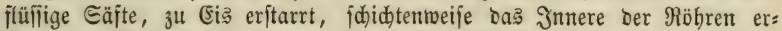

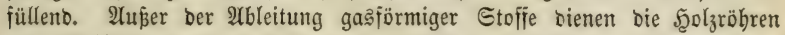
zum Theil aljo aud ber Secretion, äbnlid Den Şarzgängen im Şolze ber Nabelfölzer. (Bot. Zeitung 1859, S. 100.) Db fie an ber Reitung von Wanberfäften Theil nebmen, ift nod zu erforiden.

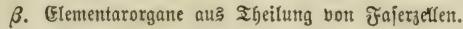

2) Primäre uno fecunoäre Marfftrahlen.

$\mathfrak{B i e}$ id) Seite 174 erwäbnt babe, bermanoeln fid nidjt alle Bellen bes Cambialcylinders in Jafern, fonbern es bleiben zrwijhen Den einzelnen Bünbeln berfelben eine ober mebrere Bellenrabien zurüđ, bie fid̆ unmittel= bar in Marfitrahlgewebe umbilden. Diés in Bezug auf jeine Entjtebung aus cambialem Bellengemebe primitive Marfitrahlgemebe, obgleid ana=

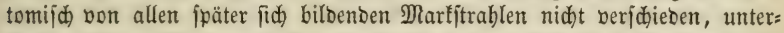

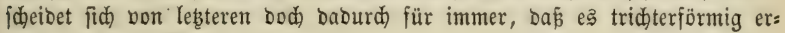
weitert in bas Marf berläuft.

In ber Spibe deక embrbonifden Triebes ber Inojpe bon Pinus Laricio (Geite 135, Fig. 5) laufen alle Marfiftrablen vom Marfe bį zur

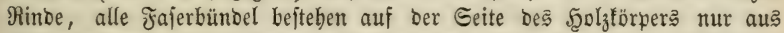

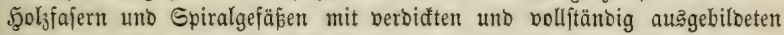
Wänden. Steigt man in Queridnitten abroärta, io gelangt man etwas über ber Mitte bes nädjitjäbrigen Triebes an eine Stelle, wofelbft inner: balb ber Jajerbünoel neue Marfítrablen auftreten. Der Marfítrabl Iaf. I. Jig. 2, q mag bief́ verfinnlichen. Die jorgfältigiten Unterjuchungen haben mich vollitänoig überzeugt, baś bieje fecundären Marfjtrablen nicht

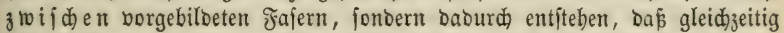
alle Fajern ein uno beffelben Fajerrabius, Durch Wieberauflöjung Der

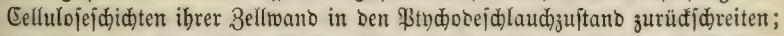
toorauf bann fämmtlide \$tndjobezellen burch Quertbeilung zu fenfred)ten

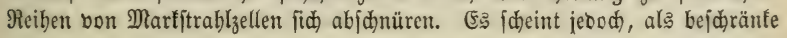




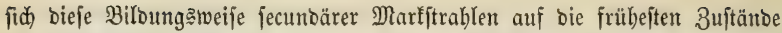

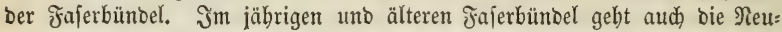
biloung ber Marfitrablen von Den permanenten Mutterzellen jebes Rabius aนs, unb zwar burch rabiale Sängentbeilung, gefolgt von einer borizontalen 2(bjdnürung ciner ber Tod)terfafern zu Martitrablzellen.

3) S⿹arzänge bes Şolztörperz ber Nabelhölzer.

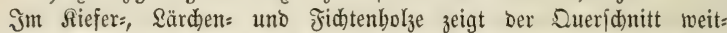
räumige, rumbe Södher, bie Der Durdjfdnitt harzabjonoernber fenfredjter (3änge fint. Bei Der Jid fte fommen borizontale Şarzgänge bier uno ba aud im Marfitrablgetwebe vor. Diefe Şarzgänge befiben feine geidlofilene Mand. Statt berjelben fino fie begrenzt von einer cinfachen Lage bün= manbigen, parendinmatifhen 3ellgemebes, Durd) weldes bas Şarz in ben Jnnenraum bes Ganges ausgejdieben wiro (Naturgejdid)te ber forftliden Eulturpflanzen, Taf. 18, テig. 3). Wie bie Bellen ser fecunbären Marf́= ftrablen, fo entiteben aud Dieje Şarzjellen aus vorgebildeten Fajern unter gleidzeitiger Rejorbtion eines Theiles berfelben zur Deffnung Des ङ゙angraumes.

4) S⿹⿺l一parendym.

Im Sูolztörper ber Birfen, Erlen, Şainbuden, Pappeln, Şajeln, Der

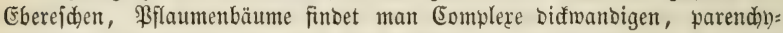
matifđen Zellgetvebę, bie, wie Borfenfäfergänge aufiteigento uno bier uno ba fid) veräftelno, bejonders im Stammente junger Birfen fo reid)lid vor:

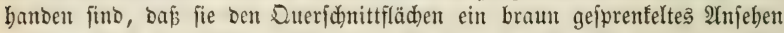
geben. Dießs ungeorontete Bellgetwebe ift, wie bas Marfitrablgemebe, 2lb: lagerungsort für Rejerbejtoffe, aud) infofern bomertenswerth, als fid auf ihm bäufig cine von fablafenten $\mathfrak{A}$ ugen nicht bebingte Maferbil bung entwiđ̌elt.

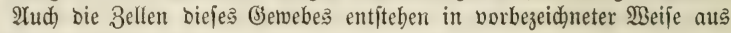
vorgebildeten fajerzellen.

\section{$\gamma$. Elementarorgane aus 3elfenbiloung innerhalb ber ซajerzelfen.}

5) Bellfajern.

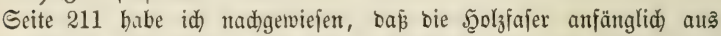
einer cambialen Bellwanoung uno aus einem \$tndobefdlaude beftebe; ba

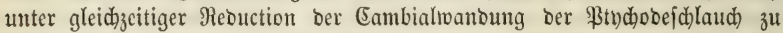

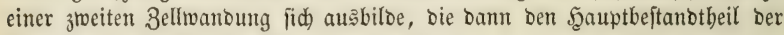
Mandungasbide bildet. Jn einer meht oder weniger grofen 3 abl bon Fafern bes Şol

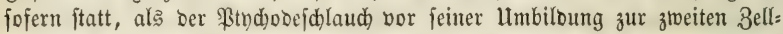
want fid in eine Mebrzabl von Bellen in horizontaler Riditung abjdmürt, moburd) eine fajer entffelt, in beren gemeinfohaftlider Cambialwantoung

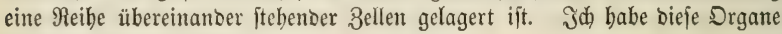
Belffajern genannt.

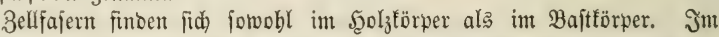

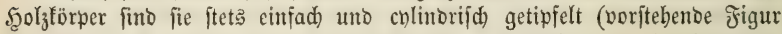
$41,4)$, aud) ba wo bie einfammrigen Sgolzfajern linjentäu= mige Iipfelung befitzen (En)reflen). Jm Bafttorper fino fie fiebförmig getipfelt (Seite 228, Jig. 41, 7). 2(n beiben Drten fint bie 3ellfajern Drgante ber Bereitung uno $\mathfrak{A}$ ufbetwahrung von Refervejtoffen, meijt Stärfmebl. 


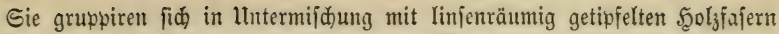
theils um bie 5ुolzröbren zu befonderen Röhrenbünbeln (Taf. I. Fig. $5 \mathrm{~d}$, Eeite 238, Fig. 42); theils bilben fie, entfernt bon ben 5̧olzröhrenbünoeln zwifden ben einfaden, cylinorija) getipfelten Scolyajern peripherifo ber: laufente Edidten (Taf. I. Fig. 2 e, テrig. $5 \mathrm{~g}$ ). $\Im$ dh babe fie in biefem Jalle Sdidatzellfajern genannt.

6) Rryftallfammerfajern.

Seite 17\%, Fig. 22 jehen wir in ber llmgebung ber Bajtfajerbündel $\mathrm{m}, \mathrm{a}, \mathrm{t}$ einzelne Fajerburdjidnitte ourd bunfle Ed)rafiitung herbortreten. Id babe bamit bie 3ahl uno Stellung einzelner Birenzfafern andeuten toollen, von benen Seite 228, Jig. 41, 9 bie Sängenamficht gibt. Dieje Baftajern unterideiben fid baburd von allen übrigen befielben Bündels: bap fie burdaus ober nur theilmeife eine großße 3ahl bifwandiger fammern enthalten, in beren jeber ein Srryitall von oxalfaurem Salfe gelagert ift,

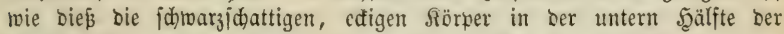
Bajtfajer fig. 41, 9 anbeuten, beren obere Şälfte bie verbifte $\mathfrak{B a n b u n g}$ Der getwöhnlinen Baftfajern (J̈ig. 8) zeigt.

Daכ Borfommen ber Sirbitullfammerfajern an ber Brrenje ber Bajt: bünbel ift ein febr verbreitetes, wenn nidht allgemeines. Die Sirbjtalle felbjt

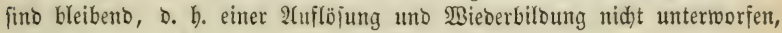
gehören baher nidjt zu ben Referbeftoffen.

7) Baftbuindelfafern.

3u ben metamorphifchen (Elementarorganen fant man enolid) audh nod bie bicfwandigen Fajern ber Baftbündel zäblen. (テ̌ig. 41, 8). Sie fin๖ urfprünglid einfaches Eichfujergetwebe uno als foldjes rabial georonet (Taf. I. Jig. $2 \mathrm{f}-0$ ). Shre llmbiloung zu Baftfajern beruht nid)t wie

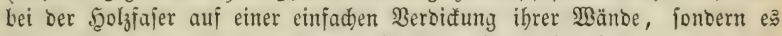
bilben fid an ben Stellen, wo eil Baftbündel entittehen joll, nach vorber: gegangener Mejorbtion ber vorgebilbeten Giebjajernänbe, Durd mieberholte

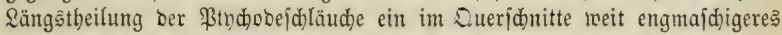
Jajergetwebe, beilen Stellung eine burd)aus ungeregelte ift (Seite 177, Jig. $22 \mathrm{a}, \mathrm{m})$, in Deren frimitiver Wantung, wie bei ben Scolyajern, paäter eine jecunbäre $\mathbb{B a n}$ bung zu jener, bie Bajtbünoelfajern in ben meiften

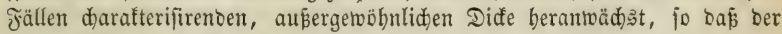
intere Bellraum meift fajt gänjlich berbrängt wirb. Ě̉ find bieß biejenigen Drgane, bie in ifrer \$ereinigung zu Bündeln Den Bajt, bie Scani: uno

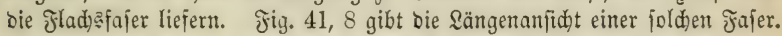

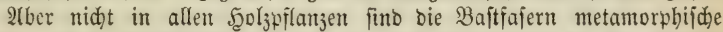

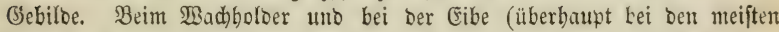
Eypreffen uno Taxineen) weicten fie in 2(noronung, Form uno Bröß̧e von Den Siebjajern nidjt ab uno müffen betradtet werben als bervorgegangen

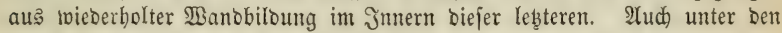
Saubhölzern gibt ez einige, Deren Baftfajern bie rabiale 2(noronung ber Giebfajern beibehalten (Carpinus, Corylus), die daber ebenfalla ben pro= tomorphen Drganen binz̧ugezählt merben nuïfien.

Die Bafțaferbünoel liegen urfprünglid) im $\mathfrak{A n j}$ d)lufie Der Fajerbünbel uno bildon in feltenen fällen (Podophyllum) bie äup̃ere Girenje belielben 
in allen Berübrungappunften mit Marf, Marfftrabl= uno Rinoegewebe. Jn einigen anberen annuellen f̧olzpilanjen (Aretium, Cucurbita), fehlt bie Begrenzung burd) Bajfajern ber Marfjtrablfeiten ber Fajerbünoel, twir finben bie Baftbünbel bann mur auf ber Marffeite unt auf ber Rinbenfeite ber Jajerbündel. In ben allermeiften gällen fehlt and ber Marffeite bes Faferbüntels ber Baftfajerförper. (Es ift mir nod) feine Syolzpflanze be: fannt, in welder aud ber Mindejeite ber Fajerbünoel bie Baftbünoel fehlen, wohl aber fommen lekbtere bei vielen anmuellen Şolzpflanzen zu überwiegender Entwickelung uno biloen ben größ̈ten Theil ber feften, profendymatifacten Dalle bes Etengel’ (3. B. Delphinium).

Dieje, bie äukere Grrenze einez jeoen Jajerbünbels befleibenoen Bajt: fafern liegent uriprünglidy in unmittelbarem 2(njd)lufie am Siebfajergetwebe. Erit fpäter fehen mir es von leţterem getrennt burd) eine fidmale 3rifden= joidht bon parendymatifden Bellen (Taf. I. Fig. $2 \mathrm{~g}-\mathrm{h}$, Seite 177 , Jig. $22 \mathrm{~g}-\mathrm{h}$ ). Jd babe biefe Baftiajerbündel primitiv genant, um fie von ben, fpäter im Inntern ber Eiebfajeridid)ten lagenweife fid bildenden, jecunoären Baftididhten zu unterideibun (Eeite 177, Fig. $22 \mathrm{~m}$ a). Innerbalb bes grünen Rinbeparendbymı jteheno, erlciben fie im $\mathfrak{B}$ erfolg eine Spaltung in ebenfo viele unter fid beräftelte Theile, als fecunoäre

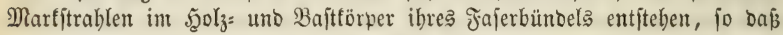
ihre $3 a b l$ aud in fpäteren Jabren fid fortoauerno mebrt, fo lange, als bie grüne Rinoe überbaupt lebentig bleibt.

\section{e) Dronung ber Elementarorgane zu Syitemen.}

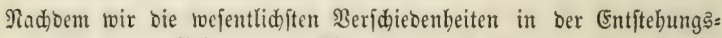
weije, in Form uno Biloung Der Elementarorgane fennen gelerut haben, menben wir uns zur näberen Betradtung ber $\mathcal{S}_{\mathfrak{y}}$ fteme, zu benen bic= jelben im Rörper ber Şoljpflanze zu[ammentreten und unterid)eiben zunädjit 3ellenibfeme von Jaferigftemen.

Das Belleninftem lernten wir bereits Seite 169-171 aud in feiner

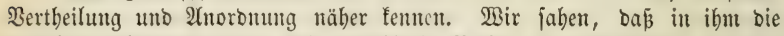
einzelnen Elementarorgane fid zuntäbjt in Reiben zujammenjtellen, bie mit ber 2ldje bes \$flanzentbeiles parallel verlaufen, 1 in benen bie Bellen mit ibren, zur Qängentadje red)twintliden (Enbfläden übereinander fteben; Daß

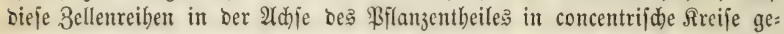

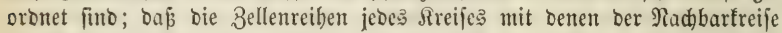
im Berbanto jtehen; bafi bajielbe aud) Der Fall fei in Bezug auf bie Beflent

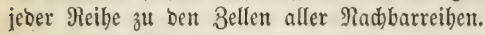

Jnnerbalb biejes uriprüngliden, parendhmatifden Bellgewebes ent=

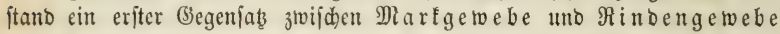

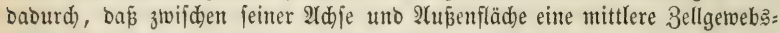
fodidt theils zu Jajerbünoln, theils zu Marfitrablgetwebe fid

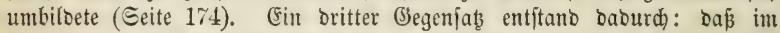
Jajerbünoel= uno Marfịtrablfreije eine concentrijhe Edjidtung permanenter

1 Ter in Blättern und blattartigen Pflanzentbcilen auftrctenden Tußnal)men tverde ida ipäter gedenten. 
ftrablen. Es ftellen fid aber beibe in ihrer fortbildoung fo bollfommen gleid, baßi bie Unterideibung eine rein genetif he fein würbe, baber ę wohl fid redtfertigen läpt, wenn man anatomijđ bie Marfftrablen über:

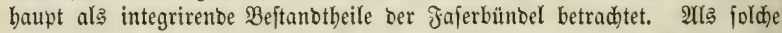
unterideiben fie fidc) von allen übrigen Beftantbeilen der Fajerbünoel, reniger burd) frorm uno Bilbung ber Drgane, als burd bie \&agerung berfelben, intem bie Längenadje ber einzelnen Bellen nicht parallel, fonbern

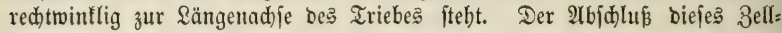
gewebes, burd bie gegenfeitige Beräftelung ber Fajerbünoel (Fig. 1-3,

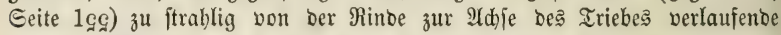
Rabien, redtffertigt bie Bezeidnung als "Strablgewebe - Actinenchym," wenn aud) in einem anderen Sinne als Şanne biefelbe verwendet, ber bas

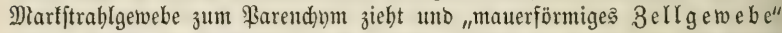
nennt, wohin es entidfieben $n i d$ t gehört, indem es in ben meiften Fällen vielmebr einem liegenten $F a j e r g e$ webe äbnlid ift (Taf. I. Fig. 5).

Dentt man fid) eine Menge von $\mathfrak{B a g e n r a ̈ b e r n}$ fo übereinanber gelegt,

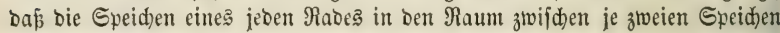
Der Nad)barräber fallen uno eingreifen (Die Seitenanfid)t in Jig. 1, Seite 131 unb bie bort gezeidneten, als Speid)enqueridnnitte zu betrad)tenden, fpindel=

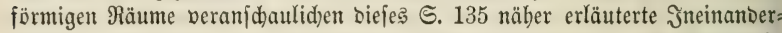
greifen); Denft mun fid bie baburd) gebildete Nabenfäule als Martfäule, bie nad) sben uno unten bis zu gegenjeitiger Berübrung ermeiterten Jelgen= fränze als Rinoemafie; Dentt man fich ferner, von ben felgentränzen aus, fürzere Speidjen mehr ober meniger weit in rabiuler Ridhtung bem Marfe zugementoet, aber bor bemfelben frei enoeno (Der $\mathfrak{B u r z e l}$ burdjidnitt

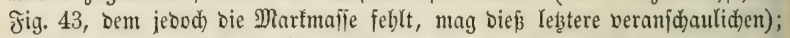
bentt man fid endlid) bie freien Räume (zlvijden ben vollfommenen Spei= d)en = primäre Marfítrablen, ztwifđen Den unvollommenen Epeiden = fecunbäre Marfjtrablen) mit Jajergetoebe auşgefüllt, fo gibt bießs ein ziem=

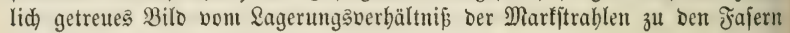

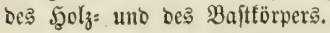

Die Bellen Der Marfitrablen bilben liegen be Reiben, beren Bellen

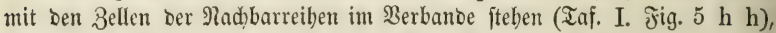
fo daß das Gemebe, von ber Seite (Jig. 5) oder im Dueridnitte des Iriebę gejeben (Taf. I. Fig. 2 p) allerbing ber Berbanoftellung von Baffiteitten in einer Mauer gleid)t. Tangentale \&ängenourd)fdnitte oder Triebesqueridnnitte bes Marfitrablgewebes zeigen entweder nur einfache Bellent= reiben (Pinus, Populus), ober eine Mlehrzabl nebeneinanber liegender Reihent (Fagus, Quercus, Taf. I. Fig. 2 p). গad) Der Zabl biefer nebenein= a noer verlaufenten Bellenreiken habe id bie Martitrablen $1,2,3 \ldots$ viellagrige, nad ber Zahl ber übereinander berlaufenden Zellenreiben

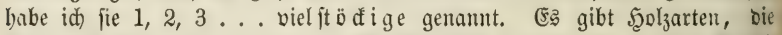
ftets uno überall mur einlagrige Marfjtrablent bejizen (bie meiften Nabel: bölzer, bie Pappeln, Weiden, Sintoen, Roftaftanien). Wo mehrlagrige Marffitrablen borbanoen fino, befteben neben ibnen ftets aud einlagrige Strablen, ba jeber fecunoäie Marfitrabl urfprünglid einlagrig ift, in feiner fortbiloung aber ebenfo toie bie primären Mart 
ftrablen mebrlagrig werben fann (Zaf. I. Jig. 2 q r). Ein blei= bender Unteridjeb jmijđjen "gropen" uno "fleinen" Marfijtrablen, bei ein un b berfelben 5olzart, befteht baber nicht; aud tann, ba bie oberen uno unteren Stodfwerfe aud) ber mehrlagrigen Martiftrahlen einlagrig fino, je nach Der sob̈he, in ber ber Dueridnnitt Des Triebes einen mebrlagrigen Marfitrahl trifft, Diejer einlagrig ericheinen. In meinen Diagnojen babe id) bie mebrlagrigen Marfitrablen mit $\mathrm{MI}$, bie einlagrigen mit $\mathrm{m}$ bejeidnet. 3u ben einlagrigen zäble idh audh biejenigen, bie nur in ben mittleren Etoďwerfen mitunter zmei=, hödjtens oreilagrig finto.

Rod fhrwanfenter als bie 3abl ber Sagen ift bie 3ahl ber Etod: werfe in ein unb serfelben Sholyart. (5s beitehen jeood aud bierin bei verjdiebenen Scolzarten nidyt jelten darafteriftijche Unterjojiebe, bie id, two fie beadtenswerth find, Durd Angabe ber mir befannten Maxima unter oem Marfftrablzeident angefübrt habe, j. $\mathfrak{3} . \frac{\mathrm{M}}{60}$ oder $\frac{\mathrm{m}}{40}$

Эn einigen Fällan fino bie mehrlagrigen Marfitrablen bon einzelnen Fajerrabien Durdjekt, 3. B. bei Carpinus (Naturgejdidte ber foritliden Eulturpflanzen Taf. 21). Id babe Marfitrablen biefer 2 trt componirt genannt unt mit $\mathrm{M} \mathrm{c}$ bezeidnet.

Die Marfftral)len find feinesิmegs fo einfad) gebaut, als biés biakner angenommen wurbe. Die Bellen ber oberften uno ber unterften Etodwerfe fint in ber Regel langitrediger, wrdjieln mit mebr ober weniger idjrägen Querideidetwänben (Taf. I. Fig. $5 \mathrm{~h} \mathrm{~h}$ ) uno fino bäufig abtweidento uno jwar linjenräumig getipfelt, währeno die Bellen Der mittleren Etodwerfe in ibren (sröfen uno Etellungäverbältniffen mebr einem liegenden, paren=

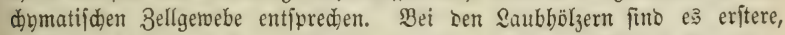

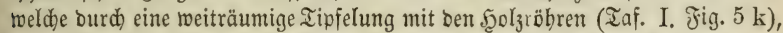

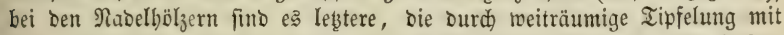
Den anliegenben Jुoljfafern communiciren (Seite 208, Jig. 31). Die linfen: räumig getipfelten Marfitrablzellen fdeinen mebr ber Gäfteleitung, Die ein= fach cylinorifa) getipfelten, mittleren Etodwerfe fdheinen mehr ber $\mathfrak{A} u$ : jpeidyerung von Rejerbeftofien bienfthar zu jein.

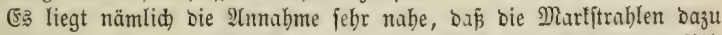
beftimmt feien, Den im Siebfajergetwebe bę Baftę rüđjdreitenben $\mathfrak{B i l}=$ bungsjaft aufzunehmen uno in bie inneren Baumtbeile überzufübren, baई bon ibnen aus nid)t allein bie Mutterzellen für Şolz uno Baft, fondern

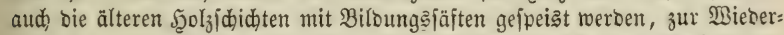
erzeugung ber jäbrlich berbraudenten Rejerveftoffe, bie fidh zun Theil in ben Marfitrablzellen felbjt ablagern. Jnoés feblt uns aud) für bieje 2Annabme Die thatfädlide $\mathfrak{B}$ egrünoung. ¿äp̧t man auf bie obere Ednittfläde eines

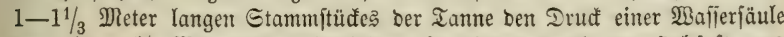
von $1^{1} / 3-1^{2} / 3$ Meter Şöhe einwirfen, fo wirb baburd) Der Sgolzjaft aub Der unteren Ednittfläd)e berauझgetrieben. Şat man bie Şoljitücfe zuvor entrindet, fo follte man meinen, es müfie ber Saft aud) aus ben geöfineten Marfftrablen nad) ausen fich ergiésen, ba biefe mit ben 5ूolzfajern in ber=

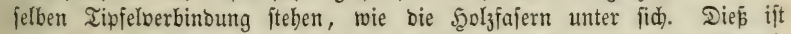
aber nidjt ber Fall, bie Marfitrablen leiten Gaft nidt nad aufent. Ringelt 


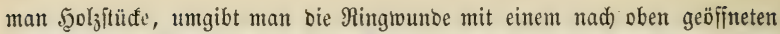
Glaşverbande, jo Daß̧ man ber Ringwunte eine gefärbte frlüifigfeit zur 2fuffaugung barbieten fann, bann fino ę bie Scolzfajern uno Şolzröbren, welche bie bargebotene flüffigfeit aufnef)men uno fortleiten, währeno bie Marfitrablen (Eid)e) ungefärbt bleiben. Jnoép babe id) bieje Berjudje erit

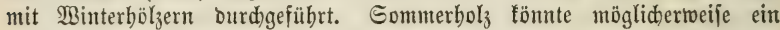

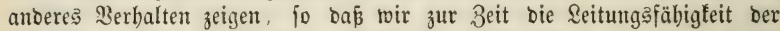

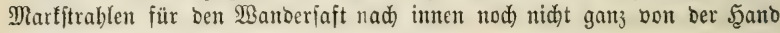
weijen bürfen.

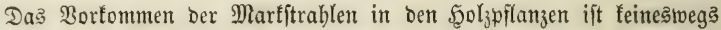
fo allgemein, als man biés bisher annahm. J゙) babe gezeigt, baß fie

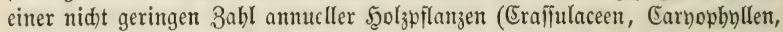

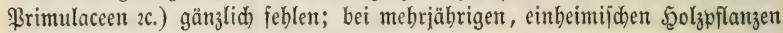
bingegen babe id) fie überall vorgefunoen.

\section{Daß đajergetwebe (Prosenchyma).}

3um Fajergewebe zäble idh alle, meift aus fajerförmigen Drganen zu=

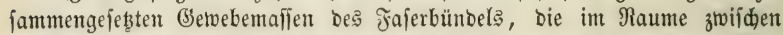
ben Marfftrablen berbreitet fino, einfobließjlid ber im Berlauf ber Ent=

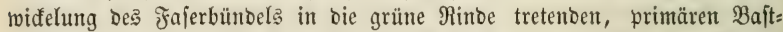

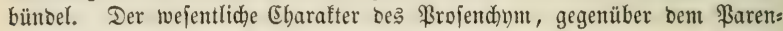
d)nm uno bem 2 ctinendfym, liegt in beffen rabialer Fortbilbung zu hori: jontal gelagerten Drganididten, fowie in bem mebr ober weniger tiefen Jnteinanbergreifen ber Fajerjpiłen jeber F̧orizontaljajidt in bie Fajer= fpiben ber über= uno ber unterliegenden Sdidten, Daber bie Drgane bieję (Setwebes nidht mit horizontalen, fondern mit idfrägen Duerwänben über: einanber fteben.

Man verfinnlid)t fich bie Stellungşgejebe biejer Getwebsmafien am beften, wenn man mehrere Bunbe Edjwefelhölzchen in einen Rreis ftelft,

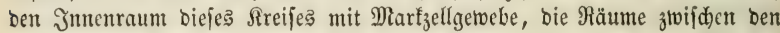

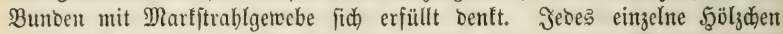
Der Bunbe repräjentirt eine Fajerzelle. Dentt mant fid bie Syölzchen beiber:

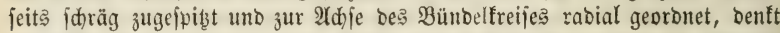
man fid) ferner mebrere folder Rreife von Sdwefelholzbunben fo überein=

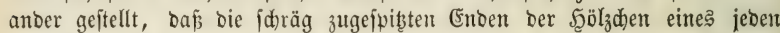
unterftehenden Bunbes in bie Buppizungsłüđen des überftehenoen Bundes eingreifen, to hat man ein ziemlid) treues Modell ber 2Horonung biejer

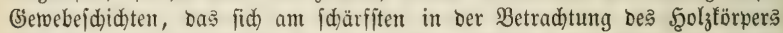

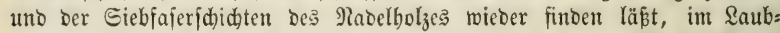

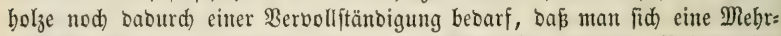
zahl reiträumiger, fenfred)t geftellter, zu Bünbelı gruppirter Röbren eine mehr ober meniger groß̧e $3 a$ hl übereinander ftehenoer Bunbe ourdziebeno uno untereinanoer verbinteno bentt.

Im jugendichen 3ujtanbe ift bie rabiale Dronung ber Fajern ober Der Şülzhen jeoes Bundes überall erfennbar. Sie erbält fid bei den Rabelbölzern mehr ober weniger vollitändig aud im fertigen 5̧olze. Bei

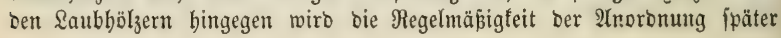


mehr ober wenizer verwijd)t, in ben cxtremen Regionen eines jeben fajer: bündels, in ber Marlid)eibe uno im Baftbünocl butd) aupergetwöhnliche

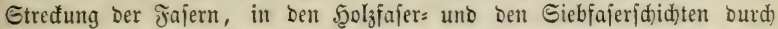
Die, mit einer Berfobiebung Der Jajern berbunoene Entitehung ber Sुolz= uno Siebröhrent.

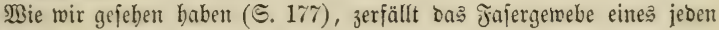
Bünbels. it

1) ben Şolyförper (Lignum),

2) Den Bafttörper (Liber).

Эd) will nadjolgeno bie wejentlidjten Berfdjicbenbeiten im Borfommen uno in Der 2Ynoronung ber vorftebeno bejdriebenten Elementarorgane aufiübren.

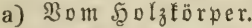

Der wejentlidjte (Sharafter aller ifm angebörenton Srgane liegt barin,

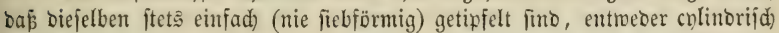
Dber linfenräumig; Daj zu bicjer Tipfelung bäufig nod) eine Epiralbiloung ber $\mathfrak{B a n o u n g e n ~ t r i t t , ~ b i e , ~ w i e ~ w i r ~ g e f e h e n ~ b a b e n , ~ e n t w e b e r ~ S p i r a l f a j e r : ~}$ biloung oder piralige \&eiftenbiloung ift (Eeite 209-212). In Den Baits bündeln ber Giebfaferidjidten babe idh critere nie, lebtere nur bei Lavatera und Malope aufgefunder.

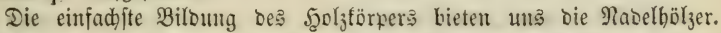
2lbgejeben von ben bisweilen getipfelten Epiralgefäpen Deß Marfcylinbers, abgejeben von Den Şarzgängen ber Sicfern, Jiddten, Särd)en, abgejehen von ben 3ellfajern Der (Enprefien, beftebt Der Şolztörper żmijd)en den Marf: ftrablen bier nur aus linjenräuntig getipfelten \$colzfajern, bie jebr regel=

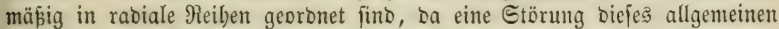

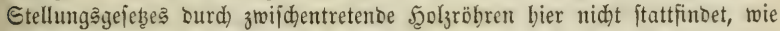
diés bei Den Raubbölzern bäufig ber fall ift. Der Dueridnitt $\mathrm{c}-\mathrm{f}$, Geite 177, テ̛ig. 22, ponie Fig. 33 fanm biejür als $\mathfrak{A b b i l o u n g ~ g e l t e n . ~}$ Jig. 22 jehen wir bie Yeţten Jajern Des Şolzrings im Bergleid) zut bent

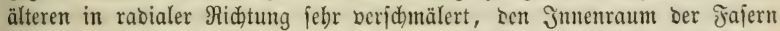
baburd) bis auf ein Minimum berengt, bie Iipfel nid)t auf ber ben Marf= ftrablen, fontern auf ber ber Rinde jugewendeten Geite ftehen. Jah babe

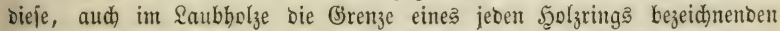
Jajern, in begenjabe zu ben früber gebilbeten "Runbfajern" Breitfajern genamut.

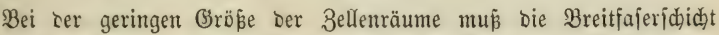
Den Did)teren uno fdwereren, baher aud) brennfräftigeren Ibeil einer jeben Jabreslage bilden. Bei Den Rabelhölzern erreid)t fie eine bebeutente Breite uno ift, im Berbältnif́zur Breite oes ganzen Jabresringes um fo breiter, je fdjmaler bie Jabrešringe fino. Daber ift bas fdmal=

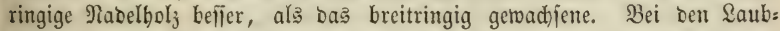
bölzern ift eine Breitfajerididst zwar aud borbanben, ftets aber fo fdumal

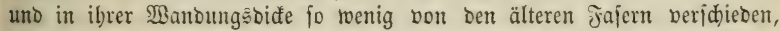
ז Begentheil fino bie breitringig gewadjenten harten Raubbölzer befier als bie idmulringig getoadjenen, ba leb̧tere berbältnifmäßjig viel mebr weit=

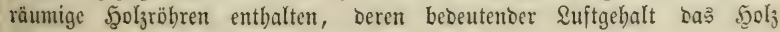


leidter mad)t. Man fann fid bavon burd ben Bergleid ber inneriten uno Der äuseriften Şolzlagen alter (Fid)en leidst überzeugen.

Weit zulammengeję̧ter ift bas ફ̧olz ber Laubhölzer.

Betradten wir ben Queridnitt eines rcdit üppig gewadjenen brei bis vierjäbrigen (Eidentriebes, am beften von einer fräftig getwadjenen Stod: lohbe entnommen, nad) ber (Blättung mit eintem fehr fdarfen Mefier, ver= mitteljt einer guten, einfaden ober beffer nod), vermitteljt einer Doppel= lupe, fo erfennen wir zwifden je zwei Marfiftrablen uno ben beiben Jahr= ringgrenzen eine $2 \mathfrak{2}$ zabl gröperer unb fleiterer runber Deffmungen - bie Durdjidnitte ber 5̧olzröbren - um uno aujer biejen, Bänoer uno ßeid)= nungen, bie burd hellere uno mattere färbung bon einem buntleren uno glänzenben freloe merflid) abjtechen.

Fig. 42.

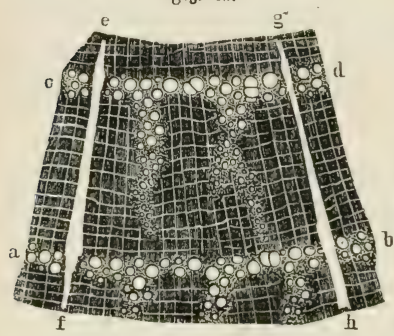

Die nebenitebenbe Fig. 42 zeigt einen folden Dueridnitt. a b, ed fint bie Srenzen eines Sholzringes, e $f, g$ fino zwei breite Marfftrab= len, zwifden benen eine große $3 a b l$ jebr fdmaler, in gleidjer, rabialer Ridutung verlaufender Marfitrablen ourd) bellere förbung herbortreten. Die Jelber zrwijhen biejen fleinen Marfjtrablen werben gebilbet von Den Queridnnitten fehr bifwanbiger, cylinorifd getipfelter $\mathfrak{g}_{\mathrm{O}}=$ fafern (હ. 228 , Jig. 41,3 , Taf. I. Fig. $2 \mathrm{c}$, Jig. $5 \mathrm{c}$ ), bie id) in meinen Diagnofen mit h bezeidnet babe (mit $\frac{\mathrm{h}}{\mathrm{m}}$, wenn biefe Jajern mehlfübreno fint). ${ }^{1}$ Die rabialen Streifen fehen wir von einer Mebrzabl peripherijd verlaufender, hefler und matter Bänder unterbrodjen, bie ibrerjeits von bett Marfjtrahlrabien burdję̧t werben. (5马 fino dief Complexe von $S_{\text {did }}$ tazellfajern, in ben Diagnojen mit $\mathrm{s}$ be= zeidnet (Taf. I. łig. 2 e, f̧ig. 5 g).

Diefen Theil bes Dueridnitt?: Nharfftrablen, cylinorifd getipfelte $\mathfrak{S g l}_{\mathfrak{z}}=$

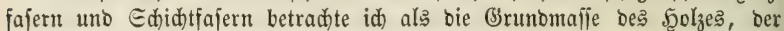
bas ober bie $\Re$ öhrenbünbel eingejprengt fino. Wir fehen in ber Figur

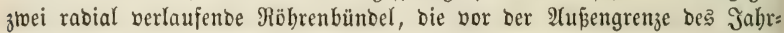
rings aufbören, au ber Innengrenze beffelben zu einem peripherifd ber= laufenben Bünbel (c d) fid vereinen.

Dieje Röhrenbünbel des Şoljłörpers befteben nun aus brei veridjie: Denen $2\left(r t e n\right.$ bon (Elementarorganten: 1) aus ben meiträumigen $\mathfrak{g}_{0} \mathfrak{l}_{z} \mathfrak{r}$ b̆ ren (Eeite 228, Jig. 41, 1; Taj. I. Fig. 2 d, Fig. 5 a), aus linfen=

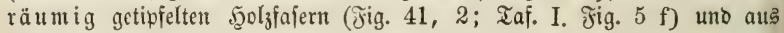
3ellfafern (Jig. 41, 4; Taf. 1. Fig. 5 d). Eritere fino in ben Diagnofen

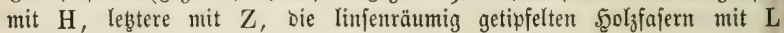

1 Da bie Gdidtfajern (s) und die Belfajeru ber Röhrenbündel (Z) überall mebl= fübrend fino, wurbe eine bem entfpreḑent ähnlide Bezeidnung in ber Diagnoje nidt nơthig. 
bejeidnet. Wo in biejen Drganen neben ber Tipfelung zugleid aud eine fpiralige Seiftung vorfommt, babe id) $\frac{\mathrm{H}}{\mathrm{sp}}$ ooer $\frac{\mathrm{L}}{\mathrm{sp}}$ gejdjrieben.

Die Diagnofe für bas (Eid)enbolz mürbe bemnad fein

$$
\text { (h s) + (H L Z), }
$$

(h s) bie Grunbmaile, (H L Z) bie 3ujammenjebung Der Röbrenbünbel bezeidjuntio.

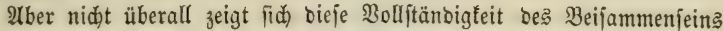
aller Elementarorgane. E马 feblt ba马 eine ober bas anbere, oder mebrere ober viele berfelben zugleid, bis zu ben Rabelfölzern binab, in benen fie alle bis auf ztwei ober auf nur eins geidrounden find (Abies Araucaria).

Dả Nadfolgenoe mag eine georängte Ueberfid)t bes von mir über biejen Gegenftano Publicirten (Bot. 3eitung 1859, S. 105) geben, be:

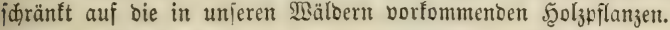

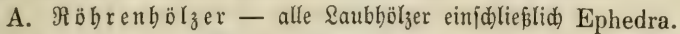

I. Nur breite Markjtrablen (unbeoingt ooer ood) für bie 2 nficht mit bem einfachen Bergrößerungäglaje).

a) Die 5ूolzröbren zerjtreut im ganzen Jabrešringe.

Vitis: $\frac{\mathrm{h}}{\mathrm{m}} \mathrm{s}+(\mathrm{R} \mathrm{Z})$.

Platanus: hs + (R L Z).

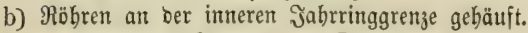

Clematis: $\frac{\mathrm{h}}{\mathrm{m}} \mathrm{s}+\left(\mathrm{R} \frac{\mathrm{L}}{\mathrm{sp}} \mathrm{Z}\right)$.

Atragene: $\left(\frac{\mathrm{R}}{\mathrm{sp}} \frac{\mathrm{L}}{\mathrm{sp}}\right)$.

c) Röhren in Bünoeln, auf Dem Queridnitt benoritijd ver= zweigt.

Berberis: $\frac{\mathrm{h}}{\mathrm{m}}+\left(\frac{\mathrm{R}}{\mathrm{sp}} \frac{\mathrm{L}}{\mathrm{sp}} \mathrm{Z}\right)$.

II. Breite unb jehr jabmale Marfitrablen, leb̧tere nidht ober ood niđbt regelmäßig zu breiten Marfftrablen fich erweiterno.

a) Die Şolzröbren zerftreut in ganzen Jabresringe.

1) Die groken Marffitrablen felten uno ourdjiekt.

Alnus: $s+(\mathrm{R} \mathrm{L})$.

2) Die gropen Marfftrablen bäufig uno ourdję̧t.

Carpinus: $\mathrm{h} \mathrm{s}+\left(\frac{\mathrm{R}}{\mathrm{sp}} \mathrm{Z}\right)$.

3) Die gropen Marfitrablen bäufig uno geidlotien.

Fagus: h s + (R L Z) - Viscum.

b) Die Şolzröbren an ber inneren Ringgrenze gebäuft.

Rosa: $\frac{\mathrm{h}}{\mathrm{m}} \mathrm{s}+\left(\frac{\mathrm{R}}{\mathrm{sp}} \frac{\mathrm{L}}{\mathrm{sp}} \mathrm{Z}\right)$.

Rubus: $\frac{\mathrm{h}}{\mathrm{m}} \mathrm{s}+(\mathrm{RL} \mathrm{Z})$.

Ribes: $\frac{h}{m}+(\mathrm{RL})$.

c) Die 5̧olzröbren zu umfangreidjeren Bünbeln bereint, von ber inneren Brrenze rabial nad ausen berlaufent.

Quercus: hs + (RLZ). Corylus: hs + (R Z). 
III. Ein IInteridjed in ber Breite Der Marfitrablen ijt ztwar nod erfennbar, beidränft jid aber auf bas 2 ki 3 fache ber Breite fleinfter Marfitrablen.

a) Die Şolžröbren zerftreut im ganzen Jabreşringe.

Acer: $\frac{\mathrm{h}}{\mathrm{m}}+\left(\frac{\mathrm{R}}{\mathrm{sp}} \mathrm{Z}\right)$ Liriodendron: $\mathrm{h}+\mathrm{R}$;

Philadelphus, Ilex: ( $\left.\frac{\mathrm{L}}{\mathrm{sp}} \mathrm{Z}\right)$. Cornus:

$$
\mathrm{s}+(\mathrm{RL}) \text {. }
$$

b) Die Şolzröbren an ber inneren Ringgrenze gebäuft, bie übrigen zerftreut.

Ligustrum: h s + (R L Z). Amygdalus, Prunus, Cerasus, Padus: hs $+\left(\frac{\mathrm{R}}{\mathrm{sp}} \mathrm{L}\right)$. Pyrus, Sorbus: s + (R L Z). Torminaria, Aria, Cydonia, Chamaemespilus, Amelanchier, Crataegus: $s+\left(\frac{R}{s p} L\right)$. Mespilus: $s+$ $\left(\frac{R}{s p} \frac{L}{s p} Z\right)$. Sambucus: $\frac{h}{m}+R$.

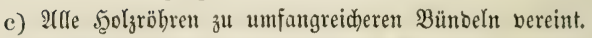

1) Röhrenbünoel an ber inneren Ringgrenze gebäuft, bie äup̧eren in concentrifdent Sdichten.

Morus: h s $+\left(\frac{\mathrm{R}}{\mathrm{sp}} \frac{\mathrm{L}}{\mathrm{sp}} \mathrm{Z}\right)$. Celtis, Ornus, Fraxinus: $\mathrm{RLZ}$.

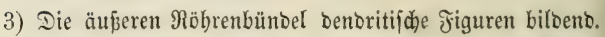

Lycium: h s $+\left(\frac{\mathrm{R}}{\mathrm{sp}} \frac{\mathrm{L}}{\mathrm{sp}} \mathrm{Z}\right)$. Ostrya: h $\mathrm{s}+\left(\frac{\mathrm{K}}{\mathrm{sp}} \mathrm{Z}\right)$. Rhamnus: $h+\left(R \frac{L}{s p}\right)$. Ptelea: $h+\left(\frac{R}{s p} \frac{L}{s p} Z\right)$. Ulmus: $h+\left(\frac{R}{s p} Z\right)$. Evonymus: $h+\left(\frac{R}{s p} \frac{L}{s p}\right)$. Robinia, Caragana, Cytisus: $\frac{\mathrm{h}}{\mathrm{m}}+\left(\mathrm{R} \frac{\mathrm{L}}{\mathrm{sp}} \mathrm{Z}\right)$. Genista, Colutea, Sarothamnus: $\frac{\mathrm{h}}{\mathrm{m}}+$ $\left(\frac{\mathrm{R}}{\mathrm{sp}} \frac{\mathrm{L}}{\mathrm{sp}} \mathrm{Z}\right)$.

IV. Nur fdumale Marfftrablen von gleider Breite.

a) Die Sgoljröhren zerftreut im ganzen Jabreşringe.

Tilia: h s $+\left(\frac{\mathrm{R}}{\mathrm{sp}} \mathrm{Z}\right)$. Aesculus: $\mathrm{h}+\left(\mathrm{R} \frac{\mathrm{R}}{\mathrm{sp}} \mathrm{Z}\right)$. Populus: h $\mathrm{m}+(\mathrm{RZ})$. Betula: $\mathrm{s}+(\mathrm{R} \mathrm{L})$. Buxus: $\left(\frac{\mathrm{R}}{\mathrm{sp}} \frac{\mathrm{L}}{\mathrm{sp}} \mathrm{Z}\right)$. Staphylea: $\left(\frac{\mathrm{R}}{\mathrm{sp}} \mathrm{L} \mathrm{Z}\right)$. Vaccinium: h $\mathrm{m}+(\mathrm{R} \mathrm{L})$. Rhododendron, $\mathrm{Ca}$ lunna ete. ( $\mathrm{R} \mathrm{L} \mathrm{Z).}$

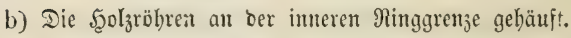

Juglans, Carya: h $s+(R \mathrm{Z})$. Salix: $\frac{\mathrm{h}}{\mathrm{m}}+\mathrm{R}$. 
Lonicera, Viburnum: $s+\left(\frac{\mathrm{R}}{\mathrm{sp}} \frac{\mathrm{L}}{\mathrm{sp}}\right)$. Frangula: $\frac{\mathrm{h}}{\mathrm{m}}+(\mathrm{R} \mathrm{Z})$. Hippophäe: $\left(\mathrm{R} \frac{\mathrm{L}}{\mathrm{sp}} \mathrm{Z}\right)$.

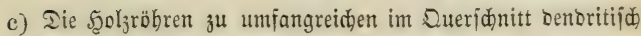
geftalteten Bündeln vereint.

Castanea: h s + (R L Z). Daphne: $h+\left(\frac{R}{s p} \frac{L}{s p} Z\right)$.

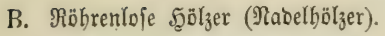

I. Mit Şarzgängen (H Z).

Pinus, Cedrus, Larix, Picea: L $+\mathrm{HZ}$.

II. Ohne Şarzgänge:

a) Mit Bellfajern.

Juniperus: L Z.

b) Dhne Bellfajern.

Taxus: $\frac{\mathrm{L}}{\mathrm{sp}}$. Abies: L.

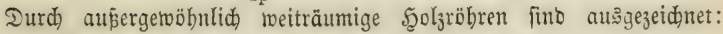
Quercus, Fraxinus, Castanea, Juglans, Robinia, Norus, Ailanthus, Ulmus, Hippophaë; von fleineren א̧̋̈lzern: Vitis, Clematis, Atragene. Celastrus, Aristolochia, Thecoma, Nenispermum, alles $\in_{d y}$ lingprlanjen!

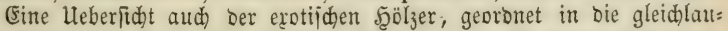
tenton Diagnojen, habe id in Der Bot. Beitung von v. Mohl uno v. Ed) led)= tentoal 1859 , S. 105 gegeben.

Ylle in 3orftebenbem aufgeführten, Den Marffitrablen uno Der 3 er: theilung Der Röhrenbündel entnommenen Gruppendaraftere fino fithon ber Betrachtung fobarfer Dueridnitte bermitteljt ber einfachen supe zu ent= nebmen. 2lbjictlid habe idy bie feimeren anatomifden Unterfobiebe in ber 3abl Der Ragerungen und Etodwerfe bes Marfitrabls vermieden, um Der

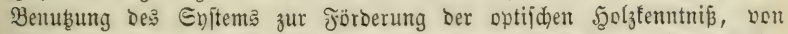
Eeiten beß Forftmanne nid)t entgegenjutreten. Die Scoljoiagnofen ber ein= zelnen (Sattungen fino alleroings nur Durd) bas zujammengejeb̧te Mifroifop วu verfolgen, fönnen Daher für Den mit biejem Injtrumente nidbt bertrauten

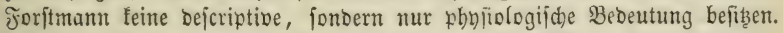

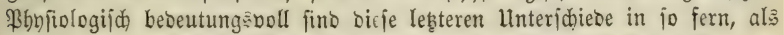
fie Jingerzeige geken in Bejug auf bie abjolute Rotbmentigteit biejer oder

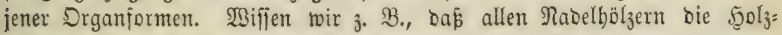
röhren fehlen, ohne daj baburch irgeno eine ber widtigeren uns befannten Sebenterjdinungen eine 2 (bänderung erleibet, fo berliert Laburd) bie $5_{2} \mathrm{I}_{3}=$

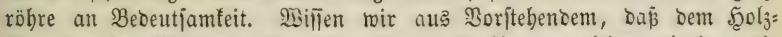
förper bieler Bflanjen bie cylinorifłe, Daj bingegen feiner einjigen bie linjentäumige Tipfelung fehlt, fo mülīen wir leb̧terer eine größere Bebeutung beilegen, ala erfterer.

Die kbyfiologifche Bebeutung bes Şolzlörpers ift junädjt bie einer jeften uno bauerbaften Etütze aller jüngeren uno jüngiten Baumtheile

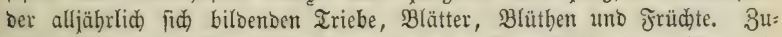
gleid) ifit ber Şoljförner aber auch berjenige Baumtheil, in reldyem bie

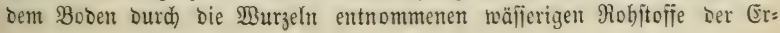


näbrung bis in bie Blätter bes (Sipfels emporfteigen. Die äd)ten, einfachen

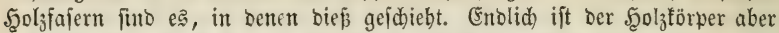
aud) Magazin für eine niḑt unbeträdhtlidhe Mentge von Rejerbeftoffen, bie fid) alljäbrlid, bejonbers in ben Bellen bes Marfitrablgetwebes uno in benen Der Bellfajern anjammelu, reid)licher in ber $\mathfrak{B u r}_{3} \mathrm{ll}$, als im oberirbifden Stamme. Bei mandent Sgolzarten nelymen aud bie einfadjen Fुolzfafern bieran Theil, mie bieß bie vorftebenten Diagnofen burd bie Bezeid)nung $\frac{\mathrm{h}}{\mathrm{m}}$ nad)weifen. Die linfenräumig getipfelten $\mathfrak{S}_{0} l_{3}$ fajern fübren nie Referveftoffe.

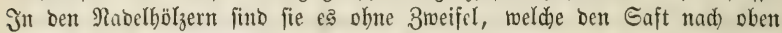
fübren, da fie allein ben Faferbeftano bilden (Abies). In ben \&aubbölzern

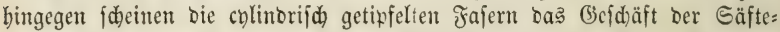

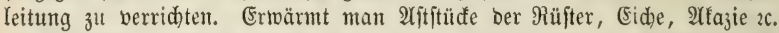

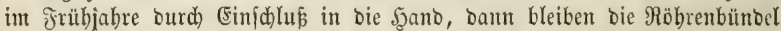
aus R L Z troden, wäbreno bie Queridnnittfläd(hen ber cylintorifd) getipfelten

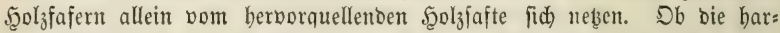
zigen Secrete in Den Şarzgängen Der Riefern, Fiddten uno Särdsen zu Den Rejerveftoffen gerechnet werben bürfen, ift febr zweifelhaft. Bis jebt babe id) ftets nur 2luffpeiderung, nie eine Minberung ber şarze wie ber äthe= rificen Dele rabrgenommen.

b) Bom Baft f̈rper.

Der Bajt, nad) immen vom Scolfförper, nad) aupen von ber grünen Rinbe begrenzt (Taf. I. jig. $2 \mathrm{f}-\mathrm{i}$ ), befteht wie ber Sgolzförper aus Jahre⿻彐丨=

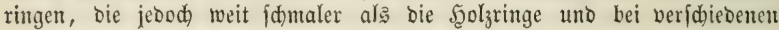
Şolzarten verid)ieben breit fino; äußerft fdimal bei Budbe, Şainbuche, (Eibe; febr breit bei Eidje, Rüfter, Sinde. Die Sdjidjtenbifoung fieht man am beften an Duerfdnitten 4 bis 5jähriger Rindentriebe; es ift beren $3 a b l$

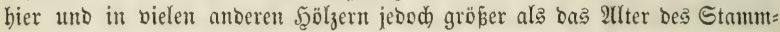
theils, Daburd), Daßj alljäbrlid) 2 bis 3 Sdjidten von Baftbünbeln in jeber Jabreşjoidjt gebildet weroen, woourd) bie twirfliden Jahrringgrenzen fid verwifichen.

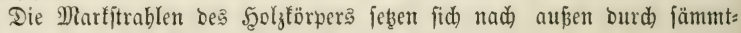
lide Sdjidten Des Bajtes binourd) obne Unterbred)ung fort; ihre Bellen fino aber im Bajte fiebförmig getipfelt uno büntwantiger.

3wifden je zweien Marfjtrablen befteht bas Bajtgemebe aus Sieb= fafern, Siebröbren uno fiebförmig getipfelten Bellfafern,

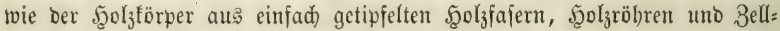
fajern befteht. Allle bieje Drgane fino uno bleiben ftets im bünmantigen Eambialzuftante. Die Den Baft im tednif bündelfafern entfteben erft fpäter aus vorgebildeten Siebfafern, zwar bei ben meiften, aber nidht bei allen Şolzarten, z. B. nid)t bei Pinus, Populus, Fraxinus.

2(ud) bie 2 noronung bes Siebfajergemebes ift ber bes Sholzgetwebes entipredent. Wie bie Şolzfajern bilden aud bie Siebfafern rabiale Reiben, beren Jajern mit ben Jajern ber Nadbarreiben im Berbande liegen. Wie bort fo theilen aud) bier bie Bellfajern biefe 21noronung, wie oort fino aud) bier bie Röbren unregelmäpig Dem jajergenebe eingeftreut. (Ein wirt: 
lider, bleibenber llnterfdieb befteht baher nur in ber fiebförmigen Tipfe= lung, in bem Berharren ber Jajermände im cambialen, b. h. eintwanbigen 3ujtande und in bem bleibenden Borbandenjein eines Ptndjodefallaude? (Eeite 211, Jig. 33 a, b), Der in Der Şolzjajer zur fecunbären Fajerwano fid entricifelt hat (bajelbjt §ig. $33 \mathrm{c}-\mathrm{f}$ ).

Seite 177 Fig. 22 bezeidnet $\frac{\mathrm{h}}{\mathrm{b}}$ bie Durd) bie permanenten Mutter=

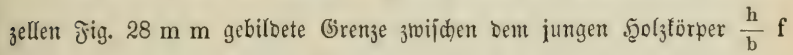

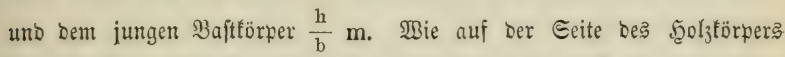
Die Şolzröhren dd (Geite 228 Fig. 41, 1) aus einer Berjdmelzung von Jajerzellen herborgełen, wie im umiange biefer Şolzröhren linfenräumig

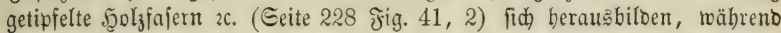

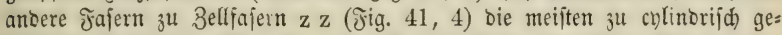

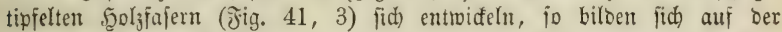
Seite bes jungen Bafttörpers unter Denjelben llmbiloungşborgängen äbn= lidhe, aber fiebförmig getipfelte Drganformen, bie id Seite 177 frig. 22

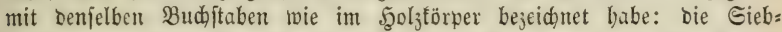
röbren $\mathrm{d}=$ Eeite 228 テig. 41, 5, bie Eiebfafern $\mathrm{x}=$ Jig. 41 , b uno bie Eiebzellfajern $\mathrm{z}=$ Jig. 41, \%. Man fönnte bie Bajtbündelfajer

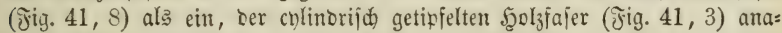
loges Gebiloe betradten, allein leb̨tere ift entidiecen protomorwh, erftere eben jo entidieben metamorph, D. h. aus vorgebildoten Eicbfajern uno Siebzellfajern heroorgebent.

Ille einjäbrigen, aber nur eine geringe $3 a \mathfrak{h l}$ mehrjäbriger Şolz̧flanzen (Fraxinus, Populus, Pinus) biloen in ibren Bajtidideten nur Siebfajer= gervebe, abgejeben bom primären, in bie Rimbe tretenten Bajtjajerbünoel

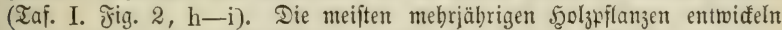
auker biefem primären Bajtbündel in jeber Jahreslage bes Bajtes eine ober mebrere concentrifde, Durd bie Marfitrablen unterbrodene Edidtungen von Baftfajerbünbeln, Deren Seite 177 Fig. 22 zmei, bei $m$ unt a, auker Den primären Bünbeln t bargeftellt fint. Bereiţ Geite 231 babe id̆ gefagt, Dáp bieje febr langitrectigen, biftwanbigen, in ben Bündelıt ganz unge= oroneten Fajern metamorphijde Drgane fcien, bie aus vorgebiloeten Siebfajern entjteben uno in ibrer gegenjeitigen Beräjtelung baß bilden, waß mir ben Baft nennen. Serjenft man ben Bafttörper ber Sinbe, Rüjter, Papiermaulbeeren 2c. Yängere 3eit in ftehenbes $\mathfrak{B a}$ ajer, fo berfaulen forohl Daß Bellgemebe Der Martitrablen, als bas zwifden Den Bajtfajerbünoln lagernoe Siebfajergemebe (Seite 177 Fig. 22, f-g), ę bleiben nur bie Bajtbündel $(\mathrm{m}, \mathrm{a}, \mathrm{t})$ unverleţt; fie trennen fid fablententweife wie bie Blätter eines Budes (baher "liber") in jeber Edidjt ben 3ujammenhang

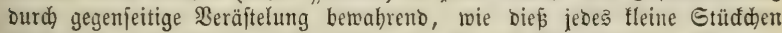

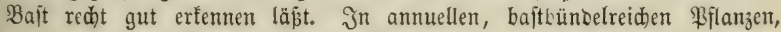

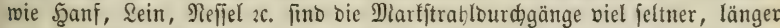
uno fommäler, bie frajern legen fid gerabliniger aneinantor, tremten fid

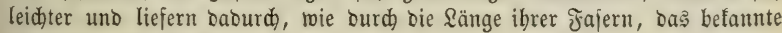
Material zum Beripinnen. 
Das Snftem Der Bajtfajern fowohl wie das Siebfafergemebe erleibet vom Jabre Der Entftebung ab einen 3uwad) surd) Bellenmehrung nidjt mehr. Der Bafttörper 1 a Eeite 177 Fig. $21 \mathrm{im}$ einjährigen Triebe befizgt fdhon Die Grobe, wie berielbe Theil $1 \mathrm{f}$ im jedjsjährigen Iriebe. Der mit zunehmender Dide Des Triebs nothmentig fid) erweiternde Raum zwifden je zmeien gleich) alten Baftbünoeln füllt fich bis zul einem gewiffen Illter burd) fortbauernbe Bellenmehrung Des zwifd)enliegenden Martftrahlgetwebes.

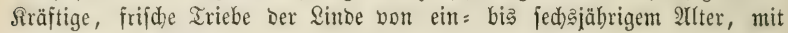
ber Supe auf fajarfen Duerid)nitten betrad)tet uno verglidjen, zeigen bief

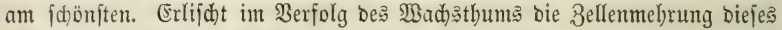
(jemekes, fo wie bes Rinbejellgeivebes, Daun müfien notbmendig Sängsirifie im Mindeförper entîteben, bie bis zur Tiefe bes nod mehrungäfähigen Marf́: jtrablgntwebes einjdneiben, mit bem Abjterben beffelben von aupen nad)

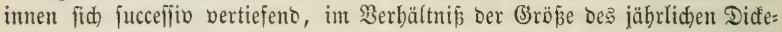

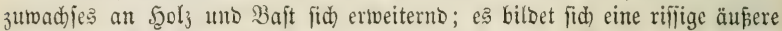

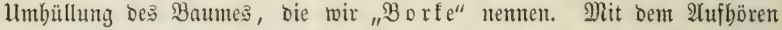

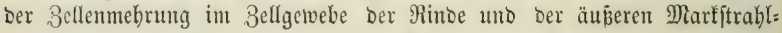
enben beginnt bie gropartigite aller Rejorbtionserideinungen, inoem all:

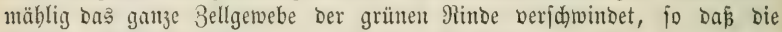
älteften, äuperftent Baftlagen unmittelbar Dem Sortgetwebe fich) anlegen (i. bie

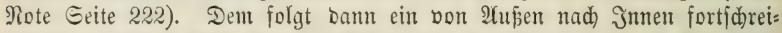

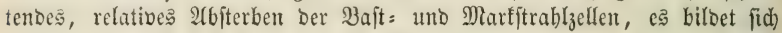

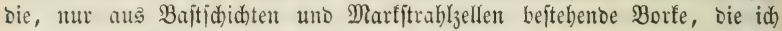
zum Unteridiebe anderer Borfebilisungen "Baft borfe" genannt babe (Eid)e, Eiche, Rüjter (z. Ihb.) Pappel, Weide, Sinbe, Riefer, Särdhe zc.). Heber bie, Dem relativen 2(bfterben ber Baftidid)ten vorbergehende 3wifhenbildung von Siortididten babe id) bei ber Betradtung bes Rorffellgetwebes aus: führlid) gejproden (Seite 221).

Ibgefeben bon Den Junftionen ies Bajtförpers in Bezug auf bie eigene fortbildung, bient berjelbe, in Bezug auj bie ganze \$Flanje, ber Rüdleitung Des Durd) Die Blätter bereitenden Biloungşafts in alle tieferen Biflanzentheile. Es geht bick hervor, nid)t allein aus bem weiterhin bas: gelegten Einflufie vou Ringivunden auf bie Ernäbrung uno Fortbiloung aller tieferen Baumtheile, fonoern aud) aus bem Eeite 196 Dargelegten Ser: $^{2}$

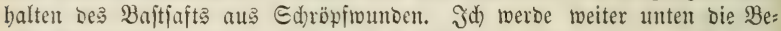

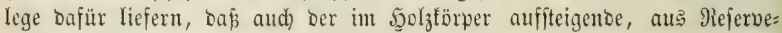

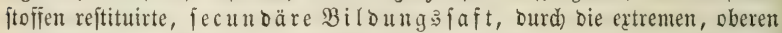
Baumtheile in Den Bajt übergehen müfie, um, wie ber primäre Biloungs: faft in biejem rüđjd)reiteno, von ba aus allen zu ernäbrenben Bauntbeilen zugeben zu fömen.

Die Fortbetwegung bes rüdjdreitenben Manberfafts gejdiebt aus: id)liejlich im Sicbfajergewebe Der Bajtididaten. In Den anajtomofirenden

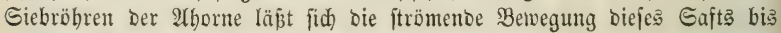
it Daß Blattgeäber binein unmittelbar beobadten. Mcldje Rolle bierbei Den Eiebfajern zugetheilt ijt, bermag idh bis jeb̧t nod nid)t anzugebent. Die

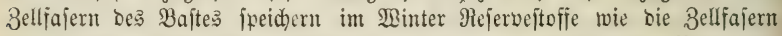
Des Sgoljes, vorberridhento Gerbjtoff. Leber bie phofiologifde Bebeutung 
jdidnitte, bie id in meiner Naturgejdidte Der forftliden Eulturpflanzen Iaf. 2 (Jidite), Iaf. 18 Jig. 15 bis 17, Iaf. 30 (Riefer), Taf. 28 unto 45 (37) (Birte) gegeben babe, mögen das Weitere erläutern. Şier muß id mid) Darauf bejd)ränfen, Die Analogien zwijhen Den Drganjuftemen bes Blattes uno bes Etengels angebentet zu haben, damit Der \&ejer Ed)lüffe

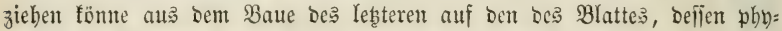
fiologifohe Bebeutung ziemlid) flar ausgefprod)en ift, in ber meift flädhen= förmigen Berbreitung Der Blatticheibe, in Deren Berbalten zum Sidote, wie in oer Soblenjäureaufnahme, Sauerftofi = uno Mafferounftausfheioung bes:

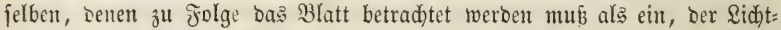
rwirfung in höherem Grrabe als alle übrigen Bilanzentheile jugänglides Drgan, Durd bas bie Bflanze zugleid ibre 2 úsenfläde all= jäbrlid um bas Bielfade vergröfert, um bent atmofphärifonen

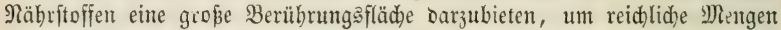

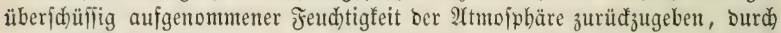

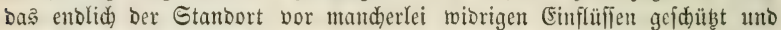
Dem Boben alljäbrlich ein beträdtlicher Theil, Der 2 tmwofphäre uno bem Boben entzogener Stoffe, im Blattabfalle als Dungntaterial zurüdgegeben wirb, obne bie er in feiner grudtbarfeit fid nid)t erbalten fann. Heber

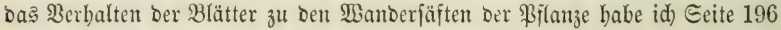
meine $2(n$ id $)$ ten ausgefprodjen.

g. Abreidungen vou Borfteberbem im Bau ber $\mathfrak{B} u$ rzel.

WBir haben gejeben (Seite 174), baß̄ bie Unbiloung Der Bellen zu Fajern in Stengel bündelweife gejdiebt un๖ daß bie Fajerbündel um einen imneren, cylintorifden, zetlig bleibenben Marfförper fid gruppiren. Das ift

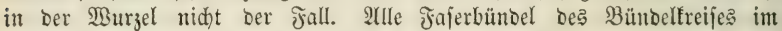
Etengel vereinen fid) in ber Murzel zu cinem centralen Jajerbünoel. (Ë

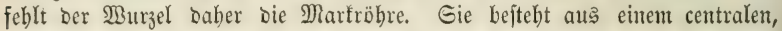
alljäbrlid wie Der Gtamm Durd) concentrifde von Martjtrablen Durdjekbte

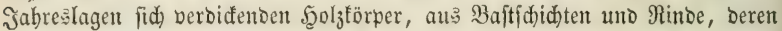
Bau uno Entwidfelungs̄berlauf im $\mathfrak{B e j e n t l i d j e n ~ b i e j e l b e n ~ f i n o ~ w i e ~ i m ~ E t e n g e l , ~}$

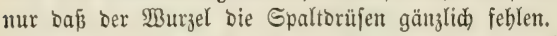

(Ein jebr wejentlider unt folgenteider llnterjuied zeigt fid aber in

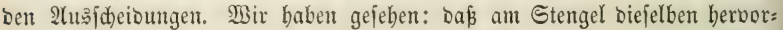
gehen, theils aus einer nad) anken geridteten $2(b$ zw weigung cinzelner Fajer: bündel ober Fajerbüntoltbeile (Blattausfacioung Seite 133), theils aus einer Beräftelung Derjelben in Der Blattadjel (Sinojpenbildoung Seite 144).

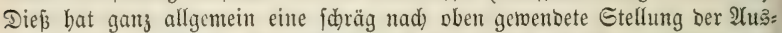
faceibungen zur Folge, bie jugleid) nad) bejtimmten (bejeţen auftreten uno fich wieberbolen. Daber bie llebereinftimmung in Blattjtellung, Beaftung

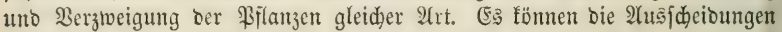
am auffiteigenton Stode entlid) nur am einjährigen, frautigen Iriebe ent= fteben, baher Dent aud), abgejeben bon Reprobuftionas:(Erjd)einungen, ben

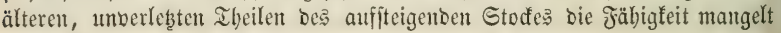

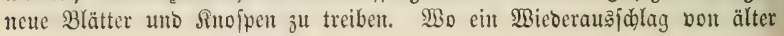


als einjäbrigen Iheilen bes alfiteigenden Stodes ftattinnot, ba entipringt er entweber einer bereits am frautigen Triebe gebilbeten aber in Der Ent=

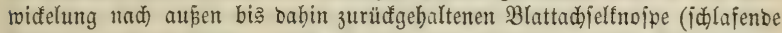
$\mathfrak{A}$ (ugen - Eryptoblafte), oocr er feb̧t eine borhergegangene Berwuntoung

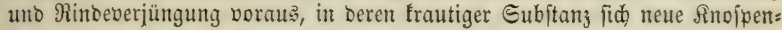
feime biloen fömen (2lobentibfnofpen).

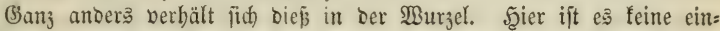
fache Beräftelung uno $\mathfrak{Y}$ uşcheioung von Fajerbündeln bes Bünbelfreifes,

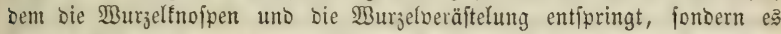
ift bas 3ellgewebe eines vorgebildeten Marfitrahla, bas fid jur (Sirunolage

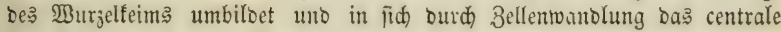
Fajerbünol bes neuen $\mathfrak{B u r z e l a j t e s ~ e n t r i d e l t . ~}$

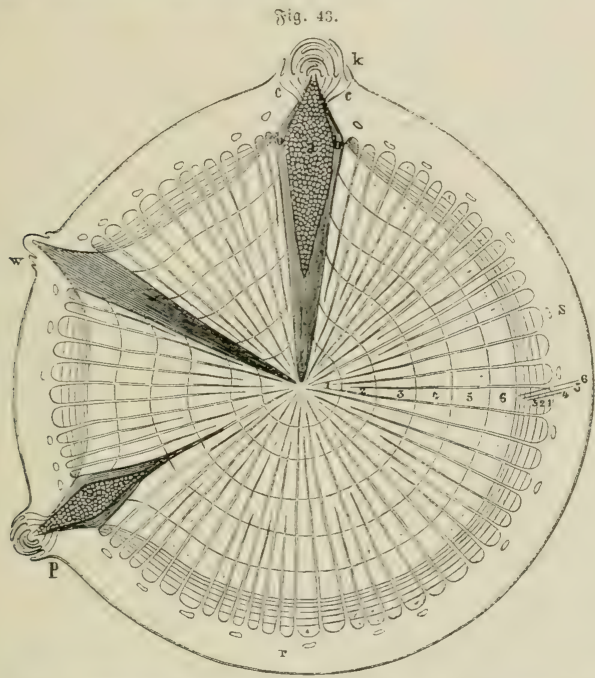

Jn ber voritehenden figur 43 gebe id ben Queridnitt eine jeds: jährigen Wurzeljtranges ber \$appel. Die Marfröbre fehlt. Den jechs,

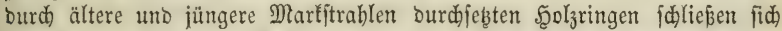
eben fo viele fobmälere Baftlagen an, Deren gleidzeitige Entfitebung mit Den Solzlagen Durd) gleidje Zahlen bejeidjnet ijt. In ber bie Baftlagen um=

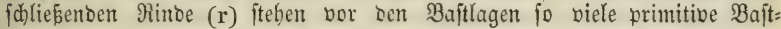
bünol (h-i Eeite 177) als ber imnerite Sgolzring Marfjtrablen zäblt, ba mit Dem Simzutreten neuer Marfftrablen in fpäteren Jabren nidjt gleid): zeitig aud) eine Theilung ober Mebrung biejer primären Bajtbünoel ftatt= findet. Drei ber Marfitrablen baben fid zu Grunbitüfen neuer Murzel= feime (w) ober neuer Wurzelbrutfnojpen $\mathrm{k} p$ ausgebildet, bon Denen bie 
obere $(\mathrm{k})$ id)on in ber einjäbrigen $\mathfrak{W}$ urzel, bie untere $(\mathrm{p})$ erfit in ber vier=

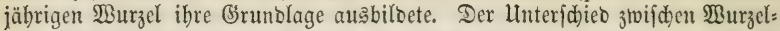
und Burzelbrutfnoipe bejteht, wie bie Figur anbeutet, mur barin, bas in erjterer (w) alle Drgane zu Fajern fid) umgebildet haben, bie Marfröbre fehlt, wäbreno in ber $\mathfrak{B}$ urzelbruttnoipe $(\mathrm{pk})$ ein innerer Complex $\mathrm{z} u$ Marfgetwebe (a) fid) ausgebildet bat, woourd) bas biejes umgekento fajer: gewebe, zu einem Bündelfreife georonet, wie bie Snojpenteime bes auf: fteigenten Etodés zu Blattausidheioungen (c c) und zu Blattadjelfnoipen=

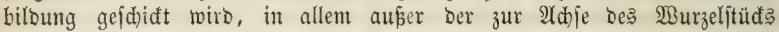
redhtwinfligen Stellung feiner Bafis, einem Triebe bes auffteigenden Stodes gleid) fid fortbilbet.

Diefe Arbweid)ungen in Uriprunge ber Wurzelausfdeibungen haben

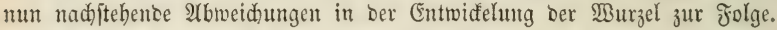

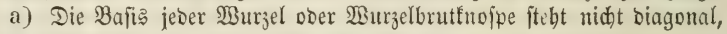

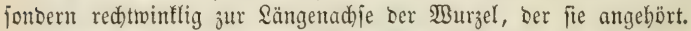

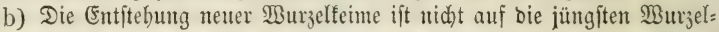

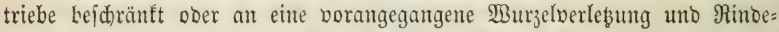
perjüngung gebutoen (obgleid) aud) an Der $\mathfrak{B u r z e l}$ 2loventiotwurzel= Doer

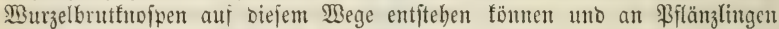

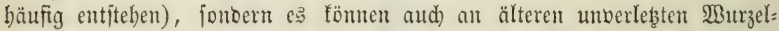

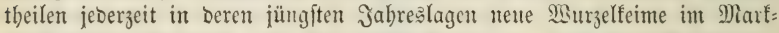
ftrablgewebe fid biloen, eine (Eigenthüunlidfteit, bie, wenn fie nidht beftänoe, Die Erfolge Dis ßjłlanjgejdäfts in bohem Grabe verfümmern müroe.

c) Der $\mathfrak{B}_{\mathrm{B}} \mathrm{rzel}$ feblt jene, Dem auffteigenten Stode eigentbümlidje

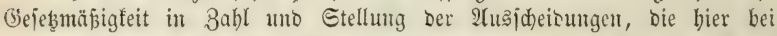
weitem mehr bem gegebenen (Entwifelungšraume uno bem Bebarfe fid) an= pafit. Damit feblt Dann aud bie Internobialbiloung unb felbjt bie äuferc Begrenzung Der einzeluen Jabreștriebe.

d) BFlanjen mit enditänoiger, fdon in Der Sinojpe vorgebildoter Blütbe (Acer, Aesculus etc.) laffent erfemten, daj̄ hier ber ganze Säıgenzumad): eines jeben Jahres Durd) 3rifdenbiloungen uno Bellenwad)sthum erfolgt, in Jolge Deffen vorgebilicte Drgane cine Drţ̌veränterung erleiben, Der im Booen bie Jeftbeit beffelben entgegentreten würbe, Daber bie $\mathfrak{B}$ urzel in ber That mur an ihrer Spize fid berlängert.

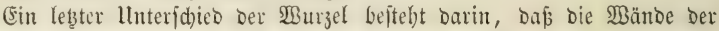
5ुolzfajern viel bünter fint als im oberiroiichen Baume. Die $\mathfrak{B u r z e l}$ ift Der Scauptablagerungsort Der Rejerbeftoffe. Sie finden fid bier aud in einfacken Sुolzfajern Da, two bieje im Stanme fein Mebl fübren. Diefe Beiträumigfeit ber Fajern fteht fider in Bejiehung zur 2 (ufnabme möglid)

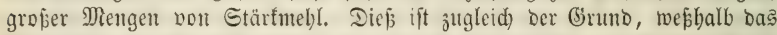
Burzelfoly fo febr viel leid)ter ift als bas Etammboly, went ber Baum zul einer Beit gefüllt twurte, in ber bie Rejerbeftoffe gelöst finto.

Lleber bie Unterfajiebe Der Iriebiwurzeln, Jajertwurzeln uno Rraut= iprofien babe id) idjon Geite 157, über bie Junftion ber 2Burzelı Geite 191

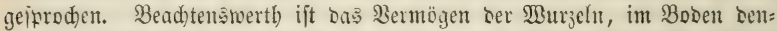
jenigen Drten fich borzugstweije juzumenten, an benen ihnen bie nöthige Jeudtigfeit uno Rahrung fich Darbietet. Daj bieß nid)t etwa Folge Der 


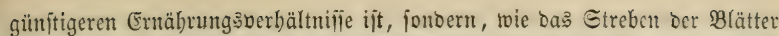
uno Iriebe nad bem Sidte auf einer immeren Urfache berubt, geht cinfad) aus ber Ifatjache herbor, Daß́ im feuchten, frudtbaren Boden bie 13 urzel= entwidelung ftets eine geringere ift, als im trodenen, unfrudtbaren $300 \mathrm{en}$. In leşterem fendet bie Riefer ifre $\mathfrak{B}$ urzeliftränge oft $30-40$ Ed)ritte weit

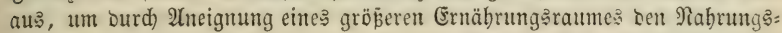

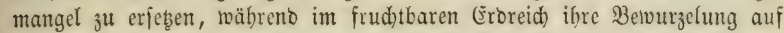
wenige Quabratruthen fläd)enraum fid) befdräntt. $\mathscr{A}$ uj gleidem Boben uno bei gleidjer Fruchtbarfeit ber oberen Bodenj(didten burd) aufgetragente Rajenafdje bringt bie Rieferwurzel tief in ben Boben, menn zugleid ber Untergruno burd) Riolen befruchtet wurbe; fie bleibt mit furzer Betwurzelung in ber Bobenoberfläd)e, racnn lebeteres nid)t geidah.

\section{h. Die Referveftoffe.}

Mir baben Geite 180 gejehen, daj dem Embrno in Gamentorne von Der Mutterpflanze eine größ̈ere oder geringere Menge organifder, meijt organifirter Etofie, bauptiäd)lich Etärfmehl, Slebermehl und Del, feltener

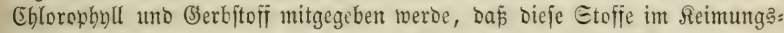

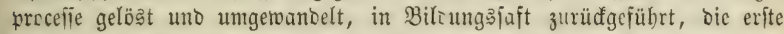
Nabrung bes Embryo fino, remi biejer aus ber Samenruhe erwacht. Eie bilben zulammengenommen einen Sorrath von Rejerbeftofien, welde bie Mutterpflanze Dem Embrno beigegeben bat.

Der Bergleid bes Gerwichts biejer Mejerbejtoffe in Samentorne Der Birfe, Weibe, Affazie mit bem Irodengewid)te ber einjäbrigen Bflanze ergibt ohne SSeiteres, baj biejelben bei weitem unjureichent fint zu: $\mathfrak{B}_{0}$ lfentoung

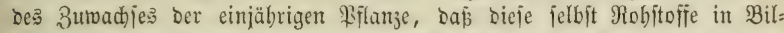

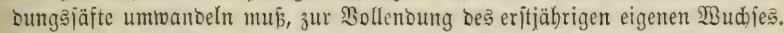
Jnbef ift es felbjt hier menigitens 3meifelbaft, ob eine unmittelbare Ber=

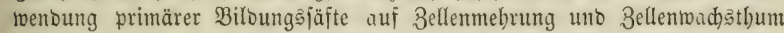
ftattinoe. Die in ber Entwifelung itehenbe Eamenflanze enthält in ihren älteren ber neu gebilbeten Theile aud) im eriten Jahre bebeutende Mengen bon Stärfmehl, uno es fönnte wohl fein, baf aud) in ihr ber Rohftoff bie berjdiebenen Umbiloungştufen in primären Biloungsiaft, Rejervejtoff, fecundären Biloungşaft burdlaujen mus, ebe er auf Bellenmehrung uno Bellenwadsthum berwendet werben fam, bas ber ltnterfobied bierin zwijden ein = uno mebrjäbriger \$Flanze fid auf einen rajderen Berlauf ber \$ुan=

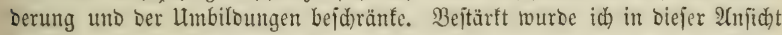
ourdh Die Ergebnifīe einter meiner neneften Unterjudungen, benen 孔u Folge

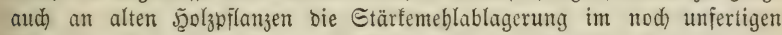

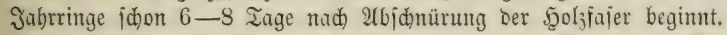

Wie bem aud) fei, io ift es andererfeits unjweijelhaft, baj bie ein=

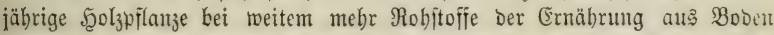

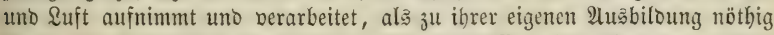

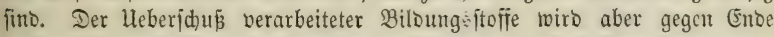

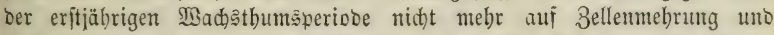
Belfentwad) sthum berwentot, fonoern er verwantoelt fids, wie in ben Bellen 
Der Samenlappen Doer bes IItbumen ber Samenförner, fo in beftimmtent Bellformen ber einjährigen Pilanze in biejelben Rejerbeftofie, bie wir aud im Samenforne borfinden, mit bem Unteridjiede, baß̉ bas Stärfmehl uno Der fefte B̧erbftoff bei weitem vorherridhen, Rlebermebl uno Del nur in geringen $\mathfrak{M e n g e n ~ a u f t r e t e n , ~ b a g e g e n ~ b a ̈ u f i g e r ~ e i n e ~ b e b e u t e n b e ~ M e n g e ~ z u đ e r = ~}$ haltiger Gäfte Dem Bellgewebe verbleiben, Die idh im Samentorne nie vor: gefunben habe. 1

Wie die Mutterpflanje Rejerbeftoffe für ben Embryo, fo bereitet bie

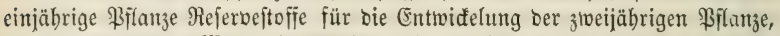

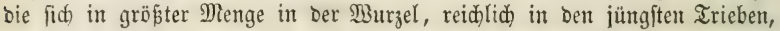
weniger reid)lid) in ben älteren Theilen bes aufiteigenten Stodés ablagern.

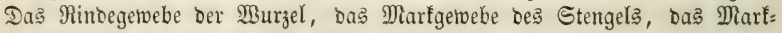
jtrablgemebe beider uno bie 3elffajern fino bie Şauptablagerungsorte ber Rejerbeitoffe, bod) berwanbelt fid) häufig aud) bas (Ehlorophyll ber ober:

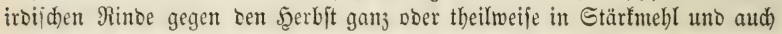
Das Siebfajergewebe ift bäufig theilweife damit verfeben.

Bie bie amorphen, flüfifigen Rejerbeftofie (3ưfer=, Summi=, Sdyleim= Söjungen, Dele - vielleidjt gebören and bie Şarze babin) entijtehen, wiffen wir zur Beit nod) nicht. lleber bie Entitebung ber organifirten Rejerbe: ftoffe: Etärfmehl, Rlebermehl, Eblorophyllf̈̈mer, Ehlorogen = uno Cefluloje= förper, Gaftbläsdjen 2c. habe id) meine Unterjud)ungen in einter bejonberen 2frbeit: Entwidelungsgefd didte Des Billanzenteims, Leipzig 1858, zujammen= geftellt uno bie \$ermuthung ausgejproden, baßs bie amorphen Rejerveftoffe Unmtwanolungsprodutte fino vorgebildeter organifitter Rejerbeftoffe.

\section{i. Sefrete.}

Áţer ben vorgenamten, theils flüfitgen, theils feften uno organifitrten

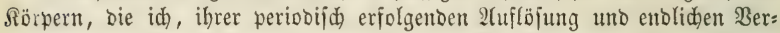
mentung auf Bellenbiloung wegen, Referveft of fe genannt babe, babin

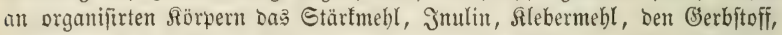
bebingt aud das Chlorophyll, an nid)t organifirten Sörpern Budfer, Bummi,

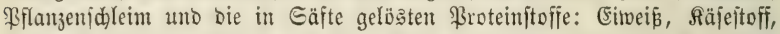
Faferftoff zäblento, gibt es nod) eine Reibe nidht organifirter Stoffe, beren periobijabe Mieberauflöfung und Berwendung $n$ id) $t$ nad) weisbar ift.

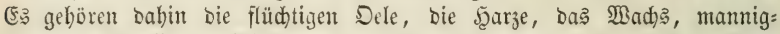

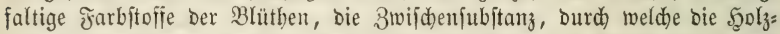
fajern untereinanber verfittet fint, Das Zylod)rom Der Rernholzfajer uno

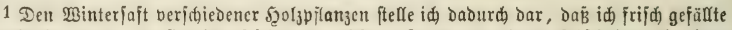
Stammftüde von 8-10 (Sentim. Dide uno 1 Meter Sänge am oberen $2 b j$ d)nitte nit einer

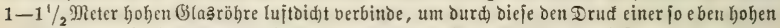

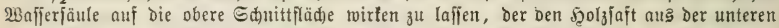

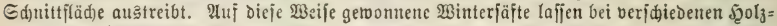

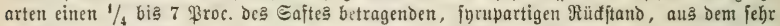
berjdiedene firyftalformen berfdjiedener Bữer = uno Gleisarten ausjdeiden. Am zuder=

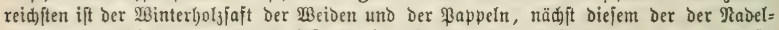
bobljer. Dem (Eid)en = und affajienjafte ift ein rojarother Farbeftoff (Xinlod)rom), Dem Safte aแక Aesculus und Ornus ift $\mathfrak{A} c$ sculinlöjung beigemengt. Der Sy)rup entbält $1 / 10$ bis $1 / 3$

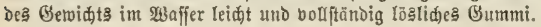


Sirbftalle, theils foblenjaurer, fiejeliaurer ober idjwefelfaurer, theils pflanjen= faurer Ealje mit unorganifder Baje, bie bejonoers reichlid in ben Rano= fajern ber Buftbünoel, hier uno ba aud in 3ellfajern Des Syolztörpers, zum Theil audh in parendymatij(jen Bellen abgelagert find. Der bejobänte Raum geftattet mir nidt, näher auf bie Befdaffenbeiten uno Eigenfdaften Diejer Rörper einz̧ugeken.

\section{k. Die Binterrube.}

Der Beitraum, welden die einjäbrige Bilanze vom Reimen ab bis zu völliger 2(usbiloung in 2Hiprud nimmt, ift in ben (Ebenen uno $30 r=$

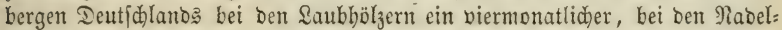
bölzern ein breimonatlider. Nad) 2(blauf biejes 3eitraums ift bie \$flanze

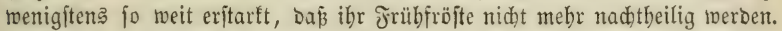

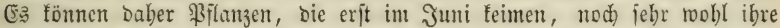

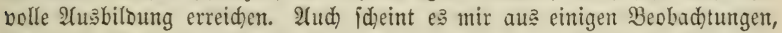

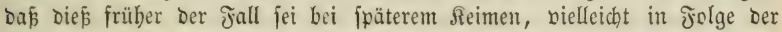
böheren, bie Entwiđełung bejdleunigenoen Eommerwärme. Eidhen, bie erit im September feimten, baben im vorigen Winter nidt gelitten, obgleid bie Sälte auf $10^{\circ}$ bei Bladfroft fitieg. ${ }^{1}$ Bejdäbigungen unjerer be imi i f en Scolzpflanzen ourd $\mathfrak{o r}$ ühfröfte find mir überbaupt nod) unbefannt uno mag zur 2(1ntabme joldyer nid)t felten ber Umijtuno beigetragen baben, Daj mehrere 5zolzarten ihre Iriebe überbaupt nie böllig ausbiloen. (Seite 137.)

Die ausgebiloete einjährige Scoljwflanje bejteht im einfadjiten Jalle ats Der, mit Fajertourzeln mebr ober weniger reidflid bejebeten Bfablmurzel un๖ aน: beren ßerlängerung nad) oben วum Etamme; aus Der Enofnojpe,

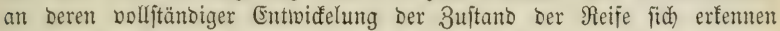

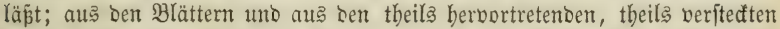
Blattadfelfinofpen, von benen bei einigen Şoljarten (Birfe, (Erle, Ulmen 3c.) cinzelne fidon im erften Jahre zu Eeitenzweige fid entwifeln, währeno bei Diejen unt anberen 50 lzarten aud bie Bewurzelung fid reidjlid) berżweigt

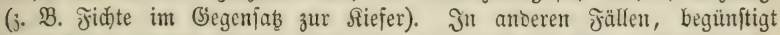

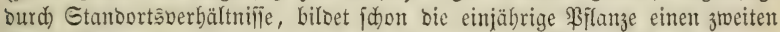
Irieb (Johannitrieb), jeltener einen britten, uno jelbjt vier Iriebe, bon Denen ber leb̧te jebody nidht fertig gemorben, fino mir an exotifdjen (Eid)en fđon borgefommen. Die Mebrzahl ber in einem Juhre gebilDeten Sängen= triebe hat aber nie einte Mebrzahl von Jahreßringen zur frolge (es ftünte ponjt fojled)t mit unjeren 3uwadjaberednungen), ftets habe ich mur einen

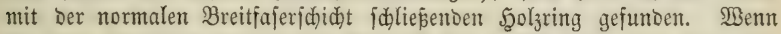
Die oben genannten Drgane mit Referveftofient erfüllt fino, tritt ıun, bei unt Ende Dftober Doer 21nfang November, eine Berminberung Der Gaft= bervegung ein, berbutben mit Dem 2lbfalle Der 3 lätter aller fommergrünen Pilanzen, Dent bei Den meiften Pflanzen bie Billoung einer Edjidjt von

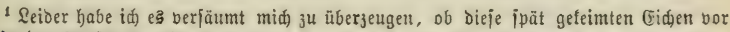

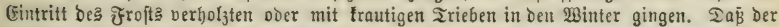
frautige, unfertige 3ujtand ber Iriebe niadt unbebingt ben Frofttod nad fid jielst, jehent

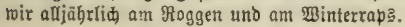


Sorfyemebe an berienigen Stelle vorbergegangen ift, an weld)er ber \$3latt=

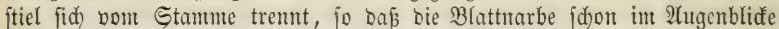

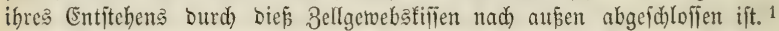

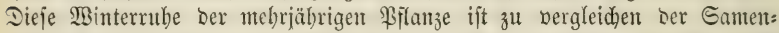
ruhe bes Eamentorns; Der $2 B$ interrulbe Der Snolle, Rübe, 3wiebel; Dem Bujtande Des gelegten aber nod) nidht bebrüteten (Eies; Dent Winteridlafe einiger Ibiere. Der Drganismus lebt, fein Seben äupert fid aber nur in bem Biberitande, Den er fortbautno Der Eintwirfunt Derjenigen Stoffe

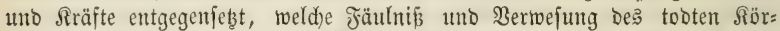
pers herbeifübren. Die vorbanoenen Gäfte fömten Durd Froft zul (5išs

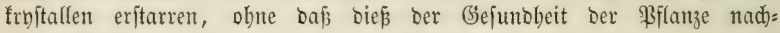
theilig wirb.

Bon Der Eamenrube unterideibet fid) bie Minterrube jeodd) barin,

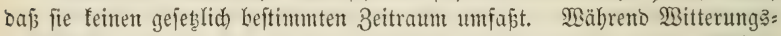
berbältniffe auf bie Dauer ber nomalen Samenrube auper Einflup bleiben, fehen wir bei milber Mintertwitterung in ber Regel bas Bflanzen= Yeben zur Unzeit erwedt. \$löb̧lid) eintretender Froft bat baum ein Erfrieren gewifier Pflanzen ober jüngeren Bflanzentbeile zur Folge, wälhento bei all= mäliger Erniebrigung Der Temperatur bieß nidgt immer ber Fall ift. 2Tnoere Bflanzenarten fino aud biergegen umempfindlid. ${ }^{2}$

1 Sebr wabrideinlid) ift es die jwijden Blattitielnarbe und Blattifielbafis fid ent=

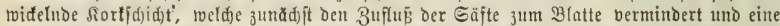
nod) wenig erforidte Beränderung bes Belfeninhalts ber Blätter, fomit bie befannten, bem Blattabfalle vorbergebenden Farbeberänderungen, endlid) daß 216ftosen be马 Blattifiels felbit jur Folge hat.

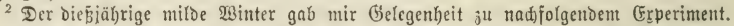

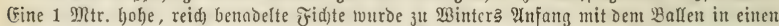
grošen fiübel gejebt. In einell ganj gleidjen Sïbel rourbe ein bidjt bancben entnommener

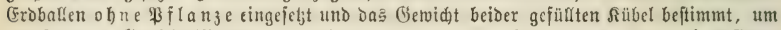
aus jpäteren (Getrid)tbifferenjen cntutebmen ju fönnen, ob Berbunftung Durd) Die \$flange aud) im 2 inter ftatffinde. In affen f.roftperioden war bie Berbunfung beiocr Sübel genaut biefelbe, bon dem 2lugenblicfe an, in tweld)em man eine (Erftarrung Des Bodentaffiers ju

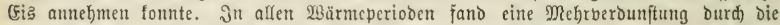
Pflanze bon bem 2lugenblife an itatt, in weld)em man bas WSiederaufthauen Dez Boden=

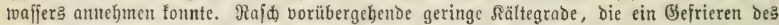
Bobentvaffer马 nid)t mit fid fübrten (ghad)ffröfie), ftörten die Berbunftung nid)t, die im Januar bei einer bis ju $10^{\circ} \Re$. gefteigetten siärme einten Mehrberluft bez bepflanzten

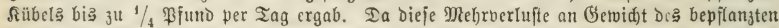

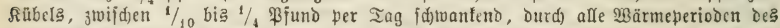
ganzen 2 inters binourd fortoauerten, oa die Pflanze gcjuno uno fräftig blieb, fo mus mit Der Berbunftung and) eine bem Getvidtberlufte entfpredende Wafferaufnabme Durd) bie Wurjeln aus dem Boden berbunden getwejen fein. Da aud) bie fiidte, in ber \$eriode bes

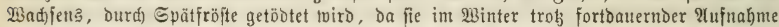
und Berbunftung bon $2 B a f j e r$, bon wedjelnoem frofte nidit leibet, fo folgt oaraus die Un=

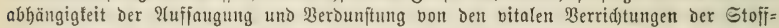
biloung und Stoffiwandlung, und mut bieje leţteren jafeinen es zu jein, bie unter zu nieberett Wärmegraden leiden.

Daß̉ aud Laubhöljer im Winter verouniten, mithin aud eine Gaftaufnahme uno Gaftbetvegung befibert, glaube id) aus folgenden (Grperiment entnehmen zu Dürfer. (Eit

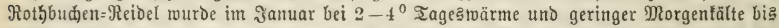

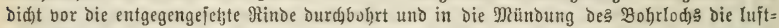

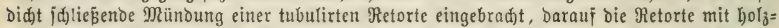

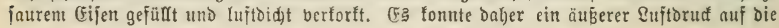


Jm Winter berringert fid ber llmfang ber Etämme bei ftarfer Rälte

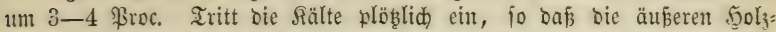
jobidten rajder als bie inmeren erfalten uno fid zujammenziehen, fo bat bieß̧ oft ein 2Afreipen bor Etäntme in ber Rid)tung ibrer \&ängenfajern

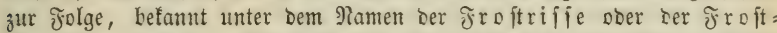
fpalten. Aluf bie Bejunbheit uno 3uwachafähigfeit ber Bäume baben biefelben nidht nothmendig einen erfennbar nadtheiligen (Finflus, idaben

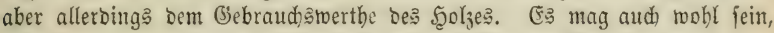

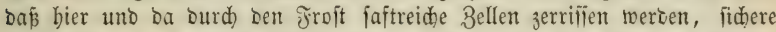

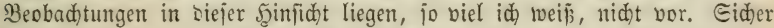
ift aber aud biés nid)t Urjache bes (Erfrierens, Dą mur Dann eintritt, wenn Durd) unzeitig erböbte Iemperatur bie Billanze aus ifrem $\mathfrak{B i n t e r :}$ fidlafe erwoctt wurbe. Das Erfrieren ift bann Folge einer Ertöbtung bes in ber Umbiloung begriffenen Pilanzenfafte uno einer rafd eintretenden

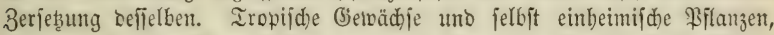
bie lange 3eit in Warmbäujern gezogen twurben, erleiben bieje Ertöbtung Des Gafts idjon bei 3-4 Märmegraben, rogegen im Freien madjfente Ithome, bie den ganjen \$sinter binourd bluten, forvie bie Iemperatur $4^{0} \Re$. überiteigt, in raidem $\mathfrak{B}$ edjel vorher un nadher gefrieren fönnen,

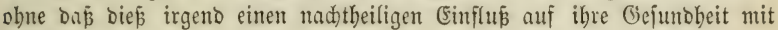
ficd) fübrt.

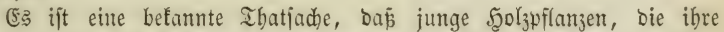

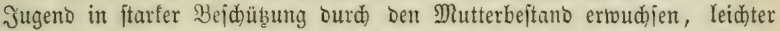
erfrieren als joldhe, bie von Jugento auf in bollem Sidjtgenufie erroudjent.

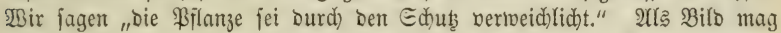

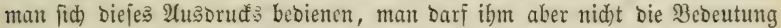
beilegen, in weld)er wir ihn auf ben thierifden $\Re$ örper anmenden, ba er hier mit bem Etoffiwedjel in nädjter Bejiehung fteht, ber Bflanze aber biejer

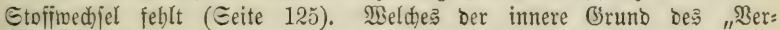
meidlid)ent" ber Şolzpilanzen fei, ift unక zur Zeit nod unbefannt.

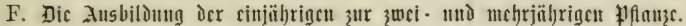

a. Ernäbrung.

WBir verliep̃en bie einjäbrige Prilanze als einen mit Blättern, Snofpen

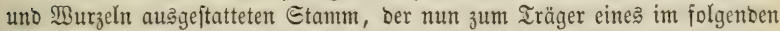
Gabre fid) fortietzenden 3uwadjes rirb uno zlwar: theils burd Entwide: lung eines neuen 尺ängentriebes aus Der Enotnofpe (Seite 134, 200); theils

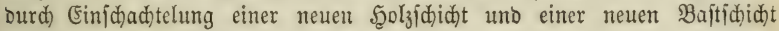
zwifden ben vorgebildeten $\mathfrak{S g l}_{3}=$ uno Baftidid)ten (Eeite 177); bebingung:

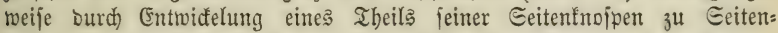
3tweigen, währeno bie niḑt zur 3weigbiloung gelangenden Geitentnojpen burd) intermebiären \&ängenzumadjs fid auf unbeftimmte Beit lebenoig er= bielten (Eeite 148, 150). Neue Blätter uno neue Snoppen biloen fid̆ in

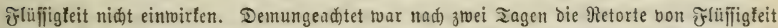

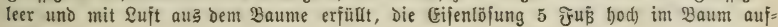
geftiegen. 
Derfelben Beije wie an ber einjäbrigen $\mathfrak{B f l a n z e , ~ i m ~ n o r m a l e n ~ B e r l a u f ~ b e r ~}$ Entwidelung mur an ben ne uen Rängen= uno Seitentrieben; neue Burzeln fönnen hingegen aud an ben älteren $\mathfrak{B u r z e l t b e i l e n ~ u n o ~ z w a r ~ a n ~ j e b e r ~}$ Stelle berfelben entftehen, Die einer Marfitrabl zur Unterlage hat (Seite 246).

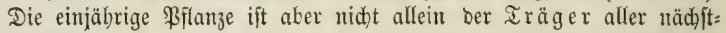
jäbrigen Bildungen, fie ijt aud bie Ernährexin Derjelben, Durd bie in ihr niebergelegten Referveftoffe, bie fid zur Frobuttion be?

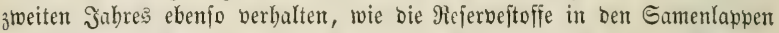
Der Eidhel zur Brobuftion der einjährigen Bflanze, während bie \$Burzeln

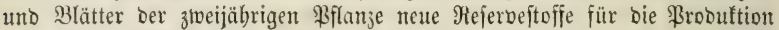
bes britten Jahres jd)affen. (Es greifen Daher, in jeocm Jabre bes \&ebens

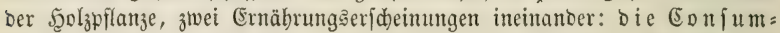
tion ber Referbeftoffe aus bem borkergebenben Jabre und bie Bilbung neuer Rejerveftoffe für bas näd ftfolgenbe Jabr.

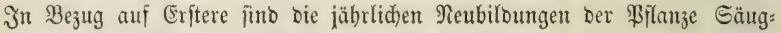
ling ber vorjäbrigen, in Bezug auf Reţtere bilben fie fid) zur 2(mme ber näd)itjäbrigen Broduttion, in ähnlider Weife, wie bie Rartoffelitaube aus Den Rejerveftoffen ber Mutterfartoffel fich) entwidelt, wäbrento fie gleichzeitig neue Snollen für nädjitjäbrige Stauben bilbet.

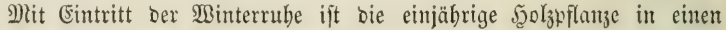
3uftanto getreten, in weldem fie viel Hebercinftimmendes mit bem Embrno int Samentorne mährend ber Gamenrube zu erfennen gibt. WBir haben Dieje Beziefungen bereits fennen gelernt. Diejelben Rejerveftoffe, weldhe Dort in Den Gamenlapwen niebergelegt fino, lagern bier im Zellgemebe bauptiäd)lid) ber $\mathfrak{B u r z e l . ~ D u r d ) ~ e i n e n t ~ b e r ~ R e i m u n t ~ a n a l o g e n ~}$ Borgang werben bieje Stoffe im orrübjabre зu Bildongäfäften wieber aufgelöăt uno im $520 l_{3}$ törper mit bem auffteigenben Robjafte emporgctragen, um in ben Inofpen auf Biloung neuer, belaubter Triebe, jwifd)en $\mathfrak{S}_{0} \mathcal{I}_{3}$ uno Bajt

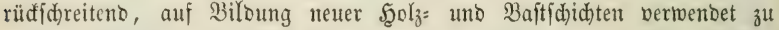

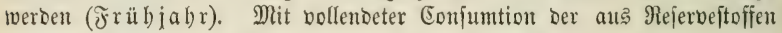
reftituirten Billoungsäfafte Des vorhergebenden Jabres ift bie Belaubung an Den baraus entitandenen neuen Irieben fo weit entwiffelt, bas fie mun Mohftoffe in Bildungsääte umzuidaffen bermag (Sommer). ${ }^{1}$ Diefe neu

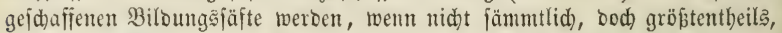

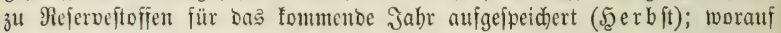
bann sie $\mathfrak{B}$ flanze von Reuem in bie $\mathfrak{B i n t e r r u b e ~ c i n g e h t ~ ( ~} \mathfrak{B}$ inter).

Wir wollen nun nadjolgento biejenigen Erfdeinungen ถę Baumlebent näher betradten, bie einem jeben biejer 2(bjduntte bes jäbrlid)en Begeta= tionscyclus angehören.

1 Sind bie Blätter erft im ausggebildeten 3uftande befähigt, Mohftoffe in Biloungsftoffe umjuwandeIn, Danm müffen nidyt allein fie felbft, jonbern aud) bie Iriebe, an benen fie fid

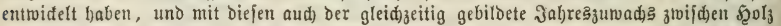
und Baft ber älteren Baumtheile aus Bildungsftoffen bes vorbergebenden Jabres fich ent=

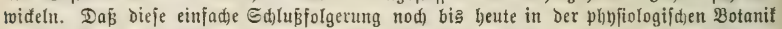

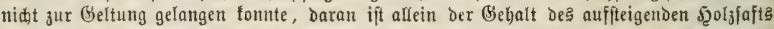

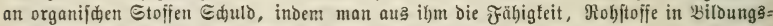
ftoffe umwandeln zu fönnen, aud) ber \$urzelzelle zuipreden zu müffen glaubt (f. Sd)leiden, (Srundzüge Band II. S. 466). 


\section{Die Frübperiobe ber 2 egetation - Seimungaperiobe.}

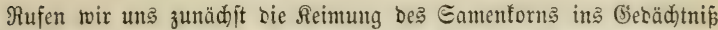

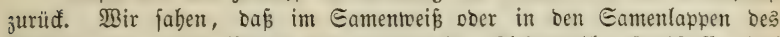
Embryo eine gewifie Menge bon Etärfntehl, Rlebermell, G’erbftoff, Del als Rejervenabrung niebergelegt ift, baj bei einer burdjidnittliden Tagestemperatur von minbejtens $8^{0} \Re$. Der iđlummernoe Reim bes Samen=

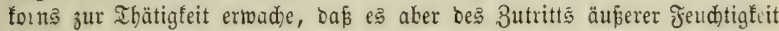
uno bes Gaueritoffe ber atmoiphärifchen \&uft bebürfe, um bie $\Re$ ü $\mathfrak{d}=$ biloung ber Referbeftoffe zu Biloungşaft, unter $\Re$ oblenfäure: $\mathfrak{A} u s=$ fdeibung zu rermitteln uno baburd) bie Seimung zu weffen uno zu unterbalten.

Ganł Diejelben Eridheinungen bietet uns bie einjälrige uno jebe ältere 5̧olzpflanje in ber Jrühperiode ihrer Begetation. Die vorbergegangene Winterrube entiprid)t vollfommen ber Samenrube besె Reintlings. Wie im Samentorne, an ber Rübe, Ŝlwiebel, Snolle, befindet fich bie Belaubung

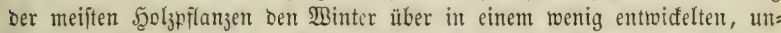
fertigen 3uftanbe; wie bort find aud) bier beceutende Mengen bon Rejerbe= ftoffen aufgefpeichert, befonders in Der $\mathfrak{B u r z e l , ~ i n ~ R i m b e ~ u n d ~ M a r f i e l l e n ~}$ Des Etamme, in Defien Marfiftrablen uno Bellfajern, gegenüber Dem Samen=

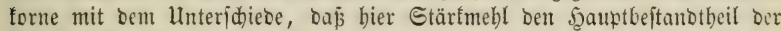
Rejerbeftoffe biloet, Rlebermehl uno Del nur in fehr untergcoroneter Mtenge, jefter Sierbitoff nur bei einigen Pilanzen (Eid)e, Roje, (sinfter zc.) in be= Deutenterer Menge vorbanden fint. Nabe biefelben Imperaturgrade, bie Der Reimungß̧procép erforbert, finto aud) nothmendig, um bie Şolzpflanze

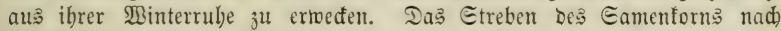

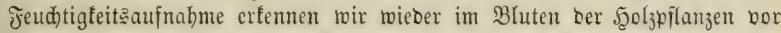

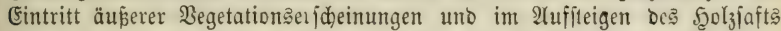

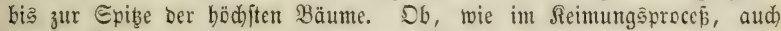
bon ber Baummurzel Eaueritoff aus bim Boden aufgenommen werse, wilien wir zur Beit nod) nidht. Die günftigen Folgen ber Bobenloderung fönten aud) ausidbließlid) auf Bejiebungen ber Suft zu Bodenbeftantheilen be= ruben. Die Produfte ber Referbeftofflöfung im aufiteigenden Scoljafte 3uffer uno Bummi - fino biefelthen twie bie ber Reimung bes Eamen= torns; łurz, Der Rüdjidritt ber Rejerveftoffe zil einem flüfiligen, Der Man= berung von Belle zu Belle fäbigen Bilbungşafte (oen id) fecundären Biloungşaft genannt babe, gegenüber bem, unmittelbar nad) feiner Be: reitung in ben Blättern zur Bellenbiloung ober Rejerbeftoffibereitung ver= renbeten, primitiben Biloungsfafte) ift Derjelbe uno febet biefelben $B e=$ bingungen boraus, im Samentorne wie in ber ein= ober mebrjäbrigen Sgolzpflanze. Die Frübperiode Derjelben ift eine rabre Reintungsperiode,

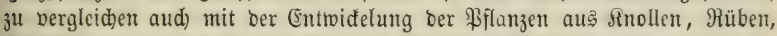
3wiebcln, jo weit bieje das Material für bie Bellenbildung ber baraus et: wadjenden $\mathfrak{B f l a n z e}$ Kiefern. ${ }^{1}$

' (fin Unteridieb ber burd ifre Sinollen gleidjalls mebriäbrigen fartoffelpflanze bon

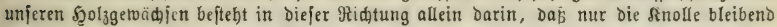

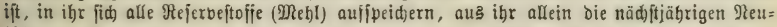

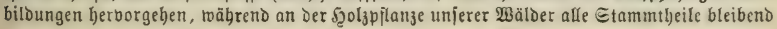


Wir haben in biefer Beziehung nadfolgentoe Erfdeinungen bes \&ebens Der Scolzpflanzen näber zu betrachten.

a. Die Bewegung Des Gafts in Szoljtörper ber Bäume.

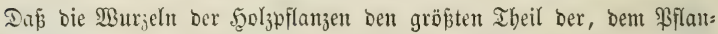
zenleben nöthigen Jeudtigfeit aus bem Boben auffaugen, bap bie auf: gejogene Jeud)tigfeit biß zum (bipfel Der hödjten Bäume aufiteige, ift feinem 3weifel unterivorfen. Das Melfen ber Blätter uno das Berborren

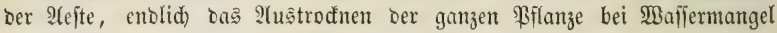
in Bereid) รer $2 B$ urzeln beweist bieß̃ zu Bienüge.

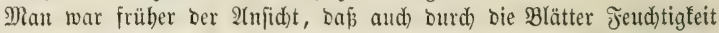

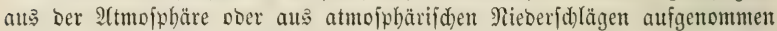
twerbe. Im trodéenen Giemäuer nurzelnde Sgolzpilanzen, ${ }^{1}$ bie Eaftpflantzen ber Büfte, bie rajd)e (crftarfung wolfer Blätter nad) eintretenoem Eprühregen fdien bafür zul fpred)en. Durd) nadfolgenten Berfud) babe id) Das (begen= theil erwiejen. Durdjidneibet man mit einer Säge bie Splintidjidt bon Bäumen ber Budje, Sgainbude, Birfe, Pappel, Mcise runo herum bi马 einige 3oll vor Der Marfröbre, jo hat biể wäbreno Der nädjten Jabre

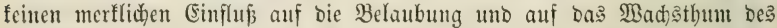
Baumes, weil aud bas Rernholz für das aufgenommene

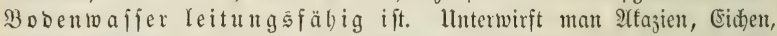
lllmen Derjelben Dperation, Dann erjd)laffen bie Blätter bes Baumes jelbjt

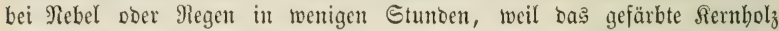
Diefer Scolzarten nid)t leitungäfäbig ift für bie aufiteigenden Baumfäfte, Deren Emporfteigen im Eplinte Durd) befien ringförmiges Durdffduteiden unmöglid) wiro. Da bem obnerad)tet bie Berounjtung ber Blätter fort= bauert, muifien. Qebetere rajd) erfidlaffen in Ermangelung ber 3ufubr Den Ubgang erfeł̧enter Eäfte.

Die Fortbauer Der Serdunftung aud) nad) ausgefülrtem Ringidunitt beweist, Daß̧ bie Berounftung nid)t bie Folge eines von unten ber wirfen= Den Drudés fein fann.

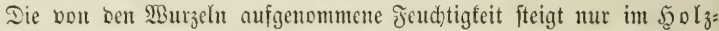
$\mathfrak{f o ̈ r p e r ~ a n f w a ̈ r t s ; ~ M a r t , ~ R i n b e , ~ M a r f f t r a b l e n ~ u n o ~ B a j t b a u t ~ n e b m e n ~ a n ~}$ Der $2 \mathcal{A} u f l e$ it ung nidst Theil.

Jm Şolztörper Der Mabelfölzer, ber nur aus Jajern uno Marfftrablen= jellen jufanmengefebt ift, fino es obne Bweifel nur erftere, weldhe ben

find, bie Referbeftoffe, twenn aud hauptjäd)lid, Dod) nid)t alfein in ber $\mathfrak{B}$ urzel, fondern aud) im Stamme niedergelegt werben, Die näd)ftjäbrigen Tleubildungen aus ihnen, vott allen

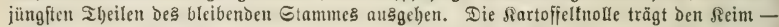

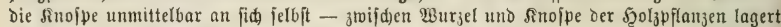
Der Stamm mit feinen 2(eftell und 3weigen unb crheifdt bie Eäftewanderung Durd) bie bor= gebildeten Baumtheile.

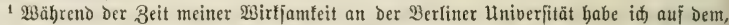
woht 5 Mtr. hohen (Gemäuer dę benad)barten (

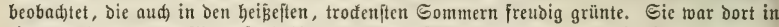
einem unbedeutenden Maueripalt bis nahe Armeşfärfe berangewad)ien. (5马 ift idiver anjus

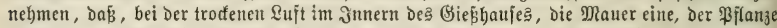
gentigende đreudtigfeit rährend beiß̄er Sommter betwabrt baben follte. Berlin fann in Bejug auf Sommerdüre etraas leif̧ten!! 
Eaft nad) obent leiten. Im Saubholze treten zu Den Jajern nod) bie Röhren. (Es ift mir bis heute nod) zlweifelhaft, ob leb̧tere an ber Eäftes leitung nad) oben Theil nebmen. Im Sholzförper ber (Eid)en, Rüftern,

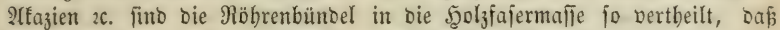

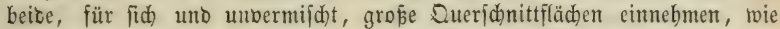
Dieß Eeite 238 Fig. 42 barftellt. Edneioet man im Frübjabre von be: laubten Bäumen einfüfige, $1-2$ 3oll jtarfe $\mathfrak{B a l z e n f t u ̈ f f e ~ m i t ~ i d a r f e n ~ D u e r = ~}$

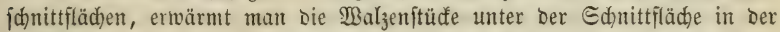

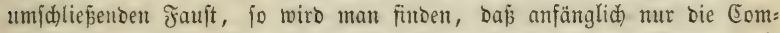

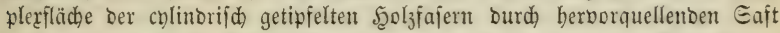

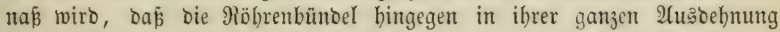
trocfen bleiben. Şat fid) Die Jlüffigfeit auf ber Duerfläche bes Jajercom:

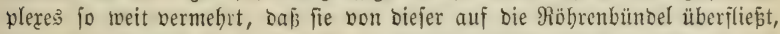
Dann tritt fie von oa in ben Raum Der Solzröbren binein, und mun erit

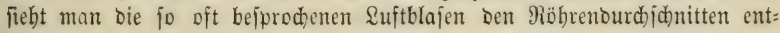
fteigen. 1

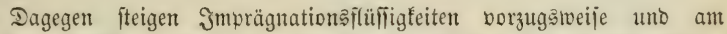
rajdejten in ben Scolzröbren aufwarts, wemn biefe von Ed)nitt= ober MBuno: fläd)en bes Baumes aufgefogen werben. (Es ift aud) feinem 3meifel unter:

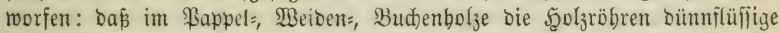
Eäfte fübren. Id) habe midh bavon burd) Unterjudung gefrorenen WBinter:

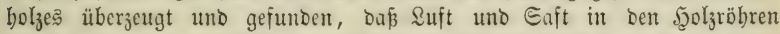
ebenjo miteinanoer wedjeln, wie id) biep jogleidy in Bezug auf bie $5_{2} l_{z}=$ fajern näber barlegen werbe. Wir müljen baher audb biejen \$unft zur 3eit nodh als eine offene frage betradten.

Das Streben nad Ergrünoung ber Urfache des Gaftiteigens bat fonon eine grope 3ahl von Şnpothejen ins Seben gerufen. Die Slappen uno Bentile Der \$byfiologen Des borigen Jabrhunberts muften Den befieren op:

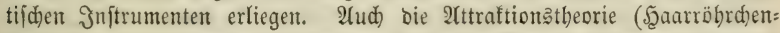
fraft) ift robl allyemein aufgegeben, feit wir miīien, Daj jeoe Der leitenden Jajern ein in jid) böllig geid)lofienes Drgan ift. $\mathfrak{A}$ Deren Etelle ift ję̧t febr allgemein bie Erflärung aus endosmotifden Erideinungen ges

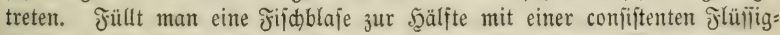
feit, з. 3. 3uderwaffer voer B̋ummiwaffer, taudt man bie Blaje in reine Waffer, jo tritt ein llebergang Des leb̨tern burdh bie Blajentwanto ein, bie= felbe füllt fich, wenn fie zugebunoen ift, bis zum \$lą̧en, ober es erhebt fid), wenn bie Blaje offen ift, bas Riveau bes allmälig lid beroünnenoen 3ucfertwafiers meit über jeinen urfprüngliden Stant. Diefe Eigenijhaft ber Thierbäute bat man nun willfürlid) auch Der \$flanzenbaut zu= gefdrieben. Man nimmt an, bás burd̆ bie \$erounjtung aus Den Blättern bie böheren Bellen einen concentrirteren Gaft entbalten als bie tiefer lie: genoen, Dás jebe Belle aus ber zunädjit tiefer ftebenten fich in gleider

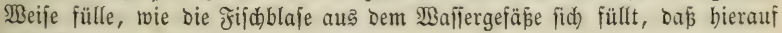

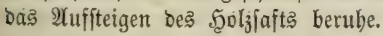

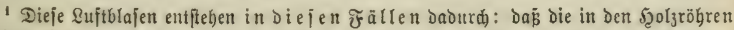

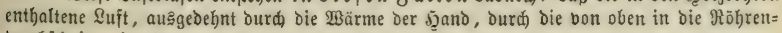

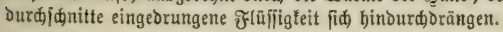

5̨artig, Selyrbư̆ für đ̛̈riter. 1. 
Die 3uläfifigfeit biejer Erfläruntgşmeife feķt voraus:

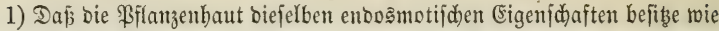
bie thierifahe Blaje. Jod habe in ber 3 ot. Beitung 1853 Seite 309 uno 481 nad)= gemiejen, baß bieß in Bezug auf Buder= uno Bsummilöjungen nidjt ber Fall ift.

2) Dá̧ ber Unteridied ber Menge aller im Eafte gelösten Stoffe,

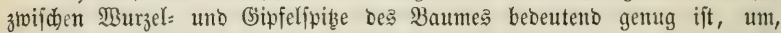

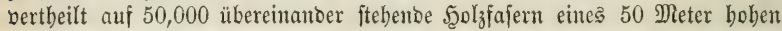
Baumes (eక gibt beren von 100 Meter ફ̧öhe), zwifden je zmei übereitanoer ftebenber Fajern eine, für lebhafte cnoosmotifhe Steigung genügende Dif= ferenz in ber Menge gelöster Stoffe zu bebalter.

Meine, biefem Ëegenitanbe zugewendeten Unterjudjungen ergaben an

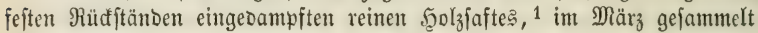

\begin{tabular}{|c|c|c|c|c|c|c|}
\hline Betula & Gipfeljaft & 1,30 & Broc. & Wurzeljaft & 1,20 & Pro \\
\hline Fagus & $"$ & 1,50 & " & $" \prime$ & 0,90 & \\
\hline Carpinus & $"$ & 1,70 & $"$ & $"$ & 1,30 & \\
\hline Tilia & $"$ & 0,70 & $"$ & $"$ & 0,13 & \\
\hline Quercus & $"$ & 0,10 & " & $\prime \prime$ & 3,00 & \\
\hline Larix & " & 2,80 & " & " & 1,20 & \\
\hline Populus trem. & $"$ & 7,00 & $"$ & " & 2,00 & \\
\hline
\end{tabular}

Nur bei ber Eiche ift baber unter voritebenten F̧olzarten ber $\mathfrak{B u r z e l =}$ faft reider an \&öjungen, als ber Binfelfaft. Nur bei ber Bappel uno Sinde ift ber Mebrgebalt bes Gipfelfaftes ein jebr bebeutenber. Bei ben

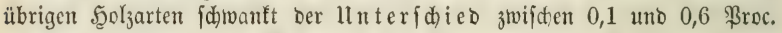
bes Saftgewid)tes. (Ein Melyr von 0,5 Broc. an fejtem Rüafitanoe, wer= theilt auf 50,000 Fajern, ergibt einen llnteridjed bon 1 Milliontbeil auf je zmei übereinanber ftehenden Radjbarzellen. Wir miffen aber, baß̧ felbft

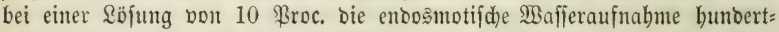

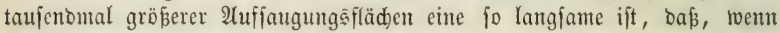
wirflidy jene gleid)mäßige Bertheilung Der \&ojung jtattfände, Dennod̆ eine täglid)e Serbunitungşmenge fid Daraus nid)t erflären würbe, bie an armešs bicfen Stangenbölzern mebr als 5 Pfund pro Tag betragen faun.

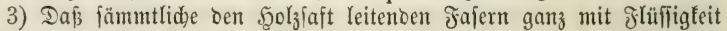
erfüllt jino, oa nur in biejem Jalle bie be iben Scautfläden ber Edjliep= baut Des Iipfelfanals mit Der Flüffigfeit in Berübrung fteben fönten, wie

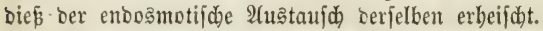

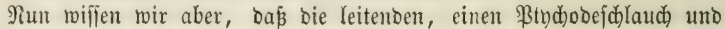

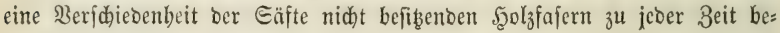
Deutende Suftmengen entbalten.

Benn ein (Eubifmeter frijđ) gefällten Iannenbolzes $^{2}=2090$ \$funbe,

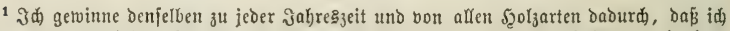

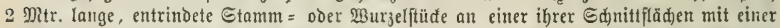

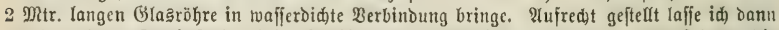
von ber oberen Sd)nittfläde einige (Eubifjolle Farbftofflofung einjaugen, worauf bann bie

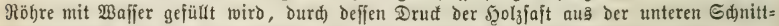

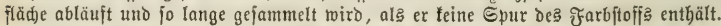

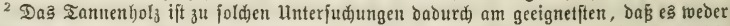

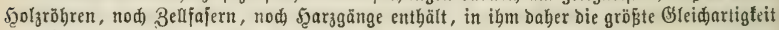
bes leitenden f్jajergetwebes befteht. 


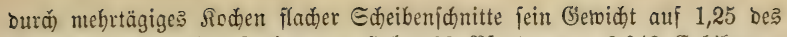

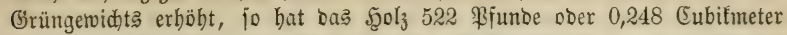
Wajper aufgenommen, bas $\mathfrak{B a f j e r g e t w i đ g t ~ b e s ~ E u b i f m e t e r ~}=2135$ Pfunbe gejeb̨t. Rach mifrometrifder Ermittelung ergab fid in obigem falle ein

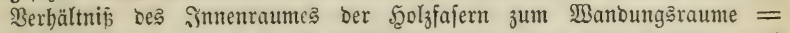
68,5: 65 unto wiro man nid)t wejentlid feblen, wenn man annintmt, bas $1 / 2$ Des Gejammtraumes auf bie Jajerwanoung, $1 / 2$ auf ben Feblraum

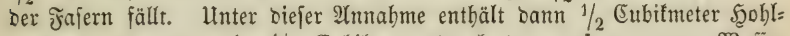
raum 0,248 oder nabe $1 / 4$ Eubifmeter burd) bas aufgenommene $2 B a f i e r$ verbrängte \&uft, alfo zu nahe gleid)en Bolumtheilen \&uft uno Şolzjaft.

Dem Beję ber Edwere nad) müpte fich nun im Fajerraume \&uft unb Gaft in ber Beife fonbern, wie bief bie nebenftebenoe Darftellung

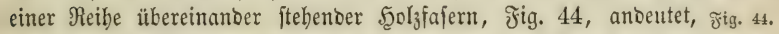
in benen ber Gaft mit w, bie \&uft mit l, bie Bellwano mit $\mathrm{c}$, bie Sd)ließ̧baut der Tipfelfanäle mit s bezeidnet ift, Seb̧tere fönnten nur einjeitig mit bem Scolzjafte in Berübrung ftehen, eine enoos:

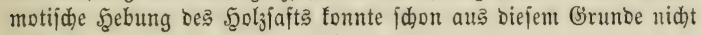
erfolgen.

Betrad)tungen biejer Ifrt, fowie ber Umitanto, daj bie ben Singerpipizen entffrömente $\mathfrak{B}$ ärme genügt, um ben Saft bes Sted"= reije: auf bie Sdnittfläd)e beşjelben emporzutreiben, fübrten mid วu ber 2(nfidt: Daß́ beim Steigen bes Saftę bie Märme uno bie Durdh fie erzeugte Spannfraft ber Dämpfe bes Suftraumes wejentlid mitwirfeno jei (Bot. 3eitung 1853, 巨eite 312). 3war batte id fibon früher gejeben, baj Suft uno Saft im Fajerraume feinesmege überall in ber テig. 44 bargeftellten $\mathfrak{B}_{e i f e}$ gejonoert feien, Das bäufig bie \&uft ben unteren, Der Eaft Den oberen Iboil beక Gajerraumes eimnebmen ober beibe in mebrere Edhidften bertheilt fino, allein id legte barauf fein befonderes (semid)t, ba es un: möglid ift, beim \$räpariren ber Sbjefte für bas Mifroffop fo zu berfabren, Daß bie Getwifibeit nidt eintretenber Störung ber natür= lichen \&agerungşberbältniffe bes flüfiligen Eaftes getwonnen werben

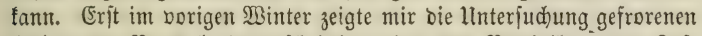

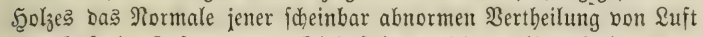
uno Saft im Faferraume. Iiép fübrte mid) zur Unterfudung Der

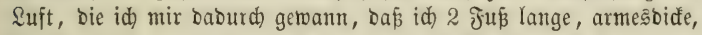
entrinbete Etammabidnitte fenfrecht in mebrftünbig gefodtes, uno

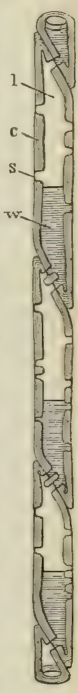
baburd) bon aller \&uft befreites, heifes Segentwaffer eintaudte uno in einem preumatifden 2 pparate bie, ber oberen Ednittfläde unter $\mathfrak{B a f i e r}$ entfteigen= Den \&uftblafen fammelte. Die \$rüfung biejer \&uft mit Rulilauge uno Pbosphor ergab einen Roblenjäuregebalt von nabe 10 Frocent! einen Siehalt Der von Der Roblenfäure befreiten \&uft bon nur 14,4 Procent Gauerftoff.

Wir baben bier aljo eine an Soblenjäure fehr reiche faueritoffarme atmofphärifde Suft, bie aller Wabrjheinlidfeit nach mit bem Bobenwafier,

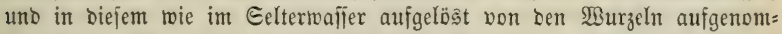
men trirb. Wenigftens ift eine $\mathfrak{Q}$ ufnahme im freien, gasförmigen 3 uftante

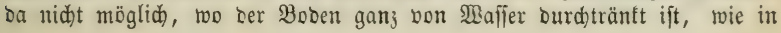


naffen Erlenbrüd)en, Weibentwerbern $2 c$. Daß̉ die Fflanzentwurzeln bie Soblenjäure nid)t allein mit bem Bobenwafjer aujnebmen, fonoern bicfelbe aud) Dem nod) nid)t aufgenormmenen Bodenwaffer ibrer nädjten llmgebung entżieben, aljo bas wedjelntbe Bobenwafjer foblenjäurereider aufnebmen, als es ben $\mathfrak{B u r z e l n}$ fid barbietet, habe id) burd) Berfudye nadjgewiefen, Die in ber erften Auflage von Liebigg organifder Ehemie Seite 190 mit= getheilt find. Der geringe Gaueritofigehalt wirb fid bereinjt vielleid)t er: flären aus Sauerftoffoerbraudh in bem, Der Sieimung bes Gamentorns äbn= licken Borgange ber Rejervejtofflöjung.

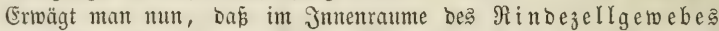
Der aufiangenten $\mathfrak{B u r z e l n}$ freie Ruft nidft gefunden wirb, fo geht baraus

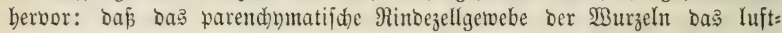
baltige Bodentwaffer aufiauge, burd fid binourd)leite, unveränoert an Daß

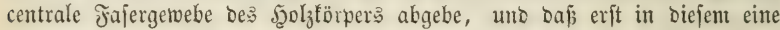
Sonberung von \&uft uno Saft eintrete, bielleicht nad) Mapgabe ber von unten nad) oben fteigenton $\mathfrak{B a ̈ r m e}$ im Snn

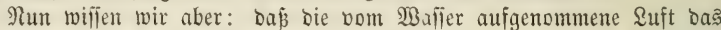
Bolumen bes Wallers nidyt vergröpert. Ábideioung ber \&uft aus

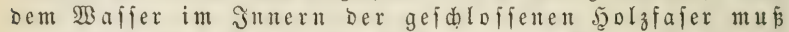
baher bas frühere Bolumen beider um bas Bolumen ber ab= gefdiebenen \&uft crböben. Daburd) muв im gejdloffenen Raume Der Fajer einte Compreffion ber Gaje, ein Drua entfteben, Der mur nadh oben wirfen fann, wenn er vou unten ber ourd neu aufgenommentes Boben= waffer fid) ftets erneut. Diejer Drud nut ift es wabrideinlid), Durd) weld)en bie \&uft eines jeben Faferraumes, burd) bie Ed)liep̧baut ber Tipfel= fanäle in ben ₹ajerraum Der nädjit überitehenden Fajer gebrängt, bie Säftes maffe in bie obere Şälfte Der leb̧teren emporbebt uno fortwirfent Den Heber: gang bes Gafte? in bie nächit höbere Fajer vermittelt. ${ }^{1}$

Jener von unten nad) oben wirfenoe Drud erflärt mun aud) bic Ihat=

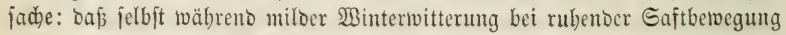

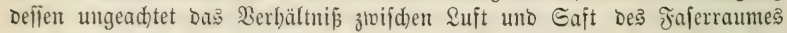
in ben oberften uno tiefiten Baumtbeilen baffelbe bleibt, baj fie felbjt bem

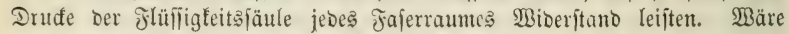
Der nid)t, Daum müpte bei milder Winterwitterung Der Gaft aller höberen Baumtheile in bie tiefern Baumtheile nieberfinten, bis zur bollftändigen

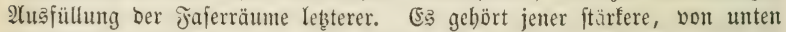
her mirfende Druf Dazu, um ben Mioeritano ber Edjlię̧bäute gegen ben Durdgang von Flüfiligfeiten zu überminben.

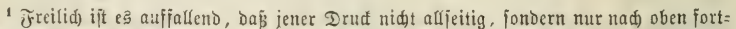

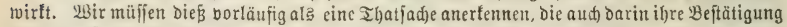

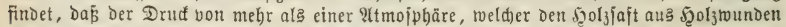

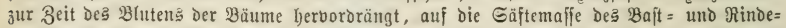
getwebes ganj obne Birfung bleibt. Wielfeid)t ijt ber Suftmangel in Den Belfräumen Diejer

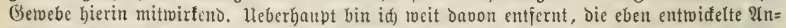

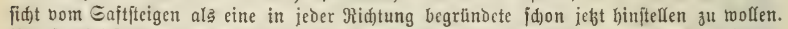

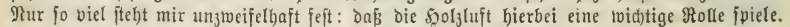
2Beldes dieje Rolle jei, bas tönnen Jabre bindurd) in obiger Midhtung fortgejejte llnter= judungen erft ergebert. 


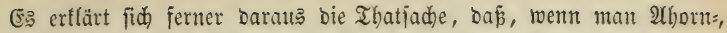

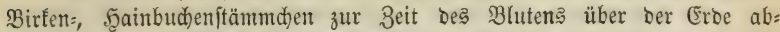
idneibet, Der Gaft ftets ser Ednittfläde entiftrömt, bieje mag nach oben ober nad unten gefehrt jein. Es ift bie comprimirte \&uft, weldhe jo viel Eaft austreibt, als $i b r$ Etreben nad einer, dem atmofphärijoben Drude

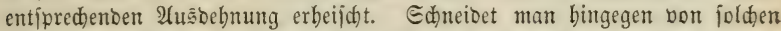

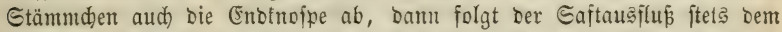
Bejes ber Edwere; er erfolgt ftets auf ber nad unten gefehrten Ednitt=

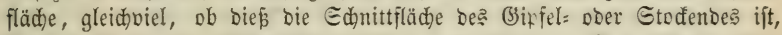
in Folge ber mun in Mitwirfung tretenden Eigenfid)were (Bot. Beitung 1853 ธ. 309).

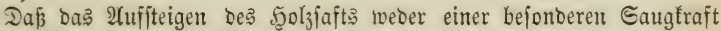
Der $\mathfrak{B u r z e l n}$ nod) einer 3ugfraft Der Blätter zugejdrieben werben barf,

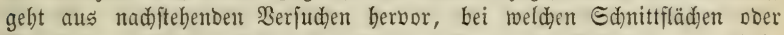
Bobrlöd)ern 20-25 Fuß boher Stangenbölzer eine 2Uuflöfung vou bolz= jaurem Eijen zur 2Afnahme bargeboten tourbe.

a) Rothbuden, bie im frübjommer aller Blätter mit ber Echeere be: raubt wurben, nabmen aus Bohrlödjern bie Eifenlöjung ebenjo auf und führten fie, wenn aud etwas langfamer, ebenio bis in bie äuperiten 3tweig= fpiţen, wie nebenftehende, belaubte Stangen. Die Blätter baben baber feinen arberen Einflup̃ auf das Gaftfteigen, als baj fie burd) Ber= Dunjtung Den für Den nadjfolgenden Gaft nöthigen $\Re$ a um idaffen; eine Funftion, bie, in Fällen eingetretener (Entlaubung, burd) bas Bellgetwebs Der Rinbe junger Iriebe biß зu fechääbrigem 2Alter binab, wenn aud it

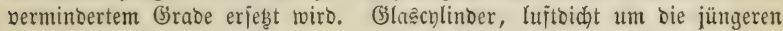

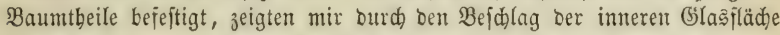
bei wedjjelnder Temperatur bie Berbunjtungâfäbigfeit ber jüngeren Rinde.

b) Boll belaubte Stangen, über bem Boben abgeidnitten uno in Sübel mit bolzjaurem Eijen geftellt, leiteten bie \&öjung ebenjo rajh bis in ben Gipfel wie Daneben ftebente, im Boben wurzelnbe Stangen, Denten bie Röjung burdh ein Bofrloch uno Iridter gegeben wurbe. Das 2 (uT̃=

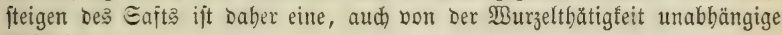
Erideinung.

c) Heber Der Burzel abgeidnittene und auch Der Blätter beraubte

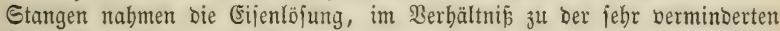

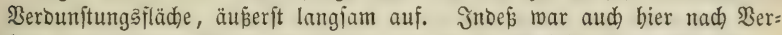
lauf von vierzebn Iagen bie Söjung bis in bie Bipfeltriebe aufgeftiegen.

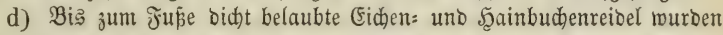

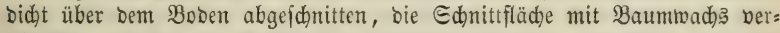
folojien, Darauf sie Bipfeltriebe zufammengebunden, eingeftub̧t unb mit Den Ednittilühen in bie Sojung geftellt. In wenigen Stunben war bieje bis zur werflebten Ednittfläd)e emporgejtiegen, ein Theil berjelben batte fid) Den abmärţ geridteten 3weigen mitgetheilt uno bas Blattgeäber bis in bie feinften Berz̧weigungen fobłwarz gi färbt.

e) 21bgeftorbenes ober gefälltes uno ganj getrodnetes Şolz, fowie

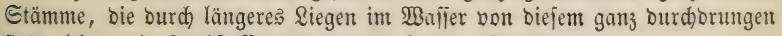
finto, leiten bie Jarbftoffe mur ronige 3ollc aufwärts. 


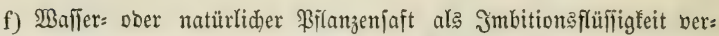
wentet, werben weniger raid) aufgejogen als Giftítoffe.

g) Bietet man bem Baume zuerft eine biluirte, nad Berlauf mebrerer Tage eine concentrirtere Söjung zur Ifufnabme, fo toiro leb̧tere ebenjo nad) oben geleitet wie eritere.

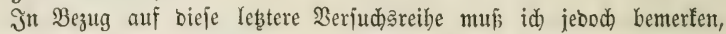
Dá̧ bie bem Baume bargebotene Flüfifigfeit bei ben Laubhölzern nur in

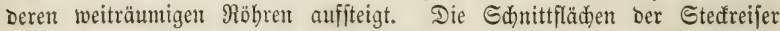
bon Ulmen, 2Ufazien, Eidhen zc. bleiben bagegen im ganzen Bereidhe ber Röhrenbünoel trođen uno nur die Şolzfajercomplex̌e werben naj, wenn man burd) Erwärmung bes Stedreifes in ber geidhlofienen Şano ben eigenten Saft auf bie Sd)nittfiähe emportreibt. Es foheint baher, als menn bie

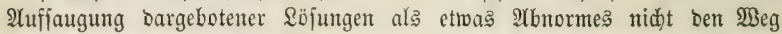
bezeidne, den ber Sुolzfaft im normalen unverleţten 3ujtanbe der \$flanze wäblt. Wenigitens muś man mit Ed)lüfien hieraus vorfidbtig fein.

Die Menge, in welder bas Bodentwajier bon ben Bflanzen aufgentom: men uno Durd) SerDunjtung aus Den Blättern an bie Suft zurüđgegeben

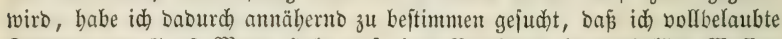
Stämme von 7-8 Meter Şöhe auf einer Brüdwage in enghalfige $23 a f f e r=$ behälter ftellte uno Den von $\mathfrak{I} a g$ zu $\mathfrak{T} a g$ eingetretenen (Semid)twerluft an

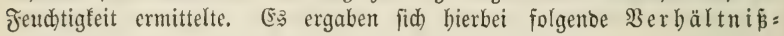
zablen:

\begin{tabular}{|c|c|c|c|c|}
\hline $50 l_{3} a r t$ & Biattzăbi & 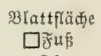 & $\begin{array}{l}\text { Berbunftung } \\
\text { pro Stamm }\end{array}$ & 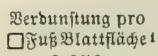 \\
\hline Erle & 1580 & 21 & 1,00 & 0,050 \\
\hline Sgainbude & 6100 & 95 & 1,10 & 0,012 \\
\hline (Eid)e & 5300 & 147 & 0,80 & 0,006 \\
\hline Rotbbuche & 6960 & 145 & 0,80 & 0,006 \\
\hline Birfe & 7300 & 76 & 0,66 & 0,009 \\
\hline İse & 4550 & 103 & 0,64 & 0,006 \\
\hline תitefer & 122,000 & 47 & 0,48 & 0,010 \\
\hline ¿ärche & 320,000 & 55 & 0,46 & 0,008 \\
\hline Sid)te & $1,555,000$ & 225 & 0,96 & 0,004 \\
\hline
\end{tabular}

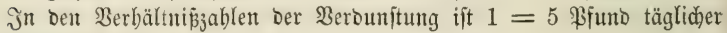
Berbunftungsmenge.

Unabbängig von Blattzabl unb Blattfläd)e ift hiernad) bie Berbunftung unt Daber aud bie Wafferaufnabme bei verfdiebenten $\mathfrak{y}_{0} l_{z}$ arten fehr ber= fdieben. Die Erle mit un 21 Duabratfú Blattflähe verountete mehr als bie Jichte nit zebnmal gröferer Blattfläche. Dffenbar wiro bie ge= ringere Befaubung burd) eine energifdere Berbunjtung Derfelben erję̧t.

(Es ift bemerfentwerth), Daß̧ Riefer uno Rärche mit geringiter \&aub= menge pro Stamm bis zum Berjud)e unter allen Şolzarten bie raja)mühfitg: ften gewejen waren. 2Uud) Die bis zum Boben reidbeaftete unt benabelte Sidte war binter ibnen im 3ntwadje zurüafgeblieben. Jnterbalb getwiffer

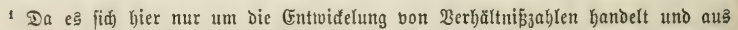

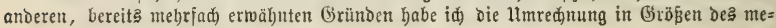
trifden Syftems unterlafien. 


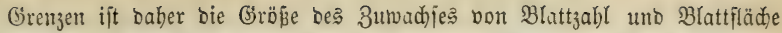
unabhängig, was id aud id)on auf anderem $\mathfrak{B}$ ege nadgetwiefen habe.

Bei Regentwetter jant bie Berbunjtung nabe auf 0 .

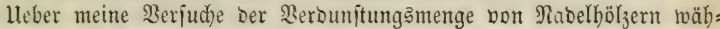
rento milder Mintermitterung hate id bereits in ber Note zu Eeite 252 beridftet, mus bier aber einer jehr widtigen Beobad)tung erwäbnen, bie id erit wor einigen Tagen eingejammelt babe.

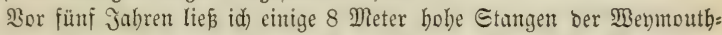
fiefer $1 \frac{1}{3}$ Meter über bem Boben in 10 Eentim. Breite ber $\mathfrak{B} u n$ flädje

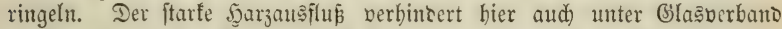

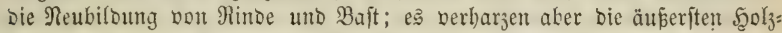

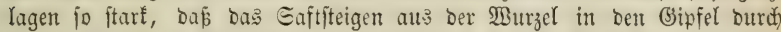

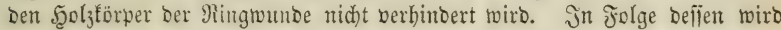

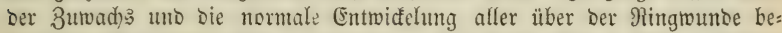

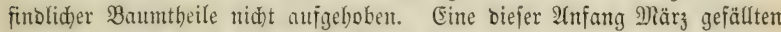
Siefern batte äuferft fräftige 1/2 Meter lange Enotriebe mit vielen Zapfen Des vorigen Jahres gebilbet. Dabingegen hatte, rwie immer, jeber 3umad) in ben unter ber Ringrounbe liegenten Bauntbeilen vom Jahre ber Rin= gelung ab aufgebört.

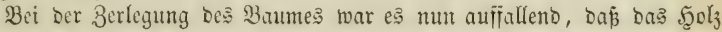

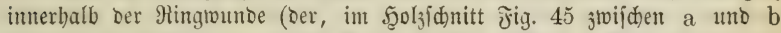

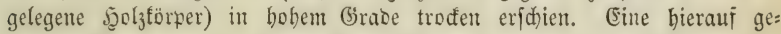

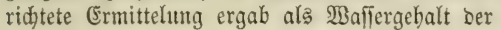

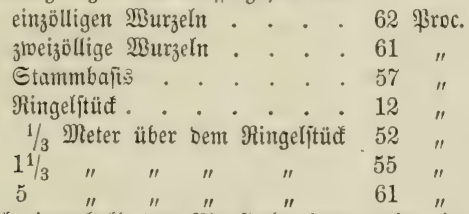

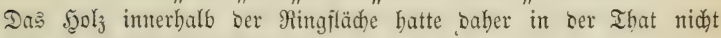
mefre als ben Feud)tigfeitsgebalt lufttrodnen Felyes.

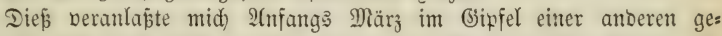

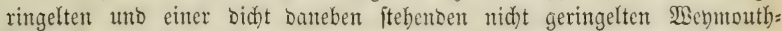
fiefer Berjuche über Berbunjtung anzuftellen. Sange, oben geidlofiene,

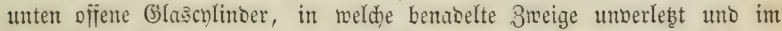
natürlichen 3ujammenbange mit Der Biflanze eingebrad)t wurben, bejdlugen fich auf ber Innenflädhe ant nidjt geringelten Baume fofort reidblich mit Jeudtigfeit. 22n Dem geringelten Baume blieben währent breier Iage uno

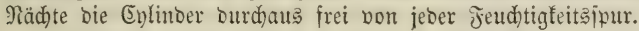

Unter burd)aus gleidhen äuferen ßerbältniffen, bei burdjaus gleidjer äußerer Bejhaffentheit uno gleidem Suftgebalte Des geringelten uno bes nid)t geringelten Baumes hatte Daber erjterer bie \$erounjtung zurüdgebalten!! Id) habe bas bie Defonomie ber Serbunjtung genannt, D. h. bie gejunbe

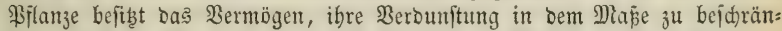
fen, als ibren $\mathfrak{B u r z e l n ~ w e n i g e r ~ F e u d t i g t e i t ~ z u r ~ 2 ( u f n a b m e ~ f i d ) ~ b a r b i e t e t . ~}$ 


\section{b. Daక Bluten ber Şolzpflantzen.}

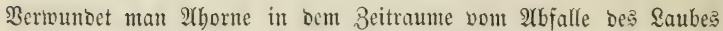

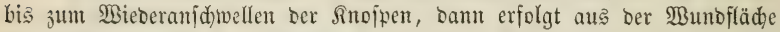

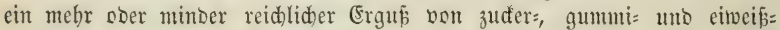

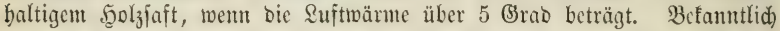
wiro in 2 merifas Utwäldern biefer Gaft jur Gseminmung bebeutenber 3udfer= mengen benußzt.

Eine berbältnifmäpig geringe $3 a h l$ anberer $50 l_{3}$ arten liefert ebenfalls tropfbar flüfifigen Erguj von ફ̧olzäften, jebod) nicht wäbreno des ganzent Minters, fontern utr in einem furjen 3eitraume vor Dent 2 tasbrud bes Saubes. Juglans blutet von Mitte Jebruar an, Fagus uno Carpinus

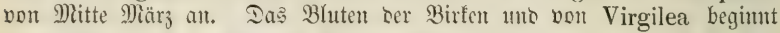

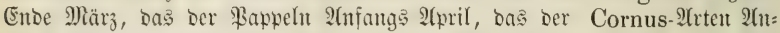
fangs Mai, Das bes Meinftodfs meift erft Mitte Mai. ${ }^{1}$ Edon biefe Ber:

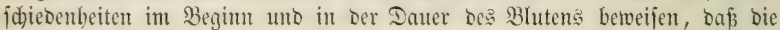

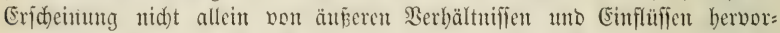
gerufen uno bebingt ift. Die 9(horne bören auf zu bluten, ebe nod) bie Sinojpen aufgebrod)en fint; bie Şainbudje bingegen blutet nod) nad) bem 2 bitäuben, wemt bie crften Blätter völlig frei geworben finto uno $1 / 2$ ibrer entididen Gröbe erreid)t baben. MBäbreno bes verwidenen, in langen Beit= perioden ungewöbutlid) milden SBinters (bis zu 10 Grad Bärme in Den

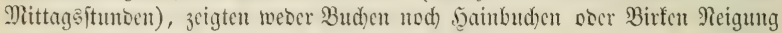

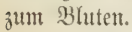

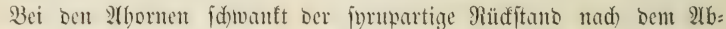

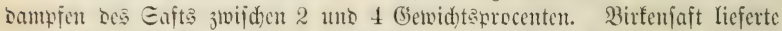

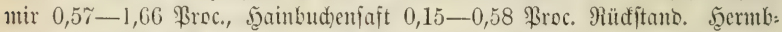

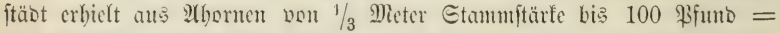
0,08 Eubifm. Eaft. Der Baum ju 0,8 Eubifm. Solzmoffe angenomment, ergibt cinen Gaftgebalt befielben von 0,1 feiner Mafie.

Eine au 2 Baffer wadjente Sirfe von etwa 0,8 Cubitm. Sgolzmaffe lieferte mir wäbrent 14 Ingen, bic jeood) nid)t sie ganje Beit bes Bhluten umfajiten, täglid) 7 Pfunto Eaft, von benen $3 \frac{1}{2}$ \$funto von Morgens

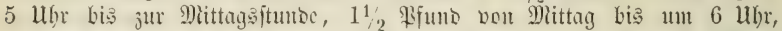
2 Pfunde vou ba bis zum anderen Morgen fid) ergofien. Das Berhältniß Des Erguffes in gleiden 3eiträunten siefer Iagesjecten ift aljo nabe $=$ 1-1/2-1/3. Die Jrage: ob bex abfliefende 5ुolziaft fdon wäb:

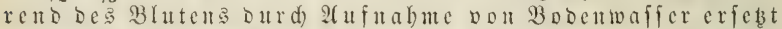
wirb, ift aud) bicrourd) nod nid)t entidjicben, ba ber ergoficene Eaft mur

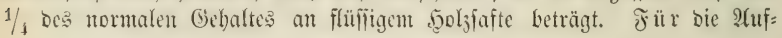

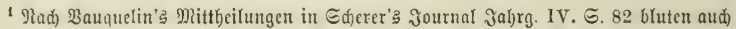

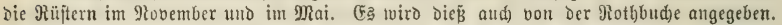
3eide follen im Safte feinen Zuffer fondem, twie ber $23 e i n j t o d$, nur pflanzenfaure Galzc

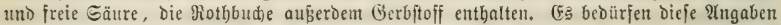
wohl nod) einer (Eontrole. 23enigiten fint dic Evrupe, bie id) in ber Geite 258 bezeidneten

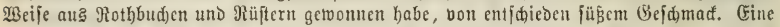

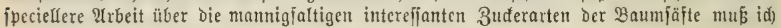
mir für cinen anderen Drt vorbehalten. 


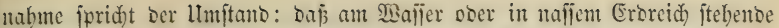
Bäume reit reid)lidjer bluten, als jolde im trodenen Boben, uno sap ber

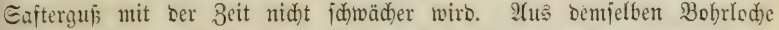
fliefent, lief ber Gaft obiger Birfe nad) 14 Tagen nod) ebenfo raid) als

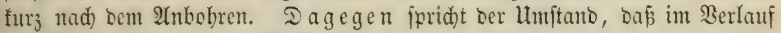
Des Blutens eine mejentliche Berringerung bes Gebaltes ber Gäfte an feften

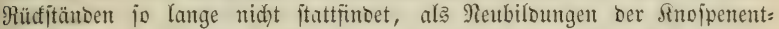
midelung nid)t cintretent. Eine Söjung fefter Rejerbeftoffe findet jur 3eit Des Bluten entidjieben nod) nidjt ftatt; ber Buder= uno Gummigebalt bes

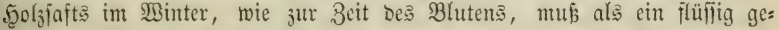
bliebenter Referbeitofif betrad)tet werben, Der nothwendig eine Diluirung er: leiben müßte, menn ber ausfließ̧ente Saft burd) Bobentwafier fid)on zu biefer 3eit erjeb̧t wirs. Bon zwei gleid) fturfen nebeneinanber ftehenden Birfen Yiēs id bie eine um 14 Iage fräter anbohren, als bie crite. Ier Darauf auڤ beioen Bäumen gleidjseitig gejammelte Gaft enthielt: aus ber vor 14 Iagen angebohrten Birfe 0,73 \$roc., ber Gaft aus ber frifd) gebohrten Birfe 0,91 ßroc. Rücfitant. Der Gaft einer frif angebohrten Sainbudi)e lieferte 51 Broc. Rücfitano, währeno Der Єaft eines vor 10 Iagen an= gebobrten Baumes 0,34 Proc. Lieferte. Ës finto Dief Differenzen, die fehr

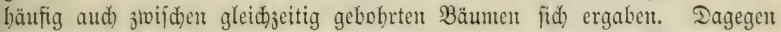
verringert fid ber Gebalt an gelösten Etoffen gegen Enbe ber Błhutzeit, un= ab̧ängig von erfolgtem (Erguş. Eine am 23. 2(pril angebohrte Scainbuche lieferte Damals 0,56 Proc. Gurup, am 13. Paai mur 0,10 \$roc. Sine Daneben ftehente an 11. Mai angebobrte Sainbude lieferte aus ben am 13. Mlai gejammelten Gafte mur 0,49 Broc. Rücfitanto. Da z̧山 biejer Beit Die Bäume bereits abgeblühet, bie Triebe eine ¿änge von 8-10 Eentim. erreidht batten uno bis jur Entridelung Deß vierten Blattę vorgejdritten

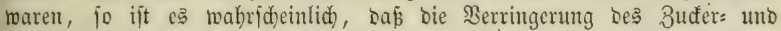
Bummigebalte aus Berwentung auf bie Neubiloungen bervorgegangen war.

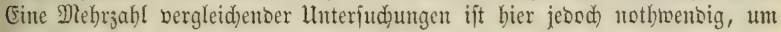
fid)ere Sd)lüfịe ziełen zu fömnen.

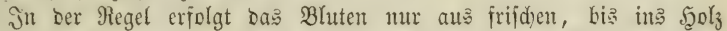
bringenben Edjnittmunden. Froftrifle bluten jebod) mitunter mebrere Jabre hinourd). Bei ber ફ̧ainbud)e babe id) einmal ein freimilliges Blaten be: obadtet, unt zwar aus ben Rnofpen, beren jebe am Morgen einen Tropfen

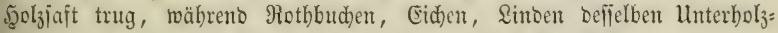
beftandes ganz trođen ftanben (Bot. Beitung 1853 厄. 478).

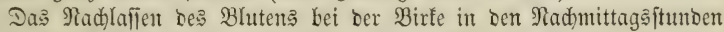

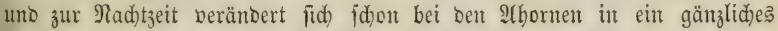

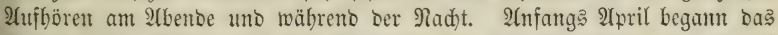
Bluten (aus S(ftwumoen) bea Morgents nit Enmentaufgang bei $2-3^{0}$ Wärme, veritärtte fich bis zu ben Mittagझ̆tunoen bei $5-6^{0}$ uno hörte ant

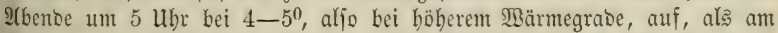

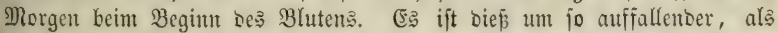
Der Baum wie Der Boben Den Temperaturberänderungen Der Suft ohne 3reifel langfam folgt, mithin am Morgen länger falt, am 2tbent länger ıarm bleiben muí. 


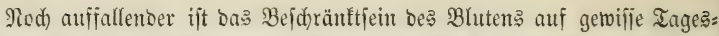
zeiten, wedjelno mit Berioden bes Einjaugens ben Bohrlödern bargebotener Fliifigigfeiten.

3uerft im frübjabre 1860 fiel es mir auf, baj̃, wenn man Scain= buden zur Beit lebhaften Blutens in Den Morgen= uno Bormittagsftumben

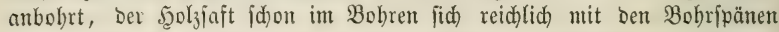

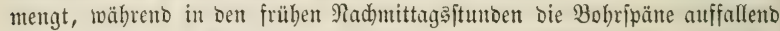
troden fint. Jd) lię̧ Daher zwei Bäume zur Beit ftärfjten Blutens (4 Uhbr

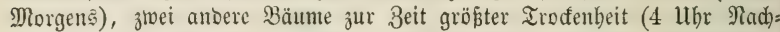

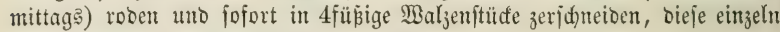
genau twiegen, bann fpalten unb trodinen.

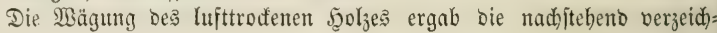
neten Bafferberlufte.

\begin{tabular}{|c|c|c|c|c|c|c|c|c|}
\hline & & & $\begin{array}{l}\text { 2In ben } \\
\text { gefäller }\end{array}$ & im $\mathfrak{B}$ & & & $\begin{array}{l}\text { 2In ben } \\
\text { ftebenber }\end{array}$ & $\begin{array}{l}n \text { trod } \\
n \text { ⿰氵äu }\end{array}$ \\
\hline Wurzeln . . & • & • & - 42 & Broc. & . & & 41 & $\mathfrak{B r}$ \\
\hline Wurzelito of . & . & . & . 42 & $" 1$ & . & ${ }^{\circ}$ & 35 & \\
\hline Stamm $1-4^{\prime}$ & . & . & 35 & " & . & . & 26 & \\
\hline $4-8^{\prime}$ & . & . & 35 & " & . & . & 28 & \\
\hline $8-12^{\prime}$ & . & . & 42 & $" \prime$ & . & . & 29 & \\
\hline $12-16^{\prime}$ & . & . & . 35 & $" \prime$ & - & - & 33 & \\
\hline $16-20^{\prime}$ & • & • & . 40 & $\prime \prime$ & • & • & 35 & \\
\hline eite uno Reijer & . & 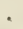 & . 33 & " & . & & . 35 & \\
\hline
\end{tabular}

Es: haben baher bie blutenden Bäune in allen ibren Ibeilen

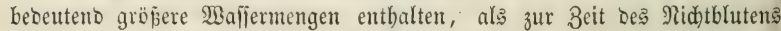
unto entipringt baraus bie Frage nad bem Berbleib bes Mlinoergebaltes an

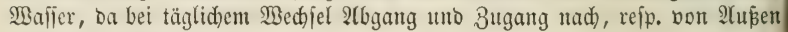
nid)t $\cdot$ wabricheinlid) ift.

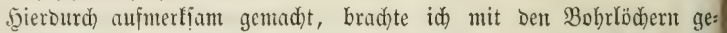

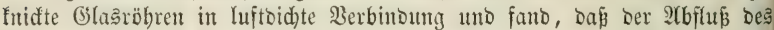

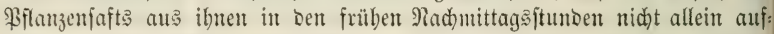

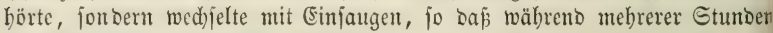
Den Ğlaşröhren Dargebotenes 2 affer in bas Innere des Baumes auf: gejogen wurbe.

Da biefer täglidse Medjel von Bluten uno Saugen, zuerft bei be1

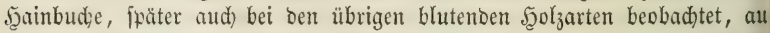

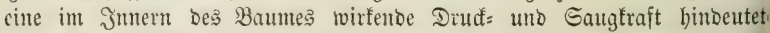

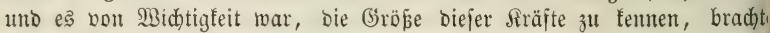
id) Die Bobrlöd)er mit Duedfilber: Mhanometern in huftoidste Berbintoun! uno fant für bie Beit des Blutents einen Heberorud in maximo bon $1 \frac{1}{2}$ für bie 3eit bes Gangens einen Mintoerorud von $1 \frac{1}{4}$ : 2 tmojphären. Di Ergebuiffe einer grofen 3abl bout Unterfud)ungen finto vout Jabre 1861 al

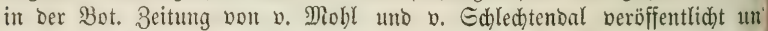
nuı id mid) bier barauf befdränten, ben baraus bergeleiteten Stanopunt meinter gegentuärtigen (Erfenntníp biejer nod) in Biełem rätbjelhaften Rebent ericheinung barzulegen.

Man batte bis baher bas Bluten ber Bäume mit eiter Bewegung de Bflanzenfafts aud) im Jnnern bę nod) unverleşten Baumę in Bejiebun 
gebrad)t. Edon früh batte id troks aller 2(ugenfälligfeit bie Ridłtigteit

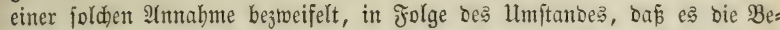
laubung Der \$Bäume ijt, weldhe burdh Berounitung Den Raum für Die Gaft:

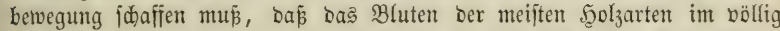

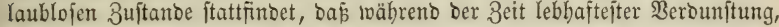
alio lebbafteiten Saftifteigens unt, wie id) gezeigt babe, aud gröfter Saft=

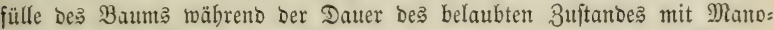
metern armirte Bäume feine Epur, weber bon lleber= nod) bon Minber=

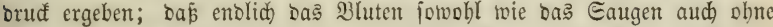

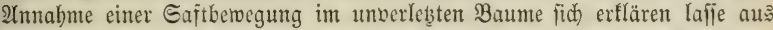
wedfielnoen $\mathfrak{B}$ olumtverbältnifien Der im Jnnern ber Bellen eingejd)lofienen,

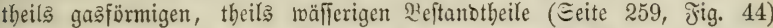
baburd), Daj zur 3eit bes Bhutens Ǵaje aus bem Wafier in Den \&uft= raum ber Bellen ausgeidieben, zur Beit bes Gaugens Gaje in ben Saft= raum aufgenonmen werben. ${ }^{1}$ Bon biefem Gefidtępunfte aus habe id bie unverleb̨te Pflanze zur 3eit de ber zum Theil mit Waffer, zum Ibeil mit comprimirter Suft bid)t an= gefüllt ift. Wajier und \&ujt befinden fid) in biejem Edjlaude in Mube;

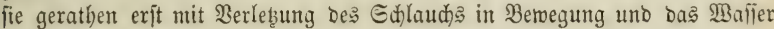
Des Gd)laudbs wird Diefem jo lange entfitrömen, bis bie ibm beigemengte

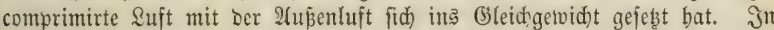

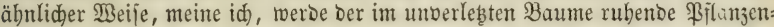
faft in ber Beit bes Blatens erft burd) bie Derleb̧ung bes Baumb in Be= wegung gefekct.

Bie aus meinen neueren Unterjudungen bervorgebt, ift bas Bluten eine, nid)t allein in Bezug auf Beitbauer, jonbern aud örtlid) bejdränfte ¿ebenserjdeinung einzelner Pflanzen. Sit bie 8-10 wöchentliche ßeriobe

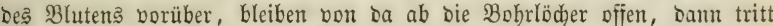
aus Demielben Bobrlodje eine Bhlutung nie wieber cin, ohne baś, auper

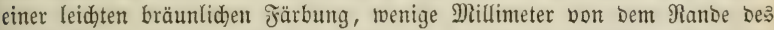

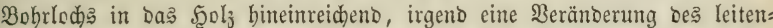
Den Fafergetwebes erfennbar toäre, namentlich feine Berftopfung Der Fajer=

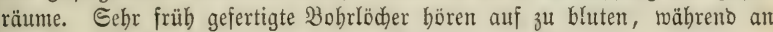

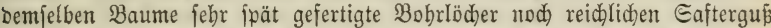
unter hohem Ueberbrud ergeben. Bei ber hohen Drudfraft, bie bas Mano= meter im blutenDen Baume nad)weist, bei ber geringen Drudffaft, bie ge=

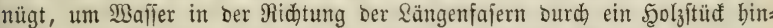
Durd) zu prefien, ift fidon bieß eine völlig rätbjellbafte Ibatjade. Derielbe Birfen=2litjtub, befien Sdhnittflädbe aufgehört batte zu bluten, wäbreno bie Manometer frifd gefertigter Bobrlöder in Demjelben Baume nod) $3 / 4$ Atmo= iphäre Heberorud erzeugten, nachbem er vom Baume abgeidnitten worben

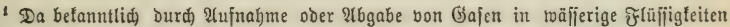

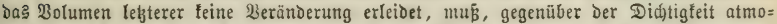

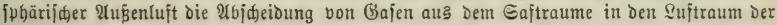

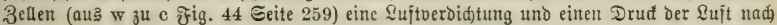

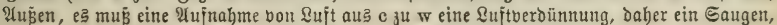

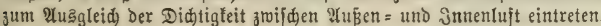




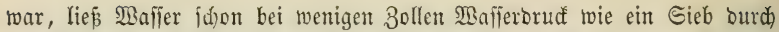

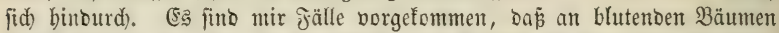
bie gleidzeitig mit zwei im Durd)meffer Des $\mathfrak{B}$ aums fid gegenüber ftehenden Manometern armirt waren, an Denen bie Enoen Der beiben Bohrfanäle nur wenige 3olle auseinander lagen, Das eine ber Manometer bebeutenden lleber=

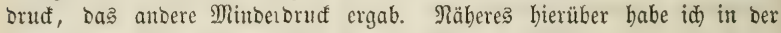

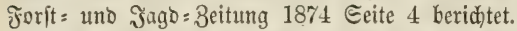

Je mehr man mit ben Das Bluten Der Bflanzen begleitenten Erfacei= nungen befannt wiro, um fo gröfer wiro bie 3abl ber bamit verbundenen

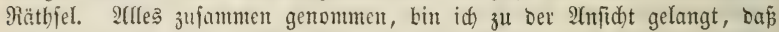
Das Bluten als cine burd)aus für fid) beftebende Rebentsericheinung betrad)=

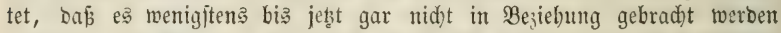
bürfe mit ber Betwegung bes Safts in ber fid ermäbrenten uno wadfenten

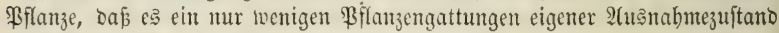
Der $2 B$ interrube fei.

c. Die Söjung Der Rejerbeftoffe int aufiteigenden rohen Rahrungajafte zu jecunbärem Bildungşafte.

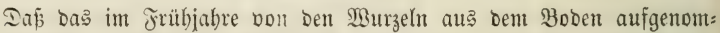
mene Baffer alle biejenigen Bobenbeftantheile mit fid führt, bie wir be=

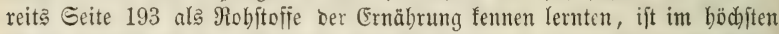
Grabe wabrid)einlid. In biejer Şinfid)t fann man ben auffteigenden Jrüb= faft ber Bäume roben Rabrungajait nemen. Diejer Saft ift aber

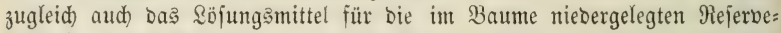
jtoffe. ${ }^{1}$ Durch Bermifdung mit ben Rejerbeftofflöjungen wiro er zu bem, mas id ben fecunbären Bilbungsjaft genannt babe, im (segenją̧ 孔u Dem in ben 2 lättern bereiteten uno aus biejen im Baftföner ab= wärţ fteigenden primären Biloung $\{$ af te.

Wie wir gejeben baben, fteigt ber Frübfaft in ben cylinorifds:getipfelten, bei ben Rabelfölzern in Den linienräumig=getipfelten \$colzajern aufwärts. Jn ber gropen Mebrjahl ber Sgoljpflanzen enthalten bieje Drgane feine fefte Rejerbejtoffe; Mark, Marfftrablen, 3ellfajern, Rindejellen, in Denen bie= felben aufgefpeidgert fino, bienen aud nid)t ber Eäfteleitung nadh oben. Daber fann bie $\mathfrak{B u r z e l}$ Monate binourd Bobenwafjer aufnebmen uno nad) oben Yeiten, obne Daj ibre Referveftoffe baburd) gelöst merben. Ju ber

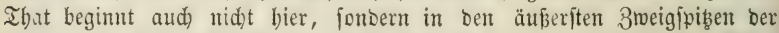

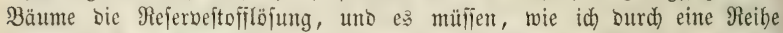
fpecieller Beobadtungen in ber Forft = uno Jagbzeitung 1857 Seite 292 gezeigt habe, burdjidnittlid) żwei Monate verfließsen, che bie Mlehllöfung von ben 3reigipiz̧en bis zu ben Burzelfpizen binab vollendet ift. Wie Der Boben an Das Samentorn, jo geben bie fäfteleitenden Fajern Jeudtig= feit an bas meblbaltige 3ellgemebe $a b$; in ihm tritt, wie in Den Gamen=

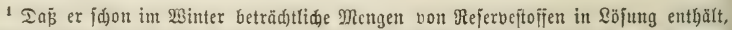
befitehent vorjugstweife aus veridiede:ten Bufferarten uno Summi, mit geringer Beimengung

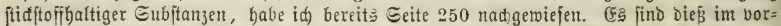
hergehenden Eommer bereitete Bildunggitofife, Die nidbt zur Berwentung auf Meblbiloung gelangten. 


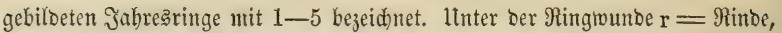
$\mathrm{b}=$ Bajt, e bie Jnitiale eines im Jabre nad) Der Ringelung gebilbeten Fyolzringes. Snt ben unter ber Ringwumbe befinolichen Baumtheilen geht im

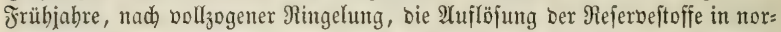
maler Beife vor fich, ber baraus wieberbergeftellte Billoungşaft wirb, burd) ben entblößten Şolztörper ber Ringwunde binourd), Den böheren Baumtheilen zugeführt unb bort auf Reubiloungen verwenbet. Dagegen bört unter ber

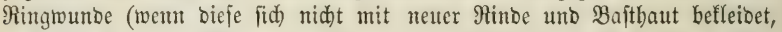

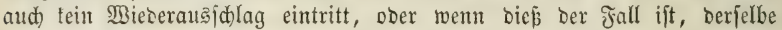

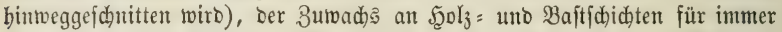
auf. Jint erften Jrübjabre nad) ber Ringelung entjtebt jwar bi e 2 nlage eines ntuen $\mathfrak{S}_{0} \mathfrak{l}_{3}=$ uno Baftringes, bie aber nie mebr als bis zu bödjitent $1 / 3$ ber vorbergebenden Ringbreite vorid)reitet, aud nie mit einer Breit=

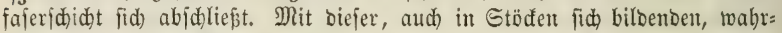
fdeinlid) aus ben Rejerveftoffen ber Rinbe uno Baftjdidt fid bildendent

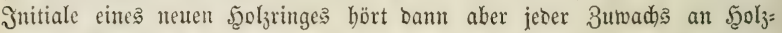
uno Baftfajern in ben unter Der Ringmunbe befindliḑen Baumtbeilen für immer auf, obgleid) biefe aud) ohne Stotausjallag nod) viele Jabre bin: burd) lebentig bleiben uno ifre Junttion ber Jeudtigfeitsauffaugung ans Dent Boben uno ber Reitung bes Gaft nad) oben ungejtört verrid)ten fönnent,

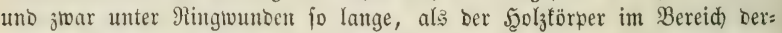

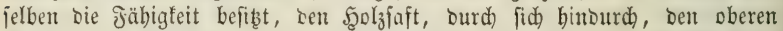
Baumthcilen abzugeben. Dieje Seitungsfäbigfeit verliert ber entblöfte $5_{0} l_{z=}$

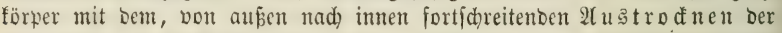

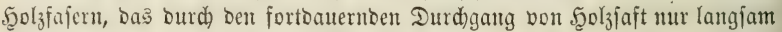
vor fid) gebt uno an fingersbiffen Stämmen ober 3weigen in Der Regel ¡j)on im zweiten Eommer, an ftarfen Etämmen, 3. 3. Der Sintoe, erft nad) mebreren Decumien bis zum Mlarfe vollendet ift. (Eben fo lange babe id)

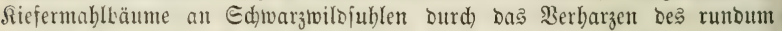

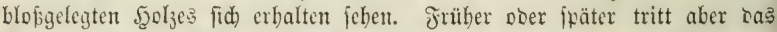

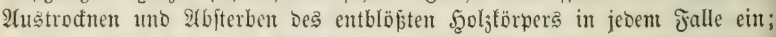
es hat Daffelbe Danu bas ?lbfterben ber überftehenden Baumtheile unfeblbar uno mit biefem aud ben Iod ber unter ber Ringwunte befindliden Baum= theile baun zur Folge, went an biefen feine 2(uङ)daläge fid) bilbeten. Sit

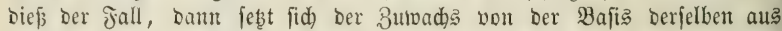

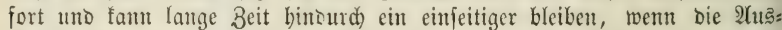

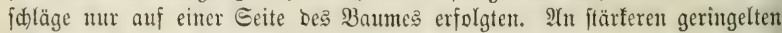
Bäumen füntoigt fid bas 2tbfterben fdon cinige Jabre vorber an, ourdh Berfürzung Der Jal)reștriebe, Berminberung Der $3 a b l$ und Brö̈ße Des Laubes, wahrideinlid) in Jolge bes nidyt mebr zureidjenton Gaftzuflufies non unten.

Ringelt man junge Siefen mebreremale ftets in ber Mitte zwifhent je ziveiun nod) benabelten Quirlen, baum erfolgt, won ben benabelten Aeften auß, normale Şolzbiloung bis zu jeber tieferen Ringrumbe; von jeber

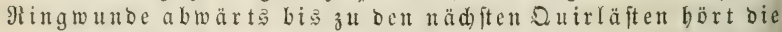

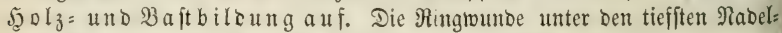
äften unterbrid)t Den 3uwadas in allen ticferen Baumtbeilen.

Mingelt man im Jrühjahre Seitenäfte $1 / 2-2 / 3 \mathfrak{M}$ itr. entfernt vom 
Fig. 46. bie Entroifelungsfolge des am oberen Ednittranto bes

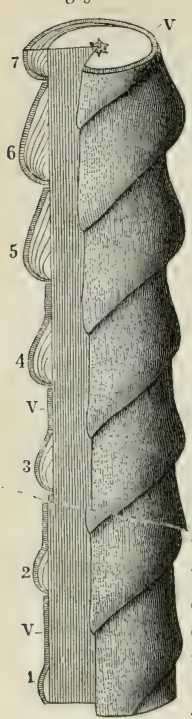

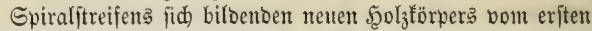
biş zum fiebenten Jabre bargeftellt, un zu zeigen, baß̄, ehe Der neue Sgoljtörper ourd) Edichtenbiloung bis zum unteren Ednittrande ber Spiralwunde emporgeftiegen ift, bei v v jebe Neubiloung von ફ̧olz= uno Bajtfajern ausjebst. In unjeren Rieberwälbern experimentirt Lonicera Periclymenum in biefer Beife und erzengt bie fpiralig getwuljteten Manderjtöde, bie twir häufig in ber Şanb ber 5anbwertsburjden feben. Şier ift es fd)on ber, mit zu= nebmenoer Berbidung bes Stammes burd) bas nicht nad)=

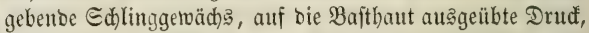
ber biefelben (Erid)einungen wie bie Spiralwunbe Durd) Unterbrechung ber normalen Manderung Des in Der Bapt= baut abjteigenden Biloungsjaft ing Reben ruft.

Bir fönnen uns biefe (Erjheinung nid)t anders er:

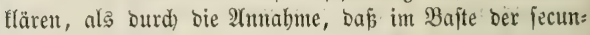
bäre Biloungsfaft im ungeftörten Berlaufe feiner WBanberung mu jwei Ridhtungen eimfd)lagen tönne, bas fenifiadote 2 bjteigen und bie vom abfteigenben Strome rabial nad) immen firrtgeferzte ßerbreitung; Daj erft ba, wo bem abiteigenten Safte sin Sgindernif entgegentritt, biejer zu einer Abweidung in periwherifder Rid)tung gejwungen wirb, hier, am oberen Sdmittixnde bes Spiralfannittes, auf bom fürzeiten 2 Bege bon Belle zu iselle nach unten fich verbreitento; Daßj in Jolge biefes umatii. Lidan Berlaufs

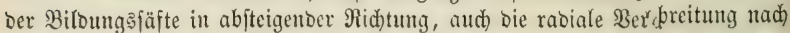
bem Eambium bin, auf jenen, anfänglid) fdomalen Gaftitrom über bem oberen Ednittrande Des Epiraljtreifens jid) bejoränfe; Daj Damit eine Un= bildung Der ben Gaft leitenden Elementarorgane bervorgerufen wejtoe, Der

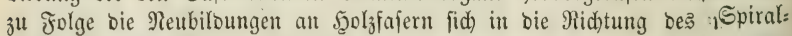

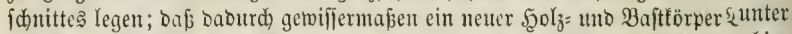
ber Rinto fid) bilbe, Der fid fpiralig un ben alten Solzförper winbet und bin=

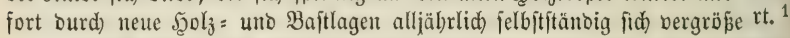

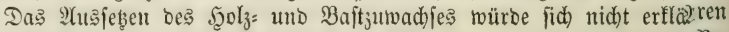
laflen, wenn ber fecunbäre Bilbungşaft, aus ben im Sgolze lagernoen s: Rle:

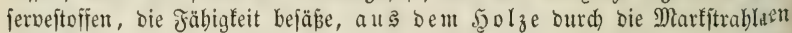
Dem Cambium ummittelbar zuzugeben. SBir müljen vielmchr annebmeret,

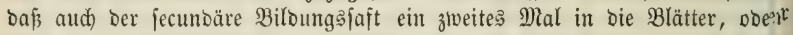
ood) in bie jüngiten Iriebe aufiteigen müfie, um bort feinen Uebergang inet

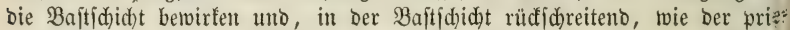
märe Biloungşaft, vou ibr aus Dem Cambium von auben ber zuzugebone.

1 Id befibe in meiner Sammlung phyfiologijd)er \$räparate einen (Eidenjtamm Diefer!

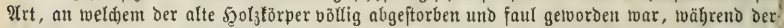
fpiralig getwundente neue Şoljtörper fortbauerno im fräftigften 3utwadje ftand. Heber bie

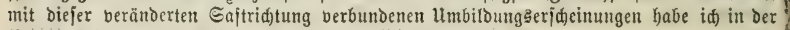
Botan. Beitung 1854 Seite 1 meine Beobadtungen mitgetheilt. 
Die Exiralmunbe uno beren Folge gibt uns aber nod) einen anderen Jingerzeig. Wäbreno bie Fुolzbiloung auf Den oberen Ednitt= ober Druat= rand der Epirale reoucirt wirb, mäbreno fie, felbft innerhalb ber weitläuf: tigiten Binbungen anfänglid̆ auf einen febr fleinen, unterften Fläđjenraum

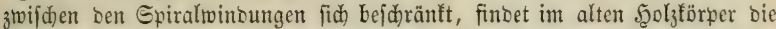
Mieberanjammlung von Rejerveftoffer aus primitive m Bilbungsfafte Durdhaus normal in allen Theilen innerbalb bes Bereides ber Exirale ftatt. Darau barf man folgern, Daß ber von ben Blättern bereitete, in Der Baft= baut nieberfteigende, primitive Bilbungsfaft, nad) jeinem, wabrideinlid) Durd bie Martftrablen vermittelten Uebergang in ben Scolztörner, im leiten=

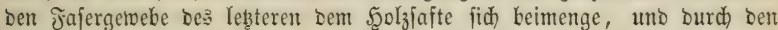
auffiteigenben 5ुolzjaft allen ienjentigen Drganen zugefübrt werbe, in benen

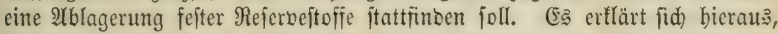

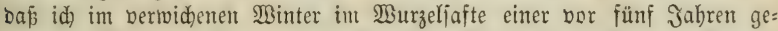

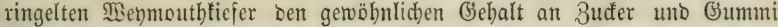
finben fornte, ber nur burd) ben abfteigenben Baftfaft borthin gelangt fein fann.

(E⿹ Leibt uns nun noch bie Frage, ob aud ber fecundöre Bil= Dungsjaft nothrwenbig in bie Blätter aufíteigen mülle, um feinen Rüú= tweg in Den Bajt antreten zu fömen, ober ob biej aud idjon in Sinoipen ober in Den jüngiten Irieben ohne entwiđelte Blätter geịhehen fönne. Daf in äleren Trieben ein Hebergang $n i$ id ftatfinbe, zeigen uns unjweifelfaft Die Folgen ber Ringtumben.

Jür Den llebergang aud in Sinofpen uno nod) nidt belaubten Trieben ipridut bie Ihatjache, baj nidht jelten Die Jabrringbilsung in ben jüngiten Irieben зu enter Beit beginnt, in welder bie Inofken eben aufbred)ent. Ifแs einem meiner frübeften \$erjuche ging ferner herbor, bafs, wemn man Jolzpflanzen im Jrübjabre entfnojpet uno aud fpäterbin jebe Blattentwidé lung Durd) frübjeitiges 2(bbrecten neu entitebenoer Sinojpen berbinbert, Dennod eine Neubiloung bon Scol ${ }_{3}=$ und Baftfafern eintrete, wenn aud in bejdränfter 3abl. Iđ babe ferner nadgetwiejen, dapi in feltenen fällen

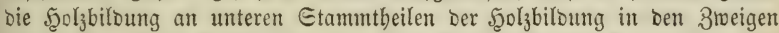
vorangeht. Dieje Erfahrungen uno einige Reprobuftionserfocimungen toaren

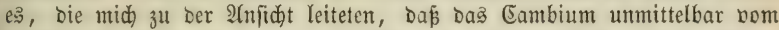
Şolztörper aus burdh rabiale 3ufübrung von Rejerbeftoffen gejpeist werben fönne. Sndép liegt in ben Gdlü|̄en aus Reprobuttionseridheinungen auf Den Berlauf Der normalen Thätigleit immerbin eine großße lunjiderbeit, uno

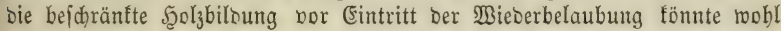
auf ber ßerwentung ber audj in Rinoe und Bajthaut aufgefpeiderten Re=

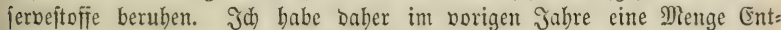
laubungsverfude von neuem angeftellt, bin baburd) aber leiber nod nidst 3u einer ficheren 2(njidauung gelangt, ber Edwierigteit wegen, bie fid ber abjoluten Unterorüđung ber \$Bieberbelaubung bei Den Saubbölzern entgeyen= ftellt. Es ift mir bis jeb̧t nidjt möglid getwejen, bie Berfud)spflanzen un=

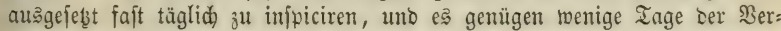

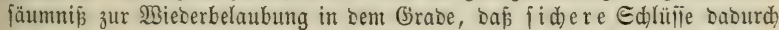

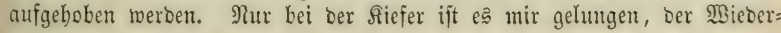


belaubung aud) ber jüngiten Triebe ohne Töbtung berjelben vorzubeugent. Sie geidah an mebreren, 3 Meter hohen $\mathfrak{P}$ flanzen $\mathfrak{A}$ nfangs Suni, zu einer 3eit, in weldyer bie jungen Triebe bereits eine Sänge bon 10 Eentim. er: reidht batten, bie Rabeln an Denfelben burdfidnittlid $3 \mathrm{Mm}$. aus ber Sdeibe hervorgetwadjen waren. Die fo tief wie möglid am Iriebe mit ber Sdheere abgejdnittenen Nabeln ftarben an ben vorjäbrigen uno älteren Irieben, am bieß̧jäbrigen jungen Triebe bingegen bielten fid) bie Stukge lebendig, mudjen

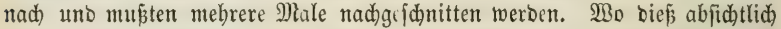
nid)t gejdah, erreidten bie Stuke, aus ber Blattbajts nadjwadjento, im Saufe bes Sommters zum Theil über $1 / 2$ ber normalen Rabellänge.

$\mathfrak{A}_{n}$ ben fortgefę̧t entnabelten $\mathfrak{B}$ flanzen wudjen bie biejjäbrigen Iriebe

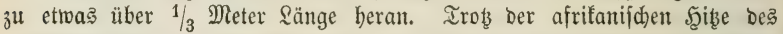
Sommers uno bei einer Bobenoürre, bie felbit Ballenpflanżugen bes grüb= jabrs zum Eingeben bradte, erbielten fich nid)t allein bie jungen Iriebe mit ben Rabelituţen lebenbig, fontern es bilbeten fid aud) bie Enofnnofpen regelmäßsig aus. Selbłt bie bäufigen 2Ingriffe von Pissodes notatus, die faft täglid) an ber Minoe ber jungen Triebe zu finton waren, angeloctt burd) Den immerhin frautfaften 3uftano Der Bflanzen, beeinträdbtigten bie Ent= widelung ber Triebe nid)t. 2(ud) bie Şolzringbiloung, obgleid) gegen bie Der belaubten Riefern etwas zurüđơgebalten uno gefdmälert, ift in normaler Meife erfolgt. Erif in Spätherbit ftarben bie in biejer Beife miß̧bantolten Bflanzen fämmtlid.

Die Entnabelung hatte baber in biefen Fällen ben Ulebergang bes fecunoären Bildungafafts aus bem fgolz= färper in ben Baft nidt verbinbert.

Dagegen blieben zmolfjäbrige Siefern, bie biß zur Mitte ber breijäh=

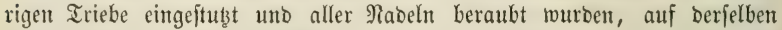

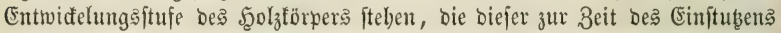
errcidjt hatte. Die meiften ftarben nadj biejer Berlez̧ung in furzer Beit, ohne irgeno eine Reproduttionserfcheinung; einige begünftigt burch belt Stanoort, erbielten fid trobsom bis zum Şerbite frifd uno jaftig mit grüner Rinoe.

2Andere zwölfjäbrige, $4-5$ Meter hohe Siefern wurben nur an ben

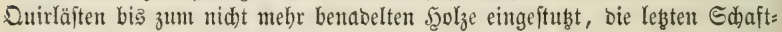
triebe wurben mit ber Sdecre wie im erfterwäbnten Experiment entnadelt, berblieben aber Dem Baume. Der Erfolg war genau berjelbe, wie an ber erfterwäbnten $1 \frac{1}{3}$ Meter bohen Riefer. Der biepjäbrige Irieb hat fich bier wie bort normal ausgebiloet.

Behalten bie bis zum ztwei= ober breijäbrigen Iriebe eingeftubten 2refte iłre vorjäbrige ober mur bie zwei= Doer breijäbrige Benabelung, baun biloen fich unfern ber Edbnittfläd)en zwifden ben Rabeln neue Rnofpen für neue Rängentriebe; bie Scolżbiloung gebt unter Dem Stub̧ fo rajd) uno fräftig vor firth, als im unberlek̨ten 2ljte.

Daraus bürfen wir mun vorläufig folgern, baß ber fecunbäre Biloungş=

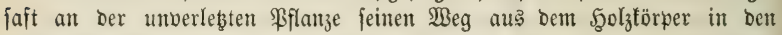

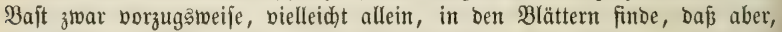
wenigitens in sällen eingetretener Entlaubung, biejer Uebergang aud) int 
Jnnern ber jüngiten Iriebe ftattfinten tönne, Daj bagegen alle älteren, nidjt

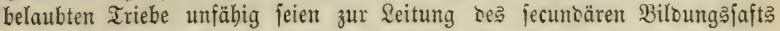
aus bem 5̧olze zum Bajte.

Benn nun burd) eine Mebrzahl von Beobadtungen es fid beftätigt, bas̃ aud ber mebriäbrige, belaub te Trieb ber Eäfteleitung aus $\mathfrak{S c l}_{z}$ in Baft bienftbar ift, Das bieje Funftion burd Entlaubung aufgehoben wiro Doer mit bem natürlidjen Blattabfalle erlifdt, fo leitet bie Thatjache, oa

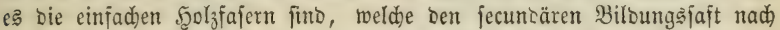
oben führen, auf ben Giebanten, ę werbe biejer Saft von ben Solz Des 2ldjengebildes an biejenigen Fajerbünoel abgegeben, bie, in jabräg nach oben gemenoeter Ridjtung, bom Marfcylinber aus burd) Scolz, Baft und Rinbe zur Blattbafis verlaufen unt im Blattfiel fid) fortieben (รig. 5, 9, 12). Die nad)gerviefene Reitungşähigfeit ber entlaubten, nod) in ber (Ent= widélung ftebenben, jüngiten Triebe wirb fid bann burd) bie $2(n n a h m e$

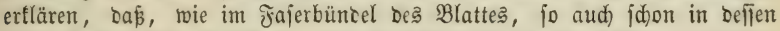
anfängliden, ben Bajtförper Des. Triebes ourdjebzenoen Theile ein Heber=

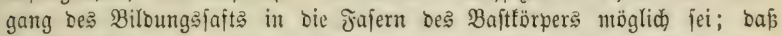
bie Jajerbünbel ber Blattauşfheibungen, vielleidjt aud) ber Rnoppenaus= fheibungen (Jig. 12, 13) i don innerbalb bes Iriebes, dem i ie a ngehören, Da two fie ben Baftlörper befielben Durdjitreiden, zur Brüđe werben für bent llebergang ber jecunoären Biloungşäafte aus bem Scolz= förper in Den Bafttörper.

Bir fommen baburch zu ber Ed)lupbetradtung, baj ber von ben

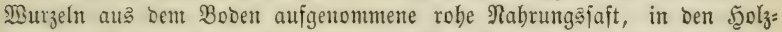

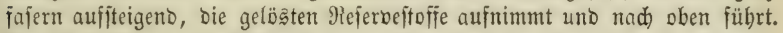

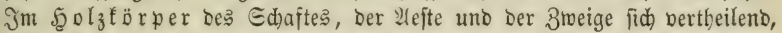

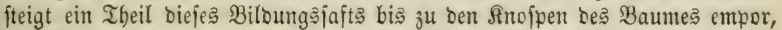
¿as Material für Den Sängenzumads benfelben zufübreno; ein anterer Theil

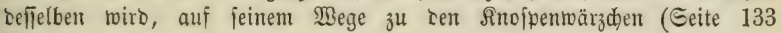
Jig. 3-5) jämmtlidher Sinofpen, ehe er bortbin gelangt, von ben im $\mathfrak{S g l}_{\mathrm{ol}}=$

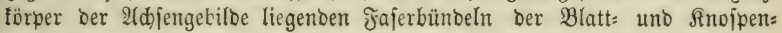
auşđjeibungen aufgenommen uno nadh aupen abgeleitet. ${ }^{1}$ 2uf biejem $\mathfrak{B e g e}$ gelangt er in bie Blätter Des jungen Iriebes jommergrüner, in bie Blätter aud) älterer Triebe immergrüner Solzarten uno burch fie zurül in ben Bafttörper Der Triebe, won bem aus er Den Mutterzellen zwifden Scolz und Bajt zugeführt wirb, Den Didézumadj引 zwijhen beioen vermittelno.

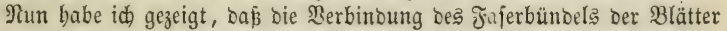
mit bem Scolzlörper Des Triebes bei ben frmmergrünen \$flanzen mur ein Jabr, bei Den wintergrünen $\mathfrak{B}$ flanzen Durd) unterrindigen Jumadgs nur wenige Sahre fidd) erbält, baf fie fłäter aufgehoben werbe Durd 3rifden=

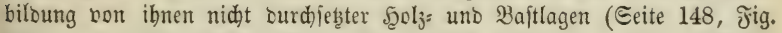

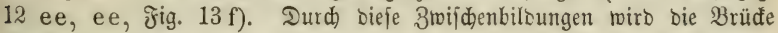
abgebroden, über bie ber fecunbäre Billoungs̄jajt feinen $\mathcal{H}$ ebergang aus Solz in Baft bewerfftelligt, Der baher in Der unverlę̧ten fommergrünen

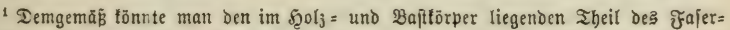

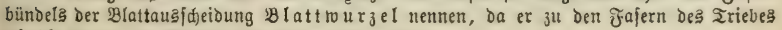
rie bie Burzel ber \$flanze zum Boden fid berbält. 
Pflanze nur im einjäbrigen, in Den $\mathfrak{F f l a n z e n ~ m i t ~ m e b r j a ̈ b r i g e r ~ B e l a u b u n g ~}$ aud) in ben nädjit älteren Irieben ftattfinden fann, fo tweit biejelben nod belaubt find, Da bei biefen ber unterrinbige 3uwadjs ber Blattwurzeln ebenjo lange fortbauert. Nur auf biefem Mege bermag id) bie Unterbred)ung Des

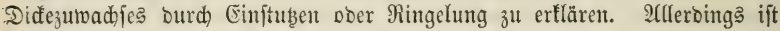

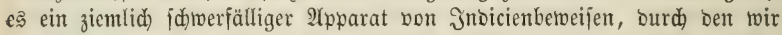
zur Ẽffärung gelangt fint; eine birefte Betweişfübrung wiro uns bier jebod) vielleidyt für immer entzogen jein.

\section{Der Begetationajomer.}

Mir haben im Borbergebenden gejehen, Dá̉ Das im Jrübjabr von

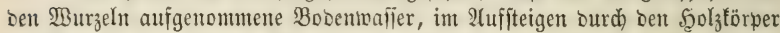
Der Bilanze, bie gelösten Rejerbeftoffe aufnebme uno baburd zu fecunbärem

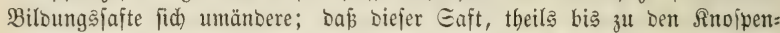

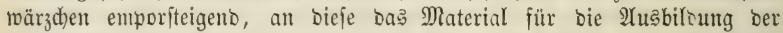
Snoipe zu neuen \&ängentrieben abgebe, anderentheils, Durd) Die im Scolztörper ber Triebe liegenden Blattwurzeln aufgenommen, bon leb̨teren

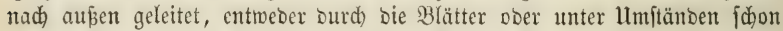
in Den Irieben, an bie Siebfajern Des Baftes abgegeten werbe, um in biejen abjteigeno, Den permanenten Mutterzellen Der Fajerbünoel uno ber

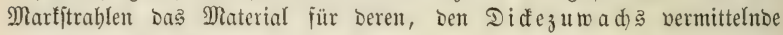
Fortbilbung zu liefern.

Diejer Gaft in ben leţten Etabien vor feiner enoliden Bermenbung uno Jixirung, Dent id) Cambialfaft neme, weil er bor flüfilige Theil Dellen ift, toas Dubamel "Cambium" nammte (Eeite 178), gewinne id) aus

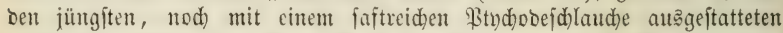

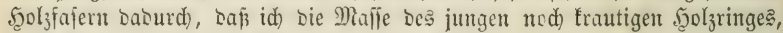
nach Sintwegnabme Des Bajte?, vermittelit Glasjherben abjdabe uno Das 2(bgefdabte außpprefie. Man crlält baburd) cine, ourd eine Menge bei=

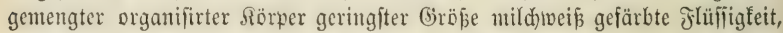
Die, filtrirt, wafferflar ift, an Der \&uft fid) balo bräunt. Zu einem Ber= gleidhe biefes Gafts mit bem Bajt= umb joljafte bot mir bie (E) id e eine

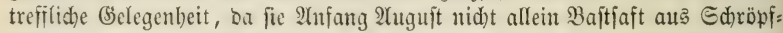
munben, fonbern gleid)zeitig audh Şolzfaft in tropfenförmigem (Erguß aus ter

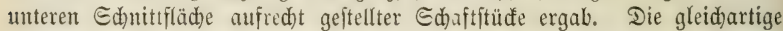
Brüfung Der brei veridhiebenen, auf gleidem Gtandorte ermadjenen Baum= theilen an bemijelben Iage entnommenten Säfte ergab nadjfolgende Unterfadicbe:

1) Der Scolziaft (Eeite 250, 264).

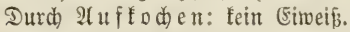

Durd) abjol. 2trfobol: mur Spuren bon (5ummi.

Durd) 2 m moniaf: feine phosphoriaure Bittererbe.

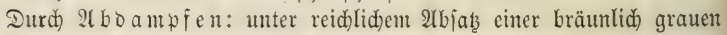

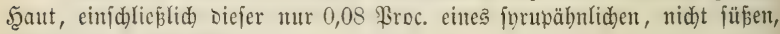

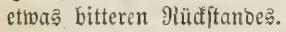

Durd) Einäfdern bes Evrup: 0,5 Froc. 2ifde, fajt mur Salijalze.

2) Der Baftiaft (Eeite 197).

Durd) $\mathfrak{A} u f f$ od en: (Simein 0,05 Broc. 
Durd) 2Ulfobol: nur Epuren von (5)ummi. 2An organ. Molefülen 0,15 ßroc. (vergl. Seite 197).

Durd) $\mathfrak{A}$ m moniaf: geringe Spuren einte fleintörnig frbftallinijden Rieberidlages.

Durd 2 bo ampfen: obne jenen 2tbją, Syrup 27 Broc.

Durd) Einäfdern bes Enrup: 4 ßroc. vom Snrupgetwidyt 2(jhe, meifit Raltfalze.

3) Der Eambialiaft.

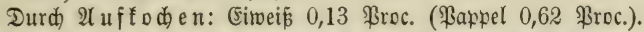

Durd Affohol: (3ummi 3,6 ßroc. (\$appel 0,7 ßroc.).

Durd) 2( mmoniaf: phosphorjaure Bittererbe 0,17 Broc. (Bappel 0,26 Proc.).

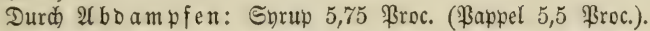

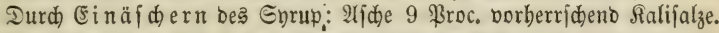

Der beoutende Gebalt des Cambialiafts an Bhosphorjäure gibt biefer auch für bie $\mathfrak{S}_{0} \mathfrak{l}_{33} u$ d)t uno für bie forftlidje Bobentunde biejenige höhere Bedeutung, bie ihr ber Sanbmirth längit zugeiftanben bat. Bergl. Э. v. Riebig: Uleber bas Berbalten bes Ebilifalpeters, Rodjalzes und bes

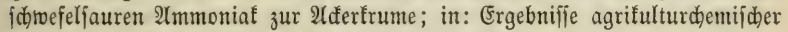
Berjude, Şeft II., Seite 9, Erlangen 1859, Enfe.

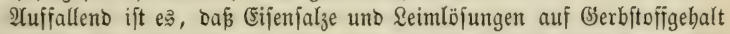

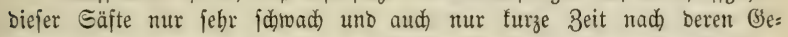
winnung reagiren, wäbrent jeber Sägejhnitt bie Spuren einer Reaftion von Eifen zeigt.

Da bie \&öfung uno Berwenoung Der Rejerveftofie aus bem vorber: gebenoen Jabre in ber erften Saälfte bes Aluguft bereits bollenoet ift ober ihrer Bollenoung bod fehr nahe fteht, oürjen wir ben bier unterjuchten Selziaft wobl als einen joldhen betrachten, ber bem aufiteigenden Rohjaft am nächften fteht burd bie geringe Menge in ihm aufgelöster fefter Stoffe. Dagegen zeidnnete fich biejer Gaft bor ben übrigen auffallend aus burd) Entwicfelung einer gropen Menge bon Suftblajen fodon bei gelinder Er: wärmurg, binbeuteno auf eine außergemöhnlich groß̉e Beimengung von

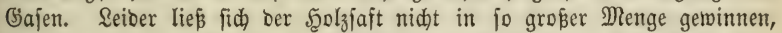
um eine näbere Beftimmung Der \&uftart Durdzufübren. Das frübe Ent= meiden aus bem Gafte bei ber Ermärmung beutet aber auf Soblenjäure (vergl. Seite 258).

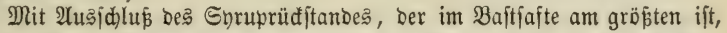
fteigert fid bie Menge ber in ben Eäften gelöster Stoffe in ber Meiben= folge, in ber fie vorftebent aujgeführt find, bie zugleid aud ibre wabr= ideinlide Alterşfolge ift.

Das, ras id̄ voriteheno als fnrupartigen Rücfitano bezeidnet babe,

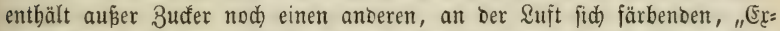
trattioftoff," (?) Der vielleidyt mit Dem (3̈erbftoff in naber Beziebung fteht.

Wir haben nun bie đrage zu erörtern: ob, ober roie weit bie auß Rejerbejtoffen wieberbergeftellten Biloungşäfte genügen, zur Darftellung beß jäbrlichen 3uwachjes an 3 lättern, Trieben uno Sgolzlagen.

Für bie einjährige \$flanze reidhen bie im Eamentorne ber Birfe, Ef che, 
Rüfter nur in jebr geringer Menge abgelagertent Rejerbejtoffe obne 3weifel

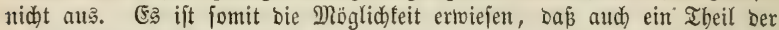

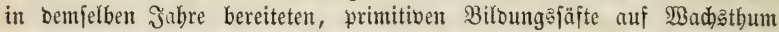

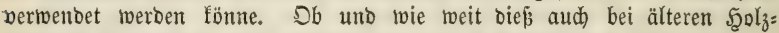
pflanzen ber Fall fei, läßst fid bis jekst mit Sidjerbeit noch nid̆t jagen.

Entältungḡverjuche an alten Riefern uno an Särdenreibelbölzern, wobei alle 3reige auper bem leb̧ten Sdaftriebe Dem Baume entnommen wurben, ergaben bei ber \&ärche nicht allein eine berbältniß̄mäßig reid)liche Wieber= belaubung aus ber Entwidfelung vieler jojlafenden 2 (ugen bes Sd)afts zu neuen Trieben, fonbern auch) eine, im eriten Jabre nad) Der (Entäjtung gegen bie vorkergebenoen Jabre unverfürzte Jabrringbreite. Erit im żweiten

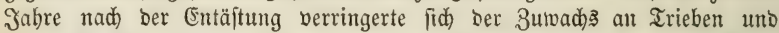
Jabrešringbreite auf ein, ber verringerten Blattmenge entiprechendes Mini= mum, von too ab bann ein langfames Steigen bes 3uwadjes eintrat, im

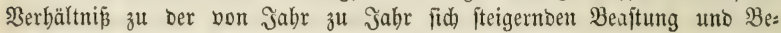
laubung. (ङ. Joritt= uno Jagozeitung 1856, ؟. 365.)

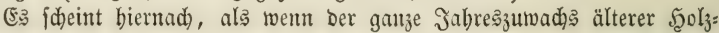

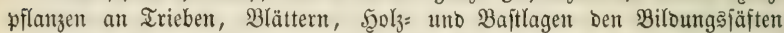
entftamme, bie, im vorkergehenden Jahre bereitet uno in Referveftoffe ber= wanbelt, auf bas nädjitfolgenbe Jabr übertragen werben.

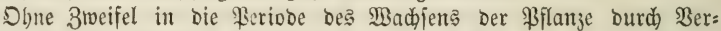
menoung ber überwinterten Meferbeftoffe tief eingreifent, nadben aus bem jecundären Biloungşafte neue Triebe uno neue Blätter entitanden fino, tritt

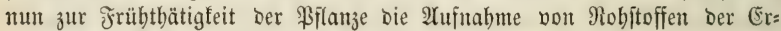
näbrung burdh bie wieberbergeftellte Belaubung uno beren Berarbeitung zu primitivem Bildungşafte, über Die id bereits Geite 193-199 meine $21 n=$ fichten niebergelegt babe. Den 3eitraum biejer Ihätigfeit nenne id ben Begetationsfommer.

Obne 3weifel fint es die Blätter unjerer Sgolzpflanzen, vielleidgt aud bie jüngerent Iriebe, jo lange Deren Rindezellgemebe Dem \&idhte zugänglid) ift, in benen Die erite Berarbeitung ber Robjtoffe zu Biloungşäften unter

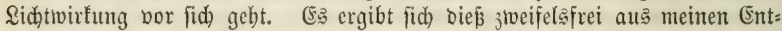
laubungģveriuden (ङ. 192-199), aus bem nad)gewiefenen Einflufie, ben bie, nach ber Entlaubung in Den nädjiten Jabren fteigente Blattmenge auf bie

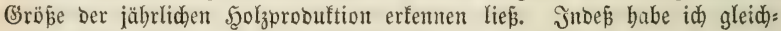
zeitig nadjgetwiejen, daß̉ biefe jäbrlidłe Steigerung ber $\mathfrak{B i e b e r b e l a u b u n g ~ m u r ~}$ bis zu einem gemifijen (3rabe ber \&aubproduftion fortoauert, Daßs, wenn ber bis zum (Sipfeltriebe entäftcte Baum nad) Berlauf von 5-6 Jahren eine Saubmenge wieber erlangt hat, bie einer normalen 5-6jäbrigen Beaftung entipridt, aud) bie normale Irieblänge uno Scolzringbreite wieber eintrete; baj eine von $\delta a$ ab nod) mebr gejteigerte Saubntenge auper (Finflup auf

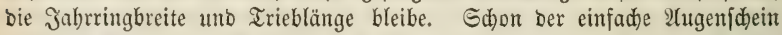

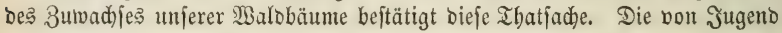
auf im zreien erwadjjene, bis zum Boben beaftete uno benabelte fidste

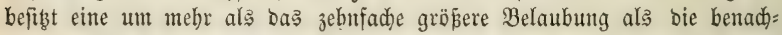

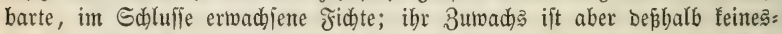
wegs ein zebnfađ) größerer. SBent er unter günjtigen Stanoprts̄berbältniffen 
Durdidhnittlid als ein um Meniges gröperer fid ergibt, fo liegt bief theils in ber gröperen uno unbebinderten Bewurzelung, theils in bem llmjtande,

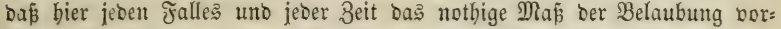

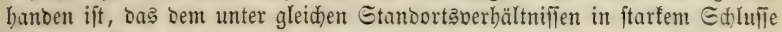
erzogenen Baume, befonders bei vernadläfïigten Durdjorjtungen, wenigftens 3eitweilig robl fehlen bürfte.

Die Jrage, weldhes bie ber größten Maffenprobuttion beక Baumes entipredente Beaftung uno Belaubung fei, in weldyen Grabe ein, Den 3 u=

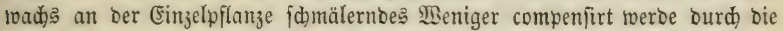
größere 3ahl ber ßroducentent des gebrängt erwadjenden Scoljbeftandes, ift

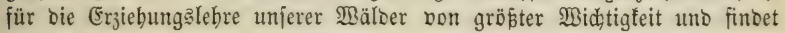
im Balobau ibre näbere Erörterung.

\section{Der Begetationsherbit.}

Der in Den Blättern bereitete primitive Bildungşajt, ben wir bereits Geite 197 näher fennen lernten, verläpt biefe, rüđfidreitento burdh ben Bhattitiel, gelangt von biejem auß in bas Eiebfajergewebe ber Baftichidutung uno fteigt in biejer möglidjft tief abroärţ, jo baß von ibm zuerjt bie $\mathbb{B} u r=$ jeln, Dam bie tieferen, Darauf bie böheren Etammtheile, erft bann bie

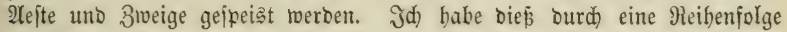

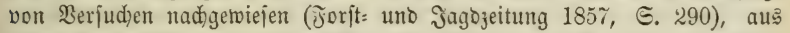
Denten hervorgeht, Dof Diefe aufiteigenbe Jüllung bes Baumes mit nieber= fintentem Bildungşaft bei ber Eide nom Juli bis Mitte September, beim

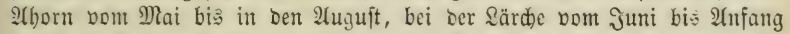
Dftober, bei ber Siefer vom Eeptember bis Mitte Dftober Dauert, alio bei veridbiebenen Sgolzpilanzen febr berjdieden lange 3eiträume, bon $1 \frac{1}{2}$ bis $31 / 2$ Monate in 2 Anfpruch nintmt.

Jn ber Murzel antgelangt fpeist ber in ber Bafthaut niebergejtiegene

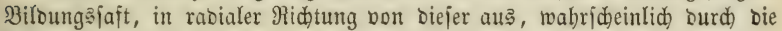
Marliftrablen fid berbreitent, fowohl bas 3ellgewebe ber Rinbe als bas

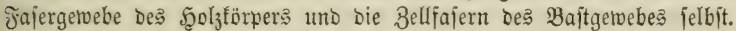

In allen Den bam Biloungşafte gefpeisten Elementarorganen, Die

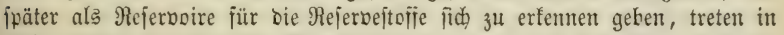

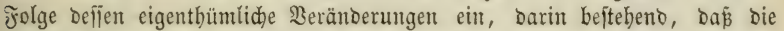
innerite (jecunoäre) Belfwanoung in Den 3uftano bes \$tndhobeichlaudes jurüffdreitet uno ein neuer Bellfern entiteht, ber oen, in Dem Ptndjodes raum aufgenommenen Bildungşaft in fich aufnimnt, burch biejen wäds引t

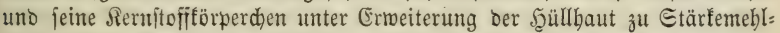
uno Rlebermeblförnern auß̧bildet, währeno das fernförperchen zu einem

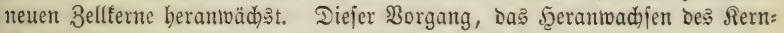

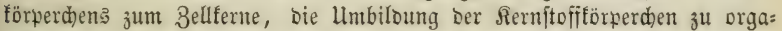

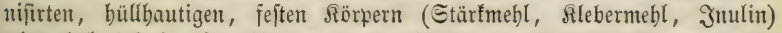
wieberholt fide jo oft, bis ber inmere Bellraum mit biejen förpern mehr

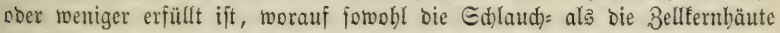
rejorbirt twerben, fo baj ben Winter über bie förnigen Rejerveftofie ben Bellraum ofne andere Beimengung erfüllen (Eeite 181, Jig. 25).

Wenn id bie 3eit, in weldjer bie Referbeftoffe für bą nädjte Jahr 
fid) bilben, Den Begetationsherbit nemue, fo barf man bas nid)t wörtlid) nebmen. In ber That beginnt bie Biloung ber Rejervemeble fdon viel früher. In ben Bellfajern uno in ben meblbiloenden Şolzajern, fowie in

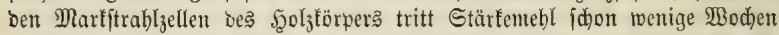

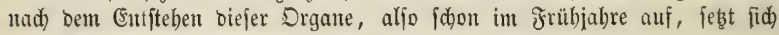
aber wie bie Sholzbildoung jelbit bis in Den Syerbjt fort.

Bas bie Menge betrifit, in ber bie Referbeftoffe fid bildon, jo ift bieje eine febr veridiebene, nidft allein bei verjdiebenen 5 golzarten, fonbern aud in verfdiebenen Baumtbeilen. Sn Den 2 surzeln junger Bflanzen, ber

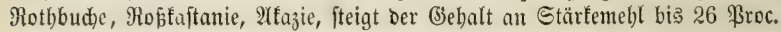

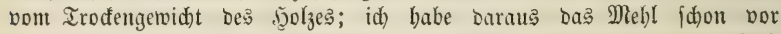
40 Jabren in einer zum Brobbaden genügenten Menge rein Dargefteflt

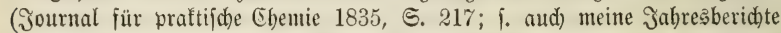
1837, Seite 607). 2Aud bie $\mathfrak{2 B u r z e l n ~ b e r ~ \Re a b e l f o ̈ l z e r ~ e n t h a l t e n ~ b e d e u t e n d e ~}$ Meblmengen, werur audb weniger als bie Raubbölger. Fine bem geringent Meblgebalt bes St a mme 3 immergrüner Rabelbölzer entipnungene 2 (nficht: "bei biefent werbe im Blatte bas D $\mathrm{rgan}$ zur Bereitung Der Bildungşäfte,

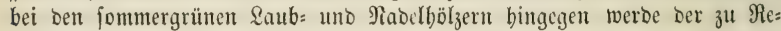
ferbeftoffen fixirte Bilbungsiaft für bie Blattreprobuttion bon einem Jabre auf bas andere übertragen," erleibet in Bejug auf bie immergrünen Mabelbälzer eine Bejdränfung, ba bieje fid) in Bejug auf Rejerbejtoffgebalt Den fommergrünen $\mathfrak{B f l a n j e n}$ bod) nidgt jo fdroff gegenüber ftellen, a(ş id) Diés bamals glaubte. Rädjitoem ift bas Mlehl am reid)lidjiten in ben jün= geren 3weigen ber Şoljpflanjen abgelagert. Im Stanme armboiffer Reibcl= böljer fudte id ben (Sebalt an Referbeftoffen ju beftimmen aus bem Irocen= getwidtbergleide bes im MBinter uno beß zur 3eit vollfommener \&öjung bor

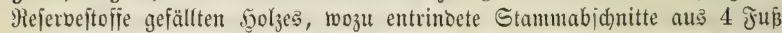
Edhafthöbe von Bäumen verwentet murben, bie, gleid) alt uno gleid) träf: tig, alf gleidhem Standorte nebeneinanber erwad)jen waren. (5:3 ergab fid bieraus, auf Den Rubiffuß F̧olzmajie bered)net,

für bie harten Raubbölzer 3 \$funo $=7$ Proc. Des Trodengewidats, für bie weid)en \&aubböljer $2,35 "$ " " für bie Rabelföl er . 0,85 " $=3 "$ " "

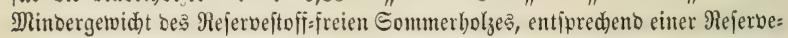

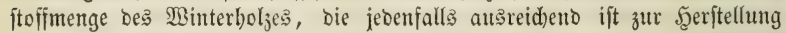

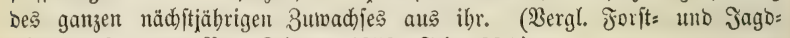
zeitung 1857 uno Bot. Beitung 1858, Geite 335.)

Der ßegetationsherbit ift Die Zeit bes Reifens. Frudft und Same reifen mit vollenteter 2 (nfammlung ber Referveftoffe, uno werben bann von ber Mutterpflanze abgeworfen. Die Snolle, Rübe, Briebel reifen mit ber Ansbiloung ifrer Referveftoffe, bie Mlutterwflanze trent fid bon ihnen burd) ihr 2(bjterbert. Der Stanm bes Standengewäd)jes (Sambucus, Ebulus,

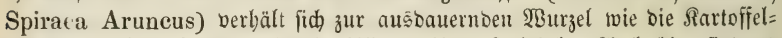
pflanze zut ibrer Snolle, wie bie Silie zu ibrer 3roiebel. 2(ud) bier find es bie Rejervejtoffe ber $\mathfrak{B u r z e l}$, aus Detten bie Eproffen ber näd)itjäbrigen Bflanze fid bilden. Die Belaubung deş jommergrünen Baumes (in feltenent Fällen felbft ein Ibeil ber Bejweigung: Taxodium, Glyptostrobus) ver= 
bält jïh zu ben bleibenten Pflanzentheilen wie ber Etaubenjtengel zu feiner Murzel, wie bas Gamentom jum 3arfen, wie ber 3apfen ober bie frucht= fapjel zum Baume fich berbält; fie reift im Scerbfte unter eigentbümliden Stoffi = uno Farbeberänberungen ihres Befleninbalts unb twiro alşbann twie Same uno Frud)t bon ber Whutterpflanze abgeworfen. Dá äusere Ein=

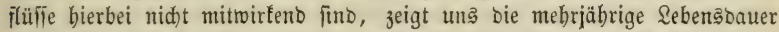
Der Blättir felbjt nabe verwanbter nebeneinander twachjenber Pflanzenarten (Quercus Robur uno Ilex, Prunus domestica uno lusitanica, Larix europaea uno Cedrus Deodara).

Dem Begetationsherbite gehört enolid, aud bie Bollenoung ber Inofpen: bilbung an, Deren Beginn, in Bezug auf bie Enbfnofpen, furz vor Boll= enoung des Sängenjumachjes der Triebe eintritt, währeno bie Seitentnofpen jdion räbreno ber Triebbiloung fich außbiloen. (Es jeblen mir zur 3eit nod) biejenigen Reiben methobiider Beobadtung, bie notbmendig fino, um

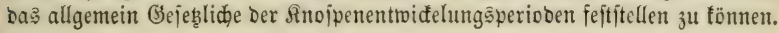

\section{Der Begetationswinter.}

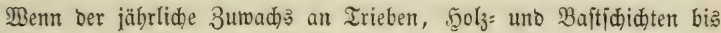
3ur $\mathfrak{B}$ ollenoung ber Breitfajeridjidt ausgebiloet iit, wenn in ben Snoipen auch bie anticipirten Billoungen ses nädjitjäbrigen Triebes vollenbet, wenn

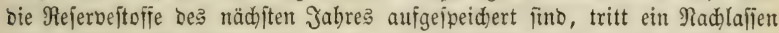
und enolid, bei groit, ein Etoden ber Saftberwegung in allen Bilanzen= theilen ein, Durd weldes bie vitalen Juntionen bes Piflanjentörpers in einen Rubeitand treten, ähnlid) Dem Rubeftande des reifen Eamenforna, Der reifen Rnolle, 3roiebel, Rübe.

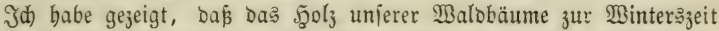
feinesmegs mejentlich weniger Saft entbalte als jelbjt jur 3eit bes Blutens Der Bäume. Wenn bem uneradtet bas Winterbolz auf Querj(b)ittf(ächen weniger feudft erjheint, als zu jeber anderen Beit, wenn es im Şerbit uno Binter nicht mebr gelingt, Durch (Erwärmung in ber geidhlofienen Şano Flüfiligfeit auf bie Edanittfläh) ber 3roigitüđe empor zu treiben, jo liegt

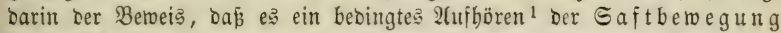
jei, weldę die jheinbar gröpere Irodenbeit des Minterbolzes zur Jolge bat, woraus man weiter folgern barf, baj bie Eaftbemegung felbft, menn aud) bon phpilfalijhen Erideinungen getragen, bennod an fich eine vitale

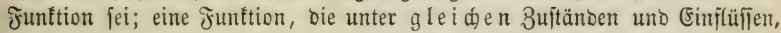

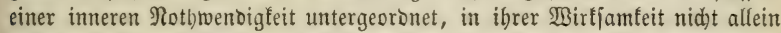
abgeändert uno bejdräntt, jontern periobijd ganz unterbrodjen wiro.

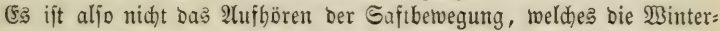

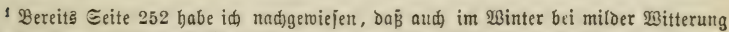

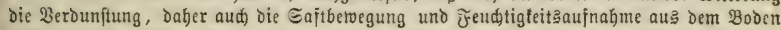
niđgt gänzlid) aufföbre. Bei ben fommergrünen Bäumen ifi fie burch ben Blattabfall aller= Dings aud in lvarmer Winterwitterung bejd)räntt auf bie geringe Beıbunftunggftäche ber jüngeren 3reige. Grotijøe 9labelföljer, Deren Triebe im 5̧erbite unfertig geblieben waren,

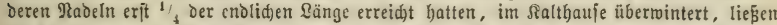

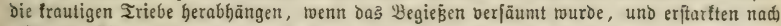

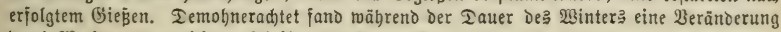
Durd) ஐadjatbum an feinem Igeile ber \$ilanjen ftatt. 


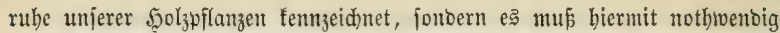
eine Reränberung in ber Ratur bes Saftes verbunden fein, bie fich Darin auşpridyt, Daß er im 3uftande Der 2 Binterrube tweit weniger empfänglid)

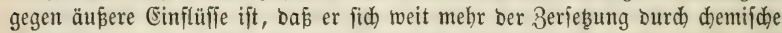
Agentien entziebt. Der Binterjaft unjerer Waalobäume ${ }^{1}$ fann bis in ba

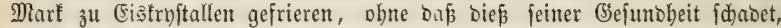

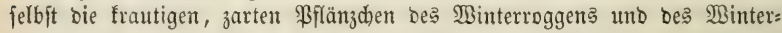
rapjes werben vom groft nidht getöbtet, wäbreno beriflbe Saft im Frübjahre nad) Beginn ber Begetation vom Frofte unfehlbar getöotet rirb, uno jehr

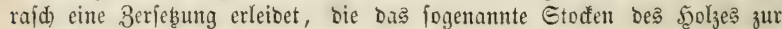

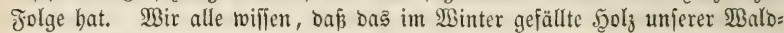
bäume reit bauerbafter ift, als Dả Solz ber im Sommer gefällten Bäume.

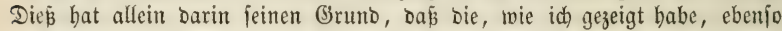

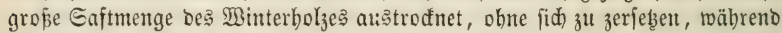
Der Saft bes Sommerbolzes unter Dinfelben Berbältnifien fich rajid zerjez̧t uno zum Rähritoff für eine Menge nieberer ßilzgebiloe wird, beren Reime,

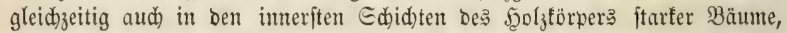

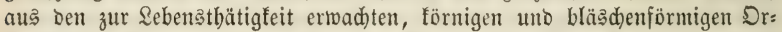
ganis̄men Des Belleninhaltes entiftehen, \$ilzbiloungen, bie id bep̧balb unter

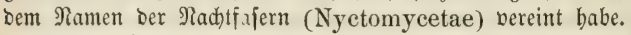

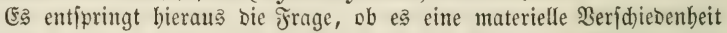

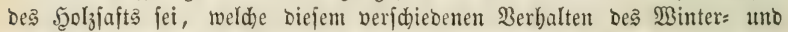
bes Sonmerjafts zum (šrunbe liegt. $\mathfrak{B a}_{\mathrm{a}}$ id) bierüber ermitteln fonnte, fpridft gegen biefe 21nnahme. Shne 3weifel finben materielle Beridjieben= beiten bes Winter: uno des Sommerjafts jtatt, fajon in Folge ber Rejerves ftofflöjung, allein biefe f(deinen Dod) mebr bie Duantität als bie Dualität Der gelösten Stoffe zu betreffen. Der im December und Januar bei milloer

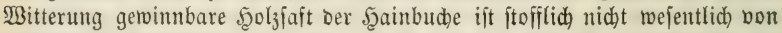
Demjenigen berfdieben, Den man nod) zur 3eit bes Laubausbrudjes ges winnen fann, obyleid) zu Diejer 3eit bebeutenoe Meblmengen gelöst finto.

\section{b) $\mathfrak{2} a \mathfrak{d} \mathfrak{s} \mathrm{t} \mathfrak{b}) \mathfrak{u}$.}

Radjoen wir im 3orkergebenton gefehen baben, in welder Meije bie Pflanze fich biejenigen Robitoffe aus ibrer llungebung aneigntet, Deren fie bebarf, zur Darftellung berjenigen Bildungşäfte, bie, von Zelle zu 3elle manberno, Den Gtoff zu weiterer Bellenbiloung uno Bellenmebrung, alfo zum Wadjsthum ber Fiflante in fid) tragen (Seite 193); nadbem wir ges fehen haben, wie uno wo jene Mohjtoffe zu Biloungsftoffen umgemanbelt werben (Seite 195); nadjoem id gezeigt babe, wie uno two jene Bildungs: ftoffe aus Neubiloungen verwenbet uno fixirt werben (Seite 195, 268, 278); meldes bie Bege feien, auf benten bie Bildungşäfte zum Drte ibrer ent: liden Berwenoung gelangen (Eeite 269-275), wenoen wir uns mun zur Betrad)tung ber $\mathfrak{B a d}$ sthumberideenungen jelbit.

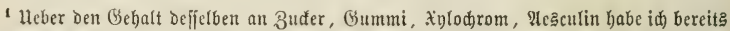

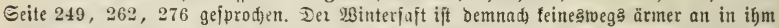
aufgelösten Stoffen, als Der Sommeriaft. Die rajdere Berfebung Des Sommerjafts läpt fid) bieraus entidieden niă)t erflären. 
Bereits Ceite 165,171 babe iđh nadgewiejen, baj nur bie erite Belle einer jeben Pflanze (uno bie ihr berwandten eriften Enoofpermzellen bes Reimjäđdens) ber freien Bellenbiloung aus bem Belfferne ihre Entitebung berbantt. Eeite 169,171 zeigte iđ, Daß uno wie aus ber Urzelle ein mehrzelliger Rörper herborgeke, burd) Theilung ber vorgebilbeten Bellen in Todterzellen; ba

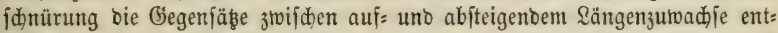

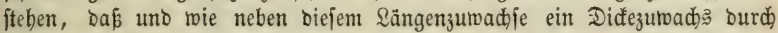
fenfredte 9 (bidmürungşrid)tung herbortrete, wie fid im Bellgetwebe ber

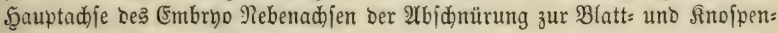
aușidheioung biloen (Seite 170).

Ferner zeigte id, wie burd) eine oritte biagonale 21bidnürungşridatung im radjienden 3ellgetwebe bes (Embryo Fajerbündel entiftehen (Seite 174);

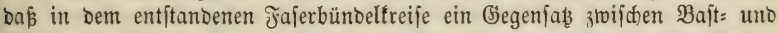
Soljtörper entftebe, und baj bon ba $a b$, in jebem \$untte ber Grenze

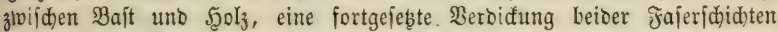
burd Sängentheilung einę ßaares permanenter Mutterfafern eintrete

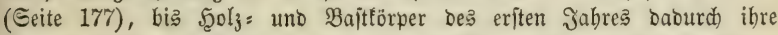

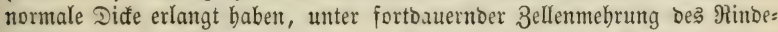
zellgemebes burd) 2(bidnürung in rabialer uno tangentaler Richtung (Eeite 218, 220).

Wir baben bier baber nur nod biejenigen Wadzthumberidheinungen zu betradten, Durd) weldhe bie fertige einjäbrige Bflege zur zmei= unt mehr:

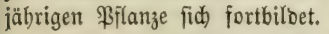

Denfen wir uns eine Bollfugel, bie in ihrem ganzen ltmfange all:

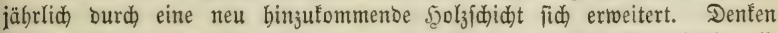
wir uns ferner eine 50 olf ugel, bie auf ihrer inneren $\mathfrak{B}$ anofläde all= jäbrlid) eine neue Bajtididst bildet. Denten twir uns ferner bie Şoblfugel über bie Bollfugel gelagert, fo mag biés Bilo als Grnmolage bes jährlichen Edhaftzumadjes bienen, bahin abgeänoert,

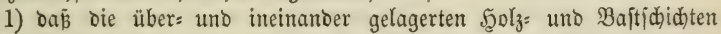
nidht fugelförmig, fonoern zu einer febr langitreçigen Spindel ausgezogen fino,

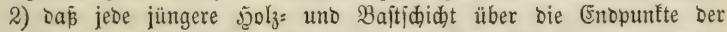
Sängenadjie Der nädjt älteren Spindel binaus zum Jahres: poer \&ängen= triebe bebeuteno berlängert, gewifïermañen außgezogen ijt,

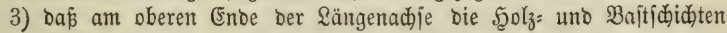
nidht gejwlolien fint wie am $\mathfrak{B u r z e l e n o e ~ b e r ~ \& a ̈ n g e n a d j e , ~ f o n b e r n , ~ i n ~ b e r ~}$

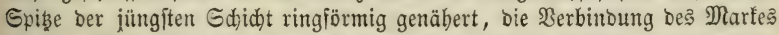

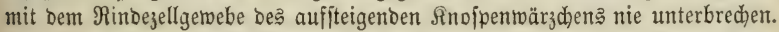

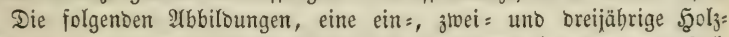

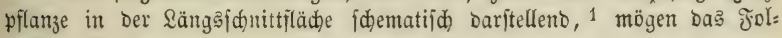
genbe erläutern.

1 Durd ein Berjehen fino in dicje $\mathfrak{A} b$ biloungen nur bie übereinander gelagerten $S_{2}$ ol $3=$ lagen aufgenommen. Man tann bie feblenden Buftididten in ben ßaum $\mathrm{r}$ fíd hinein=

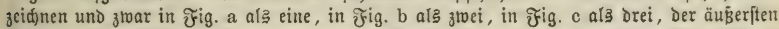

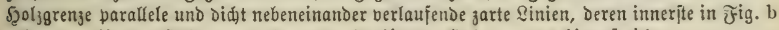

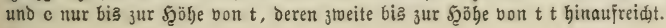




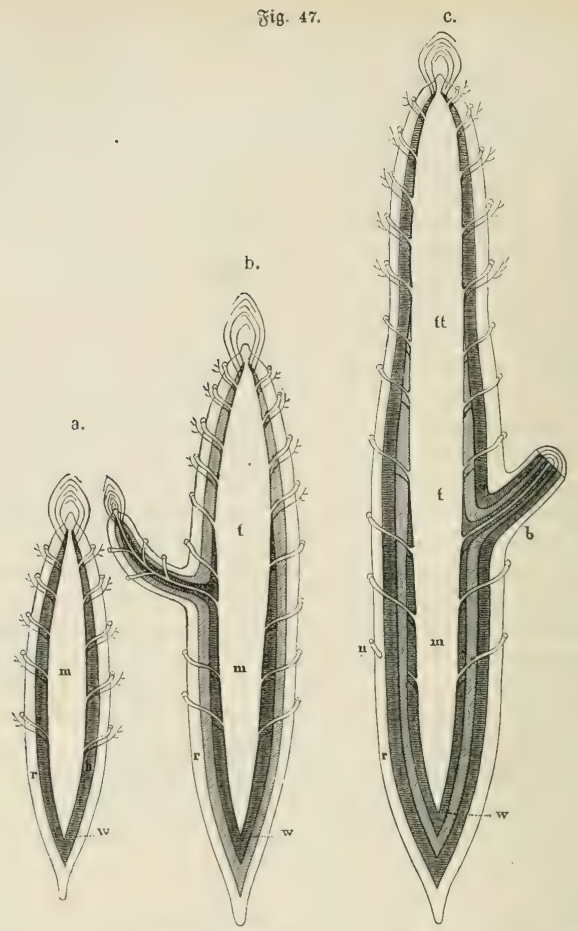

Jig. a zeigt bie einjährige \$flanze, in welcher m Łas Mart, $r$ bie

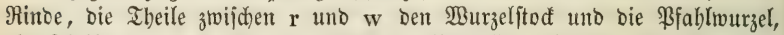
bie Theile unter w bie eigentliche marflofe $\mathfrak{B u r z}_{\mathrm{g}} \mathrm{l}$ bebeuten. Son ber

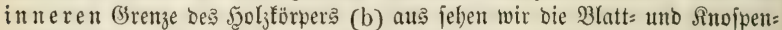
ausfjeioungen je zwei nad) ausen fid abjdeiben. Die leb̧ten, oberften

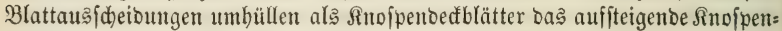
wärzchen, beffen Zellgewebe, burd) ben unter ifm verengten, aber ge=

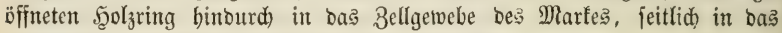

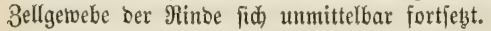

In ber zweijährigen \$fflanze (Jig. b) finden wir ben (borizontal ge: ftrid)elten) Şolzförper ber einjäbrigen \$flanje nur baburd) verämbert, Dap bie ringförmige Deffmung beffelben unter Der Sinofpe Durch Bergrößerung Des Marfgewebes bei uno unter $\mathrm{t}$ zur normalen Marfröhrentweite ausein:

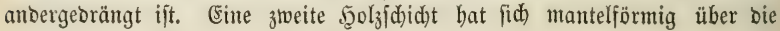
erite abgelagert. Inter $t$ biloet biejelbe im Queridnitte einen ztweiten, burd) 


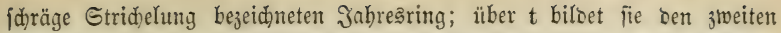
Jahrestrieb, Der in jecer Şinfidt bem erften Jahreätrieb ber einjährigen \$iflanze gleid̆t, von bem nur bie inneriten Epiralgefäp̈bünoel wie bie Bait: lagen fid) ununterbrochen in ben zweiten Jabrestrieb fortię̧en (bergl. ভeite 135 fig. 5).

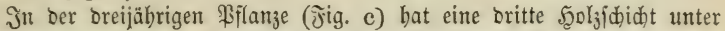

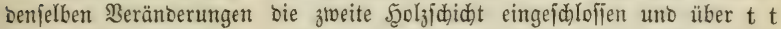
einen britten Sängetrieb, unter $\mathrm{t} t$ einen britten Jahreşring gebildet. Daș: jelbe ift ber Jall im abfteigenden Etode w, Deffen Jabrestriebe Der Raum= erfparnis wegen fehr verfürzt gezeidnet wurben.

Diejer jäbrliche 3umachs an Jabreşringen uno Qängentrieben zmijden ben vorgebilbeten Sabreâringen uno über ben vorgebilbeten Sängentrieben

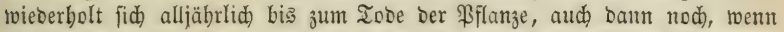

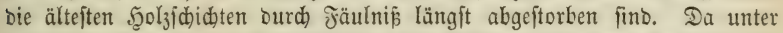
normalem Berlauf Der Entrictelung neue Blätter uno neue Sinopen fich nur am leţtjäbrigen Triebe bilben fönnen, ba ber F̧olyring älterer Baum= theile nur eine Jortieksung bes Jahreätriebs nad) unten ift, io müpte ein

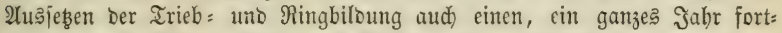
bauernben, laublojen 3ujtanto ber Bilanzen mit einjäbriger Belaubung mit (iid) fübren, ber aujerbalb ber Grenzent unferer Erfabrung an lebenten Pflanzen liegt, Daher wir aus ber 3 ahl ber Sängentriebe ober Der Jabres:

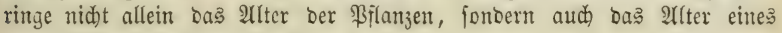
jeben Baumtbeils ermitteln fönten.

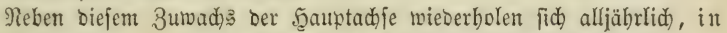
bem neu binzutretenden \&ängentriebc, bie Aluşdeioungen an Blättern ut Snopen (Seite 133); e马 roieberbolt fid Die anticipirte (Ent=

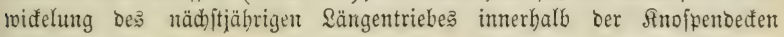
(Seite 134).

In Den älteren $B a u m$ theilen mädbst ber Fnofpenftamm Der Blattadjel, burdh unterrinbige Triebbiloung, innerbalb ber neu binzutre:

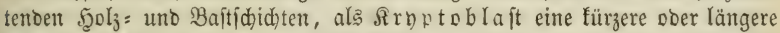
Reihe von Jabren in horizontaler Ridung nad) aufen (Seite 148), bis er enolid) abjtirbt, unter Umitänoen alङ Sphäroblajt in ber grünen Rinoe nod) mehrere Jabre fortwadjento, Jig. 14 (Seite 153). Bei ben PFlanzen mit mebrjäbriger Belaubung erbält fich aud ber Blattftamm inner:

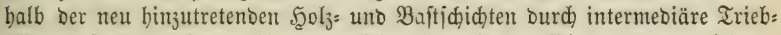
biloung fo lange fortwachfento uno lebentig, als bas Blatt grün uno lebents: thätig bleibt (Geite 151). Seidht fann man fich burch einige Sängenidnitte

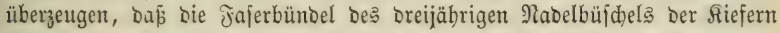
mie ber vier = bis adtjäbrigen fidhten $=$ ober Tannemabeln, jo lange bieje grün uno faftig finto, ourch alle nach ibnen entiftandenen $5_{0} \zeta_{3}=$ uno Baft=

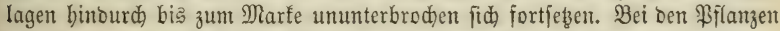
mit einjahriger Belaubung erlijht ber \&ängejuwaḑs bes unterrindigen fajer= bündels Der Slätter iđon im erften Jabre (Seite 150 Fig. 13).

Säufig fđon am cinjäbrigen Iriebe, aber aud) an älteren Baum= theilen, fo lange bie Blattadfelfnofpen als Siryptoblafte burd unterrimbigen Eängezumads fidd) lebendig erbalten, entricfeln fid aus einer ober mebrerent 


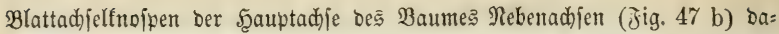
Durd, baß ber in ber Blattadjelfnofpe wie in Der Enofnofpe ber Şaupt= adjle anticipirt gebiloete, näditjäbrige Sängetrieb in feiner Enttwičelung zum 3weige und Ifje weiter fortichreitet. Befobieht biés ohne Beeinträbtigung Des Sängezumadjes ber Scauptadje, fo geht Daraus bie Beztweigung

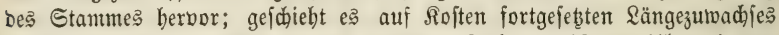
Der Szauptadje, fo entfteht baraus bie $\mathfrak{B}$ er äftelung (Sronenbiloung) Der= felben, bie bei ben Baumbölzern meift erit in höherem alter eintritt.

2lbgefehen von Der abiveidenten (Entwidełungşrid)tung, unterliegen bie Rebenadjen, Der 3weig uno Der 2(jt, genau Denjelben Ernäbrungş:

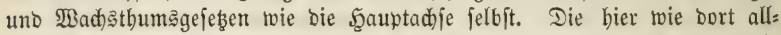

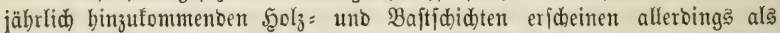
eine unmittelbare Fortjebung ber $\mathfrak{S g l}_{3}=$ uno Baftidjidten bes Stammes

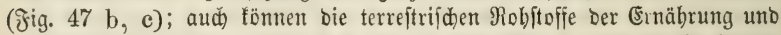
bie fecunbären Biloungşäfte bem 3roige ober 2 jte mur burd) bie Scaupt= adje, Durd ben Stamm zugehen. Demuneradtet zeigt ber 2 (fit ober 3meig

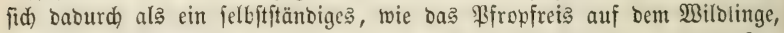

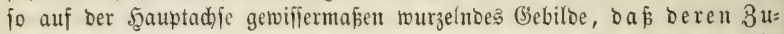
wads burdaus an bie eigene Belaubung, baber a ud an bie eigene Triebbiloung gebunben ift. Der laublofe 2rft bilbet, wie Der laublofe Edhaft, im erften Jahre vollitänoiger uno Dauernoer Entlau=

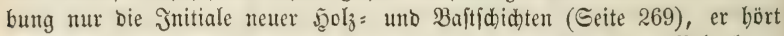
non ba $a b$ auf zu wadjen uno jtirbt febr balo, wenn fid) eine Belaubung nidgt wieberberitellt.

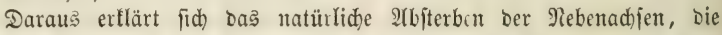
natürlide Reinigung Des Stammes von ben unteren $\mathfrak{A}$ eften. Wenn bem Blatte bie nöthige Ridtwirfung entzogen wiro, Dam laun es feine funt: tionen nid)t erfüllen, primäre Biloungşäfte nid)t bereiten. Der veridjattete 2lit lebt fortan nur von ben ihm burd) Die fümmernoen Blätter zugefübrten

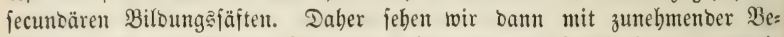
fhattung am beroämmten $\mathfrak{A}$ te bie Belaubung, bie Triebbiloung und bie Jabreşringe besె Scolzes uno beș Baumes zunebmeno fleiner uno (d) wäd)lider werben, uno entlid) gänzlida aufbören, wir feben ben beroämmten 2 (jit enolid abfterben, wäbrento an allen übrigen, in ihren Extremitäten ber ¿id)twirfung ausgejekten Baumtbeilen oer üppigite 3uwads ftattinoet.

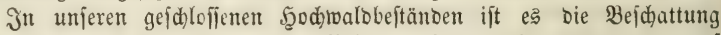
Der gebrängten Єdirmflächen aller Beftandsglieber, bie verbämmeno auf bie tiefere Beaftung einwirtt uno ein 2 bjterben Derjelben gemöbnlid erft im żebn = bis zmanzigjäbrigen Beftanbsalter zur Folge hat, bann nämlid, wenn ber alljährlich böher auffteigenoe Blattidirm fid fo verbidtet hat, Dáp er bie \&idttwirfung auf bie tiefere Belaubung aufbebt. Wir fagen bann, Der Beftand reinige $j i d$. Wir jagen, ber Beftand $\{$ d eibele (id) a $u s$, wenn bie llnterbrüdung fidh nid)t mehr allein auf bie tieferen 2fefte, fonbern aud) auf biejenigen Pflanzen erftređtt, bie in folge geringerer

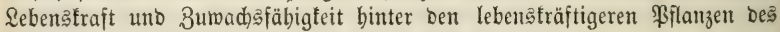
Beftandes zurüdbleiben uno von biejen übergipfelt we. Den.

Wie bie Fig. d Seite 148 unt Jig. 49 ergibt, reidt jeber 2 fit mit 
feiner $B a f i s$ bis zur Marfröhre bes Gtammes, uno erweitert fid) bon ba

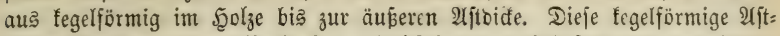

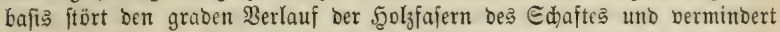
bie Epaltigfeit Derfelben um fo mebr, je älter ber 2 jit, je länger uno breiter ber Affteil wirb. Je früber ein Edaftzmeig abftirbt ober abgehauen wirb, um fo fleiner ift ber 2ifteil, um fo geringer ift bie Etörung int graren Berlauf der Şolzfajern bes Edaftes, um fo früber bört bie Störung gänz̧lich auf.

Eine andere Folge bes früber eintretenden uno böber binauf fid fort=

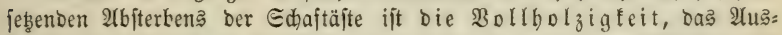
balten bes Edjafts in ber Diffe. $\mathfrak{A}$ bem im Jreien ermadjenen, tief beajteten Baume führt jeber $2\left(j \mathrm{t}\right.$ bem $\Theta_{d a f t e}$ eine gemifife Menge für ben

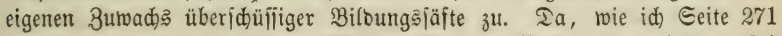
gejeigt habe, bie fecunoären Bildungäfäfte bes Bajtes nur abwärts fid fortbetwegen, fönnen bie aus ben Aeften bem Etamme zugehenten Biloungs: fäfte auch nur ben unter jebem 2lfte befindliden Sctaftbeilen zugeben. Da bieje zugleich aber auch) ncd) Biloungsfäfte aus ber böberen Beaftung empfangen, fo mus ber Zugang an folden uno in Folge befien ber $3 u=$ wads - bie Jabrringbreite - in ben unteren Baumtheilen eine gröp̄ere als in ben oberen Baumtheilen fein, es muß̄ fid ein mebr fegelförmiger, abholziger Edjaftwudbs berausbilden. J̄m Baume mit hohem fronen=

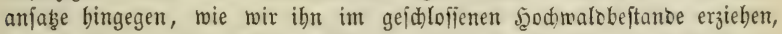
ift ber 3ugang von Biloungşäften zunädjit ber Frone am größten, er

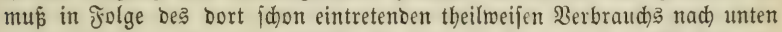
bin abnebmen. In Folge beffen ift bann aud an folden Bäumen ber Bumads in ben höheren Edhafttheilen ein gröferer, oft bis zum Doppelten Der Şolyringbreite in tieferen Eăafttheilen. Je mehr bießs ber fall ift, um fo mehr nähert fich bie Edyaftform ber $\mathfrak{B a l}_{3 e}$, trok ber nad oben hin geringeren $3 a b l$ ber Jabreslagen.

Wenn $\mathfrak{S}_{0} \mathrm{l}_{3}$ beftände, Die in voller Beftociung ermudjen, erft in böberem Beftandsalter fo lidjt geftellt werben, Dás ibre Srouten fid frei entwidf In fönnen, bann bleibt in Der Regel ber Rronenanją̧ ein unberänderter, es wirb baher aud ber (Einflup bellelben auf bie Bertbeilung bes 3umadjes in bie Ed)afttheile fich nidht veränbern. (Ergibt fid in jolge foldher Durd)= lidtungen eine bauerno 3 uwadberböbung am Edaftholze, fo fann biefe nur auf vermebrter Blatt = uno 2 urzelmenge beruben (f. Bano II. Wahl ber Durchforitungåarten).

Sebe lange bauernbe, zu gröperer Stärfe beranmadjenbe Beajtung bat enolich auch linregelmäßigfeiten in ber 2Hbrunoung, uno im graben Berlaufe bes Edaftrudjes zur Folge, bie für viele 3roede ben Werth bç ๔daftholzes ebenfalls herabjeken fann.

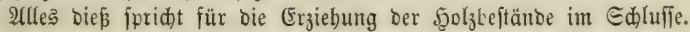

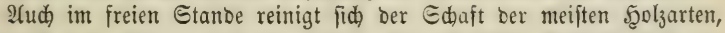
wenn aud nur bis zu geringen Şöhen obne fünitliche Beibülfe von ber

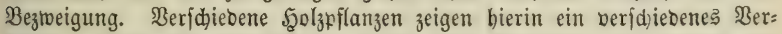
balten. Unter ben Plabelhölzern befib̧t bief Rermögen am meiften bie Särche, am wenigiten bie Fidhte; unter ben \&aubbölzern befiţen es bie 
2lipe, Birfe, Erle am meiften, bic Budbe uno Şainbuche am wenigiten. Man iff geneigt, aud) bieje Reinigung Der Berbämmung unterer 2Refte burd) bie böhere Belaubung zuzuโdreiben. Dem twiberipridt aber fdon ber Üm=

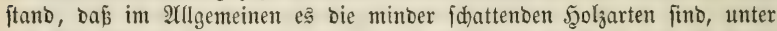

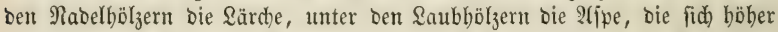
aufwärts aud im freien Etanbe reinigen. 2 (ud) müpte bann bie Reinigung auf Der Norb= unt Sübfeite ber Bäume in fehr verjdiebener Beit ein= treten, was entf(dieben nid)t ber Fall ift. Aud) bierin, wie in fo vielem 2fnberen müfien wir uns geftelen, Daj eine felbit nur bypotbetifde (Er: flärung nidjt gegeben werben fann.

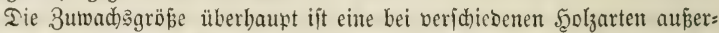
proentlid) peridjiebene. Sanze Jamilien, die ber Baccincen, Ericeen, SD: lameen 2c. treten wenigftens in ber bcimifden flor nur mit Bflanzen ges ringer 3uwad)âfäligfeit hervor, sie aud) unter ben allergünfigiten Stano:

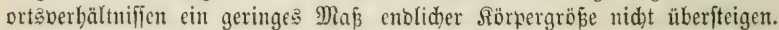
21nbere Jamilien, jelbjt einzelne Gattungen zeigen bierin bie größten ßer=

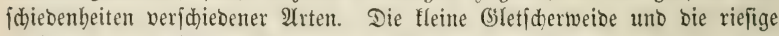

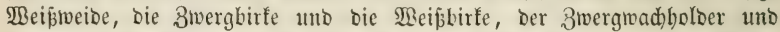
Die birginijhe Eeber bieten Beifkiele bar. Antore Jamilien, wie bie ber

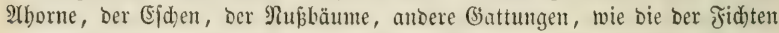

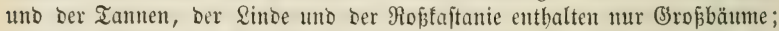
jener fpecififiden 3 uwadjsäbigfeit gegenüber befteht bier eine generifde $3 \mathrm{u}=$

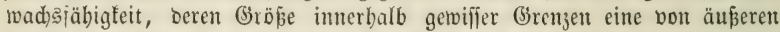
Einflüffen Durd)aus unabbängige ift, trobs ber vollfommenften Ueberein= ftimmung im anatomifden Baue fowohl, als in oer demifden Eonftitution Der verfdiedenartigiten Beftandtheile Des Bflanzentörpers, Die felbft Salix herbacea gegenüber Salix alba nid)t verläugnet. B $\mathfrak{B}_{\text {e }}$ fann man,

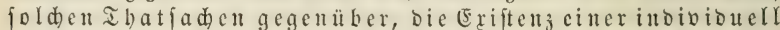

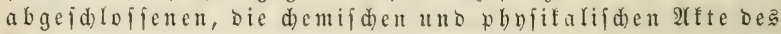
Bflanzenlebenzbeherrfdenden Gonderfraft in 2tbrebeftellen?

Bon Den ipecifijden Unterid)ieden Der 3umad)äfäbigfeit gelangen wir 3um Racenunteridiebe berfalben. Der Sanowirtl) fennt eine Riejengerite,

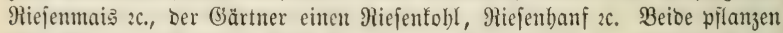

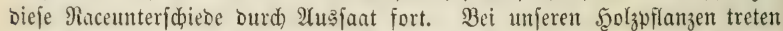
biefe Unteridjiede in folge ihrer langiamen Entwidelung weniger herbor, oder vielmebr, es fint biejelben nod) zu wenig erforfd)t uno beachtet. Die 3ahl eigenter Beobad)tungen in bicier Rid)tung ift nod) zu gering, als baई id) einen beftimmten Sebrjatz Darauj bauen möd)te; jo viel glaube ids aber id)on jeb̧t aus ibnen ableiten zu dürfen, baj ber Game aus ben beft=

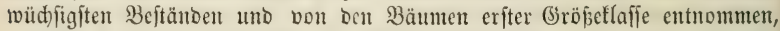

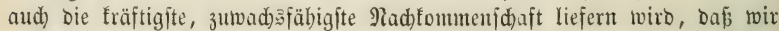
aud) auf biejem Wege nid)t wenig auf Berbefferung fünftiger $\mathfrak{B a l}_{\text {bzuftänbe }}$ Ginwirfen fömnen.

Nod) einten Ed)ritt weiter, uno wir gelangen zur inbiviouellen $3 \mathrm{u}=$ wad)säblgfeit, zum Mebr ober Minber berfelbon, felbjt unter ben \$ffanzen

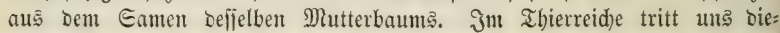
jelbe mit ber gröpten Beftimmtheit entgegen, weil bas Thier meift fdon 
nach 2Lblauf weniger Sahre feine entlidje Rörpergröpe erreidht uno bon ba ab, jelbit bei ber reidflidften Ernäbrung, abgejehen von ben borïber:

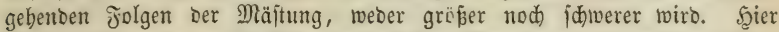

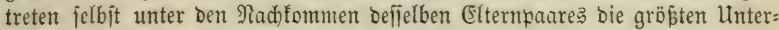
jajiebe endlidjer Rörpergrößje herbor, Die, abgejehen von Siedthum ober Berfrüppelung, unjtreitig fdon im Reime (iegen, burd) Bunft ober Ungunit

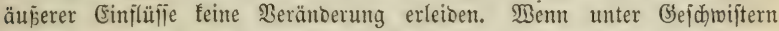
Der eine mit fünf, ber andere mit jed)s Jus in jeinen Eduben jtebt, wenn ber eine blondes Sgaar uno blaue Afugen, ber anoere fatroarzes Şaar uno braune 2 ugen bat, io finto bas indinibuelle, idon in Reime gegebene Unterfdiebe, bic fid) biş zur Edärfe finnlicher Wahmehnung, bis zur

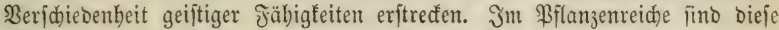
Unterjdiebe weniger jdarf auşgeprägt, bod) treten fie aud) hier bem jorg=

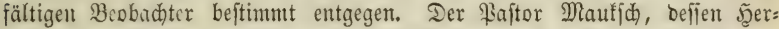
barium wir bier befiken, unterfacied 250 ! Formen ber Salix silesiaca in ben Sarpathen, beobadjtete jebe Derielben viele Jabre binourd) und ver:

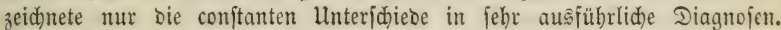
Biele unferer Sgolzpflanzenarten würben bei gleid eingebender Beobadtung Yehnlidyes ergeben. Эđ̆ balte es für viel näher liegeno, wenn man bieje Unteridiebe für indiviouelle bält, als bas streben fie fänmtlid auf

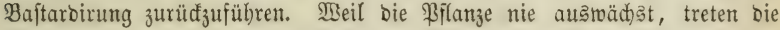
Unteridjebe in ber 3uwachäfähigkeit an ihr reniger forarf als an Thiere herbor. Jnteé fehlen aud) bierfür in unjeren $\mathfrak{B a l}$ aldngen bie Fingerzeige nid)t. Dả gleidartige uno gleidjaltrige Dberbol im Mittelwaloe zeigt Unterfobiede im Maffengehalte bidht nebeneinander, unter burchaus gleidjen äuperen Einflüị̄en erwadjener Bäume, bie biミs zum żwei= ober breifad)en

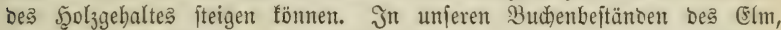
Die, aus natürlicher Bejamung berborgegangen, bon Jugeno auf regelmäp̄ig Durdfforftet wurben, zeigen bie 150 Stämme bes 120jäbrigen gefdlofienten Beftanbes bod) noch Mafieunteridiede bis nahe jum Ireifaden Des Şolz=

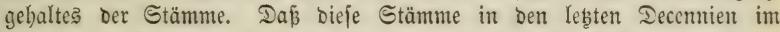
Budbje zurüdblieben, ift theilmeije Jolge ifrer Heberginfelung, baf fie aber übergipfelt wurben und nidjt jelbjt übergipfelten, ift eine folge ibrer geringeren 3umadjäfähigfeit, ibrer geringeren Lebenäfraft, bie jebr wohl im früberen Sebensalter eine gröfere gewejen fein fann, in Folge befien fie bamals bem oominirenden Beftande angebörten, bie bei einem gröferen Theil Der Bilanzen Des Jungorts früher, bei einem fleineren Theile fpäter fich berringert, in Jolge befien bie Hebergipfelung fortbauerno fid) erneuert,

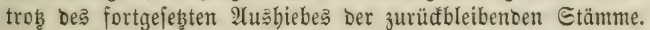

Befteben unter Den Bilanzen berjelben $\mathfrak{A}$ rt berjobiedene Grabe indi=

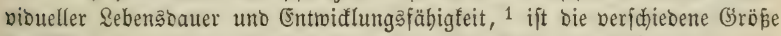

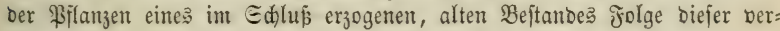

1 Wenn Der Urwald Riejenbäume erjeugte, wie fie unjere beutige Forftwirthidaft nie wieber herborbringen twird, jo liegt bic Urjađje feinesmegs alfein in Dem bamals größ̄eren

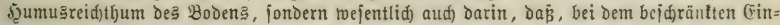
greifen ber (5ultur uno ber Benußung, jene lebensträftigiten Bejtandsglieber im Stande

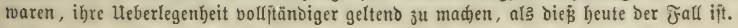

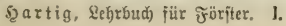




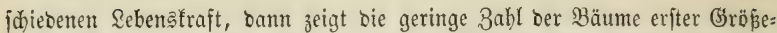
flaile bes haubaren Beftanbes $(16-20)$, daß jelbit unter Şunberttaujenben

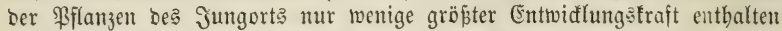
fino. Je größer bie urfprünglide Bahl ber Pflanzen eines Jungorta ift, je gleidmmäßiger bieje Bflanzen in ben gefammten Stanoraum fid theilen, je jorgfältiger barauf gejehen wiro, Daßs bem Beftande währent beffent ganzer Rebensbauer nur folde Pflanzen entnommen werben, bie fid burd

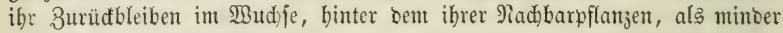

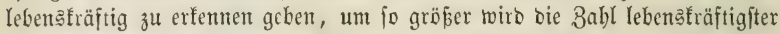
Pflanzen fein, dic bia zum 2lbtriebe den Beftano bilden, um fo größer

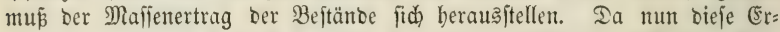

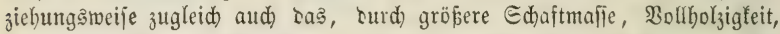

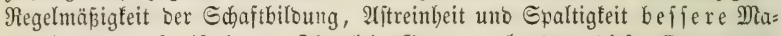
terial erzengt, fo ift in ber Ihat fein Gruno vorbattom, biefer Erzengungs:

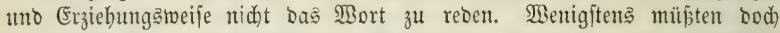
bie Fürpred)er einer 5ูerftellung fflanzenarmer Beftände, einer Erziefung ber Pflanzen im unbejdränften Etanoraume, Eottajidjer als Eotta felbjt,

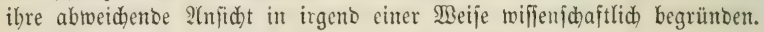

2 n berjelben Pflanze ift bie Zuwad)sgröpe bebingt:

1) Bom Standort - von ber Sunme ber rohen Rahrungsfoffe, bie aus ber llmgebung Der \$illanze biefer zugehen fönnen, uno zwar in Den 3eiträumen, in benen bie Pflanze zur 2lufnabme berfelben gejobiatt ift. Bir nemten diés bie Frud)tbarfeit des Standorts. Sie ift Gegenftano bor Bobentunbe uno Rlimatologie.

2) Bon ber (sefunbleit ber Bflanze.

3) Bon ber Eumme ber Ernäbrungargane, ber Barzeln

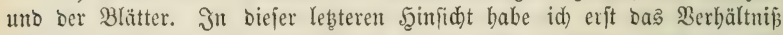

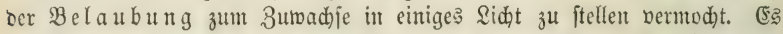
hat fid() aus meinen Unterfuchungen ergeben, bá eine gewifie Blattmenge nothivenoig jei, theils zur 2fufnabme ber atmojphärifchen, theils zur 2rifil= milation auch ber terreftrifden Räbriftoffe, wenn ber 3uwadbs in einer ber

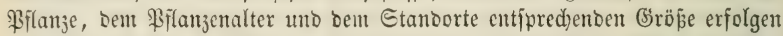
joll. Jür Särden uno Riefern, Etangenböljer, ftellte fid bie Menge ber biezu nötbigen Belaubung als bie einer vollen Beaftung ber lek̨ten fünf Jabreş=

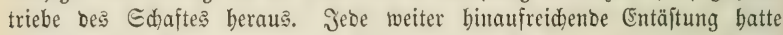
unfehlbar cine Berringerung Der Şolzringbreite im zuveiten Jahre nach Der Entäftung zur Folge. Burben bie Stangen bis auf Den leksten Bipfeltrieb entäftet, bann verringerte fich bie Jahreşringbreite int ztweiten Jabre auf

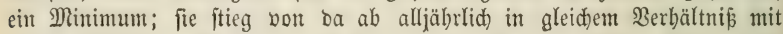
Der zunebmenten Beaftung uno Belaubung bis zum fectsten Jabre nad) Der Entäftung, in weldyen bie frühere Sgolzringbreite wieberbergeftellt war.

Heber diejen (3rab nothrwendiger Belaubung hinaus, ber bei anberen Bflanjen uno in anberm Bflanjenalter jebod ein fehr beridiebener fein toirb, uno wabrjobeinlid) in böherem 2 (lter ein gröperer ift, focint eine größere Saubmentge auf Steigerung Des 3umadjes nidht ober nur unbes Deuteno einzumirfen. (Fine zwanzigjäbrige bis zum juß̧e bid)t benabelte

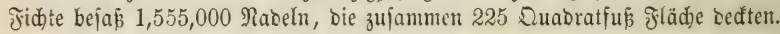


Obgleidh biejelbe, bon Jugent auf im Jreien erwadjen, fteţ eine ver: bältnīmääig eben fo grofie Blattfläd)e getragen batte, war ifje Edaft= bolzmaffe bod) nur um einige Sifunbe idfwerer, als bie einer eben fo alten, von Jugento auf im Edhlufie erwadfenen, Daher gering benabelten fidhte. Eine gleid) alte Riefer mit 122,000 গabeln, bie eine Jläd) von nur

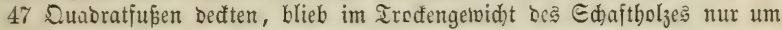
$1 \frac{1}{2}$ Ffuno binter ter Jichte zurüdf. Eine von Jugend auf im Jreien er= wadjene uno bis zum Boben bejmeigte Fidhte, bie eine zebnfad) größ̈ere Nabelmajle trägt uno bon je her getragen hat, als bie Daneben ftebenbe,

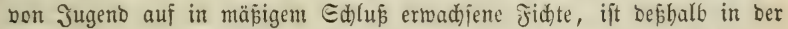
Debrzabl ser fälle niăt mailenbaltiger als Setztere. Ueberflüffige jährliche Saubproduftion mus nothwendig bie Menge bes bleibenden 3uwadjes verminoern. Die unter ben Jorftleuten ber (ottajiden Edule febr berbreitete Meinung, Dá mit Der Menge Des Saubes aud bie Menge Des 3uradjes fteige, entbehrt baber, auperbalb Der eben bejeidneten engen Osrenzen, jeoer thatjächlichen Begrünoung.

Als Bemeis des, Den 3uwadbs fteigernoen Einflufies ftärterer Bes

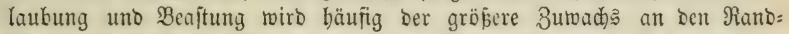

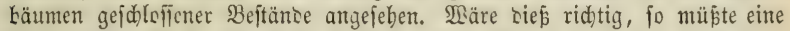
in Demfelben Naje räumlid)e Stellung aller Bäume Des Bejtandes Den= jelben Erfolg zeigen, was im Alllgemeinen gewi

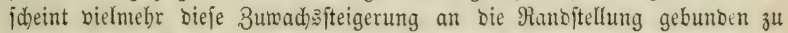
fein, uno sürfte Der, ourd) sie Temperaturbifferenzen in unb auper bem Beftande am Rande Derjelber gefteigerte Suftwidjel, es Dürfte ber Umitand

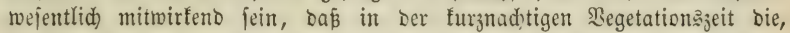

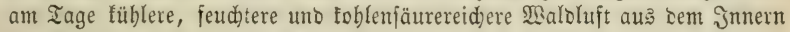
Der Beftände, währeno Der Tagešzeit forţauerno sem Beftandsrande zuftrömt.

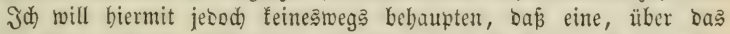

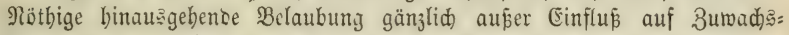
jteigerung fei, bielmebr gebe id) zu, baf auf einem in feinen unorganij(t)en Beftandtbeilen frudtbaren Bodn, Defien ßroduftionstraft unter ser Jrei= ftellung nid)t wefentlid leizet, ber 3uwachs bes einzelnen Baumtes im vollen Standraume ein um etwaß größ̄erer fein fönne. Meine Bebauptung bejđränft (iid) Larauf, daf bas bierauf beruhenoe 3uwachs= Mlebr biejenigen 2 usfälle an 3umachs nidht erfę̧e, bie aus ber, unter biefen Umftänoen noth= wentig geringeren Froducentenzabl heroorgebin. Die Wabrheit biejes Gakes

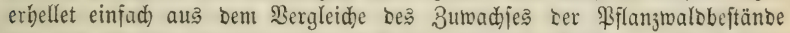

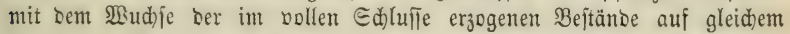

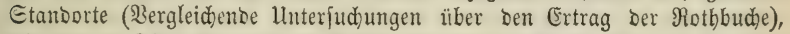

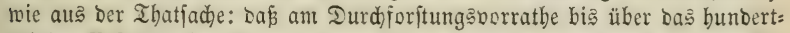

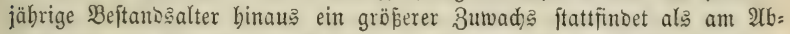
triebsoorrathe (Enjtem uns 2(nleitung zum Etudium Der for fitwirthidaft: lebre, Geite 217). (5z beruht bieß einfad) auf Dem Umitande, baj ber

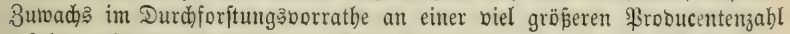
exfolgt, als ber 3umads am 2thtriebsvorratbe. Scundert Eubifjū über: ginfelte Bäume wadjen alljäbrlid) eben fo biel, mitunter fogar mehr ž als eben fo biele Cubiffús bominirente Bäume, aus ¿em einfadjen (Brunde, 
weil jene etro in 4-5, Yeb̧tere in einem Baume ftedent. Man fann fid

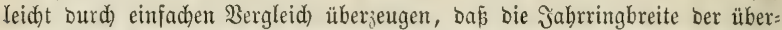
gipfelten nod) nid)t völlig unterbrüdten Bäume feineșegs fo weit binter

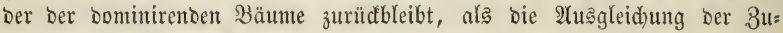

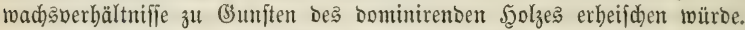

Im böberen, meijt jenjeit Der (5renze üblider Sgodwaloumtriebszeit liegenben 2 (lter ber Bäunte, tritt ein Beitpunft ein, in weldhem ber fronen=

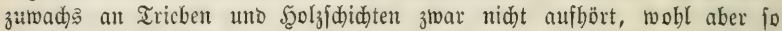

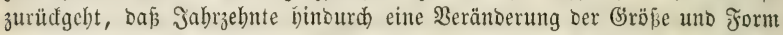
Des Sronenraums nidłt augenfällig wilb. Demungeadtet fann bie Sirone Dod) gejun und voll belaubt fein. (5: muß Dieß зur Folge baben, baß ein groß̧er Ibeil ber unverminoert bergeftellten Bilbungsfäte, bie früber auf Den größeren Sironenzurwad) berwentet wurben, bon ba ab Dem Sdhafte

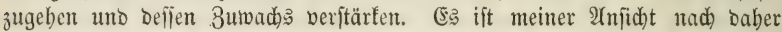
nidit bie 3eit ber Rronenausbreitung unt ber baburd) gefteigerten Belaubung,

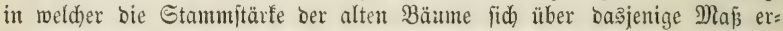
höht, Das wir im gefdlofienen Stande immerbalb üblid)er Umtriebşzit er=

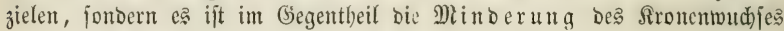

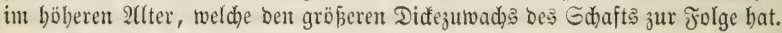

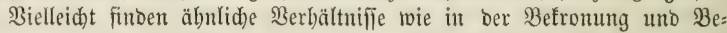
laubung aud in Der Betwurzelung ftatt. Mir wifien barüber aber nod gar nichts, wie überbaupt bas ganje 3erbaltent Der Bewurzelung zum Boben ein nod) jefr wenig gefantes ift. Dic bier uno ba entbaltenen Alngaben tragen 孔u jehr bas (jepräge von Jictionen, als baf ifnen irgeno ein 13 erth) beizulegett wäre. (Es mag baber hier bas genügen, was id̆ Eeite 157

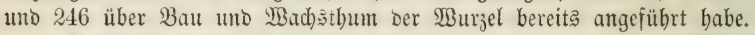

2luperbem femen wir mu nod) eine vorübergehente \$Bad)sthums: ftcigerung, bie bann eintritt, went Bäume, bie längere Beit im Beftandş=

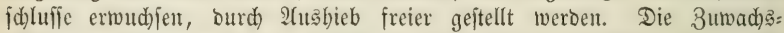
erböhung erfolgt zu raid), als baß bermel)rte $\mathfrak{L} a u b=$ ober $\mathfrak{B}$ urzelmenge bie Urjache berjelben fein fömnte. Sic finbet ftatt aud bei 2 ushieb von Ober: holz aus bicht beftoftem Interbolze ohne Beränberung ber Bobenbejduffen= beit. Heber bie Urjad)e biefer fdjon nad) wenigen Jabren auf bie frübere

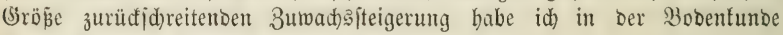
Seite 87 meine 2 (nfid bt ausgeiprod)en.

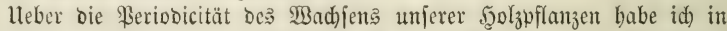
Der Jorft = uno Jagozeitung 1857 Seite 281 cine Reibefolge von Berjudhen

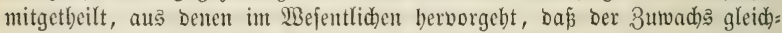
zeitig mit Dem \&aubasbrud)e, bei uns 2lnfangs Mai, in oen 3meigfpiben beginnt uno bier gegen Enoc 2 utgujt vollenbet ijt, aljo nabe vier Monate bautert. Selten eilt bie Scolzbiloung in ber Triebipibe bem Laubausbruche etwas voran.

3on Den 3weigipizen jentt fid Der 3uwadjs langam nad) unten, fo

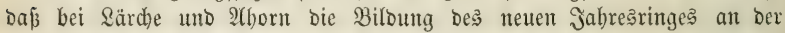
Bafiz Des Stanmes um vier $\mathfrak{B o d h e n ~ f p a ̈ t e r ~ a l s ~ i n ~ D e n ~ I r i e b i p i b e n ~ e i n t r a t . ~}$ Bei (Eid)e und Riefer bingegen war finon 2Anfangs Mai bie Jabrringbiloung an Den unterften Stammtbeilen eben fo weit, mitunter weiter borgefdritten, 
als an ben oberften 3weigipizen. Bei Särd)e uno 2(horn twiro Dann aud

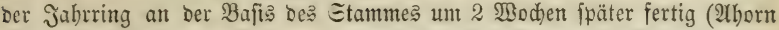

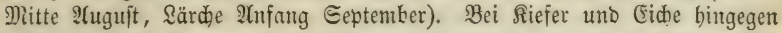
erfolgte bie Bollenoung Deక Jahrešringes in 3meigen uno Stammbafiz

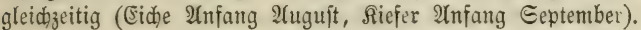

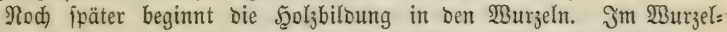

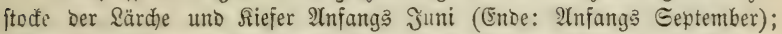
in Dem Des 2 Uhorn gegen Enoe Juni (Ence: 2 nfangs Eeptember); in Dem Der (Eid)e fogar erft gegen Enbe Эuli (Enbe: gleidfalls 2tnfangs Eeptember).

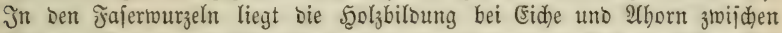

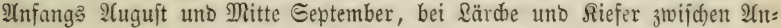

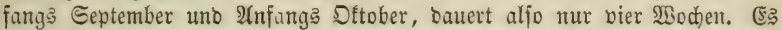
ift Daher bie fidon im Jebruar ober März eintretende Biloung von Rraut= fproilen uno neuen Triebmurzeln eine mit bem Sgolz̧utwadje ber älteren Jajerwurzeln ganz auper Berbinoung jtehenbe 3utadberjabeinung.

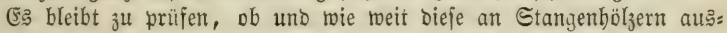
geführten Llnterjudhungen mit Den Beiträumen Des Butadję ftarfer Bäume übereinitimmen.

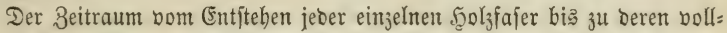

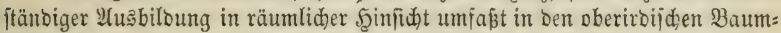
theilen 4-6, in ben unterirbifden Baumtheilen 2-4 Woden.

Neueren Beobachtungen an Phaseolus zufolge foll Daß tägliche Badbs: thum biefer Bilanje borzugsweife in ben @tunoen bor Eonnenuntergang bis Mittemadht liegen, von ba ab bis Eonnenaufgang fid) allmäblig verringern,

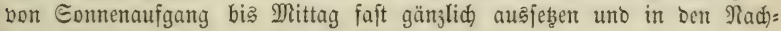
mittagştunden fid rieber fteigern (テrifher).

\section{G. Heproduktion.}

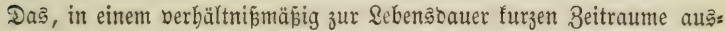
getwadjene Ifhier nimmt täglid) Nahrung zu fich, verbaut biejelbe, biloet buraus neue Rörpertheile, obne baburd) id werex zu werben (abgefeben von Den vorübergehenden Folgen ber Maftung). (Fin, ber tägliden Nabrungäs aufnahme, ober bielmebr ben aus biejer entitehenoen Neubilbungent ent= iprechendes (Bewiḍt früber gebiloeter Rörpertheile twird in gas = uno bunit=

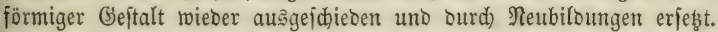

Fine Reprobuttion in Diejem Sinne findet bei ber Bilanze nidit ftatt. Die fertig gebildete Pilanzenzelle bleibt bis zum Tobe Der Pflanze ober

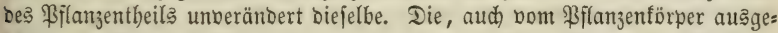
fäiebenen Gaje uno Dünite find nidft rie beim Ihfere Ercrete bereits fertig gebilbeter Rörpertheile, fondern eక find, ben (Excrementen bes Thiers ber=

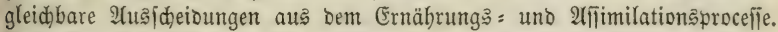
Daber fennt bie \$flanze biejen Stillitand bes ausgewadjenen 3ujtandes nidt.

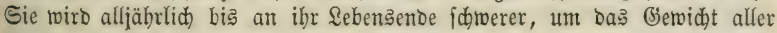

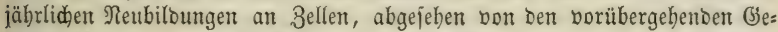

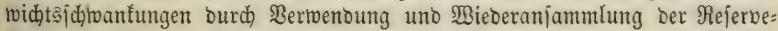

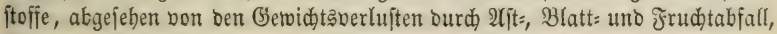




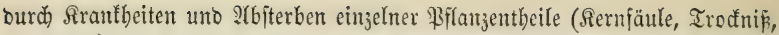
Brand 2c.).

2(ud) bie jäbrliçe Ermeuerung ber Iriebe, Blätter, Snoppen gebört

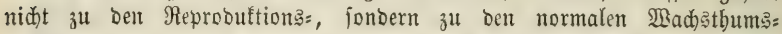
erjheinungen. Selbit bie, in Folge franthafter 3uftänbe ober getwalt:

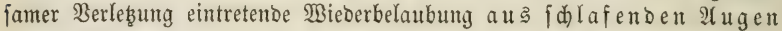
(Seite 150) gehört nidjt bierber, denn fie erfolgt aus vorgebildeten, in

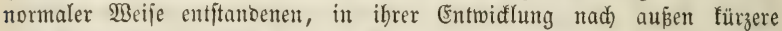
Doer längere Seit zurüưgehaltenen Snofpenbiloungen. Den Begriff pflanz= licher Reprobuftion bejoränfe id auf Bildungen, bie in Folge gewaltfamer Berleb̧ungen im $\mathfrak{A}$ eime neu entjtehen, bie $\mathfrak{B} u n$ fläche mit einer ber:

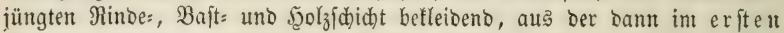

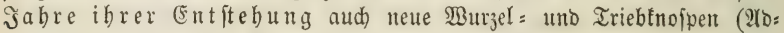
ventiofnofpen) entîteben fönnen.

3u ben Reproduttionserjheinungen Der Jgolzpflanze zähle id baber:

A. Aboentib=:Adiengebiloe.

1) Die Uleberwallung.

2) Die Befleioung.

B. Abuentiv= Rebenadjen.

3) Die 2loentiojtammfnofpe.

4) Die Yoventiowurzelfnofpe.

5) Die $\mathfrak{B u r g e l b r u t . ~}$

A. Atoventid: 2 d jiengebiloe.

\section{Die lleberwallutg.}

lleberall, wo ourd eine Edalmmunde Rinde unt Bajt, jelbjt bie äuperen Şolzlagen bintweggenommen werben, biloet fid im nadfolgenben Jabre an ben (brenzen ber $2 B$ un

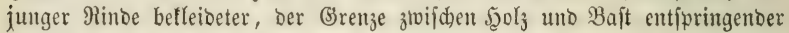
Wall, in roldhem ein bolziger, nad) ber Sdalmflädhe bin bogig umgefiprte: Rern, von eiter neuen Baft= uno Rindelage befleibet ift. Die lluter:

Fig. 48. ju(d)ung von Ducrid)nitten zeigt jobn bem einfach belwaffneten 2luge,

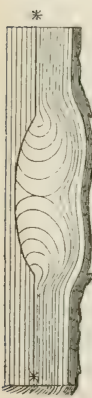

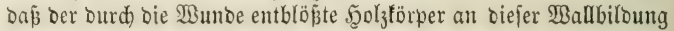

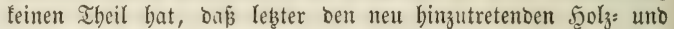
Bajtlagen entipringt, bie, in jebem folgenten Jahre burd) neu binzulonmenoe Echidjten fid bergrößerno, entlid) in ber Mitte Der Edalmfläd)e zufammenftopen, worauf fid bann bie normale, ununterbrodene $50 l_{z} b i l$ oung wieberberitellt.

Die nebenitebence Figur zeigt in ber Einjentung zroijden ** cin vor adt Jabren hergejtellte Edalntmunde unt Deren Heberwallung von fechs unvollitänoigen Mulftringen, über benen in Den lek̆ten beiben Jabren fid) zwei ununterbrod)ene 5ुolzlagen ausgebiloet haben. Da die äuperen Borfelagen aut Der Reproduftion nidbt Theil nebmen, erbalten fid) bie (Srenzent ber Sdalmmunde äuser: (ic) nod) lange Beit, oft für immer erfennbar.

Da ber, burdh bie Sdjafminunde blokgelegte Fुolyförper in 


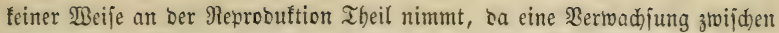
ibm und ben Heberwallungälagen nicht eintritt, io erflärt fid bieraus leiḑt,

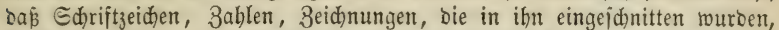

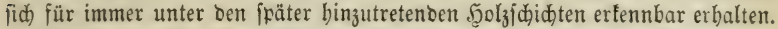

In ganz äbnlicher Beije erfolgt bie Leberwallung von 2iftituben.

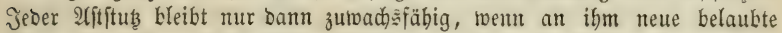
Triebe fich bilden (Geite 281). Jit baß nid)t Der Jall, bann vermag er filbit aud) feine lleberwallungsiddidten zu biloen. Jinbet an ibm eine Uleberwallung ftatt, bann gebt bieje ftets von bemjenigen Baumtbeile aus, bem ber 2lititub̧ entiprungen ift. Die audb bier alljäbrlid binzuttretenoen

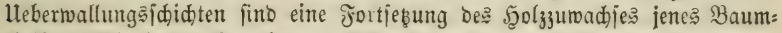
theils. Wie im vorbergehenoen Falle Daburd eine Süde auşgefüllt wiro,

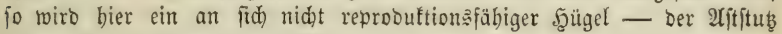
- abmäblid überwadjen. Die nebenftebenbe Figur 49, Den Sängenjobnitt eines völlig über= wallen $2($ it titukęe bariftelleno, in weldem bie mit * bezeidnnete Sinie bie Brenze bes 5 golztörper: 3ur 3eit ber Einftub̨ung bes 2litę umido)reibt, wird biés obne wei=

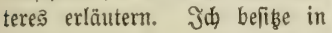
meiner Sammlung einen Eidhen= aftiftuc von $1 / 3 \mathfrak{M}$ tr. Sänge, ber mie rebentebeno bis zur Spibe burd 60 aufiteigende Şoljlagen vollitänoig überwallt ift. Der längit abgeftorbene 2 iftitub̧ jelbit ift in oiefem falle als ein ourd)= aus inbifferenter Rörper zu be: tradten. Erfolgt bie Ueberwallung rajd), fo fann befien Sgoljtörper

รึ่. 49

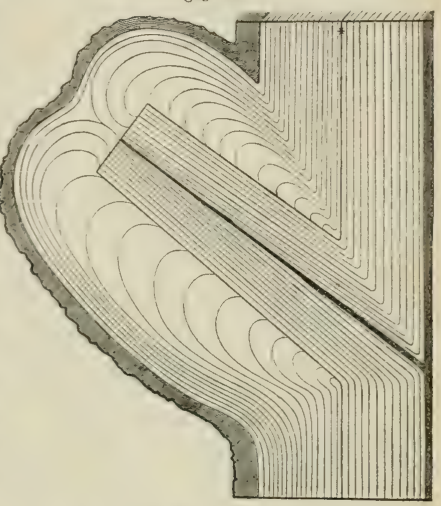
iid) bollfommen gejuno erhalten; erfolgt jie langiam, uno ift fie erit bann

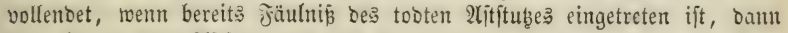
fann lestere vom ?(itftubs ans aud) bem Stamme fid mittheilen uno Rern: fäule zur Foige haben. Fgoljarten mit geringer Dauter ifres Şoljes forbern Daber einen rajderen Beridluß ifrer $\mathfrak{B}$ unofläden ourd Sdalme und $2(j \mathrm{t}=$ ftub̧e, wenn bie ber ted)nifden Berwentoung fo nadtheiligen Folgen vermieben werben follen. Der Beridhlú ber $\mathfrak{B} u n$ flähen erfolgt aber rajdjer, je fleiner bie Mumbläde, je fürzer ber 2 rftitub ijt, er erfolgt auf gutem Standorte,

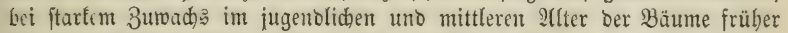
als auf idsledtem Boben uno in böberem Baumalter. Şierauts entipringen

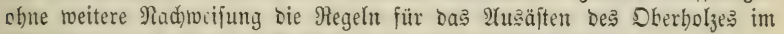
Mittelwaloe uno für ben Sopfbolz= uno Sanneidelholjbetricb.

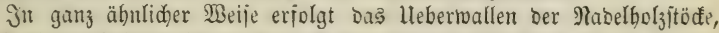

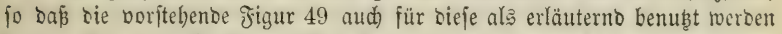
fantr. Der rejentlide Unteridieb berubt nur barin, Daß bie Uleberwallung 
am \aublojen Şaupttriebe erfolgt. (Meine 2Utriduten bierïber Seite 271 und Forit = uno Jagbjeitung 1844 Geite 96, 1846 Geite 5.)

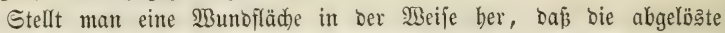
Rinbe uno Baftläche mit nid)t abgelößten fläd)en in Berbinoung bleibt, Danu bebecát fich mitunter mur bie imere Baftjeite, mitunter mur bie

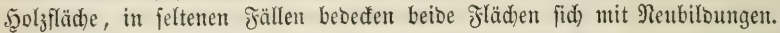

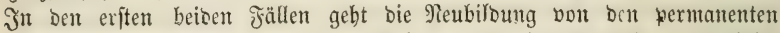
Mutterzellen bes Baftes uno bes Fुolzes aus, bie, je nadjoem fie beim 2Lblöfen bes Baftjtreifenţ auf ber Baitjeite oder auf ber Şolzjeite verblieben, auf ber entfprechenden Seite Die Reubiloungen an $\mathfrak{S g l l}_{3}$, Bajt unt Yinde biloen, wie id bies in meiner Naturgeididste ber foritliden Eulturpflanzen Iaf. 70 Sig. 5. nadjgewiejen babe. Daraus erflärt fich audo bie oft

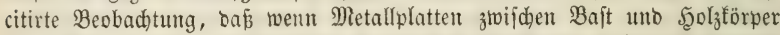
eingeid)oben werben, bieje fpäter in mand)en Fällen im Şolze, in amberen Fällen im Bajte wieder vorgefunoen werben. WBird eine Metallplatte

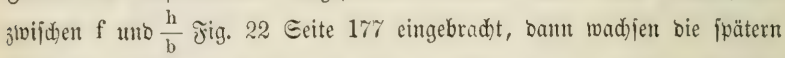

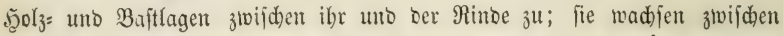

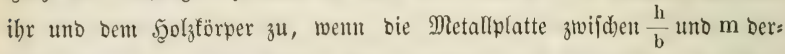

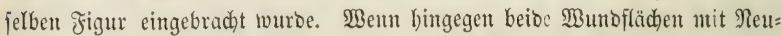
biloungen fich) bebecten, Daun ftanment nur bie ber Baft feite aus ben permanenten Mutterzellen Der Eambialfdid)ten, währeno bie ber Solzleite in einer $\mathfrak{B}_{\text {Beife }}$

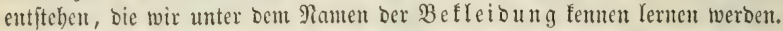

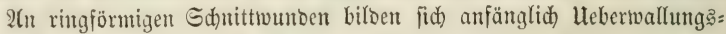

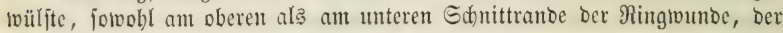
Ball am unteren Sdntittranbe bleibt aber fdon nad) einigen Boden in

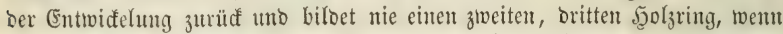
nid)t in ibm 2roventivfnofpen entftelen, Deren Triebbiloung uno \$3elaubung ibn im Zuwadje erbält. Der Ball am oberen Ed)nittranbe bingegen mädbst

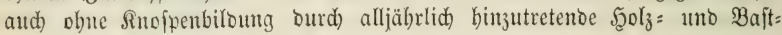

テrig. 50 .

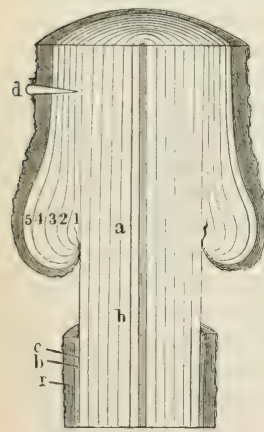
fduidten fo lange, als ber über ber Ringmumbe liegenbe Baumtbeil fid) lebentig erhält.

Sin ber nebenitebenten Jigur 50 feben wir ben Rängenjd)nitt eintes zwifhent a uno b vor fünf Jahren geringeltent Stamme. Die Ringmunbe a b ift ohne alle Reprobuftion geblieben, bie 2 Un flädhe Des Şolztörpers liegt beute nod) fo nadit wie zur 3eit ber Beriwunoung. Lleber ber Ringlwutoe baben fid) in allen Theilen des Baumes fünf Şolz= uno Bajtlagen in normaler Beife gebiloet, beren unterfter Theil wie in Fig. 48 uno 49 zu einem Ueberwallungsmulfite fid) erweitert uno umgefippt hat. Unter ber Ringrounde bingegen hat fid) nur im Jahre nad) Der Berwunoung bie Initiale eines Jabrringes (c) gebiloet (vergl. S. 269).

Queridanittfläd)en, bie, wie bie Şiebgf(äd)en 


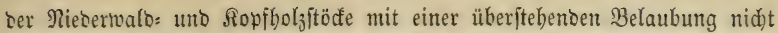
in Berbintung ftehen, biloen im erften Эabre nad) bem Şiebe zwijden $\mathfrak{S}_{0} \mathrm{l}_{3}=$ uno $\mathfrak{B}$ ajttörner ebenfalls einen Heberwallungsioulit, ber, wie in vor=

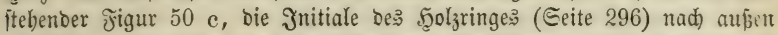
abjoliep̧t. Ǎbgejehen von ber abnormen fortbiloung biejer Jnitiale an Etöđen ber Beiftanne, Rärche, feltner ber Jidhte, bleibt biefe für inmer auf ber Figur 50 e bargeftellten, nieberen Entwidelungsftufe, wenn nid)t Durd) Aroventiofnofpenbiloung im lleberwallungshulfte, ober burd) Rrbpto: blaftenentwidelung (Eeite 150) Didst unter biejem, er jelbit uno ber Stod in fortbauernoem 3uwadbje erfalten wirb. Эa fomme bierauf bei ber 2loventiofnofpenbiloung zurüd.

Streng genommen gebört bie Uleberwallung niḑt zu ben Reprodifttions=

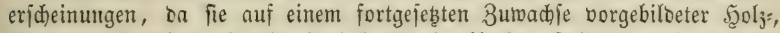
Bajt:̨uno Mindelagen berubt, id) babe fie aber bierbergeftellt, eineștheil ba fie Dod) immer nur alక Jolge eingetretener Berleţungen auftritt, antorentbeil’ meil reprobuttive (Erjdeinungen bäufig mit ihr verfnüpft find. Mit bemfelben Rechte fönnte man allerbings aud) Arnptoblafte und Ephäroblafte (Seite 150, 153) bierberziehen.

\section{Die Befleibung.}

Wenn man im Jrübjabre, mähreno ber 3eit, in weldyer bie netten 5ुoly = uno Bajtlagen fid bilben, armsoiden Stangenbölzern einen 2-3 3oll

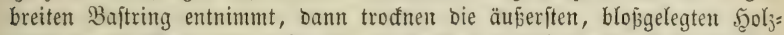
lagen in ber Rigel jebr bald aus, fie fterben in Folge belien bald ab, uno es erfolgt auf ber $\mathfrak{B u n d f l a ̈ d}$ feine Rerroduftion, fonbern nur eine Berwal=

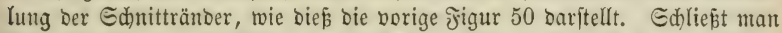

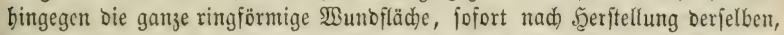
in bie beiben 5älften eine? ber Sänge nad) in zwei Stüde geiprengtent Sampencylinbers ein, verfittet man bieje unter fid unt mit ber Baumrinde luftoidht berntitteljt Baumwad)

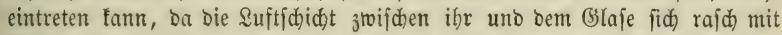
Wafferounit aus bem aufiteigenden Syol 3 faft jättigt, bann bilbet fid fidon

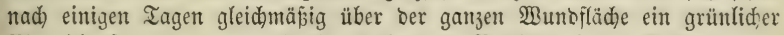
Rinbefdorf, unter bem weiterhin .5olz= uno Baftbünoel im Reime neu

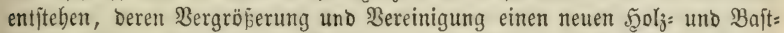
förper bilbet, ohne Dạ eine Berwallung ber früberen Echnittränder hieran Theil nimmt. Durd biefe Reubildungen ftellt fid im neuen Bafte ber unge=

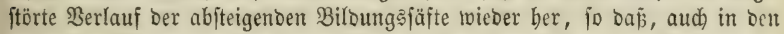
unter ber Ringmunde liegenden Baumtheilen, ber $50 l_{z}=$ und Baft3utwad) 3

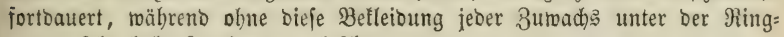
runbe fehr bald für immer erlöfdrt.

2An, bon $\mathfrak{B i l}$ ober Beerenjammlern geiđälten Budjen, Eiden, Erlen zeigt fich) bie Befleibung ber $\mathfrak{B}$ unofläd)en mitunter aud im Freien, ohne irgend cine fünftlide Beibülfe. Da Der eben bejdriebene Błą̧verbanto nur Daburd) mirft, baß̧ er um bie $\mathfrak{B u n b f l a ̈ d h e ~ e i n e ~ m i t ~ J e u d t i g t e i t ~ g e j a ̈ t t i g t e ~}$

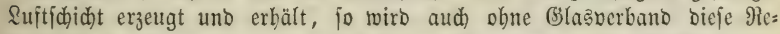
proouftion eintreten, wenn zur 3eit Der Bermundung bie Maldhft mit 


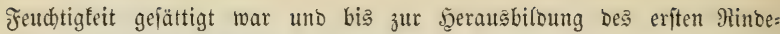
fijorfes in biefem 3 ujtande verbarte.

Die Eeltenbeit uno bie meijt örtliđe Bejdränfung ber im Jreien fid) bilbenden Befleioungen batte unter ben Phyfiologen bie 2fnfidft berbor: gerufen, ę jei biefelbe Folge eines zufälligen Berbleibens von Cambium

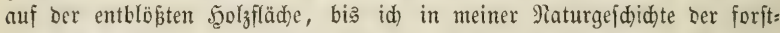
liden (Eulturpflanzen (Tafel 70 Fig. 1-3) eine Reibefolge bon Beobad)= tungen veröffentlid)te, denen ju Jolge bas Bellgewebe ber Marfitrablen bes

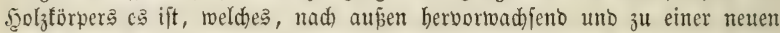

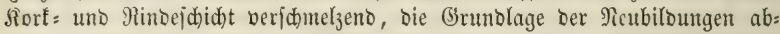
gibt, Der 2 rtt, Daj nadh eingetretener Beridinelzung ber einzelnen Bellgetwebs:

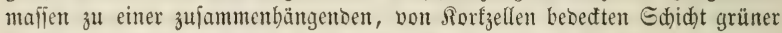
Rinde, in lețterer, feitlid eines jeben Marfiftrahls, neue Jajerbünbel aus Bellenmetamorphoje wie in (Embrno entîtehen (ङ. 209).

ซึig. 51.

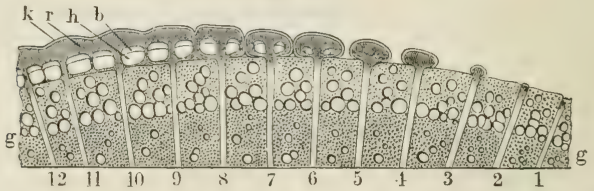

Die voritehenoe Jig. 51 gibt eine Darftellung De: Entwidelungaver= laufes Der Belleibung. Sie ftellt einen Ibeil ber Duerfdnittfläde eines entrinbeten Eidhenjtämmdhen bar. 1-12 fino Marfftrablen, $g \mathrm{~g}$ ift bie Grenze Des vorjäbrigen Syolzringes, bezeidntet burd) bie bidtere Etellung

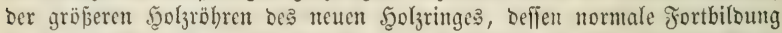
burd) Das Ringeln unterbrodyen wurbe. Das twas im Bereidye ber Mart: ftrablen über ber Grenjlinie $\mathrm{g} g$ liegt, ijt alio ber 2 tufang eines neuen Jुolyringes, fo weit biejer in Jrübjabre vor eingetretenter Pingelung fich normal entwicfelt hatte. 2In den mit 1-12 bejeidneten Marfitrablen babe id) fortlaufent biejenigen Beräntorungen angebeutet, weldhe fich auf bie

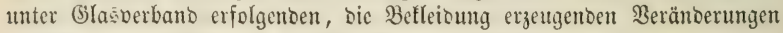

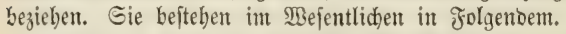

lleber 1 baben bie äuß̧erjten Marfitrahlgetfen cine grüme färbung er= balten, angeocutet Durd) Edraffirung. Die Marfiftrablzellen baben fid in

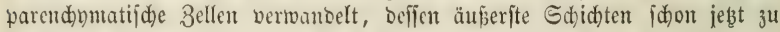
Sorfjellen fid) umbiloen. Jn 2-4 ift bas neugebilocte ßarendinm über bie

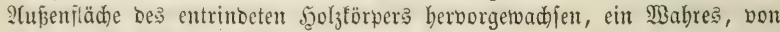
Sorfgenebe befleidetes Rinbeparenchym. Lleber 5 fehen wir, jeberjeit ser

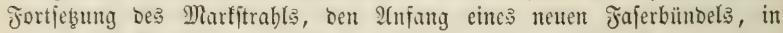

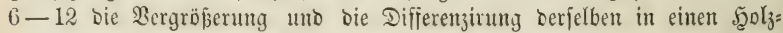

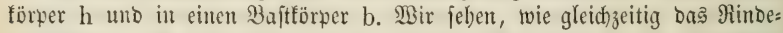
zellgetwebe $\mathrm{r}$ fid) bergrößert, bis bic einzelnen Neubiloungen fid gegenfeitig

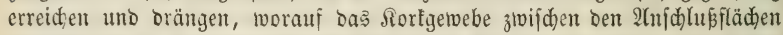

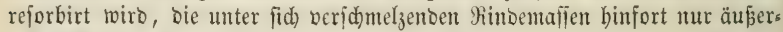
lid) befleideno $(\mathrm{k})$. 3wija)en ben neuen Fajerbünoefn verwanbelt fid) als: 
bann bas Rintegewebe wieber in Marfitrahlengemebe. Bon ba ab biloen

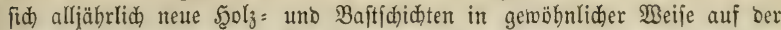
OSrenze zwifden Şoly uno Bajt Der neuen Fajerbünoel (b h). Bei Ellern, Ebereiden, Särden jind aber bie Fälle nidht felten, in benen bie neutn

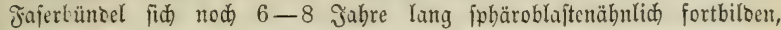
wäbrent bei Budjen, Şainbuchen, Birten, Eiden bie Jabrringbiloung in ber Regel fibon im zweiten Jabre burd)aus normal berläuft.

In feltentern Fällen gelingt $e^{3}$ aud an Nabelhölzern, bejonbers an

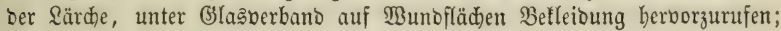
ę erioäd)

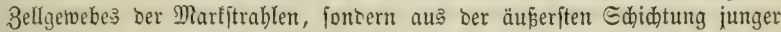

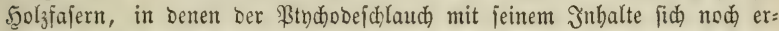

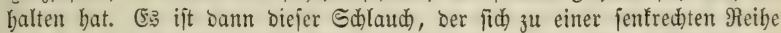

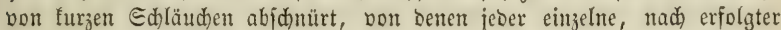
Einjtülpung uno 2 bjonnürung eines berjüngten Gajlaudes in ben Innen: raum zur Bellwanoung in gefabiloerter Beije fid umbilbet. Unter Rejorption Der urjprünglichen Jajerwänbe bilben alle bieje Iheilzellen ein zujammen=

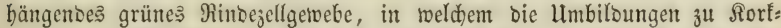
gewebe, zu Fajerbünoeln mit Şoly und Baft eben fo vor fid geht, wie bei ber Befleibung von 2 Bunbflächen ber Raubbölzer.

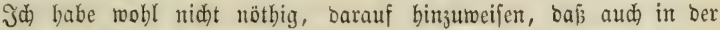

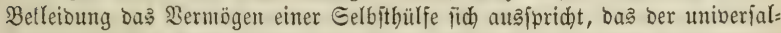

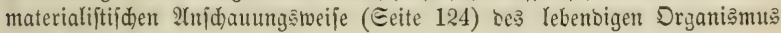
aufs entidiebenfte wiberipridt.

\section{B. Adventiv: গRebenadjen.}

3. IDventiv $=\mathfrak{R n o j p e n .}$

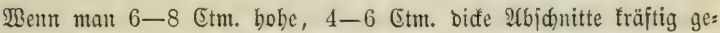
madjenter Stänme ober $\mathfrak{A}$ ejte ber Edjwarłpappel auf einen Ieller mit nafiem Sand ftellt, uno biejen in twarmer \&uft mit einer SHlasglode bedectt, bant bilbet fid, im $\mathfrak{B}$ Binter wie im Eommer, zwifden $\mathfrak{B a j t}$ uno $\mathfrak{S c o l}_{3}$ bes oberen uno bes unteren Edynittrandes eine 3ellgewebsmafie, mit beren zunehy=

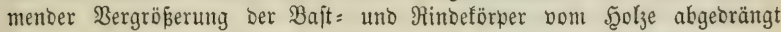

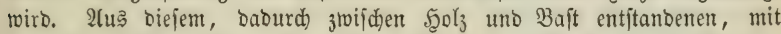
parendymatifdem Bellgetwebe erfüllten, feilförmigen Epalte erbebt fich bant Das Zellgetwebe wallförmig über bie Echnitt= fläd) und bilbet ben Heberwallungsining a b c d ber nebenftebenden Abbiloung, in

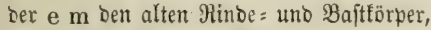

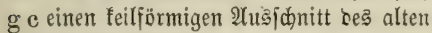
Solztörpers barftellt.

Jil ber neu gebildeten 3ellgewebs: mafie treten mun ztwei mejentlid beridjiebene Umbiloungşorgänge ein. WBie im jugend: liden 3ellgewebe bez Embrno, fo entiteben aud bier neue Fajerbündel Durd) Bellen:

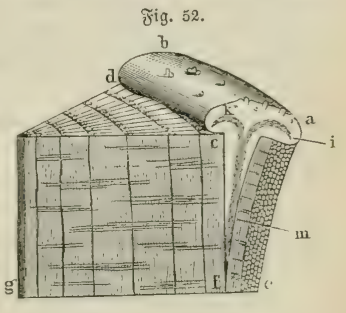




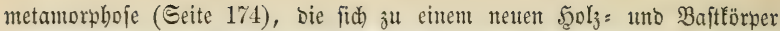
conftituiren, ber in Reilraume fid) Dem alten Bafttörper anlegt, im Ueber= wallungşzellgewebe bingegen in rabialer Ridtung fid) verzweigt uno jeberjeits

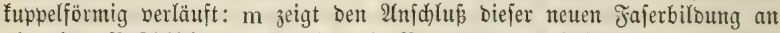
bie alten Baftidjichten, ik zeigt bie Berzweigung beffelben im Bellgewebe ber Uleberwallung, beren überliegente Bellichichten baburd) bie Bebeutung bes Sindezellgetwebes erbalten.

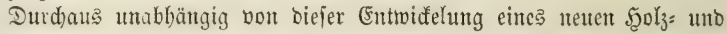

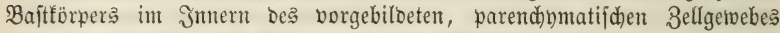
Der Leberwallung, fieht man mu in Dem Rinbetheile beffelben, unfern ber

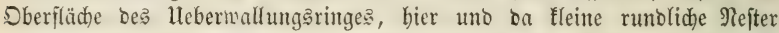
eines ungemein fleinzelfigen Zellgemebes entittehen, wie es mir fdeint burd) örtlich) bejw)leunigtes Tempo ber Selbittheilung groper Rindezellen. Darauf entitebt über biefen Zellenteftern ein fappenförmiger mit Dberbaut befleibeter Epalt, deffen (Enfftehen id) erfläre aus einer gegenfeitigen Berwadjfung Der überliegenden Rimbezellenjf(fid)t, unter gleidzeitiger Rejorbtion ber

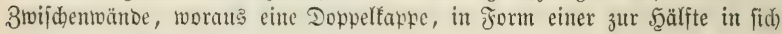
jelbjt eingeitülpten Blaje entiteht, beren innere Şaut bas Bellennejt hinfort als Dberbaut befleidet, wälgrento bie obere Saut zerreifit uno ben beran=

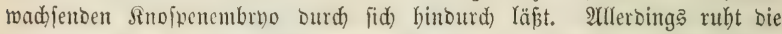
Erflärung Der Dberbautbiloung mur theilmeife auf birefter Beobadtung,

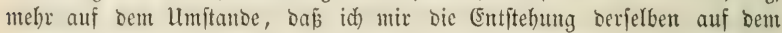
heranwadjenden Sinofpenteim in feiner anberen Beife zu Deuten vermag.

Die nadjfolgende Figur 53 zeigt ben \&ängefdnitt a e Der vorhergehen:

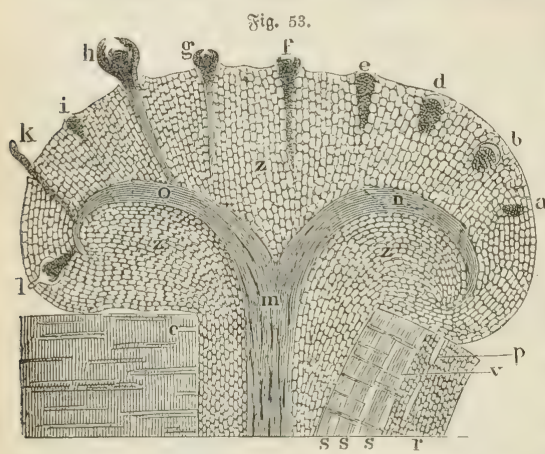
ben そ̇igur in größerem Mapjtabe, und in a-h Dic Entridelung ber IDoventiofnofpe in bifto: rifder folge. Bei a Deuten bie \$unfte bas, im gropzelligen \$aren= d)ym entiftanbene Rlein= getwebe an, über bem iid) bei b nad) ausen bin ein fappenförmiger Spalt gebilbet bat, Deffen imere Bremblinic Das Rleingemebe als Oberbaut befleibet. Bei d hat bas Rleingemebe fid) etweitert uno ben fappenförmigen Spalt nad) aujen gebrängt, Deffen

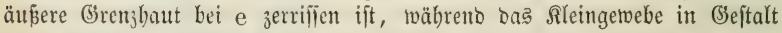

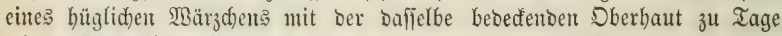
tritt. Dießs fleine Bärzhen hat fortan Durdyaus bie Bebeutung bes ter= mintalen $\mathfrak{R}_{3}$ äzchens (gemmula ascendens) jeber anberen normalen Inoipe. Bie Dort treten aud bier erft unbollfommene, bann bollfommene Blatt=

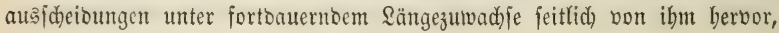




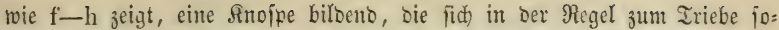
fort weiter auşbilbet. Dieje Inofpe allein berbient ben Tamen Hobentiv:

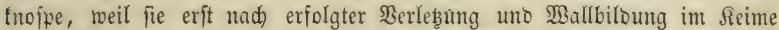
neu entifteft, was bei ben ichlafenben 2Augen (Geite 150) nidbt ber Jall ift.

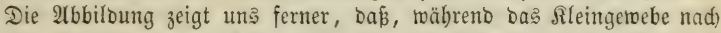
aupen zur Sinoipe emporıäd)s̆t, gleidzeitig eine Berlängerung befielben nad) unten jtattfinbet (e-h. Wie im Selfgervebe Des Embrno, fo entfteht aud bier im Sleingemebe ein Sireis von Jajerbünoehn (Geite 174), Der fich zu cinem, im Durdjidnitte ringförmigen Scol3 = und Bafttörper confituitu uno

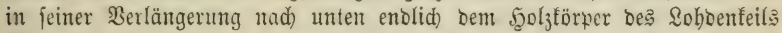
fich aujaliejt $(\mathrm{h})$ uno mit biejem vernächst.

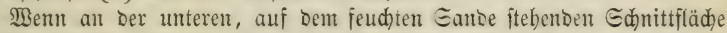

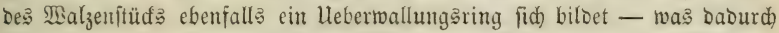

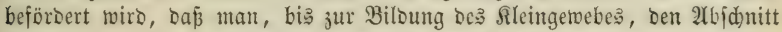

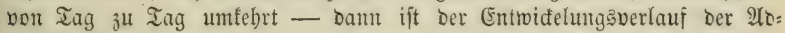
ventibfnofpen von a-e hier berjelbe, wie in ber nad oben gefehrten Heber: twallung. Das herbororingente uno in Den feuct,ten Sano bineinwadjente Sinofpentärzd)en (i-e) bilbet bann aber feine Blattansidcheioungen uno

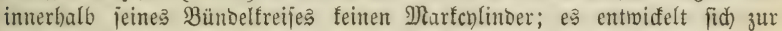
Murzelfajer $\mathrm{k}$.

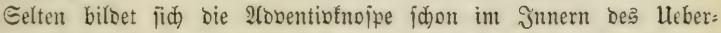

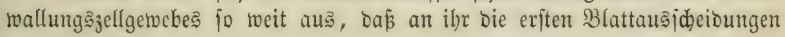
erfennbar fint (l).

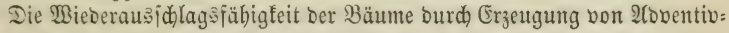

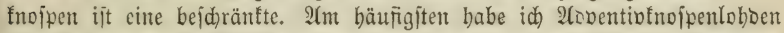
nod) bei Eidye unb Rothbudje gefunben, Dod erfolgt aud) bei biefen ફ口olz=

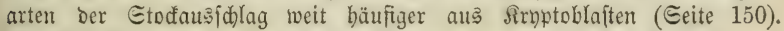

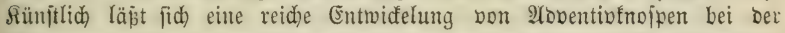
Rindereprobuftion unter (3laŝberband berborrufen (Seite 297); fie erfolgt ohne weiteres bort mur am unteren Sd)nittrante ber Ringtounde; umidnürt man aber bie Mitte ber Ringmunoe mit eintem fajarf angezogenen Drabte,

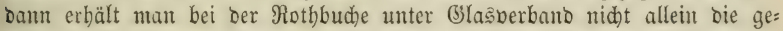
wöbnlidhe Befleioung, jondern aus biejer aud) groß̉e Mengen von 2loventio: fnofpen. Hleberbaupt fömen \{̂obentiofnoipen nur wäbreno ber Bildung Des Ueberwallungstoulfte entifeben; Da: fertige Bellgewebe Derielben berliert

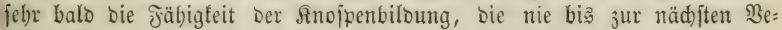

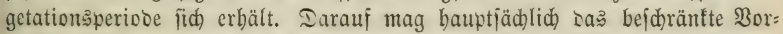
tommen biejer Biloungen beruben.

Bereits vorjtebento habe id) gejagt, baß ber im feifförmigen Ueber= mallungsipalte fid bildende neue $5_{2} \mathrm{l}_{3}=$ uno $B$ aftförper in Den tieferen

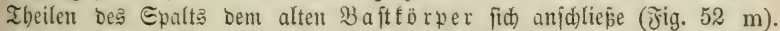

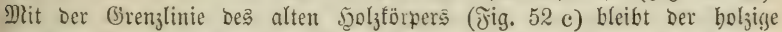
Solbenfeil auper organifder Berbintung. Dieṕ hat dann bie Jolge, dấ üppig entwicfelte Yoventivfnofpentohoen int Sturme ober wenn fie bon (Eia:

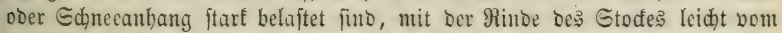
5jofztörper befielben abgebrod)en werden. Die umftehente Figur mag biefs erläutern. Sie ftellt bie Epaltflädhe eines Stodes bar, in weldher ber mit * 
Fig. 51.

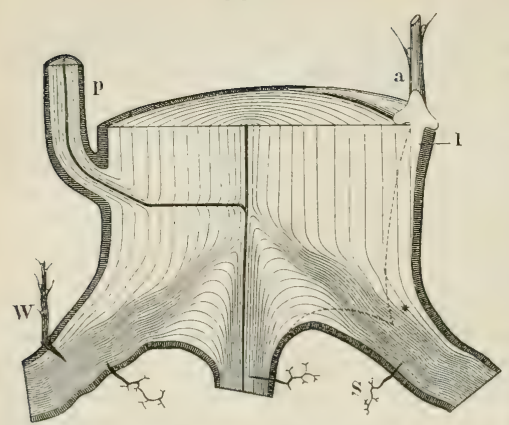

bezeidnnete Theil fïd leben= ১ig un๖ jäfteleiten๖ erbält, twäbreno ber jenfeit ber punftirten Sinie Yiegende Stodtheil jebr bald auper Funftion tritt und abjtirbt. Die 2loventiploboe a ift Durd) ibren Soboenfeil 1 ॥ur mit bem borizontal geftridelten Baft = uno Rinbetörper berwadjen.

In ntebrfacher Şints fid)t weit günjtiger ftellt (iid) bie Sirnptoblaftloboe (p) zum 5ुolze bes Mitter: ftodes. Sig. 13 Seite 150

zeigt bie Entwidelungsfolge bes Rryptoblaft bor jeiner äußeren Iriebbilbung;

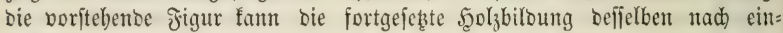
getretener äuperer Triebbiloung fo weit erläutern, als baraus herborgeht,

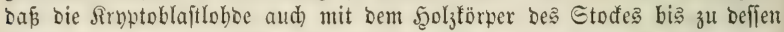
Marfröbre in organifdem Bufammenthange fteht, uno baburd nid) allein gröperen Sgalt an ibm befibt, fonoern aud) weit günftiger auf ibn zurüd= wirft in Bezug auf Befunobeit uno Dauer Des Mutterftodés.

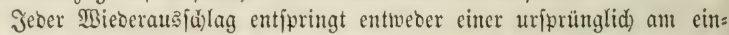
jäbrigen nod) frautigen Iricbe gebiloeten Blattadjeffunofpe uno beren, biz

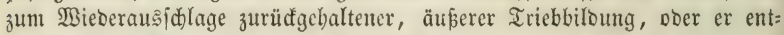
fpringt einer 2(bontiofnofpe. 2(nbere (Entftebungäarten gibt es nid)t.

Die Sroptoblaftloboe fann baher übcrall aus unverleb̧ter Rinoe hervor:

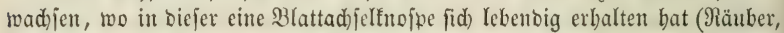

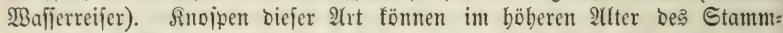
theiles burd) $\mathfrak{S}_{\mathrm{c}}$ äftelung fid) mebren; bagegen fömen fie an älter als einjäbrigen Irieben nirgents neu entiteben. Die 2roventibloboe bingegen fann zu jeber Beit an jebem Baumtbeile entiteben, aber nur bann, menn Durd) getwaltjame Berleb̧ung Deffelben ein Ueberwallungszzellgewebe erzeugt wiro, mit bem fie gleid)zeitig unto mur in befien jugenolidem 3 uftanoe fid außbilbet (Eeite 300). SToventiofnofpen fönnen jeood), wie Blattadjel= fnoipen, mebrere Jabre in ifrer Entwidfelung zu Irieben zurüdgebalten bleiben (2loventibfruptoblafte). Wenn in jeltenen gällen aus älteren lleber= wallungen Iriebe fid) entwideln, bann find es 2(toventivfrbytoblafte, aus benen fie entipringen.

14. $\mathfrak{A}$ b bentiv $=\mathfrak{W}$ urzeln.

Es ift eine febr befannte Eache, baß̧ oberirbijaje Baumtheile ber

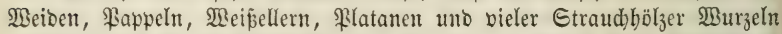
treiben, wenn fie als Stedreifer ober Eeşitangen mit feud)tem (Eroreid) in Berbinbung gebrad)t werben. Gelbjt bie neiften Rabelbölzer, fajt alle (En)= preffen, IYraufarien uno Pobocarpeen lafien fid burd) Eteffreifer vermebren. 
Wo diés, wie bei ber groṕen Dlebrzahl ber Saubholz= uno Nubelholz= bäu me nidyt soer nidgt leid)t gelingt, sa zeigt bod) bie Murzelbiloung an

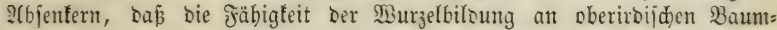
theilen eine allen $\mathfrak{S g l}_{\mathrm{z}}$ pllanżen zuftänoige ift.

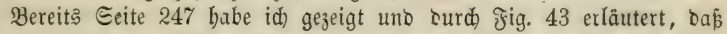

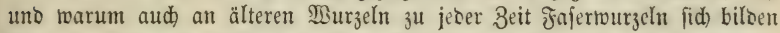
fömnen. Jig. 54 zeigt bei s joldhe atoventiotwurzeln, bie erft im böberen

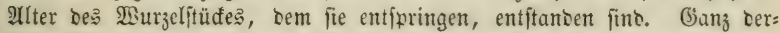
jelbe Biloungsporgang burd) Darfftrablmetamorphofe finoet aud ba ftatt,

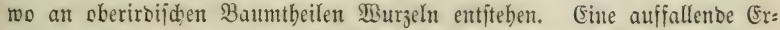

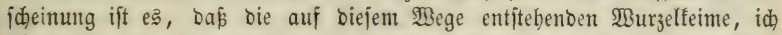
glaube immer, ihren 2 (usgang burd einen Senticellenfpalt nebmen. Man

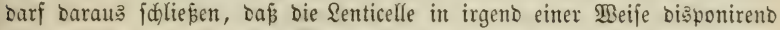
auf bas ibr unterliegente Marfftrablgewebe einwirfe, obgleid) id) gezeigt habe, Dap bie Senticelle feinesmegs eine Durd)brechung, fonoern mur eine beutelförmige Serfertung Der äuperen Sorfijellid)id)t iit, bie wobl baburdh wirfen tönnte, baf fid) in bem äuperen Renticellenraume bie Bobenfeudtig= feit in größerer Menge anjanmeln uno crbalten fann. Bielleid)t ijt bierbei

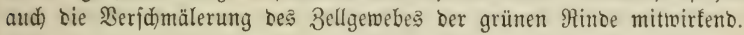

\section{5. $\mathfrak{B}$ urąclbrut.}

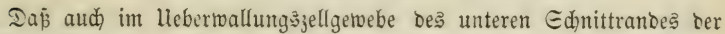
Etectlinge 2loventibmurzeln entiftehen fönnen, Darüber babe id bereits Geite 300 ben betreffenden शadmeis uno Erläuterung gezeben.

Eine nidft geringe 3abl von Fुolzpflanzen bilden an ihrem $\mathfrak{B} u$ rzel= ft o de Snofpen, Deren Marfröhre in Die Martröhre ber Pfahlwurzel eir= mündet, bie auch in jeber anderen anatomijdjen Bejiebung burdjaus ben Blattadjelfnofren ber oberiroifden Baumtbeile entipreden, uno wie biefe als Sirnstoblafte ober Bradyblafte bäufig mebrere Jabre ruhen ober nur

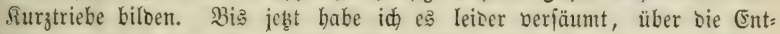

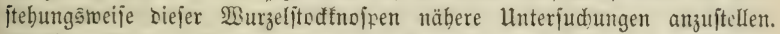
Wirfliche Blattachjelfnoppen fönnen eš faum jein, ibr Gtand am 2 urzel= jtode ift bierzu ein zu tiefer; 2loventibfnopen fino es obne 3reifel nid̆t, Dagegen fprid)t ber 3ujammentang ihres Martes mit bem ber \$rahlwurzel; ebenfo wenig tönnen fie eine IInbilsung von Burzelfnofpen fein, ba fie nidht, wie bieje bem Diartitrablgemebe entipringen. Unter unjeren Eultur=

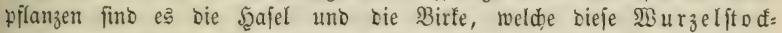
Enofpen reidslich befizen, bie an ibnen ben, aus bem Boben berbor=

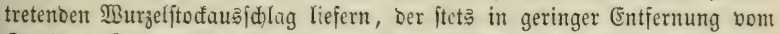
Etode zu Tage tritt. Bei einigen Etraudbölzern, 3. B. Rubus, Spiraea, Rosa, Rhus, geidjiebt bieß erft in gröperer Entfernung vom Etode. Man nennt baun bie aus bem Boben herborfommenoen Ed)ößlinge, 2t us Etolonen, bie fid non wirflidjer Wurzclbrut baburd leidjt unterideiden

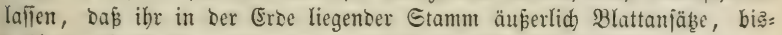
meilen aud) Sinofpenrubimente, innerlid) eine Marfröbre befig̨t.

$\mathfrak{B} u$ rzelbrut bingegen nemnen wir Edößlinge, bie einer birflid)en, marflofen Burzel entfpringen (Jig. $43 \mathrm{w}$ ), wie bief ber Fall ift bei 
Populus, Robinia, Alnus incana, Prunus, Elaeagnus, Hippophaë,

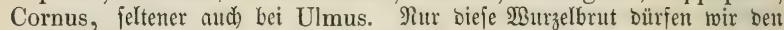

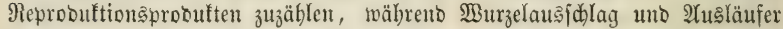
ber normalen Biloung angebören.

Burzelbrut entitebt, wie bie $\mathfrak{B u r}_{3}$ eläpte entitehen, aus Marfitrabl= metamorphofe, mit bem Unterichiebe jebod, bas nidjt alle Marfftrablzellen fid) in Fajern umbilben (Seite 247, Fig. $43 \mathrm{w}$ ), jonbern baj ein centraler Theil berfelben zu Marfjellen fich ausbilbet (oajelbjt $\mathrm{kpa}$ ), Dent bie Fajer= zeflen (b b) umftehen. Mit Diefem Gegenfabe von Marf unt Faferbünoel=

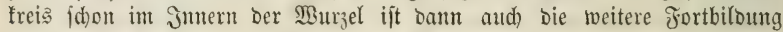
zur Saublnofpe und zum oberirbifden Baumtbeile ausgejprodhen, bie in=

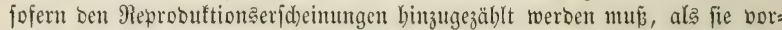
berrichent Folge eingetretenter Srantheit ober Berleb̨ung Der Mutterpflanze ijt.

\section{Strefen und Beugen.}

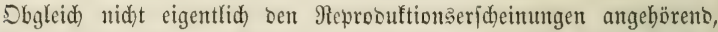
will id) bier einer febr auffallentoen, ber Drebung Des Blattes nad) bem Sidhte äbnliden Eridheinung an älteren Etamm= uno 2Afttbeilen gebenfen, burd) weldhe bie gernbe Ridhtung gefrümuter Baumtheile fid) beritellt.

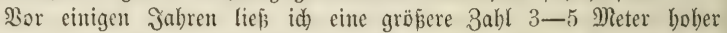
Jidhten auf Bruftböhe abjdncioen, uno jwar bid)t über ben Ouirlen nod lebendiger und bentabelter, Durd bie Bej(hattung ber oberen $\mathscr{Y}$ efte in hori= zontale Rage niebergebeugter Geitenäfte, Deren viele an ifrer Bafis nabe 2 Entim. bid waren. Ed)on nadh Berlauf von feds 2Bod)en waren ein Ilyeil ber oberiten 2(ejte um mehr als bie Şälfte bes red)ten MBinfels auf: gerid)tet, im Şerbite ftanden bicje zum Ilyeil fdon fentred)t.

Der Sibs biejer Bewegung ift die Bafis Des fid) aufridtenten Afites,

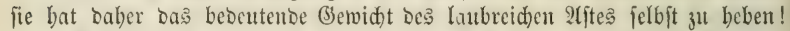

Eine äbnlid)e, aber in entgegengefebter Ridutung wirfenoe Erfcheinung ift bas 2 eugen. Der Fidenteft gebt unter bem Drud ber oberen $B_{e}=$ laubung aus ber balb aufgerideteten, cublid) in bie horizontale Sage ein. Man fömte bies als eine Wirfung ber Sdjwere beuten uno id) glaube felbjt, bafs biefe cs ift, bie ben fichtenaft im böheren Baumalter unter

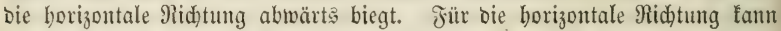
man biej nid)t zugeben, Dem längere uno fd)werere $\mathscr{Y}$ efte als bie, weldhe an Der frei ftebenten jungen Fid)te bie horizontale 9idchtung angenommen baben, finto im (Sipfel alter Bäume nod) balb aufgeridftet. 2Alud fpred)en

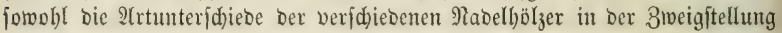

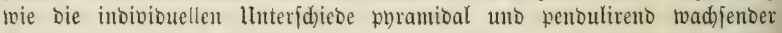
Bäume gegen bie 3urüdfülbrung auf rein med)anifde Urjadjen. Der $\mathfrak{B} y$ ): ramidenivuds berubt auf einem Hebergetwid)t bes Strectens, ber pendulirende

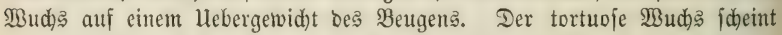
auf periobifden Edbwatungen ziwijhen Streden uno Beugen zu beruben.

Itm auffallentiften tritt bas Strectent uno Beugen an ber Sirummbolz=

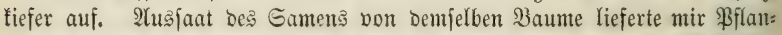
zen von febr verifoiedenem Şabitus; theils cinftämunige, grabe aufftrebente, theils vom \$3Dden aus pyramidentwüd)fige, ebenfalls einftämmig auffitrebente, 
theils foldhe mit mebr ober weniger nieberliegender Scauptadjje. ITn leb̧teren fino nur bie leksten $6-8$ Jahreątriebe aufgeriohtet, ber Baum mag alt ooer jung fein; der nieberliegente Edhaft verlängert fich alljäbrlid, Daß Sinie zwifden ibm uno bem aufgeridteten Gipfel rüat alfiäbrlid) meiter vom

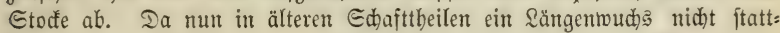
finoet, fo ergibt fid) baraus unt aus ber mit zutebmenoem alfter unver=

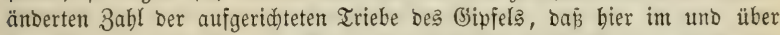
Dem Snie ein Etrefent uno Bengen Des Sdhafta, felbjt bei einer Dide von mebreren Bollen ftattfindet. Die Scolyfajern bes Sinies legen fid in bie 2dife bes liegention Edjaftheils, fie ftrecfen fid in Bejug auf bieje, fie beugen fid in Bejug auf bie bas Sinie bildenten Jahreatriebe bes Giipfels.

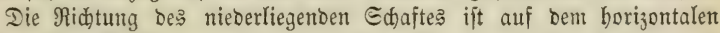

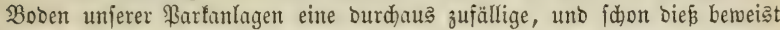

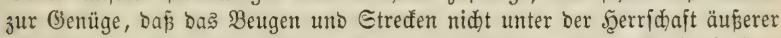

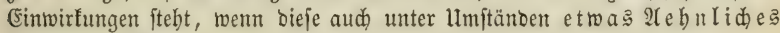
herborrufen fömmen.

Jungorte mit jebr fniđigem Edhaftwudje verwadjen biefen oft io, baj man fifon bor Dem mittleren 2llter nid)ts mebr bavon bemerft. Eine für

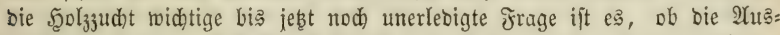
gleidung fnictigen $E d)$ aftwudjes allein auf ercentrifher Jahrringbilbung Lerubt, oder ob aud hier ein Etrecfen ftattfinden fönne.

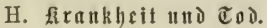

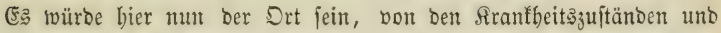
vom Pflanzentode zu ipred)en, wemn nidht bie vorgezeidneten räumliden

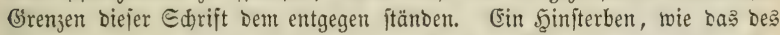

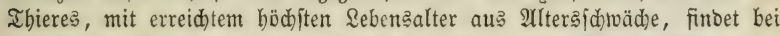
ben Baumbölzern nidjt ftatt. Durdh Stefreifer ober 2Abjenter würbe fid biejelbe ßilanze bis in alle Erwigteit lebendig erbalten lajien. Blöblider Iob berfelben ift fteţ ein getwaltjamer. In ber Regel ifft Rernfäule bie

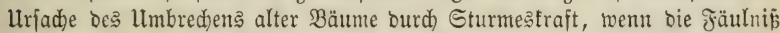

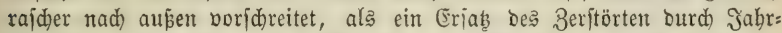

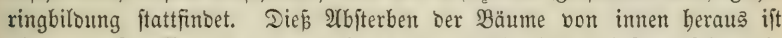
aber eine Srantheit, beren nothwenoiger Eintritt wenigitens febr weit entfernt liegt. $\Im$ d) habe eine 4 Meter in Brufthöhe siffe Enprelie (Campoxylon subarcuatum Der Grube Bleibtret im Siebingebirge gemefien uno bejobrieben (Bot. Beitung 1853, Seite 604), beren innerfte Scolzringe, bei einem 2 Iter von 3100 Jahren, noch ebenio feft uno, als wenig ver=

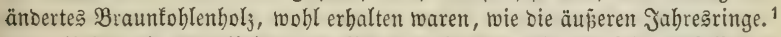

Heber die Sirantheiten der Bflanzen befiben wir ein febr umfafiendes Berf von Menen: \$flanzen=ßathologie, Berlin 1841. E־ミ beftätigt jeood

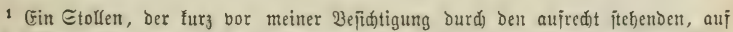

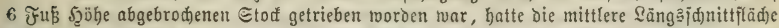

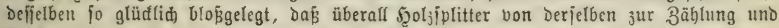

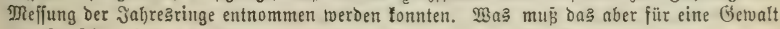
getvefen fein, bie den gejunden, 11 Fub difen Stantm zu bred)en vermodte!

5gartig, Segrbudi) für đöriter. I. 
aud) bieje Ed)rift, Daj zur Beit unto fo lange, als bie normalen Rebens= verridungen ocr Bflanje nod) fo tocnig gefant find, bie Senntnifs ocr abnormen, franthaften 3uftänoe nur von untergeoroneter praftifher $\mathfrak{B}_{e}=$ Deutung fein fönnen.

\section{Siteratur.}

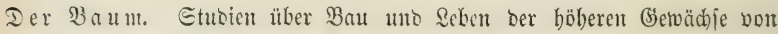
Dr. 5. S d a d) t. Berlin 1853.

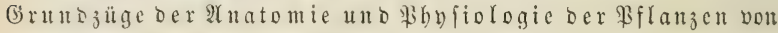
Dr. Ulnger. WBien 1846.

(5) rundzüge ber wiffenidjaftliden Botanif vou Dr. Sd lei= ben. 1843.

Bflanzenphyiologie won Dr. Meyen. 1837-39.

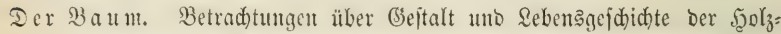

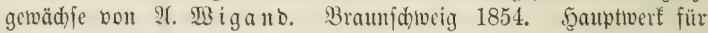
morphologifde Baumfenntni的.

Deutiche Joritbotanif von Dr. Nörolinger. Stuttgart, Eotta 1874. 1. Bant. Whyfiologie ber நgolzpflanzen.

Da meine eigenen zur Beit nod) zeritreuten Atrbeiten über \$byfiologie

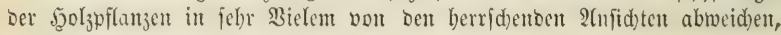
will id) eine Heberfid)t berfelben bier folgen laffen.

\section{a. In felbftitänoigen Sdriften:}

lleber Berwantolung oer polncotylen \$flanzenzelle. Berlin 1833. Entftebung

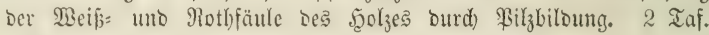
2tbbilto.

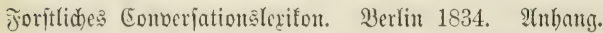

Die organifde Cbemic von Dr. S. Licbig. 3raumfdrweig 1840. (Darin meine S̉erjud) über Ernäbrung ber \$fflanzen. 1. 2(ufl. Eeite 190 bis 195.)

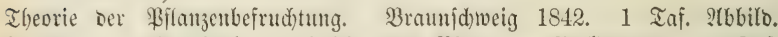
Beiträge zur Entridelungsgcichid)te Der \$flanjen. Berlin 1843. 1 Iaf. atbbilo.

Reben Der Pflanzenzelle. Berlin 1844. 2 Iaf. 2Ubbild.

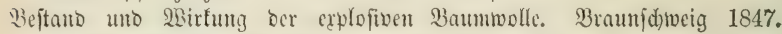
(2tratonie ber Baitfajer.) 1 Iaf. 2xbbito.

Bergleid)enoe lluterjud)ungen über ben (Ertrag ber Motbbud)e. Berlin 1847. 5ुoljidinitte.

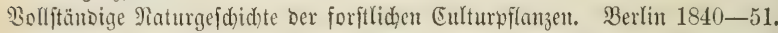
120 Iaf. 2tbbillo. (Darin Beiträge zur 2tutatomie Der Şolzhflanzen,

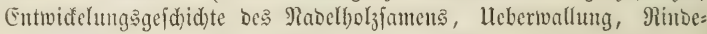
reproduftion, Renticelfen, \$räbentiv = uno $\mathfrak{A}($ oventivfnofpen.)

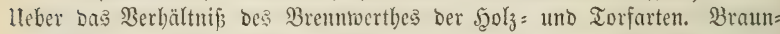
id)weig 1855. (Darin über Eaftgekalt, 3huten uno Eaftiteigen ber 5elzpflanzen.) 


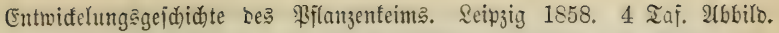

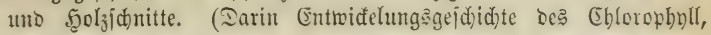
Stärtmebla, Rlebermebls, Bellmandung.)

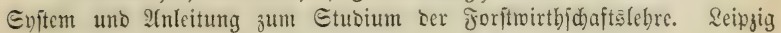
1858. (Darin $\mathfrak{W a d j}$ ithumşgang ber fidhte.)

(3erbitoff Der Eidhe, Stuttgart, Eotta, 1869.

b. In Beitidriften:

1) Meine Jabresberid)te. Berlin 183\%, I. 1-4. (Iarin über

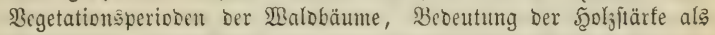

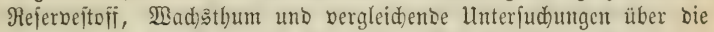
Drganijation Des Etammes Der einteimifden Balobäume.)

2) 2trgemeine Forft= uno Jagozeitung: lleber Thaubiloung burd) bie Bilanzer. 1840. Є. 17. Berid) über \&iebigz organijhe (E)emic. 1840. Є. 100. 1841. Є.253. Riünitlid) Erzengung neuer

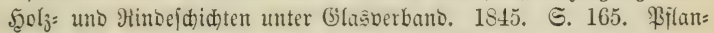
jentrnäbrung. 1845. Є. 221 . Heberwallen Der Nabelloljitöde. 1816. ङ. 21. Ifnatomiiche Charafteriftif ber europäifden Rabel= Göljer. 1848. Є. 439. Lleber Wirfung Der Sälte auf Das Bolumen

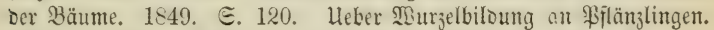
1849. ๔. 201. Heber die Junftion ier Blätter. 1856. ๔. 363. Uleber Begetationacuclua uno Pejervejtefie. 1856. ๑. 361. Heber

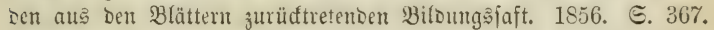
Ueber Den (Beb)alt Der Etöde an Meferveftoffen. 1856. G. 370. Heber Die Begetationsperioben ber Malobäume. 1857. G. 281. Leber Den

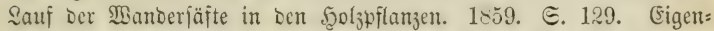
thümlidfeit Der (Entwidélung junger Ricfern. 1859. Є. 411. Jnitiale 5ूoljbiloung. 1859. E. 412. Iaß Etreden Der ફூolzuflanjen. 1859.

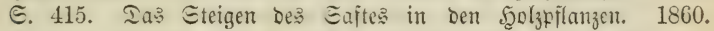
Є. 25\%. Der Edröpfiaft Des Eiebfajergetwebes. 1860. Є. 259. Derbunjtung. 1860, Є. 260 . Bewegung bes Gaftes in ten $\mathfrak{g}_{0} \mathfrak{l}_{3}=$

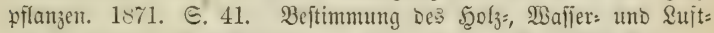
gebaltes ber Deutichen Walobäume. 1871. E. 81. Periodijde Edjwan=

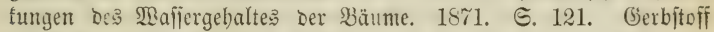
Der (Eid)e. 18i1. Є. 249. Heber generatio spontanea, நgofimam, 1871. ธ. 358, egu 18\%2. Є. 184 . ¿ärdjentrebs. 1872. ङ. 184. Abwelfen ber Bäume mit belaubter firone. 1872. Є. 294, 296. Bluten Der Bäume. 1872. Є. 299. Temperatur Der Baumluft. 1873. Є. 1, 145. Błhten Der Bäume auझ alten Bobrlöd)ern. 1874.

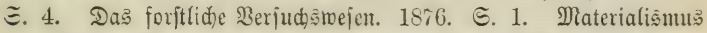

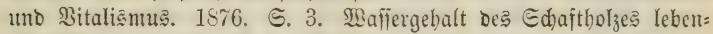
Der PFlanzen. 1876. G. 6. Serbunftungämenge junger Şolzplanzen, 1876. \$hotometrifdes. 1876.

3) Botanifde 3eitung bon v. Mobl un v. Sdledtendal: Dr:

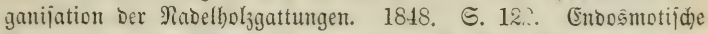
Ëigenidjaften der \$iflanzenbäute. 1853. Є. 309. 481. Heber Die Eberbaut. 1853. Є. 399 . Jreimilliges Bhuten Der Şainbud). 1853. 
G. 478. Heber bie Irbuntiofnojpen ber Senticellen. 1853. Є. 513 . Gtearopten aus Juniperus virginiana. 1853. ङ. 519. Enttidife=

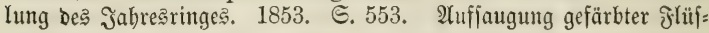
figfeiten Durd) Sted̆reifer. 1853. $\quad$ S. 61\%. Berbalten einer Stärf= meblart zur \$Bärme. 1853. Є. 638. Biloung uno Entwidelung ber fogenannten Rnofpentwurzeln, Entftehung ber Blattad) jelfnoipen. 1854. ङ. 1. Heber bie Duerwände in Don Siebröhren. 1854. ङ. 51. lleber bie Junttionen bes 3ellferns. 1854. G. 574. 877. Berbalten Dę Bellfernz bei Der Bellentbeilung. 1854. G. 893. Berbalten bes Bellfern bei ber Bellbrutentwicfełung. 1855. ङ. 166 . Uleber bie Billoung ber Bellwanoung. 1855. ङ. 185. 222. Entwidélung ber Epiralfajerzelle. 1855. S. 201. Entitelung ber Marfitrablen. 1855. ङ. 21\%. Die Inofpendecfen von Salix, Magnolia. 1855. Є. 223. Beiträge zur Entwiffelungsgejdid)te ber Pflanzenzelle — Vaucheria Cladophora - Oedogonium - Spirogyra - Palmella. Heber

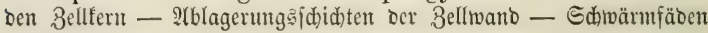
Der 2 Antherioien. 1855. G. 393-513. (Conferva reticulata. 1846.

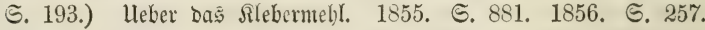

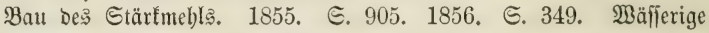

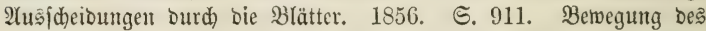

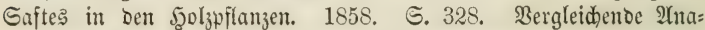
tomie Der \&aubbölzer. 1859. ङ. 93. Bluten Der Şainbud)e. 1861. ङ. 17. Der Sdröpfiaft. 1871. S. 18. Der Eambialiaft. 1861.

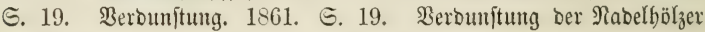
im Minter. 1861. G. 20. Defonomie ber Berounftung. 1861. ङ. 19. Unteridiede Des (behaltes an fejten Stoffen in Wurzel= uno in Bipfelfaft. 1861. S. 22. Âffaugung von Jarbitoffen burd) Wuntfläden. 1861. G. 22. Entlaubunggberfud)e an Der $\mathfrak{B e b m o u t b = ~}$ łiefer. 1862. Є. 70. Ringelung bängender 3weige. 1862. S. 81. Folgen bes Druđes einter Spirale auf bie Suftbewegung im Baite. 1862. ङ. 81. Mingelwerfuche an ber Edjwarzfiefer. 1862. Є. 82. Etedflinge in horizontaler \&age. 1862. G.82. Berwegung bes Saftes im Bafte. 1862. G. 82. Bhluten Der (Eid)e uno Des 2 Ballnuß̧baumes, 1862. Є. 89. Berbalten alter Bohrlöd)er zur Säfteleitung. 1862.

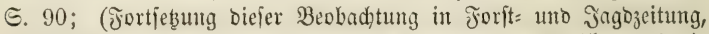

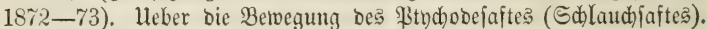
1862. Є. 191. Bewegung Deß Gafte’ in Den Mildjaftgefäßen. 1862.

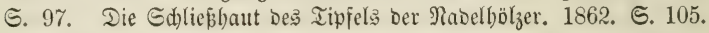
Berounftung Der 3weigipiben im laublojen 3uitanoe. 1863. G. 261.

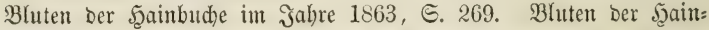
bude, Mothbud)e, 2lborne, Birfe im Jabre 1863, ธ. 27\%. Enoošs

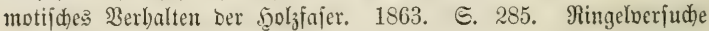
an Der Sinde. 1863. ङ. 286. Ringelverjuche an Rabelholzäjten. 1863. G. 286. Funttion bes Siebfajergenebes bei ber Säfteleitung.

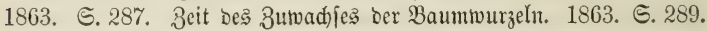
Abfterben Der Jajerwurzeln. 1863. G. 289. Die Ed)liephaut Des

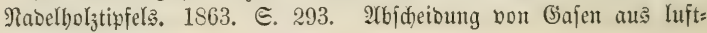


baltigen Jlüifïgfeiten beim Eingehen in capillare Räume. 1863. S. 301.

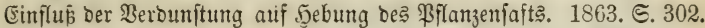
Das Gerbmehl. 1865. Є. 53. 237. Berbalten ber Blätter zur atmojphärifden Feudtigfeit. 1865. S. 238. \$ilzbiloung im feim= freien Raume. 1868. S. 902.

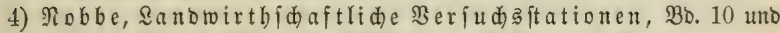

11. Weitere Belege für $\mathfrak{B i l}$ bbiloung im feimfreien Raume.

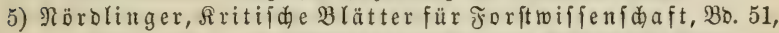
Şejt 1 uno 2. Beridterftattung über bas $\mathfrak{B i l l f o m} i d)$ Berf: bie

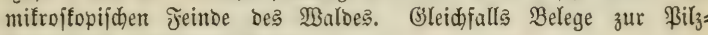
biloung im feimfreien Raume.

6) Sariten, Botanijde Unter $\{$ d) ungen, 1867, 1) Bur Entwidfe= lungşgeididte bes 3ellferns; 2) Ueber ben Bau Der \$ollentwantung uno ber Fovilla. 2 Taf. 2lbbillo.

7) Gibungaberidte ber $\mathfrak{B}_{\text {iener }} \mathfrak{A} \mathfrak{f}$ abemie ber $\mathfrak{B}$ iffenidaften,

1) Entwifelungşolge uno Bau oer Scolzafafwanoung, Maibeft 1870.

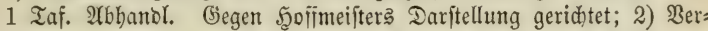
jaudfung tooter organifider Stoffe. Maibeft 1870. 1 Taf. 2(bbilb.

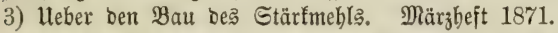

8) ந̧andelablatt für Walberzeugniffe 1875. 1) Banillin aus bem Cambialjafte ber Nabelbölzer; 2) Beiträge zur Renntni的 des fpecif. Gewidyts ber Syolzarten.

3weite $\mathfrak{A}$ btheilung.

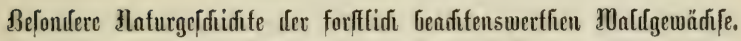

\section{Eriter AfGjunitt.}

\section{Syftem umd cyarakteriftik.}

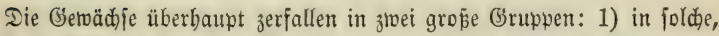
bie fich burd) einfade Reimtörner fortpflanzen, D. h. Durdh Reime, an

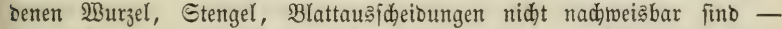
famenlappenlofe Bilanzen (Acotyledones Juss.), bei benten zugleid, ein 3ujammentirfen zweier verjdiebener (Gejhledter zur Entftehung bes Reimes nidt erfennbar ift — verborgen=e bige Bflanzen (Cryptogamae Linn.); 2) in foldhe mit beutlich unterfdiedenen männlichen uno meiblichen

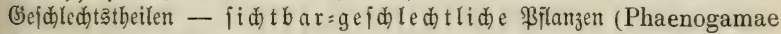
Auct.), beren 3ujammentwirfen einen Reim erjeugt, ber (d)on im fertigen Gamentorn bie Şauptheile ber $\mathfrak{F f l a n z e : ~}$ Burzel, Etengel, Blattausfdeioung er= fennen läpt - jamenlappige \$flanzen (Cotyledoneae Juss.). theilungen

Die (Eryptogamen ober Átotylebonten jerfallen wieberum in brei $\mathcal{U b}$ : 
1 a. in foldye, bie nur aus parendy)matijdent Bellgewebe beiteben unb feite beftimmt ausgenrägten Blattformen ausbiloen (Aphyllae Dec.). Dabin gehörelt

a) bie $\mathfrak{Q}$ afieralgen - Algae Lindl. Mei itt grüı gefärbte Fäben oder Ed)lcinmaffent oder blatt= ober coraflenälntliche Billoungen, mur im Maffer lebent;

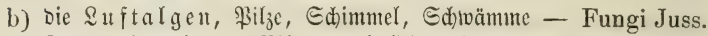
Den vorigen in Der Biloung äbulid, aber mur in feudbter Suft uno im Boben lebeno;

c) Die Fledten - Lichenes Hoffm. Rur in ber \&uft, an Baumitämmen, Mauern, Jelfen wadjentoe, vieljäbrige Pflanzen von warziger, rintentartiger, bärtiger ober gelappter form; von ben Bafferalgen burd) ifrent Etandort, bon ben Suftalgen burd) vieljäbrige Rebentsonter, wie burd) Iremung Dę Bellgetwebes in eine Rinoes, Marf: uno Brutidjidt unteridjieben;

1 b. in foldje, bic ebenfalle nur aus parendymatifden Bellgetweben be= ftehen, aber bef́timunt auşgeprägte Blätter tragen. (Foliosae Dec.); d) If rmle ud) ter - Characeae Rich. Die Blätter ftengelförmig, quirlftänbig, Ed)adtelhalm =ähnlid). Seben nur im $\mathfrak{B a f f e r}$;

e) Lebermole - Hepaticae Juss. Die Blätter ausgebreitet; Frudtfapfeln olyne Dedêt. Jungermannia bäufig an ber Rinbe ftehentoer Bäume ftrahlig fid verbreitento. Marehantia auf Felfen;

f) \&a แb mo fapjeln mit Dedél uno Saube. 2At Baunitämmen, Felfen uno nuf Dem Bobent;

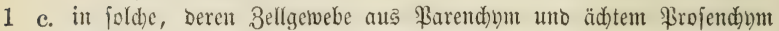
зufammengejęt ift (Cr. vasculares);

g) $E_{d}$ adtelhalmt - Equisetaceae Dec. Blätter unbeutlid), quirljtäıbig, zu cinter furzen röbrigen Gd)eibe verwadjent. Sdaft gegliebert. Jn Sumtpfen, Mooren uno Wiefen;

h) Jarrenträuter - Filicinae Juss. Blätter entwiffelt, Stengel nid)t gegliebert; theils im Waffer Yebent: Marsilea, Pilularia, Isoëtes, theils auf feudtem $300 \mathrm{cn}$, wie bas moosäbnlid be: laubte Lyeopodium uno bie äd)ten farren (Filices) mit webel= förmigem Raube.

Die \$̧änogamen oder Eotylebonteen zerfallen in zivei atbtheilungen: in cinfamentappige (Monocotyledones Juss.) uno mebriamen= lappige \$bänogamen (Dicotyledones).

Die Monocotyledonen unteridyeioen fid im Seime ourd bie ver: einzelte erfte Blattausfdeioung (Daber Der Siame); fermer burd) bie zer= ftrente Stellutg Der Gefäß̈bünol jwijd)en Dem Bellgetwebe bes Stengela, in Folge beffen: Mangel eines gefdiloffenten Mart:, Sgolz= und Mindeförpers; Durd) an ibrer Bafis fdueioig erweiterte Blätter mit parallelem Sierlauf ber Riele obne Rippenverjweigung; burd meift einfad)en, nidht veräftelten Sdhaft unto burd) Mangel ber Blumentrone.

Die Monocotylebonen jerfallen in foldhe mit verwadjenem frucht= 
fnoten - Symphysogynae Rich., uno in joldhe nit freiem orrudtentoten - Eleutherogynae Rich.

3u Exiteren gehören bie familien:

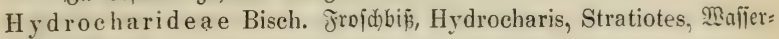
pflanzen;

Scitamineae Bartl. Bantanengewädje. Erotija).

Orchidinae Bisch. Drchioeen - Orehis, Ophris, Cypripedium; Ensatae Bartl. Ediwertblättrige Moncotyleoonen - Iris, Galanthus, Narcissus, Gladiolus, Crocus.

3u Qeb̨teren gebören die Familien:

Liliace a Juss. Rilien. Convallaria, Paris, Colchicum, Tulipa, Allium, Lilium, Ornithogalum;

Palma e Juss. Balmen. . (Erotijh);

Aroidea e Bartl. Solben. Typha, Sparganium, Acorus, Arum, Calla:

Helobiae Bartl. Eumpflifien. Alisma, Triglochin, Potamogeton, Lemna;

Juncinae Bartl. Grastilien. Juncus, Luzula.

Gl u m a c e a e Bartl. Bulggräjer. a) C y p e r a c e a e: Cyperus, Schoenus, Scirpus, Eriophorum, Carex. b) Gramineae: Phragmites, Arundo, Elymus, Triticum, Milium, Agrostis, Aira, Poa, Bromus, Nardus u. v. a.

Die Dicotyledoneen unterjeisen fid im Seime von on Mono: cotulcboneen baburd, baj nid)t ein, fonbern zwoi (bei ben meiften Plabel= böljern mehrere) Gefäpünoel, gegenüber itehento zu ren erften Blättern

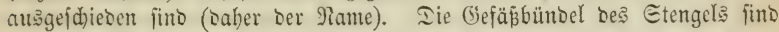
ju einem Rreife vereint uno bilben cen, bas Bellgetwebe in Marf uno Rinbe

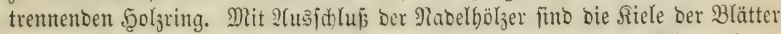
gerippt, bie Etengel meift vielfältig verżweigt uno veräftelt, eine Blumenfrone

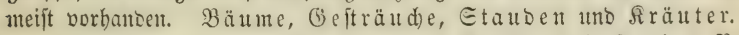

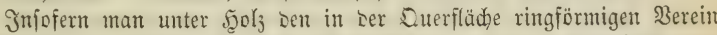

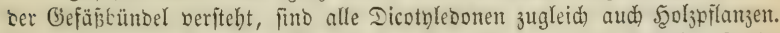

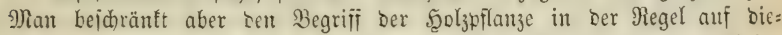
jenigen Dicotnlen, bei benen bcr Etengel uno bie 3reige eine mebrjäbrige

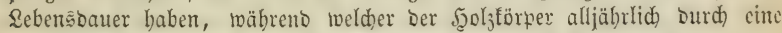

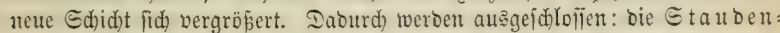
geroäd) le mit mehrjäbrigem Etengel, aber alljährlich abjterbenten 3weigen, wie bie Raute, Ruta graveolens; Der Bartenquenoel, Thymus vulgaris; bie Salbey, Salvia officinalis. (5) merben ferner ausegefdolien Die Siräuter: Şolzpflanzen mit alliäbrlich abjterbendem Etengel, wie bie Erobeere, Fragaria; Daß Bingelfraut, Mercurialis; bie Tollfiriche, Atropa etc. $3 u$ ben Sräutern gebören auch) alle einjäbrigen bicotylen Bflanjen. Die Iremung ift jeond) eine fünftlidje, Denn wir baben bäufig Gejträude, Etauden uno fräuter in einer Gattung beijammen, wie z. 33 . Spiraea (Aruncus), Sambucus (Ebulus) etc.

Mad) Der Blüthenbiloung habe id) Die Solzhflanzen eingetheilt in făupkenblumige, feld)blumige uno fronblumige froljpflanjen. 
Bei ben \{dupwenblumigen Sgolzpflanzen ift bie Blüthe über: haupt unvollftänbig, ein wabrer Reldh fehlt ebenfo twie eine wahre Blumen= frone, an beren Stelle blattäbnlide, ¡đuppenförmige Umbüllungen ber meift getrennten Befrudtungşwerfzeuge auftreten. Zwifden ber eigentliden Sd)uppe uno bem frudchtfnoten tritt bäufig ein feldähbuliches ober blätteriges Drgan auf, theils frei, theils mit bem frudtftnoten berwadjen; an ber männlicken Blume Perianthium, an ber weiblicken Perigonium genannt. Die einzelnen $B$ lumen fint in ber Mehrzabl meift fpiralförmig uno georängt um einen gemeinfdhaftlid)en Blumenboden geftellt, mit bem fie einen Bapfen ober ein תätbden biloen.

Bei ben feldblumigen f̧olzpflanzen ift zwar eill normaler glodenförmiger Reld vorbanden, es feblt aber bie Blumentrone. Blüthe: ftanto meift vereinzelt; Blüthe theila eingeidledtig, theils bermaphrobitifd.

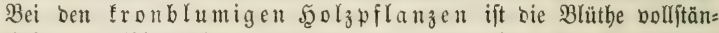
big; Reld) uno Blumentrone umgeben bie in berfelben Blume vereinten männlid)en uno weiblid)en Befrudtungstwerf 3 euge.

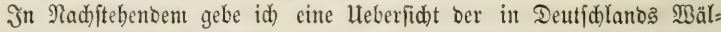
Dern wilbwadjenten Şolzpflanzen bis zur Unterideioung ber Gattung.

\section{Sduppenblumige Şolzpllanzen - Lepidanthae.}

1 a. Blattfiel ohne Rippen. Cier natt, am Brunde eines offenten

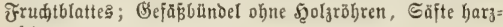
reid.).

\section{A. Iladclblätfcrigc $S$ d) $u p \mathfrak{p}$ ublumcr - Acerosae.}

2 a. Frrudt vieljamig, zapfenförmig, der (Fimuno dem Blumen= boden зugetehrt (Monöecia)

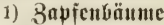

3 a. Blätter, einzelftändig, fđeidelos, mehriährig.

4 a. Blätter walzig, vierfantig .... Fidte Picea excelsa.'

4 b. Blätter platt, ¡́fwertförmig . . . . Tanne Abies pectinata.

3 b. Blătter an älter als einiäbrigen Irieben in Büjd)eln, jom= mergrün, ohne Sd)eide . . . . $\& a ̈ r d) e$

3 c. Blätter zu $2-5$ in gemeinjafaftlider Gd)cide, mehr= jährig . . ..... Siefer Pinus.

4 a. 2-3 Madeln in einer Sacide

5 a. Slüthe und Bapfen niedergebeugt.

6 a. Blattid)eident 4-5mal länger al̨ breit . . . . P. austriaca.

6 b. Blattjdeiden 2-3mal länger alढ̨ breit . . . . P. sylvestris.

5 b. Blütbe und Bapfen bis furz bor ber Reife aufgeridtet P. Pumilio, uncinata, Mughus.

4 b. 4-5 9labeln in einer Gd)eide

5 a. Die jungen Triebe mit rother $\mathfrak{W}$ olle . . . . . P. Cembra.

5 b. Die jungen Iriebe fahl (cult.) . . . . . . P. Strobus.

2 b. Frud! vieljanig, zapfenförmig (Thuja), oder fuglid) und becrenähnlid (Juniperus); Der (Fimuno dem đrudtboden abgetehrt (dioec.) . . . . . 2) (I)prefīen Blătter quirlf̣tänoig, frrudjt eine Sdeinbcere

$\mathfrak{B a h h o l d e r}$ Juniperus communis.

2 c. Frudat einjamig, eine Edjeinbeere, (Eimund aufgeridtet (dioec.) . . . . . 3) Eibent

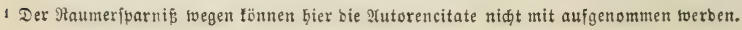


Blätter jpiralig georonet, ¡đfuertförmig, Abies-ähnliđd,

aber zugefpigt . . . . . . . Eibe

Taxus baccata.

1 b. Blattfiel gerippt; oas frudtblatt зu einem gejdlofifenen

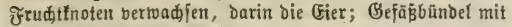
Şolgrỏhren; Gãfte toăfierig.

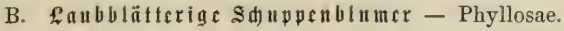

2 a. Männlide und weiblid)e Blumen, getrennt $a$ uf veridhic= benen $\mathfrak{B}$ flanzen (Dioecia).

3 a. Ұ̛rüđte beerenähnliđ. Blätter mit leudtenden $\mathfrak{B a d s =}$ tröpfiden . . . . . . . 4) Bagel (5) agel

3 b. Frudt eine aufipringende Rapfel mit bielen ranbjtän= bigen (Eiern ........ 5) Meiben

4 a. Frud)tfnoten und Staubgefäß̄e der Sauppe unmittelbar

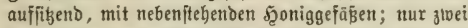
tappenjörmig berwadjiene finoipendedblätter $\mathfrak{B}$ ei be 5 a. Blattfitiel Drüjenlog (Gymniteae).

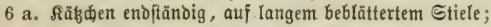

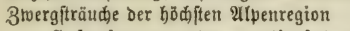

S. herbacea, retusa, reticulata.

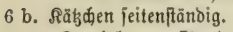

7 a. Frudtfnoten figend oder furz geftielt, Stiel nidit über $1 / 3$ Der đ̛ruăttnotenlänge lang.

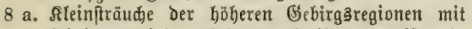

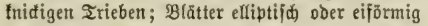
Doer verfehrt eiförmig, meift nidjt zweimal, felten äber breimal fo lang al breit, tabl oder biat feidig behaart

Blätter did)t jeidig behaart: S. glauca, Lapponum (arenaria), canescens.

Blätter fahl oder jđ,wach und hinfäligieidig be= haart. S. Myrsinites, caesia, prunifolia Waldsteiniana, arbuscula, phylicifolia (formosa) - hastata, glabra, Hegetschweilerii.

8 b. Bäume, Mittel = und Groß̧fträude Der Gbene, bejonders der f్lušufer, jelten uno nur bereingelt in bie Gebirge uno $\mathfrak{B a ̈ l d e r}$ eintretend, mit jalan= fen, ruthenförmigen Irieben, mit berlängerten fómalen Blättern, beren \&änge die eigene Breite um mehr als bas Dreifache überifteigt.

9 a. Die jüngeren Hefte mit blaumeißem Reif. Baum= roüdifig

10 a. Ufterblātter jo lang inie ber Blattiftiel

10 b. Afterblātter fürzer wie ber Blattftiel.

11 a. Griffel gefpalten, Jruđtfnoten gang $\mathrm{fahl}$.

11 b. Sriffel furgnarbig, đrrudffnoten am Stiele behaart, Blätter und Iriebe hinfäallig $=\mathrm{Fil}_{3}=$ baarig...........

11 c. Griffel furznarbig, Frudttnoten uno termi= nale Blätter jeibig bebaart

atpentreiben.

Myricaceae.

Myrica Gale.

Salicinne.

Salix.

(B) letidertweiben.

Urpento

Reiftueiden.

S. acutifolia.

S. praecox.

S. pomeranica.

S. maritima.

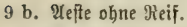

10 a. Staubgefäß̨e verwadjen, glätter faht oder hin= fällig=jeibig=behaart, oberjeits glatt

\$urpurweiden.

11 a. İiterblätter fehlen.

$11 \mathrm{~b}$. 2fterblätter vorhandent.

12 a. Frudtfnoten geftielt, Griffel furg, Ilarben turz, tolbig, gejpalten

S. purpurea.

S. Pontederana. 
12 b. Frudittnoten fiţend, Grriffel berlängert, glarben verlängert, fadenförmig, fperreno,

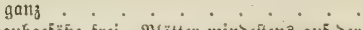

$10 \mathrm{~b}$. Staubgefäpe frei, Blätter mindeftens auf Der S, rubra. unteren Fläd) bleibend=jeioig ober filzig be= haart, oberfeits gejurd)t ober nadeltiffig, Mar= ben meift fadenförmig. . . . . .

7 b. Frudtfnoten lang geftielt, Stiel meift über $1 / 2$ ber Æ̛ruđtfnotenlänge . . . . . . . . . .

8 a. Itntere Blattfläd) bleibend $\mathrm{f}_{\mathrm{i}} \mathrm{I}_{3} \mathrm{i} \mathrm{g}$ behaart: 9lar: ben furs unb eiförmig, fibeno ober fajt fitzeno (Mald= tosiden),

9 a. Dbere Blattieite bleibeno behaart, 3tweige und Stamm ipanmrüdfig.

\author{
Epitrueiben." \\ sablweiden.
}

10 a. Sinojpen fabl

$10 \mathrm{~b}$. Sinoipen behaart

S. aurita.

S. cinerea.

9 b. Dbere Blattfeite faht, Bweige und Stamm chltn= Drijd).

10 a. Blätter runoliá) oder elliptijă, gröp̈te Breite in oder unter der Maitte ... . .

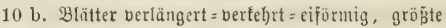
Breite über ber MRitte...... .

8 b. Untere Blattfläd)e tabl Doer i e i o en l) a a r ig

9 a. Gro $\tilde{B}=$ und Mittelfträude ber Ģebirge unt des See= ftrandes. B(ätter ziber oder toenig unter $\Re$ toth)= buđenblattgröß̄e, Ǵriffel berlängert: S. laurina, silesiaca, nigricans (punctata).

$9 \mathrm{~b}$. Sileinjträud)e, meijt niederliegend unঠ durd) $\mathfrak{2} u s=$

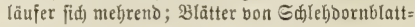
größ̄e oder wenig größ̄er, an Der Spize oft ge= faltet oder bornipibig; Sä̈gden flein, Grififel furz und jehr furz. (ङandreiden).

10 a. Blätter unterjeits nid)t angepre $\bar{t} t=\{e i b e n b a a r i g$, nid)t filberglänzend. (G)

\section{S. Caprea.}

S. grandifolia.

1 2rten ber Spitiveiben:

1 a. Slätter beiberjeits rein grüu, b. h. bie Grunbfarbe ber unteren

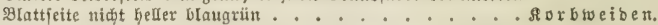

2 a. 2Yfterblätter fehlen ober feb̆x flein, Behaarung ber unteren

Blattjeite biđt uno filberglänzeno . . . . . . S. viminalis.

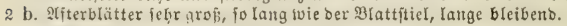

3 a. \$lattrant ganz pber wellig geferbt ........ S. stipularis.

3 b. \$lattranb weitläuftg=briffig=\{̈gezähnig ...... S. viadrina.

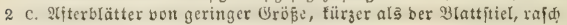
abiallentb.

3 a. Blattranb brüfig=\{ägęä̆nig, nie gangranbig.

4 a. Die Rantbrüfen bis zur Blattbafis, oft bis an bie Seiten

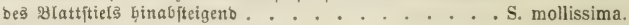

4 b. \$lattbafis brïlenlos.

5 a. (3röß̆te Błattbreite über ber Mitte ........ S. Kochiana.

5 b. Größte 3lattbreite unter ber Ditte . . . . . S. holosericea.

3 b. Blattrand flady ivellig geferbt, oft ganzranbig . . . . . S. Smithiana.

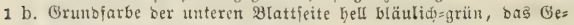

äber mețx ober wentiger gelblid .......... Jilziveiben.

2 a. Betaarung hinfällig=feibig . . . . . . . . . S. acuminata.

2 b. Behaarung fammtig . . . . . . . . . S salviaefolia.

2 c. 乌̈ebaarung mehlig=fil

3 a. Slätter breit=oblong=elipti间. . . . . . . . . S. Seringeana.

$3 \mathrm{~b}$. Blätter fd̈maI=oblong=lanzettlid.

4 a. Brö́te glattbreite über ber Mitte. . . . . . . S. farinosa.

4 b. Größ̈te Blattbreite in ber Mitte . . . . . . S. subalpina.

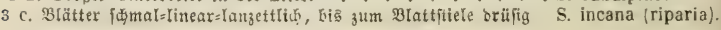


tociben.) S. depressa, myrtilloides finmarchica, ambigua, relata, lantana, rersifolia (fusca Lin.).

10 b. Blätter unterjeits angeprest=jeidenbaarig, $\mathbb{f l}=$ berglänzenঠ (Sandweiden Der (Ebene). S. argentea, repens, angustifolia - rosmarinifolia.

5 b. Blattfitel an ber Gpike orüftg (Adeniteae)

6 a. Sduppen der Rübjen bleibend; Minde in Sduppen abblätternt (wie Platanus), die Epige der jährigen Iriebe gefurdt; @träudjer

7 a. Blätter verlängert lanzeltlid), unterjeiţ glanjlog, binfällig behaart.

8 a. Blumen ztoeimännia̧

8 b. Blumen oreimänniß

7 b. Blätter oblong=elliptijđ, unterieita glärjend, ourd́)= aus tahl . . , . . . . . . . .

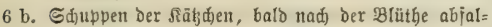
lenb; Rinde riffig; Die jungen Iriebe twaljig; Bäume

7 a. Blattrandorüjen grün ober fótrarz.

Blätter leberartig fteif, lebbaft glänzend twie ge= firniß̄t, ftets ganj tahl.

8 a. Mịterblätter fehlen oder ortajenförmig . . .

8 b. Ufterblätter blattförmig.

9 a. Blüthe, bier = bis fünfinännig, Irad̆t ber S. pentandra . . . . . . . . .

9 b. Blüthe drei= bis viermännig, in Tradjt und $\mathfrak{B}_{\ell}=$ iaubung der $\mathrm{S}$. fragilis näher ftehend

7 b. Blattorüjen mit toeif̈em Eefret, Blätter toeniger fteif uno glänzend, bor bölliger Entwidelung feidig oder bleibend feidenbaarig.

8 a. AF̂terblätter nierenïörmig, untere $\mathfrak{B}$ lattịläđ)e grün

8 b. 2(f̈terblätter lanzettliđ), untere Blattīläçe blaugrün

8 c. Ufiterblätter verịdrindent flein, pinjeljörmig be= haart; Iriebe nidht brüdig. . . . . . .

4 b. Frudtfnoten unঠ Etaubgef. auf einem teld)artigen Irä= ger; biele nidht vermadjene Rnoppendedblätter $\mathfrak{\beta}$ a p pel

5 a. finoipen troden, bchaart.

6 a. Rarben biertheilig, Blätter unterjeits filbermei
6 b. Marben ad)ttbeilig, Blätter unterjeits graubaarig, filberbaarig geftreift

5 b. Snoipen fahl, mehr oder tweniger flebrig.

6 a. Jrud̆ffnoten berlängert, โd)lanf; $B$ lätter runolid, grob=buditig=\{ägezäbnig

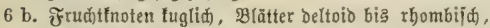
eng=hacłig=jägezäbrig.

7 a. Edaft in 2ifte bertheilt, Wudbs jperrig . . .

7 b. Shaft aushalteno, Wudhs phramioal .

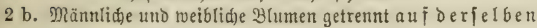
ßilanze (Monoecia).

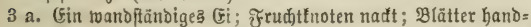
förmig gelappt, mit jadeioigen 2lîterblättern 6) Pßatancu

3 b. Mehrere ađ̆jenjtändige (Fier, Blätter einjad) mit freien,

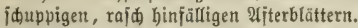

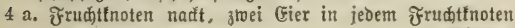
(Gymnocarpae)
Manderweiden.

S. hippophäefolia. S. undulata.

S. amygdalina.

Baummeiden.

S. pentandra.

S. tetrandra.

S. cuspidata.

S. fragilis.

S. Russeliana.

S. alba (vitellina).

Populus.

P. alba.

P. canescens.

P. tremula.

P. nigra.

P. dilatata.

Plataneae.

(cult.) Platanus occidentalis.

BBetuIaceac. 
5 a. Drei Trubthtnoten auf jeder Sduppe, die Sduppen binfällig: Staubfäden in einer Gruppe . . Birfe Betula.

6 a. Baumwlidfige Arten.

7 a. Blätter und Triebe tabl, leb̧tere raub durd) Waăbs= abjonderung, bie Borfe älterer Bäume am fọ̉e ftart aufgerifien
B. alba (verrucosa).

7 b. Blätter und Triebe behaart, ohne $\mathfrak{B a d b a b j o n o e =}$ rung, die Borfe nie ftarf aufgeriffen $\because$. . . B. pubescens (alba Lin).

$6 \mathrm{~b}$. Straudinüdifige 2 (rten.

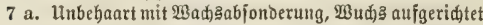

7 b. Behaart obne Wadjabjonterung Der Iriebe, $\mathbb{B}$ udg nieberliegend

B. fruticosa.

B. nana.

5 b. 3wei frudtfnoten auf jeder Sduppe, Iebtere bleibent;
Staubfäben in brei Gruppen
Eller Alnus.

6 a. Snofpen geftielt.

7 a. Blătter runঠliđ) mit teilförmiger $\mathfrak{B} a$ fỉ uno gebud)= teter Spife, flebrig; ßinde graubraun . . . .

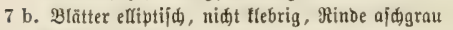

A. glutinosa.

$6 \mathrm{~b}$. Snojpen fitgend

A. incana.

A. viridis.

4 b. Æruditfnoten mit einem ßerigonium innig berwadjen (Hymenocarpeae).

5 a. 3rei (Eier in jedem frudtfnoten, swei frudtfnoten in jeder Blume . . . . . . 8) Syajelt

6 a. Fruđ̆tbed)er blattähnliđ̆, einblättrig.

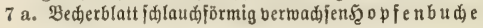

7 b. Bedjerblatt offen, oreilappig . . \$̧ornbaum

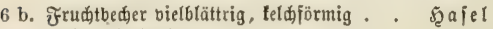

7 a. Rinde fortartig

5 b. Gedts ober viersehn (Fier in jedem frudttnoten.

6 a. (Fin frudttnoten in jeder BItume, Frudtbedjer offen und ungetbeilt . . . . . . . 9) Eidjen

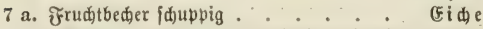

8 a. Blätter ganlz faht, an ber Bajis gefräujelt, Blüthe uno frudht geftielt . . . . . . . . . .

8 b. Blätter mehr oder weniger, bis auf wenige berein= zelte ફ̧ärden behaart, a॥ Der Bajį eben. Blüthen und frrüd) fiţend

7 b. Frudtbed)er zottig

Ostrya.

o. vulgaris.

Carpinus.

C. Betulus.

Corylus.

C. Colurna.

C. Avellana.

b. 3 trei frudftfnoten in jeder Blume, frrudbedber ge= id)loffert uno flappig . . . . 10) Effern

B) ud e

6 c. Drei frudifnoten in jeber Blume, 14 Gier in jedem Frudttnoten, Frudtbed)er geidilofien und flappig

11) Miaronen

Marone

3 c. (Fin adjenjtänoiges aujgerid)tetes ( $i$ in jedem frrud)t= tnoten, ein frrudtftnoten in jeðer Blume; Blätter gefiedert

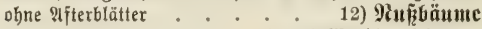
(eult.) $\mathfrak{B}$ a $\mathfrak{l} \mathfrak{n u \mathfrak { B } b a u m}$

\section{Quercineae.}

Quercus.

Q. pedunculata.

Q. Robur.

Q. Cerris.

Fagineae.

Fagus sylvatica.

Castaneae.

Castanea resca.

Juglandineae.

Juglans regia.

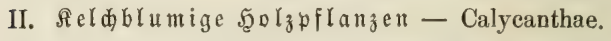

1 a. Blätter gefiedert

13) Gidjen

(5jo)e

Fraxineac.

Fraxinus.

F. excelsior. 


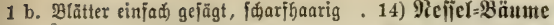
2 a. Bluthen in Räbøenform . . . . Maulbe erbaum

2 b. Blüthen bereingelt (polygamifa) . . Sirgelbaum

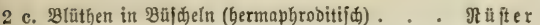

3 a. 21fterblattmarben mit bleibenden weiBen Büjdelhaaren .

3 b. Rfterblattmarben fabl

4 a. Frudt fahlrandig, furgeftielt

$4 \mathrm{~b}$. Frudit getwimpert, langgeftielt

1 c. SBlätter einfad, ganłranbig, fternbaarig . 15) Dleaftern

Seefreuzdorn

1 d. Blätter einfaœ, ganzranbig, fahl oder tweiđhbaarig: alpina

16) Seibelt

Eeibelbajt

D. Mezereum, alpina, Laureola.
Wricene.

Morus.

(cult.) M. alba.

Celtis.

C. australis.

Ulmus.

U. suberosa.

U. campestris.

U. effusa.

Hippophäe.

H. rhamnoides.

Thymeleae.

Daphne.

III. Ŝronblumige Şolzpflanzen - Corollanthae.

A. Blumentrone einblättrig, b. h. bie Sironenblätter find von if̧rer Bafis aus mebr oder treniger weit hinauf mit einander ber= madien (Monopetalae).

1 a. Seldh frei, Bläthe bereingelt, Blumentrone regelmäbig.

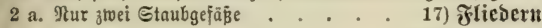

Rbeintweide

(Syringa vulgaris)

Ligustringe.

Ligustrum.

L. vulgare.

2 b. Mehr als ztrei Staubgejäpae.

3 a. Blumenfrone in ber Rnofpe gefaltet ober gebreht.

4 a. Blätter redjififtänoig . . . 18) शiadjtidjatten

5 a. Etengel rutbenförmig . . . Bo f 3 . . rm

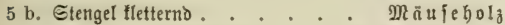

4 b. Btätter gegenüberftebeno . . 19) Drefblument

Sinngrün Vinca. V. minor.

$3 \mathrm{~b}$. Blumenfrone in ber finofpe dachig.

4 a. Blüthen gefellig; Blumenfrone tief geipalten, ausge=

breitet, oft ungleifí) .....20) Porite

Rienporft

4 b. Blüthen zeritreut, Blumentrone f̂lă gejpalten, gloden= förmig.

5 a. Blüthen ađhtmănnig . . . . . . 21) Seiben

Sumpfheide Erica tetralix, Sandheide Calunna vulgaris.

5 b. Blüthen zefnmmännig.

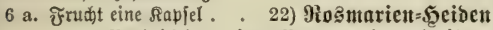
Boleiblätrige Rosmarien=Seide,

6 b. Frudjt, eine Beere . . 23) Bärenbeer=5eiben Bärenbeerftraud

1 b. Reld mit dem frudtfnoten bermadjen, bie f్rudt mit ben Seldagipfeln gefrönt.

2 a. Blätter twed̆jelffäntoig . . . . . 24) \$reip̧elnt

3 a. Blumentrone tief gejpalten . . No Dsbeere

Sumpf $=$ Poososeere

ת o os bere

3 b. Slumenfrone flad geipalten . . Sgeidelbeere

4 a. Blumentrone glof́enförmig, Blätter immergrün, Beeren roth.

5 a. Griffel, bie Blumentrone tiberragend, Rron३beere . V. Vitis Idaea.

\section{Thodoreae.}

Ledum. L. palustre.

\section{Ericeae.}

Calunna rulgaris.

\section{Andromedeae.}

Andromeda polifolia.

Arbuteae.

Arbutus uva ursi.

\section{Vaccineae. \\ xycoccos. \\ O. palustris.}

Vaccinium. 
5 b. Brififel nid)t alts Der Blumentrone herborjteheno . . V. intermedium.

4 b. Blumenfrone eiförmig, Blätter fommergrin, Beeren blaujd)rarz.

5 a. Blätter ganjranbig. Sumpióbere .

V. uliginosum.

5 b. Blätter fein gefägt. ફ̧eidelbeere . . . . . . V. Myrtillus.

$2 \mathrm{~b}$. Blätter gegenüberftebeno.

3 a. Blumentrone nut uแregelmäpiger Randtbeilung, meift rőhrenförmig . . . . 25 Ģaisblatt,

L onicera.Caprifolium, Peryclimenum, $\mathrm{Xy}$ losteum, nigra, alpigena, caerulea. L in$\mathrm{n}$ a e a borealis.

3 b. Blumentrone regelmäp̈ig, raoförmig ausggebreitet

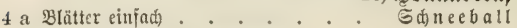
V. Opulus, Lantana.

4 b. Blätter gefiedert ....... Jolder S. nigra, racemosa, Ebulus.

B. Blumenfrone aแล mehreren bis zum (Grunde getrennten Blät= tern befteheno (Polypetalae).

भ. Die Staubfäben und Rronblätter bem Reldje entipringend, entfernt bon Der Bafis bes oder ber Frud)tfnoten (Calyeiflorae).

1 a. Der Reld mit Dem Frudttnoten verwadfen.

2 a. Frudtfnoten einfäadrig.

3 a. Blätter immergrün; Sd)marojer .

27) Mliptelı

Miftel

$3 \mathrm{~b}$. Blätter jommergrün; J̛nd)t cine bielfamige Beere

28) Mibic

Ribes Grossularia, alpinum, nigrum, rubrum, petraeum.

2 b. Frud,tfnoten зtei oder mehrfädhrig.

3 a. $1-2$ mal jo viel Staubgefäße als \$lumenblätter, Blathe= ftand doldig. . . . 29) Edjirmblumen

4 a. Błumen cintueibig, biermännig: Dூartriegel

5 a. Blattgentolde mit gemeinjidaftlidjen Ded̋lättern am Grunde

5 b. Blüthendolde obne Dedtblätter

4 b. Blument 5-10tweibig, 5-10männig . . Ephen $3 \mathrm{~b}$. Biernal fo biel Staubgefäß̈e als Btumenblätter

4 a. Fruđttnoten holzig (Xylogynae).

\section{0) S(p felfiridjtfer pomaceae.}

5 a. Reld nur biz gur Plitte mit Dem Frudtfnoten ver= wađjen, Blätter ganzranoig. Quitten= Mi

C. vulgaris, tomentosa, laxiflora.

5 b. Sield) volfftändig mit dem đrudtlnoten verwabjen.

6 a. Blütbe einzelfiändig .... Mispel,

6 b. Slüthe in Dolden ..... Sgagerorn

7 a. 2-3 jelten weniger Briffel und Steine . . .

7 b. ftets nur cin Griffiel uno Stein

4 b. Fruditfnoten fleifdig (Sarcogynae).

5 a. Biele (Eier in jedem Frudtfnoten. . . Quitte Cydonia. C. vulgaris.

5 b. 9kid)t mehr als orei (Fier in jedem Frud)tfnoten.

6 a. Blütben bereinzelt oder in Büfd)eln. Die unmittel=

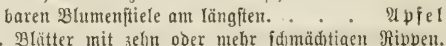

7 a. Blätter mit zel)n oder mebr fdjmäd)tigen Rippen.
Birn (P. nivalis, Pollveria)

7 b. Blätter mit $4-8$ ftarfen Rippenpaaren. $\mathscr{2}$ ebffel: P. Malus.

\section{Unbelliferae.}

Cornus.

C. mascula.

C. sanguinea.

Hedera. H. helix.

Mespilus. M. germanica.

Crataegus.

C. oxyacantha.

C. monogyna.

Pyrus.

P. communis. 
6 b. Blüthe in Dolden, die unmittelbaren Blumenftiele am fürseften. (Sorbaria).

7 a. Blätter gefiedert, đr rü
8 a. Snofpen tahl
S. domestica.
$8 \mathrm{~b}$. Snojpen behaart
S. aucuparia.

7 b. Blätter fandförmig gelappt, bie unteren Sappen iperrend oder zurüdgebogen, frridgte braun $(E[S=$

beere Torminaria.

T. europaea.

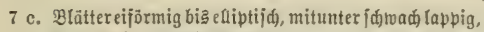
iägezäbnig, frrüdote roth.

8 a. fronenblätter auagebreitet. . Me hlbeere

9 a. B(ätter elliptija) mit eiförmiger Bajis, unterjciţ bleibend filbertweip .

Aria.

A. Theophrasti.

9 b. Blätter breit =eiförmig, mit faft herzfōrmiger Bafis, lappig = jägejähnig, unterjeits grau= filzig

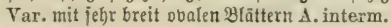
latifolia.

$8 \mathrm{~b}$. Rironenblätter aufgeridatet. 3toergbeere

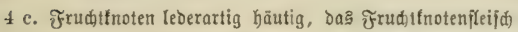
verorängt (Dermatogynae). Blüthen in Traubeı

Tra benbirn

$1 \mathrm{~b}$. Der oder bie f̧ruditfnoten mit Dem Reldje nidjt vertoadien.

2 a. frudtfnoten in ber $\mathfrak{R e h r z a h l ~ . . . . ~ 3 1 ) ~ M i o j e n ~}$

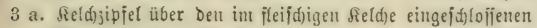

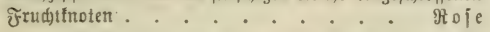

$\mathfrak{I} \mathrm{m}$ häupigften R, canina uno tomentosa, jelten pimpinellifolia, cinnamomea, rubiginosa, arrensis.

3 b. Reldzipiel unter Den freien frudifnoter.

4 a. Frrüdthen einjamig.

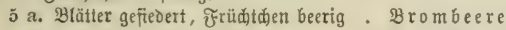
Rubus Idaeus: Şimbere, R. fruticosus, caesius, saxatilis: Brombeere.

5 b. H(ätter einfad), Jrüd)tć)en troden mit gefiedertem Grifipel Silbertours

4 b. Früdtchen mehrianig . . . . Spierftraud)

A. intermedia.

Chamaemespilus.

Ch. ariaeformis.

Amelanchier.

A. vulgaris.

\title{
Rosaceae.
}

Rosa.

Rubus.

\author{
(1)
}

Dryas.

D. octopetala.

Spiraea.

S. salicifolia.

2 b. 9lur ein ơrughtfnoten.

3 a. Der ffrudtfnoten einfammrig.

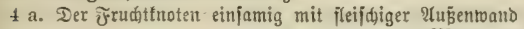

5 a. Blumen und frübte vereingelt ober in tursen renig=

32) M)antofn Amygdaleae. blumigen Doloentrauben.

6 a. Frrühte bereift, Der Etein platt und uneben, Frudt= ftiel fürzer als bie frud)t. . . . Pf f a ume

7 a. Blumenftiele faht

Prunus.

$7 \mathrm{~b}$. Blumenitiele flaumig.

P. spinosa.

8 a. 2leftden jammtig behaart

P. insititia.

8 b. Heitchen tabl .

P. domestica.

6 b. Früd)te nidts bereift, Stein fuglid), glatt, Frudtftiel länger als bie đrudjt ..... Sirjithe

7 a. Blütbe bereinzelt oder in Büldeln.

8 a. Blattitiel orifitg .

Cerasus.

8 b. Blattiftiel orüjenlos

C. avium.

7 b. Blithe in Traubenoolden

C. Chamaecerasus.

C. Mahaleb. 


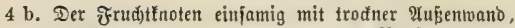

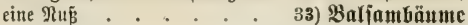

Sumad)

4 c. Der frudtfnoten mehrjamig, Blumenfrone fdmetter= lingsförtmig, bie frudt eine Şülje

\section{4) Sürliengetuädoje}

5 a. Die Şülfe mit Duerwänden, Blätter fiebenzäblig Beltiden

5 b. Die Sülfe ohne Duermänoe.

6 a. Blätter einfađa ober breiłählig; Staubfädent einbrübrig.

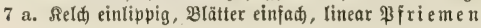

\section{7 b. Seld 3tweitippig.}

8 a. Selch bis jur Bafis getheilt, Blätter einfad) lan=

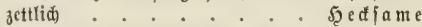

8 b. Sield nid)t bis zur Bajis getheilt.

9 a. Griffel freisformig zujammengerollt $\mathfrak{B}$ ejen=

(Spartium seopar. Lin.).

pfrieme

9 b. Griffel geftreftt, bie Marbe jeitenftändig.

10 a. Blätter einfad . . . . . Binfter Genista.

Dornenloje: G. sagittalis, tinctoria pilosa ; bornige: G. germanica, anglica

10 b. Blätter oreizăblig . . Bohnenbaum Cytisus.

C. laburnum, alpinus, nigricans austriacus, supinus.

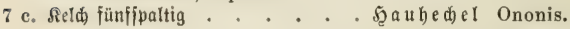

O. spinosa, hircina, Natrix.

6 b. Blätter meh̆r ałą oreizăhlig, Staubfäben ztweibrübrig.

7 a. Şülfe berlāngert, platt . . Sd otendorn

7 b. Şullfe verlängert, cylindrif̧ . (Erbjenbaum

Robinia.

cult. R. Pseudacacia.

Caragana.

cult. C. arborescens.

7 c. Şülie blajenförmig aufgetrieben. B

Colutea.

C. cruenta.

$3 \mathrm{~b}$. Der Frudtfnoten mehrfammrig.

4 a. Blätter fibeno fauppig, mit ben 2 eftchen abfalleno

35) Tamariจten

Tamariste

\section{'Tamaricaceae.}

Tamarix.

T. germanica.

4 b. Blätter fił̧en๖, niđ̆t binfällig, immergrün

36) Maujujbecen

$\Re$ a ujd beere

4 c. Blätter geftielt, ideibig.

\section{Dimpetreae.}

Empetrum.

E. nigrum.

5 a. Staubgefäße bor Den 3 lumenblättern ftehen〉

37) Яreแzobrute

6 a. Blätter gegenüberftełento oder faft gegenüberitebeno

Rreuzorn

6 b. Blätter wedofelftànoig.

7 a. Blumen viertheilig, getrennt=gejdledtig $\mathfrak{B}$ eg

$7 \mathrm{~b}$. Blumen fünftheilig, 3witter. . $₹ a u l b a u m$

R. alpinus, pumilus.

Catharticus.

C. vulgaris.

Frangula.

F. vulgaris.

5 b. Staubgęäß̈e żwifden den Blumenblättern fteheno. 
6 a. Die frudht cine Beete . . . . . 38) Sülict Stadelhülie

6 b. Die Frudat einte Rapjer

39) \$impernüij̄c

7 a. Die Siapjel fleijoig

ธpindelbaum

7 b. Tie Rapfel blafig, bäutig

\$impermú

3. Die Staubjäben und fronblätter unfern ber Bapis des

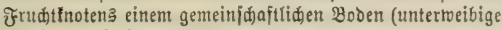
ङdheibe) entipringent (Thalamiflorae).

1 a. Mehr als ein frudtfnoten in jeder $\mathfrak{B}$ lume, filetterer

40) Walbreben

2 a. Brumen in Traubet Waldrebe

2 b. Błtumen einjelftän๖ig

arpenrebe

1 b. Slur ein Frudtfnoten in jeder Blume.

2 a. Iriebe bornig

2 b. Triebe unbetwafinet.

3 a. Blumentrone unregetmāß̄ig

42) Rop̧faitanien

Ros̄taftanie

41) Sauradje

ธaurach

Ilex.

I. aquifolium.

Staphyleaceac.

Eronymus.

Er. latifolius, europaeus, verrucosus.

Staphylea.

St. pinnata.

\section{Clematideac.}

Clematis.

C. ritalba.

\section{Atragene.}

A. alpina.

\section{Berberideae.}

Berberis.

B. rulgaris.

\section{Aesculaceae.}

Aesculus.
3 b. Blumentrone regelmäß̄ig.

4 a. Blätter wedjelftändig .

5 a. Blätter fternbaarig

5 b. Blätter fúfliçłthaarig.

6 a. Blätter beiderjeiţ grün

6 b. Blätter unterjeitミ blaugrün

$4 \mathrm{~b}$. Blätter gegenüberftekeno

5 a. Blattitielipibe tabl, snoipendecfen fleijaig

5 b. Blattpitieljpike bärtig.

6 a. Rnojpendeden fletjidig

6 b. Snojpendectent bäutig.

7 a. Blätter fümflappig

Var. mit tieferen meijt ganzrandigen Sappen A. austriacum.

7 b. Blätter oreilappig
43) Rintocu

sinde
44) शfforne

A. hippocastanum.

\section{Tiliaceac.}

Tilia.

T. alba.

T. platyphylla.

T. europaea.

aborn Acer.

A. platanoides.

A. pseudoplatanus.

A. campestre.

A. monspessulanum.

\section{3̧weiter $\mathfrak{A}$ Gjduitt.}

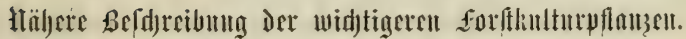

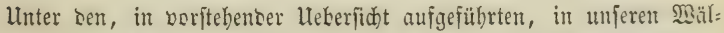
bern twadjenben Sgoljarten, ijt bei weitem bie gröfte 3ahl nidht Giegen= ftand foriftiden 2Inbaues; jie haben mur in jopern eine foritlide Bebentung,

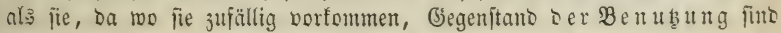

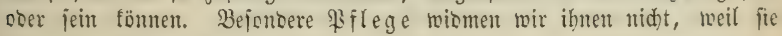


Dem 3wede Der Joritwirthid)aft: Erziefung Der gröften unt werthoollften 5olymafie auf gejebenent glähenraume, nicht entipreden; entweber weil fie jul langfam wadjen, twentig Maffe erzengen, ober weil ber 3uwadjs in einer, mur $̧ u$ bejdränttem (Sebraud geeigneten Form erfolgt, ober weil

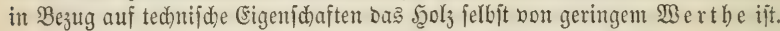

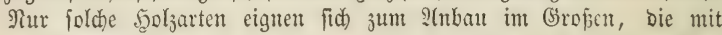
grofer Maffenprobuttion einen boben (Sebraudstorth in from uno (Süte Des Probuft's verbinden. (Ẻ treten baju aber nod) andere Bebingutgent.

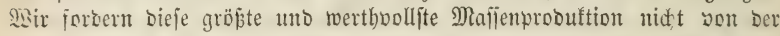
einzelnen Pfflanje, fonbern vom Foolzbeftande ber Fläde. Die

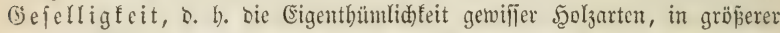
Stummigabl, im gebrängteren Etanbe und in reinen Beftänoen nebentein=

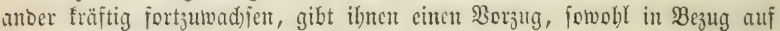

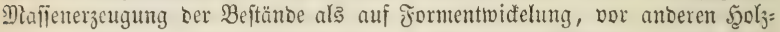

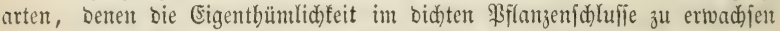
nid)t in Dem Maje juftebt, went ibre Mafien= uno Mertherzengung an ber einjelnen Biflanze aud) ebenjo grop oder gröfer ift. Bei erfterer erjebst bie größ̄ere Etammzall der Beftänoe reid)lich Den 2(usfall im 3uwadje be: einjelnen Baume?.

$3 u$ ber Eigenthümlidfeit ciner geringen $3 a b l$ von golzarten in ge= Drängtem Etande nebencinander fortzumad)fen, mus fid ein geringerer ober böherer Grad von Unempfindlidfeit gegen wechielnoe Stanoortäberbält:

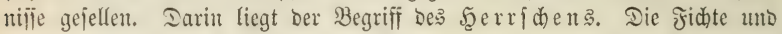
Tamme bebecten ganze Biebirge, bie Riefer grofie (Ebentr, Die Bude, Die Erle, jelbit bie (Fid) gehören nod) hierber. (ङs mürbe ber gröften Gorg=

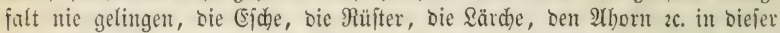

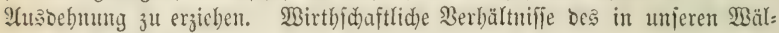
Dent vorberrichenden, Durdh bie Güte bes in ifm ertwadfenten Feolzes er= trajreidfiten Sgodiwalobetriebes, geben im allgemeinen ben reinen, ges

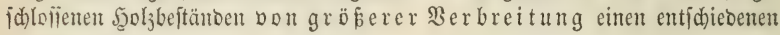
3orz̆

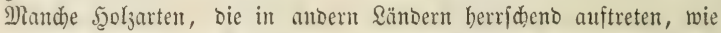

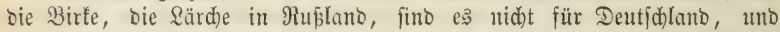
jelbjt imerbalb ocr (Grenjen Deutichlands finden bierin nod) Unterjodiede ftatt, 3. B. für bie 2Beiṕtanne, F̧ainbuche, Birfe.

5ुoljurten, bie für Deutid)lano herridento uno gejellig zugleidy fint,

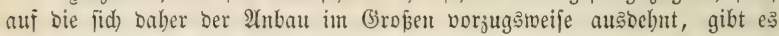

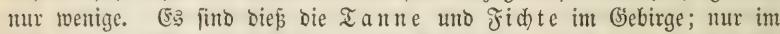

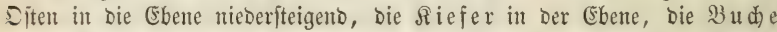
in Der Ëbene bis zu Den böheren Borbergen hinauf, bie (Ei de uno Birfe in ber Ebene bis ju ben nieberen Borbergen, bie Er le für ben Moorboden.

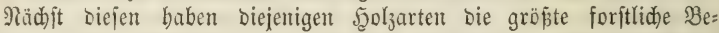
Deutung, bie zwar ebenfalls gefellig auftreten, aber wählerifder in Bezug สuf Etantortabefdaffenbeit fino, baber fid) nie in ausgebreiteten Beftänoen

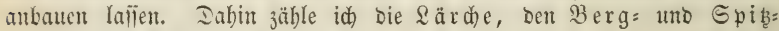

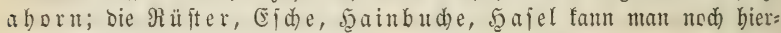
herjichen. 
Enolich bilsen eine oritte Gruppe sicjenigen 5olzarten, sie aud in

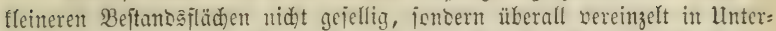
mengung mit anteren פoljarten auftreten, wo bie Rultur nid)t in Die natürlichen ミerbältniile eingegrifien hat. Iabin gebören für bie flimatija)en

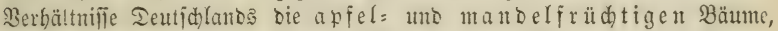

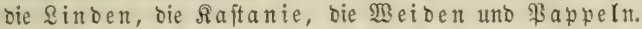

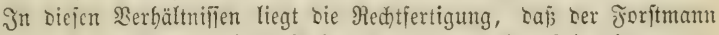
nicht allen fulturpflanzen gleiche Ifufnerfjamfeit uno Eorgialt roibmet uno Daburd ijt es wieberum geredffertigt, wenn Der Jorjder nidjt allen ârten

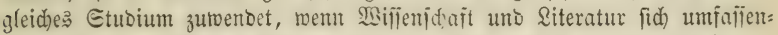
ber mit ben forftid midhtigeren als mit ben weniger widhtigen Sgolzarten

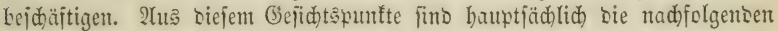

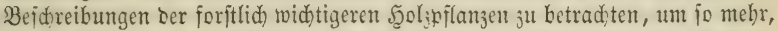
sa die Grenzen diejes Berfes eine haushälterijde Benubung des Raumes jorbern. Execiellere 2Angaben entbält mein Sebrbud ber Pflanzenfunbe. Bon Diefem (Gifidtspuntte aus bake id) aud bie in ber vorigen Auflage siejes Merfes gemäblte Eintbeilung Der Sulturpflanjen in berridende uno untergeoronete Sgolzarten beibebalten. Dan veritebt unter criteren

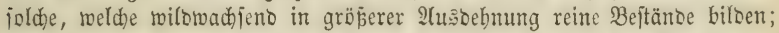
unter untergeoroneten 5oljarten bingegen jolde, bie in Der Regel mu in Untermengung mit berridenden Şölzern, in reinen Beptänben mu surd) fünjtidhe Sultur vorgefunten merben.

A. Bon Den berridenben Soljarten un Deren Gattunga二 verioanden.

Gie zerfallen in stwei natürliche familien:

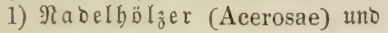

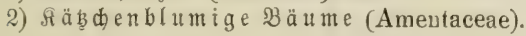

\section{Siftes Eapitel.}

\section{Die Mabclfjülžer (Acerosae)}

bilben eine, nidjt allein surd äupere Jorm, fonbern auch surch inneren Bau und forftlides Berbalten von ren übrigen Solzmflanzen jharf geidie= bene Gruppe bon $\mathfrak{B a l b b a ̈ u m e n , ~ u n t e r j o b i c b e n ~ b u r c h ~ b i e ~ e i n f i e l i g e n , ~ n a b e l = ~}$

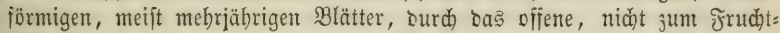
fnoten berwadjene, entweber gar nidbt ober nur ourd eine Eduppe be: fleibete Jrudtblatt; ourd) Den nadten Gamen; ourd Die Gleidförmigfeit

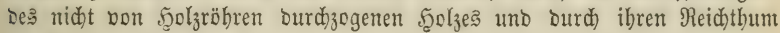
an îlüdtigen Delen uno Sarzen.

Die Nabelbölzer zerfallen, wie Die voritebeno mitgetbeilte Gnnonfi: nad)weišt, in $3 a p$ fenbäume, Evprejjen und Ėiben. Unter diejen

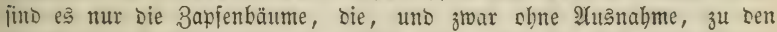

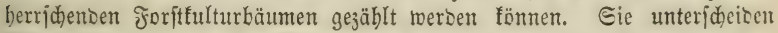
fid) bon Den übrigen Rabelföljern ourd) Die 3tweijabl Der bängenten C̈ier

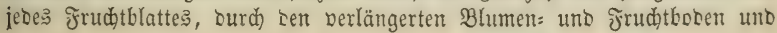


bie barauf beruhenoe (nur bei Thuja äbnlidje) 3apfenfrudht. Dit wenigen

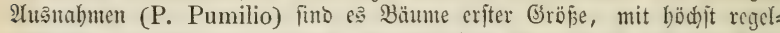
mäpigem, grabem uno twalzigem, unveräfteltem ober erît in böberent 2flter fid) in 3weige zertbeilenden Edafte (Pinus), mit weidem Syolze, bas erft in böherent 2Alter ourd) Serbarjung einen mäpig hoben (Grao ber Şärte, Sd)were, Dauer uno Bremnfraft erbält, Die aber sem obnerad)tet zu ben widhtigiten Sulturpflanzen gebören, theils burd) ibre grofe Maljenprobuftion,

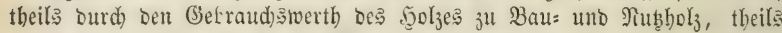
Durd) ibre, mebre als bei irgento einer anderen Familie ber 5ुolzzplanzen

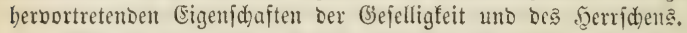

SBie bie Snnorfis nad)weist, zerfallen bie einheintifden Bapfenbäume in bie Gattungen: Fidate (Picea), Ianne (Abies), \&ärd) e (Larix) uno Riefer (Pinus). Die lebte (Battung unteridjieben vor allent llebrigent Durch) Dic, mur an Der cinjäbrigen Pflanze einfad)en, - päter überall büfchelitän=

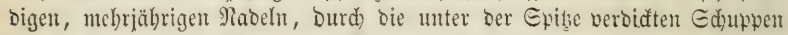
Der 3apfen uno Den im böberen Ifler zur fdjirmiörmigen Srone veräjtelten Sd)aft. Larix unteridieben butch bie fonmergrünen, an ben jährigen Irieben einfad)en, an Den älteren Trieben büjd)elftänoigen fdeciodofen Pabełn uno bie fleinen ciförmigen Bapfen mit nidgt verbidter Edqupen=

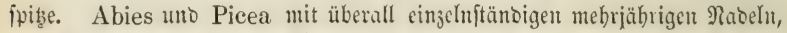
bie bei Abies platt= uno fdwertförmig, bei Picea waljig=bierfantig fint. Picea mit bängenton 3apfen uno bleibenoer 3apfenidunpe; Abies mit aufgerideten 3ałfen, Deren Ed)upten mit rem Gamen gleidzeitig un früber ala bie Epindel abfallent.

1. Die Jid)te, Picea excelsa Lam. (Pinus Abies Linn. Pinus

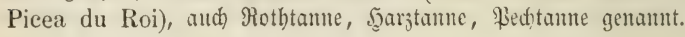

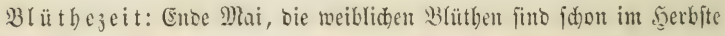
erfemtubar.

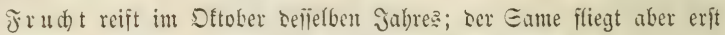

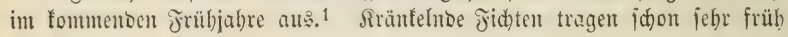

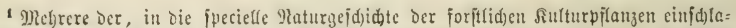
genden Gegenftände find, Der leidfteren lleberifid)t, theila Der Bejieljungen wegen, in benen

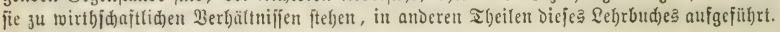
Dahin gebören:

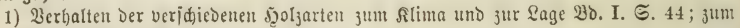
Boden 230. I. G. 117.

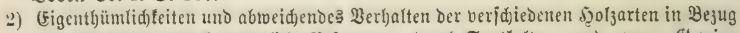

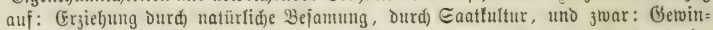

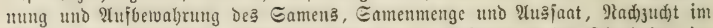

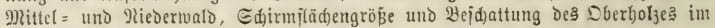

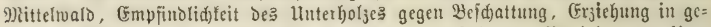
mengten Beftünden, Beftandstwed)iel, (Erjiehung in verid)iedenen Betriebarten, Um= triebsjeiten, unter verjajiedenen Etandorts= und Conjumtionsverbältnifien, Durd)= forjung G. 3 D. II.

3) Maffenerträge 3ð. I. ธ. 111, 2\$D. III.

4) Brentifofiertragswerthe Bo. III.

5) Formjabten BD. III. 


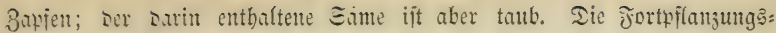
jähigfeit ber Bejtänte tritt jelten vor Dem 60. Jabre, bei ftarfem $\Theta d$ lup uno in raubem Silima viel präter cin. Unter güniftigen \$iserbältnifïn faun mant alle $4-5$ Jahre auf reidjlidgen Samen rechnten.

Der $\Xi a m e$ berbreitet fich reit vom Etamme, verträgt feine jtarfe Decfe, jordert aber wunben Boben. Er erbält fidd, jorgfältig aufbewalst,

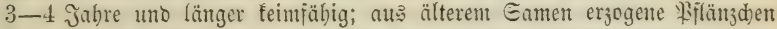
fino aber jabrächlid) uno geben bei ber geringiten Miserwärtigteit, wenn jie bieje in Den criten Jabren betrifit, ein. Der Eame geht 5-6 פisodjen nach Der Frübjabrşant auf.

Dic junge Prlanje bleibt im eriten Jabre flein; bas Stämm(d)en tvito jelten über 3 Soll lang, Die SBBurzel jertheilt fid gleid) unter bem

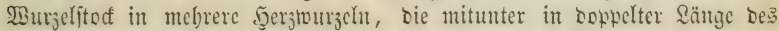
Etanmes uno bielfach beräftelt in bic Iiefe oringen. DRitunter ift un cin

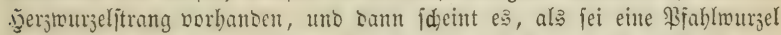

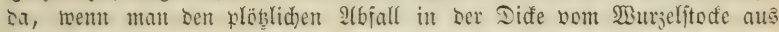

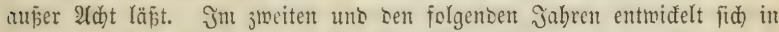
Der oheren Bobenj(bid)t ein ftarfer S⿱⺈

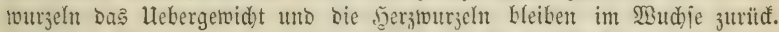

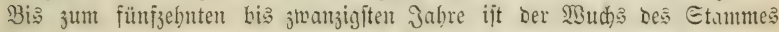
jehr langjant, bejonders in bent Durd) Büj(t)lpilanjung erzeugten Beptüntent. Sion sa $a b$ fteigt er beträdtlid) bis zum vierzigiten Juhre uno bält saum bi verträgt sie Jidute in ben erjten Jahren mehr als Die Siejer, weniger als bie Tanne, ertholt jid) aud) leidhter als bie Siefer von ben nadththeiligen Jolgen zu ftarfer Befdattung.

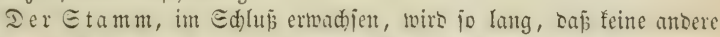
Donfjart ber Jidete bierin gleid) fommt. (Er biloet einen graben, runtoen uno vollholjigen Edhaft, Der jich nie in 2 efte vertheilt. Jm Jreien wiro ber Etamm jwar ebenfalls bod, aber febr abbolzig uno reinigt fich gar nidht von $\mathfrak{Y}$ ejten, bie mit zunebmender Sänge bei ber ftets geringen Etärfe

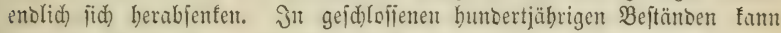
man 80 bis 85 Broc. Etammbolzmaffe amtebmen.

Die firone ift jelbjt im bohen Ifter nod) purantibenförmig, inenig verbreitet uno entbält gröptentheils mur joinad)e Pefte unter 8 (Sentm., uno Reijer, im Banjen jelten mebr ala $8-10$ Froc., morunter $2-3$ \$roc. Sijt=

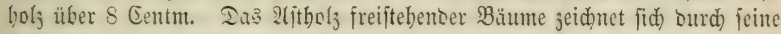
Bäbigfeit, 5ูarzreid)thum uno läıgere Dauer aus.

Die Belaubung ijt reider uno in bäberem Mabe bejdatteno als

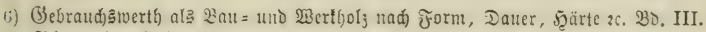

7) Sdimere bes 5013es BD. III.

8) Brenntrait, roh) und vertoblt, fiohlenausbringen Bo. III.

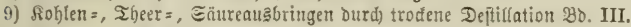

10) 2(jd)egehalt $\mathfrak{b}$. III.

11) Gebalt an Gerbjtoff und Gialfuşäure Bo. III.

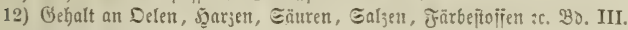

13) đreinde B̧ס. II.

14) Srantbeiten BD. II. 
Die Der Riefer, wegen ber fehr bicht ftehentont Plabełn unt ber fochirmförmigen Etellung Der 3meige. Die Blattmenge bürfte nicht gröjer jein als bei ber

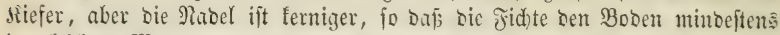
in gleidem Maje twie bie Riefer verbeffert.

Die Bewurzelung ift flad ausftreideno uno febr bebeutent, fo bas man beim biteb der Stämme aus Der \$fanne 15 bis 20 \$roc., bei 1 fubiger Stodböbe 20-25 \$roc., bei 2 fupiger Etod́böbe 25-30 \$roc. ocr gejammten Şolzmaile an Stodflyolz erbält.

3etrieb: mur im Syod)walbe: in febr raubem Slima plänterweife. Fïr

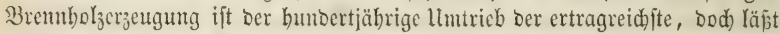

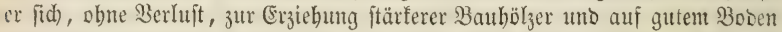

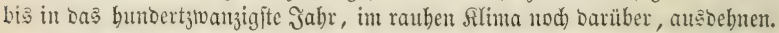

Fortfflanjug: Jn Der Ebene und itteralf, wo vom Mintobrud)

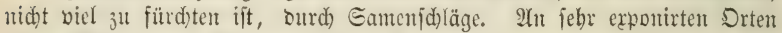

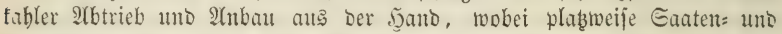
23ïjd)elpflanzungen aus \$flantzämmen am gebräud)lidjiten fino. Bei ter

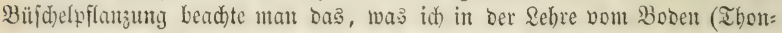
croe) über cine bierjelbjt beobad)tete Sirantheit ber Jidhtenbüfdel auf fehr. bintendem Boden gejagt babe. Die Jid)tentlanzung orei= bis vicriäbriger Gtämmtden liefert cinen fiderem Erfoly als bie Santen, Da bie Ganten in oreien bis zu biejem sllter vielen Gisfabren unterworfen finto.

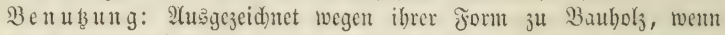
gleid) sie Siefer von längerer Danter; wentiger zu Werflyolz wegen ber grofen

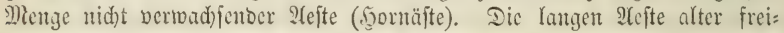
ftehentoer Fid)ten geben cin trefflid)es Material zu Fled)tzäunen. 2(tz Brenn=

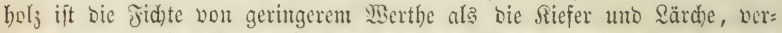
hältnibumäpig befier ift fie als Sobllyoly, mo bejonders bas Etoctholz Der

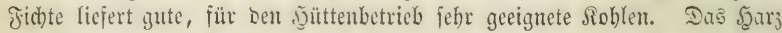

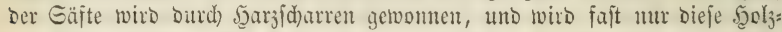
art bierzu benuţt. Dic 9linde wiro von Den Gerbern bejonbers zur Edjär: fung Der Ireibfarben bemuţt. Dic Mabeln junger Iriebe follen bier uno Da als Sd)affutter berwentot werben.

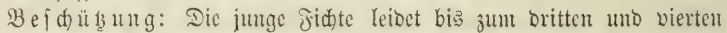

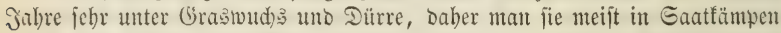
erzieft und erft in jenem 2fiter ins Jreie verpflangt. In Etangenorten fodabet

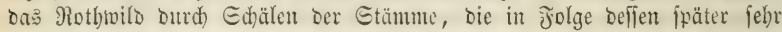

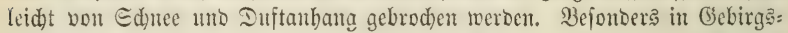
forften, wo wegen hoben uno lange liegendon Ed)nees bas WBilopret aus Mangel

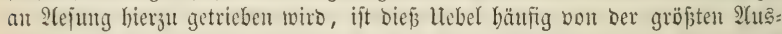

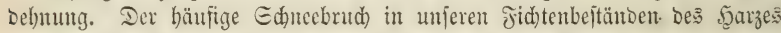
hat mur theilweife feinen (Sruto in ber ungleiden 2Yjtentmicfelung Der in Biijdeln aufgetwadjenten \$iflanjen. Sm böberen $\mathscr{X}$ (ter leibet bie Rotbtanne

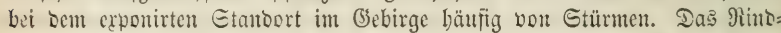

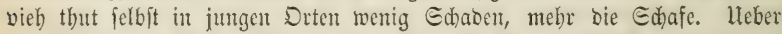
bie Injetten ber fidute babe id) im britten Banbe ausiührlich gefprod)en. ${ }^{1}$

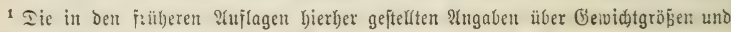
Brenmerthe babe id) im jweiten sande (foritbenuljumg) 3ujammengeftellt. 
2. Iie Ianne, Abies pectinata Dec. (Pinus Picea Linn., Pinus Abies du Roi), aud) Miseiptanne, Eilbertanne, Ebeltame genumt.

Die weiblide $B$ lüthe entfaltet fid im Mai ans Blüthenfnnipen, Die jøon im Minter erfennbar fino, aber fajt nut in Den äuperiften 3meigen ser Baumgipiel entiteben. 1

Die ơrud reift Enbe Ceptember ober 2 nfang Dftober, uno ber Game fällt Dann in wenigen Iagen mit ben Bapienjduppen jugleid) uno früher als bie Epindel vom Baume, baher man beim Eammeln be Eamens Een ridtigen Beitpuntt genau beobadten muj. Im Edhlufe ermadjen, merben bie Iannen gemöbnlid) erft mit bem fedjigiten bis fiebsigiten Jabre

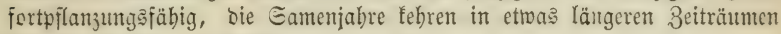
wieber, als bie ber Jijute.

Der Same verbreitet fid wegen jeiner Edmere weniger weit als

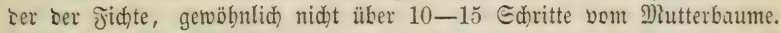

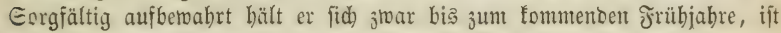
aber jehr bem ßerberben anşgefę̧t uno foll bejonoers tweiten Iransport

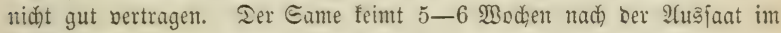
Frübjahr.

Die junge Pflanze bleibt in Den eriften Jabren jebr flein, fo baf fie im jed)ŝten bis achten Jabre meift nidht über $1 / 3$ Meter bod ift, umo mebr in bie Geitenälte als in bie Scöhe mäd)at. Erft vom zmanzigiten Jabre ab fteigt ber Jumad) beocuteno uno bält bam bis ins bobe 2llter

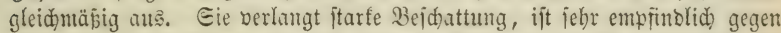

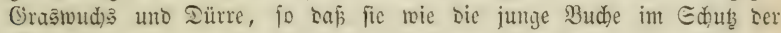

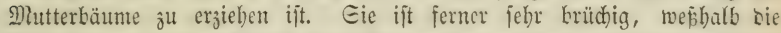
Iuझhiebe mit grojer Eorgfalt geführt werben mitffen, gebt aber nidht is

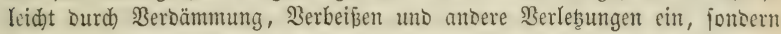
entwiđelt Geitenfnojpen zи neten Trieben.

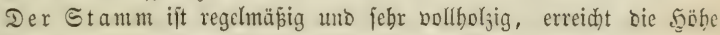
Des Fichtenjtammes, übertrifft biefen aber in ber Dide.

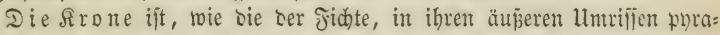
mibal, aber nidht wie bort aus aufgeridhteten, fpäter hängenben, fonbern von frühefter Jugeno bis zum bödiften 2flter auz faft rechtwinflig vom

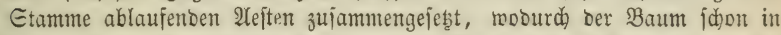

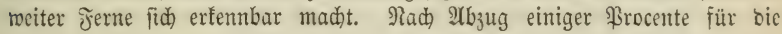

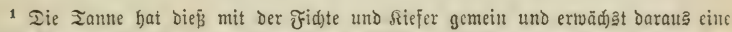

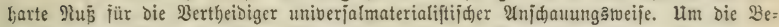

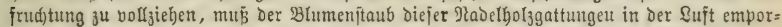

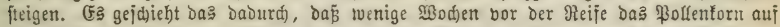
jeder Eeite bie Dberhaut befielben 3u einer gropen Blaje fic abhebt, die fich mit $23 a f j e r g a$ fülit. Dadurd) riro das \$ollenforn leidjter als bie atmojpljärijd) Suft und faun nur in Diejer wie ein Ballon unter Dith)ülfe Deß auffteigenden Suftitroms zui tweiblidjen Blütbe emporfteigen. Dem Pollen ber Şainladtaume, Der Särđhe, bei benen männlidje uno weib: lişe Blumen auf Demjelben Bweige bereint find, twie überbaupt jedem anderen unter ben mir befannten \$ollenarten fehlt Dicje überbaupt ganj bereinjelt Daftehende Blajenbildung. (E⿱ ift

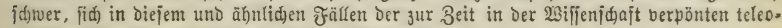
logifden Betrađtungen zu entid)lagen. (2Bergl. S. 125.) 


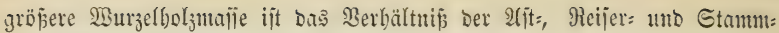
holzmaffe gleid bent ber Fidjte zu feķen.

Dic Belaubung ift in Folge ber breiteren Blätter uno ber fdhim: förmigen Stellung Diejer uno Der Broeige jebr bejchattento, bürfte Der Buche wenig nadjiteben. Die $\mathfrak{B e i}_{\mathrm{f} t a n n}$ verbefiert ben Boben in Demjelben Mafie wie Fidhte unt Riefer.

Die Bewurzelung ift weniger auggebreitet uno wentiger flad als bie ber Fid)te; 3twar feblt eine tiefe Bfablwurzel, ber 23 urzelftod fpaltet iid) aber in mebrere ftarfäfitige, in bie Tiefe bringende Şerzmurzeln. Daher ijt bie Rodung fdjwieriger uno auf ftenigem Boben erbält mant weniger

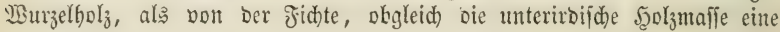
gröpere $i j t$.

Betricb: in 5̧odivalde; verträgt nod) am bejten plänterweije $B_{e}=$

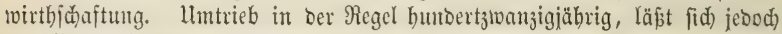

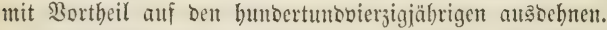

Fortpflanzung: Durd) Duntelidbläge, im ?fllgemeinen nad) Den

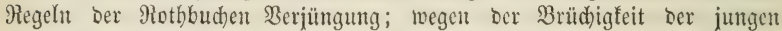

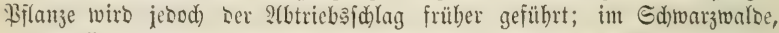

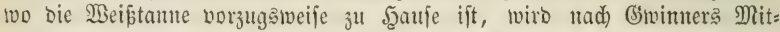
theilungen Der Şicb in bie Saftzeit bis zum 2lugnit bin weridhoben, um

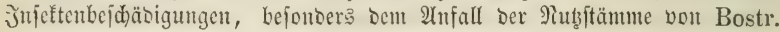
lineatus vorzubengen. 3um ?(nbau werben bie \$flanjen meift in geif)üh: ten Pflanzfämpent erzogen, uno in 3-5 Jahrent womöglid) mit bem \$flanj= bohrer ober bod nit bem Ballen berpflangt.

20пubुu cignet, Dod) bon nod) geringerer Danter als Das Jid)tenbolj. Starfe Stämmte

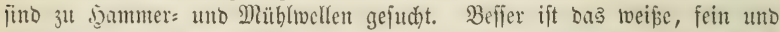

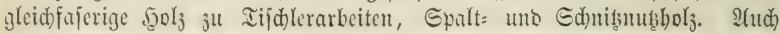

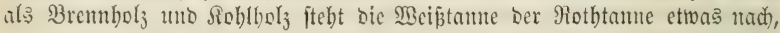

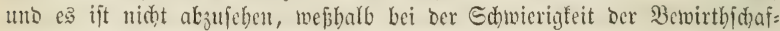
tuntg erftere vor ber leşteren ju begünjtigen fein follte, wo nidjt 3mecfe

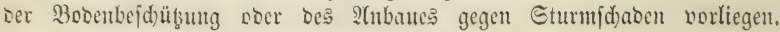
2tus Rinbebeuten wiro Ierpentin getwonnen.

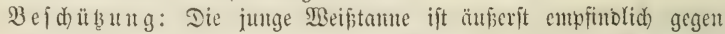

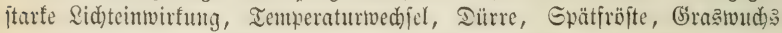
unb unt mit groper Eorgfalt ju erziefen; aud miro fie mebr als bie

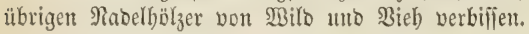

\section{Dic $\&$ ä $x$ d)e, Larix europaea Dec. (Pinus Larix Linn.)}

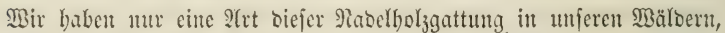
uno and bieje finoet jid) nidet cinbeimija), fontern bier uno ba in Folge fünftliden $\mathfrak{A n b a u t s}$.

Die Błätbe erfcheint Enoe 2(pril, gleidzseitig mit ben Blättern, auß ben bidên Ecitenfnojpen ber ztwei= uno breijäbrigen Tricbe. Die männliche Blüthefunipe fann man fdon im Minter an ber runben Form uno an ter bis in bie Epibe gehenden kraunen Bejduppung erfennen; die weib: 
reinigentoen Sd)uftes zum 9 (ntbat im Mittelivaloe als Dberbol empioblen trorben ift. Den Bosen beffert bie Särche wentger ala bie übrigen शabel= böljer, nid)t in Folge geringeren jübrlichen Saubabfalles, ber in ber Ihat

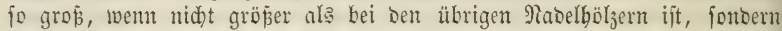
in Jolge geringeren Bobenfdubses und rajderer 3erfeşutg ber bünteren Mabeln.

Die Bewurzelung ift in Der Jugeno tief, vom 30iten Jabre ab bilben fid) bie Eeitentwurgeln mehr aus. (Eine eigentfide \$fahlwurzel bat

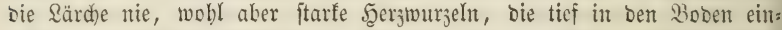

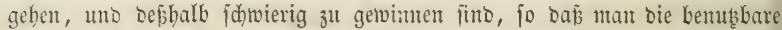
Stodfbolzmenge nidjt über $12-15$ \$roc. anjełent fann.

Betrieb im 5odiwalde, aud) im Mittelwalde als Dberboly. Dic

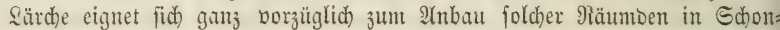

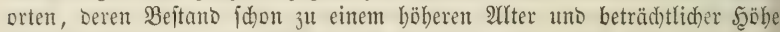
berangewadjen ift. In lücfigen Bubdenorten, wie foldhe nod) bäufig im 30-40jäbrigen 2(Iter fïd) vorfinben, fant bann bie Särd)e mit ber Buche

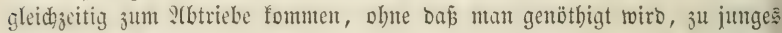
$50 l_{3}$ in 5jeb zu bringen. Sinten böher als 60jährigen ltmtrieb würbe id

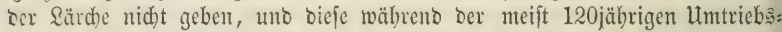

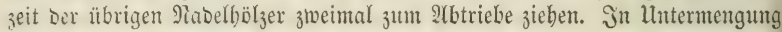

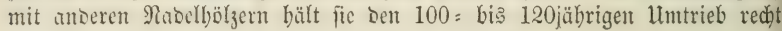
gut aus.

Jortpflanzug. Wegen des meift nod theuren Gamens wiro bie

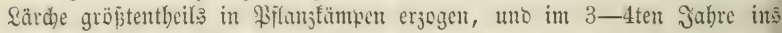

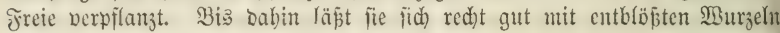
berpflanzen, fpäter forbert fie einen Ballen.

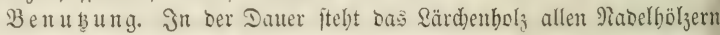
voran, uno gibt bei groker Sdyffllänge ein febr gutes Bautholy, jebod nur in jujwäd)eren Eortimenten. Eebr gcjudht if̣t es zum Edjiffbau un zum

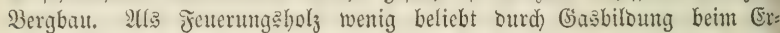
wärmen unt Das Darau herborgehende Prafieln unt Fortipringen ber

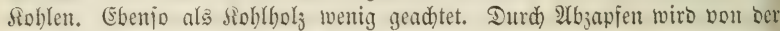
Särche ber benetianijhe Terpentin getwonnent.

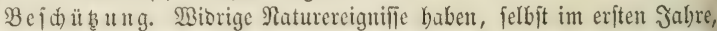

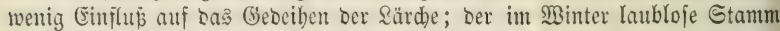
lcibet wentig vou Єdnecorude uno Sturm, bie tiefe Bemurzelung hinbert bie

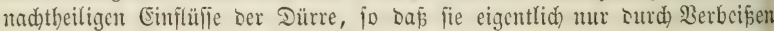

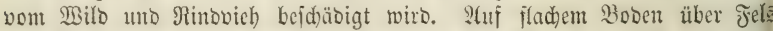
ober Thonllager werben bie Etämme bäufig vom WBinbe gebrüaft uno bann am Stammentoe fäbelfrumm. Geit 1845 leibet bie \&ärd)e an einer frebs:

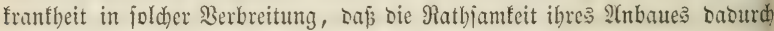
zmeifelhaft wiro. Heber bie Sniftent ber Särche vergl. 3๖. III.

\section{Die Riefer, Pinus.}

Mir baben in Datutjalano fünf verjojiebene Arten biejer Gattung: bic

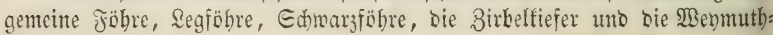




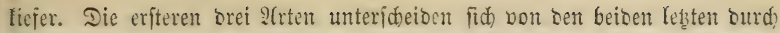
bie 3ahl ber bon einer Edeibe umiblolienten Nabeln, weldhe bort 2, bier 5 ift. Inter ben zweiblättrigen Siefern unterid)eibet fid bie gemeine fitefer surd) ifre gejtielten, abwärts Doer zur Seite gebogenen, zur Reifezeit grauen, bei ber Edivarzföhre ftrohgelben 3apfen, von ser Edwarzföhre aup̃ertem surch bebeuteno fleinere, zugefpiz̧tere Bapfen uno surd, fürzere, beller grïne,

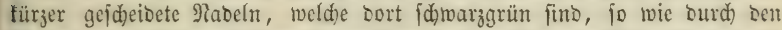

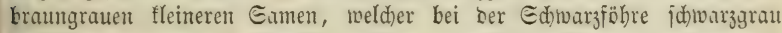

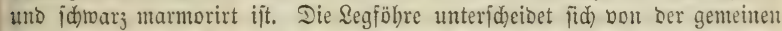
mo Edhwarjföhre nidht allein burdh bie an Eeitentrieben bäufig iehlenoen

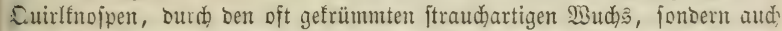
curch Den Gamen, Defien flügel nicht über bie boppelte \&änge Des Gamen=

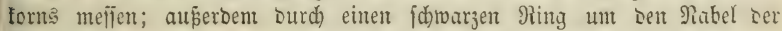
2lpophnle des bis turz vor dor Reife aufgeridteten Bapfens. Unter Den

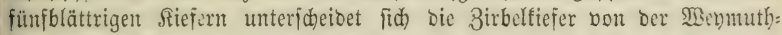
fiefer nidgt allein burdh bie biffen eiförmigen 3akfen uno bie grojen, nu: mit einem slügelrande umgebenten Gamentöner, fonbern aud burd) bie mit rothem Mollbaar filzig befleioeten jungen Iriebe.

\section{a. Tit gemeine fiejer, Pinus (Pinaster) ${ }^{1}$ sylrestris Linn., aud) föfre, fitelnte, Finte genannt.}

Die B Lütben erideinen im Mai, uno ber gelbe männlide Eamen: ftaub wiro mitunter in fo ungeheurer Menge auझgeftreut, Daf er Meran= laijung jur Eage vom Edwefelregen gegeben bat. Die rothen weiblidjen

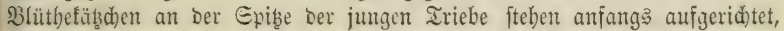
neigen fid aber fdon nadj 8-10 Iagen zur Seite.

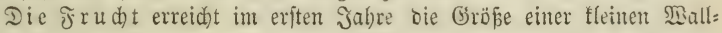
๓иई, wächs im fommenden Eommer vollitändig aus, reift im Dttober; Die 3apfen offinen fid aber exft im März ober 2(pril bes folgenben jrüf)= juhres, aljo 22-23 Monate nad) ber Blüthe und ftreuen ben Samen aus. Diefe lange Dauer ber Jrudhtbiloung ijt allen Rieferarten eigen, Den Iamen

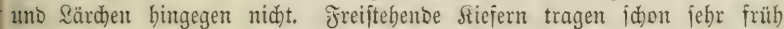
tuuglichen Sumen in Menge, Dft fobon mit Den 15 ten Jahre. In ge: fălofienen Drten tritt bie Mannbarteit mit bem 50jten bis 60iten Jabre cin, etras ipäter auf feuchtem fruchtbarem 3 boen als im trodnen Eande. Ebenjo mad) Serjdiedentheit Des Bobens und Dir Beftänbe fanm man alle 3-5 Jahre

1 Die Riejern mit zmei gladeln aus einer Sdeibe werben in nenerer Beit mit Dom Gattunggnamen Pinaster unterjdjieden bon ben Sief̣ern mit orei gladeln aus einer Edjeide, die Den Gattungsnamet Taeda erhalten. Dieje Bermebrung Der Gattungsnamen ijt bei Den

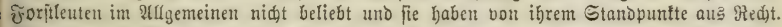

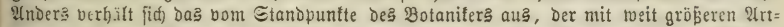
mengen berielben Gattung zu jaajien bat; wenn aber in berjelben Gruppe wie fier 20 , wei=

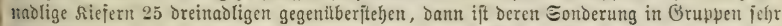
gered)tfertigt unto es erfeidftert ben Umgang, went jede Gruppe ifren Gigennamen erbält,

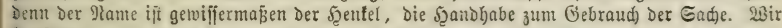
Forftleute, Die wir als foldhe mit gar teinent oreinadligen uno mit einer geringen 3 aht 3 toei= undliger Silejern in Berübrung fommen, mögen bei Dem Gattunganamen Pinus beharren,

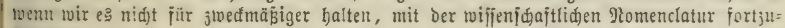
íc)reiten. 
ani ein reidhlides Eamenjabr rechnen; manthe Drte tragen fajt jäbrlids Gamen.

Der Same berbreitet fid 30 bis 40 Sdyritte uno weiter vom Mutter: itumme, je nadbom bie Säume langidäftiger fimb uno bie Suft unrubiger ift. Went ber Boben nid)t allzufilzig verangert ift, bebarf ber Eame nidht nothmentig ciner Bertwundung bes Bobens unb ciner Bebectung, bie aber allerbing Dą Gebeiben ber Eamenfdläge fehr förbert. Der Same bält fich

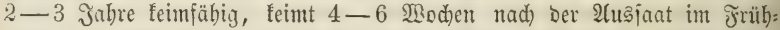
jahre; von älterem Gamen fommen viale \$flanzen erft im folgenten Jrül)= jabre zum Borfajein.

Die junge $\mathfrak{B} f$ lanze bleibt im eriten Jabre febr flein, wiro felten

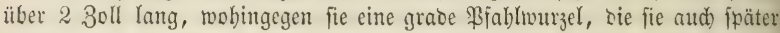
bebält, in Doppelter bis breifader Sänge fenfred)t in ben Booen fojict. Die Siejer mad)t fid) baher früh non ber Jeudtigfeit ber oherften 3Bobenfdid)t umabbängig, indem fie bas $\mathfrak{B}$ affer aus Der Tiefe heraufäebt, Yeibet Daber

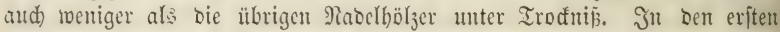
Jabren erträgt bie Riefer mäpige \$3efdattung, verlangt aber fidpon mit bem 3ten bis 4ten Jabre ungebinberte Sidteinmirfung, bebarf Der Befduttung übrigens gar nid)t. Der Jauptibud) iteigt beträdtlid) bis zum 50 iten Jabre uno bält von da ab bis zum 80 iten, auf gutem Boben bis zum 100ften Jal)re ziemlid) gleid)mäsig aue.

Dor St amm mädst in Jreien jebr fperrig, reinigt fid in geringer

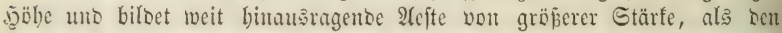

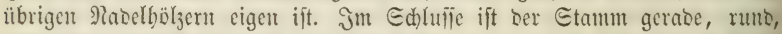
aber wentiger vollholjig alङ ber ber Jid)te, fo ba

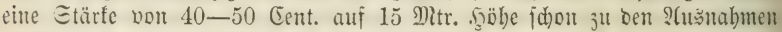
gebört. In 120jäbrigen gefd)lofienen Beftänoen fam man bie Stammbolj= maije auf $72-75$ ßroc. anjeber.

Die frone entbält mehr uno ftärfere 2tefte, alङ bie Der übrigen Plabelbölzer, ift bis zum s0ften Jabre pbramibal mit vorberrichentom Sängen=

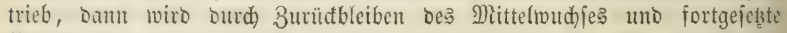
2erlängerung Der Eeitenăfte bie Sirone fdjirmförmig. Die 2(fit = uno Pieifer=

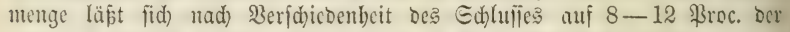
ganjen Scolzmafie anjebsen, worunter 2-4 Proc. Reiferboly ftedent.

Die Belaubung, trok ber Den übrigen Nabelfölzem nicht nad)= ftebenten Slattmenge, bejdattet bennod) in Jolge Der günftigern, nid)t jđhirmförmigen Etellung bes Saubes, nädjt Der Särdje am menigiten. Der Bobenbefferung ift bie Siefer in hohem Grabe föroerlid).

Betwurzelung: Edont bont eriten Sabre ab treibt bie Riefer eint tieje \$iablwurjel, dic fid meift bis in bohe 2l(ter vorberrid)ent erbält; in Den crften Jubren ift Die Entwidflung Der Seitentwurzeln febr gering; erit mit sem 20 jten bis 25 ften Jahre biloen fie fid) ftärfer beraus, fino aber jtet’̧ jebr abboljig uno veräfteln fich balo in bünne Stränge, bie auf (d) lewtem Eanoboben in Singersbide, oft $30-40$ Ed)ritt weit, bid)t unter Der Erbe ausfftreid)en. Die Murzelmenge auf mittelmäp̄igem Soben faun auf 15-20 ßroc. Der Đejammtmafie angejebst werben.

Betrieb mur im hodfwalde umo fothlagmeife, on fid bie Siefer megen 
ihrer Cmpfindlidfeit gegen $\mathfrak{B}$ efdattung uno ibres fojledten $\mathfrak{B}$ udjes auber Єdhlü nid)t für bie plänterweije Betwirtbichaftung eignet. Man fann ohne Derluft an Majie mit rent Umtriebe bis auf 40 Jabre zurüdgeben, miro

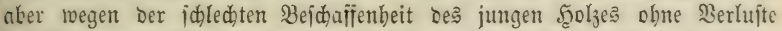
im Gelbertrage jelten unter ben 100jäbrigen Umtrieb hinabgeben sürien. Ier 120jäbrige Umtrieb ift ber gewöbnlidjere zur Bau= uno Siub̧boljerzeu= gung auf gutem Boben.

Jortpilanzung: Durd) Gamenjoläge bei ziemlider $\mathfrak{B i l l f u ̈ r}$ in ber

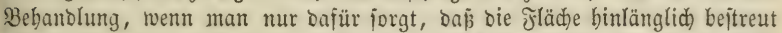
wirb uno bie jungen \$illanzen balo gehörige Sidjteintwirfung befommen, leiḑt

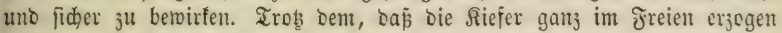

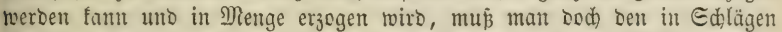
erfolgten Miedermudss nidyt zu plözlich frei ftellen, ba berjelbe burd ben

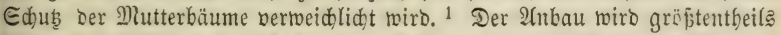
Durd) Saat bewirft, Da fich bie junge Pflanje wegen ber ftarfen \$fahlwurzel uno ber wenigen Eeitentwurzeln fdper uno nur bis zum britten Jahre mit

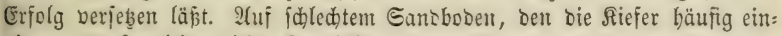
nimmt, bürfent feine bidte Gaatkulturen gemadjt werben, fonbern man mup

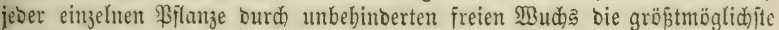
Blattmenge zu verid)afien fudjen, um biejelbe von ber Bodenfrudjtbarfeit mögliçit unabbängig zu maden.

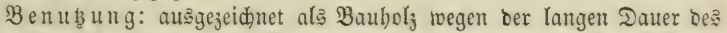

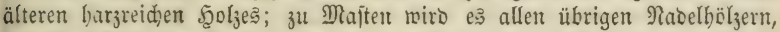

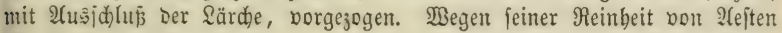

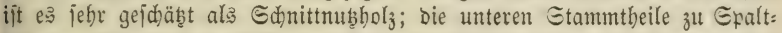
böljern, befonoers zu Ralt: uno Ealztonnenbölzern uno zu Edjindeln. Das Etangenhol 3 3u Baummaterial, Baum=, Sgopfen= uno Bohnenitangen, wie zur Dadjoedung; bie barzreiden Etöfe jur Theeridmellerei uno zur Er: leuchtung.

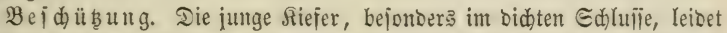
febr boll Duft uno Edjneebrud, Daber fie nidht fürs Gebirge geeignet ijt. Son längerer Berbünmuntg erbolt jie fich bei ber Freiftellung nur ideinbar, mad)t zwar in Den eriten Jabren gute Iriebe, bleibt aber balo im $\mathbb{B}$ udje zurüd und liefert nie einen guten Beftand, wenn fie audi nidht, wie ge: wöbnlich, ein Raub ber Jnjetten wirb. Şre bitteriten Feinbe fino leb̨tere

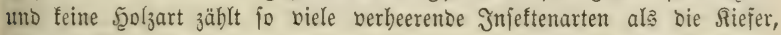
wie aus 3ర. III. bervorgeht.

b. Die $\Xi$ d) marjtiejer, Pinus (Pinaster) Laricio Poiret. (var. austrica Hoess., nigricans Host.), D̈fterreidijidje fitefer,

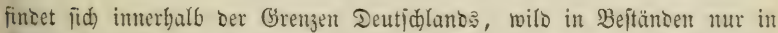
Nieberöfterreid, angebaut aud in Norboeutfoblano, uno unterideibet fich, auper bem bereits 2fngejührten, von ber gemeinen ßiefer bejoncers ourd. ibr: Etanoortabedurfnif, inbem fie nicht mit jo geringen Graben ber Boben= feudtigteit als jene borlieb nimmt, überbaupt aber einen frudtharem Einbentern Boben uno jonnigere 2age jorbert, bejonter: auj Ralfgetirgen

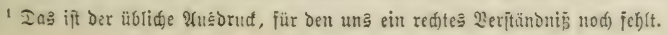


fräftig vegetirt. शäije foll ibr eben fo nadtheilig fein, als Trodenheit. Dis

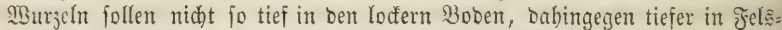
ipalten einbringen uno ben Etanm in böherem Mafe kefeftigen, jo dap Dericlbe aud in Giebirge ben ftärfften Stürmen Wiberjtand zu leiften ver: mag; fie joll, nach Jeiftmantel, in Der J̃ugend weniger raj̧ wachjen,

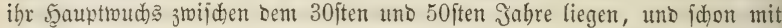
sem 70jten Jabre eine bebeutende Berringerung Des 3utoadjes uno Sid)t=

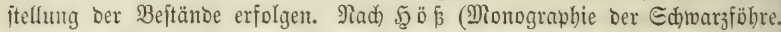
Mien 1831.) berbält fï) Diés anders: Dem 100-120jäbrigen Untrieb wiro Dort ein gröperer Ertrag zugejdrieben als bem 80jäbrigen. Die Edbraarz= föbre zeichnet fich ferner Durch cine febr reiche Belaubung uno Bobenbefferung, jo wie Durd, gröperen Şarzreichthum auझ, womit Dann natürlich eine gröpere Bremfrajt uno Dauer verbumben ift. Das Gerwid)t Des Rubiffupes gibt jeiftmantel in allen Bujtänben um 2 Pijuno böber an, als bas ber gemeinen Riefer.

e. Iit \&cgföhre, Pinus Pumilio Haenke (Mughus Scop.), and) firummholjtiejcr, Siniekoly, 2rlpentiefer gentant.

Eie unterjheibet fï) von allen übrigen fiefern conjtant Darin: Dafs Die Blüthe und die Daraus crwadjenden Bapfen bis jtoei Monate por Der Reife aufgeridgtet fino, ferner Durd) cinen fdwarzen Ring um Den Siabel jebes 3apfenid)uppents. In Der Biloung ber 2(popbrjen treten baun wejent= lide 刃erjdiebenbeiten auf, Die auf Derjelben Bflanze nto in jebem Jabre

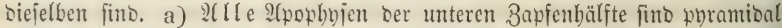
erbaben nno etwas, aber nid)t bebeuteno nad) Der Zayfenbafis bin zurüd: gefrümunt (Pumilio). b) Siur Die Dem Sidte zugefebrien 21pophbjen der Interen 3apfenbälfte jind fonifd) erweitert und febr ftarf zurüdgefrümmt (uncinata). e) Ille 2 powbyfen, aud) dic ber untern 3apfenbälfte fino gleidiörmtig fajt eben (Mughus). $\mathfrak{A} u \tilde{B} e r b e n t$ fomnten nod andere, auf Derjelben Bilanze conjtante, Dbigent untergeoronete Bapjenabänberungen vor,

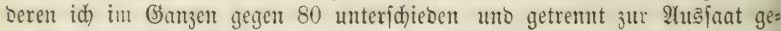
bracht babe. Nach $6-8$ Jahren werben bie früb zapfentragenben, jebst ztwei= jäbrigen, getrent zu erbaltenden Pflanzen ergeben, weldhe Bebeutung ben io aupergetöbnlich gropen Bapfenunterjobieben beizulegen ift.

Ansianat Des Gamens von derjelben Bflanze ergibt \$flanzen bon jebr verjdiedenem Wudje. Am jeltenften find Die Der gemeinen Riefer jebr wabe ftebenoen, einjtämmigen, grabe aufgeridteten Formen. Şäufiger fino Lbramibale Jormen, bei Denten Der aufgeridtete Gdyaftrieb Den Boriprung vor Den Duirläiten zmar nod bebält, lebtere aber jobn von unten a uf io träftig fid) fortbilben, Daß cin foramibaler Straud baraus berborgebt. Durch) viele leije llebergänge, in Denen ber Sdafttrieb immer mebr zurüd: bleibt, ein ober zwei Suirltriebe nabe bem Boben zu überwiegenoer Ent: wicfelung gelangen, biloet fich au Diejer ber eigentlid)e Rniebolzitamm, ber, $1 / 3-1 / 2$ Mtr. rallel Der Bodenoberfläche verlauft uno nur in Den lebsten $5-6$ Jabres: trieben in einer entgegengejebsten Iniebeugung fid wieber aujrid)tet. Heber 


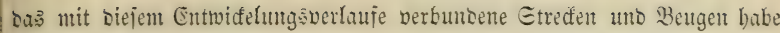
idj) Єeite 304 gejproden.

Mir baben, Da bieje Differenzen im Mudje and in unieren cbenten

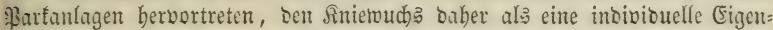

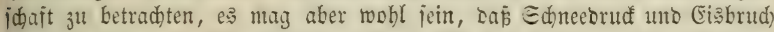

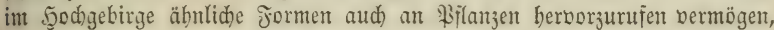
sie obne bieję einen aufgeridteten Stamm entricfelt bätten.

Fie friechenten $\mathfrak{A}$ eite bilsen undurdbringlide Difungen, bic bis gegen

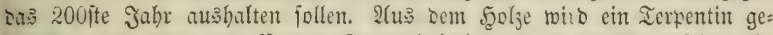
momten, Der unter Dem Ramen Rrummboljöl aud im (jebicht gefeiert ift.

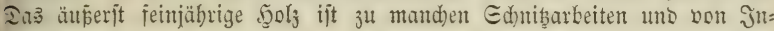
itrumentenmad)ern gejdäb̨t.

\section{d. Die Zirbeltiejer, Pinus Cembra Linn., Cembra sativa, Itrbe,}

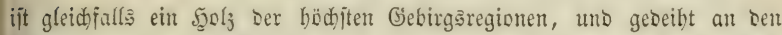
Baumgrenjen Da, mo feine antere Solyart mehr fortfommt; iie ift jebod) an biejen Etunoort nidht gebunben, fonbern jteigt in bie IGäler finab, uno jelbjt in ben Ebenen unjeres nöroliden Deutjalands gebeibt fie red)t gut;

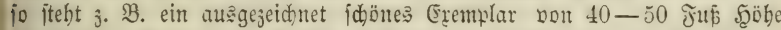
in Berliner Thiergarten, fräftig twachjent unto früd)te tragent. Eic forbert

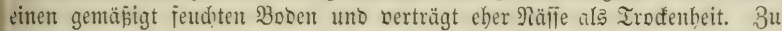

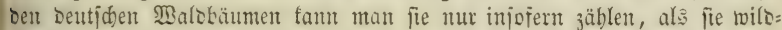
madjend in Tyrol gejunten wirb.

In ifrem jugendichen Werbalten jolf jüb) Die Birbclfiefer, nad) vou $\widetilde{S}$ d) bis zum 10ten Jahre jebr langjam uno bujaig wadhjen, Eduts verlangen

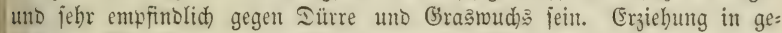

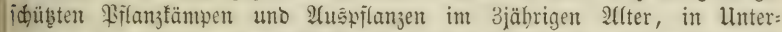
mengmig mit Fideten uno \$seiptannen, wird empiohlen. Ier Game, im jrïbjabr gejäet, liegt ein jabr über, was um jo merfmürbiger ijt, ba iớ)

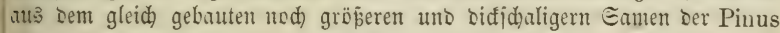

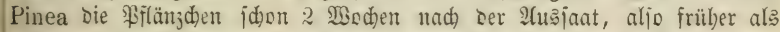

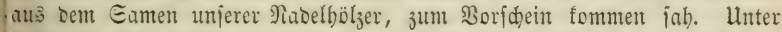
2 अiuno Birbelnuifien, bie id im vorigen Jabre erbielt, fant fid fein

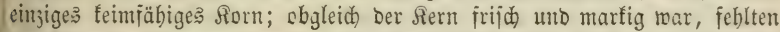
Die Seime im Eamen gänjlid, an beren Etelle eine leere Janut von Der

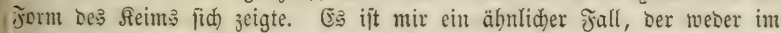
2llter bes Eamens nod) in Mangel ber Befrudung jeine Urjade baben tuun, nod nidłt vorgetonmen. Man prüfe baber ben auşzujäenten Gamen

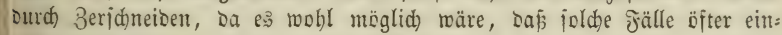
treten und biejer Şolzart eigentbümlich finto.

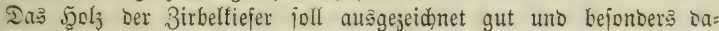
ourd, ju Mäbeln gecignet jein, Daj jein (jerud) ben Jnjetten fehr zumider

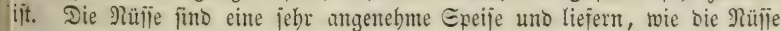

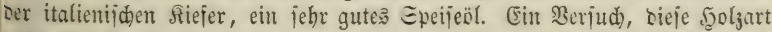

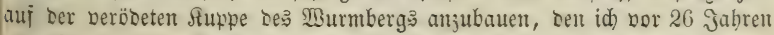

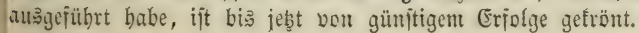


e. Die Weimuthfiefer, Pinus Strobus Linn. (Strobus virginiana),

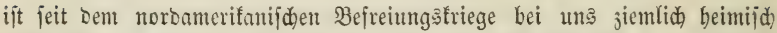

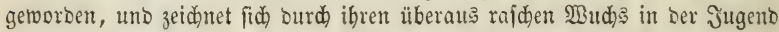
vortheilfaft aus; bis zum 40 jten Jabre erreidht fie auf tiefgrünbigem, leh)= migen Canto = ober fanoigem \&ehmboden mitunter eine Şöhe von 20-24 Meter, und eine Stammbife bon $1 / 3-1 / 2$ Meter. Bei biejem rajden

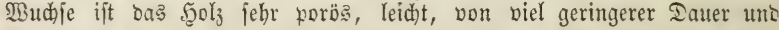
Brenntraft als bas ber eintheimifhen Nabelfölzer, inbem es weniger reid

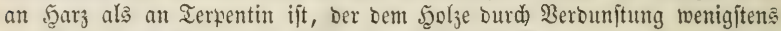
theilfweife entweidyt. Bum Berbauen in Dadjtüble bürfte $e^{2}$ wegen feiner

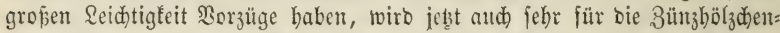
Fabritation gefud)t. Die Mambarfeit tritt fehr früh ein; 20jäbrige Stämme tragen oft fidon feimfäbigen Gamen in groper Menge. Ser Same reift jdjon im Eeptember uno fällt gegen Enoe bes Monaț aus. Die junge Siflanje forbert zwar zum fräftigften Gebeihen ungebinberte Sidteinwirfung, Dod) fiebt man auf einigermajen lideten Drten in ben 2 Beimuthtiefer:

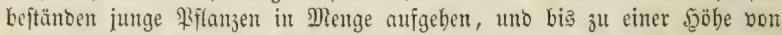
4-5 Jū red)t frentig berantwadjen, fo bā fie meniger empfinolid gegen Beidattunty als bie Riefer zu foin fajeint. Bỉ jeb̧t ift ibre frortpflanzung

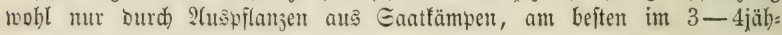
rigen Alter, betrieben worben.

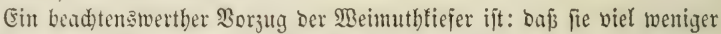
als bie gemeine Riefer von Injeften bejwäbigt wirb, sa fie bie ibr eigen= thümliden Snjetten in ihrem saterlande zuridfgelafien bat; nur eins ber: jelben ijt ihr gefolgt uno jwar Coceus Strobus (Jahreaber. I. 4 S. 643), weld)es Die Stämme uno 3weige oft in jo ungeheurer Menge bededt, on fie wie mit Ednee befallen fheinen. Unter Den einheimifhen Injeften idabet bie Raupe Laria dispar ourd) Entnabeln wenig, fo wie einige Borfentäfer Der Riefer fid bierber verirren.

\section{¿lweites Sapitel.}

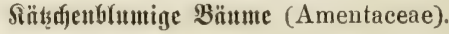

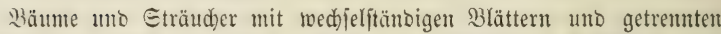
(Befidledtern, theils auf eintem, theils auf veridjebenen Stänmen, bie Familien 5-12 ber vorftebenden Ennotfis umfafient. Die weiblide Blume

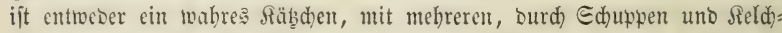

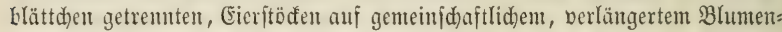
booen, Der fräter jum Frudtboon wiro, mie bei ben Birfen, Erlen, Meiben, Bappelu, bei bem Dornbaum uno ber Sgopfenbude, Doer fie beftebt alls einem ober mehreren Eierftöfen mit anfïizenter Siarbe,

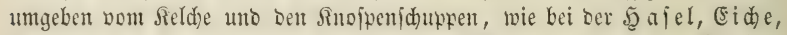

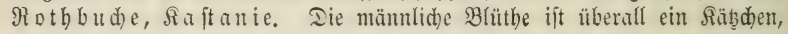
3wijden befien Sdukpen die freien Staubbeutel, zwijdent mefor ober wentiger Seldiblättchen, biejen angebeftet finto. 


\section{1. Ėi ḋe, Quercus.}

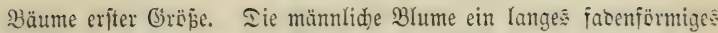

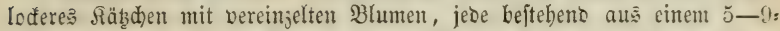

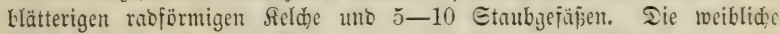
Blume ift ein mit einem \$erigonium verwadiener Fntulfnoten mit zwei: oier oreitbeiliger Narke, untgeben bon einem rothen Seldhe, zu 1 bis 4 entweber an einem berlängerten Stiele ober gehäuft in ben Blattadjicln

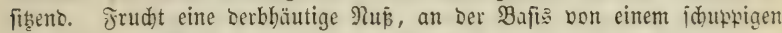
becherförmigen Reldhe umgeben uno getragen.

Wir fennen in Deutjallanos Bälbern nur brei veridiebente Eidens arten: Die Iraubencide, Stieleide unto bie Zerreide. Bei ser Eticleide fino die Blätter ganł fabl, bei ber Traubeneidje mebre oder weniger

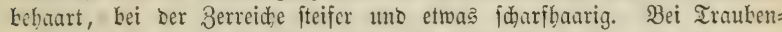
unto Berreide ift bie Blattbafis eben, bei Etieleide fraus. Bei Irauben: uno 3erreiche fino Blumen uno Jrüdte fibeno, bei ber Etieleidhe auf ver: Yängertem Etiele vertheilt. Bei Trauben: mo Stieleide ijt bas frud)t: bed)erden mit Elcinen anliegenden Eduppen befleibet, bei ber Berreide fint Dieje Eduppen zu langen 3otten auşgezogen. Bei ber Etieleidye ftehen Lie waljigen Rarben auf verlängertem Griffel; bei ber Traukeneidhe liegen

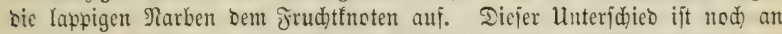
Ien reifen früdten $3^{\mathfrak{u}}$ erfemen, bejonoers an ben vorjeitig abgefallenen, bie man unter älteren Bäumen zu jeber Jabrȩ̧zeit auffinon fam. Trauben= uno Etieleidhe baben einjährige, oie 3erreidhe bat jweijäbrige Frudtreife.

Die Botanifer ftimmen gegentärtig barin überein, Daß̧ Quercus pubescens Willd. nur cine ftärfer behaurte form ber Q. Robur iei, melde Seb̧tere, je weiter jüblid, um jo bäufiger uno reidhliąer bebaart jei.

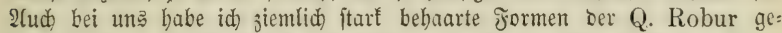
funcen, meift beiduräntt fich ihre B:baarung im nörbliden Diutichland auf

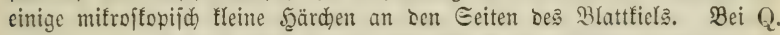
pedunculata babe ich felkit biefen geringiten (Brab Der Bebaarung nie auf: gefunten. Ulebergänge im Blütheftante fommen bingegen vor, wabrichein: (ic) Bajtarbbilbung.

a. Iie Etieleid)e, Quercus pedunculata Ehrh. (Robur Linn.), aud) Eommercide, Frübeidje genannt.

B \üthe. Anfang Mai, meift nod) bei nid)t vollitänbig entwidelter Belaubung.

Jr $\mathfrak{u}$ d) t. Die befannte, hier geftielte, bei ber Traubeneidhe faft fiel:

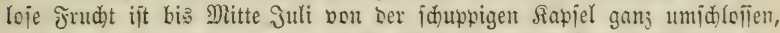

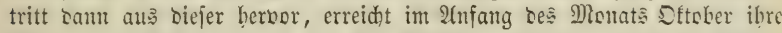

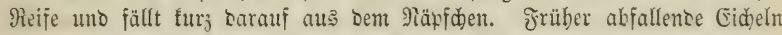
fino ungeiuno uno feimumfäbig. Jreiftehende \$ilanzen uno kejonbers Etcơ:

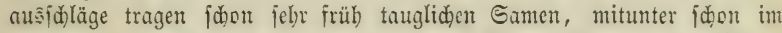
Ireipigiten Jahre; Gamenlobent im raumen Pflanjwalse uno im Mittel. malbe erreiden ibre Manubarfeit jelten vor ocm jedjigiten Jahre; mentig:

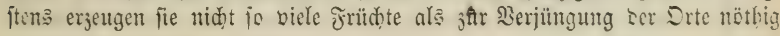


ijt. Jint gcid)lofientn Beftande tritt bie Berjünguntgäfähigfeit bes Rern=

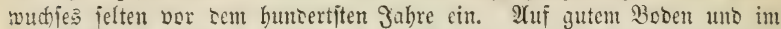
niloen flima tann man alfe $3-4$ Jahr, unter ungünfitigen Stanoorts: verhältniffen alle 10-12 Эabre, auf ein reidhlides Samenjabr rednen. Ein= jelre Manbpflanjen tragen jaft jäbrlich fo viel Samen, als man zur $\mathfrak{B} e=$ ftellung ber \$flanżämpe nöthig bat.

Der Same verbreitet fid wegen finer Edjwere nur wenige હdyritte von ber Sdjirmfläde be Mutterbaumes, verlangt eine Dede von \&aub ober Eroe, wenn er währent beş Minters nidgt vom frofte leiben jolf; bält jid nur bei jorgfältiger 2 uffbewabrung bis jum nädjten Frn̈bjabre feimfäbig uno feimt nađh Der ફ̧erbitjaat fehr früh im Jabre, mitunter fợon

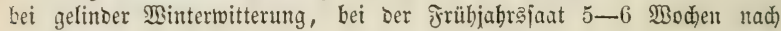
ber $\mathfrak{U}$ uajaat.

Die junge Pflanze läpt bie Rernftüfe in Der Crbe zurüf uno

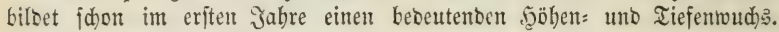
Unter günitigen Berbältnifijen twirb ber Stamm nidjt jelten 20 Cent. lantg;

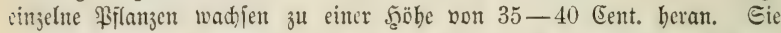
ift Daher gegen (sraşwud) Dürre nidht jehr cmpfindlid) uno leioet am meiften burd Serbeifen nom Millo uno $\mathfrak{B}$ ieh.

Stammbiloung. Die junge Eide zeigt fdon in ber früheften

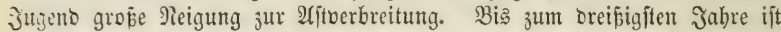
Ler 2 unds jebr langjam, fo baj man jelbjt auf gutem Boben in gejdjlof= jenen Beftänoen jelten Stämme über 0,03 Ebmtr. 5goljmalfe fintoet. Einen

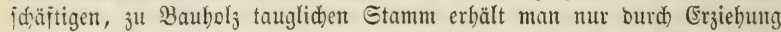

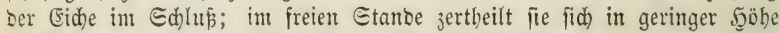
in Iejte uno legt an bieje ien gröpten Theil bes Buwadjes auf. Jm

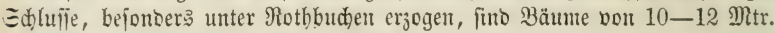
Edhaftlänge nid)t jelten. In geid)loffenten 120-150jäbrigen Orten famt man sie Etammbolzmaffe auf 60 Proc. Der gefammten $\mathfrak{y}_{0} l_{3}$ erzengung anfeţen.

Sinuenbiloung weit verbreitet, Ferrig, mit bielen ftarten, flads:

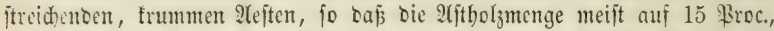
worunter mu 4-5 Broc. Reiferboly, angenommen werben fann. In Jrein erwadjen, jteigt bas 2 (itholj nid) jelten über 20 Froc. Der Ge= jammimajie.

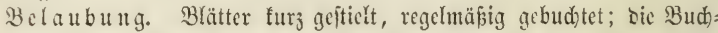
ten Dringen, vom Llmrifie nadh ber Mittelripte hin, nid)t bis zur Şälfte

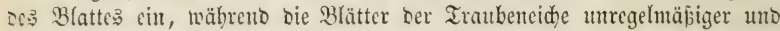
oft biß über bie Mitte Der Blatthälfte eingebudtet finto. Die Siclaubung ijt gering; bas Blatt jerjeţt fich rafd uno bie frumuserjengung ift babev viel geringer als bie ber Rothlud). Die Etellung bor Blätter ift untregel= mäpig, Küijhelförmig, mehr bängento uno niçt io fohirmförmig twie bie bes Budfenlanbes, Daber bie Eidje meit meniger als bie Buche keichattet, jo

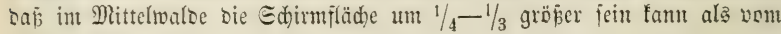
Budenoberbaum.

Margelbiloung. Eăn in erfen Jahre bringt bie junge Eide

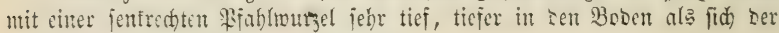


Etamm über semjelben verlängert. Tie 3ahl uno Etärfe ocr Eetten= wutratln ijt bingegen jebr unbeseutent. Ticie Murzelbiloung bleibt bis jum

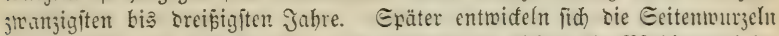

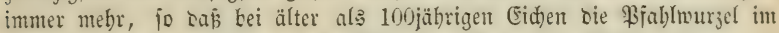

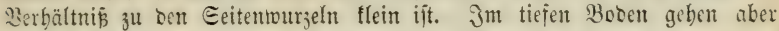
and sie Seitmmurgeln 2-3 Deter tief ein. Die MBurzelbilcung ser jungen (Eide madht cs nothmentig, die zum Berpflanzen beftimmten Sodut und Jeijter burd Umjeben nad) erfolgtem Beidneiben berjelben, jur Entwiffes lung einer gröperen Menge von Eeitentwurzeln zu nötbigen. Man fann it Den meiften Fällen bie $\mathfrak{B}$ urjelholzmenge 120-150jähriger Bäume uno $B_{i}=$ itänoe auf 20-25 ßroc. Der Gejammtmalie anjeţett.

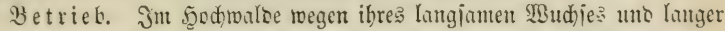
IHșauer getoobulid im 150jährigen llmtriebe, mehr in Mentgung, bes

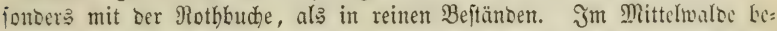
ionters als Dkerbol $\}_{3}$; meniger als Unterbol wegen ibrer Emprintolid)teit gegen Bejdattung. Im Nieberwalbe, bejonders an fladgrünoigen Eommer:

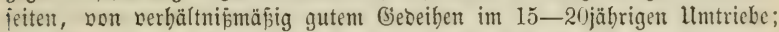
jur Benuţung oer Epiegelrinbe in Edälwaloungen in 15: biङ 20jäbrigen llmtriebe. Ala Ropiboly liefert bie Eidhe zwar fräftige Iriebe, ber Etamm miro aber balo fernfaul uno hohl. Befler als Edmeioclboly.

Fortpilanz un g: Durd) natürlide Bejamung ntamigfaltigen Ed)mi: rigleiten unterworfen bei bem lidhten Etande Der meiften alten Beitünde,

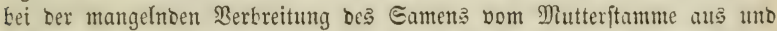
Lei bem jebr früh eintretenton Sidtbebürfnifie ber juntgen Eamempilanje, moburd cine jehr bunfle Eamenjolagitellung uno baloige ftarfe Sidtung nththwendig wirb, bor fid häufig bie शothwendigfeit cinter haushälterijden

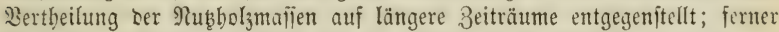

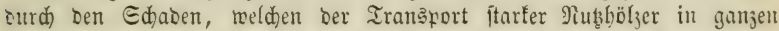
Etümmen aus bem Jungholje veranlapit. Daher meift fahler 2lbtrieb uno

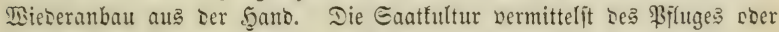

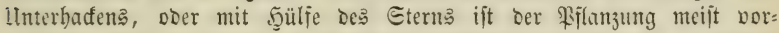

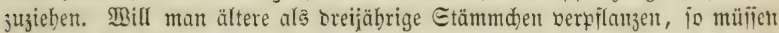
bieje in $\mathfrak{B}$ flanżämpen bazul porbereitet werben.

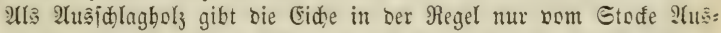
Ifläge, Der jebr tief an ber Eroe herborbridjt, baher bie Etödi tief ges

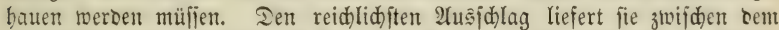
jtoanjigitent uno oreipigiten Jabre; bod fann mun fie aud nod im 40jäb= rigen llmtriebe mit Erfolg bebanoeln.

Benuвung. Wegen ber langen Dauer De马 Solzes ift bie Eid)e bejon=

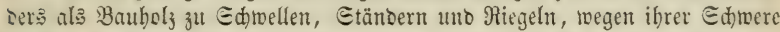
meniger $3^{\text {ll }}$ Balfen uno Eparren gejudt. Borjüglids ift fie für bon Ed)iffis:

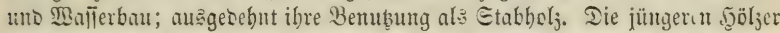

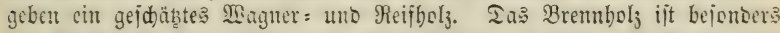

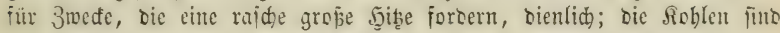

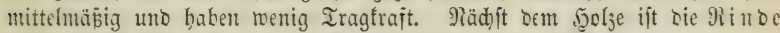

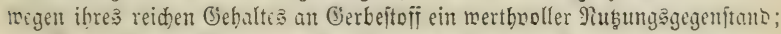

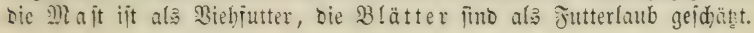




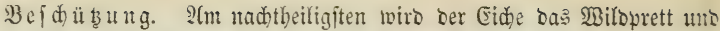

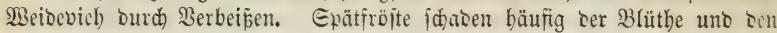
jungen feimenden \$rlanzen; SBintertälte Dem unbedeçten Eamen. Eräter ift Die junge (Eidje gegen Jroft uno Sitze, Dürre uno Brasmuds, Duft unt Edneeanthang ziemlid) unempfinolid); aud leibet fie ivenig oon jn= feften; Widferraupen, bejonters bie ber Tortrix viridana, bie \$rocelfitons raupe, Der froftiờmetterling uno Der Maifäfer entlauben bișweilen bie $B_{\ell}=$

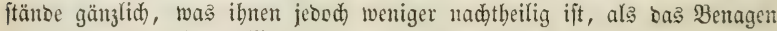

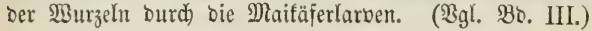

b. Iic Iraubueid)e, Quercus Robur Roth, aud) Mintereid)e, Steintide, Bergcide genannt.

P(up̃er Dem bereits 2 ufgeführten unterideibet fid bie Traubeneidie

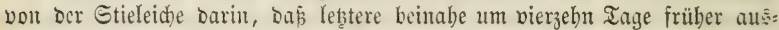
grünt umb blübet, währento bie Jrüd)te int Seerbjte faft gleidzeitig reifen, wef̧halb sie Meinung: „Daj bie Etieleidye wegen früherer Eamenreife mehr. fïr biebirge uno norbifde (begenden geeignet," fidh nid)t redtfertigen läpt, inbem Der Same ber Iraubeneid)e erfabrungs̄mäpig aud) im Gebirge immer nod) jeitig genug reift, un bie fortpflanjung zu vermitteln. (ङ. 33. I. S. 47.)

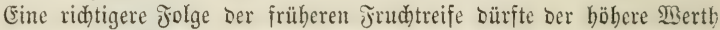
ber Etieleidje als Majtholy fein, Da die Maft wegen bes früberen $B e=$

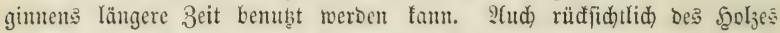
gibt man Der Etieleidje Den Borzug, Da Daffelbe zäher uno elaftifher ift

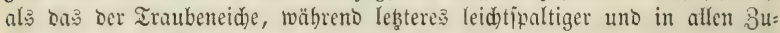

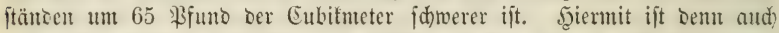

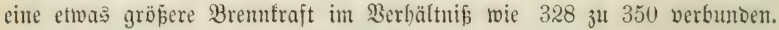

Die Belaubung Der Iraubeneid)e ift weniger büfđelförmig, gleidmmäpiger wertheilt, als bie ber Sticleiche, beidattet baher mehr, uno twüroe befhalb bie Stieleide im MRittelwalde ben Borgug verbienen.

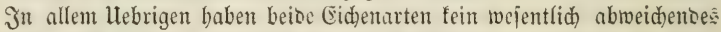
গerbalten, uno gilt bas, was id von ber Etieleide gejagt babe, für beibe.

\section{c. Die biterreidijd)e (Eidfe, Quercus Cerris Linn. (Quercus austriaca W.)}

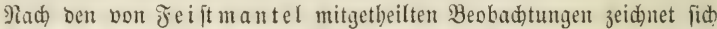
Dieje (Eid)e Durd) jebr groje, im Ditober reifende Jrühte aus. Bei den

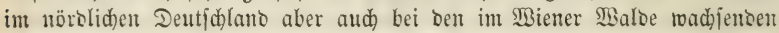
3errcident finto bie ơrüdte nidht größer als bie ber vorgenannten (Eid)en,

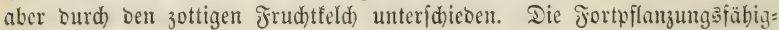

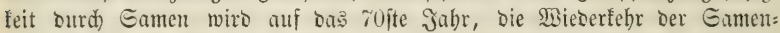

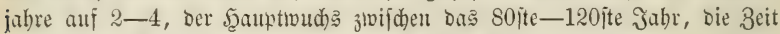

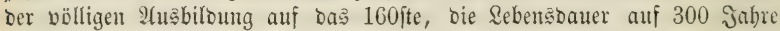

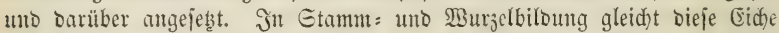

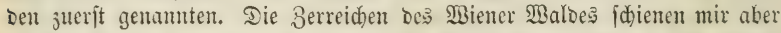

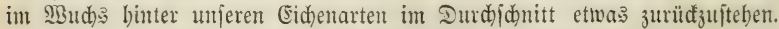
Dic fteiferen, fajt leberartigen Blätter fiţen in biḑten Büjueln bei ein= anber uno bürften ber bumuझbiloung förberlider jein als bie unjerer Eiden. 


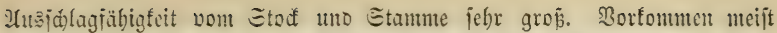
in Lintermengung mit Der Rothbudhe, felten in reitten Bejtänoen unb bann

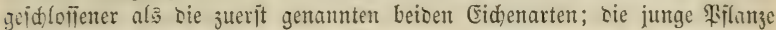

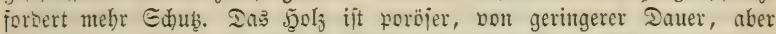

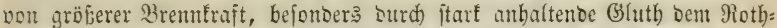

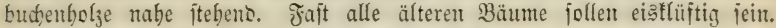
Die Jrüdte brauden zwei Jabre bis zutr Reife. 1

\section{Rotbbude, Fagus sylvatica Linn.}

Błätbe. Die mümlide Blüthe ift ein faft fuglides Sïbden an langem Stiele; Dic Reldhe Der einzelnen Blüthen 5-6theilig, mit 10 bis 15 Etaubjäoen. Weiblidłe Blüthe, ençtänbig an langem Blumenjtiele; in niertbeiliger Şülle zwoi Cierftöđfe, jeber mit brei langen fabenförmigen शarbent. Blüthezeit im Mai bei voller Belaubung.

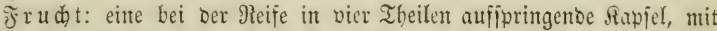
jmei breieçigen Jrüdten - Budjecfern. Reifejeit Enoc September uno 21n=

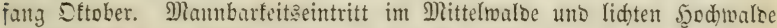

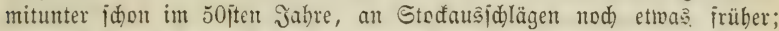

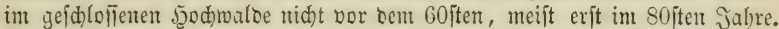
In rubbem Rlima fanm man in ber Regel alle 4-5 Jabre ein Eamenjabr ertorten, im miloen Sllima tritt joldes mitunter nur alle 10-15 Jabre eirr.

Same: fällt im Eftober aus uno bebarf ciner Bebectung Durd ¿aub ober Crobe, went er ben Minter nidft vom Jroite leiben joll. Die Natur gibt ifm bieje ourd Das jhäter abfallenoc Saub; bei Rulturen erbält er

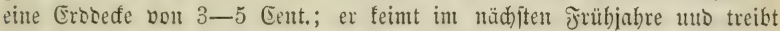

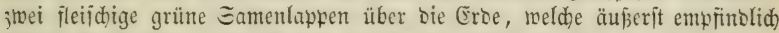

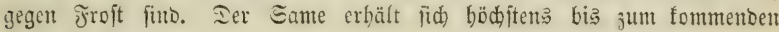
Jrübjabr feimfäbig.

Die junge Bifanze erjojeint aus bem im Serbíte gefäeten Gamen

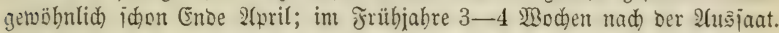

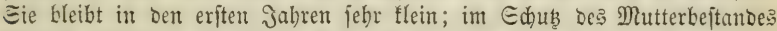
wiro Der Etamm im erften Jabre felten über 8-10 Cent. lang. Iie Wifablwurgel bringt tiejer cin und entwicfelt in ben erften Gabren nur menige Jajerturtzeln, gar feine Seitentwurzeln.

Der $S_{t a m m}$ berbreitet fid in freien Gtande meit in bie Yefte und reinigt jĭh mu auf $3-4$ Mtri; im Edyluije bilbet er einen jebr voll= boljigen, mitunter über 20 Mttr. aftreinen bodjtämmigen Edaft.' Bis jum

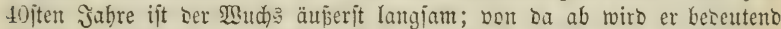

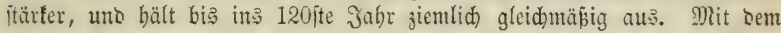
140 ften Jahre fangen bie Beftänbe an, lüdig zu merben; nad) bem 150 iten

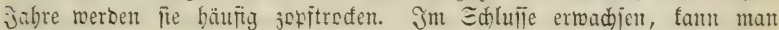
60-65 Broc. Der ganjon jolzmaile cines Baumes als @tanmbol; an= nebmen.

Die frone ijt im freien Etanoe jebr weit verbreitet uno reagclmäpig

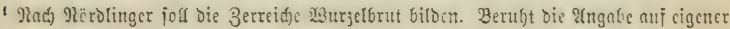
Beobadatung?? 


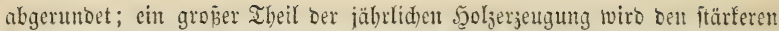
Yeitell aufgelegt, ooch nicht in eben bem Mape, wie bei ber Eidhe. Jm

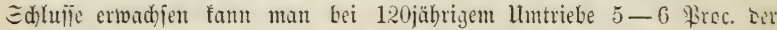
5oljmalie auf fiärfere, S-10 \$roc. auf idwäd)ere Sefte mo Reijer redntm.

Belaubung. Da bie Jahreştriebe regelmäpig mehrere Blattachiel: fnoipen zu belaubten Geitentrieben außbilden, bie Sebens̄ouer bar Bradu= blafte eine lange, Daher bie intere Belaubung Der Frone cine reidhe, ift bie Saubmenge jehr groß́, uno bie Bejd)attung wiro Durd bie füd)erförmige Etellung Der Geitentriebe, wie Durdh Die fefte Etellung ber Blatifläd)en zum Sid)te jebre grós, io báp feine andere unjerer Syolzarten bie Buthe bierin übertrifït. Durd bie grope, jäbrlich abfallente Blattmenge uno beren lang= fante Berjetzung büngt bie Budye Den Boben reidhlid.

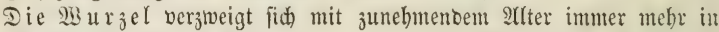
itarfe, flach ausftreidjende Geitenäfte, wäbreno bie \$iablwurzel im $\mathfrak{B u c h j e}$

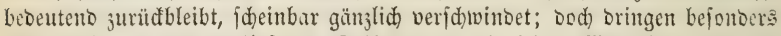

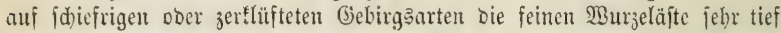

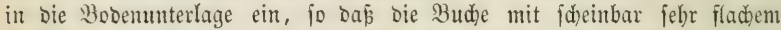
Boben vorlieb nimmt. Die Stodholjmafie baubarer Bubbenorte faum auf 20 bis 25 ßroc. angejebst meroen.

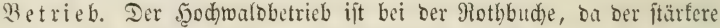

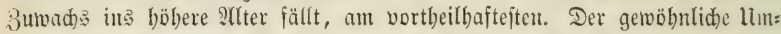
tricb ijt Der 120jäbrige, auj jebr gutem Stanoorte ber 100jäbrige; jelten iit er auf 140 Jahre verlängert. Jm Mittelwaloe twäd) bt bie einzelne \$flanje

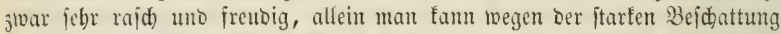

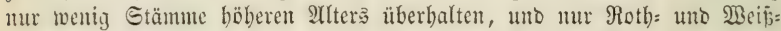
butdemunterbols verträgt eine Bejdirmung volu $1 / 2$ ber Fläche, bejonders

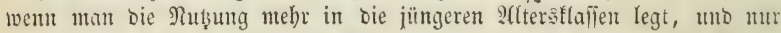
wenig altes şolj überbält. Im Rieberwalde uno als Unterbols in Mittel= malde ift bie Rothbude weniger empfeblenblverth wegen ibrer geringen

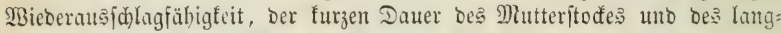

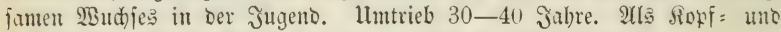
Educiodhols ift bie Rothbud)e nod weniger empfehlenswerth.

Jortpflanzung: vorzugsweife Durch Dunfelidläge, da bie junge

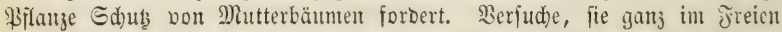
Durd) If nfaat fortzubringen, fino zwar bin uno wicber unter günitigen Etandortäverbältniffen geglüaft; Der glüđflide Erfolg iit aber zu unfider Durd) bie (Empfindlidfeit ser Gamentappen gegen fraṕ, bei Dem lamgen

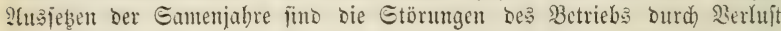

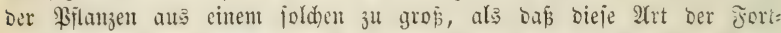

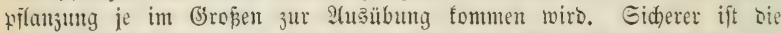
Sultur burd) Brlanjung. 2tm bejten fodlägt bie Pflanzung orei= bi

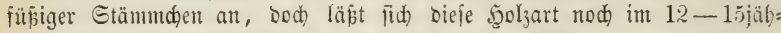
rigen :Alter jicher berpflanzen, wobingegen die Bilanjung 2-3jäbriger Etäumment weniger fider als bei ben meiften ber übrigent Syolzarten ift.

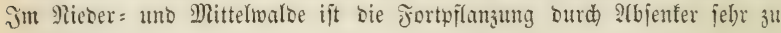
cmpreblet.

Der Şicb im Rieberwalșe tum ipät, nod in bar Eaftzeit geführt 


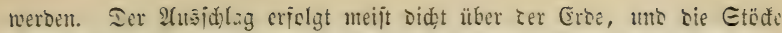
werben baher tief gebauen. Iod vertrügt bieje Solgart mehr als ansere cinen bohen Etoufieb. Eđjon mit bem britten Siebe werben bie Mutter:

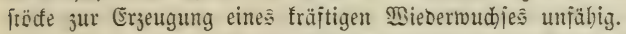

Benu bu ung. Begen geringer Dauer ift bie Bude als Baubols gar

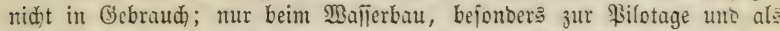

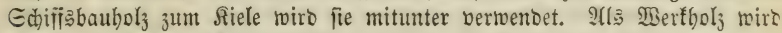
Tie fajt nur зи Budbbinderipäbnen, Felgen uno einigen anbern Magner:

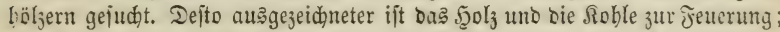

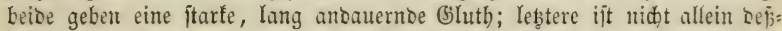
balb, fonbern aud wegen ibrer gropien Iragfraft für ben Şüttenbetrieb

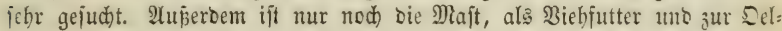
bereitung, S̉egenftant einer Rebenmuşung.

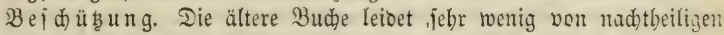
Einflüiflen. Die Blütbe leibet mitunter von Epätfröjten. Den jungen

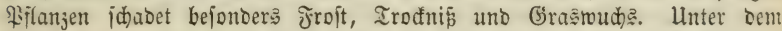

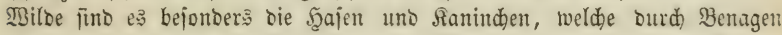
ber jungen Stämme oft jebr füblbaren Edaden anriohten, in Eamenij)lägen mit jungem 2ufidlag uno ftarfer Saubjojid)t thut mitunter bas Edwarj: milo burd Bred)en beträthtlichen Edjaben. Eehr nachtheilig werben häufig

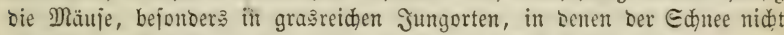

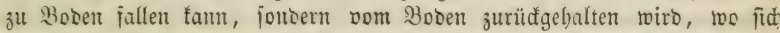
Dann bie Mläuje ber ganjen Ungegeno unter ber Edneebede зujammen: jieben uno bie Etämmdjen benagen. Unter ben Snfeften idjabet bejonder: ser Maifäjer burd Benagen ber Murzeln. Die 3abl ser auf bie Buche angeniejenten Injeften ijt jebr gering; sie Raupen einiger Epanner, ser Bombyx pudibunda uno Tau fommen mitunter in grȫerer Mienge vor; Lod) nur erftere baben in jungen, 1-4jäbrigen Ecfommger. bis jeb̆t fühl= baren Edaben gethan.

\section{Birte, Betula.}

Mämnlidye uno waiblidye Blüthen getrent auf einem Etamme. Die

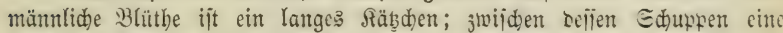
einfache Blume mit 6-12 Etaubfäben. Meiblide Blüthe ein Siätiden mit breilappiger Edumpe uno Drei Frudjtfnoten, jeder mit jobei faben:

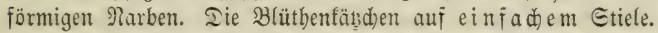

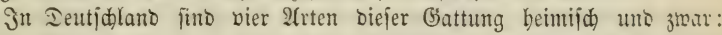
Betula alba, pubescens (odorata), fruticosa uno nana. Die beicen

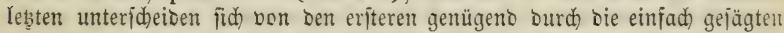

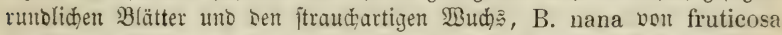

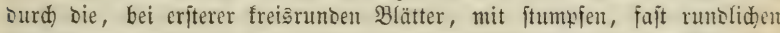
Gägejäbnen, welche an ben länglich eirunben Blättern ber leb̨tern 24rt edtig cmoen. B. pubescens unterideibet fid von B. alba Durd) bie Bebarang ber Blätter, Blattitiele uno jungen Triebe wie burd) ben Mangel ber wadts:

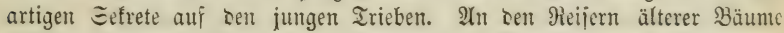
erlijht allerbings einerjeits bie Bebaurung, andererieits bas Eefret, allein ait älteren Bilanzen tritt ein Untericheioungsmerfmal in ber Borfebilsung 


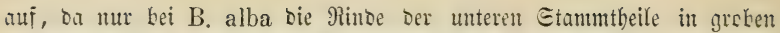

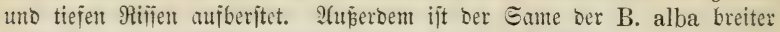

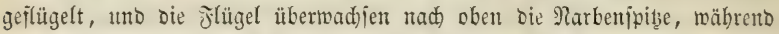
bei B. pubescens bie Rarben frei unt über bie frlügel binausftelent.

a. Die פ⿺廴

Die Blüthe erjdeint gleidzeitig mit bem Saube, Enoc April, 2th= fang Mai. Dic Jrucht reift fehr veridjesen; in miloen Rlima uno bei

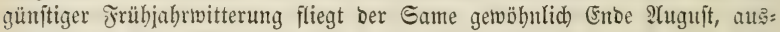
nabmsmeife idon Ifnfang 2luguit ab; früber abfliegentoer Game ift noth: reif unt taub.

Bei frätem Jrübjabc uno in raubem Slima uno taltem Boben fliegt Der Same meift gezen bie Mitte Des Geptember:, mitunter erit Ente bicfes Monats ab. Freijtehento Birfen tragen gewöhnlid idon int 15ten Jahre,

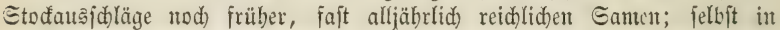
geid)loilenen Stangenorten tritt bie Mannbarfeit meift idfon mit bem 25 iten Эabre ein.

Der Same mill zroar nidjt ftarf bebeft fein, feimt fogar obne alle Decfe recht gut, berlangt aber einen wutben Soben, auf bem er, went Birfenmutterbäume in nid)t 3 grofer Entfermung vorbanben finb, überall von jelbjt anfliegt, getwöhnlid) ba, two man bie Birfe nid)t baben will. Ier Same verbreitet fich jebr reit vom Mutterbaume, uno eine alte Birfe fann mebrere Mlorgen beftreuen. Die Reimfäbigteit erbält fïd) nicht länger al: bis "zum Frübjabre nach ber Reife.

Die junge $\mathfrak{B f l}$ a nze erfd)eint mit jivei fleinen, runblichen, glänjento= grünen Samenlappen über ber Eroe, bleibt lange fehr flein, unto erre:d)t im eriften Jahre meift nidht mebr als eine Şöhe von $4-5$ Cent. Die

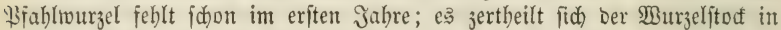
mebrere, flad) ausiftreidhente Seitentourzeln, fo Daf bie Bemurzelung faum Die Sälfte Des oberiroijden Rängentwudjes in bie Tieje oringt. Daber leibet Die junge Birfe am meiften ourch Dürre, wäbrent fie gegen froft = uno Sidteintrirfung unempfintolid) ift; idäblid) wirb ibr im erften Jabre das ZUfffrieren beక Bobenßె, fpäter zu ftarfe Bejdattung.

Der Stamm reinigt fid aud) im freien Etante auf $5-6$ Mitr.

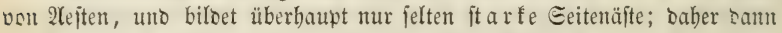
bie Stanmbolzmaije verbältniß̄mäpig gröfar ift als bei ben vorker ge: namten jolzarten, io daj man biefelbe auf 80 Proc. anjezen fantr. Unter allen 5̧olzern biloet bie Birfe ben abholjigitent Echaft, in Jolge früher Sidtitellung, oer nidht jeltent nod) Durdh friummungen uno Rniffe verun= italtet ijt.

Die Srone ift prramioenförmig uno wenig auggebreitet; ftärfere Hejte find nur in geringer Menge vorbanoen, oas Meifte ift gewöbutida Reijerbols unter S Eent. Durdmelier. Bon 60jährigen Birfen fann man

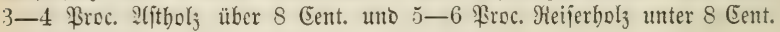
ourdiditittlid) annelmen.

Belaubung: bünn und licht. Die 3lätter ichatten aud saburd) wentiger, baj fie nieberbängen, berweglid) fint uno sem Sidhte nidht bie nolle 


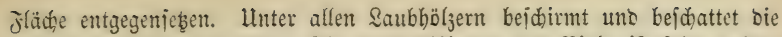
Birfe baher am wenigiten. Die Şunusbiloung ber Birfe ift fehr gering, uno wir zählen fie zu Denjenigen 5ुolzarten, weldhe ben Boben am meiften nerid)lechtern. (Es liegt bie Urjadje nid)t in ber geringen Menge bes jähr= (id) erjengten Saubes, jonbern in Dem furzen Berjebungazettraum beflelben, Eer bet ber Buche oreinul länger ift, baber fich in Budłenbeftäntoen auch Ereimal mebr 5ुนmus anjanmeln muß̧ als in Birfenbejtänoen. Ohne 3meifel iit aber and bie frübe Sidtfftellung uno bie geringe Befdattung uno Be= ¡(f)übung des Boben: Durd) Die Birfe bierbei mitnirfent.

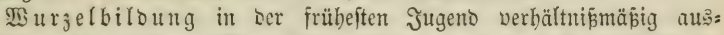
gebreiteter al( im böberen Alter; ftetz gering, in mebrere flad) alsiftreichente

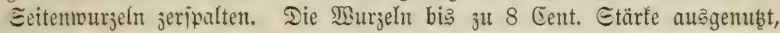

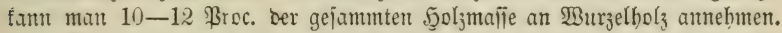

Betrieb. Eigentlid) für feine ber veridiebenen Betriebsweifen bes

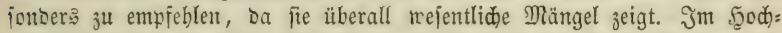
walbe, wo jie wegen ibrer frübzeitigen, nid)t allein ben Ertrag idmälernoen,

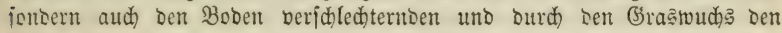
Mieberanbau eridwerenoen \&idtjtellung felten in böberem, als 60jäbrigen

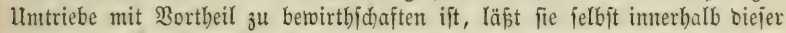
Grenzen febr früh im $\mathfrak{B} u$ dje nad) uno gewährt einen geringen Ertrag an Manle; im Mittelmalbe als Dberboly fababt fie Durd ihren Eamen, inoem Der Birfenantlug getwöhnliç balo bie ertragreicheren Unterholyarten verorängt. Im Mittelmalbe gereid)t ihr übrigen: ibre geringe Beidattung zur (Empfeh= lung, io sás jie über jehr empfintlidem, 3. 3. Sgajeln= ober Birfemunterbolz Da: bejte Sberholz abgibt. Sm Mtittel= uno Rieberivaloe als Unterhol $\mathfrak{l}_{3}$ ift fie

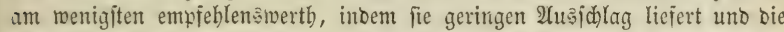
Mutteritöde jebr balo eingeben. Den Umtrieb im Edalagholje fafie man io

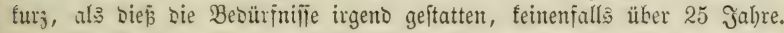

$\mathfrak{U}$ m bejten erjiebt man bie Birfe in Untermentgung mit anberen $\mathfrak{S}_{0} \mathrm{l}_{3}$ : artent jum 2(ushitebe in Den Iurdforitungen. 3u Sopr: uno Edneibelholje iit bie Birfe nidyt tauglidy.

Jortpilanzung. So leidyt bie Birfe ba anfliegt, wo man fie nidht Gaben will, uto fid) überall einorängt, glüăt ihre Berjüngung ourd) Samen=

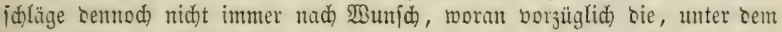

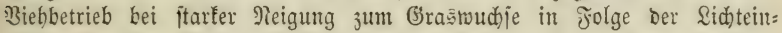

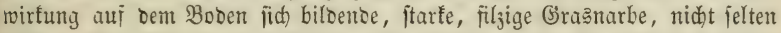

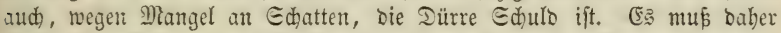

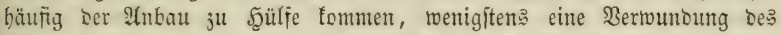
Booens ftattfinoen. 3ur Piflanzung wäblt man am bejten 4-5jährige Sohben von "2/3-1 Mtr. Söhe. Will man ältere Gtämme verpflanzen, fo mitīen

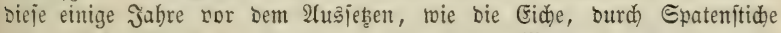

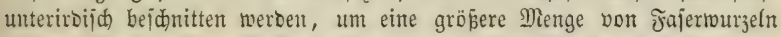

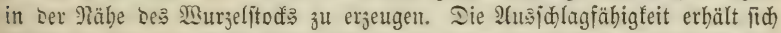

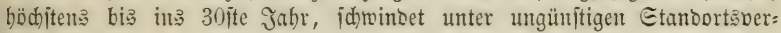
Fältnilien bismeilen iđjon mit Dem 15ten Jabre. Die Mutterftöfe geben gemöhnlid) beim britten Şiebe ein, uno liefern idbon beim jweiten einen frär= liden Afusichlag, ser immer nur ant uriprünglichen Stode jebr tief erfolgt. 
2Burzelbrut Yiefert bie Birfe nie, Wurjelausjidläge liefern in geringer Menge bie entblöft liegenoen Seitentwurzeln.

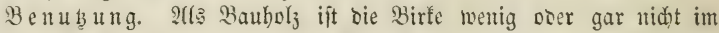
Gebraud). $2(n$ Werthölzern liefert fie $\mathfrak{M}$ öbelfoly uno bejonoers sie fleineren Wagnerböłzer: Seiterbäume, Deichjelftangen, Ed)littenfựen, Sarrenbäume, \$flughölzer in jebr guter Dutalität; ferner ₹afreife uno Befentreifig. Şo die Birfe in geringen Mengen angebaut ijt, getwährt fie baber einen hohen (Ertrag;

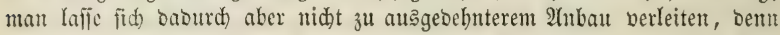

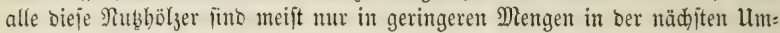

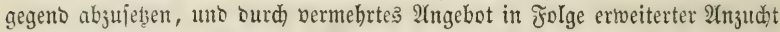
twiro nid)t allein ber 2(bjałs nid)t gefteigert, jonbern in vielen fr̈llen aud ber

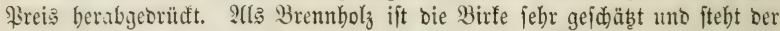
Budbe wenig nadh, obgleid) fie nidht bie Summe ber $\mathfrak{B a ̈ r m e , ~ w i e ~ j e n e ~ e n t : ~}$

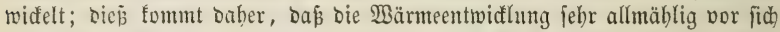

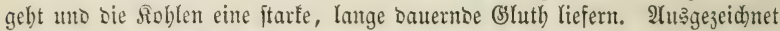

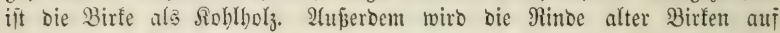

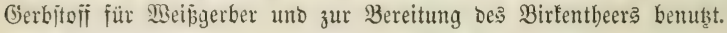

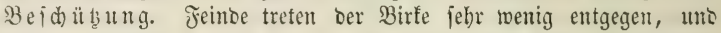
mur in Der frübejten Jugeno leibet fie bei ber fladen Betwurzelung leidft burd) Dürte. Llnter ben Jnjeften gibt es faum einige Blattweften, Midૈler: raupen, Rüijel= unt Blattfäfer (Rhynchites Betulae, nana, Chrysomela Capreae), meldje ben Blättern idaden. Der Stamm wirb mitunter von

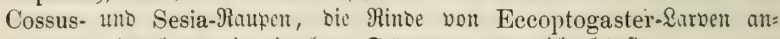
gegantgen, jiood) nur in einzelnten Stämmten, uno nidht bäufig.

\section{b. Iit weid) faarige $B$ irfe, Betula pubescens Ehrh. (odorata Bst. alba Linn.), Pudubirle, Edusuarzbirfe,}

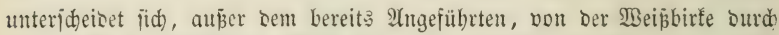
eine Dunflere, rothbraute Rinoe Der jungen Iriebe uno Pflanjen, Daber

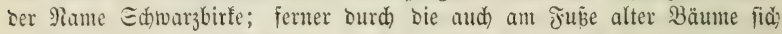
geid)loilen erbaltende Sorfborfe, burd) bie mebr horizontale \$erbreitung ber ftarfen S(efte alter Bäume uno burd) ein grobfajerigez $\mathfrak{S g l}_{2}$, zeigt jonft bicjelbe Etammbiloung uno Stammböhe, wie bie weip̌e ßirfe, mit ber fie an feuchten Etellen fajt überall in Deutichlant in einzelnen Exremplaren ge:

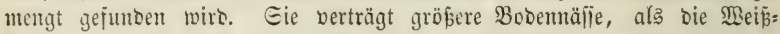
birfe, uno finot fid) Daber nidst felten in llutermengung mit ber (orle, wo jene jurüfbleibt; cahingegen nimmt fie nid)t mit fo trodenem Etant: orte norlieb. 2llles llebrige bat fie mit ber Meijbirfe gentein.

c. Dic Straud)birfi, Betula frutieosa Pallas, aud) Eumpfoitfe, Morafitbirfe,

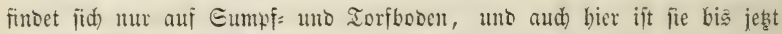
mur in Bayern uno Meffenburg aufgefunben. Der ftraudhige Etamm er= reidht jelten eine Şöhe von $1-2$ Meter.

d. Die 3wergbirfe, Betula nana Linn,,

ift ebenfalls ein Eumpf= uno Iorfgemächs, das felten bis $1 / 2$ Meter bod

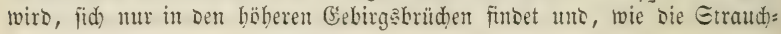
birfe, feine foritlidic bebeutung bat. 


\section{Die Ẽrle, Alnus,}

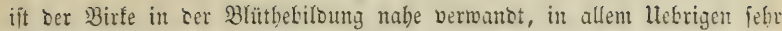

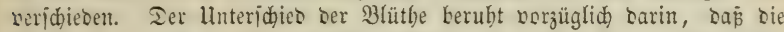

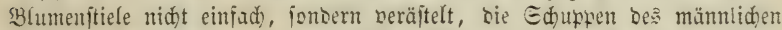

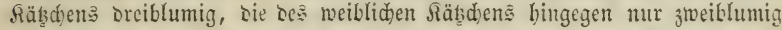
uno bleibend jino, ju einer 3affenfrud,t verboljent, bie nod lange nach Dent Átüfliegen beక Gamens am Baume bleibt.

MBir fennen orei Erlentarten unjerer M̉älser, uno zmar Alnus glutinosa, incana uno ovata. Seb̧tere untericheitet fid bou erfteren burch

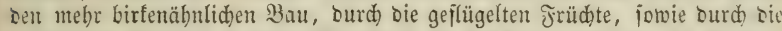

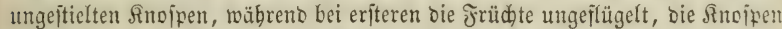
geftielt find. A. incana unterjweibet jich bon A. glutinosa burd) bie ju= geipiz̨ten, Dort abgerunbeten oder an ber Epił̨e eingebud)teten Blätter, teren

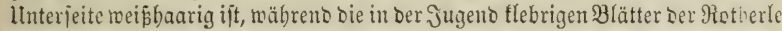
nur in ben Wintefn ber Blattabern braune F̧aarbüidel tragen. 2(4d) bie jungen

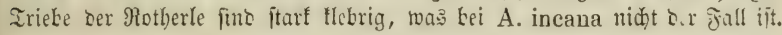

\section{a. Dic $\Re$ otherle, Alnus glutinosa Gärtner.}

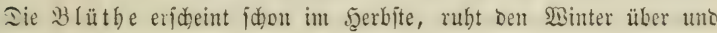
blüht int März auf.

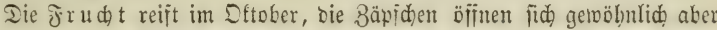
crift in ben eriten Wintermenaten oes Jabres uno Der Eame fliegt auj ben

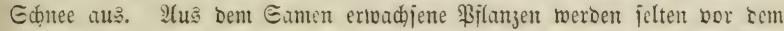
vierzigiten Jabre frudtbar; nur von Jugento auf in freien ermadjent Gtämme erreichen ihre Mambarfeit id)on mit Dem fünizebnten bis zwanjigiten, Etodfoden mitunter idon mit bem zehnten Jabre. Die Eamenjabre treten bäufig ein, uno wieberholen jĭd meiftenz in 3 -4jäkrigen Berioben.

Der Same, eine fleine, breit gebrüfte, itumpf:tantige, braune, bart=

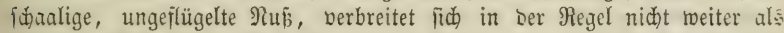
20-30 Sd)ritte bom Nhutterifamme, berlangt einen wumben Boben, boch geringe Defe, bie ighm am bejten burch Betrieb mit Edjafheerben gegeben miro. Der im Frübjubr gejäete Eame feimt nad) 5-6 פBochen.

Die junge Bilanje erjcheint mit zwei rundlichen, blapggiünen Gamen= lappen, uno erreicht im erfen Jabre eine Şäbe von 15-18 Eentim., kei

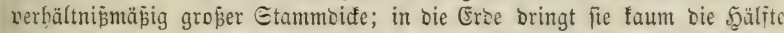
riejer Qänge ein, berbreitet fid, aber nit einem jtarfen $\mathfrak{B u r z e l f i l}_{3}$ weit in Die Dberfäche Des Bobens. Eie leibet Daber in Der eriten Beit leid)t surd) 2(uffrieren Des Bobens, ift jeht empfindlid) gegen Befdattung, jeroch meniger im erften uno żweiten Jahre, al’ jpäter.

Der Stamm reinigt fid in freien Etande in geringer \$öbe, ielten

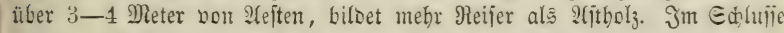
bingegen idjiebt Der Etamm jebr in bie \$ुöbe, unt bitoet einen geraben, regel= mäjigen, ziemlich vollholjigen Ed)ajt, mitunter von 15 -20 Meter \&änge bi

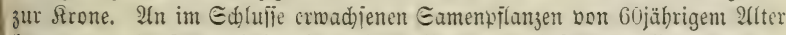
fann man bic Etammbolymañe auf 75 Broc. Der Gejammtmajie anjeţen.

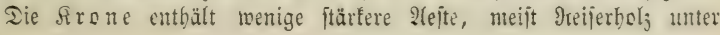


8 Cent., uno breitet fïh) phramibenförmig wenig uno nur in bell unteren

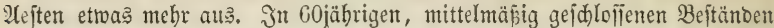
funn man 8-10 \$roc. 2(jtholz annebmen, wovon nur 2-3 \$roc. Der ganjen Baummafie bie Stärfe von 8 Eent. überfteigt. Dả Şolj ber 2 éfte jeidhet fid) burdh jeine grope Brüchigteit aud) in grünen 3ujtanbe aus, Daher man mit bem 24 abiebe in jungen Drten febr vorfidtig fein mus.

Belaubung mittelmäßig, Durch Den bidten Sd)lup junger Drte bis

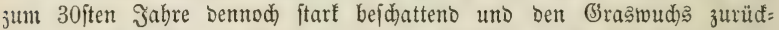
Galtend. Bei böherem Alter werben bie Beitänbe aud obne übertriebene Durdforitung lidjter, halten fid bis zum 60 iten Jabre größtentbeil( Dod')

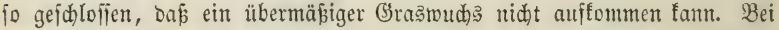

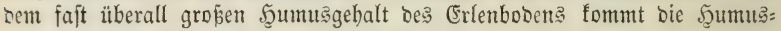
erzeugung Der Blätter faum in Betradt.

Bewurzelung. Der Burzelftod fpaltet fich) nicht tief unter Der Eroe in mebrere jebr abholzige Scerzmurzeln, Deren Seitentwuzzeln größ̄ten= theils järäg in ben Boben bringen uto mur theilweife, auf nafjem Boben

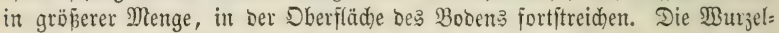
menge ber Eamenpflanzen ift baher mur gering uno gröptentheils aus fd)wadhem Scolze beftehend. Man fann fie nidht höber als 12-15 Proc.

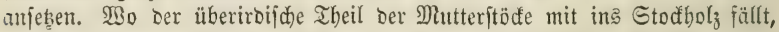
wie bieß̄ in ber Regel gejdieht, Da tann bie Etodholzmaile bei hohen Stöden mitunter 30 ßroc. überfteigen.

Betrieb. Für Den eigentliden Sodbulobetrieb ift bie Erte zwar weniger als für ben Riebertwald geeignet, ba ihr Şauptwudjs in bie erften

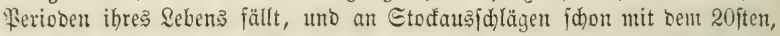

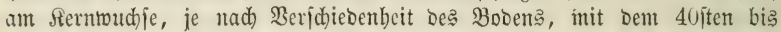
50iten Jahre bebcutento nachläßt; bod) wiro man häufig burd) Eonfumtions: Berbältniffe, namentlid) Durd) Mangel an 2(bfał̧ für bas fdiväd)ere Material

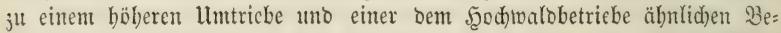

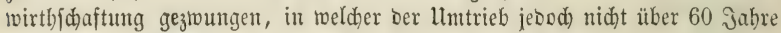
anz̧ueţen ift. $3 \mathfrak{u}$ Dberbolz im Mittelwalde eignet fid) bie (5rle wenig, oa jie fehr früh im $\mathfrak{B u}_{\text {udje }}$ nad)läßt utb nur auf feud)tem Ganbboben längere Beit aţ̧ält. Der geeignetjte Betrieb Der Erle ift im Nieberwaloe, in weldhem jie bei 20-25jäbrigem Umtriebe Den bödjiten Majieertrag abwirft. Je

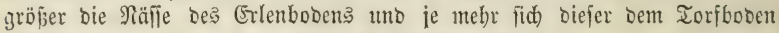
näbert, um fo fürzer mú man ben Umtrieb faifen.

Jortpfanzung. Bei Der Behandlung Der (Erle im 60jäbrigen ந̧od)= walbumtriebe gejdieht bie Berjüngung burch) Eamen uno Stocfausfoläge. Itm einen guten Rernwuchs zu erzettgen, Dürjen bie Bejtänte nicht früher angehaten werben, als ein volles Samenjabr eitgetreten ift, inoem auf

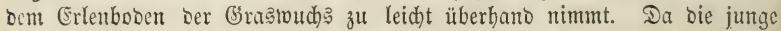
Erle jebr unter Schatten leibet, und bie erfolgentoen Stodfoden burd) Den

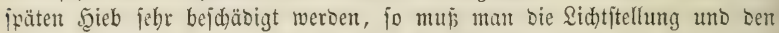

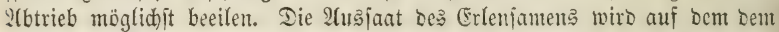

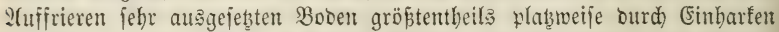
Des Samen's bermittelft eines Red)ens betwirtt. Die Erlenpflanjungen foblagen beiler an, als bie Eaaten, am beiten bie Pflanjung 4-Gjäbriger Soben, 


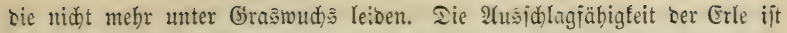

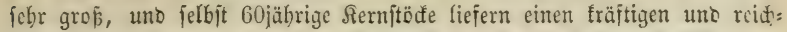

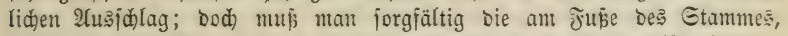

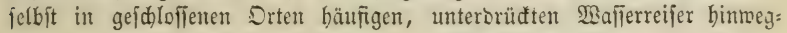

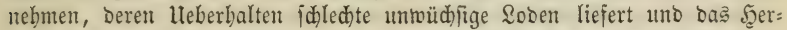

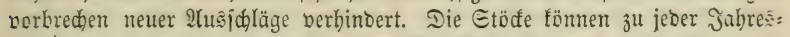

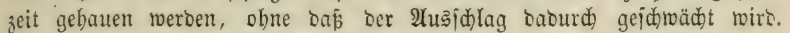
Wurzelbrut liefert bieje Erle nidjt.

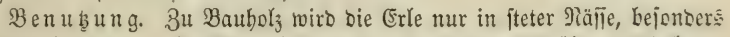

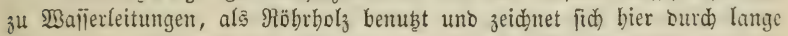
Dauter aus. Die majerigen Etammenden mandjer Bäume werben von bent

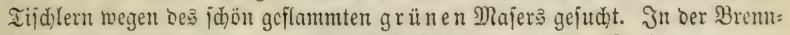
güte jtebt bie (Erle zwar ben meijten Syolzartent weit nad), ijt aber wegen ber rubigen gleidmäpäigen flamme, bie fie bilbet, bejonbers in Ränbern, two bill Saminfeuer unterbalten wirb, jehr gefdäbzt. Die Rinoe enthält biel Gerks:

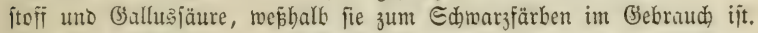

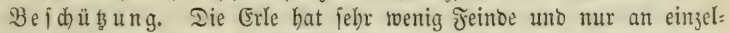
ftehenten Bilanjen werben bie Bejđäbigungen ber Blätter burd Galleruca Alni uno Chrysomela aenea, jowie einiger Blattwejpen, mitunter füblbar.

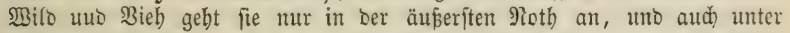

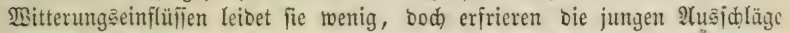
mitunter bei Exätfröîten, im böheren Gebirge mitunter nod) fehr irät sic

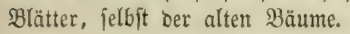

\section{b. Die Weiperle, Alnus incana Dec., and noroifde Erle.}

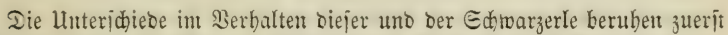

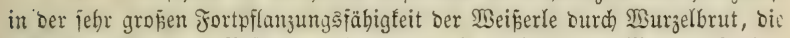

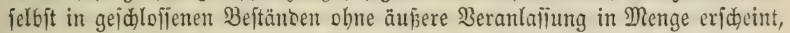

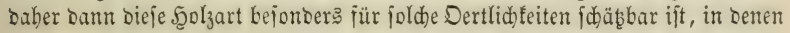
Durd regelmäpige hobe Heheridwemmungen bie ßerjüngung ber Edjmarzerle

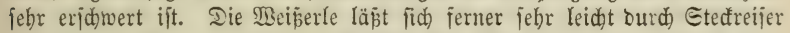

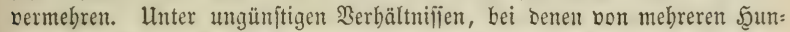
Derten Rotherlenftefreijer fein cinjiges anjolug, mudfen von ber Weip̈erle

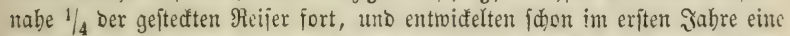
auffalleno reiche Betourzelung. Eobann erträgt fie in ber Jugeno eine ftärfere

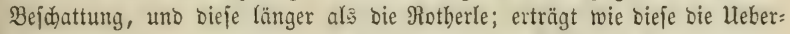

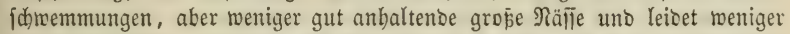
von Epätfröften. Das Şolz ift weit weniger brüđig als das ser Rotherle. Da fie ein Baum bes holen ?lorbens ift, io findet fie fich in ben Ebenten Ientichlands nur bin uno mieber, gebeibt aber aud, oort bei furzem, 30 Jahre

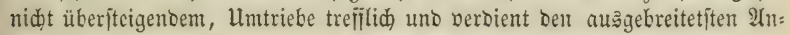

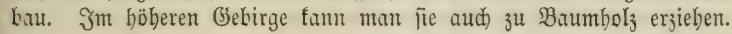

c. Iie $\Xi t r a u d e r l e$, Alnus orata Schr. viridis Dec. (Anobetula), and) Erlenbirfic runbblätterige Birfe, $\mathfrak{A}$ lpenerle genamt.

(Ein 2-3 Mitr. Göber ätiger Etraud), weldyer an bent rauben $2(6:$

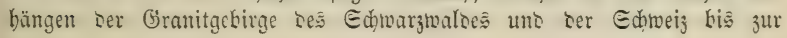


Baumgrenje hinaufiteigt uno bort bie Arummtholjtiefer erfeb̧t; in ber Edjnei; bejonoers burd) Berbinberung Der Saminenbiloung midtig, fonft bon feiner forftliden Bebeutung. Eein Etanbortäbesürinip ideint mehr bem ser Birfen

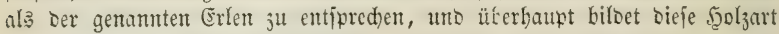
in mebrfacter Şinjidt einen llebergang żwifhen beiden Gattungen.

\section{B. Bon Den untergeoroneten Şolzpflanzen.}

Эă) jäble von biefen biejenigen Atrten hier juerit auf, weldhe ihrer 3lüthebiloung nad) mit sen bereits genannten berrichenten Saublölzern in einer natürlidjen Familie ftehen.

\section{Drittes Sapitel.}

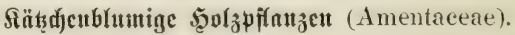

\section{Die zahme $\mathfrak{R} a$ itanie, Castanea vesca Gärtn.}

Blüthe. Mämnlide uno meiblide Blumen an ein uno semielben felv lang gejogenen, aufrecht ftelenden Bhumenboben; bie mäunliden Blumen wil ber Spiţe, bie weibliden getrent an ter 2 afis bes Blumenbobens; arftere bejtebento aus einem gefdloffenen fünfipaltigen Seldhe, befien interer

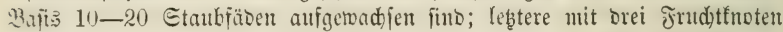
uno fabenförmigen rothen アarben, umgeben von einer grünen, vielblättrigen jur itadjliden Jrudthülle erwadjenden Eupu!a. Blüthezeit Ende Juli.

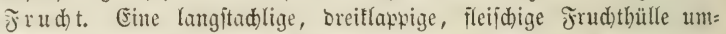

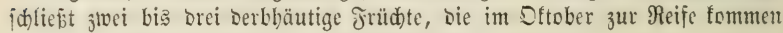
แแno aน๖ Den aufipringentoen Şüllen fallen.

Der Same triro am bejten im Serbit ber Reife ausgefäet, 3-5 Cent. mit Croce bededt, morauf er fobr zcitig in nädjten Frübjabre feimt und bie Eamenlappen in ber Eroe zurüfläft. Mannbar mit bem 40 jiten Jahre. Eamenjabr in 2-3 Jabren wieberfebrent.

Die junge \$flanze ift fehr empfindlid gegent Frojt uno bebarf

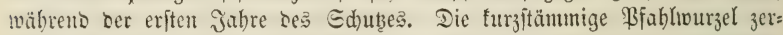
theilt ridh nidht tief unter bem Boden in mebrere 5ुerģwurzeln uno Eeiten=

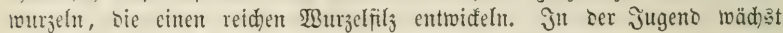
fie nidst jonberlid) rajo, erft mit bem 30jten Jabre beginnt reidflider $3 u=$

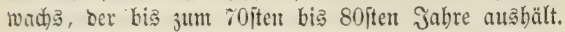

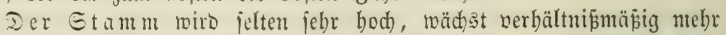

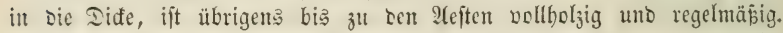

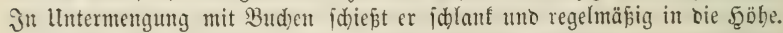

Die Srone ijt jtarfätig, weit verbreitet, iperrig; ber obcrirbifde Baum in feinem 2 euperen bem ber (Eid)e ant näd)ften fteheno.

Die Belaubung iit noll uno nidst viel weniger idatteno als bei ber Rotbbuche.

Die Betourjelung itärfäftio, in ser Tieje uno in ber Sberfläche weit verbreitet.

Betrieb: meift in ltutemengung mit Buchen uto Eiden im 5ुod)= walse uno Mittelmalce jut Bemuţung Der Jrücte; im Mitteltwalo ftarf 


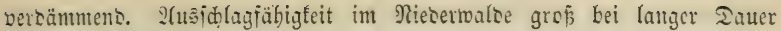
Der Mlutteritöđe.

Fortfflanjung wie bie ser Rotbbude; meift Pflanjung aus Pilanjgärten.

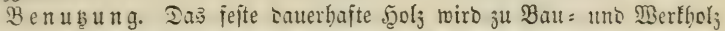
roie bas ber Eidje verwentet. Jn Franfreid mirb aud Etablyolj Laraus

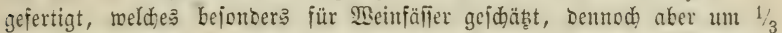
wohlfeiler als Das Eidenftabboly ijt. Die Bremtrajt im verfohlten 3u= itante ijt gleidh ber bes Rothbuchentholzes.

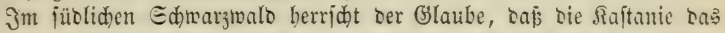

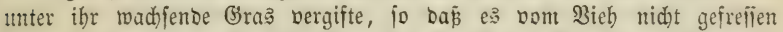
wirt. Unter bier madjenten Bäument habe id Den Boden nad Regen oit twie mit Dinte befleaft gejehen, wabridneinlich in Jolge ciner Eecretion von Gerbitoif aus Den Blättern, Der vom Regen gelös̆t uno abgejpült twiř. (E: jteht bies vielleidht mit jener Erfabrung im 3ujammentange.

Beidü ţung befonders gegen Jroft uno Dürre, porant gegen Men=

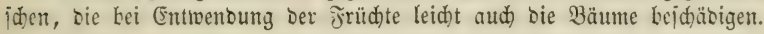

\section{Dex 5ornbaum, Carpinus Betulus Linn., aud Iseipbuche, 5ुain= buche, Sagebude genant.}

Blüthe. Die weiblide Blume ift ein locteres Rätzden mit einfachen bluttartigen Ed)uppen, Deren jeøe zwei Blumen, mit breilappigem Jrud)t=

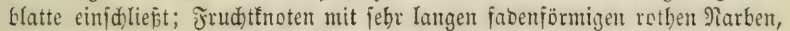
jeber mit einem feldjartigen Perigonium verwachjen, befien Bipfel an ber

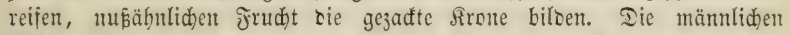

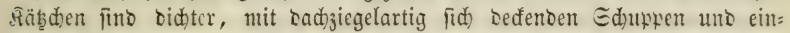
Fader 10-20männiger Blume ohne Reld) uno Ŝrone. Blüthejeit Ente Itpril ober 2 nijang Mai.

Die frudt ijt eine zujammengebrüfte, gejurchte, jebr bartid)alige

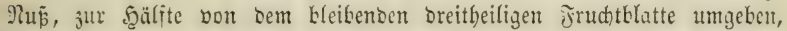
ju 4-10 auf genteinjwaftlid)em Stiele. Eie reift im Dotober uno fliegt balo darauf ab, jeood) erit nad) Dem 2rball dez Raubes. Die Mannbarfeit

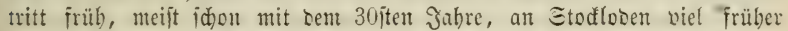
ein; bic Eamenjabre tehren in 3-4jäbrigen Beiträumen wicber.

Ter Same verbreitet fich 10-15 Edritte vom Mutterbaume, uno geht in Edlägen aud shne bejonbere Eorge für Bebefung reid)lid) aui. Er feimt erft $1^{1}, 2$ Jahre nach Der Eamenreife, 1 Jahr von ber Frübjabr: jaat $a \mathfrak{b}$ gereçnet.

Die junge Bilanje bleibt in Den eriten Jahren jebr flein, uno

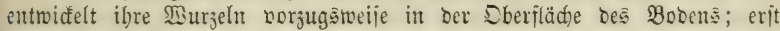

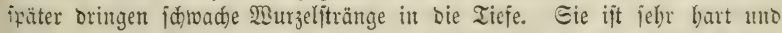
funn ganj im Jreien gejogen meroen, erträgt aber in ben eriten Jabren tine mäpige Befchattung jebr gut, uno erbolt fid bals, jelbit von ftäteres Berbänmung. Sie wiro jwar vom Milse uno Bieb ofturf nerbilien, crbolt

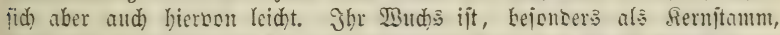

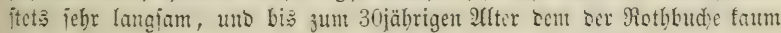
gleidłzuiteflen, ipäter bleibt jie binter sieicr bedeutens jurïa. 
Der Etamm ift jebr abboljig, felten grabe uno ftets mebr ober weniger fpannüütig gewadjen. Sm Ed)lufie ertoadjen reinigt er fich alf 7-8 Mitr., felten höber, won 2lejten; im Jreien bleibt er jtete febr tief beaftet. Silbft in Sahlulie erwadjen fam man bic Etammbolymalie nidit ïber 60 ßroc. anjeß̧en.

Die Irone ift im Jreien febr berbreitet, nit bielen wagereă)t aus̄:

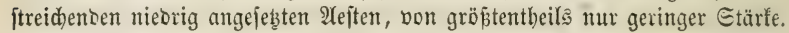
Im Ed)lulfe tann man 12-15 ßroc., im Freien 15 bis über 20 ßroc.

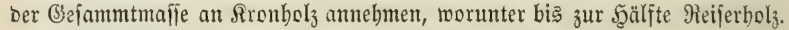

Die Belaubung ift beinabe eben fo verbänmeno, als bie ber Roth: budce, Durch Die weite Berbreitung uno horizontale Gtellung vieler fleiner Bradyblajte, bie ber Jabrestrieb nod im Jabre feiner Erzeugung entwictelt. Die Blattmenge bingegen ift geringer als bie ber Rothbuche, uno bie $B e=$

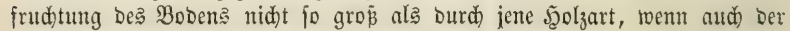
Unteridied nidat jebr bebeuteno ijt.

Die Berourzelung ift flad) und weit auștreidento, aus vielen

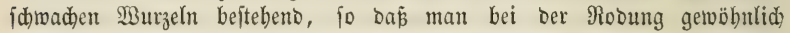

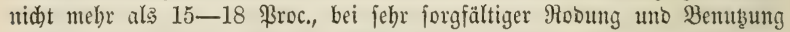
aud ber entfernteren, fdrwaden 2lejte über 20 Proc. Wurjelholz erhält.

Betrieb in reinten Sgodiwalobeftänden nut hier uno ba, uno twegen

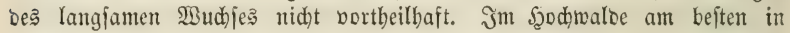

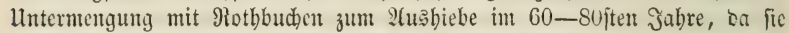

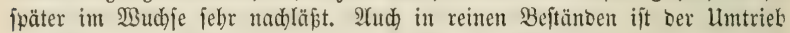
nid)t höber als 80 Jabre anzuleken. Für ben Mittelwalo ift fie mur als Interbolz benuß̨bar, uno barf wegen ifrer Sronenausbreitung uno ftarfen Beid)attung als Dberbolz gar nid)t gebuldet werben. Mlan bält aber gern

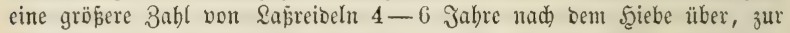

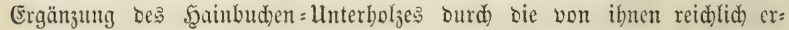

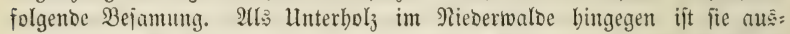

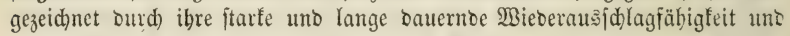
bie reidhlide Bermebrung burdh freimillige Albjenter. Sie gibt bier bei 20= bis 30jäbrigem Untricbe verbältniß̄mäßig einen böberen Ertrag in Mafīe,

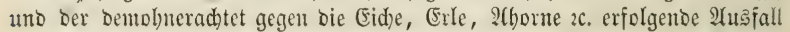
wiro reidlid Durd) bie vorzüglide Bejdaffenbeit bes Mlaterials als Brent=

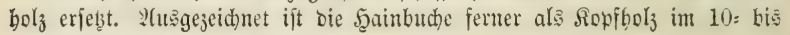
12jäbrigen Umtriebe.

Jortpflanjung leidht burd) natürlide Bejamung, wenn bie junge

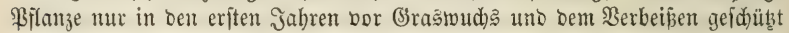
ijt. 2(ud) bie Freifaaten gerathen gut, und bie \$rlanzung fann obne Sorberci= tung bis zur J̧eifterftärfe ausgefübrt werben; Dod) id)lagen Sobenpflanzungen

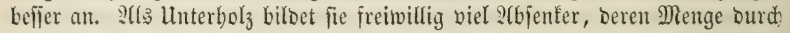
Inbäufung von \&aub um ben Stod febr vermebrt werbent fann. Ifud) fünjt: liche 2lbjenter fdhlagen febr gut an, muifjen aber $3-4$ Jabre unberüḩt im Boden liegen, ehe fie vom Mutterftode getrent werben. Die Weifbuden= nicoerwäloer balten fich) Daber obne Rojtenaufwanto volfer beftodt als die ber

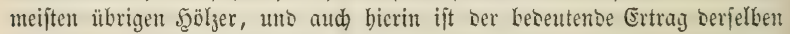

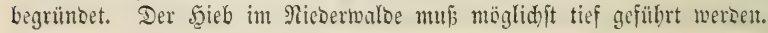




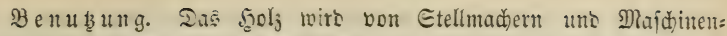

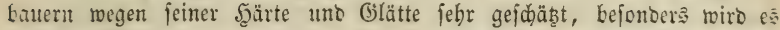

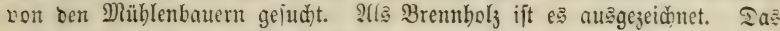
grüne \&aub gibt ein guteş \$iebfutter.

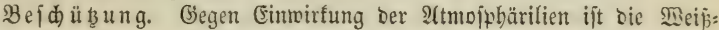
buche ziemlid) unempfinolid); in erponirten Sagen leiset fie mitunter vom

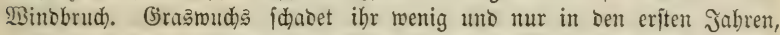

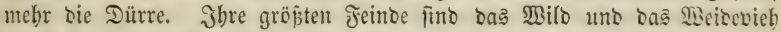

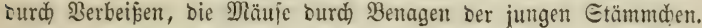

Dem Şornbaume febr nabe verwanbt ift

\section{Die}

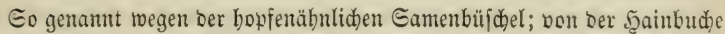
Darin verjobieden, Daj bas bort offene, breilappige frudtblatt bier zu einer

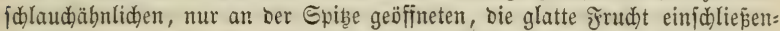
Den Seülle vertwadjen ijt. Sie finbet fid im fübliden Defterreich wilowadjent. Eie unteridgeibet fich bom Scornbaume ferner burd eiruno zugejpitite, an ber Bafis berzförmige Blätter uno ourd) abgeftumpfte Snofpen. Şbr forftlde

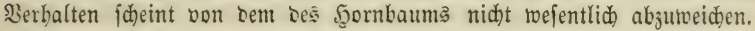

\section{Die Sgajel, Corylus.}

Sträuder, mitunter baumartig, mit getrennter männlidjer uno meib=

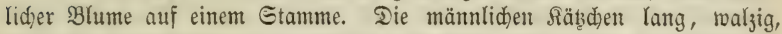
mit ad̆t turzgeftielten Etaubbeuteln, zwijhen breifantigen, ganzranbigen Eduppen. Weiblidbe ßlüthe: zwei Jrudtfnoten in gemeinidaftlidser offener Eduppe, jeber Frudttnoten umgeben bon einem mit ibm verwadjenen \$erigonium, zwifhen letiterem uno Der Єduppe bie aus mebreren ber= machjenen Blättchen gcbilbete Cupula; jeber Jrudtfnoten mit jwei langen fabenförmigen rothen 2arben un zroei bängenden, achenftänoigen Ciern, won Denen in ber Regel nur eines zum Gamen fich ausbiloet. 4-10 blütbe=

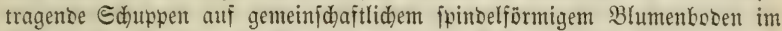
Snnern Dex Sinojpe. Jrud)t: eine einjamige $\Re u \tilde{s}$, umgeben von sem nach ber $\mathfrak{B l u ̈ t h e}$ beranmadyjenten Becherchen.

Wir baben brei 2 rten biefer Gattung: bie gemeine Scafel, bie baumartige und bie Samberţhajel. Sie unteridjeiden fich bejonters in ber Bildung bes Frudtffeldhes, welder bei erfterer furz, bie Frucht nidjt weit überrageno, glođenförmig, bei Der Ramberts̄nup bopkelt fo lang als sie frucht, breitheilig, bei beioen einfach, bei ser Baumbajel bingegen Doppelt, weit geöinnet, bie äußere Şülle vielfad) zeridhlibt, bic innere bin=

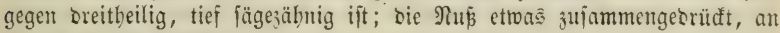
Den Eeiten ftumpifantig.

a. Dif gemeinc Şajel, Corylus Arellana Linn.

Blüthe. Die männlide Blüthe erjoeint jojon in Şerbite, bie weib: liche in Frübjabr, bei milder SBitterung mitunter jajon im vebruar, ge:

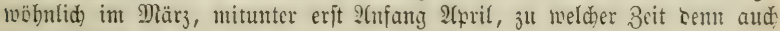

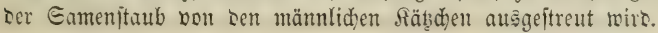


Die $F^{r} u d t$ reift im Eeptember. Die Mambarteit tritt fidon mit bem fedjsten bis adten Jabre, an Stodloden nod früber ein. Eamenjabre häuศig.

Der Same verlangt Bebectung mit Erbe ober Saub, ment er nidht erfirieren, ober von Mäujen, Eidbörndhen zc. aufgenommen werben foll. (Fr läß̈t fid) überwintern, berbirbt aber leidjt und wirb am beften gleich

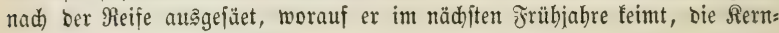
ftüde in ber Eroe zurültalieno.

Die junge Bilanze fommt erit mit bem britten Jabre in rajden $\mathfrak{B} u c h 3$, Der bis zum 20ten Jahre aushält, bann fich bebeuteno verringert;

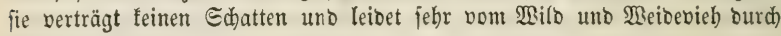
Berbeifen.

Der Stamm zertbeilt fid über Den $\mathfrak{M}_{\text {uzzelftof }}$ in viele Triebe, bie bis zum 12-15ten Jabre grabe uno follant in bie Şöhe gehen, einten 5-6 Meter bohen Etraud bildeno, bann fid mebr in bie ?efte ver= breitent.

Die Belaubung ift ziemlid berömmend uno bent Bobent güntitig.

Die Bewurzelung flach laufent, weit verbreitet uno veräftelt.

Betrieb. Jim Nieberwalbe in 10-15jährigem Umtriebe zur Er: зeugunty von Reifftöđen; für den Mittelwalo ronig tauglid), oa fie feiren Eđatten erträgt, höchitens unter Birfen ober 2 (akpen Dberbaum.

Fortpflanzung burd) Stodfausjollag leidt uno fider. Der 2 tus: foblag eriplgt am Mutterftode, bidit unter ber Erobe, unb bilbet feine eigenen Wurjeln, woburch fid bie Stöde von felbft unaufbörlid beriürgent. Man mup die Etöđe baber jebr tief bauen. 2Ubjenter gebeihen gut, Stedfinge

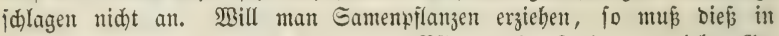
Eaatfämpen geidehen, da Eame uno Pflanzen im Freien zu vielen Cies=

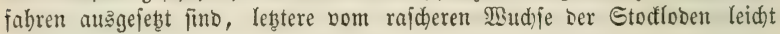
berbämmt werben.

Benubuıg. Mailenertrag im 12jäbrigen ltmtriebe bei 6füßjiger

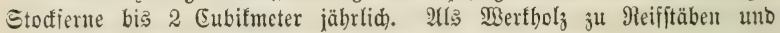
Rorbrutben jebr gejdäk̋t.

Befめübung: bejonders gegen Willo, Meibevieh, Uleberidattung unto Dürre.

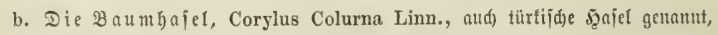

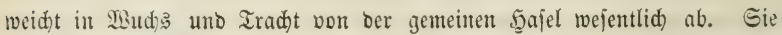

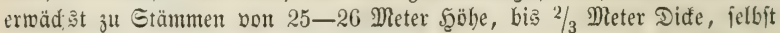

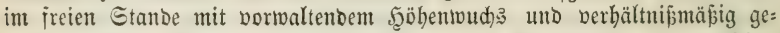

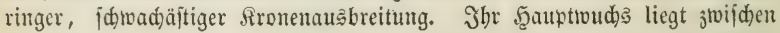
Dem zmanzigiten uno vierzigiten Jabre; bejonoers üppig foll fie in llnter= mengung mit Mabelfölzern wadjen. Mambarfeit mit bem zwanzigiten

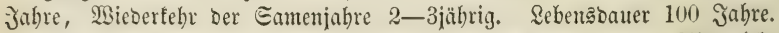

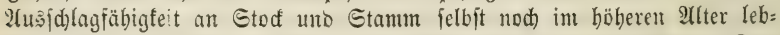
bajt. Die junge Bilanze liebt in ben eriten Jabrent einigen Edubs. Das

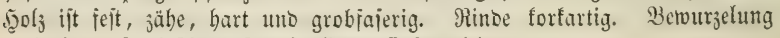
verbreitet, ftarfäitig. Int jüblichen Defterreiđ. 


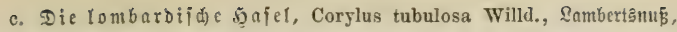

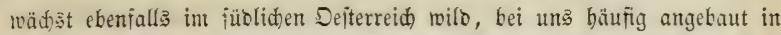
Deden uno Gärten, ftrauchartig, wie bie gemeine Salel, mit ber fie audh fonit am meiften übereinjtimmt. Gregenitano foritliden $\mathfrak{A}$ nbaues ift fie nid)t.

\section{Die ßappeln, Populus.}

Bäume von mittlerer Gröb̉e, mit verlängerten Räß̨̧enblütben, uno

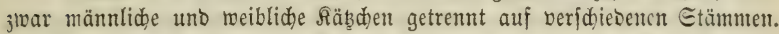
Die männlichen bejtehen aus vielfach jerfalikgten meijt mit Şaaren kefeb̧ten Edhuppen; am Grrunte berfelben ein fegelförmiger, jadräger, unjertheilter Träger, auf meldhem 8-20 Etaubbeutel ftehen. Frudtitano uno Єduppe Der weiblichen Blume ebenjo twie bei ber männliden Biume; ber eiförmige

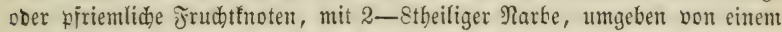

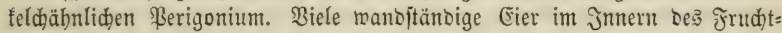
Enotent.

Unter Den jüni 2(rten europäij̧er \$appeln untericheioen fid. P. alba uno canescens burch behaarte Snojpen. Die Unterjeite ber banbförmig gelappten Blätter von P. alba ift überall gleidartig waís bebaart. Bei P. canescens zeigt bie Unterjeite ber B(ätter, Durd) abweid)ente Etellung

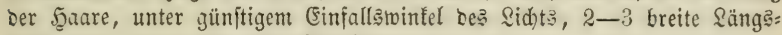
binben auf jeber Geite ber Mittelrippe.

Unter ben Pappeln mit fablen, flebrigen Sitcipen hat P. tremula, wie alba uno canescens, ffriemlid berlängerte Fructftnotent; bie fehr langgeitielten, budtig=|ägezähnigen Blätter fino nur an ber Epişe Fier uno sa brüpig.

Bei P. nigra und dilatata, beibe nur unterichieden burdh ben bei P. dilatata aushaltenden Edaftrudba, Durd) bie bei männliden Bitanjen angebrïdten 3reige uno bas weidere biel leichtere $\mathrm{Fg}_{3}$, fino bie Jrudft= fnoten fuglich bis eiförmig, bie Blätter beltoio bis rbombifd, bioht jäge= jähnig un๖ alle 3äbne orifigg. Sie fino nur ju verwechjeln mit P. betulaefolia (Ifmer.), Die jid) aber Durch Bebaarung ber jungen Triebe unter:

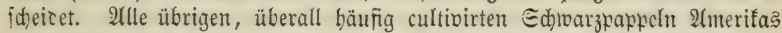
unterideiben fich leidt burch) feine Sorfrippen, Die, von ben Blattnarben aน๖, die Triebe binablaufen (P. canadensis, monilifera, angulata, serotina). Die rajdhüdjigite unter biejen ift $\mathrm{P}$. serotina $\mathrm{m}$. (Be= laubung erît mit Der IIfazie gleiḑ3eitig). Unter günitigen Umitänton bei lns bis 16 Eubitmeter in 45 Jabren fer હtamm. Ilnjtreitig ber rajds: wüd)igite Baum.

a. Die 3itterpappel, Populus tremula Linn., aud) xipe, (Eipe, ajde genamnt.

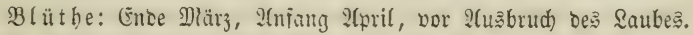

Jrudt: reift gegen Enoe Mlai uno Der Game, mit wolligen $2 \mathfrak{n}=$

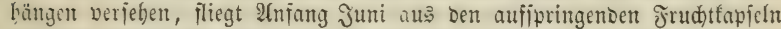
nb. Freiftehende Bäume tragen mit ¿em zwanjigiten bis fünfunbjwanjigiten Jahre jajt jäbrlid Gament.

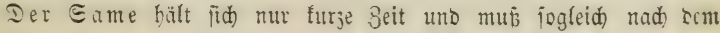


2(bfliegen eingejammelt, unt wieber auşgefäet toercin. Der Yeidhte wollige Game wiro vom $\mathfrak{B i n}_{\text {be }}$ jehr weit weggeführt. Säpt man ben Eamen nad)

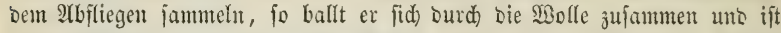
Dann jobierig auşujäen; man jŏneibet baher bie famentragenden 3weige Łur $r_{3}^{2}$ vor Dem 2tbfliegen bes Gamens ab, uno beftedt bamit bie anzufüenoe fläde, auf ber er fid) bunn regelmäpig bertheilt uno nad bem Nofliegen Durd Yeidtes Ueberfratzen des Bodens mit ber Eroe gemengt wirb.

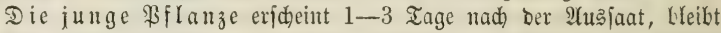
im erften Jahre fehr flein, uno wiro bef̧alb, aud wegen bes leidtent Mipratbens ber Saatculturen, bäufiger aus gejuntor Mutzelbrut erzogen,

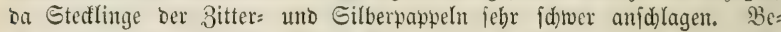
idhattung erträgt fie nidht. (Segen $\mathfrak{A}$ tmofphärilien ift fie ziemlide unempfinto: lid. Edhon im zweiten Jahre mebrt fich ihr 3uwad) bebeutento, fo Daf żweijäbrige Samenţlanzen nidgt felten eine f̧öbe von $1 / 2-2 / 3$ Meter er:

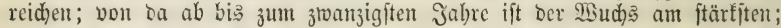

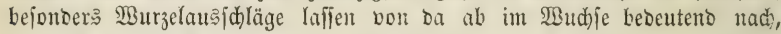
wäbreno Rerntwuds mitunter nod) im fedjigften Gabre lebbaft vegetirt.

Der Stamm ift gerabe, bollholjig, mit wenig ftarfen, meijt mur

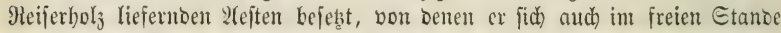
meift über 7 Meter hod reinigt. Man fam über 80 ßroc. oer gejanmten 5eolzmafie aut Stanmbolz anmebmen.

Die Rrone ift renig ausgebreitet uno fdwachätig, fo Dap man von 60jäbrigen Gtämmen nidj)t mehr als $6-8$ \$roc. Sronbol 3 , worunter mux 2-3 ßroc. 9 (jitholz, rechnen faum.

Die Bclaubung ift idwad), uno burd) bas an langen Etielen herabhängende, niđt fobirmförmig geftellte \&aub, im Berhältniß̄ zur Blatt= menge wenig bejdattento. Den Boocn befiert bie stipe, theifs wegent ber geringen Menge fdwad)er 3 3ä̈tter, theil’ wegen ber früben Freiftellung, wenig.

Die $B$ ewurzelung ftreidht in vielen fodwaden Eträngen nidjt tief

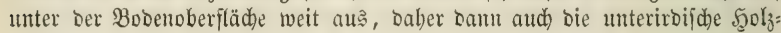
maffe mur gering ift, uno mir bei fehr jorgfältiger Rooung auf 8-9 \$roc. angefebtt werben barf.

Der Betrieb in reinen Beftänben ift in allen Betriebșeijen wegen Der frübjeitigen Ridutftellung uno bes baburd) geringen (Ertrages nid)t bor= theilhaft; in einzelnen Stämmen unter anderen Şolzarten, bie Den Boben jajirmen, erzengt bie 2lipe im 60jäbrigen 5jod)waloumtriebe eine größere

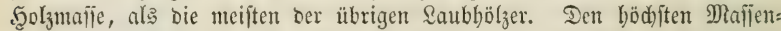
ertrag gemäbrt fie ala $10-15$ jäbriges $E_{\text {d)lagbol }}$; im Mittelwaloe ijt fie wegen groper (Empfindolidfeit gegen Bejdattung nid)t gut als linterboly. Eber fömte man fie auj pafiendem 30 ben in einzelnen Etämmen als Dber: holz buldoen, ba fie wenig beidattet, wenn fie fid) nidyt fo leidht bem lnter=

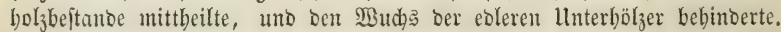

Jortpfranzung, vorzugstweife ourd) WBurzelbrut, oie jebr reidflich ïberall nad) Dem Şiebe ber Mutternflanze uno jd) on bor bemjelben zum

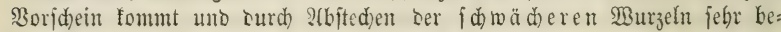

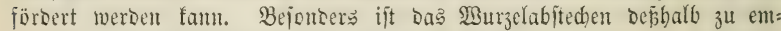
weblen, weil bie erfolgenten Edjöplinge fid) Durd) Gejuntheit uno frentiges 
Giveihent vor benen, bie von jelbjt erjolgen, auş3eid̄nen. Durd) Eamen

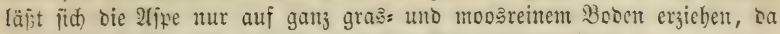
Dir leidfte rollige Eame jonjt nidht zur Eroc fommen tann.

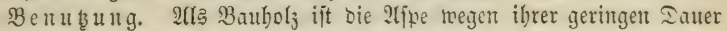
menig gejudt, uno nur zum Werbauen ganj im Trodnen, befonders in

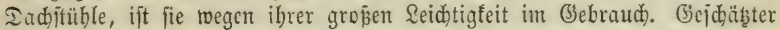

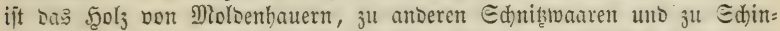

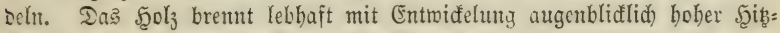

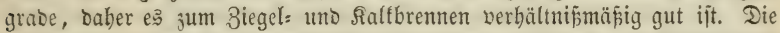
Rohlen fino weid) uno zur Єchieppulverbereitung tauglid); bie Rinte wirb

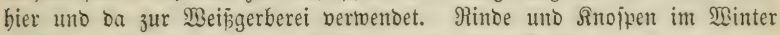
gefällter Etämme geben bem $\mathfrak{B i l b e}$ eine trefflid)e 2lefung.

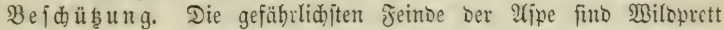
uno Meibebieh Durd) Berbcipen. Mehrere Bodfäfer uno Edmetterlings:

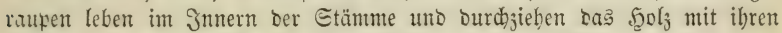
Gängen; Chrysomella Populi uno Tremulae entblättern oft in unt gebeurer Menge, jomohl als Raupe wie als Räfer, Die jungen Edjöblinge.

\section{b. Die $\Xi d$ twarjpappel, Populus nigra Linn.,}

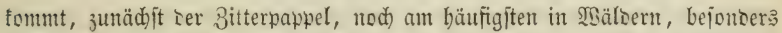
in Den fandigen frijden Flupnieberungen bor. Sie unterjdeioct fid bon Der 3itterpappel burd) größpere Etärfe uno Şöhe Der Stämme, eine ver=

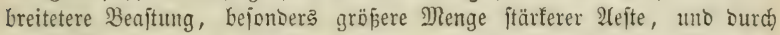
eine ftärfere, mehr in bie Iiefe bringenoe, aber aud) in ber Dberfläd)e weit verbreitete Betwurzelung, jowie burd) ftärfere Bejhattung. Der Malien= ertrag ber Edivarjpapwel ift nod) gröper als ber ber 2lipe, bejondors als Schlagholz int niebrigen Umtriebe; bas $50 l_{3}$ ift aber un einige \$fun leidjter und bie Brennfraft in Dem Werbältnif wie $185: 226^{3} / 4$ geringer

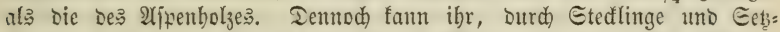
jtangen leidht unb jicher zu bewirfenber Unbau bei ber grofen Maflen= erzentyung Da, wo es barauf anfommt, in furzer Beit Dem Brennbolzntangel abjubelfen, went ber Berbraudjsort in Der Päbe Des Erzeugungsontes ge: legen ift, Die Tranţెportfojten baher nidjt zu hod) fint, mit Bortbeilen ber= bunben jein. AYtägezeidnet ift bieje Şoljart ourd) bie, ofit ben ganjen Etamm

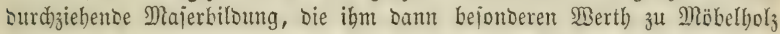

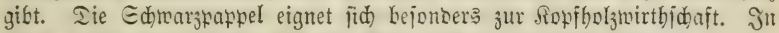
allem ltebrigen meidht jie bon ber alje nid)t ober untebeuteno $a b$.

e. Die Silberpappel, Populus alba Linn., und d. Die Graupappel, Populus canescens Smith (rid)t Wildenow).

finto in ibrer Etammbiloung, Betwurzelung :c., wie in ibrem forftlichen Ber: halten unter fid gar nidt, von ber 3itterpappel wenig unteridieben.

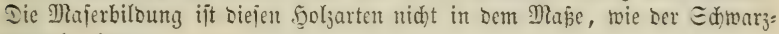
pappel, eigent.

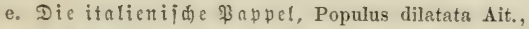

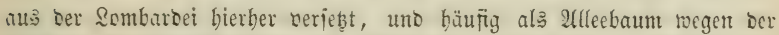
geringen fronenaubbreitung uno Bejouttung keionters an Fumititrafien 


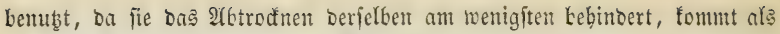
forftlidide Eulturpflanze nidyt in Betracht.

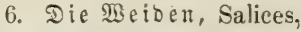

ftimmen in ber Blüthebiloung uno Frucht mit Den \$appeln nahe überein,

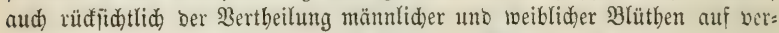

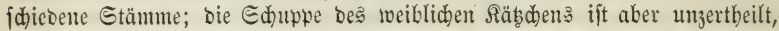
ganzranbig uno an Etelle ঠę̧ bei Populus feld)äbnlidjen Irägers fteht bier nur eit fleines, orüfiges Drgan, Şonigor üje genant, fo bap fowohl Staubfäoen als Frudhtfnoten mit ibrer Bafis unmittelbar ber Eduppe an:

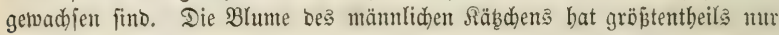
$3^{\text {twei }}$ fehr langftielige, mitunter veriwadfene, ober 3-5 Staubfäbent. Echr eigentbümlid) ift bie, nur aus cinem fapwenförmigen Defflatte beftebento Sinoppentede uno beren oft bunte Färbung über uno unter einer 3one un= fern Der Bafis.

Unter Den S. 313-315 aufgefübrten Weiben baben mur wenige forft: lidje Bebentung, wenigitens nidht für Deutidlano. Die Gletidertweioen, beren natürlid)er Etanoort bie böd)iten 2Ulpengebirge bis zur Ed)neegrenje fino; die Alpentweiben, bie ebenfalls ben höheren Allpengebirgen an: gebören uno nur auŝnabmsweife in tieferen Regionen vorfommen, wie S. phylicifolia auf Der Brodłentupre, S. hastata bei Stollberg im ફ̧arje, Iondien auch an ihrem natürliden Etanborte fo vereinzelt, baj biefent 3werg=

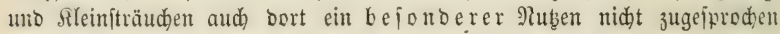
werben fann.

Dic Reifweiben, leidht erfembar ourd) ben bläuliden Duft ber 2-4jäbrigen Iriebe uno bas lebbaft eigelte Bellgetwebe ber inneren ßinoc fino baummüdfige Weiben von rafdem $\mathfrak{B u d j}_{j}$ unto reider Betwurzelung, bejonbers geeignet jum 2 Inbau auf Dünen, jelbit auf trodenen Sanbjdollent nod) febr frentig vegetireno. S. acutifolia, (caspica Hortul.) mabridein=

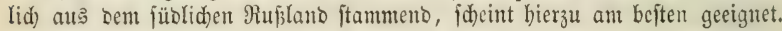
S. praecox (daphnoides) ift Betwohner des Ditjeeftrandes, S. maritima, cben baher, mabrja)einlid) ein Baftaro oer Borigen uno ber S. repens. S. pomeranica fdeint in \$ommern ril(owadjento nidjt vorzufommen, ift aber bie in unjeren Gärten verbreitetfite 2frt.

Unter ben ßurpurweiden bat nur bie in Den Ebenen Deutidlands

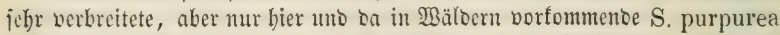

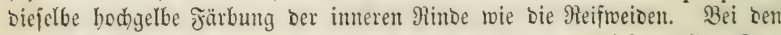
felteneren Irten S. rubra uno Pontederana finto von biefer gelben fär: bung ber Säfte mur Epuren vorbanoen. S. purpurea biloet jebr lantgs

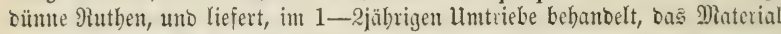
für sie feinen Rorbmacherarbeiten. Der feud)te Ganto ber Jlufufer unt

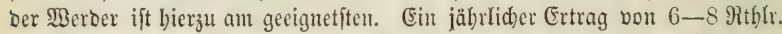
wro $1 / 4$ Sgettar bei ljäbrigem Untriebe ift burdh bie Etedflingcultur bel S. purpurea zu erzielen. Es ijt merfwürbig, wie gut bie meijten Beioen= arten ben 1jäbrigen Untrieb ertragen. Wir haben bier cine 2(npflanjutg von mehr als breipig 2 eibenurten, bic jeit vierzehn Jahren alljäbrlid

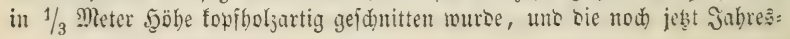


triebe von über 1 Pleter Sänge bilbet. S. helix ift mur Siarietät non S. purpurea.

S. rubra uno Pontederana madjen zu DRittel= uno Grofiträud)en heran, fino cbenfalls Ufermeioen uno liefern gutes Mlaterial zu gröberen Sorbmacherarbeiten uno fajohinen.

Die Epibmeiden fimo ebenfalls Uierweiben, meift Grofiftäuche, theilmeife jogar baumäbulich im böberen 2llter uno unter günfitigen Un! ftänben. Die roidtigfte uno verbreitetfte $\mathfrak{A}$ rt ift $\mathrm{S}$. viminalis. Im 2 : bis 5jäbrigen Umtriebe bebandelt, liefert fie jäbrlid über 3 Eubifmeter Maijent:

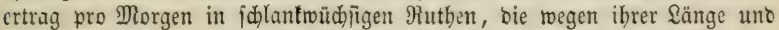
Siegfamteit zu gröberen Sorbmadjerarbeiten vorzugstweife gefurdit finto. Eultur burd) 2 jährige Stedfreijer, bie zu $4-6$ nefterweife geftedt wersen;

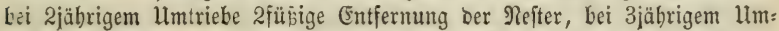

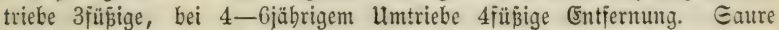
fallechte Balowiejen fino z̧u folden Eoolen jebr gut geeignet unt lieforn

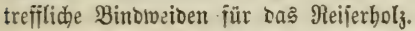

Unter Den Sahlweiben fino S. cinerea - die gróne Werftweide,

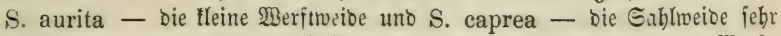

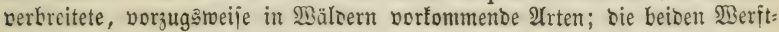
meiben mebr auf feud)tem Sloorboben, bie Sahlmeibe auch auf bem trodenen binbenden Sebmboben fräftig wadjento. Die beiben Merftweiben jino ftets itraudjwüdijg, S. aurita, meift niđt über 1 Meter, S. cinerea, 3 bi

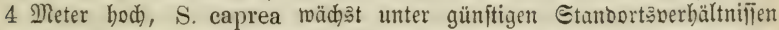

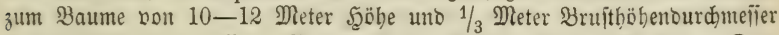

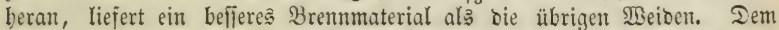
ofnerachtet ift aud bie Gablweide im Malowirthidaftabetriebe bäufiger. Sejen: ftano ber Bertilgung als ber Jüriorge, uno nur im Nieberwalbe toürbe fie Fiid) auf geeignetem Stanoorte Durd) bie Seidhtigfeit Der Bermebrung ber= mittelft Etedreijer empfeblen. Die Snnofpen uno bie meidbe Rinbe biejer

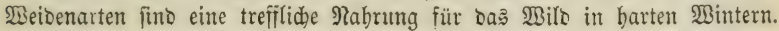

Unter ben $\subseteq$. 314 von S. grandifolia biş versifolia aujgefübrten Weiben, Flein= uno Mitteliträude ber Gebirge, fommen S. nigricans (var. trifida) unt S. depressa audy am Ditieeftrande vor.

Widtiger fino bie Canbmeiben ber Ebente: S. argentea, repens, angustifolia, bielleid)t mur Abänderungen ein uno berjelben frrutoform: S. repens; Rleinjträudhe von $1 / 3-1$ Meter Şöhe mit mebr voer reniger nieberliegenden, $\mathfrak{A} u$ s̆läufer treibenden Trieben uno filberglänzenter $\mathfrak{b} e$ haarung, Durd) ibre Berbreitung auf Dem Dünenjande ber Meerestüiten, a $u$ belien Befejtigung fie einigermajen beitragen. Sie fint aber aud im Bimenlande bejonders des nördlichen Deutidlands ziemlid verbreitet unt bejonbers auf feudtem Eand: uno Şaibeboben bäufig. S. rosmarinifolia bingegen, Den vorigen jebr äbulid, aber mit jebr fleinen fajt fuglidien

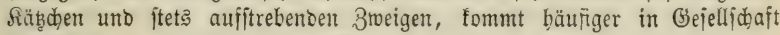
ter $\mathfrak{B e r f t w e i b e n ~ a u f ~ m o o r i g e m ~ B r u n b e ~ b o r . ~}$

Die Mandelweiben theilen mit ben ßurpur= uno Epibmeiben $3 e r=$ breitung und Etanoort in Den Freilagen Der Ebene, nur vercinzelt uno nidjt hod in bic Gebirge aufiteigent. Es finto joar Dittel= uno Grops= 
fträuche, aber jitemlich trägroüchitg, Deren 2 (nbau feine bejonoeren S:or: theile bietet.

Unter ben Baumweiden ift $\mathrm{S}$. alba am meiften verbreitet, bes jonbers eine 2tbart berjelben mit Dottergelben ober gelbrothen 3weigen:

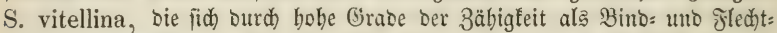
material auşeidnet. (E3 gibt wohl faum ein Dorf in Deutichlant, in

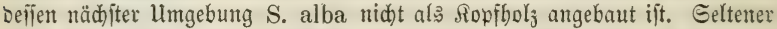

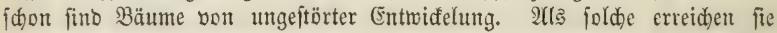
unter günftigen Standortäverbältniffen eine f̧öhe von $15-20$ Meter bei einer Stammitärfe von $1 / 2-1$ Meter, ftehen jeood an Majd)wüdfigheit binter

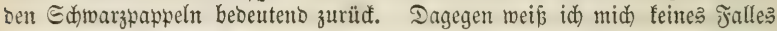
ju entfunten, in weldem bieje $2 B c i b e$ im nörbliden Deutidjlant ztweifelsfrei

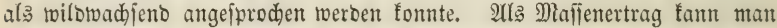

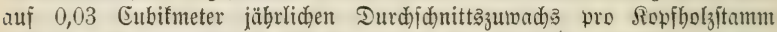

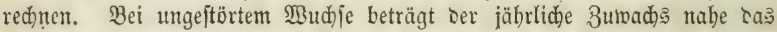

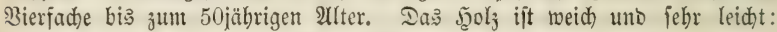
Erziebung burch Stecireifer uno Seb̧itangen.

Die übrigen Baumweiben fino ibrer Brühigfeit wegen bei weitem meniger empfeblengmerth. Nur auf fehr idtwerem Boben, auf bem S. alba vertünmert, verbienen fie als Sopfhols in Bejug auf Mafienerzeugung ben

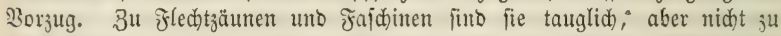
Binomaterial. S. Russeliana uno mehr ned) ein Bajtaro zwifden ifh uno S. alba ift jetod) als Rofifolz im nörolichen Deutid)lano jehr verbreitet.

\section{Jुiertes Eapifel. \\ Dic (Ej) juet (Fracineae).}

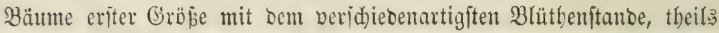
3 witterblumen, theils getremten (Befd)ledtern auf einem ober verfdiebenten Stämment. Der Błlume unjerer Fraxinus excelsior fehlt bie Błhmenfrone umo bie fleiten Relḑzipfel finto raja) binfällig (bei ben Mannaejden (Ornus) ijt eine Blumentrone vorbanden); bie einfachen Jrudtfnoten mit ztweitheiliger Narbe, wie bie zweitheiligen Etaubbeutel, iteben auf langen Etielen büjdel: weife beijanmen; am (S)runbe Der weiblid)en Blütbe jtehen meift zivei un= vollfommen ausgebilbete Staubfäbent. Frud)t einjantig, zungenförmig ge= flügelt. Blätter geficbert, gegenüberitebento.

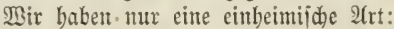

\section{a. Die gemeine (Fid)e, Fraxinus excelsior Linn.}

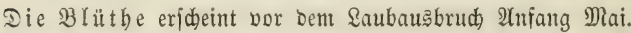

Die Frudt reift im Detober uno fliegt gemöhnlid im Rowember ab, Dod) bleibt fie mitunter ben ganzen Winter über am Baume. Mannbar mit bem 40 iten Sabre, freiftebeno nod) früber uno fait jährlid famentragent.

Der Same berbreitet fid 10-15 Edritte bom Mutteritamme und finbet aud auf cinem nidht $\mathfrak{j} u$ jehr begrajeten Boben eine zum fieimen erforberlidje Sage, inbem, wie bei ben Nabelbölzern, Der Flügel ben Samen 
beim 5erabfallen in lotbred)ter Stellung erbält. Reimung ein Sabr nact

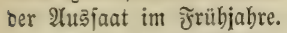

Die iunge Bflanze ijt nur im eriten frübjabre gegen orojt empinolich, berträgt feinen Edhatten, fam ganj im Jreien ersogen werben, leibet aber jehr unter Grastwuds uno burd) Derbeip̌en, wef̧balb man fie gewöhnlid in Eaatgärten ergieht uno mit 5-6 Jabren ins Freie vervflangt. Şbre Betwurzelung ift flach, aber weit berbreitet unto reid)lich veräjtelt.

Stamm uno Rronenbiloung nabe Der Der (Sidge, aud) rüd:

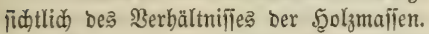

Belaub.ung etwas lidjter als bie ber (Fid)e, ben Boben in nod) geringerem. (Srabe befrudtent.

Bewurzelung fehr ausgebreitet, jowohl in ber Tiefe als in ber Dberfiädje Des Boben:; Der Etodfolzertrag ift baher bei nidt jebr weit= greifenter Robung bedeutento geringer als ber ber Eidje uno Budhe uno roiro jelten 15-16 \$roc. überjteigen.

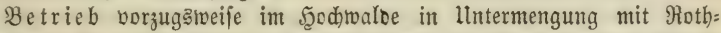
buden, wo ibr zur horftweife reinen Erajiebung mit Bortheil bie feudsteren movrigen Siepen, Brud) = uno Biejenränber anjumeifen fint; unter foldhen Berbältniīen ijt fie aud als Dberboly für Den Mittelwalo empfeblenstwerth. Alt Unterhols und für ben Nieberwald ift fie tweniger zu empfehlen, oa ihre

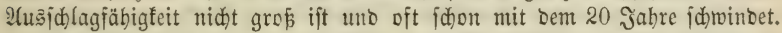

Jortpflanjung. Der Âtulug von Mutterbäumen erfolgt zivar ges

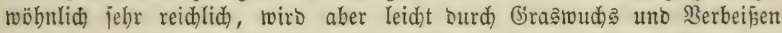
vernidtet, baher man bieje 5ुolzart befier in etwas böherem 2Ulter aus: pifanjt. Die ßiflanzungen gebeiben febr gut. In Nieberwalbe fann man

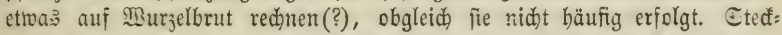
linge baben mir nod) nicht anjwlagen rollen, obgleid) fie fid bis sum Scerbjte belaubt erbalten.

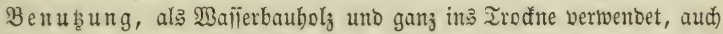
jum 5ुäujerbau jebr gut, obglcid wenig gejudt; in abwechjelnoer Irodfenteit uno Jeuhtigfeit bon geringer Dauer. Bejonbers geidüazt wegent ber grop̄en 3ähigfeit зu Magner = uno Majdinenbaubölzen. Megen ber bäufig idön geflammten Tertur von Tijc)lern, bejonoers in hiejiger G̈egeno, gejudt. Die

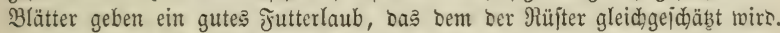

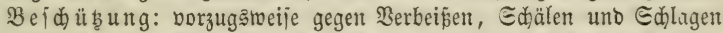

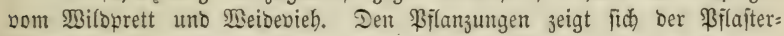
fäfer (Lytta vesicatoria) ourd) rwieberboltes Entblättern fehr nad)theilig.

Eine jehr empiehlenswerthe (sidje ijt Frax. pubescens bejontoers für idwereren trodenen Boben, auf weldhem unjere Ejiche gar nidht mebr fort= tonmut. Eie ift bort jebr rajd)wüdjig uno jotwohl burd) Eaat als Bflanjung ungetoöbnlich leidht uno fider anjubauen.

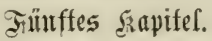

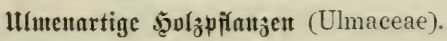

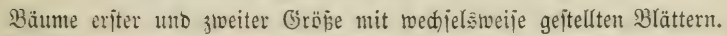
Die Blüthe jweigeidlechtig obne Blumenfrone, mit einjadem zmeinarbigem 
Frudtftnoten uno menigen, bem Reldye aufgewadjenten Etaubfäben. Dic Frud̆t eine bäutige frlügelfrud)t (Ulmus) ober eine fleifdige Eteinfrudt (Morus, Celtis).

\section{Rüfter, Ulmus.}

Bäume erfter Grö̈́pe mit eiförmigen, lanty zugefpiłten, am Gticle ungleid)en, bowpelt gefägten Blättern. Blüthen büfdelweife an furzen Etielen mit fünftheiligem ßeldhe, freiem zweinarbigen Frudttnoten umb 4-8 Dem Reldhe aufgewadjenen Staubfäben. Frubt einjamig, rumblid) geflügelt.

Bir unterjdeioen brei beridiedene Arten. Die Jelorü fter, raube $\Re$ ï fter uno bie $\Re$ orf rü fter. Allle brei 2 rten fommen mit forfigen flügeln Der 2-6jäbrigen Iriebe vor, bie eine $\mathfrak{A} r t$ häufiger, bie anbere minoer bäufig; cin 2(rtunteridcied läpt fid) Daber bierauf nidht grünbent. Bei U. effusa fino bie Błhumen 8männig, Błhumen uno Früchte viel fürzer als ber Gtiel, leţtere am Ranbe gemimpert. Bei U. campestris uno suberosa

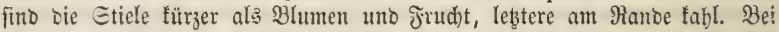

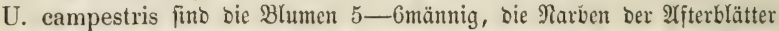
tahl. Bei U. suberosa fino bie Błumen 4 männig, bie शarben ber 2 ffter= Llätter an Der Rüđjeite mit fteifen fillberweifen Borftenbaaren befef̧t.

\section{a. Die Sorfrüfter, Ulmus suberosa Willd.}

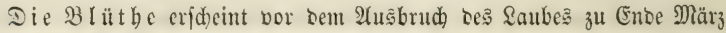
Doer 2 Unfang 2 tpril.

Die テrudt reift зu Enbe Mai ober 2nfany Juni, fliegt alsbalo ab uno wiro bon geringem Minbe weit vom Mhutterbaume bintweggefübrt. 2(n freiftebenten Bäumen tritt Die Mambarfeit fdon mit bem 25-40ften Sabre, an Etočlloden viel früber ein; Samenjabre bäufig.

Den Eamen fammelt man burd) 2 (bpflüfen und wäblt bazu bie 3eit, wern ber erite, meift taube Same bereits abgeflogen ift. Die mehlige

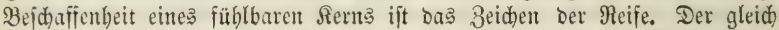
nach Dem Einjammeln ausgejäete Same feimt fdon nach brei Wodhen uno

Die junge ßiflange erreicht fdon im erften Jabre eine Sgöbe von 10-15 Eent. Dod) fann ber Game auch bis zum nädften Jrübjabre auf: bewabrt werben. Unter ber Croe bildet bie junge \$flanze eine furze \$fahl= lourzel mit fräftigen Seitentwurzeln uno reidem fill bon Fajerivurzeln, bod fintet man auf locterem Boben Pflanzen, bie mit ber Bfablwurzel eben io tief in Den Boben bringen als ber Stamm lang ift. Jn Den erften Jabren werträgt fie mäßjigen Edjatten, fann aber ganz im Freien erzogen werben.

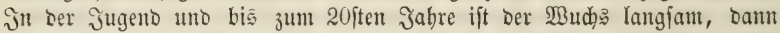

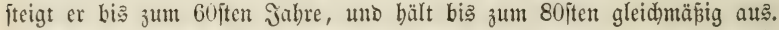

Der Stamm ift felten regelmäfig, immer abbolzig, felten bäber als 7 Mitr. rein von $\mathscr{A}$ ejten, oft gebogen. Die Stammbolzmaffe fann auf 65 bis 70 \$roc. angejekt werben.

Die Sirone: wenig verbreitet, mit langen, felten ftarfen, aufge: ridhteten $\mathscr{A}$ eften. Sironboly jelten über 15 Proc., worunter 5-6 \$roc. Reiferbolz.

Belaubung: nid)t verbämment, ber ber Eiche gleid zu ftellen. 
Bewurzelung. Şerzwurgel in mebreren ftarten Gträngen in bic Tiefe geheno; jeitlide Serbreitung nur auf fladem Booen bebeutent. Etod: boljertrag 15-20 \$roc.

Betrieb. In ffluphiederungen mitunter in reinen Scodwalobeitänoen,

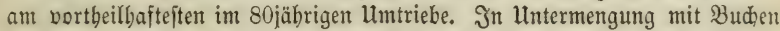
uno (Eidhen bält fie ben 100-120jäbrigen Umtrieb aus, wenn fie aud im

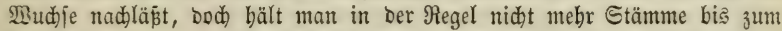

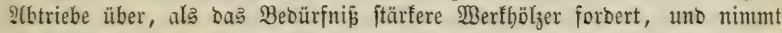

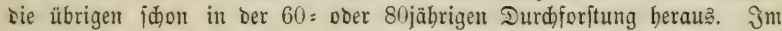
MRittelwalde ift fie ebenio als Dberbaum wie als Unterbolz uno für Den Nieberwalobetrieb empfeblensmerth, oa fie reid)lid bom Stode ausijdlägt

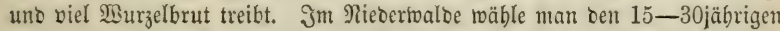

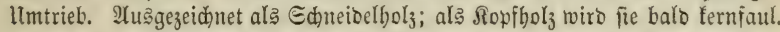

Fortpflauzung meift burd) (Erzichung in \$iflanztämpen uno $2(45:$ pflanzen als Soben ober Seeijter, um fie gegen bie größten Feinbe ibrer

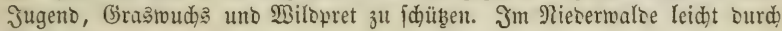
2(bjenter.

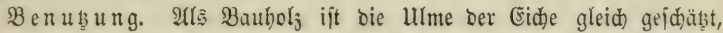

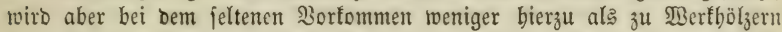

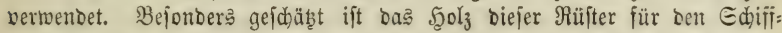

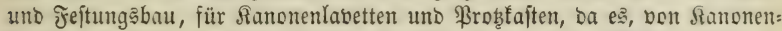
fugeln getroffen, weniger fplittert als allę übrige Şolz. Mlajrige Etünme werbén von Tijhlern jebr gejucht. Die Rinbe zu Bajt, bie Eafthaut un= gemein reich an Ed)leim (vergl. Jabreabberid)t I. 1. Є. 163), Jutterlauk vorzüglid) gut.

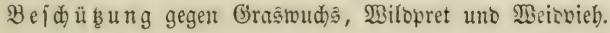

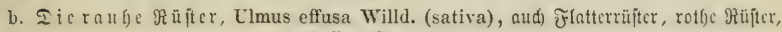
23afferrïpter genamt,

c. Die Felorüfter, Ulmus campestris Linn.,

weiden in ibrem forftliden 3erbalten bon ber vorgenaunten $\mathscr{A}$ rt nidjt ab.

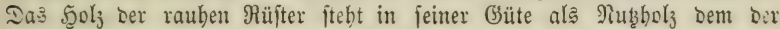
Rorfrüfter wentig nađ, wobingegen vorfommenoen F̌lorüfter wenig geidäb̧t ift.

In bieje ramilie gebören ferner:

2) Der Maulbeerbaum, Morus alba Linn. uno

3) Der Zürgelbaum, Celtis australis Willd.,

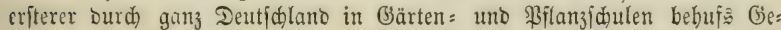
winnung Des Esibenraupenfuttere fultivirt, leḳterer im jüblichen Ieutid):

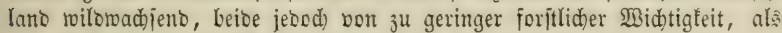
baj id bier in ibre Bejdreibung weiter einjugeben braudhe.

\section{Sedistes Eiapiter.}

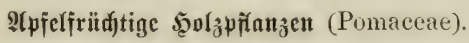

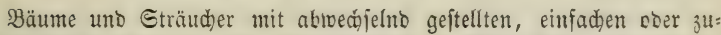

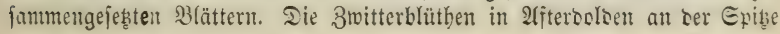


Der Triebe, befteheno aus einem, mit ben Frudtffnoten vertwadjenten, an Ranoe fünftbeiligen Reldje. Fünf tweipe ober rojenrothe Blumenblätter Der interen Seite Des Reldranbes aufgetwadjen. (Sin bis fünf Jrud̆tfntoten unter fid) uno mit bem Relde mebr ober weniger verwadjen; eben jo viel

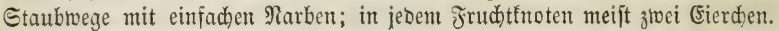
Etaubgefäß̧e in Der Mehrzahl, ringförmig ber intern Eeite bes Seldrandes entfpringento. (Sin bis fünffädbrige 2 (pfelfrudbt oder Steinfrud)t.

IIS Sulturpflanzen unferer $\mathfrak{B a ̈ l o c r}$ baben wir aus biejer Jamilie mur folgento Gaattungen aufzufübren.

\section{Die Şageborne, Crataegus.}

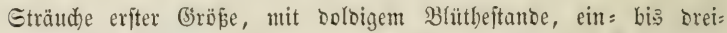
famigen, rotben Früdten. Die bei uns einbeimijd)en keioen 2 trten, Der fpib̧blätrige uno oer ft umpfblättrige Sgageoorn untericheioen fiá): erjterer burd) ftets einjanige, leb̧terer burd) meijt 2-3jamige Frucht.

a. Der ipitjblütterige Dagedorn, Crataegus monogyna Linn, aud) cintucibiger oder einjamiger $\mathfrak{B e i p b o r n ~ g e n a n t , ~ u n d ~ b . ~ D e r ~ f t u m p f b l a ̈ t t e r i g e ~ f ृ a g e b o r n , ~}$

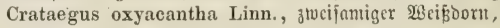

beibe unter bem gemeinfdaftlidjen গamen Der Weif̧oone befannt, fino nur in ber ?ä̈be von Ealinen ein (J)egenftand ber Forittultur, uno werben Dort

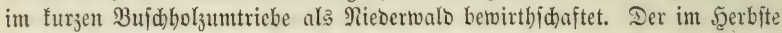
gejüetc 1-2 Eent. hod mit Erbe bebecte Eame teimt nad) $1 \frac{1}{2}$ Jahren uno fann ganz im Jreien erzogen werben. Stodausidlag lebhaft, wenig

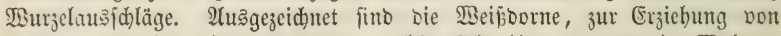
becten. Einzelne ältere Etämme, weldhe fich) hier unb ba in Wäloern

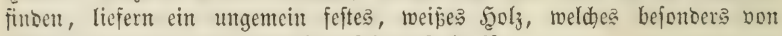
Majhinenbauern und Drechlern jebr gejudt iit.

\section{Die Mifpeln, Mespilus.}

Gejträuche zweiter Größse mit vereinzelten Blumen uno mebr als zmei

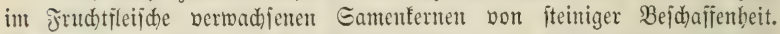
I. germanica Linn. Die gemcine Mijpel, mit flachgejägten, läıglid̆) elliptiiden, unten filzigen Blättern, ift nirgents Gegenitano ber forftulturr,

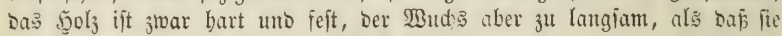
Des ?tnbaues würoig wären. Sie fonmen jwar bier und on in Rieser= waloungen, jebod) nur zufällig vor.

\section{Apfel, Pyrus.}

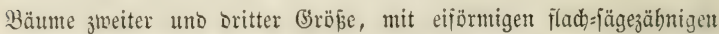
Blättern uno bereinzelten ober buifdelftänsigen Blüthen, Deren Etiele ent=

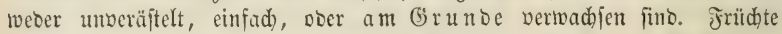

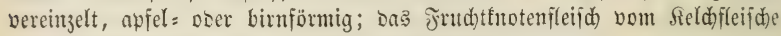
in Durdjidnitte ber Frudt nidjt unterideiobar.

Das Milobbit roar in früberen Beiten uno fo lange als bie Majt eine

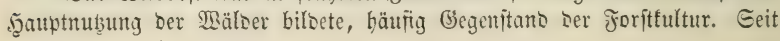


Die Majtmuburg uno aud bie Mildbahn ibre 2 Biătigfeit verloren baben,

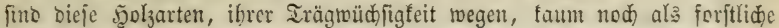
Sulturpflanzen 3 betradten, uno beridwinden mit jebem Jabrzebeno mebr aนรื นnjern $\mathfrak{B a ̈ l d e r n . ~}$

a. Der wilde affelbaum, Pyrus Malus Smyth (sylrestris), Jyolzapfel,

b. Der wilde birnbaum, Pyrus communis Linn. (pyraster), Szolzbirm.

blüben im Dai; bie Frudt reift im Geptember. Der Eame zur Gaat wiro fo behandelt wie ter Der Etabeere. Die junge $\$$ Pflanje erideint im nüdften ₹rübjabre uno ijt gegen bie Witterung abgefärtet, erträgt aber aud Bejdattung ziemlid lange. Bewurzelung tief uno weit burd eine

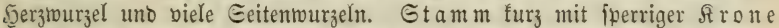

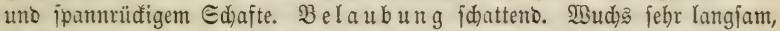

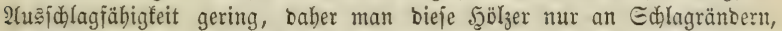
an Wegen, Iriften 2c. Dulbet, niđ̆t ober menigitens nur in Ibiergärten,

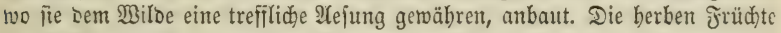

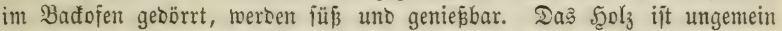
bart, fejt uno zäbe, von Dredblern uno Majdinenbauern febr gejdäbst.

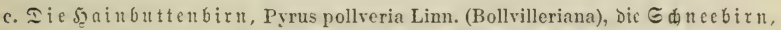
Pyrus nivalis, bie Duitte, Cydonia rulgaris,

fint nidat Begenftano ber Joriftultur, uno bier nur ber Dollitünoigfeit wegen aufgefübrt.

\section{Ebereiden, Sorbaria.}

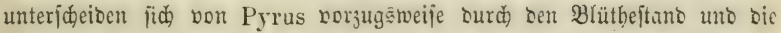
fleineren, beerenförmigen, leuchteno roth ober braun gefärbten ofrüchte, bie nur bei S. domestica benen ber Gaattung Pyrus äbnlid fint. Der Unter=

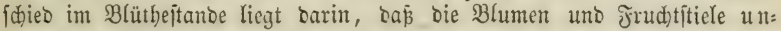
fern Dex Blüthe beräjtelt fino, jo baj ber über biejer leb̨ten 3eräjte: lung licgende Theil Der Etiele fürzer ift als ber unter ihr liegende Theil Der Etiele, woraus eine wirflide Doloenblüthe herborgeht.

Die geringe 3abl ber 2frten biejer Gruppe zerfällt in bie Gattungen Sorbus, Torminaria, Aria uno Chamaemespilus, beren Unteridjiebe in Der Blatt = und Fruchtbiloung id. Є. 319 erörtert habe. Unter bie forit= liďen Siulturpflanzen aus biejer Ģruppe fann man zäblen:

a. Ier 20 gelbecrbaum, Sorbus aucuparia Linn., and (Ébercide, Guitjdenbaum genannt.

Blüthe im Mai.

Frud t reift im Eeptember. Mannbarfeit fohon febr früh; an frei=

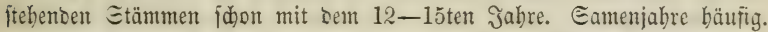

E a me: bält fich folledt und imus nod im Serbite ber Getwinmung auşgejäet meroen.

Die junge \$flanze erideint zeitig im nädjten Frübjabre, bleibt int eriten Jabre flein, bewurzelt fich aber jtarf in ber Dberflüa) Des Bocens; leibet leidht von Dürre. 


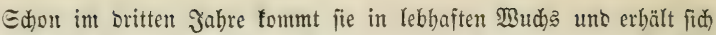
Sarin bis zum 40-50jten Эabre. Sie erträgt in ben eriten Jabren Beidhat= tung, leibet wenig bon Jröften, uno fann ganz obne Sdhus erzogen merben.

Der Stamm ift gerabe, in Freieir mit niebrig angejeşter Frone, aud) im Ed)luffe felten böber als 5-7 Mtr. gereinigt. Der ganze Baum felten über 14 Mtr. Das Berbältní ber Şolzmaffen in Stamm, Sirone

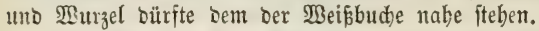

Die Srone ijt längliḑ=fugeliḑ, mit breiter Bafis uno wenigen, jtarfen Ueiten. idatteno.

Die Bela $\mathfrak{b}$ ung mittelmäß̧ig, an irei ftehenben $\mathfrak{B a ̈ u m e n ~ m a ̈ ß i g ~}$

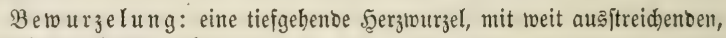
fajerreiden Geitenwurzeln.

Betrieb: im Şcdwaloe nur nebenbei, bejonbers an Brudränoern

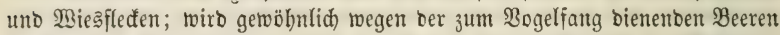
in einjelnen Exemplaren erbalten, fonft mur Durdforftungaholz. Itus bem: jelben Grumbe Dulbet man fie in einzelnen Stämmen al’ Sberbolz im Mittel: maloe. Im Rieberwaloe liefert fie ziemliden Maffenertrag.

Jortpflanzung: meift burd) Pflanzung in Cbärten erzogener, ober aus ben Beftänoen entnommener $B$ flänllinge, bie man an günfitigem Etant: orte getwöhnlid) in Mange findet. Şieb ber Stöde tief, außer ber Eaftzeit.

Benu \$ung: Dauer gering, wegen feiner 3äbigfeit ift bas f̧olz zu

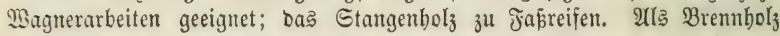
mittelmäp̄ig. Die Jrübte liefern ein außerorbentlid gutes Edaffutter, werben auđ in Branntweinbrennereien uno zum Bogelfange benub̧t.

Befdübung: bejonbers gegen Dürre.

b. Der Spcierlingbaum, Sorbus domestica Linn., aud Eperberbaum, jafme (eberejue,

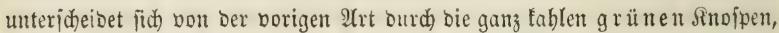
burd) bie biel gröperen, fleinen $2(e p f e \mathfrak{n}$ ober Birn and in ber gelben

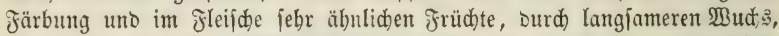

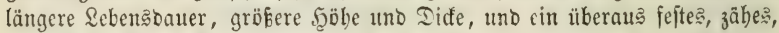

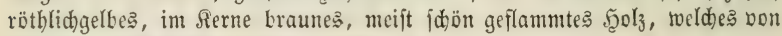

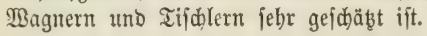

c. Dic (Elsbeerbirne, Torminaria europaea Dec. (Sorbus torminalis Crantz). Blütbe: in Mai.

Jrudt: reift im Eeptemler uno mus balo gepflüat werben, Da fie lange am Baume bleibt uno ibr von Den Bögeln jebr nadtgeftellt wirb. Man verwahrt bie Früchte ben Winter über auf bent Boben flad) auजs gebreitet, wäht im Frübjabre Den Cament aus uno gibt ibm bei ber 2 นus: fant eine Dede bon $5-6 \mathrm{Mmtr}$. Croe, worauf bie Reimung in 3 bis 4 Moden erfolgt. Mambar mit sem 25-30iten Jabre. Samenjabre bäufig.

Die junge Bilanze fann ganz im Jreien erjogen werben, berträgt aber in ben eriten Jahren mäpige Bejdattung uno erbolt fid) jelbjt fpäter beim Berpflanjen ins Jreie vom Drude. In bun erften Jabren bleibt fie flein, bringt mit einer Şerzwurgel tief in sen Booen, bildet jeoodh jahl= 
reidfe Eeiten= uno Fafermurzeln, fo das fie aud auf fladjem Boben fids

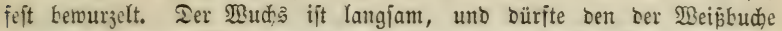
nidft übertrefien. Mit bem jedjigiten Jahre hat jue ibre Bolfonmenbeit

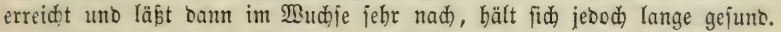

Sta mm unregelmäpig, aud im freien Etanbe auf $5-6$ Meter von 2ejten rein, bis zur Rrone ziemlid bollbolżig.

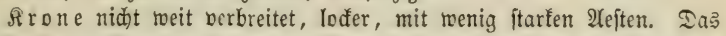
Berbältniß̄ Des Etamm=, Fron= uno Marzelbolzes türfte Dem Der Erlenfern= ftämmme am nädjiten fitehen.

Belaubung loderer, wentig berbämmeno.

Betrieb: einzeln im 5ुod)walbe an ben Bejtanḑränbern, bäufiger als Dbcrbaum im Mittelwaloe, two fie twegen geringer Bejdattung uno guter Etammbiloung im freien Stanbe fo weit zu begünitigen ijt, als bas

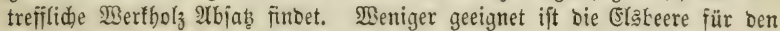
Nieberwalo, ba fie follecht bom Etode auşajlägt unb bie langam wach= jenten Etodfoban bald bon ben anderen Syoljarten übergipfelt werben.

Fortpflanzung: Durd) Eamen meift in Bilanzfämpen uno $\mathfrak{A} u \xi=$ fillanzen als Sohbe ober Sgeifter. 2(ud) Der im Freien erfolgento berbuttete 2uffidlag fann in Pflanztämpen zu taugliden Pflänzlingen erzogen werben.

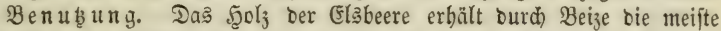
Zebnliđ̆feit mit Mabagoni, ift von alten Etämmen fäb̈n geflammt uno

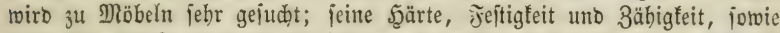

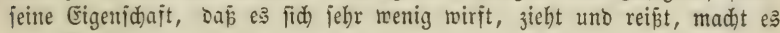
зum Majdinenbau jebr geeignet.

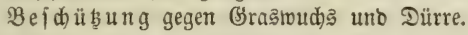

d. Ier פeflbecrbaum, Aria Theophrasti l'Obel. (Pyrus Aria Crantz) und

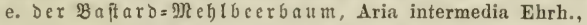

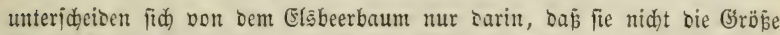
unto Didfe Jente erreiden, meift ftraudjartig bortommen, bagegen befier

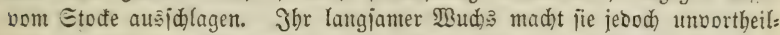
haft, io bas jie rohl gebuldet, aber jelten ober nie angebaut merben.

\section{Siebentes Siapiter.}

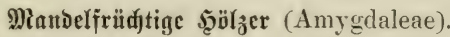

Bäume uno Sträuder mit abrodjelno geftellten einfadben Blättern uno 3mitterblumen mit fünftheiligem Sicldhe unt fünfblätteriger, tweiser, ben Seldrante aufgewadjener Blumentrone, einfachem freien, mit bem Fielde nidt berwachfenen Frudtfnoten mit einfacter Narbe, bis 20 bem

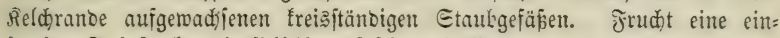
jantige Eteinfrudt mit fleifdiger faftiger ફ̧ülle.

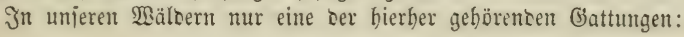

\section{Bflaume, Prunus.}

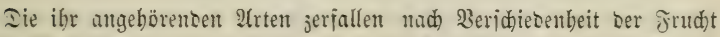

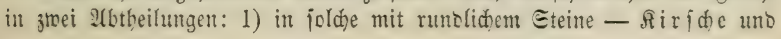


2) in foldhe mit längliḑen Steine - Bflaume. Die §irfden jet: fallen in foldje mit soloenförmigen Blüthebüicteln, Cerasus, Chamaecerasus uno in joldhe mit traubenförmigen Blüthebuijcheln, Prunus Padus, Mahaleb.

Die $\mathfrak{B f l a u m e n ~ z a ̈ b l e n ~ b r e i ~ 2 ( r t e n : ~ P r u n u s ~ d o m e s t i c a , ~ i n s i t i t i a ~}$ uno spinosa.

Bei P. avium (Eüffiride) ift bie Unterfeite ber Blätter bebant, ber Blattjtiel zweibrüfig; bei P. Chamaecerasus (3wergtiriche) fino beibe Blatt= fläd)en fabl, bei leb̨terer bie Cägezäbne brüfig. Bei P. Padus ijt ber Blattitiel zweiorüfig, bei P. Mahaleb nid)t. Prunus domestica unter= fajeibet fid bon insititia uno spinosa Durd beiberjeits fable Błätter, P. insititia von spinosa burch eirunbe, bei P. spinosa länglid lanzett=

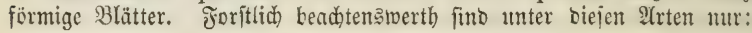

\section{a. Die 2ogelfiride, Prunus Arium Linn.}

Blüthe im Mai.

Jrudt reift im Эult. Mambar mit bem zmanzigiten Эabre; Gamen: jabre jehr häufig.

Same, im feuchten Eande aufbewahrt, wiro im Serbfte gefäet, 1 Sentim. mit Erbe bedect, uno geht bann im fommenden Frübjabre auf.

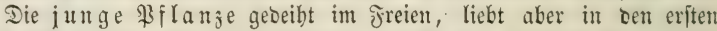
Jabren Gđub uno mäpige Heberidattung. In ben eriten Subren wädșt fie langjam, befiert fich vom fünfzehnten Jahre ab uno bat mit bem fünfjig:

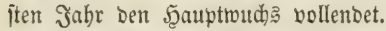

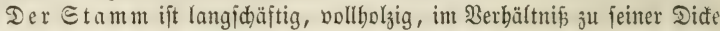

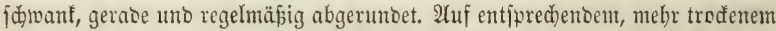

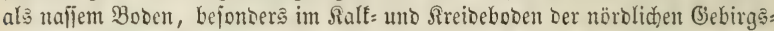
einflänge ift jein $\mathfrak{B u d}$ ş ungemein üppig. Die $\mathfrak{R}$ rone ijt jelbit im freien bod angefebt uno nidht meit berbreitet. Die Belaubung lidft uno wenig verbämmeno. Bewurzelung: Jెerzwurzel mit ftarfen Aeften in bie Tiefe bringento uno ftarfe Seitenmurzeln weit ausjtreident.

Betrieb: im Syodrwalde feltener als im Mittelmalde ars Oberboly, wo man ihn gewöbullid) als Dberftänoer böchften als angehenoen Baum abnukent famt.

Fortpflanzung. Meijt Durd Bflanzung unter ben Mutterbäumen

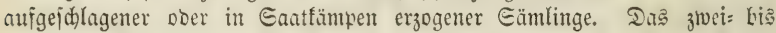
sreijäbrige $\mathscr{A}$ Iter ift zum Berwflanjen bas Befte, fpäter entwidfelt bie Siride bie fajerwurzeln weit vom Etode uno ift bann meniger fid)er zu verpflanjen.

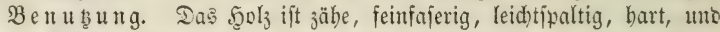

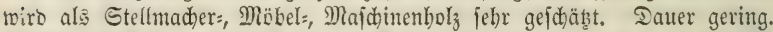
Jrüd)te als Nabrungsmittel uno zur Branntweinbremerei. Das an franten

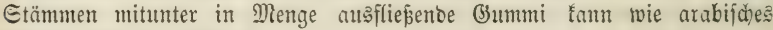
Gummi benubst werben.

Befd) üß口ung bejonters gegen Den Diebitahl Der Jrüd)te, wobei gemeinbin aud Der Baum verberbt wirb. Die Edwierigfeit, biejem vor= ôubengen, hebt in vielen fälfen sie mancherlei sortheile, welobe ser ?tubau Deకె Baumę gewäbren toüroe, auf. 
b. Die Iraubenfirjde, Prunus Padus Linn.;

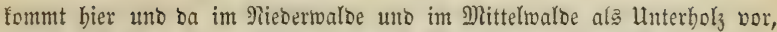
too fie fich burdh bie reidjlich erfolgende $\mathfrak{B u r z e l b r u t ~ j e b r ~ g e i d ) l o f i e n ~ e r h a ̈ l t . ~}$ Int furzen Umtriebe ertragreidy, jebod) mur auf jehr gutem Boben. Reif= ftäbe. Pulverfoblen.

\section{c. Die 2 Beidielfiride, Prunus Mahaleb Linn.,}

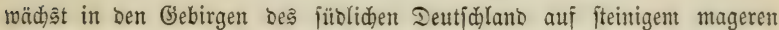
Boben, wiro ein 2-3 Meter hoker Straud, Dejien fablanfe Edjößinge wegen ifres angenebmen Gieruches unter dem Namen Reidjelröbre zu Bfeifenröhren verarbeitet uno weit verfübrt werben. Blüthe im Dai; Jruchtreife im Juli oder 21ugujt. Ulmtrieb im Niebermaloe 15-25jägrig.

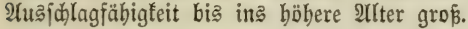

d. Iie Gartenpilaume, Prunus domestica Linn., uno e. Die Gartenjalche, Prunus insititia Walt.,

fino fein Gegenitand ber Joriffultur, wohl aber hier unt ba verwifdert.

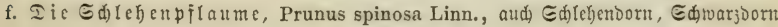
genannt.

(Fin 3-4 Meter boher, Dornenreicher Etrauch, Der in ber शäbe von Ealinen ein gefdäkgtes Material für bie Grabierwerfe liefert, uno fid barin bis 20 Jahre lang erbält. Erziehung ourdh Gaat uno Ausapflanzen ber

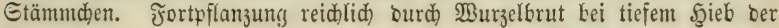
Mutterftöđ̆e.

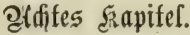

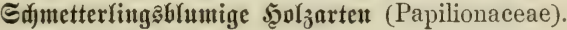

Der Seld napf:, gloden= ober röbrenförmig, am Ranbe fünftheilig,

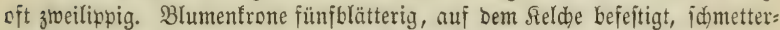
lingşförmig. Zebn unter fich) berwadjene Staubgejäāe: Jruḍtfnoten frei,

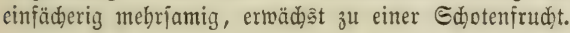

\section{Swoten= Dorn. Robinia Pseudacacia Linn.}

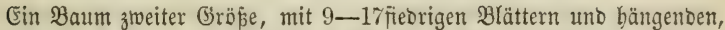
vielblumigen, weip̄en, monabelphijhen Blüthentrauben uno bornigen 2(ejten.

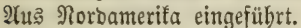

sluthe im Suni.

Jrü d) te reifen im Dftober, bleiben aber ben $\mathfrak{B i n t e r ~ u ̈ b e r ~ a m ~ B a u m e ~}$ bängen. Mamnbarfeit oft jdon por Dem fünfzebnten Jabre; fajt jäbrtid Eamen.

Der Same hält fid viele Jahre bindurd feimfäbig uno geht jebr gut auf.

Die junge $\mathfrak{B f l a n z e ~ w a ̈ d ) ~}$

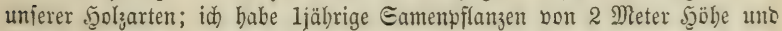
über 1 Eentim. Etammourdimefier gejogen. Die $\mathfrak{S}_{\mathrm{S} u r z e l n}$ gehent nidut tief 
in bie Eroe, fonbern berlaufen flad) uno weit in ftriaförmigen Strängen in ber Dberfläd) bes Bobens fdyon im exften Jahre $2-3$ Edyritt weit.

Der Stamm ift abholzig, mit niebrig angefester, weit verbreiteter,

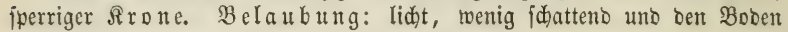
wenig befferno.

Betrieb: im Şodjwalbe wegen groper Brüdjigfeit nidht ratbjam; al: 巨d)lagholz in 10-15jährigem Umtriebe auägezeidnet wegen beż rajden

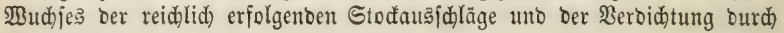
Burzelbrut.

Fortpflanzung: leidt. Durd Eamen, jeit bieje Feolzart fid an unfer Slima getwöhnt hat. Sie verträgt feinen Edatten, uno fann im Jreien ergogen werben.

Benusung. Das $2 f_{a}$ ienholz übertrifft in ber Dauer felbjt bas

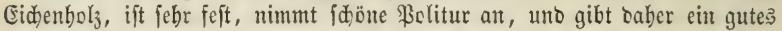

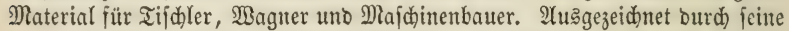

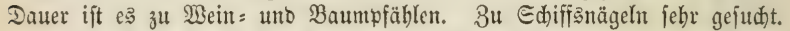

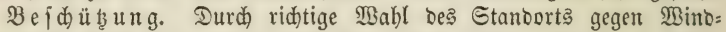
brud), Durd fpäte Eaat gegen Epätfröfte, Durd) früben Scieb gegen Früh)= fröfte; in ben eriten Jahren gegen bą Echälen ber Stämme von Şajen uno Ranindsen. Der allerbings redht grofe llebelftand, báp bie abfallenden

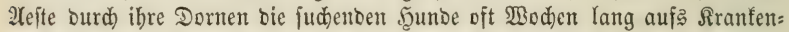
lager bringen, hat biejer, auf gejoübtem Stanoorte fo jebr empfeblens: werthen Sूolzart bie Enmmathien aller ber Forftleute entzogen, bie zugleich) jäger fint. Miloungen bat fie it biejer Richtung bejungen uno mit ber Bilotase gleidageftellt.

\section{Detentes salapitel.}

\section{Die Afjorne (Acerineae).}

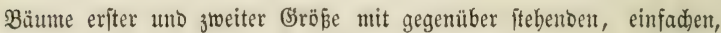
meijt gelappten Blättern uno adjelfiänoigen Traubenblüthen ober Doloen=

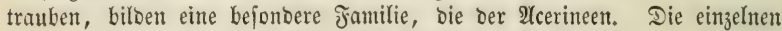

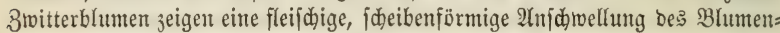
fitels, Edeibe (Discus) gentant. Die Sdeibe ift von einem fünf= bi३ neuntbeiligen Sieldhe begrenzt, beffen imerer Seite ebenjo viel Bhumenblätter entipringen. In ber Mitte ber Scheibe ftebt ber zweifammrige Jrudjtnoten, um meldjen meift 8 Staubgefäße geftellt find. Sn einzelnen Blumen ver: fümmert Der Frudtfnoten, bie Dam bloß männlidbe Befrudtungşwerfzenge tragen. Die Frud)t ijt eine am Grunbe berwadjene boppelte flügelfrudht.

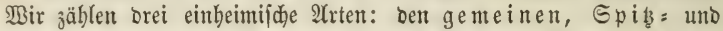
Felbaborn. Erfterer unterjecibet fid burd hängenbe Blütbetrauben, Die bei lebteren boloenförmig uno aufgeridhtet ftehen; ber Spiz̧aborn, bon ben beiben anderen 2 rten burd bie lantg uno fein zugejpibsten \&appen ber Blätter.

a. Der gemeine $\mathfrak{A}$ horn, Acer pseudo-platanus Linn., atdi) Bergahorn genannt.

Die $\mathfrak{B}$ lüthen erideinen im Mai.

Die $F^{r} u d t$ reift im Ceptember und fliegt nod in oemielben Monate 
$a b$, unter gemöbnlichen Berbältnifien fid nidht über $15-20$ Edritte vom Mutteritamme berbreitent. Mannbarfeit ber Eamenpflanzen felten vor bem vierzigiten Jahre, ber Stodlohoen biel früher.

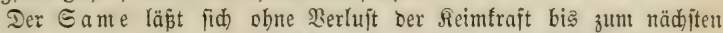
Jrübjahre aufbewabren; er bält fid zwar nod länger, berliert aber sann bebeuteno an G̈üte. Nad Ler Frübfaat feimt ber Eame in 5-6 Moden unter 1 Eentim. Erobecte.

Die junge $\mathfrak{B f l a n z e}$ wiro im eriten Gahre felten über 8-10 Eentim. hod); tiefer bringt fie mit einer beftimmten Pfablwurzel, aus ber nur wenig furze Faferwurgeln entipringen, in bie Eroe. Som jebnten Jahre ab er=

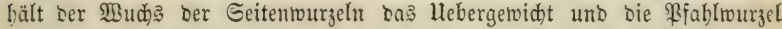
bleibt zurüd. Jn Den erften Jabren erträgt ber $2($ horn ftarfe Bejdattung, mus aber fpäteftens im fünften bis jec)sten Эabre frei geftellt, fant übrigen? red)t gut ganz im freien erzogen werben, wo er mur in sen erften Monaten, jo lange er nod) bie Samenblätter trägt, leid)t von Epätfröjten leibet.

Ter Etamm erreidt, im Ed)lujie ertwadjen, nidt jelten cine Sänge von 13-14 Pieter, ijt etras abholjiger als ber ber Rothbudje uno nidt io regelmäpig abgerunbet. $\mathfrak{A} u$ d) im ₹reien reinigt er fich auf $6-7$ Meter uno höber von $\mathfrak{2} e f t e n$, ift baher für ben Mittelwalobetrieb geeignet. Man fann bie Stammbolzmajie auf 65 \$roc. Der gejammten Şoljerzeugung ein= zelner, im mäßigen હdhlū ertwadjenten Stämme anjeţen.

Die $\mathfrak{R}$ rone ift nabe bie bur Rothkude mit einer gröperen Menge

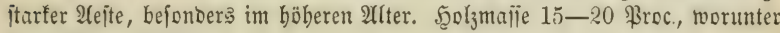
5-6 Proc. Reiferholz.

Die Bela ubung ift reid), Dod) Durd bie unregelmäpige Etellung bes Saubes weniger bejchatteno als bie ser Rothbuche. Nur ganz ftarfe Etämme verbämmen beinabe in gleidjem (Srabe. Bodenbeijerung gleid ber Rothbuche.

Die Berourzelung ift im böberen Alter zablreich uno ftarfäftig,

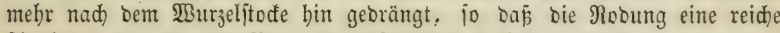
Yusbcute von 20-25 \$roc. Der gejammten F̧olymafie ergibt.

Betrieb im Şodwaloe meift in Unterntengung mit Rothbudjent uno Eichen. Im Mittelwalbe ebenjo ausggezeidnet als Oberbolz, wie als Unter: hol $_{3}$, зu leb̧terem aber nur aus Sernlocen überzubalten, Da Stodfloden leid)t

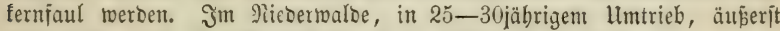

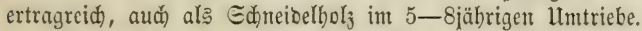

Jortpflanzung. Meift in Budenjamenjdlägen, ba ber Shorn= anflug bie Bejđattung längere 3eit ganz gut erträgt uno im Buden= boben gut gebeiht; ficherer noch ift bie Erziehung in Eaat: unto Pflanz=

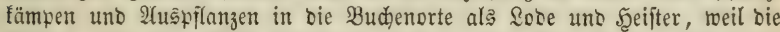
Ihorne febr vom Wild bejđäbigt werben. Im Nieberwalbe erfolgt ber

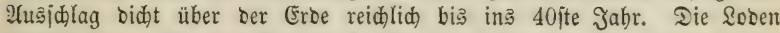

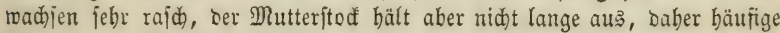
Ergänı̆ung nothłwendig wirð.

Benubzung. $3 \mathfrak{u}$ Bauboly ift Der gemeine 20 horn wegen geringer

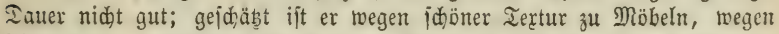

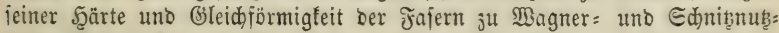
holj. 2(usgezeidnet als Brennbolz. Saub zum Edhaffiutter; Cäfte zudererreid). 


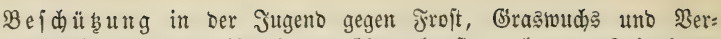
beipen. Epätfröfte idjaben ifm in Der Ebente bänfiger ala dem Epib̨aborn.

b. Der Spitjahorn, Acer platanoides Linn.,

ftimmt im $\mathfrak{B e j e n t l i c h e n ~ m i t ~ D e n t ~ g e m e i n e n ~} 2($ horn überein, erreid)t aber

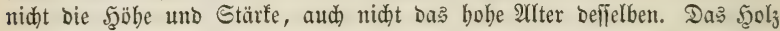
ift etwas fefter uno bärter, bagegen weniger fein, bidht uno meip als bas ber vorigen 2 rrt. Der in ben jungen Trieben uno Blattjtielen mildyige Lebensjaft unterideibet biefe 2 rt von ber vorigen. Der Sgolzjaft ift zuder: reider ala bei jenen.

c. Der Felbahorn, Acer campestre Linn., aud) Masholderahorn genanut,

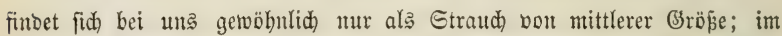

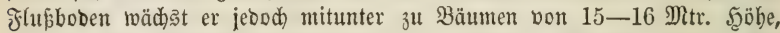
$1 / 3-2 / 3$ Mitr. Stammourdomefier uno bis 3 Ebmtr. Scolzmafie heran. Ift Baumlyolz ift fein $\mathfrak{B u d}$ ) Sajlagholz im Mittel = unto Rieberwalbe gebulbet wirb. Jm Mittelwalde ift er Dep̧balb gut, weil er etwas mebr Gdatten erträgt als bie vorge: namten $2(r t e n$; hier und im Nieberwalde bermebrt er fid reid)lid burd Burzelbrut(?) uno liefert in 15-20jäbrigen llmtriebe einen reidjen (Ertrag; aud) nirb Der Magholoer nid)t fo jebr verbififen, wie bie übrigen 2(horne. Der Same foll oft ein Jabr über liegen, ehe er aufgebt.

Das Solz Des Masholoer zeidnet fid burd feine aupergewöhnlide

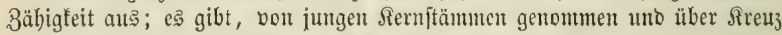

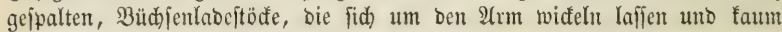
ju verwüften finto. Son Iifd) Iertur, von Dred)slern uno Majdinenbautern wegen feiner Fejtigfeit gefudt. Befaunt ift feine Serwenoung zu Den geflodtenen Jubrmanmbeitjden.

d. Der Dreilappige $\mathfrak{A}$ forn, Acer monspessulanum Linn.;

fehr vereinzelt und ftraudbüd)fig im füböftlid)en Ieutid)lant.

\section{Befintes sapiter.}

\section{Dic Riofźfajtanticn (Hippocastaneae),}

ftimmen in ber Blüthebiloung in Mandhem mit ben 2 (hornen überein, fo

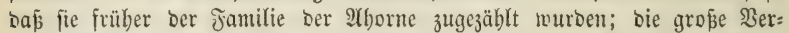
jobiebenbeit Der leberartigen 1-3fäd)erigen, 1-3jamigen Rapfelfrud)t trennt fie jebod, wie ber übrige Bau, beftimmt von jenen, fo baf fie tad) bent neneren Botanifen eine bejonbere Jamilie, bie Der Şippofajtaneen, biloen. Rad)folgento cine, feit Jahrbunderten einbeimija getworbene $\mathfrak{A r t}$ :

Die $\Re$ offatianie, Aesculus hippocastanum Linn.

Blüthe im Mai.

Frud t reift Ende Eeptember, IHIfang Dftober, fült Dann ab uno \{hüttet ben Samen aus. Mannbarfeitseintritt im 20-25iten Эahre.

Der Same verlangt eine ftarfe Erobecfe uno feimt im folgenden 
Frühiabre 3-4 Wochen nach ber 2(uşaat. Wo möglid made man bie

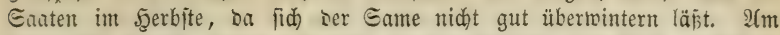
bejten bält er fich, menn man ibn, an vor Mäujen uno Milo gejoüutsten Drten flad) auf ben Rajen ausjidjütet uno idwadh mit Saub bebedt, weldes ourd) Reijer feítgehalten miro.

Die junge Pflanje crideint mit Burüflafiung Der Sernftüđe int Boden uno erreidht fifon im eriten Jabre eine Şöhe von 15-20 Eent. In Der Eroe entricfelt fie eine furje bide \$fablwurzel, aber febr viele weit

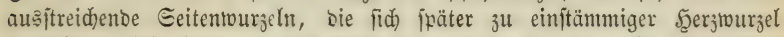

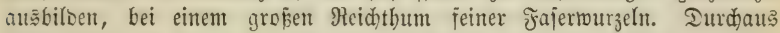
Freier Etano ijt ihs in Der Jugento, bejonders an jonnigen Jreilagen, fehr jumiber; am bejten gebeiht jie bei jtarfem Eeitenjchatten, berträgt jogar eine mäpige Ueberjđattung.

Gegenjtano ber Foriftultur ijt die Rof́tajtanie felten, bäufig aber wiro iie vom Joritmann зu 2lleebäumen uno für Ihiergärten erzogen, wo fie bem Mild eine trefiliche $\mathcal{U}($ ejung abwirft. Die Bejotatung ift jehr ftarf, baher bieje

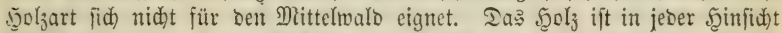

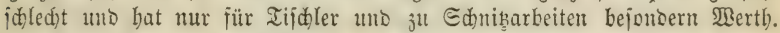
Die Rinoe ijt reich an Gerbitoï, sie Jrüchte fino ein gutes Biebjutter.

\section{Elffes Enapifel. \\ Die Rinton (Tiliaceae).}

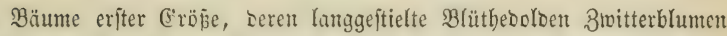
tragen. Die Blüthe mit 5theiligem Relde, šblättriger Blumentrone uno einfad)em, langiticligem, eintarbigem Frudtthoten, umitanden von vielen,

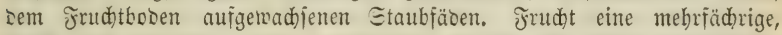
jeond) meift einfamige, nicht aufipringende Sapjel, Blattítano abwedjelno; Blätter herzï̈rmig.

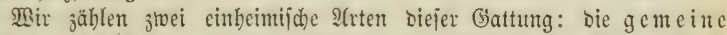
unt die grofiblättrige Sinde. Seţtere unterjdeidet fid von (Erfterer burd) wenige, miit nur sreiblumige Blüthenbüidel (baber pauciflora Hayne), Durd) bie gleidjörmige \$ertheilung Der ftärferen Behaarung auf Den beibor= jeiţ gleidfarbig grünen Blättern, wäbreno bei ber biel bäufiger bor:

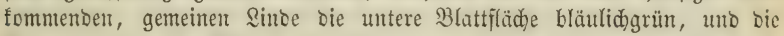
Behaarung in bie 2(djeln ber Blattrippen bärtig zujammengebrängt ift.

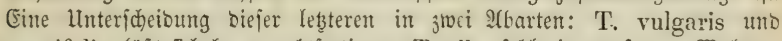
parvifolia läpt fich faum rectffertigen. T. alba feblt in un feren Mälocrut gänzlid. Die groß̄blättrige Sinbe T. platyphylla ift jelten; bäurigg nur in (3ärten unt ßarfanlagen.

Die gemeine \&inbe, Tilia europaea Linn., aud) Berglinde, Mintertinde, Etcintinde genannt.

Blutthe gegen Enbe Эัuni.

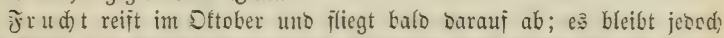
fäufig Eame ben $\mathfrak{B i n t e r ~ u ̈ b e r ~ a u f ~ D e n ~ B a ̈ u m e n . ~ F r e i j t e b e n t e ~ B a ̈ u m e ~ t r a g e n ~}$ meiłt jđon mit bem 25jten Jahre Eamen. Eamenjabre bäuifg. 


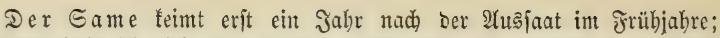

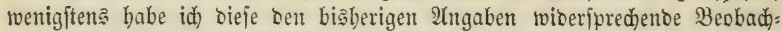
tung vor mebreren Jabren in groper 2 (4abchnung in unjerem foritgarten gemad)t. Nan mup baher Dem Gament eine ftarfe Dedfe geben, went er wäbrento ber langen Gamenrube nidjt von Mäujen uno Bögeln, bie ifm jebr nad)gehen, verzebrt werben foll. Er läpt fid gut aufbewabren, baher man ifn, um bie Zeit möglidfft ab̧zutürzen, in weldher er bent Mäuje= uno ßögelfraßs ausgeję̧t ijt, erft im Jrübjabre fäet.

Die junge Bflanze hebt bas fălaudförmige Rentítüa wie bie

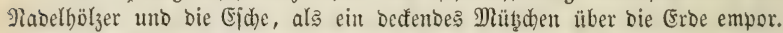
Die erften Blätter fino fünflappig wie AYbornblätter. Sie bleibt int criten Jahre über ber (Erbe fehr flein, verbreitet fid weit unter ber Eroe, ber= trägt Sdatten, fann aber audj im Freien erzogen werben.

Der Stamm reinigt fid mu im Salufie von Aeften uno bilbet Dort einen vollbolzigen regelmäß̋igen Єdaft; man fam bier 65-70 \$roc., im Freien hödjtenכ 60 ßroc. Stammbolzmajie rechnen.

Die $\mathfrak{R}$ rone ift im Freien febr tief angejebet, boll uno ftartäitig, io

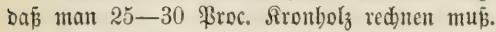

Belaubung jehr veroämmeno, fajt Dunfler als bie cer Rothbude, wie bieje ber Bobenbefierung förberlid.

Bewurzelung: ftarfäftige, febr tief gebende Secrzwurzel mit vielen

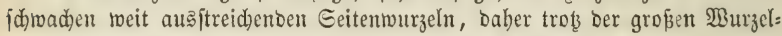
menge bie Rodung gewöbnlid) nidjt über 12-15 Proc. erträgt.

Betrieb im Scodmaloe, jebod felten rein, meift in Untermengung mit anberen, jowohl Laub: als Nabelbälzen; im Mittelwalbe weber als

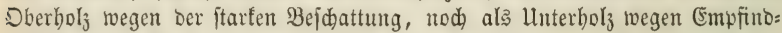
lidfeit gegen Befdattuny als Ed)lagholz zu bulden. Im Nicberwalde am ergiebigiten in 20-25jübrigen Umtriebe. $2(3$ Sopf = uno Edneibelhol benub̧bar.

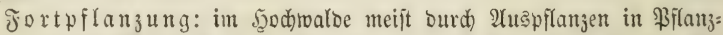

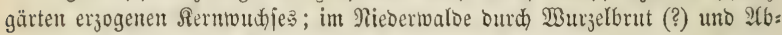

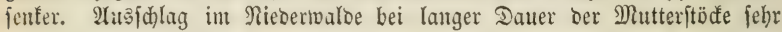
reid)lid) uno fräftig.

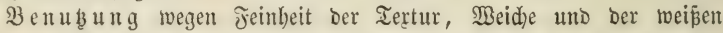

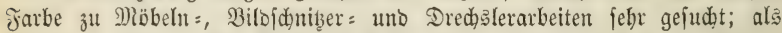
sBunnbolz fdled)t. Die Rinde Des Ed)lagholję liefert ben Bajt, bie Blätter cin mittelmäßsig gutes Jutterlaub, ber Game ein treffiliches Epeijeöl.

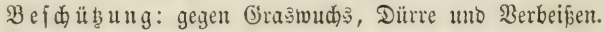

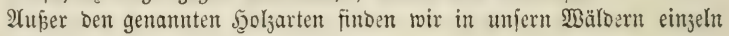
แแก ว̧ufällig:

Şartriegel (Cornus Mascula, sanguinea),

5ูollunoer (Sambucus nigra, racemosa),

$\mathbb{B}$ egoorn (Rhamnus catharticus, Frangula),

Sd neeballen (Viburnum Opulus, Lantana),

Rbeintweibe (Ligustrum vulgare),

Spindelbaum (Evonymus europaeus, verrucosus, latifolius),

Bimpernú (Staphilea pinnata), 


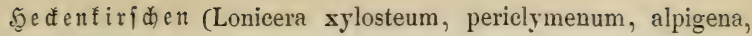
caerulea),

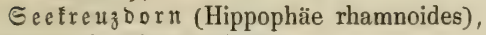

Sumad (Rhus cotinus),

ङauerad) (Berberis vulgaris),

Jobanuiąbere (Ribes alpinum, nigrum),

Eibe (Taxus baccata),

bejonbers in Nieber = uno Mittelwälbern. Sie werben ba, wo fie vor: fommen, mit benubst, fino aber, wie aud mande ber in ben gentannten o ja=

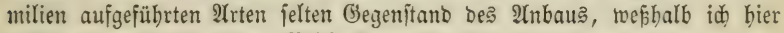
nidgt toeiter auf ibre näbere Bejdreibung eingehe.

\section{Dritter Afbjifnitt.}

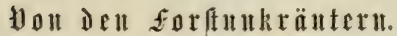

Unter Forftunfräutern veritebt man biejenigen Balbgewädje, welăe in

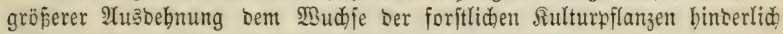
werben. Sie zerfallen in żwei 2Abtheilungen, in:

1) bebingte unto

2) unbebingte

Joritunfräuter. Bedingte joriftunfräuter find $\mathfrak{B a l}$ agewädje, welche ben

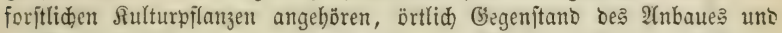

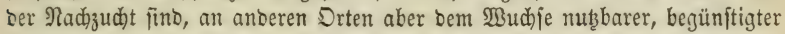
Solzarten entgegen jtehen. Dahin gebören z. B. Birfen, Bappeln, Meiben, Sinoen, ja felbit Nabelhöljer, ülerbaupt Scoljarten, weldhe burch größere uno

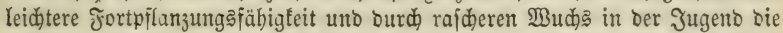
Eăläge überjiehen uno begüultigte, langjamter wadjenbe 5̧olzarten über= gipfeln uno unterorücten. Dieje bebingten Forftunfräuter haben wir bereitङ im borigen 2(bidnitte fennen gelernt, uno id) fann midy baber bier auf bie 2(ngabe berjenigen Mittel bejäränfen, welde bem Forjtmanne зu Gebot fteben, ibrer nadtheiligen Mirfung entgegen ju arbeiten. Dieje fino:

1) Şinwegräumung Der Mutterbäume folder Şolzarten aus Drten uno Deren Nadbarjdaft, bie Der \$erjüngung ober bem 2Nbaue unterworfen werben follen, mehrere Jabre vor ber beahfibtigten ßerjüngung, getwöhnliç in Der lebiten Durăforítung.

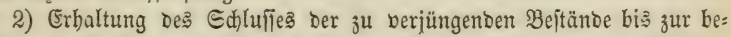
abichtigten Berjüngung, Da bie bebingten Forftunträuter mur in lichteren Drten fid anjiebeln.

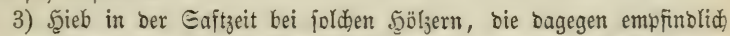
fino; im Eommer nad, ber Eaftzeit, bei benen bieß nidht ber fall ift, um bie erfolyenden $2(u s ̧$ ) Binterfälte verniḑten zu la İen.

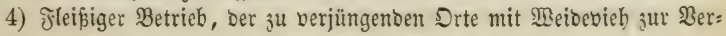


tilgung ber bereits vorhanbenen Samenpfläuzdhen uno bes nad̆ bem 2 น⿰氵 biebe erfolgenben $\mathfrak{B u r}_{3} \mathrm{el}=$ und Stodauşatlages.

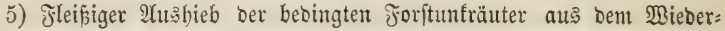
wudcje, ehe fie verbämmend werben in ber Gaftzeit poer fpäter.

6) Şintwegnabme Derjelben in Den Durdforftungen.

unbebiugte For ftunfräuter fino folde, bie, ben Forftultur: filanjen nachtheilig, felbft nie Begenftano ber Joriffultur fino, wenn fie aud), wie z. B. Wadholoer, Bejenpfrieme, da, two fie bereits vorbanten, ein Gegenjtano der Benub̧ung fino. 2lber jelbjt biefe unbedingten Forft: unfräuter find biés nidht auf jebem Stantorte unb ba jiemlidj harmloje

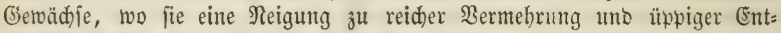
tvidelung nidjt jojon längit funo gegeben baben. Die gefürdjtetften Forit:

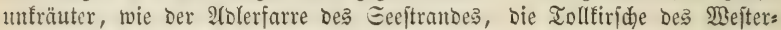

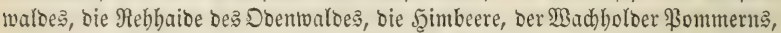
Ier twarzige Epinbelbaum Ditpreupen, Der Rienporit Dberid)lefiens fommen jwar an anderen Drten aud vor, aber nidt in gefabrorobenoer Menge neben= cinanber üppig fid entwidelnto. Wir wollen in Jolgentem bie widtigften ber= jelben, imb zlwar zuerft bie Fुolzpflanzen, Dann bie Rräuter uno entlich) bie Grräjer näber betradhten.

\section{Eirftes Siapite?.}

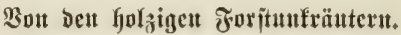

a. Jumergrüne (S) fiträud)e.

1. $\mathfrak{W} a$ d) $\mathfrak{h}$ older, Juniperus communis Linn.

Ein Mabelfoljitraudh, jelten baumartig, mit blauen Beerenzapfen, uno wirtelitänbigen Pabeln.

Etaudort: mur auf fräftigem gemäpigt feudtem, fanbigem Selym unt Rehntboden wädst er fo bicht unt überzieht fo grope Stellen, daj er Der Jorftultur binberlid) wiro. Jm trodinen Gande ftellt er fid) ftets ber:

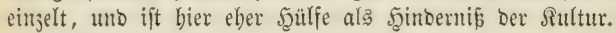

IB $u$ di) 2 langiam, jelbit in ber Jugento.

Jortyflanzung mur Durd) Den Samen. Blüthe im Mai; Fruchts reife im Şerbit bes folgenden Jabres.

Bertilgung: genügeno Durd) 2(uşbieb. Sn Edlägen fann man, bei Dangel an Samenbäumen, aแझ̆geäjtete ftärfere Stämme zum Edukge in ben eriten Jabren überbalten.

\section{2. Şülje, Ilex Aquifolium Linn.}

(Eit 3-ð Mtr. hoher Straudd) mit leberartigen, am Rante lantg: ftadyeligen Blättern uno rothen Beerenfrüdten.

Etandort: mur im lebmigen frudbtbaren Boben ober im nafien

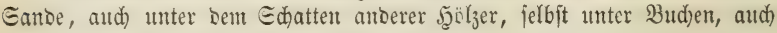

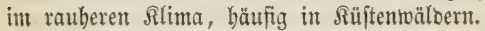

IB $u$ d) uno breite Blätter verðämmıno. 
Fortpilanjung: Durd) Eamen. Blüthe im Mai, Frudtreife int Ditober. Eame liegt $1^{1 /} / 2$ Jabr im Boben.

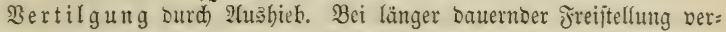
¡dwintot bie ફ̧ülje allmäblig von jelbjt.

\section{Jgeide, Erica (Calunna) vulgaris Linn.}

(Eroholjitraud); jelten über $2 / 3 \mathrm{M} \mathrm{tr}$. hod, mit gegenüberiftebenoen, ¡ăuppig anliegenten Blättern uno rothweiß̄en, glocéenförmigen 3twitterblumen.

ङtandort: auf trodinem unfrudutbarem Eanoboben uno lebmigem Sanoboben, in freitr ober menig bejdatteter, jonniger Sage.

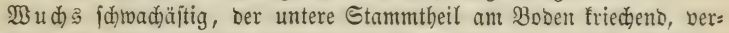
idhlungen uno bidten Beftano bildent; Die Enojweige aufgeridtet. Etämme von 2 Cent. Durdemefier jebr jelten. SBurzelfily jebr bicht. Biloet asitrin=

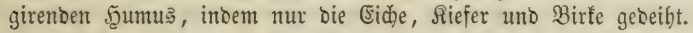

Fortpflanzung Durd Gamen uno Abjenfer. Blüthe im 2(uguit, Gamenreife im Sttober.

3ertilgung mit ber Şade burd) Abidälen ber cberen (Erojididt (Plaggenhauen), jeood) nur bann nothwentig, wenn bie Şeibe einen bidten

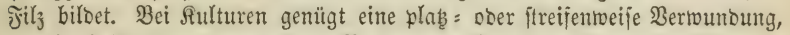
sa bie Sgeibe ben verwunbeten Boden nur langlam twieber überjieht; bie gänglidje Räumung wiro nidgt allein fehr foftbar, fonbern fübrt aud ein

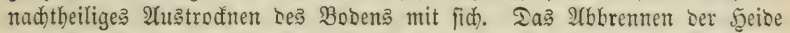

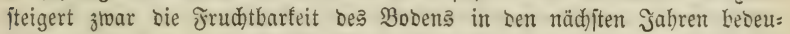
tent, ruft aber einen itarfen (Grasmudis berbor, Ler bem Siederwudje oft nad)theiliger wirb als bie bleibenbe Sceibe es ift.

\section{Die łrenвelbeeren, Vaccinium Vitis Idaea Linn.}

Ein jelten mebr als 15-20 Eent. boher (Erobolzittraud) mit trauben= förmigen, weik̄en, gloffenförmigen 3witterblumen uno rotben fäuerlid) füpent Beeren.

Etandort: vorgugatweije ben Giebirgämälbern mit jeuddtem locferem

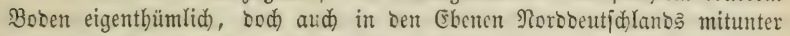
meit verbreitet, bejonbers ift fie ben Şodinäldern eigen, wäd)引t zwar im mäbigen Edatten, berid)winbet aber nidjt burd) Jreiftellung, jonbern ge: Deift recht gut im Freien.

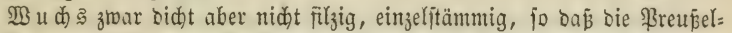
beere in ben $\Xi d)$ lägen felten nachtheilig wirb. Nur ben ganj leidhten

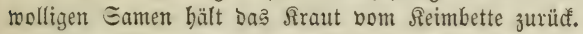

Bertilgung ourd bie Şadée nur beim A(nbau nöthig.

\section{Bärenbeere, Arbutus Uva-ursi Linn.}

Ein friechenbes immergrünes Eroboly; im Mai mit glodenförmigen Switterblüthen, im Eeptember mit runoer, faftiger, rother 5 bis 6 ja= miger Beere.

ङtandort: auf trofnem, janbigem, unjudbtbarem Boden; in jüb= lidjen Deutidjlano aud im (Sebirge; bei uns mitunter, Dod) jelten, in Riefernbeftänden fleine ffläden biđat überzieben๖. 


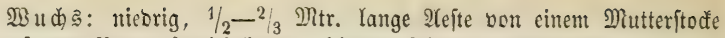
aus auf bem Boben fortfriedent, Şinert feltent die Befamung.

Bertilgung: burd) Abbieb bes Mutterftocts mit ber Scade.

6. Sichnporft, Ledum palustre Linn.

Ein ${ }^{2} / 3-1$ Mtr. hoher Straud, im Jumi uno Juli mit bolsen= förmigen tweisen 31witterblumen, im September mit brauner fünffäd)riger Eamenfapfel. Die immergrủnen, lanjettförmigen Blätter oben grün, unten braunbaarig, am Ranbe gerollt.

Etandort: auf feudtem unt nafjem Moor uno Eumpfbodent.

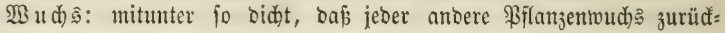
gebalten wirb.

Bertilgung: Der Riehnporft wirft nidht allein nadtheilig Durd Berbämmung, fondern aud burd) ben aus ibm fid bildenoen, febr $a b=$ ftringirenten Scumus, in weldem feine anbere Şolzart gedeibt. Man fumn Den Boben baber nicht anders fultiviren, als burd) (Entmänjerung mittelft

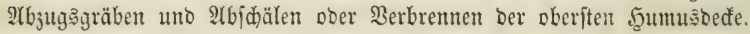

\section{b. Sommergrüne (jefträud)e.}

7. Dic Szcibelbeere, Vaccinium Myrtillus Linn.

Cin fommergrïner (Eroholjitraud) von hödjtens $1 / 2$ Meter Şöbe, im Mai uno Juni mit rötbliḑen glodenförmigen 3ritterblumen, im Jull uno 2Yuguft mit blaufdwarzen faftigen Beeren.

Standort im nöroliden Deutidlant: bie (Ebenen unt ber Meerews: boben, im jüblichen bas Gebirge, auf trodnerem Boben, Kefonbers an

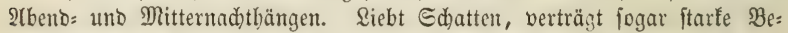
[d)attung, uno läpt nad ber Freiftellung bebeuteno im Mudbje nach.

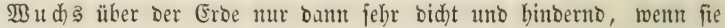
ftarf uno oft berbiffen wiro; befto filziger unter ber Eroe; ber ßerjüngung jebod felten binoerlid.

Bertilgung: wo es nöthig feit follte, burd bie Seade platas ober ftreifentmeife. Da bie \$accinien jelbit cinen frudtbaren Scumus biloen, io ift bie Bertilgung burd) Jeuer nid)t vortbeilbaft.

\section{Simbeere, Rubus Idaeus Linn.}

Ein 1-1 $1 / 2$ Meter hober Etraudh, mit unpaar gefieberten, orei bis fiebenzäăligen Blättern uno einzeloornigen Blattîtielen; im Mai uno Junt mit weisen, fünfblätterigen, viclweibigen Blütbedoloen, im 2luguft mit rothen wohlidmedenten Beeren.

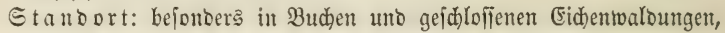
auf binbentom feudstem Boben in ber Ebene unt in Borbergen.

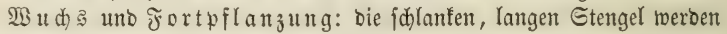
im zweiten Jahre fruchttrageno, unt gehen nad) ein= ober zweimaligem

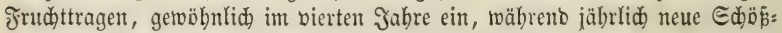

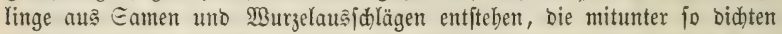

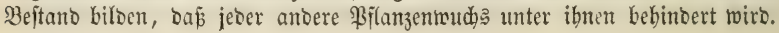




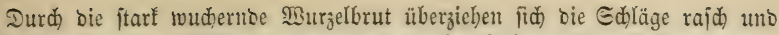
Didat mit biejem Unfraut, io baja in vielen Jabren feine Bejamung an= fílagen fann uno bie bereits vorbanbenen Eamentflanzen unterorïđt werben.

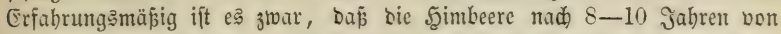

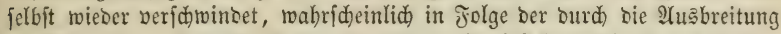

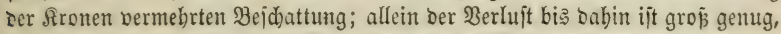

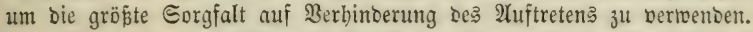

Bertilgung. Wenn bie Erfahrung lehrt, daßs eine Dertlidfeit bem

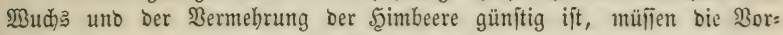
bereitungs

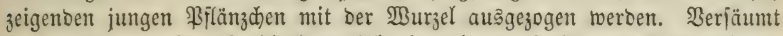
man bies, uno bat bie Simbeere fich einmal außgebreitet uno bewurzelt, io ijt bem Uebel faum mebr zu fteuern, indem bas 2 bjäneiben ber Iriebe

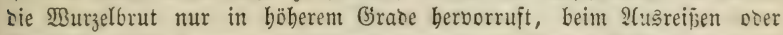
Stubbaden bod immer nod) $\mathfrak{B}$ urzeln gentug im Boben bleiben, um im nädjiten Jabre einen neuen Beftano zu biloen.

\section{Bejenpfrieme, Sarothamnus Scoparium Linn.}

Ein 1-2 Meter hober Strauđh, mit ftrabligen, wenig blätterigen

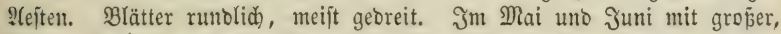
¡đön gelber Edmetterlingablume; im 2(uguit uno Eeptember mit breiter, brauner mebrjamiger Şülje. 3weige fünffantig.

Etantort: auf trodenem, jandigem $\Omega$ ehm uno lebmigem Eano, in freier

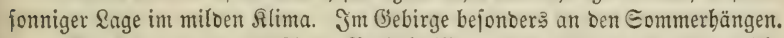

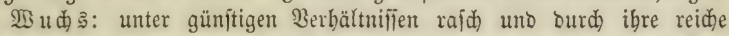
Bermebrung aus Gamen grop̃e Flähen bidt überziebeno; uno bann Der Berjüngung uno bem 2 (nbau nadthrilig; mehr vereinzelt, wenig veroämmeno uno binberno, auf bem ibr eigenen trofenen Boben; bann mebr vortheil= baft als nadytheilig. Edjatten erträgt bie \$irieme nidht uno erfriert bäufig in falten $\mathfrak{B i n t e r n . ~}$

Bertilgung: ourd) S(แล̧bieb vor ber Eamenreife, gemeinfin gegen 2(byabe Des Materials ohne grofe Solten zu bemirfen.

Geltener uno nur in geringer 2 (uכbebmung jeigen fich unter äbnridjen Berbältnifien Den Sgolzwudbs bebinderno:

10. Ginjter, Genista germanica Linn.

11. Бூ a hedel, Ononis spinosa Linn.

12. Sૃc fiame, Ulex europaeus Linn.

Bertilgung twie bei der Bejenpfrieme.

13. Der rothe Seollunder, Sambucus racemosa Linn, uno 14. Die 5golfunderitaude, Sambueus Ebulus Linn.,

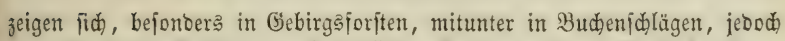

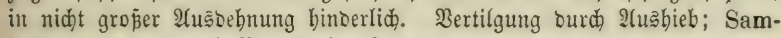
bucus Ebulus burd) Robung im Gommer.

15. Der trarzige Epinderbaum, Evonymus rerrucosus Scopoli,

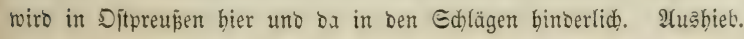




\title{
马ెweites Giapifel.
}

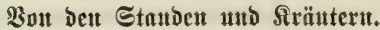

\author{
16. Tolffiride, Atropa Belladonna Linn.
}

Eine 1-2 Meter bobe a us ba uernoe Staube mit eiförmigen, ganz: rantigen $\mathfrak{B}$ lättern, im Juli unঠ 2 (ugujt mit fünfmänniger, eintweibiger, braunrotber Blüthe, ähnlid) Der Rartoffelblüthe; im September mit firichen= ähnlider, braunjobarzer, zmeifächeriger, fehr giftiger Beere. Standort faft mur in Gebirgen, befonbers in Bud)enfollägen, bieje mitunter ganz über=

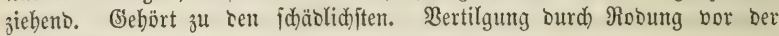
Samenreife.

17. Fingerfut, Digitalis purpurea und ambigua Linn.,

2/3-1 Meter hobe, zweijährige Stauben mit lanzettiörmigen, am Ranbe geferbten Blättern, im Jüni uno 2(uguít mit fđön gefärbter, fingerbut= äbnlidjer, eintweibiger, zweimänniger Blume; im September mit zmeifädherigen, flaffenden Rapfelfrüd)ten. Standort ebenfalls roržgşweife in ben Bud)en=

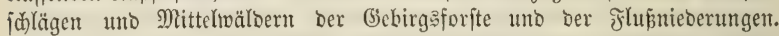

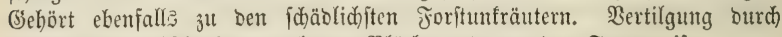
wieberboltes 2lbidneiben nadh ber Blüthe uno vor ber Gamenreife.

18. (E berid), Epilobium angustifolium Linn.

Eine a usbauernoe Staube mit ${ }^{2} / 3-1$ Meter hoben Stengeln, mit id)malen, lanzettförmigen, fait ganzrandigen Blättern; im Julli uno $\mathfrak{A}$ uguit mit blaurothen, bierblätterigen, cinweibigen, ad)tmännigen Blüthen in auf= redten Irauben; im Eeptember mit bierflappiger, ben wolligen Gamen

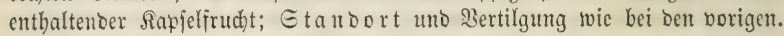

19. Sarthet, Hypericum hirsutum Linn.

Haรdauexn. Etengel $1 / 3-1 / 2$ Meter bod), äftig, haarig, mit - längliden, Durd)fid)tig getipfelten, unten weid)haarigen Blättern; im 2 Uuguit mit gelben, fünfblätterigen, Dreimeibigen, vielmännigen Błumen, beren Etaubfäben in 3-5 Bünbel verwadjen fins. Im September mit brei= biß fünffäd)erigen, vieljamigen Sapfchn. Im (3ebirge auf trodnerem, fdjattigem Boben. Bertilgung wie bei ben vorigen.

\section{Bünโcl, Ajuga reptans Linn.}

Etaute mit vierfantigem, glattem Etengel uno friechenben $\mathfrak{B u r}_{3} \mathrm{el}$ ¡proilen. Blätter breit, eiförmig, gewimpert. Im Mai uno Suni mit blauten ober weiß̄en, wirtefitänoigen, zweiweibigen, viermännigen Sippenblumen; Staubfäben ungleid); im 2(uguft mit vier nadłten, nubartigen Eamentörnern. Bejonbers ben Eaaffulturen burd) Ueberrajen ber Saatplätze nad)tbeilig.

21. Taubneffel, Lamium maculatum Linn.

Stengel $2 / 3-1$ Meter bod), mit herziörmigen, zugeipib̨ten, gejägten, oft weipflectigen Bättern; im Mai uno Jumi mit rothen wirtelfitänoigen 
Sippenblumen. Befruchtungstheile wie bei Ajuga; Unterlippe mit einem

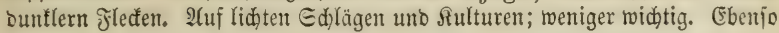

22. Waldnejiel, Galeobdolon luteum Hudt. 23. Biejt, Stachys germanica Linn. 24. 23 ir beldofte, Clinopodium vulgare Linn. 25. Hieracium sylraticum. 26. Mercurialis. 27. Impatiens. 28. Verbascum. 29. Senecio. 30. Spergula.

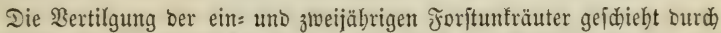

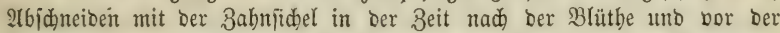
Eamenreife; erfteres, Da fie fonjt wieber auşjolagen, lek̨teres, um bie Jortpflangung burdh ben auşallenben Eamen zu verhintern. Die Ber=

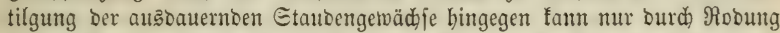
betwirtt werben, inbem bie abgejdnittenen \$flanzen zu jeber 3eit vom Etode

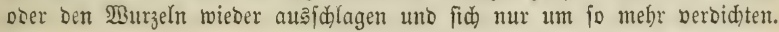

\section{Drittes Sapitel.}

\section{ßou Den Binjen und Gräjern.}

Sie forbern alle einen höheren (5rab Der Sidteintwirfung, Fetdd):

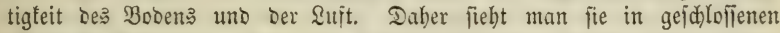
fäattigen Beftänben, unter Der Iraufe jdattender Bäume ebenjo ivenig, wie auf trodenen Blö̈en üppig wad)jen, fondern nur in einzelnen, wenig

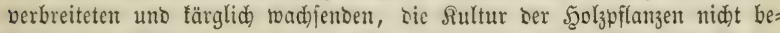

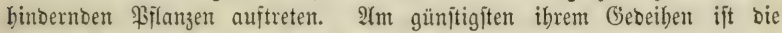
Beit, in Der bie Beftänbe Behufa ber Berjüngung ausgelidtet werben, weil fie bort nicht allein bas nöthige Sidht, fonbern aud, in Folge bes nod reidylid borbandenen Walobumus, deffen Baffer anjiebenoe uno binbente Sraft wir bereits fennen gelernt baben, bie nöthige Jeudjtigfeit vorfinden. Eine Urjache bes gröperen Jeưhtigfeitsgrabes auf binbenderem Boben gelidsteter oder abgetriebener Drte ift ferner bie Sainwegnabme ber Jel $_{3}=$ pflanjen jelbjt, bie früber burd) ifre $\mathfrak{B} u r z e l n$ bem $B$ oben bie Feudjtigfeit

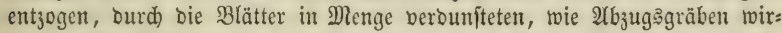
fent. Die Birfung ber Sgolzłflanzenwurzeln in biejer Şinfidst ift jo grop, Daß auf jebr bindendem Boben mitunter Berjumpfung ba eintritt, wo vor Der Entholzung Der Boden nur gemäpigt fencht war. Daher fehen wir nach)

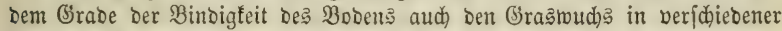
2(rt unt Mentge, wie mit beridiebenem $\mathfrak{B u}_{\text {bje }}$ auf Den Edlägen erijheinen. In einem loderen Boben, ber, aud ohne bie ableitenbe Ifätigfeit ber Jolzhpflanzentwurzeln, bie Jeud)tigfeit leid)t berounftet ober in bie Tiefe finten läpt, ift vom (3raștoudje bei tweitem nid)t fo viel zu befürd)ten, als auf Boben, Der burd) gröperen Şumus ober Thongebalt bie Feudtigfeit

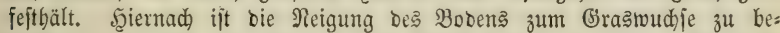
urtheilen, bie fid aljo fiton bor ber Edhlagftellung bei einiger Alufmert: famfeit ziemlid ficher erfennen läpt.

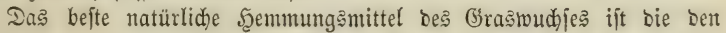

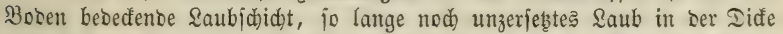
ciniger 3olle ben Boben bebectt uno Darüber fejt liegt. Mant mus baber

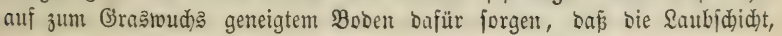




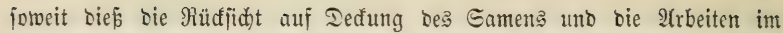
Sd)lage geftattert, möglidjit ungeftört erbalten werbe, worauf ber Sd)ut Di: Ed)lages bor Mino uno bie Dunflere Etellung wejentlidh einwirfen.

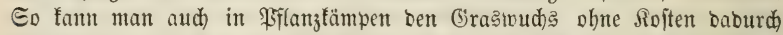
jurüdGalten, bas man bie Pilangbeete einige 3oll hod) mit Saub bebect.

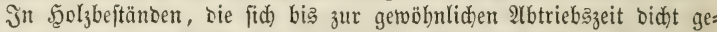
id)lofien erbalten, in Rothbud)en=, Iannen=, Fid̄enbeftänocn, bei furzem

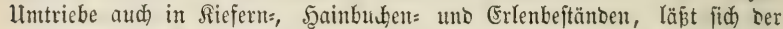

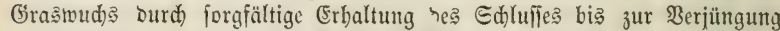
unterbrüden. Berben foldhe BeftänDe Behufa Der Berjüngung Durdhlidftet,

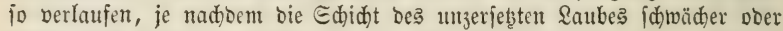

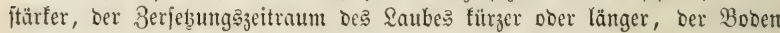

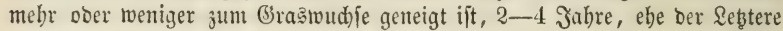

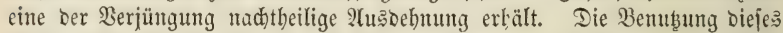
3eitraumes für bie Berjüngung ift von bejonterer $\mathfrak{B i d t i g f e i t}$ für folde Dertlidfeiten, in benen bie Joritunfräuter erfabrungsmäßßg bem Wieber= wudje nadtheifig werben. Sier muß man bejonters barauf fehen, bie Ed)lagitellung nidft vor Eintritt eines Samenjabres auş̧üübren uno bieje io buttel balten, als bießs mit ben übrigen $\mathfrak{B} e r$ bältnififen vereinbar ift. Eo nüßslid uno für viele Fälle notbwenbig die Stellung von Borbereitungä= id)lägen ift, läpt fich Dod) nid)t verfennen, Daj burd fie ber Sampf mit

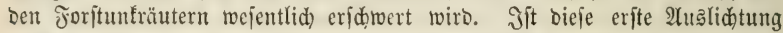
aud) ber 2(rt, baf ber Unfrautwudbs eine o ie Berjüngung bindernoe Aubehnung nidht erreiden fann, fo wiro bod ber Reim zu foldem bis 3แt Serjüngung ausgebilbet, Der Dann, nad) ber zweiten Sidfung, viel

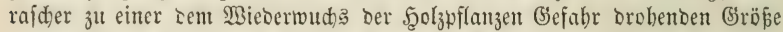

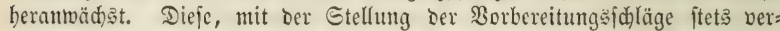

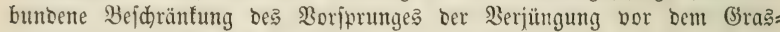
uno Innfräuterwudje, ift bie Urjadhe, wefbalb Eritere nid)t zum allgemeinen Wirthjofat (Srastwudje geneigt fino, mur nad) forgfältiger \$rüfung unbebingter Noth= twenbigfeit ausgefübrt werben bürfen.

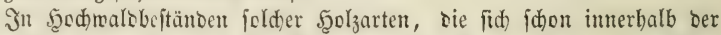

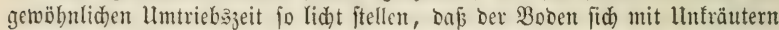
uno Gräfern überzieht, in Eidjen=, Birfen=, Siefern= uno Särdenbeftänden, finoen bie obigen Rücfichten nid)t ober nur in untergeoronetem (Brabe ftatt. Der Sampf nit Den Foritunträutern forbert hier in ben meiften Fällen bie Berwenoung bejonoerer 2Arbeităträfte.

In Den Buddennittelwaloungen bes jüblichen F̧arzranbes bălt man

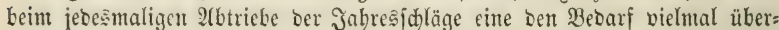
jteigende 2(njabl bou Lapreioel, uno felbjt nod) viele ber abzunubenden

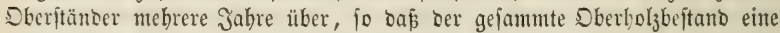
gleidmääige, cinem Buchenounfelid)lage nahe ftebende Befdattung wirft, Durd) reldhe nid)t allein ber (3rastwudb, fonbern aud bie holzigen Jorift=

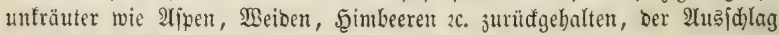

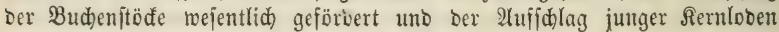

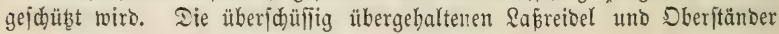


merben bann nad) und nađ), bie leb̧ten ipätejtens fedja Gabre nad) bem

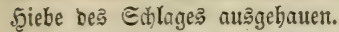

Die veridjiebenen 2(rten ber Foritunfräuter erjdeinent in ber Regel nidat gleidzzeitig, jonbern in einer gewijīen, auf verfabiebenen Etanoorten

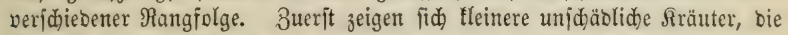
idon im vollen Beftante borbanoen maren, mie Asperula, Anemone, Mercurialis, Paris 2c.; fie veridbindon mit ber sidchtitellung uno es treten

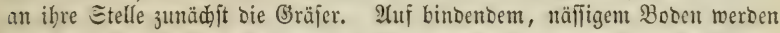
bie Grräjer nad) 1-3 Эabren bon Binjengräjern verbrängt, in ber Regel begleitet non Moojen, bejonters Polytrichum-2trten. Diejent ober oen

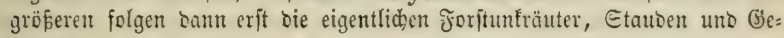
jträudoe.

Die Bertilgung Der Giräjer burd Arbeiţfräfte fam nur bann von

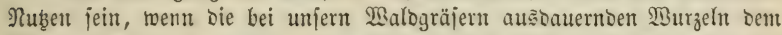
Boben entnommen merien. Ein blokes 2tbjuneiben ober Albweiben ber

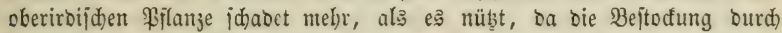

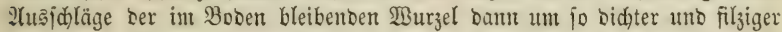
wiro. Die Bertilgung ber Gräjer mit ben $\mathfrak{B} u r z e l n$ ift aber jebr foît=

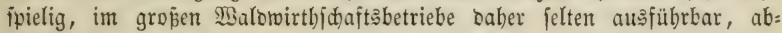
gejehen bavon, Daj fie fich in ben meiften fällen nidht ohne gleidzeitige

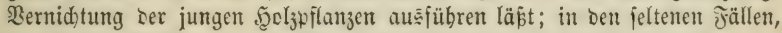
mo fie auşübrbar ijt, muj fie im Exätiommer ober Seerbjt gejdeben, ba

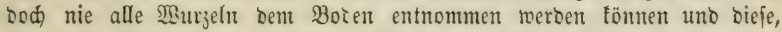

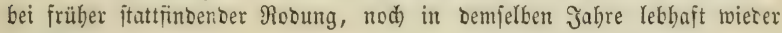
aแลื่อไlagen.

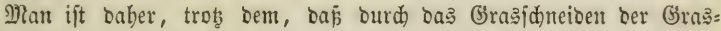

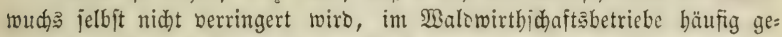
nöthigt, biej bemrod ausführen zu lafien, um ben jungen Bflanjen renigs ftens für bas laujenbe Jahr \&idht zu veridaffen. In vielen fällen wirb

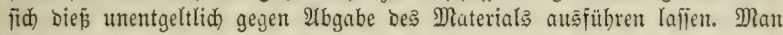

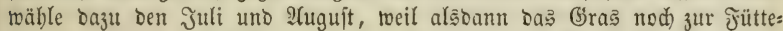

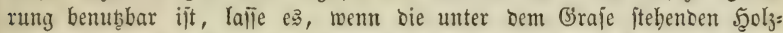
yflanjen nod) flein fino, abidneiben, uno zmar mit 3ahnideln; auf locerem

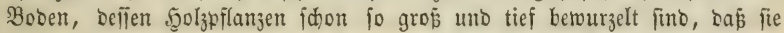
nicht mitgejogen werben, lafie man bas Giras burd) 2(uşrupfen hinweg= ichafien.

Die Gräjer jint 1-2jährige Pflanzen, bie nady erfolgter Blüthe uno

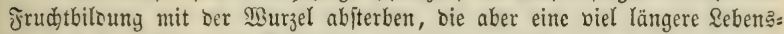

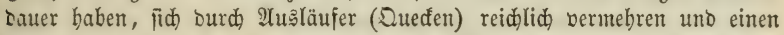
bidten fillz (Rajen) bilben, wenn Durd) 2(bjdmeiben ober S(bweiben bie

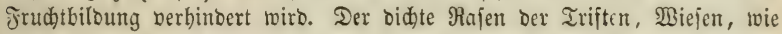

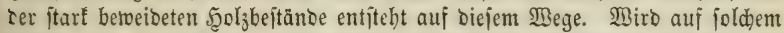

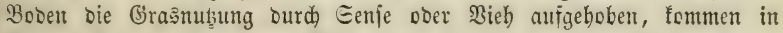
Folge befifen bie Gräjer zur Blüthe uno Fruddt, jo lichtet fidy ber Rafent von jelbjt burd) bas 2(bjterben ber fructificirenden Bflanzen uno wirb für

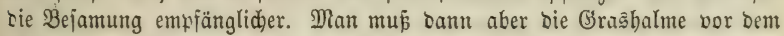

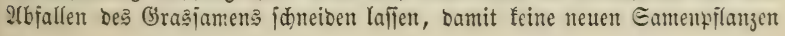




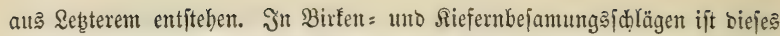
Berfabren häufig bon gutem Erfolge, Dem aber nidjt jełten bie veridhiebente Reifezeit Des. Saments veridjiebener (Jrabarten entgegenjtebt.

Die Şräfer werben nid)t aflein burd) Beroämmen ber jungen Scolz=

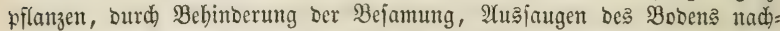
theilig, fondern aud baburch, Daß fie ben Boben austrocinen, inbem fie bie feineren atmojphärifden ?ieberialäge aufjangen, im Sommer bie Befeudtung bes Bobens burd) ben Morgen= und 2Abenthau berbinden, unt, burch bie gröfere uno rafdere Berounftung uno $\mathfrak{B a ̈ r m e j t r a b l u n g ~ b i e ~}$

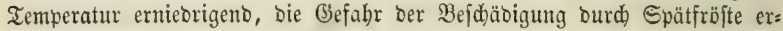

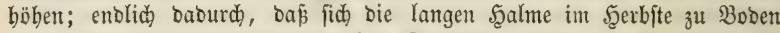
legen uno bei bidtem Stanbe eine Brabbecfe bilben, Durd weld)e Der Edjnee nidjt zu Boben fallen famn. Unter biejer Dede ziehen fid bann bie Mäuje aus ber ganjen Ungegento zujammen uno järotent bei Mangel

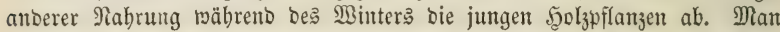
entfernt foldhe Ģrabbecten mit bölzernen, ftartzäbnigen Şarten im Bor= winter nad bem erften Jrofte, inbem al(̧bann bie Scalme fid) ohne Mübe vom $\mathfrak{B u r z e l j t o d e ~ l o ̈ j e n ~ u n o ~ z u j a m m e n b a r t e n ~ l a f i e n . ~ B e i ~ b e r ~ \Re u b b a r t e i t ~ b e s ~}$ Materials als Strelt wiro bieje 2 rbeit felten mit gropent Roften wer: bunben feir.

Die Walbgräjer zerfallen in orei Familien:

1) Simjen (Junceae),

2) Rięgräfer (Cyperaceae) uno

3) G̈räjer (Gramineae).

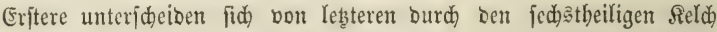
Der, an Den Enben ber waljigen, fnotenlojen Stengel in Bünbelu ftehenden

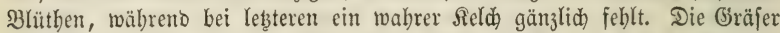
unterideiben fich von Den Rieogräfern leidht Durd ben bohlen fnotigen Stengel uno bie geipaltenen, ben Inoten entipringenben, bort ganzen, nur im 2llter aufreißenden Blatticheident.

Beadtenswerth als Unfraut fino unter ben Simien:

Balbjimie (Juncus sylvaticus),

Şainfimie (Luzula pilosa).

Unter ben Riebgräjern:

$\mathfrak{B}_{\mathrm{B}}$ lobinfe (Scyrpus sylvaticus),

Riebgras (Carex remota, sylvatica, hirta).

Unter Den Çräjern:

Borftengras (Nardus stricta),

F̧a $\mathfrak{a g r a}$ (Elymus europaeus, caninus),

Quede (Triticum repens),

ફ̧irjegras (Milium effusum),

Etraūigras (Agrostis vulgaris),

Sd)miele (Aira eaespitosa, flexuosa),

Rifpengras (Poa nemoralis),

Irefpe (Bromus giganteus). 
(Fine benutbare Charafteriftif biejer Gräjer in botanijder uno forftlicher Simjicht erforbert mehr Raum, als hier offen fteht, baher id für

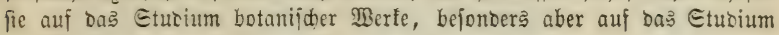
ber Crräfer in Den Gallägen jelbit verweifen muई́.

\section{Diertes siapiter.}

\section{Bon den Jarren.}

Bernächje mit langem einfachem Etengel, Der, zugleidh Blattjtiel, in ein vielfad) und żierlich getrebertes grō̄es Blatt endet. Reimtörner in baufen=

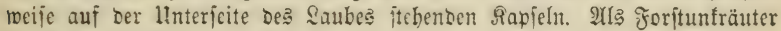
befonders iकäblic).

\section{Sdilofarren (Aspidium filix mas.) uno}

Al lerfarren (Pteris aquilina).

Eriterer untericheidet fid bon lețterem burch Doppelt gefieberte Blätter

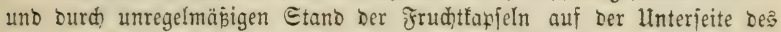

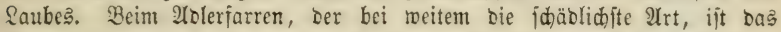
Blatt rreitheilig uno jeber biejer Theilc boppelt gefiebert. Die Frudtfapieln fteben in fortlaujenben Sinien am Rande Der Blättchen; beim farägen Durd)= idnitt ber Tisurjel uno Des Etengels jeigt fich in ber Mitte eine Edattirung äbnlich Dcm Bilde eines boppelten 2rolers.

Der Etantort biejer Gemädjie ift ein jeuchter, etras befoldteter Boben, bejonders jolther, ber mehr soer meniger reich an Stauberbe, Moorerbe

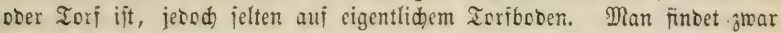

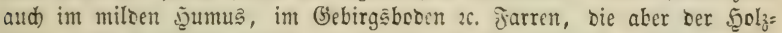
fultur nidt hinberlic merben, ba fie nur einigeln borftweife auftretert. Ior 2lolerfarren bingegen biloet diđ̆te Beitänte uno überziebt grofie Streden jo,

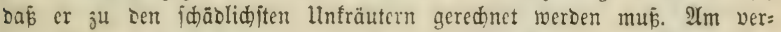
breitetiten uno in jaft unourdbringlichen Dididten bon $3-4 \mathfrak{M t r}$. Säbe, rabe iđ) ibu auf cen balbinieln Iars uno 3 ingit ber Ditfeefülte ge=

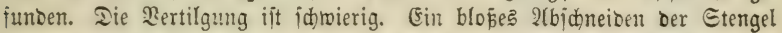

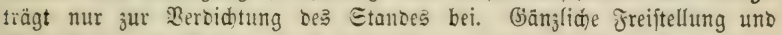

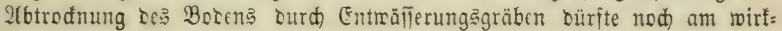
famiten jein.

\section{siterafur.}

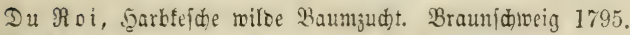

Bechitein, Forftbotanif 1810. 4te Aufl. 1821.

Meum, Foritbotanif, 3te Aufl. Dreăsen uno Leizzig $183 \%$.

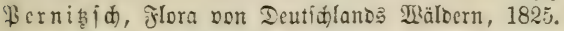

Beil, sas forjtliche Berhalten Ecr beutidjen Walbkärme, 3te :Afil. Berlin 1839.

Ib. Scartig, Sehrbud) bor Pilangenfunde in ihrer 2lmmenbung auf frorit= mirtbidaft 1851.

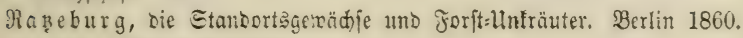

gartig, Rehrbud für Förifter. 1. 
Dr. P. Senft, Elafification uno Befdreibung ber Felsarten. Breșlau $185 \%$.

Dr. B. Eotta, Deutidlanos Boden. 2te 2Yufl. Dresoen 1860.

Dr. J. Fुanftein, über bie Reitung bes Gafts Durd bie Rinde. Berlin 1860.

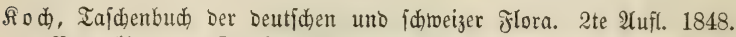

Dr. Nörolinger, Deutide Foritbotanif. Stuttgart 1876. Э. (3. Cotta. Iuberbem bie meijten forftliden encyflopäbifden Sehrbüder, befonders von Feiftmantel, (S) winner, Sauneshagen. 


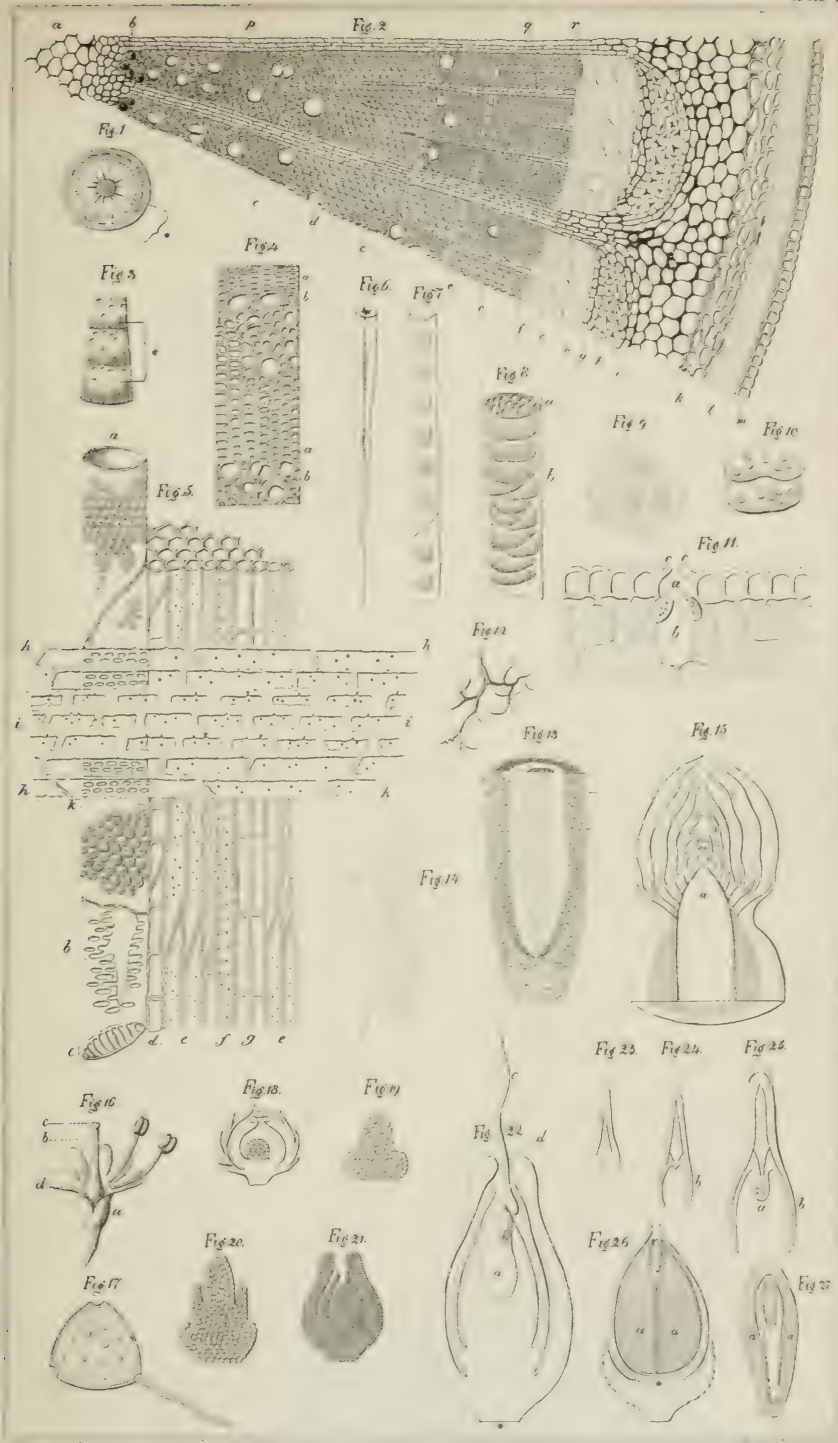





\title{
feldrund fitr fälter \\ uno
}

\section{fïr die, weldje es werden wollent.}

\author{
ఇon
}

\section{Dr. Beorg Lutwig fortig}

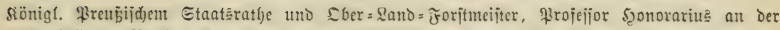

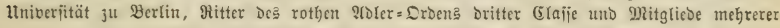

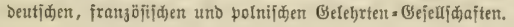

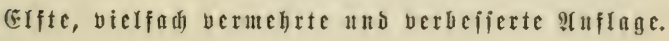

Rad) Des 23erfaffers Tode herausgegeben

bout

Dr. Tlyedor fintig und Dr. Robert fantig.

$$
\text { Bweiter Band }
$$

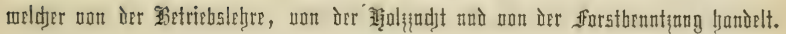

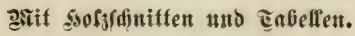

Stuttgaxt.

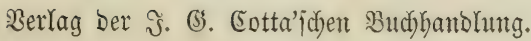




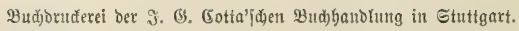




\title{
Sulfaft des zweiten Dantoes.
}

\author{
3 weiter $\mathfrak{S a u p t}$ their.
}

\section{Girfer P(b/d)titt.}

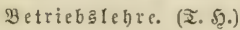

I. Bom $\mathfrak{B a l b t w i r t b i d a j t a b e t r i e b e ~ i m ~} \mathfrak{A}$ lgemeinen.

Erfte Sapitel. Borbegriffe . . . . . . . . . . . . 4

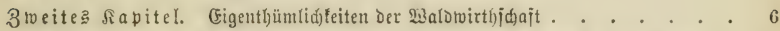

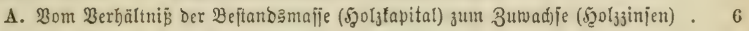

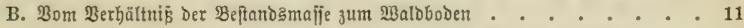

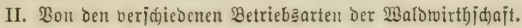

Drittes Rapitel. Dom Betriełe ber Şodwaldomirthidaft . . . . . . . 16

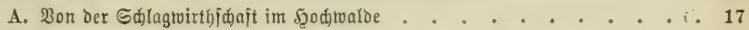

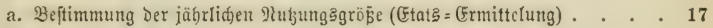

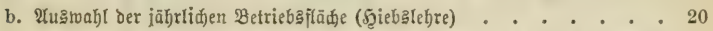

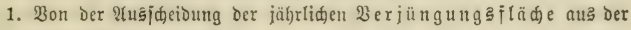
periobifaen . . . . . . . . . . . . 2 21

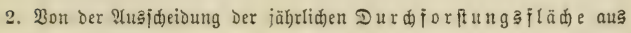
Der periobifaen . . . . . . . . . . . . . 23

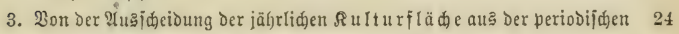

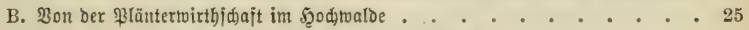

3iertes Rapitel. 2om Betriebe Der Miederwaldwirthidaft . . . . . . . 26

₹ünjtes Rapitel. Wom Betriebe Der Mittelwalbmirthjめaft . . . . . . 28

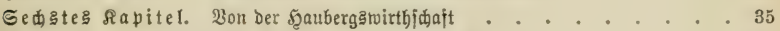

Eiebentes Rapitel. Bon Der Baumfeldtirtbidajt. . . . . . . . 35

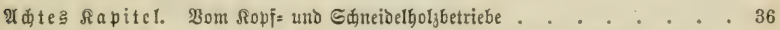

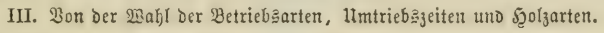

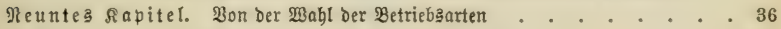

3elnte 3 Rapitel. Bon Der Wabl Der Umtriebşeiten . . . . . . . . 40

Elftes Rapitel. Bon der Wahl ber Şolzarten . . . . . . . . . . 44

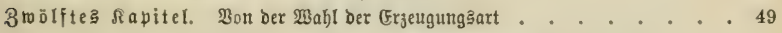

Dreizehntes Rapitel. Won ber Wabl ber Ergiehunģart . . . . . . . 53

IV. Bon Umwandlung Der Betriebăarten, Şolzarten, Umtriebe.

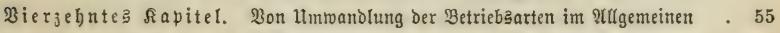

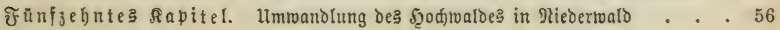




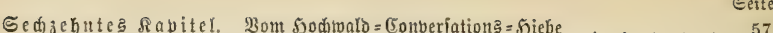

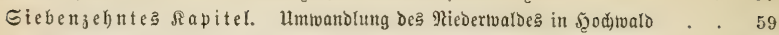

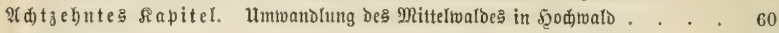

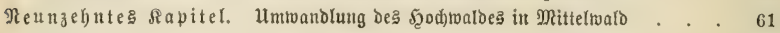

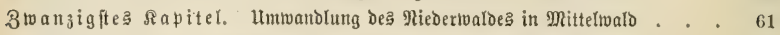
(Finundzranzigites Rapitel. Heber ben Medfel Der Şolzarten . . . . 61 3reiundztoanjigftes Rapitel. Heber Beränderung Des Umtriebs . . . 64

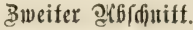

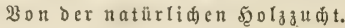

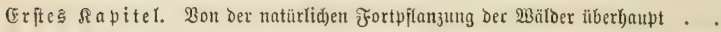
3 weites fiapitel. Bon ber forjtmäpigen 2bholgung eines haubaren Bud)en= Şodtwaldeę $2 c$.

Drittes אapitel. Won der forftmäpigen Bebandlung jolder Buden = Şod) wal=

Dungen, Die zwar haubar, aber nid)t gejdlofien bejtanden fino

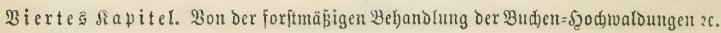

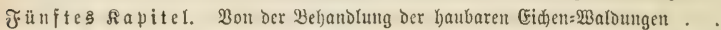
Sed引te Rapitel. Bon ber Bewirtbjuaftung Der cinjeln mit baubaren (Eidjen beftandenen Diftifte

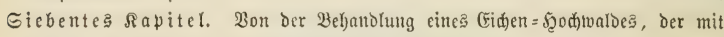
haubarem und jüngerem Şolze vermijat beftanden ift . . . . . . .

Rdtes Rapitel. Bon ber Bebanblung foldjer baubaren Seddwaldungen, die aแล Bud)en und (Eiden vermifd)t beftehen .

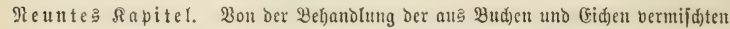
Waldungelt, weldhe haubares und jüngeres $520 l_{3}$ 3um Beftand baben . . . .

3ebntes fiapitel. Bon der Bef)andlung Derienigen f̧odjwaldungen, die mit

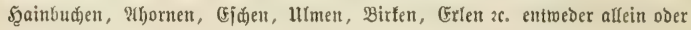
vermilidit beftanden find

Elftes Rapitel. Bon ber bebanolung ber nidjt gefdlofien beftandenen Tamuen= maldungen

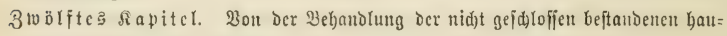
baren 2 Beiṕtannen=23albungen .

Dreizelntes Rapitel. Bon der Behandung Der Gaubaren fidften=2Baldungen Bierzehntes Rapitel. Bon Der Behandurg ber haubaren Riefern= Baldungen

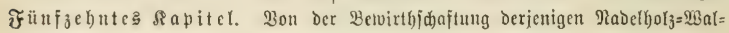
Dungen, weld)e mit haubarem uno geringerem 5̧olje vermifd)t beftanden find. Sed)zel)ntes Sipitel. Bon Der Behandung Der haubaren Sgodjualdungen, weld)e mit $\mathbb{R} a u b=$ und Rabelfols vermijd)t bejtanton fint

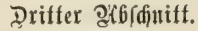

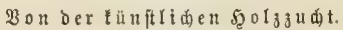

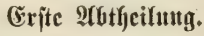

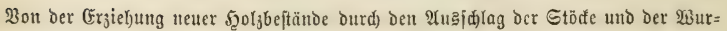
zeln abgehautener $\mathfrak{L a u b h o l}=$ Stämme $x$. 
Dritte马 Rapitel. Bon Betvirtbidaftung ber Sૃainbuden=, Birfen =, 2horn=,

Fident = und Ulmen= Riederwaloungen . . . . . . . . . . . . . 118

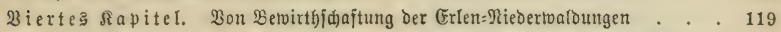

ชünftes Rapitel. Bon ber forftmäp̈igen ßetwirthidaftung ber Mitteltwälber

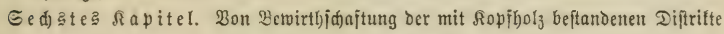

\section{3weite Qfutheilutug.}

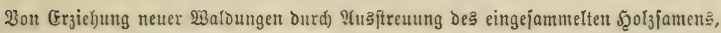

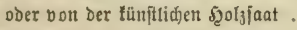

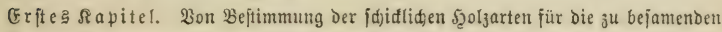
Diftritte $2 c$.

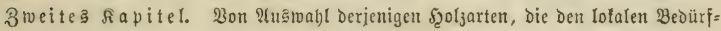
niffen am meiften entipreden $2 c$.

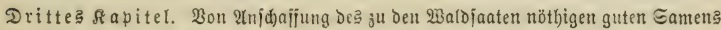

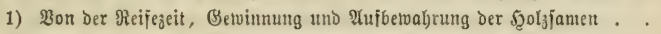

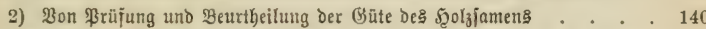

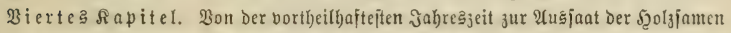

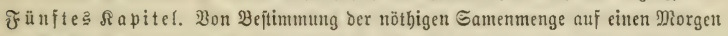

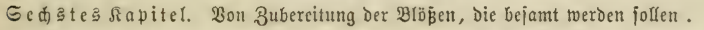

Sicbentes Rapitel. Won den Bortbeilen uno Madtheilen Des didten oder

weniger diđten ธäens. . . . . . . . . . . . . . . 153

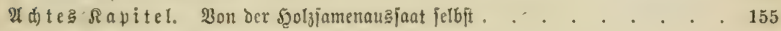

A. Bon ten reinen Gaten . . . . . . . . . . . . . . 156

Saat ber Giđeln . . . . . . . . . . . . . . . . . 156

" ber Budieln .. . . . . . . . . . . . . . . . 158

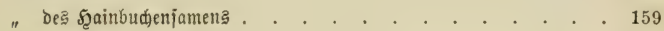

" Deక Ahorffamens . . . . . . . . . . . . . . 160

" Dę Gjdenjamens . . . . . . . . . . . . . . 160

" Dеร Ulmenjamens . . . . . . . . . . . . . . 160

" Des Erlenjamers . . . . . . . . . . . . . . 160

" Dę Birfenjamens . . . . . . . . . . . . . . 161

" Dę Tannenfamenz . . . . . . . . . . . . . 161

" Deకె Fidtenjamens . . . . . . . . . . . . . . 162

" Dę Siefernjamens . . . . . . . . . . . . . . 163

" beร \&erđenbaumjamens . . . . . . . . . . . . 164

B. Wou ben bermijöten ङaaten . . . . . . . . . . . 165

Ple unte Rapitel. Bon Befdübung und \$ilege Der Waldjaaten . . . . . 168

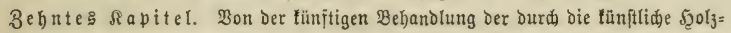

faat erzogenten Beftände. . . . . . . . . . . . . . 168

\section{Dritte Âtheilung.}

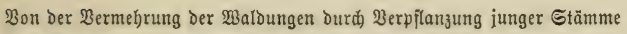

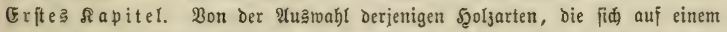

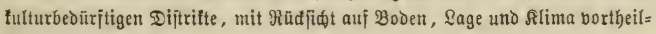
baft anpilanjen laffen. 


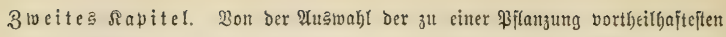
Szolzart . . . . . . . . . . . . . . . . . 170

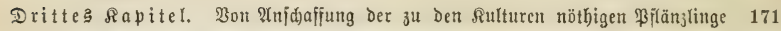

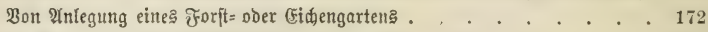

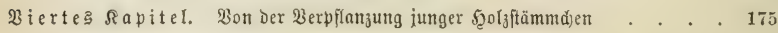

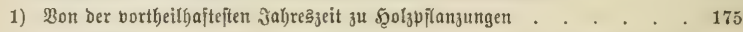

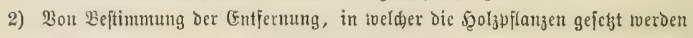
müffen . . . . . . . . . . . . . . . . 177

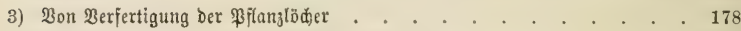

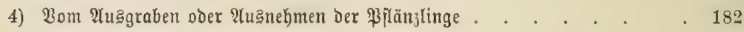

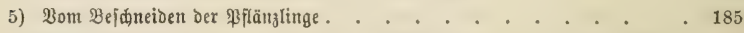

6) Bon Der Behandtung Der auझ̧gebobenen \$flänjlinge, wenn fie nidjt alşald berfegt merden fönnen. . . . . . . . . . . . . . . 187

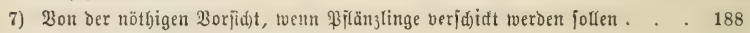

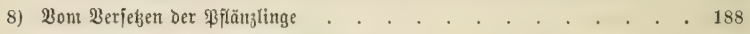

9) 3om ßerwahren der gepflanz̆ten Stämme . . . . . . . . . . 191

\section{Bierte Abtheilung.}

Bon ber Şolzbermebrung Durd Stedreifer oder Steflinge . . . . . . . . . 192

1) Bon 3uridtung Der Stedflinge . . . . . . . . . . . . 193

2) Bom Einjełen ber Stedtinge . . . . . . . . . . . . . 193

3) Bon ber Pflege ber angemađjenen Steffinge . . . . . . . . . 194

\section{Jiintite $\mathfrak{A}$ btheiluttg.}

Bon Der Şoljbermebrung Durd) Lbfenfer .

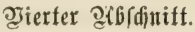

Bon 2(ntoendung Der zubor abgehandelten Scolzerziebungs= Methoden.

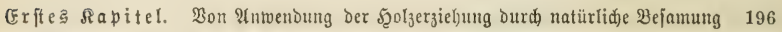
3 weites Rapitel. Bon Inmendung Der tünflidien \$2ol3faat . . . . . . 197 Drittes $\{$ apitel. Bon 2(ntwenoung ber Şoljerziefung Durd) ßerpilanzung junger

Stämmd)en beim Ærorfthaußhalte . . . . . . . . . . . . 198

Bierte马 Rapitel. Bon Antenoung Der Şolzerziehung aus Stedreijern . . . 200

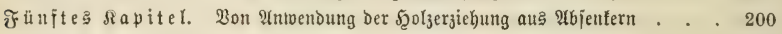

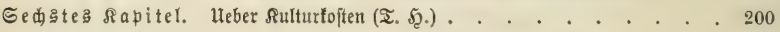

Siteratur. . . . . . . . . . . . . . . . 203

\section{Dritter Saupttheil.}

Die $\mathfrak{B}$ ! b benuвung.

Cinleitung . . . . . . . . . . . . . . . 207

1) Der Nułungąplan . . . . . . . . . . . . . 207

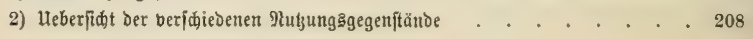


3) Bebeutung un $\mathfrak{B}$ erthberbältnifịe berielben . . . . . . . . 209

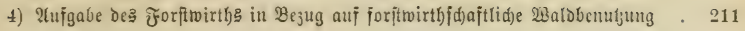

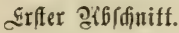

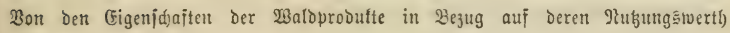
(2Ba arenfunde) . . . . . . . . . . . . . . . . 212

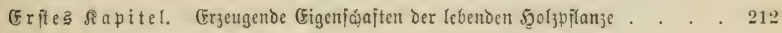

I. In Bejug auf Şolzertrag:

A. Maffenerjeugung . . . . . . . . . . . . . 212

a) beridicdener \$ૃoly= und Betrieb引arten . . . . . . . 213

b) beríaiedener Umtriebşзeiträume . . . . . . . . . 215

c) verjdiedener Erzeugungs= und Erjiebungsart . . . . . . . 217

B. Formerzeugung * . . . . . . . . . . . 218

II. Rindeertrag . . . . . . . . . . . . . . . . 219

III. frudt uno Samenertrag . . . . . . . . . . . . . . 221

IV. Saubertrag . . . . . . . . . . . . . . . . 222

V. Säfteertrag . . . . . . . . . . . . . . . 224

VI. গebennuģunggerträge . . . . . . . . . . . . 225

3 weites fiapitel. Gemerblide (figenja)ajten der Waloprodufte . . . . 228

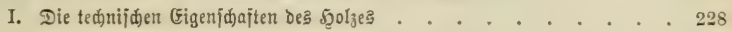

1) Sdjwere . . . . . . . . . . . . . . 228

2) Brenntraft . . . . . . . . . . . . . 2 230

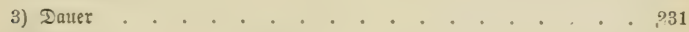

4) Şärte . . . . . . . . . . . . . . 233

5) Æfeptigteit . . . . . . . . . . . . 234

6) Spamitrajt . . . . . . . . . . . . . . 231

7) Epaltigteit . . . . . . . . . . . . . . 234

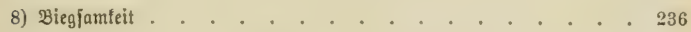

9) 3 äbigteit . . . . . . . . . . . . . 2 236

10) ङめpinden . . . . . . . . . . . . . . . . 237

Zabellarijde Bujammenftellung . . . . . . . . . 238

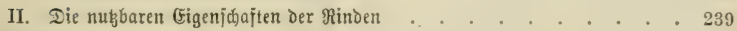

III. Der früdte unঠ હämereien . . . . . . . . . . . . . . 241

IV. Dę \&aube马 . . . . . . . . . . . . . . . . 242

V. Der Gäfte . . . . . . . . . . . . . . . 242

VI. Der Mebenprodufte . . . . . . . . . . . . . . 243

Drittes fapitel. Den ßreis der 28aldprodufte bejtimmende Berhälniffe . . 243

I. Belaftung besి Producirten mit ben Untopten:

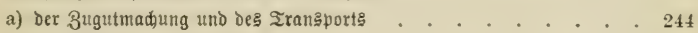

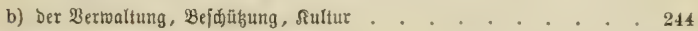

II. Beftehen und Dringlidfeit bę Bedarj马 . . . . . . . . . 245

III. Seltenheit oder ફૃäufigfeit dę ßrodulț . . . . . . . . . . 246

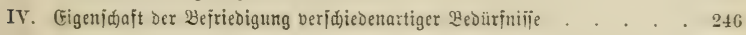

V. 2lonopol oder Concurrenz . . . . . . . . . . . . . 246

VI. Eompenjation bon Bortbeilen und 9adtheilen. . . . . . . . . 246 


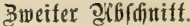

Bon Der $\mathfrak{Z}$ aloprobuftennułung (Setwerb 3 tunde) .

Erftes Rapitel. Bom Rohmubungabetriebe.

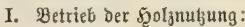

1) 3eit Des Besuges.

2) Drganifation der 2rbeiţ̨träfte . . . . . . . . . . . . 249

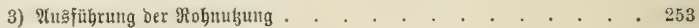

a) Die $\mathfrak{A n w e i f u n g ~ . ~ . ~ . ~ . ~ . ~ . ~ . ~ . ~ . ~ . ~ . ~ . ~ . ~ . ~ . ~} 253$

b) Die fälltung . . . . . . . . . . . . . . . 255

c) Die Aufarbeitung. . . . . . . . . . . . . . . 258

II. Betrieb Der Rindennubung . . . . . . . . . . . . . 261

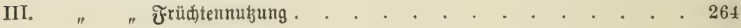

IV. " " Laubnubung . . . . . . . . . . . . . 265

Г. " " Säftemułung . . . . . . . . . . . . . 266

VI. " "Rebennubungen . . . . . . . . . . . . 267

3weites Rapitel. Bom $\mathfrak{Z}$ alogewerbebetriebe.

I. Bom Sägholzbetriebe . . . . . . . . . . . . . 272

II. Bom Spaltholzbetriebe . . . . . . . . . . . . 275

III. $3 o m$ Gdnifholzbetriebe . . . . . . . . . . . . . . . 281

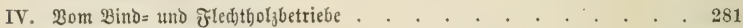

V. \om Rŏhlereibatriebe . . . . . . . . . . . . . . . . 283

VI. Der Iheerfidwelereibetrieb . . . . . . . . . . . . . . 317

VII. Dag ßedffieden . . . . . . . . . . . . . . . . 317

VIII. Das Rienruß̈brennen . . . . . . . . . . . . . . . 318

IX. Dą $\mathfrak{A}$ d

\section{Drifter Deffofutt.}

Bom Maldproduttentandel (Şandelstunde).

Erftes Rapitel. Bom Trangport Der 2 aloprobufte . . . . . . . . 319

3reites Rapitel. Bon 2fufberwahrung der Walbprodufte . . . . . . 329

Drittes Rapitel. \$reigbeftimmung . . . . . . . . . . . . 331

Bicrtes Rapitel. Bertauf . . . . . . . . . . . . 333

₹ünftes Rapitel. Budfüfrung uno Rednungs̆legung . . . . . . . 333 


\section{Bెweiter Sompttheil.}





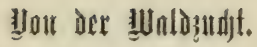

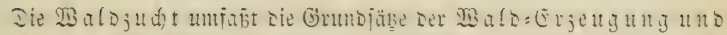

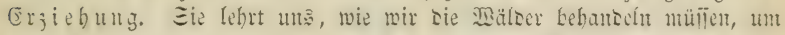

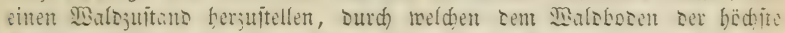

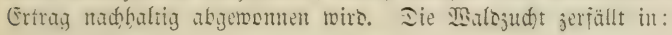

1) Betriebalebre uno

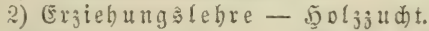

Sie Betriebslebre - Sebre vom Betriebe ser Malcmirtbidait,

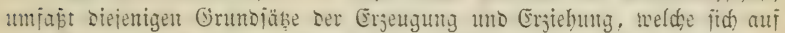
Die Geiammtheit ju cinem Wirthidaftstörper vereinter Beftünte be: şieben. - Die Sebren:

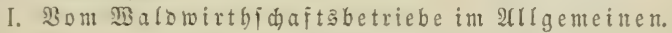

II. Bon Den veridiedenen Betriebsarten.

III. Bon Der Mabl ber Betriebsarten, llmtriebseiten,

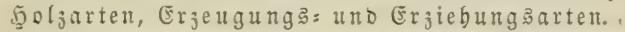

1V. Boultmanolum der Betriebarten, joljarten un Umtricbajzeiten.

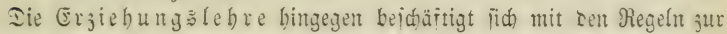

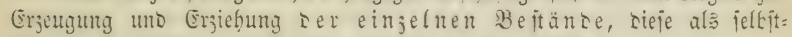
ftänoige Einjeltbeile E2:.

1) $50 l_{3} 3 u d t$ und

2) รูolzanbau. 


\title{
Griter 9f(bjduitt.
}

\author{
Betriebs=aebre.
}

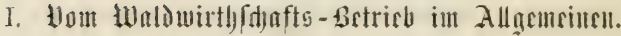

\section{Sirftes Eiapitef.}

Worbegriffe.

Die jortminthichaft wic sie Sunswirthichaft mit ihren einjelnen 3rocigen:

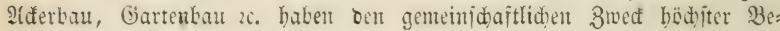

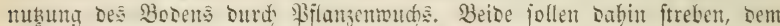
Bocen bie yröpte, merthoollte Mienge von Maturerjeugnifien abjugewimen.

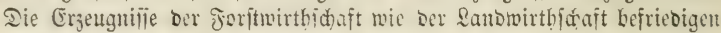
unentbehrliche, jäbrlid mieberfebrende Besürnifie. Beide müïen

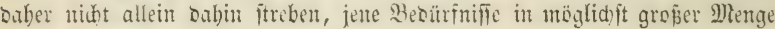

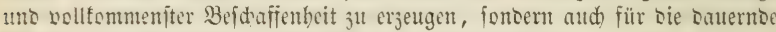
Befriedigunty serjelben in paateren Beiten Eorge tragent.

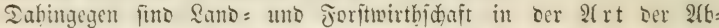

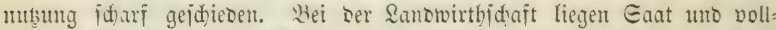

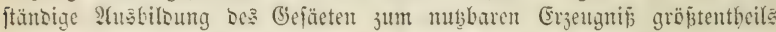
interbalb cins jübrigen 3eitraumes. Der Sanowirth bemult baher größtent=

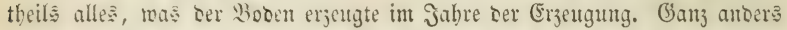

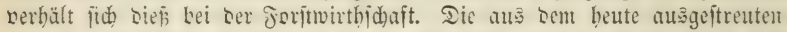

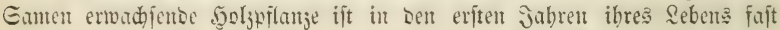
wertllas; ïe erbält erit mad) vielen, mitunter erit nad) mebr als bunbert Sabren eine Gröbe uno Form, wie fie jur Befriedigumg mandyer Besürniffe Durchaus erforberlid ift.

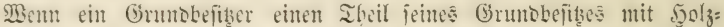

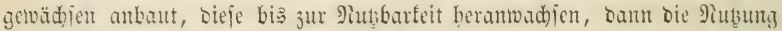

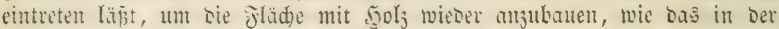

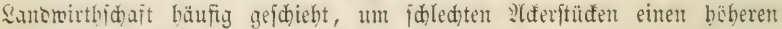
Ertrig such SBabbau abjugemimen, fo ment man bas einen a นs: libenten Betrieb bes Malobaues, on Seţterer in biejem Jalle

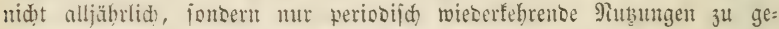
mähren vermay, abgejeben von ben Bormuţungen, bie aud in biefem falle

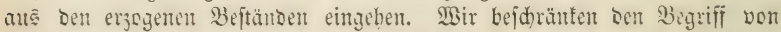
gisalowirthichaft auf biejenigen Jälle fortbauernoen Betriebes, in wetden ein alljährtid) wieberfebrender Bebarf eite, in Menge wie Be=

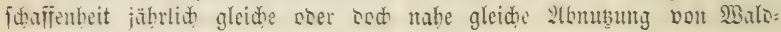
probuften crbeifoct.

SBenn mir sbue Unterbrectung jäbrlid) eine 100jäbrige Cidhe abnuţen 
jollen, io fino saju 100 Ëidhen nöthig, von senten sie jüngite cinjährig,

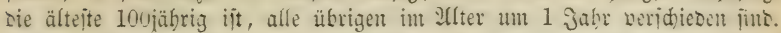

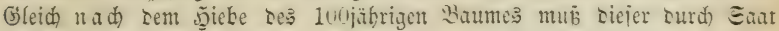
erjebst mersen. Sic jünglte ser 100 Pilanjen liegt Dan im Eamentom uno miro bimen Jabreșirijt cinjäbrig; sie ältejte ijt 99jährig un miro

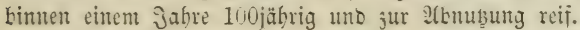

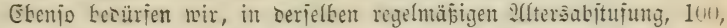

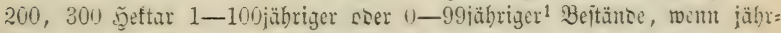
(id) 1,2 soer 3 jeftar 100jäbrigen boljes abgeholjt wersen iollen.

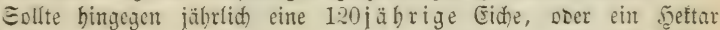
120 jäbrigen B.jtanoes abgebolgt merten, io bebürten mir 120 Fiden 1-120jäbrig ober 120 Đ̧eftar 1-120jäbriger Bejtän๖e.

mare aber die jläd)e gegebin, io müre fich Die ser eingelnen Be=

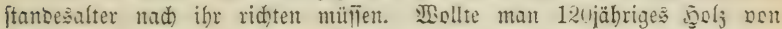

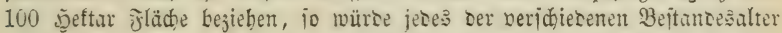

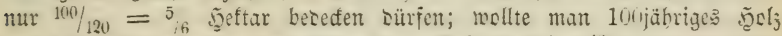

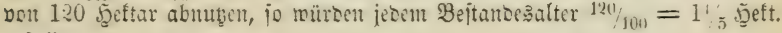
วนта丿llen.

Jese, einer alljährlich wieserfebrenben Яiubung entiplechente Reibe

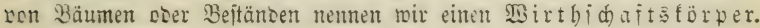

Der 1vojäbrige Baum entbält aber nicht mebr die ganje ફूoljmalle

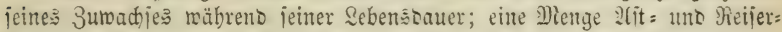

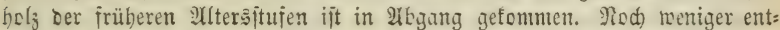
bält ser ganze 10ujübrige Beitano, senn in ibm jino auper sem Zlbiall an 2ljthol; ses borbantenen Bejtantes eine groje Menge ganjer Pilanjent ser früberen खltersitujen ausgejdieben. Wie groj bie Babl biejer, ourch gegen:

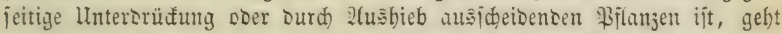

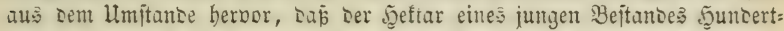

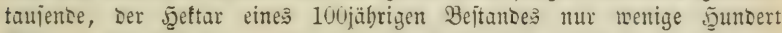

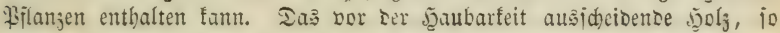
gut mie das verbleibende, iit ein Theil tes Gejammtjutwathies, es roiro jum Ibeil Durd feriorij to reberfehrende Bormuthugen nermerthet.

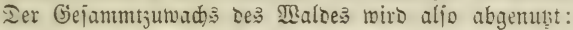

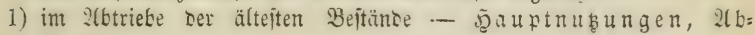
triebsnusungen.

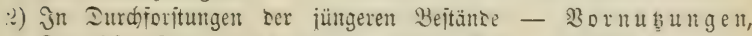

Iurchior

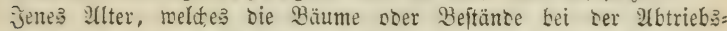

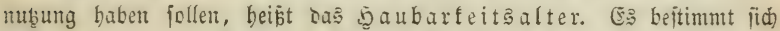

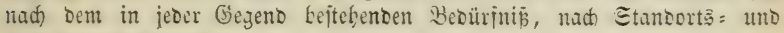
Bệtanő̉verbältmīīen.

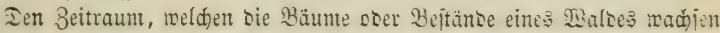
mülien, bis jie jene: allgemeine స్aubarfeitsalter erreidyen, nennen wir Ien

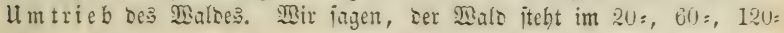
jährigen llmtriebe, uno bejeictnen samit aljo aud) sen Butraum, in reldsem 
alle gegentuätig vorkmoench Beftänte: vom 1-120jährigen (ocer wom

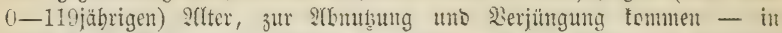

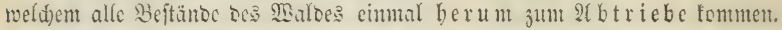

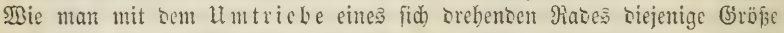

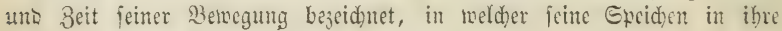
frübere \&age zurüoffehrent.

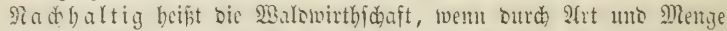

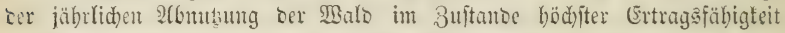
erhalten ober in fürzefter Beit in biefen 3uftanto verfeșt wiro uno, inner= balb biefer Grenzen, eine gleiămäßige Befriebigning ber Beoürnifie gefidert ijt. 1

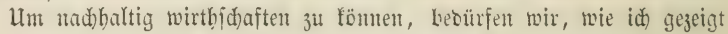

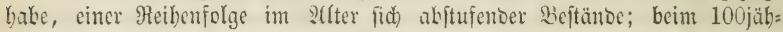

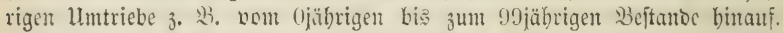
Die Summe Des alljäbrlich an siejen Beftüntent erfolgenion Zumadjes ftellt

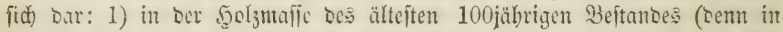

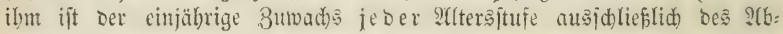
ganges alfigefanmelt; 2) in oem feriobifd erfolgenton Durdjoriturgs

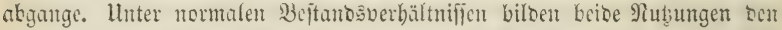

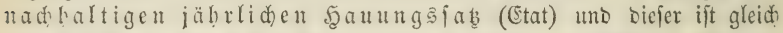

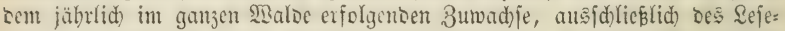

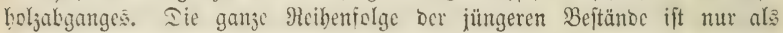
9) littel 3u betrad)ten, baubares $\mathfrak{S g l l}_{3}$ zu erlangen; fie biloet bie Beft a no

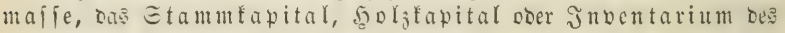
Malde?.

Ulle Beftünde, weldhe jufammen auf bie jäbrlid)e Erzengung eintes

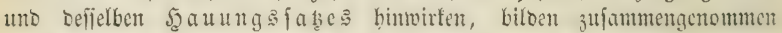

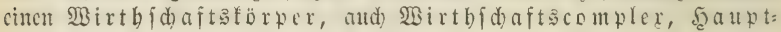
theil ober $B$ lo denaunt.

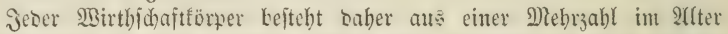
fich abifufenter Beftünoe entweder gleifer ober berfdicbenartiger Syolyartent.

Ein Revier, Sermaltugstörfer, Bermaltugscomplex

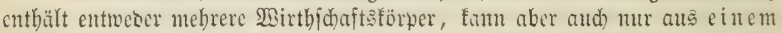
foldon beftehen. Man verfteht Darunter cinen $2 B$ als, ser unter einem uno

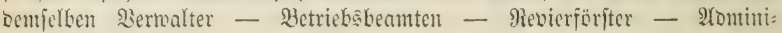
ftrator ftebt.

\section{Bweites sianited.}

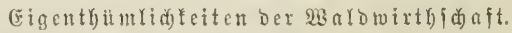

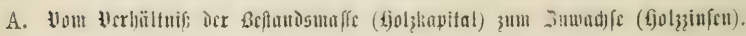

WBir haben gejehen, daj in einem jeben Wirthidufftštörper furz nad) Eent f̧iebe des baubaren Beftantes bie ganze Reibefolge ber Beftänbe nur

1 Daß Gleidbleiben Der 9tubung liegt nid)t unbedingt im Begriff Der Madhaltigteit,

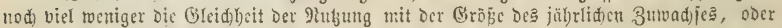
Die Befriedigung aufüntiger bedürfnifie überbaupt. 


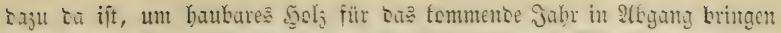

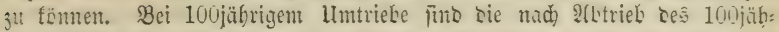

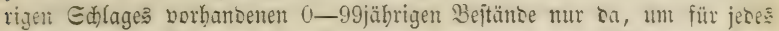

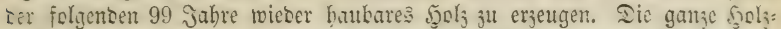
malle aller 0-99jäbrigen Beftänoe ift saber einem jinjentragenten fixptals

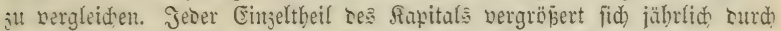
3umaç․ Der Ojährige Beftano ermächst zum 1jährigen, oer 10jäbrige зum 11 jürigen, Der 99jübrige zum 100jührigen. Die Bimjen bes Sapitals fino saler gleich Dem 3umadje aller Beftüne bimen Jabresfrift. Ia bie

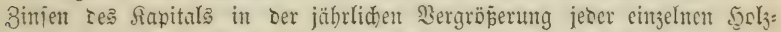

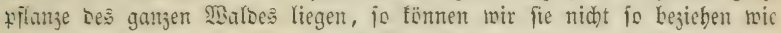
fie antordjen, obne cen ganjen SBalsbejtano akjumuben. SBir verringern

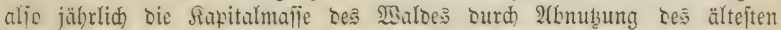

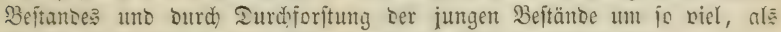
jie fid im vorbergebenten Jabre surd, 3unad) vergröfert bat.

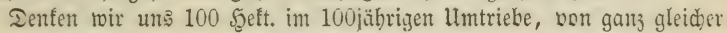

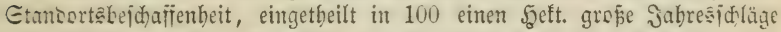

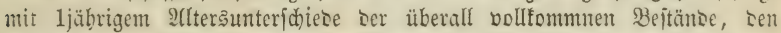

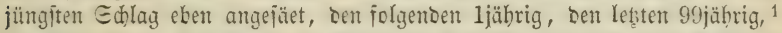

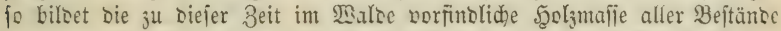
Den normalen Sapituluorrath. Der jübrliche Bumad) offelben lefteht in

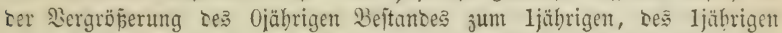
aum 2jäbrigen u. i. f., Des 99jäbrigen jum 100jäbrigen Beftanbe; ๖er jähr:

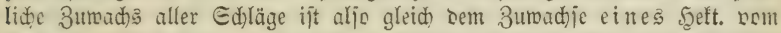
Oten bi: 100ten Jabre. Ein Sgeft. 100jähriger Beftuno mürbe taber Diefelke

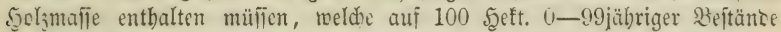
bimen Sabreşrift zumäbst, twenn nidht in ibm mäbreno ter Beit jeines Beftebens eine Denge Scols theils perfault, theils in Durdiforitungen benutst märe. Der mit 100jährigem Golje beftunbene Sett., soer überbauft ber ältejte Jabresid)lag einer normal beftantenen : Balofläche entbält saber

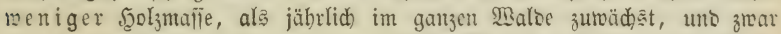
um is viel weniger, als ber jäbrliche 2 bgang auf ber ganjen 2 als: flätre beträgt, insem man, wie sken, antebmen faun, saj auf einem sceft.

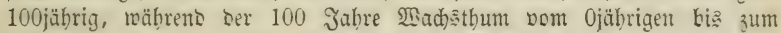

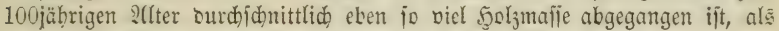

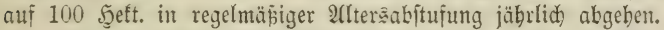

Um Den vollen 3umad) z zu bejieben, muf saber jübrlich nidht allein

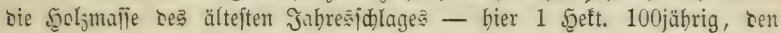
jübrliten fgaunngafat biloen, fontern zul Diejer noch oer im ganjen Maloe

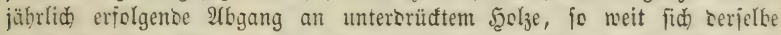
zu Gut maden läpt, binzutreten, mäbreno oer nidht benub̧bare Iheil bes

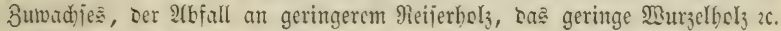
aufer Rechnung bleibt. 3. B.

1 Alferbinge befteht cin fold)er Laldojuftano, ben wir einen iocalen nemen wollen, rirgenos, wiro aud nie bejteben; wir bedurjen eires fold)en Bilees aber jur möglidjten Berdentlidjung Der $23 i r t h i d a f t$ berbältnifife. 


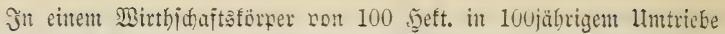

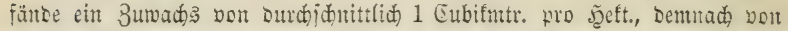

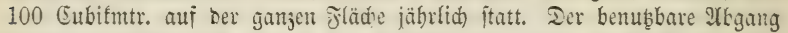
betrüge Durdjidnittlid jährlich 0,1 Eubifntr. pro sett., fo würoe Der 100:

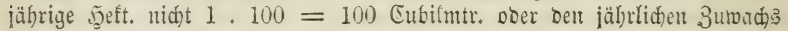
Der ganzen Fläche entbalten, fontern mur 0,9 $100=90$ Eubifmtr.

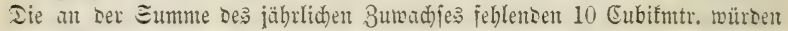

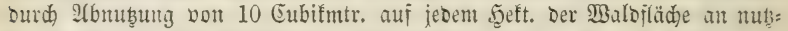

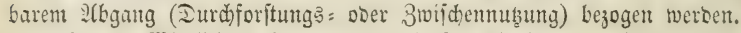

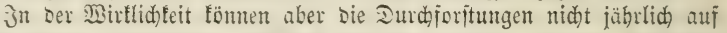

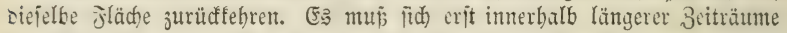

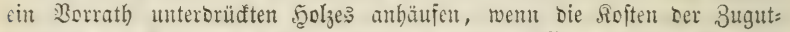

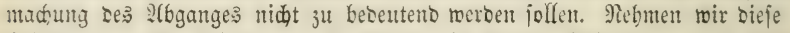
Beitrüume ju 20 Jahren an, io würben in obigem Beifpiele, auber ber

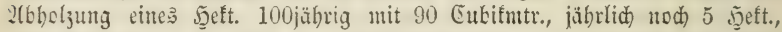

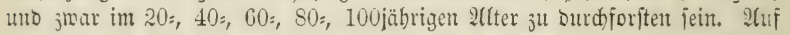

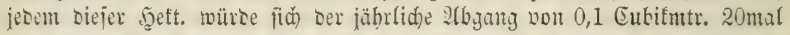
aujgehäuịt baben, baher pro ફुeft. 2 Cubifmttr., auf allen 5 jुeft. bie an

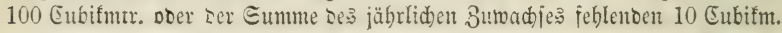

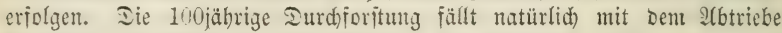
julammen uno erböbt set 2tbtriebsertray des baukaren Drtes.

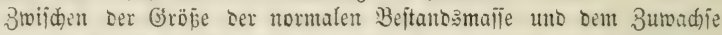

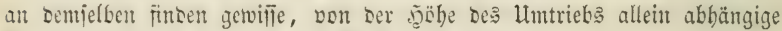
2erbältnilie unter Der, in Der Mirflidffeit nidft, ober ood) mur felten zu= treffentoen 2 (nnabme jtatt:

1) Iaßs Die Brobuftion allein vom Stanoorte abbängig un überall anf ber Wirthjohaftşläche biejelbe ift.

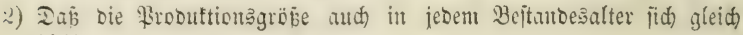
bleibt.

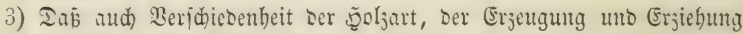
entweber nidjt bejtebt, oder, jo weit fie befteht, feinen Cinflup auf Die Probuftions:Menge außืubt.

Bei ljährigem Lmtriebe 3. 3. eines Seibenthegers, wo bie ganze Fläd)e jührlidi) ju feitten forbruthen abgetriebent wiro, ijt bie ganje jähr= liche 2tbubung 3utwachs ober Bimjenertrag.

Die normale Bejtunowmalle eines im 2jäbrigen Umtriebe ftehentent,

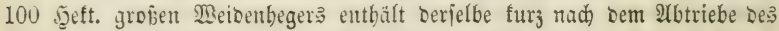

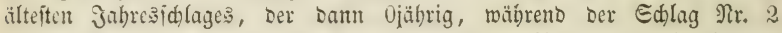

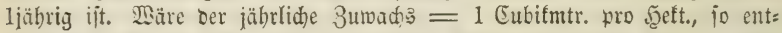

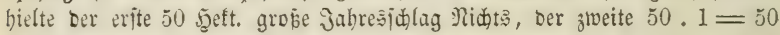
Eubifntr.; sie normale Bejtanosmaile wäre aljo $=50$ Eubifmtr. Der

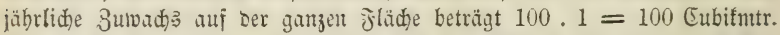

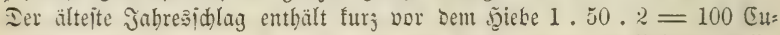

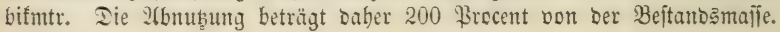
Derur $50 \cdot 100=100 \cdot 200$.

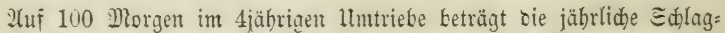
flädje 25 Morgen. Derielbe jührliche Suwadgs von 1 Cubifmtr. Fro beft. 
angenommen, bereduttet jid sie Bejtandsmalje auj $0+(25.1)+(25.1 .2)$ $+(25.1 .3)=150$ Cubifmtr. Ier jübrliche 3umach 3 iit $1.100=100$.

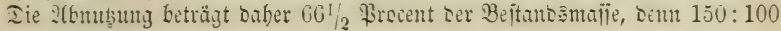
$=100: 66,6$.

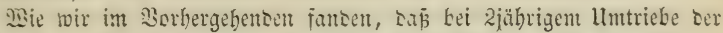

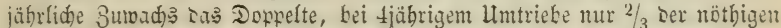
Bijumb mehr, wie aus folgenber Iakelle herborgeht:

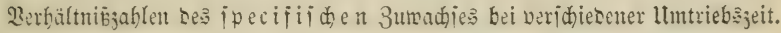

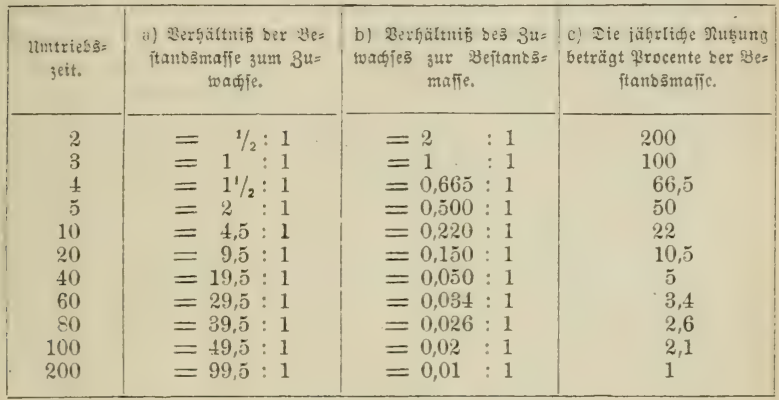

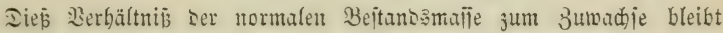

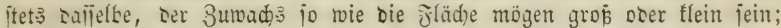

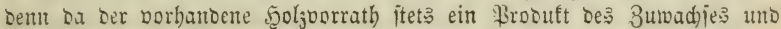

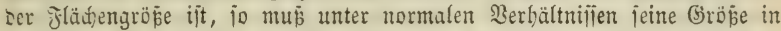

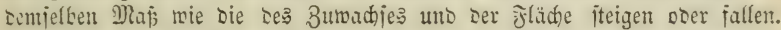

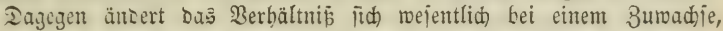

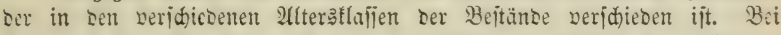

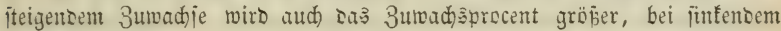
8umadje jintt es.

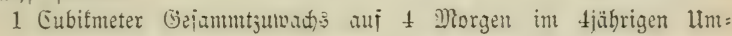
triebe ergibt

bei gleiđbleibendem 3umads

$$
\begin{array}{r}
\mathrm{z}=0,25 \mathrm{v}=0,00 \mathrm{v}+\mathrm{z} 0,25 \\
0,25=0,25-0,50 \\
0,25=0,50-0,75 \\
-\frac{0,25}{1,00}=\frac{1,75}{1,50}-\frac{1,00}{2,50}
\end{array}
$$$$
\mathrm{v}: \mathrm{z}=1,50: 1,00=0,666 \ldots
$$

bei fiteigendem 3uwađ̆s

$$
\begin{array}{rr}
z=0,10 v=0,09 v+z= & 0,10 \\
0,20-0,10 & 0,30 \\
0,30-0,30 & 0,60 \\
0,40-\frac{0,60}{1,00} & \frac{1,00}{2,00}
\end{array}
$$$$
\mathrm{v}: \mathrm{z}=1,00: 1,00=1,000
$$

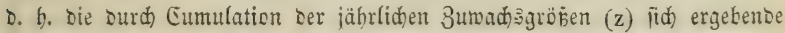

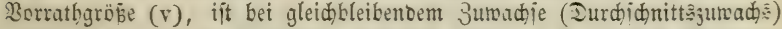
größ̄er $(1,50)$ als bei iteigentem 3umadie (100); trob gleichem Geianmt= 


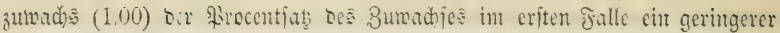
$(0,66)$ als im letiten Firlle $(1,00)$, allein in Folye oer umrichtig bereduneten Sorratbgröße.

Jd) merbe in ber Sefre von Ler. Crtragsberednung (33o. 111) auf Diejen Gegenftand jurüđfommen, Defien id) bier mur ermähne, un zu zeigen,

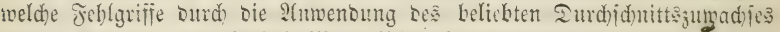

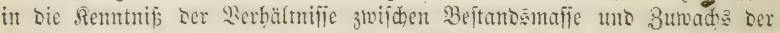
Mäloer bincingetragen werben, wie nothwensig ea fei, buth Ertrags:

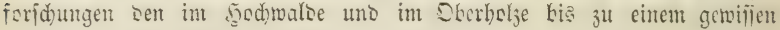
Ifter fteigenten Buwady femten zुแ lemen.

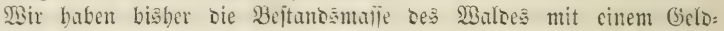
fapitale, ben 3umadis an Dex Beftanosmaffe mit Den Binfen cines Geld: fapital: verglichen. Diefer Sorgleich ift abor mur bejiehungsmeife zuläjitig, in gewifier binficht surfaus umaffent. Bei jesem Gelofapitale ift ber Binfenertrag von ser Gröpe bejelken abbängig, er fteigt uno fällt in scm:

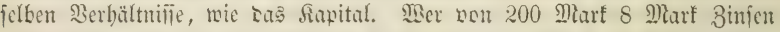
sieht, wiro audh non 100 Marf 4 Mart, non 300 Mlurf 12 Marf Bimjen

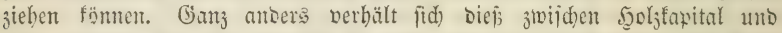

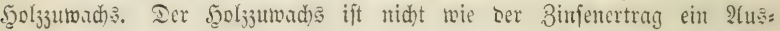

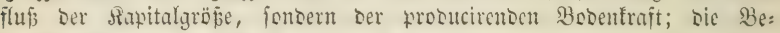

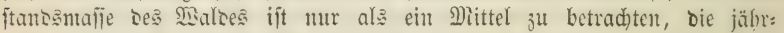

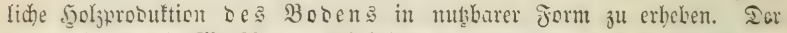

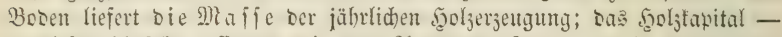

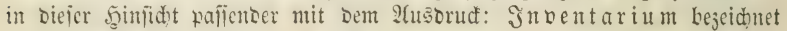
- beftimmt Den Baerth ser Mafjenerzeugung. Daber ift oie Mafie Des jührliden Sgolzzunadjes überwiegeno von ber Booenfraft abbängig uno

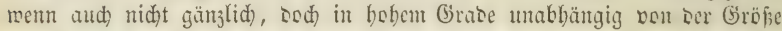

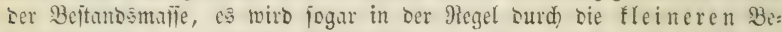

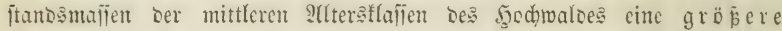

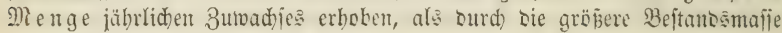
Der böheren Afters̈lafien.

Abgefeben bierbon, unt unter at nabme einer gleidbleibenben

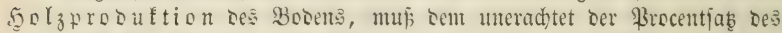
3uvachje mit fteigenoer llmtriebs3eit, aljo mit gröperer 2(nbäufung non Bejtunsonmajien allmählig finten, wie sief bie Iabelle Eeite 9 zeigt, mo: felbjt jür Dent 2 jübrigen Umtrieb 200 \$recent, für Den 200jährigen Untrieb mur 1 Procent Buwads nadogewiejen jurb. Diefe Berringerung bes $3 \mathrm{u}=$ mad) ziebung zur Gröpe uno zu bon Edmantungen bes abioluten 3uwadjes,

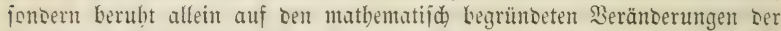

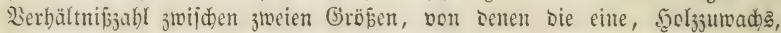

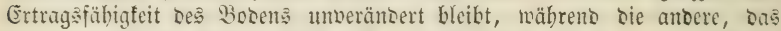

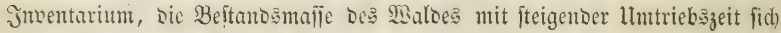
veränocrt, Daher id sieje Berbältnifjablen mit dem Namen ber fpeci.

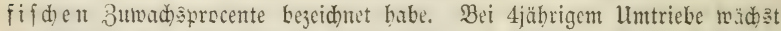

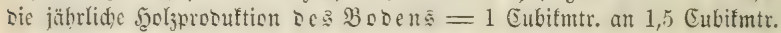

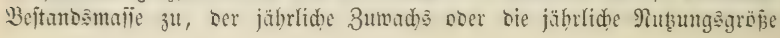


Leträgt alio 66,6 果recent ber Bejtandsmajic; bei lojjäbrigen Umtricke

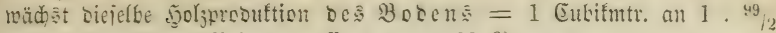

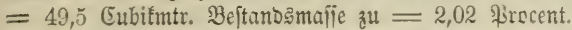

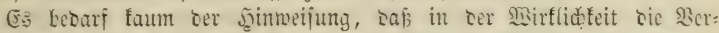

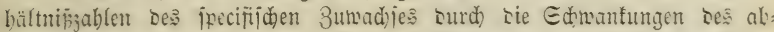
inluten Buwadjes nidjt unmejentlid mobificirt mersent. Eie fupien auf oer

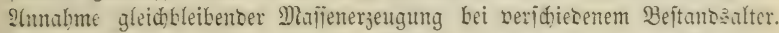

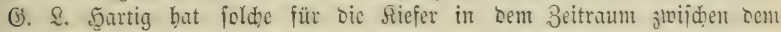
20jten uno 120jten Gabre, id jelbit babe fie für sie Rothbude unt Sidte

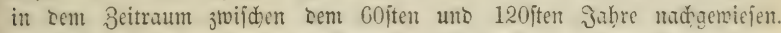

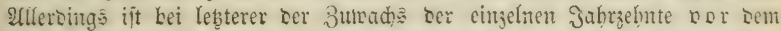
G0jten Jubre jebr veridieben, aber ser Iurdjidnittsumados aus ben eriten

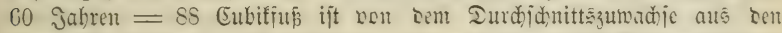

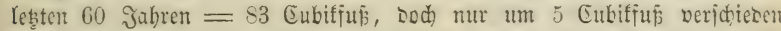

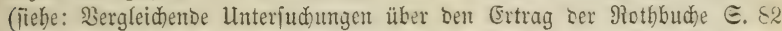

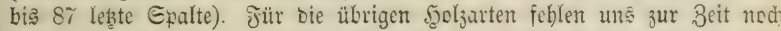
cine genïgende Nenge foldher Beobadtungen, wie jie notbimentig fint,

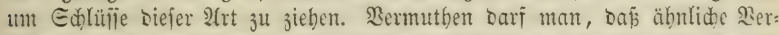

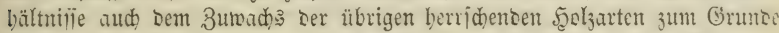

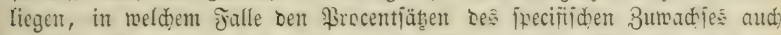
praftijate Bebentung nidht nerjagt merben fann. Jesenfalls wiro man aber

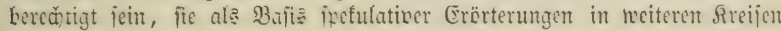
zu benuben.

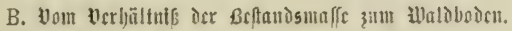

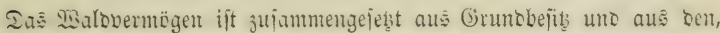
Den Boben bedectenten Beftünour. Tienn man bie lesteren in ibrem 2 bältuije zu bem an ibuen erfolgensen 3 umads als ein mers

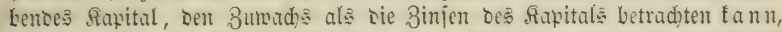

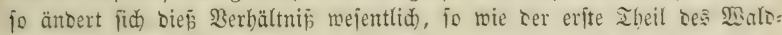
vermögen:, Der Boben, mit in Betrad)t gejogen mirs. Jn sicjem Julle ift ser bosen als ber probucirenoe Theil bes 2ermögens,

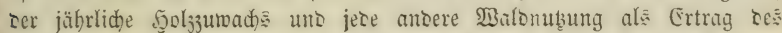

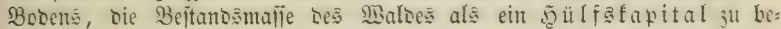
trachten, nothmendig, um bie jährlid)e Joljerzeugung bes Bobens in ge= braudaföbiger form abmuben zu tönnet. Ga liegt nid, entfernt ein

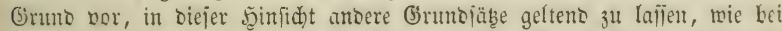
jebem ber übrigen probucirenden Gewerbe. Ias \$ermögen im lanomirth: ¡̈haftlichen Befitithum bejteht gleidfyalls aus Grumbeigenthum uno einem Jnnentarium zum Betriebe ser Sanowirtbidaft. Der Sanomirth zieht bis

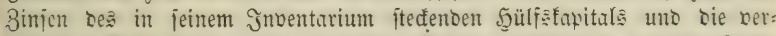

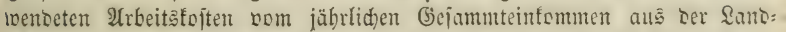
mirtbidaft ab uno betradtet Den berbleibenoen Uebericus als Ertrag feines

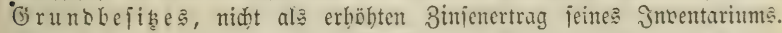
Siönte ciu Sanomirtb aus ber Serifllberung fitnes febenten unt troten

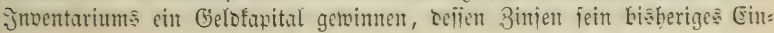


fommen verboppeln, io wübe er, abgejeben von bejonberen Siebbabereien, thöricht bandeln, wem cr nidit fofort jur Beräuferung lodritte.

Ein jolder, für jebes andere Gewerbe abnouner Jall ijt bei ter Forft= wirtbichaft im böberen Intriche nomal. Die Iabelle $\Xi .9$ zeigt uns,

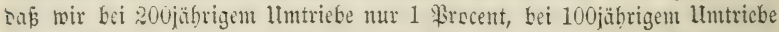
nur 2 Brecent von ber Dajie oç Jnventarium unjerer Mälor all:

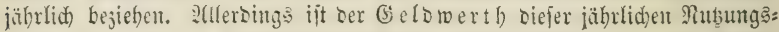

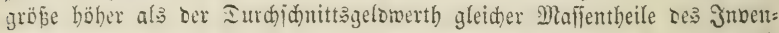
tarium: in Saubbolymäloern, meld)e norjugstmeije Brennitofi liejern, ift

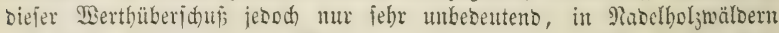
uno beim Nubboljbetriebe $f$ an $n$ er, ganj aubergemöbnlicte gälle abges

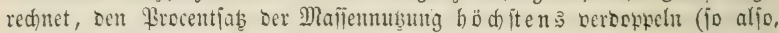

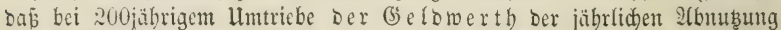
anf 2 Brocent rom Gelonertbe Der Beitunosmalle Des Maldes, bei 100iäbrigen Untriebe aui 4 Precent fid) iteigern fann (Dergl. Iabelle

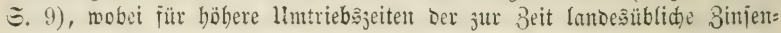
genuis immer noch unerreid)t bleibt, ein geringes Bodeneinfommen böditent?

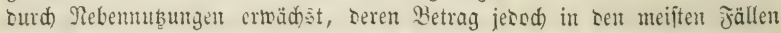
von 2lominiftrations: = uno Culturfoiten vollitänoig abjorbirt roiro.

Bei ser Malomirtbidajt in böberen llmtriebe erreicht baber oer (Seld=

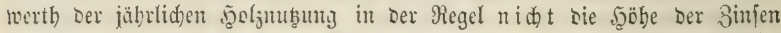

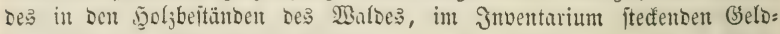

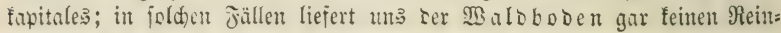
ertrag. Erit bei lintriebsjeiträumen, Die mur Dem Mieberwalobetriebe ent=

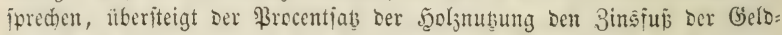

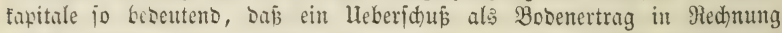
geftellt werben fimm. Tabelle ङ. 9 ergibt für den 20jäbrigen llmtrieb

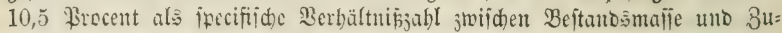
wads. Iie mertbverbaltuilie beiber geben eine bebeuteno böbere Gteigerung des Rrocentiuses ju Gumiten des Ertrages, ba bei nieberem

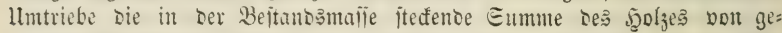
ringitem Gelowerthe (Meijerbolj) bei toeitem gröber ift als bei böberem 1 m: triebe. Dem unerad)tet jino alle biermts abjuleitenton Dorzüge Des fürzeren

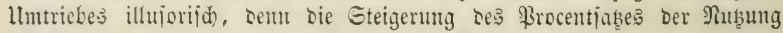
bei fürjerem llmtriebe liegt nidt in einer Ertragserböbung, jonbern in einer 2erringerung ber fiapitalgrö̈e bei gleidbleibentem ober in ge= ringerem Berbälnib̄ jinfentem, geringwertbigeren Bumadje. Der Befiber

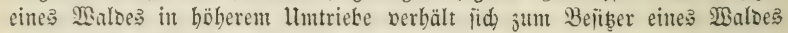
in fürjerem IIntricbe wie jich jtwei Rapitalijten ju einancer verbalten, von Denen Der eine anß 1000 Thaler Eilber 2 Procent jum Rominalwertbe an Binjen bejieht, mährent Det anbere at: 200 Thaler 10 Procent Binjen in Bapieren von balbem Nominalmerthe erbält. WBirfliche pecuniäre Bortheile

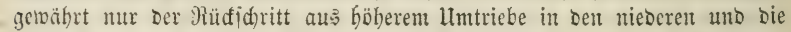

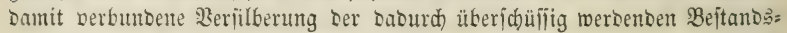
maffen, bie, in Eilber verwanselt, einen böberen Binfenertrag abmerfen als in ibrem früberen 3 uftande.

Bir jorftleute baben uns oaran gemöbnt, bei ifeculation Be= 


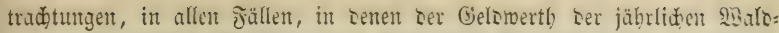

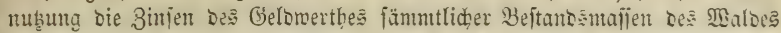
nicht erreidft soer nidht überiteigt, Den Boden als nidt prosucirento, bie

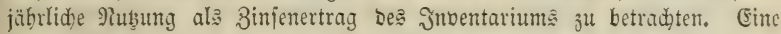
flarere Einfidyt geminnt man, wenn man entyegengejețt, ben Boren in allen fällen als probucirents, bie Beitundsmafien in fo weit als ein toote?

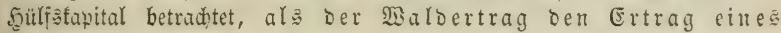
Sobens von gleider Befdafienbeit un $2 a g e$, wie ibn jebe

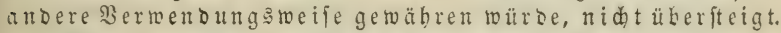

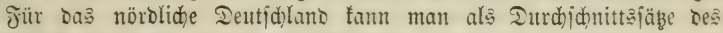
Reinertrages (o. h. bie 3injen bes lebenten uno todten Inventariums, io

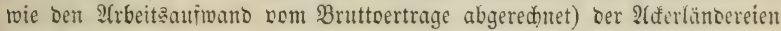
antebmen:

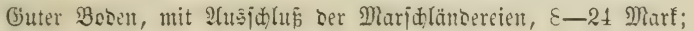

mittlerer Boden $12-15$ Marf;

iobledter Boden 4-6 Marf;

Jaibeland, wie Das Der Süneburger Şaibe, 3 Mlart uno Darunter.

Etellen wir oem gegenüber unjere $\mathfrak{B a l b e r t r a ̈ g e ~ m i t ~ 4 0 , 6 0 , ~ s u ~ E u b i f f u p ~}$ jäbrlicther Jjoljerzeugung mro Magoeburger Morgen guten, mittelmäß̄igen

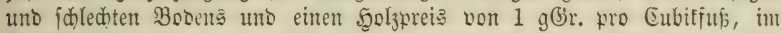

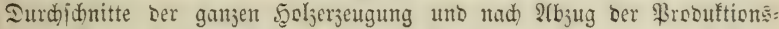

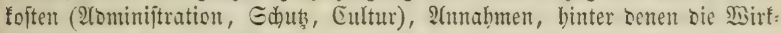

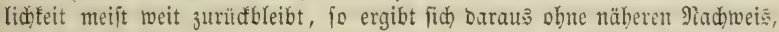

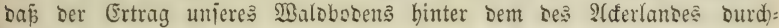

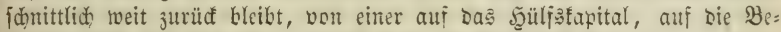

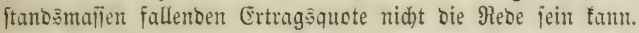

Eine Bertheilung Des Malbertrages auf Bobelt = uno Feülf3̧apital ift

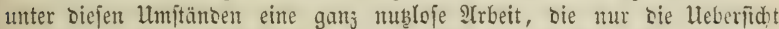

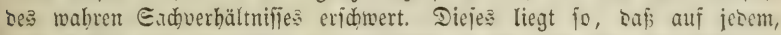

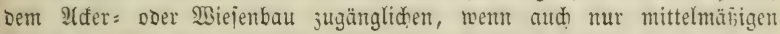
Boben ber Ertrag alt foritfiden Wroduten binter Dem Ertrage Der Samb:

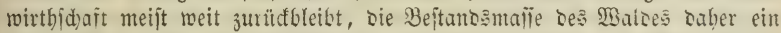

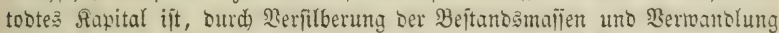

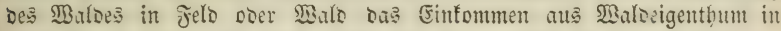
allen Jällen erböht, in vielen verboppelt uno veroreifacht mertent fam.

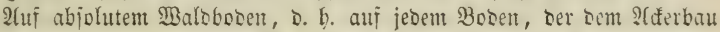

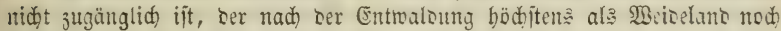

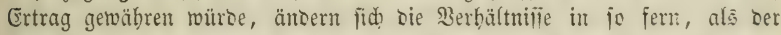

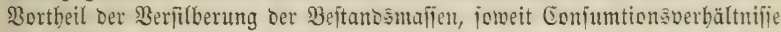
Fie geftatten, weniger grób ift. Alugehobent wiro er aud in biejem fall

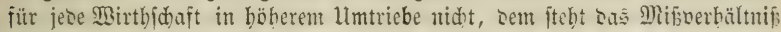

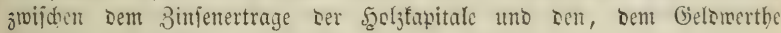
Deffelben entipredentoen Beldofapitalzimien entgegen.

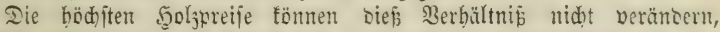

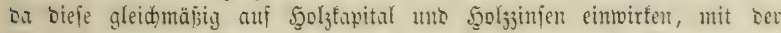

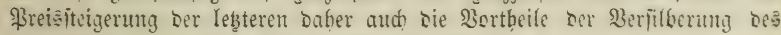
Solzfapitare in gleichem Merbältnifie fich erhöhen. 


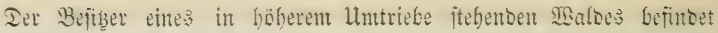

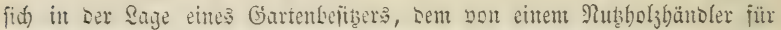

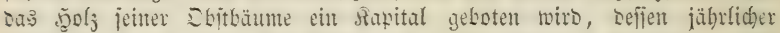

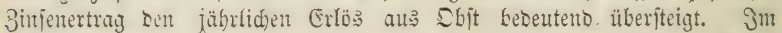

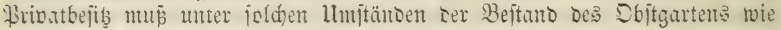
ser unjerer siafloer jebr gejährbet jein, uno mur bie angeborne Siebe ju 2lllem, was wir als unjer Eigenthun betradten, biefelbe Zuneigung, bie jux Bemubung ber Sobnjufre treibt, wäbreno bie eigenen \$ferbe in Etalle

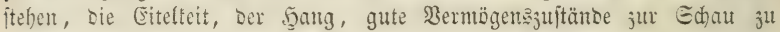
ftellen, Derjelbe, welder Den Mentier veranlafit, Taujente im werthodlen

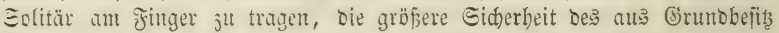

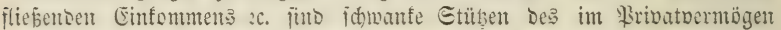
befinofiden unbejuräntten Isalrbejibes, mijựer, weil fie auf Der Bajis

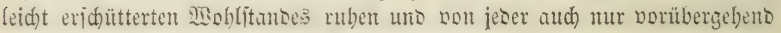
eintretenoen Bebürftigfeit leidft bejeitigt werben.

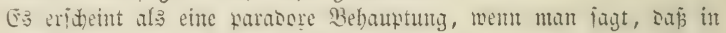

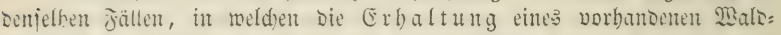

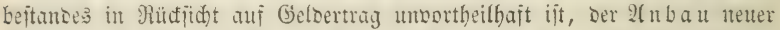

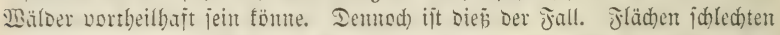

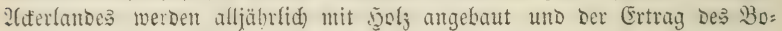

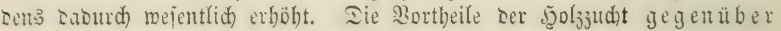
Der früberen (andwirthidaftliden Benubug Des Bobens find

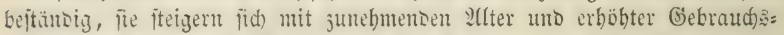

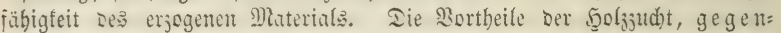
über einem bie erjogene Bejtanosmaje repräientirenden Gelstapitale, ichminten! bingegen für den jur gebrautşähigen Etärfe

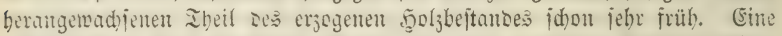
auj Errielung Des höbiten (jeldertrages geridete malomirthidaft

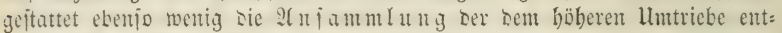

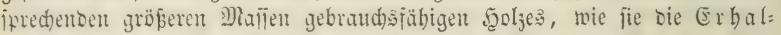
tung Der von unieren Sorfahren un vererbten Bejtandsmaijen Der Däl= Der julăpipt.

Ia Gilo sor Mepräjentant aller übrigen Giüter ijt, wiro Der Privat=

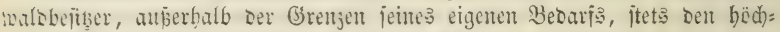

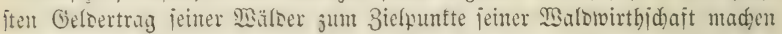

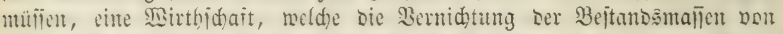
Fobertr Getraud) wiro ihn sabon jurüđjubalten vermögen. Bei jebem anberen probucirenden Gimerbe tam man jagen, Бaj, Da Mladjiage uno 2(ngebot ben Freis ber

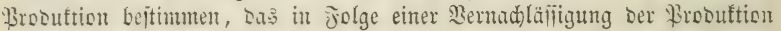
fintense Alngebot Den \&reis erföhen, uno der erbübte \$reis oen Produ=

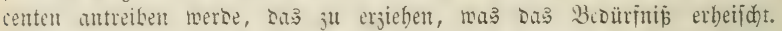

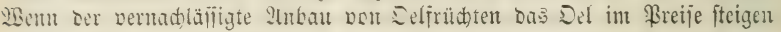

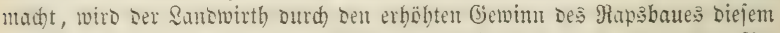
unfeblbar wieber jugewendet. Isare bas Del ein cben io Dringendes Be=

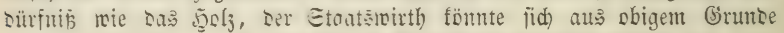

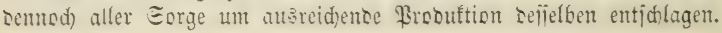




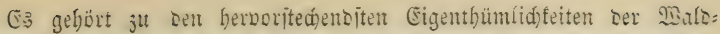

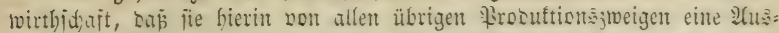

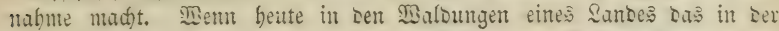
freten Malsmirthichajt liegense Dejtruftive Princip jut Geltung fäme, mütrc

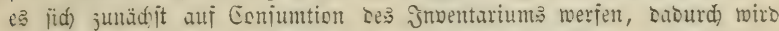

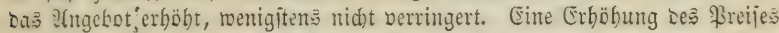

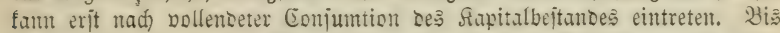
Labju tritt ein in ser Preißerböbung begrünteter Intrieb ju fifleglicher

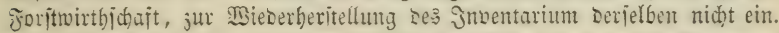
Ier Santwirth fann ieinen vernachläiligten Zlder, sen herabgefommenten

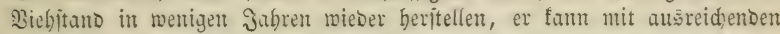

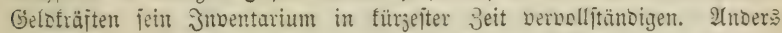

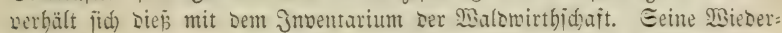
beritellung jorbert unabänoerlid) einen langen Seitraum. Afuch ment ber Eubiffü 100jährigen Ëidentoljes einen Iutaten tojtete, würbe Dentech Der jorjtwirth nach nollenteter Eonjumtion Des Ĵnventarium 100 Jabre warten

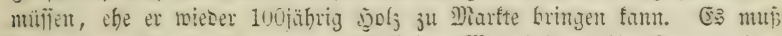

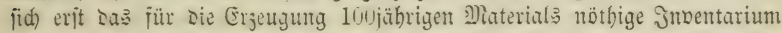

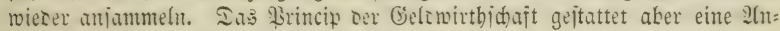
jammlung gebrauchăfäbiger Bejtantōmajīen ničt.

Diejen Endjoerhältnis jtoht nun bie, bejonter: für bie flimatijonen

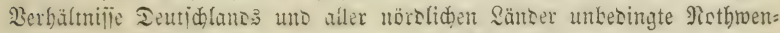
sigfeit Der Wisaforrouftion gegenüber. Die Eideritellung sauernoer, nad)=

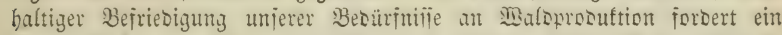

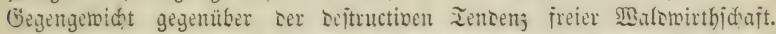

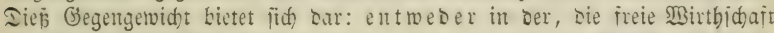

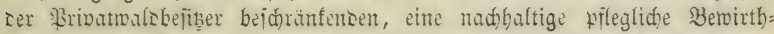

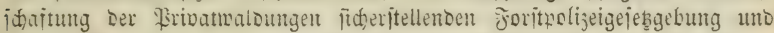
Eberaujitigt, Doer in einem, Die Eringentiten Bosürnifie ser Nation an

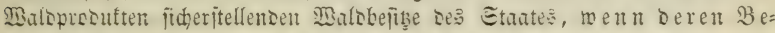
wirthidaftung Dem höditen werthooll jen giaturalertrage з $u$ getwendet ijt, oder nöthigenfalls in Beidem jugleich).

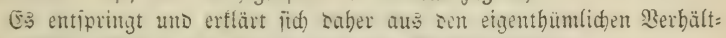

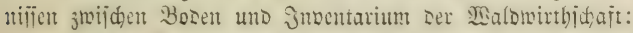

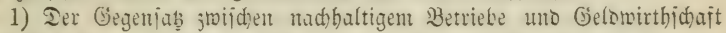
in cen Maloungen, jwijden conjernativem uno sejtruttivem \$rincipe; Rebtere?

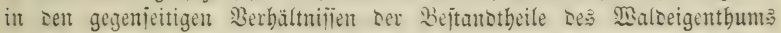

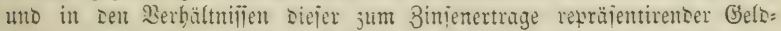

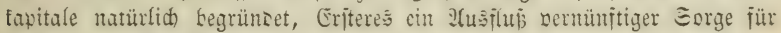
3utunft unt গachtonment.

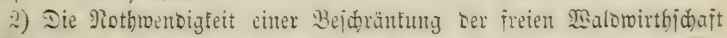

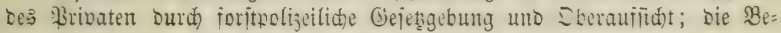
Dittgungen unt Die Órenżen Diejer Bejđbräntungen.

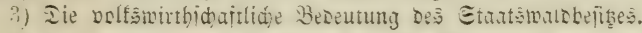

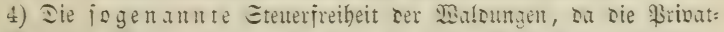

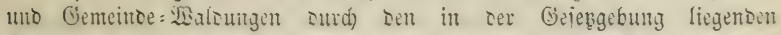

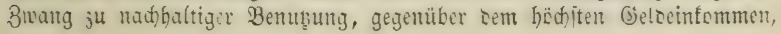


it ber Ibat, 3u Gunften oes Gemeinmobles, inbireft böher befteuert funb als jebes andere Befitithum. Sur oa, mo bie Malomirthidaft ber \$ris

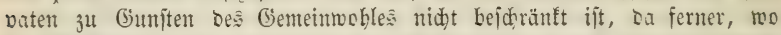

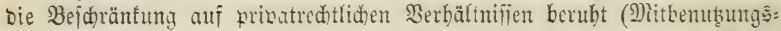

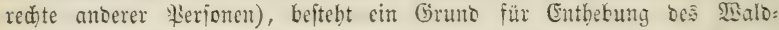
cigenthums von birefter befteuerung nidyt. Die Gtaatşmaloumgen fönten bei biejer Jrage natürlid gar nidjt in Betradht fommen, Dem jese Eteuer: erbebung mürbe nur 3ahlung aแล ciner Sgand it bie andere berfelben Perjon jein.

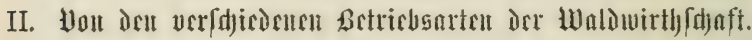

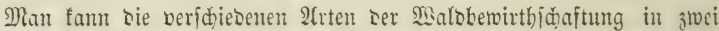
5auptgruppen, in reine uno in gemijote Betriebarten, tremen.

Bei Den reinen Batriebarten liegt eine anberweitige benuţung bes

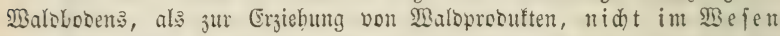
Des Betriebs, es fömen aber, im ungeftörten Serlute befielben fich

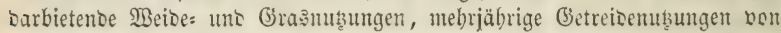

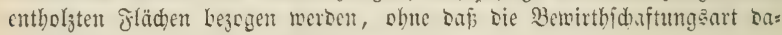
Durd) ऊ̧u bent gentengtent übergeht. Şierber gebörent:

bie Şodwalomirthidaft,

bie Niebermalomirtbjichaft,

bie Mittelwalowirtbidaft.

Den gemengten Bemirthichaftung: Mlethoren bingegen liegt bic Joee

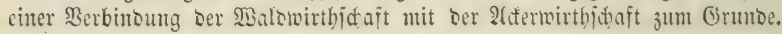
Ës gebören babin:

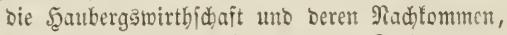

bie Baumfelowirtbichaft uno beren Tödter,

Der Ropf: und Gdineibelholz=Betrieh.

\section{Drittes canpitel.}

2om Betriebe Der 5edualdowirthidaft.

Unter jodmalsketrieb rerjeht man oiejenige Betriebsisart, bei weldher

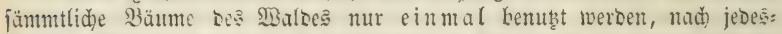
maliger Abmutsung anbere froligflanjen an sie Etelle ber biumeggenont: menten tretent.

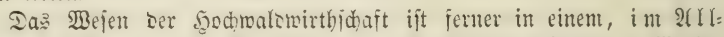

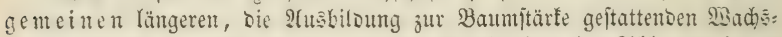
thumbzeitraum ber Syoljpflunzen, verbunben mit einer im Arflgemeinen

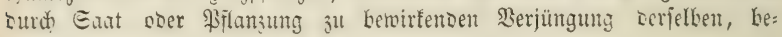
grünot.

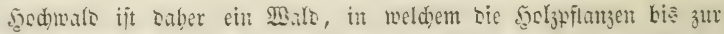

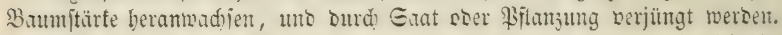

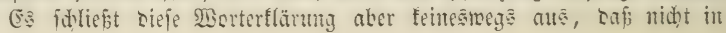




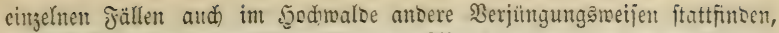

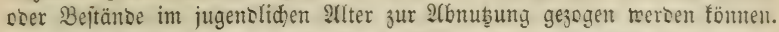

Die Birthidaft im Sgochwaloe zerfällt in ben folagmeifen uno in ben plänterweifen Betriek.

\section{A. Bon ber Єdlagwirthidaft im Şodralbe.}

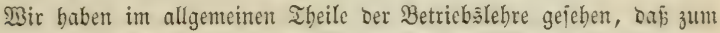

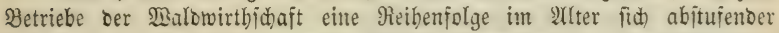

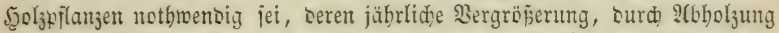
eines ber Majie nad sem 3utwaj) gleid, grofien Theiles ber ältejten $50 l_{3}=$ pflanzen, jäbrlid bintweggentommen wiro.

Ed) lag weife nemut man Den Betrieb ber Şodimalomirthid)aft, went

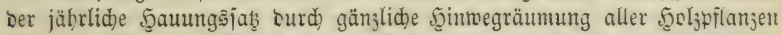
Des ju verjüngenden Bejtandes innerbalb eintes ober weniger Jahre kejegen

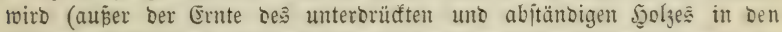
jüngeren Beitänden); wäbreno beim $p l a ̈$ ütertweifen Betriebe, mo bie

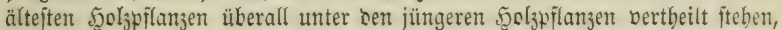

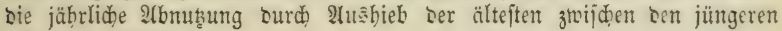
Bilanzen gejuieht.

Die nädjte jolge res idylagmeijen 2(btriebs, bei meldem in einem Doer in wenigen Jabren alle Den Beitand bildenden f̧oljfflanzen wegge:

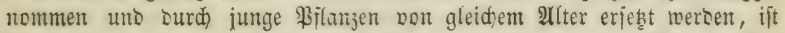

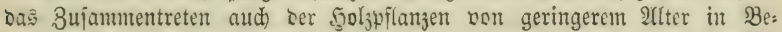
ftänbe, beren jeber aus \$ilanzen bon gleidem $\mathscr{U}$ ter, baher auch im $\mathfrak{A l l}=$

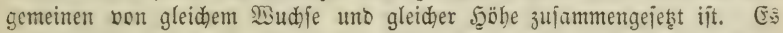

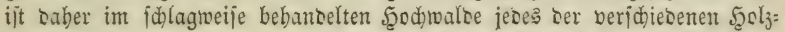
alter in Bejtänbe vereint, uno Die Etufenjolge Des Soljalter: jtellt jich in

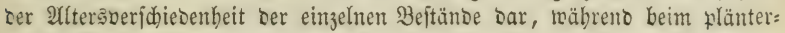
weijen Betriebe bie verichiedenen Fुoljalter ïberall untereinanoeritteben. fentlidien:

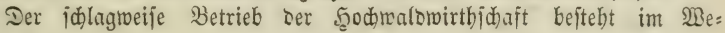

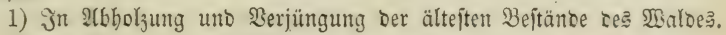

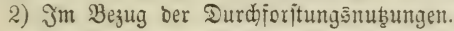

3) Эm গ̧ollzug ber nöthigen Culturen.

(E⿱

1) Wie viel farm uno ioll jährlich Den obmaltenoen Berbültnifien

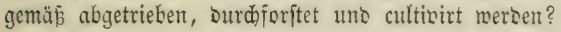

2) $\mathfrak{B} D$ uno

3) Bie joll biés gefcheben?

Mir werben uns nut zubörcerft mit ber erften biefer ivragen be: fक̆äftigen:

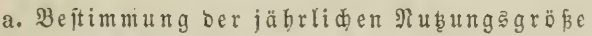
(Etataermittlung).

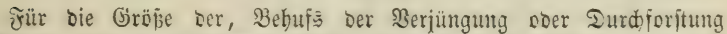
jübrlich in Şieb ju nebmenten fläde, bedarf ber Joritwirth eines auf

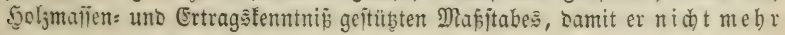




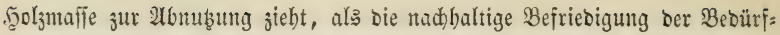
nifile geitattet, nid) weniger als bie Bejtandsmanien uno Ertragger: hältniīe des $\mathfrak{B a l}$ aes erlauben.

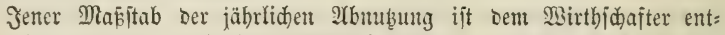
weber in eiter vorausbeftimmten Sdlagiläde - Jabresidlag -

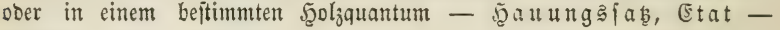
gegeben.

Was bie f̧olzung vorau引beftimmter

$$
\text { Jabreajd läge }
$$

anbelangt, fo babe id jobn im vorigen fapitel gejeigt, baj, wenn ein Balo in jo viele, gleidbiel Şolżmajie erzeugende, Flächen zerfällt wirb als

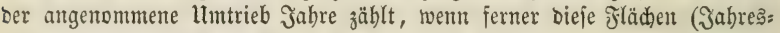

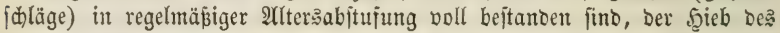

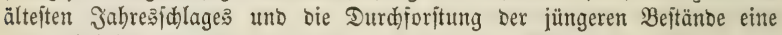

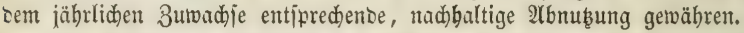

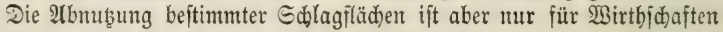
anwentbar, bie in furzem Umtriebe jtehen (Nieberwald), und zwar aus jol= genten Gืründen:

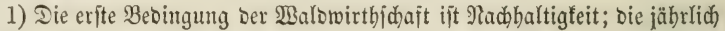

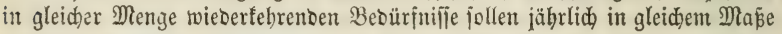

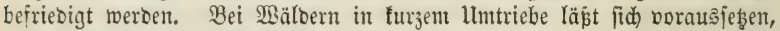

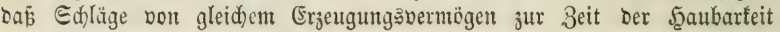
ihres Bejtanbes aud jiemlid gleiden Ertrag gewäbren werbent. Der Scod)= wald im hohen Umtriebe ift bagegent nidht allein einer größeren $\mathfrak{D}$ enge und

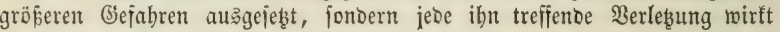
weit längere 3eit, als bein turzen Untriebe, auf Den 3uwachs ein, fđạmä= lert aljo ben 2 btriebsertrag in höberem Maß̣e.

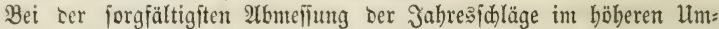

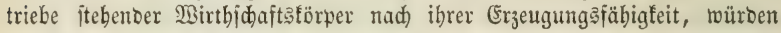
Diejelben aljo Dod nie gleiden (Ertrag getwäbren, uno bei ber Nothwentig= feit gleid)er jäbrlidjer (Eimnabmen, Borgriffe in bie jüngeren Sdläge ver= anlailen, weldhe balo bas ganje Birthidafținjtem über ben Scaufen werfen würben.

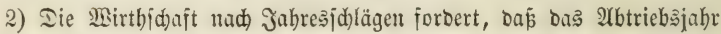
eines jeben Beftantes lange vorber fejtgejtellt uno eingebaltent werbe. Bei

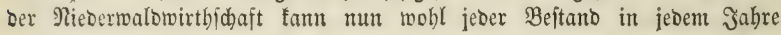

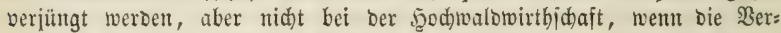
jürgung an bas unbeftimmte Eintreten Der Eaumenjabre gebunden ift, two

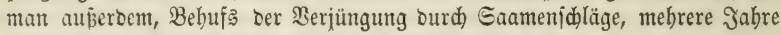
bindurd) auf ein uno berfelben glädhe wirtbidaften muß́.

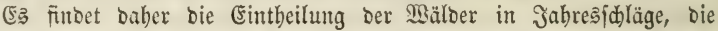

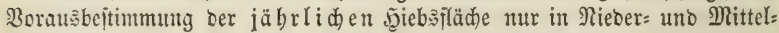
walbungen Etatt. Bei oer Şodivalowirtbidaft mus aus ben angefübrten (5ründen Dem Wirtbjdafter ein weiterer Spielraum gegeben werben, und bieß geidjieht burch bie Eintheilung bes Waldes in

Berioden fläd) $n$,

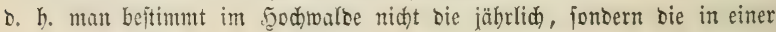




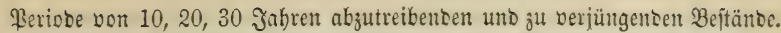
Unter \$eriobe berfteht man ben fejtgeję̧ten Beitraum, uno bejeichnet ben zu= nädjit liegenten als erite, bent jolgendent als zmeite Periobe u. j. j.; unter

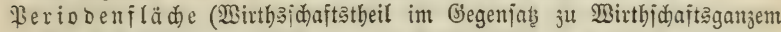
- Wirtbjojâjtäförper) veriteht man bie Gejammtheit ber in biejem Beitraume abzumuşenden Bejtanbeß̊läd)en.

5̧ätte man $\mathfrak{z}$. B. einen 100jäbrigen Umtrieb unb 20 jäbrige Werioden ant

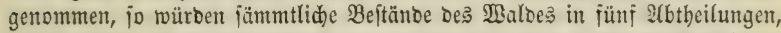

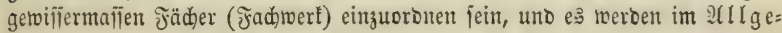

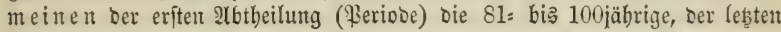
(iünften) Periobe bie 1= bis 20jäbrigen, ben bajwijhen liegenten Perioden bie ibnen entipredenden Bejtandabalter zugetheilt werben.

Eache Der Tax̧ation ijt $e_{3}$, bie Bertheilung ber vorbanbenten $B_{e}=$

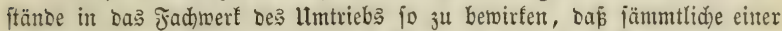
uno serjelben Periobe zugetbeilten Beftänoe jur 3eit ihrer $\mathfrak{A b n u b u n g ~ e i n e n ~}$ eben jo gropen uno eben jo qualificitten (Ertrag abmerfen, als jebe ber übrigen Berioben jur Beit ibrer 2lbmuķung (\$roportional=Theilung).

Eache Der Betriebsregulirung ijt ę bingegen, bie Bertheilung ber

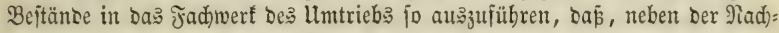

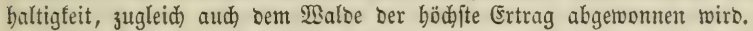

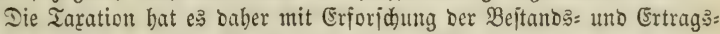

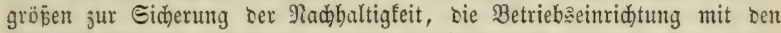

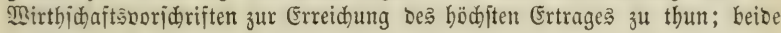
müijen fich aber gegenjeitig in bie Şänbe arbeiten.

Wenn bem Wirtbichafter burch Eintheilung bes $\mathfrak{B a l b e}$ in Perioben= flächen befannt iit, weld)e Beftänbe innerbalb 10= ober 20= ober 30jäbriger 3eit=

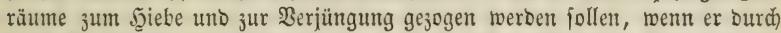

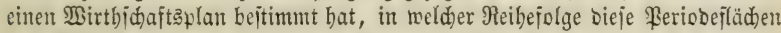
3um $\mathfrak{A b t r i e b}$ und jur Nerjüngung fommen jollen, jo bedarf er bod) immer

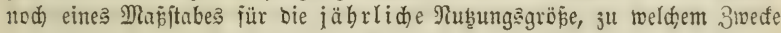

Der jäbrlide 5ुaunugsjats (Etat)

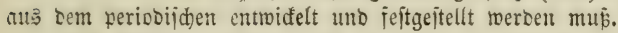

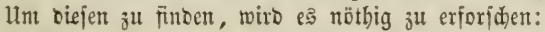

1) Wie viel 5ूoljmalie entbält jeber Bejtano gegentwärtig.

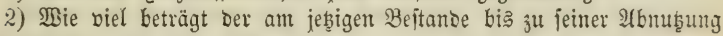
(Mitte ber Abtriebsperiode) eriolgende 3uwadj.

3) Beide Eumment ergeben Den 2tbtriebsertrag eines Beftandes, nadibem vout Zuwachje ber Durdjoritungsabgang ab=, und ben Perioben, Denen er $j^{u}$ (Sute fommt, zugeidrieben murbe.

4) Die Summe Der Abtriebäerträge aller, cinter Periobe zugeidric: benen Bejtänoe, und bie Der Durdjpritungen, welde berjelben Lieriode ju

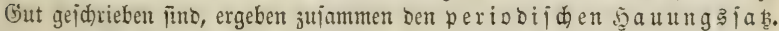

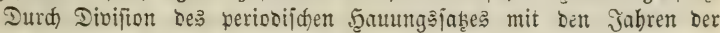
Periobe erbält man ben jäbrlichen 5ूaungsia - ben jährliden

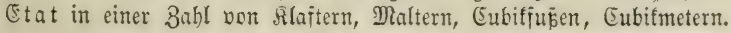

Leber bie beridjedenen Metboben Der Ertragsermittelung banoelt ber

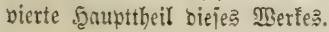




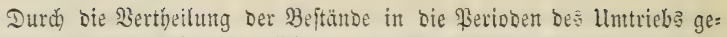

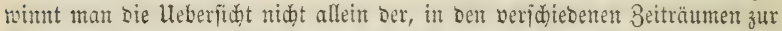

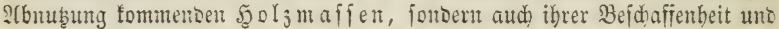

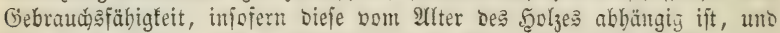
man vermag baher, fich ju erfenten gebende Mifiverbältniffe ourch Sergröß̄e:

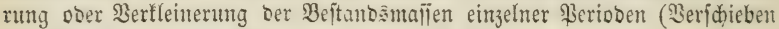
Der Beftäntoe) auşugleid)en.

(5: liegt Diejem Berfahren feineŝtwegs bie bäufig untergejđobente joee zum

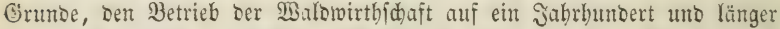
voraus beftimmen ju tollen; wir jüfhren samit mur Den Beweis̄, Daf umjere jeb̧ige Berwirtbjouftung uno Benubung in jeoer Ridutung cine nad): haltige jei; dafi wir bas von unjeren Sorfahren überlieferte \$salovermögen

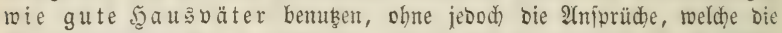

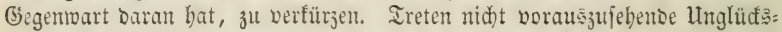
fälle, teeten 2(nforberungen an bie Reiftungen des Maldes auf, bie fich)

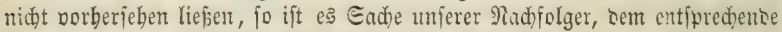

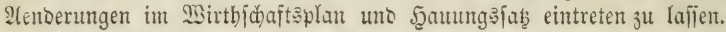

Dem Wirtbidafter ift naty Derartigen Ermittelungen nidjt allein be:

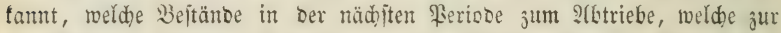
Durdforifung fomment, er weis nut aud), welden (Ertrag bie Gejammtheit Ier, einer jeben \$eriooc zugetheilten Bejtäıtoe gewähren miro, uno wic viel

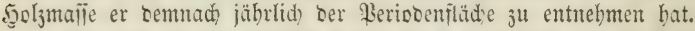

Wie uno mo ber jührliche 5ुaumng Den Periobenfläthe bezogen werben foll, ift nidjt boraus bejtimmt, fonbern

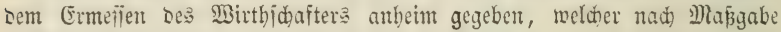

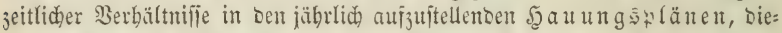
jenigen Beftünoe zu bezeid)nen hat, ourd) beren 2(btrieb ober Ed)lagftellung,

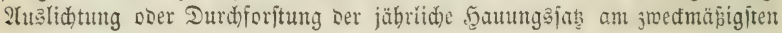
bejogent werben fam.

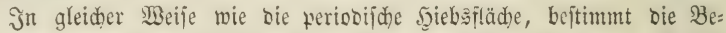

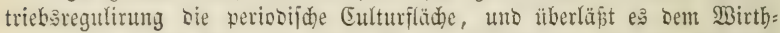
fichafter, in jebem jabre biejenigen Fläd)en zu beftimmen uno im jäbrlichen Eulturolane zu veranjólagen, beren aläbaloige Cultur am nöthigiten uno ztwedmäpigiten eridjeint.

\section{b. Bon ber 2 แswabl ber jäbrliden betriebsfäd)e (Giebjlebre).}

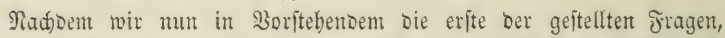
bie frage: Wie viel foll abgenuşt werben, zu vorläufigen Erörtermy

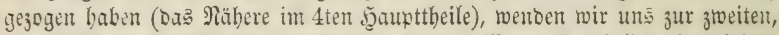
Die Mahl ber Dertlidteit betreffenten ornge: $\mathfrak{B}_{0}$ joll jährlich abgetrieben,

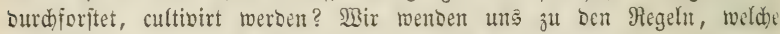

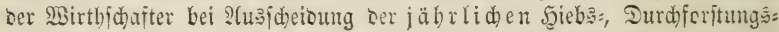
und Eulturfläbe aus oer periobificen zu beobadten bat. Diep ift Gad)e Der giebs: uno Cultur= \&eitungalehre, währent bie britte Der geitellten Frngen: Die $2 \mathfrak{4}$ 预

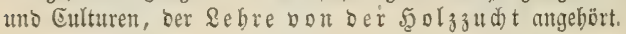




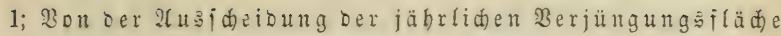
aus ber periodifden.

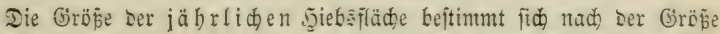

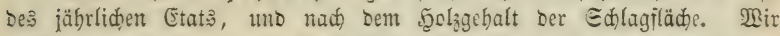

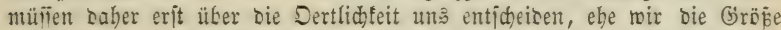

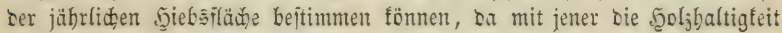
ber Galäge eine anbere wirb.

\section{Ueber bie $\mathbb{S} a h l$ ber Dertliditeit.}

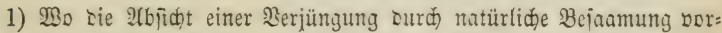
liegt, fömen bei ser Mahl nur folche Erte in Rüficht treten, welde fich in einem veriüngungşä̆bigen 3 uftanbe befinben.

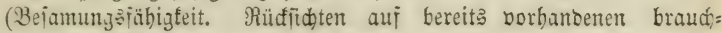

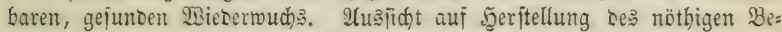

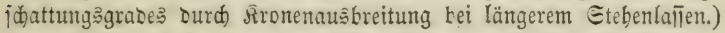

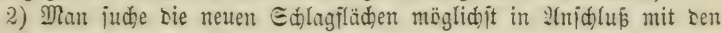
jüngit gejübrten zu bringen.

3) Diejenigen Drte, reldhe im geringiten 3umachie fteben, fino zuerit зแ verjüngen.

(llnwüchitge Beitänbe auf gutem Boben früher als eben jolche auf idlechtem Soden.)

4) Drte mit abnehmenter Gebrauçäähigfeit jino früher ju ver=

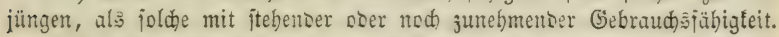

5) Drte, welde jich in einem Suitanbe befinden, Der eine Nerjoblect)= terung Des Bocoens bejürdten läbt, fino früher zu verjüngen, als folde, - weldhe Den Broen yor nadbtheiligen BerünDerungen id)üsen.

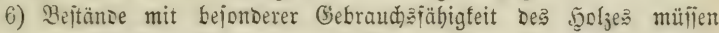

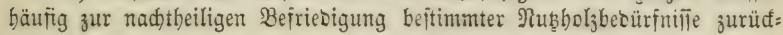
gejeşt werben.

i) Beitänte, weldhe Dim Berbrauchsonte ober einem Etapelorte Dber bem Etallungşorte grō̄en Mengen Weibebieh am entfernteiten liegen,

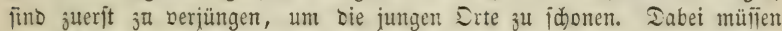

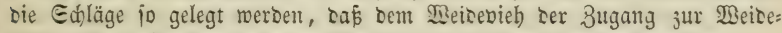
fläd) nicht erid)wert, ober bie Ifrlage pon Triften nothwentig twiro.

8) Die ङめläge mülien io gelegt uno nötbigenfalls vertbeilt werben,

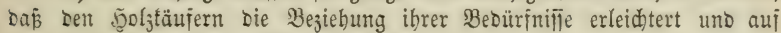
bem minbeit fojtipieligen Wege möglid mirb.

9) Beftänઠe, Deren Berjüngung in Der Gegenwart mit Eulturfoften ver=

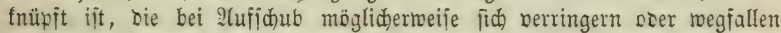

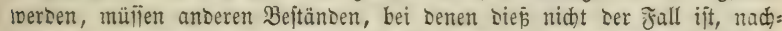

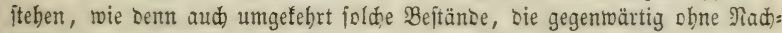

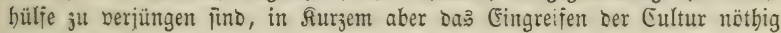
machen würben, anberen, bei benen siés nicht ber žall ift, vorzuziehen fino.

10) Die Єdläge müīen ber Eturmgegend entgegen geführt rerben; theils

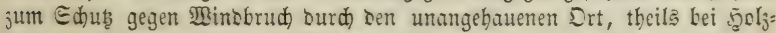
arten mit leiđtem Eamen jur Förberung ber Bejamung vom jtehenben Erte auß. 
Ueber bie Gröbe ber jäbrlichen Derjüngungafläte.

5ुat fich ber Mirtbidafter, mit Berüđichtigung biejer riditigiten be:

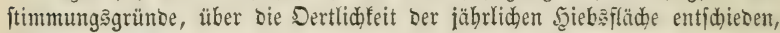
fo fragt es fich mun nod):

Wie gró bie Edylagfläde für bas vorliegende Jabr gegrifien merben müifie.

$\mathfrak{B O}_{0}$ feine Rüdjichten auf natürlidje Bejamung ftatt finoen, bejtimmt

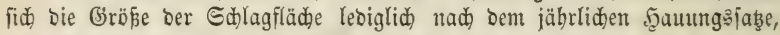
uno es wiro eine fo grope frläde entholyt, als zur Decfung bee Etats er: forberlidi ift.

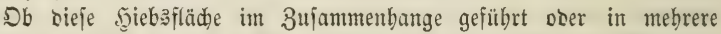

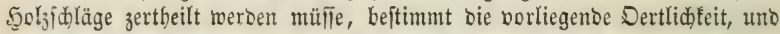
mandhe ber in Beziehung auf bieje ebengenannten Rüffichten. Gebr fleine

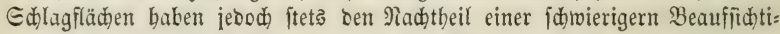
gung, einer gröperen Serbämmung bes Wieberwudjes an ben Edlag= ränbern Durd) Den ftehenton Drt, Bermebrung ber 2(bfubrrwege, grȫerer Beidäbigungen Durch Weibevieh ober gröferer Betwahrungfoften.

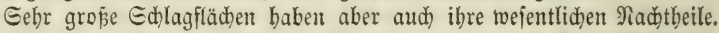

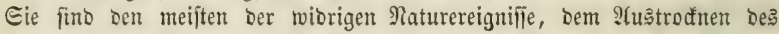

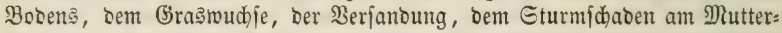
beftande zc. in böherem (jrabe unterworfen; fie erfd)weren bem 50 lzempfänger wie ben Weibeberedtigten Den Bejug ibres Bebürfnifles an Waloerzeug= nilien in ben 3eiten, wo ber Edjlag bem Erfteren fehr entfernt, ben \&eb̧teren febr nabe geführt wirb; fie belaften lange 3eit binourd einen uno ben= jelben Edub̧beamten mit aller 2 rrbeit, wäbreno bie übrigen feiern, ftehen

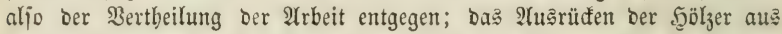

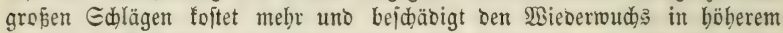
Ģrade; grofie Sabläge entrodjien fpäter Dem Siebe, müifien alfo länger ge:

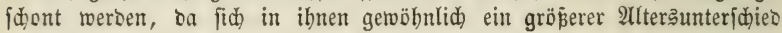

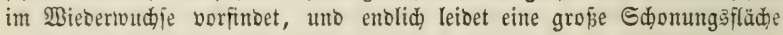

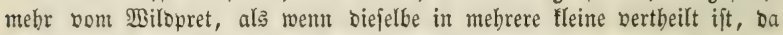
Das Milto längere 3eit in ifr verweilt uno hungriger wirb.

3ur Bermeioung Der Nadtheile zu groperer Edläge theilt man ben

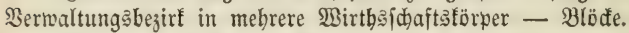

Wo ber alte Drt Durd natürliche Bejamung verjüngt werben foll, beftimmt theils die Bieberfebr ber Samenjabre, theils bie \&änge Des 3eitraum, welderzwifen Befamungs= uno Ábtriebs: fdlagliegt, bie Gröpe ber in Şieb zu nehmenten Shlagfläd).

Bei allen Şolzarten, bie häufig Eamen tragen, unter ß̧erhältnifien Die häufige Gamenjahre erzengen, wiro bie \&änge bes 3eitraums, weldher

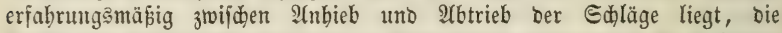
Größ̉e Der Schlagfläbe bejtimmen. Wäre biejer Beitraum z. $\mathfrak{B} .4$ Jabre, fo mürbe man eine Jläd)e in Şieb zu nebmen haben, auf weldjer das jäbrliche (5tatsquantum 4mal entbalten ift, uno jäbrlich ben Etat ourdh

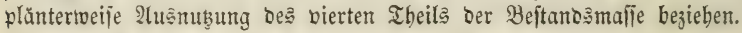

Ireten bingeaen bie Samenjabre in längeren Beiträumen auf, als̆ 
Jahre zwijden 2(nhieb uno 2tbtrieb liegen, fo wübe man, menn man bie

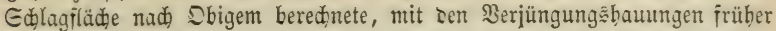
fertig werben, als ein neues Eamenjabr ben 2tnbieb neuer Ed)lagflähen gêtuttet, uno genöthigt fein, grope flächen in \$orbieb zu nebmen, moraus

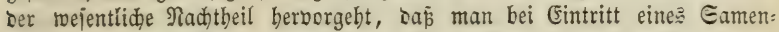
jabre jebr grofe Berjüngungäbiebe erbält, in Denen man, ourdh ben vor:

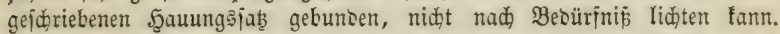

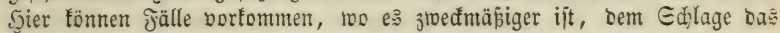

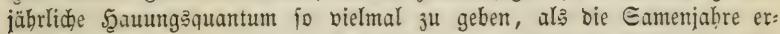

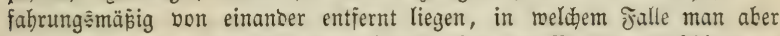

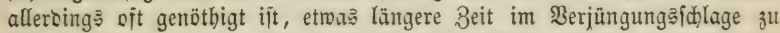
wirtbidaften, als belien Natur cs erforbert. Man wiro baber meijt beiler

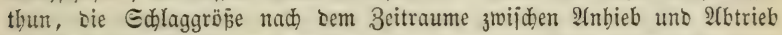

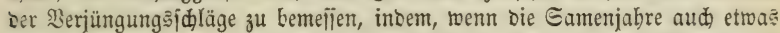
länger ausbleiben, man fị bis zum (Eintritte berjelben mit Durdforitungen, im Nothfalle aud mit febr sunflen Sorbieben binbalten fann.

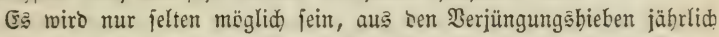

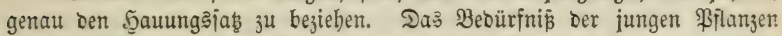
forbert häurig eine veritärfte ober verringerte 2 (bnub̧ung. $\mathfrak{S}_{0}$ in einem Birtbidaftaförper mebrere Edläge geïübrt werben, fann bier einer ben an=

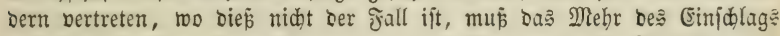

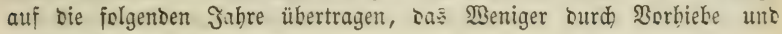
Durdforftungen gebectit werben.

\section{2. İ Der periobijen.}

Die Wahl ber Dertliđlfeit ijt hauptiädlid vom Beoürfnip bę

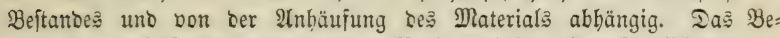
Dürfni

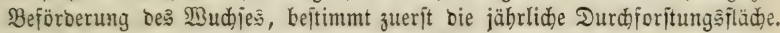
Der Anbäufungşgrad Des abjumusenten Materials mirft in jofern barauf eit, als in vielen fällen bie Durdforftungen nur bei höheren Ğraben ber

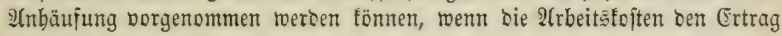
nidht überiteigen follen.

Nächjt toem fönnte man fagen, Daj alle Durdjorifungen auf ichledtem Boben benen auf gutem Boben vorangeben, benn offenbar leibet ber $B_{e}=$

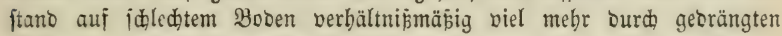
Stand ber 5olzpilanzen, als ber auf gutem Booen.

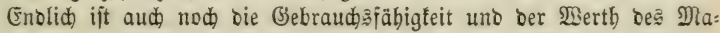

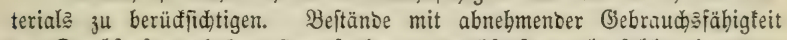
Des Durdforitungăboljes fino früber ju burdyforften, als joldhe, in venen Die übergipfelten Etangen fiळ noळ längere Beit zu erhalten bermögen.

Bon ber Gröbe einer jährliden Dur d for ft ung smafie fann nicht

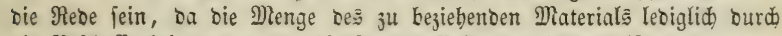
bie Befhaffenbeit bes zu burchforiftenden Beftande beoingt ijt.

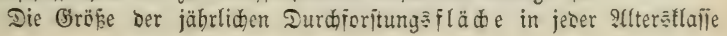


fittoet man Durch Divifion ber Gröpe jeber Beriobenfläche, in weldyer Durdforitungen bezogen werden, mit ben Jabren Der Beriobe.

Würbe 3. B. Die erite Durbjorjtung im 40iten, bie lebte im 80jten

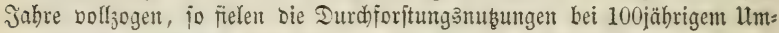
triebe uno 20jäbrigen $\mathfrak{B e r i o b e n , ~ i n ~ b i e ~ 2 t e , ~ 3 t e ~ u n t ~ 4 t e ~ \Re e r i o b e . ~ H n t e r ~}$ ntormalen Berbältnifien ift jeðe Beriobenflädhe in obigem 1000 Şft. grosent

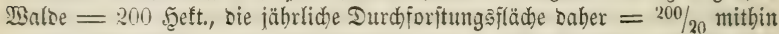

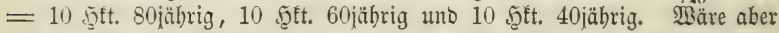

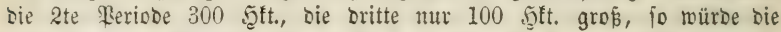

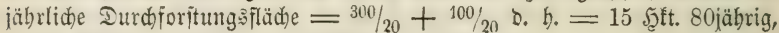
5 S与tt. 60jäbrig $2 c$. jeint.

(5.3 finden num aber beim beftehenten (Snuntiac Der ßerjüngung Durd) natürliche Bejamung Berbältnilie ftatt, weldhe ez nidot ratbjam, mit= unter nidht thunlid) maden, Die Iurdjpritungen nad ben Rejultaten obiger Berechnungen ju bejieben. Wir baben gejeben, Daj aus Den Berjüngunģs= bieben in manden Jahren viel mehr, in anderen weniger Material genom=

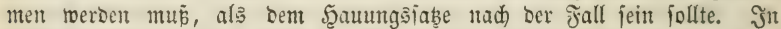
eriterem Jalle mürben Dann bie Durdforjtungabiebe mitunter ganz aus? fetsen ober in berringertem Grade bezogen werben mülien, theils um Den fd)on überbauenen (Etat nidjt nod) mehr jul überidreiten, theils unt im

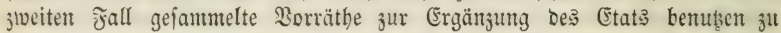

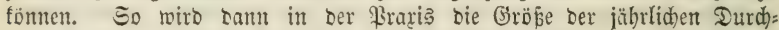

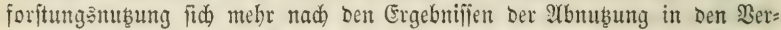

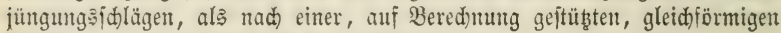
Bertheilung Des periobifhen Durdforitungšertrage: herausftellen.

\section{2Uşdeibung Der jäbrlichen Culturfläde aus ber periobifden.}

Die Gröbe Der jührlicden Culturfläde fann im aflgemeinen nidbt als ein beftimmter Theil ber periobifden angefehen werben, jonbern bejtimmt

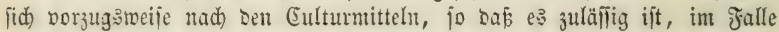
Die Dittel vorhanton find, Die ganje periobifdse (Sulturfläche idton in ben erften Jabren Der Periode in 2Unbau ju bringen; je früher bießs geidehent fann, um jo beiler ijt es..

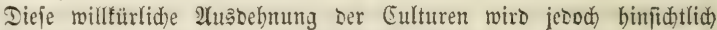

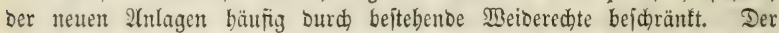
Baldbefiber darf bäufig mur einen beitimmten Ibeil ber Balbflädhe, meift $1 / 5$ Doer $1 / 6$, Der 2 Seidenubung entzieben; bat mu bie Edonungäläche

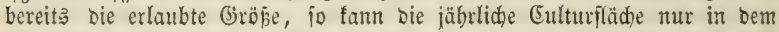
Berbältnif bergröß̄ert werben, als man im Stanbe iit, bie Ed)onungs: fläche burd Einträumung Der Dent Bieh entwadjenen Drte žu verfleintern.

Für bie $\mathbb{B} a \mathfrak{h l}$ Der Dertlid teit gelten folgende Regeln: jujdidfer.

1) 2tle nabbeffermben (Eulturen fint ben neten Ifnlagen vorant=

2) Unter Den nachbefiernoen Culturen fint biejenigen zuerit zu vollzieben, bei benen ber Unteridjed im Alter ber bereiţ vorbantenten uno ber anzu= 


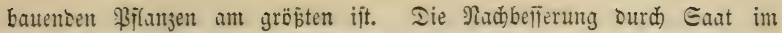
älteren Drte mü jrïber gejdeben, als sie im jüngeren.

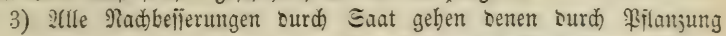

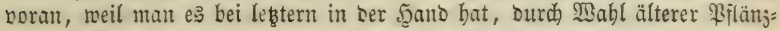
linge entitantone $\mathfrak{A}$ (ltersunteriojiebe auşagleiden.

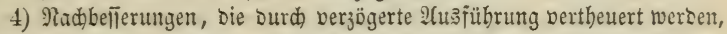
ober einen weniger guten ober ficheren Erislg bejürd̆ten lajien, jins jolden

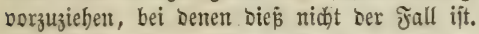

5) In Eamenjabren gehen bie bem gemadjentn Samen entipredenten Satculturen ben Bilanzculturen voran.

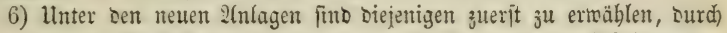

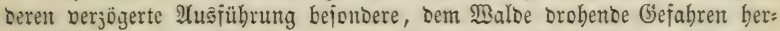
vorgefen fömen, 3. B. Inbau von Eandidollen, Betwebrungen, Entwälīe= rungen, Dammbauten $2 c$.

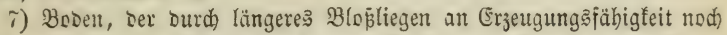
Berlujt erleibet, ober burch zunthmende Seröbung, 2:errajen zc. Göhere

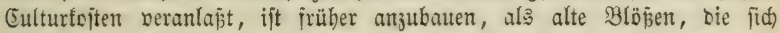
nidjt mehr peridhledtern uno nid)t mehr idgwieriger anzubauen werben, als bas bereits ber fall iit.

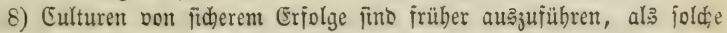
von unfidherem Erfolge, woblfeile Eulturen früber als theuere; beibes, um

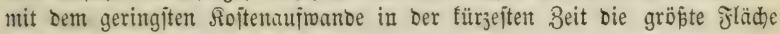
in 3umadjड z̧u bringen.

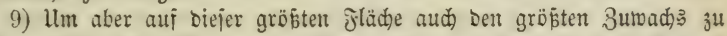

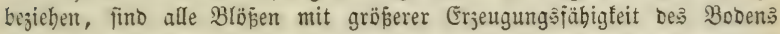

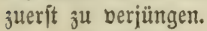

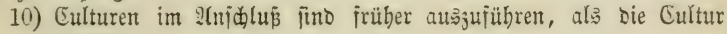

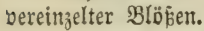

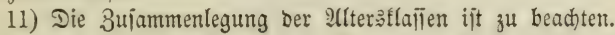

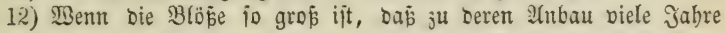

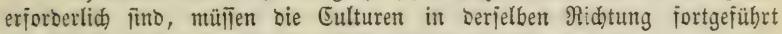

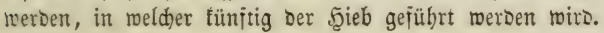

\section{B. Bon ber Plänterwirthidaft im $\mathfrak{5} \circ$ chaloe.}

Wie mir gejeben baben, unterideibet jĭh Der Pläntermalo vom jällag=

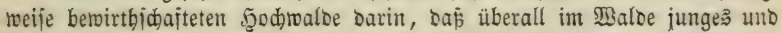

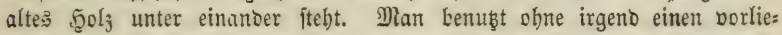

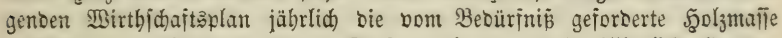

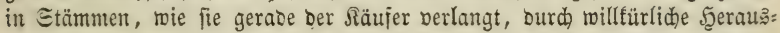

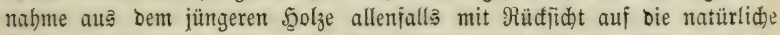

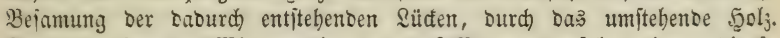

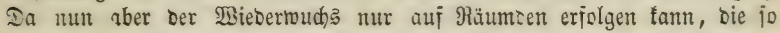

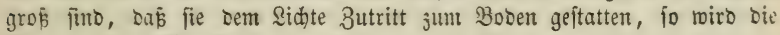
Mengung Der Alters̈tlaīen gemeinfin eine horjtweije jein.

Die Rađtheile biejer Betriebąteije liegen ju ofjen bor Atugen, als Dá je, wo bas . Dunty jein füunte, wenn nidft polijeilidhe Rüdfichten ifr Bejteben forbern. 


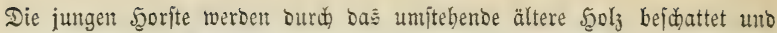

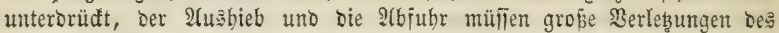
jüngern Şolzes nadh fid jiehen; bie Beibe mú entweber ganz wegfallen

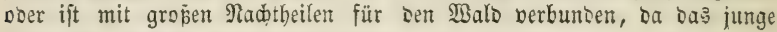
Scolz nidjt gejdübst werben fant 2 .

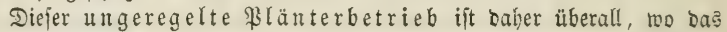

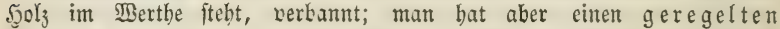
\$länterbetrieb zur Eprache gebradist, welder im jübliden Deutidjlano bier uno da fidon feit längerer Beit in ?Inwendung fein foll. Diejer ge=

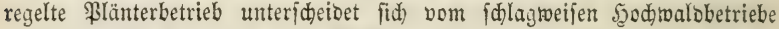
nur barin, baj bie ältejte ser \$eriobenflädhen, in weldhe aud bier bie

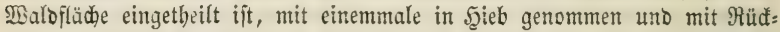

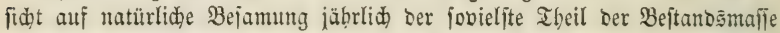

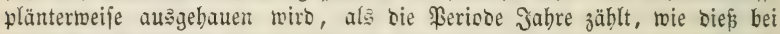

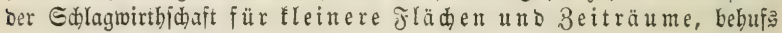
ber Berjüngung ourch natürliche Bejamung, ebenfalls gejdieht.

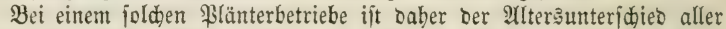
einer uno Derfelben Periobenflädje angehörender Bilanzen bö biften 5 fo groß̧, als bie ßeriobe Jabre jäblt; er wirb aber gemöbnlich viel geringer

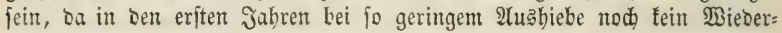

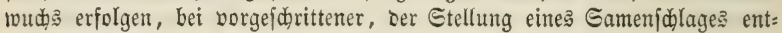

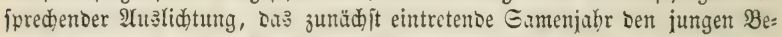
ftano erjeugen miro. Bei turzen ßerioden uno joldhen Syolzarten, die in ber Jugeno viel unt lange Gdhatten ertragen, mag saber ber Betrieb toohl antwenobar fein, obgleich es febr idiber fein wiro, oie 2lušlidtung ftet?

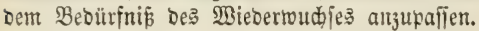

\section{Djiertes ßapuifel.}

Bom Betriebe ber Rieberwaldwirtbidaft.

Unter Rieberwalo veritehen wir jeoe Betriebsweije, bei ber burch

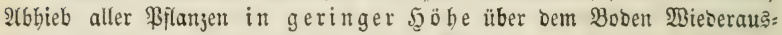
fülag erzeugt uno eine mehrmalige Benuşung oerjelben \$flanzen beztweeft miro.

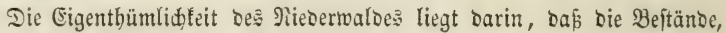

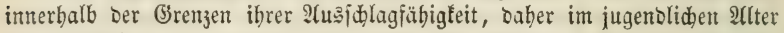

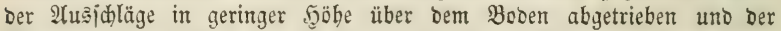
Bieberwuds im âlgemeinen aus Stod uno Burzelausidlag beran: gezogen wird. 1

Die Birtbidaft im Rieberwaloe wiro allgemein auf vorausbejtimmten Sd)lagfläden betrieben. Der ganze Wirthidaftätörper miro in fo viel Gdläge eingetheilt, ala ber Umtrieb Jabre zäblt. Mit Berüdfichtigung einer

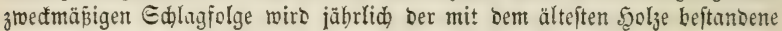
Sdlag abgetrieber.

Die Gälageintbeilung im Rieberwaloe tann fein:

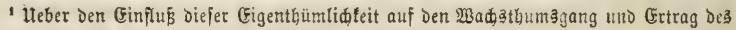
Niedertbaldę. E. BD. III "Ertraggermittelung Der 9tiedermälder." 
1) geometrija),

2) proportional ber Bobengüte,

3) proportional ber Beftantoeggüte.

Die geometrifice Edageintheilung.

Man veriteht barunter bie Eintheilung Des Baloes in gleid grope

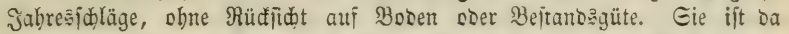
altwentbar, wo ber Boben uno bie Bejtänte von aleidem Froduftions: vermögen fino, too auß̉erbem ein, wenigitens annäherno riditiges Aflters:

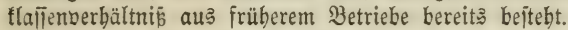

Eie ijt ferner überall anmentbar, mo ez auf ein ftrenges Gleidbleiben

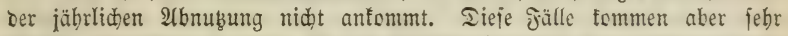

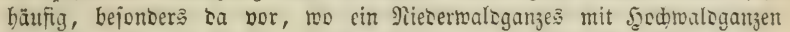

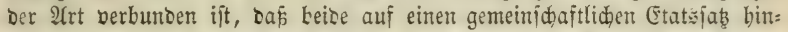

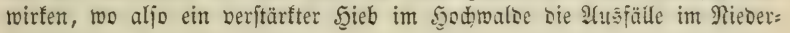
walbertrage zu bedfen vermag.

Die Der Bobengüte proportionale Edlageintbeilung.

Man veriteht ourunter bie Eintheilung Des Maloes in Eutläge von

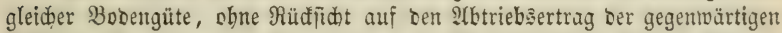

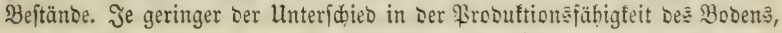
um io mebr näbert fid bieje Eintheilung ter Theilung in gleidy groß̉e

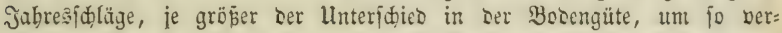
fäiebener ift bie Giröbe ber einjelnen Edläge, bie um fo gröfer werben,

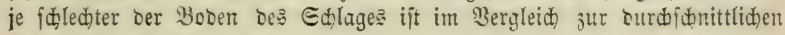

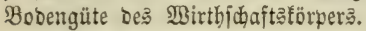

Sie ift antwenobar:

1) $\mathfrak{B O}_{0}$ bie Beftände lich bereits renigiten annäberno in einem bieier

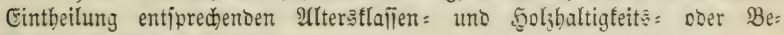

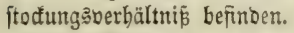

2) 20 währeno oer exften গiederwaloumtriebseit ein Gleidubleiben oes jäbrliden Atbgabejaţe nicht unbeoingt nothwentig ift.

Die Der Be itandesgüte proportionale Edlageintheilung.

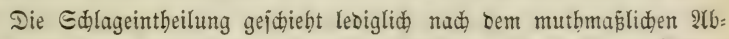
triebsertrage Der gegenwärtig vorhanbenen Beftänoe, alio nath ber Booen:

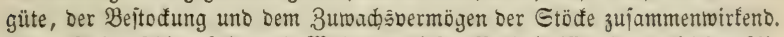

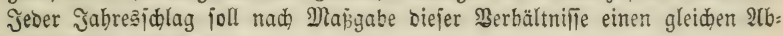
triebsertrag getwäbren.

Sie ift überall antwentbar, $\mathfrak{m} u \bar{s}$ aber $d a$ angetoentet meroen, too

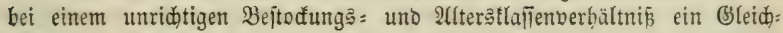
bleiben ber jäbrlichen 2(bnuşung ftreng gefordert wirb, wie in ben meijten alleinjtebenoen Birtbjobaften.

In biejem รalle ift bann aber bie Eintbeilung nur für ben laufenden Untrieb gültig.

Etwas Weiteres ift über ben jebr einjuchen Betrieb Der Nieberwalo= wirtbidaft bier niat zu fagen. Dem Birtbidafter ijt in jebem falle bie 


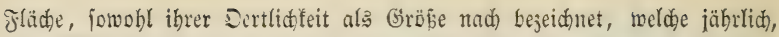

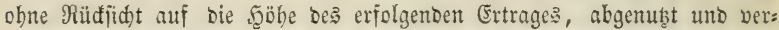

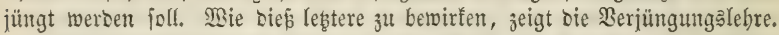

Im 5odwalobetriebe werben in Der Regel alle Bilanzen ber einzelnen Beftänbe interbalb einer Umtriebszeit abgenub̧t uno burdh neue Filanjen

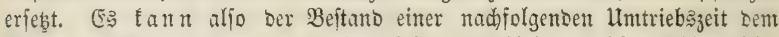
Befturtoe Des vorbergegangenen llmtriebs möglidertweije böllig gleid

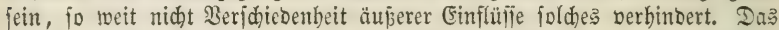
ift it gleicher Seife ber Fall beim Dberbolzbejtanto De: Mittelwaldes.

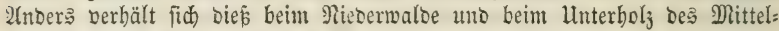
ivaldes, beim Ropi = unto Edneidelfolze, in jolge ses mit jebem nad)=

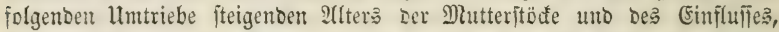

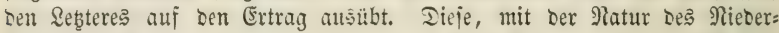
walobetriebes untrembar verbunbene, mit Dem 2 fter Der Mutterftöde ver:

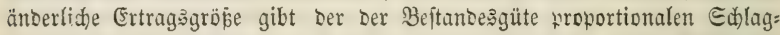

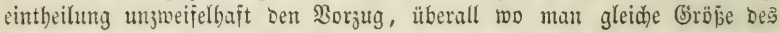

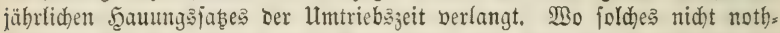

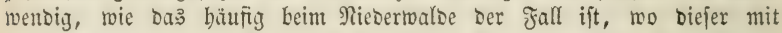

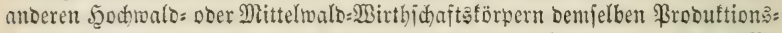

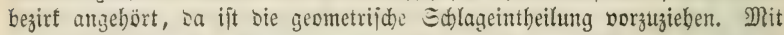
Seșterer fällt bie Der Bodengüte proportionale Ed)lageintheilung zujanmen,

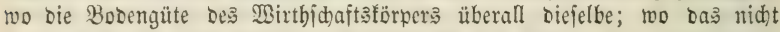

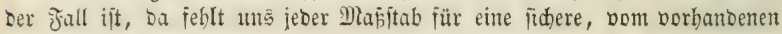

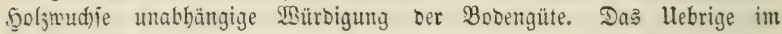
3ten Banbe.

\section{Tilltrftes Sapitel.}

2om Betriebe ber Mittelwaldwirthidaft.

Ter Mittelwalo ift eine Berbinoung ser Şodfwalomirthidaft uno Der Rieberwaldwirthichait auj ein uno berfelben Fläche, uno żwar in ber 21rt,

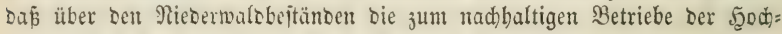
walbwirthichaft erforberliden Etammtlafien in lichtem Stande erzogen werden.

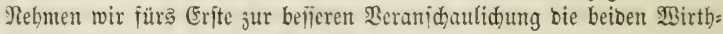
idaften als getrennt uno für jich bejtebento an.

Im Riebernalde, ober wie wir jum Unteridiebe fagen, im llnter: bolze ift Der Betrieb gleid) dem eines reinen Niederwaldes. Wie bort, befteht aud) biev eine Eintbeilung ber ganzen Salofläche in fo viel Einzel= theile, als ber feitgeiebzte Umtrieb Jahre zäblt; mie bort ift auch bier bie

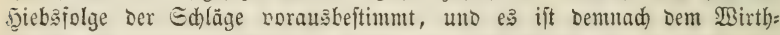

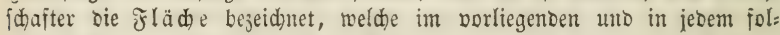
genten Jahre Der llmtriebşzeit jur 2 bholjung gezogen werden joll. Rebmen wir Beifpiels megen einen 30jäbrigen Umtrieb uno Eintheilung in 30 Jahreş= 似läge ant.

Denten wir un: nun biejelbe fläbhe als zur Erzilebung 120jährigen Sberboljes beftimmt. Bei ber 5ुodmulbmirthidhaft mürden hierz̧ 120 Edlag: flädent nöthig jein. Mir haben aber nur 30 Ed)lagflächen, uno müfien 
Daher Die für Den 120jährigen Dberholyumtricb erforderliden 120 alter: ftufen in bieje 30 Ealläge vertbeilen, uno jwar folgendermajen:

\begin{tabular}{|c|c|c|c|}
\hline Eđlag शr. 1. & Eđulag 9ir. 2. & ๔థ̣lag গr. 3. & Edjlag $\Re$ ir. 4 . \\
\hline 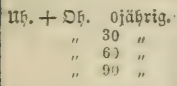 & 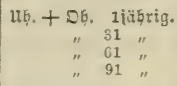 & 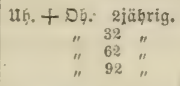 & $\begin{array}{c}\text { ub. + Dh. 3iäbrig. } \\
" 133 \text { " } 33 \text { " } \\
" \text { " } 93 \text { " }\end{array}$ \\
\hline ङdflag 2ir. 27. & હథ̨lag গ!r. 28. & Etolag भr. 29. & હむlag 9:r. 30 . \\
\hline 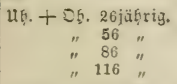 & 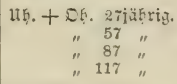 & 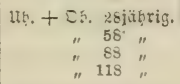 & 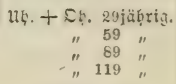 \\
\hline
\end{tabular}

Eo enthält alio Der jüngite Edhlag (1) gleidjeitig $0=30=60=$ und 90 jährig $50 l_{3}$, Der folgento (2) $1=31=61=91$ jübriges, Der vorleţte 28:,

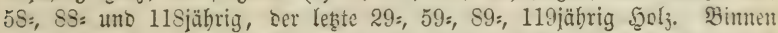

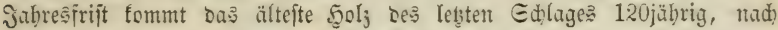

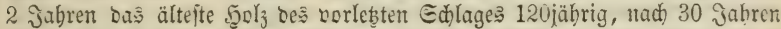

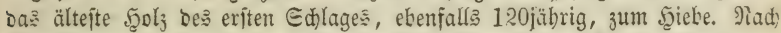

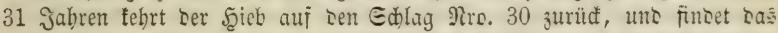
gegenmärtig 89jährige நolj zu 120 jährigem crwadjen; nach 60 Jahren febrt Der Ģieb auf 2 ?r. 1 wieber, uno finoet oas gegentwärtig 60jährige $50 l_{3}$ 120jährig vor น. ๆ. Ғ.

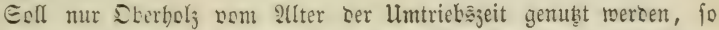

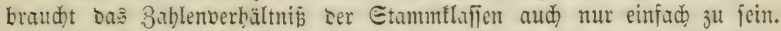
Eo viel 120jäbrige Etämme jäbrlid pre Nlorgen benuşt merben follen,

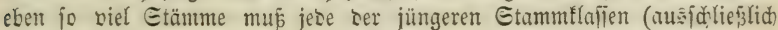
bem mutbmaşlidjen $2($ bgange) umfaifen.

Till man bingegen Dberbolz oon allen Etammflatien musen, fo mus Die Etanmzahl ier jüngeren Ulterğtafien um fo größ̈er fein, je mehr

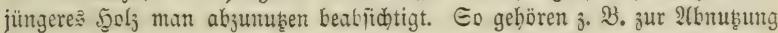

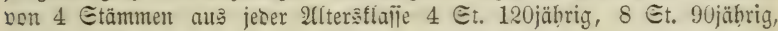

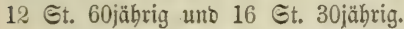

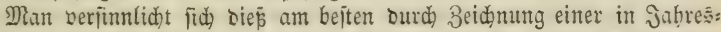
ióläge abgetbeilten Jäläe, in seren Abtheilungen man bie berichiebenten Bejtanowalter einträgt, wie bie voritehente Iabelle zeigt.

Die Sberholy= uno bie Unterholywirthidaft finton nun auf ein uno

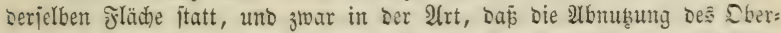
loljes uno bie des Unterholzes gleidjeitig auf gleioher, ber äliejten

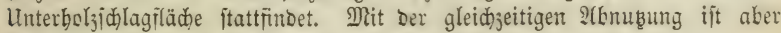
aud bie gleidyeitige Berjüngung verbunden, uno es fino baher Sker: uno

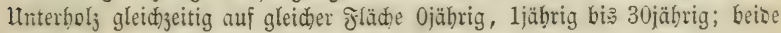

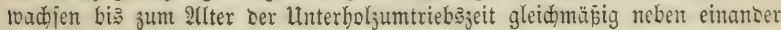
auf, uno trennen fid erft von Da $a b$, indem Das Eberhols fortmäc) ast, bas

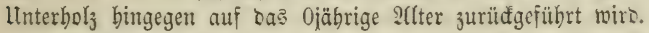

Ein weiterer 3ujanmenbang beiber Mirtbidhaften liegt surin, safi bor Dherholjbeituno jut Ergänzung de Dberboljes mitruirtt. 


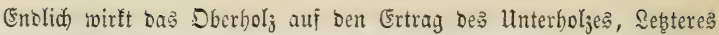
nuf Den Dberholjertrag ein, uno e? ift bie Sauptaufgabe ber Mittel= malowirtbichaft:

nad) Soljart, Stammjahl unb Stammbiloung einen Oberbolabejtanb herzultellen, welderbeim böditen Selbit: ertrage bas llnterbolj $i m$ Ertrage möglicht wenig zu=

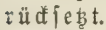

Der nachtheilige Einflú Des Dberholzes auf Das Unterholz liegt in ber Bejobattung und Bejohirmung.

(Eine gleid grob̉e Bejdirmung uno Bejchattung idabet weniger,

1) je ungünitiger die Standorţ̧verbältnifije fino;

2) je geringer ber lumtrieb im linterholze und im Dberbolze ift;

3) je faledtwädjiger ber Unterboljbeltano uno je langidäftiger ser Dberfoljbeitano ift;

4) ie weniger emprintolid) bie llnterboljart gegen Beidattung ift (max.

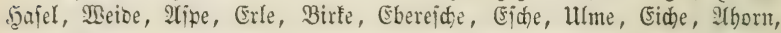

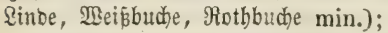

5) eine gröbere Bojdirmung fobabet weniger, je meniger biefelbe bes

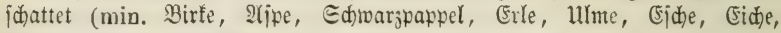
2thorn, Sinbe, Meifbude, Rotbbude max.).

Rad) ben beitebenton 2 ngaben fann man als Marimum uno Minimum ber Edhirmfläche:

furz nad Dent Sciebe $1 / 3$ und $1 / 6$,

furz nor Dem 5iiebe $2 / 3$ und $1 / 3$ ber ganjen Jlädhe antebment.

Nebmen mir beippielsmeije an, es fänden Berbältnilīe itatt, unter benten $1 / 2$ Der Släd)e furz vor bem Siebe bejohirmt jein fann, fo würbe fid) Die pro Settar Durd) Dberholz ju beidirmende Jläd)e auf $\frac{10,000}{2}=$ $5000 \square \mathfrak{M}$ tr. berechnten.

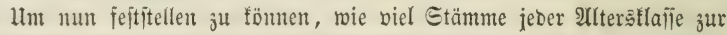
Şerftellung Des beabjichtigten Beidattungägrades pro .̧eftar übergebalten

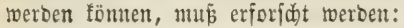

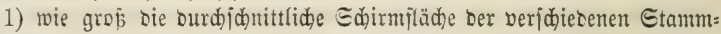
flafien ift, unto entipriąt.

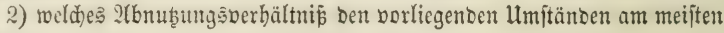

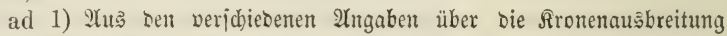
bes Dberbolzes ergibt fich in abgerunbeten 3ablen

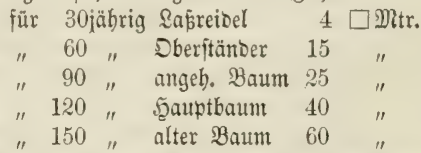

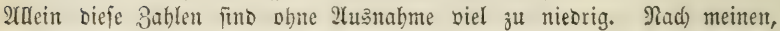
in meintm Sebrbuche oer Bflanjentunoe mitgetbeilten Unterjuchungen mus man für bas im freien Stande Des Mittelmalbes ermadjene Oberhol $l_{3}$ an= nehmen: 
a) Rothbude:

für 30jäbrige \&ajreibel

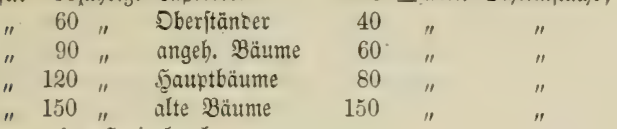

b) 5ूainbude:

für 30jährige Łápreibel

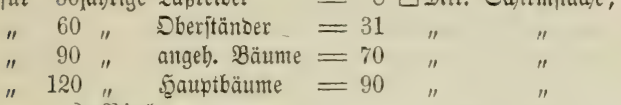

c) Birłe:

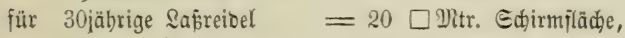

" 60 " Dberitänber $=31 \quad$ angeh. Bäume $=45$ "

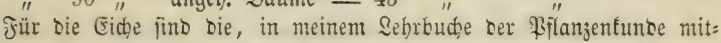

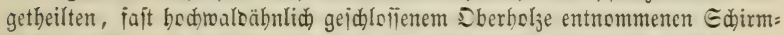

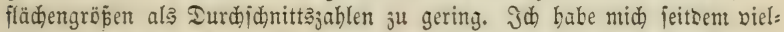

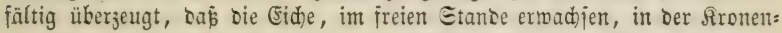

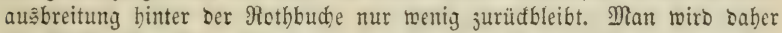

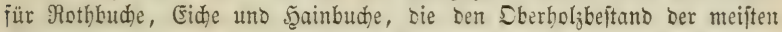

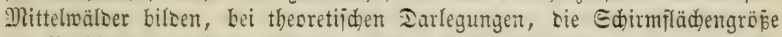

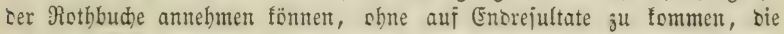

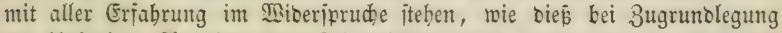

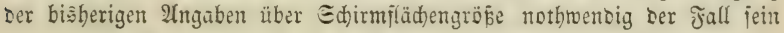

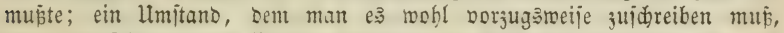

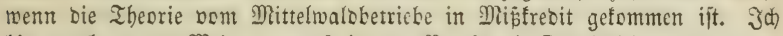
bin Durđaus Der Meinung, Daj in Der Praris Die Dertlidfeit uno Der vor=

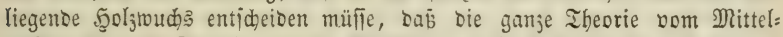

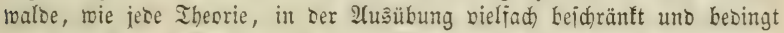

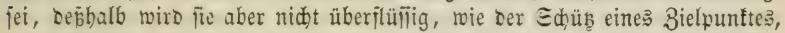
einer Eáeibe nid)t entbebren fann, aud Dann, ment jein Etreben biejelbe zu treffen, nod io oit bergeblid ijt. Die Theorie, sas Enjtem bleibt ebenio eine nothwendige Grumblage bes Betriebs, ment man nidt ins Blaue binein wirthichajten, jeine strebens jĭb bewust jein will, wie jie für bas Stubium

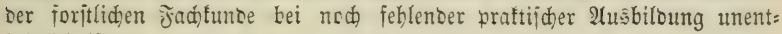
behrlich ift.

ad 2) 2luper ber Bejtimmung Deß Durd Das Sberholy ju bejdirmenden

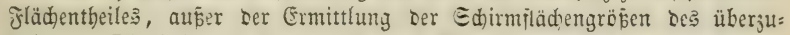

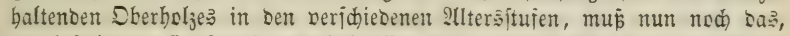

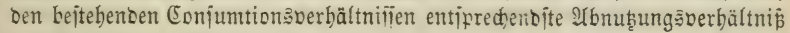
ermittelt unt in Rechnung gezogen werben.

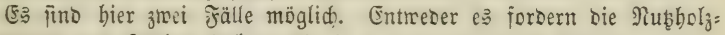
conjumenten nur fitärfere Ђölzer, wie jie der anjunebmende Dberholjumtrieb

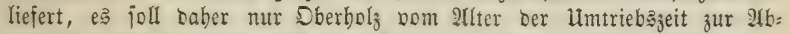

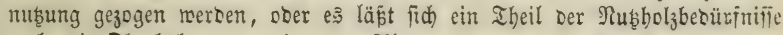
auch) mit Sberholz bon geringerem AYtter uno geringerer Stärfe befriebigen, 


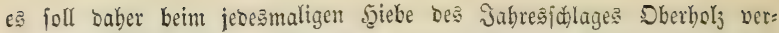

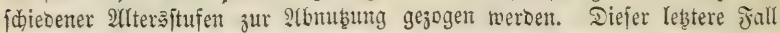
ift nid)t allein ber bäufiger vorliegenbe, fonbern er fübrt aud) für ben $\mathfrak{W a l}_{\text {b: }}$ befiţer größjere \$ortheile mit fid), Da bą jüngere Dberholy einen ftärferen

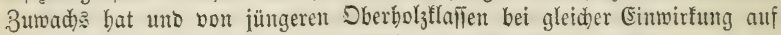
Das Unterbolz eine größ̄ere Eđirmfläde uno Etammizabl zuläfịig ift.

Jm erften jalle werben, abgejeben bon ben für celt erfabrungs:

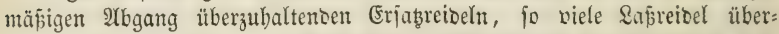
gchalten, als Dberboly vom 2 llter ber llmtriebszeit zum Şicbe fonmen foll.

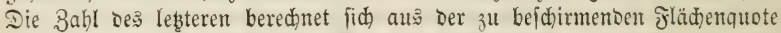
(3. B. $1 / 2$ Der (Srumbfläche furz $\mathfrak{v o r}$ Dem Fुiebe) uno alı Der Gunme ber

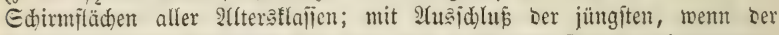

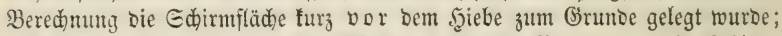

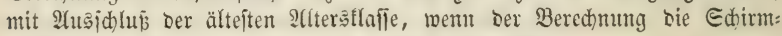
flächengrö̈pe furz nady Dem Şiebe zum Grrutbe liegt.

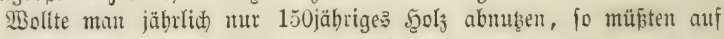

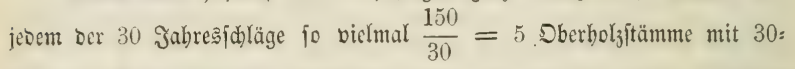
jübrigem 2Ultersunteridjiebe vorbanten fein ober erzogen merben, als bie feítgeitellte Edjirmflächenquote geitattet.

Eollte $\hat{\jmath}$. B. Sie Şälfte der Grundfädhe furz nor dem Şiebe de? Exlages nom Sberbolze überidurmt fein $=5000 \square M$ Mtr. pr. Şettar, fo

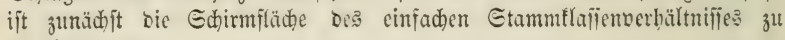
beredinen:

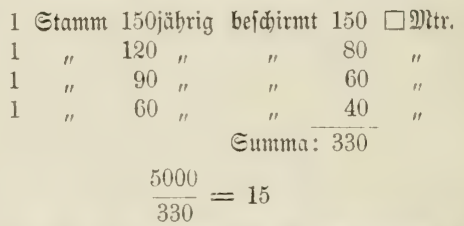

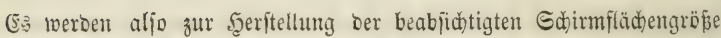
beim jebesmaligen Şiebe des Gdlages 15 Rapreidel überjubalten uno 15

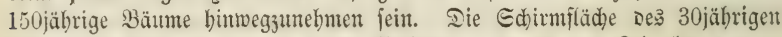

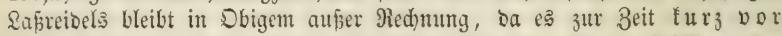
Dem Siebe nod im Unterbolze ftedt. Segt man ber zul bejdirmentent Fläd) ben Dberboljbeftand furr nad) Dem Şiebe, aljo bas Minimum Der Bejकirmung innerbalb 30 Jahren zum Grunte, fo bleibt in Dbigem bie

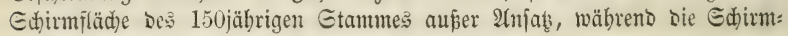

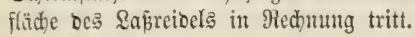

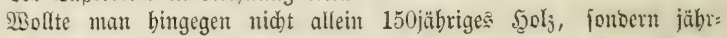

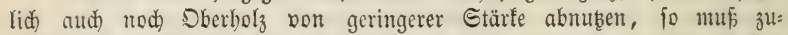

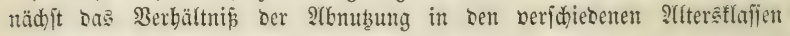
bejtimmt merben.

Wollte man 3. B. von jebor Sberbolzflafie alljäbrlid) gleidhe Etammit= zabl abutben, fo mürbe das cinfadte Etammflailenverbältnif fein: 


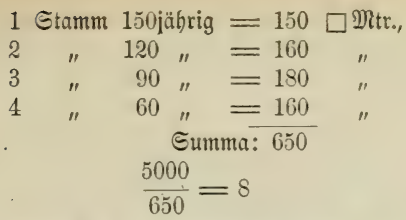

Man würbe aljo jührlidy $2.8=16$ Sapreibel (auker ben (Erjaķreioeln) über= zubalten uno aus jeber Der vier Etummflaīen 2 Etämme abjunuถ̧en baben.

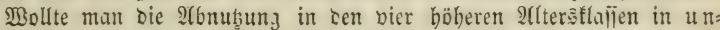
gleiden Etammzablverbälmilīen, 子. $\mathfrak{B} .=1,1,0,4$ bejieben, fo

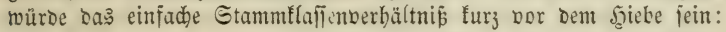

$$
\begin{aligned}
& 1=1 \text { Stamm } 150 \text { jäbrig }=150 \square \mathfrak{M} \text { tr., } \\
& 1+1=2 \text { " } 120 \text { " } 120160 \text { " } \\
& 1+1+0=2 " \text { " } 90 "=120 " \text { " } \\
& 1+1+0+4=6 \text { " } 60 "=240 \text { " } \\
& \text { ङumma: }=\overline{670} \text {, } \\
& \frac{5000}{670}=8, \text { aljo } 8+16+16+48 \text { Stämme. }
\end{aligned}
$$

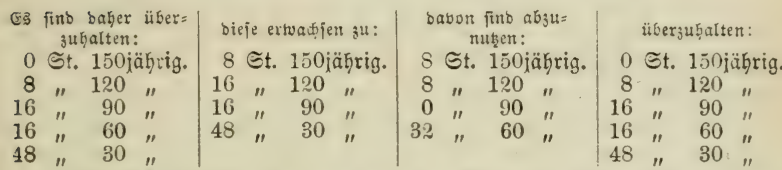

Die Edirmfläde ift mun zwar um G̉eringes gröfer als bie biab: fintigte, allein bas läft fidh nidht änbern, Ia sie Etämme nid)t theilbar find, mithin ber Oberholyfactor, hier 8, feimen Bruchtheil leibet. Diejer Unteridieb ift aber auch bon feiner Bebeutung, Denn in Der BBirflidfeet

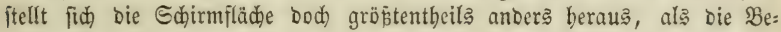
redhung fie bejwecte.

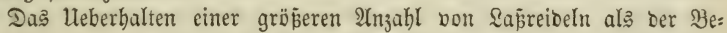
trieb forbert, wirb wegen bes überall ftattindenten Afbanges nothwendig.

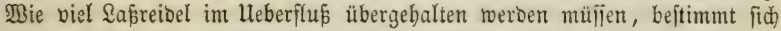

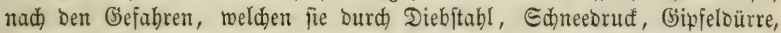
Baumichlag 2c. ausgeję̧t fint. Da bie Sapreibel wenig beichatten, io ift es Regel, lieber etwas mebr Stämme aus bem llnterholje überzuhalten, al’ Der erfabrunģmǟige 2lbgang erforbert, um für alle fălle gefichert zu jein. Die unnöthig übergebaltenen Reibel werben Dann beim nädjten Şiebe Gintweggenommen.

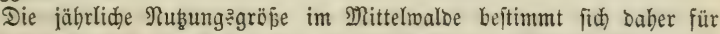

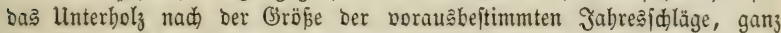
eben fo wie beim Rieberwalsbetriebe. Die Dberboljmuţung bingegen bejtebt

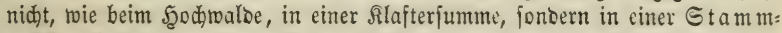

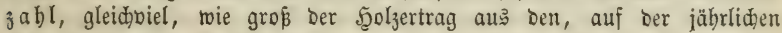
Schlagfläde bes Unterbolzes in ben Şieb fallenden Stämmen ift. Der 


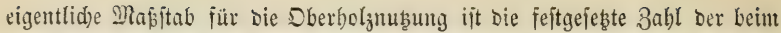

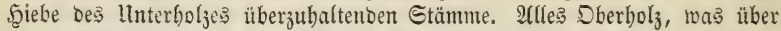
biefe 3ahl vorbanoen ift, fällt ber 2trt anbeim, uno bilbet bie jährlidje Dberholżub̧utg.

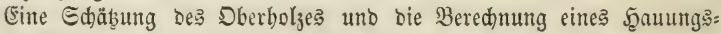
fakses in Slaftern, wiro aber ba notbmendig, wo ein regelmäßjiges, ober

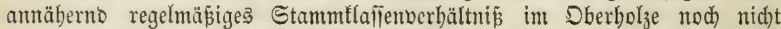
beftebt, fontoern erft bergeftellt werben joll. In vielen, id möd) fagen in ben meiften ber jeß̧t bejtehenoen Mittelwälber tritt biejer Jall ein. Die neiften unjerer $\mathfrak{D}$ ittelwäloer fteben erft ein ober einige Unterbolzumtriebe binourd) in eintem regelmäjigen Betriebe, uno entbalten über bem Unter= bolze, aufer sen in bicjer Beit erzogenen \&aj̃reibeln uno Sberitänbern, eine

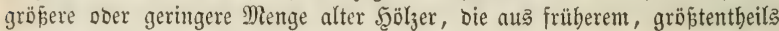
plänteriveife befandelten Scochwalde heritammen, wep̧halb wir fie pafjento

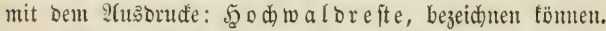

Mit biefen Şodjwaloreiten uno ibrem 3uwadje mup man nun jo lange baußhalten, bis bie vorbanbenten jüngeren, uno bie nod) überzu=

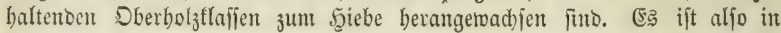
Diefem Falle eine boppelte Ertragaberedyung 3 untwerfen. Die erite be= jieft fich lebiglich auf Den (Ertrag aus bem jebt vorbanoenten uno nod über: zubaltenton jungen Dberbolze, von beute ab bis zu bem 3eitpuntte, two bą verlangte Stammtlafjenwerbältníp bergeftellt jein, mitbin audj eine bolle Dberboljmukutg eintreten wiro.

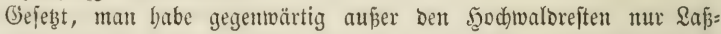
reibel über Dem Unterbolje, lebstere aber in groper Menge übergebalten, fo wiro man beim nädften Silebe eine gröpere ober geringere $2(n z a b l$ von Dberftändern, beim Darauf folgenten Şiebe Dberftäntoer und angehente

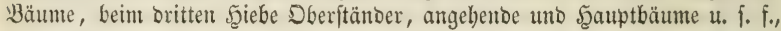

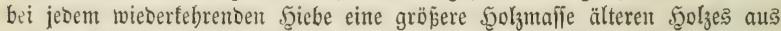
Dem gegentwärtig jungen Dberbolze zu bejieben baben. Wir wollen annebmen, Der Sd)lag verfprädhe beim nädjiten ફ̧iebe 100 Eubifmtr. 60jäbrig, beim jweiten Şiebe 200 Eubifmtr. 60jäbrig uno 400 Eubifnttr. 90jährig; beim Dritten .̧įebe 150 Eubifmtr. 60jährig, 300 Eubifmtr. 90jäbrig, 150 Eubifmtr.

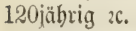

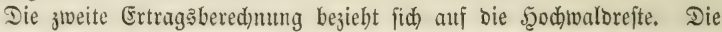

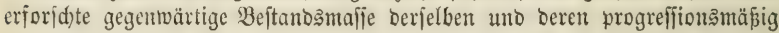
abnthmender 3uwadjs jujammengenommen, wiro nid)t gleidmäfig, fonbern mit Rüđfiddt auf Die jteigenden Erträge Der jüngeren Dberbolzflafien in eben Demjelber, aber umgefebrten Berbältnif́, aljo abnebmeno auf ben Beitraum von beute bis zum Eintritt ber vollen Dberbolznußzung bertbeilt, fo baj ber finfente 5ूaung

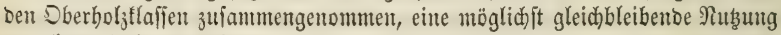
an altem $\mathfrak{S g l}_{\mathfrak{l}} \mathfrak{y}_{\mathrm{e}}$ getwähren.

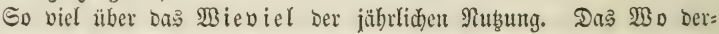
felben bebarf feiner näberen Erörterung, oa Der Şieb ftets an vorauss bejtimmte Sd)lagfläden, wie beim! Rieberwaldbetriebe, gebunden ift. Da: Wie finbet feine Erörterung in ber Beriüngungsłebre. 


\section{Sedjstes Siapiter.}

Bon Dex gabergswirthidaft.

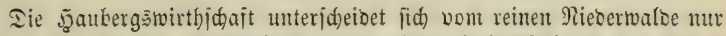

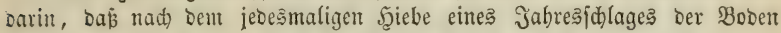
3wijden Den Stödèn, nadjoem ber Rajen abgeplagget wurbe, mit ber Şain= bade umgebadt, gebaint wirb. Die abgejdälten Rajenjtüde werben bant jum Trodinen aufgeftellt, uno wenn fie abgetrodnet fino, nit bem im

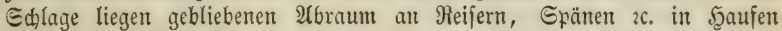
gejeb̧t uno zu 2ljhe gebrannt, welde über ben gebainten Boben ausgejtreut

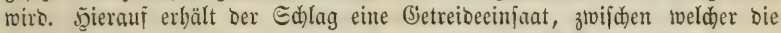

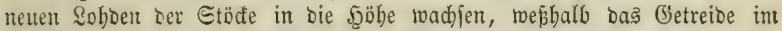
5. Werbjte borfidtig mit ber Sidjel ausgeidnitten werben mußs.

Sit ber Ed)lag gut mit rajd) wadjenden Sgolzarten beftodt, fo wiro

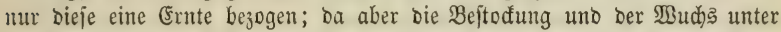
Der Bearbeitung Des Booens, bejenders burd) Beritörung Der feinen Thau= wurzeln leibet, io ijt bie Beftofung meift jo lidht, Daß im folgenden Jahre nod) eine zroeite int lez̧te Getreibeernte bezogen werben fann.

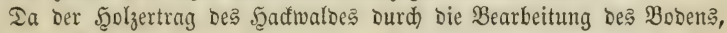
burd) Das Berbrennen ber Dammerbe unto Durd bie unbermeiblide Be= ¡đäbigung ber Stöde gegen Den bes reinen Rieberwalbes wejentlid) ber:

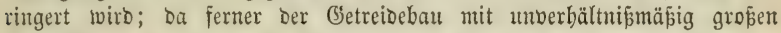
Irbeitgtoften verbunben ift, jo redtfertigen mur ganz aujergetwöhnlid)e Ber: bältnilie, wie im gebirgigen, büttenreidjen, bebölferten unto aderarment Jürjtentbum Siegen bieje Betriebämeije, uno jelbjt von bort aus haben iid in neuepter Zeit Stimmen gegen fie, uno wohl mit Recht, erhoben.

\section{Siebentes ERapifel.}

Bon bex Baumfelowixthidaft.

Die Baumfelomirtbidaft unteridyeibet fid von ber Scodwalowirtbjaft

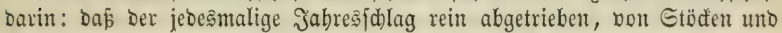

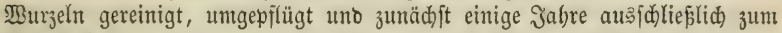
Getreibebau verwenbet werben foll. Şierauf foll ber Ed)lag reihentweife in einer joldjen Entfermung bepflanzt werben, da man in ben erjten Jabren

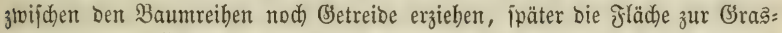
erzeugung, enolid nod) zur Weibe benutzen fann, bis die \$rlanzung fid völlig geidloijen hat.

Die 2 (nwenoung biejer Betriebsart Dürfte fid auf foldje Brivatwäloer von geringer 2(uכbehnung befdränten, in Denten Der Grunbeigentbümer jelbit sem Adferbau uno bem $\mathfrak{B a l b b a u}$ voritefbt. $\mathfrak{B O}_{0}$ bas nid)t ber Jall

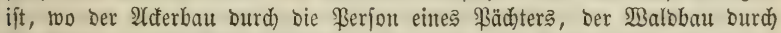
bie Berfon eines Berwalters betrieben wirb, ba fteigen fid bie unber= meirbaren Edäbigungen ber einen burd) bie antere Betriebsmeije zu einer Şöhe, bie Lem Fortbejtanbe beiber anf berjelben Fläd) entgegenfteht. 


\section{Pidifes Enapifel.}

Bom Ropf = und Sdneidelforz=Betriebe.

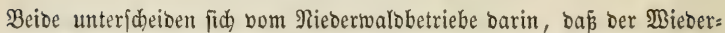
wudjs nidht an einem in geringer Şöbe über bem Boben abgebauenen Stode, fondern Durd 2 (bbieb in einer Scöhe von mindeftens $1 \frac{1}{2}$ Mitr. erzeugt wiro. Beim Ropfloljbetriebe wiro ber Stamm in einer Şöbe bon $1-3 \mathfrak{M t r}$.

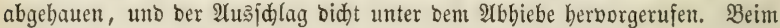
Sdneibelbolzbetriebe läpt man bent Etamme feinen Sängenwudds entweder

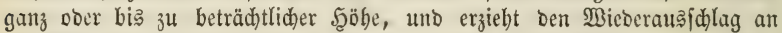
Den 2 tbbieben ber Seitenäjte in Der gantzen Ränge bes Baumes.

Ropf = uno Sthneibelhol 3 wiro gröptentbeils nur in einzelnen Stämmen

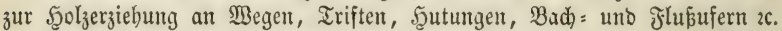
angebaut. Die 3 ahl der vorbandenen $\subseteq$ tämme, in fo viele Theile

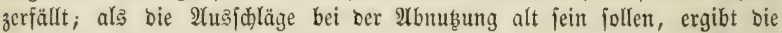
3ahl ber jäbrlich) abzumutzenden Stämme, bon Denen bie mit ben älteften

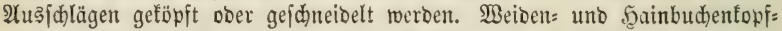

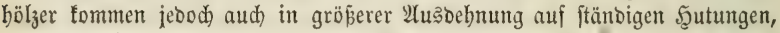

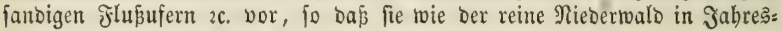

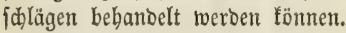

\section{Wou Der Wabl Der Betricbsarten, H(mtricbşeiten und fjolzarten.}

Wir haben in Borbergebenden die berfuiebenen Betrieksarten fennen gelernt. Durdh jebe berjelben fanm unter getwiffen Berbältniffen ber Bwed

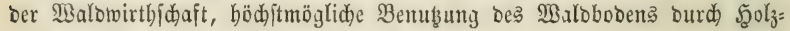
zud)t erreid)t werben. (Ebenjo fann hier bieje, bort jene Inmtriebşzeit ooer Scolzart ben büdjften Ertrag zu getoäbren geeignet fein, uno ę ift baber

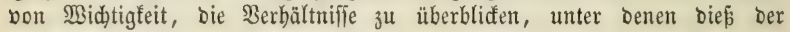
Fall ijt.

\section{Oetentutes Eapitee.}

2on ber $\mathfrak{B a h l}$ der Betriebsarten.

Jnt ber Sebre von ben veridiebenen Betriebsarten babe id biefe in reine uno gemengte eingetbeilt, für leb̧tere bereits bei ibrer Darftellung bie F̧älle ihrer 21nwenobarfeit furz bezeid)net, baber wir ez̉ bier nur mit ben reinen Betriebsarten, Dem Şods=, Mittel= uno Rieberwalobetriebe zu thun baben.

Im Allgemeinen ift bie 3weđłmäß̨gfeit ciner jeben Betriebsart von

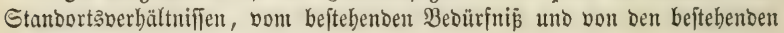
Bejtanbe

\section{Der Şodralobetrieb.}

Heberall, wo bie Berbälnifife ben Nabelfolzbetrieb forbern, ift ber Şod)=

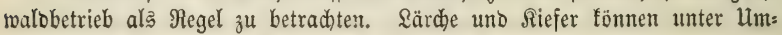
ftänben jebod aud als Dberbolz im Mittelwaloe erzogen werben. 


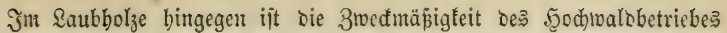
nidjt fo unbebingt, ba bie Laubbölzer in ber Jugino cine größ̈ere \$Brenn=

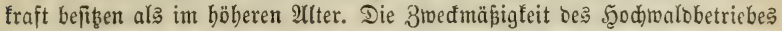
bängt baber bier zunädjit von ber gröperen Mafienerzeugung uno bom

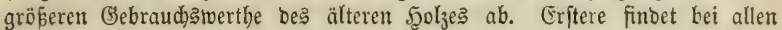
5ूolzarten Etatt, Die in ber Jugento fehr langiam wadjen, wie bie Roth= budbe, wohingegen bie Straudbölzer, Wappeln, Weiben, 2Ycacien, unter

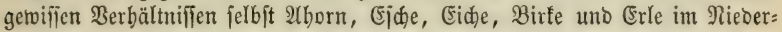
walbe einen größeren Brennftoffertrag zu getwähren vermögen, al’ im Scod)= ralbe. Bejonbers ift bię auf fehr fladgründigem Boben ber Fall.

Man Eaun aber nidht fagen, dá in biefen fällen ber Şodjwalobetrieb meniger Maffe getwäbre, als ber Ricberwalobetrieb, fonbern mur, báf ber Pappel= 2c. 5ुodjwalto tweniger als ber \$appelnieberwalo erträgt.

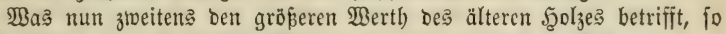
bejteht biejer in ben meiften fällen und żoar in foldjem Maje, dás er

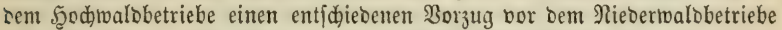

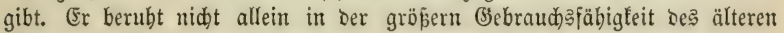

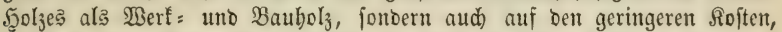

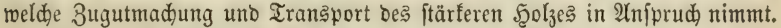

Der Şodiwalobetrieb ift baher ba an jeinem \$laß̧e, wo bie weite Ent= fermung ber Berbraudjobrte bebeutente Iranaportfoften erforbert; unbedingt

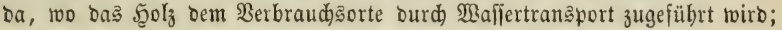
bebingt beim Lanbtransport, ba in gleiden (5)cridttbeilen jungen $\& a \mathfrak{b}$ : boljes biejelbe Brennitoffmajie als im alten 5 golze enthalten ift. Allcr: bings ift aber ber Raum, welden gleide Bremiftoffmafien einnehmen, im

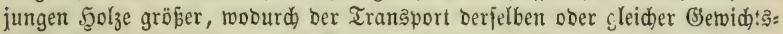
theile. jungen Sgolzes in ber Regel viel theurer ift als in älterem uno

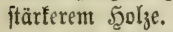

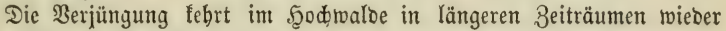
wie im Riebertwalde. Wo bieje baher mit bejonberen Befahren soer groß̈en Roften berbunden ift, hat Der Şodrtwalobetrieb Borzüge.

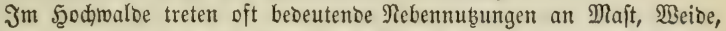
Streu 2c. ein. Wo bieje von bejonoerem 2 Berthe fino, findet ber Szoctwalo

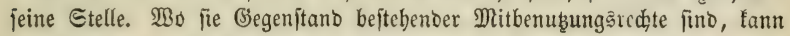
ber beftehende Betrieb erjt nađ Arblöjung derjelben veränbert werben, io

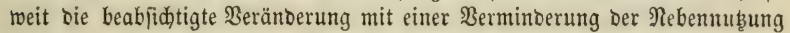
nerbunben ift.

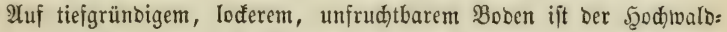
betrieb vorzuziehen, da mebr Dammerbe erzeugt und biefe beffer erhalten wiro, als im Rieber: uno Mittelmalbe, two ber Şumus bei ber oft rieber: fehrenden Entblößung Des Bobens rajd) berflüd)tigt. Sclbft bei burdjaus voller Beftodung uno bei vollem Edjlufie des Nicbermalobeftandes gegen bie 3eit feiner Sgaubarfeit, tritt Dennod) nad) Dem Şiebe ein Zeitraum Der Entblößung bes Bobens ein, da bie geringe Edirmfläde bes Stodes mit jungen Sobden an bie Stelle ber gropen Edirmflähe bes Stodes mit alten Soboen tritt. Beim Sodwwaloe, wo ein ganj neuer Beitano an bie Stelle bes alten tritt, fann eine Bodenentblöfung und eine Betminberung 
ber auf Şum!sreidthum rubenben Bobenfrudhtbarfeit ourd) bie Berjüngung vermittelfit natürlidjer Bejamung gäılłlid) umgangen werbent.

Ĵm rauben Sllima, bejonoers ba, wo häufig Spätfiöfte eintreten,

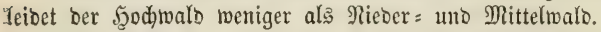

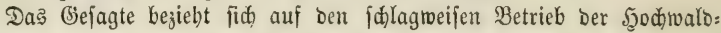
wirtbfdhaft. Eミs gibt aber auch Jälle, wo ber plänterweije Betrieb feine Stelle fintot, unb zwar:

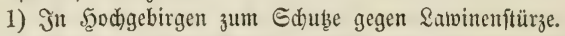

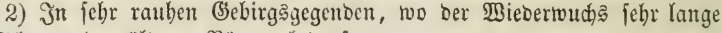

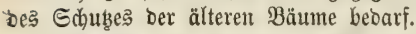

3) $\mathfrak{2}$ n fehr flippigen Berghängen, an Denten fid nur einzelne be: famungşäbige Stellen finten, uno wo bie burd) Jeljen getremnten einzelnen

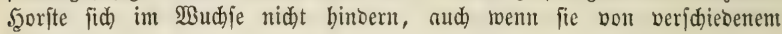
alter finto.

4) $\mathfrak{A}$ uf Den fanbigen Dünenhügehn ber Seetüften, too eine Mengung

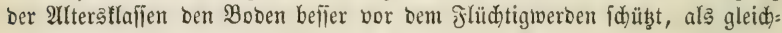
altrig erzogene Şodjwalobeftänbe im vorgerüđten Alter.

\section{Der Niebcrwalobetrieb}

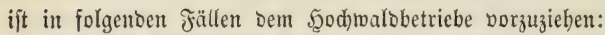

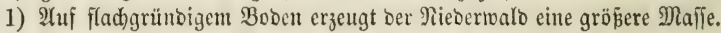

2) Bappeln, Beiden, Acacien, die Scainbuche, aud wohl (Ellern unt Ifhorme, bejonders Mapholder geben im Riebermalde gröfere Mafien.

3) Beoürfnifie an Galinen=, fllecht=, Jajdinemmaterial, an 2 Beinpfäblent, Sohrinoe, Futterlaub $2 c$., fömnen ber Ẽrzeugung bes Rieberwaldę einen bejondern Werth beilegen.

4) $\mathfrak{B O}_{0}$ fich Der Berjüngung Dor Beftände burch Samen bejontore Scinberniffe entgegenftellen, 3. 33. Ueberid)wemmungen in (stäbrüd)en, weldhe Den Samen zulammenfidinemmen oder fortfübren.

5) Die 9ieberwalbwirtlffdaft berbient ferner ba ben Borzug, two bie

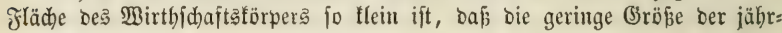

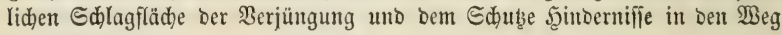
legen rürbe.

6) Empfehlenemerth ijt fie für ben Betrieb joldher ßrivat= oder (Semeindes b̈ölzer, bie nidyt unter 2fufficht funbiger Forftmämter ftehen, fonbern von ben (Figenthümern Doer Giemeindeborftänden felbjt bewirthichaftet rerben; nidht allein weil ber Betrieb am einfadjiten ift, fonbern aud, weil Febler im Betriebe nidgt fo groje Berlujte unto üble Folgen nach fid zieben, aud leidter uno in fürzerer 3eit wieber aแडzzugleidhen fino.

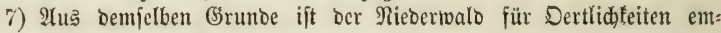
pfehlenşwerth, bie bem Diebjtahle auşgeję̧t fint, weil ber häufiger wieber= febrende 2Abtrieb bäufiger uno früber Gelegenbeit bietet, bie burch $5_{2} l_{3}=$ biebjtabl probuttionslos geworbenen fläd)en wieber in (Ertrag zu bringen.

8) Эn Fällen, wo eine 3 löße mit $\mathfrak{J g l}_{\mathfrak{j}} \mathrm{l}_{3}$ angebaut werben foll, bie

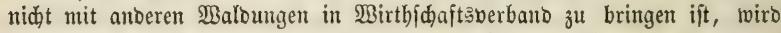
Nieberwalobetrieb ftattfinben müfien, ba ber Befiţer fī felten bazu ver=

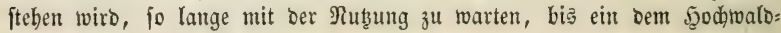


betriebe entipred)entes 5oljtapital fid) angejammelt bat. Gieben bingegen

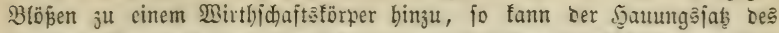

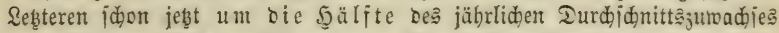

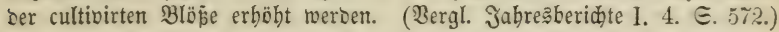

9) Uleberall, two burd) nid)t nadbaltige Benuţung, Durd fehlerbafte

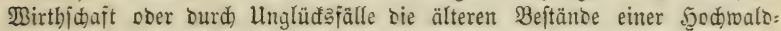
wirtbidaft verloren gegangen fino uno bie bejtehenoen Bebürinilie eine

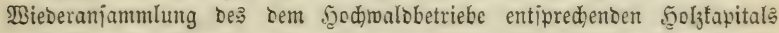
ourd 3uwachseriparnifj nicht geftatten, muई bie Birthidaft mit ben herab: gefommenten Borräthen fortgefüfrt, ser Piebermalo auch ba beibehalten werben, too Der Sgodmalsbetrieb ein weit böheres Eintommen gewähren

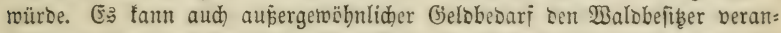

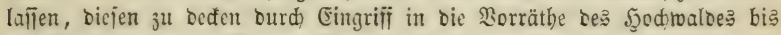

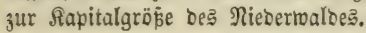

\section{Der Mittelralobetrieb.}

1) Wie wir in Der Sehre von ber Ernäbrung ber \$ilanjen gejehen

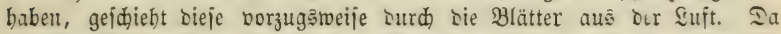
nun im Mittelwalbe niđt allein bie Menge Der Blätter unjtreitig gröper ift, alక bei ben übrigen Betrieba arten, fonbern aud Sidjt uno \&ujt in böberem Maje auf fie einwirten tömten, io iollte man meinen, Der Yittelwalo müife

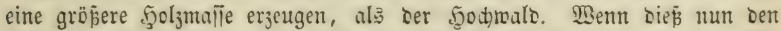

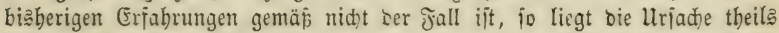
in ber, gejen bent 5odwalobeitano geringen $3 a b l$ ber Sberholjbäume uno in beren nadtheiliger Einmirfung auf bas llnterboly, bejonbers in bem

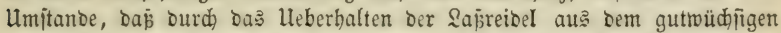
unbejđjirmten Unterbolybejtunoe bicfer int bie Dberboljilläche übergeht, twäbrent,

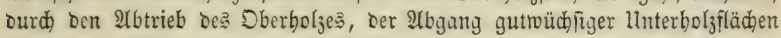

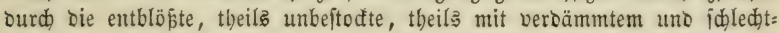

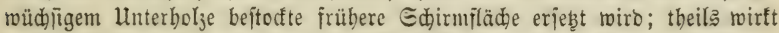
aud bie Edwierigteit, cin ridtiges ßerbältnif zrijden Sber: uno Unter= bolj herzultellen uno ju erbalten, auj Berringerung Deß Ertrages ein. Da: gegen will id) dic Möglidfeit, Duj cin ibeal bejtantener Mittelvalo bem

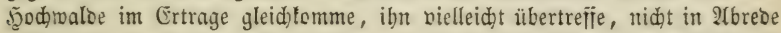
ftellen; ob es aber je gelingen riro, cinen iseal vollfonmenen Mittelwalo berzuftellen, uno wenn bies einmal gejdeben, diejen 3uitan zu erbalten, bejtoeifle id jebr.

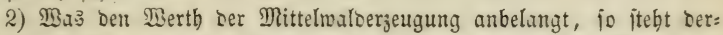

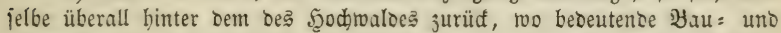

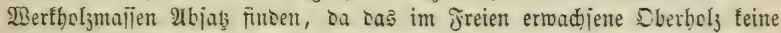

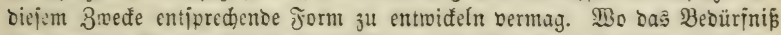

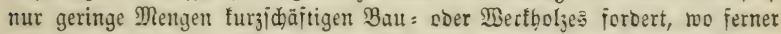

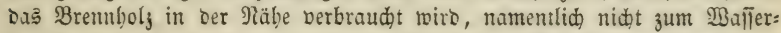

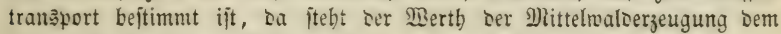
ber Fुodmalberzengung faum nach.

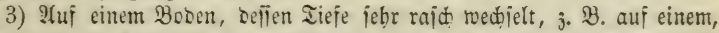

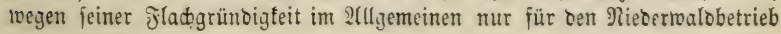


geeigneten Boden, befien Unterlage an einzelnen Etellin jïh tiefer fenft, fönnen bieje tiefgrünbigeren Stellen žur Dberholjerjiehung benuk̨t werben. Dod) wird fich in biejem Jalle nie eine regelmäpige Bertheilung bes Dber= bolzes bemirfen lafien, überbautpt bem regelmäpigen Betriebe mandje Şemmung entgegentreten.

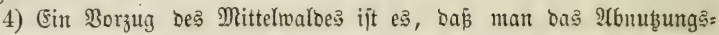

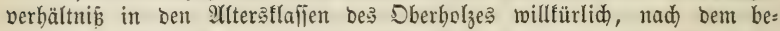

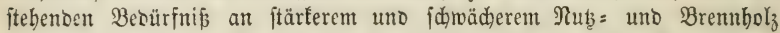

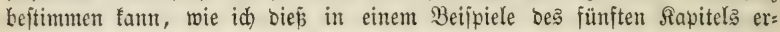
läutert habe. Man bat baber nid)t nöthig, mie im 5ुodwalobetriebe, ganze

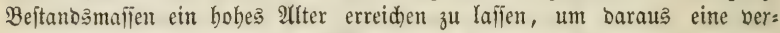

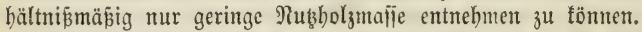

5) Worzüglid widhtig ift ber Mittelwalsbetrieb als Uebergangșmirth=

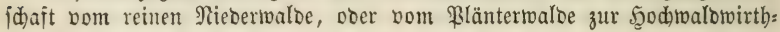
idhaft, ba nur ourdh ibn biejer llebergang mit geringen Drfern in ber Gegenwart betwirt werben fann.

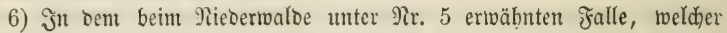
bejonders bei fleineren Sanbiritbidjaften häufiger Statt finbet, fann fich ber Sanowirth Durd) ben Mittelwalobetrieb bie nötbigen Merfbölzer in erforber= licher Menge erzieben.

\section{Beflintes Kapapité.}

Bon ber $\mathfrak{W} a \mathfrak{l}$ ber Umtriebszeiten.

Was unter Umtrieb zu veritehen jei, ijt bereits in Der Einleitung jur

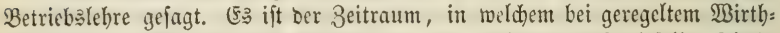
ichaftäbetriebe $\mathfrak{A} b t r i c b$ unto Berjüngung oer Beftände auf biejelbe Flädhe

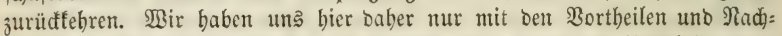

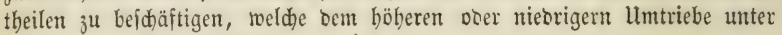
veridbiebenen Berbältnifien eigen fint.

Bom Umtriebe im 5 odibaloe.

Die Solzpflanzen follen im 5ुod)waloe in ber Regel Baumitärfe er=

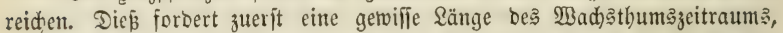
ber fid) noch näber beftimmt, went eine Berjüngung Durd) natürlide $\mathfrak{B}_{e}=$ famung beabfidtigt wiro. In bicfem Jalle barf ber lintrieb nid)t fürzer

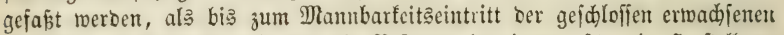

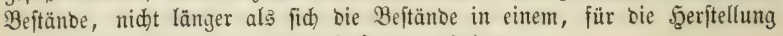
eines Sameniळlages geeigneten 3 uitante erbalten.

Der Miambarteiţeintritt oer 50 lapflanzeu ift bebingt:

1) Bon Standorţberbältuifien. Se ungünjtiger bieje fint, je mebr baburd ber Fiflanzentud s zurüdgebalten twiro, um fo früber tritt Blüthe und Frudtbiloung ein.

2) Bom \&idtgenufie. Atle freittebenten, im Freicn erradjenten Bflanzen tragen früber Samen, als bie im Sd)lǘ crwadjenen. $2 \mathfrak{A n}_{\mathfrak{n}}$ Sommerbängen tritt bie Fruthtbiloung früber ein, als an Mitternadtjeiten.

3) Berlek̨ungen ber Bilantje follen auf Bejhleunigung bes frudbt: 
barfeițeintritts binwirfen, woran id jebod zmeifle. Allerbings tragen Etod"= loden früher Eamen, als Samenpflanzen, bie 6jährige Stodlobe auf $30=$ jäbrigem Stođe muß aber einer 36jübrigen Eamenzilanze gleid gefteflt werben.

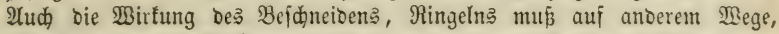

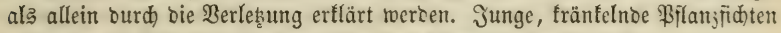
tragen ztwar frühjeitig 3affen, aber Der Same barin ift taub.

Im gemöhnliden Sd)lufie erwadjen, auf mittelmäpigem Boben, tritt bie Frortpflanjungäfäbigttit unjerer Malobäun!e burd) Eamen, ober ridjtiger

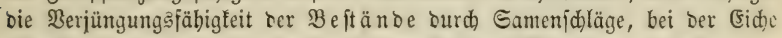
uno Rothbuche im 80. bis 100. Jahre, bei ber Weip̄tante im 70-80.,

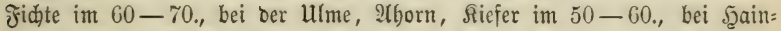
buden, Erlen, Birfen, Ejwen im 40-50. Jabre ein.

In vollem Ed)luîe und auf gutem Boben tritt biejer Beiłuntt fFäter, bei ungünftigem Stanborte und im lidten Stanbe tritt er früber cin.

Da bie gant alten Bäume bis zu ibrem Eingehen reid)lid) Eamen tragen, fo beftimmt fich bie andere Girenze ber Berjüngungşäbigfeit nidht nadh ber Dauer ber Samenerzeugung, jonbern nad) Der, im böberen 2Xlter Der Beftänbe junebmenoen Berminderung ber Stammzabl Durd) Diebjtabl, Unglüđä̧älle :c., rooburd nidłt allein bie 3abl ber zur Bejantung nötbigen Stämme, jondern aud) die Saubdede und Fruchtbarteit bes Bobens vet= Iorent gebt, Berrajung eintritt 2c., jo bas wir in biejer Bejiebung mit ber Utmtriebasbeftimmung ebenfalls an ein beftimmtes Bejtandsalter gebunoen

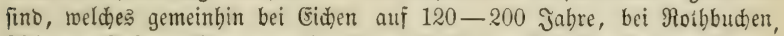
Fidten, תiefern, Taunen auj 100-120 Jabre, bei Beipbudjen, Erlen, Birfen auf 60-80 Jabre feftgejęt rwiro.

Jnnerbalb biejer (Erenzen ber Berjüngungşäbigteit burd Bejamung:

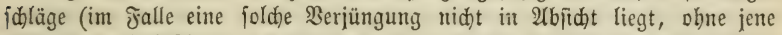

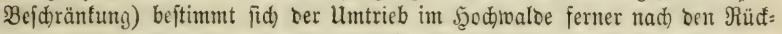
fidten auf Erzeugung ber größten 5̧olzmafie.

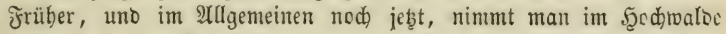
ein Eteigen bes 3uradjes bis ju rinem getwifien, bei reriddicoenten $\mathfrak{y}_{\mathrm{r}} \mathrm{I}_{3}=$

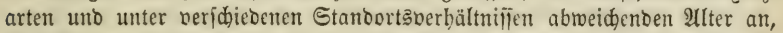

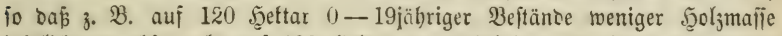
jäbrlid zumadble, als auf 120 5ुettar 0 -39jäbrig, auf leţteren weniger als auf 120 5ुettar $0-59 j a ̈ b r i g$, auf biejen meniger, als auf 120 Şettar

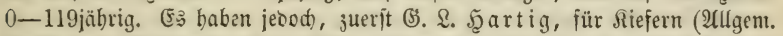
Jorit: unb Jagbardio VII 1826), fräter $5 g u n b e \mathfrak{g}$ agen (Pfeil fritijde \$lätter X. 1, Geite 139) uno id) felbft für Buchen uno fidbten nachge: miejen (Jorftwirtbidaftslebre G. 17S uno 198), baf bei biejen Sgolzarten Der Majienertrag beridiebenter f̧odjwal bleibe; Daber es Denn für biefelben, roenn man nur bie Maffe ber Er: zeugung berüđfidtigt, jiemlich) gleid) fein mürbe, in weldsem Umtricbe jie bewirtbidaftct werben. Bejonders beadtensెwerth ift bię für ben \&aubbolj: betrieb, two bas junge $\mathfrak{J g l l}_{3}$ böberen Brennmerth hat, als bas ältere.

Demuneradtet wiro in ঠen meiftin fällen audi) für jene Şoljarten ein Eteigen Des 3uwadję bis zum 80. Jabre angenommen werben müfīen, wenn man allein bie, unter gemöthnliḑen Berhältnififen zur Einnabme 


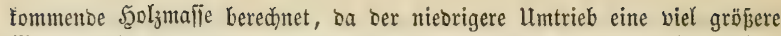
Menge geringen, entweber gar nidjt, ober bon Raff = uno Sejebolzjammlern

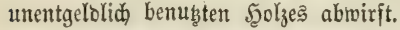

Itnter ungünftigen Standorţ̧⿻erbältnifien lajien die Bejtänoe

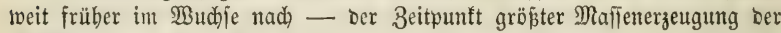
Beftände liegt Dem Beburtsjabre viel näber, baher benn auf falechtem Boden, int ungünftigen Rlima 2 . Der llmtrieb fürzer fein muई. Dertlid

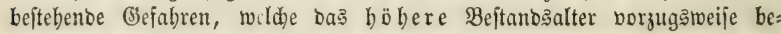
broben, wie Binbbrud), Snfeftenfrás zc. madben eine Berringerung Des Umtriebs, foldje (befahren hingegen, weldhe bem jü ngeren Bejtanos: alter entgegentreten, wie 3. B. Ģefabren ber Berjüngung, Sdnee uno Duftbrud, Befdäbigungen ourd Bilbpret und Beibe= vieh zc. machen eine (Erhöbung Des Umtriebs wünjhentwerth. Selbit bie

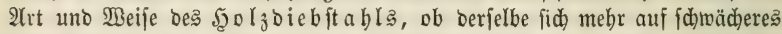

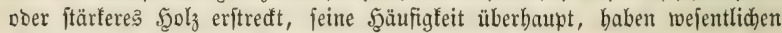

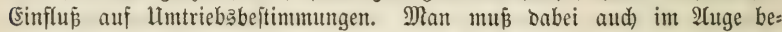

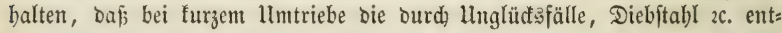

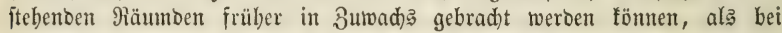
bohem Untriebe, wo fie lange Beit binourdh ertraglos liegen bleiben mü|īen.

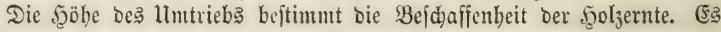
treten bemuad) aud bì bejtehenoen Beoürfnifie uno bie bavon abhängenten

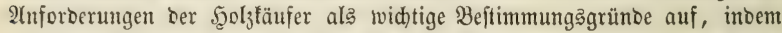
bon jenen Ânforberungen ber $\mathfrak{B} e r t \mathfrak{h}$ un exnte abbängig ijt. Wir müffen Demnad jtets einen joldhen llmtrieb er= wäblen, bei weldem die Befdaffenbeit ber jäbrlichen Sgolzernte Dem bes ftebenoen Bedurfnifie an vollfommenjten entipridt.

Die Soften ber Berjüngung finfen mit ber Scöhe bes Umtriebes,

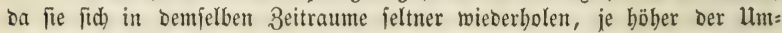
trieb ijt.

Mit b̆̈berem llmtriebe verminbern fid bie Sioften ber 3ugutmadung unto bes Iransports.

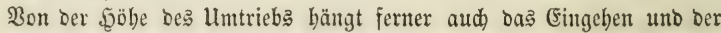

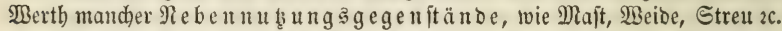
ab. Wo Diefe eiuren bejondern $\mathfrak{B e r t h}$ befiten, nod) mebr, wo fie (Siegenftano beftebenoer Mitbenubungaredite fino, müfien fie bei llmtriebsbes ftimmungen berüffichtigt werøen.

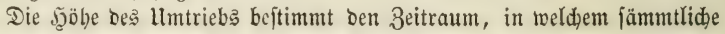
gegenwärtig vorbantenen Beftänbe zum 9 bbtriebe uno zur Berjüngung fommen.

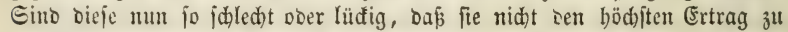
getvähren vermögen, fo ift mit fürzerem Umtriebe ber Bortheil einer früheren Scerftellung befferer, o. b. ertragafäbigerer Beftände, ber= butmoen.

Rüđfichtlid) Der mittelbaren uno ummittelbaren Bortbeile einer unter=

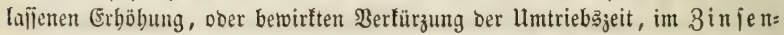
ertrage veriflberter פolztapitale, berweife id auf Sapitel 2.

Enolid haben wir nod) zu erwähnen, bá ba, to mebrere Wirthichafts: forper auf bie Befriebigung einer uno berjelben Bebarfammafie hintwirfen, bieje 
fich gegenjeitig vertreten fönten, fo, baß Wirthjhaftätörper mit vielem alten

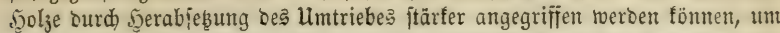

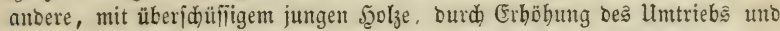

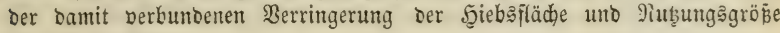
¡đonen zu fönmen.

Bom llmtrieb im Niebertwalbe.

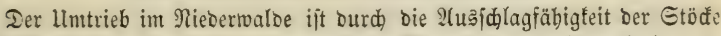

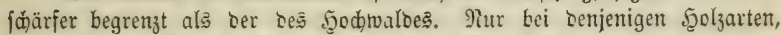
welche reidlid Wurzelbrut treiben, wie die 2lipe, WBeip̄eller, Acacie, ift ber

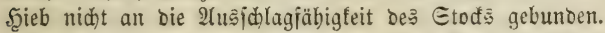

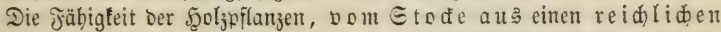

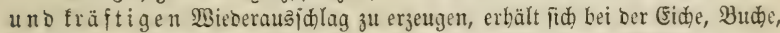

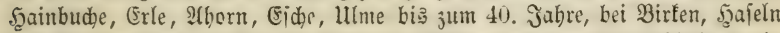
uno Acacien bis zum 20., bei \$appeln, SWeiden uno den Strauchbölzern bis зum $10-15$. Jabre.

Jmerbalb biejer (Brenzen treten bei Untriebabejtimmungen zientlid) bie: jelben Rüđfidoten ein, wie im Sgodwalbe.

Bas die Rüffidten alf Erjeugung Der größten Syolzmafie betrifit, fo mú man Den llntrieb um jo türjer falien, je idled)ter uno flachgrünoiger ber Booen ift. A(ber aud auj beliferem Booen wiro, mit 2 (us:

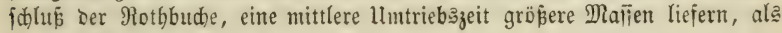
bie oben bezeidnete.

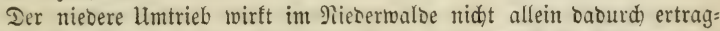

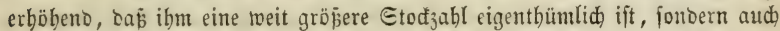

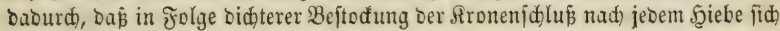
rajher wieberberjtellt, ber Boben zwijden ben Rronen ber einzelnen Mutter= ftöde fürzere 3eit unbejđirmt bleibt, Daber weniger veröbet als bas bei langent Ummtrieke ber Jall ift. (ङ. Banb III Ertrajsermittelung ber Rieberwäloer.)

Der $\mathfrak{B}$ ert $\mathfrak{b}$ Der Do olzerzeugung bängt bom beftehenden Bedürní̄ ab; bier fant nur ftarfes Reidelboly hober IImtriebe gejucht jein, bort hat

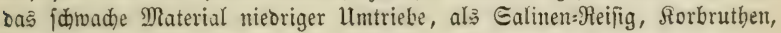
Banditöđe, Jajdinen ic. böberen $\mathfrak{B}_{\text {erth. }}$

Der fürsere Umtrieb liefert einen reidlicheren Wieberausiclag,

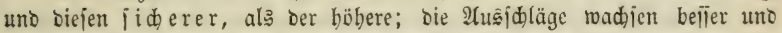

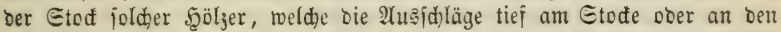
Murjeln entroideln, erbält jid länger uno voller, wohingegen bie Etöđte jolder 5yolzarten, Die nur reinen Etodiuswhllag über Der Erse entwicfeln, bei bäufiger roieberholten Şiebe meniger lange aušbauern. Wo baber bie

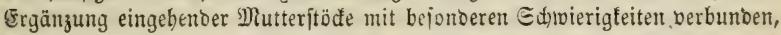

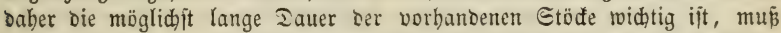

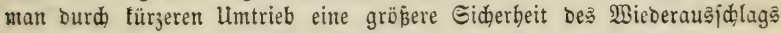
gewinnen.

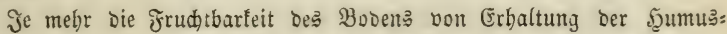
jđidht abbängig ift, um jo türjer mup Der llmtrieb angejeß̧t merben, ba Die gröpere Babl Der Mutteritöde Des furjen llmtriebs eine geringere Dauer ber Bobenentblöpung nach oem atriebe jur Folge hat. 
Rebennubungen baben bäurig aud auf bie Beftintmung be: Riebermaloumtriebs (Einfluj. Weioc, Streu, Raffbolz 2 . berringern fid) mit Dem Umtriebe, uno fallen bei einem Umtriebe unter $15-20$ Jahren faft gänjlich aus. Benuķung ber Exiegeltrinbe ber Eichen= Niebermälber forbert einent $15-20$ jährigen Umtrieb.

Bom Untriebe im Mittelwaloe.

Der Untrieb im Unter bolze Des Mittelmaldes bejtimmt fich im ât=

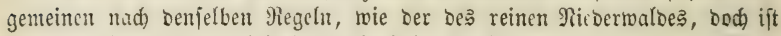
bier ein fürzerer Umtrieb in nodh böberem Grabe als oort vortheillbaft, weil bie nadtheilige (Einwirfung bes Dberbolzes auf bas Untirboly mit ber Innäberung Der Blattichirme beiber fteigt. Je weiter ber Unterbolzblatt= idirm vom Dberboljblattidirm entfernt ift, um fo roniger verbämnat leb̧terer.

Sür ben Umtrieb im Dberholze gelten im Allgemeinen bie für ben

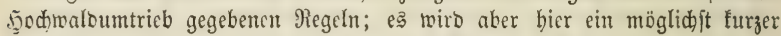

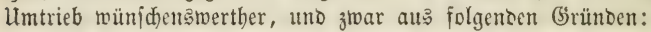

1) Ǵleidhe Echirmiläde, gebifbet aus ben Sronen junger Dberbölzer, bejdattet uno idfabet viel weniger, als wenn fie aus ben fronen alten Dberbolzes zujammengejeb̨t ift, theils wegen ber größern Didtheit ber

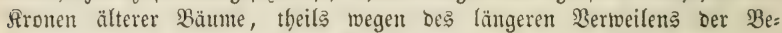
fitattung auf ein uno berfelben Stclle unter grof́fronigen Bäumen.

2) Bei gleidem Bejoattungagrabe fam daber eine bebeutento gröB̈ere Edhirmfläd)e auڤ jungem Dberbolze übergehalten werben, obne ben Bud Des Unterbolyes in böherem Grade jurüđzubalter. Bei gleidem Be:

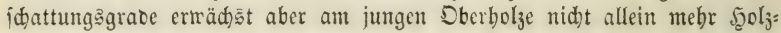
mafie, als an älterem, ionoern aud verbältni jomäfig mebr Stammbolz.

3) Die größere Stammabl ber Dberböljer bei nicorigem llmtriebe erleichtert bie regclmäpige Bertbeilung ber Stämme.

4) Die Jällung geringeren Dberbolzes ift mit geringeren Beidä= bigungen Der Saß̧reidel uno Unterbolziftöde berbunden.

5) Bei geringercm Dberboljumtribe fann man mit größ̌erer Sidher: heit gejunbe Stofloden ju Sberbolz überbalten, die den böheren Umtrieb nid)t auşhalten würben.

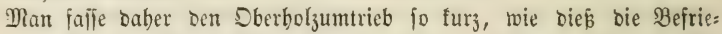

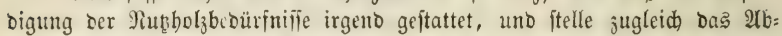

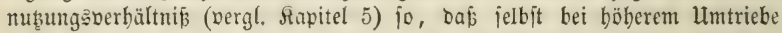

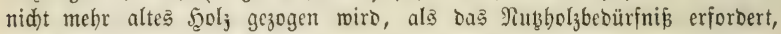

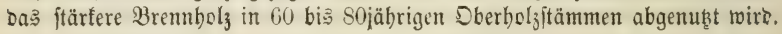

\section{Elftes Eapitel.}

Bon Der Eahl Der Dol3arten.

1) Gie wirb juerft burd Standorţoerbälniffe beftimmt. Wir wiffen, Daj, went aud mandhe Bodenarten ien Inbau ber meiften bei=

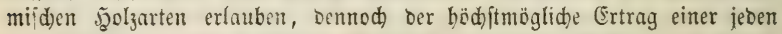

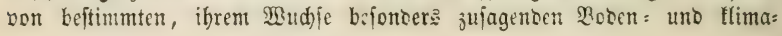




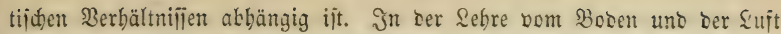

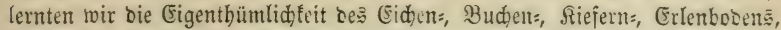

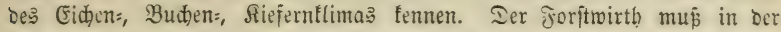
ibm gezebenen Dertlidfeit bie beftebenoen Berbältmilie erforiden, uno nach ibnen feine $\mathfrak{B a b l}$ treffien.

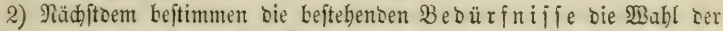
f̧olzarten. Für Bauholzbeoürfnifie find vorzugämeife die Nabelhölzer unto sie Eidhe; für Wertbölzer bie meiften barten Saubboljarten, für Brenn= bebarf bejonders biejenigen 5 golzarten geeignet, wildye im tleinen Raume groje Brennftoffimertbe enthalten, wie sie Rotbbudje. (Ias Meitere fält ser Sebre von ber forftbenub̧ung anbeim.)

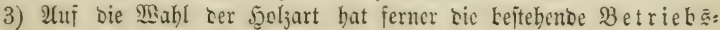
weife einen wejentliden Einflü.

Jür sen 50 do malobetrieb in reinen 3 eftänoen eignen fid auper sen Radelhölzern nod) bie Rothbuche und Eide, im furzen Umtriebe Die Birfe uno Eller, mobingegen Die übrigen harten Saubhöłjer mebr zur Erziehung in gemengten Beitänben, uno ztwar:

bie 2 borme, Eichen, Ulmen in llntermengung mit Rothbuthen,

Die Ejđhen =, Bogelbeer:, Eläbeerbüume uno bie Birfe bei gewifien Bobenverbältnill. $n$ jur Ilntermenyung mit ber Crrle, geeignet fint.

2tujerbent paifen jur Grziehung in gemengten Beftänben:

§iefer uno \&ärdje,

Fidite uno Tanne,

Ianne uno Rothbuche,

Rothbuche unto Eide,

Riefer uno Birfe. 1

Für Den Riebertoalobetrieb find natürlich nur biejenigen Şolz= arten anwenobar, weldhe überbaupt Stod = ober $\mathfrak{B} u r z e l a u s j$ d lag liefern, Da ein 40jäbriger ober nod geringerer Umtrieb im Nabelbolye immer noch feinen Nieberwalðbetrieb begrünbet.

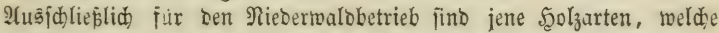

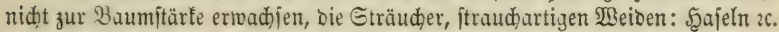

2luch ciejenigen Feolzarten fann man bieher zählen, weldje zwar zu Bäumen ermadjien, aber im böberen llmtriebe be马 Şodjwaldes einen jehr geringen Ertray gewäbren, wie 3. B. die Pyrus- uno Prunus-2trten, Sorbus, Robinia Pseudacacia 2 .

Ulnter jenen Şoljarten beftimmt juerft bas 23 . oürfniß̄ bie anzubauente Şolzart. Jür Brenn = unt Foblholzerzeugung fint befonbers bie Athorne,

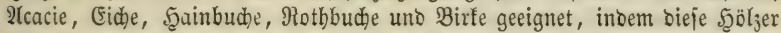

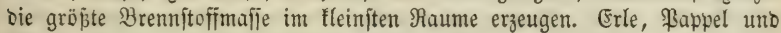
Weibe erjeugen ztwar aud) bedeutente Diengen Brennitofi, aber gleide

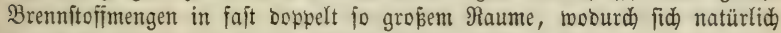

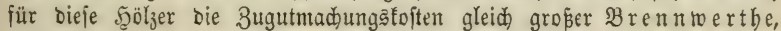
bom 2 Abbiebe bis zum Bremen, oft peropppeln.

1 Heber (Erziebung gemengter Beftände ift im adten fiapitel (vermijđte Gaaten) Der 3 tweiten 2btheilung Des dritten 2bidnittes mekr gejagt. 
Inberweitige Beoürfuifie befriedigt bie Eidne (Epiegetrinbe), bie Sinoe

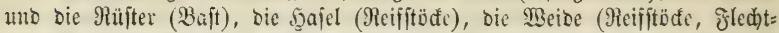
und Jajdinenmaterial), (Eid)e, 2lborn, Ejahe, llme, Birfe (tleine Rub̧=

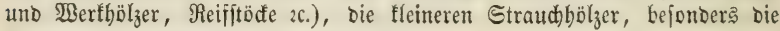
Dornen und Sdhleben (Salinenreifig).

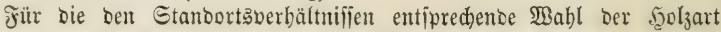
gelten bie in ber Rebre bom Boden mitgetheilten Bezeidnnungen; wie im 5odyaldo baben wir aud im Riederwalde einen bejonbern Budhenboden, פBeibenboden 2c., ber jebod) oft ein anberer ift, als int Jyod)walbe. Der Erlenboben ift in beiben Betriebsarten gleid); Der (Eidhenboden tann viel flaăgrünbiger fein; ber SBeibe entiprechen bejonbers bie naffen unt feuchten

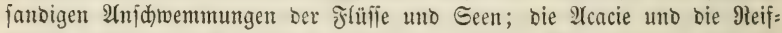
tweiben gebeihen noch auf bem trofeneren janbigen Meeresboben. Für bie

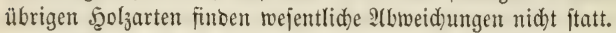

Bei Der $\mathfrak{B a b l}_{\text {Der }}$ goljarten für Den शiederwalobetrieb fommt ferner

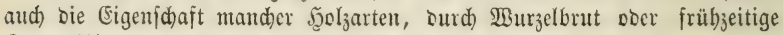
Gamenbiloung bie fläche voll beftodt $3 u$ erbalten, in Betracht.

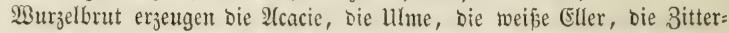
pappel, bie \$rumbsarten uno viele Gtraudbbölzer. Durd) frübzeitige Samen=

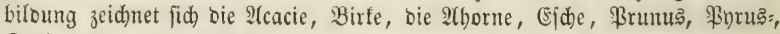
Sorbusartert, uno die Straudbböłzer au引.

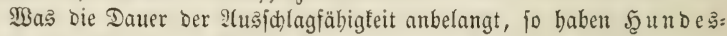
bagen uno 2 nobere ben Grumbjał̧ aufgejtellt, bap biejelbe mit bem natür= liden 2 (lter der \$flanje im Berbältnif ftehe. Danad) müß̄te aber bie Dauer

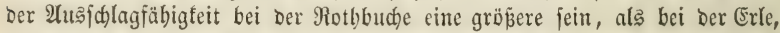
was gewi

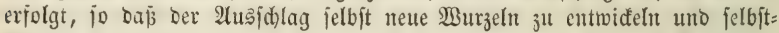

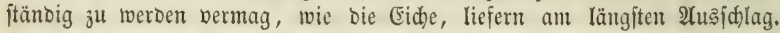

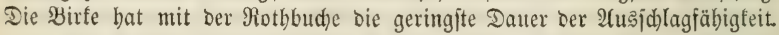

Den meiften uno fräftigften Mieberausfolag liefern (Eid)en, 20horme,

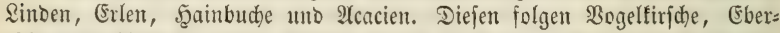

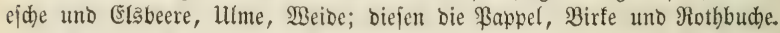

Şü ben Mittelmalobetrieb palfen in Den lnterboljbeftanto bies jenigen Sgoljarten, weldhe bem Miederwalobetricbe, für ben Oberbolzbejtano paffen bie joclyarten, weldhe Dem Sodjwalsbetriebe entiprecten, jeond) mit folgenben Einjørärfungen:

1) Mlan wäblt zum llnterbolzbeftande gerne bitfelbe joglzart, wie für Den Dberboljbejtano, um leţtern aus erfterem überbalteı, erfteren aus leţterem ergänzen ž łönnen.

2) 3um Unterholjbeftanbe wäblt man 5̧olzarten, melche möglichit wenig von Der Bejdattung bes Dberbolzes leiben; zum Dberholze fold)e, Die mög= lidjit wenig bejalten, um beim geringiten Berlujte am Unterbolzertrage Durd) Befdirmung, Die möglidjit größ̧te Dberholymenge überhalten zu tönnen.

Den meiften Edatten als Interbols ertragen: Rothbude, Sinbe,

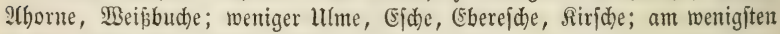
Eiche, Birfe, Erle, 2lipe, Meide, Şafel.

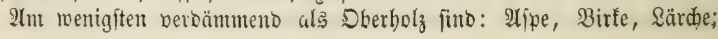




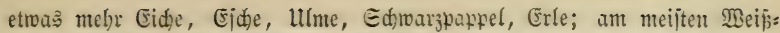

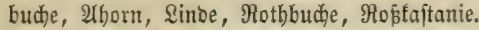

3) Das Dberholy muñ geeignet jein, im freien Etanbe einen Stanm

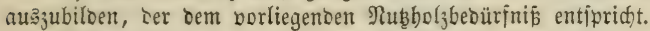

Jn ßeziehung auf bie einzelnen 5ुolzarten baben wir nod) Folgendes зu bemerfen:

Die (Fid)e.

Go bäufig bie Eiḑen gegentwärtig als alte Bäume im Mitteltwalbe vorfommen, ber fie nod) aus bem ßlänter= ooer Urwaloe überfam, io

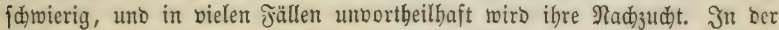
früheften Jugeno leidet bie Eiche fehr vom Wilopret uno unter ber Be:

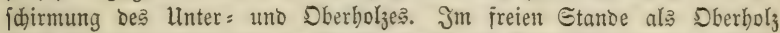
bleibt fie nidt aflein jebr im $2 B u d j$ je jurüd uno liefert eine geringere Majie

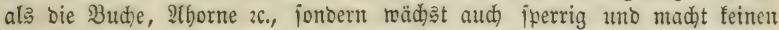

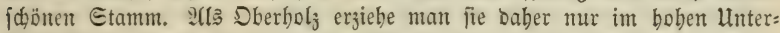
bolzumtriebe, auf tiefgrüntigem frudtbaren Boben, im milben Silima, benn bie Fälle, wo fie auf flachem Boben jreubig vegetirt, gebören zu ben jel= tenen 2(u⿳亠一nabmen; aber aud) auj günjtigem Etanoorte ziebe man bie Eiche

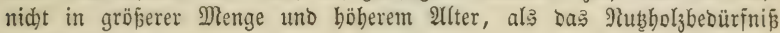
burd)aus erforbert.

Itla Unterboly ift bie Eiche bejonbers an Mittagieiten ber Berge, anf armem jelbjt flachgrünoigem Boben ertragreid), jie leibet aber feine ftarfe Beidattung. Je foledter ber Bobent ijt, um io länger behält bie (Eid)e

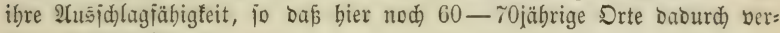
jüngt werben fönnent.

Heber emprindlichem Unterboly fann bie Eiche $1 / 4-1 / 3$, über weniger empfindlichem $1 / 3-1 / 2$ ber flädhe befichirmen.

\section{Die. $\Re$ othbude.}

Gie wädjat im freien Etande bes Mittelwalbes jebr gut, probucirt

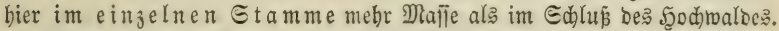
3ur Brennboljerzeugung ift fie baher im Mittelraldo bas geichäbtefte Dber: hol $l_{3}$, und bejonders auf Raltboden oder humojen Rebmboben paljent. Eie verlangt feine bejondere Bodentiefe.

Begen ibrer ftarfen Bejhattung ift nur Buchen= ober Scainbudjen=

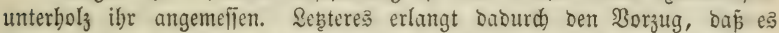
mehr Stodloben treibt, fï überhaupt voller bejtodt erbält. Der Roth= buchenftoof liefert mur 2: bis 3mal reidhliden 2 ușidlag. Die Etöde müifen hod) gebauen weroen.

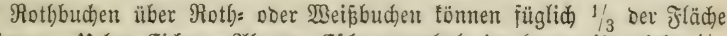

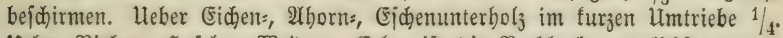

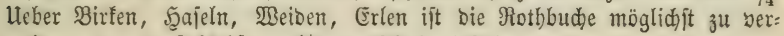
meiben, und barf bödjitens $1 / 6$ ber fläd)e bejhirmen.

\section{Die $\mathfrak{M}$ еів̈buめe}

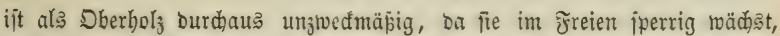
viel bejattet uno als Baumbols itet: im geringen 3uradje ftebt. Dabin= 
gegen ift fie als Unterbolz febr zu empfeblen, indem fie eine ftarte Bes fंdattung erträgt uno lange ausbauert.

\section{Die 2 thorne}

finto als Dberbolz im furzen bis 80jäbrigen llmtriebe ertragreich, fpäter bleiben fie im $\mathfrak{B u d j e}$ jebr zurüđ. Die Befdattung alter Bäume ift nicht mefentlid geringer als bie ber Mothbuche. Der Feloaborn ift nur als llnter:

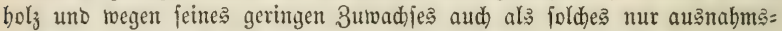
wiife zu erzieben. 2(la llnterbolz ift ibr (Ertrag aukerorbentlid), aud) leiben fie eine ftarfe Bejdattung.

\section{Die Eidie}

forbert einen feudten bumofen Boben; ifre eigentlicher Stanbort ift ber fefte

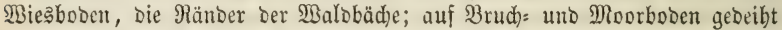
fie fd)led)t. Sie nui jeood) ebenfalls in nidjt zu hobem llmtriebe als Dber: holz uno in mäpiger Bejdattung als llnterholz behanbelt werben, bann ift jie auf pafiendem Standorte fehr ertragreid. Der Bejdattungsggrad Der Eide ift etwas geringer als ber ber (Eid)e.

\section{Die $\Re$ ü jter,}

bejonbers bie raube Rüfter ift in Den Shujnieberungen beimija uno liefert Dort, auf einem humusreidjon feudsten \&ebmboden vorzügliḑen Ertrag, mebr als Dberbolz wie als linterbolz. T(l

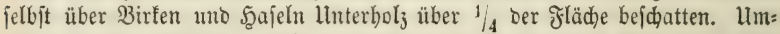

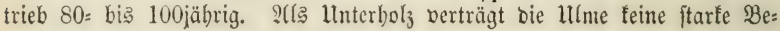
idattung, läpt aud) balo im $\mathfrak{B u d j j e ~ n a d ) . ~}$

\section{Die Sinbe}

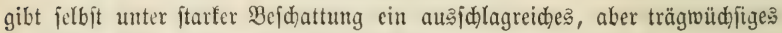
Ilnterboly, weniger taugt fie als Dberboly.

\section{Die Birte.}

Unter entipredjonoen Bobenverhältnifien liefert Birfenoberholz über Scainbuchen =, Buchen =, 2thorn = Doer Eidjenulterbolz einen bohen Mafien crtrag burd) bie geringe Beidattuny unb große Stammzahl, in ber fie über:

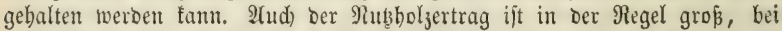
bent Merthe Der Birfe für Ģejdirrboly. Shrem verbreitetern 2(nbau als Dberbol $z_{3}$ tritt bie Edjwierigfeit entgegen, Den Unterholzbejtano von ibr frei zu balten, in weldem ihr (Frtrag Durch) geringe Duer Der Mutterftöcfe, wie burd) Sobenweridled)terung, ein geringer ift. Tur auf eigentlichem

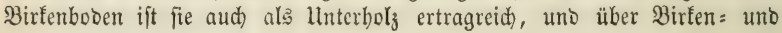
Scajelunterbol $\mathfrak{l}_{3}$ bas befte Sberholz.

\section{Die Erle}

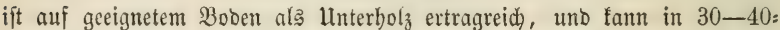
jäbrigem Umtricbe bebandelt merben, wenn nur bas ftärfere Material $2(b j a b$ finbet. Wenig taugt fie als Dterholz, ba fie balo im $\mathfrak{B u d}$ je nadjläpt. 
Bejonbers ift biế auf bem eigentlidjen Brudbboben ber fall. Sänger bält bie Erle im naाjen Dünenfante an Flups = uno Geeufern aus, two fie mit Bortbeil зu Baumbolz übergebalten werben famn, ba fie wenig bejaltet; ood) muß bie Sage gejdüb̨t fein, ba fie leidjt bom Winbe getworfen wiro uno brïdjig ift.

\section{Die $\mathfrak{A}$ ipe}

ijt ebenfalls weber als Unterbol in Ler Jugent ztwar rajd, läpt aber jebr balo nad uno bejonders bie reidhlid erfolgente Wurzelbrut geht gemeinhin jehr rajd wieber ein. 2lla

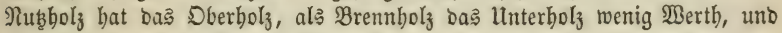
wie bie Birfe verfdjledtert aud bie 2(jpe ben Boben.

\section{Die Sajel}

fann natürlich nur als Unterboly erzogen werben, uno gibt einen hoben

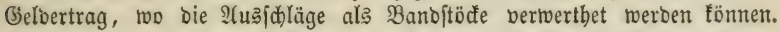
Sie erträgt aber wenig Edjatten uno riro mit Bortheil mur unter Birfen ober Särchen Dberbolz zu erzieben jein. Bieeigneter ift fie für fleine ber= einzelte Felobölzer als für grö̈pere Waloflüd)en.

\section{Die $\mathfrak{B e i b e n}$}

fint Kein $\mathfrak{S C l}_{3}$ für ben Mittelwalo, ba fie feinen Sdatten leioen uno nur in ganz $\mathfrak{f u r z e m ~} \mathfrak{H}$ mtriebe Ertrag gewäbren.

Bogelfiride, Ebereide, Elabeere 2 .

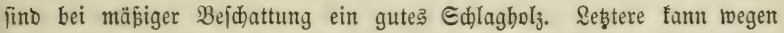

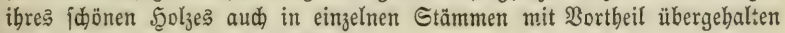
werben, ift aber jebr trägwädjig.

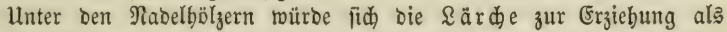
Sberbolz am beften eignen, ba fie aud im freien Stanbe fids bon 2leften reinigt.

4) Beftimmt aud bie angenonmene Umtriebşzeit bie $\mathfrak{B a h l}$ ber an= zubauenden Sgoljart, in welder Beziebung bas zu beadten ift, was id

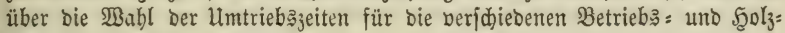
arten bereits gejagt babe.

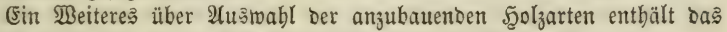

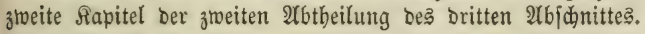

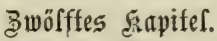

Bon Der $2 B$ ahI Der Erzeugungsart.

Junge Beffänbe fönnen entweber mit Şülfe eines vorbandenen Mutter:

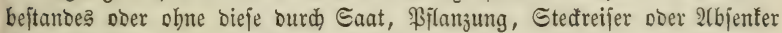
erzergt werben.

Der Beriüngung burdh natürlidbe Befamung fteht ber grope Bortbeil

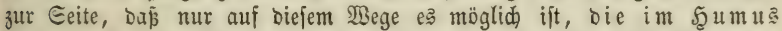
Der Dammerbe begründete Bobentraft unverminbert a bem alten auf ben jungen $B$ eftand $z$ übertragen, wenn bie 
lebendige Saubbecte bes alten Beitanbes nicht eher bintweggenommen wirb, ehe fid nidjt ein neuer Sdjub burdi ben erzogenten jungen Beitanto gebilbet hat. Es ijt biḗ ein, auf ben jungen Beitano fo mädtig eintwirfenoer Bor= theil biejer (srzeugungsart, baj id) ihn jebem anberen weit voranftelle, um fo mebr, je mehr bie Frudtbarteit bes Bobens auf belïen Reidthum an Dammerbe berubt, je weniger bie Şolzart bes fünftigen Jutugorts geeignet

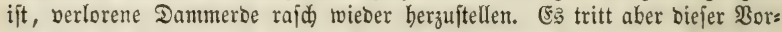
zug nur ba herbor, wo bie zu berjüngenten alten Beftänbe nodh fo ges fa)loffen fino, baj fie bie Dammerbe bis zum 2(btriebe fid zu erbalten ver= modten. Das ift vorberrideno ber fall in Budhen=, Jidhten= uno Iannen= Bälbern, jeltener in Riefer = uno (Eid)en=, nod) jeltener in Birfen = uno

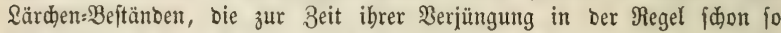

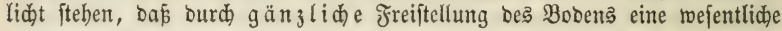
Berringerung ber organijden Bobentraft nidgt mebr ftattfintet.

Ein zweiter erheblidber Bortheil ber Selbftbejamung liegt in bem ge: ringeren Roftenaufmantoe, Den biejelbe erheifdt. Ës ift ztwar ber Roften= aufwand an Rüderlöhnen Diejem Bortbeile entgegengejtellt worben, inbej fino Sebtere io grop nidbt, wo nid)t eiu unnötbiger \&uxus mit bem Rüđén getrieben wirb. ${ }^{1}$ Will man je be Bejdäbigung am Jungorte ber= meiben, bant werben bie Rüderlöhne allerbings in bielen Fällen zu hohen Beträgen anwadhjen, will man bingegen nur biejenigen Bejdäbigungen bes Wiebermudbes vermeiben, Die auf Den bereinftigen Ertrag bes: felben von Einflu $\bar{\beta}$ find, bann laffen fid bieje Rojten auf geringe

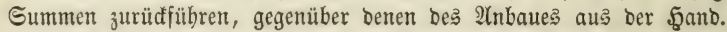

Fin britter Borzug Der Selbitbejamung liegt barin: Daṕ obne über=

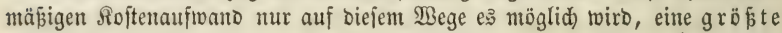
Menge junger Şotzpflanzen in einer Bertbeilung zu erzieben, in ber bie größte 3ahl berjelben einen, ifrer fräftigen Fortbilbung entipred)enden Stand:

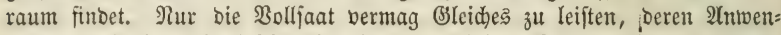
Dung jeood) eine jebr bejdräntte ift. 2Ulle übrigen Rulturmethoden würben,

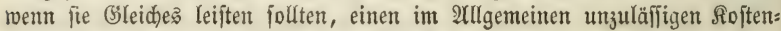
aufwant erbeijden. Weldes ber Einflū ijt, Den eine gleidmäßige Ber= theilung beక gejammten Stanbraumes auf bie Şerftellung uno Erbaltung gröpter Mengen lebenžfräftigfter ßflanzen uno baburch auf bie Mafien=

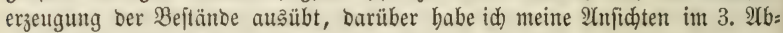

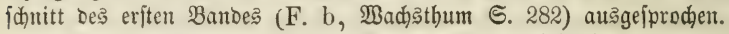

(5in 3uwadsgemint ift überall ba mit ber Selbftbejamung verbunben, wo fan im Jabre nad) ber Sdjlagitellung reidlider Wieberwudbs erfolgt. Der, an ben übergebaltenen Mutterbäumen erfolgenøe, Durd bie Freiftellung gefteigerte 3uwachs fann in jolden Fällen als ein Ueberjd)uß ber jäbrlidjen

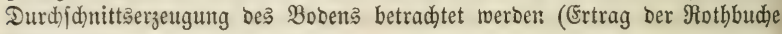
Seite 136).

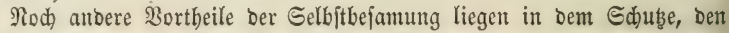
Der Mutterbaum Dem $\mathfrak{B i e b e r i v u d j e ~ g e g e n ~ F r o f t , ~ S ̧ i ß ̨ e , ~ D u ̈ r r e ~ u n o ~ F o r j t = ~}$

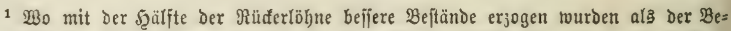

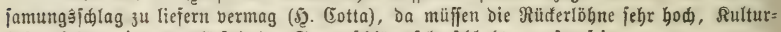
toften jehr gering und (Frfolg Der Samenid)läge jehr jalled)t getwefen jein. 


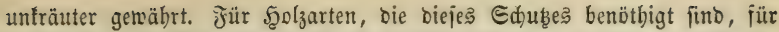
Rothbude und Weiftanne wirb bie Eelbjtwerjüngung immer vorberrideno bleiben. Allerbings laīen aud bieje Şolzarten im frreien fid aufbringen,

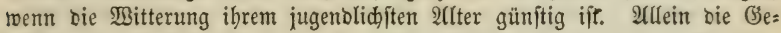
fabr grofer Berlujte ift immer uno überall vorhanden uno bieje \$erlufte, wenn fie eintreten, find, bejonders bei jelten fid wieberholenden Gamen= jabren fo grōs, baß fie, aud bei feltenerem 2 (uftreten, bie Bortbeile weit überwiegen, bie ber $\mathcal{U}$ nbau aus ber Şand zu getwähren vermag.

Itİ Nadtheile ber Eelbitbejamung fino bauptiädlid bie Störungen ३u betradten, weldhe eine vorausbeftimmte uno georonete Wirtbichaftsführung bei ungetwöbnlid lange auşetęender Eamenproduftion bäufig erleibet; über= haupt bie Bebinderung freier Şicbsleitung, Bermehrung Der (jejdäfte uno Eridimerung Der Eontrole.

(Es gebören ferner bierber bie Berlufte ourd) Minbbrudh in ben ge:

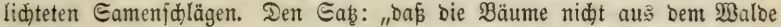

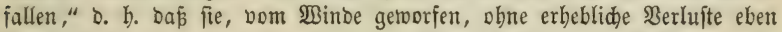
fo geerntet werben fönnen, als im regelred)ten Sd)lage, mödhte id nicht unteridreiben. Sdyon ber Umitano: Daf man bierbei nidht Seer ber Jahreş= geit ift, in weld)er bie 3ugutmad)ung geid)ehen mus, fteht bem entgegen,

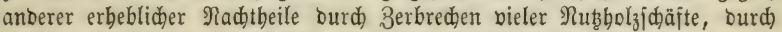

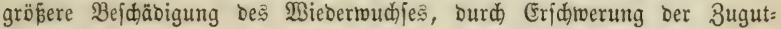
machung nicht zu gebenfen. J゙d balte $e^{3}$ vielmebr für geredtfertigt, in exponirten Sagen ber Bebirgsforite, in benen ein Merfen ber Mutter= bäume mit Babrjheinlidteit vorausejeben werben tann, von ber $\mathfrak{B} e r=$ jüngung burch natürliche Bejamung gänzlich abzufeben.

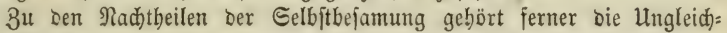
wüchjigfeit ber J̧ungorte, bie bann eintritt, wenn bas erfte Samenjabr un= bejamte Süđén lię̧, bie erit in jpäteren Gamenjabren in Beftano fommen.

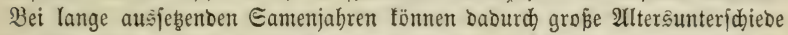
im Jungorte entiftehen, bie befonders baburdh nadtheilig werben: baj fie Die $\mathfrak{W i e b e r a u f g a b e ~ D e r j e l b e n ~ f u ̈ r ~ b i e ~ B i e b m e i d e ~ v e r z o ̈ g e r n , ~ i n d e m ~ b i e j e r ~ Z e i t = ~}$ funtt vom 2llter ber iüng ften Pflanzen abbängig ijt. Bei ftarfen Willo=

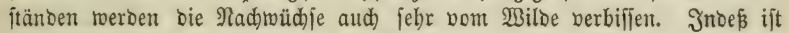
Diefer Nadbtheil ein bedingter, er fann aud baourd gänzlid) bermieben werben, bas man nidt zu lange auf Nad)wudbs wartet uno bei redjtzeitigem

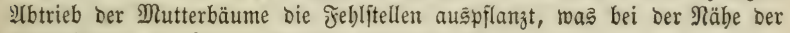

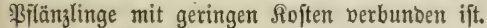

Enolid idmälern bie Gamenidläge eine alläbrlid freie Dis̄pojition

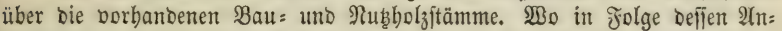
forberungen unbefriebigt bleiben müfijen, bie nidjt alljäbrlid mieberfefren, fönnen Daraus Berlujte im Nub̧holzhandel beroorgeben.

In ben allermeiften fällen werben bie Ractheile ber Selbjtwerjüngung binter ben Northeilen weit zurüđjtehen. Das ift überall ber Fall, too eine, surd) mebrjäbrige Bobenentblößung berloren gehenoe Dammerbejdidyt nod) vorbanben, bie mineralijde Bobenfraft eine geringe ijt, fo wie ba, wo

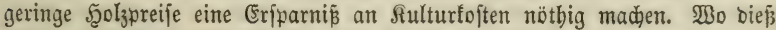
nidat ber frall ijt, two auserbem bie freie Dişpofition über bie Bäume ber 
an Sciebe ftehenben Drte vortheillhaft, two eine, an bie ßerjüngungşäbigfeit ber Bejtänbe uno an ben Eintritt ber Samenjabre nidht gebunbene Sciebs:

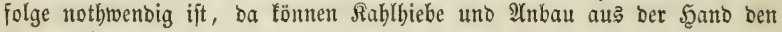
Borzug befitzen.

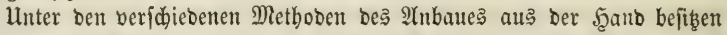
mur Saat uno Bflanzung eine allgemeinere 21ntwendung. Der 2Mbau burd Stedreifer bejdränft fid) auf $\mathfrak{B e i b e n = S o o l e , ~ b e r ~} 2(n b a u$ Durd) Sekgitangen auf Beiben= uno Bappelns, Ropf: uno Sdneibelbälzer. Durd Albjenter

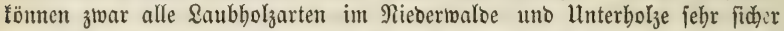
vernebrt unb bie Beftodung verbidtet werben; allein biefe Bermebrungs: weife tojtet nidht allein viel 3eit uno 2 trbeit, fonoen fie ift auch in bes

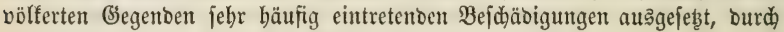
Scrausreifen ber eingelegten Csipfeltriebe aus bem Boben.

(3egenüber Der PFilanzung ftebt ben Saaffulturen ber geringere Solten: aufwand uno bie größere Pflanzenzahl zur Seite. Seb̧tere bat einen böheren

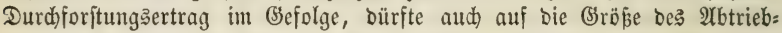
crtrages ber Beftänoe nicht ohne Sinflup jein, uno zwar in ocmfelben $\mathfrak{B} e r=$ bälniß̄ mehr, ala bie Bertbeilung ber Samenpflanzen eine gleid)mäpigere

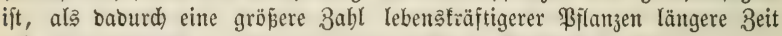
fid präbominireno zu erbalten vermag (Bb. I. 2(bjd)nitt 3. F. b.).

Bei gleidem Roftenaufwanto dedfen Saatfulturen ben Boden früher alŝ Pflanzungen.

Ein guter Erfolg ber Saatfulturen ijt weniger von ber (bejdicflidfeit

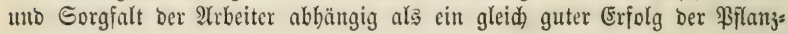
fulturen.

2Ad) bie von Эugento auf ungeitörte Entwidfelung uno fortbiloung

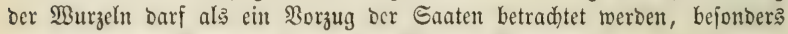
gegenüber ber \$flanz̧utg älterer un๖ ftärferer Bäume.

Dagegen broben ber Saatfultur im Freien mebr uno größere S̈efabren als ber \$flanzfultur unt bieje fitto um jo länger fortbauernt, als ber Budjs ber Samentflanzen in Don criten Jabren ein langlamer ift. Sdjon Dem Samentorne treten in Mäufu, Bögeht, Sdhwarzwilo, in Dürre uno ßlab̧regen Gefabren entgegen, unter Denen bie Pilanzung nidjt mebr zu leiben bat. Sie feben fid fort in Unfrautwuds, 2Uuffrieren bes Bobens, Bodendürre, Spätfröfte, Berbeißen $2 c$., Seffabren von Denen ber ältere Bflänz= ling wentiger ober gar nid)t getroffen twirb. Lluter Stundortzberbältniffen, bie bas Eintreten joldher Bejwäbigungen nit großer Wabrjheinlid)leit er= warten lafien, hat bie Bftanjung entichiedene Borzüge.

Dbgleid) im Aftlgemeinen theurer, crmäpigen fid bod bie Roften ber

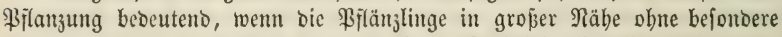
Erziebungatoften zu baben fint. Das ift ber Fall bei allen Nadbbefierungen fleinerer Fehlftellen in Jutgorten aus Saat poer Selbftbefamung, bie, aud)

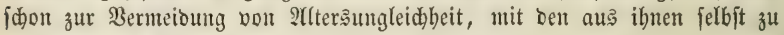
entnehmenden Pflänzlingen berbollftänoigt werben.

Bei Scolzarten, beren Same nur furze Beit fich feimfäbig erbält, fann wäbrent auşę̧ender Samenprobuftion nur burd) Bflanjung fultivirt werben.

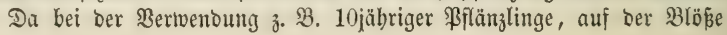




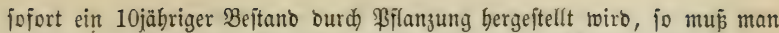
Diejer einen 10jährigen Durdjidnittảjutwadj

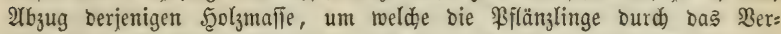

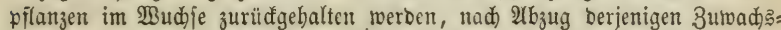
majie ferner, um meldye aud fpäter ber Pflanzbeftano binter bem Eaat= bejtande zurüableibt. In ben allermeiften Fällen wiro fdon ber 2(usfall an Durdforjtungäbölzern jenen in nidjt feltenen fällen an fïd illujorifoen 3umadsgetwinn überiteigen.

\section{Dreizelintes siapiter.}

Bon Der 2 ahl Der Erziehungart.

Im Mittels, Rieber: uno Ropfbolzwalbe beftehen feine wejentlid ver: iabiebenen $\mathfrak{A n j i d}$ ten über bie weitere Behandlung ber erzeugtın Bflanzen bis ju beren $\mathfrak{A b n u b u n g , ~ e ̨ ~ f a n n ~ r a b e r ~ v o n ~ e i n e r ~} \mathfrak{W}$ abl ber Erziebungsart im Allgemeinen bier nidts gejagt werben, was nidjt in ber Sebre bon ber

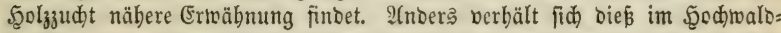

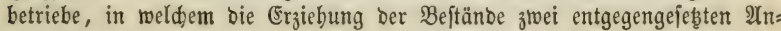
fichten unterliegt.

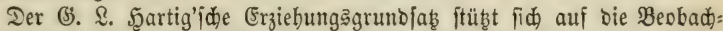

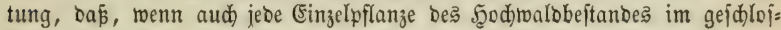
fenen Stanbe eine geringere Scoljmaije erzeugt als bei unbehinberter Ent= widelung im freien Stanbraume, Dennod) ber Maffenertrag ber $B$ eft an $D$ s: fläden bei ftetả geidloñenem Etanbe, burđ bie gröpere 3ahl ber Pro= Ducenten, nidst allein ein größerer, fonbern aud ein werthoollerer fei, in Jolge gröperer Edjaftlänge, Nollholzigfeit, 2(itreinbeit unb Spaltigfeit ber Bäume. Fr ftüb̧t fid ferner auf bie Beobachtung: baf bie lebenșfräftigften Pflanzen eines Beftandes fich als joldje erit in einem böberen Bejtandsalter, bann зu erfennen geben, roenn bie Uebergipfelung ber minber lebensfräftigen PFlanzen bereits eingetreten ijt.

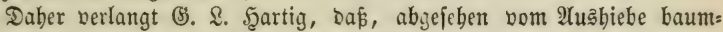
artiger Forftunfräuter, bie erfte Durdforftung in bie jungen Beftänbe erft baun eingelegt werben folle, wenn bie natürliche Reinigung bereit? eingetreten ift; Daj biefe Durdforftungen fid wieberholen follen, wenn eine jo großse Menge von Stämmen roieberum von ben lebensträftigeren übergipfelt wurben, um bie Ropten bes 2fuşbiebes, bes 3ujammenbringens

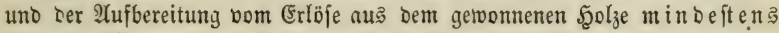
becten zu fönnen; bás bei jeber biejer bis zum 2lbtriebe fortbauernoen Durdforitungen nur bie übergipfelten Bäume bintveggenommen werben jollen, b. h. Dá in ber Durdfforftung nie ein Baum gehauen werben jolle, ber burd bie erlittene Uebergipfelung nidbt idon als minber lebenșträftig fich zu erfennen gegeben bat.

5. Cotta bingegen berlangt: Daß fánon im jugenoliden 2llter ber Beftänbe, balo nad erfolgtem $\mathfrak{A}$ btriebe ber Mutterbäume, ourd) mebrere

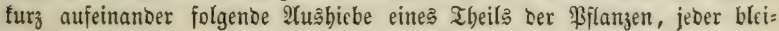
benten Biflanje fo viel Stanbraum gegeben werbe, als diefelbe für bie, von Rađbarpflanzen unbebinderte Entwidelung ibrer Beżeigung bebar, 
um an leşterer eine möglid gröpte Blattmenge zu erżieben uno zu erbalten.

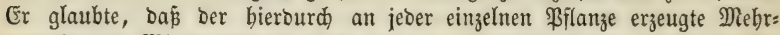

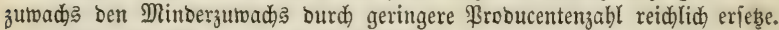

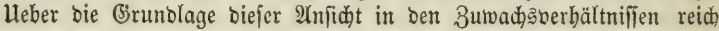
uno minoer reid belaubter Bäume babe id im 1ten Banbe (अbidnitt 3. F. b.) gejproden. (Es ging aus bem (5ejagten herbor: baß̧, jenfeit einer gemifien Grenze nothwentiger Belaubung, Der 3uwaḑs ber Bäume burd ein Mebr berfelben fid nidt erböhe. 2Ybgejeben bon ben größtentbeila

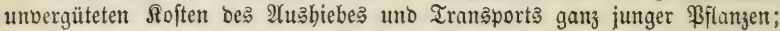
abgefeben von ben bebcutenben Berlujten mųbarer Durdforitungäbälzer; abgefehen bavon: bás nur auf einem, in feinem mineralifden Bejtanoe fehr frudbtbaren Boben bie Einzelpflanze im unbejdräntten Stanbraume rafcher

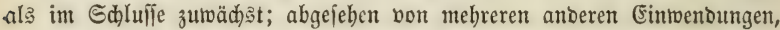

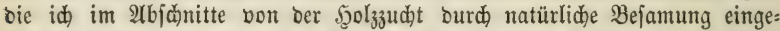

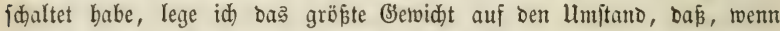

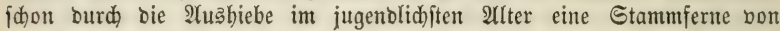
6-8 Jusen hergeftellt werben foll, biefe nothwentig fich aud auf prä=

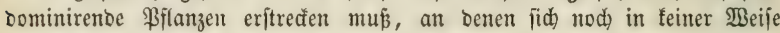
crfennen läpt, ob fie zu ben lebensfräftigften ober minoer lebensftäftigeren gehören.

In neuerer Beit ift nod eine ztweite 2rbweid)ung bom Şartigiden

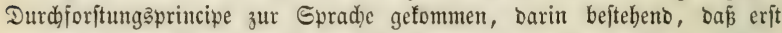
vom mittleren Alter ber ந̧odnalobejtänoe aufwärţ eine ftärfere Durd) forftung cintreten folle; Dañ, won bem Beitpuntte $a \mathfrak{b}$, in tweldem bie $\mathfrak{B} e=$ ftänbe ibren Ђöbentwuds unt ibre Edaftbiloung nahe vollendet baben, ber Sronenausbreitung burd ftärfere $\mathfrak{A}$ ushiebe volle Freibeit gegeben werben folle. (E⿱ in Den Durdforftungsorratb ber Şodyalobejtände bebeutende

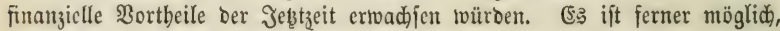
Daf auf einem, in feinem antorganifichen Bejtanbe fräftigen Boben auf biejem MBege ein ftärferes Gdafthols erzogen wiro, obgleid aud bier:

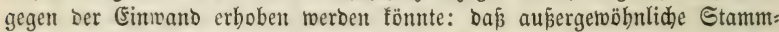
ftärfen, wo fie nidt au३ außergetwöhnlider Stanoorţ̧güte berborgeben, erft in böheren Baumalter, unb zroar erft bann fid außbiloen, wenn ber

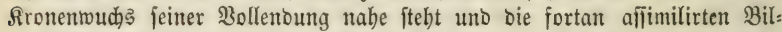

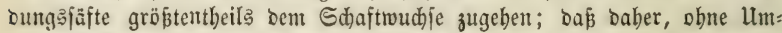
triebserhöhung, in bem furzen Beitraume vom 80ten - 1.20ten Jabre, bei

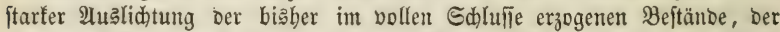
gefteigerte Sronenzuwads ben größeren Theil ber Biloungşäfte für fid in 2(njprud) nehmen uno bem Edaftzumadje entziehen werbe. Unjweifelbaft iit

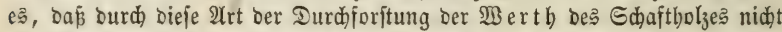
verringert wirb. Dagegen muß id bie Steigerung bes gejammten 3uwadjes

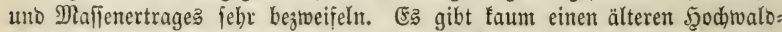

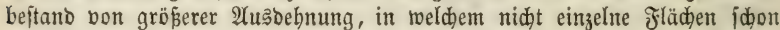
Yängere 3eit unter einer, jenem Durdforitungaprincipe entiprechenden, weit=

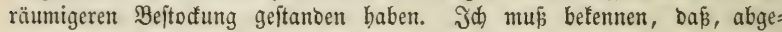

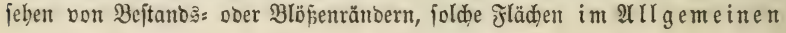


mir niabt ben Cinbruaf binterlailen haben, als jei bort bie geringere Stamm=

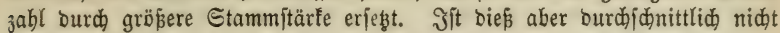

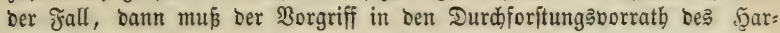
tigiden ßrincips einen 3uwadbauझ̆fall ergeben, im Betrage berjenigen Sुolzmajie, bie an ben vorzeitig bintweggenommenten Durdjoritungştämmen bis zu beren rechtzeitigem 2 btriebe nod erfolgt fein würbe.

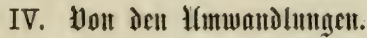

Wir haben im Borbergebenden nidht allein bie verjojiebenen Betriebs: arten fennen gelernt, fonbern aud bie Berbältnifïe, unter benen bie eine

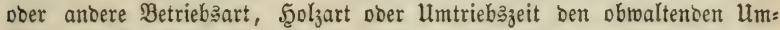
ftänben entipredjeno ift. Beigt es fid nun, baß̄ leşteres in einer vorlie:

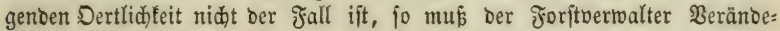

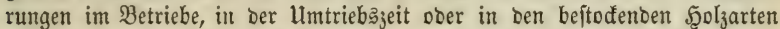
eintreten laffen, beren ßorlauf gleidffalls an gewifie Regeln gebunben iit, bie in Folgendem ihre Daritellung finben werben.

\section{Dृierzefintes \$apitel.}

Bon Untwanorung Der Betriebsarten.

Bei Ummandlung ber Betriebsarten hat man barauj zu ieben:

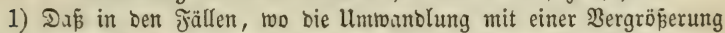
ber Beftandకెmaijen nothwentig berbunden ift, wie ३. $\mathfrak{B}$. beim Uebergange

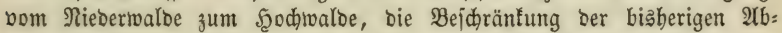

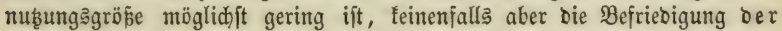
bringend ften $\mathfrak{B}$ ebürfnifie unmöglid wiro. Ein Ummanolungällan, ber biejer Bebingung nidt entipridt, wirb, wenn aud begonnen, Dod nie nollentet werben, fonbern von bem 2lugenblide $a b$, wo bie Ridst: befriebigung beginnt, aufgegeben werben, ba bas wirflide Bebürfnip

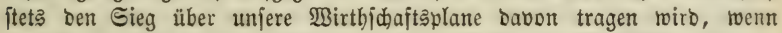
canbers eine Befriebigung befielben nođi im Reiđje ber Möglidłteit liegt.

Dả Mittel, weldes wir bejitzen, dieje Rlippe ber Mirthidaftsplane

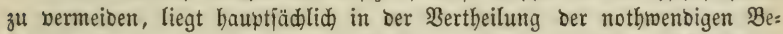

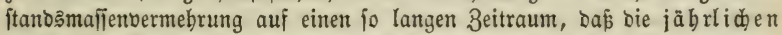

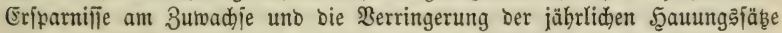
nicht größ̈er fino, als bie Befriebigung ber Bedürfniffe bieß geftattet.

2) In ben Fällen bingegen, wo bie Umwandlungen mit einer $\mathfrak{B e r}$

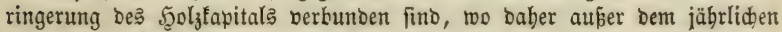

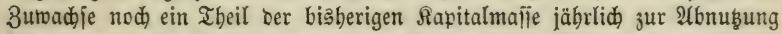
fommt, wie beim Utebergange von ber Şodjwald: zur Mittelwalowirtbidaft, von ber 5ुod = ober Mittelwalowirthidaft zur Rieberwalbmirtbidaft, muई

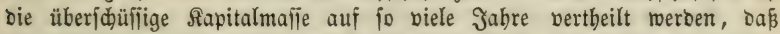

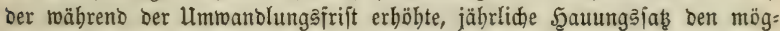

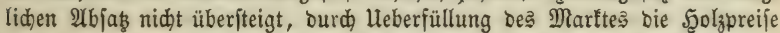
nicht io weit hinaborüat, baj ber bieraus hervorgehende Mindorerlös die 3ortbeile bes böheren Materialertrages überfteigt. (E⿹ i it ferner barauf $3^{4}$

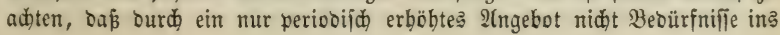


Seben gerufen werben, bie fpäter nidjt befriebigt werben föunen uno twent fie unbefriebigt blciben, bie Reigung zum Diebitahl erböben.

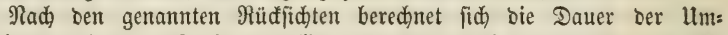
wantlungsperiobe, auf bie natürlid auperbem nod Stantorts: uno $\mathfrak{B e}=$ itanoŝverbältnifje twejentlich eintvirfen.

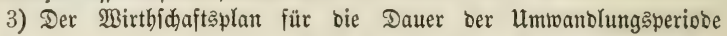

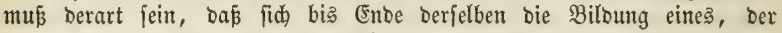
neuen Betriebsart entipredenden 2Ulterätlaffenverbälnifię der Bejtänbe er: warten läpt.

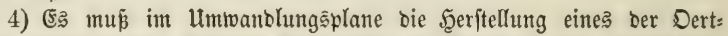

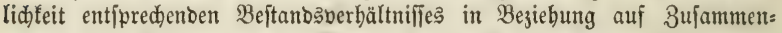
legung ober Bertbeilung Der AYteraflaffen, auf Sdlagfolge, Ridłtung ber Şiebaleitung zc. berüdfidtigt werben (vergl. bejonbers bas, was id im

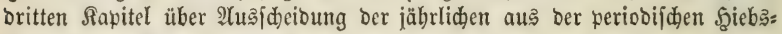
fläche gejagt babe). (Enolid)

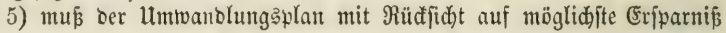
an Beit uno Rulturfoften, Bermeioung von Buwadşverluften verfapt werben.

Sür bie veridiebenen $\mathfrak{A}$ rten ber Umwandlung gelten folgente allge= meine Regeln.

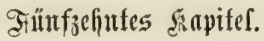

Ilmwanolung bes 5ुody toaldes in Riebertwald.

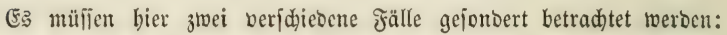
uno jwar 1) ber Jall, wo im biakerigen Betriebe bie benadbarten Alterßflafifen beifammenliegen, uno 2) two fie febr gemengt untereinanoer vorfonmen.

Im erfteren falle, wo mit geringen $\mathfrak{H}$ usnabmen bie baubaren Drte, bie mittelwüdfigen uno bie jüngeren Beftänoe in brei ziemlid geidhlofienen Eompleren vorfommen, bilbe man aus jebem berjelben einen befonbern Wirtbidaftstheil uno theile benfelben nad) ber 2lnleitung über ben $\mathfrak{B}_{e}=$ trieb ber Rieberwalowirthjdaft in fo viele Jabresjdläge, als ber Nieber. waldumtrieb Jabre umfaffen foll. In einem Theile bes, bie haubaren Drte entbaltenten Şaupttheila beginne man jogleid) bie Berjüngung burd Samenidläge uno fübre fie in einer Nieberwaloumtriebşzeit zu Enbe, in: bem man entweder nady ber Wieberfehr ber Samenjabre ober nad sem 3eitraume zwifden $2 \mathfrak{n}$ bieb uno $2(b t r i c b$ eine größere ober geringere $3 a b l$ von Jahreşकlägen zujammenfapit.

Эn bem bie jüngften auझ̆[lagfäbigen Drte enthaltenben Şaupttheile fann fdon jeķt (rwie in ben gegentwärtig mit haubarem $\mathfrak{F}_{0} \mathrm{l}_{3}$ bejtandenen

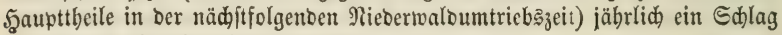
ala Riebertwald abgetrieben twerben.

Der Şaupttbeil mit mittelwüdfigem Şolze bleibt bingegen, auker ben nöthigen Durdforjtungen uno Borbieben, im Saufe ber erften Rieberwald: umtriebşzeit, uno bis er zum verjüngungşäbigen 2Alter berangewad)jen ift, unberübrt, wiro bann, wie ber erite Scaupttbeil gegentwärtig, burd) Samen= ¡d)läge veriüngt.

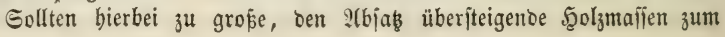




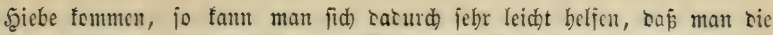
Samenjalläge niđjt gänzlich vom Mutterkejtanbe befreit, fonbern mur fo

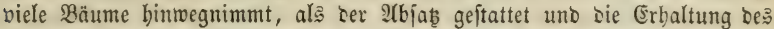

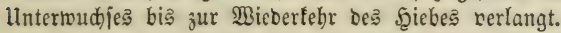

Im jiveiten falle, wo bie berihiebenen Beftandäalter jebr gemengt untereinanter borfonmen, wohin man aud) Den Pläntermalo redgnen fam,

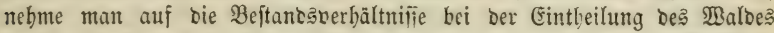
in Sgaupttheile uno in Jabre: id)läge feine ober nur untergeorbnete Rüđfidt.

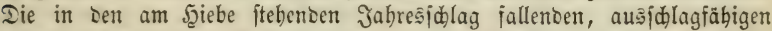

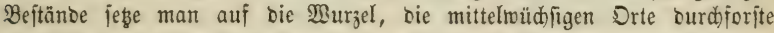

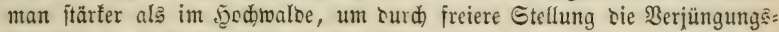
fähigfeit burdh Eamenidläge früber berbeizuführen; die alten Drte Des am bicke ftehenden unt ber zunädjt liegenden Edläge ftelle man in Gamen=

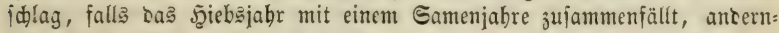

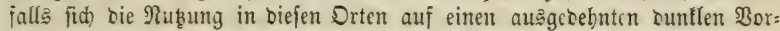

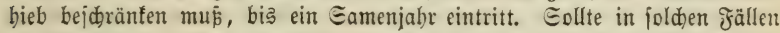

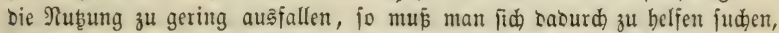

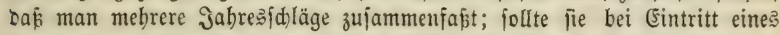
Gamenjabres ju grof werben uno bon 2tbją̧ überfteigen, fo baue man nur

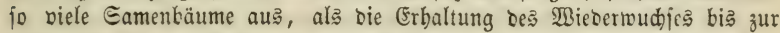
Wicberfebr bes Şiebes bringeno berlangt.

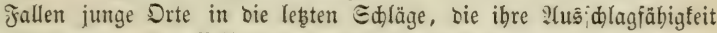

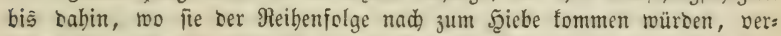

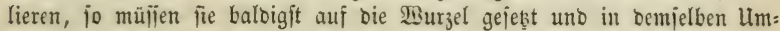

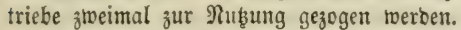

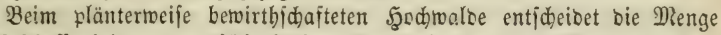

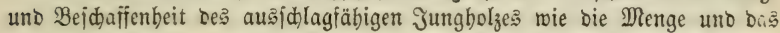

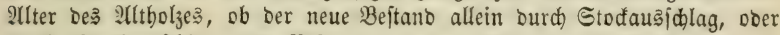
burd Stofausidlag uno Bejamung, ober allein burd Stellung eine? Eamenjoblags bergeitellt werben mū́ ( ber mit altem uno jungem $\mathfrak{S}_{0} l_{3}$ beftanbenen Edjäge in ier Sebie von ber

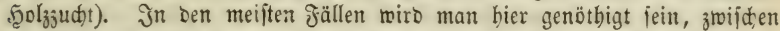

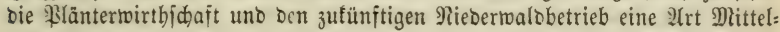

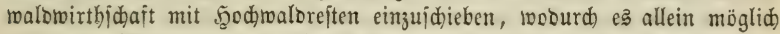

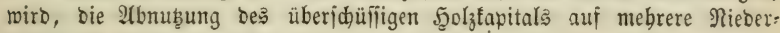
maldumtriebe ju vertheilen.

\section{Sediszefintes sapiter.}

Bom 5ृodrarb= Conjerbationghiebe.

Das von (5. \&. Şartig vorgeidlagene mit obigem Namen bejeid:

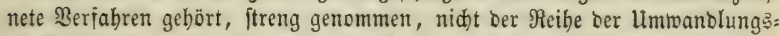
metboben an, mag aber, ba es fich ihnen bod eng anjidließst, mit ben Borten Des Berfafiers bier feine Stelle finden.

„Bei ber Forjtmirtbiđaft fommt, leiber! nur zu oft ber fall vor, baf́ man $\mathfrak{B a l}_{\text {a }}$ ungen findet, bie vormals ju ftart angegriffen soer überbauen murben, uno nun bon eigentlid) baubarem $\mathfrak{S g l j}_{\mathrm{j}}$ fajt ganz entblöft fint. 


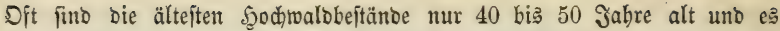
fann baber, wenn man fie wie Şodywaloungen behanbelt, nur bał ganz unterbrüđte Stangenbol $\mathrm{l}_{3}$ ausgeforitet, aljo im Bsanzen nur wenig aus ihnen genommen werben, weil ber bominirende Şolzbeftano erit in fpäteren Beiten als 50 od twals zur Benukzung fommt."

"Reidht nun, wie es gewöhnlid ber Fall ift, bas wenige Durdfor:

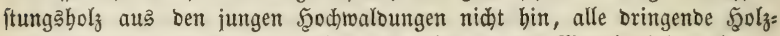
bebürịniffe zu befriebigen; fo bleibt oft fein anderes Mittel übrig, als toe: nigitens in einem Theile ber Şodmalobeftände auf eine 3eitlang bie Nieberwalowirtbidaft mit ber Şodwaldzudt zu verbinden,

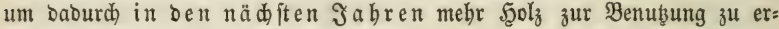
halten. Man treibt baher einen Theil ber $40=$ bis 50jäbrigen Scodbrald =

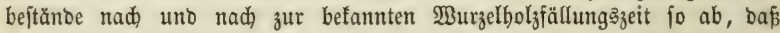
alle 14 bis 16 Fuß eine, ober auf jebem Normalmorgen 150 bis 200 von Den jt ärfften Stangen in gleidher Bertbeilung fteben bleiben."

"Durd eine foldhe Şauntg wiro man nidst biel reniger Sgolz befom: men, als wenn man einen getwöbulichen Wurzeljoblag gebauen bätte, uno man wiro zugleid) ben 30 ortheil baben, Dás bie ftehengelaffenen Stangen in ber Folge wieber einen 5odwalobejtano formiran. $\mathfrak{A}$ ud werben bie $a b$ : gebauenen Stangen vom Stod redst gut wieder auşమlagen, unb ę werben bieje Soden nad) Berlauf von 30 oder 40 Jabren eine anjebnlide $\mathfrak{B} e=$

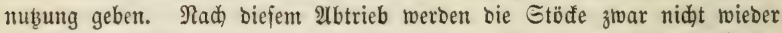
mit Erfolg ausfidlagen, weil bie viełen, bei ber eriten .̧auung übergehaltenent

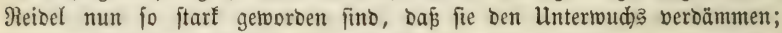
bagegen ift aber aud ber Scodiwalobejtand erhalten worben, ber nun be= trädtlich) ftarke Bäume hat, uno nöthigen Falls auf bie befannte $\mathfrak{Y}$ rt in Dunfelichlag geftellt uno burd natürliche Bejamung wieber bejiüngt wer: Den. fam."

"Da ber jährliche Scolzertrag von einem Morgen gut behandeltem Rieberwalo bei weitem nidht fo gró ift, als bon einem Morgen gut be=

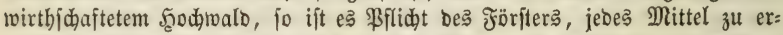

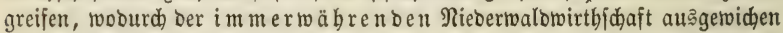

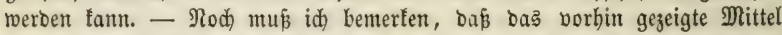
mur ba anvenobar ijt, too man aus Erfahrung reís, baf bie in ben Sdlägen übergebaltenen Stangen bom Schnee und Duft nid̈t zujammen= gebroden werben; in ben meiften Fällen wirb man burd vorberige mebr:

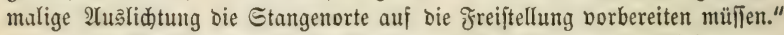

Eine Modifitation Des (5). L. Sgartig'iden Eonjervationshiebes, an= gerwendet auf Rothbuđenbeftänbe von 50-70jäbrigem Âtter, bie burd̆

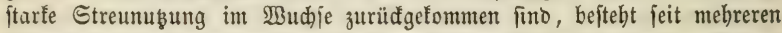

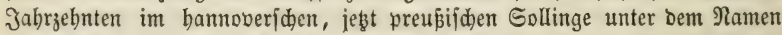

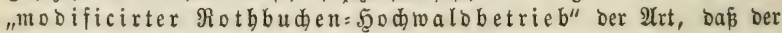

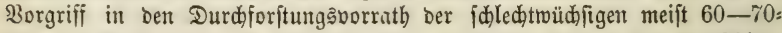
jäbriger Budhenorte erit bann eintritt, wenn bie Stöde ihre 2(usfidlag:

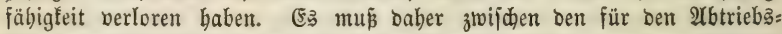
bejtalı verbleibenden Bäume ein Bobenjoub hergejtellt werben uno gejdiebt bas Durch ftreifenweife Budhenjaat. Mit bem Bortheile eines $\mathfrak{B}$ ezugs an 
ftärferem, baher werthoollerem $50 l_{z}$ ijt bie Annehmlid̆feit verbunden, ohne vorbergegangene 2rblöjung ber Streuberechtigten bie betreffenden Beftänoe ber Saubnubung entzieben zu bürfen, alleroings ziemlid theuer erfauft, burd ben bebeutenoen Rulturfoftenaufmano, nidjt allein für ben ourd, Buchenjaat berzuftellenten. Bobenidubs, mebr nodh für bie Sintwegidafïung Des im Edhatten Des fí) fóliefenten Oberitanbes verfrüppelnoen Unter= wudjes. Beim Conjerbationsbiebe fielit fid ber Bobenjकus aus bem

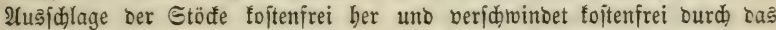

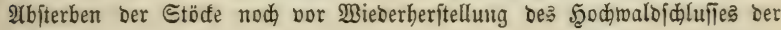
übergebaltenen Bäume.

\section{Siebenzefintes Sapapifel.}

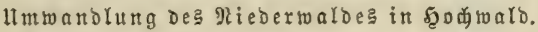

Wenn es barauf antommt, bieje Ummanolung mit ber möglidit ge= ringiten Edmälerung be bişherigen Errtrage uno mit Şeritellung eine?

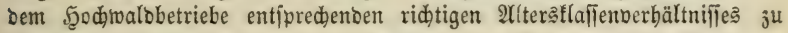
bervirfen, fo mödte bas folgenbe Berfahren ben Borzug bor ben bisher in Boridlag gebradten haben.

Man beftimme bie Umtriebszzeit bes zufünftigen Şodivalbes möglidjit

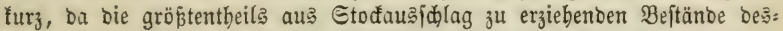

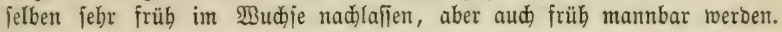
3. B. 90 Jabre.

Şierauf theile man ben $\mathfrak{W a l}$ in brei gleidy grope ober proportionale Şaupttheile A, B, C. Mit Den für ben Şodmalobetrieb nöthigen Rüd:= fidten auf Gdjlagfolge 2c. juche man ber 2tbtheilung A bie älteiten, bei 30jährigem Nieberwaldumtriebe baber 20-30jährigen Єaläge, ber 2(bthei= lung $B$ die 10-20jäbrigen, ber 21btbeilung C bie 1-10jäbrigen ßejtäntoe zujulegen. एङ ftört jeodd) bie Ummandlung nidjt, wenn aud in jebem Şaupttbeile alle Afltersflañen vortommen. Seben biejer brei Şaupttheile theile man in 30 (bei 120jährigem Sgodrwaloumtriebe in 40) Jabreşadläge.

Bäbreno in Den nädften 30 Jabren bie Sgaupttbeile B uno C nod als Rieberwalo bebanbelt uno jäbrlich in jeoem ein Sd)lag gehauen wiro, ift ber Şaupttheil A einer veridiebenen Bebanblung zul unterwerfen, je nachbem er jüngere uno ältere Beftänoe (1-30jährig) ober nur älteres

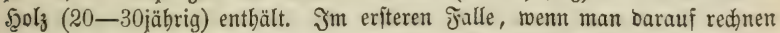

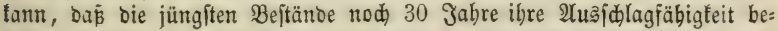
balten, fübrt man jäbrlich wie in B uno $\mathrm{C}$ nur einen Sabreşjdlag, in A

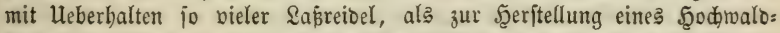

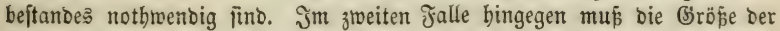

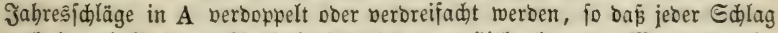
noch innerbalb feiner 2 (uş Dann mit biejem Şaupttheile allerbings vor 2(blauf ber erften Umwandlungş: periobe fertig, allein gerabe baburd wirb ber Gejammertrag aller brei Şaupttheile auşgeglid̄en, indem man mit jeoem Jabre in ben Şaupttbeilen $B$ und $\mathrm{C}$ älteres $\mathfrak{F}_{2} \mathrm{l}_{z}$ z zum Şiebe betömmt.

Nach 30 Jahren hat man bann in A 30 -60jäbrige ober $50-60=$ 
jäbrige Oberitänber mit linterwuchs, in B uno C bingegen 1-30jährige Riebertwalojøläge.

In ber żweiten 30jäbrigen ßeriobe wirb bann $B$, in ber britten

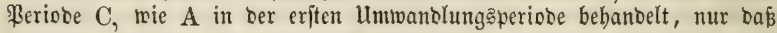
man in ber zmeiten uno britten ßeriobe bie Jahreşd läge beftimmter ein= zuhalten vermag, wie in ber eriten ßeriobe.

Man erreidst bei biejer Ummandlungsmethode nidjt allein bie (Fin:

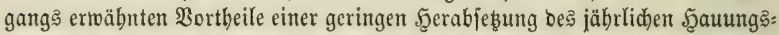

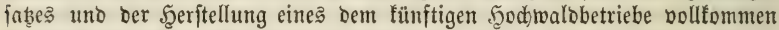

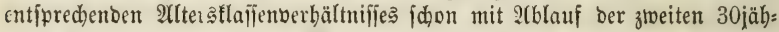
rigen Unmwandlungaperiobe, fonben man wirb aud im Stande fein, bie Utmmandlung felbft vollfommen auşufübren, ba man in B einen 30jäbrigen, in $\mathrm{C}$ einen 60jährigen 3eitraum zur Borbereitung Der Drte für bie $\mathfrak{l t m}=$ wonolung bor fid bat.

Wo bie Eingangs geftellten Bebingungen nidht ftatt finben, ba fann man ben ganzen Ricberwalo ohne weiterses berantwadjen laffen, indem man fid bi३ zur Berjüngungäfäbigfeit burd) Samenjaläge mit bom Şicbe

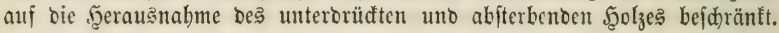

\section{Dedifzefintes siapite?.}

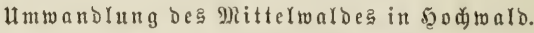

Man entmerfe zuerft mit untergeoroneter Rüdfidt auf ben gegenmär:

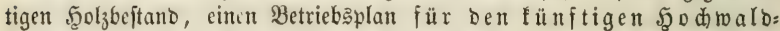
betrieb, ourd) welden bejonbers, jowohl im $\mathfrak{B a l b e}$ als auf ber Rarte, bie Crrößpe uno \&age ber fünftigen ßeriobenfläden feftgeftellt wiro. Sit biernach Der $\mathfrak{B a l b}$ in fo viele Theile zerfällt, als ber tünftige Şodjwald: umtrieb Berioden zäblen foll, ift ferner aud) bas Jabr bes Beginutę einer jeden Periode uno ber 3citraum bejtimmt, in weldhem bie ifr zufallentent Beftänbe zum 2lbtricbe unb zur Berjüngung fommen jollen, fo entwerfe man für bie Bebanolung ber borbandenen Mittelwalobes itän be, wäbreno ber Dauer be erjten, cbenfalls möglidjit furz zu faffenten Umtriebes cinen Wirtbjd)aft引plan, beficn Boridriften babin geben mülfen, auf jeber ßeriodenflädje biß zum Beginne ibres 2(nbiebes cinen Şolzbeftano $j^{4}$ erzeugen, ber alşbann verjüngungäfäbig ijt.

Şätte man z. B. einen 90jäbrigen Umtrieb uno Einrid)tungşzeitraum

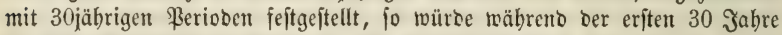
bie erjte ßeriobenfläche verjüngt, bie zweite uno britte bingegen fo behan= belt werben müffen, bafs fie nad) 30 uno 60 Jabren einen zur Berjüngung geeigneten \$golzbejtano entbielten. Wie nun bie ßerjüngung, fo twie bie Borbereitung zu berjelben betwirft werben müffen, barüber lafien fid feine allgemeinen Regeln aufftellen, ba biếp allein bon ber Menge uno Befdjaffen= heit Des Sber= uno Unterholzes abbängig ift, mitbin eine unzählige Menge veridhicbener fälle dentbar finto. (Bergleid)e bie Berjüngung mit altem

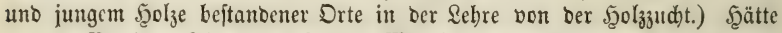
man 3. B. einen jebr gut beftodten Mittelnalo mit fräftigen Miutterftöđen, io mürse man mäbreno ber eriftn 30 Jabre anf ber eriten Feriobenfläd)e 
jäbrlid) einen Edjlag rein abholzen, uno ben Mieberwudjs aus bem Stodf: aușjhlage erziehen; in berjelten Beit würbe man auf ber zmeiten ßerioben= fläd)e gleidfalls jährlid einen Edjlag in Şieb nehmen, Dabei aber alles

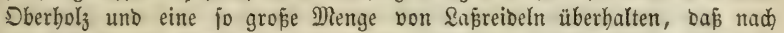
30 Jahren eine Berjüngung burd) Samenjdläge möglid) rwirb; gleidjall( in ben erften 30 Jahren twürbe audi auf ber britten \$eriobenflädbe jäbrlidy ein Ed)lag gefübrt werben, mit Şintvegräumung Deşenigen Dberbolžes, welches feine 60 Jabre auşzubalten vermag, Dabingegen mit Heberbalten fo vieler Sapreibel uno Dberitänoer auđ gejunber angebender Bäume, baई nad) 60 Jabren bie Nerjüngung burdh Eamenjaläge möglid wirb.

Im Berlauf Der zmeiten ßeriobe ift bann ber Beftano ber eriften Periobenflädje zu burdforften, ber ber ztweiten burd Samenjaläge zu ver: jüngen, währent auf ber leşten eine Benuķung ber nod) erfolgten Stod:

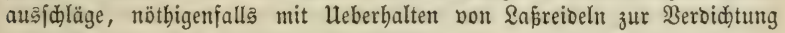
Des zufünftigen Mutterbejtanoes ftattfinot.

In ber oritten Beriode fino die erite uno ztweite ßeriobenfläche zu Durchforften, Die britte burdh Samenjaläge zu beriüngen. Der Şodiwalo: betrieb tritt alio fodon mit $\mathfrak{B}$ eginn ber britten Beriode mit Scerftellung eines

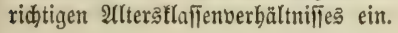

\section{D̈teutzefintes siapife!.}

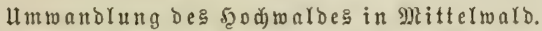

Sie wirb im Allgemeinen nach Denjelben Grunbjätzen, wie bie Um:

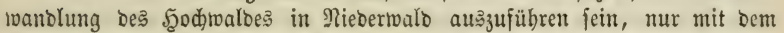

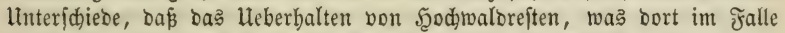

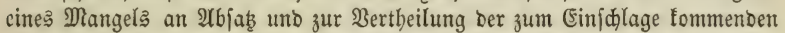
bebeutenden Şolymafien auf einen längeren 3eitraum auß̉nabmsmeife vor:

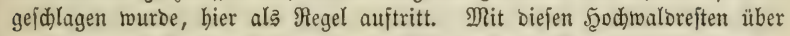
Dem erzeugten Unterwudje mú Denn io lange gemirtbjhaftet werben, bis man aus bem llnterbolze einen Dberbolzbeitano erzogen bat. (23ergl. Sapitel 5.)

\section{Zైarzigftes çapifel.}

Umwandung Des Riebertolde马 in Mittelwald.

Das Berfabren ergiebt fid genügeno aus ber Sebre vom Mittelwalo:

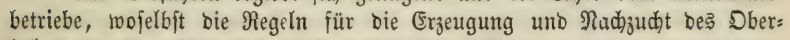
holzes aus bem Unterholze zujammengeftellt finto.

\section{Simutrozmanzigftes siapitel.}

Heber ben Wedjel ber Deorzarten.

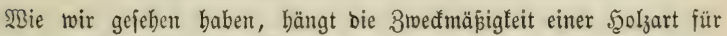
cine gegebente Dertlichteit fowohl von Standorts: und Beftandşberhältnilïen,

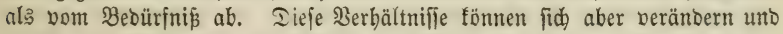
fomit eine bisher ber Dertlidłeit anpafiende Şolzart ber Erreidung bes

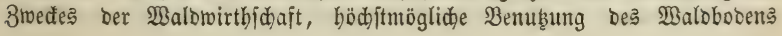


Durd) Erziebung von Walbproduften, - nid)t mebr entipred)en. 5̧äufig fommen aud nod) Fälle vor, two eine joldhe Zmectmäpigfeit twegen man= gelnber (Einfidet nody gar nidbt bejtanden hat.

In beiben fällen ift es Sad,e bes froritmannes, an bie Stelle ber

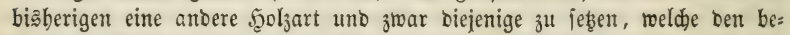
ftehenoen Berbältniijen am meiften entipridt. Weldje Scolzart bie zu be: günjtigende fein muiffe, finbet theils in bem $\mathfrak{A b j}$ dnitte: über bie $\mathfrak{B a b l}$ ber Scolzarten, theils in Der \&efre bon Der Bodenfunde uno ber Foritbenuķung Erörterung; bier haben wir uns nur mit ben Berbältnifien, burd) weldhe

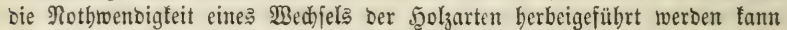

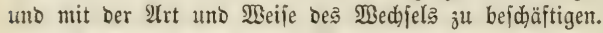

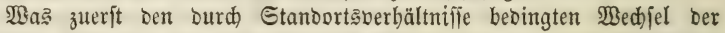

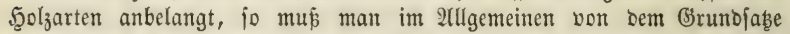

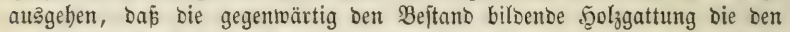

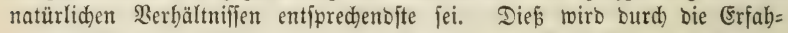
rung vollfommen beftätigt, Denn wir finden in ber Wirflidfleit bie in reinen

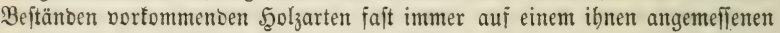

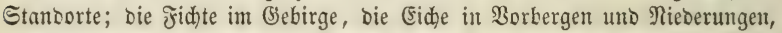
bie תiefer in Dem jandigen Mleeresboben, bie Erle im Brud)boben, bie Weide an janbigen fllup̧ufern :c. Diés ift mu theilweife Durdh Rultur veranlā̄t, gröptentheil’ Jolge "eines Ramłfę um's Dajein," natürlidje Folge bes llmitandes, baf́ eine jebe folzart auf bem ibr am meiften ent= ipredenten Boden am freubigiten gebeiht, unt, alle übrigen 5olzarten über= radbjend, bie Fläde für fid allein in ?tniprud nimmt.

Daß Borfommen ber Şolzarten in reinten uno ausgebreiteten $\mathfrak{B} e=$

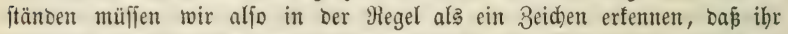
Etanoort gerabe ihnen am meiften unto mehr als allen übrigen Sgolzarten

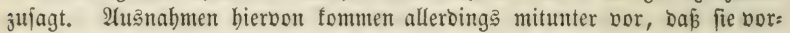
liegen, bebarf bann aber ftets wenigitens oer Wabrjokeinlidłeit.

Die Eigenthümlidfeit eines Standorţ ift zujammengejeß̧t aus Be:

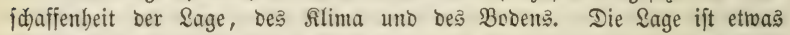

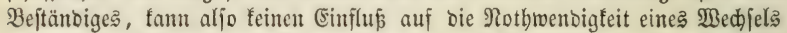
baben. In faft gleident Grabe ift aud bas $\mathcal{R}$ lima als beftänoig zu be= trad)ten, wenigitens bürften fich für Deutjd)lano menig Fälle nadbeifen

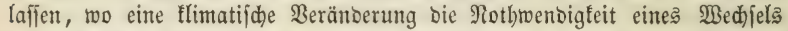

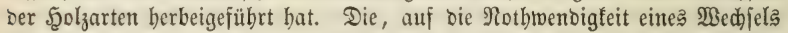
Einflüfie übenden Beränberungen bes Standorta befdränfen fid baber auf Beränberungen Des $B$ Doenß, uno biefe auf Berringerung ober Bermeh= rung des Dammerbegebaltes unt Jeudtigfeitsgrabes. Fine Bermebrung oder Berringerung Der unberänderliden Beftanbtheile bes $\mathfrak{B} 0=$

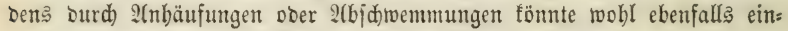
wirfen, tritt aber nur felten, 子. $\mathfrak{B}$. in Gebirgäwaloungen, und bort nur in langen 3eiträumen herbor, fo Dás ibr, wie ben Beränderungen burd) Sanbflug, nur untergeoronet ein (Einfluf auf ben Wedjel ber Şolzarten zuzujdreiben ijt.

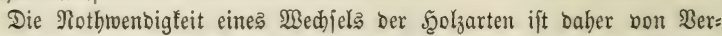

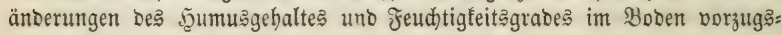


meife abbängig; mo biefe nidht Statt gefunben baben, bejtebt aud feine Beränberung bes Etantorts, uno alle nadfolgenben Beftandzgenerationen Derielben Fुolzart werben ebenjo gebeihen, wie bie vorhergehenten, fo weit bas Gebeihen vom Etanbort überbaupt ahbängig ift. Den 2(nfichten über eine in

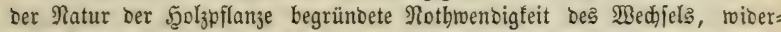

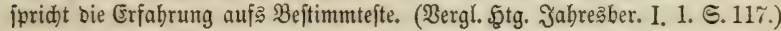

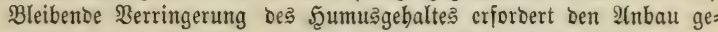
nügiamerer, aber aud) foldjer Şolzarten, bie ben Boben rieber frudbtbarer ju madjen bermŏgen; baber nidht ber Birfe, $\mathfrak{A}$ (jpe, jondern ber Riefer, Fid)te 2c. Erböhung ber Bobenfruळtbarfeit gejtattet ben 2 nnbau eolerer ફ̧olzarten.

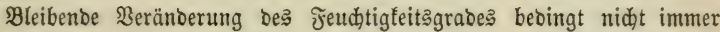

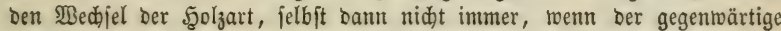
5yolybeftand in Folge Des beränberten Feud)tegrades frant wirb coer gar eingebt, da Der neue Beftand Derfelben Scoljart mitunter eben fo freubig ba twädşt, wo ber alte fräntelte, inoem die junge Bilanze ibre Drganifation

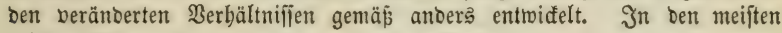
foldjer Fälle wiro aber allerbinģ eine Beränderung ber Şolzart, wenn

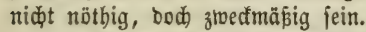

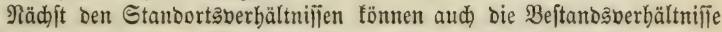

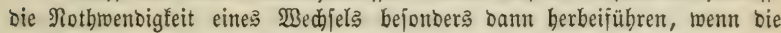

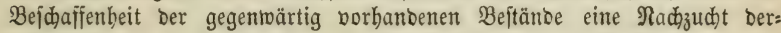
jelben S2olzart nidst geftattet, wie bei Rothbuden uno Weistannen, Doer

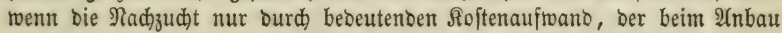
einer anberen Fुolzart bintwegfällt, zu erreidhen ift.

Dáp enolid aud eine 2(enderung bes bisher beftebenden Bebürfniffes

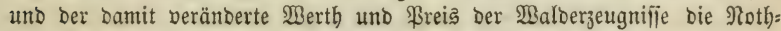

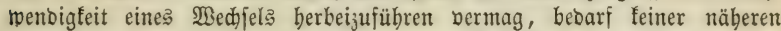

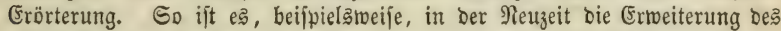
Eifenbahnneb̧es, burch welde die Ennjumtion ber Mineralfoble einem größ̈eren Eonjumententreije fid erjकloffen, uno ben Brennbolzberbraud) bejdränft

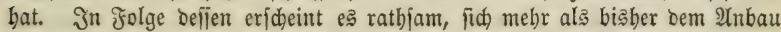

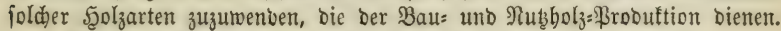

$\mathfrak{I} \mathfrak{m}$ bäufigiten uno anmenobariten fino folgente Beftandswedjel:

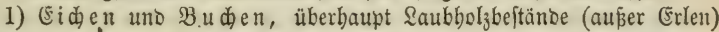
auf $\mathfrak{M e e r e s b o b e n ~ m i t ~} \mathfrak{R}$ iefern. Diejer $\mathfrak{W e d j e l}$ wiro bejonbers ba bäufig nöthig, two ber Boben nur burdh grope Şumusmafien, bie ifm bei er:

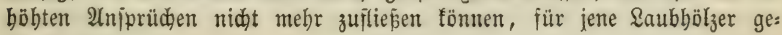
eignet twar.

2) Rothbuden mit (Eiden: wenn ber Booen ber (Fid)e angemeñen,

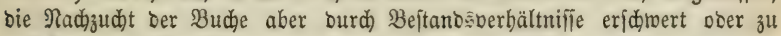
unjicher roirb. Jn flupnieberungen fann an bie Stelle ber Eidjen in biejem Falle bie Rüfter in reinen Bejtänoen, in Borbergen Ejđden uno 2 borne, wenigitens in Untermengung treten.

3) Eiđen uno Buden, überhaupt Saubholzbejtänoe im Csebirge

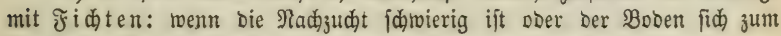
Radłtbeile für jene Saubbölzer veränøert bat. 


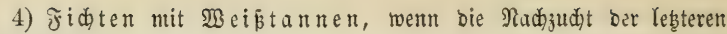
unfider wirb.

5) Fidten uno $\mathfrak{I} a n n e n$ mit $\Re$ othbuden: im Gebirge, wenn

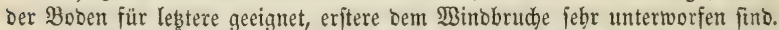

6) Birfen mit Erlen ober Erlen mit Birfen bei Berringerung Doer Erhöhung bes Feudtegrades im Bruchboden. Sit bie Berringerung ber Jeudtigfeit febr bebeutento, fo fann mitunter an bie Stelle ber Erle im (Bebirge bie Fid te, in Der Ebene bie Riefer treten.

(Bibt fich in einer borliegenten Dertlidfeit bie Notbwendigfeit eines Bechjels Der Şolzarten zu erfennen, fo wirb biejer größstentheils nur burch

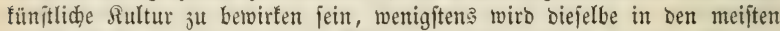

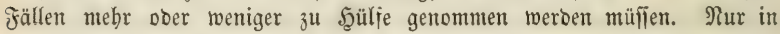
Dem Falle, wo bie zu begünftigende $\mathfrak{S}_{0}$ ljart $_{\text {nit }}$ Der zu bertilgenden bereit

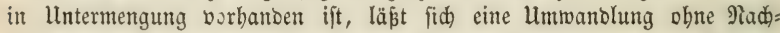
bülfe burd) 2 nbau mitunter bewirfen. Man ftellt alsbann einen Sament id)lag in bem Jahre, too bie zu veriüngende Şolzart reidhliden Samen trägt, bält nur io viełe Bäıme ber zu vertilgenton $\mathfrak{J}_{0} \circ l_{\text {zart }}$ über, als ber

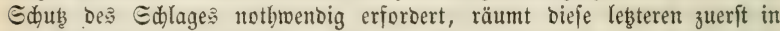
Den Sidht= uno $2(b t r i e b s$ d)lägen bintweg, pflangt bie \&üfen im jungen Drte

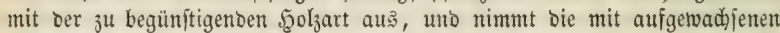
Bflangen der zu vertilgenden Gुoljart, joweit biép Der Beftand erlaubt, in Den Durdforitungen beraus. Eine weitere Errörterung finoet biejer Sbegen= ftand in Der Syolzjucht, wo Die Berjüngung gemengter Beftänbe gelebrt

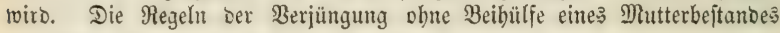
fallen ber Lebre vom Sgolzanbaue ankeim.

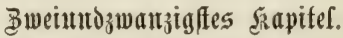

Ueber $\mathfrak{B e r a ̈ n d e r u n g ~ D e s ~} 11$ mtriebs.

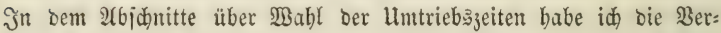
bältnifie nad)gewiejen, welde bei ben berideiebenen Betriebäarten auf Ulm=

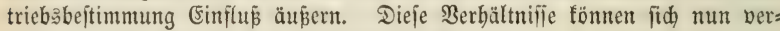

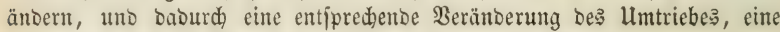
Itbfürzung ober Berlängerung befielben notbwendig mad)en.

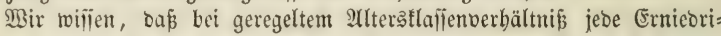

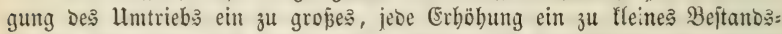

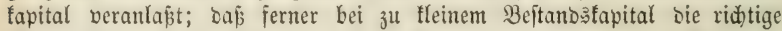
(Sröße idon allein burd Untricbserniebrigung, bei zu groß̄em Beftands: fapital Durch llmtriebserböbung bergeftellt merben fam. Beftebt bie \$er:

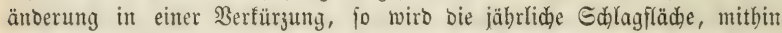

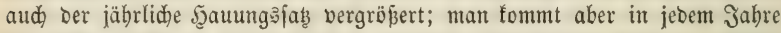

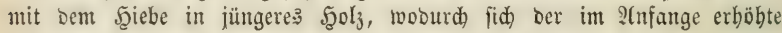
Ertrag allmählig wieber berringert, bis er, burdy ben mit bem fintenoen

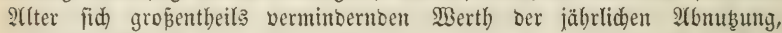

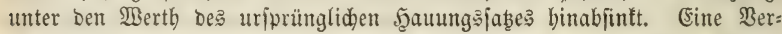
längerung Des Umtriebs bat hingegen \$erfleinerung Der Şiebsiläche, Sd)mü=

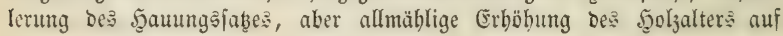




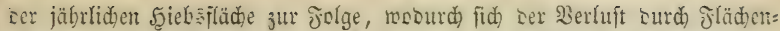

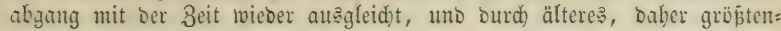
theil's werthoolleres Material oft mehr als vergütet wiro, wemt bie llm=

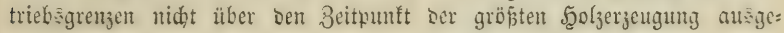
Dehit toerbent.

Die oben genannten Folgen Der Umtriebsoeränderungen fint nun in

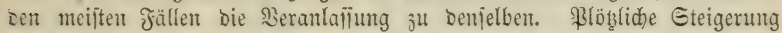

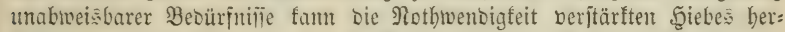
beifübren; biefer fam nur Durd) 2(bnub̧ung von Sapitalmafien bejogen

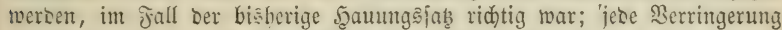

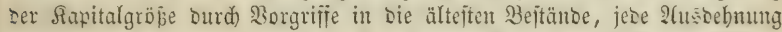

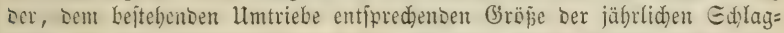

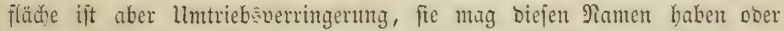

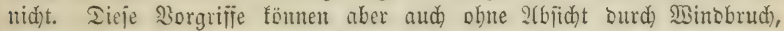
Injeftenifhaben 2c. herbeigefülut werben uno Intriebśberänoerungen nöthig madien.

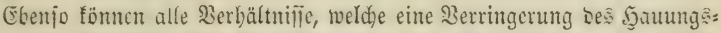
fabes, eine Grböbung Des 2lbtriebalters ober Nerringerung ser Sciebs:

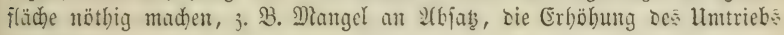
erbeijoner.

Eine jebe Beränourung Des allgemeinen Untrieb hat eine Serände: rung Des bisherigen Betriebshlans jur Jolge, unb jieht baher die Er: neuerung obcr wenigften: bie Lmarbeitung belfelken nad) fid. (5.5 mus vor allem sie frage erlesigt merden: joll ser beftehente Sapitulüferia)ū

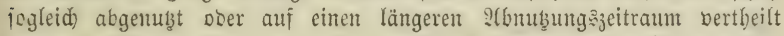
merben? foll ber Sappitalmangel in möglidjit furzer ober in längerer Beit eingepart werben?

Tie Frage, ob vorbanbene ober burd Umtriebserniebrigung

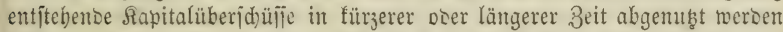

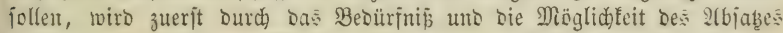

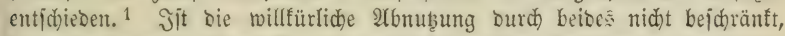

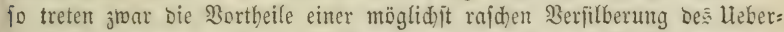
iduffes beftimment auf, Der Jorftmann bat aber Darauf Rüfificht zu neh)= men, baf́ burdh bie vorübergehende Eteigerung ber jährliden Şolzabgabe feine, Den zuf ünftigen, bleibenden albgabejab̆ überjteigenten Besürf= nilie erjeugt werben, Deren Jortbeftehen immer tiefere Eingriffe in bie

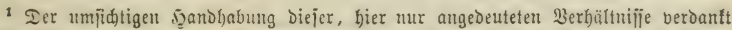

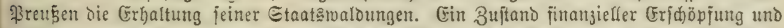
Die Borahnung nafer (Erfebung gegen Das von Franfreia) auferlegte jod), hatte bie frage

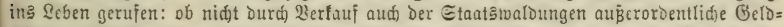

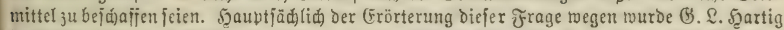
im Jabre 1811 aus roürtembergijd)em in preup̄ifhen Etaatabienjt berufen. थrs (5hef ber

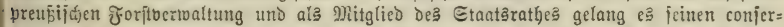
vatiben Grundfügen, unter Dem energijden Beiftande Deß Damaligen fronprinjen bie joce

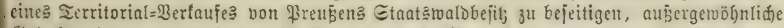

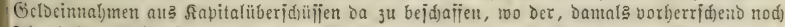

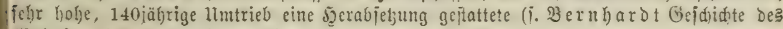
Maldeigenthums. Berlin, Epringer 1874. Bnod II, E. 240). 


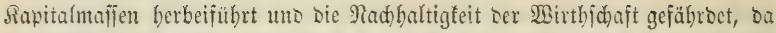

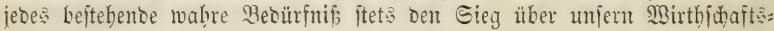
plan babontragen wiro.

Die Ztbnutzung frage fincet ferner ifre Erlebigung in ben Beriüngungs: nerbältnifient Der Dertfidfeit. Befteht an einem ober bem andern (stumse Die Nothwentigfeit einer Beriüngung burch natürlide Befanung, fo läp̈t

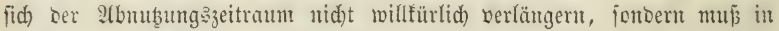

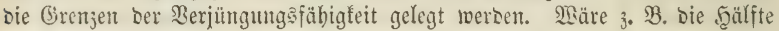

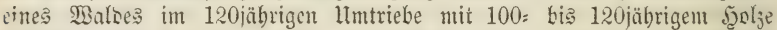
bejtanoen, die Erfahrung bätte aber gezeigt, Daj, fdon mit bem 140 ften Jahre, Der Serjüngung outh natürliche Bejamung großße Edmierigfeitent

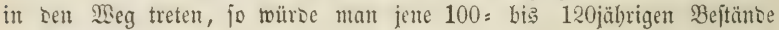
it ciutem 3eitraum von 40 Jabren zu verjüngen baben. Heberfteigt in

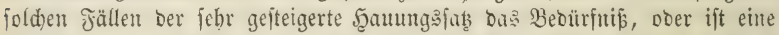
joldhe bedeutente Eteigerulg ans andern Groünon nidht rathjam, fo wiro man jid) oft burd) cine borïberzebenoe in einten Theil ber älteren Beftänoe eingelegte Mittelwalbmirthfd)aft belfen fömen, Deren Bwed babin gerid)tet

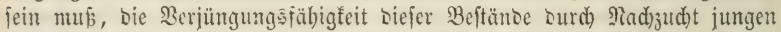

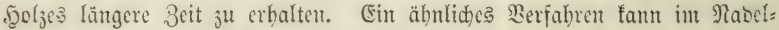
holgmaloe Dur(t) cine 2Art geregelten Plänterbetriebes in Antwendung tretert.

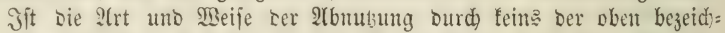

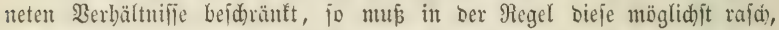
jebod) nit Rüdficht auf Şerftellung eitte triebe entipred)enoen :Iterstlaffenverbältnifies betricben wercen. Die (5runo:

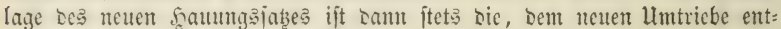
iprechento größ̄ere Şiebsfläche.

Jimien bingegen Bejd)ränfungen in ber 2(buubung Etatt, fo mus

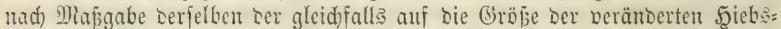

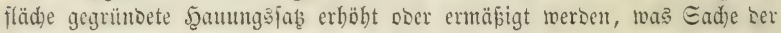
Betriebsregulirung uno Iaration ift.

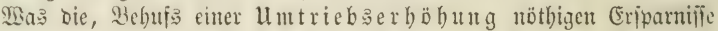
an 3unadjje anbelangt, fo twiro in Dent meiften Fällen bas Beourfiniß,

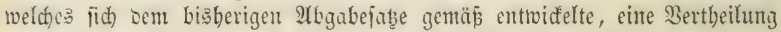
Des nöthigen Rapitalzulabes auf längere Beitrüume fordern.

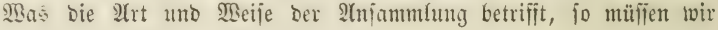
3twei veridjiebene fälle unterideiben:

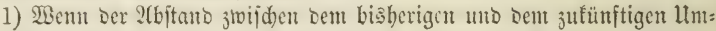

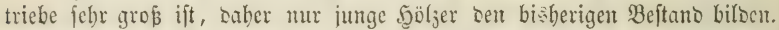

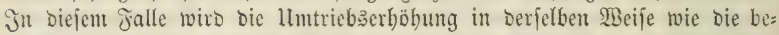

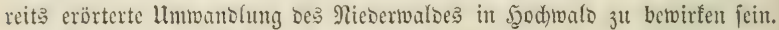

2) Ment ber 2 (bftano weniger grof ift, Der biäberige Bejtano bem=

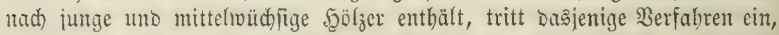

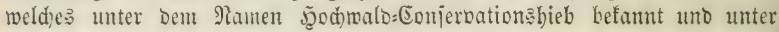
ben Llmmandungen Der Betriebarten ebenfalla erörtert ift.

Jit Dent wenigen Sällen, wo eine Sertheilung Deș nöthigen Sapital=

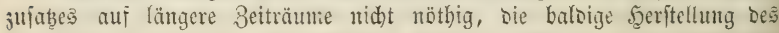
Dem höhcren lumtriebe entipredjenten fapitals nerlangt mirt, befduränfe 
man die jäbrliche 2tbnuţung, auß̧er cen berittärftent Iurd)forftungen, auf

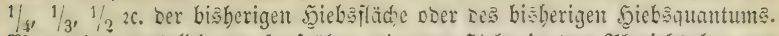

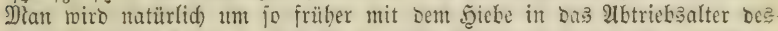
neuen Umtricbs fonmen, je mehr man sen bišberigen Şaung

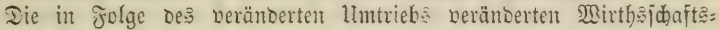
voridriften fint Gegenitano Der 3etriebseinridutung uno Der Iaration, ge= bören bemnach nidjt hierber.

\section{3weiter $\mathfrak{T}(6 j$ jounitt.}

Bon ber natürliden $S_{2}$ olzzudid. 1

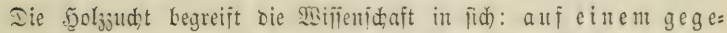

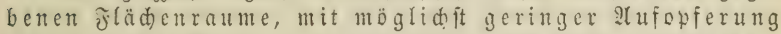
oon 3eit uno beld, fo bieles und gutes . als $\mathfrak{n} u \mathrm{r}$ möglid $i$ ft.

Man theilt fie $a b$ :

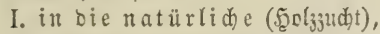

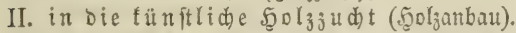

3ur natürliden bolzzudt fann mur die Jortpilangung ber

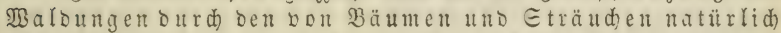

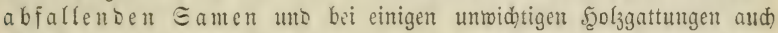
Die Jortfilanjung Durd) freiwillig entitehenbe Marjelbrut

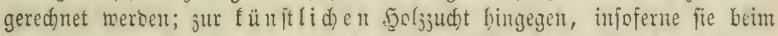
Foritweien im Ğ ro Şolz̧beftände.

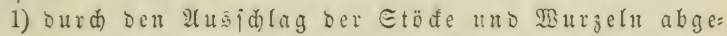
bauener Scolzpflanzen;

2) Durd 2(ustreung des eingejammelten 5olziamens;

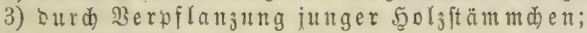

4) Durd Gtedreifer und

5) burd) $2(b i e n f e r$.

2Ulle übrigen bei ber Dbft= uno Sumitgärtnerei noch anmentbaren wirt=

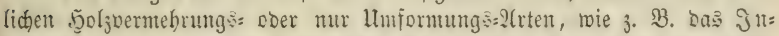
einanderblaten, Das \$froffen, Eopuliren, Dculiren uno Eergl. fönnen beim Foriftwejen nidgt in Betrachtung fommen.

\section{Eirftes Eanitel.}

2on Der natürliden ₹ortpflanzung Der Wälber überbaupt.

Wenn man ben Gang Der Ratur bei Fortpflanzung Der Wälber be: trachtet, fo bemerft ntan, Dáj Ler ভamen nad erlangter bölliger

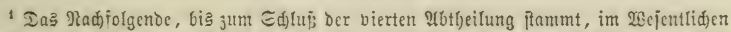

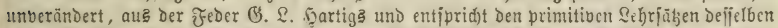

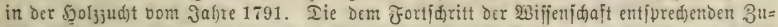
jäbe aus neiner feder, jo weit jie mehr als reoaltionelle Renoerungen betrefïen, babe id,

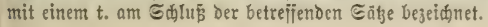


Neife von den Bäumen fält und neue Bflanzen erzeugt, wenn er entreber burd) bas fodon auf ber Erbe liegende und nadber nod) abfallenoe \&aub eine Bebedug exhäl, Doer twen die Dberfläde des Érbbodens fo bejdaffen ift, Dá Der Gamen burd) Das Mods oder (j) langen $\mathfrak{t a n}$. Bugleid) bemertt man aber aud, dafi bie aufge= feimten \$flanzen nur auf folden Stellen fortioaden, wo Sidt, Sonte un Regen im erforberliden (strabe auf fie

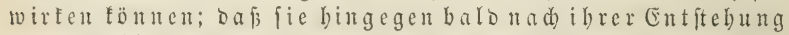

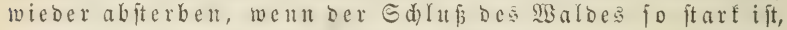
Dap feine Gonnentrahlen un zen zu treffen bermögen; doer went im segentheile der

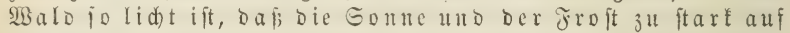
Dic jungen Bflanjen witfen, ober baj bie Jorfunfuater den Boben ausfaugen, ober bie bejamung bindern, doer bie jungen joljpflanjen überwad) fen un orftiden, oderwie man in ber forftiprade fagt - veroüm ue

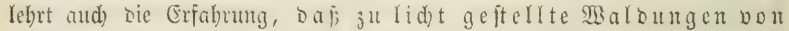
bem Sturme leidt umgeloorfen werben, und baf bie jungen

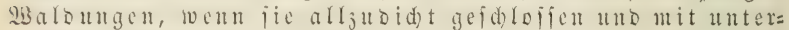
Drüdten Etämmen angefüllt jind, weniger gut toad) fon, als wenu man das unterorü de Şolz vou 3eit zu 3eit beraus tuh men $\mathfrak{l a ̈ j}$ t.

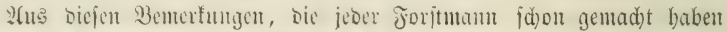

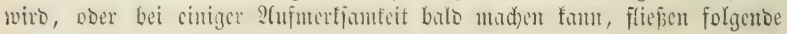

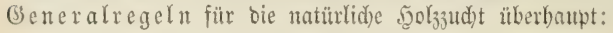

\section{(Erite Bienernlregel. 1}

Seber Malo ober Saum, won bem man erwarten wirl, Da jer fid burd) natürlide bejamulg folf fortpflauzen fönuen, mú fo alt fein, dás er taugliden Eamentragen tatt.

\section{3weite Generalregel.}

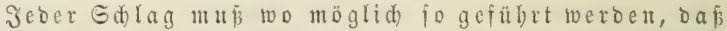

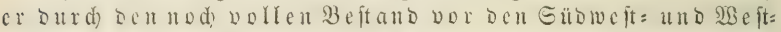
ftürmen gejdübt ift; befontors wen die abzutreibende un zu verjüngende fुolzgattug nur flad) wurzelt, zu boben Bäumen ertoäd at und ber Boden lodéter ift.

\section{Dritte Gencralregel.}

Seber SBalobifrift, ber ourd) natürliche Befamung cincu burdan a bolltommenen neuen bolzbeftanderbalten

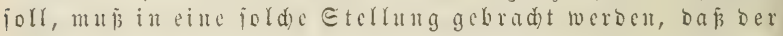

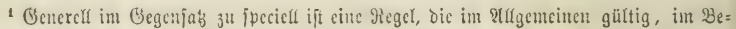

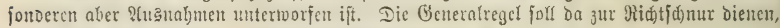

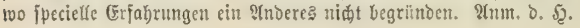


Boben, vou ben a tf sem Edage iteben zu lajpuben 3 äu men, allentbalben eine binlänglidge Bejanungerbalten fann.

\section{Bierte Biencralregel.}

Jeder Sdlag múp jo gejtellt werben, das er bor er: folgter Bejamung nidet it arf mit Gras un fortunfraut betoadien $f a n n .1$

\section{Jïilfte Beneralregel.}

Bei Dolzarten, beren Gamen burd) Froft zum St ufteimen

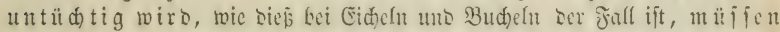
Die Edläge jo geftellt werben, Daj bas \&aub, welde bem 2tbiallen bes Eamens benjelben bebedt und idütit, bom Winde nidt weggetrieben werden fann.

\section{Sed) ște (jenerafregel.}

Alle $\varsigma_{d}$ läge müfien lo geitellt werben, baj bie barin a uigefeimten Pflanzen, is lange fie nod zärtlid) jinb, hin Yängliden $\Xi$ d)

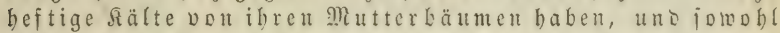
ber Gonne, als oem Regen meber zuwenig tod zu vicl ats gefegt jint.

\section{Eicuente Gisneralreger.}

Sobald bie jungen, Durd natürlide Befamung erzo=

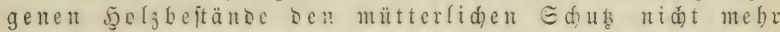
nöthig baber, müfien fie nad) und nad burd vorfidtige Megnabme ber Mutterbäume an oie Witterung gewöbnt uno enolid ganz ins Freie gebrad)t werben.

\section{2d dite benerafregel.}

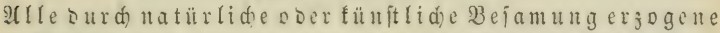

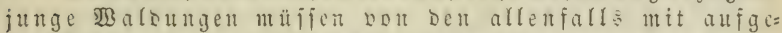
wadbenen, weniger nübliden foljgattungen unb von dem

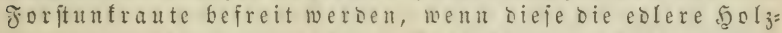
gattung, aller angementeten sorjidt ungeadet, juver= berben broben.

\section{Seunte Gicueralregel.}

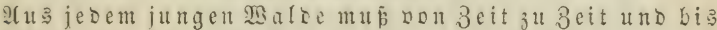

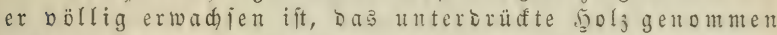
werben, bamit bie Etämme, toelde ben ober dominiren, befto beffer wadjen fünen. Der obere

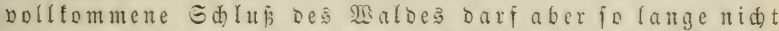
unterbroden mersen, bisman bie 2lbitdtbat, an ber Etelle des alten 23 albes eitten neuen zu erzieben.

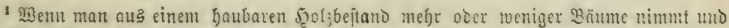

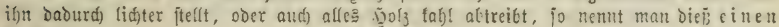
उ क्ष I a g. 


\section{3ehnte (ieneralreger.}

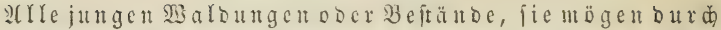
natürlide ober fünftlide Mlittel erzogen worben fein, mülien fo lange gegen jebe Befdäbigung burd Beibvieb ze. ge: fdübt werben, bis ibuendafielbe feinen $S_{\text {d) }}$ aben mehr zu= fügen fant.

alle bieje beneralregeln müfien, wo god) twalowirtbidaft ge:

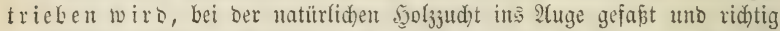
angementot twerben. (Beichieht biefs, fo fönnen bie Walbungen, ohne bie

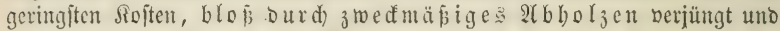
Die volltommenften neuen Beftünoe bervorgebracht werben. \$3o man aber Siederwalbivirthidaft treibt uno burd) natürlide Bejamung nur ben 2lbgany ser entfräfteten Stöcle mad) uno mad) erfétent will, Da fömnen

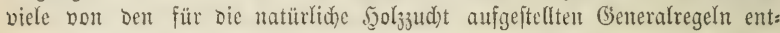

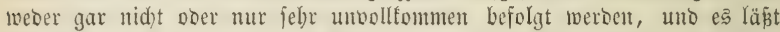
(iid) Daber aud) nidht mit Sidherbeit auf Den gewünjdent (Erfoly ber natür=

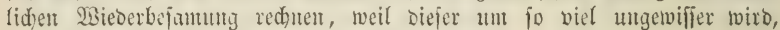
je mekr man bon jenen (seneralregeln abweid)t.

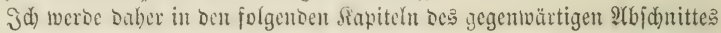
zeigen, wic bie borbin aufgezäblten Genteralregchn angetwentot werben müffen,

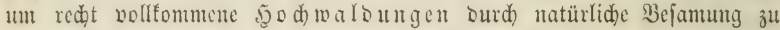
ergieben; in Dem folgenton 2(bid)nitte aber werbe id) S(nleitung geben, wie

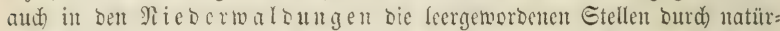
lid)e Befumung fo gut als möglide in Beftuto gebradet ober befto ff werben tömren.

\section{Bameites santef.}

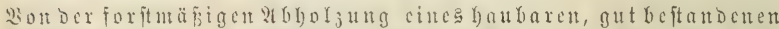

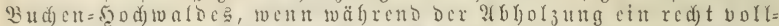

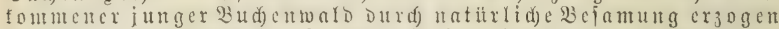
werden forl, and bon Der ferneren Befandung Des neu erzogenen Beftandes big zur Beit, wo cr wieber haubar wird.1

In ser Betriebslebre fints sic Bülfid(ten nadjgemiefen, weld)e bei ber

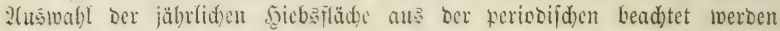
miilient.

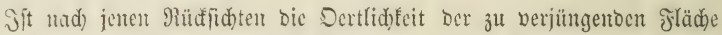
bejtimunt uno beabfid)tigt man bic Berjüngung burd Ed)lagftellung ju be:

1 Saubar fann ein Beftand in verjdiebener ફinfid)t fein.

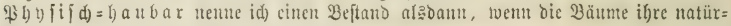
lid)e Gröpe uno volle 2luabiloung erreid)t baben.

Detonomif $(\dot{b}=\mathfrak{b}) \mathfrak{b}$ ar aber ift ein Beftand alsbam, wem er fo alt ift, als er

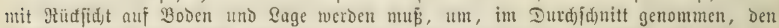

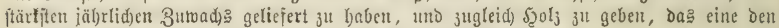
beftehenden Bedüriniffen borjüglid) entfpredende Stärfe und Ojüte bat.

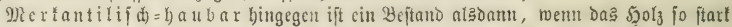

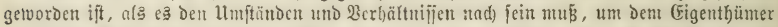

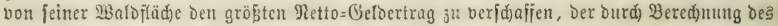

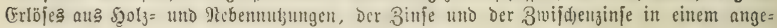
nommenen 3eitraume zu crlangen ift. 
mirfent, io jọreitet man im şerbjte nor ber Jüllung, io lange nod) bas

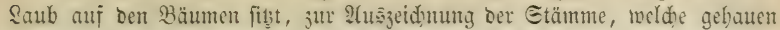
merben müfien, um Den Beftund in eine folde Etellung zu bringen, bie sen im vorigen Sapitel anfgefül)ten Genteralregeln entipriḑt. t.

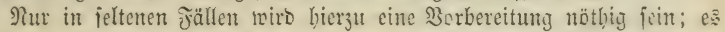
fömnen aber Bejtänte vorfommen, in bonen bic Bäume, julbjt im böferent

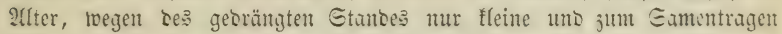

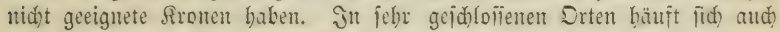

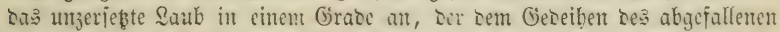
Gamens binberlid ift. In iolden Jällen, Die bei einer regelmuäpigen Wirth:

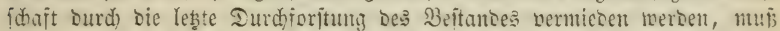
man vor ber eigentliden Ed)lagitellung cine Auslid)tung vornthmen, bie

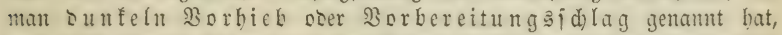

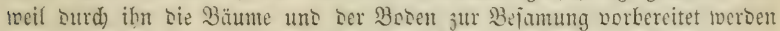

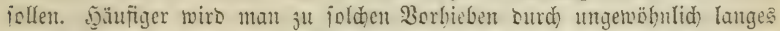

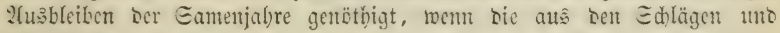
Durdforftungen ju entnefmenoen froljmaflen jur Erfüllung bes Şitbs: quantumes nicht binreidjen. $t$.

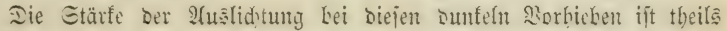

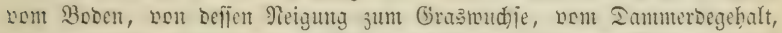
voll ber Sage, theils non Der Bahl ber Etämme auf Dem Mlorgen, seren

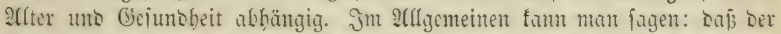

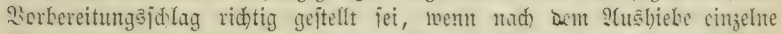
Graŝpitien Dem Boten entiprofien. Man barf ben Majptab für iolcte

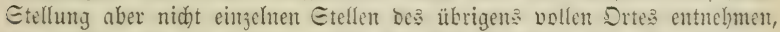

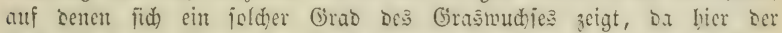
Eeitenjdatten wirfiam ift. Sisolite man ben ganzen Ed)lag nad foŕd)en

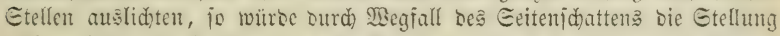

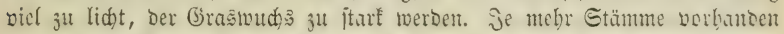
fino, un fo fleiner fino sic fironten uno um fo rajder uno meiter wersen

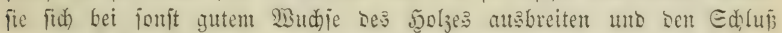
micberberftellen. Je reniger Etämme vorbandent fins, unt fo nachtheiliger mirft bie moitere Berringerung Dor @tammzahl aü bie Fräter sintretense Eamenjolagitellung, bie weit nolltommener mit einer gröperen Menge ge: ringer Bäume, als mit toenigen ftarfen Bäumen kewinft werben tunn; Daber es benn aud nidht rathjam ijt, Den Sorbieb in Der Simmegnahme Der Etämme 3ter uno 4ter R̊laije bejteben zul lafien, uno mur f̆tarfe Bäume für bie Єd)lagftellung überzuhalten. Im ? Illgemeinen barf aber bei sunteln

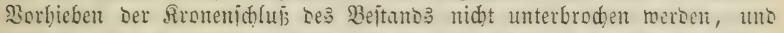

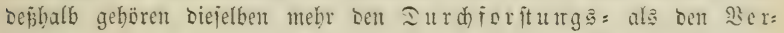

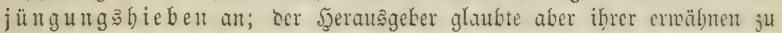
müfien, ba fie bon sen meiften ser netteren foritjobrifitteller leşteren zugejäblt werben. $t$.

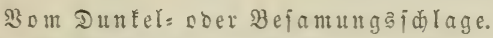

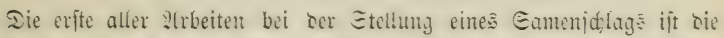

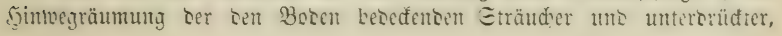


jur Ed)lagitellung jelbjt unbesingt nidft benubbarer Etangen, fo wic bie Şin=

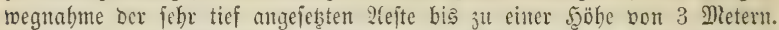
Erft wenn bieß gejd)eben ift, vermag man zu keurtheilen, welde Etämme

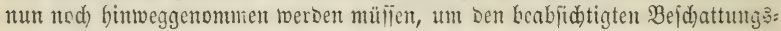
grab herzuitellent.

Die Stellung bes Gamenjolages jelbjt ift veridicben, je nadubem bereits 2(ușid)ten auf ein Eamenjabr vorbanben jimo ober nid)t.

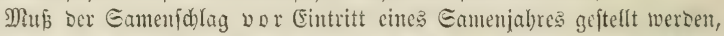
fo lafie man jo vicle Mutterbäune fteber, o a Der 3 weige fid beinabe berübren (7te 2(ufl. S. 12). Finten aber jugleid̆) Berbältniffe ftatt, Die eine fehr bunfle Etellung überbaupt berlangen - raubes Rlima, Dürre, Grastwuthas is. - io fann bic Etellung nod) etwas Dunfler jein, uno zwar in Dent Maje, als cin geringes Jneinanter: greifen Dex äuferften 3 reigftiben biefs betwirt. Ia bie einzelnen Edhirmfläden meht ober weniger freisförmig uno von ungleider brö́pe fint, bleibt auch in lebtetem falle slwifden ifnen nod) Maum für Sid)teinfall.

SWito ber Gamenlid)lag bingegen erjt in eintent Eamenjabre gcitellt, Daber nach S(bfall bes Eamens gebauten, ober enthält er bereits cine be=

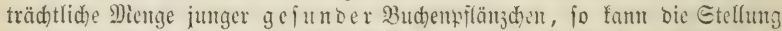

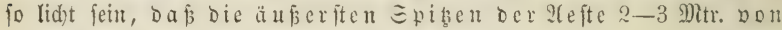
einauber entfernt find. (7te Sluft. S. 13.)

Dieje Regeln muifien überall in ?tmmintoung treten, wo nod) feint beftimmten, an Drt-uno Etelle felbjt gejanmelten Erfahrungen vorliegen:

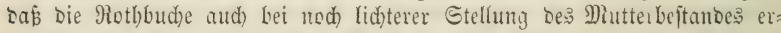
jogen werben fann, wie bié̃ $\mathfrak{j}$. B. in manden Gebirgaggegenden alferbings Der Fall ift. Die in lidfterem Gamenfidlage crzogente Buche fam man bam? aud) Durd frühere uns ftärfere ?luslichtung uno Durd) früberen ?(btrieb vom Mhatterbeftanoe befreien. Man hüte fid́) aber ja, bei $2(b w c i d u n g e n$ non obigen Picgeln voreilig 3 Merfe zu geben. Bei Der Mothbud)e ift ein Mifilingen gejäbrlider als bei jeber anteren frolzart, ba bie Eantenjabre bei ibr fo lange ausietsent. $t$.

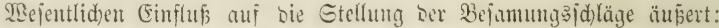

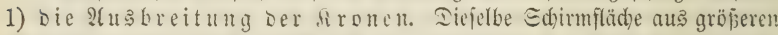

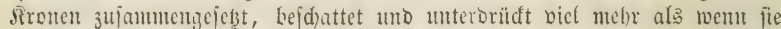
aus einer gröferen Babl fleinerex fronten jufammengefebt ift. Die ltrjache ijt Der in lebterem Frlle rajdere Medhel jwijhen bom befduatteten uno

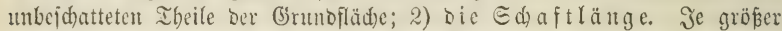
bie Entfermm jtwifhen Edirmfläd)e und (srmmoflüd)e ift, um fo weniger

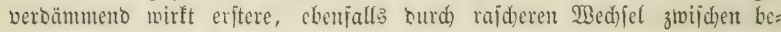
idatteter uno belentdeter (Brunbfäd); 3) bie Expofition. Sidt = uno Bärmeeinnirfung Der Eome auf gleid) groß̉e (brrunbfächen finto größjer, je mebr fid ber (Einfallamintet ber Eommenftrablen bem rechten WBintel näbert.

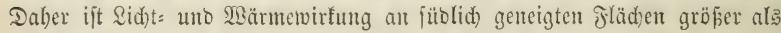
auf Der (sbente, auf letberer gröber als an nörolich geneigten ofladden. Sie ijt größjer an weftlid) als an öftlid) genteigten flächen, weil bie weftlid) geneigte fläd)e bie Eomenftrahlen zur Beit Der gröften \&uftwärmte, in Den

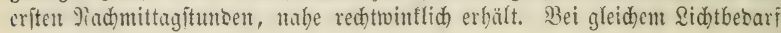




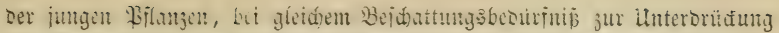

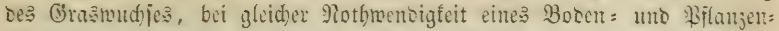

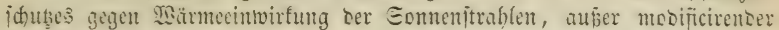
Mitwirtung ancerweitiger Nerbältnifīe gedad)t, fumn baber die Ed)lagitellung

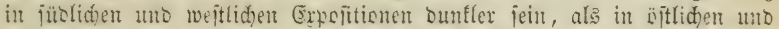
nörblichen; 4) Der Neigunģıinfel an Berghängen. Jn Jolge

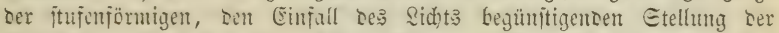

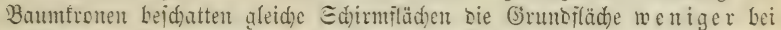

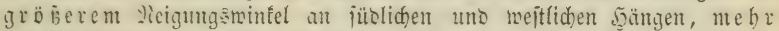

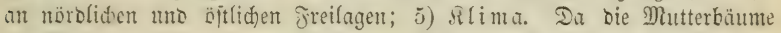

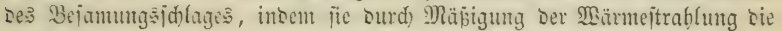

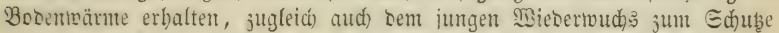
gegen Froitidaden bienten jollen, ber froit aber nur als Epätroit auj

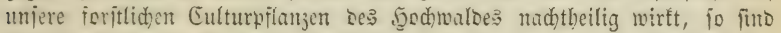

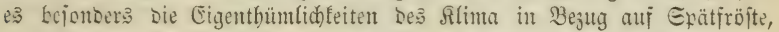
weld) mejentlid)ent Einflu; aui Die Etellung Der Bejamungşidläge aus̄üben.

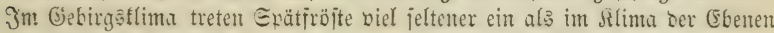
uno Der Dorberge, in jüsliden uno wejtliden hänfiger als in entgegen=

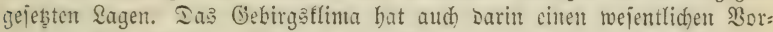
jug wor sem fllina ser (5benten und Borberge, Das Der mecijt frübe umb

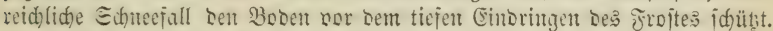
Ias twame, trofene flima ber s̈ftlident uno jübliden Lagen fortert Bodent=

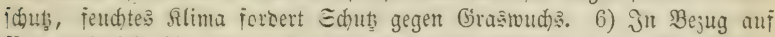

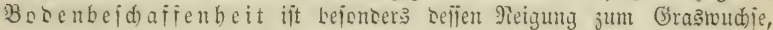
geringer in gebirgigen als in ekenten, garinger in nörolichen uno seftliden

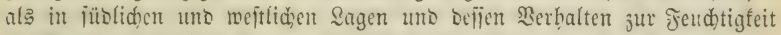
in Bejty auf Edylagitellung ju berücfïdtigen. Siant man Den Boben, Durch

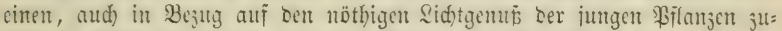

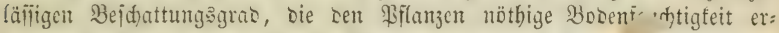

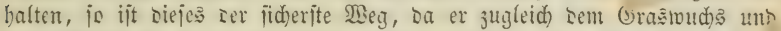
Den Exätfroftidǚen entgegenfteht. Jit ser Boben bingegen non einer foldhen

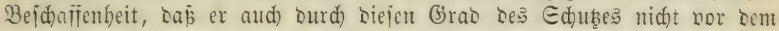
2tustrodnen gejidert werben fam, Daun ijt es nothwenoig lidht ju ftellen, um Den Hiflanzent sură Thu uno Regen Das jujuventen, was ibnen Der

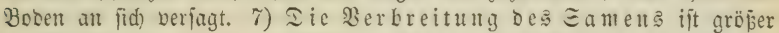
an Bergbängen als in Der Ekene, größ̈er in Dertlichfeiten, bie beftigeren

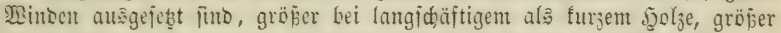

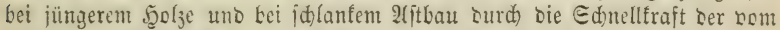

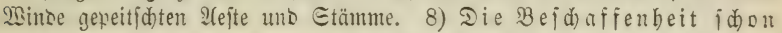

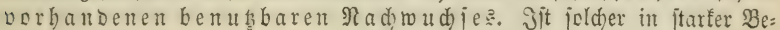

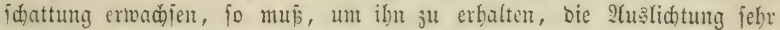
allmählig uns boridotig geidhehen. Ĵm entgegengejeşten falle fann man fidfter ftellet uno rajder nadbauten. $t$.

Was bic 2tustwaht ser Bäume, die als Sumenbäume ükergebalten werben joffen, anbelangt, fo miro siejelbe surd) bie Potbmentigfeit einer mïglidjit gleidfïrntigen Bertheilung ber Etämme ober vielmebr ber burd) jie ju bewirfenton Beidfattung beidgränt. Jnmerbalb serjolben wäble man 


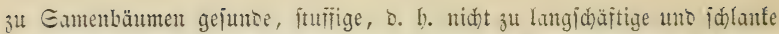

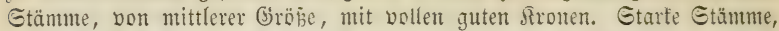
Die beim ?hfarbeiten uto keim Irunsport aus Dim Witedermudje gröperen Edaben an leķterem veranlaffen, balte man nux an Den Ed)lagränbon, an $\mathbb{B e g e n}_{\text {uto }}$ Beftellen über. Jeben megzunchmenten Etamm bezeidine

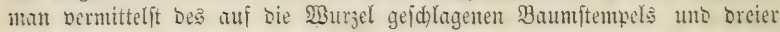
am Ed)afte nad beriblibenen Bidutungen angebantener Platten.

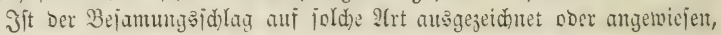
fo meroen bie Seoljhauer ju 3 uno 3 , oder zu 6 uno 6 in Partien getheilt, Der Ed)lig in elen fo viele ungeführ gleidue Theile zerlegt, als $50 l_{j}=$ bauerpartien ba fins, uno es weroen bieje I Deile, die an idbiefen Fläd)en

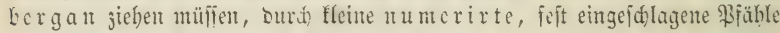
bemerflid gemad)t. Sgierauf wirb geloost, un zu bejtinmen, wie bie şolj= bauerpartien auf einanocr folgen folfon, uno wem bief gefdeben ift, uno

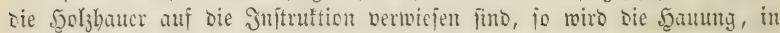
io forme es cine idjefis fläd)e wäre, unten angefangen uno nudb oben fortgejeşt.

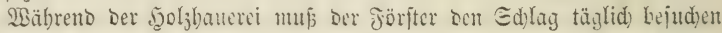
unto barauf jefen, baj bie golybater feine unangemiejenen Bäume fällen ober bejdäoigen; Daj fie bie Bäume fo tief wic möglid) an ber (croc ab: bauen ober abjägen, uno bei allem Slafter= ober Malterholze Dic Eäge gebraud)en, ım ibm die gehörige Edheiterlänge ober fllobenlänge зu

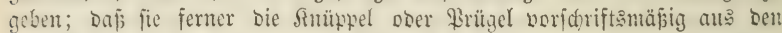

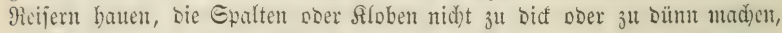

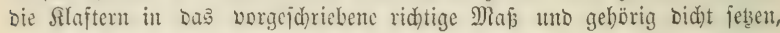
umb bie Reifer orbunugântäfig auffinben; - Daj fie ferner feine gefäbr:

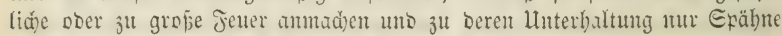

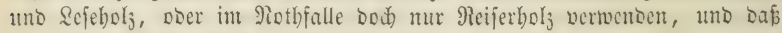
fie überhaupt ben Snbult ibrer Juftultion aufs Genautefte erfüllen.

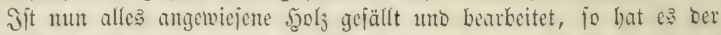
Förjter nad) Den berfdicoenen Eorten zu muteriren, uno went es bou feinen Sisorgejebten controlint uno alitignirt ijt, io muis Dafür gejorgt werben,

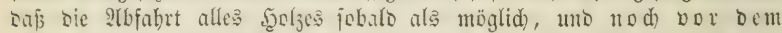
Ibautwetter in Jrubjahre, crifolge; weil fonjt bie vielleidht fidon vor:

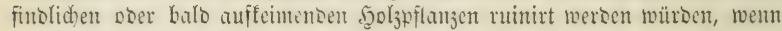
bie Albfabrt bes Şoljes fpäter ftattinten follte.

Sătte ber Diftrift, mo im Winter gehauen werben foll, im Serbite zuwor eine Bejanung von Budidn erfalten, fo Darf er mit ben Majt: (d)weinen Diepmal nid)t betrieben merDen. Durd Das Jällen uno Bearbeiten Des Soljes wiro ber Eamen Dod) gemug unter Das Saub fommen, uno ber

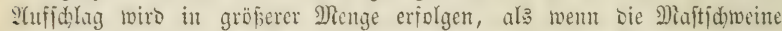
cinten grofien Theil ber Bud)etr aufgejehrt baben. ${ }^{1}$ Der Befamungsidalag mus folglich in bicjem Jalle, ober wenn idgon taugliờ junge fiflanzen

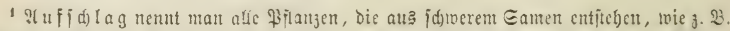

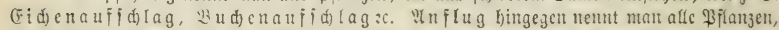
Die ans beflügeftem, ober mit siste bejettem, oder jonft leiditem Eamen, Den der Wind betrāđtliđđ) tveit fortbervegen tann, etradjen. 


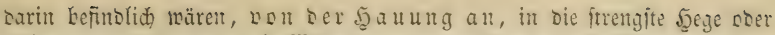
Echomung gelegt werben. 1 Siären aber weber Eamen nod) Bfilantzen in tem

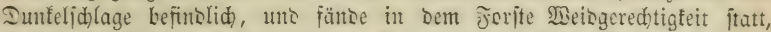

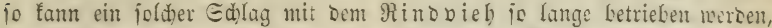
bis Plajt ober Eamen criolgt. Dicjer Betricb mit Rinbvich ijt nid)t allem

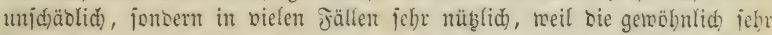

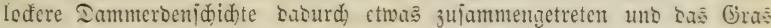
uno Forftunftaut burdh bas Sieb bertilgt mirs. Pad crfolgter uns ab:

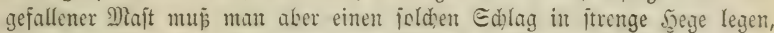

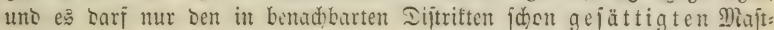
id)weinen, bei ge! in bem Setter, ber rajde Iurdtricb einigamal ge: jtattet mersen, Damit fie bic Budjeln, bein Gud)en mad) Jojieften ume SBürmern, ober jogenannter Erbmałt, unter sab Saub noer in bie Erse

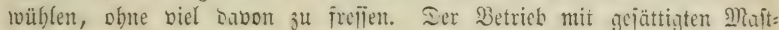

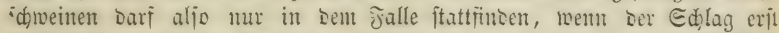

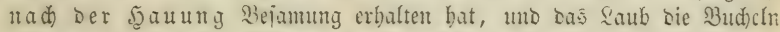
nidjt gebörig kebect. Wären aber bie Edweine in siejer Simfidyt nid): nöthig, fo lajie man fie weg, weil fie mehr ichaben als nütien, wenn ber

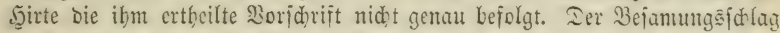
bleibt mun in biejer sunfefn Etellung fo lange, bis er gröptentbeils, soer

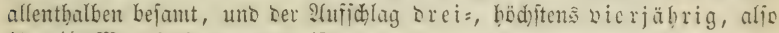
$1 /-1 / 3$ Mti. bod getoorben ift.

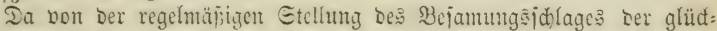

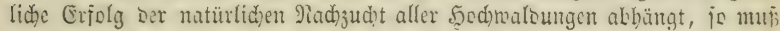
ser Joritmunn bie oben gegebenen, aus langer Errfahrung abgeleiteten Regeln jo genau wie möglid) befolgen, uno ben Bcjamungsidalag ganj ber isor:

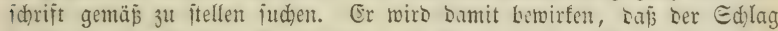

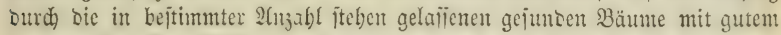

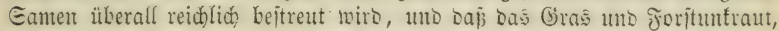

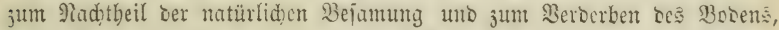

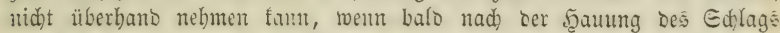
feine şudmajt wädst. 2Atd wirb er ourd) cine folde sunfle Etellung

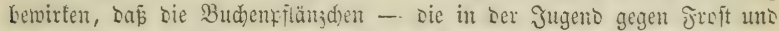

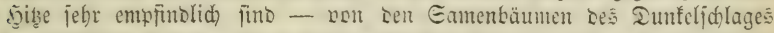

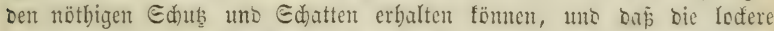

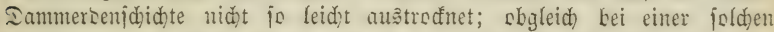
Etellung io riel sidt, Eome uno Regen auf bie fleinen Bitanjen wirfen fant, als vorerft für fie nöthig uno nübzlich ift. llekersief́s getoäbrt and

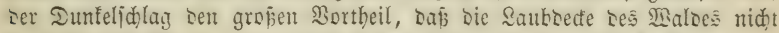
jo leidft vom Winte meggetrieben merben faun. Dieje Saubsede ijt in cintem

Xu弓id) lag aber nent man alle Soden, die aus Den Etöden abgehaucner frolj= pillanjen berborfonmen. Unto

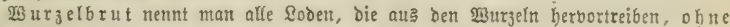
Dá̄ Der Baum ober Strauda abgebauen ift.

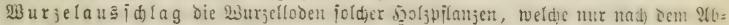
biebe Des baumes Soben bon ber 2burzel auts licjern.

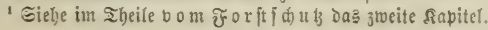




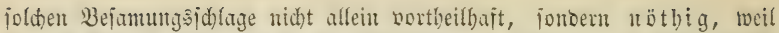
jie bas Seimen Des unter ihr liegenoen Eamtens beförbert; bie \$Wurzeln ber

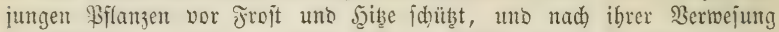
Den Bilanzen sur Rabrung bient. Nur an joldhen Drten im Edjlage, wo

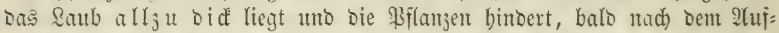

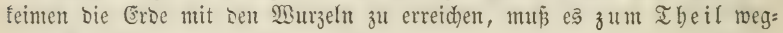
gejolifit werben.

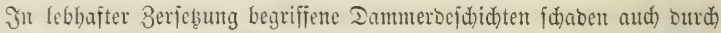
übetreidhe Entroidflung bon Soblenfäure, ourd) weldbe bie, für bie Reimung

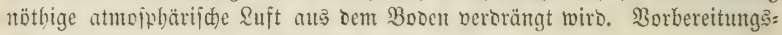
fisläge fino bier an ifrer Stelle. t.

Ille bicje wid)tigen Bortbeile fallent tweg, wem man einen Bejamung:

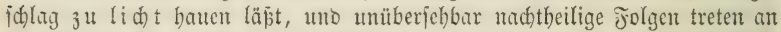

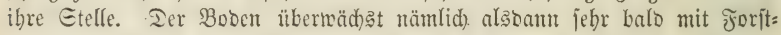

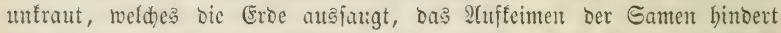

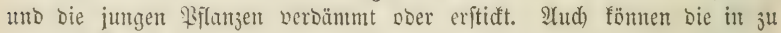
geringer $2(n z a b l$ ftehen gebliebenen 3 äume, ober fold)e Stämune, Die feinen tunglichen Eamen bringen, Den Boben nidht gebörig uno allenthalben be= jäent, unt rent aud) bier uno ba Pilanzen auffeimen, fo werben fie bod) Durd) bie ju heftig auf fie rirfenbe Somenbize und Rälte balb wieber ruinit. - 2fujerbem werben oft viele Stämmte nom Wino umgeriffen, es

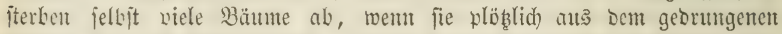

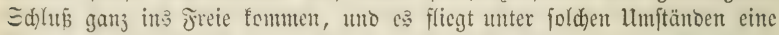

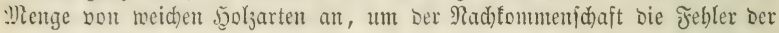
gegenmärtigen Förịter zu vertünbigen. Dergleid)en zu liđłt gebauene Ed)läge bleiben baber, went nid)t beionders günftige Umitände cintreten, viele Jabre lang obne guten sadumuds, uno nur in sem Jalle wiro in ber Jolge

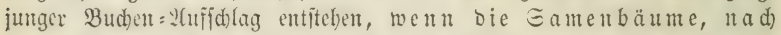
einer langen Reibe non Jabren, bider geworden und poviele Aejte an ibnen gewadien jind, oaj der Beftand beinabe

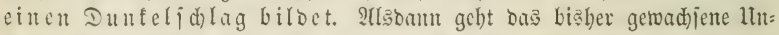

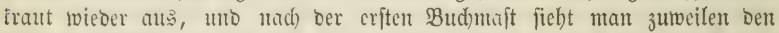
Ed)lay mit Bflanzen fajt cben jo überbedt, als wenn man ilyn vor 15 ober 20 jahren fogleid) regehnäpig gebauen bätte. - Mer baher feine Ect)läge ju lidyt bautet, ber erreid)t im günjtigen Falle nad) 20 Jabren, jehr oft

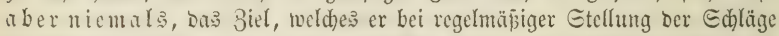

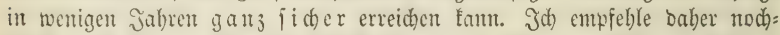
mals aufs Dringenoite bei ber Stellung Des Befanungsid)lages äuperit

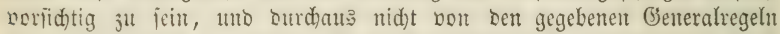

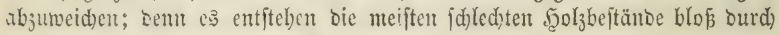
Die feblerbafte Stellung Des Bejamungşollages.

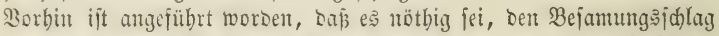
nad) eingefallener $\mathbb{D}$ a ft aufs Strengite zu begen, uto ibn nidyt früber

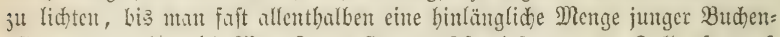

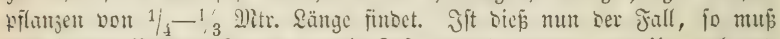
Dem jungen \$iadwudje etwa nebr \&uft gemad)t merben, um ihn nad) und nad) an sie Sistterung ju gemöbnen, uno ibn Der Bersämmung zu ent= 


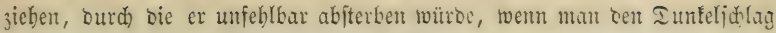
alsbann nidid et

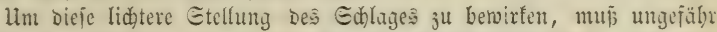
$1 / 4$ ober $1 / 3$, bödjtens aber bic gälfte von bell Eamenbäumen, uno jwar immer bie it ärfiten ba reggenommen werbert, wo ber meifte 2fufid)lig

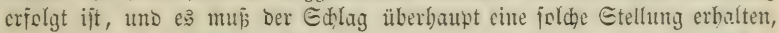

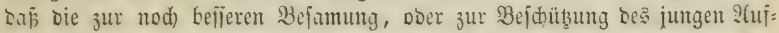
foblages ftehen blcibenden Etämme, fo vicl als möglid, in gleid)e Ent: fernumg fonment. - Weil man aber in Winter Durd) Den Edhnee gebinoert

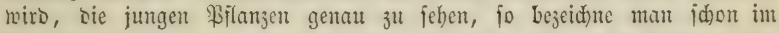
Epätberbite, nod) ebe bic Blätter abgefallen finto, alle Etämme, die weggebauen werben muifien, mit brei \$latten am Ed)afte - roie bei Der

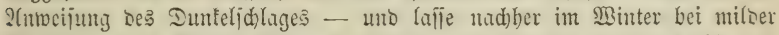

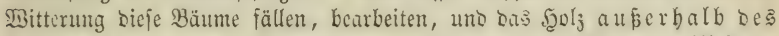
Ed lages, an ben Etellwegen, Dber auf jomit blopien Pläb̧en auflaftern,

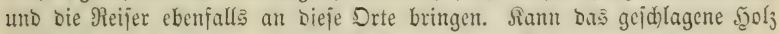
aber obne grope Sioften nidgt alsbalo aus sem Edilage gebracht werben,

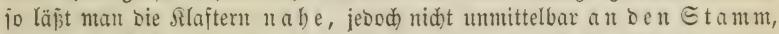
Der noch ftebenbleibenoen Bäume fețen, Damit bie flüchen, reldje allenfalls Daburd) Des jungen 2 (ufif lages beraubt werben, bei ber nädfften 9) )ajt eine frijo Bejamung crbalten tömnen. Sn biejem Falle ijt es aber

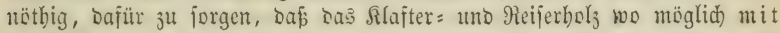

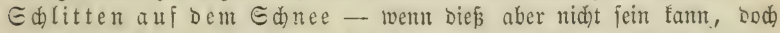

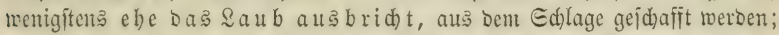
weil jouft an Dem jungen 2(ufid)lage viel verborben werbent fömute. — Eollte

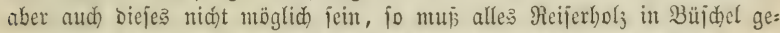
butben, oben auf bie nit Unterlagen verfebenen Slaftern gelegt uno ber Ed)lag Dod wenigiten nod) bor Jobannißtag ganj geräumt werben, Damit bie jungen Bflanzen, beld)e mit Siluftern bebectt

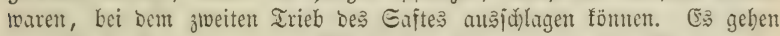

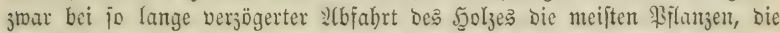
bebceft maren, berloren; sod erbolen fich aud) viele wieber. Eollte aber

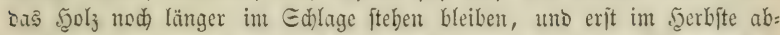

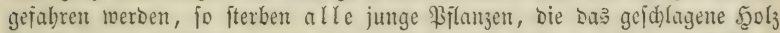

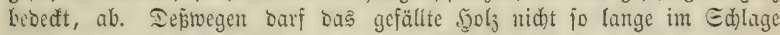

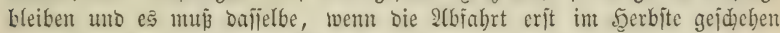

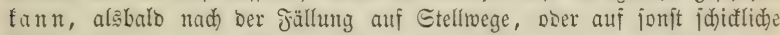
Pläb̨e getragen ober gefahren werben, wem bié aud) einige Roften ver: urjadjen jollte. - In einer foldyen Gtellung nennt man Den Edlag

einen \&idtidlag.

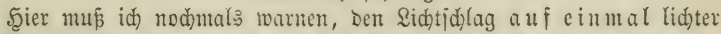
jut ftellen, als id es empioblent babe. WBiro cr auf einmal $j u$ lidet, io nimmt das Joritunfraut balo überbanto, Der Boben trofnet in Eommer

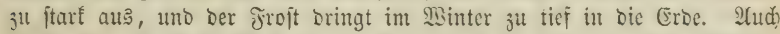

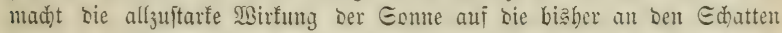

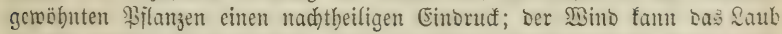

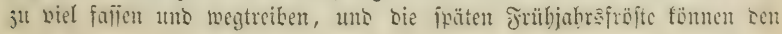




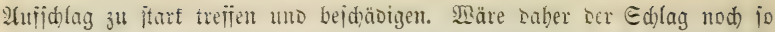

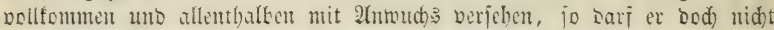
a $S_{d} u$ bुbäunte vorerft nod) ftehen bleiben, um bie fo cben angefübrten

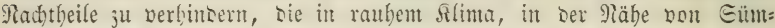

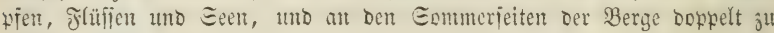
fürdbten find.

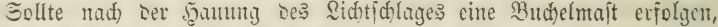

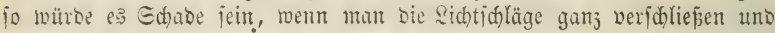
bas Ederid) Darin gar nidht benuşen loolte, oa joldhe Ed)läge gemöbnlid) Den meiften Eamen bringen. - Man nerpad)te baber Dergleidjen Ed)läge jum Budbelnjammein; wolvi bie 3utdeln abgejdlagen uno auf unter: gelegten groben Sacten søer \$lämen bon grober Seintwanto aufgefangen wersent. Eollte fid) Daju aber teine Gelegenbeit finten, io laffe man bic Maitidweine Morgens früh, und fo (ange fie nod) bungrig fint, bei Jro it ober trodener B itterung, wödentlich einigemal und ctwas

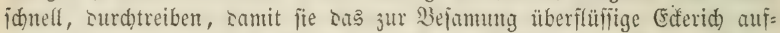

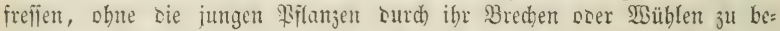
jdäsigert. Enbalo Der Föriter aber kemertt, Daf ein folder Durd)trieb Edhaten veruifadt, muई cr benfelben auf Der Stelle verbieten, uno ę muई Der Maitidweinfirt überbaupt safür nerwntwortlid) gamadt werben, wemn ex bie ihm gegebene \$oridhrift übertreten unto ben Ed)lag bejdäbigen lafien

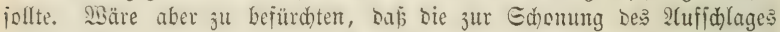

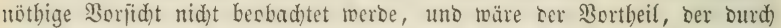

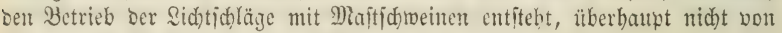

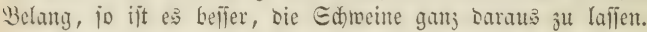

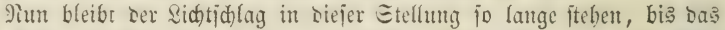

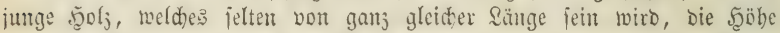

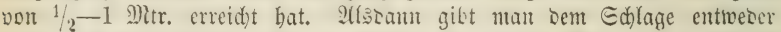
noć) etme 2fuslidfturg, ober es werben im milsen Slima alle Bäume berausgebauen, ment nid)t bejontore Umjtäno nötbig madhen, bap am

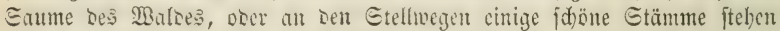

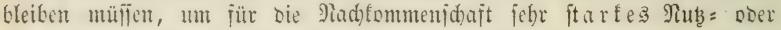

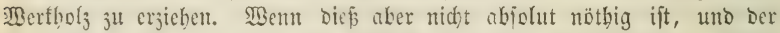
Budjentbodivalo einen fo langen llmtricb bat, baj bie Etämme zu MBerf: bolz Dod jtarf genug werben, io halte man gar feine alten Bäume über, weil fie fünftig am jungen bie an ihnent juwäd)

In jebr rauhem Siltmta, unt to mo non Epätfröften viel zu fürd)ten

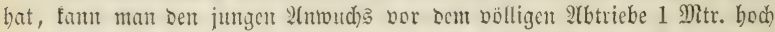

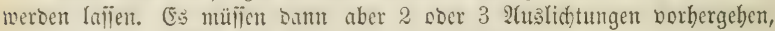
bamit ber junge 2 (ntwuchs nicht beroanmmt werbe.

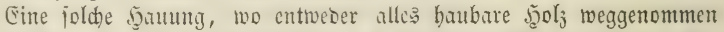

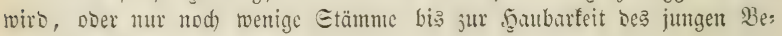
ftantoes ftehen bleiben, heipt

Abtriebsidalag.

J̧ier ift bejonters ju empfehlen, Daß jumge fgolj bor sem bölligen 


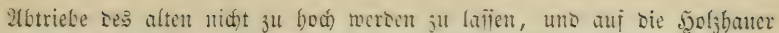
genau 2ditung ju giken, Daj fie sie gejällten Büume alsbalo auลäften,

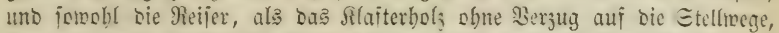

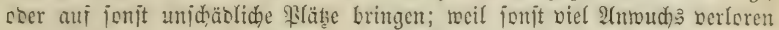
geben würe, wom Die Rlaftem uno Reijer in Dem $S_{d}$ lage jelbjt

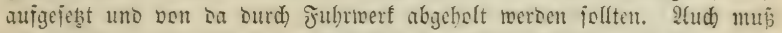

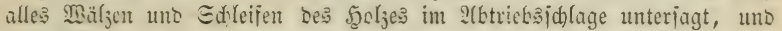
Das Fällen ber Bäume weser bei ftarfem Jroft, nod jur Beit, wo ber Sajt idon in Borwegung ift, geftattet werben, weil bie jungen Etänmmenen ju biejer Beit leid)t entjweibred)en, wem jie von ben umfallenten alten Bäumen getrofịen werber. $\mathfrak{2}\left(\mathfrak{m}\right.$ beften ift $e^{3}$, went man bergleidhen

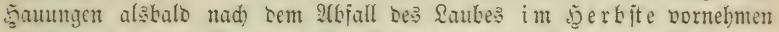

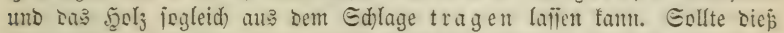

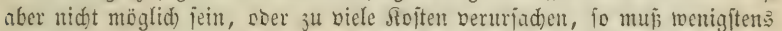

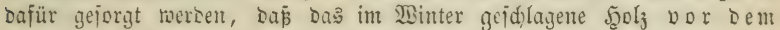

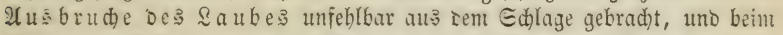
Ibratien belfelben io twenig Edaben mic möglid) verurjad)t merbe. Die 5ुoljijubrleute bürjen saber nidgt an jebe Silafter jabren, jonoern muifïen auj

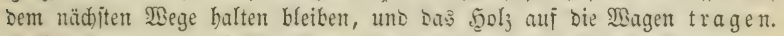

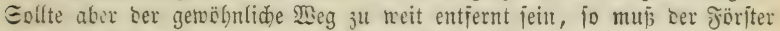

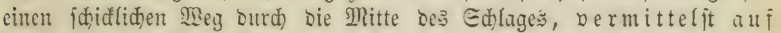
Stangen ge itedter Etrobrifde, abjeidnen, unb biejen Meg, wenn alles junge Gehölje burauf jollte ruiniut worden jein, nadber burd) SFlanjung wieber in Beftand ju bringen judjen.

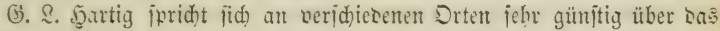

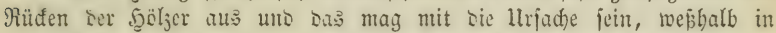
Etautsforjten, iil Denten bie Damit nerbundenen bescutenton fojten aus Lem

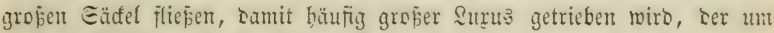
jo mehr 2tntänger in forjtlidten Sireifen findet, als es gerabe bie renom:

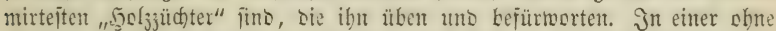

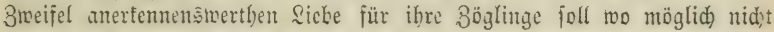

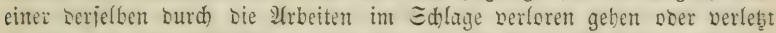

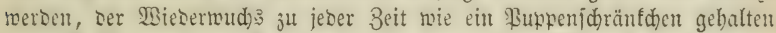

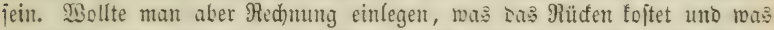

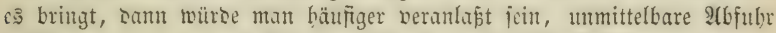
jelbit sa eintreten ju laijen, wo ideinbar crhobliche \$leid)äbiguntgen ieß

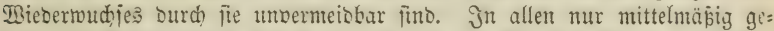
lungenen Derjüngungen fintet man bei einiger ミorgfalt Raum genug für unjकädlid)e 2(bfubr. Jn allen guten Beriüngumgen fint jo vicle \$ilanjon

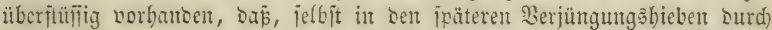

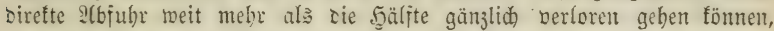

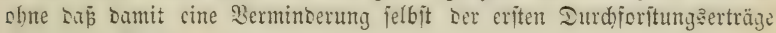
verbumben ift. $t$.

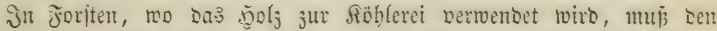

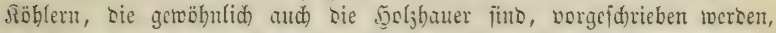

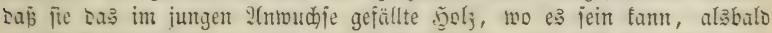

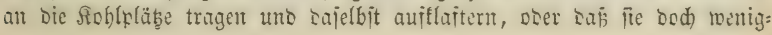




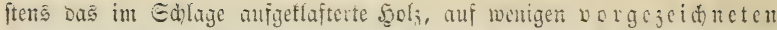

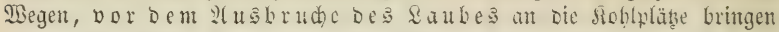

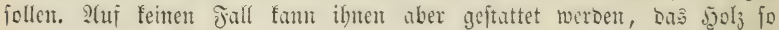

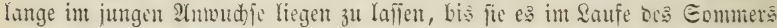
nad) und nad verfoblen. Die Röblerei nuf baber in ben fdon bejamten Edlägen juerft anfangen, unt es Darf nidjt eher ein Meiler in Brano gebrad)t werben, bis alles $S_{20 l}$ bei ben Siohlpläben fteht.

Rad)bem Der 2(btriebsidlag bon allem geidlagenten behölze gereitigt

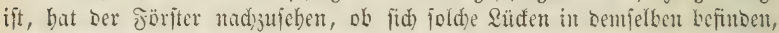

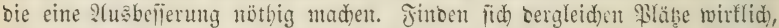
fo müfien fie, wenn ifre Gröbe 6-7 $\square$ Mltr. mo mebr beträyt, alsbalo in ber Entfentung bou 1 Mitr., entweber mit Budfen ober mit Cidhen von

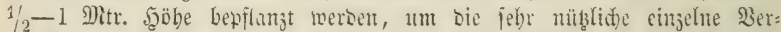

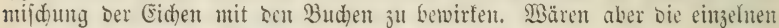
leeren Etellen nid)t $6 \square$ Mltr. gró̈ uno wollte man bicje fleinen Blößen

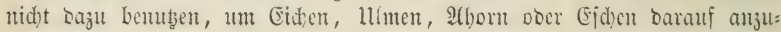
fflanzen, jo ijt es nid)t nötbiy, fie mit Buden ju bepflanjen, meil das Dafcin jold)er einzelner fleinen Blöpen auf Den füntigen Şolzertrag leinent

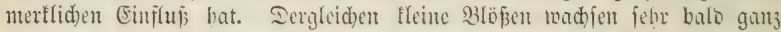

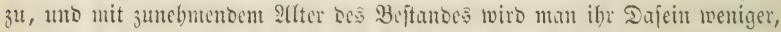

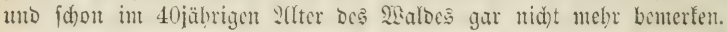

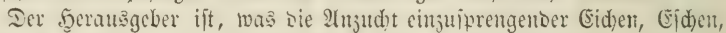
2(horne «c. betrifit, mit 3oritehenom nid)t ganz cinverftanben. Die in

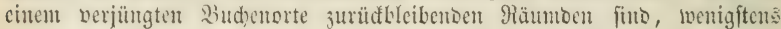
gröptentheils, Räumoen geblieben, entweber wegen idjed)ter Seichafien:

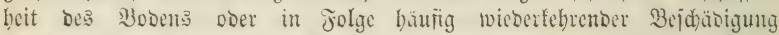

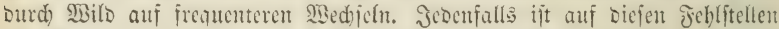

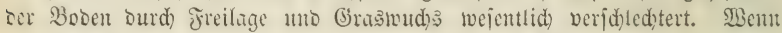
mun bie Erfahrung lebrt, safj dic cmpfoblene uno febre emperflenswerthe

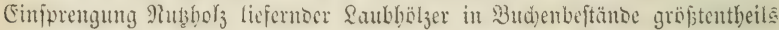

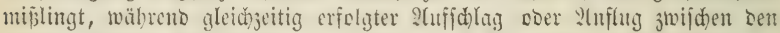

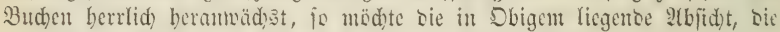

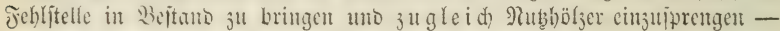
zwoi fliegen mit einer filnppe zul id)lagen, in bielen Fällen bie lltrade fiin, Daj teine getrofien wurse. Smectmäpiger Dürfte ç fein, Die Jeblftellen mit Budhen, in böherem Sllter bes umgebenden Beftubes mit ber gentïg=

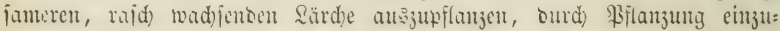

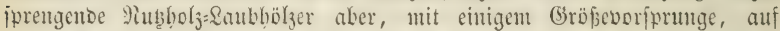
fleine Probeftellen mitten in Den bid)tejen Budenumfid)lag zu sflanjen, in boun fie nidut allein Den beften Boben in woll erbaltenter Siraft mo burd) Das

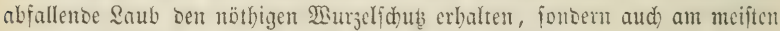
vor ben Bef̧äbigungen burd) Milopret gefichert fint. $t$.

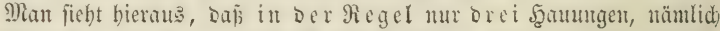

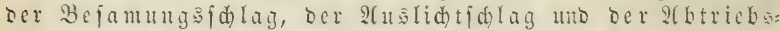

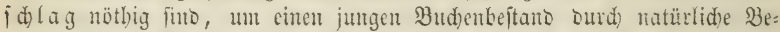
jamung ju erzieben. MBent aber, wie biej jumeilen geidiebt, son 3eit ju

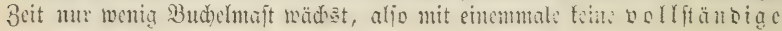




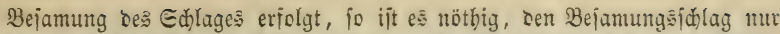
theiltweife lidfter zu ftellen uno bie nod nidft binlänglid bejamtent Theile

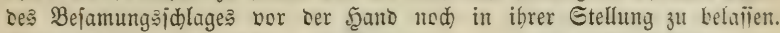

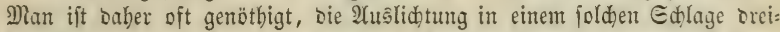
bis viermal vorjunebnten, um einen burd)aus vollfommenen jungen Bejtano zu erjieben.

Nun wäre aljo an ber Etelle beş abgeboljten alten Maltes ein Durch: aus bollfommener neuer ober junger $\mathfrak{B a l}_{\mathrm{D}}$ erzogen. Diejer nú immer nod) unt io lange aufs Etrengite gebegt und vor jeber bejdäbigung ke= wahrt werben, bis er jidh nadh 20 oder 30 Jahren unten gereinigt bat,

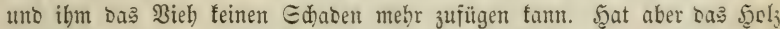
eine foldhe Söbe uno Etärfe erreidht, Dáp Das \$ieh nicht im Etanoc ijt, ben jungen $\mathfrak{B a l b}$ auf irgento eine $\mathfrak{A}$ trt 3 bejdäbigen, jo faun ihm wenn 2 Beibegeredtigfeit a uf bem Diftrifte baftet - ber 3 u tritt wieber geftattet werben.

Sollte, wie es jebr oft gejdieht, jogenanntes unjrudhtbares uno weide Solly, als Birfen, $\mathfrak{A}$ ipen, Eaalweiben u. ogl. im Edlage ange: flogen fein, uno ben jungen Budbentwalo ju unterbrüden anfangen, fo mu

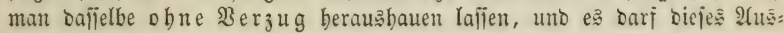
bauen nidht io lange beridoben merden, bis bas angeflogente Gehölj erjt eine vorz̧üglid brauchbare Etärfe erlangt hat. Mollte man Dajfelbe, wie $e^{?}$ leiber nur zu oft gejoieht, jo la inge ftehen laijen, fo würbe am jungen Budhenmalbe bei weitem mehr Echaben gejdehen, als bas fänumtlidje weidhe Gehöls werth ijt, und man würbe, burd bie fatalen Jolgen belehrt, ju fwăt bereuen, meinen Rath nidjt befolgt ju baben. Man nebme baber, ic

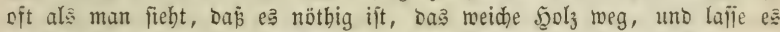
fogleid aus bem jungen Dididit $\mathrm{tragen}$, bamit burd jeinen Drud soer burd) bas 2(bfahren fein Edaden geidehen fantr. Iod) büte man fid), von

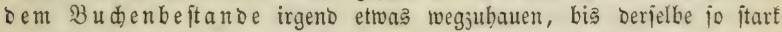

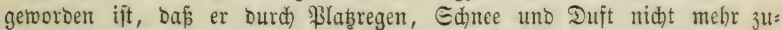
fammengebrüat werben fam. Sit aber ber Beftano $30=$ bi 40 jäbrig ge= worben, ober fo weit herangewadjen, baj bie it ärften Etangen 15 Eentm. in unteriten Durdmeñer baben, jo fann uno mus im mildern Sllima,

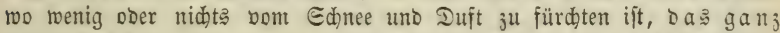
unterdrüdte, uno bas von ben bomintrenten Stangen übermadjente Gehölje unter ftrenger 2 uffid t berausgebauen werben. Märe aber

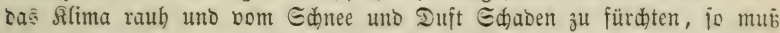

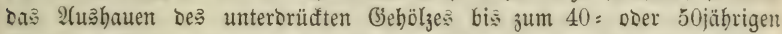
Alter bes Beftanbes, ober jo lange verichoben merben, bis bie itürfiten Reibel 15-20 Emtr. im unteriten Durdamefier erlangt baben, uno Der DSitterung troţen fönnen. - Bei biejer eriten Durdbau u

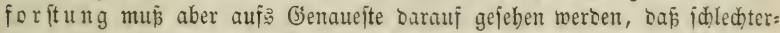

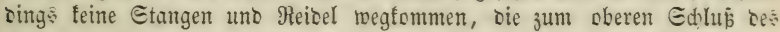
Walbes beitragen, ober, wie man fagt, on minirend fint. Nan tarf raber nur ganj oder halb abgeftorbenes uno vollig üter:

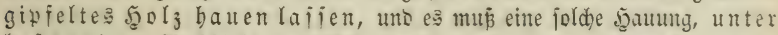

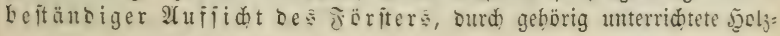


Gauer gemad)t werden, Damit Durd) ju ftarfes angreifen ber Beftand nidht

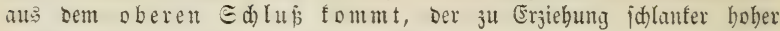
Bäume niemals unterbroden werben barf.

Gemöbnlid blaiben auf sem நुeftar, im Durdjidnitte gentommen, 6000-7000 Stangen iteben, ment man anf gutem Boben einen 40jäbrigen

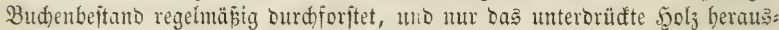

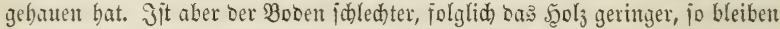
gemöbnlid bie beften $7000-8000$ Stangen auf jebem Seftar jtehen, went ber

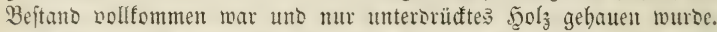

2us biefer eriten Durdforfung entiftehen bie widtigen Bortheile, Dan man eine beträdtlide Menge zwar geringen, aber ood) febr guten Bremt: boljes erbält, uno daf bie ftebengelafienen Stangen in ber Folge ungleich itärfer wadjen, als wem ba: unterbrüate Gichöls nidht weggenommen

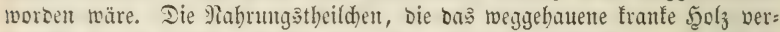
brandht haben würbe, flię̧en nun Den gejunben Etangen зu, bie ftehen=

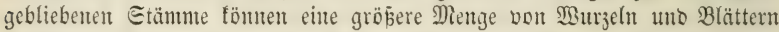
entwidefn, Daher aud) mehr Nahrungsjtoffe aufnehmen uno verarbeiten, uno man wirb über ben ftarfen 3uwad) erftauten, rem man nad) Ber= lauf von 5 ober 6 jabren einte jold) Stange abhauen, uno ben 3utwads vou Der Beit Der Durdjorftung an mit bem 3umach ser lebten Gabre vor Der Durdforitung vergleiden will.

Eo aufialleno mübsich cine joldhe Durdforftung aber ift, fo febr

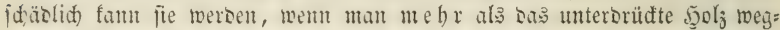
nimmt. Wian befolge saber bei allen Iudforftungen Die Gieneralregel: lieber etras 3 biel, als zu wenig $50 l_{j}$ fteben zulaifen, un thie eituen dominirenden Stam toegunebmen, aljo

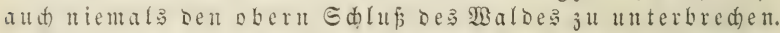
- Wier bieje einjade Negel biobadtet, oer tant feinen Jebler madhen,

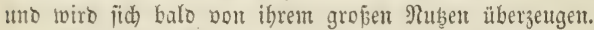

Jn foldyen Gegenten, wo Das geringe Etangent uno Reijerboly einen

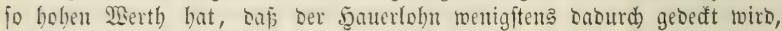

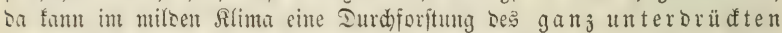

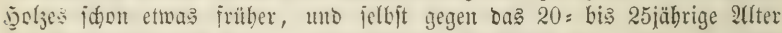

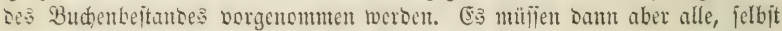
id) wade Etangen, sie mit bem Gipjel jum Edhlup beitragen, jorgfältig veridont merben, Damit nid)t Flabregen ober Ednee Dergleiden Bejtänoe

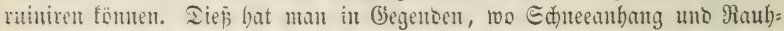
reif sit vorfonmen, jebr zu fürdeten. Dian muj saber bei einer folden Durd)=

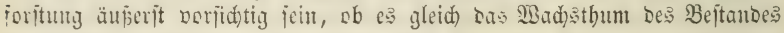

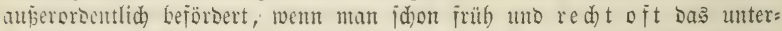

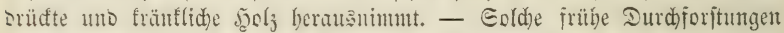

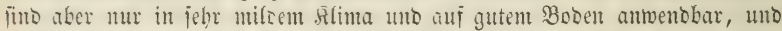
fömten saber nid̆t im Allgcmeinen empfohlen wersen. WBo man fie shne Gejabr anwenden fann, oa fino jie allerbings jefor nüblid). In rauben Gebirgagegenten aber toürte sas Rejultat meiftens jehr traurig ausfallen.

Dian Durdforjte alio unter obigen Šerhältnifient alle jungen Bejtänto

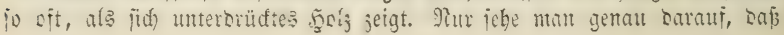




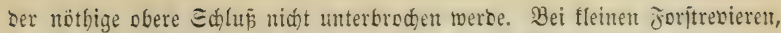

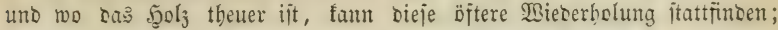
jonjt mus immer jo lange gewartet werben, bis bie Bejtänoe jo biel unter=

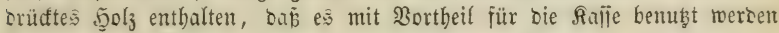

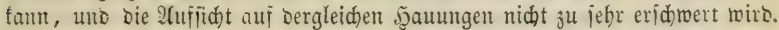

In neuefter Beit hat man bie Durdforftung ganl junger Budchenorte int 10ten bis 15̆ten Jabre bis ju einer Entfermung ber Etämme von 2 bis 3 Mtr. empjeblend jur Epradje gebradt. (Begen Diejelbe dürite fid) ein=

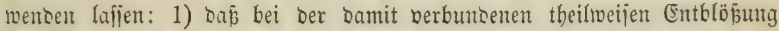
Des Bobin, wenn fie aud nur wentige Jabre bauert, burd) Den bermebrten

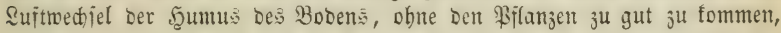
raich berzebrt wird; 2) baj burd) ben Berlujt Der Dammerde, Durdi ben vermebrten \&uitzug uno bie unmittelbare Eintwirfung ber Eonnemitrablen auf sen Boben, lebsterer jeine Jeudtigfeit berliert, mas bejonbers auf einem

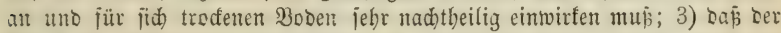

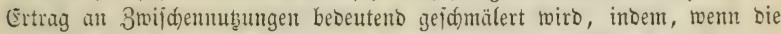
erite Durffipritung eine Entjernung ber Stämme von 3 Mitr. Geriteflte, Die nüájite nothwendig eine Gmetrige uno bie barauf jolgente eine 12metrige Entiernung Der Etämme herbeifübren muई. Es niro baher in vielen Fällen nur cinte, hödjitens werben 3 wei Durdforjtungen mubbares Material ab=

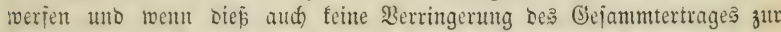
Jolye bat, jo ijt Dodh samit ber Nad)theil berbunben, Daj man jich bei 2(usbleiben von Gamenjabren nid)t in Dem Map̃e auj Durdforitungs:

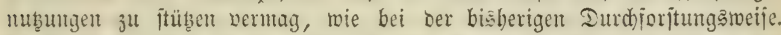

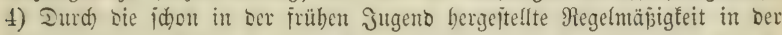
Entfernung Der Etämme wiro man genöthigt, bei Dent folgentont Durd)=

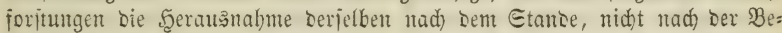
idhafjenheit Der Stämme зu bejtimunen; man wiro, wenn man Den Bejtano nidht lüctig bauen will, oft genötbigt jein, einen guten mildfigen Etamm meģunebmen uno einen wentiger wüdjigen iteben zu lajien. 5) Die geringe

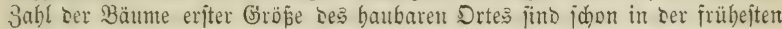

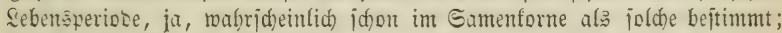

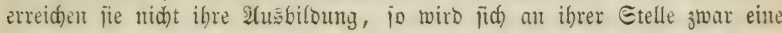

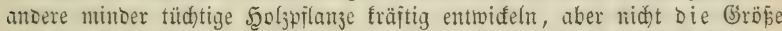

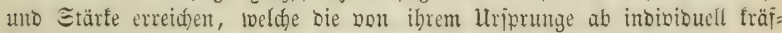

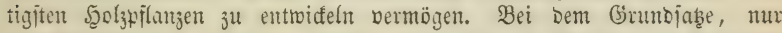

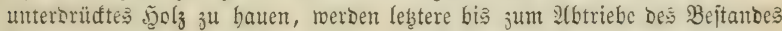
erfalten, beim jrüben Durdjorjten in beitimmter Entjernung gropentbeits ifjon in ber Jugento weggehauten, da ibre eigenthümlidhe normiegende $3 u=$

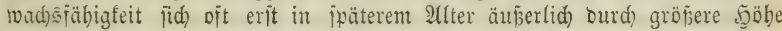

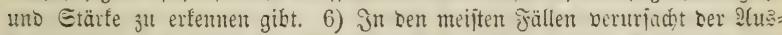
bieb eines nod werthlojen Miaterials nidjt unbebeutenden Roitenaufwant.

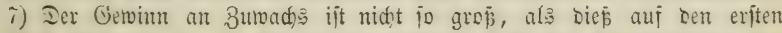
3(ide erid)eint, ba bie Steigerung Eelielben nad) Der Durdforitung mu

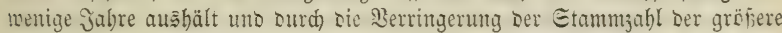

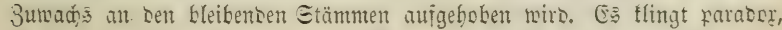

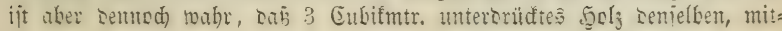




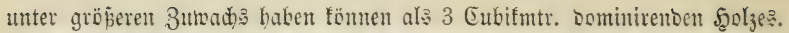
Mant wiro siés begreiffidy finsen, wem man crmägt: Dáp eritere in 100 , leb̧tere in 10 Bäumen cntbalten jein fömten uno jene 100 Bäume meḅr

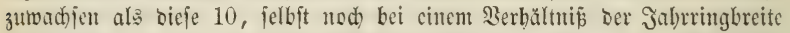

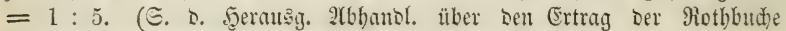
ङ. 140: (Ertragseigenthüntid)feiten Der veridiebenen Durdjforitungšweifen.) t.

Der Das eritemal burchforftete junge 3 ud hentwalo bleibt mun fo lange mit

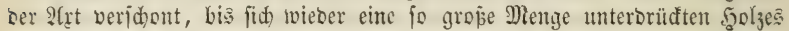

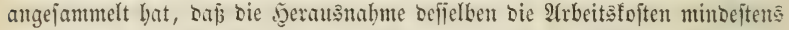
ju erjeţen veripridt. (bemöhnlidh gehört baju ein 15: bis 20jähriger Beitraum. Der in 30 ften bis 40 iten Salhre burdforitete Bejtano wiro alio gemeinbin

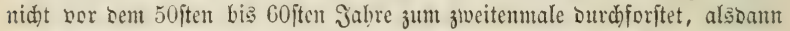
aber mus ex von allem bis dabin wieser unteroriudten . werben. - Man nebme aljo wieder nur bas übergipfelte 5olz weg und lafie alles bominirene fteben. - Bei biejer Durd:=

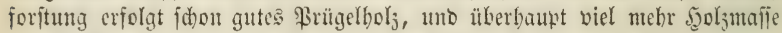
als bei Der Durd)forjtunty im 30= ober 40jäbrigen ?flter Deş Beftantes.

(Semöbulid bleiban bu ber Durdforjtung eines $50=$ bis 60jäbrigen volffommenen Budsunalbes im milben Rlima,
wern Der Boden gut ift, .
1500 bis 1800 Retoel,

menn er aber idjled)t ijt,

bingegen im rauben $\mathfrak{R}$ lima,

werm ber Soben gut ijt, . . . . 1800 " 2400 "

wenn er aber idjledter ift, . . . 2 2400 " 3000 "

auf Dem Sgettar iteben, uno man miro nadber mit S"ergnügen bemerfen, Dap sicje burdjoriteten Drte auffalleno ftärfer wadjen, als vorber.

Эn Dicjer Gtellung bleiben nun bie burdforfteten Beftänbe bis zum

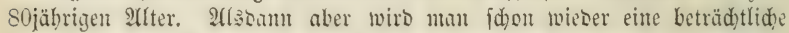

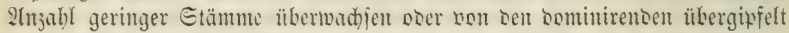
finbert. Man nimmt baber alle biefe übergiffelnoen Etämme weg, und besbad)te bie vorbin gegebene (jenteralregel aufs Gentuefte.

Eino die Budbenteitünoe vollfonmen, fo bleiben bei ibrer Durdi: forjtung im sujäbrigen Allter, went is a flima milo ift,

auf guttem Bobent
auf johlecterem Boben aber
.

im rauben Rlima bingegen

auf gutem Boben

1200 " 1500 ,

unto auf folledteren Boben

1500 " 1800 "

auf Dem Scettar jteben, biß Der Beftano in 100jäbrigen "Sllter wieber, wie anfangs gezeigt wurbe, verjüngt wirs. Eollte aber cine 120jäbrige $4 \mathrm{~m}=$ triebascit ftatt finben, aljo jeber Bejtant 120 Jabre alt werben mitiīent, io

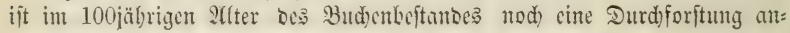

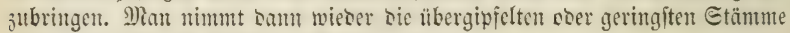
tweg, unt läfit in milocm $\mathscr{R}$ lima

auf gutem Boben

auf fdled)terent Boben aber

600 biฐ̄ $750 \mathrm{Gt}$.

750 " 900 "

in ranberem frima bingegent 


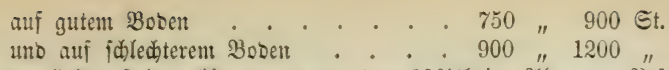

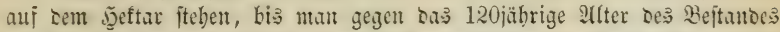

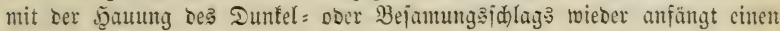
jungen $\mathfrak{2}$ ald $\mathfrak{z}_{\mathfrak{H}}$ erzieben.

Durch bie vorbin empfoblenten regctmäpigen Durdjoritungen, bie alle 20 Jabre in oen Budenbeftänoen vorgenommen werben nuïjïl, erlangt man, wie id jidon oben bemerft babe, bie jebr widhtigen Bortheile, daj

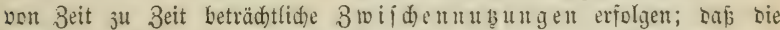

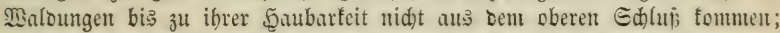

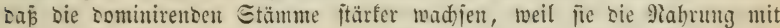
ธen franfen übergipjelten Stänmten nidgt ju theilen braudhen, uno Daj aljo

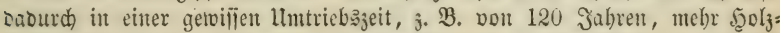
mafje erjogen mirb, als wenn man ben Salo yon jeiner Entitebung an bis 3u feiner Janbarfeit gar nidt durdhauen wollte. Sn biejem falle geht

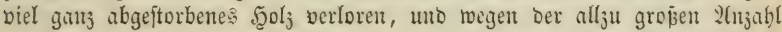
Der Stämme fömten enolid felbjt bie bominirenten nid)t mebre beträdytlid

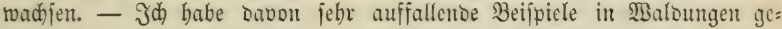

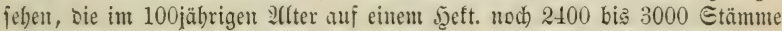
enthielten, uno niemals burdjorftet worben waren. Şier tounte man an Den unterbrüdten Etangen cinte grof̧e 2(nzahl Der leşten Jahrringe faum

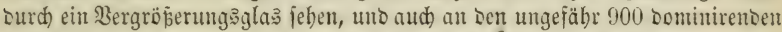
Etämment waren bie Ringe von Den leksten $30^{\circ}$ Jahren fo idjmal, baj ber biäherige jührlide Buwads vom ganzen Beftano nidht halb jo viel betrug, als in jeoem jolgenten Jahre an oen 900 bomintrenden Stämmen juwud:s, nadoem id bieje merfwüroigen Beftünde batte bordjoriten laffen. ${ }^{1}$

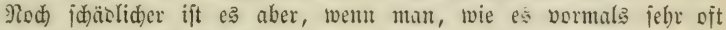

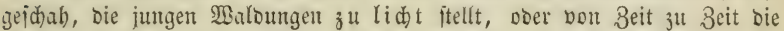

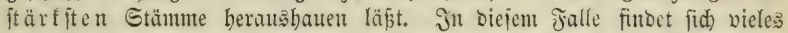
Jorituntraut cin, bas ben Boben auşaugt, uno ber Edhnee uno Duft Drüden Die (d)wad)en nid)t mebr geid)lofienten Etangen zujammen. Ifud) werben alsoan bie einjelı aufwadjienton Stämme furz uno äjtig, uno e eriolgt binnen ciner gemilien llmtriebşjeit an Den fteben gelafienen halb unterbrüdten Etämmen bei weitem fein jo jtarfer 3uvadb, als wem man von 3eit ju 3eit bie fräntefnoen Etänune megnimnt uno Die jämmntlicten Doninirenben bis zur Saaubarfeit ftehen läp̆t. ${ }^{2}$

jod empieble Daber nodmmals, Die Durdfforitungen weder ju unter:

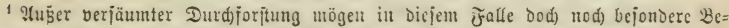
ftandes= und Standortäberhåtniffe mitwirfeno gewejen jein, Da auj fräftigem Soben uno

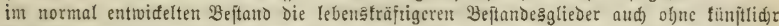
Beibülje Den nöthigen Stanoraum jid) ju verjdafjen vernögen. Wïir haben hier auf Dent frudtbaren Budenboden unjeres (Etm eimjlagende $2 e r j u d e$ in $60-80 j a ̈ b r i g e n$, ftart be=

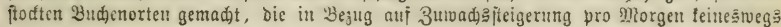

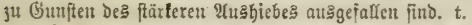

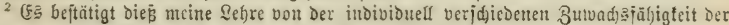

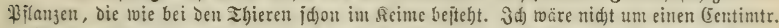

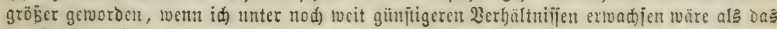
Der Fall getwejent iit. 
laijen, nod) fie ว̆u übertreiben, fonben bie vorbin gegebenen, aus meiner vieljäbrigen Crfahrung abgeleiteten Regeln aufs genauejte zu befolgen.

3ugleid) mú id wieberholt empfehlen, bie Durdforitungen in 30 bis

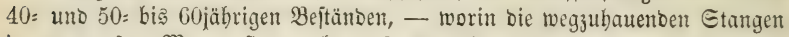
in 3u grofer Denge fimo, als daj man fie alle mit bem Malbjtempel zeidunen tönte - unter immerwährender 2 uffidht bes görfters,

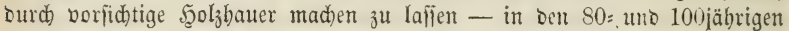
Bejtänben aber jeben wegzunehmenoen Stamm mit bem Walojtempel auf Der Wurjel, uno, bamit man fie von allen Seiten her fehen fant, surd) brei \$latten am Edhafte zu bezeidnen. - Nur burdh eine foldhe Bezeidonung

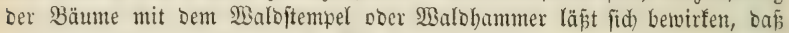
jebe eigenmäd)tige fällung, Die fidh Die Syolzhauter gern erlauben, zu ent: Decten ijt. Beidnet man aber Die Bäume, bie weggebauen merben follen,

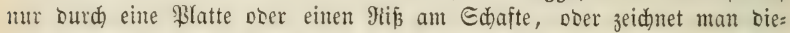
jenigen, weldhe ftehen bleiben follen, mit einem ßip am Gtamme, uno gibt man benjenigen, weldje gehauen werben follen, gar Kein 3eidjen; fo ift es Den Şolzhauern leidist, Den Förfter zu bintergeben.

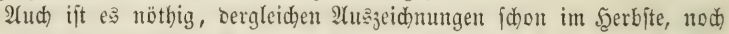
ehe Das Laub abgefallen ift, vorzunebmen. (Es läăt fid alsoann bie Şes

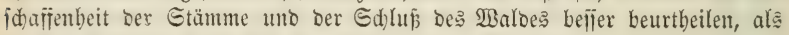

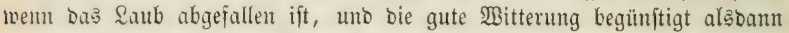

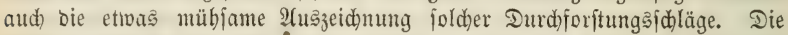

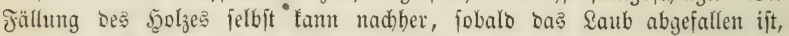

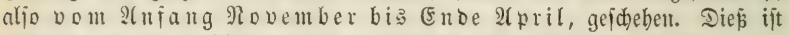

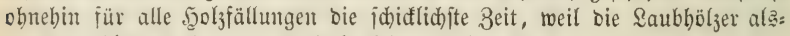
Danm entblättert fino, Das $\mathfrak{J g l l}_{3}$ feine völlige Reife erlangt hat und ber

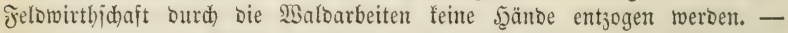

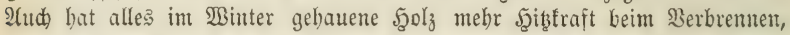

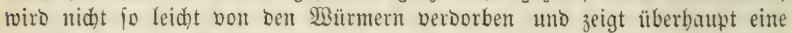
längere Iauer, als roent man es im Saft hat fällen lafien. - In Dem

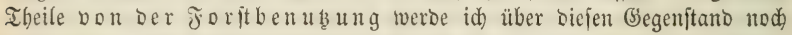

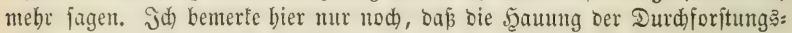

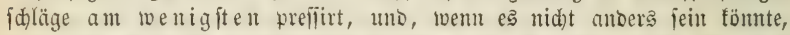
gegent das Jrübjabr vorgenommen werben fant. Dagegen müfïen bie fichon

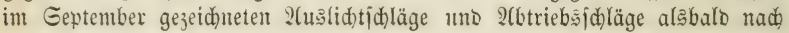
ben 2lbfalle Des Laubes, aljo vor Eintritt bes ftarfen Froftes borgenommen werben. Sit in biejen $G_{d j}$ lägen bie 5ुaunng geendigt, fo folgen bie Be= famungsidbläge, uno auf bieje bie Durhforjtungşalläge.

\section{Drittes sirnifel.}

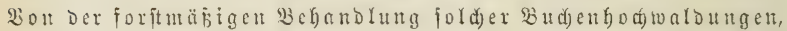
bie zroar aud mit haubarem 5olje, aber nidt mefr gefdolofien beftandell find.

Db man gleidh bie meiften baubaren Budbentodiwaloungen von ber

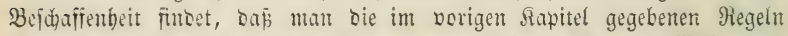

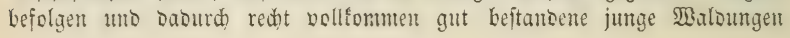


erziehen fanm, fo gift es ond aud biele, seren Bejtano nidyt von ber 2frt

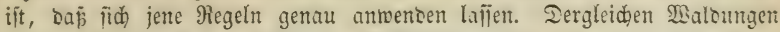
fino nämlid) Durd) bas bejtündige 2 (uslidten, obne eine Şegung bamit ju verbinben, oft fo aus bem Ed)lup gefommen, saj fid) bie Bäume mit ben äนjerjten Episen ibrer 2(ejte bei meitem niđ̆t mebr berübren, aljo teinen

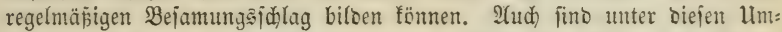
ftänden, wenn fie idgon viele Jahre lang ftattgefunben baben, bie Bäume getoöhnlid mit vielen uno gropen Yleften, bis tief zur Erbe berunter, bes febst, uno ber Boben ijt getwöhnlid mit einer Plajentede, ober mit Şeide:

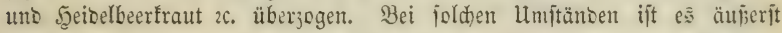
fämer uno oft gar nidat mögliá, blóp burdh natürliche Bejamung uno burd:

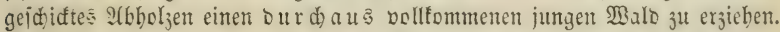

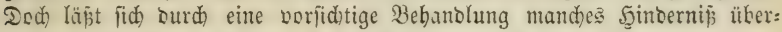
rinben uno ber 3mect ziemlid) vollitänoig erreiden.

Die erite Interfuchung uno Ueberlegung mus oabin geridytet jein, of nod) jo viele Bäume vorfindlid) fint, Daj fie twenigftens bic fyalfite von ber J̈täde, morauf fie ftehen, bejamen fömen? - Jinden fict meniger Bäume, uno ift ber Bejtano fo lid)t, baj oer MBino sas \&aub fümmtliç

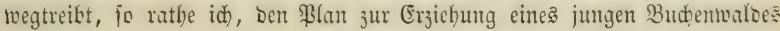
aujugeken, uno eine für ben Boben, bie \&age uno bie Bebürinifie pailente

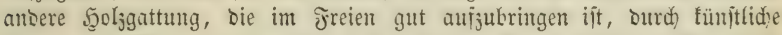
Eat ober \$flanjung anjujiehen, wie in Der Jolge gelehrt werden mirs.

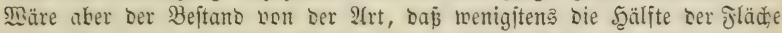

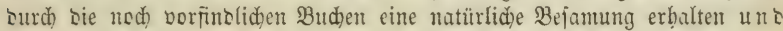
bas abgefallene $2 a u b$ ben Eamen bebeden fann, io warte man

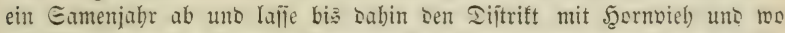
möglidy auch redgt oft mit Edmeinen betreiben, menn man finben jollte, Daṕ biefe ben Boden aufbrechen.

Jit mun eine binlänglidhe Menge Eament gemadjen, io lajie man, jobulo bie Bucheln abgefallen jint, ben Bäumen bie vielleidgt jebr tief

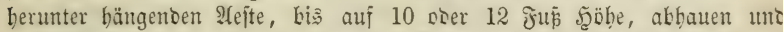
Dent Diftrift in Sgege legen. Şierauf laile man, wenn ber Boben mit Seide = un Sgeibelbeerfiaut beradien iein jollte, bie leeren Etellen mit ber \$iflugegge verwumben, bierauf biejelben mit Budjeln uno Sुainbuden= ober Birfenjamen überitreuen, uno dann mit einem jomeren

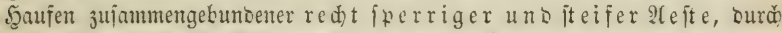

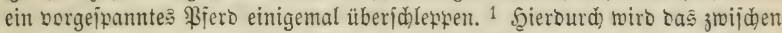
Der Şeide uno Dem Sceibelbeerfraut befinsliche Moos uno Raub aufgefrabit, uno ber meifte Eamen in eine joldhe Sage gebradht, oaj er feimen tann. Gollte aber bie \$flugegge feine :Inwenoung finten, io müfïen alle Etellen, mo bie natürlid) abgefallenen Budbeln vom Saube feine Bebectung crbalten haben, nodh vor einfallentem Froft jeiđ̆t umgehäđelt, bie leeven Etellen aber im nädjten Jrübjabr flats: oser jtreifenweije mit Buđ̣eln aus oer நunt bejamt werben, wie joldtes im adten Rapitel ses jmeiten 2tbidnitte

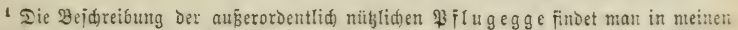

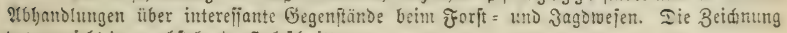
bavon giebt ber nadjitehende Şoljidnitt. 
gelehrt wiro. Dhne bicje Atrbeit ju unternehmen, wiro man viele Jahre lang vergeblid) auf bintängliden 2(ufichlag warten, uno baburd mebr an 3utwach berlieren, als bie Rulturfoiten betragen.

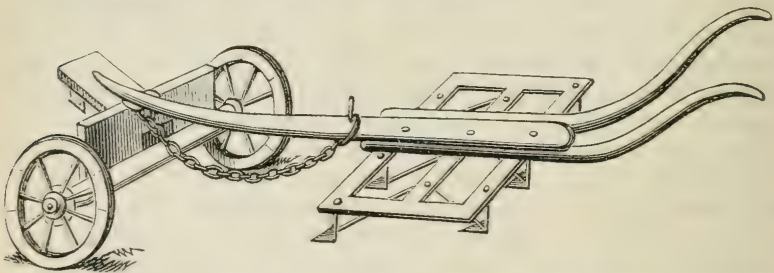

MBenn es aljo nidht ju änbern ift, fo toentoe man bie Siojten bes Un:

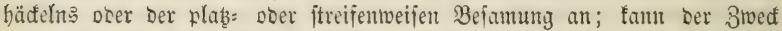
aber Durch ben bei weitem wohlfeilern (Bebrauch ber Bflugegge unb bes Ed)leppbriches erreidt twerben, io wäble man bieje Methode.

Sie übrigens ein Edhlug, went er allentbalben mit jungem Şolze bewadjen iit, nad) uno nad abgetrieben und fenter bebandelt werben muf,

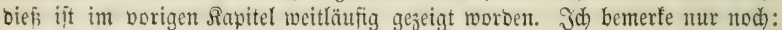

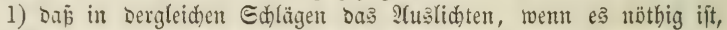
Durd) MBegnabme mebrerer 2 ejte oou ben Samenbäumen ge=

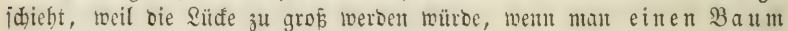
weghauen wollte;

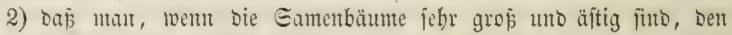
völligen abtrieb berjelben nidt zu lange aufidieben barf, weil jonft Durd) Den Sturz uno bie Bearbeitunty vieler uno groper Bäume ber junge

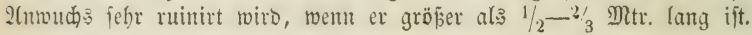

\section{Djiertes Siapifel.}

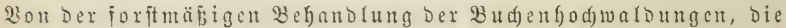
mit l)aubarem und jugerem $50 l_{3}$ e vermifd t bejanden find.

Menn für cinen Budenthodwalobejtano, ser baubares uto jüngeres

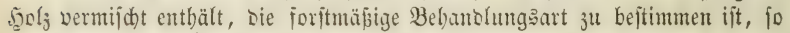

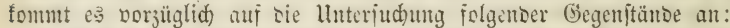

1) Db ber lluterwud) fo gering ift, baj ex i id beim Fällen ser alten $\mathfrak{B} a ̈ u m e$ beugen, wieder aufridten uno fortwadjen föne?

2) Db, went ber Unter= unb Beituds aus Stangen uno Reidelubejtebt, Diejelben nod nidt unterorü oft ober fänt= lid, und aud in folder Menge borbanden find, um nads

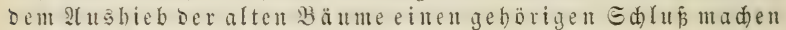
uno Dex isitterug troben ju tönen?

3) Db bie vorbandenen ftarfen Bän e in jo gropier $\mathfrak{A}$ a jahl oa itub, bas jie, went ber llntermuds überhaupt un= bollitänoig ober untauglid) fein follte, nad weghaung bes 
Ilnterruches ben Dijtrift aujs neue genugiam zubejaneu in Stande find ober nidt?

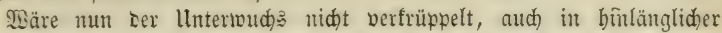

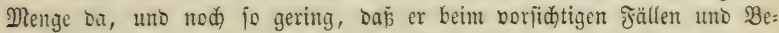
arbeiten ser alten Bäume nid)t jo jebr Noth leiben fann, io lafie mau bie alten Bäume mit Der Borjüht heraushauen, Die id in ztweiten Rapitel

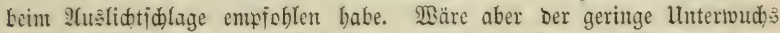
verfrüppelt uno jeit langer Beit unterbrüat, jo lajie man ibu ju einer

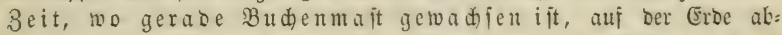
jdneiben ober abbauen, uno Die alten Bäume, wenn ibre 2tejte ju tief auf Den Bosen herabbängen, $3-4$ Mitr. hod ausäjten. Đierauf lege man ben Diftrift in fege uno bebandle ibu gerabe io, wie ich, vom I ichlage an, im zmeiten frupitel gclelurt babe. - Eollten aber uid)t fo viele alte Bäume Da jein, Dap̉ jie beinabe einen Dunfel: ober Bejamung : idhlag formiren fönnen, io miitien die leeren Etellen, un cinen gleiden

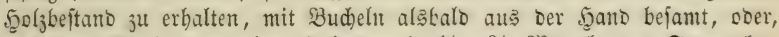

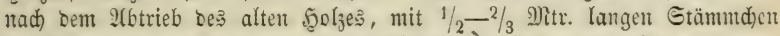
berilanjt merben, wie im zmeiten albidnitte gejeigt rerben wirb.

Märe aber ber Unter: uno Beimuch idon zu Stangen uno Reibelu

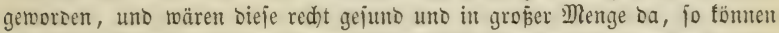
Die alten Bäume, bie in einem jolden Jalle eintseln fteben merben, vor=

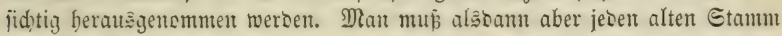
Dor Der jällung bis in bie Rrone ausäten, nachber umbauen un baڤ

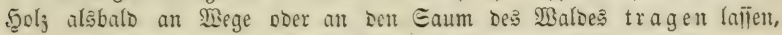
meil jonjt surch bie $2(b f u b r$ Defielben mebr Edaren gejdieht, als Durch ba:

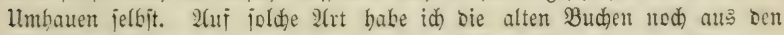
$20=$ hiz 40jäbrigen Etangenorten nebmen lajien, obne Daran viel ju be=

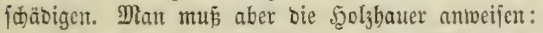

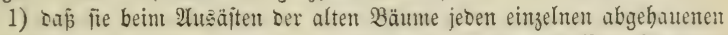
Qlit jogleich auj bie Eeite bringen, Damit fich das babon getroffene Etungen= bolz alabalo rieder aufrichten tann;

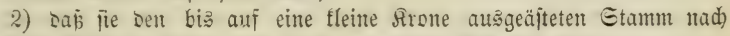
Derienigen Ridutung fällen, wo er an twenigiten Ed)aben thut;

3) Daj jie alle ourd) oen Eturz̧ Des alten Etammes̉ gebogente Etangen iogleich wieber aujitreden, will fie fonjt ibre Edhellfrait verlieren, uno nie rieber gerabe werben;

4) Dafi jue beim Bearbeiten Der alten Bäume feine Stangen ruiniren ober abbauten, uno

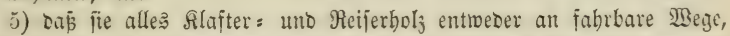
Doer an joldie Drte bringen, wo ourd bie Ubjabrt fein Gdaben ge= fabeben fann.

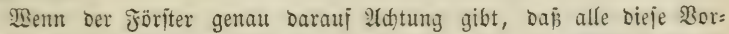
idriften bejolgt werben, fo wirb man eritauten, wie menig Ed)aben surw

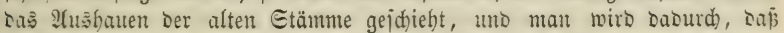
man bie Etangenorte von Een alten Derbämmenten Bäumen gercinigt hat, Dent jungen Walbe eine grobe Mohlthat erzeigen. 2(ud) werben fid) bie

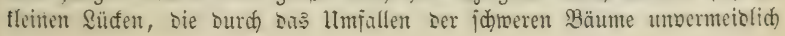




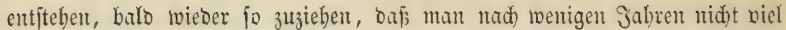
Dawon bemerfen fann. Golfte aber aud) bie Spur cines jold)en veripätetent 2lußhiebes längere 3eit benterflich jein, io ift es boch vortheilfafter, bie alten Bäume mit Borfid)t aนs ben jungen Stangenorten zu neb)men, als fie länger barin fteben unto ben jungen $\mathfrak{B a l}_{\text {b }}$ mit jebent Jahre nod) mebr verbämmen zu lafijen. Siur madhe man feinen Berjud̆, bi e alten $B$ äume

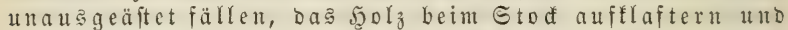

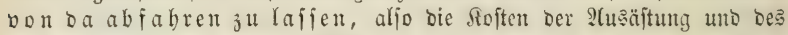
Seraustragens zu eriparen. Man wiro alsoamu ju fpät bereutu, meinen

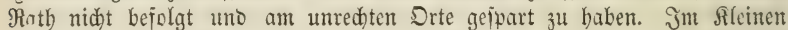
babe id mefrere Berjuche Der 9 (rt gemadht, bin aber immer erfidsodent, went id ben Erfolg fah. Dagegen babe id niemals bie 2 Anoronung einer 2(uşbaunng Der alten Buchen aus Etangenorten bereuet, went fie mit ber vorbin empfohlenen Borfidt uno unter Der $2($ ufi

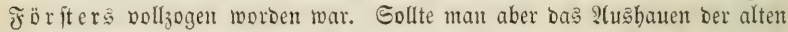

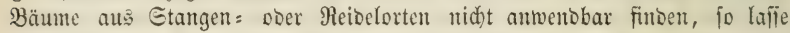
man bie alten Bäume wenigftens etwas ausäften uno jo lange ftehen, bi bie Stangen uno Reidel jo weit berangewadden fino, Daj man aus ihnen

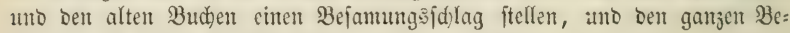
ftano burd) natürlide Befamung veriüngen fann.

(5) fönnte aber aud Der fall jein, daj bie alten Bäume in einem Etangenorte fo nabe beijammen fteken, baj er, rentm mant aud alle nur möglidye Borficht beobadtet, nad) Dem 2(ushieb Der alten Budhen bod fo

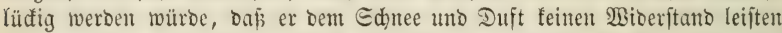

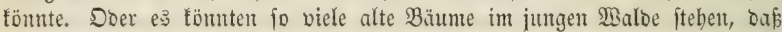
biefer in furzer 3eit ood) zu jehr verbänmt werben würbe, wenn man aud) Die alten Stämme etros a Inmiänoen babe id) ant beften geiunten, ben ganzen Beftunt, alio Das

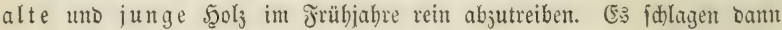
bie Stöcfe Der Stangen, rem fie nabe über ber Eroe mit jojarfen Jn: ftrumenten red)t glatt abgebauen uno abgejd)nitten worben fino, febr fidön

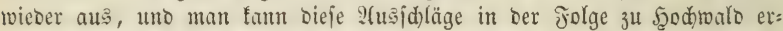
zieben, uno eben io behandeln, wie id) im zweiten Rapitel weitläufig aus: cinanter gejeb̨t babe. Dod) muß man einen jolden Berjud) erit im Sileinen

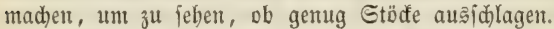

Wärent aber Die Etangent unto Reibel fidon gipfeltroden oder frant; ober nicht in joldher Menge vorhanden, dab man von bem eben erwähnten

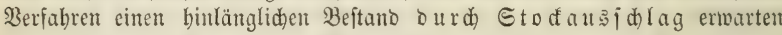
Dürfte, fo bleibt fein antoeres 9)ittel übrig, als in einem Jabre, wo $B u d e l n$ gewadfen ji niederbauen ju lafien, ocn Diftrift in einen aus alten Bäumen uno Reibeln beftehenton, fo viel rie möglich) regelmäpigen Dunfelid)lag zu ftellen, uno ihn in ber Folge nad) Der in ztweiten Rapitel gegebenten 2(nnweifunt zu behandeln. - Gollten nadher bie einzelnen 2 tusid)läge ber Etöde, bie balo eitten żl groß̌en Boriprung befommen, bent Gamenaufidlag berbämmen wollen, io müfien fie obne 2fufidub reggenomment werben, weil fie jonft alles geringere Samtentholy weit um fid her veroerbent. Säpt man aber bie 
exiten Etodausiabläge wegnefmen, jobalo fie $1-1^{1 / 3} \mathfrak{M}$ tr. hod gemorbent fint, jo veridafit man ben anjungs langiamer wadjenton Gamentoden 3eit, um mit ben nachber wieber neu entitehenten Stodfoben in bie Sä̈he ju fommen. Man verjobiebe baher bas 2(bhauen ber Stofloben nid)t jo lange, bis fie als Brentholz nuţbar getworben fint, uno nebme mehr barauf Rüđ: füft, einen föbnen jungen Walo zu erzieben, als einen etroas größ̄eren

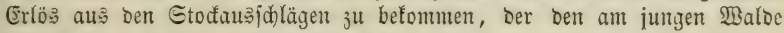
verurjachten Sdjaben bod) nidht erjeß̨en würbe.

Wäre aber enolid ein Dijtrift mur plabzeije, fo wie id ebent er: mäbnt babe, mit alten Buchen beftanden, uno bätte er plab̧weije, ober, wie man beim Forjtmejen jagt, borft weife idönen Stangen= uno Reibel= beftanto, io ift es belier, einen foldjen Diftrift jeşt nod) nidht abzutreiben.

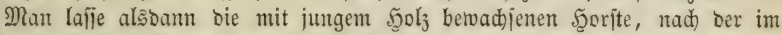
ztweiten Rapitel gegebenen Borjobrift, regelmäpig burdforjten, uno warte mit Der Berjüngung Des ganzen Diftriftes jo lange, bis Dab jeţt junge Sgoly jo ftarf geworben ijt, Daf es taugliden Samen bringen fant. Şat cs aber biefe Etärfe erreidjt, fo ftelle man ben ganzen Diftrift in einent fo

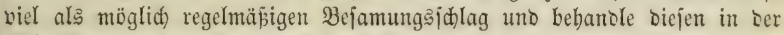
Jolge io, wie id im zweiten Rapitel gelebrt babe.

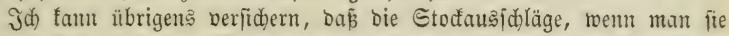

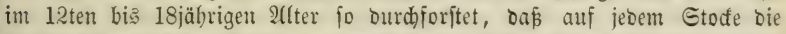
ftärfite Etange itehen bleibt, in Der Jolge 34 5ुodjwalo erzogen uno in einen

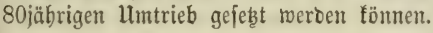

\section{Tilluftes Eapifel.}

Don Dem forftmäbigen \{btrieb uno $2 e r j$ üngung Der baubarn (Eid)enlodidaloungen ut ifrer ferneren befandlug.

Beim 2(btrieb eines baubaren (Fid)entwaldes uno bei ber ferneren Be: Gantlung bes wälrento des 2tbtriebes burd) natürliche Bejamung erzogenten jungen Waldes finden alle Regeln ftatt, bie id) für ten 2(btrieb ber Buchen=

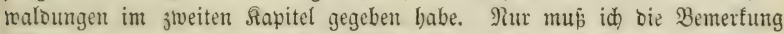

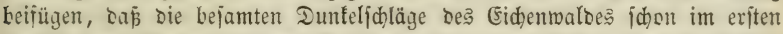
5r.rbjte ober Minter nad) Dem 24uffeimen Der jungen Eidhen et was gelichtet

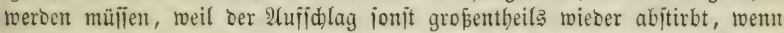

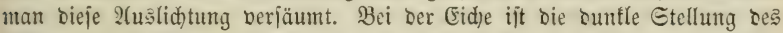
Echlages nur bef́rwegen nöthig, um Den Boden bis zur Bejamung von Un= fraut befreit uno mit Saub bebecft zu erbalten, aud eine ourchaus gleide uno binlängliche Heberftreuung mit (Fideln zu bemirfen, uno bie Eideln

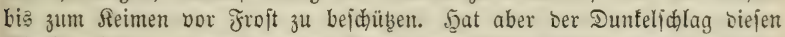

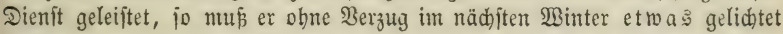
werben, weil bie junge (Eidhe Den zu lange anbaltenoen Echatten nidht er: tragen fann. Nur im eriten Jahre begnügt fie jid mit ben menigen Eonnen: frrablen, Die ben Boden bes Dunfelidlages erreichen; im zweiten Jahre aber will jie bie balbe Tageşzeit über abwechjelnt in oer Gonne unt im E(j)atten fteben. - Eelbjt gantz im Freien bringt man bie jungen Eichen bei reitem beffer fort, als in einem Dunfelichlage, worin sie jungen Budent 
mehrere Sahre lang vortrefilid) wadjen. - Man veriäume aljo bas baloige

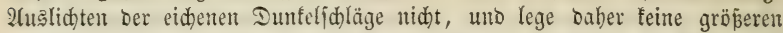

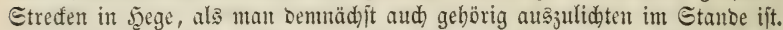

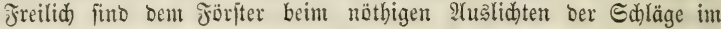

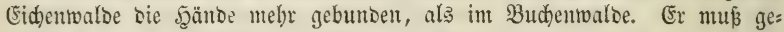

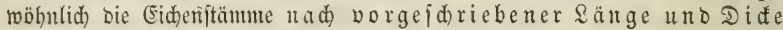
antweijen, unto barf oft aud nidft io viele umbauen laffen, als gerade

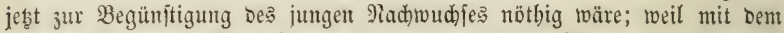
(Eid)ent=, Pluks= unb Bauboljoorrathe an Den meiften Drten Febr öfonomif getvirthidgaftet werben mū̄. Bem man aber vom Eidentwalbe ben älteften,

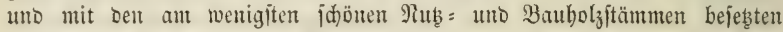

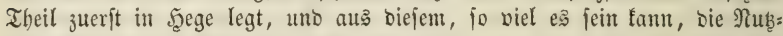
uno Bauholzbedurifniffe alle Jabre befriebigt, fo fantm man ihn nad) unt nach io viel als nöthig iit auslidsten, uno entolich ganz abtreiben. - Werben nadber von Beit ju Beit neue Theile eningebegt uno eben fo bebandelt, fo fann man entlid ben ganjen Bald veriüngen uno neue Beftänoe erbalten, Die theilweije ein gleides uno aud) ein gehörig abgeftuftes Allter haben. Jolgt man aber Der, leiber! mur zu allgemeinen Bewobnheit, bas jäbrlid)

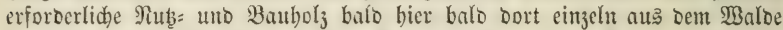

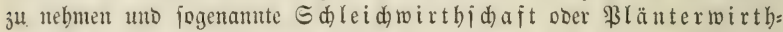
id) aft zu treiben, fo faum in vielen Jabren wegen bes zu bidten Sd)lufię feine junge Brlanze geoeihen; entlid aber wirb ber $\mathfrak{B a l}$ allenthalben auf eimmal fo lid)t, baj mu Iluffdlag in Menge erfolgt, bem aber nid)t

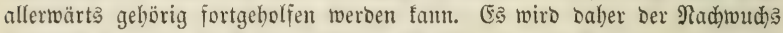
früppelbaft, ober Durd) Das Fällen, Bearbeiten und 2(bfahren Des alten 5elzes fehr bejdäbigt, uno fanu überbaupt niemals jo gejdont werben, al: wenn man ben Eidenbaumtwalo theiltweife in Ed)läge ftellt, uno bieje, fo biel möglid) nad) Den im zweiten Rapitel gegebenten Regeln bebanbelt.

Gefebt aber auch, Der Fid)embalo befäme bei Der Plänterwirth=

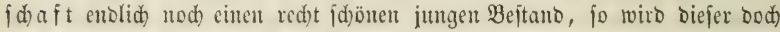
Durdan vo nf fajt gleid)em Allter fein, uto man wird baber bei weitem Fräter erft micoer cine Baubolzbenuţung barauß jieken fönnen, als menu man viel früber angefangen bätte, Den $\mathfrak{B a l}_{\mathrm{D}}$ theilweife z̆ verjüngen uno iiberhaupt io jul wirthidaften, wie id) es vorbin empfoblen babe.

Die fatalen Folgen jenter \$länterwirthjichaft in ben (Eid)entwaloungen äusern jiđ() allenthalben bei genauer llnterjudung ber Forite. Fajt überall

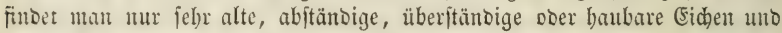
junge Eiden von 1 bis 60 Jabren. Dagegen feblen bie Eiden von 60: bis 140jährigem 2llter fajt ganj, weil zu jenter 3eit, wo Dieje bätten auffeimen muiffen, bie \$(änterwirtbfd)aft allgemein twar, folglich) entweder twegen be:

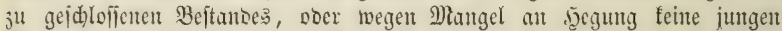
Eid)ent auffomment fomnten. Seit 60 Jabren aber - twurben bie Eident=

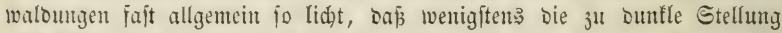

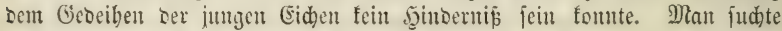

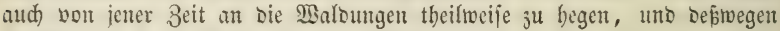
fomten bie beträdtlid)en imtgen (Eid)entwaloungen, Die man in einigen Gegenten von Deutid)lanto mit Bergü̈gen bemerft, antfommen. 


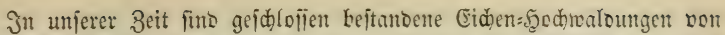
böherem 2flter immer feltener getworben. In Den alten lidhten Eidfentorten fteben bie wenigen Bäume fo weit von cinander entfernt, baj́ meijt nur cin geringer Theil ber G̈runbfläche von ibrem Eamen bejtreut twerben faun uno aud) auf biefem Iheile ber abfallente Game burd Einbacten unter= gebrad)t merben muई. Die bierau erwadjienden Rojten bleiben binter benten einer Eaatfultur auf nadtem Boden nidst weit zurüd uno überjteigt biefe fehr bäufig in ben Fällen, wo ber in jeinen anorganijołen Bejtanotbeilen meift fruchtbare, Dem Acferbau zugängliḑe Boden auf einige Jabre ber Santo: mirtbichaft überlaijen werben fann mit bem Borbehalt unentgeltlicher Eichel= cimjaat in bie lebste Getreibeausjaat. Man ift in biejem falle in Der $2(b=$

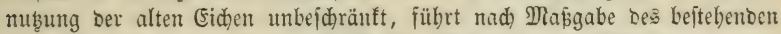
Bebarf̧ größ̧ere soer fleinere Sablbiebc, übergibt bie Sablfläd)en auf einige

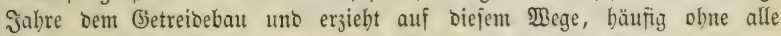
Solten, hflanzenreiche Jungorte von trefflicher Bejdaffenbeit. t.

Was bie in Den jungen (Eid)enwaldungen vorzutebmenten Durd)= forftungen betrifit, io werben folde gerabe fo, wie bei ben budenten jogd)= malobeftänben borgenommen. Ia aber bie Eichenhod)waloungen eine längere, uno zwar im miloen Rlima auf gutem Boben wenigitens eine 160jährige, im rauberen Rlima aber wenigitens eine 180jäbrige llmtriebszeit exforbern, um Darin gebörig ftarfe Bauboljitämme zu erzieben; fo mú ber Cichen= beftano im 40jährigen 2Alter pro .5eftar bis auf bie beften 5500 Etangen, im 60jäbrigen 2Ilter bis auj bie bejten 1800 Reibel, im 80jäbrigen Altter biß auf bie bejten 1200 Reibel, im 100jäbrigen $\mathfrak{A l t e r}$ bis auf bie bejten 900 Etämme, im 120jährigen 2llter bis auf bie bejten 600 Etämme, int $140 j a ̈ b r i g e n ~ \mathfrak{U}(t e r$ bis auf bie beften 450 Etämme, uno im 160jährigen IIter bis auf Die beften 300 Etämme surdforftet, uno entweber int 160: jährigen ober im 180jährigen ?flter wieber verjüngt werben.

\section{Sedjstes Sapitel.}

Don Der bewirthidaftung Der nur einjern mit baubarem (Eid)en= holze beftandenen Diftrifte.

Bei Der Bemirtbidaftung ber einzeln mit baubaren (Eidhen bejtanoenten

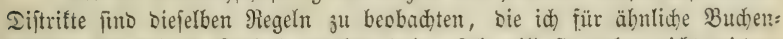

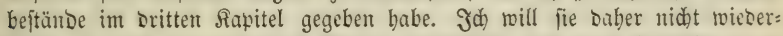
bolen, jondern nur auf jenes Sunitel vermeijen, uno nod bemerfen, oa alle Eidheln, bie beim. Jroft blosliegen, unfehlbarerfrieren uno zur Reimung untauglid) werben. Man barf baher nid)t ver= fäumen, ben abgefallenen Eideln vor eintretendem froft auf eine ober bie andere $\mathscr{A}$ rt eine Bebecfung zu beridhaffen, weil jonft non ber voll= ftänoigiten Bejamung nidt eine \$illanje zum \$orịchein fommen würbe. -

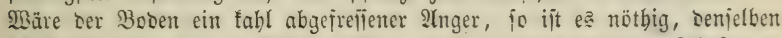

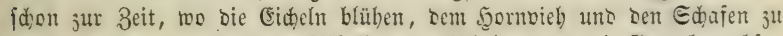
verbieten, Damit er bis zum 2(bjallen ber Eid)eln etwas mit Gras betwadjen

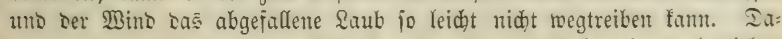

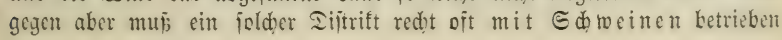


rerben, Damit bieje Den Boben fo viel wie möglid) umbreden unto für bie natürlid)e Befamung empfänglid machen. Bern man aber nidgt ertoarten

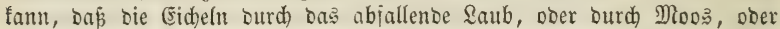
ourd) bie von Echweinen umgebrodbene (Froe eine Bebectung erbalten, io bleibt nichts übrig, als ohne Beitverluft den mit Eideln bejanten Boben

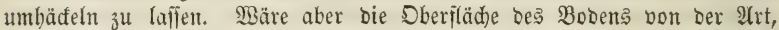
Dás bie abgebadten fleinen Broden nid)t balo zerfallen, ocer foftet bas allgemeine lumbäđeln zu viel, fo ift es jiderer uno woblfeiler, bie fünjt:

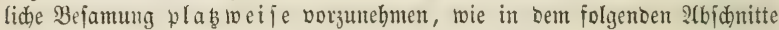
bei Der Eidelfaat gelebrt werben wiro.

\section{Siebertes sapited.}

Bon Der forftmäfigen behandrung eines (Eidentyodwarbes, Der

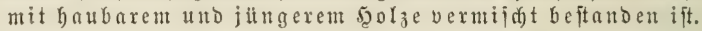

Für bie Bervirtbid)aftung cines Sidhenbodhaloes, Der baubareß uno

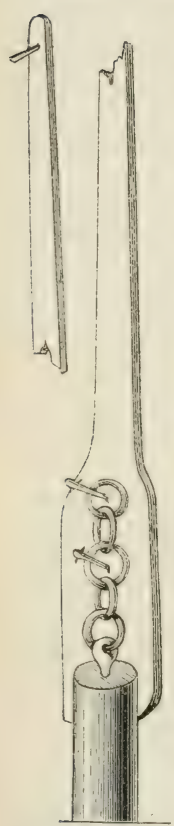

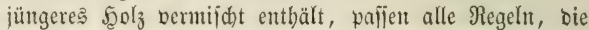
id) für eben fold)e Buchentwaloungen im vierten Rapitel gegeben babe. Nur ijt es nidht möglid), das 2(bfabren

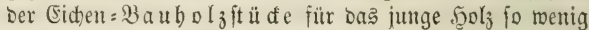
nad)theilig zu maden, als Durd) bas $\mathfrak{B}$ egbringen beక Brentublzes gejdeben fann. - Durd) Das 2tbfabren bes Baubolges gef(hieht gewöhnlich mehr Edaden, als Durd

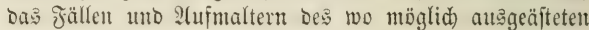
Baunte. (E⿱ if baber bejondere Borficht nöthig, um biejen Sdraben, jo biel es fein fann, zu vermindern.

Borzüglid fudbe man ju betwirfen, daßs alle Baus

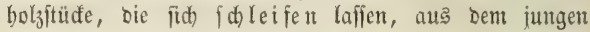
Beftanto bis an bie nädjten fabrbaren $\mathfrak{B e g e}_{\text {, bermittelft }}$ Des nebenftebeno abgebiloeten Rotbaumes, gefdileift unv Dajelbit erjt aufgclaben merben. Gollten bie Etämme aber zum Ed)leifen zu fojwer fein, uno jollte, ohne viel am jungen Solze zu verberben, aud nidbt an fie bin gejahrent werben fömten, jo lafle man - injofern bie Beftimmung Des 5colzes es erlaubt - Dergleident Stämme an Drt uno Stelle befdlagen, uno in foldhe Stüde zer: jägen, Dafs jebes an den benadbarten $\mathfrak{B e g}_{\mathrm{c}}$ geidleift werben fantr. - Dbgleid biejes Bejimmern, felbft bei aller mur mögliden Borfid t, Shaben berurjadt, jo bes trägt biefer bod) nicht fo biel, als wenn ein langer $\mathfrak{W e g}_{\mathrm{S}}$ bis zum Sagerplab̧e deş Baubolaftammes bätte gebauen werben müifien. Sino aber bennod) neue $\mathbb{B e g e ~ n o ̈ t h i g , ~}$ jo müfien biejelben auf bie am wenigiten nadtheilige 2trt uno fo ausgezeiduttet uno angelegt werben, ba viele Stämme auf einem $\mathfrak{B}$ ege abgefabren

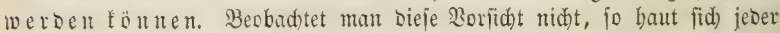
Juthrmam einen eigenen $\mathfrak{S e g}_{\text {, went }}$ er baburdh etwas beauemer und 
fa) neller jum Siele ju gelangen glaubt, uno es wiro enolid ber Mald gänglich verborben.

Ebenjo menig Darf Den Fubrleuten geftattet werben, bie Bauboljitüfe

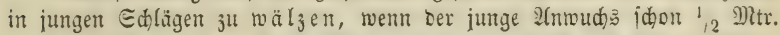

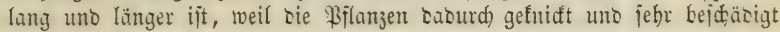

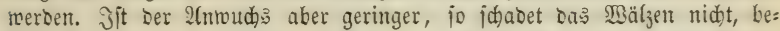
fonters renn es bei હdnee geidieft. - In ber Folge riro vom Trans: port bes Sgolzes mehr vortonimen.

\section{Didites siapitef.}

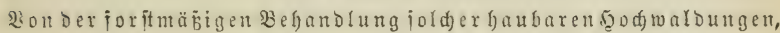
Die aus $\mathfrak{B}$ uden unb eiden vermijd $t$ beftegen.

(Es ijt jebr oft Der Jall, daj bie Budenhodwaloungen mit (Eid)en vermifht bejtanoen fint, unb man bemerft allgemein, baj bie Eidfen vor: züglid) gut waćjen, wemu fie einzeln zrwijden gejololienen Budben, ober

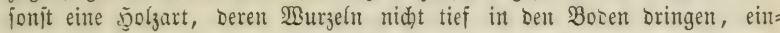

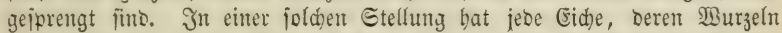
befuntlich tief in ben Boben jtechen, einen grosen Crnäbrungšraum uno

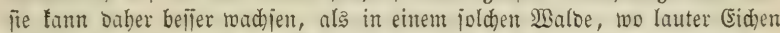

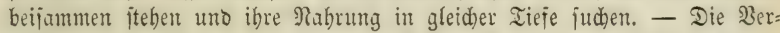
mijdung ber Budentwaloungent mit Esiden ijt Daber allentfalben zu em= pfehlen uno วิu begünjtigen.

Bei bem 2 btriebe bergleiden vermijater Baloungen jino alle Regeln ju beobahten, bie id für ben 2(btrieb der Budentwaloungen im jweiten Rapitel gegeben habe. - Man jtelle aljo einen jolden $2 B a l o d i t r i f t$ in cinen a 3

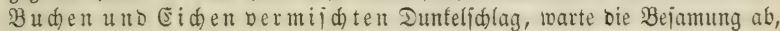
uno beobahte nur bie Şorïnt, ben Dunfelidlag an joldhen Stellen, wo viele Eichen aujgeteimt jino, etras früber ju lidsten, weil bie junge (Eid)e Ien Edyatten niabt lange ertragen fam. Sm übrigen aber bebanole man Den 2(btrieb uno Den währeno Des 2(btriebs neu ergogenten vermifoten 13 bald

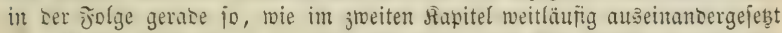

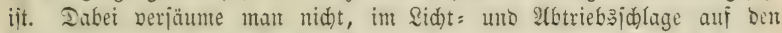
fleinen leer gebliebenten Etellen Eidheln unterz̧ubaten, oder fleme Eiḑen zu fiflanjen, wenn ourd) natürlidbe Bejanung feine binlängliche Menge junger

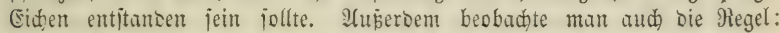
Die jur Jällung beftimmten alten (Eiden aủ Der Mitte bes

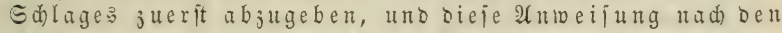

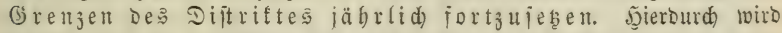

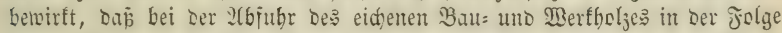

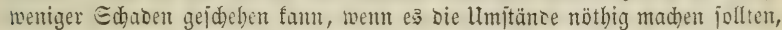

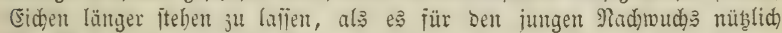

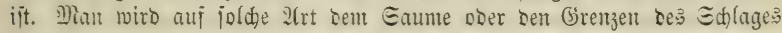

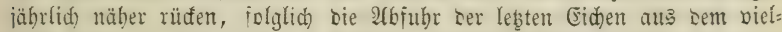

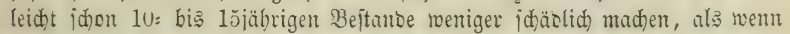
ju biejer Beit nod) Bauftämme a gefabren merden müß̈ten. 
Weil aber bei einem 100= ober 120jäbrigen Hmtrieb ber Bud)en=

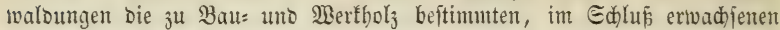
Eidjen oft nidbt ftarf genug fint, fonsern 180 bis 240 Jabre alt werbent

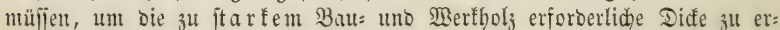
langen, io ijt es nöthig, Das in ben aus B̧uchen uno Eichen vermiföten Waldoungen, beim völligen ?(btrieb ber Budben, auf jebem Şett. 6 bię 12, uno, went es bie Umitänbe erforbern follten, 12 bis 18 von ben fdjönften 100: ober 120jährigen Eiden ftehen bleiben, unto bis zur 5ुaubarfeit beß neu erjogenten $\mathfrak{B a l b e s}$ übergebalten merben. Şierburd wiro man in Der Folge bei jedeșmaligem 2tbtrieb des Budenwaloes ftarfe 200= bis 240jäh= rige (Eid)en zu Bant= uno $\mathfrak{B B e r t b o l}_{3}$ finden, unt aud) von Denjenigen (Eid)en, bie gleides ?(Iter mit ben Buchen haben, bie zur weiteren Unterbaltung nötbige 2(nzahl jöbüner Stämme auşwäb) fen fönnen.

Eollte man uad s(blauf einiger Jabre jeben, daj - wie es oft zu gefdeben filegi - an Den zur lleberbaltung beftimmten (Fid)en eine Menge jogenamter $\mathfrak{B}$ a jiferreifer zwifdent ser Wurzel uno ber firone am Etamme herborgetonmen fino, jo muß man bieje Meijer, ehe fie 1 Mitr. lang werben, bidit am Stamme abhauten laffen, weil fie fonft Der Rrone bie Plabrung rauben uno juweilent ifr gänzliches : (biterben verurjaḑen.

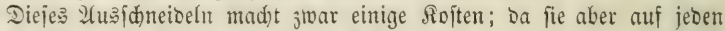
Stamum jehr wenig betragen, uno bieje Dperation mur einigemal uno nur fo lange von 3eit zu 3eit wieberbolt werden muj, bis ber junge $\mathfrak{B a l}$

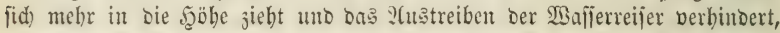
jo find bieje Rojten unbebeuteno gegen Den Daburd) bewirften 9iuben. ${ }^{2}$ Bei lluterlaffung biejer Borfid)t habe id, bejondera auf etwas ntagerem Booen, die fdönften zur Heberhaltung befimmten (Eichen von oben her: unter abiterben jehen, weil bie außgetriebenen Bajierreijer fajt alfen von

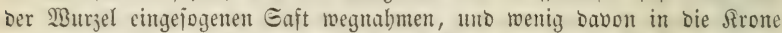
aufiteigen liešen. 2Anf redht gutem Bobent wiro 3 mar bie Srone unter foldhen IlmitänDen nidht bürr, weil bie 2 ỉurzelı jo viel Eaft einjaugen, als zur

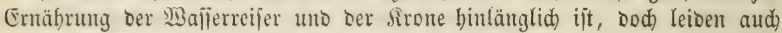

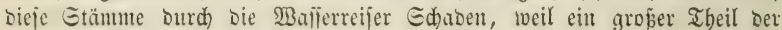
für bie sirone bejtimmten Eäfte z̆ unnüben $\mathfrak{B}$ Bajerreijern verarbeitet wiro

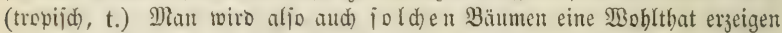
unD ifren 3utads an ser Irone vermebren, wenn man von Beit zu Beit

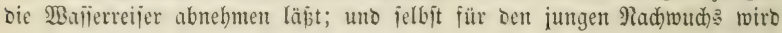

1 Man wähle biergu bejonders foldje Etämme, bie an Geftellen, $\mathfrak{B}_{\text {egen }}$ oder am $\mathfrak{B}_{e}=$

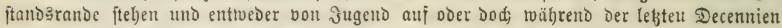

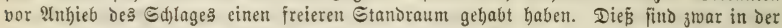
Meget nid)t Die idöniten, jđäftigften Stämme, twie man fie meift nur im geid)lofienen $B_{e}=$

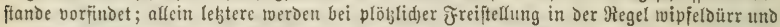

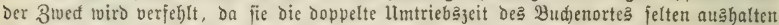
und meift id)on nad) furjer 3 eit cingejd)lagen iverden müfïen, was Dann wejentlide $B_{e}=$

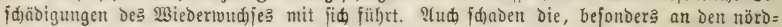

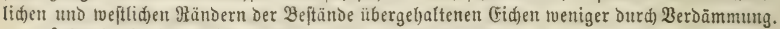

2 3rvei mit einer leidten Gteigleiter uno jdarfen Bcilen verjehene J̨oljhauer tönnen

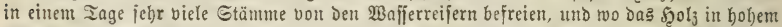

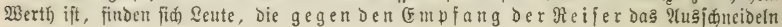
verriditen. 


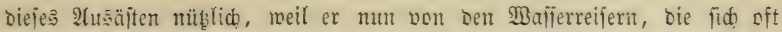
fehr berbreitern, nidút berbämmt werben fann.

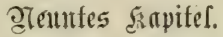

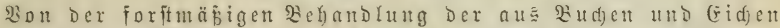

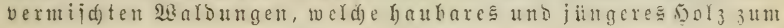
Beftand haben.

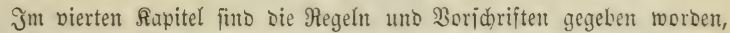

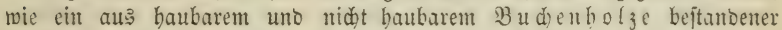

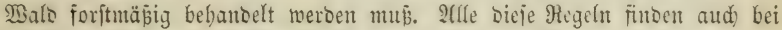

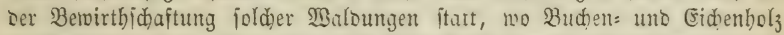

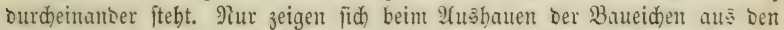
Etangenorten biefelben Edrwierigfeiten, bie id im fiebenten Siapitel ab= gehandelt habe. Man ftubire Daber bas vierte uno liebente Rapitel, io

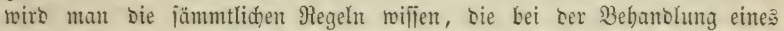

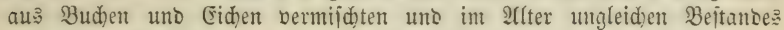
anjuwenoen finto. Sd bemerfe nur nod, baf man beim atbrieb eines jolden

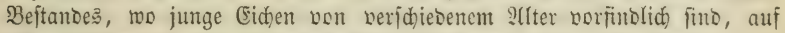
jesem Şettar 12 bis 18 mittelroüdjige Etämme, uno aud̆ eben jo viele fübune ftufige Reibel ober Etangen überbalten funn, meil bie Eidjen über: baupt am jungen 2 alde nid)t biel und nod weniger als andere 5ुolzarten

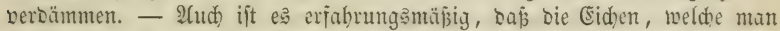
in ibrem 20= oder 40jäbrigen Ifter, ober nod früber, abbaut uno am Etocfe ausidlagen läfit, in Der Jolge Do(t) nod) idbönes Baubolz liefern, menn man in 30 jäbrigen $\mathfrak{A}($ ter ber Etociusjalläge eine Durdjoritung vor: nimmt, uno auf jebem Etod nur bie ftärfite Etange ftehen läpt. Sd babe foldbe Beftänbe gefehen, bie 150 gabre alt waren uno portrefflidje Baus holzitämme enthielten. Dod) habe id bcim fällen foldyer Eidgen imuner bemertt, baßs fie, von Der Erose an, 1 Mntr. lantg im Rern faul maren,

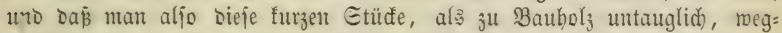

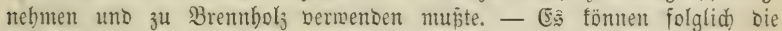
von 40jübrigen uno jüngen Etö fen auşgeid)lagenen Soben, wenn fie zur gehörigen 3eit io vereinzelt werben, ¿aj auf jebem Etod mur die fräftigite Etange ftehen bleibt, in Der Folge zwar fd̈̈ne Bauhbljftämme werben; man Darf fie aber bod) fein höberes als 150jäbriges 2(lter erreident lafien, weil jonft bie Fäulnif́, bie burd) das albhauen in Der Mitte bes Etode?

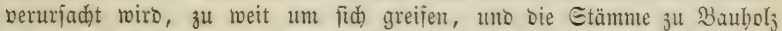
ganz unbraudbar madben würbe. Diejes Faulwerben bat man um io viel frïber uno in einem um io viel böberen Grabe zu fürchten, je ftärfer bį

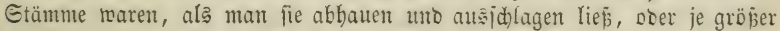

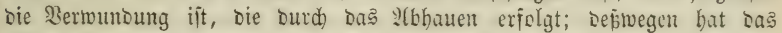

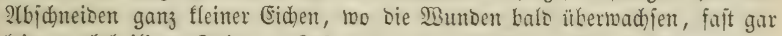
feine nachtheiligen Jolgen. ¿äp̈t man aber 60jäbrige Reibel abbaten uno

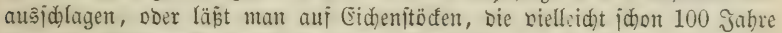

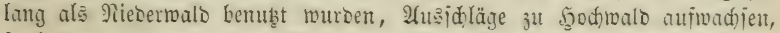

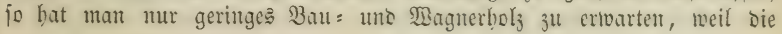

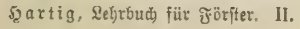


Fäulniß in Mittelpunfte bes Stodes unt am unteren Theile bes Stanmes

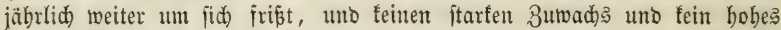
IIter geftattet. (Fidhen ber 2 rt baben gewöbnlich nabe über Der Erbe Snollen

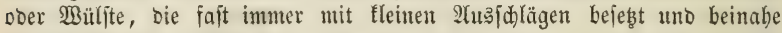
ein untrügliches Beiden find, baj Der Stamm ein, wenigitens unten,

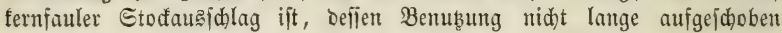
werben Darf.

\section{Befintes sapitel.}

2on ber forftmäbigen begandung berjenigen sed waldungen, Die mit sainbuden, 2fhornen, (E્den, Ulmen, birfen, Erlen sc. entweder alfein ober vermijut beftanden jind.

Die Bemirthidhaftung ber in Der lleberidrifit genaunten Şod)walbungen ijt nur wenig von ber im zlweiten, britten unb bierten Rapitel weitläufig befariebenen Bebantlung ber Budentwaloungen veridieden. Dem obgleid ber Bejamungsidhlag, wegent bes weit um fich fliegenden Saments ber oben

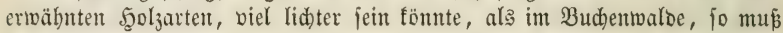

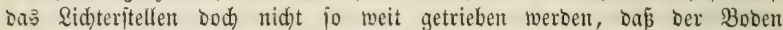
fid) jebr begrajen, bas $\mathfrak{L} a u b$ weggetrieben werben, bie (5rbe zu biel aus=

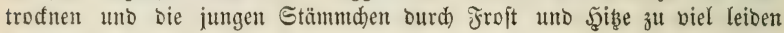
fönnten.

Man ftelle Daber cinen folden Malo in einen regelmäßigen, jebod mux balb fo Dunfeln Bejanungsidjlag, als im Buchenbodwalde, mit 3 bis 5 Mitr. Entfermung ber äuperiten 3roeigipizen, liđ̆te Denjelben aber etwas jrüber als im Buctentwaloe, nänlid) ivenn bie jungen Bflanzen 15 bis 20 (5tm. hod) geworben jint, gebörig aus, uno treibe, fobalo ber junge $\mathfrak{A}(n=$ wudbs bie böbe von 30-50 (Stm. erreidht bat, alle alten Bäume $a b$, jo wiro man jeinen 3wed jebr vollftänbig erreidjen, uno einen vortrefifliden jungen Balo auf Der Stelle Des benubten alten erzielent.

Jn ber Folge Durdforfte man Delt jungen Walt von feinem 20: ober 30 jäbrigem 2llter an alle 10 ober 20 Jabre eben po, wie im zweiten Sapitel gelebrt worden ift, unt jeb̧e bieje Dperation bis zu feiner Scau= barfeit fort. Diefe rüroe idh für bie 2thorn=, sidhen= uno ulmentbodiwal= Dutgen auj 80 biß 100 Jabre, für bie Scainbuthen auf 80 Jabre, uno für bie Birfen = uno Erlenbodmäloer auf 60 Jahre beftimmen, weil bie Erfabrung lehrt, Daj bei einer fold)en Umtriebszeit, im Durdjidnitt ges

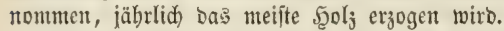

Da bie $\mathfrak{B}$ irfenbeftänoe von 70 : bis 80jäbrigem $2(t+e r$, aud wenn

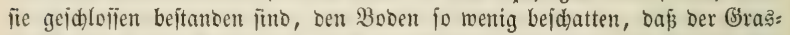
wuds 3 burd) bie Bejdattung nidht zurüdgehalten wirb, fo wirb bier eine Berwuntoung Des Bobens burd) bie Scade ober bie Walbegge notbinendig, bie man jogleid) $n$ ad) Dem 2 bfliegen Des Samenz vollzieben läßjt. Nad Dent 2 fbfliegen bes Eamens vom vollen Bejtante wirb bann in bemfelben

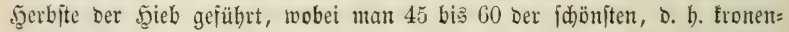
veidjten Stämme pro Şettar überbält, um, im Falle die Befamung febl= jolagen follte, von ibnen eine erneuerte Bejamung erwarten zu fönnen.

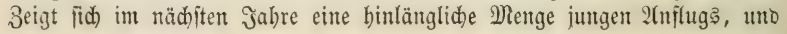




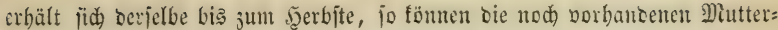
bäume jđdon im nädften Winter abgetrieben werben.

3ur Beriüngung Der Erlenbodroldoungen Dari man fefr ge=

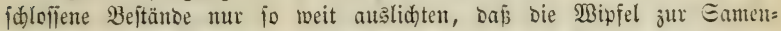

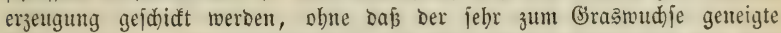
Boden verrajet. Die llnterbred)ung Des Blattjdirmts oarf baher nur jehr gering fein, uno $1 / 3-2 / 3$ Pitr. nidjt überiteigen. In biejer Stellung laffe man ben Edlag bis jum (Eintritt eintes red)t reident Samenjabres. Da Der Şieb in ben Erlenbrüd)en wegen des weidjen Bobens unbebingt mit Dcm Eintritte Des erften Jroftes beginnen muß, ber Ẽrlenjamte aber erjt frät, mitunter erit mit Beginn bes Frübjahres ausfliegt, jo ift bie Deinung

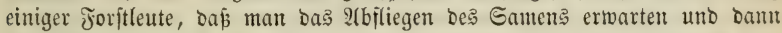
Den Sdjlag rein abtreiben jolle, felten auşfübrbar, ba ber Şieb nidjt vom 2lbfliegen bes Samena, fonden vom Cintritte des groftes abbängig ift. So lange Der Same auf Den Bäumen ift, mus baher nothwendig Edlag=

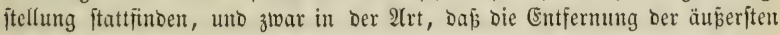

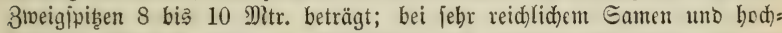
fronigen Bäumen faun bie Entfernung nod) etras größer fein. Sít ber

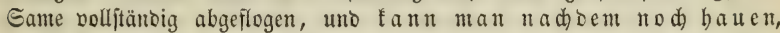
fo iłt ę jweftmäpig, bie übergehaltenen Gamenbäume nod) in bemielben Winter soer Jrübjabre wegnebmen zu Ialjen, wenn man von ben gehauenen

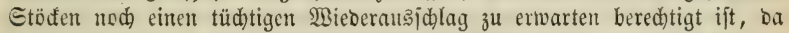
in Diejem Jalle Die fpätere Şcraușnabme ber MRtterbäume am jebr brüchigen

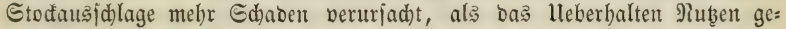
mährt. Sam man bingegen wigen hohen 2 Alter’ Der Stöđe ober bei über= haupt hobem Umtriebe auf feine Mtitwirfung ber Stöde bei ber $\mathfrak{B}_{\text {erjüngung }}$ Des Bejtandes rednen, fo übertrage man Den Mutterbejtano jobenfalls auf

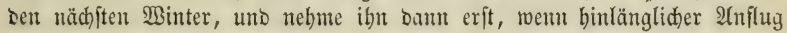
erfolgt ijt, gänjlich binweg.

\section{Elftes Eiapitel.}

Bon Der for ituäbigen bebanblung ber haubaren gejdloifenen 23eipiannentoldungen, wenn es darauf antommt, Durd) natür= Yide bejanung einen redt bollfommenen neuen beftand zu ex= jiefen und an biejem in Der Jolge den 3 utwad) fo biel wie möglid วิน befördern.

Wenn ein baubarer Meiptannentwalo abgetrieben unto wäbrend Dę 2(btriebes cin neuer Beftano burd) natürlid)e Befantung erzogen werben joll, io müñen alle Regeln befolgt werben, bie idh in zmeiten Sapitel für bie Bewirtbidajtung uno Berjüngung haubarer $B$ udentwaloungen gegeben babe, weil bie Weiptauten=\$aloungen fajt gerabe jo, twie bie Budjentwaloungen behandelt fein wollen.

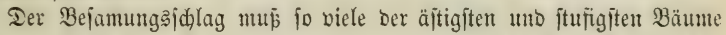

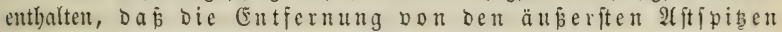
Der nadbarliden $\mathfrak{B} a ̈ u m e ~ 1 \frac{1}{2}-2$ Nitr. beträgt. - $n$ biejer Etellung Des Sdlages marte man eine Bejamung ab. Jit fie erfolgt, jo 
lafie man ben Eălag allenthalben mit eifernen Rechen ober Szarfen auf: trabeen uno in ftrenge Sjege legen. Wäre aber ber Samen fofon im Seerbjt

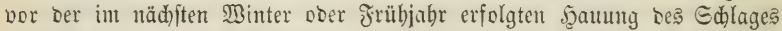
abgeflogen, io ift bas ?2uffratien nid)t nöthig, weil ourd bie Bearbeitutg Des gefälten Şoljes ber Eamen bod) binlänglich unter bas Mods uno an bie Eroe fommen und auffeimen virb. 1

Einen folden Befamungsiflay lafie man mun fo lange fteben, bis

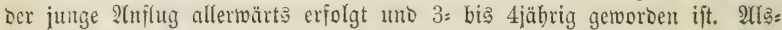
Dann nebme man, wo möglid) bei Ed)nee, bie ftärfften Etämme, unt über: baupt bie Şälfte Der Gamenbäume weg uno beobad)te alle Borfidtsmaßs:

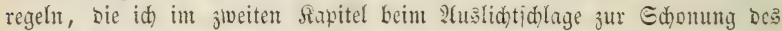
jungen Nadwudjes cmpfoblen babe. Sit aber ber junge Raddwudjs $1 / 4$ bis $1 / 3$ Mitr. hod) getworben, Dan lafie man alfe alten Bäume aus bem Ed)lage nefmen, weil Der junge Wald nun Der Wittenmy völlig ausgefebt

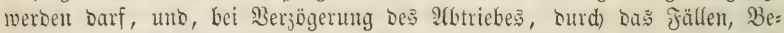
arbeiten uno $13 e g b r i n g e n$ ber alten $3 a ̈ u m e$ jebr bejäbigt werbent toürbe. ${ }^{2}$

Fun lafie man ben erjogenen jungen $\mathfrak{R B a l}_{\mathrm{D}}$ inmer nod) unt fo lange hegen, bis ihm Das \$ieh feinen Edjaben mehr jufügen fam, umo wemt cr 25, im jebr rauben Slima uno auf fohledtem $\mathfrak{B}$ osen aber 40 Jabre alt geworben ift, io lafie man ifn jum erfemmal von unterorü fftem 5olje befreien.

Rad) biejer eriten Durdjorftung bleiben gewöbullid) auf bem Sgeftar 5500 bis 6000 oominirente Etänme ftehen, uno Das gehaucne unterbrücte

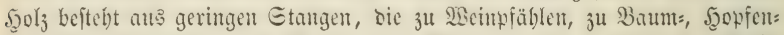
uno Bobnenitangen, jum Brand, jur Röblerei uno ju fonjt manderlci

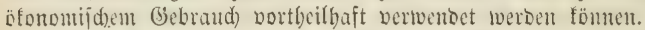

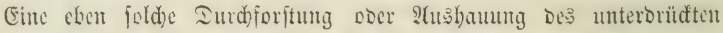
Şolzes wiro in ber folge von 20 zu 20 Jabren, uno zwar fo wieberbolt,

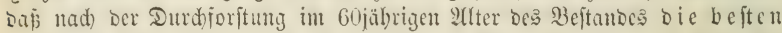
1500 bis 2400 Etänme, in Sujäbrigen 2flter Dic beften 900 bi马 1:00 Stämme, uno im 100jäbrigen 2l(ter bes Sejtanbes bie be ften 750

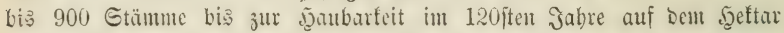
fteben bleiben. Gollte aber dic Untriebsjeit auf 140 Jabre beftimmt jein, fo muf; Der Beftanto im 120jäbrigen 2fter bis auf bic bejte 600 ober 750 Etänmi Durdforftet, uno bie \$erjüngung, wie vorbin gezeigt wurbe, wieber vorgenomment werben.

Da id) im jweiten Sapitel sie Bortbeile Der regelmääigen Durd)= forftungur auseinanoer gejest uno aud alle \$orfichtsiregeht angefübrt babe, Die man babei beobad)ten mus, fo will id alles biejes bier nidjt wieber=

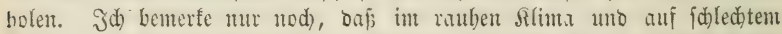
3ooen bie erifte Durdforftung oft bis zum 50jäbrigen 2Alter bes Bejtanbes,

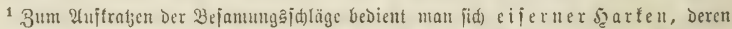

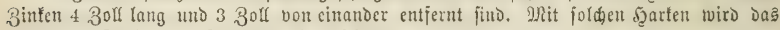
Moos und Raub mur aufgetrajt, aber nidit weggezogen.

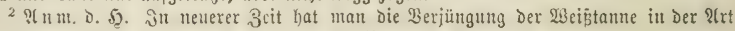
cmpfoblen, Dap fie entweoer in fdumalen Gtreifen vom Walorande aus nad) Jnnen vor=

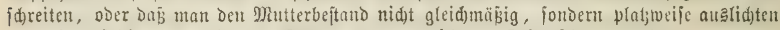

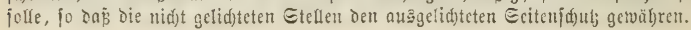


unt überfant jo lange veridoben meron mus, bis im mifsen Slima sie erite Alaffe Der onminirentent Etangen, über bex Ëroe gemefien, 12 bis 15 Etmt., uns int rauben Silima 15 bis 20 Etm. im Iudmejeres fhat. Si üher vorgenommene Iurdjoritungen mürben genagt fein. Sienn aber cin Bejtano die eben ermäbnte Etärfe erlangt bat, jo fant uno muf er ven Dem unterorüaten, franten uno abgeftorbenen joglze bejreit werten, uno

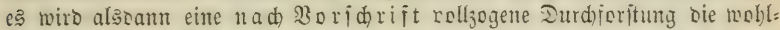
thätigiten Folgen haben, weil ber oominirente Beitano nachber einen fïarferen

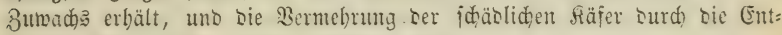
fermung bes franten Syolzes berbintert wirb.

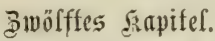

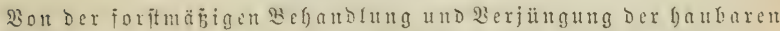

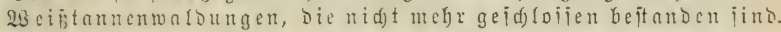

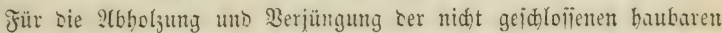

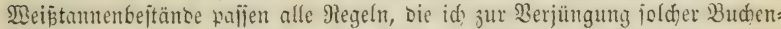
bejtänbe in oritten Rapitel gegeben habe. - Man lege alio einen jolden Diftrift, nadbem Der Samen abgeflogen ijt, in Sege, laije ben

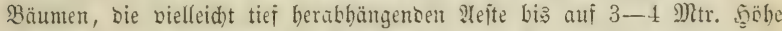
abneḅmen, uno bie ganje Dberiläd)e mit eijernen Rechen tüd)tig überfraţen.

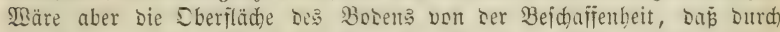
Das eben errähnte Mittel Der Eamen nid)t an bie Eroe gebradt werten förnte, io lajie man die ju ftarf befdiwülten Etellen entweber plaşıeije

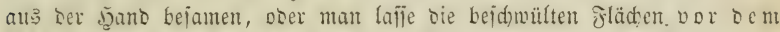
Zlbjliegen des Eamens mit Der Bflugegge bearbeiten. Rachber be=

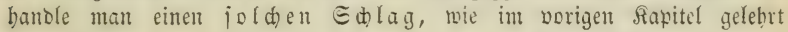
roorbent ift.

\section{Dreizefintes Eapitel.}

Bon Der forfimä̈igen begandung Der baubaren und geidlofien bejtandencn ĩidetentualoungen, went burd) natürlide bejamung ein bolfommener neuer Bejtand erjogen und biejer in ber Jolge jum möglidj ft ftärfiten 3 utwads gebradgt toerben folr.

Bei Der $\mathfrak{A}$ (bboljung uno Berjüngung Der baubaren fichtentwaloungen fint siejelben Regeln zu bciolgcn, die in elften uno zmöliten Rapitel jür

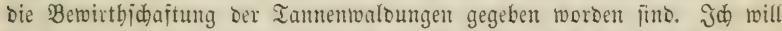

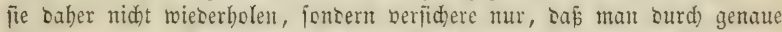
Befolyung jener Regeln in ebenen

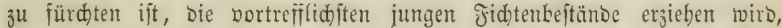
renu man bie erite Etellung Des Befamungşadlages ganj nad) Der 3or: färift gemadht und für bie Dertwunoung ber Dberfläche Des Edhlages gejorgt hat. - Man befolge baber jene Regeln aufs genautefte, uno lajie, jobalo Die Eamenbäume $3 a p f e n$ baben, bie Etöde ber gebauentr Etämme aubrroben, bie baburd) entitanbenten Söd)er gehörig cbnen, bas ভtoutholj bor Dem 2tbiliegen Des Gamens megbringen, uno im Frübjabre, isbalo ser Samen abgeflogen ijt, ben ganjen Edhlag mit eijernen Rechen überziebent.

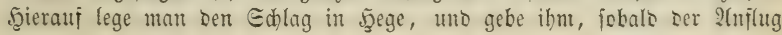


bintänglid erfolgt unb 2 bis 3 jabre alt ijt, cine etwas lid)tere Eteflung. Sat aber ber ?(nflug bie Seöhe von 25-30 (Etm. erreidyt, fo nehme man, wo möglid bei Echnee, alle Bäume weg, uno idjaffe fie aläbalo aแs bem Ed)lag. - Wäre bingegen bie Lage bes Drtes von Der 2(rt, baj eine 2(us wegen bes Winbes nidht ftattfinden faun, fo nehme man beim erften Siebe

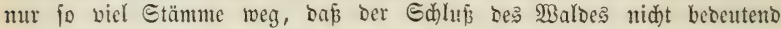
unterbrodjen wirb, warte ein Samenijabr ab, uno lafie fdidon im nädjiten Şerbite nach erfolgter Bejamung bie Samenbäume bei Ednee alle auf cinmal wegnebmen. Sollten fid nad) Demt völligen 2(btrieb ber Gamen= bäame bier uno Da nod leere Stellen finben, fo bejeşe man fie mit fleinen,

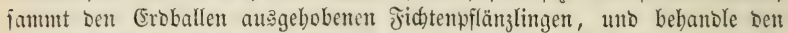
jungen Walo in ber Folge gerabe jo, wie im elften Rapitel gelebrt worben ift.

Dieje Methode, bie haubaren Jidutenwaloungen Durdh natürlidbe

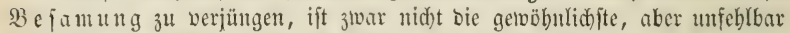
bie fiderfte. Man lafie fid) baber Durd) bie faft allgemeine Bebauptung,

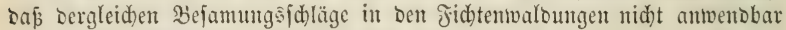
feien, nidht abidrecfent. Mer bießs bebauptet, hat es entweber gar nidjt wer:

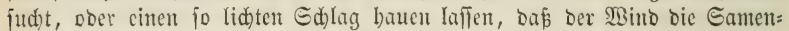
bäume Yeid)t umwerfen foumte. Mian ftelle aber Den Sd)lag ganz nad) meiner Sioriderift, uno beobadte alles, was id nod weiter empfoblen babe, io miro man Den Erfolg ber Erwartung entipredeno finben.

Piur it Bebirgen an foldten Srten, wo Der MBino, Der Erfabrung gemuan, cine auperoroentlid) ftarfe WBirfung hat, und vorzüglid) beftig auf=

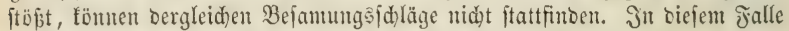
mäble man, wenn utürlide Befamung ftattfinoen forl,

\section{ben ftreifweifen fablen 2 btrieb,}

unt gehe babei auf folgende 2 trt zull 2 erfe:

Man greife, nad Der befaunten Generalregel, Den Beftand auf Der Ditjeite ober auf Der Nords:Ditjeite zuerft an, unt entblöfe einent 25 bis 35 9)tr. breiten, fd)räg am Berg berunter jiebenten Streifen gant von

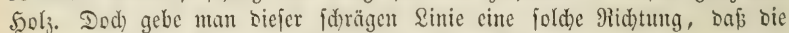

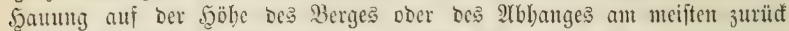
bleibt uno im Thal fid) vorzieht. - Nun laffe man, fobalo binlänglide Bałfen an bem ftebenten Drte hängen, bie Etöde auf ben abgetriebenen Etreifen ausroden, bie baburd) entftandenen Bertiefungen mieber cbnen,

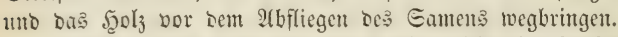

In Der Jolge laffe man ben Ed)lag nicht eher fortfeţen, bis ber ab: getricbene Etreifen Durch natürlide Befanung vom ftehenden Dote her mit jungen gidutenfflanzen binlänglid betwadjen ift. Dann aber lafie man Den abgeboljten Etreifen um 25 bis 35 Mtr. breiter machen, und fabre auf gleid)e BBeife fort, bis ber ganze Beftano abgeholzt uno veriünt ift.

Damit man aber Den anf folde ?(rt fabl abgetriebenten Etreifent bie erforberlide Beit lafjen fann, vom ftchenben Drte ber befaut zu werben, fo muifien in ben andern haubaren Diftriften, bie ber 2 sino nidt fo febr treffent faun, Bejamungsid)läge angelegt uno ats biefen in ber 3roijhen: jeit bas benötbigte 5ol3 genommen werber. - Eollte aber in Den ße= 


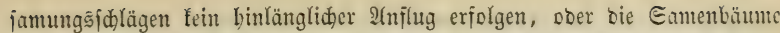
nom Winoe großentbeils ungeworfen werben, fo bleibt weiter nichts übrig, als biefe Ed)läge ebenfalls fahl abzutreiben, uno outd bollitäntige fünjt: lide Bejamung ober Bepflanzung mit jungent $50 \mathrm{l}_{z}$ wieber in Beftanto jut bringet,, woz̧u in ber folgenten 2lbtheilung 2fntweifung ertheilt werben wirt.

Die alsbaldige vollitändige fünftlide Bejamung ober Bepflanzung Der abgeboljten Streifen ift überbaupt in joldten Fällen, wo

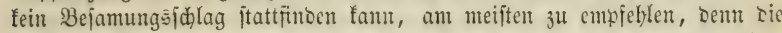
natürlide Bejanung vom ftehenten Drte ber ijt gewöbnlid fo unjulänglich,

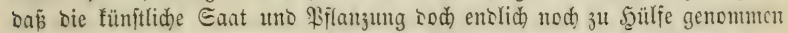
meroen mus, wenn man volifonmene Beftände baben will. Simmt man mun bie vollitänbige fünftlide fiultur aläbalo nad) bem 2 tšroben Der Etödfe, unb fo lange ber Boben nod nid)t mit Untraut überzogen iit, bor, fo ber: urfad)t fie weniger Soften, geräth befier, uno man geminnt in menigen Jabren mehr an 3utwadis, als bie Roften ber füniflichen Eaat soer Pflanzen betragen.

Andi empfehlen Einige, im Fall cin foldter fahl abgetriebener Etreifen nidgt balo natürlichen 2 (nflug erbalten follte, einen 20-30 Mitr. breiten Etreifon vom baubaren $2 \mathbb{B}$ albe itehen zu lajien, binter sem: felben rieber einen neuen Gtreifen abzubolzen, uno riebs folange fortzufeben, bis bie älteften Etreifen binlänglid mit jungem Şolje bewadjen jind. Gie nemen sieje fraungsurt Cou= lifienidräge ober Epringidläge. - Doer man foll einzelne forrite fteben lafien, bamit biefe bie bejamung um fich ber verbreiten tönen.

Beibes hat meinen Beifall nidht. Denn ift ber Sot bem Sigine fehr

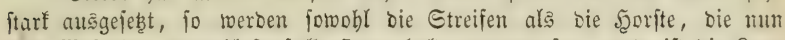
Dem Seftrino ganz blopigeftellt fint, balo umgeworfen, uno ift bie Sage Des Srtes von ber $\mathfrak{A r t}$, baj bergleichen Etreifen uno Scorfte bou Wino

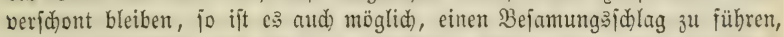
morauf ber Wind nod) weniger nadtbeilig wirfen fann, weil ber Wals bod) balb gejdlofien ift.

Эd) rathe baher unter allen Berbältnifien uno Lmitänoen, tro vom

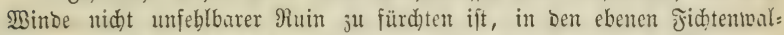

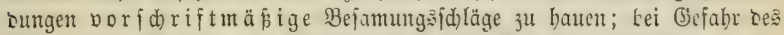

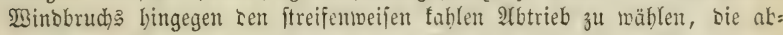
getriebenen Etreifen aläbalo nad) Dem Roben ber Etöce bollftünoig alt

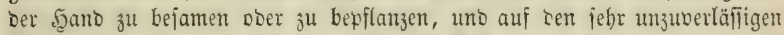

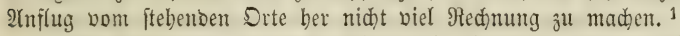

ja) habe nod) nie einen überall gleiden und volffommen beftandenen jungen fidtentwald gefehen, ber beim ftreifenmeifen

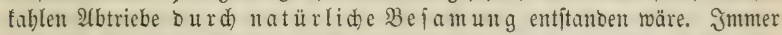
fand id) bergleichen Beftänoe jebr unvollfonmen, uno nur fidmale Etreifen auf ber abgeholzten Flädhe, nämlid, Diejenigen, meldhe Dem ftebenten Drte jcoesmal am nädjten gewejen waren, hatten erträgliçen Beftano, weil zut

1 3ur Befamung oder Bepflanjung ber fabl abgelyoljten fidjtenfaläge wiro ma:t im: 3reiten 2 b fdnitte die nöthige \&nleitung finden. 
3eit, wo Der Eamen aus Den 3apfen fliegt, oft fo wenig WSinto weht, Dẩ Der Samen faum einize Ruthen weit bom ftehenoen Drte wegge: trieben wirb.

Bie übrigens ein junger Fihtenbeftano in ber Folge uno bis ju

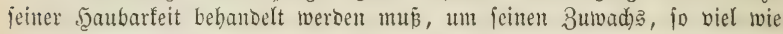
möglich, ju beförbern, biế faun im elften Sapitel nachgelejen werben, weil bie Befanthung ber Tannen= uno fidstentwaloungen barin bollfommen gleid) ift.

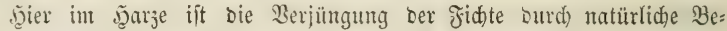

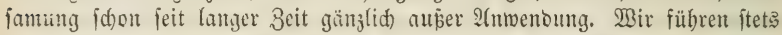
Siablithläge unto bepflanjen fie in $11 / 2-2 M(t r$. Entfermung mit Fid)ten= bilid)elt aus juvor in Der Rähe des Sd)lages antgelegten Saattämpen. Der

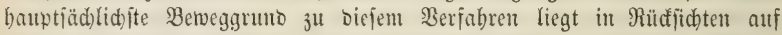
Erbaltung ber Dem Siehitunde jeber Gebirgabebölferung fo nötbigen 2 Beibe. Bei unferer heutigen vervollfonmmeten Foriffultur finoet oas $\mathfrak{B i e h}$ in ben

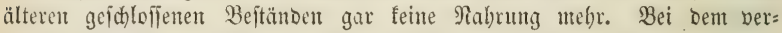

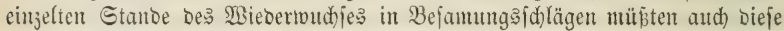
vont ber jütung veridyont bleiben, wenigiten: io lange, als ber Fुnf Des fdiweren Biehes die cinzeln ftehende Sflanze nod) ju verleşen bermag. Später hört aber, bei Der Bertheilung Der größeren Bflanjenmenge, ber

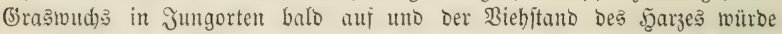

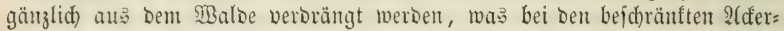

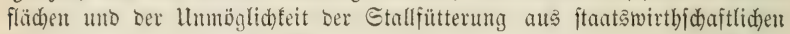

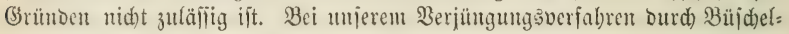

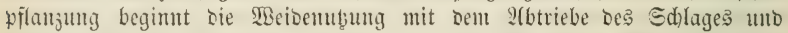
Dauert ununterbroden bis jur 3eit, in ber fich Die 2 Mtr. entfernten Buijdel völlig geichlofien baben, worüber, beim langfamen Wudje ber Sidjte in Der Jugeno, cin Beitraun von 10 bis 15 Jahren vergelt. Der reidce (Brasmuchs jwifchen ben entfernten Büideln auf Dem erít entboljten

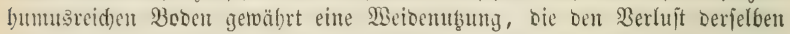

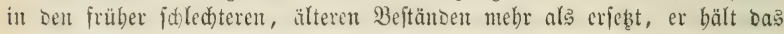

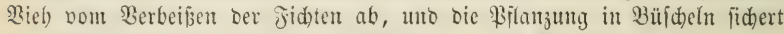
Die Sultur vor bem Bertreten butd) Den 5uf oc 2 Beidebiches. t.

\section{Djierzelintes Eanpite?.}

Bon Der forftmäsigen Befandung Der אiteferutualdugen, went burd) natitrlide befamung eit neuer $\mathfrak{B a l}_{\mathrm{b}}$ erzogen werben foll.

Die Bemirtbidaftung ber Rieferntwaloungen weid)t nur barin von ber in ben vorigen Sapiteln auseinanber gefesten Bebanthug Der Tament uno

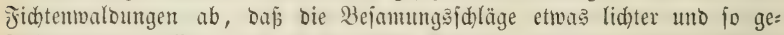

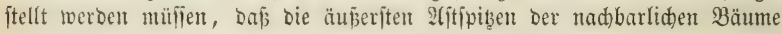
3-5 Mitr. von eintutoer entfernt fino. Dieje lidstere Steflung des $\mathfrak{B} e=$ famungsidhluges ift bepwegen nöthig, weil bie jungen Siefern Den Schatten

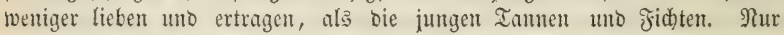
auf cittem feftr bürrent fanbiget Boben, bejonters auf foldyen, ber in

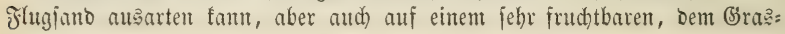


mudje jebr zujagenden Boden ftelle man ben Eamenjalag ounfler, jo Dap bie 3weigipizen $2 / 3-1$ 9) 2 tr. nou einanber entfernt bleiben.

Nadh Dem Şiebe tes Befamungsidhlages laffe man bie Etöde unt alles übrige $\mathfrak{F}_{0} l_{3}$, ehe Der Samen abfliegt, auß bem Ed)lag bringen unt, wenn e⿱ jein fann, bie ganze fläd) beకె Edjlages, jobald ber Eamen abgeflogen ijt, mit eifernen Rechen ober mit einer eijernen (Egge über:

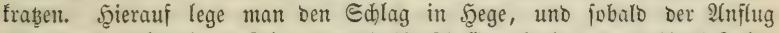
allerwärts binlänglid) erfolgt uno 20 bis 30 ( $t$ tm. hod), oder 3 bis 4 Jabre alt ift, nebme man, wo möglidy bei Ednee, alle Samenbäume a uf ein= mal meg. Man fann aber aud), wenn binlänglid)er 2(nflug erfolgt ift,

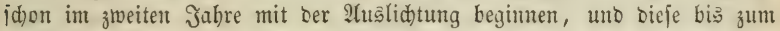
vierten und fünften Jahre vollenden. Notbmendiger mirb bieje allmählige Iuslid)tung, je Dunfler bie erfte Ed)lagitellung gefübrt murbe. Bei län=

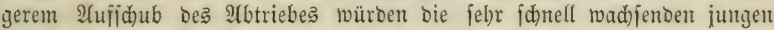

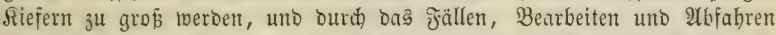
Des . erfranten, uno gropentheils, bejonbers unter oen Eamenbäumen, wieber abiterben.

Eollte ein binlänglidber 2 nflug mur theilweife im Sullage erfolgt

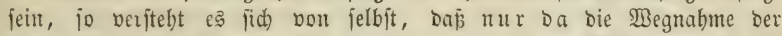

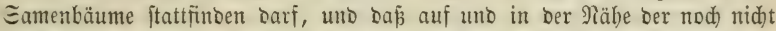
binlänglich angeflogenen Etellen bie Samenbäume bor Der Şanb noch fteben bleiben mülīen. Wären dieje Stellen aber Elein und vielleidht audi ftarf mit Ġras uno anderen (beträdjen überzogen, jo nehme man auch ba bie

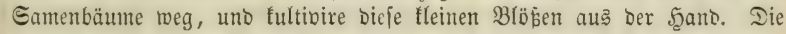
baourch entitebenoen fioften fint nidjt fo grop, als ber Echaben, ber un= vermeit lid) am jungen $\mathfrak{B a l D e}$ erfolgt, wenn die Eamenbäume fpäterbin aus bem Sdlage genommen werben.

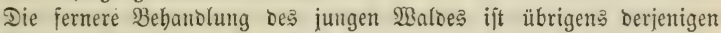
gantz gleid, melde id im elften Sapitel meitläufig auseinandergejebt babe.

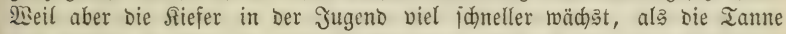
uno Jichte, fo fann bie erite Durdforftung fohon im 20= ober 25jäbrigen Ulter ober noch früber ftatfinden, wenn Der Beftano, wie bief auf gutem Boben oft ber Fall ift, bie im elften אanitel bejtimmte Etärfe erlangt baben uno viel unterbrüctes ooer ganz abgeftorbents Stangenfolz ent= balten jollte.

\section{Filnfzelintes Eapitel.}

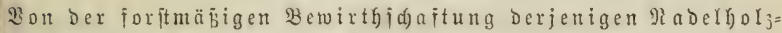
walbungen, welde mit haubarem und geringerem, ober ganj iungem 5rolze gemijat bettanden jind.

Bei ber Betwirthidaftung foldher Rabelfoljwaloungen, bie mit bau=

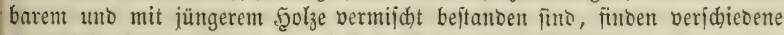

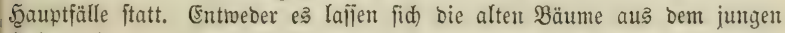

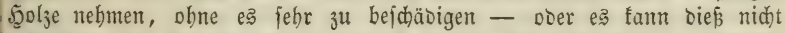

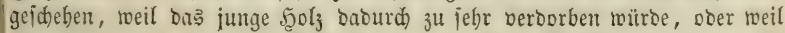

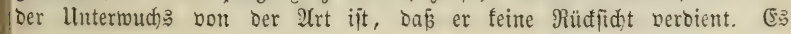


fommt baber auf gentaue Unterjuchung bes beftantes unto auf Erroägung ber Ulmitänbe an, ob bas Gine ober bas 2nbere im gegenwärtigen Jalle antwenobar uno nüblich ift.

Wäre ber luntertwudbs ober 2 (nflug nod) fehr gering, wollfommen gefuno uno in hinlänglidher Menge ba, uno fönnen bie alten Bäume, ohne viel am jungen Sgolze zu verberben, nod) berauggenommen werbelt, fo zögere man mit biefem Serau引hauen nidt, uno nebme bie alten Bäume mit möglidjiter Sdjomung Deక jungen 5̧oljes weg. - Wäre aber baక junge $\mathfrak{S g l}_{3}$ unterorüat, fdon verfrüppelt, ober nidjt in binlänglidber Menge vorbanoen, Doer von ber Befdaffenheit, Dós, wenn man bie alten Bäume wegnebmen wollte, bie ju einem vollfommenten Bejtanto erjorberliche Menge junger \$flanzen nidht ïbrig bleiben würbe, fo lafie man folden Unterwudbs zu einer Beit, wo es gerabe vielen Samen gibt, weghauen ober wegidneiben, ftelle Den Diftrift, nad ber in ben vorigen ßapiteln gegebenen 2Inweifung, in

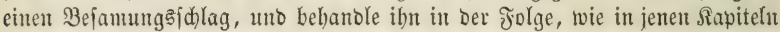
gelehrt morben ift. Nabelfoly, bejonbers Fidjtenthorfte, welde ben Boben fehr bid)t bejdirmen, mülïen idon mehrere Jabre vor Der beabfid)tigten Sd)lag= ftellung weggeräumt werben, Da mehrere Jahre verfließnen, ehe ber gebecfte Boden für bie Saat empfänglid) wirb. Selbit \$Bflanzungen gehen auf foldem Booent aus.

Sollte aber oer Beimudjs fdon zu Stangen uno Reibeln herange= wadjen feit, uno nidnt nur in groper Mlenge, fonbern and in freubigem Madhsthum da ftehen, - weldhes mur bei feljr einzelnem Stand ber alten Bäume möglid) ift, fo furbet fein $2($ (ushauen bor alten Bäume ftatt, meil Daburd) zut viel an jungen 50 lze verborben werben würbe. Jn biejem

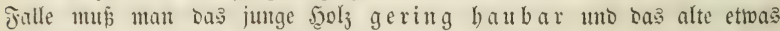

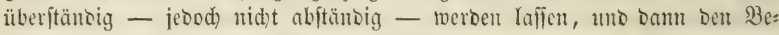
ftano nad) ben betamten Regeln verjüngen. ${ }^{1}$

Bären aber bie alten Sicfern von ber Befdaffenbeit, bap fie bei Yängerem 2tuffdube Der fällung verberben, fo bleibt freilid nid)tä äbrig, als jolche Bäumc mit möglidjter Ed)onung ocs Stangenlolzes balo beraul z̆ nebmen uno z̆แ benuz̧en.

Mlan mus überbaupt bei ser Beftinumung ber Bewirtbjofaftuny folder Walbungen immer alf Die allgemeine Erfabrung Rüleffid)t nebment, Dap bie beim Sturz Der alten Bäume zerid)metterten Rabelholjitämund)en von Stod

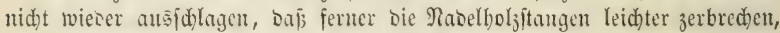
aud ment lie gebrüdt fino, fid) weniger leidut wieber aufrichten, als sie \&aub:

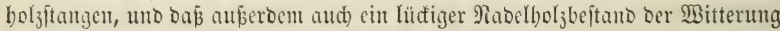
in Der Jolge meniger WBideritan leiften tann, als cin cbenfo lüctiger \&anbbolz= wall. Daber wiro es in folden Fällen meift ratbjam fein, den ganzen Beftano abzutreiben uto burd) fünjtlidje Sultur wieber in Beftant zu bringen.

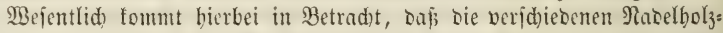
arten in jehr veriabiedenem (Brabe empfindlid) gegen Bejdattung fint. $2(m$ meiften ift bas ber Jall bei Der Riefer, aus Deren Borjprunghorften, wenn

1 Ueberftändig nennt man einen jeden Walo, twemt er äter ift, alక.er, ber ange= nommenen ltmtriebsjeit nad), werben foll. 2 b ftänbig bingegen ift cill $23 a l b$ atgoann, wern er anfängt im Gipfel troden zu werden. 
fie audh mur bią zum 10jährigen 2llter unter Dem Drud eines Dberftunbes mudjen, nie cin fräftiger Beftano erwadjen wirb. Sie werben febr balo zu

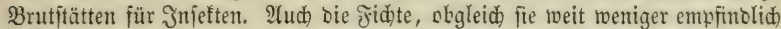
gegen Befdattung ift, als bie Riefer, ermüd) st aus Boriprunghoriten nur

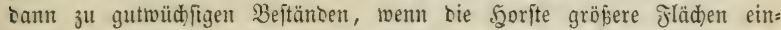
nefmen, Der Etantort ein febr günftiger ift; mogegent Die Ianne, jelbjt nach lange bauernoer uno ftarfer Befdattung, obgleid räbrent serjelben io langiam fid) entrvidelno, baj 30 -40jährige Piflanzen oft unter $1 / 2$ Meter bod) fint, bie Folgen ber \$erbämmung in wenigen Jabren vollitänbig über:

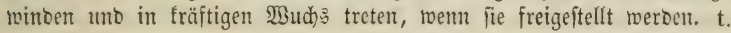

\section{Sedjefintes Sinpited.}

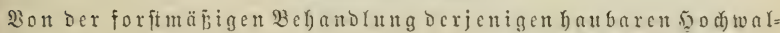

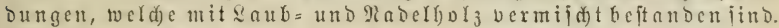

Bei Ber Bewirtbidaftung Derjenigen Baloungen, welde Saub = uno Nabelholz vermijidt enthalten, entitehen bie Fragen:

1) Eolf bie Bermifdug fünftig fortgevflangt wer: Den? Doer

2) Bill man einen reinen Beftano erzieben? uno

3) Welde von Den vermifden 5olzarten foll in dieiem Falle rein erzogen werben? 1

Goll bie Bermifdung fünftig fortzesflanzt veroen, io ftelle man ben baukaren Diftrift, mad) ben, aus ben vorigen Rapiteln binlänglich befannten

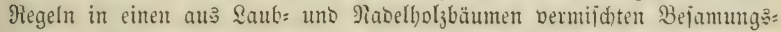

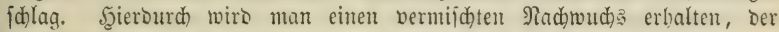

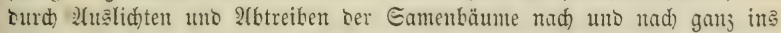
Freie gebrad)t, uno in ber Folge, nad) Den im zweiten Rapitel gegebenen

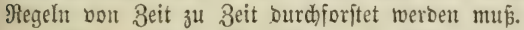

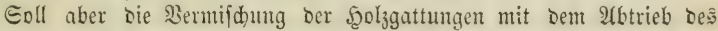

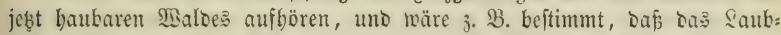

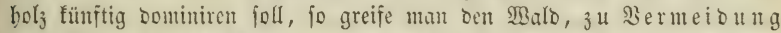
Des Nabelbolzanfluga, von ber Guic= Weit o ober Meft= Seite an -

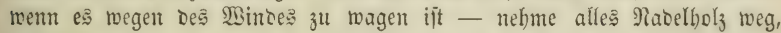
uno bilbe aljo aus lauter Sautboljbäumen - cinen fo viel möglich regel: mäpigen Dumfeliłlag.

Soll aber tas siabelholy begünitigt uno rein erjogen werben, io haue

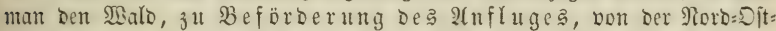

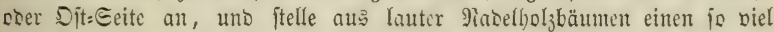

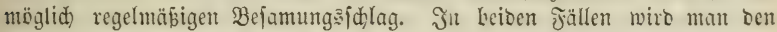
3ned erreidfen, went man bie in Den porigen Sarpiteln in oft empfohlenen Plegeln gehörig befolgen, uno sie bier uno sa leerbleibenten Eteflent burdh fünftliche Saat uno \$flanzung auझbefiern will.

Eollte bei 2(nmentung aller Sorfid) bod) wieber ein mebr ober me: niger bermifiter junger Walo entitanden fein, fo rathe id nid)t, ihn art bejteht.

'Beim đorituejen nennt man cinen Bejtand rein, went et als eineriei Şolj= 
Durd) foftbare fïnftliche Siltur alsbalo in einten reinten Beftano umbu= formen. Man lafie lieber einen jold)en jungen Balo vermijd)t aufwadjen, und juche bei ben fünftigen Durdforitungen, Durd) Wegnabme ber weniger

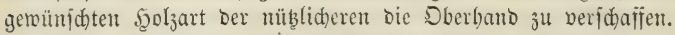

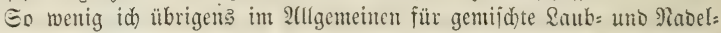
holylualoungen ftimme, fo jebr empfeble id) ess, lieber bie Bermifdung

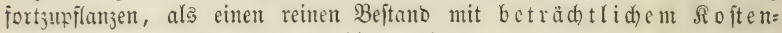
a uf wanb zu erzieben, Doer wohl gar einen unvollfommenen Beftano da: ourd) zul beroirfen. (5s ift immer vortheilhafter, volltommen. beftan=

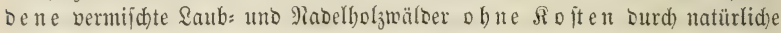
Bejamung 3 er eriehen, als reine Beftäno burd) foftbare Mittel z̆l erlangen, ooer bei llnterlaijung ber immer fofttearen fünttlichen Sultur, jwar reine, aber unvollfommene Baldungen zu baben.

\section{Dritter M(bjidnitt.}

Bou Der füuftliden Sgolzzudt)

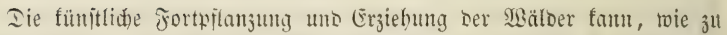

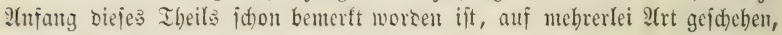
unto zwar:

1) Durd ben Stod = und $\mathbb{B}$ urzelasidfag abgebauener \&aublolzbeftänbe;

2) Durd Ausfreung oes eingefammelten நूolziamens;

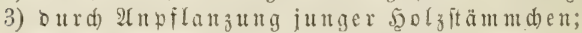

4) Durd Stedreifer oder Stediuge, un

5) Durch Atbleger ober Atbienter.

Jebe von biejen Malderziehungsmethoden hat unter bejondern llm= ftänden ibre bejonbern Borjüge. (E.⿹ fommt alfo aud) auf bie Unter: fud)ung Der ltmitäntoe an, um jul beftimmen, ob man biefe oder jene zu wäblen habe.

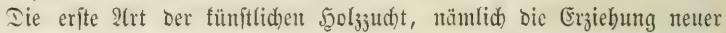

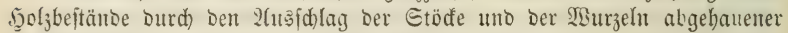

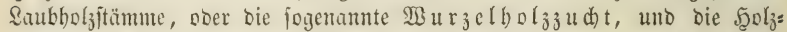
vermebrung Der atbleger ober 2(bjenfer fino natürlicherweife mur ba möglid, too idon Walobejtäno vorfintlich finto. Die Sat uno Bflanzung uno Die $\mathfrak{B} e r m e b r u g$ ourd) Stefreifer aber find bie Mittel, unt

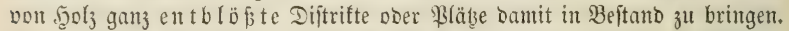

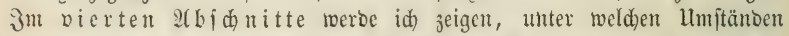

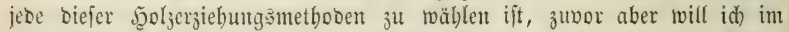
gegenwärtigen 2 biduitte jebe befonters abbandeln uno bie fidherite Antei: tung bazu ertheilen. 


\section{Erfte Autheilumg.}

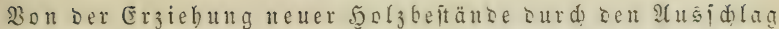

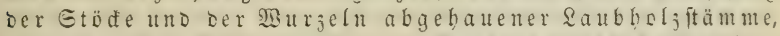

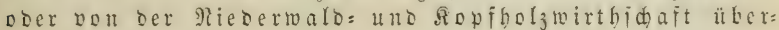
baupt.

Die Erfahrung leht, daj alle Saubholjarten aus Dem Etodi uns

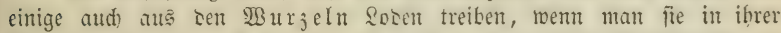

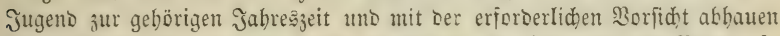

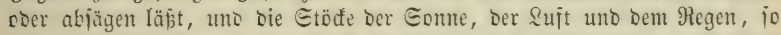
biel mie nöthig iit, auझjebt. Dieje :(ușj)läge ermadjen nadher zu Bäumen over Büidhen, wie es bie Goljart, ber Bobert, Die Rage uno anbere ltm: ftänoe verftatten, uno ber Etod bringt biejelbe \$Birfung, nad wiecerfolter 2tbbauung der A(uŝjhläge, jebesmal uno jo lanye herbor, als er felbjt ober jeine $\mathfrak{B}$ urzeln am Seben bleiben, und bie zu Bifoung und 2Atstrei=

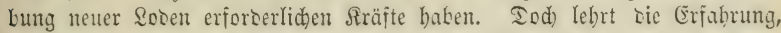
Iaf bon Den meiften Şolzarten ein io bebanbelter Etod niemals jo lange leben uno AHsjobläge geben fam, als Derjelbe gelebt baben mürde, roem ser erite Stamm non ifm nifft getremnt uno Die Seritümmelung nid)t io

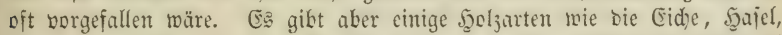

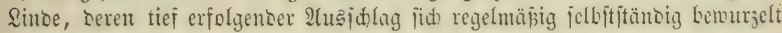
uno zux unabbängigen neuen BFlanze wirs, Deren Etöde mebrere butbert

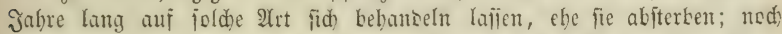
anbere gibt es, bie bei jeben neuen stbtriebe eine Menge Wurzelbrut treiben uno ben Beftano baburd) noll beftoct erbalten, wic bic Wreiperle, Die Prapeln, Rüjtem, 2(fazien; Dngegen gibts aber bei weitem mehrere, Deren Gtöde bei ciner foldhen Behanolungsart nux eine furze Iauter baben uno faum z'wei = ober breimal 2(uş) läge herborbringen, wenn man bieje 20 ober 30 Jabre alt werben läpt.

Go verfdiesen mun bie Dauter ber Etöde ijt, fo rerjdiesen fino aud

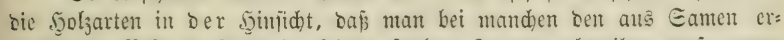

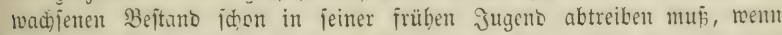

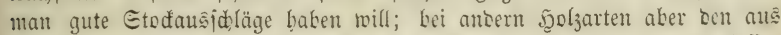
Eamen erivadienten Beitano nor Den eriten 2(btrieb älter merben lajien fann, uno bod mit Eidherheit auf Etodfusichlag rechnen barf. Bis zum 30jäbrigen 2(lter iă)lagen jwar bie Etöde fajt bon allen Laubbolj:

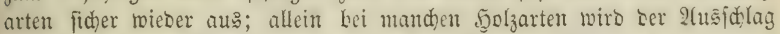
mit zunehmentem 2 (lter immer miplicher uno bleibt endlich ganz aus, wenn bie Stänme älter finto.

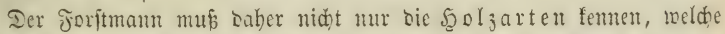

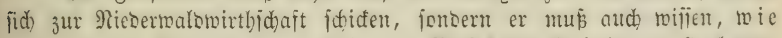
alt bie aus Eamen ermadjenen Bejtäne bei jeber bolant bö hiten se fein bürfen, went man fid) nad ibrem 2(btrieb guten Etod:

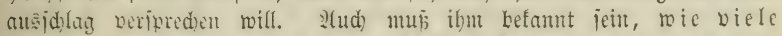

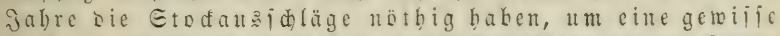
Iide ju erlangen, ut bis in weldes afler bon ben Etöten nod) guter 2(ușidhlag erfolgt. 
3ur befieren Heberfidht oiejer, ans ber Erfabrung abgeleitcten ?otizen bradte id fie in nadjitebente Iabelle $A$, worin id aber mur biejenigen

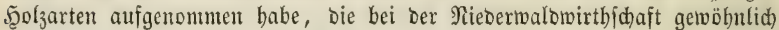
borfommen uno bejondere ßüfifdt veroienen.

2uker Den in biejer Tabelle enthaltenten Notizen tomment aber aud bei Der Nieberwalowirtbjafaft nod folgentoe Gegenftänbe in Betrachtung:

1) Weldes ift bie ididlidite un befte Jabreszeit zur fau $a$ ng ber Sdläge im Rieberwalbe?

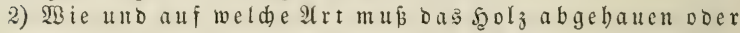
abgefägt werben, bamit bie Stöfe redt gut wieber a แร્ळlagen tön uen?

3) Mie itark múb bie Eonne, bie \&uft und oer Regen a uf bie Stöde und ibre $\mathfrak{A}$ asidläge wirfen, um vollfom= men gut wadjenzu

Ulito

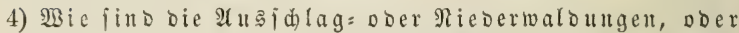

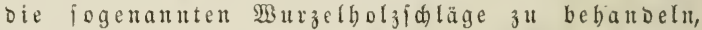
um bie nad und nad abgebenoen Stöfe ourd neue Bflanzen wieber zu erfezen und Daburd der Nicbers walowirthidaft eine immermäbrende Dauer zu ver: id) a fien?

Bir wollen baber jeden biejer Gegentänoe juwor bejonbers abhandeln.

1) Bon Der fdidelidfen Jabreszeit zur f̧aung ber Sdläge im Riederwalbe.

Die Erfahrung lehrt, Dab bie ber Sonne ausgeję̧ten Stöde bon ab= gebautenen jungen Saubholjitangen aus ibrer Rinoe neue Soben hervor= treiben, bas 2tbhaten mag zul eiter Jahreszeit borgenonmen worben fein, weldhe es wolle. Dagegen ift es aber aud volltommen erfabrungsmmäpig,

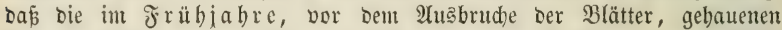
Nieberwalbichläge bie meijten uno fräftigiten Soben treiben uno ben fabön= ften Radjwuds geben. Nimut man bie Shaunng im Sommer vor, io

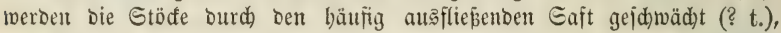
Das $\mathfrak{S g l}_{3}$ ift weniger gut zum Branto, e? geht ein Theil bes Buwadjes verloren, ber Şauerlohn ift theuer, bie allenfalla sorfindliden Samenloben

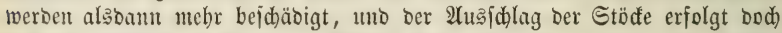
erft im nädjiten Frübjabre. Nimmt man aber bie Scauung im Şerbite vor, nadjoen das \&aub gefallen ift, io entfteben zroar bie borbin ange= fübrten Nadhtheile nicht, man bat aber in biejem Falle, fo wie aud im

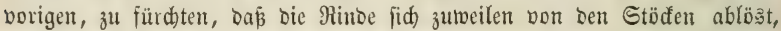
wenn im Binter nad) anbaltentom Regentwetter plök̨lich ein ftarfer Froft

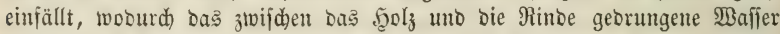
gefriert, fid) befauntlid babei auşbebnt uno bie Rinbe bom f̧olze loșreipst. Bollte man bingegen bie Şaung im $\mathfrak{B}$ inter vornebmen lafjen, fo mürbe nidyt allein ber foeben angefübrte nad)tbeilige llmitano eintreten fönnen,

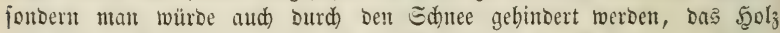
tiej auf Der Erbe abzuhauen, und bie Bearbeitung bes Snippel= unt Reijer= bolzes im Eannee vürbe viele lntequemlidfeit verurfachen. 


\begin{tabular}{|c|c|c|c|c|}
\hline \multicolumn{2}{|c|}{ 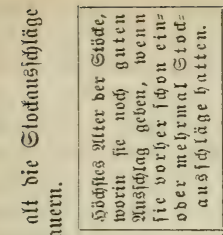 } & \multicolumn{3}{|c|}{ 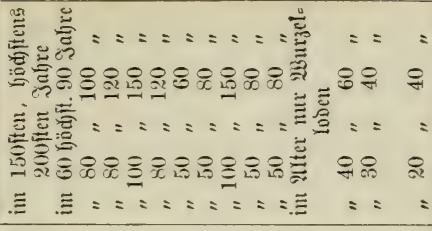 } \\
\hline 跣 & 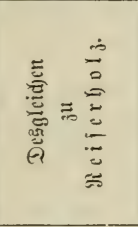 & 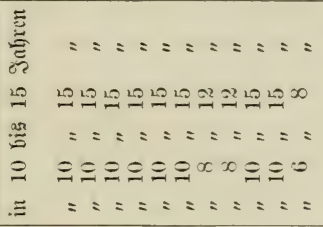 & $\begin{array}{l}== \\
\infty \propto \\
== \\
00 \\
==\end{array}$ & \\
\hline$\Xi$ & 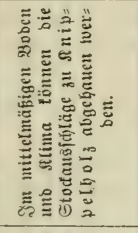 & 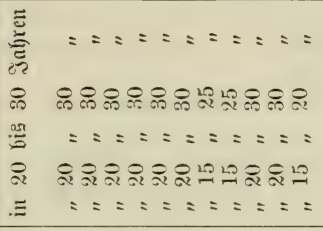 & 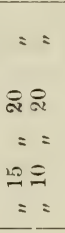 & $\begin{array}{l}= \\
\stackrel{2}{\Omega} \\
= \\
= \\
=\end{array}$ \\
\hline 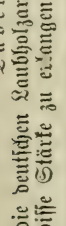 & 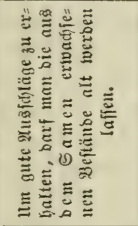 & 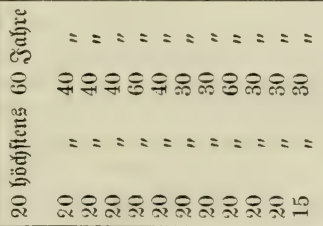 & $\begin{array}{l}== \\
2020 \\
== \\
2020\end{array}$ & $\begin{array}{l}= \\
8 \\
=\end{array}$ \\
\hline 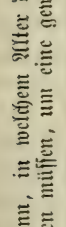 & 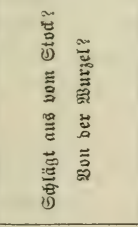 & 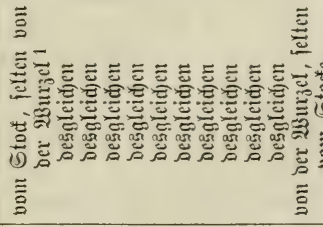 & 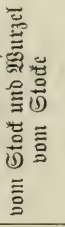 & 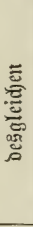 \\
\hline$\Xi$ & 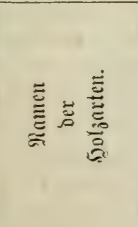 & 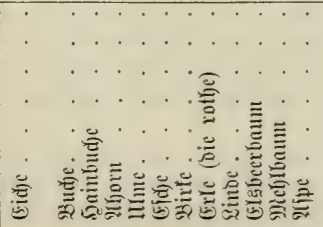 & 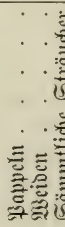 & \\
\hline
\end{tabular}


Man firtoet baber bie 3eit, vom 2lbgang bes Ednees an, bis Dabin, too bie Snojpen anfangen aufzujd)ellen, folglid) bon ber Mitte bes Februars bis in bie Mitte des 2 prils, als bie fodidfidjite uno

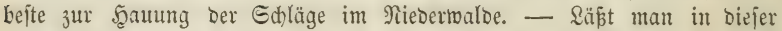
3eit bie Scauung vornebmen, fo ift alsbann ber oben erräbnte froftichaben

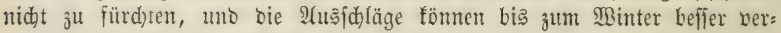
bolzen unt nadher ben froit befier aushalten, als wemn man bie feauntg fpäter, im Jrübjabre uno erft im $\mathfrak{M l a i}_{\text {i }}$ vornchmen wollte. In biejem Jalle fommen bie Âsjolläge fpäter hervor uno bleiben in rauhen Ges: getroen an Den Epizen oft fo reid), báp fie in WBinter vom froft grofen= theils wieber ruinirt werben. (? t.).

Wenn es aljo bie Umitäloe erfauben uno teine bejondere Rüdfid)ten eintreten, fo baue man Die Esläge im Rieberwalde von ber Mitte de Februasbiz in bie Mitte des 2 prils. Nur wem die eben bes ftimmte Beit nid)t binteidht, um alle Rieberwalojhläge bauen zu fönnen,

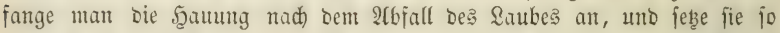
lange fort, bis Echnce fällt. Man vermeioe aber fo viel mie möglid bie

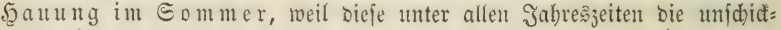
lidjite unt nadhtheiligite ift.

2) Bou Den Regeln, bie bei der Şaung oer Sd)läge im Niebersaloe zul beobadten find.

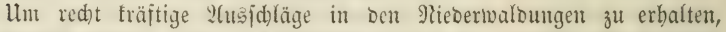

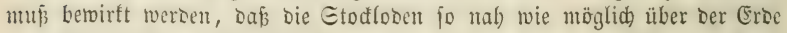
bervorfommen, daj bie Stöfe reber gejplittert oder aufgerifien, nod an

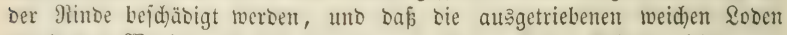

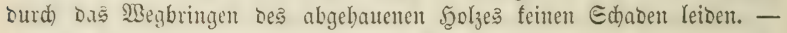
Diej madht bie Befolgung nadjitebentor Megeln nötbig:

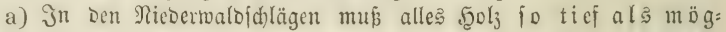

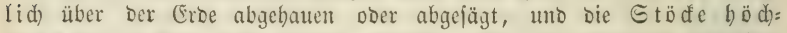
ften: 8-10 Etm. hod gemad)t werben. Bei alten fnorrigen ober fno: tigen Etöden aber - Die, jobalo Eamenloden neben ihnen aufgenadjen fino, ganz weg müî̄en - bat man $4-5$ Etm. lange Stifte fteben zu lailen, Deren jüngerc idlafende 2Augen einen fidhern uno lebensfräftigern

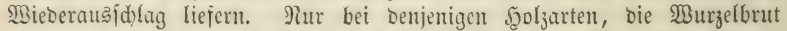
liefern, faum man ftets tiefen şieb fübren uno bat nid)t nöthig, fich an Den Şieb im jungen ફूolze วu binben.

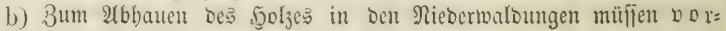

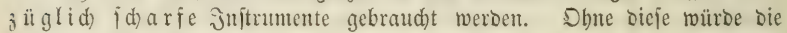

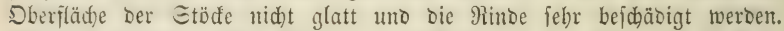
Bei ber frauntg folder Etämme uno Etangen, bie bicfer als 8 (5tm. fino, mililien baber $i$ darfe un breite $\mathfrak{A}$ exte, bei geringerem $\mathfrak{S g l}_{3}$ aber idarfe Sepen ober Beile gebraudt werben, weil bie fleinen Etämmchen in ber Eroe logreifen oder fpalten, wenn man fie mit einer fidweren 2Yrt abbauten läp̧t.

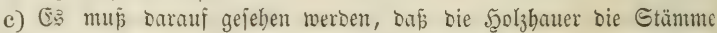

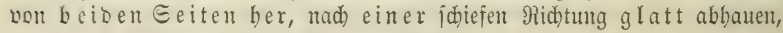
Damit Das Wailer auf ben Etöfen nid)t ftehen Kleiben uno ber Etod nidit 
ipalten fann. Depmegen muß jeber Etange von einiger Dide anf beiscn Eeiten cine gleidje tiefe Sierbe gegcben, bie fleineren bingegen mitifen burdn cinen fräitig gefül)rten Sieb weggenommen werten. 2(uf feinen fall

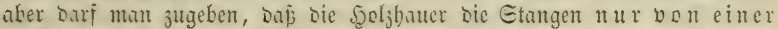
Eeite einferben, jie sam auj bie Eeite biegen uns abbanten. Jimmer mirb surch ein foldes \$erfabren ber Etod bejd)äsigt ober aufgerifien wer:

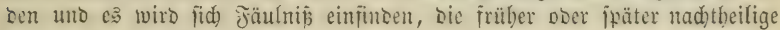
Jolgent hat. Enolid)

d) пиј mit Etrange Darauf gebalten werben, baßj alles geid)lagenc

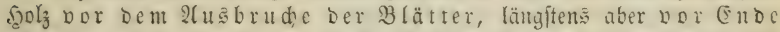

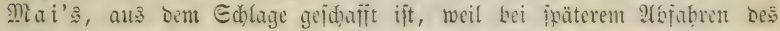
Sgoljes bie martigen neuen Soben fehr verborben werben.

3) Bon Der nöthigen $\mathfrak{B}$ irfung Der Sonue, Der \&uftumb Des Regens auf bie Sdläge im Riebermalbe.

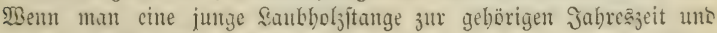
mit ber erforberfiden Borfid)t abbauet obcr abjägt, fo fommen faft immer am Stode Sobsn bervor. Dieje Soden jterben aber balo nadyber mieser

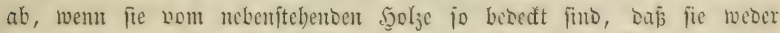
bou ber Eoune, nod wou sor freien \&uft, nod nom Piegen getrofien merben fömen. Sit bingegen ber Etod gan; frei, uno gar feiner be=

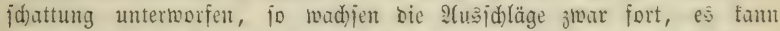

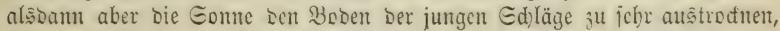

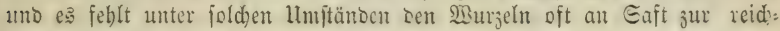

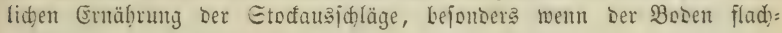
grünoig mager uno ber Some jehr ausgefebet ift.

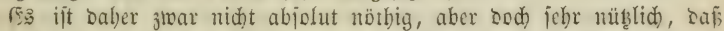

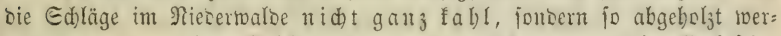

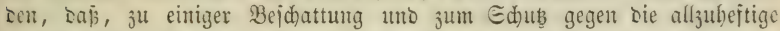
Ennnenbikse, geringe Etämme, ober Meibcl, oder Etangen in gleider Dertheilung fteben bleiben. Shre 2nzabl Darf aber nur fo grof iein, Daj; Durd Den Edyatten Der Gipfel, jebeamal etra ber 10te ober 16te Theil Der fläche, worauf fie jteben, bebect wirb. - Die Menge Der nötbigen Doer nübliç̧en Edjattenbäume hängt aljo von Der Größje ibrer Giłfel ab,

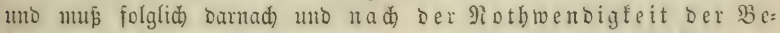

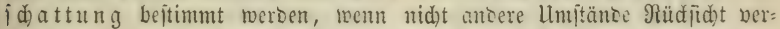
sienen, bon benen id jogleid) resen werbe. - Iod ijt es nidht wortheil= bajt, fehr groje Etämme in Len Nieberwaloungen zu lajien. Ein groper

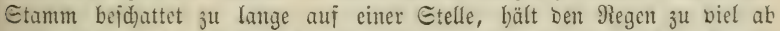

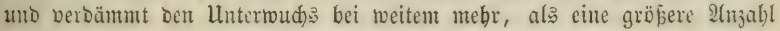
gleid) vertbeilter fleinerer Etämme, bie zulammen genommen eine eben io groß̧e flädse, aber nicht an einanoer bängeno, beiđatten.

4) Bon Der Bebanolung Der Nieberwaldungen, um bie nad und nad abgebenden Stö de Durd) te ue Pflanzen wieber zuerjeben.

Es ijt vorbin gejagt worten, Daj geringe Stämme, Retbel unc Etangen auf Den Wuzzelfalägen fteben bleiben müfien, um Edatten ben faftigen Lobenim Eommerabredjeluse 
lung zu geben, und das $\mathfrak{A}$ ustrodnen bes Bobens einiger= ma веnzu mindern. Die Stöde biejer Stämme, wenn fie nad einigen Jabren gehauen unt aus bem Edalage getragen werben, erieken bie alteridwachen Mutteritöde. Eben diefe Stämme bienen aud Dazu, um burd ibren

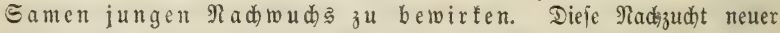

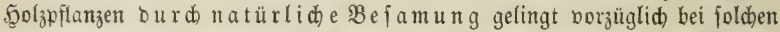

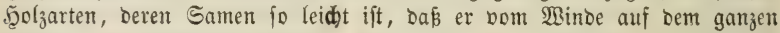
Edblage verbreitet werben fann. $\mathfrak{B o n}$ folden 50 lzarten aber, bie fdweren Samen bringen, ber nicht allein gerabe unter ben Mutteritamm fällt, fon= bern aud noch auberbem ftarfe Bebecfung forbert, fann burch bie natür: lide Befamung in ben Riebermald ungen nidit biel bewirtt werben. Man läjt Daher in biefem Falle nur bie zur befdattung nüßliden

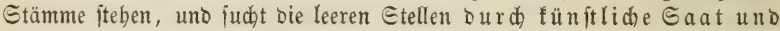
Bflanzung auszufüllen, oder man wedfelt von Beriobe zu ßeriobe mit ber 5ुod) = uno Riebermalbwirtbidaft $a b$, wie in ber Folge gelebrt merben wirb.

\section{Erfles Eapited.}

Bon Der forftünigen Beroirthidaftung Dex eidenen waldungen.

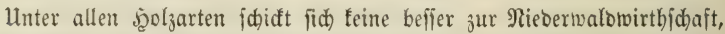

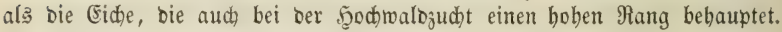

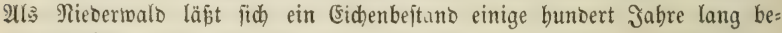
wirthjdaften, obne dá man bas 2usgehen ber Stöffe zu fürdhten bat,

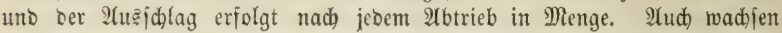
Die Soden johnell in bie ḩöhe uno geben nidht allein ein vortreffliches Brenn= uno Roblholy, jonoern aud bie bejte Berberrinde, uno furz por bem 2 (bs= tricb zumeilen aud etwas Mait.

Snlt num ein 30: bis 40jäbriger Eidgenbeftand als $\Re$ ieberwald abgeboljt uno bebandelt werben, io ift vorber zu beftimmen, $\mathrm{Db}$ man bie Sobrinbe bembken will, poer nicht. Soll fie nidht benukgt merben, fo

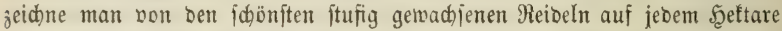
120-160 in gleider $\mathfrak{B}$ ertbeilung aus, uno lafie alles übrige $\mathfrak{S c l}_{\mathrm{z}}$ in ber Mitte bes $\mathfrak{M a} r z$, nad) ber im borigen Rapitel ertbeilten Borfdrift, red)t tief am Boben glatt abhauen, noch beffer aber, abfägen. Dả ge:

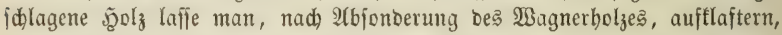
bie Reifer aufbinoen, uno alles vor Ende Mai's aus bem Sdalage fdaffen.

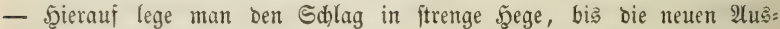

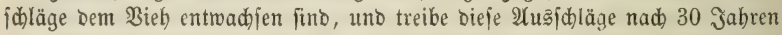
auf biefelbe 2 rt wieberbolt ab. - Bei biejer şauung nebme man alle bei Dem erften 2 btrieb ftehen gebliebenen $\Re$ cibel meg, und laffe bagegen wieber ebenjo vicle von den ftärfiten Stodauşichlägen ittehen.

Aluf biejelbe 2 rt wiro bei jedem 2lbtrieb berfahren, roourd) man

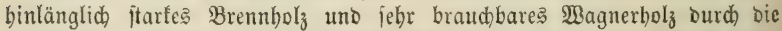
jebesmaligen 60jäbrigen \&aß̄reibel bezieht, bie nebenber aud etwas Majt abwerfen.

Will man bemirfen, dap nad ber Şaunng Des Sdlages bie zum 
Uleberbalten bejtimmten \&apreibel ober Stangen in redt gleidjer ßertbeilung.

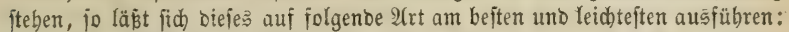

Man ftellt in ber Entfernung, in reldher bie Sapreibel fteben bleiben. jollen, 3 ober 4 groritofficianten ober aufmertjame $\mathfrak{S}_{0} l_{3}$ hauer in eine Sinie,

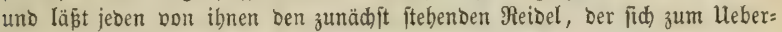
balten qualificirt, mit einer $\mathfrak{B i e b e}$ ober einem dünnen Etrobjeile umbinoen.

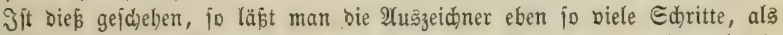
jie von einander entfernt iteben, bortwärts gehen, Scalt machen, abermals bie

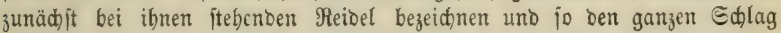
bis zur entgegengejeß̧ten Seite Durchzieben. Dort merben fie auf biejelbẹ $\mathfrak{H}$ rt georonet, um auf ben anjhließ̧enden Streifen bie Saß̧reibel zu bc: zeidnen น. โ. พw.

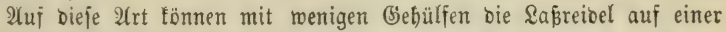
groken fräde jebr balo bejeidnet merben, uno man wirb, wenn bas bas

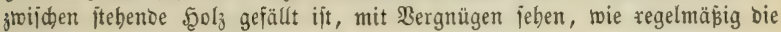
Sapreijer auf bem Schlage jtehen.

5̧at man Gelegenbeit, bie Lobrinbe gut zu berfaufen, fo warte man

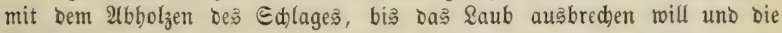

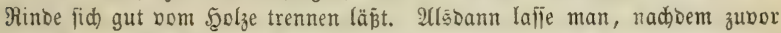

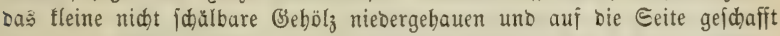

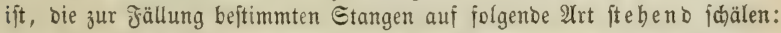

Bermittelft leichter Şepen miro jebe Etange, jo hod man reichen

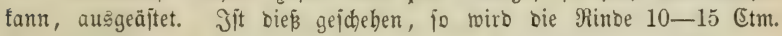
über ber (Erbe, Durd mebrere Silebe, runo um bie Stange Durdjidnitten. SEierauf twiro bie Rinde, fo hoch man reichen fann, bon oben bis unten

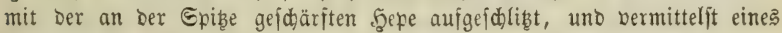
jogenannten \&ohfd libers, ber entmeder bon Eifen ober bon hartem 5ुolze jein fann, abgeftopen, uno borerit oben an ber Etange bängen ge= laijen. Jît Diể gejdehen, fo merben bie gejwälten Stangen nabe über ber Erbe glatt abgebauen, ber obere Iheil, too ę fich thun läpt, böllig gefdült, bie Rinde an ber Eonne getrodnet, in gleich großße Bürben ober

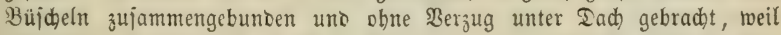
bie beregnete Sohrinde an ihrer Büte berliert, befonders wenn fie bem

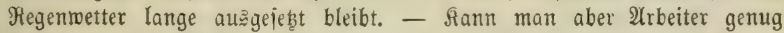

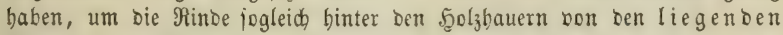
Etangen abjujd,älen, oder find bie Etangen fo lang, Daj obnebin ber

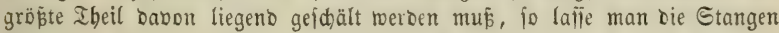
überbaupt liegend idälen, aber niemals mehr umbauen, als in cinem Tage gejçält werben fönnen, weil fich jonjt bie Rinde weniger gut ablöst, menn ber Saft zum Theil bertrodnet ift.

Iurd) biejes Edälen gebt zmar an ber Brennholzmaine etwas ver= loren; Da aber bas Pfuno yon biejer, bejonders gejdäb̨ten, fogenannten Spiegel= oder Gilanglobrinde, wenn fie böllig bürr ift, oft mit 3 bis 4 Piennigen bezablt ivird, wo das \$funo Brennbolz im bödjten $\mathfrak{A} n=$ idslage nur $1 / 4$ ober $1 / 3$ Wfennig toftet, fo ift ber Bortbeil bod jebr groß Ja, es fino mir fälle befannt, wo auß der Sohrinde mebr Belo erlöst wurbe, als aus bem Sgolze, wobon fie genommen war. 
wer fid) aljo ciduente Rieberwalbungen anlegt uno fie zugleid auf Sohrinoe benubzt, Der wiro nidht mur eben fo vieles uno gutes Sold als

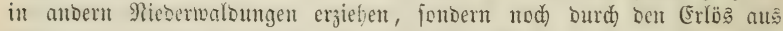
Sobrinte, Dic man allerwärts um cinen hoben Breis anbringen fann, wid)=

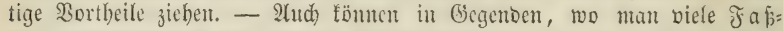
reife braud)t, aus ben eidenen Nieberwalbungen bic Dauerbafteften Rieife bezogen uno theuer berfauft werben.

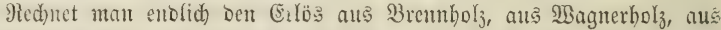

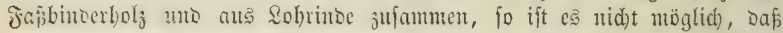
bie mit anbern Syolzarten beftandenten Nieberwaloungen ocn cidnen im (5x: trage gleid) fonmen fönnen.

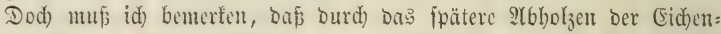
rinbenfdläge ibr folzertrag in $r$ auben begenden etwas ber: minbert wirb. Die Soden fommen nämlid, weun bie Sd)läge im Mai gebauen werben, fpäter zum Borid)cin, als in foldyen, bie im März gebauen werben. Sie fömen baber in rauben Gegenoen, wo ber siinter früh) einfällt, oft nid)t gehörig verbolyen, uno bicjes hat ber Erfabrung

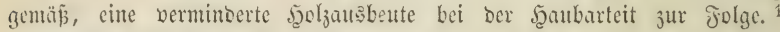
Defifenungeadtet ift Der 3ortbeil immer ned) wid)tig genug, wenu bie \&ob= rinbe um ben gewöbnlid)en \$reis verfauft werben fam, uno im mild en Silima, wo bie fłät augegetriebenen Soscn bis zum SBinter faft immer ver=

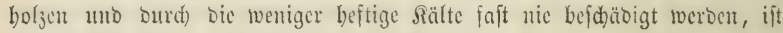
bon biejem llebel aud) wentiger zul fürchtent.

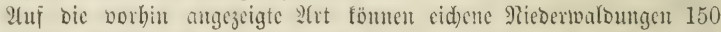

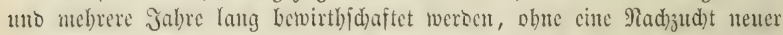
Gtöcte nötbig zul baben. Tritt aber endich) biefer Jall cin, fo mus bie

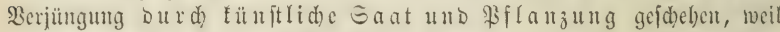

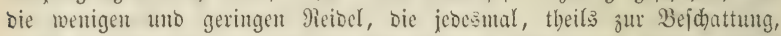

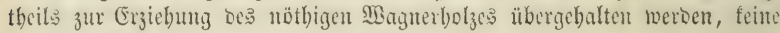
binlängli d)e Befanung belvirfen fönnent.

\section{马ెweites Gapitel.}

Bon Dex forftü̈ßgen Bewirthidaftung Der Bud dennieber= waldungen.

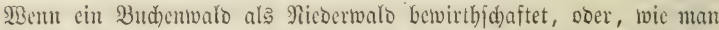

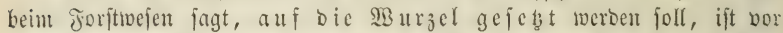
allen Dingen bie genauc Unterfudung nöthig, ob Der Beftanto nod) nidft 3u alt unb zum Stoctinsjid)lage nod) gejojictt jei. - Fände man bei biefer

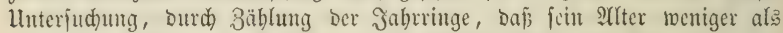

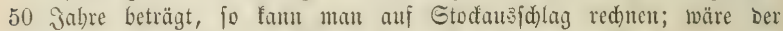
Beftano aber älter, fo barf man Den 24uइjulag Der Stöde, ber mit

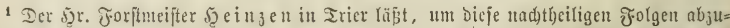

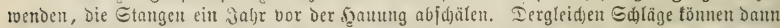

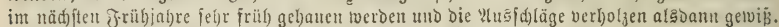
Durd) Den fräftigen 28 แd)

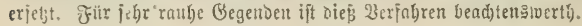




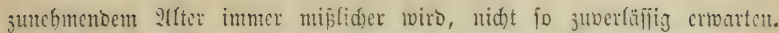

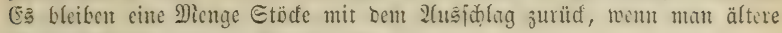

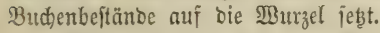

Bejonters aber lehrt bie Erfahrung, Daj bie Bud)en= unt Birfens bejtänoe, weld) auf gutem Boben fteben, nid)t jo gerne vom Etocf ans: idlagen, als jold)e, dic auj magerem Bosen madjen, uno daí Budene

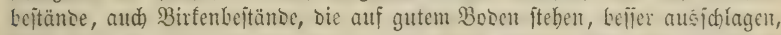
wenn man fie, iobalo ber Eaft circulirt, bauen läpt, uno aljo burd? Den ausflię̧enben Saft etwas entfräftet.

Man wende alio bieje Erfatrungen bei Der Bitwithidaftung Der Buchennieberwaloungen an unb beftinme feinen Biftuns zu Sicserwalo obce

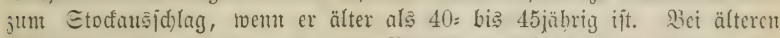

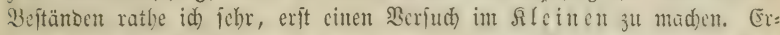

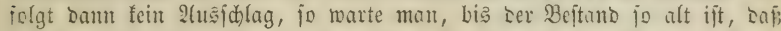
er bie erforberlidie Mlenge von Eamen trägt, um ourd) natürlid) Bejamung Den Diftrift zu verjüngen, und Diejen nen ž erjichenden $\mathfrak{B}_{\mathrm{B}}=$

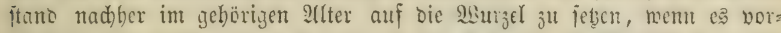
theilbaft ooer nöthig jein follte, ifn in Der Folgezeit als Plicoerwalo jube: roirtbichaften.

Bei ber Sauunty oer Buchenniebortwaloungen fino ilbrigens alle im ?llgemeinen fdou empioblene Dorfictemafregeln ju beobadten, uno juteșmal bie nöthigen Ed)atten= uno Eamenreibel, wie im vorigen Rapitel gezeigt rorben ift, ftehen zulafien.

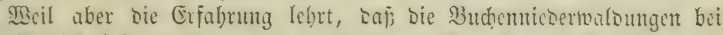

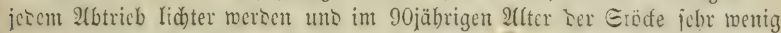

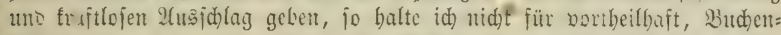

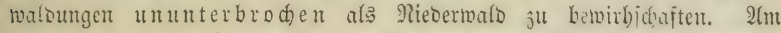
jicherften wirb bie inmerwäbrenbe Dauer sor zu Sicserwalo bejtinmten Buchentwaldungen begrünbet, went man ben aus Gamm erwadfienen $\mathfrak{B a l}$ int 30jährigen 2lfter auf bic Murzel jeşt, auf jeocm Soffar bie ftärfiten

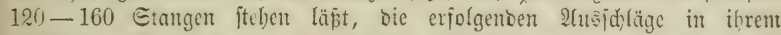
30jäbrigen 2llter bis auj bie beften 3200 Etangen Durdjorjtet, nad) fernercm 2tblauf bon 30 Jabren Den Beftand surdh natürlide Bcjamung, auf bie mun fichon befannte 2 frt verjüngt, uno belt neuen sisalo nadher loieder ebenfo bebantelt. - Durdh sine jolde Bemirthidaftunty wiro man

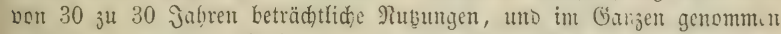

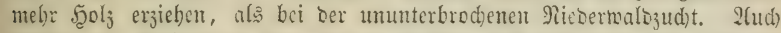
werben sie Salbungen teine (befahr laufen, nad) uno nad) fidst uno mit

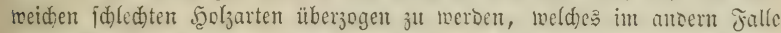
früber oder fpäter getwí; geidiebt.

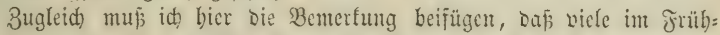
jabre abgebolzten Budjenftöde erjt in fünftigen Jrübjabre Soden treiben, uno baj aljo nidht alle berlorent fint, bie in erften Eontmer nad) Der

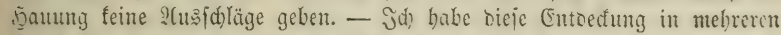

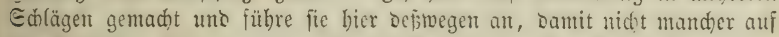
Ien Giebanten fommen möge, alle Etöde, bie im eriten Jabre feine \&obcn getrieben baben, ausroben şu lailen. Nur biejenigen Etöcfe, meld)e im żweiten 
Sommer nad ber Şauung bes Edjlages feine Soben treiben, finto abgeitorben uno fönnen, renn eş bie übrigen Umitände erlauben, gerobet werben.

Sollte ein buchener Nieverwalodiftrift fadon jo unvollfommen beftodt fein, Daf auf bie vorbin gejeigte Ifrt feine volljtänoige Berjüngung our d natürlide $B$ Bejamung möglich ift, io rathe id Den Blan zu Erziebung cines neuen Buchenbeftambes auj3ugeben, uno ben Diftrift mit fonft nüb: Xid)en, für bie Riebertonlomirtbichaft mebr geeigneten Fुolzarten in Beftano 3u bringen, wenn man burdfaus Rieberwals baben will. Jn biejem Jalle Laffe man, wie es ber Boben unto bie fonjtigen Umitänoe erheifden, Birfens,

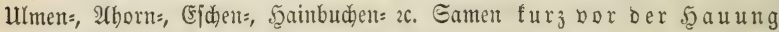
bes Sdlages in Dempelben austreuen, uno, wenn es fein tann, fidon im Şerbit zuvor Eideln unterbacfen. Durd) bie Bearbeitung uno oas

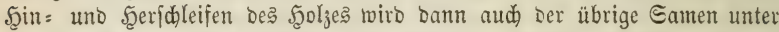
Das Saub uno Moos fommen, uno belier aufgehen, als went man bic 2(uşaat $n a d$ d) ber bölligen Räumung bes Sd)lages vornebmen läpt.

\section{Dritfes [arapitel.}

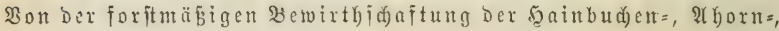

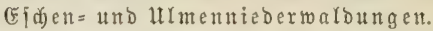

Bei ber Rieberwalomirtbichaft fimb bie mit Szainbuchen, 24homen, (Ejd)en, Ulmen 2c. entroeber allein Doer vermija)t beitandenen $2 B a l$ bungen be= fonters vortheilhaft, uno nad ben eidenen bie vorzüglichften. Sie fablagen bei regelmäpiger 3 ehandung bom Stod jebr fidjer aus, geben redjt gutes uno mitunter das befte Bremtholz, uno erbalten fid immer volltwüchig, weil ibr Canten oft geräth, , vom Mino allenthalben über bie Echläge ver: breitet miro, und eine Menge PFlanzen erzeugt, bie ben Stbgang ber alten Stödée binlänglid̆ erję̧en.

Bei Der Şaunt foldeer Mieberwalobeftänto fino bie oben gegebenen

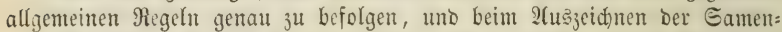
unto Sdhattenreiod finto biejenigen Sgolzarten z̧u wählen, ocrent Fortpflan: zung man vorzüglich wünid)t, uno Durch beren Heberbaltung bas beite

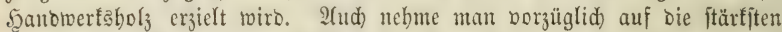
uno redit ftuig gewadjencn Reibel, bie ben meiften uno beften Samen tragen uno bom Edhree uno Duft fo leidht nidht gebeugt uno zerbrod)en werden fönten, Rüđfid)t, uno lafie bei jebeşmaligem 2tbtrieb auf jebem Seft. 120-160 joldjer Reibel ftehen. Sollte aber ber Diftrift ber Sonne jebr ausgefebt uno mager jein, oder viele leere Stellen enthalten, fo ber: bopple man bie ?(nzah)l biefer Reibel, unto bermindere fie it ber Jolge, wenn fie bie leeten Stellen binlänglid) bejamt und ben Ed)lag in ben

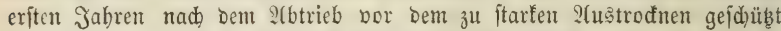
haben; Damit ihre zu großse 2 nzahl bie Stodfausfaläge uno bie neu er: zogenen Samenloden nidht veroümme. Diejes Aluşhauen eines Theils der Samenreibel faum 3 bis 4 Jahre nadh bem Itbtrieb bes Gdjlages gejdeben, und es miro baburd) an ben jungen 13 alse fein merflicher Sdaben ber=

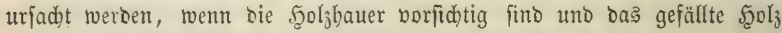

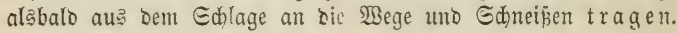




\section{Djiertes §apitel.}

Bon ber forftmäвigen Betvirthid)aitung Der mit (Ëlen betwajenen Pieberwaldungen.

Wenn bie erlenen Rieberwaloungen auf einem Boben ftehen, ter fo

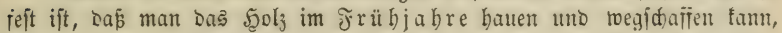
io werben fie gerabe fo behandelt, wie id im vorigen flapitel gelehrt habe. Nur Darf man in.fold)en Edlägen, bie oft uno lange unter Maffer fom: men, bie Stöde nidht ju niebrig mad)en lailen. Sie müî̈en jo hod iein,

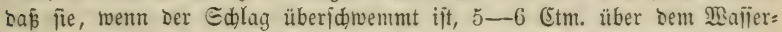
ipiegel herborragen. Diḗ gilt aber nur für Ueberidbemmungen von

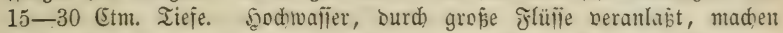
cine $\mathfrak{A}$ (unnabme. Iort fann man freilid) bie Stöde nid)t jo bod madjen,

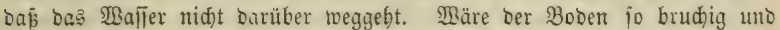

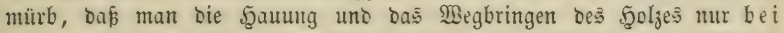

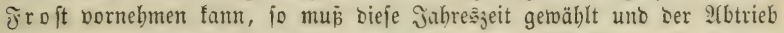
vorgentommen werben, jobalo als bie Brüd)e zugänglid, fino, ba man nie norausjeben fann, wie lange ber jroit anbalten wirb, und bie jroftperiode

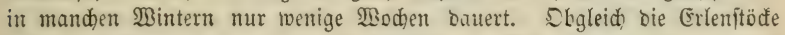

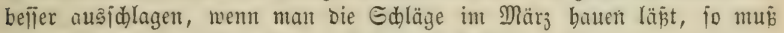
man fid bods in biejem fralle nad) ben Umitänoen ridhten.

(Seröbnlid) find bie mit Erlen bejtandenten Diftrifte fo feudst ober

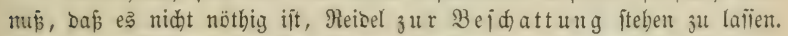
Man bat aljo mur für Reidel 3 ur $\Re$ adjla at $j^{3}$ jorgen uno jo viele fteben zu lalien, als zur Erreidjung Diejes 3weđes unt jur Erjiebung Des nötbigen Scanbmerfäboljes, ober ber erforberliden Brumenröbren nöthig

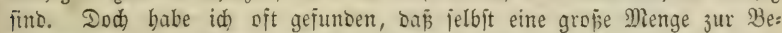

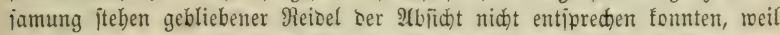

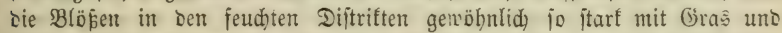
Unfraut bewadjen waren, daj feine natürlide Bejamung uno jelbjt teine

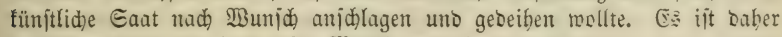
in biejem Fall bas fider ite Mittel: bie leeren Etellen bei jedes: maligem Abtrieb, mit fleinen, in $\mathfrak{B} a$ umidulen erjogenen Erlenftämmden zu bepflanzen.

\section{Tintftes Siapifer.}

Bon Der forftmäbigen Betoirthidaftung Der Mitteluälder. t.

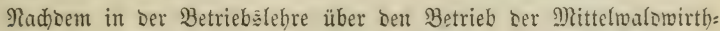

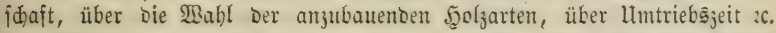

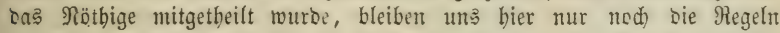

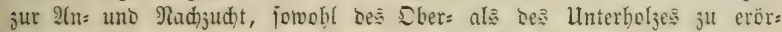
tern übrig.

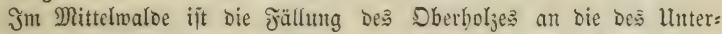

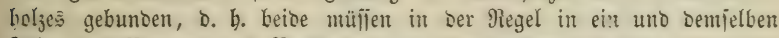

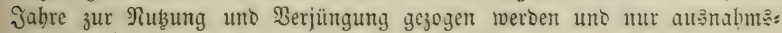
weife ift es geftattet, einzelne in ben Shieb fallende Dberholjitänme zum 


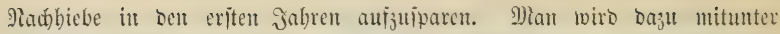

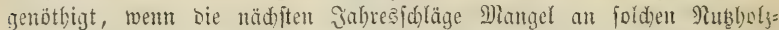

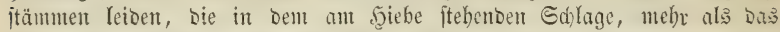

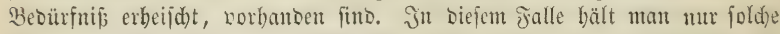
Etämme über, bie bidst an Geftellen, Wegen ober an ben Ränbern Des Edlages iteben und beren fäflung und Transport als bem mit 2-3= jäbrigen Soben betwadjenen Edlage teinen soer tur geringen Gdjaben ber: uriadjen faum.

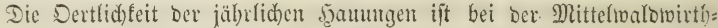

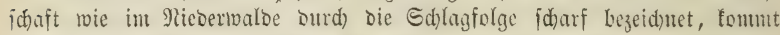
Daber bier nid)t meiter in Betrad)t, ebun fo menig wie man im Mittelwaloe

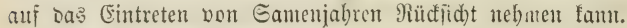

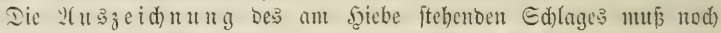
im Saube vorgenommen toerber, am ben Grab ber Befdattung unt bas S3erbäItnī Deffelben zur Befdirmung, ferner bie Berbämmung und Den

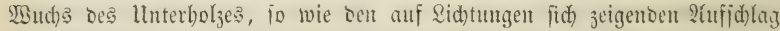

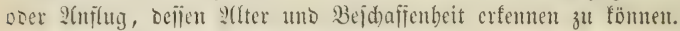

Bei biefer erften 2(uszzeid)nung merben:

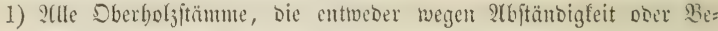
bui Der Şerftelfung ciner rid)tigen Bertheilung ober zur Berringerung ju itarfer Bejdattung unbebingt bintweggenumuen merben müfien, Durd) Ed)aft: biebe in orei beridbiebenten. Richtungen bezeidntet.

2) भlle 15-20 Ed)ritte wiro ein jum Ueberbalten, wem aud) mur

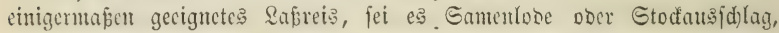
Dutd) Untwintoen Des Edaftes mit einem Stroh= ober Reiferjeile anșige jeidinet. (Bgl. S. 115.)

3) Daffelbe gejdhiebt mit alfen Stangen, bie fidh bejonbers zum lleber: balten analificiren, obne Rüdfict)t auf ibren Stanbort. Dießs gilt bejons Ders für alle Gamentflanjen uno für biejenizen 5̧olzarten, anı Denten man Den ertragreidjiten Dberbolzbeftanto ermartet.

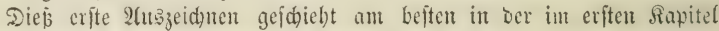
Dicier 2(btheilung empfohlenen 2(trt; ond) mus hier ber Sd)lag zweimal Durd)gangen werben. Beim eritenmale bält man fid bei ber 2tuş3eid)untg ftreng an bie Entfermung; beim zweiteumale wirb bie zuleß̧t genaunte 24 : jeid)mutg ber bejonocrs aualificirten Stangen vorgenommen.

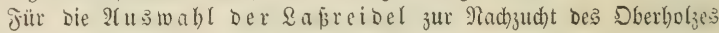
gelten folgende Regeln:

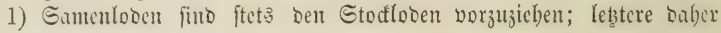
mur in Ermangelung eriterer überzubalten.

2) Ulnter ben borbandenen Eamenloden entidjeioct die zu begün=

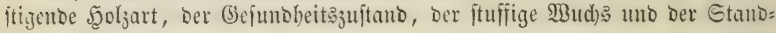
ort bie $\mathfrak{B a h l .}$

3) Unter Den veridiedenen fgolzarten liefern bie Erle uno Sinte

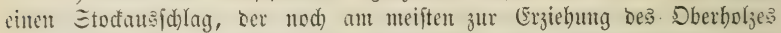
gocizut ift. Diefen folgt ber Stodausfolug Der Rothbude, Der Şain=

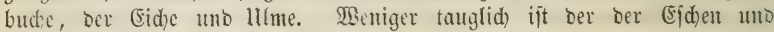

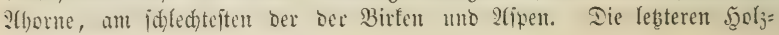




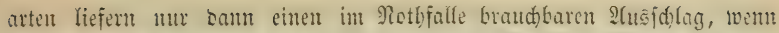
Diejer ber erfte einer jungen Gamentilanje ift. Son ältercu ooer von

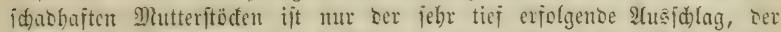

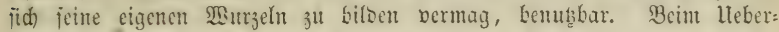
balten ber Stodloden tommt Der Umtrieb im Dberbolze uno das $9(6=$

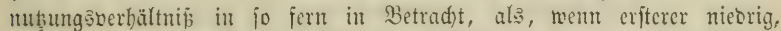

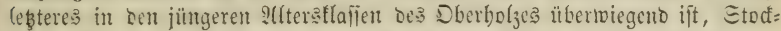
loben eher als int entgegengefebten Jalle übergehalten werben fönten.

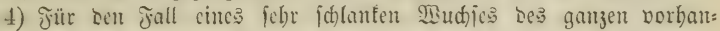
Denten Innterbolzbeitanoes bat man vorgejdlagen, aie Reizel nid)t einzeln,

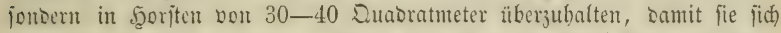
gegenjeitig aufred)t erlyalten. 2(llein Daburd) ourfte mohl faum ber beab=

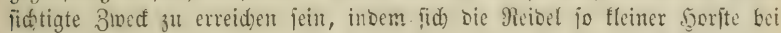
geringen Ed)neeanbang ebenfo leid)t legen, als bie vereingelt jebenden.

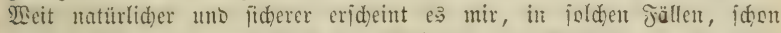
mebrete Jabre bor bem fricbe bes Gdlages, cine ?tuseid)mung ocr über:

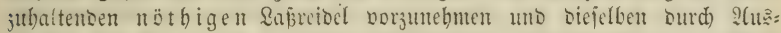

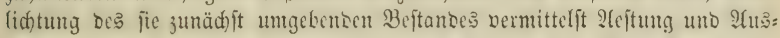
bieb auf bie freiftellung vorjubereiten. Ind) barf sicje ?luslidftung nidt jo flöblid) geidehen uno io weit gechen, baj ber lnterfolybeftuno basurd)

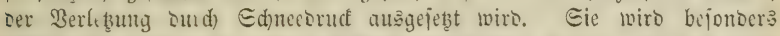
nöthig bei jungen im Didten $\Xi$ d) lidfer Freiftellung bäufig mipfeloür werben mo Etampfiproffin treiben, Dam aber eben io wenig zum jortwadjen im Dberboljbejtante taugen,

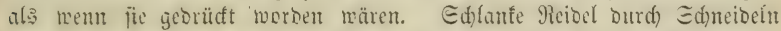
oour Einjtubien jür sen freicn Etano geeignet ju madon, bleibt ftets cin

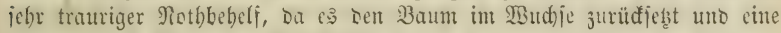
übornatürliche Sänge bes Mitteltriebs veranlajt, Der nidot felten burd) cigene Sd)were uno Durd bie Der majtigen Blätter niebergejogen wirb.

5) Reioel mit gabelförmig getheilter frrone hält man nidht gerne über, Da jolde Stümme bei Ednee= Doer Duftunbang in Der Gabel leidht ipalten.

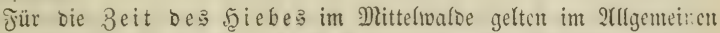

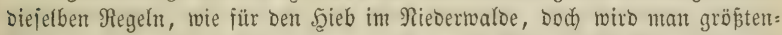

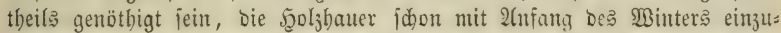
legen, sa wegen Der Fällung Des Dberfolzes dic Itrbeiten in Ed)lage längere 3eit eriorbern uno, Da Das Dberbolz inmer zuleb̧t gebauten merden

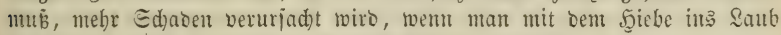
fommt, als bief́. beim reinen Riebermaloe ber fall ift.

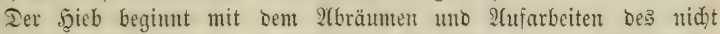
jum Uleberhalten bezeidneten Unterholzes uno gelten bierbei biejelben $\Re e=$ geln, wie jie jür ben Şieb im Rieberwaloe gegeben twurben. Ilnterorülte

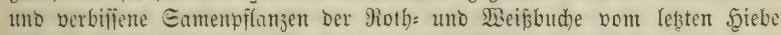
werben nidht auf bie $\mathfrak{B} u r z e l$ gejebst, jonbern bis jum nädjten Şiebe über: gebalten; iie balten in biejem falle beffer mit ben neuen Soden aus, als wenn man fie wie bas übrige lunterbolz berjüngte.

jit bus llnterhols aufgearbeitet, io funn man ben Sberholjbeftano 
flar überidauten, uno biejenigen Gtämme bezeidnen, weld)e, auper ben bes reits angeplätteten, Dem bejtehenden Betriebsplane gemäß nod in Den Scieb

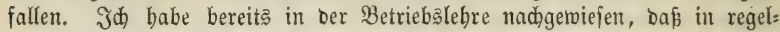
mäßig beitandenen Mittelwäldern bie 3abl ber wegjunebmenden Dberbol

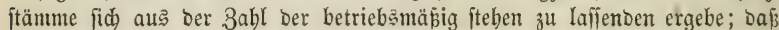
bingegen in Mittelwäloern mit Şodjwalbreften ber Şieb burdh einen be:

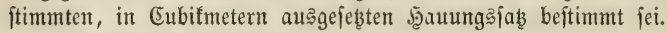

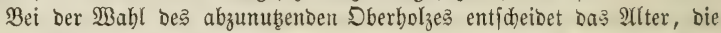

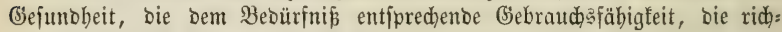
tige Sertheilung ober ger Stanoort, bie Berbämmung, sie. Stellung ber

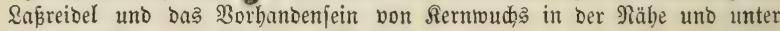
Den Stämmen.

Erit menn ber Şieb Deş Dberbolzes, mit möglidjter Sorgfalt gegen Bejđäbigung Der jüngeren Dberhölzer uno ber übergebaltenen Sapreibel vollendet iit, werben mun aud) bie im Leberiduß übergebaltenen Sapreibel

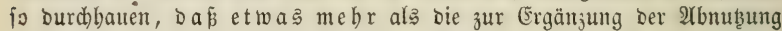
unt Şerftellung ober Erbaltung Des ridtigen Oberboljllaffenverbältniffes nötbige $3 a$ hl in möglidjit gleidmmäpiger Bertbeilung im Ed)lage ftehen bleiben. Bie viel bieß mehr betrage, beftimmt:

1) Der erfabrungşmäßige $2 \mathfrak{b g a n g}$ nach Beenbigung bes Schlages burd) Diebitabl, Ednneebruá, Bipfeldürre.

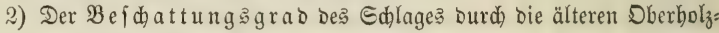
flafien, uno überhaupt bie Menge ber bereite borhandenen Dberhol $h_{j}$ tämme.

3) Die Befdaffenbeit bes älteren Dberbolzes. Şat man biel unwüd)iges ober gar abitünoiges Dberbolz, fo bält man mebr Reibel über, als im entgegengefersten Falle.

4) Die Befdaffenheit ber Lapreibel. Shat man vicle bejon:

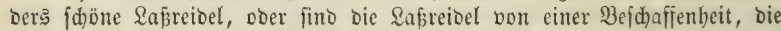
bebententen 2(bgang befürd)ten läpit, fo bält man eine gröpere $3 a b l$ über.

5) Die Befdaffenbeit des Unterbolzbeftandes. Sit ber Unterbofzbeftano fehr jidledtroüdijg, bedarf er nothwenoig einer Ergänzung ber Mutteritöfe uno fann ihm bieje burd) Bejamung boun Dberbolze zuge= menbet werben, io bält man eine fo großje Menge von Saßreibeln über, Daßs beim nädjiten Şiebe burdh fie uno bie übrigen Dberholyftämme eine Edjlagitellung und Berjüngung burd) natürliḑe Bejamung vorgenommen werben fann. Man greift Danı gewöhnlid) mebrere Edläge zujammen uno bebanoelt fie eben io viele Jabre bindurd, wie 5ुodjwaloverjüngung:

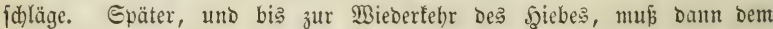

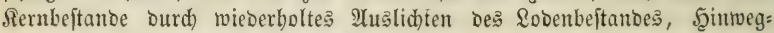

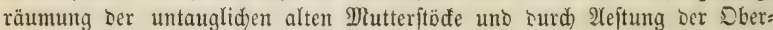
hölzer hinteidjent Sidjt berid)affit werben.

Sino mun bie überflüffigen \&apreibel mit benfelben bereits aufgefüfrten Rüdfid)ten Der I(uäwabl hinweggenommen uno aufgearbeitet, ift ber Sd)lag vom Şolze uno 2Ubraum gereinigt, fo weroen im näd)ften Frübjabre 2-3= metrige Sgeifter folder Şolzarten, bie man im Dberholzbejtande vorzugs: sveife begünftigen will, an bie Etellen ausgepflanzt, wo \&apreibel fehlen, bie Süđen im Unterholzbeftanoe aber, wenn fie von gröberer 2fusbefnung 
Finto, surdh plaţmeife ober Etedjaten, fleine Süđen uno joldhe zwijd)en Etöđen mit rajdem Sobentwudje, burd) Bflanzung 2-3metriger Etämme

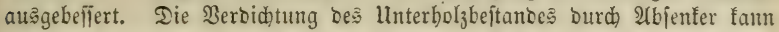
erit bann eintreten, wenn bie meuen Soden $3-4$ Meter hod geworben finto.

Bei bohem Umtriebe. im Interbolze lege man im 20 jten bis 30 jten Jabre eine Durdforitung ein, toobei Darauf zu jehen ift, baj nur joldhe im $\mathfrak{B u c h j e ~ z u r u ̈ d g e b l i e b e n e n ~ E t a n g e n ~ g e b a u e n ~ w e r b e n , ~ b i e ~ m i t ~ s o m i n i = ~}$ renten auf einem Stode ftehen; feine einjeln ftehente Stange, fie mag

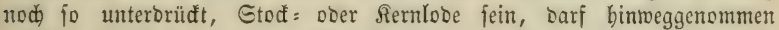
werben, wenn fie einer зu begünftigenten .5olzart angebört, wobingegen

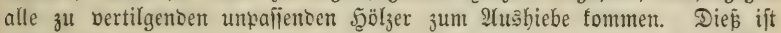
Dann aud) ber Beitpuntt, wo bie crwähnte 2 (uङ̉jeidhnung Der beim nädjten 5̧iebe überzuthaltenten Lapreibel vorgenommen uno biejen, wenn es nöthig

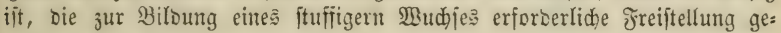
geben werben fantr.

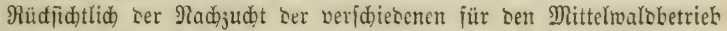
geeigneten 5ुolzarten ift nod zu bemerfen:

\section{Radjudt ber Ëide.}

Durd) Gaat geichieht jie am bejten bermittelît Des Sterns, inbem bie aแšgejäeten Eicheln bann am twenigiten von Milo uno Mäujen Ieiden. Man

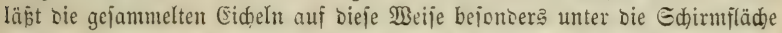
Der im tommenoen Jabre wegzunehmenben Dberbäume ftefen, fum auper:

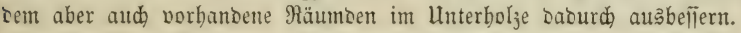

3ur Eid)enpflanzung muई man entweder gan junge 1-3jährige \$iflänz=

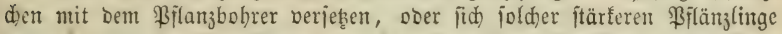

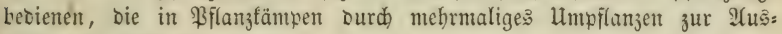
fflanjung vorbereitet wurber.

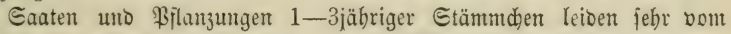
Bild, uno fino bei einigermaß̄en ftartem Miloftanoe faum aujjubringen.

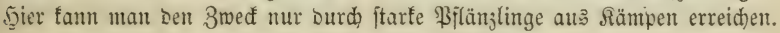

\section{Die $\Re$ a d zud t ber $\mathfrak{B} u$ de}

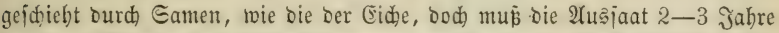

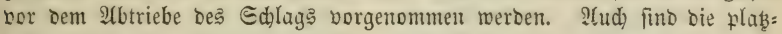
weifen Culturen mit Der Şađe bier gebräuchlider.

Bebecfung Der Gautpläb̧e mit ¿aub ift jehr gut. Ueber ben bejanten Etellen bält man beim Siebe etwas mehr Dberholy als gemöhnlid über,

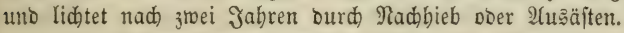

3ur Budbenpflanjung, weld)e leid)ter uno belier geräth, als bie (Fidjen= Hflanjung, fino Silänglinge, welche idon eine Beit binourch im freien ge= ftandin baben, Das erfte Erforbernip. Dan fann fie baber erit in einem fpätern 2Ulter, getwöbnlid) nidht vor bem 8. bis 15. Jabre verpflanzen, da

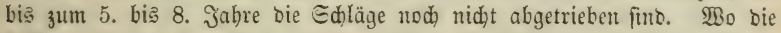

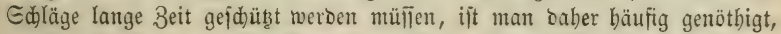

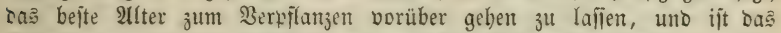

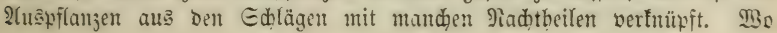




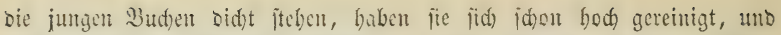
man erbält bier ichwad)e Etämme mit balben sironen. Etuffigu, vollbe:

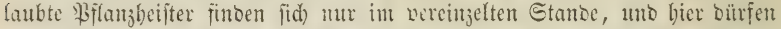
fie nidht, wenigitens nid)t in Menge, wiggentommen werben. Man fommt

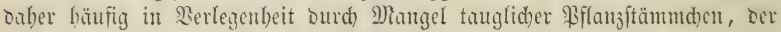

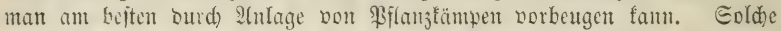
Bftanjfïmpe müfien unter bem Edjirme von Nhutterbäunten angelegt werben,

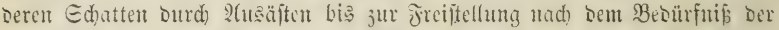
inngen Buche altmäblig verringert wirt. Der Same wiro in Rillen von 30 Etm. Entfermung geiäct. Da bie Bud)e nur in frühciter Sugend cine Bfablwurjel bejutzt, fo braud)t man fie nidit wie bie (Eid)e umjupflanjen,

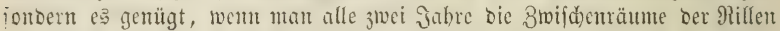

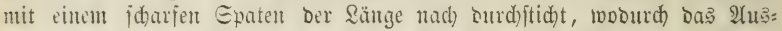

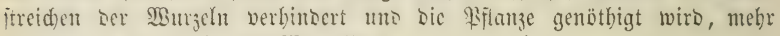

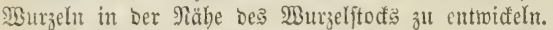

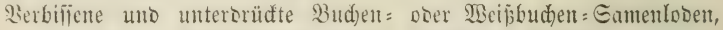

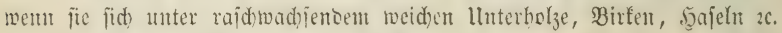

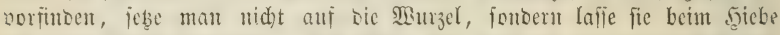

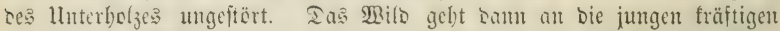
Etodlosen bes lluterholzes, woourd) sen Eamenloben ein widtiger 23or= iprung gegeben wiro, uno fie Beit geninnen, Dem SBiloe zu entwadjen. Eeß̧t

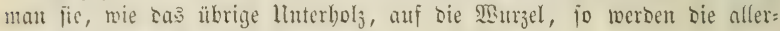

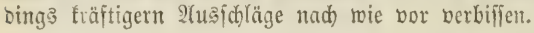

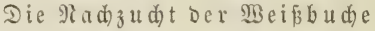

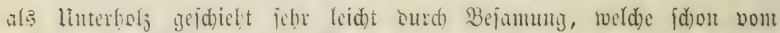
20-30jäfrigen Interbolye in Mienge erfolgt. Will man cine reid)lide Be=

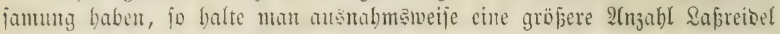
über, uns refme jic als Sberftänoer beint näd)jen 2(btriebe wieber ber: ant. 2(ud) Qocempilanjungen mit biejer Syoljart jolagen febr gut cin.

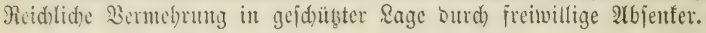

\section{Die Rad zud t Der 3 irfe}

Dutd) Eament verlangt groje Sidtiftellung uno wunben ßoden. Sn biefent

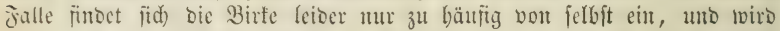
bant aus unzeitiger Eriparnis an Rulturfoiten, oft als Unterboly, felbjt unter umpajfenoen Dberbölzent, gebulbet, wą surdyaus verpönt fein follte. 3um Obertholj mús fie eingefflanjt werbon, the bie Rinbe über sem Boben rifiig wirt.

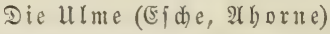

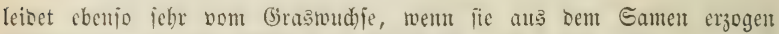

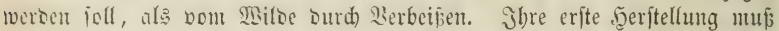
Daber gemeinhin Durd) Fiflantjung ftarfer Etämme betwirft werden, Die bent

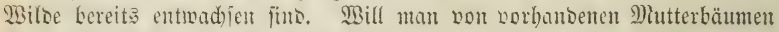

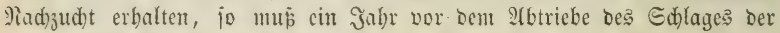
Boocut nach 2tbfall ses Eamens 20-30 Ed)ritt im Itmtreife ber Mutter: 


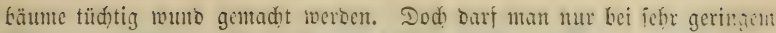
2Biloftande und langer Seiocichonung boffen, bic Eamentilanzen aufjubringen.

\section{Die গadzud)t ber Errle}

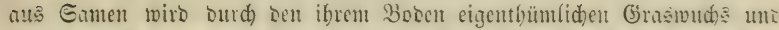
Durd) Das 2luffrieren befielben erfdwert. Das befte Mlittel gegen bas Shuf: frieren ift Erbaltung Der Grawnarbe. Man mui aber Dann Den Eamen Durd Pechen mit Dem Boben in Berül)rung ju bringen jud)en, unt im Esmmes

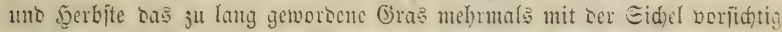
aแsjidneiden laijen, bis bie \$iflangen einigermajen herangetwadjen fint.

Iurd) Siflanjung ift sie Erle itets biel leidter portjubringent.

\section{Die $\Re$ adsud}

Durd) Eamen ift manchen Edyierigfeiten unterworfun, sa fic cincs feht wunden Bobens und groper Sidteintwirfung bedarf.

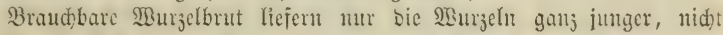
üher 20-25 Jahr alter, gejunber Etämme; זمd fam man aud yon älteren

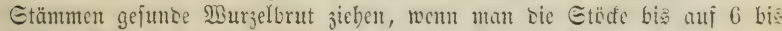

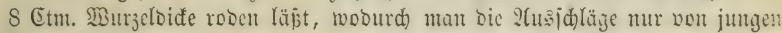
MBurjefn bofommt. Dit erfid)eint nad) Sidjiftellung Der Eáläge eine Mingi SWurzelbrut, obne baj alte ?(jpen auf Dem Ed)laje vorbanton waren. Eic

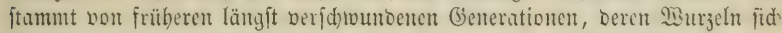

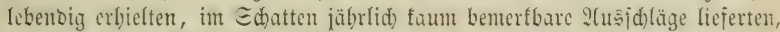

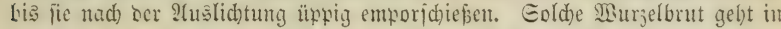

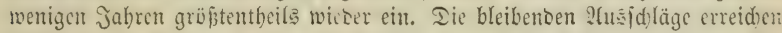

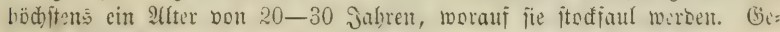

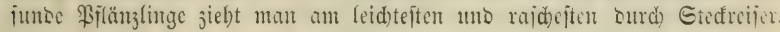

\section{Sedistes Sanpifer.}

2on ber forftmäpigen Bewirthidaftung Dex mit Ropffol beftandenen Diftrifte.

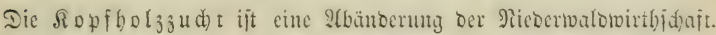
Bei biejer hauet man die Etämme nube über ocr Eroe ab, unb läpt fie aus:

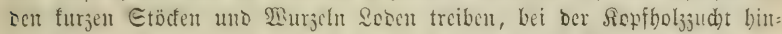
gegent butet man Den Stamm in oer Şöbe von 2-3 Mtr. ab, ätet ihn

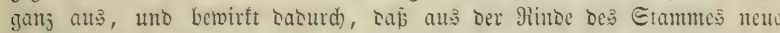
2(usid)läge beroorfommen; Die mant von 3eit ju 3eit abbauen läpt, jobalı

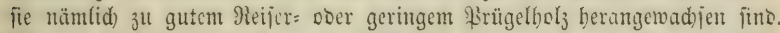

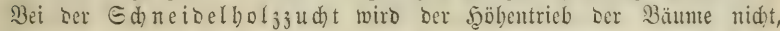
jonbern mur bie Eeitriäjte bidft am Etanme weggenommen, morauf ber

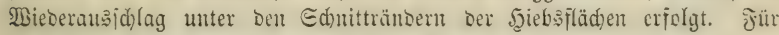
sieje Bemirtbjidaftungsmethooe jobicten fid) borjüglid):

Die (Fide, bie Ulme, bie Elde, bie Şainbude, bie Sinde, bie \$appern und bie baumartigen 2 eiben.

Alle bieje Şolzarten lajien fid) als Sdyneibelboljitämme bewirtbjáajten. Iod) finbet man bei ber Jुanbudje uno ben SBrioun müblider, jic in be: 
Ђöbe von 2-3 Mitr. abzutwerfen uno niebrige Sopfholźttämme aus ifnen zu maden, Die alsoan eine bujdidte Rrone uno einen reinen Sdaft bc: fommen, weil an \&eşteren bie fdlafenden Itugen bereits abgeftorben fint,

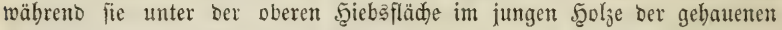

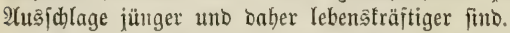

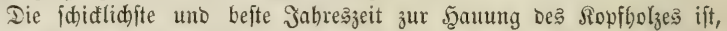

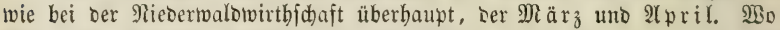
man aber mit bem in ber Sonne getrodneten Saube Schafe, Biegent unt felbjt Rinovieh füttern will, meldhes in ben nöroliden (Segenben Deutjd)=

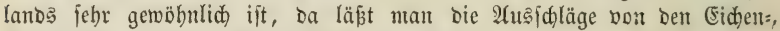

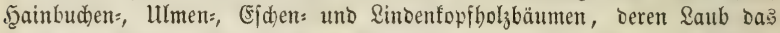

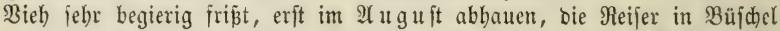
binben uno an ber Somne trodnen. Durd) bie nötbige $\mathfrak{B a b l}$ biejer

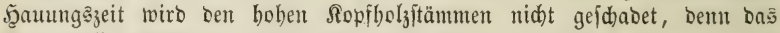

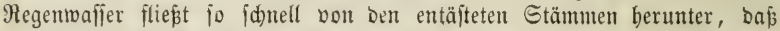
bas (Eintringen zwifden bie Rinbe nidt erfolgen, alfo aud bas oben er= wäbnte Sosfrieren berfelben nidgt ftattindoen fann. 1

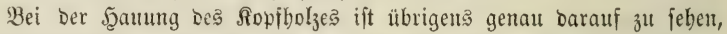

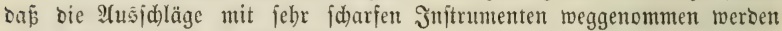
uno daj bie Rinde nidht befääoigt wirb. Bei Eiden, Ulmen, Sinben, ßappeln uno Weioen müfien bie 2(uşaläge immer ganz nabe am St a mme meggehauen werden; bei Den Efichen uno şainbuchen ift es nöthig, 6-8 Etm. lange, bon unten hera uf färäg abgebautene Stifte ftebent zu lafien, Damit bie Soben an biejen, mit junger zarter Rinbe bebedtent Etumpen ober Stiften beffer austreiben fönnen.

(Bewöbnlid) werden bie Ropfholzftänme alle 4 bis 10 Jabre - nad)= Dem bie Syolzart fantell wädst, Der Boden gut ift, uno man mebr ober weniger ftarfes $\mathfrak{S g l l}_{\mathrm{z}}$ verlangt, abgeäftet unto eine nidgt unbebeutenbe Menge

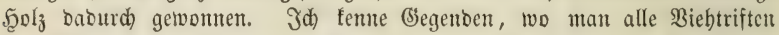

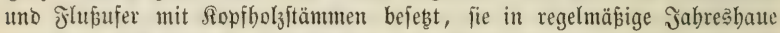
abgetheilt uno baburd bemirft hat, baß nidt mur ein groker Ibeil des nöthigen Brennbolzes erzogen, fonbern aud) Durd) bie fogenamten $S_{\text {d }}$ af $=$ wellen eine fehr grope Menge ફ̌en uno Strob jäbrlich erpart wirb. Dié bat bie wohltbätigen Jolgen, Daßs ber Sanomam meniger gezmungen ift, Durch bie. Balsweibe Edfaben zu thun, und, went er bas Stroh ber:

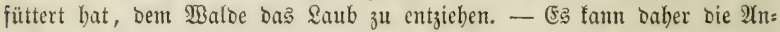

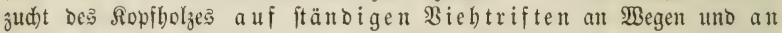
Den Ufern ber $\mathfrak{s}$ lüfe und Teide, fowohl um Şolz, als um futter zu erzieben, unb baburd) bie Baloungen zu fijonen, nidjt genug empfoblen werben.

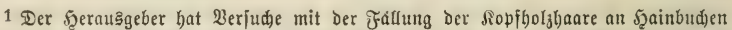

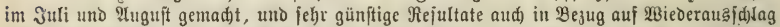

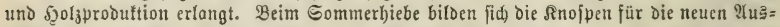
jd)läge in reid)liderer Menge id)on im Şerbfte nad) Der Fällung, uno ber Ropj hat im

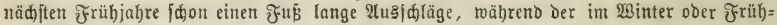
jabre enthaarte fopf nod) mit ber sinofpenbiloung ju thun hat. 


\section{Bwcite Abthcilutg.}

இon Der Ergiebung neuer Waloungen burd) A sitreuung Des eingejammelten Sgolzjamens, ober oon ber füntlidenen நुolzia at. 1

Bon Der fünftliden 5̧olzjaat überhaupt.

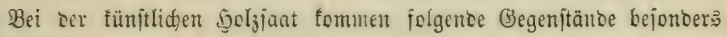
in Betrachtung:

1) Die Beftimung berienigen Solzarten, welde fid auf oem зu bejamenben Diftrifte, mit $\Re$ üfid t a uf. Boben, Sage uno Rlima vortheilbaft anziehen laifen;

2) Die $2 \mathbb{4}$ swahl Derjenigen Şoljart, bie ben localen $\mathfrak{B}$ es bürinifien fünftig am meiften entipreden und überbaupt am bortheilhafteften jein wirb;

3) Die $\mathfrak{A}$ id afiung guten Samens;

4) Die ridtige $\mathfrak{B} a b l$ ber $\mathscr{A} u s f a a t z e i t ;$

5) Die Bejtimmung einer hinlängliden Menge Eamens auf jeben Saatplata;

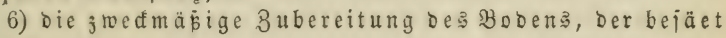
werben ioll;

i) Die Beftimmug, wie bidt bie Saaten gemadt werben iollen;

8) Die $\mathfrak{A} u$ jiaat jelb ft;

9) Iie beidübug un Bilege ber bijamten Diftrifte, uno

10) Die fünitige Behandlung ber burd bie fünjliche Selzlaat erlangten Bflanzen uno be ftände.

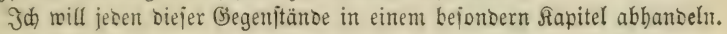

\section{Grffes Sapitel.}

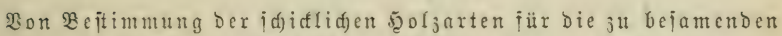

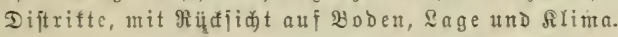

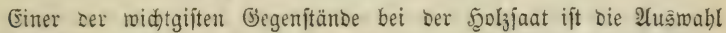

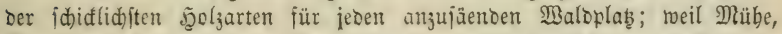
Beit uno fiojten verloren gehen, wenn in biejer Jinjidt eine zwedwibrige

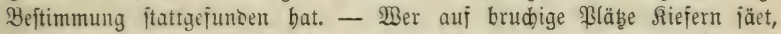
ser wiro jeinen 3 wed eben jo menig erreidjen, als berjenige, weldjer auf bürren Ganbboden Erlen angejät hat; uno eben io wirb aud jeber Jebler Der unridtigen 2 Luज̂twabl in Betrefï Des Alima bie nadtheiligiten Folgen baben,

${ }^{1}$ lleber Den Betrieb Der Eaat = und Der Bilanjtulturen liegt aus ber Meujeit ein jo

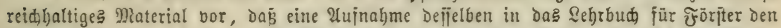

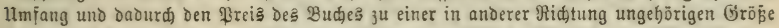

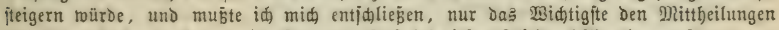

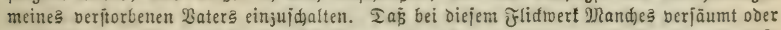

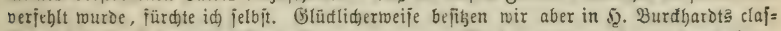

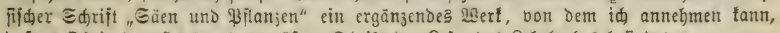

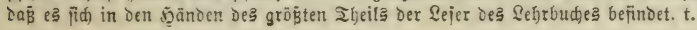




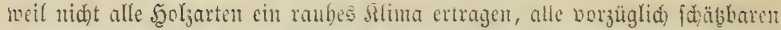
froljarten im miloen Silima fohr gut uno biele nur bort am beften geveiben.

Jm exften 5aupttheile ift fdon nad)gewiefen worben, meldes

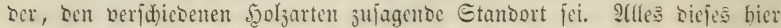

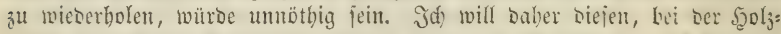

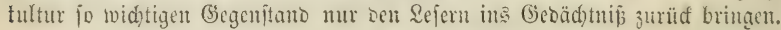

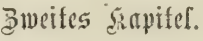

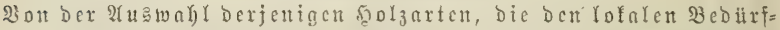
nifien funftig an meiften cutipredien und am vortjcilbafteften jein werben.

Mem oer Forftwirth, nad) Ma

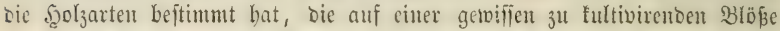
mit gutem Erfolg angejogen merben f̈̈̈n nen, fo mú er mun unter biejen

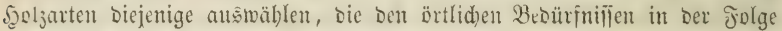
an beften entiprechen rirb. - Es fommt aljo Darauf an, bie Beountruifie jul unteriud)en uno nad) Mlapgabe serjelben bie befte Sgolzart zu wäblen.

Padjitehentoc Piegeln finto aus Der Erfahrung abgeleitet, uno tönnen Daher für biejen toidtigen Gegenjtanto benuşt werden:

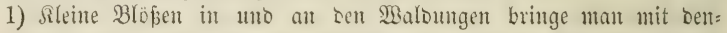
jefben Scolzarten, wont ber fie umfoliefentoe ooer angrenzento Diftrift

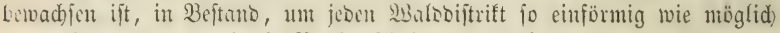
ju madjen uno baburch bie Betwirtbid)aftung zu erfeid)tent.

2) 3ur Erzichung Dcs Bantholjes wäble man foldye Diftrifte, bic nicht allein ben erforberlid) guten 3oben, fondern aud) eine fold)e \&age

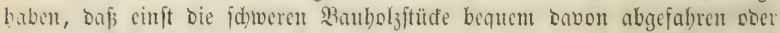
verīlöst werben tömen.

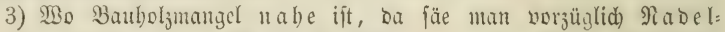

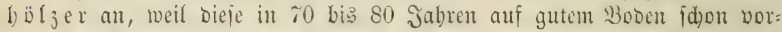

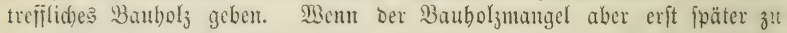
[effürd)ten iit - wie man foldhes Durd) Die Taxation Der Jorfte erfabren fam - io fultivire man alle id)id̆liden mlöpen mit (Eid)en, weil Dieje bis babin ertwadjen fein werben, und unter allem das bofte mo Daucrbaftefte Baubols geben. - 2tud) fann Durd bie $2(n j u c h t$ Der vortreff=

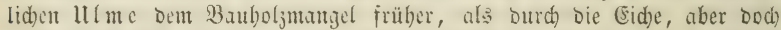
nid)t io im 2fllgemeinen uno im (Grojen abgeholfen werben, als burd) bie

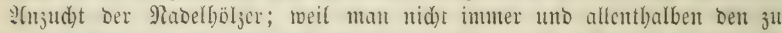

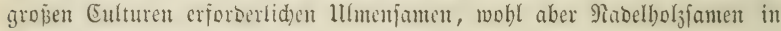
Dienge baben fann.

SBie hod)wid)tig es ift, möglidjit bauerbaftes Material auf alle 5 golj: bauten zu verwenden, fpringt in bie 2(ugen, wont man ertwägt, Daj mit

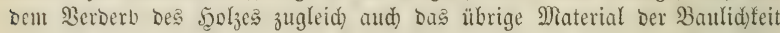
und bic auf biefe bermenocten 2(rbeitstoften werthlos werben. Je gröjer

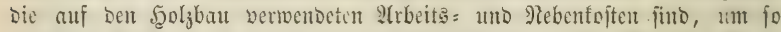

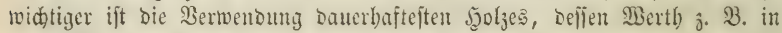
Eecichifen von jenten Roften rft um Das Mebrfade überfticgen wiro. t. 


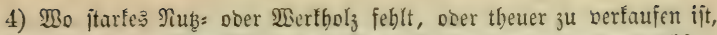

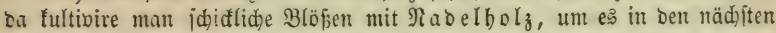

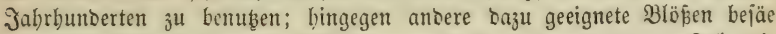
man mit (Eid) eln, um ber Nadjfommenfidaft in ber fpätern Jolyezeit

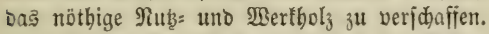

5) Mo Brennbolzmangel ift, ba bejäe man bie Blöpen vorjüglid mit Nabelfolj, uno mäble baju im milsen Slima bie $\mathfrak{R} i \in f e r$ mit Serden vermijdt, im rauteren aber, uno wo ein S(nlauf von Weiboieh

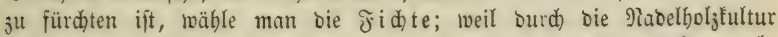
binnen ciner gemifien 3 eit boi weitem mebr $50 \mathrm{l}_{3}$ erzogen weroen faun, ala

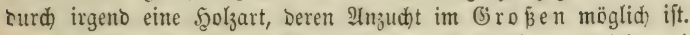

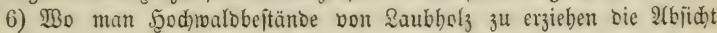
bat, räble man borzüglid bie $\mathfrak{B} u$ dhe uno bie (E) $i$ be, entrocber allein, ober mit einanoer vermifdt; weil bieje beiben Scolzgattungen fid jefr gut 3ujammen vertragen, uno fowohl megen ber Bortrefflid)teit ibres Scolze?, als Der Majt = uno Delbenubung wegen, vorzüglid) begünftigt ju weroen

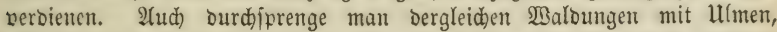

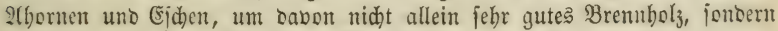

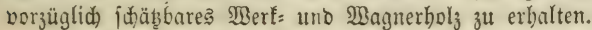

7) Wo man Rieberwalbungen anjulegen für gut fintset, zielhe man vorzüglich (Eid)en=, Şainbuchen uno Birfen an - movon man fehr oft cine beträd)tliḑe Menge Eamen um billigen \$reis befommen uno 2(njaaten im Brofen madjen fann - uno judje bieje Diftrifte mit Utmen, 2thornen uno (5jden zu burdjprengen. Wo ber Booen aber zu feudt ift, ergiebe man Erlen unb Birfen. Borzüglid) aber begünjtige man, wo es bie Unt=

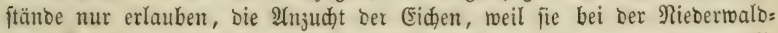
wirtbjibaft nid)t allein eine fehr lange Dauer haben, fondern aud vortreff= liches Bremboly geben uno burd bie Solyrinse fowohl bem 2 aldeigen: thümer als bem Etaate aup̧eroroentlid) nübslid weroen.

8) Bur Eultur folder Blöpen, bie. Dem Somenbrande ftarf auggge=

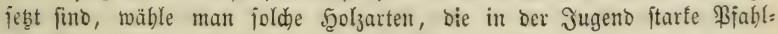
trurzelnt treiben, uno baber io leidht nicht bertrodinen.

9) 2 n Drten, bie ben Gturmminden fturf auşgefęt fino, baute man jold)e Şolzgattungen an, bie wegen ibrer ßfahlwurzeln bom Minde nidat leidgt umgemorfen werben tönnen.

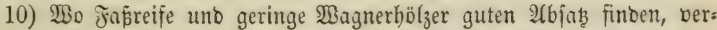
mijde man fajt alle Gaaten mit Birfen, uno baue bieje, jobalo jie eine brauchbare Diffe erlangt haben, Doer ben bominirenden Beftano bier uno

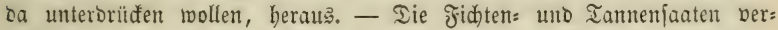
mijche man aber nicht mit Birfen, weil jene von ben Birfen zu balo über= wadjen uno audi biele von ben Birfenäften burdh bas ßeitichen an ben Gitpfeln bejöäbigt werben.

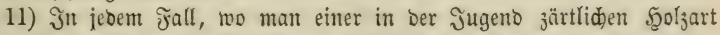

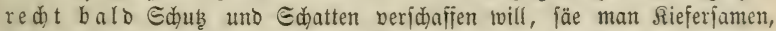
3 bi 4 Jabre vorber, in 1-2 Mitr. entfernten Etreifen aus, uno fo= balo bie Riejern Edług geben, fäe ober pflanze man bie zärtlid) Şoljart jwijden bie Sieferreiben. Diefe muiflen aber, jobalo fie iţren Dienjt

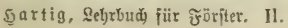




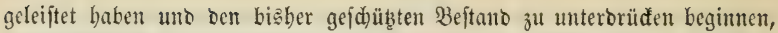
obne $\mathfrak{2}$ uffdub und felbft sann, wenn fie mur $8 \mathfrak{R}$ tr. bod fein follten, meggenomment werbert.

Da e: Keine Scolzart gibt, bie in ben erften Jabren ibrer Rimbheit idncller mädsst, zugleid mehr Sdhatten uno Sdub gewährt, uno faft unter allen Berbältnilien fidjerer gebeiht, als bie Riefer, jo ift fie, um Sdub

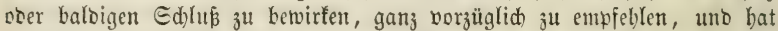
mir fdon oft - felbit in jebr raubem Slima - bie nortrefflidjiten Dienfte geleiftet. Dod) wieberbole iḍ nodmal, bas man bie Siefern zur red)ten Beit reguebuten mus, weil fie fonjt für ben jungen $\mathfrak{B a l}_{\text {alo, }}$ ben fie be= jäüben jollten, wegen ibrer Edjnelfwüdfigfeit, in ber Folge eben fo jdäblid, merben, als, fie ihm vorber nüblid waren.

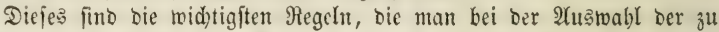

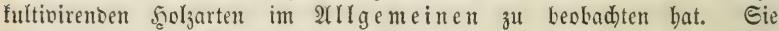
joliefen aber bie אultur anberer 50 lzarten nid)t aus, moburd) vielleidyt auf einer fleinen fläd), unter bejonbern llmftänten cin nod) gröferes Bortheil zu erlangen ift. Für 2 Balbanlagen im Brofen aber werben tie vorbin gegebenten Regeln fid) immer bebaupten, uno Demienigen, Der fie befolgt bat, in ber 3ufunft völlige 3ufriebenbeit geinäbren.

\section{Drittes Eapiter.}

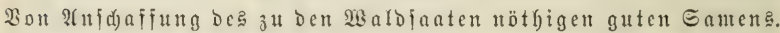

Guter Eamen ift eine ber erften unb widtigiten Erforcerniffe bei ber

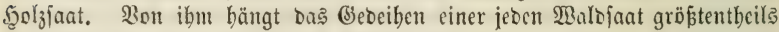
$a b$; benn es wiro ohne guten Eamen feine Eant glüten, obgleid biele mit gutem Eament gemadte, aber feblerbaft vollzogene Malbjaaten veroerben.

Un aber guten Samen zu erbalten, nus ntan benfelben entweder felbit einernten lafien, ober bon Samenbänblern faufen. Der Jorftwirth mus baber wifien, want ber Samen bou jeder 5ुolzart reifet; wie er am zwedmäfigiten einzuernten und nötbigenfalls aus feincu Bebältniffen zu bringen ift; ferner: wie er am beften, un wielange er aufbetwabrt wer= Den fann; wie die Gs üte Dez feilgebotenen Sameng zu unter=

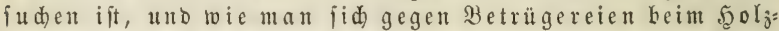
fameneiufaufe fidyern fann.

1) Bon ber Reifezeit, betwinung uno $\mathfrak{A} u f b e w a b r u n g$ ber felziamen.

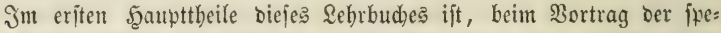
ciellen Naturgeidichte ber Fुolzarten, biejer B̈egenftand fdon berübrt, uno bie Reifezeit jebesmal angegeben worben. Dieje genau zu beobadten uno mur völlig reifen $S_{\text {amen }}$ zu fammeln, ift abjolute গothmendig= feit, weil ganj unreifer Gamen gar feine, uno oer nidyt böllig reife Samen nur menige uno $\{$ d to ä d) lide Pflanzen gibt.

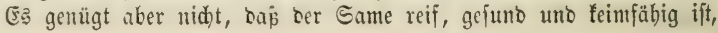


er foll aud guten 5gertommens jein, eine Bebingutg groken Er: folges ber Eaatfulturen, bie zur Beit nod) viel zu wenig berüdfidtigt ift, für bie id bier plaibiren möd)te.

Wie im Thierreid, io beftehen aud im Pflanzentreid inoiviouelle

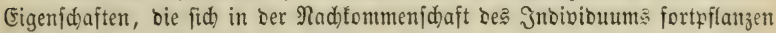

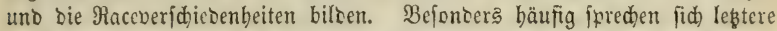

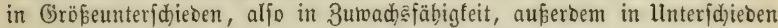
Der Tradt aus. Der Sanbwirtl) fennt einen Riejentoeizen, Riejenmais, Der (Järtner einen Riejentobl, Riefenbanf. Sie wifien, baj fid biefe uno anoere

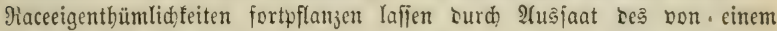
Racemitgliebe eingefammelten Gamens. (5) liegt nid)t entfernt ein Gruno vor, refshalb fid biej bei unieren Şolzpflanzen nid)t ekenjo verbalten follte, wir fino aber in ber Froduftion unjerer 30̈glinge nod) nid)t bis zu ciner 3ud,twabl borgeidritten, für beren gute Erfolge mir bie augen= fälligften (Erfabrungen vorliegen, bie wir aud) im Malbe leidst burdfübren fönnten, wenn wir es zum Ģefę̧ erbeben mollten, für ben einzulammelnden Samen in ben Beftänben bie größjten, wüdfigften unb woblgeftaltetften Mutterkäume auşzutoäblen, uno als fold)e bauerno zul bezeidnen. Id)

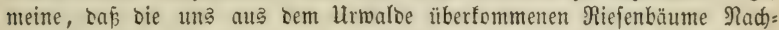
fommen folder Racen feien, uno meine, Daf́ Das, was mir burd) (5r= j̧iebung gleidjaltriger, gefd)loffener Bejtänoe an Sïrpergröfe ber Einzelpflanze

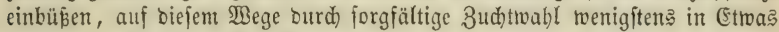
wieber eingebrad)t werben tönne. $t$.

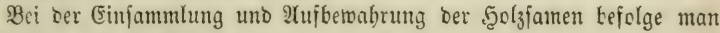
nadjitebende aus ber Erfahrung gezogene Regeln:

1) Den Samen ber Eide ober bie (Eid)eln jammle man auf folgenoe 2 (rt:

Die Beftäntoe, in benen man fammeln twill, lafje man zur Beit, wenn bie mabigen Eideln abfallen, uno bis zum 2(bfallen ber reifen gejunden

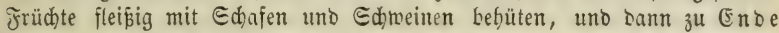
Septembers ober $\mathscr{A}$ ufang Dftober theils abgefallen find, fo biele a uflefen, als man nöthig bat.

Eollten biefe Eicheln - mobon 55 Siter $=$ ein abgeftridyener Ber= liner Edeffel, 1 im Durdidhnitt genonmen, 56 ßjuno wiegt uno 12,800

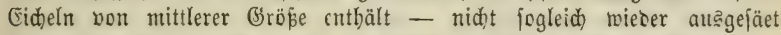
werben fönnen, fo lafie man fie alsbalo auf einem Epeider bünne aus: einanoer jüütten, uno täglid einmal umftóken, bis fie böllig bon a abgetrodnet fint. Jif biés geideben, jo fäütte man fie $1 / 3$ Ditr. bid im Gamenmagazine auf, uno lafie fie jo lange liegen, bis bie Eaat bolljogen wersen fam. Sollte bicfe aber nod beridoben merben müfien, fo lafie man zuweilen nacjieben, ob bie Eidjeln feimen wollen. Bemerft man bię, io müffien fie auf bem Magajine bünner gelegt, alle paar Iage einmal umgeftofen uno baourd bas Seimen verbindert merben. Bur Şerbjtiaat

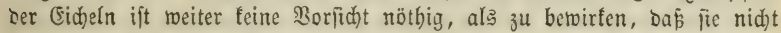
feimen und nidt ftoden, rogegen fie im Magazine gefiddert merben tönnen.

1 Der Berliner Sdeffel alt enthält $3058^{13} / 14$ fubifzoll rheinlänoijdę Pás an Raum. $=55$ Siter $=100$ Reupfund beft. Waffer. Ein altę Pfund riegt 467,4 Gramme. 
Will man aber Eiddln im Frübjabre auäjäen, fo barf man fie dent Winter bintourd nidft auf oem Samenfpeidger liezen lafien, weil fie ba зu fturf austrodinen ober gefrieren, uns in beioen fällen zur Eaat untauglid, werben. ${ }^{1}$ Benigitens ift es ein feltener Fall, menn bie Eidjeln unter folden Umitänden bie ins Frübjalyr gut bleiben. Durd) eine ftarfe Be: Dectung mit Stroh faum zroar ber Froft abgebalten, aber bas zu itarfe

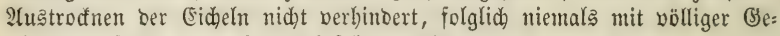
wiß̄beit auf Den gewünidten (Erfolg gerednet werben.

$\mathfrak{A m}$ fidherften conferbiren fid bie Eidgeln biङ zum nädjten frübjabre auf folgende $\mathfrak{A r t}$ :

Pan wäble in einem, gegen ben Itnlauf ber Sdyweine geficherten

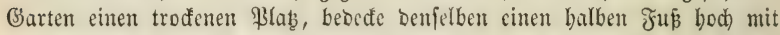
Saub ober mit Stroh), uno idütte bie borber etwas abgetroctneten (Sidjeln in einem fegelïörmigen 3 Fuß hohen Şaufen barauf. Nun bedecte man biejen Şaufen einen balben Jú biå mit Stroh, belege biefes einen balben

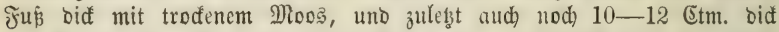
mit Erbe, bie aus einem un bie Mietbe zu ziebenten Oraben genommen wird. $\mathfrak{A}$ uf ber Spitze bicjes Jegels aber bringe man einen locteren Strob):

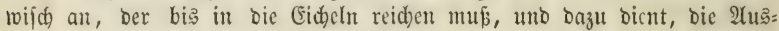
Dünftung berfelben ourdjulaffen. Diefen, ober bieje Regel lafje man fo bis zum nädjten Frübjabre fteben, uno man wiro finben, baj fich bie (Eid)eln bortrefflid) conferviren. Dod) mus man bie Saat fo balo wie möglich int Jrübjabr bornchmen, uno wenn feine barten fröfte mehr zu fürdten fino, bie Erobede non Den Miethen abzichen laffen, weil bie

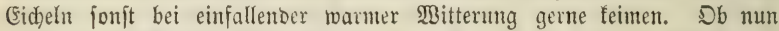
gleid) biejes Reimen, wenn is nidyt allzu ftarf crfolgt ift, bie (Eid)eln zur

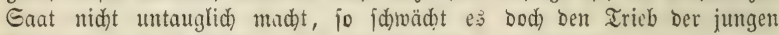
Prlanzen, unto ift baber jo niel mie möglid) ju verbinbern.

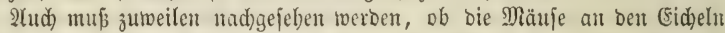
Edaben thun. Finbet man biejes, fo fönnen fie leidt burd) aufgeftellte Fallen loeggefangen werben.

Etroas uniftänolid)er, als bą cben eriväbute, ift folgenoes 2ufbe: wahrungsmittel:

Man wäble einen erböhten, böllig trođenen Drt, uno nehme barauf

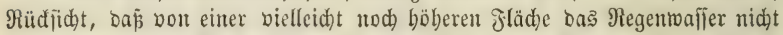

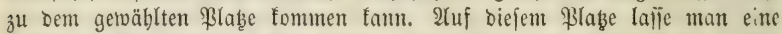
3 bis $3 \frac{1}{2} \mathfrak{M}$ tr. lange, $2 \mathfrak{M t r}$. breite, uno $2 \mathfrak{M}$ tr. tiefe (3rube maden, und Diefelbe an ibren Eeiten uno auf bem Grunbe anşmauen, wenn fie oft 3ur 2(ufbewahrung ber Eid)eln benuţt werben foll. SBill man fie aber mur e inmal baju gebraudjen, fo fallage man 2 bis 3 Mltr. lange Präble ober Etangen nabe an bie fenfredenten Mänbe ber (5rube, und ftopfe zwifden

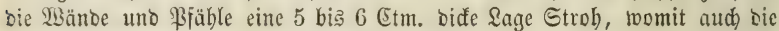
Grrumbflädje Doer Soble ber Brube belegt werben muß

In bieje entroeber ausgemauerte ober mit Stroh betleibete (s)rube fäütte

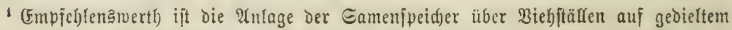

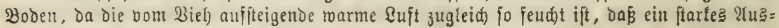
trodnen ber Fidgeln nidt eintreten fann. 
man abredjielno eine $1 / 3$ Mtr. hobe Sage borber akgetrodneter Eid)eln uno eine eben fo bide Sage büres Saub, bis bic Grube nur nod) ${ }_{1} / 3$ Dtr. tief leer ijt. Die leb̧te Edhidhte Eidjeln beocdfe man hierauf ftarf mit Saub, etroas Stroh uno einer \&age Bretter, uno überfäütte enolid bieje Grube jo bidf

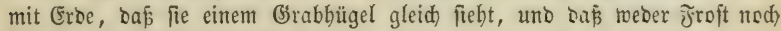
Regen zu ben Fid̄eln bringen fönnen.

In biejer Brntube laffe man bie Eideln bis zum frübjahre liegen, uno man wirb finben, ba fa fie fid auf joldje 2 trt fehr gut erhalten. - Mir ift wenigitens nod) niemals ein foldjer Birjud) feblgejdlagen, uno wenn bie

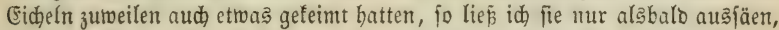
ehe bie Reime welfen fonnten, uno crzielte Dann jedesmal ben beften Erfolg.

Yud fann man bie Fideln, bie aber nidt gefeimt baben Dürfen, auf folgende Irt conferviren. Man lafie in cin altes, mit

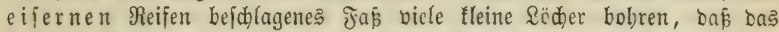
Bailler allenthalben durdjidjieșen, feine (Fichel aber beraustommen fann. Diejes Jaß fülle man im Şerbfte nit Eidyeln, uno berjente es an einer

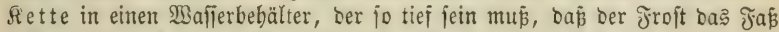
nicht erreichen fann. - Im Jrübjabre ziehe man bas fan hervor, fo wiro

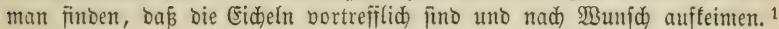

2Uuperbem fanm man aud (Eid)eln bis zum Jrübjabre conjerbiren, wenn man fie in ein veridlolienes Befäp bringt uno biefes tief ins Bajier verfentt. - Iod) wiro man einjehen, dá̄ alle bicje 2 Aufbewah=

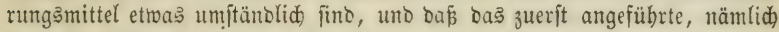
bie $\mathfrak{A}$ ufbewabrung in gebedten fegelfürmigen f̧aufen ober

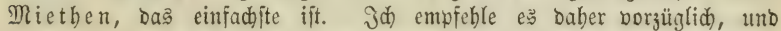
marn eben fo jehr bor ber, bon einigen Edriftiftellern empioblenen $\mathfrak{A} u f=$ betrabrung ber (Fideln zmijden Sand im Reller. Nod jebesmal find mir bie auf jolde 2 rt aufbewahrten Eidgeln unter ber barten 6 dale am Rern entweder johimmlid) geworben, ober fie fino zu ftarf auşgetrodnet,

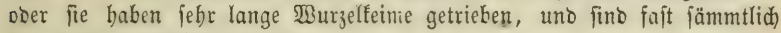
zur Eaat untauglich geworben.

2) Den Samen ber $\mathfrak{B} u$ de ober bie $\mathfrak{B} u$ deln fammle man auf folgenioe 2 trt:

Eobalo bie Eamenfapicln fid aufgethan baben uno bie Bucheln ab:

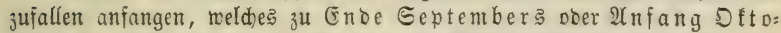
bers zu gejdeben pflegt, laije man bie Bäume befteigen, bie $\mathfrak{A}$ efte ver: mittelit langer Stangen eridüttern, und bie baburd abfallenten $B u d$ eln auf untergebaltenen grofien Tüdern aufjangen; ober man lafie bie abge: fallenen Bucteln auflefen; oder man laije, too e⿱乛龰 sie Umitände erlauben, bie Budeln fammt bem Saute zufammenfehren, unb fo rieber aus= jäen. Eollte es aber nöthig fein, fo lafie man bie Budjeln entmeder im

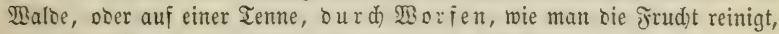
bon ben Blättern 2c. trennen un๖ bann erit auşäen.

Mū́ man Buđjeln, wovon 555 Siter ober ber abgeftridhene Berliner Echeffel, went fie ganj rein find, 46 Sfuno wicgt, uno circa 80,000

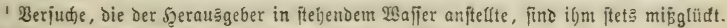
3n fliekendem $2 a$ affer mito fid die Boridurift befier berwäbren. 
Bucheln enthält, bis ins Frübjabr zur Saat aufberwahren, fo lafie man fie nach ber Einjammlung auf einem Epeidjer bünne auseinander bringen, täglich einmal umitopen uno diejes fo lange fortjeken, bis fie völlig von auß̧en trođen fino. Şierauf joütte man fie auf bem gebretterten Samen= fpeider 0,6-1 Mir. hod aufeinanter, und bebecfe fie $0,3 \mathrm{M} t \mathrm{tr}$. biff mit Stroh, bamit jie nidht gefrieren uno zu ftarf austrodnen fönnen, uno laile fie fo bis zum frübjabre liegen. 2tud fann man bie Bucheln gerabe fo,

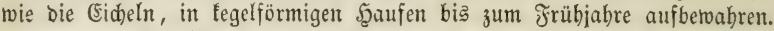
2llle anoere $\mathfrak{R}$ ittel fino weniger gut uno mit mebr Umjtänoen berfnüpft. Die Serbitjaat ift jedenfalts vorzuzieben, uno mur im ^otbfalle überwintere

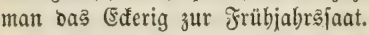

3) Den Şainbuden= Samen fammelt man am leidsteften, fo balo bie Blätter abgefallen find, auf folgende 2 (rt:

Man läpit bie Samenbüfchel entweber mit ber Şanto abpflüđen, ober - meldes faneller bou Statten gebt uno mit feiner S̈efabr berbunden ijt - man läpt burd vier Seute ein groß̧es Tud unter ben Baum balten, uno burd einen fünfter Ifrbeiter bon Samen, bermittelit einer langen Stange, bei winofifllem $\mathfrak{B}$ etter abichlagen. Weil biejer Gamen getwöbnlid)

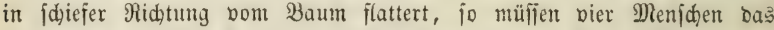
Iud) an ben Ecten balten uno jich fo berregen, da fie ben Samen auf:

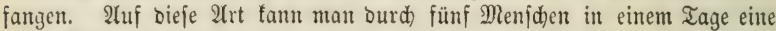
grope Menge Gamens jammeln lafjen, obne bejorgen zu müfïen, bá jemano bei biejer 2 (rbeit berunglüden werbe.

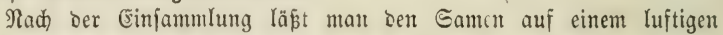
Speider ganz abtrodinen, hierauf, went man ihn rein baben will, auf einer Tenne breiden uno $b u r d$ ) $\mathfrak{B}$ orfen von ben Flügeln trennen.

Elf Raumtheili geflügelter Eanten geben gemöbnlid 1 Raumtbeil reinen Samen. - Bom geflügelten Samen wiegt 1 Єdeffel = 55 Liter 6 ßfunt, uno abgeflügelt 47 \$funo. Das \$funo entbält 16,736 Rörner.

खent es möglid ijt, io jäe man ben Sgainbuchenfamen noch im Sgerbjte wieber aus; wo nidht, jo bringe man ibn auf einen gebretterten

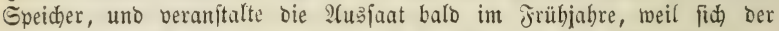
Samen nur bis bahin gut erbält. Bon älterem Eamen gebt wenig oder nichts auf.

4) Der Birfenfamen twird ourd) Afbiteifen, im September uno 2 fnfang Dftobers, gejammelt, auf einen luftigen Boben bünne auseinander gebracht und oft umgewendet. Nadhber werben bie Samenzäpfd)en zwif̧cen den Szänden jerrieben, uno ourch ein Sieb mur von bent Blättern gefäubert, weil fid) bie Sd)uppen vom Eamen nid)t abjondein lafjen. - Mod leidter aber geht bie Einjammlung bon ftatten, wenn man von foldhen Bäumen, bie im nädjften $\mathfrak{B}$ inter gefällt weroen jollen, bie $\mathfrak{A}$ ejte mit bem Samen abbauen läßst. Der Gamen fam nadber bequem abgewflüdt uno wie joeben gelebrt worben ijt, ferner behandelt werben.

Der Sdefiel $=55$ Siter wiegt gewöbullid 11 ßjunt. - Sann oer Gamen alabalo nad) ber Einfammlung wieber ausgejäet weroen, fo gerathen sie Gaaten am bejten; wo nidht, fo bringe man ben Samen, nadbem er 
ourch fleipiges Ummenoen wohl abyetrodnet ijt, in sas Eumemmagujin, uno jorge für balbige 2(usjaant im näd)iten Frübjabre, weil älterer Eamen jait immer nur wenige \$flanjen gibt.

5) Den 2 bornjamen jammelt man in Dttober, fobalo feine fltigel braun geworoen fint. Die Einjammlung fann entweber burd $2(b=$ ftreifon mit ben Şänoen, ober auf biefelbe Irt gejdehen, twie id) bei Der Ëinfammlung bes Sुainbudenjamens gelehrt habe.

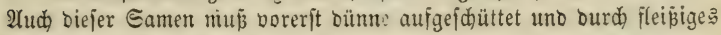
Ummenten abgetrodinet weroen.

Der Sdheffel $=55$ Siter von biejem Samen wiegt gemöhnlid 14

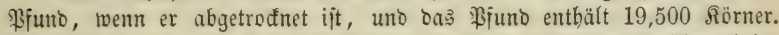
Der $\mathfrak{A}$ hornjamen läßt jĭh auf einem gebretterten luftigen Speider cinige Jabre lang jur Saat braudbar erbalten.

6) Der Efdenfamen wiro wie ber $\mathfrak{B e i j b u d j e n j a m e n ~ g e f a m m e l t ~}$ uno aufbetwabrt.

Der Edneffel $=55$ Siter wiegt gemöhnlid 19 Piund. Das Piuno entbält 19,350 Rörner.

Diejer Gamen bleibt bödjten’ jmei Jahre zur Eaat braudbar. Şon älterem wiro man wenigitens nidit viele Pflanzen erbalten.

7) Den lltmenfamen jammelt man zu 2fnfang Juni ourd $\mathfrak{A} b=$ itreifen mit ben jän̈ben. (Er muß bierauf jogleid, auf einem luftigen Booen abgetrodinet werben, weil er balo erhibgt uno ber: birbt, went er in cinem Sacfe nur eine furze Beit zujammen=

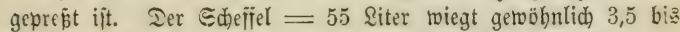

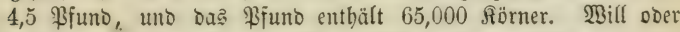
tunn man biejen Samen nicht aläbalo rieber auşäen, jo läs̆t er fich auf einem luftigen Boden bis zum nädjten frrübjahre auj: bewabren. 2Yelterei Єamen gibt mur wenige Bilanzen.

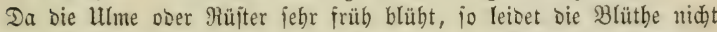

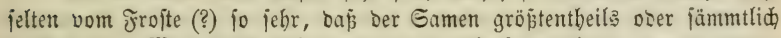
taub viro. Man mup baher bor ber Einiammlung genau unter= judten, ob bie Eamenbälge aud) meb̧lige Rerne entbalten, uno wenn biē ber Fall nidht ijt, bie Einjammlung unterlafien.

Der fofort nad bem Cinjammeln ausgejäete Eame feimt nad we:

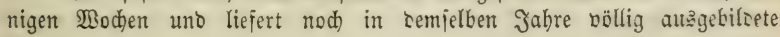
Pflanjen.

8) Den Ërlenfamen pflüdt man im. Dltober, fohalo man bes

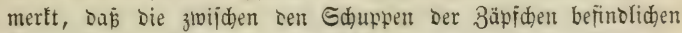
Samentörnden braun uno mehlig gemorben fint. Nods ke: quemer ijt bie Einiammlung, wenn man an joldten Erlen, bie ohnebin in nädjiten $\mathfrak{B i n t e r}$ ober Frühjabre gefällt iveroen jollen, bie mit 3äpfden bejeb̨ten 3weige abhauen uno sann bie Bäpfden abpflüđen läpt. Man bringt bieje bierauf in mäpige Bärme, bis fị̆ bie Eduppen geöifnet baben, unto tremt ben Samen burd) Rütteln in einem Siebe von ben Bäpiduen.

Der Edeffel $=55$ Siter von biejem Samm riegt gewöḅnlid 34

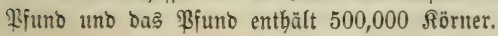


Der Ertenjamen bleibt zwar einige Jabre lang zur Saat braud)= bar, wemn er im 2Infang oft umgeftochen uno auf einem luftigen gebret= terten Speider aufbetwahrt worben ift; Dodh hat ber frifhe Samen auf: fallento Borzüge.

In ben eriten warmen $T$ agen Des $M$ Rärz ober $2(p r i l$ flicgt Der Erlent= famen bon felbit, meift nod auf ben Sdnnce aus. Den beften Samen erbält man, twenn man zu biejer Beit bie Erlenftangenbörzer Durd 21xt: hiebe erfकüttern uno ben bei rubiger \&uft in gröferer Menge nieberriefefn: ven Samen auf großßen Seinentüdern auffangen läp̧t. Der allerbinges nid)t unbebeutenoe Sammlerlobn wirb reidlid) vergütet Durd) bie borzüglide (Siüte Des io gemonnenen Samens. t.

Der abgeflogene uno vom Maffer zujammengefd)wemmte Erlenfamen fann mit leidjter Maulbe in grofer Menge gefammelt werben. Es ift aber

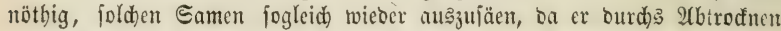
feine Reimfäbigfeit verliert. Daher ift ber vom Eamentänoler erfaufte Errenjamen bäufig fo idjled)t, woil er oft mit abgetrodueten Ed)wenmiamen untermengt wiro.

9) Dex Iannenjamen wiro zu Entoe bes Septembers uno 24n: jang Dftobers Durd) 2(bbreden ber Bapfen gejammelt. Siad) ber Einjanmlung bringt man bie Bapfen entmeder auf cinen luftigen Boden, uno läpt fie ba fo lange liegen, bis bie Sduppen burd́

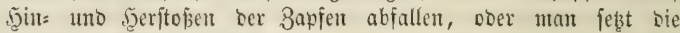

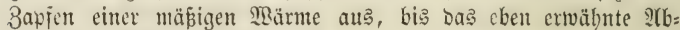
fallen ber Sd uppen erfolgt.

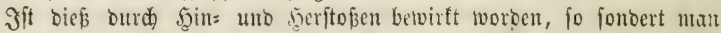
Den Samen burdh ein Eieb bon ben Ed)upen, rcibt ibn zlwifhen ben 5̧änben, ober in einem nur zum vierten I Iheil angefüllten Sadfe, baj bie flügel abbredjen, uno mad)t ihn, bermittelfit einer Sd)wingwanne, ganz rein.

Der Sdheffel $=55$ Sitcr Samen mit Flügelı wiegt gemöbnlid

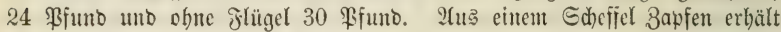
man $2^{\frac{1}{2}}$ Bfuno geflügelten Gamen, movon bas Bfuno 9 bis 10,000 Rörner entbält.

Diejer Samen läpt fid einige Jabre lang zur Saat braudbar er: halten; er mús aber im Slagazin nid)t zu bid auf einander liegen, uno im Infange oft umgeftod)en worben.

10) Der Fidtenfamen wirb ourd Abbreden ber 3 apfen

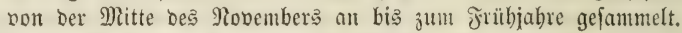
Man jeł̧t bierauf bie 3aufen entweber einer mäpigen Stuben= wärme als, ober bringt jie im Jrühjabre an bie Sontrentärmte, bis fich bic ভdypyen geöfnet baben, uno ber Sament burd eine Eriduütterung ber 3apfen herausgebradht werden fann.

Goll bas Afustlengen bes Samens ing Grope geben, fo bejtumnt man ein cigenes Bimmer in bem untern Theile cines wo möglide ge= mauerten Ģebäubes baju. In dieje马 Simmer läj̆t man cinen, ober, wenn ę groż ift, einige Defen feß̧en, bie mit 9iöiten verjeben fein müfien, um fie mit Nabelbolzzapfen heizen žl fömen. Docr man läpt an ben Eeiten 
Circulirfeuerfanäle wie in einem Ireibbauje anbringen, um bas 3immer allenthalben bis auf $18-20$ Grad erwärmen zu fönnen. Sit Diejer Fenterungsapparat auf bic vortheilhaftejte $\mathfrak{A r t}$ eingeridłtet, jo läp̆t man an bie Mänbe uno in bie Mitte bes Bimmers Gierüfte machen, Daf möglidft viele, 2 Mitr. lange uno $3 / 4$ Mtr. breite mit gegittert geflod)tenten Drathböben berjebene 5ुorten, uno żnar nur $10-12$ Etm. bon einanber entfernt, übercinander geidgoben werben fönnen. Unter bieje Şorten aber

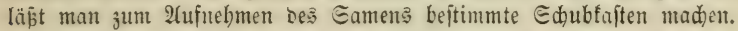

Sit bicjer Strparat fertig, jo füllt man bie Sgorten mit 3ałfen, uno läßt ber 2 uşlengftube eine Wärme von $20-24{ }^{0}$ Reaum. geben. Dieje febt man jo lange fort, bis bie 3arfen geöfinct fint. Bemerft man Dié, fo rüttelt man bie auf ben 5gorten liegenten 3apfen von oben bi३

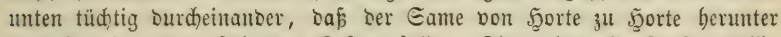
unto in bie unten ftebenten Raften fällt. Sinb aber alle Bapfen völlig uno io weit wie möglich geöffnet, fo bringt man fie, um allen barin bes

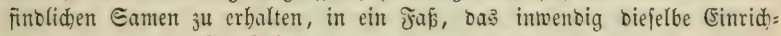
tung hat, wie bie Qeierfäj]er, worin man bie Butter bereitet. In biefent

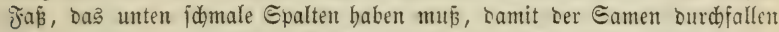
uno in einem untergeftellten Gefä́s aufgefangen werben fann, jöwingt man bie Bapfen jo lange berum, bis fie ganz entjamt fino, uno nut zur 5̧eizung Der Wittöfen uno ber Jeuerungsffanäle verbraud)t werden tönnen.

Eolf madher ber Eamen feiner Flügel beraubt uno ganz fauber ge: madjt merten, fo jpritgt man ifn ctwas mit Saffer an, uno reibt ihn fo lange in cinem mux zum vierten Theile angefülten Eađe, bis bie flügel abgegangen jino. Jit bief geidehen, fo bringt man ben Samen joglcid)

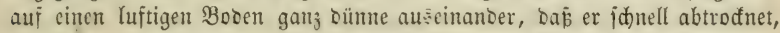
unt jeparirt nadber bie flügel bermittelft einer Edjwingwante bon ben Samentörnern. Mill man aber ben Gamen in be $r$ Sonne ausflengen, fo

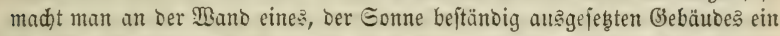

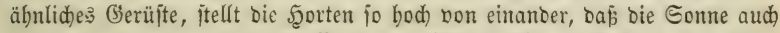
Die binten liegenden Bapfen treffen faun, läp̆t ein fleines Wetterbad) Darüber anbringen, unb zunädjit unter bie unterfte ફgorte einen Sdubfajten mit einem Boben von grober Seinewano verfertigen, Damit Der auf ber Seinemano lie: genbe Eamen balo abtroctnen faun. Bei ftarfer uno anbaltenoer Eonnen: hikge riittle man bie 3apfen von ber oberften bis jur unterften f.orte tüdtig burdeinanter, uno fammle enolidy ben in bie Sdublabe gefallenen Samen. Eino aber bie Bapfen fo weit wie möglid. geöfintet, jo bringe man fie in

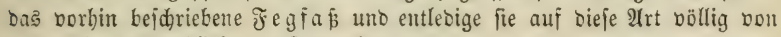
ben noch zurüfigebliebenen Samentörnern.

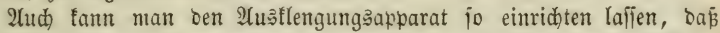
mant alle Şorten bei Somnenjhein berborzichen uno bei ungünjtiger TSitte= rung unter bas Dach jojieben fann. Unter jeber Sgorte mup bam aber cin Єđubfaften angebrad)t werben.

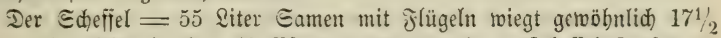

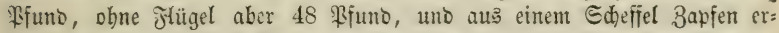
folgen gemöbnlid, 2,25 \$funo geflügelter, Doer 1,4 Pfuno abgeflügelter Samen. Das Pfuno Samen enthält 75,000 Rörner. 
Den Fidtenfanten fann man 3 bis 4 und oft nod mebr Jahre zur Saat braudbar erbalten, went man ihn auf einen luftigen gebretterten Boben fdüttet, nid)t bid auf einanber bringt, uno ihn, bejonbers im Eommer, zuweilen umited)en läpt. Der frijhe Game hat aber freilid grope Borjüge, uno mant fant mit 10 Bfuno eben jo vidl ausridten, als mit 12 bis 15 \$funben bon älterent ๔amen.

11) Der Riefernfanen wiro ebenfalle burdy 2tbbreden ber Bapfen von ber Mitte bes Novembers an, biş žum ₹rübjabre gefanmelt.

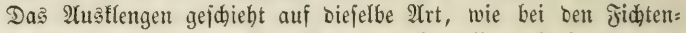
zapfen gelehrt worden ijt, und auch in Betreff ber $\mathfrak{Y}$ (ufbetwahrung

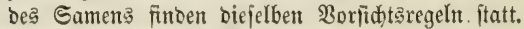

Der Sheffel $=55$ siter Samen mit Flügeln wiegt gemöhnlid) 14 \$funo, ohne flügel 52 Biuno, uno das \$funo Gamen entbält gewöhnlid

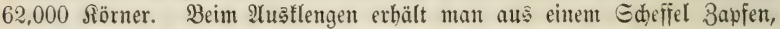
worin getwöhnitd 3500 bis 4000 Stüde befindlid find, 11/5 Piuno Samen mit Fłlügelı, voer $0,85-0,93$ Bfuno obne Flügel.

12) Den Serdenbaumfamen fammelt man burd) 2(bbrechen ber 3apfen vom Monat Jebruar an bis ins Jrübjabr, weil bie Er: fabrung lebrt, dáp bie Bapfen, welde früber uno fdon im November gebroden werben, fid) nid)t fo leidht ausflengen lafien, als biejenigen, weldhe ber Winterfälte am Baume aus: geję̧t warent.

Das 2tusflengen geidjieht gerabe fo, wie bei den fichtenzapfent gelebrt morben, entweder burd Dientwärme ober burdh bie Sommenbike. Dod) mus id) bemerfen, Daj bie Serdenzapfen ben Sament weniger gerne, als anbere Nabulholzzapfen, ausfallen laijen, uno baj felbit int andern Jabre now viel Gament auşällt, went man bie 2tusflengung burdh bie Somne betwirtt. Man werfe baber in biefem Jall bie Bawfen im erften Serbite nod nidat weg, fonbern lebe fie im nädjten Frübjabre uno Eommer ber Sonme nod)= mals aus, fo wiro man finden, daj jie nod) eine beträd)tlid)e Menge Eamen geben. Der zuerft ausfallenbe Same ift aber immer ber befte. ${ }^{1}$

Der Edeffel $=55$ Siter Samen mit Shlügel riegt gemöhnlid $18-18$ Bjunt, abgeflügelt aber 54 Bimb. Sin Edeffel 3apfen liefert 8 \$fun geflügelten ober 6,5 \$iuno abgeflügelten Samen, unь bas \$funo enthält 85-90,000 Rörmer. Diejer Samen läpt fich einige Jabre zur Saat brau(d)= bar erbalten, wenn man ibn auf einem luftigen, gebretterten Boden aufbeioabrt

- Der Jerauggeber bat, geleitet Durd Das Werhalten Der Bapfen am Baume, Dent

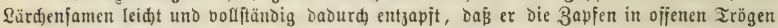

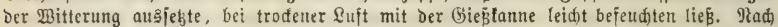
jeder IInfendtung öfineten die in ber Gonne twieder abgetrodncten $3 a p f e n$ fid) in höherem

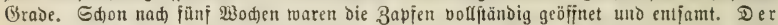

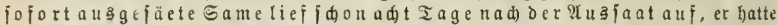
aljo bie eriten Stadien feiner Reinung idon im 3apfen ourdlaufen, fo dás trofs ber ver-

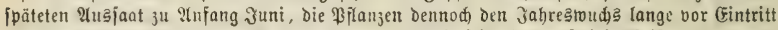

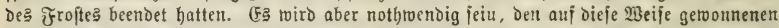

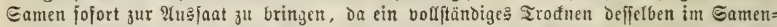

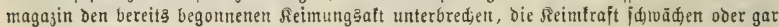
aufheben rürde. 
und jumeilen einmal umitict. Eine fleine Quantität fann man, wie jeoen anoern feinen Samen, am beften erbalten, wenn mant ihn in einem groben Gacfe an einem luftigen Drte aufbängt. Er ift alsoanı vor Mläuịefrá ge= fidhert, uno bie Suft fann bie groben Säffe befier burdhoringen, als bie feinen ober aus bidt gewobenem $3 e u g$ gemachten હäfe.

13) Die 3 ürbelfiefernzapfen werben in ber Mitte bes Dftobers abgenomumen, ber Sonnentoärme ober einer mä figen Dfentärme ausgejeß̧t, uno auf bieje 2 rt entjamt.

Der Samen ober bie ?äille, movon ber Edeffel 45 Pfunt wiegt, lailen fid nur einige Jabre lang zur Saat braudbar erhalten. Sidherer gebeihen aber bie Rulturen, wenn man ben Samen alşbalo im Şerbjte ober im nädjiten frrühjabre vieber auşäen fann. Der Game liegt im Boden ein Sabr über.

14) Die $\mathfrak{B}$ imuthątiefernzapfen werden im September, fobalo fid) bie Sduppen zu trennen anfangen, gebroden.

Man feb̨t fie bierauf Der Eonnentwärme aus, bis bie Eduppen ganj eröfinet fino, uno ber Gamen burch (Eridütterung ber Załfen auşfältt. Diejer faum hernach burdh Reiben zmifden cen Syättoen abgeflügelt, in einem groben Eadfe an einem luftigen Drte aufgehängt, uno einige Jabre lang zur Eaat brauchkar erbalten werben. Der Edeffel miegt alsbant 51 Pfuno, unঠ das ßfun entbält 28,000-30,000 Sörner.

15) Den Blatanusiamen fammelt man am beiten erit gegen Das ₹rübjabr.

Mup man iḅn aber ichon im Spätberbjte einernten, fo läp̧ mat

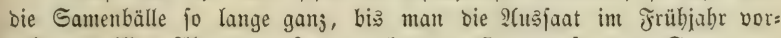
nebmen will. 2lläbann erft zerorüfț man fie uno fäet ben Samen. 2tuf folde 2 rrt bält fich ber Samen bis zum Jrübjabr bejier, als toent man bie Gamenbälle beim Abnehmen in Şerbite idon zerorüatt. Dod)

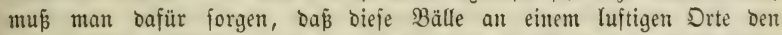
Binter über aufbetwahrt werben. Im nörolichen Deutjallano wirb biejer Samen felten reif, uno aud im jüblidjent nidjt immer.

16) Den $\mathfrak{A} f a z i e n j a m e n$ jammelt man im Dftober, jobalo man bemertt, Dás bie Rörner recht hart geworben fimo. Man fann bie Ein= fammlung aber auch) bis zum März aufidieben.

Man pflüăt aläbann bie Fुüljen $a b$, legt fie in bie Sonne ober jeb̨t fie einer mäpigen Dfentwärme aus, bis fie aufgejprungen fint, unt jucht bann ben Samen entweder mit ben Fingern ober im Gropen ourd) Dreiden berauรืุ̧ื

Der Samen bleibt einige Jabre lang zur Saat gut, went mant ibn in einem groben Sače an einem luftigen Drte aufbängt.

Die Einfammlung uno 2 ufbetwahrung Des Eamens bon ben übrigent Şolzarten übergebe idh hier, weil Davon leine großje Quantität gejammelt wiro, uno jeber obne Afnleitung eine fleine ßartie Samen wiro einerntent fönnen. Jd bemerfe nur, bas bie in faftigen Beeren befindlichen Eamen: förner am leidteften $\delta$ urd $\mathfrak{A} u s$ wafden gewonnen merben fönnen.

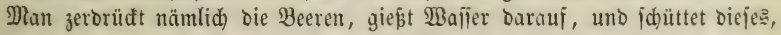
wenn fid bie fleifdige uno faftige Mafie mit oem Mafjer verbunben uno 


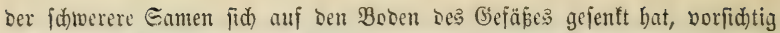

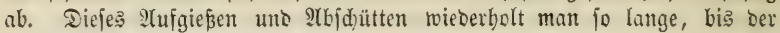
Gamen ganz reist erideint.

Dod) wiro man finten, baf bergleidhen Samen fid beffer zur Saat erbalten, wenn man fie in ben Beeren ftecten läp̆t, biefe auf eintem luf= tigen Boden trodnet uno fo obne weiteres im nädjiten Jrübjabre ausfäet, in fo ferme bie freilid vortheilhaftere $\mathscr{H}$ usjaat ber frifden Beeren im Serbfte nicht geidelen founte.

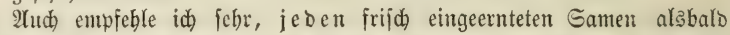
auf einen gebretterten luftigen Boben b ü nne auseinanber zu bringen

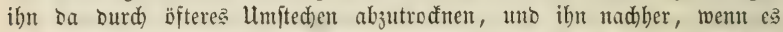
cine fleine Duantität ift, in einem groben Sade an cincm Kuftigen Drte

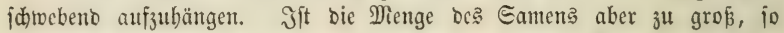
foütte man ibn auf einen luftigen gebretterten Boben, ber ber Bärme im Sommer nidjt zu fehr auşgejelst ift, uno fteche ifn zumeilen ım, Damit frifde \&uft bazwifden fomme. - Nod beffer aber ift $\mathrm{e} s$, went man ben Samen im Eommer gar nid)t unterm Dadhe liegen läbst, fondern

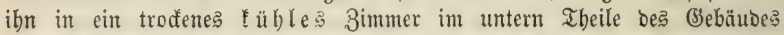
bringt. Ángeftellte Berfuche baben mich belehrt, baß̃ ber Samen bei foldher Behanblung ein Jahr länger zur Saat braudbar bleibt, als in bem Jalle, wo ber Gamen wäbreno ber Enmmerbibe unterm Dadje auf bent Speider liegen muß

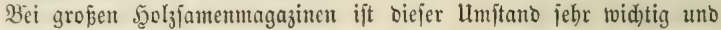
follte baber nie außer 21d)t gelaffen werben.

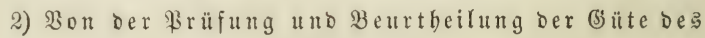
5ูolziamen

Benn ein Föriter vou glüfliden Erfolg feiner Balbjaaten verfidert

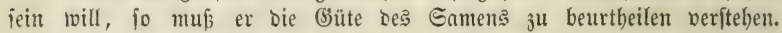
Şierbutch wiro er nid)t mur in Stano gejetzt, zu beftimmen, ob ber ges madjene Eamen fo gut ift, Dap er bie Einfanmlung uno 2(uşaat ver: Dient, fonberu er triro baraus aud ermeffen, ob ber feilgebotene Samen tauglich ift, unto ob uno it weldyem Berbältnif an ber fonft von gantz gutem Samen auf cinen Morgen erforberlichen Menge ein 3 ują̧ nöthig wiro, um eine vollftänoige Sultur zu madhen. Mangel an Renntnif́ biefer

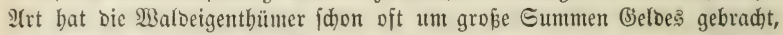

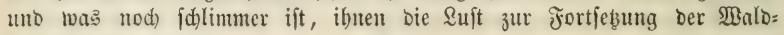
fulturen benommen.

JW empfeble baber aufs bringentite, Den Eamen bor jeber (Fin: fanmulung, ober oor jedem 2fnfaufe, ober oor jeber Rultur aufs forgfäl= tigite ju unterijuden, uno bie Saat lieber aufjujichieben, als jobled)ten Samen ju fammeln, zu faufen ober auszuftreucn, weil baburch nur Roften ent= fteken uno bod) nidt:s genüb̨t wiro.

Ulm aber ben Eamen gebörig beurtheilen 孔 fönnen, muß man fid befaunt maden, wie ber vollfommen gute uno reife Samen von jeber Şolzart,

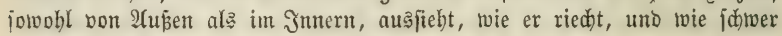
ein getwiffes Maß́ Davon wiegt. Findet man nad)her bie Samen mit biefen 


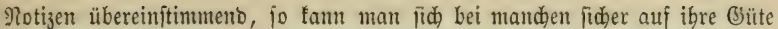
verlallen; bei andern aber faun weber bas Altter, nod bie vielleid)t verberblid)

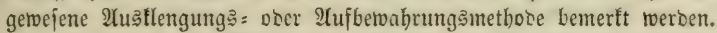

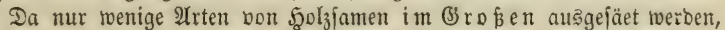
uno biejer (3egenftano bon Widjtigleit ift, fo will id) mid nod) beftimmter Darüber äufern, uno bie Beiden anfübren, woraus wenigitens auf bie

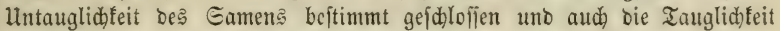
mit ziemlider Gేeniß beit beurtbeilt werben faurn.

1) Bon bem Samen ber (Eid)en, oder bou ben (Eideln.

Un bie Tauglidjeeit ber (Eid)eln zu unterjuden, fdneide man mebrere

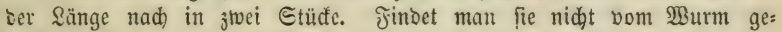

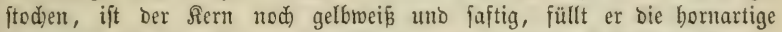

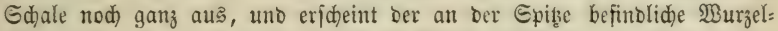
feim nod) gejunt uno jaftig, io ift bie (Eid)el unfeflbar gut. Sit fie aber bom $\mathfrak{B u r m}$ geftoden, ober ift ber fern in ber Edjale braun, blau ober fidwarz geworben, ooer io geidrumbfen, baf er locer barin liegt unb

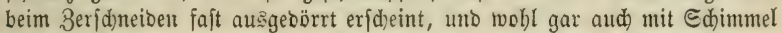
überzogen ift, ober bätte fie cinige 3 oll lange $\mathfrak{B u}$ uzelteime getrieben, bic nachber vertrodinet twären, fo taugt bie (Eidjel zur Eaat nidyt. Man fpare dann bie Mühe uno 2tusfaatfoften, denn es wiro feine Pflanze aufgeben.

2) Bon ben Samen ber $\mathfrak{b} u d e n$, ober bou ben $B$ udeln.

Bei Unterfud)ung ber Budjeln finteibe man mebrere ber Sänge nad)

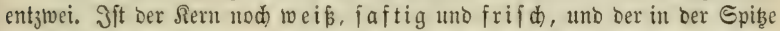
befinoliche Wurzelfeim von eben Derjelben Befdaffenlyeit, uno fahmedt der Sern nud füß uno mandelartig, fo ift bie Bud)el zur Saat tauglid). Sgat ber Rern aber eine anbere ale bie weipe garbe und einen ranjigen wiberlichen

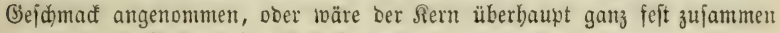
getrodnet, fo ift eine folde Buchel 3ur ভaat unbraucbbar.

3) $\mathfrak{B}$ oin Samen Der Şainbude.

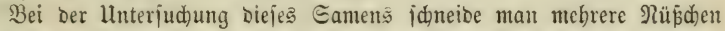
entjwei, um zu jeben, ob fie auch Sern entbalten. Findet man bief, fo twiro ber Samen für gut angefproden, uno er wiro getvís aufgeben, wenn er nidjt 3u alt ift, weldhes man ibm freilids nidjt anjehen fann.

4) Bom Samen ber Ulme.

5) $\mathfrak{B o m}$ Samen ber Erle uno

6) bom Samen ber Birfe.

Ulm bie Ğüte bicjer Samen zu unterjud)en, zerid)neibe man mebrere Rörnden mit cinem fpiben Febermefïer. Sinoet man bei biefer Unterjuduung Das Sernden mebligt, uno zeigen fid beim 3erbrüdfen bes Samens zwijden

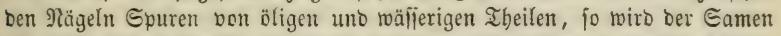
gut fein, wenn er nid)t zu alt ift, cas malt ibm aber nidbt anjeben fann. Fehlt aber bie meblige Rernjubjtant gänjlid, fo taugt ber Samen gan getwip nicht, uno man pare aljo bie $\mathscr{A}$ usjaatfoiten.

7) Bom Samen bes 2 borns.

Bei ber Unterjudjung biefes Єamens nehme man bie graubraune Єdjulc non bem am flügel befindliden Gamentorne. Jindet man bic barunter 
liegenoen zujammengerollten Samenlappen fdën grün, faftig un๖ frifo, fo ijt ber Eament gut. WBären bie Eamenlapwen aber von anberer Farbe, noer fo bür, Daf fie fid) ztwijd)en ben Jingern zu Stanb zerreiben lafjen, fo taugt ber Eamen nid)t. Dod) ift Die grüne Jarbe ber Samenlappen fein untrüg= lides Rennzeiden ber Güte siefes Saments. $\mathfrak{A}$ ud ber biel zu alte bat oft bie grüne Farbe nod, uno gebt bod nidht auf.

8) $\mathfrak{B} \circ \mathrm{m}$ Samen ber Ef d e.

llm Den (5jhenjamen zu unteriud)en, zeridneidet man mebrere Rörn= den. Sinbet man in ibnen bie blauweipen Rernftüđe nod wad) säbnlid), fo ijt ber Eamen gut; ift bieje Maffe aber zu ftart auß̈gebört, fo ijt ber Eamen getwöbnlich zu alt, uno geht nid)t auf.

9) Bom Samen ber $\mathfrak{R}$ abelbölzer.

Bei ber Unterfudung bes Rabelbolzfamenz zerfdoneibe man ebunfalls mebrere $\mathfrak{R o ̈ m e r . ~ F i n b e t ~ m a n ~ f i e ~ m i t ~ b o l l f t a ̈ n b i g e n , ~ f a f t i g e n ~ u n b ~ f t a r f r i e : ~}$ d)enden berben Rernen angefüllt, io ift ber Samen für gut zu balten; fino aber bie Я̈̈mer faft leer, sier bat ber Eamen feinen eigentbümliden (Berud) uno (SIlanj verloren uno vielleidst aud eine ungetwöbnliche Farbe erbalten, fo taugt er zur Eaat nidit. 1

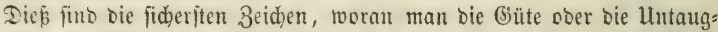
(id)teit ber angeführten Samen erfennen fam, twem man fie auf ber Stelle burtheilen muईs. Sidjerer miro man freilid) belebrt, wenn man 3eit bat, 3erfud)e im Rleinen anzuftelfen, um aus Der Menge Der wirflid) aufgeben: Den Pilanjen auf bie Güute des Eamens zu jolliểen. Man fäet zu bem Ende won jeber Samenart, bie balo aufaugeben fflegt, unb bei beren $\mathfrak{B} e$ untheilung obnedićs feine Beitimmtheit möglid) ift, eine gezählte Menge Eamentörner in einen mit Erbe gefüllten Iopf ober in einen Sajten. Diejen jtellt man bierauf an einen temperirten Drt, begiejt bie Erbe, fo

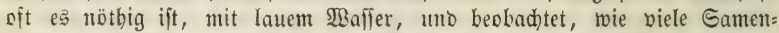
förner auffeimen. Diefes ift Das fiderfte Mlittel, die Gü̈te Des Samens ju erforidjen, uno es follten von j: ber Forftoireftion in jebem Binter mit Dem jur nädjten Jrübjabrąjaat beftimmten Erlen=, Birfen=, Llmen=, 2thorn= uno Sabelfoljiamen bergleiden Berfuche angeftellt werben, um bie Güte Ic se vorrätligen Gamens genau z̆ prüfen, uno barnad bie Menge bes auf jeben Morgen auşufäentoen Gamens jut beftimmen. Dod werben vom beften Gamen nid)t alle Sörner auffeimen. Saufen brei Biertbeile Doer $2 / 3$ bavon auf, jo ift ber Samen fdon für gut zul balten; geht aber nutr Die ફূälifte alf, fo ift er für mittelmäßig aljuipred)en.

Jin neuerer Beit bebient man fid zu foldhen Reimberjuden bider Blatten aแs poröfem Thon, in Deren Dberfläd)e halbtuglide Bertiefungen eingebrüat fino, bie fid gleid)mäßig feudt erbalten, wenn bie Thon= Flatten mit ifrer Ilnterfeite in eine flache Mafferjobidt gelegt uno ber zu priffente Єame in bie Bertiejungen Der Dberjeite gejtreut wiro. Man hat

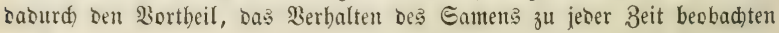
วัl tönกา.

1 Iem Tannenfamen fifadet ber gegenjeitige Drud. Soll er berfendet werben, fo

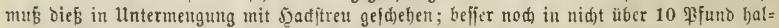
tenoen Eäđen, bie an Der Dede eines ylantwagen jd)webeno aufgehängt reeroen. 
Meberhaupt aber ift es jehr anzuratben, nur ven betannten Eamen:

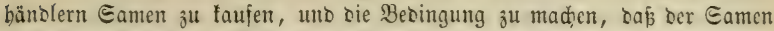
alsbald auf cinen veridloffenten luftigen Boben büne auseinanoer gebrad)t uno erft nach 2 (blauj bon 14 Tagen gemegen mersen foll. Daburd miro man gejidjert werben, daj man feinen abjicttlich angefeudhteten uno viel= Ieid)t gar mit feinem Eano bermengten Eamen befommt, uno baई, menn er auch betrüglid) angefeudtet wäre, Der Eamen bod) nidht verberben fann. Eollte jich ater ein Eamenbänoler auf bieje Bebingung nidbt einlajien

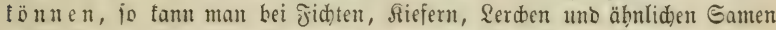

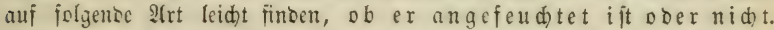
Man greife nämlid) mit einer ganj trodenen band in ben Eamen, brüde eine நambooll red)t feft zujanmen, uno eröfine num bie berauș

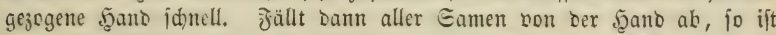
er troden; fleiben abor vicle förmer an ber trofiten Saut bängen, fo ift Dor Eamen gewißj angefeuchtet, um feine Ed)were auf eine Beitlang zu nermebren uno Den Räufer zu betrügen. S(ud fann man burd) Daڤ Reiben

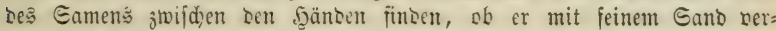
mengt ift. 1

\section{Ḑierfes såpife!.}

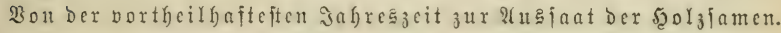

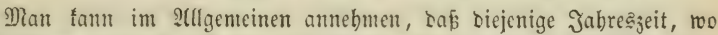
Die Scoljianten von ber Natur ausigeftreut werben, bie vorzüglidfte Gaat= 3eit ijt, mentn alle übrigen llmftänoe ebenfalls natürgemäb

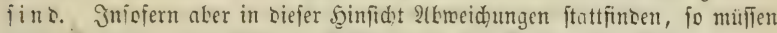

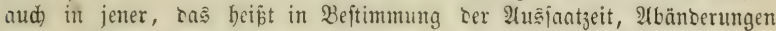
gemadt twerben, wenn Eaburdh Wirfungen entftehen, sie bas Bebeihen ber Saat beförbern. 3. B.

İm natürlichen 3ujtanto fällt sie \$udhel im Serbjte unter sen mïtter= liden Baum, fie triro mit ¿aub bedect, feimt jdon im 21pril, uno wiro gegen die Exätfröte non ber Mitter geidühţt. Eäct man aber Budeln

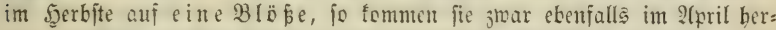

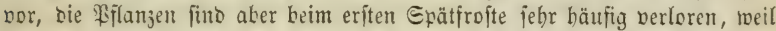

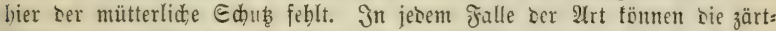
liden jungen Bflanzen bor Frojt gefidert werben, menn man ben Eamen

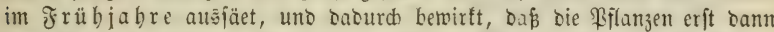
zum Borjdein fommen, wenn teine Exätfröjte mebr einfallen. 2tuß̧erbem

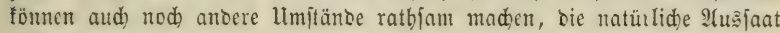
зu veräntern.

Man befolge Daber nadjfebente, Durd Die Erfahrung beftätigte Regeln:

1) Tie (Eid)eln jäe man aląbalo nad der Einjammlung im Jerbjte

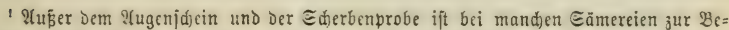

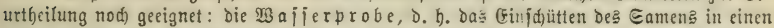

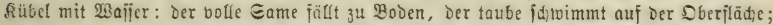

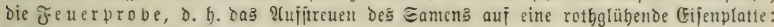

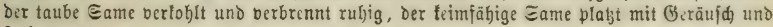
ipringt babei getoōfntid) etras in bie Seb̧e. 
wieber aus, ber Saatplatz mag Sdyub̧ haben oder nidjt. Wemt aber zu fürdten ift, Daß̧ zabme oder wiloe Edjweine, Rehe ober Dädje sie aus: gejäeten Eid)eln nerzebren werben, ober wenn es̉ ungewöhnlid biele Mäuje gibt, fo weridiebe man bie Saat bis ins Frübjabr, um fie gegen bie (be: fabr, a ufgefreffen zu werben, fo viel nie möglid) zu fdüßen. 2(ud) ift bie grühjabrşaat alsbann vorzuzieben, went man ben (Eid)eln teine ge: nügeno tiefe Lage in 30 on geben fann. (Es ift in bicfent falle zu fürd)ten, Dẩ bie in ben Saatpläz̧en liegenden (Eid) eln erfrieren.

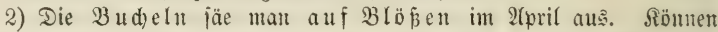

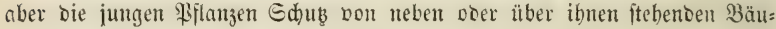
men uno Büiden haben, uno tritt auperbem ber Fall nicht ein, baj Ed)weine ober Mäuje bie Gaat ruiniren werben, fo füe man bie Budeh im Şerbfte.

3) Den Şainbudenfamen fäe man in Sgerbite oder in Jrüh= jabre. Je früber man ibn in bie Erbe bringt, Defto keffer geräth bie Saat.

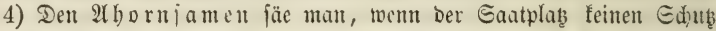
hat, im Frübjabre; wenn es aber eine Sinjprengung in Schläge wäre,

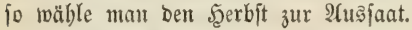

5) Den Ëjdenfamen jäe man fo bald rie möglid) im Seerbfte ober Grübjabre wieber aแt?.

6) Den Ulmenfamen fäe man entweber alabalo nad) feiner Reife im Juni, oder wenn bief nid)t möglid) ift, fo nebme man bie Saat balo int näcjiten frübjabre vor. Dic 5eerbitjaat geräth zwar audd, bod) nid)t fo

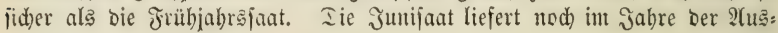
faat bie jungen \$flanzen.

7) Den Birfeniamen jäe man alabalo nach ber Peife im Serbite Doer red)t bald im Frübjabre. Je früber biefer Gamen in bie (crbe tommt uno je frifcher ber Samen ift, Defto befier geräth die Saat.

8) Den (Exlenfamen fäe man im Şerbite nad) Der (Einjammlung ober bals int Frübjahre. Beides wiro gerathen, wemt ber Gamen, bie Bebandlung uno bie Bitterung gut fino.

9) Den Iannenfamen fäe man two möglid) im Şerbjte, fonjt aber red)t balo im Frübjabre.

10) Den Fiditenjamen,

11) Den Rieferfamen,

12) Den \&erdenfamen, und

13) Den $\mathfrak{B e i m u t b}$ atiefernjamen fäe man fo balo wie mög:

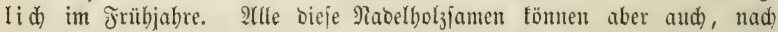
meinen wieberholten umo gelungenen Berfuchen, im Seerbjte gefäst werber,

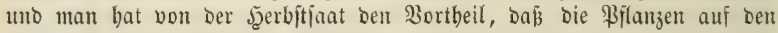

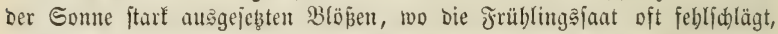
im Frübjabre balo zum \$oridsein fommen, uno, nad) meiner (Erfabrun, nom frojte felten etwis leiben.

14) Den Birbelfieferniamen jäe man entweder im Şerbjte doer

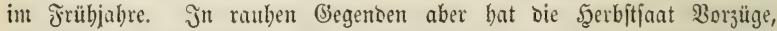
weil bort ber Boben erft im Mai bom Sd)nee entblöpit wiro uno bie Pflanjen von ber Frübjabrşatat zu pät berborfommen. 
15) Den ßratanusiamen, mo

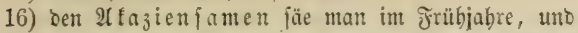

17) von ben übrigen Sgolzarten, sie aber beim jorithaushalte in Grofien feine Rüdfid)t berbienen, jäe man sen Ermen ju ber 3eit aus, too er vom Baume fällt.

\section{马ilntrfes şapifel.}

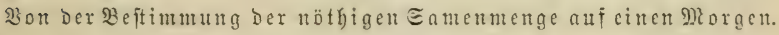

Ein widhtiger Giegenftanto bei ber sialojaut ift bie ridhtige Bejtim: mung ber nötbigen Eamenmenge. Simunt man ju vicl, io werben bic Soften unnöthig vergröpert, unt es ijt (auf johledtem Bocent t.) jelbjt für Ins Gedcihen ber jungen Walsfulturen nadbtheilig, wenn bie ßiflanjen all: jubidht beijammen fteber. Siimmt man aber zlt wenig Eamen, fo befommt man nidht Pflanzen genug, uno es werben unter folden Umjtänom Shad: jaaten ober Radjpilanjungen nötbig, bie oft bei weitem mebr folte:t, als menn man jur erften Eaat etwas mehr Gamen genommen uno saburd bic গad)befierungen vermieden hätte. roijien :

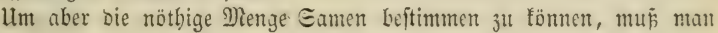

1) wie nabe die Pflanzen von jeder Sholzart im erften Jahre beifammen teben ober aufgeben mujien, um nad $21 b=$

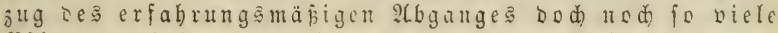

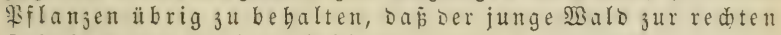
Beit in ben gebörigen Sdulús fommen fann. Uno

2) wie biele Brunbe guten Eamen auf einen Morgin Der (Eriabrung nad) nöthig finb, umbie erforberlide Menge Bflanzen zu erbalten.

Was ben eriten \$unft betrifft, fo fommt es auf bie Soljart an, of nämlidy bie jungen \$flanzen sabon fith alshalo ftarf uno tief bemurzeln soer nidht, uno ob fie von ber Enmtentişe ober von Injeften menig sow viel zu leisen baben. Sm eriten falle braudt man nidht io viele Eamer:

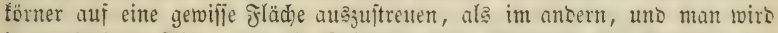
in Demjentigen 2̂lter, to Die Sulturen allen Gefabren Der Sinobeit ent=

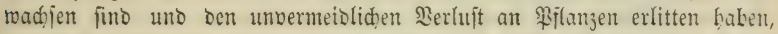

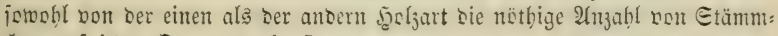
chen auf jeber Duabratruthe finten.

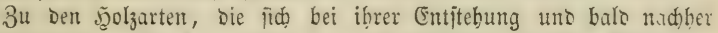
iturf berwurjeln, uno eben sefwegen surch anbaltende trodene PBitterung, ober burd bas 2fuffrieren bes 3obens, ober burd) Injeften weniger als

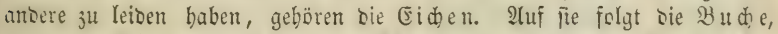

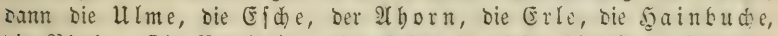

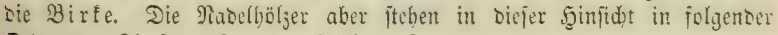
Dromung: Riefer, Serde, Fidte, Ianne.

Will man nun, Daj bie angejäeten Diftrifte balo in Edfus fommin jollen, fo mus bei ber Bollfaat jeber Suabratjus im eriten Eommer folgende $\mathfrak{A}$ (nzahl bon $\mathfrak{B f l a n z e n}$ wenigftens enthalten:

șartig, Regrbud) für છ̈örtter. II. 


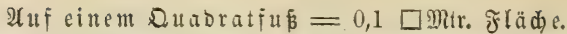

Wenn Boden und Sage gut ind, werigitens:

Ei ble.... . 2 Pflanzen,

Buthe . . . 4 "

Ulne . . . . 4 "

(5id)e. . . . 4 "

Aborn ... 4 "

Erle... . 6 "

Birfe . . . 8 "

5ainbude . . 6 ."

Serche :. . 6 " "

Siefer . . . 6 "

itid.te . . 8 .

Tanne. . . 8 "

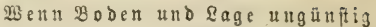

iit o, twenigftens:

(5ide . . . . 4 Bflanzen,

Bud che . . . 6 "

Ulme . . . . 6 "

Efकe. . . . 6 " 6

Ihorn ... . 6 "

Erle... . 8."

Birfe . . . 10 ."

Sainbude. . . 8 "

Serde. . . 8 "

Riefer . . 8 "

Fidte . . . 10. " .

Ianne . . . 10 "

Damit man aber bei jonjt jotedmäpig veranjtalteter Eaat bie fo ebont beftinmte 2Anzabl von Riflanzen wenigftens crbalte, io muf, ber Er: fubrung nad), biejenige Menge gute it Gamens auf jeben Morgen auझ gejäct merbet, sie id hier folgent angejeł̧t babe.

Eamenmenge auf $1 / 4$ நeftar (genauer 0,255322 Jeft.) $=1$ Morgen

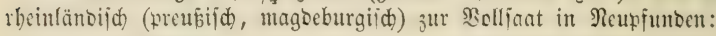

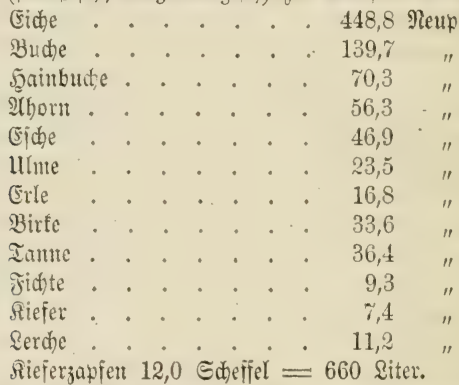

Bei itreifent= uno bei plaģweijen Eaaten berminoert fid biefe Samen:

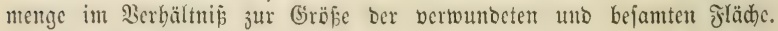

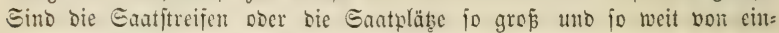

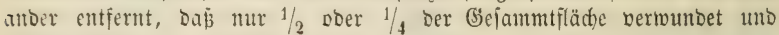
bijamt miro, io ift aud mur $1 / 2$ ooer $1 / 4$ obiger Eamenmengen aujall= wenten, bod fflegt man 10 bis 25 Broc. mebr Gamen aufauventen als bie biernady beredhete Samenmenge.

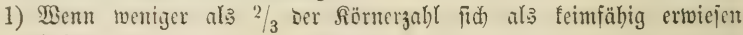
baben.

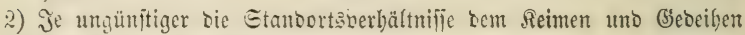
Der Samenpilanjen finto.

3) כ̃e grö̉er bie Summe Der Gefinhren iit, die ben Gamenpflanjen entgegentreter. 


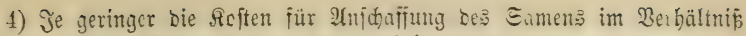
ju allen übrigen Roften ber Eaatfultur fino.

5) J̄e böher bie Ertraģergebnille einer bichteren Eaatfultur fict) berednen.

Dieje 2(ngaben fönnen aud) zur Beftimmung Der Eamenmenge jür vermijabte Gaaten benub̧t merben. Gejeșt, man molle $1 / 4$. Seftar Blöpe

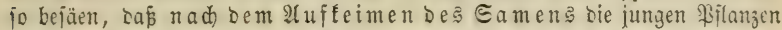
ungefähr zum Dritttheil aus Eid,en, zum Dritttheil aus Budten und jum Dritttbeil aus Birfen befteben jollen, fo fäe man bci ber Bolliat

252 Pruno (Ficheln,

$66 "$ Budjeln uno
$16 "$ Birfenjamen aus.

Isch) Dari man nidjt glauben, Daj alšounn Der angejäete WalD einjt bei jeiner Şaubarfeit in Demjelben \$erbältnif bermifat fein merbe.

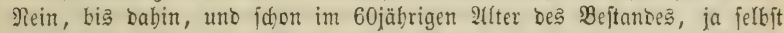
nod) jrüher, fann or vielleid)t jebr bolltommen jein, uno ${ }_{14}^{1}$ an Eidjen, $1 / 4$ an Buchen und $2 / 4$ an Birfen zum Beftano baben; er fann aber aud nur $1 / 8$ (Eid) $n$, Ii $\mathfrak{B}$ ud en une den Rejt an Birfen enthalten. - Bis zum 30jäbrigen 2flter mirb in ben jungen $\mathfrak{Z} a$ alsbejtänoen eine unglaubliche

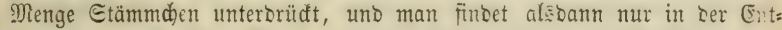
jernung non $2 / 3$ bis $1 \mathbb{M}$ tr. eine nod) lekente, uno in Der Entfermumi non 1 bis 2 Mtr. eine onminirenoe Etange. Biß jum G0jäbrigen Mfter aber merben jodon mieber. Diele Etämme ïbermachjen, uno bie Entjernung ber Dominirenden beträgt bann getwöhnlic) 2 bi: 3 Mitr. - im 60= ober 90jäbrigen $\mathfrak{A}(t e r$ aber 3 bis̄ $4 \mathfrak{M t r}$. Auch Dieje Erfahrungşiäbe, jowie aud) Die Beobadtung, baj biejenige Sgolzpilanzen, bie balo nad) ibrer (Er:

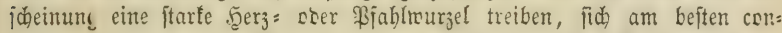
jerbiren, aljo weniger Albgang erleiden, muifien bei ber Beftimmung ber Samentenge auf einen Morgen in Betractung fommen. -

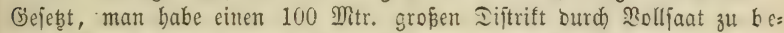
jamen uno müniche, Daj er nady Şerlauf nou 60 Jabren rein mit Ẽid) en beftanden fein mödte, man fönnte aber bie für bicjen Diftrift ou einer reinen (Eid)eljaat erforberfiden (sid)eln nidot anjchaffen, jo fam ber

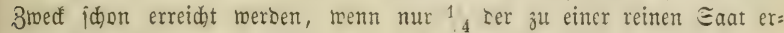
jorberlichen (Fidheln auzgejäet, uno jtatt ber übrigen $3 / 4$ entweder Birten= jamen, nod) befier aber Şainbuchenjamen mit ausgeptreut werben. ${ }^{1}$ In Diejem fall merben zomar bei reitem mebr Birfen ober Şainbuchen als Eidhen auffeimen; wenn man aber burd) nerfidtiges भHabauen ber Birfen

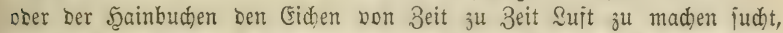
io miro ein joldher Bejtano, - injoferne bie Eicheln gut aufgegangen

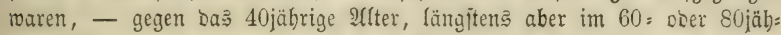
rigen $\mathscr{U}$ (ter, ein ganj reiner (Eid)entwalo jein. 2 uch rire man burd) bie bisherige Bermifdung am (jelbertrage nichts nertoren baben, weil bas Şain= buchenourdforitungagholz ehen io theuer uno nech theurer nerfiuft werben

1 Wenn biele Birten mit ben (Eidjen aujwadjen, jo werben bie (Fidjen burd ben an=

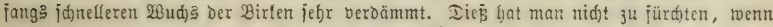
Jainbudjenjamen jugleid) mit ben (Eid)eIn gejäet wirb, weil bie jungen (Fidjen uno ñain=

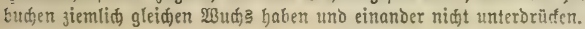


funn, als das eidjente, Das Birfentolz aber im ßreis nidjt biel geringer ftebt, uno fein Ertrag burd) bie Benub̧ung ju Fapreifen $2 c$. an manchen Drten jebr erböbt werben faun.

Uuf ähnlidhe 2frt verfährt man bei ber Berechunng der Samenmenge

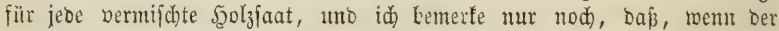
Gamen alt uno augenf(heinlid) nidot ganz gut ift, immer wenigiten $1 / 4$ Der vorhin beftimmten Samennenge me hr genommen werben mup, als wenn Der Gamen frifo unt erprobt gut ift.

\section{Sedistes diapiter.}

Bon ber 3 ubereitung Der Błöpen, bie bejamt werden follen.

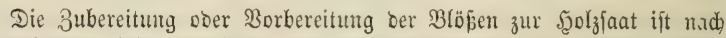
bent Umitänoen jebr verjdieben. Es fommen bier vorzüglid in Betradtung:

1) Die Renntnif, wie ftarf ber auszujäendc Eamen mit Eroebebed fein mus, und

2) auf weld)e 2Art ifm biefe Bebedung, nad) Beridiez

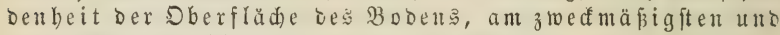
zugleid am woblfeilften zu beridaffen ift.

Was den eriten Giegenitanto betrifft, jo ift im erften Şaupttheile, bei

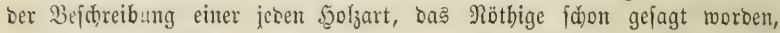
uno man wirb fich unter andern nod) erimuern, baj in Betreff ber beim Foritwefen im (5rofen vorjüglid) wid)tigen Sgolzarten folgenoe Beftimmungen ftattgefunoen baben:

1) bie (Eidel will bebedt fein

3 bis 8 Etm.,

2) bie $B u$ bl

$1,5,5$ "

3) ber Ahorniamen

4) ber ulmeniamen.

$0,7,1,3$

5) Der Éfdenjamen

$0,5 \quad$ " 0,7

. $\cdot 1,4$ " 2,0

6) Dex jaiubudenjamen . . . 0,7 " 1,3

7) Der Birfenfamen . . . . 0,3 " 1,3

8) Der Erlenfamen . . . . 0,3 " 0,7

9) Dex Iantenfamen . . . 0, " " 1,3,

10) Der Fidteniamen . . . 0,3 " 0,5 "

11) Der Rieferniamen . . . 0, " 0,7 "

12) ber Serdenfamen . . . 0,1 "0,3 "

Se loferer uno je trodener ber 3oocen ift, um fo tiefer, je fefter uno feud)ter ber Boben iff, um fo fladjer mup bie Bebedung imterhalb ber berzeiduneten (brenzen jein. Afuf fefr trocfenem Booen ift Bertiefung bes Reimbettes, anf fehr nafiem Boben (Frböhung beffelben burd) aufgetragene Erbe żweđtmäpig.

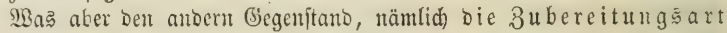

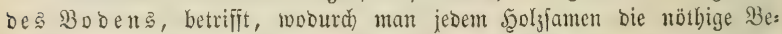

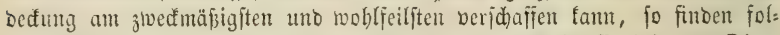
gende Metboden ftatt, wovon, nad) Maigabe ber Befalfifenbeit Der Dber:

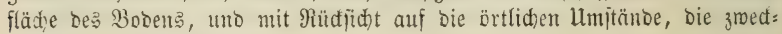
mäpigite zu wäblen ift: 


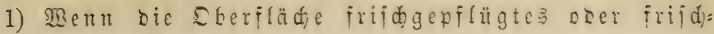
gebautes \&ano ift, oder

2) renn bie Dberfläde im vorigen Jabre nod gebautes Felb toar, ober

3) wenn bie Dberfläde star jeit mebreren Jabrenbrad gelegen hat, aber Dod non ber Befdaffenheit ijt, bas fie beim Umadern unb surd das llebereggen zerfällt, io ift an

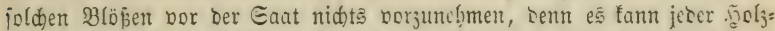
jamen, wie ich im nädjten Rapitel jeigen merbe, ohne weiteres Daralif gejäet uno ifm bie nötbige Bercafung leicht veridafit merben.

4) Eben io menig ift eine Norbereitung bes ?20bens nöthig, wenn

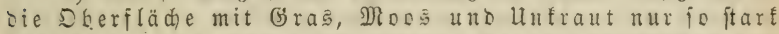
bededt ijt, baj man ourd eijerne Eggen ober Reden ben

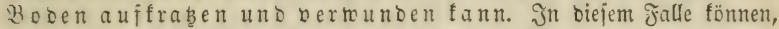

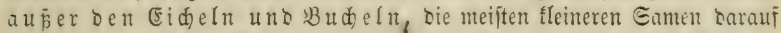
gejäet, uno nach ber 2Ausjant vermittelit Der Egge an unt in bie Eroe ges= bracht merben, wie id auch im jolgenten flapite! seigen merbe.

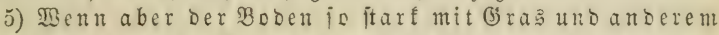
Unfraut überzogen ift, Daj ourd Uebereggen nidh a geridet werben tann, uno baj jelbit beim llmadern grope Edjollen

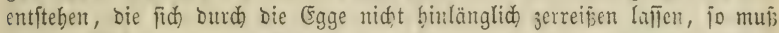

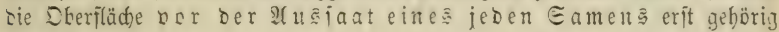
jugetichtet werben.

Diejes fann auj mehrerlei $\mathfrak{Y}$ rt gejheben.

\section{Erite Methode.}

Man laīe, wo es geidehen fann, den Boden im frütjabre umadern,

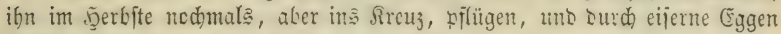
tüdtig zerreipen uno zur Eaat bereiten. 1

\section{3tweite Methobe.}

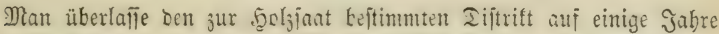

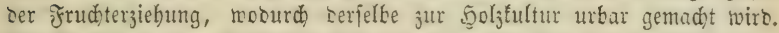

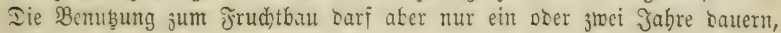
meil ber Boben fonjt zu jehr ausgejogen werben fönnte.

2 uf einem fo vorbereiteten Bosen gerathen bie Eaaten une Pilunjungen bortrefflich.

\section{Dritte Methoic.}

Man laije im Jürbjabre oen Rajen entmeder allentbalben ober

1 Sieine Fläden in Foritgärten oder Baumidufen fanu man audf) tiej $u m g r a b e n$

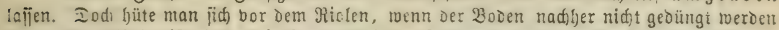

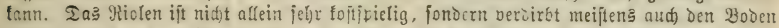
itir bie Sgoljiant, reil baburd bie gute Iammerde ju tief untentyin, uno ber ganj raube

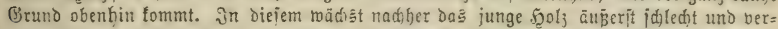

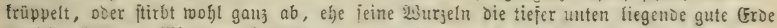
erreiden tönnen. Wiro der riolte Boden aber mit etras ftarfen Stämmen bepilanjt, io wadien bieje bortrejilid barin. 
mur ftreifentweife abjdäen, unt, went el gantz bürt ift, auf fleine Sgaufen bringen uno berbrennen. Jit biej geicheben, jo laffe man bie burch: gebrante Eroe, bie mun eine Menge 2lidbe entbält, auf bie geidjälte Jlädhe wieder aușftreuen, uno auf bieje in mand)en Qändern fehr befannte 2 trt, bie man gewöbutlid) Das Şainen nemt, ben Boden zur Scolźfultur vor: bereiter.

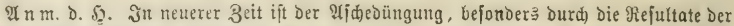

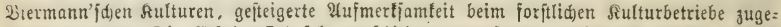
wendet worien. Iie Erjolge find fehr berijdieden ausgefallen, theils fehr günftig, theits

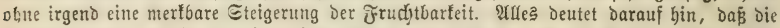

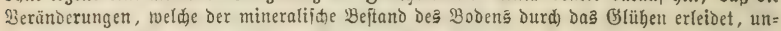

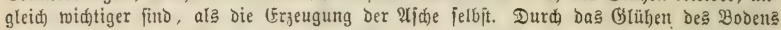

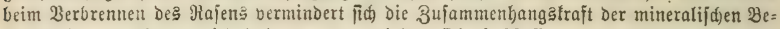

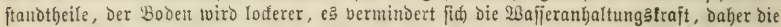

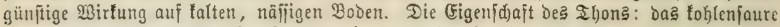

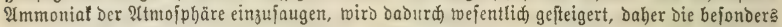

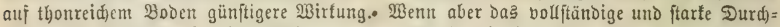

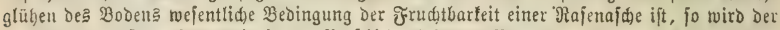

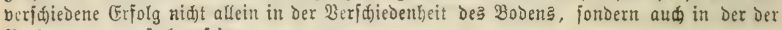
Berbrennung zu fudjen jeiti.

\section{Bierte Miethode.}

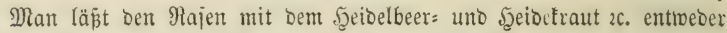
allenthalben ober ftreifentweije mit ber 5 ade abidälen, wenn er trodent ift, bie Erde abtlopfent, unt bas Rraut = uno $\mathfrak{W}$ urzelwert zur Düngung Der Jelder wegbringen. In manchen Sänbern ift biefes bie

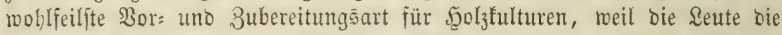
2(rbeit red)t gerne une ntgeltli d) verridten, wenn man ihnen bafür bie ^Rajen überläp̆t.

\section{Fünfte Methode.}

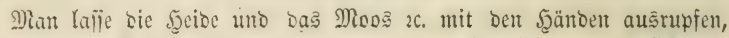
unio auf bieje 2(rt ben 3oben verwunden uno fo viel wie möglich ent= blöpen. Daburdy fann in arment Gegentent bie Streu uno Der Dünger ver= mebrt uno an manchen Srten ber 3oben menigitens für bic Sinfaat $\mathfrak{f} l$ e $\mathrm{inex}$ Gamen, bie nur mit ber Eroe vermifd)t fein toollen, bintänglid borbes reitet werben.

\section{Gedigte Methobe.}

Man lajie die mit Gras bewadjene fläche mit Der $\mathfrak{B f t u g e g g e ~ ( \mathscr { H } b .}$ f. G. 88) freuzweife berwunden, bie fleinen Gamen nad)her ausitreutu uno bann mit cinem Saleppeitrauche überzieben.

\section{Sicbente Miethode.}

Man laije nadh Mapgabe Der bifponiblen Sulturfolten uno ber ge: münfd)ten Didtigfeit Des zu erzielenben Bejtandes Etreifen oder Pläßze her= rid)ten uno ben 2(braum zur Eeite ligen. Sit biek gefdehen, fo laffe man ben Bobin mit ber Şade ctmas auflodern, Damit nadber ber eingejäete Eamen befier untergebarft werten fann. Eollen aber Eidjeln ober Budjefn gejäet merben, fo lafie man bie Eroe 4-6 Etm. tief aufhaden, uno aus 
bem vermunbeten Etreifen soer \$lab̨e auf oie anbere Geite sichent, um sic Fideln nad Der 2Uşaat bamit зu bebecten.

Will man bie Gant itreifent weife maden, fo lafie man auf ber Ebene bieje Streifen bon Morgen

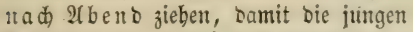
Bflanjen von ber nebeniftehenten Syeibe zc. ober wo tine Seeibe ift, burdh bie auf die Mittagşeite bes Etreifens ober Deక Quabrates zu legenden Rajen einige ße: idoattung erbalten. Will ntan aber cine ftreifenteife Saat am $\mathfrak{B}$ erge madjen, io laffe man alle Streifen wagered) $t$

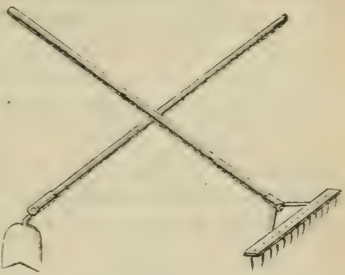
Doer horizontal jieben, Damit bet ftarfen Regengüifen bie Erte fanmt

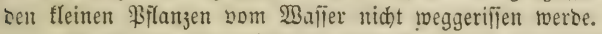

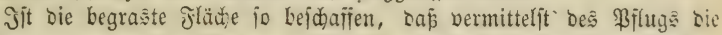
Etreifen gezogen werbent tömten, fo foftet biés nicht jo viel, als bie fitreifen: tweije Bearbeitung vermittelit ber Şade. Der \$flug fann aber nur gebraudt

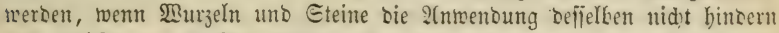

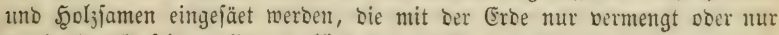

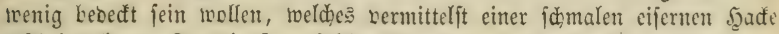
geideben fann. Jür bie Eaat folder Gämereien, Die eite tiejere Bebeçung

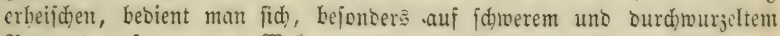
Boben bes fogenannten Malo: filugę, eines jebr malitiv unto Dauerhaft gearbeiteten 2(der: yiluges, befien Edjaar aber, wie bie nebenftebende $\mathfrak{A}(6)$ ildoutg in Seitenanitht und 2 ufficht bar: ftellt, eine zmeimürfige ift. In

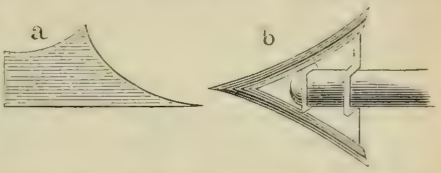
Diejen, bis $1 / 2$ Mitr. breiten Jurchen erbält bann ber auڤ̄geiäete Eame (Eidteln ober Buchectern), bie entipredente Bebectung ourdh eine ebenjo gebaute, aber fleinere Echaar, bie an bie Etelle ber bintweggenommenten gröperen Edaar

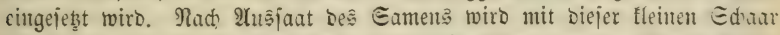

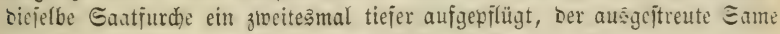
nac) beisen Geiten geworfen uno jugleid mit Erob besedt.

\section{adde Methobe.}

Wenn eine mit Şeide ftart bewadjene fläche bejant werben joll, is laije man im Eommer, bei trodener Witterung, Die Sgeise abbremten um

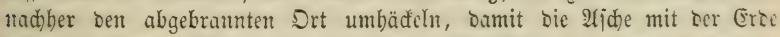
rernuengt werbe. Dan madje aber eine folde Brantoperation mit ber ge: lörigen Borficht! Bejonders berjäume man nidht, an allen Eeiten, wo bas Jeuer weit um jidh greifen uno Edraben thun fönnte, einen 1 Ditr. bieiten

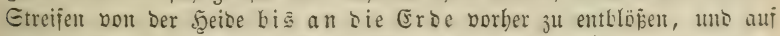
jecen Jall cine binlänglide Menge Menjẹen parat zu balten, sie, wo to

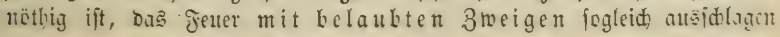


muiilien. Sollte aber eine jolde Eengung mit augenjideinlider (befabr ver: bunben, aud in ber Gegento nidht gemöhnlid jein, unb vielleicht weit uno bveit Jenerlärm berurjad)en, fo unterlaffe man fie lieber uno wento von . Delt borbin beidricbenen Borbereitungemethoden bie fdidflidjte an.

\section{Reutute Methode.}

Wemn bie ju befäente fläche eine Sandidyolle ift, auf wilcher ber

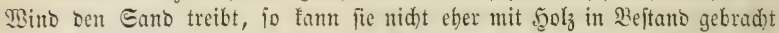

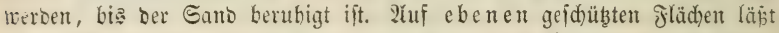
jid) Diejes zuweilen baburd berwirfen, daf man ben Biebheerben ben Ueber:

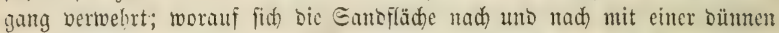

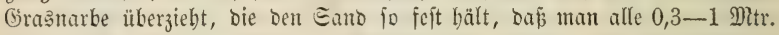

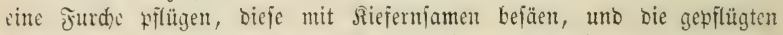
Etreifen mit Riefernftrauch) besecten lafjen fanm. Sat aber bie Eanofidolle

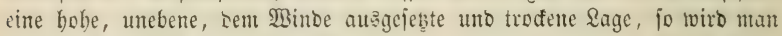
vergebens auf bie getwünjd) Benarbuny warten. In fold)en fällen bleift

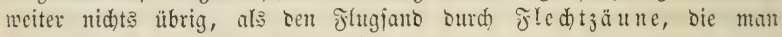
Coupirzäune mennt, fejt zu balten.

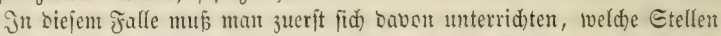

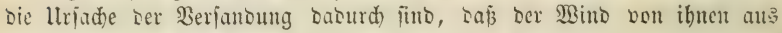
Den Eano wegtreibt. Dicje Stellen müijen mit flled)tzäunen jo bejeb̧t werben, Daj ber MBinb Den Sano nidid mebr zu faffen vermag, modurd natürlich bie Drte, auj welden fid ber weggetwehte Gano ablagerte, obne weiteres

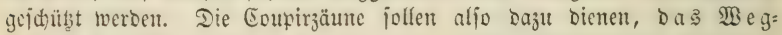
weben des Sandes juberbindern, nidt, ben treibenten Sanb auf: zujangen.

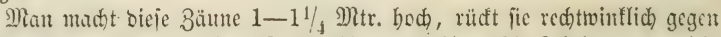
Den berrichenten Mintojtrid) auf ber Ebene 80 bis 100 Ed)ritte, an nidjt übor 10 Grab geneigtent Jläden 50 bis 80 Edrritte, bei 15 Grab Elevation 30 bis 50 Edritte, an nod) iteileren Şängen 10 bis 20 Edritte fraralled auseinanter, uno jud)t bic fleinen Bertiefungen ober (Einfehlen ebenfalls mit einem Baute ju untgeben. Bei Berfertigung joldjer Büute viro alle $2 / 3$ bis $3 / 4$ Mtr. cin $P$ fahl feft in bent Sano gejdlagen, hierauf merten

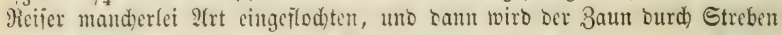

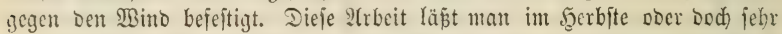
bulo im Irüljahr berridten, fo lange ber Gano nod) fendt ift. Sino bie 3äune fertig, fo läpt man, fobals wie möglid) im frübjabre, in oer

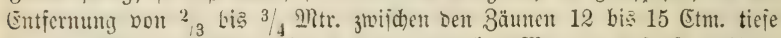
jurden pflügen, uno biejelben mit ser boppelten Mlenge bus fonit nötbigen abgeflügelten, erprobt guten Riefermjamens bejäen uno ben Samen mur 0,4 (Etm. Did mit Gano bebeden. Sit aud) biejes geidehen, io müffen bic bejamten Jurden mit frijden Riefernjtraud) - ber fdon parat fein muj - ingleide unto jo boredt werien, baj bie hoble Eeite ser gemöhnlich trumment 3meige nad) unten fommut, uno bá bie abgebrodecten ober ab: guthatencu Theile ser Sroeige bem gewöbnliden Minbitride entgegen licgent. isäre es aber möglid), bie ganize foläd)e zlwiid)en ben Coupirzäunen mit Sitefermineigen ju tedocden, io ift biés bejto befier. In biejent falle füngt 
man bie Defung an berienigen Eeite an, mobin ber șino ben Eant bisher trieb, legt poer ftect bie abgebautenen Theile ber 3weige iem MBinoitridese entgegen, uno läp̈t bie 3weige fo legen, Daj bie Epiben ber zweiten 3weig= reihe $1 / 3$ ㄱ. 2 tr. über bie abgehauenen Theile ber juerft bingelegten 3weig= reibe ïbergreift. Eollte bie Ganofläd)e febr abjdüfilig uno zu befürdyten

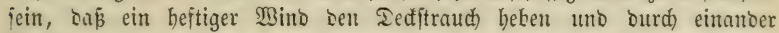
merfen würbe, io läß̄t man lange Stangen über ben Straud̆ rechttwinflid legen uno bieje rermittelit Şaden befejtigen.

3ur Bedecung cines Porgens, wenn mur bie Saatfurden eine Bebectung erbalten follen, fino 8 bis 10 jweijpämtige Jubren Dectreifig riöthig; joll aber bie ganze flläde badjiegelförmig bebectit werben, io erforbert Diejes 20 bis 25 ร̌uhrent.

Die Riefermiaten serathen bei folcher Bebanolung, uno wenn ser Sommer nidgt allzu trocen ift, oft portrefilid) uno merben in wenigen

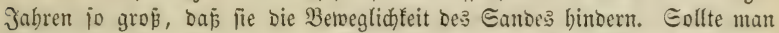
ater nad) einigen Jabren, wo bie aufgelegten 3weige bie Mabeln verloren Gaben, benterfen, baj die Riefermflanzen vom Sano bedecft werten ober Durd) ben Sonnenbrano litien, fo mus über ben bürren Decfiftraud) nod) cine Icid)te Bedectung mit frifchen Bweigen vorgenommen werben.

Auj bieje 2Art fant man bie loderiten Sandidgollen mit Siefern in Bejtano bringen, oen flugfano immer feithalten, uno bon folden Gano:

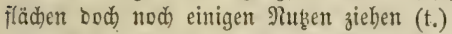

Diejes fint bie bei ber ioritwirthidaft im Groben anmenobaren S3or:

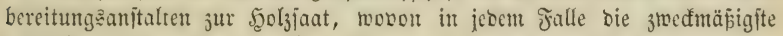
gemählt werben muई, wie id̆ im folgenten fapitel jeigen werbe.

\section{Siefentes Sapitel.}

lleber bie Bortgcile und Radjecile bez bidten ober weniger Diduten ธäen?.

2elle Şoljfulturen fino mit Sojten verfnüpft, uno die Sioften finb um io viel gröper, je bidster man bie Rulturen madjen läpt. Daher ift bic Jrage: wie bidt man iäen un bflanzen mülfe, um ben be=

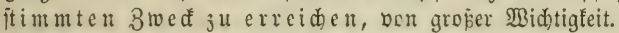

Das sidute. Säen und Pflanzen hat jwar, wenn es nidbt über= trieben ift, auf cen fünftigen ફgolyertrag feinen nachtbeiligen Einflub̆,

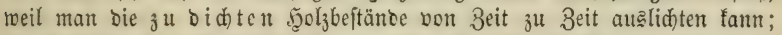

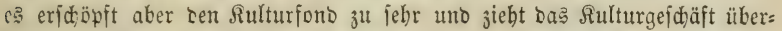
baunt зu fehr in bie Sänge. Daburd) geht oft mehr Zumadbs verloren, al: man butrd bas febr bidhte Säen uno \$ilanjen zu erlangen bofft.

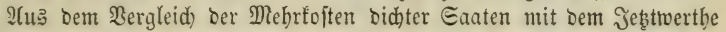

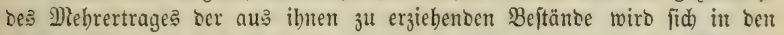
meijten fällen ergeben, daj bie Eaaten, meldhe bidhter als $11 /$ s $M$ tr. ge= maht werben, eine unnübe bielo: uno Eamenveridtwentoung find. Nur in Dom falle famt ę nöthig jein, bie Eaaten bid,ter ju machen, went magerer Boben der Ennne ftarf ausgejesct ift, uno recht kalo mit jungem Sonlze

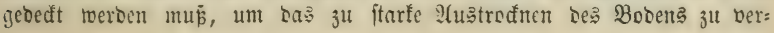


binbern. In fold)en fällen müjien bie Gaatitreifen uno Eaatpläţe $2 / 3$ bi 1 Mtr. entfernt angebradst merben. Eonit aber wäble man immer bie Ent= fermutg bon $1 \frac{1}{3}$ uno, wenn die $\mathfrak{K} u l t u r f$ ften fehr gering feiu follen, von $1^{2} / 3$ Mitr. Man erjpart sa ourd, uno went man bie Eaat: ftreifen id) mal uno bie Eaatpläb̧e fleiu mad)t, unglaublid) viel Gamen uno belo, wie man joldes aus ber Iabelle B erfehen fann. Ja, es foumen

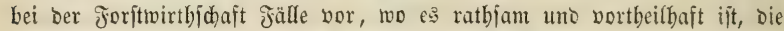
Saatfitreifen uno Saatplätze nod) weiter als $1 \frac{2}{3}$ Mtr. entfernt antzubringen,

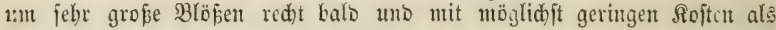
Walb wieber nutzbar zu maden. Ş̉ babe biejen, beim Jorftmejen äujerft widhtigun Begenftano in einer bejonteren Gdrift, unter bem Iitel:

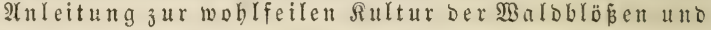
zur Berednug bes bazu erforberliden Roftenauf: toandes,

abgehanbelt, worauf idj ben Sefer berweife, Da biejer Gegenftano bier nid)t fo weitläufig vorgetragen werben fann.

\section{Dedifes sanpitel.}

Bon der Szorzjamenaugiant jerbjt.

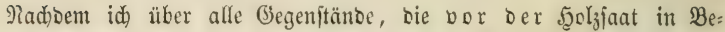
trad)tung fommen, bas ?iotbige gejagt babe, will id nut aud zeigen, wie bie Saat felbit veranftaltet inerben muß̧. (Ebe id) aber für jebe einzelne

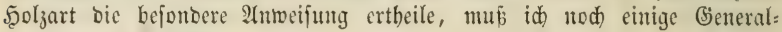
regeln vorausjodiden.

\section{Erite Bencrafregel.}

Benn eine beträdtlide gläd) bejäet werben foll, fo theile man bie: felbe vorher in mebrere, aljo in fleinere Theile $a b$, uno in eben fo viele Theile bringe man and) bie zur $\mathfrak{2}$ (ujaat beftimmte Santenmenge. Daourd)

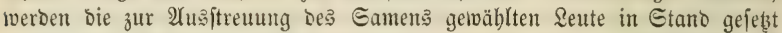

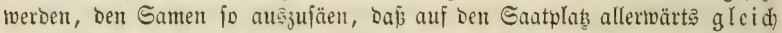
viel Samen zu liegen fommt. Beobad)tet ntan bieje \$orfidst nicht, fo wirb

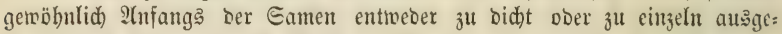
ftreut, uno erft gegen Das Ente ber Gant, ment nämlid bie nod) zu bi: fäento gläd)e uno Der Gamentorrath) fleiner gemorben fint, uno ibr Ber: bältnif zu cinanoer befier beurtheilt werden faun, bemerft man ben febler. Finoet mun Der 2 Uuștrener, baf er nidht auslangen werbe, fo ftreut er von nun an ben Samen einzelner; fielgt er-aber, baj er übrig behalten werbe, fo ftreut er ihn bidter au als vorber. In jebem Jall gibt bief́s aber einen ungleiden Beitano.

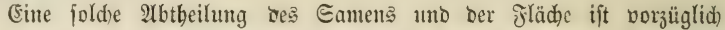
nöthig, wemn Gaaten ftreifen: ober plaţmeife gemad)t werben. Eoll aber eine fläh)e überall befäet werben, uno wollte man bie vorbin empfoblene 2(btheilung Der Fläđ)e uno Des darauf beftiminten Gamens in fleinere Fartien nid)t madhen, fo theile man wentigitens ben Samen in zwei gleide Theile, uno lafie mit ber erften şälfte ban ganzen Plaß̧ ber \&änge nad), 
unb nit ber anbern Şälfte in bie $Q$ uere befäen. Reidt bum bei ber erften Ueberfaut ber Gamen nicht, fo fam von bem Dorrath jugejebet uno Dir Eamen bei ber Uekerjat in bie Duere etmas einzelner auझgeftrent werben; bleibt bei ber eriten Ueberjaat aber übrig, fo läp̧t man ibı bei

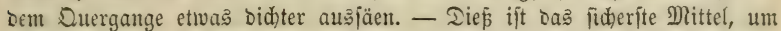

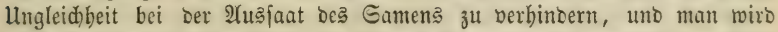
Durđ) Befolgung biejer. Regel bei fleinen Eamen, bie man auf ber Erbe nidat bemerfen fautu, audid nidst Gefabr laufen, baj fadmale Etreifen viel= leidht gar niḑ̧t befäet werben. Eollte dieß beim Uebergang in bie Ränge wirflid) gejdeben fein, fo befommt ein joldjer Etreifen bod beim Hebergang in bie Suere bie halke Gaat, bie oit ichon binreidht, um eine शadjaat entbebrlid zu maden.

\section{3tweite GicueraIreger.}

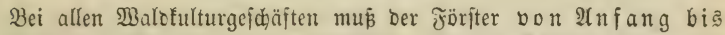
our völligen Beendigung yegentwärtig fein unb Adhtung geben, baí

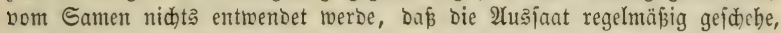
uno bas bie Bebecung beflelben uno überhaupt alle Dperationen volltommen gut gemadt werben. Der Förfter foll immer bie leşte \$erjon fein, bie ben

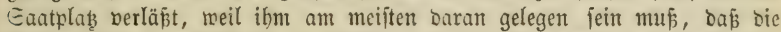
Eaat geräth. - Berjäumt ein F̈orfter, bie ftrengite 2 uffid)t bei ben Gaaten

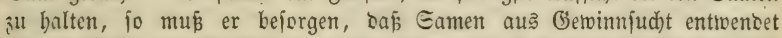

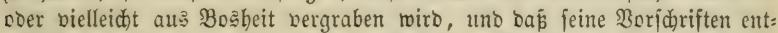
weber aus Seidftinn ober aus böjem Millen uno Edabenfreube jebr unvoll= ftänbig ober gar nidht befolgt reerben.

Mir funo bergleiden Fälle befannt, uno id empfeble baber nodjmals hei Malofulturen äuperft vorfid)tig zu fein, weil biejenigen Menfden, bie mun 3u bergleiden $\mathfrak{A}$ (rbeiten gebrauden mup, jebr oft redt berzlid) wünjden, ba Die ganze Saat verberben möge.

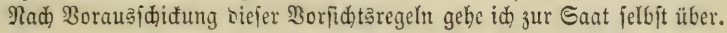

\section{A. Uou Delt reitten Saaten. ${ }^{1}$}

Bei Der Eidjeljaat jomohl, wie bei ser Gaat bes Buchenjamens wiro

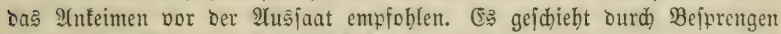
Des auf Dem Boden in fladhen Edidten ausgebreiteten Gamens mit weidhem

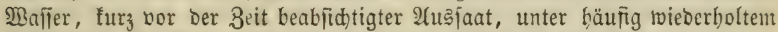
Umitchen uno Wieberanfeudten fo lange, bis bie meipen Reimipiben aus Den Gamenförnem berborbreden, worauf ber Same (ridtiger: Die Jrüdte)

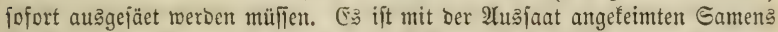
Der Bortheil verbunden, Dấ Derielbe viel fürzere Beit im Booen liegt, Daber

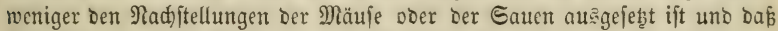

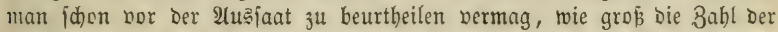

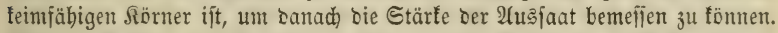

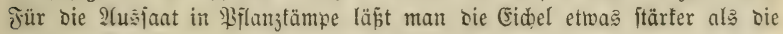
geftreut wirto. 
Budfeter unt io lang anteimen, baj man oen Seim abbreden fann. (Es miro baburd die Entwidełung der Ffabltwurzel aufgeboben und eine reide Entwičelung von Seitenwurzeln bergeftellt, bie in ber Sberididąt bes Bocens verbleiben, uno eine bas Umpflanzen jebr begünftigenbe $\mathfrak{B u}_{2}$ elbilsung zur Jolge haben. 2Aud bie ein Jabr über liegenten Eämereien, ว. B. Der Şail=

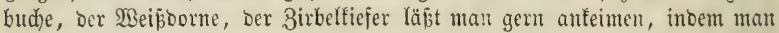
fie, mit Gano untermengt, einen Fuई tief unter bie Bobenoberfläd)e vergtäbt unb bis zur Reimung liegen läpt. Der janbige Boden nußs aber febr lodéer utto mur mäß̈ig feudht jein, oa fonjt leidst Stodung bes Gamens eintritt.

\section{Saat ber (Eideln.}

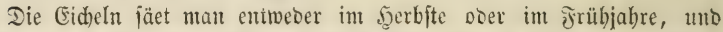
auf ben $1 / 4$ şettar jino bei der Bolljaat 4488 Pfuno erforberlich. Siehe Seite 146.

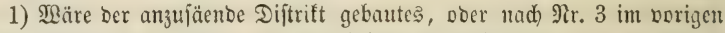

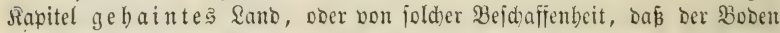

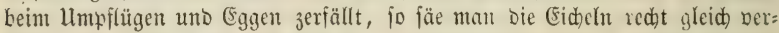
theilt aus, laije bann Don Diftrift io fobmalfurdhig mo fo wentg tief mic möglich umpflügen, uno nadher frcużweije jo lange übereggen, bis bie Erte, fo biel fict's thun Yäp̆t, in fleine Broden zerrifien ift.

Benn man 2(rbeiter bat, alf bie man fid) bollfommen berlafien barf, io fam man bie (Eid)eln auch binter bem Bfluge einftreuen laffen. Man wiro badurd) aber an 9 (rbeitslohn nid)ts gewinnen, uno bie (Slleid)= heit ber Ifusjant weniger leid)t bewirten, als wenn man bie Eicheln vor ber Umaderung ausiftreuen läp̧ uno nadjichen fann, ob bie (Sid)eln gleid) vertheilt ïno. Bei bermijhten Saaten bingegen ift bas Einjtrenen ber Eidheln binter Dem Pfluge amwenbbar, bejonders wenn nid)t ber ganze Diftrift

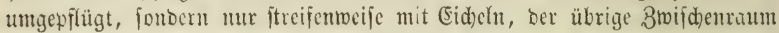
aber mit einer Solzart in Bejtand gebrad)t werben joll, beren Eamen in frifd) umgepflügtes \&ano nicht gejäet werben barf.

Bill man Roggen oder Winterforn ${ }^{1}$ mit ausjäen, woburd), we nn Der Boden gut ift, ein beträdthlider Sortheil entiftehen fan, fo Darf

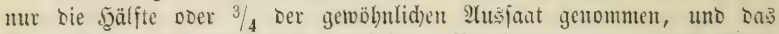
Sorn mup im Sommter mit forgältiger Berjh)onung Der jungen Eichen abgeidnitten merben. - Eine jolde Mitiaat des Roggens fidadet Den jungen (sid)en nid)t, uno nüb̧t oft burd) bie Bejdattung.

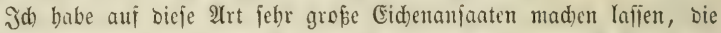
vortrefflid) gelungen finto. - Meiftens wurbe Der Boien nad) 9it. 3 im vorigen Sapitel gehaint, unt nad)her mit Eidgeln uno 9loggen bejamt. Jn frudtarment Gegentent veriteben fid bie Seute jefre gern Dazu, Den Boden unentgeltlich zu baden uto zu bremen, wenn man ihnen erlaubt, Daj

1 Bei ciner bor einigen jabren in unjerem (Gime ausgejührten freijant bon (Eid)en

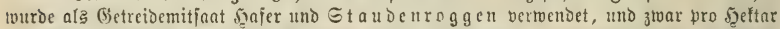

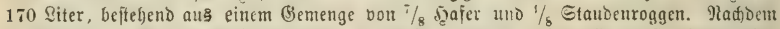
in Gommer nad) der frrübjahrs̄ausjaat der 5ुaftr geerntet, blicb alle 15 (Eentimeter eine

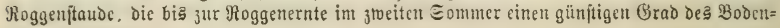
id)ulzes betvi:ften. 


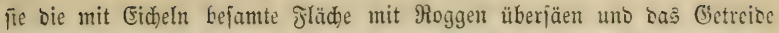
ernten bürfen. Eie fammelten mir fogar bie (Eidjeln unentgeltlid), uno ver: ridyteten aud alle übrigen mit ber Rultur verbunoenen $\mathscr{A}$ rbeiten gegen ben

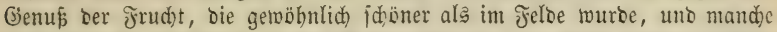

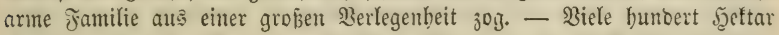
babe id) auf foldbe 21rt bejamen laijen, ohne da Das Mindefte fojtete.

Scat man bie Stbfidt, Den Rulturort mur it re if en we eife mit Eiddeln ju bejäen, um Eamen unb Roften zu fparen, fo läpit man in beliebiger Entfernung zwei ober brei Furchen bid)t neben einanber fflügen uno bie Eidjeln hinter bem Pfluge fo einftreuen, daj auf ben Meter einer jeben Jurche 15 bis 20 Eidjeln zu liegent fommen. In die leţte offen bleibente Jurd)e fann bann ein anberer Eamen, Der weniger Erobebecung erforbert, gejäet uno burd) eiferne Şarfen mit Errbe, fo viel nöthig ift, bebefft mercen.

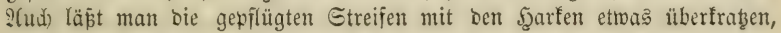
Samit nur bie gröpten Erböhungen ber Furden etras abgeftofent werben.

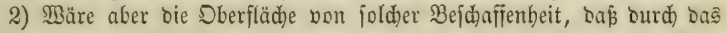
Utmpflügen groje Sdhollen entftehen, bie fid) burdh bie Egge nicht flein

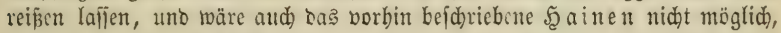
fo mus ber Eaatplaz itreifentoeife ober platgeife verwumbet un

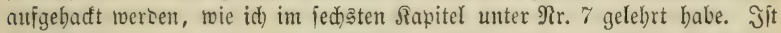
Diej gejweben, fo jäet man bie (Fidjeln, wowon man in biefem Jalle bei weitem weniger, uno nur bie in ber Tabelle B beftimmte Menge braudbt, in bie Streifen oder Pläże, unb becectt fie mit ber zur linten Eeite lie=

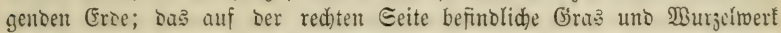
aber läpt man neben liegen uno berfaulen, weil $\mathbf{e}$ fonjt wieber antwadjen unb ben jungen Eidjen in ber Folge fojaben tönnte.

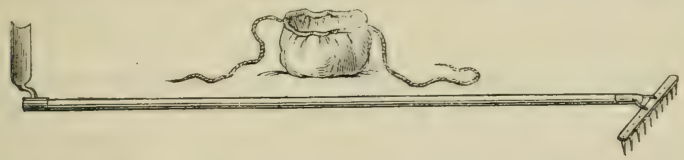

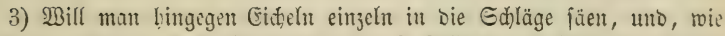
man fagt, unter= ober einfprengen, fo ftellt man mebrere mit breiten Sacfen uno einem angebängten Beutel ober einter Sdjürze boll Eidheln ver: iehene 2rbeiter in ber Entfernung, wie man wünjकt, baf bie (Eid)en auf= feimen mödten, in cine Reibe. Şierauf läpt man jeden eine fleine Jlädhe yon ungefähr 15 bis 20 Ctm. im Duabrat 5 bis 6 Ctm. tief auflodern, 3 bis 4 Cideln bineinmerfen, uno bie fllar zerbafte Eroe twieder barauf

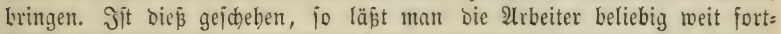
rücen uno bie vorhin bejdriebene Speration io lange wieberbolen, bis ber ganje Edblag mit (Eid)eln eingefprengt ift. Wäre aber bie Dberflädhe fo

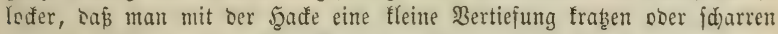
tum, fo lafle man in bieje Bertiefung 2 ober 3 Gidjeln merfen uno bie Erte sarüber her ftopen. Beise Berridutungen gehen jebr fontl won Etatten, 
uno man fann mit wenigen (Eid)efn ober aud anberen Eamen grokie Strecfen burdjprengen.

Doer man fted)e mit einem fpibigen Inftrumente fleine, 6 bis $8 \mathrm{ctm}$. tieje Södter in bie Eroe, twerfe in jebes cine (Eidgel, uno fülle bieje عöder mit Crre, die man mit bem Juß zujammen jdart, wieber boll. ${ }^{1}$

\section{Saat ber Budeln.}

Die Butheliaat fam entweder im Şerbite ober im Frübjabre vor:

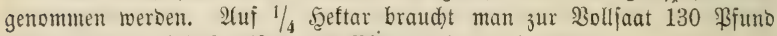
guten Samen, bei Streifen und \$läben aber biel tweniger.

Bei ber Gaut jelbjt gebt man zu $2 B e r f$, wie bei ber eben bejdritbenten (Eid)elfaat, nur mit bem Unteridjies, baf ntan, wo gepflïgt werben fam, Den Booct zuer it umprlügen, bann bie Buddel ausftretten uno nad) her bie Jlädhe in bie Quere ftarf übereggen läß̆t, Eanit bie \$Buddeln nid)t tiefer al’

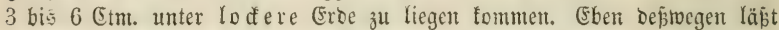
man aud für bie Buchelfaat bie Streifen uno Pläbe nur fo tief auflofern, Dá bie fo eben beftimmte Bebecfung möglich wiro.

Die ftreifonweife ober flab̧reife Saat und bie Einfprengung werben eben jo gemadist, wie bei Der (Eichelfaat gelebrt worden ift.

Ia bic Buche, bejonters fo lang fie nod) bie Eamenlappen an fidt) trägt, jowie überbaupt in Den 5 bis 6 erften \&ebensiahren gegen jroit empfinolich ift, uno aud) ourd) żu ftarfe Eonnentibe oft Noth leioet, io

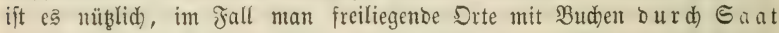
fultiviren will, 4 bis 5 Jabre vorber cinen folden Blab̧ in ber Entfer= mung von $1 \frac{1}{3} \mathfrak{M}$ tr. ftreifentweife mit Siefernjamen z̆l bejäen, uno wemn Die Riefern $1-1 \frac{1}{3} \mathfrak{M}$ tr. bod) fint, bie Budeln plaţweije oder fitreifen= meife Dazwifhen zu fäen. Dod barf man nidht verfäumen, bie Riefern in ber Jolge megzunebmen, ebe fie bie jungen Budjen bersänmten. Heber=

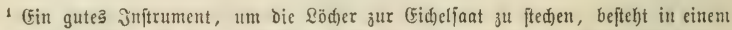
15 Centmtr. langen, am breiten Ende 5 Centmtr. Difen, unten aber fpiben verfiäblttu

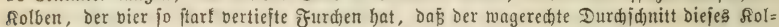
bens einem vierjtrablichten Sterne ähnlich jieht. Diejer fternförmige fpibe folben fteht mit einer 25 (entmtr. langen und 3 (Eentmtr. Diden eifernen Stange in Berbindung, ober ift vielmel)r ber unterfte Theil berjelben, und die Etange bat oben eine 15 (Eentmtr. lange Şülie, um cinen 6 Eentmtr. langen bölzernen Etiel, ber oben mit einem 30 Eentmtr. langen Duer=

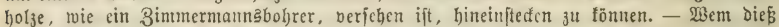

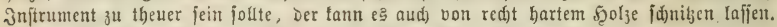

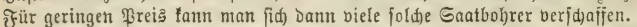

Wenn man mit biefem Jnftrumente in bic (Erbe ftid)t, und Den fternförmigen folben umbreht uno herausjjiel)t, fo entịteht daburd) ein mit loderer (Erbe jum Theil ausgefüflter

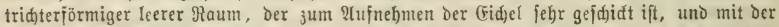

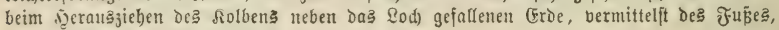
oöllig ausgefüllt toerden fant.

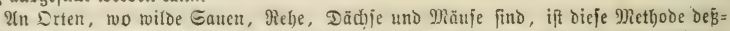

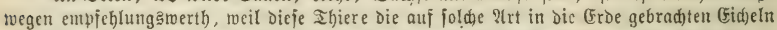
nidst fo leid)t finden, als wenn dicje Speration vermittelift Der Jjacfe gemad)t tworden ift.

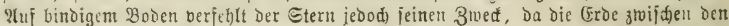

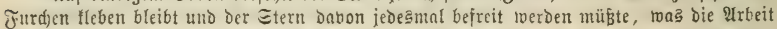

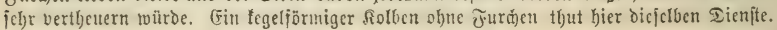


haupt aber bürfte es in einent jolden Jalle bejier jein, itatt of 23udje eime anbere ફ̧olygattung วิน wäblen.

\section{Saat beş ఏainbudenโamen.}

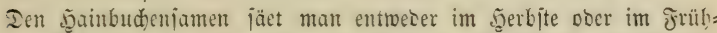

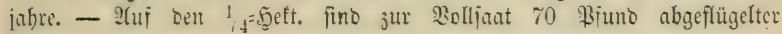
Eamen nöthig.

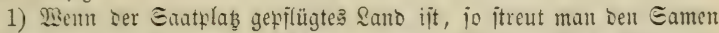

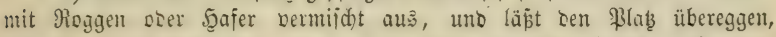

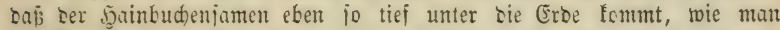

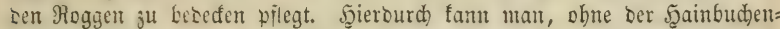
fultur ju ifuabon, einen juweilen nidht unwid)tigen ßortbeil bon ber Frud)t baben.

2) Wäre aber bie Sberfläde des Eatplaţe altę Baulano, oder ïberbaupt von ber Bejdafjenbeit, Daj ber Eamen vermitteljt einer eijernen Egge an bie Eroe gebracht werben tann, io iäe man Den abgeflüyelten Eamen aus uno laile die Sterfläd)e mebrmals freujweife übereggent. Jit

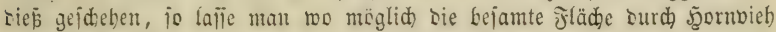
uno Edafe tüdtig jujammentreten, uno lege jie bann in Şege.

3) Eollte sie \$ermundung Des Bobins vermittelft ber Egge nidjt

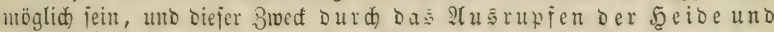
Des Dicoies erreidt werden fönnen, jo laile man bieje Speration madjen, itrue nadber Den Eamen aus, uno lajje Den Sautplab mit 5ृornvieh

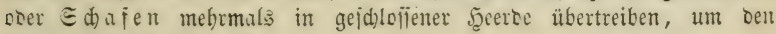
Samen baourdi beitreten zu laifien.

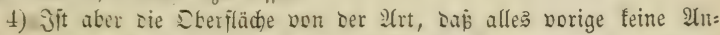
wenoung finben faum, io laije man biejelbe itreifen= ober plabtoeije

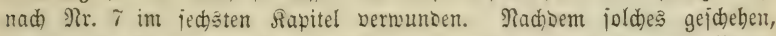
jäe man Den હanten auf bie etmas a uigeloferten Etreifen ober Bläb̧e, uno laije ibn vermittelit eijerner Meden soer bुarfen, wonou in jeocm joritrebiere menigitens 6 ober 12 Etüf auj berrichajtlide fiopten ande= id)afft merden uno immer norräthig fein jollten, 0,3-0,6 Etm. tief unter Die Erbe bringen.

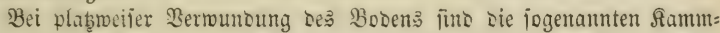

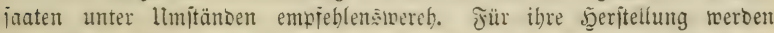
Die \$läke nad) Der Sonnenjeite hin etwas jtärfer vertieft, io dap jie

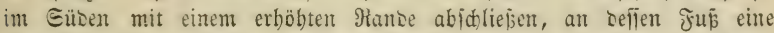

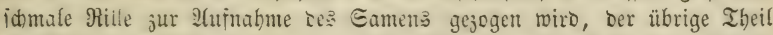

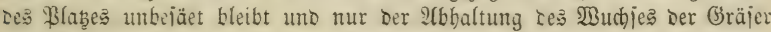
uno Unffränter bient. Die vertiefte Sage Der Eaatrille uno bie Eromano in Eüben, Die nötbigenfalls Durd) aujgebauten :(braum nod) erböht werben fann, iidfern oem Eamen einen böheren Jeuchtigleitägrad uno joübुen Die

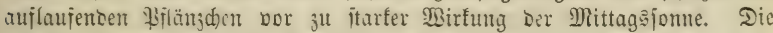

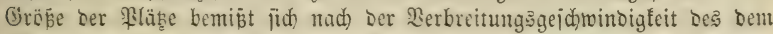

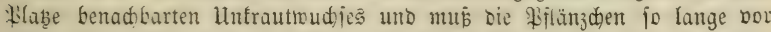

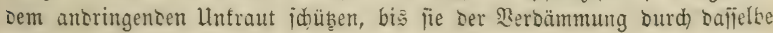
entwadjen fitto. $t$. 


\section{Gat des 2 bornfamen.}

Den 2 bornjamen fäet man entroder in ફgerbite oder im Jrübjabre. 24u ben Morgen fino zur Rolljat 94 Pfund Eamen erforberlich.

1) Jit ber Saatplabs erft frifd gepflügt, fo ftreut man bent Samen im Serbfte mit Roggen ober im Jrübjabre mit Scafer vermifd barauf, uno läst Die Dberflädhe mit einer Egge überzieben, Dafi der Eamen 1,3 Etmt.

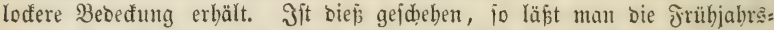
fiat aud nod) überwalzen, Damit bie (Erbe ctwas feftgebrüct wirb, um bie Jeudtigfeit befier zurüdbalten zu tönnen.

2) Bäre aber Der Boben fein frifdgepflügtes Sano, jo lafje man die Sberfläde ftreifen= ober platsweife nad) $\Re r .7$ bes fochsten fiapitels verwunben, die Eroe etroas auflodern, ben Gamen bineinjäen, uno ver: mitteljt eiferner Rechen 0,7-1,4 Ctm. biaf mit Erbe bebecten.

\section{Saat bes (5idenfamens.}

Der Sidenjamen fann in Serbjte ober Jrübjabre gejäet wersen.

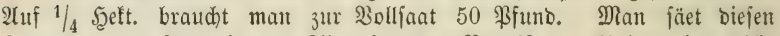
Gamen gerade jo, wie den Ahomjamen. Nur ift bas Ueberwalzen nidht nötbig, weil die \$flanzen meiftens erft im anbern Jabre erjobeinen, bis wobin fid) bie Eroe obnebin zujammengefest baben wirb. Dā bie Ejaden: faaten felten gelingen, wenn man bie $\mathfrak{B} f l a n z e n$ vom unfrat nid)t befreien fann, habe id im erften Jaupttbeile, bei ber Befdrei: bung biejer Solzart jobn bemertt. In Bud)en= ober (Fid)endunteljalägen,

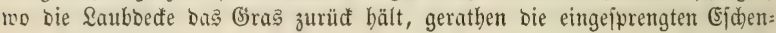
faaten am beften.

\section{Saat bes Ulmenjamenక.}

Den Ulmenjamen fäet man entweder im Juni, alşbalo nadj ber Einjammlung, oder im Jrübjabre. 2Auf $1 / 4$ Seft. fino zur Bolljaat 24 Bituo Eamen nötbig, weil barunter gewöhnlid viele untauglidye Rörner fino.

1) Jit Das Sand gepflügt oder gegraben, fo ftreut man Den Gamen Darauf, uno fudht ibn Durd Ueberjoleppung einer umgef ebrten Egge, in Slemen aber bermitteljt cines bölzernen Rechens, mit ber Eroe nur fo viel zu bebeden, Dafs man ben Gamen nidjt mebr fehen tann. Jit diế geideben, fo läpt man die Gaat überwalzen, im Rleinen aber leidht eintreten.

2) $\mathfrak{B a ̈ r}$ bingegen die Dberfläche fein gebautes Sano, fo muf fie

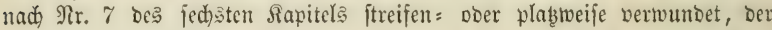
Eamen Darauf gejäet uno bermittelft einer eifermen Sुarfe mit Der Froe nur wenig bebedt werben.

\section{Saat des Erleniamens.}

Den Erlenjamen faun man im Serbjte ober im Ærübjabre aแsfäen.

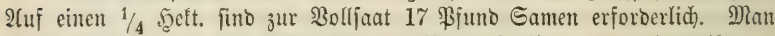
mad)t aber bic Gaaten getwöbnlid nad) $\mathfrak{x}$. 7 ftreifen = ober plastreife.

Die $\mathfrak{A}$ ज̧jaat jelbit gejdicht, wie joeben bei ber ulmenjaat gelebrt morben ift. 
abtrectnet uno int Minter oft bom froft geboben wirb. Man fam fich Daher mur auf fidwerem Boocn uno went bie Sberfläd) bis jum $\mathfrak{B}$ inter etwas mit Moos uno Gras bewäd) st - wie foldes in rauben Gegenden oft Der Jall ijt - einen glüfflidjen Erfolg von einer folden Gaat ber: iprechen. Heberbaut aber büte man fid jebr, jold)en Boben aufpflügen

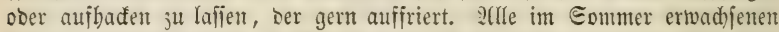
Piflanzen werben fonft im Binter vom frofte ausgejogen uno berborbent. Dicjes jäblidje $\mathfrak{A} u f f$ rieren bat man ba zu erwarten, mo bie erijte Erd: idide feidt ift uno aus leidter Stauberde beftebt, bie eine Thon= lage ober andere bindende Erbe unter fid bat. Bei Regen=

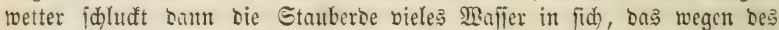
ju binbenden Untergrunbes, nidht weiter einbringen fann, fonbern meiftens lange in ber Etauberbe fich aufbalten mus. Fällt mun unter fold)en llm=

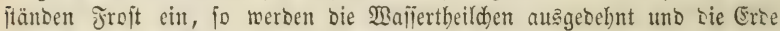

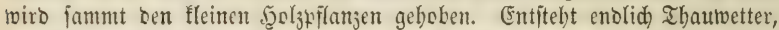
jo idmilyt natürliderweife bas Cis, ber Boben fintt in jeine frübere Sace

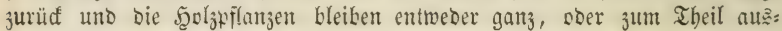
gezogen, auf ber Dberfläde liegen uno verberben.

2) Märe ber Boden mit Moos, bün ftebender Scaibe, fdivicligem Gras zc. betwadjen uno fo bejdaffen, baj fid Die Dberfläd) burd) eiferre Eggen soer Redan nermunoen läpt, jo jäe mant den Eamen aus, uno lafje Den Boben mit eifernen Eggen ober Rechen recht ftarf überfrałen, bamit

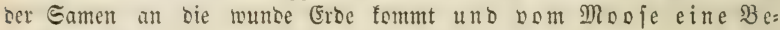
beđung erbält.

3) Sann baburd) aber feine Bebedung mit Nhoos betwirft werben, fo mú bie Dberfläche itreifen= ober plaţweife vermundet, bie Erbe 3-5 Etm. tief aufgelodert, Der Eamen buranf geftreut uno bermittelit cines eijertun நarfen $2 / 3-1 \frac{1}{3}$ Ctm. Did mit Der Eroe bebedt werber.

Die Menge bes zur ftreifen = ober plaß̧weijen Rultur erforberlidjen Santens fann man alts ber Tabelle B erjeben.

$2(m$ bejten gelingen bie Iannenfaaten, wenn Der Saatplats burd) Darauf ftchenbe Bäume nod) etras befdattet ift. ${ }^{1}$ Id babe baher, wem id) einent idjledten Saubholjbiftanto in einen Iannen = ober aud in einen Jidhtentwalo umformen wollte, ben Beftano jo viel wie möglid bunfel ftellen, Den Iannen = ober Jidftenjamen bineinfäen, uno bie noch mit Saub uno

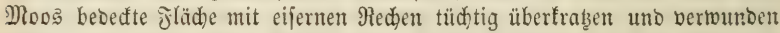
laffen. In einer folden Bejdattung geht Der Eamen gewöhnlich fdön auf, uno bie jungen Pflanjen erbalten fich vortrefflich, wenn man nadj 2 ober

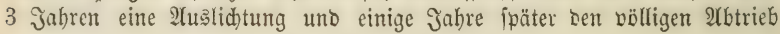
Des \&aubbolzes vornebmen läpt.

\section{Sat bes Fidtenfamens.}

Den Jidjtenfamen jäe man im Frübjabre, fobalo nur ber Ednee ab: gegangen ift, benn bie frühen Eaaten baben fajt immer ben Borjug vor

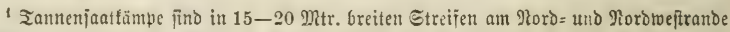

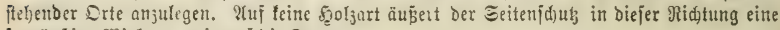
jo günfitige $\mathfrak{B}$ irfung, twie auf bie Zanne. 
Den ipäter gemadften. Der Fidjtemiamen fann aber audh noch bis Ento Mai, uns, wie id jofon oben im vierten fapitel gejeigt hake, jelbft im Seerbîte gejäet werben.

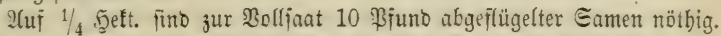

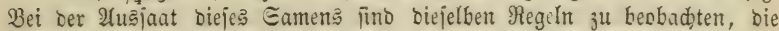

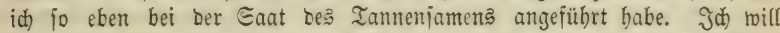
fie baber nidht mieberbolen, jonoern nur noch bemerfen, baj ber Fiddten= jamen $1 / 3-2 / 3$ Etm. bid mit Erbe bedect jein muj̃. Huf jteinigent Boben, voer no bie Etöde nidht gerobet twerben, läp̆t man bie Saatpläbchen zum Theil nahe an grope Eteine, ober an bie Etöfe, unb zroar auf bie Minter= jeite berjelben maden, bamit bie jungen Jidten baburdh bejdattet merben uno bejto belïer wadjen. 2An iteilen Bergieiten läp̈t man bie Eaatpläb̨den Treppenitujen äbnlich baden, bamit ber Eamen kei jtartem Regen nicht meggeidivemmt merbe.

Ia bie jungen Jidften ben abmedielnien Edatten einige Jabre lang jebr lieben, fo gerathen sie ôidftenjanten vorjüglid) gut, menn man jolche Saubholjbeitänbe, bie man in Fidhtentmalo umwandeln will, ekenjo wie id bei ber Iamnenfaat bejdrieben babe, in einen etwas lidten Bejanunges: id)lag jtellt, ben Jidjtenjamen außjtreut uno mit eijernen Sarfen unter bas হaub uno Moos ober in bie Croe bringen läp̄t. Die Echattenbäume müijen aber nad) 2 ober 3 Jabren gelichtet uno bie jungen Fidften nach uno nadh gang ints Freie gebradt werben, ehe ifnen surd bas Wegnebmen Der Edattenbäume gejhabet werben fann.

\section{Saat des Rieferniamens.}

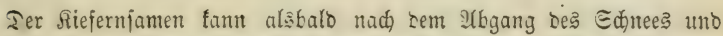
bis zu Enoe bes Maimonats gejäet werben. Iod, haben bie früh gemachten Saaten fajt immer aujfallente $\mathfrak{B}_{\mathrm{or}}$ üge. Eelbjt bie im Şerbjte gemaditen Siefernjanten gelingen ficher, skgleidh fie im Grobien nur mit porjäbrigen Samen ausggefübrt merben fönnen.

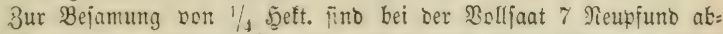
gejlügelter Eamen nötbig. Mant fann aber audi) einige Bintube meniger nehmen, wenn ber Gamen vorjüglich gut jein jollte uno bafür geiorgt viro, baj ber Gamen bie gehörige Bebecfung erhält.

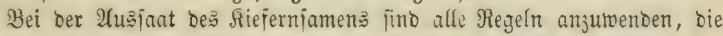

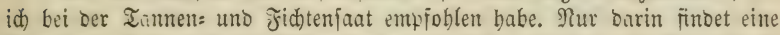
Q(u

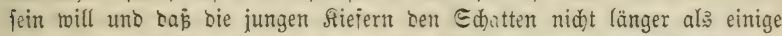
Jabre ertragen fönnen. Wenn man aljo Riefernjamen in einen mit Dber= holz nod) beftambenen Echlag gejäet hat, jo mus man nach Ublauf einiger Jabre alle ₹äume rognebmen uno bie jungen Riefern ganj ing Freie

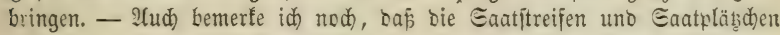

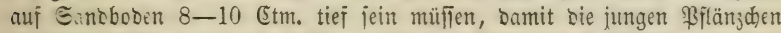
im Edub jteben, von bent oft baruker berwachjenten Ģraje nidjt ju jtarf

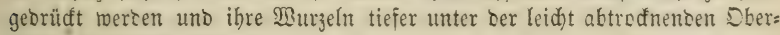
fläche austreiben fönner.

Zfuper Der Eaat mit auşgeflengtem Eamen werten im \$reupijocn 
febr viele uno faft bie meiften Sieferntulturen mit Siefernzapfen ober wie man fie bier nemt, $\mathscr{R}$ iefernäpfeln gemad)t. Man ftreut im früb: jahre bie Riefernzapfen in bie mit ber Şadfe Doer bem Pfluge gemadten Rinnen ober \$läbe uno läßt nad)her, fobalo bie 3apfen burd bie Somnen= wärme aufgejprungent fino, bicjelben ohne 9 Uuffidub, bernittelit ftumpfer Bejen ober, weldes beffer ift, bermittelft eijerner Şarfen ober Rechen

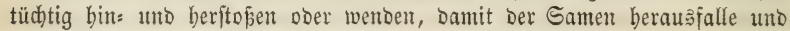
mit 'ber Erbe vermengt uno etwas bebed twerbe.

Getwöbnlich) ftreut man bei ber Bolljaat 10 bis 12 Berliner Ed)effel, à 55 Siter, vermittelft einer 2 Burfichaufel auf $1 / 4$ Seft. aus, welches auf ben Normalmorgen ungefäbr 15 Sdheffel beträgt. Dhan fann aber aud mit $2 / 3$

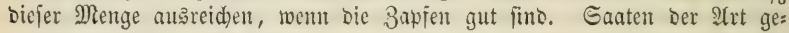
rathen vorzüglich, went man fie alf Sand vornimmt, bas im Jabre vor: Ker nod) mit frudyt beftellt war. Man läjst bann bie Zapfen balo im Frübjabre redgt egal ausftreuen uno fobalo fie ourd bie Somtentibe auf: geplabst fint, bermittelft einer eifernen Egge, an bie man cinen leidten Dorn: bujd) ober fonft einen leidten Straud bindet, frenzweife übereggen, bamit

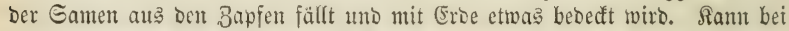
fortbanternom Somtenjohein Dieß übereggen einige Tage nadher wieberbolt werben, fo ift e⿱乛龰 befto befier uno es fällt baburd) aller Samen auts ben Bayfen.

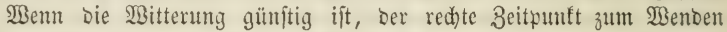
nid)t verfäunt unt bem ausgefallenten Eament $b u r d$ bie Şarfe etwas Bebecfung nit Eroe weridaffi wiro, fo gerathen Dergleidjent Gaten vor: treffliç). Bem aber im Jrühjabr lang anbaltendes Regenwetter einfält, weld)es für bie mit ausgeflengtem Sament gemad)ten Rulturen febr günjtig ift, fo mißlingen bie Zapfenfaten gewöhnlid, weil fid) Die Bapfen mur

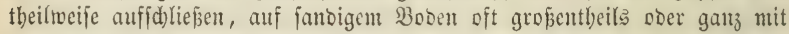
Sant bebedt twerben ober aud in bie geöffneten Sduppen fo viel Gand gejdwemmt wirb, baf baburd) ber Game am Ifusfallen verbinbert wirb.

Saat bes Serdenbaumfamen?.

Der Serdienjamen faum vom Abgang Deß Sd)nees au bis zu Enoe Mai uno felbjt im Şerbfte gejäet werbert. Die red)t balo im Jrübjabre gemadten Saaten baben getwöbnlid) ben \$orz̧ug.

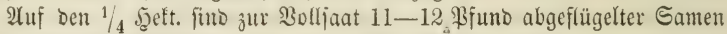
nöthig, weil er gewöbullid biele untauglidgen Rörner entbält.

Die 2Alsjaat felbjt wiro gemad)t, wie bei ber Ricfermjaat gelebrt worben ift. Da aber biejer Gamen nod) gur Beit etwas theuer ift, fo fann man woblfeiler zum 3 wedfe tommen, wern man 3 bis 4 Pfun Rerdenfamen uno 8 Bfuno Siejerjamen wohl untereinander mifot uno aus: fäet. Şierburd) entfftehen fo viele Serd)entflanjen, daj gegen bą 60jäbrige

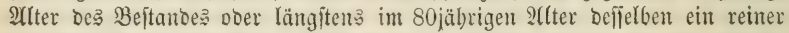
Serdhentwald Dajtehen wirb, went man bie Serchen, bie in Der Jugeno ge: wöbnlid) Dominiren, bei ben Durdfforjtungen borzüglid) begünftigt.

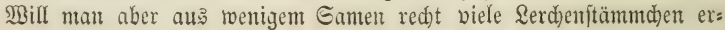

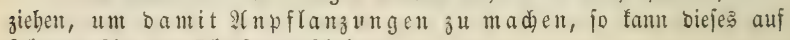
folgenoe $\mathfrak{A}$ rt am fideriten gejdeben. 


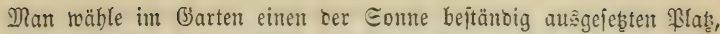
Der red)t guten Boben bat. Diejen lafie man umgraben uno von allen Unfrautmurzeln forgfältig reinigen. Sgierauf theile man ibn in gewöbn= licje Sänber von 1,6 Mtr. Breite ab. Sit biés geidheben, io zeidne man 5 gleidh weit bon einanber entfernte Etreifen auf jebes Sand, trete bieje Streifen etroas feft uno bejäe fie ftarf mit Serdenjamen. ${ }^{1}$ Diejen bebect man mun 0,4 Etnt. biä mit locferer Erbe unb oben barauf lege man eine Düne Decfe von verrupftem Moos. Eollte es nöthig jein, fo begiejse man bie Gaat mit geftandentem ober nid)t zul faltem $\mathfrak{M a f f e r}$, befreie fie von Unfraut, fobalo mur bie unb ba etwas zum Boridbein fommt uno berecfe bie jungen Pflanzen im Seerbite vor eintretenbem Jrojte mit Saub. Edjon im nächiten Frübjaḅr ober Şerbite nebme man bie fleinen Bflänzdyen heraus, jetse fie auf gegrabenes gutes santo einten Juf weit auseinanber uno giefe fie nach bem (Finjeben aläbuld an. Diefes Begiepen mieberbole man, jo oft es nötbig ift, und halte bie Bflanjung boult

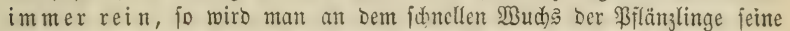
Jreube fehen uno ans einer geringen Menge Samens in 3 ober 4 Jabrent eine unglaublide $\mathfrak{2} \mathfrak{n}$ zabl vortrefflicher Serchenpflänjlinge befiţen.

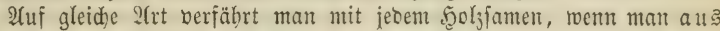
toenig Samen möglidjt viele Bilänjlinge erjiehen will.

Durd) Die 2(nweijung jur 2tuפjaat ber Gamen von ben in biejem $\Re a=$

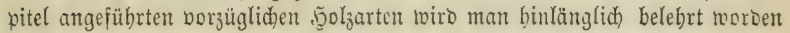

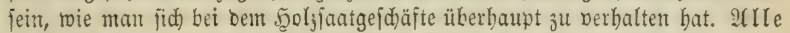

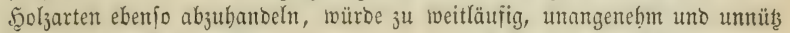

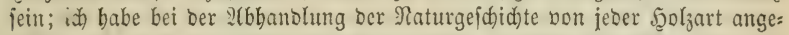

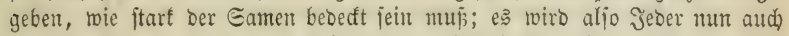

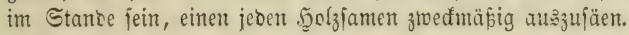

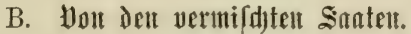

AU

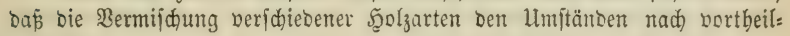
bait ift.

Man unternimmt eine foldye Bermifidung entweber

1) $u m$ jie für immer beizubebalten, ober

2) um ourd bie beigenifde frolzart früber eine $B e=$ $\mathfrak{n} \mathfrak{u} u \mathfrak{n g}$ z $u$ erfalten, Doer

3) um mit moblfeilem Samen den nöthigen Sdlúp jtwi= iden einer 5olzart, woodn der Samen theuer ober felten ift, zu betwirfen ober

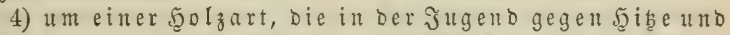
Sälte empfinolid) ift, Gdubz zu veridafien, bis jie biefen nid t mebr $n$ öthig hat.

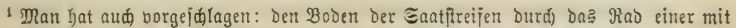
Eteinen bejawerten Rarre fejtorüden, ober Den Boden für bie Eant gar nidjt auflodern, fondern in ben Saatitreifen nur abplaggen zu lajien. 
Jm eriten J̃alle, wo die Bermifadung für immer bleiben foll, mup mon bie Mall treffen, oaj Solzarten mit tieforingenben

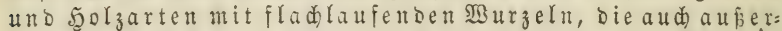
Dem gleide Ednellwädigfeit baben uno einerlei $B$ eband: lungerforbern, untereinander vermengt werben. Wie z. 3 .

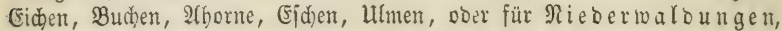

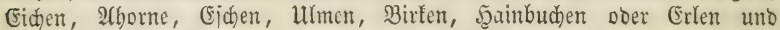

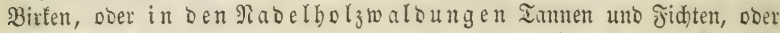
Siefern uno Serdjen, soer in ben vermifdten $\& a \mathfrak{a}=$ uno $\Re a b e l=$ walbungen Buben unb Fiditen Doer Tamen.

Jm ziveiten Jalle, wo burd) bie beigemif de te folzart nur früher eine Brijhennubung entiteben joll, ijt bie Birle, wegen ber

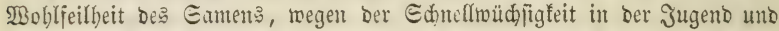
wegen ber Eigenjafaft, Daf fie wentiger als jebe andere Şoljart verbämmt, befonters bortbeilfaft. Dod) Darf man fie nidft unter Fichten uno Iamen fäen, weil fie siefe şolzarten zu balo überwäd)ât, uno weil fie aud mit ibren fdwanfen 2 eften bie (Sipfel berielben peitid)t uno bejdäbigt. 1 Heber: baupt aber mup man Den von Der Birfe als 3wijhenbenuşung verlangten 3ortheil nidjt zu weit treiben, uno siefe Soljart meber ju bidt aufwachjen, noc) zu groj ober alt merbent lafien, weil fie fomft an ber eoleren Syoljz= gattung mebr fdrobet, als fie burd) fich jelbjt nübst; ob fie gleid, wenn

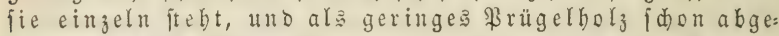

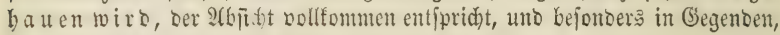
wo man viele fapreife braudbt, jebr müblich wiro.

Jm oritten Jalle, wo man nämlid mit wohlfeilerem Samen

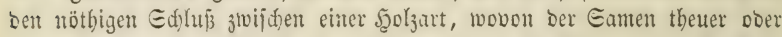

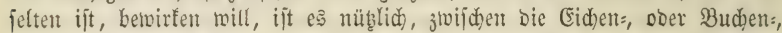

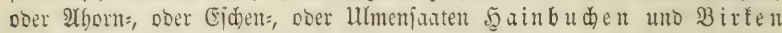
zu fäen, uno jie in ber jolge nad) uno nad) beraušzhauen; bie Serchen=

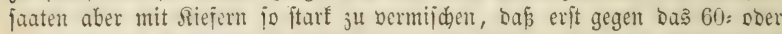
Das S0jährige ?f(ter Der Serchenbeftuno rein riro, madjoem bie Siefern als 3mifdenmukung ausgehauen morben fint.

Jm vierten Jalle bingegen, wo ourd) bie beigemijate Sgotzart

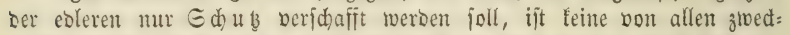

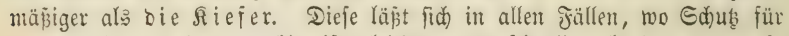

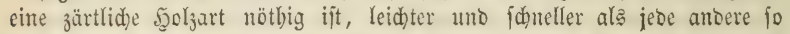

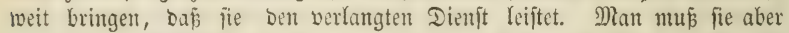
unter folden Umitänoen auch mur als Daڤ, was fie fein joll, nämlich als

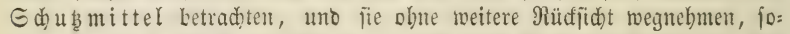
balo fie biejen Dienft geleiftet bat. Säpt man fie länger fteben uno will

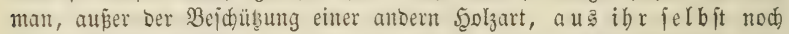

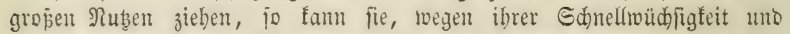
Berbämmung, in ber Folge eben jo nudtheilig meroen, als fie vorber nüblich mar.

Sorzüglidie Dienjte leijtet bic Riefer, menn man fie unter Şidten

1 Sein Ammenmäbrden, wie \$feil bebauptet! D. Sุ. 


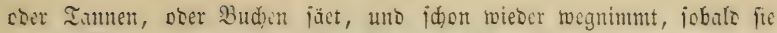
$1 / 2-2$ Mtr. bod gemorien ift. $\Re \circ$ d) befier ijt es aber, wem man

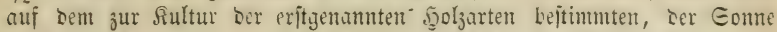
ftart ausgepthten Orte, 5 bi 6 Jabre borber, in 4 füpiger Entfernung

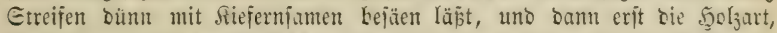

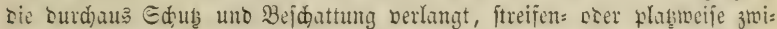
iden bie jungen Riefern jät poer fiflangt. - Sommen bie jungen Riefern mit Den Buben, Iannen uno Jidten zugleid) bervor, fo madjen bie

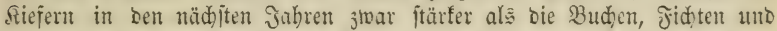

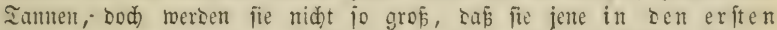

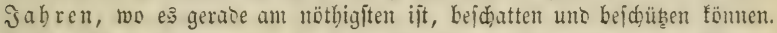

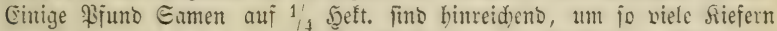
su erbalten, als man zul einer jolden Bejdattung uno Bejdüţung nötbig bat,

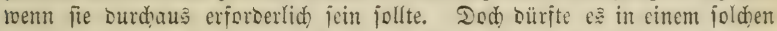

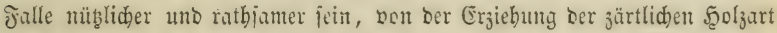
abjultehen, uno ben ganzen Iiftrift jogleich oollitünoig mit אiefern in Beftant zu bringen, wemt bie Umitänbe bief erlauben.

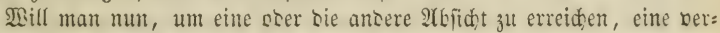
mijote Syoljiant madjen, is befolge man nut bie vorbin gegibenten Eant= regeln, uno bringe benjenigen Eamen, ter bie ftärfjte Bebeçung baben muj, 3uerjt, uno benjenigen, welder fie am wenigiten erträgt, 3 ule Eroe. 3. 3. man wollte Eicten=, Buden= unt Birfenjamen unter einanber füen, uno Der Eaatplat märe gebaltes \&ano, fo itreute man bie Eidjeln 3uterit aus uno lafle fie jeid)t unterpflügen. Şierauj füe man bie Budteln oben auf uno laffe ben Diittrift ins Sireu; übereggen; ift aud Diejes geideben, jo jtreue man ben Birfenjamen aus uno lajie mun ben Eaatplats mit ber ber: febrteri Egge überidłleppen.

Wie biel Eamen übrigins von jeber foljart bei nermijdten Eaaten,

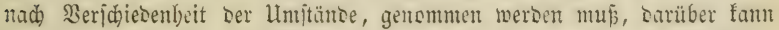

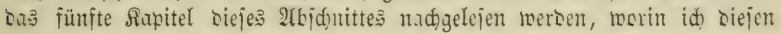
Ǵegenitano binlänglich auseinantoer gefeșt babe. ${ }^{1}$

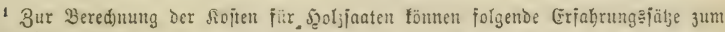
Giruno gelegt werben:

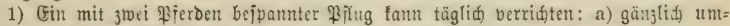

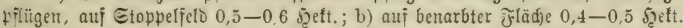

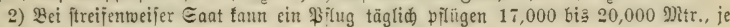
nadjoem ber Boden befalifien ift.

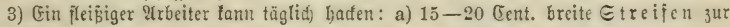

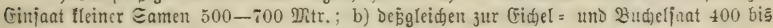
500 Mtr.; c) 14-15 Boll breite Etreifen für (Einjaat fleiner Eamen $300-400$ Mntr.;

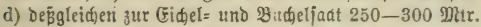

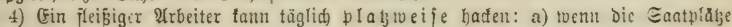

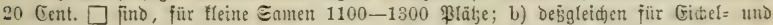

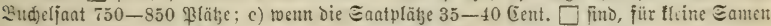

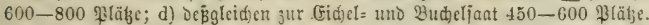

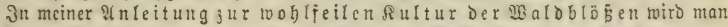

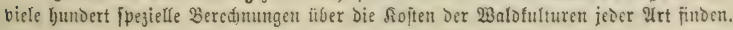




\section{DIentutes sapiter.}

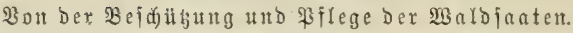

BBem der Foritwirth auf bie in Den vorigen Rapiteln gejeigte 2 (rt Malojaten ober Pflanzungen gemad)t bat, fo muj es mun feine erfte Eorge jein, bieje Sulturen gegen alle antwentobaren Befchäbigungen, entweber al引s balo nad) Der Saat doer Bflanjung zu fidjern, Doer weldhes nod befier und in biełen fällen nöthig ift, er mus $\{$ d) on vorber ben zur Rultur bejtinmten \$lab befricoigen Yaffen. Ohne bieje Borjicht würoen alle Mübe

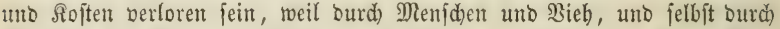

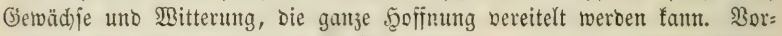

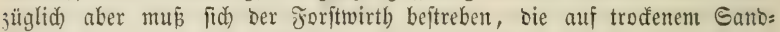
booen, ober an Den Der Some ftart ausิgefêțten mageren Bergwänben gemudten Gaaten mit Reijern, mo möglid) bon $\Re$ iefern, leidtt zu über: bectin, auch) alle Sulturen auf ibren (Brenzlinien als gebegte Diftrifte $j_{0}=$

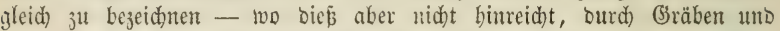
Berzäumungen bon muncherlei $\mathfrak{A}$ rt baß jabme $\mathfrak{B}$ ich uno Bilo abzuhalten, nötbigenfalls aud) bie Stridbögel, bis ber Samen aufgegangen ift, zu ber:

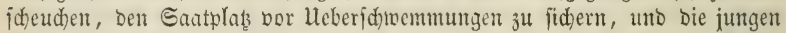
Bjflanzen jo viel wie möglich von lntraut zu befreien. - Bei fleinen famp: fulturen fann man biés fo wohttbätige Befreien von Unfraut fehr volls

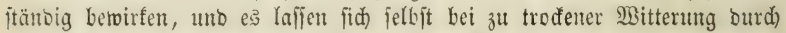

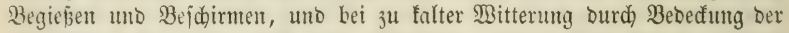
Eantlänter mit Saub, biele llebel abronoen. Diejes fann aber bei grofen

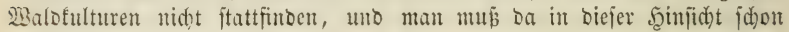
mefor Dem Bufall überlafien.

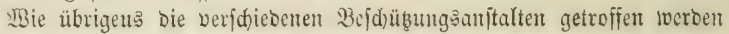

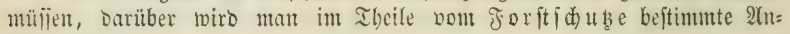
leitung finben.

\section{Befintes Eapited.}

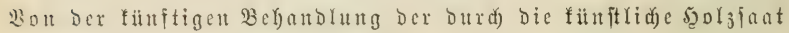
erzogenen $\mathfrak{B}$ eft än De.

Die fünftige Bebanolung uno Bemirtbid)ajtung ber burd) bie fünit=

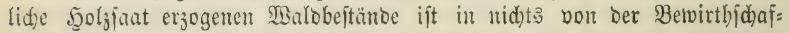

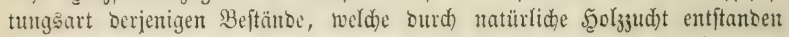

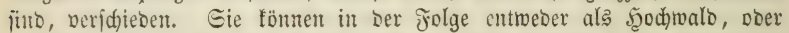
als Nicberwald, ober als Mittelwald behandelt werben. Jँm erften und

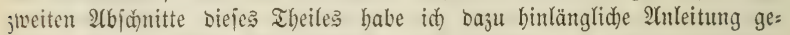
geben, worauf id ben Sefer verweife. Joh bemerfe ur, baß es fid jeber jorjtwirth angelegen fein laffen muईs, jobe Sultur zur gebörigen \$ollfom= menbeit ăl bringen, uno jeoe vielfeid)t nidjt ganz gelungene Stelle obne 3eitverluft auszubefiern, und bem ubbrigen Theile gleid) zu maden.

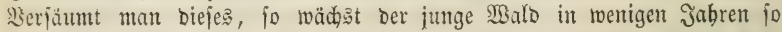

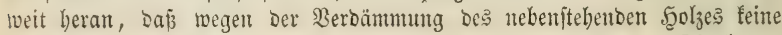

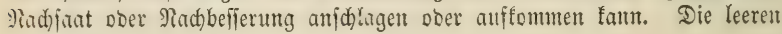


Stellen merien bann voun jungen Balse umijhlolien, uns liefern bis zur 5ुaubarfeit bes ire ungebenden Bejtanbes feinen Ertrag. - Id emrfehle baher jefr, niḑt eher neue Blöß̈en in Fultur zu nefmen, bis bie bormal’ gemadoten unb vielfeicht nid)t ganł gerathenen אulturen in gebörigen Etano

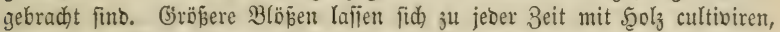
bingegen bie fleinen leeren Etellen in ben älteren אulturorten ober Edlägen,

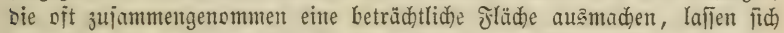
fFäterbin nidht mebr mit $\mathfrak{S c o l}_{3}$ in Bejtant bringen. Soldher Boben ift baher als ein tootes Sapital zu betradten, bas oft 100 uno mebrere Jabre lang feine 3injen trägt, uno bem Maloeigenthümer in geraumer Beit nicts

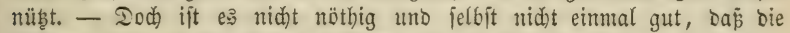

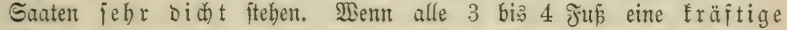
Bflanze fteht, auf beren Erbaltung man mit Eidjerbeit redjnen fann, io ift leine Nahbellerung nötbig, uno es finto alle Roften, bie man Darauf

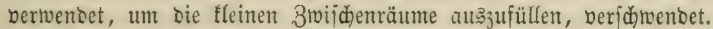

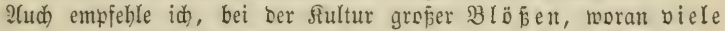

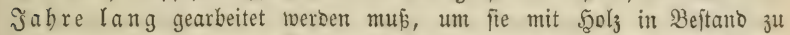
bringen, a uf fünftige Bewirthjdaftung $\Re$ ü di d t uno bie Eaat an Derjenigen Geite anjujangen mo jie jo fortzuiek̨en, wie

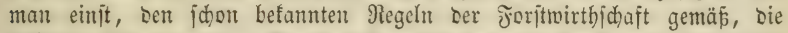

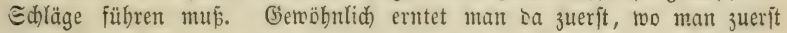
gejäet bat. Ђä̆tte man alio bie Eaat von ber verfehrtent Eeite angejangen,

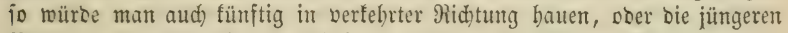
Beftänce bor ঠen älteren abbolzen müfïen. Bei fleinen Blößen, womit man in toenigen Jalbren jertig ift, fommt freilid biejer ltmitano nid)t in

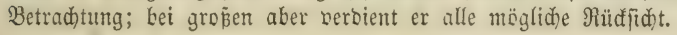

\section{Dritte Abthcilung.}

Bou Der 3ermebrung Der Maloungu burd Berfilanzung junger Stämme.

23on ber 5̧ol

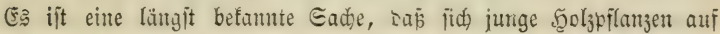
einen andern Stanbort berjeşen lafien, wenn man bei biejer Dperation mit ber gebörigen 3orīid)t ju Merf geht. - 3uerit mag man wohl biej

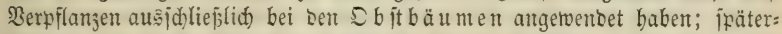
bin - aber bod jhon vor mebreren bunbert Jabren - bat man auds

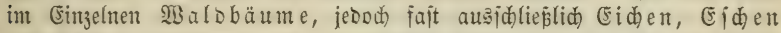
unb $l l l m e n$ verpflant, uno in neueren Seiten hat man bei ber forits

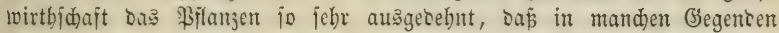

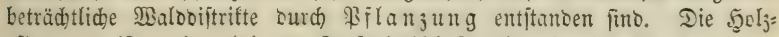
pflanjung ift baber bei der Joritwirtbichaft als ein im Gropen an=

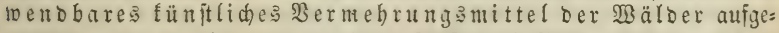

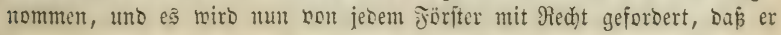




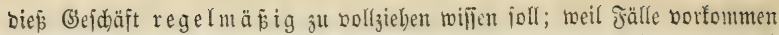
fönnen, too ein Walogrunoftüa entmeder nur einzig uno allein, ober bod am woblfeilften uno ficheriten ourd Bilanzung mit 5ुolj in Beftanto gebracht werben funn.

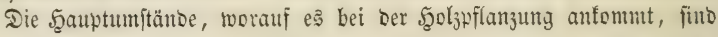
folgenoe:

1) Der jörter mus wifien, in welden fallen bie Pflan= zung ber Saat vorzuzieben ift.

2) Er mús unter ben Şolzarten biejenigen auszu= wählen berfteben, die ben örtlichen bebürfnifien am beften entipreden und überbaut am meiften nüben fön nen.

3) Ěr múp fid tauglide Bflänzlinge a veridaffen wifien, unt

4) Ẽr mú bie Bfanjung felbit regelmäbig unb fo zu maden verfteben, baf bie Stämmen fider an: uno forts radjen tönnen.

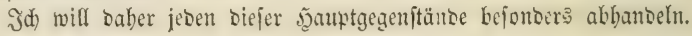

\section{Srftes Sinpiter.}

3on ben Fären, in benen dic \$flanjung ber Eatfultur vorju= zichen ift.

Der Bflanjbetrieb wirb nothwentig in Jahren auşekenter Gamen:

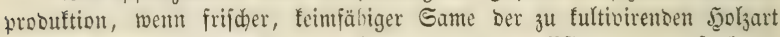
aud) im Scandel niḑt zu bejiehen ift, Dagegen junge Pilanjen, aus früberen Eamenjabren ftammeno, in tunglidjer Bejouffenteit worbanton fint; er wiro nothwenbig bei berfäteter 2(uabefferung fleinerer foblitellen in Jung: orten uno Da, wo oer siseisegang nid)t fo lange fiftirt werten fam, als nötbig ift, bie Eamenpflanjen Dem Weidebiek entwadjen 3 lehen. (5: ift

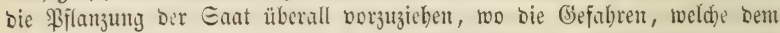
ausgeftreuten Eamen uno ben Daraus eribudienten jungen \$iflanzen in ben erften Jabren entgegentreten, aupergenöbnlid) grós, mannigfaltig unt ber

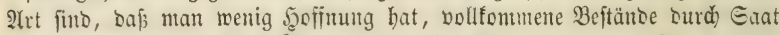

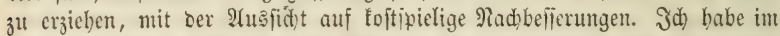

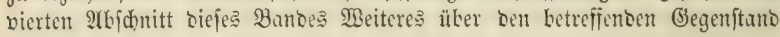
mitgetheilt, $t$.

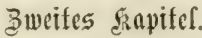

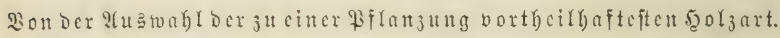

2(ud) biejer (begenitant ift im zweiten Rapitel ber vorigen Arbtheilung unt in ber Betriebalebre id)on verbandelt worden. Sd bemerfe buber mur nod, baj, wenn Pflanjungen mit $\{$ d) on beträdtlich ertad fenen Gtämmen gemadit merben müffen - wie foldhes ber fall ift, wenn Bieh= triften Doer Weibepläb̧e bepflanjt werden follen - alabann vorzüglich $\& a u b=$ böljer gewäblt werden mülïen, weil biefe belier als bie Rabelbälzer an= fd)lagen, wenn man fie mit etmas ftarfen Etämmen verfebst. 2(ud) wiro

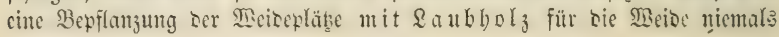




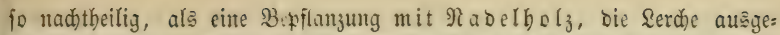
nommen, weil unter bem \&aubholze mehr (Braß, unter bem Pabelholze aber gemöbnlich biel Moos wädșt. - Will man alio, baf bie Weibebered)tigten in ber folge nidft übervortbeilt werહen follen, fo mäble man zur Bepflanzung Der beftänoigen SEeisepläze ¿aubbolz, uno ztwar vorzügliç) (Fid)en, Sgainbuden, Ulmen, Ėjden uno Ahorne; wo es aber feudt uno

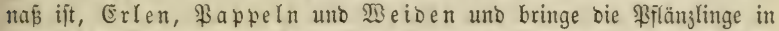
eine foldhe Entfernung, Daf zmifden ibnen, aud wenn fie ermadien fino, nod) Gras herborfwrofien fann. S.at man aber auf nachbaltigen Meide=

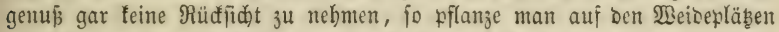
bie Etämme fo nahe beifammen, da pie wenigftene gegen ihr 60jäbrigę IIter in Eđlus fommen; wie im vierten Sapitel nod weiter aușeinanber gejeb̨t werben roiro. Fann aber eine Blöbe lange genug gehegt unb folg=

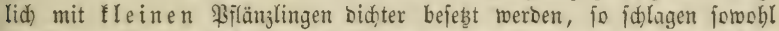
Die Raub: als Natelbolzpflanjen gut an, wenn man bie Dperation ridetig gemacht hat, und es treten als̈bann nur bie Rüdfitdten ein, bie ber Boben,

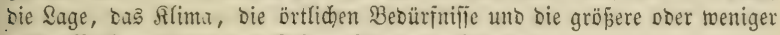
grofe Nothmendigfeit bir Roftenerfparung exfordern.

\section{Dritfes siapifel.}

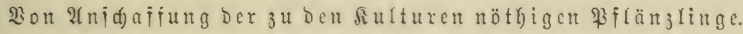

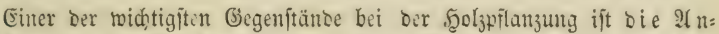
fd) affung guter \$illänzlinge, weil das (Bebeihen einer foldhen fultur

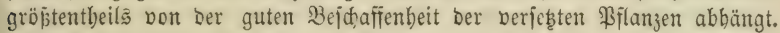
- Will man mit glüdlichem Erfolge pflanzen, fo barf man teine \$iflänz=

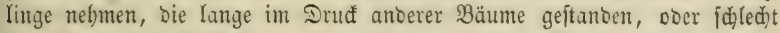

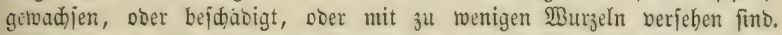
Uno auperoem ift es audj nid)t rathiam, beim jorithaushalte Stämme zu fflanzen, bie über ber Erbe mebr als 5, bödjitens aber 8 (tm. im Durd):

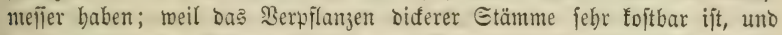
nur in red)t gutem Boben gelingt, wenn alle möglide Borficht erfäboft wiro.

2 m ficherftin machien alle Syoljpflanjen wieber an, went man fie in ibrer zarten Jugeno, uno nod che fie $2 / 3 \mathrm{M}$ tr. hod weroen, berfebt, weil

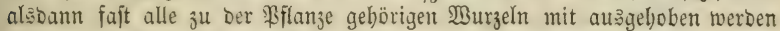
fömnen. Gröpere Bflanzm lafien fid ztoar aud berjeken; man wiro aber iumer einen jtärfern 2 bgang baken, als bei Pflanzungen mit jüngeren

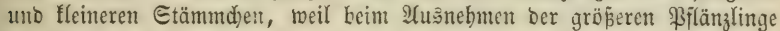

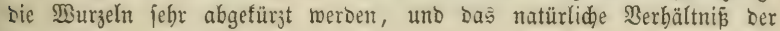
Burzeln zum Stamme zu fehr veränbert wiro.

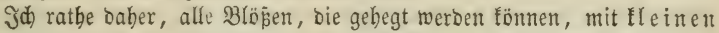
Jुolzhflanzen zu befę̧en, uno mur in Dem Jalle, wo fleine \$ilänzlinge Den llmftänden nad) nidit auffommen fönnen, gröpere Etämme zu fflanzen.

Eollen nun Pflanjungen mit Syolzarten gemad,t werben, wowon in

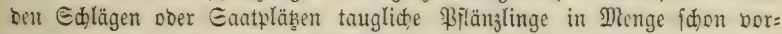
banton find, io ijt weiter nichts nöthig, als fie ba vorfichtig heraus zu

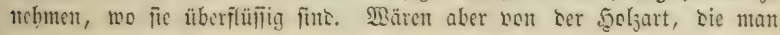


anjuplanjell gut fintet, nod feine Bilanzen vorbanton, ober mill man Bflanzen, bic ibre feinen $\mathfrak{B}_{4}$ zeln in weiter Entfermung vom Stode cnt= widefn, in büberem Ifler berpflanzen, jo muj man jolde fid) erzieben,

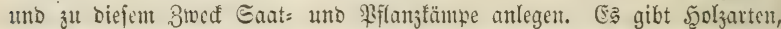
Die im natürliden 3ujtande nur menige Eeitenwurzeln, bagegen aber, bis jonbers in gutent Boben, eine ftarfe $\$$ frablwurzel austreiben. Simmt man nun joldhe Etämme in cinem IItter, two fie jum ßerpflanzen auf Weise=

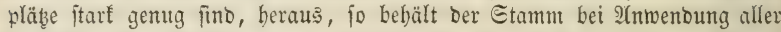
Borfidt Dodh nidjt 2 surzeln genug, um gut an= uno fortroadjen zu fönnen.

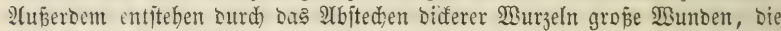

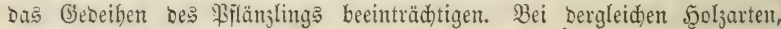
roju vorzügliă Die (Eidhe gehört, ift es ber (Erjahrung nad fehr vor= theilbaft, fie in Der Jugent, und z̧war in ber Şöhe bon $2 / 3$ bis 1 Mitr., eimmal zu verpflanzen, unt renn fie bie Didfe eines Büdjenlaufs erlangt

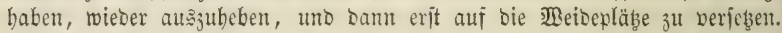

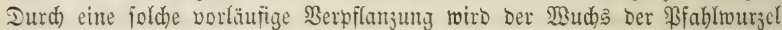

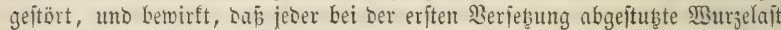

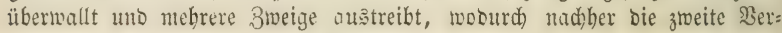
jeţung um fo viel fidererer anjolalägt.

Mier ben Interjobiè Der \$flanzungen mit präparirten uno nicht prä=

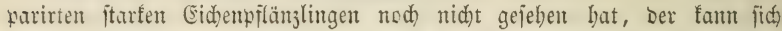
feinen Begriff sabon maden, wie groj uno auffallento Derfelbe ift, uno twie viel beffer, jowohl bie präparirten (Eiden, als a ud alle übrigen

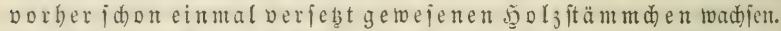

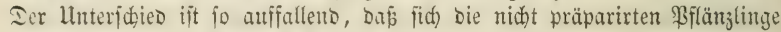
un ber matten Farbe ifres Sanbes uno an Den geringen Trieben mehrere Sabre lang febr beutlich erfennen laffen, unb einen bei weitem ftärferen $\mathfrak{A b g a n g ~ b a b e n , ~ a l ’ ~ c i n e ~ e b e n ~ j o ~ g r o ß j e ~} \mathfrak{A}$ njabl präparirter Stämme.

Dbgleid) bieje Borbereitung einigen Afupano crforbert, fo wirb biejer bod) Durd) Das bejiere Geoeiben ber Rulturent reidf(id) erfeşt, unt man follte Daber allenthalken, wo man \$ílanjungen mit grosen 3 Mtr. boben Stämmen 3u madfen genötbigt ijt, bieje Borbereitung nid)t berfäumen. — Sbent Dieje Norbureitung fanm in Dem Jorftgarten, monon oben bie Rebe war, bemirft

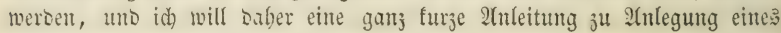
jolden Joritgartent bierber jeb̧en.

Bon Anlegungeines Forit= oder Ėidengartens.

Man wäble einen geyen bie rauben Minde gejwübten \$laţ, ber nahe bei sen Blöpen liegt, bie tünftig bepflangt merden jollen, ber auch fo groj ift, Daj bie erforberliche Injabl von Fifänjlingen barauf erzogen twerben fann, Der guten Şosen hat, uno in biffen Näbe MBaffer befinolide ijt.

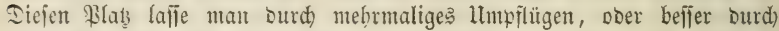
tiefes Itmgraben loctent uno von allem Intraut reinigen, als went er Frudht tragen jollte. Jit biế geidehen, jo theile man ihn ourd mebrere Rreujwege in Feloer, wie einen Gemüiegartent $a b$, uno lafie ibn mit eintent baltbaren 3aune umgeben.

In biejem (G):rten bejüe man, nad) Inleitung ber in ber borigen 


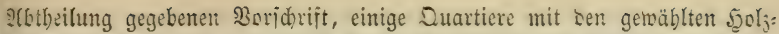
jumen reihentocije, wto lalle fie fo oft es nöthig iit begienen, uno von Innfraut immer rein bulten. ${ }^{1}$ - Jm nädjiten Seerbite beseçe man bie jungen Pflanzen mit Saub, und im folgenben, längiten aber im zlveiten Jrüfjahre ober Syerbite nach Der Eaat verjeb̧e man bie erjogenten Fiflanzen auf Den übrigen, vorher nodmals umgegrabenen Theil beș Giartens, in

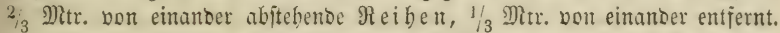
- Sit biej gejdeben, io gieje man bie Prlanzen an, uno balte fie bon

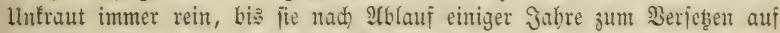

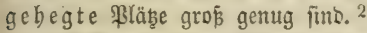

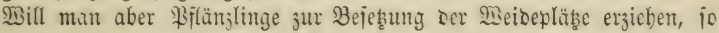
nefme man bie im jweiten Jabre ichon einmal nerjeşten \$iflanzen, fobalo

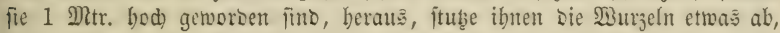
unto berpflanje fie abermals, wie im nädiften Rapitel gelehrt wersen wiro,

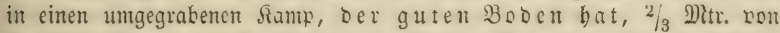
cinamber entfernt, in Reiben, uno balte ben Boben ven Unfraut kefreit.

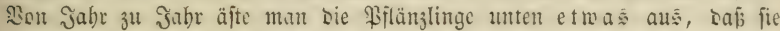
nad uno nad cinen reinen Edaft befommen, uns lafie fie jo lange fteben, bis jie bie erforberlide Etärfe erlangt baben. 2(5samn nebme man alle Biflanjen, bis auf biejenigen, weld)e zum tünitigen Sgol

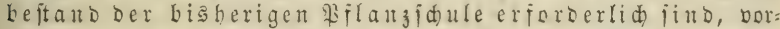
jid)tig heraus, uno verjețc dieje nun mit vielen : auf bie M̉eibepläß̨е. ${ }^{3}$

Bei einem ioldyen Serfahren wiro man aus mentgem Eamen uno auf

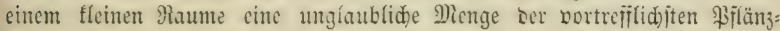

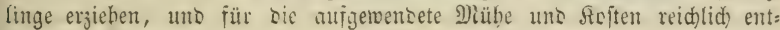
idjäbigt werben.

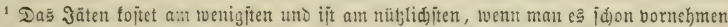
läbt, jobald jid) nur wenig lutraut jeigt. (Fin Menid) tann alsoann in einem

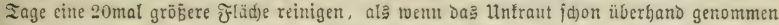

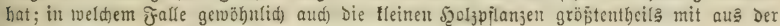
Eroe geriffen ober losgejogen uno verborben twerden.

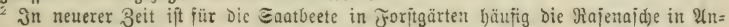
wenbung gebrad)t worden, über bie id bereit? Seite 150 einige Bemerfungen eingeidaltet

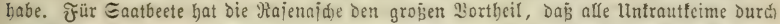

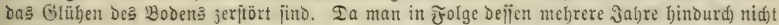

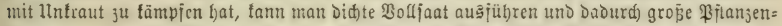
mengen auf fleiner Fläđle erziehen, Der man dann aud), mit bemjelben foften = und 3eit=

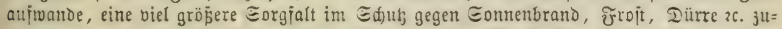

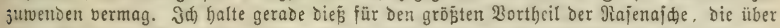

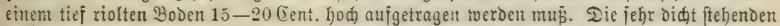
jungen Pflanzen müifien bann aber, wentigitents theilweije, fdon im zweiten 3abre verpilanjt

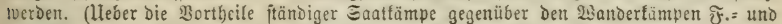

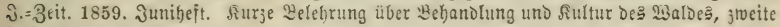
2uศ̣. 1859. G. 179.)

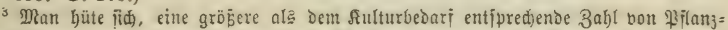

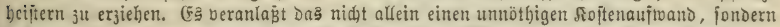

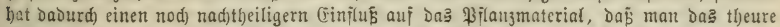
Material nidft fortwerfen mag, in Den fiämpen zแ Did)t beifammen fteben läp̈t unD badurd

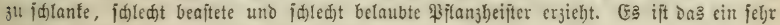

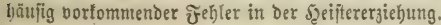


Şätte man aber von Derjenigen ந̧oljart, bie man jum Ber flanjen vorbereiten will, fdon fleine Sflanzen in Menge vorräthig, fo ift bie Saat im jorftgarten freilid nidt nöthig. Man fann fie baun mur aus ben Edblägen unb Eaatpläben, wo fie oft in großer Minge überflüfilig

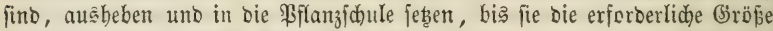
erlangt unb binlängliche $\mathfrak{B u r z e l n ~ b e f o m m e n ~ b a b e n . ~ D i e j e ~ B e r m e h r u n g ~ b e r ~}$ Wurzeln fann aud) nod) baburd) betwirft werben, wenn man einige Jahre bor bem Keţten Berfflanzen, in ber Mitte zwijhen Den Reihen, mit einem

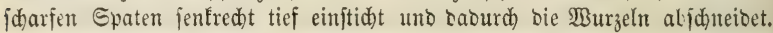

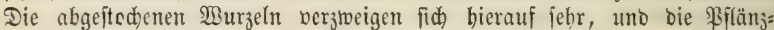
linge wadjen nadber keffer an, wenn man fie auf ben bleibenden Stanonrt beriekst bat.

Die (Fid)e ijt gegen bief unterirbifde Beidneiben Der $\mathfrak{B} u r z e l n$ fehr empfindlid), felbft bis zum 2(bjterben einer Menge 6jäbriger, nod in ben Saatrillen ftehender Bflanjen meines Forftgartens. Der verftorbene Dber: forftrath Sönig fdentte beim Befuche biefer 2Anlage Dem Falle ganz be=

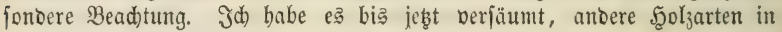
biefer Şinfid)t зुu prüfen. $t$.

Will ober fann man bieje Sorbereitung aber nidht ftattintoen lafien, uno follen bod) grofe Seifter verpflangt merben, fo wähle man wenigitens

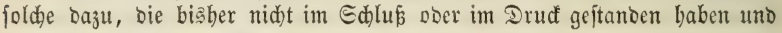

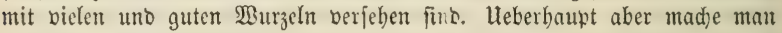

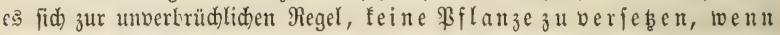
fie nidit viele und vollf ommen gute $\mathfrak{B u r z e l n}$ hat. Nur in bem Falle ift bas Bregentheil berzeiblid, went bie Syolzart megen ibrer Seltenbeit

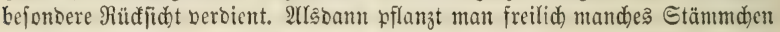
auf (b̧eratbetwohl. Samm man aber für bie, als nidht vollfommen tauglid)

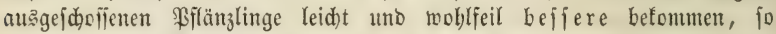
pflanze man ben $\mathfrak{A}$ เs Bfänzlinge. Die meiften Dabon merben verberben Dber verfümmern, und bann fino nid)t allein bie Sojten für bas twieberbolte 2 (uşgraben ber Pflanj= löder zc. berloren, fondern es wiro eine folde Pflanzung aud) lüđtig uno weniger fđän, als menn bei ber erften Rultur alle Stämme zugleich) an= uno fortwadjen.

Şat man bie 2(bjidht, in einem foldjen Joritgarten ober Rampe Fiduten= pflanzen zu erzieben, bie obne weitere $\mathfrak{B}$ orbereit ung idon nad einigen Jabren beraugenommen uno büfdelweife ins Freie verpflanjt werben follen wie bieß in vielen Gegenden gefobieht - fo ift bie \$erfahrungsart febr einfad). Man läpt bann ben Ramp umgraben, uno fo viel wie möglich von ben TSurzeln bes Unfrautes uno ocn zu biffen Steinen befreien. Şierauf werben in bas flar gebarfte Sano 5 bis 6 (5tm. breite uno 2 bis 3 $5 \mathrm{tm}$. tiefe Rinnen, bie 25 હtm. bon einanber entfernt find, gezogen, mit Samen ftarf bejäet, uno biejer bann $1 / 4$ Etm. bid mit loferer Croe uno etwas Moos bebedt. - Eobals Unfraut zum Borideine fommt, wiro biefes entfernt, und $b$ a s beftänoige Reinbalten fo lange fortgejebt, bis bie Bflanjen 2 Doer 3 Jahre alt fimb. - 2llabann werben fie in grofen Ballen alis:

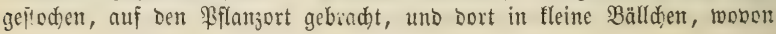


jebes 3 bis 4 Pfflanzen enthäit, zertheilt, uno bieje in fleine Södder gepflangt, bie man mit Mloos uno einizen fleinen Sieinen bedectit.

Fidftene Büjdelpflanzungen mit Eroballen gerathen febr fider,

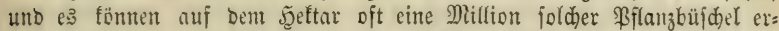
zogen werden, wenn bie Eaatreiben im Rampe sidht genug mit Pflanzen betwadjen finto.

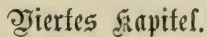

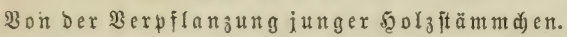

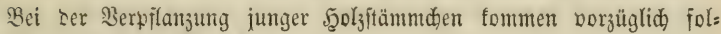
gente Giegenftänbe in Betrachtung:

1) \$2elde Jahresjeit ift jum Sooljoerpflanzen bie befte?

2) Sn mas für eiıe Entfernung find die Bflanzenzu fegent?

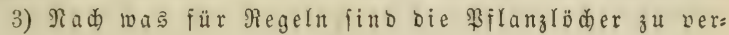
fertigen?

4) $\mathfrak{B a}$ für $\mathfrak{B}$ orịdt ift beim $\mathscr{A}$ usgraben ber Bflänj= linge zu beobadten?

5) Rach welden Regeln find bie Pflänzlinge an ben Burzeln uno 2 ejten zu bejdneiben?

6) Was i jt für Borfidt zubeobadten, wenn bie augges hobenen Bilänjlinge nidht alêbalo rieber in bie Eroe gefebt werben fönnen?

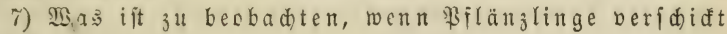
werben follen?

8) $2 \mathfrak{a}$ jür Regeln jind beim Einpflanzen felbit zu be= obadten? uno

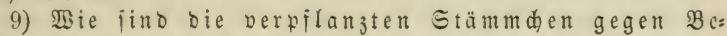
fïäbigung zu beribabren?

Jd) will baber alle bieje Fragen einzeln beantworten.

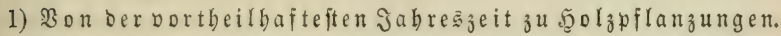

Die Beit, in welder Baumplanjungen vorgenommen werben föunen,

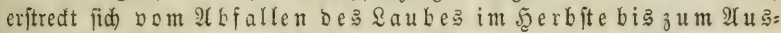
brud) Der Blätter im Frübjabre. Denn, obgleid aud Stämme im Eommer berfilangt werben fönnen, wenn man ifnen befondere Pilege geben fann, io ift bod) beim Joritweien eine joldhe Pflege nid)t möglid, und aljo aud bie Bilanjung im Enmmer, fowohl in biejer, als in mancher

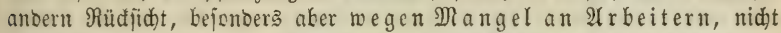

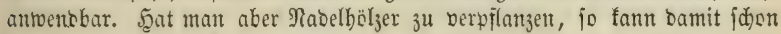
im September ber 2 nfifang gemad)t werben. ${ }^{1}$

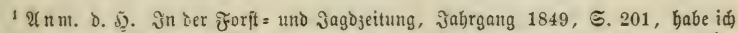
eine Reihe borläufiger $\mathfrak{B}$ erjude über Eommerpflanjung befaunt gemad)t, aus benen fid im

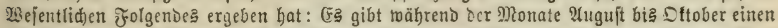
$3-4$ twödentliden 3eitraum, ber bei Den verjdiedenen Şoljarten zwijd)en verjdiedenen Zer=

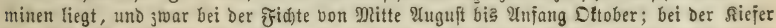

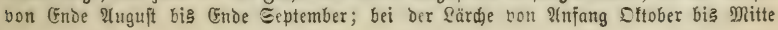


Es fommt aljo nur auf bie Beantmortung ber Frage an: ob bie Fुerbit= ober Minter= ober Frühjabrapflauzung vorzu= zieben ift?

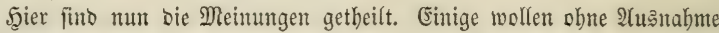

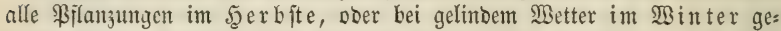

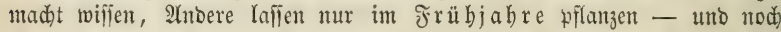

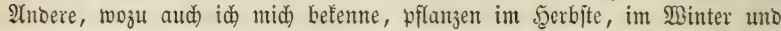
im Frühjabre, nachbem es bie lumitände vortheilhaft madjen.

Die Şerbjt: unt Minterpflanzung balte id nämlid in Dem Jall für bie

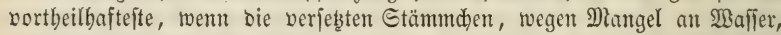
nicht angejhlämmt ober ftarf angegofien werben fönnen. In biefem Falle betwirft ber Regen unt bas Ed)neemaffer, Dap fid bie Eroe um bie Murzeln

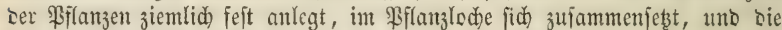
Feudtigfeit befjer bält, als wenn man bie Bflanzung, obne anzu=

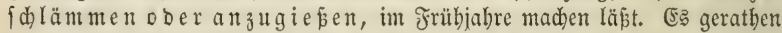

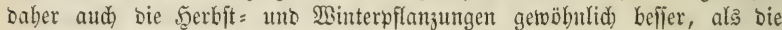
Jrübjabroflanzungen. Bent man aber bie gepflanztent Stämmdyen alabalo

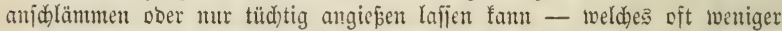
llmitänoe uno Soften verurfadit, als man gewöbnlid) glaubt - fo bat bie, fo früb to ie möglid) gemadte Jrübjabroflanjung nad) meiner (Er:

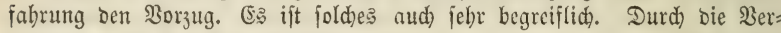

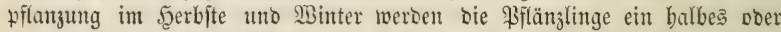
ein Bierteljabr lang gleidjam nur eingej hlagen, uno in cine Sage verjeşt, moraus fie fichled)terbings feinen 3 ortbeil zieben, wohl aber Nadytbeil haben fömnen, Da Der 3ujtano, worin fie fid befinden, immerbin fränfelno genaunt werben faum. Nimmt man aber bie \$flanzen $\mathrm{r} e \mathrm{~d}$ t $\mathfrak{b}$ ald im Frübjubre, alfo furz bor bem 2fnfanty Der neuen Begetationęperiobe, aus ber Eroe, unt pflanzt fie fogleid) wieber ein, fo bauert ber untbätige unt fräntelnoe 3uftano cine bei tweitem fürzere Beit, uno jese Pillanze faum bann fogleid vieber antwadjen. Dod nuf man in biejem falle burd) ftartes 2tnjalämment

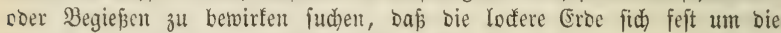
Burz̧eln feb̧t und alle 3wijhenräume auşfüllt. Unterläp̧ man biejes, fo

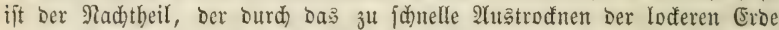
erfolgt, größer, als berjenige, Der saburdh betwirft wirb, baß bei Der Seerbit=

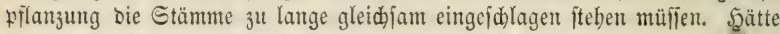

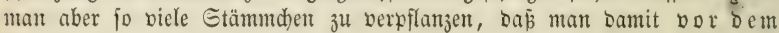

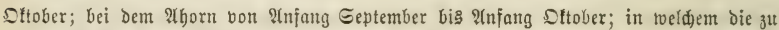
Diejer 3eit berpflanjten Stämme fogleiđ nađ̆ der \$flanjung eine große Menge neuer $\mathfrak{B u r}_{3}$ eln

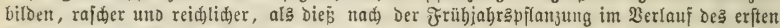

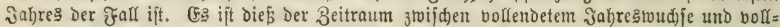

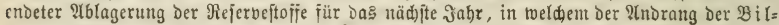

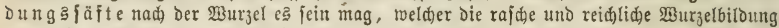

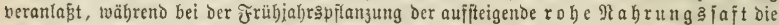
Bildungsftoffe von ber 23 urge! nad) oben hin ableitet, auperdem ourd) bie frijden Sd)uitt= fläd)en aud) frembe, Dem Drganismus möglid)ertueife nadtheilige Etoffe in gröperer Mienge

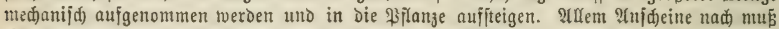
cine innerbalb der bezeidneten Tcrmine gemad)ie Pflanjung auf cintem \$oDen, Dent aud

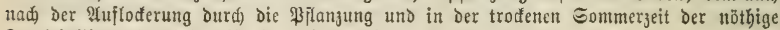

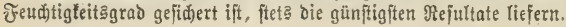


Beginn Der Эegetation im Jrübjabre nidet fertig wero:n fann, fo ift

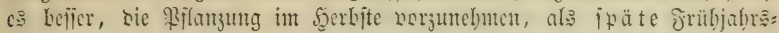
pfiflanzungen zu mad)en.

jd) rathe baber, infoferne angejdlämmt ober angegofien weroen fann, jebr buld im Jrübjabre - went biejs aber nidjt gejueben

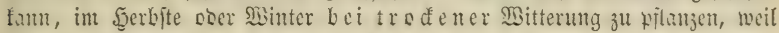

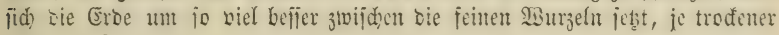
utb feinet fie ift.

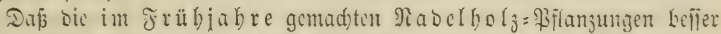
therathen jolfen, als bie im Serbfte gemudhten, mern in beiben Jüllen feine

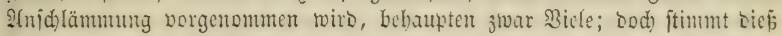
nid,t mit meiner (Eriabrung überein. Tiur in tom Jalle fand id) bei unter:

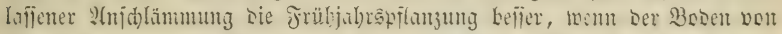

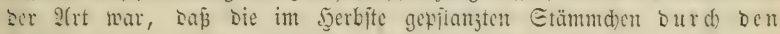

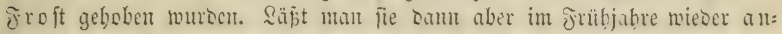
treten, fo fam man saburd) bic jonjt freilid) nad)tbeiligen folgen wer: bindern. Seim grojen forfthat Borzug bebauptert.

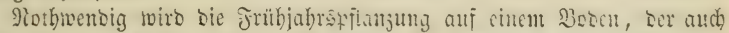

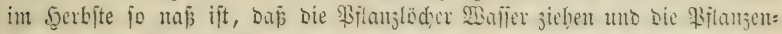

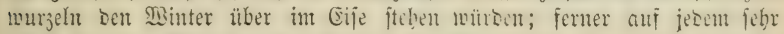
feften S3oden. Merben auf Setzterem bie Biflanjlëder in serbite gemad,

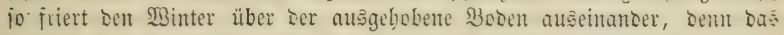

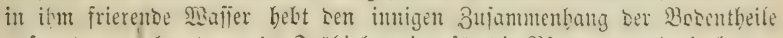
auf uno man bat ban im Jrübjabre eine für sic \$iflunjumg gchorig locere Bobenfrume.

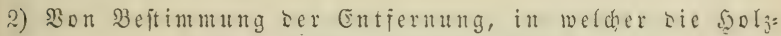
pflanzen gefebt werben müfen.

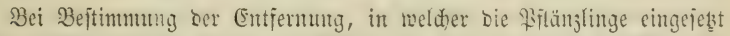

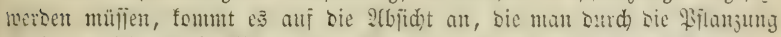
erreicten will. Dieje 2(bjid)t fann jebr veridieben jein. Ĵt will saber bie gemöhnliden fälle surdoghent uno sie Entfermung angeben, bie in joom Falle zu wäblen fein mödte.

\section{A. Bei Bepflanzun Der Meciopläbe.}

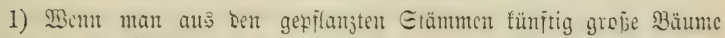
erjieben uno Den IBciogenup nid)t ganz verorängen mill, jo pflanje man Die ftarfen Seifter $S$ bis 10 Mitr. weit all einander. Eolltent aber bie

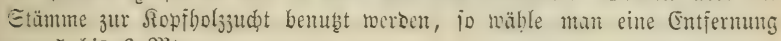
yout 5 biล 6 Mitr.

2) Wäre aber auf oic WBeioe feine Piüdidut jut netmen, fo fiflanje man alle 3 Mitr. eincn Seifter. Sn biejom Jalle jimo auf ${ }^{1}$ is Şett. 610 Etüt

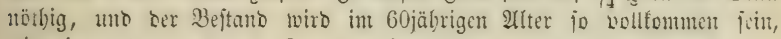
wie einer, ber aus bem Samen aufgemadien uno einigemal burchforfitet tworben ift. 
B. Bei Bepflanzung folder Diftrifte, bie gebegt werben

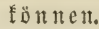

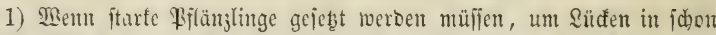
2 bis 3 Mtr. hod errodjienten Edylägen 2 . auş3ubefiern, fo pflanze man in ber Entfermung von 2 bis 3 Ditr. Der Beftant wiro im 60jäbrigen Alter gan vollfommen feir.

2) Rönnen aber fleine Bilänjlinge von $2 / 3$ biß 1 Mitr. Sänge gejeb̧t

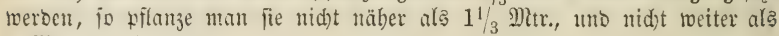
$2 \mathfrak{R}$ tr. alseinander.

\section{Bei Ánflanzug oon Feloremifen}

feţe man alle Meter ein Stämmdhen.

\section{Bei $\mathfrak{A}$ nflanzung von $\mathfrak{A l l e}$ en}

rilue man bie Gtämme 5 bis 8 Mtr. auşennander, uno

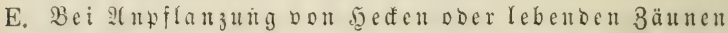
feḅe man bie łitänlinge, went fie ftarf fino, ${ }_{3}$ Mtr., wenn fie aber gering finto, $1 / 6$ Mtr. auseinanter.

Durd) eine Befflanzung in 1,3 Mitr. Entfermung ser Bffanzen werben bie Rulturtoiten mebr als Doppelt io grof́, als bei einer $\mathfrak{B}_{\mathrm{c} p f l a n z u n g}$ in Der Entfermug von 2 Mitr., olne taj ein mejentlider Northeil barau ent= fteben fam, weil aud) im Icbzten Falle bie \$flanjung balb in Ed)lup fonmut, uno ber Biftano gegen bas 40jäbrige Sllter fdon ganj bollfommen wirb.

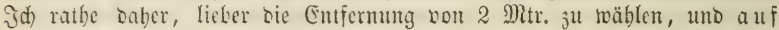
oie tünftiche Refrutirung ber bier uno ba ausgebenden Gtämmden genau ju jeben, als boppelte fioften zur (Erreid)ung bess: felben 3wedes anjumendent. - Die Entfermung von 1,3 Mitr. bingegen wähle man nur in som Jalle, wonn ber Boben nidt gut unt bie Rage einc Sommerieite ift. Ilnter joldhen limitänden wirb bie \$lantage fich balo

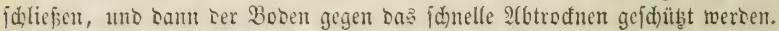

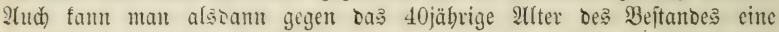

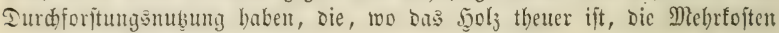
ber bichten Bflanzutg vergütet.

3) Son Berfertigung Der \$fllanzlöder.

Bei 3erfertigung ber Bflanjlöder fommen folgentoe Begenftänte in Betractung:

a) bie Beit, want fie gemadt werben müfien;

b) Die Entfernung und Dronung, in toelder fie gemadt torben mülfen;

c) Die nöthige $\mathfrak{B}$ eite un a Iefe berielben, uto

d) Die Hbjonberung oer (Erbe nad) ibrer veridiedenen $B$ s: fdaffenbeit unb (ื) üte.

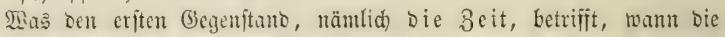
Pilanglöcher gemad)t werben müifen, fo tann biefs zwar zu jober Jabreşzeit gejdeben; indelien wirb man bod) woblfeiler baju fommen, went man bieje 


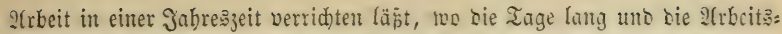
löhne verbältnipmǟig geringer fino, als in ben furzen Epätherbit = uno Wintertagen.

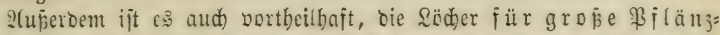

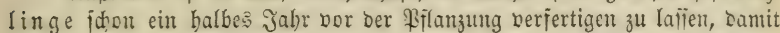
bie anıgeworfene (Erie gleidjam gebrad)t uno lofer werbe. Bei fleinen Bflanjlöd)ern bingegen ijt bie vorläufige Berfertigung nid)t fo nöthig, uno fie finbet aud nur im Serbite itatt, weil jonjt, wenn bie fleinen Söcher

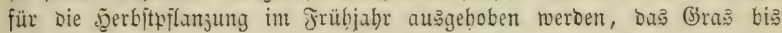

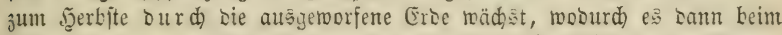
Bflanjen an Der nöthigen loderen Erse feblt. - Man lajpe saber für sie Siflanjungen, meldhe mit fleinen Etämmden im Sgerbite gemad)t werben, bie

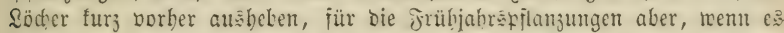
fein tann, bie Söder jebesmal im Şerbjte zubor madjen, bamit ber Boden burd Ien groft gelocfert merbe, mas bejonbers auf jebr bindigem boben 3u empfeblen ijt.

In Betrefi Der Entiernung ber Wiflanjlödjer ijt fhon oben Daß

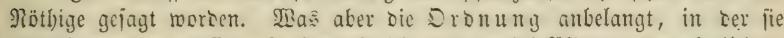
gemadht nersen müifen, io bemerfe id), sais ç kei Fiflanzungen mit fleinen

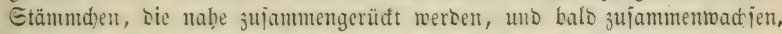

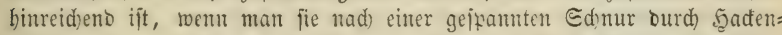
idoläge in Der bejtimmten (Entfenumg, Die man Durd) Sinoten bejeidnen fann, abjeichnet, uno fei ber zmeiten zc. Reibe, bie 巨d)mur jo vorrüdt, Dap bie Wrlanje.t in Dreied, wie man ben Soht pilanzt,

¡u fteben fommen.

Eino aber \$lantagen mit gropien 5ुeiftern, die weit auseinanoer ge:

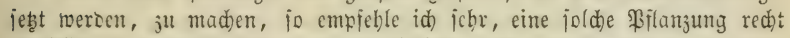
fünttlich inmmetriich und io ju veranftalten, bás man allernärts, wo man jteht, genau paljenbe 2llleu erbliat. Jeber \$orübergehende miro caun jeine Jreube an einer jolden regelmä̈igen \$ilanzung haben, uno zaraus jeben, buf Derjenige, welder fie gemadht hat, Strmung uno Pünftlidteit liebt.

Ber mur etras Geometrie beritebt, wiro bieje leidte Dperation zu machen wiilen, man mag bie Suabratpflanzung ober bie fiflinzung im S̊reujverbande ic. getwählt baben; wolei eś vorzüglid) auf glcidhe, horizontal genteliene Entfermung Der Etämme und rechtminfelige 3ujammenjeţung ber

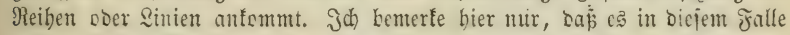
nöthig ift, sie Puntte, wo die Biflänjlinge hinfornmen jollen, vorber genau abzupflö den uno Die Söder abzuzirfeln, Damit bie S(rbeiter nidht irren fönnen. - Man fiflöfe baber zuterft alle \$unte ganz genau ab. Jit biés gejdeben, jo binse man cin jpiţiges f̧olz an ein Dopteln genommenes

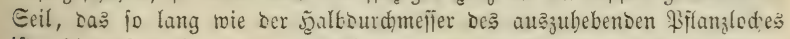

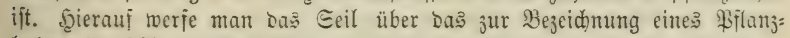
lod)es eingefd)lagene Präblchen, uno frab̧e mit bem Daran gebunoenen jpib̨igen 5ूolje einen bemertbaren Sirfel in ben Rafen. Durd) sieje Dorzeidnumg entitehen nadber lauter vollfommen runbe Söcher, mo man fumn überjeugt 


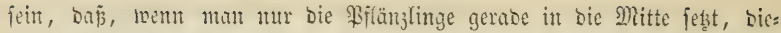
felten cben io genau auf cintumber pafien werben, als vorber bie einge:

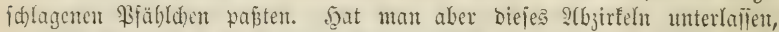
und bie \$lantage nod fo pünttlid) abgepflöct, fo wirb mat fimben, Dafs bie Strbciter unglaublid bon ber ridtigent Stelle abtweiden, uno es wiro

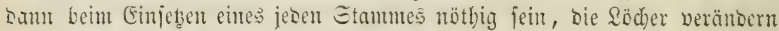
зи Laffen uno jeben : Sflänzling aufs neue einzubifiren.

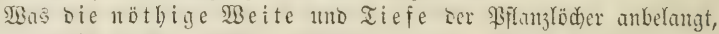

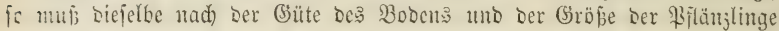
beftimunt werben. Sit ser 30 ben gut, fo braudjen sie Bflanjlöder mur fo

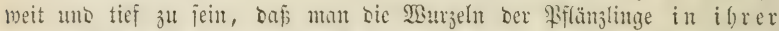
uatürliden $\Re i d$ tung beancm bineinbringen fann. Sift ber 30 ben aber nidut gut, fo ift es vortheilhaft, bie Qöd)er 10 bis 15 (Etm. we iter maden

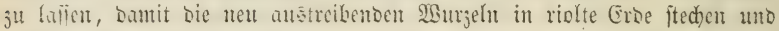

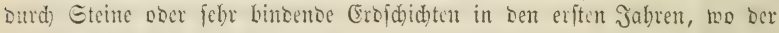

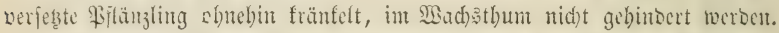

E: fommt aljo auf bie Güte beß Boben's uno auf bie Bröpe ber

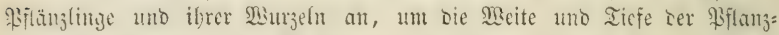
löder jul beftinunen. Jm ?tlgemeinen aber fömten folyenoe Megeln gelten:

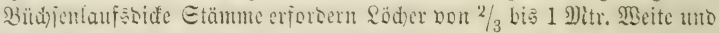

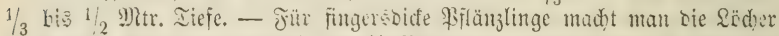
$1 / 2$ bis ${ }_{13}^{2}$ Mntr. weit und $1 / 4$ bis $1 / 2$ Mitr. ticf - nod fleinere Etämmden

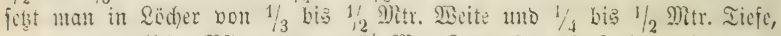

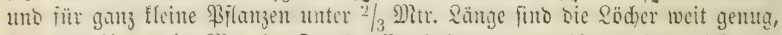
went fie $1 / 4$ bis 1,3 Mltr. im Durd)mefier haben und 15 bis 20 (Etm. tief fint.

Eind Die Bflälylinge aber nur 15 bis 20 (Etm. grob́, io mad)t man Die \$flutjlöd)er mux 15 (5tm. weit unto 8 bis 10 Etm. tief.

Heberhaupt aber lojpe man sic Qöd)er nimals tiefer mad)u, als jie

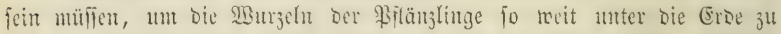
bringen, als fie vorber beseft waren. Die meiften Bflanjungen nerberbon

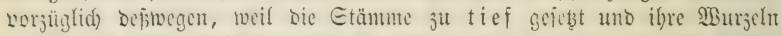

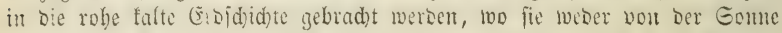

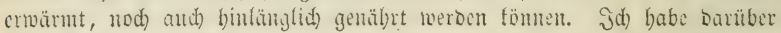

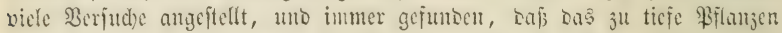
Die nadtheiligften Jolgen hatte. Siur in leidtem Ganthoden fönnen sie Biflärzlinge etwas tiefer gejetzt merben, als fie vorker ftanben.

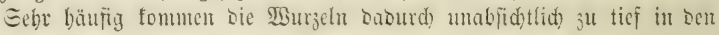

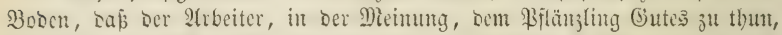

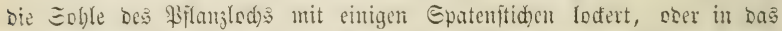

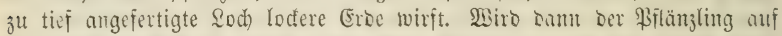

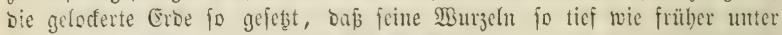

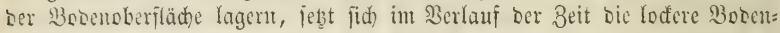

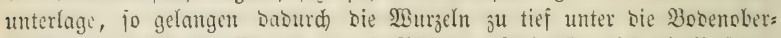

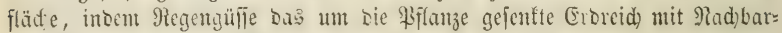
erbe ansisdmemmen. Man gewöbne bie 2frbeiter taran, bie Eohle des

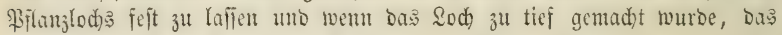
cingetworfente (Ertreid) vor Dem Cinjeb̧en der Biflange feftzutreten. 


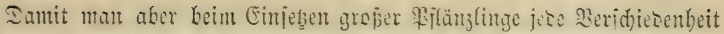

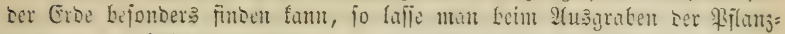
löder ben Rajen auf bie rechte Geite, bie Darauf

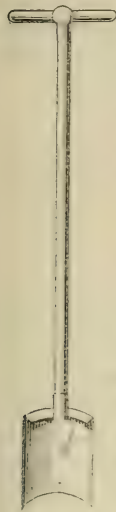
folgenbe gute Erbe auf bie linfe Ecite, unb bie tiefer unten berausfommente jollechtere Eroe, mit Abjonberung aller zu bicten Steine, gerabe bor ben 2trbeiter aufbäufen. Durd) eine foldje 2 (bjonderung Der beridjiebenartigen Erben - bie feinen 2 ugenblidf mebr 3eit erforbert, alę wenn alles auf einen f̧aufen Durdeinander getworfen, unb bie befte Eroe mit ber idjledtejten bededt ober vermifot wiro - entjteht Der Bortheil, baf mán beim. Einjeţen Der \$Fflänjlinge jebe Erbart ficon abgejonbert finben, uno aljo nad) Beoürfnip toäblen uno fafneller fertig werben fann. 2(ud) bat bei gropen Bilanzlödern, bie man oit ein balbes Jabr bor ber \$flanjung auşbeben läpt, biefe Abjonberung nod Dett \$ortheil, baf bie Mitterung auf bie in brei fleineren Şäufden getheilte Erce fräi: tiger wirft uno fie lockerer uno beffer madt, als rom biejelbe Mafle von Erbe auf einen gröperen 5ुaufen getworfen ijt. ${ }^{1}$

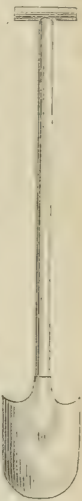

Bebient man jich bei ber Bflanjung bes pogentamten \$flanjbobrers,

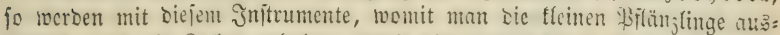
nimunt, and sic Sëder gebohrt, Iamit bie ausgohobenen Ballen genau in

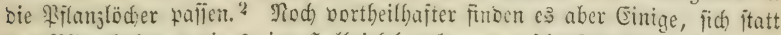
Des Wfanjbofrers eines im 5albjirfel gebogenon idaren eifernen Exaten

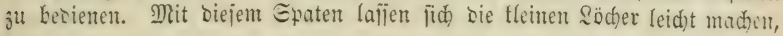

1 Ter jorgiältigiten Eortirung de马 (Erorciá)ร Dient cin 3njitrument, Da马 jḯ) mit cinem

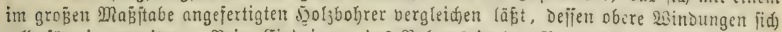
tefferiörmig erweitern. Beim (Ëinoringen Dis Bohrer马 in ben Boden idjneiset Deijen teffer=

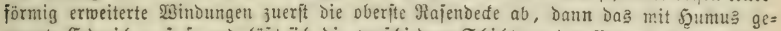

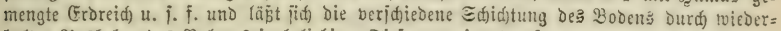
holte? Auझheben De马 Bohrers in beliebiger Tieje von einander fondern.

2 Der Bflanjbofrer beiteft aus einem eifernen 20-25 Eent. Langen hoblen balben (infinder, Deffen Iurd)mefijer 15-20 (Eent. ift. Inten uno auf beiden Eeiten ift otejer Syalb= c)linber mit Etahl belegt uno jojarf geidliffen. Sben in ber Matte ijt einc 1 Jitr. lange und 1 (itm. Dife eijerne Stange angejd)teī̄t, Die oben eine 4 (5tm. grō̌e Deje hat, um cin

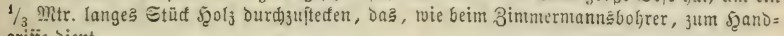
griffe bient.

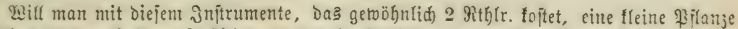
alisheben oder ausbogren, fo jtidt man ben Sjalbcylinder, 8-10 (5tm, bon Der PFlanje ent=

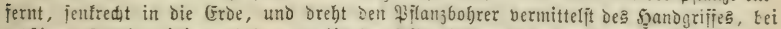
mäs̈igem Drufe, einigemal herum, bis ber \$flanjbolrer jo tiej cingeorungen ijt, als ber Balfen bod jein joll. Sgierauj biegt man Den Bohrer etwos zur Geite, uno hebt mit bem= jelben die Pilanje heraus. - Ia Die Söder jum Cinjetgen biejer Ballen mit bemjelben

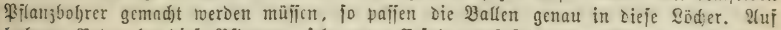
Ioderem Boden bat bieje \$flanjung jebr guten (Erfolg; auf jebr jeftem Bodent reniger, da

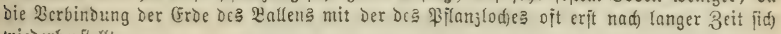
wiederherftellt.

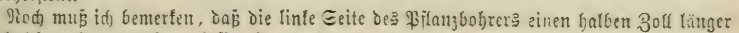
ift, als bie rehte, bamit er beffer in Die Erbe greift, menn er umgedreht roird. 


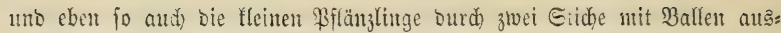
nebmen.

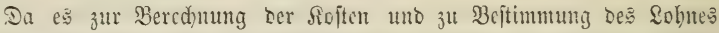

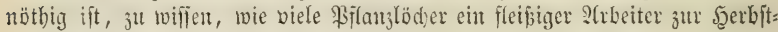
uno Jrübjabräjeit täglid) anfertigen fant, fo theile id̆ bier meine barüber

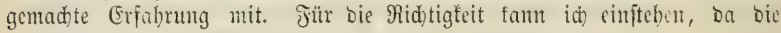
Berjuche in meiner (3egentwart gemad)t worben find.

\begin{tabular}{|c|c|c|c|c|c|}
\hline \multicolumn{2}{|c|}{$\begin{array}{c}\text { Sröbe ber \$Lą= } \\
\text { röder. }\end{array}$} & \multicolumn{3}{|c|}{ Ein fleip̄iger šrbeiter verfertigt tägliḍ } & \\
\hline $\begin{array}{l}\text { Mुeite } \\
\text { Dber } \\
\text { Durde }= \\
\text { meffer. }\end{array}$ & Iiefe. & $\begin{array}{l}\text { Rocterer ober } \\
\text { leidfter Boben } \\
\text { obne Eteine. }\end{array}$ & 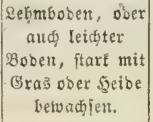 & $\begin{array}{l}\text { Lehunboben mit } \\
\text { Lleinen Steinen } \\
\text { untermengt. }\end{array}$ & \\
\hline Centim. & Centim. & & & & \\
\hline 15 & 10 & 1000 & 800 & 750 & 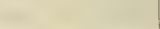 \\
\hline 20 & 13 & 600 & 550 & 500 & \\
\hline 25 & $1 \check{2}$ & 500 & 450 & 400 & Mit Dem getoöbn= \\
\hline 37 & 15 & 450 & 400 & 350 & (fichen Spaten oder \\
\hline 42 & 20 & 300 & 250 & 220 & Der Sgacfe gemad)t. \\
\hline 55 & 32 & 180 & 160 & 140 & \\
\hline 80 & 37 & 100 & 80 & 70 & \\
\hline
\end{tabular}

4) Bom 2 usgrabeu Doer $\mathfrak{A} u s$ tebmen ber Pfläuzlinge.

Da: 2(ugraben ber Bflänjlinge mus mit vieler Sorfid)t gefdehen,

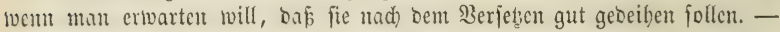
93ie felten gebt man aber bei biejem (jejdjajte mit ber erforberlichen Bor: fidft ju Serf! Die Arbeiter wiflen oft nid)t, wie biel ç oarauf antommt,

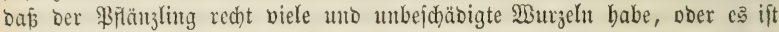
ihnen nid)ts Daran gelegen, ob bie Pflanıung geräth Doer verbirbt. Man fieht saber oft Biflänzlinge anf bie unvernünftigite SYrt und fo ausgraben, als wenn fie zum 3 erbrennen beftimut wären. Daber fommt es bent aud), Daj jo viele berjekste Gtämme verberbent ober verfümmern, bie vor= trefflid) würben gewadjen fein, wemr man fie beim ?(t)

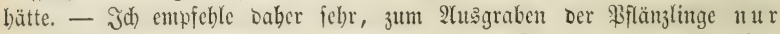
vorfidtige \&eute zu gebrauden, fie bei ber 2lrbeit nidst zu übereilen,

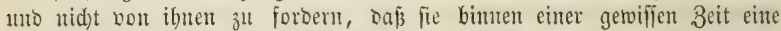
beftimmte $2(n z a b) l$ Pflänzlinge ausgraben, fondorn nur fleiß̄ig arbeiten, uno

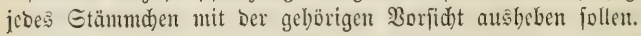

Danit aber bicjes (bejdäft regelmäpig unto gut gemad)t werbe, jo ertheile man ben $\mathfrak{A}$ rbeitern folgente Snftruttionen:

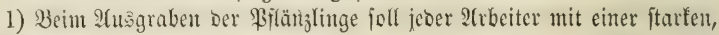
red)t idarfen saade uno Epaten uno cinem ftarten idharfen Meffer ver: jeben jein. 


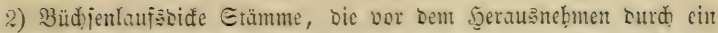

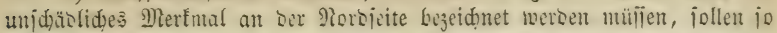

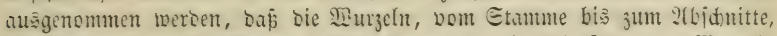

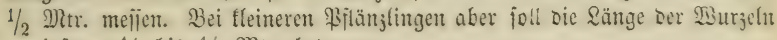
wenigitens $1 / 4$ bis $1 / 3 \mathrm{M}$ tr. betragen.

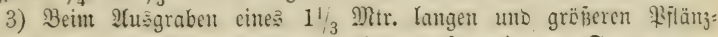
lings jolf bamit angejangen werben, ¿aj man fo meit bom Etanme ent=

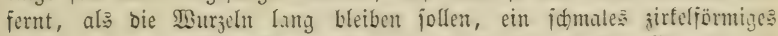

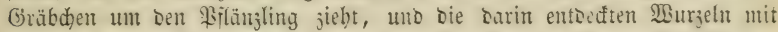
cinem itarfen Eprateri abjicht, ober mit Dem Milier abjogneiset. Sit biejes gejobben, jo joll von allen Eeiten mit bem Epaten ichief unter ben Sallen gejtoden und bie fenfredten Sargeln abgeitopen meroen. (Wan beoient jiđ bierzu mit gutem Erfolge bäufig eines ganţ aus Eijen gearbeiteten Etōeijens mit 15 (Etm. breitem idjaufeligem Ente.) Sit auch Diejes geicheben, jo mú Der \$ilänzling mit bem Sallen

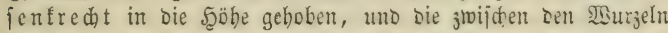
bejintiche Erbe, bermittelft ber Jinger, abgenomment uno

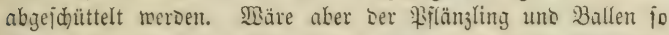
idwer, bap er nidht gehoben werben fann, io ift bie Erse ver:

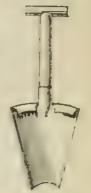

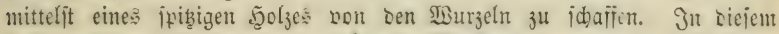

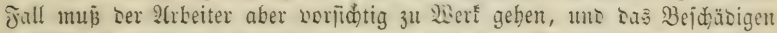

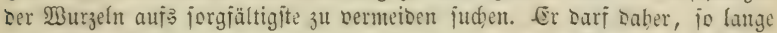

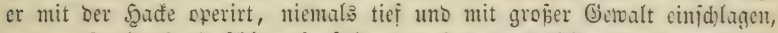

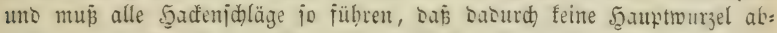

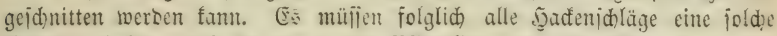

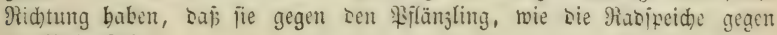
Die Rabe fteben.

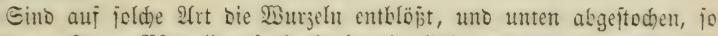

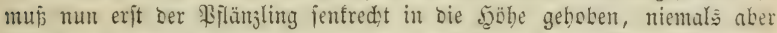

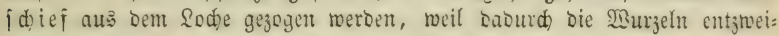
breḑen fönnen, bie biaber mit Mübe gejónnt wurben.

Wären aber bie \$flänjlinge nod) fleit, io ift Das norbin ermäbnte (óräbdhen nicht nöthig. In siejem Jalle jtioht man nur mit cinem jơrien Epaten bie $23 u m c \mathfrak{n}$ in gchöriger Entfernung vom Etümunden ab, gräbt

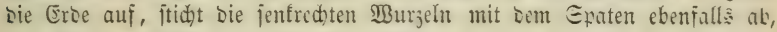
uno bebt ben .PFlänzling aus bem Lodje.

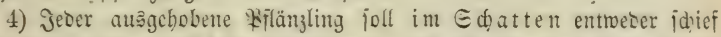
a uigeftellt, oier boridtig bingelegt, niemuls aber Der Eomte auș: gejest ooer bart aujgejtojen ober hingeroorfen mersen, weil joujt bie 23irzeln Gdaden leiben.

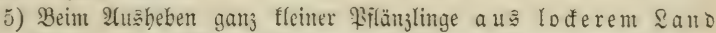
ioll Der 2 rbeiter in gehöriger Entfermung mit Dem Epaten etmas tief in Die Erbe itechen, Den Boden mit Den \$Flanzen etwas heben, uno mun eine ganze 5̧anboll Pflanzen zugleid) herauşiehen, weil auf

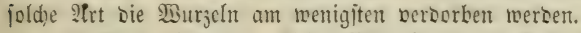

6) Eins aber ganj fleine \$filänglinge mit Eroballen aus ben Eat: fämpen zu nelmen, to sie Piflangen in Peiben ober Etreifen bidt bei= 
fammen ftehen, fo mus ju beiben Eeiten jedcr Reibe zuterft mit cincu id)arfen Spaten etwas fodief eingeftochen, uno bann burdi 15 (Etnt. ent= fernte Duerfid)e Die Bflanjenballen berausgenommen werben. - Dicie

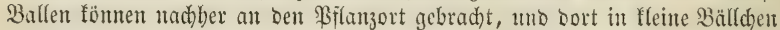
vertbeilt werben, wenn man bie slbfid)t bat, Büidelyflanţungen zu mad)en,

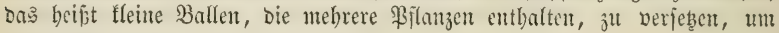
Defto ficherer ben Brwed zul erreidjen.

7) Bent ganz fleine Pflanzen bei weid)ent Boben an ben $6 d)$ lägen gerupft werben follen, fo hat ber Strbeiter jebesmal eine ganze f̧and: voll zugleid) zu fafien unb ausjurupfen, weil forft bie 23 urzeln abs reiß̄en, went man jebe Pflanze einzeln ausziebt. Uno

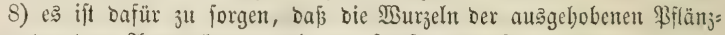
linge tweber bent 2fustrodnen, ntod) Dem frofte auşgejeb̧t werben.

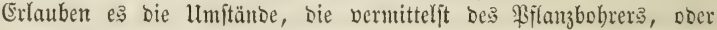
aud) bermittelfit eines balbjirfelförmigen Epaten autggenommen, ober bie nad) Nr. 6 ausgebobenen, ober bie mit einer Bflanz=

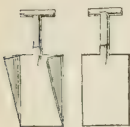
¡da a fel ausgeftod)enen Bffäulinge mit Exbballen zu berjeben, jo ift biejes bejonders bortheilfaft. Man muj Dann nur das 2Ubfallen ber Erbe zu berbindern. fuchen, bie \$flänglinge alşbald in Rörbe ober auf Bretter ftellen, fie aut Den Drt iffer Beftimmung tragen, ober auf Sdicb: farten babin bringen lafien unt wieber einpflanzen, ehe bie Eroe troden wirb uno abfült. ${ }^{1}$ Sollen grofise Etämme mit Eroballen verfebt werben, weil bieje fonft nidjt leidht wieber anmadjen, fo mup eine jolde Berpflantzung im Binter beim Jroft geidchen, Damit bie (ErDe ourd) Den Transport nidht abjällt. Jn bicjem Jalle läpt man bei getinber Mitterung Den Stanım Durd) enten Graben Losarbeiten, träutt ben Ballen nit $\mathfrak{B a f f e r}$, bebt ibn nachber, wenn ber Eroballen Durdgefroren ift, heraus, uno bringt ibn auf cinem niebrigen sBagen an ben Drt jeiner Beftimmung, wo Das Bffanjlod bei gelinbem Better fdon gemad)t worben ift. - Dergleiden Bflanzungen fint aber für Den Jorftwirtl) zu toftbar, ımo fallen mur bann vor, wenn in

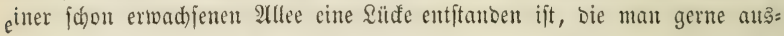

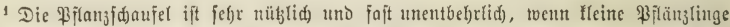
aub jehr loderem Sano auggeftod)ct und auf Santidjolfen verpflanjt merben milffen. (Eine

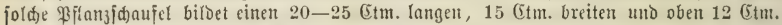
weiten hohlen Seil bon jtarfem (Eijenbled), Deffen cine breite Eeite offen ijt, unto rermittelft cines 20-25 (Stm. langen und 15 ( $\mathrm{tm}$. breiten Sdiebers gejd)loffen twerden fann. Sotwoht an biejem Gdieber, als an Dem Drcijeitigen bohlen fieile ift obent eine firtide angebrad)t, um beibe bequem in den Gand fteden ju fönnen. Siehe bie obige Beid)nung. 21ill man mit diejen Inftrumente cine Pflanze ausnebmen, fo ftid)t man mit Dem breilappigen, an affen Geiten

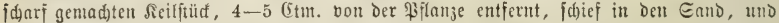

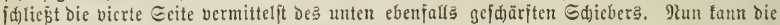
Pflanze auf ciner Trage zwijden winflid) gegeneinander geneigten Brettern fannt ber im

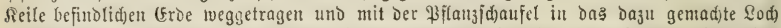

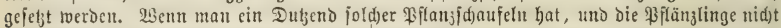
weit getragen 3 werden brauden, fo geht bie \{f(rbeit rajd) von Statten und fillturen ber

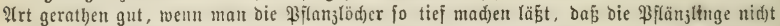
fo fcid)t vertrofnen fönten. Bein Einjefjen bringt man bie Edaufal in ein mit bemjelben

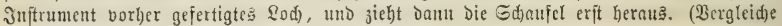

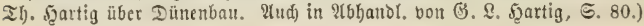




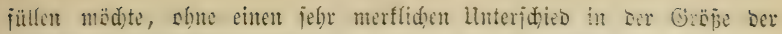
Etämme ftatt finten วัแ lailen. 1

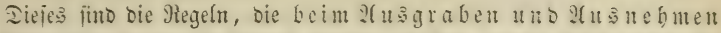

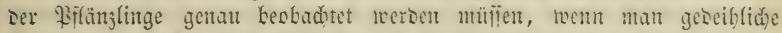

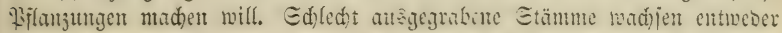

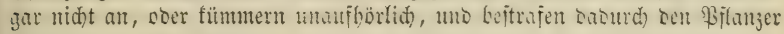
für feine Ilnadtjamfeit.

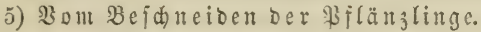

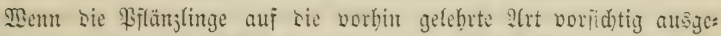

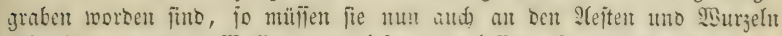
bejonitten mersen. Siollte man siejes unterlajien, jo mürsen bie surdjs

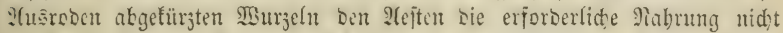
veridaffen fönnen. Es würbe fid saber ber wenige Eaft in ben mit vitelt

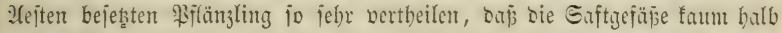

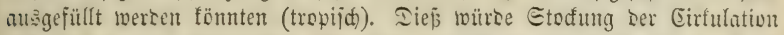

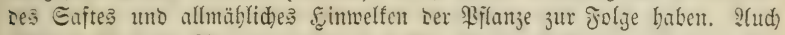
wüben sie heim 24agraben mit sem Epaten abgeftodgenten uno beim $2(b=$

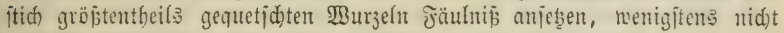

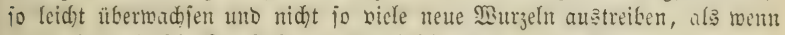
jie vorber mit jdarjen Injtrumenten bojonitten morben jims.

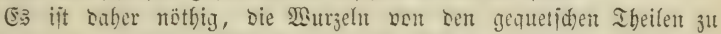
bejrcien, uno von jeom Priängling jo viele Ilcjte abjujdmeicen, bis man

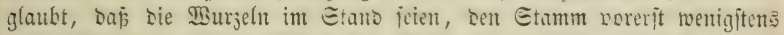
notlbürfitig zu ernäbren. Bei siejem Bejdmeiden, wobei man fich ber be= famten $f$ rum men Baummejier besient (an beren Stelfe in neuerer Beit bie allbefanten, jehr zu empjeblensen Baumideerent getreten fino), gibt

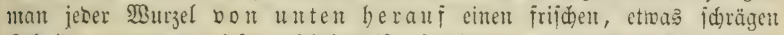

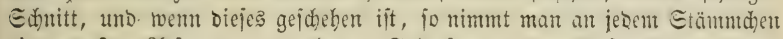

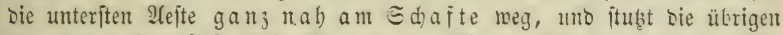
non unten herauf jo weit $a b$, bis man glaubt, Daj ein fallenbes Ber=

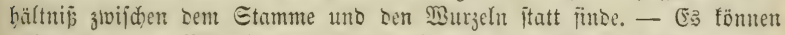
Daher biejentigen Prlänjlinge, weldhe vicle uno gute Misurzeln baben, mehr

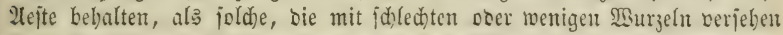

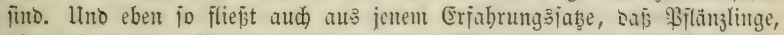

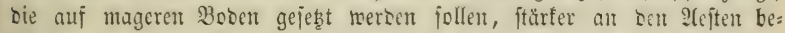
idnitten werben müfïen, als jolḑe, bie in guten Bosen gerflanjt werben.

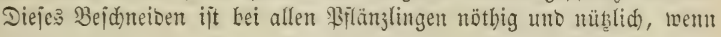

1 will man ptarfe @tämme mit fidjerem Eriolge berpilanjen, jo ift es nöthig, idjon

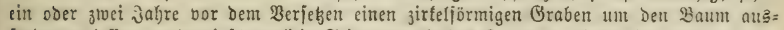

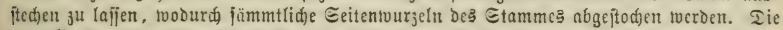

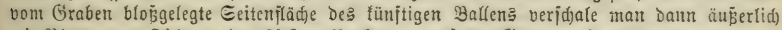
mit Pintten bou Fidaten odir Sitejern=Bonfe, worauf der Ǵraben twieder jugetworfen wiro,

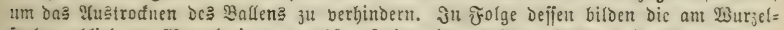

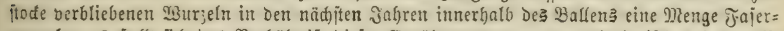

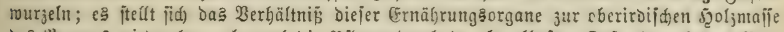

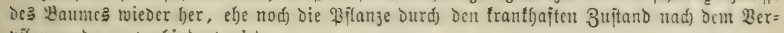
pilanjen Daran berfindert wirb. 


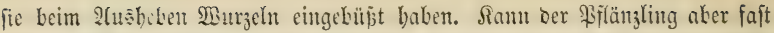

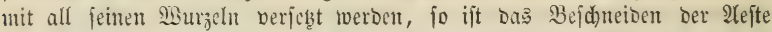

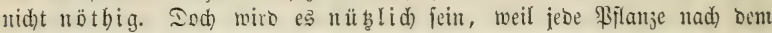

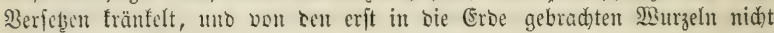
fo vollftänbig genäbrt toeroen fann, als wenn biefe erit wieber böllig an= gewadjien find. 1

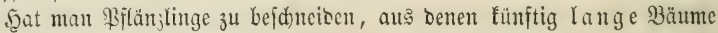
werben follen, fo mus man ibre bipfel forgfältig fobonen. WBill man aber

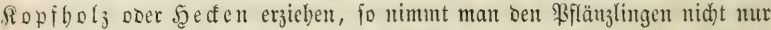
alle 2 ejte, fonoern ftutb̧t ihnen aud) Dent $S_{d}$ aft fo weit fdräge ab, als man e's übthig uno gut finot.

Dod) Darf man nidgt glauben, Daf aus einem Brlünzling, Der Dent Gipfel bcrloren hat, niemals cin fdöner, geraber und hober Baum toerben

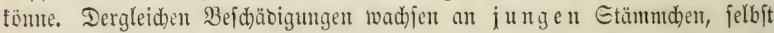
wern es glabelholy ift, wieber aus, uno man fieht oft in ber golge bie Epur nid)t mebr Davon. - 2Een daber die \&aubholzpflänzlinge jul lang finto, uno oben überbängen, fo ftube man ihre Ylefte ettoas cin,

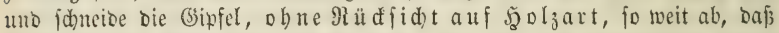

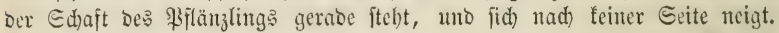

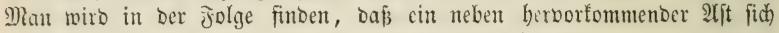
gerabe in bie Scöbe bebt uno bett verlornen Gipfil erjekt.

llebrigens fam id) berfidern, dás ę Borurtbeil ift, went man glaubt,

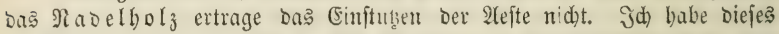
zur Probe fo weit getrieben, dás id) fleinen Mabeltholzitämund)en, von $1 / 3$ bis $2 / 3$ Mitr. Söble, alle 2 Cefte nabm, und fie fino beffer gewadjent, als biejentigen, welde alle ibre S(efte bebalten batten. Durd einen Neriud)

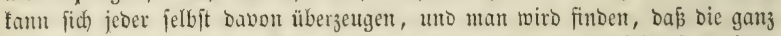
ausgefdneidelten fleinen Rabellyolyftümmd)en aus ber Bipfelfnofpe einen ftarten Tricb maden, Defien Edjwere fie aber frumm biegt. (E: ift baber

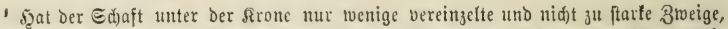
fo nelyme man Dieje bid)t am Stanme $10 \mathrm{cg}$, jcood) ofne bie Edjaftrinte zu verleben. Die llcberwaflung geht in biejem Falle viel rajd)er von ftatten, als wenn man 2 fiftutjen ftehen

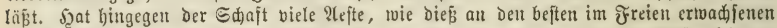

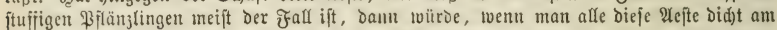

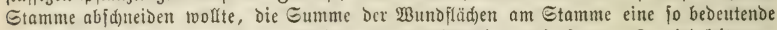

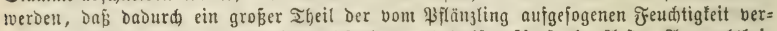

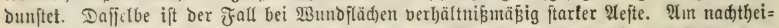

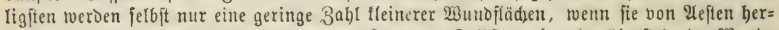

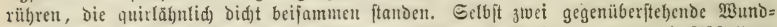
fläd)en, wie fie beim Beidnneiben Der 2lyorne, (Ejd)en, Saftanien zc., Durd bie 2(ftiftellung regelmäpig erzengt werden, fdaden viel melgr als die boppelte oder dreifad)e 3 ahl ver=

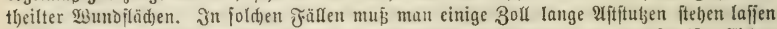
und Dieje bann erjt Ginwegnehmen, wenn ber \$iflänjling volftommen angemadjen ift. (Eidhen

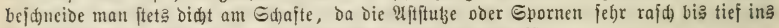
Edafthol3 hinein abfterben, was bei ber Budide nidt ber frall ift.

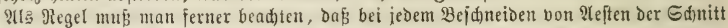
ftets bid)t über ciner finofpe, bejijer nod) über cinem Bradybtajten gefübrt tvito, wenn Sebtere vorbanden fins. Die Heberwallung Der 28 unde geht in biejent falle viel rafd)er von ftatten, als twenn Der Gdunitt unter einer finofpe oder in ber Mitte zivijuen zweien Inojpen gefïlibrt twiro. 


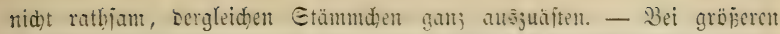

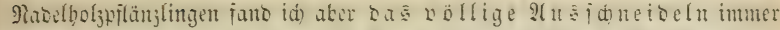

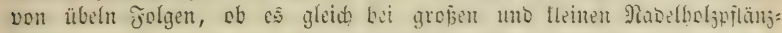

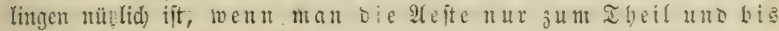
3ur Sölfte wegnimmt.

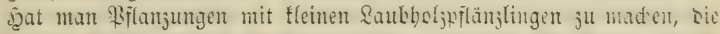

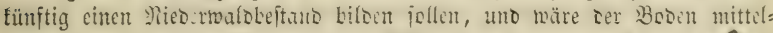

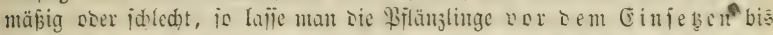

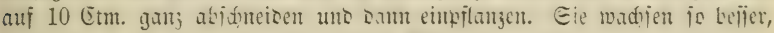
als menn man fie auf bie geröbullide 2 (rt fflangt.

6) Bon Der Bibatiolung ocr angebebenen bifünjlinge, went jie nid) alsbalo verietst merben fönten.

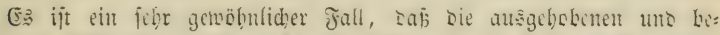

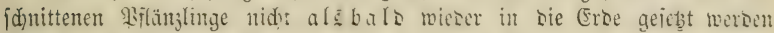

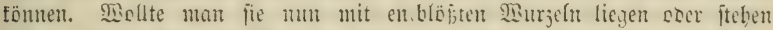
lafien, io witroen bic SBurgeln balo anstrodtin, soer viellicht aud ge=

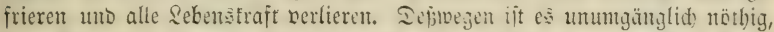

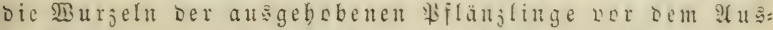

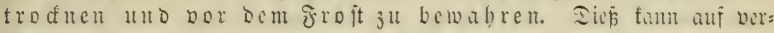

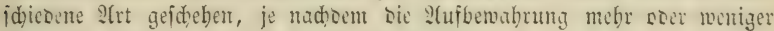
lange bauern foll, und bie llmitände es zulailent. ${ }^{1}$

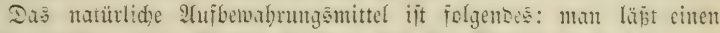

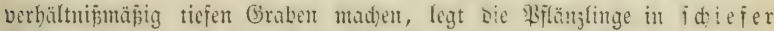
Midftung binein, uno besedt bie 9 suzeln mit loderer Eros.

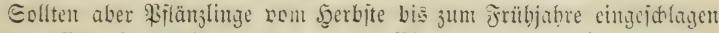

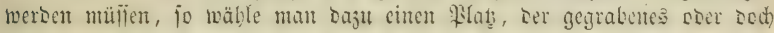

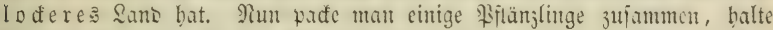

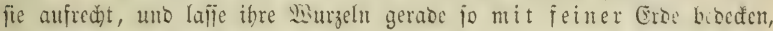
als beun man fie fiflanjen wollte. Sgierauf balte man in bas sutd bie

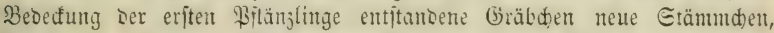
bebecte fie auf gleidje 28 rije, umb fabre samit im Cirfel fort, bis alle

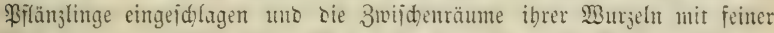
Eroe genau atşgefüllt fint. Pun gicbe man sie ganje Malie tüdtig mit פBajier an, uno lajie alles ftehen bi: zum Jrübjabre.

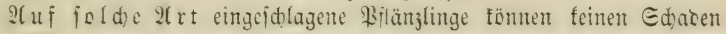

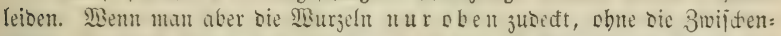

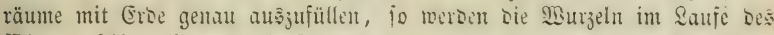
MBinters jdjimnelig und die Etämme verderben. Eollen aber die \$iflänglinge nur wentge Tage oder. Moden eingeldlagen bleibu, io ift es idon

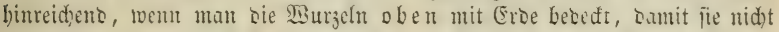

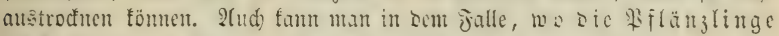
uad) rouigen Tagen idon veriebt werden, beielben mit ben

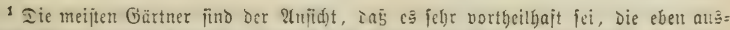

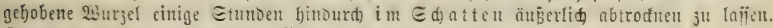

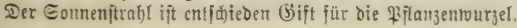




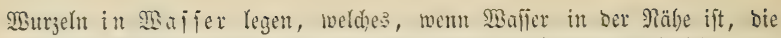
wenigiten limitänbe veruried)t und ber ?(bjicht vollfommen entiprid)t.

5at nan aber Bfiänglinge anझ̧gehoben, bie, wie bie Siefern, bas

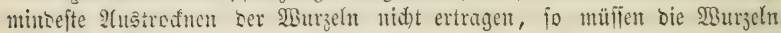
iogleid) in naffes Jions gepadt werben.

7) Bou Der nöthigen Boricht, wenn Bfränzlinge verididt werocu follen.

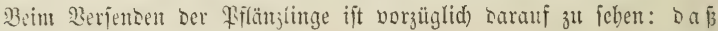
Diefelben burd bas 3 ulamenbinben feime Bejdäbigung lciben, baj bie murjeln und alefte nidt jerbroden werben,

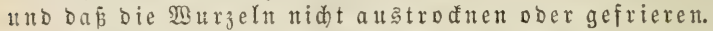

Die Bilänjlinge müifien baher żwar feft, aber bod) fo aufeinander gepadt werben, זas fie jid) unter cinanber folbjt nidjt reiben, uno eben fo weniz won ben Etriden mb fetten befchäbigt werben fömten.

(Sibt ber Iransport nid)t meit, uno ift Der Şimmel bebedt, fo fömen

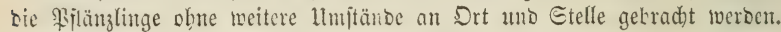

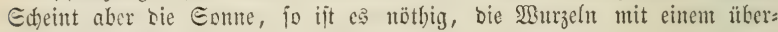

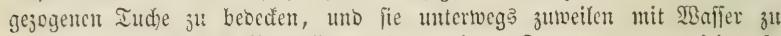

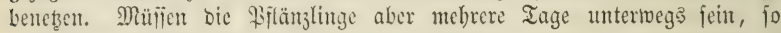

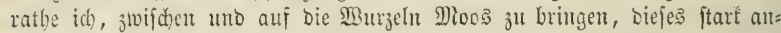
jufeudten, nahber sie ganje Malie mit einem Iud zu bcoecten, uto bie

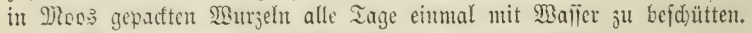

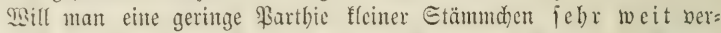

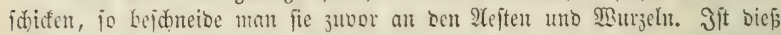

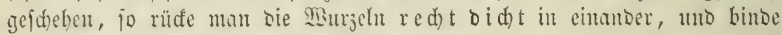

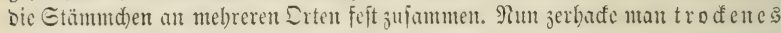

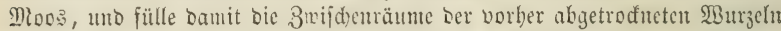

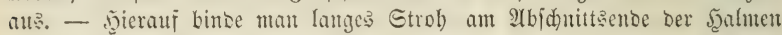
jujammen, uto formite Darans cin Etrohrad. In bie Mitte biejes Pades

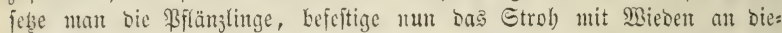

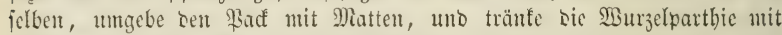

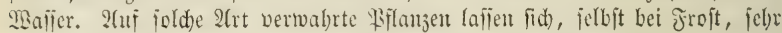
weit veridjider, ohne baj jie ben minbeften Ed)aben leiben.

\section{8) Bom Berieben ber Bflänjlinge.}

Mem sie \$flautlöd)er nad) ser oben ertheilten Boridrift gebörig ges

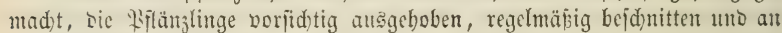
Den Ort ibrer Beftimmung gebrad)t find, fo müfien fie mun aud mit ber

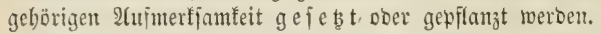

Sierbei fino folgenoe Regeln vorzüglid zu beobadten:

1) Man febe die Bflänzlinge von gleider bröbe jebess mal zujammen, weil jonft bie fleiteren in ber Folge unterbrüdt werben, Iwerin man fie zwifden bie größeren gevflangt hat.

2) Man jebe die Stämme nidt tiefer, ober bod nidt biel

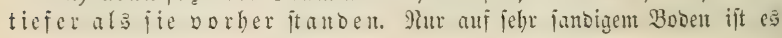




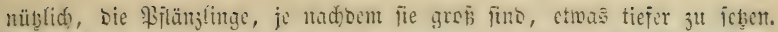

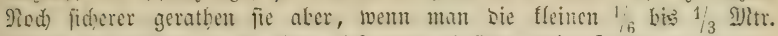

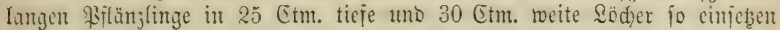

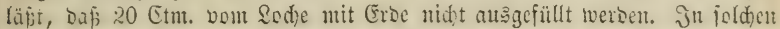

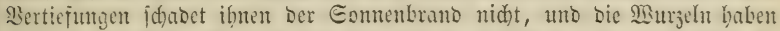
mein Jeudtigfei.. Es barf bas aber mur ba gejdehen, wo man fider iit,

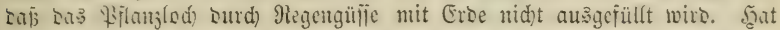
man \$itinglinge genug, fo laije man bei allen Sulturen mit ganj flcinen

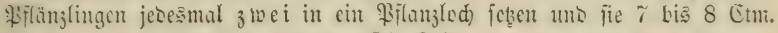

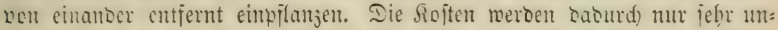

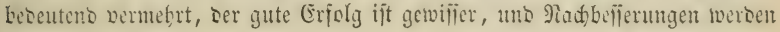
jelten nöthig fein.

3) Man jorge bafür, bafi die 93 urzeln ibre natürlide

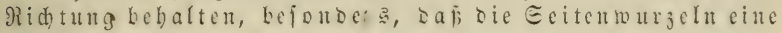
wagred) te ¿age befommen.

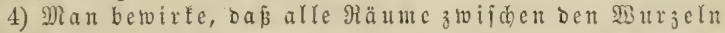
mit ber beften, redit feinzerriebenen Erbe fo bidt toic mög= Iich a

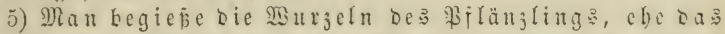

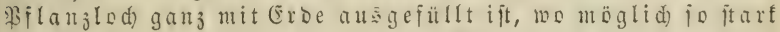

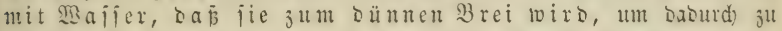

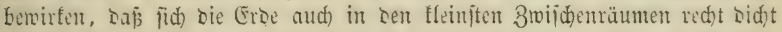

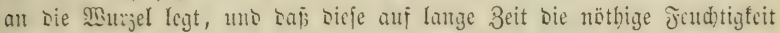
erhalten.

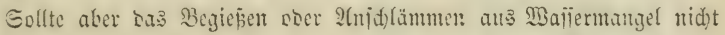

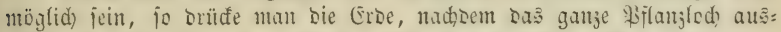
gefüllt ijt, mur gelin o jujumen, moburd) Der cben crmähnte 3 med jwar audh, aber bei weitem niá̛t jo vollitändig erreid)t wirb.

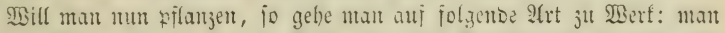

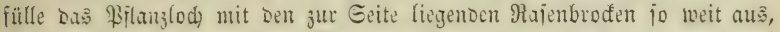

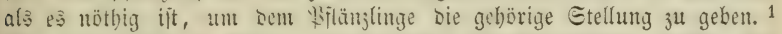
Sun trete man bieje Hajen, bie verfefrt cingelegt werben müfien, fejt

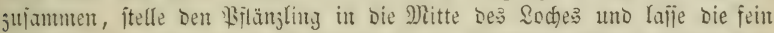

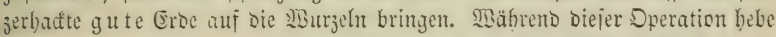
man bie Eeitenmurzeln mit ben Jingern in bie ફुöhe, Daj fie eine

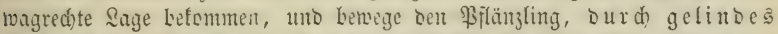

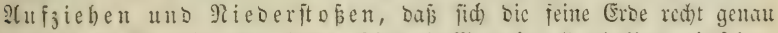

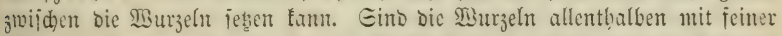

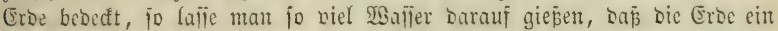
Srei wirb." Siun efne man bas Sod) mit Der bei Berfertigung Defielben

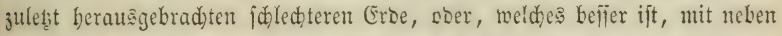

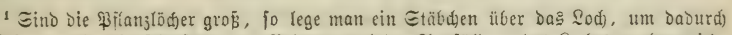

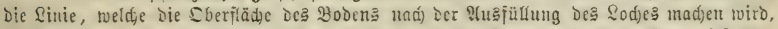

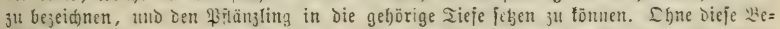

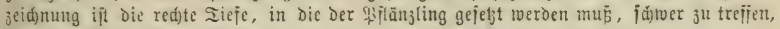
wenn die Piftanzlödjer gros find.

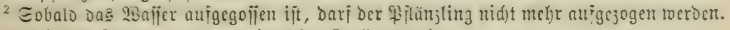
Man mup̈ ihm bejwegen vorber bie redte Gtellung geben. 


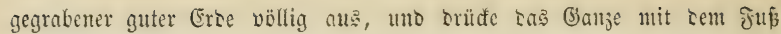
gelinde zufammen.

Märe ber Drt ber Eome ftarf ansejebt, fo lafie man Rajen ab=

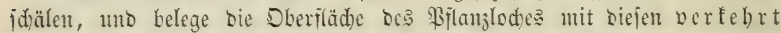

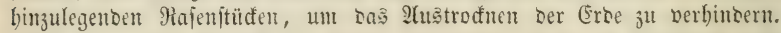

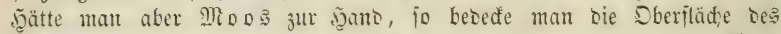
Yiflanjlodes biaf mit Demfelben, uno befeftige es ourd) anfgelegte fleine Eteinte oder burd 4-6 eingeftod)ene fleine \$räbldhen. Eine foldhe Bebectung bält bie lodere Eroe lange feudt, uno es fanu das Regenwafifer beffer ourdbringen, als Durdh aujgelegte Rajen. Eelbft gröbere Eteine fam man im Notbfalle auf bie Siftanzlöher legen, um ben Boben feucht zu erhalten. - Eolt cin groper Bifläzling obue Bfabl ftiben, jo lafie man um feinen Etamm einen 10 bis 20 (Etmt. boben fegelförmigen, uno nad) bem Ziflänjling etmas tridterförmigen bügel von Erse ober Mafen bilben, um Da: Edwanten io viel wie möglid) ju verbindern, uno ras am Stamm

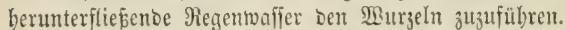

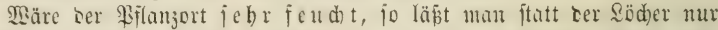
Den Rajen abjcälen, ieţt Den Riflängling auf die bermunsete Etelle uno

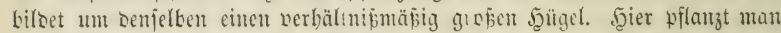
alfo nidst in, fonbern auf bie Erse. - Wflanjungen ber Ârt gerathen

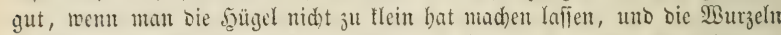
baburd) fo bebectt hat, baj bie şügel fo leidht nidht austrodnen tömnen. Einto an ben jult pflanzenten Etämmolyen Eroballen, jo merben biefe mitten in bie Fiflanglöcher geftellt, und es minffen biefe Ballen fowohl unten ale neben mit locerer Eroe jejt aușgejüttert merben, bamit bie Suft bieje Ballen nicht auștroçnen fann. 1

1 Die Fiflanjung in Erohüget über ocm Boden ift in neuerer Beit aud auj gewöhn= lidjem, feud)tem, jelbjt trodnen woden mit gutem (Erfolg in : Inwenoung gebrad)t worden

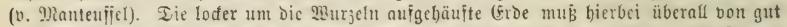

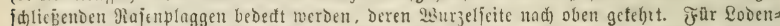

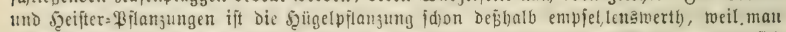

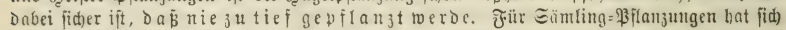

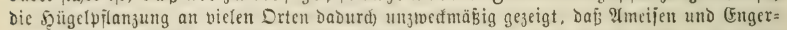

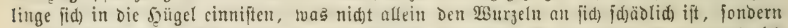

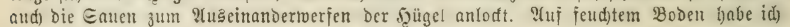
jelbf̣t Bud)en= Şeifterpilanzungen baburd) vernid)tet gefunocn.

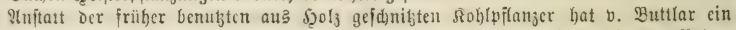
jemereres jnftrument bon (Eijen conjtruirt, mit Dem trid)terförmige \&öder in ben Boden gepeçt werben, um flcinere $1=$ bis 3jährige Pflänjlinge in Dicje zu pflanzent. Wie beim Rohlpflanjen wird bann dic Erde curd cinen Etid) neben bem ßilanglodje, mit Demfelben

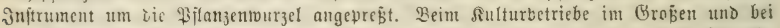

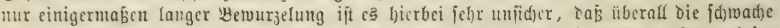

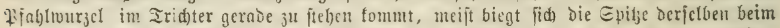
(Einfenten nad) chen, jelbjt Da!n, wenn bie WBurzel mit Sebmorei und Eand bijolwert wirb.

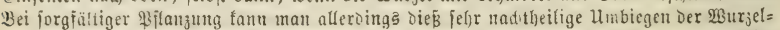
ivifen vermeioen; beim \$ilanjhetriebe in Großsen ift dies felten mögtid. Taber bediene id)

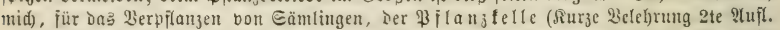

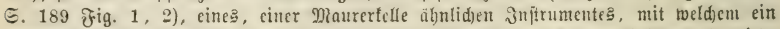

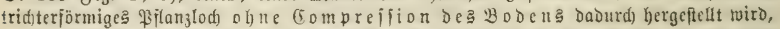

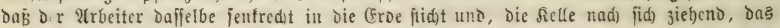

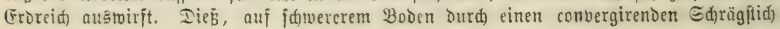




\section{9) Bom Bermabren ber gepflanzten Stämmi.}

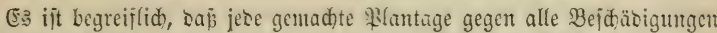
binlänglid) gejchüb̨t werben muईs, wenn fie einen guten Erfolg baben joll. Sever mit kleinen Etämmchen befflanjte Diftrift mus baher, wie bei ben Eaaten in ahten Siapitel ber borigen ?tbtheilung gejcigt morent ift, in ftrenge şege gelegt, uno, wo e $e^{3}$ nöthig $i$ it, bermittelit Gräben ooer

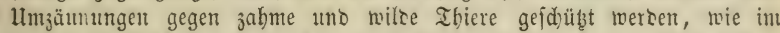
3tweiten Theile beftimmter gelchrt merben mirs. - Sat man aber gröfere

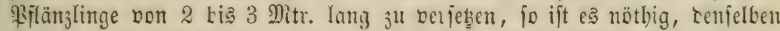

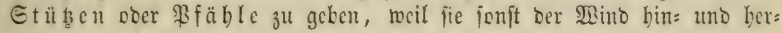
treiben uno ber Ed)nee fie umbrüdent würbe.

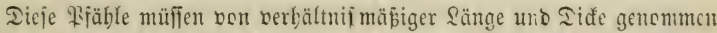

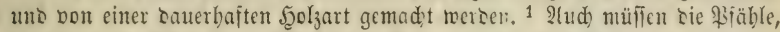

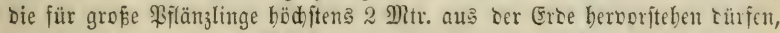
bor bem Eesen der Pflänjlinge feft in bie Sëder geftóen meroen, weil fonft, wenn es na dher gejdieht, bie Murzeln bonurd) bejdäbigt werben, unt bie Bäble in ber loceren (Erte nid)t foft ftehen. - Man ftofe

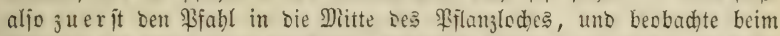

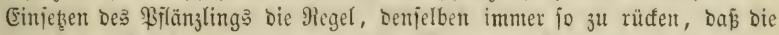
gezeidnete Norbjeite loieder nad) siejer Weltgegeno fommt, uno baf ber Pfabl a uf Der Mittagsieite fteht, um bem Bflänlinge in sen beipen Mittagsitumben einigen Ed)atten zu geben.

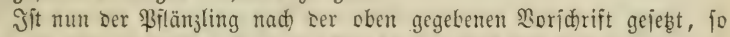
lajie man ibn mit Binoweisen ober Etrobjeilen in form einer 8 einigemal, bod nid)t feft, an Den Prabl beften, oocr, wo einfadje Bänoe angebrad)t

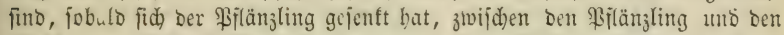
Biabl einen Büjel Moos ftowfon, Sanit feine Reibung ftatfinoen fann.

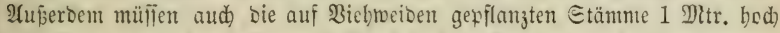
mit Dornen, ober befier mit $\mathfrak{B a} d$ bolberftraud umbunben merben.

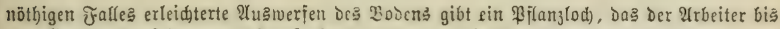
zum Grtunde überjeben, an Defjen jenfrechter 2sand er bie Wurzeln anlegen und ordnen fann, worauf er dos geloderte, ausgenorfene (froreid) bon ber Eeite her an die Wisurjeln an=

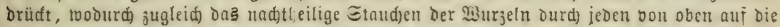
Pilanjerbe wirtenoen Drud vermieden wird.

2uf jebr loderem Boden, bejonders im Brud)boden ift aud) bie Piflanjung in ben Stid jebr empiehlengmerth. (Ein getwölnnlid)er Gartenjpaten toit jentredit in Den Boden gejteft und burd) Sein= und Şerbiegen bes Etiels ein feiliörmiger Epait gebildet. Find) bem an jedes Ende des Epaltes ein Prlänjden eingejert, tritt Denjelben der 2trbeiter, mit beiden

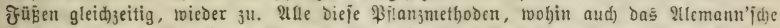
Werjabren gehört, find jeood) nur auj 1 = bis 3jährige \$flanzen antwenobar, oeren Seiten:

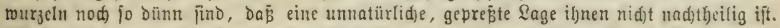
Sino die Eeitentourjeln jdjon mel)r als 2 Mimtr. Did, oann müfjen fie mit Eroe jo cint= gefuttert werden, toie fie früher gerid)tet waren.

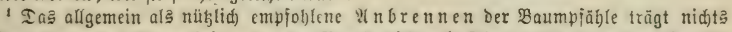

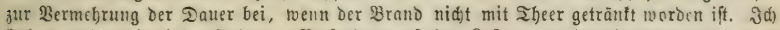

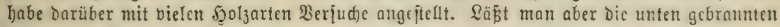
PFäh)le $1 \frac{1}{6}$ Mitr. über und unter ber (Frde mit Sheer einigemal bejtreiden und biejes ror dem

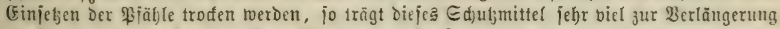

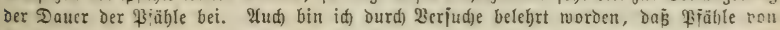

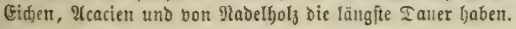




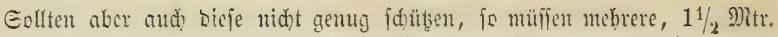

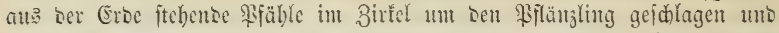
Durd) ftarfe 2Bieben mit cinnoer verbunten werden, um alle Befdäbigungen

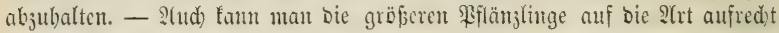

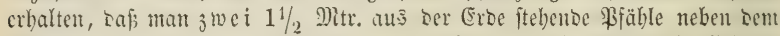

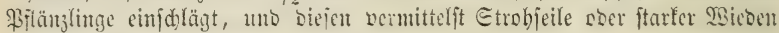
an bie \$räble befejtigt.

jit ç möglid), cine bepflangte Sichmeibe nur einige jabre lang,

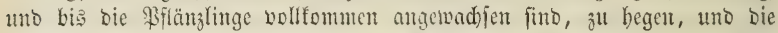

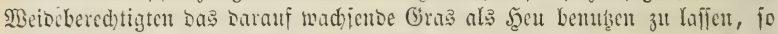

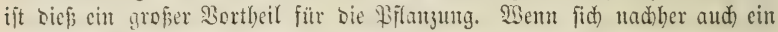
Etüa Sirb an einem folden fơ on völlig angemurzelten Stänmod)en reibt,

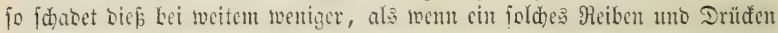

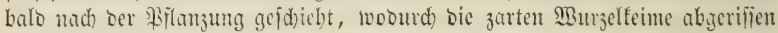
und biele gifläılłhinge ganz veroorben werocn fömen.

\section{Wierte Abtljeilmeg.}

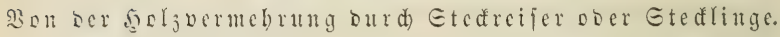

Edron in bon äteften Seiten ift sic Sermefrung uno fortpflanjung

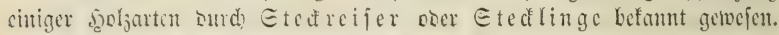
Iamals pflanjte man aber gewöbnlic) mur sic 照eisen uno \$oppeln auf

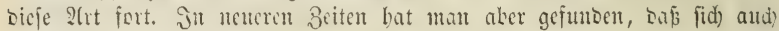
einige andere \&aubliblzer (bie Weipeller uno bie Platane, auker biefen bie meijten Etraudhboljer, wic Evonymus, Cornus, Ligustrum, Ribes, Rubus, Spiraea etc., aud Juniperus, Thuja), mchr ober weniger leidt uno fidser Durd) Etedreifer fortpflanjen Yafien, Iren man bie Dperation gelyöriy madt, sie Etedlinge im eriten Jabre immer foud)t erbält uno ibnen

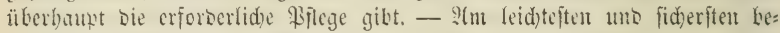

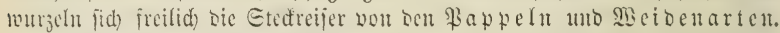

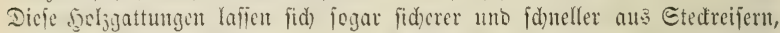
als aus Eamel erjichen. Bei ber Jeritwirthid)aft rerben fie saber aud) faft nie surd) Eamon, fondern ourd) Edunttlinge erjogen, went man ibre 3ermebrung fiu $n$ ft $(\mathrm{i}$ d) betwirfen will.

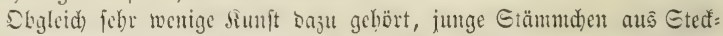
lingen zu crjieben, fo mup man Dod bie nöthige Semutnis babon haben,

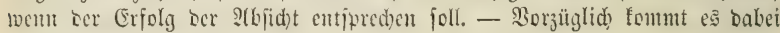
auf folgente Gegenftünde an:

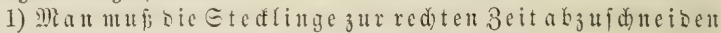
unb ibnen bie gehörige form zu geben wifien.

2) Man múp jie gebörig in bie Eroc zu bringen ber= iteben, uto

3) Man muß fie gebörig zu pflegen wiffen, bis fie fid entweber felbft überlafien ober auf einen andern Drt ber. ietst weroen teñ nen. 


\section{1) গুon Der 3 uridtung ber Etedinge.}

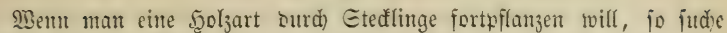
man Bäume ober Büfde von biefer 5ुoljart aus, morant redt ftarfe 1 bis 2jäbrige Iriebe fich befinben. Dieje Irieke nebme man im Jrübjabre, $\mathfrak{t}_{u} \mathrm{r}_{3}$ vor bem $\mathfrak{A} u f f$ dwellen ber $\mathbb{R}$ nofpen ab, uno formire babon lauter Etäbden, bie 25 Etm. lang fins. Unten gebe man jebem biejer Etäbdjen

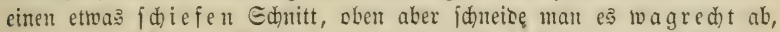
Danit man fich beim (Einfted)en bie sano nid)t beföäsige. - Eollte man non einjährigen jtarfen Єdüijien nid)t Etedfinge genug kefommen fönnen, fo fint aud) finberșbife zmei = unto strijäbrige 3rweige braudbar. Man nimunt ibnen alle Geitenäjte, uno jajneibet fie gerabe jo 34 , wie bie ein= jäbrigen. Dod) haben Die einjäbrigen Citedlinge sen \$orzug, wenn $j$ ie $j_{0}$ Did, und wo möglid bider, als ein ftarfer Jeberfiel find.

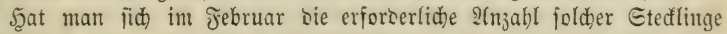
veridafij, fo binbet man fie viertelhunbertweife zujammen, uno follägt fie,

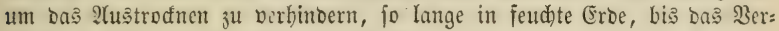
feß̧en Derfelben borgenommen werben fann.

Bill man aber ftatt fleiner Stedfinge grojec, 3 bis 4 Ditr. lange Etangen von \$appeln ober Weiben fiflanzen, bie ekenfalls fid) bewurzeln, jo juche man recht gerabe Etangen voll 4 bis 8 (tm. im unterjten Durd): meīer 3 u crbalten. Diefen nebme man alle Aejte, gebe ihnen unten uno oben einen etwas $j$ diefen glatten 2 fbjonitt, uno besecfe fie entweber an unterften Theile mit feuchter Erbe, ober bringe fie fo lange in Majier, his bie \$fllanzung vollzogen twerben faun. 1

\section{2) Bom Einjeben Der Etedinge.}

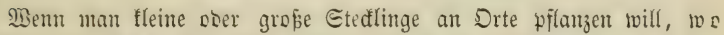
fie fültig iteben bleiben jollen, fo fonmt es barauf an, ob ber Boben jo mürb ift, Daj bie Eted́linge, obne an Der Rinbe eine $\mathfrak{B e}=$ fdübigung zuleiden, gerabeju in ben Boben geftod)en werben fönten

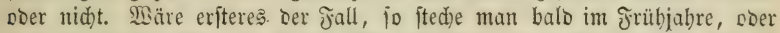
aud) im Erätherbjte, bie fleinen \$Flanj̧täbdhen etwas jodief uno fo weit in bie Eroe, Daj nur $4 \mathrm{ctm}$. Davon beroorragen. Die gröperen Bilanjitangen aber fteche man ${ }^{1 / 2}$ Mitr. tief fenfred)t in Den $3300 e n$. Sam biés aber, mie es gemöhnlid) Der Jall ift, obne bie Rinbe am unteriten 2(bidnitte zu he: idäbigen, nidht gefdeben, jo müffen für bie tleinen Etedtlinge $1 / 3 \mathrm{Mtr}$.

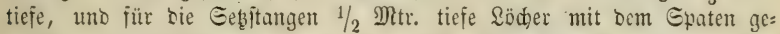
mad)t, bie Etecflinge auf bie vorbin trwähnte 2 rt bineingejeß̧t, bie \&öd)er mit guter Errbe ausggefüllt und tüctig angegrfien werben. Will man aber in einer Pflanzldule Pappeln ober Weiben aus tleinen Etedlingen erziehen, fo laffe man cin gutes, ser Sonne ausgejeţtes, uno burd) nidts verbämutes Sanb tief umgraben uno von Unfraut reinigen. SRenn bicf

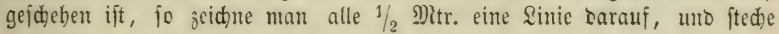

1 In unjeren 2ulfeen babe id) Ectjftangen ber \$yramidenpappel bon 15 bis 16 (5tm. Durdjmejier und 7 bis 8 Jitr. Jë̈be nit Dem beften (Friolge verwenden fehen. Eie wurden $1 \frac{1}{2}$ Metr. in die Groe gebradt.

5ूartig, ¿ehrbud für F̈̈rf̣ter. II. 
in ber Entfernung von $1 / 3$ Mtr. einen Etedling, ettoas $j$ dief - jeocd)

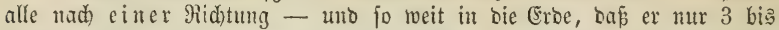

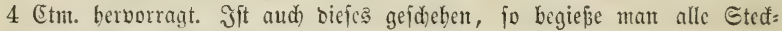
linge ftarf mit $\mathfrak{B}$ affer uno laffe fie nun anwurgeln.

(Gemöhulich bringt man bie im Jebruar gejdnittene Stedfinge und Geţitangen Kalo im Frübjabre in bie (Erce. Dieß̧ fann aber aud) im Gpät:

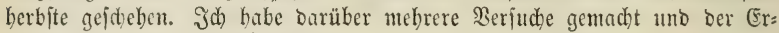
folg war jebesmal nad) "Moujid).

3) 2on ber Bflege ber angerad fenen Stedinge.

Wenn bie Stedflinge auj bie fo cben erwähnte $\mathfrak{A}$ rt in bie Erbe ge: brad)t uno juweilen begofien worben fint, fo wiro jeocr febr kalo im früh= jahre cinige 2tuetriebe maden. Dieje laffe man bis nad) Jobannistag fort:

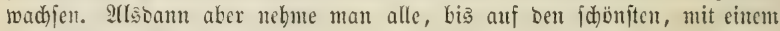

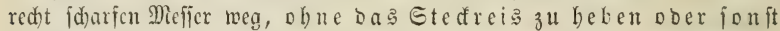
zu bewegen, uno laije die Bflanjidule von allem Unfraut reinigen. Jm folgenoen frübjabre nehme man oen oberften, gewibnlid vertrodneten Theil bes Steffreifes bis an den neuen Etamn glatt weg, ohne ben Rflänj: ling 3 u beben - weld)es burd) einen foiten Iritt mit beioen Jünen Did)t

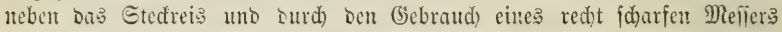
berbinoert werben famt - uno lajie bie Pflanjidule abermals von Unfraut

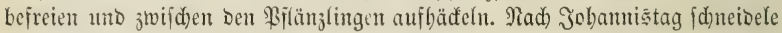
mant bic Stämmd)en $2 / 39$ tr. bon unten herauf aus, uno lafie fie nun io lange fortwadjen, bis fic im britten ober vierten Jahre zum Berfę̧en inz Jreie ftarf genug fino.

Bill man aber ants bert, fogleidh an Den Dot ihrer Beftimmung ge:

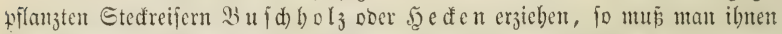

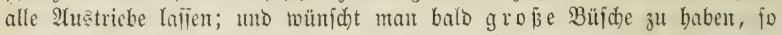
läp̆t man 19 Mtr. im Durd)meiler grop̉e uno $1 / 2 \mathfrak{M}$ tr. tiefe trid)terförmige Söder mad)en, legt mebrere Etedflinge an Der Eeite fochief cin, füllt Das

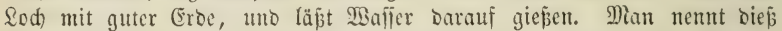

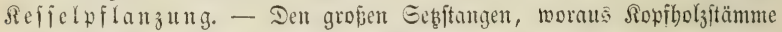

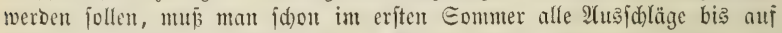
biejenigen, weld)e ben Sorf ober bie Siroute bilben follen, ahidneiben, um

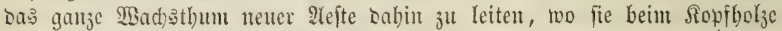

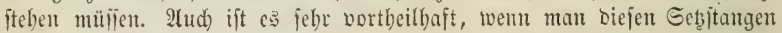
im jlveiten Jrübjabre bic gewöbulid) bürrn Stumpen über Der Sirone, mit ciner red)t jobarfen Banmfäge wegnimmt, uno bie abgefdnittene fläche mit

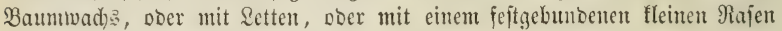

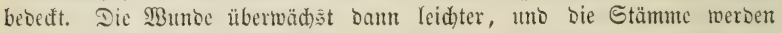

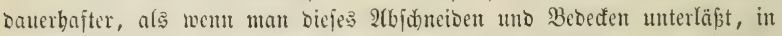

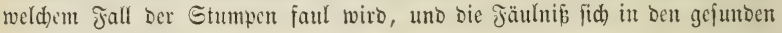
Stamm fortuflanzt.

Borz̈ülid) müblid) fan bie Sultur burd) Stedrcifer werden, went man gebörig abgetroffnete $\mathfrak{B r a ̈ d}$ e mit $\mathfrak{b g l}_{3}$ in Beftano jul bringen bat. Şier ift Der 3oocn gewöbnlich io mürb, Eaj bie Stectinge obne Beiteres in bie Erbe geftod)en werben tönnen. Bemn man aber foldse 


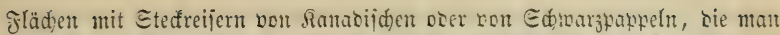
ıtm fehr geringen Breis geidnnittent erbält, allentbalten befteđen läp̆t, io fönnen bergleiden Fläden auf cine wohlfeile ?(rt für bie Folge einträglid) gemadt mersen. Dod) geben bieje beiben Sgoljarten ein id)lcd)tes Brent= material, uno es biro saber immer nüb̨lider jein, Dergleiden Sorte mit fleinen Erlen uno Birfen zu Kepflanzen.

\section{Siiufte Altheilumig.}

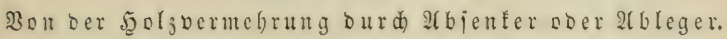

Obgleid) bie f̧oljoermehrung burd) A(bjenter woht niemals bei ber Foritwirthid)aft allgemein merben roirb, jo will id) fie bier ood turz be: fdreiben, ta man fie in einigen (begenten wirflid) antwentet, um lidst

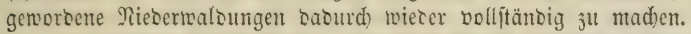

Die meiften \&aubbolzarten, uns ielbit bie Majtbuchen, lafien fid ourd)

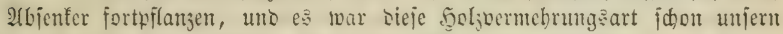
Dentiden Ureltern befannt, bie fie gemöhnlich Daju bemuksten, um auf ben

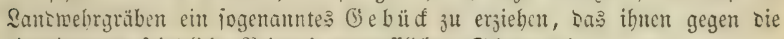
eintringente feinolide Reiterei vortrefflichen હchub gab.

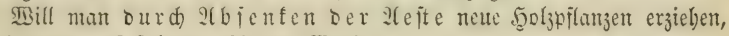

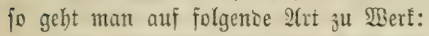

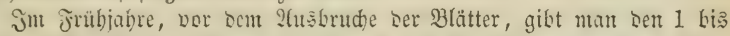

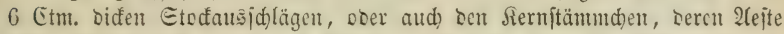
man abjenten rill, nabe an Etocfe, ober nabe über ser Evoe eimen fajt bis in bie Mitte oringenten 5ूieb ober Eimidnitt. Sierauf biegt man bie eingejdnittene Etange boridotig jur Erbe, nadoum man bieje vorher von allem Gras, Moos, \&unb zc. befreit, aljo gant muno gemadts hat, uno befeftigt bie $2($ itpartbie entweber mit cinent eingeioblagenten ftarfen Şatent, ober vermittelit sarauf gelegter Eise, Daj fie in biejer Sage unfeblbar bleiben mup. - Jit biés gejdehen, io riro sie 2litpartbie allentbalben 15 bis $20 \mathrm{Etm}$. Diff mit guter Eroe bedectt, uno es reerben nadber bie Epiben ber stejte, obne jie jeood ju fniden, fajt redbtrointelig uno fo in Die 5ुöhe gehoben, Daís mur 3 ober 4 Sinoipen bavon aus ber Froe herwor: ragen, uno daj ber unfeflbar fenfecht itehende Theil eines jeben $2(b=$ legers 15 his 20 Etm. tief, uno rumoum mit guter Erbe umichlolien ift.

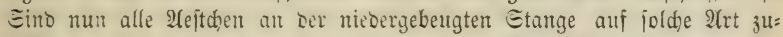

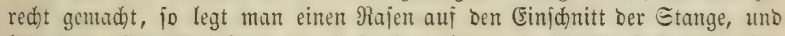
läpt mut alles menigitens orei Jahre lang in biejem 3ujtanbe. Im 4ten ober 5ten Frübjabre ftid)t man nadher bie mun hinlänglid beivurzelten Abjenter bon ber niebergebengten Etange mit einer red)t jobarfen Epate ab, nimmt bie überflüfiligen zum Serpflanjen heraus, mo läft fo viele ftehen, als jut Completirung bes Beftundes nöthig fino. 2(ud) baut man alaboann bie nietergebeugt getwejene Etange unten glatt $a b$, um neue Etodausijaläge 3u berwirfen. 


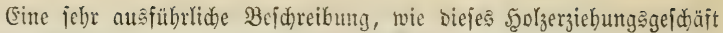

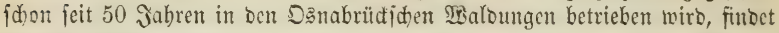

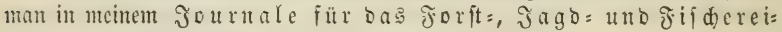
weic nom Jahr 1809, Seite 209. 1

\section{Bierter 9 (rojunitt.}

93ou Atwendung Lex zuopr abgehandelten frolzerziebunge methoden.

\section{Erftes Eapiter.}

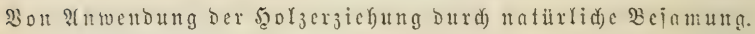

Die Jortpflanzung Der SBaloungen burd) natürlid)e Be $\{$ a nung ift bie wohlfeilfte, uno bie ant wenigften mühjame unter allen fgoljerziehungs:

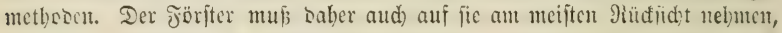
uno alle nod) mit $\mathfrak{S}_{2} \mathfrak{l}_{3}$ binlänglid) beftandenen baubaren $\mathfrak{W a l}_{\text {boijtrifte, nud }}$

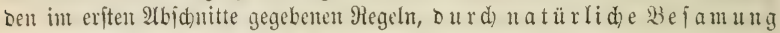
3u verjüngen uno in red)t vollfommenen Beftant zu bringen fud)en. - Pur

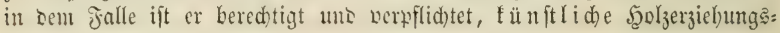
mittel einzujd)lagen:

1) wenn bie zu geringe $\mathfrak{A}$ uabl ober bie Untauglidefeit ber a uf eiuem Diftrifte nod) vorfinbliden $3 a ̈ u m e$ nid)t ge= itattet, einen boltommenen jungen Beja ung zu exzieben, ober

2) wenn bie vorfinblide folzart io faledt ober fo unfaficud ift, sa je cine llmformug nöthig ober nüblid wirb, ober

3) wenn b̈rtlide Lage uno Berlältnifie, z. 3. Wind: brud), oie Jortpflanzug ourd) uatürlide Befamung nidt erlaubert, ober

4) wenn wegen gänzlider Eேntblö́̈ug von Şolz die natürlide $B e f a m u n g$ uidht möglid ijt, ober

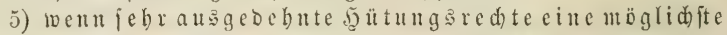
B̧efdränfung Der EdoulugSfläd) und fürzefte Dauer Der (d) onzeit verlangen.

6) Wenn ber cutworfene Betriebsylan abuubug ein= zelnex bejtände vor Eintritt ibrer Manubarkeit verlangt.

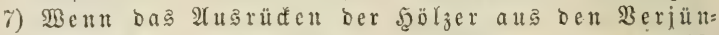
gungsidlägen mit ungewönli d) bohen $\mathfrak{A}$ often berbunden ift.

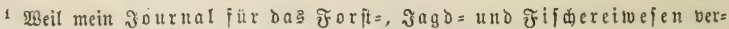

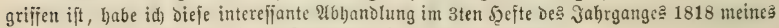

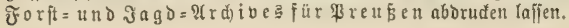


8) Wenn man genöthigt ift, lange Beit mit remalten Jolze eines Bejtandes ju wirthidaften, wiez. B. in Eiden= $b$ a ubolabejt än ben.

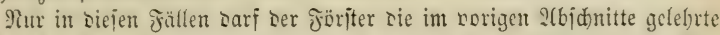

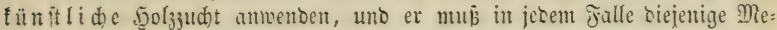

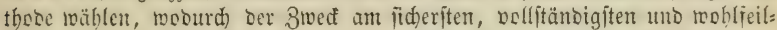

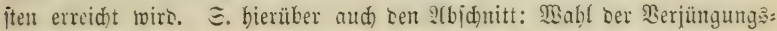
arten, Geite 49.

\section{Bెweites Sapiter.}

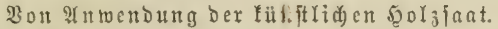

Sie im vorigen :(bidnitte weitläufig abgebanoelte fünjtlid)e Malo = soer ñoljian ijt gewöhnlid) ba einjadjite, wohlfeiljte und fiderite Plittel, wosurd)

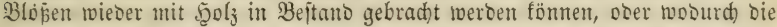
unter mand)en llmitänoen nötbige $\mathcal{U}$ miformung eine bemadjienen ミiftriftes bemirft werben fann. Dieje Rulturmethode erjorbert aber eine itrenge und langmierige Segung, Die nad, 3eridiedenbeit ber $50 l_{3}=$ arten 10 bis 25 jahre, ober überbaupt fo lange baurm mus, bis bas \$ieh

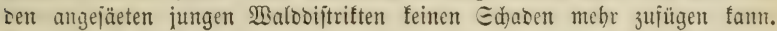
24uperiom fommt es aud) nod) auf bie Unterfudung an, ob Das (siras uno

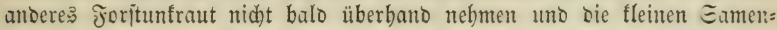
loden überwadjien und veroümmen toirb; ob nebenjtebende ältere Sgolizflanjen Dem (Geseiben ser burd) Gaat fiäter entitanoenen Gamenloben nidt binoerlich) jein werben; ob wegen be马 Яlima unb Der Sage ein guter Erfolg bon ter Eaat zu erwarten ift, uno ob Durch eine andere Rultumethode derfelbe 3 mect vielleid)t eben jo vollftändig uno wo blf eiler erreidt werben faum.

Fänoe man bei Unterjud̆ung all biefer Çegenftäntoe,

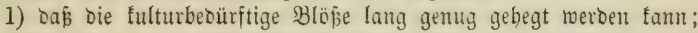

2) ठa⿱⺊ Şinbernip ftattfinden wirb;

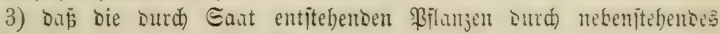
Geböls niḑt beroämmt roerben tönmen;

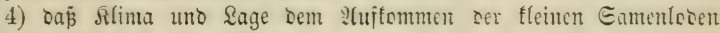
nidit allyu binberlid jein werben;

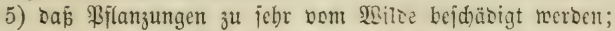

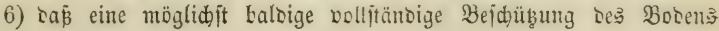
Dringend notbroendig jei, uno

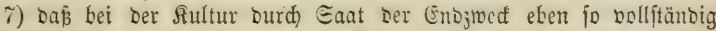
uno to oblieiler, als auf eine andere 2 (rt, crreidht werben fann, fo wäble

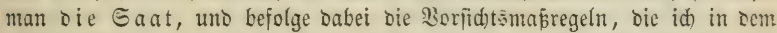
rorigen Ubidnitte emyfoblen babe. Man mirb saburd) nidht allein in sent

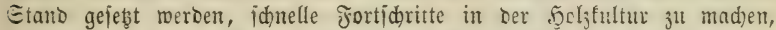

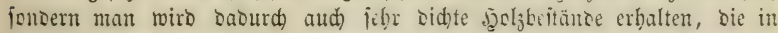

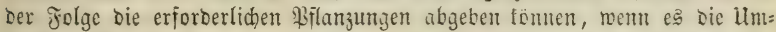

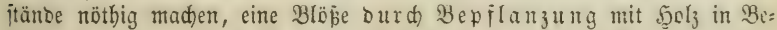

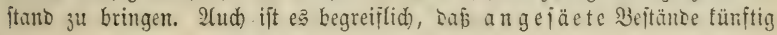


mebr Scoly bei ben erften Durdforftungen geben, als bie wertiger bidyt angepflanzten. Sat and) bic Cinzelpflanze im freien Stante einen

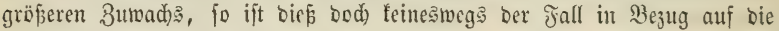
Beftantosmafie pro Şettar.

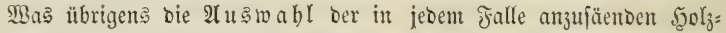
arten betrifft, fo babe id in ber zweiten 2tbtheilung Des vorigen

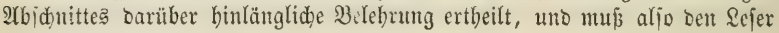
Dorthin zurüctweifen.

\section{Dritfes arapitel.}

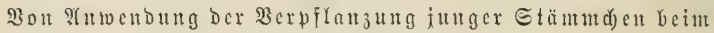
ชoxftyatghalte.

Sin bem vorigen Sapitel babe id gezeigt, unter weld)en Unnitäntoen bie IBalofultur burd) Saat ber Bflanzung vorzuzieben ift. Es gibt aber audid Fälle, wo bie \$fflanzung Borzüge vor ber Saat bat. Dieje Jälle fino folgende:

1) $2 B e n n$ ein fulturbeoürftiger Difitrift entrocoer gar nidjt, ober nidjt fo lange gehegt werben funn, wie es cine Gaat erforbert, fo ift eine $B_{e}=$ feל̧uny mit 2 bis 3 Mtr. langen Piflänjlingen, Die man gegen bie $B_{e}=$

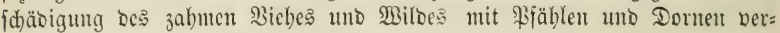
wabren mis, tiöthig.

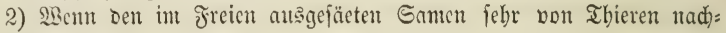
geftellt wirb.

3) Wenn ber Boben in Der Dberfläde fehr fahled)t uno troden, in einiger Tiefe aber feudst ift.

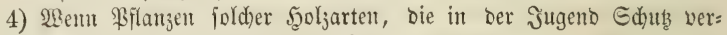
langen, auf $\mathfrak{B l o ̈ ß e n ~ a n g e b a u t ~ w e r b e n ~ f o l l e n . ~}$

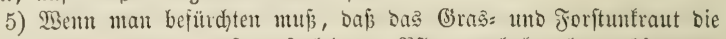
fleincu aus bem Eamen crit aufgeteimten \$flanzen balo überivadjent und verbänmen wirb; aud) in biefent Galle bat Die Bepflanjung mit $2 / 3$ bis $1 / 2$ Mitr. Langen Etämmtden, bic man 1 bi: 2 Mtr., ober audh nod) weiter von cinanber entfernt, einjeb̧en läpt, ben $\mathfrak{B}_{\mathrm{or}} \mathrm{ug}$.

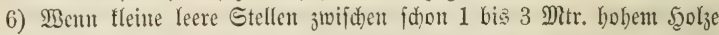
auşubefiern finto, fo bepflamze man biefelben mit cben fo grofen, ober bod)

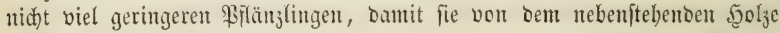
nid)t verbämmt werben fönnent.

7) Bem man gemengte Befänoe erziehen unto ber langiamer wad)= jenben Scolzart einen Sorjprung geben will.

8) Benn Blöß̧е in rauhem Sllima mit நgolzarten, bie in ibrer zar: teiften Jugento gegen bie raube Bitterung jebr empfinolid) finto, ober went

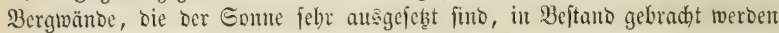
follen, fo wähle mant bie Bepflanzung mit $1 / 4$ bis $1 / 2$ Mtr. Langen Stänmd)ent, unto feb̨e fie 1 bis 2 Pitr. von cinander entfernt cin. Mant wiro baburd

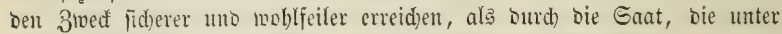
foldjen llmittänoen oft mifitäth) uno mut felten zum. Biele fübrt. 


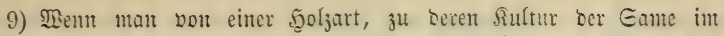

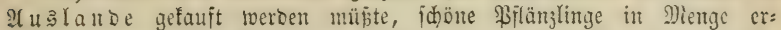
jogen hat, uns ohne Radtheil aus ben bejamten Diftriftent nebmen faun, jo benuţe man bieje ju \$ilanjungen. Eollte aud ein Mlorgen auf bieje 2(rt jul fultiviren etwas mehr fojter, als bei ber fultur burd) Bejanum,

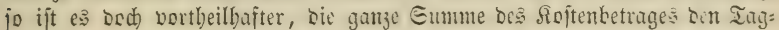

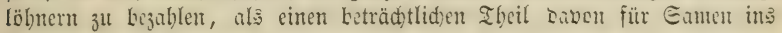

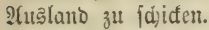

10) \$Benn Sulturen $\hat{\jmath} u$ madjen fint, woju fein entipred)enter Gels:

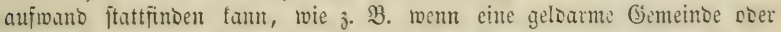
anDere Eorporation fultiviren foll, fo fhenfe man iff aus sen oft bicl

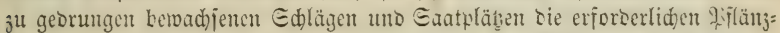
linge, uno balte fie nur an, Die Sgandarbeit bei Der Wilanjung ju berridten.

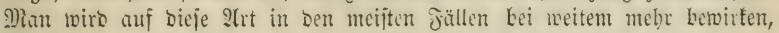

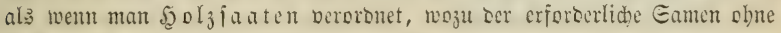
Soften nid)t angeidafit werben fann. Unt

11) wenn wegen Gamemnange(s überhaupt teine Exaten gomad)t

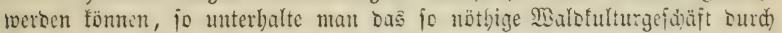

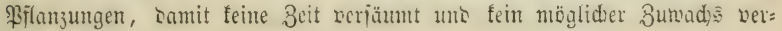
Ioren werbe.

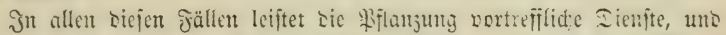

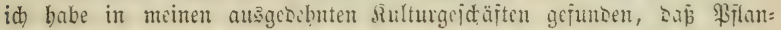
jungen, toenn jie mit ber gebörigen 30 ridat und Eparjam= feit gemad t werben, entreber gar nid)t, ober nidit bicl theurer fint,

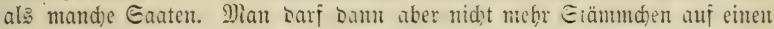
Miorgen piflanzen lajien, als 3 u cinem vollfommenen Sisnofejtand wirflich

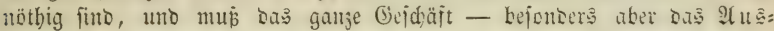
graben, Befdneiben uno Ëinflanzen Der Etämdden Durdh bollfommen unterridtete und voridgtige Rcute bejorgen, und bie

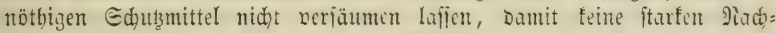

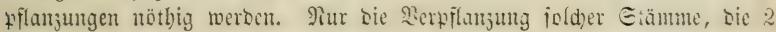
bis 3 Mitr. lang jimo, ijt gewöbnlid) foftbarer, als bie Eat. Räpt man

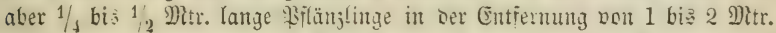

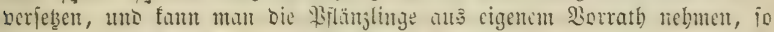
foftet Die Bepflanjung eines Morgen gewöbuliț nidjt mibr, und cit meniger, als bie Enat, wem sor Eamen nidgt mohlfeil ift unto die Llm= ftänbe nicht febr günjtig find.

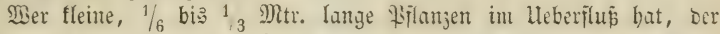

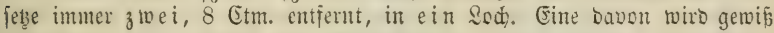

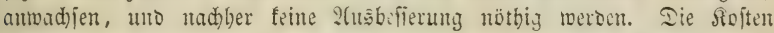
weroen basurd febr unberentene vermethrt uno ber glüdliche Erfolg ift getwifier.

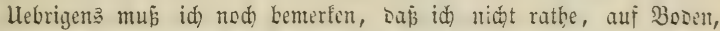
ter jolechter als mittclmäpig ift, itarte Pflänzlinge zu feţen. Die

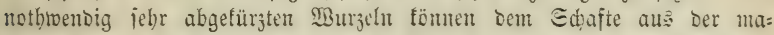
geren Erbe nidit Aabrung genug zufübren, unt es berberben Daber bie

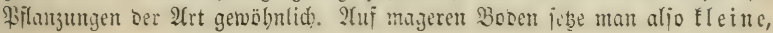


wo möglid mit Erroballen antagehobene Biflänllinge, ooer juche ihn mit

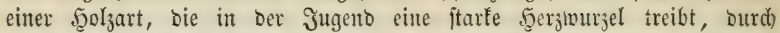
Saut in Beftano zul bringen, weil bie mit ftarfen Serz= ober $\mathfrak{B}$ fahlwurzel verfebenen fleinen \$flanzen von Der Eonnenbibe nidht fo leidgt berborben werben.

\section{Dூiertes Erapitel.}

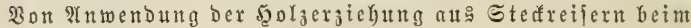
Foritwejen.

Die Balofultur burd) Stecfreijer ift unter allen biejenige, weld)c in ben wenigiten fällen 2 (ntwentoung finoet, afjo bei ber Forftwirtbidjaft am jeltenften vorfonmt. - Man benub̧t bieje Şolzbermebrungsmethobe,

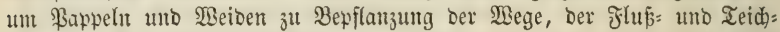
ufer uno ber nafjen Beibepläz̧e z̆l erjieben, und mur jelten toiro dieje Şolzerziehungäart in Balbe felbjt angewenoet.

Tie Bejtectung ber gebörig abgetrodneten Brüde mit Saaltweiben uno

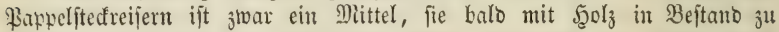
bringen; wenn man aber Dergleiden Brüd)e mit Erlen uno Birfen Durd) Saat oder Bifanzung fultivirt, fo werben fie in ber Folge biel eins träglidser. Nur bie Bejtedung ber Eanbid)ollen mit Rappelnftectreifern fann 3utweilen nübslid) merben. Dodh ift ber 2(nbau ber Eambidollen mit Riefern noch viel vortheilfafter.

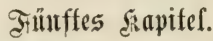

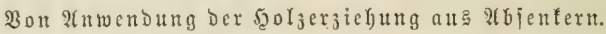

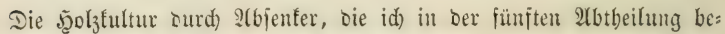

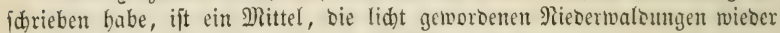
3u completiren. Sie ijt aber mur in fleinen Privatwalsungen anmentbar,

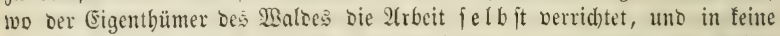
2turedunt bringt. In gropen Rieberwaloungen, uno wenn alle $\mathfrak{A}$ rbeit baar bejahlt werben mus, Dürfte dicic Metbode ju foltbar merben, uno Durd) fünftlide Gaat ober Pflanjung oer 3wed woblfeiler uno fiderer zu erreiden jein.

\section{Sedistes Sanpiter.}

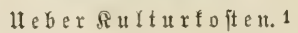

\section{Enntelt.}

\section{A. $\mathfrak{A n l e g u n g}$ oon Satfämpen.}

1) Eidhenjaatfamp: a. Sameunenge pro $1 / 4$ Şett. $=1$ Mago. Mlorgen 750 BF́. à WFo. 1/2 bis 2 Wig.; b. Bobenbearbeitung 50 bis 60 Marf;

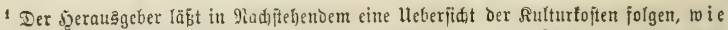
fold)e fid) nad) unjern fulturlagerbudacrn aus f(d)şäbrigem Durd)idnitte ergeben. Der Taglohn beträgt 6 gG̈r. pr. Mann. Der hier jum Grunde gelegte Walomorgen =1,3 Magde=

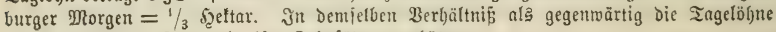
theurer getworden, fino aud obige Lolnjäfe zu erböben. 
c. 2Uasjat 9 bis 15 Marf. (Eaatfreifen 25 (Etm. breit uno 32 Ctm. ent= fernt.) Es elfolgen circa 60,000 Etüd einzelne \$flanzen. - 2) (5iden:

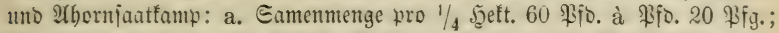
b. Bocenbearteitung 50 bis 60 Mart; c. 2(uşaat 15 Mart. 3) Ellern=

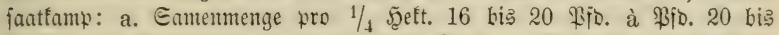
60 Pfg.; b. Bodenbearbeitung 12 bis 24 Marf; c. 2(usjaat 1 bi 3 Marf.

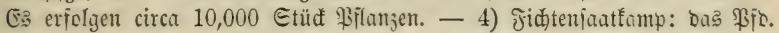
Gamen toftet 10 bis $15 \mathrm{Pfg}$. (im Sandel 40 Pfg.). Die Soften Der 2 (us: fat belaufen lich) auf $4 \frac{1}{2}$ bis 9 Marf. Eamenmenge und Bobenbearbeitung: a. mildoes תllima uno guter Boten, Samenmenge 68 PFD., Bobenbearbeitung 45 Marf; milies Silima uno mittelmäpigo: Boden, Samenmenge 93 \$io., Bobenbearbeitung 45 Marf; b. gemäpigte马 §lima uno guter 30 Den, Eamen: menge 93 Bfo., Bobenbearbeitung 60 Marf; gentäpigteß Sllima uno mittel= mäp̄iger Boden, Eamenmenge 120 Ffo., Bodenbearbeitung 85 Marf; c. raukes Rlima uno guter Boden, Gamenmenge 120 PFo., Bobenbearbei= tung 90 Mlarf; rauhes א̊lima uno mittelmäß̈iger Boden, Samenmenge 140 Pis., Bodenbearbeitung 115 Marf; d. Fteiniger beras̆ter Boden, Samten= menge 140 Pid., Bodenbearbeitung 148 Marf; e. bohe freie Sage und mittelmäāiger Booen, Eamenmenge 140 Bío., Bodenbearbeitung 165 Marf; f. jebr ungünjtiges Terrain, Eamenmenge 140 \$fo., Bobenbearbeitung 175 Dirf. - Die Bearbeitung Des Boden马 befteht im Umbaden Defielben nthd Reinigen von Steinen und Wurzeln. Die Gaatftreifen find 25 Etm. von eintutoer entfernt. (5: erfolgen 160,000 bis 300,000 Etüd Büid)el.

\section{B. Pebenfoiten bei $\mathfrak{A n l e g u n g}$ ber Gaatfämpe.}

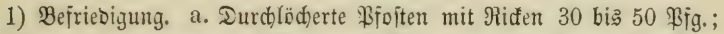
b. 3 Pitr. hoher Eeţ̧aun $86 \mathfrak{P i g . ;}$ c. 2 Mtr. hober Epielzaun 56 Pfg.;

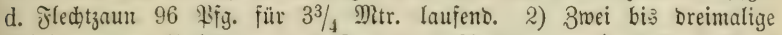
Reinigung von Unfräutern uno (jrą burch 2(usjäten pro 1/4 Şett. 15 Mart 80 ßfg. bis 24 Marf.

\section{Soften ber Saaten.}

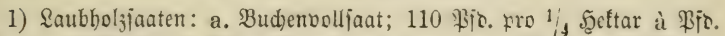
1 Pig. = 1 Marf 10 Pig.; Bobenbearbeitung uno 2 usjaat 10 Marf;

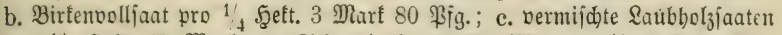
pro $1 / 4$ Seft. 17 Marf; d. (Eidenplabiaat; 250 Fifo. pro $1 / 4$ Seft. à Fio.

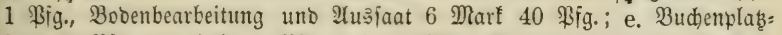

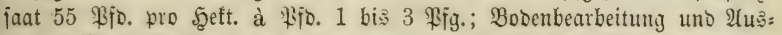

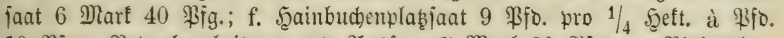
10 Pfg.; Bodenbearbeitung uno 2 luşaat 7 Marf 20 \$fg.; g. Birfenplat:=

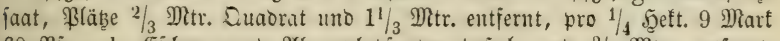
60 Pig.; h. Eichn = uno Athornplab̧faaten bejigl. uno $2 / 3$ Mitr. entfernt, pro $1 / 4$ Seft. 18 Marf; i. Eidgenjtectiaat, 40 bis 270 Pio., Bodenbearbei= tung 1,2 Mart -4 Marf 20 Pig., $\mathfrak{A}$ tujaat 0,8 bis 1,6 Marf; k. Budjen= ftedfaat 20 bis 90 Pfo., Bobenbearbeitung 1,2 Marf - 3 Mart, 2(uज゙= faat 0,8 bis 1,2 Marf; l. Einbacten non Eidgeln pro $1 / 4$ Seett. 7 bis 9 Mlarf; 
m. Einhacen bon Budbeln pro $1 / 4$ Seeft. 4 bis 6 Marf. - 2) Mabelfoly= jaaten: a. Jidutenbollfaat pro $1 / 4$ Sgett. 9 bis 10 Marf; b. Fid)tenrillenfaat. aa. auf geebreten Studenlöd)ent und munbem frifdem 3oden 75 Wfo. pro $1 / 4$ Şeft., Bobenbearbeitung 9 Dart, bb. auf beraștem guten Boben 70 \$fo. pro $1 / 4$ Seft., Bodenbearbeitung 10 Marf, cc. auf berastem mittel= mäpigem Boben 75 Pfo. pro $1 / 4$ Sceft., Bobenbearbeitung 12 Marf; c. Sidd)= templabjaat. aa. \$läbe $2 / 3$ Mitr. Quabrat groj uno $1 \frac{1}{3}$ Mtt. entfernt

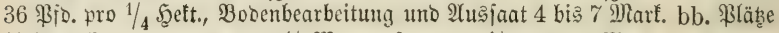

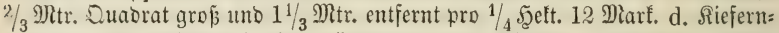

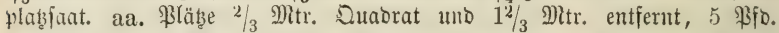

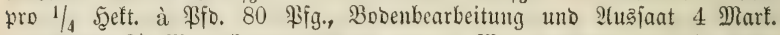
bb. \$läbse $2 / 3$ Mtr. Duabrat groß uno 1 Mtr. entfernt, fro $1 / 4$ Soft. 15 Mart. - Meinigen Der Enatpläß̨e pro $1 / 4$ Şett. 3 bi 9 Mart.

\section{Pffanzument.}

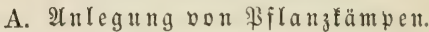

Saubholjitämme, $2 / 3$ bis 1 Mtr. hod) in $2 / 3$ Mtr. Entfernung pro

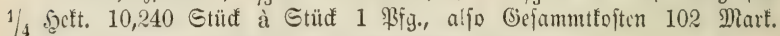
Befriebigungatojten firto bei ben Eaatfämpen angegeben.

\section{B. $\mathfrak{R}$ often Der Bflanzung.}

1) Saubholzłflanzungen. a. Şeifterpflanzungen. aa. Etarfe Saublyolz= ftämme auf offenter Şube. $\alpha$. Steiniger Boben, weiter Iransport uno ftarfe Behügelung à Stüđ $12 \mathrm{Bfg}$.; $\beta$. mittelmäfiger Boben unt Defigl. it Stüld 10 \&ify.; $\gamma$. guter Boben, niđtt zu weiter Transport uno Defigl. à Gtüd 9 Pfg.; $\delta$. fehr guter Boden, gantz naher Irațport uno Defggl.

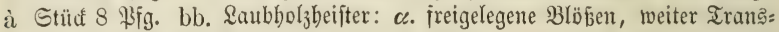
port uno ftarfe Bebügelung à Stüd 10 Pfg.; $\beta$. auf Edlaglinien in ben Niebermälbern, ftarfe Şeifter à Etüđ 10 \$fg.; $\gamma$. ftarfe Şeifter auf un=

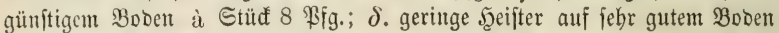

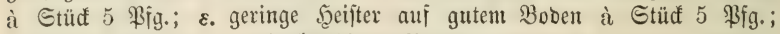

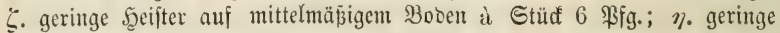
Seifter auf ungünftigem 3oben à Stüd 7 \$ig. b. Robentfanzungen: aa. bon $1 / 3$ bis 1 Ditr. Scöhe, in Büfdeln mit Ballen $\alpha$. auff fehr gutem Boben à Stüd 1 Wfg.; $\beta$. auf gutem Boben à Stüd $4 \frac{1}{4}$ \$ig.; $\gamma$. auf ungünitigem Boben à Gtül $1 \frac{1}{2} \mathfrak{P} f g$. bb. von 1 bis $2 \mathfrak{M}$ tr. Sूöbe. $\alpha$. auf günf́tigem

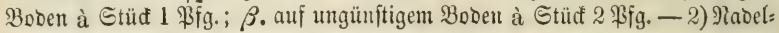
holzpflanzungen. a. Riefermpflanzungen mit Ballen pro Taufeno 7 Marf;

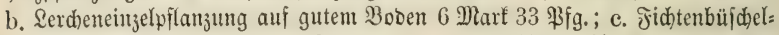

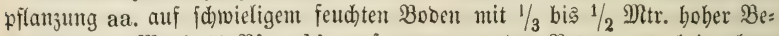
hügelung 13 Marf 40 Pfg.; bb. auf gutem wunben $\$$ Iransport 2 Marf 12 \$ig.; auf gutem wutoen 30 den und bei weitem Iranßport 3 Marf 14 Pfg. ce. auf gutem berastem $B$ oden unb bei nabent Iransport 3 Marf 57 \$ifg.; auf gutem berasten Boden uno bei weitem Iransport 4 Marf 40 \$fg.; dd. auf runbem fteinigten Boben unt bei nabem 
Tranß̧port 4 Mark 62 \$ig.; auf wutbem fteinigten Boben uno bei weitent Tranzport 5 Marf 5 \$fg.; ee. auf jebr fteinigtem $\mathfrak{B}$ boen unt bei nahem Iranझport 9 Marf 10 \$Fg.; auf febr fteinigtem \$oden uno bei weitem Irangs: port 9 Mart 70 \$fg.; ff. in Geröllen, wo bas einzutragende (Eroreid) nidjt cntfernt 46 Mart 50 \$fg.; in Gerölfen, wo baß einzutragentoe (Froreid ent= fernter 105 Darf 50 Pig.; gg. auf berastem fteinigten Boben, bei nabem Tranjport 4 Mtarf 80 \$ffy.; auf berastem iteinigten Bober, bei weitem Tranţ̧port 5 Miart 26 Pfg.; hh. an fteilen Şängen auf gutem Boden 6 Mart; an fteilen ફ̧ängen auf mittelmäp̈igem $\mathfrak{B}$ boen 6 Marf 40 \$ig.; an fteilen

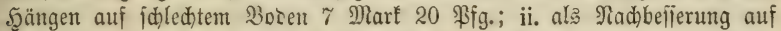

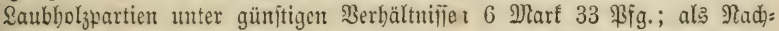

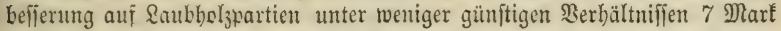

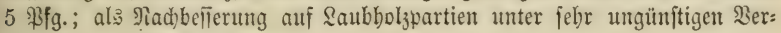
bältmifîen 10 Mart $60 \mathrm{Bgg}$.

\section{Stedflinge (Raubbol 3 ). à Etüđ $1 / 2$ Pf.}

IV. T(bjeitfer (Buđ)en). à Stüđ 10-18 $\mathfrak{B}$.

\section{Bon ben Rebenfoften.}

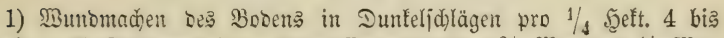
6 Mart. - 2) Grabenarbeit: a. Entwäfferungggräben $2 / 3$ Mtr. unt $1 / 3 \mathfrak{M t r}$. breit uno $1 / 2$ Mtr. tief ì $3 \frac{3}{4}$ Mtr. 26 Pfg. ; 1 Mtr. uno $1 \frac{1}{3}$ Mtr. breit uno $2 / 3$ Mtr. tief à $3 \frac{3}{4} \mathfrak{M}$ tr. ' 30 \$ig.; $1 \frac{1}{3}$ uno $1 / 3$ Mtr. breit uno 1 Mtr. tief à $3 \frac{3}{4}$ Mtr. 45 Pfg.; $1 \frac{1}{3}$ unt $1 / 3$ Mntr. breit uno 1 bis $1 \frac{1}{4}$ Mtr. tief

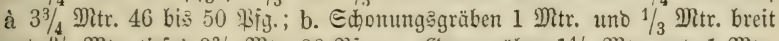
uno $2 / 3 \mathfrak{M}$ tr. tief à $3 / 5, \mathfrak{M}$ tr. 26 Pig. c. Grenzgräben $1 \frac{1}{3}, \mathfrak{M}$ tr. uno $1 \mathfrak{M}$ tr.

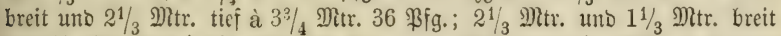

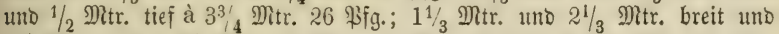
$2 \frac{1}{3}$ Mitr. tief à $33 / 4$ Mitr. 30 Pfg. d. P(bjugşgräben à $3 \frac{3}{4}$ Mitr. 20 Pfg.

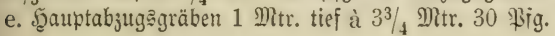

\section{Siterafur.}

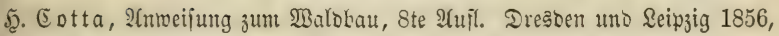
heraużgegeben bon v. Berg.

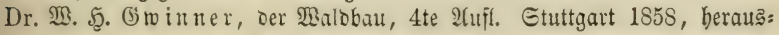
gegeben bon Dengler.

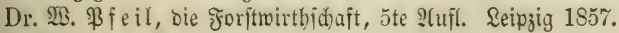

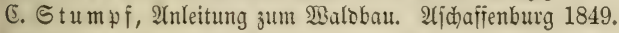

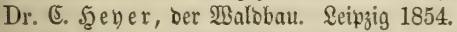

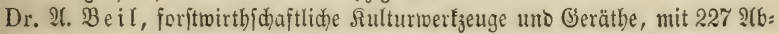
bilb. Jrantfurt a. 9). 1846.

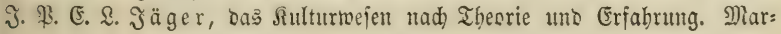
burg uno \&eipzig 1850. 


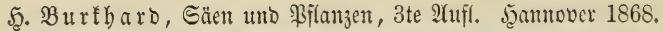

v. Manteuffel, bie Şügelpflanzıng, 2te 2Ufl. Seipzig 1858.

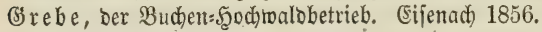

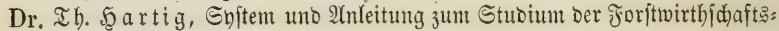
lehre. Seipzig 1858.

Dr. (S. \&. Şartig, Belehrung über Bebanthung uno Rultur bes Waldes, 2te $\mathfrak{2}$ uflage 1859 , herausegegeben von Dr. Th. 5artig. 


\section{Dritter boatptffeif.}

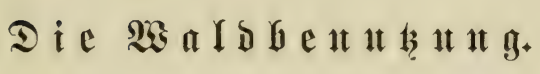





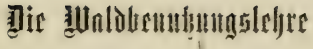

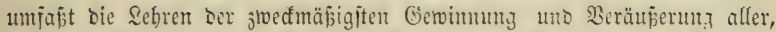

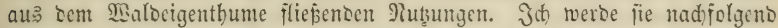

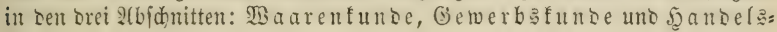
fun be baritellen.

\section{Einfeituttg.}

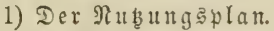

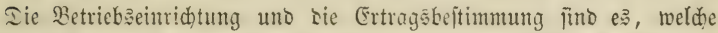

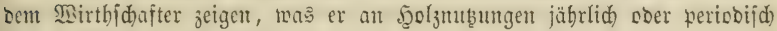
jeinem Saloe zu entrebmen bat.

Jn Mittelwalse uno in Miederwalse ift bur(h) jent Borausbeftimmungen bem WBirthfdafter für jebes fommende Jahr ein Flädentbeil des Wirth=

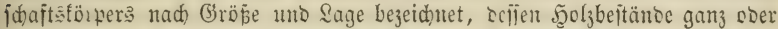

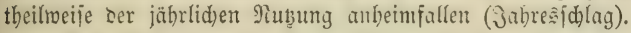

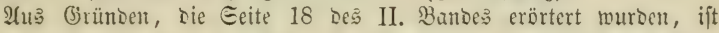

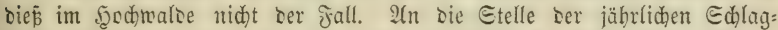

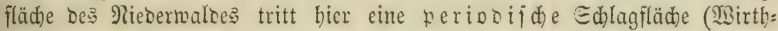
idaftstbeil, Weriobenfläche), beren (bröpe gleich ift der jäbrlichen, bem

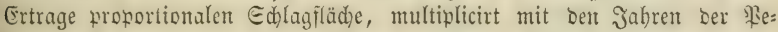

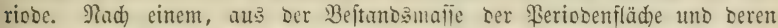

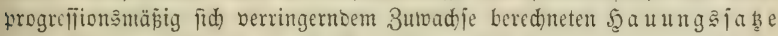
tviro alşbunn alljäbrlid), burd) 2(uffitellung eincs

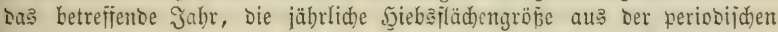
gejoliebent.

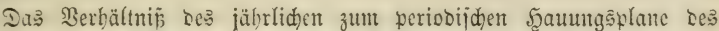

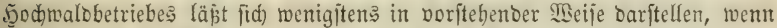

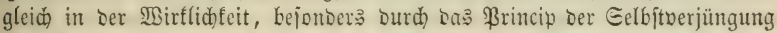

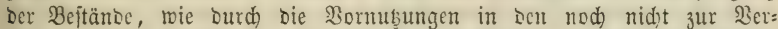

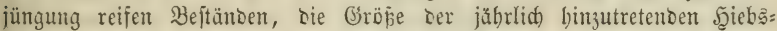
$f(a ̈ d) e n$ eine fehr veränberlid)e, mitunter jelbít mebrere jabre gänzlid aub:

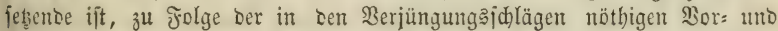

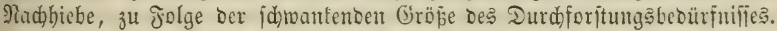
Jmmerbin nüifien aber bie jährlidjen Edwantungen in ber, Dem Ertrage proportionalen Giröße ber jährliden Şiebŝfläden, audh bier früher soer paäter fid) ausgleidhen. 


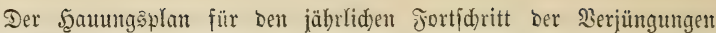
unb Durdfforftungen ift zugleidh ber $\Re u$ ţung Jabr, nädjit Der Menge, nun aud bie Befd) affenbeit ber zur Ein:

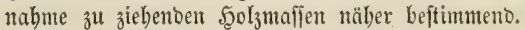

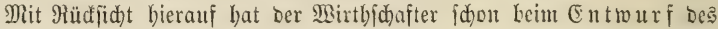

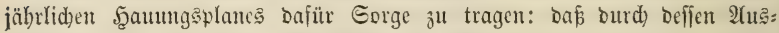
fübrung alle oringenden Bedürfniffe ber Confumenten befriebigt werben

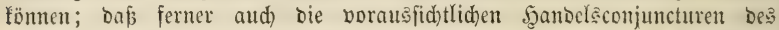
näd)ften Sabres möglid)it Berücffid)tigung finden; Daf enolich Die S(bnutzung

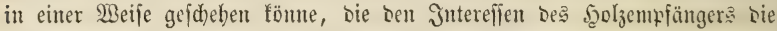
zujagenbite ift.

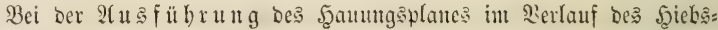
juhbres bat ber Wirtbidhafter, in feiner (Eigenichaft als Ied)nifer Dafür Gorge

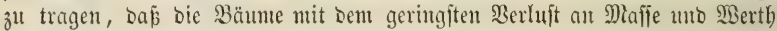
zum (Einfd)lage gebrad)t, baj fie mit bom geringiten Sioftenaufwande zu Serfaufseinbeiten aufbereitet werden, bie Den ?nforberungen Der Eon: fumenten mögliçft vollitänoig entiprechen.

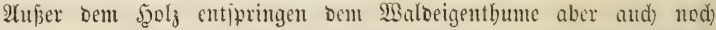

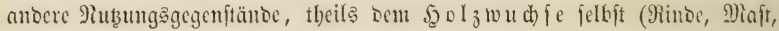
B(ätter zc.), theils Der bon biefem unablängigen BDDenprobuftion

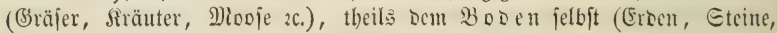
(Erbloblen 2 .) Doer nubbaren Recten angelörento.

Der größere Theil biefer গebcunubungen febrt alljäbrlid in gleider ober nabe gleid)er SBeife wieber uno begrünoet cinen ftänoigen

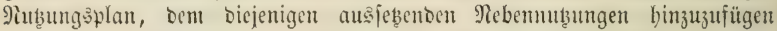

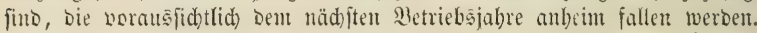

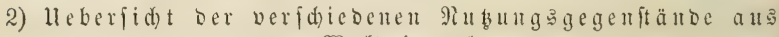
Dem $\mathfrak{B a l b e i g e n t b u m . ~}$

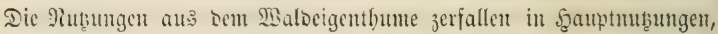
Ifbilmbungen und Piebennubungen.

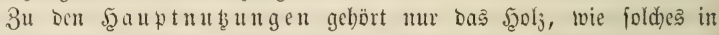

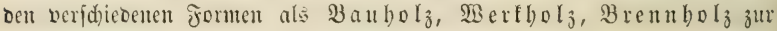
Ernte, 24ufbereitung uno \$3erwentoung fommt.

3u Den Theilu nid)t imumer als gejonberte ?hubutgègegenftänoe erboben werben, fondern

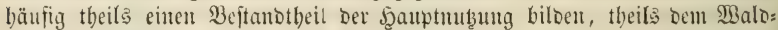
boocn als Bcfamung ober als Dungmaterial verbleiben. Dabin gebören Dic Minden, bic Gäfte, bie jrüd)te un bie Blätter Der Bäume.

Dic Ibeilmubungan unterjd)eiden fid) weientlid) baburd) von ben M(eben=

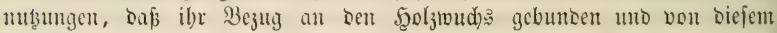
abbängig ift.

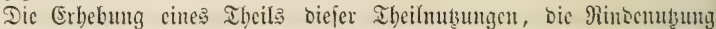

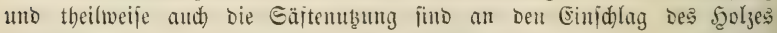
gebunben, von Dem fic bezogen werben. Genifife Eaftenub̧ungen, oic Jrüdtes uno Blattmußzungen fönnen aud) von ser Kebenden Scolzpflanze fortbauerno bezogen weroen. 
theilen:

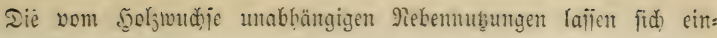

1) in joldhe, bie ser producirenden Sirajt bes MBalobobens entipringen,

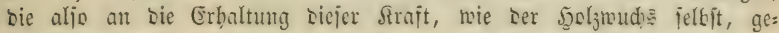
bunden fint.

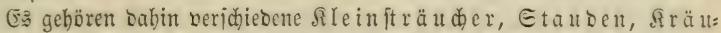
ter, Gräjer, Mooje, Jledten, sum Iheil benjelten Smeden mie ser

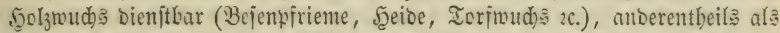
Jutter, ober burd) ibre Jrühte als Eneije, ober als Iungmaterial wer: twendobar.

(es gebört bierher aud ber, unter Umitänden surd) vorülecr:

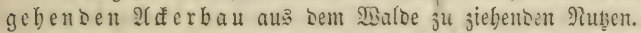

2) In folde, bie non ber Erbaltung ber frosucirenden Sirujt Des Bobens an fich unabbängig finb. Dabin gehören:

a) mineralifidenuriprungs: Croen, Eteine, Galje, Mctulle;

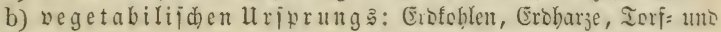
5ูนmนเిlager;

c) animalifden ll riprungs: Эago, Jiiderei, Bienengudt;

d) Baargefälle ober ?tbgaben aus llebertragung nu t: barer Re

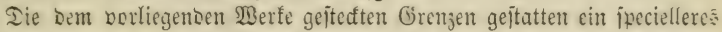
Eingeben in Die nom Scoljwudje unabhängigen शebennuţungen nicht. Fur

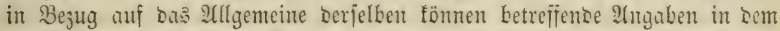
nadfolgenden Enfteme $\mathfrak{U}$ ufrabme finden.

3) Bebeutung un Sierthoerbältnifie ber veridiebcnen

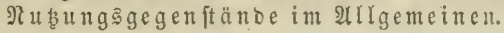

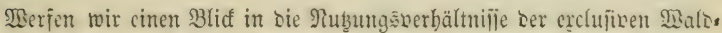
wirthjdaft, fo erfennen wir, baj von ben aufgefübrten, nerjobedenartigen

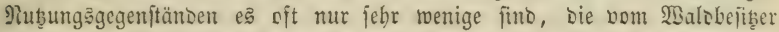
erhoben werben, baj felbit nidjt unbebeutende Theile ber Şauptnubsung,

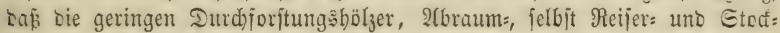

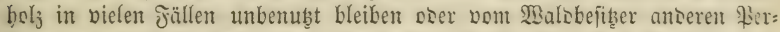
fonen unentgettlid) ober gegen jebr geringe ßreije überlañen werDen, ganj abgejehen von Rechter Dericlben, Die ihn bäufig daju verpfilidten.

Iie Urjaçe biejer, gegenüber anberen \$robuftionşzmeigen aufjallentent

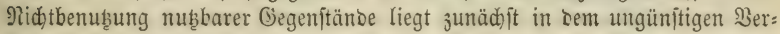

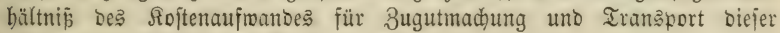

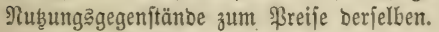

Der Malobejtieer, wenn ex nidht jugleid) Sanowirth ijt, nuĩ alle auj

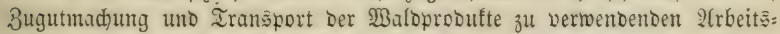
fräfte erfaufen, er mū bie erfaufte $\mathfrak{A}$ rbeitşafraft überwaden, wenn fie sas

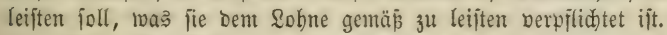

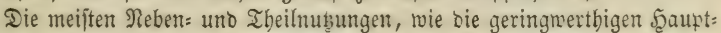

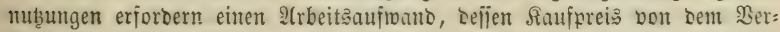

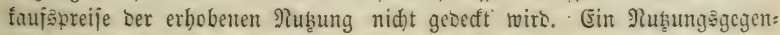
ftanb biejer $\mathfrak{A}$ (rt twürbe jwar nidjt für ben Conjumenten, moḅl aber für 5̧artig, \&ebrbud für ₹̋rriter. II. 
Den Walsbefişer werthlos fein; er müp̈te unbenubst bleiben, ment nidht bem Walobefitzer Der benadjbarte Sanbwirth uno Der länolidje Scantoarbeiter jur Seite ftänbe mit einer Strbeitß̊traft, bie, weil fie eine eigente ift, feiner

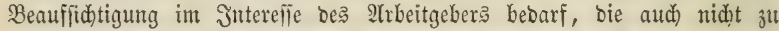
Marftpreifen, unter Umitänden gar nid)t in Redunung geftellt wiro, fo weit

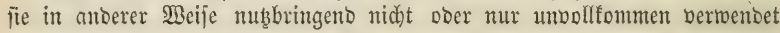
werben farnt.

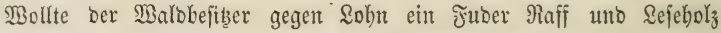
jammeln unb berfahren laffen, e? twürben fich nur felten Säufer finden, bie ifnt im Saufpreife bie Darauf verwenbeten Snften zu erfeben geneigt finb,

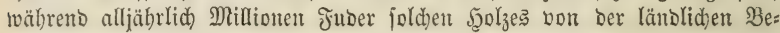
bölferung eingefanmelt, geheimjt unt mit Nuben berwenbet werben, jo weit fie eine zeitweife nid)t ober nidht hod berwerthbare 2lrbeitatraft alf bie Getwinnung berwenbet bat.

Ilnter biejen Unftänden fann aber ber Gseminn, weldyen ber Malds

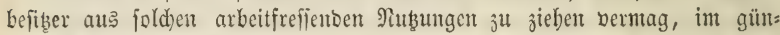

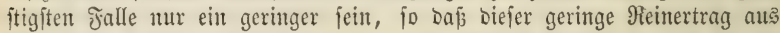
ibnen oft gänjlid) aufgehoben wiro burd) indirefte Radtheile, bie fie im

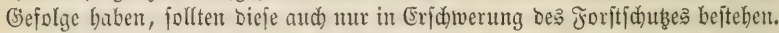

Itbgejeben von Der, Dả SBaldeigenthum bäufig belaftenton Mitbe:

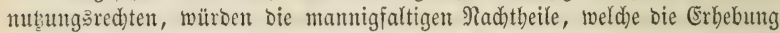
Der meiften Peben= und Iheilntbungen Durd fremoe S(rbeitstraft im Gefolge

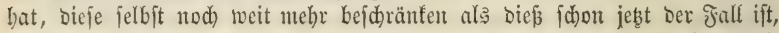

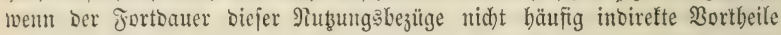

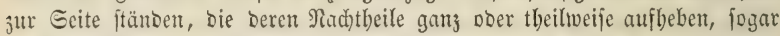

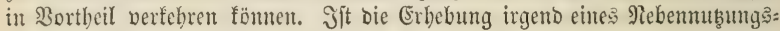

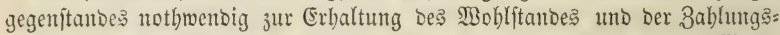

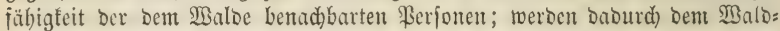
bejitzer 2(rbeitatoften erjpart, Meliorationen unentgeldlich ausgeführt; cm:

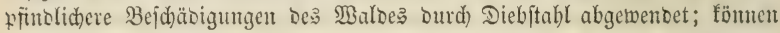
Dem Balde unmittelbar Gefahren ober Radtheile aus bem Nidhtbezuge

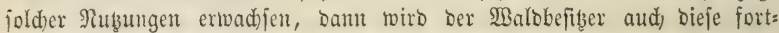
Danerno, wemu aud) unentgelolid ourd) frembe 2(rbeitsfraft, zur (Erbebung Gringent müiffen.

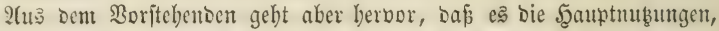

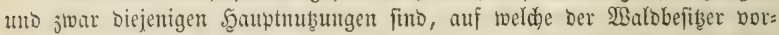
jugäweife fein 2 (ugemmerf zu ridhten hat, bie ben größten $1 B e r t h$ im fleinften Raume Darbieten, bie Denfelben Merth mit um fo geringeren Unfopten be:

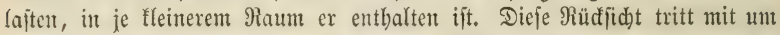
jo mebr in Den Bordergruno, je höher bie $\mathfrak{A}$ rbeitalöhne, je entfernter bie

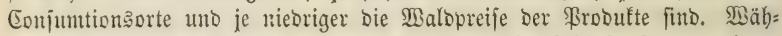
reno Sdiffbautholz, Stabholy uno \&uruß̨̧ölzer bie forgfältigfte 3ugutmad)ung

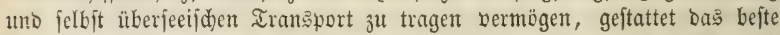
Bremuholz nid)t mehr als ben A(xentrantsport weniger Meilen, ift baß \$appel=

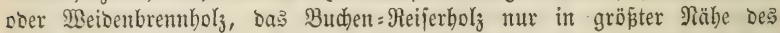
WalDes berwerthbar, alleit Der gröperen Unfopten megen, bie feinen Ber= brauch belajten, baher bemt auch bie (Erleidhterung bes Tranzports burd) 


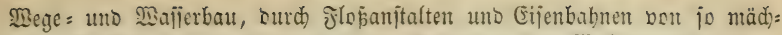

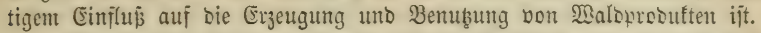

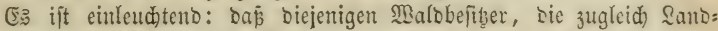

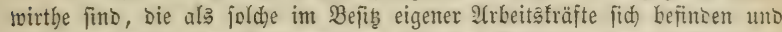

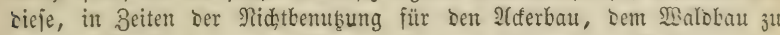

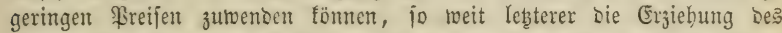

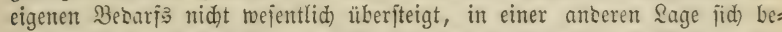

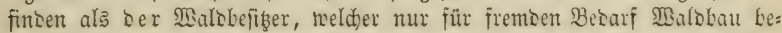
treibt. Mäbrento für lebsteren allein bả Pettoeinfommen enticheideno ijt jür

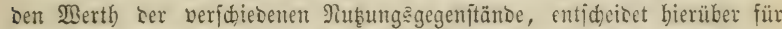

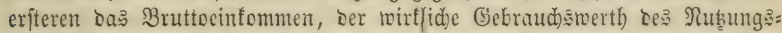
gegenjtandes, unbeeinträd)tigt bon Den auf Diejem lajtenten Unfojten ber

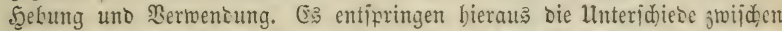

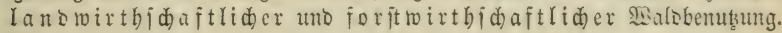

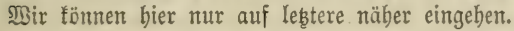

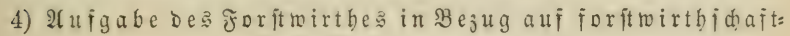
lide $\mathfrak{M}$ alobenusung.

Sie wir gejefen baken, funb ę im forjtmirtbichaftliden Baldbaue

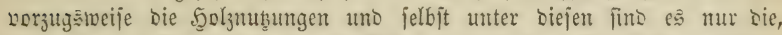

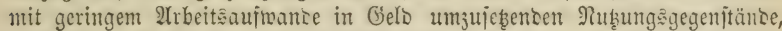

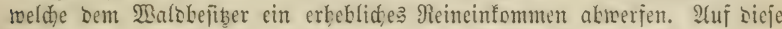

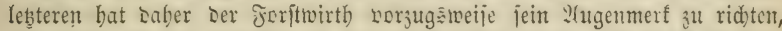
Die gröpte Menge berjelben in Der mertholljten Form uno Bejdaffenbeit, io wie im fleinften Paume nidht allein zu probuciren, fontern aud) aus=

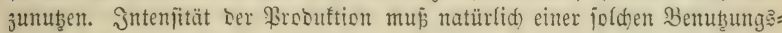
weije vorkergegangen fein.

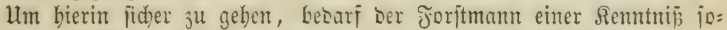

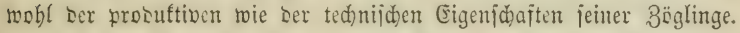

Da bie Probuttion jür fremben Bebarf nothwenbig Probuttenhandel

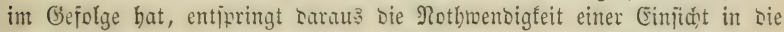

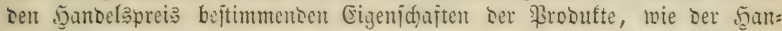
Delsberbältnifĩe felbjt.

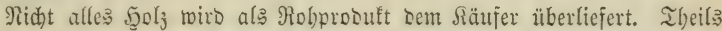

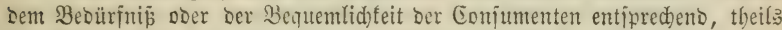
3ur Erleidterung bes Tranßports, erleidet ein Theil bellelben fdon im

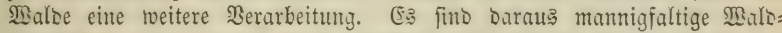
gewerbe hervorgegangen, Deren zrectmäpigiter Betrieb ser Jorftwirth 3u leiten wifijen muю.

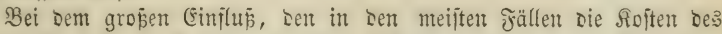

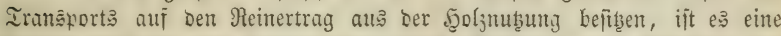
weitere 2fufgake Des Jorjtmantes: Durd) Befierung uno Mebrung ser Iransportanjtalten bieje Rojten möglidjt ju verringern.

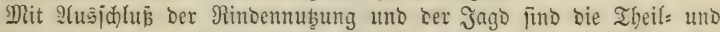

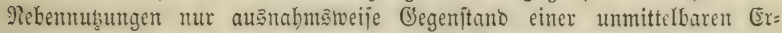

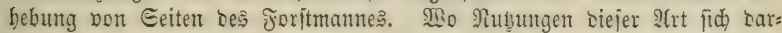

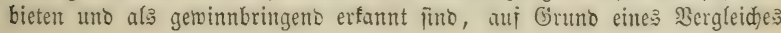




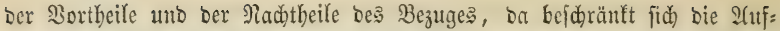
gabe Des Forftmantes in Den meiften Fällen auf eine padtweife lleber:

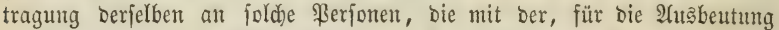
nöthigen Intelligenz, STrbeitstraft uno Sapitalbefitg auggeftattet fint, bie ¡ugleid) bie nöthige Sidherheit für bie- Entrichtung Des, nach bem Rein= ertrage bereduneten fadtgeloes, wie für bie Einthaltung berjenigen (Srenzen Der Benuß̧ung getwäbren fönnen, bie ber Walobefiţer als notbmentoig er:

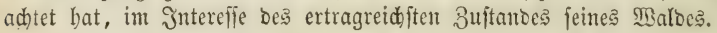

Siermit finto zugleid) biejenigen verfdicbenartigen Gegenftänto näher

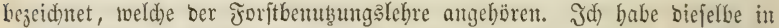

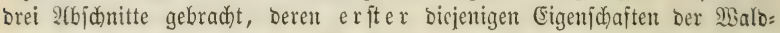
produfte behantolt, weldhe a) bie Mafien = uno Jormwerbältnifie ber \$ro:

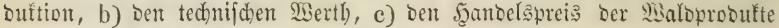

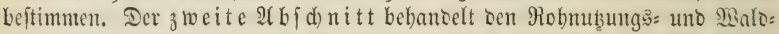

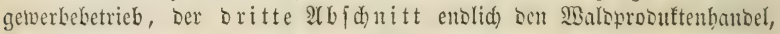
2ufbetwahrung unt Irantaport ber $\mathfrak{M}_{3}$ IDprodufte.

\section{Eriter $\mathfrak{A}($ bidjuitt.}

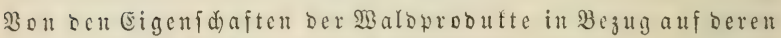
$\Re$ औ

Der Walomirth für fremoe Eonjumtion ift zugleid) \$robucent uno

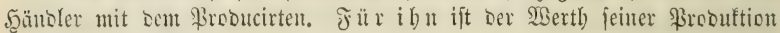
Daher zujammengefebst:

1) aus Art unt Menge Des \$roducirten (?(rt: uto Mengeertrag);

2) aus Dem (Sebrauds)

3) สแเ Dem Rattogeldertrage, Den Das \$roducirte ju getwäbren ver: mag (Preiąertrag).

\section{Sirftes sapited.}

(Erzengende (produftive) (Eigcnid)aften ber Icbendon froljpflatze.

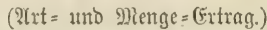

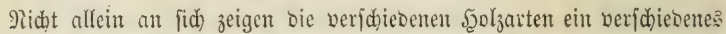
Berbalten, it Bezug auf bie Menge befien, was Durd fie bem Boben ab: getwomen werben fant fowohl, als aud in $\mathfrak{B} e$ jug auf bie (biöpen= uno Jormberbăltniffe, in benen fid) Das Broducirte in Der Yebentoen Pflanze bar:

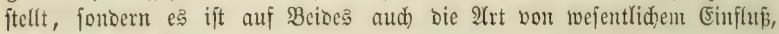
in welder bie Bflanje erjengt uno erzogen murbe. Dieje Beridjiebentheitent fino $\mathfrak{e} \mathfrak{s}$, bie wir zunädjit in $\mathfrak{s}$ atuge fallen wollen.

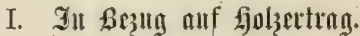

\section{A. Mafieucrzengutg.}

Edyon als Arteigenthümlid)teit zeigen bie voridiebenen Sgolzartent eine

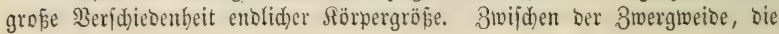




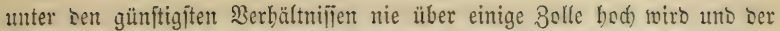
3u Riefenbäument berantwadjenten Meip̄weibe liegen idjon in Derjelben (Sattung alle Ulcbergangågröpen.

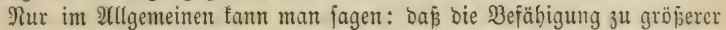

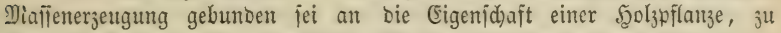

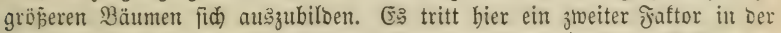

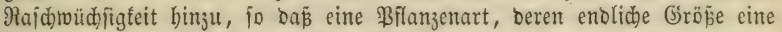
geringere ift, bentod bie größere Maffenerzengung getoähren faum, wemn

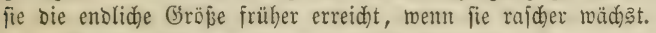

Endlide Rörpergrößje uno Rajhnüdfigfeit bejtimmen ben Grad Der Majiemprobuttionsfäbigfeit Der Einzelpflar.je (Baummafienproduftion). Jim Jorjtwirthidaftabetriebe fommt aber weniger bieje in Betradjt als bie jummarijhe Größ̄e ber Majienprobuftion einer Mebrzahl zum Bejtante ver: einter Bäume (Bejtunoșmaffen =\$robuttion). Daburd) tritt nod) ein britter

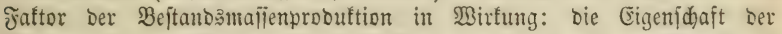
\$iflanjenart in gebrängtem Etanbe fräftig nebeneinanber fortwachjen, ourd)

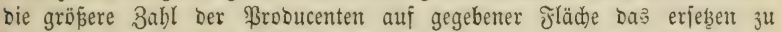
fönten, was burch ben bejd)ränften Stanbraum jeber Einjelpflanje an \$robuftionäfäbigfeit verloren gebt.

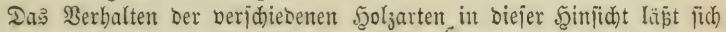
mur auf Dem $\mathfrak{B}$ ege ber Erfabrung ermitteln. Da aber bie bierüber unz vorliegenten Erjabrungs̄äăbe ben veridiebenen Betriebsarten entnommen finto, lafien fich bie 2(ngaben auch mur mit Bezug auf bicje binjteflen.

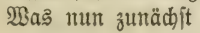

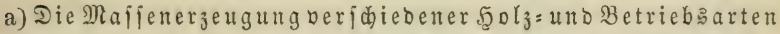

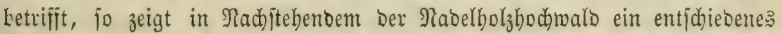

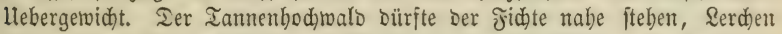
uno Megmouthfiefern fthen im Mafienertrage ber Fidhte nod) bebeutent voran. Den ber leșteren $=1$ angenommen, bürfte bie $\mathfrak{B e y}_{\text {moutbtiefer }}$ auf 1,1 , bie Serche auf 1,2 , allerbings nur für nieorigen nidht über $60 j u ̈ h)=$ rigen 1 Imtrieb anzujeten jein.

2rbgejeben von Dem geringeren Malienertrage ber Riejer, ift ber Saub:

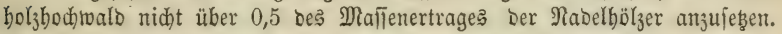
Es gilt bieß jebod) nur für guten Etandort. Je idjled)ter biefer ijt, um jo

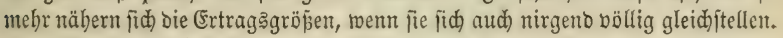

Im Saubholze ift aud) ber Unteridied im Ertrage ber beridiebenen

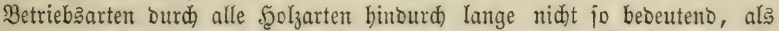
man bieß früber annabm. Nur ber Eidjen=, Buchen= uno Birfennieberwalo

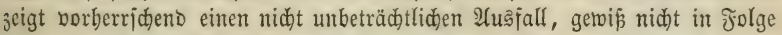
geringerer 3uwachşähigfeit ber Etöđe, jonbern in Folge ber häıfiger rwieber: febrenten uno für gleidhe Beitbauer längeren Bobententblöfung. Frlent= uno

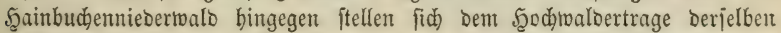

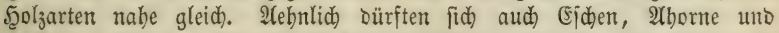

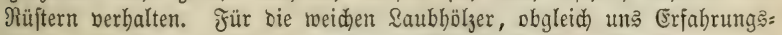
jäbe jur Beit nod fehlen, fann man mohl mit Gerviahbeit ein bebeutentes Hebergetwicht bes Nieberwalbertrages über ben 5ुochwaldoertrag annehmen. 
Erzettgente Eigenifdaften der Yebenden Şolapflanze.

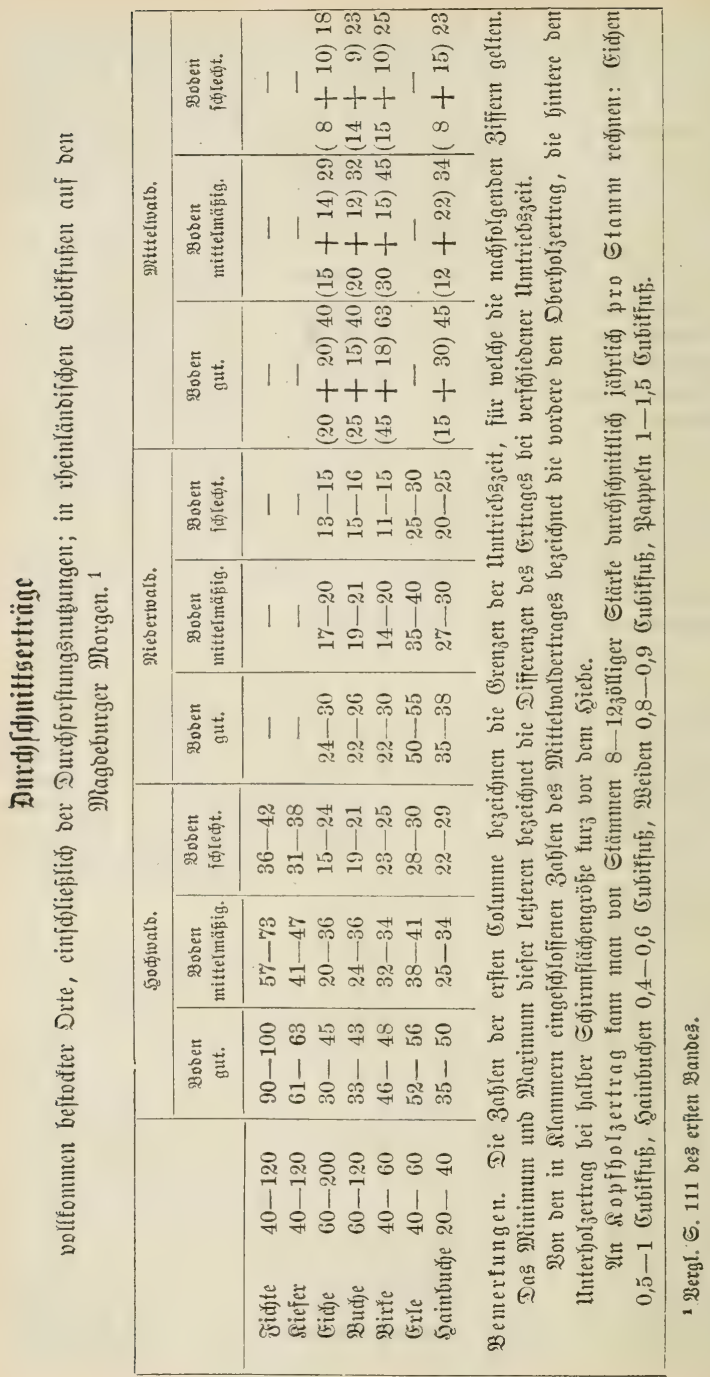


Im M) Rittelwaloe ftebt bie Birfe böber als im Şod)walbe uno zwar ungefähr im ßerbältni命 $=0,6: 0,5$. Die übrigen Saubbölzer bingegen

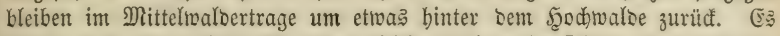
berubt bieß aber auf ber 2(mnabme gleid)er Sgolzart im Ober = unt im Unter:

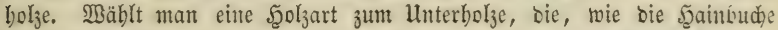
ftärfere Bejobattung erträgt, gibt man biejer eine wenig fdattente Sber: bolzart, 3. B. Eide, Birfe, \$appel, (5ide, Serdye, bann wirb ber Mittel= waldertrag bem Scodjwaldertrage fidher nidht nadjitehen.

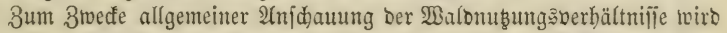
man nidjt biel feblen, wenn man als Durdjidnnittsją̧ Ler Maflenprobuttion nadjftebende ßerbältnißzablen anninumt:

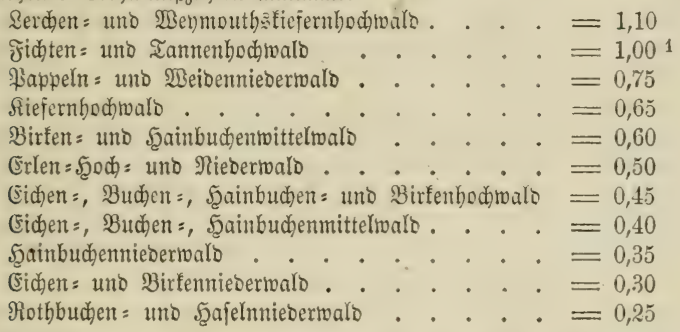

b) Die Mafjenerzengung verfdiebener umtriebszeiträume.

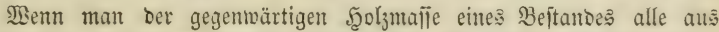
ibm vorber bejogenen Durdfforftungserträge binzuzäblt (ङ3ejammtertrag fro Mlorgen) uno in bie Eumme mit Dem Beftumbălter bivioirt, erbält

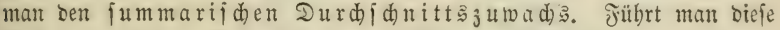
Rechnung mit ben Ertragsifunmen beridjiebener Beftandsalter aus, bant

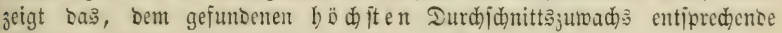

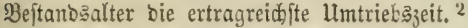

Wentet man bieje Beredinung auf bie in 1. Banbe ๔. 112 mit= getbeilten Şartig'id)en (Erfabrungätafeln an, twie id Diej in Der lebtten Columne Derfelben Erfabrungstajeln ङ. 170 meiner Edrift "Enjtent und Inleitunty zc." ausgeführt habe, Dunn ergibt fich ein Eteigen Des Malient=

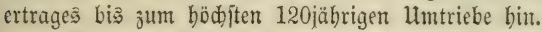

Merfwürbigerweije ijt biep fortbauernde Eteigen Des Mafienertrages

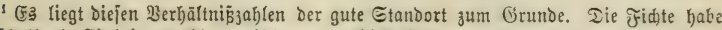

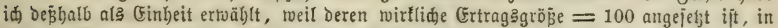

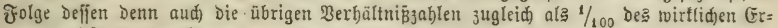
trage gelejen werden fonnten.

2 Die formel lautet eigentlid): Gejammtertrag pro Morgen ober 52eftar $\times$ 5iebs. flächenjaltor. Da lef̧terer unter normalen Beftofungäberbültnifien fteţ ein Brud)theil ber

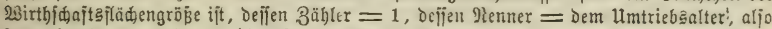
für 20jäbrigen Umtrieb $=1 / 20$, für $120 j a ̈ b r i g e n ~ u m t r i e b=1 / 120$, jo ergibt bie Dibifion bes Gejammtertrages pro Morgen mit dem, alక Umtriebsafter angenommenen Bejtanosalter, diejelbe Sifjer, twie die Multiplifation mit Dem Şiebäläđ)enfaftor. (Ǵejammtertrag pro Morgen $=100$, Itmtrieb 20jährig: $1 / 20,100=100 / 20$ ). 
in alle jpäter nufgeitellten Erfahrungştafeln übergegangen, Demobnerad)tet aber feinesiwegs riditig.

Sn Den Şartig'iden Ertragstafeln liegt bie Urjade Des fortbauemben Steigens in bem Umitanoe: Daf bie Durdforfungsinthungen erit vom 60. Jahre ab in 2trjaks gebradht wurben.

6. ․ S马artig jeigte zuerft, Daj wenn man auch bie früheren Durd)= forjtungen vom 20. Jabre $a b$ in Rechnutg ftellt, Der Maffenertrag Der

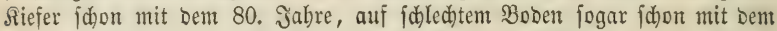

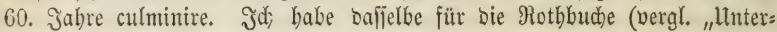

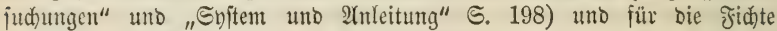
("Evitem uno 2 (ntleitung". 178) nad)getwiejen.

Da brei in ifrem $\mathfrak{B a d}$ sthumagange fo fehr beridjiebene Scolzarten in

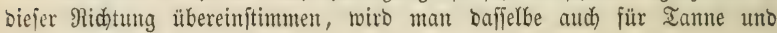
Eidhe antehmen bürfen. 1

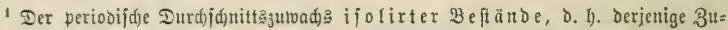
wadjs, Den man erbält, twenn man von ber Beftandşmafie einer fpäteren Beit bor voff= jogener Durdjforftung, Die Beftandontafife einer früleren Beit na d) vol(3ogener Durdiforftung

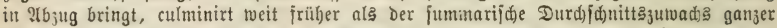

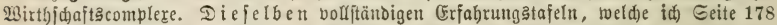

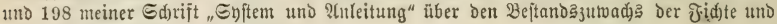
Rotbbuche mitgetheilt babe, aus Denen

$$
\text { im } 20-40-60-80-100-120-140 j a ̈ h r i g e n ~ U m t r i e b e
$$

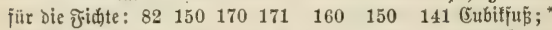

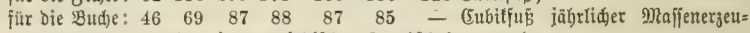
gung herborgehen, ergeben einen periobijden Durd)janittşutwad,

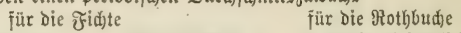

\begin{tabular}{|c|c|c|c|c|c|c|}
\hline Beriodenjabre & $20-25$ & 228 & 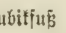 & 71 & bit & igrl \\
\hline 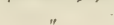 & $25-35$ & 226 & , & 83 & " & " \\
\hline " & $35-40$ & 190 & " & 131 & " & $"$ \\
\hline " & $40-45$ & 195 & $"$ & 130 & $"$ & $"$ \\
\hline " & $45-55$ & 223 & $"$ & 123 & $"$ & $"$ \\
\hline$"$ & $55-60$ & 206 & $"$ & 113 & " & $"$ \\
\hline " & $60-65$ & 201 & $"$ & 98 & " & $"$ \\
\hline$"$ & $65-75$ & 166 & $"$ & 91 & $"$ & $"$ \\
\hline$"$ & $75-80$ & 160 & $"$ & 84 & $"$ & $"$ \\
\hline$"$ & $80-85$ & 127 & $"$ & 89 & " & $"$ \\
\hline " & $85-95$ & 110 & $"$ & 81 & $"$ & $"$ \\
\hline$"$ & $95-100$ & 114 & $"$ & 80 & $"$ & $"$ \\
\hline " & $100-105$ & 121 & $"$ & 77 & $"$ & " \\
\hline " & $105-115$ & 88 & $"$ & 77 & " & $"$ \\
\hline " & $115-120$ & 99 & $"$ & 60 & " & $"$ \\
\hline$"$ & $120-125$ & 87 & $"$ & - & " & $"$ \\
\hline " & $125-135$ & 88 & $"$ & - & $"$ & $"$ \\
\hline$n$ & $135-140$ & 97 & $"$ & - & $"$ & $"$ \\
\hline
\end{tabular}

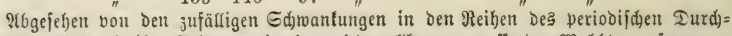
idnittzulvadjes, bie ihre Grflärung in einer nidft volffommen paffenden Wahl ber zujammen= geftelften Beftände finden (trobु ber 3ugrundlegung eines und deffelben Weiferbeftandes),

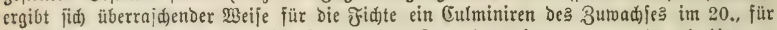
Die \$̧ud)e im 35. Jahre und cine fortbauernde 3uwadjaberringerung von ba ab bis jum

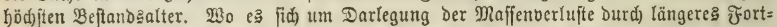
wadjen ifolirter Beft ände bandelt, ba fino natürlid bieje Bifjern entideideno un b

* Der Begiehungen wegen, in benen biefe Biffern zu ben weitern Entroidtungen

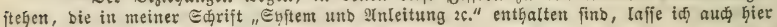
bie Grösenangaben unberänbert. 


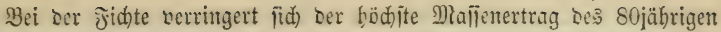
Untriebs mit jeber un 20 Jabre höberen Untriebäzeit zientid) gleidgmäpig um 6 \$rroc., bei ber Rothbud)e uno Siefer nur um $1 \frac{1}{2}$ Proc.

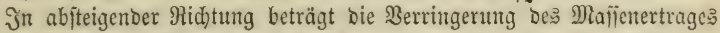

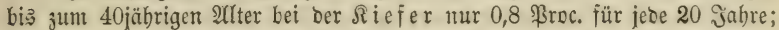
für bie $\tilde{J}^{i} \mathrm{~d}$ ) te bis zum 60 jäbrigen ltmtrieb nur 0,6 Prec., bis zum $\left.40 j a ̈ h\right)=$ rigen Umtrieb bingegen 12 Proc.; für bie $\mathfrak{B} \mathfrak{u} d$ ) e bis jum 60jäbrigen $l l m=$ trieb ahwärt: 1,1 \$roc., bis zum 40jäbrigen Umtrieb abwärţ bingegen 22 ßroc. beכ hödiften Maīenertrages.

Durd bie Beridjebenbeit ber Beftodung șerbältnifie je ber 4 m trieb

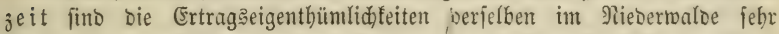

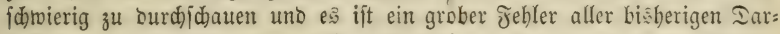
ftellungen, wenn bieje auf berjelben Grunblage wie im 5ुod)walbe gejdelyen.

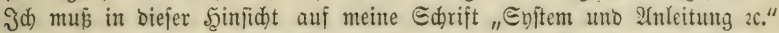
bertweifen uno fann bier nur bervorbeben: Daj auf Gruno meiner Berech)= nungen für Rothbuden, Şainbuchen uno Ellern, alio für Sgulzarten von jehr verichiebenem Sohbentudaje, übereinjtimment ber 20jäbrige Umtrieb als Der ertragreidjte fid ergab.

Jür ben Mittelmalo fehlt unక 3ur Beit nod) alles Material einer (sint ficht in bie Wirfung bes Umtriebs auj ben Maifentertrag. Wir bürfen aber aud) bier annebmen: da einem furzen, nid)t über 60jäbrigen Dberbolzumtriebe, bie bödjte Mafien= probuttion getwäbre.

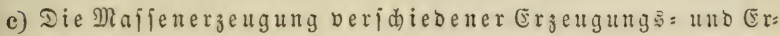
jiebungäart.

Die Erzeugungasart hat in fofern einen wejentliden Einflup auf ben Mafientertrag Der Beftänbe, als von ibr einestheils bie Erbaltung ocr Bobenfraft bes alten für ben neuen Beftand, anderntheils bie Etammzahl uno ßiflanzenvertbeilung in lebsterem abbängig ift.

Mähreno bei ber Berjüngung burd) Eelbftbejamung sie volle Bobent fraft bes Mutterbejtandes auf ben Jungort übertragen wiro, Yeķterer aljo bom früheften Alter an in feiner fräfitigen Entridfefung begünjtigt ift, muई ber Jungort aus Rablbieb unt Inbau bie berloren gegangene Dammerbe erit wieber neu bilben. Daf́ biés um fo nadtheiliger auf ben jungen $\mathfrak{B}_{e}=$

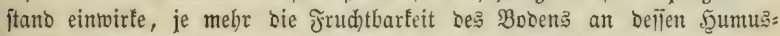
gebalt gebunden ift, bebarf nur ber 2noentung (Bo. II. S. 50).

Heber Den Einfluf gröferer Etammzabl auf Die Mafienerzengung habe idi 2Bo. II. S. 51 gefproden.

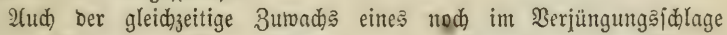
ftehenben Reftes nom Mutterbeftanoe uno bes bereits erfolgten Wieber=

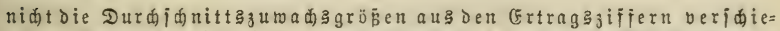
Dener umtriebsjeit, Die ftets nur bie frage nad ber ertragreidften umtriebszeit ganzer $\mathbb{B} i r t h i d a f t s c o m p l e x e$ entideiden tönnen.

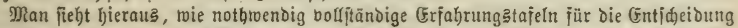

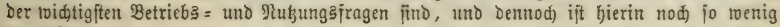
gearbeitet! 
mudjes fann eine nidjt unerbeblide Mafienerzeugungşjteigerung berwirfen

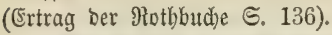

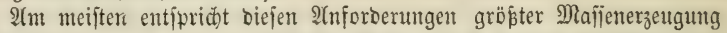
bie Selbftwerjüngung, weniger bie Gaatfultur, nod) weniger bie Pflanjung, beibe in bem Mapse weniger, als bie angebaute Pflanzenzahl eine geringere ift.

Die Beftanoserziebung auf bem 2 Bege ber Durdforftungen ift in $i p=$ fern von grofem Einfluई auf bie Mafienerzeugung, als biefe zu jeber 3eit bann bie gröjte fein wirb, wenn eine, Dem Beoürfnip ber vollen (Er= näbrung entipredende Belaubung uno Betwurzelung jeber Einzelpflanze, ver: bunben ift mit ber gröjten Stammzahl ber Bejtanosflädze. Snoem id zeigte:

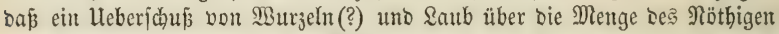
cine 3umadjifteigerung nidht im (Siefolge habe, 1 fübrte id baburdh aud

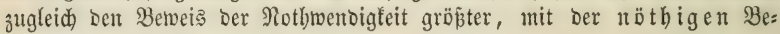
wurzelung uno Belaubung vereinbarer ßroducentenzabl Der Beftänte.

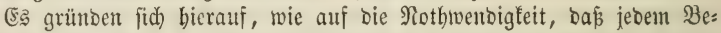

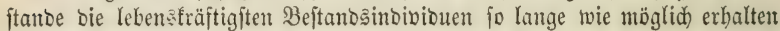
bleiben, biejenigen Durdjorftungšregełn, weld)e 3o. II. G. 53 aufgefteflt und 3b. I. Є. 290 motivirt wurben.

\section{B. Formerzeugung.}

$3 \mathfrak{u}$ ben Yebenbigen Eigenidaften ber Şolzpflanzen gebört ferner bie

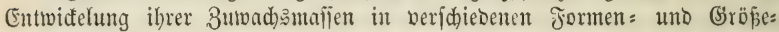
werbältniffen, bie, wie sie veridhiebenen ted)nifden (Eigenidaften bes Şotz= förpers felbit, von großjem (Sinfluffe finto auf bie Gebrauddafäbigfeit uno

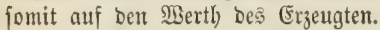

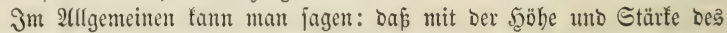

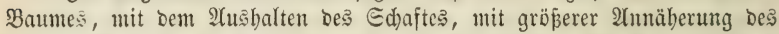

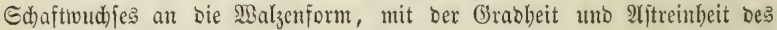

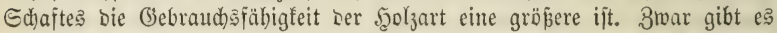

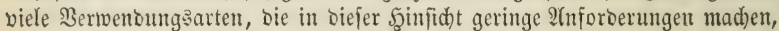

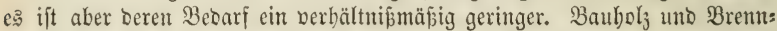

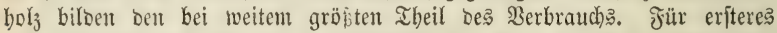

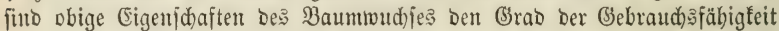

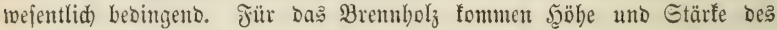
Baumwudjes in jofern wejentlidy in Betradt, als auf bas gröbere, majiligere Ed)afthol beoeuteno geringere 3ugutmad)unga = uno Iransportfoften als

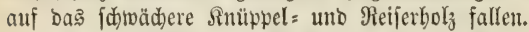

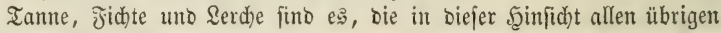

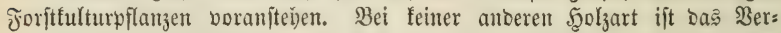

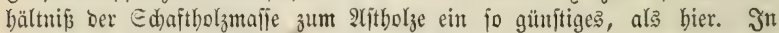

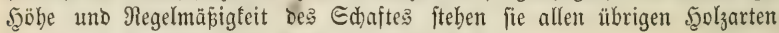
boran, im Stärfezuwad)

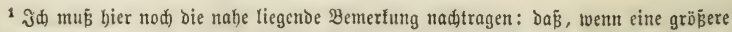
als nothwendige Belaubung ben 3utwad) jdüffige Saubmenge biefen lebteren nothmendig verringern mus; Denn bicienige Menge von

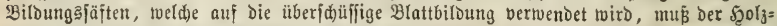

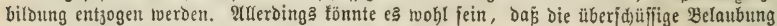
für inre eigene 2 tuabiloung dos Material bereitet. 


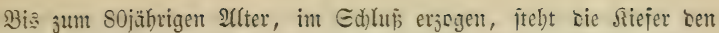

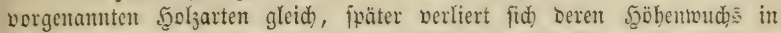

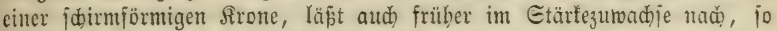

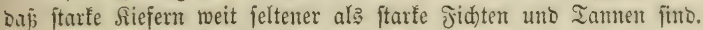

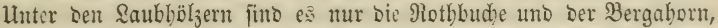

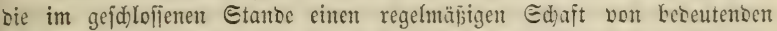

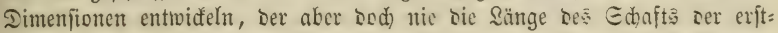

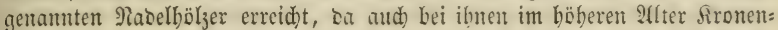

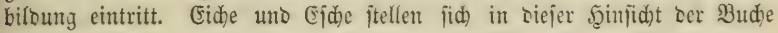
uno Dem Bergahorn nur unter aupergemöhnlic gümitigen Stanoortâver: bältnifien gleid) und aud) biês nur soum, wenn fie, eingejprengt in Buchen

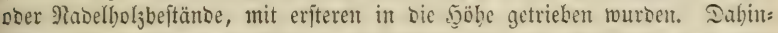
gegen fteben Eid)e uno Ejohe im Etätizuwadje Der Rothbude unto bem Bergalorne mindeftens gleid.

?(ud) bie Eller gebört nod) mit зи Denjenigen \$golzarten, bie einen

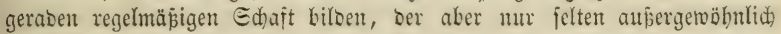
ftarfe Dimenfionen erlangt.

Alle übrigen, in unjern Sig̈locrn angebauten Saubbołjbätme, Der

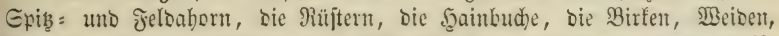

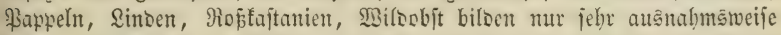

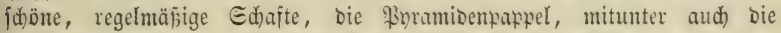

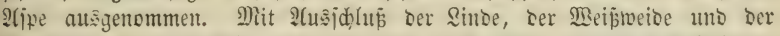

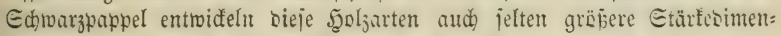

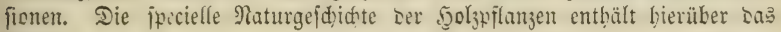
Miäbere.

Erziebung im gejololienen Etande förost bie Baumböhe, sie Grao:

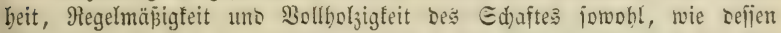
I(jtreinheit; fie fteht sem Etärfejumadje in Den tieferen Etammthcilen, Der Sronenbiloung uno ajtwerbreitung entgegen. Id babe bierüber im eriten Banbes bas 9töthige gejagt.

\section{Hiitidertrag.}

Die Minden mefrerer fyolyarten find entweder jelbit, als Bintematerial, Sorf, von bejonderem Gebraud,şwerthe (Rüfter, Sinbe, Rorteiche, Birfe) ober fie entbalten Etofife non bejonterem tedjuifden ober mebicinijuen

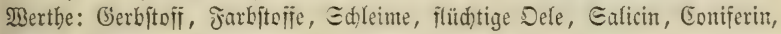
Betulin, Ebinin, Daphnin $2 c$.

UrE Bindematerial bient bie Bajthaut ber Müjter uno ber Sinbe

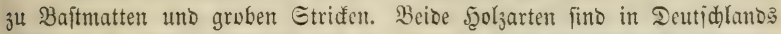
Mäloern zu wenig angebaut uns zu jelten int ibrem ipontanen Borf́cmmen,

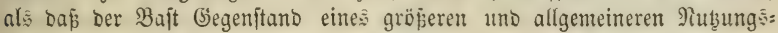
betriebes fein fönnte; Santlente, Tagelöhner, Gärtner beziehen wobl hier uno Da ibren eigenen Bebarf surd) Eelbitgeminnung, bie grofe Mafle De?

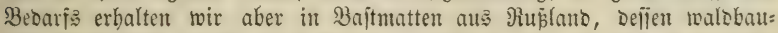

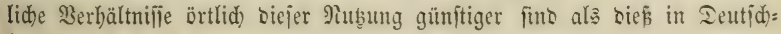
lanto ber Fall ift. 


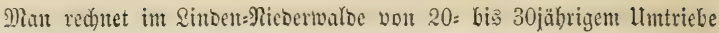

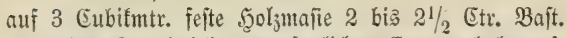

Die Rorfeide bes jübliden (Emopa bält unjern Minter nidht ans: wir erbalten ben meiften fort auß Spanien. Bei einem jäbrlidjen Buwadje volt 3 bis 6 Mitlimtr. Dide lieforn jtärfere (Eid)ent alle 5 bis 6 Jabre 350 bis 400 Pfo. Sorf, wovon jebod) 60 bis 80 Proc. in Wegfall fomment. 2(us

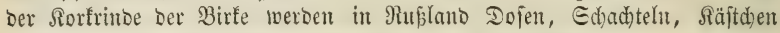
gefertigt, bie eine zierliche Dauernoe Frefilung annebment.

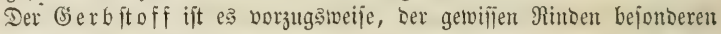

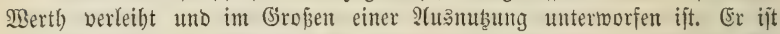

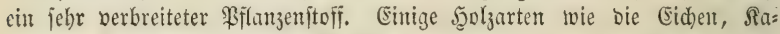
ftanien, Sreuzoorne ic. entbalten ify in allen ifren Theilen; Den Simon, Blättern, Früd)ten fehlt er fajt nirgenos. Bejonders reich an S"erbitoff fint Die Baftlugen, wo er Den Minter übor in fejter Form in beftimmtelt Drganent abgelagert ift. Wie alle ïbrigen Referveitoffe roiro er int Frübjabr im lebendigen \$iflanzenfafte aufgelöst uno fdeint baburd) erft jeine fräftigite SBirfung als Gerbmittel 3 ch crlangen, beftebento in feiner denificen Berbinoung mit bem \&eime ver Thierbäute, bie baburd) zu Seber ungetwantolt uno ber Fäulnif für lange Beit entzogen werben. SBie alle übrigen Rejervejtoffe wiro andh Der Gerbjtofi im Jrübjabr auf bie

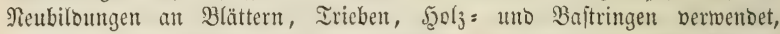

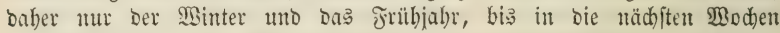
nad) Dent Beginne ber Sinofpententwidefung eine reid)lid)e 24ubeute liefern. 3๖. 1. ธ. 182.

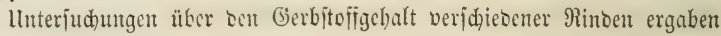
folgende Rejultate:

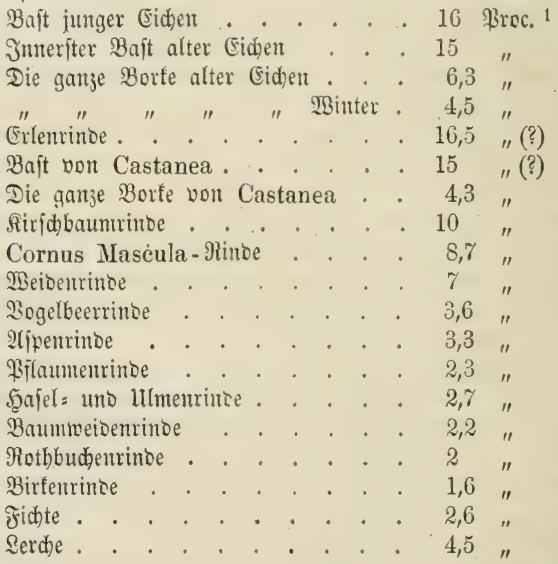

1 Giehe meine Gdrift über den Ģerbftoff Der Gidje. 


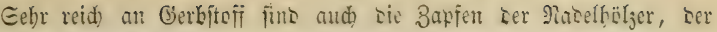
Eidgenrinoe nabe gleid.

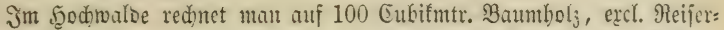

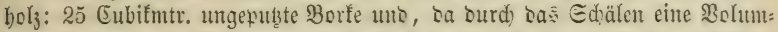
wergröperung bes Slafterraumes ftattfinbet, S5 bis 92 Eubifmtr. geiduältes

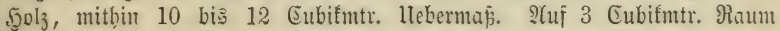
fann man 1,4 Eubifmtr. fefte Pintemmalie redunen, Den Cubifmtr. Yuft=

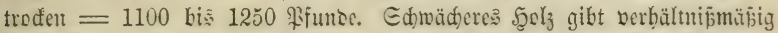

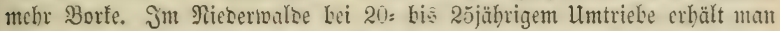
auf 3 Cubifmtr. Sortfolzmajie 0,6 bis 0,8 Eubifmtr. Epiegelrinte, Den Eubifmtr. $=700$ bis 750 \$ifunde Irnctem zervid $t=1,5$ Cubifmtr. ieite

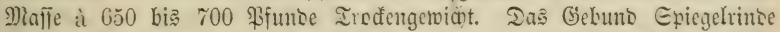

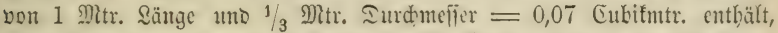
gut gebunsen, feltent voll 0,4 Cubifmtr. fejte Majie uno iviegt burdjidnittlid)

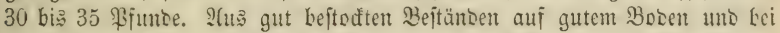

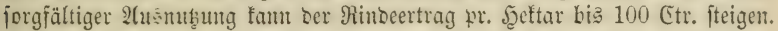

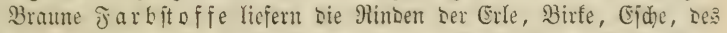

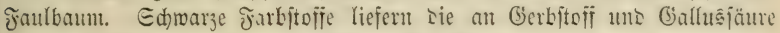
reiden Rinton, bejonders Der Eiche uno Rajtanie.

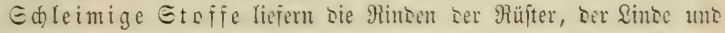
Der Mgeiptanne.

Flüdtige Dele in ben Rinben Der Pabelbölger.

Medicamente uno Ireguen wie bas Eniferin un ans biejem

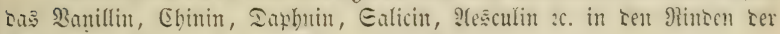

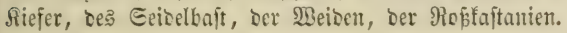

\section{III. frudjt- III) Samenerting.}

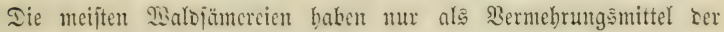

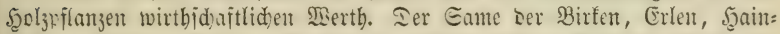

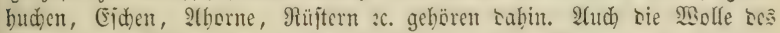

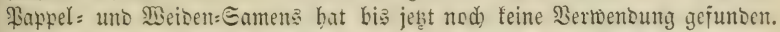

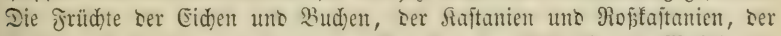

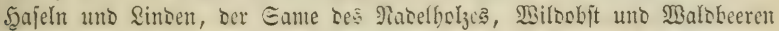
beritiebener afrt fommen theils als Biebjutter, theils zur Delgetwinnung, theils als Eveife nod beute in Betrad)t, obgleid) Deren Bebeutung wefentlid geringer geworben ift, jeit bie S(rbeitâträfte im \$reije geptiegen uns bic

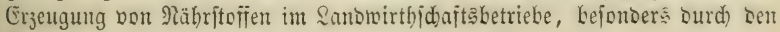
2lubau ber Sartoffel eine reid)lidere getworben ift.

In Jabren reidliditer Jruchterzengung redutet man Durdjidnittlid

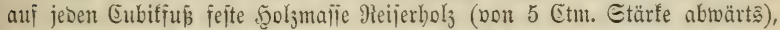
in ben 100jäbrigen uno älteren (Ei $i$ d) enbejtän ben 0,8 bis 1,5 Siter Eidueln, um fo mebr, je älter bie Bejtände fino uno je geringer beren Stammjabl ift. Solle Majt tritt jeond jelten offter als alle 4 bis 6 Jabre

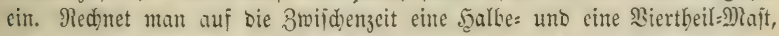

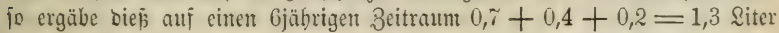

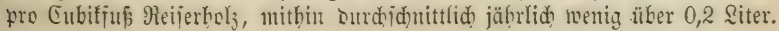




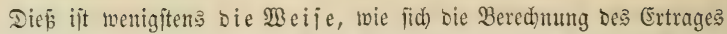

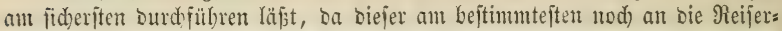
boljmafle gebunten ift, beren Mlenge, wie bie ber Frudterzengung, mit ber

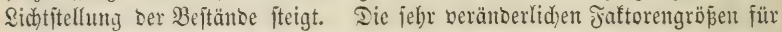
bie Bercd)nutg wiro man für jeses Mlajtjabr leidht Durd) einige birefte Unter= juddungen prüfen, refp. berid)tigen fönten.

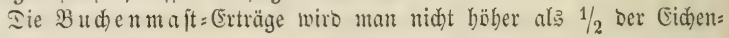
erträge anjeşen Dürfen.

Mie alle Iurdidnittsfärec haben aud bie vorftebenten einen fehr be=

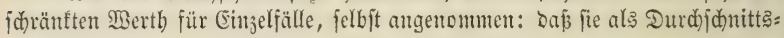

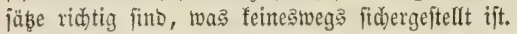

Ille übrigen Jrüd)te uno Eämereien fömen nid)t (Segenftano einer

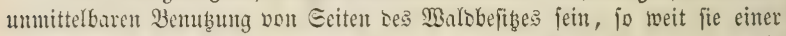
anberent, als ber 3ertwentung zur Erat bienen. 2(ud) bier würben bie Roften bes Einfammelns jeben Getwinn abjorbiren. Ës mú bas Sammeln, allenfalls gegen eine geringe Bablung, foldhen Seuten überlajien werben, bie ibre ?(rbeitsfraft zur Beit mur gering roer gar nid)t in Red)mung ftellen uno feiner Beaufijidtigung bebürfen, ba fie fiut fid fanmeln.

\section{IV. fauluctrag.}

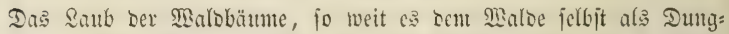
material uno Bodentia)ub entbebrlid) ift, wirto theils als Jutterlaub, theils als Streulaub berwendet.

Iie 2tugaben über Futterla bertrag find nod) febr bejdräntt uno

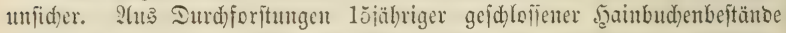
erbielt id) a) Saub 10 Proc. Des Grüngenid)ts Der ausgycbaumen Stämme, pr. Sett. 275 Etr. grüne $=125$ Ctr. Luftrodenes \&aub. Jm Nieberwalse:

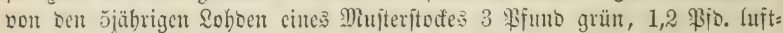
troden; von Den 10jäbrigen Solbocn cines Miufteritodes 6 \$fo. grün, 2,4 \$fo. lufttroden; von 20 jäbrigen 20 boen 22 \$fo. grün, 10 Pfo. lufttrodén anSaub. Bei 10jupiger Etodferne würben 260 Etö̈fe Daher 2600 \$fo. luft= trofit $=26$ Etr. Jutterlaub crtragen. Dberbolzbäume Des s)ittelwaloes mit 12 ßroc. Reiferbols unter 2,5 (tm. Durd)mefier aut $26 b i e b c$ liejertent 190 Bip. Saub auf ben Eubifmtr. fefte Meijermajle. Sopfbolyreijer unter

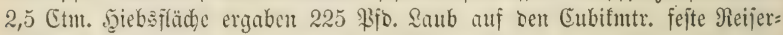
maile. Cin bettar mit 20 bis 50 Ctm. Siopf holjitumment gut bejtanden ergab 120 Etr. Luftrofene: Saub (i. meine Paturgejd). Der forfitl. Rulturpfl.).

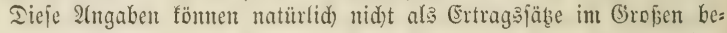
trad)tet werben, ba fie aus fleineren, normal beftodten Serfuds)slächen ber: vorgegangen fino.

Reidbaltiger fint bie Angaben über Den Etreulaubertrag Der Balbbejtänoe.

2Bą zucrijt bie jäbrliche Sauberzengung voll beftocter Drte betrifit, fo entbält bierüber meine Paturgejdidhte Der forftl. Sulturkflanjen eine Reiben= folge bon $\mathfrak{A}$ ngaben, Denen id Rachfolgenbes entnebme.

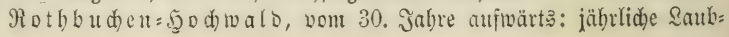




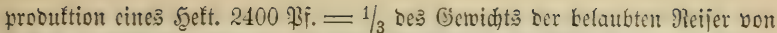

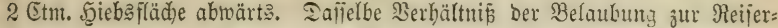
holymafie aud im Dberbolje bes Mittelmaldes. Im Nicbertwalbe truy ber

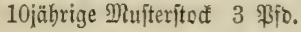

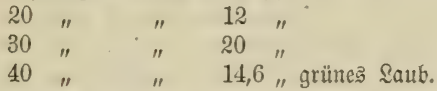

Nimmt man für ben 10 jäbrigen llmtrieb eine 1,3=, für Den 20jährigen 1tmtrieb 2:, für ben 30 uno 40jährigen 3metrige Entjernung Der 9)htter= ftöfe an, fo ergibt fid) eine Saubproduftion in 2 (lter ser llmtriebşeit $=$ $1620 \cdot 3=4860$ Pfunbe pro $1 / 4$ Seltar.

$720 \cdot 12=8640 \quad "$

$405 \cdot 20=8100$ "

$259 \cdot 14,6=3800 \quad$ " (1000 \$fD. friī $)=458$ ßì

Sufttrofengewid)t im Durdididnitt).

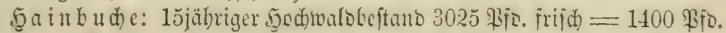

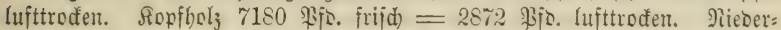

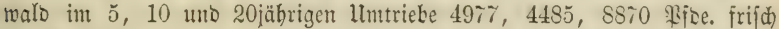
pr. ${ }^{1 / 4}$ Seeftar.

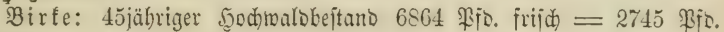
lufttroden.

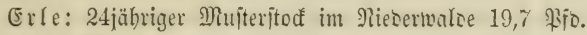
16
"
17,5 .

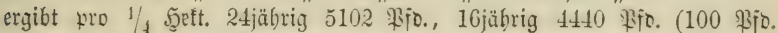
grünes $\mathfrak{Q} a u b=43$ Pfo. lufttrofen).

Sicfer: 60jübriger geichlofiener Sejtano 5300 \$io. einjährige Mabeln (im Mai bes folgenden Jahres) $=3300$ Bipe. Lufttrođen.

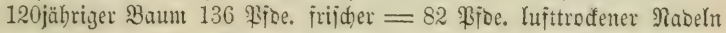
aller brei Jabrgänge.

lufttroden.

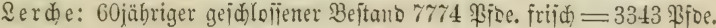

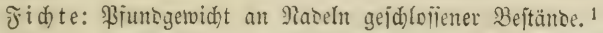

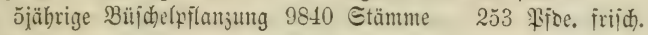

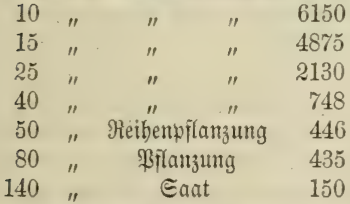

$\begin{array}{lrrrr}\text { " } & 793 & \text { " } & \text { " } \\ \text { " } & 4922 & \text { " } & \text { " } \\ \text { " } & 16770 & \text { " } & \text { " } \\ \text { " } & 11550 & \text { " } & \text { " } \\ \text { " } & 97757 & \text { " } & \text { " } \\ \text { " } & 16566 & \text { " } & \text { " }\end{array}$

1 Es find Dieje Crjahrungsjäbe einem Theile derjenigen Bejtände entrommen, denen

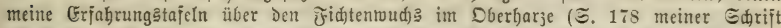

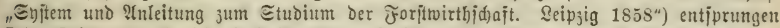

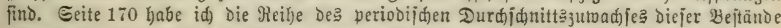

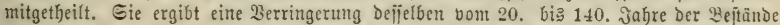

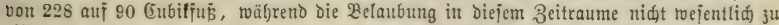

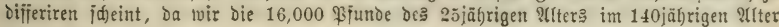
wiederinden. 


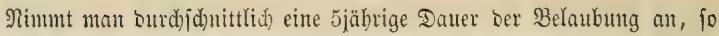

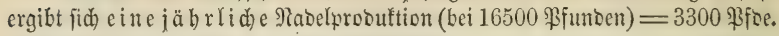
Grüngemid)t $=1700$ (?) Sifoe. Lufttroden.

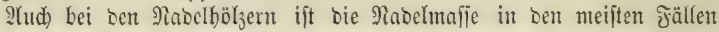
jiemlic) gentau $=1 / 3$ bes (3etwidts ber grünen Reifer von $21 / 2$ (Etm. abrürt?.

Bei Weitem geringer fino die $\mathfrak{A}$ ngaben über ben Streutertrag, wie folcher nad) Dem ?(bfalle deş Raubes haubarer uno geringhaubarer Beftänoe vom Boben gefammelt werben fann.

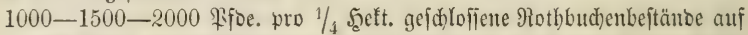

(d) ledbtem, mittelmäfigem uno gutem Standort, wemt eine Etreunutzung

vorher nod nidat ftattgefunben batte.

300-600-1000 \$Foe. in Rieferbeftänden,

800-1000-1200 अipe. in Sidjtenbeftänden,

500-800-1100 \$fbe. in Eichenbeftänoen,

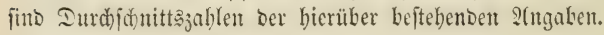

\section{Sïftertrag.}

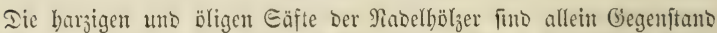

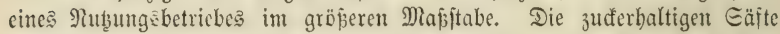
Der ?lborne umo Birfen forbern nidjt allein cinen, im Berbältnif zum möglichen (seminne zu gropjen 2trbeitsaufwano, fondern aud) zu groper Mengen theuren Brenmmaterials für bie 2rboamofung; ibre Betvinumg ift

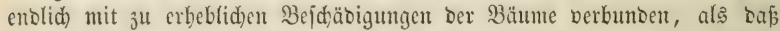
eine fold)e in fultibirten .änbern mit Nuben betrieben werben fann. In 2(merifa's Urwäldern fann ber, bis ju 3 \$roc. Buder enthaltenbe Gaft ber 2(horne begenftand cines Sutbungabctriebes fein, weil bort weber bas zum 21boampfon des Gafts nötbige Bromuboly, nod) bie Berleb̧ung ber Bäume in Betrad)t fonumt, nid)t aber bei unt?.

Athgejehen von Den, Durd) Den Iheerid)welereibetrieb zu getwinnenten

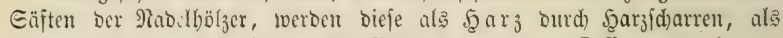
Ierpentiu Durdh ?(nbohren Der Bäume ober burd) Deffinen Der in ber Sinoe Der Beiptanne liegenben Ierpentinlyalter genomen.

TSa ben 5arzertrag ber Jid)te betrifft, fo red)net man, wäbrento einer 20-25jäbrigen Bemuk̨ung 80-120jäbriger Beftän๖e, Durdjid)nittlid) pro Stamm jährlid) $1 / 4-1 / 2$ \$fund Şarz, movon nabe bie Şälfte zur \$ed)=

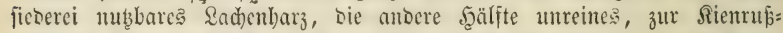

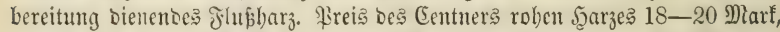
belaftet mit nabe 3 Mlarf 2 rbeițlohn für bie Bearbeitung von 300 Bäumen.

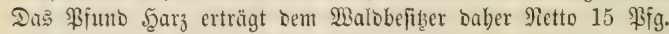

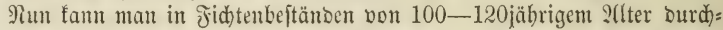
(d)nittlid) 0,03 Eubitmtr. 3umad) pro Stamm uno Jahr red)nen. Nimmt man $1 / 6$ 3uwad) šberluft Durd) Das 2 (nbarzen an, fo beträgt diȩ́ auf 3 Bäume,

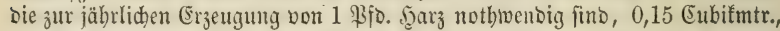

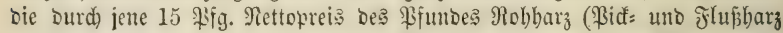
zufanmengenommen) erfekst werben müfien, abgejeben von bem Mintorpreije

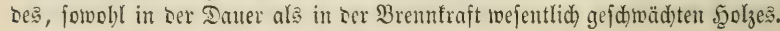


Dicjer \$3erlujt an 2lafie uno Syolzpreis ijt ein fo bebeutenter, Daj

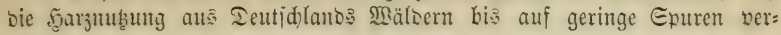
fadwumben ijt. ${ }^{1}$

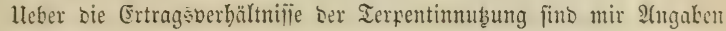
nidht befannt.

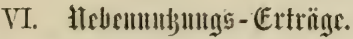

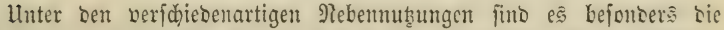

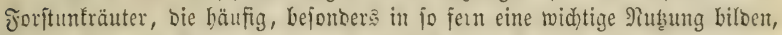
als burd) Deren 2(bgabe an ben Sanowirth bem Becürfnip an Jutter= ober

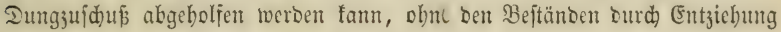
bon Saubitrel зи jdyaben.

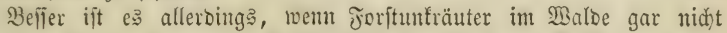

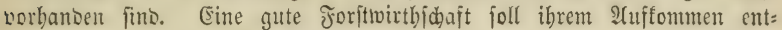
gegenwirfen. Intés läpt fid) Diejes nid)t immer bermeiben, in Jolge wioriger Miatureignifie ober getwifier, ourd) bie llmftänoe gebotener Betriebs: operationen.

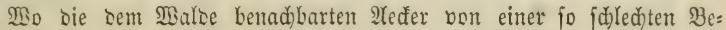
id)afienbeit find, baf fie aus eigener Dungerzeugung fich nicht erzengungs: fräftig zu erbalten vermögen, ba fam ser Jorftwirth, aud obne redtliche Serpilichtung, oft genöthigt fein, ben Lantowirth theil(s burd) (Einräumung

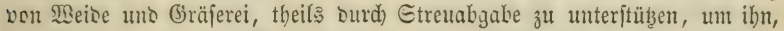

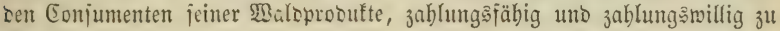
erbalten.

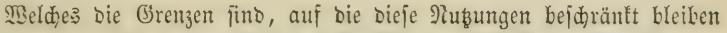

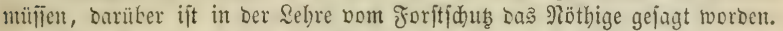

Den $\mathfrak{B}$ cibeertrag Der Wälber bemift man nad ber Diorgenjabl, meldhe eine Suh bebarf, um von jenfenreinem, unbeadertem uno unbewal= Detem Boben ifren Jutterbebarf wäbrend der Meidezeit ju bejiejen. 9lan nimmt hier vorberrident als Bebarf einer Subweide an (i. \$üjdel (Ench): clopäbie):

\section{But.}

Fiden = und Budenboden $1,5-2,5$

Erlenboben . . . 1,5-2,5

Birfenboden . . . 2,5-5,5

Jichtentboben . . . 2,5-3,5

Sieferboben . . . 3,6-5,0
Mittelmäణig.

$4-6$
$4-6$
$6-7$
$4-7$
$5-10$

๔đ্̣া ‘̛̣̆t.

$\begin{array}{rc}7-12 & \mathfrak{M r g} \cdot{ }^{2} \\ 12-32 & \prime \prime \\ 12-32 & \prime \prime \\ 16-32 & \prime \prime \\ 16-64 \quad "\end{array}$

Je nadbem ein jolder Boben mun raums ober vollebejtmoen ijt, ge: hört zum Bebarf einer Rublweide

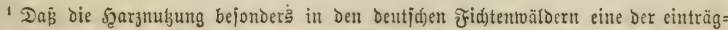

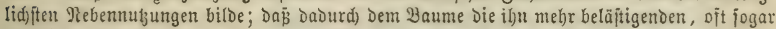

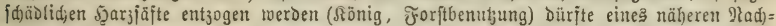

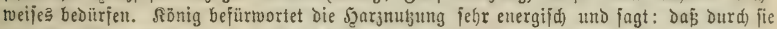

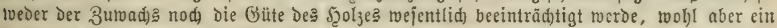
jüfrlides (Ginfommen bon $1 \frac{1}{3}$ Thaler pro Mlorgen ergielt werden fönne.

${ }^{2} 1$ pr. Morgen $=1 / 4$ Settar.

Şartig, \&elgrbud für f̈örïter. II. 
in Buchenbeitänoen Das 3 -20fadje obiger Morgenzahl,

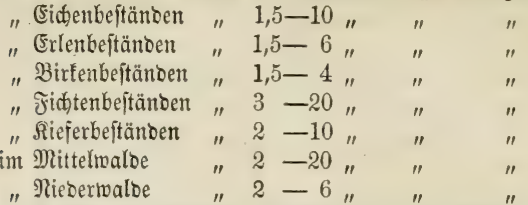

Je nad) (Süte bes Jutters und Entfernung ber Beibe wirb ber $\mathfrak{B e r t h}$

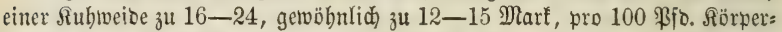
gewid)t зu 3-4 Marf angenommen. Niebriger bei nur theilweijer Ernäbrung Des $\mathfrak{B i e h e s , ~ b i s ె ~ z u ~} 1$ Mart binab.

Der Sulbweibe gleid) werben gerednet $2 / 3$ Pferbetweibe, $3 / 4$ bis $4 / 5$, 3ug= odje, $1 \frac{1}{3}$ Füllen, $1 \frac{2 / 3}{3}-2$ Färie, $2 \frac{1}{2}$ Salb, 8-10 Ed)af uno Ed)wein, 24-30 (3anకె.

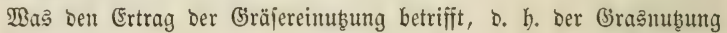

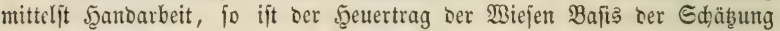
uno biejer nad) ben in \$üjhels Encyclopäbie gegebenten 3ujammenjtellungen: \$on bejten Riederungäwiejen 18-30 (Etr. pr. 1/, Sgett. im Jutterwerth $=1$ Giewöbnliche Rieberungs:,

gute Feld: uno $\mathfrak{B a l d}=$

wiefen . . . . 12-18 " " " " " $=0,8$ Gaure, falte $\mathfrak{B i e f e n , ~ t r o d e n e ~}$

Jelo = uno Malowiejen $4-12, "$ " " " " " " " " $=0,6$ Trodene Şöbentwiejen . 2-5 " " " " " " " $=0,5$

Ier Ertrag unter Seitenjdatten ftehender, fleinerer Balowiejen ift um 40 \$roc. geringer als ber Ertrag freiliegender Wiefen.

Der Ertrag unter Eeitenidatten ftehender Maloblößjen ift bödjiten зи 60 Broc. Des Ertrages der betreffenden Wiejentlafie zu veranjidlagen,

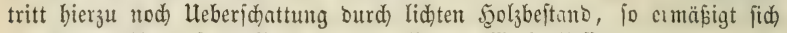
Der Ertrag bis auf 15 \$roc. Der betreffenden Wiefentlalfe.

2(uperdem ift ber futterwerth bes Balograjes 5-10 \$roc. geringer als Der beక Wiejengrajes. Wa.

Den Streuertrag a Noofe, Jeiben zc. Getrifft (über bent Streuertrag aus ber Belaubung babe id jidon vorbergehent gejproden), fo ijt biejer beridieben, je nadbem nur bie Pflanjen, ober mit biejen jugleid) aud bie oberifte burdwurzelte Boben: idid)te Dem Walde entnommen twiro (\$llaggen uno Bülten).

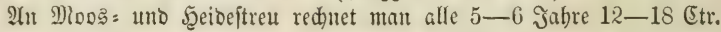
Troctengewidht Ertrag pro $1 / 4$ 5eftar unter günjtigen, $6-12$ Etr. unter

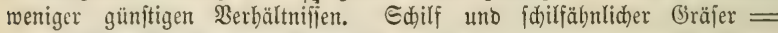

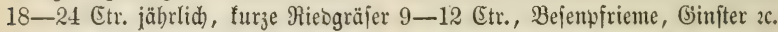
10-16 (Etr. jäbrlich. 3u einem Eentner trodèn gehören an (Brüngetwidyt bolzige Unfräuter 2 Etr., Ģras 4-5 Etr., Edjilf unt Binjen 6-7 Etr. 2ll B Blaggenertrag pro $1 / 4$ Şeft. unbejdirmter Boben rechnet man 42-60 Juber à 10-12 Etr., auf Graşboden in 4-5jäbrigem, auf ફ̧eide: boben in 10-14jäbrigem Umtriebe. 


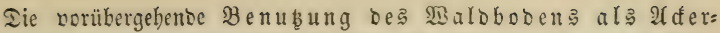
I a no wirft nur beim Bejtandswodjel und jloar nur fo lange einen Rein= ertrag $a b$, als ber vom alten Beitunde berftammende Scumus eine Düngung unnöthig mad)t (Neurob). Sie barf aud mur auf Boben ftattintoen, ber

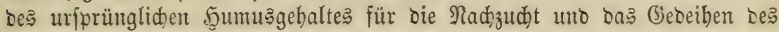
jungen Beftanoes ganj ober theilmeije entbebren fann, aljo nur auf einem, in jeinen unorganijien Bejtantheilen frudtbaren Boben; gar nidht auf leidtem, trodenem, 2-3 Jabre auf leidtem, feuchtem, 4-5 Jabre auj idwerem, jeudhtem Sehmboocn. Aber jelbit in biejer Bejobränfung ijt Der Reinertrag ein geringer Daburch, Dafi bie bebeutenien Rojten ber Urbarmadung ben Ernteertrag reniger Jahre belaijten, die Ehtfernung ber Robefläden bon ben

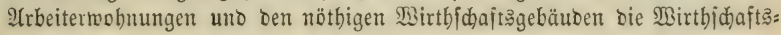
foiten roejentlich erböben.

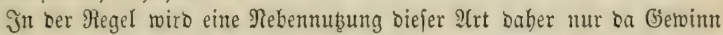
bringeno jein, 1) mo Mangel an, in ftänoigem Sanowirthidaịts̄betriebe

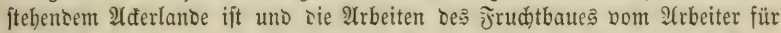
eigene Red́nung betrieben merben (Sadtoalowirtbidaft); 2) wo ein bellerer Boden zugleid aud für bie Bearbeitung günjtig gelegen ijt; 3) mo ourd

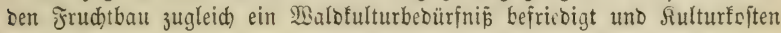
eripart merben.

Je nadbem ber Boben jarwieriger urbar zu machen ift, wirb man bem Santowirthe $1-2$ Jreijabre gemähren, Dann $1 / 4-1 / 3$ Des Ernteertrage al Badhtgelo bejieben tömen. Der Betrieb Des 2(derbaues auf Rojten bes Walbbejithers jelbit trirb biejem nur in bem Falle Gietwinn bringen tönnen, loen er felbit zugleid aud Lanogutsbefiber ift.

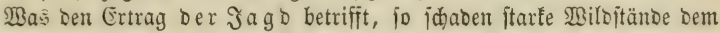
WalDe mebr als jie einbringen. Mäp̈ige Wilojtänbe tönnen einen Rimertrag

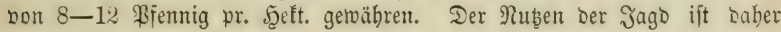
weit mebr cin mittelbarer uno zwar burch ibre Birfung auf Die Thätigfeit bes Joritmannes. Man bat es vielfältig bervorgeboben, Daf ourch bie

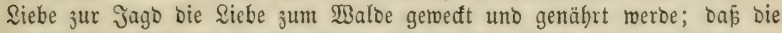
Jago Den Joritmann in Den Walo uno an Drte fübre, Die, von Betrieb: gejdäften oft lange Beit unberübrt, obne biés ifm entfrembet mürben, baf bie Jago ifn im Ueberblid aller Balotbeile erhalte uno ibn zu forftliden \$abrnebmungen fübre, Die ifm obne dießs entgangen jein würDen. (5) liegt etras $13 a b r e s$ bierin, namentlich burd) Den IImitano, baf ber Jorftrirth

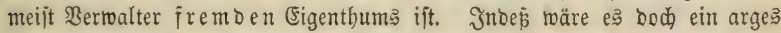

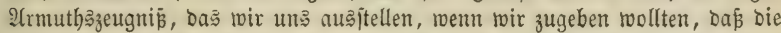

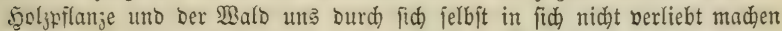

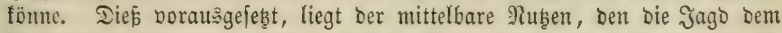
Baloe getwährt, barin, baj feine Bejhäftigung mehr als bieje geeignet ift, Die Combinationsgabe bes jungen forfmantes zur Eombination s: ¡ähigfeit auşzubilben, eine Jäbigfeit, die nirgenos von jo grojent Ein=

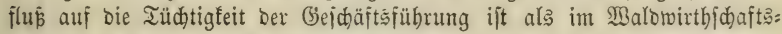
betriebe, bejonders in $\mathfrak{B} e z u g$ auf Jorftfduks.

Der Naturalertrag Der übrigen Nebenmubungen bes Maloe: i it nad)

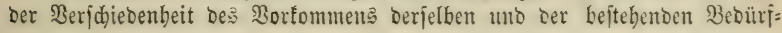




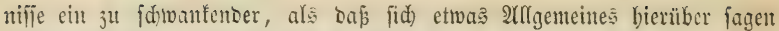

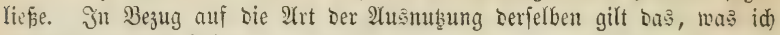
Geite 165 gejagt habe.

\section{3̧weites Erapited.}

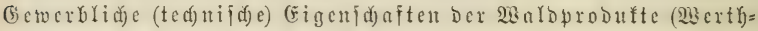
extrag).

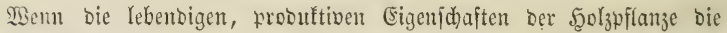
Minge und bie Afrt bes Erjengten beftimmen, fo fint cs berfibiebente intere

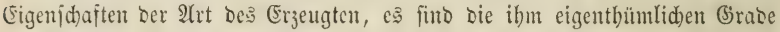
Der Brennfraft, Der Dauer, Der Ђä̈rte 2 ., weldhe bie Bermentobarfeit, Den

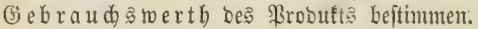

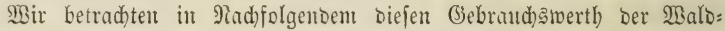
wrooufte, unabhängig vom Bcoürfnific. Die Dariftllung jenes, vom B̉e= Dürfuifie, von Den Untoften, wie bou compenfirenden Bortheilen ser 2lid)t=

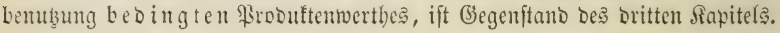

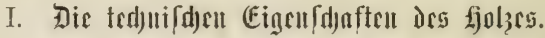

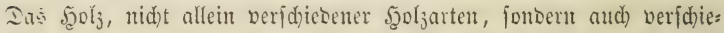

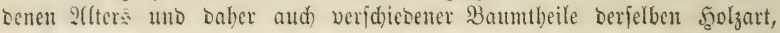
veridiebener Enttwidelung unter beridjicbenen Standort: und Beftande?:

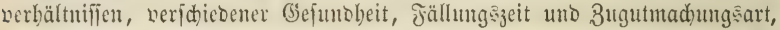
3eigt fid mebr ober weniger verjd)ieden in Bejug anf eine Pieihenfolge flynfi=

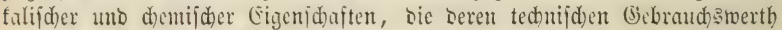
bebingen. Son biejen Eigenfidaften bebe id) bier bie nadfolgenoen, als bie ted) niid) widtigeren hervor:

Eduwere, Bremfraft, Dauter, Şärte, Ecfitigfcit, Elafticität, Biegjam: feit, Bäbigfeit, Spaltjamteit, Echwinden. ${ }^{1}$

\section{1) Die Edinere}

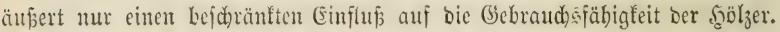
Eine geringere Belaftung Der Gebüube Durd) Derent obere Theile gibt Dem

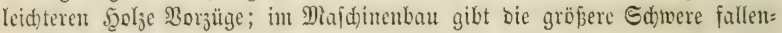
ber Majdinentheile dem fdwereren Scolze oft Borzüge.

Defto widntiger ift bic Ed)were Des Syolzes in Bezug auf Dent Trans: pert, Deffen Soften imerbalb gewiffer (Srenzen lwentiger wom Bemid)t als

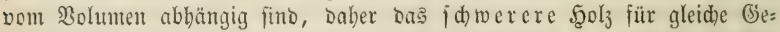

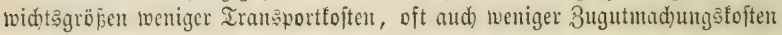
erforbert.

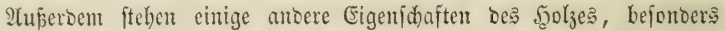
Die Şärte, Die Jeftigfeit uno Die Bremmirfung gleid) groper Raumtheile veridiedenter Fुoljarten mit Der Edjwere berfelben in einem nabe gleidhen

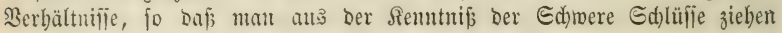

1 \{re weniger widftig übergebe id) bier bie \$erjdiedenbeiten ber Struftut, Der Farbe,

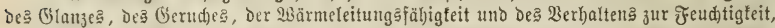

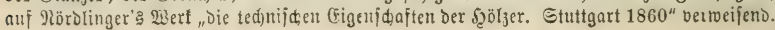




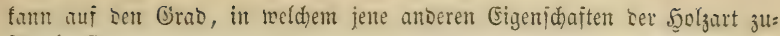
jtändig finto.

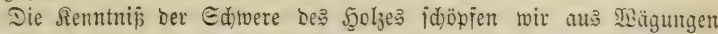

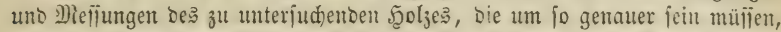

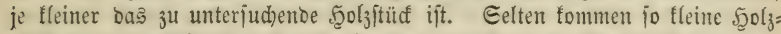
ftüđe zur Unterjud)ung, saj nidht eine jebe gute $\mathfrak{B a g e}$ zur Giewidhtsbejtimmung

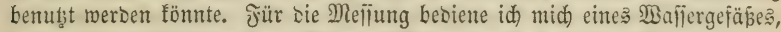
befien Epiegelfläd)e in Dem Dhäe berfleinert werben funn, als bie Quer:

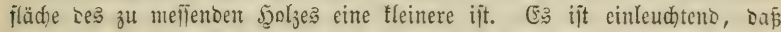
ntan ben Cubifinbalt ciner Etricfnabel mit Derjelben Genauigleit mie ben

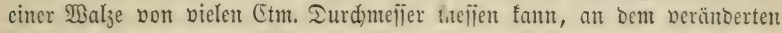

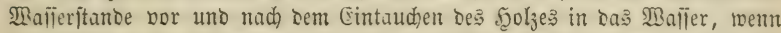

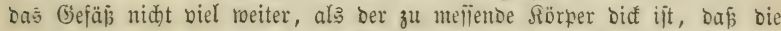
aud) bierbei nod unvermeibbaren Beobadtungsfebler un jo geringer werben,

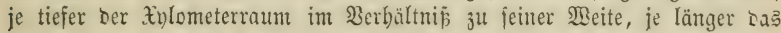

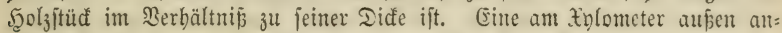
gebradte grabuirte Glašröhre uno Edwimmer erböhen bie Gejdwimbigfeit

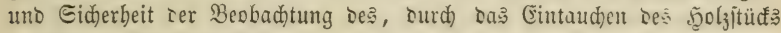

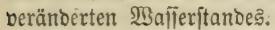

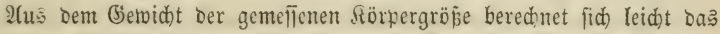

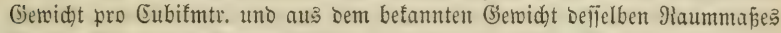
Regentwafier von beftimmter Temperatur bas (pecififide (Bemiá)t.

Das Griungewidht eines Eubifmtr. in 3ollpjunden liegt bei unjeren Malbbäumen:

bei den harten Saubböljern jwijden 1650 uno 2240 PFino

bei ben weichen Saubbölzern " 1400 " 1800 "

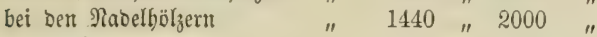
Suftrodengeroid)t:

bei barten \&aubbölzern . . " 1150 " 1660 "

" weiden " . " 1000 " 1150 "

". Tabelfölzern . . . " " 1050 " 1200 "

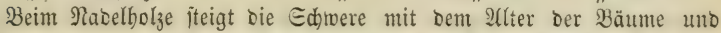

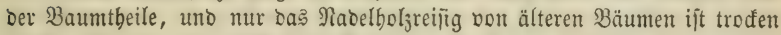

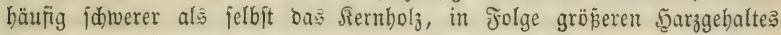
unt enger Jabrešringe; beim Saubbolze, bejonders beim harten Saubtolze, mit größ̄erem Mehlgehalte be Splint entgegengejeşt.

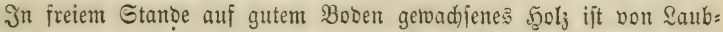

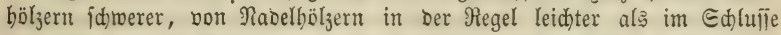

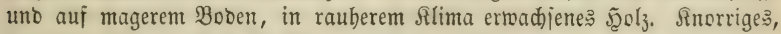
majriges, äftiges .

Srantheiten uno Jehler Des Baums verringern sie Єdiwere aud ber nod) gejunben Baumtbeile.

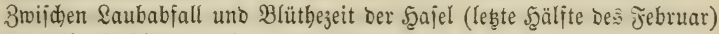

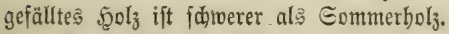

Rajd) abgetrodnetes und auper \&uftjug im trodenen Raum aufberwabrte

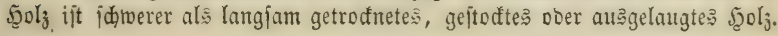




\section{2) Die Brennfraft.}

Ungefäbr 80 ßrocent Der Şoljerzeugung werben in Deutidjland als Feuerung:material berwendet. Bou ber Fällung bis zum enolichen Berbraudje

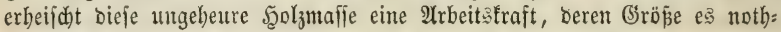
wenbig mad)t, bem Conjumenten ein möglidjt brennfräftiges Şolz barž bieten, oa ourd intenfive Brennitofiprobultion uno burd bie (Erziebung bes grösten Brennwertbcs im fleinften Raume ein bebeutenber Iheil jener $\mathfrak{A}$ r: beitşfraft erfpart uno auf andere Ġegenftände nub̧bringent verwenbet werben fann. Der \$roducent felbjt ift in jofern bierbet interefiirt, als ber Con= fument ben \$rtis, Den er für feinen Bebarf zahlen tann, nach ben Bejammt:

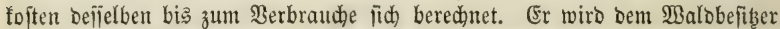

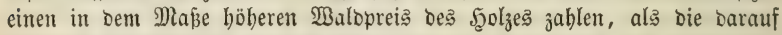
fallenden Untoften ber 3ugutmaduung und bes Transports fid berringern.

Daber ift bie Renntnif des Brennwerthes verfdiedener Scolzarten, Baumalter uno Baumtheile für Den Forftmann von groß̉er Beoeutung.

Bon Den berjofiebenten $\mathfrak{A}$ rten ber Brennfraftermittelung bat bis jebet

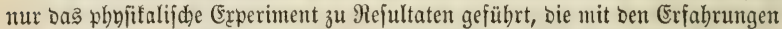
uno 2Anfidten ber Eonfumenten nabe übereinjtimmen. Die neueren Unter=

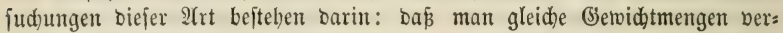
fdiebener Brennitoffe von gleidem, geringen Jeud)tigkeitsgebalte (lufttroden), unter gleiden Graden der \&uftwärme, Der Berfleinumg Des Bremnftoffßs, Der Edhidtung, Radfeuerung 2 . in Demjenigen Feuerungsapparate verbient, für ben man bie $\mathfrak{b r e n n t r}$ irung bes Materials ermitteln will, bie eine andere ift bei gleichen Brennitoffe im Stuben= ofen, auf bem Jêuerherbe, unter bem Dampffeffel, im Badfofen, Ralfofen $x$. Die Märmemirfung bes verbrannten Brennftoffs, gemeffen einestbeils nad) Graden uno 3eitoauer Der Erroürmung bes Jeuerungsapparates uno ber,

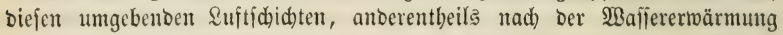
uno Rerounftung in Sejäßen, bie mit Dem Feuerunģapparate in unmittel= bare Berbinoung gebradbt fino, ergibt eine Reibe von Berbältnißzablen Der Bremtraft, went man bie Brennwirfung eines beftimmten Brenmitoffes

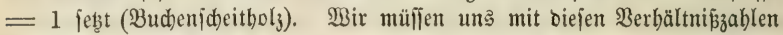
begnügen. Alle Berfud)e, Die von einem Brennitoff wäbreno ber Berbren= unung aușgebento $\mathfrak{B a ̈ r m e m e n g e ~ z u ~ e r m i t t e l n , ~ f i n o ~ b i s ~ j e t ̧ t ~ m i f g l u ̈ đ t , ~ b a ~}$ jeber Jeucrungsapparat bas Entweiden einer mit Sidherbeit nidht bejtimm=

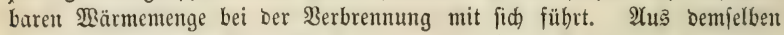
Brrunde wärbe eine Befanntidaft mit Dir abjoluten Brennfraft, wie folde bie (Shemie zu ermitteln jid bejtrebt bat, faum von prattifder Bedeutung fein.

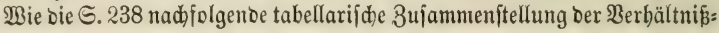
zahlen aller befaumten technifhen (Eigenichaften bes $\mathfrak{S}_{0}$ lzes zeigt, fteigt bie Brenn=

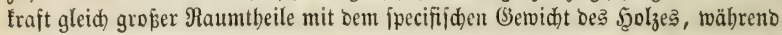

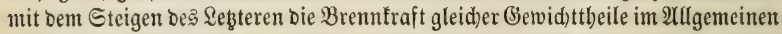

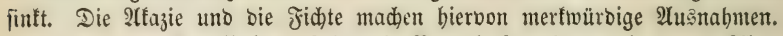

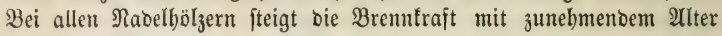
Der Bäume uno Baumtheile burd fteigenden Şarzgebalt. Nur bie in Der

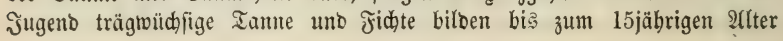




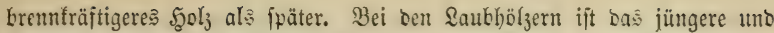
mittelalte $\mathfrak{S g l}_{3}$ am brennfräftigiten.

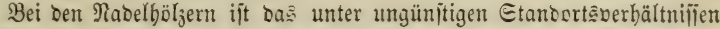
erwadhfene, fdmalringige, bei ben Saubbölzern bas breitringige $\mathfrak{S C l}_{3}$ am brennfräftigiten.

Srante, abjtänbige, anbrïđige Bäume baben auch in ben gejunben Baumtbeilen geringere Brenntraft.

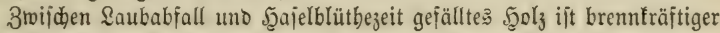

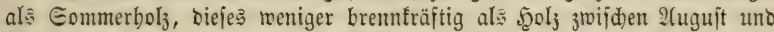
शovember gefällt. Wurzel unt Reijerbolz verliert surch Den Eommerbieb mebr an Brennfraft als Stammbolz.

Durd) bas rajdere Abtroctnen ift gejpaltenes fुoly uno bieję um fo brennfräftiger, je bünner bie Edyeite ausgeppalten wursen.

Mit Dem natürliden Eaftgehalte berbrennt ijt bie Brennwirfung beకె 5ुolzes bi: $341 / 3$ geringer als bie beffelten Sुoljoolumen im trodenen 3ujtande.

\section{3) Dauer.}

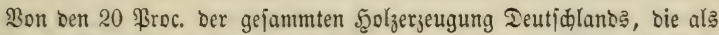

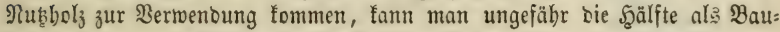

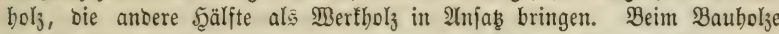

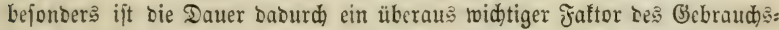
werthes, baß auf bieje 5̧ölser nidjt allein eine weit gröpere Eumme bon

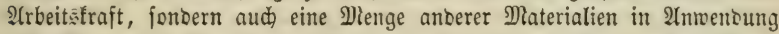

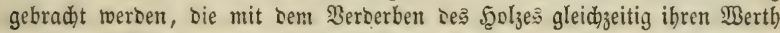

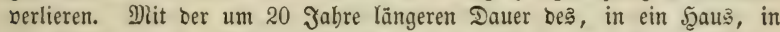
ein Єdiffi, in eine Brücte verbauten Scolzes, erbält fid aud alles übrige in Dieje (Bebäube verwenbete Material um fo länger im (Gebrauche.

Die Erfabrungen, weldje wir über bie veridjiedente Dauter verfdiebener

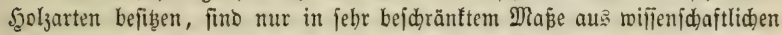
Unterfud)ungen herborgegangen. Eine großartige Berjudjäantalt batte mein verftorbenter Bater im (5arten ber Berliner Thierarzneijdule erridtet. Eॄ̉ ift bießs, fo viel ich reißs, bie erfte uno cinzige, bie überbaupt aufgeftellt wurbe. Nur für bie geringen Etangenljölzer ergaben fid Rejultate fodon

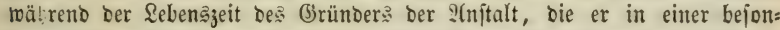
Deren fleinen Edhrift veröfifentlid)te. Nad feinem Iode übernabm Dberlant:

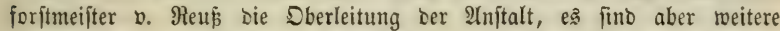
Mittleilungen über Rejultate nidht befannt geworben, bie Anftalt ijt fijon bei Rebzeiten bes Borjtandes eingegangen.

Die beftebenden Angaben über bie Dauer bes Jgolzes fino baber wobl obne 24 ünabme allgemeinen Erfabrungen uno Bergleiden entnommen, wie fich joldye aus ber Beobadtung alter Baulidfeiten ergeben baben. Mtan Darf Den barüber lautenten Bahlengröß̈en baher aud nur einen bejdränften wifienjdaftliden Berth beilegen, wenn man beridfidtigt, bás bie auf biejem Wege beobadteten Thatjad)en unter febr veridhiebenartigen äuperen Einflüijen fich gebiloet haben.

Tie Seite 238 nachjolgenbe tabellarijhe 3ujammenjtellung gibt bieje

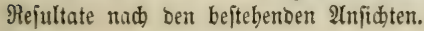




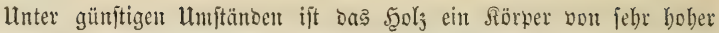
Daner. Unter Den Utemfilien, bie in ben ägyptifoden Ratafomben nufge= funben wurben, finben fid folde aus weiden Szolzarten bon fonjt geringer Dauer, bie fidc) völlig. unweränoert erbalten haben. Trocfenbeit Der Suft und gleidbleibenoe, niebere Iemperatur find bier wirfente Urfache. Daber zeigt aud) Das Fुol

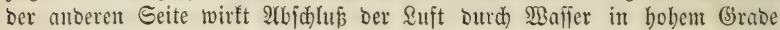
conjervirento, fo baj jelbjt bas leid)t unb rajd fid) zerjebente Budjen= uno

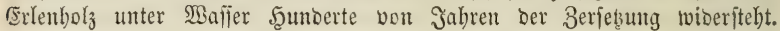

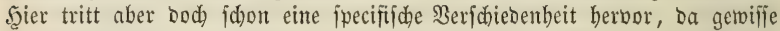
Şolzarten: Weioen=, Bappeln=, Rinbenbolz aud) unter Majfer fich rajd zer=

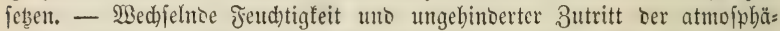
rifchen \&uft, bei beren gewöhnliden Iemperaturgraben, bejchleutigen aber bie Zerję̧ung in bem (Srabe, daf felbft bie Dauerhafteften . Jabrzebnten Deren Einwirfung erliegen.

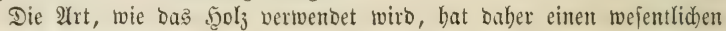
Einflup auf Deffen Dauer.

Yrber aud bie 3eit uno 2(rt Der Bugutmad)ung beftimmt bie Dauer De? Şolzes.

Qäßjt man Die Bäume über ein, von Den Stanoortsoerbältnififen ab= bängiges, gewiffes $\mathfrak{A}($ ter fräftiger Entwifelung binats fortwad)fen, bann verfallen bie älteren Baumtheile einem frantbaften Buftande, befîen Folge bas 2Uftreten nieberer \$il

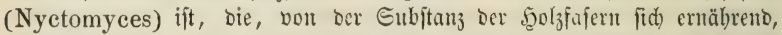

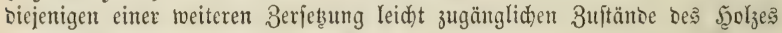

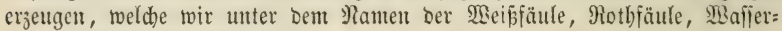
fäıle, Remnfäule zc. fennen.

Sällt man bie Bäume in ber Eaftzeit, bann fino e३s bie fleinften organi= firten Sïrper des Bflanzenfafts, weld)e zu Pifzen nieberer Bildung fid) untwantoln unb, wie jene Tadjtfajern Das Fajergewebe buthwadjent uno,

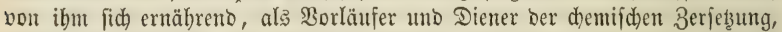
Dasjenige veranlaffen, was twir bas Stoden bes F̧olzes nennen. Dieje lltwilze

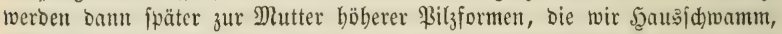
Maueridyamm (Merulius lacrimans) ober laufenten Ed)twanm (Boletus

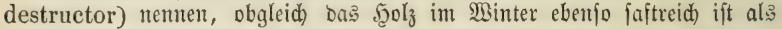
in Sommer, obgleid ber Minterfaft weniger rafd verounftet als ber Sommer= faft, ftodf bemohnerad)tet bas im Minter gefälte $\mathfrak{S c l}_{3}$ nicht, ober ood) bei weitem nid)t fo leid)t, rafd) uno ftart als bas Eommerboly. Wir minffen bas

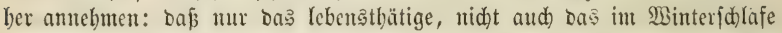
liegente Safttörperden einer Umbiloung in \$iljtörper befäbigt fei. Der 2/n=

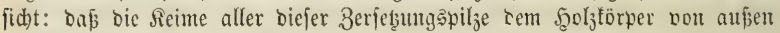

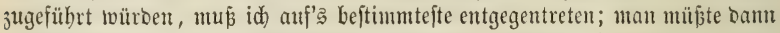

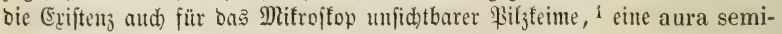
nalis in veränbertem $\mathbb{M}$ ortimute amebmen!

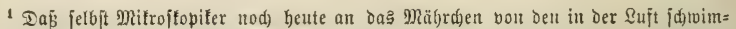

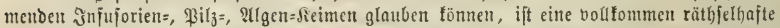

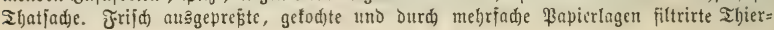




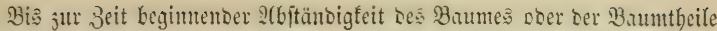

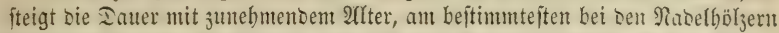

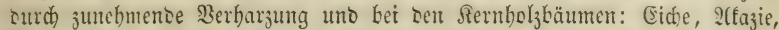
Rüfter, (Fid)e, Durch zunebmente Durdbringung ber 5olz

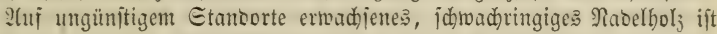

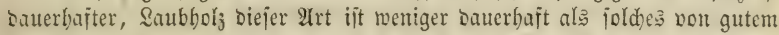
Etanoste. Beim Saubholze tritt bieß um jo mebr heronr, je mehr bie Şolz= röbren an ter inneren Juhreşringgrenze fid zujammenitellen.

Rajches A(btroduen Des Soljfaftes burd Entrinden uno Eraltun crböbt

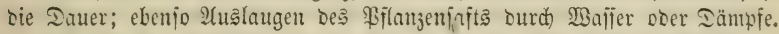

Unter ben werifiebenen in Soridhlag gebradten Mitteln bie Dauer

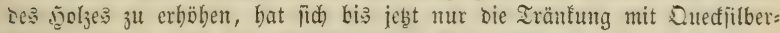

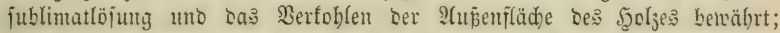

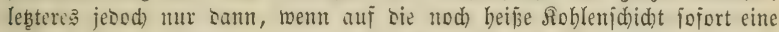

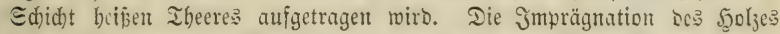
mit beridjebenartigen Metallialjen ergaben meinem 3ater feine erbeblid) günjtigen Rejultate. Temofnerachtet jino bieje Mittel in neuefter Beit in grósem Masitabe, bejonders von Eifenbabnbebörocn in 2(mwentung gebracht worben. Man verifrad) fiá) babou jebr vicl. Jetet aber, nadjeem bie

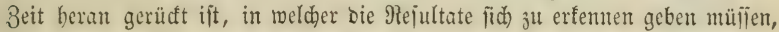
ift alles jebr ftill geworben uno ntan hört jobn bier uno ba einige nifís=

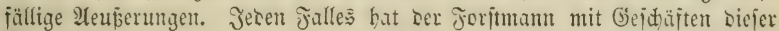
2(rt nid)ts 3u thun.

\section{4) Die. bärte.}

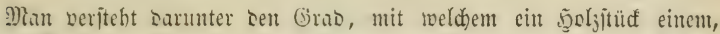
auj jeine Malje einwirfenben Drude Widerjtano leijtet, ohne eine 3ujanmen=

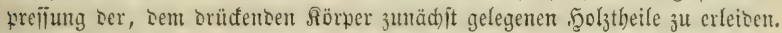

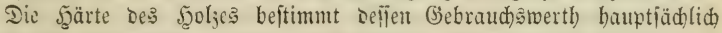

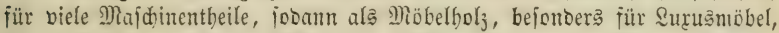

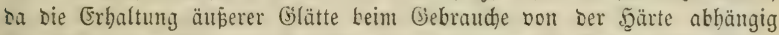
ijt. Wiste sie nadfolgende Tabelle jeigt, berlaujen bie Grabe biejer Eigen=

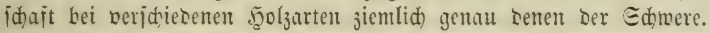

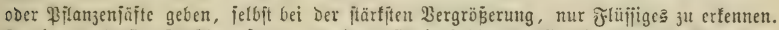

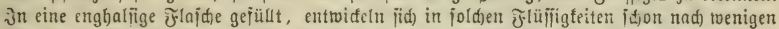

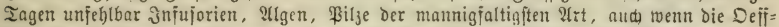
unung ber Flajde mit Baumwolle ober Dergleidjen lofe beritopit wuroe. Wir fennen bie

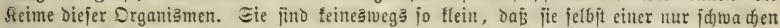

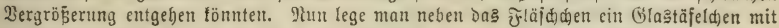

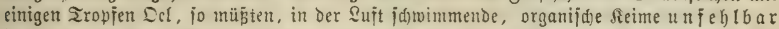
in tweit reidfliderer Menge dem Sel, als Durd) Die Baumwolle hinourd ber Jnjujion Ju= gehen. Iavon jeigt fich aber feine Eput. Euftitaub genug, aber nidjts mas organifiden

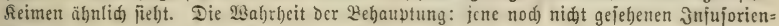

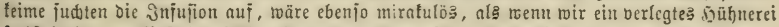

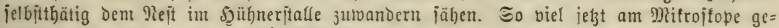

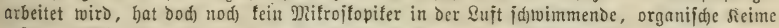

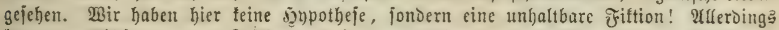
fönnen Piłziporen bem Sujtitnube beigemengt jein; jie jind ilym aber nid)t jo häufig,

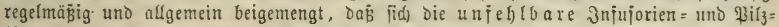

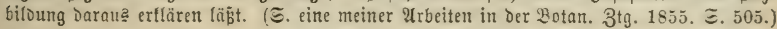


2eltre Bäume uno Baumtbeile fino bärter als jüngere, in folge ber

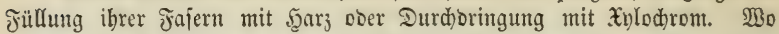
beioes nidht ftattfintet, wie bei Den weidhen Raubhölzern, bem 2thorn, ber

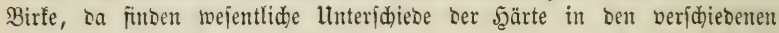

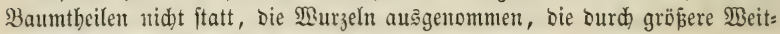

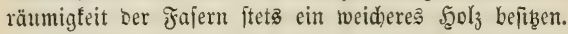

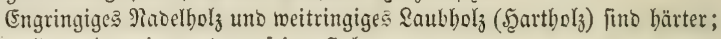

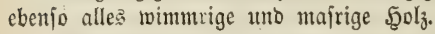

Ânbrüdigleit Des Baumę verringert bie Şärte.

Albwelten auf sem Stamme uno Dürren beş Scolzes im Raudjfange erböben die ફ̧ärte.

\section{5) Die Feftigleit.}

Man verfteht Darunter לen (brad, mit weldem bie f̧ölzer einer, auf Deren 3erreifen ober 3erbrecben wirfenden Sraft Mioeritano leiften uno unterideibet eine Sängenfeftigfeit, Duerfeftigfeit uno Drehungs:

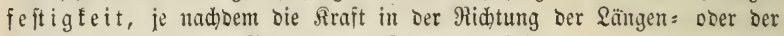
Queradje ober in ber Ridtung Der Tangente wirtt.

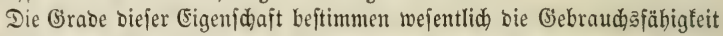

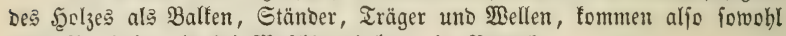
beim Baubolze als bei Majdinenbölzern in Betrad)t.

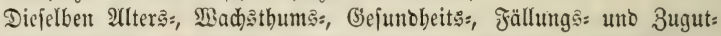

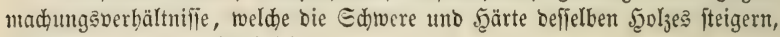
crböben auch belien Jejtigteit.

\section{6) Die Gpannfraft}

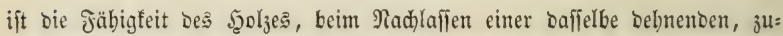

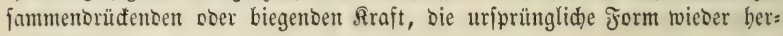
autellen.

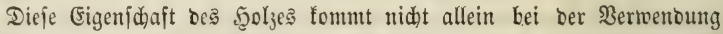
als Baubol $l_{3}$ uno beim Nafichinenlau in Betrad)t, fondern fie beftimmt aud)

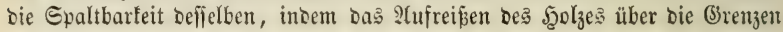

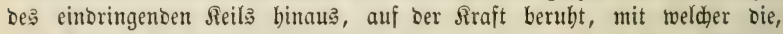
vom Reile aus ibrer urfprüngliden \&age gebrängten Şolzfafern biejenige Rid)tung wieber einzunehmen ftreben, in Der fie vor Dem Einoringen bes

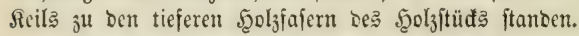

Dberirbiiche Baumtbeile uno in biefen bas jüngere, äupere Fुol fitto

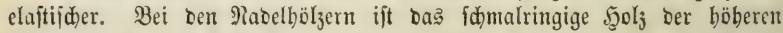
Biebirgslagen, des fladgrünoigen unt trođenen Stanoorts am elaitifajten.

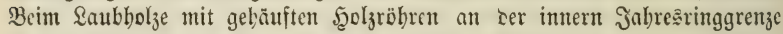

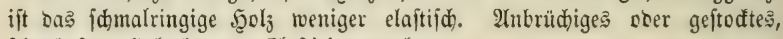
fdabbaftes $\mathfrak{S g l}_{\mathrm{O}}$ hat an Elafticität verloren.

\section{7) Die Epaltigfeit.}

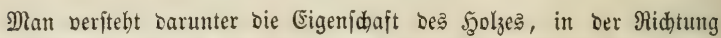

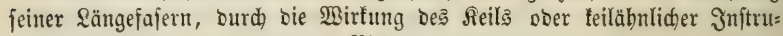
mente, fid leidht uno in graber Ridbtung zu trennen. 
Dieje Cigenidaft hat für ben Foritmann birefte Bebeutung barin, baj

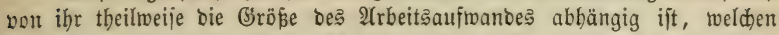

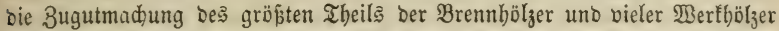
exforbert. Afuñerdem fino einige Walogewerbe, oer Epaltholzbetrieb, at böhere Grabe biejer (Eigenidaft Des Sholjes gebunten.

Dbgleidh bie Spaltigfeit Des Şolzes rejentlid) gebunben ift an bie Epannfraft ber Syolzfafern, fo treten bennod eine Menge mobificirenter

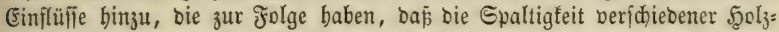
arten feineșegeg in gleiđem Maße mit ber Elafticität zu= ober abnimmt.

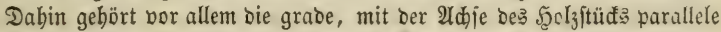
Sage ber Syolzfajern, burdh welde bas Epditen wejentlid geförbert wirt. Daburd fheiben aus ben Epaltbölzcrn eine Menge bon fुolzarten aแร, Denen ungerabe Sagerung ber Fajern 2(rteigenthümlickfeit ift, bie baber felbjt bei böheren (3raben Der Elafticität Dod geringe Epaltigfeit befitzen.

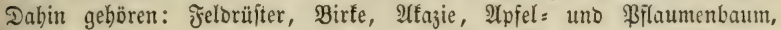
wäbreno bei Der Şainbudbe geringe Spaltigleit mit geringer Elafticität ge: paart iit.

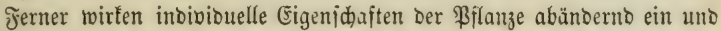

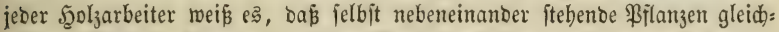

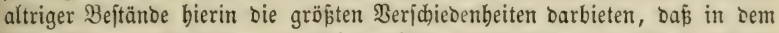
einen Baume alle Fajern parallel ber \&ängenadje liegen, in einem anderen alle Fajern fpiralig um bie Sängenadje verlaufen, idhon äuperlidg erfennbar am Berlaufe Der Rinderifile. Allerander Braun mollte bieje, meine Erachtens

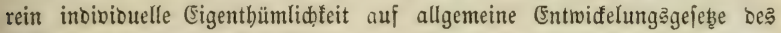

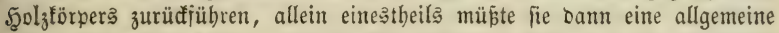

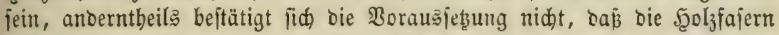
uriprünglid) mit horizontalen fläd)en über einanoer fteben uno erit fpäter mit ihren fich zuipiţenden Enden in einander greifen.

2lud bie Ergiebungameife wirtt wejentlid auf bie Epaltigteit baburdh ein, baß̃, je mebr Seitenäjte am Sdafte zur Entwiđelung tommen uno je älter biejelben werben, ebe fie burd) Beroämmung abiterben, in um fo böherent (3rabe uno um fo weiter nach ausen bin bie Scoljfajern aus ibrer

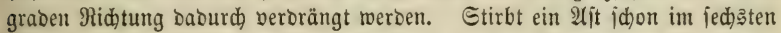
Jabre bei einer Dife von $1 / 2$ 3oll $a b$, fo reidt fein Uleberreft im Sgolje nom Marfe aus nur bis zum feçsten Jabreşringe uno aud in biejen inneriten Şolzlagen veranlap̧t er nur eine geringe $\mathfrak{A b r w e i d ) u n g ~ b e r ~ j a j e r n ~}$

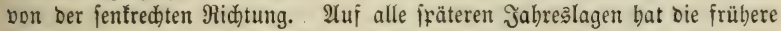
Beaftung in Diefer Seinfidbt feinen ftörenden (Einflußs. Taber erzieben wir

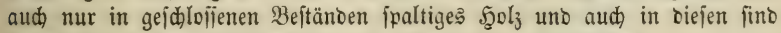
e? nur bie tieferen Stammtheile, bie leidht uno grabe fpalten.

Die in Der nadjolgenoen Tabelle verzeidneten Berbältnif̧̧ablen fino

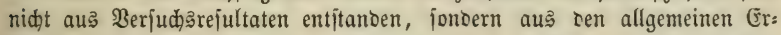
fal)rungen beim Spaltbetriebe. Berwenbung eines Fieila, Der burd fein Eigengetwid)t allein bie Epaltung bemirlt, aber in feiner Sraftwirfung im Augenblide beక Spaltens aufgebalten werben fann, würbe wabridgeinlid

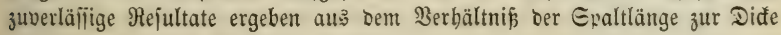
bes eingebrungenen Theiles vom Reile. 


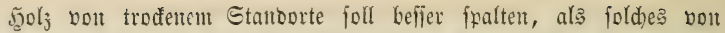

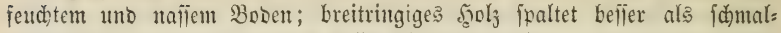

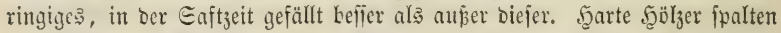

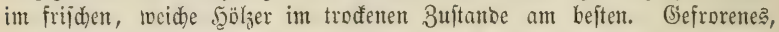
grüne: fgol $_{3}$ fraltet fel)r id)wer. $2\left(m\right.$ leid)teften ipaltet alles Sgol $_{3}$ in ber Ridtung Der Marfitrablen. Im Edwarzwalbe beftebt Dic Meinung, baf tas linf ipalten laile. (?)

\section{8) Biegiamfeit}

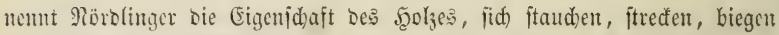
fu laifen, obne Wicocrherftellung ber früberen form (i. Spantraft).

Die Grabe Diejer Eigenidhaft wurben ermittelt: entweber aus ben

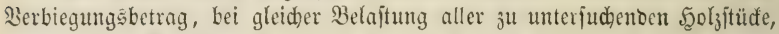

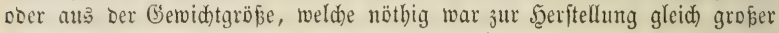
Biegung (ooer einer Biegung bis zum Bredten).

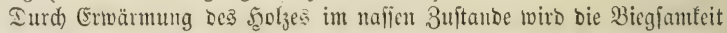
it bohem Grade erböbt. WBiro Das fo gebogene $\mathfrak{S g l}_{3}$ in ber gefrümmten Form erbalten uno getrocnet, Dam verbart es faäter in biejer form aud) bei Bieberanfeuchtung. Die bogenïörmig gefrümmten Stocffrüđen fino ein

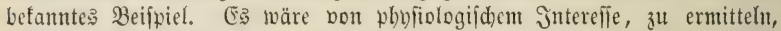
ob hierbei eine Debnung Der 5olyfafern auf ber converen, eine Contraftion auj ber concaven Eeite Des Bogens cintritt, ob die Jajern babei in ibrer gegenjeitigen Berbinoung verharren, oder ob fie fid) unter einanoer ver= jibiebent.

\section{9) 3 ähigleit.}

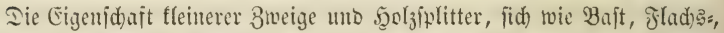
Şanfiafer bin uno ber biegen, zerren, brehen zu laffen, obne zu bredyen oocr ju zerreißen, berulgt hauptfäd)lid) wohl auf ber Weiträumigfeit ber

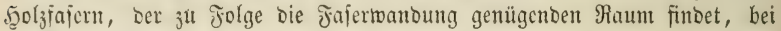
Der Biegung nad) bem Jnnenraume hin auszumeichen. Daber ift bas loeit=

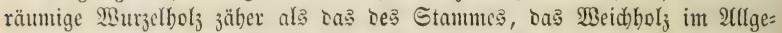

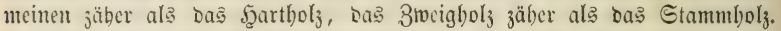
Dod) fommen bier bäufig Atbeidungen vor. Eo ift baß \$appelholz fpröber als bas nahe berwantote Weibenholy, bas Ertent=, Sinben=, Esiḑen=, Riefern=

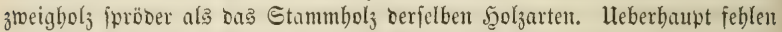
uns bier nod) bie nöthigen wifienid)aftlid)en ltnterjud)ungen burdhau gleid)= merthiger Şolzitüde beridjiebenter Şolzarten unto Baumtheile, Daber bie in

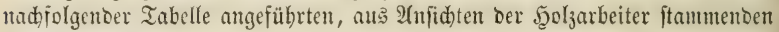

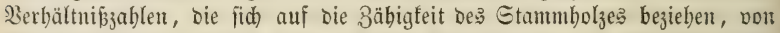
jehr jweifelhaftem Berthe find. Jebenfalls wirb man bei wiffenj(t)aftliden

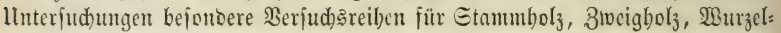
bolz beritellen müfien.

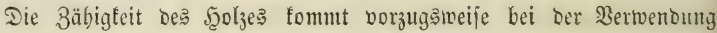
bejelben als Fledht= uno Binomaterial in Betrad)t. 


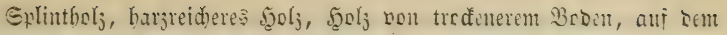
Elamme abgemelftes Sgolj, beliţen höbere Srabe ber 3ühigfeit.

\section{0) $\subseteq$ do toind.}

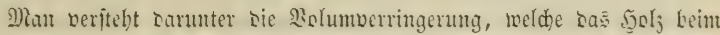

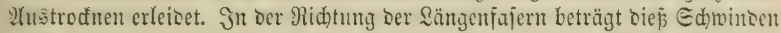
meift unter 0,001 uno jteigt jelten auf 0,005. Erten, Ejden, Birfen, Bapteln,

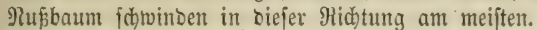

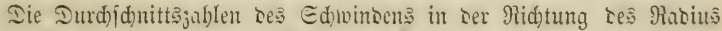

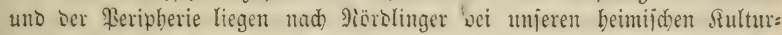
wffanzen zwijden 2 uno 7 . Broc. lineare Eontraftion. Solkes.

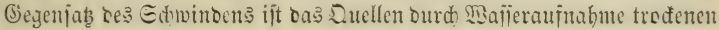

Iurd) ungleide siliteraufuabme uno Daber ungleides Euellen ver:

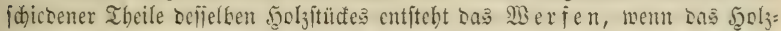

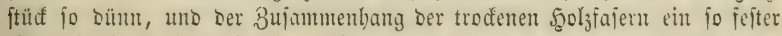

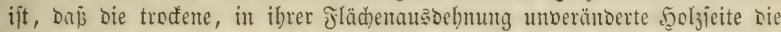

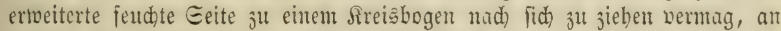

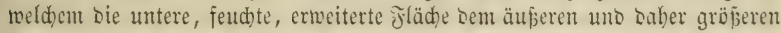
3̉ogen, bie obere, trodente, fleinere illäd) bem imneren, Daler fleineren

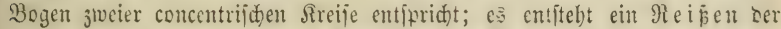

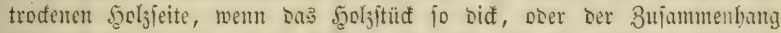
Der trodenen Jajem cin io Ioderer ijt, Daj von ber trodenen tleineren

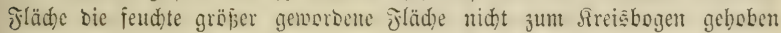
werben fantr.

Daber bejtimmt ber eigenthümliche Girad Deڤ Edyminten einer fुoly:

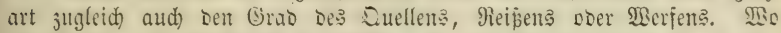

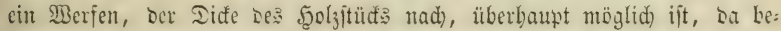

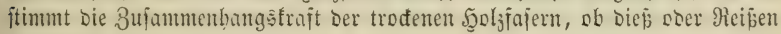
ftattfinten wirb.

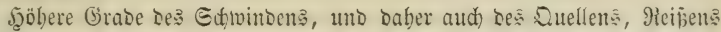

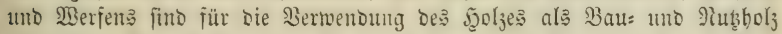

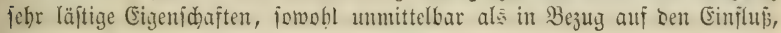

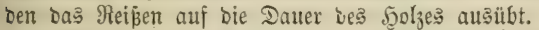

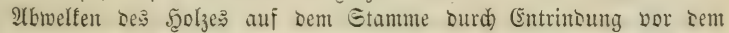

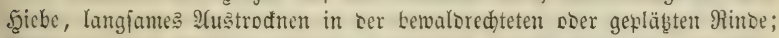

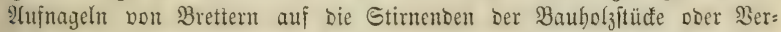

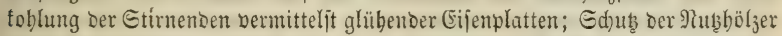
gegen ftarten \&uftzug forobl als gegen unmittelbare Einwirfung oer Eomnen=

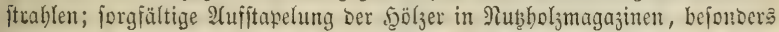
aufrechte Stellung, verbunben mit bäufiger wieberboltem Umfebren, fino bie

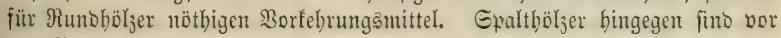

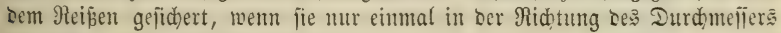
Der Sänge nad) getrenut werben. 
Iabelfarifde 3ufaumenifelfung phyfifalifder Eigenjdjaften ber Deutjdjen Bałbbüume in Berbältniß̧zahlen.

\begin{tabular}{|c|c|c|c|c|c|c|c|c|c|c|c|c|c|c|}
\hline \multirow{3}{*}{ 5olzarten. } & \multirow{3}{*}{ } & \multicolumn{4}{|c|}{$g r \in n n f r a f t$} & \multicolumn{2}{|c|}{ Dauer } & \multirow{3}{*}{ 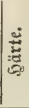 } & \multirow{3}{*}{$\mid$} & \multirow{3}{*}{ 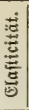 } & \multirow{3}{*}{ 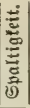 } & \multirow{3}{*}{ 芯 } & & \multirow{3}{*}{ 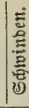 } \\
\hline & & \multicolumn{2}{|c|}{ Sodwirfung. } & \multicolumn{2}{|c|}{ 5eiztoirfung. } & \multirow{2}{*}{ 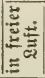 } & \multirow{2}{*}{ 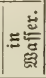 } & & & & & & & \\
\hline & & $\begin{array}{l}\text { Bolu= } \\
\text { men. }\end{array}$ & $\begin{array}{c}\mathbb{B} e= \\
\text { widit. }\end{array}$ & $\begin{array}{c}\mathcal{B e s}_{\mathrm{e}} \\
\text { foidit. }\end{array}$ & $\begin{array}{l}\text { Bolu }= \\
\text { men. }\end{array}$ & & & & & & & & & \\
\hline 2tpferbanm & 9 & $6-7$ & $3-4$ & 5 & 8 & ? & ? & 8 & $?$ & $?$ & 1 & ? & $?$ & 5 \\
\hline QSFlaument. & 8 & ? & $?$ & $?$ & ? & ? & $?$ & 9 & ? & $?$ & 1 & ? & ? & 4 \\
\hline Siridjbaum & 8 & ? & ? & ? & ? & ? & ? & 9 & ? & $?$ & 1 & $?$ & ? & 7 \\
\hline 2ffajie.... & 8 & 9 & $8-9$ & 5 & 9 & 9 & 9 & 7 & 9 & 9 & 2 & 2 & ? & 3 \\
\hline (Fid)e & 7 & $5-6$ & $1-5$ & 1 & 6 & 9 & 9 & 6 & 8 & 5 & 8 & 2 & 4 & 3 \\
\hline Budide & 7 & $7-8$ & $2-9$ & 5 & 8 & 3 & 8 & 6 & 5 & 5 & 8 & $?$ & ? & 8 \\
\hline Sqainbudje. & 7 & $6-7$ & $3-5$ & 3 & 7 & 3 & 6 & 8 & 2 & 2 & 2 & $?$ & 6 & 8 \\
\hline Eid)e & 7 & 5 & $3-5$ & 3 & 6 & 4 & 5 & 7 & 8 & 4 & 3 & 6 & 8 & 3 \\
\hline Raptanie.. & 6 & 3 & 2 & 3 & 5 & 6 & $?$ & 6 & $?$ & $?$ & 4 & $?$ & $?$ & 8 \\
\hline 2(fyorn... & 6 & $6-7$ & $3-4$ & 3 & 5 & 3 & 6 & 8 & 6 & 4 & 3 & 5 & 7 & 3 \\
\hline Rüiter... & 6 & 3 & 3 & 3 & 5 & 8 & 8 & 7 & 7 & 6 & 2 & 3 & 9 & 2 \\
\hline Waffnub́ . & 6 & $?$ & $?$ & $?$ & $?$ & $?$ & $?$ & 6 & $?$ & 6 & 4 & 6 & $?$ & 9 \\
\hline Şajel .... & 5 & 4 & $3-7$ & 4 & 5 & ? & ? & 4 & ? & $?$ & 6 & $?$ & 8 & 6 \\
\hline Birte & 5 & 7 & $2-7$ & 5 & 6 & 2 & $?$ & 3 & 6 & 7 & 1 & 1 & 8 & 6 \\
\hline Eberejde. & 5 & 6 & 9 & 5 & 6 & $?$ & ? & 4 & ? & ? & 1 & $?$ & ? & 4 \\
\hline Eerdye ... & 5 & 4 & $1-6$ & 5 & 7 & 7 & 7 & 4 & 2 & 3 & 7 & 7 & 5 & 1 \\
\hline Sicfer & 4 & $1-8$ & $1-9$ & 5 & 4 & 7 & 8 & 3 & 1 & 1 & 8 & 9 & 2 & 2 \\
\hline ( $\mathrm{Fr}$ & 4 & 2 & $4-9$ & 9 & 2 & 2 & 8 & 2 & 3 & 3 & 7 & 8 & 1 & 6 \\
\hline Jid & 3 & 3 & $3-6$ & 9 & 8 & 5 & 4 & 3 & 2 & 5 & 9 & $?$ & $?$ & 1 \\
\hline $\mathfrak{I}_{0}$ & 2 & 3 & $7-9$ & 7 & 2 & 5 & 3 & 2 & 1 & $?$ & 9 & $?$ & ? & 1 \\
\hline Mob́fajtanic & 2 & 4 & $4-9$ & 5 & 5 & 2 & 1 & 2 & ? & ? & 6 & $?$ & ? & 2 \\
\hline Eind & 1 & 3 & $1-6$ & 4 & 5 & 1 & 1 & 1 & 5 & 8 & 7 & 4 & $?$ & 7 \\
\hline Puat & 1 & 2 & $8-9$ & 7 & 2 & 2 & 1 & 1 & 7 & 1 & 5 & 3 & $?$ & 1 \\
\hline Tiseide. & 1 & 1 & 6 & 5 & 1 & 1 & 1 & 1 & ? & 1 & 5 & $?$ & 3 & 1 \\
\hline
\end{tabular}

Bemerfungen zu vorftebender Iaberle.

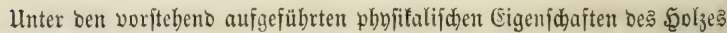

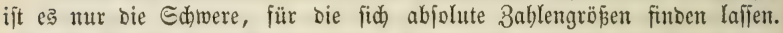
Für alle übrigen Eigenidaften fenten wir nur $\mathfrak{B}$ erbältnifzablen ihrer Berjdiebenkeit bei berjdiedenen Scolzarten. Da bie Maximal= uno Minimal= größen biefer Berbältnízzablen auf verjdjebener Bafis ruben uno fehr ver= idieben weit von einanber entfernt fteben, lafien fid bie Berbältniß̈zahlent

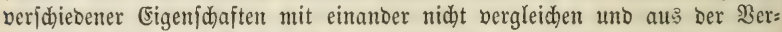
bältnif̧̧abl jelbit ber (Jrab nid)t beurtbeilen, in weldbem bie eine oder andere

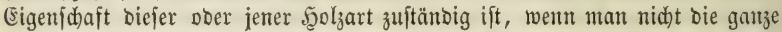

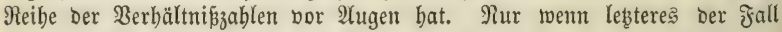
iit, läpt fich für jebe beliebige Reibe von Solzarten, wie eine foldhe vor= fteheno verzeidnet ijt, finden, weldjer unter ihnen Der hödjte, weldher ber niebrigite (ङ̋rab jeber (Eigenifaft zuftänbig ift. Bezeidnet man erfteren überall mit 9 , lekzteren mit 1 , fo lafijen fid) alle übrigen (Srabe zwifden beiben

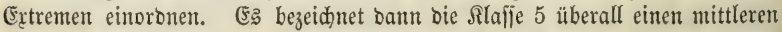
Srab, bie Rlajien 3 uno 7 bezeidnen bas Mittel zwifden leb̧terem uno einem ber beiben Ertreme, Die Rlaffen 2, 4, 6, 8 wieberum Mitteltwerthe zwifden 9 uno 7,7 uno 5 - 
2ui biejem $\mathfrak{B e g e}$ ijt bie boritebende Tabelle entitancen, beren 3 wed

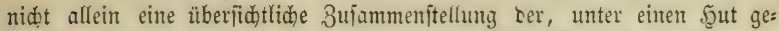

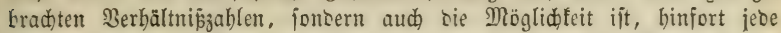

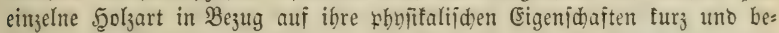

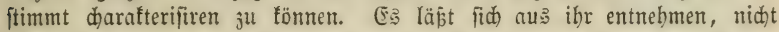

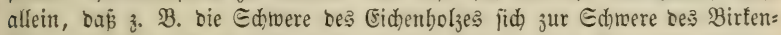
holjes wie $\pi / 9$ z $5 / 9$ verbalt, bas, unter ben in ber Iabelle a ufge: fübrten beutiden $\mathfrak{B}$ aumbölzern, bas Pflaumenbaumbely bie bödjiten,

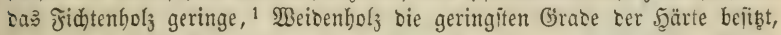

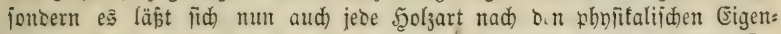

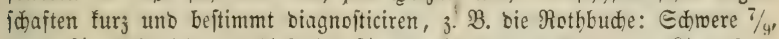

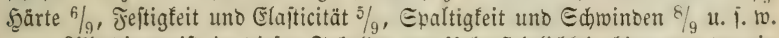

2ulerbings ift in biejen Tabellen ber lleberfidtlidfeit bier uno ba ein geringerer Ģrad non Gienauigfeit ber ?Angaben zum Dpfer gebrad)t. Alllein alle bie aujgeführten Eigenjajaften finto fehr veränberlicher Goröß̈e uno bie, auf jie jich bejiehenten $\mathfrak{A}$ ngaben grünben fich) größtentheils auf einjelne, ober auf eine jo geringe 3 abl von llnterjudungen, baj wir nidt hofien bürjen,

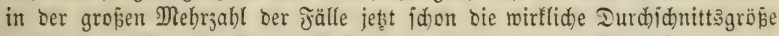

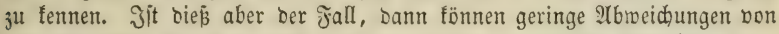

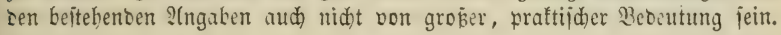

\section{Dis muburen Eigenfduaften ier Killds.}

\section{(Seite 219.)}

Der bei tweitem grö̈̈te Theil ser Rinteproduttion fommt als Brenn= material zur Berwentoung uno bejib̨t als joldes mintoftens benjelten

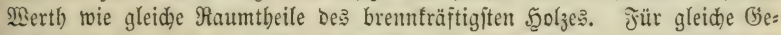
widttheile fand id einen bis zu 25 Proc. böberen Brennwerth. Bejonbers zeidnnete jīh bie Borte ourd) längere Dauer ber Ermärmung in Jolge lantg= jamerer Berbrennung, zugleid) aber aud burd höhere Şib̧wirfung aus. Da nun aber sas Trodengemidht ber Borfe ungefäfr um 20 \$roc. geringer als

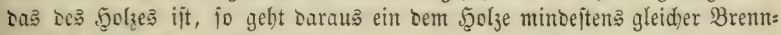
werth ber Borfe herbor.

Biegjamfeit, im Berein mit Bäbigfeit, fino bie Ëigenjadaften, meldhe

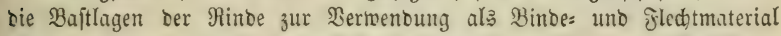
geeigntet maden. Dieje (Eigenidhaften mödten fid) wohl in ber Baftidid)te mebrerer unferer Syoljpilanjen finben, fie müfien aber bereint fein mit einem Reid) thume von Bajtbünolit uno einer Entwidelung ber Bajtlagen, welche bie Gerwinnung zu einer lohnenden madt. Tas ift nur ber Jall bei ber Sinoe und Rüjter, vielleid)t auch bei ber $2(f a j i e$ uno bem Maulbeerbaum.

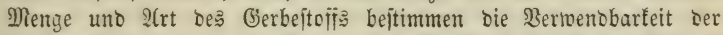

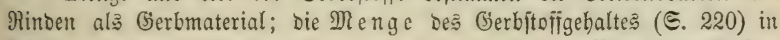

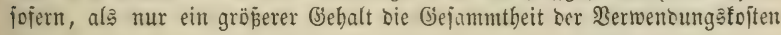

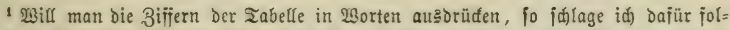
genbe bor: 9) hödjte, 8) nahe ober fajt hödjite, 7) bohe, 6) über mittelmäp̄ige, 5) mittel= mäs̄ige, 4) faum mittelmä ̋̌ige, 3) geringe, 2) nahe oder jajt geringîte, 1) geringite Grade biejer ober jener C̈igenjalajt. 


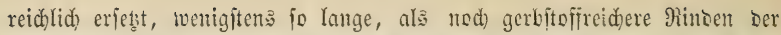
Berwenoung fid) Sarbieten uno nad biejer bie Seberpreife fich bilben; bie It $t$ bes Gerbitofis, als von biejer sie Dualität bes Sebers abbängig ift. ${ }^{1}$

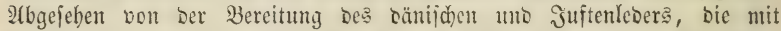

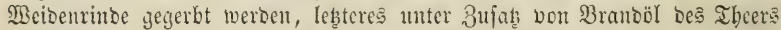
aus Birfentinbe, bat bis jetst mir bie Eid)enrinde in ber Robgerberei cin gutes Seber geliefert. Sie bebcutento ser Bebarf an Cidenlohe ift, geht

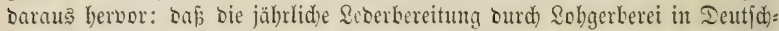

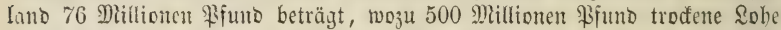
nötbig fint. Serfud)e mit Ellernrinte licferten bei einem um bas Dreifad)e

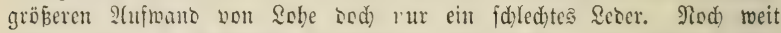

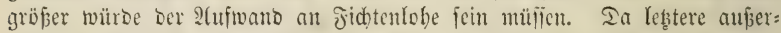
bem ein idwammiges poröles séber gibt, wiro fie mur aud mur bie uno

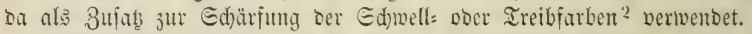

Die Epiegetrinbe Der (Eid) wirb bon tüd)tigen Gerbern allein zur Serftellung bes Eobffeders, bie Rinde alter Eiden mur zur Bereitung von Dberleber verwendet. Eie befişt and daburd) einen wejentlidjen \$orjug

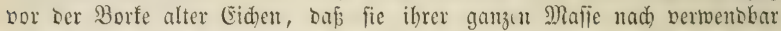

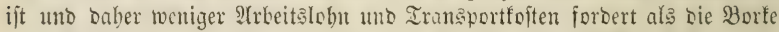
alter (Eid)en, von ber mu bie imteren Eaftlagen gerbftoffreid) finto, bie tooten äuperen Baftlagen bingegen Durd) \$uteen in WBegfall gebrad)t werben

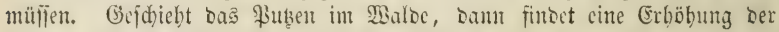
Transportfoften nidht ftatt, ber $E$ d)asen beftcht aber cincsitheils im \$uter= lobne, anoerntheils im 2lbgange bes tobten Borfetheils, ber fo zerfleint wird, Dafis ar jeinen Werth als fenerungsmaterial verliert. Jn Der Be:

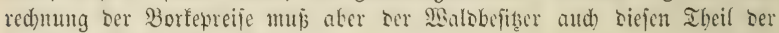
Borke in 2tnjaks britgen.

Die gewöhnlidson \$reije ser Eidsubaumborfe juno 6-8 Mithlr. Her Slafter. Gepuţte Borfe nabe dą ¿optelte. Epiegelrinoe per Slafter

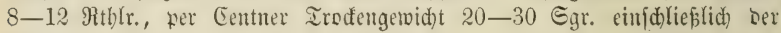

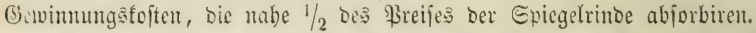

2(us dom llmitande, daj im jüblichen Deutjolano mebr mit Eplegel= rimoi, im nöroliden mebr mit Etammborfe gegerbt, im füblid)en Deutid)= lano aber Durdfidnittlid) ein befieres Reoer erzeugt wiro, bat man Der Epregelrindelobe aud) aualitative 3orzüge jugejdrieben. In folge zabl: rcidjer Petitionen fino bann aud) jeit 1848 im nörbliden Dentid)(ano viele

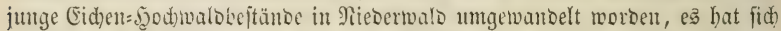
aber bis jeb̧t fein befonderes Drängen Der Gerber ju ber antgebotenen Epiegel=

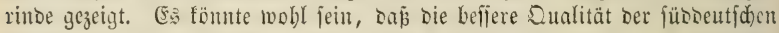
(Eid)entinben bauptiädlid) in flimatijden $\mathfrak{U} r$ jadgen begrünoet ijt, in äbnlider

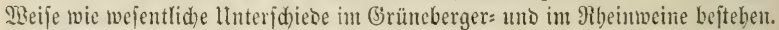

?(uperbem wirb am Rlein bie SBeibentinbe in cinigen fabriten auf Ealicin berarbeitet.

1 Man unterid)eidet überbaupt: Lohgerberei mit Gerbftofi, 2Beişgerberci mit alau uno Gämijd)gerberei mit Zetten als Ğerbunittet.

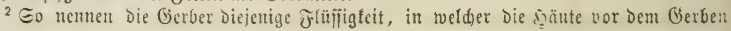
mit fdrwadjen Eäuren bebanbelt werber. 


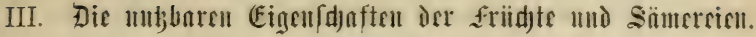

(Seite 221.)

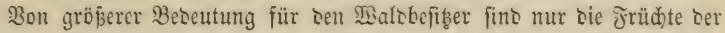
Eident uno Budhen, burd bie gröpere Menge, in ber fie in einzelnen Sabren erzeugt 'merben, beibe bauptiädylich als Biehfutter.

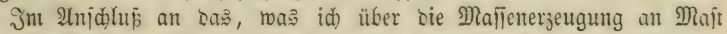
Eeite 222 hereits anfübrte, habe id bier bejonders Des Jutterwerthes Der

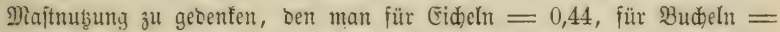

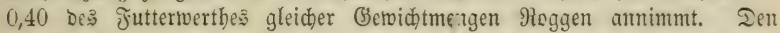

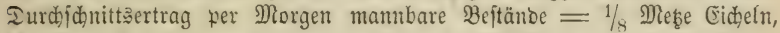

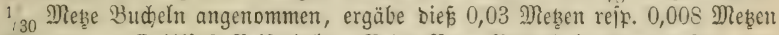

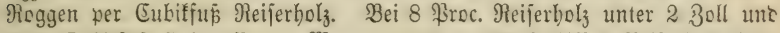

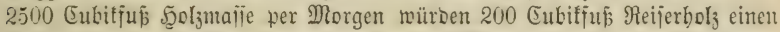

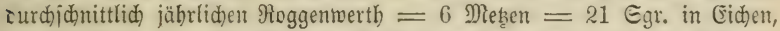
$=1,6$ Meșen $=5 \frac{1}{2}$ Egr. in Buden ergeben, norausgejeţt, oás Der ganje Maftertrag bemub̧t werben tönnte, was nun allerbings bei weitem nidit ber Fall ift.

Nach Eeite 221 rürbe bei voller Majt ber Morgen mit 200 Cubiffus

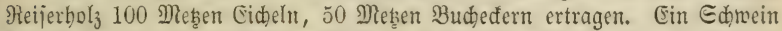
hebarf bei 9-10wödentlider Maftzeit 9 Edeffel Eidjeln ober 11 Edheffel Buchedern. Ies mannigfaltigen 2 bygangeș negen mup man aber minteften 14-16 Edeffel Eidueln, 16-20 Edeffeln Buchedern an \$roduftion redunen; e: würben aljo für bie Majtung cines Edweins per Centner $21 / 2$ Norgen majttragenoe Eichenbeitänoe, $5^{3} / 4$ Mlorgen jold)er Buchenleftänbe gebören

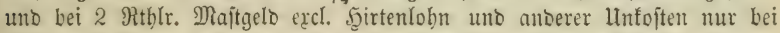
vollen Maftjabren ein Ertrag bon 24 Egr. Fer Morgen in Eicten, non 12 Egr. in Bubjen zu erlangen fein.

Das Budedectig faun auberbem aud) jur Delgetwinnung benukgt werben. Der Edeffel liefert 6-10 Bfunbe eines jehr jamadthaften Epeijëls, bas bem ßrobenceröl nidjt nadjteht.

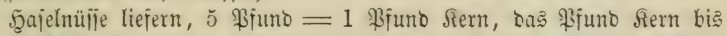
65 ßroc. Del, Sincenterne 1 Pfund aus 24 \$iund Jrüdte, liefern 48 \$roc.

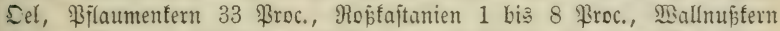
40-70 \$roc., Nabelfoljjame 24 Prec., beide leb̨tern cines fetten, austroct: nettoen, in ber Delmalerei gebrauchten Deles.

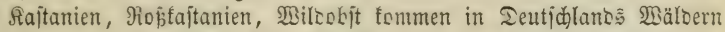

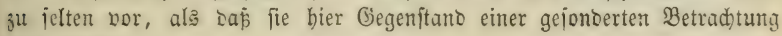
jein fönnten.

Die Beerenfrüdte Des 5̧eibel= uno ßreifelbeerftraudes, sie Şimbeeren, Brombeeren uno (Erbbeeren fino nur nub̧bar ourch) Die Arbeitâtraft beš 2(rmen, Ler jeine Sinder mit Cinjammlung berjelben bejäjätigt. Unter ibnen liefert

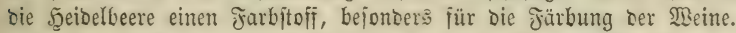

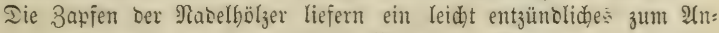

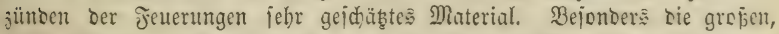

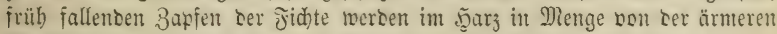
Bebölferung gejammelt uno mit Gerninn in bie Etäste verfautf.

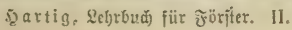




\section{Die Umb, baren Eigcufdjuften Des fanbes.}

(Seite 222.)

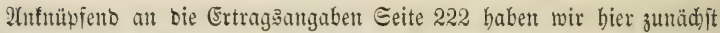
Den Futterwerth bes Saubes ju betradten. Sint getrodinet unb eingebradit

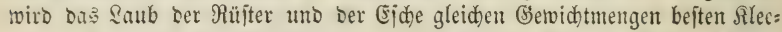

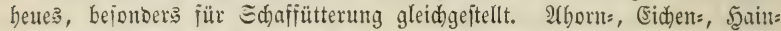
budenlaub, audd wohl nod) Pappelnlaub itehen gutem Biejenheu gleids. Rothbuchen=, Erlen=, Birfens uno ફ̧ajelnlaub ftehen bem Jutterwerthe mittel= mäbigen $\mathfrak{B}$ iejenhenes nabe.

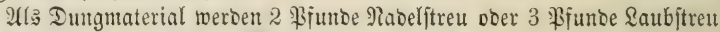

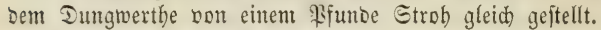

Die Nabeln Der Riefern und Fidsten weroen in neuerer Beit zul einem wollähnlichen Etofife (Walowolle) verarbeitet, von meld)em ber Eentner mit

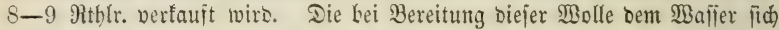
beimengenton ätberijhen Dele und Söjungen machen bajfelbe zu einem beil= träftigen Babemittel (Riejernabelbäber).

\section{Die unbuaren (Eigrufdaften ire Süfte.}

(Seite 224.)

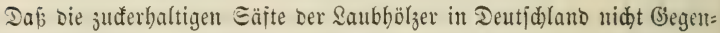
ftano Der Benuß̧ung fein fönnen, babe ich bereiţ Eeite 224 erwäbnt.

Die flüdtigen Sele Der Rinbe fammeln fid) nur bei ber Ianne in fo

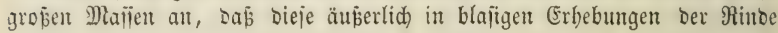
erfentubar werben, io bajis jie, Durd) Deffinen der, bis taubeneigrofent Beulen aușfließ̌ento, unmittelbar gewoment werbent föment. Man getwinnt Daburdi ben Strap̧burger. Terpentin, bofien Cinjammeln jwar bent Baume in teiner Beife jojabet, aber nidjt mebr als einen bohen Iagelobn abivirft, ba bie Bäume bis zum Gipfel mit Steigeifen beftiegen werben müfīen.

Ien ventetianifden Terpentin getvinnt man von ber Serdje burd) 2(n= bobrent uno Serjpunten ber Bobrlöd)er, aus Denen bann alljäbrlich ber in ibnent angejammelte Terpentiu auझ̈gelöffelt miro. Den Walobefitzer idjabet

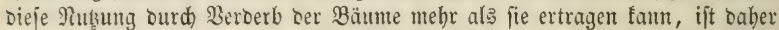

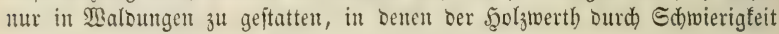
Des Irausports ein äußerit geringer ijt.

Die Birbelfiejer liefert in äbnlidjer Meije ben farpathijđjen (?) Balfam, bie Sirummboljtiefer bas Sirummbolzöl. Den reidjten Ertrag an einem ähnliden Eafte würbe wohl bie \$Benntouthtiefer abwerfen.

Die gröpte Menge Deß Ierpentins, Der gemeine Terpentin, ift aber ein Pebentroouft ber Ifyceridwelerei uno ber Dienverfohlung, ber baburd erbalten wiro, baj ber getwonnene Theer eine nod)malige Dejtillation erleibet,

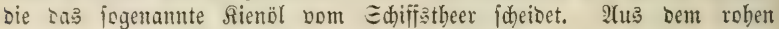
fienol twiro bann burd) mehrmaliges Defitlliren ber rectificirte gemeine Ierpentin gewonten.

Leber ben Săzagetwinn $;$. Seite 224. 


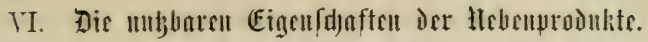

(ङeite 225.)

Wir baben bier, von Den, Eeite 225 aujgê̈übrten Nebenmubung:

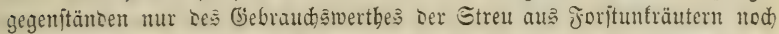

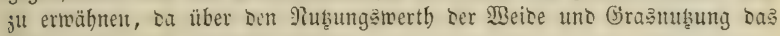

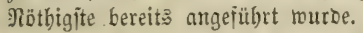

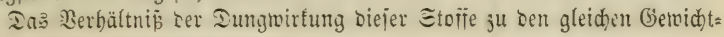
mengen Etrob riro angentommen:

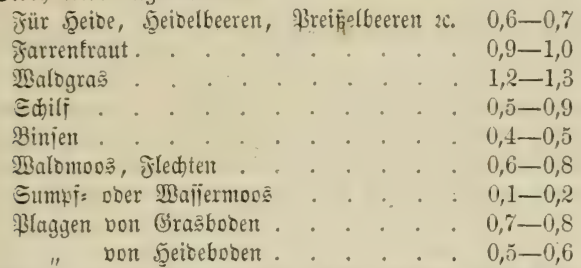

In B.jug auf bie Iungroirfung leb̧terer tommt $\mathrm{e}$ ü übrigens febr auf

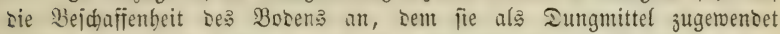

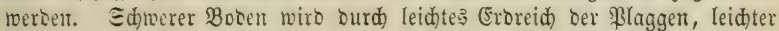
Boden ourd idweres (Eroreid) Derjelben in Dem Maje berbeffert, Lap Der Iungwerth der \$laggen in jolden Fällen ten bes Ctrobes überfteigen fann.

Die Intrautitreu bat um io böheren Wertb, je jünger bie Pflanzen cingeerntet werben, je reidjer jie an Blättern unb jungen Irieben ijt.

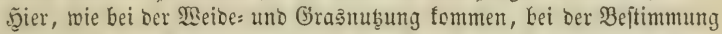

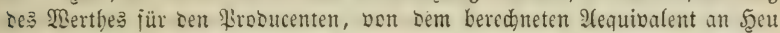

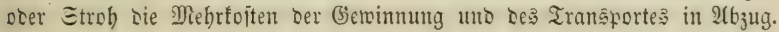

\section{Drittes sapitel.}

Den Preis der maloprodufte beftimmende Bergältnific (Preias=

$$
\text { ertrag). }
$$

Jür die grope Mebrzabl der MBaløbejtger, Die jür fremben Bebari frobuciren, iit Menge und Gebraudstoerth nidht allein entideibeno in Bejug auf die Bortheile, bie ibnen die eime ocer die andere Broouttion jul gewäbren vermag, jonbern $e_{3}$ ftellen fich biejen beiben Jattoren nod eine

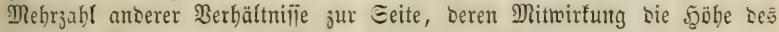
enolichen Reinertrages des Bälcer bejtimmen. Dabin gebören:

I. Die Belajtung bes Brobucirten mit ben Untoiten,

a. Der 3ugutmadyung uno bes Iransports,

b, Der Bertwaltung, Bejdübung unb bes 2 nbaues.

I1. Das Bejtehen und Die Iringlidteit bes Bebürinifies (Tadirage).

III. Die ఏäurigfeit oder Eeltenbeit des Borbandenjeing (Angebot).

IV. Monopol ober Eoncurrenz anderer Brobucenten.

V. Die Eigenjळaft Des ßrosucirten, möglichjt vicle Besürinif̈e zu beiriebigen.

VI. Eompenjation von Bortheilen ober Nadutheilen Der Probuttiou ober

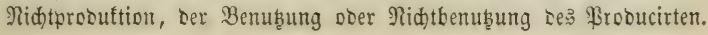


Wir betrachtent bie vorgenannten Gegenftänoc bier nur mit Sinfidjt auf bie frage: ob eine ober bie andere $\mathfrak{B}$ robuftion, in $\mathfrak{B}$ ejug auf fie, für

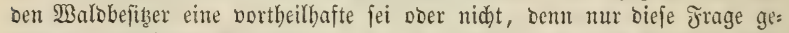
bört ber forfftidjen פsaarentunde an, in fofern unter bem Einfluffe jener Berbältnifie bie foriflidbe Waare cine verfäuflidse ober unverfäuflidje, cine im Berfaufe einträgliḑe ober minoer einträgliche ijt. $9(u d$ ) geftattet ber

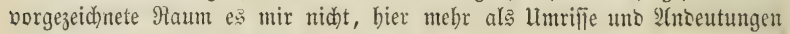

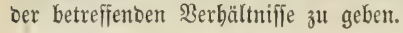

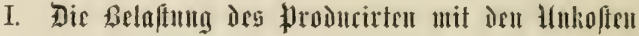

a) Der 3 ug tmadung uno bes Irausports.

Dbgleich Der Maldbefiterer in Der Mebrzahl ber Fälle Die Roften Der 3ugutmad)ung uno Des Iransports nid)t unnittelbar trägt, inbem er fid)

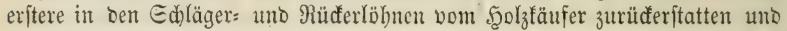

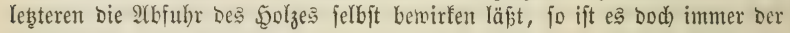
Walbbejiłzer, Der Diefe Soften mittelbar trägt, Dem ohne Zrweifel würoe Der Räufer bas \$robutt bem Walbbefiber um ben Betrag Der Untoften theurer

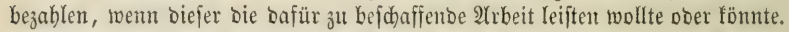
Mas nun für das (Banze ridhtig ift, gilt aud) für jebent Theil bes CSanzen. Jnmerbalb getwiffer Birenzen wirb ber אäufer Dem ßroducenten das \$robutt un ben Betrag Der ihm erfparten Unfoften thcurer bezablen, gleid)biel ob ber

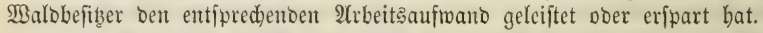

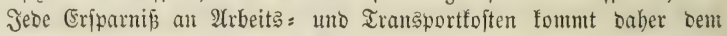
Malobefizer zu Giute, alle biefe Untojten muईs in ber Ihat ex tragen.

Daraus crflärt es fid): Dap im $2 B a l b e$ fo vicle, an fid rerthoolle Probufte unbenub̨t bleiben müffen. Jn ber Mebrăahl oer Jälle gebören

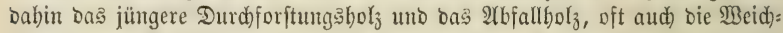
bölzer, das Reiferbol uno felbit bas geringere Simüpwelholz, forvie eine Menge von Nebenumbung

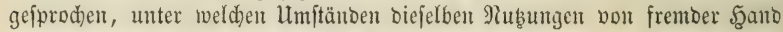
erboben werben fömnen uno wirflid erboben werben.

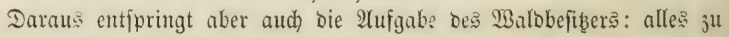

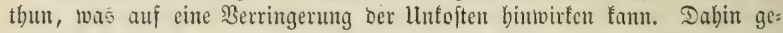

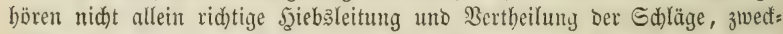

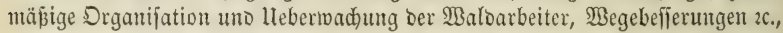
jondern vor allem bie Erziełung bes gröpten Wertbes im fleinjten Raume; Denn Der Eubiffur Baubolz à 4 Sgr. forbert biefelben Iransportfoften wie Der Eubiffuf Scheitholy à 1 Sgr., er foftet weniger Transport wie ber Cubiffup Reiferbol $\}_{3}$ à $1 / 2$ Sgr. Diefe Mafregel ift um fo nothwendiger, je

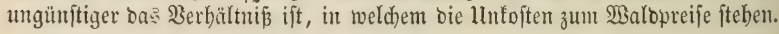

b) Die Belaftug ourd Bertualtungä=, Be $\Re u l t u r f$ ften.

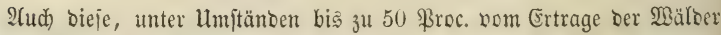

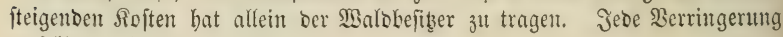
Derjelben erböht feinen Reinertrag. 
Bertwaltung, Echus, fultur werben um fo jorgiältiger ausgeführt unt ïberwad)t merben, je fleiner bie Gejwäjtabejinfe fint, mit beren Berfleinerung aber bie Sioften für Berwaltung und Edjut fich erhöhen. Gieringeres biel'o=

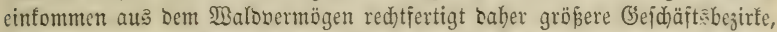
joweit bie baburch erwadjenden Berlufte an Einfommen binter bent Eripar=

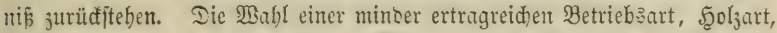
Serjüngungasmeife fann burd) Eriparnifie an folden ltnfoiten gered)tfertigt fein.

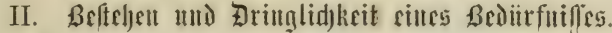

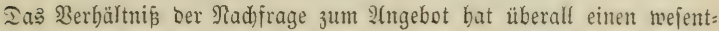

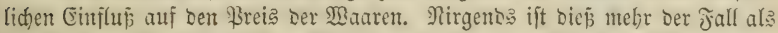

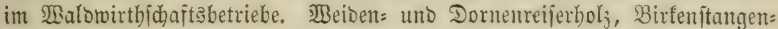

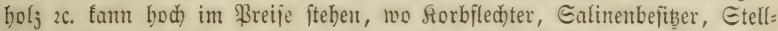
mader Deflen beburfen; eine Erzengung über Den beftehenden Bebarf madjt ras Mefrerjeugte für ben Waldbejizer werthlos over jebt es auf bie ge= vingiten Brentholzpreije zurüd. Das thenerite Eichenjijifibauholy ober Etab: holz muß als Bau= ober Brennboly zu geringeren Breijen berfauit werden, Ino Das Beoürfniß an Erifterem uno damit bie Madafrage mantgelt.

Nun find aber Beburrinis uno Nad)frage veränderliche Dinge unto Der Joriftrirth fann nidht, wie Der Sanowirth, Diejen ßeränberungen mit feiter

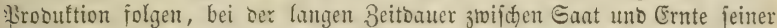
Brooutte. Pau Dem bleibenton Beoürfnif́ funn uno mú ex oiejelbe an=

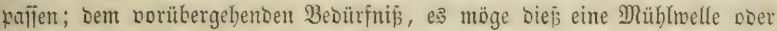
eine forbrutbe fein, wiro er mur barn Gienüge leiften fömen, wenn bas Material bazu zufïtlig im Walde jid vorfinbet. Jn Bezug auf bie muth=

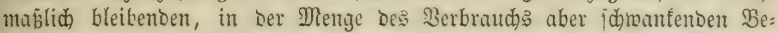

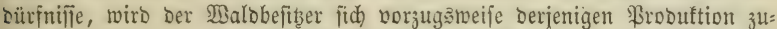
menoen müijen, Deren (Gebraudjąwerth möglidjt wenig herabgejebt tviro,

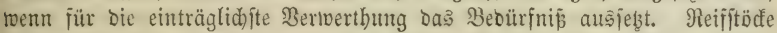
uno forbruthen, wenn fie als jolche feinen 2 tbjab finton, finfen auf ocn

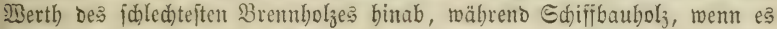

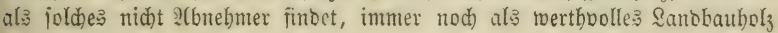
ober Sdeitbolz berwenobar ift.

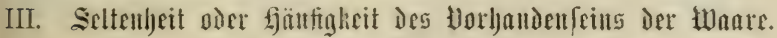

Eeltenbeit eines Brodufts bei bejtebendem Beoürinif erzengt unter Den Bedüritigen itets einen Wetteifer in Ertwerb Des Bejiţę, Der bem \$robu= centen eine \$reisfteigerung über bie gewöbnlichen Normen binaus gejtattet. jift bie Maare in ausreichenter Menge vorbanden, fo fällt bieje Preis: iteigerung fort. Sit fie in überflüijiger Menge vorbanden, Dann bat ber Broducent 3u erwägen, ob e马 ibm größere Bortheile bringt, wenn er burd)

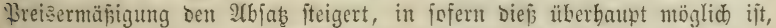
cter weun er bie normalen Breije baburd jefthält, Daj er Dem, ben Bebarf überiteigenben Theil ber Probuftion eine anoere, woblfeilere Berwentung 


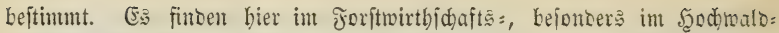
betriebe jehr häufig ourdaus abnorme Berbältnifije ftatt. Șir erreidum, bäufig abjichtliç, bie böbere Giebraudbäfübigfeit ber \$robufte, jogar mit

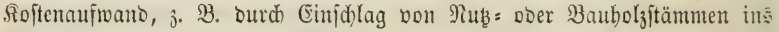

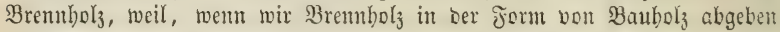
mollten, Der Baulfolzabjałz gänzlich aufbören, ber Baubolzbedarf mit ben als Bremtholz verfauften Bäumen befriebigt merøen würbe.

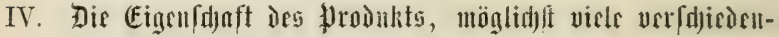 artige Bediurfuifle 3 befriedigen,}

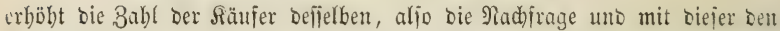

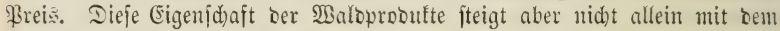
2llter Der Bäume uno gibt Dem Sgod)walde uno Dem Dberbolzbetriebe im Nieberwalde, fo wie ber Göberen limtriebş3et und Den ALtriebserträgen nor

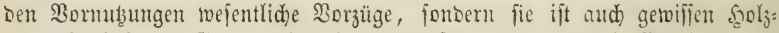
arten in böberem Grabe zuftändig uno beftimmt Iaburd) bie $\mathbb{2} a b l$ ber ast:

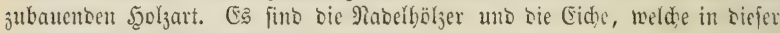
Şinfid)t allen übrigen Fुolzarten voranjteben.

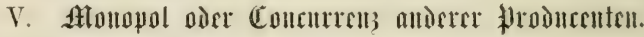

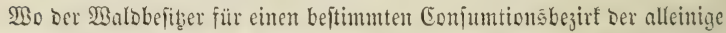
Probucent ijt, Da würtoe er, wenn er nidyt, wie Der Etaat als Malobejiţer, Rüđjichten auf Das Giemeinwohl zu nebmen hätte, willtürlid)e \$robutten: preife erheben fömen, fo meit ibm nidgt bie 3ugänglidfeit bes \$roduft?

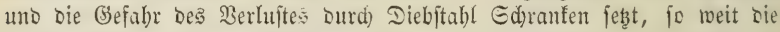
3ahlungŝfäbigfeit jeiner $\mathfrak{A}$ bnebmer reidt. Eoldje Monopolpreije werien in Der That vom Malobejį̧er häufig bezogen, ber gar oft ben Cubifjuß Bobnen:

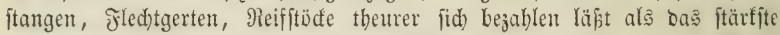
Bauboly. Da hingegen, wo auf bie Erfülllung befielben Bedarfs cine Mlebl:

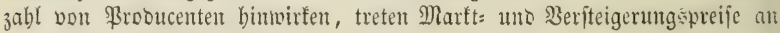
bie Stelle rilltürlicher Monopol= ober Iaxpreije.

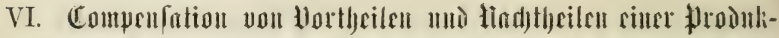

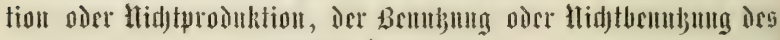 bereits flroduciuten.}

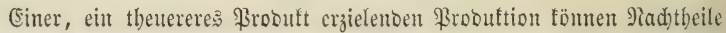
zur Eeite ftehen, bie Der Erzichung wohlfeiferer Waare Den Borzug geben,

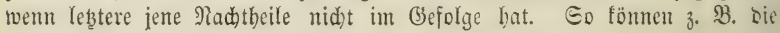

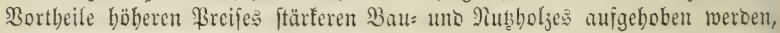

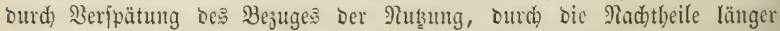
Dautember Nidutbefriedigung bes Bebarfes. Eine gröpere Summe oder

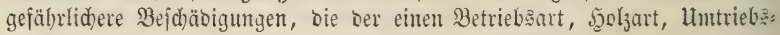
zeit mebr als einer andern eigen finte, fömten bie Wabl einer mintoer ertrag= 


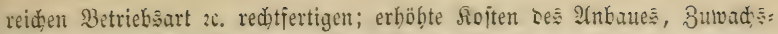

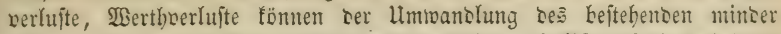
Ertragreiden in bas Ertragreidhere entgegenftehen. Eelbft auf bie Erhebung

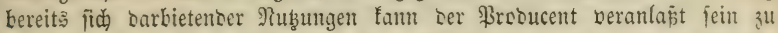

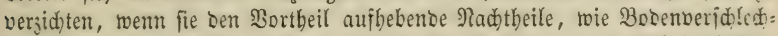

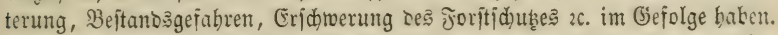

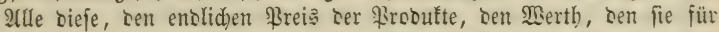

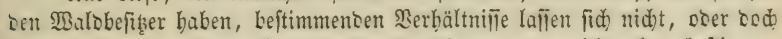

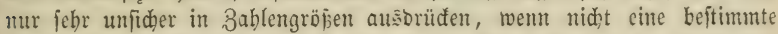

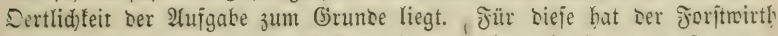
siejenigen 3ablengrö̈en feitzuftellen, bie er nothwenbig fennen muj, menn

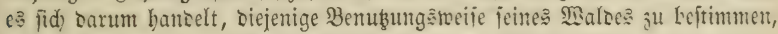

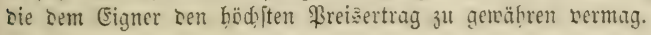

\section{3weiter $\mathfrak{A}(6 j$ fditt.}

3ou der :

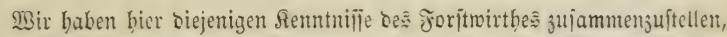

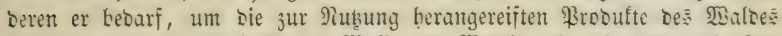

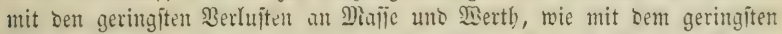

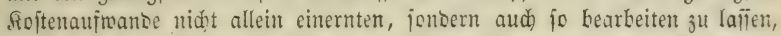

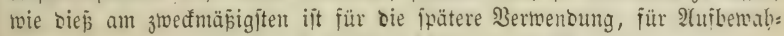

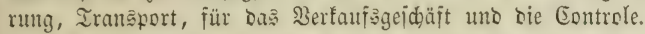

Diejer 2(ufgabe entipred)en biejenigen (jejdäfte, bie id im erjten ßapitel als bem $\Re \circ b n u$ ţน

Nidet jelten unterliegt aber bas Robmaterial, theils zur Bequemlidfeit

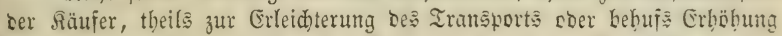
bes tedriiden 2 Serthes, idon im Malde einer meiteren Berntbeitung, die, fo weit fie vom forftmanne jelbjt geleitet oser sod keaufictitigt miro, tent Walbgetwerbebetrieb begrünot.

\section{Erftes Eapitel.}

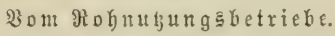

(E) liegt bemielben bie 2A

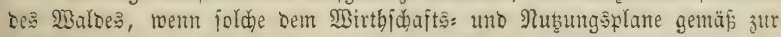
Erhebung fommen follen, in einer 2 seife möglidjt twohlfeil einzuernten, bie

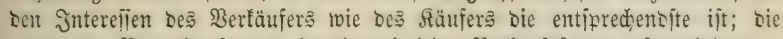
geernteten \$robufte jobann in bie primitipe \$̧erfauföform aujuarbeiten.

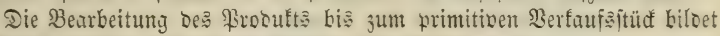

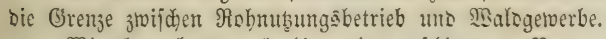

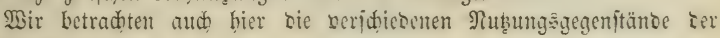
Reihenfolge nad). 


\section{Betrieb Der fjolzum\}แ!g.}

(Geite 212, 228.)

\section{1) 3cit ber .5orzmutung.}

Heber bie Beit Der Şolzmubung in Bezug auf Berjüngung uno Repro:

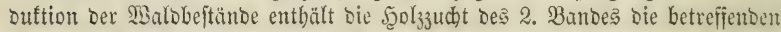

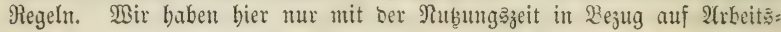
fraft uno \$robuftentwerth zu thum.

(5: ift einte unzweifelhafte Thatjad)e, Da

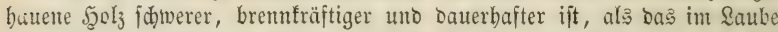

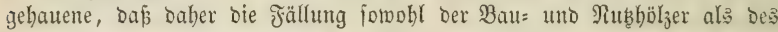

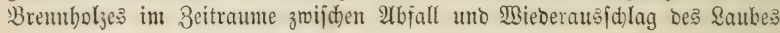
geideben müfie. Diés ift bann auch) Der Beitraum, in roldsem bie Jeldo

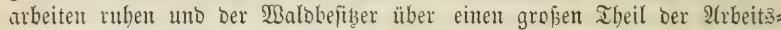

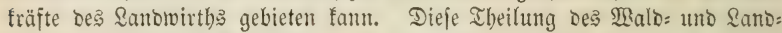
wirthes in biejelbe 2 (rbeitstraft ift einte volfsivirtbidhaftlid) felr beadtens: werthe Berbinoung biefer beiben Gewerbe.

Die 3eit bes laublojen 3ujtandes Der fonmergrünen Bäume zerfällt

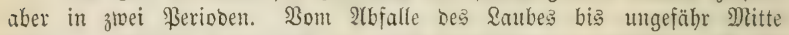
Jebruar, überall genan bis zur 3eit begimnenter Jajelblüthe, ift bie Saftbetwegung in ber $50 l_{3 p f l a n z e}$ ali ein Minimum befdränft (bei ben

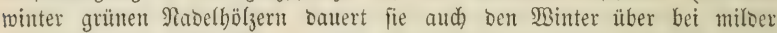
Mitterung fort. S. 3ర. I.), Die Şiebaffläden in biejer 3eit gebauenter Bäume uno Baumtbeile erfdeinen trodentr, obgleid) bas Winterbol mindeftens eben io reid) an Eäften ift, als zu jeocr anberen 3eit. Nad)

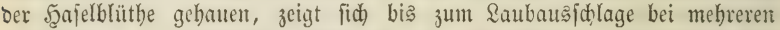

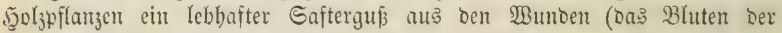

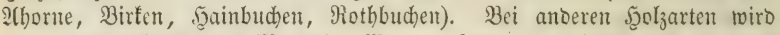

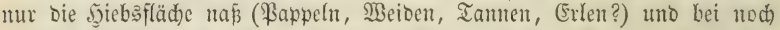

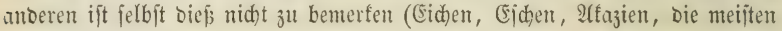
Nabelfölzer).

Man ninmt nun an: Dafs Bäume in biefer Saftzeit gebauen, b. b.

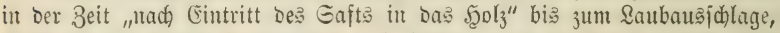

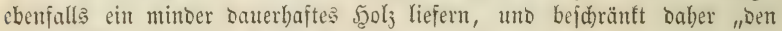

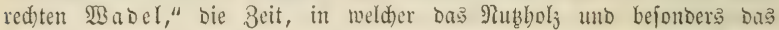
Baubols gebauen werben joll, auf Den Beitraum jwifden Saubabfall uno 5eajelblüthe.

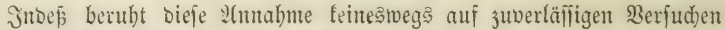

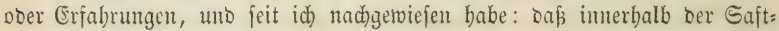
zeit weber eine Bermebrung bes Saftgebalteß, nod) eine mirflide Fortbewegung

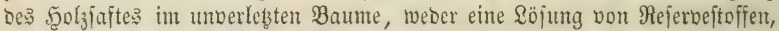
nod) irgento eine erfennbare Beränbcrung im Bejtantbe bes f̧olzes ftattfinte, fann ich in ber That feinen bermünftigen (5runto für bie Ifnnabme finten: dás bas Saftholz fallechter als bas 2 Binterbolz. fei.

So vermutbe id ferner auch: Daj eine Fällung $1-1 \frac{1}{2}$ Monate vor

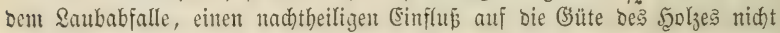

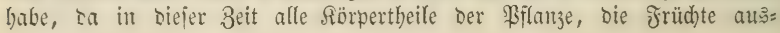


gentonmen, idfon völlig ausgebiloet, bie Rejervejtofie bereiţ gereift uno

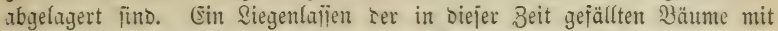
bem belaubten Wipjel, Dürfte jogar Der Güte, numentlid) ber Dauer beక 5ुolses rejentlid zuträglid, jeir.

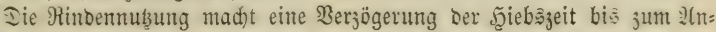

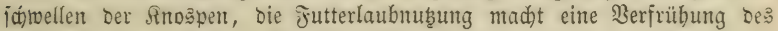
f̧iebs bis in ben Monat 2 Uugujt nothlwendig.

Die $\mathscr{U}$ ufbereitung Des gebautenen 5ुoljeß läp̆t man it ber Regel Der jällung unmitttelbar folgen, uno nur bie Gientmung Des unteriroijenen

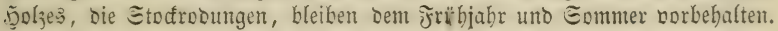

\section{2) Drganifation ber 2trbeitâfträfte.}

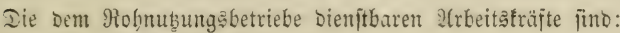

a. 21norbnende uno Reitente,

b. Beaufifitigenoe,

c. 2Uuşübrenbe.

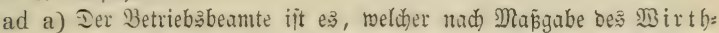

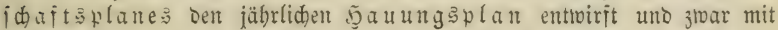

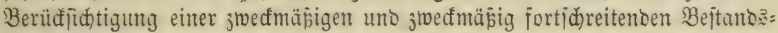
verjüngutg fowohl, wie mit Rücficht auf bie Bebürinifie uno bie Bequems

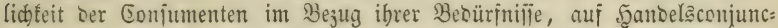

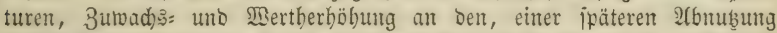
vorbebaltenen Beftänoen, (5onjerbation Der Bocenfraft, Eriparniß̄ an 2Arbeit:

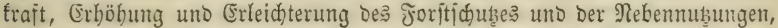

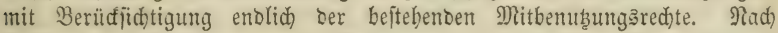

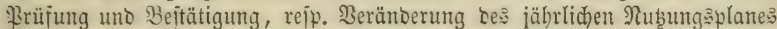
ourd bie injpicirenden uno birigirenten 30 orgejetsten, hat ber Wirthidafter

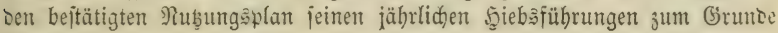
3u legen.

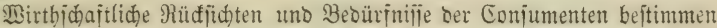

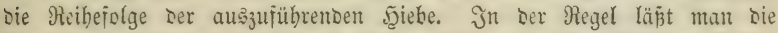
Beriüngungshiebe und bie Şiebe im ?iebermaloe wie im Unterfolze bes Mittel: malbe: allen übrigen 5aunngen vorantgeben, Diejen sie Rablbiebs uno ent:

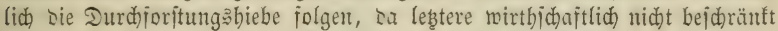
Fino uno Daber baju Dienen fönnen, ein Lem Boranjwlage gegenüber er=

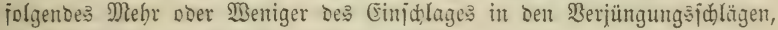
burch Einjpahrutg ober Borgriff auszugleiden.

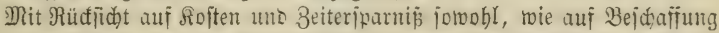
siner guten 2ltbeit, hat Der Betriebsbeamte ferner iür ausreidenoe uno be:

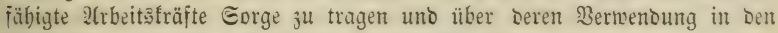
veridiebenelt Ed)lägen Bejtimmung zu treffen.

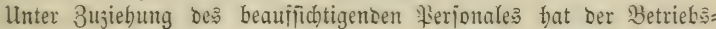
beamte iohann, in jebem zum .̧iebe fommenten Ed)linge, biejenigen Bäume

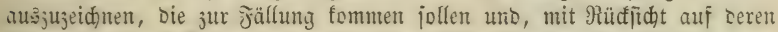
Berwendung, Beitimmungen zu erlajien über bie 2Art ifrer 2tufarbeitung

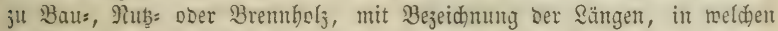

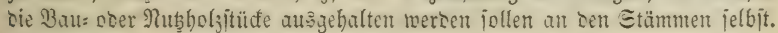




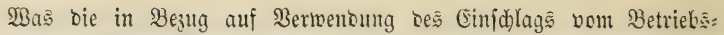
beanten $j u$ treffenden Sejtimmungen betrifft, fo finto biefe abbängig von

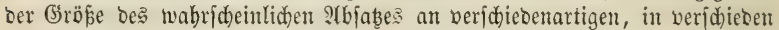
bohem Breife ftehenten Gortimenten. Entbielte ein Beftano in fallenoer

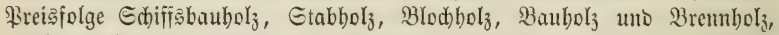
fo ift zuerft zul ermittehn, wieviel von jebem böber im Breife ftehenden Sortiment abjetbar ift. Dief Duantum ift Dann in Den fdöniten uno

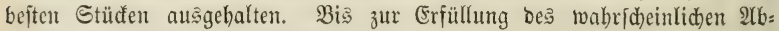

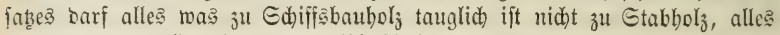

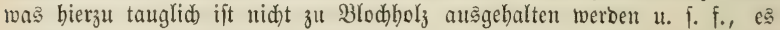
müpte Denn bie Befriebigung unabmeisbaren Bebarfes dem Walobefiker ein Dpfer auferlegen. Melyr won Den theureren Sortimenten auzzubalten, als bem

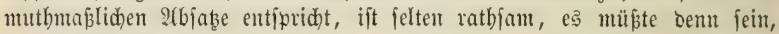
Daß bie Formung zu einem theureren Sortiment bie \$ermenoung als wohl= feileres Sortiment nidyt beeinträdtigt.

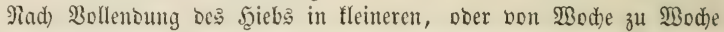
in größeren Ed)lägen, hat foDann Der Betriebsbeamte Die aufgearbeiteten

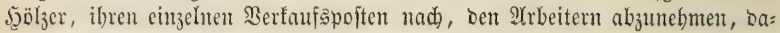

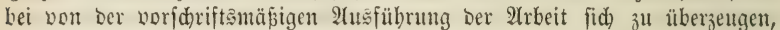
Die llutarbeitumg tabelhafter 2(rbeit anjuoronen, Das tabelfreie Material, wo

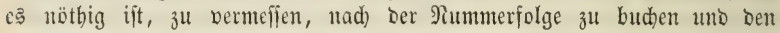

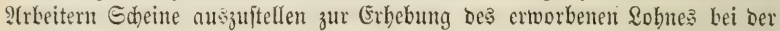
jorfttafie. Es bat berfelbe frülyer ober fpäter Berfaufs: ober Empfang= idheine an bie fidd melsenden Sïufer nder Empfänger auszulftellen, auf Denten Das Material wie ber an Die Saffe einzuzablente Softenpreis ver:

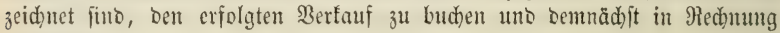
zu ftellen.

ad b) Der beauffidytigende Beamte bat zunäd)it für bie Etellung ber nöthigen 2(rbeitsträfte Eorge zu tragen, in ber Megel unter Mittwirfung

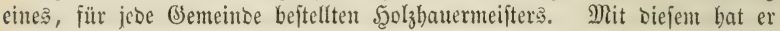
Den Şolzanweifungen in Den Echlägen beizumohnen uno vom Revierbeamten

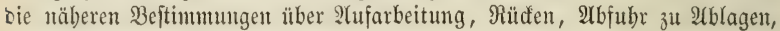
Magazinen 2c. entgegenzunel)men. (5x hat bie 2(rkeit in jebem Sdylage unter

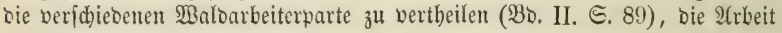
felbjt zu überwadjen, bas aufbereitete $\mathfrak{g}_{0} \mathfrak{l}_{3}$ zu numeriren, in ein $2 \mathfrak{C b} u b r=$

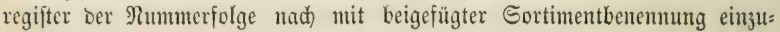
tragen uno bei Der S(bzäblung, Sermefiung uno 2Ybnabme beffelben bon

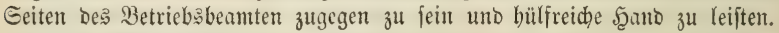
Die nom Betriebsbcamten ausgeftellten, bei ber Forftfafle bezahlten \$er: faufşzettel hat ber Ed)ubeamte vom Räufer an beftimmten 2(bfubrtagen in Empfang zu nebmen, bas erfaufte $\mathfrak{g}_{0} \mathrm{l}_{3}$ Dem Räufer banad) zu überweijen, bie promungşmäßige $2(b f u b r$ zu überwad)en, bie 2(bgabe im 2(bfubrregifter mit Dem Ramen Des Empfängers uno Dem Tage ber 2tbgabe zu vermerfen uno bicje mit Dem \$̧erfaufazzettel fo lange zu belegen, bis bieje als Beleg Der Raturalred)ming vom Betriebsbeamten eingeforbert werben, gegen Em= Hangabejdeninigung im 2 (bfubrregijter.

ad c) Man unterideibet ein ftänoiges uno ein unftänoiges Balbarkeiter: 


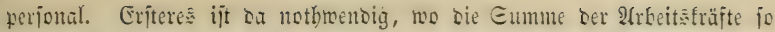
gering ift, baj eine, um fie beftehento Concurrentj andorer \$robucenten oier

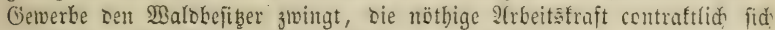

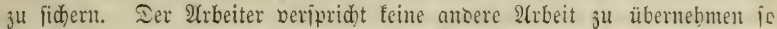

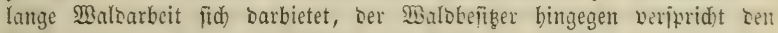
Wialoarbeiter fo lange ju kejöäfigen als WalDarbeit überbaupt fid barbietet, ifn aud nur bann abjulegen, wenn er entweber ganj arbeitsunfäbig getoorben ift, ober Sergeken fid idultoig gemad)t bat, auf weldte contraftlid tis Strafe Der 2tblegung geję̧t iit.

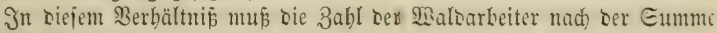

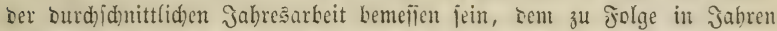
gefteigerter 2frbeit nidht jelten eine, Dem Bitriebe nadtheilige Beridferfung

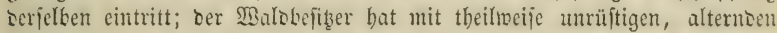

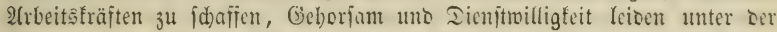

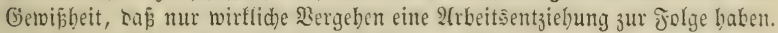

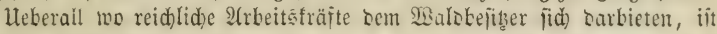

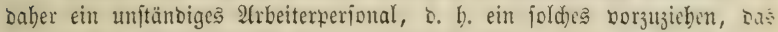

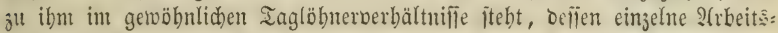
fräfte willfürlid uno täglid einberufen uno abgelegt werben fönnen. Di Waloarbeit ijt eine überall jo keliebte, daj, wo bie nöthige 2trbeitâfraft

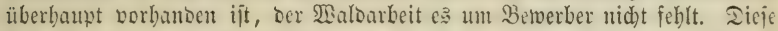
freie Concurrenj ber Arbeitąträfte um bie Malharbeit bat aber einent meient= lidhen Einflup auf Gelboijam, Dienftwilligfeit uno Erwerb ser nöthigen

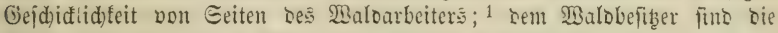

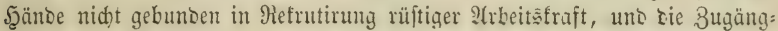

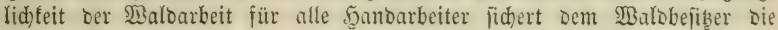
nöthige 3ahl geididter $\mathfrak{A}$ (rbeiter aud) bei aujergemöhnlid) geiteigerter 2 rbeit,

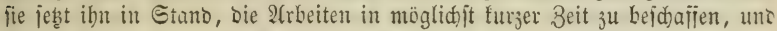

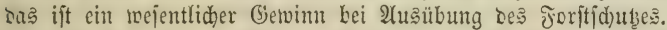

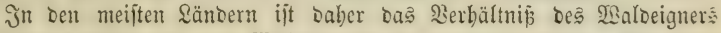
soer feiner Etellbertreter zum $\mathfrak{B a l b a r b e i t e r ~ e i n ~ b u r d ) a n ~ f r e i e s . ~ D i e ~ u n t e r ~}$

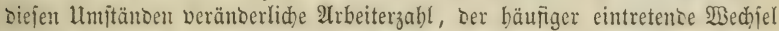

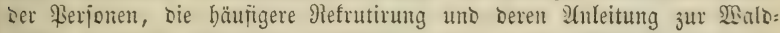

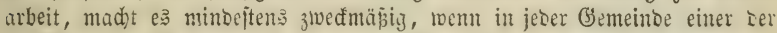
intelligenteften $\mathscr{U}$ rbeiter als Dbmanı aller Hebrigen jum F̧olzhauermeijter erwählt tviro, Der, in biejer Eigenjidaft als Untergebener bes Ed)utbeamten,

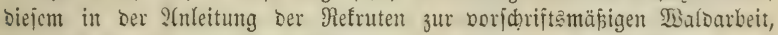
in Der Heberwachung aller Maldarbeiter, in Geftellung ber $\mathfrak{A}$ rbeiterzabl, in Der gleidymäß̈igen unD gered)ten Bertheilung ber Arbeit unter bie veridiesenen

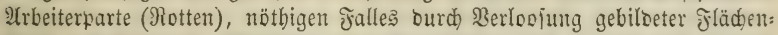
theile, in Controle, R(bnabme unt Numerirung Des aufbereiteten Sgoljes, Erbebung uno Bertheilutg ber Söhne an Die Sialourbeiter zc. 3ur Eeite jteht,

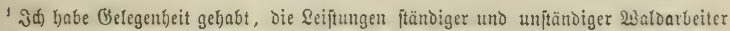

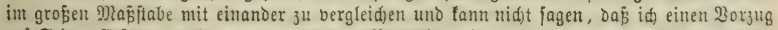

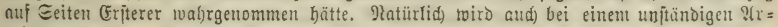

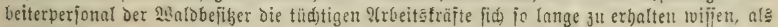
jis tüdtig find. 
für bieje Dienftleiftungen burch eine geringe Tantieme entjäbibigt toirb, ïbrigens aber bie gewöbnliche Walbarbeit wie jęer andere Balbarbeiter berrichtet.

Diefe Sandanger ber ङdubbeamten ${ }^{1}$ äupern bejonbers auf ben Forit:

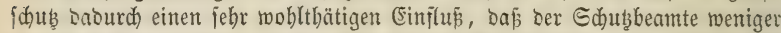
an bent Sdjlag gefejfelt ift uno ben übrigen Reviertheilen auth wäbrent ber

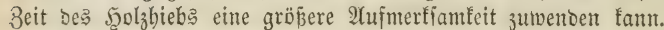

Der (Sebrautd) Der Malojäge forbert ba马 3ujammenarbeiten ztweier 2(rbeiter. In ber Regel vereinen fid) aber 3 -5 2(rbeiter zu gemeinidaft: licher 2 trbeit, bie jowohl burd) Theilung als burd Wedjel ber veridjeben: artigen Siraftanjtrengungen wejentlid) geföroert twirc. 2(uch) fomment nid)t felten $2(r b e i t e n$ vor, welche bie gemeinjohaftliche Rraftanftrengung einer Mebr: zahl von 2rrbeitent erforbern. In biefen Waloarbeiterparten finton bann

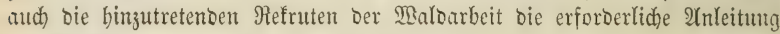
jur $\mathfrak{A}$ rbeit.

Die gemöbnlichen Sanbwerţ̧entge für bie Malonrbeit: Eäge, 2 rrt,

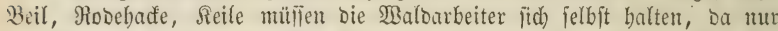
in biejem falle ein möglidjit fdonender (sebraud) zu erwarten ift. Ia

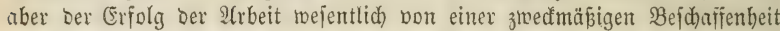
Der WBerfjeuge abbängig ift, fo muß ber Walobefitber barüber wadhen, baj bie 2 trbeiter fid mur foldter bebienen.

Die säge. In neuterer Beit bebient man fich faft nur nod) bes

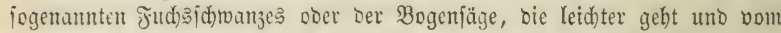
2frbeiter eine reniger gebüdte Gteflung erforbert. Fine Blattlänge von 3 Jusen, eine Blatthöbe von 2 Zollen bei einer Blattoide von $1 / 3$ Sinie; 14 Eägezähne auf 4 rbeinläntifa) 3olle, bie mit ihrer Grundlinie ein

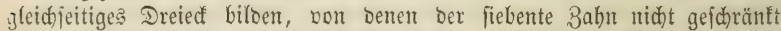

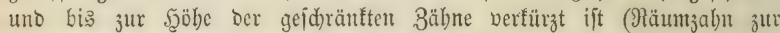

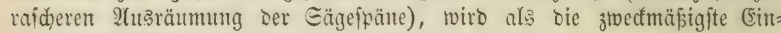
vidutung betrad)tet.

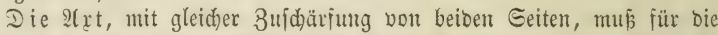
2lrbeit in bartem 5olze breiter, fürzer und bünner, für bie 2lrbeit in

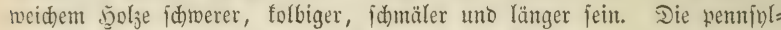
vanijade Epraltar̨t mit erböhter Blattmitte hat trobs vieler Empfehlungen feinen Beifall gefunoen.

Das $B$ eil mit cinfeitiger 3ujhärfung Der Edjncide ipaltet fahled)t, idneibet aber gut uno tommt baber voizugsiveife bei Rïrzung Dee Reifer:

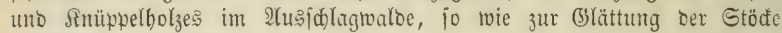
Dajelbit in 2 (nwenoung.

Die 5̧ippe, in Form eines fehr ftarten, etwas eingebogenen Mefiers mit redtwinflig abgebrodener Spibe, an beren Stelle ein red)twinflig nady

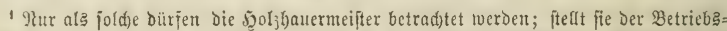

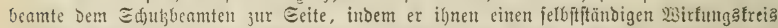
3utheilt, bann folgen Daraus Heberbebung und Reibungen, Die jefr nad,theilig auf Den Dienft eintvirfen tömten und in Der Regel Den baldigen Berfult gerade Der tüd)tigiten Solzhaner=

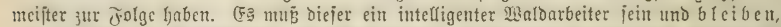

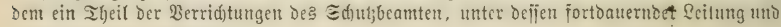
Dberaufifidat, übertragent ift. 
vorne geriduteter ftumpfer Ednabel bas Cinoringen in Den Bocen berbintert, bient zun 2 (bbujden von $\Re_{0}$ rmüdjen, bei febr früben Durdforitungen $2 c$.

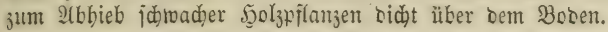

- Die 3 ugiidel, ein ungefähr 30 ctm. langes, ftartes, fichelförmig nad) Jnnen geftrümmtes Meffer, mit ciner rechtrinflig zum Eichelourd):

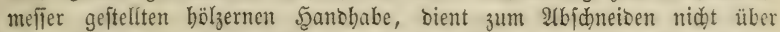
2-3 Ctm. ftarfer Bortwüdje ober Etofausidaläge bidht über Boben over Etod Durd) einen fräftigen 3 ug nad) Dben uno förbert bie 2(rkeit Daburch,

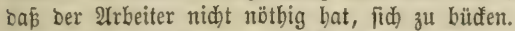

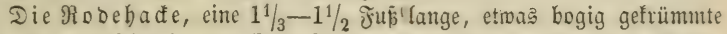
5acte, Die einterjeits in Das Debr für ben . Sactenftiel, anbererjeits in eine ¿uerjhärfe non 2 3oll Breite auझgearbeitet ijt, bient zur Erbarbeit beim

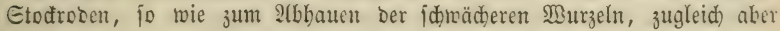
auch als Şebel für geringere \&ajten.

Reile, meift aus Rothbudentholz mit breiten Jabreşringen won mittel:

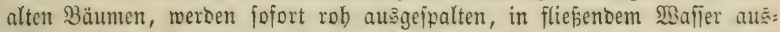

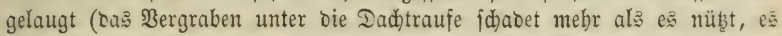
mübte sen balo nach bem (Eingraben anbaltendes Regentwetter eintreten), jodann langjam getrodunet (mand)e $\mathfrak{B a l b a r b e i t e r ~ b a ̈ n g e n ~ b i e ~ R e i l e ~ z u ~ b i e j e m ~}$ 3wede in ben Raudfang) uno erjt nady zwei Sabren verwenbet. In jowwer: ipaltigem, bartem Şolze uno bejonbers bei Єtofrobungen ijt ber \$erbraud von Reilen uno Reilfholy ein erbeblicher uno ser Walobefitzer begünjtigt taber ben Giebrauch eifezner Seile, bie aber fobledter zieben uno weniger leiften als bölzerne.

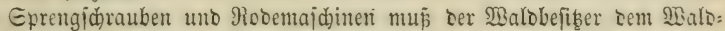
arbeiter liefern, too fie angementot werben follen. In neuerer 3eit ift be: fonber: bie $G_{d}$ ufteridhe Robemajdine für bie Robung ber Etöde geringerer bis mitteltwüdfiger Bäume uno ber $\mathfrak{B a}$ alste ufel für bas $u$ m: reipent ftebender, aud ftarfer Bäume, bejonters auf flachgrünoigem Broen mit Grfolg verwendet morben.

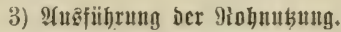

a) Die $\mathfrak{A} n$ reifung.

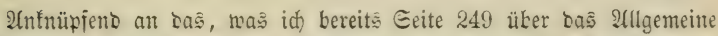

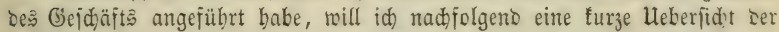
üblichen Mermenoungsarten folgen laīen, io meit bieje von Einjlup auf

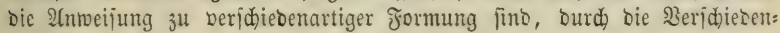
heit ber Scolzpreife verichiebenartiger Sortimente. ${ }^{1}$

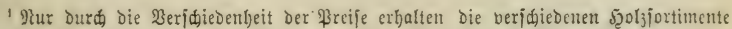

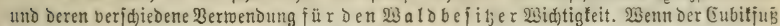

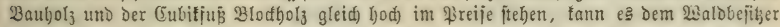

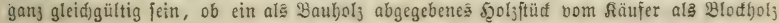

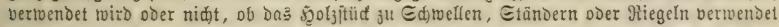

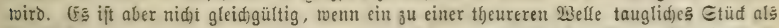
Bloftbol3 abgegeben wirb. Eelbft Dann, wemn jid) augenbliflid) fein fiäufer für bie welle

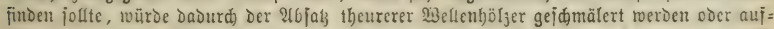

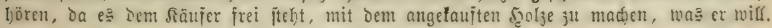


Die (Eid)e, befontor: bie für ben Edjiffbau jebr gejudten Srumm: börzer fint es, bie in ter Regel an bödjten im Preije itehen. Diejen

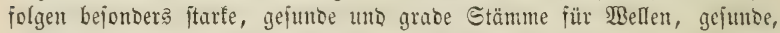

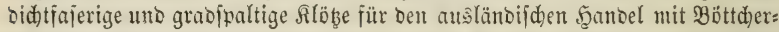

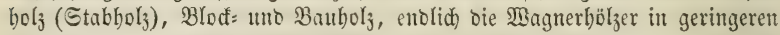
Etärfen, jo wie gerifjene Banojtöde für bie gröperen Böttcherarbeiten. $\mathbb{B}_{0}$

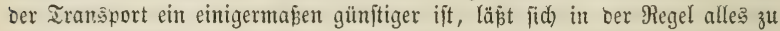

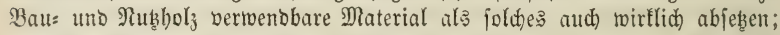
atte (Eichenbejtäntbe enthalten aber in ber Regel fo viel idabbaftes Material,

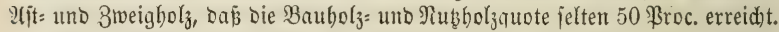

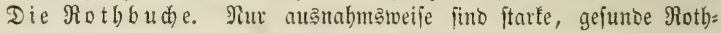

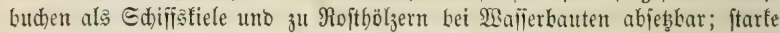

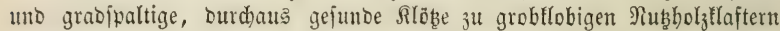

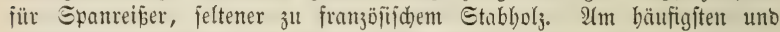

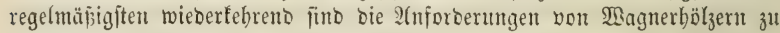

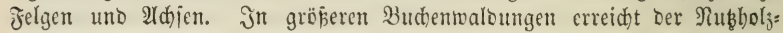
abjaţ felten mebr ale 5 groc. Des (sinjolages.

Die Şainbud) ift bejonbers zu Schrauben, Sämmen, \$refīen beim Majdinenbau gefucht. Dą̧ Beoürfníß ber Müfler bieran fichert einen

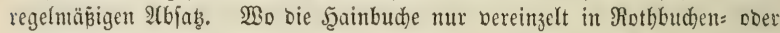
Eidenbeftänoen borfommt, fann ber 2(bjałs auf 30-40 Proc. Des Ein= fălages jteigen. Der Bebarf ift aber mit $\mathfrak{B e n i g e m ~ g e b e c t t , ~ D a b e r ~ b e i ~}$

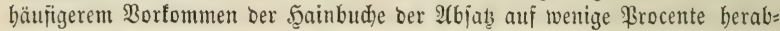
finten fann. Dießs gilt aud) jür bie nadhfolgenden \&aubbölzer.

Die 2lborne uno Eid)en liefern fajt nur Wagner: uno Tijaler:

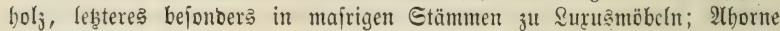
ju parfettirten Fußböben, Breflen, Stollen zc. Ejden fino aud) zu Bau= holj uno in geringen Stämmen zu ausgefpaltenent Ruberitangen gejud)t.

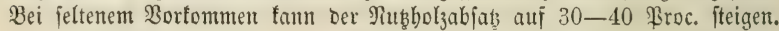

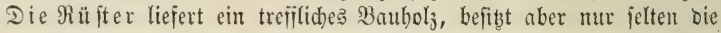

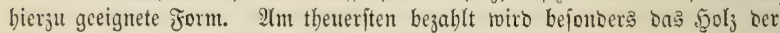
Rorfrüfter für ben Edhiffbau uno zu Ranonenlafetten, be` geringen Eplit=

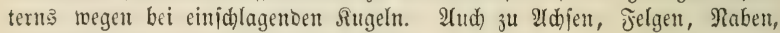
Bandftöden ift bie. Rüjter jebr gejdäąt.

Die $\mathfrak{A f} \mathfrak{a}$ jie liejert, ibrer langen Dauter wegen, im Nieberwalo bes banbelt, bie beften Beintrabmen, fhönes, hartes Möbelbolz uno rourbe in neuejter 3eit von Englano aus ju Edjiffanägeln jebr gejudt. 21uftäufer bezablten bei uns bis $1 / 2$ Mthlr. für ben Cubifjuß 83ölliger uno ftärferer Stammitüfé.

Die $\mathfrak{B}$ irfe. Die büufig gejlammt ober majrig getoadjenten Stämme fino als Möbelhols gejud)t, am Fube gefrümmte Stämme zu Edjlittentufen, ichmädhere Stangen zu Seiterbäumen, \$flugitangen $2 c .$, Banbitöde, Bejenreifig.

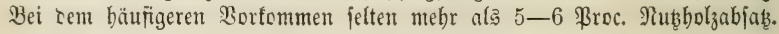

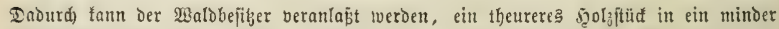

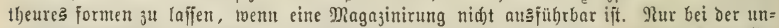
cntgeldidien 2logabe von Bau = Doer 9lubhölzern an Beredigte tommt alferding bie Ge= braudaşäbigłeit in minimo toeiter in Betracht. 


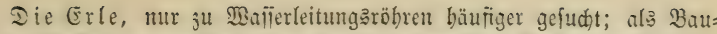

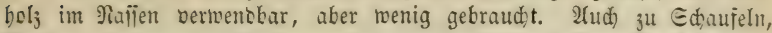

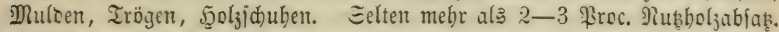

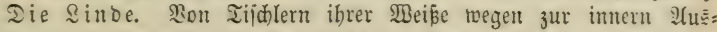

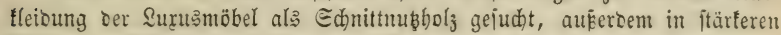
Blöden зu Bilojdniķerarbeiten, зu Muloen un Trögen.

Die Bappeln bienen ifrer Seidtigteit regen sum Berbauen in trodenen Räumen, bejonders in bie Dadjitülle. In neuerer Beit ijt be= jonbers bas Edwarjpappelholz von ben Eijenbahnbehöroen jebr gejucht und

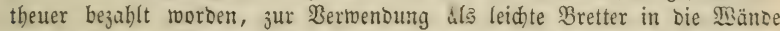

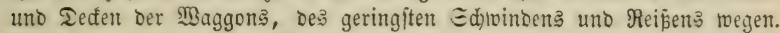

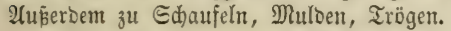

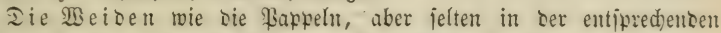

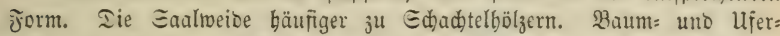
weiben zu Jlecht= und Fajdinenmaterial ergeben, mie aud bie 5 ajel ju Banojtöđen uno barte Straudhölzer zu Salinenreifig oft über jo ßroc. Nukูholzquote.

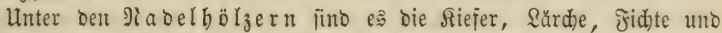
Tanne, welde bie bödjite, bis ju 80 Proc. mögliche Rub̧holzquote abmerjen

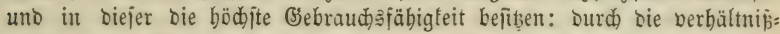
mäp̃ig geringe Bajtung, Den graben, regelmäāigen uno auझhaltenten Echajt:

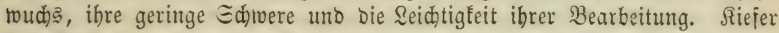
unto Särche finto bann aliperbem burdh ibre lange Dauer auşgezeidjnet.

$\mathfrak{P} \mathfrak{m}$ bödjiten im \$reije jtehen Riefer uno Särde in jebr itarten Etäm= men als Majtenbölzer, wo ber Transport ibrem 21bjab̧e günftig ift. Der

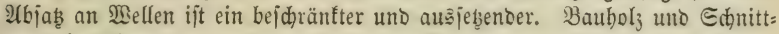

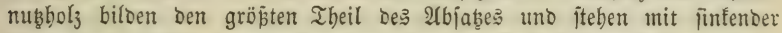
Sänge uno Etärfe in abnebmenbem \$reije. 2(ud) Etangenbölzer: Bobl: itämme, Sattitämme, Scopfenitangen, Bohnenitangen, Saungerten finden క̆lt Breifen reidjlidjen 2rbjaţ, bie, auf den Cubiffü berechnet, nidht jelten

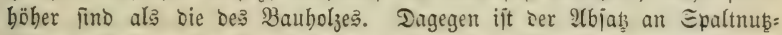

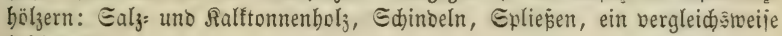
bejchräntter.

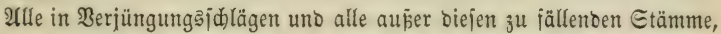
bie über 6 " jtarf fino, müfīen im Beifein beß Betriebs̄beanten auj einer

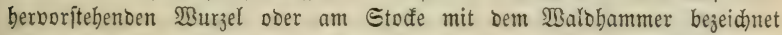
merben, bamit ber Betriebsbeamte zu controliren vermag, ob unangewiejene Bäume von ben Sgoljhauern gefällt oder von 2lnberen geftoflen worben fino. Die Brennboljbäume beoürfen einer meiterent Bejeidnung niđht. Bäume,

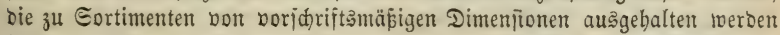
follen, erhalten burd) ben Reiper, ober Durd Beilbiebe, ben Şolzhauern

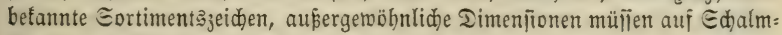
flächen mit Röthel angegeben werben.

b) Die fällung.

Die Fällung ber Bäume fann in oreifad) beridiebener $\mathfrak{W e i j e ~ g e j d e h e n : ~}$ Durd) Rooung, 
burch) Ulm jägen,

burd) Umbauent.

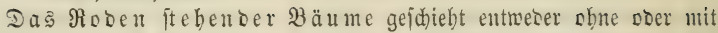

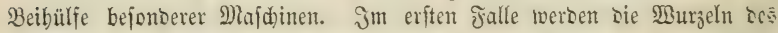
Baumes mit Rodebade uno Spaten bis zu einer Stärfe von 3-4 Etm. von ber Erbe entblöpt und in Diefer Dide, bie $23 u r z e l n$ Der Fallieite aber außerDem am Stode, abgehauen. Eine Der längîten uno ftärffiten $\mathfrak{B u r}_{3} \mathrm{eln}$, entgegengefeşt ber Eeite, nad) welder ber Baum geworfen werben foll, mirb als Şebelarm benub̧t uno vermittelift ftarfer Şebebäume fo weit ges

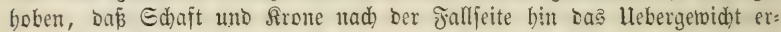

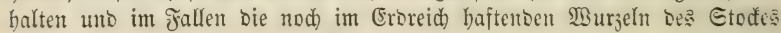

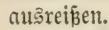

Eoll bas Stodhol mur als Brentholj berwenbet werden, bann wiro bie 2Arbeit mejentlid geförbert, wenn ber nod) ftehenbe Stamm in getwöhn= licher Etodböbe auf Der Dem Fallbett entgegengejestiten Geite bis zur Mitte einen Eägejodnitt erbält. Werben bann, redhtwinflig von beioen Entoen bes Eägejdnitts abwärta, Seile in bie Etodmitte getrieben, gleidzseitig in

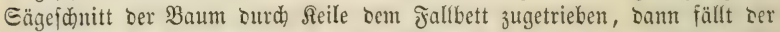

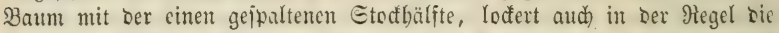
3meite Etodhälfte mehr oder wentiger. Der 2(rbeiter erfpart fid bierourch

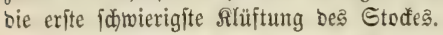

Edjon früber bediente man fid, theils jur Beftimmung oer faltrids: tung, theila zur Beförberung bes Jalles langer Geile, bie unter ber Baum: frone befeftigt uno von 2ribeitern angezogen wurcen. Llnter bem Ramen "Walsteufel" bemufit man beute fturfe Şanf= ober Drabtfeile mit Settentwerf wereint, bie mit einem (Ende 7-8 Mitr. bod) am umbureipenden Baume, am ansern (Enoe am Etode eines benadbarten Baumes befeftigt, butd) Flajd)enzug uno \$ुebel mit geringem Sraftaufwande fo ftarf angeipannt werben fönnen, ¿ajs, ohne vorbergegangene Eroarbeit, felbft alte Bäume mit ber ganzen Betwurzelung untgeriffen werbent.

Die Mortheile eitrer foldhen Rodung liegen nid)t allein in Erfparnif

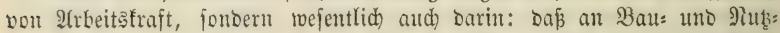

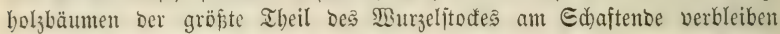
uno als Puthigol $\}_{3}$ vermerthet werben fann, werthoolle Siniehölzer aus Edhaft uno ftarfen Geitentwurzeln ausgebalten weroen fömen.

Demobneradtet wiro Das Moboen ftebender Bäume ftets nur eine

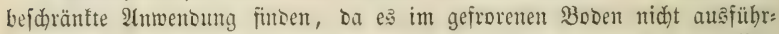

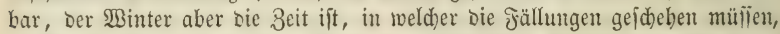

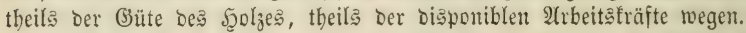

Jnt Der Regel mülien Daher bie Bäume im Winter mit Gäge ober 2rrt gefällt uno aujgearbeitet, bie im Boben berblicbenten Stöđe erft im Jrübjabre, wenn ser frojt aus bem Broen ijt, uno int Gommer gerobet weroen.

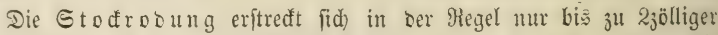

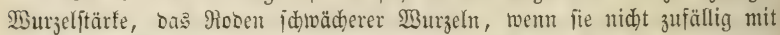

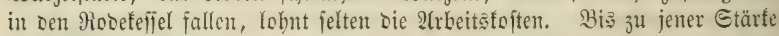
muiljen bie $\mathfrak{B}$ urzefn mit ber Rosebacte blopgelegt, froann runo herum bidt 


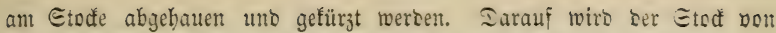

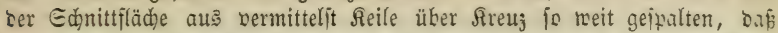

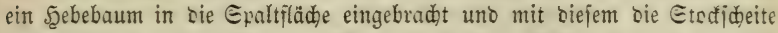
ausgebrodhen rerben fönnen. Bei jehr itarfen Etöden berient man lich.

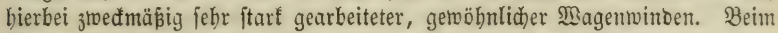

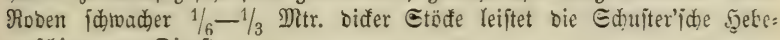
majhine gute Dienjte.

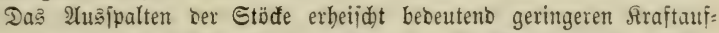
mant, wenn ber oberiroijde Theil berielben $1 / 2-2 / 3$ Mtr. hod itt. Alller= bings fällt baburd ein bebeutender Theil yerabe bes ftärfften uno keiten Tuthboljes in bie Etodbolzmalle uno man bat baher bas Etebenlanien boher

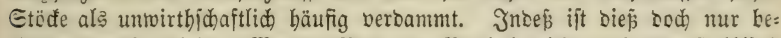

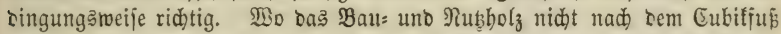
verfaujt, jonoern in Eortimenten bon bejitimmter Sänge uno Etärfe zu feften Preijen abgegeben wird, wo bas Gipfelbolz zur Befriebigung oer

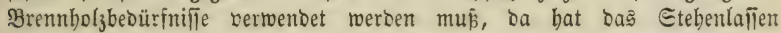

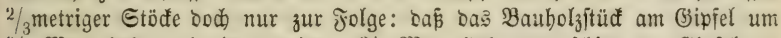

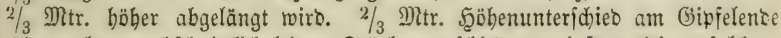

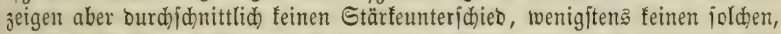
Der bei Meîungen für Den Berfauf bemertbar miro. Die jolge ift alio nur: Dás eine $1 / 3-1 / 2$ metrige Brennboljlänge desె GSipfelä bier vom Etamm: ende entnommen wiro, wojelbft fie ber gröferen Etärfe uno des $\mathbb{B} u r z e l=$ anlaufes megen bei weitem mallenbaltiger ift, ben $\mathfrak{B}_{\mathrm{e}} \mathrm{th}$ ber Etodtholz: flafter in hohem Grabe erhöht, Diejer ein viel befieres Anjehen gibt uno

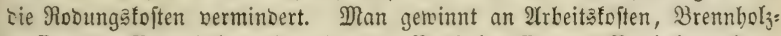

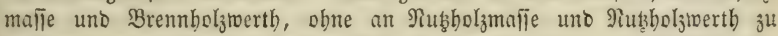
nerlieren, was alleroings ba ber Fall ift, wo bie ganze, zu Nuthbolz ver:

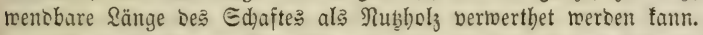

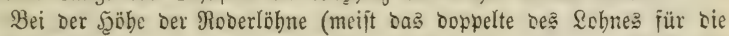
E丸eitholzflafter) uno ber Tranझporttoften (in Jolge ber geringen Dalīe im

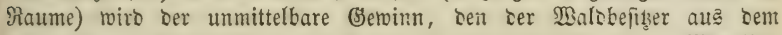
Gtockbolze zu zieben vermag, meift nur ein unbebeutenoer jein. Mittelbar fam ifm aber ba ein meịentlidjer Bortbeil erwadjien, wo obne Etodtholy= nußsung er genötbigt jein rourbe, bie Brennholzbebürnilīe theilweife mit

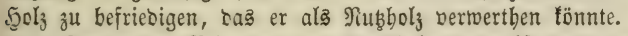

Der geringe Reinertrag ber Stodbolzmmbng ift bann aud bie Urjache,

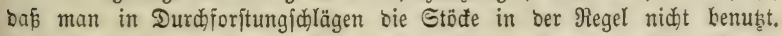

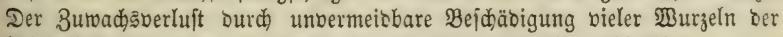
ftehenbleibenden Etänme, mürbe jenen geringen Bseminn abjorkiren.

Das umiägen ift für alle Bäume über 15 (tm. Etärfe bie üb: lidjfte Fällunģart. Der $\mathscr{A}$ rbeiter hat zuerft bie Fallridhtung bes Baume

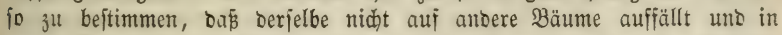
beren 2Yeften bängen bleibt, baś er beim Nieberfallen an braucbarem Wiebertoudje möglidjt wenig Edjaben thut, oap er an Bergbängen gegen Berg falle uno ein möglid ft ebene Auffallen auf bervorragenbe Steine, Etöđfe, Slaftern, üker Giräben scer

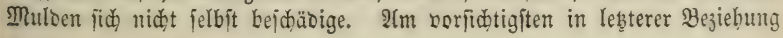


fino jehr langidäjtige Majtenbölzer uno joldbe Eidhen зu bebanochu, in ceren Beajtung Rrummbölser für Den Ediffibau enthalten fint.

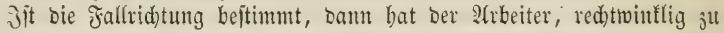
biejer, auf ber ifjr entgegengejeb̧ten Baumjeite ben Sägejdnitt in einer 5öhe über Dem Boben anzulegen, Die bei Etämmen bis 40 (Etm. Durd)= mefier bem Scalbmefier, bei ftärferen Etämment bent britten $\mathfrak{I}$ heil bes Durd)= meffers ber Stodfläde entfpridt uno biejen Sdynitt bis auf $3 / 5$ Des Durd)= mefïers, jeben Jalles aber über bie Baummitte binaus zu fübren, da jonft bas Stammente beim Umbrecten bes Baumes leid)t auffpaltet. Durd) nadgetriebene Seile ijt Das Slemmen ber Eäge zu verbintem: \$arallel Dem Eägefonnitte ift fobaun auf Der entgegengeję̧ten Eeite cin Şauferb

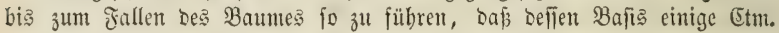
unter ber Şähe bes Gägefdunitts liegt, bei einer Şöhe Des Rerbes bis zu $1 / 3$ Des Stodourdmeffers. Je weiter ber Sägejdnitt über bie Mitte bes Baumes binausgeführt wirs, um fo niebriger tann ber Şauferb gebalten werben, womit nid)t allein eitt geringerer 2(bfall von Şaufpänen, fontbern aud) Nutubolzgeminn in fold)en fällen verbunden ift, in weld)en ein böherer

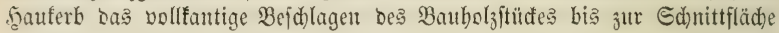
verbindern würbe.

Das Umba uen gejuiebt nad) Denfelben Regeln wie Das Umiägen, mur baj an bie Etelle bes Eägefdnittes ein eriter Şauterb tritt, ber, Da er wie ber Ednitt über bie Mitte Des Baumes reichen muja, um fo mehr

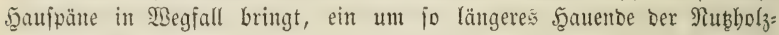
bered)nung entżieht.

2upserbent geht beim Umbauen bie Möglideteit verloren, aud in fd) wierigeren Fällen Dem Baume eine beftimmte Fallridtung burdh Ireiben vermittelît ber Reile im Eägejd)nitt geben zu fönten, baber nur Bäıme unter 15 Ctm., meift mur joldhe unter 10 Etm. ungehauen werben.

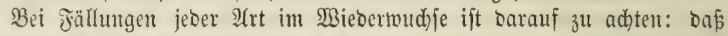
bie Bäume nit ber Srone auf bie nod) nid)t, ober mit Dem jüngften f̧olze beftandenen! Jlächen bingetworfen merben, Daß̧, two Der Wiebertwud) überall gleid) bid)t uno bod ift, bie Sronen ber benadbarten Bäume auf eine uno biejelbe Stelle geworfen werben, bamit anftatt vieler nur eine Süde ent= ftebe; das bie gebogenen Stämmdhen vom Drưfe möglidjit rafd befreit uno wieber aufgeridtet werben; Dap in fatwierigen fällen burd) vorbergegangene Suesäften ber ju fällenben Bäume ber Edjaben am $\mathfrak{B}$ iebertwudje möglidjit verringert twirb.

\section{c) Die $\mathfrak{A}$ ufarbeitung.}

Der gejällte Baun miro zunädjit entäjtet, wobei barauf zu feben, Dap Der 2(bbicb Der 2efte uno 3lweige ganj bidht am Edafte, rejp. 2Yjte ge=

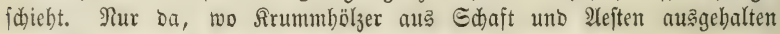
werben follen, bebarf es einer vorbergehenten 2tusmeifung.

Bau= und Ruţbölzer werben fobann in ben vorgejobriebenen \&ängen

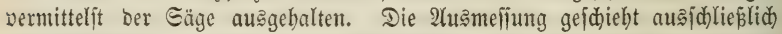

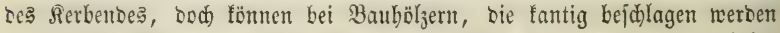
umb bei Blöđén, Die aนร Der Şanto gejdnitten merben, ein ober einige 


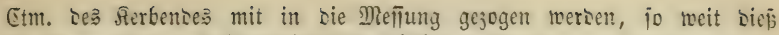

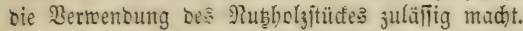

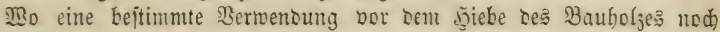
nicht norliegt, will Rönig ein 2 blängen beß Edaftes alt ber Etelle, wo Dellen Durchmeñer $1 / 3$ tes Durdmeñers in Brujthöhe beträgt.

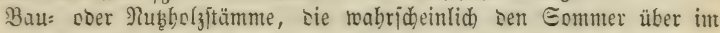
Malte liegen bleiben, ehe jie abgegeben werben, müfien betoaloredtet, ๖. h. von vier Geiten jo weit behauen werben, daj zmijden je jweien

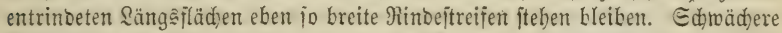

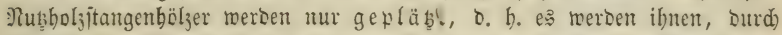

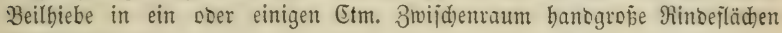
binweggebauen.

Die Dertlicfteit entidjeiset: ob Unterlagen von Rntwpeln ober ein

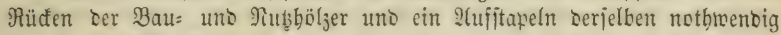
Doer zloedmäßjig ift.

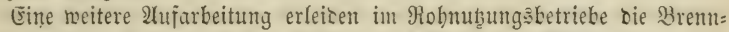

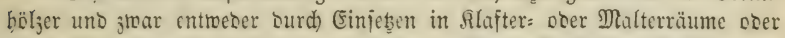

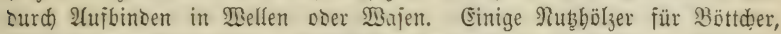

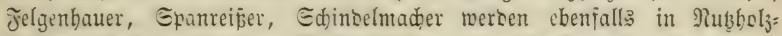

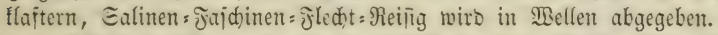

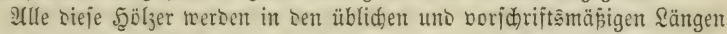

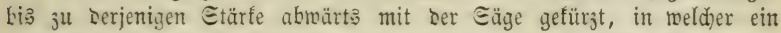

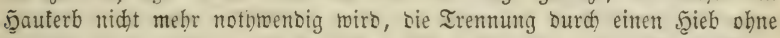

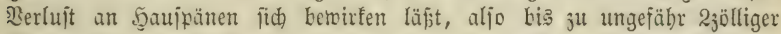
Stärfe binab.

Mas bie こcheitlänge betrifit, jo ijt sie metrige vorberrident, uno nur Da, mo viel Brennbolz berfohlt wiro, gibt man aud bem übrigen Brennholje sie für den Röhlereibetrieb zmedmäpigite $1_{13}^{1 / 1}-1^{2} / 3$ metrige Edheit= länge Der Conjormität wegen. Bei 1metriger Echeitlänge legt fith aber sas $50 l_{3}$ bichter in Den Slafterraum, bie Edjeite fino leid)ter zu ipalten uno ju hanobaben, Der Räujer erjpart über 10 Broc. an Eddneioelobn für weitere Berfleinerung bes 5olzes.

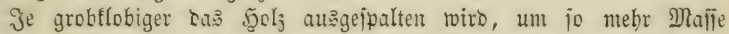
entbält bas Daraus aujgejeḅte Raummap. Damit die Mapae gleider 2rt auch bierin gleidwerthig merben, mus baher eine beitimmte Edeit= $h_{0} l_{3}$ itärfe vorgejdrieben jein, bie für getwöbnliches Brennboly zwijden

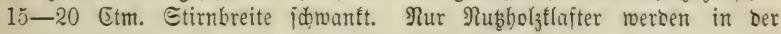
Regel möglidift grobtlobig abgegeben.

3um ?lufieten in Flaftern jortirt ber Malbarbeiter Das Brenntyolz in

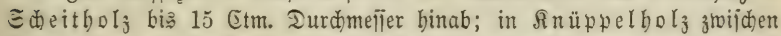
5 uno 15 Etm. Etärfe; in Stod holz aus graten Epitien uno geringem Surdjorifungsholz unter 8 ober 5 Etm. Etärte; in Reiferbol $5-8$ Ctm. Etürfe, wo joldees ridat, wie getwöhnlich, in Wajen auf:

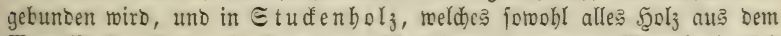

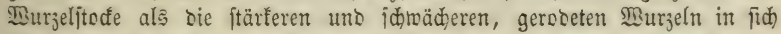

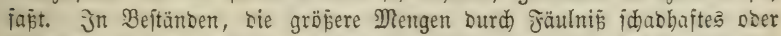

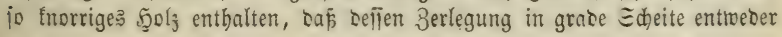




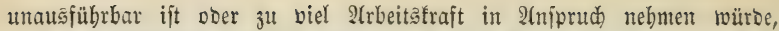

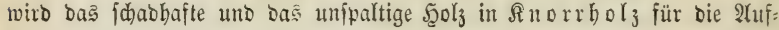
flafterung auggefofieben.

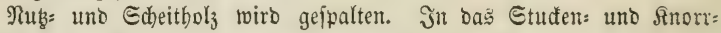
bolz werben theils geipaltene, theils ungeipaltene Etüfe aufgenommen, bas $\mathfrak{S}_{2} \mathrm{Ol}$ ber übrigen Sortimente bleibt ungefpalten.

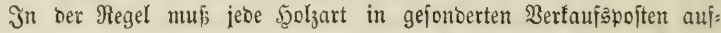
bereitet werben. Nur Dam bürfen beridjiebene Şolzarten in biejelbe Allafter oder Belle ju|jammengebrad)t werben, wenn burd bas 3ujammentragen

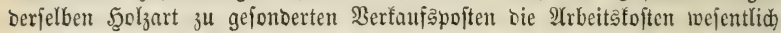

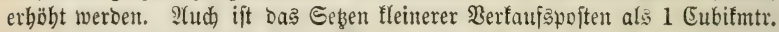

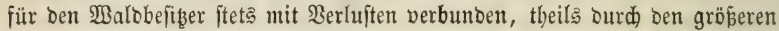

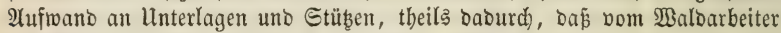
Der fleinere Berfaufäpoften in ber Regel reidjlider gejebt wirb, als bief gejdeben follte. Dießs zu bermeiben ift in gemengten Beftänden Das Seţen gemengter Slaftern ober Bajen um to eher zuläfiig, je weniger bie bes treffenden Şolzarten im Brennwerthe veridjieben finto, 3. B. Budbe, Şain= buche, Birfe oder Fidate uno Iante, ober Riefer uno Särche.

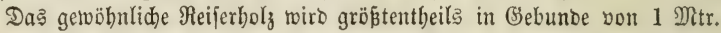
Sänge uno $1 / 3$ Mtr. im Durdimeffer vermittelft Binoweiben aufgebunden un

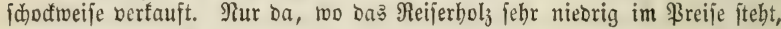
Doer wo bas zum $\mathfrak{A}$ ufbinden geeignete Material fehlt, legt nian aud) bas Reijer: holz in Meterräume żwifden Bäble voer man berfauft Daffelbe fuberweife.

Dą Setzen ber Rlaftern gejdieht too möglid) auf horizontaler (Ebene zwifden $\mathfrak{B f a ̈ h l e}$, die in Den Boden eingejdlagen uno vermittelft eines

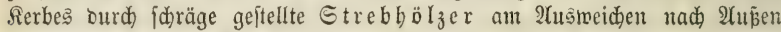
verbindert werben. Die Befeftigung Der \$räble Durd) Babetreifer, Deren 3meigipizen in Den STlafterraum gelegt uno burdh bie aufgelegten Edeite feitgebalten werben, gibt jwar Dem Sfahle eine größzere Jeftigfeit, Dem WBaldarbeiter aber Sselegenbeit ju betrüglider Rlafterung, da bas, bie Eaheite rechtwintlig trenzente Reifig cin bidtes Bujammenlegen erfterer ver=

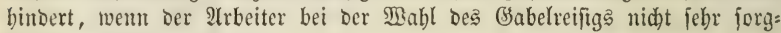
fältig zu $\mathfrak{B}$ erfe gebt.

Die Rlaftern follen ftets zwijđen \$fäble, nie an Bäume ober Jelfent 2 .

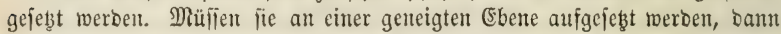

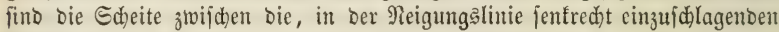
Bfäble in bie Sgorizontale zu legen uno bie Rlafterböbe ift red) troinflig 3̆u Der geneigten (Šrunofläd)e abzumefien.

Bem die Rlaftern nidjt jebr bald abgefabren werben, auf feuchtem Boben uno über bereiț vorbanoentem Bieberwudje ift $e_{\mathfrak{s}}$ ratbjam, fie auf Unterlagen bon Edjeitjtüđen aujzujeten, bie Der Silafterlänge nad in Dopwelter Reibe auf Den Boben gelegt werben. Wenu zur Bermehrung be: \&uftzuges bie Unterlagen nidht ber ganzen \&änge nad) auf bell Boben ge: legt, fonbern zu einem, in Der Mitte Der Rlafterlänge aufgeftellten Bode

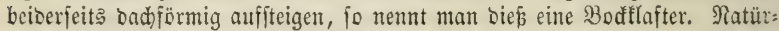
(id) muई in biejem Falle bie Dberfeite oer Slafter eben fo giebelförmig

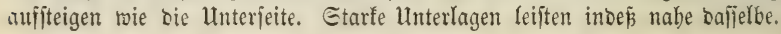




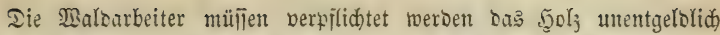
bis auf 30 bis 40 Edfritte Entfermung an folde Stellen zujammenjutragen,

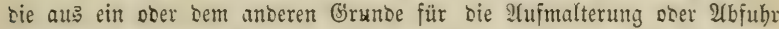
borsugisweife geeigntet fint; ein 3ujammentragen auf weitere Entfernungen

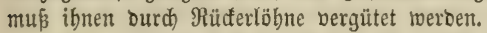

Die unterften Edheite, jo wie bie weldhe bie \$fäble berübren, merben io gelegt, Daj bie Rimsejeite nach unten uno aupen gefehrt ijt. Im Innern Ier Rlajter fint bie Echeite möglidjt bidjt, aber niđht mit benjelben Spalt= flädjen zujammen, jonbern jo zulegen, bas bie Rernjeite jebes folgenden Etüđes Der Rinbenjeite bes unterliegenden Stüđtes zugetehrt ijt.

Eine gute, gleidförmige uno bidte Alafterung erpart oem Walo:

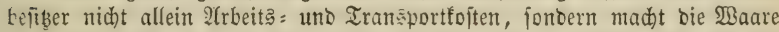
aud) anjebnlicher uno begebrter. Sie ift bejonders ba empieblenswerth, too

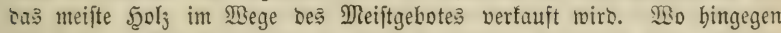

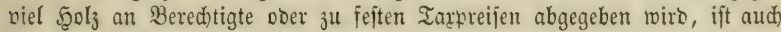
hierin bie goldene Mittelftrá̧e einzuhalten.

Wenn Das $\mathfrak{g}_{0} l_{3}$ uno bejonder: bas gejpaltene einige 3eit im Walde iteft, berliert es burd) (Eintrodnen an Bolumen. Wierben voll gejeste Rlaftern abgefahren uno troden wieber aujgejebct, Dann legen fid bie Edjeite

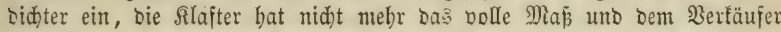
ober Magazinverwalter feblt jebe Controle, ob nidjt aud auf anderem Misege Bejtandbeile Des angefabrenen Scolzes in 2tbgang getommen fint. Dief zu

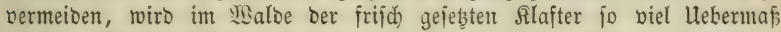
gegeben als Das Єdmintemáp beträgt. Rlaftern, Die im Qaufe Des näbjten Sommers abgefabren werben, gibt man in ber Regel ein Heberma pon

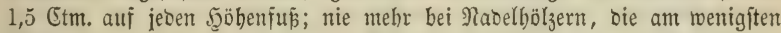

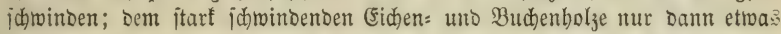

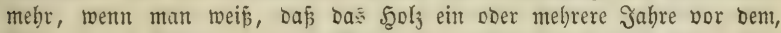
Bertaufe auf 2tblagen ober in Magajinen aufbetwabrt werben mus. Des

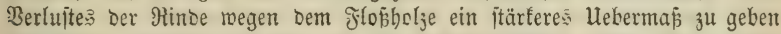

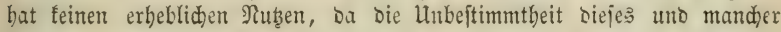
undere unwermeibbare 3erhuft Den Zlwect einer barauf berubenden Controle aufbebt.

\section{Betrieb ier Rintemthung.}

(ङeite 219.)

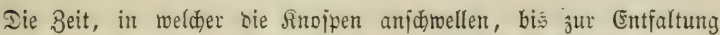
cer erften Blätter, umfajt ben Beitraum, in weldhem bie Rinbe am leid)=

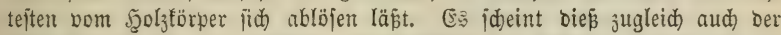
Beitraum zu jein, in weldem ber Gierbitoif be Baftes in einem ber ge=

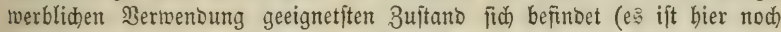
Biele: unaufgeflärt). 2(uperbem foll nod) einmal "um Johannistag" bie

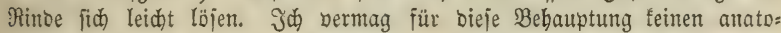

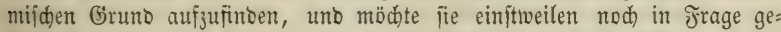
jtellt milīen. Jeben Jalles jteht Der Johamnitrieb in Eeiner Beziehung jur ungebinberten Fortbilbung Des Jabrestinges uno es ijt nid)t einzujeben,

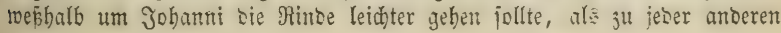


3eit zlvifhen Johami anto Dem Beginn Der Begetation. 2Aber aud ab: gejehen hierbon, muß ein grofer Igeil bes (Serbitofis, Der, twie id gejeigt habe, ein Rejerbeftoff ift, um Sobanni auf Reubiloungen an Bellen uno Jajern berwendet jein, bie Jobannirinbe würbe fiderer einen bebeuteno ge: ringeren Serth als Gerbmaterial befizen als bic Matrinte. ${ }^{1}$

Die Eidenrinde mirb in veridiedener weife getommen von alten (Eid)en uno von jungen Stangenbälzern.

Eollen alte Eidjen entrinoet werben, jo mup bießs in ber bejeich= neten Beit fofort nad) Jällung Des Baumes gejdeben, uno bürfen feine Bäume im Sorrath gefält merben, ba fdon nad) 24 Stunben bie $\mathfrak{2}$ it: rinbe gar nidht mehr, bie Etanmminoe weit fdctwerer fich ablöjen läpjt. Das Entrinben beginnt am gefälten Baume an Den Uleften, bie in Der Regel bödfftetis bis zu 3=centiger Stärfe, oft nur bis zu 5 ober 7 =centiger Etärfe entrinbet werben, ba Die Entrinbung Der idiwäd)eren Aefte uno

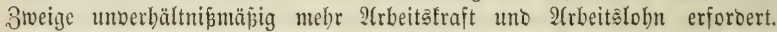
$20 b l$ aber werben bier uno da bie 1-2jäbrigen Pieijer ungejdält uno getrodinet auf ber Sobmüble jerquetidnt uno mit Dem 5ुolze als Sohe verwentet.

Das Entrinben Der ftärteren 3weige uno ber idfwächeren 2fefte ge: fajieht meift Daburd), baj bem, in 1 =metrige Etüđe gehauenen $\mathscr{U}$ jte,

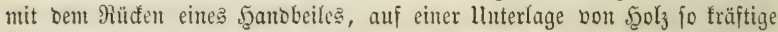

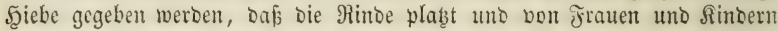

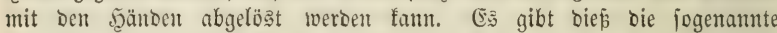

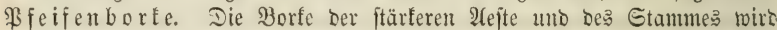
mit ber $\mathfrak{A}$ r̨t in Edeitlänge geringelt, ber Sänge nad) mit bem Beile auf: gebauten mo vermittelit langer Reile von bartem Scolje abgelöst. Die 2(rbeit idfreitet won oben nad) unten vor, weil bie gröbere Borfe aud)

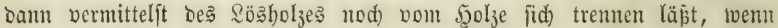
bie höhere Borfe fidon fehr feft geworben ift.

Der aufgerifiene Ibeil Der Eidjenborfe, obgleid ebenfalls aus \$3aft: idjidten bejtebento, entbält jo geringe Mengen Ġerbjtofi, Daß er vom Gierber binweggenomment uno nid)t mit zur Sohe berwendet twirb. 2Af bejonderen Wunfad Der Gerber gejdhieht bas \$uben Der gröberen Stammborfe oft fdon im Walde und bann fo viel wie möglid) vor bem Sdälen mit

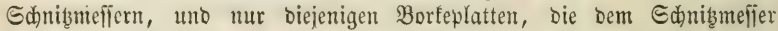

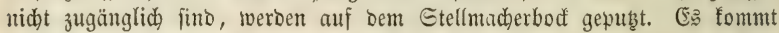

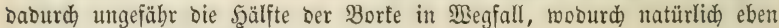
fo viel an Tranipprtfoften eripart wirb.

3um rajden 2Ubtroctnen twird die \$feifen: แnto Etüctborfe auf $1 / 3$ bis $2 / 3$ Mtr. bohe Unterlagen von feinem Reifig in Scaufen auf= gejojidtet, jeber Şaufen Dann mit groben \$latten Der Stammborfe um= ftellt, Die Rindejeite nad) anfen gefebrt, und bie obere Deffmung ber \$lattentwantung mit groben Borfeplatten überbect, bie Rinbejeite nach

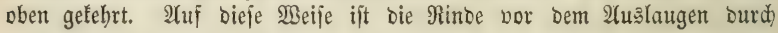

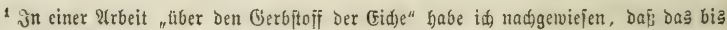

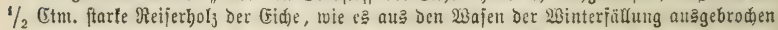

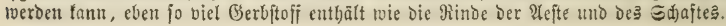




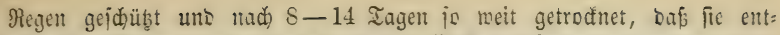
meber in Rlafterräume aufgejebst ooer in Sisellen aufgebunten werben fam. In beiben fällen werben bie grópen 3 orfeplatten mit ber Rinbejeite nach

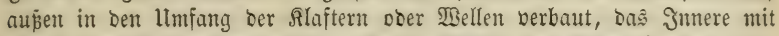

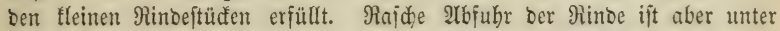

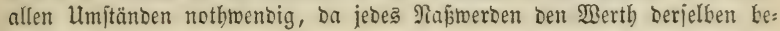
beutent verringert.

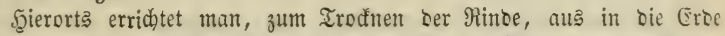

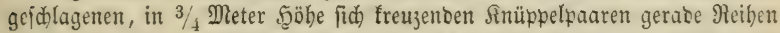

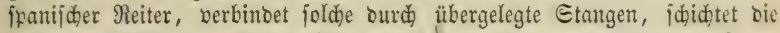
fleineren Borfeftüde auf Unterlage bon Reljern unter ben Etangen auf utr bilbet über ihnen ein fortlaufendes Daç aus Den groben Sorfeplatten, Denen bie Stangen zum Stübpuntte bienen. Die Borfe trodinet burd, ben ftärferen \&uftzug rajdjer, läft fid) aber nidjt jo vollfommen gegen Regen

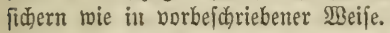

Die Geninnung ber jogenannten Epiegelrinbe bon jungen (Fidjen, meift bon Stočlohoen bes Rieber = und Mittelwaldes, geidieht meift am ftebenoen Scolze ber 2 rt: Daß̧, nadboem ber Gtod einige Etm. über oem Boben mit bem Beile gefränzt wurbe, vermitteljt eines, einem Garten= mejer ähnlidjen, an einer 2 Mtr. langen Stange befejtigten \&ohreifers, bie Rinoe all brei ober vier Eeiten bez Edyafts von oben nad) unten ber Sänge nad, aufgerifien wirb. Bermittelit bes $\&$ ohjd liker 3 , eines balb: fugliden Eijen? bon $5 \mathrm{5tm}$. Iurdmefier, bas wie ein Gieplöffel in cinent Etiel außlăuft uno an einer furzen Etange befejtigt $\mathrm{i} j \mathrm{t}$, werben barauf bie Sängsinfife burdh \&öfung ber Rinbe baburch erweitert, baj man, bie platte

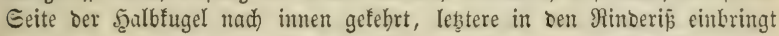
unb fie bon unten nach oben fortidiebt. Sit bieß in allen Rinberifien vollbracht, bann löfen fich bie Rindejtreifen von unten nad) oben leid)t uno ofne zu zerreifen vom Şolze ab unb bleiben mit ber Gipfelrinte jo lange in Berbinoung, bis fie abgetrodnet fint, worauf bie Stangen gefällt, bie Rinbeftreifen abgerifien unt, in Bunbe zujammengebunben, centnermeije verfauft rerben.

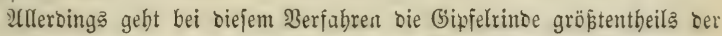

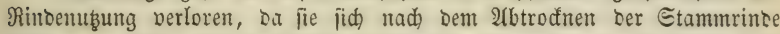

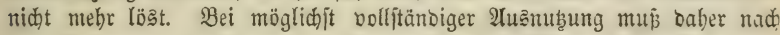

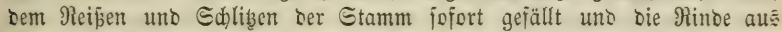

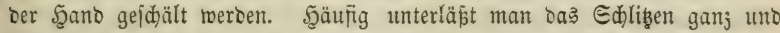

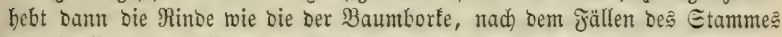
vermitteljt eines feilförmigen Injtrumentes vom Şolze ab.

Die Rinde der Fidjte geht bis in Den Monat Juni gut. Da fie bei

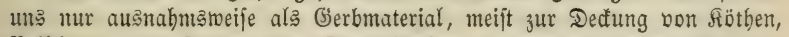
Befleibung ober Decfung von B̉artenhäujern $2 c$. bertwentet wiro, lö̧t man fie bei uns runo um ben liegenden Stamm in einem $2-3 \mathfrak{M}$ tr. langen Etüđe bom 50 lze $a b$, bas fid) beim Irodnen zujammentollt. Dieje Rollen werben bant idoctweife berfauft.

Die Rinbe ber Sinbe geht erjt gegen Sohanni leiđt bom Şolze. Eie wirb in möglidfit grabe aufiteigenden, 8-10 Etm. Ereiten Etreifen 
geriffen, vom 5̧olze abgchoben uno bann frija), in Bünbel gebunben, ver=

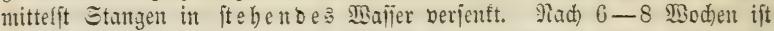
Die Maceration vollentet. Die Jabrešlagen bes Bajtes laijen fid) Dann leid)t von einanter trennen, in fließ̄enbem $\mathfrak{B a j j e r}$ auŝtwajchen unt fortiren. Die jüngiten innerften Jubreslagen liefern oen feinjten, Die äußeren Jabres= lagen ben groben Bajt.

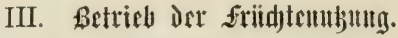

(ङeite 241.)

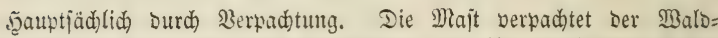
befiber, womöglid an ben ફyütungaberedtigten, ber ibm bin bödjten \$ad)t= preis geben fann uno wiro, weil ihm aus ber Pachtung jugleids ber grofie

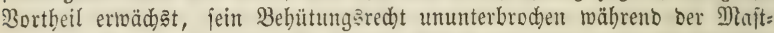

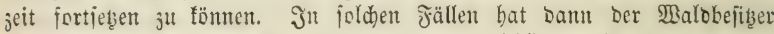

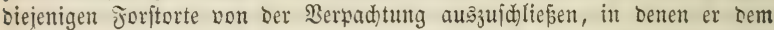
Päcter bie Maft gar nidht, ober mur burd) 2(uflejen von Menid)enbänton

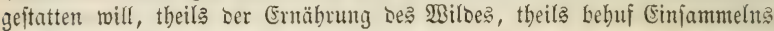
bes eigenten Bebarfes an Eaatfrudit wegen.

(E) föntun aber Fälle eintreten, in Denen \$äd)ter für bie gefammte Majtmubuttg bes Jabres nid)t vorbanben, ober nidft geneigt fino, einen Dem Werthe berjelben entiprechenten ßad)tzins zu entridten. Jin joldhen

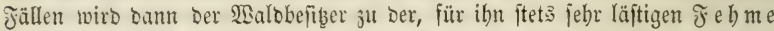

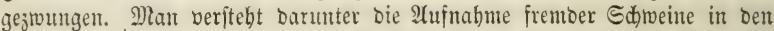
Malo, gegen ein zu entrid)tenbes Majtgelo (Eeite 221), mit ber Berpflid)=

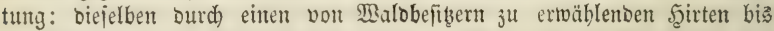

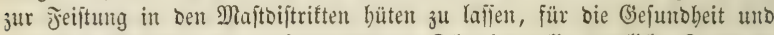

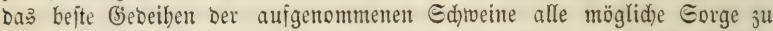
verwenden, endlid) bie gejeifteten Ed)weine bem Befiber gegen bie Entrid)= tung bes bebungenten Maitgeloes wieber zurïđžzugeben.

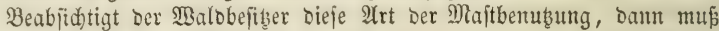

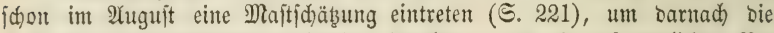

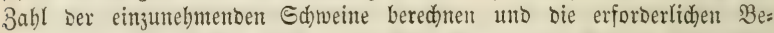

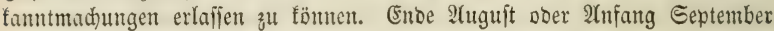
werben alsoann bie angemelbeten Edineine aufgenommen, bamit fie bor

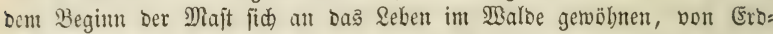

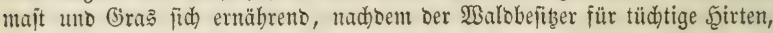

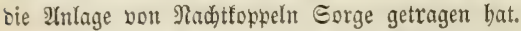

Ein Şirt allein fant bis 200 Sdrweine büten. 2Uuf jebes Şunbert

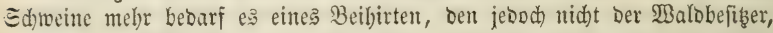

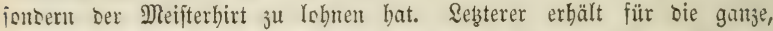
9-10wöchentlidje Dauer ber Majtzeit, auf jeoes Sdwein 30-40 Bfennig 5üterlohn. Ter Şirt mus mit ben Rrautbeiten uno mit ber $\mathfrak{B a r t u n g}$ ber Edjweine gut befinnt fein uno berpflidtet werben, von eingetretenten frant= beiten uno Iobeşällen, im leșteren Falle unter ßorzeigung des gefallenen

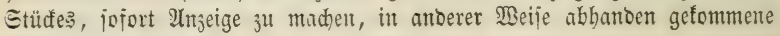
Edjueine ơll eriełsen. 
Die Buchten müīen auf trodenem, loderen, bie Jeudigtigeit leidjt

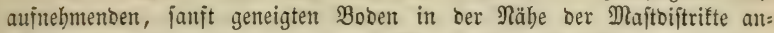
gelegt, mit aufredt eingegrabenen $2 \mathfrak{M t r}$. langen Edheitbölzenn eingezäunt uno bejonbere Berjaläge für frant twerbende Sdjweine bergeridtet twerben, bie ber Şirt beim erften 2Unjhein einer Rrantheit jofort bon ber Şeerbe auşuideiben bat. Man red)net auf je 4 Sdineine 1 2(re Budjtf(äd)e.

Müīen bie Sdineine aus den Majtbijtriften jebesmal weit zum Mafier getrieben werben, bann berlaufen jie einen grop̈en Theil ber Jeiftung. Эe öfter fie zum Majper gelangen fönnen, obne bie Maftoiftrifte zu ver=

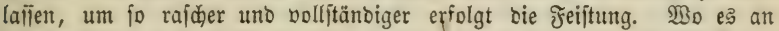

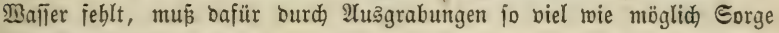
getragen werben.

Bei ber 2Afnabme ber Sdjeine in bie Fehme ift jebes berjelben, neben ben Ramen uno Bobnort bes Befiteres, nad After, Ģröße uno weiteren Rennzeid)en genau im Regifter zu bejđreiben, auperbem burd) aufgebrante Nummern ober SBudjtaben zu fennzeidjnen, bamit bei ber Wieberabgube ber, in ber Maitzeit fid) febr veränbernden, Sdtweine feine Jrrungen eintreten fönnen.

Die Mieberabgabe ber gefeifteten Sdreine gegen Erlegung bes Majt: getbes mǘ an bemfelben Tage im Beifein aller Befiz̧er erfolgen, bamit

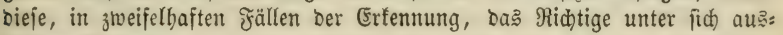
maden tönnen.

Bleibt nad) Feiftung ber, in bie f̧auptmaft aufgenommenen

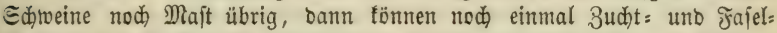
idweine zur $\Re$ a dmaft aufgenommen werben, bie bann bis zum Sdnees fall fortoauert.

In Jabren geringen Maftertrages, wenn aber einzelne Bäume reid):

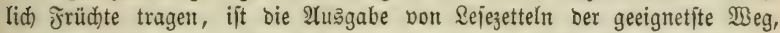
einigen Nuben aus joldem Ertrage zu zieben. Mebr ber Controle als einer (Finnabme wegen werben jolde Scheine audy für bie Sammler bon Б̧ajelnüīen, Walobeeren zc. ausgejtellt.

Riefern=, Jichten=, Särchen =, Erlenzapfen werben am woblfeilften wäb= rent Deక Binter bon ben, in ben Schlägen gefällten Bäumen gejammelt, unt jtwar gegen Iagelohn von Sinbern uno Frauen unter $2(u f f i d)$. Finton jold)e fällungen nid̆t jtatt, ober ijt bie in ihnen zu fammelnoe Gamen: menge nicht ausrreidheno, mülīen bie Früd)te von ftehenden Bäumen ein= gejammelt werben, bann ift 2Accorbarbeit vorzuziehen uno foitet bann ber Edjeffel an Sammlerlohn bei mittelmäß̄iger Samenprobuttion uno 90-100 \$ig. Tagelohn annäherno: Riefern 80-100 \$fg., Fichten 20-40 \$fg., \&ärchen 100-150 \$ig., Şainbuchen, Ejdhen, 2hbrne 80-120 \$ig., Birten, Frlen,

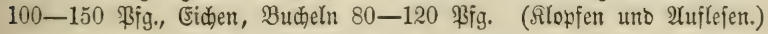

\section{Betrieb Der faubutbutg.}

(Seite 242.)

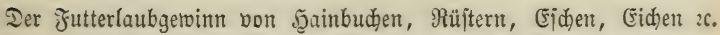

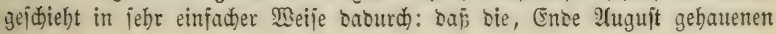




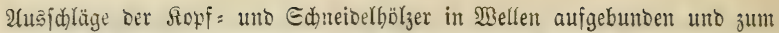
rajoln 21btrodnen vercinzelt aufgeftellt werben. Die mit bem Laube ge: trodineten Reijer werben bann Den Winter über Dem Biehe vorgetworfen,

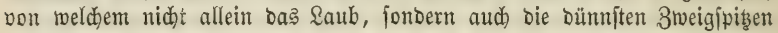
abgefreffen werben, worauf bas übrige Reifig zur Feuerung verwendet wirb.

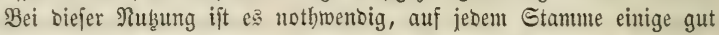
belaubte 3ugreifer überzubalten, bamit ber Baum nicht im Gafte ftičt.

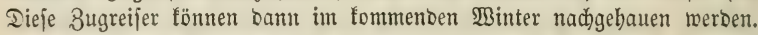

Da bie im 2luguft getöpften Stämme fdon im Şerbite bie Seime für

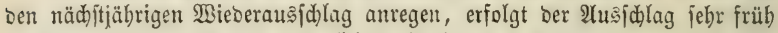
im tommenten Frübjabre unb leibet häufig von Spätfröften, Daher ber Jutterlaubbieb nur ba mit gutem Erfolge auf bie Dauer zu betreiben ift, two man von Spätfröjten toenig zu befürchten bat.

2ud) in ben nächitjäbrigen Sd)lägen bes ఇieberwaldes uno bes Unter: holzes im Mittelmaloe, twie in Den jüngeren Durdforftungshieben des Sodnwalbes fönten bebeutenbe Mengen Futterlaub in ähnlidjer Weife ges

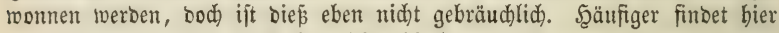

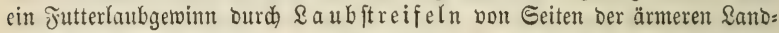

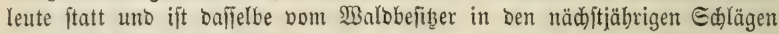
jur Unterftüb̧ung ber Bebürftigen io lange uno fo weit zu geftatten, als

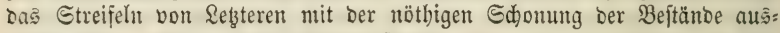
geübt wirb. Einen unmittelbaren Geminn wirb Der Waldbefizer in Den meijten Fällen aus ber bieftattung niḑt beziehen fömnen, ba bie bebeuten=

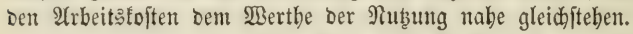

Dą̧ abgefallene Saub bient bem Waldboben alక Dungmittel uno

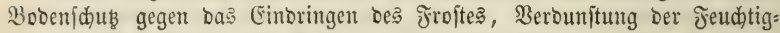
feit uno Berbinderung Des (3ras: uno Untrautwudjes. Jebe Serminberung

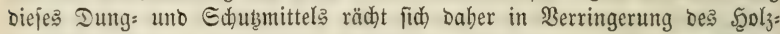

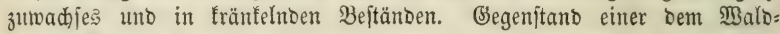

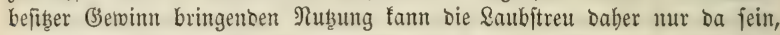
wo fie vom $\mathfrak{B B i n b e}_{\text {in }}$ Gräben zujammengeweht wiro, ober too fie in Muldent in Llebermenge fich anjammelt. Selbjt in foldhen fällen ift es nidgt rath:

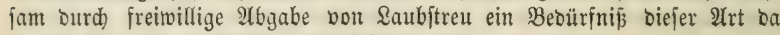
zu erwecten, wo es bisher nidht bejtanber hat.

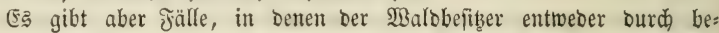
ftehende Eervitute ober burdh ein unbedingtę Bedürni⿰ Der benadbarten YAferbefizer gezwungen ift, einen Theil ber jäbrlichen Eteuerprobuftion an Seţtere abjugeben. Welchen Bejdränfungen in joldhen Fällen bie Etreu=

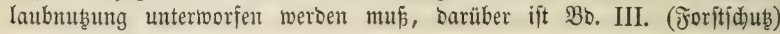
bas Nöthigfte gejagt.

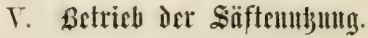

(Geite 242.)

Bon einem mirflichen Şetriebe der Cäftenukgung ijt gegentwärtig in Deutidlantos $\mathfrak{B a ̈ f t e r n ~ n i r g e n t o s ~ m e h r ~ b i e ~ \Re e b e , ~ a u s ~ ( s t u ̈ n b e n , ~ b i e ~ i d ~}$ bereits Geite 224 bargelegt babe. Heber bie $\mathfrak{2}(\mathfrak{r t}$ ber $\mathfrak{I}$ erpentingeminnung 


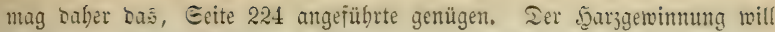
ich bier mit furzent Borten erwäbnen.

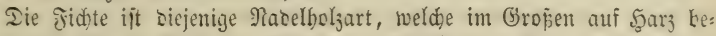

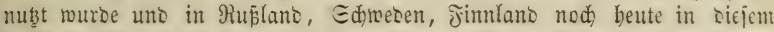

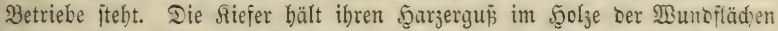

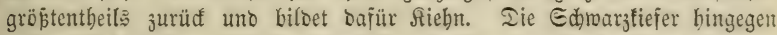
foll reidjlich Gaftergup liejern, Derielte aber jebr langiam zu 5̧arz erbarten.

Bebuf ber faragetwinmung werben bie haubaren uno geringhaukaren

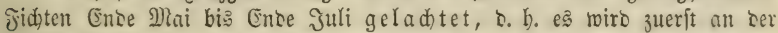
Ditieite be saumes bermitteljt eines Jnjtrumentes, bas einer bogig ge: frümmten Bimmermantä:Suerart äbnlid) ift, ein ober 3twei Baftitreifen von

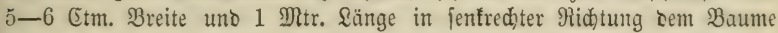

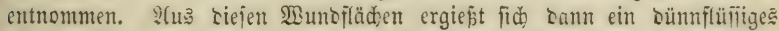

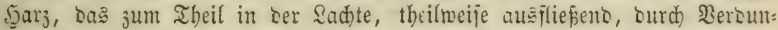
jtung bes beigemengten Terpentiơ uno ber mäjirigen Baumiäfte ju jeftem

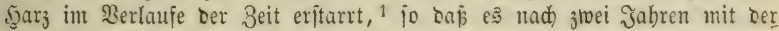
badfenförmig geittellten Echärfe Der Şarzpide im Suni aus̃ ser Sachte ge: iffarrt uno in untergeftellten Rörben aufgefangen merben funn. Diejelbe

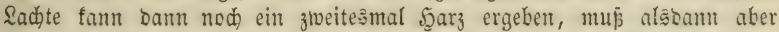

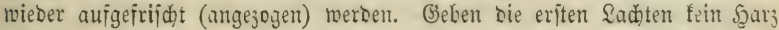

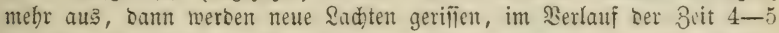
im Umfange Des Etamme: Heber sen Ertrag Eeite 272 uno weiterbin über ßedfieben uno ßiehnrußbereitung.

\section{Betrieb Det Ilebemmbmugen.}

(Seite 243.)

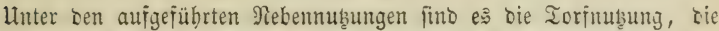

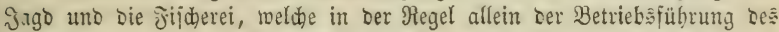
Foritmantes in Den meijten Fällen angehören. Nur über Łen Torfbetrieb fann id bier in Umrifien bas $\mathfrak{B}$ ejentlidjite mittheilen.

Wenn in einem Walobejiththume biaher unbenutzte Torfbrüd)e vorbun: ben fino, Deren Benuşung beabjichtigt wiro, mus burdh Unterjuchungen 3uerit feftgejtellt werben, ob eine Iorinuşung überbaupt möglid) uno ob fie mit $3 o r t h e i l e n$ für ben Befitber verbunden ift.

Şindernilie Der Benußzung vorbandener Torf̈rüdhe liegen bäufig in Der Unausführbarfeit einer, wenigitens theilweijen Ċntwälïerung Łer Brüçe, wohin auch ber Fall gehört, in welchem die Entwäjierung mit jo bebeu=

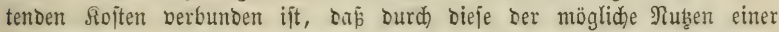

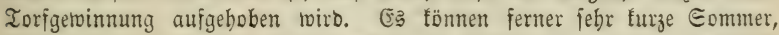

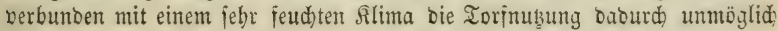

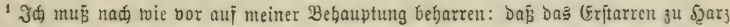

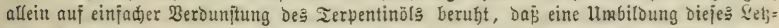

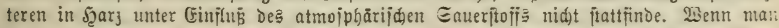
Terpentinől Jabre lang in jreier Luft aujbewabrt, verbleibt allerbing sin jäher, flebrige:

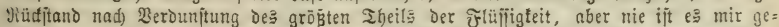
glüft, etwaß in Rüđjtande ju crhalten, toaß mit fejtem Syarje aud) nur entfernt vergliden werben fann. 
machen: Daj Der Iorf nidht Den, für ben Irantsport nötbigen Iroden= heitzgrab erlangt. Der Torf trodfnet zwar auch in Der MSinterfälte, wenn

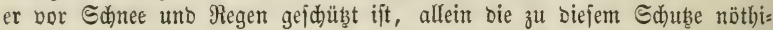

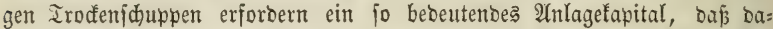

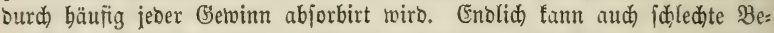

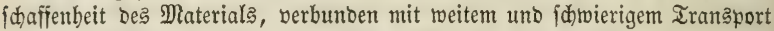
bis zur Berbraudjstelle, bei geringen Breifen anberweitigen Feuerungs: materials, es famn bie geringe Mäd)tigfeit bes benub̧baren Iheil’s ber Lager

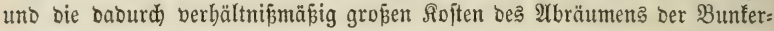
erbe einer Benub̧ung ber Torflager entgegeniteben.

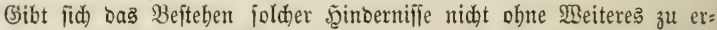
fennen, Dann müffen entiprechende Unteriud)ungen in Bezug auf bie Mlög= lidfeit uno ben Rojtenaufwand ber (Entwäfferung burd) Bohrberjuche uno

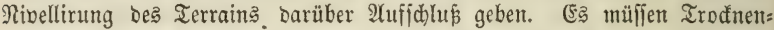
uno Bremtraftwerjuche mit fleineren Torfmengen angefteflt werben, bie fid) Durd) Bolkrung aus veridjiebenen Tiefen bes Torflagers getwinnen lafien.

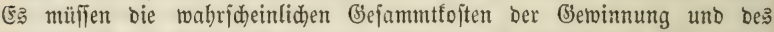
Transports zur Serbraudjitätte, einerieits Den zu erwartenden Torfpreijen, anbererjeits ben mittelbaren $\mathfrak{B}$ ortheilen gegenüber geftellt werben, leḅtere

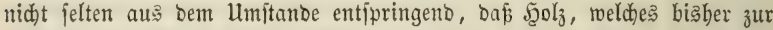
Dečung von Brennbolzbedürniffen abgegeben werben mupte, burd) bie

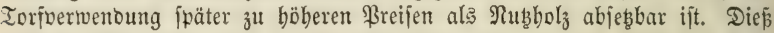

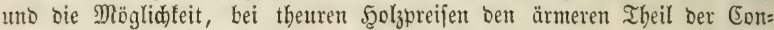
fumenten mit einem woblfeileren Brennitofife berjehen uno baburd bem

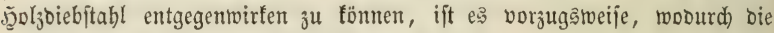

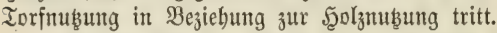

(Ergeben fich aus biejen Unterfud)ungen Şinderniffe ber Torfmuß̧uty

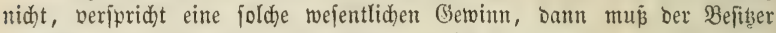
zutächit zu ben $\mathfrak{A}$ rbeiten ber Entroäfferung fdreiten.

Die Entwäfierungsarbeit ift verjdieben, je nadbem bas Torflager ein Sodjmoor ober ein Fennmoor ift.

Sodhmoore bilben fid in ber Regel nur in höberen Gebirgłlagen auf einem, bie Feudhtigleit nidgt burd)laffenden, muldenförmigen Boben, bem auper reidliden atmoiphärifden Nieberfolägen aud) nod) langiam fliepen: bes Duelltwajier zugeht, in Folge befien eine Berjumpfung entfteht, bie ber Begetation, bejonders der Sumpfmodie (Sphagnum) günitig ijt. Die unterften älteften Gienerationen biejer Sumpfmodje fterben $a b$, regeneriren iid) fortsauernto an ihrer Dberflädhe, wodurd) im Berlaufe ber Beit bie Moosjfchidten hügelförmig über bie Bobenoberfläd)e emportoadjen, wäbreno Durch Capillarität bą $\mathfrak{W a f j e r}$ aus ben unterften, Durdh bie Sdiwere ber vberen Moosidididen comprimirten Sagen fortbauerno zu bem oberjten nod vegetirenten Moospoliter emporiteigt. Im Berlaufe von Эabrl)unoerten

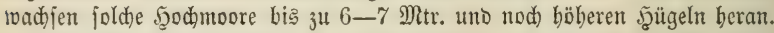

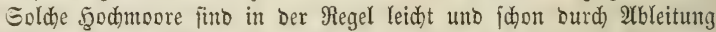

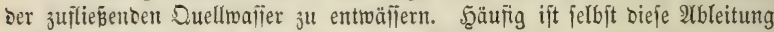
nid)t nothwentig, bas Moor fant ohne Beiteres bon feinem am böd)ften gelegenen Ranbe aus in ङtidh genommen werben. Dagegen ift aber ber 
Tori meift ein leidster, menig brennfräftiger Mlooštorf, ber nur it feinetr älteften, meift wohl aus vorbiftorifcher 3eit ftammenden હdjichtungen,

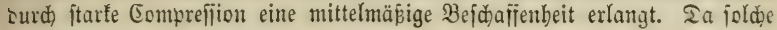
5od)moore meift nur in fehr feudtem Silima fid entroidefn, ift bier aud

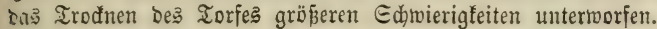

Je nnmoore bilben fid aus ftehenoen Getwäfiern, bie in ber Regel ihren Mafjergebalt nidyt von außen, fonbern von Duellen beziehen, die bem Ballerbefen felbit entipringen. Soldhe, mebr in ben Ebenen unt Tieberungen als im Bebirge vorfommente Berwäfier überzieben fich vom Mande aus allmäblig mit einer Ediđate von Moofen, wie mit zablreiđhen anberen ভumpf = uno $\mathfrak{B a f f e r p f l a n z e n ~ u n o ~ b i l o e n ~ f i d ~ z u n a ̈ b j f t ~ z u m ~ J e n n ~}$

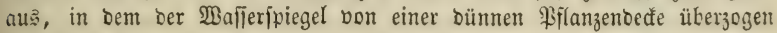
ift. 2Auch bier fterben bie älteren $\mathfrak{B f l a n j e n g e n e r a t i o n e n ~} a b$ uno regeneviren fid oberflädlid. Die abgeitorbenen \$illanzen erleiðen aber eime meiter: greifenoe 3erieb̧ung ala im 5ुodmoore, wabrideinlid unter Mitmirfuntg

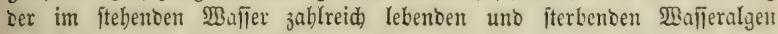
uno jnfujorien. 2Uls ftrufturloje, id)lammähnlide Eubjtanz finfen fie auf

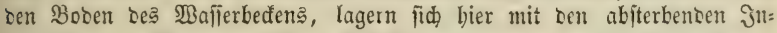
fujorien uno Algen zu richten Edjidten fo lange $a b$, bis burdh fie ber

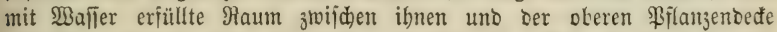
gänzlid berbrängt uno mit Torf auşgefüllt ift. Bis jeţt ift mir nod fein Fall befannt getoorben, in weldhem joldhe Torfmoore ber Ebene, wie

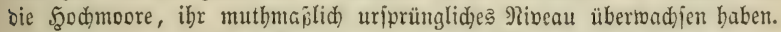

Jenumoore fino meift idwerer 3 u entwäliern, als Szodmoore, fie liefern aber oen befieren Torf, wenn er aud mit Gano uno Sebm in böherem Girabe gemengt ift, Durd bie Regengüīe, die Dieje Crobeftant: theile in bas $\mathfrak{B a f i e r b e d i n ~ z u j a m m e n i d h e m m t e n . ~ D i e j e ~ M o o r e ~ f i n o ~ i n ~}$ ber Regel zugleid aud bie ergiebigiten Durdh bie oft beträdtliche Tieje, in

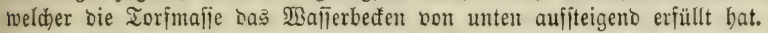

3 wijhen biefen beiben Iorfarten fteht ber Torf ber $\mathfrak{B}$ iejenmo ore, Der fid) Durd 2 erfumpfung in flachen, berbreiteten Mulden bildet, Deren

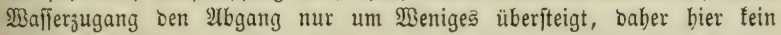

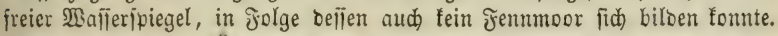
Wie in Den Sodbmooren wadjien bier bie torfbilibenden \$flanzen bon ber Gole des Moores nah oben, fie bejtehen aber borzugaseije aus Eumpi: gräjern, Binjen, Edilf uno anderen, felbjt bolzigen Wurzelpflanzen, oeren abgejtorbenen Beftanotbeile, bei geringerer Räjie, burdh reidblicheren \&uft= jutritt einen, bem Şumus faurer Biefen uno ber Erlenbrüdje fdjon ähn= lidern Torf bilisen, zwifhen bem uno bem Şumus jener, unmerflidie

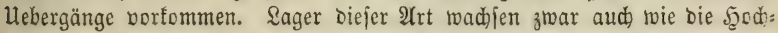

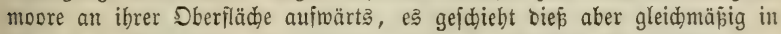
ber ganzen \$erbreitung Des Lagers, niđht in bügliden Einzelerhebungen, mahrid)einlich in Folge geringerer Eaugfraft ber rajdjer uno in höberemt (3rabe fï̆ zerię̧enden Iorfmafie.

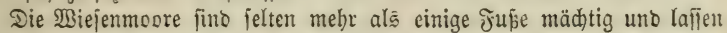

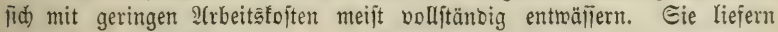
einen Iorf (meijt Rajentori), Der befïer als Der Tori ber Şodimoore, aber 
mentiger gut als Der Torf aus ben tieferen Sagen ber jennmoore ift. Sie

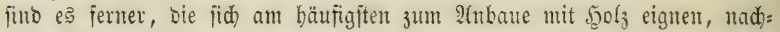
bem bie Iorfididten ganz ocer theiltweife auggenutst fints.

Menn bas in Betrieb jul nebmente Iorflager nicht fhon eimen $2(b=$

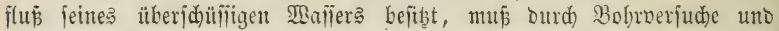
Sibellement Der niebrigite Ibeil befielben ermittelt uno bie Ridhtung be: ftimmt werben, nad) meld)er bon bort aus bas IRafier abgeleitet werben

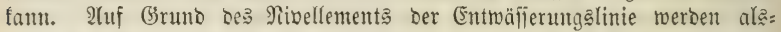
bann Die Grabenarbeiten am entfernteften Srte begnumen, nadh Lem Sager

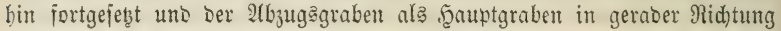
in bas Torflager binein erweitert, je nad) Bebarf eines rajcheren 2 afijer:

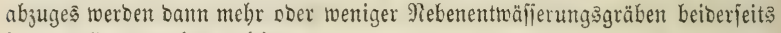
in Den Şauptgraben geleitet.

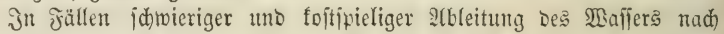
Alupen, ober wenn bie benadbarten Grundbefiţer das Redt baben, bie Auinahme und jortfübrung Des jugewiejenen Maffers ju verweigem, lafien jich jolde Sgimbernifïe mitunter überwinben, vermittelit Durdbredung

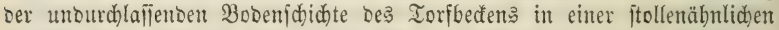
Durdjentunty Derifelben am ticiiten Theile Des Becfens, tie Das $2 B a f f e r$ in

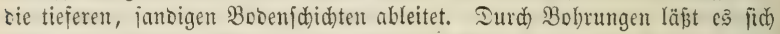
ohne grobe Solten ermitteln, ob folde Durdbbrechungen mit Bortheil aus= jührbar fino oder nicht.

Nachoem ber gröpere Theil Des, bett Etid behindernon Bafiers ab: geflofien ift uno ber Torf fid) etroas gejeşt hat, fant mit bem Stid bes gonnen werben. Man mählt bazu in ber Renel bie böher gelegenten, aljo

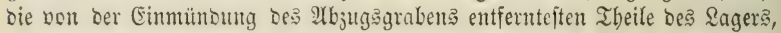
räunt Die oberite, nod) nid)t mub̧bare $\mathfrak{B} f$ lanzentede (Bumfereroc) ab. Bermittelit flacher uno idmaler હtedfidhaufeln bon Eifen merben bann bie Toriftücte (Eoben) in vorgejdriebenem Maape bantweije ausgeftsd)en, auf troctentm Boben auperbalb ses Etides in fleine Irodenthaufen gejebst uno in .̧aufen von 1000 Doer vom Mehrfachen biejer Etüđzahl zujammengefeb̧t, nadbem bie Soben lufttroden getoorben fint.

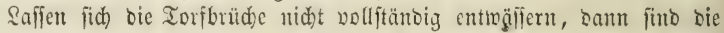
unteriten, beften Torflagen, vom Mafier Durdborungen, oft jo weid) uno breiig, baj fie fich nid)t fteden lafien, fonbern gejdöpft werben müffen. Die breige Majie wirb Dann in offene, auf bem Bosen ftehende Rabmen eingefüllt, in benen bic Torfmafie verbleibt, träbreno bas $\mathfrak{B a f f e r}$ in ben Boben einfinft. Sit biế gröptentbeile gejohehen, ber Iorf baburd) genü= gent feft geworden, Lam werben bie Jormen binweg gentommen und bie Eocen in Trodenbaufen geftellt. 3um Interifiebe nom gemöhnlichen Sted)= torfe heis̄t Torf biefer 2Art form= ober Bactorf, aud) Baggertorf, went bas Material vermittelit grobleinener Eäcfe an langen Etangent aus ber Ed)lammidjichte ftehenter Getwäfier emporgeboben tourbe.

Tiefere Torflager erfordern weniger Afrbeitstoften ser Sieminmung als

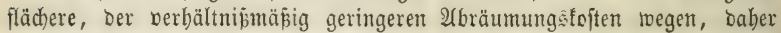
Dann felbjt bei günitigen Torfpreifen Lager unter $1 / 2$ Meter Mädtigfeit unbenub̧t bleiben, ba bie Soften Der æxbräumung uno bes Jortichaffens ber 
Bunfererbe ben Gervimu abjorbiren. Bei $1-2$ Meter Mädtigfeit Der Sager fann ein 2 trbeiter täglid) 1-2000 Eosen itedjen, wenn bieje nid)t

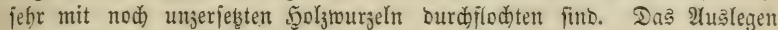

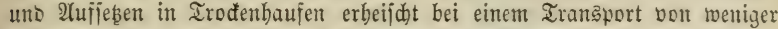
als 100 Edrritte $1 / 3-1 / 2$, Das Áffiebzen in Winterbaufen $1 / 6-1 / 4$ Tage= lohn pro Taufent Eoden.

Baggertorf uno bie Frormtorie aus ben unteriten Edjidjten ber Jenn=

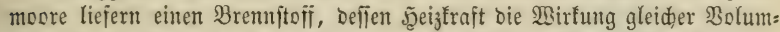
theile Buddenideitholz nid)t felten erreidt. Sleid)e Bolumtbeile Torf von mittlerer Brenngüte, mobin namentlic) oer Stid)torf Der Fennmoore uno bie jhledteren Bactorfe gebören, baben Den balben Brennmerth von Budhen= ideitholy. $3 \mathfrak{3} 1 / 3$ bes Budentronntwerthes fann man gleidhe Bolumtheilc bes Rajentorfa uno Der oberften Єdjidten des Jenntorfes anjeţen, wäbrento Der Mooștorf ber Şodmoore faum $1 / 4$ Der Brentgüte bes Buchentholzes erreidt.

Wenn bie Iorfbrüd,e nid)t böllig troden gelegt wurben uno bis unter ben Hleibenten $\mathfrak{B} a f f e r p i e g e l$ ausgenubst fino, fann man auf eine, allerbing langfame Wiebererzengung ber Iorfmaffe redunen. 2(m rajdeften toadfent bie 5ुodmoore nady. Man fann bier auf eine jäbrlidje Edjidterböbung

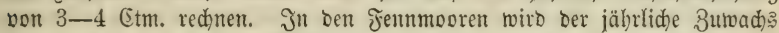
auf $1-2$ Etm., in ben sisiefenmooren auf $1 / 2-1$ Etm. angenommen.

$3 u r$ Serminderung Der Transportfoften, jo wie zur Eteigetung bes Seizeffects ijt häufiger bie Berfohlung Des Torfes in Meilern, Sefen ober

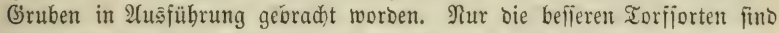
bierzu mit Bortbeil verwenbbar, aber aud) nur joldje bejiere Eorten, beren 2(jd)engebalt fein zu großjer ijt, weil übergroßße Slichennengen in bem,

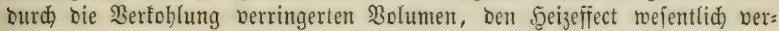
ringern. Ia nun gerabe bie befferen Torfe audb bie ajdereideren find,

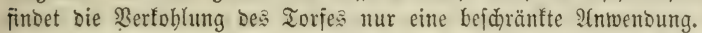

Trodener Torf liefert ben Gerwidyte nad) $25-35$ Proc. Foblen und bieje verbalten fid) in ibrer Fुeizwirfung zu gleiden Getwidttheilen trodenen Solzes $=1: 1 / 2$ bis $3 / 4$.

In neuerer 3eit fino aud Fajertorfe ju einem auperorbentlid com= paften und brennfräftigen Jeuerungșmaterial burd) Majajinen bergeftellt toorben, in benen bie Jajern zerfleint werben, um fie Dann, in einen fteifen Brei vermanbelt, in Eentrifugalmajdinen rajd uno bollftändig zll einer jebr barten bidten Majie einzutrodinen.

Sino die abgebauten Iorflager jo weit bauerno entmäilert, Laß̃ ein 5olzanbau ftattinden fann, Dann fint Birfen, Erten, Riefern am meiften bierzı geeignet.

\section{马̊meites Sanpiter.}

2om 2 alogetwerbebetrieb.

Ulle biejenigen (seidäfte, ourd) weldye bie Mohprobutte ses Walbes in ibrer Jorm uno Bejchaffentheit weiter veränbert werben, als bieps bie

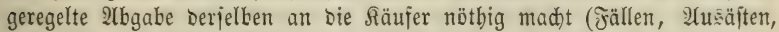

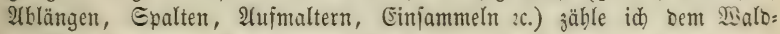
gemerbebetriebe з̆น. (E) gebören babin: 
A. Shne Gtoffoeränoerung.

I. Der Gägholzbetrieb,

II. Der Spaltholzbetrieb,

III. Der Edynittbolzbetrieb,

IV. Der Bino = uno Flechtholzbetrieb.

B. Mit Stoffoeränoerung.

V. Der Röhlereibetrieb,

VI. ber Ibeeridinelereibetrieb,

VII. bie ßedjitederei,

VIII. sie Rienrupbereitung,

IX. Das 2 (j) bebrenten.

\section{I. Đom Sïnlıolzbrtrielue.}

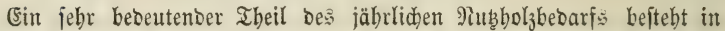

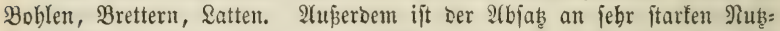
holzblöđen an vielen Drten ein bejdränfter uno ber $\mathfrak{B a l b b e f i t z e r ~ f i e h t ~ f i d ~}$ bäufig genöthigt, ftärfere $\mathfrak{B l o ̈ d e , ~ w e n n ~ f i e ~ a l s ~ f o l d h e ~ f ́ c i n e ~ I t b n a h m e ~ f i n o e n , ~}$ zu gewöhnlicheren uno gefudteren Baubolzoimenfionen vermittelft ber Eäge

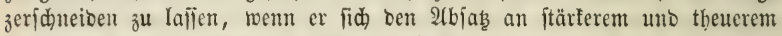
Sुolze nid) ganz verberben will, burd) 2(bgabe foldher ftarfen Şölzer in ganzen Gtämmen zu Bauholźreijen. 2(uß̌erbem jteben bem 2tufidneiben ciner, bem $\mathfrak{A b j a \not ̧ a ~ a n g e m e f i j e n e n ~ M e n g e ~ v o n ~ S t a ̈ m m e n ~ z u ~ B o b l e n , ~ B r e t t e r n ~} 2$. nod) andere Bortheile zur Eeite, wenn bié́ fónon im $\mathfrak{B a l b e}$ vor bem $\mathfrak{B e r}=$

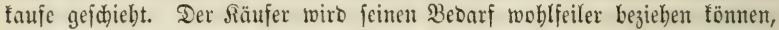
wenn er es mit feinem 3nifdenbänoler zu thun hat, ber bod aud von feinem Bejdäft leben uno dic Baare um biefen Betrag vertheuern muई́;

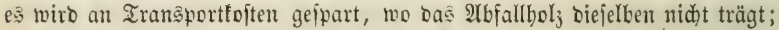
Der Iranąport fdwererer Etämme wirb nad) bem Beridneiben ein leid)terer; bie genauere (Sinfidt in die Bejdaffenbeit des zu erfaufenden Scolzes, die

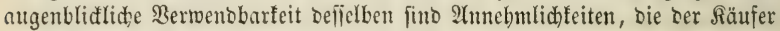
Durch böheren Freis gerne bergütet.

Der Sägholzbetrieb fanm entweder aus ber Şano ober auf Gäge: müblen gefübrt weroen.

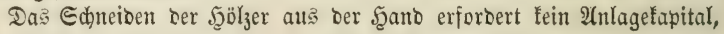
feine bejondere Berwaltungs: uno Beauffidtigung:toften unt fann von genöbnliden Waldarbeitern, unter 2Inleitung eines Bimmermann fehr balo erlernt werben. Der Betrieb fann baher ohne Edaden fürzere ober längere 3eit ausfeben uno ba zu jeber 3eit in Antwentung gejest weroen, wo bie Berbältniffe ibn vortheilbaft eridgeinen lafien, es famn bieß unmittelbar am Drte ber Fällung gefdel)en uno baburd) ber Tranßport aus ungünftigen Lagen febr erleidtert werben.

Dagegen bringt bie gröbere Şantofäge nahe Dą Doppelte an Eäge: fpänen in Wegfall als bie Dünnen Etabljägen im Bunogatter ber neueren

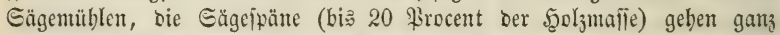
verloren, bie breitejten uno baburd werthpollften Bretter verlieren an ihrer Breite ourd) bą nothwentige Bejdlagen ber Sberjeite uno bie Bretter 


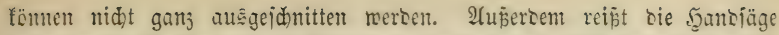
tiefer in bie Bretter, Der Iijhler soer Bimmermann mus beiberfeit me hr

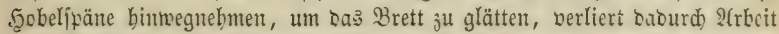
un Brettoide. Entolid rörbe für bie Şerftellung gröp̄erer Brettmengen in ben meiften Füllen bie nötbige Arbeits̄fraft feblen, Da kei gewöbnlicher

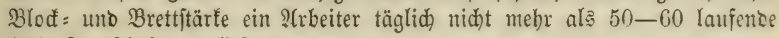

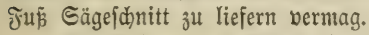

In Eidhen = uno Nabelholgmaloungen mit einigermanen erheblichem Edneiobolzabjałs wiro Daber cin Gägmühlenbetrieb immer wünidenștorth

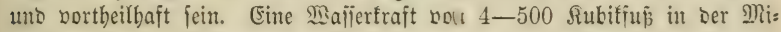

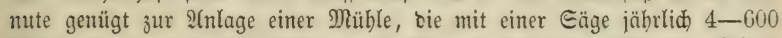
Blöđe fanteioen funn. Dieje getwöhnliden mit einer Gäge am Bloče arbeitenden $\mathfrak{M}$ üblen bedürfen aber ftarfer Єägeblätter, liefern raube Bretter

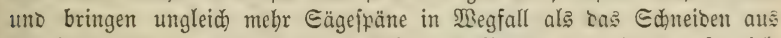
ser Sano uno die neueren Eägemüblen mit Bunogatter, in Dem fo vicle Eägeblätter farallel neben einanoer in ber Entfermung ber Brettbide ein=

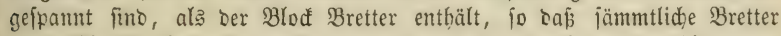
cines Blođes gleidzeitig geidnitten merben. Die 3ahl Der Eägeblätter er:

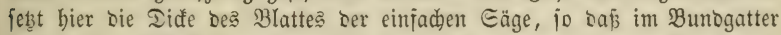
viel bünnere Eägeblätter berwenbet werben fönnen, wooburd ber Eägelduitt

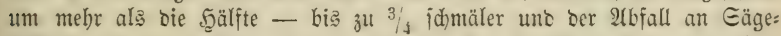
fränen um bie Şälfte geringer bir als bei ber Berwenbung einzelner Eägen. Der Edjnitt ift zugleid) fdärfer, reift mentiger in bie Bretffläd)e uno erleichtert bie frätere Bearbeitung mit Dem Şobel wejentlid). Meühlent biejer (sinriḑtung fömnen tägliç) $12-14$ Blöđe auf jeoem Buntgatter ¡tmeiden, bas Jahr binourd baher bebeutenoe Brettmengen liefern.

Diés alles funo io wejentliche Bortheile eines möglichit volltommenen

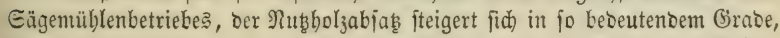
surd) Die Darftellung einer tabelfreien Waare, daj bie fioften ber Afnlage einer mit allen Bervollfommnungen bes neueren Majobinentwejens augs: geftatteten Єägemüble fich überall vergüten werben, wo ber 2 bjał̧ an Brett: maaren ein fo bebeutender ift ober zu werben verfpridht, baf cine fort= cauternoe Beidäiftigung Der Mühle in 2(uज̂ficht iteht.

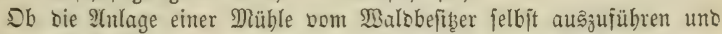
unter 2(bminiftration ju ftellen ober zu verpad)ten, ob fie ser Prinat= inoujtrie зu überlajien jei, bängt zuntäbjt von Dem Borbandenjein zuber= läfiger uno vermögenter Unternebmer $a b$. Firtoen fid folde vor, bann

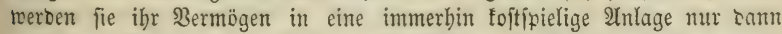
verwenten fömnen, wenn ihnen ber Malobefiker bie 3uficherung fortbauen= ter Sieferung Des Robmaterials gewäbrt uno zwar zu ßreifen, die ben übliden Gewinn aus bem Unternebmen fidher ftellen. Dieje notbwentigen

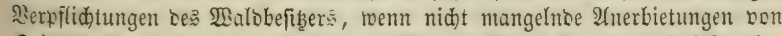
Eeiten anderer ßerfonen, fino es, weldhe ben Malbbefiţer jutm Eelbitwerlag uno Eelbftbetriebe beftimmen fönten. Im Allgemeinen wiro er fid aber

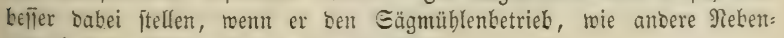
getwerbe, Der \$ribatimbujtrie überlaffen fanm.

Die peridiebenten, burd ben Gägebetrieb herzuftellenten maaren fino:

şartig, \&efrbuc) für förfter. II. 


\section{1) Rrummbörzer für ben Sdiffbau,}

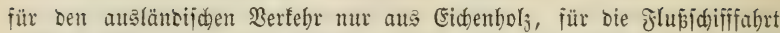

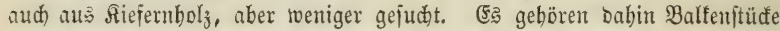

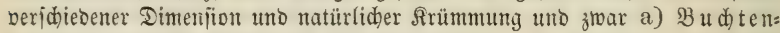
böljer, went bie Rrümmung eine bogenförmige, b) Shölzer, wetm die Rirummung von ber Mitte Des Balfenitüđs aus eine nad) ztwei entgegent=

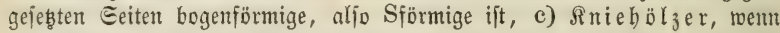

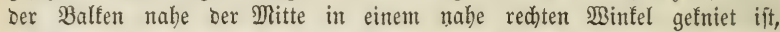
d) (G) a belbölzer, wenn ber Balfen nabe ber Mitte fid) gabelförmig theilt. (jabel= uno Sniehölzer werben aus einem Ed)aftitüd ba ausgearbeitet, too für erftere in gleider şöhe żmei, für lebstere mux ein ftarfer 2 fft ober

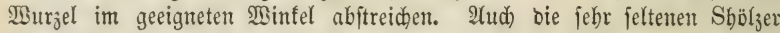
Finten fich meijt mur in ber Eontimuität bes gefrümmten Sdaftes mit einem itarfen 2 jite, bie Budbten häufiger in Edaftittiden allein.

Zlle bieje 5ölzer werben fehr theuer - bis zu einem Thaler und

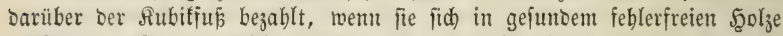
vorfinden. Somment Eidenbejtände mit unregelmäbigem Sdhaftwudje zum

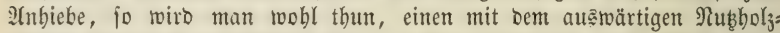

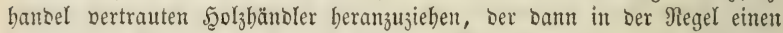

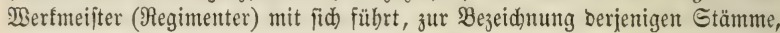

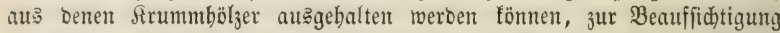

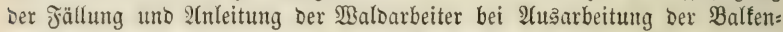

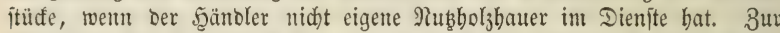
Eriparung von Transporttoften uno um borbandente Febler fdon im $2 B a l d e$

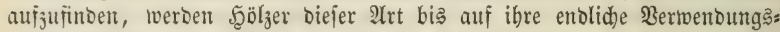

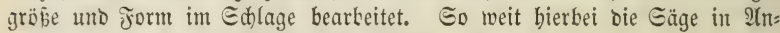
wentoung tritt, fam biés mur bie Şanojäge fein.

\section{2) Balfenitü de}

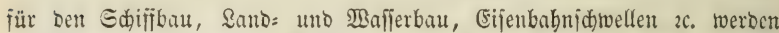
im Edjlage ober auf ber Mäble mit Der Gäge in ber Regel nur bant bearbeitet, wem auڤ ftarfen Stämmen eine Mebrzabl jobwäd)erer Balfen= ftüde gefdnitten werben joll. Der Berfauf in runben Blöcfen ift zwar immer vortheilhafter, ber Malobelïber fann aber zum 2lufidneiden ftarfer Blöfe in Balfen genötbigt werben, wenn foldhe als theureres Rundboly feine 2lbnebmer finben, ba befien Berfauf ju Den geringeren \$reijen Des

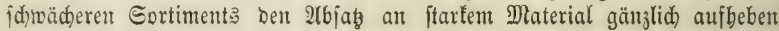
würbe. Ė ijt bießs biefelbe, im eigenen Jnterelle gefübrte Bevornumbung

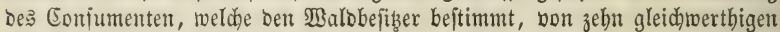
Bäumen mit erbeblichen Roiten ncun zu Brembolz aufarbeiten zu lajien, Den jehnten, mit biejen Roften nidgt belafteten Stamm bem Enfiumenten

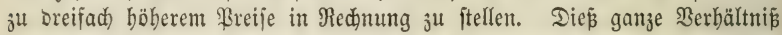

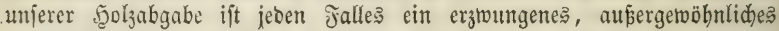
uno unnatürlidkes uno es ijt fraglid: ob nidht unter getwifien Bebingungen

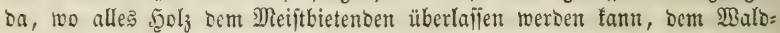
befiber ein gröferer Geminn ermadffen würbe, aus ber Albgabe aller 


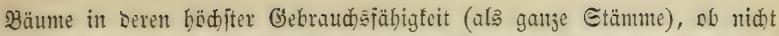

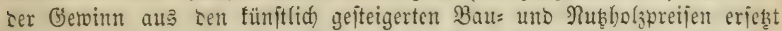

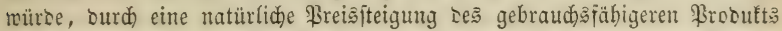
im. Allgemeinen. Jecen Jalles twürbe ein bieraus herborgebendes 9ivelles

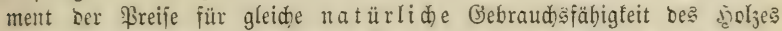

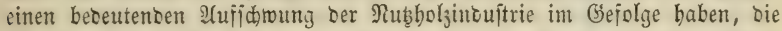
wir burch fünftlich gejaraubte शuţholjpreife zu unjerem Edjaben bntieder balten.

\section{3) Boblen und Bretter}

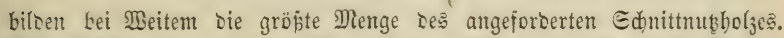

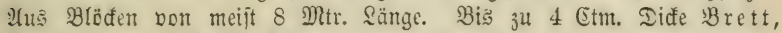
über 4 Ctm. Dicte $\mathfrak{B}$ oble genaunt. $3 \mathfrak{u}$ Brettern ijt bas gejundefte,

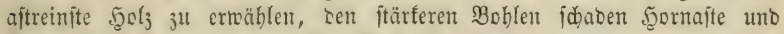

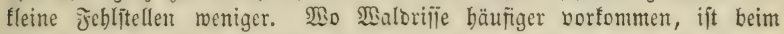
Uuifidneiben barauj ju acțten, daj jolde in ben Eägejdnitt fallent.

\section{4) Satten.}

Menn bie 3u Brettern ober Boblen gejd)nittenen Blöde in recht= winflig jich freuzenoer Ridtung burdidonitten werben, entitebt baourd bie Satte. Edwäßjere Sattjtümme ionneibet man auch bermittelijt Der Rreis̄jäge.

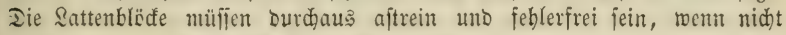
biele Satten an ber Jeblitelle brechen follen.

\section{Der Sunltjoli̧betricl.}

Fap̧cauben, Felgen uno Ereidjen, ভdjindeln, Eplieken 2c. fino furze

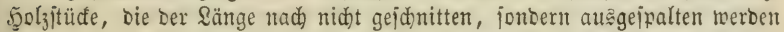

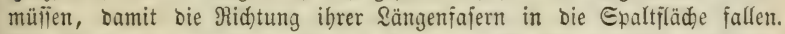

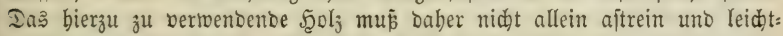
ipaltig, jonbern es mú auch grabipaltig jein, Damit bie gegentiberliegenten Seitenflächen zu parallelen (Ebenen fid̆ ausipalten.

Ia Der Spaltbolzbetrieb feine foltipieligen Sorridutungen erbeifht, ift

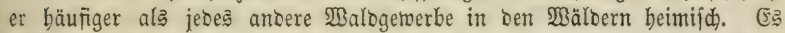
fteben ihm aber nod mandhe andere Bortheile zur Geite. Bejonders ift

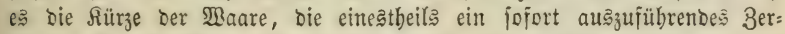

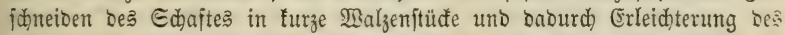

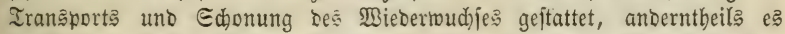

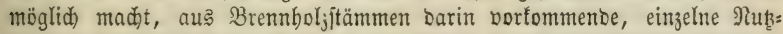
holzwalzen auşzubalten. Das jofort nach Der Jällung eintretente Berlegen

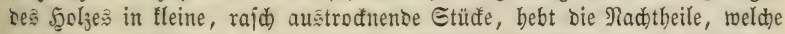
Der Şieb ber Bäume in Der Eaftzeit behufs ber Rindenub̧ung in Bezug auf Tauer bes .̧olzes mit fich fübren würbe, baber ber Epaltbolzbetrieb

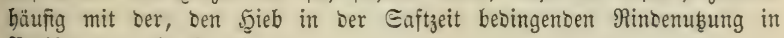
Berbinoung gebradt wirb.

Nabe baijelbe erreidyt man allerbings burch bie $\mathfrak{A}$ tifbereitung vout

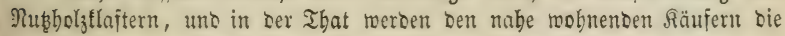


Gpaltbölzer größtentbeils in biejer frorm abgegeben. Für bie entfernter wohnenden Confumenten ift es aber eine bebeutenbe Erfparni的 an Irants:

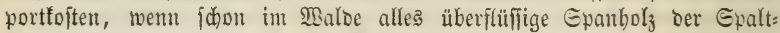

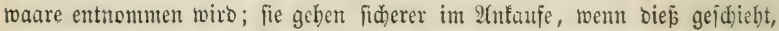
ba mandes Scheit Der Nubbolizflafter bei weiterer Bearbeitung Dod nidat fo außfällt, wie bieß Der Malbarbeiter voraußgejetzt bat, enolich tritt bei

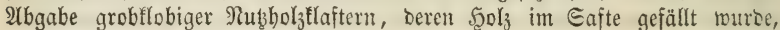
weit eher ein Etoden ber Säfte ein, als̄ wem bie Epaltwaare fofort nach ber fällung möglidjit flar auşgepalten wirb.

Die veridjiebenen, im Walbe bäufiger gearbeiteten Epaltwaaren fint:

\section{1) $\subseteq t a \mathfrak{b} \mathfrak{h o ̈ l} \mathfrak{z} \mathfrak{e r}$.}

Man verfteht barunter bas $\mathfrak{S}_{0} \mathfrak{l}_{3}$, was von Böttcher zu ben Dauben uno Böben Der Fäfier unb Bottide 2c. werarbeitet twirb. Für ben auजs:

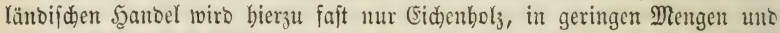

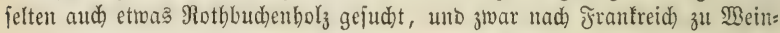

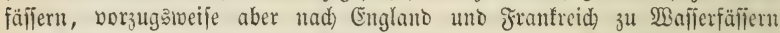

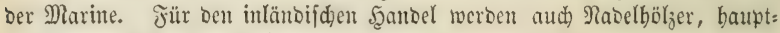
fäblich zu Ralf: uno Salgtonnen vermentet.

(Fid) en, Stabholz:

Bent in ciuem anzugreifenden (Eic)enbeftande Stabbols gearbeitet werden

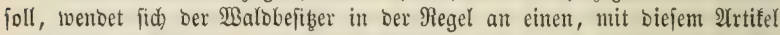

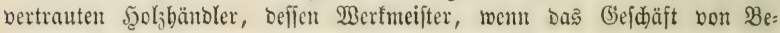

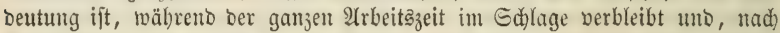

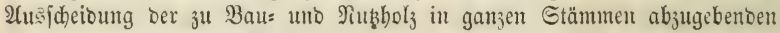
Bäume von Seiten Des $\mathfrak{B a l}$ befizers, aus Den übrigen Bäumen nach beren

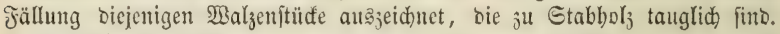

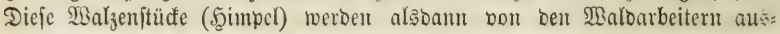

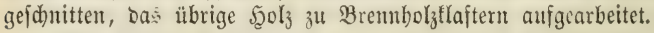

Die meitere Bearbeitung Der außgehaltenen Scintpel ift in ber Regel nidht Gadje ier gewöhnlid)en Saldoarbeiter, oa bieje 2(rbeit befonoere Rennt: nifife uno Jertigfeiten erbeif(d)t. Entweder ftellt oer Şoljhänoler bie Stab= holzichläger, ober ber Malobefizer jud)t fich fold)e aus Rebieren zu ver: fidaffen, in benen bäufiger Stabbolz gearbeitet murbe, umb biefe $\mathfrak{A r b e i t e r}$ ein bejonderes Getwert bilben.

Die aus Den Şimpeln zu arbeitenden Gtabholjfortimente fino:

Biepenitäbe $5^{\prime} 2-4^{\prime \prime}$ lang, $1 \frac{1}{2}-2^{\prime \prime}$ bicf, $4-7^{\prime \prime}$ breit. ${ }^{1}$

Drboftitäbe $4^{\prime} 2^{\prime \prime}$ lang, $1^{1} / 2^{\prime \prime}$ bič, $5^{\prime \prime}$ breit.

Ionnenitäbe $3^{\prime} 2^{\prime \prime}$ lang, $1 \frac{1}{2} 2^{\prime \prime}$ bidf', $4 \frac{1}{2}-5^{\prime \prime}$ breit.

Drhboftbodenjtäbe $2^{\prime} 4^{\prime \prime}$ lang, $1 \frac{1}{2}-2^{\prime \prime}$ biff, $4^{1} / 2^{\prime \prime}$ breit.

Ionuenbobenftäbe $1^{\prime} 10^{\prime \prime}$ lang, $1^{1 /} / 2-2^{\prime \prime}$. bid, $4^{1} / 2$ " breit.

Franjholz $3^{\prime} \cdot 2^{\prime \prime}$ lantg, 5 -6" im Duabrat.

Rlapploly $2^{\prime} 8^{\prime \prime}$ lang, 4-5" im Quabrat.

Dicje Stabbölzer weroen in Rinfen verfauft uno entbält ein ßinfen

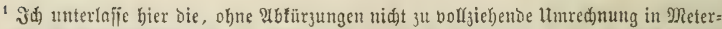
mañe, da cs mir unbefannt ift, ob Dem entipredente Aenderungen in Der qraris bereits eingetreten find. 
Biepenitäbe 24s, Exhoitjtäbe 372, Tomenitäbe 496, Sxrbejteosenjtäte 992 ,

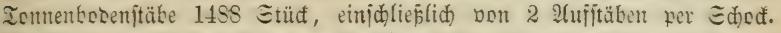
Fer Preiß per Rinfen ijt in Der Regel Derjelbe, es may biejer aus \$ienen= jtäben ober aus Sobenitäben bejtehen.

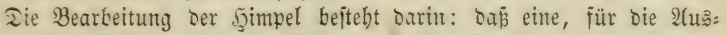

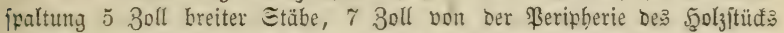
entjernte, concentrijoce freislinie ber Dueriläd)e in voll $230 ̈ l l i g e$ Theile getheilt wirb. Jeber ber auf bieje Weije bejtimmten Theilpuntte gilt bann als Marfe einer rabialen Epaltung. Die bicrourd) erbaltenen Echeite werben al3bann vermittelit eines idj)eren Stabiallägerbeiles jull einem regel= mǟigen Balfenitüufe von obigen Dimenfionen kebauen, ·jebenfall bie ganje Eplintlage babei hinweggenommen. Es马 ift betwundernbiberth, mit weldher

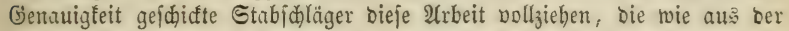
Berfitatt bes Tijhlers berborgegangen eridjeint.

Die bearbeiteten (gebeilten) Etäbe merden je jłmei uno jwei abivech)= jelno über einantor gelegt uno thurmï̈rmig aujgebaut, bei einer Thurm: böhe von 5-6 Jusen, oben mit Etäben gebefft uno mit einigen idweren Echeitern bejdmert. Sino jie in biejer Aufiftapelung rajd getrodnet, bam

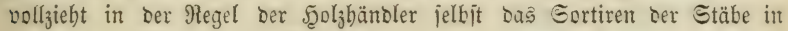
Rrongut, $\mathfrak{W r a d}$ uno $\mathfrak{B r a f t w a d}$. In exiteres tommen alle voll= uno übermaß̄baltigen, burchaus feblerireien, in bas Brad biejenigen, Durd) зи geringes $\mathfrak{M a j}$ minberwerthigen uno joldje Etäbe, Deren geringe

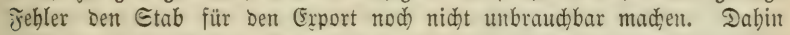
gehören; grobe Ter̨tur, Rotbitreifen, Die beim 2Atstrodinen beridjwinden, fleine gejunbe 2 (jitfleden, geringe $2(b$ weid)ungen ber Beilfläche von ber Epalt=

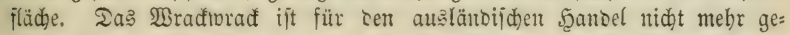

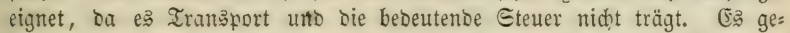
hören bahin bie flüglig unt bie über ben Epan gearbeiteten Stäbe, joldhe

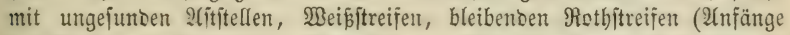

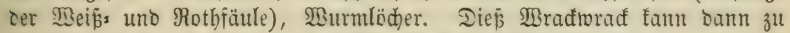

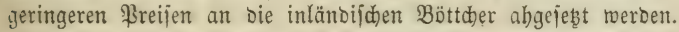

Bei Şimpeln über 30 3oll Durdmener red)net man auf jebe $5-6$ 3oll Umfang, bei Simpeln von 20-30 3oll Durdmelier aui $6 \frac{1}{2}-7$ 3oll, bei geringerer Stärfe auj alle 8 3oll Umiang einen Etab. 5ुat man bie

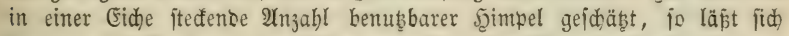

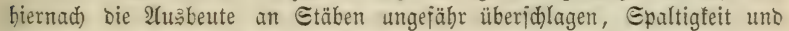
G'ejunถbeit voraußggeję̧t.

Bei Contrabirung mit Sgoljhändlern ift es ratbfam, Denjelben leine jejte 3uīderung beftimmter Mengen зu geben, jonbern ifnen mur bas зu=

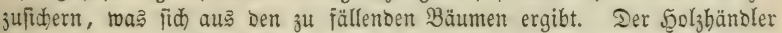
ijt bann meniger wäblerijch uno man fommt nid)t in bie \&age, mehr (Eid)en

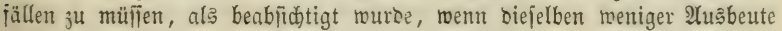
an Stäben ergeben, als man vorausgeję̧t bat.

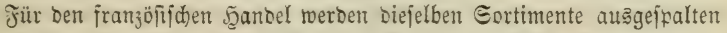
und gebeilt. Die Sänge ift biejelbe, Die Breite und Dicfe aber etras ges ringer, $3-4^{1} / 2$, rejp. $1-1^{3} / 4$, 30 ll.

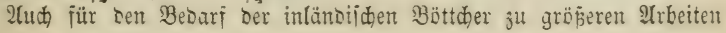


gelten biejelben Dimenfionen ber Stäbe, biefe werben aber in ber Regel nur auşgejpalten, nidjt gebeilt.

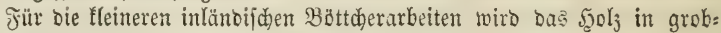
flobigen Nuţholjflaftern von 1 Mtr. Edyeitlänge abgegeben.

Radelbolzitäbe

ju $\operatorname{Ralf}=$ uno Ealztonmen, fo wie für viele Böttcherarbeiten im häuşlid)en

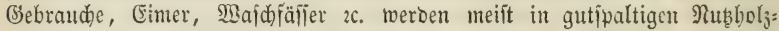
Ilaftern von $1 \mathfrak{M t r}$. Sdjeitlänge abgegeben uno mur in ber Mähe von Salinen,

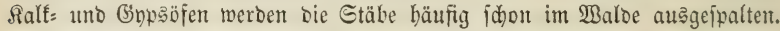

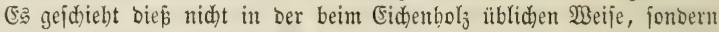
es wiro ber Sुimpel zuerft in Edheite von 7 3oll Stirnbreite zerlegt, bon jedem Edjeite Der Rern bis 3ll 4 3oll 3reite, Dann Rinde uno Eplint io

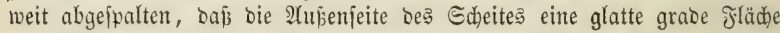
Darftellt uno endlid) in ber Rid̆tung parallel biefer Fläble, aljo in tangen: taler Rid)tung alle 3 oll ein Stab ausgeppalten, Deren Breite baber eine veridjebene, zwijden 7 und 4 3oll jobrwanfende ift. Je 60 Stäbe jollen zufammengenommen 310 3oll breit jein. Der Rinten bält 248 Etäbe. Man verwendet auf joldhe Durdjidnittlid) 50-60 (ubiffú Şolzmafie uno

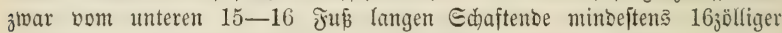
Stämme. Sgöhere Edhufttbeile fino nidht mebr genügend fpaltig.

\section{2) Jelgenbol?.}

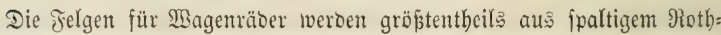

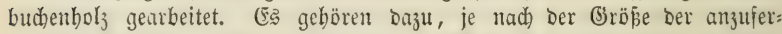
tigenden Rabfränze, 60-100 $\mathrm{Etm}$. lange Rlöbe bon minbeftents $40 \mathrm{Ctm}$.

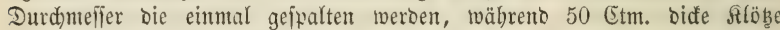

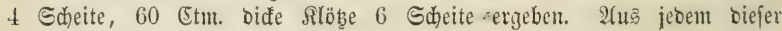
Sheite wirb alsoann ein Balfenftüa von 10 (5tm. Dide uno 20 Etm.

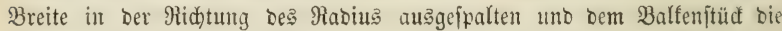

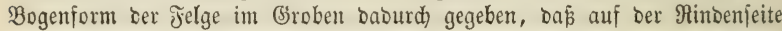
beiberfeits bie Enofanten zur Darftellung Der converen Seite, auf ber ßern=

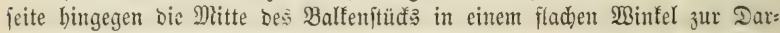

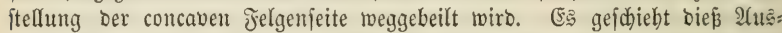

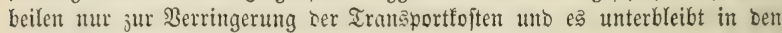
meiften Fällen, bie Jelgen werden als gerabe Balfenitülée abgegeben, wenn ber Transport fein meiter ift.

Die geringite Menge von $\mathfrak{A}$ bfallfolz erfolgt bei Berwenoung $50 \mathrm{Ctm}$. bicfer Rlöbe, bie, über Rreuz gefpalten, vier J̈elgen liefern.

Da Die Berarbeitung jull Felgen einen böheren Grao von Exaltigfeit

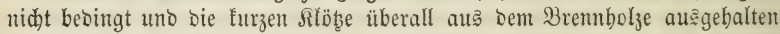
werben fömnen, bie 2 (nforberung feine unbebeutenbe uno eine jäbrlidy roieber: febrenoe ift, hat ber Jorftwirth um fo mehr Darauf Bebacht zu nchmen,

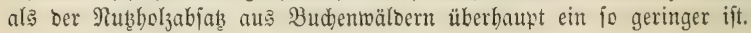

3) Speidenbolz.

Das Material 3u Rasfpeichen wiro gröptentheils aus jungen gefunden Eidyen: ober Ejdentlöben von $30-40$ Etm. Etärfe uno $3 / 4-1$ Mitr. 
Qünge, in einer Diçe von 6-r Ctm. in Suabrat ausgefpalten. Ia 5oll mus gut uno grabipaltig fein, ba sie Epeiden niḍt über oen Irabt gearbeitet fein bürfen.

\section{4) $\mathfrak{A} \mathfrak{x} \in \mathfrak{n} \mathfrak{b}$ ö $\mathfrak{z} \in \mathrm{r}$}

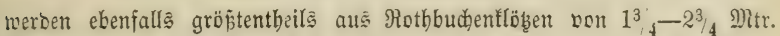

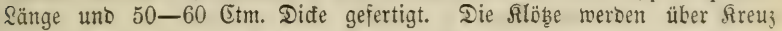

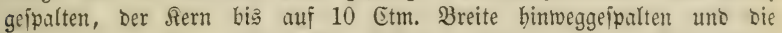

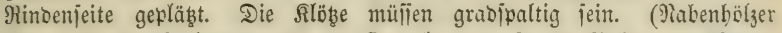

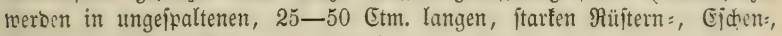
Fichent: uno Bubentlöken abgegeben.)

\section{5) $\Re$ iftenbölzer}

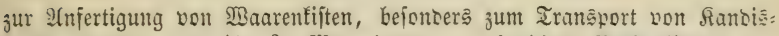
zuđer, werben aus $1 / 3-2 / 3$ Mtr. langen, gutipaltigen Buchenflöţen von ${ }_{2}{ }_{13}-3 / 4$ Mtr. Etärfe, $1 \frac{1}{2}$ Ctm. Itarfe Brettchen nach vorgeidriebenten Mapen ausgefpalten, die zu einer Rijte gehörenten Bretter julammen= gebunden uno bie G'ebunde fajodweife abgegeber.

\section{6) Edueffel und Siebränber}

werben aus $1-3 \mathfrak{M t r}$. langen, Durd)aus grabe uno gutipaltigen, fehler:

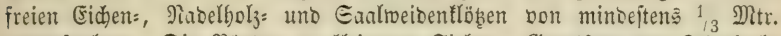

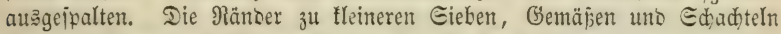

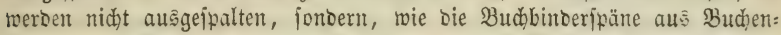

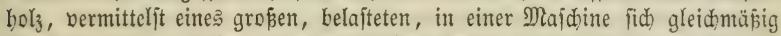

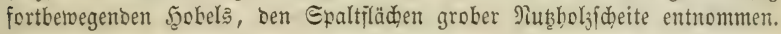

\section{7) Sdinbeln}

fint $2 / 3$ Mtr. Yange, $8-10 \mathrm{Ctm}$. breite, an Der Rindejeite $2{ }_{2}^{1}$ Ctm.

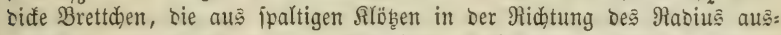

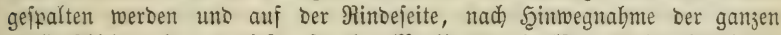

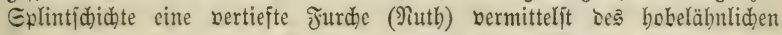
Niegeleifens erhalten, jur $\mathscr{U}$ ufnahme ber fđmmäleren Fernjeite einer zmeiten Edjindel, um baburdh ber befannten Edjinbelbebachung gegenjeitiges Эn: einanbergreifen uno befieren S2alt zu geben. Sie werben vorjugâweife aus

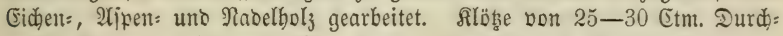
meffer fint bazu bie geeignetiten, wenn fie Durchaus grabjpaltiy fino

Um bas Rrummitehen ber fdwachen Sdinbeln zu berbinbern, werben biejelben nach bem 2luşpalten, je żwei uno żmei abredjelno, in gefreuz̆ter Richtung thurmförmig auf einanber gelegt uno in 1-2 Mtr. Thurmböhe mit fojweren Rloben gedecft uno belajtet.

Eplintrein gearbeitete Echinbeln aus gejunbem Eidjentoly liegen $30-40$ Jabre als Dadbedectung, Edindeln non fernigem Riefern= uno non 2fipen=

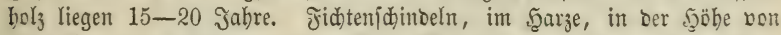
Braunlage, in geidlofienem gutwüdjigen Beftante erwadjen, liegen 15 Jahre;

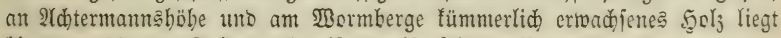

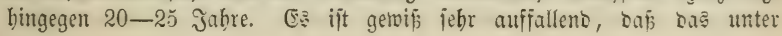




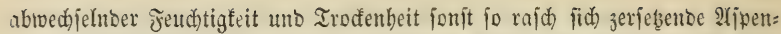

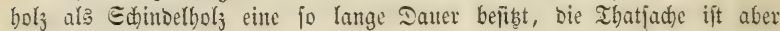
eine feititebende.

Die Ganglofiche Sdindelmajdine, in : Preife von 150 bis 200 Thaler, burd) ein Bferb ober eine gleidje Wafferfraft in Betwegung gefegst uno von einem Yroeiter bebient, liefert täglid $600-1000$ Sdjindeln.

\section{8) Splié̈en}

fint 1 Ritr. lange, 10-12 Etm. breite, 1-2 (5tm. Diffe Brettchen juแr

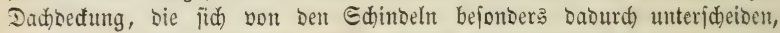

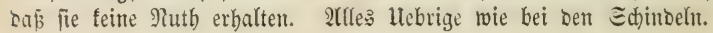

9) Daळipäne,

Brettchen von 30-35 Etm. Sänge, 6-8 Etm. Breite uno 1/2 (5tm.

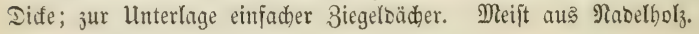

10) $\mathfrak{B}$ einpfäble

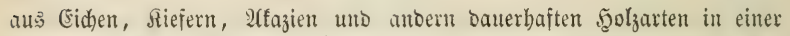
Singe von $2-2 \frac{1}{2} \mathfrak{P}$ tr., $3 \frac{1}{2}-4$ Ctm. im Quabrat ausgeipalter. Die

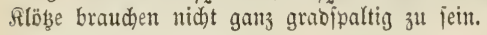

\section{1) Reifit ö $\mathrm{d} e$}

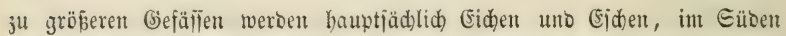
aud) bie cole Rajtanie verwentet. 2(m gejudoteften zu Böttichreifen find junge Etämme von 10-12 Mtr. Sänge uno 12-15 Ctm. Bopfitärfe, bie über Sireus gejpaltun werben. In (Ermangelung fold)er faum aber aud̆

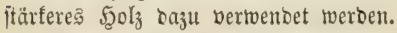

Jä́reife (3-5 Mtr. lang, $3 \frac{1}{2}-4$ (5tm. 3opfftärfe), Tonnen= reife (2-3 Mtr. lang, $2-3$ Etm. 3opiftärfe), Eimerreife (1-2 Mtr. lang, 1-2 (stm. 3opfitärfe) merben bauptfäd)lid aus jungen Birfen, Scajeln, Weiben fadoctweije in Punden abgegeben. Das Epalten überläpt der Malıbefiţer Dem Räufer.

12) Beitfdenftiele.

Die befaunten, biß jum ફ̧anogrifi vielfältig geipaltenen uno zoffartig

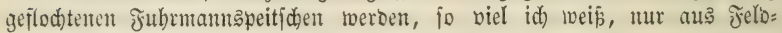
ahorn gefertigt uno bas Material baju, junge 10-15 Etm. bife Stangen, jebr gejudtt uno theuter bezablt.

13) Sdy wefelbölzer.

Dic Fabrifation ber 3ünobölzden hat in neuerer Beit eine folde 5ुöbe

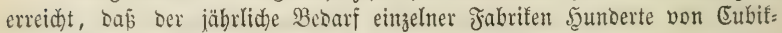
meter $\mathfrak{S}_{2} \mathfrak{l}_{3}$ überfteigt. $2(m$ meiften wiro $\Re$ abelhol Saubholy berwentet. Die Rlöbe müfien jehr grabjpaltig fein uno werbent Dejhalb fait mur bie unteren Etammenden in einer Sänge von $2-3$ Mtr.

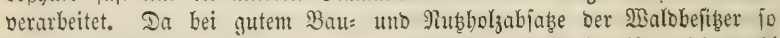

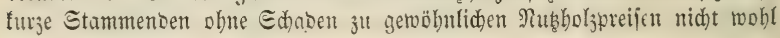




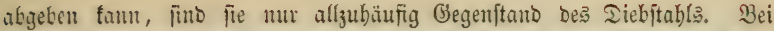

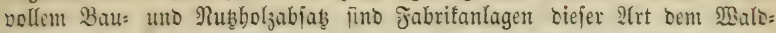

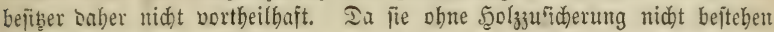
fömen, hat es Der Waltobefiţer in ber Scanto, ourch Bebingungen, oie er an jolche 3ulidjerung fnüpt, Dem llebel möglidjt vorz̧ubeugen. Dabin ge:

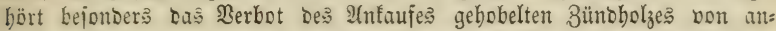
Deren Berionen, Ia eine Controle mur bamn möglid, ift, wetn ber Jabris

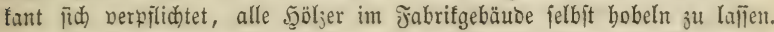

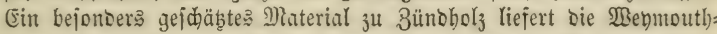

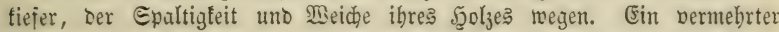
2(nbau biejer rajd)müdjtgen uno burd) Den bidjten Edblup, in sem fie er:

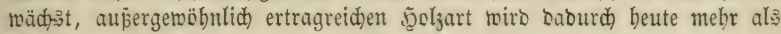
früher empfeblengtwerth.

\section{4) Bapierholz.}

Die Bermenoung von Beidhöljeln, bejonbers von Fridten, Iannen, Mebmoutblieferholz auf Ed)leifmüblen als Surrogat Der Seinenfajer jur

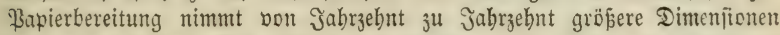

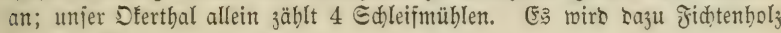
in allen Dimeniionen verwendet.

\section{Der Sdunilyolz̧betrieb.}

Befonder: in Gebirgiforften mit aug̈gebreitetem Bergbau bat ber gröpere Bebarf an Echaufeln, Trögen uno Mulben ein Gemerbe berbreitet, sas jich mit Darjtellung biejer Ultenjilien bejdäftigt. Sie weroen bier

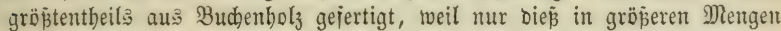

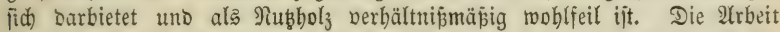
erforbert bejonoere Renntnifie uno Jertigteiten, fann von getwöhnliçen $\mathfrak{B u l}_{\text {a }}$

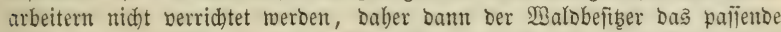

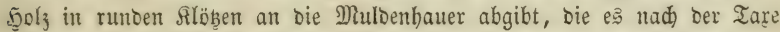

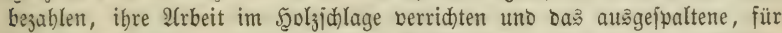

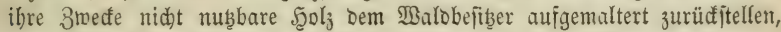
wen! biejer es nidht für bortbeilbafter bält, bie weitere Berwenoung aud

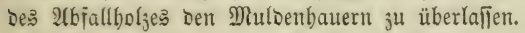

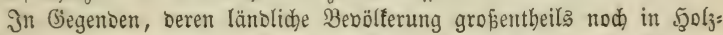
fajuben gebt, ijt auch bas Material ju biejen teine unbebeutende 2Ubgabe. Der Seidtigfeit bes Edubes und befien leidfterer Bearbeitung wegen fint

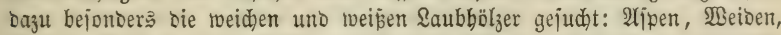
Sinben, Roß́tajtanien, Birfen, aber aud Ellern. Das bierzu taugliăe Material wiro in grobgefpaltenen Nubsholzflaftern abgegebent.

\section{Der Bilto- แnt fled)tjolzbetrieb.}

Bejonders an ben Mfern Der Fitüije uno Geen, in Meibenwerbern und

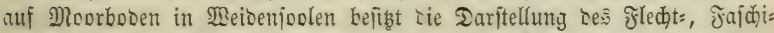
nens uns Binbmaterials nicht jelten eine herooriftechenbe Bebeutung. Wirs auch in ten meijten Fällen sas Material roh an sie Siäujer abgegeben unt 
biefen bie weiterc, getwerbs̄mäpige Berarbeitung überlaffen, fo fommen bod gerabe bier bäufiger fälle vor, in benen entweber ber eigene Bedarf Doer Die Bequemlid feit ber Räufer, ober augenblidflidjer Mangel an Arbnebmern Den Walobefiţer zu weiterer Berarbeitung jwingt.

\section{1) Sorbrutben}

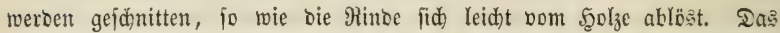
Injtrument zum Entrinben befteht in ciner leierförmigen Jeber von ftarfem

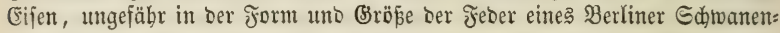
halseifens, befien Enben jebod toalzenruno fint, bidht aneinanberftehen, vom

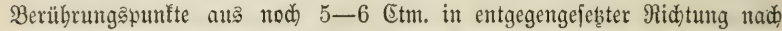
aupen gebogen. Dieje $1 / 3-1 / 2$ Mtr. Gobe Feber wiro vermitteljt Sdyrauben unto Rlammern in ber anfgeridyteten Stellung einer Snra auf einem fidweren,

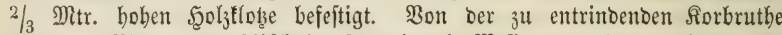

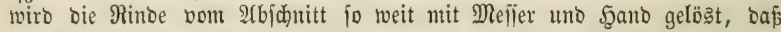
Ier $\mathfrak{A r b e i t e r ~ b a s ~ n a c t e ~} \mathfrak{S}_{2} \mathrm{l}_{3}$ faffen fanm, bidht über biejer Stelle wiro bann

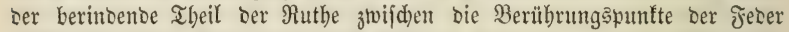
geflemmt unt bie Ruthe mit einem fräftigen 3uge aus ber vom Eifen feft= gehaltenen Rinbe herausgezogen. 1

Die von Der Rinbe entfleibeten Rorbruthen werben, wenn fie ftärfer

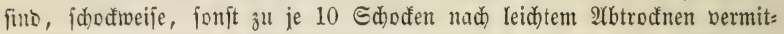
teljt Binbmeiben feft zufammengebunben, Damit fie fich im bölligen 2(btrod"s nen gegenjeitig gerabe zieben.

\section{2) Binbweiden.}

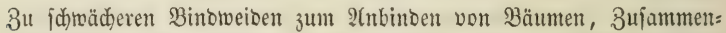
finben bon Reiligholz zc. Łömen auper ber Erle und den Raubbölzent mit weiter Marfiöhre: Rof́taftanien, Ejđhe, 2(horn zc., jämmtliche Laubhölzer

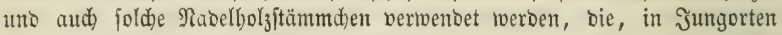

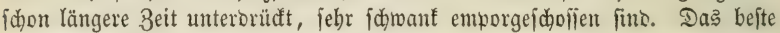
Binomaterial liefern allerbings bie gelbe Baumweibe, Rüftern, Birfen, 5ुajeln; immer aber müfilen bie gejonnittenen Sdjößlinge minbeftens 24 Etunten abtrocknen, che fie bie gehörige 3ähigfeit erlangen. Jür Pflanz= fämpe liefern aud Binjen ein gutes wohlfeiles Binomaterial, went fie S-10 Iage abgewelft fino. Sollten fie bierbei zu troden getworben jein, fo müfien fie wie Stroh uno Bajt vor ber Berwenoung wieber angefeudtet werbert.

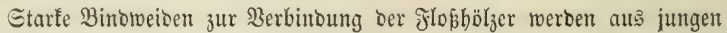

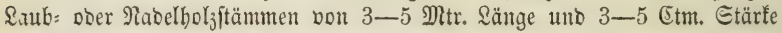
Durch Drebung um ibre 2Y(t)je über Feuer angefertigt.

\section{3) Fafdinen}

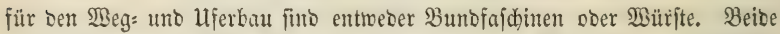

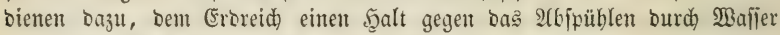
soer gegen bas Eimjhneiben bon Wagentäbern zu geben. 3um gleid): fabrifen.

1 Diejer Federeifen bebient man fith aud bei ber Rindegetvinnung für bie Galicin= 


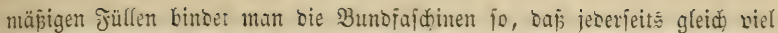

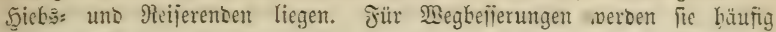

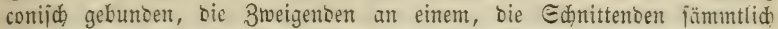
an bem antern Enoe. Man legt alæbann sie Epißzen ber Bumbiaichinen in bie Mitte Des Iseges, bie Bafis an bie Eeiten, fo daj bie Räber ber Bagen über bem ftärferen $\mathfrak{S}_{\mathrm{o}} \mathrm{K}_{3}$ laufen.

Burit=Fajchinen, Kejonders für fortlaufenben Ujerbau, fertigt man

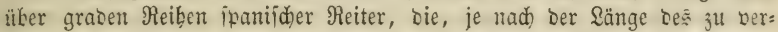

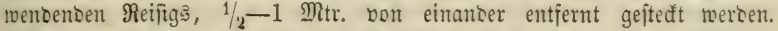

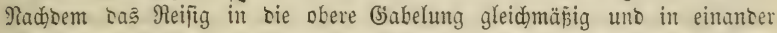

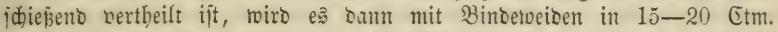
Entfermung zu feitten, Geliebig langen Büriten bon 20-30 Etm. Iurd): meîer zujammengebunben.

\section{Der Eäblereibetrieb.}

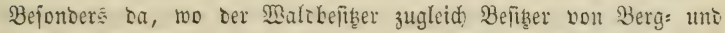
büttenwerfen ift unb als ioldher ben eigenen Bebarf an Soblen fid jelbit

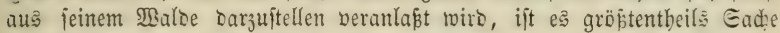

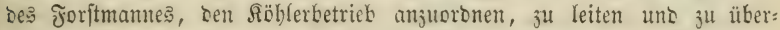

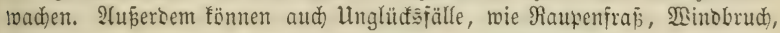

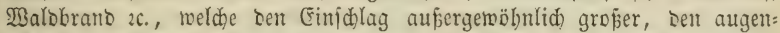

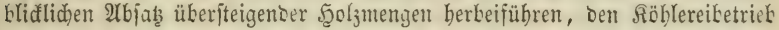
notbmenoig maden, um burch S̉erfohlung bes in bent nädjten Jabren nidjt

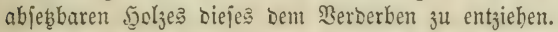

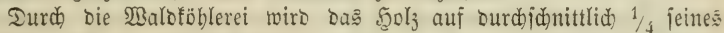
Bemidates, auf $3 / 5$ feines Dolumen rebucirt. Ilnter $\mathfrak{l} m$ it än ben fam Gieraus Dem $\mathfrak{B a l b b e j i z e r ~ e i n e ~ m e j e n t l i c h e ~ \$ e r r i n g e r u n g ~ b e r ~ T r a n s p o r t f o j t e n ~}$ und eine ifm northeilbafte Erroeiterung Des Eonjumtionsbejirfes erwadjen; Dann nämlich, menn bie Soblen unfern ser Soblitellen auf Räbne berladen

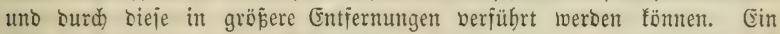

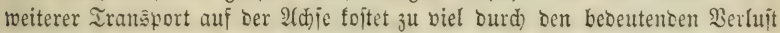
an Fufrtrimffe, b. b. an Johlenftaub, ber burch bie gegenjeitige Reibung Der Roblen bejonders auf idjlechten $\mathfrak{B e g e n}$ entifeht.

In biejen uno ähnlichen Fällen bebarf der Joritmann einer Senntni

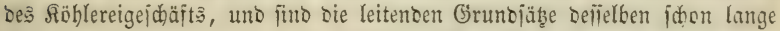

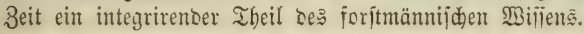

\section{a) Chemijdę.}

Die reine Solzfajer bejteht aus 52,65 Roblenitofi, 42,10 Eauer:

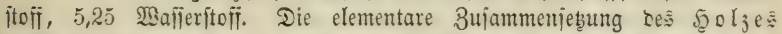
weidft hierwen mur wenig, aber ftets um Etwas ab. Das Marimum Des Rohlenftofïgehaltę geht niḑt über 50,2 (Ulmus, Larix), Mlinimum niđat unter 48,5 (Salix, Fagus, Betula). Daई̃ Marimum des Guueritofí: gebaltes jteigt alf 45,1 (Fagus, Betula), Das Minimum finft nidt unter

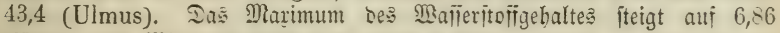
(Tilia), bas Minimum finft niht unter 6 Proc. (Quercus, Fraxinus). 


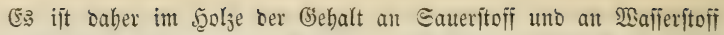
itets größ̈er als in ber reinen Şolzafer. Sn lebterer fteben beibe genau in Demielben Berbältnifije wie im $\mathfrak{W a f f e r}(8: 1)$ uno müffen $e^{3}$ baber anbere brennbare, Dem Şolze beigemengte Stoffe von böherem saueritoff: uno Waiferitofigebalte fein, weldye jenem Unteridiebe zum Sirunbe liegen. Dogleid) hier nod mandjer 3weifel borliegt, ber mur gelöst werben fann

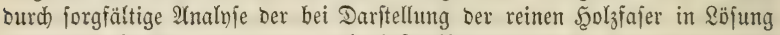
gebradten Stoffe, mag man bod einftweilen annebmen: Daṕ es ber ver:

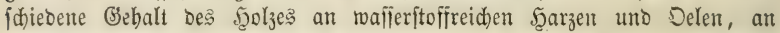
jaueritoffreidem (3ummi uno Schleim fei, ber bei ber Berbrennung beక Şolzes in Mitwirfung tritt.

Der, aud) bem Sholze nie feblento, theil’ aus Säften, theils aus Slebermebl ftammente Eticfifoffgebalt, erreid)t fein Marinum mit 1,5 \$roc. im Meibenbolze, jein Minimum mit 1 \$roc. bei ber 2 fpee, jo weit bie vorbandenen Unterjuđungen reidjen.

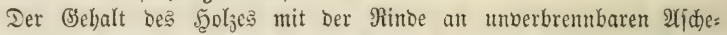
beftantbeilen fatwantt zmijhen $1 \frac{1}{2}-3$ \$roc. Maximum bei Sinte, Budde,

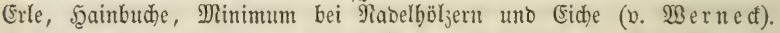
Ias $\mathfrak{S}_{2} \mathrm{l}_{3}$ allein entbält $0,12-0,95$ Proc. unverbrembarer $\mathfrak{B}$ eitandtheile.

Jrifch gefällt fönnen fplintreiche Etangenhölzer von Rabelholz bis $3 / 5$

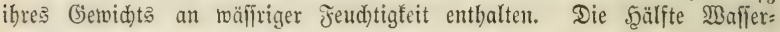

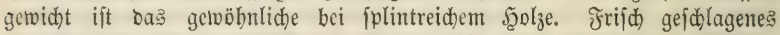

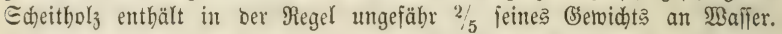
Geppaltenes Scoly, weldhe Jahre lang in offenen Sduppen aufbetwahrt, einen Trodentheitsgrab erreidte, in weldem es bei Berminberung bes feud)= tigfeitsgebaltes ber Suft innerbalb mebreter Moden nidht mebr wejentlich leidhter, bei (Erböbung ber Sufffeudtigfeit bingegen rafd) fdowerer miro (luft: trocen im wiffenfdaftlichen Einne), entbält immer nod) nabe 20 \$roc.

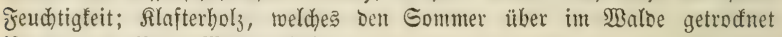
ift: 25-30 ßroc. Wafiergebalt.

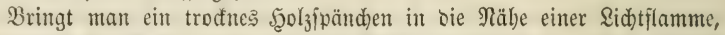
fo enţünoet es fid bei einem getwiffen (5)abe ber Erbiţung. Wir nenten bief Das $\mathfrak{A} \pi$ ünDen. Die unmittelbare Berübrung mit einer Flamme ift Gierbei nid)t nothwendig, fonbern nur bie (Erbibung Des brennbaren Rörper?

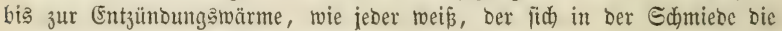
\$feife an glühendem Eifen anzünbete.

Die Entjünoungânärme ift für verfđjiedene Brennftoffe und für bent felben Brenmitoff unter berid)iedenen 2(ggregatzuftänoen veridjieben. \$bos: whor entzünot fich leidter als Sdiwefel, biefer leidter als Şolz, Sioblen= pulver leidter alङ Soblenitüufe, feiner Eifenorabt leidter als grober.

כit Der brentubare Sörper angezüntet, fo ift Der brennerioe Theil bes:

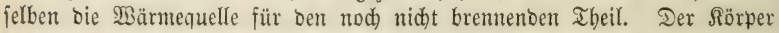
brennt fort, renn ber brennenbe Ibeil beffelben ben nidbt brennenben in genügentem (5rabe erbist.

Die Särme, nadbem fie bas hygrojcopijde Waffer bes Bremnitoff̈ verbantrft hat, löst bie organifhe Berbinoung Des Sohlenftoffis, Gaueritoff?

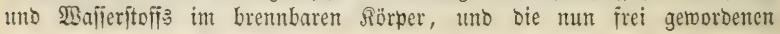


Glemente fömnen jid) untereinanber zu anseren, in ber Nerbrennungähib̧c fliidhtigen Berbittoungen vereinen.

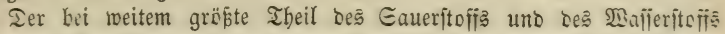

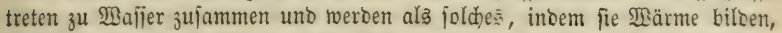

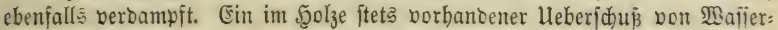

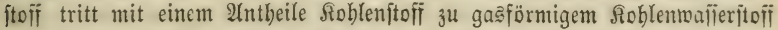

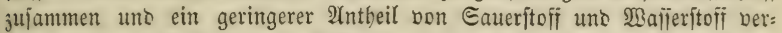

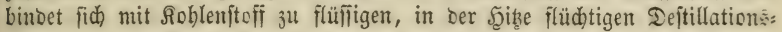

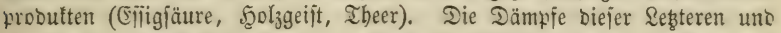
bie Rohlenwafieritofigaje fino $e^{2}$, weldhe bie olamme bilben, inbem fie mit Dem Gaueriftoffe Der Suft zu Soblenfäure verbrenten, wenn ein ourd bie Särme felbit bermittelter rajher Suftwedjel genügente Mengen atmo:

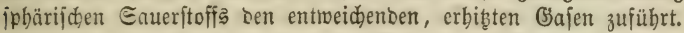

Sift bas nid)t in genügendem Maje ber fall, bann verbrennt in Der Jlamme Les fich zeriebenden Roblentafieritofigajes voreilig ber Wafierjtofi unl ber zu feimften Soblentheilden reoucirte Soblenftoff tritt als $\Re$ aud) aus ber Flanme bervor, bem fich unter Umitänben in ber Siţe verflüd:

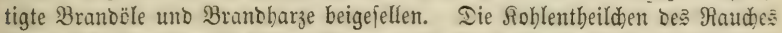
jetzen fich entrocber an falten Sörpern als $\Re u \tilde{\beta} a b$, ober fie reerben vom

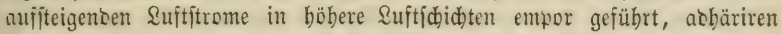
Dort Den Walierdämpfen ber Wolfenidjidt, mit ben $\mathfrak{B}$ olfen fortjieheno fo

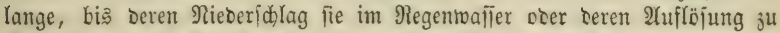

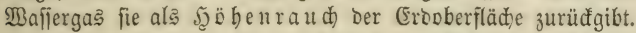

Der brembare Rörper $i$ d we blt, glimmt, glüht, wenn entrober ungenügenter \&uftwedjel fo geringe Eauerftofimengen ibm zuführt, baj eine 3erbrennung ber entweid)enben brembaren Gaje nidft ober nur unvoll: fommen eintreten fann, ober went bie 3erfeb̧ungsprobufte Dem brementen

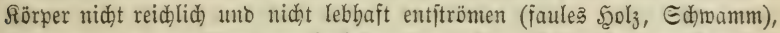
ober wenn bie gasförmigen 3erję̧ungsprobutte felbit nidst brenmbar fime

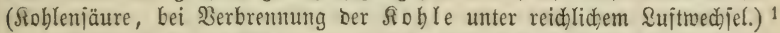

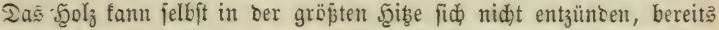

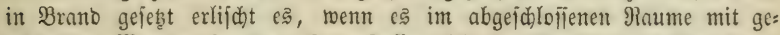
nügenoen Mengen fremben Gaueritoffes nidht in Berührung treten fann, obgleid) bei fortbauernber (Erbisung aud) bie 3erfeł̧ung fortbauert, bis ber

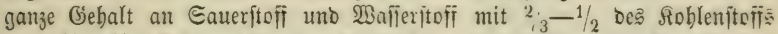
bon $1 / 2-1 / 3$ Soblenrüdjtano als flüdtige Deftillationsprobufte (TBalier,

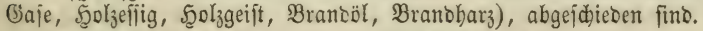

Es ift biés ber ßrocé̃ ber Berfohlung.

Die \$robufte biejes Brocefles fino genau biejelben, wie bie der Ber: bremung; Denn aud bei leşterer bilden fid unter ber bremmenten Dber:

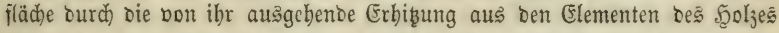

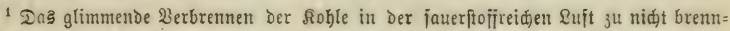

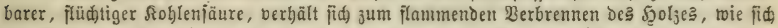

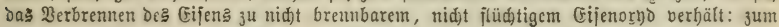

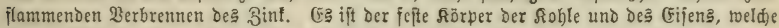
brenten, D. h. mit dem Eaueritoif ber \&uft fid bercinen; es find die, Durdi) Crmärmung

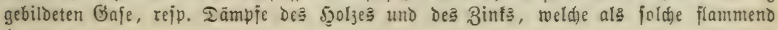
brennen. 
junädjt alle jene flüdtigen $\Re$ oblenftofiperbintoutgen, bie aud im veridjlofienten Berfoblungsraume gebilot und aus biejem aufgefammelt werben fönnent. (Fin Unterjdied zwifhen Berfohlung uno Berbremung bejteht mur Darin:

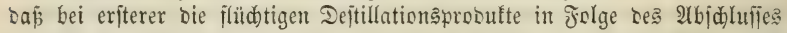
fremben Gauerftoff's nidht wciter beränbert werben, baj nach 2lbjheibung

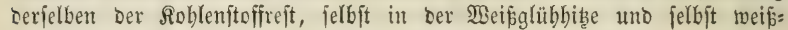
glübeno mie Blatina, feine meitere Beräneerung ober Berminoerung er: leibet, wäbreno bei ber Berbrennung ber binjutretende Eauerftoff nidht allein alle jene Dejtillationsprodutte, jonbern aud) Den Roblenrüfftano bi: auf bie 2ljhebeftanotheile in Roblenjäure und Mafier berwantelt.

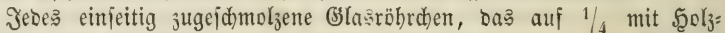
pplittern ober Sägejpänen angejü̈llt, über einer Epirituslampe febr langjam erwärmt unto enolid) erbib̧t wirb, berïnulid)t bie ourd) Die פärme im ab:

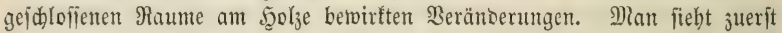

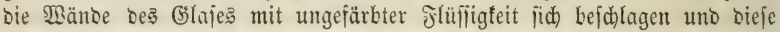

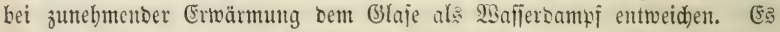

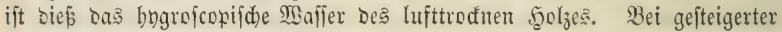

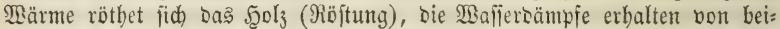

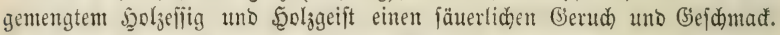

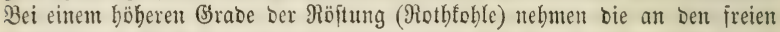

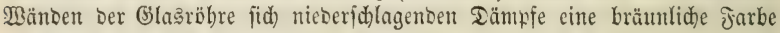
an, burd) bie fid) beimengenten Branoöle. (Erbist man mur bie oberften

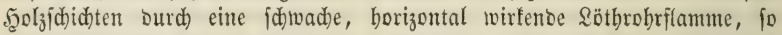
fiebt man einen Theil biejer braunen Slüfifigteit audd nad) unten fid) jenten uno bie nod) nid)t gebräunten f̧olzmafien Durd)bringen (Branoöle uno Branobarze - Theer). ந̧ält man jeţt ein brennentes Şolzipänden an

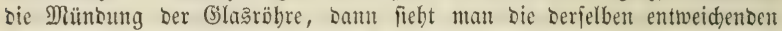
Băa un Dämpfe fid) entzünden unt mit lebbafter Slamme fortbrennen.

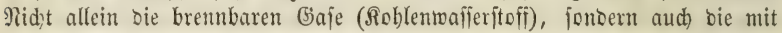
ihnen entweidenden, in Łer Şize berflüdtigten Brantoöle bilben bieje Slamme.

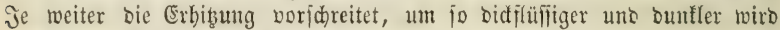

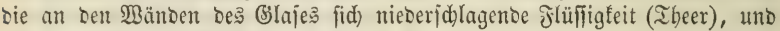
jwar in Folge zumehmenten Hebergemidhts Der Branbharze über bie leidter uno rafder fich berflüdtigenton Brantöle. Sft bie (Erbik̨ung eine ftarfe uno raja) fid fteigernbe, jo wirb aud) ber Theer nad) aupen verflüd)tigt; bei geYinber uno langfamer (Erbił̧ung fentt er fid) vermöge feiner eigenen $\Theta_{d j}$ were abwärts. Bei fortsaternder $\mathfrak{B a ̈ r m e w i r f u n g ~ v e r w a n b e l t ~ f i d ~ b i e ~ r o t h b r a u n e ~ F a ̈ r b u n g ~ b e s ~}$

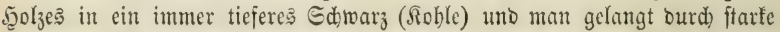
Erbiß̨ung (Motbglüben) enolid ju eintem Punfte, wo bie meiften flüd)tigen Stoffe ausggetrieben find. Das Bolumen bes Şolzes bat fid alsondn auf ungefäbr die Saälite verringert. Diejer Roblenteft fann in bem verfitteten (3laje beliebig lange 3eit in ber Blübbike erbalten werben, obne baj er fid) weiter jerieb̧t uno vermintert. Wiro er aber in freier \&uft erhib̨t, Dann ver= brennt er mit bem Gaueritofi berjelben flammenlos ju ßoblemjäure. Bei

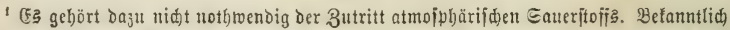
faun eine vollfänoige Derbrenmung aud im verid)loffenten Maaume betwirtt werden burd) bett Gauterftofi beigemengter Metallorboe. 
grofer Şibe unt geringem Eauerjtoijjutritt liejert allerbings aud bie Sohle eine jobache blaue Flamme burdh Biloung von Soblentrinogas, went man

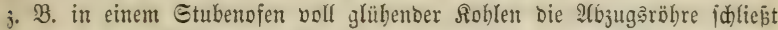
noer menn bie \$irfung besె (b̉ebläjes auf ein Edmmiebejeuer plöblid) aufhört.

Die \$robutte ber ßerfoblung fint:

1) binäre, gaşförmige Berbinoungen,

Roblenjäure $=27,3$ Roblenitofi, 72,7 Eauerftofi,

Rohlenorubgas $=43$ Sohlenitoff, 57 Saueritoif.

Soblentwaiferitoffigas:

a) Brubengas $=75$ Rohlenitofi, 25 Walieritoif.

b) Selbiloendes Gas $=86$ Sobienftoff, 14 Wafierfitofi.

Uleber bie Menge Der Roblenjäure befiben wir noch feine Angaben. Die Nienge ber übrigen gaşförmigen Sohlenftofiwerbinoungen gibt $S_{t o} I_{z} e$ nur 3u 3-4 Eubiffú, \$ettenfojer 3 $81 / 2$ Cubiffú auf bas Pfund

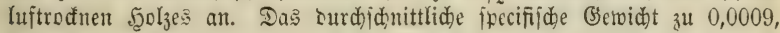

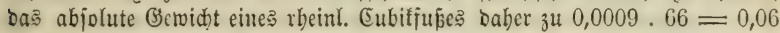

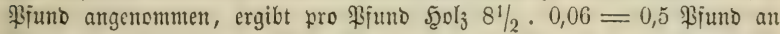

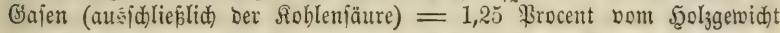

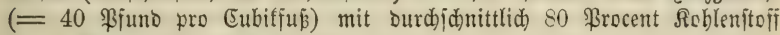
$=1$ Procent vom Sुolzgetvidat.

Snapp fübrt bie YUgaben cines Ungenannten an, nad) benen bie Fermanenten Giaje 6,5 Brocent vom Gerwidte Des Sgoljes betragen. Die Etolze'ichen Berjudje ergeben 20-24 Proc. Minbergetwid̆t ber gejammelten

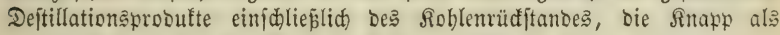
"umberbidtbare" Stoffe (Baje) in Redmung ftellt (i. weiter unten).

2) Binäre, flüfilige \$erbinoungen.

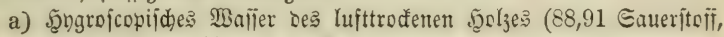
11,09 खajierftofi) $=20$ ßrocent.

b) Wafier, welches entifteht aus ber $\mathfrak{B}$ erbinoung Des Saueritoffis uno Wafierfitofís ber Fुol 3 jajer.

Nach Den Elementar:Inalyjen \$eterien uno Edöbleræ entbält

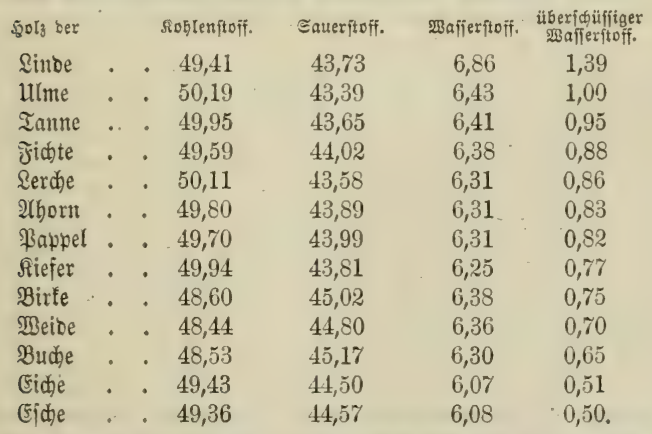

Nimmt man an: ¿añ aller Eaueritofi fid mit $1 / 8$ feines Gervidts 


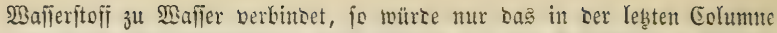
verzeidnete Wajierftoffgemidyt übrig bleiben uno mit Soblenftoff 3u Soblent= wafferftofigas fich verbinden tönnen.

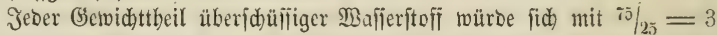
Gervid)ttbeilen Sohlenitofi 3u Şrubengas, ober mit $86 / 24=6$ (Sewicht:

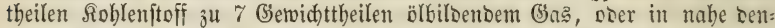
felben Berbältnifīen zu Branoöl жc. verbinden, ber Rohlenftoffiabgang bei

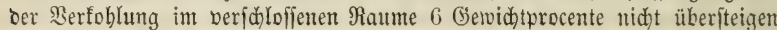

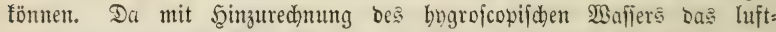
trodne Şolz aus 20 ßroc. Waffer, 40 Proc. Roblenftoff uno 40 Procent Gauer: unt Bafieritoff bejteht, ${ }^{1}$ mürbe in biejem Jalle Der Soblenftofireft $40-6=34$ Proc. jein müfien. 2(us waijerfreiem $\mathfrak{g}_{0} \mathfrak{l}_{3}$ mit 50 Proc. Soblenftoff würben $50-6=44$ \$roc. Roblentüffitand möglid jein.

Nimmt man an: bas aller Sauerfoff theils mit 0,37 feines Ges

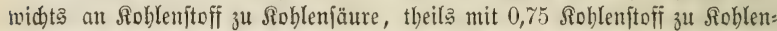
ornogas, theils mit gleiden (šewidttheilen Sioblenjtoff zu Effigfäure uno Solzgeift, theils mit bem 2,4 fachen feines (Semidete an Roblemitoff zu Brantharz zujammentrete; ninme man ferner an, das in biefem falle ber

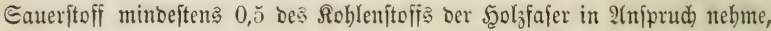
io wurbe ber verbleibente Rohlenftoffreft won 20 ßroc. Des lufttrofnen 5olzes nicht einmal ausreicheno fein, um mit 6 Proc. Wafferftoff Rohlen= inafierjtofi zu bilden. Es mürbe gar fein Roblenteft verbleiben.

Beibes ift nun erfabrungsmäßig nidht ber Jall. (5benjo wenig wie aller Sauerfoff mit $\mathfrak{W a f f e r f t o f f}$ fid zu Waffer verbinbet, eben fo wentig tritt alter Sauerftoff uno Mafferftofi mit Soblenftoff zu flüdtigen Şerbin: Dungen zufammen. Leber bas Duantum ber Wafferbiloung bei ber De:

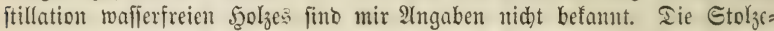

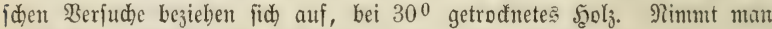
10 Broc. als Bafiergebalt defielben an, fo iverben $32-3,2=28,8$ Soth

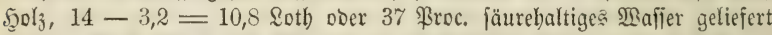

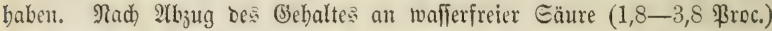

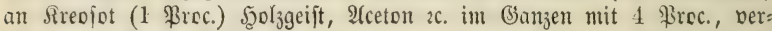
bleiben 33 Proc. Majjer, mithin $50-33=17$ ßroc. Elemente Des Maffers für bie flüdtigen Roblenftofíberbindungen. Da fïh leţtere nad Den Stolze'id)en $\mathfrak{B}$ erfud)en für bie Saubhölzer auf 31 Brec. (Darunter $8-9$ Froc. Theer) für Jid)te und Tame auf $36-38$ Proc. (Darumter 11,8-13,7 ßroc. Theer) bered)nen, fo würte Der Roblemitoffgebalt ber: felben zwijden $31-17=14$ Froc, uno $38-17=21$ \$roc. Yiegen.

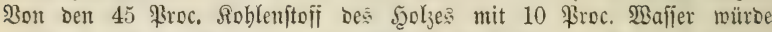
Daber 24 bis 31 Froc., bon wafierfreiem 5ुolje 29-36 \$roc., von luft=

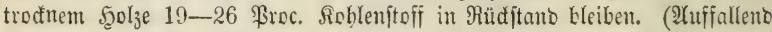
ift bierbei allerbing ber zwifden 20 uno 24 \$roc. fotwanfente Betrag an unberbidhtbaren Deftillationsprobuften.)

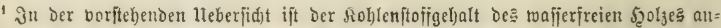

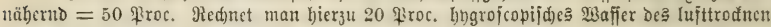

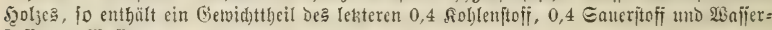
ftoff, 0,2 Wajfer. 
3) Tentäre, flüfïige ßerbinbungen.

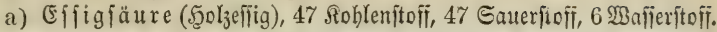

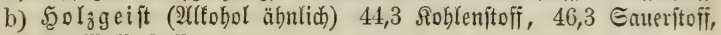
9,4 Bafieritoff.

c) B̧randöl 88 Saueritoff, 12 פBafieritofi.

d) Branbbarz 63 Roblenitofi, 26 Sauterftofi, 11 Bafierftoff.

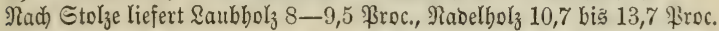
Theer (Branoöl uno Branbharz). Begen 6 \$roc. biejer Stofie, von benen

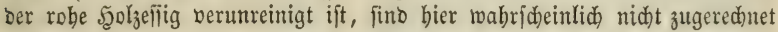
tho würben ben oben angegebenen Betrag von 20-24 \$roc. unveroid)t: bare Stoffe um eben fo viel verminbern. Seine 2 uabeute von $41-46,8$ \$roc. robem Şolzeffig entbält febr veridjiebene Mengen wafjerfreier sfifigfäure uno

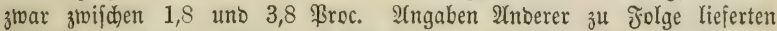
100 PFo. Scolz 25,5 Roblen, 9 PFo. Theer, 59 SFo. roben Sgolzefitg und 6,5 Pfo. permanente Gaje (Snapp), wäbrent Stolje mebr Soblen = uno

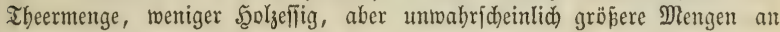
unberbidutbaren Deftillationsprobuften erbielt.

4) Feite Roble.

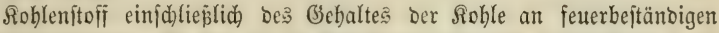

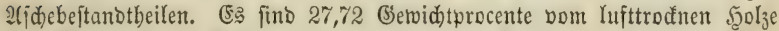
bas Maximum an Roblenaubbritgen, weldes Sarjten bei langamer $3 e r=$ toblung in veriblofienem Raume gefunben bat; 24,6 Proc. ift unter gleidhen Berbältnifien bie Minimalgröß̨e; bei ben meiften Scolzarten fadwantt bie 2usbeute zwifden 25 und 26 ßroc. Hebereinitimmeno biemit find bie Berjudbreiben Siobert's; Die von Stolze uno Winflers erreiden meift nur

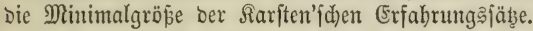

Durdfidnittlich böbere 3ablen finben wir bei "b. Berg, 2Anleitung zum Berfoblen bes Şolzes, zweite 2Uuflage, Darmftadt 1860," Der fie ebenfall Durd) Retortenverfohlung getwann. Die Maximaljäbze fint: Fidftentourzelholj 34,05 ßroc., Ertentwurzelholz 31,85 ßroc., Buchen 60jähriges Stammbolz 32,83 \$roc., \&ärd)en Stammbolz (Splint) 30,13, Minimum 24 Proc., vor= berricheno 28-29 Broc.

Wie eine, Seite 295, mitgetbeilte Tabelle zeigt, crbielt idy felbit, bei gleidzeitiger Berfohlung veridiebener Baumtheile Der Eiche unter ge= fämoljenem 3inn, aljo unter abjolut gleider Wärmetwirfung. Differcnzent

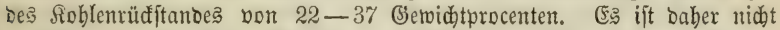

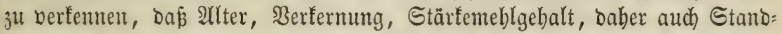
ort uno Wühbfigfeit bes Baumes cinen wefentlichen (Finflup auf ben Rohlen= rücfftano gleid) groper Cellulojemengen ausüber. (Siebe meine Ratur: geidjidyte Der forftliden Rulturpflanzen S. 130.)

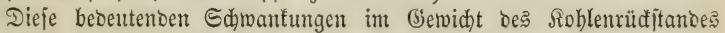
fömen, bei ber Berfoblung in berfdloffenen Raume, nux berborgerufen merben ourd bie beränberlid)e (Jröß̈e Der Deftillationsprobutte, burd) bie, wenn beren Betrag ein größerer ift, Dem Şolze eine entipredjent gröfere Menge von Roblenjtoff entfül)rt wirb. Edon aus ßorftebenbem geht hervor, daf bie Borausfekung: alfer Eaueritoff ber Şolzafaer verbinoe

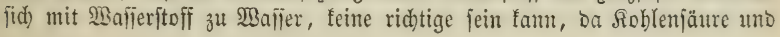


Roblenorbbgą jomohl, mie bie ternären Berbinoungen bebentente Gaucr: ftoffmentgen jür fich in 2̂njprud) nebmen, baber man aud toeit mebr als Der vorjtehent bered)nete, überid)üfige Bafierftoff zur Billoung bon fohlen:

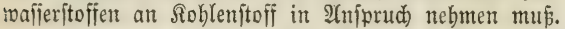

2luserbem bleibt nad) Beridjiebenbeit ber ßerfohlungahbibe mebr ober weniger Gaueritofi uno Bafieritoff mit oer Roble verbunben. Biolette (Yournal für praftijd)e Cbemie, Band 54, S. 313) gibt bierüber folgento 2ufid)ไüfึe:

Das Şoly von Frangula vulgaris, bei $150^{0}$ von allem hygros:

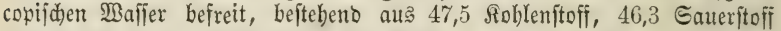

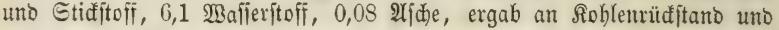
in jebem Theile biejes Rücfitanbes an nidt ausggetriebenem Sauer = uno खafieritofi

in 100 Theilen bes Rüditanbes:

\begin{tabular}{|c|c|c|c|c|c|}
\hline $\begin{array}{c}\text { Zemperatur. } \\
280\end{array}$ & $\begin{array}{c}\text { Soblenriäfitans. } \\
36,2\end{array}$ & $\begin{array}{c}\text { Soglenfifoif. } \\
71,6\end{array}$ & $\begin{array}{l}\text { Enuerit tifi. } \\
22,1\end{array}$ & $\begin{array}{c}\text { Bafieritofif. } \\
4,7\end{array}$ & $\begin{array}{l}\text { 2ride. } \\
0,57\end{array}$ \\
\hline 350 & 29,7 & 76,6 & 18,4 & 4,1 & 0,60 \\
\hline 432 & 18,9 & 81,6 & 15,2 & 1,9 & 1,20 \\
\hline 1032 & 18,7 & 81,9 & 14,1 & 2,3 & 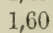 \\
\hline 1160 & 18,4 & 83,3 & 13,8 & 1,7 & , \\
\hline 1250 & 17,9 & 88,1 & 9,2 & 1,4 & 1,2 \\
\hline 1300 & 17,5 & 90,8 & 6,5 & 1,6 & 1,1 \\
\hline 1500 & 17,3 & $94,5$. & 3,8 & 0,7 & 0,7 \\
\hline 1500 & 15,0 & 96,5 & 0,9 & 0,6 & \\
\hline
\end{tabular}

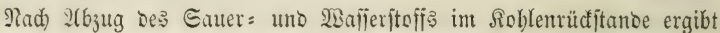
jid) Daher ein Soblenitoffireft für bie Temperaturen uno Sdymelabisen

$280^{0}$ 3inn $\left(-\frac{1}{-}\right) 36,2-9,70=26,50$ Siolenitoif uno side

$350^{0}$ Blei $(+) 29,7-6,68=23,02$

4320 2Antimun $18,9-3,20=15,70$

$1032^{0}$ Silber $\quad 18,7-3,07=15,63$

$1160^{\circ}$ Sitpfer $\quad 18,4-2,85=15,55$

$1250^{\circ}$ Giplo $\quad 17,9-1,90=16,00$

$1300^{\circ}$ Stahl $\quad 17,5-1,42=16,08$

$1500^{0}$ Eifen $\quad 17,3-0,78=16,52$

Darüber Blatin $\quad 15,0-0,23=14,78$

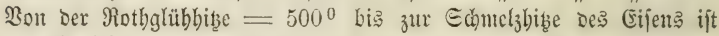

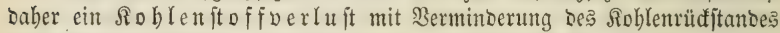
nid)t mehr verbunten. Die Gteigerung bes Sohlenitoffs auf 16 unb bar=

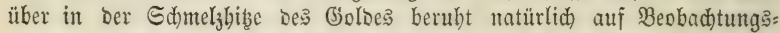
fehlern. Beadtentwerth ijt ferner bie bis ju $1000^{\circ}$ finfenoc, von $i a$ ab

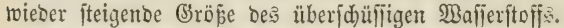

Ment ein Theil bes Gauerftoffis ber J̧olzfajer unt ocr ibm ent=

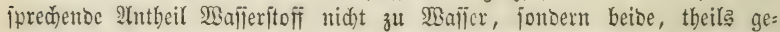
trent, theils vereint mit Soblenftoff zu binären unt ternären Soblenftoff:

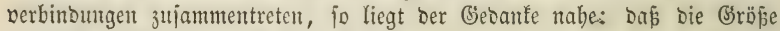

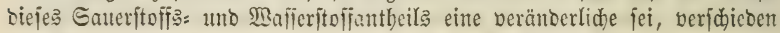
mit Seridhebenbeit Des Temperaturganges Det Nerfoblungahike. 
3n Der That fano Rarften bei jebr rajder Etcigerung Ler Bertoblungş= biçe, gegenüber einer langjam voridgreitencen Errmärmung, einen, zmijden

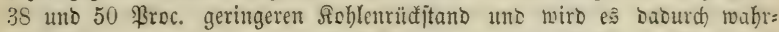

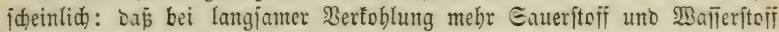

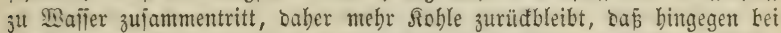

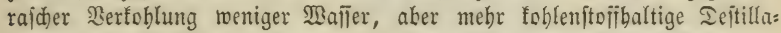
tionaprobufte gebiloet merben, uno in Dem Mape Der Roblenrüditano ein geringerer werbe. (5s fönnte aber aud wohl jein: saj, bei rajd gefteizer= ter (Erbibung, nod) nidht berflüdtigter Iampi bes bugrojcopifden Majer: in jeine Clemtente zerlegt uno burd) Die \$Berbinoung biejer mit Roblenitofi

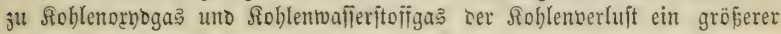
merbe.

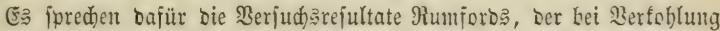

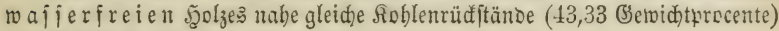
für Nabelfolz, bartes uno weiches Saubholz erbielt.

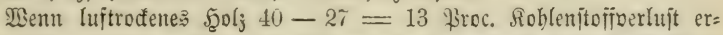

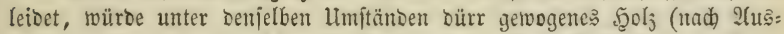
treibung alles bygrojcopijकen $\mathfrak{B a f i ̈ e r}$ ) nit 50 \$roc. Siohlenjtoif 16 \$roc.

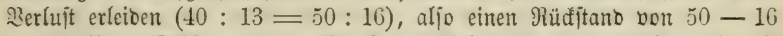
$=34$ Proc. Roble ergeben. Rumporo erbielt aus bürrem Solze mebr als

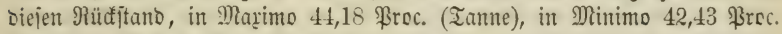

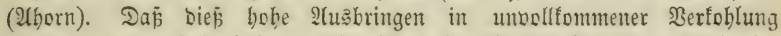

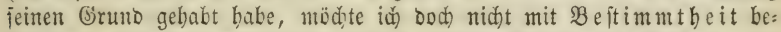

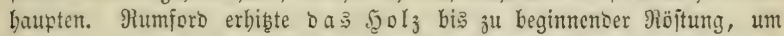

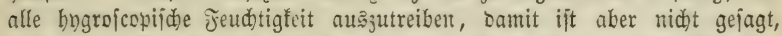

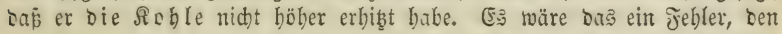

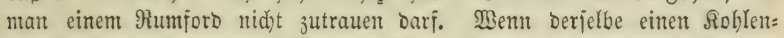
ftofiperluft bon nur $50-44=6$ Proc. erbielt, fo tönnte bie geringe Gröp̉e Dieję 2 (bganges möglid)ermeije in ber gänzlichen Entfernung allę hygrojcopiichen Maliers, jowie Darin begrüntet fein, Daj bei ber ftarfen Erbițung bes Syolzes auch ein Theil bes demifd) gebunbenten Gauer = unb

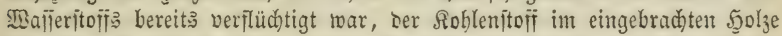
Daburd) mehr als 50 \$roc. von befien Genvid)t betrug. v. Berg erbielt

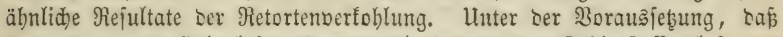

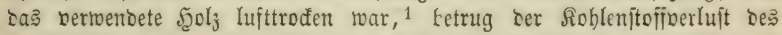

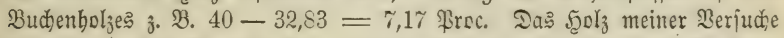
war kei $+600 \Re$. adt Iage lang getrodnet, wiro aljo noch 10 \$roc. Walfer, mitbin 45 ßrec. Soblenjtoif enthalten baben. Genau biejelbe Ber= tohlungshise, genau Derjelbe Iemperaturgang, weldhe Das Eplintholy ber 140 jäbrigen (Fid)e auf 22 \$roc. Sohle rebucirten, ließ̧en vont Eiden Rern= holje bis 37 Proc. Soble jurüd. Wäbreno leb̧teres $45-37=8$ Froc. Soblenftofi abgegeben batte, verlor eritere $45-22=23$ Fro.

(E⿱

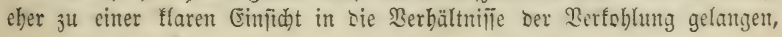

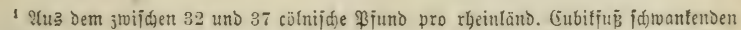

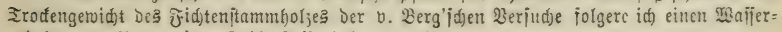
gehalt $=20$ Proc., einen Rohlenjtofigehalt $=40$ \$roc. 
che nidft bem Rohlenausbringen im berjdlofienten Raume cine genaue, quantitatibe Ermittelung Des Roblenitoffgebaltes aller flüdtigen Deftillations: wrobufte gegenübergeftellt wirb. Heber bie Menge ber entweidjenton Soblen: fäure uno Des Soblenornogaję baben wir nod gar feine birefte IIngaben.

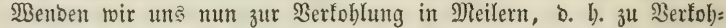
lungsapparaten, Denen bie ßerfoblungshiß̧e nid)t von außen zugeht, fondern Durch ein Snnenfeuer erzeugt wiro, bas auf Rojten ber Berbrentung eine? Theiles bes zu verfoblenben Bremiftoffs unterhalten wirb, Defien Unter=

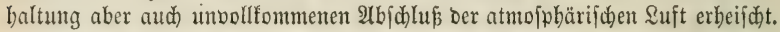

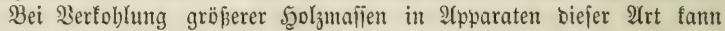

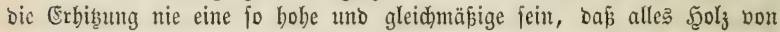
jeinen flühtigen Beftanotheilen vollftändig befreit wirb. Wollte man biefs erzielen, jo würoen bie Berlufte an Jeucrungsholz, an übergaren uno ver: brententen Sohlen jeben möglidjen 3ortheil bei weitem überiteigen. J̃ Der That ift aber aud eine vollendete 2 bj feibung aller Deftillationsprobufte für ben tedynifden Berbraud) ber Soblen nidjt nothwenbig, nidjt einmai wünichenswerth. Erzeugung hoher Şißgrabe, Durd) Berbrentung eines Bremitoffs, in weldbem bie Brennfraft auf bas flemite Bolument rebucirt wutrbe, ift ber weientlidjfte 3 wedt bes Rohlenberbraudes. Sdyon im $3 \mathrm{u}=$ ftande ber Rothfoble, die nod) über 50 Proc. Der (Gejammtmenge aller flüd)tigen Deftillationsprobufte enthält, ijt in biejer Da: Maacimum Des Bremnftofis enthalten, $1 / 4^{-1 / 3}$ mebr als in gleiohen Bolumtbeilen Des luft: trocfenten 50 olzes. Bis zur Darftellung Der Meilerfoble gehen von jenem \$) Raximum Der Brennfraft 6 Broc. verloren (Gaubage), abgefehen von Dem Meljraufwanbe an Jeuterungşmaterial, uno bennod) entbält bie getwöbnlide Meilerfoble burdifdnittlid immer nod) $18-20$ Froc. an flüdtigen Deftil= Yationsproouften.

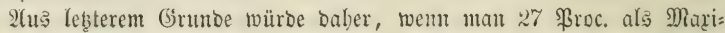

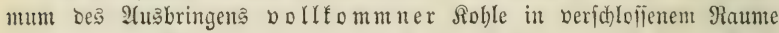
aunimunt, bie Meilerfohlung $27+18$ bis 20 Proc $=32$ Proc. Soble

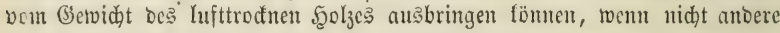

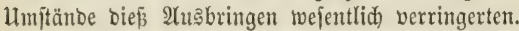

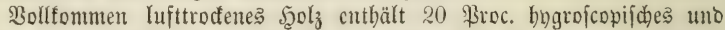
autäberno 35 \$roc. aus Gauerftoff uno $\mathfrak{B a f f e r f t o f f}$ fid bildendes $\mathfrak{B a f i e r .}$ Dicje 55 Proc. $2 B a f f e r{ }^{1}$ erfordern zu ihrer Berbampfung $5 / 40$ Soble (Rnapp).

Gdjon hierourd reouciren fich jene 32 ßroc. auf 28 \$roc. Sobletreft.

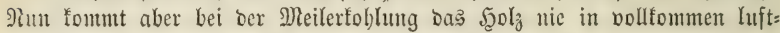
trodentem 3ujtande zur Berfohlung. Jede größere Feudtigfeitsmenge Des 5colzes erforbert nicht allein eine gröfere feuerungamenge zur Wafierber= bampfung, fonben fteht aud) mit an uno für fid geringeren Sohlenftoff=

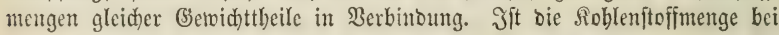
20 \$roc. Wanfier $=40$, jo ijt fie bei 30 \$roc. Maller $=35$; bei 40 Proc. WBafier $=30$; bei 50 ßroc. Mafijer = 25. Sit ber Jeuerungsbedari bei 40 Broc. Soblenitofi (55 Mafifer) $=5$, fo ift er bei 35 ßroc. Roblenjtofi

1 Da aud) bei ber Berflübtigung aller übrigen Deftiffationsprodufte 28ärme gebunden wiro, jo tant man bier bie ganje Єumme des હaueritofis uno Wajferftofï ju Wafjer ber= butben annebmen. 
$=5,5$; bei 30 \$roc. Siohlenitoif $=6$; bei 25 Proc. Sohlenitoif $=6,5$, ba bie Summe bes zu verbampfenten Mafiers in biejen Fä̆llen bon $20+35$, auf $30+30$, auf $40+25$, auf $50+20$ jich erböbt. Jür gleide

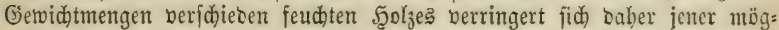

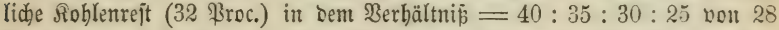
(i. obent) auf 24,5, 21, 17,5 (betwid)tprocente vom lufttroctenten .5olje. Bringt man biervon nun nod) Den fteigenden Jeuerungabebarf bes feud = teren $520 l_{z} e$ mit $0-0,5-1-1,5$ in $2 b_{3} u g$, fo berbleibt ein Soblentejt

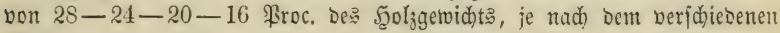
Waffergehalte befielben.

Es wirb aber nidyt aflein Durd bie \$afjerberbantifung fortbauerno Wärme gebunben, fontern e⿳亠 entiübren bie Dämpfe unb Gaje freie $\mathfrak{B a ̈ r m e , ~}$

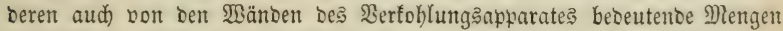
ausitrablen. Dieje und Die Menge Der, zur Erzeugung und Erbaltung Der

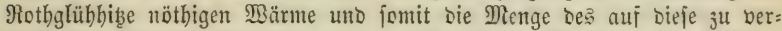
wenoenden Brennitoffs, feţt Snapp $=1,6-2,6$, im Mittel aljo $=2$ \$roc.

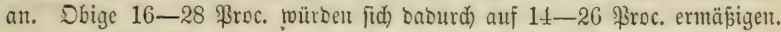

Der 2 ntheil gebunbener uno ber mit ben Deftillationspprobuften frei

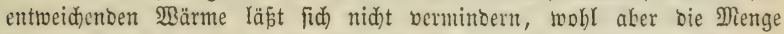
Der nad) aujen ftrablento entweidenden Bärme burd) 2(bid) lú ber Märme:

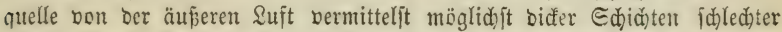
Märmeleiter. Şolz, Roble, locfere Erte, Roblenftübbe fino nidbt allein jelbit, jontoern aud butd bie in ihnen eingeidlofiene Suft fit ledte Märnte= leiter. $2 \mathfrak{m}$ geringiten ijt baber Der Märmeberluft nad aujent ba, wo ber

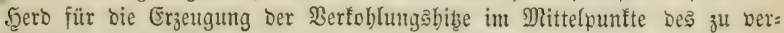

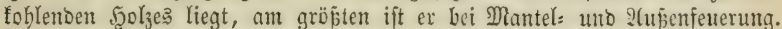

Enolid) Darf man nidgt überfehen: Daf bei Der Berfohlung in Meilern

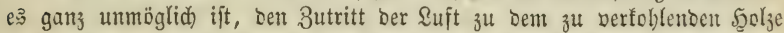
fortbauerno fo abjumefīen uno zu leiten, baj nidgt zu Beiten bier ober ba 3u reidhlide Sufftmengen unnötbigen Brennitofiperbrauch zur Folge baben.

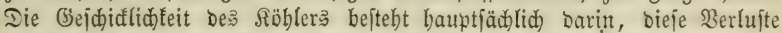
mögliăjit gering zu baltent. Banz bermeiben fantu er fie niḑt, uno man

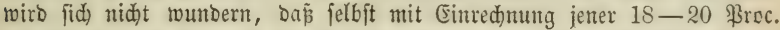
zurüđgebliebener Elemente für Deftillationșprodutte, aud gute Sïbler burd): (id)nittlid) nid)t mehr als 20 Setwidtprocente an Soble ausbringen, wemt man alle ermäbnten unvermeibbaren Berlujte zujammenzäblt.

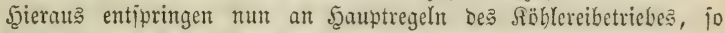
meit fich foldhe auf bieje allgemeine Betradhtungen jtübert:

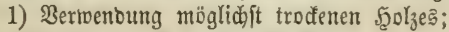

2) langjamer Gaang Der ß̧erfoblung;

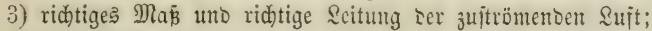

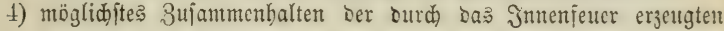
Wärme im Berfoblungşraume.

b) Strufifalifides.

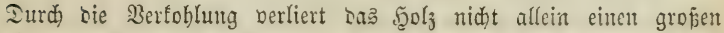

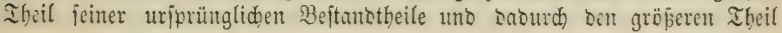


feines (Semidets, fonbern es verringert fich aud fein Bolumen, obgleid

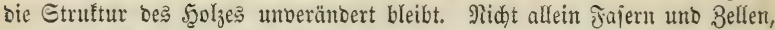
jonoen aud bie Eleinften Theile berfelben, Der Spiralfaben, Der Tipfel, bie Boren lafifen fich umberjebrt in ber guten Soble nadjweifen.

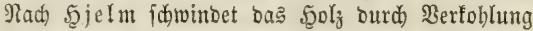

in ber \&änge um $12,5-18,75$ ßrec.

" "Breite " 12,5-25

" "Dide "25 \$roc. "

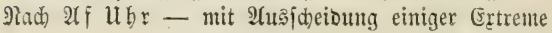

Sängefditwinoen 4-8 \$roc.

Dideidbinben 11-19,"

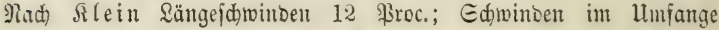

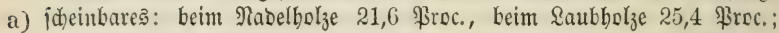

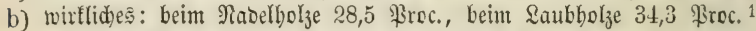

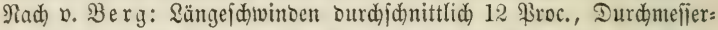

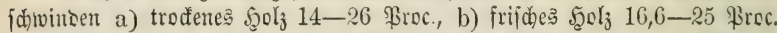
In einer zweiten Iabelle entbaltene 2Ingaben über Edbinden oürren Buthen= uno frifden Shainbudbentyolzes "in ber Stätc" um 42,9 Broc, beruben wobl auf eittem Drudfebler.

Madd eigenen Beobad)tungen am (Eid)enbsly veridiebener Baumalter uno Baumtheile (i. bie nadhiolgentoe Iabelle)

\begin{tabular}{|c|c|c|c|c|}
\hline Rängeverlujt & $8-18$ & Broc., & Budjenbolz & \\
\hline Breiteverluit & $17-33$ & " & " & 35 \\
\hline Tiefeverlujt & $14-29$ & " & " & \\
\hline Mañeverlujt & $40-59$ & " & $"$ & \\
\hline
\end{tabular}

Bei Dor Mefintug Des Sohlenvolument unter Duedfilber ijt bafielbe nur

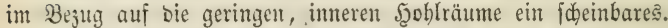

Heber Bolumprocente bes Roblenaußsbringens befiken wir Ingaben von (5. \&. S5artig, vollftäntig mitgetbeilt itt ben früberen Auflagen biefe Rebrbuches, wonach ergeben:

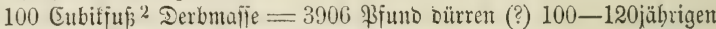
Buden Edheitholzes: 840 \$runo $=21,5$ \$roc. Soblen in 30 \$roc. Derb= majie $=70 \%$ Broc. Raumgemäp von der Derbmafie des Scolzes, dellen

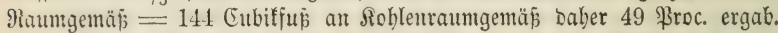

100 Eubiffú Derbmafie $=4200$ \$ĭuno. Buden Smüppelholz aus 60-90jäbriger Durdjorjtung: 960 \$fund $=23$ Proc. Soblen in 32 Prec. Derbmajie $=75$ 1/3 Proc. Raumgemäṕ von Der Derbmaile Des Scolzes,

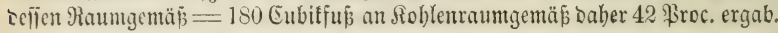

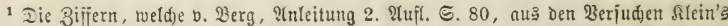
iiber wirflid)es Gdminden anführt, bejichen fid a uf bie Differens zwifden fdeinbarem

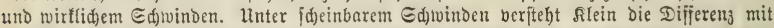

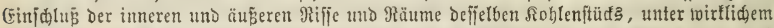

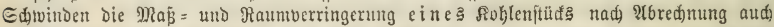

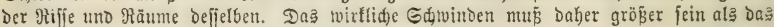
ineinbare.

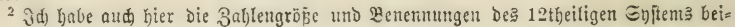
bebalten, ba eine Umrechnung in Das metrifd)e Syftem febr unbequeme 3iffern ergeben haben

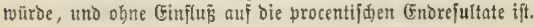


Det Söhfereibetrieb.

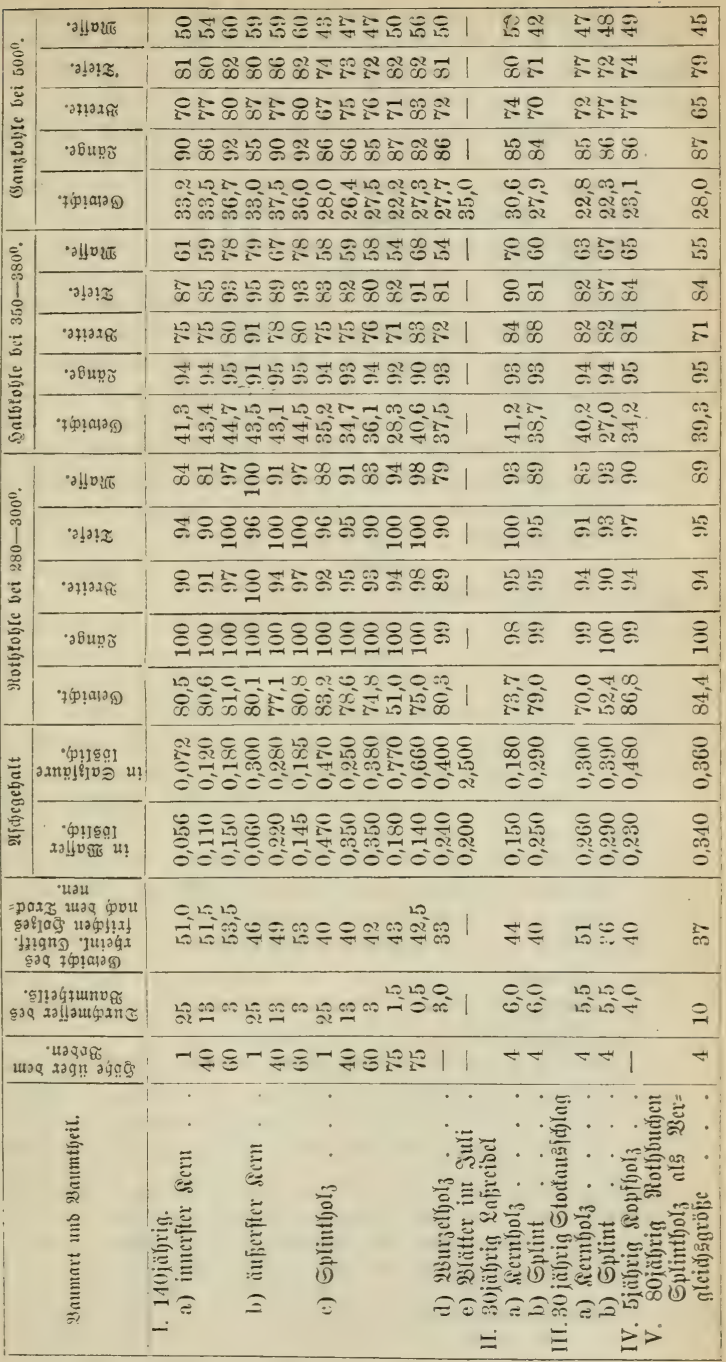




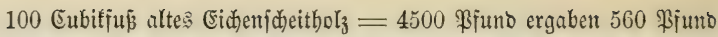

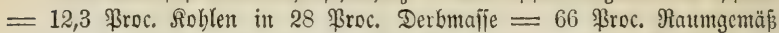

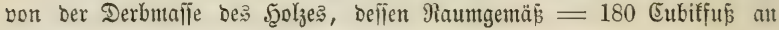
Rohlemraumgemǟ baber 37 Proc. ergab.

100 Eubiffu Derbmañe $=4600$ Pfund 18-20jäbriges (Eibentitangen= holz: 744 Pfund $=16$ Proc. Soblen in 31 Proc. Derbmafje $=73$ Proc.

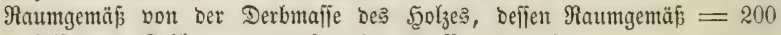
Cubiffuß an Roblenraumgemäs baher 37 ßroc. ergab.

100 Cubiffuß Derbmafje $=3600$ Bfuno 70-80jäbriges Riefentidheit: $\mathfrak{h o l}_{3}: 578$ Pfuno $=16$ Proc. Sohlen in 34 ßroc. Derbmalie $=80$ Proc.

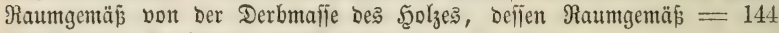
Cubiffuf an Roblentraumgemäß Daher ergab 55 Broc.

100 (Eubiffū Derbmafie $=3000$ Pfuno Riefernprügelbolz aus Durd)= foritungent: 512 \$funo $=17$ Broc. Soblen in 34 Proc. Derbmaife $=80$ \$roc. Raumgemäp von ber Derbmaffe Des Şorzes, Deffen Raum:

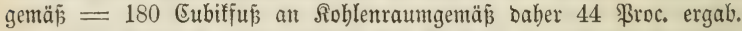

Der Bergleich biejer 3iffern für Buchen = und Siefernjoheitholz mit

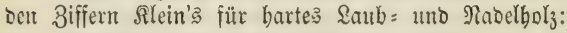

Getwidtprocente nady Şafienfraş Budhe 21,5 Siefer 16 ßroc.

$$
\text { " Slein " } 23 \quad 30 \text { " }
$$

Şoly und Roble Derbma

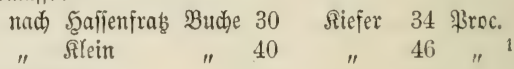

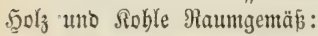

nach Şafienfrab̧ Buche 49. Siefer 55 ßroc.

" Slein " 67 " 85 "

Feolz in Derbmajie, Roble in Raumgemǟ̄:

Itad) Safilenfrats Buche 70,6 Riefer 80 \$roc.

" Iltein " 90 " 107 "

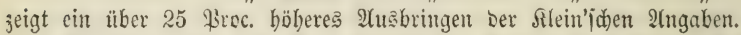

2f llhr. Sgolz uno Sohle Derbmaffe: Siefern 46,5 Proc., Sidtent

52,2 Proc., raber wohl jueinbares Sdininoen.

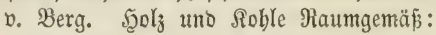

a) Edyeitholz:

Buden uno (Eid)en: (Setwid)t 20,0-22,0 \$roc., \$olumen 52,0 bi 56,5 \$roc.;

Birfen: Getwidjt 20-21 Proc., Bolumen 65-68 \$roc.;

Siefern: Betwid)t 22-25 $\mathfrak{F r o c . ,}$ Bolumen 60-64 \$roc.;

Fichten: (Jemidft 23,0-25,8 \$roc., Bolumen 65,0-74,5 \$roc.;

b) Jidhten Stodfholz: Gerwidyt 21-25 Proc., Bolumen 50 bi: 65,3 ßroc.;

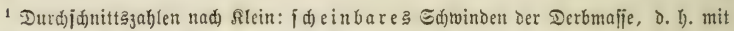

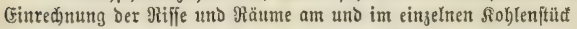
beim Saubholge 50,8, beim Madelfolge 45,7 \$roc.;

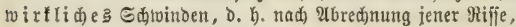
beim Saubholze 61,7, beim Radelfolje 54,9 \$roc.

E马 verbleibett aljo an Fefter Maife:

to irfli d $100-61,7=38,3$ ßroc. $100-54,9=45,1$ ßroc.

¡ 由) einbar $100-50,8=49,2$ \$roc. $100-45,7=54,3$ \$roc. 


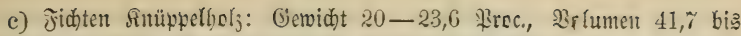
50 ßroc., bie Sitüppel bis z̆l 3 30ll Durdjmefier. gefeęt:

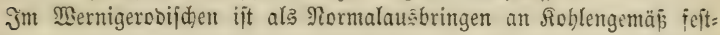
glattes Buden @deitholz 64 Broc. oom Şolggemäß

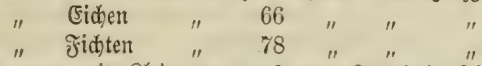

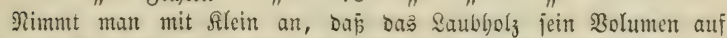
0,50 , bas গabelfoly auf 0,54 burd Nertohlung berringere; ninmt man

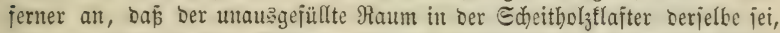

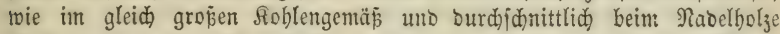
25 Proc., beim Saubbolze 30 Froc. betrage; nimmt man endlid bie Menge

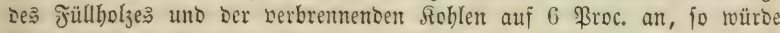
Ti் biernach das Gemäpausbringen beim Saubbolze auf $0,50-0,06=0,41$, beim Nabelbolze auf $0,54-0,06=0,48$ von jeber Einbeit bę ein: geję̧ten uno ơüllbolzes berechnen.

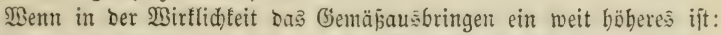

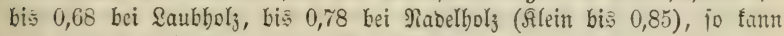
Dießs nur in Folgendem jeinen Grruno baben.

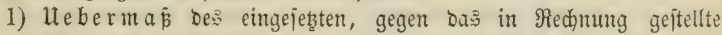

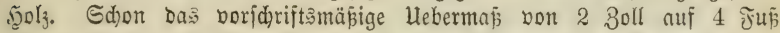
Slafterböhe bringt einen Mebreinjabs von 4 Proc. mit fidf, ber in ber Regel nid)t zur Bered)nung gezogen wiro, Daburd) Erböbung obiger 0,44 auf 0,48 , obiger 0,48 , auf 0,52 .

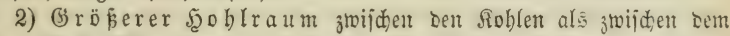

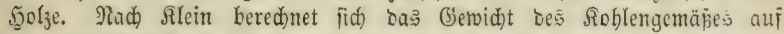
0,56 Des Terbfohlengetwidts, woraus fid ein Şohlraum von 0,44 De: Roblengemäp̄es ergibt. Dabon ab $0,11^{1}$ für ben Scohlraum int Snnern

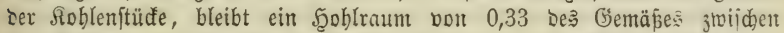

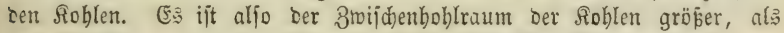

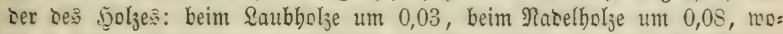
burd) fich obige 0,48 bce Saubbolyes auf 0,51 , obige 0,52 Des Plabelholjes auf 0,60 erböhen.

3) Cistingeres Shroinden als oben angenommen wurbe. Der nod) bleibenten Differenz zwif̈cen 0,52 uno 0,68 bes \&aubholzes $=0,16$; jwijhen 0,60 uno 0,78 bes Niabelholzes $=0,18$ entipredeno, müß̈te bie Saubholztoble nidgt auf 0,50 , foncern auf 0,66 , bie Nabelfoljtoble nidjt auf 0,54 , fonbern nur auf 0,72 bes Şoljuolumen fid berfleinern. MBiber:

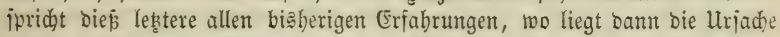

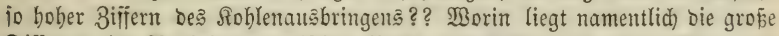

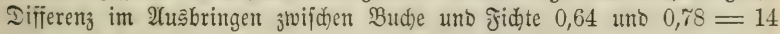
noer nach ๖. Berg 0,57 uno $0,75=18$, ba bie Differenz im fdcinbaren Edrwinden zwijhen beiben nad) Rlein (Beilagen Eeite XXVII) mu $47-43,8=3,2$ beträgt.

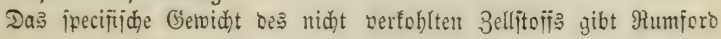

1 Eiehe bie vorhergebende Rote. 
$=1,53$ für bie \&aubholjfajer, $=1,46$ für bie Rabeltholyfajer. Neuere Unterjudungen ergaben nur 1,29 als Marimum für ben 3elliftoff ber

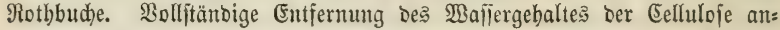
genommen, würoe fid), ba in ihr Rohlenftofi uno bie Elemente beß Waffers nabe zu gleiden Theilen entbalten fino, bas fpecififde (Semidyt bes reinen

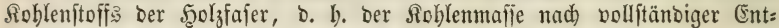
fermung bes Sauer $=$ uno 2 Bafferftoffgebaltes burd) ftartes Gilüben in ber 5ुike Des idjmelzenton \$latin nad) Rumford allf 3,3 , nad) ben neneren Unterjudungen mur auf 1,8 bered)nen. Dent: $1,53.66=1.00,98$ \$funo Der rbeinländifhe Cubiffuß Eelluloje. Davon 0,5 . 100,98 $=50,49$ Pjun Elemente des $\mathfrak{W a f f e r s}=0,77$ Cubiffun, bleiben 50,49 Pfund $=0,23$ Eubiffus = 219 Pfuno der (Eubifipa reiner Soblenitoff $=3,3$ fpecifiches Gerwid)t (Diamant 3,5, Graphit 1,8-2,27 fpecifiides (3iewid)t). 1,29.66 $=85,14.85,14 \cdot 0,5=42,5$ Wf̣un Elemente Des $\mathfrak{B a f f e r}=0,65$

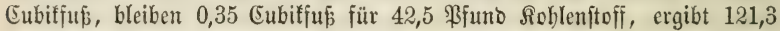

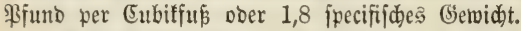

ßom Joritfantibaten Scerrn Scorn bierjelbjt auf neine Beranlajïung vollzogene, birefte Beftimmungen Des ipecififon (Serwid)ts fein pulberi=

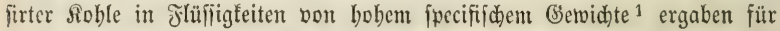
gemöhnliche Suchen Meilerfohle . . . 1,38 ipec. Serwidht Diefelbe im Flatintiegel ftart geglüht. . 1,65 " " gewöbuliche Birfen Meilertoble . . . 1,44 " " " Erlen Meilerfoble - . . 1,52 ". "

Dbgleid bieje Pefultate red)t gut entipred)en bem," oben " aus bem ipecifijden Eellulojegewid)t beredjneten Sohlengewidgt von 1,8 (bie Mintor: größje Der Mefultate ift offenbar cinem nod) nidt entfernten Sauer = uno Wafferftoffantheile zuzufdreiben) gebe id) ood) zu bebenten, Dap bas fpeci= fijd)e Eellulojegewid)t bon 1,29 an fid gering erfdeint, ba es bem fpeci=

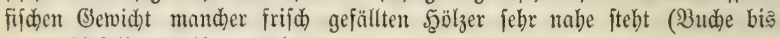
1,15, Alpfelbaum bis 1,26.)

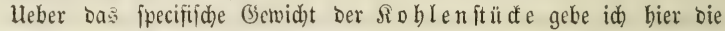

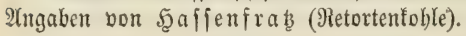

$\begin{array}{ll}\text { Birfen } & 0,203=13,5 \text { 'funo. }{ }^{2} \\ \text { (Ej)en } & 0,200=13,2 \quad " \\ \text { Elabeeren } & 0,196=12,9 \quad " \\ \text { Budjen } & 0,187=12,3 \quad " \\ \text { Seimbuchen } & 0,183=12,1 \quad "\end{array}$

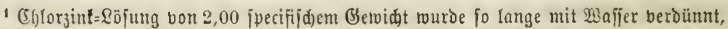

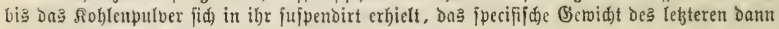
Dem ipecifijden (Betwid)te Der Ealylöjung gleidgejebt.

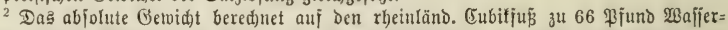

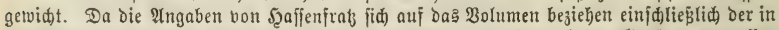

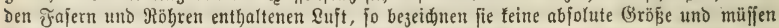
für biejelbe Szoljart fekr beridieden fïa) ergeben, je nadbem für bie Unterjudung ein mebr oder weniger porös getwadfenes 50 lo bertwendet wirb.

Die Strgaben bon Rilein fübre id bier nid)t an, weil bei jeinen Berfudben eine theil=

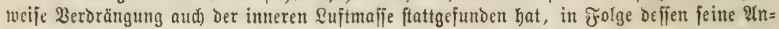
gaben eine unbeftimmbare Etelle eimnehmen jwifhen dem jpecifijden (Getvid)t ber Sohlenjtüfe unt ber lufftreien Soblenmafie. 


\begin{tabular}{|c|c|c|c|}
\hline Ulmen & $0,180=$ & 11,9 & P「un \\
\hline Fidtentein & $0,176=$ & 11,6 & \\
\hline Ahorn & $0,164=$ & 10,8 & \\
\hline Eidhen & $0,155=$ & 10,2 & \\
\hline Birnbaum & $0,152=$ & 9,0 & \\
\hline Erle & $0,135=$ & 8,9 & \\
\hline Sinbe & $0,106=$ & 7,0 & \\
\hline
\end{tabular}

Sn Jolye bes nicht vollitänsig entfernten Eaueritoffiz uno wailer:

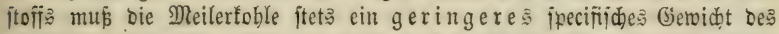

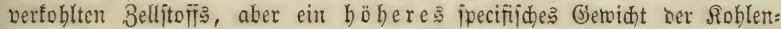
ftürfe ergeben, als bie boch erhiz̧te Retortentoble. Eeite 186 ber Inlei=

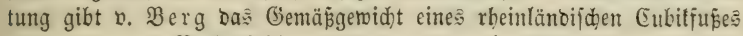

Budbentoble $=11,5-12$ cöln. Pĭunbe.

Sieferntohle $=10,0-12$

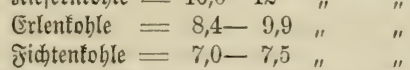

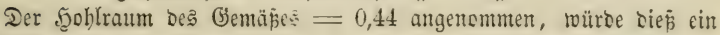
Derbfoblengetwidt ergeben

Budentoble bis 21 Pfuno $=0,318$ ppec. Ëenidht.

Rieferntoble " 21 " $=0,318$

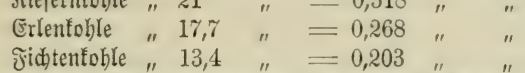

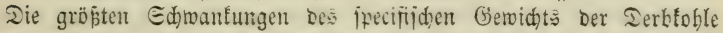
ein uno Derjelbent fyoljart ergeben fid aus oer voritehento mitgetheilten Tabelle:

altes Eiden Rernbols bis 31 \$funo $=0,47$ ipec. (semid)t.

Eiden Splinthol " $19 "=0,29 "$ " "

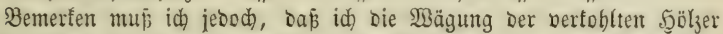
erît einige Iage nach Der Serfoblung auझ̆übren fonnte, nachoem fie ohne 3reifel bereits erbeblide Diengen Jeuditigteit aufgenommen hatten. Dajlelbe gilt aud) wohl von sen v. Berg'idhen Durchjidnittảzablen.

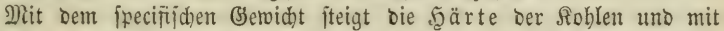
Diefer bie für ben Şüttegebraud widhtige Iragfraft. Beibe fimb nidht

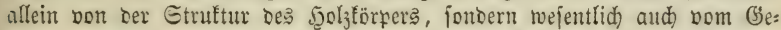
halte beffelben an Etärfemebl abhängig, bas eine jebr harte, fobmer ver: brennlidbe Soble liefert. Da jelbjt bei ber Edjmeljhibze bes Blatin nod)

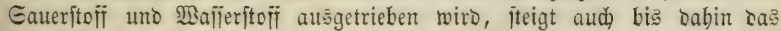

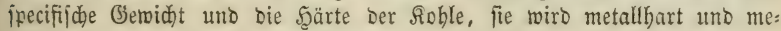

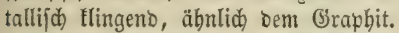

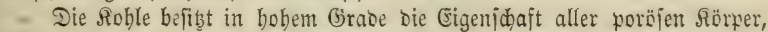

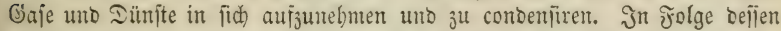

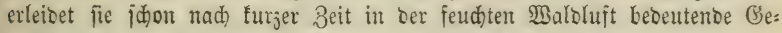
midhtjunabme uno jwar nach 2 a a innerbalb 24 Etunoen:

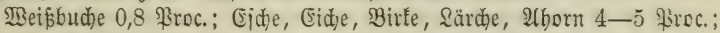

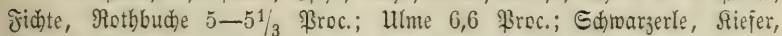
Beibe, Ianne 8-9 \$roc.; Єdhwarzpappel 16 ßroc.

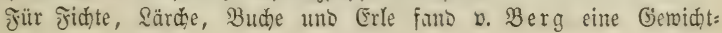




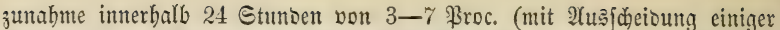
Extreme: 1,09-9,38). Jnterbalb brei 20 ochen: 8-12 Broc. (Extreme: $4,71-13,47)$.

Nad) Berlid fteigerte fid bie in Den erften Iagen bon Birfentoble aufgenommene Feudtigfeitsmenge bon 4,35 \$roc. binten 85 Tagen auf 8,44 Broc. Nach Rarften fann bie (Servidstzunabme bis auf 20 \$roc. iteigen.

Un liquiber Feudtigfeit nimmt bie Soble nad) Sllein innerbalb $5-8$ Dimuten 20-40 ßroc. auf. Nad $\mathfrak{b}$. Berg fteigert fid bie Menge bes aufgenommenten $\mathfrak{B a f j e r s ~ i m t e r b a l b ~} 192$ Stunden bis 137 Broc.

In $\mathfrak{2}$ mmoniafgas abjorbirt bie Sioble bas 90 adche, an Roblenfäuregas

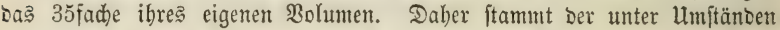

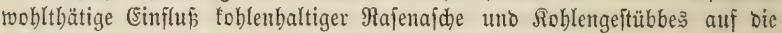
Begetation.

Einer dentifden Zerfeţung ober einer Berminberung ift bie Siohle in Der atmojphärifden Suft nid)t unterworfen; fie fann beliebig lange Beit unveränbert aufbewabrt werben. Regenwetter und bauernbe Berübrung

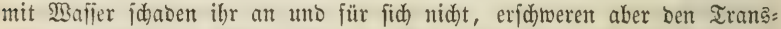
port uno crforben Bremiftofi zum Bieberabtrodinen. Jeudhte Roble er: leibet beim Iranţport aber weniger \$erluft burd) Jubrfrimpfe.

Die Rohle wirft felbit antifeptifd, o. h. fie verzögert bie Berjeb̨ung mit ihr in Berübrung ftekentoer organifjer Stoffe. Sie bat entolid) bie

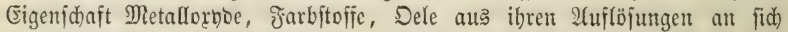

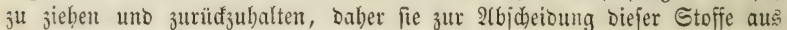
ơ flärenton fłüfifigfeiten berwentot mirb.

Da bei ber Berfoblung Des Şolzes Lebeutende Mengen bon Bremnfoff

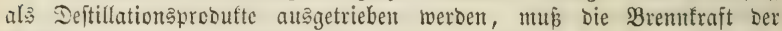

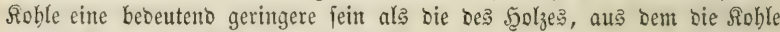
Dargeftellt wurbe. Man fann biefen Berlujt auf $40-45$ Broc. ber Brent= fiaft bes 5̧olzes anjeţen, alf 50 Broc., wenn man bazu ben Şolzberbrauch

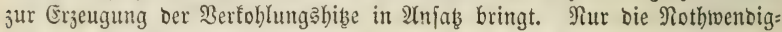
feit ber Rebuttion bes Brennitoffis auf geringiten Raum zur Erzengung

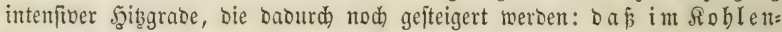

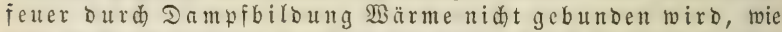

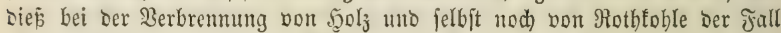
ift, enolid) die reoucirende WBirfung ber Sohle beim Edmelzen ber (Erze redtfertigte Den Sohlenberbraud.

c) Metbodifdes.

a) arrgemeines.

Dả Gejhäft ber ßerfohlung erforbert befonbere Borridhtungen, Durch twelde Der 3utritt ber atmoiphärijhen \&uft zun bertohlenten Şolze ent=

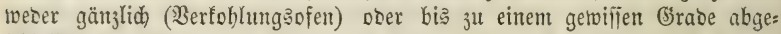
id)lofien ift (Dienmeiler, Meiler, (3ruben). Diefe Norridtungen fino ent= weber beftäntoige für twieberbolten Giebraud) (Dien, Dienmeiler, Ģruben) Doer fie werbon nur für ein Berfohlungşgefoüft hergeriătet (Meiler). Die 


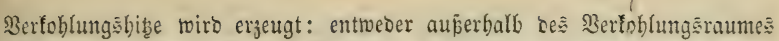
(Dien), ober innerbalb des Berfoblungsraumes Durd, Şerbrennung cine Theiles ber zu vertohlenden 5ुolzmalle (Dienmeiler, Meiler, Grutben).

\section{1) Dic verkolllumg Durds Außsnfort.}

\section{Dex Bertohlungafen.}

Man veriteht barunter einen vollfonmen verid)liepbaren, aus Metalls

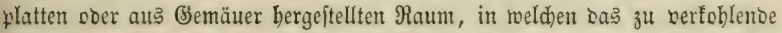

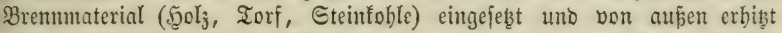
wiro burd) Cirfulirfanäle, bie von einem Jeuerberbe ausgeben uno ent=

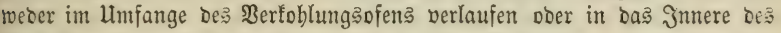
Serfohlungerraumes hineingeleitet fino. ${ }^{1}$ (Eine Borridtung, bei weldter ber

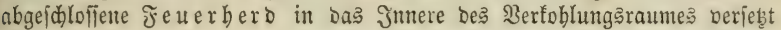
ift, rurbe mir bis jekst nid)t befannt. Sie roüroe in jofern zwedmäpiger jein, als baburd jebem vom Jeuerraume eintretenoen Märmeverlujt nach aupen vorgebeugt fein twürbe.

Alud) ber Theerofen gebört bierber, ein bactofenförmig aufgemauerter Bertohlunģ̌raum, in Deffen ganzem Ulmfange ein Feuerungŝraum mantel=

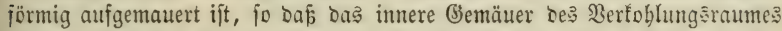

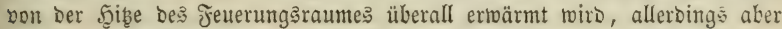

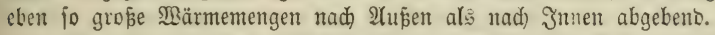

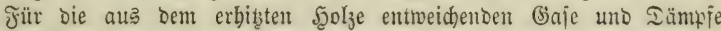

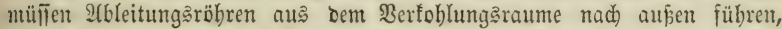
¿ie baju bienen fömen, entweber bieje Dejtillation引probufte aufjufammeln uno zu benuţen ober fie bem Feuerungsiraume zujuführen uno bajelbjt al: Brentuitofi zu verwerthen.

Da im Berfoblungsofen eine Berbrennung nidjt eintreten famn, muß

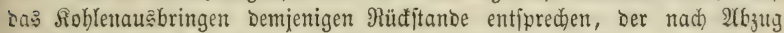

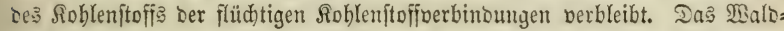
trodenholy, wie es meift zum Einjeb̧en in ben Dien fommt, entbät gegen 30 \$roc. MুGafjergebalt. MBir haben gejeben, Daj Demjelben ein Rohlen=

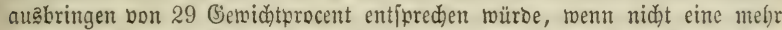

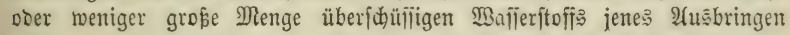

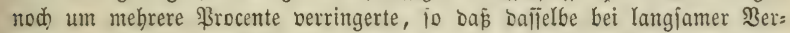
tohlung felten über 25 Proc. fteigt. Der Meilertohlung gegenüber mürbe

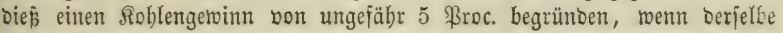

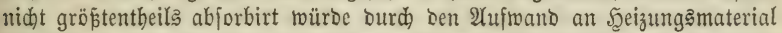
Des Dfens, wo bie Menge beffefben nidjt twefentlid) verringert wirb burd) bie Mitwerwendung bes gas: und bampfförmig Dem Soblholze entweidenten

1 Findet die Crhibung Des Werfollungäraumes mur von aup̌en ftatt, jo barf letjterer

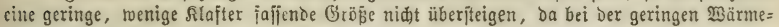

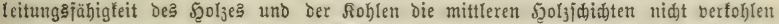

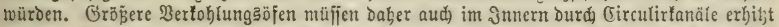

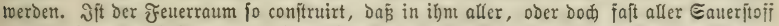

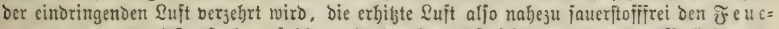

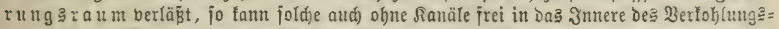
raume cingelaijen werden, ba fie cine Berbrenmung nid)t ju berwirfen vermag. Szicrauf

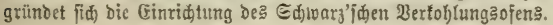


Bremitoffs ober wo ein 2 (ufivano an Jeuerungsmaterial gar nid)t beftebt, burd) bie Bertwentung einer Fुike, bie ohne bas mublos entweichen würbe, twie 3. B. Die Esidtfflamme beim Sdjmelzen ber Eijentzze.

Sdreibt man ber Dfenberfoblung ein Mebrausbringen in biejem \ebs: teren Falle von 5 ßroc. zu gut, fo wiro bafielbe bod) mehr als aufgehoben

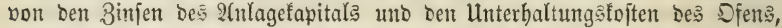
ferner von $1 / 2-3 / 5$ Der 2 Anfubrlöhne des zu berfohlenden Şolzes für bie Strede vom Shlage bis zum Dfen, Den günjtigiten Fall angenommen, in

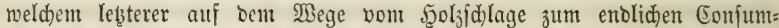
tionsorte ber Sioblen gelegen ift, was jebod) bei Der Drts̄beränderung ber

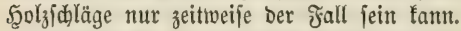

Dagegen hat bie Dfenwerfohlung allerbings ben wejentliden Borzug, baj fie weber bon ber Jahreszeit, bon Wino uno Better, nod von Der

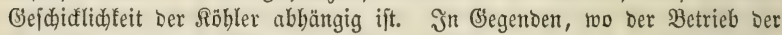
Baloföhlerei wegen Mangels tüdtiger Sïbler auf niebriger Stufe fteht, fam Daber aus ber Sfenverfoblung twohl einiger Nuben entfpringen. Beniger Berth mödste id) auf Den aus Den gejammelten Deftillations: probuften zu erwartenden (Be)winn legen. Seit in allen größ̂eren uno vielen Mittelfïäbten bie Gảerlend)tung eingeführt ift, werben bei ber Defitllation

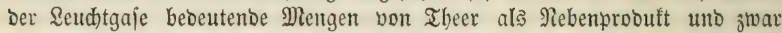

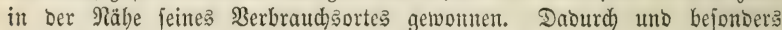

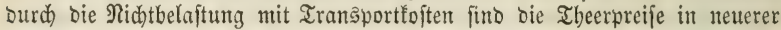

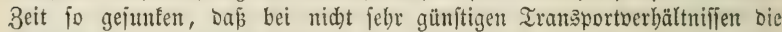
Berwenoung Der Deftillationisprooufte als Jentumgämaterial bie bortbeil= baftere ift.

(Finer tü đ)tigen Meilerfoblung gegenüber gewäbrt bie Dienverfohlung ficher feine Bortheile.

\section{2) Dic Ucrkoblung Durd) Zutucufuter.}

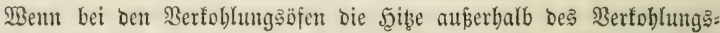
raumes erzcugt und in biejen geleitet wirb, fo gejohieht bie \$Jerfoblung in allen übrigen 2(pparaten Durd) eine ફlike, die im Berfohlungşraume felbjt

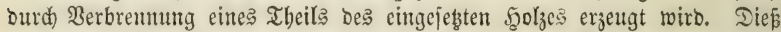

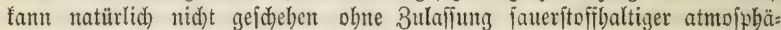

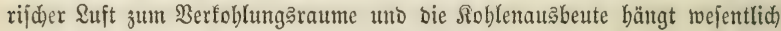

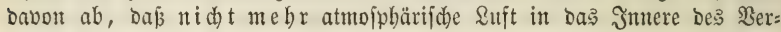
foblungsraumes gelangt, als zur Berbrentunt einer Duantität bon Solj unb Rohlen gehört, Deren Wärmeentwifelung gerabe aušreidht, Das übrige Şolz in Roble zut verwanteln. Seder Heberid)uß zutretender Suft vermin=

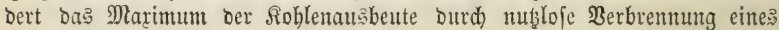
jeiner Giröpe entiprechentoen Roblentheiles.

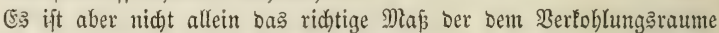
zuzulafienben atmojphärifden \&uft, meldhes bie Roblentausbente beftimmt, jontern fajt mebr noch bie ridstige \&eitung berjelben zu benjenigen Stellen Des Bertoblungsraumes, von benen aus bie Berfohlungahike noch zu wirfent bat. SMito bie \&uft zu Stellen geleitet, wo bief nid)t mehr ber fall ijt, fo beivirft fie bier eine nublofe Berbrentung von Soblen, wäbrento an ben 
Der Şize bebüriftigen Etellen bie Betfohlung ins Etocien geräth, Defien Folge ein beoeutender Berluft an ftrahfenter Bärme uno bes biejer ent=

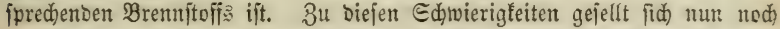

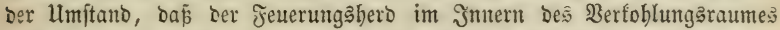

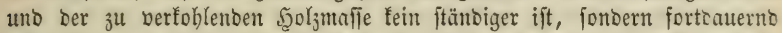
jeine Sage veränbert, in Dir 2(d)je bes Berfohlung abrwärt马 fenten uno bie Bertohlungăhike gleidmäß̄ig nach allen Seiten ber

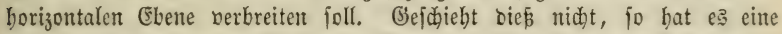
ungleid)mäp̄ige uno zum Theil unvolffommene Berfohlung zur Jolge. 2Alle bieje Edjwierigfeiten einer bas hödjite Roblenauabringen betwirfenter Soblung

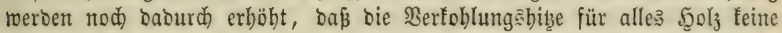

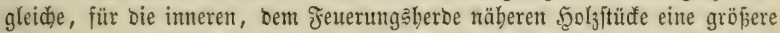

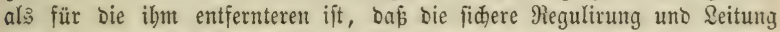
bes Jeuers wejentlid) an eine möglidjit bidjte uno gleidmäßage Edjidtung Des . Solzes gebunben ift, baher bann ber gute Erfolg bes Roblents wejentlid,

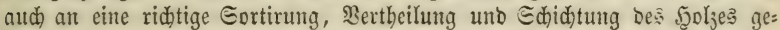
butben ift. Berüđfiddtigt man nun nod) Die mantuigfaltigen (Einflüfie Der Bobenunterlage uno Der Witterung auf bas Berfohlungagejdäft, jo wito

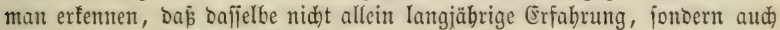

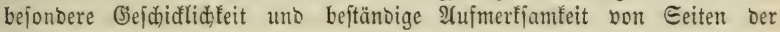
Sïbler erbeifat.

Die perfobiebenen Borrichtungen, beren man fid) jur Berfoblung burd? Immenfeuer bedient, fint folgenoe:

\section{Die Dienmeiler.}

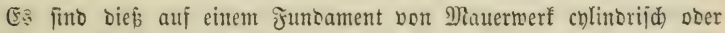

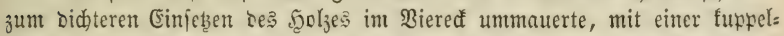
förmigen $\mathfrak{W o ̈ l b u n g ~ o b e n ~ g e j ( h l o f i e n e , ~} 3-4$ Ntr. bobe, 2 Pltr. weite

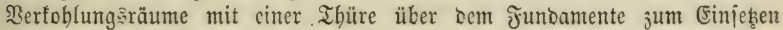

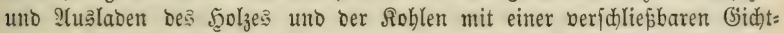

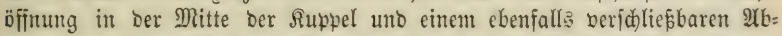
зuģrobre für bie (Saje uno Iämpfe, in weldhe ber zu vertoblende Brenn=

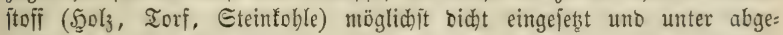

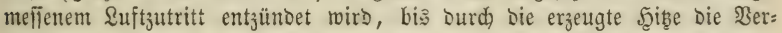
foblung vollenbet ift, worauf bann Durd) gänzlichen 2(bjd)luß ber Suft baß innere Feuer eritictt uno Der Dien gefüblt wiro.

Der für bie ßerbrenung nötbige gemäpigte \&uffţutritt wiro erzeugt: entweber Durd einen int Funbamente angebrad)ten, rom Bertohlunģ̧raume

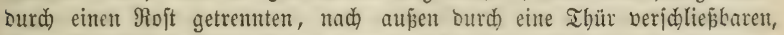

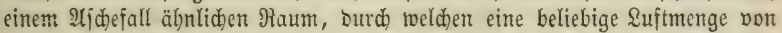
unten ber zum 3 erfohlunģraume gelafien merben fann, bie anfänglid burd?

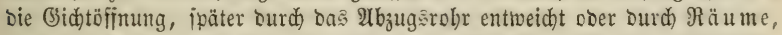

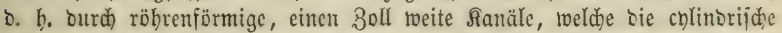
Itmmauerung Des Serfohlungşraumes in wagrechter Ridłtung runb herum

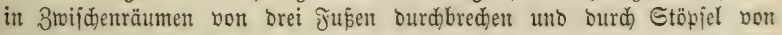
ausen veridhliệbar find.

In Den Eienmeilern biefer leţten $\mathfrak{A}$ rt geht Der \&uftzutritt burd) Die 


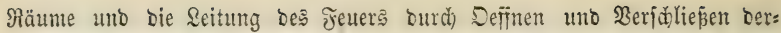
felben ganz fo bor fich, wie twir biế ipäter bei ber Meilertoblung fennen Yernen werben. Der Unterjajied bon biejer leķteren liegt mur barin, Dap bie Meilerbedte eine ftänbige aufgemauerte ijt.

Bei Der Berfoblung in folden Dienmeilern werben bie Dfentwände in bobem Brabe erbiąt uno wirb ein erheblicher Theil ber Berfoblung betwirft

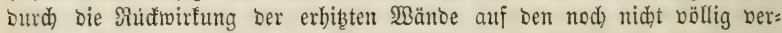

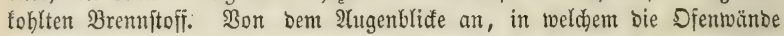

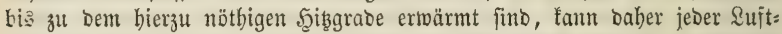
zutritt abgejकlofien uno baburch jeber weitere Bremntofiperbraud aufgehoben

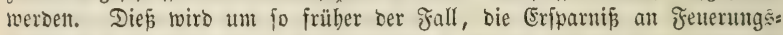
material Daber eine um fo größere fein, je reniger $\mathfrak{B a ̈ r m e ~ b i e ~ D i e n t a ̈ n b e ~}$ nad) 2(upen abgeben, baber man bem Dfen häufig eine zweite Umfafĭungs: mauer gibt und ben Raum zwijhen beiben Manern mit trodenem Sant

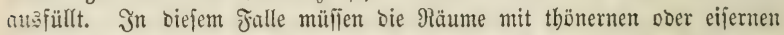
Riöbren ausgefleibet merben, ba ber Gand fie fonft veridütten würbe.

Ifle bic mannigfaltigen Radtheile ber Dfenberfoblung fitto aud) ber Berfoblung in Dienmeilern eigen uno bieje berbinden fid nod mit manchen Piachtbeilen Der Meilerfoblung, bejonbers mit Der Sdibierigfeit, ben Ruft=

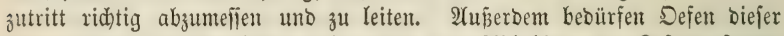
2(rt eines 2-3wödentliōen 3eitraumes zum 2(btüblen, Der Softentaufmano für bie Serftellung ciner größjeren 3abl berfelben, wemn groß̧e Şolzmafien 3u bertoblen fitto, würoe ein febr bedeutender fein, daher bann für bie 5oljoerfohlung Dfemmeiler mur außnahmşweije in 2lmwentung treten. Sie

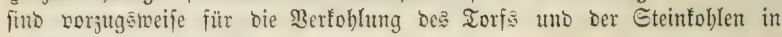
Gebrauct.

(3) $x$ uben

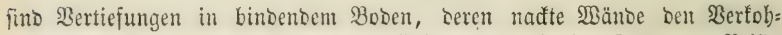
Kungshaum bilben, Deffen obere weite Definung burd) eine Decfe bon Reifig uno Stïbbe unvollfommen geidlofien wirb. Ein \&uftzutritt von unten finbet entweber gar nid)t ober burd) Sanäle ftatt, bie entweber neben ber Grube im (Eroreic) abrärts ziehen uno in bie Bajis ber Grube einmünoen ober, wenn bie Grube an einem Berghange gelegen ift, vom (Srumbe ber=

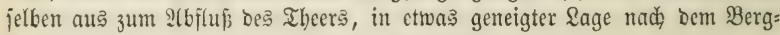
hange fich binziebent, an biefem zu Tage treten.

Die einfadjften (Sruben find trogförmige Bertiefungen bou 3-4 Meter im Quabrat unt 2 Meter Tiefe mit fladjer Soble zum Berfoblen von

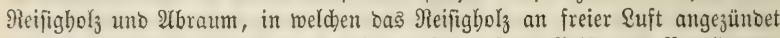

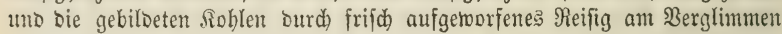
Durd) unvolffommenen \&uftabjhlus verbinbert werben. Mit bem 2(ufwerfen frifcher Reifigmajien wiro fo lange fortgefahren, bis Die (Srube mit Soblen angefüllt ift, bie man alsboann zur 2(j)egetwinnung von oben nad) unten

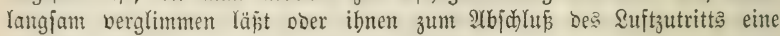
Erobecle gibt und bie Roblen baburd) erfitict.

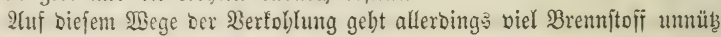

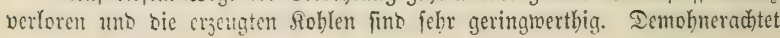


ijt biế cine Metbobe, bie ba, wo sas Reijerholz auf ben Eđlägen feine

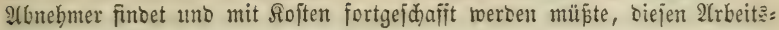
aufwanto wohl zu erjekent vermag.

Beflere Soblen aus ftärferem Şolje mit einem geringeren 2Aujwanto an Feuerungsmaterial Yiefern tridterförmige Gోruben, in bie bas fgolj eingefeşt uno von oben nad unten unter einem Raub) unb (Erberad) wie bei

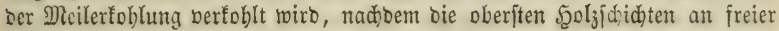

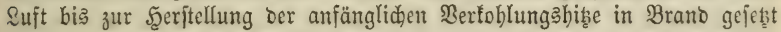

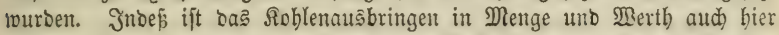

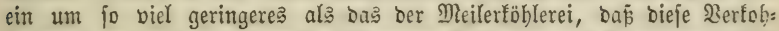

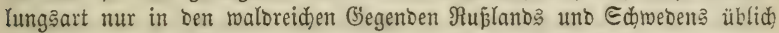
ijt, Gejonbers ber Theergetwinnung uno Der Erjparni mit ber Serftellung gemauerter Theeröfen berbunben fein würbe.

\section{Meiler.}

Wenn bei allen vorgenannten Nerfoblungäborridtungen bas . Solly in

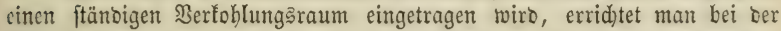
Meilerfohlung um eine jeve, behufs gleidjeitiger Berfohlung zujanmen=

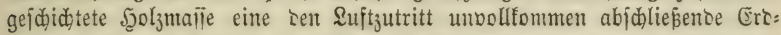
Decte, welche bie Stelle ber foliden Ulmfallungsmauern bes Berfoblung:

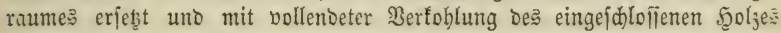
zerftört twirb.

3 u ben bereits ভeite 302 angebeuteten Sdimierigleiten jeber Roblung mit Jntenfeuer tritt baher bei ber Meilerfohlung nod bie Nothmentigfeit

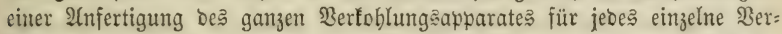

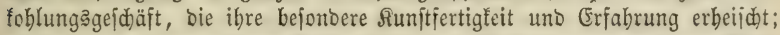

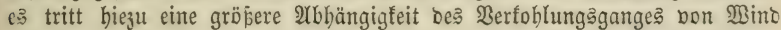

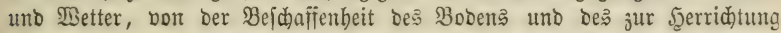
Der Decte fid sarbietenden Materials in Jolge ber geringeren Didjte uno Şaltbarfeit leţterer.

Daber ift bann bas Soblenausbringen bei ber Meilerfohlung nidht allein am meiften bon Der Sunftfertigteit uno Eorgfamteit Deకె Röblers, jonbern mejentlich) auch bon manchen 3ufälligfeiten und Dingen ab̧ängig, Die Der Röbler nicht zu beherridjent vermag, baber eine fobantentere als bei jeber anderen Roblungsmethobe.

Trobidem ift bie Berfohlung in Meilem bie bei weitem borherridente

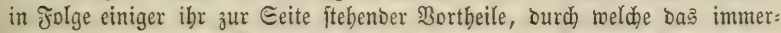
bin nidht bebeutenbe Mebrausbringen jelbjt ber bejten unter allen übrigent Berfollungäarten aufgehoben wirb, wenn fie bon geididiten föblern ges leitet wirb. Dieje Bortheile liegen:

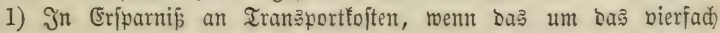

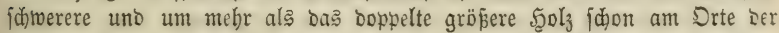
Fällung in Soble umgetwanbelt toiro.

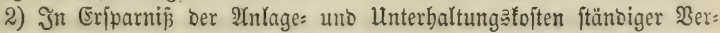
tohlungäben.

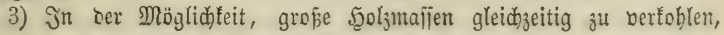

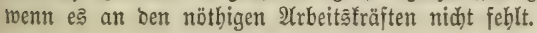


4) In ber gröperen Edywere uno Brennfrafit ber Sohlen, bic im Meiler burdfidnittlich nidht fo vollitänbig als im Sfen ihrer Deftillations: probufte beraubt meroen. $\mathfrak{A}$ ud bie jogenannte gare Meilerfoble entbält immer nod) 6-8 betwidtprocente in gröperer Şiţe fid berflüd)tigentor Stoffe unb zlwifden biefem 3ujtanbe Der Meilergare uno bem ber Roth= tohle mit $20-25$ Froc. nod) zu berflüd)tigender Beftanbtheile enthält jeber gare Meiler alle Hebergangsftufen. Sn ber That, wenn bie Berjudatob=

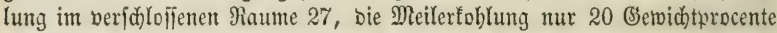
an Roble ergibt, fo überfteigt ber Getwid)twerlujt an Soble bei Der Meiler= fohlung Dennod) jene Differenz von 7 Proc. bedeutent und zwar um ben Betrag ber in Der Meilerfohle nod) enthaltenen zu verflübtigenben Beftand: theile. Der (sebalt an lebsteren beeinträd)tigt jeood) ben Werth ber Soble

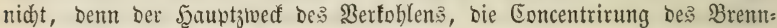

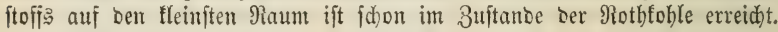

Dieß fint bie Grünbe, bie bis jeķt ber Meilerfoblung bor jeber an= Deren bie bei weitem überwiegende 9 nnwentung veridjafit baben. Da einer Diejer Girünoe bieje Roblungsmethode vorherrichent in ben Wald und unter bie Reitung bes forftmannes verweist, fo ift fie es, ber twir bier eine näber eingehende Betrachtung wiomen müfien.

Die veridiebenten Metboden Der Meilerfoblung fino im Bejentlicten: Berfoblung in ftehenben Meilern

a) Deutiche Meiler,

b) italieniface Reiler,

Bertoblung in liegenoen Meilern.

Bei ber Berfohlung in ftebenden Meilern werben um einen centralen fenfred)ten Feuerungsraum (Duandelraum, Duanbelichad)t) bie zu verfoblenten ફुöłzer treişörmig in aufgeridteter Steflung uno in brei über=

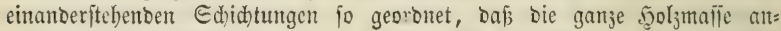
näberno eine balbługlidbe Form erbält. Die 2tufenfläd)e diejes halbfug= liden $50 l_{3}$ to

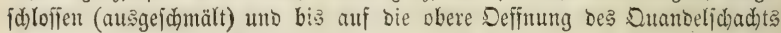

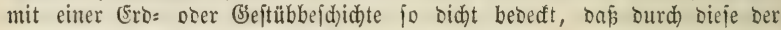
freie 3utritt ber \&uft zum Syolze abgeidhloffen wirb. In bem mit leidht cntzünolidem Bremiftoff erfüllten Duanbelraum wiro Durd) Şerbremmung Des erfteren bie Berfohlungahibe erzeugt, Der hierzu nötbige \&uftzug burd)

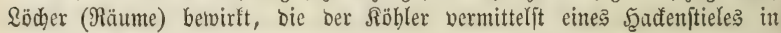
Der Erobecfe anbringt uno bie Berfohlung burd) Berfallus ber oberen uno Deffmung tieferer Räume allmälig von oben nad') unten fortgelcitet, bis bie

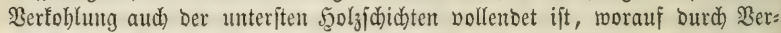

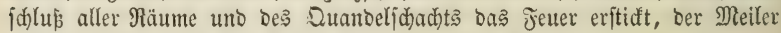
gefühlt twirb, bis bie Soblen gelangt weroent fömten.

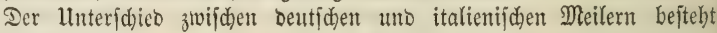
Darin, Daj

1) bei erfteren Der Boben unter bent Meiler borber gelodiert roiro, fo Daßs ein gemäp̧igter Suftzug burdh Den Boben in Den Meilerraum ftattfinoen

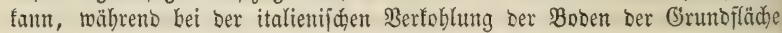
fo feft fein muf, baj surch ibn ein Suftzug nicht ftattfinbet; 


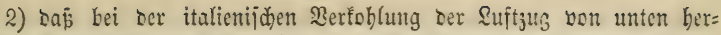
geftellt wirb burd) eine (Srunblage bon Baumftämmen, bie, in rabialer Rid̄tung jum Mittelpunfte Der Meileritelle mit Dem Gipfelende nad) Jnnen

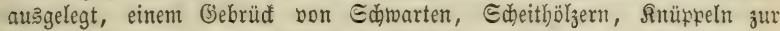

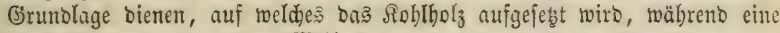

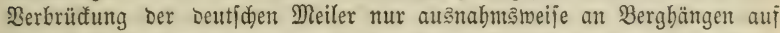
jehr flachgrünbigem ober moraftigem Boben ftattinbet, wenn sie शoth: mentigteit einer $\mathfrak{W a h l}$ jolder Stellen borliegt;

3) baईs, währento bei Der beutichen Rohlung Der Meiler aus $60-100$

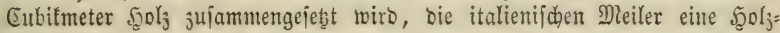
majje von 300 uno mehr Eubifmeter enthalten, uno jtwar in ungejpaltenen,

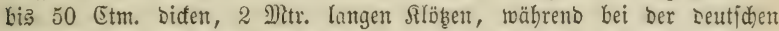
Sohlung alles jtärfere Şol gejpalten, in Der Form gewöhnlider Slutter= bölyer eingejeל̨t wirb;

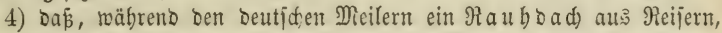
Farnfraut, Mions 3c. gegeben mirb, Das, eingeflemmt zwifhen bie fleinen

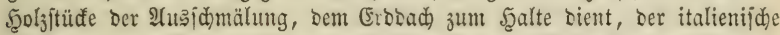
Meiler nur ein (Erboad über ber $\mathfrak{A}$ uș non 0,6 Mitr. an nad) oben bis auf 0,2 Mitr. fid verringert. Stärfere

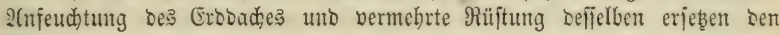
Mangel be Rauboadhes.

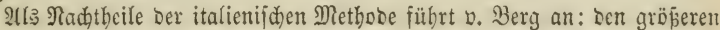
Jeud)tigteitägehalt ser verwenbeten ftarfen Runbhölyer, bie aud fein io bidstę Einjeß̨en als Edjeithöljer geftatten; einen Materialverlujt von gegen 18 ßroc., theils an Jüllhols, theils an Ėinjas in Jolge lange bauernoer Unterbaltung ftarfen テeuers im Duandelraume; die Nothwendigfeit groß̄er

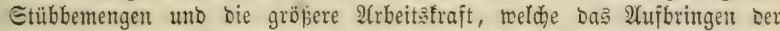

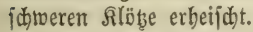

Lleber Berfoblung in liegenden Deilern gibt uns v. Berg ausführ= lidje Nadjridjt (Inteit. 2. 24ufl. Seite 18\%), ber wir Jolgendes entuebmen.

2(uf einer ebenen, um 5 ßroc. geneigten fläd)e wirb bie Meilerftelle, in einter Sänge bon $8-10 \mathfrak{M t r}$. unt $4-5 \mathfrak{M t r}$. Brcite in ber form eine

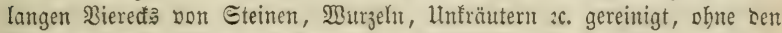
Boben mebr als uöthig ju lodern. Bon 10-20 Etm. jtarfen Stänmen erbält bieje Etelle eine Unterlage, bie, getoöbnlid) ats orei Stämmen von ber Sänge ber Sohlitelle beftehent, io ausigelegt werben, baj bie Stelle burch ite in vier gleid)breite \&ängäfelber getheilt ift. Suter über bieje Unterlagen, bie auf loderem Boben eine Unterftüb̧ung von Eteinen erbalten müī̄en, bamit fie bie Sajt Les Rohlfoljes nidit in ben Boben brült, werben als: Dann bie 3-6 Mtr. langen, ungefpaltenen, wo möglidh fidon längere 3eit

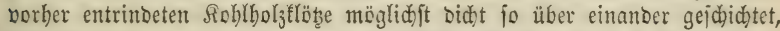
Don fie einen, an ber unteren Schmaljeite bes Shlongum 2 Mitr. an ser oberen Sd)maljeite 3 Mltr. hohen Soljiftof bilden, ben man mit einer auf idrwad) geneigter (Ebene gejeksten Runbholjflafter vergleidyen fann, mit bent Interidjiede, baj bie $2-3$ Slafteritübsen Der unteren 巨dimalpeite $75-80^{n}$ nad) Snnen geneigt jtehen, mähreno sie sbere Edhmaljeite oer Stüken saburd) nicht bebari, Dañ fie badförmig um $1 \mathfrak{M t r}$. unten meiter al? olen 


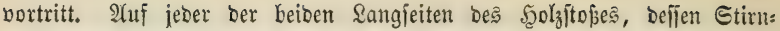
flächen beiberjeits eine fentrechte (Ebene bilben müfien, an ber fid) ein (Ero: bad) nidht balten würbe, werben in einer (Entfermung bon 15 (tm. eine Reibe Piäble fenfrectit in bie (Erbe gejd)lagen und an ber inneren Seite biefer Эerpfäblung eine Wano bon Edwarten, Brettern ober gefpartenten Stämmen aufgebaut, zwijd)en ber uno ben Stimfläd)en beș Sioblholzes eine 15 (5tm. breite Baffe verbleibt, in weld)e bie Stübbe eingefüllt wirb. Eine gleide Berfdalung zum 3wifdenfülfen ber Etübbe umgibt aud) bie untere

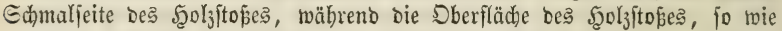

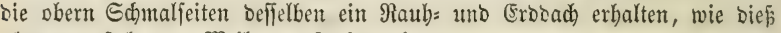
über ben ftehenten Meilern gefertigt wiro.

Das 21nzünden bes Meilers gejohieht Durch einten 15-20 Etm. weiten, mit Bränben, Epänen 2c. erfüllten Feuerungăanal, ber burd̆ 2Yuslaffung

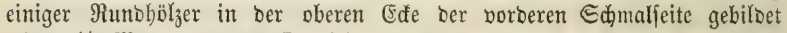
wirb, $1 / 2$ Mtr. unter Der Dberjeite, 25 (Stm. Giuter Der Borberieite. Son biejent Ranal aus rirb bas Jeuer burd) Jukräume nach unten uno bann allmälig von vorne nad binten geleitet.

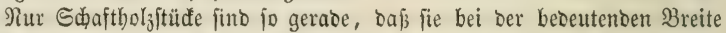

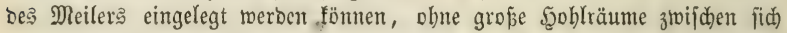

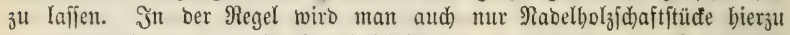
verwenden fönnen, ba in Saubbolzbeftänoen Der 2lbgang am Srummbols

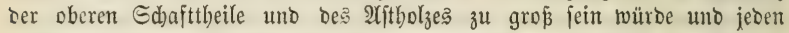

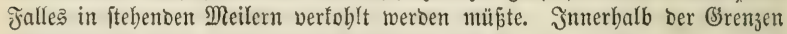

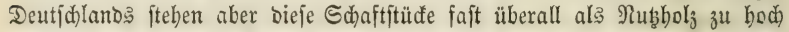

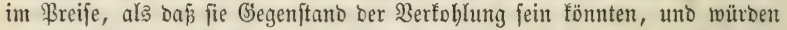
bei uns bie liegenton Meiler mur bann 2Ynwendung finden, wo burd) Mind:

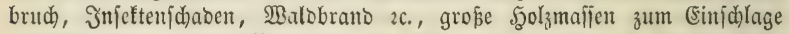
foumen müfifen, beren Menge ben möglid)en Pub̧bolzabjaß̧ bei weitem über=

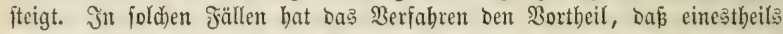

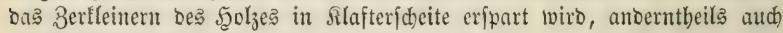

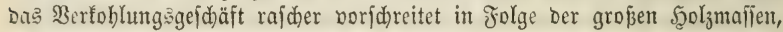
Die in einen Meiler geferst werben fönnen. Shud ift bie Berfohlung in liegenben Meilern weniger von ber Mitterung abhängig uno erforbert fie

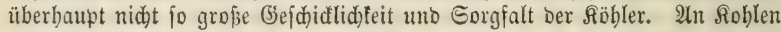
liefern bie liegenden Meiler gegen 5 Proc. weniger ale bic ftebenten Meiler uno bie Roble ift leidfter.

\section{Die Berfohlung in. ftehenden Meilern.}

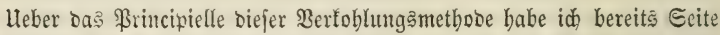
306 gefprod)en, es bleibt mir baher bier mur nod) bas (Gejdäftliche Der: felben zu erörtern, inbem id mebr als bei ben übrigen Metboben in ba Epeciellere eingehe, Da bie Merfoblung in ftehenten Meilern in ben beutfden Wäloern fajt bie allein beimifde ijt.

\section{a) Beit Der Roblung.}

Ein gemäß̆igter Suftzıg aus Dem Boden in Don Meilerraum ift eine wejentlidje Bebingung gutent Erfolges Der Rohlung, Daher bann ber Winter 


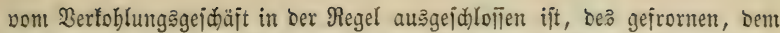

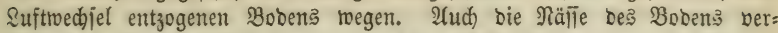
hinbert ben Suftwedjel, baher benn audf bas Frübjabr, fo lange bie Minter= näjie noch im Boben ijt, weniger gute Sohlungşrejultate als ber Eommer uno Serbjt liefert, jebr loderen grobjanbigen Boben ausgenommen, in meldem bie frübjahresfeuchtigteit ben allyuftarten \&uftwedjel mäpigt. 2fuch fteben im \$inter uno Frübjabre bie 尺ürze Der Tage, Edneefall uno an= bultento Regengüijie Dem wohlfeilen uno eriolgreiden b’ejdäft entgegen.

b) $\mathfrak{B a b l}$ und Bearbeitung ber $\mathfrak{R}$ oblitellen.

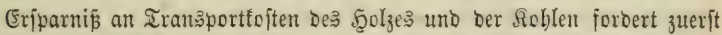

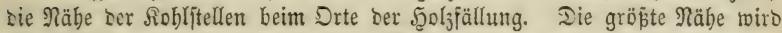
aber bäufig unmöglid̆ Doer unvortbeilhaft.

1) Durdh ungünjtige Bobenverbältnilīe oder Şinternifie ber Goblenabjubr.

2) Durdh Jeutersgefabr.

3) Durd nadtheilige Cinftüije bei einer ben Minde exponirten Sage Der Mieileritellen.

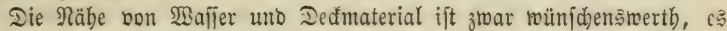
wirb aber inmer woblfeiler fein, beibes zur foblitelle als bas fohlholz зu eintem Drte zu transportiren, an welchem jentes ju baben ijt.

ad 1) Ein beftes Soblenausbringen forbert eine mindejtens $1 / 2, \mathfrak{M t r}$. tieje Bobenfrume, ant kejten von leidhtem locferem Sebmboben mit Damm= eroe. Sodferer Cant fübrt bem Meiler von unten zu viel \&uft zu unt mup Durd 2Afbringen eine? bindigeren Eroreid引 berbeffert merben. Etrenger Ihonboben brent fich ju fejt uno verbinbert baourd ben Suftzug von unten. 1 Untermengung mit Dammerbe, Gano, Sohlenjtübbe bebt bicje

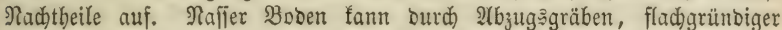
Boben fann burd) 2Uuftragent von (Erbreid) verbeīert werben. Tie ver: ¡obiebene Berflüftung ber felifigen Bobenunterlage ift nur bei flad)em Woben von erbeblidem Einflus, faum in jolden Füllen aber Dann einen ungleiden Suftzutritt aus Dem Boben und in Folge befien einen unregelmäpigen Siang

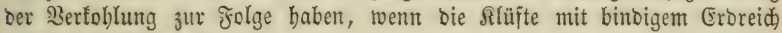
nidet ausgefüllt jin๖.

2uf locferem Boden ift es vortheilfaft, bie Stellenarbeit fhon im 5.erbjte vor ber Roblung ju vollenden, Damit ber gelocerte Boben ben Winter über fid robeber feßzt.

Ulte Roblitellen haben Den Norjug vor neu anz̧ulegenten, theils ber Roftenerfparni仍 unt Der vorbandenen Stübbe, theils einer befieren Soblung megen.

1 3ur Erhaltung Des, bie Berfohlungahitje erjeugenden Jnnenjeuers ift fortoauernder

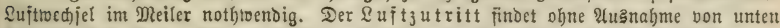
ftatt, theils Durd) Den Boden, theits Durd Die, unter Der fohlenden Sgoljididit liegenden

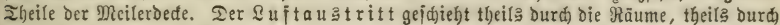

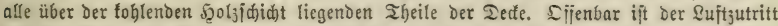

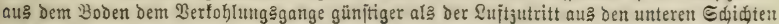
Der Meilerdefe, injojern er unmittelbar zum Luandelraume tritt uno der radialen Berbrei=

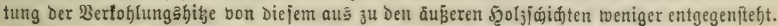

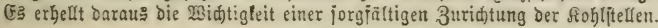


ad 2) Die älteren Soblentoronungen fdreiben aud für ben Şarz eine Räumung ber Umgebung bes Meilers in 60 Sdritt Entfermung von allem leidst feuerfangenden Materiale bor. Sn neuerer Beit ijt man an bielen Drten in biefer Şinfid)t fehr forglog getworben in Folge mangelntoer (5x=

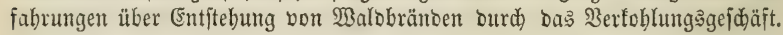

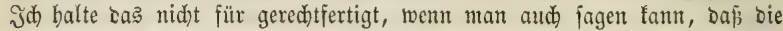
Jeuersgefabr in ber fendten (bebirgaluft eine geringere ift ala in ben $\mathfrak{B a ̈ l}_{=}$ Dern ber Ebene.

ad 3) Se geiduüterter bie Sage ber Soblitelle gegen Minto ijt, un io

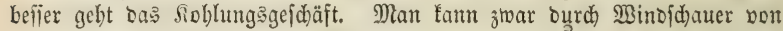
Boblitämmen, Sdywarten noer Reifigmellen bem Meiller fümittiden Sd)ub geben; ę ift bie Erridjtung berfelben aber mit erbebliden 2 rbeits: und Tranţortfoften verbutben, wenn fie ibren 3wed bollfommen erfüllen follen.

Meiler von 100-150 Eubifmtr. Scolzmafie (einjobließlid Raum) er:

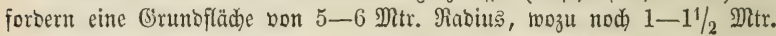
für ben Gejtübberano fonmen. Dieje (Srrunbflädye muß burd)auts in ber borizontalen Ebente liegen, an geneigten Flächen baher in ben Berg ge= arbeitet twerben, wobei bie gewomtente (5rbe auf bie Ihalfeite gejtürzt uno nötbigen Falles burd) einen Jled)tzaun feitgebalten wiro. (3ejdeht biép lez̧tere Durd) eine Mauer, fo nennt man foldhe Soblitellen: Mau erftellen; geichiebt ęs burd) eine borizontale, auf einem (beriift ausgelegte uno $1 / 3-1 / 2$

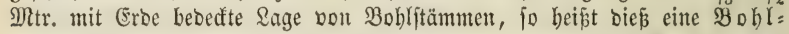
itelle. Heber Maueritellen toblt fid) befier als über Boblftelln, fie fino

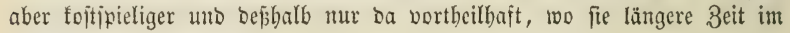
(Sebraude bleiber.

Jn allen Fällen mū́ der Boben der Rohlitelle von allen Steinen, S⿱B̈urzeln, Rajen bis zu $1 / 3-1 / 2$ Mtr. Tiefe gereinigt, geebnet, abgejirfelt uno von jebem Buntte bes Umfanges nad) Dem Mittelpuntte bin gleids= mäpig um 15-20 Etm. erhöbt twerben, fo bas bie Gruntofläche bie Gejtalt cine

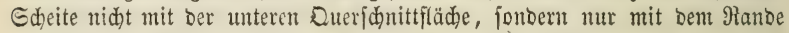
berfelben ben Boben berïbren, woburd) fowobl ber Suftzug von unten als

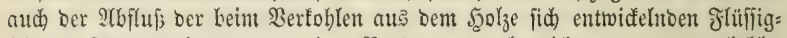

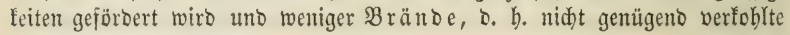

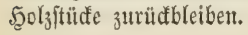

c) Sortirug un Bearbeitung bę Roblholzes.

Menn die Berbältnifie es irgeno geftatten, verfollt man jebe Sgolzart in gejontorten Meilem und mur unter Umitänoen, Die eine toejentliche Cr:

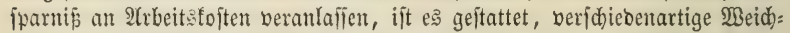
bölzer ober veridiebene barte Saubbolzarten gleidzeitig in Demjelben Meiler

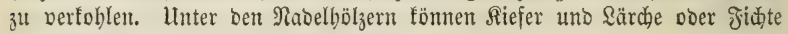
uno Tame ohne Rachtheil zulammengejebt werben.

Die Gortirung umfaßst bie gemöhnliden S3rennholjfortimente: Gdeit=

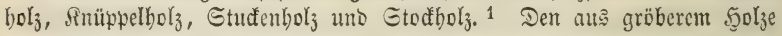

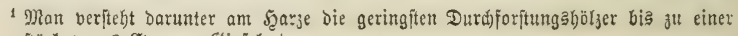
Gtammftärfe bon 2 Ctm. am Gipfelente. 


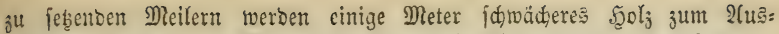
fămälen beigegeben. 2Ulles antrüddige $\mathfrak{S}_{0} \mathrm{l}_{3}$ wiro entweder in bejonderen

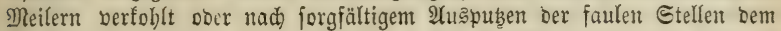
Etuctenbolze zugetheilt, leșteres biß zu 4 (5tm. Stürfe gerobet, um geringes IRaterial zur güllung ber Fुoblräume in Etudenmeiler z̧u getwinner.

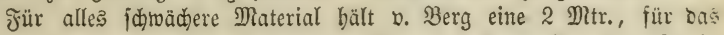

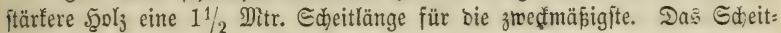
uno Etucfenholz iit 3 u 20-25 $\mathrm{Ctm}$. Stärfe auङzujpalten; erfterem fint

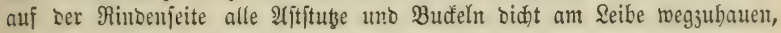
um ein möglidjt biđattę Einjeß̨en zu begünjtigen.

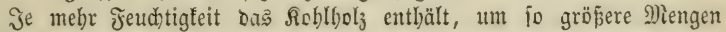
von Feuerung material werben erforberlid zur Erzeugung ber notbrenbigen Berfohlungashike, um io mehr Arbeițfraft erforbert bas Ifnbringen zur Meileritelle unt Das Cinjeksen. 2Alles gejpaltene Siohlholz muß baber min= Defteng einen Eommer über auf Sablid)lägen oder in lidten Beftänben trodfnen, ehe es verfohlt wirb. Epaltholz in fehr geidlofienen Beftänden uno alles ungejpaltene $\mathfrak{S}_{0} \mathrm{l}_{3}$ wirb bingegen mit gröperem Bortheil fofort verfoblt, ba mit Dem bier fehr langiamen 2(ustrodnen eine Berfebung Der Scoljajer Scano in Scano geht, bie Dem Rohlenausbringen fowohl, wie ber Ģüte ber Rohlen in hohem Grabe jobabet.

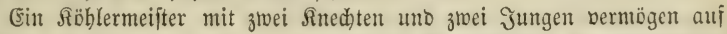

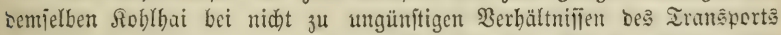
uno Der Şolzbereitung bon ?tnfanty Mai bis Enoe Dftober 2500-3000 Cubifmtr. Raumgemǟi zi verarbeiten.

\section{d) Midten bes Meilera.}

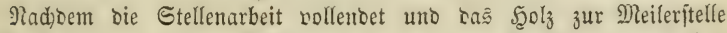

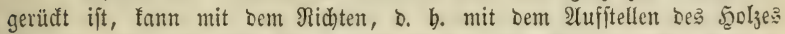
um einen mittleren fentred)ten Jeuerungşraum (Duanbel) begounen werden. Diejer mittlere Feuerunģ̧raum fann in beridiebener 2 seije bergeftellt werben. Entweder wiro in Der Mitte Der Meilerftelle ein $\mathfrak{P f a h l}$ von nahe ber Şöbe Le Meiler: jenfredst in ben Boden getrieben uno von oben bis unten mit

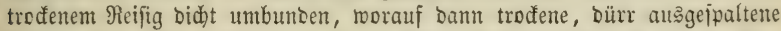

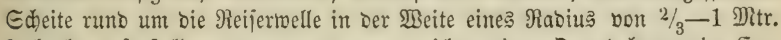
fenfred)t aufgeftellt weroen; oder man erridgtet einen Duandelraum in Cen=

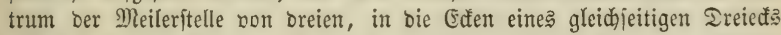

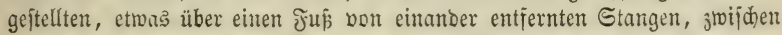
oie leidyt fetterfangente Materialien eingeididtet werben, nadibem am

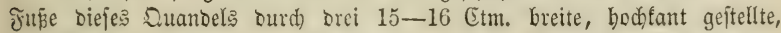

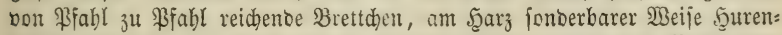
finber gentannt, ein leerer Raum gebilbet wurbe, wenn ber Meiler bon unten angezünbet werben joll. In biefem fralle reidht ein $1 \frac{1}{2}-2$ Mtr.

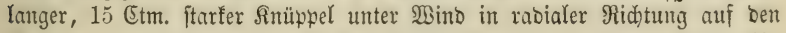
Boben gelegt, bis in ben Bünoraum bes Suantels, um zu biejem bin cinen auf Dem Boben verlaufenten. Zünofanal bilben zu fönten, indem man

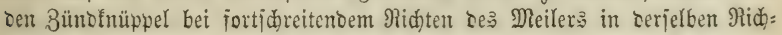

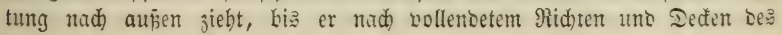


Meilers ganj binweggenommen wirb, um burd) ben an feiner früberen Stelle entitandenen Sanal bermitteljt einer 3ünoftange, an beren Epib̨e Birfen= rinbe ober Rienjpäne in Flamme gejeb̨t fino, bie Suanbelfüllung von unten anz̧ünoen zu fönten.

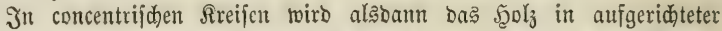
Stellung fo um ben Duanbel gerichtet, baj bie Spalteiten nad Jutuen,

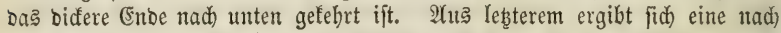
aupen zunelymente Reigung ber Sdeite zum Duandel von felbft, bie in

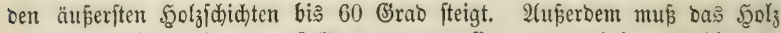

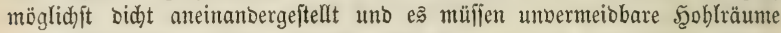
mit geppaltenen Stüden ausgefüllt werben. In jeðe concentrifdo Rreis=

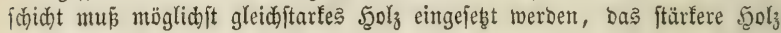
näher bem Duanbel, abgejeben von ben, biejem z̧unächjt geftellten trodenjten unt bünneren Scheiten.

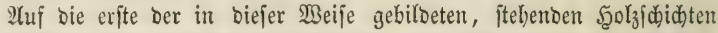

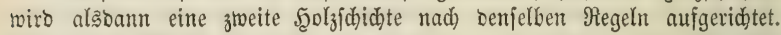

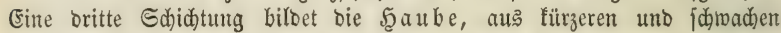

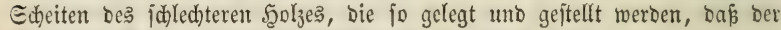
Meiler burd) fie zur paraboloibijchen form ergänzt wirb.

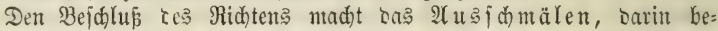
jteheno: baj im ganzen Umfange bes gerichteten Meilers bie, zwifhen ben

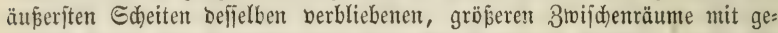

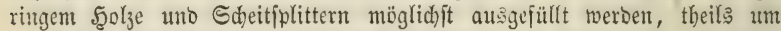

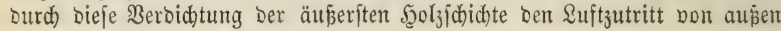

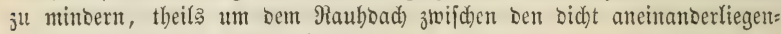

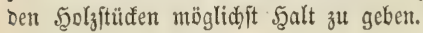

\section{e) $D a s \Re a \mathfrak{s} b a d$.}

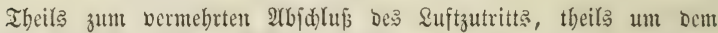
äuperften (Erboab)e cine geid)lofiene Unterlage zu geben, erbält ber aus= geid)mälte Meiler zuerft überall eine 14-16 Etm. bohe Lage von Piajen, Moos, Raub oder grünem belaubten Nabellgolzreifig. Den bidteften Mer= id)lup biloen Rajemplaggen, bie bicht an einanbergelegt werben, bie Blatt= jeite nad unten. (5: minifien aber bie nidft biel über einen Quabratfuj

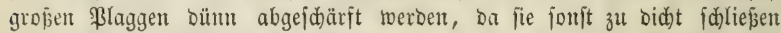
uno leidht ein Sdätten bes Meilers, o. h. ein theilweifes Abwerfen ber

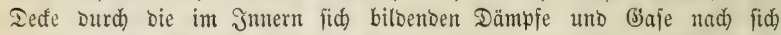

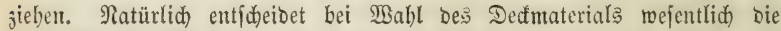
Seidtigfeit bes Bežlges, baber man in Fidtent= unb Iantenbeftänben vor=

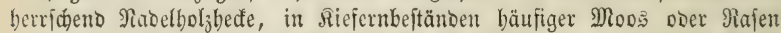
vertuentet, da bie iperrige Riefernbeffe fid nidht bid)t genug bem 50 (ze anlegt.

\section{f) Die $\Re$ üftung.}

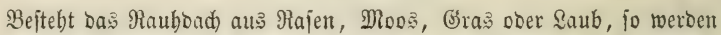
fhon bor 2Anfertigung seffelben, an Den Fup bes Meilers, 15 (5tm. bohe

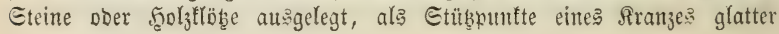




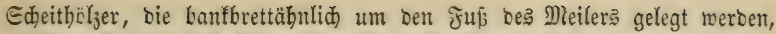

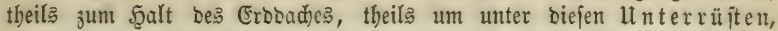
Durd) Sinwegnabme ber Deffe zu jeber 3eit ben 3ug von unten beliebig

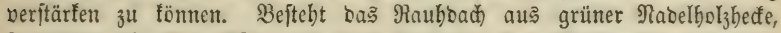
fo werben bie Unterrüften erft nad Jertigung bes Raubbades auągelegt. Das ift immer Der Jall bei Den oberrüften, beftchento aus graben Eḍeiten, bie von ber Mitte cines jeben Unterrüjt aus, aus ber auj= geridteten Etellung io auf bas Raubbad gelegt werben, baj ibre oberen

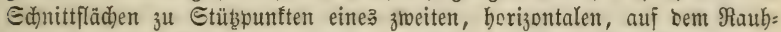
Dad) liegenden Siranzes von Edeiten Dienen. Dieje Sberrüften weroen jebod) nur bei fo fteilen Reilern angetwendet, an benen bas (Erobad) ohne biefe ziveite Ilnterftüb̨ung fid nidht balten würbe, aber aud) bant, wenn bei fehr trodenem Wetter bas Erboad) feinen Salt verlieren würbe.

\section{g) $D a s$ Erobad.}

Der über Dem Raubdad gerü itete Meiler erbält nun überall eine äup̃erfte Bebecfung mit feudter (Erbe, bie über einem Raulbadje von Rajenplaggen nur wenige Centimeter bod) зu jein braud)t, über einem Rauly= Dad) yon Şede, Moos 2c. $15-20$ Etm. hod aufgetragen roirt. Bon Burzeln uno Eteinen burd) 2(uăharten gereinigter, janbiger \&ebmboden if bierzu am tauglidjiten. Edywerer Boden muß mit Sant gemengt, Sano mú burd 3ujaß̧ von \&ebm ober Thon binbiger gemadjt werben, wenu

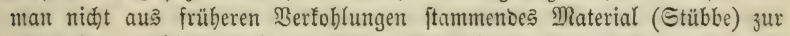
Şand bat, weldyes burd bie frübere Bearbeitung und burd bie Beimen= gung von foblenjtaub meift ben geeignetfen Brab ber Socferheit befibt.

Mit biefer Erob wiro zuerft ber Fū Dę Meilers bỉ über bie Unter= rüften runo berum, Dann bie Şaube betoorfen, morauf alझbann bas 2tut=

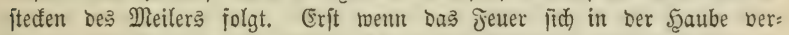
breitet, erbalten auch bie übrigen Ibeile ber MReileraupenflädje bas (Erboac\%. v. Berg bejürnortet jebod die \$ollenoung Des ganzen Erobaches vor Dem

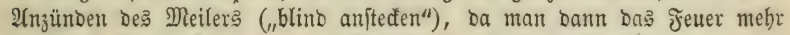
in jeiner Ġetralt bat, als beim 2(njtecen "mit offener Bruit.."

\section{h) Die テৈerarbeit.}

Der fo hergeridtete Meiler fann nun angejünbet unb verfoflt werben. Das $\mathfrak{A n z u ̈ n}$ ben gejdiebt entweber von unten burch ben Bünotanal in er= wähnter Meife, ober von oben in ber Şaube, bie bann weiter offen bleiken uno mit (eid)t brennbarem Material auڤ̉gefüllt fein muю.

Beim 2 (nzünben bon unten brennt ber im Duantelraum enthaltente Brennitoff raị nad oben bin aus uno erzeugt eine Scibe, ourd weldye ein Iheil Des Bremiftoff̈s ber Scaube geröftet und brennwilliger wiro. Der

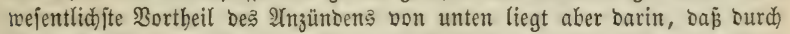

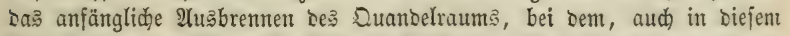
Jalle fiäter von oben nach unten fortfdreitenden Berfohlungägange, burd) bie in Der Umgebung Des Quanbelraums bereiț eingetretene Röfung, Der

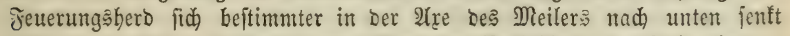
uno einen alleitig gleidmäp̄igeren Gaang ser Berfohlung zur Jolge bat. 
Bom Ruanbelraum aus berbreitet fich bas Jeuer zunädjt in ber ge: Decten Şaube Des Meilers uno muई dort einige Beit lebhaft brennen, um

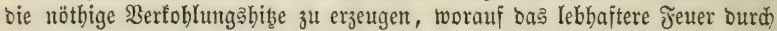
Erweiterung bes (Erboaches von oben nach unten allmälig bis zum Edjweblen

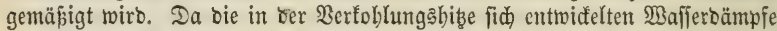
uno (Gaje nach oben bin rajd zu entweidyen burd) bie (Erbbede berbindert fino, bilDet fid) über ber glübenoen Soblenj(didjte jebr balo eine, ber äujeren

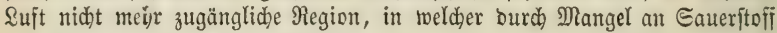

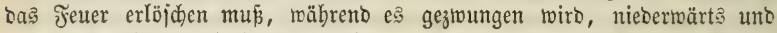
zur Eeite fid) auszubreiten, genäbrt Durd) bie, bon Der (Srunofläde bes Meiler aufiteigende atmojphärifłhe \&uft, bie, in ber glühenoen Roblen=

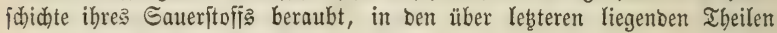
Der Meilerbede ifren 2 (bflúp finbet. ${ }^{1}$

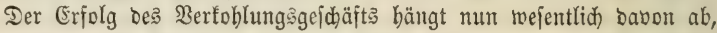

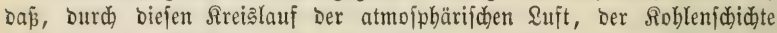
nidht mehr Gaueritoff bon unten burd Boden uno Meilerbede zugefübrt wiro, als nothmentig ift, um bie Berfohlungshişe zu unterbalten, ba entgegen=

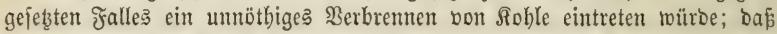
ferner ein rafdes Entweiden Der, über ber glühenten Soblenfdidte be: findlicken, beక Gaueritofḟ beraubten, mit Giajen und Dämpfen gemengten Suft verfindert wirb, burd Berbidtung ber Meilerbecte, oa anben: Jalles Das Jetter aus ber fdywehlenden in bie bereits verfoblte, überliegente Meiler: fodidhte cinbringen uno einen mubzlofen Soblenverbrano зur Jolge baben

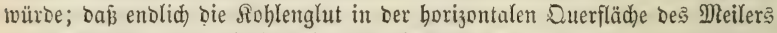
ununterbrochen uno gleid)mäpig fid abwärts fentt, ba jebe Unterbrechung ber idjweblenten Querfläd)e ben 3utritt fauerftoffibaltiger atmojphärificer

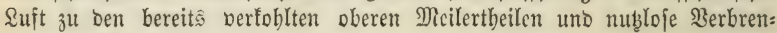
mung zur Folge baben würoe.

Ter Siöhler hat baher wäbrento ber Feuerarbeit Darauf zu fehen:

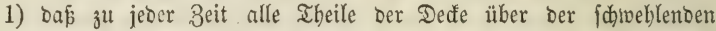
Scolzidichte möglidjit berbidtet werben, um ein raiches Entweiden ber

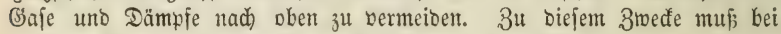
trocener Bitterung bie Dede burd Befprengen mit $\mathfrak{B a f j e r}$ feudst erbalten, uno bamit fie eine möglidjit geidhloffene Unterlage behält, müffen bie ver=

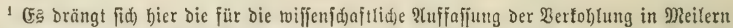
tvid)tige ₹rage auf: ob Die 3ertor)lungshife von cinem beftimmten Feucrungstaume aus=

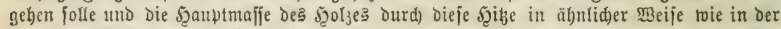

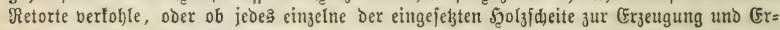

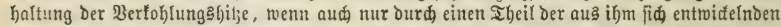
brembaren Gaafe, einen Beitrag liefere? Shne Brweifel finbet beim wirfliaen Berfoblungs= geidüft im Meiler Beides neben einander ftatt. Weld)es ift aber die überwiegende und ge=

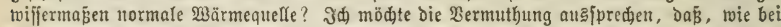
Der Reijerholjtohlung in (Bruben, fo auth im Meiler jedę einjelne Şoljidbeit zur (Frzeugung

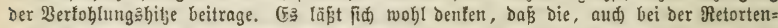
berfohlung entweidenden brennbaren Gaje in ber fajwehlenden Szoljididit fid entzünden, fo

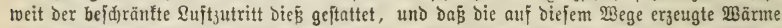
Die idwehlenden Ed)eite in glühenden $3 u$ ftand verjegt, olne bas bamit ein grö́̈erer fohlen=

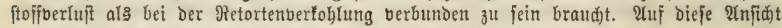
gründet fid bie nadjolgende Daritelfung ber Feutarbeit. 


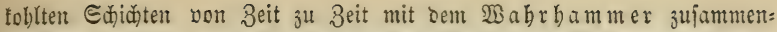

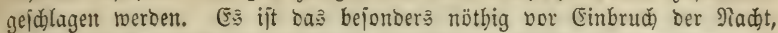
it ber bie Beaufíd,tigung nidht jo jorgfältig ausgefüfrt werben tamn, als bei Tage;

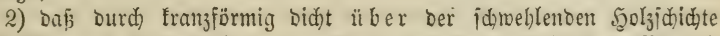

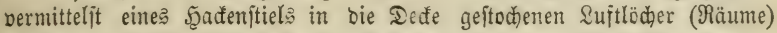
Der atmojphärijden \&uft, ben entbunbenten Bajen uno Dämpfen ein 2(b=

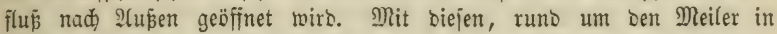

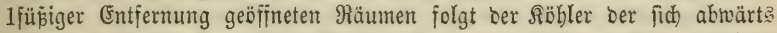

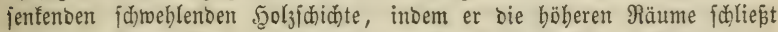

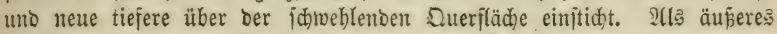

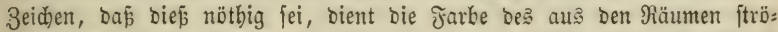

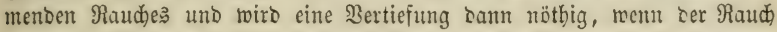
aus Der gelblicken Färbung in bie weife uno blaue Färbung fich verändert. Die eriten Rüume werben in Der Regel exft 24 Stunten nad bem SInftecten bes Meilers unter ber Şaube gejtodgen. Dieje Räume bienten gleidzeitig

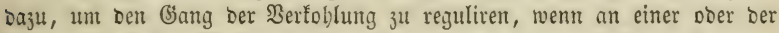
anderen Stelle Des Meilers bieje rajd)er als an anderen Steflen nach unten

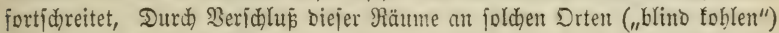
wiro barunter ber \&uftjutritt bon unten vermindert uno Der Fortid)ritt be Jeuer gemäpigt. Der Siöhler foll auj bieje WBeije bie futweblente 5golz= fadid)te fo viel wie möglid) in ber borizontalen Duerfläde bes Meilers erbalten.

3) Sit an einer ober ber antoern Etelle bes Meilers der Suftjug von unten

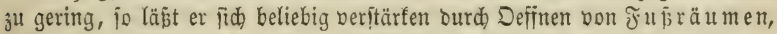
D. b. Durch Sintwegnabme eines Theil

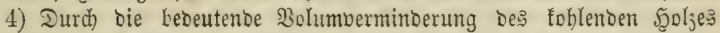

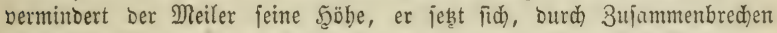

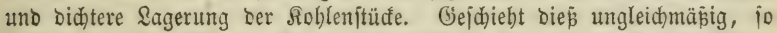

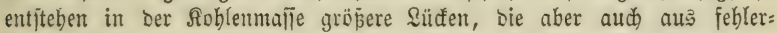

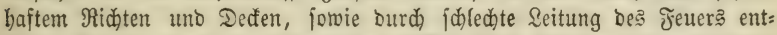
ftehen fönnen, wenn in Folge befien örtlid Durch lebhaftes flammenfenter Scolzmallen zur Werbrenmung gelangent. Uleber folden Stellen fentt fid Die Deçe mehr als an anderen Drten, ę entjtehen "ల̈üllen" Die Der

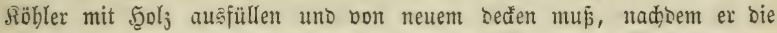
alte Decfe hinweggenommen uno mit ber Füllitange bie Sohlen zu=

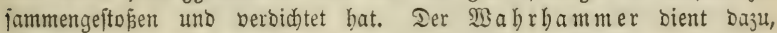

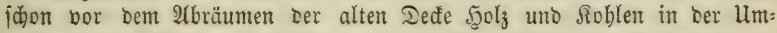

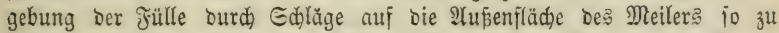

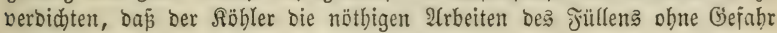
Des Eimfintens in ben Meiler verridten fann.

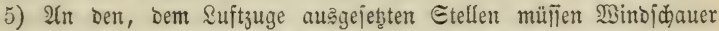
von ber Şöbe bes Meilers in belien ganzent Umjange aus Boblen, Sntt=

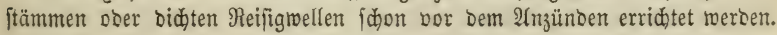

\section{i) Das 2 b tü}

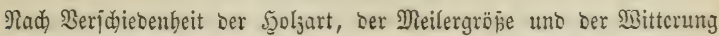

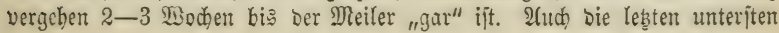


Räume werben bann burd) Stübbe verjolofien uno erft nad) Y(blauf von 24 Stunben bie trodene Stübbe ftreifentweife von oben nach unten bintveggenommen, flar geharft uno nieber auf bie entblöpte Etelle bes Meilers geworfen, bamit fie zwijd)en die Roblen binabriejeln uno bas nod vorbanbene feuter rajher erfticfen.

\section{k) Das \&angen un Sortiren ber $\Re$ oblen.}

Wenn ber Meiler nad 2 blanf weiterer 24 Stunben abgetüblt ift, funn er angebrodfen werben. Un etwa nod vorbanbene glimmente Soblent

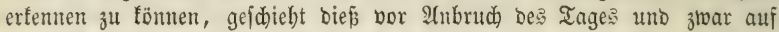
Der Dem $2 B$ inde entgegenjebzten Seite bes Meilers, vermittelit einer lang:

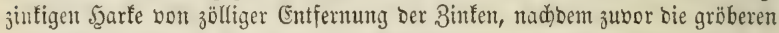
"Sefefoblen" mit ber Şand binweggentommen wurben. Die fleineren,

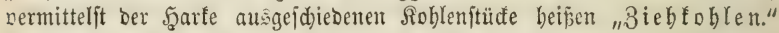

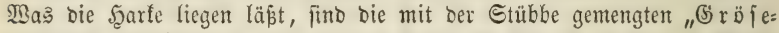
tohle n" (Sohlentlein) unter zölliger Didee, Die nur in günftigerent fällen Des 2 H fakes burch ein grobes Sieb won ber $S_{t}$ übbe getrennt werben.

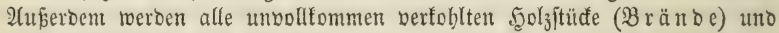

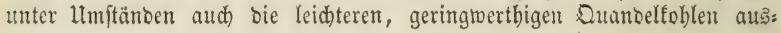
gejulieben.

\section{1) Der Transport ber $\mathfrak{R}$ oblen im $\mathfrak{B}$ alde}

gefdieht meift in ztweiräbrigen Sarren mit fenfredten, geflod)tenten Seiten= wänben uno 3 Eubifmeter Raum. Bur Controle bei ber 2tblieferung ift es gut an eitum ber Etänber ein $\mathbb{M a ß}$ anjubringen, an weldhem erfidbtlid) ift, bis jul meldhem (jrabe bie Sohlenthöhe bei 1, 2, 3 Stunden Trans:

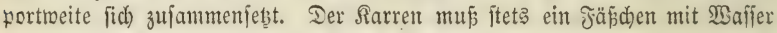

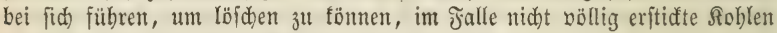
verlaben wurben unt in Branto geratben jolltent.

\section{m) Eontrole ber R̈̈bler.}

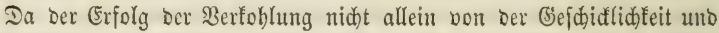

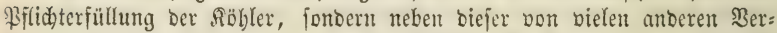
bältniffen abbängig ijt, über bie Der Röbler nidat zu gebieten bat, fo ift ę für jeben einzelnen Fall ummöglid, mit Sičerbeit zu beurtbeilen, ob

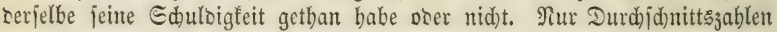

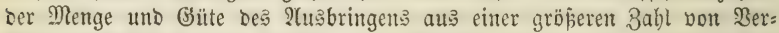
foblungsrejultaten geben bierfür einen Itnbalt. Für jeben cinjelnen Fall

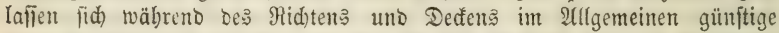
Ed) lïile ziehen aus ber Sorgfalt mit ber bas gegebente Material bearbeitet,

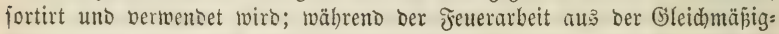
feit, in ber alle Ifeile bes Meilerumfanges fid jeb̧en, aus ber geringen

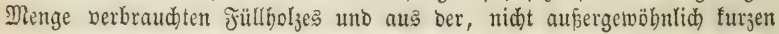
3eitbauer ber Fenerarbeit; nad) leb̧terer aų ber geringen Menge zurüd= gebliebener Bränoe, aus einem günjtigen ßerbältnif́ ber \&ejetoblen zu ben

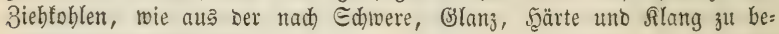
uttheilenten Soblengüte. 


\section{VI. Đer Tjerefdueljlereibetricl.}

Daß Naterial für benjelten liefern bie Etöde älterer Siefern, in beren Murzelitode, wenn fie 8-10 Jabre nađ̆ bem 2Hbiebe bes Etammes

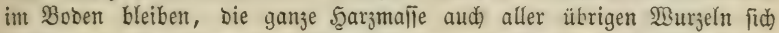

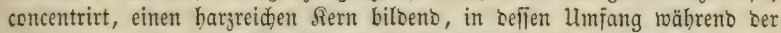

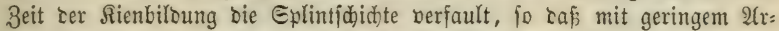
beitsaufwante bie harzarme Eplintididote hinweggenommen werben fann

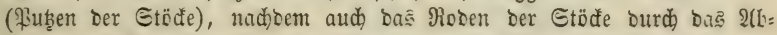
faulen ber Misurzeln uno Des Etoçiplintes mefentlid erleidtert murbe.

Der Theerofen zum Berarbeiten ber gepukten Etöfe bejtebt aus einer aufgemauerten Grunclage, auf weldher ein Sien in Form ber länolidyen

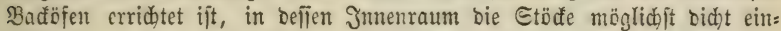
gefdidytet werben. Ulm biefen inneren Sfen ift ein zweiter äbnlid gebil=

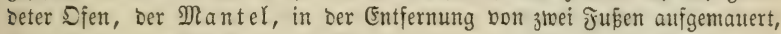

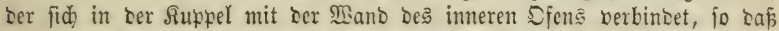

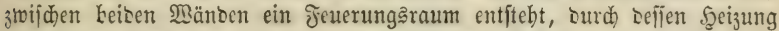
Der innere Dfen uno bas in biefem entbaltene $5_{2} \mathrm{l}_{z}$ bis zur 2 abgabe aller Iepitllationşprooufte erhig̨t werben fann, beren gaêförmiger Iheil in ber 5öbe, Deren flüiniger Theil: Şolz̧äure, Scolzgeift, ITheer (Eeite 289) auf Dem

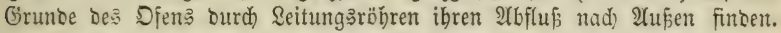

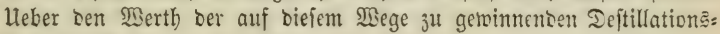
probufte babe id bereits, Seite 302 geiproden.

\section{Das pedjficden.}

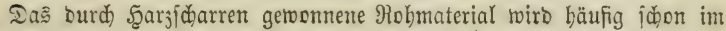

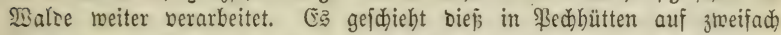
Derifhiebene 2 rt. Entweber wirb bas rohe Şarz über gelinbem freiem feuer in grofen Seljeln erroärmt, beren Boben 15-20 (tm. hod mit $\mathfrak{B a f i e r}$

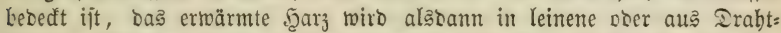
ringen geflod̆tene Eäde gefülft uno burd bicfe binburd geprefst, um bie,

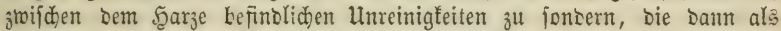
Pedgrieben im Saće zurüablciben, ober man bebient fid baju bejonderer

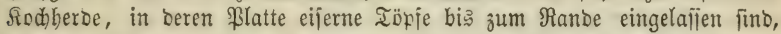

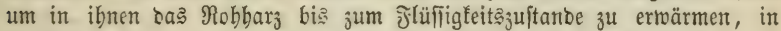

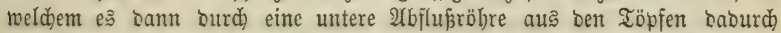
gereinigt abflieṕt, baj bie 2(bzugşröhre im Iopfe burd ein engmajdige? Irabtgitter verid)lofien ift. Die ßed)grieben bleiben bann in ben Töffen

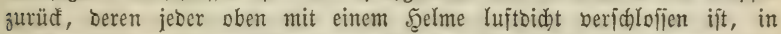
weldem fich bie in ber Wärme entweidjenoen ätherifaen Dele fammeln uno als Terpentinöl in eine gläjerne Sorlage übergeben.

Die leb̧te ber genannten Beminnungsmethoben hat nidht allein ben

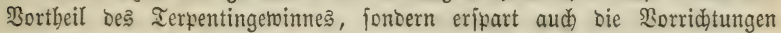

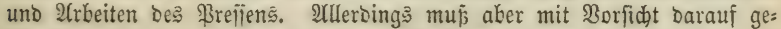

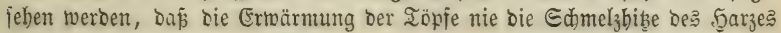
mejentlich überfteigt. 


\section{Das ficuruß̧uremtel.}

Die febr verumeinigten Şarzmafien, welde aus ben Sadten auf bett

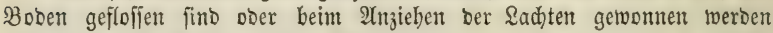

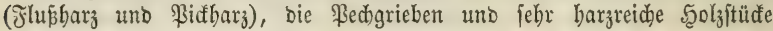
geben bas Material für die Rienrupbereitung. Es geidjieht biefelbe in niebrigen Defen, Deren Jeuerungsraum zum Berbrennen bei geringem \&uft= zutritt eingezid)tet ift. 2(us bem Dfen läuft ein nabe borizontaler Raud)= gang in eine 3-4 Meter bobe, 5 Meter meite, aus Badfteinen aufge= mauerte Raudfammer, in beren Decfe eine 3 Meter in Duabrat baltenbe Defintung verbleibt, bie burd einen eben fo weiten, 3 Meter bohen Sact

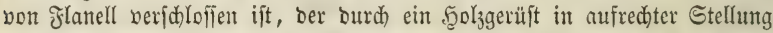

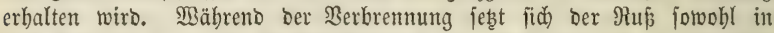
Dem Raudgange als in Der Raudffammer uno im Flanellfacte ab uno wiro von 3eit zu 3eit gejammelt.

\section{Das Afdreturemten.}

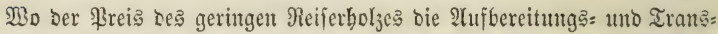

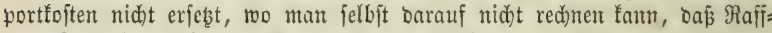
unt Sejebolzfammler bie Reinigung ber Ed)läge vom 2Ybraum vollziehen,

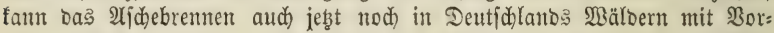
theil hetrieben werben, inbem überall ber $\mathfrak{X}(j)$ egetrim wentigitens bie $\Re a ̈ u=$ mungstoften erferien wirb. Das $2(j$ debrenten gejdiebt bant in 3 Meter tiefen Crogruben, in benten das zujammengetragene Reifig angezündet utto ourd fortiauerno nad)getworfenes ßeifig an einer zu lebhaften Berbrennung

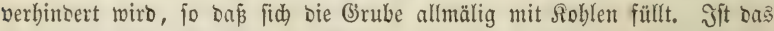

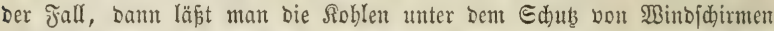
allmälig von oben nad) unten verajden uno verfauft bie getwonnene $2(j d)$ an Eeifenfieber ober an Rottajdefiebereien, wo folde in ber Näbe finto.

\section{Dritter $\mathfrak{A b j} j$ juitt.}

Bom $\mathfrak{B a l b p r o b u f t e n h a n b e l ~ ( 5 g a n b e l a t u n o e ) . ~}$

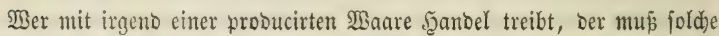
zunäd) jt zu Marft bringent. Şit nun aud) für ben Scolzfäufer in ben meiften

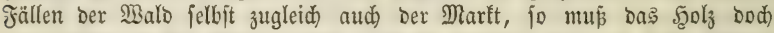
aus biejem an ben Berbraudsort geidafft werben, uno id babe bereit? Darüber gefprodjen: Daईs, audi went Der Siäufer bie Sorge für Den Trans= port unmittelbar felbit übernimmt, bie Roften befielben mittelbar bod) vom Berfäufer getragen toerben, Der Räufer baber bod immer nur Mitteläperjon in Bezulg auf ben Tranzport jei.

Die nidjt jofort in 2Abjaţ zu bringente Maare bat ber Şänblex fo= bant fo aufabetwahren, bap fie jo viel wie möglid) bor Berja)led)tenung

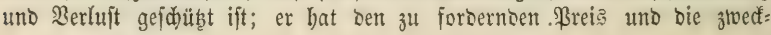




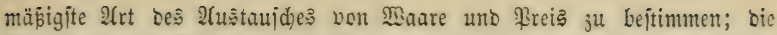

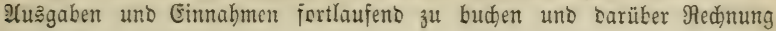
34 legen.

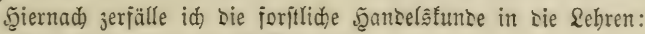

I. $\mathfrak{B o m}$ Iranjport ber $\mathfrak{B a l}$ aprodufte.

II. Bon beren $\mathscr{A}$ (uf́berwafrung.

III. Bon Der Preisbejtimunung.

IV. Non Dem 2tbgaberrejen.

V. ミon ber Budjübrung uno vom Redfunngawejen.

\section{Erffes Erapitel.}

2om Trangport ber Maldprobufte.

Einem jeben \$robuttionabejirfe ijt ein beftimmter Conjumtion

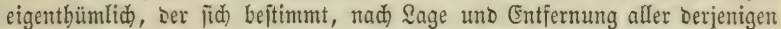
Conjumtionsorte, bie am \$erbraudje bes, im betreffenton Probuftionsz bejirfe Erzeugten jid betheiligen. Probuftions = und Conjumtionabezinf tönnen зujammenfallen, menn in erjterem liegente Berg= uno Şüttenterfe,

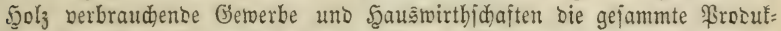
tion für fich in 2 njprud nehmen. In ber Regel nehmen aber aud bie Bewohner ber, Dent Walde nabe liegenden Drtidaften an ber Eojumtion Iheil. In Dem Maje als aud) entferntere Drtichajten fich bierbei bethei: ligen, in bem Maje als eine idwache Bebölferung, Mangel an boljcont=

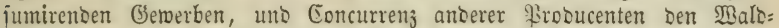
Lejițer nöthigen, jeinen \$rocuften in weiterer Jerne Abjak ju veridaffen,

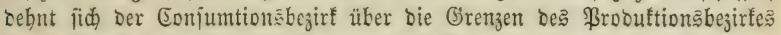

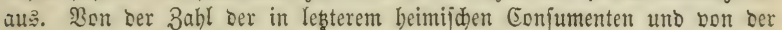

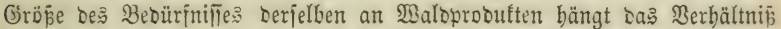

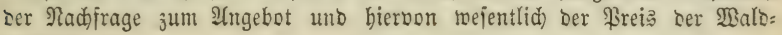
probufte ab.

Je enger bie Grenzen Des Conjumtionshezirfes fino, von weldyen bie Probuftion ganj in $\mathfrak{A}$ jprud genommen wirb, um jo geringer fino bie Transportfojten, weldhe bie ßrobuftion belajten, um jo geringer ijt bic

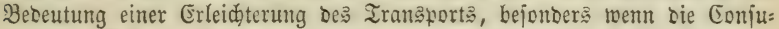

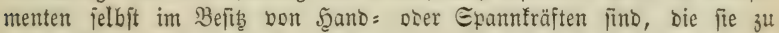
joldher Beit auf Den Iransport berwenten, in ber eine anbertweitige muls=

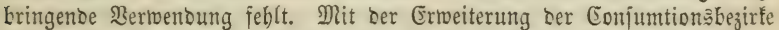
jteigt bie Belaftung ber \$robuftion mit Iranţportfoften, fteigt bie \$3ebeu= tung erleidhterten Irantsportes nidgt allein burdy Berminderung Der, ben Produftenpreia beraborüđfenden Unfoften, jonoern mehr nod) Durd) Erhöhung Der Nadjfage und Concurrenz.

Menn man jagt: Daj jęber Srrojden, Len Der Walobejiţer auf Er: leideterung Des Iran3ports berwende, Demielben burd) böbere Produften= preije bergütet toerbe, fo ijt biej bnher nur bebingungâtweije wabr; es ift nur wahr für grȫere Conjumtionabezinfe, für sie Jälle nothwenoiger (rs=

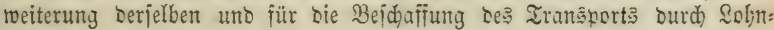
arbeit. 
Den bödjten ßreis wiro der Waldbefizer für feime \$robutte nur bann erzielen, wenn ihm ein Conjumtionsbezirf angehört, befien Bebarf bem 2 ngebot minoejtent gleidjiteht. Jit bas nidht ber Fall, bann fann

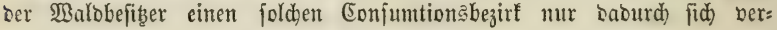
ichaffen:

1) Dap er einer ßrobuftion fich zumenbet, bie im fleinften Raum

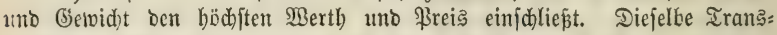
portfraft, weìd)e einen (Eubiffus $\mathfrak{B u d}$ en Edeitholz à 20 ßfg. fortberwegt, bewegt cben fo weit cinen Eubiffurs (Eichen Nub̧bolz à 60 Pfg., belaftet leb̧teren alfo mit mur $1 / 3$ ibres \$reifes ober fie bermag ihn bei gleidher Belaftung breimal weiter fortzubetwegen. Sie berfebt ibn in eine fedjs̄mtal

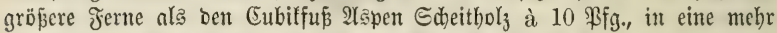

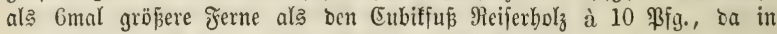
Ieb̧terem eine, un beinahe Daß 5fad)e gröfere Raumfüllung bie Transport=

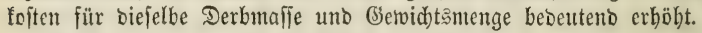

Daber fonmt $e^{2}$, dapj felbft in bevölferten aber walbreiden Gegenden noch beute fo vieles, an fid wertbolles Reijerbol $\}_{3}$ in Balde verfaulen mun, wenn $\mathrm{c}^{2}$, wie man zu fagen pflegt, "oie Trautsportfoften nicht trägt." Daffelbe gilt hier uno ba aud nod) boin fdwäd)eren Sinüppelholze, von ben jüngeren Durd)forftung引hälzern, felbjt bon ftärfercm Weidbolze, bäufiger nod) vom Stodfolze burd) Das Seinzutreten ber hoben (Betwinmungstoften. Sie müffen bem (Sinfammeln Durd) bie ärmere Bevölferung unentgeldlich

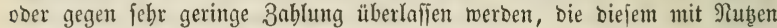
fid) unterzieben fam, wenn fie bie barauf zu berwendende $\mathfrak{A r b e i t g f r a f t ~ n i d ) t ~}$

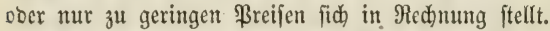

Der Ergiebung Des größten $\mathfrak{B}$ erthes und \$reifes im fleinften Raume

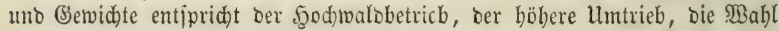

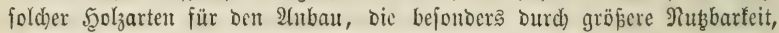
Brentfraft und Dauer im $2 B e r t b e$ anderen voranfteben, (Erziebung pflanzen= reidjer in Schlup erwadjentor $\mathfrak{B}$ eitänoe. ${ }^{1}$

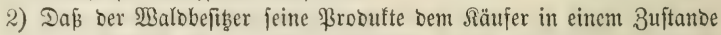
barbietet, in weld)ent fie mit Den geringften Soften transportirt werben fönnen. Dabin gehört vor Aftlem bie Albgabe in einem möglidjt trodünen

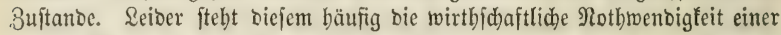

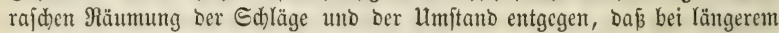
Steben ober Riegen Des Şolzes im Malde, biejes zul fehr theils bem ßer= berben, theils bem Diebjtable ausgejeb̨t ift, baß bie Magazinirung in Räumen, bie gegen beibes Edhub gewähren, mit bebeutenoen Roften unb

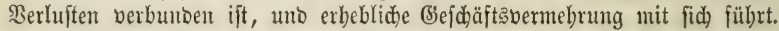
Demofneradtet fömte in biejer Ridtung offenbar mebr gejdeben, als bief

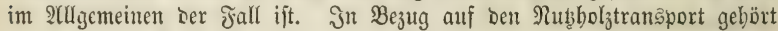
babin aber audy bie Bearbeitung ber Ruţholzftämme auf benjenigen Theil,

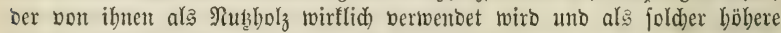

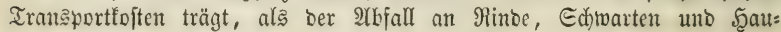
\{łänett.

1 Siebe bierüber meine Gdrift „Enftem und Inleitung зum Gtudium ber frorftwirth= id)ajtzlehre," Seipsig 1858, S. 225-242. 
3) Dap ber Balsbefiţer bie Transportfoiten ummittelbar verringert זurd) Erleichterung bes Transports in ber Berbelierung ber Trantsport=

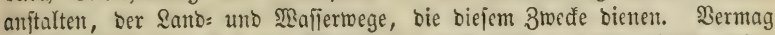

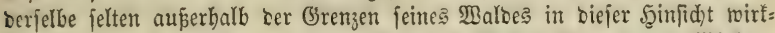
fam zu jein, fo wiro er bod, aud in ber Bejdräntung feines Wirfens

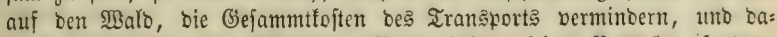
burd) nidht allein eine entipredjente \$reiserböbung feinc \$robutta, fontern

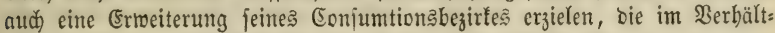
nif zur Serringerung ber Transportfoften eine gröfere ift.

Was ber Malobefişer in biejer Scinfidjt thun müfie, bas ift es, weldhem twir hier eine nähere Betrad)tung wiomen toollen.

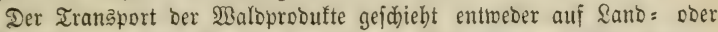

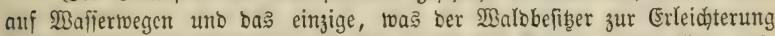

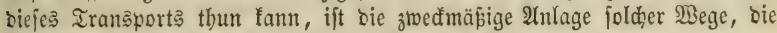
fortbauernoe crhaltung berfelben in gutem 3uftande.

\section{Wom Waldwegeban.}

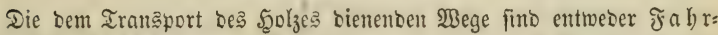
wege ober $\Re$ ut $\{$ d twege. Suf erfteren merben bie Saften burd eine 3ugfraft fortbewegt, auf leţteren betwegen fie fid auf einer gleid)mäpig geneigten (Sbene gan ober bod) bauptfädhlid bermöge ihrer Edwere.

Die Fabrwege find $\mathfrak{B}$ ald wege im engeren Sinne ober $\mathfrak{A} u n \mathfrak{f t}$ ft $\mathfrak{x}$ a в en, je nachoem fie auf bem natürlichen, nur geebueten, bon $\mathfrak{B}$ urzeln uno Stcinen gereinigten uno entwäflerten $\mathfrak{B o b e n}$ berlaufen, ober bie Jahs: bahn über bem natürlid)en Boben aus einem anderweitigen Material, aus

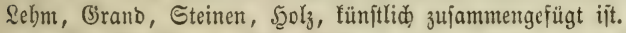

Die Rutidwege fino Edmeerwege, went die Fortbewegung Der Qaften auf ihnen, über querliegende Etreidrippen gefodiebt; ę find $\Re$ ie $j$ en,

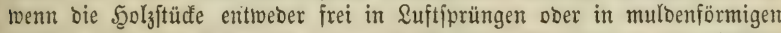

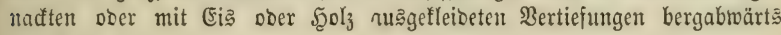
(iic) fortbetwegen.

\section{A. Bon sen $\mathfrak{\text { Barbmegent. }}$}

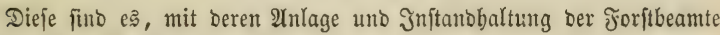
vorzugstweije betraut ift.

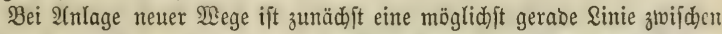
bem Drte Der $\mathfrak{A} b f u \mathfrak{l} r$ uno bem Bicle zu projeftiren, Der Erfparniß an $\mathfrak{A}$ rbeit, Iransportfoften uno an Grunbfläde wegen. In biejer gerabeften Riḑtung

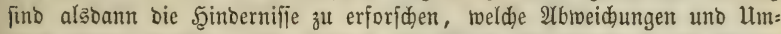
wege nöthig madhen. Die baburch bergröperte Gejammtlänge bes Weges ift alइbann zu vergleiden mit anberen mögliden $\mathfrak{B}$ egridtungen, uno untor allen biejenigen für bie $\mathfrak{A}$ Inlage zu beftimmen, welche Den grös̄ten Bejammt=

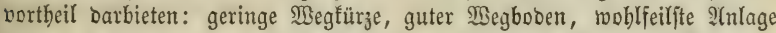
uno Injitantbaltung, geringite Berlufte an Scolzproduftion uno Bejtands: maffe, leidtefte Uleberwad)ung ber 2 (bfubr, mebrfeitige Benub̧ung aud al:

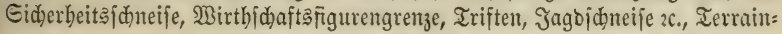




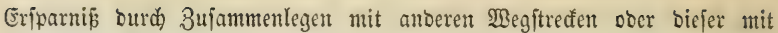
Dem neuen Bege.

Ier befte Boben für bie $\mathfrak{A n l a g e ~ v o n ~}$ Balbwegen ift ein folder, ber genügende Feftigfeit befibt, um im Sommer uno bei troctner $\mathfrak{B}_{\text {Btterung }}$

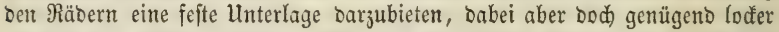
ijt unt eine folde Unterlage befistet, Die ein rajdes Einoringen bes Regen= waijer: in bie Tiefe geftattet. Socferer Sanbboben uno ftrenger Thonboben fint am ungünftigften; jantiger Rehmboben unt lebmiger Santboben fint am günjtigiten.

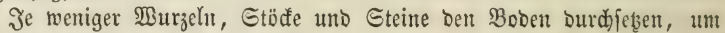
jo geringer fino bie Roften ber Inlage.

Da getwöbnliche $\mathfrak{B a l}$ awege mit Saften in ber Megel nur walbaus be:

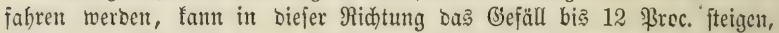
nötbigen Falles und wam ber Boben für Şemmidulb geeignet ift, bis 15 Proc. Wirb auf bem Wege biel mit Ed)litten abgefabren, fo läpt man bas Brefäll 5-6 \$roc. niđft gern ïberfteigen. Steigungen walbaus türfen auf fejtem Boben 7 , auf fantigem 30 en 5 \$roc. nucht überiteigen.

Nothmentige Ueberbrüałungen, Danmbauten, Rnüppeloänme zc. ver: theuern bie 2Unlage und Unterbaltung.

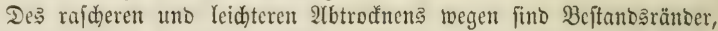

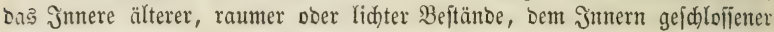

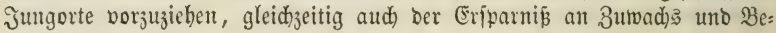
itandsmafle wegen.

Die geringfte Breite ber 1 salowege ift $21 / 2$ Meter. Es nüffen bei fo geringer Breite aber 2(ušbiegepläb̧e in Entfermungen bergeftellt werben, bie eine gegenjeitige Remtnip̄nabme fid begegnenter Juhrleute jo früh ju=

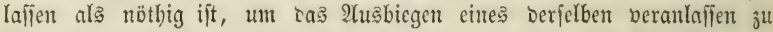
fönnen. Beffer ift ę, bcm Wege überall eine Breite von $4 \frac{1}{2}$ Meter $3 u$ geben, nid)t allein bes überall möglid)en 2 (uäbiegens megen, fonbern aud, Damit bie Jubrleute mit sen Gieleifen wedjeln fömen. Da bierourd bie Siege fihr conferbirt. und Befferungsfoften vermieben ober bermindert

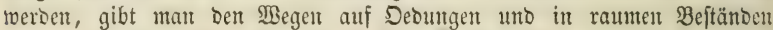
eine nod) größere Breite von 5-6 Meter. Das ift aud) ratbjam, wenn

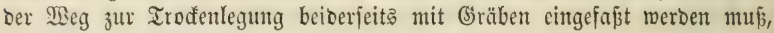

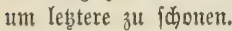

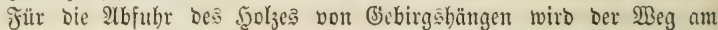

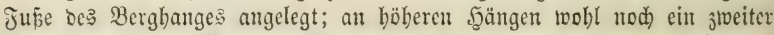
2Lbfubrweg in Der Mitte Des Berghanges.

Sit ber Maloweg ausigeftedt, jo begnügt man fich in ber Ebene mo im Şügellanbe bäufig mit Blanirung ber einzelnen Uncbenbeiten. Eine

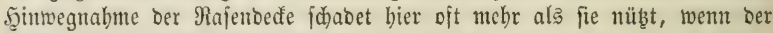

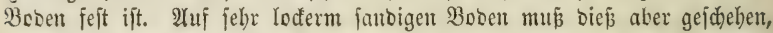

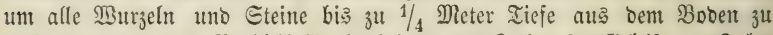
entfernen, Da Deren Berbleib Unebenbeiten und \&̈̈d)er im Ëeleife zur Folge hat, bie beftänoige Wegebefferungen nöthig machen.

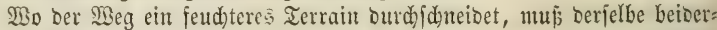
jeits mit 2(bzugsgräben eingefapt, unt bie baraus ju entnebmente (5rbe 
3ur Erböbung des Meges it einer, beiberjeits mit 2-3 Froc. abjallenton פSölbung aujgetragen werben. Zur Edonung Der Gräben erbalten joldhe

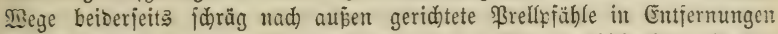
von 4-6 Meter. Eumpfige Stellen, Die Der Weg burdjidneidet, tömtent nur surd foften Ianmbaul ober Snüppeldämme fahrbar gemacht werbent. (ङ. Sunjttwege.)

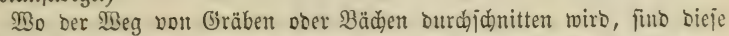
entrveber zu überbrüden, ober cs ift Der Durd)laj vermitteljt Doblen ju betoirfen, D. b. gemauterte ober aus einem bohlen Baumitamme gebildete Sanäle, bie mit Erbe überidüttet werben, jo baj über bem Santle ber Weg unberänbert fith fortjeşt.

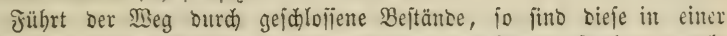

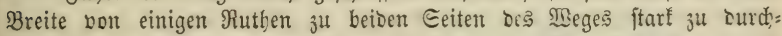

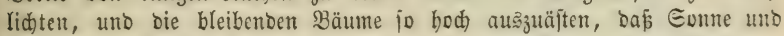
Wino bie Wegftreffe nad jerem Regen raid) abjutrodnen vermögen.

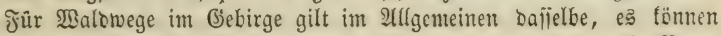
bier aber nod) bejonbere Sorfebrungen nötbig werben, Kejonbers in Bejug auf bie größeren \$affermafien, welche von ben benachbarten Gebirgăhängen

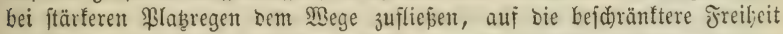

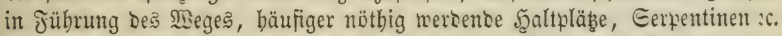
Wege, die an Bcrghängen hinziehen, erbalten in ber Totalität be w wentig gemölbten ßrofils nad) anjen einige 3olle Eteigung. Ein (5raben an ter

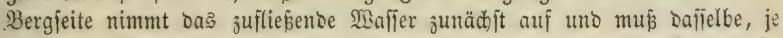
nad) Der Menge des Mafjerzuflufies bom überliegenden Berghange, in gröp̈eren ober geringeren $\mathscr{U}$ bjtänoen, Durch) Dohlen unter bem IBege bin. Durd) nad ber unteren Bergieite bin abgeleitet werben, wofelbjt man ien

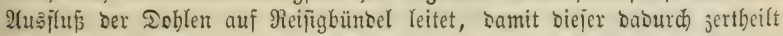

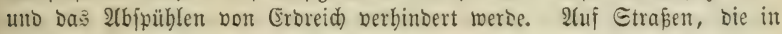
weiten Streden umunterbrochen geneigt fino, weist man ras auj ber Etraje jelbit fidh fammelnbe Regenwajier Durd), bon Etrede zul Strede idräg in Den Boben gelegte Boblitämme $a b$, bie $2-3$ (stmt. über bie Megfläd)e emporiteben, auf ber Thaljeite aber Durd) Pflafterung mit leb̧terer aus:

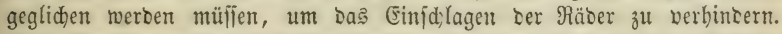
Dieje. Afweijer müfien in jold)en Entfernungen bon einander gelegt wetben,

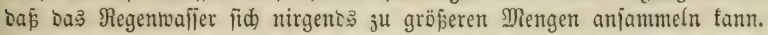

Was bie Unterbaltung ber Walbrege betrifit, fo ift es bie erite

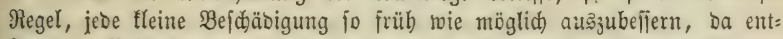
ftandene Bejdäbigungen bei fortsauernber Bemubung fid fo rajd ber:

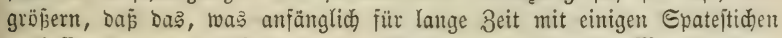

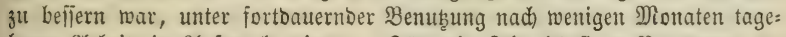
lange $\mathfrak{A r b e i t}$ in 2(njprud) nimmt. Jür bie 3eit bäufiger Benub̧ung ges

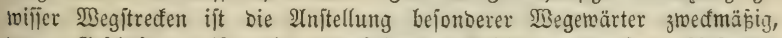

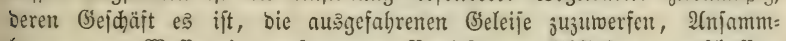

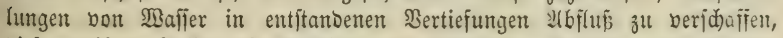

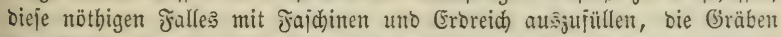

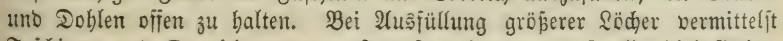

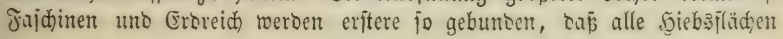


Das eine, alle Meijeripiz̧en das entgegengefebzte Ende bilbent. Mit bem Reiferenbe ineinamberjoliefent, werben bann bie Fajdinten je zmei, red)t=

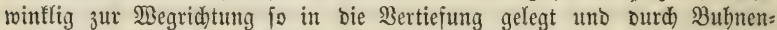

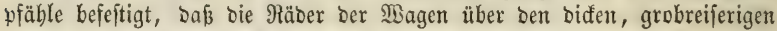
Theil ber mit Erbe überidütteten Fajdinen fid betwegen.

\section{B. Siuntititrą̧en.}

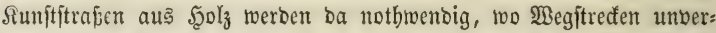
meibbar über ein jumpfiges Ierrain gefübrt werben müffen. Shbre Jerti=

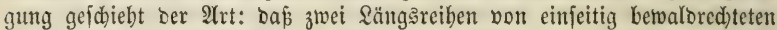

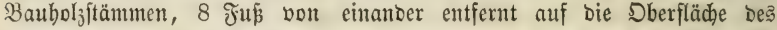
Moores gelegt, bie Stämme jeber Reibe unter fich, ourd feitlid) feft: genagelte Berbinbungझhölzer, bereint werben. Diefe Stämme bienen in Der Mitte gefpaltenen Boblftämmen von 3 Meter Sänge zur Unterlage und $\mathfrak{B} e=$

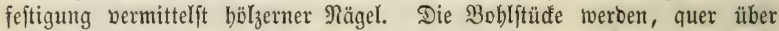
Die beiben Unterlagen, bidst an einanber gerüdt, fo ausgelegt, Daj bie Spaltfläd)en nad oben gefebrt fino, nadbem, bamit fie feft auf ber nad, oben gefebrten, betwalorechteten Seite Der Unterlagen ruhen, jeberjeits 1/2 Meter vom Ende Der Boblitüđfe aud) bie Rinbenfeite zu einer, ber Spalt= jeite parallelen fläd)e zugebauen wurbe.

Mit Dem Jeftnageln ber Bohlitüde auf bie Unterlagen ift bie Bohl= flätte fertig. Dieje bient mun entweber nactit zur Ueberfabrt, Dann nämliç, werut Der Sumpf fo weidy ift, Daj eine Belajtung Der Boblitätte mit Eroe Diejelbe uno bas (Erorcid) unter den $\mathfrak{B a f f e r f p i e g e l ~ b i n a b o r u ̈ đ e n ~ r u ̈ r b e ~ D o e r ~}$ fie wiro mit einer jdibaden fajdjinenlage gebectt, bie felbit wieber eine J̃üllung unb Decfe von (Eroreich erhält.

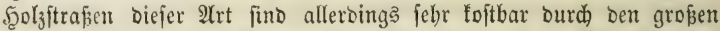
2lufwand an Şolz, Dent ibre 2Anlage erforbert uno bie furze, 25-30 Jabre felten überifteigente Dauer bes Şolzes. Sie werben daber auch nur ba ausgefülfrt, two bas Şolj in geringem Breife ftebt uno Dammbauten,

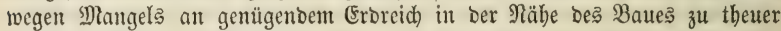

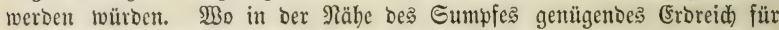
Dammbau zu haben ift, wirb mant Durd foldhen bei bedeutender Tiefe De Moores zwor nid)t an 2Unlagefoften, wohl aber an Unterbaltungstoften wejentlidy fparen.

Der Bau vou Sumftitrapen aus Eroreid, uno (Seftein (Ebaufieen) ift in ber Regel nid)t Gad)e beక Jorftmannes, er ift eక aber bei uns im

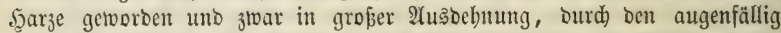
günjtigen Einflus, ben biejer vollfommene Begebau auf Erbjöbung ber

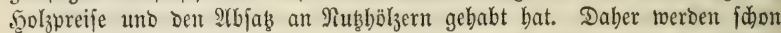
jeit mebreren Jabren befäbigte Forittandibaten auf einige 3eit Den $\mathfrak{B e g e =}$ Kaubebörben zur Unterweifung zugetheilt uno nach erlangter Semntni仿 beim

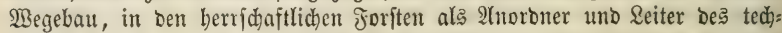

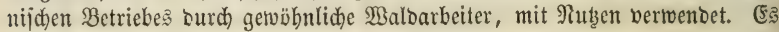
mag baher aude (siniges bierüber gejagt fein.

$\mathfrak{B a}_{\mathrm{a}}$ bie \$lantage betrifft, jo gilt it Bę̧ug auf biefe Wege baffelbe,

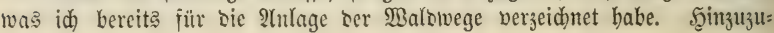


fügen ift bier mur, daj bei einer 2-3metrigen Єteinbahn jebcrjeits ber:

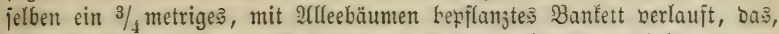

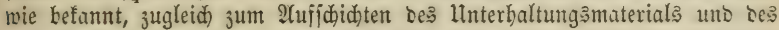
Afraumes bient uno von ber Steinbalnn surd) bie Manbiteine gejdicon

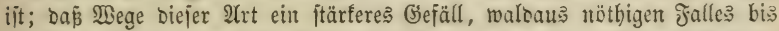
15 \&roc. ertragen (maldein bëdjtens 5 \$roc.), wenn fie nicht jugleich Com= nunicationswege finto, bie mit Lajten befabren werben, in weldhem falle

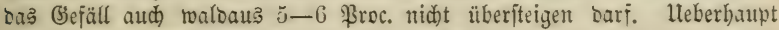
meibet man ftarfes (jefall fo biel roie möglid, ba es bem Єd)littentransport

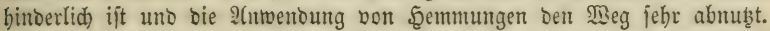

Die 2 rbeiten nöthiger Entwäfiferungen uno Dir Wlanirung bes $\mathfrak{W e g e}$

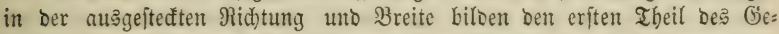

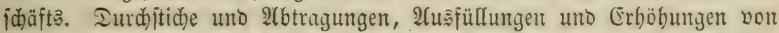

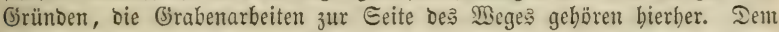
\$lanum gibt man, roen es irgeno auşïhtbar ift, "auf loderem Ganoboden eine oberfte 10-15 Etm. tiefe Edjidte von Sebmboben, Dem \&ebmboben cine eben fo hobe Edjidte von grobförnigem Eanto ober Rię. Dieß \$lanum erbält mun ein \$flafter von Eteinen (Pactlage), ütber Diejes sine $6-8$ (Etm. bohe Dectlage bon 2-3 $\mathrm{Ctm}$. Diffen Etcinen, bie banu mit einer britten, j-6 Etm. hoben Edjidte bon Ries, Gand ober Croc überichüttet wirb. Edon in ber \$adłlage erbält bas Cuerprofil des Weges cine Wölbung von $1 / 2-3 / 4$ Gejäll auf jeben $1 / 3$ Mtr. ber Breite.

Qebmchaulfeen erbalten feine \$afflage, jondern über sem Blanum eine

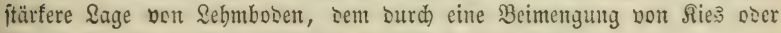

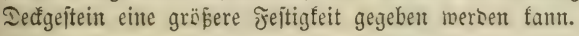

\section{Bon Dent 9iutididwegen.}

Rutidjwege fönnen jelbitberitänolich nur in Gebirgștualoungen uno alld bort mur ba angebrad)t werben, wo von böheren Gebirgäbängen ab= märts auf gröp̄ere Etrefen cin ununterbrod)enes, für bie jelbjtitänbige Fort=

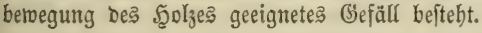

a) Sdmeertuege.

Segt man einen jobtweren Förper auf eine borizontale flädhe, fo liegt er auf biejer fejt unt funn mur burdh einen feiner Edywere entipredhenten Sirajtaufwant fortberwegt werben. In bem $\mathfrak{M a j e}$ als bie fläche in eine geneigte Rage veriekst ift, wirb biejer Riraftaufwano ein geringerer, bis ein Neigungsgrab eingetreten ift, ber eine felbjtjtänoige Jortbemegung ber \&ajt

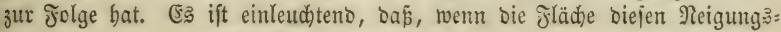
grad nidht ganz erreid)t, ihm aber nabe ftebt, eine jebr geringe Sraft ge= nügt, um bebeutenoe Saiten auf ihr abwärţ zu betwegen, baj̄, wenn jie

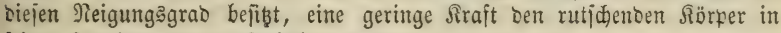
jeiner fortberwegung aujzubalten bermag.

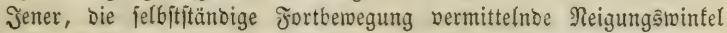

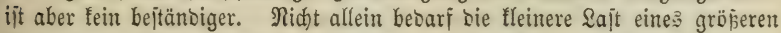

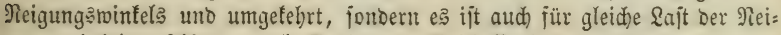

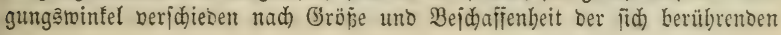




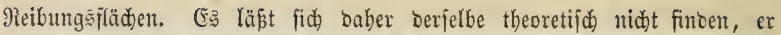

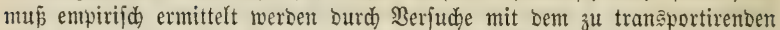
Material, liegt aber für ben Transport von Surzbölzern auf Sd)litten

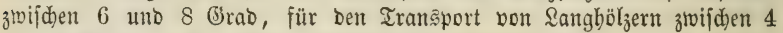
uno 6 Brad $=4-5$ ßroc. Befäll.

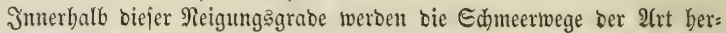
geftellt, Daß̧ man grabe entrinbete, $2 \mathrm{M}$ tr. lange uno bis $15 \mathrm{Ctm}$. Didfe

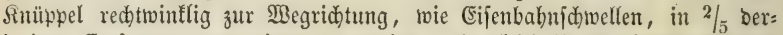
jenigen Entfermung von cinanber außlegt, bie gleid) ift ber Sänge bes auf biefen Streidrippen Durd) Sdleifen fortzubewegenden Rörpers. Die Etreid)rippen werben bis auf $1 / 3$ ihrer Dide in ben 30 oben berientt uno Durd) ztwei ftarfe \$flöde feftgehalter, bie auf ber Ihalfeite am Enbe jeber Mippe in ben Boben eingefdlagen werben. Die Dberfläd) Der Streidrippen

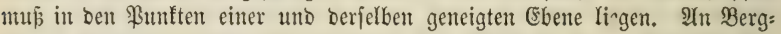

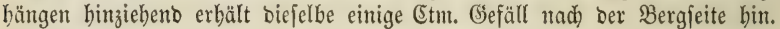

Der Tran3port auf biejen Sdjmeerwegen, bie ibreit Ramen bon ber Berwenoung fettiger Stoffe zur B̧lättung Der Streid)rippenoberfläch)e erhalten baben, gefdjiebt cntrober in Gdhlitten ober in bereinzelten Sangbälzen, nad) Deren poer ber Edflittentufen Sänge bie Entfermung ber Streidrippen

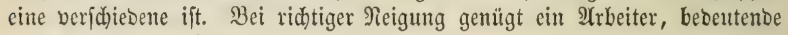
Saften bergab zu leiten.

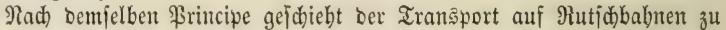
ebener Erbe obne \$erivenoung von Streidrippen, hauptjäd)lidy in Sdhlitten,

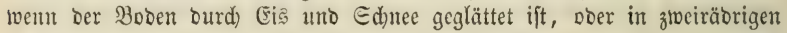
Sarrent auf, in längeren Etreffen genteigten Sbauffeen, Deren Scenumung an fteileren Genfungen Durd einen Szemmftod beivirft roirb, ber eine grabe Zerlängerung Der Sarrenare nad binten ift unt bie Betwegung burd) Drudf

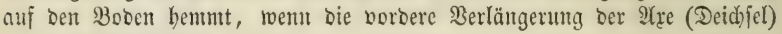
in bie f̧öhe gebrüđt twiro.

\section{b) Miejen.}

Die naturiwüd)igite Rieje fab id im Edjwarzmalbe, gewifiermapen

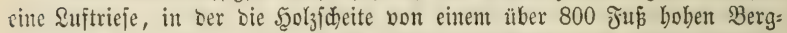
bautge in \&uftiprïngen von mebr als bunbert Jupen bem Thalgrumbe zu= flogen unt in Dem weiden Boden beffelben wie Nabeln in einem Nabels fijien ftecfen blieben, wenn fie biejen mit ber Stim trafen. Die Edheite

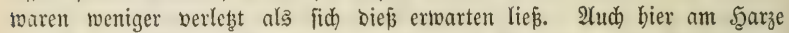
formt ein berartiger Transport, wenn aud felten bor, bei weldyent bie G(d)eite vom Bergtanme mehr polterno unto fid überitürzeno als rutideno in bas Thal gelangen.

Miejen im engeren Sime fint Mulden ober Röbren, bie bei einer

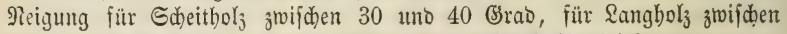
20 uno 30 Crrad von Den Bergböben in: Thal fid binabjieben.

9)an unteridheibet Eroriejen, Scolzriejen unt Eifonriejen.

Eroriejen finto muloenförmige Nertiefungen im Booen, bie in ber

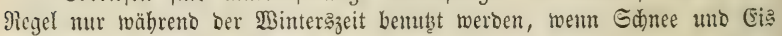
Den Boden gefeftigt uno Die 2ÄBenflädhe geglättet baben. 
Sुolyriejen fint bergabjichente \&ängşreihen ganjer entrinbeten Etamm: ftüđe, beren je 7 ober 9 soer 11 nebeneinanderliegente Etämmte zu einer sben offenen Mulbe bermittelit Unterlagen uno Berbinoungsftüưen vereint

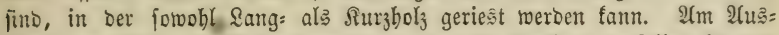
yange ber Rieje im Thale vermintert man bie Gentung berjelben in bem

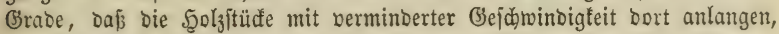

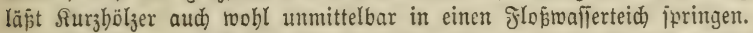

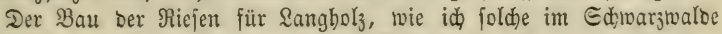
gejeben babe, gejđieft folgenoermapen. Nachoem am Eingangspuntte ber: jelben eine genügenoe 2(nzahl bon Etämmen angefahren fino, wiro baร erfte Mulbenglied gelegt uno bie Etämme für bas zwoeite GSlied im erften

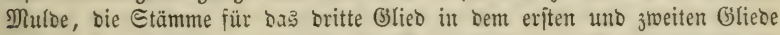

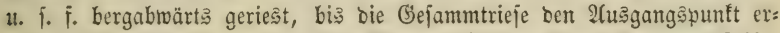
reidht hat. Man fichert auf biejem Wege zugleich audi bie Bemegungşfähig: feit bes Şolzes in jeber Mulbenitrede. Sinto alle Şoljitämme in ber Rieje zu Thale geförbert, Dann werden bie Stämme bes oberften Muldengliebes, bam bie bes jweiten, britten, vierten B́liebes gelöst uno in ben noch liegenden tieferen Streffen Der Rieje zu Thal gebradt, bis aud bie zum Bau ber Riefe berwenteten Etämme in Diejer jelbjt im $\mathfrak{T}$ bale angelangt fint.

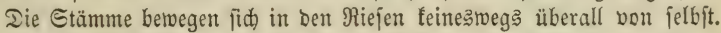
\$o bief ber Jall ift, werben fie burdh Eeile an einer allzurajd)en fort: betwegung verbindert. Wo Das Gefäll füt eine felbjtittänbige Jortbetwegung nid)t auşreidst, werben fie an Eeilen bergab gezogen. Sie fteben alio mäbreno ibrer ganzen Reije unter fortoauernoer \&eitung burd Menjdenhano.

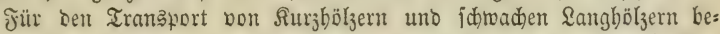

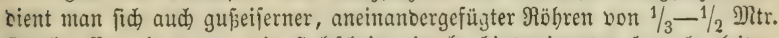
Durdumefier, in benen sie Şoljicheite einzeln bintereinander bergab gleiten.

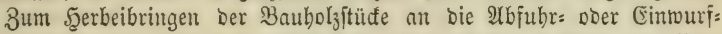
ftellen bedient man fid bes Sottbaums, einer ftarfen Deidjel zum Sor= fpann eines Wierbes, beren binteres (Enbe in eine Edaufel fid) errbeitert, auf beren oberer Seite Das Ropfente Des zu betwegenden Etammes ber:

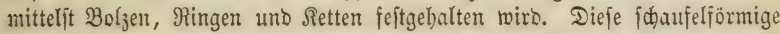
Unterlage Des vorberfen Etammentes hat Den 3roed ju verhindern, daj beim Jortziebent auf Dem Bodent durd) Borfpann bas Sopfende Des Etamme

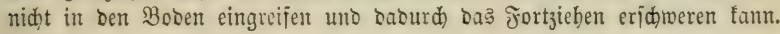

\section{Bom Wajïcrtranąport.}

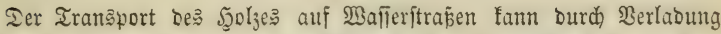
Defielben in Giefäpe oder ourd) bie Edmimmfraft bes Şolzes jelbit geidehen.

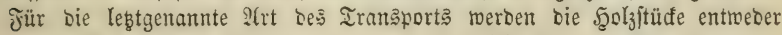

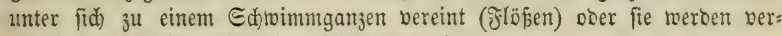
einzelt Dem $\mathfrak{B a f i \pi e r ~ u ̈ b e r g e b e n ~ ( ङ d w e m m e n ) . ~}$

?̦uf allen öffentliden Getwäjiern, bie jugleid ber Edififijabrt bienen,

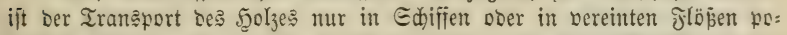

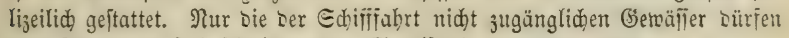

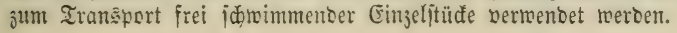




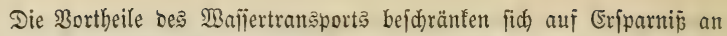
3eit uno Iranzportfoften, bie jeood) nur ba beftefen, too baburd gleid): zeitig gröfere $\mathfrak{S}_{0} \mathrm{I}_{3} m a f j e n$ in Entfermungen von minbeftens einigen Meilen verjeb̧t werben fönnen ober wo ein für ben Sanotransport bödjit jabroieriges Terrain lesterem entgegenftebt.

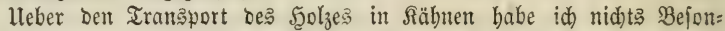
Dereş zu erörtern; Das Material bleibt dabei obute 216gang uno unveränbert wie beim Sanbtranşport; jebem 2 Balobefiber, beffen $\mathfrak{B a ̈ l b e r}$ eine geeignete Sage baben, ftebt biep Iranesportmittel offen, es ift baffelbe aber mit nidjt unbebeutenden Foiten verbunben burd) Den 2Attauf poer bie Miethe ber

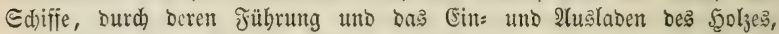
fold)e Fälle auşgenommen, in benen bie Sdjiffer obne andere Befdäftigung fino ober Rüuffahrten mit Ballajt antreten müpten. Die Sorge für mögs

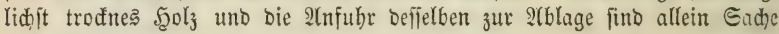
Des Foritmantes.

Der Transport bes Şolzes burd) Flößzen zerfällt in bie $\mathfrak{L} a n g h o l z=$

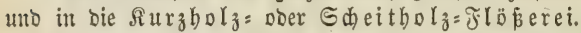

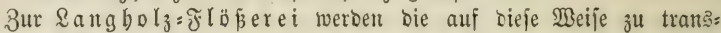
portirenden Bauboljitämme zlveifeitig betwalored)tet uno nad) genügendent

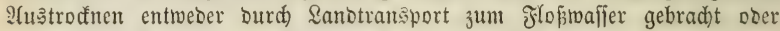
bortbin im Jrübjabre kei Syodmafjer auf ben Bsebirgäbäd)en bereinzelt ge=

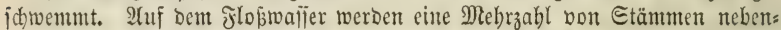

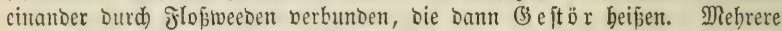

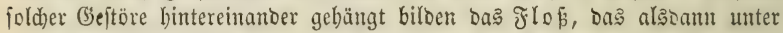
Seitung burd) Ediffer bie Jahrt ftromab maden fann, nadjoem es in ber Regel als Dblajt nod veridiedenartige Surzhölzer erbalten bat. Die 3abl Der in ein (Beftör zu verbindenden Stämme und bie Bahl ber (Seftöre in

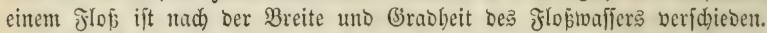

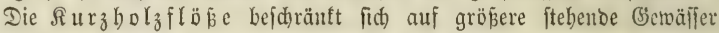

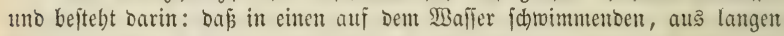

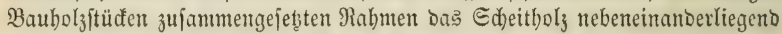

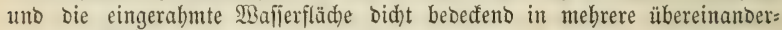
liegente Edjianten eingetragen wiro, beren obere bie unteren Edjidten ins Maller binaborüđen. Einte 2Hzabl übergenagelter Stämme berffärft Dent

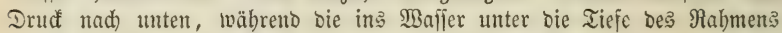

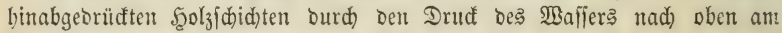
Begidwimmen verbindert werden. Sarine heipt in Ditpreupen biejes

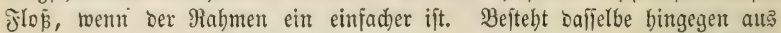
mebreren, eine tiefere Seitenwanb bilbenden, ïbereinander liegenben Bau= bolaftämmen, bann beipt baffelbe eine Matatiche.

Das Sduemmen bes Şoljes beftebt barin: Dap mant bie verein=

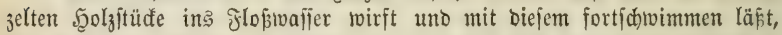

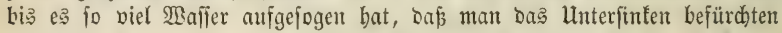

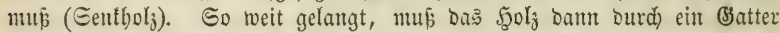
(Jlofredgen) aufgebalten, au Dem $\mathfrak{B a f f e r}$ genommen (ausgewajden) uno

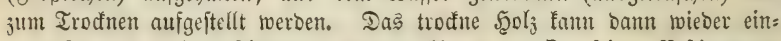
getworfen unt weitergejdwemmt werben, bis es am Drt feiner Beftimmung 


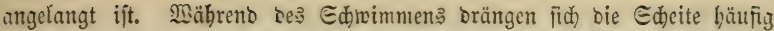

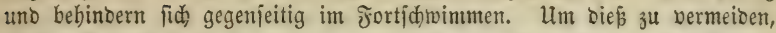

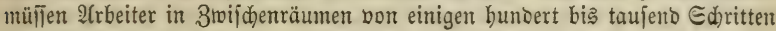

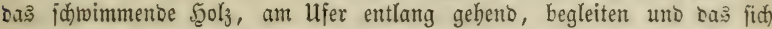
ftautenbe $5_{2} \mathrm{l}_{3}$ bermittelit langer, an ber Epişe mit einem Etad)elbafent,

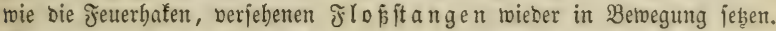
Man nennt biés bie $\Re$ a d flö हैe.

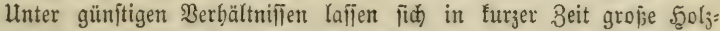

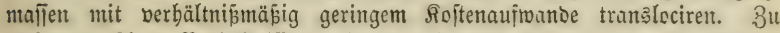

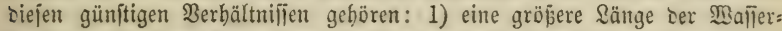

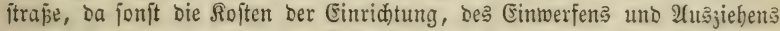

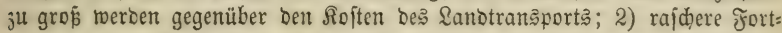
betwegung bes floptwailers, Da von ibr bie Dauer bes Iransports abbängig iit, mit ber bie Menge Des Bertuftes an Gentbolz, bic Berminoerung ber

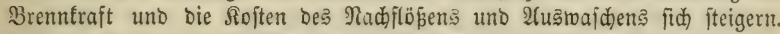
4 Ctm. Befäll auf 33 Mtr. Ränge ift bas Minintun für bie nöthige (jes

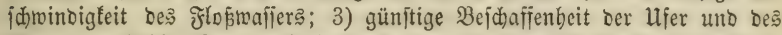

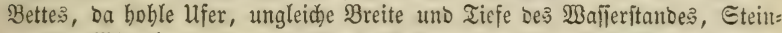

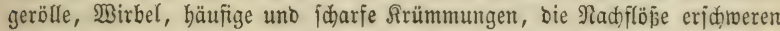
uno vertheuern, gröpere $\mathfrak{B e r l u j t e ~ a n ~ E e n t h o l z ~ b e r b e i f u ̈ h r e n ~ o b e r ~ z u ~ f o j t : ~}$

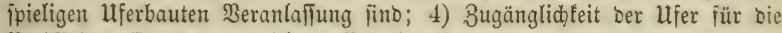

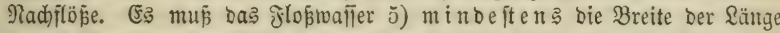
รe:

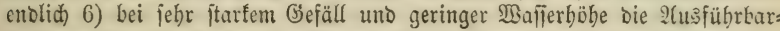
feit von $\mathfrak{W} a f f e r f t u b e n$ Darbieten, bie in cinem, nadh bem Manjerbebarf mehr ober weniger hoben, Das Thal redtwinflig burdfidneibenden Damme bejtehen, zur Ifnjammlung bon Deidjwafier, bas mit ben eingemorfenen Surzb̈̈(zern gleidyseitig Durd) eine Ed)leuje abgelañen merben tum. Da

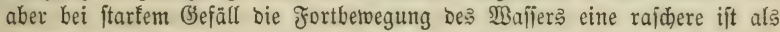

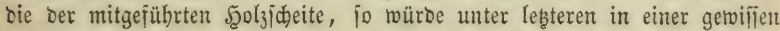
nach Dem G’efäll beridiedenen Entfernung bas Edbemmmalier berlaufen,

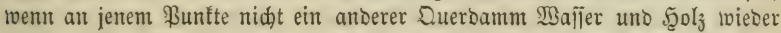

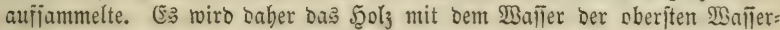
jtube von Damm zu Damm getwijiermajen fortgejpühlt.

Die nit bem Gejdäjt bes Edinemmens berbunbenen Betlufte bejtehent borzugsweije im 2lbgang Der Rinbe unt im Eentholy. Der Berlujt an Brenntraft ift jeit v. Wernef offenbar überjëägt worben, Da bei ben von

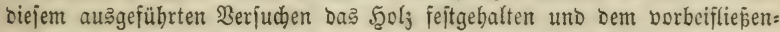
Den Wafier ausgejeb̧t war, woburch obne 3weifel ein ftärferes 2(uslaugen herbeigeführt wurbe als beim Ediwemmen, wobei baß Sgol? mit mebr ober meniger berfelben Wafferumgebung fid) fortberwegt.

\section{Zweites sapifel.}

Bon 2 ufbetwatrung ber $\mathfrak{Z}$ aloprobufte.

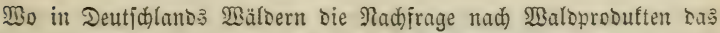

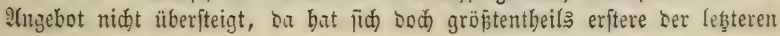


gleidgeftellt, io Daß im gewöbnliden Berlaufe Des Birtbidafabbetriebes Die jährliḑe Produften=Einnabme fofort ihre 2rbnebmer finoet, eine längere 3eit Dauernbe 2Uffbewabrung nidht nothwentig wirb. Gelbit in ben felt= neren Fällen einer, bas Bebürfniß ber Conjumenten überfteigențen 2 Lbgabe= fäbigfeit wirb ber Waldbefiber befifer thun, wenn er bie mit \$iabrjacinlid)=

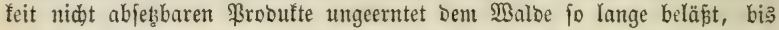

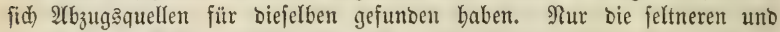

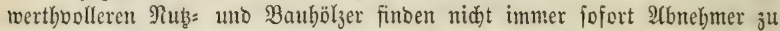
Den, ihrer Bejdaffentheit entipredenden \$reifen uno fann bier eine Dlaga= jintrung uno Aufbetwahrung notbmendig werben, wenn Rüdfichten auf \$e:

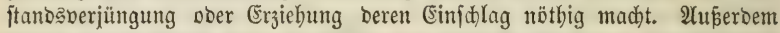

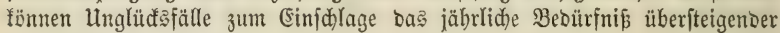
5ुolzmafien żingen.

Das $\mathfrak{S}_{0} l_{3}$, in entipredjenter Meije jubereitet, getrodnet uno ben (Fin: wirfungen wed)felnoer Witterung entzogen, läß̄t fid lange Beit hinburd) umberänbert in jeiner vollen Gü̈te aufbewabren. Bei bem gropen Raume,

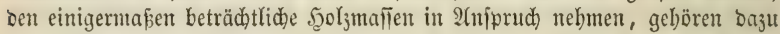

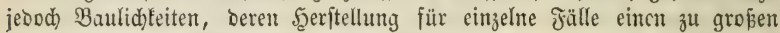

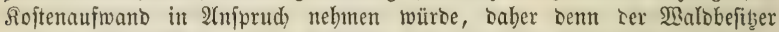
aud) in biejen Fällen auf eine längere 3eit bauernbe 21ufbetwabrung großer

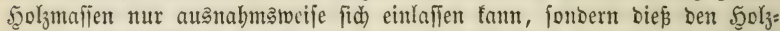
bänolern überlafien muईs, an bie er ben überidüfifigen \$orratb, wenn auch zu ermäßigten \$reifen zu ükerlaffen gezłwungen ift. Für fürzere Beiträume

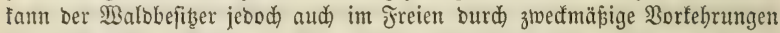

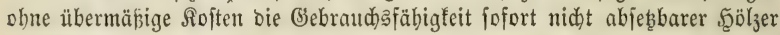
conjerviren.

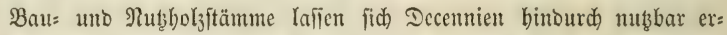
balten, wenn fid Belegenbeit barbietet, fie in gefundes 23 affer zu bringen.

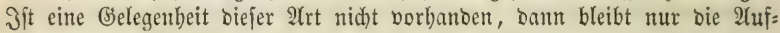
jtapelung im $2 B a l b e$ an einer trodnen, leid)t beidatteten, Dem \&uftzuge nid)t zu febr ausgefebsten Stelle. Die betwalored)teten uno in vereinzelter Sage zuvor möglidjt auzgetrod̋eten Stämme werben bier auf Unterlagen

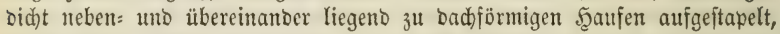
bie geneigten Fläden bes Dadjes to möglid mit Edaalbrettern gebectt uno

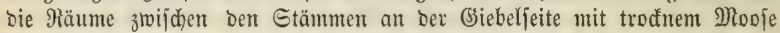
veritopft, wem man nidjt in einigen 30 llen Entfermung von jeber Siebels

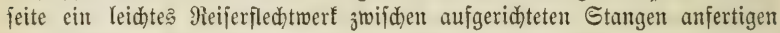

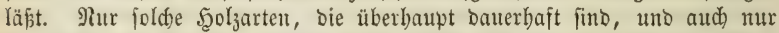

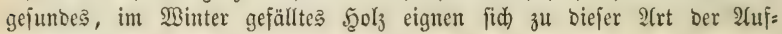
berabrung.

Brennbölzer, felbit ber Dauerbafteren Şolzarten, lafien fich nur im geppaltenen 3uftanoe mebrere Эabre obne \$erminderung ihrer Brenngüte erbalter. Reifer: uno Rnüppelbolz muß fofort zur Berwendung gebradht,

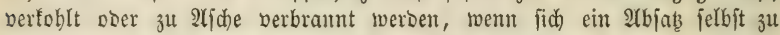
berminberten Freijen nidat finben läpt. Dafjelbe gilt aud für Das Edeit= bolj ber minoer bauerbaften Solzarten. Epalthöljer, bie längere Beit auf= bewahrt werben follen, fpaltet man jobrad) aus uno jeşt bie Edheite nidht 
jofort in sie getoöhnlichen Slafter, jonoern läp̃t fie mehrere Wodhen in Irodenhaufen ftehen, je jwei uno zwei Edheite fid frenzeno, thurmförmig

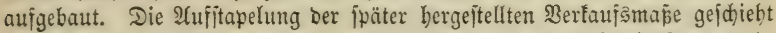

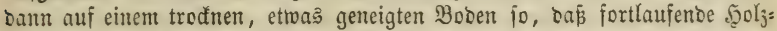
bäıfe von 3-4 Meter 5öbe auf Unterlagen parallel nebeneinanber in Ënt= fermungen bon $1-1^{1}$, Meter aufgefebt werben, bie Reiben bes berrfotenten

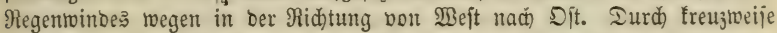
Edidhtung Der Edpeite an beiben Enten jeber Bant erbält biefelbe ben nöthigen Şalt.

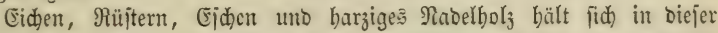
Sieije aufgeftapelt 6-8 Jahre, 2thorn:, Birfent=, Erlenthols uno weniger

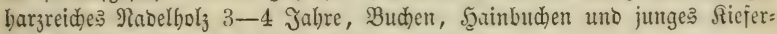
bolz hödjiteng bis zum britten Jabre brennfräftig.

Wiro der Malsbejizer Durd Injetten=, Jeuer: ober Sturmidaben

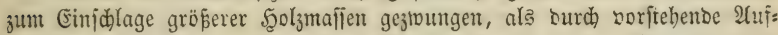

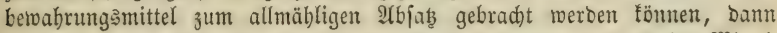

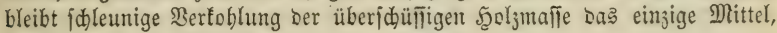
Diejelbe Dem gänzlidjen \$erberben zu entziehen.

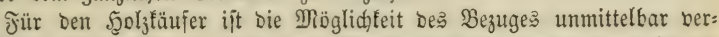
inenobaren Materials oft eine grofe 2(mel)mlidffeit, bie er gern in er=

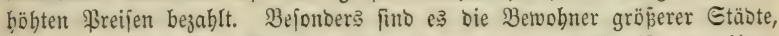
Die felten über einen Raum berfügen fönten, ber nötbig ijt, um ibren

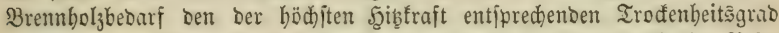

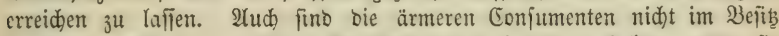
Der Mittel, bie bierzu nöthigen Borräthe an Şolz fich zu balten, wenn jie

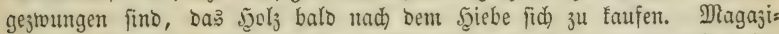

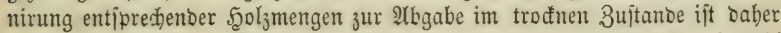

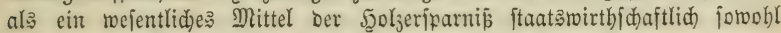

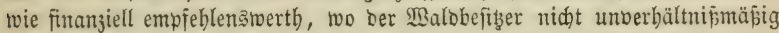
groje Sojten auf Şerridtung uno Unterhaltung ber bierz̧u nöthigen über=

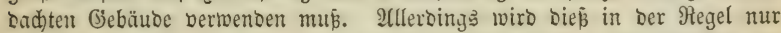
Da ber Fall jein, wo alte unbenubete ober geringloerthige Baulidfeiten Der Magazinirung fic barbieten.

\section{Dritfes sapitel.}

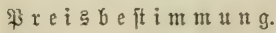

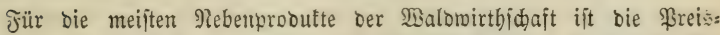
beftimmung eine einfache uno fidpere, ba fich) in anberen probucirenden (bie: werben, Deren Erzengnifije beftimmte Marftpreije bejitzen, nabe berwante Etellbertreter finben. Die Breife ber Mait, Der Gräferei, Der 2iseide, ber

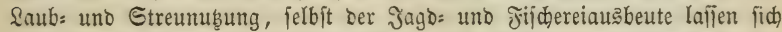

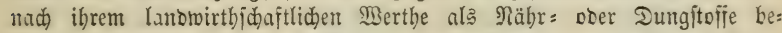

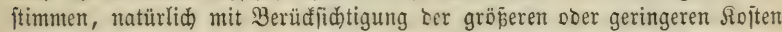
ber Gselvinnung, bie in ber Regel voun Emffänger jelfjt vollzogen wirb.

S(noers verbält fich bief mit dem Sgauptprodufte Des Tisaloes, mit sem Şoly. Alterbing bat and biejes feine Etelfwertreter im Baujtein, in 
Torf, Braunfoblen unb Steinfoblen; allein abgejehen von beren bejaränttem Borfonmen, ift Der Preis Derjelben ein fo bebingter un beränoerlidjer,

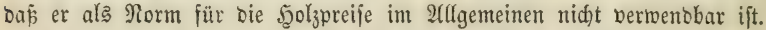

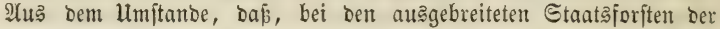
meiften beutjden Räntoer, Der Conjument größ̈tentbeils nur einem \$ro:

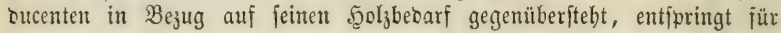
Icţteren eine Art Şandelsmonopol uno baraus bas Strebent nad) eigen= mäd)tiger ßreisbejtimmung auf rationeller Bafis (5golztaxen). 2Ul jolche bat man manderlei in Boridlag gebrad)t. Man berednete einen Rapital=

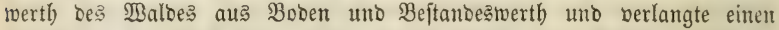
Nettoholzpreis, ourd) Delien Erbebung bie 3injen jenes Sapitalwerthes ge=

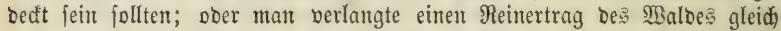
Dem, welden ber Boden in irgento einer anbern, ertragreidften uno aus:

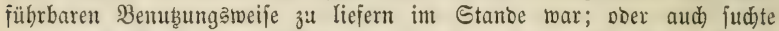
man ben freien Confurrenzpreis irgeno eine verfehr untertworfenten Gegenftandes, 3. 3. eines gemififen G̉etreibemañes in

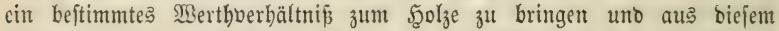

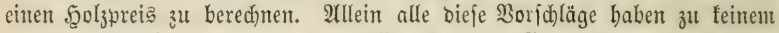

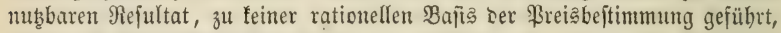

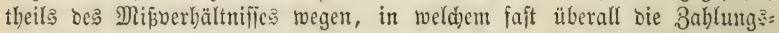

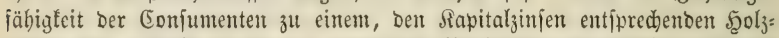

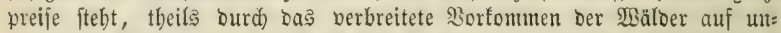

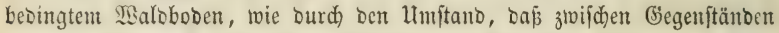

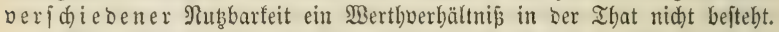

Man hat fich baber genöthigt gejeben, bie örtlid veridiebenc $3 \mathrm{a} h=$ lungäähigfeit Der Eonjumenten als Crunblage ber Breiabeftimmung jul berwenten, wie fid) foldhe zu erfenten gibt theils aus ben Durdjidnitts: gröfen Der Berjteigerungapneije bei freier und außreidender Confurrenz ber Conjumenten, theils aus ben Marftpreifen bei bejtebentem 3wifdenthandel.

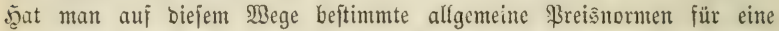

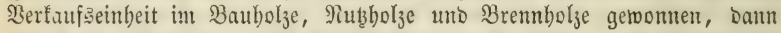

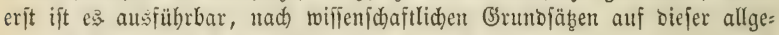
meinen Gruntlage Tarpreife für bie verfdiebenen Bau=, Nubs= uno

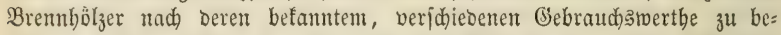
rednen unb zur Erbebung zu bringen. Der Breis eines Cubiffußes Buden: id)eithol $\}_{3}^{3}$. 2. würbe aus Eteigerungs = uno Martpreifen zu ermitteln, Ier Preis des Budben = Anüppel = ober Reiferholzes bingegen aus Deffen

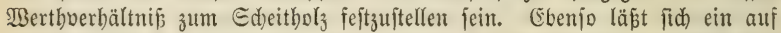

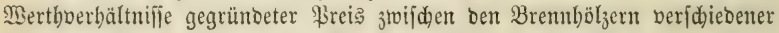

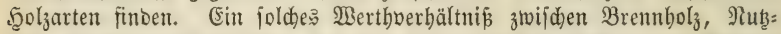

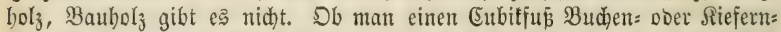
Brennbol

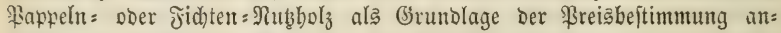
nimmt, ift gleidgültig. Nadffrage uno $\mathfrak{2}$ ngebot einerfeits, anoererjeit’ bie

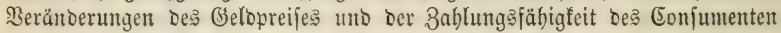

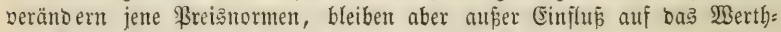

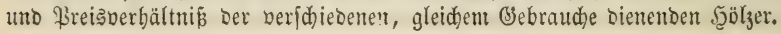




\section{Dூiertes אapifel.}

$\mathfrak{a b g a b e r o j e n . ~}$

Man unteridjeibet im Joritprobuttenbandel ben Berfunf aus freier Şand vom Bertaufe nach bem Meiftgebot.

Der Berfauf auล freier Şano geidieht nad) Bered̆tigungs =, Begün=

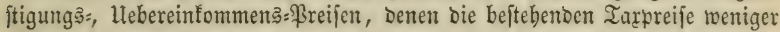
ober mebr zum Grunbe liegen. Sebzteres ift bejonbers ba ber fall, two

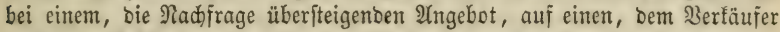

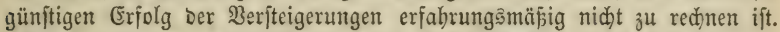

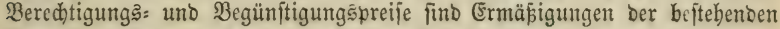
Iarpreife. Erftere ruben auf reditliden Berpfichtungen, leştere entipringen Der $\mathfrak{A}$ rmuth eines Theils Der Eonjumenten uno ber Errabrung, Dấ biefe jum Şolzoiebjtahl georängt fein würben, wenn, bei einer bas 2lngebot über: jteigenden Nadjirage, bie Conturrenz vermögenberer Conjumenten bas 21ngebot зи Steigerpreifen für fid̆ in 2 nfprud) nimmt, bie కer ärmere (Eonjument nid)t zu eridjwingen vermag. Allerbings geben joldhe Begünitigungstarpreife nicht felten Beranlajiung zu einem wiserredtliden 3wijhenbandel, Dem:

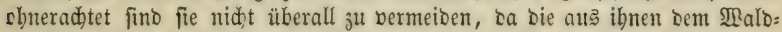

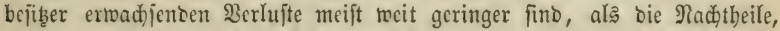

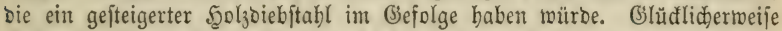
ift e⿻s Der Bezug non Maff = uno \&ejehol

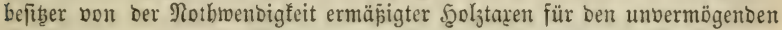
Theil ber antobnenten Cojumenten enthebt. 2An beftehende Marft= ober Iarpreije nidjt gebunbene Hebereinfommenspreije fint ba nothmenoig, mo nupergemöhnlide Solzarten uno Exrtimente zum Berfaufe fonmen, für bie sine Confurrenj mebrerer Säujer nidjt beftebt. Ės gebören babin bejonders

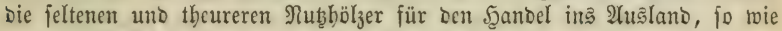
ausergemöbnlid bejdäbigte ober berborbene $\mathfrak{B a a r e .}$

Эn allen übrigen fällen berbient ber ßerfauf nach bem Meiftgebot sen $\mathfrak{B}$ orzug bor jeber anbern Berfaufämeife, Denn nur auf biefem Mege

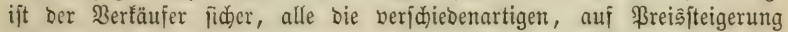

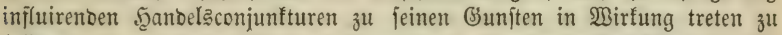
lafien, nur auj biejem Wege erljält er eine entipred)enbe (Entjđäbigung für biejenigen Roften, bie er auf bie beffere Şerftellung ber Maare wie auf Deren leichteren Trangport uno Nerwenoung aufgementet bat.

Ullerbings entipredten bie Steigerpreife nidyt immer bem rirfliden Giebraudswerthe ber Maare, inbem mannigfaltige Borurtbeile ber Conju= menten oft bem minoer Werthodlen einen böheren \$reis zumenben, ober

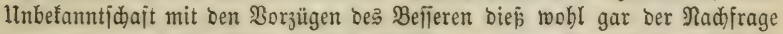

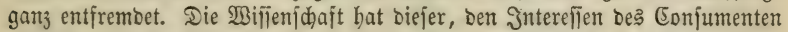
fomohl, wie jtaat引mirthidaftlid) nad)tbeiligen Untenntniß entgegenzumirfen.

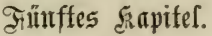

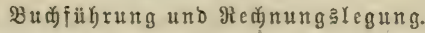

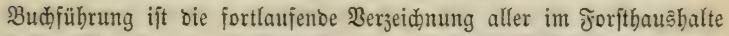

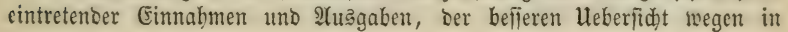


tabellarijđer Form, getrennt nad) ben verfdiebenten Gegenftänben Der Fin:

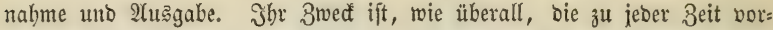

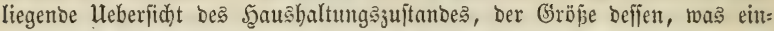
genomment ober ausgegeben iift, was in Folge beffen nod) einzunebmen uno auşugeben beibt, gegenüber bem jäbrliden ßoranjdlage ber Einnabment

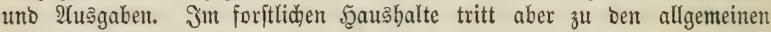
Zwectent ber Budfü̈brung nod ein bejonderer Eontrolzwed bintzu, Der mando

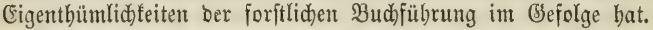

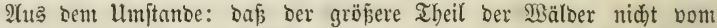
Eigenthümer jelbit betwirtbidaftet werben fann, fondern ber Serwaltung anberer Berjonen anvertraut werben muj, aus bem Umitande ferner: Daj im Malde große nub̧bare Borräthe aufgebäuft fint, beren Menge und $B e=$

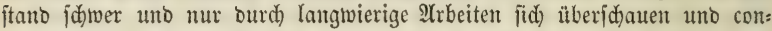

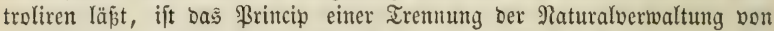
Der Belberbebung im Forithauthalte entfprungen. Der Revierbeamte bat nur bie Naturalproduftion z̆ll erbeben uno auf bie Empfänger anzumeijen,

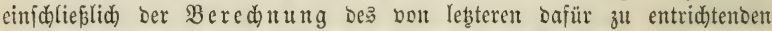
Gelobetrages; er hat bie Seiftutgen Durd) Arbeit3fraft in Empfang 3u nebmen und die für foldhe ju gemäbrende Bablung zu beredunt. Die

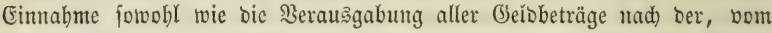
Revierberibalter aufgeftellten Berednung ift Eache einer getrenten Rafien: vertwaltung. Daraus entipringt eine gegenjeitige Eontrole ber Naturalver= waltung uno ber bielberkebung, in ber eine möglidjt fichere Getwäbrleiftung

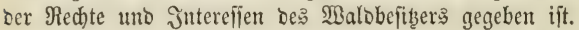

Eine zmectmäpige Echärfung biejer (Sontrole finbet bäufig noch ba:

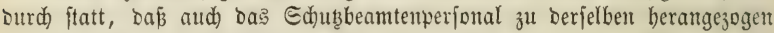
wirb, Durd) eine Budffübrung über Naturaleimnabment uno Itbgaben in

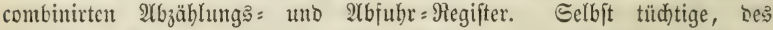
Ed)reibents funbige Solzhanermeifter fönnen in Den Eontrolapparat ge: jogen werben, wenn ihnen bie exfte 2lufitellung aller, zunäd)ft bom Ed)ubs: beamten zu revisirentor uno zu attejtirenoer \&ohnzettel übertragen wiro. Je größer bie 3abl ber Berfonen ift, bie in fortlanfenter Mitwiffenjafjaft Der erfolgten Einnabmen uno 2 usgaben erbalten werben, um fo ficherer ift ber Malbeigenthümer vor Unred)tfertigfeiten Des einen ober bes anberen jeiner Beamten, um jo jicherer finblebtere vor unbegründen $2(n f$ 光ulbigungen.

Ez ift aber nothtwenoig, baj überall bie Budfführung auf bie cin: fadjite Jorm zurüfgefübrt werbe, went fie nidbt ben (Sefdäften ber beften Betriebsfübrung wejentlid) (Sintrag thum uno Daburd) mehr fidaben als

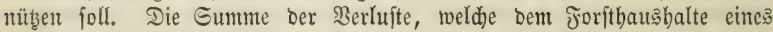
Sanbes aus ber Unreblidfeit einzelner Beamteter möglidberweife er: wadffen fant, ift ein Kleiner Brudhtheil Derjenigen \$erluite, bie unfehlbar

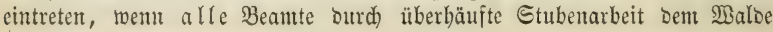
entfrembet werbert.

Da jajt jebe Naturaleimabme im Joritivirtbjafaftabetriebe mit fremben

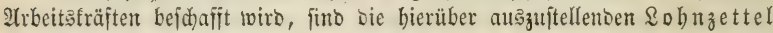
Grrundlage Der Budfühtung. Der Sürze toegen fint auf ihnen bie gleich)= 


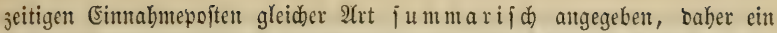

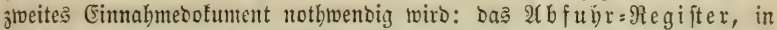
weldes jeber eitzelne Berfaufspoiten in fortlaufenter Nummerfolge auf bejonocre Sinie eingetragen wiro, mit Bentennung ber 2trt uno Ģröpe Defiflben.

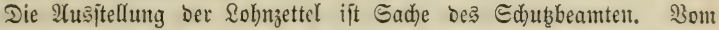
Revierbeamten rebioirt uno in ein Sobnmamuale eingetragen, erbebt auf fie Der Arbeiter ober Defien Dbmann bas berednete Sobn bei ber Salje. Wiffent

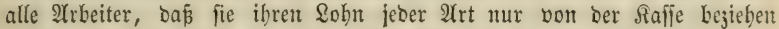
büren, fo liegt bierin ein wejentliches Moment ber Eontrole.

2(ud) bas 2 bfuhr= Regifter, fo genannt, weil ber Gdubbeante binter jeoen Berfaufäpoften Den Empfänger Defielben fräter einzutragen,

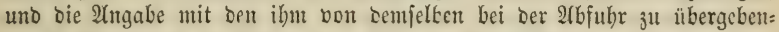
Den Berfaufäsettel zu belegen hat, fühnt ber Edubbeamte. Das correfpon= birenbe $\mathfrak{A b}_{3}$ äblung $\mathrm{S}=\Re$ egi fter bes Betriebsbeamten ift eine gleidlautende 3ujammenitellung ber 2 (ngaben in Den $26 f u b r=\Re e g i f t e r n$ aller Ed)ubbeamten

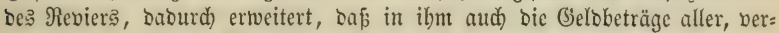
einzelt aufgefübrten ßerfaufäpoften Kercd)net unto angegeben finto, aud

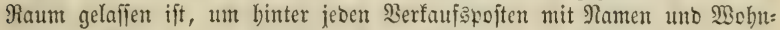
ort bes Räufers oder (Empfängers zugleid) aud bie গummer bes aus:

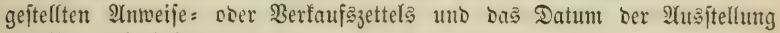
Defielben aufzufübren.

Das, auf Grund vom Betriebabeanten berwirter 2(bnabme ber auf= bereiteten Berfaufaspoften aufgeftellte 2 bुzählungšregifter enthält baber nicht

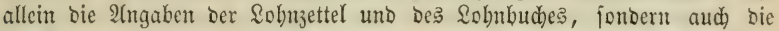

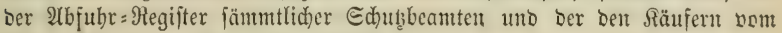

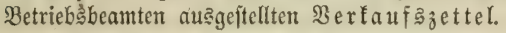

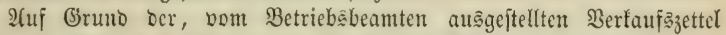

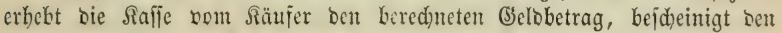

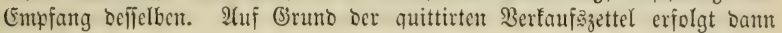
bie 2tnweifung Des erfauften Begenftandes non Geiten bes betreffenden

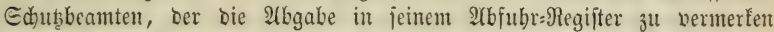
uno mit bem Berfaufżettel зu belegen hat. Eine von Der Raffenverwal= tung gefübrte, Die 2(bid)rift ber eingegangenten uno quittirten \$erfaufazettel

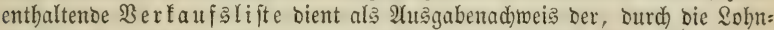

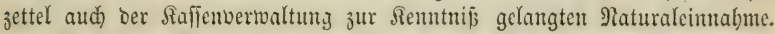

IUf bicje \$eije tann jowohl aus Den Büdern bes Gd)ukbeanten

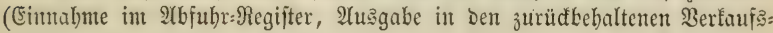

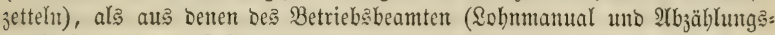
regifter) uno Der Saffe (Qobnjettel uno Berfaufeslifte) Der Matural= Soll=

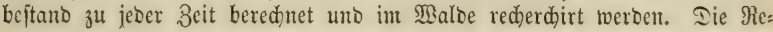
fultate Der Berechinung Des Natural= Sollbeftandes müffen in allen brei Fällen biefelben fein, fo weit nidht ausgeftellte Berfaufäsettel nod unbe= zahlt in ben Şänoen Der Entpfänger liegen, für Deren Einzahlung bei ser

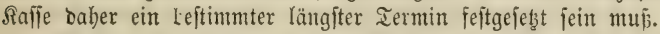

Wa: nut auperbem nod gefdieht zur leidteren Ueberidut ber (Ein:

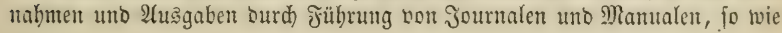


Durch Aufitellung bon (5rtraften zc. ift eine, mur bebingt notblwenbige 2leben: jache uno gehört nidht bierber, wie id aud ber bejonoeren Budffübrung über

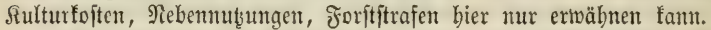

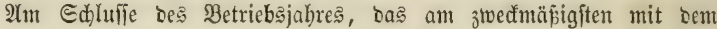
eriften Suli beginnt und abjoliepst, ba bas Ralenderjabr eine, bie Dar: fteflung uno $\mathfrak{H}$ eberfid)t ftörente Epaltung Der Finnabmen uno 2(usigaben bes Winters mit fich fübren würbe; auperbem im Sommer bem forft=

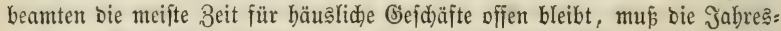
red)mung angefertigt weroen, eine bofumentirte Heberfidht aller im Saufe Des Betriebsjabrs cingetretenter Einnabmen uno 2 (4ägaben, uno banad beక Norratbes, Der für bas nädjpte Betriebsjajar verbleibt.

3ur leidteren Ueberiid)t fint in ber Jabreșrednung bie verfodicbenen

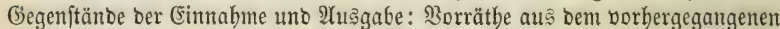

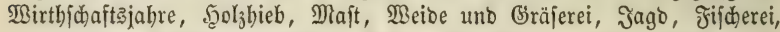
Etrafgeloer, Malogewerbebetrieb, Silltur, Megebau zc. in bejonderen Iiteln uno Rapiteln getrennt aufgeführt.

Der Betriebsbeamte legt bie Raturalred)nung, b. h. bie nad)

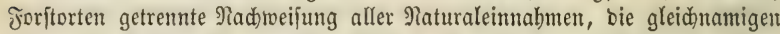

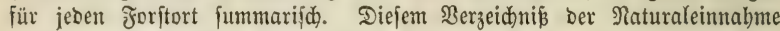
fteht bas ber Naturalatsagabe (uno Eoll:Einnabme an (selb) gegenüber,

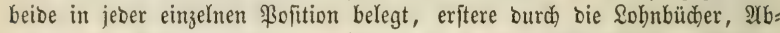

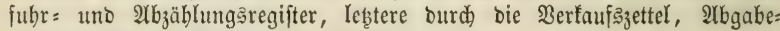
antweijungen uno Berjteigerungşliften.

Der Safienbeamte legt bie (beloredinung, Deren Einnabme jeben einjelnen Berfaufæpoften mit bem, für biefen eingegangenen Belloerlöfe,

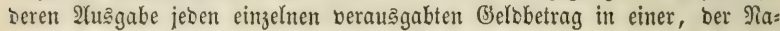
turalrechnung gleidhen ober äbnlichen Sonberung nadiseiat. Die Belege

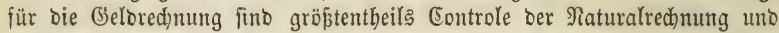
miiffen beibe in ifren 2 (ngaben uno namentlid) in ibren (Enorejultaten über: einftimment.

Beibe Rednungen bereint fino Gegenitano ber Revifion einer oberen

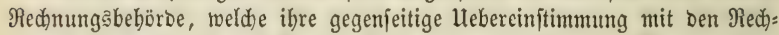
nungsbelegen, fowie ihre Ridstigteit in calculo prüft, ibre Monita aufge= fundener Differenzen uno Redjungsfebler aufitellt, bie von ben Red)= nungsfübrern zu erlebigen fino, worauf ber beridtigten Gabreşred)nung bie

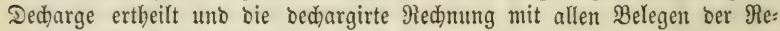
giftratur bes Reviers zurüdgeftellt wirb. 
Taft: II .

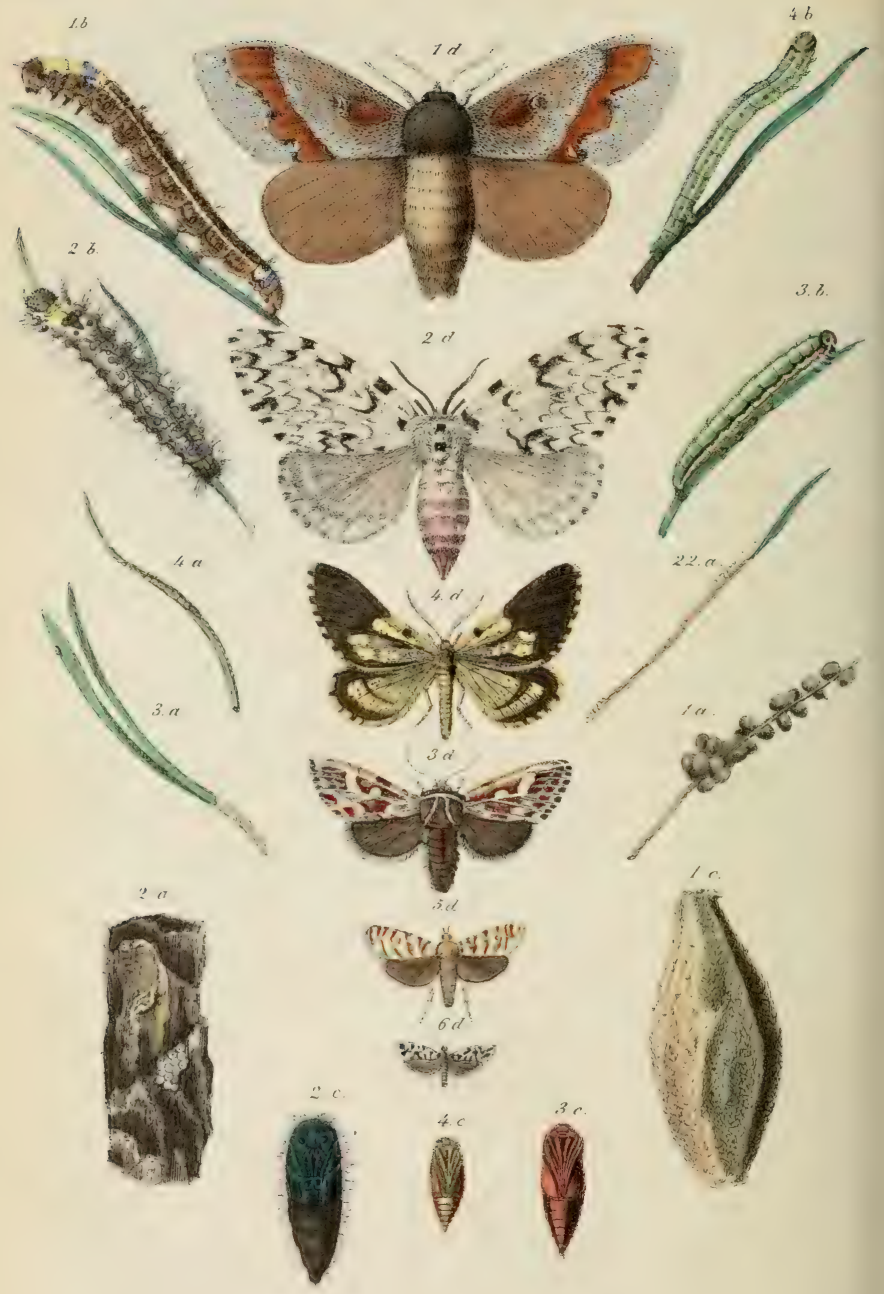


Taf III.

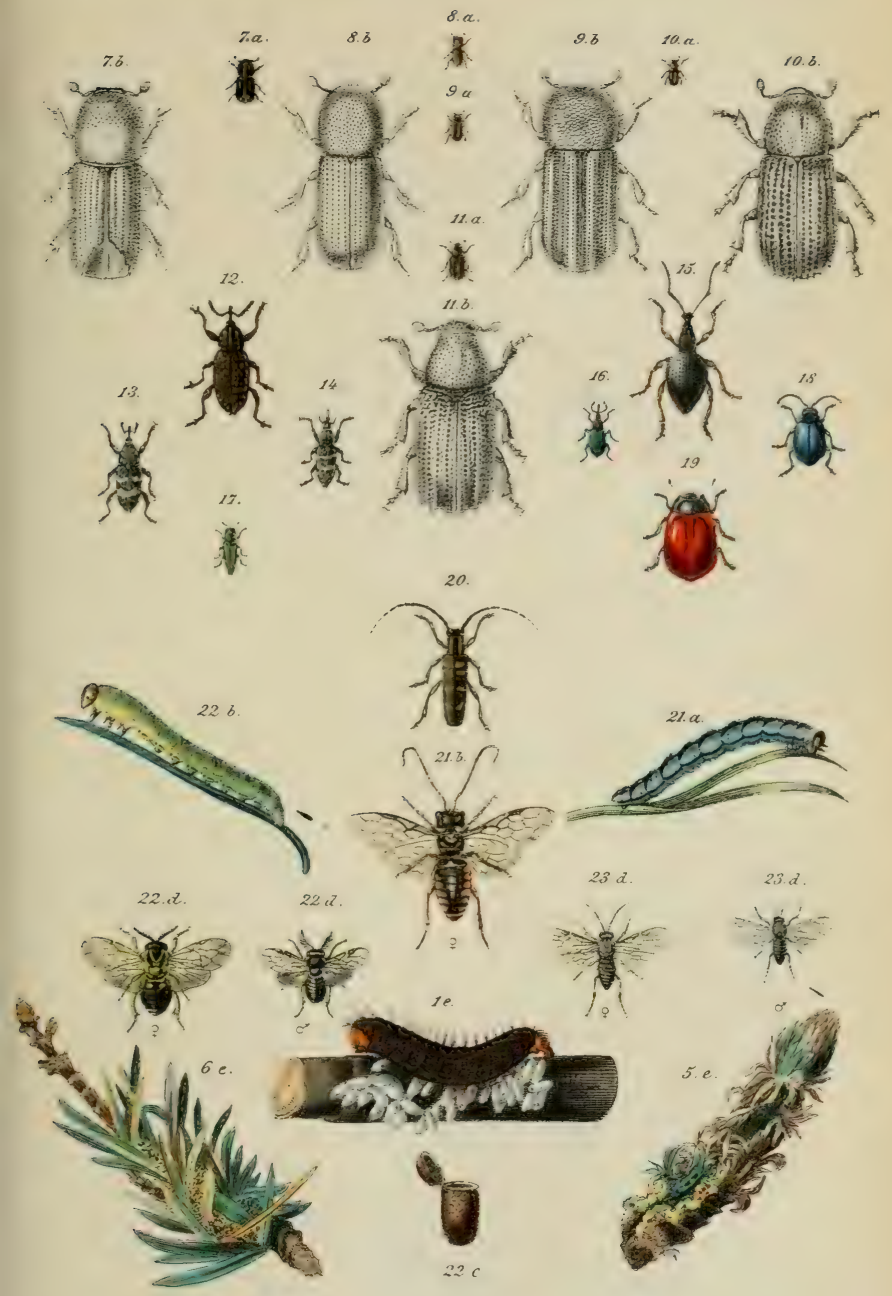





\section{felorluld für fublter}

unto

für die, welife es werden wollent.

2on

Dr. Beorg Lutwig fontig

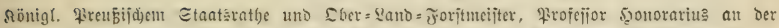

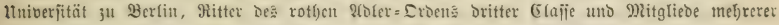

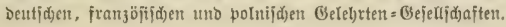

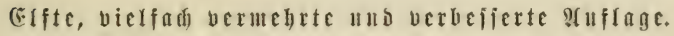

Mind) Des פerfafiers Tode hernusgegeben

von

Dr. Chendor fintig umo Dr. Kobert fjarting.

Dritter uno Yebeter Banto

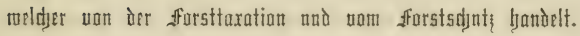

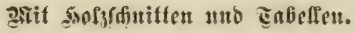

\section{Stuttgnxt.}

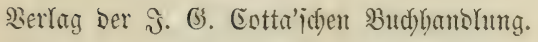




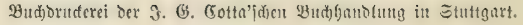




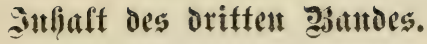

\author{
Bierter Sautheir.
}

20u Der Forittaxation

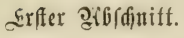

atrgemeiner ฐheil.

Frites fiapitel. Foritliafe Gieometrie

I. Grenzbermelfung 4

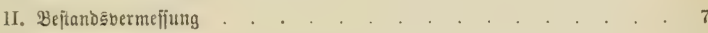

III. WalDtheilung : . . . . . . . . . . . . . . s

1V. Sartizung . . . . . . . . . . . . . . 11

Siteratur . . . . . . . . . . . . . . 12

31veites Rapitel. Joritlide Bodentutioe . . . . . . . . . . . 13

Drittes Rapitel. 5ூolgmę́funde . . . . . . . . . . . . . 14

I. Э马а й

A. Maffenermittelung licgender Bäume . . . . . . . . . . . . 14

B. Maffentermittelung ftehender Bäume . . . . . . . . . . . . . 18

II. Beftandstaration.

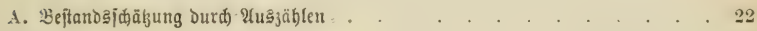

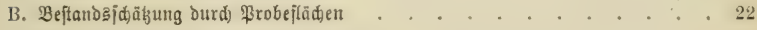

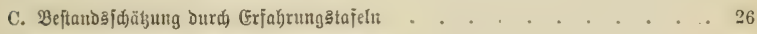

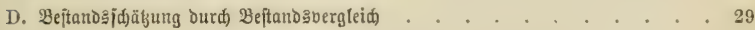

Viertes Sapitel. Bumad)కermittelung . . . . . . . . . . . 32

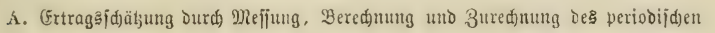
3utwadę . . . . . . . . . . . . . . . . 34

I. 3uwađ̧̧6ered)nung all eiuzefnen Băumen . . . . . . . . . 34

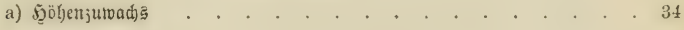

b) Stärtejutwad马 . . . . . . . . . . . . . . . 35

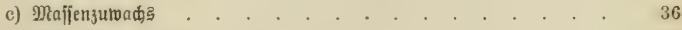

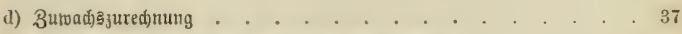

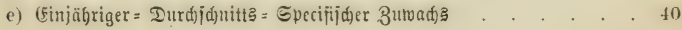


II. Butwaç引bered)nung ganzer Beftänd . . . . . . . . . . . 41

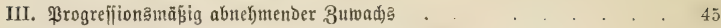

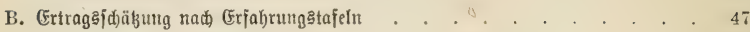

I. Confrultion Der Erjabrunģtafeln . . . . . . . . . . 47

II. Anwendung Der Erfahrungstafeln . . . . . . . . . . . . 51

1) Erfahrungstafeln . . . . . . . . . . . . . 52

2) Majijentafeln . . . . . . . . . . . . . . . . . . 54

@iteratur. . . . . . . . . . . 58

\section{Bweiter อृf(b/ditift.}

Tngeluendeter Ibeil.

(Erftes Rapitel. Ertragsermittelung .

I. Ertraģermittelung Der ફ̧od)wälder . . . . . . . . . . . . 61

A. Die fradwertmethoden . . . . . . . . . . . . 61

a) Dą Baumzahl = fadmert . . . . . . . . . . . 61

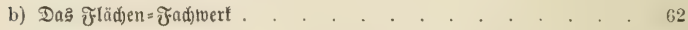

c) Das Rlaffen = fađtwert . . . . . . . . . . . . . . 62

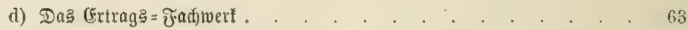

1) Die geometrifden $\mathfrak{A}$ beiten . . . . . . . . . . . . . 65

2) Begrünoung Dę Wirtbidaftaplane . . . . . . . . 65

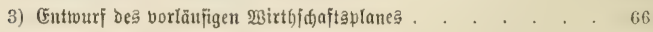

4) Der Tarationgplan . . . . . . . . . . . . . 67

5) Anfertigutg oder ßrüfung ठer Erfahrungstafetn . . . . . 69

6) Die 2tbidäz̆ung . . . . . . . . . . . . . . . . 70

7) Da马 Tarationsregifter . . . . . . . . . . . . . . 71

8) CErtragsregelutng . . . . . . . . . . . . . 73

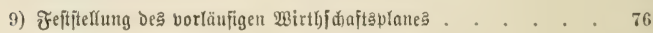

Siteratur. . . . . . . . . . . . . 76

B. Die 2 Beijermethoden . . . . . . . . . . . . 77

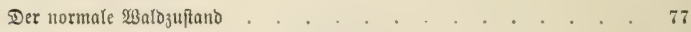

Der fingirte 2 albjuitan๖ . . . . . . . . . . . . . . . . 82

Der reale $23 a$ azouftand . . . . . . . . . . . . . . 84

Ueber Mutuutgatweifer . . . . . . . . . . . . . . . 84

Bom alfgemeinen 9hłungermeifer . . . . . . . . . . . . 85

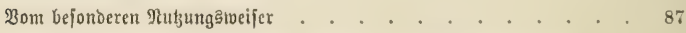

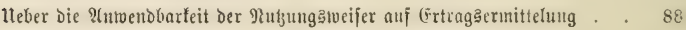

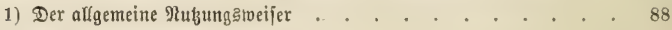

2) Der befondere 9lubungstweifer . . . . . . . . . . . . . . . . . . . . . . . . . . . 95

3) Der heterogene Auţunģweifer . . . . . . . . . . . . 99

Siteratur . . . . . . . . . . . 104 


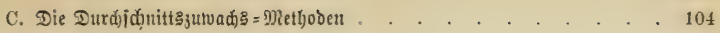

Siteratur . . . . . . . . . . . . . . 105

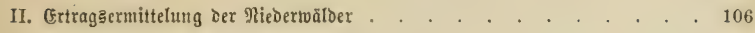

III. Ertragsermittelung der Mitteltwäloer . . . . . . . . . . . . 114

Siteraiur. . . . . . . . . . . . . . . 119

3weites Rapitel. Walowertbberedunng . . . . . . . . . . . 119

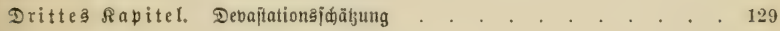

Siteratur . . . . . . . . . . . . . . 130

\section{Fïufter ફूauttheil.}

$20 \mathrm{~m}$ forjtidus.

(Erite Rapitel. Won Der 2ufijidt über bie Walogrenzen

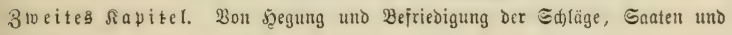

\$Flanjungen

Drittes Rapitel. Won Den Waldwegen und Der 9lotbwendigteit ifrer Unter=

baltung

2iertes Rapitel. Bon Räumung der Sdläge

Fïnftes fiapitel. Won Der Şoljberidgendung und ben Mritteln, fie abju=

wenden .

140

Sedstes Rapitel. Dom jolzoiebitall

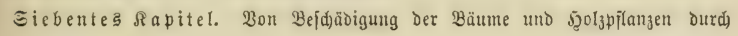
Menjón

1) Bom Wiebjdrteiden

2) $230 m$ Bejenreisjanneiden

3) Bom Quirlíneiden .

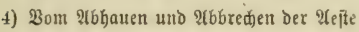

5) $\mathfrak{B o m}$ ße⿻) = unঠ Sienholahauen .

6) Bom Ringein ber Bäume

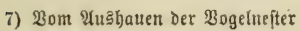

8) ミom Gaftabjapien

Idtes Rapitel. Bon Der Waldreide 
Giebenzelntes Rapitel. Bon lleberidnemmung ber Waldungen . . . . 166 $\mathfrak{A}$ Фtzehnte马 Rapitel. Bon ber Berjandung . . . . . . . . . . 168 Reunzebntes Rapitel. Bon ben Sturmminden . . . . . . . . . 168 3ranjigftes Rapitel. Wom Froftifhaden . . . . . . . . . . . 169 Einundztwausigftes $\mathcal{\Omega} a$ pitel. Bom Duft= und Sdneeanbang uno vom jyagel=

juladen . . . . . . . . . . . . . . . . . 169 3 weiundjwanjigites Rapitel. Som Sd)aben Durd auferorbentlide Düre 171 Dreiundzwanzigftes Rapitel. Bom Saben durd) bie Mäuje . . . . 171 Bierundztranjigites Rapitel. Bom Sdaden durd Bögel . . . . . . 173

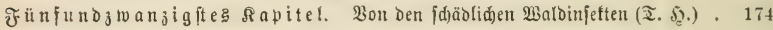

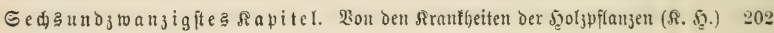
Siteratur für ben Forftiaus 


\section{Ḑiterter souttheif.}





\section{Ellit Der Forfthntiontr.}

Birtbidaften heipt: mit ben, aus einem gegebenten Bermögen fliejenden Cinfommen Bebürfnifje einer ober mebrercr ßerjonen nüglidjt vollfänoig uno nachbaltig ${ }^{1}$ befriebigen.

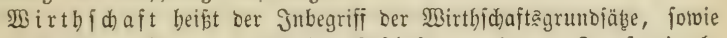

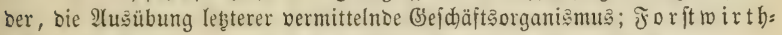
$\{$ ch af t heifft biejer, menn bas gegebene Bermögen ein $\mathfrak{B a l}$ ift.

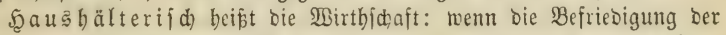
Bebürfmiffe nid)t allein möglidjit voll ft än $b \mathrm{ig}$, jonbern aud $n a d b$ bltig ift; menn für ausergemöhnlidge Beoürfnifile fo wie für Beiten ber શoth ein Eparffemig erübrigt uno jurüđgelegt wirb- Refervefond $3 ;$ wenn enolic) Durd) Die 2 (rt Der $\mathfrak{B}$ irtbichaftsfübrung für bie Darftellung ber größten Menge von Mitteln jur Befriebigung Der Beburfniffe Eorge getragen wiro.

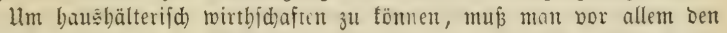
Bermögensft a no Der Wirtbidaft fennen, man muß millen, über weldhe

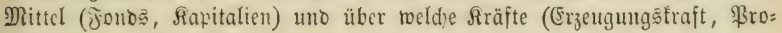

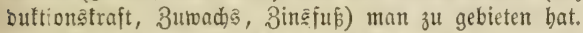

Taxation, $S_{d}$ äbungşlebre, ift bie Rebre bon Der Erforidung

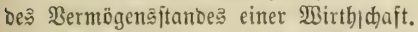

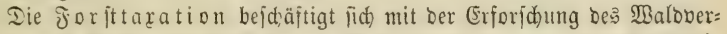

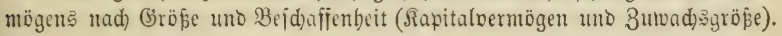

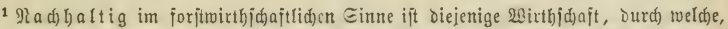

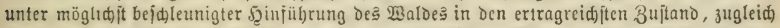
Eorge getragen ift jür Die bejriedigung des wirfliden bedarfes an Tikaloproduften

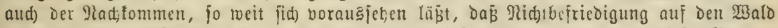

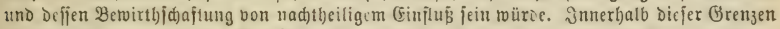

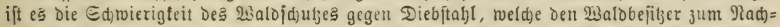

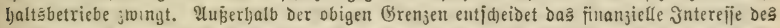

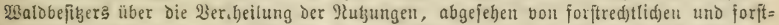

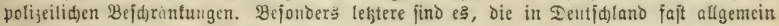
einen Iladibalisbetrieb voridareiben.

In feinem ber veridjiedenen producirenden Getwerbe hat bie Madjhaltigftit ber 9kubung

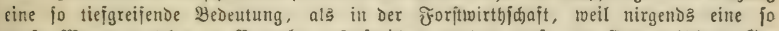
groje Menge nubbarer \$rodutte aufgejpeichert werben mus, um (Enten böberer Öe=

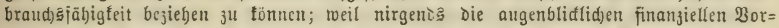

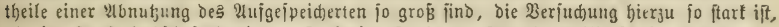
als im Forftriribjdaftebtriebe. Derjenige Theil Der Tarationstwifienid)aft, welder fid)

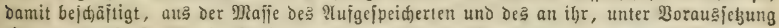

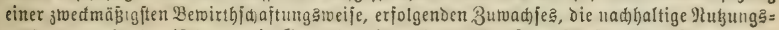

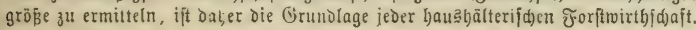




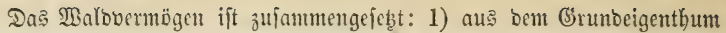
(Boben); 2) aus den Den Boden bedectenden Scolzbeftänden (Borrath), Sgolzz fapital, Inventarium).

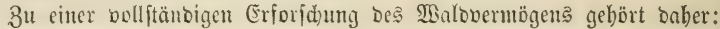
A. (Ermittelung Des 2(realbeftanoes; a) nad) feiner räumliden 2usbebnung (Bermejing), b) nad) jeiner (Erzeugungstıaft (Bonitirung). B. Ed)äßung bes Şoljtapitals; a) nad) femer gegemuärtigen biöfse (Şoljtaration); b) nad) feiner (Erzeugungatraft (Erragstaration, 3umad)sbered)nung).

Scientad) zerfällt bie jorfttąation in folgente $\mathscr{U}(b j$ )nitte:

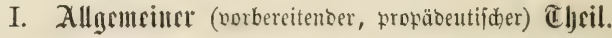

A. Forftlid) (S) c metrie: Sebre von ber Ermittelung ber flähen= größe bes $\mathfrak{B a}$ aloeigenthum?

B. Forftlide Bodenfunde un Slimatologie: Sebre von Der Erforfdung Der Erzeugungstraft Des Etanborts.

C. Forftlid)e Solzmébtunde: Sebre von der Ermittelung gegen=

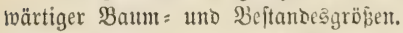

D. Forftlid)e 3 uwad sbered)ung: Sebre bon Der (Erforid)ung vergangener uno zufünftiger Baumt= uno Beftanbesgröfen uno baourd) Der Erzeugungafraft Des Beftandes.

\section{Augrwrideter Tleil.}

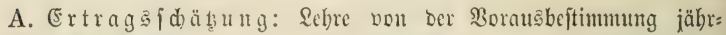

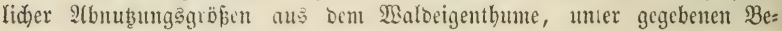
ftands = uno 2 irthidjaftsoerbältniffen.

B. Walowerthid) äıug: Sebre von ber (Emittelung bes gegen= wärtigen Gelorwerthes ber Siäloer unter verfdiedenen Einflüfien Der Dert=

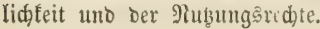

C. Devajtationsid) ä usug: Sebre von ber Ermittelung ob uno

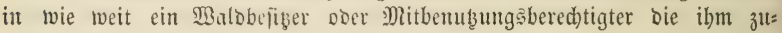
ftehenden Nubूungąbefugniffe überidritten habe.

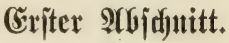

\section{Itrgemeiter Theil.}

\section{cirftes sapitel.}

Forftide (beometrie.

Ermittelung ber Fläd)engröfan ift bei jeber Iaration, bei ber ę̧ fich nid)t allein um Ermittelung Des Szolzgebaltes einzelner Bäume bandelt,

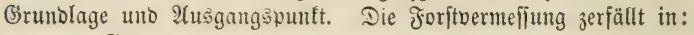

I. B̧renzuermef\{ung;

II. Beftanbsoermeffung; 
III. MBal ot heilung (Eintheilung in Jagen, Edläge rc.);

IV. $\Re$ artirung.

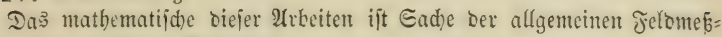
funbe, ber prattifden Beometrie.

Dieje finn nid)t Gegenftund unferer Crörterungen fein, obne bie bent

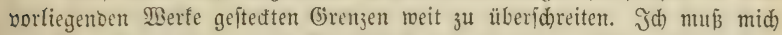

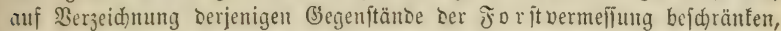
bie auferbalb Des Sreifes Der allgemeinen flädhenmefitunce liegen.

\section{Heber oie $\mathfrak{W a b l}$ ber Jujtumente für $\mathfrak{B}$ alobermej fugen.}

Balbmefïungen baben, im Begenfaks zu Felomefïutgen, mandhe Eigen= thümlidfeiten, befonders berborigerufen ourd) bie Beftünde, Durd) Die Bes fdränfung ber Jernfidt, bie Edwierigteit ocer llnausfübrbarfeit einer Controle uno Berid)tigung Der einzelnen 2(rbeiten Durd) Ridtpunfte uno Diagonalen, Durd) Das oft jebr untegfame Terrain, Durd bie Jeudtigfeit ber Waldluft zc. Sie äusern zunädjit einen rejentlidjen (Einfluis auf bie $\mathfrak{B a h l}$ Der Mefinitrumente.

Spiegelinftrumente fint für Balomefïungen in Der Regel zu theuer, zu contplicirt, unbequem zu transportiren, liid): zu bejdäsigen uno Die 2 rbeit bamit ift 3 febr von Der Witterung abbängig.

Iem (Sebraud) Des Mejtifdes tritt befonders bie feudte Malduft uno Deren (Einflús auf Daß 3eidnentapier, Die 2(bbängigfeit ber 2Arbeit

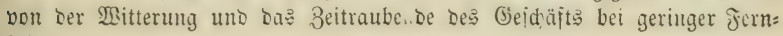
fidht entgegen.

Die Boufiole ijt Daß einzige Sniftrument, bas mit Den Borjügen einer leid)ten uno fideren Şanbbabung, aud) im ungünítigiten Ierrain, bie Urbeit bei ungünjtiger Witterung geftattet. Dieje Borzüge furo es, bie

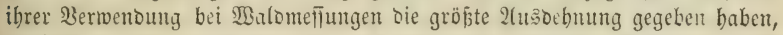
obgleid) es nid)t ju leugnen iit, Daj Die Damit bejchafften 2(rbeiten, felbjt bei Der größten ভorgfalt des 2frbeiters, weniger juberläilig fino, beionder? in Gebirgajorjten über eijenbaltigem \$oocn uro Bejteinen, wojelbjt beim

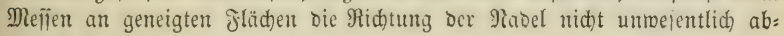
gelentt wirs.

Es ift Daber, bejonders in Gebirgsforiten, Der (sebraud) bes Deps=

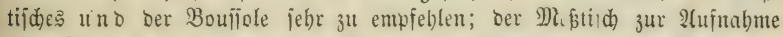

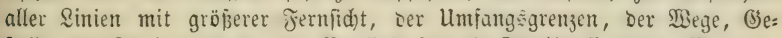
itelle, oer Thalgrünoe ic., Die Bouñole für bie Detailmeliungen. Nian ge: winnt baburd für alle Bouffolemefingen fefte 2Unbaltspuntte zur Berichti= gung, eine trefflid)e uno fidere Controle, bie Detailmefïungen werben oa= Durd) wejentlich bejchleunigt uno man eripart an fioften, indem es in biejem Jalle zulänig ijt, ein weniger eingeübtes, wohlfeileres ßerjonal für bie Boufiolemefiungen zu berwenden.

\section{Die (5renzuermeflimg.}

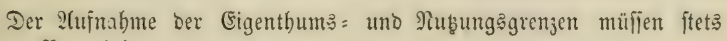
iolgende Borarbeiten borangeben: 


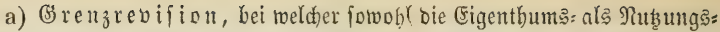

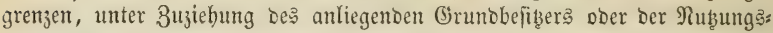
beredtigten, begangen reroen, um zu ermitteln, ob uno intwiefern nod)

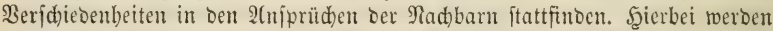
alle als ridgtig beiberfeits anerfannten (Brenzzeid)en uno Grenzlinien auf= genommen voer beftätigt, nöthigenfalles aufgefrijht. Finden fid) hingegen

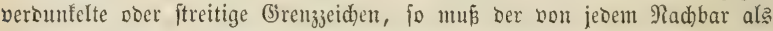
ridtig in Ulnfprud genommene Brenzerlauf aufgenommen uno bas von

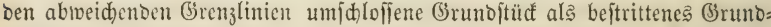
ftüd fpeciell vermeffen werben, Deffin Erwerb ober Berluft bann B̈egenftanto eines Bergleides ober proceffualifden Berfabrens ift, worauf bei ber $\mathfrak{B}_{e}$ triebseintridtung uno Taration bie nöthige Rücficht zu nebmen ift.

b) Ilnterfud)ung ber Berbältnifje, weld)e eine Beränberung ber gegen= wärtigen Eigenthums: Doer Nubungsgrenzen bortheillhaft ericheinen laffen.

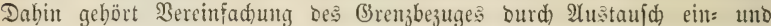

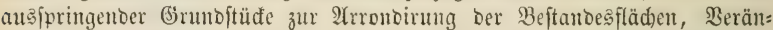
Derung Des Befibitandes Durd Servitutabfinoungen, Durd) Eintaufd bon Baldiviejen uno Baloädern, burd) bortheillbafte (Erwerbungen ober Ber= äunerungen.

c) Unterfud)ung, ob unb wie weit vorbanbene ältere Mermefinutgs: arbeiten vorbanden unb bemubzbar find. Aeltere Grenzoermeffungsarbeiten fino nur Dann braudbar, wom fie nit Dem gegentuärtigen Sejił̧itanoe aufs Benauefte übereinftimmen. Bei älteren Beftandobermeffungsarbeiten ift abjolute llebereinftinmmung mit Den gegentärtigen Berbältniffen nidht fo unbedingt nothwendig, ia es fid babei nid)t, wie bei Brenzbermelïungen um Mein uno Dein hanbelt. (5s genügt fdyon, wenn bic 2Abweid)ungen 1 \$rocent, unter Unrftänben weru fie 2 Brocent ber flädengröfe nidłt überfteigen.

Diejen Sorarbeiten folgt Die Bermeffung Der Eigentbumegrenzen,

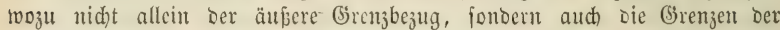
innerbalb beffetben liegenden fremocn (Grumbitüde gebören, nad) Nummer, Sage, Entfernung uno Befdaffenbeit Der Girenzpuntte.

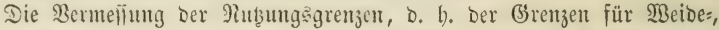

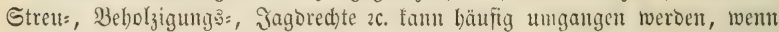

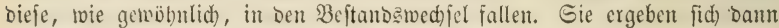

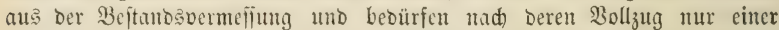
gegenfeitigen Beftätigung. Э̆ anoeren fällen müffen bieje Brenzen aber fo aufgenonment uno bezeid)net werben, wie bic Eigenthumsgrenzen, alld bann, wenn Der bezeidnete Beftandäwedjel fein bleibenter ift.

Die Refultate Der Grenjoermefilung werden in eitter befontoeren Grenz= farte, genöbulid) 50 Ruthen auf 1 Decimalzoll, und in einem Brenzver= mefiungäregifter verzeidnet. Die (Brenzłurte entbält bie figürlid)e Daritel=

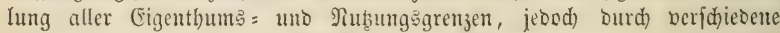

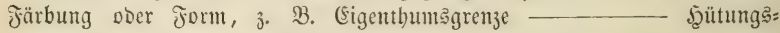
grenze ... Streumuķungågrenze —... ... - unter=

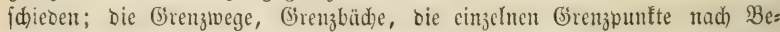

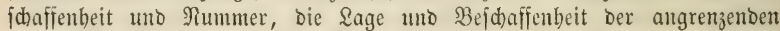
(5runoftüđe, bic permanenten Siadbarpunfte zc. Das Çrenjbermeffungs: 


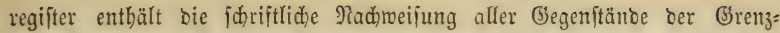
vermeflung in tabellariicher form uno bie geridtlid beglaubigte, anerfen= nenbe Unterjarift fämmtlidjer Эnterefientent.

\section{Beftandsvcrmeffiug.}

Gie umfap̄t: a) bie Größ̄e, Sage, Bejdaffenbeit ber, immerbalb ber Eigenthumşgrenjen liegenoen prosuftionțunfäbigen Fläd)en: Wegc, (̉eftelle,

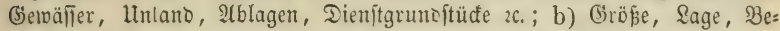
idaffenbeit ber produttionäfäbigen filäden, bie jur Beit probuftiongloz

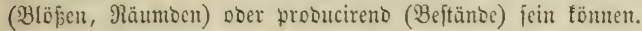

Die Maldblöben werben gewöhnlid) ur bis zu $1000 \square \mathfrak{D}$ tr. Fläden=

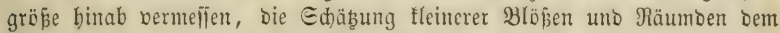

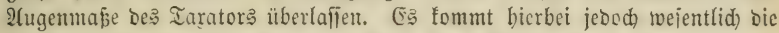
Bejdaffenbeit זes Bejtantes in Betrad)t, in weldem dic Blöpe gelegen ijt. In alten Beftänben, seren 5olzmafie Durd) ftummoeife Edä̈zung ermittelt

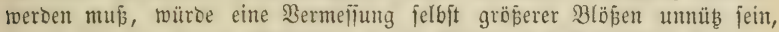
ebenjo in ganł jungen Bejtäno.n, ๖eren Blöß̨en noch fulturfäbig fino.

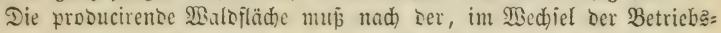

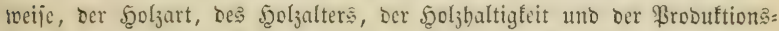

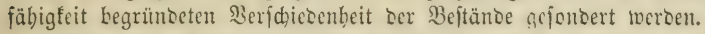

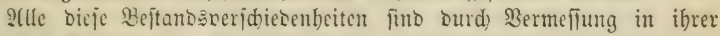
räumlid)en 2 Als̈bebnung, Sage unb form ju fonbern, injofern fie ent weder a uf ben fünftigen Betricb undertrag ober auf bie

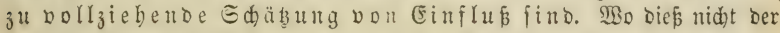

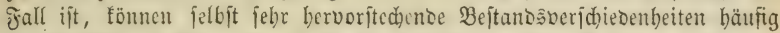

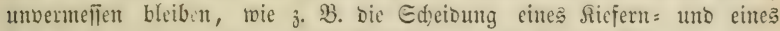

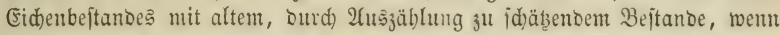
Tie fünftig ein unb Derjelben Sultur uno Berwirtbiduftung unterworfen merben jollen. Ob ein fold)er jall borliege, noer nid)t, fam fid) nur aus bem

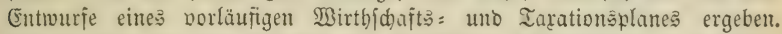
Der Taxator bat ocm Geometer oie betreffenoen Jultruttionen zu ertbeilen,

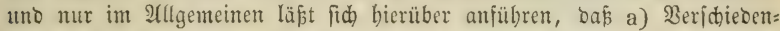
beiten ber Betriebsart fajt immer ciner Sonderung beoürfen, da fie von

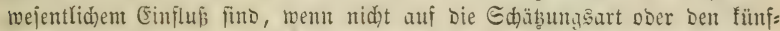

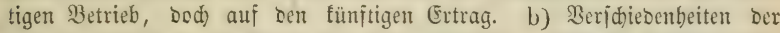

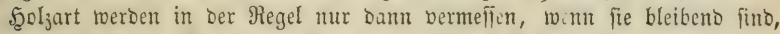
wenn fie einen Miorgen ober ntebr in reinem Beftande betragen. Sorft= weife boer vereinzelte llntermengung veridiebener $\mathfrak{g}_{0} l_{3} a r t e n$ ju würoigen,

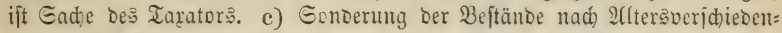
heiten ift bauptjäd)(id) abhängig von Den burd) Den vorläufigen Betriebsplan

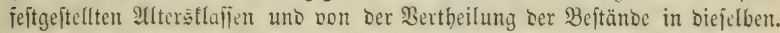

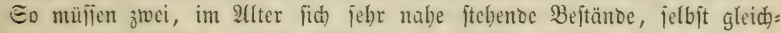
artige Beftandstheile, Durd) Bermejiung gejonoert werden, wemt fie ber=

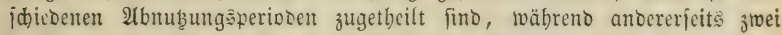
im 2(fter viel mehr abıeid)ente Beftänoe eine ungetrennte 2(btbeilung bilden

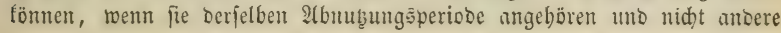




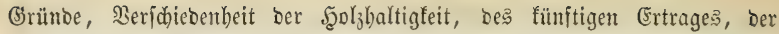
2tbtriebą= ober Edhätzungäweije eine Eonberung nöthig mad)en. d) Son= berung Der Beftände nad) Deren $\mathfrak{S}_{0} l_{3}$ haltigteit ift nötbig in älteren Beftänoen, je näber fie bem 2(btrieb fteben, wenn Die Cdäßsung burd) Brobef(äd)en vollzogen werben foll. Eie ift meniger nöthig in jüngeren Beftänben, beren

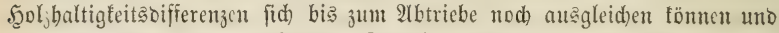
mur auf näbere ober entferntere Durthforftunģ̌erträge von Einfluß fint. Sie ift unnöthig für alle ältern Beftände, Die ciner Sd)äß̧ung burd) $2(4 \xi=$ zählen unterworfen werben follen. Die gröpte Sorgfalt ift da auf Son= Derung ber Beftände nad) ibrer Sgoljhaltigfit zu vertwenten, wo eine, Der Ertraggäljigteit Der Beftänoe proportionale Strlageintbeilung auşgeführt werben foll. e) Die Beftanosionoerung nad) Dem Broduttionşbermögen Der $\mathfrak{B}$ eft än oe fällt getwölutlid) mit ber, nad) Maǵgabe Der Sgolzbaltigfeit zufammen, Da eriteres getwöbnlid) burd) letgtere beftimmt wiro. (Es laffen

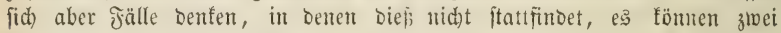
Beftänte in jeber Şinfid)t conform fein uno Demobnerad)tet, 3. $\mathfrak{B}$. in Folge

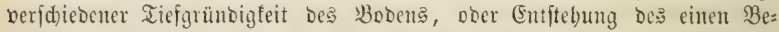

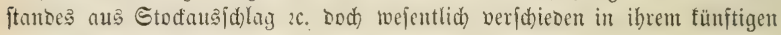
Entwidłungşverlaufe fein.

\section{Dic Waldifjeilung.}

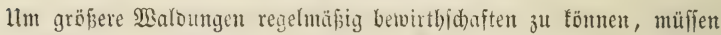

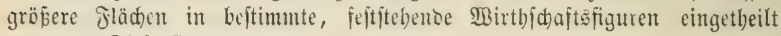
werben. Diefe fint:

\section{a) Meviere}

fino $\mathfrak{B a r b f l a ̈ d ) e n , ~ D e r e n ~ B e w i r t h j d ) a f t u n g ~ v o n ~ e i n e m ~ u n o ~ D e m f e l b e n ~ B e r w a l t e r ~}$ geleitet wirb.

Die (G̈rößze ber Reviere beftimmt fid):

Rad) Dem (Beldertrage ber Bäloer, infofern man annelymen mus, Daßj bie Berwaltungstoften einen gemiffen firocentfak bes Reineintommens (6-10 \$roc.) nid)t überfteigen bürfen. Sie beftimmt fidh nad) bem (Bes=

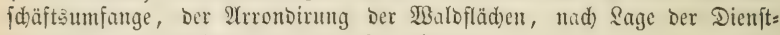
wolnung, ber Conjumtions: uno Stapelorte.

2Bie bie Berbälniffe im nörolid)en Deutid)lano vorliegen, ift bei zu= jammenbängen๖er Sage Der WGaloungen unD übrigens günftigen Berbält=

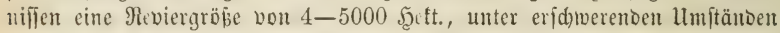
von 2-3000 j̧ett. bie żwetimäpigere uno it oer Wirflid)feit vorberrfdenoe, uno mur bei parcellirter \&age uno weiterer Entfernung Der ßarcellen ift

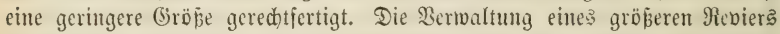
Durd) einen austeidyculo befoldeten Beamten wirb in Der Regel eine beffere jein als bie Berwaitung fleinterer Reviere Durd) färglid) befoldete Beamte.

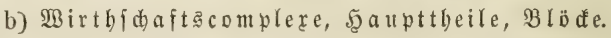

Man verfteht barunter eine Summe verfdiebener $\mathfrak{B}$ eftänbe bie in Bezug

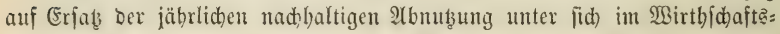
verbaube ftehen; bie Summe berjenigen Beftände, die auf Erfüllung eines 


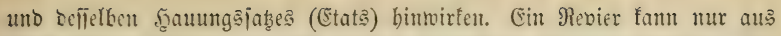
einem Blode beftehen, e's fam aber aud) mebrere berjelben unfaijen. Die Oröß̧e ber Blöde bird beftimmt:

Durd) Beridedednbeiten Der Betriebsart. Dod) lafien fid Eleinere

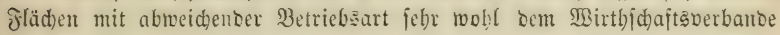
ber berridenden $B$ itriebsart cinoronen.

3eridiedent)eit bes llmtriebs uno ber Şoljarten, injofern bieje bleikeno

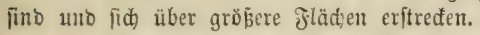

Der llmtrieb felbjt wirft auf Blodbiloung Durd) jeinen Einflup auf bie Ed)laggröfe und die Tladtheile jehr grofer und jebr fleiner Edhläge.

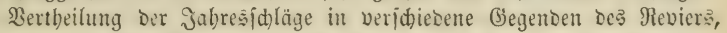

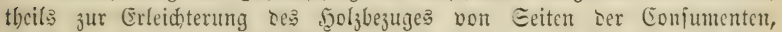

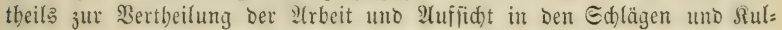
turen unter cine Miebrzabl non Gdubbeamten.

Durd) Rüfichten auf beftebenoe Mitbenubzungarechte, twic Weibes, Streu:, Beholzigunģred)te.

Durd) abgeionterte Sage einzefner Foritorte, bie es nothrontig madjen fann, in jebem berjelben jäbrlid) einen Sdlag zu bauen.

c) Birthidaftatheile, Beriodenfläde.

Im Şodhalobetriebe wiro ser Lmtrieb, o. h. Ser Beitraum, in

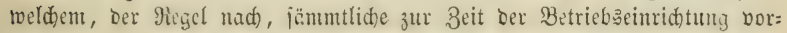
bantenen Beftänoe zum 2tbtriebe uno zur Berjüngung tommen follen (bie in biejem Beitraum neu ju erjiehenoen Bejtänoe bifoen bie Beftundamafie für bie nädjte llmtriebşzeit), in mebrere gleich großje, 5 bis 30 Jabre umfafiente \$eriosen eingetbeilt. Seoer biefer \$erioben wirb eine fo grofe 2fnzahl bon Beitänoen jugetheilt, Din früheren \$erioden bie älteren, Den fräteren Ferioben bie jüngeren Bcítänbe, Daj fie zujanmengenommen zu 3eit ibrer Ibbnuţung einen eben io hohen 2(btriebsertray zu liefern ver= fprecben, als bie Summe ber Beftänoe jeour ber übrigen Đerioden. Zlle cin uno Derfelben ßeriode zugetwiefenen Bejtänoe bilden zujammengenommen

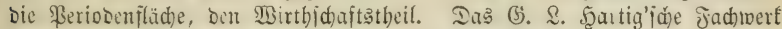

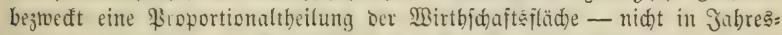
joläge - jonbern in \$eriobenjhläge. Es ijt nidht nöthig uno in ber

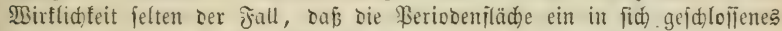
(5anze bildet, bie einzelnen Beftänbe find bäufig von eintander getremnt uno in andere Beriodenflädent eingeiprengt. Mitunter ift cine vollftändige $\mathfrak{A} r$ : ronbirung ber Beriodenflächen nidht einmal münjdenswerth, aus benjelben Grünoen, die oft bie Biloung veridiebener Blöde nöthig machen.

Bejentlider 3rect Der Beriobentintbeilung ift bie Eidherftellung Der Padbaltigfeit in Der Benutiung, Durd) fläd)en uno Beftanosvertheilung,

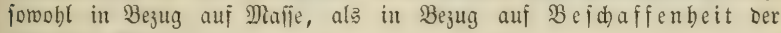
jäbrliden $\mathfrak{A b n u ß z u n g . ~}$

Gegenitano geometrifder Arbeiten iit bie Cintbeifung in Berioben= fläd)en eben fo menig, wie bie in Blöde unt Reviere, fonbern bie Berio=

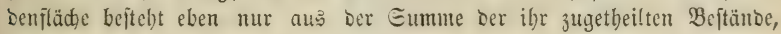
und fintot in Ditfen ifre Begrenzung. 


\section{d) Jabreşidläge.}

Im Mittel = uno Nieberwaloe treten biefe an bie Etelle ber \$eriobent:

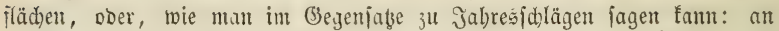
die Stelle der Beriodenfdäge; dent eben mur barin liegt der Unter=

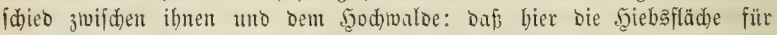

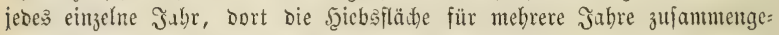
nommen vorausbeiftimmt uno bejeidjnet ift.

Dic Srünbe, mekbalb bei Betriebsarten mit furzer Untricbşzcit eine Eintheilung in Jahreşid)lăge zuläpig ift, habe id) Seite 22 des II. Bandes angeführt, ebendafelbjt aud Seite 33 bie verffiebenen $\mathfrak{A}$ trten ber Sdjlag= cintbeilung uno Deren $\mathfrak{A}$ nnentobarfeit in berfdjiedenen fällen angebeutet.

2Bas bie 2tusfülfrung ber verid)iebenen 2Arten ber Gdlageintheilung betrifft, fo ergibt fid bei ber geometrifden 5 d) lageintbeilung

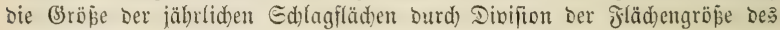
Bloces mit Den Jabren bes llmtrieb?.

Bei ber Sdlageiutbeilung proportional ber Sgolzhaltig= feit ober Ertrag säbigfeit ber Beftänbe, weroen fämmtlide $\mathfrak{B} e=$

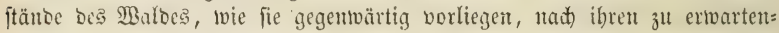

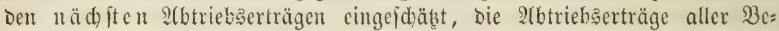
fiänbe funmint, in bic Summe mit Den Jah)en bes Untriebs bibioirt unt, mit Berüffidtigung einer guten Ed)lagfolge, jebem Ed)lage bie fläd) fo gropen 2tbtricbsertrages zugetwiefert, als ber Duotient aus Dbigem forbert.

Bei ber Sdlageintheilung proportional ber Ertrags:

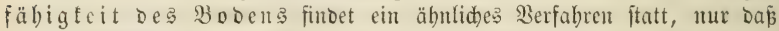

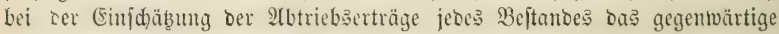

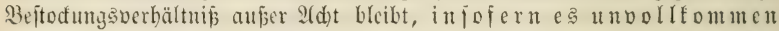

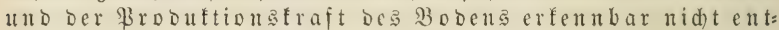
fpred)end ift. Die (sinjdäßzung Der 2(btriebserträge gejdicbt Dann unter If nnab me einer normalen Beftodung.

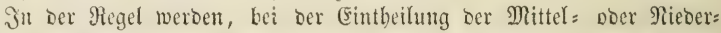
wälder, bie Complexe burd) cin bon Diten nad) Weften ziebendes f̧aupts geftell in zwei antüberno gleidgrope Theile getrennt, bie Edjlagluten red)t:

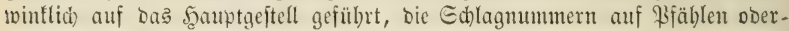
Steinen am Szauptgeftell nerzeid)uet uno bie Ed)laglinien felbft ourd) fdomale Sdneifen Doer burd) Stid)gräben fenntlid) gemadht.

3 um Edus gegen sie austrodinenoen Ditwinde uno gegen Efätfroft oronet man bier Die Ed)lagfolge am beften von Wieften nad) Diter, fo Daj Der junge Ed)lag rom ftebenden Drte in Diten gefdüţ̨t ift.

\section{e) Eorftorte - Diftrifte.}

Man verffebt unter Jorftort in Der Regel einen, aus einem voer mebreren Beftänocn beftebenocn Maldotheil, Der Durd) natürlid)e (Brenzen abgejondert uno mit einem bejonocren Irivialnamen bezeidnet ift.

Die Eintbeilung in forftorte ift bäufiger eine zufällige ober burd) bie

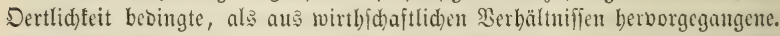

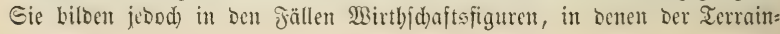


wedjele biefleit uno jenfeit ser natürlichen (Brenzen cinen wefentlid)en (Ein:

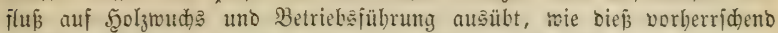
in Siebirgenvaldorn ber fall ift. f̧icr tritt bie Eintheilung in forftorte an bie Stelle ber Jageneintheilung in ben Wälbern ber Ebbene.

\section{f) Jageneintbeilung.}

Man berfteht barunter bie Eintheilung ocr Mälser in regelmäfige Quabrate von ungefäbr 50 . Sgeftar Fläd)engrȫe surd recttwinflid) fid) freu= zente, 14-40 Mitr. breite Geftellimien, von benen bie von Diten nach

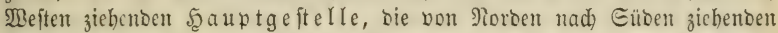
Feuergeftelle genamt meroen; lebteres, weil es einer ifrer 3loeffe itt, bie Söidung ber, bei ben vorherridenten $\mathfrak{B}_{e}$ ftrinoen meift nad Diten voridreitenten Malobränte ju erleidtern. Die Qunbrate ober Gigen er: feţent bie Etelle ocr Forftorte Des Gibirga in ben gropen ebenen MBaldungen

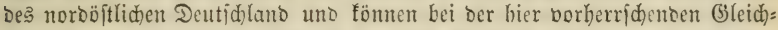

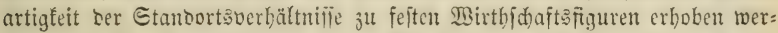

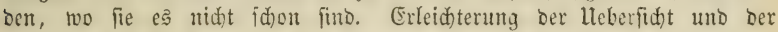
Eontrole ber Mirtbijaft ift ber Scauptzmed biejer Eintheilung.

\section{g) 2 b b heilung (beftändige)}

beist jeber in fid gefdlofiene raaldtheil, ber, nad ber bejtehenden Be= triebsoronung, jowohl jebst als in ber Jolgezeit, gleidzeitig uno gleid)artig abgetrieben, verjüngt, cultivirt uno Durdfforftet meroen joll.

\section{h) Unterabtheilung (unbeftändige 2rbtheilung)}

nennt man Beftandtheile cincr Ytbtheilung, bie vom Samptbeftanbe ber leb̨teren in form unt bemirthichaftung gegentoürtig abmeich)en, bie aber nad) Der Wirthid)aftsoronung fpäterbin mit bent 5anuptbeftanoe ber 2(bthei= lung zu einem gleid)artigen (Sianzen fid gẹtalten follent.

\section{Die fiartirm!n.}

Die bitolide Daritellung Der Bermejiung: uno Eintheilungsarbeiten

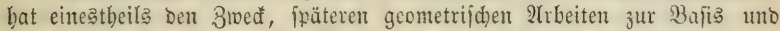
jum 2 nnhalt zu bienen, anderntheils foll fie eine leidfe uno fidjere lleber: fiabt aller Darfteflbaren Berbältnijie Der Betriebsfläden gemäbren, jo weit biefe auf ben Betrieb von Einflup fint. Der erite 3medf forbert cinen

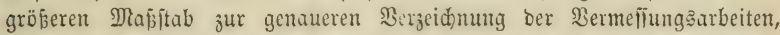
uno man unterjheibet baber Epecialfarten, auf benen ein Decimalzoll

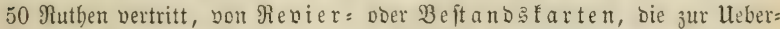

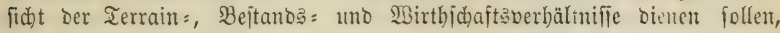
iür bie baher ein fo großer Majittab bem bequemen (bebraudhe und ber Lleberfid)t hinderno fein würse, Die Daher gröptentheils 250 Nuthen auf ben Decimalzoll geben.

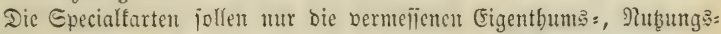

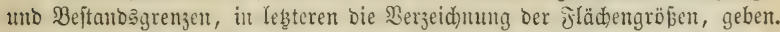

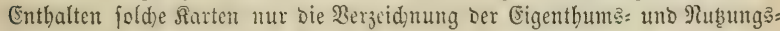
grenzen, fo neunt man fie Brenztarten. 
Die Revierfarten bingegen follen überfeben lafien:

1) Die Terrainberbältniffe. Darftellung Der Erbebungen uno $\mathfrak{B e r}=$ tiefungen Durdh Ed)rafiirutg; Unlano, Eeen, fłüfie, Eümpfe, Mege, Iriften 2 c. Durd) befondere, Der $\mathfrak{B S i r f l i c h f e i t ~ m o ̈ g l i c h i t ~ a ̈ b n l i d ) ~ n a d o g e b i l o e t e ~}$ Beid)en;

2) Die 2 Birthidhaftsiguren, bom Blod bia zur Unterabtheilung binab burd) beftimmte (brenzlinien bon einanoer gefondert. Eintbeilung in Jagen, Sdläge, Diftritte. Name, Nummer oder Sitera berjelben;

3) Die Berfdiconenheit Der Soljarten, rein ober vorherridend burd)

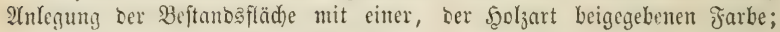
horftweife obcr vereinzelt burd) (Einzeid)nung trupptweifo ober bereinzelt fteben= Der, ben Fुolzarten Leigegeboner Beidhen in Der (Brunbfarbe ber vorberr= fitenten $\mathfrak{S}_{2} \mathfrak{l}_{3}$ art;

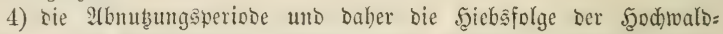
beftänoe, Durd) (Einfaffung Der Grrenzen jeoes Sejtandes vermittelit cines an Der inneren Eeite Der Grenjlinie berlaufenoen fdemalen Farbenftridbes bejonterer, Der \$eriode zugeeigneter Farbe. Atupersem Durd) Einzeidnung ber Beriobentummer in bie Beftandsfläd)en;

5) Flächengröß̨ ber einjehnen 2btheilungen ourd) eingeidriebene be: namute 3ablen;

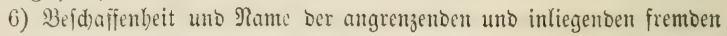
Grumbitïđe, Drtichaften 2 .

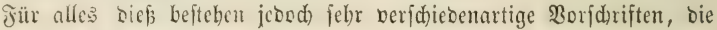

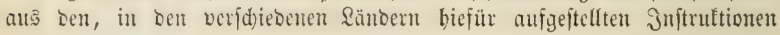
34 entuebnen fino.

Şaungsplanfarte nemut Cotta cine bilolide Darftellung bešs jenigen Suftandes Der Wirtbidhaftsfläd)en, in Den fie, Durd) Den für ben Einridtungşzeitraum zu entwerfonden Betricbälan, übergefübrt twerien follen, alio cine biloliche Darftellung oc Betriebęfläd)e.

Situationsfarten fino bilolide Darftellungen der Bröpe uno

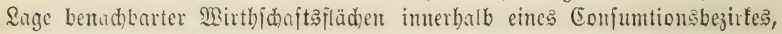

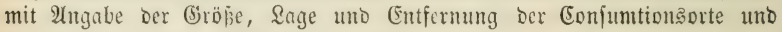
ber ben Iransport erleid)ternden 2 njtalten.

\section{Siferafur.}

Genuert, Beiträge zur Foritwifienifdaft. 1783. Defien Ânweifung zur Taxation. 1791.

(3). ․ Sartig, Jnftuttion für Forftgeometer uno Iaratoren. 1816.

5ुosfelo, Jorftaration II. Bano. 1824.

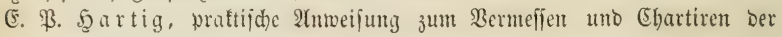
Forite. 1828.

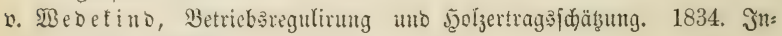
ftruftion. 1839.

Siebig, Joritbetriebarregultimng. 1836.

Rübgifd, Injtrumente uno Dperationen ber nieberen Bermeffungafunft. Eaffel 1875. Theod. Ray. 


\section{¿̂weites Siratel.}

Foritlide Bobenfube.

Die Refre von ber Bonitirung Des Malobodents ift in ber forftlichent Bobentumbe be er erten Banbes gegeben, und id berweije bejonbers auf

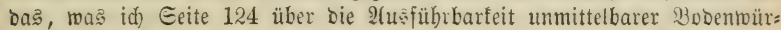
bigung gejagt babe. C5: ift ein Durd) Dent Damaligen Etantopunt ber ans

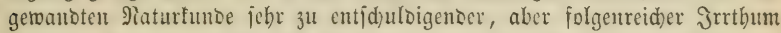
Cotta's, wenn er unmittelbare 3odentwürbigung rorid)reibt uno dic (Ertrags=

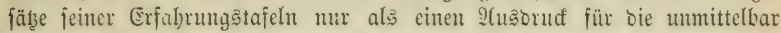

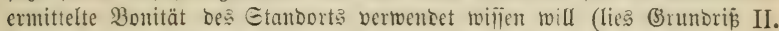

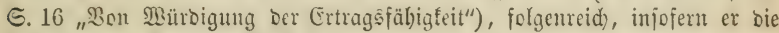

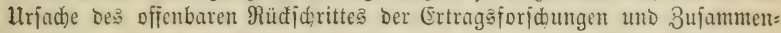
ftellung berfelben in Erfabrungstafeln ift (vergl. mcine 2Abbandlung über Den Ertrag Der Rothbuche S. 3 unb "Controberjen" $\subseteq$. 34). Meine imnige Heberžcugung ift $\mathrm{cs}$ : Daj unmittelbare Bonitirung uns nie jull einem fideren 3iele fübren werbe uno oa fraft Des Bobens aus ben Rejultaten verflofiener \$robuftion in bielen

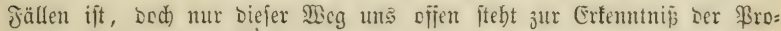
Duttionstraft unjeres Wialobodens, bei vorbandenem normalen fyolzmudje aus biejem jelbit, bei abnormem oder fehlentoem Szoljtwudje aus analogen Etandortşverbätnifîn ju entnebmen. Diefs find jeood) indiviouelle, viel=

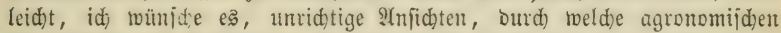
Senntniffen uno forjdungen feinesiwegs ber Etab gebrochen merben tamt.

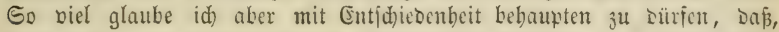
beim beutigen Stande unjerer agronomijden Senntnif, in praftifáter Beziebung es volltommen genüge: bie Etanoortöberjhicoenbeiten, Die Beridiebenbeiten in Slima, Sage, Boden, nur io weit žu berüdîd)tigen, als fie fid im \$illanjenwuchje zu erfennen geben; Dás ę genüge, obne

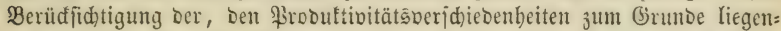
ben Urjaden, bie in Walde vortontmenden Derịdicbenbeiten, nad) Dia $=$ gabe Der gröfieren ober geringeren Entfermungen ibrer Extreme, in brei bis fünf fllafien: I. fel)r guter, II. guter, III. mittelmäßiger, IV. jebr mittelmäßiger uno V. fकlleçtec Stanoort, einzuoronen.

Bei \$godwalocomplęen werben die Froduftivitätägrenzen getwöbnlid mit Den beftandsgrenjen zujammengetworfen. Eebr bäufig fallen beibe (3renzen in Der That zufammen, indem meiftens cin Medfel Der Etanto:

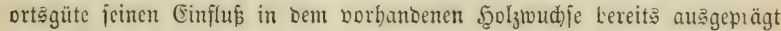

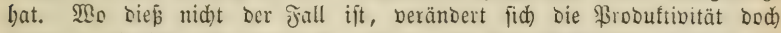
felten jo plöb̨lich uno wejentlid, daj $e_{3}^{3}$ von heroorftechendem Einfluß auf bie Ridtigfeit ber (Ertragsbered)nungen ift, wenn aud in ber 2 (nnabme ber Bonitätşgrenjen etwas bom wirflid)en Berlaufe abgemiden wiro.

(Eઃ genügt baber in ben meiften fällen, für jebe $\mathfrak{B} \in$ jtandşigur

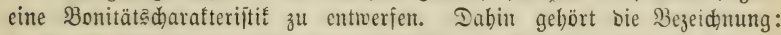

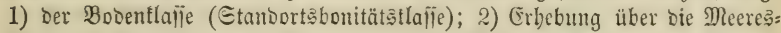
fläde; 3) Bejeid)nung ob (5bene, ober büglidb, oier bergig, mit Anngabe

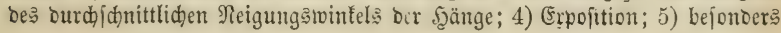




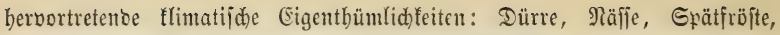
Sturmidhaben (allgemeine ober befontoere Sturmlinie).

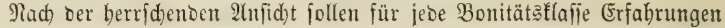
über bon Şoljtoud) gefammelt uno in (Erfahrungstabellen zufammengeịtellt

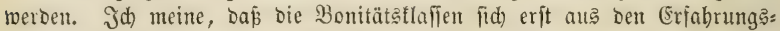
tafelı entroicfeln fönnen uno lebere die Bafis ber Bonitirnng fein müfīen.

Siteratur: Siebe Band I. Edhlup Der Bodentunde.

\section{Driffes Siapiter.}

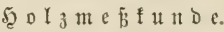

Gie Yehrt bie Ermittelung Der gegenwärtig vorhantenen $\mathfrak{S}_{0} l_{3}$ maflen, jomohl einzelner Bäume als ganzer Beftänbe, uno zerfällt biernad $I$. in bie Baumtaration uno II. in bie Beftantostaration.

\section{Baumung̨itnoc}

ober bie Qebre bon ber Ermittelung ber Grröfen und Maffen einzelner Solzpflanzen zerfällt $A$. in bie Rebre bon Der Maffencrmittelung liegender Bäume, B. in bie Lebre von Der Maffenermittelung ftehender Bäume.

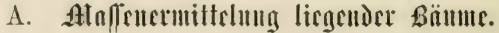

1) Me\{fung und Bered)nung.

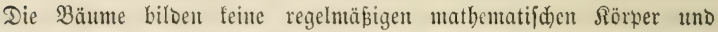

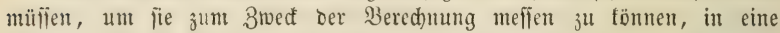
Mebrzabl tleiner Iheile zerlent oder zetlegt gerad)t werben, von benen jeber einzelne ber form eine mathematifonen diörpers gleidht ober möglid,it nabe ftebt. WBir zerlegen Daber Den Baum burd) Querjdnitte, red)twinflid) auf bie 2tre gefübrt, in Eeftionen, ober benten uns bie Berlegung in Sef= tionen auşgefüfrt.

Die auf biefe Beife gewomenen walzenäbnlid)en Beredunungstbeile

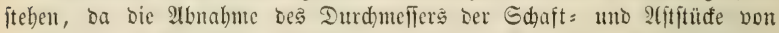

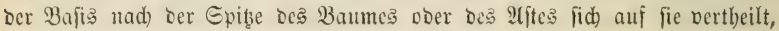
Der Jorm Des abgeftubten Sigets ant näd)ften uno nü̈sten biernad) bered)net

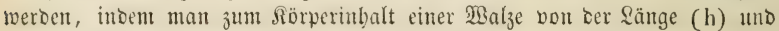
bem verglidhenen ober mirfliden, mittleren Radius (r) [Durdmefier (d) Doer llmfang $(u)]$ Der Geftion $\left(r^{2} \cdot 3,1416\right.$. h ober $d^{2} \cdot 0,7854$. h ober $\left.\mathrm{u}^{2} \cdot 0,07958 \cdot \mathrm{h}\right)$ Den britten Ibcil ciner $\mathfrak{B a l z e}$ von gleidyer Ränge uno einen Durdmeffer bon $1 / 2$ Der Durdmefferbifferenz beiDer Enofläben Deß ab=

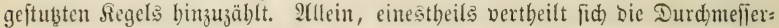

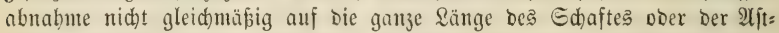
ftüde, fo daj eingche Eeftionen, befonders rie untern, maficnbaltigern, Der Walzenform fehr uabe ftchen, altocrntheile ift ber wirtlide mittlere Durdimeffer jeoer Eeftion, in Folge Der annäbernd paraboloibifdent Form Des Ed)aftes in Der Megel etwas größer als Der mittlere Durdomeffer ans benen beiber (Enffläten, mo enolid) gibt Die Bered)nung ber Duer: fläden aus Durdmefier ober llmfang in allen ben Fällen ein gegen bie 
\$Birflidfeit böheres Rejultat, in weld)en bie Querfläd)en, wie gewöhnlid), mebr ober weniger ercentrifd) uno unregelmäßig fino (bergl. Unterjud)ungen über ben Ertrag Der Rotbbuche હ. 19). Dicje bas Rejultat ber Bered)= nung exhöhenden Unregelmäfigteiten geten in ber Megel einen Heber=

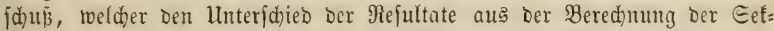
tionen als abgejtub̧te Regel ober als $\mathfrak{B}$ alzen auşgleid)t, wenigitens gibt Dic Bered)ung Der Eeftionen als abgeftub̧te Regel ober als abgejtuß̧te pa= raboloibija) Regel burdhidnittlid) nidt genaucre Mejultate, wie bie Bered)nung Der Eeftionen als Balzen, wenn bie Geftionen nid) zu lang find und Durdmeffer ober llmiang in ber Mitte ber Geftionen gemellen merben. 2luf mathematijd)e Bienanigteit müfien wir idjon bier cin für allemal verzichten und es twüroe ourd)aus umpraftijd) fein, ein complicirteres unt zeitraubendes \$erfabren ber Bercenung zu wäblen, wenn es uns nicht wejentlich fidjerer fübrt.

MBir bercdnen baber bie Seftionen als $\mathfrak{B}$ alzen it ü ơ aus ibrer Sänge uno Dem Durdimeffer oocr Umfange ihrer Mitte nad) ocn oben angeführten Formeln. Je fürzer bie Eettionen genommen rocroen, um io gentauer wil bas Rejultat. Dic 3erlegung in eine grope Menge von Ecttionen ift aber in ber \$raxis bejd)räntt burd) bie bamit jidh fteigermbe Urbeit Des Meffens uno Bered)nens. Sür bie genaueften wiffenidaftlichen Jorid)ungen genügt cinc Seftionālänge bon $2 \frac{1}{2}$, für taratorijde 3wecte von 4, für Den Berfauf bon 8 (Etm. gropem unterfdie be ber Durd)=

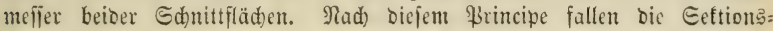
längen jebr veridjiebell alls, je nad)bem ber Ed)aft vollbolziger ober $a b$ = holziger ift, an im Ed)lup erwadyfenen Bäumen ourdhidnittlid) 3-4, 4-5, 5-8 Meter mefieno.

Die Sänge Der Settionen niro mit sem Eentimeterftode, ber Durdmeffer mit Der Rluppe, ber Umfang mit Dem Mébbande ges mefiert. Eine Befdreibung biefer Jnftrumente und ibrcr 2 fntrenoung babe id) in meiner 2frboit "Uleber Den (Ertrag Der Rothbuche 2c. Berlin 1847, Jörftnel" uno in ben neueren 2Uflagen ber Enbiftabellen gegeben, welde leţtere zur (Erleidhterung und 2(bfürzung jotwobl, wie zur Sidjerung bon Jeblern bei Dem Bejめäft Der Berchnung bienen.

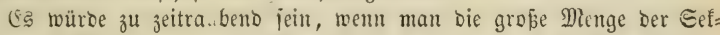

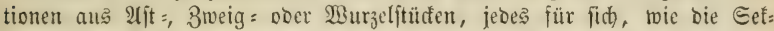
tionen Des Edaftes berectnen wollte. Man muв baber bas Berfabren

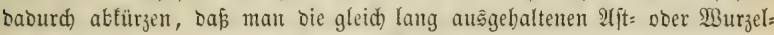
ftüđe nach ihrer Stärfe in mehrere Rlafien vertheilt uno jebe Stärteflafie nach Der (befammtlänge aller ihr angebörenten Seftionen uno einem mitt= leven Durdmeffer berednet. Mefilung uno Bered)nung Diefer Baumtheile gibt aber itet马 nur amnäherno ridtige Rejultate. Shr Eubitinbalt wiro Daber, wie our Des Reiferboljes, meift und fiderer Durd) (Jetwid)t ober Raumfüllung beftimmt.

2) $\mathfrak{B} a ̈ g u n g$.

Bei ber Unoollfommentheit aller ftereometrijhen Mafienermittelungen läp̆t fid) eine genauc Renntniß bes Mafiengebaltes ser Bäume uno ein: 


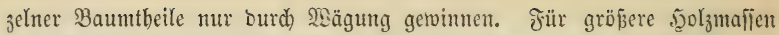
Deङ Edaftes, ftarfer 2fefte uno Der BBurzelftöffe ift bierzu bie Brüd = Doer Iecimalwage am geeignetíten. Für 3weigholy, Reiferbolz uno (d)wäd)eres Wurzelboiz, in $\mathfrak{B}_{\mathrm{H}} \mathrm{llen}$ zujammengcbunden, find gut gearbeitete Federmagen id)on ibrer geringen Größje uno \$ortatilität wegen empfeblensmertb). Die Senntnib allein Des Betwid)tes der Maffen genügt aber nidyt zur Erfor: fdung Deş (Eubifinbaltes. Sd) babe in meinem \&ebrbudhe oer \$Flanzen=

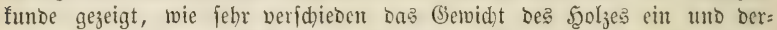

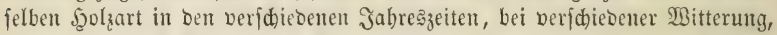
in verfdiedenem 2ylter, nad) Etammtheilen, Etanoort, Jahrringbrcite $2 c$. fei. Dief́ madet es notbwentig, an jeocm Baume, jogar an jebem Baum= theile, befien Mafiengehalt Durd) SEägung gefunden werben folf, Das Gie:

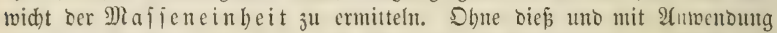

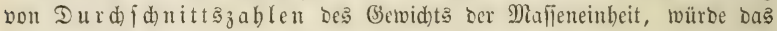
Refultat Der Ermittelung in Den meiften fällen meniger ridtig foin, als bas Der Meffing uno Beredumng. Mein Berfabren in biefer Scinfid)t ijt folgenoes.

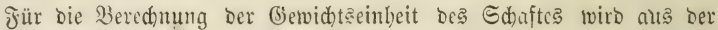
Mitte ${ }^{1}$ jeber Exttion eine, aud für andere 3rocfe zu verwentonde Duers

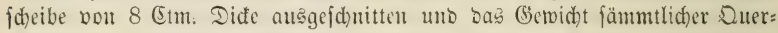
fdeiben d, S Sdaftes zuianmengenommen, fdon im șaloc, unnittelbar

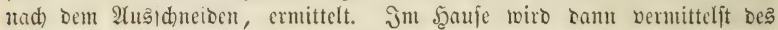
Finometers Der Cubifinbalt aller zujammengenommenen Ederben gemeffen und Daraus bas Durd)idnittagewid)t Der Maffeneinbeit Des Ed)aft 's be: reduet; Denn, fint Die Duerfdriben in gleid)en 2(bftänoen gefd)nitten uno

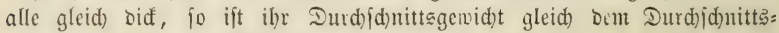
getwidte bes ganzen Sdhaftes.

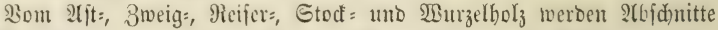
oder Wellenbumbe von amuäberno 4-5 \$imo Ed)were im Walde getogen, um Das (Bewid)t Der Mafjentinbeit aud) Diejer Baumtbeile genau crmitteln 孔u föntren.

Die einfadjiten .̇ylometer fino irbene Steintöpfe von binlänglidher

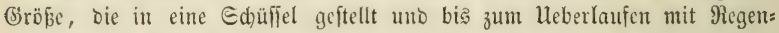
wajfer gefüllt merben. Taudjt man bie vorber gewogenen Szof 3 ftüde in bas Baffer Des Iopfes, fo fließ̧t aus leb̧terem fo viel $23 a f j e r$ in Die Gdunffiel,

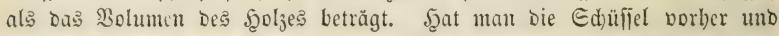
Daun wieber mit bem ïbergelaufenen $23 a f f e r$ getoogen, fo ergibt fid aus

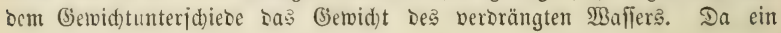

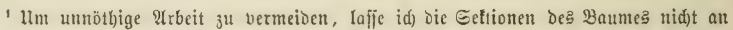
ifren Gnopuntten tremnen, jondern die Suerfanitte ftets nur in ber Mitte jeder Geftion

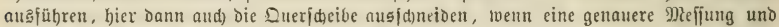
Bered)ung im Şaufe ausgefütrt weroen foll. Die unterfte Eeftion nebme idj ftets in $2 \frac{t}{2}$ Mitr. Sänge, jo Daß̧ Der erfte Suerja)nitt in $1 \frac{1}{4}$ Mir. (Bruftböbe) gefüfrt wirb. Sollten Die übrigen Geftionen in 5 Mar. Qänge berednet merden, fo würde ber zmeite Duerjanitt 5 9ltr., Der britte 10 , Der viette 15 2/tr. u. f. f. vom Etammende entfernt geführt werden.

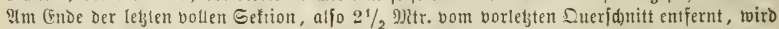

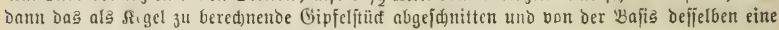
Querideibe als Grrundịtädse entrommen. 


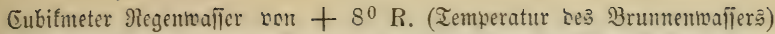
1213 Neupfuno miegt, fo läpt jïh) aus bem Piundyewidhte bes verorängten

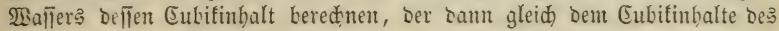

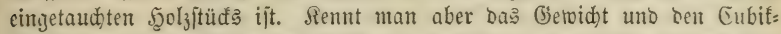

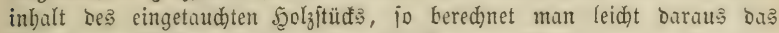
Gerwidht ber Maljeneinheit ober bes Eubifmeter. Divibirt man mit bicjem in bas im Wralde ermittelte (jemidnt bes Baumes ooer Baumtheils, io

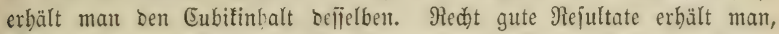

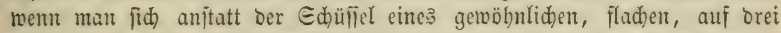

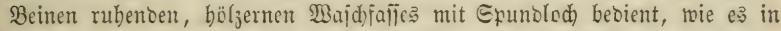

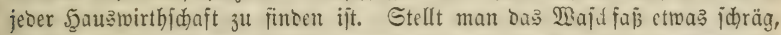

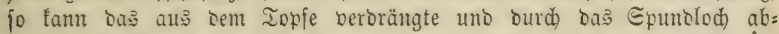
laufenoe Majīer leidjt aufgefangen twerben. Man mú bann nur barauf

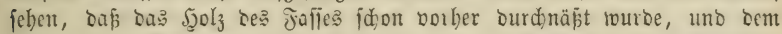
jebes maligen (Bebrauḑe cinige Eintaudhungen uno 2 bzapfungen vorbergeben lafien, um ben Wafferwerfujt burd) abbärirenbes Waffer zu vermeiten.

Für genauere Meilungen, bejonters fleinerer, jelbjt Der fleinften

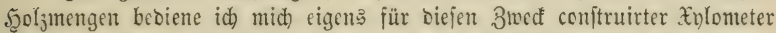

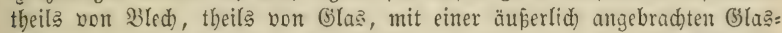
röbre, von Deren Iheilung der Cubifraum bes beränderten IRaileritandes unmittelbar abgelejen rerben fann. Jैd babe bieje Juftrumente in meiner

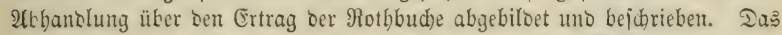

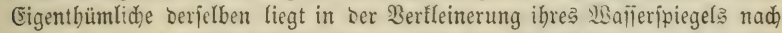

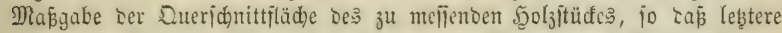

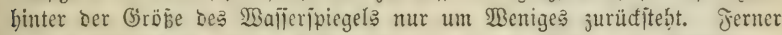

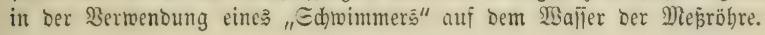

\section{3) Raum füllung.}

(Eine, menn aud) unbollfommene, für prafiijde 3wecte aber in bielen

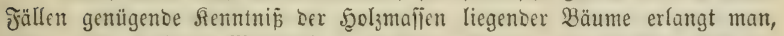

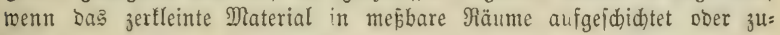
fammengelegt ober zujammengebunben, uno wenn, mit Şülfe allgemeiner Erjabrungşäțe über die in jolchen Räument enthaltenen Şolzmaljen, Der

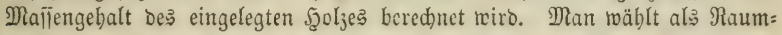

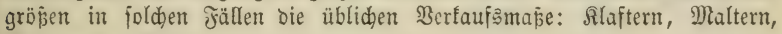
Bellen Doer $\mathfrak{B a j e n .}$

$\Re$ önig gibt nadjtehende Mallengehaltaprocente ber Rlafter=, Malter=

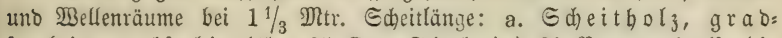
fpaltig: grobipaltig (über 25 (Etm. Etimbreite) 80 ßroc.; mittelipaltig (15-20 Ctm. Etimbreite) 72 Proc.; Hleinfraltig (10-15 Etm. Stirnbreite) 64 Proc.; f rummipaltig: grobipaltig 71 Proc.; mittelipaltig 61 Proc.; fleinjpaltig 57 ßroc.; f notige 3 Sđeitholy: grobipaltig 64 ßroc.; mittel= ipaltig 58 \$roc.; b. grabes Snüppel= uno Reidelholz (itärferes 58 Proc.;

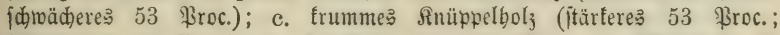

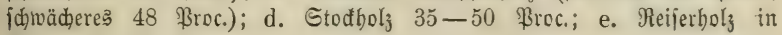
Bellen 20-35 \$roc.

Bei jeber 15 Etm. geringer ober größ̄er als $1 \frac{1}{3} \mathrm{Mtr}$. Edheitlänge

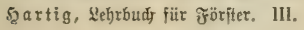


erböbt ober verringert fid ber \$rocentjab: um 1 ßroc. Kei grabem Edjeit= holze, um 1 $1 \frac{1}{2}$ ßroc. bei frummem Edeit= uno grabem Sinutppelholz, um 2 ßroc. bei tnotigen Sdheit= uno frummem Snüppelholy.

Bereinzelte controlirende Beriuche ergaben mii ftets geringere Procent= fätse; für umfere Mlalter (5 . 4.4) grabjpaltiges Buchenjaceitbolz von 18-22 Etm. Etimbreite felten mehr alङ 60 ßroc.

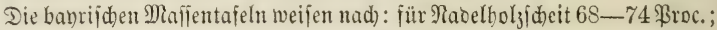

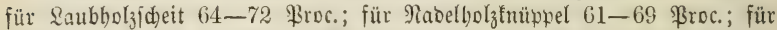
(Eic)enfnüppel 49-57 ßroc.; für Snüppel der übrigent Saubbölzer uno ber Riefer 55-65 ßroc.

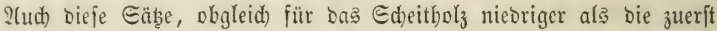
aufgefübrten, überfteigen nod) meine Erfabrungen uno ftimmen nur bann Damit nabe überein, wenn man annimmt, baj bei oen Maffenermittes In ngen bie Malter, einjalieplid) des llebermapes von 1 3oll auf jeden

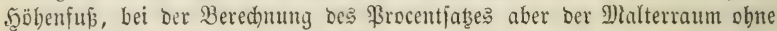
Hebermaß in Rechnung gezogent wurbe.

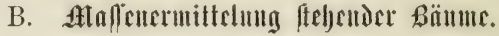

Bejonbers bei taratorijden $2(r b e i t e n$ ftebt es nid)t immer in unferer Mad)t, bie zu taçirenoen Bäume bebuf̧ einer genaueren Meffung uno $\mathfrak{B} e=$ red)ung fällen zu lafien; wir müfjen uns, allerbings unter Berzichtleiftung

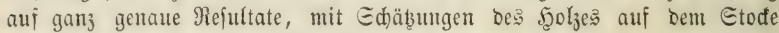

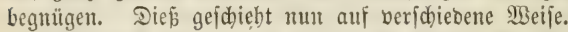

1) Durd) Ermittelum Der, für Dic fubifde Bered)nung nöthigen \&ängen

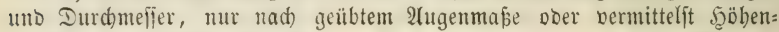

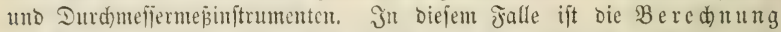
Des Mafingehalts bon ber, wie fie an liegenten Stämmen gefdieht, nidht

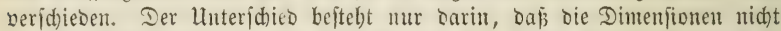

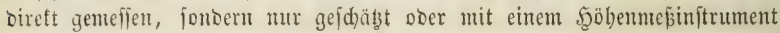
ermittelt werben.

jin Den neneren $\mathfrak{A}$ uflagen Der Eubiftabellen babe id mebrere $\mathfrak{A r t e n}$ von jöbenmeffern bejabrieben uno abgebiloct. Llnter diefen ift ber 5̧öben= mej3irfel, ein gewöbnlidger $1 / 2-2 / 3$ Mir. langer bölzerner 3irfel mit zwei \$itiripiben an Den Edjentefenden, einem Diopter auf Der Surbel uno einem Etellbügel in Der Mitte Der Ed)entul, Das wohlfeilfte, tragbarite uno bie Arbeit am meiften förbernoe Inftrument.

In Der S. 19 folgenden Jigur jei $\mathrm{mb}$ bie Stanolinie des Meffenoen

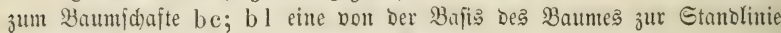
red)ttwinflid) abgeftectte Sinie; a ber 2(ugenpuntt bes Meffenden, io fam man, wenn ber Binfel a b c aud) mur nabe ein redter ift, ab als bie

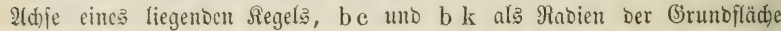
biefes Regels betradten. Der von a alls in Der Weite von b a c ge=

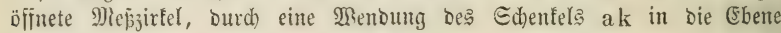
bak gelegt, wiro Daher mit feiner Bifirlinie ak bie Sinie bl in einem Funfte k Durdfidneiden, Defien (Entfermung von b gleid) be ober.gleid) ber $3 u$ befitimmenten Baumböbe ift, Die Daber auf Der Qinie bl unmittelbar gemeffen 


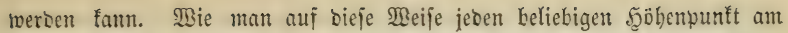
Baume auf bl übertragen fann, fo fann man aud jede auf bl abgeftedte ¿änge auf în Baum über: tragen. Will man nun Den Durdmefifer beక Baumes in irgeno einem Ђ马öhenpuntte riffen, 3. $\mathfrak{B}$. in 10 Mtr. Şöbe, fo jtectt man bieje \&änge auf ber Sinie blab, ว. 23. bk, über: trägt fie auf Den Baum b c uno nimmt, bon a aus, ben Durdmeffer bes Baumes de

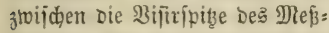
3irfels. Da nun de eben io weit vom $\mathfrak{A}$ uge bes Mefienden entfernt ift, als ein in $\mathrm{k}$ bem Meilenden vorgehaltener Maßs= ftab $\mathrm{fg}$, fo läß̈t fich de auf $f g$ übertragen, wenn ein (B)es bülfe dent Mapítod in $\mathrm{k}$ ber Sifirlinie Des Mteflenden recht: wintlid) entgegenbält, uno żmei übergebängten, verijuiebbaren ßapierblättern nach ber Wiseifung Des Ilefienten bie bent Durd): meffer entipredjende Entfermung hi gibt.

Bei einiger Hebung ges räbrt biế rein empiriche $\mathfrak{Q} e r=$ fabren fo ridtige Rejultate, rie

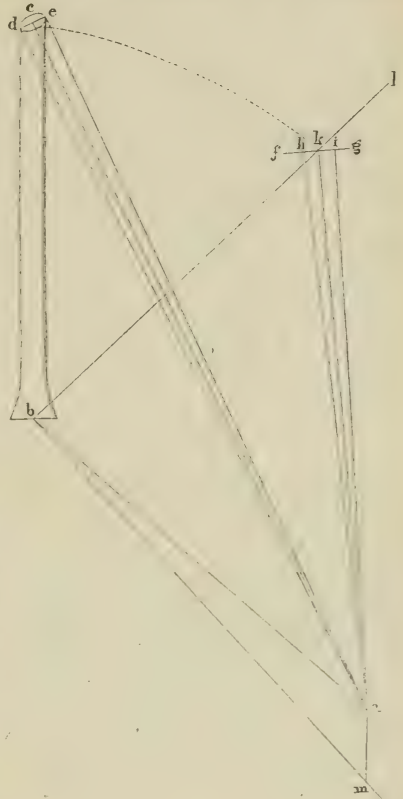
reniger contplicirte uno wobl= feilere Inftrumente fie gewäbren tönucn. Ueberbaupt carf man von allent ben bielen verichiebenen Meps= injtrumenten nidst verlangen, saj jeber, Der fie in bie Şanto nimunt uno

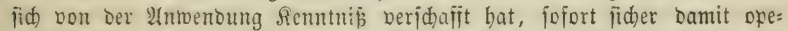

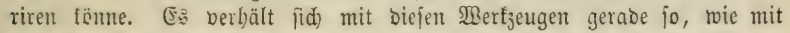
Dem Pinjel bes Malers uno bem (briffel bes Rurferfted)ers, seren 2Yntwen= Dung llebung forbert, wemn bamit ctwas Tüchtiges geleiftet werben foll.

2) Durd) Mafienjd)äbung. Sie berubt auf Der, mur Durch)

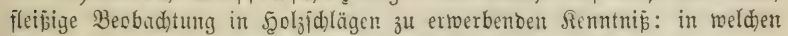

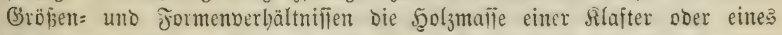
Reiitgbunces fid) im Etumme uno in ber Frone eines ftehenten Baumes Daritellt. Bei Der હdjäß̨ung j̧erlegt Der Iax̧ator ben Baum in fo viele Einzeltheile, als Maltern ober Reifigbunbe nad) jeinem (ugenmaje bei ber Iufarbeitung erfolgen würben. Bei jebr unregelmäpigem Baummudje ift Diés bie fidherfte Edjäbungşweije.

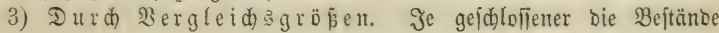


ermadjien, je gleidmäpiger ber Єd)lup ber Bäume ift, um fo tweniger weiden Bäume von gleident unteren Durd)mefifer in ibrer form uno it ibrem

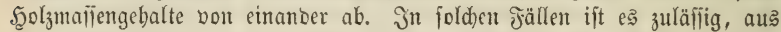
Dem Durch frübere, fpccielle Ermittelungen befaunten 50 ragebalte ähnlidher Baumformen von gleichem unteren Durdmefier Edylüfie zu zieben auf ben 5ुolzgebalt Des zu föäkentien Baumes. Man mähłt zu Mobellbäumen für bieje 2 rt Der Edäb̧ung in ber Regel sie im Reviere üblidjen $\mathfrak{B a u b o l}=$ fortimente von befimmten Dimenfionen, für bie fid Durdjidnittääbe be

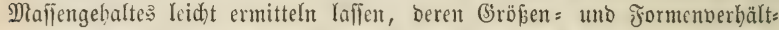
niffe burd) dic bäufigen Bauborzanweifungen fid) bem 2 (uge imprimirt babent.

4) शad) Formzablen. Sine 3abl, welche angibt: wiebielmal ber Fुolzmafiengehalt eine: Baumes ober Gdaftes in Dem Raume eines Regels ober Enlinders non aleider şöhe und von gleid)em unteren (Brufthöhen:) Durdmefier enthalten jei, nemut man 2 alzenfab ober Regelfab, je

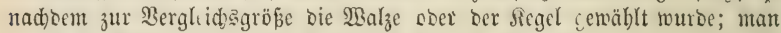

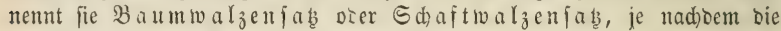
berglidjene f̧oljmaffe die bes ganzen Baumes ober mur bic bes Edaftes ift. Ein Enlinocr von 20 Mitr. Szöhe uno 18 (Etm. Durctmeffer entbält 0,5 Rilometer. Fänoe man nun, Daß̧ ein Baumid)aft non gleider Şöhe unto gleidom 3 rufthöbenourd)meffer ${ }^{1}$ mur 0,25 Eubifmtr. enthielte, fo müroe Der Walzenjaţ für biefon Edhaft $0,25 / 0,30=0,5$, ter Siegelfał würbe

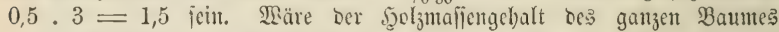
$=0,3$ Cubifmtr., fo würbe bor Baumbalzenfakz 0,3/0,5 $=0,6$ ber Baum= fegelfaţ $0,6 \cdot 3=1,8$ fein. Denft man fid) bic Dlafie ocs Baumes wie eine früfigheit in Den boblen Enlinoer obiger (bröpe bineingegofien, io

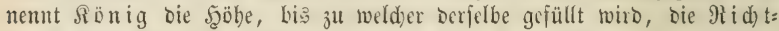

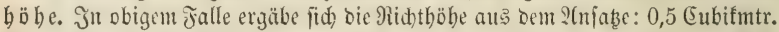
2Balzeninbalt: 20 Mtr. Sänge $=0,25$ Cubifntr. Edaftholzmafle: 10 Mtr. Balzenlänge $=$ Midhthöhenjahl. Man finbet baber Die Midhthöbenzahl aus Dem Walzenją̧e (in obigem Jalle 0,5) Durd) Divifion mit Der (Enlinder:

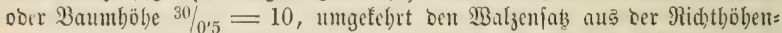
zahl ourd) Divifion ser leb̧teren mit Dex Baumböbe $10 / 20=0,5$.

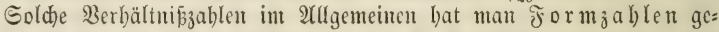

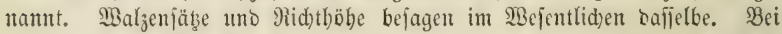
erfteren ift ein Maffentbeil, bei leșteren cin Söbentbeil ber Bers

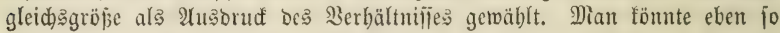
gut einen Durchmeffertheil (in Brufthöhe) zum S(uşoruct mählen.

Die Formjabl muई un fo größer fein, je vollboljiger ber Edjaft uno je aftreider bie Rrone ift, um fo fleiner, je fegelförmiger bor Schaft und je ärmer bie Srone an $\mathscr{U}$ ejten ift.

Man ijt nun von ben Borauşę̧ॄungen auşgegangen:

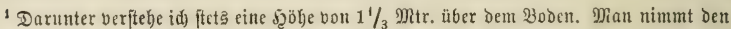

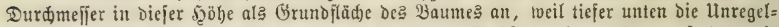

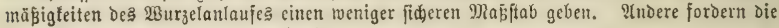

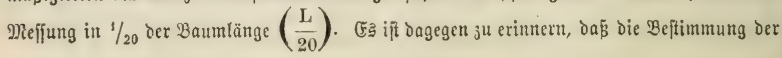
Şöbe fte hender Bäume in vielen ỡalfen unaugfübrbar ift. 


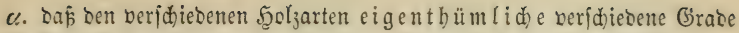

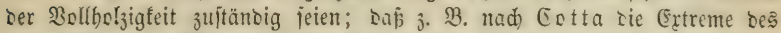

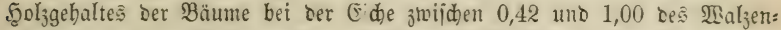

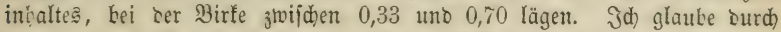

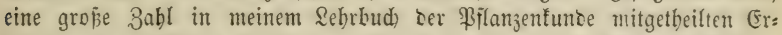

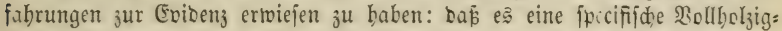
feit gar nidjt gebe, bas bieje allein burch inbivisuelle Eigenidaften, surd)

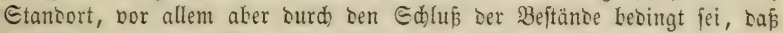

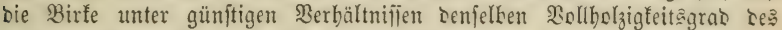
Edafte? befitien fönne wie (Eidje uno Bude,

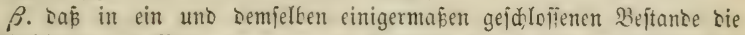

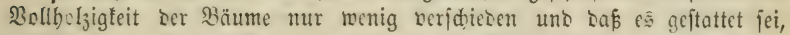
auß Dem an einigen Bäumen ermittelten నollbolzigfeitägrare Ed lüfie auf

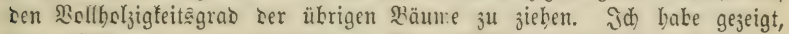
Daf felbjt unter sen isminirenen Etanmflafien wollfommen gejoflofiener

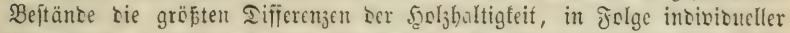

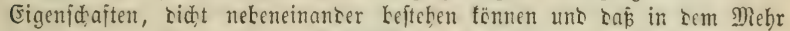

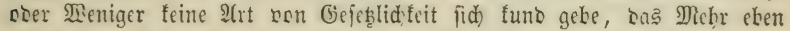
fo bäufig in sen idmäderen als in sen geringeren Etammtlajien liege,

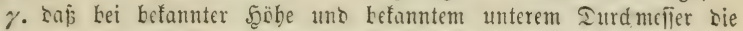

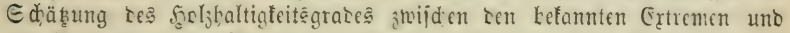

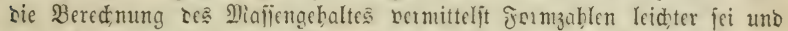

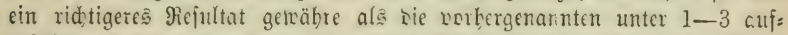

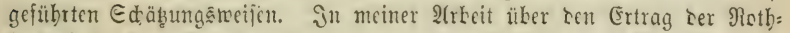
budje bake id sie Grünte einer entgegengefesten 2(nfidet entmicelt. Diefe fins:

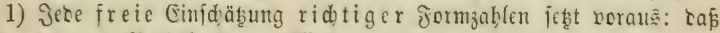

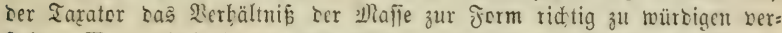

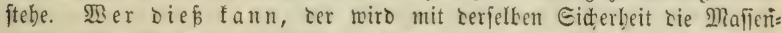

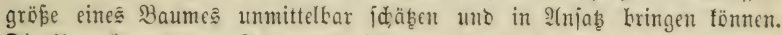

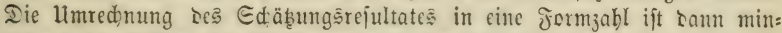

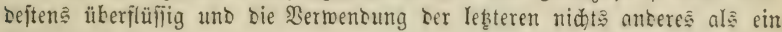
Birfelichlus. ${ }^{1}$

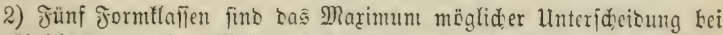

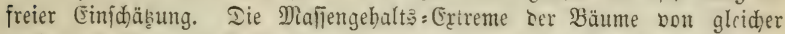

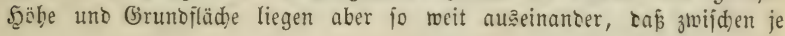

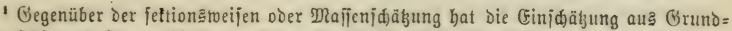

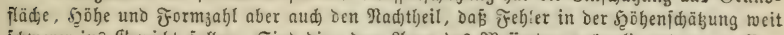

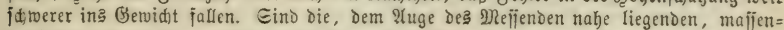
baltigften unteren Stammtheile eines Baumes ridtig geidäbt, Dann bat ein Febler in ber

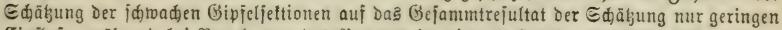

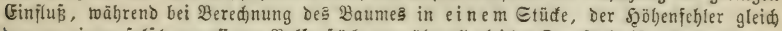
bem an einem falj gemeijenen Balfenjtüđe bon überall gleid)er Querfläde ift. Bejonoers in

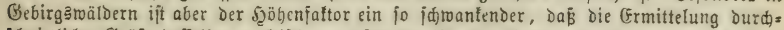

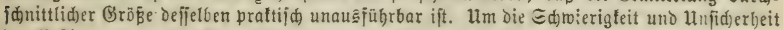
Der Beftimmung ganjer Baumbōhe zu bejeitigen, finot \$rē̄ler ben Mafiengebalt ber Bäume

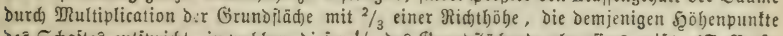

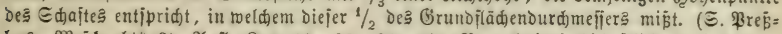

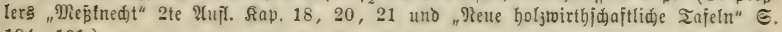
184-191.) 


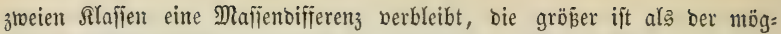

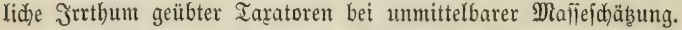

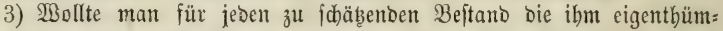
liden formzablen burch Mefilung und Bered)ung von Mujterbäumen ber

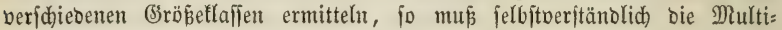

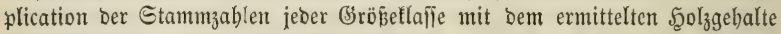
ibres Mujterbaumes genau baffelbe Rejultat ergeben, wie bie Unred)ung beffelben Şolzgehaltes in eine Formzahl uno beren $\mathfrak{B}$ ertwentung.

In neuerer 3eit hat mant Diefe (Sintwürfe ziemlid) allgemein als bes grïnbet anerfannt; man glaubt aber burdh eine Reibenfolge von Beobad)= tungen zu Dem Mejultate gelangt zu fein: Dás aus ber Berednung einer

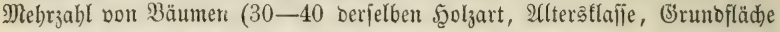

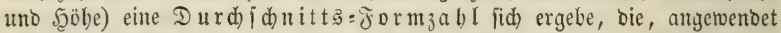
auf cine gleich groß̉e ober größere Stanmıabl anderer, in Obigem über= einfimmenter Beftänoe, ein ftets richtiges Berednungšrefultat ergebe.

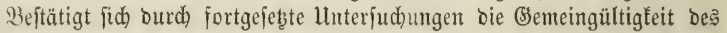

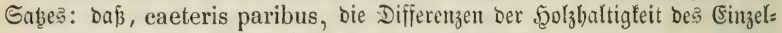
ftammes fid) ftets in Derfelben Durdidnittsformzahl aufbeben, wie folde bie Bairifden uno Stahl'fden Mafientafeln geben, Dann bleibt für

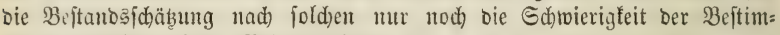
mung Durdfidnittlider Beftandeăb̈he, oa aud hierbei bie 50 be ein einflubeiderer Jaftorift wie bei jedem Seftionsoerfabren. Mit Rüffid)t bierauf twird cine Brüfung Der praftijden Bebeutung bes

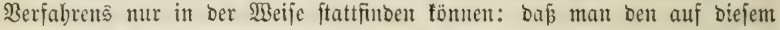
Wege erlangten Beredbuntgäergebnifilen bie 2 ufmalterungšrejultate ber taçir= ten Beftände gegenüberftellt. Befonders in Bebirgäforften bürfte bie Edprerigfeit rid̄tiger Şöhenbejtimmung eine grofe fein, bei ben bort ftatt= finbenben großen Sd)wantungen im Şöhentwudje.

\section{Beitanoßtaxation.}

Dhgleid) ber Beftano ftet’ $\mathfrak{A}$ ggregat einer Mebrzahl cinzelner Bäume

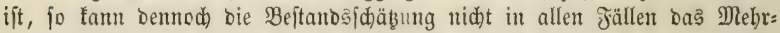

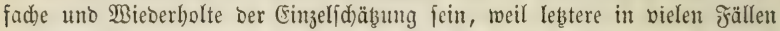
bei grốen Baummengen, bejonders ber jüngeren Beftände, zu viel Beit

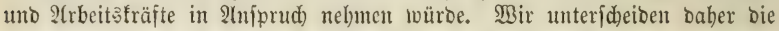

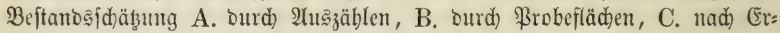
falbrungstafeln, D. Durd Beftantognergleid).

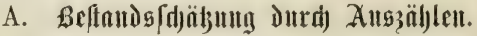

Darunter ift jebe Edäßzungsmeife zu verfteben, bei welder jeder (Finzel= theil bes Beftandes für fid) aufgentommen und bie Beftandesmaffen burd) Summirung des Majiengehaltes aller Einzeltheile gefunten wirb. Diép ge: idieht entweder burd) 2(njprechen ber Malle jeoes einzelnen Baumes nad) Maltern ober Subiffußsen, ober burd) Einoronung Der Bäume in Stärfe= flaffen uno Bered)nung oes Şolzgebaltes nad) Mujterbäumen. 


\section{a. Die Eingelf ä äung.}

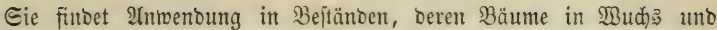
Mafienbaltigfeit fo ungleid) fino, Dap fid Jorm= ober Gröbeflafien gar nid)t

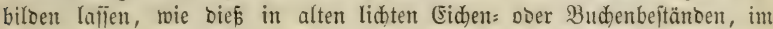
Sberbolze bes Mittelwaldes, in plänterwaloähnliden Beftänoen niơ)t felten

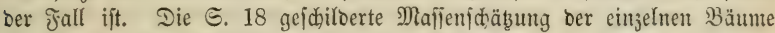
verbient in jolden Fällen entidjieben ben ßorzıg.

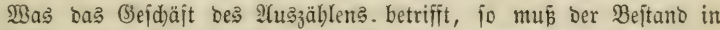
graben Sinien Durdggangen, bie in bieje fallenden Bäume gejđäb̨t, baß

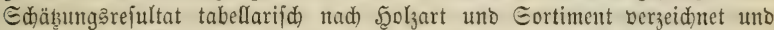
bie tarirten Bäume als foldhe burd) einen Edjalm fenntlid gemadht werben, meldher ber nädjiften Ganglinie bes Tarators zugementet ift. Gino eine

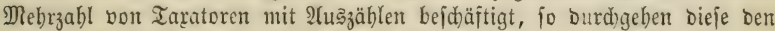

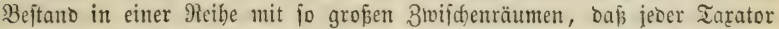

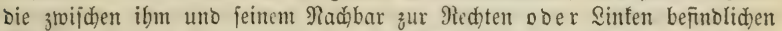
Bäume amprecten fann, ohne bie gerabe Banglintie zu verlanjen. In Diejent Falle ift nur Der äuserfte an ber (Srenze Des nod) nicht tarirten Beftanbes bingebende Iarator bon einen Şolzhauer begleitet, zur Şerftellung ber, nad) Dem nod) nid)t tarirten Beftante bintweijenten Edalmlinie an ben

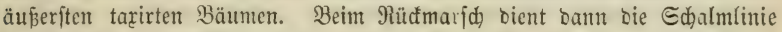
Dent äuperften fflügelmam zum Megweijer, wäbreno ber inmerfte fłügel= manu eine neue Sđ̆almlinie anpläben läp̧t.

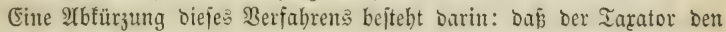

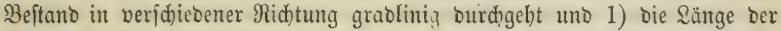
(banglinie nad) Ed)ritten beftimmt, 2) alle genau in bie (S)nglinie fallen= Den Bäume zäblt uno taxirt. $\mathfrak{A} 11$ sె Der Stammzahl in Der Ġanglinie be: rechnet fid bie burdfidnittlid)e Etammferne, aus biejer bie Stammzahl pro

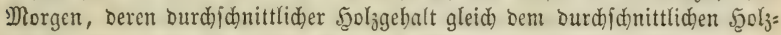
gebalte ber in ber Baanglinie taxirten Etämme angenommen roiro.

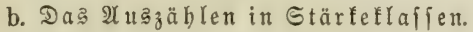

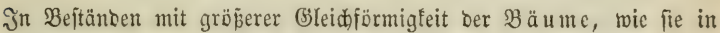
Nabelholzbeftänoen und in jehr gejdlolien ermadjenen Budjenbeftänoen vor=

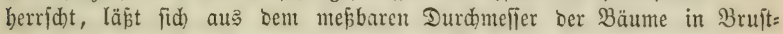
böhe mit jiemlider Benanigleit auf Dent Mañengebalt Derjelben idlicjent.

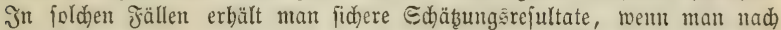
Áu Den bäufiger vorfommenben Extremen ber Bruftböbenourdomefier Stärfes flailen von beifpielsweife 3 (Etm. Unterid)ico im Bruithöhenourd)mefier bildet uno bie Bäume bes Beftanbes nad) ifren, mit Der Slluppe gemeñenen Brufthöhendurdhmefier in eine Sllafientabefle einträgt, in tweldhe bie Bäume jeber Gtärfetlafle nad) Durdhmefier uno Sreis̆fläd)e in Brufthöbe (11/3 $\mathfrak{M}$ tr.) eingetragen werber. 3. $3 .:$ 


\begin{tabular}{|c|c|c|c|c|c|c|c|}
\hline \multicolumn{2}{|c|}{$\begin{array}{l}\text { 1. Stärfeffafiée. } \\
14-12 \text { Etm. }\end{array}$} & \multicolumn{2}{|c|}{$\begin{array}{l}\text { 2. Stärfeflafie. } \\
11,9-10 \text { Etm. }\end{array}$} & \multicolumn{2}{|c|}{$\begin{array}{l}\text { 3. Stärfeflaffe. } \\
9,9-8 \mathrm{Ctm} .\end{array}$} & \multicolumn{2}{|c|}{$\begin{array}{l}\text { 4. Stärfeflafíe. } \\
7,9-6 \mathrm{Ctm} \text {. }\end{array}$} \\
\hline $\begin{array}{l}\text { Durd,n. } \\
\text { Ctm. }\end{array}$ & $\begin{array}{l}\text { Arreisfääçe } \\
\text { in } \square \mathbb{R} \text { tr. }\end{array}$ & $\begin{array}{l}\text { Durdim. } \\
\text { Ctm. }\end{array}$ & $\begin{array}{l}\text { Sireisflädqe } \\
\text { in } \square \text { Mtr. }\end{array}$ & $\begin{array}{l}\text { Durdim. I } \\
\text { Etm. }\end{array}$ & $\begin{array}{l}\text { Sireis̄flänge } \\
\text { in } \square \mathbb{M t r .}\end{array}$ & $\begin{array}{l}\text { Durfim. } \\
\text { Etm. }\end{array}$ & $\begin{array}{l}\text { Streisfläde } \\
\text { in } \square \text { Mtr. }\end{array}$ \\
\hline $\begin{array}{l}13 \\
12 \\
13,5 \\
14 \\
12,5 \\
13,5 \\
12 \\
14 \\
13,5 \\
12,5 \\
\text { u. โ. w. }\end{array}$ & $\begin{array}{l}0,0133 \\
0,0113 \\
0,0143 \\
0,0154 \\
0,0123 \\
0,0143 \\
0,0113 \\
0,0154 \\
0,0143 \\
0,0123 \\
\text { u. โ. w. }\end{array}$ & . & & & & $\therefore$ & \\
\hline & $\frac{0,1342}{10}$ & $\begin{array}{l}0,01 \\
\text { mefif }\end{array}$ & $\begin{array}{l}\square \text { Mit } \\
\text { Mafute }\end{array}$ & $\begin{array}{l}\text { tilex } \\
\pi 1\end{array}$ & tammfl & $=13$ & ก. Durd $=$ \\
\hline
\end{tabular}

Bedient man fids einer Siluppe, auf ber neben ben Durd)meffer= größen bie correfpontirenton Rreiŝflächen angegeben funb, fo tönnen leb̧tere unmittelbar abyelefen uno in ber Iabelle berzeidnet werben. (5s wäre bann muţlos, aud Die Durdhmefier jeces einzelnen Baumes zu verjeid)nen,

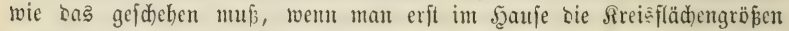
neben bie gemefifenen Durdmeffer eintragen fam, mozu id) in ber 10. 2(uflage

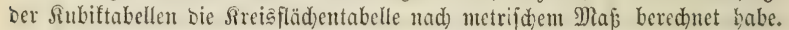
Jm Sopf Der Tabelle Sarf Dagegen bie 2(ngabe ser Durd)meffergrößen nid)t feblen, sa nach ibuen bie Bertbeilung ber Beftandogglieber in bie gebiloeten Stärteflajien geidieht.

Wie bie borftebende Tabelle für bie erifte Stammllaffe zeigt, werben

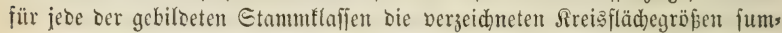
mirt uno in bic Summe mit ber Stammzahl ber Stärteflaffe bivibirt, um bie mittlie Etammgruntofläd) eines Baumes zu finten, bie bann, auf bie correfpondirenoe Durd)meffergröß̉e (13 (Etm. Der Iabelle) żurüđgefübrt, Der

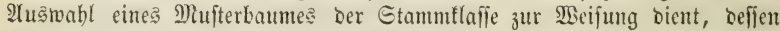
Maffengebalt als burdfidnittlider Mafiengebalt fänmutlicher Stämme Der: felben Rlafie betrachtet wiro, Defien Multiplication mit Der Stammaabl ber

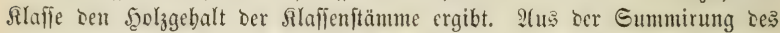

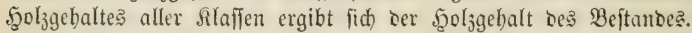

Ohne 3weifel ift man im Stante, fich in Sentnip Der Stammgrunos fläd)engröfe aller Rlaffenftämme jeocn Beftantos zu feţen uno aus beren

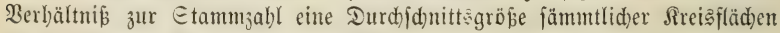

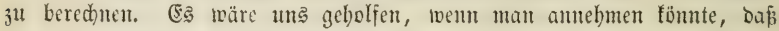
innerbalb jeder Stammflaffe eines Beftandes die Mafjenbaltigfeit feiner Einzel:

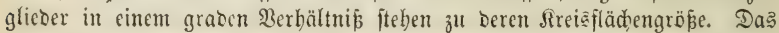

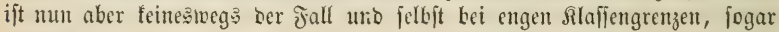
unter Den Stämmen gleider Rreisflädhengrößje berjelben Stanmflaffe finden beocutenbe Sariationen bes Maffengchaltes jtatt, je nadjoem bie $\mathfrak{B o l l}=$ boljigfeit, bic in gejd)lojenen beftänden fo fdmierig zu erfentende Sdjaft= 


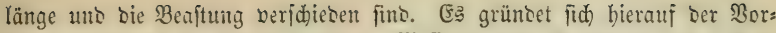
fadlag Draubt's: Durch fällung, Neliung und Berednung ober 2tuf= arbeitung einer $\mathfrak{M e b r z a b l}$ von Mufterbäumen jeber Stammflailc Mufter=

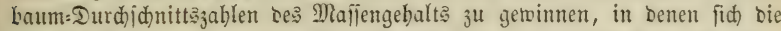
bei Bercd)nung nur eines Nujterbaums für jeoc Etammflafle möglidjen Mifigriffe uno beren Folgen, went nidht aus̈gleidfen, Dod abjtumpfen.

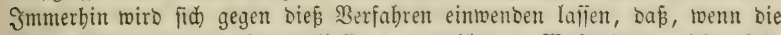
Mehrzabl ber für jebe Stammflaffe zu ertwäblenden Mujterbäume feine febr

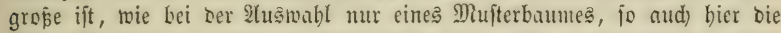
Untheileftraft Des Tarators bas Befte thun muf. Jit fie aber eine fo grofe

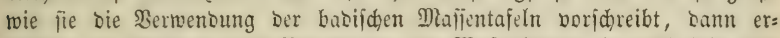
forbert bie Meffung uno Berechnung Der Mujterbäume fo viel Zeit uno

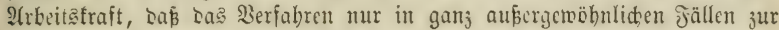

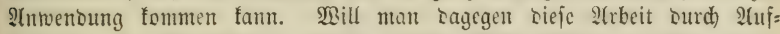
arbeitung Der Mufterkäume in bie üblid)cn Serfaufs̄maje umgehen, Dann

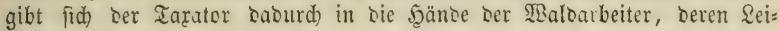

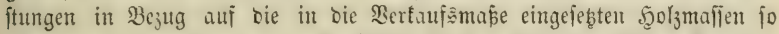
jober zu controliren uno auf gleidjer Stufe zu erbalten fino. Bon an= Deren 2frbeitşfräften uno unter minoer ftrenger Controle volljogen, fann Das Ergebuif ber Aufarbeitung Des Bejtandes ein jebr neridhiebenes jein von Dem ber \$robefällungen.

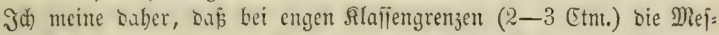

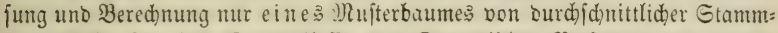
grunbfläde für jede Etammtlajie Dem Draubtid)en Serfabren vorzuzichen fei, renn innerbalb ๖er Bäume Durdjidnittlicher Etammgrun๖fläde die

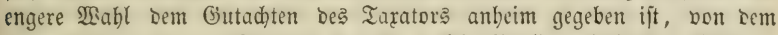

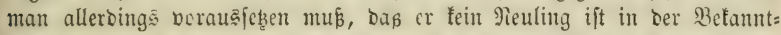

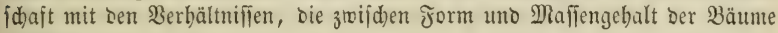
befteben.

Mein Eobu Robert, in jeiner Edyrift über Rentabilität Der Fidftent= nuţboly = und Budenbrennbolzwirthidaft 1868, hat das zul vorftebender Tabelle erörterte Berfabren jeines (3rofibaters sabin ermeitert, Daf er, burd) Divifion Der Stammgruntflädje des ganzen Bejtandes mit ber 3 abl ber gebildeten Stammllañen, für jeve Derjelben gleid)e Stammgrunoflächen, aljo auch annäbernd gleid)e Şoljmaffen fintet, um für jese berjelben, burd) Divifion ber Stammgrun๖fläd)e mit ber Stammzabl jeber Rlafie, für bieje

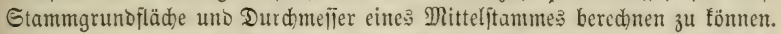
Daf aud bei diejem Berfabren das 2fugenmaj bes Tarators Das Befte

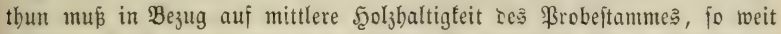

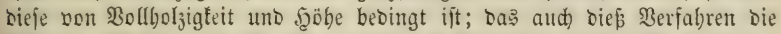
Jällung, Mejīung uno Bered)unng ooer die 2lufarbeituny Der Diufterbäume

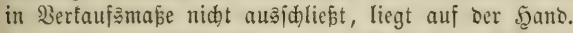

Berlangt man nod gentuare Mefultate, als auf Den eben bezeidneten Wegen erlangt worbun fömen, fo theile man Die Rolumnen jeber Stamm= flaffe in brei Unterfolumnen, imprimire fid) genau bie form bes Mujter= baumes uno trage biejenigen Etämme, weld)e biefer form und Bollholjig= feit entipreden, mit ibrem Durdhmener in bie mittlere Solumne, Die auf= 
Falleno vollholzigeren unter + , bie abholzigeren unter -, uno crmittle Etärfe uno Rubifinhalt biejer leģteren burd) Jnterpoliten.

Man fönnte, anftatt birefter 21ngabe Des Rubifinbaltes, aus biefem, ber Şöhe unt ber Stärfe, eine Formjahl beredunen uno in 2tra ab bringen, id) fanm aber feinen andern Erfolg bavon erfennen, als bap bie 2Arbeit für jeben Baum um żพei untübe Multiplifationserempel vermehrt mirb.

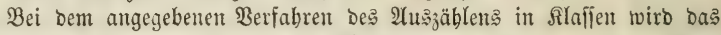
Rejultat um fo genauer, je enger Die Slafiengrenzen gezogen werben. Som= men in einem Bef̣tande einzelute außergetwöbnlid ftarfe ober aupergetwöhnlid) fdibad)e Stämmte vor, fo twerben bieje, went fie in bie Rlaffificirung aufs gentomment werben, entweber Die Slafienzahl uno bie 2trbeit febr vermehren, ober cine bebeutenbe Ertweiterung Der Rlafiengrenzen z̧ur Folge haben. Man thut Daber wobl, folche Baumgröpen in bie Slajfentabellen nidgt aufzu=

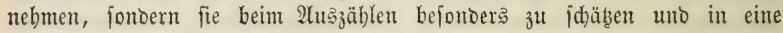

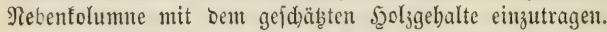

Bei Mefiung Des Durd)mefierş Der auşzuäblenten Stämme, vernit=

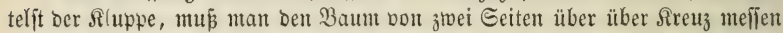

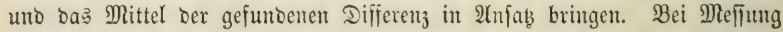
vieler Stämmte ift biē fehr zeitraubeno uto erntübent. Man fann bie 2rrbeit baourd) abfürzen, Daß man, beim Durdgeben Des Beftands in

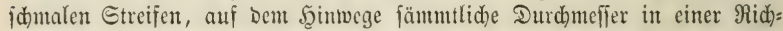

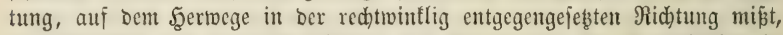
Da, bejonbers auf geneigten Fläd)en, bie Ercentricität ber (3runtofläd)en in ber Regel gleid)e Lage hat.

Daß bei biejem Berfabren, bei Berzidjtleiftung auf genauere Rejultate mannigfaltige Arbfürzungen eintreten tömen, bebarf faum Der 2fnbentung.

\section{B. Beftands(d)äbแแ Durd) frobrfläd)en.}

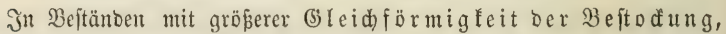
wem aud) mit geringerer (3leidfförmigfeit ber Baumgröß̧e uno Baumformen, jelbft in gemengten, lüdigen, berfdiebenaltrigen, horftweife beftandenten Drten, went bieje ungleidbeiten fid) gleidmäbig über ben ganzen Drt verbreiten, gelangt man zu fiderern Iatzationsergebniffen,

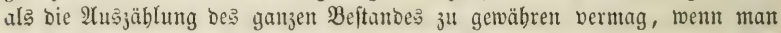
cinen flcineren, Die Beftodung Dę ganzen \$eftandę repräfentirenoen $\mathfrak{B}=$

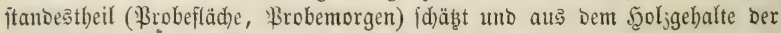

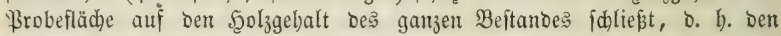
5̧olzgebalt Der Frobefläd)en mit Dem Duotienten aus ber Flächengrößje biejer uno bes ganzen Beftantes multiplicirt.

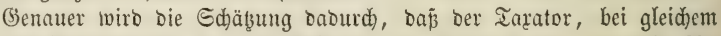

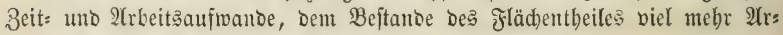
beit mo Sorgfalt zumenten fann, als Dem ganzen Beftande.

Die 2 ufnahme bes Beftandes oer Probefläde uno Beredi)=

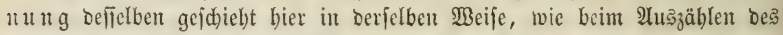
ganzen Beftandes in Etärfeflañen Seite 23. Der Unteridjied beruht nur in ber B̧efd)räntung oer Taration auf einen ober einige fläd)entbeile. 
Die Gentauigfeit ber burdh Brobejläd)en zu betwirfenden Beitanoș: iđäb̧ungen iit abbängig von einer rid)tigen 2 usmahl, von ber Gröpe, frorm uno Begrenzulig ber Probefläd)en.

\section{1) $\mathfrak{A} \mathfrak{a} \mathfrak{s} a \mathfrak{b l}$ ber Probefläden.}

Der Beftano ber Probeflädje joll ben Bejtano in Banjen, bejonders

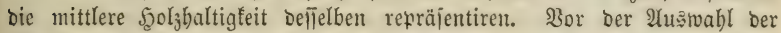

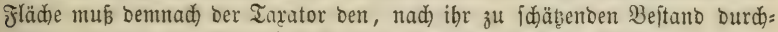
geben, um fid) eine Befanntiøaft mit ber burdjidnittlichen Beftociung, 5̧ol3=

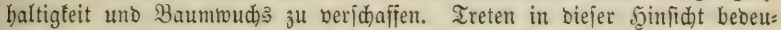

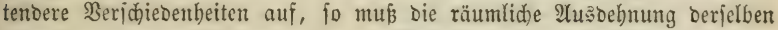

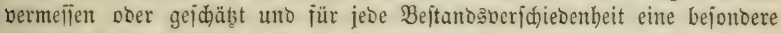
Probefläche auล̃gewählt werben. Die Gienauigteit ber Echäßzung bängt bier

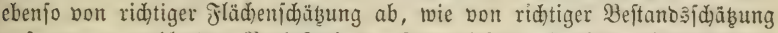
auf ben zu wäblenben Frobejläd)en. Jebe biejer wejentlichen Bejtunożver:

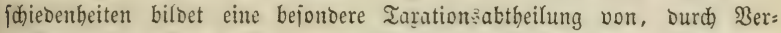

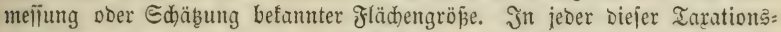

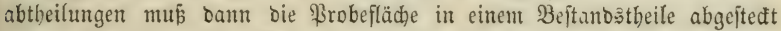
werben, ber bie mittlere Beftockung uno நुolzhaltigfeit berfelben repräfentirt. In bergigem Ierrait ift ber mittlere शleigungs winfel ber Taz̧ationabthei=

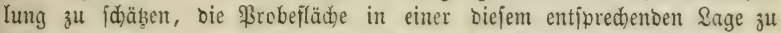
räblen uno nad) ber borizontalen (sirunofläche abzumefïen. Weitere Bor= fdriften für bie 2tuêwabl lafien fidh nidht geben, fie ift allein Eache rich=

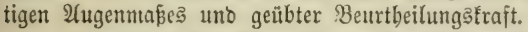

In miefern bie 2(ușabl der ßrobefläd)en für 2Ufîtellung von $\mathfrak{E r}_{\mathrm{r}}$ fahrungstafeln uno überbaupt für willenjobaftlidhe Ertragşforidungen eine andere fein mülile, fiebe weiter unten, uno "Ertrag Der Mothbuche".

\section{2) Ģröß̨e dex Brobefläde.}

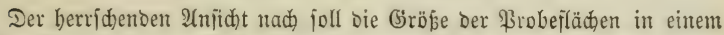

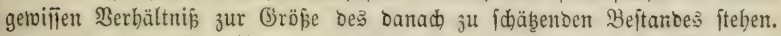

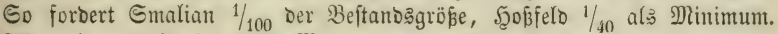
jめ) meine, bajs ein 1000 Morgen g oper Bejtano ebent jo ridhtig Durd $1 / 1000$ Der Flähe geidjäß̨t werden fömne, als ein 100 Morgen grofer Be= ftand burd $1 / 100$, wenn beioe gleidye (5rabe gleidförmiger Bejtociung be= fiţent. Sn einem Эuntgorte faum $1 / 10$ Morgen beflere Dienjte leijten, wie 10 Morgen in einem alten Beftanbe gleider Größße. Die B̋leidförmigfeit

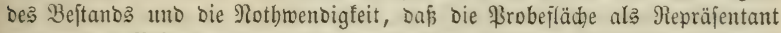
bes ganzen Bejtandes ober Iarationstheiles, diejelben Berjojebenbeiten in

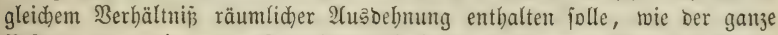
Beftano ober bie ganze Tarationsabtheilung, beftimmen alfein bie Gröpie ber Brobefläd)e. Dagegen fam man anmelmen, Dań in alten lidaten

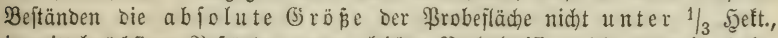

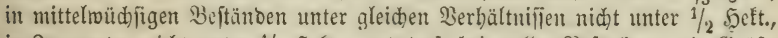

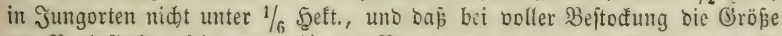
ber Brobefläde nid)t unter $1 / 2$ ber 3 orgenamnten betragen bürfe, tweil bei

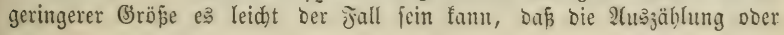




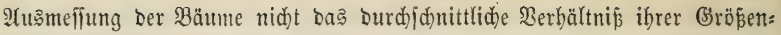
flaffen ergibt.

3) Form ber Frobefläde.

In bollfommen gleid)artig beftanbenen Drten ift biefe gleidgültig uno man wällt in Der Regel bas gleidfeitige ober nabe gleidfjeitige Rechtect.

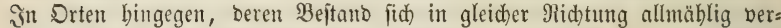

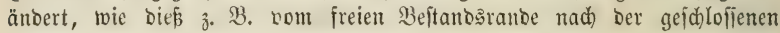
Mitte hin, von ber Thaljohle nadb bem Bergfamme binauf faft immer ber Fall ift, ba wäblt man lieber bie Form bes Dblongum uno legt biés fo,

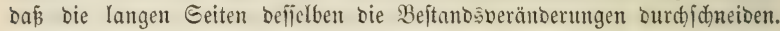
Daf bie breiectige Form leim 2lbftecten mand)e Bequemlidfeiten biete, babe id): Ertrag bei Rothbuche, S. 48 erörtert.

\section{4) 2 usmeffung Der $\mathfrak{B r o b e f l a ̈ d e . ~}$}

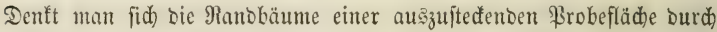
gerabe Sinien mit einanoer verbunoen, ebenfo bie zunäd)ft uno auperbalb

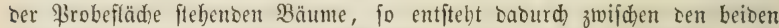
geoachten Sinien ein baumfreier Gürtel im llmfange Der Probefläche. Die

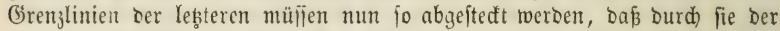
baumfreic (butrtel in jwei gleid) grope Theile getbeilt wirb. Moollte man bie Grenzlinie näher an bie innere \&inie des Gärtcts legen, fo mürbe bie Brobefläcbe im Berbältniß zur \$̧olzmafie zu flein, Das Taratum aljo zu hod), umgefehrt würoe es zu nieorig ausfallen. In alten lidhten Beftänben uno

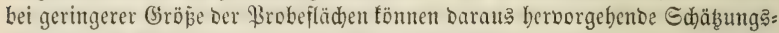

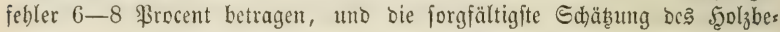
ftanbes Der \$robefläde in hohem Grabe rerfäliden. Natürlid tann in ber Braçis sie Theilung Des baumfreien SGürtels nid)t mit mathematif(her Sdjärfe augefübrt merben, der Begenftand berbient aber bie bolle 2tufmerfamfeit Des Taratores beim Atusftecten ber Grenzlinien, bie burd Sdalmlinien,

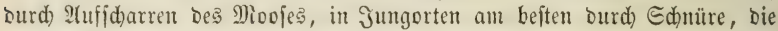
auf ben Boben gelegt weroen, fenntlid) zu madjen fint. Id) beoiene mid)

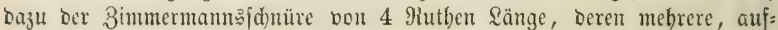
gebocit, man leid)t bei fid) fübren fann uno bie zugleid) für bie Sängen=

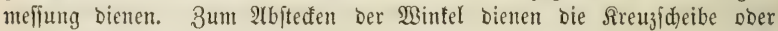

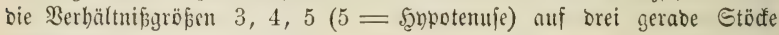
abgetragen.

I(ud) biés Taxationşberfabren fann mannigfaltigertweife bereinfad)t in

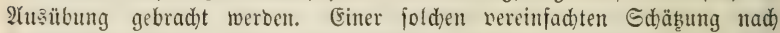
Frobefläden bebiente fid) mein berftorbener. Bater bei ben fuperficiellen 2 (b) ¡däßzungen grofer Walobejtanosmaffen in unglaublid) furzer Beit. Sein Berfabren beftano barin: Daf er idjon beint eriten einzigen Durd)geben ober Durdffabren Dę̧ zu fdäbenten Beftandes in geringen Entfernungen \$robe:

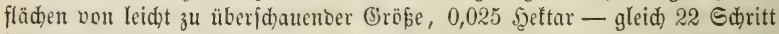
Duabrat (er pflegte bief́ ju motiviren: "Das ift bie Entfernung, in ber man iid) auf Ircibjagen bie Scafen anlaufen läpt," Die man baher am fidjeriten

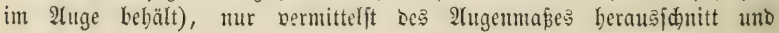




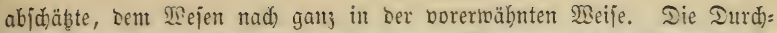

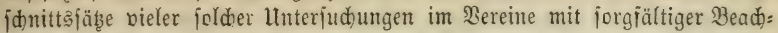
tung bes fräd)enverbältniffes guter, mittlerer uno geringer şoljbaltigteit

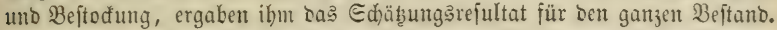

Die 5ol3baltigfeit ganj junger Drte ermittilt man ourd) Brobefläd)en

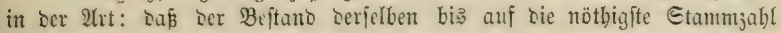
ftarf burdforftet, bie auझ̆gebauenen Etämme nad) 尺änge un Etärfe jortirt, gejäblt, gemefien, berednet ober gewogen ober in Mellen zujammengebunoen wercen. Die, im Berbältnif zum 2(übieke geringe 3abl ter ftehenbleiben= ben Etämıme famn bann obne gropen Beitaufwano auşgezählt uno ben ge: bilbeten Stammflaffen hinzugerechnet werben.

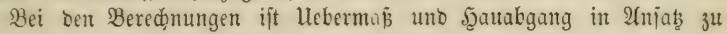
bringen.

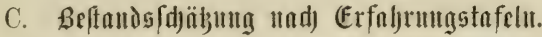

MSenn man bie Rejultate früher vollzogener frejieller Єdäß̨ungen,

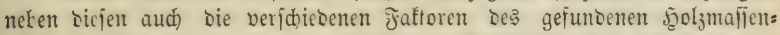

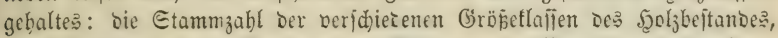

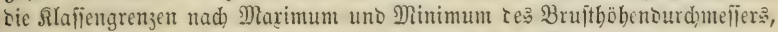

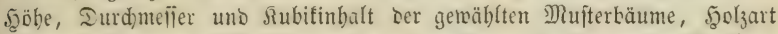

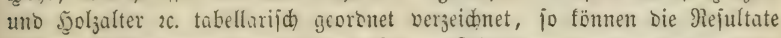
früberer Edÿb̨ungen unmittelbar auf nene Edäß̧ungen angementoet mercen, indem man bie Mafjenfaftoren Des zu id)äkenden Bejtandes mit buren

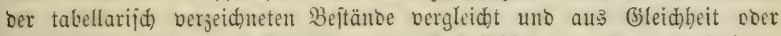

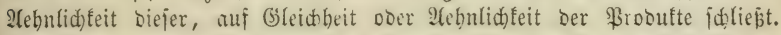
Dic Summe der Beftandsmañenfaftoren: Etammzahl Der Gröpetlalien,

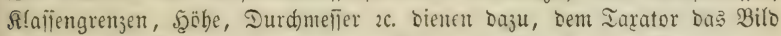

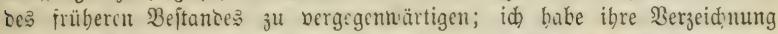

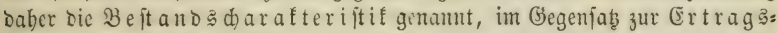
ziffer, bie bas Produtt aus Din Fraftoren angibt (i. Ertrag Der Roth=

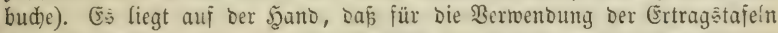
ju Bejtanosfoübangen, bie Charafterijtit ein eben jo mejentlicher Bejtand: theil Derjelben ijt, wie bie Ertragsiffer, baj leb̧tere allein in biejer $B_{i}=$

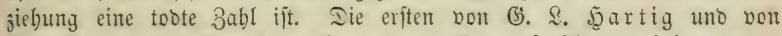
Bauljen aufgeitellton Eammlungen von Ertragsforjounghrejultaten ent= balten eine, wenn audi) niđht volljtändige Eharafteriftif ber unterfuchten Beftände. Eotta mai ę, der bicien 1 Beg zuerit verliej und nur bie Cr: traģ3iffen neben Şolzart uno \$̧oljalier berjeidjnete. Er motivirt jeinen

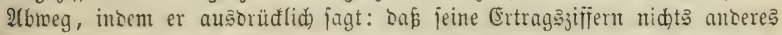
jein follten, als ein $\mathfrak{A} u s$ or $u$ d für unmittelbar uno unabbäuig vom

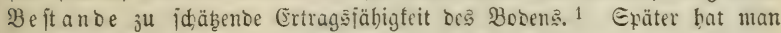
Die Unaliäübrburfeit diefer non Eotta geftellten Jorterung unmittelbarer Bobenmürbigung wobl erfannt, ift aber senncd) auf bem Lequemeren Mige

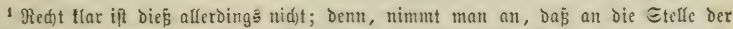

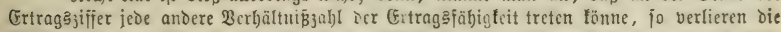
Maffeutafeln ben (Sharafter ber (Erfahrungstofeln gänjlid). Iennod) fdeeint $e_{\xi}^{5}$, als babe (5otta bierbei Die lanotvirtbidaftlid)e Bodenbonitirung nad) fiörnerertrag im 2luge gebabt. 
jur Compofition von Ertragstafeln geblieben, baber bent aud alle bic neueren Ẽrfahrungstafeln bon Cotta, Rönig, Şundeshagen, Pfeil, Emalian, für tą̧atorifobe 3ıecte gänzlid) unbraudbar finto. Die babifden (5rtrags: tafeln geben werigitents einigen 2(nbalt in 2(ngabe ber Stammabl uno ber Durchidonittlichen Beftandshöbe.

Das Material für bieje, am wenigften zeitraubenoe uno bentud fichere

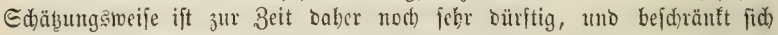

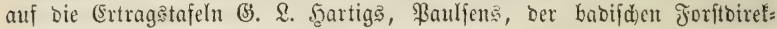
tion, Die wenigen Beiträge, bie id in meinem Selrbude ber Fflanzentunde, in Der $\mathscr{A r b e i t}$ über Den Ertrag ber Mothbud)e uno in meiner Forftwirtbidafts: lehre gegeben babe uno Die, wledje mein Sobn Robert befannt gemadht hat. (Es ift getwip fibr wünfdensmerth), Laf fid) ber praftifaje Jorftmann biefem Forjdungszmcige mehr als bishcir zumende. 2uf frinem Woge fant ex leidter uno fidjerer einen bleibenoen Namen in Der Siteratur erringen, ber eben fo ficher und für immer bom (Ertragsforfdungerejultate binjugefügt

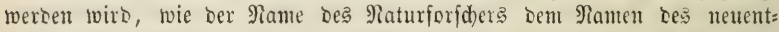
Dectten Naturförpers. 3ubem betrifft bießß alles 2Yrbeiten, bic bei jeber

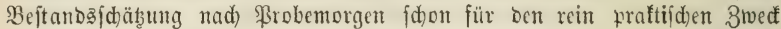
bejhafit werben müffent. (Es fehlt mur Laran, Daj fie vollftändig mit Ángabe einer Beftandes:-(Sharatteriftif verzeid)net und ohne 2 seiteres in irgeno einer forftlidfen 3eitfd)rift beröffentlid)t werben. Die nacte That: jache genügt bier vollfommen und jeoer, audh Der fleinfte Sbeitrag ift eine Bereid)erutg unjerer $\mathfrak{B i f j e n j}$ aft.

Bas id) unter einer vollftändigen Berzeid)nung ber Beftands= Ebarafteriftif uno Der Ertragsziffern veritche, geht auts nebenftehendem ভd)ema (ভ. 31) berwor.

Eine begleitende Edjilderung Der Stanoortsonrbältniffe, bejonders ber Rage, Erofition, Erbebung über bie Meereझfläche, Neigungşwintel Der Fläche, Bebirgart, Iiefgründigfeit bes Bobens, Bobenbeftandtheile, flima=

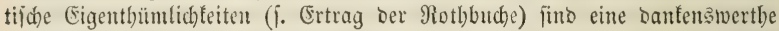
Beigabe, bodh nidgt umbedingt nöthig, ba bie befte Etamborts= Ebarafteriftif in ber Beftutos = (Sharafteriftif liegt. (Sleid) Dantensmerth) fint biftorifde

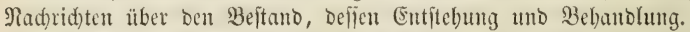

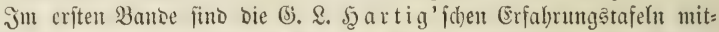

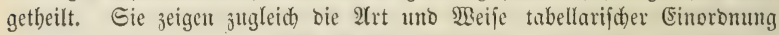
ber einzelnen \$ofitionen. Die ßaulfen'ichen Errtragstafełn fino vollftänoig in meiner 2lrbeit über Den (Ertrag Der Miothbud)e enthalten.

Befizen wir erft eine gröpere Eammlung jolder Erfabrungen, bie fid bei vicljeitiger Theilnaljme in furzer 3eit erwerben läp̆t, Dann wirb bas fo

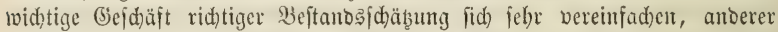

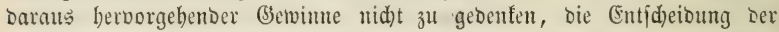
wid)tigften Betriebsfragen betreffend. Sid fam es bem jungen forftmanne

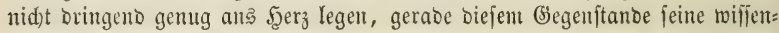
(d)aftlid)e Thätigfeit vorzugameije zuzumenden, anjtatt fid in Spefulationen uno formeln uno Iheorien zu verlieren, bie, wenn fie nid)t Ergebnif febr gereifter Erfabrung furto, in ber Maffe Der borbandenen Dinge bicfer Strt verid)minten unb zแ Den unbantbarften $\mathfrak{B}$ ejdäftigungen geljören. 


\begin{tabular}{|c|c|c|c|c|c|c|c|c|}
\hline \multirow{5}{*}{ 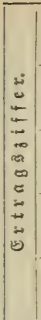 } & & \multicolumn{2}{|c|}{ 'vuนกท } & 莣 & 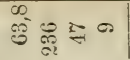 & $\begin{array}{l}120 \\
150 \\
60\end{array}$ & 8 & 贷 \\
\hline & & \multicolumn{2}{|c|}{ - ใqव } & 莣 & $a i$ & 12 & - & $\stackrel{\bullet}{\sim}$ \\
\hline & & \multicolumn{2}{|c|}{ 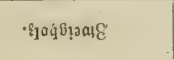 } & 芦 & $a: \cong-1$ & $\stackrel{62}{-1}$ & s? & 12 \\
\hline & & \multicolumn{2}{|c|}{ 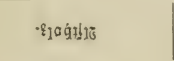 } & 莣 & $0 \begin{array}{llll}25 & 02 & 0\end{array}$ & § & - & $\bar{a}$ \\
\hline & & \multicolumn{2}{|c|}{ 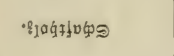 } & 䓌 & $\infty \underset{\delta}{\infty} \stackrel{\infty}{\sigma_{1}} \infty$ & 於 & $\stackrel{\oplus}{=}$ & $\begin{array}{l}\text { m } \\
\text { के } \\
\text { के }\end{array}$ \\
\hline \multirow{12}{*}{ 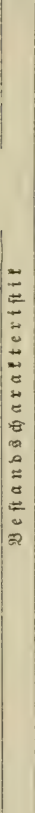 } & \multirow{9}{*}{ 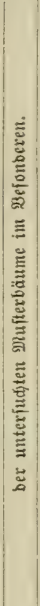 } & \multirow{2}{*}{\multicolumn{2}{|c|}{ 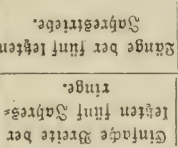 }} & 节 & $\alpha \stackrel{m}{\tilde{\eta}} \stackrel{m}{\tilde{\nu}}=$ & 1 & $\prod_{\infty}^{q}$ & 1 \\
\hline & & & & 䮍 & 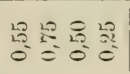 & 1 & $\frac{\pi}{0}$ & | \\
\hline & & \multirow{5}{*}{ 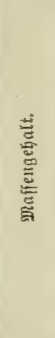 } & - vแนแก & 莣 & 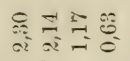 & 1 & 1 & 1 \\
\hline & & & 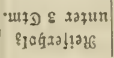 & 离 & $\begin{array}{lll}0 & 0 & 0 \\
0 & 0 & 0 \\
0 & 0\end{array}$ & 1 & 1 & 1 \\
\hline & & & 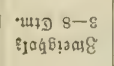 & 莣 & 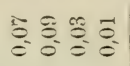 & I & 1 & 1 \\
\hline & & & 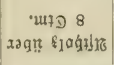 & 竎 & 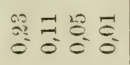 & I & 1 & 1 \\
\hline & & & 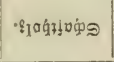 & 莣 & 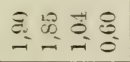 & 1 & 1 & 1 \\
\hline & & \multicolumn{2}{|c|}{ 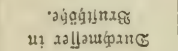 } & $\stackrel{\Xi}{\Xi}$ & 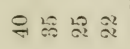 & 1 & 1 & 1 \\
\hline & & \multicolumn{2}{|r|}{ วhgot } & 芒 & 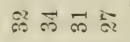 & 1 & 1 & 1 \\
\hline & \multirow{3}{*}{ 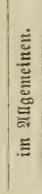 } & \multirow{2}{*}{ 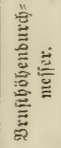 } & 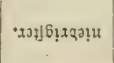 & 芯 & 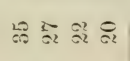 & 1 & $\stackrel{2}{\sim}$ & 1 \\
\hline & & & - & 站 & 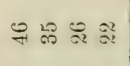 & 1 & $\exists$ & 1 \\
\hline & & \multicolumn{2}{|c|}{ 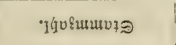 } & (1) & $\stackrel{\infty}{\infty} \cong \stackrel{0}{=}$ & $\stackrel{Q}{\subseteq}$ & ๙ & $\frac{a}{2}$ \\
\hline & & \multicolumn{2}{|c|}{ 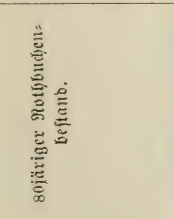 } & 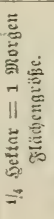 & 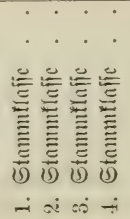 & 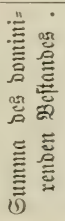 & 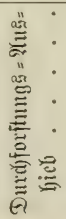 & 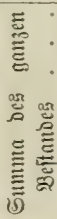 \\
\hline
\end{tabular}




\section{Beftands(d)äluแng Durd) Beftandsvergleid).}

(Seübte Taratoren bermögen ein ridtiges Urtbeil über bie \$golzhaltig=

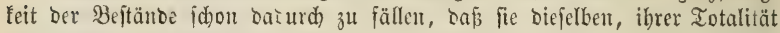

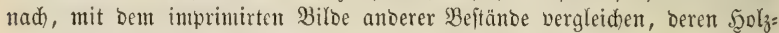
gebalt fie fiüber freciell erforid)ten. Die Jäbigfeit jold cin fummarijhes Urtbeil zu fällen, ift baber nur burd) cine grope Babl vorbergegangener fpecieller Ilnterjudungen von Seiten bes Iaxators jelbit zu ermerben. Die Ulebung uno (Erfibrung allein genügt aber nod) nidht für ven (Erwerb biefer Jäbigfeit, es gebören לazu bejonbere Gaben. Wie nid)t Jebermann bie Sabe ber Didhtfunjt, Malerei, Mujif bejibct, fo bejibst audi) nidht Jeoer= maun bas Bermögen, Gröfe und Jormenverbältuifle ridatig aufalfafien, biefelben fid) zu imprimiren uno zum $\mathfrak{B}$ ergleidhe mit anberen (Sröpen uno Formen zu verwenden. Ialent für 3eidnenlunit, namentlid) für freies उeid) ncu, ift ber fiderfte Srüfftein für taratorifde Ialente; beibe ruben auf gleider Bafis. Es gibt teine feffere Borübung für taçatorifche $\mathfrak{B} e=$ idäftigung als llebungen in freien 3eidnen. Wer bazu fein Talent

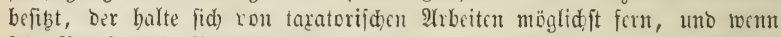
fein Beruf bieje Bejdäftigung fortert, sann vermeibe er bor allem bie Sd)äßzung nad) Bergleid) ftets auf birefte Miffung uno Bercthnung.

\section{Dூiertes diapited.}

3 wad germittelung.

Jür ๖en an bäufigften vorliegeneen 3wed ber Taxation, für bie Er: mittchutg bes nadbaltigen 21bgabejabes ber Wäloer, ift bie Renntnifí ber gegenmätig vorbanoomen foljmaffen nid)t ausereichond. In biefem Jalle lautet Dic 2lufgabe Des Jorfttąators: unter Rorausfebung einer, für bie nädjite Untrichszeit porgezeid)neten Bcwirthid)aftungşweife, in ber Eumme 1) bes gegeutuärtigeu Joolzoorratbes; 2) Des Zumadjes an ibm wäbreno ser Dauer Der Ilmtriebszeit; 3) oer Durhforftungsmubungen auร Den in Der laufenden Imtriebszeit für ben näd)ften llmtricb ne $u$ z $u$ er: ziebenden Beftänden, die Srbnubumgsgröpe der llmtriebszeit zu er= mittelı, um aus biefer oon, einer jeben ßeriobe und jebem jabre zufallent= ben Scauungşą̧ bered)nen zu fömnent.

Der Buwads am 5golzoorrathe ergibt fich

a) aนร bem 3 utwadjzeitraume,

b) auڤ oex 3 urad) Wuldoes.

Der 3 urad szeitraum beptimmt fid aus einem Beroirtbidaf: tungsplane der 3utunft für bie Daucr bes laufenden Untriebs, burd)

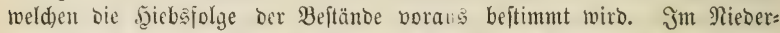

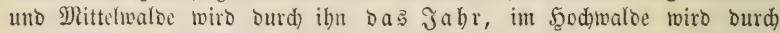

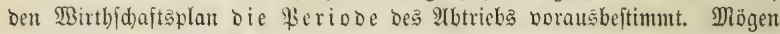
Die 3reeifel in Betreff Der Durdfübrung Dicfer, auf mebr als bundert Jabre binausecidenden, wirtbjofifliden Borausbejtimmungen nod) fo febr 
geredffertigt jein, es änbert bief nid)ts an beren Nothwentigfeit; went uno wo überbuupt bic Nad)baltigfeit ber 2(bnuß̧ung fo weit gefichert fein joll, als biejs überbaupt möglid) ift. Denn oer SBirtbichaftsplan beftimmt ben 3 uwad) şe itraum, uno biejer ijt ein eben jo wiótiger Jaftor ber 3uwad) झ̆maffe als bie Buwad)

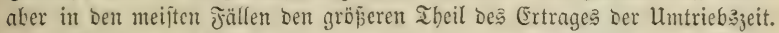

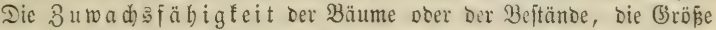
Derjenigen 3utwad)smafle, un bie biefe fid in ber 3utunft bis zu ifrem Ubtriebe vergrößern werben, läpit fid an ifnen ummittelbar nidht ermitteln,

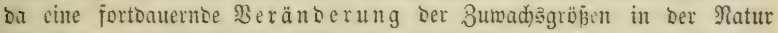
Des Baum: uno Beftandesmudjes begrünoet ijt. $3 \mathrm{u}$ bem, inmerbin mur

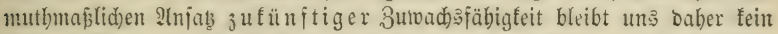

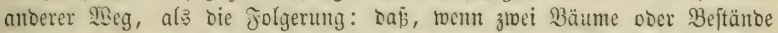

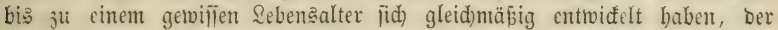
jüngere sicjer Bäume ober Beftänbe aud) in Der jolgejeit fid fo ent= wideln werbe wie ber ältere Baum ober Beftano fid) entwide lt bat. Siur in biefer Bejoräntheit bat bie Ermittelung verflofiener 3unads: größen taratorifabe Bebeutung.

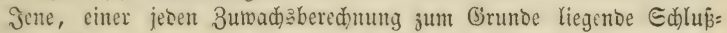

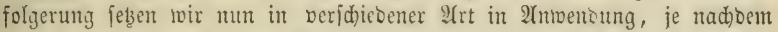

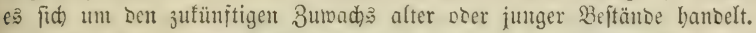

Sin allen älteren Bejtänten, bie einen we fentlichen \$ifanzen= abgang uidht mefr erleiben, läpt fid nidut allein bic Maffe bes Sorbandetten ulto Bleibenden mit zientid)er Genauigteit ermitteln,

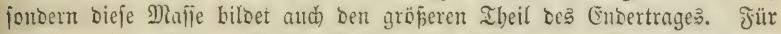

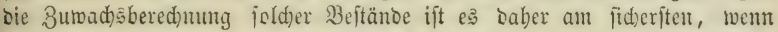

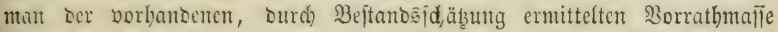

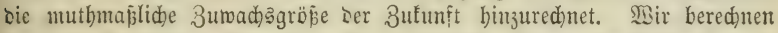

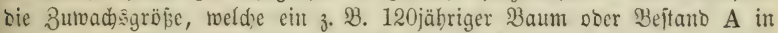
Den leţtwerflolienten 20 Jahren gehabt bat, Dridden bas Ergebni in einem Frocentjałse zur 5̧olzmalle dellelben \$aumes im 100 jäbrigen 24 ter aus, unD bered)nen bie nutfmapliche 3uwad)

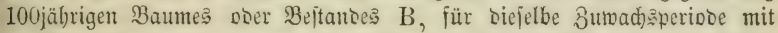
Demiclben Procentją̧e, wenn die Bäume A und B bis zum 100. Эabre

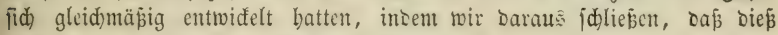
aud in ber folgezeit ber Fall jein werbe. S. 37.

Die Ermittelung Des 3unadję Der $\mathfrak{B}$ ergangenbeit hat baber un in Bezug auf jene Jolgerung taratorifde Bebeutung.

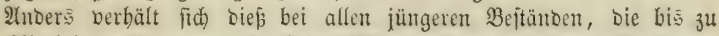
ihrem A(btriebe nod) einten wejentlid)en Pflanzenabgang erleizen. Je jünger Der Beftano, um jo gröfer ift leţterer, mit um fo geringerer Sidjerbeit läpt fid) aus Der Majie Des \$orbandenen Die Majie des bleibenden Bor:

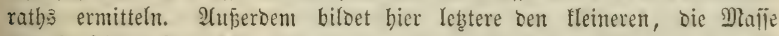
Des fünftigen 3uwadję biloet don gröperen Ibeil be: Enbertrages. E. witre Daber, felbit menn bie Mafic Des bleibenton Borratbes ridstig er=

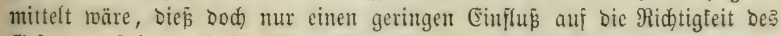
Bejammtrejultates baben fönten. 


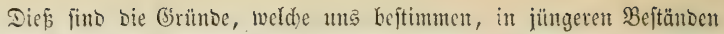

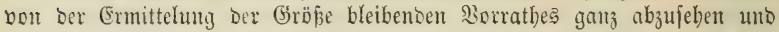

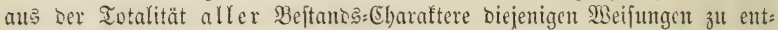
nefmen, welche nothwentig finto, $1 \mathrm{~m}$ ben zut taxirenton Beftanto mit andoren

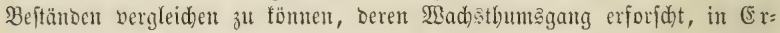
fabrungataffelu verzeid)uet und für bie Reihefolge Der 2Ultersftufen mit Beftands:(Sharalteriftif auseftattet murbe. Die Hebereinftimmung Der

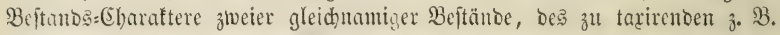

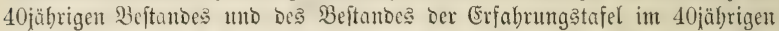
Alter, geftattet unt Donn aud) bier obige Jolgerung: Daj went zwei $\mathfrak{B} e=$

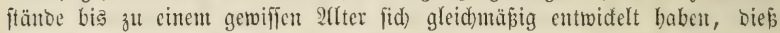

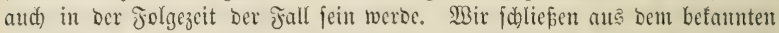

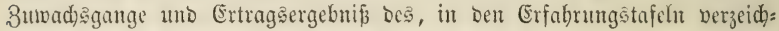
neten älteren Beftantes, auf Den unbefamten Buwad) sgang uno Ertrag Des jungen Drtes.

Demgemäp zerfällt bie Sehre von ber 3utwad)sermittelung in zwei

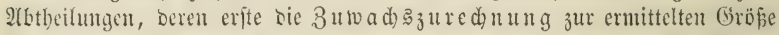
bleibenden Sorratbes oer Beftände, beren ztweite bie Rebre von 2lufftellung

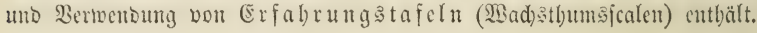

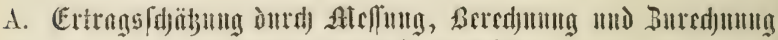 periodifdsen Bumad) (es.}

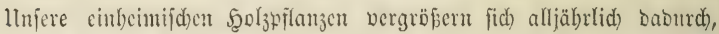
bafj fid) in ganzen llmfange bes vorjäbrigen Solztörpers cine neue . Solz=

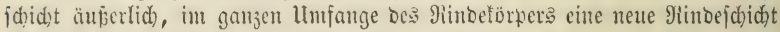
(Baftididt, Gafthaut) innerlid) anlegt, fo: Daj bic äusere (jorenze oer

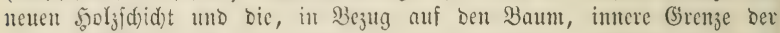
neuen Bajtid)id)t fid unmittelbar berülyen. Denjenigen Theil ber neuen

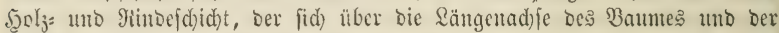
Boumtheile binans ermeitert, nenten wir bon Jabrestrieb, \&ängen= trieb, benjenigen Ibeil bes Jabreŝluddfes, Der fid) fdon borbanoenen Baumthcilen feitlid) anlegt, nemten wir ocu Sabresting (Şolzring uno Bajtring).

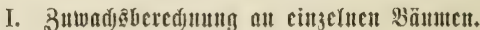

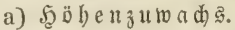

Die (Srenje ber \&ä thgentriebe erbält fid) längere Beit mur bei ben

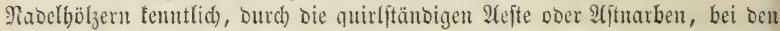

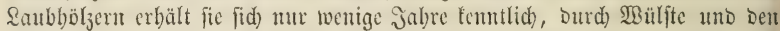
gcorängteren Etand Der tlcincren Eeitentnofpen. Es läpt fid) aber aud

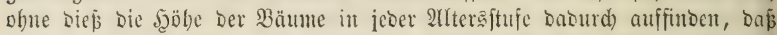
man, auf Rutejd)nitten in gemefienen Şöbon, Die Jabresringe zäblt uno Die Babl Derjelben von Der, bas Baumalter angebenden Babl ber Gabre ringe auf einem bidst über bem Boben genommenen Dueridnitte de:

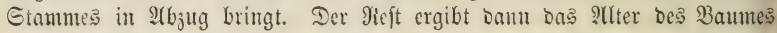
in ber gemeffenen Şöhe. Ein Saum, Der über bem Boben 100 Jafres: 


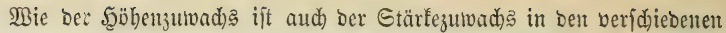
Baumtbeilen nidht gleiḑ. Bei gleiḑen Stanoorts̄berbältniffen äupern bie

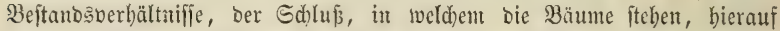

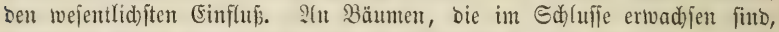
nimumt bie Breite cintes jeocn cinzelnen Jabresringes nad) oben hit zu. Jd

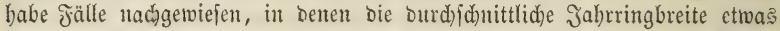
über Der Mitte Des Edaftę nabe Das Doppelte Der Jabrringbreite in \$ruft: böhe betrug. Im freien Stanoc erwadjen, nimmt bie Mingbreite in nod) gröferent Berbältnif nach oben bin $a b$, fie faun in uno über ber Mitte Des Ed)aftes weniger als bic Şälfte Der Ringbreite bes 3rufthöbendurd)=

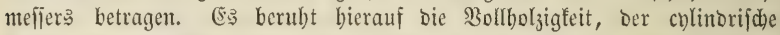

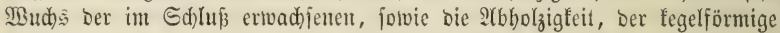

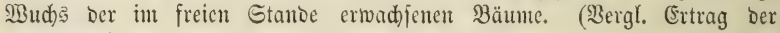
Rotbbude.)

2(us Diejen Beobad)tungen gebt unwiberleglid) herbor, bafi bie Breite

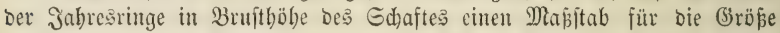
Des 3umadjes an ganjell Baum nid)t getwäbren fömuc; baj man, went

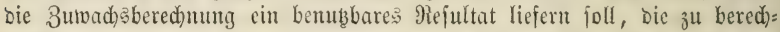
nendon Bäume notflvendig fällen, boß man fie, ebenfo wie für die Ermittclug Des Mlafiengchaltz nung (brittes Sapitel S. 14), in Geftionen zerlegen und Den Stärfe: juwach a a jeber Seftion meffen müfic, ber fid) für jebe beliebige

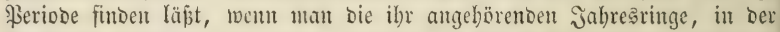
Mitte ber Geftion, anf einen fentred)t auf bie $2(d)$ je Derfelben gefübrten Dueridhnitte zäblt, miß̧t uno bie gefundene 3reite mit zwoi multiplicirt.

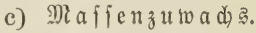

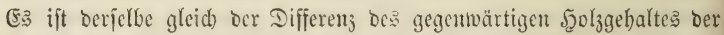

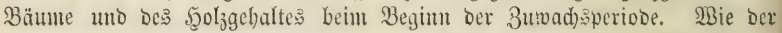
gegentwärtige Şolzgchalt ermittelt werbe, ift im vorigen Rapitel (Seite 14)

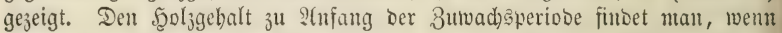
man ben mittleren Şalbmefier Des Duerjonittes berielben Eeftionsiängen, aus weldhen ber gegentwärtige Szolzgebalt bered)net wurbe, vertïrzt uno bie einfad)e Breite ber, in ber 3uwad) speriobe gebiloeten Jabrestinge in Red)= mung jieft $\left(\mathrm{R}^{2} \cdot \pi \cdot \mathrm{H}\right)-\left(\mathrm{r}^{2} \pi \cdot \mathrm{h}\right)=\mathrm{z},{ }^{1}$ f. obert. Nur Die Bipfel= feftion wiro un jo biele jupe türzer in S(mjaß gebradst, als ber burd)=

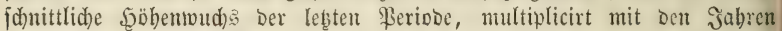
Derfelben, ergibt. Die Differenz des gegenvärtigen uno frïberen Şolz= gebaltes aller Geftionen ergibt den periodifhen Buwad)s des ganjen Baumes, aus bemt fid) Dutrd) Divifion mit ben Jabren Der ßeriobe ber jäbrlide Durdjidnittşunadjs Der Beriode berednet.

Man fam aber aud) in gleid)er BBeife Den 3uwads jeber früberen, als Der Yekstwerflofienen Beriobe, wenigiten: für bie Schaftholzmaffe Der

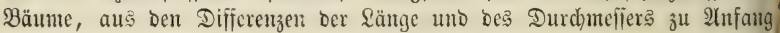

' $\mathrm{R}=$ gegenwärtiger mittlercr Şalbmeffer ber Geftionsąuerfiäd)en; $\mathbf{r}=$ Dem, um Die Breite Der in Der 3utuadgperiode gebildeten Jahreäringe verfürjten Şalbmefier; $\therefore=$ Subolph'idge $3 a \mathfrak{b l}=3,1416 \ldots$ 


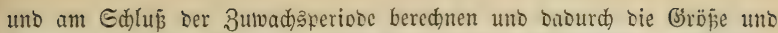

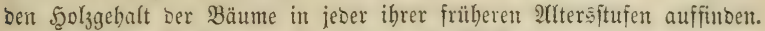

Daffelbe Serfabren tritt bei ben in Rlaijen eingetheilten Eeftionen

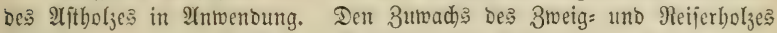
ermittelt man gemeinf(haftlid), Durd) Bäblung Der Jabreşringe auf ber unteren 2tbhiebilädje bes 3weigholzes uno durd) Dinifion ber ganzen 3weig = und

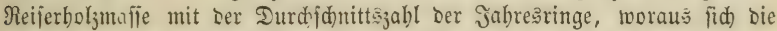
Durdjidnittlid) einjäbrige Procuftion an 3meig= und Reiferbolz ergibt.

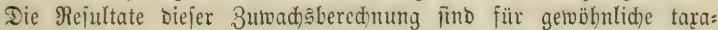

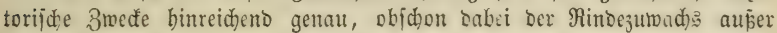

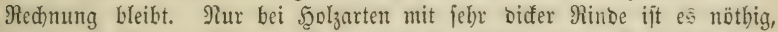

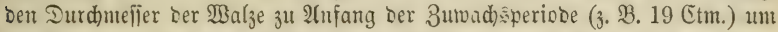

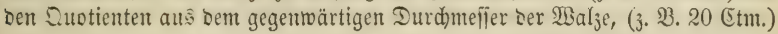
in Die Doppelte Pintobreite (3. B. 1,5 Ctm.) $\left(\frac{2.1,5}{20}=0,15\right.$ Ctm.) berringert in Rechnung zu ftellen $(19-0,15=18,85$ (tm.) Dagegen ift,

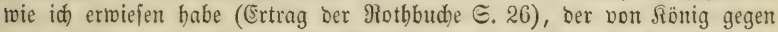

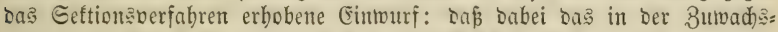
periode in 2(bfall fommende gols unberüafich)tigt bleibe uno um jeinen Betrag bie 3umadoggröfe verfälịe, völlig ungegrüntet; im Gegentheile trifft biejer Bormurf bas bon ifm aus biejem (5runde, anftatt bes Geftions: verfahrens, empfoblene Berfabren Der Bered)nung nad) Formzablen, bas

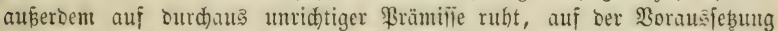
nämlich), Dá bie Formzahlen Der Bäume interbalb Der gewöbnliden 3eit=

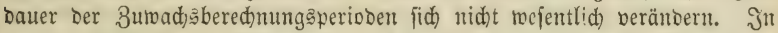
meinem Sebrbudje ber Pflanzenfunbe habe id Durd eine grofe Menge von

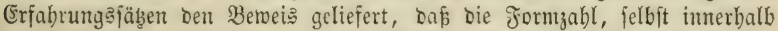

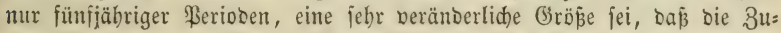

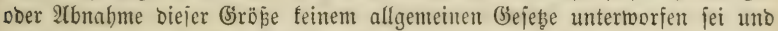

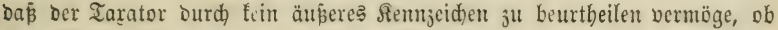

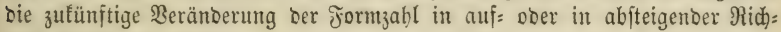
tung itattfinden werbe.

2tlerbings ijt bie 3uwad) sbered)nung in Geftionen ein zeitraubenbes umitänolides Berfahren, allein bei ber jo fehr ungleid)en Breite ber Jabress:

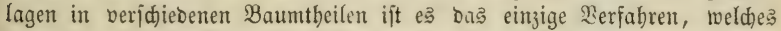

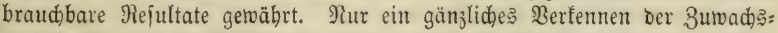

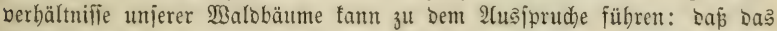

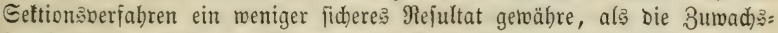
bered)ung am ftehenden Baume unter 2Amentung ber Formzablen.

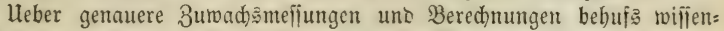

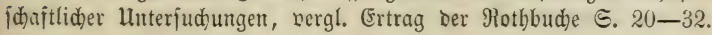

d) 3 utad 3 zurednug nad) Brocenten uno nad Rajien.

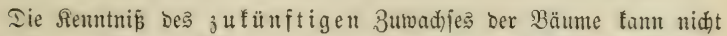
unmittelbar an ihnen felbit erworben rerben, fondern nur batourd), baj wir aus bem berflofifenen, borbanoenen uno baher mę̧baren Buwadje anderer älterer, unter gleiden ober äbnliden Standorts = uno Beftanos= 
verbältniffen erwad)fener Bäume Gd)lüfie żiehen auf ben fünftigen Buwad) Dę jüngeren Baumes.

Wir meffen uno berechnen ben 3uwad)s einer verfloffenen Beriode an einem Baume ober Beftante A. inbem wir bon feinem gegentwärtigen . Şoly=

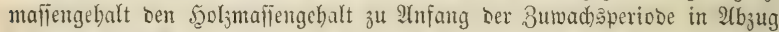

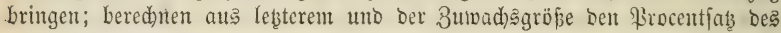
jäbrlichen Buvadfes uno nebmen an: Daj ein anterer, jüngerer, unter äbulichen Standortš uno Beftunosverbälniffen crwad)fener Baum a, beffen zufünftiger 3uwades in 2(njas gebrad)t werben foll, um burd) 3uredhung Deffelben zur gegentwärtigen $50 I_{3} m a f j e$ die Baumgröfe am Ed) wad)

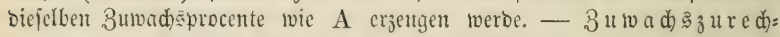

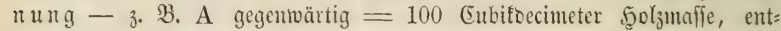
bielt vor 10 Jabren 90 Eubifoecim. Es fino aljo an bem 90jäbrigen Baume A in ber \$eriode bis zutm 100 ften Jabre Durdjichnittlich jäbrlid) 1 Cubifoecim. = 1,11 Frocent ber Sgolzmafle bes 90 jährigen 3 aumes 3ugewadjicn $(90: 1=300: 1,11)$. WBir nebmen mun an, baj a, gegen= wärtig 90jäbrig uno 85 Enbif́ccim. $50 l$ ljmaffe enthaltento, bis jum 100 ften

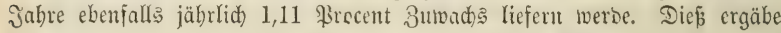
für a cinten jährliden 3uwad):s von mur 0,9435 Cubif́occim. (100: 1,11 $=85: 0,9435$ ) aljo 0,0565 (Eubifbeciu. weniger als A.

Bei Dem vorftelento gefdjilderten ßerfahren, Das wir mit bem Mamen Der Frocentzured)nung näler bezcid)nent wollen, äupert bie biröfe bes gegent= wärtigen 5yolzgebaltes des Baumes ober Beftantoes a, einen wefentliden

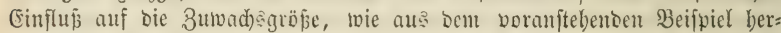
norgeht, wo, bei gleidem Procentfaţe, bie 90 Cubifdecim. Des Baumes A in 10 Jahren un 10 Eubifocciut., dic 85 Enbif́becim. Des Baumes a nur

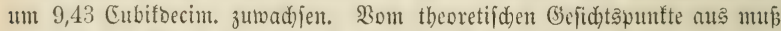
bieß als ein Fehler betrad)tet werben, Dern es lebrt bie Erfabrung: Daß unter gleiden Stanoorts: un 3 eftanosverbälnificu bic

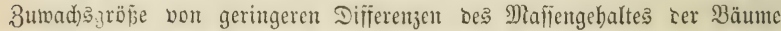

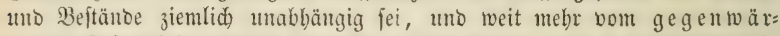
tigen Befundheitaultande uno ben gegentwärtigen Stunbortsverbält=

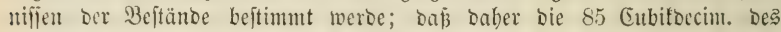
Baumes a cbenjo gut um 10 Cubifoecim. binnen oen nädjten 10 Jabren fid) vergröfiem fö nnen, als bie 90 Cubifoecim. Des Baumes $\mathrm{A}$ in Dem= felben 2ater uno berjelben 3eit fid) vergröpert baben, baj saber $\mathfrak{M}$ a $\{$ fen=

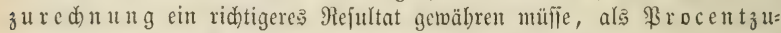
re d) $n$ un g uno Der 2 Hujaty lauten müfie: $90+10=100$ aljo $85+10=95$.

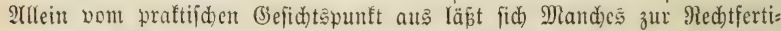

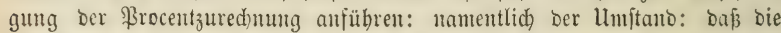

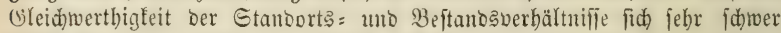

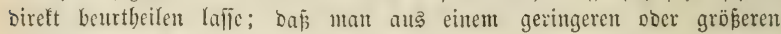
Maffengebalte bes Baumes a auf cinen Etantort geringerer ober gröferer

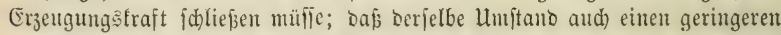

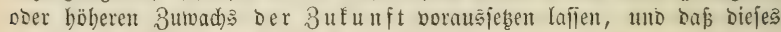
Mebr ober Beniger burd) bie Brocentzurednung, wenigitens antäherno in 


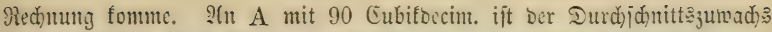
bis jum 90ften Jabr ${ }^{0} / 90=1$ Cubifoecim., alt a mit 85 Cubifoecin. in gleidem 2fter ijt er ${ }^{5} / 90=0,9444$ Cubitoecim., alio Durá)id)nittlid) um 0,0556 Eubitoccim., geringer gewejen. Die Different in Den Mejultaten ber Frocentjurid)nung uno ber Mafienzuredinumg ift in bempelben falle 1 $0,943=0,057$ Eubifoecim. fteht aljo Den Differenzen Des Durdfichnittliden

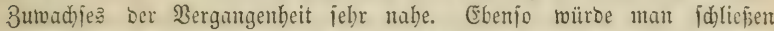
bürent, Dás rent a im 90. Jabre größjer ift als A im 90. Jahre toar, biē eine Folge Leibeno günjtigerer Berhältnifie fei, unter benen a erwudja, Der Buwad)s von a aljo aud) im Serfoly cin gröferer jein werbe als in

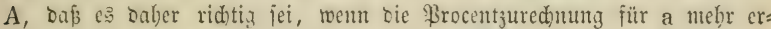
gibt, als für $\mathrm{A} ;$ з. 2. $100: 1,11=95: 1,0545$, aljo 10,5̌15 Eubifoccim. 3umades in 10 Jafren $=0,545$ Cubifoccim. mebr als at $\mathrm{A}$.

Nan wiro aus Dbigen erfennen, baj̧ bie Procentzured)ung nid)t bloje Rid)ung wejentlich eingreifenbe Bebeutung hat.

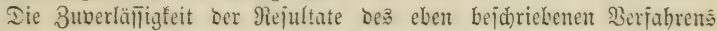
ber Precentzured)ung, ebenjo wie Der Manjenzured)nung, rubt aber ganz auf

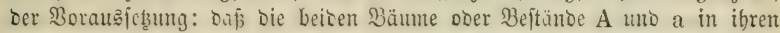

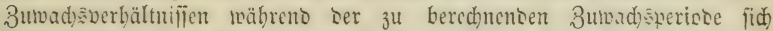
menigitens nabe gleidjtehen. Iieß ift die munde Etelle tes Serfabrens bei ben unenolicten 2(bweidungen, bie bierin borfommen uno bei ber Edhicrigfeit ier Beurtheilung, sb jolde uno in meldsm Grabe fie be= ftehen. S3iclleid) twiro es uns Dereinjt gelingen, Dieje Sllippe Daburdh

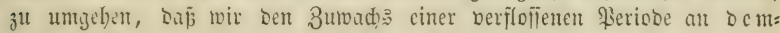
jelben Baume soer an bemiclben seitunde ermitteln, für sen er in

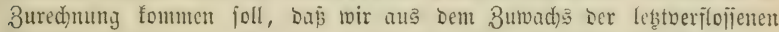

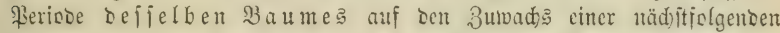
Feriobe ichliejen. Der 3uwadjs einer nädjiffolgenten Beriobe ift aber ftets ein anderer, als ber ber vorangegangenen Beriobe; beibe um fo mebr ver:

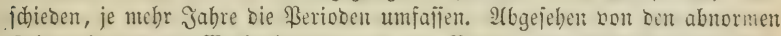
Edjivantungen Des \$Bad)

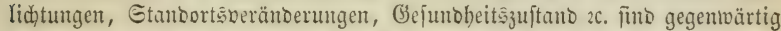
unjere Semutnifje vom normalen Bad)

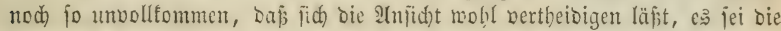

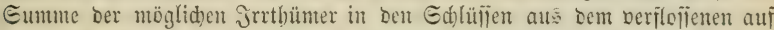
Den füntigen nicht mefbaren Buwadbs Derfelben Bäume minoften

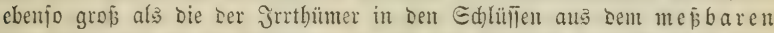
3umadj) eines älteren Beftandes A auf Den fünftigen 3umad) cintes ähn= lichen jüngeren Beftantes a wäbrend berfelben Illteraperiobe. Evrg=

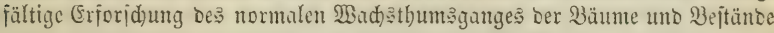

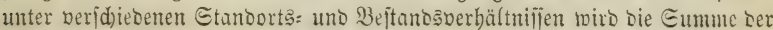

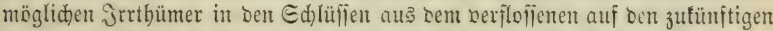
3uradis befielben Beftandes fehr verringern uno bicjem Berfabren, bas in

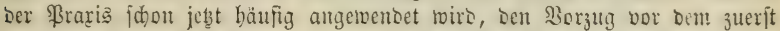

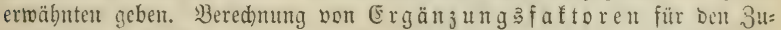
touchs Der 3ufunft aus Dem Der Sergangentheit, abgeleitet aus wirfliden 


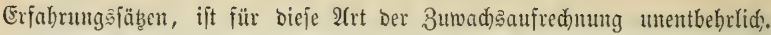

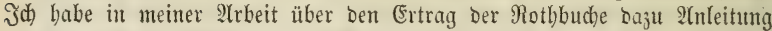

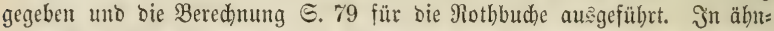

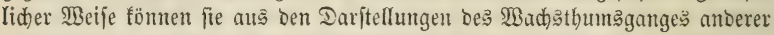
Sholzarten, wie foldhe in ben Buwadjatabellen meines Rebrbudbes ber Pflanzen: funbe entbalten fino, leidht beredinet werben.

Man bat aud mobl in Borid)lag gebrad)t, Den Buwadje cines Baumes Doer Beftandes A aus Der Differenz feiner 50 olzhaltigfeit uno ber eines anbern jüngeren unter gleidjen Stanborts: uno Beftandsberbältniffen erwadjenten Baumes a ju crmitteln, uno biefe Differenz als ben fünfti=

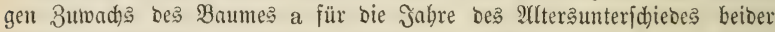

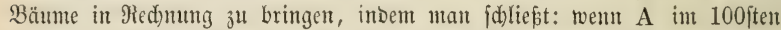
Jabr 100 Eubifdecim., a im 90. Jahr 90 Eubifdecim. enthält, fo wirb a in ber ßeriobe vom 90. biङ zum 100. Jabr ebenfalls zu 100 Eubifbecim. Gerantwad) jen, mitbin einen 3uwadjs von 10 Cubifbecim. periobifd, von

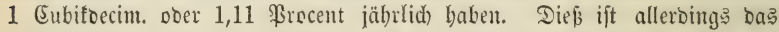

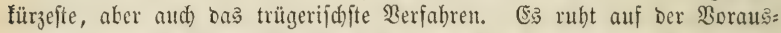

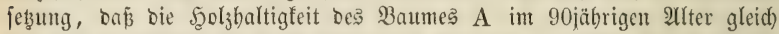
war ber gegentuärtigen Şoljhaltigleit bes Baumes a, liefert mut Dann cin

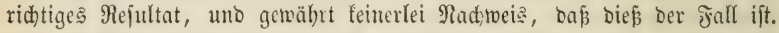

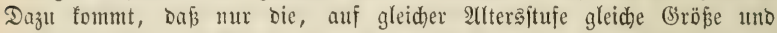
Mafienbaltigfeit ber Bäume A ıno a genügente Bürgichaft gibt, für bie (Sleidheit ber Stanoort bei biejem Berfahren ebenfalle fehlt.

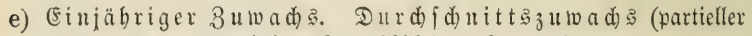
und totaler). Specififider 3 urados.

Den wirllichen einjäbrigen 3 uta a s erbält man, went in ber formel $\left(\mathrm{R}^{2} \cdot \pi \cdot \mathrm{H}\right)-\left(\mathrm{r}^{2} \cdot \pi \cdot \mathrm{h}\right)=\mathrm{z}$ ber Huterfdied jwijhen $\mathrm{R}$ uno $\mathrm{r}=$ ber Breite eines jabrringes, ber llnterfdied jwifhen $\mathrm{H}$ uno $\mathrm{h}$ $=$ ber Sänge eines Së̈hentriebes ift. Bei ben grofen Sd)wanfungen in oer \&änge Der Jäbhentriebe uno Der Breite ber Jabresringe einzelner Jabre meffe man biefe jerod) nid)t einzeln, fonbern beredne fie aus fünf= jäbrigem Durdjidnitte.

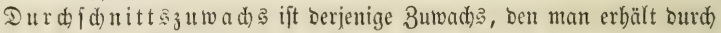
Divifion ber $3 u$ wad $s$ maffe einer längeren ober fürzeren $3 u$ wadjperiode mit ben Jabren Der Feriobe. Er ift in ber Regel fleiner als ber wirk=

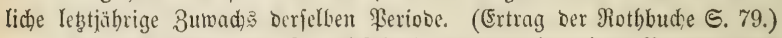

Den einjäbrigen Durd) fd)ittşutwad) eines Baumes oder Seftandes erbält man Durch Divifion ber Şolzmafie berfelben mit bem Âter

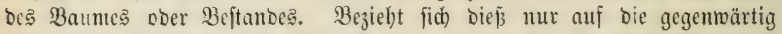
borbanoene 5olzmaffe des Banmes ober Beftandes, fo nenne id) foldcen Durd)fdnittajumad) unvolf ftändig (partiefl); ift ber gegentärtigen

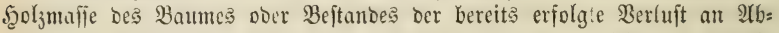
fall und Durdforftungshol binzugerednet, fo nemue id) ben Durd)= idnittåzumad)

Periooifden Durdidnittşuwads erbält man burd Divifion 
ber Mafienerzeugung einer, nidjt bas ganje Baumt= ober Beftonbsalter um= jafienden ßeriobe, mit ber 3ahl ber ßeriobenjabre.

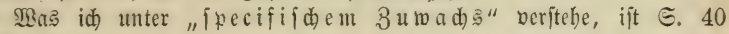
erörtert.

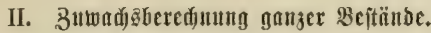

Wie Der muthmajliche fünftige 3uwachs eines jüngeren Baumes nux burd 3uredinung bes, in gleider 3uwad) älteren Baumes mit genügenter Sidjerbeit gefunden werben tann, fo ber: bält fich) Dießs aud) mit Der 3uwad)引bered)mung ganzer Beftände. Wie bort werben aud) bier fleinere Differenzen ber Şolzhaltigfeit uno, wie man jaliē̄en fann, audb fleinere Differenzen Der Brobuftionafruft Des Stanoorts ober

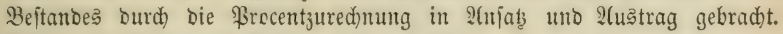
Größjere Differenzen miilien vermieben werben.

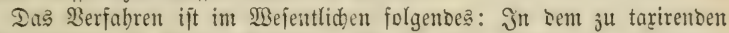
SBalde merben bie älteren Beftänte, für bie allein Bered)nung bes perio=

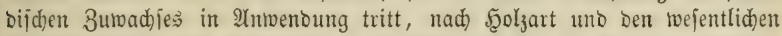
Berfdiebenheiten Der Etandorts: und Beftandesgunte in (3ruppen gebradst, 3. 3. I. Buche: A. guter Stantort, a. guter (gefd)lofiener), b. mittel= mäßiger (raumer), c. fđhledter (lidter) Bejtano; B. mittelmäßiger Etanoort a.-c., C. fisledter Etanoort a.-c., je nadjoem fid in Bezug auf $3 \mathfrak{u}=$

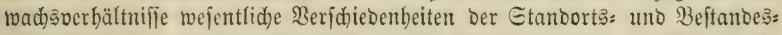
güte vorfinden. In jecer biejer Bonitätäabtheilungen tviro eine \$robefläthe

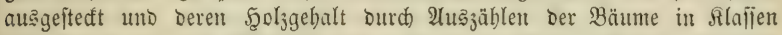

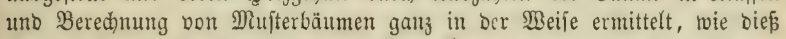
Rapitel 3 sub C. angegeben ift. $\mathscr{A}$ n jebem ber getwäblten Mujterbäume wiro ber 3uwadjs einer leb̧twerflofienen \$eriobe in vorftebeno gejdjiloerter Weije beredhnet, Durd) Multiplifation mit Der 3ahl Der filaffenftämme Der

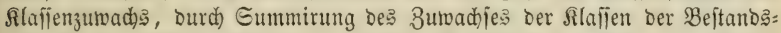

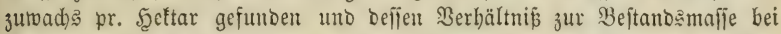

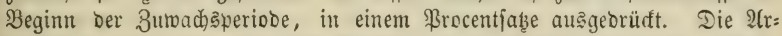

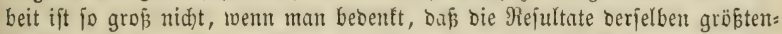

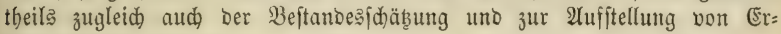
fabrungstafeln bienen.

Die auf obige $\mathfrak{B}$ eije für bie beridiebenen Şolzarten, Standorțs uno Beftanosberbältniffe gefundenen Brocentfäze ber Buwadłberedhnung werben Dan in eine Erfabrungstabelle über Den 3 utod ds älterer Drte zufammengeftellt uno faäter, Lei ber 3umadjşured)nung, auf jüngere Beftänoe entipredender Stanoorts: uno Beftanoesgüte in 2fnwentung ge= brad)t, wobei jeood) als Regel zu beachten ift:

1) Dá ber \$rocentfab̧ einer Beredmungझ̆periode mur für gleidlautende \$erioben in 3urechnung treten barf.

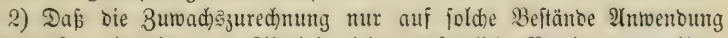
finben bürfe, bie biß zum 2tbtriebe teine wejentliche Berringerung ibrer Stammzahl erleiden werben.

ad 1) Man bat nämlid biaher, obne bejtimmte Boridnrift bes 2્lter

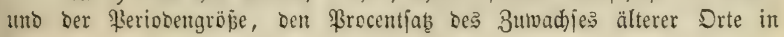


"Gaubaren" Beftänben, aljo wohl größtentheils in Beftänoen ermittelt, bie ifrem Ifbtriebe nahe ftelen, uno biefen Procentfat auf bie 3umachşured)= mung für biel jüngere Beftänto uno viel längere Perioben in 2Yntventung gebrad)t, was nothwendig ein jefr unrid)tiges Ergebni muß

Fine Mothbudse, bie im 80. Jahre 62, in 100. Jahre 103, im 120. Jabre 133, im 140. Jabre 158 Eubifctm. Şolżmaffe entbielt (Ertrag Der Rothbud)e S. 113), ergibt für bie

3uwad)sperio de vom 80-140. Jahre 2,6 ßroc. 3uwachs,

\begin{tabular}{|c|c|c|c|c|}
\hline I & " $\quad 80-120$. & $"$ & 2,9 & " \\
\hline & $" \quad 80-100$. & $"$ & 3,3 & $"$ \\
\hline & " $100-120$. & $"$ & 1,5 & $"$ \\
\hline & " $120-140$. & $"$ & 0,9 & " \\
\hline
\end{tabular}

Man würbe aljo bei ber Bered)nung eines 120 jährigen Bejtanbes für

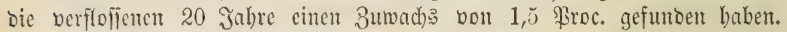
Benoct man biefen \$rocentfatz auf bie Bered)unng Des 2tbtriebsertrages eines gegentwärtig geringhaubaren, 80jäbrigen Drtes im 120jäbrigen ?(tter an, fo ergibt fidd ein in 3 ezug auf Len 3 uwad)s um 93 \$roc. zu geringes Refultat, Dems Der \$rocentfats für bie \$eriode vom 80. bis 120. Jal)re ift

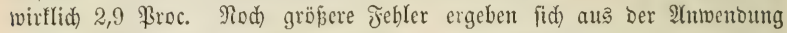
auf, in 2llter unt Beitbauter abweidento 3utwad)eperioben in allen Fällen,

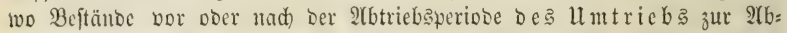

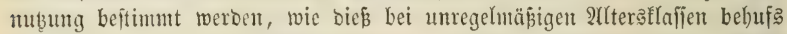

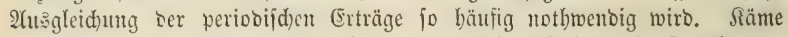
Der obige \$rocentjakz bon 1,5 auf einen 80jährigen Beftanto in Zured)nung, Der fdon in Der erften 20jäbrigen \$eriobe zum 2tbtriebe beftimunt wiro, fo mürbe bie Differenz von 1,5 umb 3,3 Froc. einen Febler von 120 Proc. in Der 3ulwadbimaffe ergeben.

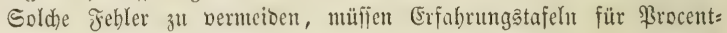
jured)ung in 3ufunft folgentoermanest conftruint werben.

Berioben :

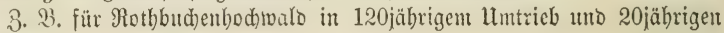

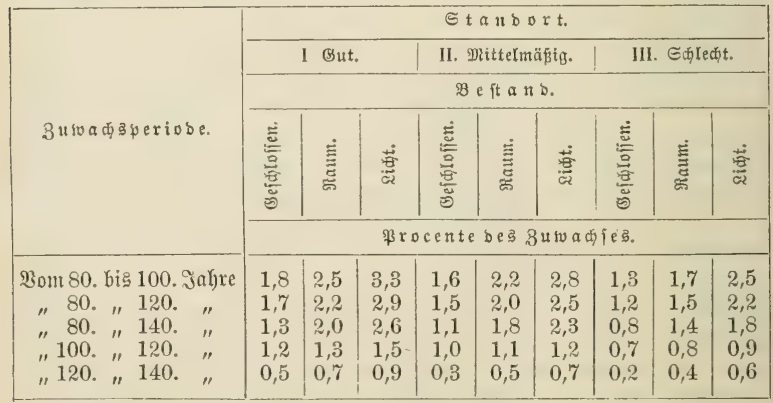




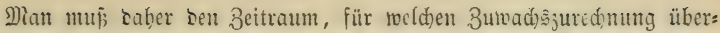

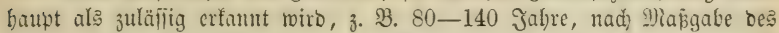
llmfanges der Umtriebsperioben, in fürzere, diejen entiptedende 3umados:

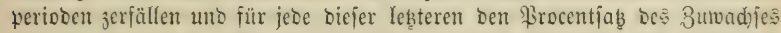
gejonocrt berednen. Wie in Dem oben gegebenen Beifpiele, bei 20jährigen

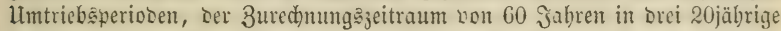
ßerioden $(80-100,100-120,120-140$, die \$rocentjäbse Der übrigen Rerioben: $80-120,50-140$ ergeben fid ourd) Berechnung aus eriteren) getheilt ijt, fo würoc bei 30jäbrigen \$erioben ber 3uredunugšzcitraum von

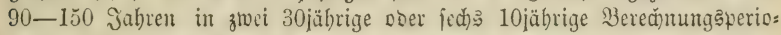
Den, bei 10jäbrigen Perioben rer Bured)nungşeitraum von $80-140$ Sabru in jed) 10jäbrige \$erioben ober in brei 20jäbrige Perioben berednet, im Ieb̧teren Jalle bie Frocentjäbe für bie 10jäbrigen Perioben Durd) Jnterpoliren ermittelt werden müī̄en.

Bei Der Beredfnung Der 2(btriebserträge ourd) 3uwad)รzurechnung jur

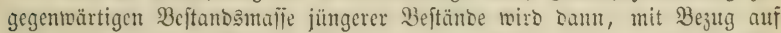
Das oben gegebene Beijpiel, bei normaler $\mathscr{A b t r i e b s z e i t ~ f u ̈ r ~ d i e ~} \mathfrak{B}_{e}=$

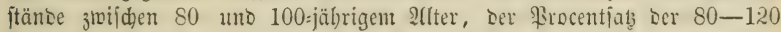
jährigen Butwadsperiode, für die 100-120jübrigen Bejtänoe, Der Diejer Weriode entiprechende ßrocentjats in Red)umg fommen; bei abuormer

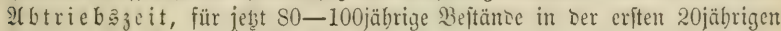

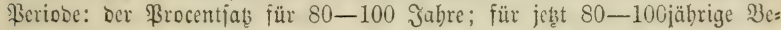
ftänbe in ¿er oritten Periobe: ocr Frocentiab für $80-140$ Jabre; für bie

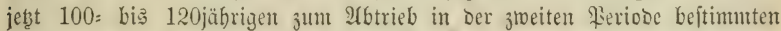
Bejtände: Der Frocentjał̧ für 120-140 Jabre, wenn der Bejtano 120jäbrig ober nidht viel jünger ijt; eine Mittelzabl jwijhen oen Wirecentjäben ber 100-120jäbrigen un oer 120-140jäbrigen 3utadjperiobe, wenn Der

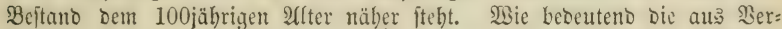
nachläpigung biejer llnterjdeibungen hervorgehenoen Jehler fint, ergibt ein Bliaf auf bie vorftehende Iabelle.

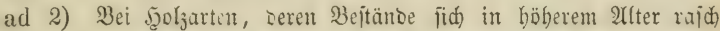

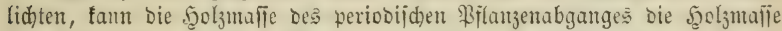

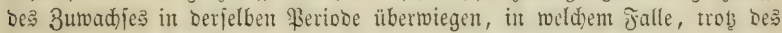
an ben bleibenoen Bäumen vielleidht jogar fteigenten 3uwadję, bemodh eine Berringerung Der Bieftanosmajle ftattinoen, Der Abtriebsertrag am Ed) lup einer 3umad, speriobe geringer fein fant als bei Beginn Derjelben. Wollte man in fold)en Fällen ocn an einem älteren Bejtande ermittelten

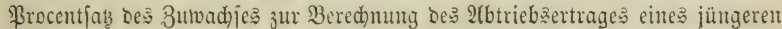
Beftandes berwenden, ober mollte man jelbit nur Die wirflid) erjolgte $3 u=$ wad)smafie Der gegentwärtigen ゆoljmafje Des jüngeten Beftanbeś binjujählen,

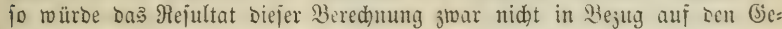

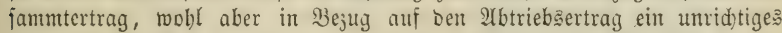

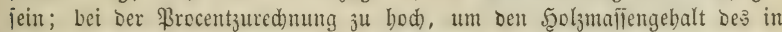
Der 3uwachsperiode erfolgten Piflanjenabganges uno Den 3umad)s, Der an Den Bäumen befielben erfolgt firn toürbe, went fie fteben geblieben wären;

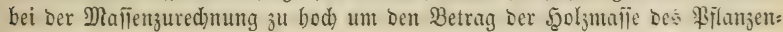
abganges. 2(ber nid)t allein Der, die 3uwadsmalle überfteigente Rapital: 
berluft burd) Bflanzenabgang, fonbern überbaupt jeber Bflanzenabgang ber= fälid)t bas Rejultat ber 3uwad)şzured)nung um ben Betrag feiner felbit, injofern es fid) um (Ermittelung bes 2 b triebsertrages bandelt. Diép

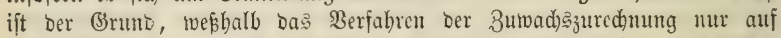
foldbe Beftände angewendet werbcn follte, oie, nad 2 lter un $\mathfrak{B} e=$ fto fug, bis zu ibrem 2 btriebe feinen, ober wenigftens feinen wefentliden Pflanzenabgang vorausfeben laffen,

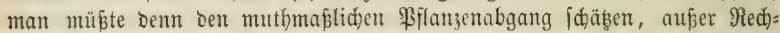
nung lafien, uno nur bem bleibenten Beftanostheile den bis zum 2tbtriebe

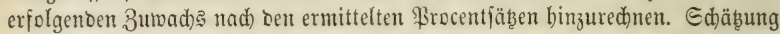
bes muthmaßlid)en \$iflanzentabganges ift aber, bei ber hierin nad) Stand=

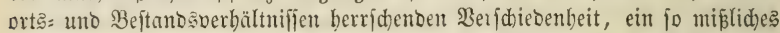

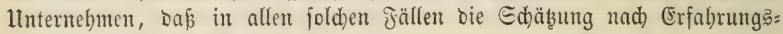
tafeln zuberläßsiger ift.

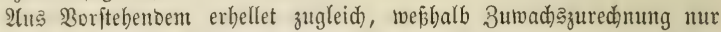
für bie Bercdnung Des 2lbtriebsertrags älterer Beftände anwendbar ift, Da mur in biefen Der Bflanjenabgang fid) auf einen (srab berringert hat,

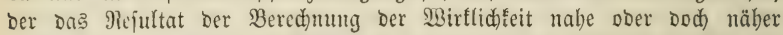
bringt, als bief bei ber Berwendung unferer beutigen Erfahrung ștafeln auf Sd)äß̧ung Dir 2rbtriebserträge älterer unvolltommenter Beftänoe Der Fall ift.

Die \$rocentiäb̧e für Die 3uwad)ş3ured)nung find ftets in Den Beftän=

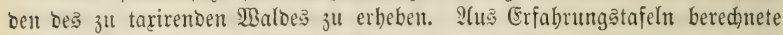

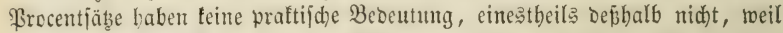
Erfabrungstafeln ftets aus Den Erträgen vollfommen beitandener Srte hervorgegangen jein follen, 3uwad)3jured)ung überbaupt aber nur noth= wentig wiro burd die in älteren Beftänden borberridenden Abbeidungen von normaler Beftodung, Şoljmafle uno Buwad)s; anderntheils nidyt, weil in allen fällen ibrer 2(mwenbbarfeit ber Ertragşaßs ber Erfabrungstafeln viel einfacher unmittelbar in 2(nją̧ gebrad)t wiro.

Die ridtige 2fnwenoung einer Buwadistafel, wie fie voritehento bei=

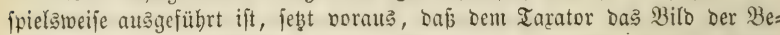
ftänoc, Denen fie entnommen tourbe, befannt ift, baj ber Tarator aus ber jelbjt ausgefübrten Bearbeitung wiffe, was unter gutem ober (d)led)tem Stanoort, unter gejolofienem ober lid)tem 3eftanoe in bem betreffenoen Reviere zu verftehen fei. Sollen joldhe Zumadstafeln bon anderen Taxa= torent anf bie Beftänoe anberer Meviere angementet werben, fo ift es noth= wentig, die fehr fonwanfenten Begriffe von Stanoortabefdaffenbeit uno

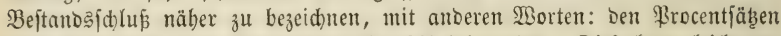

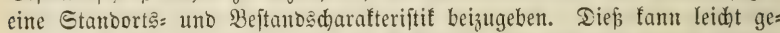
faheben; in Bezug auf Stanoort, Durd) 2tngabe ber einfad)en Breite fämmt= lider Jabreşringe ber betreffertoen ßeriobe in Brufthöbe, wenn man nicht auch bic burdfidnittliden Baumgrößsen in bie Eharafteriftif aufnebment will; in Bejug auf Beftano, Durd) Altgabe bes Durdjidnittliden Stanoraumes Doer ber Durdjidnittlidhen Stammferne Dir Bäume des Beftands, woraus (iid) zugleich bie Stammzabl entuebmen läpt. 


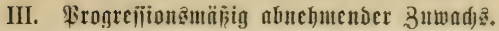

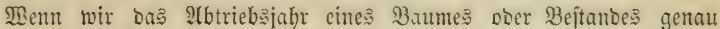
vorberbeftimmen fömter, wärbe fid bie Şolzmafie Defielben zur 3eit Der 2(butusung, burch 3ured)mung Des ermittelten bis zum 2(btricbe erfolgenden 3uwadjiç зu gegentwärtigen 5ृolzmajie, obne weiteres vorberbeftimmen

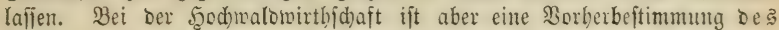

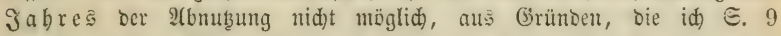
Dargelegt babe. $\mathfrak{B i r}$ müijen ung damit begnügen, eine Periode Der

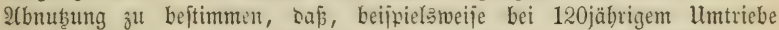
uno 20jäbriger Perioceneintheilung, ein gegennärtig 90jäbriger Beftano in Der zlveiten Feriode ober, von beute an gered)net, zwifden Den Jubren

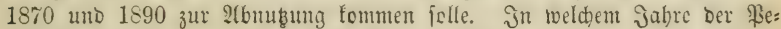
riobe Diē gcideben werbe, ob im Jahre 1871 ober 1889 ober Daz̧wijhen,

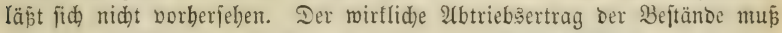
aber jehr verifhicben ausfallen, je nadjoem biejelben zu 21 fang ober gegen

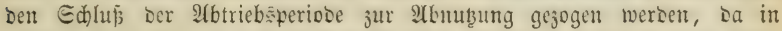

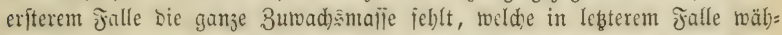
reno Der \$erioce noch erfolgt. WBir müfien uns Daher Damit begnügen, für bie Dauer ber $\mathfrak{A b t r i e b s p e r i o b e ~ n u r ~ d i e ~ E u m m e ~ b e z ~ 3 u m a d j e s ~}$

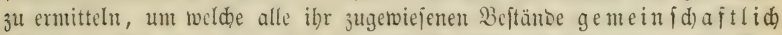

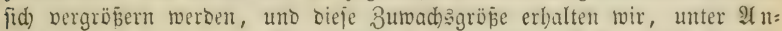

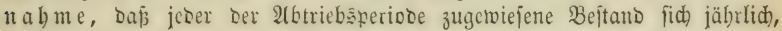

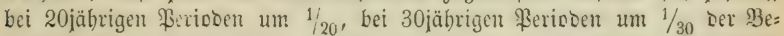

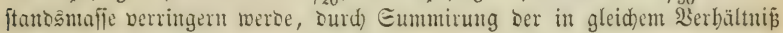
abnebmenden jäbrliden 3utwađggrößen.

Srogreffionsmäpig abnelymeno nennen wir baber einen, in gleidem

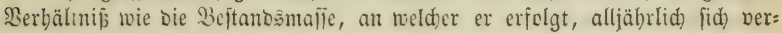
ringernoelt 3uwads.

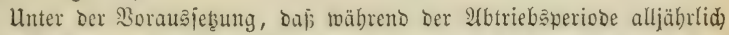
gleide Theile der Beftanosmafie eines jeden Beitandes abgebolzt

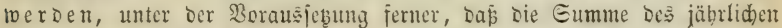

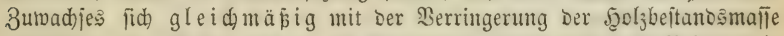

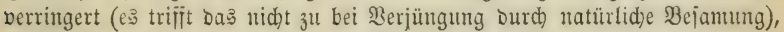
ift bie Eumme bes 3utwadjes Der 2lbtricbsperiode gleich Der Eumme ciner

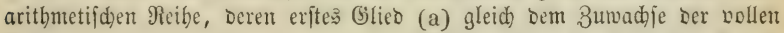
Beftandsmafie im erften Jabre, Deren Ǵlieberzabl (11) gleid) Der 2 nıjahl

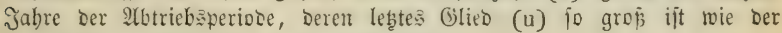
Unteridieb zwifden Den einzelnen Bliebern.

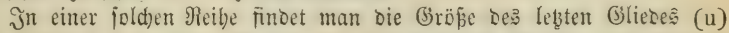

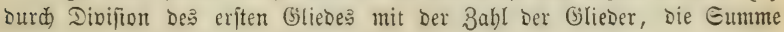
Der Reibe (S) nad) ber Jormel $\frac{a+u \cdot n}{2}=S$. ober, sa $u=$ ber Difie= renz Der Gllieber, es saber cinerlei ift, ob man u uno a jummirt, ober ftatt Dellen Dic Bahl Der Glieber um 1 erhöht, mad) Der formel $\frac{a \cdot n+1}{2}$ = S. 3. B.: 


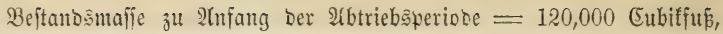
3utvads $=1$ ßroc., ergibt für

$a=1200$ Eubifoecim.,

$\mathrm{n}=20$ Jabre (20jäbrige ßerioben vorausgejełt),

$\mathrm{u}=\frac{1200^{\circ}}{20}=60$ Eubifbecim.

$1200+60 \cdot \frac{20}{2}=12600$ Eubifoecim., ober $1200 \cdot \frac{21}{2}=12600$

Eubiftocint. Daju obige 120,000 Eubifoccint. Beftantsmmafie, er: gibt 132,600 Eubitbecim. 2(btriebsertrag.

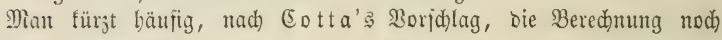
mciter ab saburd), Daßa man $S=a \cdot \frac{11}{2}$ feţt, ober, mit 2 osorten $b a=$

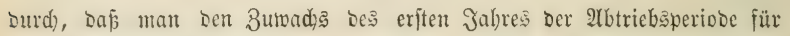
bie Sälfte Der ßeriosenjabre voll bered)net; $1200,10=12000$. (5马 er=

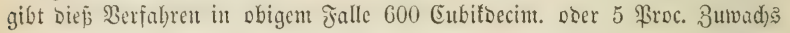

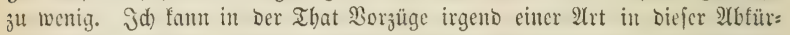
zung nid)t erfenten. Der angegebene (Jrunt: Bereinfad)ung uno Erleid)te:

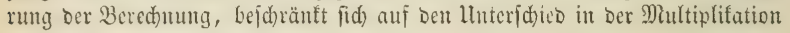
mit $\frac{21}{2}$ oocr mit $\frac{20}{2}$ (!!) unb befteht gat nidjt, wenn man bic von (5. \&.

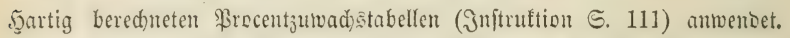
Uuf ber anderen Eeite ift Der, bei biejer ?(btürzung wiffentlid) in bie Red)mung aufgenommene jebler von 5 ßroc. immerbin nid)t unerheblid,

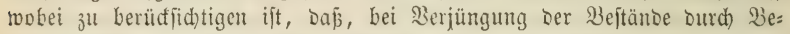
janumgsidläge, aud) bie Soransfebung einer, mit Serminberung ber be=

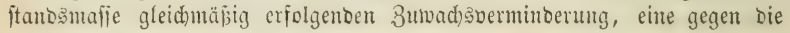
Mirflidéteit geriugere Buwadjggröpe ergibt.

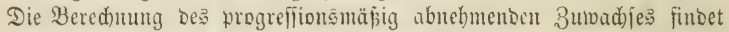

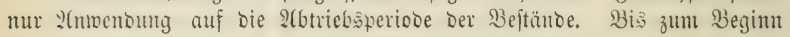
Der Ifbtriebęperiode wiro Den gegenwärtigen Beftanomafien ber volle $34=$ wad) binz̧ugerednet.

3. 3. ein gezentaärtig 85jäbriger, 3um Itbtriebe in ber 3weiten 20 jälfrigen \$eriode eines 120jäl)rigen Untriebes beftimmter, raumer 3ejtand

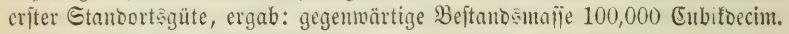
Pad) vorftebender Tabelle beträgt Der 3uwachs für bie 3uwadjaperiode vom 80. bis 100. Jal)re 3,3 Proc., ergibt jäbrlid) 3300 (Eubifbecim., für die Feriode voll 3300 . $20=66,000$ Eubifoecint. Es beträgt baber bie $\mathfrak{B} e=$ jtandsumafie am Sd)lup Der \$erinde 166,000 Eubifoecim. Der \$rocentiatz

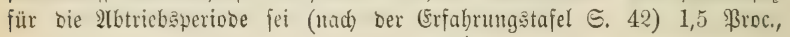
baber $\mathrm{a}=166000 \cdot 0,015=2490 ; \frac{\mathrm{n}+1}{2}=10,5$; Die Summe Deз progreffionsmäßig abnebmenoen 3uwadjes $=2490 \cdot 10,5=26,145$; ๖azu bie Beftand smaffe 3u 2Unfang Der 2tbtricbsperiode $=166,000$ Eubifbecim. ergibt 192,145 Eubifbecim. 2(btriebsertrag.

Diejer Albtriebsertrag würbe in Der Mirflidfeit mur erfolgen, wemn 


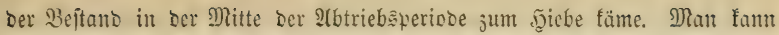

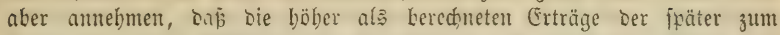
Sciebe fommenden Beftänie uno bie geringer als berechneten (Erträge ber

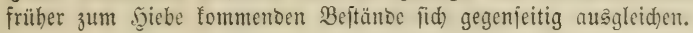

\section{B. Ertrags[d)älumug uad) Erfabruแngtafclu.}

In Borftehendem babe idh Dargethan, Daßj und warum, ourd) $3 \mathrm{ut}=$

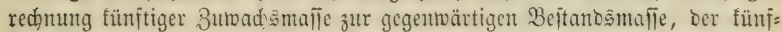
tige 2(btribbertrag mux fold)er Beftänbe möglidjt ridhtig berechntet merben fönne, Die bis jun $2(b t r i e b e$ feine mejentlid)e Beftandşeränberung in Bejug auf Etanmzahl erleiben werben, Daj caber ser fünftige ?totriebertrag nur Der älteren, Dem 2(btriebe näher ftehenton beftänoe eintes Waldes Durd)

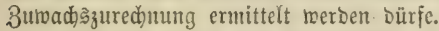

Jür bie jungen uno mittefwüdjigen Beftänoe muj an bie Etelle ber 3uwad) nad) Erfabrutgstafefr.

\section{Conitufution ber Errfahrutgątafefn.}

Menu wir in einem jeķt $10=$ coer $20 j a ̈ b r i g e n$ Beftanbe einte möglidbjt gentaue Beitunbsaufnabme mo Ertragsbered)nung in ber $\mathfrak{A}$ (rt vollzieben,

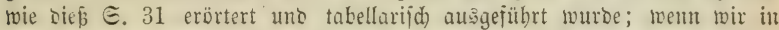
bemfelben Beitande, auf Derjolben \$robcfiäche Dicje Unterjud)ung alle 10 oder 20 Jabre micberbolen; wem bieji lunterjud)ungen bis zum :llter ber Saubarfeit fortgejețt uno rant bie Rejultate Derjelben, in ber $\subseteq .31$ Diejes

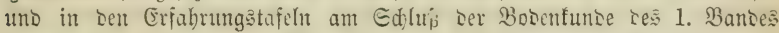

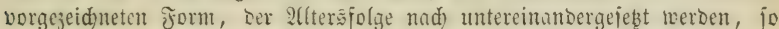
getwinnen wir eine llekerficht Des Wardhthumganges, jownhl ber einzelnen Bäume bes unterjudten Bejtanos, als aud) ber ganjen Bejtandsmanje, ibrer quantitativen uno qualitativen ßerästoerungen; aus Der Differenz Der

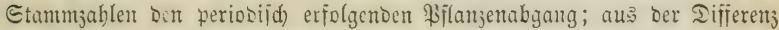
ber Mafien jotwohl im Einzefnet wie im (Janzen Den periobifid) erfolgten 3uwad); wir getwinnen eine lleberijid) fämuntlid)er \$eränderungen, bie ber

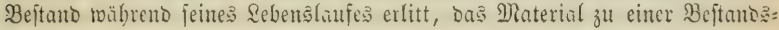
biograpbie.

Finoen wir nut einen anderen jüngeren Beptano a., Der mit bem unteriudten Beftanoe A. auf gleider allterştufe in allen wejentliden $B_{e}=$ ftantbeilen übereinftimmt, fo werson wir aus ser Ucbereinftimmung

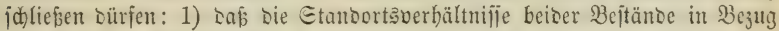
auf bishberige \$robuftionstrajt fid einanber gleid) feien, bieje baber wahl: ideinlich aud) in Serfolg gleidhe WBirfung äufern werben (wesm nidht

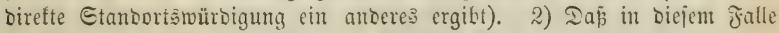
Der Beftano a. fid in gleider ober äbnlider Reeije fortbiloen werbe, wic

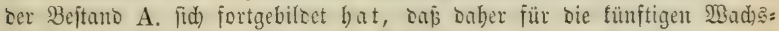
thum majgebeno betradjtet uno jubftituirt werden bürfen.

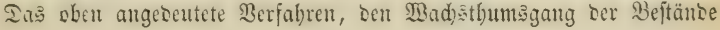


zu ermittelı, ifit jebod) nur für ben furzen Untricb des હd)lagholzes im शieber = uno Mittelwalbe wirflid auझ̈übrbar. J̈̈r ben, ein Menfdentulter überjteigenden Untrieb des Şodwaldes und bes Dberbolzes liegt uns bas Enorefultat Der Unterfud)ung zu fern. WBir bcoürfen ber vollftänoigen Er: gebnifje biejer forjoungen johon jebst.

Dem gegenwärtigen Bebürnifs zu genügen, bleibt uns baler fein anderer $\mathfrak{B e g}$, als bie Unterfuchung fđon gegentwärtig vorbanbenter Beftänbe berfdiebenten aliters, von benen jeber einzelne bie entipred)ente afltersitufe ein unb beffelben Deftanbes zu repräfentiren geeignet ift.

(5) ift einleudtend, daj die Zujammenjtellung ber $\left\{\right.$ d ie bener $B_{e}=$

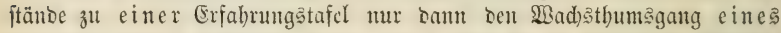
Beftandes ridhtig barftellen tönne, wenn jeber ber zu mählenben Bejtänbe

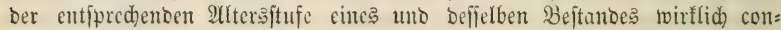
form ift.

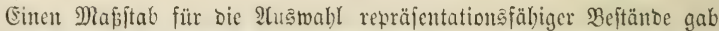

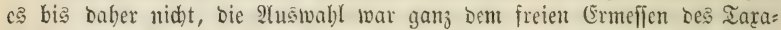
tors anbeim gegcbon, woraus die Mlöglid)teit grofer Jrtungen uno vieler vergeblidben Arbeit entiprang. Das von mir vorgeid)lagene Berfabren (Ertrag Dor Rotbbudec), Durd) Bered)nung von We ciferbcftän ben cinen Anbalt zu gewimen für bie 2 usmabl repräjentationsiäbiger, in eine Er= tragstafel zujammeilzuftellenter Beftände ift im Wicjentlicten folgenocs.

Eoll für ein beftimntes Pevier cine Erfabrungstafel, \}. B. für Die

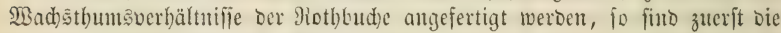

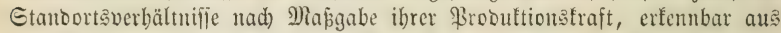
ben Refultaten bereiţ exfolgter Proouftion, in orei bi: fünf Bonitäts= flaffen zut bringen. Jn Der Regel werben orei Bonitätaflafien genügen, uno mur in Sebirgstwaloungen fömen in Folge febr veridjiebenen Bobens uno Slimas mebr al: orei Slafīen nötbig werocn. In jeber diefer Bonitäts= flafien, die mit "gutcr, mittelmäfiger, jhled)ter Stanoort" zu bezcichnen find, mirb cin möglid) it bolltonmen beftodter uno, fo weit e? fid) erfemen läfst, unter normalen S3crbältniffan crwad)jener Bejtano, Der ältcite, biefen Bebingungen entipred)enoc, weld)er fid Darbictet, ausgetwäblt, mobei ferner zu berüdfidtigen ift, Daps die Baumgröpen bes zu erwäblenden Beftanbes im Mittel fteben jwifden Den Extremen in ben gleidaltrigen Beftänoen ser: felben Bonitätatlafle.

In jebem Dicjer orei ober fünf Beftänbe wiro eine ßrobefläche auš getwäblt, Der Bejtano Derfelben in gleicher Weije auggezäblt, gemefien, berednet uno verzeidnet, wie dieß $\quad$ S. 31 angegeben wuroc. Eine Er: meiterung Der 2 Yrbeit beftebt nur Darin, Daßj an jebem Der gerwäblten Mujterbäume nid)t allein bie gegentoärtige ફ̧öhe, Bruftböbenourdntefler uno (cubifinbalt, fonbern bieje aud) für jebe frübere $10=$ ober 20 jäbrige Beriobe gemeffen uno beredutet wirb, wobei Mefiung uno Bered)nung fid. allein auf Den Gdaftholjgebalt Der Bäume crftreden. Die Rejultate Diejer $\mathfrak{U}$ rbeit werben bann folgendermajen berzeidnet: 


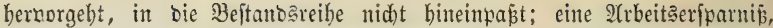
moourdh bie auf Den MBeiferbejtano verwendete 2 (rbeit reid)lid) vergütet wiro,

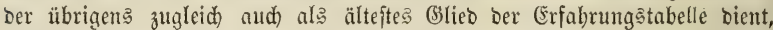

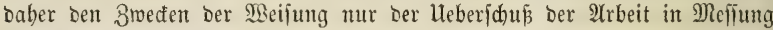
uno Berednung früherer (bröfien zur Raft gefdrieben werben barf.

Ein anderer, in ঠer Begrünoung ঠer Beftantß̧wahl auf Beiferbeftände liegenber, wejentlider Bortbeil befteht barin, baj wir babei einer un=

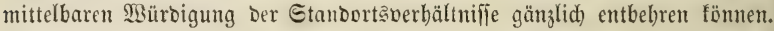

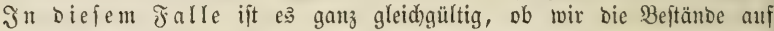
Bajalt= ober Salf= ober Gambboben, ob wir fie auf flad)= ober tiefgründi= gem, auf feuctem ober trodinem Bober, im günftigen ober ungünftigen

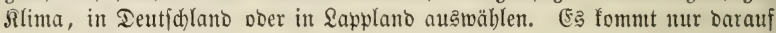
an, Dá bie bisherige Produftionsfraft bes Stanoorts ber zu wäblenben

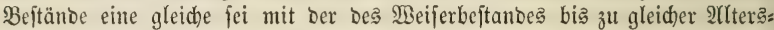

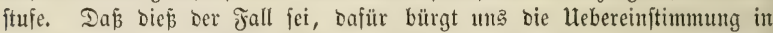

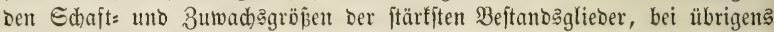
voller Beftodiung, bafür bürgt bie Uebereinftimmung ber Rejultate ver=

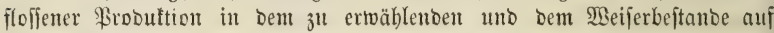
gleid)er Alteręftufe, weit fidherer als bie forgfältigite, ummittelbare Stano: ortämürbigung.

Durd) bie Rabl Der, in eine (Erfahrumgatafel zujammenzuftellenden, Beftünoe nad) cintem SBeiferbeftande werben aljo erfüllt: 1) Dic Bebingung repräfentatiber (Eigenid)aften, 2) bie Bebingung gleid)wertbiger Stanbortş= verbältnifife.

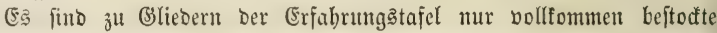
uno normal gebildete Beftänoe z̆lt erwäblen, da nur bieje als Maßjtab

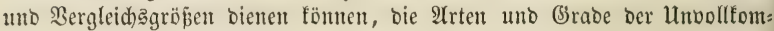
menbeit uno linregelmäpigfeit zu zablreic) uno zu vielgeftaltig finto. Wą unter voller Beftodung uno unter normaler Bildoung, was unter voll= f ommenem $B$ e ft a nDe zu verftehen jei, Darüber läßjt fid ein allgemeiner

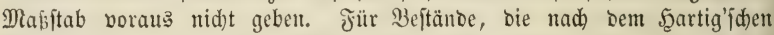
Brincipe erzogen uno behanbelt werben, gehört bazu nid)t allein boller Rronenfdlußs, jonbern aud eine Stammzahl, bie bereits feit längerer 3eit normalen Durdforftung: 2 bgang ergeben uno eitre, bem entipredifente Sdaft= uno Rronenbiloung zur Folge gebabt bat.

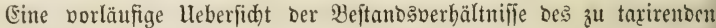
Rebiers, für weldhes Erfabrungstafeln anfgeftellt werben, der Stammzabl, Der Baumformen uno Bauntgrößen in Den befieren Beftäntoen ber beridies

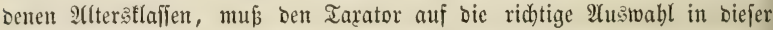
Sinjidht vorbereiten. Die fertigen Erfabrungstafeln felbjt fino es erft,

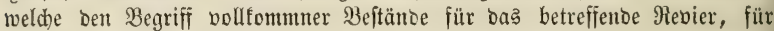

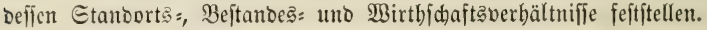

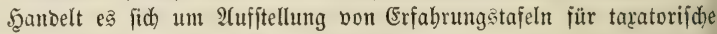
3mede, bann ift in ben als vollfommen beftanden erfanten

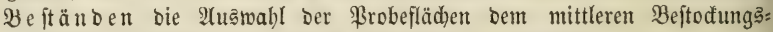
uno Şoljhaltigfeitigrade Derfelben entipredent zu betwirfen.

Eind bie nach bem Meijerbeftantoe ermäblten Probefläd)en in ber 
Geite 32 bargefteliten Beife aufgenommen, berechnet unb verzeid)net, finto

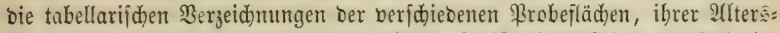
folge nad) georonet, untereinander geftellt, io ift bie Erfabrungstabelle im Wejentliden vollenbet. Wie aus einer foldyen $\mathfrak{B}_{\text {ielbeft a no }}$ tabelle

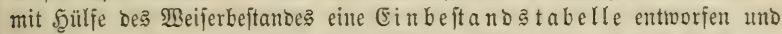
Durdb bieje bie unbermeiobaren, zufälligen Edhwanfungen beక Durd) $3 \mathrm{u}=$

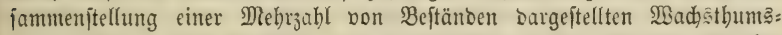
ganges naturgemäṕ beriđtigt uno ausgeglidjen werben fönnen, barüber babe id in meiner 9 (rbeit über Den Ertrag Der Rothbude gejproden.

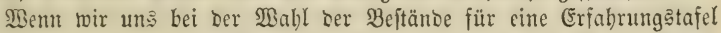
umittelbarer Stanoortâüroigung entheben fömen, wie id) vorfteheno bargethan babe, io gilt bieß nidgt zugleid) aud) in Bezug auf 2 ntwen= Dung Der Erfahrungatafefn; dem es fömnen żwei Beftänte, z. $\mathfrak{3}$. Der Meijerbeftano im 20jten Yabre auf tiefgrüntigem 30 ben uno ein anderer Bejtano in gleidem 2llter auf flactgrünoigem 30 ben, fo lange bie geringere Bobentiefe ber geringeren $\mathfrak{B}$ utrolantâbreitung nod) genügt, einanber voll= fommen gleid fein, und bennod) in ber 3ufunft einen febr veridiebenen

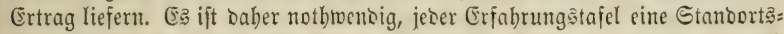
Charafteriftif in Bezug auf Boben, Sage uno Slima beizugeken, bie fid

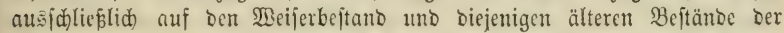
Erjabrungștafel bezicht, für welde man antehmen fann: iap fid Das Enorejultat ber Probuftionafraft bes Stanoorte fdon bargejtellt hat. Iflle jüngeren Beftänse müīen bierbei auß̄er $2(d)$ t bleiben, wie aนล Dem oben angefübrten Beijpiele bervorgeht.

\section{2)mendung Der Certragştafeln.}

Wie aus ber Tabelle Є. 32 berborgeht, zerfällt jebe Erfahrungștafel

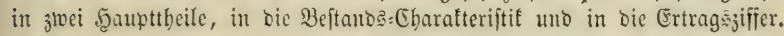

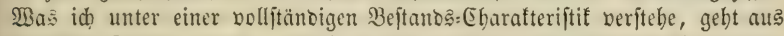
Derjelben Iabelle bervor. (5). \&. Scartig gibt nur Die Etammzabl uno Den Eubitinbalt ber einzelnen Etammtlajien, fowobl bes sominirenten als bes unterbrüđten Beftandes, moraus fid Die Durdjidnittlide (3röfe

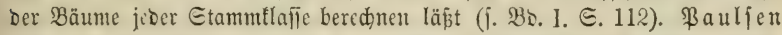
gibt nom bominirenten Beftante Etammzahl, Durdjid)nittlide Szöhe, Durd)= jönittliden Durdhmefier uno Syoljgchalt aller Etämme obne Sonderung Der Etammflaifen; pom unterbrüäten Beftanbe Etammzabl unt f̧olz= gehalt in einer Eumme. (ङ. Ertrag Dor Rothbude, in Inhange: Die Fauljen'iden (Ertragstafeln.) Die 2(ngabe Durdidnittlider Etammyröß̈e aller Siflanzen bes Beftanoes ift in jo fern niớt zwedmäßig, als jeber Bergleid erft cine jebr umftändlide $\mathfrak{A}$ uşzäblung, Defjung uno Bereçnung aller Beftantsglieber forbert, mähreno sie Bertheilung in Stärfeflafien Den Bergleid) febr erleidtert uno vercinfadt. Die Durdjidnittajabl aus ber 5ुöbe, Dem Durdemefier, Dem Eubifinbalte aller Stämme ijt aber aud) eine jebr unfichere Bergleid)agröß̄e in allen Fällen einer einjeitig unvoll= fommenen Beftodung. Eind Die Beftandşglieber in Größjeflaffen cingetbeilt, jo läp̧t fich fifon aus ber Conformität Der eriten uno zmeiten Gröpentlaffe 


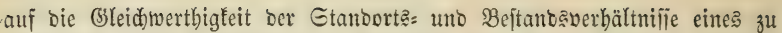

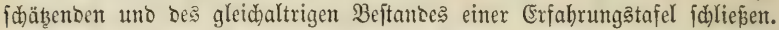

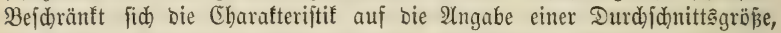
fo fönnen jwei in Der Ihat burdhaus gleidjwertbige Beftänoe fehr ber: fajiebene Durdjidnittägröpen ergeben. 3. $\mathfrak{B}$. wenn in bem einen berjelben bie Stämme vierter oder fünfter (Größ̈e Durd) cine etwả verftärfte Durd)= forftung binweggenommen wurben. Die babificen Ertragstafeln geben

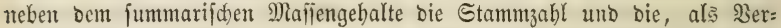

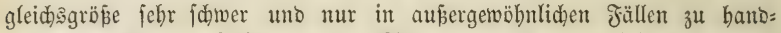
habente mittlere Beftanbshöbe. SIlle übrigen Ertragstafeln geben $\mathrm{gar}$ leine Beftands:- Eharaftere, fondern neben bem Şolzalter nur ben Mafien= gehalt bes Beftandes pro Morgen.

\section{1) Erfabrungatafeln.}

Die Ântwentung folder Ertragstafeln, weld)e mit einer Beftanos:

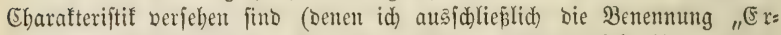

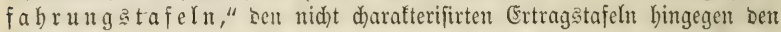
Namen "Maffentafeln" zuwenoen möhte), auf Beftimmung Der Durd)=

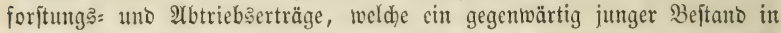

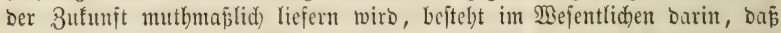
man bie Charaftere Dellelben mit oen, in Der Erfahrungstabelle gegebenen,

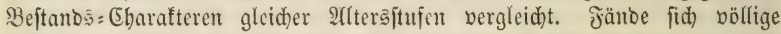
ober annäbernoe Hebereinftimumung ber Ebaraftere beiber, fo toerben, wenn

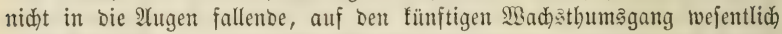
abänberno mirfenoe Stanoortşberidiebenbeiten befteben, bie fünftigen Durd)= forftuntgerträge uno ber 2(btriebsertrag Des zu fdäßzenden Bef̣tanbes, Dem Der Eriabrungstafel gleid) anzujeten fein. (5). \&. Sgartig beftimmt aud) für biejen Jall, Daßj bie Ertragsanjäßze für ben zut taxirenben Drt mur $7 / 8$ Derer in ben Erfabrungstafeln betragen follen, theils aus Rüdicht auf ben Ulmitant: Daj berjenige Grab bolltommener Bejtodung, wie er ben Er:

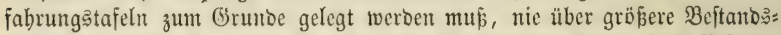
fläd)en berbreitet ift, theils um burd) ben berringerten 2 njaţ einen Rejerbes

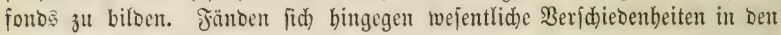

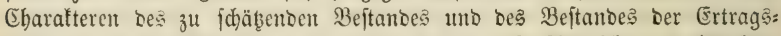
tafel, jo ift jutädjt barauf zu feben, worin bieje $2(b$ weid)ungen beruben, ob im Sgolzivud fe ober in ber Beftodung.

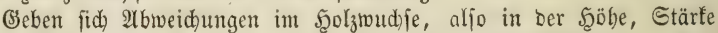
uno im Mafiengebalte ber Bäume bei übereinitimmentor Beftofung zu er: fennen, Der $\mathcal{A} r t$, Daß

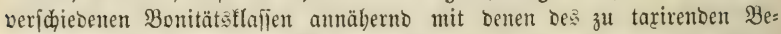
ftanbes übereinjtimmen, fo ift Der gleiđaltrige Beftanto berjenigen Bonitäts=

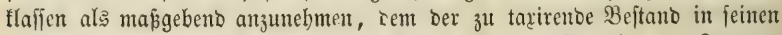

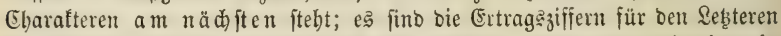
in Demjelben Berbältnifile aud für bie Zutunft böber ober niebriger in

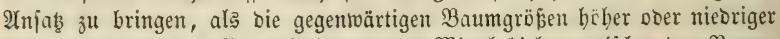

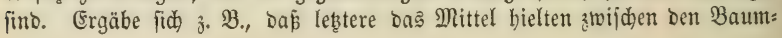




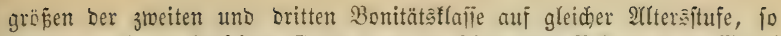

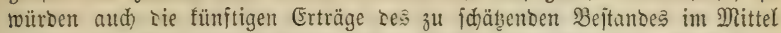

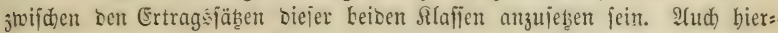
bei ift eine unmittelbare Stantortsmürbigung gar nid)t zu umgehen, be= fonbers in Bejug auf foldje Etanoortânerbältnifie, sie, mie z. $\mathfrak{B}$. Jlach)=

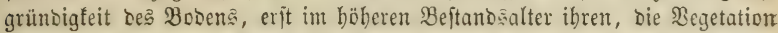

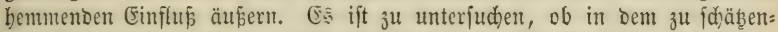

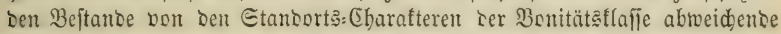
Berbältniffe vorliegen, ob unb in rold)em (Srabc fie eine 2(btweid)ung von

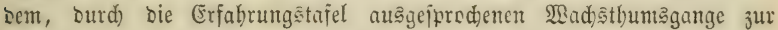
Jolge haben werben, in weldem Jalle bann nidbt bie gegentwärtige

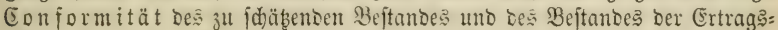
tafel auf gleider Iftersftufe, fonbern ber Etanoort jelbjt über bie

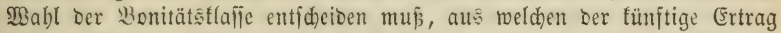

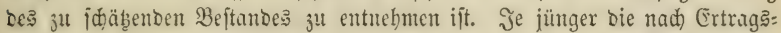

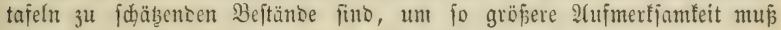
man biejen leşteren Öegenjtande zumenoen.

Beben fid Afrweidungen in ber Beftodung bei übereinjtimmentem

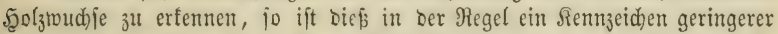
Etanoorţ̄:Sualität, wenn ber gröpere Etanoraum, in amähemo gleid)= mäßjiger Bertheilung, fdon längere Beit beftanden bat uno niăt fo grop iit, oa je Eaburd) eine borübergebende Berringerung ber Bodenfraft

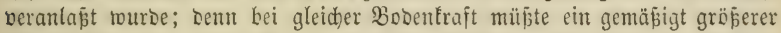
Etandraum ben 3uwad) ڤer einjelnen Etänme, bejonbers ben Etärfe: зuwad) in Bruftbobhe gefteigert baben. (Ë ift jobann sas 2(ugenmerf Darauf ju ridten, wie lange uno in weldhem Grabe bie vorliegentoen $U_{n}$

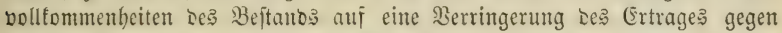
Dent bes Beftandes der Erfuhrungatafel cintwirfen werben. Buerit fino bie

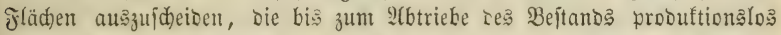
bleiben merden; Räumben uno Blö̈̈en, Die für Den laufenten Untrieb nidft mebr in Beftand gebradyt werben tönten. Shre Fläd)engröpe twiro

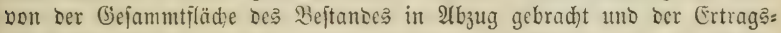

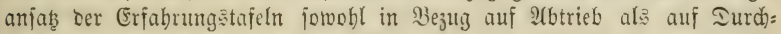

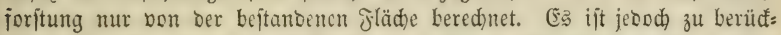
fid)tigen, Dajs, wenn ber Beftano biele fleinere Räumbent entbält, Deren (3ejammtflädhe, in Bejug auf Ermäßigung Der $\mathfrak{A} b$ triebserträge, nid)t wie jie vorliegt, berechnet werbe, jonbern nad) 2lbzug ber halben Edjirm:

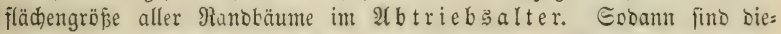
jenigen Unbollfommenheiten зu mürbigen, bie nur auf 2 egjall ober Ed)mä=

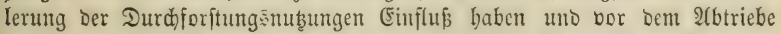

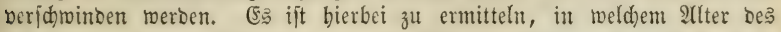
gegenträrtig jungen Beftandes bie ber (Erfabrungstafel entipredende bolle Stammahl in gleichmäßiger Bertbeilung vorbanden, und wie grop

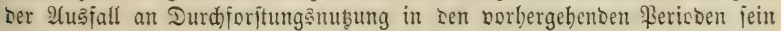
wirb, 3. $\mathfrak{B}$.:

Der gleidwerthige Bejtano Der Erfahrungätajel ergäbe für Den $\Re_{0} l=$ beftano Stammjabl: 


\begin{tabular}{|c|c|c|c|c|c|}
\hline 20 ¡ten & sabre & $10,000\}$ & 18,500 & Et. & Durd for \\
\hline 40 iten & " & $1500\}$ & 1000 & $"$ & $" \prime$ \\
\hline 60 iten & $"$ & 500 & 230 & & \\
\hline 80 fiten & " & $270 ?$ & 200 & & $"$ \\
\hline 100 iten & $"$ & $194\}$ & 76 & " & $"$ \\
\hline 120 jte & $"$ & $152\}$ & 42 & $" \prime$ & $"$ \\
\hline
\end{tabular}

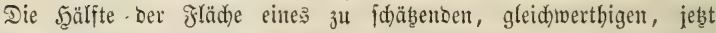
40 jäbrigen Beitandes enthalte pro Morgen 1000 Stämme, von benten 500 in gleid)mäpiger Bertbeilung fteben, fo toürben Der Durdforftung in Der Beriode vom 40 ften bis 60íten Jabre nur 500 Stämme anheim fallen, alfo nur bie Şälfte des Durdforftunģertrages biejer ßeriobe, für bie folgenton ßerioben ber Ertragsfals ber Erfahrungstafel auf $7 / 8$ ermäßigt in $\mathscr{A}$ กją̧ z̆ bringen fein.

Die anoere 5̧älfte ber Fläd)e enthalte zmar 500 Stämme, aber mur 250 in gleid)mäßiger ßertheilung, fo twüroen bis zum 100. Jahre mur 306 Stämme in bie Durdforfitung fallen. Ees ift zu erwägen, in weldjer ße=

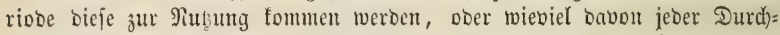

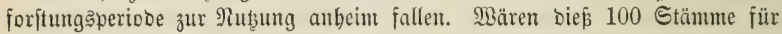
bie 40-60jäbrige, 150 Stamm für bie 60-80jäbrige un๖ 56 Stamm für S0-100jäbrige ßeriode, fo würbe für bie 40 -60jäbrige ßeriobe $\frac{150}{1000}$ $=0,10$, für die folgende Periode $\frac{150}{230}=0,66$, für bie 80 -100jäbrige

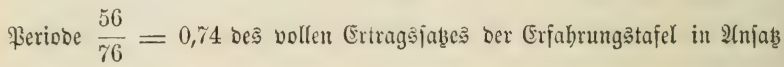
fommen.

Beftehen neben ben Unvollfommenheiten ber Beftodung aud Ylbwei=

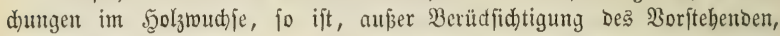
aud) Darauf zu adjten: ob uno in weld)em (Grabe bie Seb̧teren cine Jolge Der Erfteren find, uno mit ber allmäbligen Seerftellung Deక నollbeftands im böheren Beftandsalter verfatwintent werben ober nid)t.

\section{2) Maffentafeln.}

Bereits vorbergebento habe id) erwähnt, baj uno warum (Eotta bie von ihm aufgeftelten Ertragstafeln jeoer Beftanţd)arafteriftif beraubte, inoem er

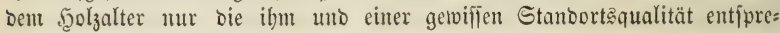

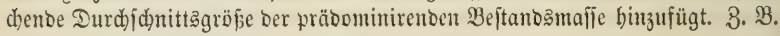

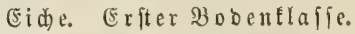

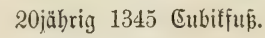

$\begin{array}{rrrr}40 & \text { " } & 3260 & \text { " } \\ 60 & \text { " } & 5535 & \text { " } \\ 80 & \text { " } & 8730 & \text { " } \\ 100 & \text { " } & 11000 & \text { " } \\ 120 & \text { " } & 13865 & \text { " } \\ 140 & \text { " } & 16450 & \text { " }\end{array}$

160jäbrig 18744 Eubiffuß̄.

$\begin{array}{llll}180 & \text { " } & 20866 & \text { " } \\ 200 & \text { " } & 22832 & \text { " } \\ 220 & \text { " } & 24442 & \text { " } \\ 240 & \text { " } & 25652 & \text { " } \\ 260 & \text { " } & 26460 & \end{array}$


Durd) Angabe Der Beftandsmafie allein wirb ber Mapitab vermifat und unfider, benn wir vermögen nid) zu erfennen, welden Antbeil bie Brobuftionstraft oes Etandorta, welden 2 ut theil bie von ber Srobuttiongtraft inuerbalb gewiffer (5) ren= zen unabbängige Stammahl an ber Beftandsmaffe bat. Die 2ngabe ber Beftanosnafie hat baber nur banu Bebeutung, ween ibr bie

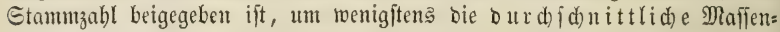
gröfe der einzelnen Bäume auffimben zu fömten. Ifngabe Der Stammzahl unb Der Sejtandsmaffe ift bie geringfte forberung, bie man an cine braud)= bare (Ertragstafel, felbft für biejen erften günftigften Jall, ftellen muई́. Man fönte mir mobl cinwerfen: bie Borausfeţung roller Beftodung ber: träte bie Stammzablangabe in ben (Erfabrungstafeln; worauf id entgegne: Dás ber Begriff voller 3eftocung an fid) viel zu fdwanteno ift, un baraus

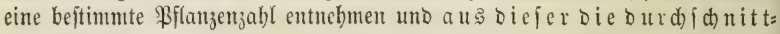
lide (Gröze ber Einzelpflanze bered)nen zu fünen; Dás Der Begriff voller Beftodung erft feftgeftellt werbe burd) bie 2Aufnabme ber Stammzabl in bie Ertragätafel.

Sm zweiten falle: went Der zu fääbende junge Beftano die F̧olz= maffe ber Ertragatafel bei unvollfommener beftod ung entbält,

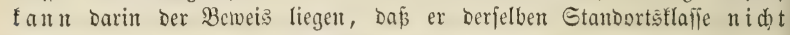
angehöre. Jn Jolge ber llnvollfommenbeit in ber Stammzahl müpte bie

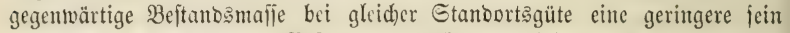
al: Die bes gleidhaltrigen Beftanocs Der Ertragitafel, wonn nid)t bie Un: vollfommenbeit ber Atrt ift, bajs fie zur lltjad)e eines verftärften Baum= wudhes wurbe. Ob uno in reldem Grabe einer ober ber antere biefer Sälle vorliege, weld)er Stantortaflaffe ber junge Beftano angeböre, wenn nidbt Der, mit weldher er im Beftandsmafiengehalte gleidher Illtersftufe über=

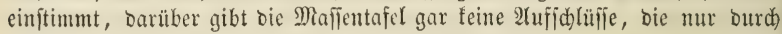
Den Bergleid) ber Baumgrößen zu erlangen fint.

Im britten Falle enolid, Dem bei weitem bäufigften, ment bie gegen= wärtige Beftanosmafie eines Drtes mit Der Des gleidgaltrigen Drt tragstafel ni d) t übereinftimmt, aljo bei jeber 2tmventoung ber Majfentafeln auf Ertragsbeftimmung gegenwärtig unvolltommen bejtandener, aud im Mafiengehalte binter bem Rormalen zurüdftebenber junger \$Baldungen, fann fid) Die Beurtheilung Der Standortsgüte uno Daraus bes zutünftigen $3 u=$

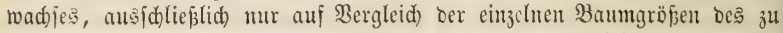

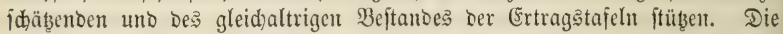

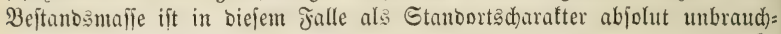
bar, benn ein 60jäbriger (Eid)enbeftant mit mux 3000 Eubiffußs ફ̧olzmafie fan

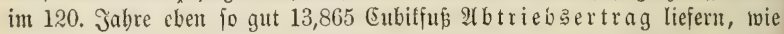
ein anderer voller Beftano mit 5535 Cubiffuß̧ Sgolzmaffe im 60. Jabre. Die Einoronung Des Beftantos in eine ber gegentwärtigen $\mathfrak{S}_{0} l_{3}$ baltigfeit entipre: d)enoe Bonitätąllaffe würbe ein eben jo umrid)tiges Rejultat getwäbren, als ber Єd)

Es: ift Daber in feinem Jalle bie Beftantsmaffe allein als Stand:

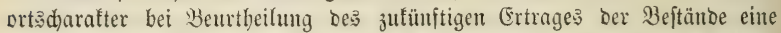

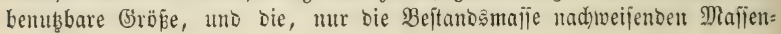


tajeln entbalten nidjt bas Daterial für bi e Beurthei!ung ঠes zufüni:

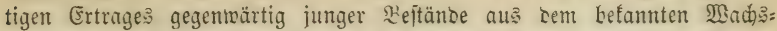
thumagange uno Erträge älterer Drte, Der in ihnen verzeidnete $\mathfrak{W a d}$ : thumagang ber Bejtantsmalien mag ridhtig jein soer nicht.

(ङ

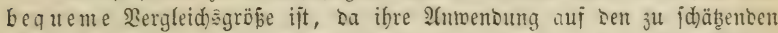
Bejtano Doch immer eine Edhäß̧ung Der gegentwärtigen Fुolzmafie beffelben bebingen müroe, mas jescrfalls viel zeitraukenter uno unjid)erer ift als Der getrennte Bergleid Ler Etammzahlen uno Der Baumgrȫ̄en.

In Den Maijentajeln fino Die Durdjporitungserträge nidht verzeidnet;

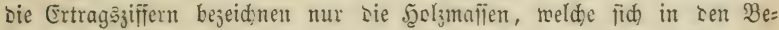
fiänben jeber $\mathfrak{A}$ (terşftufe nad) volizogener Iurdforjtung rorfinten, fie geben

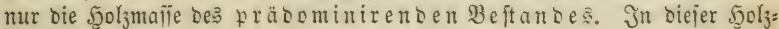

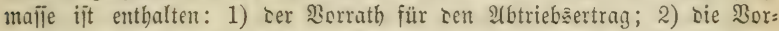

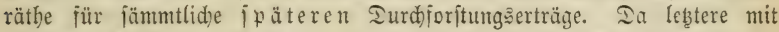
jeber Durdforjtung fid) berringern, fo ergibt bie Differenz zmeter benad)= barter $\mathfrak{B}$ pititionen Der Maijentafeln, $\mathfrak{j}$. B. in obiger, 100jübrig $=11,000$

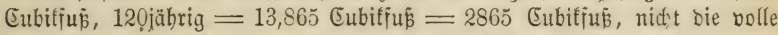

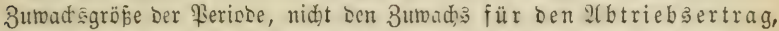

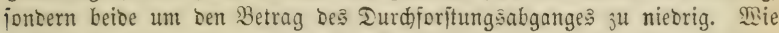
groj biejer leb̧tere jei, ijt in ben Maljentafeln nidjt nadjegewiejen, mithin bleibt auch bie Gröpe bes mirflichen uno bes bleibenten Buwacţjes ber ßerioben unbefannt.

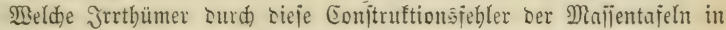

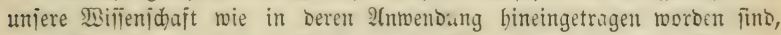
wiro fich näher aus einer Erjabrungstabelle ergeben, Die id) im Eingang

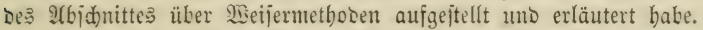

Die Maijentajefr grünßen jidh nid)t auf Einzeljälle birefter Beobad):

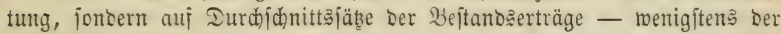
Joee nact. Daber jtammt, Durchaus fonjequent, bie Bejeitigung aller Eha: rafteriftif. Mlan bat bie 2 mịcht aufgeftellt, Daß ourd eine fleipige Ber= zeidnung und Gammlung wirflich erfolgter Beitanoserträge bie taratorifकen

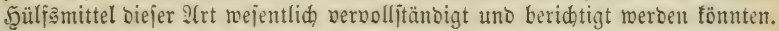

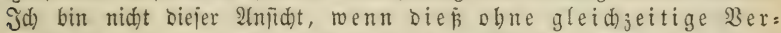
zeidung ber Bejtandadaraftere geidiebt. MSenn wir beute

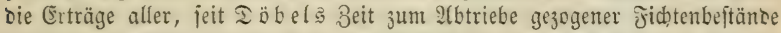
müsten, fo würbe cine Durdjidnittşabl bieraus red)t interefiant uno braud): bar jein für Beurtteilung Der burdjidnittlid̦en jäbrliḑen (Erträge aller Jichtentebiere Europa's ober eines Sandes ober allenfalls einer Probinz; jie twüroen aber fibn werthles jein für sie Beurtheilung ber Erträge eines beftimmten Revier3, nod) mehr für bie eine bejtimmten Beftantes: eben

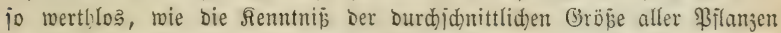
eines Plenterwaldes oder Mittelmaldes jein würoe, für Beurtbeilung ber

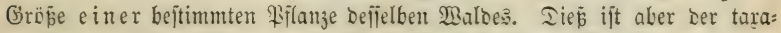

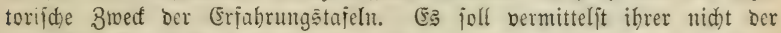

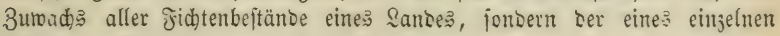
beftimmten Beftanoes ermittelt werben. 
Ebenjo, wie gegen bie taratorijhe Berwentoung ber Jormzahlen, fant man aud) gegen bie Der Mafientafeln nid)t feft genug auftreten, unb biē thut wabrlich ?oth, Dent ibre grope (Sinfad)beit und bie Unmöglidfeit einer

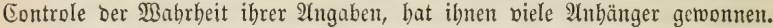
(5: ift wabr, Durd Befeitigung Der Charafteriftif Der Stammzablen uno Des \$rlanzenabganges gemäbren die Majientafeln einen unbegrenzten Spiel=

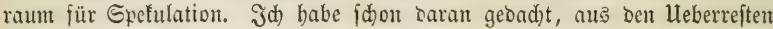
umferer Brauntohlen= uno Steintohlenflor Mafientafeln über ben Şolzmud) gefdloilenter Enprefientwäloer Der Molaffe: uno Sireibeperiobe; aus meiner

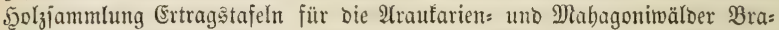

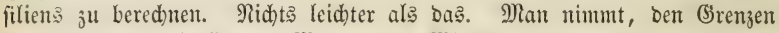

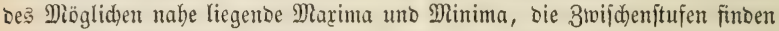
fich Durd) Interpoliren. (Es fommt bann beim (bebraud) foldher Maffen: tafeln wie bei tem ber jormzallen mur barauf an, bie ridtige Rlaife zu treffen, und bief ift nidet Eadje defien, ber die Crtragstafel fabricirt hat, fonbern befien, ber fie anwenton will. Erifterer wäjht feine Şänbe

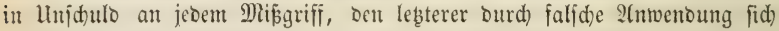
¡u Edulden fonmen läpt; der Tarator fann in jolden fällen bie Sd)ulo Dem Bater Der Mafientafel zufdieben. So ift beiben Iheilen gebolfen.

Bon jeoem, ber mathematijh zu benten bermag, werbe idh mid gern

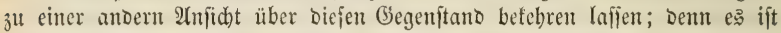

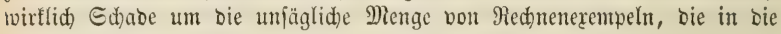
Jormzablen= uno Manjentafelangelegenbeit geftedt worocn fino.

\section{Lif erafur.}

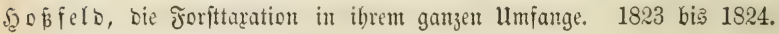
Siltoburghaujent.

Rönig, Forftmathematif. 2te 2 fuflage. 1842. Gotha. Emalian, Szolzmę̧funde. Stralfund. 1837.

(3. \&. Şartig, Cubittabellen; herauggegeben von Th. Ş. 10te 2luflage. Berlin 1859. Die Einleitung enthält cinen $\mathfrak{A} b r i \bar{\beta}$ Der 5ूolzmếfunbe.

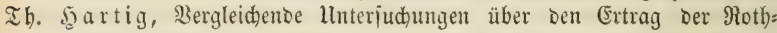
bude, nebit Anleitung zu vergleidenten Ertraggfor= (i) ungen. Berlin 1847 .

Sabrifdje Mafilentafeln. M(ünd)en 1846.

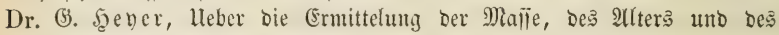
Buwadjes Der Şolzbeftünoe. Deffau 1852.

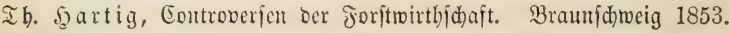

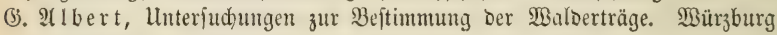
1854 .

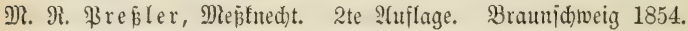

Derielbe, Şolżwirtbichaftlidje Iafeln. Dreẅben $185 \%$

Ib. Szartig, Enftem uno Anleitung zun Studium ber Forftivirtbidafts: lebre. Seipzig 1858.

Dr. Robert Sgartig, über MBadsthumsgang umo Ertrag Der Rothbudee, (Eid)e, Ricfer uno Der SBeifintante. Etuttgart, Eotta 1865. 


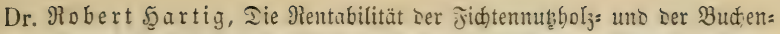
brentholjwirtbidjaft im Syarje uno im MBejergebirge. Etuttgart, Eotta 1868.

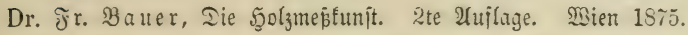

\title{
3weiter 9 (bjidnutt.
}

\author{
$\mathfrak{A}$ getwendeter $\mathfrak{i}$ beir.
}

\section{Erffes Enpifer.}

Ertragsermittelung.

In vorbergebenten 2 biditte haten wir gejehen: mie man zur Rennt=

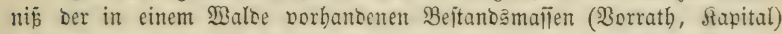
uno Des an biejen zu erroartenoen, zuf ünjtigen Buwadjes (Binjen) gelangt.

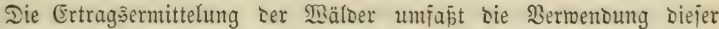
Remutnīie auf Erforjoung des nadbaltigen Ertragez, D. b. einer

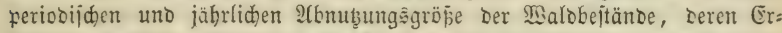
bebung mëglidjit vollitänoig entipridht, einerjeits zer Crrbaltung ober baloigen

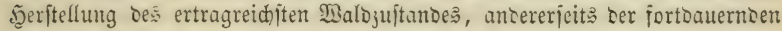
Befriebigung oringenter Bebürninilie (Є. 3).

Die Ermittelung bes nadbaltigen Ertsages ber wälder bat ihre be=

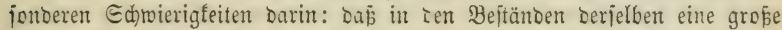

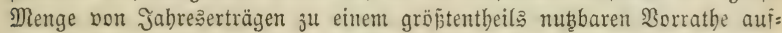
geppeichert fino, ber nur in jeltenen Jällen, uno aud) bann nur vorüber=

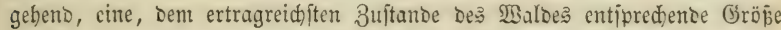

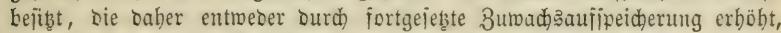
Doer ourdh Eonjumtion aud eines gewifien \$orratbtheils verringert weroen

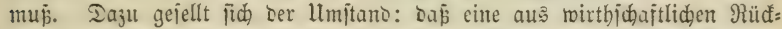

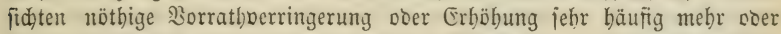

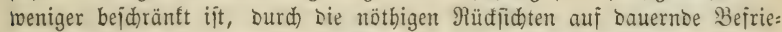
bigung ber gegentoärtigen nidht allein, jondern audh) Der tünjtigen, Dringen= Den Beoürnifje, rooburd) Die \&öjung Der grage: wieviel uno welde Be= jtandsmajien alljäbrlich Dem Maloe entnommen werden bürfen, wenn keioen Forberungen Des शadbaltabetriebes möglidjt entiproden werben foll, eine fehr z̧ujammengefę̧te uno joblwierige triro.

Der Tarator joll 1) bie ganje, gegenwärtig borhandene Bejtan๖ majie De: Waldes, 2) Den, an biejer unter gerifien 30 ra je⿻̧一𠃋 uno 3) Den Durdforitungsabgang an ben im Saufe Der Umtriebsjeit an Die Etelle Der abgenub̧ten tretenoen neuen Bejtünoe wäbreno Der Iauter Des laujentun Umtriebs auf Den Zeitraum Des Umtriebs in Menge uno

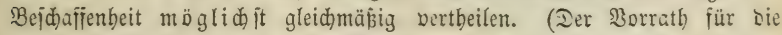

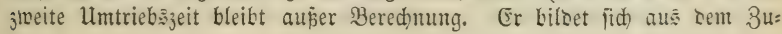


wadje ber jungen Beftänoe, bie im Saufe ber erften Umtriebşeit an bie

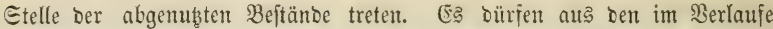
Der erften Umtriebszeit angebauten Doer nadjgezogenen Beftänben baber aud mur bie nothmenoig zur Erbebung fommenden Durdforftungęerträge in bie Bered)mung Des Sejammtertrages ber erften Umtriebşzeit aufgenonmen werben.)

Diø, auf Die ßerioden Docr Jabre des erften Umtriebs zu vertheilende

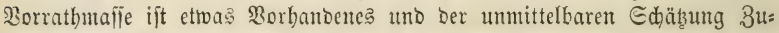

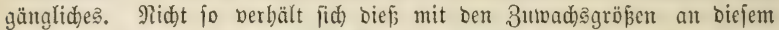
Porrathe, Die einerfeits von ser tünftigen 3 utwadsfähigfeit ber bor= bantenen Beftände, andererfeits von bem 3 wad) şeitraume, ben fie nod) zu Durdeleben baben, und endid bon ber Betwirtbidaftugas= weije berjelben abbängig fint. Won biejen brei Jaftoren fünftiger $3 \mathfrak{H}=$

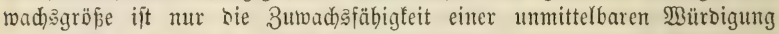
3ugänglich, auf (sruno: theils ber vorliegenden 3uwadsergebnifie vergan= gener 3eit beffelben Beftandes, theils oer Standortägüte. Die eben fo widtigen Jaftoren: Der 3uwad) 3 zeitraum uno bie Bewirtbjdaftungşweije Der Beftände, mülien burdh eine Summe bon Betrieb引boridgriften projeftirt

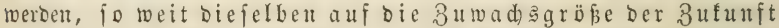

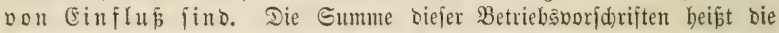
Betriebseinridtung. Sie ift bie Bafis jeder Ertragsermittelung uno von biejer untrennbar. Mag bic 2(uşübrung biefer Frojefte nod) fo żweifel=

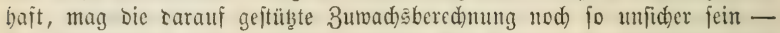
wir fömen ifrer nidgt entlebren für bie Bered)nung uno nadblyaltige $\mathfrak{B e r}=$

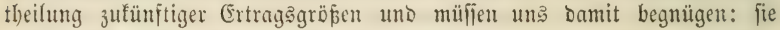

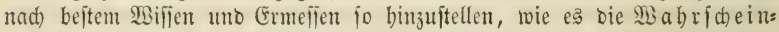
(id) feit fünftiger 3uftänbe uno Berbältniffe erbeifdt. Für bie Mürbis

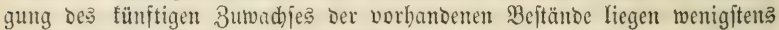
Sebtere ber Beurtheilung vor. In Bejug auf Den Durctoritunģ̧ertrag ber

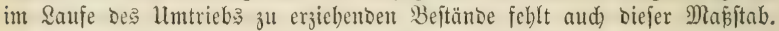

Unter biefen Umptünoen ift allerbings je be (Ertragşbered)mung nid)t

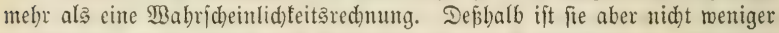

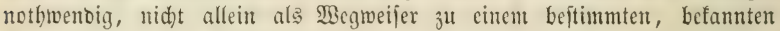
3iele, jonbern aud) als Jujtificatoriun unjerer gegentärtigen ßebandlungs̀=

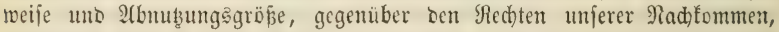
gegenüber unjerer Berpflichtung: ein gropes, von unjeren Borfabren un überliefertes (semeingut ber Ration: Die nothwendige Betwaloung bes

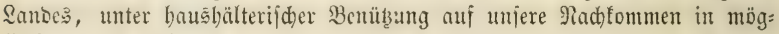
lichjt gutem 3ujtanoe zu übertragen. Treten fpäter Şerbältniffe ein, bie wir nid)t vorausfeben founten, wiro ourd) foldte eine andere Bewirth= (i) aftungsart nothwendig, ein anderer 3uwachsgang berbeigeführt, fo fann

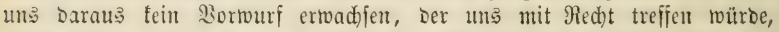
merm wir in einer planlofen WBirtbjdaftsfübrung nur ben Jnterefien Der Begentwart Golge leiften.

Der Mentier befintet fich in Derfelben Sage wie mir. Er jeb̧t einen gewiffen 3inßertrag feintr Rapitale aud) für bie Jolgezeit voraus uno be: rechnet Darnad) jeinen gegenwärtigen $\mathscr{H}$ usgabe: (5tat. (Erfüflen fid) jeine

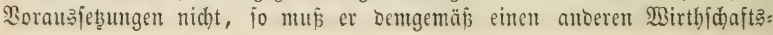


plan entwerfen. In feinem Şaushalte gereidht die Unicherleit fünftiger Einnabmen ungemefienen 2(uڤgaben ber Gigenwart zur (Entịd)uldigung.

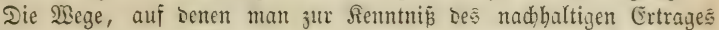
ber $\mathfrak{B a ̈ l}$ ber ju gelangen judte, fino jebr veridjiebenartige. Mir unter= ideiben im 2 befentlichen:

1) bie Fachwerfmethoben,

2) bie $\mathfrak{B e i j e r m e t h o d e n ~ u n o ~}$

3) bie Durdfidnittazumadbsmethoden.

Erftere wäblen einen projeftirten Malbjujtano, leţtere wäblen eine

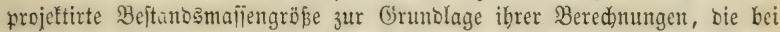

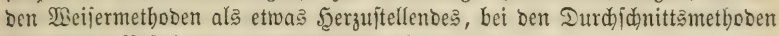
als etwas Beftehenoes angenommen wirs.

Ungerondet auf normale 3 uftäne normaler Alters flaffenteiben ber Bewaloung, liefern alle biefe Rethoden ein rid̄tiges Ergebnif. Für Walountände biejer $\mathfrak{A}$ rt, bie übrigens im Şodrwalde nirgends beftehen, bebürfen wir aber einer (Frtragsbered)nutg nidht. Das erreidte Şaubarfeitsalter würbe bier eine Dem MBirtbidafter

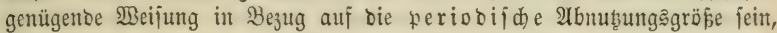

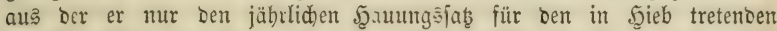

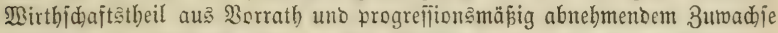

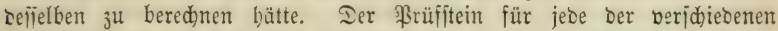
Tarationsmethoden fint bie ungeregelten, in ber lumbiloung ftebenden Walojuitänbe. Wir werden jehen, ¿ás es für bieje nur eine, in jeber

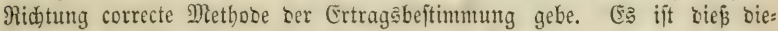
jenige Jadjwertsmethode, Die wir, unter Dem Namen Ertragsfadtuerf, tweiterhin näber fennen lernen werben.

Menden wir uns zunäd)ft zu Der

\section{Ertragseruittelıแg Der fodjuälder.}

\section{A. Die Fadjwerfmethoben.}

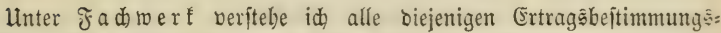
methoden, bei relchen ber lumtrieb in beftimmte Beiträume getheilt uno

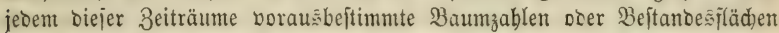

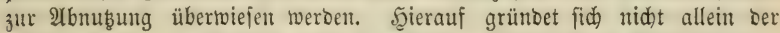
fünftige $\mathfrak{E} r \mathrm{rag}$, fonoern aud ber fünftige 3 uftano ber Betwaloung.

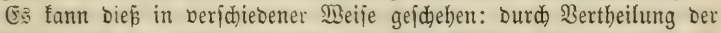

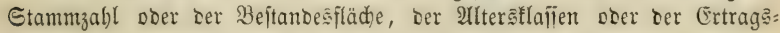
gröpen, uno unterid)eibe id biernad)

bą Baumzablfadimerf,

Das frlädenfachlwert,

bas 21terstlajienfadwert uno

dą Ertragägröß̄enfad)werf.

a) $\mathfrak{B} 0 \mathfrak{m} \mathfrak{B} a u m z a h l f a d$ to erf.

Eine Bertheilung bon Baumzahlen in bie Berioden bes Umtriebs befteht beute nur nod) für sen Dberholjbeitnno des Mitteliwalces, bäufig 
aud für ben Sopf = uno Sdneibelfolybetrieb. TBabridheinlid) ift ę mir:

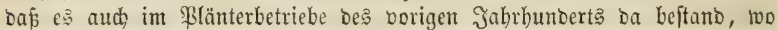

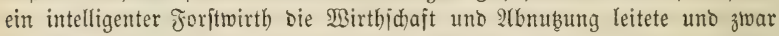

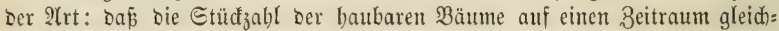

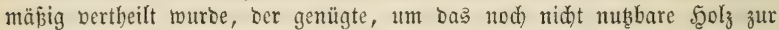

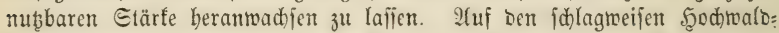
betrieb mit feinen beränberlichen Baumzablgröß̄en ift biejer Mobus nidjt antwentbar.

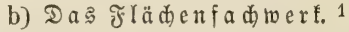

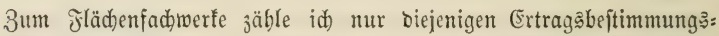

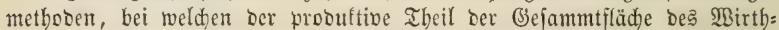
jofaftätörpers in fo viele glei d) gro fie fläd)entheile zerlegt wirb, als ber

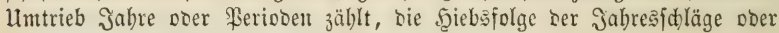
Beriobenflächen ('Birthid)afțtheile) vorauşbeftimunt wiro.

Dieje, allein auf geometrijater Iheilung Der Flädhe berubente Me: thoce ift bie vorberfidento angementote im Nieberwaloe uno im Unterholje Des Mittelwaldes, bismeilen aud im Sopfbolzbetriebe. Für Den Scod)wald: betrieb ift fie twohl projettirt morben (Nojer), aber nie zur Durdfüührung gefommen.

Die, Durd Berfdiedenbeit Der Stanoorţ: und Bejtandesgüte fowohl, wie Durd) abnorme 2llteräflafienverbältnifïe, beridjiebenten Ertragşgrößen

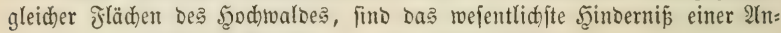
wentoung bes Flädenfachiwerfs anf Den Scodiwalobetrieb.

Man fönnte sabin aud cine Froportionaltbeilung bez Booens zäblen, fo weit bieje allein auf ummittelbarer M̉üroigung ber Stantoorts= güte berubt (Bonitätşfad)werf). Bis jeb̨t fihlt unı aber für unmittelbare

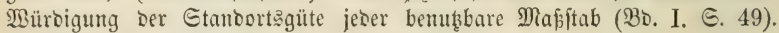
jebe auf Beftandesgüte uno Scolzwuchs bafirte \$roportionaltheilung gebört aber bem Ertragsfadimerte an.

\section{c) $D a \mathfrak{R}$ Iafienfadwerf,}

bon Beftnann bis Seennert alf Den Şodwalobetrieb vorberridento an=

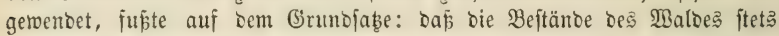

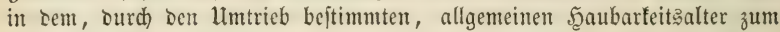
2lbtriebe uno zur Berjüngung gezogent werben follten. Diejer Grunbjab

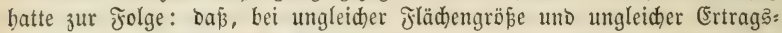

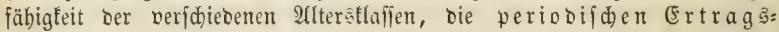
größen, Den Forocrungen Der Madhaltigfeit entgegen, fid febr ungleid)

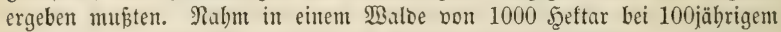

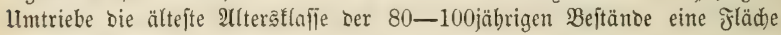
von 100 Şeftar ein, bie zweite Allters̆llaffe ber 60-80jäbrigen Beftänoe

1 Man hat in neuerer Beit bäufiger cư) Diejenigen Methoden Des (Frtrags = Fadwert 3

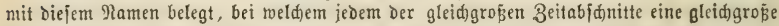
Bef̧tandesflädhe jugetviejen twird (5otta), mit Dem Borbebalte der Serftellung Dem Ertrage

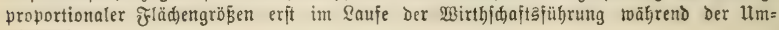
triebsjeit. 
bingegen eine Fläd) von 300 Seftar, jo ergab jidh für die erite 20 jäbrige

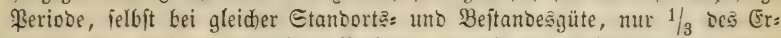
trages ber ztweiten 20jährigen Beriobe, ba mit sen Beftänben ber erften Weriobe eben fo lange gerwirtbidaftet werben mujte, wie mit ben $60-80$ = jäbrigen BeftänŁen, wenn Dieje ३3u 50-100jäbrigem Alter berantwadjen jollten. Die Bered)nung bes Ertrages ber in Şieb tretenden ßeriobenfläd)e

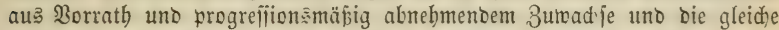
Bertheilung befjelben auf bie Jahre ber Feriobe, änoerte nidbts an ber Ungleidheit ser periosijden (Ertragsgrösen uno entiprad) fomit nid)t Dem Begriffe Der Rahbaltigteit. Daju gefellte fid Dann nod) ber Uebel=

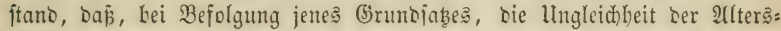
flaijen permanent wurbe. Der folgende Ulmtrieb muste fie genau fo mieber finoen, wie fie im vorkergekenoen Umtriebe vorgelegen batten. Iieje Mängel

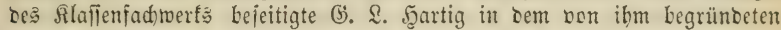
Ertragşaublwerfe.

\section{d) Das Ertragsfadwert}

unterfdeibet fich von allen vorgenannten Fad)werfmetboben junäd) it basurd) Daje ę jeine Beredungen auj cinen vorläufigen Birtbida fisplan

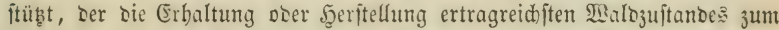

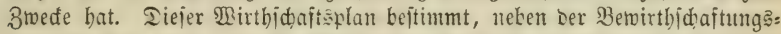

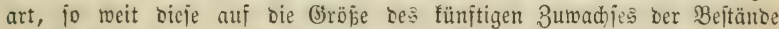

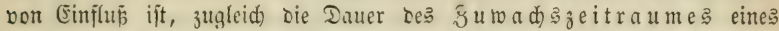
jeden einzelnen Beftantes. Die $3 u \mathfrak{w a}$ d Gegenitano bejonberer Ermittelungen im betreffenden $\mathfrak{B a l c e . ~ D i e ~ a u s ~}$

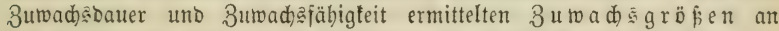
Den gegentärtig vorbandenten Beftänten, bie Sgolzmafile biejer leb̨teren uno

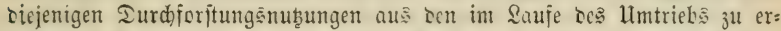

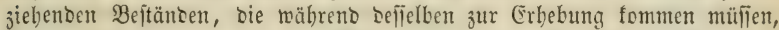
bilben jufammengenommen ten Gefammtertrag Der llmtriebsjeit.

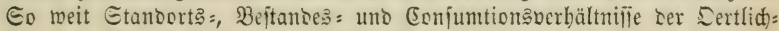
feit eine Şleidfitellung Der periodifhen Ertragęgrōpen überbaupt gejtatten, uno mit Berüdfiḑtigung mëgliditer Eirubaltung Der vorläufigen Mirth=

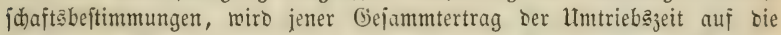

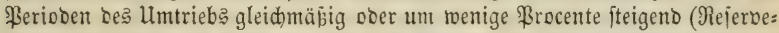
fonds) bertheilt, es wiro ber Misthidhaftstörper in Mirthfdaftstheile

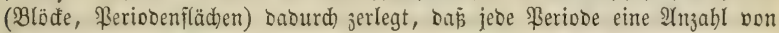
Beftänben zugetheilt erbält, Deren (jejammtertrag gleiđ bem Gejammtertrage Der Beftänbe jeber anberen gleid gropen Periobe ift.

Die Grunbisee des Şartig'iden Ertragşadbertes ift baber:

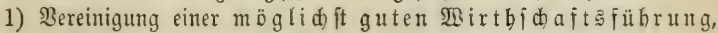
D. b. einer Walcbebanolung, burd) welde ter ertragreidjte 3 u ft a n o be Waloes möglidjt früh herbeigefübrt wiro, mit einer möglidj ft nadhal= tigen $\mathfrak{A} b$ แ

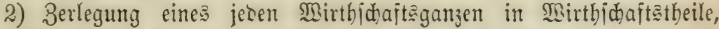
beren Flächengröpe froportional ijt, bem aus ihnen zu erbekendent Ertrage. Daburch unterideioet fich bas Scartigiche fadfwerf von jetem 


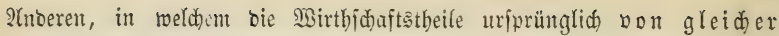

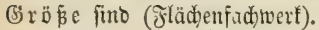

Wir werben uns bier nur mit bem

Ertraggfad werfe

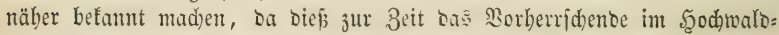
betriebe ijt.

Die Grunţüge biejer Tarationtamethode fino im SBejentliden folgende:

1) Der Taxator berfinulidgt fich Denjenigen 3ujtano ber Bewaldung feiner 3etriebefläche, bie Den gegentärtigen fomohl wie ben muthmap̧lich

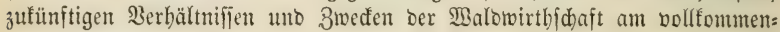
iten entiprid)t.

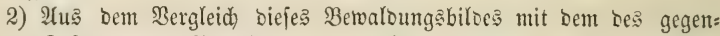
twärtigen 3uftandes Der Bewaloung entivictelt ber Taxator eite Summe von

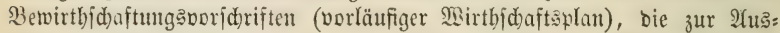

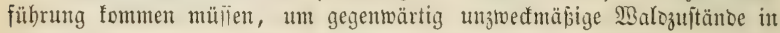

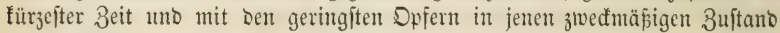
überzufübren.

3) 3u ben Beftimmungen, weldhe ber vorläufige Birthidaftaplan um= fap̧t, gebört bauptiä̋lid bie projeftirte Sicbsjolge Der Beftänbe, wobei im

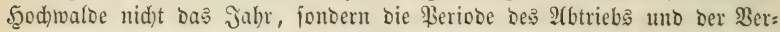
jüngung vorberbejtimmt wiro. Daraus entjpringt cinc Bruppirung fämmt:

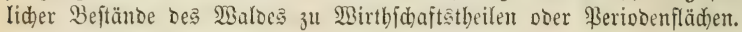

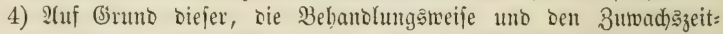
raum ber Beftände vorberbeftimmenoer WBithfidaftsoorideriften miro Der Ertrag jebes cinzelnen Beftanoeß, nad) Deffen erforidter 3uwad)sfähigfeit,

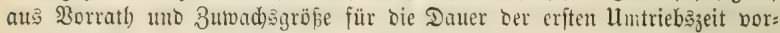
auลืbered)net.

5) Da bie hieraus beredneten, periobijhen Ertragg̨gröpen allein auf Den Unterftellungen bes vorläufigen Mirthid)aftaplanes ruben, in weldhem

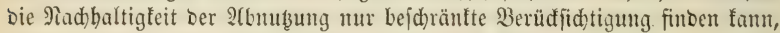

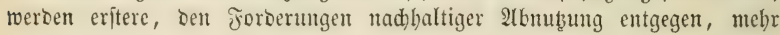

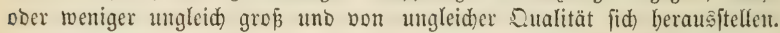

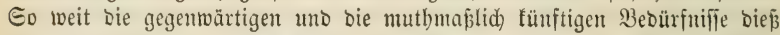

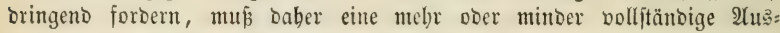
gleidung ber periobifden Ertragşgrößen betwirtt werben, bie nur gejdehen faun: Durd) S(bänberung Der Beftimmungen Des vorläufigen Mirtbid)uft: planes, in Betreff bes Durd) Diejen projeftirten 3uwadşzeitraumes uno

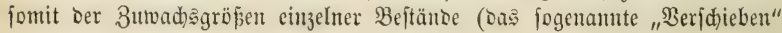
Derielben).

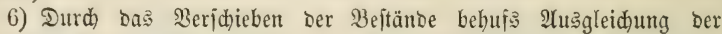

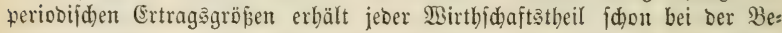
triebseinridung uno Ertragsermittelung cine feinem Ertrage propor= tionale Flädengrößze uno bief́, fo wie bie Bereinigung möglid ft

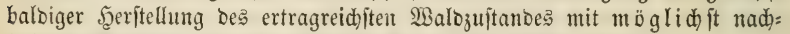

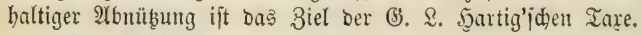

Der Bejchäftagang ift im $\mathfrak{B e} e$ entliden folgenoer: 


\section{1) Die geometrifuen 2 rbeiten.}

Nadidem, momöglid vorkergeheno, alle zur Beit wünjdenstwerthen,

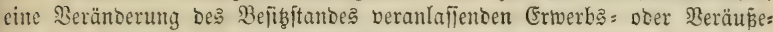

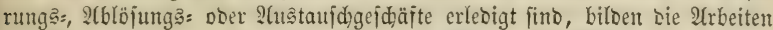

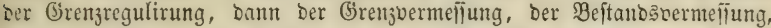
Der Eintbeilung, Deren bildlide uno färiftliche Darftellung ourd) Sarten uno Regifter, wie foldhe voritehento Eeite 7 bereits bejproden wurben,

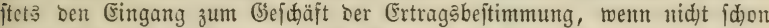

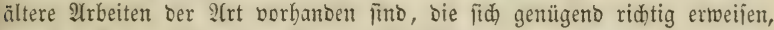
um Den Entwurf eines borläufigen \$Birthidaftałlanes barauf zu grünben.

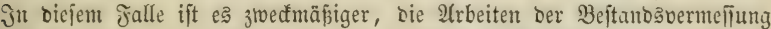

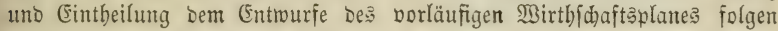
jul laīen, ba fie in vielen fällen erit burdh biejen bejtimmt werben. Heber= haupt meroen bie geometrijon 2 Arbeiten mur in jeltenen Fällen eine böllig

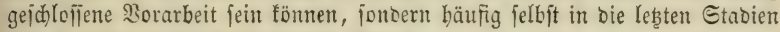

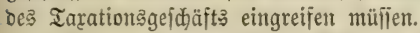

Bei ben geometrijden Arbeiten Der Beftandsocrmefiung foll vom

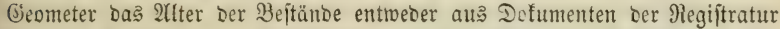
Doer Durch Bäblen ber Jahreşringe auf Dem Etamme ermittelt uno für jebe Solzart eine ipecielle 50 labeftand 3 tabelle angejertigt merben,

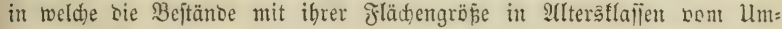
fange ber ßeriobenbauer eingetragen werben, $\mathfrak{z}$. $\mathfrak{B}$.

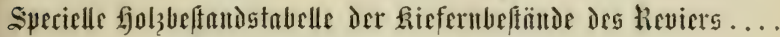 Wirtlj[dafttleiles - Blodes}

\begin{tabular}{|c|c|c|c|c|c|c|c|c|c|c|c|c|}
\hline \multirow[t]{2}{*}{$\begin{array}{l}\text { Benennung bes } \\
\text { Jagen, } \\
\text { forftorts, } \\
\text { 2btheifung. }\end{array}$} & \multicolumn{2}{|c|}{$\begin{array}{l}\text { 1. Stafife } \\
120-100= \\
\text { jäbrig. }\end{array}$} & \multicolumn{2}{|c|}{$\begin{array}{l}\text { 2. Alaije } \\
100-81= \\
\text { jägrig. }\end{array}$} & \multicolumn{2}{|c|}{$\begin{array}{l}\text { 3. MIajie. } \\
80-61= \\
\text { jübrig. }\end{array}$} & \multicolumn{2}{|c|}{$\begin{array}{l}\text { 4. Яโаโfe. } \\
60-41= \\
\text { jägrig. }\end{array}$} & \multicolumn{2}{|c|}{$\begin{array}{l}\text { 5. SIajie. } \\
40-21= \\
\text { jübrig. }\end{array}$} & \multicolumn{2}{|c|}{$\begin{array}{l}\text { 6. SIaile. } \\
20-1= \\
\text { jüFrig. }\end{array}$} \\
\hline & - & & 5eft. & re. & 5eft. & e. & Sget. t. & Ire. & Sgett. & थre. & Seft. & $\mathscr{A r}$ \\
\hline 1 a.... & 150 & s & - & - & - & - & - & - & - & - & - & - \\
\hline 1 b. . & - & - & 18 & 10 & - & - & - & - & - & - & - & - \\
\hline 4 c. . . & 90 & 1 & - & - & - & - & 一 & - & - & - & - & - \\
\hline 5 а. . . . & 180 & 9 & - & - & 一 & - & - & - & - & - & - & - \\
\hline 5 c. . . . & - & 一 & 60 & 50 & 一 & - & 一 & - & - & - & 一 & - \\
\hline 8 b. . . & 200 & 5 & - & 一 & - & - & 一 & - & 一 & - & $\bar{c}$ & - \\
\hline 8 c. $\cdot$ & $\overline{100}$ & - & - & - & - & 1 & - & - & - & - & 60 & 30 \\
\hline 10 b. i. i. . & 100 & 50 & - & - & - & 一 & - & - & - & - & 一 & - \\
\hline Summa Riejer & 1500 & 20 & 500 & 100 & 2000 & 60 & 1000 & 80 & 2000 & 10 & 2000 & 50 \\
\hline
\end{tabular}

2) Begrünbug bes $\mathfrak{B}$ irthidaftsplanes.

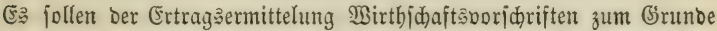

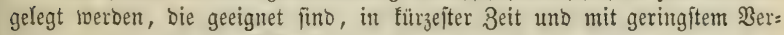
lufte an 3utwads ober Gelomitteln, einen gegentwärtig minber ertragreidjen

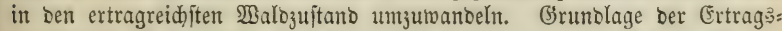
ermittelung ift baher bie jeft ftellung bes ertragreiditen Siblo= 
zuftandes, bebingt burd) die örtlid) veridiebenen Berbältniffe: bes Standorts, des Bebürfuiffes, ber Eigenthumşerbältniffe und ber $\Re$ u

In twiefern Stanoorts:, Conjumtions:, Eigenthumberbältniffe uno

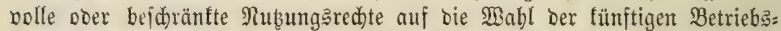

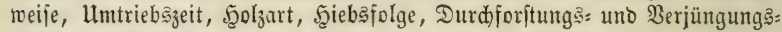
meije von Einfluf fei, findet $\mathfrak{B}$ b. II. Є. $36-55$ Erörterung.

Eotta gibt in biejer Bejiebung bie zmed̆mäßjige Boridnrift: Durd)

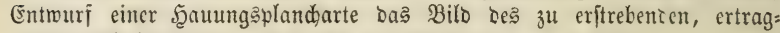

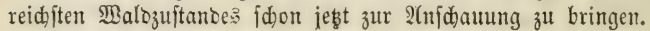

Der 3eitraum, welcher vom Jabre ber Taration biş zut Şerftellung

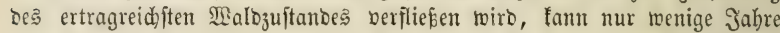

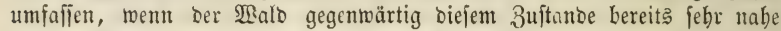
jteht, er fann aber aud) nuperbalb ber Brenzen bes allgemeinen Umtrieb3 liegen. Eotta trennt bicjen Beitraum vom allgemeinen Umtriebe uno nennt ihn Den (Einrid)tungzzeitraum. (5). \&. Saartig bat eine foldhe Tren= nung nicht für nötbig erachtet, fonbern führt bic Berechnung ftets unge= trennt bis zu Enoe bes allgemeinen Umtrieks.

3) Entwurf bes borläufigen Birtbidafţolanes.

Iie Summe ber Betriebsooridriften, benen die Beftänoe bes Walbes binnen ber erften Umtriebązeit unterworfen werben müfien, um fie bem, nad) Boritebenoem entworfenen Bilde Des ertragreidjten Malozultandes in

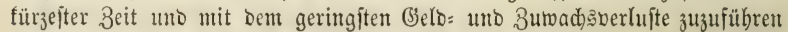
uno, weiter binaus, barin zu erbalten, biloen ben vorläufigen SSirtbfdafts: flan. Borläufig nemt Şartig biefe Betriebsoborjdriften, weil fie fid ipäterbin für einen Theil ¿er Beftänce Durdh bie (Sleidjtellung ber perio:

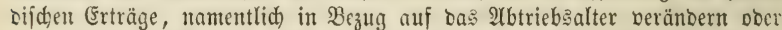
bod) Deränbern fönnen, Daher bic Jeftftellung Des Wirtbfdhaftzplanes erft

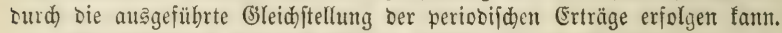

Der vorläufige WBithfichaftaplan umfaß̧t folgenbe Beftimmungen, jo: wobl im 2llgemeinen als in Bezutg auf bie einzeltuen Beftänoe, in fofern lețtere einer 2 (bmeid) ung bom 2 Allgemeinen untertworfen fint.

a) In weldjer Betriebsart bie Beftänbe gegenwärtig uno zufünftig bebantelt merben jollen uno nadh weldyen allgemeinen Regeln ber Betrieb gefübrt werben joll. follen.

b) In weld)em allgemeinen limtriebe bie Beftänbe bebanbelt werben

c) In weldher ßeriobe jcoer einzelne Beftano mit Rücficdt auf Stano=

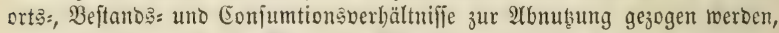
Daber: weldyes auf bie Mitte ber 2rbtriebşperiobe berechnete Scaubarfeits:

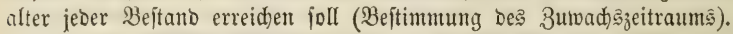

d) In weldhen Beiträumen uno in toelcher 2 (rt uno Etärfe bie Bor:

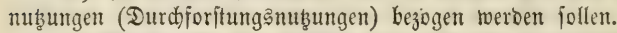

e) Mamm uno mit welden Syolzarten bie gegentwärtig vorbanbenen Blöben angebaut werben follen, uno wie biép gejohen joll.

f) Ituf weld)e WBeife bie \$erjüngung ber zum Şiebe fommenten 


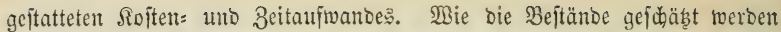

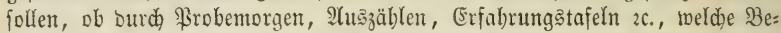

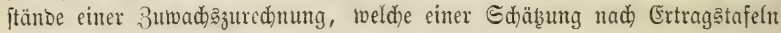
unterworfen werben follen.

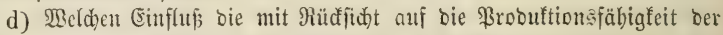
B̉eftänoe vorläufig zu belwirfente Ssleidjtellung ber \$eriobenfläd)en auf Daڤ Taxationsgefdäft haben wirb.

2U⿱ nif ser verfdiedenen IIteraflafien erfidytlich. Summirt man bie Bejtands: flächengrößjen gleidjer ßerioben aller berienigen Scolzarten bes Reviers, Die

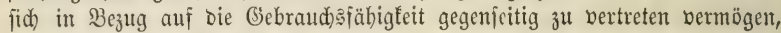

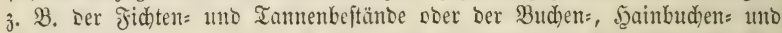

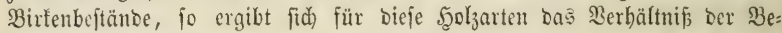

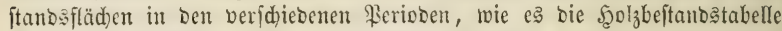
ङ. 65 für Dic Siefer allein beifpielsweife barftellt. Bei Der gröftentheils

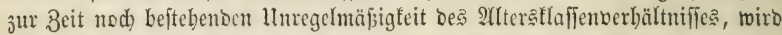
fid) aus Der Solzbeftanostabelle für einzelne ßerioben ein Mangel, für an=

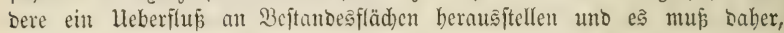

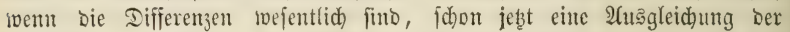
Fläden auf Gruno der Beftandstabelle ausgefübrt merben. In ber Iabelle G. 65 ift die Summe aller Sieferbeftänoe $=9000$ Şeftar; ę werben aljo bei gleicher Bertheilung jeber ßeriode 1500 Seftar zufallent.

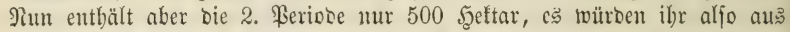
Der 3. \$eriobe die feblenden 1000 J̧eftar, ber 3. aus ber 4. Beriobe bie

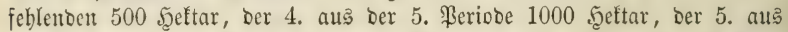

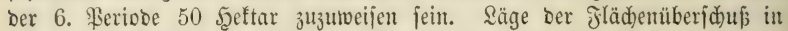

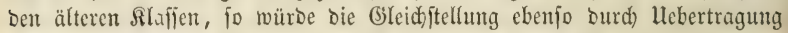

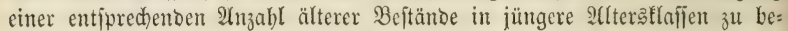
wirfen fein. Dabei gilt als Regel: Dap beim Berjojieben aus älteren in jüngere Slaijen ftets bie befieren, in gutem Buwad) fitebenden Bejtände,

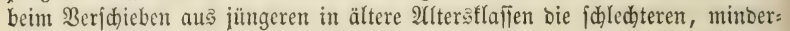
wüd)figen Bejtänoc zul erwäblen fint, ba burdh bie frübere Berjüngung [dlechterer Beftänoe Der 3uwadja erböbt roiro.

Jallen ein ober ber andern ßeriode überwiegeno (c)lechte Beftände zu, fo fann bie flächengröße biejer \$eriobe fdon jeşt im \$erhältní̄ der ge= ringeren Ertragşäbigfeit ifrer $\mathfrak{B}$ eftanosmafie gröfer angefeţt werben. Man

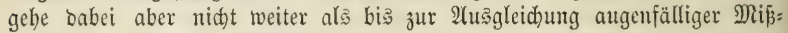

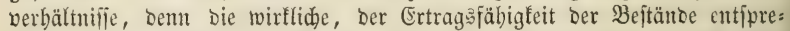

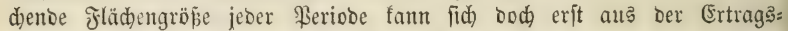
beredbunng uno periobiicber GEleidjftellung Der Erträge ergeben. Dieje ganze Borarbeit ber J̈lädenausgleid)ung bat nur Den 3roed: eine Menge vergeblider $\mathfrak{A}$ rbeit an (Ertragsumrednungen zu exiparen. Durd) bie vor:

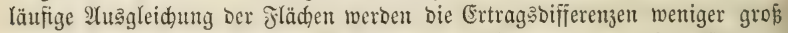
auşfallen, man wiro weniger Beftänbe zu veridjieben uno weniger Ertragş= fäbse in foldaje anderer ßerioden umzurednen baben.

e) Weldhe Abweid)ungen nom normalen Şaubarfeitsalter aus ber

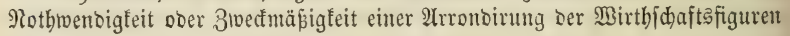




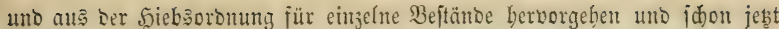

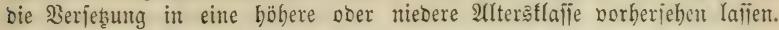

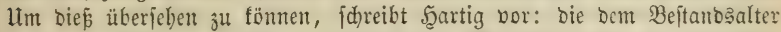

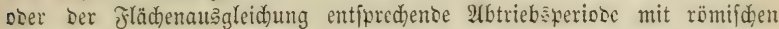
Biffern in bas Brouillon einer Beftandafarte einzutragen uno at? bem lleber:

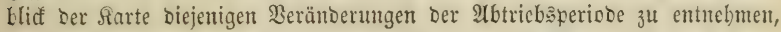

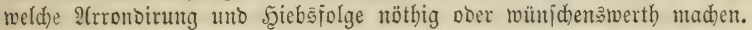

Es iłt żmedmäpig uno erleid)tert bie Leberfidst, went man nad) Bollen= Dung biejer 2frbeiten bie Rejultate Derjelten in eine, ber Frecicllen $\mathfrak{S}_{0} \mathrm{l}_{3}=$ heftandâtabelle gleich conftruirte $\mathfrak{A} b$ trieb sfl affentabelle eintragen läpt, Der Ârt: Daś biejenigen Beftänte, welche in ber ibrem Aller entjprechenden Alterstlafie verblieben fino, biejelbe Etellung wie in Der .̧oljbejtandostabelle behalten; siejenigen Beftände oder Beftandätheile aber, weldhe bebufs nötbiger fläd)enausgleidjung, 2trronbirung, ober ber Şicbsteitung wegen, in eine anbere Peitobe beridoben murben, in biejer leketeren mit iffer Fläche uno ibrem wirflid)en Allter verzeid)net werben. Sur Arbeitäerfananí fann man beise Tabellen combiniren, indem man in ber 5olzbeftanoştabelle bie einer Aflterštlaije abgebenoen Beftänse mit rother Dinte unterftreidt, bie zugeben= Den $B$ eftänbe mit rotber Dinte einträgt.

5) 2tnfertigung oder Prüfung Der Erfabrungatafeln.

Edyon int erjen 2(bjonitt S. 41 babe id) Darauj bingemiejen, baj

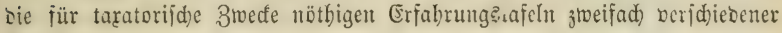
Aft jein müfiett.

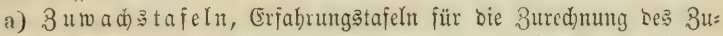

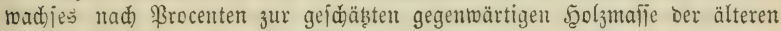

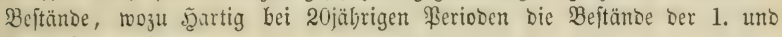
2. Periobe redunet.

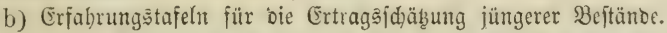

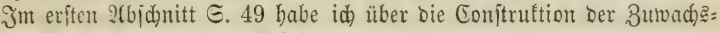
tabellen, S. 47 über bie Der Erfal)rungstabellen gefprod)ent.

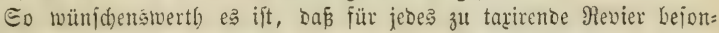
Dere Erfabrungstafeln angefertigt werben, fo fehlt bod) bierju, bejonoer? bei juperficiellen, rajh) ju beendenden Edjäb̧ungen, nicht felten bie nöthige

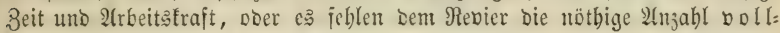
font men bejtandenter Drte berjchiebener Âtersitufe, wie fie jur 2Affitellung von Erfabrungstafeln erforberlich finto. Jn foldhen Fällen ift bie Berment= Dung jogenannt "allgemeiner Erjabrungstafeln" zuläjigig, roun bieje, wie

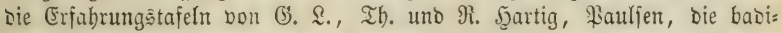
id)en Ertragstafeln, neben ber (Ertragsziffer zugleid) aud eine Beitands:

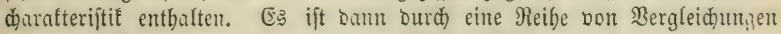
ber in Den (Erfahrungatafeln bejeidneten Beítandabilder mit Den gleidaltrigen

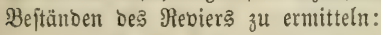

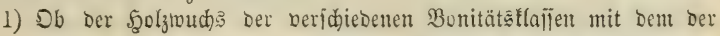

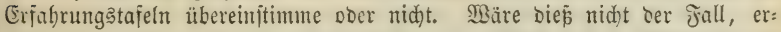

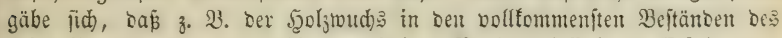

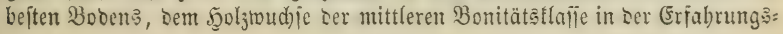


tafel gleid) ober ähnllid) jei, fo toürbe bieje leketere für bas betrefjende

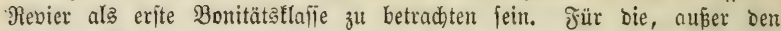

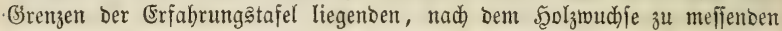
Bonitätąlafien bes Stanoorts, müfijen bann jeoenfalls Unterjud)ungen bes

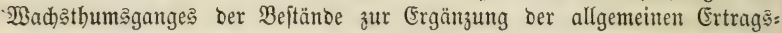
tafeln ausgeführt werben.

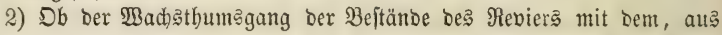
Den (Erfabrungstafeln zu entnebmenden $\mathfrak{B a d}$ ) auf Etammzahlverringerung als Baumwudds übereinjtimme poer nid)t. (Er:

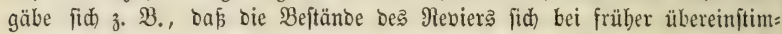

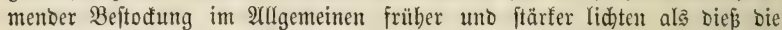

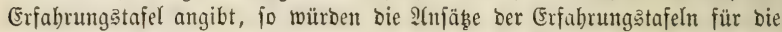
ipäteren Durdforftunggerträge uno für bie 2Abtriebserträge in bem ent=

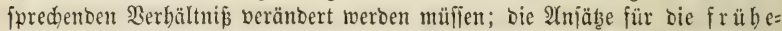
ren Durdforftungäerträge müßten ermäpigt werben, wenn bie Beftänoe fich

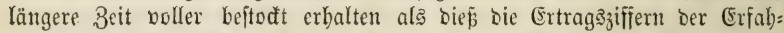

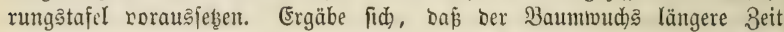
auşält voer früber nachläpt als bie (Erfabrungstafel nadłweișt, fo würben

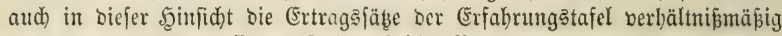
beräntert werben müfien. Gollen foldje Beränberungen niđ̧t zu groben Jrrungen Beranlajīung geben, fo müfjen nidjt allein bie Ertraģziffern, fon= bern aud bie Beftandşaraftere ber Erfal)rungstafel ben Beränberungen erfterer entfprechento beränoert werben. Die allgemeine Erfahrungstafel bient bam gemifīermak̂en nur als Sfelett für bie a uf allgemeine Beobad)=

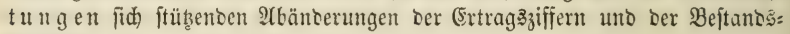
daraftere.

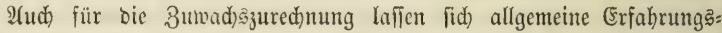

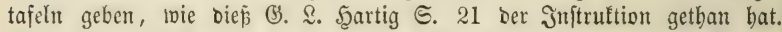
In wiefern eine Erweiterung biejer Zuwadstafeln in Bejug auf bie 2 nngabe Der \$rocentfäțe veridieben langer 3umadjsperioben nothwendig jei, in wie=

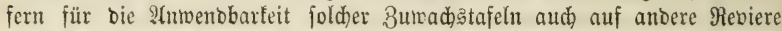
uno von andern Taratoren eine Beftandsd)arafteriftil notbiwendig fei uno gegeben werden fönne, habe id) S. 48 erörtert.

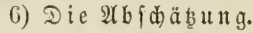

Gino alle bie vorgenamten Borarbeiten beß cigentliden Gdübungs: geid)äftes vollzogen; liegen bie 3utwadstabellen uno Erfabrungstafeln bem Gebraudbe vor; ift burd) Den Iarationsplan beftinumt, weld)e Beftänoe burd 3uwadhşured)nung, weldhe ourd) Erfahrungstafeln gejdäbst werben follen;

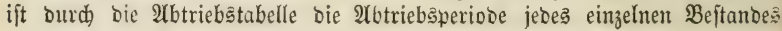
feftgeftellt, fo fam mun zur 2tbjääbung jelbjt gejdritten werben.

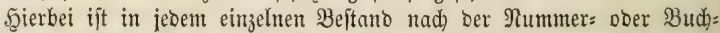

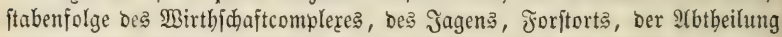
uno Unterabtheilung Folgentes zu unterfuden unt zu verzeidynen:

Für alle 2 btheilungen:

a) Angaben ber Dertlid)eit nad Jagen, Foritort, 2rbtbeilung 2 .;

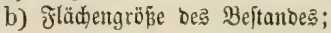


c) Beftanos̄alter;

d) Etandortäbejhaffentheit;

e) Bejdreibung bes Bejtandes;

f) Bemerfungen über befien fünftige Bemirthidaftung.

Jn ben älteren, ourd 3 utoadszurednung zu fdägen= ben $\mathfrak{B}$ eft änben:

a) Die gegenuärtig vorhanbente Şoljmafle bes ßeitanbes getrennt nach

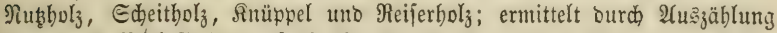
Doer burd ßrobefläden auf bie Є. 22 bis 29 erörterte $\mathfrak{W e i j e . ~ D i e ~ F a ̈ l l e , ~}$

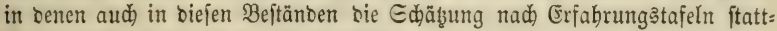
finben muŝ, habe id 5.29 bezeidnet.

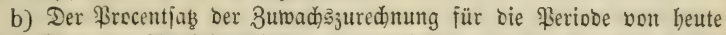
bis zur Mitte ber 2rbtriebąperiobe; зu entnebmen aus ben 3uwadstabellen nad) Maisgabe ber Stanbortswerbältnifie uno der Etammferne.

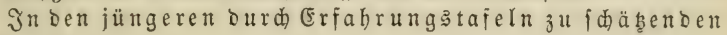
Beftänoen:

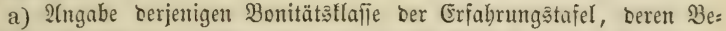

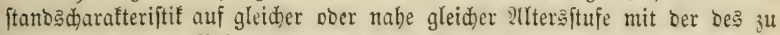
fääkenoen jungen Beftandes am meiften übereinjtimmt, Є. 5:2.

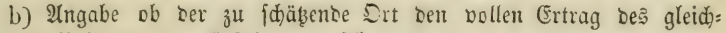
werthigen ßeftanoes our Erfabrungstafel, oder ob er weniger uno um wie viel weniger er an Durdforftungs: uno 2tbtriebserträgen ju liefern ver: prriabt, 3. 3. Durdforftung im 40. Jabr $1 / 4$, im 60. Jabr $1 / 3$, im 80.

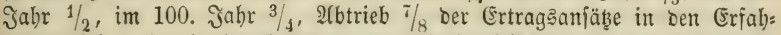

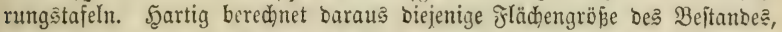
auts weldyer ber volle Ertrag ber Erfahrungstafel exfolgen wirb. Wäre in obigem Falle der ganje Bejtano 100 Şeftar gró , fo lautet bie Ingabe: im 40. Jahr von 25, im 60. von 33, im 80 . bon 50 , im 100. Jabre bon 75 Seft. Der volle Durdforftungęertrag von 87,5 Seft. Der volle 2 (tb: triebsertrag Der Erfahrungstafel.

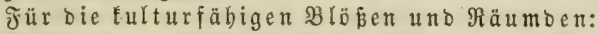

a) Die ßeriode, in welder bie אultur betwirft werben joil, oie nur unter ben bringenditen limitänben eine anbere als bie erfite \$eriobe fein barf.

b) Die Şolzart, mit welct)er bie fultur bewirtt werben foll.

c) Die 2Ingabe ber Sulturmethobe, in jofern biejelbe wejentlidjen Einflup auf ben künftigen Durdforftungęertrag bat.

Die Rejultate biejer Unterfudungen uno Bejtimmungen werben in ein Taxationsprot ofoll tabellarifd verzeidnet, befien (Finridtung im $\mathfrak{B e}=$ fentlichen folgende ift (i. S. 72).

Mit bem Tarationsprototoll fint bie Arbeiten im Reviere bollenoet uno $e^{3}$ forgt nun bie 3ujammenftellung ber gejammelten Iarationşrejultate zunädjit in:

\section{7) Das Tarationsregifter.}

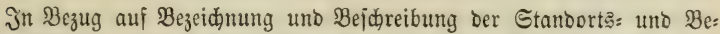

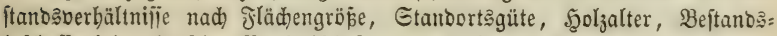
bejdaffenheit, Łünftige Berwirthidaftung enthält bas నarationsregifter bie= 


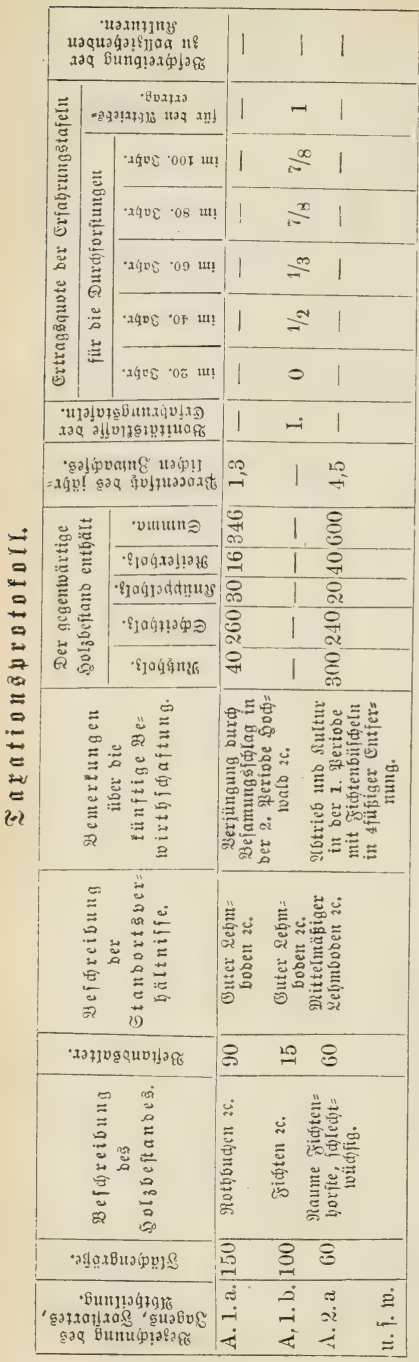

\begin{tabular}{|c|c|c|c|}
\hline$\frac{9}{4}$ & 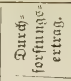 & 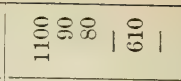 & 吕 1 \\
\hline & & $|1| 1 \mid \sum_{\infty}^{8}$ & 范 \\
\hline & 苟㤩吾 & 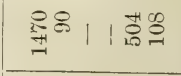 & 5 \\
\hline & & 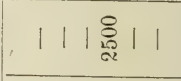 & 总品 \\
\hline & $\bar{Q}$ & तु్ & ఏ્ન \\
\hline & & $11 \stackrel{8}{\stackrel{3}{\sharp 1} 111}$ & 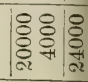 \\
\hline & & 있요 & 5 \\
\hline & & 11 & $5^{6}$ \\
\hline & 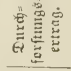 & 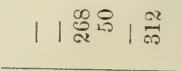 & 亭 \\
\hline & & 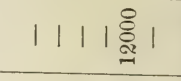 & $\begin{array}{l}8 \% \\
8 \\
8 \\
8\end{array}$ \\
\hline & 它兽要 & 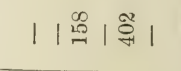 & ¿্ৰ: \\
\hline & 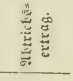 & 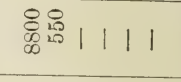 & 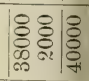 \\
\hline & & 육워 & \\
\hline & 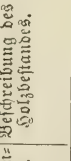 & 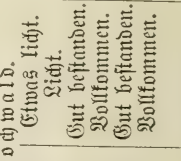 & 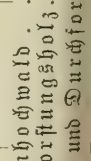 \\
\hline & & 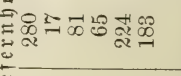 & 范 \\
\hline & & 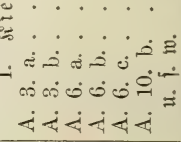 & \\
\hline
\end{tabular}




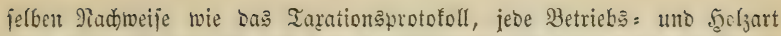
aher gejonbert uno bie aus Dem Taxationsprotofoll beredneten Iurd)= forjtung: = uno 2 (btriebserträge aller Beftäıbe in bie betreffenten Ferioben

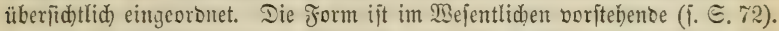

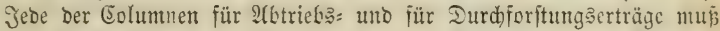

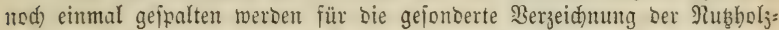

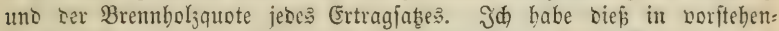
ber Iabelle Der Raumerparnis megen unterlafien; in ber Itnwentung ift

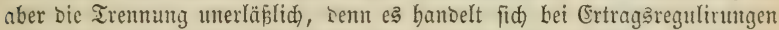
nidht allein Darum, Die Ertragsmafie überbaupt gleidmǟig ju vertheilen,

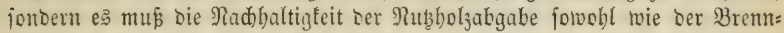

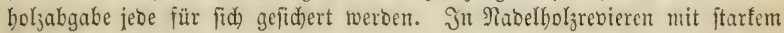

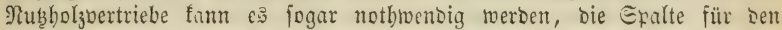

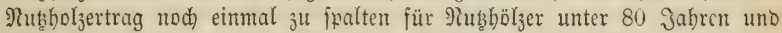

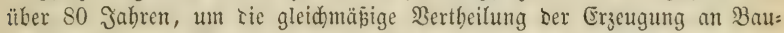

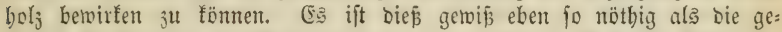

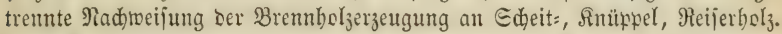

5. \&. Şartig zieht in Das Iarationsregifter alle bie Detailangaben, auf reldhe fidy Die Ertragäbered)ung grünbet. Daburd roiro bie Iabelle jebr erveitert uno unbebülflid. Jd) balte ifre Uebertragung aus Dem Tarationsprotofolf in bas Tarationsregijter nidyt für mejentlich. Bei Re=

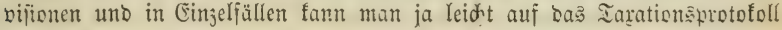
zurügefgehen.

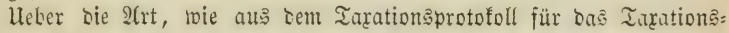
regijter bie Ertragsjäbse ber einzelnen Beftänbe berechnet werren, hanoelt ธ. 34 uni 54 .

\section{8) Ertragsregelung.}

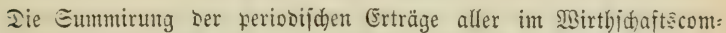
flexe borfonmenden 5ुolzarten ergibt Den Gejammtertrag jeber ßeriode; Die Eummirung Der Erträge ber Perioben ergibt ben Ertrag ser Untriebseit. Iutch Divifion biejes Seşteren mit Der 3abl Der ßerioden erbält man bie

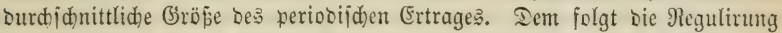

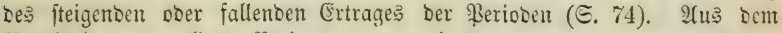
Sergleid) ber regulirten \$eriobenerträge mit ben Ertragşummen bes Tara:

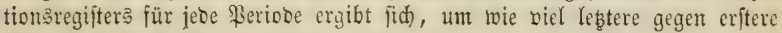
孔 gró oder zu flein ausgefallen fino.

In voritebenoem Beifpiele: $40,000+41,400+39,000+24,000$

$$
+48,000=53,000=245,400 \cdot \frac{245,400}{6}=40,900 \text {. Es ift alio }
$$

40,9000 ber ourdjidnittlidje periobijhe Ertragsjab̆. In allen Fällen, in Denen nidjt unabmeiäbare Bebürnifie ber Gegentwart, obcr ein llebergemidat alter baubarer ober überbaubarer Bejtänoe, bie eine baldige albnuţung un=

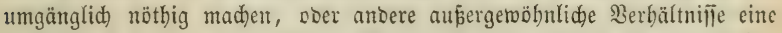

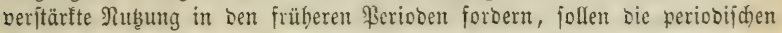

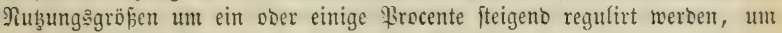
anj bieje \$Bcile für jede ßerione cinen Rejerbefonds ju bilben, wie cin 
fold)er für jeden einzelnen ber jüngern Beftände fdon burd Bered)nung bon nur $\% / 8$ bes Ertrages ber Erfahrungşabellen gebiloet wurbe.

Nebmen wir mun an: ę follte für 40,900 Enbifmtr. Durdjidntttlid, ber periobifde Ertrag um 1 Brocent fte igent regulirt werben, fo erbält, bei ungraber ßeriobenzahl, bie mittlere ßeriobe ben Durdhidnitţertrag, bie nädjit älteren ßerioben ben Durdjidnitţertrag - 1 Frocent falleno, bie nädjit jüngeren ßerioben +1 ßrocent fteigent. Bei graber ßeriobenzal)l erbalten bie beiben mittleren ßerioden ben Durdjidnittaertrag + uno - ber

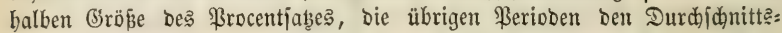

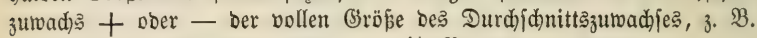

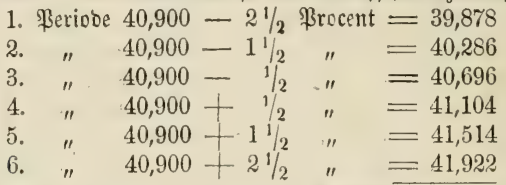

$$
\text { Summa } \overline{245,400}
$$

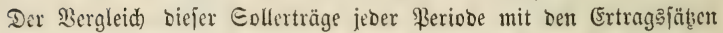

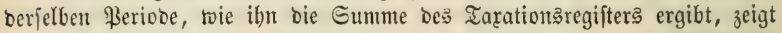
ıun, um wie viel bie einzelnen \$erioben zu reid)lid) ober zu gering beoadt

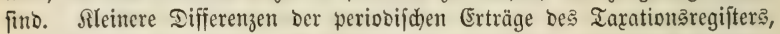
gegen bie ber Regulirung, bleiben bierbei unbeadtet, größ̄ere Differenzen

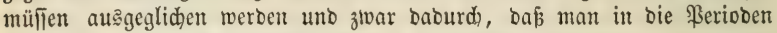
mit zu geringem Ertragsjakge aus ben benadbarten $\mathfrak{B}_{\text {erioben }}$ io viele $\mathfrak{B}_{e}=$

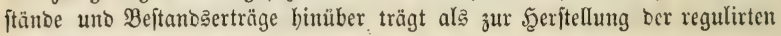
Ertrags̄größ̨e nöthig fino.

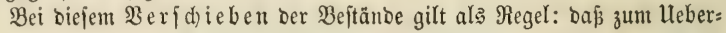
tragen aน๖ früberen in fpätere Perioben bie jüngeren, befferen uno im bejten 3umadjie ftehenten Beftänoe, zum Borjobieben aus fpäteren in

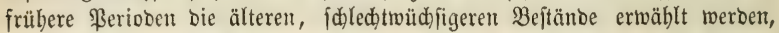

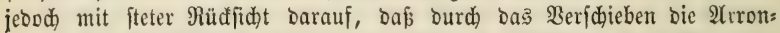

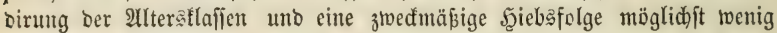
geftört wirb, oaber benn bie Sarte hierbei ftets zu Rath gezogen werben muई.

In bem borliegentoen Beifpiele bes Sitertrages nad bem Taxations:

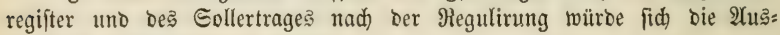
gleichung folgendermaken ftellen:

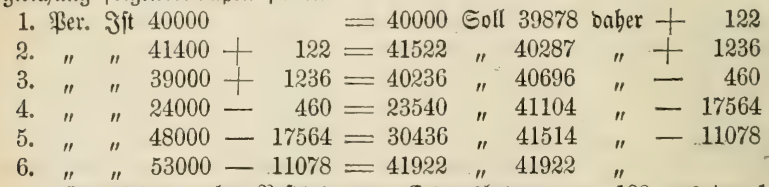

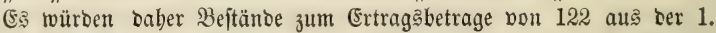
in bie 2. Beriobe, zum Betrage von 1236 aus ber 2. in bie 3. Beriode zu übertragen jein; ba leb̧teres aber ben Bebarf ber 3. \$eriobe nod nidit bectit, fo fino nod) 460 aus ber 4 . in bie 3. Periobe zu verfeben; 17,564 aแล ber 5 , in bie 4., 11078 aus ber 6 , in bie 5. \$eriobe. 
3um Berjojieben fönnen mur 2 btriebserträge verwentoet toerben, ba

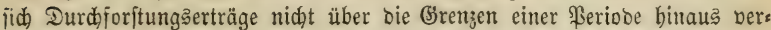
idjieben Yaffen. Es ijt aber ber Durdforjtungäberlujt (als joldber) beim Berichieben ber 2tbtriebserträge in eine frübere, Der Durdforftungşzugang

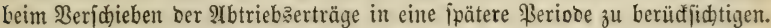

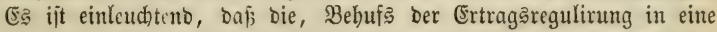

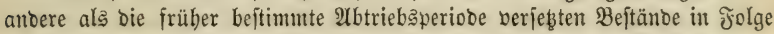
ber Beränoerung bes 3uwad)szeitraumes aud eitten anoeren 2tbtriebs: uno Durdforitungsertrag ergeben uno hiernady umgerednet werben müfijen. Sit

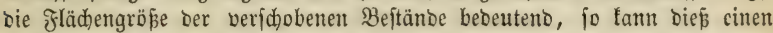
wejentliden Einfluf auf Den (B) efammertrag Der Ulmtriebszeit unt ber einzelnen Berioden haben, uno es wiro häufig nad) (Erfterem eine

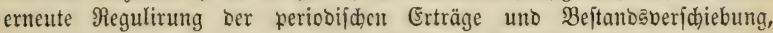
mögliderweije nod) eine britte Bearbeitung ftattfinoen müfîen, bie fid jebod) immer nur auf menige einzehne \$ofitionen beforräntt. Die 2trbeit ber Gleidftellung ift jo grop nidjt, wie man es wohl oargeftellt hat, bes jonbers bann nicht, twenn, bei Bearbeitung ber 2tbtriebstabelle aus ber

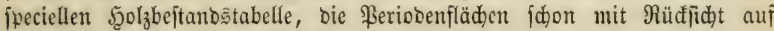
bie Ertragsfähigfeit ber ßeftänoe ausggegliden murben. Hebrigenミ, wer

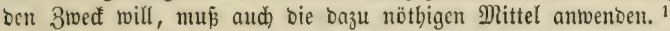

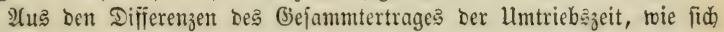
folde aus ber Beredinung vor und nad) ber Micgulirung ber periodifden Erträge berausftellen, erfennt man bie Spfer fowobl in Ertragsmafie als Ertragsmerth, weldhe ber (Slleidftellung Der periobijden Erträge,

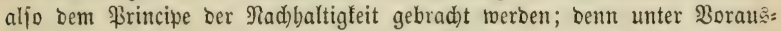

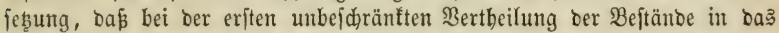
Jachwerf bes Umtriebs ftets bie ertragşreidfte Arbtriebszeit gewählt wurbe, fann jede Beränderung berjelben nur Berlufte nadh fid ziehen. Daj bie

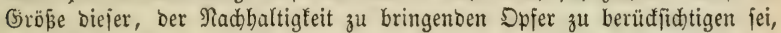
uno unter Ulmftänben ben Sieg über bą ßrincip ftrenger Nadbaltigfeit getwinne, bebarf faum Der Inbeutung.

Durd bie 2lusgleidung ber periobifden (Erträge uno bie baburdh ver: änderte fläd)engröße ber ßerioben ift leb̧tere nun proportional ber

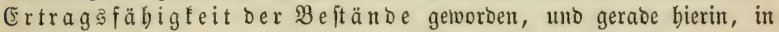

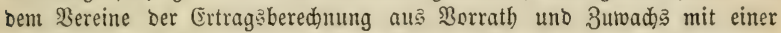

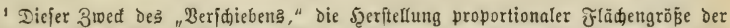
Wirtbidaftstheile, ift häufig bertannt oder unteridäbt worden. Man hat geglaubt, baß̄

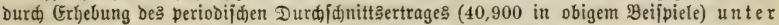

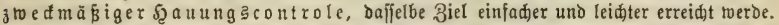

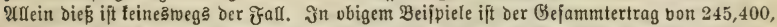

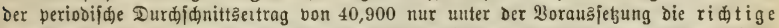

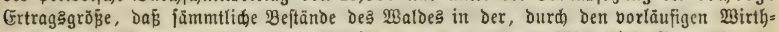

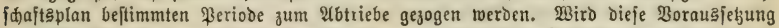

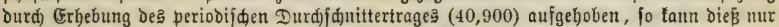
gejđeben unter Beränderung Des, Dem Gejammtertrage des umtriebs zum Grunde gelegten

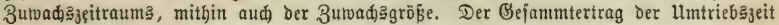
und fomit ber periobijde Durdjidnittertrag riro bamit ein wejentlid anderer, uno ę ift

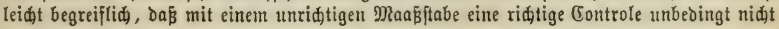
gefübrt teerden tann. 
proportionalen Ed)lageintheilung (PBeriodenjaläge) liegt ber F̧auptdarafter Diejer Fadinerfmethode: Die Sid)erung bes Ertrages burch f(äd)envertbeilung.

9) Jeft ftellung Des vorläufigen Sirtbidaftaplanes.

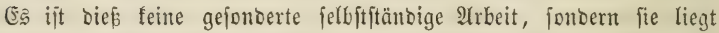
eben in ber vollendeten 2 (ueg gleid)ung ber periobifden Erträge; benn, fino bieje feitgeiteflt, io find e⿱乛龰 auch bic jeber ßeriode angehörenten Beftänte in Bezug auf Betriebatweife uno Umtriebszeit, in Bezulg auf Die Zeit Der

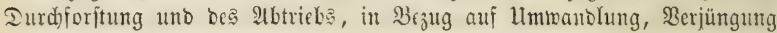
uno Rultur. Das Iarationaprotofoll uno bas vollendete Iarationaregifter entbalten alle in Diejer Scinficht nöthigen Brftimmungen uno Nadiveife.

Şiermit ift im Sisefentliden bie Taxation beendet. Die beridjiebenen Ercerpte aus bem Iarationsprotofolle uno Regifter; bie Ge seraltabelle zur leichteren Uleberficht ber Eortimentwerbaltniffe bes Ertrages ber ber: ifiebenten Rerioben; ber generelle $\mathfrak{B}$ irthfdaft引plan und ber ge=

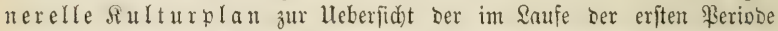
jum Şicbe unt jur Sultur fommenden Flädhen unb Deren Shehanolung;

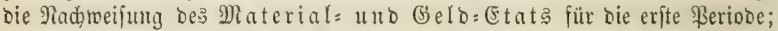
Das (5ontrolbud) uno bie Revierbefdreibung nad) Lage, Boben,

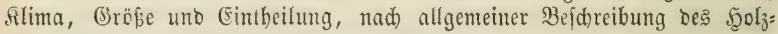
beftandes unt ber Berwirtbfhaftung Deffelben, nad allgemeinen Sroduttions: unD Conjumtions: Berbältniffen, Des Umfanges Der (Sigentbumb = und

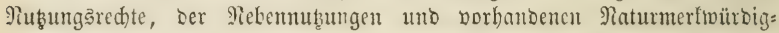
feiten, glaube id) bier übergehen zu bürfen, ba fie teine mejentliden $b^{3}=$ ftumbtheile Des Bsejdäfts, fondern mur bie Jorm ber Dariftllung betrefien. ${ }^{1}$

\section{siferafur.}

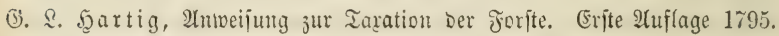
Bierte 2fuflage 1819.

Defielben Jnjtruftion für Jorftgcometer uno Iaratoren, 1819. Berlin.

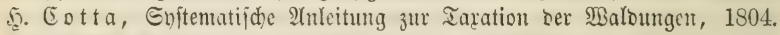
Deffelben 21tweifung 3ur jorfteinrid)tuny und 2(bid)äbung. Drešben 1820.

v. Slifftein, Berfud) einer 2(nweijung zur Foritbetriebs = Regulirung.

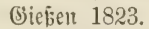

Rornitid), Shnleitung zur Einridutung zc. Der Forite. Reipzig 1836.

v. Saedefins, Die Fad)wertmethoden; mit Radmeifung ibrer Duellen, fritif( jujammengejtellt uno beleudtet. Jrantfurt 1843.

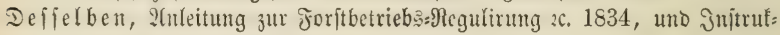
tion Daju. Darmitabt. 1839.

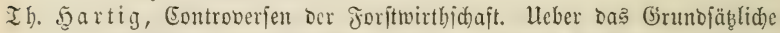
in ben Taxationsoorfariften 52. Cotta's uno (3). \&. Şartigs. Braun= jofweig, 3iewey 1853.

Defielben, Snftem und 2(nteitung zum Etubium ber Forftwirtbidaftas= lebre, Darin aud (Befdithte bor Taxationemillenidjaft. Seizzig 1858.

1 Gine frormel für bas (Ertragsfadtwert: $\frac{\mathrm{rv}+\mathrm{rsz}+\mathrm{x} \cdot \mathrm{srz}^{\prime \prime}}{u}=\mathrm{H}$ habe id im

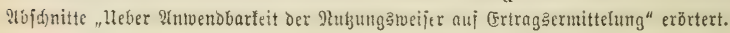




\section{B. Die $\mathfrak{B e i j e r m e t h o b e n . ~} 1$}

Unter Beijermethoden veritehen wir bięenigen Atrten ber Crtrags:

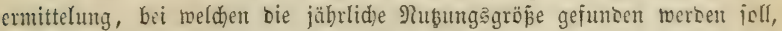

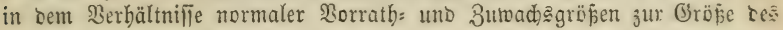
gegentwärtigen Sorratbes uno Suwadjes; währeno das Ertragáfad)wert

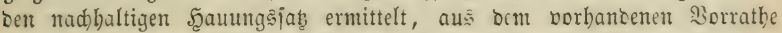

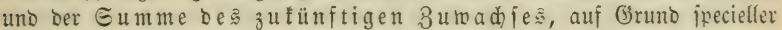
Wirtbidafțooridriften für bie 3utunft.

Die 3reifel an ber 24ufredterbaltung ber Betriebsooridriften bes Fadjwerfs und Dem Eingelyen ber, auf (5rund biejer beredneten 3uwad)

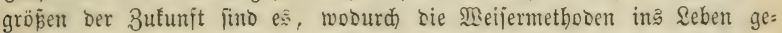

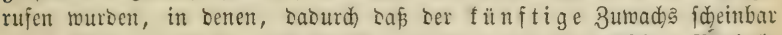

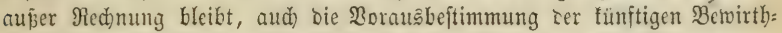

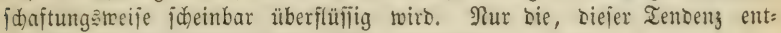
iprechenben Tarationsmethoden zäble iđh hierber.

Ueber bie normalen, fingirten und realen 2 alozuftäne im $\mathscr{A l l g}$ emeinen.

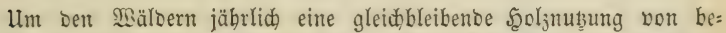
ftimmter, burd ᄃas Baumalter Kebingter Gebraud)

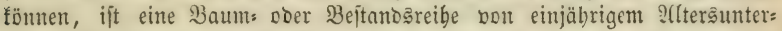
fajiebe uno gleicher Baumzahl oder Bejtandägröfe, vom Eaatbejtante bił 3um 2 (btriebsalter binauf, nötbig.

Um alljährlid einen ફ̧eftar 10jährigen 5ुolzes abmuß̨en zu fönnen, fino 10 Settar Scolzbejtand nötbig, von benen ber jüngite Eaatbejtand, Der folgenbe mit einjäbrigem . . Der jehnte Şeftar mit 9 jäbrigem Sgolze be= ftanden ift. Dieje Beftänte unter fid in 2Birtbjafaftäberbanbe iteheno, bilden baß Rapital, Das Jubentarium ober Den Borrath (v) Der

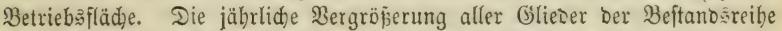

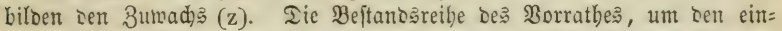

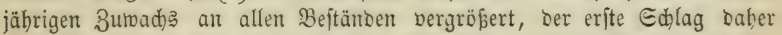

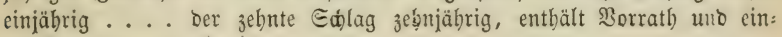
jäbrigen 3umadjs $(\mathrm{v}+\mathrm{z})$.

\section{Der normale Balozultano.}

Normal wird ber Buftano einer ßetriebäflädje genannt, menn bie, in

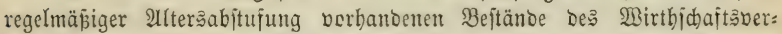
banbes bon gleider oser ber Ertragşäbigleit proportionaler, Dem llmtriele

1 Bereits in einer Abbaudung: Die formel für das fadter gegenüber Den ibeifermethoden, in Der allgemeinen forjt = und Jagoseitung, Jahrgang 1850 ,

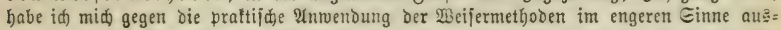

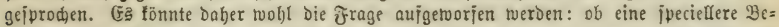

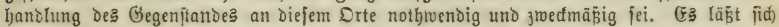

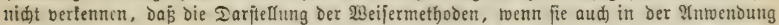

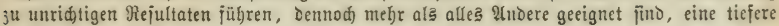

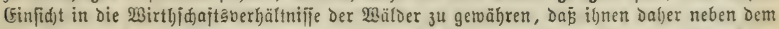

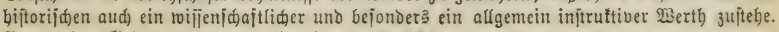

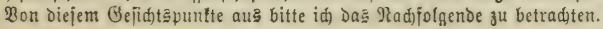


entipred)entor Flädjengröpe fint, uno eine ibrem 2llter entipredbende, volle Beftodung befiken.

Da in Den Beftänben einer Şod)walobetriebâfläd)e, nid)t alle Bäume Das After ber Umtriebajzeit erreiden, Der gröfte Theil berfelben fdon in früberen \$erioben Des allgemeinen 4 mtriebs burchforftungşweije zur $\mathfrak{A b}$ :

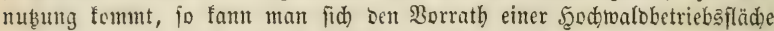
zerlegt Denfen: in Den Porrath für ben 2(btriebsertrag uno in jo viele Durdforftunģ̧vorräthe, als Durdforftungesperioben angenommen fimb.

Siur Der Atbtriebsonorrath ift bleibend, o. b. fowobl für bie laufende als alle folgenoen llmtriebszeiten feiner $\mathfrak{M}$ affe nad) unverändert, alljäbr:

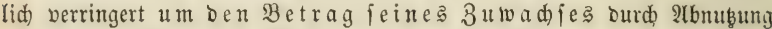

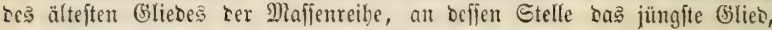
Der Eaatbeftano, tritt.

2tle Durdforitungàvorrätbe bingegen fint a

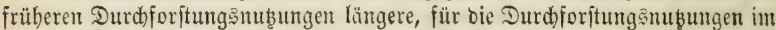
böheren 2ufter fürzere 3eit. Der Borratb für bie Iurdforftung im 10. Jabre twiro im 10. Jabre, Der Borrath für bie Durdforftung im 100. Sabre wiro im 100. Jahre hinweggenommen, uno im ¿aufe berfelben Untriebszcit auf

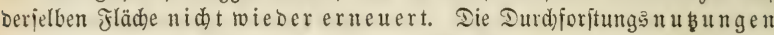

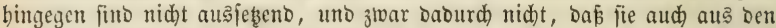
Beftänden Des für den zrweiten Umtrieb zu erziebenden Borrathes bezogen werben müfīen, bie fucceffic an bie Etelle ber abgetriebenen Beftänoe ber

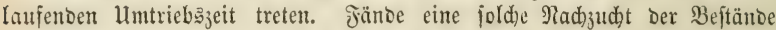
für eine nädjite Ilmtriebsjzeit nidht ftatt, fo mürbe in Der That aud jebe Durdforftungŝnuţung im \&aufe Der erften Umtriebşzeit mur einmal eingehen.

Dießs zu berimnlichen, rebucire ich in nadjolgendom Beifpiele, fowohl

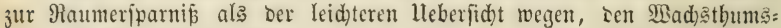

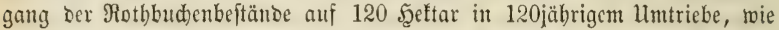
id) jolden in ben Erfabrungstabellen S. Ł3-92 meiner 2(bbandlung über Den

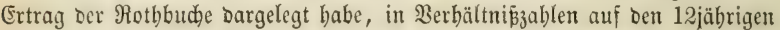
Umtrieb; fo baß bie $\mathfrak{B}$ eränberungen, weld)e bort bon 10 zu-10 Jabren ver=

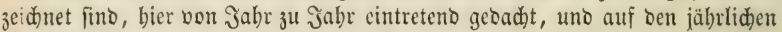
2(btriebsertrag $=10(10,500=10)$ rebucirt find. Multiplication jeber einjelnen Berbältnifzabl mit 1050 ergibt baber Deren wirtlide (3röße in

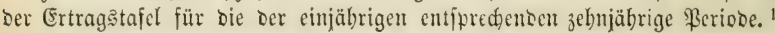

Jun ber nebenjtehenden Iabelle (i. S. 79) find Die Mafjenreiben ber einjelnen 2tbtriebs: uno Durdfipritungserträge getremnt bargeftellt, uno zwar im 3uftande furz vor Dem Şiebe bes älteften Echlages, aljo Borrath und cinjäbrigen 3uwads enthaltent. Die erfte Columne zcigt bie Mafienreihe Des Abtriebertrages, bie zweite gibt bie Maflenreihe für Den mit bem $\mathfrak{A b}=$ tribe gleidjsetig erfolgenden Durdforftungsertrag im 120jäbrigen, 12jährig

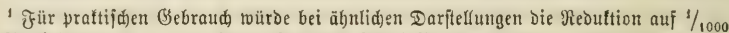

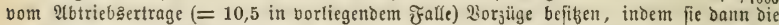
3orrath = un Buwadęröß̈en Der (Erfahrungstafel unmittelbar aus bem Decimal=

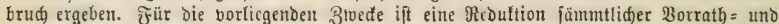

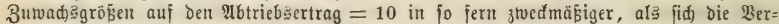

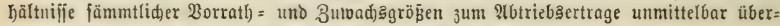
bliden lajfen, da fie in Decimaltheilen vom \&btriebsertrage baftehen. 


\begin{tabular}{|c|c|c|c|c|c|c|c|c|c|c|c|c|c|c|}
\hline \multirow{5}{*}{ IIter. } & \multicolumn{13}{|c|}{ Mbtriebsalter ber glafienreigen. } & \\
\hline & 12 & 12 & 11 & 10 & 9 & 8 & 7 & 6 & 5 & 4 & 3 & 2 & 1 & \\
\hline & \multicolumn{13}{|c|}{ Stammzabl ber $\mathfrak{D}$ affenreihen. } & \\
\hline & 152 & 19 & 23 & 31 & 45 & 70 & 160 & 350 & 650 & 2500 & 6000 & 40000 & 300000 & \\
\hline & \multicolumn{13}{|c|}{ 5olzmaffe in $1 / 1050$ bes mirflidien Betrages. } & \\
\hline 12 & 10,00 & 0,570 & $\begin{array}{l}0 \\
10 \\
10 \\
0 \\
-1\end{array}$ & & & 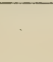 & & & & & & & & \\
\hline 11 & 8,86 & 0,570 & 0,580 & 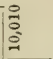 & & & & & & & & & & \\
\hline 10 & 7,56 & 0,565 & 0,575 & 0,610 & $\begin{array}{l}\frac{\rho}{2} \\
\frac{0}{2}\end{array}$ & & & & & & & . & & హె \\
\hline 9 & 6,24 & 0,560 & 0,570 & 0,605 & 0,650 & $\begin{array}{l}\text { ज़ } \\
\text { 心 } \\
\infty\end{array}$ & & & & & & & & $\begin{array}{l}\text { से } \\
\text { से } \\
\stackrel{5}{=}\end{array}$ \\
\hline 8 & 4,93 & 0,520 & 0,540 & 0,580 & 0,640 & 0,690 & $\underset{8}{8}$ & & & & & & & $\stackrel{\equiv}{\equiv}$ \\
\hline 7 & $3,7: 2$ & 0,420 & 0,480 & $0,530 \mid$ & 0,600 & 0,680 & 0,910 & 号 & & & & & & \\
\hline 6 & 2,52 & 0,300 & 0,390 & 0,490 & 0,579 & 0,631 & 0,850 & 0,970 & 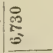 & & & & & \\
\hline 5 & 1,42 & 0,170 & 0,223 & 0,302 & 0,445 & 0,600 & 0,760 & 0,880 & 0,720 & $\mid \begin{array}{l}0 \\
\text { E⿱ } \\
5 \\
15 \\
15\end{array}$ & & & & \\
\hline 4 & 0,64 & $0,100 \mid$ & 0,138 & 0,182 & 0,300 & 0,450 & 0,450 & 0,490 & 0,603 & 0,600 & 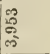 & & & \\
\hline 3 & 0,20 & 0,050 & 0,065 & 0,087 & 0,126 & 0,198 & 0,236 & 0,310 & 0,400 & 0,430 & 0,360 & $\frac{\hat{\sigma}}{\alpha}$ & & \\
\hline 2 & 0,06 & 0,010 & 0,013 & 0,017 & 0,024 & 0,050 & 0,070 & 0,150 & 0,220 & 0,290 & 0,320 & 0,280 & 点 & \\
\hline 1 & 0,003 & 0,000 & 0,001 & 0,001 & 0,001 & 0,002 & 0,001 & 0,011 & 0,017 & 0,060 & 0,120 & 0,210 & 0,040 & $\stackrel{8}{2}$ \\
\hline
\end{tabular}

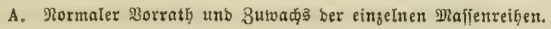

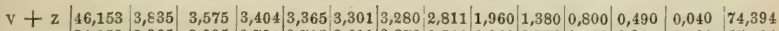
\begin{tabular}{l|l|l|l|l|l|l|l|l|l|l|l|l|l|l|l|l|l|l|l|}
$\mathrm{V}$ & 36,153 & 3,265 & 2,995 & 2,794 & 2,715 & 2,611 & 2,370 & 1,841 & 1,240 & 0,780 & 0,440 & 0,210 & 0,000 & 57,414 \\
\hline
\end{tabular} $\mathrm{z} \quad \overline{10,000} \frac{0,570}{0,580} \frac{\overline{0,610}}{\overline{0,650}} \overline{0,690} \mid \overline{0,910} \frac{\overline{0,970}}{0,720} \frac{\overline{0,600}}{0,360} \frac{\overline{0,280}}{0,040} \frac{\overline{16,980}}{0,16}$

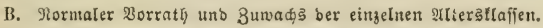

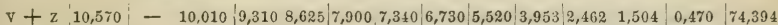

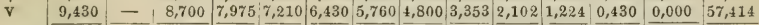

$\mathrm{z} \quad \overline{1,140}-\overline{1,310} \overline{1,335} \overline{1,415} \overline{1,470} \frac{1,580}{1,930} \overline{2,167} \frac{1,851}{1,238} \frac{1,074}{0,470} \overline{16,980}$

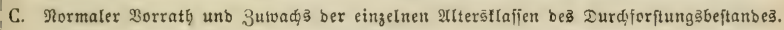

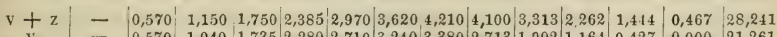

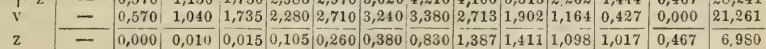

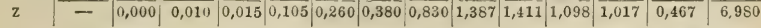

D. Normaler Borrath uno Зutwaçs ber einzelten Altergttafien bes bleibenben Beftanbes.

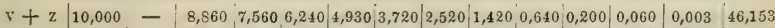

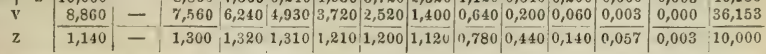

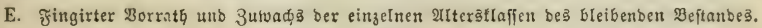
$10 / 12=0,833 \ldots \ldots$

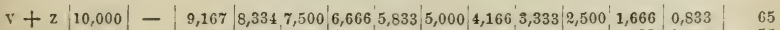

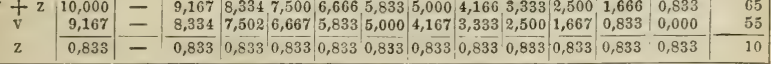


gebachten 2(lter. (Der 2lbtriebsertrag im 120 jährigent 2Ufter befteht auß $152+19$ Stamm. Die 19 Stämme würben bei 140 jäbrigem llmtriebe Der Durdforftung in 120 jäbrigen $\mathscr{2}$ fter anbeim fallen; Die Eonftruftion Der Erfabrungstafeln forbert, baj man fie aud bei 120jäbrigem lumtriebe als eine mit bem 2 bbtriebe zufammenfalfenbe Durdforfungs̆mbung betradtet). Die folgenben (Eolumnen zeigen bie Mafjentreiben ber früberent,

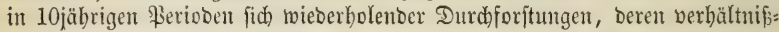
mäpige Größ̨e zum 2 btriebsertrage $=10$, bie obere Enoziffer nad)weișt.

Denft man fid) bie Columnen jeocr Maffenreike getrennt uno fo auf einanoer gelegt, baß bie gleidjaltrigen Fäder über einanber liegen, jo ent= halten bie forrefponbirenoen Fäd)er ben Mafiengebalt jeber 2Yltersłlaffe ein=

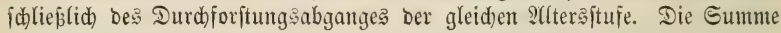
Der Maffen gleid)er 2fltersflaffe ift binter jeber horizontalen Reihe angegeben. Die Summirung biefer 3ablen ergibt bie F̧olzmafle Des Bollbeftanbes $=$ 74,394, ebenjo wie bie Eummirung ber Reibe $\mathrm{v}+\mathrm{z}$.

Jür ben in ber Tabelle oargeftellten normalen 3uftano Der Betriebs: fläche im 12jäbrigen Umtriebe ifjt:

Der Borrath für den 2 (btriebaertrag . . . . $=36,153$

Der Borrath. für Den Durdfforftungsertrag . . $=21,261$

Der (Sefammtoorrath. . . . . . $=57,414$

Der Gefammtzumadjs Der Umtriebszeit ift:

a) für Den 2(btriebs̉ertrag $12.10 \ldots . .=120,000$

b) für Den Durd)forftungsertrag 12 .6,98 : = 83,760

Summa Borrath uto 3umad) . . . $=261,174$

Der Durchforftungazzumady erfolgt:

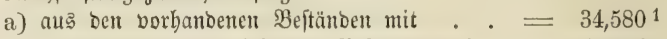

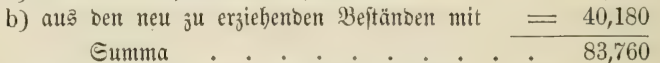

Der vorbanbene normale Norrath ergibt baber:

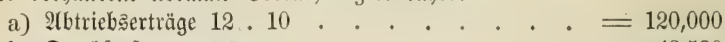

b) Durdforftungझెerträge . . . . . . . . . . . $=43,580$

Summa . . . . . . . . . . . $=163,580$

Der Zuwadjs an Den verjüngten Bejtänben liefert:

a) Den normalen Borrath für bie ziveite Untriebszeit mit $=57,414$

b) Den Durdfforitungảabgang mit . . . . . $=40,180$

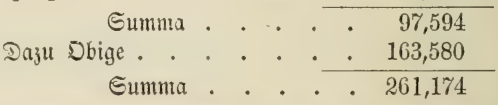

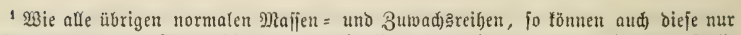
gefunden berben burd) (Eonftruftion und unmittelbare Summirung. Jm borfiegenden Falle Dente man fich Die normale Beftandsmaffe obne ?ad)зud)t neuer Beftänte allmäblig conjumirt. (E⿱

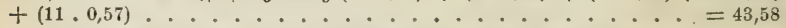

Man benfe fidf) ferner auf Der entblöpten Betriebsfläd)e jübrlid) 1 Gd)lag

angebaut, fo ift Der Durdforftungąertrag im Laufe der Umtriebs

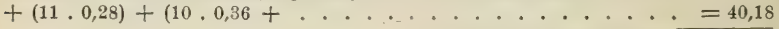

Inf beiben Betricbg̨läd)en $=83,76$ 


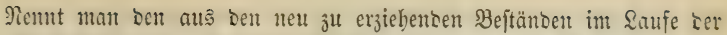
crften Llmtriebşeit exfolgen Den Dudforfortungsabgang $x$, io ift in vorliegen= Dem Falle $\mathrm{x}=\frac{40,18}{97,594}=0,41$.

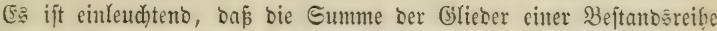
twie sie vorftehenten, nid)t burd) Jormeln, jonsern mut ourd) unnittelbare Gunmirung gefunben werben fömnen. In Berfabren läfit fid aber auf folgenbe $\mathfrak{B e i j e}$ abtürzent: $\mathfrak{z}$. $\mathfrak{B}$.

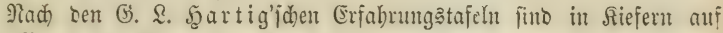
gutem Boden Die Ertragâääbe wie nadjolgeno angegeben.

\begin{tabular}{|c|c|c|c|c|c|c|}
\hline \multirow{2}{*}{$\begin{array}{l}2 \text { elter. } \\
20\end{array}$} & \multirow{2}{*}{$\begin{array}{l}\text { Bollbcftanb. } \\
1221\end{array}$} & \multirow{2}{*}{$\begin{array}{l}\text { Durdffor }= \\
\text { fturgşab= } \\
\text { gang. } \\
480\end{array}$} & \multirow{2}{*}{$\begin{array}{c}\text { Feriobifi } \\
\text { Eleibentber } \\
\text { \$eftanb. } \\
741\end{array}$} & \multicolumn{3}{|c|}{ 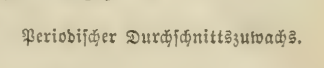 } \\
\hline & & & & $\frac{1221}{20}$ & $=61$ & ट̈ubifjuई. \\
\hline 40 & 2016 & $340^{1}$ & 1676 & $\frac{2016-741}{20}$ & $=64$ & $"$ \\
\hline 60 & 2965 & 340 & 2625 & $\frac{2965-1676}{20}$ & $=65$ & $"$ \\
\hline 80 & 4030 & 530 & 3500 & $\frac{4030-2625}{20}$ & $=70$ & $"$ \\
\hline & 4530 & $(530)$ & $(4000)$ & $\frac{4530-3500}{20}-$ & $=\check{~} 1$ & $"$ \\
\hline
\end{tabular}

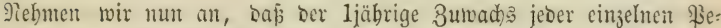

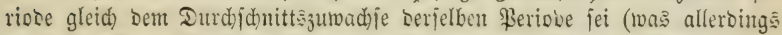

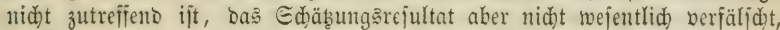

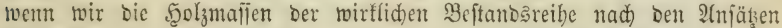

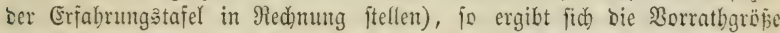
Des Sollbeftandes für 100 Mlorgen in 100jäbrigem llmtriebe nad) ber formel $\mathrm{a}+\mathrm{u} \cdot \frac{\mathrm{ll}}{2}$, สนล folgenber Bered̆nung:

$$
a+u \quad a+u \cdot \frac{n}{2}=s .
$$

1 -20jähr. Beitand $(0+61=61)+(20.61+0=1221)=1282.10=12820$ $20-40$ jäfr. $\quad$ " $(741+64=805)+(20.61+741=2016)=2821.10=28310$ $40-60$ jäbr. " $\quad(1676+65=1741)+(20.65+1676=2965)=4706.10=47060$ $60-80$ jäßj. " $\quad(2625+70=2695)+(20.70+2625=4030)=6725.10=67250$ $80-100$ jähr. $. "(3500+51=3551)+(20.51+3500=453:)=8(81.10=80810$ Summa $8542+311+14762=23618 \cdot 10=236150$

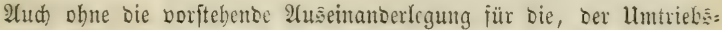
jeit gleid)e fläd)engröße, findet man ben, Dem wirfliden Buwad)ågange

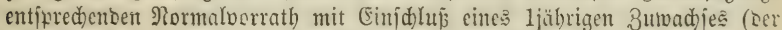
jüngite E(b)lag ljäbrig, ber ältẹte Ed)lag 100jährig), wem man in ser Erfabrungatafel bie Şolzmafien bes periobijd) bleibenden Beftande (8542),

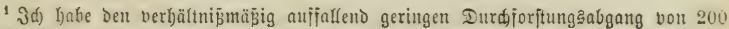

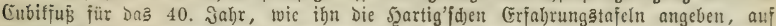

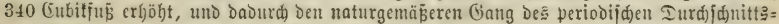

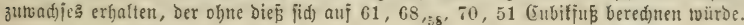

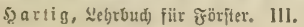




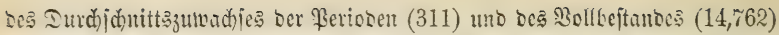

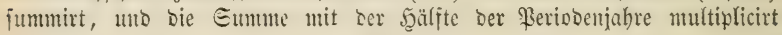
$(236,150)$.

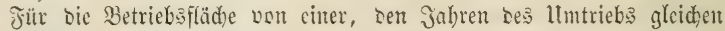
Morgenzabl, ergibt fid) 2(btriebs: uno Iurdforftungsertray (= 3utwad) : unmittelbar aus ber Erfahrungstabelle. Sn noritehentom Beifpiele ift Der

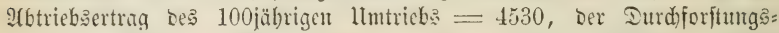
ertray $=1690$, Der Gefammtertray $=6220$ Eubiffui $(14,762-8542$ $=6220 ; 6220-4530=1690)$. Den lețteren al: ljährigen 3umach

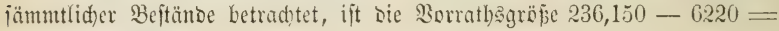
229,930 Eubiffup.

\section{Der fiugirte $\mathfrak{B}$ aldojuftad.}

Fingirt fant man einen MSalojujtano nemen, wemt mau, bei cinem

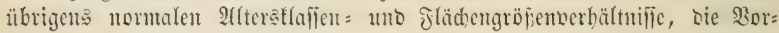
rathägröben nid)t fo berjeidnet wie fie wirflid) fino, fonourn bie Majien=

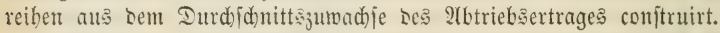

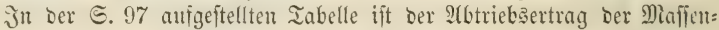

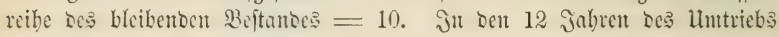
finto aljo am 2(btriebsertrage ourdfid)nittlid) jährlich $\frac{10}{12}=0,833 \ldots$.

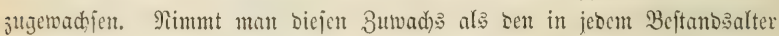

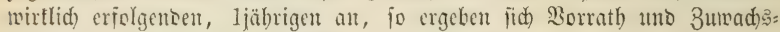
reifen, wie fie in $\mathrm{E}$ ber Tabelle $\subseteq$. 79 Dargeftellt fint.
1) $\mathrm{v}+\mathrm{z}=0,833+$
$10 \cdot \frac{21}{2}=65$
2)
$v=0,00+$
$9,17 \cdot \frac{12}{2}=55$
3)

$$
\mathrm{z}=0,833+0,833 \cdot \frac{12}{2}=10
$$

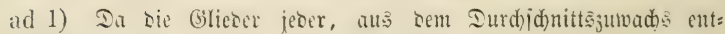
midclten Maffenreihe eine jtetige aritbmetijde Reibe bilben, erbält man bic

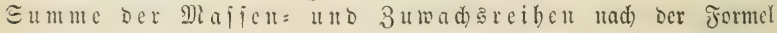
a $\frac{1}{+} u \cdot \frac{n}{2}$, in welder a bas erite, u ona lește Ǵlieo ber Mafienreibe, $\mathrm{n}$ bie $3 \mathrm{abl}$ ber (slieber bezeidunet.

Jür alle Meiben, in welden a gröfer als o ijt, mus jtets bie volle jormel in Stnwenoung treter, aljo aud banu, wem man ben Borrath

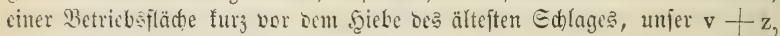
mit Dem $\mathscr{2}$ țborude v bezeid) net.

ad 2) Jit tos crifte (sfled ber Maffenteibe $=0$, wie in jeder Majenteibe bes Borrathes, fo ergibt fid füryer bic Summe ber

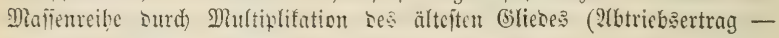
liäbriger 3uwad) mit ber balben flähengröß̧e (u $\frac{\mathrm{n}}{2}$; im Beifpiele 
$9,17 \cdot \frac{12}{2}=55$ ). Der fingirte 3orrath - ni d t oer normale -

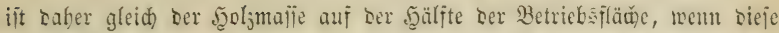
mit Bejtäncen bom 2lter ber llmtriebseit keftodt wäre, weniger bem lebtjährigen 3 umadis an biejer Beftandsmajle. Ia in fingirten

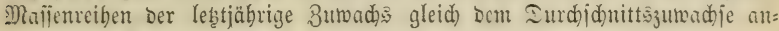
genonmen roirb, fo fann man anfatt Der Eubtraftion bes 1 jäbrigen $34=$ madjes bie 3aht ber Bffiecer um 1 verringern uno anjtatt ber formel u $\frac{n}{2}=v$, in melder u Бaร vorle bite Ǵlied ser Mafienreibe $(9,17)$

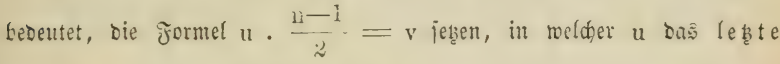
Glieo oer Majienreibe bejeichnet (im Beippiele $10 \cdot \frac{11}{2}=55$ ). Die

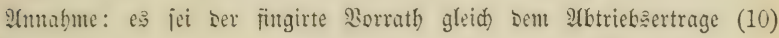

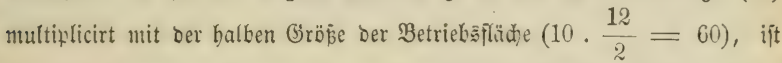

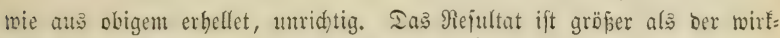
(id) fingirte Borrath $=55$, fleiner als $\mathrm{v}+\mathrm{z}=65$.

ad 3) Da in jeder Suwactsreihe a grö́per als o ijt, jo müste aud

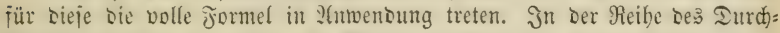
idnittajumadjes jino aber alle Gilicber gleid) grof́; man jummirt baher

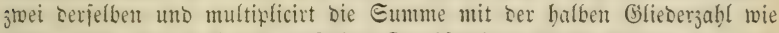
oben, fann aber and ben einfachen Durdidnittäuwad) mit ber ganzen (Slieberzahl multipliciren $a \cdot n=0,833 \cdot 12=10$ ).

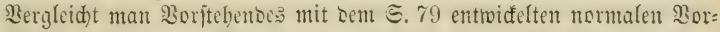

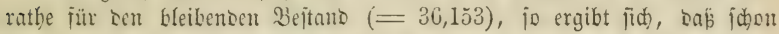
bier, wo utr ber bleibente Bejtand in Betrad)t gejogen ift, bei gleider

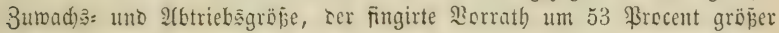
als sor normale ift. Eomjtuint man in ähnlider Seije roie norjteheno

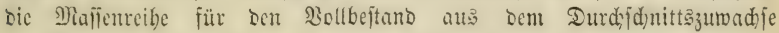
$\frac{16,98}{12}=1,415$, jo ergibt fich für fv die Ģröbe von 93,39 , mithin 63 Procent mebr als bie 2Rirflidfeit. Die Eumme ber auß Dcm Durd)=

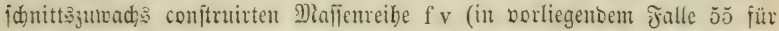
sen Gleibenten, 93 für son vollen oser frätominirenten Beftan๖) über: jteigt irgar um ein Beträdtliches nod) bie Eumme ber normalen Majien= reibe $\mathrm{r}+\mathrm{z}$ (nad) હ. 7946 für ben bleibenden, 74 für bon bollen Be=

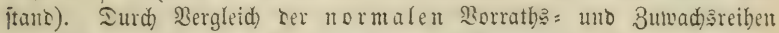
uno ভummen (ङ. $79 \mathrm{D}$ für Den bleibenden Bejtant) mit ben fingirten Reiben und Summen (E) wiro man bie Urjad)e Der Iifferens in ber un= gleidjen Bertheilung uno in ber geringen Oröbe Des 3utwadjes uno Daber

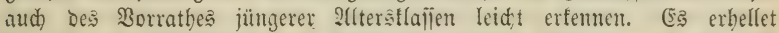

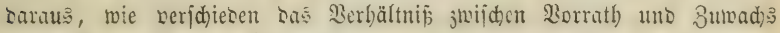
normaler uno fingirter Mafifenreiben bei gleider jummarijoer 3umad) agröpe keiber ift. 


\section{Der reale Maldzuftan.}

Real, im Gegenjage zu normal uno fingirt, fann man bie wir $\mathfrak{t}=$

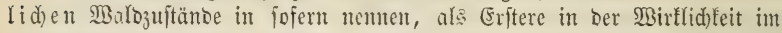

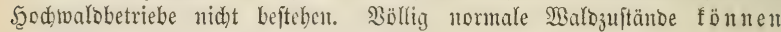

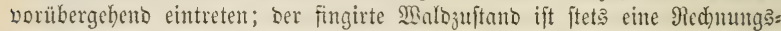
figur, Da er fich auf Atnuabmen grünbet, bie in ber Mirflidffeit nicht be= fteben, auf Die S(mnabme einer gleidmäpigen Bertbeilung Des 3uvachfes in bie verichiebenaltrigen (5lieber ber Maffenteiben einer Betriebsfläd)e. Der

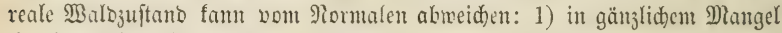

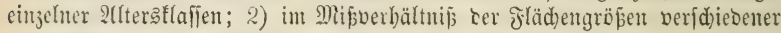
Sllter:aflafen; 3) in Mängeln Der Beftodung, bes Borrathes uno Buvadjes.

\section{Ueber $\Re$ ubug}

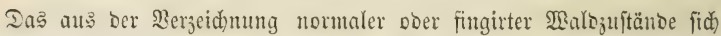
ergebende 3 erbältnif zwijd)en Borrath uno 3 uwad)

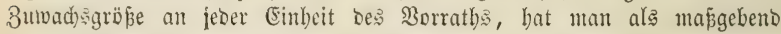
erad)tet für bie Siubungggröfe aud) aus realen, abnormten TBalbzuftänben Der beridyiebenften 2 rrt.

In ser G. 79 anfigeftellten Iabelle cinter Betriebsfläche ift $\mathrm{v}$ bes Sie: fammtertrages $=57,43, \mathrm{z}$ Des Gejammtertrages ober ber jäbrliche 3u= mad) $3=16,98$. E $\frac{16,98}{5 \%, 434}=0,296$ an jeber Cinkeit bez నorrathes. Der Mbtriebaertrag $=10$, ijt $\frac{10}{57,433}=0,174$ von jeber Cinkeit des \$ollbeftandes (präbominirenter Bef̣tano).

Mäblt man bie Mafienreiben Deş bleibenben Beftandes als Ber: gleid)agröpe, in ber Iabelle $=36,153$, fo beredinen fid $\frac{16,98}{36,153}=0,47$ Gejamntertrag $\frac{10}{36,153}=0,276$ Abtriebsertrag auf jede Einbeit des bleibenoen Beftandę.

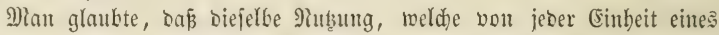
normalen Sorratbes fid berednet, wem fie bon abnormen Sorrätben ana=

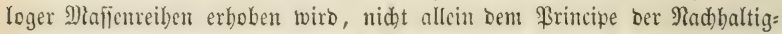
feit entiprädse, fondern aud), Durd) Borratbconjumtion ober burd) 3uwad): eriparnif, jeben abnormen 3ujtano allmäblig zu einem normalen 3uftano ïberfübre.

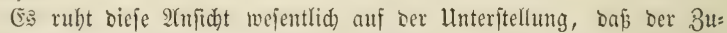
wat) auf ciner überbaupt beftodten Jläche vorzugsweife ourch bie \$ro= Duttionstraft Des Standorts beoingt, von Der Sröfe uno Befdaffenbeit Des Sorratbes innerbalb getwiffer Girenjen unabbängig fei, Dap ein, ourd) lleber:

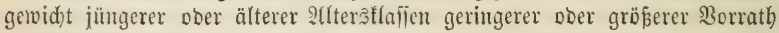

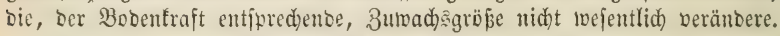

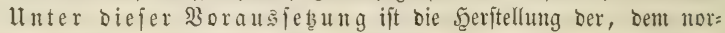

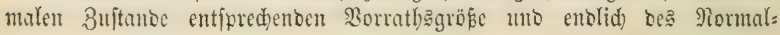




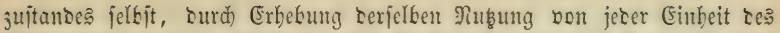
abnormen Norrathes, welche auf jebe Cinbeit bes normalen Rorrathes fällt, allerbing ge gefidert.

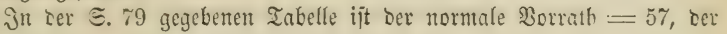
3umady am normalen Borratbe $=17$, bie Nuķung baher $\frac{17}{5 \%}=0,3$ von jeber Finbeit Der leb̨teren.

Sit in einer borliegenton Betriebşfläche ber volle Borrath vorbanten, jo wirb, burd) Erbebuty von 0,3 jeber Borratheinheit, ser 3uwads con= fumirt uno Der Borrath bleibt unveränbert.

Sit weniger als ber volle Borrath vorbanten, fo ergitt bie $2(6=$ muţung von 0,3 Des twirtliden Borrathes eine binter Dem Zuwadję zurïd=

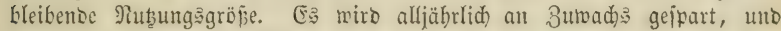

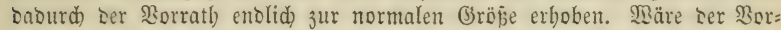
ratb einer, Den Ertragşberbältniffen ber Tabelle analog beftumbenen $B_{e}=$

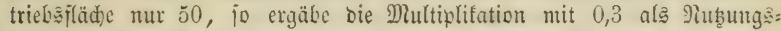

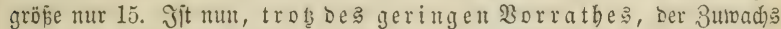
wie im normalen 3ujtanoi $=17$, jo werben jäbrlid) 2 3uwadjs erjfart

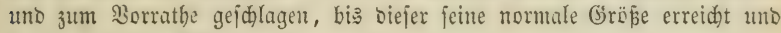
bamit ber erite Fall eintritt.

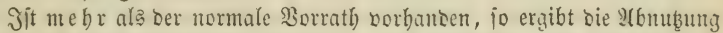
von 0,3 bes vorbandenen $30 r r a t h e s$ eine, ben jührliden (als unberänberlid's

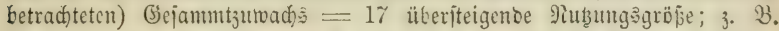
$70,0,3=21$. Es: wiro Daburdh nidtt allein ber jüfrlide (Sejammtzutwad), jonbern aud) ein Theil bes überfdülifigen Bortathes, im Beijpiele alljähr:

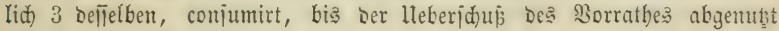
ijt, uno ber erite Jall eintritt.

Mit Der allmähligen Jeerftellung Des vollen Borrathe surd) Sutwad anţäufung ober Sorrathconjumtion ftellt fid), wenn aud) nid)t g(eidzeitig, bod) enolich, aud) ber normale Borrath, ber bolle Borrath im normalen 3uftanbe her.

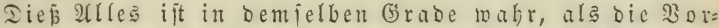
ausjebugridtig i it, baj Borratbmangel ober Ueberidu

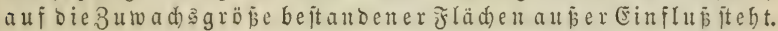

Da ber Duotient aus Borrath in 3uwad, $\left(\begin{array}{l}z \\ v\end{array}\right)$ nomaler Betriebs:

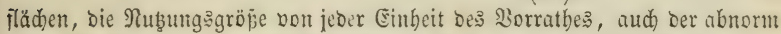

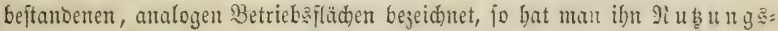

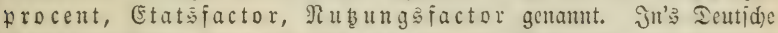
übertragen würbe $\Re$ u 2Yübruaf jein.

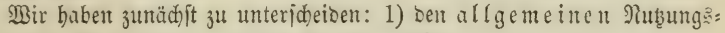
weifer uno 2) den bejonderen Rubungstweifer.

Bom allgemeinen $\Re$ ubungstocijer.

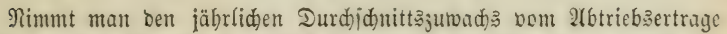
als ben in jeber 2(Iterstlaile wirflid) erfolgenoen 3urndob an, jo ergibt fid) 
Daraus eine Majïenreike Der Betriebsfläche, bie ich voritebento als "fingirter Baldzuftand" bejodrieben babe.

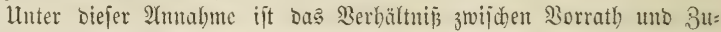

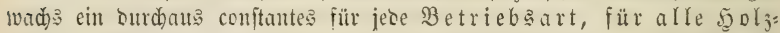

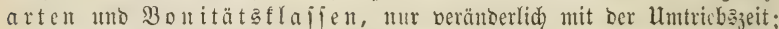

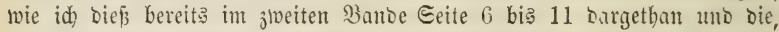

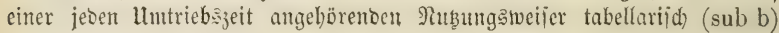
nad)gewiefen babe. 2(u bent (sub a) aufgefübrten Berbältnilie felbjt, fam man ben allgemeinen 2lubsungşweifer leid)t auf eine gröfere Bahl wout Deci= malftellen genauer berednen.

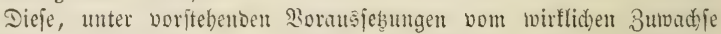
unabbängige Zumad)sgröfe babe id in sllgemeincu den ipecififden

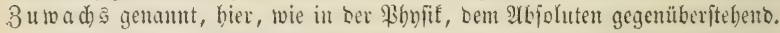

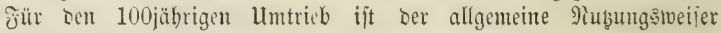
$=0,0202(49,5: 1=1: 0,0202)$. Brüfen wir Das Obige an Scifpielen auङ Der Mirflidfeit.

Die (5). \&. Sgartig’iden Erfabrungstafeln für Ricfern ergeben int 100 iten Jabre an 2(btriebserträgen anf guten Boben 4530 Eubiffuis, mittel

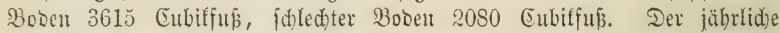
Durd) jonittezutwad): an bleibenten Beftanbe ift baber 45,$3 ; 36,15 ; 20,80$

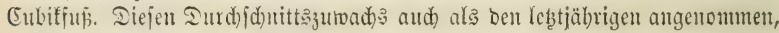

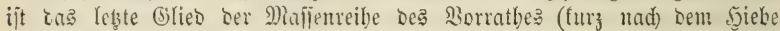

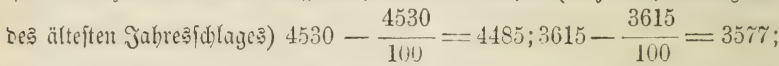
$2080-\frac{2080}{1010}=2059$. Die Emmme ser Maflenteibe ift in biefen srei Jällen nad) oer Jormel u $\frac{n}{2}$ bered)net (sa $a=0$ ), $4485.50=224250$; $3577.50=178850 ; 2059.50=102950$.

lluter ber borftebenden Amabme ift oer 2 (btriebsertrag gleid bem

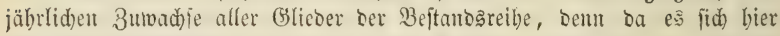
mur un ben 3uwad): am bleibenden Scitande banbelt, ift ber 3uwachs, weldyex an eine m Beft an De biunen 100 Sabren fid anbäufte, gleid, bem burdjunittliden 3uwadje aller 100 Beftanosglieber in einem Jabre, Ioent Dieje in normaler 2Ultersabfufung fteben. Das Berbälnij zwijd)en Sorrath unb der Summe bes Butwadjes ciner Betriebsfläche von 100 Morgen in 100jäbrigem Untriebe ift baber:

für guten Boden $224250: 4530=1: 0,0202$
"mittel " $178850: 3615=1: 0,0202$
" (d)led)ten " $102950: 2080=1: 0,0202$

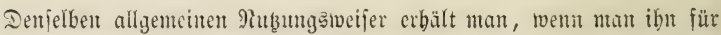
Den 100jäbrigen llmtrieb au Den Erfabrungstafeln oer ïbrigen Sgolz= arten bered)net. Weber bie veridjicoene (jröpe des abjoluten 3utwadjes,

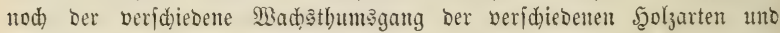

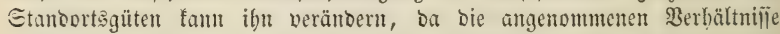
ztoifden Borrath uno 3 uroads für biefelbe Untriebszeit ftets biejelben fino. 


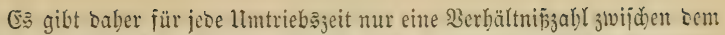

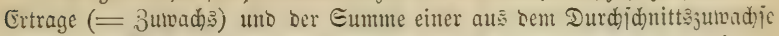

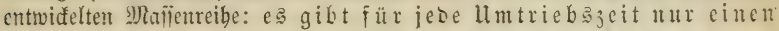

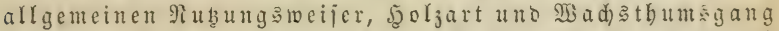
mögen nod fo beridieben fein. (Er ift Derfelbe für ben Sorrath

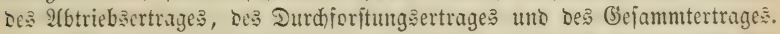

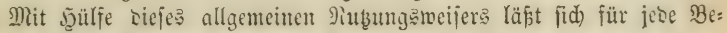

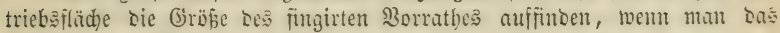
Entoglico ser Malicnreibe (Utbriebsertray ober Bejanmertrag) mit Dem

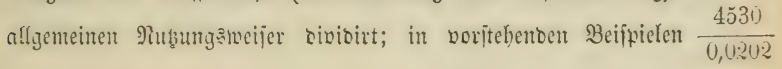

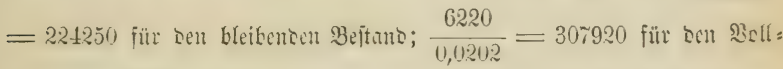
Iejtano; $\frac{1690}{0,0202}=836 \%$ für sen Iurdjperftungšnorrath) (wergl. Є. roj).

3ombejonderen ?ubugateifer.

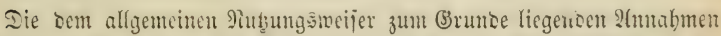

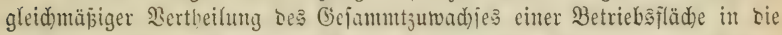

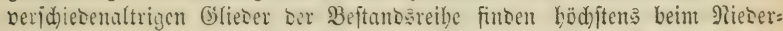
waloe in furzem llntriebe uno aud) Ba mur amäberno ftatt. In oer

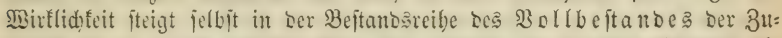
mad)s bis zll eincm gewiffen ?(lter bin, jowobl an cinzelnen Bäumen als

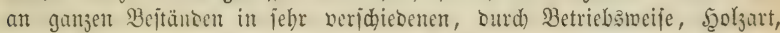
Betwirtbidfaftung uno Etanßort bedingten ßerbältniifien, fulminirt cine längere noer fürzere Beit uno funtt bann allnäblig wieber berab. Sn viel böberem Grabe ungleiơnmäpig vertbeilt ift Der 3umadjs in bie B'lieber bez blei= benden Beitanocs. Die annäbernoc Silcidjtellung bes periobifden

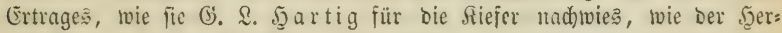

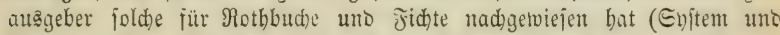
2(nleitung Geite 178 uno 198), gilt nur für bie älter als 20-30jäbrigen 2llterâflafjen uno aud) in siefen mur für ben Bollbejtano.

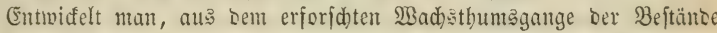
einer Betriebs̄läche, bie, ¿em normalen 3ujtande berjelben angehörenten Majienteiben, wie bię in ber Tabelle $G$. 79 beifpielsmeife geftehen ift, jo ergibt das Serhältnißß Des \$orratbes in biejen Mañenreihen zu ihrem

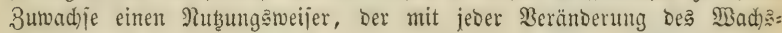
thumbganges ber Beitänoe ein anderer, alio für berjojiebene Betriebsarten, Ilmtriebszeiten, Syolzarten, ja für jebe Standortsoerjdiçenbeit veridjeben ift, infofern bieje einten abweidenden $2 B a d$ sthumsgang ber $\mathfrak{B e}$

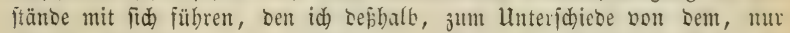

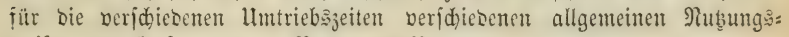
weifer, ben befonderen Nubungsweifer neme.

In Der Iabclle Є. 79 ijt ber 2Gbtriebertrag Des $12 j a ̈ b r i g e n ~ U n t r i e b s$

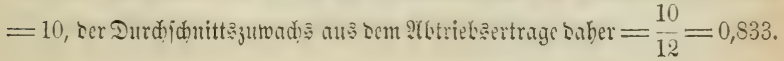




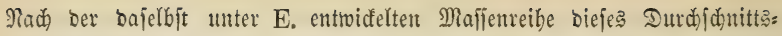
juwadjes ijt $\mathrm{v}=55 ; \mathrm{z}=10 ; \frac{10}{55}=0,182$. (Ẻ ijt $0,182=$ Dem

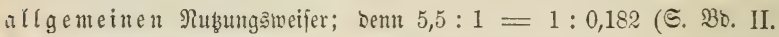
5. 9). Nad ber Iabelle ift aber, be i gle idjem 3 utwadfe, ber witfliche Borrath nur 36,153, der bejondere Nutzungameifer baber $\frac{10}{36,153}=0,28$.

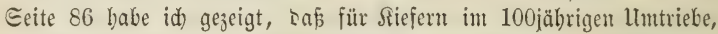

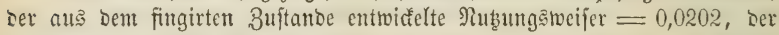
allgemeine Des 100jährigen ltmtriebs jei, jowohl auf gutem als auf mittel= mäpigem uno foblechtem Stanoorte.

In ber S. 81 erörterten Weije beredunt, ift ber wirflidje Borrath auf gutem Boden = 236,150; Der 2lbtriebsertrug $=4530$, ergibt als

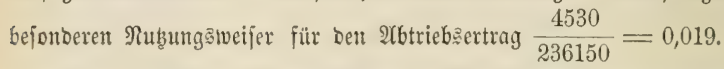

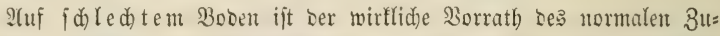
jtanbes $=126580 ;$ der 2(btriebsertrag $=2080 ;$ ergibt als bejonderet ఇubungsిmeifer $\frac{2080}{126580}=0,016$.

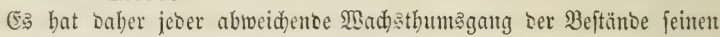

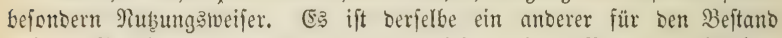
auf Der Bergfuppe, ein anderer für ben tiefgrünbigem Boben bes Thales; er fann ein anberer fein für bie Norbfeite, ein anberer für bic Silbpeite Defielben Berges.

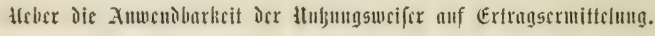

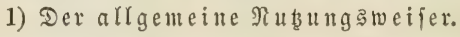

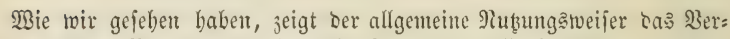

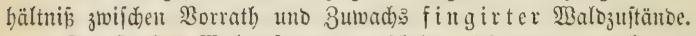

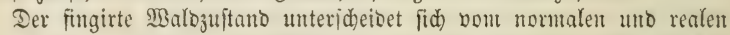

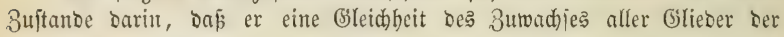

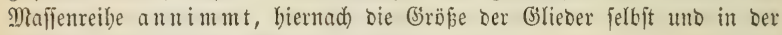
Summe berjelben ben ßorrath berednet. (Seite 82).

Unter getwöbulichen Berbältniffent finoet aber eine gleidmmǟige Ber: theilung bes Zuwadjes nidst jtatt, jonbern biejer jteigt mit zutehmentem Bejtandsalter bis zu cinem näber oder entfernter liegenden Beitpunte (Seite 86).

Dié̉ hat zur Folge, Dañ, wie Der ßergleid) ber, Seite 79 D. uno E. ausgefüfrten Beifpiele ergibt, ber Borrath de: fingirten 3uftandes ftets bebeuteno größer als der bes normalen 3uitantes, meift and) gröfer als Der bes realen 3uitandes ift.

Da bie Summe ber, aus bem Durdjodnittşumadje fonftruirten Mafjen= reihe, oa ber fingirte Borrath ftets größer ift als ber normale, ba ferrer

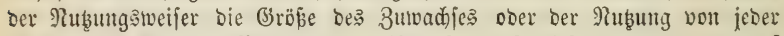
Eintheit bes fingirten Worratbes angibt, fo mup biefer, angemenoet allf 
Sen wirfliden Borrath eines normalen soer abuormen Malojuftantes,

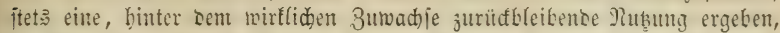

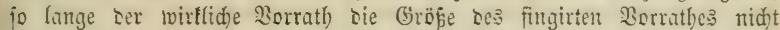
erreidet bat.

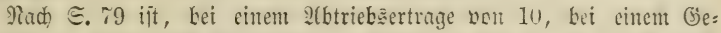
iammtertrage vou 16,98 in 12jährigem Untricbe, ber normale Norrath für eriterm $=36$, für lesteren $=5 \tilde{r}, 4$. Die Entwerion Der Mlaijenteiben

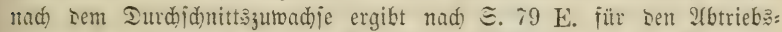

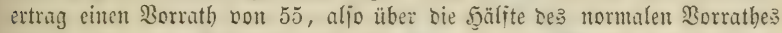
mehr. Für ben (Bejummtertrag beredi)net fid) ein 2lorrath he: fingirten

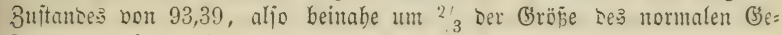
jammtoorrathes mebr.

Der Atbricbsertray beß normalen \$srrathes ijt im Beijpiefe $=10$,

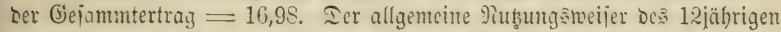
Ulmtrieb: $=0,182$, angementet alf Den 3orrath Des Pormalyuitanbe: liejert $36 \cdot 0,182=6,55$ für Den 2(btriebaertrag; $5 \pi, 4 \cdot 0,182=10,45$ jür ben Gejammtertrag, in beisen fällen sen Ertrag um 0,34 uno 0,4 De: 3uwadję zu niebrig.

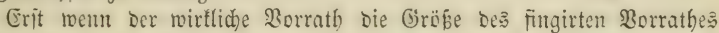
$=55$ oder 93 erreicht hat alfo bie normale (5) öbe bei weitem überiteigt, ergibt ber allgemeine Puţunģiveijer cine, Dem normalen 3uwadje gleid)e Abmuţung.

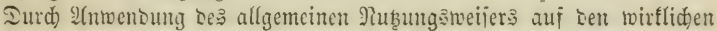
Borrath einer Betriebs ilähe wiro oaber cin Borrathämangel allerings er=

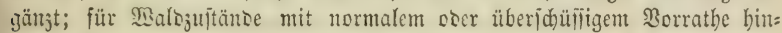
gegen iit er unanmentobar unt in bemjelben Berbältniffe jul flein als ber fingirte Borrath gegenüber bem normalen $3 u$ grop ift, Denn:

$$
\begin{array}{l||l}
36: 0,182=55: 0,28 & 57,4: 0,182=93: 0,3 \\
36: 10,000=1: 0,28 & 57,4: 16,98=1: 0,3
\end{array}
$$

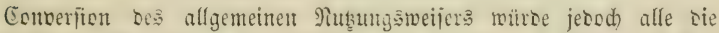

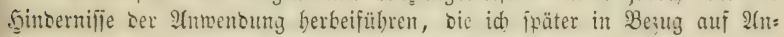
wentung Des bejonten liub̧ungäweijers bejeichnen werte.

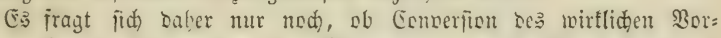
rathes, ob eine Bermandung Der Maijenreihen bes wirflichen Borrathe:

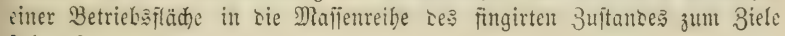
fübren?

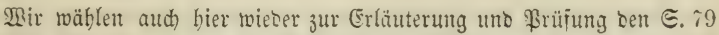

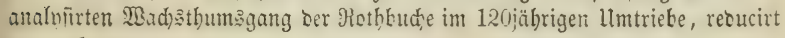
auj $\frac{1}{1050}$ unb bargeitellt im 12jäbrigen Umtriebe: 
1. Mirflidje Maffenreiken Dę bleibenden norntalen Bejtande马. Beftandarter.

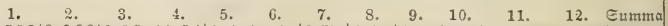

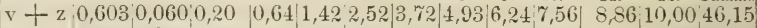

\begin{tabular}{l|l|l|l|l|l|l|l|l|l|l|l|l|l|l|}
$\mathrm{v}$ & 0,000 & 0,003 & 0,06 & 0,20 & 0,64 & 1,42 & 2,52 & 3,72 & 4,93 & 6,24 & 7,56 & 8,86 & 36,15 \\
\hline
\end{tabular}

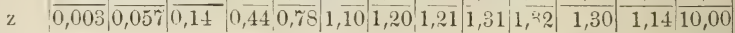
$10 / 36,15=0,277$

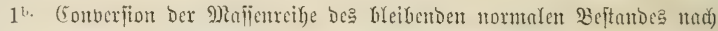

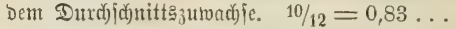

$\mathrm{v}+\mathrm{z} 0,83|1,67| 2,50 \quad 3,334,17,5,005,836,677,508,33|9,17| 10,00 \quad 65$

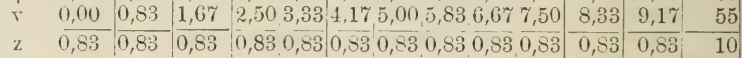

$16 / 55=0,182$

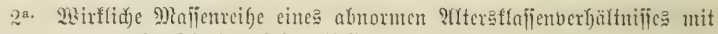

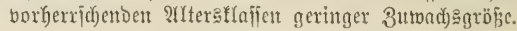

Beftandantex.

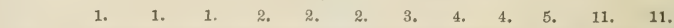

\begin{tabular}{c|c|c|c|c|c|c|}
$\mathrm{r}$ & $0,0030,0030,0030,06,0,060,060,20$ & $0,6 \pm 0,6 \pm 1,42$ & 8,86 & $8,8620,81$
\end{tabular} $r+z 0,060,0,0600,0600,200,200,20,0,6 \pm 1,421,422,5210,0010,0026,78$

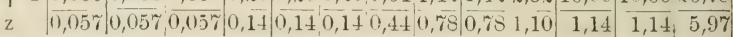

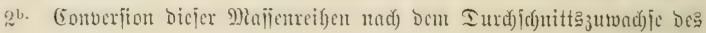
normalen 3ิuftandę.

\begin{tabular}{ll|l|l|l|l|l|l|l|l|l|l|l|l|l|l|l|l|l|} 
r & 0,83 & 0,83 & 0,83 & 1,67 & 1,67 & 1,67 & 2,50 & 3,33 & 3,33 & 4,16 & 9,17 & 9,17 & 39,16
\end{tabular} $r+z 1,67 \quad 1,67 \quad 1,67 \quad 2,502,502,503,334,164,165,0010,0010,0049,16$

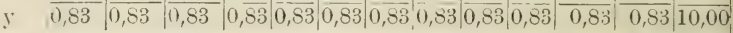

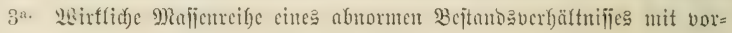
berrid)enden ?atergflafien boben Bumadjes.

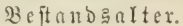

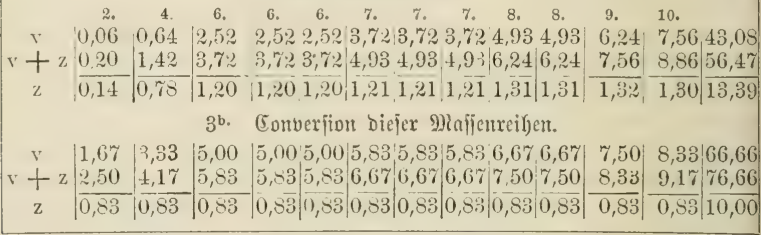

Ĵt Den twirfliden uno berwandelten Mlaffenreiben bes n ormalen

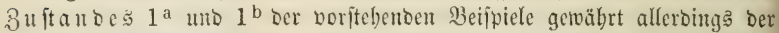

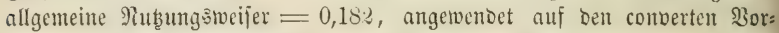

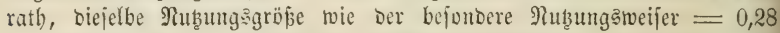
angewentot auf ben Norrath ber wirfliden Mafjenreibe, uno zwar: weil bie Berbältnijie zmijd)en wirflid)em uno convertem Borratl) biejelben find,

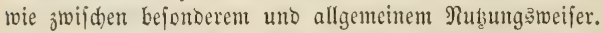

Diés mū aud in allen abnormen 2Balozuftänden ber Jall fein, in

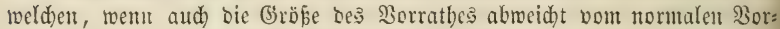
rathe, ood die Berbältnilie der Gröjen zu einanber diejelben bleiben.

Jn Jolge oer ungleichen Bertbeilung ses 3uwadjes in sie Gilieber 


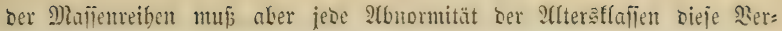
bältnifîe änbern.

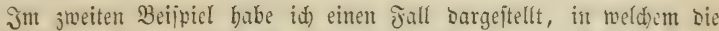

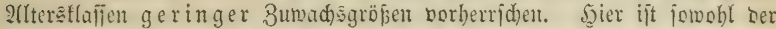
Sorratl) $=20,81$, wie ber 3 umad) $=5,97$, bebeuteno geringer als ber

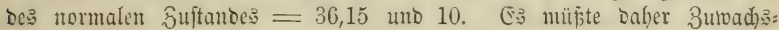
criparnis ftattfinton. Die Conberion Der Manjenteiben ergibt jum \or= rathe $=39,16$. Cis ergitst $39,16 \cdot 0,18$ ? eine Abmuthung von 7,13 , aljo

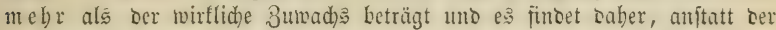
nöthigen 3uwadjerifarnif nod) bebeutende Borrathconjumtion jtatt.

Jm oritten Beippiele habe id einen Jall bargeftellt, in roeld)em bie 2(lterälajen mit gröficrem 3uradje vorberriden. Sorrath uno 3u= mads fino bier gröfer als ber normale, es müpte baher nid)t allein $3 u=$ mad) $=$;onbern aud Sorrathconjumtion ftatfintoen. Die Converfion Der Maljenreihen ergibt zum Sorrathe $=66,66$; bic Multiplifation mit Dem allgemeinen 2lubungäneifer $0,182=12,13$, aljo nod nid)t 3uwad)3: conjumtion, ba ber mirflide 3umachs 13,39 ijt.

Die 2fnwenoung

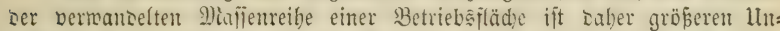

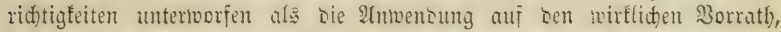
bei welden man in allen Jällen mentigitens nor einer llebermuţung ge= fidert ijt.

Wenn bei Der Anwenoung Des allgemeinen Ruthungşweijers auf Den wirflichen ßorrath Die Unridtigleit daraus bervorgebt, Daßj Der allgemeine 9luţungstweijer einem größeren Borrathe entjpringt als oer mirflid)e normale

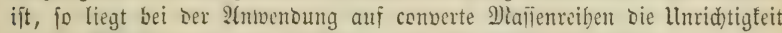
in Den 2 (bweid)ungen Des wirflichen vom Durchichnittşunadje.

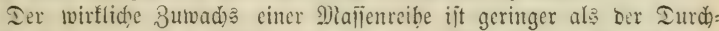

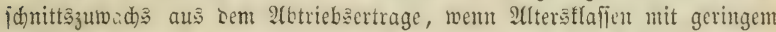

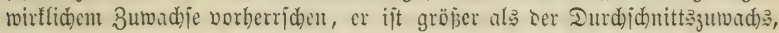
wenn Bejtänoe mit hohen Buwadje vorberrichen, wäbreno ser allgemeine

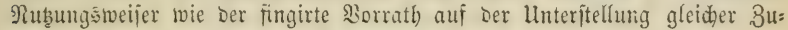
wadbzgrößje aller Glieber Der Mafienreibe ruben.

(Es ift einleud)teno, Daj biejelben Fehler, welche bie Beriventung bes

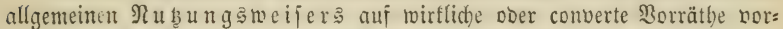
liegenoer abnorm bejtandenter Betriebsfläc)en mit fid fübrt, fid ebenjo in

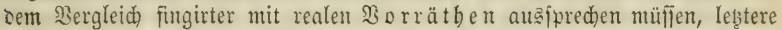

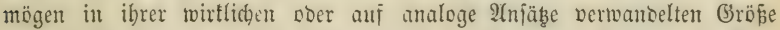

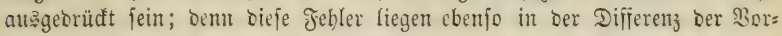

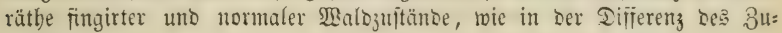
wad̆fes.

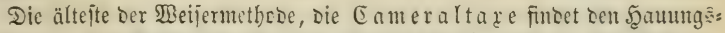
fab $(\mathrm{H})$ in Der Giröfe Des fingirten 3umadjes + ober - Der Different 3wifden realem Borrath uno fingirtent 2orrath, Divioirt burd bie Jabre Des Umtriebs (u): $\mathrm{fz} \pm \frac{\mathrm{rv}-\mathrm{fv}}{\mathrm{u}}=\mathrm{H}$.

Es ift unbefannt, ob bie Eameraltaxe eine Enverfion Der realen 
Maffenteiben forbert, ober ob fie ben fingirten Borrath (um ein Geringes unrid)tig bered)net) mit bem lvirfliden Borratbe bergleidht. WBir wollen Daker beibe galle einer \$rüfung unterwerfen.

Ilnter ber Hnnabme einer burd) Die Iaze vorgejobriebentn (Eonverfion Der realen $\mathbb{M a f f e n t e i b e n ~ i f t ~ i n ~ D e m ~ v o r f t e b e n t e n ~ B e i f p i c l e ~ ( S . ~} 901^{\mathrm{b}}$ ):

$$
\begin{aligned}
& \text { Der fingirte 3uwad) }: \mathrm{fz}=10 \\
& \text { ber fingirte Borrath: } \mathrm{f} \mathrm{v}=55 \\
& \text { Der Umtrieb: } \quad \mathrm{u}=12
\end{aligned}
$$

In sem Beifpielc $2^{\mathrm{b}}$ ift ber converte reale 30 orratb: $=39,16$

$$
10-\frac{39,16-55,00}{12}=10-1,32=8,68=\mathrm{H} \text {. }
$$

Sim Beifpiele $2^{\text {a }}$ ift ber wirflide 2:orrath 20,81 , ber wirflide $34=$ wad) 5 5,9\%. (55 müpte Daber zur Şerftellung des normalen Borratbes 36,15 (1 a) an 3uwad) gefpart meroen, wäbieno, burd) 2(buubung von 8,68 , Borrath Confumtion eintritt.

In bem Beifpiele $3{ }^{\mathrm{b}}$ ift Der reale converte Sorrath: $=66,66$

$$
10+\frac{66,66-55}{12}=10+0,97=10,97=\mathrm{H} \text {. }
$$

Jim Beipiele $3^{\text {a }}$ ift oer wirflide Borrath $=43,08$, ber wirfliche

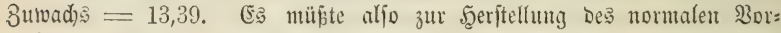
rathes $=36,15$ nid)t allein 3uwad) $=$, fondern aud Dorrathconjumtion eintreten, wäbreno das Rejultat nod) Buwadserfparniß ergibt.

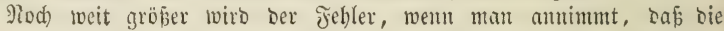
Eameraltace Den fingirten 3orrath mit Dem wirflicten Borrathe in Bergleid ftelle, gröper ned) als ourd) ummittelbare 3 erwentoung Des allgemeinen

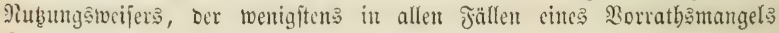
3uwad) seerparníp ergibt. (Seite 91.)

Die, auf bas jweite ber vorftebenten Beifpiele angewendete jormel ber Cameraltare ergibt:

$$
10-\frac{20,81-55}{12}=10-2,84=7,16=\mathrm{H} .
$$

Die auj Das britte Beipiel angetwenbete Formet:

$$
10-\frac{43,08-55}{12}=10-0,91=9,09=\overline{\mathrm{H}} .
$$

Jim eriten Jall, bei Borrath = uno 3uwad) smangel ift $\mathrm{H}$ gröber als

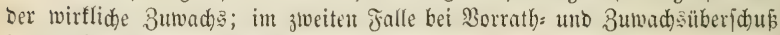
ift $\mathrm{H}$ fleiner als ber twirtlide Buradj.

Die Eameralmethode ift baber in ibrer Brunolage falid) uno jwar baburd, daj fie ben Borrath bes normalen 3uftandes mit bem Bor= rathe bes fingirten 3 uftandes verwedffelt uno badurd 3 G Gdulüfen mo Bergleichsefultaten fübrt, bie unridtig finto; ferner baburd, baj fie ben fingirten 3unad)s als eine vom 2lltersflafienberbältnifie vorliegenber $\mathfrak{B e}=$ ftandsreiben unabhängige Ģröpe betradtet, uno unveränoert aud) für bie

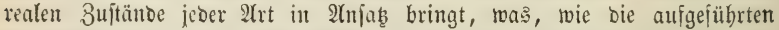
Beifpiele jeigen, eine Der 2 Birflidhfeit burdauts miberipredhende 21nnabme ift. Die Itrache, weşbalb namentlich ber erifte ber genannten Febler ber 
Cameraltare nidet früljer in feiner ganjen Bcocutung erfannt unt ansige= forschen wurbe, liegt borjugstweife barin, taj man ben 20 rrath bes Ilbtriebsertrages, aljo die Mafie Des bleibenden Beftantes nidt unterficico vom Borrathe für Den Gejanmtertrag, roie ibn bie Eum= mirung Der Malientufeln ergibt, aus benen bie Durdforftungserträge aber

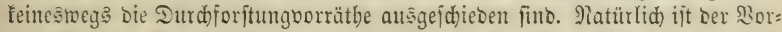
rath für Den Gejammtertrag (nach) Der Iabelle $\subseteq$. $79=57,43$ ) viel größ̈er

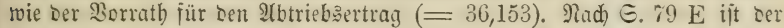

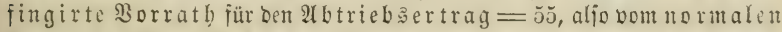
Borrathe für ben (bejam m tirtrag nidjt jebr beridieden. Dap bieje ganj วufällige 2(ebnlid)teit jweier, ifrer Bebeutung nad) burd)aus veridjebener

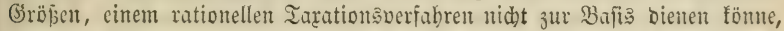

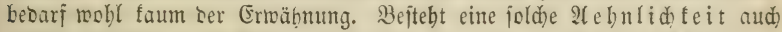

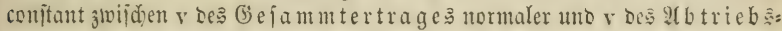
ertrages fingirter Slafienteiben, jo ift bief bod teineşwegs nothwentig Der fall aud zwifden biefen uno v abnormer Maffenreiben, auf meldye

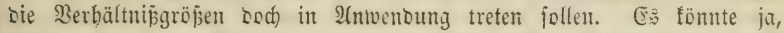

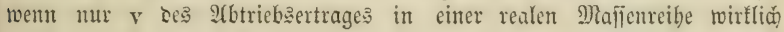
vorbanben iit, v Des Durdjorifungsertrages gröptentheila feblen, obne bup z Des Afbtriebsertrages und der 2(btriebsertrag jelbjt sarunter leiben. 2(tud) 52 un De Atbtriebsertrag aus bem Sorratbe für Den Gejammtertrag.

Benn man bie beiben groben Jefler in ber Formel für bie Cameraltą̧e:

$\mathrm{fz} \pm \frac{\mathrm{rv}-\mathrm{fv}}{\mathrm{u}}=\mathrm{H}$ befeitigt, fo witroe fie lauten:

$\mathrm{r} z \pm \frac{\mathrm{rr}-\mathrm{nv}}{\mathrm{u}}=\mathrm{H}$; baher: bie Differenz zrifden bem realen

uno normalen Borrathe ( $\mathrm{r}-\mathrm{n} \mathrm{r})$ einer Betriebialäde, bivioirt burd) bie Jabre des llmtriebs $(u)$, binzugezählt ooer abgejogent vom ivirfliden 3 u=

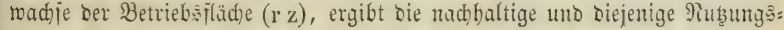

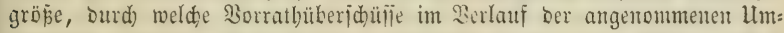
triebsjeit confumirt, 2orrathmängel aufgehoben werben (H). Daj u anjtatt Der Umtriebşzeit aud) jeben anderen Beitraum bebcuten fönne, ift einlend tento.

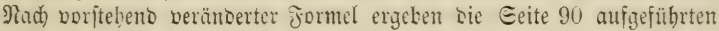
Beipiele:

$$
\begin{gathered}
2^{\mathrm{a}} \mathrm{rz}=5,9 \tau-\frac{20,81-36,15}{12}=5,9 \tau-1,: \dot{\tau}=4,69=\mathrm{H} . \\
3^{\mathrm{a}} \mathrm{rz}=13,39+\frac{43,08=36,15}{12}=13,39+0,58=13,98=\mathrm{H} .
\end{gathered}
$$

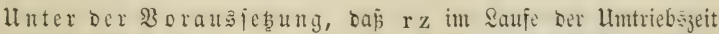

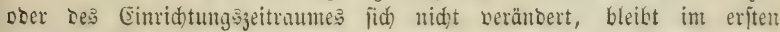
Falle jäbrlid) 1,2S vour 3uwadje unbenuţt, woourd) Der Şorratbmantgel $20,81-36,15=-15,34$ getilgt wirb, bem $1,25.12=15,34$.

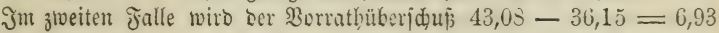
in 12 Jabren conjumirt, benn $0,58,12=0,93$; mitbin gleidyalls ser no: male 2orrath hergeitellt. 


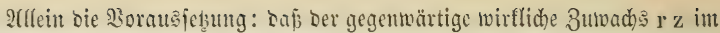

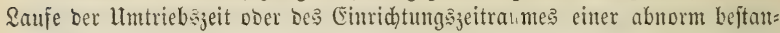
Denen Betrieb引fläche fid) nidht verä!toen werbe, ift unridgtig; mit ber allmäb=

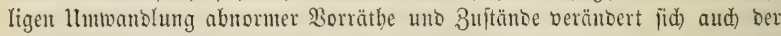
Daraus entipringente abnorme Buwad)s allmählig in ben normalen 3uwad)s.

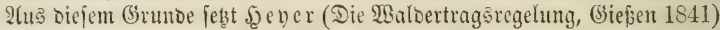
ganz ridtig an bie Etelle Des wirfliden gegentwärtigen 3uwadfes, ben

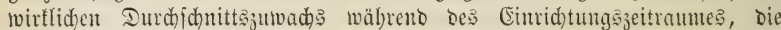
Summe des wirflid)en 3uwadjes wäbreno diefer Beit, bivioint Durd) bie 3abl ber Jabre $\frac{\mathrm{S} r \mathrm{z}}{\mathrm{u}}$.

Die 5ever'iche Formel lautet:

$\frac{\mathrm{rv}+\mathrm{Sr}_{\mathrm{r}} \mathrm{z}-\mathrm{nv}}{\mathrm{u}}=\mathrm{H}$. Dieje Jormel ift ourchaus ridtig, aber fie ift

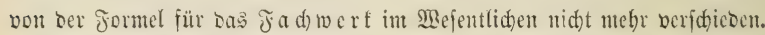

Beim Jadfwert, cben jo wie bei sen Weifermetboben, fan vie Sel:

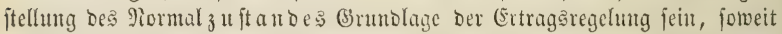
Die Serbältutife dief inmerbalb Des erften llmtriebes gejtatten; Der Unteridjeco berubt Dan eben mur Darin, daj bein Jadherk das Bild ocs normalen

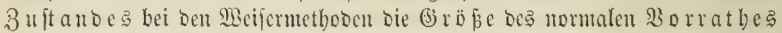
Der Betriebseinridatung uno Betriebsiübrung, fowie oer Ertragsberedung zux Ridtid)mur Dient. Das Fad)wert fam Daber cbenjo wie bie 9Beijemethoden Den 3uftano Der Betriebsläd) au Enoe Des Eimridtung seitraume mit n v bezeidonetr.

Tenut man s r z' Dic Gumme bes Buwad)jes, welcher an Dem, toäbrento Des Einridtungsjeitraumes ju conjumirenden Borratbe erfolgen wirb; nent mtan bie Sunme des Suwadjes an Dem, anf ben jotweiten llmtricb ju über= iragenden, in Saufe Dex erften Lntriebseit ju erziebenden 2orratbe s r z"; bejeid)net man mit $x$ ben Piubungsweifer für Den jummarifden Durdjor: jtungsertrag aus Dem 3uwadje für Don zweiten llmtrieb (nad) 5.80 in bem

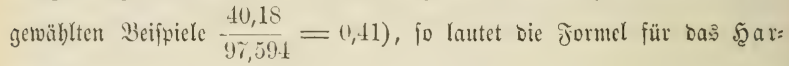
tig'ide Fadwert:

$$
\frac{\mathrm{r}^{\mathrm{v}}+\mathrm{sr} \mathrm{z}^{\prime}+\mathrm{x} \cdot \mathrm{sr} \mathrm{z}^{\prime \prime}}{\mathrm{u}}=\mathrm{H} \text {. }
$$

D. b. 3u Dem, in Saufe Der erften limtricbşeit ju conjumirenten Borratbe Dor Betricbifläche ( $r$ v) viro die Gumme Des, an Diejem Borrathe räb)=

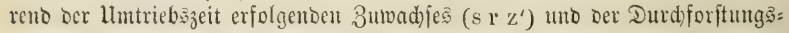
abgang aus bem für bie zlweite llmtriebsjett zut erziebenden Borratbe (x.srz") binzugezäblt, uto Die ganje Summe mit Den Jabren bes Um= triebs (u) bibioirt.

In beiden Jormeln finto rv uno u iforer Bebentung jowohl als ibrer Berwenbung nad) gleid); Denu auch beim Jad)werf fällt u nid) notb: wendig mit bem IImtriebe zujamment (Eotta's Einridutungseitraum).

S r z Der Seber'juen Formel ift gleid) sr z' + s r z" ber Fadyert= formel; o. b. Srz entbält die ganje Malje ber Erzengung im Saufe ber 


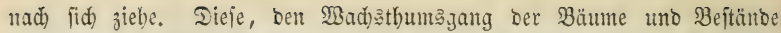
bebingenden $\Re_{3}$ erbältnifie fint aber fo unendlid mannigfaltiger $2(r t$, baj

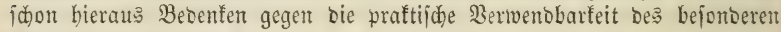

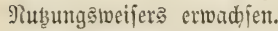

2Ullerbings lafien fiă) Sälle benfen, in benent bieje Bebenfent niddt be: iteken. In Revieren Der Evene fömnen bie Stanoortäberbältniffe twie bie

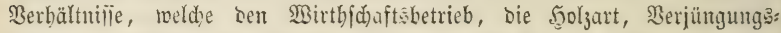
weije zc. bebingen, auf größseren Fläd)en Diefelben fein; felbft bie geringe

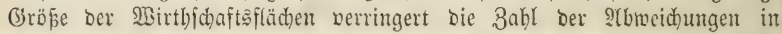
biefer Scinfidnt; in Den allermeiften Fällen if́t dieje aber fo groj, baj fie

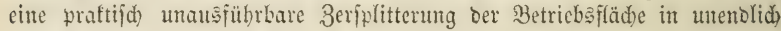

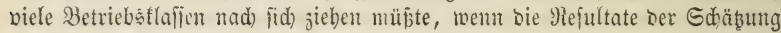

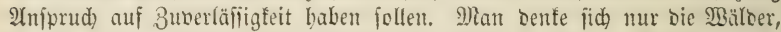
wie fie in Der SBirflidfeit gröftentheil(s beftehen, mit ber Berfobiebenlyeit

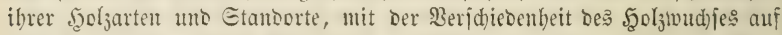

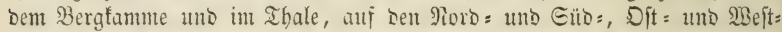

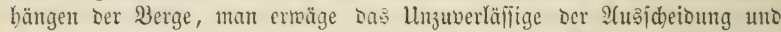
Begrenzung biefer grofien 3ahl befonders zu behantehtoer Betriebätlafien, man erwäge bie 2(rbeit, weldhe in ber Slufftellung vollftändiger (Erfahrungs: tafeln für jebe biejer Betriebstlafien liegt, für Die fich in bell meiften fällent

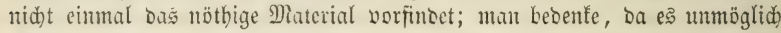
ift auf jeber ber Betriebstlafien bon oft geringer fläd,engröpe alljäbrlid) einen Ed)lag zu bolzen, bie Etörungen in Gerftellung bes Normal zu it a no bes, weldhe der ansietzende Betrieb in ben einzelnen Betriebsflaffen nothwentig zur Folge baben mur, uno man witb fdon bierin wejentliche Şinbernilie ber Antwentbarteit bes bejonteren Iiubungşweifers auf Ertragabcitimunung etfentuen.

Daju fommt: Daj die Itrt wie Sundeabagen ben bejonteren

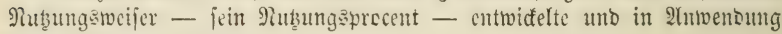
\{eb̨te, Durd)aus unridstig ift.

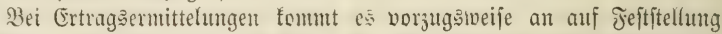
bes abtriebsertrages für fid. Die Rentnip des Gefammtertrages,

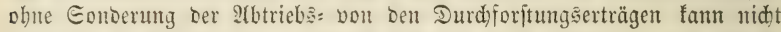

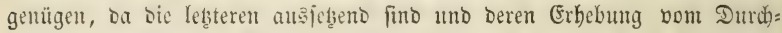

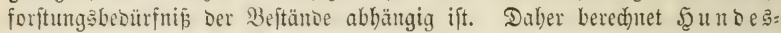

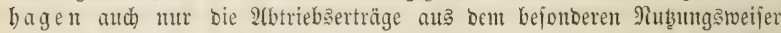

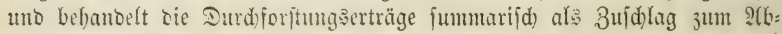
triebşquantum.

Der bejondere 9iubug

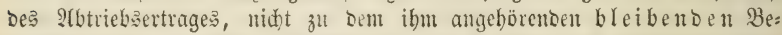

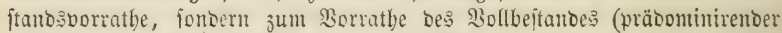
Beftanb), wie ibn bie Eummirumg ber Maffentafeln ergibt. In ber Ta=

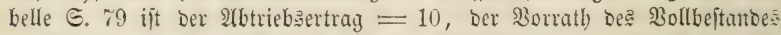
$=57,414$, worin Der Borrath für Den 2(btriebsertrag $=36,153$ uno fïr

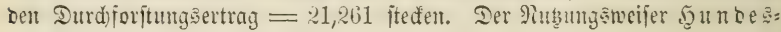
bagens ijt in siejem Jalle $\frac{10}{57,414}=0,1 \%$. 


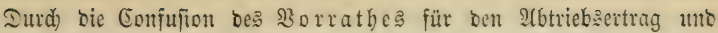

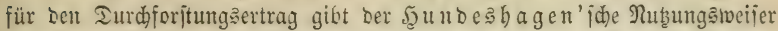
in allen Jällen ein unrid)tiges Rejultat, in Denen ber Borrath für ben

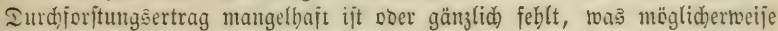
auf ben 2tbtriebertrag auper Einflús fein fant. Ës bürften aber wohl id)werlid viele Betriebsfläd)en exiftiren, in benen ein Mangel an Durd)= foritungavorrath $n \mathrm{i}$ idt befteht.

In ser Iabelle Geite 79 ijt ber Borrath für ben Bollbejtuno $=$ 57,414 ; es fönten baran 21,261, Der Borrath für ben Durdforfitung ertrag gäırłlich) fehlen uno nur 36,153 auf einer analogen Betriebs:läche vorbanden jein, obne Dáp ber 2 btriebsertrag Darunter leibet, wemn

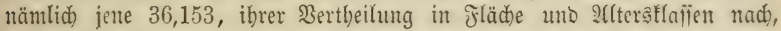
Dem 3orrathe für Den 21btriebsertrag entjpreden. In biejem falle würbe

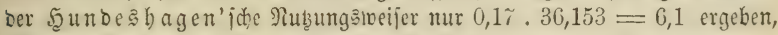
aljo mur $3 / 5$ nom wirflid) erfolgenden A(btricbsertrage $=10$.

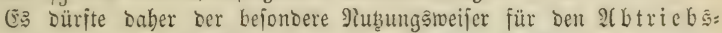
ertrag mur aus ber Maffenreibe Des bleibenben Beftandes entridelt, uno aud) unr auf belt Sorrath bes bleibenoen Beftandes abnorm Le:

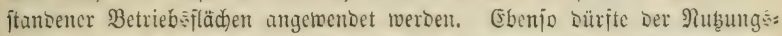

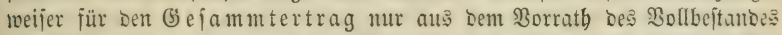
entroicelt, uno auch nur auf Den 3orrath Des \$ollbeftantes abnormer bes triebsifläd)en angementet werben. Da abor in leb̨terem falle nur Der (jes= jammtertrag, nidjt bie in biejem ftefende 2tbtriebsquote befaunt wiro, alif

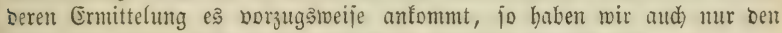
erften ber beiben Fălle einer näberen \$rüfung zu unterwerfen.

(E) fragt fic): ergibt Der, aus ber normalen Maffemreibe be 3 blei=

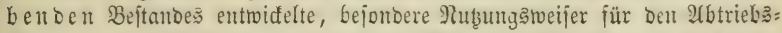

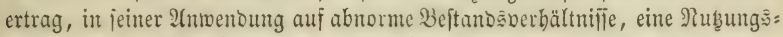

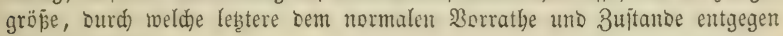
gefübrt werben?

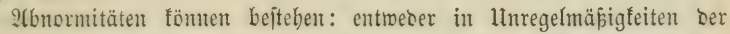
Plterśtluijent bei übrigens normaler Bejtodung ober in Mängeln ter Be=

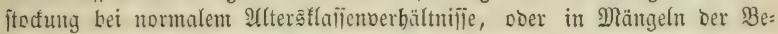
ftodiung un D Des 2Alterăllaffenverbältnifies.

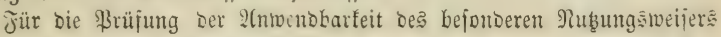

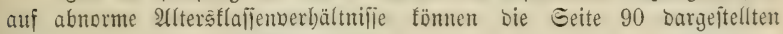
abnormen 3uitände als Beleg Dienen.

Der normale 3ujtano $\left(1^{a}\right)$ ergibt einen शub̧ungämeijer $=0,25$. Wenten wir biejen aulf $2^{a}$ an, fo ergibt $0,28 \cdot 20,81=5,83 ;$ aljo 0,17 weniger als Den wirflid)en 3 uvad) $=5,97$; es mürbe baber in Diejem

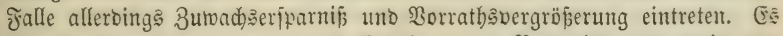
bebarf aber mur einer geringen Erböbung Des \$orratbes ober geringeren

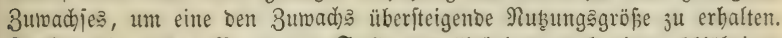
Denten loir uns 3 . B. an ber Stelle bes 5jäbrigen nod einen 11 jäbrigen Bejtano, io ift $\mathrm{v}=28,25, \mathrm{z}=6,01 ; 28,25 \cdot 0,28=7,91 ; \mathrm{H}$ aljo

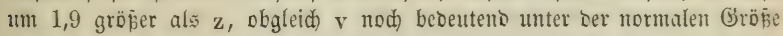
fteht, Daher 3uwaḑserparnip ftattfinden mïpte.

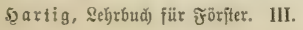




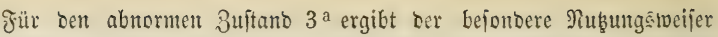
$0,28 \cdot 43,08=12,06$ für $\mathrm{H}$, aljo eine hinter bem wirfliden Bumadhje

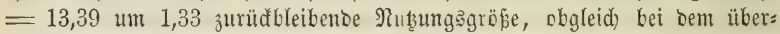
idüilitigen Borrathe Borratbconjumtion eintreten müpte.

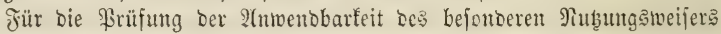

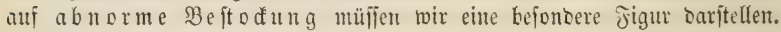

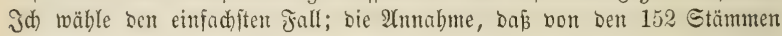
¿es normalen bleibenton Beftantes ber Iabelle $\Subset$. 79, in ben 6-9jäbrigen Bejtänton 52 Gtämme feblen. Die Mañen = uno 3uwadşreihen ftellen fid Dann folgendermaken, wenn mun Den Mafjengebalt Der feblenden Gtämme nad) bem burdjidnittlichen Majiengebalte aller 152 Etänme berfelben Mtters: flafie berechnet uno in 2 (fbug bringt.

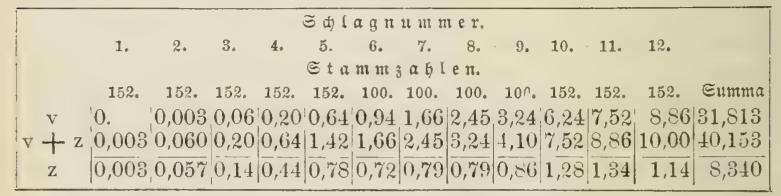

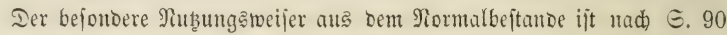
$1^{\mathrm{a}}=0,277$ uno ergibt, auf biefen Fall angetwentet, $0,277.31,813$ $=8,8=\mathrm{H}$, aljo 0,5 mefor als Den wirflidyen 3 umad) 3 , olgleid) v ge= ringer als voll ift, baber 3utod) serjparnif ftattintoen müpte.

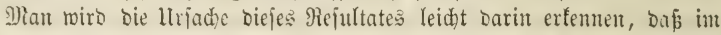
Beifpiele ber Beftantsmafiemangel in ben Aftersflafien mit hohem 3uwadje liegt. Dadurd) veränvert fid) das Berbältnifs bę Zumadję zum Dorratbe gegeli bas Des normalen 3uitances. Dả leb̧tere ergäbe nad) Ecite $901^{\text {a }}$ :

$$
36,153: 10=31,813: 8,80
$$

ces ift aber mirtlid $31,813: 8,34=36,153: 9,50$.

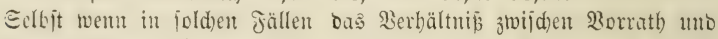
3umad) uneräntert bliebe, z. 23. $31,813: 8,80$ ober $30,15: 8,34$, würoe

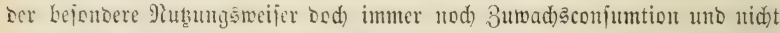
Die nöthige 3orrathanhäufung ergeben, weil bie 2(nnahme gleid)er 3 utwad)

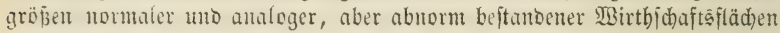
unriátig iit.

Mas beredtigt sen aber baju, abnormen Mafenreiben bic 3 unads simme normaler Miajienteiben zu unterftellen? Beim allgemeinen futungaweifer ober beim fingirten Borratbe baben wir

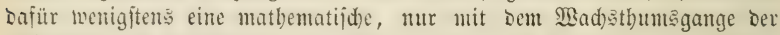

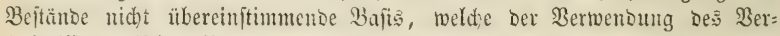
bältniffes zwifden Sorrath uno 3uwad) normaler, auf Den Sorrath ab= normer 3 ưtänoe gänzliç mangelt.

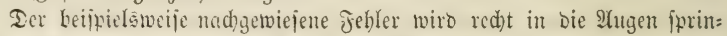
gento, werm man crmägt, Dấ bei Der 2(muabme: gleide Borrath=

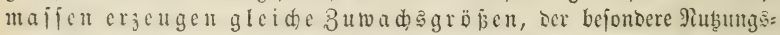
weifer itet 3 Suwad) Econjumtion, aljo nie Borratbanjammlung ober Bor: rathconfumtion ergeben würbe. Daher barf bie Methobe bei bi efem febler 
nod) nidht fteben bleiben, fie nuß Einbeit bes vergröbere als bie Einhcit ber überbollen Mafienteibe,

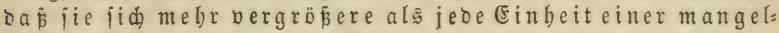

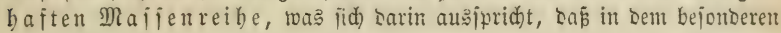

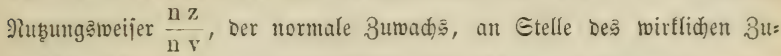
wadjes and auf bie abnormen Malienreiben ütertragen toirb.

Rebmen mir beiptelsweije an, es jei in einem beftimmten Falle ber

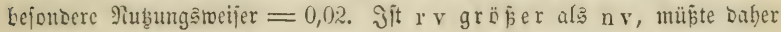
Borrathconjumtion eintreten, jo jeţt bie 2 ntwentung bes bejonderen

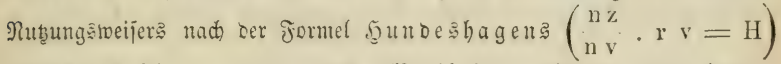
voraus, es fei $\mathrm{rz}=\mathrm{nv} \cdot 0,02$, aljo fleiner als $\mathrm{rv} \cdot 0,02$ (ba rv gröper als $n v$ ift). Jit $r v f l e i n e r$ als $n v$, müpte baher 3umadbs: anbäujung ftattfiuton, jo jeşt dic Methode gleides boraus, o. b. Dá

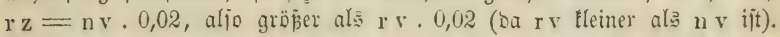

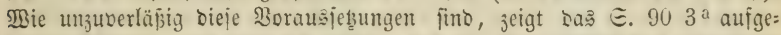
jührte Beifpiel, aus som fid ergibt, Dafi ein \$orratbüberichuß jehr woht

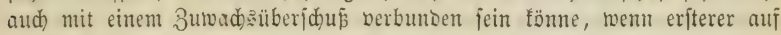
einem 2orberricten ber mittleren 2(tterstlafien mit bohem 3unadje beruht.

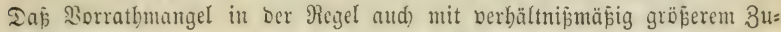
madjämangel verbunden jei, bedarf teines Beleges, ba Borratbmangel in

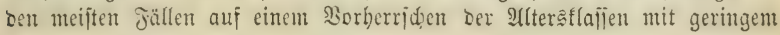
3uwadje berubt.

Der Fehler in ser 5unbeßhagen'ident formel $\frac{n z}{n v} \cdot r v=H$ liegt saher in $\mathrm{nz}$, lvie Der Jehler in ber formel für bie Cameraltare in $\mathrm{fz}$ liegt.

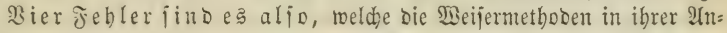
mentung auf abnorme $\mathfrak{W a l o j u f t a ̈ ı b e ~ v e r f a ̈ l i ł t e n : ~ b i e ~ u n r i d t i g e ~ S u b j t i t u i r u n g ~}$

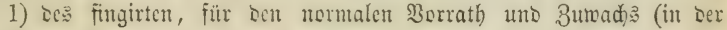
(Cameralformel);

2) Des Gejantmtvorrathes, für Den \$orrath Les 2 (btriebsertrages (nid) in ber formel, aber im Berfahren 5ूundes bagen

3) Des normalen Zuwadjes für ben Zuwad)s abnormer Majlenreiben (in ber Şundeshagen'ichen Formel);

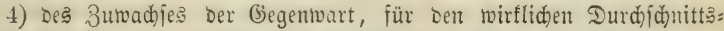
3umad) bes Bercd)ungş3eitraumes (mittelbar in beiden formeln).

Eeţen wir an bie Etelle von $\mathrm{nz}$ ben $\mathscr{A}$ äbrud $\mathrm{rz}$, jo erbalten wir

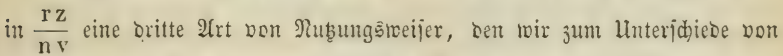

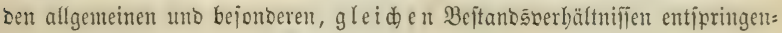
Den, baher homogenen ?lub̧ungâteifern

3) Den ungleidartigen (beterogenen) ? utungstocijer neuten fömten, ba ex aus $\mathrm{rz}$ bes abnormen Suftantes uno $\mathrm{nv}$ bes nor: malen 3uftantes zufammengeję̧t ift. 
Brüfen wir jumäd)jt bie Formel $\frac{\mathrm{r} z}{\mathrm{u}} \mathrm{v} \cdot \mathrm{rv}=\overline{\mathrm{H}}\left(\right.$ ober $\frac{\mathrm{rv}}{\mathrm{nv}} \cdot \mathrm{rz}$ ober $\left.{ }^{r v} \frac{r z}{n v}=H\right)$ an ben Eeite 90 unb 98 aufgeftellten Beifpielen.

ad $1^{\text {a }} \mathrm{rz}=10 ; \mathrm{nv}=36,15 ; \frac{\mathrm{rz}}{\mathrm{nv}}=0,277 ; \mathrm{rv}=36,15$.

$36,15 \cdot 0,277=10$; saker 3uwab)enconfumtion bei keftehenoem Normalvorrathe.

ad $2{ }^{\mathrm{a}} \mathrm{rz}=5,97 ; \mathrm{nv}=36,15 ; \frac{\mathrm{r}^{\mathrm{z}} \mathrm{n}}{\mathrm{nv}}=0,165 ; \mathrm{rv}=20,81$.

$20,81 \cdot 0,165=3,33 ;$ Daber 3 utwad)seriparnif bei mangelbaftem \$orrathe, bis zur Serftellung bes Normalvorratbes.

ad $3^{\mathrm{a}} \mathrm{rz}=13,39 ; \mathrm{nv}=36,15 ; \frac{\mathrm{rz}}{\mathrm{nv}}=0,37 ; \mathrm{r} \mathrm{v}=43,08$.

$43,08 \cdot 0,37=15,94$; baber Şorrathconjumtion bei überfoüffigem 3orrath bis zur Reduttion auf Den normalen 30 orrath.

ad $\Subset . ~ 98: \mathrm{rz}=8,34 ; \mathrm{nv}=36,15 ; \frac{\mathrm{r} \mathrm{z}}{\mathrm{nv}}=0,231 ; \mathrm{rv}=31,813$.

$31,813 \cdot 0,231=7,34$; Daher 3uwadeserparnif bei mangel= baftem Sorrathe.

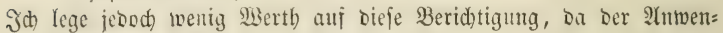

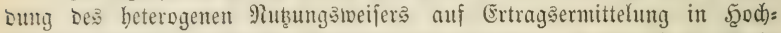
wäloern biefelben praftifden Bebenten entgegentreten, Deren id) 6.96 in

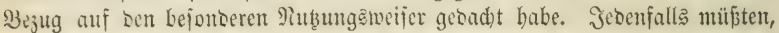
wernt ç fid) un (Erforidututg Der ?btriebserträge handelt, für bie $\mathfrak{2} \mathfrak{n}=$ mentung ber jormel erft bejondere crfahrungstafeln conftruirt merben, in Denen un Der blcibende Beftant Dic Maffenreibe bildet, Denn bie Berwen= Dung unjerer Whaffentafeh, in Denen Dic Norräthe für Mbtrieb uno Durd)= foritungşunads bereint entbalten fint, fönnen bier ebenjo wenig, wie für

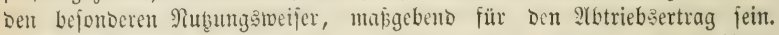
Jür Den Bifammtertrag fino fie gleidfalls nid)t verwentbar, on in ihnen Der Durdforftungäertrag nidft ausgeworfent ift. Die (3). 2. Sgartig'idjent Erfabrungstafeln würoen für bic Beftimmung des Gejammtertrags jlwar verwentbar fein, Da fie ben Bejammtertrag nadweijen, aber man würbe Dem Dod) immer nur zur Remutniß Des (jejammtertrages uno nid)t zu Der Des Afbtricbsertrage abnotmer Mafienteihen gelangen, währeno c⿱⺈ auf bie Jeftitellung lebterer bod) vorzugsmeife antommt.

24uferbem ift $\mathrm{r} z$ des abnormen 3 uftandes in ben beridieben geformten Beftäntoen Des ftammreid)en Scod)waloes, ourd) bie gegenfeitigen Bejiefungen Des Sorrathe für ben 2Abtrieb unto bes Sorratbes für bie Durdforftungen,

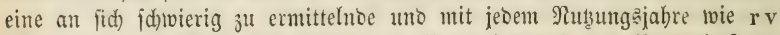

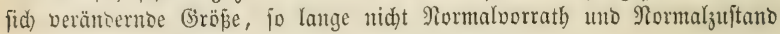
erreicht find, $\mathrm{rz}$ uno $\mathrm{rv}$ gleid $\mathrm{nz}$ und $\mathrm{nv}$ fint.

Jerner bleibt aud biefer slletbode ber allgemeine, gegen $\mathfrak{W}_{e}$ eifer= metboden überhaupt gültige Bormurf: Dan fie cinerpeita feine Bürgidaft geben in Bezug auf bie vom Bedürniक abbängige Dualität ber $2(b=$

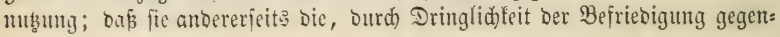


märtiger Beoürnifije, Der balbigiten Şerftellung viddtiger Alterätlaijenverbält=

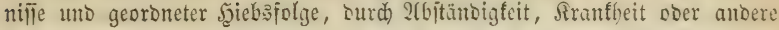
Bejtantesmängel, wirtbidaftlid) oft nothwenoige unb unatifidiebbare Ber: ringerung bes porbandenen Borrathes, jelbjt tief unter bie normule Öröpee, auteer 2(d)t laffe.

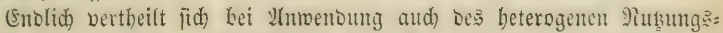
meijers bie nötbige 3uwad)seriparnif ober Borratbconjumtion nidht gleid:

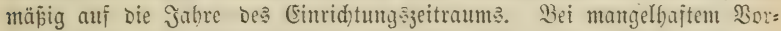
rathe ift bie 3uwachserparnis in ben erften Jahren am gröbten, uno rer: minbert fich fortforreiteno nit Der allmäbligen Jeerfteflung Des normalen 3̧orrathes. Bei überfüuffigem 3orrathe ift bie Sorrathconjumtion in Ien früberen Эabren an grȫ̧ten uno vermintort fid) allmäblig mit ser 3urüct= fübrung Der Mafjen auf ben normalen Morrath. Beides entiprid)t abe: nidht bem Begriffe Der ?achbaltigteit.

Wollte man anjtatt $\mathrm{rz}$ in ber Formel $\frac{\mathrm{s} \mathrm{rz}}{\mathrm{u}}$ jeb̧en, o. b. anftatt Des trirfliden 3uwadjes oer Begenwart rie ganje Elmme sas 3ubadjes

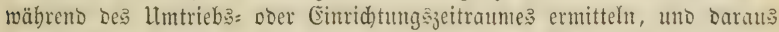

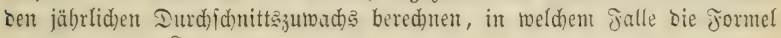
lauten witrbe: $\frac{\mathrm{Sr} \mathrm{z}}{\mathrm{u}} \cdot \frac{\mathrm{rv}}{\mathrm{nv}}=\mathrm{H}$; fo rürbe aud biefe Methode fich. bem Jadiverf im Sisejentlidyen nabejtellen; sem Srz fant nur gefunben werben

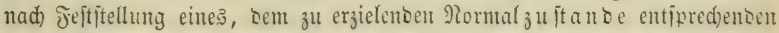

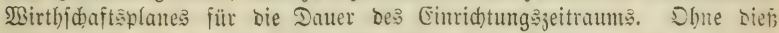

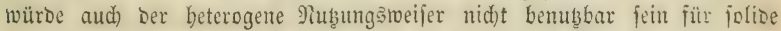
Ertragsberedmungen, wohl aber mag er antwenbbar jein bei vorläufigen

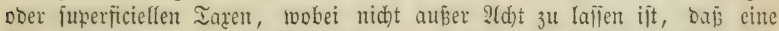

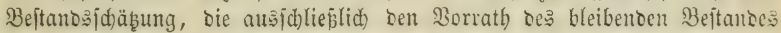
in Betrad)t jieft, Yeichter, raịd)er und Demod) mit gröperer (jemanigfeit auşübrbar ift als eine Taration des Gejammtoorrathes, da es bei erfterer

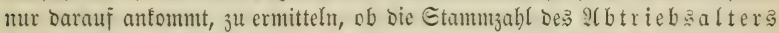
in entiprechender Baumgröß̈e uno Bertheilung in Den Beftïnoen vorhanoen ift ober nicht, um ben 2Anfab̧ ber Erfabrungstafeln im erifteren Jalle voll,

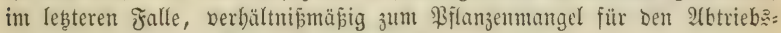
ertrag, ermäßigt in 2 Inją̧ bringen zu tömen.

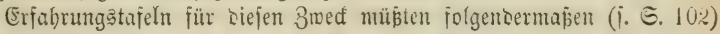
conftruirt jein.

Soldhe Erfabrungatafeln müfīen für jęe vorfommente froljart, Bes

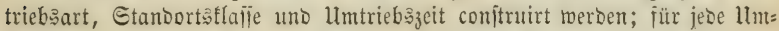
triebazzeit bejonders, weil mit biejer bie bleibende Etanmianhl bes Saubar=

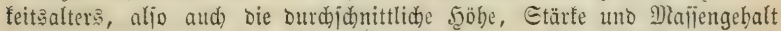
Derfelben veridieden find. Die 194 Etämme Der 2tbtriebsifläbe Des 100: jäbrigen Umtriebs baben jeķt, wie in jecer früberen Alterșitufe, cine andere

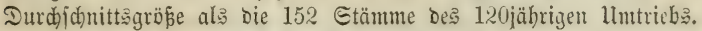

In ben für Das Jad)werf nötbigen Erfahrungstafeln, wenn fie in Der ভ. 31 bargelegten Meije conjtruirt fino, ift jugleid) bas Material

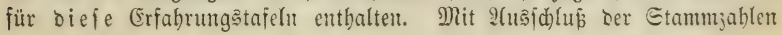




\begin{tabular}{|c|c|c|c|c|c|c|c|}
\hline \multirow{4}{*}{ थrter. } & \multicolumn{7}{|c|}{$\begin{array}{l}\text { 120jübriger Hotbbud)enl)od)mald. } \\
\text { (Exfte Bobenflaife. }\end{array}$} \\
\hline & \multirow{3}{*}{$\begin{array}{l}\text { Stantmzahl } \\
\text { bes \$oll= } \\
\text { beftanbes. }\end{array}$} & \multicolumn{5}{|c|}{ Dex ftärfftell 152 Stänme besె 20 ollbeftanbesె } & \multirow{3}{*}{$\begin{array}{l}\text { Maffenreige } \\
\text { bes normalen } \\
\text { Sufftanbes. }\end{array}$} \\
\hline & & \multirow[b]{2}{*}{ gäke. } & \multirow[b]{2}{*}{ Stärfe. } & \multicolumn{2}{|c|}{ Sdjaftholzmafie 1} & \multirow{2}{*}{$\begin{array}{l}\text { Sdaftholz } \\
\text { zutwads am } \\
\text { bleibenben } \\
\text { Beftanbe. }\end{array}$} & \\
\hline & & & & $\begin{array}{l}\text { Durdjidnitt= } \\
\text { lid, pro } \\
\text { Stamm. }\end{array}$ & $\begin{array}{c}\text { in } \\
\text { Summa. }\end{array}$ & & \\
\hline รakgre. & Stüđ. & รันธิ. & 3011. & 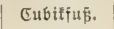 & 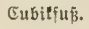 & ๔ubilfū́. & 厄u๒iffū̃. \\
\hline 10 & 50000 & 8 & 1,2 & 0,02 & 3 & 3 & 16 \\
\hline 20 & 10000 & 25 & 2,8 & 0,33 & 51 & 48 & 294 \\
\hline 30 & 4000 & 46 & 5,8 & 1,16 & 176 & 125 & 1197 \\
\hline 40 & 1500 & 60 & 7,2 & 3,72 & 566 & 390 & 3905 \\
\hline 50 & 880 & 65 & 8,5 & 8,33 & 1267 & 701 & 9525 \\
\hline 60 & 500 & 70 & 10,0 & 14,65 & 2227 & 960 & 17950 \\
\hline 70 & 340 & 80 & 12,0 & 21,63 & 3288 & 1061 & 28105 \\
\hline 80 & 270 & 95 & 13,0 & 28,65 & 4355 & 1067 & 38708 \\
\hline 90 & 225 & 100 & 14,0 & 36,00 & 5466 & 1111 & 49660 \\
\hline 100 & 194 & 103 & 15,0 & 43,50 & 6617 & 1151 & 60990 \\
\hline 110 & 171 & 105 & 16,0 & 50,20 & 7690 & 1073 & 72071 \\
\hline \multirow[t]{2}{*}{120} & 152 & 106 & 17,0 & 56,66 & 8614 & 924 & 73359 \\
\hline & & & & \multicolumn{2}{|c|}{ ธumma... } & 8614 & 355821 \\
\hline
\end{tabular}

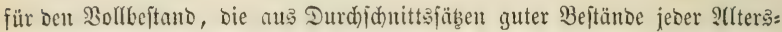
ftufe zu entnebmen fint, laifen fie fid) aber aud berftellen aus Mefintung uno Berechnung ber früberen Ed)aftholzgrößzen cin unt beffelben Beftubes vom 2llter Der Umtriebszeit (₹. Ertrag Der Rothbudhe, über Eonftruftion ber Einbejtandstabellen).

Da ber fironenholzgebalt ber jüngeren Arteraflaffen ebenfo wenig zแt bleibenten Beftandsmaffe gered)net werben barf, wie Der Sorrath für ben Durdforjtungsabgang, fo muß in bie Erfabrungstafeln überbaupt, wie vorfteheno, mur bie Echaftbolzmalie Der Bäume aufgenommen, uno ber 2 bs: triebsertrag an Sronentbol, ebenjo wie Der Durd)forftungsertrag, als $3 \mathfrak{u}=$

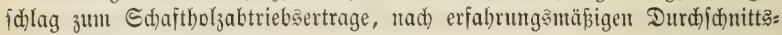
fäbent bebandelt twerbent.

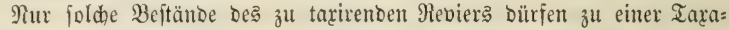

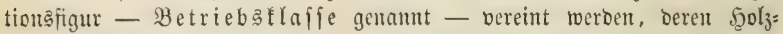

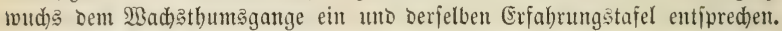

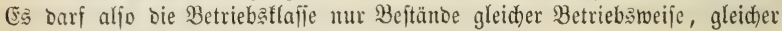
Solzart, Untriebszeit uno Etanoortägüte umfafien.

Die Größpe uno Maffen fo vieler ber ftärffiten Etämme eine be: ftanbes als im Scaubarfeitsalter ben Bollbeftand bilben, bergliden mit Den entipred)entoen 2(ngaben ber (Erfahrungstafelı für bie veridicoenten Betriebs̄=

1 Unter Sdjaftholzmaffe ift bie Sdaftmaffe biz jur Spije zu berfteben. Berztweigte Bäume twählt man niđj)t gern jur Bered)nung uno ju Mufterbäument wo biē̄ aber niđht

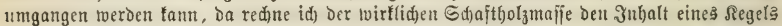

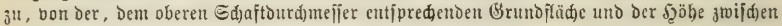

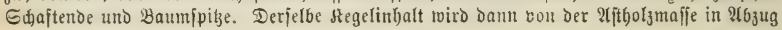
gebradist. 


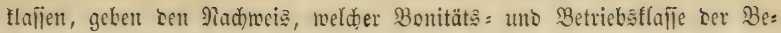
ftand beizuzäblen fei.

Sowobl Sorrath als einjäbriger 3uwachs aller berjenigen Beftänte, sie bis jum 2tbtriebe nod) Bflanjenabgang erteiben werben, ift nadh ben

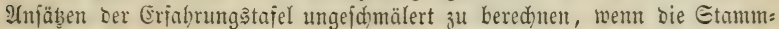

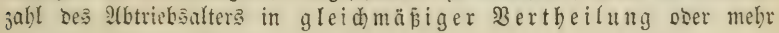
als biefe Etammzahl vorbanbent ift.

Entbült ber Bejtand nidat bie Stammzalil Des haubaren Bollbeftantes in gleidhmäpiger Sertbeilung, was in jüngeren Beftänten ftets nur Folge

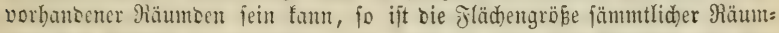
Den uno Blöfen zu ermitteln, nou jcoer $1 / 2$ ober (mit Rüdficht auf sen

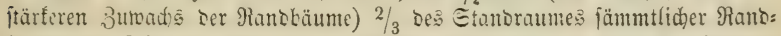

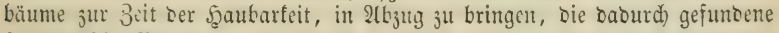

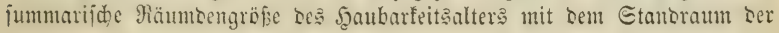

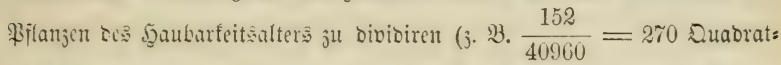
fuṕ Etanoraum jebes 120jäbrigen 3aumes, bei 10,000 Duabratfup jum=

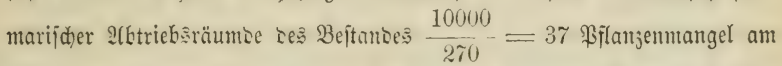
bleibenton Bejtante), woraus fid) bie 3abl ber fehlenocn Bäume bes bleis

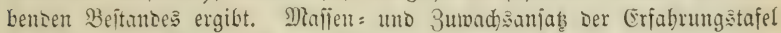

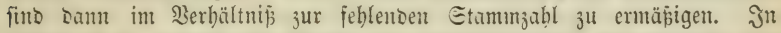

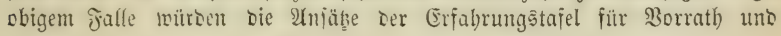
jäbrlichen 3uwadbs auf $\frac{152-37}{152}=0,76$ zu emäpagen jein.

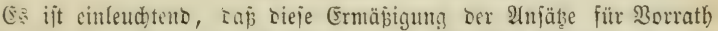

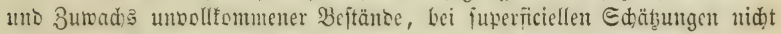
nothwentig Rejultat frecieller Berednungen jein m ü ffe, jonbern wie vieles

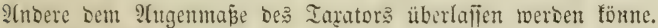

3orrath uno Buwad) aller älteren Beftünde, bi e bis zum $2 \mathfrak{b}=$ triebe feinen wejentliden Bflanjenabgang mebr erleiben toerben, fömten wie beim jadjwert unmittelbar geidjäbst uno berechnet werben. 2(ud) fie tonmen nur mit ibrem birflichen gegentwätigen \$or: rathe uno mit bem nädjtjäbrigen 3uwadje in 21njaţ.

Dic Eummirung Der gejdäţten Borräthe Des bleibenden Beftanbes ergibt $\mathrm{r}$ y ber Formel, Summirung Des gejdäbzten nädjitjäbrigen Zutoadjes aller Beitände ber Betriebsflaffe ergibt $\mathrm{r} z$ ber formel: $n \mathrm{v}$ geht aus Der Eumme Der Majienreibe Des normalen 3uftandes in oer Ërfabrungstafel un= mittelbar hervor uno ift im vorliegenden Beijpiele 355821. $\frac{\text { Flädhengrößje }}{120}$.

Die Formel $\frac{r z}{11 \mathrm{r}} \cdot \mathrm{r} v=\mathrm{H}$ ergibt in biejem Falle mu Den 2 tbtriebs= ertrag an Edaftboljmafie, Dem Damn nod) ber exfabrungâmäşig burch= (d) nittlid)e Durdforitungs = uno Sronenbolzertrag nad procentifacen Ber: bältmifien binzugefügt werben muḱ. 


\section{Siferatur.}

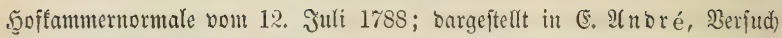
einer zeitgemäpen Joritorganifation. 1823.

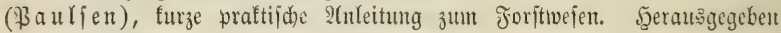
von Fïlier. Detmolo 1795 .

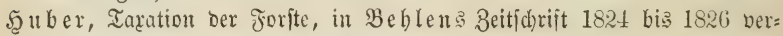
Dffentlidyt. Seit 1812 beftehento.

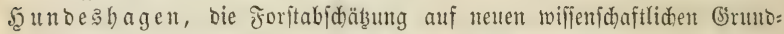

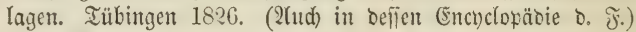

Sarl, bie Grunbjüge ciner twiffenjd)aftlid) begrümbeten Jorjtbetricbsteguli= rung. Sigmaringen 1838.

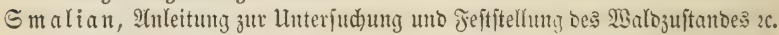
Berlin 1840.

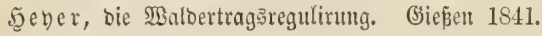

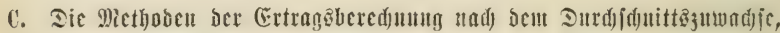

befonber: füt fuperficielle Ertraysermittelungen empjoblen, ftimmen im 2Bejentlichen Darin ïberein, Daß die 2tbtricbserträge jänmtlicber Bejtänbe

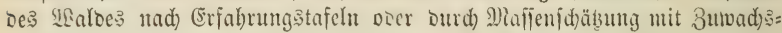
jured)nung crmittelt, Dam bie Gumme aller albtriebserträge (Sa) Durd)

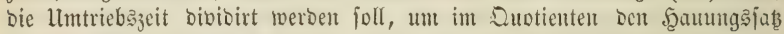
für Den 9(btriebsertrag zu finber, Dem bam Dex Durd)forftumgertrag nad) beiläufigen Ermittelungen zugefd)lagen wiro. $\frac{\mathrm{S} \text { a }}{\mathrm{u}}=\mathrm{H}$.

Die Durdjiduntts: Metboden find Daber oer Begenfab aller Meifer: methoden, Dent, wenn in lebzteren bie gegenuartig vorbanbencn $\mathfrak{B}_{\mathrm{e}}=$

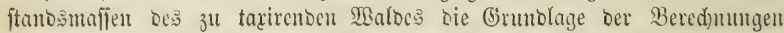
bilben, find es in erfteren ausfdylieflid) bie mutbmaflidsen Beftandsmafien Der 3 uf unft (Dereinfige 2(btriebserträge), bie jur Berednung gezogen werbon.

Man wird leid)t erfennen, oab bicje Methoben ju ähnlichen, aber nod) vid gröperen Jehlen fübren müffen, wie die Cameralmethode, da

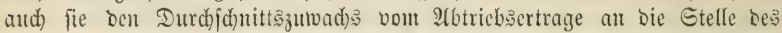

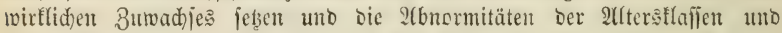

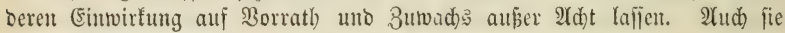
fömen Daber mur banu cin rid)tiges Rejultat gewäbren, rom Der Durd)=

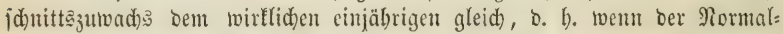
zujtano Des Maldes bereits bergeftellt ift. Jhre sfnwenoung auf abnormte Malozujtänbe ergibt in bentjelben Berbältuiffe gröfere jebler, in weldem

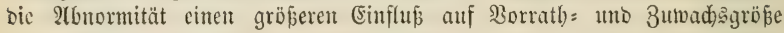
bat. (5) ift ftaumentworth, weldhe Jehler, Durd) Dic zufallige uno bebeu=

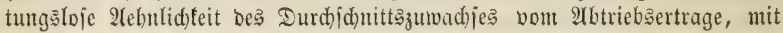
Der (Sröße Des Borrathes für 2(btrieb und Durdforftung, bividirt Durd)

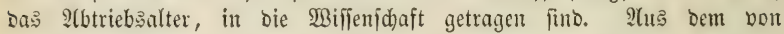

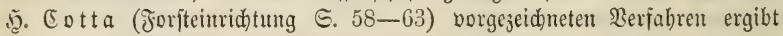

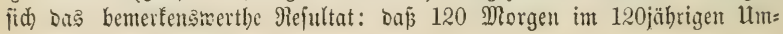


triebe, wenn fie nur vollbeft an o en jinb, biejelbe jäbrlide Nubung abgeben follen, bie Jläd)e mag gan mit 20jäbrigen, ober gant mit 100=

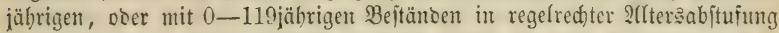
beftanoen fein. Jebler erfennt man am bejten in ibren Extremen. Shach Der reoucirten Erfahrungstafel $\mathcal{E} .79$ geben 120 Mlorgen 20jäbrig einen ALtriebsertrag von $120.10=1200$ am Edhluß Der llmtriebşeit, Daher

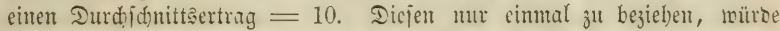
aber ocr ganze gegentwätig vorbandene Borrath für bon 2(btriebsertray nid)t auseireiden, bem lebeterer ift pro Mlorgen mur 0,06 vom 2(btriebs: ertrage, $0,06 \cdot 120=\tau, 2$ !! Borrathconjumtion bei überjüüiligem Borrathe

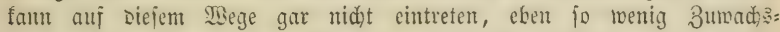

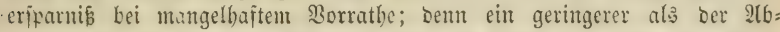
triebsertrag bes normalen 3ujtandes farn fid) inmer nur ergeben in Jolge mangelhafter Beftoctung, Die Dann chenio in 3utwach = wie in Siorrath=

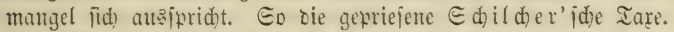

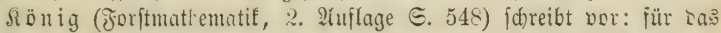

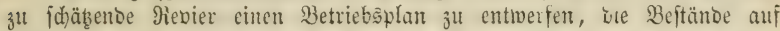
Grunt Des Betricbsłlanes in Perioben ju vertheilen, Den Ertrag jeber

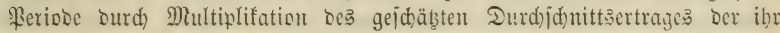

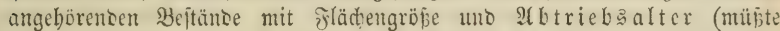
beip̄en Beftumbalter in ser Mitte oer Arbtriebaperiode) zu bereduren, uno

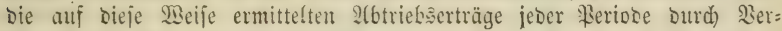

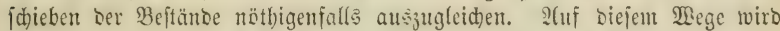
Der in Der Iaxation mad) Iurdjidnittserträgen liegenoe Febler allerbing: bejeitigt, Da burdh bie Bertbeilung Der Beitände in bas Jad)wert bes lum=

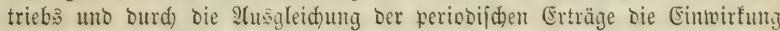
abnormer 2(ltersłlafienverbältniñe auf Borrath uno 3uwachs in 2 njab ge= brad)t twirb; allein in allem 2 lejentlidyen baben wir aud bier wieber ben

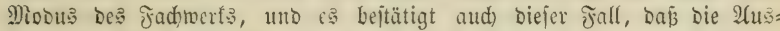
fdeioung Des Jihlerbuften in anoeren Tarationsmethoden, bieje ftets auf

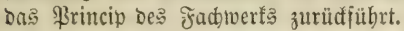

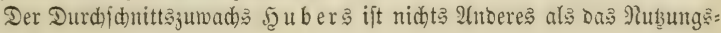

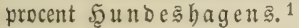

\section{Siferafur.}

Maurer, Betradtungen über einige in Die Joritnifīenjdajt eingeid)lidente

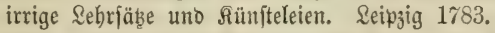

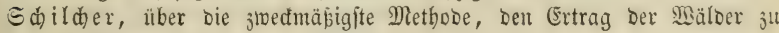
bejtimmen. Stuttgart 1795 .

5.. Eotta, Forifteinridtung. Dres̄ben 1820. S. 58-63.

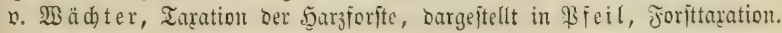
S. 118.

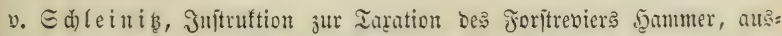

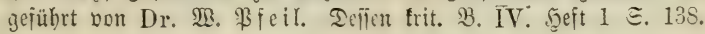

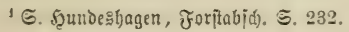




\section{Ertragscrmittclmแg 內er Hlisðcrwäldcr.}

Bereits in 3weiten Banbe G. 18 babe id̆ erörtert, warum, wenn bie Ermittelung einer gleid)en und nadhbaltigen Nubungägröße im Sูod)= waloe Bertheilung Des Borrathes uno 3umadję anf längere Beiträume

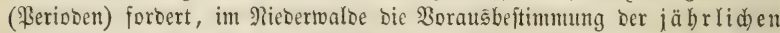

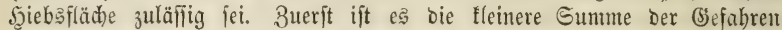
uno bic, bei furzem Umtriebe bäufiger fid barbietenoe (jelegenbeit burd)

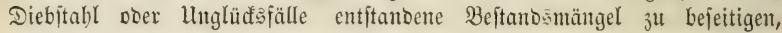

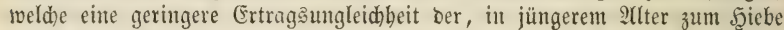
fonumenden Beftänte zur jolge bat; Dann ift es Die Unabbängigfeit ber

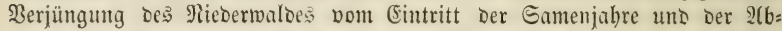

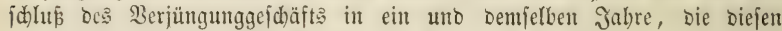

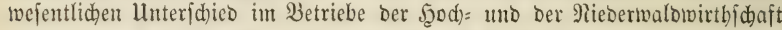

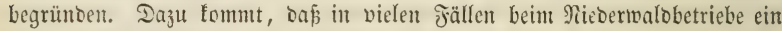

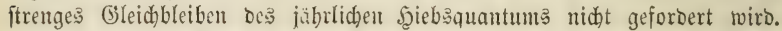

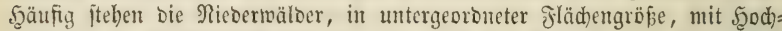

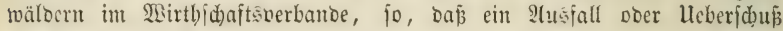

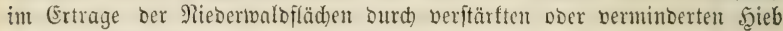

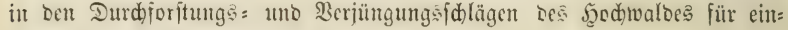
zelne כabre leid)t ausgeglichen werben fann.

Ulnter biejen llmiftünen ift

\section{Die geometrifde Edlageintheilung}

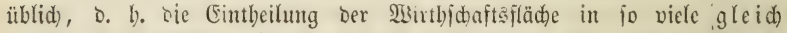
grofie Jahreșid)lăge, als ber llmtrieb Jabre zäblt. Bei glcichem (Ertrags: vermögen beß Bobens umo bei gleichen Beftodungs̄verbältniffen wiro mit biejer Betriebsortumg auch (Slcichbeit ber jäbrlichen Stbuţung verbunbent fein, fo weit biefe überbaupt erreid)bar ift.

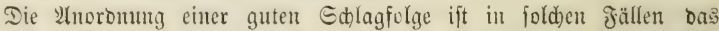
Sisefentliche. Wenn biermit Iaration verbunden jein foll, fo fam es fich ftets nur barum hanbeln, ju crforident wie viel es ift, was in ben ver=

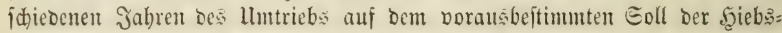

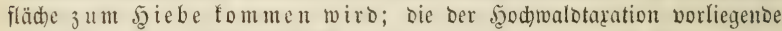

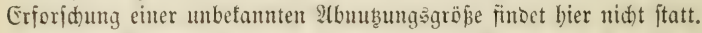

Eine \$oraubseftimmung ber ungleiden (Erträge gleid) groperer Sdylag= flädyen bes Pliedertvaldes wiro aber häıfig uno grabe in Den fällen nöthig,

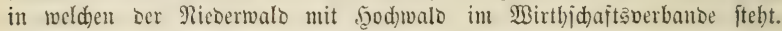

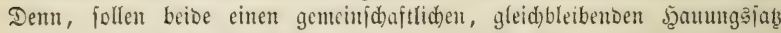

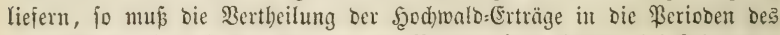

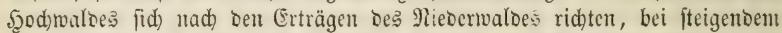

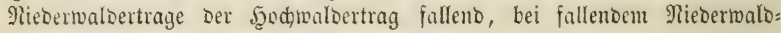
crtrage ber Sedodwalbertrag fteigento regultirt werben.

Darau folgt Dam, Daj eine Ertragsbered)mung Des Nieberibaldes in

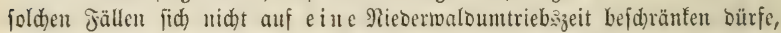

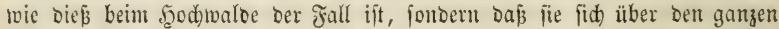

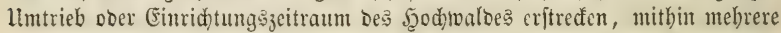

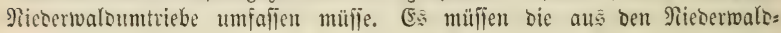




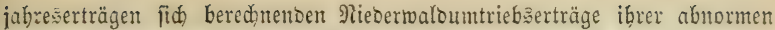

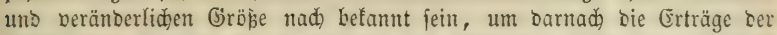

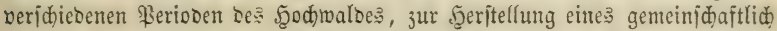

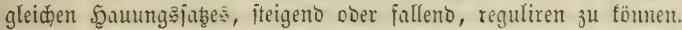

Daber ift es, wemu auch nidht unbebingt nothiventig, bod iebr zroed:= mäāig uno sie (Ertragsbered)nung nidjt allein wejentlid) erleidtemo, jonbern audd) fiderer, wenn in ben, namentlid) im Betriebe ber gröperen Etaats: waloungen febr bäufigen Jällen ciner Berbinoung beiber Betriebsarten ju

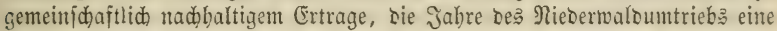

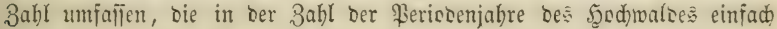
aufgebt.

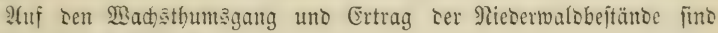
von wejentlichem Einflū:

\section{1) Die Betriebatweife feltht.}

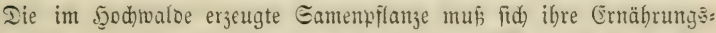
organe erft allmählig entwidefı uno vermehren, wäd) baber in ber ju= geno viel langianter als bie \$flange bes Rieberwalbes, bie ber Stndaus:

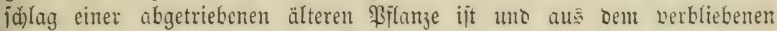

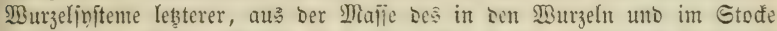
abgelagerten Bifoungsiftofifes fiton im erjten Gabre einen viel träftigem

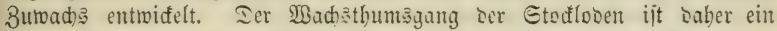
ganz anderer als ber oer Eamenpflumzen. In ten 3uwadjätabellen meiner Irbeit über Den Crtray Der Rothbud)e und it Denen meines Rebrbudhes Der Pflanjenfutoe babc id bie Cigenthümlidfeiten Der Budfe, Jainbuche, Erle, Birfe uno Sajel in biejer Şimildt Dargejtellt uno mus bier borthin vertweijen.

Eine altbere einflupreidje (Eigenthümlidteit ber Betriebsweije ijt bie boritweife Gruppirung einer Mehrzahl von Beftandsyjlicbern auf gemein=

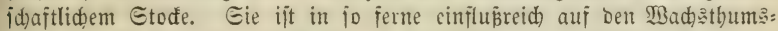
gang Der Beftän oe, als burd) ben organifchen Bufammentang ser unter= brüđten mit Den Dominirenden \&ohDen Defïlelben Gtodes, Die erfteren meniger

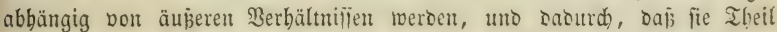
nebmen an bem von sen Dominirenton Soboen bereiteten Biloungsiafte, fich) länger im 3uwad,je uno länger lebeno erbalten als bießs, unter gleiden

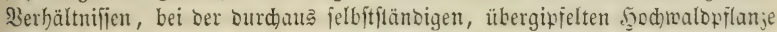

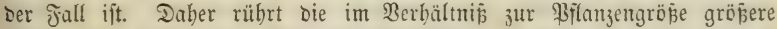
Etammzahl geidloliener Nieberwalošbeftäne uno theilmeije ber geringete Durdforftungäabgang.

\section{2) Der umtrieb.}

Da beim 5odbaloberriebe ber abgetriebene alte Beftano burd einen ourdaus neu erzoyenen jungen Bejtano erjeßt roiro, Der berjelbe ift oser fein tann, ber Umtrieb mag lang soer fur' jein, fo hat beim syodivalo:

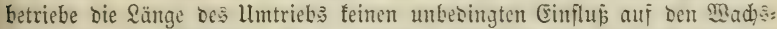

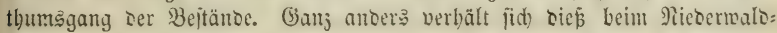
betriebe. Je böher oer llmtrieb ijt, um io größer ijt bie Edimiläde 
jebes einjeltnent Stodes, um fo geringer bie 3ahl ber Mutteritöde des

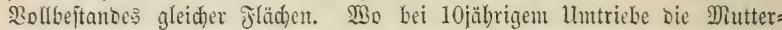
ftöcfe in 2metriger (Entfermung fich) erbalten fömen, bifset unter ganz gleiuen Etanbortšberfältniffen bei 30jäl)rigem Umtricbe eine 3metrige Stod"=

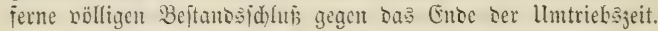

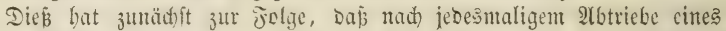
Pieberwalobeitanoes ein grofer Theil ber Fläcbe längere Beit binourd) un=

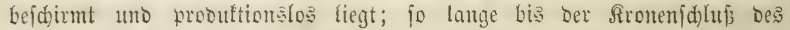
Beftantoes fid wieber bergejtellt bat. Bei fürzerem Untriebe ift biejer Beitraum in jolge Der ibm eigenthümliden größeren Etodzabl ein fürzerer, bei längerem ltmtriebe cin verbälnițmäßig längerer; Die soppelte 3ahl Der Mutterfï̈đe des fürzeren limtriebs fanm bis jum Eintreten des fronen=

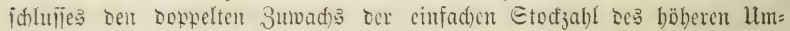
triebs ergcben, woraus bum folgt, Daß jeoe llmtriebszeit, unter übrigens ganj gleiden \$erbätniffen, ihrent bejonoeren, von ber eigentbümtid)en Stod=

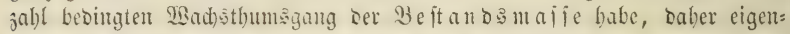
thünt(id)e 2)afien= uno Sumad)streiben und Eummen befiz̨e.

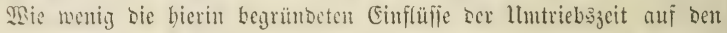

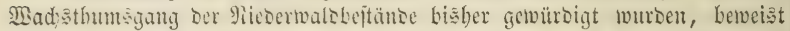

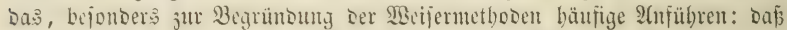

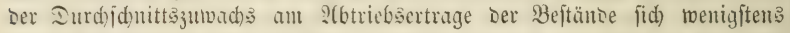

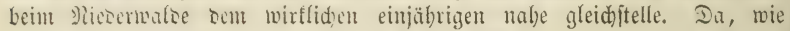

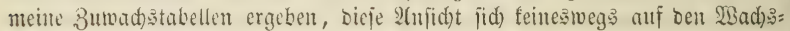
thumsgang Der Eimjclpflanje grünoch läft, fo tant fic nur bervorgegangen jein au vem Bergleid)e Der 2lbtriebserträge; 3. 3. 30jäbriger Beftümoe mit normaler (3metriger) uno 10jäbriger Beftünde mit normaler (2metriger) Etodjente. Dais aber ans einem Bergleid) ganj veridjebentartiger be=

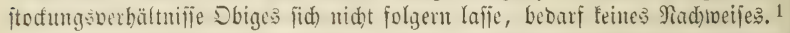

Der Eimflús ser llmtriebsjeit auf Den, eine längere Meibe von Jabren nach erjolgtem 2(btriebe, ftets räumlichen Stand Der 9)tutterföté, bat Dam

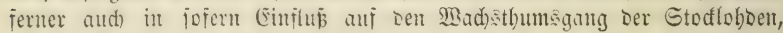
als im Pieberwalse eine 2 ercämmung überbant viel fpäter eintritt, als

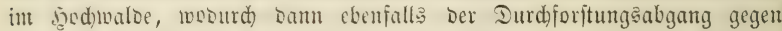

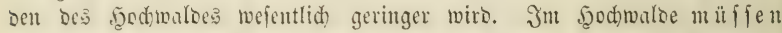
Die Durdforjtungen bejegen uno als ein bejonoerer Theil ber Biejammt=

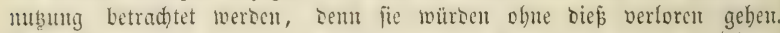

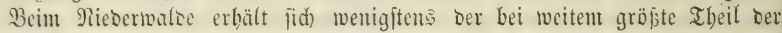
möglicherweije zu bejiebenoen Durdforjtungen bis zum 2tbtriebe, went aud) in geringem Sumadje, bod) lebentig, geht baher Der Bemtb̧ung nid)t wertorent.

\section{3) Dic Sholzarten}

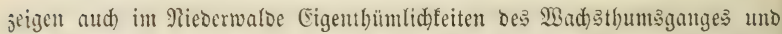
Des Suwad)je: uno jwar in viel mamigfaltigerer burd) Reprobuttionsfraft

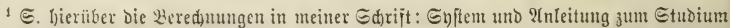

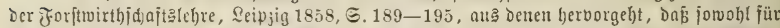

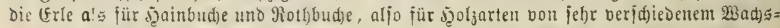

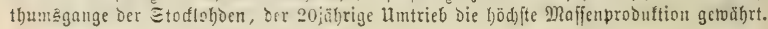


unt Stodalter bebingter Weile, wie bief im Soctiwalobetriebe ber Jall iit.

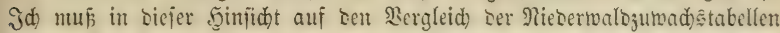

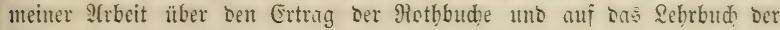
Pflanzentunte verweijen.

\section{4) Dex Etanoort}

bat einen geringeren Einflup auf ben S⿱

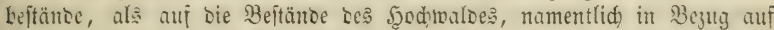

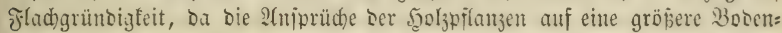
tiefe erjt in einem Allter herbortreten, Das auper ben Grenzen gewöbnlider Ricocrmaloumtricke liegt. Dagegen forbert rer Nieservalo, befonders im fürzeren Ilmtriebe, einen Boben, beffen Jnuttbarfeit weniger von ber Bei=

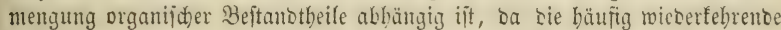

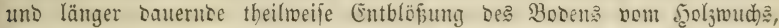

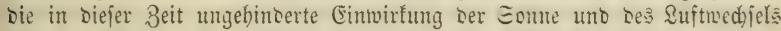
auf Den Booen, einer Strjammlung bumojer Beftanotbeile viel weniger günftig ift.

\section{5) Das Alter ber Nutteritö đé}

Wie bie Ropfbolzpflanje im beridficoenen 2llter bes Etumme cinen febr veridiebenen (Ettrag an Ropfloboen liefeit, io ijt es and in! Rieber: waloe. Nad) E. 242 meines Sebrbuds ber Fiflunzenfunbe liefern 5ain:

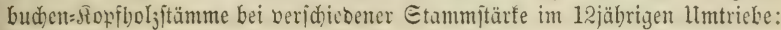
Stammitärte
2. $3 . \quad 4.5$.
6.7.
8. 12.20 3oll.

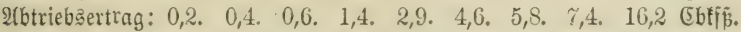

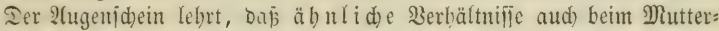
ftode DC: Riecermalses jtattfinden. Welthes bicje Berbältnifie bei Den berid)iedenen Syolzarten fint, Darïber fehlen uns nod) alle (Erfahrungen, obgleich) iie bei Der bäufig bejtehenden Untermifäung ber beriobiebenjten Etodifärfen in älteren Nieberwalobejtünten nidjt unjober ju jammeln

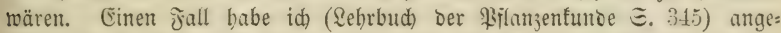
fübrt, in welchem, auf gleichem Stantorte bei 14jährigem Soboenalter, Der

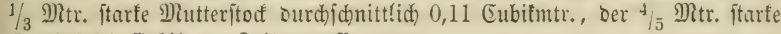
Stod 0,24 Eubitmtr. Rohoenmafie trug.

Dieje Difijeren3 Des Ertrages veridiedener Etoditärten nuß natürfid Den twejentlidfiten Einflup auf bie Erträge uno Den Wad)stbuntsgang Der Rieberwalobeftünoe äußern, je nachben bie eine ober bie anbere Etodftärfe vorberridento ift. Denfen wir uns einen aus Gamempflanzen neu erjeugtent Doer butch Untwanthlung junger ફ̧od) fo muifien in fold)em bie Erträge ber aufeinantoerfolgenoen Umtriebs zeiten

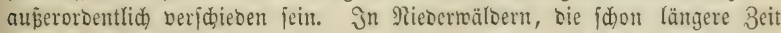

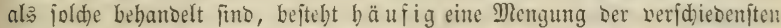
Etodalter uno Stoditärfen, in Folge bor ungleid) langen Dauter ber Etöde.

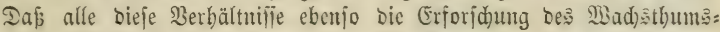

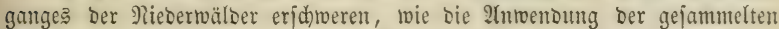

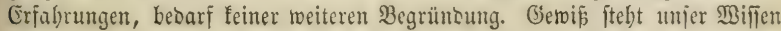

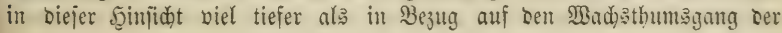




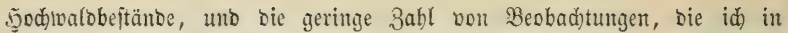
meinem Sebrbud) Der \$flanzenfunse niebergelegt babe, Dürfte bis jeb̨t Daß einzige Material jein.

(Ë folgt aus Dem Boritehenten aber auch: Dap bie Beurtheilung bes fünftigen Ertrages ber Nieberwälber aus vorbergegantgenen befannten $\mathfrak{A} b=$ tricbserträgen berjelben Flächen, eine jehr unfid)ere jei, in Folge Der, im

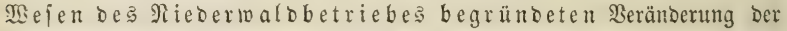

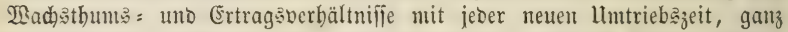

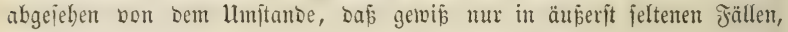
mit Den, alleroing meift befannten, früheren (Ertragsergebniffen zugleid) auch) ein Bilo Derjenigen Bejtanosberbältniffe Der Begenwart erbalten ift, Die Den befannten Ertrag zur Folge hatter.

Ilnter biejen llmftämben bleibt uns jur crmittelung Des fünftigen Ertrages ber Riedermalsbeftänoe, befonders zur Beftimmung Des Ertragę fünftiger llmtrichs̄zeiträıme, fein anberes Mittel als bic 2Uffitellung gut d)arafterifirter Erfabrungstafeln, in weldhe bie auf Den Ertrag bes शieber= waldes einflupreid)en $\mathfrak{B}$ erbältnifje aufgenommen fino, die baber aud) cine

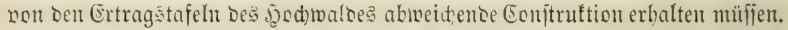

In meiner llnteriud)utg über Don (Ertrag Der Mothbudhe uno im Rebrb. D. Bilanjentunoe babe id folgende form genäblt. (ङ. nebenftchende Iabelle.)

Whie Dor Bergleid) mit S. 31 jeigt, reichen bieje Erfabrungstafehu

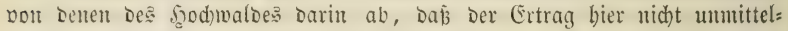
bar für eine bejtimmte Flächengröß̨e, jonoen für eine Miebrzabl von Mutter=

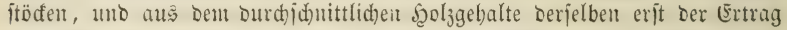

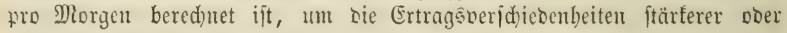
geringerer ?kejtoctung unnittelbar aus Den Tafeln entnebmen zu fönnen. Um

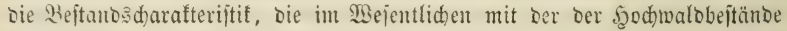
überemftimunt, vom Beftofungsgrade unabbängig zul balten, ijt fie in bie

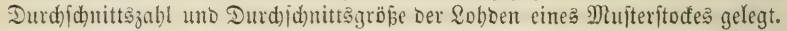

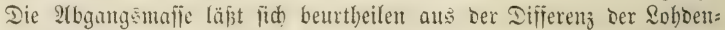
jabl bes Dufterftoctes in verícicoenem Ilter, uno würde bicje Differenz j. 3. $2,28-1,66=0,62$; multiplicirt mit bem 5eljgebalte ber 2oboen

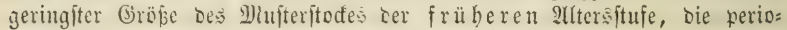

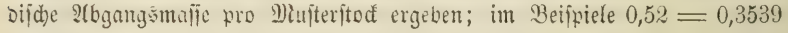
$+\frac{1}{9} 2,1747=0,5939$.

Eold)e Errabrungstafeht müpten entworfent werden, nid)t allein für

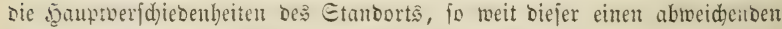
Wad) sthum jehr mejentlid), für bie beriddiebenen Etodalter ober Stodfiärfen, ba $e^{3}$

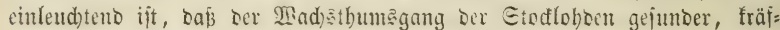
tiger, fturfer Etöde, niōt entfernt einen Miajitub geben fann für Den Mad) sthumegang uno Ertrag oer Zoboen auj jungen idwachen Stöden, ibenjomentig wie auf alten jobabhaften Stöden. ${ }^{1}$

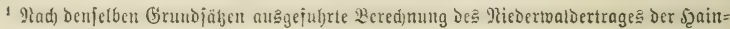
budje und oer Rotbbud)e habe id) ill meiner Gd;rift: Elftem und ?tnleitung :c. mitgetheilt. 


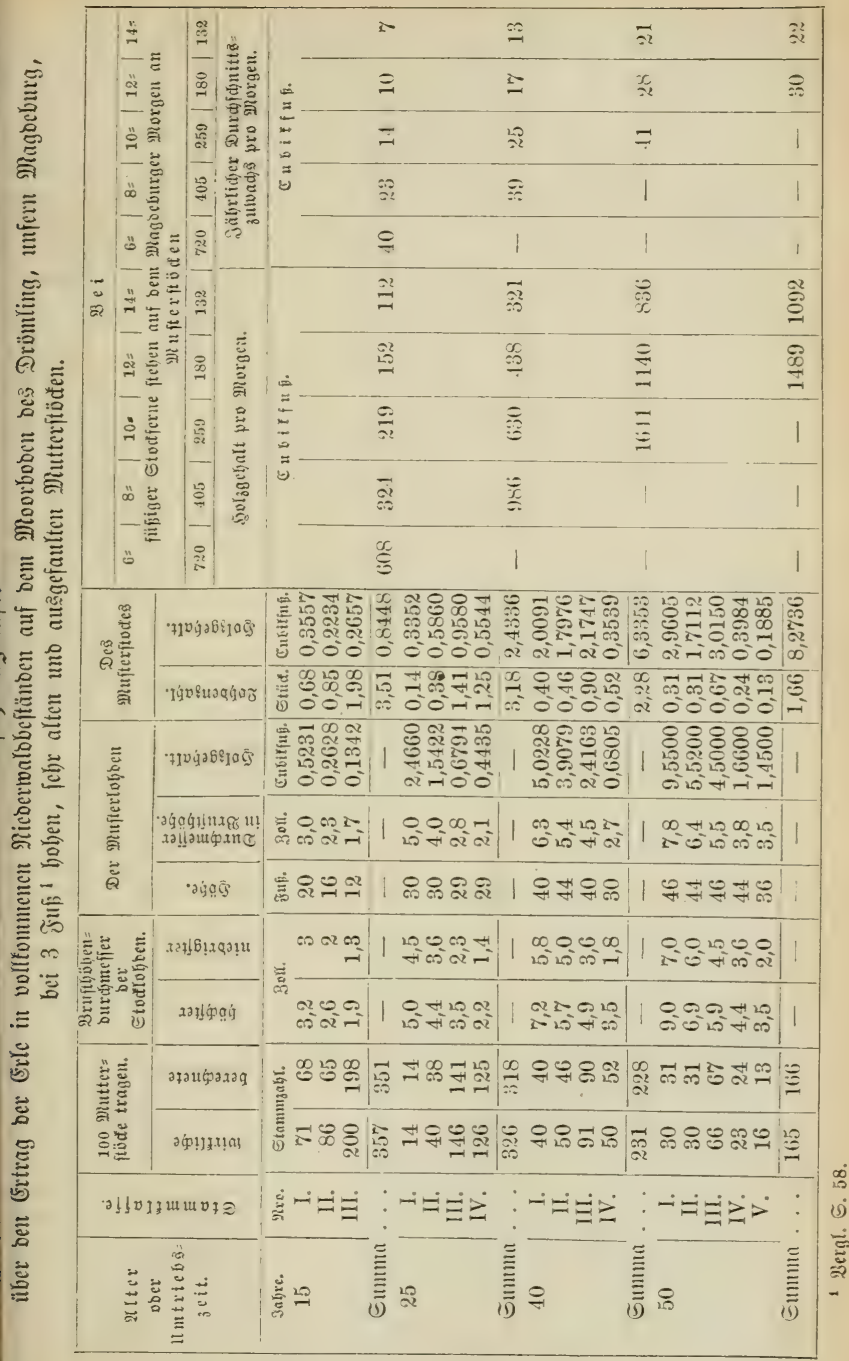


Bei ber 2tnmentung folder Ertragstafeln auf sie Ermittlung bes fünftigen Ertrages gegentwärtig junger Beftänoe, bient, foweit ber Ertrags: fał ber nädjiten lluntricbsjeit angehört, Die Cbarafteriftif ber Ertragetafeln cinerfeita, andererfeite ber vorbanoene Beftofungghgrao jun Mlapitabe. Bei

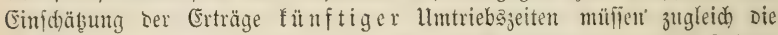
Beränderungen gemürbigt werben, weld)e Der Madäthumsgang ber Soboen erleiben wiro, in Folge ber, felbjt beim bollfommenften Rulturbetriebe ein= tretentoen Beränberungen ber Beftodung, fotwoht in Bezug auf bas vorges fdrittene Alter ber bleiben ben Beftodung als in Bezug auf bent 2lbgang alter unt Den 3ugang nener Etöde; wonad) Dant möglidjerweife ganz anbere Erfabrungstafeln in Afnwentoung zu fez̧en finto, als biejenigen, weldhe Dent gegenmärtig vorliegenden Beftanbęverbältnifīen entipred)en.

\section{Die proportionale Sdlageintheilung.}

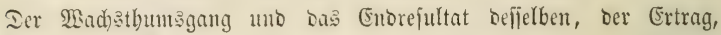
finto in gleidfem Mape von Stanoorts = unto Beftodungsgüte abbängig.

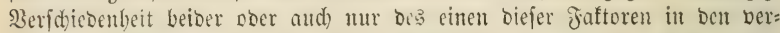

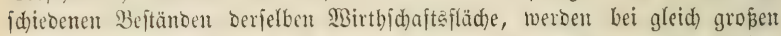

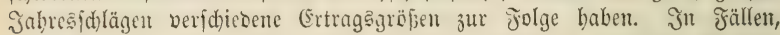

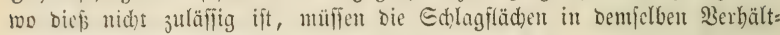

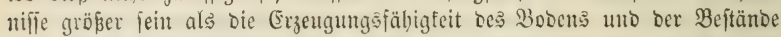
cine geringere ift unt ungefebrt. Dief ift $\mathrm{e}$, wa w wir cine (Der Ertrags: fäbigfeit) proportionale Sdlageintbeilung nemen.

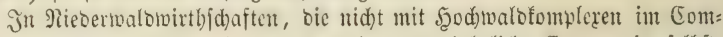
funtionsuberbande jteben, in ocnen Daher oer jäbrlidhe Ertrag ein felbjt=

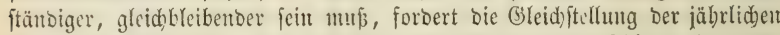

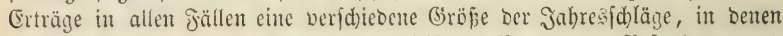
bie Erzeugungaffraft des Gtundorts veridiebent ift und ber Beftodungsgrad

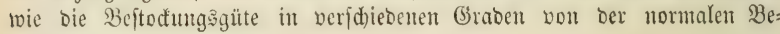
ftoctung abrocicheno ift.

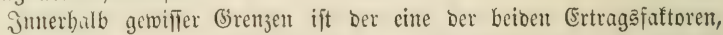
Die Etanoorţ̧güte, etwa! Beftänoiges; der jweite Faftor bingegent ift ver= älorlid): nad) Seftodungegrad, Bejdaffenteit uno $2(1$ ter ber Mtutteritöcfe.

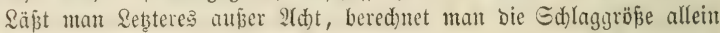

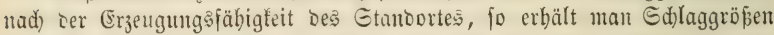
proportional ber Bodengüte. Bei oer Unausfübrbarfeit einer un= mittelbaren Bobenwitroigung faun biés nur gefcheben: inbem man ben

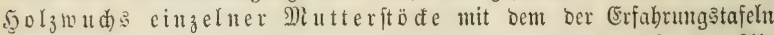
vergleidt, Danad) bie Stanoortsgüte beurtheilt, unt nad) bicjer Dent $2 \mathfrak{b}=$ triebsertrag ber Dem Standorte entfprechenden Erfahrungstafel, multiplicirt mit ber Fläd)engröße bes Beftanbes in 21njaßz bringt.

Die Gumme Der, obne Riüficht auf bas gegentuärtige Beftocturgş= verbältni仍 berechneten 2tbtriebserträge aller Beftänoe, bivibirt burdh bie Jabre bes ltmtriebs, ergibt Deli Gollertrag jebes einzeluen Jabreşd lages.

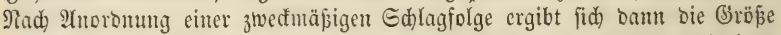
jebes einjelnent ভd)lages aus ben gcid)äkten 2(btriebserträgen berjentigen 3efitante ober Bejtandstbeile, bie ber Ed)lagoromung nad) zuammenfallen, 


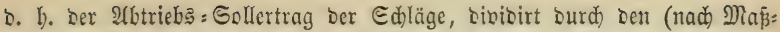
gabe ber Sobengüte veränterlichen) A(btriebsertrag pro Morgen, ergibt bie

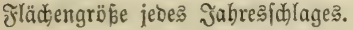

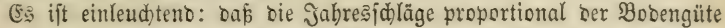
nur bam cinen gleidjen Ertrag geben fömen, wemn ber ztweite Faftor bešs felben, Grao uno G̈üte ber Bejtofung auf ber ganzen Betriebșfläche biejelben fint. Eo lange biés nidht ber Fall ift, merben bie Erträge ber einzelnen

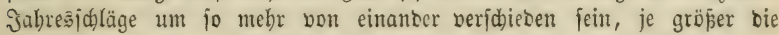
Berfobicbenbeit ibrer Beftodung ijt.

In jolden, den bei weitem bäufigiten Fällen, entipridgt bie Methooe saber nicht ben 2Unforberungen ftrenger Nachbaltigłeit in ber Benukzung,

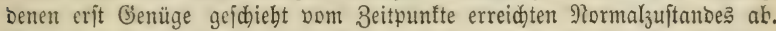

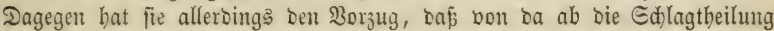
uno Edlaggröpe als eine conftante betrachtet werben barf, ba fie auf ber

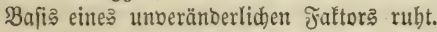

Bieht man nidgt allein bie Etanbortaggüte, fonoern aud) Den żweiten Ertragşfaftor: (3rab uno (5üte ber Beftochung, in bie Bered)nung Der Єd)lag= gröse, fo erbält man eine flächentbeilung proportional ber Ertrag s: fäbigfeit ber Beftäube im Saufe ber nädften lumtriebšzet. Das Berfahren ijt von bem einer fläd)entheilung proportional ber Bobengüte

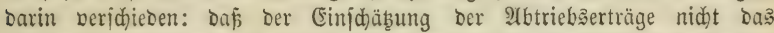
normale, jonbern bas, burch einen borläufigen Betriebäplan befitimmte, befondere atbtriebsalter -, Da male $3 u$ ftand ber $B$ ejtofung, fonoern ber wirflide 3 uftano

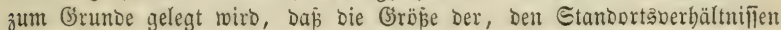

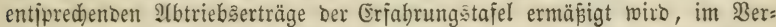

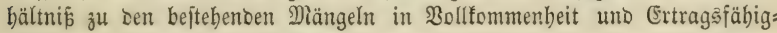
feit ber gegenwärtigen Bejtoctung.

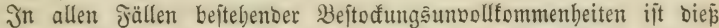
bie einz̧ige Methode ber Fläd)eneintheilung, burd) weldje eine 2 (usgleid)ung

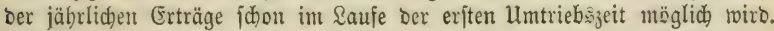
Mit jeber neuen Umtriebşzeit berliert aber bie nach biejem Brincipe voll=

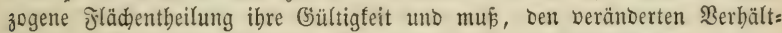
nifijen in Grad uno Gäte ber Beftocfung gemäß, erneuert werben.

Man bat baber ben Soridhlag gemacht, eine twirfliche Flädyenbertbei= lung in biejem Jalle gar nid)t auşujühren, jonbern bie Echlaggrößpe erft

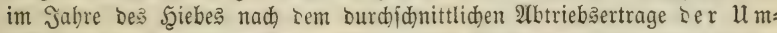

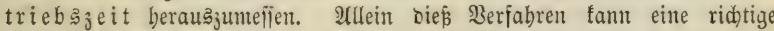
Sciebaggrö̧e überall da nidgt ergeben, wo bie Beftände theilmeije in einem

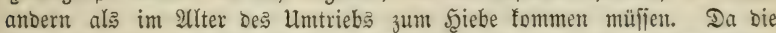
Abnuķung bes Durdjidnittliden 2(btriebsertragę ganz auf berjelben Bajis rufi, wie Die Methoden Der (Ertragsbered)ung nad) Dem Durdjidnitts:

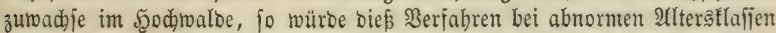
natürliă ganz biefelben Jebler in Gejolge baben, wie bas Durdjidnittš: berfabren im Soctiwalde.

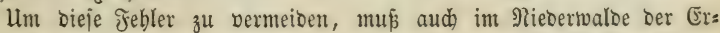

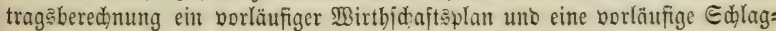

şartig, §ebrbud) für f̧örter. 11 . 
eintbeilung uno Edlagfolgeoromutg (auf ber Rarte) vorangeben, unt, in ber $\mathfrak{A}$ rt ber Fad werfmethoben, Bafie ber Ertrageredenung

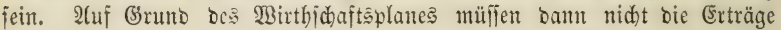
Des Untriebsalters, fondern bie tes befonderen 2tbtriebsalters, wie Dię̧ burd) bie vorläufige Ed)lageintbeilung befitimmt ift, ben (Erfabrunģs: tafeln entnommen, fummirt uno in bie Jahre des llmtriebs vertbeilt werben, morauf Dann, wie im Jad)merfe bie periobifden (־rträge burch Berfdieben Der Beftäntbe, Gier bie jübrlid)en (Erträge Durd) Berlegen ber vorläufigen Edjlaggrenzen auszugleiden uno feitzuiftellen find.

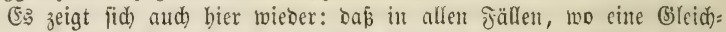

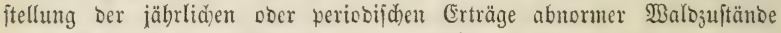

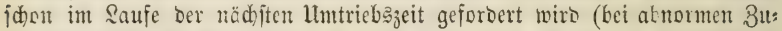
ftänsen erfüllt bie (Eintbeilung in gleid) grofe ober in Edläge proportional Der (Ertraga äabigteit bes Bobens bieje Forberung nidt), mur nad bent

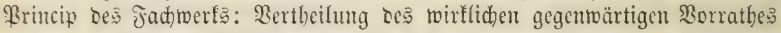
uno ber auf einen Wirtbid)aftaplan fid grünbenoen Summe bes wirflichen 3umadhjes an ifm, anf bie Jahre ober \$erioben bes Untriebs -, ein

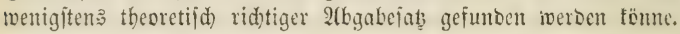

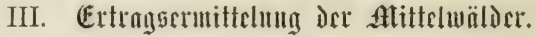

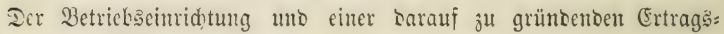
beredonm Der Mittelwäloer mus, cbenio wie den übrigen Betriebsarten,

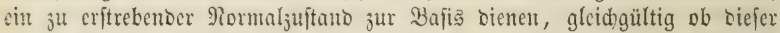
3 uftano in ber Wirflidfeit je errecht miro, necr ïberhaunt erreidbar ift Doer nid)t.

Diejer Normaljutand ift für ben Mittelmalo cine, bem Unterbolz=

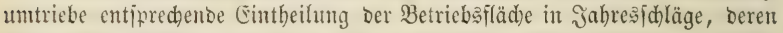
jeber einen gleiden, unt zrwar Den werthoolliten Bejammtertrag an Dber: uno Interbolz nadibaltig ju liefern beripricht.

Nad) Sollentung ocr getwöhnliden Bermeliung s: = uno Rartirungsarbeiten hat ber Iarator fid) Denjemigen 3uftano Der Betriebsiälähe zu verfinnliden,

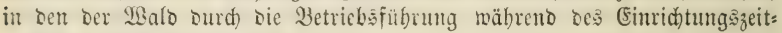
raumes berfekzt merben joll.

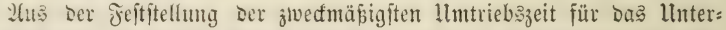
bol3, nach Den im zmeiten Bante Є. 28 Dargelegten Beftimmungggrünoen,

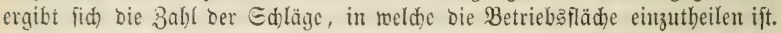

34 ben allgemcinen Beftimunugągründen ber હd)lagfolge tritt bie

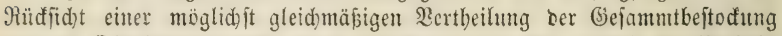

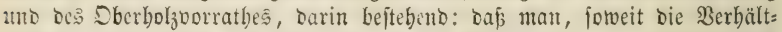
nilie Der Sertlichtcit bief geftatten, in ber Schlagoromung gut beftandene

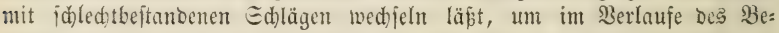
triebs unvermeisbare llugleid)beiten ber Jahreserträge Durd) Borgriffe in

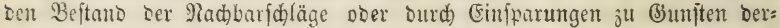
jelben ausgleiden ju fönnen, ohne Den vorgejeidneten Betriebshlan Daburd

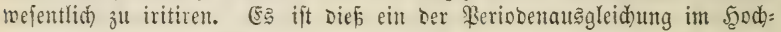
waloe analoges Berfabren. 
jit sie Edhlagiolge vorläufig georonet, io fint bie Edläge nach ber Durdjichnittliden Etantortagüte in Bonitätâtlanjen zu vertbeilen, uno für

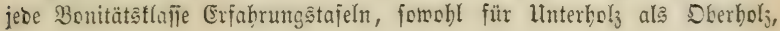
anzulfertigen.

Die Erfabrungs̄tafeln für ben Unterbolybeftano find im 2lllgemeinen gleid) Denen für Den Plicberwalo zu forftruiren, kei ber 2lustwahl Dor Probefläd)en aber jolche Beftandattbile zu erwäblen, in Denen auper nor= maler Beftocung Lerjenige (jrab ber Bejdirmung burd) Dberbolz beftelt, Der in 3ufunft ber normale jein wirs. Die Maffenteibe ber Erfabrungss= tafeln ergibt ben normalen Borrath, im Ganzen wie für jeocn einjelnen

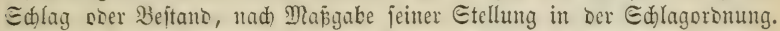

¿ie Erfahrungstajeln für ben Dberbolzheftano besürfen einer bejonsern Eonitruftion.

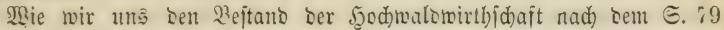
tabellarifo aufgeftellten Beiffiele in bie Majenreilye für sen Abtriebsertrag uno. in io viele Ma|lenreihen für die Durdjorftungs̄mubungen zerlegt bentent fönnen, als Iurdforftungsbejüge in ein uno Demiclien Beftanbe eintreten,

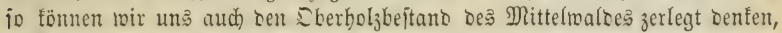

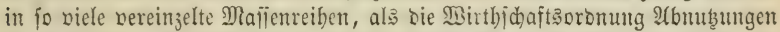
in verichiobenen 2 lteraflajien vorid)reibt (vergl. Bo. II. Є. 28 u. f.). Eoll nur

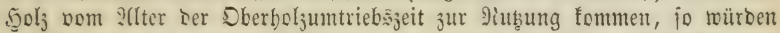
wix es nur nit einer Majienreibe jut thu baben, jujammengejeşt aus io vielen saumreiben vom 0jäbrigen bis zum 2 fbtrichsalter, als bie Etanm=

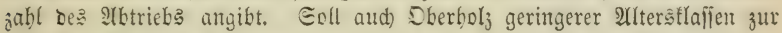
jäbrlichen Nub̧ung binjugejogen mersen, io forsert jebe berjelben ifre be:

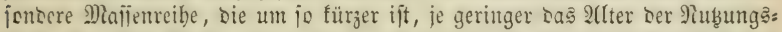

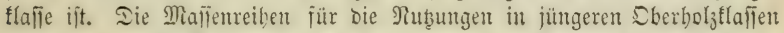

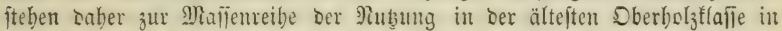

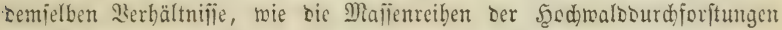
วur Mafientribe des 2 (btriebsertrages ber Şodinälber.

Ia die Edaftholjmalien aller Gitieber jeber cinzelnen Maffenreibe bleibend jint, io läp̆t jich Edhajtholzmajie uno Edhajtholzoorrath bes nor:

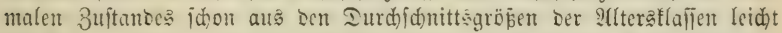
kerectnen. Etrentg genommen mü̈te bierbei, in Jolge ser Bertheilung Der Gblieber jeser einjelnen Majienreibe in Die veridiesenen Edjläge, bie Mafien: reike jelbit aus sen Iurdjidnittägröpen ber cntipred)enten 2(Yterâtlafien auf

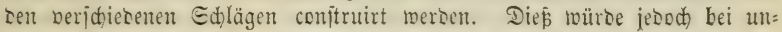
gleicher Etantortingüte ju grofien Edinantungen ber einzelnen Blieber jeder

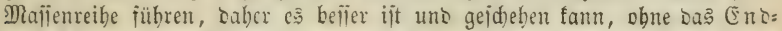
reiultat jli verfäliden, wem man bie Malfemreiben nach ber burd)=

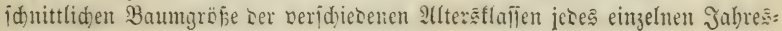
id)lages conitruirt.

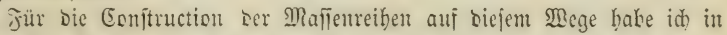
meiner $\mathfrak{U}$ rbeit über ben (Ertrag Der Rothbuche uno in meinem Sebrbuch Der Bflanzentunbe jolgendes 2 erfahren vorgejdlagen.

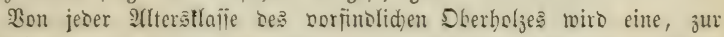

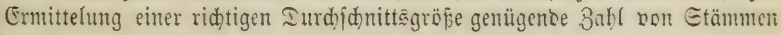




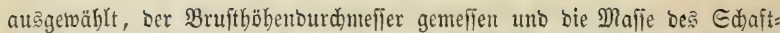

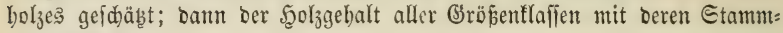
zabl bivibirt.

3. B. 90 jähriges Oberbola $_{3}$ :

$$
\begin{aligned}
& 17 \text { ङt. } 19,5-17,5 \text { cent. } 3 \text { u } 60 \text { Eubif́ctm. }=1020 \text { Eubif́ctm. } \\
& 16 \text { " } 17,4-15,5 \text { " " } 48 \text { " }=768 \text { " } \\
& 10 \text { " } 15,4-13,5 \text { " " } 40 \text { " }=400 \text { " }
\end{aligned}
$$

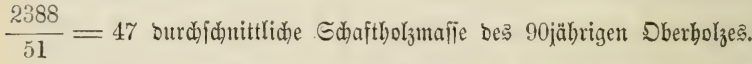

Die Bufammenftellung Der Durdjidnittlid)en Sdaftholzmafien aller im Sdlage borfintliden Altersflafien ergibt bie Mafjenreibe uno baher ben

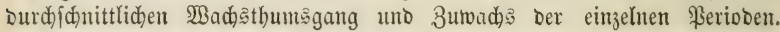
Jeblen im Ed)lage einzelne atlterstlafien, fo lafien fid bie Süden ausfüllen burd) Unterjudungen auf anbere Schläge gleider Standortabejdaffenbeit uno gleiden Baumwudjes, auf Denen bie fehlende Altersflaffe vorbanoen

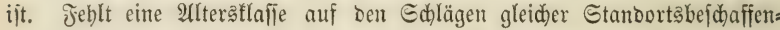
heit überbaupt, oder beftehen 3 weifel über bas alter ber 33 äume höherer Dberbolzllafien, fo mú bie Rüffe ergänzt, oder Die 3weifel geboben werben Durd) birefte 3uwadsmeffung uno Bered)nung an böberen SUlterstlafien, woburd fid bie Schaftholzgrößen uno Maffen

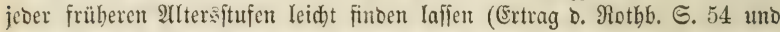

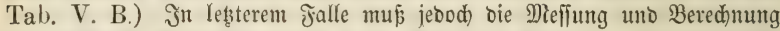
ber früberen Baumgrößen an einer Mlebrzabl ftärferer oder fobmächerer Stämme ber böberen Ilteraflaffen ausgeführt merben, um aud auf biejem

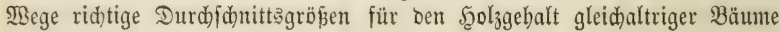
3ll erbalter.

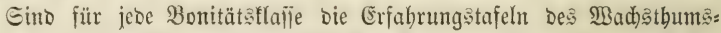

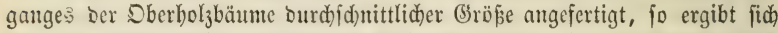
ber auf jeden Edylag fallende S(ntheil bes normalen Borratbes burd)

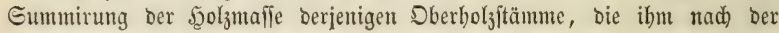
Betrieb:s= uno Ed)lagoronung zultehen, multiplicirt mit ber Morgenzahl bes Ed)lages. 3. B.:

S3ei 120 jährigem $D_{\text {berlol }}=$ uno 30 jäbrigent Unterbolzumtriebe follen bie Maflenreiken Des normalen 3 uftandes partiell vertreten fein:

a) für bie शub̧ung von 2 Stamm 120jäbrig,

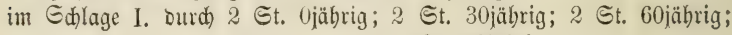

2 St. 90jäbrig.

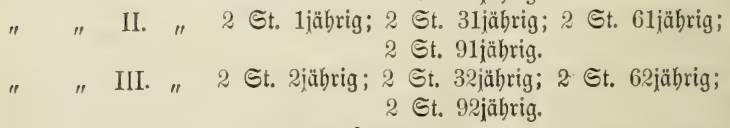

u. $\{$. w.

" " XXX. " 2 St. 29jäbrig; 2 St. 59jäbrig; 2 St. 89jäbrig;

2 Et. 119 jährig. 


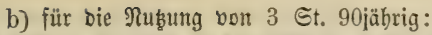

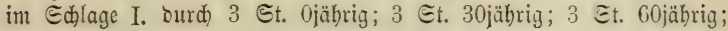

" II. " 3 Et. 1jährig; 3 St. 31 jäbrig; 3 હt. 61 jäbrig;

u. . . iv.

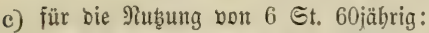

im Sdlage I. Durd 6 Et. 0jährig, 6 Et. 30jäbrig;

" " II. " 6 Et. ljäbrig, 6 Et. 31 jäbrig;

u. . w. w.

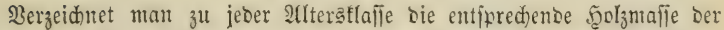
Erfabrungêtafel, multiplicirt mit der Etammıabl, fo ergibt bie Eummirung

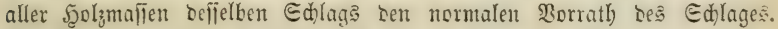
Die Eummirung Der normalen Dherholyoorräthe aller Edhläge crgibt Den normalen Dberbolzoorrath Der Betriebşfläche.

3ählt man zum normalen Dberholjworrath jedes Edjlages ben nor: malen Unterboljoorrath), jo erbält man $\mathrm{n} v$ Des Gejammtoorrathes für jeben

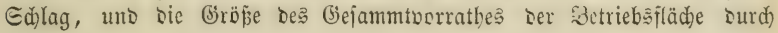
Summirung $\mathrm{n} v$ ber einzelnen Sdläge.

Jit ber Piormalvorrath für jeben einzelnen Edjlag unt für bie Eumme

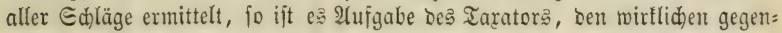
wärtigen 30 rrath uno nädittäbrigen 3 uwad) jebes cinzelnen $\Subset d$ lages nad

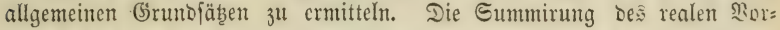
rathes (rv) und bes realen näbjtjäbrigcn 3uwadjes (rz) aller Edyläze ergibt (rv) uno (rz) Der Betriebsfläche.

Der Bergleid) von r v uno n v Der Betriebsifläde ergibt ben Sorratb:

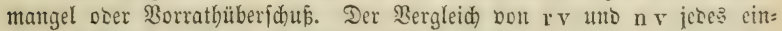

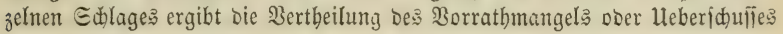
in bie einzelnen Edläge.

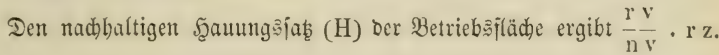
Jebes einzelnen Єdylages $\frac{\mathrm{r} v}{\mathrm{nv}} \cdot \mathrm{rz}$ ergibt, ob uno um wie biel $\mathrm{h}$ Des Sd)lages gröfer ober fleiner ift als $H$ ber Betriebsfläd).

Sit $h$ gröper ober fleiner als $H$, fo fino bie vorläufig frojectirten

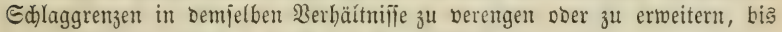

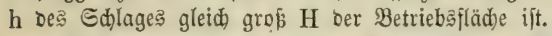

BerIangt man nod) gröfere (Senautigfeit Der Ertragšgleidjitellung, io

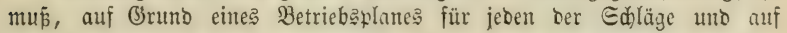
Dauer ber Unterbolzumtriebzeit, $\frac{\mathrm{Srz}}{\mathrm{u}}$ ermitteft uno anftatt $\mathrm{r} z$ ber Gegen= wart in Rechnung geftellt werbent.

Cine gejonberte (Sleidjtellung ber Unterboly = uno Der Dberboly= erträge ift bei abnormen 3 ujtänben unmöglid, da ber Seieb beß Sberbolzes an ben bes Unterbolzes gebunben ift, grope Sberholzmengen mit geringem Unterholzertrage, hoher Unterholzertrag mit geringen Dber=

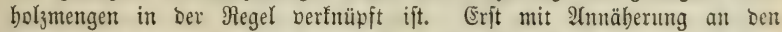
Normal 3 u ft a n b fömten aud bieje Ertragenperbältnifie fich normal geftalten.

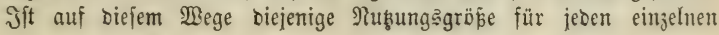


Edjlag beftimmt, burd weldhe befien Beftand bem normalen Borrathe

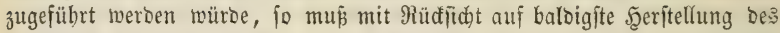
normalen 3 uft an bes für jeben Edjlag ein gejonberter Betriebaplan ent= worfen werben. 24 s biejer Betriebsregulirung ergibt fid bann audh,

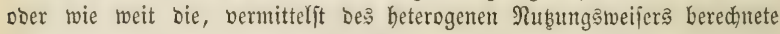

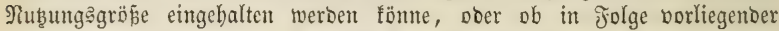
3eftandşberbältnifife, 3. 3. 2lbftänoigfeit Des vorbandenen Dberbolzes, alb: weidungen nothmentig fint. Es fonmt bierbei ganj barauf an, ob bie

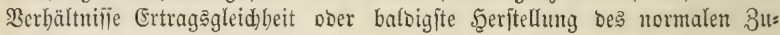
ftambes bringenber forbern.

Sn ber siüze bargeftellt befteht alio bie vorfteheno entwickelte MRethobe barin, Daßs, auf Gruno bes herzuftellenden normalen Buftanoes, Ed)lag= eintheilung uno Edlagfolge projectirt, Der Borrath Dę normalen 3uftandes für jeoen einzelnen Ed)lag, feiner Etellung in ber Edjlag= vrbuung gemäp, nach Erfabrungstafeln kerednet uno Daraus ber normale

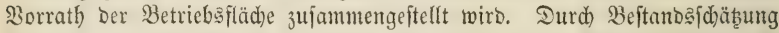

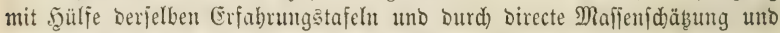

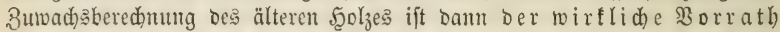

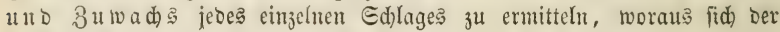

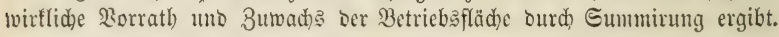

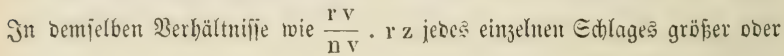
fleiner ijt als $\frac{\mathrm{rv}}{\mathrm{nv}} \cdot \mathrm{rz}$ ber Betricbäfläde, wiro bie projectirte ed)lag=

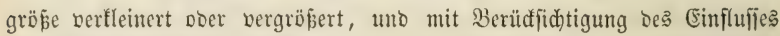

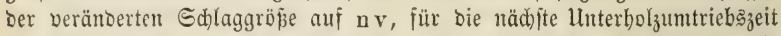
feftgeftellt, wobei barauf ju achten ift, Dajs, in bemielben \$̧erbältnifije wie Die Ed)lagf(äd)e, aud $\mathrm{rv}$ und $\mathrm{rz}$ berfelben berfleinert oder vergröpert wirb.

WSiro bei ber Madjudat des Dberbolzes die normale Stammzabl pro Morgen aus Dem Unterbolze übergebalten, fo hat bie, auf bem bezeidnnen= Den Bege unter abnormen Berbältniffen fich ergebende, allerbings febr un=

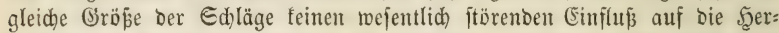
ftellung bes normalen 3uftantes in Dberholze. Bröṕcre Störungen faun baburd bie balbige Szerftellung bes normalen Unterholzjuftandes erleiben; allein biés ijt bei abuormen 3uftänoen niḑt zu vermeiben, uno bei ber

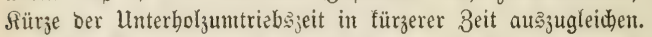

Der Pormaloorrath ift mur fo lange eine feftitehende Brö̈ßje, als bie projeftirten Edfaggrößen, auß benen er bered)net wurbe, feine wefent= liḑe ßeränberunty erleioen. Dieje muß aber, bei gegentwärtig jebr ab:

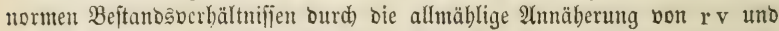
$\mathrm{rz}$ an $\mathrm{nv}$ uno $\mathrm{nz}$, mintoeftens am હd) treten, baher die Methode, bis zum erreidten Normalzultande, eine Berid)= tigung Der Sd)laglinien mit Beginn jebes neuen Unterbolzumtriebes erbeifdt.

(E⿱

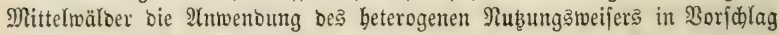
bringe, wäbreno idh ibm für ben Sgocbralo mur bedingte Berwenobarteit 3ugefproden babe. Bergleidt man aber bie 2fusftellungen, bie idj in biejer 
Şinjuct Eeite 99 gegen ihn erlyoben habe, mit ben Berbältnilien be? Mittelmalobetriebes, io twirb man finocn, baj bie weientlidjiten Sindernifie

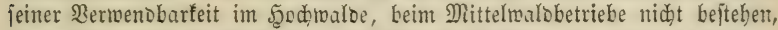

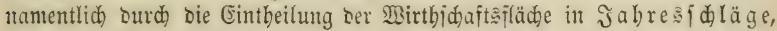

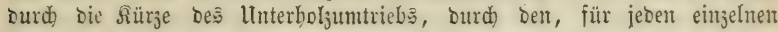

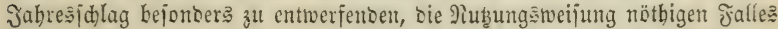
beridtigenten Betriebsplan, uno burd) bie a uf jebem Jabreşd lage Durch bie überzubaltentoen Eapreibel gefiderte Syerftellung bes normalen

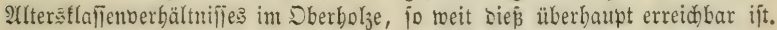
Эo) glaube baher in Borjtehendem ein fortbiloungswerthes Material nieber: gelegt zu baben, uno nur als joldes münide idh es betrachtet zu jeben.

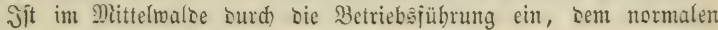

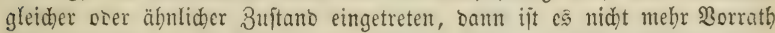

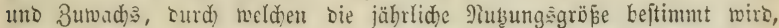

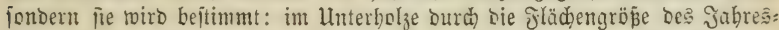

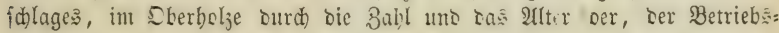
oromung nad), auf jeDem $\Subset d$ lage überzubaltenten Dberholzbäume; was auf Den Ed)lägen mehr als bieje vorhanden ift, fällt Der 2(bnuţung anbeim, Der 5ुolzmajiengehalt biejer Bäunie mag gró̉ coer gering jein.

\section{siferatur.}

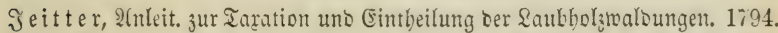
lleber Beredung oes nachbaltigen Grtrage im Mittelwalbe. Pifeif, frit. Bl. X. Fiejt 2. Є. 46.

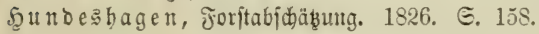

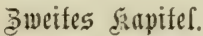

$\mathfrak{B}$ ald toerthbereditu $n$.

3)ian beriteht Darunter bie Ermittelung Deß gegentmärtigen Werfauf

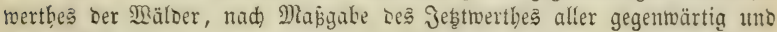
in ber Zutunit baraus zu beziehenden Renten.

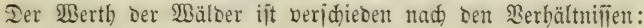

1) Deక Bermögenక̧tandes,

2) De? $2(b j a$ bes?,

3) Der গiubungsbefugnifie.

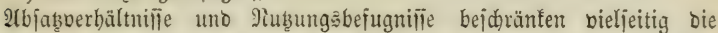

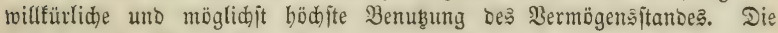
Urjache biejer Bejdränfung liegt vorzugâmeije in ber bereiţ im zweiten Bande Dargelegten Meridiebenbeit bes Rapitalwertbes und bes

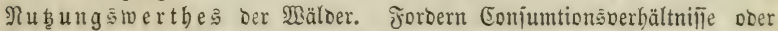

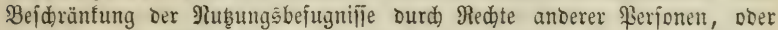
forftpolizeilide Beftimmungen bie fortbanernbe Erbebung bes nadbaltigen Naturalertrages, jo ift, mit feltenen 2fusnabmen, ber allgemeine Werth Dę Balbvermögen

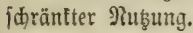


Die Walbwerthberedunutg hat baher ganz veridjebenc 2 Hifgaben, je nadbem bie Benubung bes Balbvermögens frei ober in einter boer ber anderen $\mathfrak{B e i j e}$ gebunben ijt.

\section{A. Ermittchug Des Werkanfsuertles foldjer Wülder, dic ats filtem oder Dem andern (5runde fortianermo undjualtig bewirtly- [djaftet wetien mit}

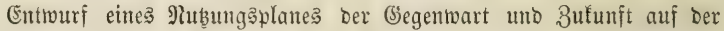

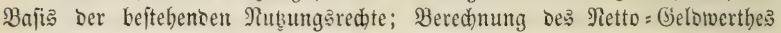
aller (Sinnabmen zur Beit ibres Eingebents, bilden den erften Theil Des (Bejdäts, aus rem fid) eine Reibenfolge non Renten ergibt, bie, wie jebe andere Rentenreike zum Rapitale Des Jesttwertbes erboben wirs.

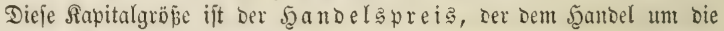
Waare zum Grunbe gelegt twerben muई

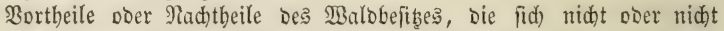

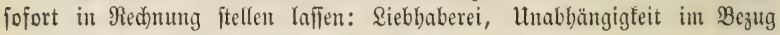

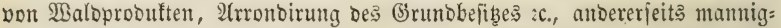
faltige Saften uno Unannebmlidfeiten, bie Der SBalobefith mit fid fübren

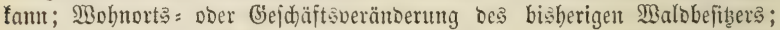

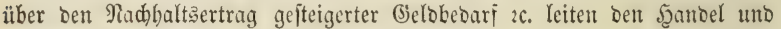

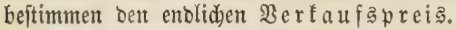

Begenftano ber Malbinerthberedyung fann mu bie Ermittelung bes Sandelspreifes fein. Es fonmen hierbel nadfolgente fragen in Betradht, bie Gegenftanb einer wiffenifhaftlid)en Controberje fein tönten.

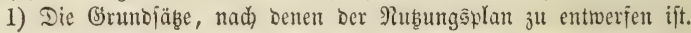

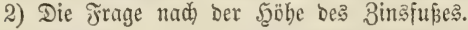

3) Die Frage, wie eine geringere Sid)erbeit Des Eingehen ber Sapital= rente Dem Balbverfäufer zu vergüten fei.

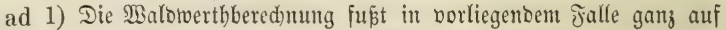
einer Betriebseintidtung uno (Ertragsbered)nutg, wie foldhe int vorber= gebentoen Rapitel bargeftellt wurbe. Es fommt lebiglid) barauf an, bie

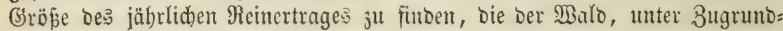
legung einer nachbaltigen Wirtbfd)aft, gegentwärtig uno fünftig liejent wiro.

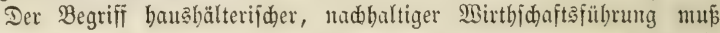
bierbei aber auf jeine engiten (b) renzen bejdränft, jebe, immerbalb

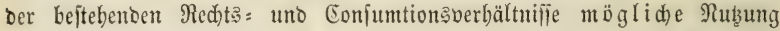
múp fo früh wie möglid) zur (Frbebung gejtellt werben. Darin unter:

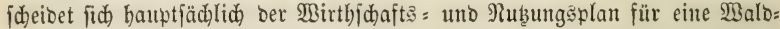

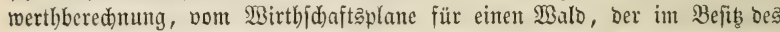

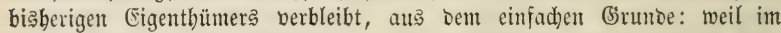
leştern Falle jebe Berzidtleiftung auf mögliderweife uno möglidjit früh z̆t erhebende Nubungen bem bleibenden (Signer fid) vergütet, entweber burd) Rapitalanfammlung ober burd) Ertragserböhung (er twüroe fonft biefer

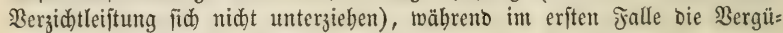
tung. Dem Berfäufer entgehen würbe.

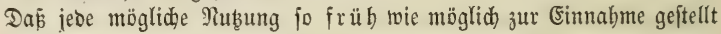


werben mú, grüntet jid) auf bie, gegenüber bent 5olzzumadje grösere Broduftionâfraft ber Gielofapitale, uno fintet im Gifeidgemidyt berfelben jeine Bejchränfung.

WBill ๖er Walofäufer jene refuniären Bortbeile nicht erbeben, mie joldhe aus einer, gegenuber Den Principien comjerbativer Joritmirthichaft,

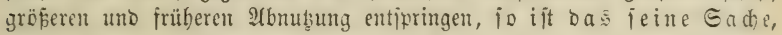
uno muг er ¿afür feine moblertoggenen Brüno: haben.

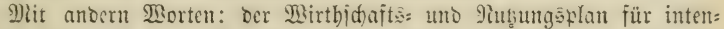

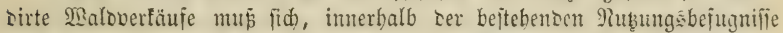

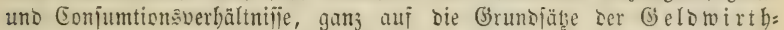

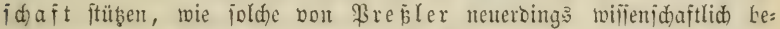

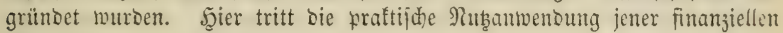
Grunofäbze in ibre Redte.

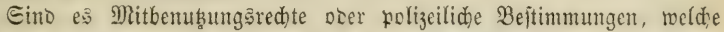

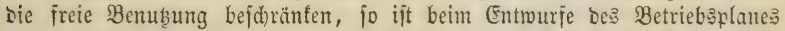

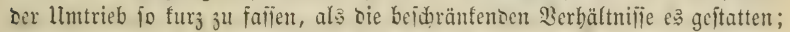

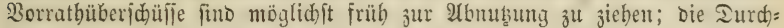
forftungen fino als möglidjit früh uno ftarf gefübrt ju berednen, bejonoers ift in bie böberen Alterätlaifen ein ftarfer Durdforftungshieb cinjulegen; furz, bie Betriebäregulirung bat alles anzuoronen, moourd) unbejdabet ber

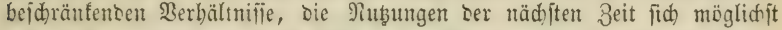
hod) jetlen, fowohl in Beiduffenhcit als Denge. 2Ulles, was cer fïujer, unbejdabet oer bejdränfenten Berbälnijje, aub bem Malbe

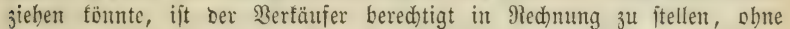

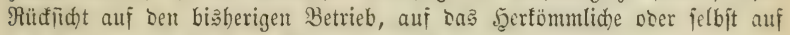

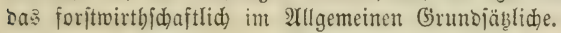

Siegt bingegen Die Beị)räntung in Eonjuntionồerbältnifien, in

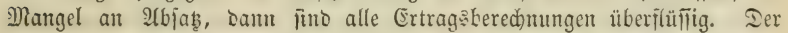
gegentärtige uno nutbmapjlich) = zutünftige 2(bjab fam, in jo fern er angen= ¡đ)einlid) Den nachbaltigen Ertrag ber Wälder nid)t überjteigt, bie allein ridatige Bajī Des Berfaujapreijes ergebur. Dagegen fino in biejem Jalle

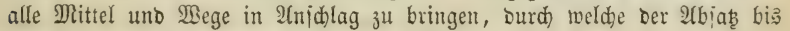
zur Fë̈be bes Ertrages gefteigert merben fann.

Sit auf Brumb einer Betriebsoromung uno Ertragşberednung Der jäbrliche Naturalertrag feftgejtellt, io ergeben bie zur Beit übliden Iurd)=

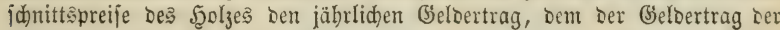
jährliden ober periobijđ)en Rebennubungen binjugeredhnet wirb. Bon Der

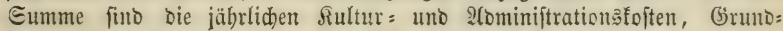

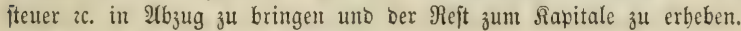

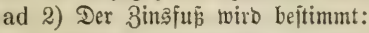

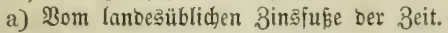

b) Bon Der Sidterbeit bes Rentenbezuges.

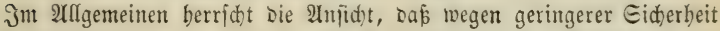

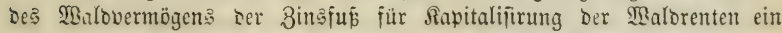
böberer jein mülīe als sor lanoeșüblict)e bei voller (bupothetarijder ooer

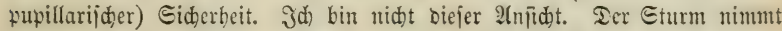
bie entrourzelten Bäume nid)t mit jid) fort, bas sisalofeuer verbrennt jie 


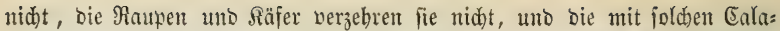

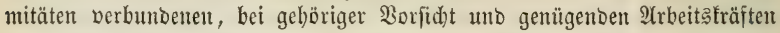

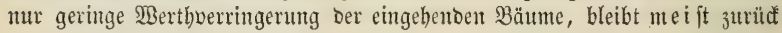
Ginter Den grojen pecuniären Bortheilen einer Berfilberung von Şolzmafien,

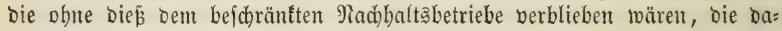

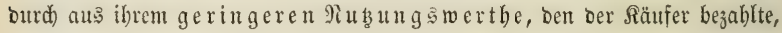
in Den höberen Rapitalwerth übergehen. Die Berlufte Durd) Dieb=

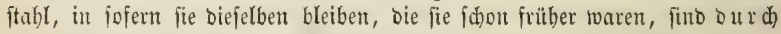

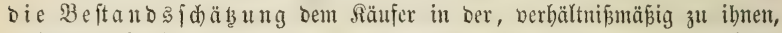
geringeren Rauifiumme bergütet: Den wenn wir aunebmen, Daf in einem Baloe jäbrlid) $1 / 10$ Brocent des Borrathes burd Diebitabl verloren gehen, fo fehlt bief $1 / 10$ Frocent auch in Der Berechung bes \$orrathes und 3u=

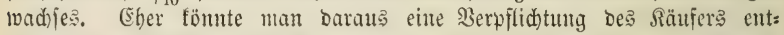

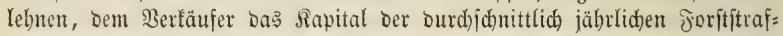
gelointraben zu entrid)ten! Für Den $\Re$ ä ufer eintes im nadbaltigen Betriebe zu bewirthichaftenten Baldes ift Der Diebitabl, fo weit or ben Durdhidnitts:

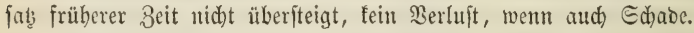

Dic Erfahrung lebrt, Daß̄ mit geiteigerter Siultur uno Jnouftrie mit

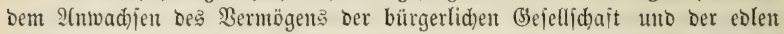
Metalle, oer Binşúp fid) beftänbig verringert hat, bie Gelblapitale alfo

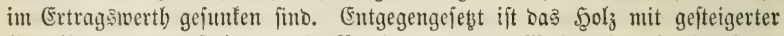
Beoülferung uno Rultur, mit Berringerung Der 2 Balbfläden fortichreitento theurer geworden. (E) liegt fein Gruno bor, anzunebmen, Daß̄ bieß̄ in ber 3ufunit jich) anders geftalten werbe, uno barin liegt eine größpere Sidjer= heit Der Cimnabmen aus Walovernögen als aus Belovermögen. Sint bie Einuahme aus 100 Marf Belobermögen vielleidt int nädjten balben Jahr= hundert von 4 auf 3 , wie fie in Der vorigen gälfte bes Jabrbunderts von 5 auf 4 gefunfen ift, io hat bas Betbvermögen 20 Procent jeincs jeb̧igen

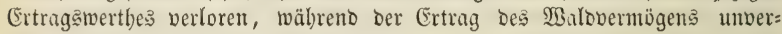
ändert geblieben, Durd) böhere Scolzpreife viefleid)t bedeuteno gejtiegent ift.

Man miro Daher, weun nicht ganı aukergewöbnlid, Merbältniffe vor: liegen, Den Binsfup fteţ Dem landesüblichen bei voller Sicherbeit gleid)= ftellen müfien, um fo mebr, on wir feinen Majitab für Den ridtigen Şrad einer Abweidung won ithm befiten.

ad 3) Die Reibenfolge ber auf ibren Rettogelowerth berechneten Mald: mubungen ftellt eine Rentenreihe Dar, für Die ein Gelstupital als gegen=

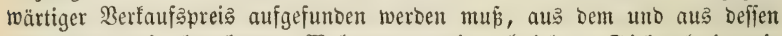
Geldertrage bie beredneten Walbrenten mit gleider Siderbeit wie alts Dem 2 alobejibe erboben werben fönten.

Beftebt bie Rentenreihe aus gleid) großjen Renteftüden, Dann bietet ihr, Durd) einfache Sapitalifirung bered)neter Sgantelspreis Dem Berfäufer

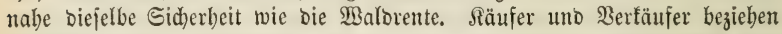

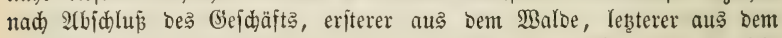

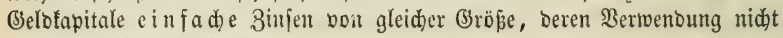
weiter in Betrad)t fommt.

Eine (Erböbung des Şandelspreifes fönnte jedod) aud in biefem Falle ibre Berechtigung finden, theils in Der gröperen Sidjerbeit bes Bruno: 
ftoctes, theils in bem bereits erwähnten Unitanoe muthmaplid) fintentoer Gelorente uno jteigenocr Solzpreije. Man fant biej jebod füglid bem

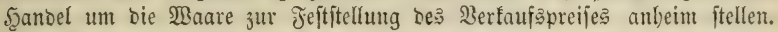

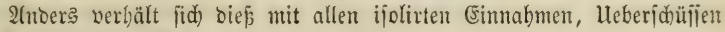
un๖ 2 (uşällen ber $\mathfrak{B a l b r e n t e . ~}$

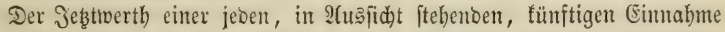
hängt nidht allein von ihrer (Bröpe, fonbern wejentlid aud) bon ber Sicher= beit ihres Eingebens ab.

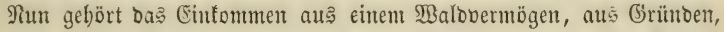
bie vorftehemo bercits erörtert wurben, 3u ben ficherjten, bie es gibt. 2Anoers verbält fid) biefs mit Dem Einfommen aus (Belofapitalien, fobalo man bem= felben eine, a uf lange 3 eit fortbauernde, vollftä noige Zinjen: cumulation unteritellt.

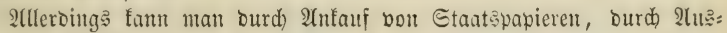
leiben ber Gelofapitale an Eparfafien, Erebitanjtalten, Bimfez̧̧ins erheben, aber johon bieje Hebertragung Des Rapitals in Den Befiţ anderer ßerjonen

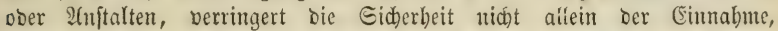
fonbern felbit bes Sapitals. Die größten (Sarantien fidjern nid)t vor fold)en Berlujten, eine unbebingte Sicherbeit ausgeliebener Sapitale gibt es nidyt.

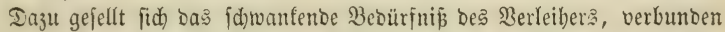
mit ber leidten Zugänglidfeit ber Sielofapitale; vor allem aber bie $\mathfrak{A} n$ ziehungsffraft, weld)e großße Rapitalmafien auf bie fleineren auëüben, ber ३u Jolge eine ununterbroḑene, auf lange Beit fortbauernbe, vollftänoige Binjenanjammlung in ber That zu ben Jllufionen gebören, benen fich ber Romanjareiber hingeben mag, bie aber nidht ins praftijhe \&eben gehören.

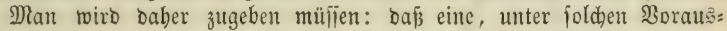

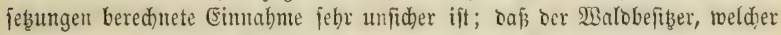

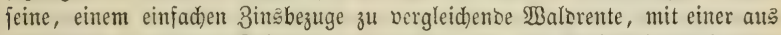
Zinfeşzins berechneten Belorente bertaujhen foll, eine Entfääbigung forbern bürfe, für bie notorifa) geringere Siderheit Der einzutaufdenden (selorente.

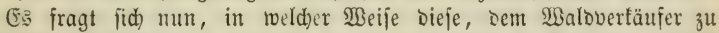
gewäbrenbe Entidäbigung gemefien uno wie biejelbe in Red)unng geftellt werben tann.

Für das Má eines folden Bergütungşuid)uifes fehlt un: zur 3eit nod) jede rationelle (jrundlage. Die $21 n n a b m e n$ Desfelben, twie folde in bie beridiebenen 2 (rten ber Berednungsweije bineingetragen wurben,

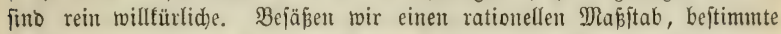

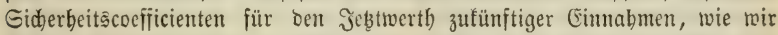
Reibungşcoefficenten für bie Betwegung bejiß̨et, Dann mürbe bie größ̈te aller Edmierigfeiten ber $\mathfrak{B a}$ alomerthbered)mung getöst fein.

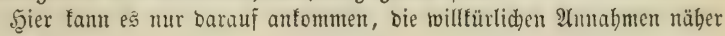
zu betradten.

Die Berechnung bes Jekttwerthes von Renten unb Rentenreifen mit 3ugrunblegung vollitänbiger Binjencumulation ift bie einzige, mit mathe=

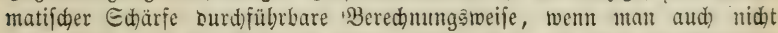
jagen tann, Daßj ibre Rejultate abiolut ridtig feien, za jojon bie Annabme 
einer halbjäbrigen Sinserbebung uno Mieberanlegung cinen ganz anberen Jeb̨twerth ergeben würbe.

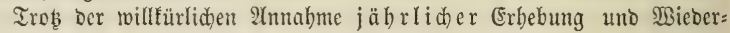
anlegung ber Binjen, liefert dic Zinjeßzinsberechnung für alle entfernteren (Einnabment Demohnerad)tet einen Jețtwerth, Der weit binter Den erfabrmig: mäpigen Balopreijen zurüđbleibt. Afllerbinge wadhjen 4 Rtblr. unter voll= ftändiger Sinfenanjammlung in 120 Jabren zul 425 Rthlr. an, aber teinem Malobejitzer twito ea einfailen, Den Morgen Malogruno, ber ifum in 120 Jahren einen Reinertrag von 425 ju gewäbren veripridst, beute gegen 4 Rthlt. einzutaujchen.

Diejenigen Bertheibiger ber Binfeszingberedtung, weldye fich aus:

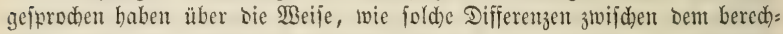
neten unt Dem erfabrungemäñigen Jekstwerthe Der Mälder zu bejeitigen

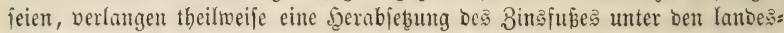
üblichen, theils rollen fie eine, an bie Berechunng nicht gebunbente Cor= rectur des Bered)nuggrejultates auf (5rumo Der bejtehenden Durdjidnitts: Doer Marttpreije.

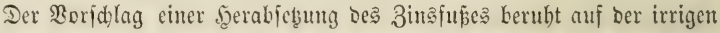

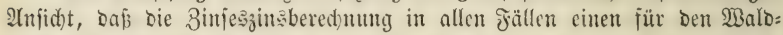

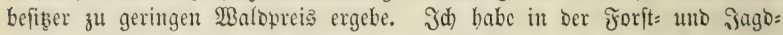
3eitung 1855 G. 87 nad)gewiefen, Daß bief teines̄wegs der Jall fei, baß

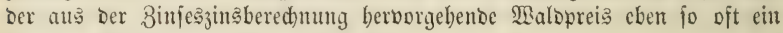
für ben Räufer zu boher fein föme. ${ }^{1}$

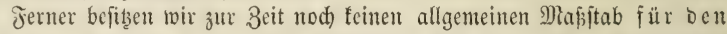

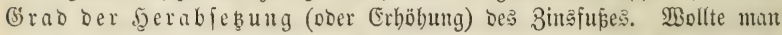
Denfelben für je sen einzelnen ₹all aus ben Differenzen der Berechumg:

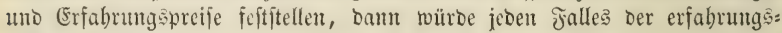

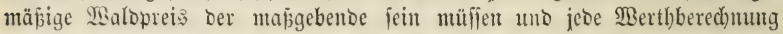
überflüfïig werben.

Dann iff aber aud́) bie Ilnfiderbeit vollftänoiger Binfencumulation

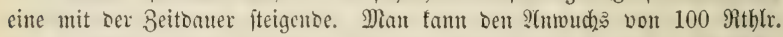
auf 210 9thll. Durd) Binjesjins imnerhalb ber nädjten 20 Jahre als wahr=

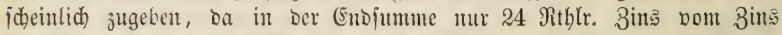
jteden; es ift bagegen bödjit unwabrideneinlid), bap biefelbe Summe in 100

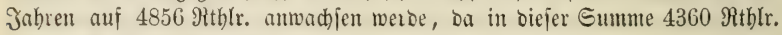
Bing vom Bints entbalten fint.

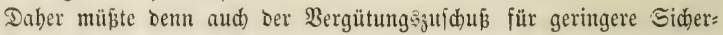
heit ein mit ber 3eitbauer fteigender fein, wäbreno Durdh Şerabjeşung bes

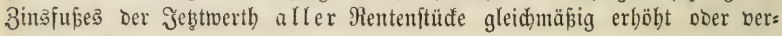
ringert wirb.

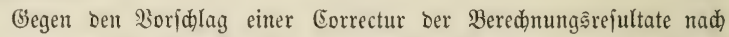

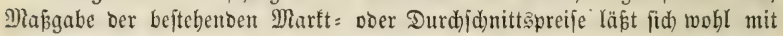
Recht einmenten, Daja, bei ber Seltenheit von Walovertäufen, Marftpreije

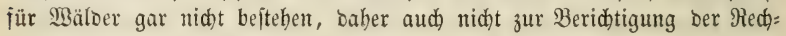

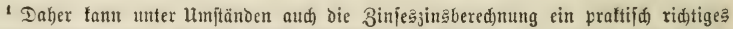
Rejultat ergeben, Dann nämlid, , wenn bas $\mathfrak{M e k r}$ und Beniger ber ju kohen und ber zu

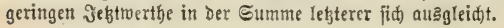


mung gebracht weroen fönnen; beftänben fie aber, bann würbe burd fie

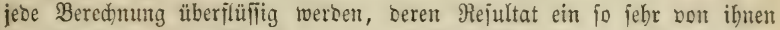
abroeidendes, id) mödte fagen: unnatürlides ift. Daj̄, bei ben gropen Ilnterfobieden Des Buldwerthes, Durdjidnittşablen aus ben bei früheren Malovertäufen gezablten \$reifen völlig toertblos fino in Bezug a u f jeben Einzelfall, bebarf faum ber 2lnbeutung.

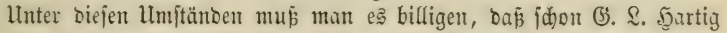

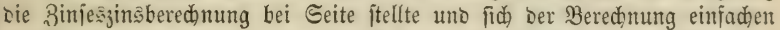

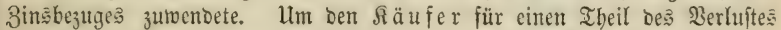

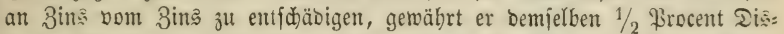
conto für jede um 20 Jahre fpäter eingehende शubung. Den anderen

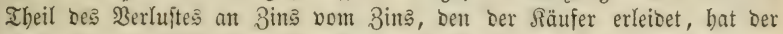

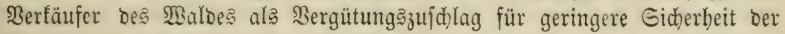

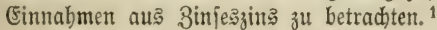

Şartiy jiebt Daber ben Bins vom Bins ebenfalts in Rechnung, aber

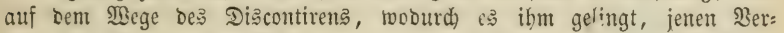

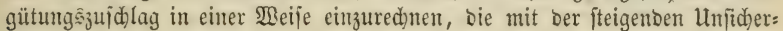
heit im \$erbältnif́ jteht.

Cine andere frage ift $e_{3}$, ob bie fo beredntete 3̧ergütung für ver=

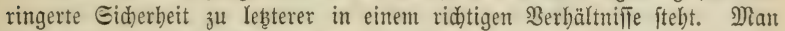

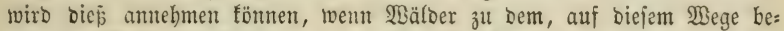

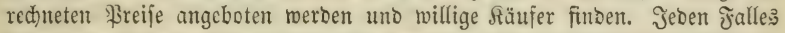

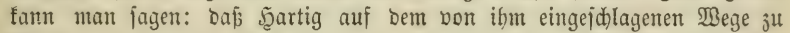

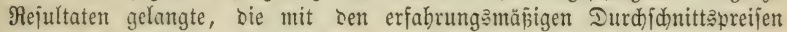

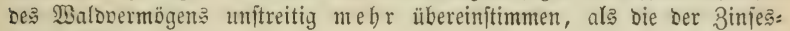
zinaberedinung.

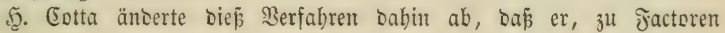

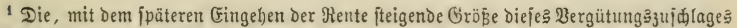

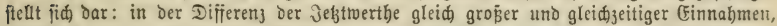

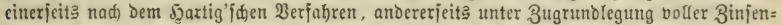
cumulation beredinet.

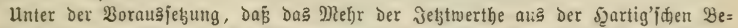

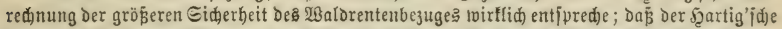

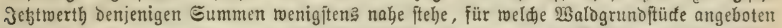

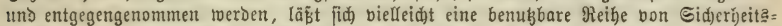

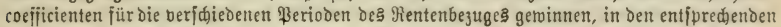
Eutienten beider jebtwertbe, burd) beren 2 tntwenden auf ben jebtwerth aus ber 3injes:

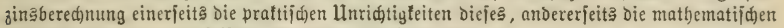

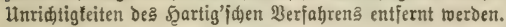

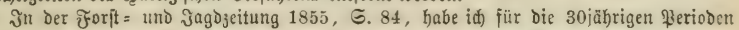

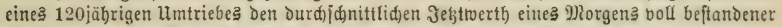
Walogruno à 400 Mrtf. Meinertrag bei 4 \$roc. Landeß̈üblid)em Binsfuß beredunt

$$
\text { I. \$er. II. \$er. III. \$er. IV. \$er. }
$$

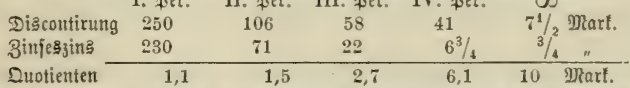

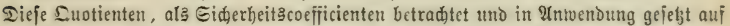

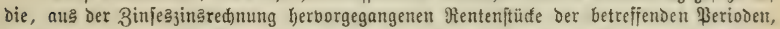

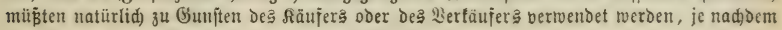

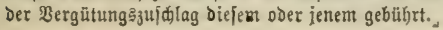




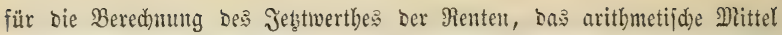
Der Jactoren für einfachen uno für Binfęzimşbęug ermäblte. Err erbält Daburd) Enorejultate, bie mit Denen bes Şartig'ïhen Werfahrens nabe über: einjtimmen.

v. Gebren jeşte an bie Stelle bes Entta'iden aritbmetifäen Mittels bas geometrifd)e Mittel ber Factoren für einfache uno Binfeszinsberednung, woburd) Die Jetztwerthe, für bie nädjten 50 Jabre Denten Des Jgartig'idjen uno Eotta'id)en Bered)ungsmodus nabe gleidftebento, für alle ipäteren Rentenbezüge fich wejentlich niebriger ftellen.

Eo viel fid aud gegen biefe Bered)unngarten bom ftreng mathema=

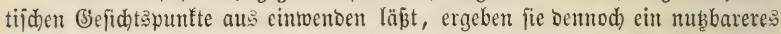
Rejultat als bie Binfeszinstechunng unto man wiro fid ibrer fo lange

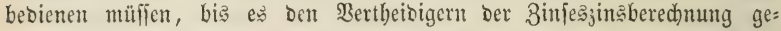
lungen ift, bie erroäl)nten praftijhen Dlängel Diejer Bered)nungs̄meife zu bejeitigent. Bis bahin ift bejontoers bas neuere b. Bebren'idhe, S. 241 Der Jorft= uno Jagbzeitung vom Jabre 1855 crörterte Bered)mungşerfabren in näberen Betracht zu zieben.

Ein weiteres (Eingehen in bie vorliegente wid)tige Jrage geftatten mir Die bier gefteçten räumliden Girenzen nid)t uno mus id auf bie in ben Jabrgängen 1855-56 Der Forft = uno Jag๖jeitung Darüber gefübrten $\mathfrak{B}_{\mathrm{e}}=$ Gandlungen berweifen. Dic Sadhe ift nod) in Keiner șinfid,t fprudjreif. Jedem

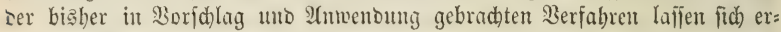
beblidhe (sinwenoungen entgegenftellen. Jeoen Jalles wirb es baber zu rathen

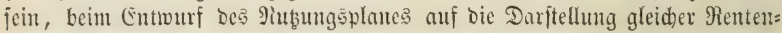

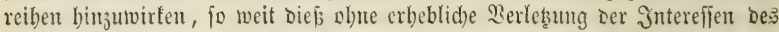
Malobefitzers möglid) ift, ba in biefem Jalle bie einfad)e Sapitalifirung bes

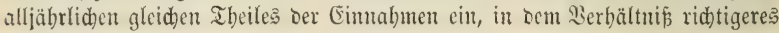
Rejultat ergibt, al’ jenter Theil ein größ̄erer ift.

\section{B. Ermittelum Des Uerkanfsurrthes fold)er Wülìer, Die Durdjaแs willkirlidg benitht werden kömmen.}

In, wie id bereits im 2. Bande Dargethan babe, Der Rapital= werth cines Maldes meift gröfer, minoeftens aber io grof́ ift, als beffent

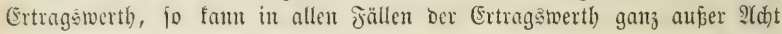
gelaffen merben, in Denen ber אäufer niđht bebinoert ift, in jeoem 2tugen=

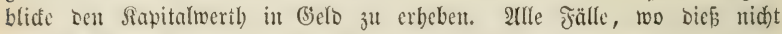
möglid) ift, aud) biejenigen, two (conjumtionsberbältniffe entgegentreten, ge: bören nicht hierber.

Der Siapitalwerth Des Malopermögents ift verfdieben, je nadjoem

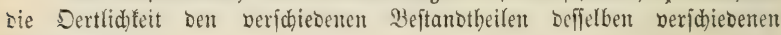
Werth gibt.

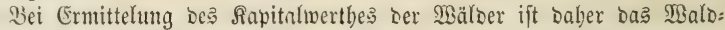
vermïgen in feine Bejtandtheile jü zerlegen unt jeber berfelben gejonoert z̆ll würbigen.

Das. Malovermögen ift zufammengejebt: 
1) aus Grruno uno Boben;

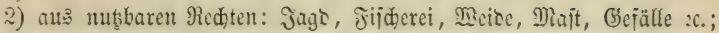

3) aแล bent tooten Эnbentarium: Baulid)feiten, R̂lturgerätbichaften :c.;

4) aus bem lebenben Intbentarium: 5ூolžbejtänoe.

\section{(3) $\mathrm{r}$ und und Boben}

ijt in jeinem Berthe werjoieben:

1) nadb jeiner Bejdafienheit: je nadbem er zu (bärten, Ader,

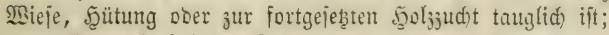

2) nad jeiner \&age: je nadidem bieje geeigntet ijt, bie bödjite

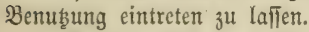

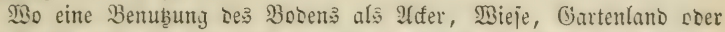
guter Weibe nad) Bejdaffentheit und Sage möglid ijt, wiro foldpe in ben allemeiften fällent einen böberen Berfaufapreis ergeben, als bie fortgejeßste Benuß̧ung Des Bobens zur Sgolzerzengung.

Da in oen meiften fällen dic Rultur = und 2(Dminiftrationsfoften, Grumbitener ac. entholzter Fläd)en zu eintm Rapitale antwadien, oelien Binjen ben tünftigen Ertrag Eer angebauten Blöpe überjteigen, jo miro man

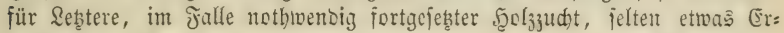

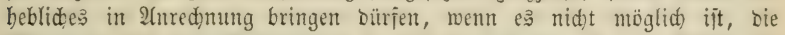

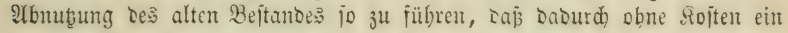
junger Dort von jelbit entiteht.

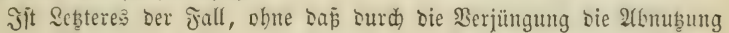

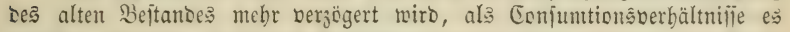

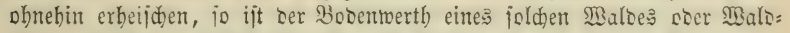
theiles gleid) Dem Jeţtwerthe aller, im Weriolg jul ermartenten Şaupt= uno

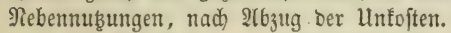

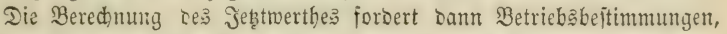
Die jämmtlich ben Biclpunft bödjiten gegentwärtigen Bodentwerthes baben müijen: Nieberwald, Ropfholz, furjer Uumtricb, rajd) wachiente f̧oljart ic.

\section{Die nubaren Redte}

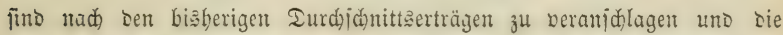

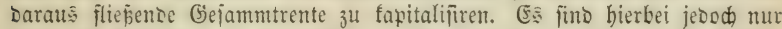
Diejenigen Pluşungen зu beranjdlagen, bie aud ferner unter ben Der Merth: bered)ung unterfellten Derbältnifien fortbeftchen tömen.

\section{Das toote Jnventarium}

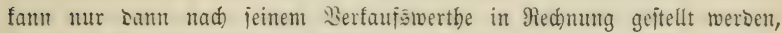

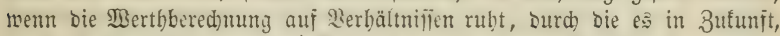

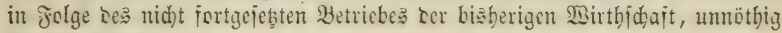
werben rürbe.

\section{Das lebende J̃nentarium,}

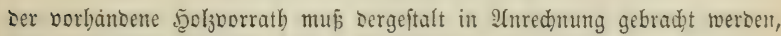

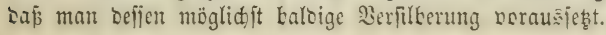




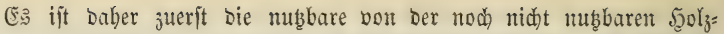

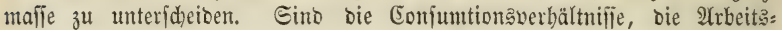

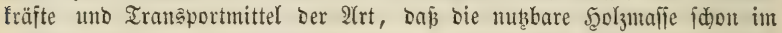
nädften Jabre berfilbert werben fann, fo genügt eire Edjäbung berfelten nad) Menge und Bejdaffentheit, unb Bereduntung Des Gelowerthes nad) Den

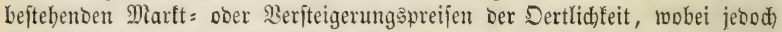
bie Ëinnirfung etwa gefteigerten 21ngebotę zu berüđfid)tigen ift. Heber:

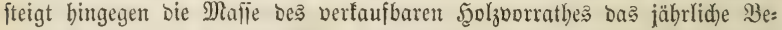

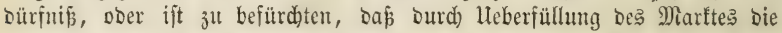
Szolzpreife herabgebrüdt werben twitroen, fo mus bieje auf einen, Den Eon= jumtionțberhältnifjen entfprechenden längeren Beitraum vertheilt, für biejen

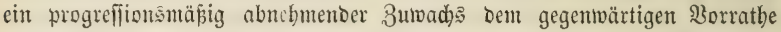
aufgered)net, bie fpäter eingebenten Nub̧ungen aber auf ben Jeţtwerth be:

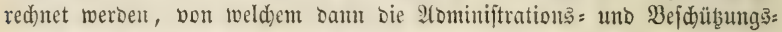

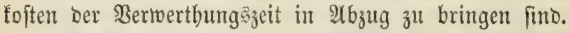

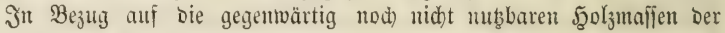
jungen Beftänte ift 3u erroägen, ob uto in wie weit $\mathscr{B} e r t h j$ teigerung, ourd

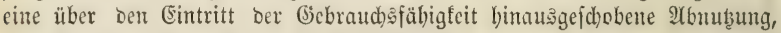
Den Binjenverluft burdh frätere Berfilberung zu beden vermag; wonad, mit

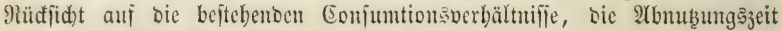
feftzuftelfen ift. Der Jebettwerth) Der bieraus entipringenton Nubungen zu

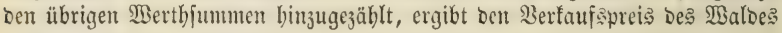
nad) feinem Sapitaliwerthe.

\section{Ermitteluแg Des Uerkaufsprei

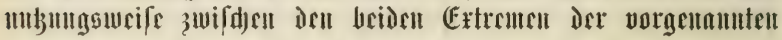 fïlle liegt.}

Unter folden llmftänoen fam wober ber (Ertragswerth) Der Mälder ben Saufpreis beftimmen, da beren fapitalwerth ein gröferer ift, nod) fant ber Sapitalwerth als 9iorm gelten, ba ber Ertragstwerth ein geringerer

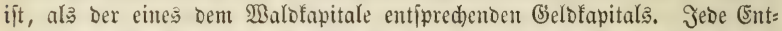

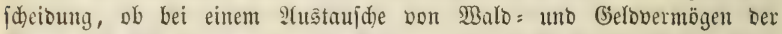
Säufer fid) mit einem geringeren Ertrage ober bor \$Berfäufer fid mit einem geringeren Sapitale begnügen jolle, wüı be unzuläfijig uno unpraftija fein. Der wabre, ben $\mathfrak{B}$ erbätuifien entipredende Baldwerth liegt unter biefen Berlälniffen zwifden Extrags= unb Rapital=

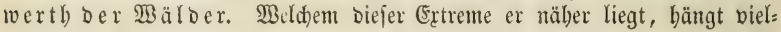

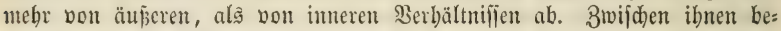
ftimmt fid) ber Walopreis nidht burdh Bered)nungen, fonbern burd ben Santoel um bie Waare. Sudht Der Baldbefiker ben Berfuuf, fo wiro er mit weniger als bem Mittel zwijhen Rapital= unt Ertragstwerth fid be:

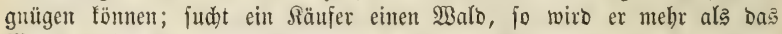
Mittel zablen fönnen, wobei natürlid alle ben $\mathfrak{B a l}_{\text {alderth }}$ indirett erböben=

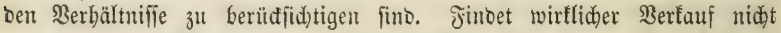
ftatt, foll oer Walowertb mur Behufa Erbfdaftstbeilung, Berpfänoung, 
Befteuerung zc. ermittelt werben, fo bürfte $e^{3}$ am zwectmäpigiten feir, bem nad conferbativen Begrifien ermittelten Ertragswerthe $1 / 4-1 / 3$ Der Differenz żwijden ifm uno dem Sapitalwerthe binzuzuzäblen, je nadoem Die Differenz felbft fleiner ober gröper ift, ba eine grö̈pere Differenz itet? Jolge größerer nukbbarer unb überiduififiger ßorräthe ift. (ßergl. meine Jafresberidte I. 4. G. 555.)

\section{Siferafur.}

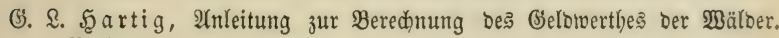
Berlin 1812.

5. Cotta, Entwurf einer Ânweijung zur Malbwerthberednung. Dreąben 1819.

v. G̈ebren, 2łnleitung zur Walbwerthberednung 1835 .

2Xlgemeine Jorft: uno Jagðzeitung Jabrgänge 1855-56.

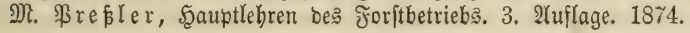

\section{Drittes Eapitel.}

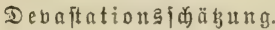

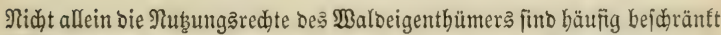

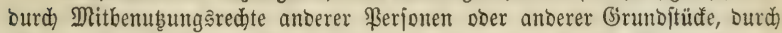
Miteigenthum, Pfandrechte zc., fonbern es fino aud bie Mitbenub̧ungs:

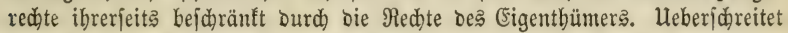

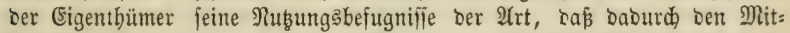
benub̧ungaberedtigten, ober bem Miteigner, ober Dem Pfanogläubiger $2 c$.

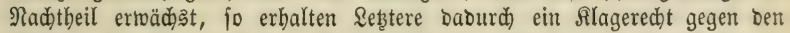

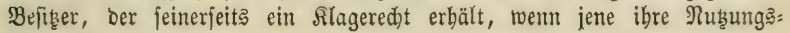
befugnifje überidgreiten.

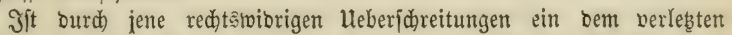

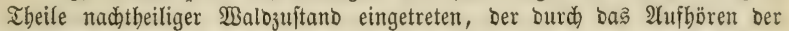

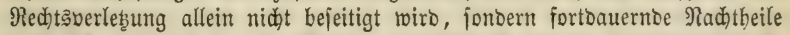

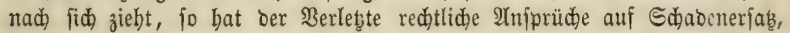
injofern bie Beeinträdtigung im Beridulden des anoeren Theiles liegt. In foldyen fällen ift es 2 ufgabe bes Taxators zu ermitteln:

1) Weldhes ber 3uitand bes Walbes por Beginn ber Rechtęper: leşung war.

2) Mie oer $\mathfrak{B a l o}$ von biejem Beitpunfte ab hätte behanbelt uno benuķt

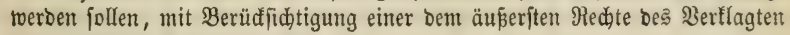
entipredenten Betwirtbjidaftung.

3) Beld)es Der biefer Betwirtbidaftungşweife entipredjende gegentwärtige Walozuftand fein müpte.

4) Weldhes ber gegentwärige Balozultant ijt.

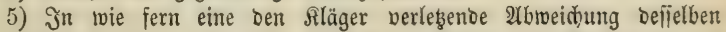

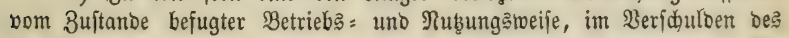
Berflagten liegt. 


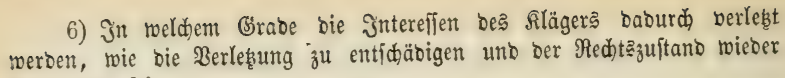
berzultellen fei.

\section{siferafur.}

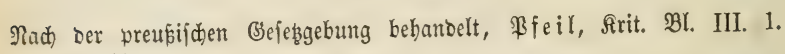
ธ. 103.

Deflen Unleitung zutr Bebantolung 2c. Ser Forite. 5. 2lbthlg. Berlin 1833. 


\section{Gึ̈nfter Santpttheif.}





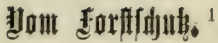

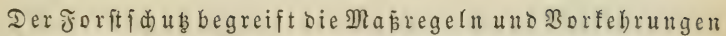
in fid, woburd) bie $\mathfrak{B} a l d u n g e n$ überbaupt, und bie barin erzogenen Produfte insbefondere, bor jebem Nadtheil fo biel wie möglid befdübt toerben müffen.

Der Jorftuirth mús Daber nidt allein alle Gefabren und Uebel, benen bie $\mathfrak{B a l}$ a ungen auggejegt find, fennen,

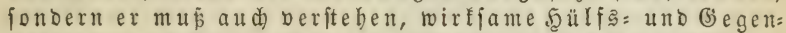
mittel borzufehren, um biegegentärtigenllebel zuentfernen Doer zuentfräften, unb biefünftigzubefürdidenden (s)efabren vor ibrer Entftebung abzutenden.

\section{$=1$}

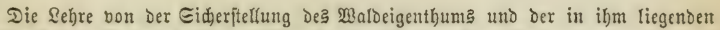

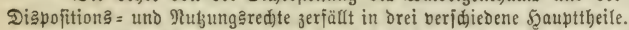

1) F̃orftre dt. Die Sebre bon Den $\Re$ edten uno redtliden Berpflidtungen des Waldeigenthümers in Bezug auf bie Behandlung und Benutbung feines 2 Baldoermeggen!.

Man faun Daz of orftred)t in zwei 2btheifungen betradten: a) bie Rebre von Den

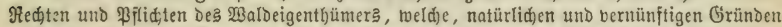
entfprewento, in bie Gejebgebung eines Sandos aufgenommen fein follten; allge=

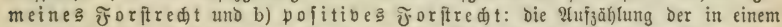

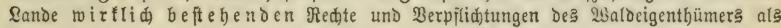
jolđer.

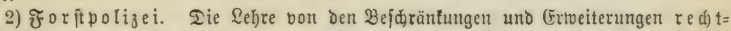

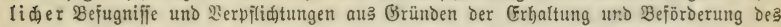

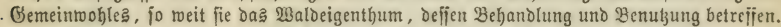

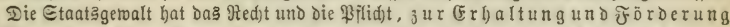

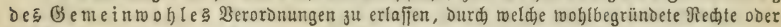

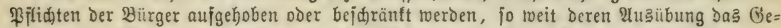

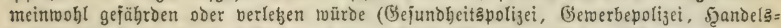

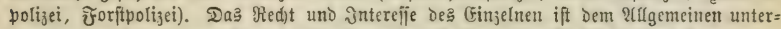

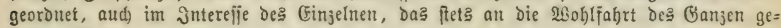
bunder ift.

Die Matur jeber forftpolizeiliden Berorbnung berubt baber in

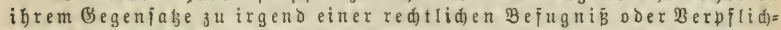

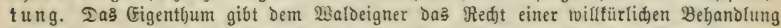

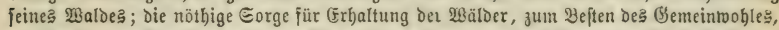

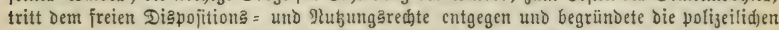

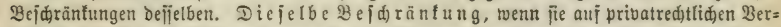

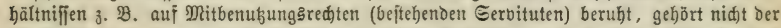
Forftpolizei, fondern Dem đorftredte an. Şiernad) Dürften in 3ufunft die Materien Deß

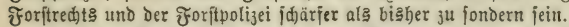

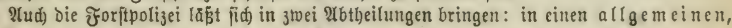

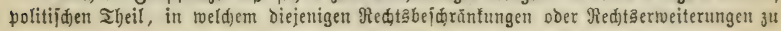




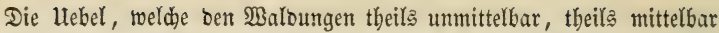
mebr ober weniger idaben, uno entweder ganz, ober zum Iheil, ober gar nidjt abgewendet, wohl aber bei ihrer Entftehung fehr gemindert werben fönnen, bringe id in z twe i Şauptfla filen.

Zur erften $\Re \mathfrak{l}$ affe redne id alle $\mathfrak{U}$ e bel, bie aus einer fehlerbaften Drganifation Des Foritwejens überbaupt entifteben, ober ihren Gruno in ber untaugliden Forftuerfafiung baben, wie z. B. Untwifienbeit bes forftperionals, 3u geringe und unflug beftimmte Bejoloung ber Foritoienterjhaft, unridatige

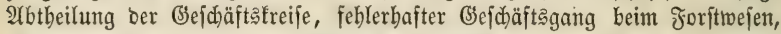

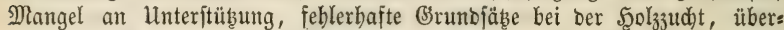

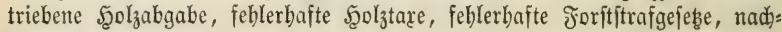
theilige Servituten u. ogl.

2llle bieje Hebel föunen mur bon ber Forftoireftion berbamnt werben, ibre Betrachtung gehört nidht hierher.

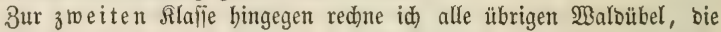
jelbjt burd) eine gute Drganifation bes Forjtwejents uno burd) bie befte Joritwirthjdaft nicht ganz entfernt, fonbern mur mebr ober weniger ver: minoert uno entfräftet werben tönnen. - Scier hat ber förfter bie widatigite Rolle zu ipielen, uno nur burd) feinen unermübeten Fleis unt Eifer fönnen bie Hebel, bie ben Foriten Berberben bringen, fo biel wie möglich bejeitigt merben.

Borzüglich gehören bierber:

1) mangelhafte Walogrenzen;

2) bernadiaffigte 5ูegung oder Befriebigung oer Sdläge, Saaten uno ßflauzungen;

3) vernadläfigter $\mathfrak{B a l}$ begebau;

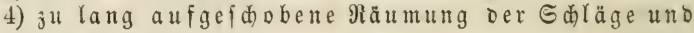
Tbfabrt bes 5̧olzes;

5) Б口olzveridiendung;

6) $\mathfrak{S g}_{2} \mathfrak{l} \mathfrak{z} b i e b f t a \mathfrak{l} l$;

7) $\mathfrak{B} e \mathfrak{i d a ̈ b i g u n g ~ b e r ~} \mathfrak{B} a$ ame;

8) bie $\mathfrak{B a l b m e i b e}$

9) übertriebener $\mathfrak{B}$ ildftand;

10) bie $\mathfrak{B}$ alograferei;

11) bas futterlaubitreifen;

12) bas Streujammeln;

13) bas ßlaggen oder Rajentaden;

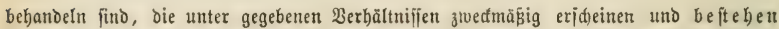
follten; in einen ipeciellen Iheil, in weld)em die in eitrem Sande beftehenden, foritpolizet= lichen Beroronungen aufgefäbrt uno motivirt fino.

3) Forftidu ub. Die Sebre bon Dem, twa s ber $\mathfrak{B}$ aldeigentbümer. inmerhalb Der bom Gefebs uno bon Den forftpolizeilid)en Borjáriften gezogenen Grenzen zu thun und

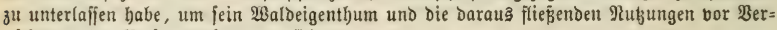

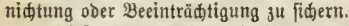

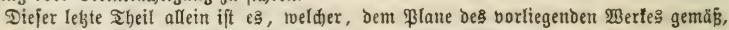

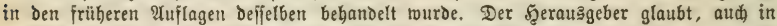

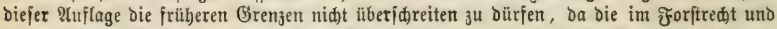

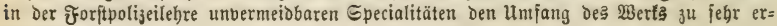
toeitern toürben. 
14) Bergwerke, Steinbrübe, Eanos, \&ebm=, Thon= uno Mergelgruben;

15) Iorfiftederei;

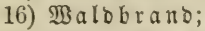

17) Ueberfdwemung;

18) Berjanoung;

19) Sturmminde;

20) Jroft $j a b e n$;

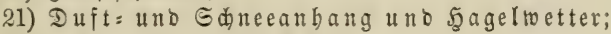

22) a úerordentlide Dürre;

23) ungewöbnlid) viele Mäuje;

24) ungetöbnlid viele famenfreffende $\mathfrak{z}$ ögel;

25) ungeröbnlid biele jufeften verichiedener art uno

26) Srantheiten.

Эä) merbe baber jeben von biejen Gegenftänden bejonbers abhanteln,

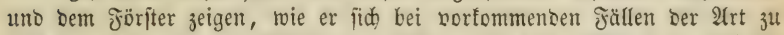
verbalten hat, um feine \$fllidt zu erfüllen, uno jeder. Edaben fo viel wie möglid) abzumenoen.

\section{Griftes Sapitel.}

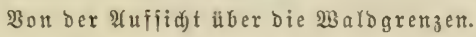

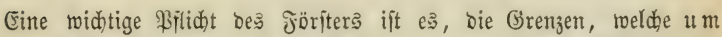

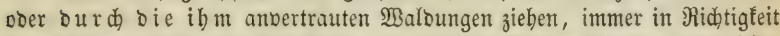

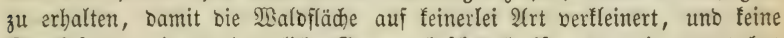
(Berechtjame, bie burd) örtlidhe (Grenzen bejdräntt ijt, zu weit ausgebehnt merde. Der Förfter mup fich Daher bie Grenzen ber $\mathfrak{B a l}$ aungen uno ber Gerbituten ober Giered)tiame, bie bielleid)t Darin ftatfinden, aufs genauefte

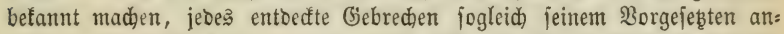

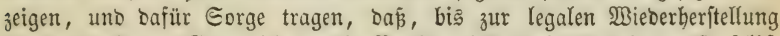
Der beroorbenen Grenjzeichen, bie \$unfte nidjt verloren geben. Er felbjt barf aber an ben Grenjpuntten nidjts vornebmen, alio feinen abgeidlagenen Doer entfommenen Grenzftein ober beroorbenen (Brenzbügel burd) einen neuen erjeşen, ober ein ausgeriffenes Malzeichen wieber einfeţen laffen, ohne von feinem Sorgeję̧ten bie Erlaubni

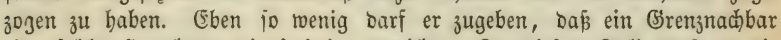
eine foldhe Şandung einfeitig verridte. In biefem Fall mus er bie Sandlung zu verbindern fuchen, wenigftens bagegen proteftiren, uno ben

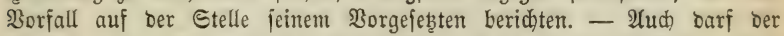

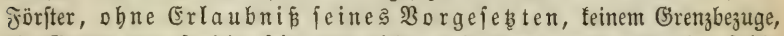
bie Grenze mag ftreitig fein ober nidit, beimohnen, uno mus eine folche von Den Nadbarn unternommene f̧anolung obne 2tufidub jeinem ßor:

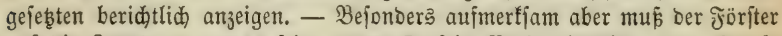
auf bie \&andesgrenze jein, wenn fie fein Rebier berübrt, uno eben jo

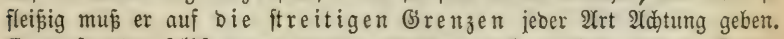

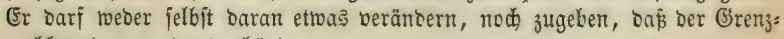
nadbar baran etras abänbere. 


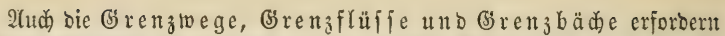

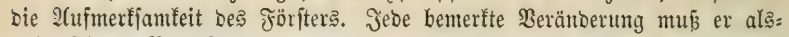

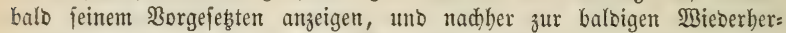
ftellung, fo viel er faun, mitzutwirfen fuchen. Wäre aber bie Esrenze eines Walbes tweber burd Steine, noch burd) (Bräben ober Şügel, ober burd) fonftige Malzeidhen beitinmt, fo hat ber Förfter barauf 2 dhtung zu geben,

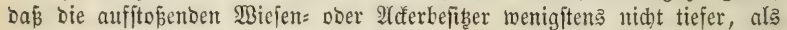
biaher, eingreifen, unt ę müfifen in biefem falle mehrere Bäume auf Der Grenzlinie, bejonders an Den (Eden ober Winteln berjelben ftehen bleiben,

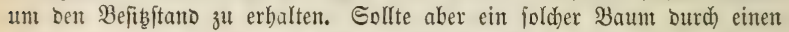
3ufall wegtonmen, fo mus ihn ber Förfter alabalo, uno fo lange Der Bunft, wo er geftanden hat, nody nidst beftritten werben faun, ourd) einen ftarfent \$flänzling zu erfezen fuchen. - Ueberbaunt aber mús ber Förfter bie bauerhafte Begrenzung ber ifm anbertranten Waloungen bei jeber Gelegenbeit in Erimnerung bringen, unt nidft eher ablaffen, bis bie Borgefebten entrober bie Beridjtigung ober Befeftigung Der Grenjen vor= nebmen, oder ibm Den $j$ d)riftliden Befdeio geben, baj biefes oer viel= leicht borwaltenten lumitände wegen nidgt gejcheben föune.

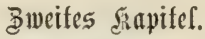

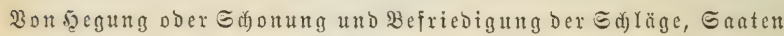

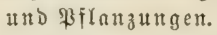

3u ben widhtigiten Siegenitänben ber Frorftwirthidaft gehört unitreitig

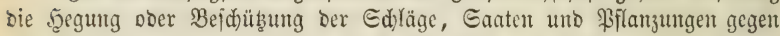
alle Bejdäbigungen, bie ihnen burd) Menjhen und $\mathfrak{B i c h}$ zugefügt merben

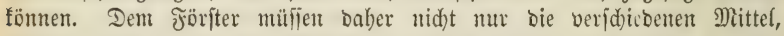
tooburdh bieje Scegung unt Bejejübung möglid) wiro, befant fein, fontoent

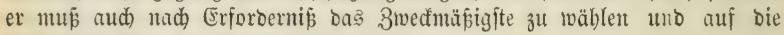
woblfeilfte $\mathfrak{2}$ (rt zu bewerfftelligen wiffert.

Die Rittel zur Şegung fint verjojieden, unt mebr ober wentiger rirfjam uno foftbar, je nadbem Menfden, ober zalmes Bieb, ober Milo abgebalten werben follen. Şd) will baher jeben biejer fälle bejonders ab= banbehn unt bic beften uno fidjerften Mittel angeben, wovon ben Umitänoen nach das palienojte gewählt merben muj.

1) Bon ben 5ूegungamitteln gegen Beidäbigung von Meniden.

Man wirb leidt einjehen, baj bei ber Forftwirtbiddaft feine Mittel angetwenbet werben fönnen, rooburd ben Menfden $u n m$ öglid gemtadst miro, Die Sd)läge und Foritfulturen zu bejhäbigen. Diés twürbe viel zu foftbar uno unausfübrbar jein. (Ẻ tömen aljo mur $\mathfrak{B}$ arnungszeiden für bie Menjhen in Betradtung fommen, bas beifst jolde Merfmale, mo: burd ein jeber benadyridtigt mirb, dás es bei Strafe berboten fei, irgend eine nadbeilige 5yandlung in bem bezeidneten Di= itrifte zubegeben, doer denjelben zu betreten.

Das getwöhnlidjite, woblfeilite uno allgentein befannte Şegzeichen fino Strohififde. Man binbet fie entweber an Stangen, uno umitedt bamit 
Des (brabens entfernt, berfehrt unt fo auflegen, Daf baburd) ein etwas fdiefer Ball entjteht. Bis babin lafie man bie arrbeit von injtruirten \&euten maden. Nun aber fömnen nöthigen Falls audh ganze Semeinben arbeiten; man mus aber Jebem einen bejtimmten Theil abmefien, uno bie Seute unterridsten, bạ fie bie örbe auf uno binter ben fleinen Rajentwall werfen

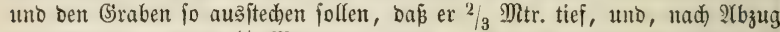
Der Böjdung, unten $1 / 3 \mathbb{M}$ tr. breit wirb. - Eine folde Berfahrungäart ift

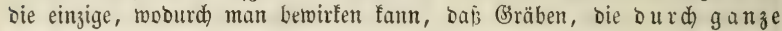

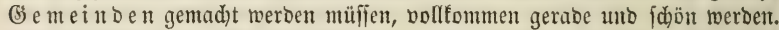

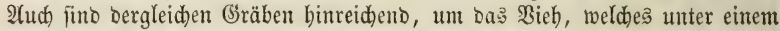

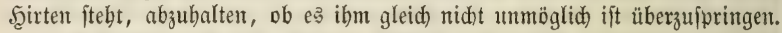

BBill man aber ben gehegten Diftrift nod) befier befoüben, jo bejeke man Den S4tsmurf bes (Srabens, in ber Entfermung von 2 Mtr., mit

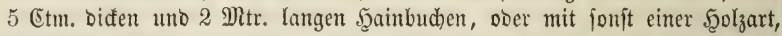
bie gern twädast, uno lafle an biefe ßflänjlinge 3 voer 4 Reiben bünner Gtangen mit WBieben befeftigen. 5̧ierburd) entifteht ein (batterwerf, bas, wenn es gebörig unterbalten wiro, felbjt bas Rotbwilb abbält, in fo fern es niddt allzu zuoringlidi ift.

Dieje 2 (rt von Befriebigung ift Die wohlfeilite und nüblidjte, bie man wäblent fann, Denn fie foühbt nicht allein ben begebebürftigen Diftrift, fonoem wiro aud) baourd), ba febre cinträglid̄.

Märe es aber nidyt möglid), eine joldhe \$flanzung unt einen Oraben anzubringen, fo laffe man alle $4 \mathfrak{M t r}$. zwei, $1 \frac{1}{3} \mathfrak{M}$ tr. über bie Croe ragente Bipiten, von geriffenem Eidjenbolze, vor eitunder jesen, uno

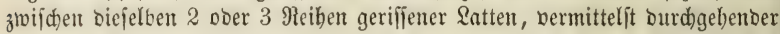
bölzerner Rägel, befeftigen. Doer man lafje alle 3 bis 4 Mtr. Pfoften jeben, uno in jebert biejer Bfoften brei, gebörig entfernte, länglidje \&ödher maden, uno jteffe burd) bieje Röder Stangen, die mit ihren Enotheilen in bet Södjern übereinantber liegen.

Sollen aber weder Sdywarzwild nod) Shajen in ben gebegten Dijtrift fommen, ober wäre ber Rothwil'sitano fo ftarf, Daj Stangenumgebungen

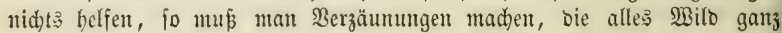
getwi仿 abbalten.

Die wohlfeilifte Umjäunung Der 2lrt ift eine foldje, wo man auf Den

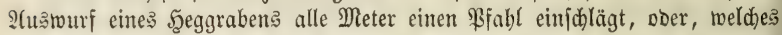
noch beffer ift, einen ftarfen $\mathfrak{S} a$ inbud) enpfläuzling einjęzt, uno dieje Pfäble Doer Pflänzlinge mit geringem Reiferbolze, jo boch wie ę nöthig ift, unten ganz bidht, uno oben weniger bidht, einfled)ten läß̄t. - Eine folche Umzäunung, bie fid) freilid) aber nur auf joritgärten ober (Eid)en= fämpe befáräntt, bält alles Wilto uno zabme $\mathfrak{B i e b} a b$, ift in Bjegenten,

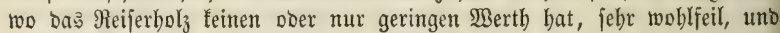
wiro aud nod in ber fpätern Beit nüß̨lich, menn man ftatt ber \$fäble

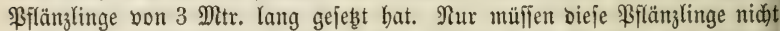
zu jobrad genommen uno mit leid)t biegfamen (Serten= oder Reijer= bolze, wo möglid mit Fidhten= ober Iannenäiten, burdfflodten werben, bamit bie Pflänzlinge vom Dnứ bes Fledtwerfes nidht leiben. 


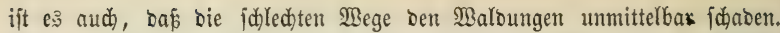
Wie mandher junge Sdjlag ift fodon burdh bie Solgfubrleute ruinirt worben, wenn fie im gewöbnliden $\mathfrak{B}$ ege nid)t fortfommen fornten uno 2 Uusmege fudcen mukten - uno wer follte nod) nidht bie auffallenbe Bemerfung gemad)t haben, Daßs aud ältere Beftände, bie allerwärts befabren und mit Jabrgeleifen burdjidntitten werben, einen geringen 3nwad) baben uno Dürre Ilefte befommen, wenn ihnen bie zol ihrer Erbaltung fo üthigen Thau= wurzeln burd bie Räber abgejdnitten morben fino.

Buweilen ift bie jhled)te Bejdaffenteit bes ganzen Fabrweges an einem jolden llebel Eduld; rft aber bemirft nur eine fumpfige Stelle,

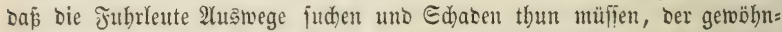

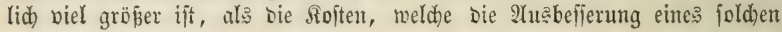
IBegę erforbert.

Der Förfter mús es fidh Daber angelegen fein lafien, Die ftarf bes

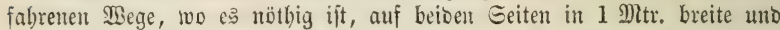
$2 / 3$ Mtr. tiefe Gräben zu Yegen, Dantit fie trodener werden unb bas $\mathfrak{A}$ แลs weiden weber nöthig, nod) möglid) mad)en. Jerner müfifen bie Rantbbäume

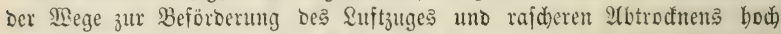

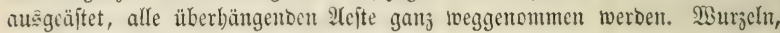
Stöçe und Eteine fino jorgfältig auszugraben unto zu entfernen, ba fie bie

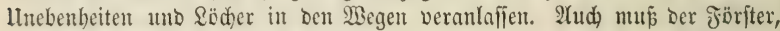
wo es nöthig ift, Doblen anbringen, alle jumpfigen Stellen mit Eteinen, int Deren Ermangelung aber nit Fajdbinen, uno sarüber gelegten ganz nabe

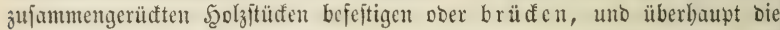

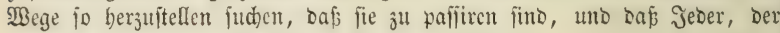
fie nidht einbält, mit Red)t geftraft werben fann.

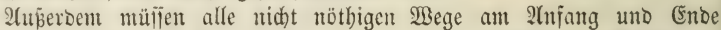
Derjelben ourdh tüdtige Duergräben veripert, bie überflüfiligen $\mathfrak{W}_{\text {ege, to }}$ es bie Unitänoe erlauben, bepflanjt, uno jeoer neben bem gemöbulichen

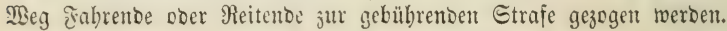

\section{Diertes diapitel.}

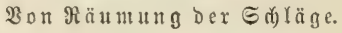

(E⿱

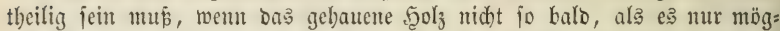
lidh ift, aus bemjelben gejdaffit wirb. Die jungen Bflanjen werben baburd) verborben, ber Eamen wirb berbindert aujzugehen, uno bie Etöde im

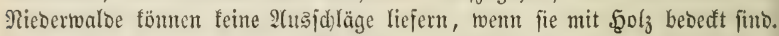

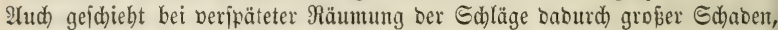
Dấ bie in bollem Saft ftehenden Roden fehr gern zerbredhen, wenn fie bom Juhrwerf oder 3ugvieb getroffen werben. Uno auberbem fint bie \$Baldungen,

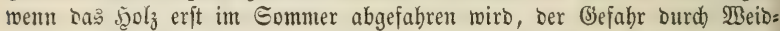
frevel ruinirt zu werben jebr ausgefebst, uno es entiteben eine Menge nads. theilige Folgen, benen man auaweiden fann, twenn man bas . Folz io balo

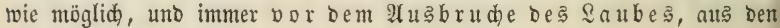
Sd)lägen bringen läpat. 
Der Föriter mus baher feine Şauungen früb gentug in Gang ju bringen unb зu beenbigen fuchen, uno alle nur mögliḑen Mittel antwenben,

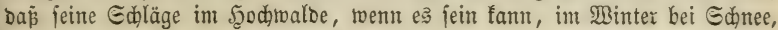
ober bod vor bem einfallenden Thautwetter geräumt werben. Die

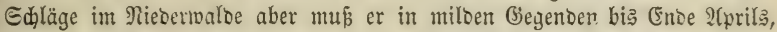
in rauben Giegenten aber längitens bis Enbe Mai's, völlig räumen lajien.

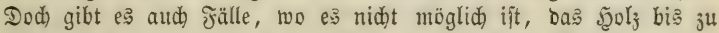

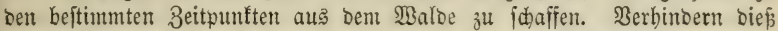

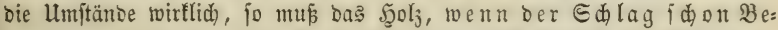
fantug ober jungen $2 \pi w u d\}$ bat, alabalo nady ber frällung an bie Bege uno Gtellungen, ober an jonjt unjuäblide Pläbe gebradyt uno bajelbit aufgeflaftert toerben, bamit ę im Laufe Des Sommers obne Rach: theil ber Edyläge abgefabren werben fann. $2(u c h$ müfien in biejem Jalle

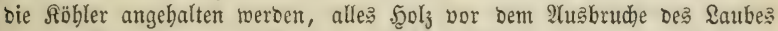
an bie Rohlpläbe zu idhaffen, uno nacher ihr 3ugbieh aus bem Malde zu entfernen. - Eollte es aber nicht möglidy fein, alles Brenn= un

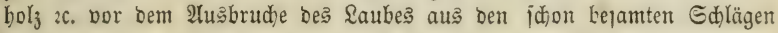
zu bringen, fo müijen wenigftens die in Wellen ober Büjdel gebundenen Reifer oben auf bie auf Unterlagen gefebte Rlaftern gelegt, und alles Sgolz vor bem jweiten Trieb bes Eaftes, aljo vor Jobannistag, aus ben Laubboljichlägen gejdaffit werben, weil fich manthe

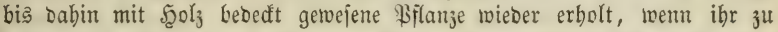
biejer 3eit nod Suft geidafft wiro. Dod geben gemöhnlich fehr viele \&aub:

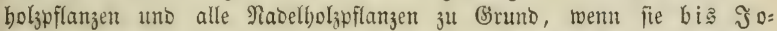
bannistag mit 5ुolz bidht bedect fins. Eollte es baber nidht möglid

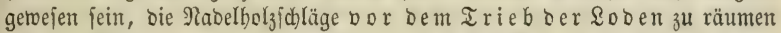

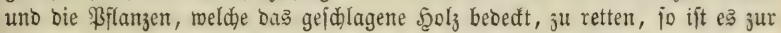

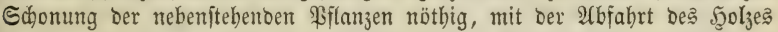
fo lange zu warten, bis bie neuen soden wieber hart geworben

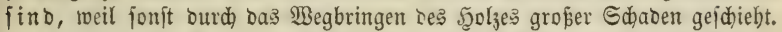
Sollten bie Miege, an weldhen bas aus bem Edjlage getragene Rlafter:

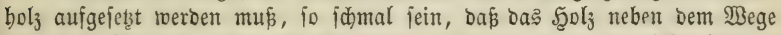

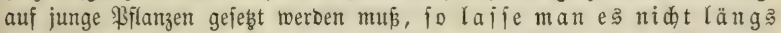
bem $\mathfrak{B}_{\text {ege }}$ in eine an einanberbängende Reibe feken. Es fdabet in biejem Jalle weniger, wenn man Gtößje von 2 ober 3 flaftern 3 bis

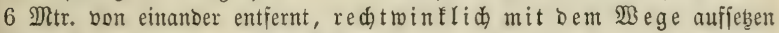
läpt. Giehen bann auch alle \$flanzen, bie Das Sgolz bedecfte, aus, jo bleibt bod) nod) ein binlänglicher Şolzbejtano, weil bie Süđen mur 1 Mttr. breit werben, renn bie Sänge Der Rlafterideite $1 \mathfrak{M t r}$. beträgt.

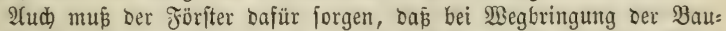

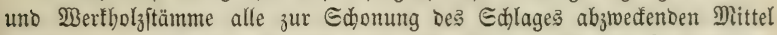
angetwendet, und baß befonbers beim Echleifen Derfelben ber Sotbaum ge: braudht merbe. So wie es fid bon jelbft berfteht, dap bie Spähne, welde allenfalls burdy bas Bebauen Der Baubolzitämme entjtanden fino, zujammen:

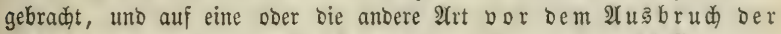

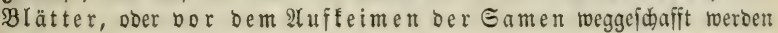
müfịen. 


\section{Tiüftes sapifel.}

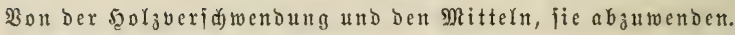

Eines ber gröpten Uebel für bie Jrorfte ift bie f̧olzberfdwen:

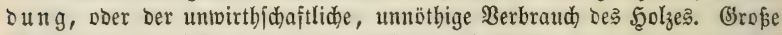
Baloungen fino fajt ganz allein burd) fie ruinirt worben, uno in mandiber

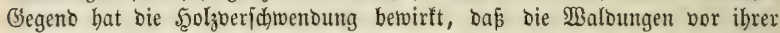
eigentliden Şaubarfeit uno oft viel zu früh, abgebolzt, ja jelbjt f̧od)wal=

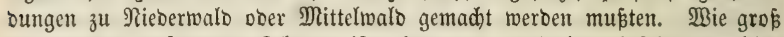
ber baburd) entitandene ভdjaben ijt, faum nur berjenige einjeben, weldher Den Ertrag ber Waldungen nadh ber Serfdiebenbeit ber Llmtriebazzeit und Der Bebanolung, zu bered)nen berfteht, woz̧u bie Sebre bon ber Taz̧ation

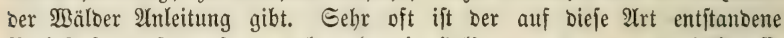

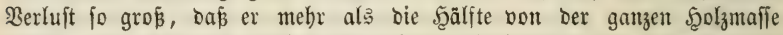
beträgt, bie man jeşt jäbrlich aus folden überbauenen uno befiregen auf bie $\mathfrak{B u r z e l}$ gefesten Baloungen beziebt, wenn fie aud wirflid gut bc: ftanden finto. Bie viel größer ift aber ber Berluft, menn bergleidjen $\mathfrak{B a l}$ Dungen auserbem aud) fibled)t betwirthid)aftet und mangelbaft beftanten fint?

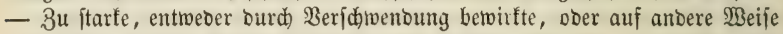

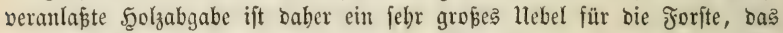
oft ourd 2lnwenoung aller fadbienlid)en Mittel nidht mebr ganz zu beilen if̂t, uno bem man eben Defiwegen aus allen Rräften entgegenarbeiten muईs.

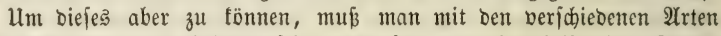
Der Sgolzberidwenoung befannt fein, uno für jebe bie twirffamiten begen:

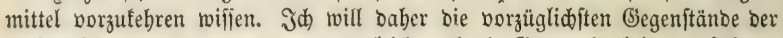

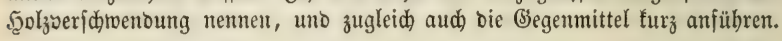

\section{Berfdwendung beim Brennbolze.}

Beim Brenthblze fängt bie Beridwentoung fobon im $\mathfrak{B a l b e}$ an. Die exite uno eine fehr grofe f̧olzberidnentoung befteht nämlid barin, Dá in manden forften faft alles Rlafterbolz mit ber $2 x t$ in bie beftimmte $\& a ̈ n g e$ gebradt unb eine Menge $\mathfrak{M}_{\text {olz }} z^{u}$ Späbnen zerbauen wirb, bie meiftenz im $\mathfrak{B a l d e}$ unbenubst liegen bleiben.

Diejer Beridwentung ijt nux Daourdh abjublfen, wenn ber Föriter

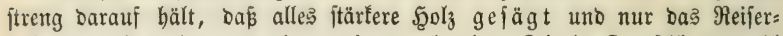
bolz entzmei gebauen wirb, wie bas heutiger 3eit in Deutjollano wohl überall- ber ₹all ijt.

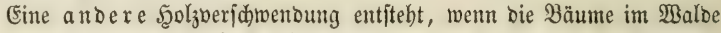
nicht fo nabe roie mögli äber ber (Erbe abgebauen uno bie Stumpen DDer Stöde Der Fäulniß̧ überlafien merben. Der Förjter muß baher in Dem Jall, wo bie llmitänbe das Stofroden verhindern, alle Bäume $j e \mathfrak{b r}$ nahe über Der Erbe uno gleidjam a 3 ber Erbe bauen laffen. Wo aber bie Umitänoe bas Stodroben erfauben, muß er bie Borfehrung treffen, Daß bie Stöde, weldhe man in biejem Fall, um fie leidter ausrroben zu tönnen,

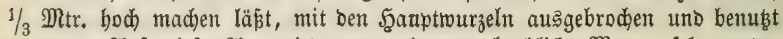
werben. 2Uuf bieje $\mathfrak{A r t}$ wiro man eine unglaublide Mlenge febr guten 


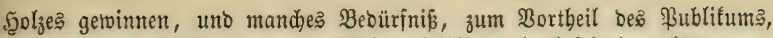
Des Walbeigenthümers uno bes Waldes felbjt, mehr befriebigen fönnen.

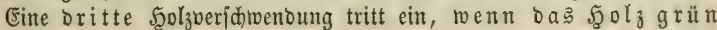
berbrant wirb. Nad meiner Erfabrung fann man mit $3 / 4$ oürren 5ुoljes eben fo viel ausridaten, als mit einem Theile frifden ober grünen

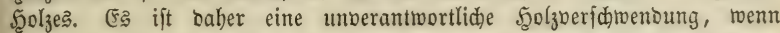

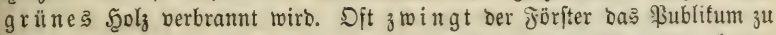

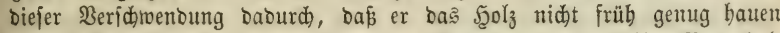

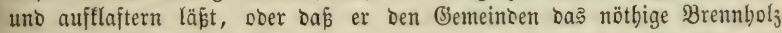

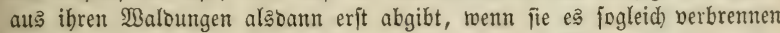

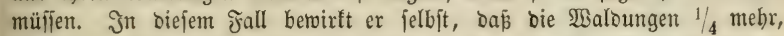
als bie wirflid nöthige S.glzmafie abgeben, uno baburd vielleidt überbauen meroen müifien.

Will Daber ein F̈rrfter aud bieje im Şanjen fefr widtige Scolzoer=

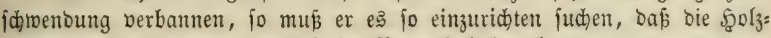
empfänger immer trodenes $\mathfrak{S g l}_{\mathrm{O}} \mathrm{l}_{\mathrm{j}}$ im Borrath baben tönnent.

(Endid viertens fann ber föriter aud baburd vieles 5 Jolz er= paren, wenn er alles Brennbolz auber ber Eaftzeit bauen $\mathfrak{l a ̈ s t , ~ w e l d e s ~ o b n e b i n ~ b e i ~ e i n e r ~ g e r e g e l t e n ~ F o r i t w i r t b i d a f t ~ i n ~ m a n d j e r ~}$ anoern Şinfidst geideben mus, aber leiber! ood) noch nidht allenthalben gejobiebt. Nach meinen phyiftalifden Berjuden geben 7 Theile aujer bem

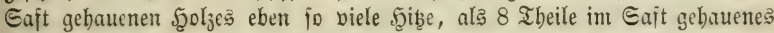

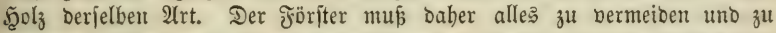
entfernen fuchen, woourd er genötbigt werben tönnte, $\mathfrak{S g l}_{2}$ im Eaft bauen zu lafien, folglid ben acten Theil oavon zu veridjwenten.

Uuser ben angefübrten Mittelı, woourd) im (banzen eine unglaub:

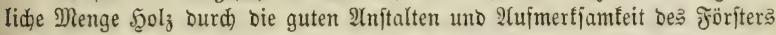
geipart twerben fann, gibt es nod mebrere Şolzerjparungamittel, Deren $\mathfrak{A}_{11}=$ oronung uno Einfübrung aber nidjt Die Eadje bes Föriters, fonbern Der Polizeibeböroen ijt.

Şieber redine id borzüglid:

1) Die Berbefierung Der Stubenöfen, Der Rodbcroc, Der Brau= und Brennereiapparate und überbaupt aller veucs rungsanjtalten, bie oft jo jebr verbefiert werben fönnen, Daj man mit

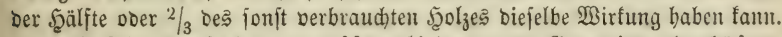

2) Die Einfübrung öffentlider Dder bemeindebactöfen. 2tud Daburd fann eine unglaublide Menge Sgol gefpart merben, meil für

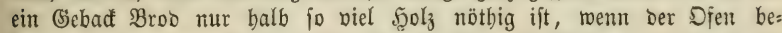
ftänbig in Der Şibe bleibt, als wenn er für jebes Ssebart bon neuem ge=

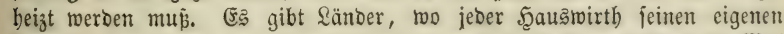
Badiofen im Barten ober im 5ुaufe bat, ben er bod wenigitens 25 Mal im Jahre zu heizen genöthigt ijt. Rechnet man nun, baई jebeșmal nur 0,03 Eubikmtr. Solz mehr berbrant merbe, als in bem Fall, wo ein

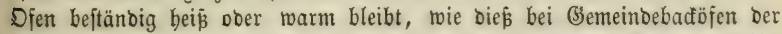
Fall ift, fo beträgt bie Eriparnifís für jebe Familie wenigiten 1 (eubit=

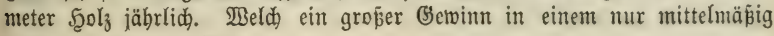
gropen Sanbe! - Hno 


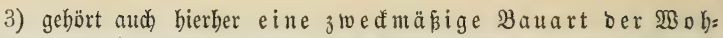

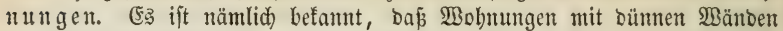

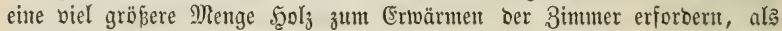

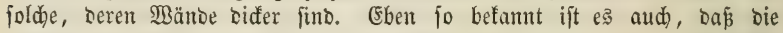
Bimmer in 5̧äufern, welde von a uzen betoorfen find, fich befier erwärment laffen, als went ber Betwurf fehlt.

(5) würbe baher zur Erfparung vielen Brennholzes beitragen, wenn

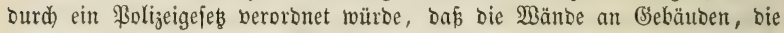

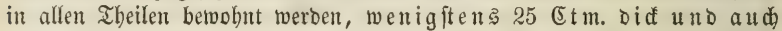
yon a úpen betoorfen fein follen. Bei Bauembüuern aber fönnte bieje Bejtimmung, um Baubolz uno Roften zu erfparen, mur a uf ben betoobuten Theil bes (马) ebäubes eingefdirät werben. - In Gegenden, wo bas Scolz theuer ift, fiebt man fidon febr oft ben be: wobnten aheil ber Bauternbäujer ven aupen betworfen, weil man ben

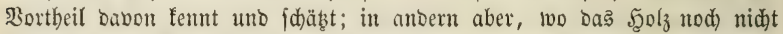
jebr hod) int Sreis ftebt, ooer mo man auf ben Bortbeil, weldyen ber Inwurf gewäbrt, nidbt aufmerffam ift, bemerft man eine joldhe 2 nfitalt zur Şolzerffarung nid)t. Im geringiten 2Anfdhlage erforbert aber bie

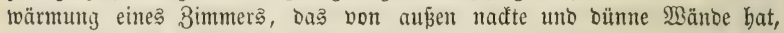

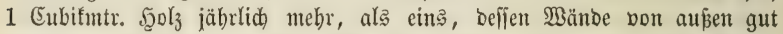
betworfen uno überbaupt biffer fino. Wie widhtig ift alfo aud biefer (Segen=

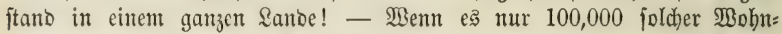
zimmer entbält, fo gehen idon Daburd) wenigftens eben fo viele (ubitmeter

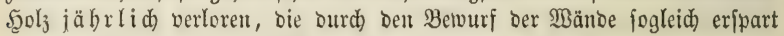
un๖ zum Betrieb nüblid)er S̈emerbe verwendet werben tönnten.

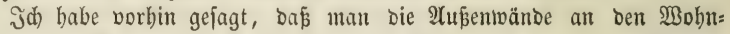
gebäuben überbaupt bider maden folle, als bishber, um mit weniger Bremt= hol $l_{3}$ die Bimmer erwärmen zu f̈̈nten. Şier wirb man ben (Fintwurf maden,

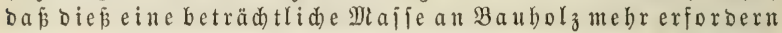
werde. Diejem gröperen Baulbolzaufwande fann aber baburd) abgebolfen werben, wenn man bie Riegel uno \$foften, bie gewöhnlid 20 Etm. breit

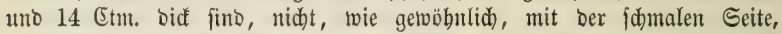
fonbern mit ber breiten Seite in bie Banto jekst. Sie tragen unb balten alsbann cben fo gut, wie borbin, unb bie Bände merben um 8 5tm.

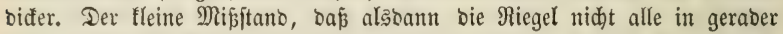
Sinie fortlaufen fönnen, fommt gegen ben Bortheil in feine Betradtung, unto bei ben Gebälben, bie betworfen werben, ift biefes ohnebin nidht be= merflida.

Dieję find bie vorzüglidjten Mittel, woourdy ber Brennbolzwerjaben:

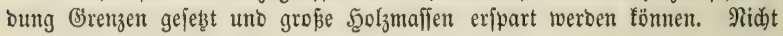
minoer naditheilig ift:

bie ßerfdrenoung bes $B a u=$ und $\mathfrak{B e r t b o l z e s . ~}$

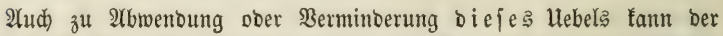
Förfter vielę beitragen, obgleid von Seiten ber ßolizeibeböroen ber fräftigfte Sdlag geid)eben mus.

Der Föriter hat vorzüglid Darauf zu feben: 


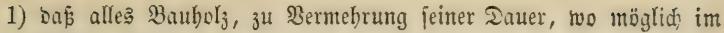
Binter gefällt werbe;

2) baj alle Baubol Erbe abgebauent werben; fomme;

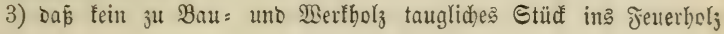

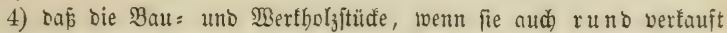
toorben find, nidht fäärfer, als es nötbig ijt, bon ben Bimmerleuten be: bauen ober bejdlagen werben;

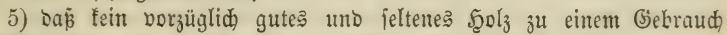
vermenbet werbe, rozu joblechteres benjelben Dienft leiften fann;

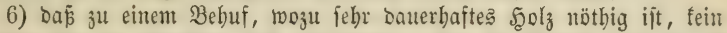

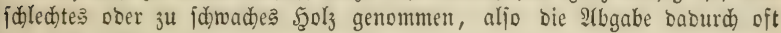
erneuert werbe; unt

7) รaj bas 3intmerbolz nidt unnöthig biaf abgegeben, uno ben 3immerleuten nidjt leidht uno möglid) gemadt werbe, bi: (sebäude über:

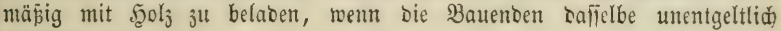
erbaltert.

Bon Eeiten ber oberften Bolizeibehöroe mus aber zu Ers fparung beß Bau= uno Werffolzes befonder: veroronet werben:

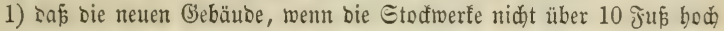
fino, mur einmal verriegelt, uno überbaupt mit $\mathfrak{S}_{0} \mathrm{l}_{\mathrm{z}}$ nid)t unnötbig aus: gefüllt werben follen;

2) Daj alle zul einem (3̈ebäude erforberliden Sjolzjortimente eine nor: gefdriebene, jolvobl nad) ben Regeln ber Baul= als Şolyiparfunjt bejtimmte Dide baben jollen, uno baj alles im Notbfalle in ber Eaftzeit ges

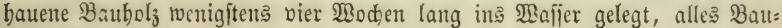

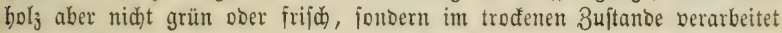
werben foll;

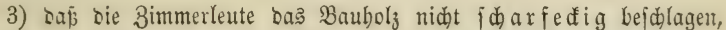

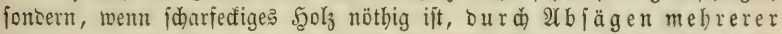
Bretter un $B$ Boblen bieje Form betwirfen, alfo fein gutes Soly muth= willig in Späbnten zerbauen follen;

4) Daj bie Edjwellen unter ben (Éebäuben am niebrigiten Drte wenigitens $2 / 3$ Mtr. über ber (Frbe liegen jollen, woourd cine unglaublide Menge Sgolj gefpart merben fann, weil bie näher an soer wobl gar in Der Eroe liegenden Edwellen bald verfaulen;

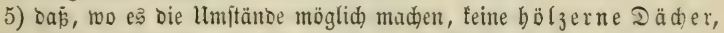
Brüđen, Mege, $\mathfrak{B l a n f e n}=$ ober Bretterzäune uno $\mathfrak{B a j p e r l e i t u n g e n ~ z c . ~ g e m a đ j t , ~}$ und alle Biebtröge entweber von Stein ober wenigitens von Boblen verfertigt, niemals aber a us ganzen Stämmen gehauen werben jollen;

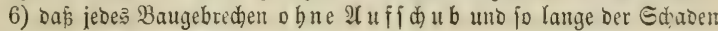
nod) nidht gró ift, ausgebefiert werben foll;

7) Dá alle neuen (bebäube in gebörig bejtimmter Entfermung jteben,

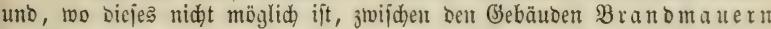
erridtet werben follen;

8) dafs die Gebäude, wo es mur thunlid ijt, entweder mit Eđjiefers รูartig, Rehrbud für ₹örfter. III. 


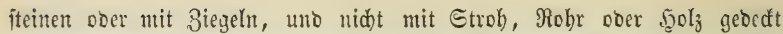
merben follen;

9) Dá̧ teine gefäbrliden Feueritellen angebrad)t werben follen;

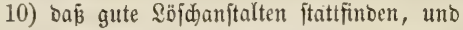

11) baj io viel wie möglid mit Steinen uno Qebmpaken gebaut werbelt joll $\mathfrak{u}$. Dgl. mebr.

Bei Antwenoung all biejer unt äbnlicher Eparmittel wiro ç möglid, Den burch Sholzberidwentoung in üble lumfände verfebten Forften wieber

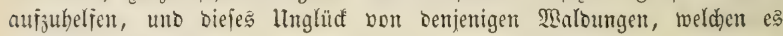
brobt, abzumertoen.

\section{Sedistes Eiapitel.}

$20 \mathrm{~m} 50$ \&

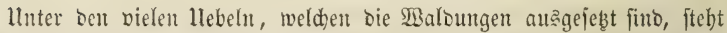

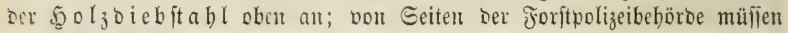
Daber zur 2(bmenoung ober vielmebr zur Berminderung biefes nid)t ganz bertilgbaren Ulebels alle mur möglichen Bortebrungen getroffen werben, unto

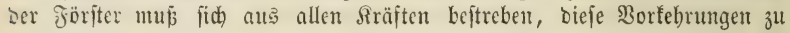
unterftübęen.

3 ben nöthigen Borfebrungen, welde bie Forftoireftiou zu

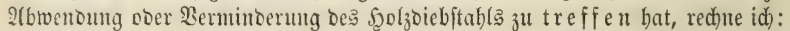

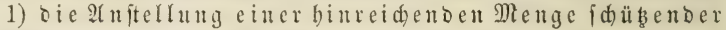
Soritbedienten, beren a useidende Bejoldunguno eine ben

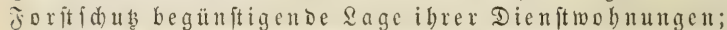

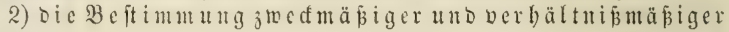
Etrafen;

3) Die Beftimung, Dás bie Strafanjäbe nid)tzu lang veridboben werben, und längftens alle Bierteljabre er: folgen jollen;

4) Die Berotoung, baf bie Strafen obne $\mathfrak{A} u f$ dub mit Strenge beigetrieben oder bollzogen twerden follen;

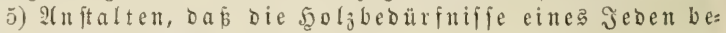
friebigt weroen fönen;

6) die Sorge, Daf ber 5olzpreis nidt allzufebr in bie böbe fiteige u. ogl.

Die Dbliegenbeit des Förfers bingegen i ft es:

1) bie Sgolzbedurfnific eines geben nad) Möglidfeit fduell uno willig jubefriebigen;

2) a If die Soljoicbe, jo wie auf $\mathscr{A l l e}$, die bem $\mathfrak{B a l b e}$ Ed) a Den zufügen, fleifig $\mathscr{A}$ d) tug zu geben, uto

3) alle llebertreter ber jorftgefebe, aljo aud alle $50 l z=$ Diebe und folzfreolerzur Beftrafung anzuzeigen.

Dumit aber Der Midter in Etano gejest werbe, Das \$ergeben ridjtig

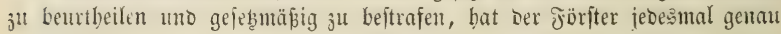
uno pflid)tmäpig ju bemerten uno in feinem Tajdenbudbe, oas er immer bei fid baben muș, aujzuzeidunen: 
1) Den Iauf= unb Beinamen bes Frevlers ober 5ुolz= diebea,

2) Den Wobnort befielben,

3) Den Tag und bie Stunde, wann er benfelben ange= trofien,

4) Den Drt, wo ber Frevel borgefallen,

5) Die Befdaffenbeit bes frevels,

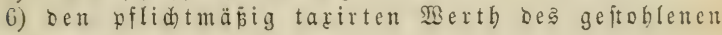
(3) egentandes, und

i) Die bejonbern $u m$ ftände, welde fid allenfalls nod 3ugetragen baben, injoferne fie zur Beurtheifung ber Eache nöthis jein möbten.

Mlle Diejes bat Der förifter zu Şauje alsbalo in cine Rugelijte jul tragen, und Dieje Sifte zur keftimmten Beit jeinem ßorgeję̧ten zur meiteren \$erfügung zu übergcben. Er felbit aber barf, auper einem ant= jtänoigen Bertweije, feinerfei Etrafen an Den Ertappten vollyiehen, uno

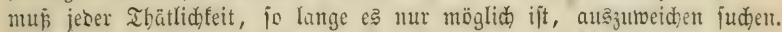
2(ud) barj ber Jörfter in sen meiften Qänbern nur jolde Frebler, bie er

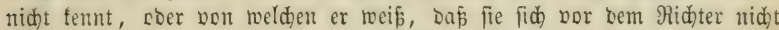
ftellen, ffänsen, soer, wenn er fid ibrer lemädtigen tamn, in Berbaft

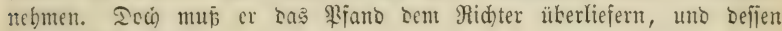
weitere Berfügung erivarten.

Sollte Der Jöriter mur bie Epuren eines begangenen Frebels ent= becen, ben fresler felbft aber nidjt babei finben, jonbern auf irgento eine

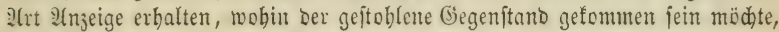

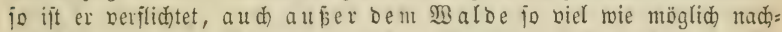
juforiden, un ben Thäter zu entoeden. In biejem Jalle muś er bie Gie: bäute Der Berrädtigen, in Beifein einiger (Beridtsperionen, genau burdjuchen, und wenn er nidhts finden jollte, mebrere Gebäude ber Madbarn, zum $\Subset$ dein, mitvifitiren, um Den Nersädtigen, ber vielleidht

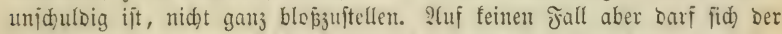

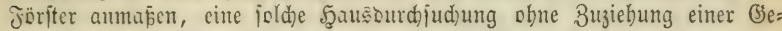
riatškerion vorzunebmen, wenn er nidht Ǵejabr laufen will, fid ber un= angenebmiten Bebandlung auइzuje⿻̧一n.

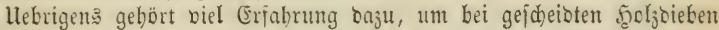
¿as zu finden, mas man fudt. Dergleichen Seute Denfen getoöbnlid vorber nad), wobin jie bas $\mathfrak{S c o l}_{3}$ verbergen wollen, uno ridhten alle 3 johon jum Emprang io ein, Daj es sft unbegreiflid) ift, wie ber (biegenftant fo jojnell hat berfitwinsen ober in eine andere form hat gebradht wersen fönnen.

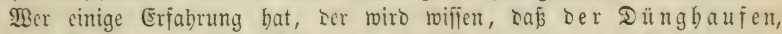
Der Dou = un Etrobjdober, Der $B r u n t e n$, Der Reller, bie

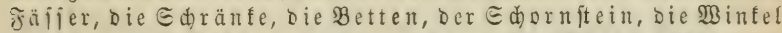
zwijhen ben Gुebäuben, Die nidht in bie Afugen fallenden

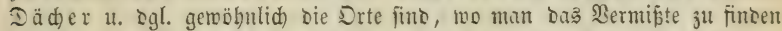

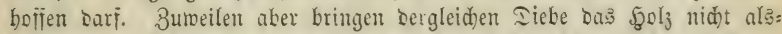
balo in ibre Gebäude, fondern fübren es in eine bentabbarte fidere Diđung, soer beritectent es io lange in bie Gartentheden, soer ins Msaffer, coer 
3mifden bie Gebäube foldher Seute, welde bie Unterjudtung nidbt trifft, bis bie (Sefahl ber Bifitation voriber ift; Doer fie vergraben es loobl gar fo

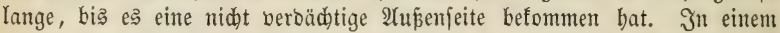
folden Falle ift es freilid) fohwer, ben Bwed zu erreichen, wenn ber Bufall ben Endhenden nidht begünftigt, doer bie Edabenfreube ibm nidht zu itatten foimmt.

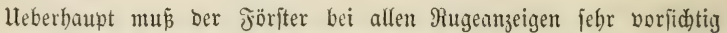
fein, uno alles aufs getreuefte fo angeben, wie er es gefunben bat. Sollten ibm aber Frebler bon andern nidit verpflidteten Senten verrathen werben, fo bat er fid aufz getrauefte nad) Den lumftändent zu erfunbigen uno sergleidjen Frebel nur in bem Fall Dcm Ridhter anzuzeigen, wenn er burd Beugen ben Frebler zu überfüfren gebenft. Sollte biefes aber nidht gejdeben fömen, fo fant er von einer fold)en 2̂trjeige

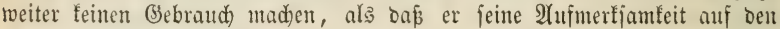
Beroäd)tigen verboppelt.

2(ud) ift Dem förfter fehr zu empfeblen, fich) bei Den Rugegeridyten, wo feine Giegenmart als Släger oft nöthig, uno um bem Richter über Mandes 2(ufichlús zu geben, erforberlid) ift, Durdh Den Dienfteifer nidht

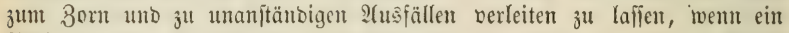
Beflagter fidh ungebübrliche 2 tusørücte erlaubt. Dieje zu beftrafen ift bie Sache bes Ridaters, uno ber förfter wiro fid burd) ein ernites, anjtändiges

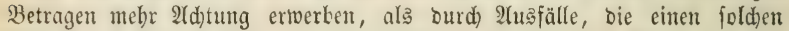
Menjden bod) nidbt beffern, uno Den Ridhter jwingen, Den Rläger uno ben Beflagten zu ftrafen.

\section{Siebentes Enapitef.}

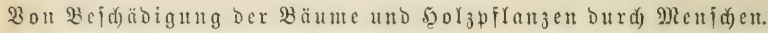

Iie ätteren uno jüngeren ફ̧olžflanzen fino mand)erlei ßejdäbigungen

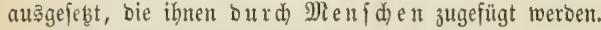

J市 redne bierher vorzüglid:

1) bas

2) Das Bejenreisfdneiben;

3) bas Quirlidneiben;

4) bas 2(bbauen ober 2(bbreden ber atejte;

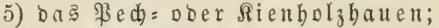

6) Das Ringeln ber Bäume oder 2(bidälender Rinde;

7) bas $\mathfrak{A}$ uhauen ber 3 ogelnefter;

8) bas Saftabzapfen zc.

Mir wollen baber jebe von biejen $B e j d y a ̈ b i g u n g e n$ bejonders betradjten.

2) $\mathfrak{B} 0 \mathrm{~m}$ Biedidneiben.

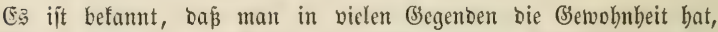
bas Getreibe in hörzerne Wicben zu bimben, uno zu biejen Wieben vor: зüglid) Birfen, зum Theil aber aud) Şajeln, Sigufter, Şartriegel, Weiden und anberes Strauchbolz zu nehmen; mitunter aber aud junge (Eid)en,

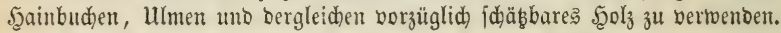

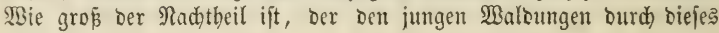


Erntemiebjodneiben zugefügt mirb, fann man fid leidjt benfen. 2(lle Jabre

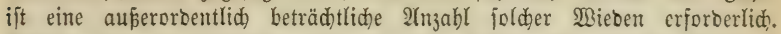

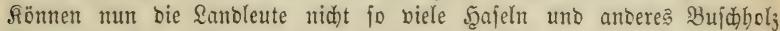
finden, als fie zu Wisieben nöthig haben, ober fällt ihnen bas Eudjen ber:

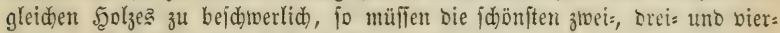

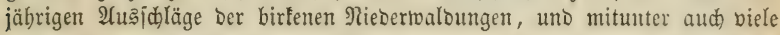

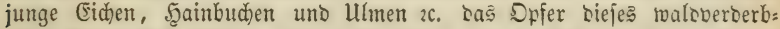
liden Ǵebraudes rerben; uno in G̈egenben, wo es überhaupt wenig Birfen gibt, geht Das Erntemiebjteblen oft io weit, baj gar feine junge Birfen uno (sid)en auffommen.

(Semöbnlich finbet man biejen fdäblichen braud in Giegenton, bie

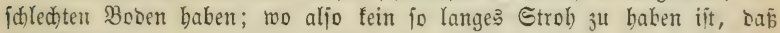
Das Setreide in Seile vou Etroh gebunden werben tann. Es gibt aber aud Giegenon, wo biejes Şinbernip nidht itattfintet, uno bie böl=

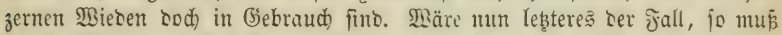

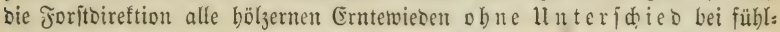

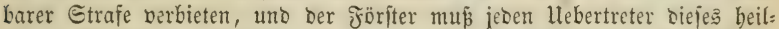
jamen Biefęęes jur Beftrafung anzeigen. SBären aber bie bölgernen Ernte= mieben, ben Umftänben nad), unentbehrlid, fo mus von Eeiten §er Jorit:

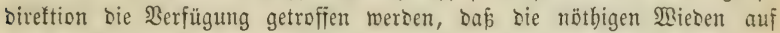
eine unjöäbliche 2(rt an bie đrudterzieher abgegeben werben tömen. (5:

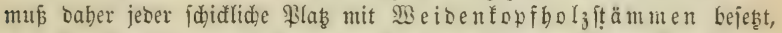

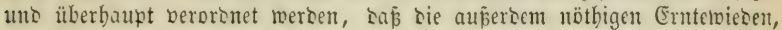

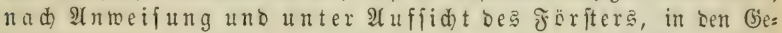
meinbewaldungen geidnitten uno vertbeilt, aue ben berridaitlidjen $\mathfrak{B a l}_{\text {al }}$ bungen aber eine binlänglidbe Menge jolder Mieben, bie nach Moridrift

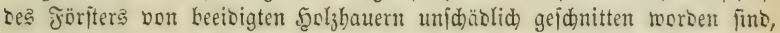
um einen io biel nur immer möglid geringen \$reis verfauft werben jollen.

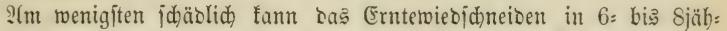

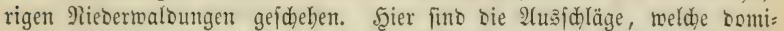

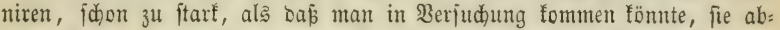
zujdrneiben, uno alle geringern $\mathfrak{A} u s j d \mathfrak{l a ̈ g e , ~ b i e ~ j i d ) ~ z u ~ E r n t e r w i e b e n ~}$ jadifen, fino entbebrlich, Da fie boch in wenigen Jabren von jelbjt bürr

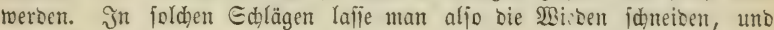

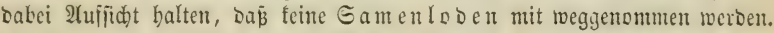

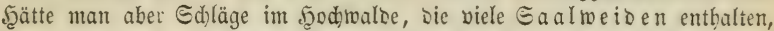
fo benube man aud bieje zu Wiesen. Man wirb baburd) Dem jungen 50 d)= ralbe nüb̧en, unb bie Ǵefahr ber Bejdäbigung von eimem andern Dijtrifte abwentert.

Eben jo nadtheilig, mur nidht fo allgemein, ift das Ed)neioen uno

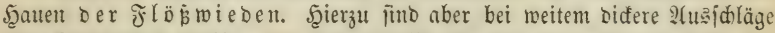

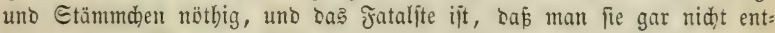
behren faum. Wo Daher flößerei getrieben wirs, mú ser J̈örfter Darauf

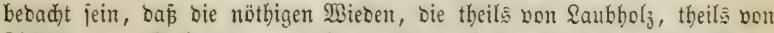
Fidten = unb Ebeltannen gemad)t werben, auf eine fo biel wie möglich un=

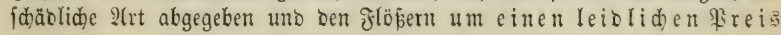


überlafien werben, bamit ber Reiz, fie zu ftehlen, berminbert wirb. Rönten bie Flöper fold)e Wieben aber gar nidgt für $\mathfrak{B} e z a h l u n g$ erbalten, ober

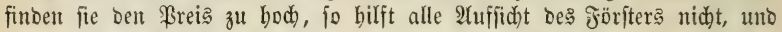

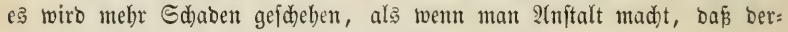
gleiden $\mathfrak{B i e b e n ~ u m ~ b i l l i g e n ~ \Re r e i s ~ z u ~ f a u f e n ~ f i n b . ~}$

\section{2) Bom Befenreişdneiben.}

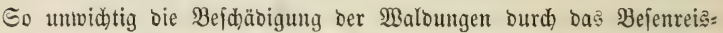
idneiden zu jein fdeint, fo nadtheilig ift fie wirflich, wenn in einer (Begeno viele Menidhen burdh bas Befenmaden Berbienjt fudcen. Die meiften Bejen, beren jährlid) eine fehr grope Menge werbraudht wirb, fino von geftob: Ienen Reifern gemaǎt, bie gemöbnlid) bei hellen $\Re$ äd) ten gebolt werben. (Fine unglaubliche Menge fidöner Birfen wiro baburd) verftümmelt,

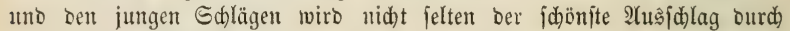
bie Frebel ber Bejenmader geraub:.

(Jemöhnlid ift Der $\mathfrak{2}$ aldeigenthümer ober beffen Berwalter felbjt Eduld Daran, Daß̧ biejer Sdjaden gejdieht. Das Bublifum will Bejen baben,

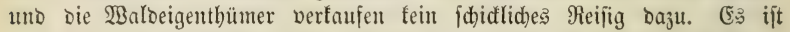

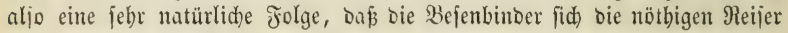
auf eine unerlaubte 2 (rt zu beridjaffen fuchen.

Will man baher ben Balo vor ben fonit unbermeiblidjen Beritüm: melungen jüüksen, jo muईs ber Jürfter bie Borfehrung treffen, baßs bie Befenmad)er Dą nöthige Reifig gegen jo viel möglid geringe $\mathfrak{B}$ ezah= lung un von bererforberliden Bejdaffenbeit erbalten fönten. Der Befenbinder fan nur feine, nicht zu fdlaffe Birfenteifer be: muben, uno man fant ibm nid)t zunuthen, andere anzunebmen. Man gebe

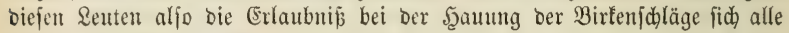
für fie braucbbaren Reijer auşzujuc)en, uno gegen billigen, fo gering twie

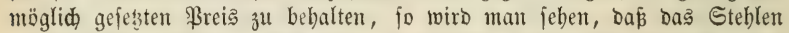
größtentbeils aufbört. Will man bergleiden \&eute aber jwingen, Das Birfenreifig unausgefudt zu faufen, ober bie ausgefuchten Meifer in einem hoben ßreis zu bezablen, jo wiro man feinen 3wed berfeblen, unt es wirb burd frevel mebr Edaben geidehen, als went man bas im Ed)lag vorgefallene zum Bejenbinden braudbare Reifig fämmtlid) ver= iḑenf f bätte.

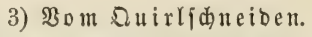

In Gegenten, wo Rabelfolzwaloungen fino, hat man febr häufig

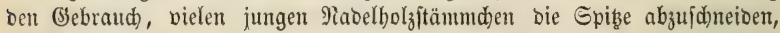
theils um $\Re$ ü d)enquirle bavon zu machen, theils um fie als $3 e i d e n$ ber (j)aftwirthidaft vor bie Şäuler zu hängen, theils um die $\mathfrak{B} e i \mathfrak{h}=$ nad) $t$ sgefdente baran zu binben.

So unwid)tig bieje Benubung ôu fein fdeint, fo mad)theilig wirft fie aber bod) auf junge Malbungen, bie in oer Räbe von Stäbten liegen.

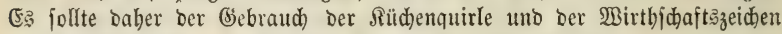

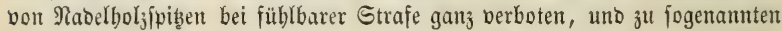
Shriftbäumden nur zufammengebundene शabelbolzziveige geftattet 
werben. Mill man aber bent \&ublifum bas ßergnügen nidjt entjiehen, feine Chriftgeid)enfe an Duirlbäumben зu hängen, io mus ber Foritbeamte bergleiden Episen auf eine unjdäblide 2 rt ausforften uno fie um geringen Breis berfaufen lafien.

\section{4) Bom $\mathfrak{A b b a u e n ~ u n o ~} 2$ bbreden ber $\mathfrak{A}$ eite.}

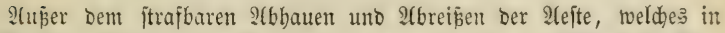
ber Ábficht gejobiebt, um Brennholz zu erbalten, fällt bieje Ber: ftümmelung uno Beichäbigung aud̆ beim $\subseteq_{a}$ men $\{a m m e l$ u bäufig vor. Dit bängt Der Eamen fo, ba ̃ man ohne Unbequemlid)teit ober Giefahr nicht baju gelangen tann. In biejem falle haben bie Eammler bie jehr fääblide (Semobnheit, bie Sfefte, woran ber Samen hängt, abjubrechen oder abjubauen, um ben Gamen unterm 3 a ume bequem abpflüten zu fönnen. SBie nadtleilig biefes aber ift, fällt bon felbft in bie 2(ugen. (E⿱ fagt, uno vom Förjter jeber llebertreter zur Strafe notiil werben.

Nur von fold)en Bäumen, bie im näditen Winter gehauen werben, fann man im Seerbite die 2 efte, moran Eamenzapfen bängen, abbauen.

Eben fo nad)theilig für bie Waloungen ift ber in manduen Gegenden eingefübrte (Gebrand), Iannen= uno Jid)tenreifig ftatt Strob zur

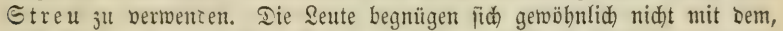
roas iünen an Dergleidhern Reijern auı Den Eḑlägen jäbrliđ) abgegeben

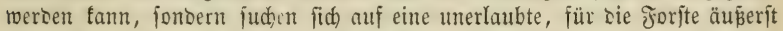

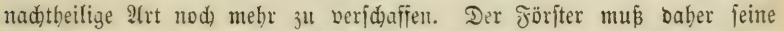
Balbunnenen aud gegen bieje Bejääbigung, fo viel in jeinen Rrüften fteht, зu beidü̈ben trachtert.

\section{5) 20 m ßed = oder Rienholzhauen.}

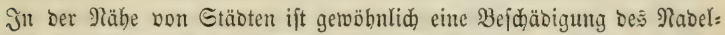
holges, bejonder: Der Riefernftämme, fehr im Gebraud, welde barin be: fteht, Da man bie Bäume $1:-1$ Meter über ber Eroe anbaut, um einen

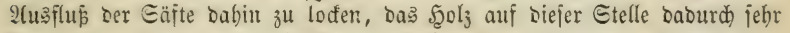

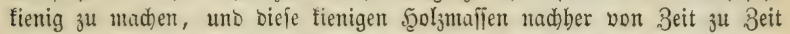
auszuhauen, um fie zum Jeueranzünden зи berfaufen. Biele ber fäb̈niten Etämme werben burd) siefes 2 (nbauten virborben, und entidy fo weit ge:

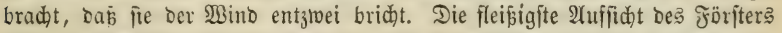
uno sie ftrengiten Etiajen fino oft nid)t binreid)eno, um biejes Hebel ganı zu vertilgen. (Semöhnlich finto bie frebler ganz arme Reute, bie man um (Belo nicht fitrafen fann, unt bie aud gegen andere Büd)tigungen unempfint:

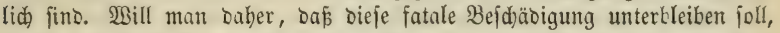
fo ijt bas bejte Mittel: Den armen Seuten, weldhe fid burd) ben Bertauf

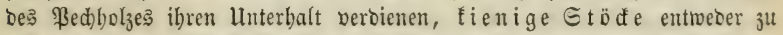
idenfen, ober gegen jebr geringe Bezablungen zu verfaufen, unt ibnen

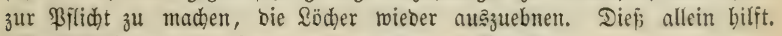
2tlle Befehle uno Strafent werben weniger wirfjam jein. 
6) Bom Ringeln ber Bäume ober Rinbeabfdälen.

In manden Gegenden, wo viele Erobeeren, 5̧imbeeren, Şei= belbeeren, Breupelbeeren uno bergleiden wadjen uno gefammelt

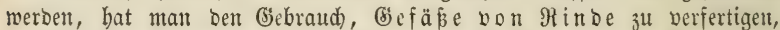
um bieje Beeren barin aufзuberwabren und zu Martt zu tragen. 2(uch babent an mandjen Drten bie Röbler, Şotzhauer uno Şirtent ben (bebraud, ibre

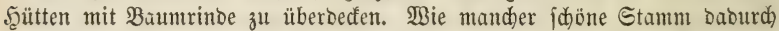
ruinirt wirb, fann man fid leicht vorftellen. Es follten baber alle Şefäpe von Baumrinbe bei Strafe ganz verboten jein, unto jeber Röbler, Şolz= bauer uno Sirte bei Strafe berbindofid gemad)t werben, fid bie zui Dectung Der Şütten nöthige Rintbe von Dem Föriter antweifen zul laffer.

7) $\mathfrak{B}$ om $\mathfrak{A}$ a bauen ber $\mathfrak{B}$ ogelnefter.

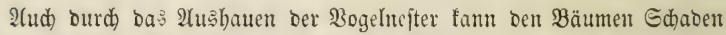
ôugefügt werbent. Die Bäume, in meldhen Bögel nijten, futto zwar fdjon im Berberben; es wird baffelbe aber nod mehr beịhleunigt, wenn groje Söher in bie Bäume gebauten werben, woburd) bem Regentwajper unt Ednce

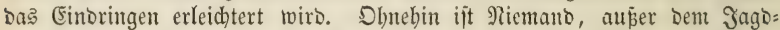

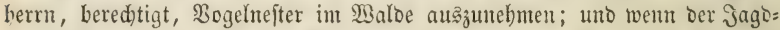
berr nidgt aud jugleid, ber Maldeigenthümer ift, fo ijt berfelbe ebenfalls

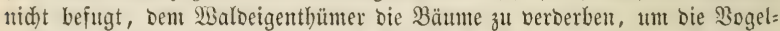

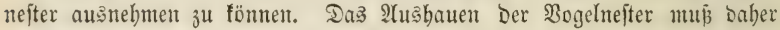
verboten uno jeoer Hebertreter vom Föriter zur Bejtrafung angezeigt iveroen.

8) $\mathfrak{s}$ om ভaftabzapfen.

Das 2ubzapfen bes Gaftes fanm jowohl beim Saubbolze, als beim Nabelholze gejd)eber. Unter.ben Saubhölzern find überbaupt wenige, beren

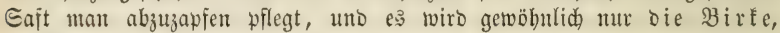
um ibren Saft zu Bereitung eines Geträntes zu gebrauthen, wietoobl felten, angebobrt uno abgezapft. Singegen foumt bei Den Nabelfölzern, bejonbers bei ber Fid)te uno $\mathfrak{I} a n n e$, an einigent Drten aud bei Der $\Re$ iefer, bas 2 bzapfen ober Entzieben des Saftes bäufiger vor, weil baraus be= fanntlid) Das ßed, Terpentin mo F̧arz gewonnen wirb, wie foldes in bem Theile bon ber For ftbenubung weitlüufiger gelehrt ijt.

Dap alles 2Ybzapfen uno Entzilehen von Saft ben Bäumen fdäblidd jei, bedarf feines Betweiję. Âper ber Entfräftung uno Berminoerung bes

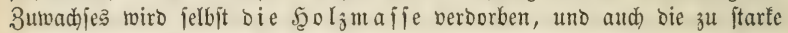
Bermebrung fääblider Walbinjeften beförbert, went biele Bäume burd) bie Entz̧iehung Des Saftes frant werben. (5s fam folglich feinem, ber nidjt

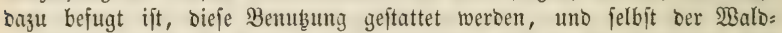

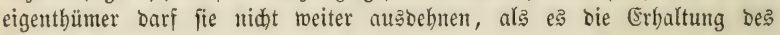

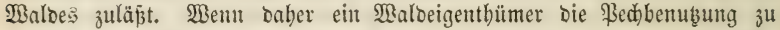

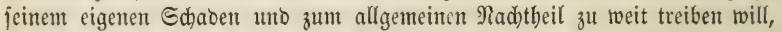

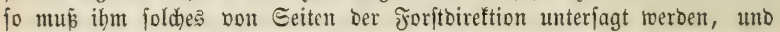
Der Förfter hat bie Dbliegentheit, bergleiden nad)theilige Shandlungen als: balo jeinem Sorgejebten anzuzeigen; fo wie es fich von jelbjt veriteht, baís 
or Jeben, ber zu ciner foldhen Şandlung überbaupt nidht beredtigt ift, zur Strafe notiren muई.

Wie übrigens sie Pedbenub̧ung fo einzuridten ift, baj fie obne grofen Nachtbeil ftattinten fann, ift bei ber Forftbenukgung vorgetommen.

\section{Didifes sanpiter.}

Bon der $\mathfrak{B}$ ald toeide.

llnter allen llebeht, Ecnen bie Maldoungen auggejeşt jüto, ift bie

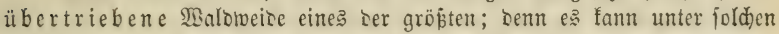
limftänoen fein verbältnifmäpiger Theil vom $\mathfrak{B a l}$ aloe in Şege genommen

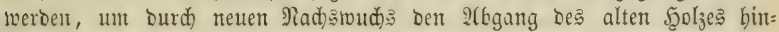

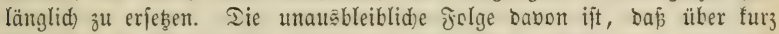

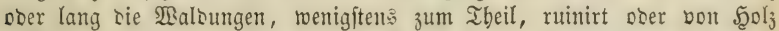
entblöpt, und bie nadfommenden Generationen in 5ुolymangel berfeb̧t

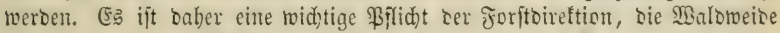
cntweber ganj abjujdaffen, soer fie bod) menigitens bi lid) feit einzujd ränfen.

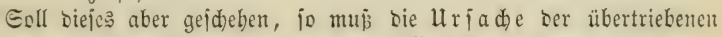

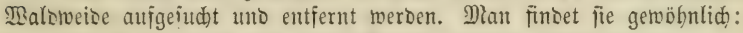

1) imvernadläjigten Biefen= uno Futterbau,

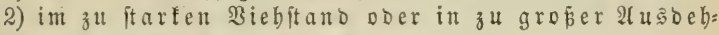
nung Der Weibgeredtigfeit, uto

3) im Maugel an gehöriger 2 uffidt.

פisas die beiden uriten Gegenjtänoe betrifit, io müfien bon Geiten

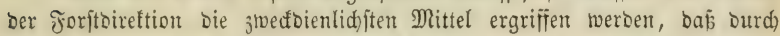
bie Berbejerung Des Wiejen: uno Aderbauts, uno, too es nötbig iit,

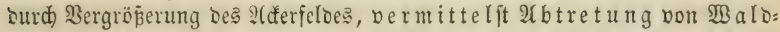

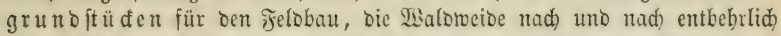

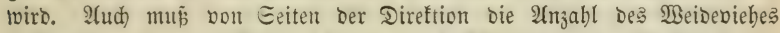

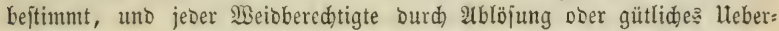
eintommen in bie gebörigen Ed)ranfen gewiejen werben. Der förjter bin=

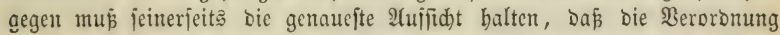
Der Dberen befolgt und alle llebertreter zur Bejtrajung gezogen werben. Borzüglid muई er Darauf balten:

1) bá immer ber gejeßs= oder veroronugamäjige Theil voll feinem Jorftreviere - bei frodwaloungen von Laubhols ge=

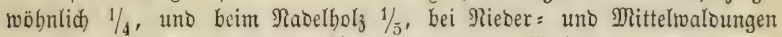

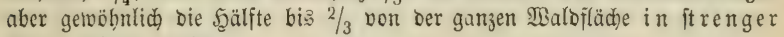
sege gehalten werbe;

2) Dá bie (5) rass ober $B$ l umentoeibe, wie es an ten meiften

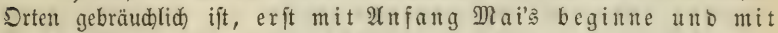

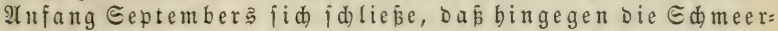
Doer Jettweide ober bie Eే đeridsmajt erft mit bem 15. Dftober anfange und mit $b e m$ Januar endige, binnen relcher 3eit bie Bormaft bis zum 20. December, bie $\mathfrak{R}$ a d majt aber, wenn fie ftutt= fiuton faum, bom 20. December bią Ende Jamuars bauert; 
3) baв zur Blumentweibe ober (5) rasmeibe un Rinbvieb, ¡dledterbings aber feine 3 iegen, Bferbe, Sdafe uno Sdweine in bie Walbungen getrieben werben, wenn bie forftoreftion feine bejonoere Erlaubni

4) Dá nidh mehr als bie erlaubte Stüđzahl $\mathfrak{B} i \in \mathfrak{h}$ ein= getrieber, und boubcibigten bemeindebirten geroeidet, fdledteroingz aber nid)t einzeln gebütet werbe;

5) bás bie Şirten mit ben Beibepläßen gebörig abs wed feln, uno

6) Dan jie bie in fgege gelegten Diftrifte aufs forgfäl= tigite $i d$ onen, bis jie bem $\mathfrak{B}$ ieh entwadjen uno zur Bewei= bung wieber angetwiejen worben find.

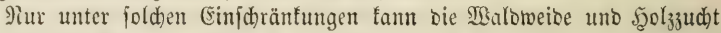
julammen bejteben: $o b$ es gleid) in forftwirthfdaftlider Sginfid biel fid)erer uno befier ift, wenn bie Balsungen bon ber Saeide ganz befreit werbent fönten.

Ifuperbem hat ber förjter nod manderlei Mittel, um bie fo nad)=

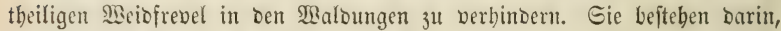
Daf cr bie Futtermalfe in ber bsegend, wo er lebt unb wirt,

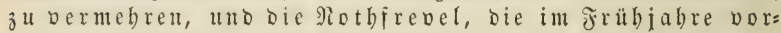
fallen, oaburd zu verbindern fuden $m u$ b.

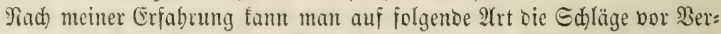

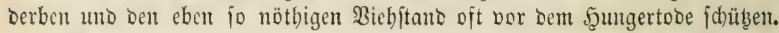

Man crlaube nämlid) Den futterbedürftigen (Semeinben, Dáp jie zu beftimmen Tagen, unter ber $\mathscr{A}$ uffidt ber Forftbebienten und Des (semeindevoritandes, (5ras aus ben jungen Sd)lägen vor= fidtig rupfen uno baffelbe unentgeltlid benuţen bürfen, fo wirb man erftumen, weld) eine auperorbentlich grope Denge futter aus bem Maloe genommen werden fann, ohne Demiflben zu idaben. Sollte audb bier und

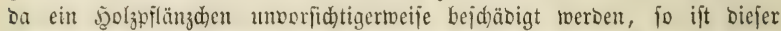
fleine ummertlide Berlujt gegen Den gropen Bortbeil, Der Dem Biebjtand

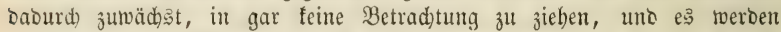
taujenomal mebr \$flanzen ruinirt werben, wemn man bieje Erlaubnip nidt ertbeilt; weil fich alsbann jeber Beoürftige mit fdueibenden Snjtrumenten bei Iag uno গaddt Futter für fein bungriges Bieb frebellbaft zu veridaffen

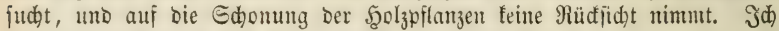
habe viele Berfuche Der 2(rt gemad)t, uno nie Urjad)e gehabt, mit Dem Erfolg unjufrieden zu fein. Die Menidjen waren gegen eine polde $\mathfrak{B o b l =}$ that immer bantbar uno zeigten zutweilen biejenigen unter ibnen, weldhe nicht mit oer gehörigen Sorficht zu Bert gingen, jelbjt an, um bie $B_{e}=$ fduldigung ber Unoantbarteit bon fid) zu entfernen, uno in fünftigen äbn= liđjen テ̌ällen gleidhe ßortheile nidjt zu verid)erzen.

2uch bat ber Föriter, weld)er Rieberwaloungen abminiftrirt, nod) ein fräftiges Mittel, um im Rothfall bie Juttermaife zu vermebren, uno ba=

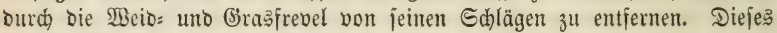
Mittel bejtebt barin, Daß man in joldhen Jabren, wo bie Futterernte fehl= geiblagent hat uno ber Mangel im Frübjabre voraus zu jeben, aljo auch 
betwadjen füt, scer, wic bie Maldriejent unt Etellmege, niemals mit feol betwadjen jollen; poer in fofern Der Fall eintritt, Daj bas Grả vorfichtig

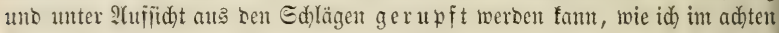

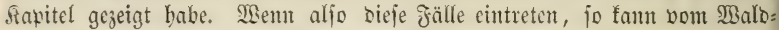
graje Bortbeil gejogen, uno von mandher feuchten Blöß̨e in einigen Jabren

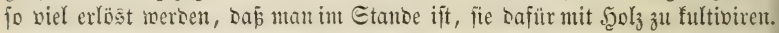

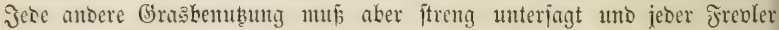
zur Strafe gebradyt merben.

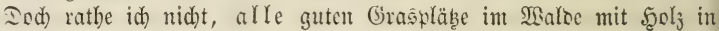
Beftano zul bringen. Beffer ift $e^{3}$, wemt man folche \$läke, die gutes gutter tragen uno von cintigem Belange fint, mit Grenzgräben un=

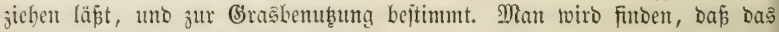

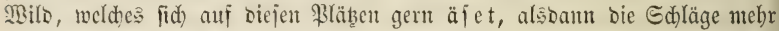

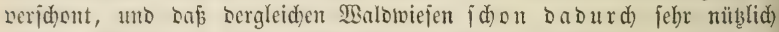

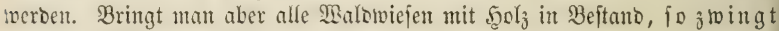

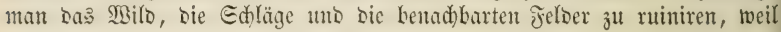
es anterstwo feine Rahrutg fintoen faun.

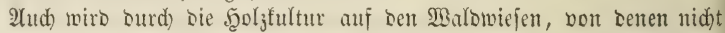
jelten vieles Şeu verfauft werbent fonnte, Der Begento eine beträdtllidje Menge

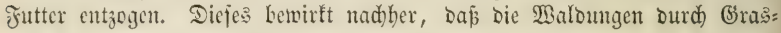
uno Baciofrevel, uno felbit burdh bas Etreulaubjammeln, went ftatt bes ionft norbanten gewejenten Sentes Stroh ift werfüttert morben, um jo biel mehr leiben müfien.

Mo aljo bie Balomiejen füt Das Millo uno jutr Bermebrung Der

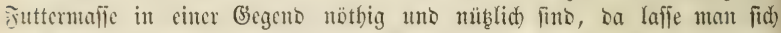

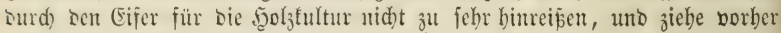
Dasienige, mas id oben gefagt babe, in gebörige lleberlegung. Maut fanm

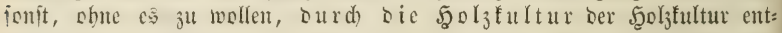

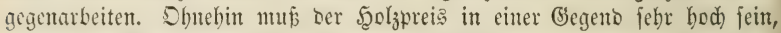
menn cin Morgen bes bejten Walbes jäbrtid jo vicl cintragen fann, als cin Morgen mur mittelmäß̈iger BBiejen. Es ift Daher aud in biefer Scin= fidnt nid)t rathjan, eine Sigalswiefe, bie gutes uno viełes Jutter liefert,

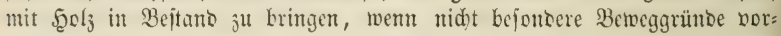
banton fins.

\section{Silftes Eapifel.}

3om Jutterlaubitreifen.

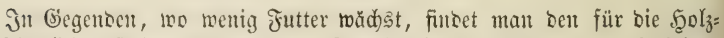
gutdt fdäblichen (bibraud), Das junge $\& a u b$ abzuftreifen, unb foldes bem Bieh zur Futterung zu geben. Wie nadtheilig biefe Dperation für bie jungen $23 a l$ oungen jei, bie baburd ifrer neut Iriebe uno Blätter beraubt merben, barf id mohl nid)t weitläufig auseinanderjeken. Das

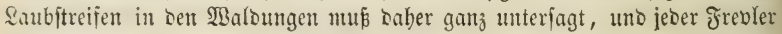
fitreng bejtrait werben.

Dod) gibt $e^{3}$ Fälle, too der fruttermangel im frübjabre auf teine antere $\mathfrak{A}$ rt, als Durd) Saubjtreifen bermindert uno Der Biebitand erbalten

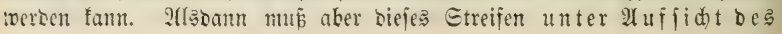


Denn aljo, nad) genauer Brüfung allex llm tänoe, und nad) $\mathfrak{A}$ n wenoung aller Gegenmittel, bie Stbgabe ser Saubitreu unt=

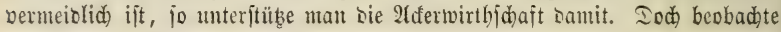
man bei ber Xbgabe folgende Regeln:

1) Mlle Diftrifte, Die fdledten Boben haben, Doer seren beftand no() nidt 60 Jabre alt ift, milifenganzber= idont toerden.

2) Jeber פgaldoiftift, der bald in Sdlag gefterlt ober verjüngt weroen foll, oari wenigitens 4 Jabre lang oor ber

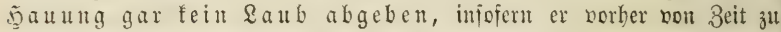
Beit bat Saub abgeben müfīen.

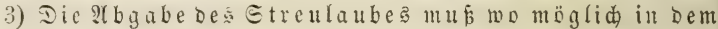
Monat Eeptember gejdeben, damit Das Saub ben Boben

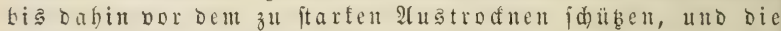
balo nad) ber abfallenoen Bläter oie Erbe oor bem ju ftaren Eindringen des Froftes bewahren fönen - uno

4) feiu Diftrift barf von $2 a u b$ gauzentblöbt, fonbern es darf $n$ ur alle 4 bis 6 Jabre ungefäbr bie Sälfte genom= men, und lieber cin etwa gröperer Jlädentaum bazu an= getriejen werben. Hu menigiten nadtbeilig ift bas Etrenbarten,

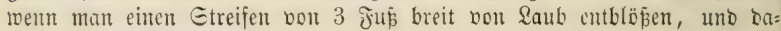
neben einten eben fo breiten Streifen mit Saub beoecft läpt.

Bci Bejolguny biejer Regeln roiro oer Joritmam jäbrlid) cine be:

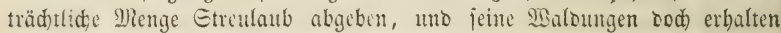

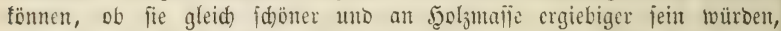
trem eine jolche 2lbgabe nidgt ftattfinden mïj)te. SBiro sem Malse aber

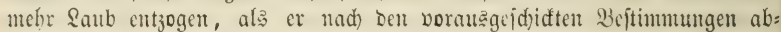
geben famt, jo berwitt eine jolde $\mathscr{A b g a b e}$ jeil Berberben, und jwar um

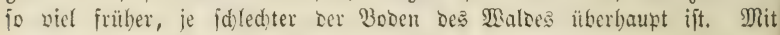

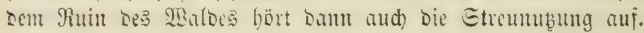

\section{Dreizelintes Eapitef.}

Bom graggen= ober Majentaden.

Jit manchen Giegenoen, bejonters in folden, sie wenig jrudt pro=

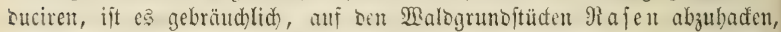

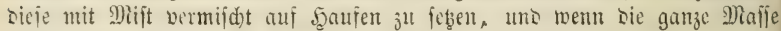
berfault ift, jic jux Düngung Der Felder uno IBiejen ju benuben.

Eo gute Dienjte Diejer Dünger bei ser Lanbloirtbiafaft leiftet, fo nad)theilig ift Das Rajenbaden fïr bie Waloungen. Eine Menge junger

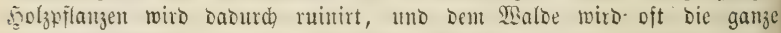
Iammerdenjdichte entzogen. Rupersent werten aud Die Thanwurzeh Der gröjeren Bäume sadud bej(çäbigt uno entblöjt, uno es tönucu nadber

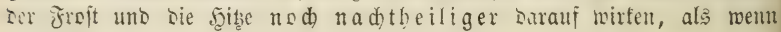
Dem Booen bas $\mathfrak{Q} a \mathfrak{b}$ entzogen roorben ift.

Alles eigemmädhtige Rajen = ober Plaggenbaden it Den Maloungen Docr auf Ien Salogrunoftüfen mup Daber aufs ftrengfte verboten und 
jeber Uebertreter zur Beftrafung angezeigt merben. Nur in rem Jalle fant

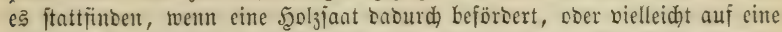

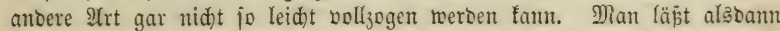

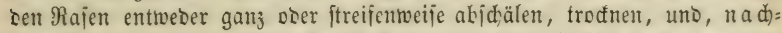
Dem bie einzelnen Etüđe tüd)tig burdgeflofft und bou Der Dammerbe fo biel als möglid befreit find, wegbringen.

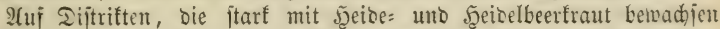
waren, uno mit Nabelholz ober Birfen in Beftano gebrad)t merben jollten, babe id dieję 2Abidhälen jebr bortbeilhajt gefunden, weil baburch bas Burzelwerf entfernt und Der Eamen an bie Eroe gebracht wurts. MTan

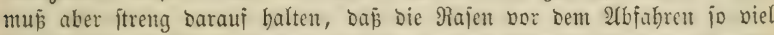

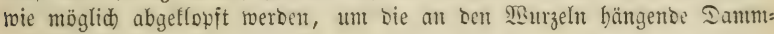
erbe im Balbe zu behalten.

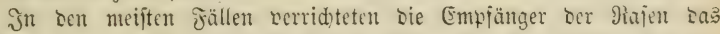
Itbidälen unentgeltlid), uno oft lieferten fie aud) nod) aupersem ben jur Eaat erforberliden Birtenjamen gegen Die Benutzung Der Majen.

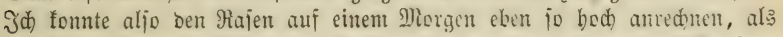

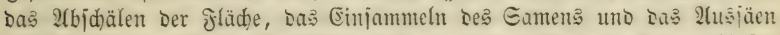
gefojtet baben würben. Beredinet mant nun biejes Rapital mit Den Sinjen

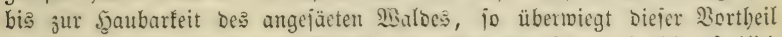

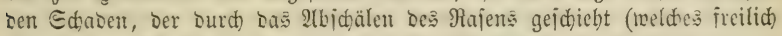
obne einigen Berlujt an Ianmerbe nidt ablaujen faun), bei weitem.

2uberbem madhen bie döblereien oft nothwendig, Daj̉ Rajen im Malbe

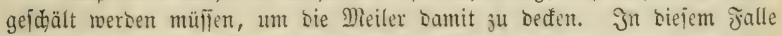
muß ser forrifter nur foldje Drte baju anmeijen, wo es am menigiten jhäb: lid) ift, coer wo es vielleid)t zur Beförberung ocr natürliçen coer fümit: lid)en Bejamung nod) nüben fann.

\section{Djierzelputes sapited.}

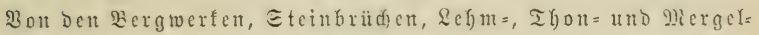
gruber.

Iisie nadtheilig cs für sen SBale ift, wenn Bergwerke, Etcin= brüde, Eand:, \&ebm=, Thon= und Mergelgruben Darin liegen, Davon wiro fid) Jeber überjeugt haben, ser Gelegenbeit hatte, bie Jolgen Davon zu jeben. (Es wiro Dasurd) oft ber beite Walogruno mit unfrudht= barer (Erbe uno Eteinen überbecft, uno aujer Dem unmittelbaren Muin aud) nod bei ber 2 bfuhr ber. Steine und Eroen gejtabet.

2Bas Die Bergwerfe betrifit, Die in manden (begenten Das cinjige

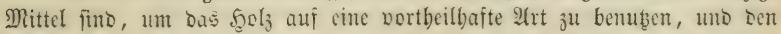

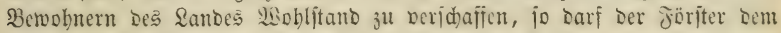
gejcķmäfigen Betrieb Derfelben freilid) nidjt entgegenarbeiten; er sarj aber aud) nid)t jugeben, saj baburd) obue शoth bem Walde gejdarct, uns

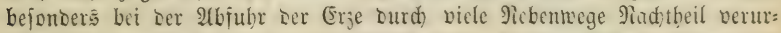
jad)t werbe. Wisas bingegen bie Etrinbriide, Eants, Sehm:, Ihon: unt Mergelgruben ankelangt, io sarf ber förfter niḑt erlauben, baj bergleid)en

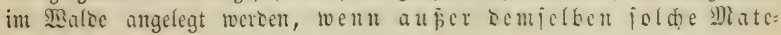


rialien auf eine weniger (d)äblide 2trt unb bou gleider (5) ü te zu haben find. Sollten aber Dergleiden (sruben nur im Balbe angelegt werben fömtnen, io bat bieß ber förfter feinem Borgefebten anz̧=

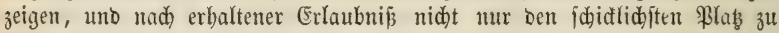

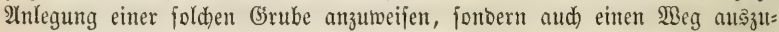
zeid̄nen, worauf bie 2 (bfubre ber gemonnenen Materialien am unfdäblidjjten gefdeben famt.

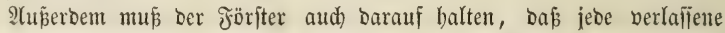
(5rube alsbalo wicoer zugeworfen uno fo viel wie möglid ausgeglid̄en, Doer nötbigenfalla mit einem (Seländer umgeben werbe, bamit man ben

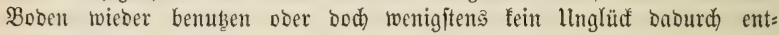
fteben fann.

\section{Iilnfzelintes saniter.}

\section{Эon Der Torfitederei.}

Eo müblid bie I vrffted)erei unter manden Berbältnifien uno Um= ftänoen an uno für fich jelbft ift, uno fo wejentlid) fie mitwirfen fanm, um bie Walbungen zu fdonen, wen mäd) tige Iorflager regelmäßig akgeftoden uno benubzt werben, fo nadtheilig fann fie im entgegengejeb̨ten Falle für bie frorfte werben. Es gibt Gegenden, wo mant wegen einer faum 0,3 Mtr. biden Edhid) te elenden $\Re$ a fen t o rfe

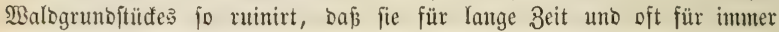

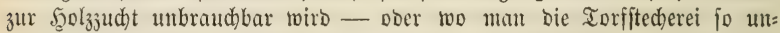
regelmäpig uno feblerbaft betreibt, baßs baburd) bie Iormtoore jelbit, uno aud) bie bentadbarten 2 Baldoiftrifte berfumpft, ober burd) unorbentlides Abfabren bes Torf̧ 2 . verborben werben.

Der Förfter muß baber bicfen llibeln entgegentarbeitent uno nidbt zu=

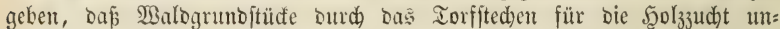
braudbar gemad)t werben, wemt iic ourd bolffultur uadbaltig mebr Brennuaterial liejern tönnen, als ourd) bie Benubung auf Iorf. Sollte aber cin $\mathfrak{X a l o g r u m b j t u ̈ d}$ mit einer mädtigen Torf:

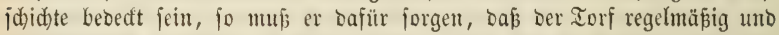
wirtbid)aftlid) geftoden uno benubst werbe, wogu man im I I beile bon ber

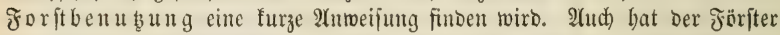
Die nötbigen Borfebrungen ju treffen, bafs bas aus Den Torfmooren ab:

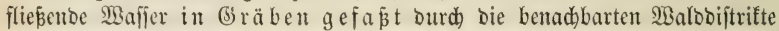
geleitet werbe, uno baß bie 2(bfabrt bes getrodneten Iorfes auf be ft $\mathrm{im}$ m: ten Megen gejdebe uno ben Malbungen feinen Edaben bringe. Die ab: getorften gläd)en aber müīen, wem es bie llmitänoe erlauben, fo balo als müglid) mit $\mathfrak{S}_{0} \mathrm{l}_{3}$ wieber fultivirt werben.

\section{Sedizelintes Einapite?.}

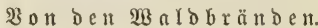

Man unterideibet Erofeuer uno Beftanosfeuer. Mit Den Fro: feuern, bie in Torf= uno Mloorbodent entitehen fönnen, wenn Şirten oder Waldarbeiter au troffenen Etellen befielben Jener anmadjen, bat ber Forit= 
mann in ber Regel nid)tร zu thun, wenn bie Bränbe gröfere Dimenfionen

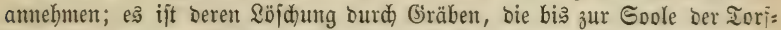
lager binabreidjen, Eałje der länolidjen \$olizeibebörben, benen fofort nach,

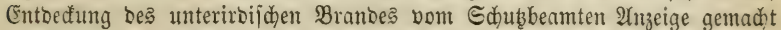
werben mus. Eofort nach Der Entîtehung entbeçte fleinere Erobränte

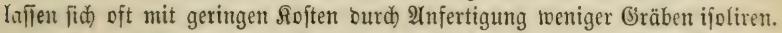

Tie Beftandsfeuer zerfallen in sanfeuer mo sipfelfeuer. Exptere, bei benen das Jeuer auf bem Boben fortlaufent, bon trodinem Grafe unb Saub, Moos, 2lbfallhols fid) näbrt, fino bie bäufiger vorfom= menton unt bie Jälle, in benten bas Rauffeuer am Moos ber Stämme

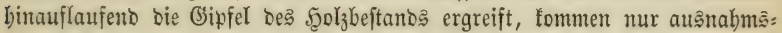
reife, bejonbers in jüngeren nod) nidht gereinigten Drten vor.

Beldye grope Berwüftungen bas Feuer in ben 2 Baltungen fijon verurfacht bat, ift befaunt. $2(m$ meiften fino bie $\Re$ abelbol 3 walbungen biefer (Sefahr ausgefert, boch fino aud) bie Raubholzwaloungen babon nicht befreit.

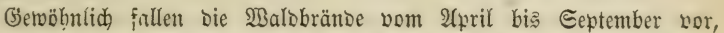

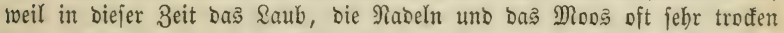
find. Doch hat man aud Beifpiele, baj bei trocener Winterszeit $\mathfrak{B a l}=$

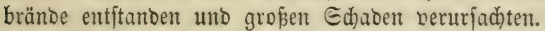

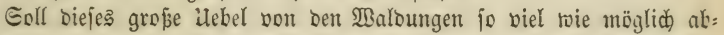
gebalten werben, fo mú man alles, was zu feiner Entftebung 2lnlaj geben fant, zu entfernen juchen, unb wenn befien ungeadtet ein Brano in $\mathfrak{B a l}^{2}$

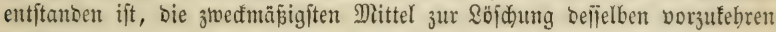
wifien.

Walobränbe entittehen aber gemöhnliç:

1). Durd Unopriditigleit,

2) Durd Bobleit,

3) Durd Eigennus แกเ

4) burd) $3 u f a l l$.

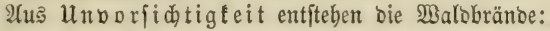

1) burd bie Şolzhauer, F̧irten uno andere im Malde be=

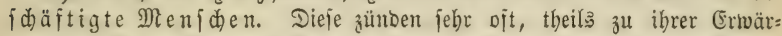
mung, theils zur Bereitung ifrer Epeifen, theils z̧u ifrem Bergnügen Jetter an, obne bafielbe mit bem \&aub uno Moos ober ben jonjtigen leid)t feuer: fangenten Materien auker Berbinoung zu jeb̧en, ober obne bie Borid t

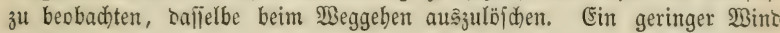
ift bann im Stande, bas Jeuer zu verbreiten uno groß́en Echaben anıu= riojten. (5s jollte Daber ein jeber, Der zu nabe bei einem Baume ober Diffidte, ober auf einem von brenbaren Materien nidjt genug befreiten

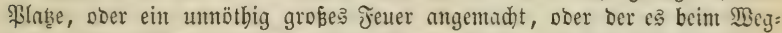

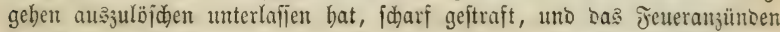
im Freien überbaupt mu bei falter ober feudter unb nafler $\mathfrak{B}_{\text {Bitterung }}$ geftattet, bei anbaltender Dürre aber allen Menichen unterfagt werben.

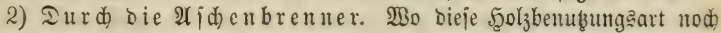
ftattintoet, wiro oft unglaublich) unvorfidstig mit bem Jeuer im $\mathfrak{B a l}$ ue um= gegangen und baburd) mand)er MBaldbrano veranlaf́t. (Es minfien Daher 
Dieje Seute ganz vorz̈̈glid unter 2Aufficht gebalten unb ihnen vom Förjter

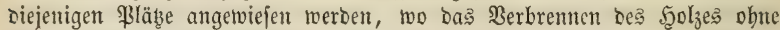
Gefaftr borgenonmen werben fant. In ber bürrent Enmmerszeit unb bei

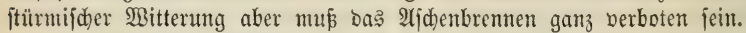

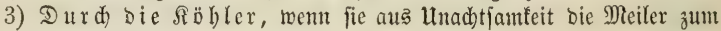
Berften bringen, Doer Den Roblenfubrleuten nidht böllig gelöjd) Soblen auflaben. Diefe berbreiten nadher bas Fenter Durd bic ganje Labung, uno wenn bam bie Jubrleute bie in Brano gerathene Maffe ausjoüüten,

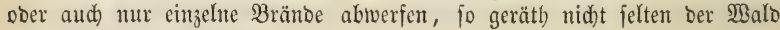
baburch in grope Gefahr.

Um biefes Unglüđ zu berfinocrn unt and bie Soblenmagajine zu fidhern, follte baher veroronet fein, Daßs bie Röhler biejenigen Rohlen, weldhe

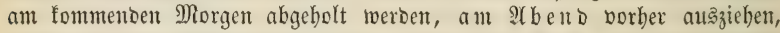
einzeln auf Den Geftübberand legen, unb in ser Sadht, wo jeber Funten leid)t bemerft werben fann, einigemal unterjud)en uno alles Feuer aus: löfdent follen. 2Utud follte jeocr Soblenfubrmant werbinolid) gemad)t werben,

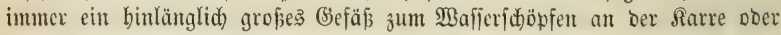
Dem $\mathfrak{B a g e n t}$ hängen zu baben, um fïh beffen nöthigenfalls bebienen uno auঙ bem nädjten Bache $\mathfrak{B a j j e r}$ holen zu fönnen.

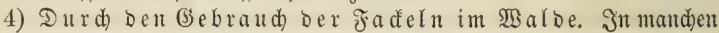

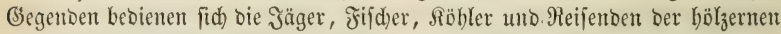
Fa dैeln, um bei näd)tliden Exfurfionen beffer fortfommen zu fönnen.

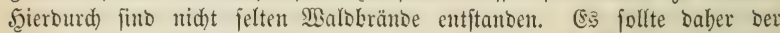
(3icbraud) ber Jacteln im $\mathfrak{B}$ al be ganz verboten, uno ftatt berfelben bie

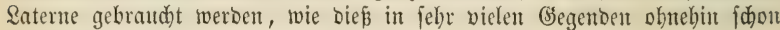
gewöbuliç ijt.

5) Durd) bie Iabafisadder. Dieje vertieren zutweilen Den brementen Gdibamm, uno berurjadjen badurd bei trodener Mitterung

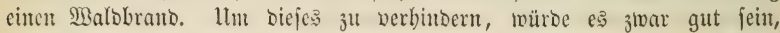

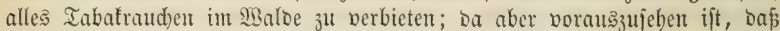
bießs Serbot niă)t gehalten werben wiro, fo möd)te es beffer fein, mur ben= jenigen zu frafen, Der im $\mathbb{B}$ ald a a s ciuter Bfeife obne Dedel ra a ut t.

6) Durd) Die Jäger. Dieje fdiejen zuneilen mit Bfropfen bon

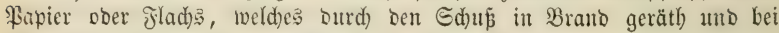
jebr trodener SBitterung gefäbrlid) wiro, went es in Saub ober bürte

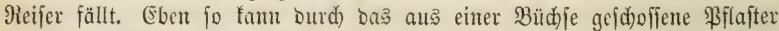
von Reintwand sas \&aub entzünoet werben. (Es follte baher bei trodener Jahreşzeit alles Edhießen mit Bapierpfropfen oder Etopfen von flad)s in Walde berboten, und jebem Эäger eingejhärft werben, bei trodenter Mit= terutg Pflafter pou Leber und Bropfen von Sälberbaaren zu bemuben, Docr wenigftens das brentente Pflafter auszulöfden, ivern er mit ber Büdje im 2 aloe gefdonien hat.

7) Durd bas Salnen ober Berbrennen ber Rafen auf Den an bie $\mathbb{B}_{a}$ ldugen grenzenden ober in benfelben liegen= Den Jeloern, ober burdh bas Berbrenten ober atbengen der becibe auf angenzenden 2 unfeneien, werben nidst felten Waldo 
fränte veranlapt. Eืs jollten Daber bergleiden Sperationen bei ftürmifoce Mitterung ganj berboten, uno mur mit ber Besingung geftattet werben, ๖a

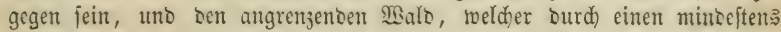
6 Jॅน breiten, bi३ auf bie Erbe vertwunbeten Etreifen abgejondert werben

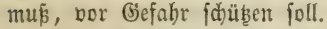

Durd Die Sofomotive oer Babnjüge. Den in neuerer Brit

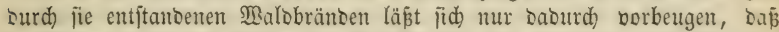
im Malbe auf beiben Seiten Der Bahnitreden bon feuerfangendem Material

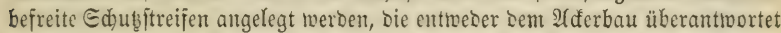

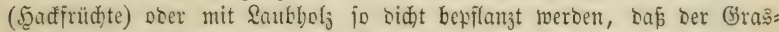

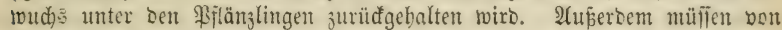
Den Eijenbahndireftionen die ftrengiten Befeble an ibre Sofomotiofübrer er=

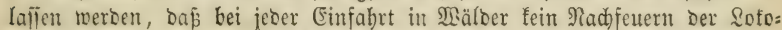

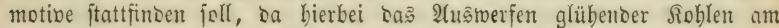

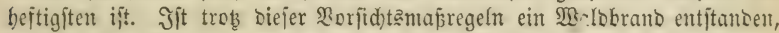

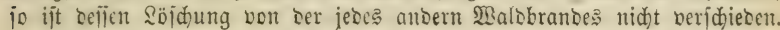

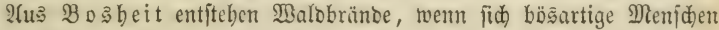
wegen erlittenter Etrafe ober aus fonjt einer Utradoe rächen, uno bem

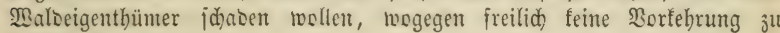
treffen ift.

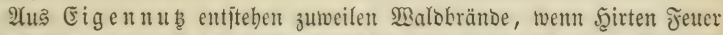

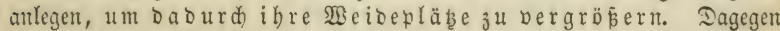

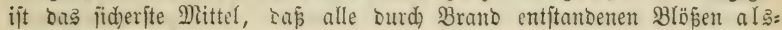
bals in ftrenge fyege genommen, fultivirt, unt erjt Lann zur Meibe wieber

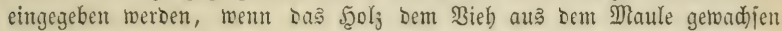
ift. linto

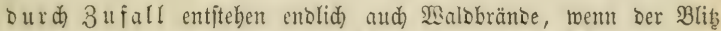
Bäume anjünøet, soer went von benadbarten bremtenoen (Bebäuben, ober auf jonft eine zufällige 2 (rt feter in ben Malo fommt.

Iie Mittel, um Baldbränse zu berbinbern, ober ibre

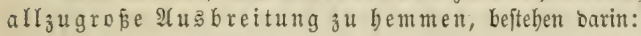

1) Dáp von Eeiten ber Direftion die borbin angefübr= ten $\mathfrak{B}$ eroronungen erlafien werben;

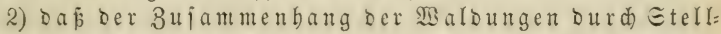
wege ober Edneifen unterbroden, aljo ber Bald ourd) Sdueifen in Jagen ober Diftrifte abgetheilt wirb;

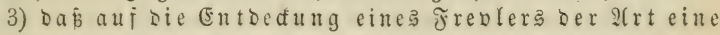
gute Belobung gefebct werbe; und

4) Dap Die Jorftberienten bei trofener $\mathfrak{B}$ itterung beu Balo doppelt fleipig bejuden, und bie barin arbeitenden Meniden vor ङdaben warnen.

Eollte aber beijen ungeadtet ein Branto in Den Saloungen entiftehen, jo fint folgende

bie beften Mittel, um $\mathfrak{B}$ albbränbe zu

1) Bei Brand in einjelnen hohlen Bäumen ift e⿱乛龰 oft

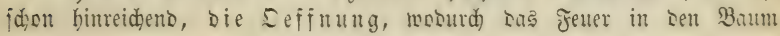


gefommen, mit Rajen feft zu berftopfen. Das Jeuer erlijdt aldann jogleid, uto ber Baum faum oft nod) lange begetiren. Went aber ber Baum aud oben Söder hat, fo fann burd) bas ßeritopfen ber unteriten Definung bas Jeuer nidyt gebämpft werben. In biejem Falle mus man einen fold)en

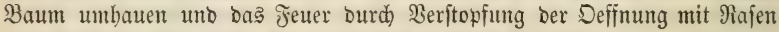

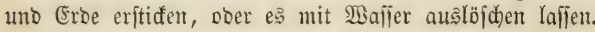

2) Entitebt aber ein Brand im \&aube und Moofe ober in ber geide, fo lalle man bas Jeuer mit belaubten 3roeigen entweber a usidlagen, ober man lafie einen zwei bis brei Edyritte breiten Etreifen, fo nah rie möglid) am Jeuter, unt bejonbers auf ber Seite, wo fid) bas Feuer binzieht, von \&aub, Moos, ફ̧eibe unb allen brembaren Materien $b i_{3}$ auf bie munbe (Erbe befreien, bamit bas Feuer nidt weiter um fich greifen uto auf Dem begrenzten Diftrifte nachber ausges

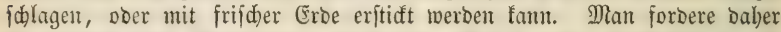
Die bentabarten Gemeinden, Şolzhauer, Söhler unb alle Menjchen, bie man in Der Eile zulammenbringen fanm, Durđ̆ Eilboten uno Sturmläuten

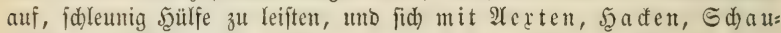
feln und $\Re$ eden beim $B$ rand einzufinden. Bis zur Antunft biefer

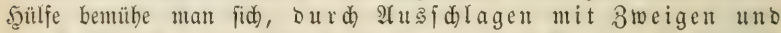
Durd) Megidarren Des Saubes un bes Moofes bie 2 usbrei= tung bes feuers fo viel wie möglid $3 u$ verhinbern. Sit aber şülfe an= gefommen, io ftelle man bie Seute auf berjenigen Seite, wo es am nöthigiten

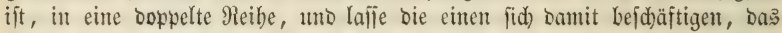

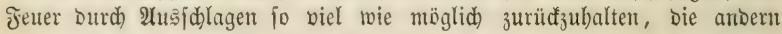
aber lajfe man in möglidjfter Eile einen twunben oder pon brembaren Materien befreieten Streifen zieben. Sollte biejer Streifen borerft and mur einen Sdritt breit fein, fo wiro er bie fortpflanzung eines nidjt febr grojen Jeutes fdjon bemmen, uno ex faum nadber nod breiter ge=

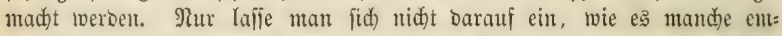
pfoblen baben, einen. (j) raben um Den Brantoplas zieben zu lafien. Diejes bautert alfzulange, uno ber bald gemadte rumbe Streifen bilft eben fo gut, als Der Graben. Sur in Dem Jall mus cin (Sraben gejogen merou, wenn bie Erde felbft brent, wie foldes in torfigen (bes

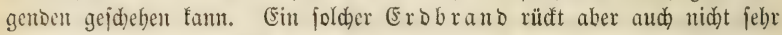
id) nell fort; und wem erft bie a uf Der Dberflä de bremnenden Materien, Durd) Anwentung ber vorbin gejeigten Pittel, bas Jeuer nicht weiter ver: breiten fömnen, fo bleibt binlänglid) Beit übrig, burd) Biebung eine (3rabens aud) Dem Erobrande bas Fortrücen zu verwebren.

3) Solfte jid aber bas Jeuer an ben Bäumen in bie 5öbe gezogen und ilfre atefte uno (sipfel fdon ergriffen haben - aljo aud oben fich fortpflanzen, fo mus, auper ben vorbin

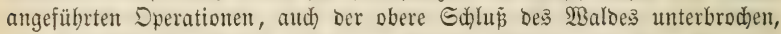
aljo eine Sdnteije gebauen, uno bie zu fällenben Etänme mit ibren $\Re$ ronen nad) Dem geuer bin getorfen werben. Da aber bas Şauen ciner folden $E_{(d)}$ eije bei aller möglichen Inftrengung viel Beit erforbert, fo barf fie nidyt zu nabe bei bem bremtenten Sgolje, jontoern fo weit babon entfernt angefangen werbell, baj bie Afrbeiter bis zur Antunft be马 Jeuers 


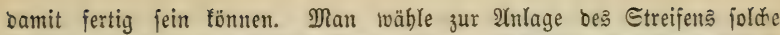

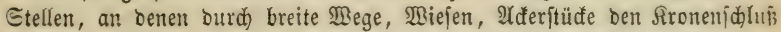

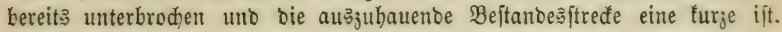
Der förrfter barf bei einem folden Unglüa mur nidht auper fafīung fommen,

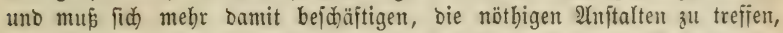

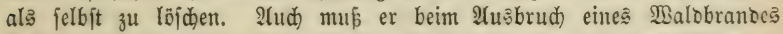
feinen Borgejeşten jogleid) babon benadridłtigen, uno wenn bả feuer ge:

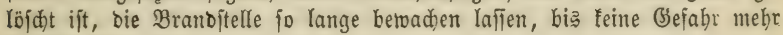
зu befürchten iit.

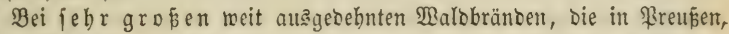
\$olen, Ruplano zc. nidjt jelten vorfommen uno oft viele taujeno Morgen Walo berwüften, find alle vorbin genannten Mittel nidjt twirfjam genug.

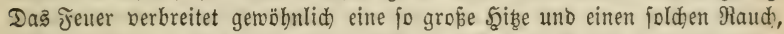

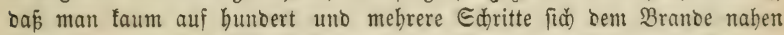
fann. In einem jolden Falle mú Dem Feuer ourd Feuer Grenjen gejeşt merben. Dię gejohieht auf folgende 2 rt:

Mebrere hunbert uno im giotbfalle Taufenoe von Edritten bom feuer entfernt uno zwar um fo weiter vom Feuer entfernt, je rajoter ballelbe fortrüđt, ftellt man auf ber Geite, wohin bas feuer fid) fortpflanjt, eine Reibe Menjwen an, uno läpt burd bieje einen jdmalen Etreifen Sgeibe, Moos zc. bermittelit bieler fleinen Jeuer abbrennen, bamit Das grof́e Jeuer, wenn ę bis zu biejem Streifen borrüät, teine গabrung mebr finbet uno nidbt tweiter fid fortpflanzen fann.

Das fleine Jeuer auf ben Etreifen läp̈t fidh, menn Menichen genug ba fino, Yeid)t in ben befitimmten Grenzen crbalten, uno ber bis zur $2 \mathfrak{A n}=$ funft Der groß̄en Feuermafie abgebrannte Etreifen verhinbert unfehlbar bas toeitere Fortrüđen bes grojen Branbes, wenn ber abgebrannte Etreifen nur einige Ruthen breit gemadht werben fann, ehe bas grope Feuer heranfommt. Man nent bieje Dperation: ein begenfeuer madjen, uno jie ijt bas einzige Mittel, um fehr grob́e Malobränלe zu löjden.

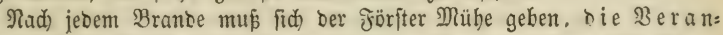
laffung bes sisalobrantes ausfindig zu maden, unb ben Etrafbaren jeinem Borgejeķten anzeigen.

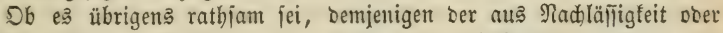

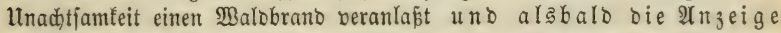
bavou gemadt hat, hart zu ftrafen, uno benjenigen, welder von einem entbedten $\mathbb{B} a b_{b b r a n b e}$ bie erfte 2(nzeige madt, gut zu belohnen,

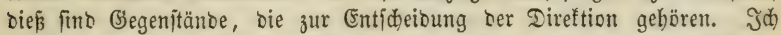

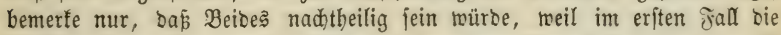
Walobränbe zu lange verbeimlicht, uno von bem $\mathfrak{B}$ eranlafier nie angejeigt werben, uno weil im andern Fall Mand,er burdh bie gute Belobnung gereijt werben fönnte, felbft feuer anzulegen. Man firafe baher ben Unwor=

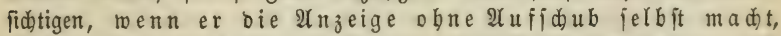

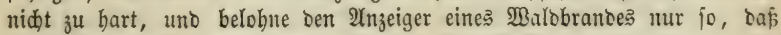
er für feine Bemübung faum entidäbigt ijt. Wollte man aber eine joldje Anzeige ganz unbelobnt lafien, fo würbe mander, ber einen Malobranto entifteben fieht, eకs зu läftig finden, bie 2Inzeige bavon alsbalo zu madyen, 
und lieber ben Wald berbrennen fehen, als eine Stunbe $\mathfrak{B e g e s}_{\text {weit }}$ ü laufen, um Şülfe herbei zu rufen. Die Beroromung, baf Jeber, ber einen $\mathfrak{B a l b b r a n b} b e m e r t$, und nidt alsbalo anzeigt, ftreng geftraft werben foll, ift zwar aud zwedimäpig, fie wirft aber nod fiderer, wenn man bentjenigen, ber fie befolgt, jebesmal aud ben $\mathfrak{B e g}_{\text {bezablt. }}$

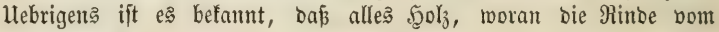
Fener ftarf gejentt tworben ift, abjtirbt. Man mus baher bergleidjen Di= ftrifte, went fie mit jungem Saubbolz beftanben finto, alsbalo nabe über

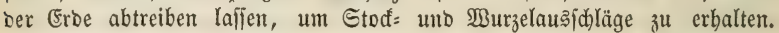
Wo biefe aber nicht erfolgen, mus burch) tünitlidye Saat uno Pflanzung io balo toie möglid) nad)geholfen werben. Nur barf man mit bem Umbauen untenter gejentter biafrindiger Riefern ober (Eid)en, ober anderer alter Bäume nidjt zu voreilig fein. Diefen fdabet oft eine foldje Sengung, wenn das feuer fduell fortrü đete, nidjt, uno fie fönten nadber zur natürlid)en Befamung beș verbraunten ßlaß̨es noch mitrirfen. Wenn aber bie Rinde untenber bis auf Den Splint berbrannt ift, fo fterben

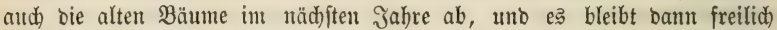

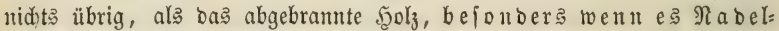
holz ift, alsbalo umzuhauen uno zu benuß̧en, bamit bem Borfentäfer feine (belegenheit gegeben werbe, fich in bergleid)en Stämmen zu vermebren. Dod) unteriuche man vorerft genau, ob bie Safthaut burd) bas Jeuer gelb getworben ift. Wäre bief ber Fall, fo fterben bie Beftänbe gewiß ab. Jit aber bie Safthaut nod) reiñ, fo übereile man bas 2(bhauten bes burdige:

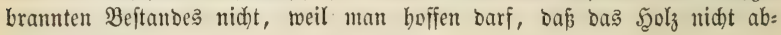
fterben werbe.

\section{Sieferzefintes sapitel.}

Bon Heberidd wemmung Der $2 B$ aldungen.

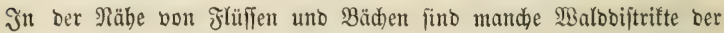

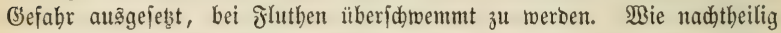

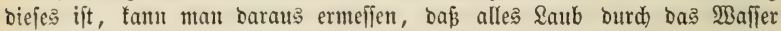
weggefübrt wirb, viele Bäume burd) Das $\mathfrak{B a f f e r}$ unb ben Eisgang umge= brüđt ober bejdäbigt werben, uno an Denjenigen Srten, bie feinen 2 bffluß haben, Sümpfe entiteher. Sommen bergleiden Ueberidwemmungen oft

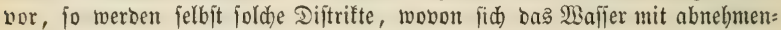

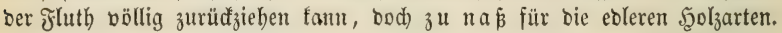
Diefe fterben baun nadb uno nad) $\mathfrak{a b}$, uno es treten weidje fdjledtere Şölzer an ibre Stelle.

Auper biejer gibt es nod eine $\mathfrak{A}$ th Heberidinemmung ober bielmebr D urd) wäfferung, bie aud auf erböbten Puntten ftattfinben famn. Sie ide eint weniger gefäbrlid, ift aber oft nod) nad)tbeiliger, als eine wirl=

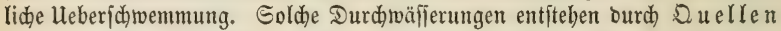

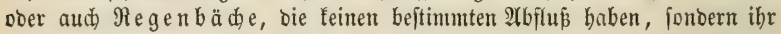
Wafler in ber oberiten (Erofdichte eines Diftriftes verbreiten uno ben 3oden

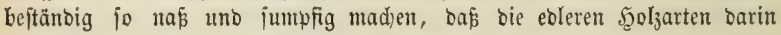
abiterben ober gar nidht auffommen fömen.

Wir baben baher zu unterideiben: 
1) wirflide temporäre lleberidyemmungen unb

2) ankaltende oder temporäre Durdioäferungen.

Eollen sieje Walbubel abgementet ober entient merben, jo muई man bie Urjache ober Entîtebung serielben з̆ erforiđjen uno wegjuräumen,

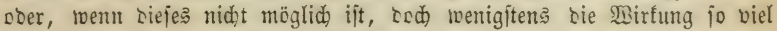
es geicheben fant zu entträften fucten.

1) Bon ben temporären wirtliden leber fdwemmugen.

Sienn ein Malobiftrift von einem flup ober Bache zureilen über= fa)memunt wirb, jo muß ju fluthjeiten 2 dhtung gegeben merben, um bie \$unfte zu erfahren, two das Wajier jeinen 24 șeg nimmt ober überfällt.

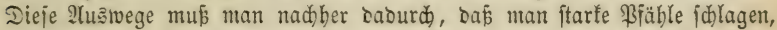

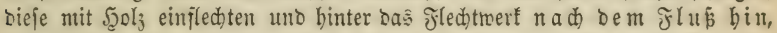
einen fejten Rajendamm madjen läpt, zu berjecrren fudjen. Eollte aber Die Uleberidinemmung Defimegen entîtehen, weil ber fleine glup ober Bad)

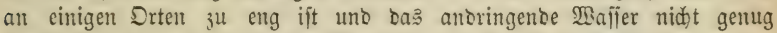

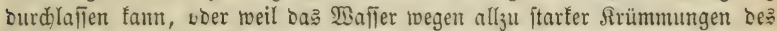

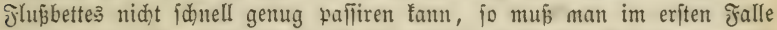

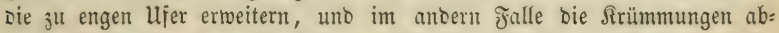

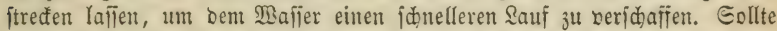
aber alles biejes nidjt mëglid und bie Heberidnemmung unvermeiblid fein, jo mus man menigitens aus ben Berticjungen bes ber Ueberidwem=

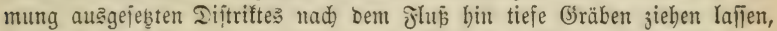

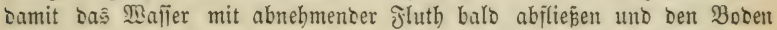
nicht berjumpien fann.

2) Bon den temporären und ben angaltenden Durd)= toafierungen. Beriumpungen.

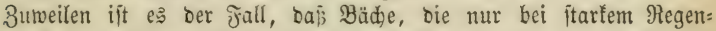

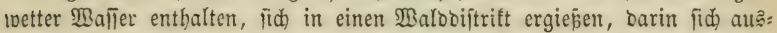

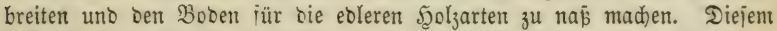

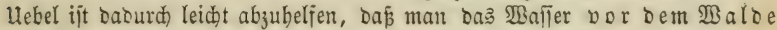
in einem tüdtigen Braben auffängt, uno in biejem (sraben ourd) ben Walo in einen benachbarten Bach fübrt.

Entjteht aber bie Durdwälierung aus $Q$ uellen, bie oft einen Dijtrift

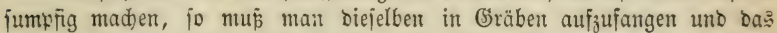
Mafler abjuleiten juchen, ehe ę fid) in bie Sberfläche verbreitet bat. Eollte man aber bie Duellen nid̆t finden fömen, ober eine ganłe frtädhe allent= balben bamit berjehen jein, fo mus man burd) bie gröpte Nertiejung, ober

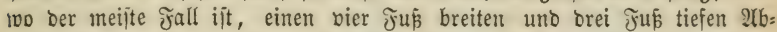
zugsgraben madjen, uno in Denjelben idief einfallende હdlibgräben verfertigen laîen, um bas überilïfige Waijer abjuleiten, uno den Boden 3̧ur Şolżultur braudjbar zu madjen.

Jreilid) foftet bie 2rbtrodnutg eines folden Brudes jutweilen mebr,

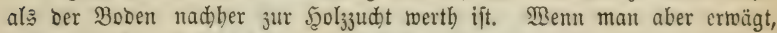

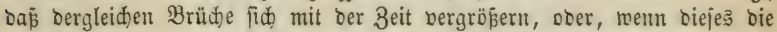

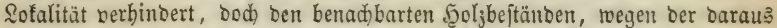
aufiteigenden falten Nebel, nact)theilig werben, fo wiro man bie 2tbtrod: nung fajt immer febr nübllid, uno nötbig finoen. 


\section{Didifzefintes siapité.}

$\mathfrak{B}$ on der $\mathfrak{B}$ e.r $\{a \mathfrak{n}$ bun $\mathrm{g}$.

Maldungen, bie an Feloer grenzen, welche aus Flugano befteken,

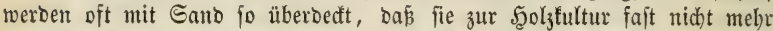
braudbar finto; uno läng ber Ditfeefüfte habe id bebeutenoe Maloftrecfen gefunden, bie fo jehr verjandet fint, baj 20-30 Mitr. hohe Riefern jeşt nur nod) 2-3 Mtr. mit ibren (Sipfeln aus bem Sanbe hervorragen. Эa, es gibt bort an einigen Stellen beträhtlidhe Sanoberge, bie mit jebem Jahre weiter fortrüden uno bie vorliegenden Waldungen ganz bedecten. Mebrere taufeno Morgett $\mathfrak{B a}$ alo find unter bem Ganbe fojon begraben, uno feine menjoliche Sraft ift im Stande, biejem Hebel $\mathfrak{B i b e r f t a n d}$ zu thun. ভ. Ih. Sgartig uno v. Bannewif über Dünenbau.

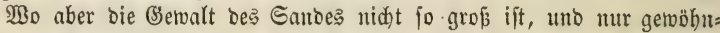
lidje Sanbididlen in uno an ben Malbungen fid) finden, ba fann ibre

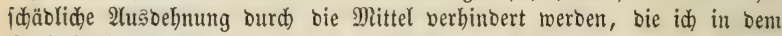
Rapitel über $3 u b e r e i t u n g$ ber Blößen zur Jeolzfaat im 2. Bande beidrieben babe.

\section{Oृ̌enrzefintes siapifer.}

Bon ben Sturmwinder.

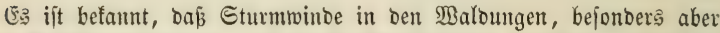

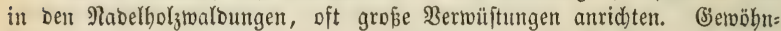
lich liegt bie Urjadje bavon in einem Fehler, Den Der Förfter bei ber Şaunng feiter Sd)läge gemad)t bat. Dod) gibt ę̧ aud) Fälle, wo ber Jorftmann

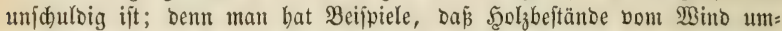
geriffen worben fino, bie nod) gar nidht angebauen waren, uno baf ein ftarfer Mirbelwint in ber Mitte eines volffommen gejd)loflenen Bejtandes Bäume umgetworfen uto große Süden gemad, hat.

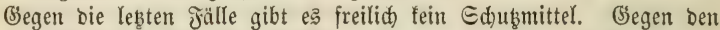

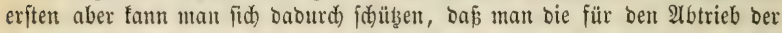

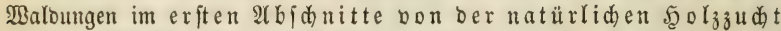
gegebenen Regeln aufa genauefte befolgt, uno bie $\mathfrak{B}_{\mathrm{e}} \mathrm{ft}=$, Sü $\mathrm{b}$ we it = un

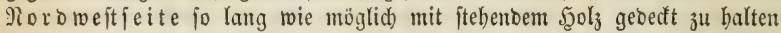

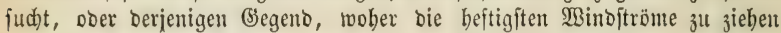
piflegen, immer entgegen bauet.

Entitebt aber befien ungeachtet ein joldes Unglüct, fo müfien bie um=

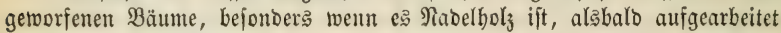

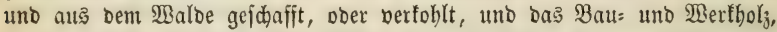
wenn es nidjt balo aus bem Baloe gebracht werben fann, gejchält ober bejoflagen, unb auf Unterlagen ober in Wafjer gebradht toerben, bamit eక nid)t verberben uno aud ber Borfenfäfer barin fid nidjt vermebren fann. 24ư muई ber Föriter bafür jorgen, baß bie aus ber Eroe geriffenen Stöde zeridslagen uno berfohlt ober fonjt bemubst, uno bie entitanoenen Söder fo viel wie möglid) auggeglident ober geebnet werbent. Sollte man aber bie Stöffe nidht benutgen $\mathfrak{k}$ önnen, fo müffen fie fammt ber baran bängenden Erbe alabalo roieber zurüdgebrüät werben, weil ę̧ fonft in einem 
fehr troden ift, uno ber Eduee wie $S_{\text {and }}$ ober bei ftarfem Mino berab: fällt, hat man biejes Uebel meniger zu fürdjten. Wie nadtheilig ber Duft= und Sdneeanbang für die Waldungent werbent fann, wenn er unge: wöbnlid) ftarf $i$ if uno lange anbält, Davon fann fid) nur berjenige überzeugen, weld)er Bjelegenbeit gebabt hat, ben Erfolg felbft zu fehen. Eine Menge erwadfenter Bäume wiro baburd ibrer 2rejte uno (sipfel

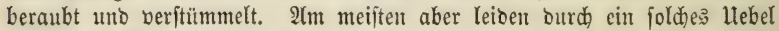

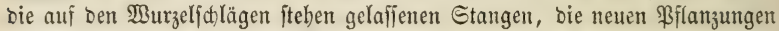
uno bie jehr bidat gejdlofienen nod) geringen Stangenorte. Dieje werben Durdh bie Raft bes Duftes uno bes Ed)nees zumeilen fo nieberge:

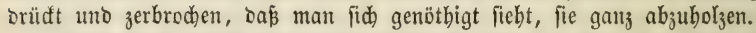

Dap gegen biefes Uebel fein Mittel möglich fei, wiro man leidat er: mefien. Illes, was der Forftmaun bagegen thun faun, beftebt barin, da pa er in Bsegenden, wo biejer Uebelftano oft vorfommt, feine Scolzarten an= jiehe, beren 2refte gerne brechen, ober an beren langen Nabeln ber Duft

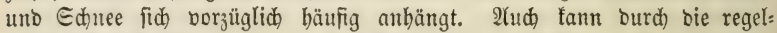
mäpige Durdforftung ber jungen Waloungen bas Uebel fehr gentintert werben, weil alşann bie Bsipfel ber Stämme bei geringem Wino fiđ

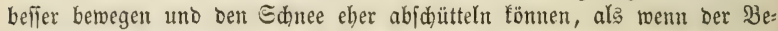
ftand allzu georängt iit.

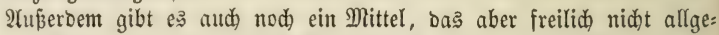
meit im $\mathfrak{B a l b e}$, fondern nur bei $\mathfrak{B}$ flanzungen uno einzelnen Stangen, an Deren Erbaltung viel gelegen ift, angewendet werben fann. Diejes bejteht

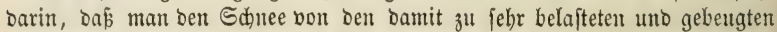
Stämmden fo balo wie möglid) abidjütteln läpt. (Fin einziger mit

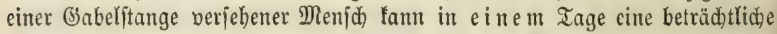
Blantage ober eine jebr grope $2(n z a h)$ auf Den Murzelfablägen gebeugter Stangen burd) $\mathfrak{A}$ nfto $\bar{\beta} \in \mathrm{n}$ vom Berberben retten, uno es würben viele

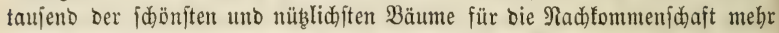
erzogen werben, wenn man biejes fehr woblfeile Mittel im Jall ber Noth sumenten wollte, woburd) id viele junge (Eid)en uno anbere Gtangen vom unfehlbaren Berberben gerettet uno oft felbit mit Şano angelegt babe. Sollten aber fallanfe $\& a$ ubbolzitangen vom Sduree gebeugt worben fein uno fid nachber nidjt wieber aufridten fönnen, fo ift bas befte Mittel, fie in Der Mitte des $B$ ogens entzweihauen zul lafien. Das Stamm= cube nirb fid) hierauf fajt immer ftreden unb eine neue frone austreiben. Bäre bie Biegung aber fo ftarf, baß́ aud) nad) bem 2 (bhauen bes oberen Theiles bas Etammende fid nidbt wieber aufridten fann, fo bleibt fein anderes Mittel übrig, als bie Stange an ber Erbe abzubauen, uno ben

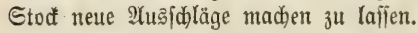

3war nidyt fo jäblid, als ftarfer Duft uno Edneeanbang, aber Dod) aud febr nadhtheilig für bie Walbungen fann ein ftartes Şagel= wetter werben. Sanze Strefen werben zutweilen babei eines gropen Theils ober all ihrer Blätter unt bes Samens beraubt, ober an ber Rinto bejääbigt, unb bie ganı jungen Pflanjen zeridmettert. (Bewöbullid ift ein ftarfer Eturmmino Der Borläufer oder Begleiter biefes llebela, uto menn beioe jufammentwirfen, fo fömten bie Folgen äuperft traurig werben. Siegen 
biejes ntebel fant ber forftmann freilich gar nidjts borfebren. Sit es ent=

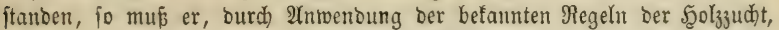
ben verurjachten Sdabent fo biel als möglid) wieber gut zu madjen fudhen.

\section{马̇weintozmanzigftes sapitel.}

Bom Sdyaben burdi a finerorbentlide Dürre.

Der Edjaben, tweldjer burd) auperorbentliche Dürre ober lang an:

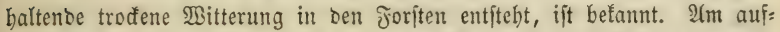

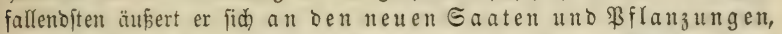
befonbers wem fie an Eommerjeiten ober auf magerem Boben gemadht

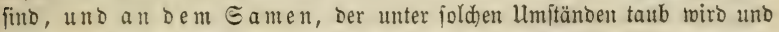
abjält. Meniger auffallent, aber bei toeitem gröper ift bingegen ber Ed)aden, ber burd) geringeren 3 utwa 5 an bem ganzen Sgolz= beftande erfolgt.

(jegen bieje: Ulebel ift nun freilid im Allgemeinen fein Mittel zu finton. Stlles, mas ber Föriter thun faun, befteht barin, baj er bie ber

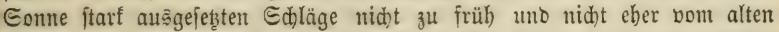

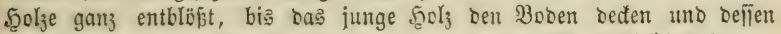
2Uatroctnen einigermapen verhinbern tunn. Ferner, baf er foldhen jungen Pflanzen, die mebrere Jahre lang jehr flein ju bleiben pflegen, uno baher nidht viele Dürre ertragen föment, surd) Bebecfung mit Reilig, ober burd) mitunter gejäete fonnellmadjente uno vielen Edjatten gebenoe Sgolzarten, Sd)uts zu verfidafien fudt, und bapi er bie Bflanzungen, wo es ge:

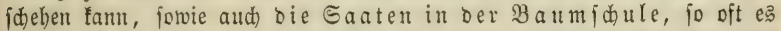
nöthig ift, begieß̄en und un bie erft gepflanzten Stämmdien eine biffe

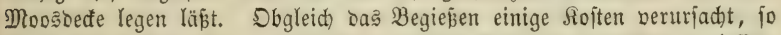

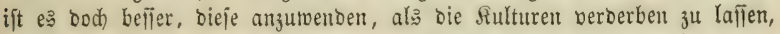
uno fie nadber mit nod) bei reitem größeren Roftenaufwano wieber bon neuem maden zu müīien.

\section{Dreuntozwanzigftes Sapifel.}

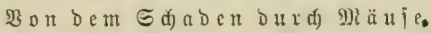

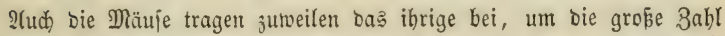
ber $\mathfrak{B a l}$ aibel zu vermebren. In manden Jabren finot man fie io zahls

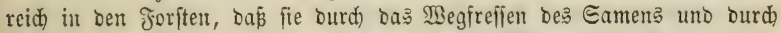

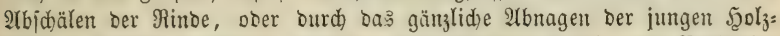
pflanzen äupierit nadtheilig werben. Die fö̈njten (Eid)el = uno Buḑenbe: famungen werben zumeilen burd) ben Mläujefráp ganz ober jum Theil zer=

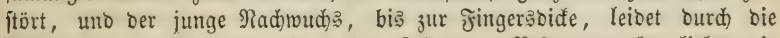
Befräßigfeit biejer Thiere oft gropen Єd)aben. Bejonbers aber licben bie

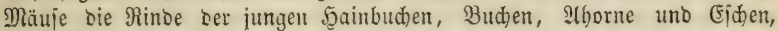

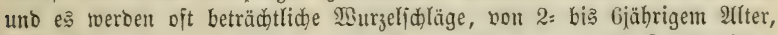
jo ftarf benngt uno bejdült, bap bie Scoen abjterben uno bie Stöffe wieber

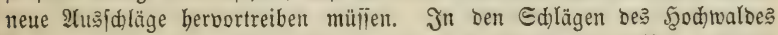
finbet man fie an ben Gonnenfeitent uno überbaupt ba am meiften uno am 
¡däblidften, wo ber 2Hufwudes 4= bis 8jährig uno fehr gefdlofien ift. Jüngere ober ältere, uno alle freiftebenden Pflanzen fino weniger biejer Befdäbigung ausgefebt, wie ich jebr oft zu bemerfen (Belegentheit hatte.

Bill man biejem llebel entgegenarbeiten, jo müfien alle Thiere, bie

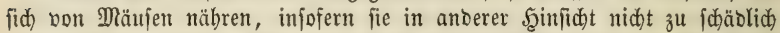
fino, gehegt werben. Borzüglich mup man bas Edwwarzmilo, bie Э̃gel uno bie (Eulenarten, ben $S_{\text {d) }} \mathfrak{h} u$ auszgenommen, ftreng hegen, uno aud) bie Findde, weldhe eine unglaublid)e Menge von Mäujen vertilgen, nidjt allzujebr zu berminbern juden. 1

2Aud) babe id bie Bemerfung gemadht, daßj gróвe zabme Sdweine Mäuje töbten uno frefien, und baj Der Betrieb ber $\mathfrak{B}$ Baldungen mit ftarfen Sd)weinen zur Berminbenung ber Mäuje ebenfalls beiträgt. 2Alle übrigen

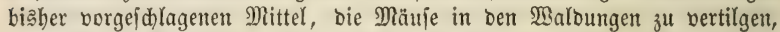

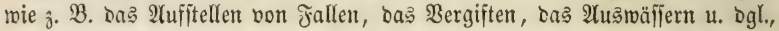
fino im Bropen nidht anwenobar, unt fönnen mur in Baumidulen ftattintoen.

Sollten aber aller angewanoten Borfid ungeadtet bie Mäuje über: bano genommen uno junge Stämmden ober Soben benagt uno geifaält baben, io ift bas befte Mittel, dieje aläbalo abidnneiben und bie Stöde neue Soben austreiben zu Yafjen, weil bie bejwäbigten Pflanzen uno 2 Uus: fa)läge fonft lange Beit fränfeln uno endlid vielleid)t ganj eingehen. Dieję Albidneiben ijt aber nur alsoann nötbig, wenn auf einer Stelle fo viele Soden bejdäbigt fint, ba purd ibren Berluft in ber Folge nod be merfbare leere Stellen entíteben fönnten. Wären aber nur einzelne uno

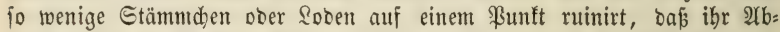
gang in ber Folge feine Nerminberung bes . Wolyertrags betwirfent fann, fo pare man bie Roften, welde bag $2(b j$ dneiben verurjadt. Dergleiden fleine Süden zieken fid) bald wieber zu, uno wenn fie bie Gröke von 1-2 Mtr. ins Suabrat nid)t überidfreiten, fo wiro baourd ber Scolzertrag bes Waloes in ber Folge um nidhts bermintert. Eben fo menig ift ę nöthig, einzelne gefdälte Soben in ben Rieberwaloungen abidneiben ober abbauen zu lafien, wenn nod) mehrere nid)t geidälte auf bemielben Stode ftehent. Sino aber alle Soben auf vielen Stöđen ganz gejdält, fo ifit ę nüb̧lid, fie abbauten z̆l laffen, un einen neuen $2(u s ̧$ )

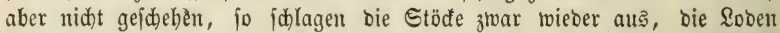
bleiben aber in ben eríten Jahren alębann viel fleiner, weil bas gefdälte

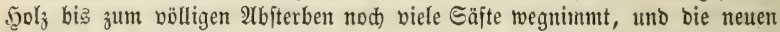
Soden alşbann fpäter hervorfommen, als wenn man im grübjabre bie ge:

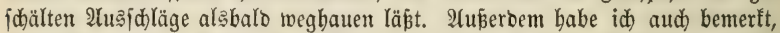

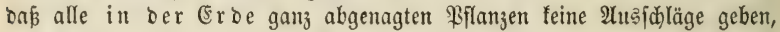
uno dape bie nahe über ber (Er be gefdälten Samenloben getwöhulid erft im zweiten Frübiabre nadber neue Alusjaläge maden. ${ }^{2}$

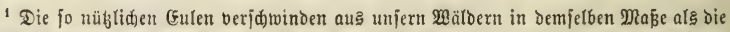

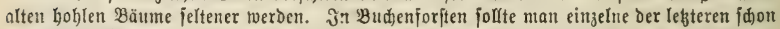

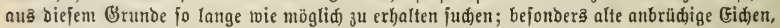
bie im $\mathfrak{W e r t h e}$ toenig mebr verlieren tönnen, da fie fich ant längften erbalten. D. 5 .

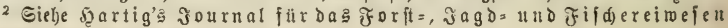
vom Jahr 1806, Seite 585 . 
Sin widtiges Mittel, bem Mäujefrá auf jungen Edonungen ent=

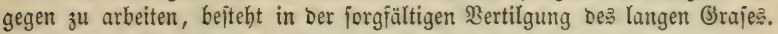

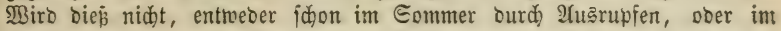
Serbite nach bem eriten Frofte burd) $\mathfrak{A}$ (usharfen weggej(hafit, io legt es fid nieber unb bilbet eine Dedfe, burd bie ber Edhnee nidht auf ben Boben fallen fann. Tritt mun Edneewetter ein, fo jiehen fich alle Miäuje aus ber Umgegeno an jolden Drten zujammen, uno la lien oft nidht eine junge Şolzpflanze unbejdäbigt.

She id biejes Sapitel idliese, mur id nod eine Borididt empieblen, Die mir, wenn id́) biele Mäuje in ben Foriten fpürte, jehr genüb̧t hat.

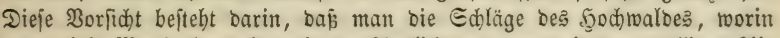

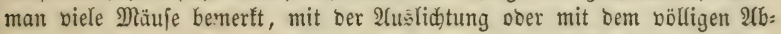
trieb ber Camenbäume fo lange verjojont, bi३ bie Mäujeplage aufbört.

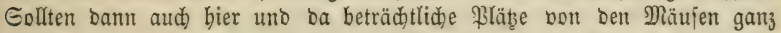
ruinirt werben, fo fönnen bieje leeren Stellen bou ben Gamenbäumen bod

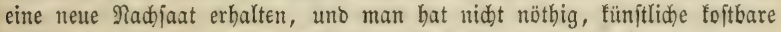
Mittel зu ergreifen, um bie Ed)läge vollwüdfig j!t maden. ${ }^{1}$

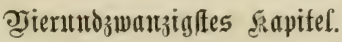

Bon Dem ङdaben, Der ben Wraldungen burd) Vögel zugefugt twirb.

In mandjen Jahren finden fid zur Etridyeit io viele Finfen,

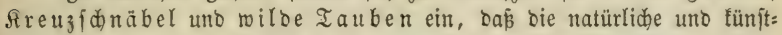
liche Bejamung ber Baloungen Daburd leibet. J(t) habe Jabre erlebt, mo im Epätherbite ooer im Frübjabre fo enorm viele Finfen geítrichen

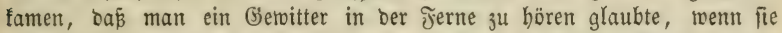

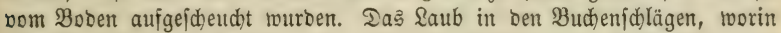
fie fich geröbnlich aufbielten, war wie von frifhlingen umgebrodien, uno to fie mehrere Tage lang berweilten, wurben alle Budheln fo rein aufge: zehrt, baß faum bie Ifrt bavon übrig blieb.

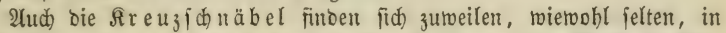
grofer Menge ein, uno verzebren vielen Nabelholjjamen uno Blüthentnoipen, uno bie wilben Iauben fallen in manden Jahren fo bäufig auf bie

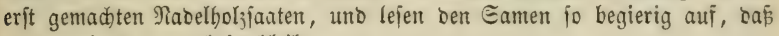
nur wenig bavon übrig bleibt.

(Begen ben Sdhaben, melden biefe Bögel verurjachen, fann man fith nur baburd ficher ftellen, Daj man bie Eaatpläb̧e einige Tage lang be: machen uno bie einfallenben Bögel verfdeuchen läß̄t. Da ein foldher fall nur felten borfommt uno ber Strich in wenigen Iagen vorüber ift, jo er= forbert bie Bejhübung ber Eaaten einen äuperft geringen 24ufwanto, ber

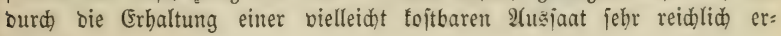
jeb̨t roiro.

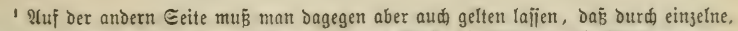
längere Beit übergehaltene Gamenbäume und Deren Mlaft, bie झläuje in bie Sd)lïge gejogen

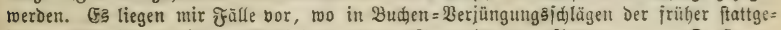
fundene Mäufefraß̄ mit Dem 2btriebe der lebten Eamenbüume aufgörte.

D. 5. 
Auberbem fकabet auch bas 2 (uergeflügel bem SBalde baburd),

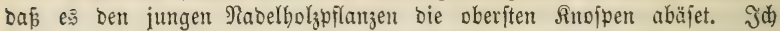
habe junge jechs: bis adjtjährige Jidhtenbeitänoe gejeben, worin beträd)t=

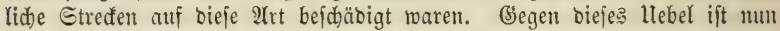
freilich fein befjeres Mittel, als ben 2Utuerwilbitano in cinem foldhen Jalle

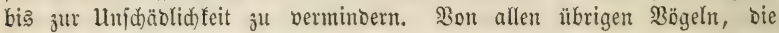
Gamen ober Sinofpen frefien, bat ber forftmann feinen io gropen গad):

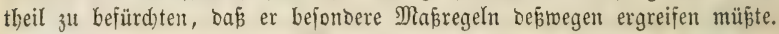

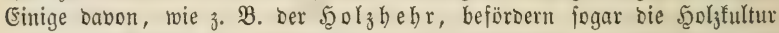

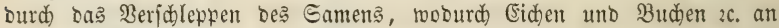
Drten auffeimten, bie olne Dajein Der Seber mit biejen Ggoljarten nidht toürben bejebt worben fein.

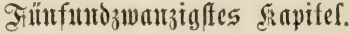

Pon bem Gduden, Dex ben 2 aldungen burd Sinjeften 3 u= gefilgt wirb.

Eine befondere 2 ufmerfiamteit mub Der Joritmann, bejonbers in

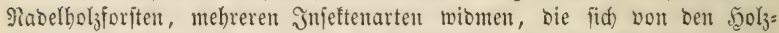
pflanzen ernäbren und, wenn fie ourd) Ilmitände in ibrer Bermebrung be:

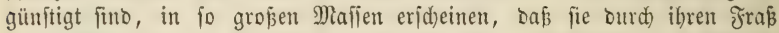
ganze Baloungen zu vernichten in Etande find. Bejonbers groß́ find bie

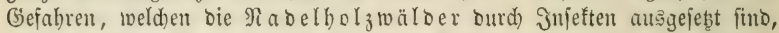
Daber in ibnen Der Forftmann bejonbere ?Iffmerfiamfeit auf bas :orban= Denjein un Die Bermebrung biejer Ihiere vertwenden mus, die ibm zu biejem 3tocte nidi)t allein ibrem 2 njeben nad in allen 3uftänben ibres Sebens als Fi, Maupe ober Miade, als Buppe uno als ausgebildetes J̃n= jeft befannt jein müfien, jonbern bon beren Sebensweije er fid auch eine

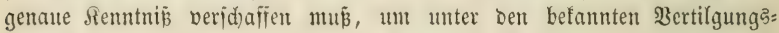
mitteln biejenigen, und bieje jur redten Beit in Antwentung bringen zu fönnen, weldse am meijten geeignet find, dem llebel vorzubeugen ober ibm Sinbalt zu thun.

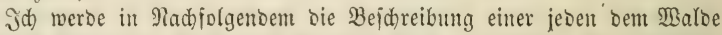
bejonbers ichäblichen Injeftenart in allen ibren 3uftänden, Deren Sebens: woife, 24ufenthaltsort, Fraß̄, Bermehrung zc. uno Die Dagegen zu ergreifen= Den Borfebrung: uno Bertilgungsmafregelı mittbeilen.

\section{I. ferillde Der firfer.}

A. Ilnter Den $\sigma$ dy metterlingen.

1) Der grofe Riefernipinner, Bombyx Pini. Tab. II. fig. 1. $\mathrm{a}-\mathrm{d}$.

Eizuftano (fig. 1. a). Die grauen, fehr bartidaligen, auf einem Enoe mit einen idwarzen ßünftben bezeidneten, etwas länglid = runben

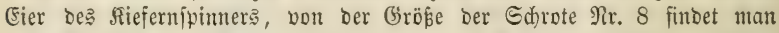
vom Mai bis zum Eeptember theils an Der Rinbe Der Stämme, theils traubenförmig um junge Riefernzweige abgelegt. (Fin Weibden legt beren 
150-200 unb mehr obue alle Bebeăung frei auj bie Dberiläd) ber Rinbe. $\mathfrak{I} \mathfrak{n}$ ben @tämmen werben biele Gier fo tief abgelegt, baj man fie bom Boben aus abreichen fann, unb zinar fintet man 10-30, jelten mebr oder wentiger auf einem fled bidłt neben einander mit einer flebrigen Feuditig=

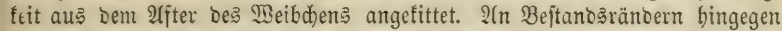
io wie an Unteribudje in älteren liḑten Drten mählt ber Edmetterling jefr gern bie niebrigen bümen Aeftchen ber ßiefer, bejonders menn fie ab:

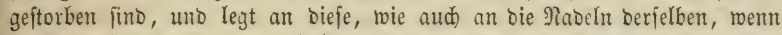
joldce borbanben fint, getwöhnlid) ben ganjen (Eiervorrath) bidst bei einanoer

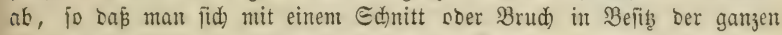

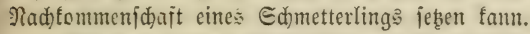

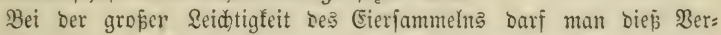
tilgungşmittel ja nid)t veriäumen. $\Im$ d) allein babe einmal bei einem

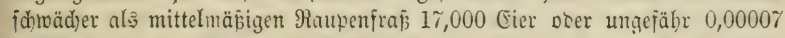

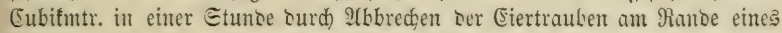
bejallenen Drtes gejammelt. Jür dä Ein;anmeln Der (Eier bon Den Etämmen fertige man eine $2(n z a b l$ Sejcher aus $1 / 3$ Mttr. im Durd)mefier baltenoen Reifen von itarfem geglübetem Eijenorabt, um meld)e Seines

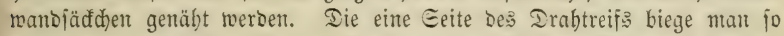

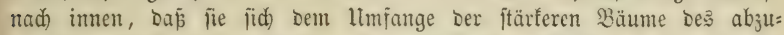
juchenden Beftandes anjohlief́t. Der fammelnde ?(rbeiter bält Dann bie

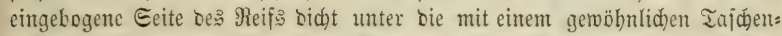
mejier abjufrabenden Eier an Den Etamm, weldhe alle in sen Bentel fallen,

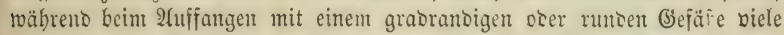
Eier neben ben Gefääranto norbeipringen uno auf oem Broten liegen bleiben, wo fie eben fo fider augfommen als am Stamme.

Sie Eier des Siefernjpimters find oft bon einer ungebsuren Mienge von Edhlupimejpen befallen, die jo flein fint, Daj Deren mitunter bis zul eintem Iuberto aus einem Či herborfomment, in bem jie ifre ganje \&ebents: jeit bis Daber jugebradst haben. Die tleinen gelben Edflupfroipen ber Eier Des Siefernjpinners babe id Encyrtus embryophagus, gröfere me= tallijd) grüne, einzeln in Den (Eiern lebende: Chrysolampus solitarius ges

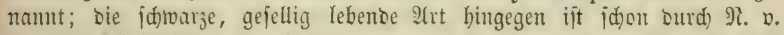
Ejenbe of bejdrieben, Der jie Teleas phalaenarum nennt. Jn Dem oben erwäbnten Falle waren non ben 17,000 Eiern ungefäbr $1 / 3$ von Edflupf: meipen befallen. Bei Der $\Re(e b r z a h l$ Derjelbent in einem Ei fann mant aljo mit Bejtimmtheit annehmen, Daj minteftens ebent fo viele Edhlupfwejpen als Raupen, biclleidt 2-3mal io viele in Den Eient entbalten waren. Es fino mir aber Fälle vorgefommen, wo idh aus 100 Eiern nur 3-4 Raupent gezogen habe.

Man mürbe fid aljo gropen Ed)aden thun uno oen शuķen bes Eier: janmelns mebr als aufbeben, went mant bie gejammelten Eici berbrenten

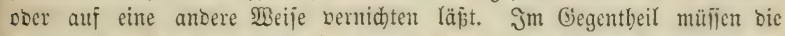
gejammelten Eier in einen 3 winger, D. b. an cinen Drt gebrad)t werben, von Dem aus bie austommenten Edhpfwejpen bas freie geminnen uno

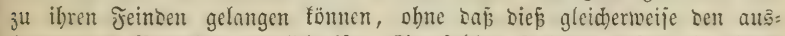
fommenten Räuden möglich) ift. Ein joldher Stwinger beftebt in einem 


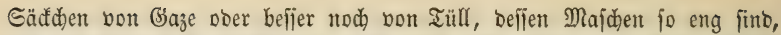
baj bie (Eier nidjt burdffallen, aber aud nidjt enger, als bierzu gerabe

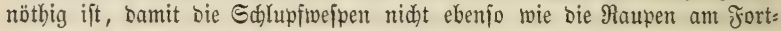
fommen verbinbert merben.

IUf Den Beitpunft bes Eierfammelns twirb man bei einiger Aufmerf: famteit Durd) bie vorbergehende Ed)wärmzeit ber Edmetterlinge aufmerffam gemadht. Die Des Monats Mai uno Juni ift wohl felten fo bebeutent, baj man mit Erfolg zum Sammeln fobreiten fann. Semeinbin gegen bie Mitte ber Monate Juli uno 2Yuguft fdnwärmen bie meiften Sd)metterlinge, aud ber Eeptemberidwarm ift mitunter nod) beträdtlid) genug, um jam= meln zu lafien.

E:s findet nämlid, wie id bief in einer 2 (bbanthlung über ben Siefern=

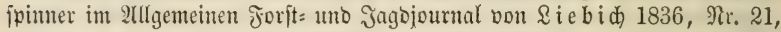
S. 162 errwiejen babe, eine mehrmalige, gemeinbin in bie Mitte bor $\mathfrak{M}_{0}=$ nate Mai, Juni, Suli, 2Uugujt uno Geptember fallende Sdjwärmzeit ftatt, von benen balo bie eine, bald bie anbere, gewöhnlid bie ber Monate Juli uno 24uguit befonbers zaflreich ift. Die Sebensbauer bes Jufetts ift aber ftets ein Jahr, fo baj bas im Montat Mai gelegte (Ei im näd)ften Mai= monat, bas im Monat 2luguft gelegte im nädjiten 2 ugujt zuแm Sd)metter: linge wirb. Da nun ber Sizuftanto gegen 20 Tage, Der Raupenzuitand etwas über 10 Monate, einjolieflid) Der Minterrube, Der Buppenzuitano 22-24 Tage, Der Edmetterlingazuftant 3-5 Tage bauert, fo erflürt fich barants bie unter unjeren fajablicten Malbraupen allein bei biejer 2 rt bor=

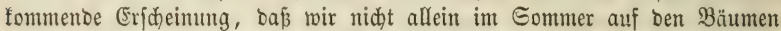

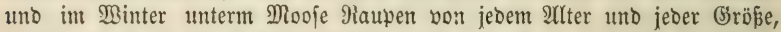
fonbern aud in mand)en Eommermonaten bas Jnfeft in allen 3uftänben,

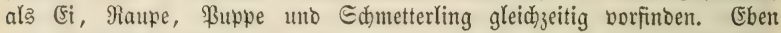
Dieje (Eigenthümlidfeit ift bann aud) bie Urjadye Der gropen Sdäblidfeit

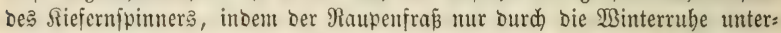
broden wirb, wenn bie Frafjeet ber einjelnen Maune aud mur 4, bödjtens 5 Monate bauert.

Raupenzuftand (fig. 1. b). Die nach ungeräbr 20 Tagen bem Eie entichlüpfende Raupe ift ungefähr 4 Millimeter lang uno gleidht fdjon in allem ber autsgemadjenten Raupe. Nadbem fie als erite Nabrung einen

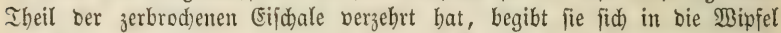

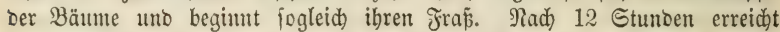
bie junge Raupe eine Sänge von 22 Mintr. $3 u$ Enoe bes eriten Monat? erreid)t fie eine \&änge von ungefäbr $2 \frac{1}{2}$, gegen Ende bes zweiten Monaţ yon 5 Ctm., wiro überbaupt bis über $10 \mathrm{Ctm}$. lang, ift von grauer, braumer ober fudbstother Grunbfarbe mit bellen filberbaarigen Rücfenjeid)= mungen uno bunfelbraunen fobrägen Queritreifen an ben Seiten. Der ganze Siörper ift mit langen boritigen Shaaren bejelzt, bie Brenze zwijden Dem erften uno jweiten, fo wie bie zwifhen bem zweiten uno britten Reibešringe

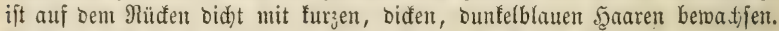
Eben fo gefürbte feulenförmige Şaare ftehen in fleinen Büjdjeln paarweife

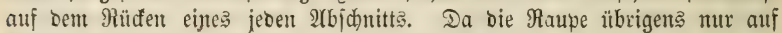
Siefern vorfommt, fo ift fie nad) obigem nicht leicht 3 u verfennen. 
Die Raupen freflen fo lange, bis bie Rälte fie nöthigt, Edut unter ben Bäumen im Mooje zu fudjen. Şier liegen fie bant in ber Regel nidut meiter als $2 / 3-1 / 2$ Mtr. boum Etamme entfernt unter bem Modje ober ber Etreu, uno un wenn beises feblt, fuchen fie fid) Durd) Eintoringen in ben Gano eine sünte Erojdidute zur Ieffe zu viriduffen. Eobalo im Jruils:

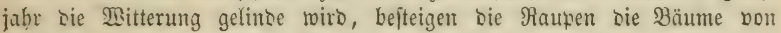
neuem. Die auggemadjenen freffen nidgt mehr, fonbern fpinten fich balo cin, Die in Den Eommermonaten bes vorhergehenoen Jahres entîtantonten

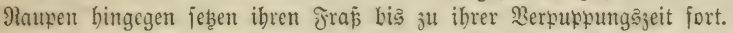

Buppenjuftan (fig. 1. c). Das (Einjpinnen ber Raupe gejojiebt gröjtentheils an ben unteren 3weigen ber Sronen, meijt zwijden Den Na= Leln, menn foldhe an bem 2(jte, morauf bie Maupe julcbet gefrefien bat, nod) vorhanden finto. In lid)ten Soten mit Unterwudbs mählt bie Raupe

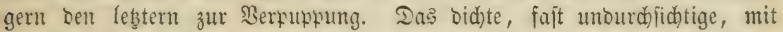
ben Sgaaren ber Raupe Durd)mebte, eiförmige, $21{ }_{12}-3 \mathrm{5tm}$. lange blaps=

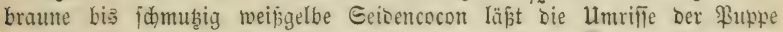
uno Der abgeftreiften lebsten Raupenbaut Durdffdimmern uno ift an Der Sopfieite Der eingeidlofienen \$luppe offen, um bem Єd)metterling Das 2(uș= friectent mïglich 3 machen. Die \$uppe jelbjt ift fehr georungen, bis $2 \frac{1}{2}$ Ctm. lang, von brauner Jarbe.

Edmeiterlingajuftan (tig. 1. d). Der fibentoe Edmetterling trägt bie flügel in einer badjförmigen Etellung. Ias $2 \mathbb{B} e i b d) e n$ unter=

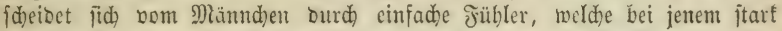
gefiebert fino, uno Durd) einen febr bitten Leib. Die flügelfpamung be: trägt beim $\mathfrak{S e i b d ) e n ~} 5-8(\mathrm{Ctm}$. , beim Männd)en etras weniger. (3rumc: farbe grau ober braun, balo heller, balo bunfler, jeber Dberflügel mit rother außgezacter, bunfel eingefapter breiter Duerbinbe uno cinem reiß̄en Monofledden.

Bertilgungamittel. Die Mittel zur Bertilgung Des Riefern: fpinnters bejobränten pid) auf Eammeln bes Jnjefts in allen 3uftänden burch Meniden. Mie biés rüdfïd)tlid) ber (Eier betwirft merben müfile, habe id bereit gejeigt unt bemerfe mur nod, dafi bamit zugleid bas $\mathfrak{A}$ uffiammeln ober vielmehr Berquetiden ber Ed)metterlinge berbunden werben muß. ße: fonbers bie weibliden Ed)metterlinge fwhen ruhig uno tief, fo bas fie leidit getöbtet werben fönnen.

Die Raupe wiro währent ber Frafijeit burd) 2Amprallen ber Etangen mit ciner 2 (rt bom Baume getworfen, mup bann aber aufgelejen uno ein=

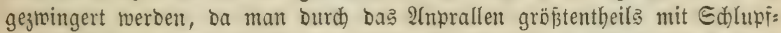
meipen bejeşte, ermattete Raupen erhält, bie fid nid)t fo feft balten fönnen, als bie gejunben. Da aljo bie Mebrzahl ber burd Anprallen zu erlangen:

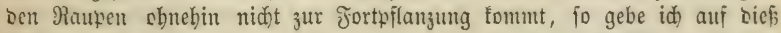
Mittel nidst biel, uno um fo tweniger, ba burch ben 21ujulag mit bem

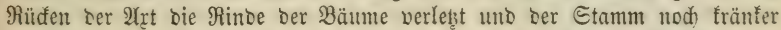

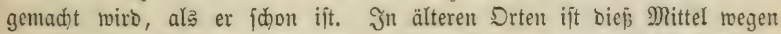
Der Etärfe ber Etämme ohnebin nid)t anwenobar uno bürfte fid) baher tas Eammeln ber Raupen uno Cocons mäbreno ber Fraj̧zeit auf Dell im hohen Solje etwa nod) borbandenen Unterwuds uno auf bie tief beafteten Mant: 
bäume ber Beftänoc, Blöpen uno Räumben bejdrünfen, wobei mant fidł) theils zum Serabjielyen, theil zum Eridunttern ber 2lefte eines an eine lange Stange befeftigten Şafens mit Bortheil bebient.

Dagegen ift bas Sammeln Der Raupen im Winterlager unftreitig Sauptvertilgungsmittel uno, wern es mit Sorgfalt ausgeführt wirb, in Berbinoung mit Der 2tnlage von Raupenzwingern allein fdon bitreid)end, fid) Diejen läftigen Jeino vom F̧alje zu fdaffien. Das Sammeln beginnt,

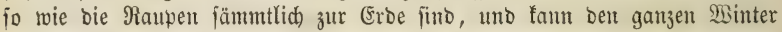

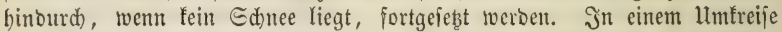

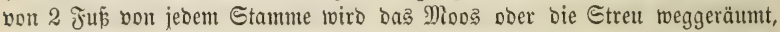
bie erftarten Rautpen in eimen Sorb gemorfen uno Der entblößjte \$3oden

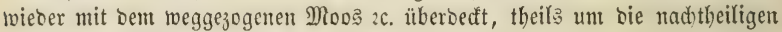
Folgen ber $\mathfrak{B u r}_{3}$ elentblößung zu vermeiden, theils um ein, nöthigenfalle wieberboltes 2(bjud)en möglid zul mad)en.

Da man nicht barauf red)nen fam, felbjt beim forgfältigften Gams= mełn alle vorbandenen Raupen aufzufinoen, ba bejonders von ben fleinften viele liegen bleiben, fo wiro es nothwentig, bie gejammelten Maupen nicht zu vernid)ten, fonbern ebenfalls an einen Drt zu bringen, Dem fie nidht,

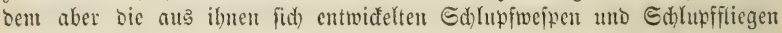
cntweiden fönten. Daburd) erhalten bie Edhlupfwefpen Der Menge nad) sas llebergewid)t unb bertilgen ben nid)t aufgefunoenen Theil Der Raupen. (Ein fold)er 3minger befteht in einem nad) Der Menge Der Maupen 0,03-0,10 5eft. grojen, mit cinem $2 / 3$ Mtr. tiefen Graben umgebenen Platge, auf weldhen bie gefammelten 9iaupen ausgej füttet uno mit Mloos bebectt werben.

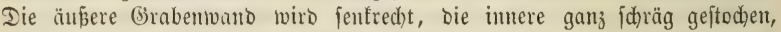
Damit, wern Maupen in Den Braben fallen, biejelben mit Reidtigfeit ins

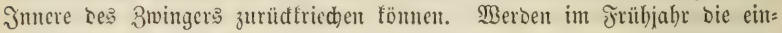

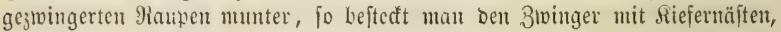
welde von ben Raupen beftiegen und entnabelt werben. Da bie Raupen in 3winger wentig frefien, fo braud) man getwöbulich mur alle $S$ bis 14 Iage neute 3loeige einzufteffen, wobei zugleid) bie an Den Yleften ber alten 3 weige bängenden (Eocons abgejud)t uno in ein mebrere (Eubiffupe balten=

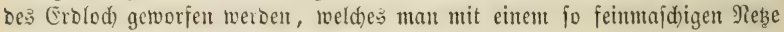
bedect, baj wohl bie nod aus ben \$uppen fid) entwidefnoen Ed)lupfwefpen, nid)t aber bie ausfommenden Ed)metterlinge bas freie gerwimen tömten.

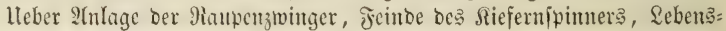

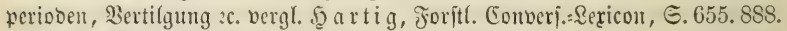
Sicbid), Ifllgem. Jorjt= umb Jagb= Journal 1836. S. 162. Şartig, Jabres: beridte I. 2. S. 246.

Fig. 1. e habe idh eine, nom widtigften feinte (Microgaster) bes תiefernipinners ausgefrefiene Raupe mit ben unter ibr angebefteten weipen Eocons ber Ed)lupfwejpen - bom gemeinen Mante oft Raupeneier ge= nannt - abbilben lafien.

In neuterer Beit ijt in ocn preupifichen Staatşmaloungen bas llmgeben Der Bäume mit eincm Theerringe fehr empfohlen unb häufig angevendet.

2) Die Monne. Bombyx Monacha. Tab. II. fig. 2. a.

Eijuit and (fig. '2. a). Die rumben, etwas niebergebriilften, blüulich)= 


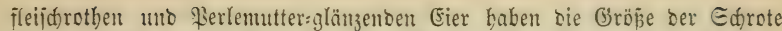

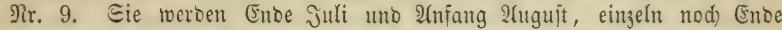
2fuguft uno 2 Anfang Eeptember nom $\mathbb{B}$ eibchent vermittelit bes in eine lange

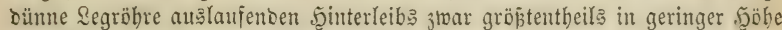
vom Boben, aber jo tief in bie Rinoeriben uno unter bie Rinoejdupyen

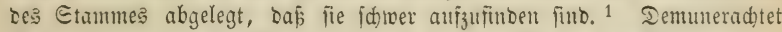
ift bas Gammeln ber Eier in neuerer 3eit mit Erfolg ausageführt worben.

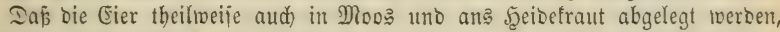
niro zmar vielfach bebauntet, mir jelbjt mangeln aber nod) (Erjabrungen bierüber. Sollte fich bie 2tngabe beftätigen, fo würbe ein Fortichaffen bes Moofes unb Unifrauts gute Dienfte thun. Man greife jebod) nidft eher $3^{4}$ biefem Mittel, bis man fid) jelbjt überzengt bat, baj viele (Fier baburch) vertilgt werden föınen.'

Drei MSodhen nad) ber Ģeburt ber Cier ift bie Raupe völlig aus̄ges

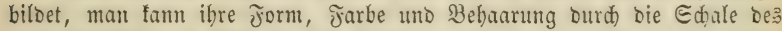
nun Dunfelfraunen Eies bentliă erfennen. Jn biejem 3ujtande, umgeben

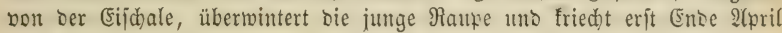
Doer 2 nfang Mai aus.

Raupenjuftan (fig. 2. b). Die junge Raupe befteigt nad) ibrem Utusfommen nidyt jogleidy ben Baum, ionbern verweilt, bejonbers bei nafjer

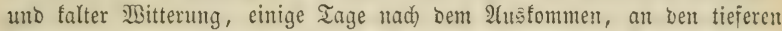
Etammtheilen, fibet bier gejellig in Şaufen beijanmen uno fann zerquetjot merben (Spiegeltöbtent). Epäter läp̆t fie fid bei einiger (crid)ütterung ber 3meige gern fallen uno bürite ju biejer 3eit in Etangenorten in Menge 3 ul vertilgen fein, wenn man bie herabfallenben Raupen auf Jangtüder aufnimmt.

Mad) $2^{1 / 4}$ Mionat, gegen Mitte Des Monat Juli, hat Die Raupe ifren

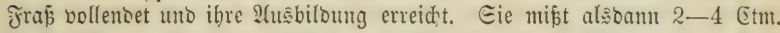

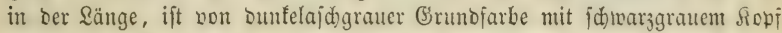
uno bellen Muntheilen. Der Rüden ijt mefr ober meniger weís, bie

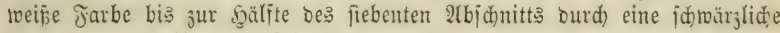
Rüdenlinie getbeilt. Der ₹eib ift reibenmeife mit blauen, rothen uno bräu=

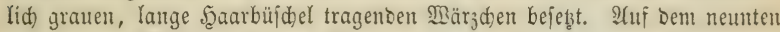

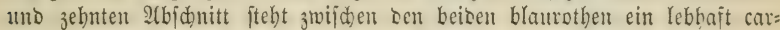

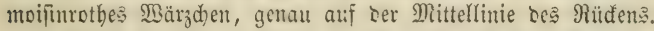

Durd) bie fituzere Tauer ber Frajjeit uno baburd), Daj alle Raupen gleidzeitig ober vielmehr mit geringem 3eitunterid)iebe freflen, miro bieje

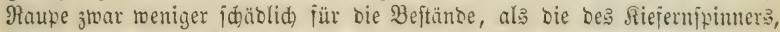
fie bat fich jeooch foron bäufig in jo groper Menge gezeigt, bafis fie bor: heerento rurbe und zwar jowohl in Siefern als in Jidisten.

2Säbreno des Raupenzuftandes barf bas Eammeln Der Maupen Durd? Suprallen und burd) $2(b l e j e n$ vom Unterwudje uno an Bejtandsränoern nidft veriäumt werbent. Bejonder: in Den Morgenftunben nad) itarfem

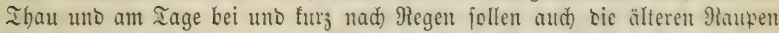
sie Bäume berlaīen uno am jupe Derjelben fich in grofien Miengen auj=

1 Die gegebente abbiloung tig. ㄴ a jeigt ein Mindejtïd ber sicfer, von meld)en bic

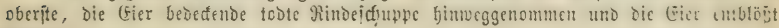
twurben. 
fammeln Yaffer. Die gejammelten Raupen müfïen ebenfalls eingezwingert

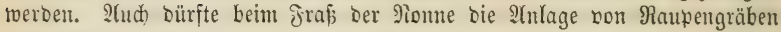
nidft exfolglő fein.

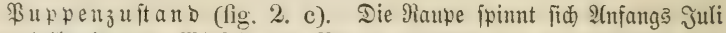
gröftentheils in Den Mizfeln ber Bäume zwifchen ben Rabelbuifdeln mit wenigen einzelnen Seioenfäben ein, ober fie bejeftigt fich nur am 2 fter an ber Rinbe Des Gtamms uno oer 2tefte. Die geftürzte, b. b. mit Dem Ropfe Der Eroe zugefehrte \$uppe ift 2-21/2 Etm. lang, lidbtbraut,

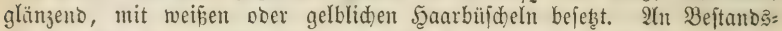
ränben uno vom Unterwudje twiro man mitunter beträdtliďe Mengen ab= Iejen fönnen; andermeitige Siertilgungämittel biejes 3ujtanoes gibt es nid)t.

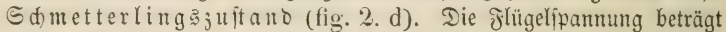

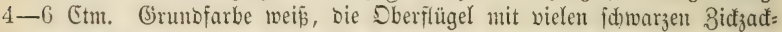
binoen uno \$untten, die llnterflügel fomubig=weiß mit Ranbfleden. Die

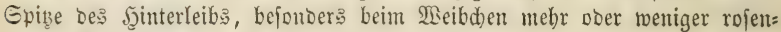
roth. Mäund)en mit ftarf gefieberten Jühlern. Die Grunbfarbe beioer Gejolededter geht mitunter in Dunfles (Srauid)warz über.

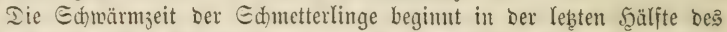
Juli. In Den frühen Miorgenftunoen, bis 9 Lhr, fițen bie meiften Ed)metter= Yinge tief am Etamme ziemlid) rubig, fo dafi fie zerqueticht werben fönnen;

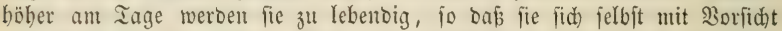
nur fdwer erfajden lafien. Sfufier bent Gammeln ber Edmetterlinge follen aud) Seudtfener iu füblen $\Re$ äd) ten gute Dienfte reiften.

I(n widtigiten: Dr. 3. 5. Эörben raupe, 1798.

3) Die Föbreneule, Noctua piniperda (Tab. 1I. fig. 3. a-d).

Eijultan (fig. 3. a). Die Edmärmzeit ber Sdmetterlinge beginnt im Itpril ober Anfang Mai. Das Weibchen legt $30-50$ grüne (Eier einzeln an bie Epitze ber Riefernabel $a b$, aus benen nad) 10-14 Tagen bie jungen Raupen herborfommen. Eine Bertilgung ber (Fier ift baber nid)t möglid).

Raupenzuftand (fig. 3. b). Die junge, 16füpige Raupe ift in Der erften Sälfte ibres Raupenlebens beinahe einfarbig grün, bį auf Den 3ul jeber Beit einfarbig rothbraumen oder gelbrothen Sopf, fwäter zeigt fid)

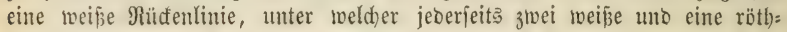
lidje oder orange Eeitenlinic verlaufen. Mitte Jull, alio ungefäh)r nad)

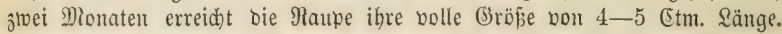
Rörper unbehaart.

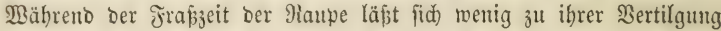
thun; man mis aber zu verminbern juchen, wo man nidht bertilgen fam. Da bie Maupe fid mebr in Etangentbölzern als in hoben Syolze finbet, io faun man bas Gammeln auf Jangtüdern burd) 2tnprallen betreiben. Bei naß̧talter Bitterung follen bie Raupen in Menge au Jupe Der Stämme

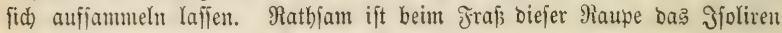
Der befallenen Drte burd Raupengräben.

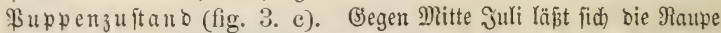
nom Baume fallen. Finoet fie eine bidhte Mloosbede, fo berpuppt fie fid unter berfelben, gröptentbeils geht fie aber in bie Erbe und vermandelt fid) 
balo ofne Cocon in eine braune, glatte, $1^{3} / 4-2$ (tm. lange \$uppe, Deren Iffer in zwei fduvarjen Epişen enoet. Şier liegt fie bis jum nädjiten

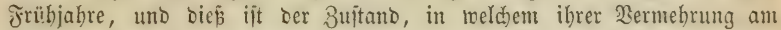
fräftigiten Durd) unausgejeţten Betrieb ber befallenen Srte mit gropent Edineinebeerben entgegengearbeitet merben fann. Etreurchen ichabet mebr, als es nübt, da bie meiften ßuppen in ber Erbe liegen.

Єd) metterlingszuftano (fig. 3. d). Die Morberflïgel bes 3-4 Etm. in ber flügelipanung melientoen, culentëprigen Edtmetterlings finto

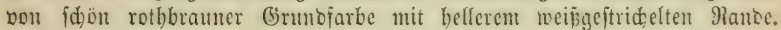
Aluf jebem sberflügel jteht ein fleiner runber uno ein gröjerce nieren= förmiger flled von weißjer Jarbe, beise ourd) eine gerade meipe Sinie ver: Gunben. Ilnterflügel graubraun mit jăwarger Binbe unb flecf. Sïrther

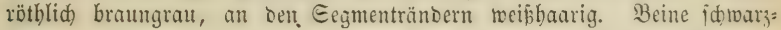

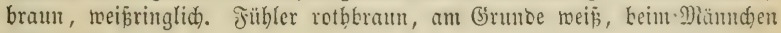
gewimipert.

Die Edmärnzeit beginnt in Frühjabre, fo mie bie Mitterung gelinbe roirb, mituter fajon Mitte $\mathfrak{A}$ pril. Ier aus ber (vrbe herborfommente Sd)metterling bejteigt jogleich bie WBipfel Der Bäume, wo bie Begattung jowohl, als bas 2hblegen ber Eier rollzogen wirb. Eine Bertilgung in biefem 3uftande ift nid)t ausführbar.

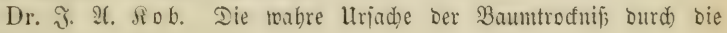
Fortphaläne, Jranffurt 1790.

4) Ier Sieferifanter, Geometra piniaria. (Tab. II. fig. $t$. $a-d$.

(Fizujtand (fig. 4. a). Iic Echrärmzeit ber Edmmetterlinge finbet

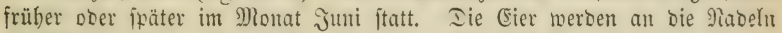
Der Siefer, aber nid)t einzeln, fonbern perljdunförmig nebeneinanber $a b=$ gelegt, io Daß́ bie 40-80 (Eier bes 23 eibd)en: nur auf wenige beijanment= ftehente Madeln berthcilt wersen. Die (Eier fino grün, runo, aber ftart niebergeorüat, io baf fie bie form eines Ed)weizerfäles haben. Ia die Eier itets bod in ben SBiffeln ber Siefer abgelegt merden, ijt Eammeln Derfelben nicht auşübrbar.

Ra uenzuftand (fig. 4. b). Die jungen Raupen erjdeinn 10 bis 12 Iage nad) Der Geburt bes Eies. Eie fint 1 Sinie lang, überall

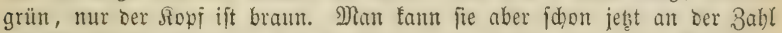
ber Baudjübe erfennen, bon benen mur am zebnten umo leb̨ten 2(bjd)nitte

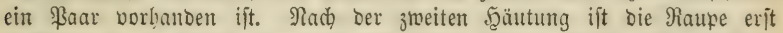
$2 \mathfrak{M n t r}$. lang, grün, jeberfeiţ mit einemt breiten เocisen Qängsftreifen. Nach) Der britten Säutung ift bie Raupe 1 Ctm. lang uno aufer Den beiben Geitenjtreifen nod) Durd) einen weiben Rüđenftreifen gejiert. (Erft nad ber vierten Şäutung tritt bie volle färbung beroor, ber früher braune Sopi wiro jeb̨t beftimmt grün, Der Eeiteniftreifen gelb, jwijd)en leķterem uno

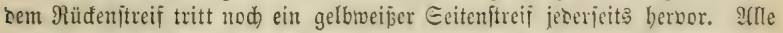

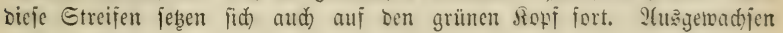
$21 / 2-4 \mathrm{ctm}$.

Die Raupe fiţt felbr fejt, jo bap Das 2(mprallen mur wenig bilft; bie

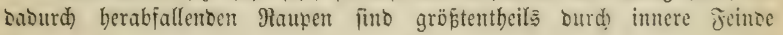




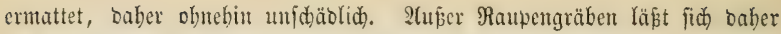
aud be biefem Infeft wenig gegen Den Raupenzultano thun.

Der Frafis ber Raupe bauert gewögnlid bis Mitte Oltober, bann freffen bie Raupen nid)t mehr, begeben fich Enoe Sttober ins Moos uno berpuppen fid) Dort in einer fleinen Bertiefung Des (Erobodens. 2(ud) Diefe Raupe hat

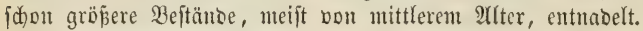

\$uppenzuftand (fig. 4. e). Die Buppe ift $1-1 \frac{1}{2}$ (Etm. lang, bram; bie borbere Seite ber אopfbälfte olivengrün, Der 2(fter mit einfad)er

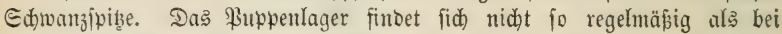

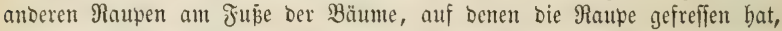
jontoern mehr auf flcinen \&idftungen. Sisen feine bidhte Mloosbecte vor= banben ift, foll bie Raupe aud) in ben Boben gehen. WBie bei ber F̈öbrent= cule, ift aud bier bie Bertilgung bauptjächlid') burd) fleißigen Betrieb mit Sdweinen zu betwirfen. Sammeln uno Streurechen bilft wenig.

Sd) metterlingşuftan o (fig. 4. d). In Der Rörperform gleiden bie Epanner mebr ben Iagfaltern, fiben aud) wie biefe meift mit aufgerid)= teten Flügeln, fliegen am Tage uno zwoar fehr behento uno rajd, baber

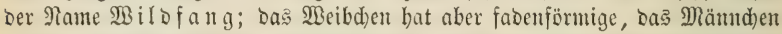

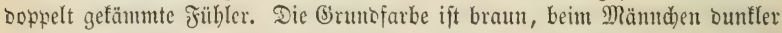

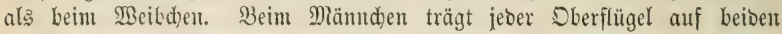
Geiten brei feulenförmige, bidht beifammenftehende, zufammen faft bie Scälfte

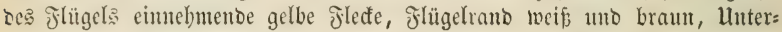
flügel braun, oben mit größ̧eren ober fleineren gelben Mittelfleden, unten mit zwei gelbreinen Durd) zlvei idwarze idmale Duerbinben burdjidnittene Qängsffreifon. Beim Weibchen ift auch bie Zeidhnutg blaffer uno weniger idarf begrent.

Bertilgungsmittel in biefem 3uitante befizen wir nidht.

fgartig, foritl. Eonverj.:Sexicon S. 627.

5) Der Rieferntwifler, Tortrix Bouoliana (Tab. II. fig. 5. d, e).

Eizuftand. Die Edwärmzeit ber Sd)metterlinge finbet Enoe Juni ober 2lufang Jull ftatt. Die Eier werben an bie Enofnofpen Der Triebe 5-15jäbriger Riefern unt zwar zwifchen bie Ed)uppen Der Sinoppen abgelegt.

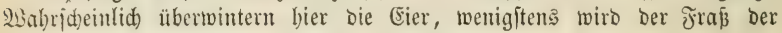
Raupe erft im fommenden Frübjahr bemerfbar.

Raupenzutand. Jm Jrübjabre geben fid bie mit Midlerraupen

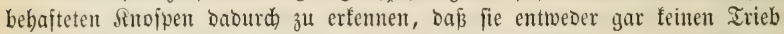
maden, ober binter ben gejunden Trieben weit z̆trüdbleiben, ein fränfliches

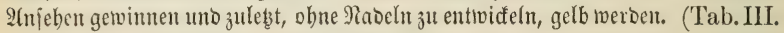
fig. 5. e.) Brid)t man einen folden Trieb aus, jo findet man in beffen

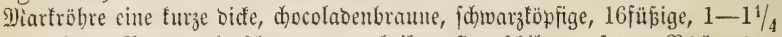
(5tm. Iange Raupe mit fdrwarzem getbeilten Sgomidjilbe auf Dem Rüden bes

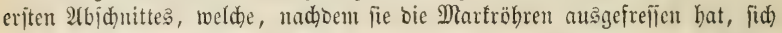

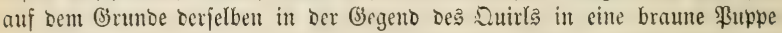
Derwandelt. Iic Raupen finto oft in einer folchen Menge vorbanben, da bie meiften Pflanzen einer Edyonung Dabon befallen fint. Da nun Der Edmetterling am liebjten bie grofien Epibzhopen des Mitteltricbs zum 


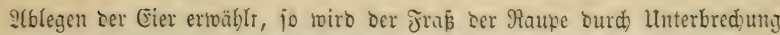
Des Sängentriebs uno Berumitaltung ber Bilanje jebr nadtheilig, went er

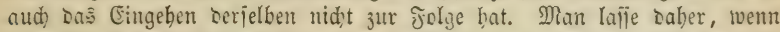

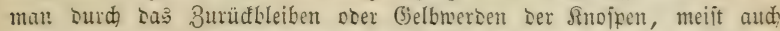

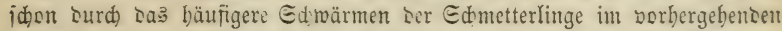

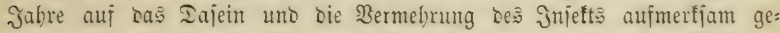

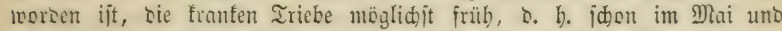

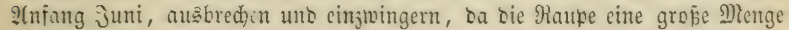
eigenthümliḍer Jeinbe beherbergt. ¿äp̆t man fräter jammeln, jo baben jid) idon viele Maupen berpupt uno liegen sann gropentheils jo tief, baj fie beim 2(bbred)en Des Triebs nidjt mitgefap̧t toerben.

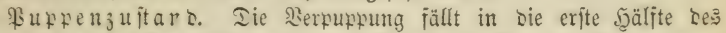
Juni. Jit ber befallene Irieb mebrere 3oll lang, fo liegt bie \$uppe inner: balb ser Marfröbre, ijt ser Trieb furz, io baj bie Rauke genöthigt murbe,

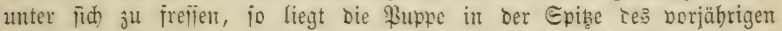

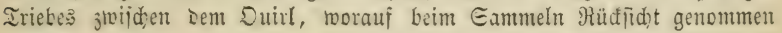
twerben mus.

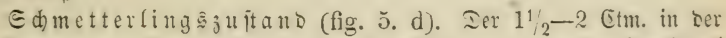

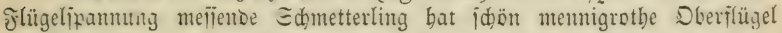
mit 5- $\mathbf{r}$ filbernen Suerbinoen, meipem franjentano, in weldyem zwei bell= braune und eine sunfelbraute Parallelbinoe. Tie Unterflügel fino braun= grau mit bellem, eimmal banbirtem Jranjenrano. Sörper uno fübler fino röthlidy=filberfarben behaart.

Iiep pino biejenigen Edhmetterlingstraupen, meldhe Der Riefer an uno für jich nadtheilig werten. Die nadjtehonoen fino weniger idäblid, sa fie theil: nidht in gropen Mentgen ericheinen, theils jich aut eine Weije er= näbren, sie rem Seben uno ber Gejunobeit Der \$flanj: meniger nad)theilig ijt. Şierber gebörent:

6) Ier Ricfernidmärmer, Sphinx pinastri. Şartig über

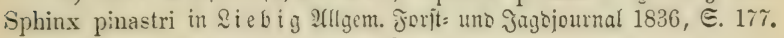
f̧artig, Jabresberidte I. 2. S. 269.

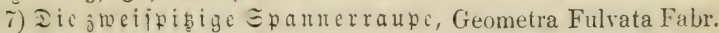

8) Dierotbföpige Epannerraupe, Geometra lituraria Lin.

9) Die porcellan:idedige Epanteraupe, Geometra fas. ciaria $\mathrm{L}$.

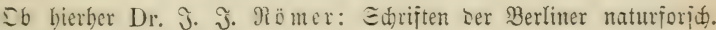
Gejelijaft V. E. 156 (1794)?

Lleber Den Maupenjultano biejer lcţten orei Epanner bergl. meine Sahres̆ber. 1. 2. Є. 262-266.

10) Tortrix piceana (oporana) lebt äuperlid) an ben jungen Trieben Der Siejer. T. duplana wie Bouoliana in jungen Trieben; T. turionana in Den Sinofpen ber Siefer.

11) Tortrix resinana uno eine 3meite verwanbte 2frt T. cosmophorana in Den Fुarzgallen ber ßiefer.

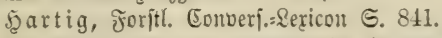

12) Tinea (Phycis) sylvestrella in den Baffen der Riejir.

sartig, Jorftl. Comberj:=2tricon G. 834. 
Uno cinige anbere, nod) tourig beobudtete, T. dodecella, Lin. (Reussiella Ratzeb.) T. pinetella ete.

\section{B. Jeinde ber Riefer unter ben}

13) Die Riefern=\&anghornblattiocipe, Lyda pratensis (Tab. III. fig. 21. a, b).

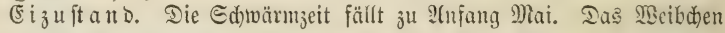
legt 30-40 blajgrüne fpintolförmige, twie ein Riummeltorn gebogene Eier eingelt auf bie SRabeln ab uno befiftigt fie ourd) einen Sitt auf ber con= veren Seite äuperlidf. Dic Raupe erfidseint nad) 8-14 Iagent.

Raupenzutand (fig. 21. a). (Sfleid) nad) bem Stustriechen aus Dem (Ei begibt fid bie Raupe bid)t unter bie (Endnofpe eincs Triebes, be:

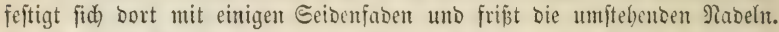

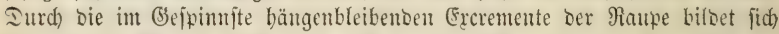
bald um bieje cine Şülje, bie nach) unten geöffnet ift uno in weldher bie Raupe, ben Sopf nad) unten gefelfrt, fişt. Mit Dem nad) unten fort=

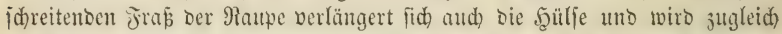
Durdh bie gröberen Excremente bicfer unt Didfter. Die Raupe frifit mu

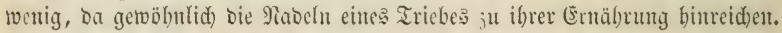
Mitte Atuaut läßjt fid) Die Raupe fallen, fricd)t in bie Errbe uno überwintert Dajelbit, obne fid) einjujpinnen, im Rarvenjuftande. Durd) fleipigen Betrieb

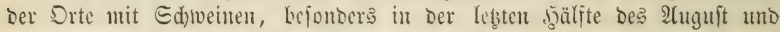
im Eeptember wirb man an fräftigiten auf ibre Bertilgung binmirfen.

Die 3weifel, weldye Siateburg gegen meine Beobadtungent ber Lyda pratensis ansgefproden bat, beruben wahrideinlid) auf ciner Șertwedjelung

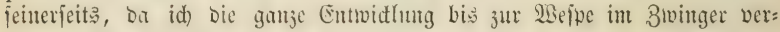
folgt, präparirte Plaupen und die 98 eipen nod) beute in meiner Eanmlung

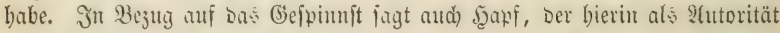
gelten faun, "Die Excremente bleiben größtentbeils in Den Gsiphimiten bängen."

Şapf: Bemerfungen über Ifferraupenfrap in Der Etanbesberridaft

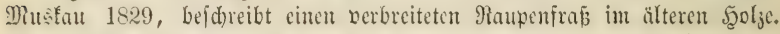
Jd) felbjt habe jie Dort bis jeb̧t mtr einjehn, alsggbreiteter auf einter orei= jäbrigen Riefernpflanjung beobad)tet, wo ocr Mitteltrieb oes gröften Theils Der \$rtänzlinge entnabelt worben war.

Die Raute miro bis über 2\% Etm. lang und bat auser Den 6 Bruft=

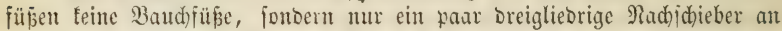

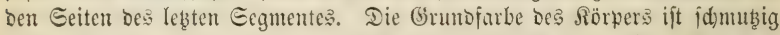

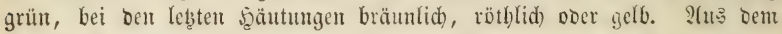

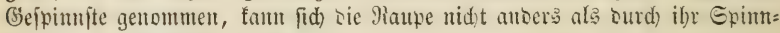
wermögen vom flecte belwegen.

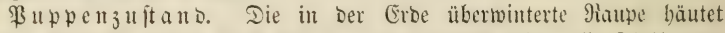
iid) bas lektemal gegen Ende 2(pril. Die Pinmple zeigt alle Theile bes volffommenen Jnjetț, Jübler, Beine, Flügel auf ber Bruft jujammengefegt. Der ganlje Rörper iit an Stelle ber barten Buppenjabale ber Edometter=

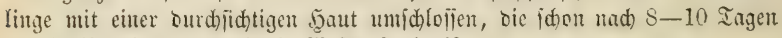
abgeftreift wiro, worauf bie $\mathfrak{B}$ eipe fertig ift. 
Incipenzuitano (fig. 21. b). Die mit vier Durdjidftigen, benen ser Etubenfliege äbnlidhen, mit wenigen 210ern Durchzogenen Flügeln ver= jebent Bejpe unterid)eibet fich bon anderen Blattmejpen burdh ben nieber= gebrücten, platten, id)arfrunbigen Sginterleib, ourd) 33glieorige borjtenför= mige Jübler von ber Ränge des Şinterleibs, Durd) einen Eeitmoorn an Den Sorberichienten, Durch ítwarje Färbung, am Sopf uno Bruititüd mit gelteen Beid)mungen, am Sointerleibe mit rojtrothem Rante. Sänge $1^{1}{ }^{1}{ }^{\prime}$ Flügelipannung $2 \frac{1}{2}$ Ctm.

14) Die Riciern=Bujdbornblattreipe, Lophyrus Pini. (Tab. III. fig. 22, $a-d)$.

Eizujt an i (Tab. II. fig. 22. a-d). Die erifte Edwärmzeit ber

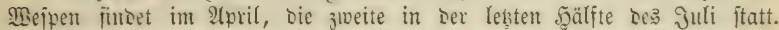

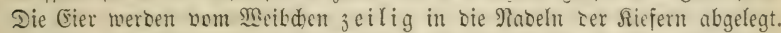

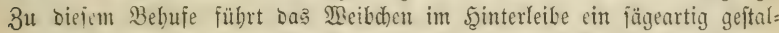

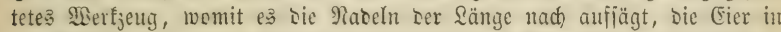

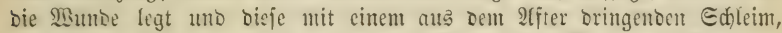
bermija)t mit sen Gägeipänen mieder berflebt. Sbgleiá/ bie mit Eiern bes bafteten Mabeln aur Der Berfittung leid)t zu erfemen fino, Das Beibden

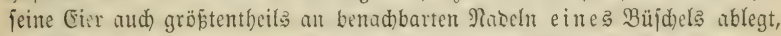
fo wirs das Eammeln ierielben ood) jelten auşühtbar jein, sa bie Eier

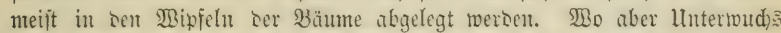
vorbanton ijt, veriäume man bas s(bjud)en nidft, da überbaupt nur wentg

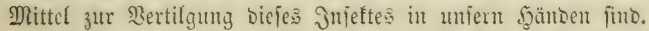

Raupenzujt a d (fig. 22. b). Tie Maupen fommen 14-20 Tage nach Der Geburt Der (Eier zun Boridein. Sn Der criten Beit leben fie familientweife beifanmen und verzehren mur bie weid)eren Theile ber Nabehn,

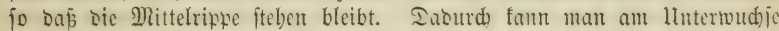
unto an ben Beftanosiänoen bie freficnoen Jamilien fehre leidst entbecten uno zu biejer 3eit mit Seidftigfeit in groper Menge einjanmeln laijen.

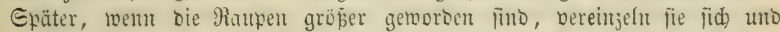

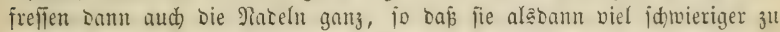

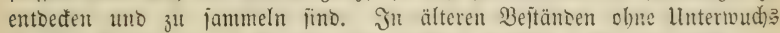
ift cine Bertilizung in Raupenzuftante faum möglich. Maupengräben zum Ed)ub nicht befallener Sorte fint bon Erfolg. Piach beftigent Phațregen,

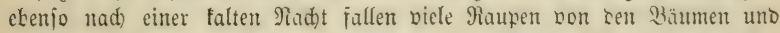
jammeln fid), um bicje roieber zu befteigin, am fube Derfelben oft in biđen Rlumper. Pinmt man bie rechte Beit walls, io förmen in joldhem Jalle groß̧e Mengen mit geringer Mübe vertilgt meroen.

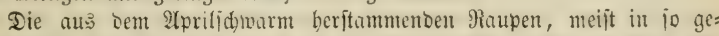

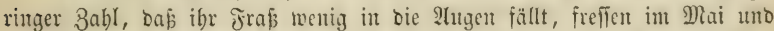
Suni, jpinnen fid) im 2 hujang Jult ein uno idwärmen meijt gegen Ente

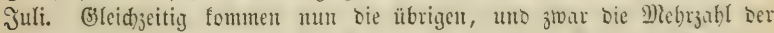
überwinterten Eocons aแts. Die Maupen Der vercinten Bruten freflen Dam

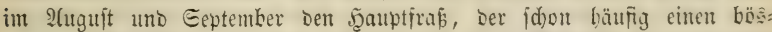
artigen Charafter angenommen uno Den To ganzer Bejtäto veranlapit bat.

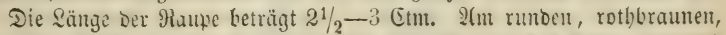

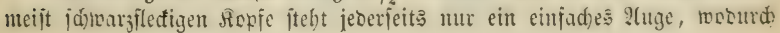


fid) bie Slattweipenraupen an bejtimmteften bon Den Edametterlingşraupen unteridjeiden. Der gelblid) grüne Seib trägt 6 Bruffiüß̄e uno 16 Baudd)

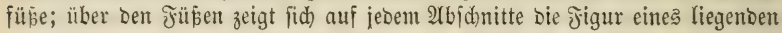
Semicolons (..) bon folwarzer Farbe; Der Rüfen ift mitunter bunfelgrün.

Buppenuftand (fig. 22. c). 3ur 3erpuppung begibt fid) bie Matpe größ̈tentbeils ins Mloos, um fid) unmittelbar über ber (Froe in ein bichtes, feites, elliptifdes, braunes (Eocon einzujpinnen. Menn man wäh) rent des Einfpinnens die befallenen Drte tüd)tig mit Sd)weinen betreibt, vertilgen bieje eine Menge von Raupen; Dief bautert aber mur wentige Iage, Dent toent bas (Socon erft fertig ift, nebmen es bie Edweine nid)t mebr an. Wo man einen Moosfily hat, laffen fid bie (Eocons Yeid)t fammeln, man gebe Daber mur Den mit bloper Etreu bededten Booen Den Sd)weinen cin, um Durd) Das Brechen berfelben auf Dem kemoosten Boven fid bą Eammeln nicht zu berberben, weldes Den 2 Sinter über fleisig betrieben

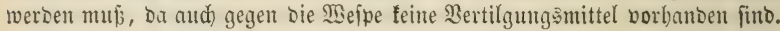

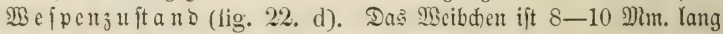
unto miß̄t in ber Flügeljpannung 1,5-2 ctm. Die Fübler fino 19= biß 20gliebrig, borftenförmig, etwaß gejägt. Heber bem ơlügelmale ift mur eine

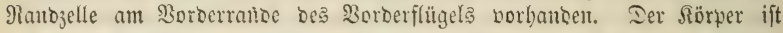

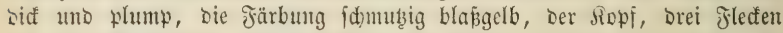

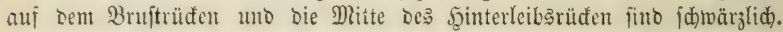
Die erjten Glicber ber braunen fübler fino gelblid). Das Mämuden hat fdimarze, oppwelt fummifeorige füller. Der Siörper ift bis auf bie weißs=

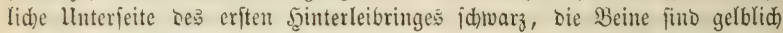

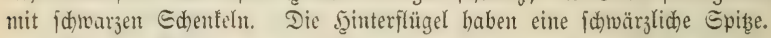

Diefelbe 3 cerbreitung uno Beocutung wie Loph. Pini ojttid) Der Elbe hat Loph. rufus weftlid ber Efbe. Heberall aber fommen einzelne fa= milien, bier jener, bort bicjer vor.

2luf ber Riefer fommen fermer folgente minoer idjäblide Blattivefpen utio Syolżweipen vor:

15) Lyda erythrocephala. 16) Lyda campestris. 17) Lyda reticulata. 18) Lyda cyanea (mabrideinlich).

19-29) Lophyrus similis, variegatus, frutetorum, pallidus, Laricis, socius, rufus, elongatulus, virens, nemorum, Pineti.

30) Sirex juvencus, die ftablblaue Şolzmefpe.

Bergl. Müller, Ueber 2(fterraupenfraß. I(j)affenburg 1821.

5̧artig, 2(nhang zum forft. Converf.:2ericon 1834.

Jartig, Die Fantilien ber Blattwefpen uno 5ुolzmeipen mit 8 Tafeln 2tkbild. $183 \%$.

5artig, Jubreşberidte I. 2. G. 270. (ङeinde ber Blattweipen.)

C. Feinde ber Siefer unter ben Säfern.

31) Der fidten: Rüffeltäfer, Curculio Abietis auct. (Curc. Pini. Ratzeb.) ${ }^{1}$ (Tab. 1II. fig. 12.)

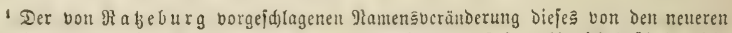
Entomologen ađgemein als Curculio Abietis bezeid)neten Räfers bin id) dep̈lyalb nidat 


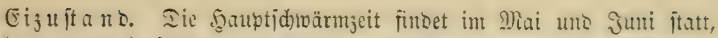

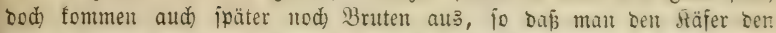
ganzen Eommer binourd findet. Die Eier werben bejonber in bie Rinte: rib̧en ber Stöde, jomohl frijder alङ älterer, jtefender uno gerooeter ab= gelegt, nur in (Ermangelung Derjelben geht Der Räfer audc) frnnte Etämme an.

¿arvenzuftand. Die obnfüfige, runotöpige, augenloje Sarve ijt 1,5-2 巨tm. lang, 4 Mimtr. breit, mabenförmig mit braunem frofre uno

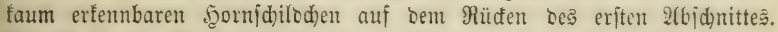
Der Sorf, bie Bruit uno bie lek̨ten Seibešringe fino mit cinzehten langen Borftenbanen bejetst. Gie lebt vont Geburtätage ab bis zum 5erbfte, Lie

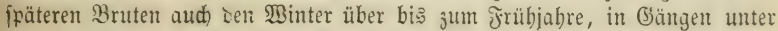

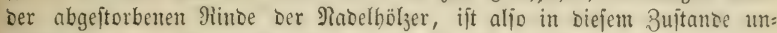
idjäblid, nagt fid Dam unter Ler Rinbe, mehr ober meniger tief in ben Eplint binein, eine eiförmige ßuppentb̈̈hle.

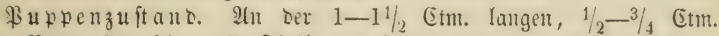

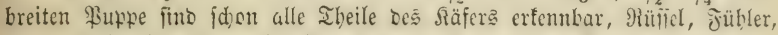
Beine, frügel auf ber Bruft zujammengelegt mo mit tmer finen, flor:

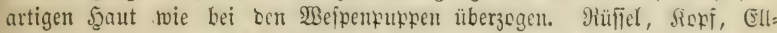
bogen uno bie ganje Sberíeite bes ภörpers fino mit ftarten, etwa ge: frümmten Iornen kejobt, beren ber $9(j$ ter zwei bon bejonterer Bröfe trägt.

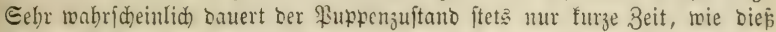
kei ben Mejen der Jall ift, geht alio ber Edmärmezeit bes Säfers wenige 23oden voran.

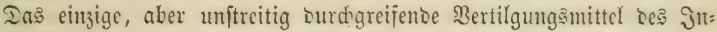
feftż in sen genannten früheren 3 uftänoen ift jorgfältige Entfermung alles

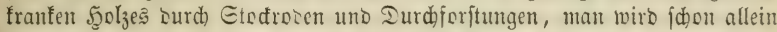
Daburch Den Bermüftungen bes Räjers Ginhalt thun tönnen.

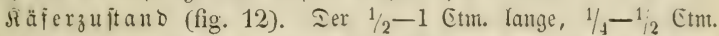

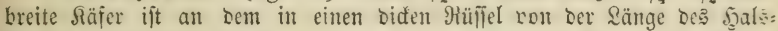

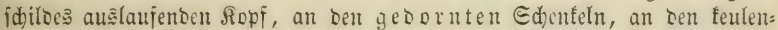
förmigen, gebrod)enten 13gliebrigen füblern, Der Duntelbraunen Grumbjarbe, ben roftrothen Eprenteln, uno Daran erfembar, dafis bas Eniledin eben= falls Dunfelbraun, nidjt twie bei berwantoten 2 rten bell gefärbt ijt.

In biejem 3ujtande wirb Der Räfer nidht allein Den jungen Riejern=

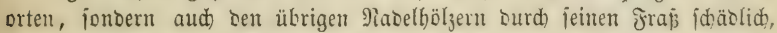
intom er theils bie Snopen, theils bie jungen Iriebe berjelben uno bie Etämme junger \$iflanzen benagt uno fie zum 2 (bjterben bringt. Bejonders

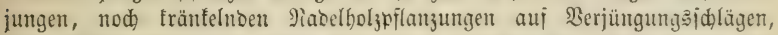

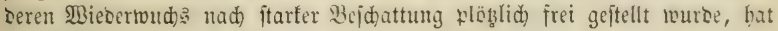
er fid idon in groker 2 Utūbehnung verberblid) gezeigt.

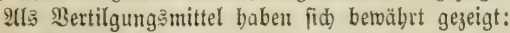

1) Janggrä beu $1 / 3$ Mitr. breit uno tiê,, mit fenfredten Sänoen unto Fallföhern bon 1/4 Mtr. Tiefe auf ber Goble bes Janggrabens, in

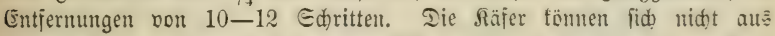

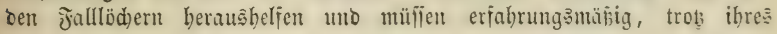

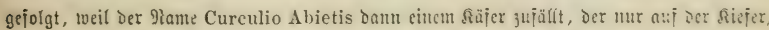

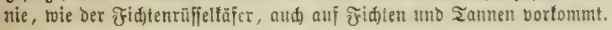


Flugvermögens, Darin umfommen. Man braudt fie baher nidjt fammeln z̆l lafîen.

2) Fanglöa er von $1 / 3$ Mttr. lang, breit uno tiej, bebectt mit Nabel= bolareifig.

3) Fangbüfdel von irifdem Madelholyreifig, in bie fid bie siäfer gern hineinziehen uno bie täglid in Den Morgenjtunoen auf ein aus= gebreitetes Jangtud) augigetlopft werben.

4) Jangideite uno Rindeplatten, Yeţtere mit ber Baftjeite unten auf den Boben auşgelegt. Die Räfer fanmeln fich unter benjefben un๖ fönnen leid)t aufgelejen werben.

5) Jaugfnüpel bou 5-8 Ctm. Dide, bie fadräg in ben Boben eingegraben werden, um bem Säfer zum 2tblegen Der Eier zu bienten.

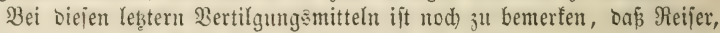
Edeite uno Blatten frifh fein muifien; Daj bie Stelle, mo man fie aus: legt, vom Unfraut gereinigt uno geebnet werben mus, uno baj alle bie genannten Bertilyungamittel in Den bom Piujfeifäfer bejallenen Drten felbjt angewentet twerden müfien.

5artig, Forftl. Eonveri.=̊ericon 1834. S. 163-165.

Rabeburg, die Joritinfeften 1837. S. 106-114.

32) Der toeifidiloige Sicfern= Rüfieltäer, Curculio notatus (Tab. III, fig. 13).

Bon Borigen unterfacioet fich Der Räfer Durd) ungezäbnte Edjenfel,

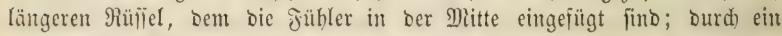

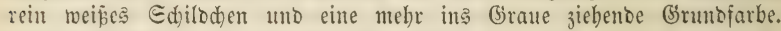
jebe flügeloedfe trägt zwei helle Duerbinben, von benen bie hintere breiter, alt ber Naht weif, am Eeitentante jiegetroth ift. Ränge 4-6 Mimtr.

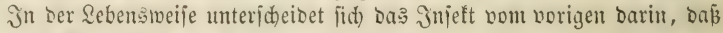

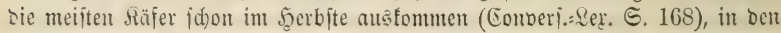

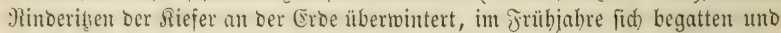
sie Eier nid)t allein in Silafterböljer und franfe Bäume $2 c$., fontern aud) und vorjugäweije an Dos Stanmende junger 3-5jühriger Siefern uno an Siefern=

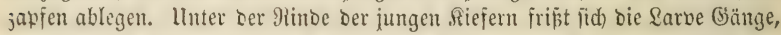
serpuppt fidh Dort, uno hat bereits öfter bedentenden Ed)aben angerid)tet.

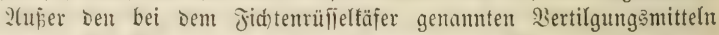
ift aud) Das ?tusjáeiden ber gelb werbenden jungen Bilanzen bis in ben Auguft aumenobar.

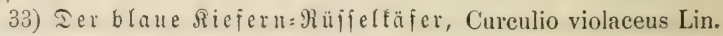
(Tab. III. fig. 16).

Der trumme Miufiel ift Dowhelt fo lang als ber Ropf; Die 12gliebrigen Jühler itehen in ber Mitte bes Mïfiels; zwifdhen Jüblerid)aft uno bieipel ift bas sinie faum bemerfbar. Färbung ounfel ftablblau; Größse 4-7 Mmtr. Ed)märmzeit in Mai. Der Säjer bohrt bie Snoppen ber Siefer an, um von Deren Marf ju zebren; bie Eier werben an junge Siefern abgelegt, in seren Euirlgegento die Sarne, bäufig mit Curculio notatus beifammen, ibre Shänge frî́t; Bertilgung wie oben.

34) Ter grofe $\mathfrak{\Omega}$ efern= Balogärtner, Hylesinus piniperda. (Tab. III. fig. 11. a, b.) 


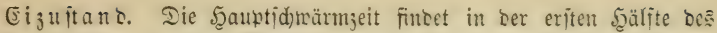

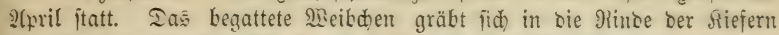
ein, fertigt einen fenfrecht in bie söbe gebenton Muttergang uno legt an Den Eeiten befielben sie (sier ab, ganı wie id) Dieß bein Jidten = Borfen= fäfer umptänolid)er bejdreiben merde. Cin zweitę (Finbolyen uno Eierlegen findet int Juli jtatt, ijt aber freilid) jehr untergeorbnet (Jahrešber. 1. 2. ๔. 195). 3um 21blegen ber (Eier wählt bas meibuten am liebiten die

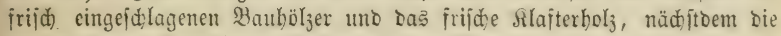

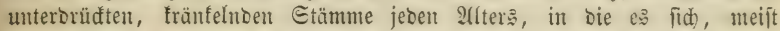

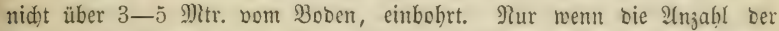
Säfer ungewöbulid) grofi ift, werben aud) fd,einbar gefunde Bäume an: gegrifien.

¿arvenjuftanc. Die madenfarbige, runo uno brauntöpfige, angen= und fuflofe Sarve lebt in ber Gajthaut ber Siejer in Sängen, bie fie fich vom Muttergange aus in mebr soer weniger wagrechter 9ichtung frifist. जn ber erften Jälfte bes Juni ift fie ausgerracjien, uno verpuppt fich am

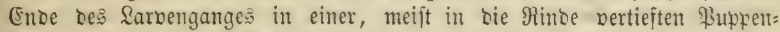

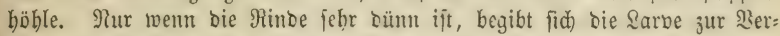

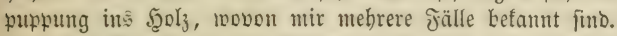

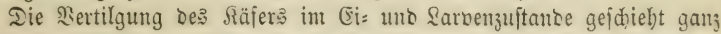

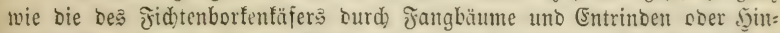
wegidaffen ber befallenen Rlafter= uno Baubölzer zc. Die Jangbäume

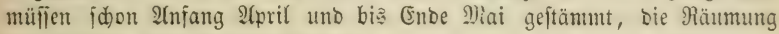
biङ 2fnfang Juni beenbet werben.

Buppenjuitand. Die $3-4$ Mmtr. lange mabenfarbige Pupte

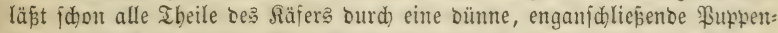

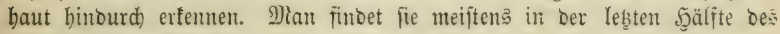

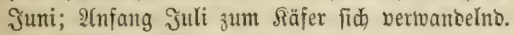

Räferzujtano (fig. 11. a, b). Der 3-4 M)tmtr. lange Räfer unterideibet fid) non berwanten formen burd) ben, aus bem vorne ver: engten Bruftichilbe herbortretenben Sopf mit faft rüfiflartig borgejchobentem

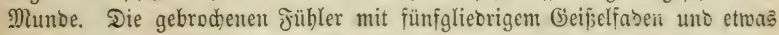

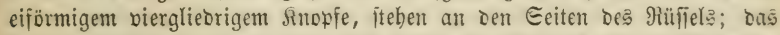
britte Jufglied ift ausgerandet, fajt zmeilałpig (modurd fich bie 21tent ber Gattung Hylesinus am leidteften non Denen ber Battung Bostrichus

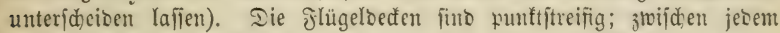

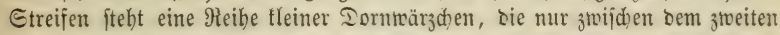

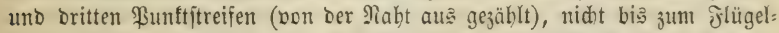

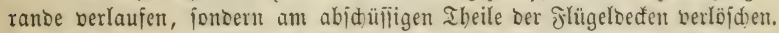
Scierin allein untericheibet fich $H$. piniperda non $H$. minor (Şartig,

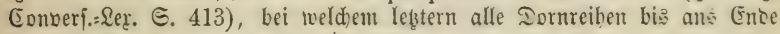

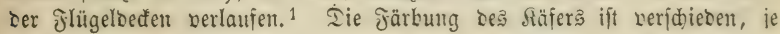

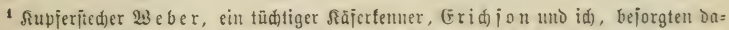

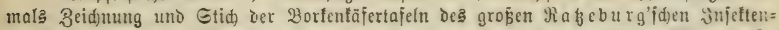

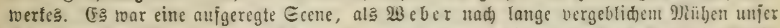

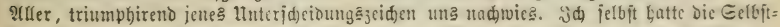

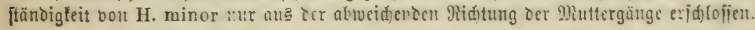


nadbom er jünger ober älter ift, nou blapgelb bis ountel pechidwarz, meift jeboch in lețterem falle mit rothbraunen glügeloeden.

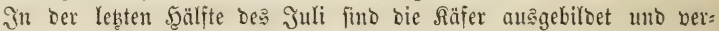
lafien ihren Geburtsort, um fich bis sum Sjerbfte bon bem Marfe ber biefs= jäbrigen Riefertricbe zll ernäbren. Der Räfer bobrt fich in ben Irieb ein,

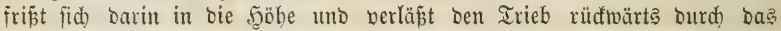

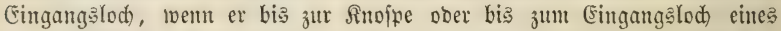
jweiten Räfers gefommen ift. Co fann ein Räfer viele Triebe verberben, uno wirflid babe id Dent Edjaben fo grof gejehen, duis man burd bie vom Minte herabgemorfenten Triebe nur hier uno ba ben Boben burdblicen fah. Daईj ein Zujammentharfen uno Serbrennen ber Triebe feinen Siuţen ge: twäbre, ber mit ben Soften im నerbälnif ftebt, fam id) nidut beftätigen, inoem id in viclen ber herabgetworjenen Iriebe $3-8$ Säfer fanto. Freilid) miro bas 3ujammenbringen uno Rerbrennen ber Iriebe mur tam bou Nutben fein, wenn vicle gleidzeitig burd) heftigen $\mathfrak{B i n t}$ bon ben Bäumen getworien und jogleid) nach bem 2(bfall vernichtet werben.

Die meiften Siaffer verlaffen mit Beginn bes Minters bie Triebe unb bohren lid) am Fune ber ftarfen Bäume in bie toote Rinde ein, um sort zu übermintern; boch überwintern cinzelne Exremplare ohne allen 3 meifel in Den Trieben, nts benen id) fie 2tnfang uno Mitte März gezogent babe.

Die Nerlebungen Der Sarve uno bes Räfers fint bäufig fichon febr cmpfindlich geworben, bod) haben fie nod) nie bas Eingehen ganzer $B_{e}=$ fitänbe zur golge gehabt.

35) Der fleine Ricfern= Balogärtner, Hylesinus minor. Scartig, Conberf.:Ser. S. 413 .

In allen früheren Buftänoen gar nidht, im Säferzuftante mur an ben cben genannten Rennzeichen von H. piniperda ju unterfdeiben, in feinen (Sängen aber baburd) erfentubar, Dás ber Doppelarmige Muttergang mehr Doer weniger wageredit um Den Baum läuft; die Sarbengänge bingegen auf = uno abjteigen. 2Anperbem treibt Das Jnlett biejelbe Detonomie mie H. piniperda, fommt zwar nid)t fo bäufig, mitunter aber in eben ber Menge wie jenter vor; int Szeineraborfer Reviere babe id ihn fogar in ber lleberzabl ju beobadten Gelegenbeit gebabt. 3ertilgungsmittel wie bei H. piniperda.

Unter ber grofen Menge von Säfern, bie nod) auf Die Riefer ange: wiejen füt, Dürften folgenoe nod einige forftlide Bebeutung baben:

36-38) Bostrichus Laricis, bidens, stenographus.

39-41) Hylesinus ater, palliatus, ligniperda.

42-44) Curculio violaceus, atomarius, indigena.

3u Den weniger widtigen Infeften Der Siiefer gebören ferner:

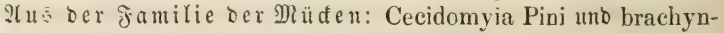
teros. Anthomya Ratzeburgii m. Die Rajenajche fliege. $\mathfrak{F}_{.=}$u. J.= 3eitg. 1855.

21 s ber familie ber Blattiauger: Rhizobius Pini, Aspidiotus Pini uno flavus, Lachnus Pini uno Pineti. (jartig, Jabres= beridt I. 4. ङ. 641 . (3) ermar 3eitfidr. für die Entomologie III. S. 368.) 


\section{II. feillie int fidjte.}

\section{A. Unter Den Gdmetterlingen.}

1) Die Nonne, Liparis Monacha. (Tab. II. fig. 2. a-d.)

Eie ift ebenio ein Jeino ber Fidte rie ber Riefer uno Der einzige gröpere Edmetterling, ber fid bis jeb̧t ber Jidute berberblid gejeigt hat.

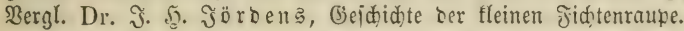

Uleber Bejareibung, \&ebenameije, Nertilgung zc. rergl. Nr. 2 ber Siefern= Snjeften.

2) Der 5arzwalowider, Tortrix comittana Trschke. hercyniana v. Uslar. (Tab. II. fig. $6 \mathrm{~d}$, e.)

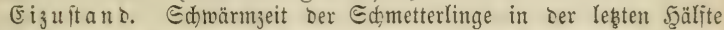
Des Mai bis in Den Juli. Die Eier merben an bie jungen Mabeln abgelegt.

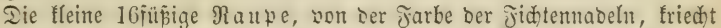
10-12 Tage nad) Dem ?(blegent Der Eier aus, umipint mebrere Nabeln uno ben Irieb, an weldem jene jteben, mit einigen feinen Eeibenfäben,

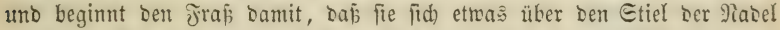
burd ein fleines runbes Sod in bieje bineinfrifit uno bas Blattfeiid ner=

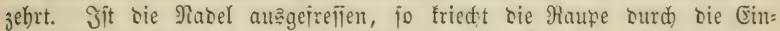
gangsojfijung mieber heraus und wählt eine neue ?abel, wäbreno bie aus: gefreliene vertrofnet, abfällt, gröp̈tentheila aber surd die Eeidenfüben feitgebalten im Gejpinmite bängen bleibt. Iaburd biloen fich um ben 3weig Connolute von trodnen Iojen Rabeln uno Excrementen ber Raure, an benen man ben Jrá́ terjelben leiḑt ju erfentuen nermag. (Tab. III. fig. 23. e.)

Die Raupen frefien bis in Den Sttober anf $10-20$ jäbrigen Roth= tannen, mitunter in ungebeurer Mienge; im நerbite läpt fid bie Pianpe fallen, rerpuppt fid) in bie (Erbe, umo üherwintert bis zur Echrörmjeit.

3) Der $\subseteq$ d) metterling (fig. 6 d) ijt $1-11_{4}$ (Etm. lang, ajd)= grau, mit filberweißßen Duerjtreifen.

Dic Bertilgung büfte allein ourd) fleißjigen Betrieb ber Sorte mit Ed) weinen zu bemirten fein. Sielleidht fino aud) Seudtfeuer von Siuben.

4) Dic Jidtenzaffenmotte, Tinea (Phycis) strobilella Lin.

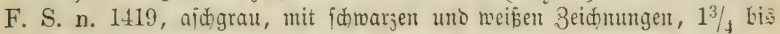
2 厄tm. Flügelipanmung, lebt als Raupe in Den Fidhtemjapfen uno ver: bient Beadtung. Rab̧eburg fübrt fie als T. abietella Fabr. auf, Sinné hat fie aber ganı unjweifelthajt befdrieber (Phal. nasuta in Abietis strobilis) und T. strobilella benannt. Ebentajelbit findet fid. eine Epannerraupe, bie ber Geometra strobilata.

UHnerbem fommen auf Der Fidfte nod) eine Menge fleiner MBidter uno Motten bor, bie lid) jeocd) im (Groben nod) nid)t als nad)theilig su erfennen gegeben baben, wie 3. 3 . Tortrix coniferana, histrionana, dorsana, Ratzeburgiana, Hartigiana, strobilana ete. Ilnter ifnen

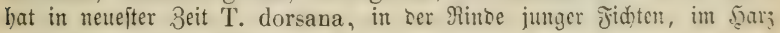
nidjt unbebeutenben Edaben gethan. 


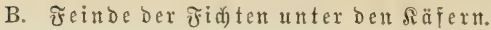

5) Der Fidtenborfenfäfer, fdwarzer $\mathfrak{W} u r m$, Bostrichus typographus (Tab. III. fig. 7. a, b.)

(5izuftand. Die Edfwärmezeit ber fiäfer finbet 2Anfang bie Mitte

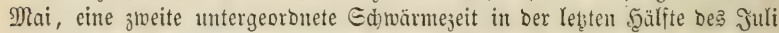

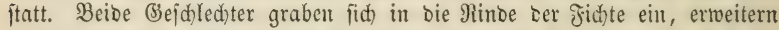
gleich) unter Dem Eingangslod) Den (Sang zu einem Norplatse, um hier bie Begattung zu vollzieben, worauf jebes Bseibden einen fenfredt verlaufen= Den Muttergantg in bic Eaftichid)t gräbt, an beiben Eeiten beffelben feine Eier in fleine Grruben ablegend und mit $\mathfrak{B u r m m e h l}$ verflebend. Da das Ablegen von $60-130$ (Fiern einez $\mathfrak{B e i b d ) e n s ~} 3-5$ Wodjen bautert, bic

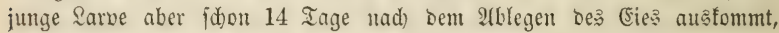
fo findet man in ber lebsten 3eit Des Eierablegens, Cier, Larben bon ber:

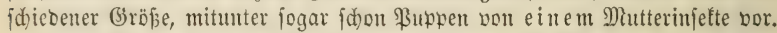

Sarbenzuftand. Die ausgemadjene 4-6 Mntr. Yange, weidhe, mabenfarbige, ohnfïfige Larve mit runbem, haarigem, braunem Sopfe obne Alugen, mit berben bunfelbraunen Jreß̧zangen, friß̧t fid) mehr ober weniger red)twintlid) bom Mittergange aus in ber Eafthaut, bie zugleid, ibre アabrung abgibt, cinen Yeid)t gefd)längelten Rarbengang bon $3-4$ (5tm. Sänge, Der mit Dem TSachsthum Der Larve fich erweitert. Das Reben Der

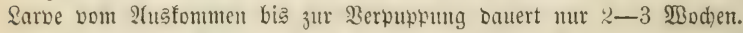

ßuppenzitand. Raht Der Beitpuntt Der Serpupung, weldher

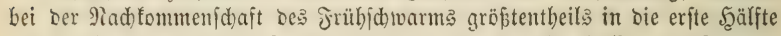

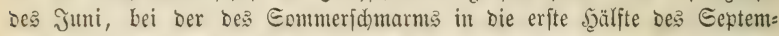
Ders fällt, fo frifit fid) bie Sarve an (Enbe bes Siabrungagganges eine rund:

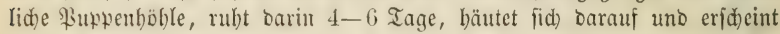
๓un als eine florartig eingebüllte täferälnlidhe \$upwe, an weldher bie (Ex: tremitäten bes SRäfers, auf ber Bruft zufanmengelegt, fichon beutlid) zu er=

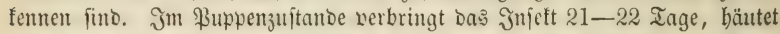
fid bann abermala, uno erfdeint mun als ein blafjer weidjidaliger fäfer, welcher fich nach uno nad) Dumtler färbt uno erbätet, feine ganz bunfel= braune Jarbe aber erit nad) Dem 2tusfliegen erbält. 2lls Säfer lebt bas

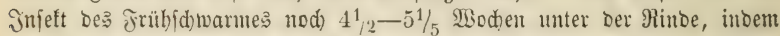
e马 fid) roie bie Rarve von ber Eafthaut ernährt uno biefe in unregełmäpigen (Bängen Durd)wüblt, wodurd) Die Regelmäpigteit in Bilde ber \&arvengänge jeritört wiro.

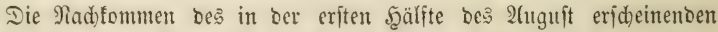
Sommeridwarms follen gröptentheils in bemjelben Jabre nidht mehr idjwär=

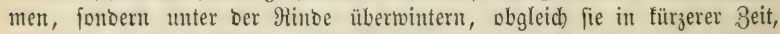
unb zwar in 6-S $\left.\mathfrak{B}_{0} d\right) e n$, ihre 2 tuabiloung erreiden. (Einmal ift jebod)

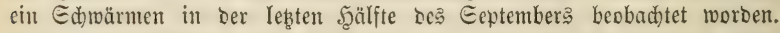

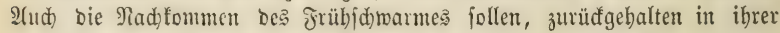
Entwiçełung burd) ungünfitige Sistterung, bäufig unter ber Rinbe bleiben uno Dort übertwintern.

Der Räjer (fig. 7. a, b) unterfideibet fid bon anberen burd) ben fugliden, in bas fapubförmig überragentoe Bruftidilo zurüdgezogenen Sopf, 


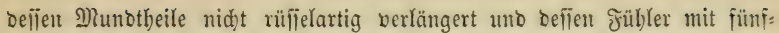

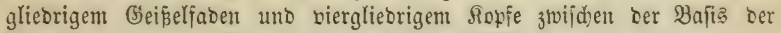

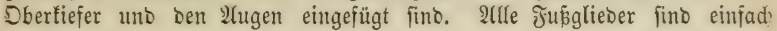
maljig. Die Qänge beträgt $4-5 \mathrm{Mmtr}$, bie Breite $2-2 \frac{1}{2} \mathfrak{D}$ imtr.; Die frlügeloeden fint binten ftarf eingebrüatt; ber baburch entittehende fdarfe Rano ijt jeberjeits mit 4 3ähnen bejest, von benen ber britte von oben am größjtent ijt. Färbung nom hellen Strobgelb bis zum ounfeln Braun.

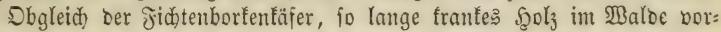
hanben ift, mur diefes zu jeinem 2Uffenthalte ermäblt, gebt er bod aud) gejunbe, ober fdjeinbar gefunbe, jebenfalls jolde Bäume an, bie obne jein Scingufommen nidht abgeftorben fein mürben, wenn er fid fo vermehrt bat,

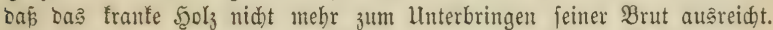
In biefem fafle bermag er aud rohl ganz gefunde Bäume frant uno zur

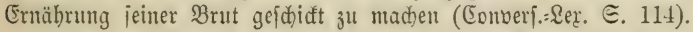

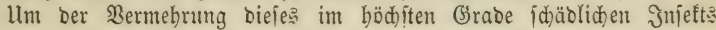
vorjubengen, hat Der Jorjtmann: 1) Die Durdforitunger. Des unterbrüatten

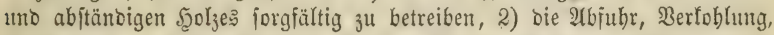
Entrinoung ober Bewaloredaten aller im $\mathfrak{B i n t e r}$ gebauenen Sölzer, weldhe

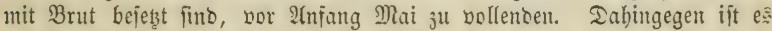
gut, wenn Scölzer, bie niḑt mit ßorfentäfern bejeb̨t find, erit im Juni ab:

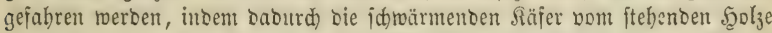

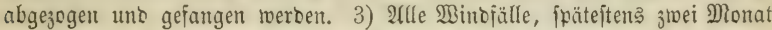
nach bem Falle entroeber aujuarbeiten, зu berfohlen ober zu entrinben, menn fie in bem Beitraume vom 1. Mai bis zum 2tuguft getworfen wurben. 4) 2Alle burd) Etum gebrüdten Etämme ipätẹtens zrrei Monate nad ben જ̈ăllen aufjuarbeiten ic. 5) In Den Ed)lägen, bejonders in Den Durd):

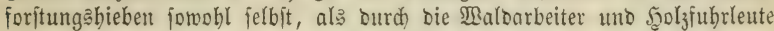
jorgfältig auf bas Borbanoenjein bes Räfers achten, uno im Jalle einer (Entbeçung, wenn aud) geringer Mengen, in allen mittelwüldfigen uno älteren Drten, bejonbers im Dlai uno 2luguft unterbrüdte Stämme füflent

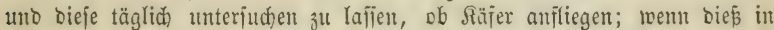
einzelnen Drten bäufig geid)ieht, id)leunigit, ehe nod) bie Edbärntzeit all= gemein wirb, eine gröpere $2(n z a h) l$ bon Fangbüumen fällen zu lafien.

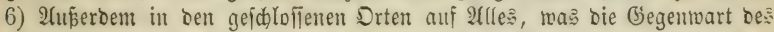

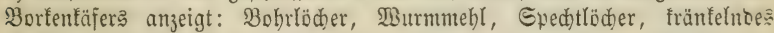

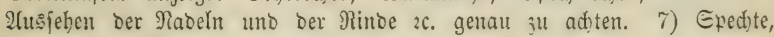
Baumläufer, Meijen jorgfältig žu föpnen.

Bertilgungsmittel bereiţ norbanbener gröperer Snjeftenmengen baben wir mur 1) in Den fautgbäumen uno 2) in Der fällung uno ent= rinoung bes vom Räfer angegangenen ftehenden . Soljes.

3u Fangbäumen, weldhe in bie nom Siäfer befallenen Diftrifte währeno ber Schwämıeit eingelegt weroen, mäblt man bie unterorüaten Doer bie Etämme vierter uno fünfter Grö̈je fo, baj burdi Jällung ber:

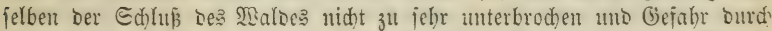

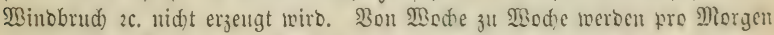
1-3 foldjer Etänme gefälft; fie bleiben umansageaffet uno mit bem Etanm:

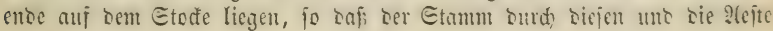


vom BDoen abgebalten wiro, was man nöthigenfalle nod) burd) Ututerlagen bejörbert. Die fdmärmenden Fäfer Yegen hierauf ihre Brut in bie Fang= bäume $a b$. Sieht man, da ja diejelben jebr ftarf befallen finto, fo Yäj̧t

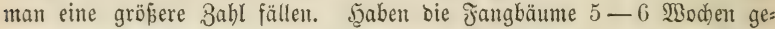

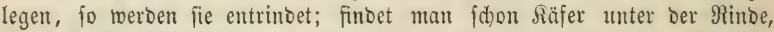
fo muв bas Entrinben auf unterlegten Tüd)ern gefhehen unb bie aus: fallenten תäfer fowohl wie bie Rinde berbrannt werben; finden fid nur

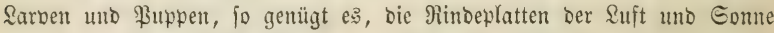

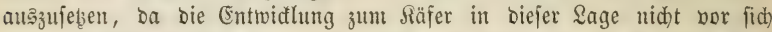
geht. Diefelbe Borfid)t mus beim Fällen uno Entrinden ber ftebenten vom Fäfer angegriffenen Şölzer angetwendet werben.

v. Sieratorpf, Jnjeften ber Fidhte 1794.

Scartig, Forftl. Eomverf.=:er. S. 108-119.

$\Re a$ b e burg, Foritinjeftert.

6) Ien zottigen Jid tenborfenfäfer, Bostrichus autographus, babe id) (Tab. III. fig. 8. a, b) weniger jeiner Sdjäblidłteit balber, als

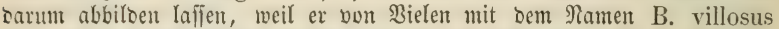
belegt wird, in ocn frülyeren 2Aflagen diejes \&ehrbud)s aber eines B. villosus, jottiger Jid)tenborfentiffers, geoad)t ift, ber in Jidnten uno in Tannen vorfonmen foll. Der in Jidften vorfommente ift wabrideinlid) unjer B. autographus, Der aus Iamten hingegen B. curvidens. Erfterer fommt unter ber Rinbe franfer uno abgeftorbener Fichten zroar bäufig gemug vor, hat fid aber nod) nidht bejonders nadtheilig gejeigt.

7) Der linirte Borfenfäfer, Bostrichus lineatus. (Tab. III. fig. 9. a, b.)

E゙

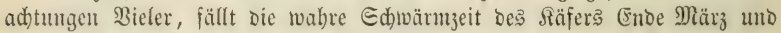

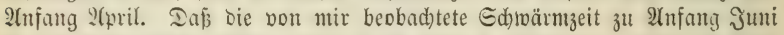

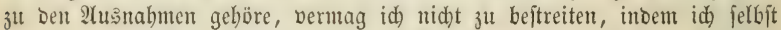

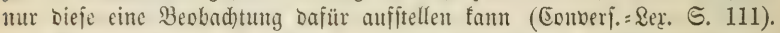
Der Räfer greift alle Nabelbölzer an, am liebften aber bie 2 Beiptante uno bie Jid)te. Ilnterorüattes Stangenboly, id)abbafte ältere Stänme, frifd)e Etöđe, bejonbers aber frif̧ gefälltes Baubols wählt er am liebiten zum

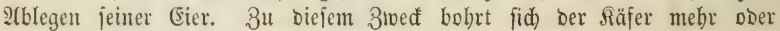
tweniger red)tminflid) in ben Etamm binein uno legt feine (5ier an bie Wänoe Des Mutterganges ab, mitunter fdeint ar bie fluglöher twieber=

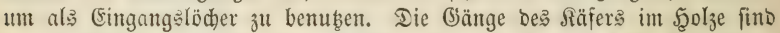

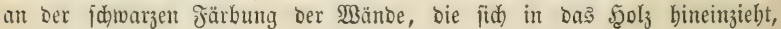
leidht zu erfenner.

Sarben= und Buppenzufand. Die Sarve bringt ibre ganze

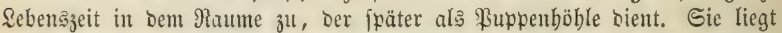

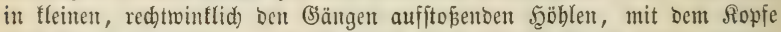
Dem Bange zugewenoet. Die Brut foll meift erft im 2luguft fertig werben. Eine zweite (Senteration findet nid)t ftatt. $\mathfrak{B}_{0}$ bie $\Re$ äfer überwintern, babe idh aud nidyt ermitteln fönnen.

Säferzujtan D (fig. 9. a, b). Der Säfer unterfabeibet fid von B. typographus burd) einen viergliebrigen Geiselfaben mit ungegliebertem 


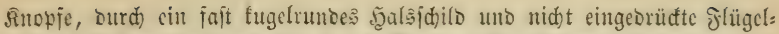
Deden. Seine 2ünge beträgt $3-4$ \$Mmtr. Die Jürbung ijt braun, auf

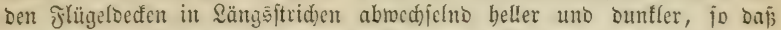

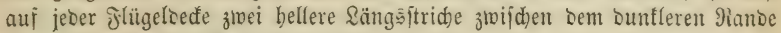
uno einer bunfeln Mittelitreife za jeben fint.

Der Edfaden, Den biefer Räfer veranlap̧t, trifit mefr dä gecrntete als bas wadjenbe $50 l_{3}$, ift aber in Bejiehung anf erfteres jebr bedeutent,

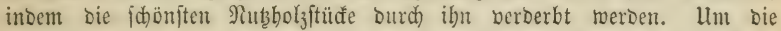

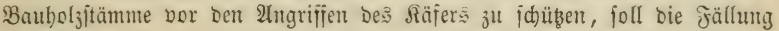
uno Das Entrinoen in ber Eaftjeit am bienlidjten fein. Da ber Şieb in Der Eaftzeit aber auf andere Siseife nadjtheilig ift, fo bat man bie Bau= böljer im J̌ebruar uno Märrz fällen, uno mit Eintritt Der Eaftzeit entrin= Den lafjen. Die Mindfälle der Jabre 1869 und $18 \% 0$ gaben mir Belegen=

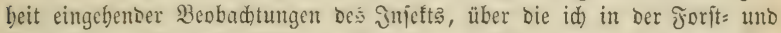
Jagozeitung, Jumibcit 1872, beridftet habe. Jd bermag jeb̨t zll conjta=

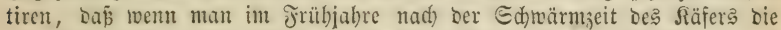

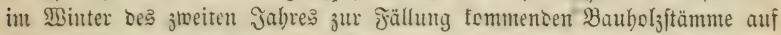
Manmăbäbe entrinben läpt, jolăe Stänmte aud wie Der nod) berinoeten Etammtbeile in ber nädfften Edrwärmbeit bon Den 2hngriffen ber fiäfer

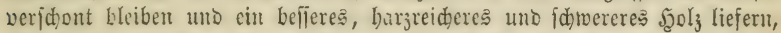
als bei gemöhnlider Minterfällung. Sie Soften Der Entrinoung weroen

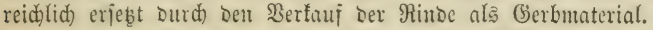

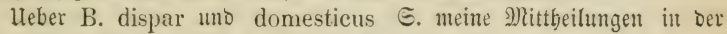
Forit= uno Jagbzeitg. 1844 ङ. 73 uno 1872 S. 181.

8) Hylesinus mieans, bis 8 Mimtr. lang, Laher ber gröfte aller Borfentäfer, lebt im \&arbenzultanoe jamilienweije unter ber Bafthaut ies

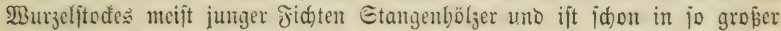
Menge aufgetreten, Daj or empfinolidjen Edyaben angerichtet bat. Jm

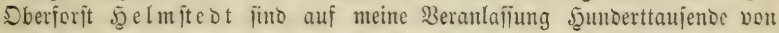
Räjern gejammelt worben, Durd) Entrinden ber befallenen Etämme biđat über Dem Boben, auf leinenen Iübern von 0,7 Mtr. Euabrat, Ienen id

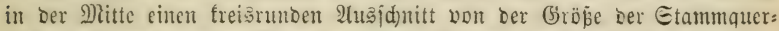

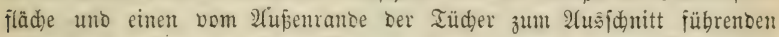

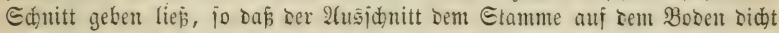
angelegt werben founte. Die vom Räfer befallenen Etämme fino leidht uno jider z̆l erfemen surd) offene Şarzröbren von $3-6$ Mmtr. Sänge, weld)e Dicht über Dem Bobent Dent Eingang zur Jrapittelle befleiden.

9) Der fidtenbafteafer. Hylesinus palliatus (Tab. III. fig. 10. a, b), jobärmt jebr früb im Jahre, mitunter fdon gegen Enoc Des Mionats März. Whie Der Borfentäfer wäblt auch er jowohl franfes,

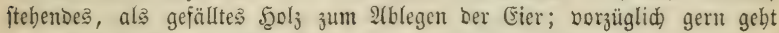
er in bie frifchen Etöcle; Mhutter= unto Rarventänge fino fleiner, äbneln aber benen Des B. typographus. Im (Brojen ift biejer fiäfer nod nid)t verberblid) getworben, joll aber jdon einzelne Etämme getöbtet baben.

Bon Dem bereits bejdriebenen H. piniperda unterideibet fid H. palliatus ourd) Dent fiebenglicorigen (Geifelfaben uno Durch Das nad) vorne fegelförmig herbortretende Brujtbein. Färbung mebr soer weniger bells 
braun, \&änge $1 \frac{1}{2}$ Sinie uno barin bou bem nabe ftebenten H. decumanus veridieben, welder viel größer ift. Bertilgung wie bei B. typographus. Beadtensmerthe Feinoe ber Fidte fino ferner:

10) Bostr. chaleographus und mierographus Lin. (pytiographus Rbrg.) Unter Fidtentinoe in Sterngängent. Erfterer im Dberbarze,

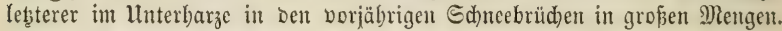
Einzelne barunter B. abietis uno H. rhododactylus.

11) Hylesinus poligraphus. IInter Fid)tenrinoe, in wageredht wer: laufenben Dopwelarmigen (3ängen wie Hyles. minor.

12) Hylesinus cunicularius. Brutftätte: Die $\mathfrak{B u r z}$ ełı Der Fidjte, Rititer im Epätjommer uno Serbit, bie Rinbe uno Bafthaut junger Fidbten am $\mathfrak{B u r z e l i t o d ~ u n b ~ u ̈ b e r ~ b i e f e n t ~ b e n a g e n t . ~}$

13) Curculio Abietis (Tab. III. fig. 12), Delt wir bereits als ge= fäbrtidjen Jein ber Riefer näber fenten gelernt haben, fommt in berfelben

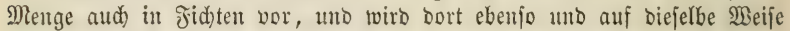

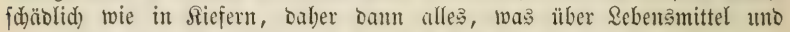
Nertilgungsmittel bort angefübrt ift, aud) bier Anwentoung finoet.

14) Cureulio ater (Tab. III. fig. 15) lebt rie Curculio Abietis

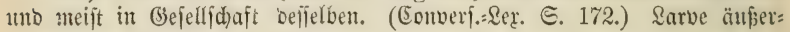
(id) an ben Burzeln im Boben.

15) Curculio hereyniae (Tab. III. fig. 14). Q(elynlid)teit mit Curculio notatus, aud in ber Sebentsmeife; aber mur in fictent.

\section{Feinde Der Fid)te unter Den 2(berflüglern.}

15) Die fleine Fidhten=Sägercipe, Nematus Saxesenii. (Tab. III. fig. 23. d).

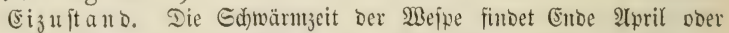
Stnfung Mai ftatt, wenn bie Sinoppen ber fid)te fid) zur Billoung bes nenen Iriebes aufiobliefen. Die begatteten Weibden legen ihre Eier in bie Sinofpen

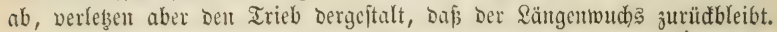

Raupenzutand. Die 20füpige, 11/2 Etm. lange Raupe bat

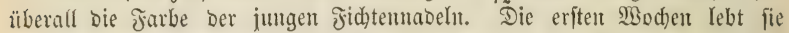

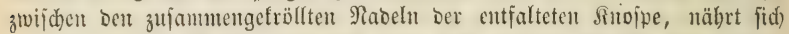
wout ben jungen Rabeln und von Dem nod) weiden fleifde bes jungen Iriebes, ber baourd) balo vertroctitet. Sit bie Raupe etwas größíner ges worben, io gebt fie andere gefmbe Eprofien an mo entmabelt aud biefe,

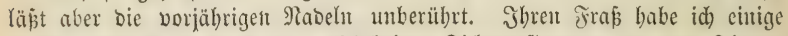
Sabre bintourd) it einer $15-20$ jäl)rigen Sid)tentf(anzung vor ben Thoren

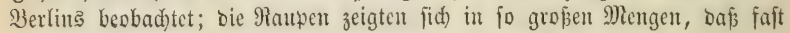
jänmutfiche jungen Triebe jerftört wurben, bentod) gingen bic \$flanjen

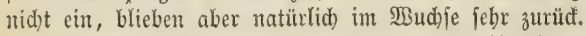

Buppenzuftan. Der Fraßs dauert bis Ende Mai, nur wenige

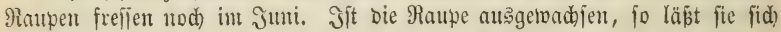

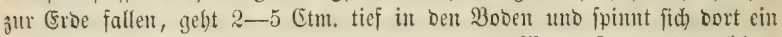

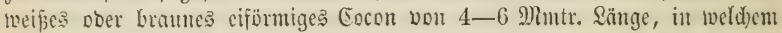

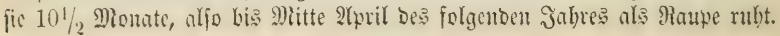




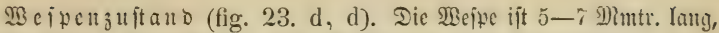
12-15 Mimtr. frügelbreitc. Die Jüblförner finb borftenförmig neul=

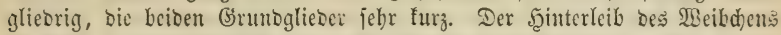
ift ftarf zufammengebrüct mit aufgeridteter Segitadjelid)cioe. Sie Şaupt=

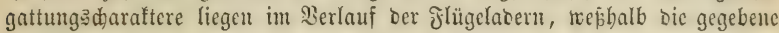
2tbbiloung genau ju vergleid)en ift. Die Brujtjeiten fino glatt uno glän=

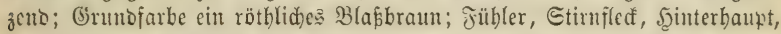

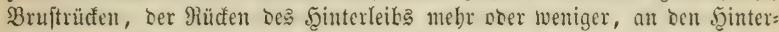

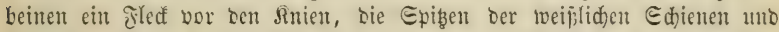

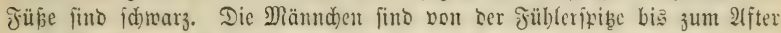
oben idwarz, unten bfafbraun; ser Sinterleib nidht jufammengebrüdt.

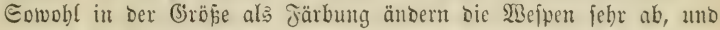

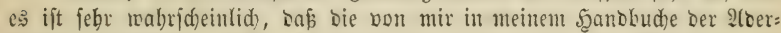
flügler anfgeftelten 2(rten Abietum uno compressus mur 2(bänderungen obiger 2 ert finto.

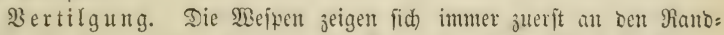
bäument ber Eonnenjeite, wo bic zarte Raupe bei ifrent früben Erfcheinen Die mifte Märme finoct; hier bat man fie aljo zu fud)en. Eollte fie in gröperer, Befahr brohender Menge erfdeinen, fo wiro ein fleip̧iger Betrieb Der Drte mit Ed)weinen das fräftigfte Dertilgungèmittel, uno um fo wirt: jamer fein, ba fid) bie Raupen jehr zufammenbalten.

\section{Die Fid)ten=\&angorn=Blattweipen, Lyda.}

Die Jidute beherbergt cine weit größ̄ere 3abl biefer Jnjeften, ala bie Sicfer, ond hat fid) nod) teine 2(rt fo nadhtheilig gezeigt, sajp fie hier in näbere Betrad)tung gejogen zu werben verbiente. Die all bäufigiten vor: tommenden 2 trten fino:

16) Lyda Abietina und Das bicjer ?trt nach Frrn. Eaxejen an:

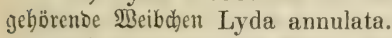

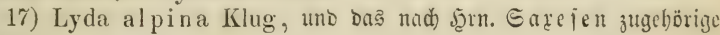
פeibchen Lyda annulicornis.

18) Lyda saxicola uno das nad) bempelben Muturforfer baju gebörige Weibden Lyda alpina Klug.

19-20) Lyda hypothrophica, Klugii, er ythrogaster.

Ebcnio renig fino bic bisher anf Der Yotbtanne biobahteten beion Buid)bormblattweipen: 21) Lophyrus hererniae mo 22) Loph. polytomus merflid) f(jäolid) geworben. Beadtenäwertber bürfte jein:

23) Dic Ricienbolztocipe, Sirex Gigas, uno 24 (oie ftabl= blaue Şolztweipe, S. Juveneus, eritere nur in Jidten, lek̨tere bort unb in Ricfern borfomment. Bebeutung bürften beioe ba befommen, wo

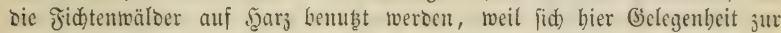

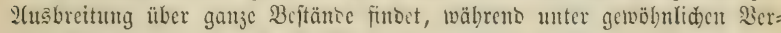
bältniffen mu cinzelne frante Bäunte von biejem Injette befallen werben,

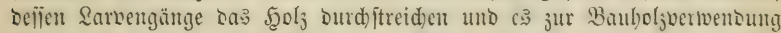

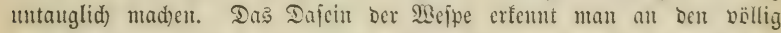

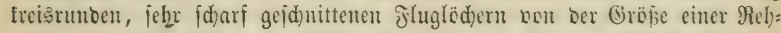

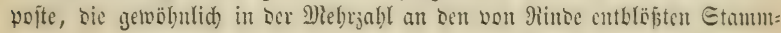




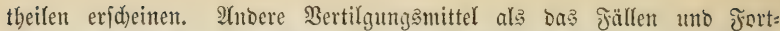

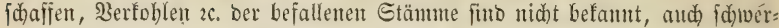

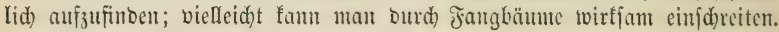

\section{D. $\mathfrak{A}$ s bex $\widetilde{s}$ milie bex Blattiauger}

verbient unter ben auf bie Rothtante angetwiejenen Injeften nod) Der (ङr: mähıutg:

25) Der Fidtenblattiauger, Chermes Abietis, Lin., ein

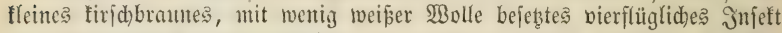

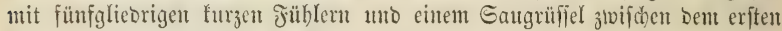
Fufipaare, Deffen gelblid)e Sarbe in Den zapfenförmigen bielfammrigen (Sallen lebt, weld)e mitunter in ungebeuten Mengen, bejonbers auf juntgen

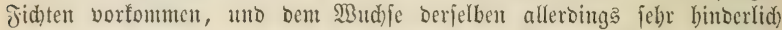
finto. Dem unerad)tet läßjt fid) wobl faum ctroas anderes zur Iilgung bes

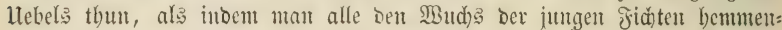

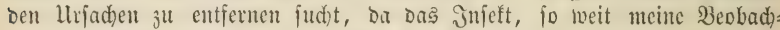
tungen reichen, ftets mur an fränfefhoon Fichten in größserer Menue er:

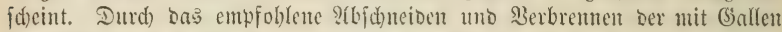
bejebzten 3weige würbe man unfeblbar ben Bflanzen mebr fdabent als mitien. (Eomberf.=Rer.. S. $145-148.)^{1}$

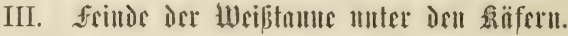

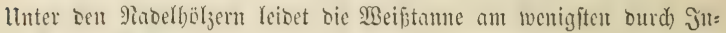

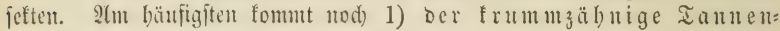
Borfenfäfer, Bostrichus curvidens, vor.

Ei 2lpril ftatfintocn. Sn Iammenflöben, bic id) burd) Sym. Sberförfter $\Omega$ a both auß Ed)lefien erbielt, fanten fid) f(d)on viele fertige Säfer neben ben Sarven, Deren Siachfommen unter ber Rinbe ftelyenoer Säume überwintern

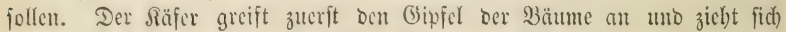
vou ba jäfrlid) tiefer hinnb. Die Mluttergänge Yaufen wagred)t um ben Stamm, twie bei Hylesinus minor, bie \&arvengänge fteigen auf uto ab.

Der Siäfer ift 2-3 Mintr. lang; bie Flügeloecten fint bintent ftart

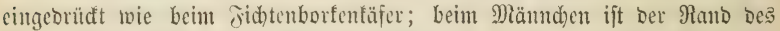

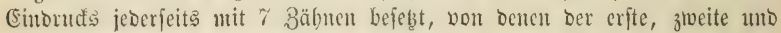
fünfte länger uno gebogen fint, woher Der Same. Seim Weibd)en finto Die Bäbne łleiner uno in geringerer Babl vorbanben; außserbem untericheibet

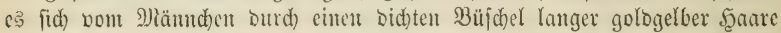
auf ber Gtirn. Seide (bejd)led)ter zeid)nen fid) aukerbem burd ungewöb): (id) tiej punftirte Flügelbeden aus. Diép ift Der Säfer, weld)er it ben frülerent 2fuflagen biejes Qebrbuchs als B. villosus aufgefül)t wurbe.

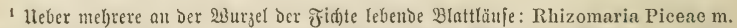
Lachnus subterraneus m. (Tetraneura Abietis an Den $26 u r z e f n$ ocr Taune) und Calobates rhizomae m. Sebtere mit einer, Den Dorthefien älnlidjen förperberedung, Tibic

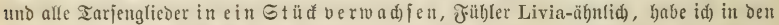

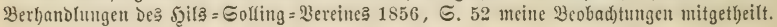


Eollte Der Säfer fid) bin uno wieber in gröperer Mlenge zeigen, io ift bie Bertilgung wohl nid)t anter引, als bie bes Jidtenborfenfäfers, surd Jangbäume 2 . 3 $u$ betwirfen.

2) Der linituteBorfenfäfer, Bostrichus lineatus (Tab. III. fig. 9. a, b), befien bereits unter sen Jidhtenfeinben gebacht ifit, wiro ber

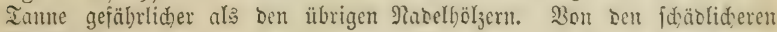
Bortenfäfern beherbergt sie $\mathfrak{E}$ ei und 4) Hylesinus palliatus.

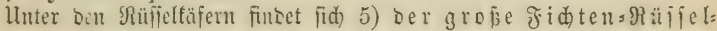
fäfer, Curculio (Hylobius) Abietis nid)t allzuhäurig in Meiptamen; bäufiger

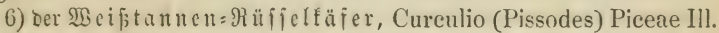

Dod) ift deifelbe bis jeşt mur in gefällten uno getvoricnen Etämmen

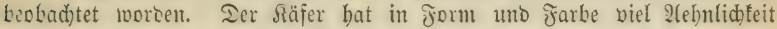
mit Curculio notatus (Tab. III. fig. 13), unterideivet fíd abor von Dicjen, wie von C. Pini (Abietis Ratzeb.) Durd) Die \$unttirung Der Jlügelocten, indem bie Bunftreiben nidht gleid)weit nolt einanoer entfernt fino, jontorn wie bei C. hercyniae abmedjelno einen breiten uno einen id)malen 3wijhenraum zeigen. S3on C. hercyniae unterid)eidet fid C. Piceae

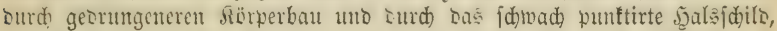
von C. Abietis (Pini Ratzeb.) bingegen burd) bie in Der Mitte Dew Rüifiels ftehenden Fübler.

Unter sen Edmetterlingen uno afoerflüglem $2 c$. fino mir nod) feine

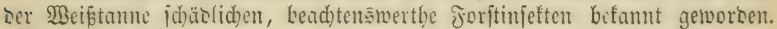

\section{IV. feitìe ذ̀c Lärdje.}

Inter sen Borfentäjem follen B. linearis, Laricis, Hylesinus palliatus unt pilosus in ber Särde vortommen, ood bat jid nod) teine Dicjer 2(rten bier merflid) madbtheilig gejeigt; baffelte gilt anch für Curculio Abietis (Pini Ratzeb.)

Ilnter Den Sdmetterlingen büfte bic fleine \&ärd)enmotte, Tinea Laricinella, Beadtutng verbienen.

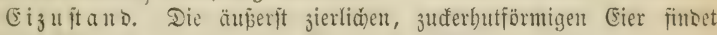
man von Mitte Juni ab auf ben Rabeln ber \&ärd)e.

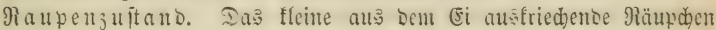
böblt bie Särchemnacel aus uno benuß̧t bie beipomene Exiţe berfelben jpäter als Gad, aแs bent es mit bem Borbertheile nur herborfommt, unt ju

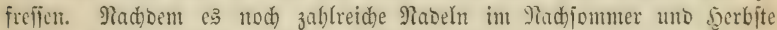
kejonbers an ber Epibe berielben befrefien hat, überivintert es in nädjter

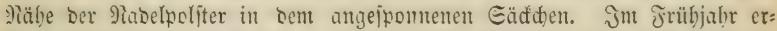

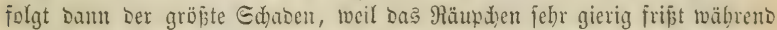

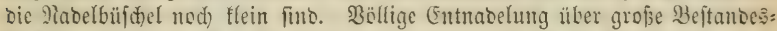
fläd)en ausgebelnt ift nidjt felten uno zumal befbalb fo verberblid), weif Der Jrap fid cine lange Reibe von jabren ju wieberholen wflegt.

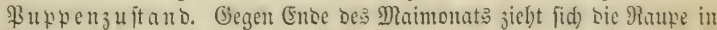

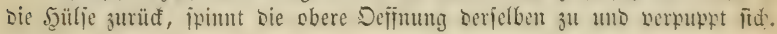


Der Sdmetterling miß̄t 7-8 Mmtr. Flügelpanung; bie Fär: bung ift überall gleidffarbig bunfel afdograu; Die idmalen flügel fint mit langen Jranjen bejeşt, fo bas lek̨tere an Den Dberflügeln länger, an ben Unterflügeht über boppelt fo lang als ber Flügeldurd)meffer fint; Fühbler fait io lang als ber Rörper, fabenförmig. Sdjwärmzeit $2 \mathfrak{M}$ fang bis Mitte Juni.

Bertilgung. Pur einzelne nod) junge Bäumdjent laffen fich burd)

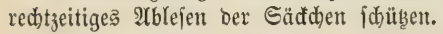

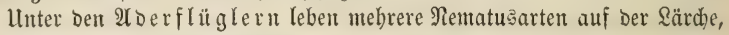

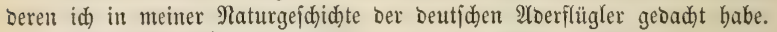

Bendtenbivertb bürften nod) bie auf ber Särdhe vorfontmenden beiben Blattianger Cocus Laricis Bouché uno Chermes Laricis m. fein, über Die id) Şeft 4. S. 643 meiner Jabresberidte gefproden babe.

\section{V. ferillid der faubljölzet.}

Die Raubböljer baben theils an und für fid) weniger feinde unter Den Jnfeften, theils vermebren fid) biefelben nidjt in bem Mape, wie viele

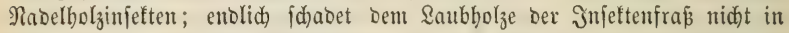

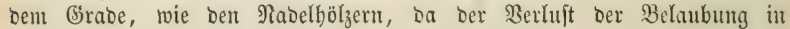
Demielben Jabre burdh Entfaltung Der Blattadjelfnofpen ober burd Den Johannitrieb wieber erjeţt wirb.

lluter ben Sdmetterlingen hat fid Der (Eid)e bie Frocefitions: raupe (Bombyx processionea), ber Sd)wammipinter (Liparis dispar), Der Froftfichmetterling (Geometra brumata), S. meine Beobachtungen in ber Jorjt= uno Sagojeitung 1874 S. 87 uno ber Eid)entwifler (Tortrix viridana) ¡đäblid) gezeigt; unter ben $\Re$ äfern ber $\mathfrak{M}$ a if äfer (Melolontha vulgaris) utı Der (Eidherminirfäfer (Orchestes Quereus); unter ben 2locrflüg: lern befonbers mebrere Sallweipenarten, wie Cynips eorticis uno rhizomae, Andricus noduli, Apophyllus synaspis.

Der Motbbude fino unter ben Sd) metterlingen Der Roth= ¡d)wanj (Bomb. Pudibunda), Der Sdiwammipinter, bie Froftipanner (Geom. brumata, defoliaria), ber Bud)etwidter (Tortrix annulana m. Jorit= unb Jagozeitung 1845, S. 342 fig. 3), unter ben Siäfern bic Budjen= pradttäfer (Buprestis viridis Lin. uno Fagi Ratzeb.), unter ben Flliegen Dic Suchengallmücten (Cecidomyia Fagi umo annulipes) nadtheilig.

Der Birfe baben fid) bisher mur einige Blattfäfer, wie Clythra tpunctata uno Galleruea Capreae, Der હ゙r le Lina aenea, Galleruca Alni uno Bostr, dispar (Jorjt= uno Jagojeitung 1844, S. 73) nad)theilig gezeigt.

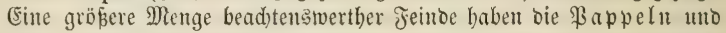
Beiben. Inter ben Sdmetterlingen ijt bejonters Liparis Salicis uno dispar, unter ben $\mathfrak{R}$ äfern Saperda populnea uno Carcharias, Chrysomela Populi uno Tremulae, Clythra tpunctata, Galleruca Capreae, unter ben 2 berflüglern Nematus angustus ibnen nad)theilig.

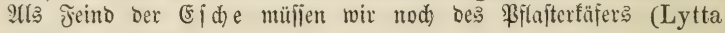
vesicatoria) gebenten.

Bon Den eben genannten Saubbolzinjeften fönten bier mur einige widctigere näher betrachtet werden: 
1) Die Maifäfer idaben nidst allein ourdh bas Entlauben ber Bäume, in weit höherem Grabe wirb Dic Rarve biefes Räjers burd ihre,

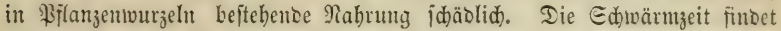

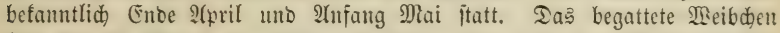
legt 30-40 (5ier in bie (Froe, aus benten fd)on nad 4--6 2 odhen ミarben berbortonmen; bieje, Engerlinge gentunt, leben im erften Eommer ge: jellig und näbrent fich von Bflanzenmoder. Jm Späiherbjte geben fie tiejer in ben Boben, um fid) Dem Jrofte zu entzieben, uno eridheinen erif im fommenten Jrühjabr wieber unter ber Dberfläche bes Bobens, unt fich in gleidjer Weife, twie im erften Jahre, zu ernäbren. Der Larbenjujtano bauert vier Jabre; in britten uno bierten, bod aud idjon int solweiten

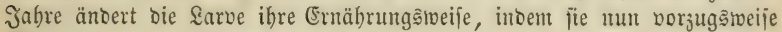

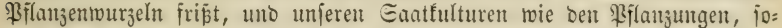
wohl ber \&aub= als ber 2abelböljer oft bebeutenoen Edaben zufügt. Ifn beisen Gommertagen joll bie Sarve in bie tieferen Bobenfodidten binab:

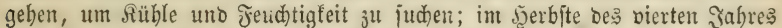
erfolgt bie Berpuppung in einer Bobentiefe von $1-1 \frac{1}{2}$ 决etern; Der Fäjer erjoheint ban im fommenton grübjabre.

Die \$ertilgung oer Maifäfer ift, bejonbers in unjern Mäloen, grojen Ed)mierigfeiten unterworfen; fleipiger Betrieb fold)er Drte, in benen fid) Engerlinge bemertbar madhen, mit Єd)weinen, uno zmar wäl)rento bes Єont:

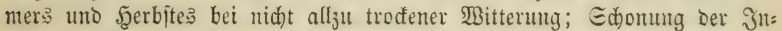
jetten vertilgenton Thiere wiro inmer erfolgreid fein. Das Eanmeln bet

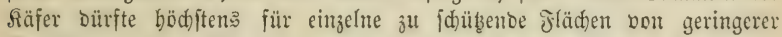

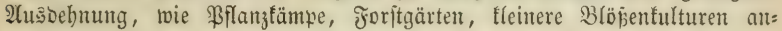
wentobar fein, Da es viel 2 Arbeitsfräfte forbert uno in eine Beit fällt, two bieje vom 2lderbaut in 2(njprud) genommen werben. (Friolgreich ift baß

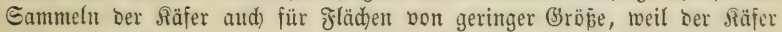

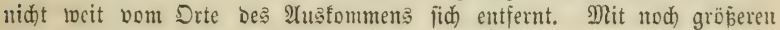
Ed)ivierigfeiten bürfte das Eammeln ber Engerlinge berbunben fein. Da ber Säfer feine (Fier nur in entblösten Boben ablegt, jđübt man Eaat= fämpe am beften Daburd), Dás man bieje bis zur Bobenberrbeitung uno

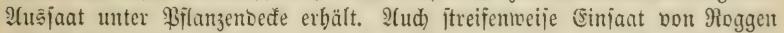
Doer Safer (bielleidt befier nod) bon Rübent) ztrifden bie Saatrillen hat mir treffliche Dienfte geleiftet. (ङ. über Anlage von Bilanjfämpen Forit: unto Jago: Zeitung Jebr. 1859.)

2) Die Budfupradtfäer, Buprestis viridis Lin. (nociva Ratzeb.) ${ }^{1}$ (Tab. III. fig. 17) uto B. Fagi Ratzeb.

1 3ur 2ermeioung aller Bifftür in ber Pomenclatur bejtelyt in ben bejd)reibenoen Maturtviijenjajajten bas Bejeb, Daßj Der Mlame, unter weldem ein Maturförper juer it it

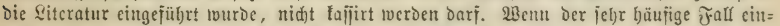

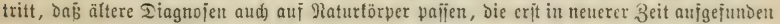
Ivurden, jo gilt als Gejeb: Dō̄ Dem bäufiger vortommenden, als bemjenigen, weldjer Dem

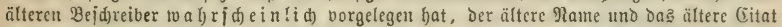
verbleibt (bier $B$. viridis Lin.), wäbrend der jeftener vorfonmende, neu nufgejundene fiörper, cinten neuen Plamen erbält (hier B. Fagi Ratzeb.). Ratjeburgä "Eollectiv=9tamen" werden

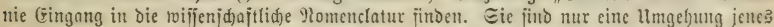
Gejebes. 
G(d) wärmzeit im Juni. Der begattete Säfer legt feine (Eicr ant bie

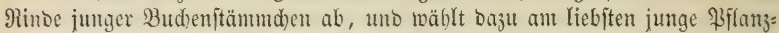

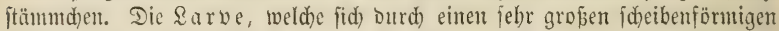
Sovf, Durd einen flachen niebergeorüdten Rörper, Mangel ber Füßse unb burd)

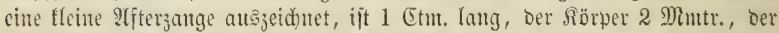

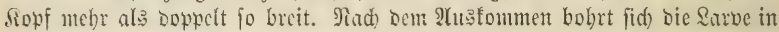
Die Minde ein uno frifit fid im Baft uno Eplinte Des Etammes abmäts, wo

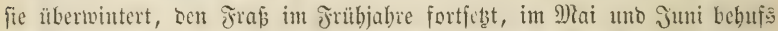

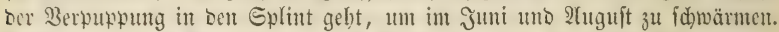

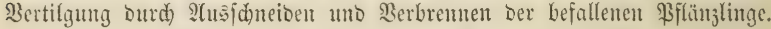

Dur Errlenblattfäfer, Galleruca Alni. (Tab. Ill. fig. 18).

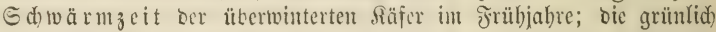

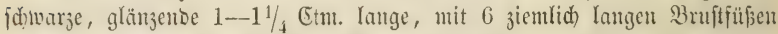

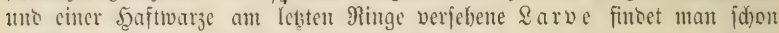
in Mlai uno Şuni anf ben Blättern Der Erle, Die fie foclettiren. Ber:

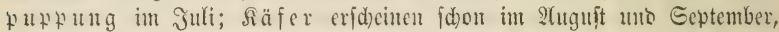

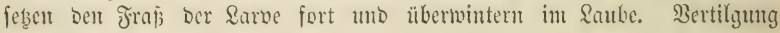
Dutrd) Sammeln Der Räfer.

Der Bappelblattfäfer, Chrysomela Populi. (Tab. III.fig. 19.)

Dicfer Säfer treibt bicfelbe Defonomie anf Bapkeln, wie Der vorige

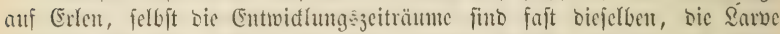

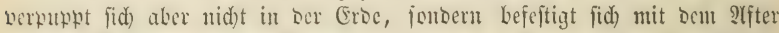
auf Din Blättern wie bie (Eoccincllen, mit bem fopfe nad) unten getehrt. Bejontors anf ßappelwurjelbrut fonmt bis Snfeft oft in fo ungebeurer

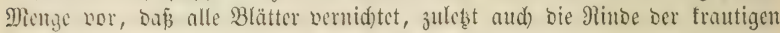
Triebe angegangen wird; aud an $\mathfrak{B e}$ eioniftectlingtrieben bat mir Chrysom.

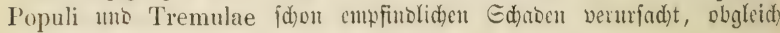
Ripentwurzelbrut in ber Räbe vorbanoen war.

刃ertilgung burd) Sammeln ber Räfer unt ber Sarben.

Der Bapfelbodfäfer, Cerambyx populneus. (Tab.III. fig. 20).

Ed) wärmjeit im Mai uno Juti. Der Räfer legt feinte Eier an bie 9linbe junger 3-6jäbriger Etämmudyen bor stipe, fo wie an bie ange= fd)lagenen Stcellinge anoerer Fappelarten $a b$; bie $\& a r b e$ frift fid int

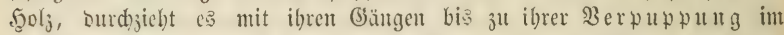
Jrübjabre Des jweiten Jabres, welde imnerbalb bes befallenen Stammes vollbrad)t wirb, worauf fid) Der Sïfer zutr Begattung herausfript. Ber= tilgumg burch Eammeln ber Säfer.

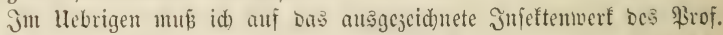
Dr. Maţeburg, fowic anf bie vercinzelten Mittbcilungen im forftliden Enverfations: Rerifon uno in meinen Jabresberichten verweifen.

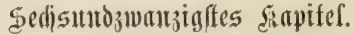

20u Den Sirnflyeiten Dex 5ூol 3 pflanzen. 1

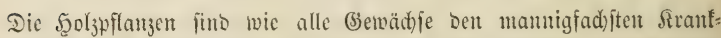

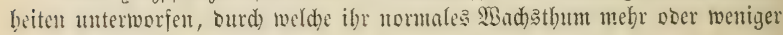

2 Berfafier Dr. Robert Şartig. 
beeinträhtigt wirs, io Daj oft bie ganze Bflanje, oft aud) nur cin 2 beil

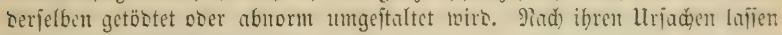
iid) Die Irantbeiten eintbeilen in:

1) Sranfbeiten Durd ungünitige Bodenverbältnilie,

2) " " " atmojphärij be Einĭlüile,

3) Berwunoungen,

4) Srantbeiten burch phanerogante Edmaroser,

5) " " Bilze,

6) " " nod) unbetamte Einftülïe.

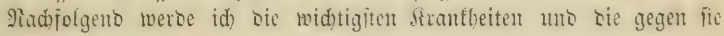

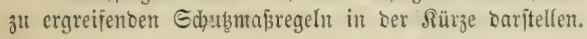

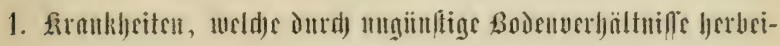 gefiiljt werdett.}

SBähreno in älterer Beit Die meiften firanfbeiten unbefannten Ein=

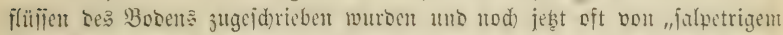
Soben" als sem Bringer aller Rrantbeiten geiprodhen wirb, baben wir in Icr That mu jebr wenige frantheiten aujujäblen, Die in sir B̧obcn: bejwafienbeit ibren Giuno baben.

\section{Die Gipfeloüre ober Bopftrodnif.}

Rem ber Boben Durd) Etreuntnabme ober ourd) Blopliegen fid Le:

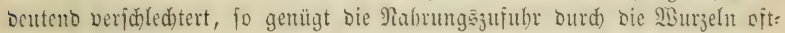
mals nit(t)t, ben oberen Theil Der Baunfronen ferner zu ermäbren, zumal wem

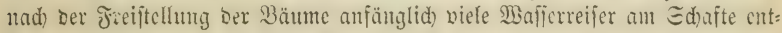
ftanben, Die Dann ben gröften Ibeil Des Nabrungsjaftes für fid verbrauchen.

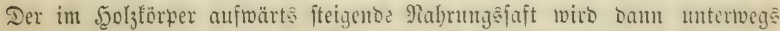
verbraud) no die Epibe Der Baumfrome berbungert ober vertroduet.

3ur Berbütung Diejer Siruntbeit, Dic befonders im gejd)lofienen Bijtunde aufgemadjene Eid)en beinfudft, wenn foldhe frei geftell toerben, forge man

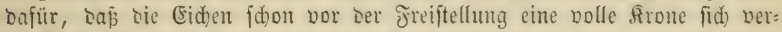
\{d)aift baben, Defbalb unmittelbar nad) ber Freiftellung feine ober mur wenig Mafferreijer bilsen. Iritt bann cinige Jabre mad) ber Freiftellumg bie Boben= verjoled)terung ein, io gelangt ber zlwar nermintoerte Rabrungsjaft bod) bis

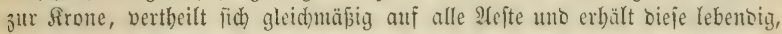
bis surd) Das Seranwadjen bes neuen Jungholjes ber Boben wieber bejdütst, bie Ermäbrung Der Bäume wieber gefteigert wirb.

Sat bie (Sipfeloüre in einem Beftumbe fid) eingeimben, fo muj surd?

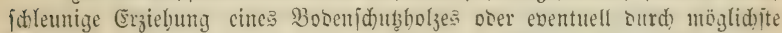
Berbinocrutg Der Streuentnabme auf Bobenverbej̄erung bingemirt merben.

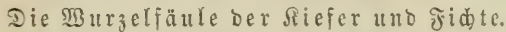

In 20-40jährigen Ricjurnjtangenorten jeigt fich jebr oft anf gröperen

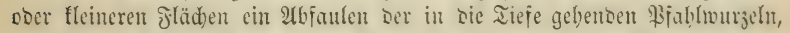
Inäbreno bie fladhitreidsenden 25urzeln gejumb bleiben. Eolde Büume werben surd ben Mins ober Edureanbang im nod) grünbenabelten 3uftanse um= 
genorfen, jterben aber bäufiz aud $a b$, ba bie wenigen fladffreidyenten Burzeln in ber trodenen Jabreßzeit nidht immer genügen, um ben Baum

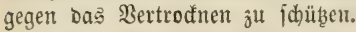

Dieje Sranfheit crflärt fid aus bem lumftunde, Dan meijt in einter Zieje von 0,5 Meter eine Bobenjodidt liegt, bie zwar jebr feft ift, aber Dem Einoringen Der $\mathfrak{B}$ fahltwurzeln fein Scindernís kereitet hat. So lange

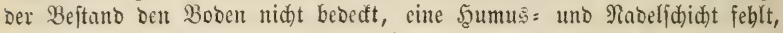
beranlap̃t ber tägliche uno jäbrlidge Temperaturtwechjel zugleid) einen aud)

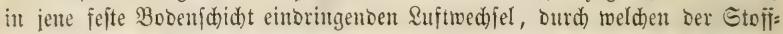

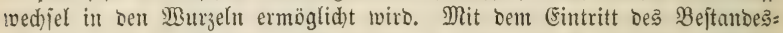

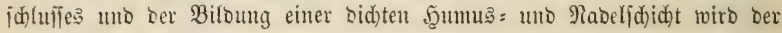

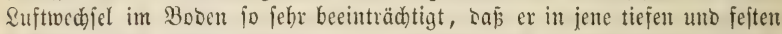

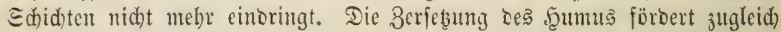
Den Reidfthun an Roblenjäure, minoert ben Bebalt an Eaueritoff in ber

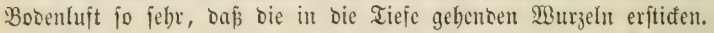

Die Fichte leioet jwar auch an Der MBurzelfäule, jeboch feltener uno

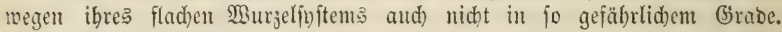
Die fogenamnte Rothfäule Der Jidbte befteht zum Theil als biefer. Murzel= Fäule. Bei Saubhölzern ift fie mir nod) nid)t bofannt getoprben. Die (Fin= wirfung ber Somte auf ben Boben in oer Beit ber Raublofigfeit hat gröperen Suftwedjel im Boben zur Folge, als im Nabelwalbe.

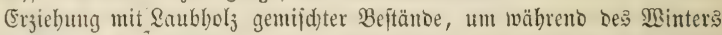

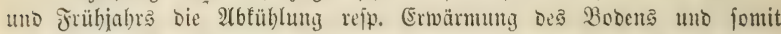
ocu \&uftuedjel zu föroern, Eteigerutg oc: \&uftwedjels im Boben ourd) (Entwäiferung (bei ftagnirender 9iäife), Bobenloferumg u. i. iv. werben nad) Den llmitänben die zu ergreifenden Maß̈regeln jein.

2fm Miceresufer leiben bie Rabel = uno Raubboljbeitänto jutweilen in hohem Mape buth das Seewaifer, weldes nad Heberfluthungen im

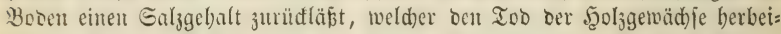

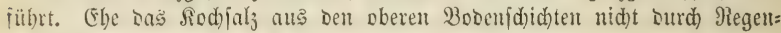

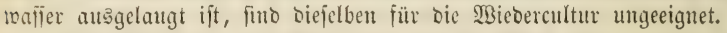

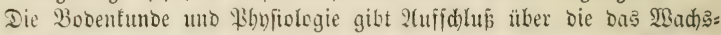

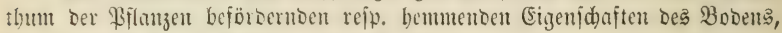
bie an biefer Stelle nid)t zu erörtern fint.

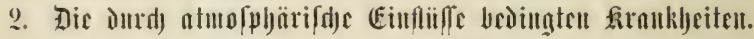

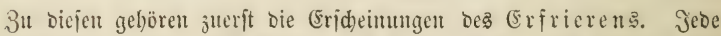

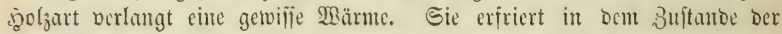
Viegetationsube erft Dam total oder partiell, wenn ibre Temperatur unter biejes Minimum binabjintt.

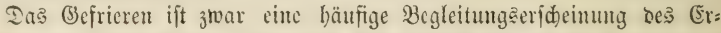

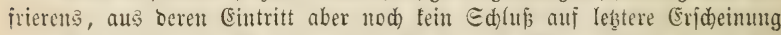

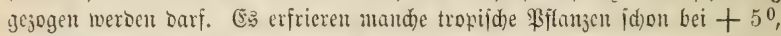
twährento norbifche SFflanzen obne Pad)theil fehr tiefe Temperaturen ertragen.

Weit leidster als im Rubejultantoe erfrieren bie \$iflanzen, wenn fie in Begetationstbätigfeit jid Lefintoen, weil bic in ber Etoffmantlung begriffenten 


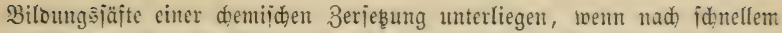

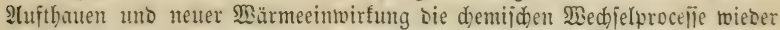
beginnen, che bie Durd) bas (Befrieren eines Theils bes Qöjung: = unc

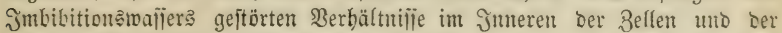
3ellentwärse wicoer hergeftellt fint. Thaut ein gefrorenes Blatt ganz all: mäblig wieber auf, fo nimmt ber flüfilige Belleninfalt, jowie bie Bellmant

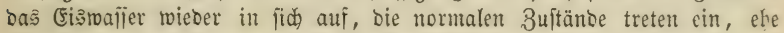
bie Temperaturfteigerung auch bie demijonen Brocefife aufs ?cue amregt.

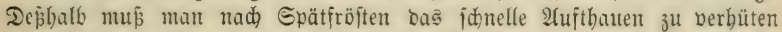
judjen ourd Begiejen mit faltem $\mathfrak{B a f j e r . ~ D i e ~ a n f a n g s ~ g e f r i e r e n t e n ~ W a i l e r : ~}$ tropfen verbindern burd, ibr 24ufbauen uno Berbunften bie zu fidnelle (Er: märmung des Bflanzentbeiles. Eine ähnlide Birfung hat Das Bebeden ber gefrorenen Rfianzen jum Ed)ub gegen bie birecten Eonnenftrablen.

Die Froftgefabr miro gefteigert burd) Malierreidthum ber \$FFlanze unto

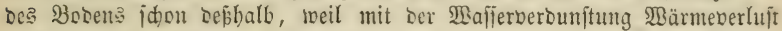

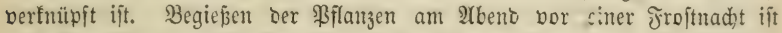
Deßßhalb gefäbrlid. Etarfer Wint bei niebriger Iemperatur ijt fadüblid,

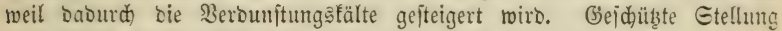
unb Untwičeln ber \$flanjen ift fomit vortbeillbaft.

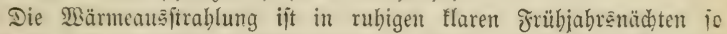
bebeutent, daki bie \$illanzen fälter werien, als die umgebenbe 2uft, unt oft eririeren, wenn leştere nod) mebrere (3rabe üher Dem Nullpunft ftebt.

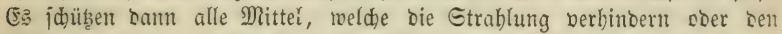
Suftzug beföroern. Die Wärmeauşfrablung läßst fich vermindern Durd) $3 \mathrm{u}=$

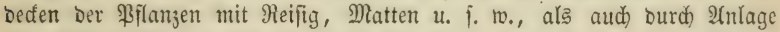

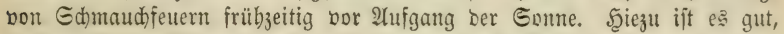
feudtes Material, als \{aub u. โ. w. зu verwenten, ba es borzugatweif

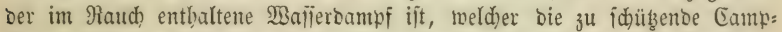

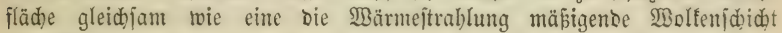
ïberipannt.

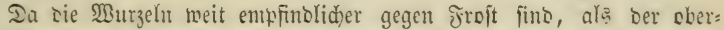

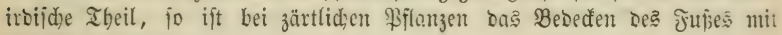
Saub zu empfeblen.

Bei älteren Bäumen bat Der Eintritt hober Sältegrabc zutweilen bas

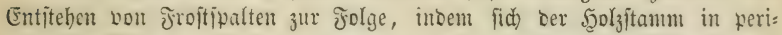
pherijcher Nidstung ftärfer zujammenzieht als in rabialer. Bejonsers ijt

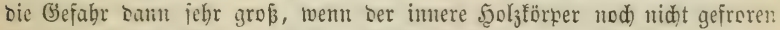

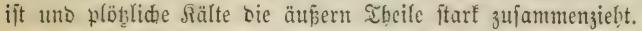

2Uf naliem Boben frieren bie jungen \$Flänzden leidt aus unt liegen

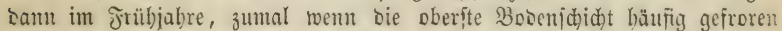

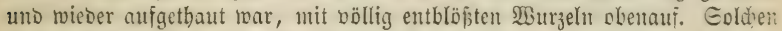

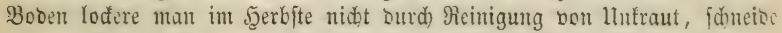
leķteres lieber $a b$, Damit bie TBurzeln den Booen nod) fejter zujammen= balten, bebecte audi) wohl senfelben in serbfte bid mit sanb uno serbinsem bieburd) Das bäufige (Befrieren unঠ $\mathfrak{A}$ ufthauen.

3u hohe Temperatur veranlabt Den Rinoenbrans, Der bejonters

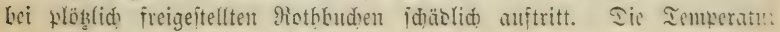


Der bümen Buchenrinte fteigt auf bor Eübiveftieite bis auf $47^{\circ} \mathrm{C}$. unb bat

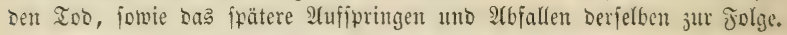

\section{Die Rabelidütte ber Riefer.}

Eelten fobon einjäl)rige, meijt erjt 2-5jäbrige Riefern jeigen oft in wentg Iagen, bejonbers in ben Mionaten März bis Mai cin Braumberben uno Ibfterben Der Nadeln, Dem ein 2tbfallen (Echütten) Der Doppelnabelı folgt. Sm Ed)ub̧e alter Bäume fonmt bie Srantbeit feftenter vor, als auf fablen ölädhen, im bidten Etunoe erwadjen, leioen fie mebr als in lidster

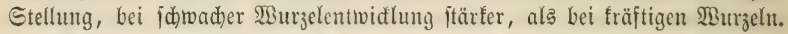

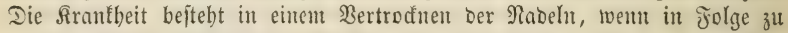

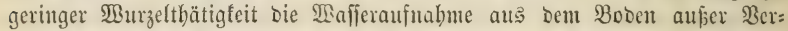

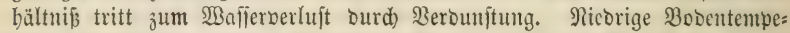

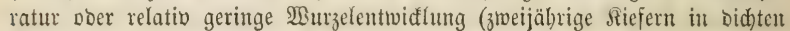
Saatrillen) cinterjeits uno bohe \&ufttemperatur, Directe Jnjolation umo trocene uno betwegte Suft anbererjeits erzeugen bas bezeiduncte Mipserbält=

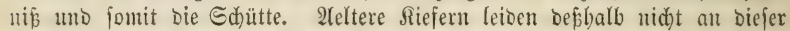
Sranfbeit, weil einestheils bie $\mathfrak{B u r z e l n}$ tiefer in ben Boben cinoringen uno von vorübergehender 2(btüflung ber oberften Erojdidc)ten unabhängig

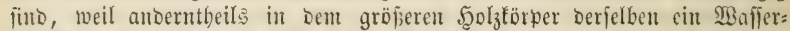

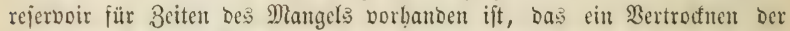

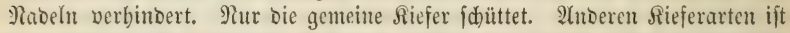

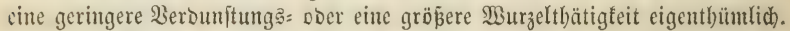

Die Mittel gegen bie Sdütte müfīen einerfeits bie Erböbung ber Bobentemperatur in früblinge rejs. F̈̈rberung ber 93 uzzelentwictlung,

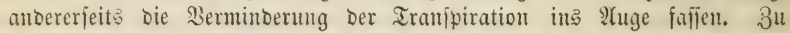
erfterer gebören: Beoedüung Des Bobens mit Raub, Reifig sc., Entwäfïerung bei nafiem Boben, Rocferung auf feftem Boben, um bas Eintoringen Der

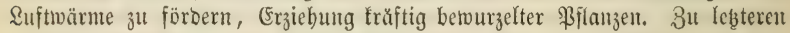
gehören: Befteden ber Saatbecte mit Rabelholjzimeigen, un Bejchattung ber: juitellen, 2Anlage ber Saatbeete an Etellen, bie gegen bie Mittagşomte

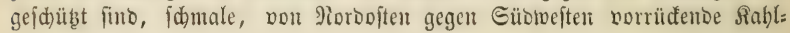
id)läge น. \{. w.

Sid) tutangel verunlajt cineștheils Das Rämmern und Bergehen unenolich zablreid)er Bflanjen unter Did)tem Beftande, erzeugt anberntheila Die jogenamnte Bleidjudut, ons Berfpillern ober (Etioliren, wenn Bflanzen, bie in \&idjt erivadjen uno mit Bifoungsftoffen verfeben finto, ins Duntle

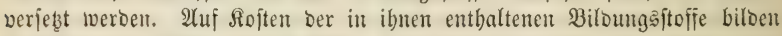
Tie żwar neue Iriebe uno Blätter, aber fein Blattgrün. Sie fömmen deps: balb auch nidjt affimiliren uno an Subftanz zuncbmen.

Sebr trodene Suft faun unter Umitänden, zumal für jugendlidje

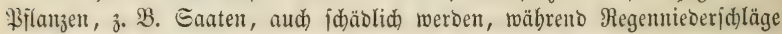
Dem 2Injakg Der Blüthe veroerblid) werben fönten. Şiergegen, wie gegen Berleb̧ungen ber Bäume ourdh Şagel, Edncebrud), Sturmwinto u. i. w. jteben uns mur wenige Mittel zur $\mathfrak{B}$ erfügung.

Sdublos jino wir ferner gegen bie Sdäben, weldhe burdh Bliba id̆läge Den Bäumen zăgefügt werben. Befdränten fíd) biefelben auf 
eingche säume, fo ift ber Edjaben aud nidft bedeutent, woht aber ift bas juweilen auftretente $9(6$ fterben ganjer Baumgruften in Folge eines Bliţ=

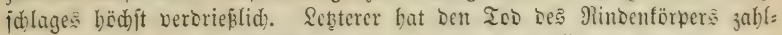

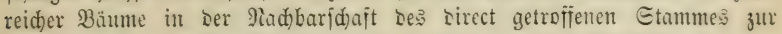
Jolge unb bicje fterben immer im Saufe einiger Jabre allmäblig $a b$.

Bervilie (3) aje zeigen jidh für das (jebeihen der Bäume im bödjiten Grase madtheilig. Bor allem ift es bie im Raudje getwerblidjer Etablifie: ment3, Der Süttenwerfe, Der Eifenbabnlotomotiven u. i. w. enthaltente id)weflige Eäure, weldje im Blattparendum Den Bellen Wafier enţieft,

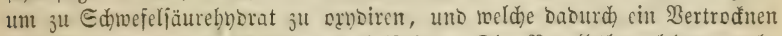
umo Braunwerben Der Blätter berbeiführt. Die शabelhölyer leiden mehr

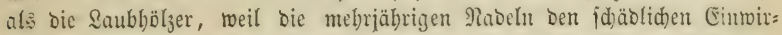

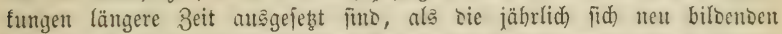
Blätter. Dą einzige anmenobare Gegenmittel befteht Darin, beim baütten=

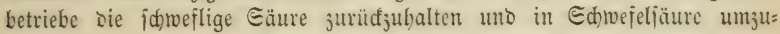
ranbeln.

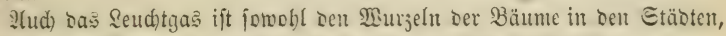

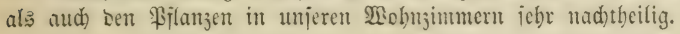

\section{1)}

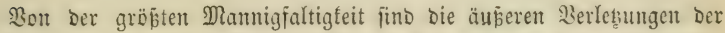

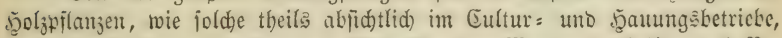

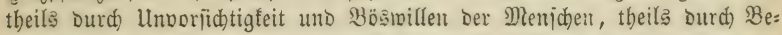

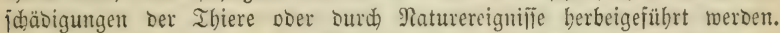

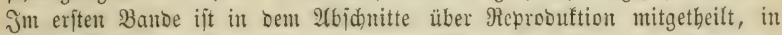
weldher Meije Der Baum bie entftandenen Munbent heilt, bie verloren ge=

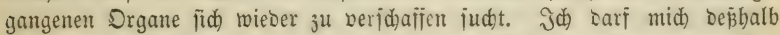
bier Darauf bejdränten, Die midjtigiten im Walde vorfommenten ßer= wundungsarten hervorzubeben.

Rinoebejöbagungen bis zum 5ूolgtörper, mögen joldhe un Den ganzen Stanm berlaufen (ßingmunden) ober nur auf eine Seite Dellelben be:

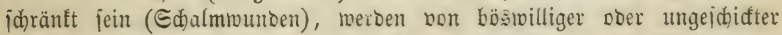

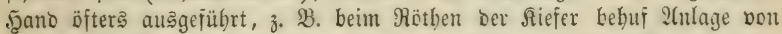

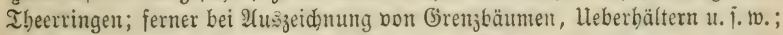

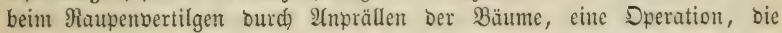

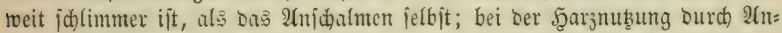

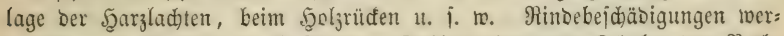

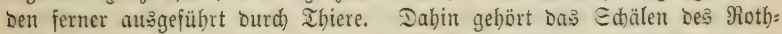
wiloes, bas Benagen Durdh Mäuje, Die Bejdäbigungen Durd) Eped)te u. j. m.

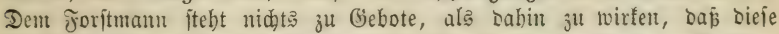

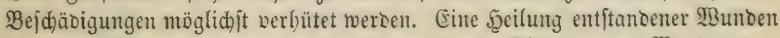

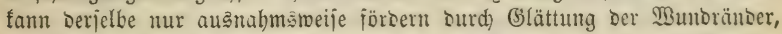
Beftreidyen mit Theer u. j. m., um dą Einfaulen зu verbüten.

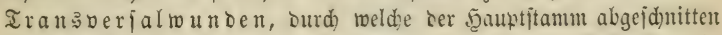

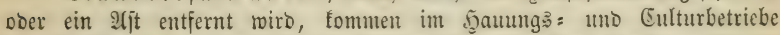

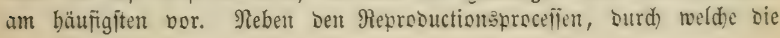


Wunbe fid fidliejt, bie entfernten Drgane wieber erfebzt werben, fdreitet

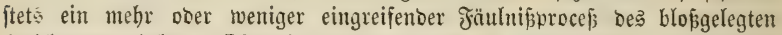

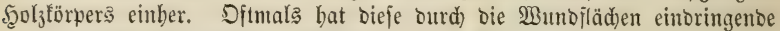

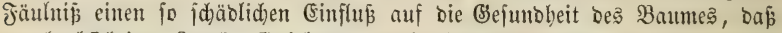
Der beabfidtigte 3wed, (Erziebung werthbollen Materials, Daburd) vereitelt wirb. Befonders gefäbrtid ift bie (Srünäitung zutr Saftzeit und überlyaupt wäl)reno ber Begetationszeit, uno jollte biejelbe nur währeno ber Beit ber Begetationsrube zugelafien merben. Die Regeln für bas Befdneisent uno ?(uลäften fino bereits in früberen $2(b j d)$ nitten dargejtellt worben.

\section{Farauklyeiteu Dutrd) pljaucrogame Sdjmatober.}

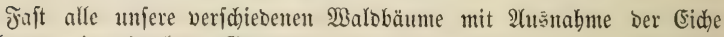
beberbergen in einzelnen (5egenden mehr, in anderen feltener anf ibren 3meigen unto $\mathfrak{A}$ eften bie Miftelpflanze, Viscum album, ein immer=

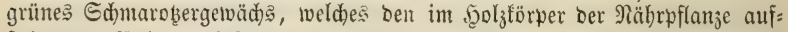

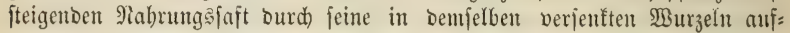
faugt. Die runben Beeren werbent bon ber Mifteloroffel unb anderen Bögeln gern gefrefien, mand)e ber in benfelben enthaltenen Samenförner fommen

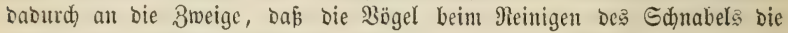

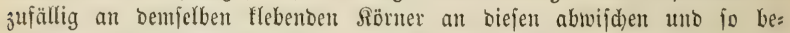

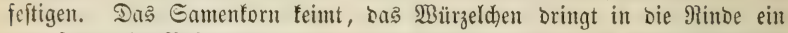
uno fentoet im Baftgewebe mebrere Geitenturzeln aus, auf beren ltnterfeite Die jogenannten Gentermurzeln entftehen, die nidht ins 50 lz cinoringent,

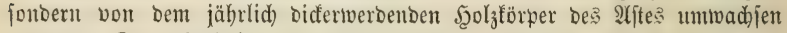

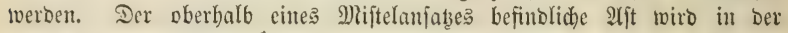
jolge nur mangelhaft crnährt uno verfümmert immer mebr. Zahlreiche M) Xifteln auf einem baum fömen biejem gropen Edjaben zufügen.

Bejonters leioen 2 Beißstante, Bappel uno Dbjtbäume oft febr unter Diefem Sd)marober. Redtzeitige Entfernung Der befallenen 3meige ift bas Lefte Mittel zur \$erbütung ciner größeren Berbreitung.

Sn Defterreich) leibet bie (sid)e und jüßse Saftanic unter eintem bem Viscum nabe verwanden Sd)maroker, Loranthus europaeus, (Eid)en= mijtel gentannt. Dieje fonmergrine Pflanze veranlap̧t bie Entftebung von

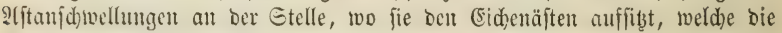

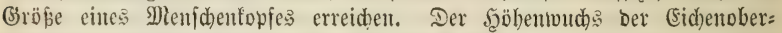
ftänoer in ben Mittelwaldungen wiro burd) Den Loranthus in ber nad)= theiligiten şeife beeinträdhtigt uno follte, ba bas 2(bbred)en ber befallenen

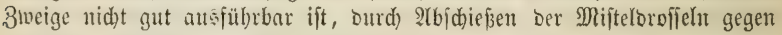
bie Beiterverbreitung gewirft werben.

Die übrigen whanerogamen Sd)maroberer find, foweit fie anf Şolz= genüd)jen bei uns vorfonmen, mur von ganz geringer Bebentung.

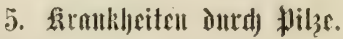

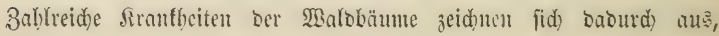

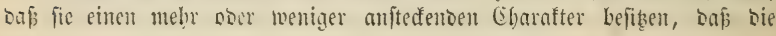


Frantbeitserideinung an einem Iheile ber \$flanje beginnt unt int Saufe ser 3eit auf anbere Theile berjelben übergeht, Daf, bie zuerjt erfrantte \$iflanze

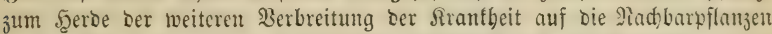
wirb. Die Unterjudung biejer Infectionztrantheiten bat bargetban, daj jie herborgerufen werben burd) bie (sintwirtung parafitif(her \$ilze, burch) Deren Sroren bie Srantheit in ber \&uft weiter verbreitet uno auf giachbar=

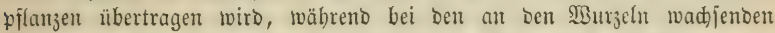
\$ilzen Die Erfrantung Der Nadbarpflanjen fdon Durd) Berülrung Der

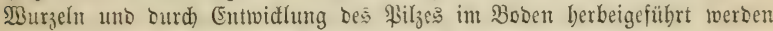
fantr. MSenn Raupen ober Räfer unjere Maloungen verwüften, fo feben

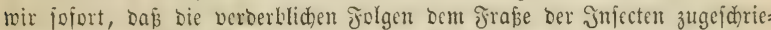
ben werben müfjen; weun bagegen paraịtijd) \$ilze berbeereno auftreten,

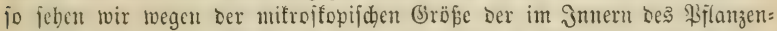
gewebes vegetirenven \$ilzfäben mit unbewaffnetem 24uge nur bie jolgen

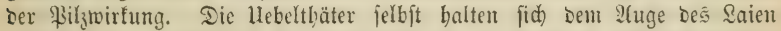
entweder ganz berborgen ober geben fid) erft in einem dft febre faäten (Ent:

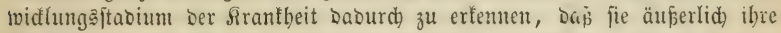
Jrudtträger, an Denen bic Gporen entifeben, entwidelun. Ia nun Diefe Seţteren von ben \&aien allein beadetet zu weroen pflegen, fo bat fid biel=

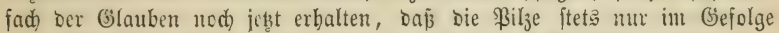
ciner Srantheit aufträten, bie anberen unbefannten Einflüfïen jugejdrieben

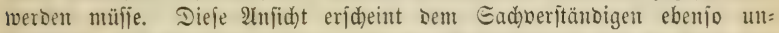
beredtigt, wie bie Bebauptung, Daf bie Riefermraupen nur in Jolge ber Entunaolung Der Bäume fid zeigen.

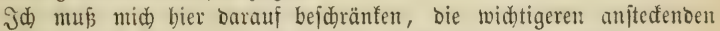
Strantheiten ber Balbbäume in ihren äuperen Erjokeinungen barzuftellen uno Diejentigen Mittel zu bejprechen, meld)e uns zu Bebote jteben, gegent beren Weiterberbreitumg einzuj hreitent.

\section{Warafiten Der fanmunuzalı.}

Der Şallimajd) (Agaricus melleus) Erjenger Des Ḑarj=

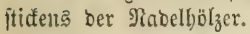

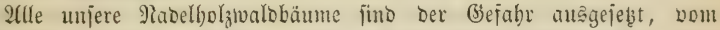

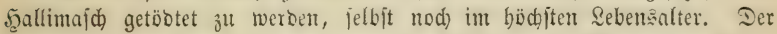

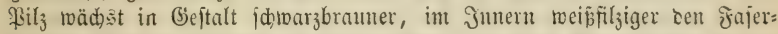

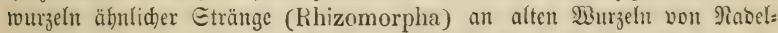

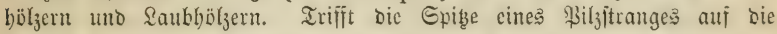
gefunoe 28iuzel eines jüngeren ober älteren slabeltholjbaumes und findet an biejer eine Stelle, an melder fie in ben weichen, lebenden Bajt ein= zuoringen bermag, fo entwifelt fid) Der Bif $_{3}$ im Bajtgemebe Der gejunden Sflanze in Bjeftalt breit=banbförmiger weiß̧er qilzbäute, allmäblig Dcm

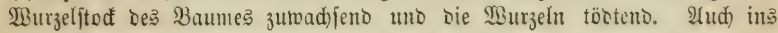

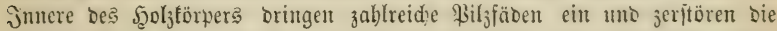

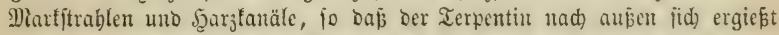
uno bie Eroe zwiid)en den Wurzeln berfittet. Sin 2(biterben bes einige Beit fümmernoen Baumes tritt Dann ein, wenn bie Bibijomorphen in

5) artig, Sefrbud) für F̈̈rfter. III. 


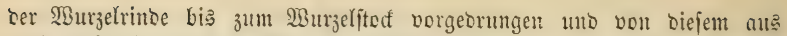
audi) anf bie übrigen wisurzeln übergetreten fino. Der Iob Seb̨terer hat baun dą̧ fdnelle Bertrodnen Der Pillanze zur Folge. Bon bon

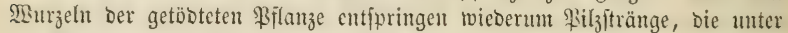
Der Bodenoberfläde fortwadyfento fid) verbreiten uno bie Nad)barpflanzen gefäbroen. In Monat Detober fieht man bie großen honigfarbencu Seut=

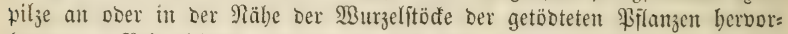
fommen. Bei bidtem Stande Der Sflanzen in jungen Ed)onungen ent= ftehen fo allmählig fid) vergröpernoe Błöß̋en, bei gröperer Entfernung ber Bflanzen von eimander erfolgt Das arbiterben mebr vereinzelt, da bie int

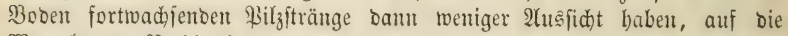

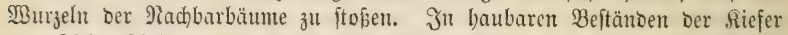

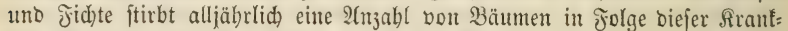

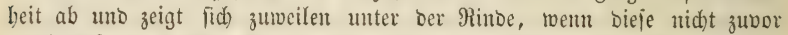

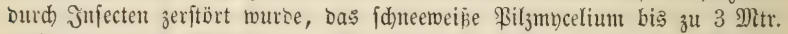

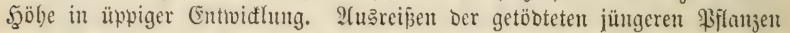
entfernt gröftentheils aud ben Sil $_{3}$ uno verminoert Daourd) bie (Sefabr Der Serbreitung; too fid) gröfere Süden zu bilben beginnen, bürfte bas 2(nfertigen 0,5 Mitr. tiefer Etid)gräben zur Jiolirung ber inficirten Stelle ratbjam feir.

\section{Der $\mathfrak{B} u$ rzelfdidnam. Trametes radiciperda.}

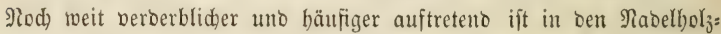
bejtänoen Der $\mathfrak{B}$ urzelidwamm. Die fhlimmite form ber Mothfäule Der Jid)te uno Silefer, nämlid bie, weldye ein 2lbjterben Derfelben uno bie

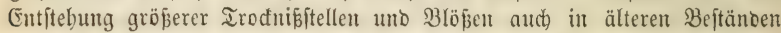
nad) fid zieht, ift biejem Barafiten zuzujd)reiben. Das auts feinten, meißen

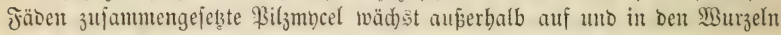
Der Fid)te, Sicfer It. F. W., tritt ba, wo eine erfranfte $2 B$ utzel mit einer

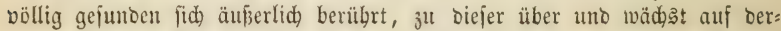
felben bis zum $2 B u r z e l i t o d$, von too es jeine Berberben bringende $\mathfrak{W}$ ande:

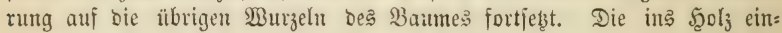
bringenoen Fäben wadjfen jaduell im nod lebenten $B a u m e$ cmpor uno färben Das Şols zuerit violett, päter bell gelbbraun, toobei fid) oft fleine, läng=

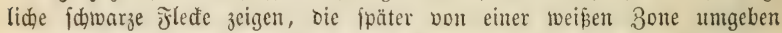
weroen. Das Junnere Des Baumes ift bei Jiưten zur Beit Des 2Gjterbene oft bis zu 6 Mtr. Szöbe faul uno viro über dem $\mathfrak{B}$ urzelftod bas im

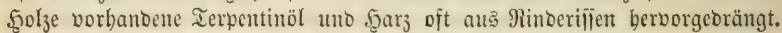

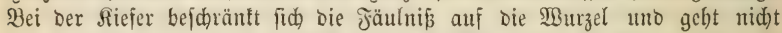
böber im Stamme empor. 2uf ben vom \$il getöbteten 13 urzeln bentertt man äuperlid) bier uno bort ben Pil $_{3}$ in Geftalt fleiter fommbiggelber Soliter zum Borfdein fommen. Die frudtträger, bie fid im Boben an

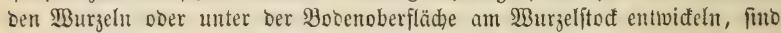
jelten conjolenförmig, meift ohne beftimmte form flädjenförmig ausgebreitet. Die fichnemeif̧e poröfe Oberfläd)e erzengt in ben feinen Sinälen bie Sporen, wäbreno bie fterilen Fläh,en ber Frudtträger zimmetfarben fino. Frutht= träger fömmen fich uni ba entwidélit, too im Boben fich Seerräume befinden. 


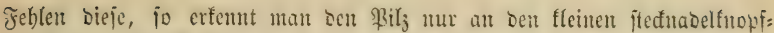

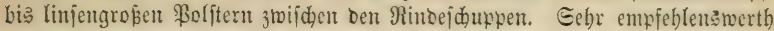
ijt bie 2(nfertigung von Etid)gräben in Der llmgebung ber \$iljpläbe, wotei

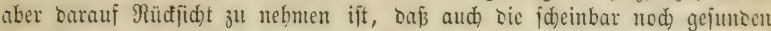

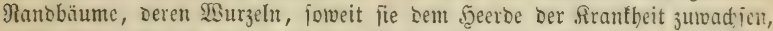
meijt ifhon erfrantt funo, bon ben Siplirungägräben ebenfalls eingejd)lojīn

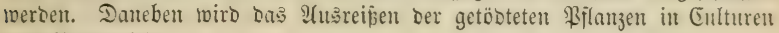
von Pluben jeir.

\section{Der MেUrzeltöbter ocr Ëide. Rhizoctonia quercina.}

In Eichenjaattämpen töbtet cin, Don unterimbijchen Etengeltbeil in Dor Piegel juerjt angreifenter Bil $_{3}$ oft Den größten Theil Der Biflanjen, mobei

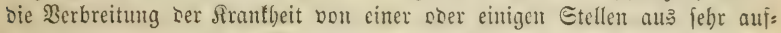

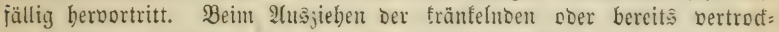
neten Sflanjen bemertt man, Daj ber unterirbija) Theil abgeitorben uno von jeinen \$ilgfäben ummoben ijt, währento an Giengel jebr seutlid') jablreide, bie G̈röbe eines groben Edhiefpulvertornes erreidjende jđwarje

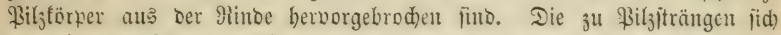
vereinigenten Jüben wadjen in ber Erce weitcx uno übertragen bie Sirrant: beit auj Die Sadbbarfilanjen. Siolirung Iutd) Etidgräben wiro aud biev anzumenoen feir.

\section{Warafiteu Des folzhoörucrs.}

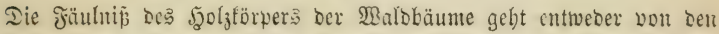
Burzeln aus uno ift bann eine weitere Entwidlungsftufe ber parajitijdent

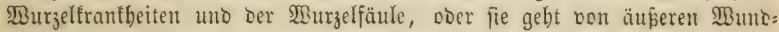
ftellen des Etammiç, D. h. bon 2litrunden ober Edälftellen, aus. Dic veridiebenen Arten Der Szolzjerftörung in lebenten Bäumen wurben bishor

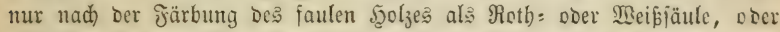

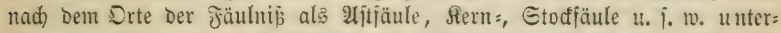

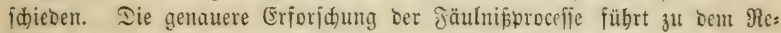
jultate, baj bie Ât ber Dabei wirfjamen Bilje faft ganj allein ben (Bang

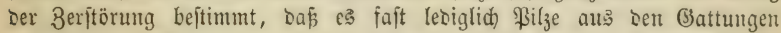
Polyporus, Trametes u. j. w. find, Die bas Sgolz unjerer Malobäume

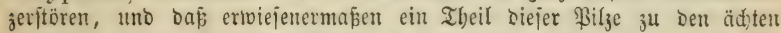
Barafiten gefört, bie ifren (Einzug in Das jumere ber Bäume Durd) $2(f t=$ loumben nebmen.

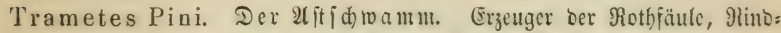

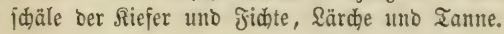

3u Den idfinmiften ßarajiten in Siefernbeftäncen gebört Der 2(jt=

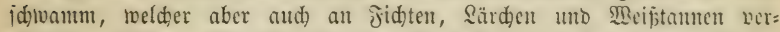
beerend auftritt. Die Eporen Des \$iljes feimen auf Den 28 unoflädsut

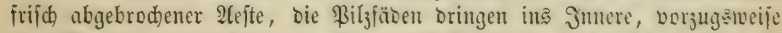

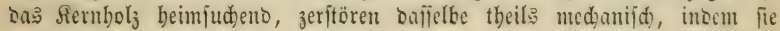


Die Bellwantungen burd)löd)ern, theils d)emifid, intom fie bie primären

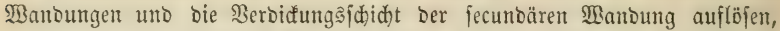
fo dafa mur bie imnerfte Grenzbaut jeber $50 l_{3}$ fajer übrig bleibt. Soldhe

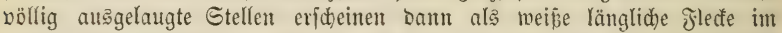

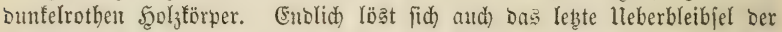

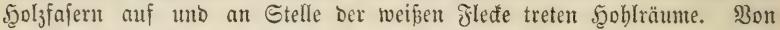

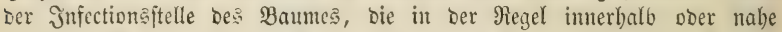
unter ber Srone Des Baumes licgt, berbreitet fid Der Barafit nad oben

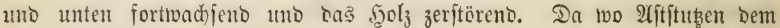
Bilze eine Brüde Durd) Den Eplint nad) anfent bieten, wäd)şt berjelbe her= vor uno biloct feine confolenförmigen frudtträger, bie alljäbrlid fich) ver:

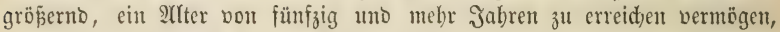
uno zahlreiche Sporen in Den Sintälen auf Der Unterjeite erzeugen.

Das rabifalfte uno febr gut praftifi ausfübrbare Begegnungảnittel gegen biefe Rranfleit, Die befonbers in on Riefemforften unberedenbare Serlufte mit fid) fülyrt, ijt Die Jortnabme aller Edwwammbäume in ben Durdfforftungen uno ben Totalitätshaumigen. Einerfeits weroen zabllofe

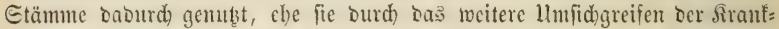
heit nabezu merthlos gemad)t werben, andererfeits lviro burd) bie Entfermung

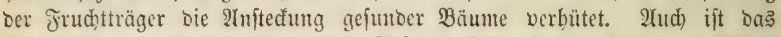

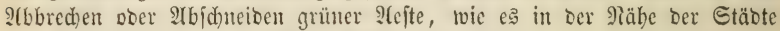
uno Dörfer oft genug geidiebt, ftreng zu ahnoent.

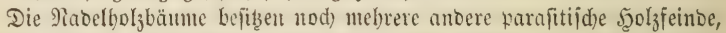
bie aber weniger häufig fint, als bie Trametes Pini uno radiciperda,

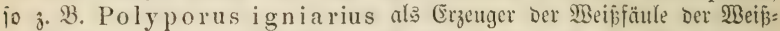
tame, Polyporus officinalis an Der \&ärd)e u. $\mathfrak{A}$. แt. 2(n abgeftor=

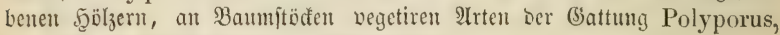
Die nidat zu ben Barafiten zu zäblen fino.

Die Raubhorbäume fint befanntlid) cbenfalls Den verfdiedenartigften Säulnipiprocefien unterworfen, von benen bie gefäbrlideren formen eben=

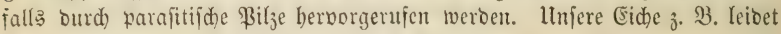
beionoers an Drei Sirantheiten. Durd) Polyporus sulphureus ent=

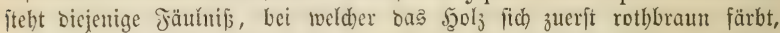
treden uno zerreiblid) wirb. Durch bas 3 ujanmentrodinen entfiteken rabiale

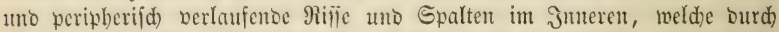

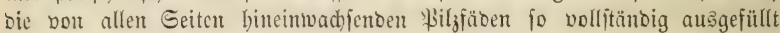

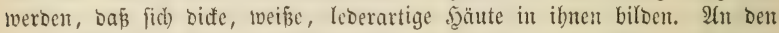

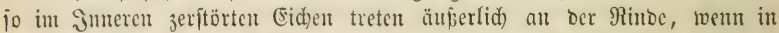

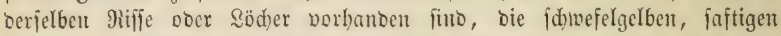

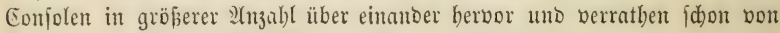
Beitem Den Buftanto Deక Bauminteren.

Fin anberer \$il $\mathfrak{y}_{3}$ Polyporus dryadeus, befien Sporen an

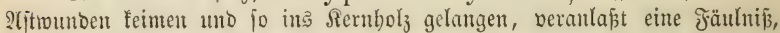

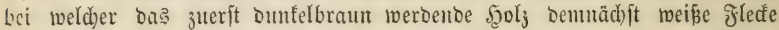

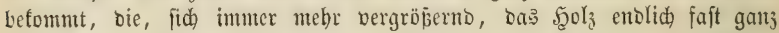

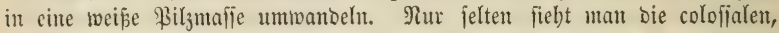
oben grauen, unten rotbbrauten, imterlid) weid)en, Diffen fruct)tträger= 


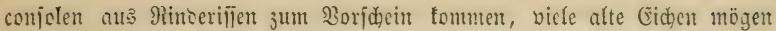
wohl böllig burd) biejen Barafiten zerftört werben, ohne daj jemals die Entrodđlung eines Jrud)tträgets an ifnen ftattgefunoen bat.

Eine ber bäufigiten Eidgenfäulnifprocenfe ift bie burd) Polyporus

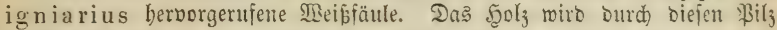
gelblid)reiß gefärbt uno gleid)mäßig mürbe gemacht. Die fajt tie Gärte be Şoljes befiţenoen, runoliden, bis conjolenförmigen, auf ber poröjen Eeite roiffarbenten Frudtträger fieht man febr oft an Den Eidhen fiken, Da bies jelben feremirent find unt, cimmal entitanten, nid)t alljährlid) mieber verfowinton, wie bie Jirudtträger ber beioen vorgenannten (Eid)enpilze.

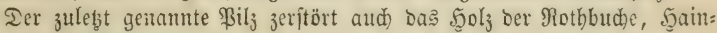
bude, ber Dbftbäume u. ¡. w.

Die Rotbbude befibat cbenfalls zablreid)e Feinde unter ben Pilzen. Die Birfe vorzugstweije icn Polyporus betulinus. TUf alle dicje Jeinbe näber cinzugeben, erideint bier um fo mentiger angezeigt, als von vielen ocrielben nod) feítgejtellt toerben muis, ob biefelben sent Baum frant mad)en fönnen, ober ob fie mur fecuneär fino, ๖. ho. mat in bereits tootem Scolze vegetiren.

(Es mag bier nod) barauf aufmerfiam gemadht werben, baf nidft alfe

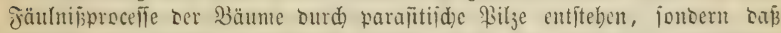
ïberall, too ber Baum äußerlid) berleţt miro, ber blofigelegte Szolztörper vertrodnet, abitirbt uno bam burd) Jäulnippilze jerieb̧t roirb. 2ie 3er:

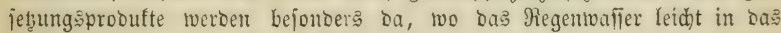

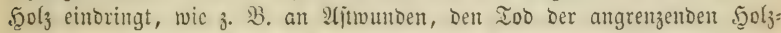
zeflen uno beren Jäulnif nad) fid̆ jithen, bod) berbreitet fich eine joldhe

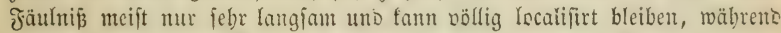

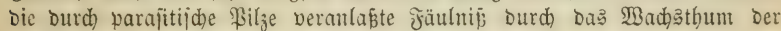

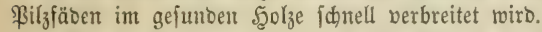

In abgeftorbenen Sูölzern fiebeln fïh sie veridiebenartigiten $\left.\mathfrak{B i}_{3}\right\}_{3}$ an, meldje daffelbe jhnefler ober langiamer jerftören, fo lange bajielbe bie jun

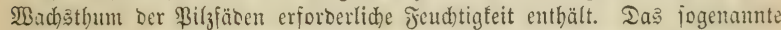

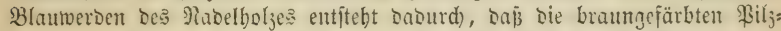

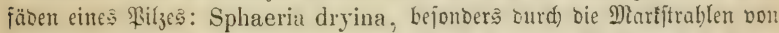

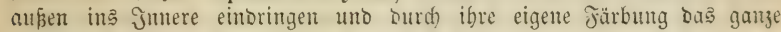

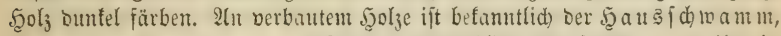
Merulius lacrymans, bejonders verberblich uno jü̈̈ht gegen ibn in

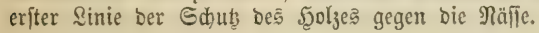

\section{faranklyeiten des Bnltes แud Der hinde.}

Die vorzugarweife im Rinbe: uno Sajtgervebe ber Bäume vegetirenton

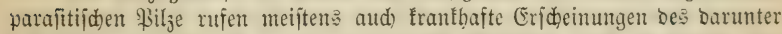

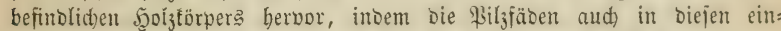
bringen uno Den $50 I_{j}$ förwer töbten ober Durd) Töotung Der Bajt= uno (a)m=

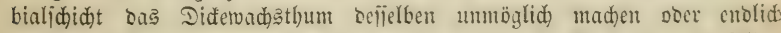

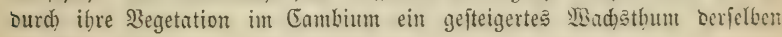
zur Jolge haben. 


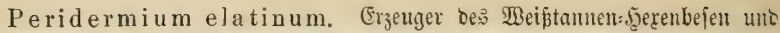

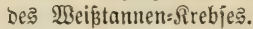

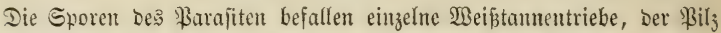
entwideft fid in biefen, ohne fie 3 ulöbten, perennirt in Rinbe= unt Baft:

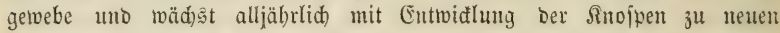
Trieben in bieje uno in Deren शabefn binein, leb̧tere nidgt töbteno, aber

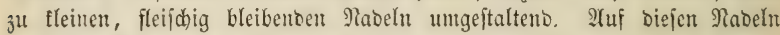

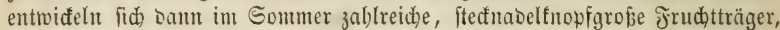
nac) beren Reife uno Eporenausftreung bie Rabeln abfallen. Dic infi= cirten 3weige bleiben auffallend furz uno werben z̆l ben jogenannten Şęten= bejen ober Donnerbejen, bie fich jäbrlidh an ben neuen Iriebent wieber be:

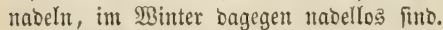

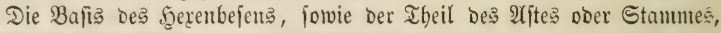
weldem ber Şerenbejen auffizt, verbiaft fid auffallent, uno lekgterer zeigt aud) nod) lange 3eit, nadjoem ber Scerenbejen abgeitorben uno abgefallen ift, cine fortbauternbe Didejunabme. Dieje wiro sutd) den limftand er=

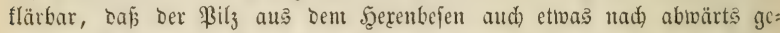
wadfen ift uno feine Mirfjamfeit fortfeb̧t, wemu ber lez̧tere längit abgefallen

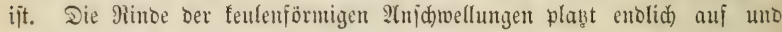

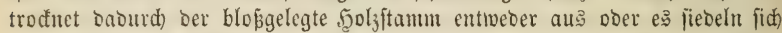

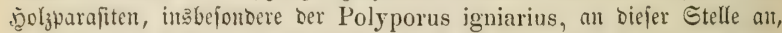

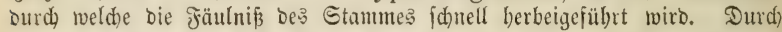
Sturm, Sduncebrut u. i. w. bridht an folden Etellen ber Stanm audy 3iemlid) oft $a b$.

In Den Durdforftutghbaungen futo die Srebsbäume, die theilweije

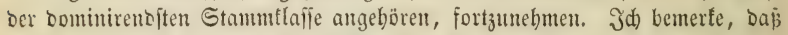
uns ber Entroidflunģgang bieje: Barafiten in allen feinen Stabien nod) nid)t

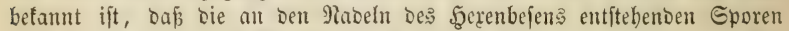
nicht fofort roiecer auf $\mathfrak{B e i p t a n t e n ~} 3$ feimen vermögen, vielmebr mit $\mathfrak{B}_{e}=$ ftimmtbeit angenommen werben muई, Daß́ bieje Sporen auf einer anderen Biflanze feimen, Dort cine Pillyform erzengen, Deren Sporen erft mieber anf Der Ianne feimen uno bie Rrantheit bervorrufen.

Peridermium Pini. Der Sicfernblafentoft, Erzenger bes Siefern: frebjes, Rienjopfes 1t. \%. m.

Diefer Barajit vegetirt im Baftgewebe jüngerer biß baubarer Siefern,

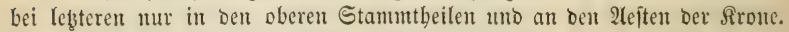
Die zwifhen Den 3elfen wadjenten Bilzäben verwandeln ben Belleninbalt in Terpentin uno veranlaffen fo bie völlige Serharzung Der Rinbe, fie bringen aber aud) ourd) bie Marfitrablen in Den Fुolyftamun ein, Der in

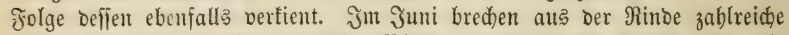
gelbe, mit Sporen erfülte häutige Blajen heroor, Deren (bröße etwa dic

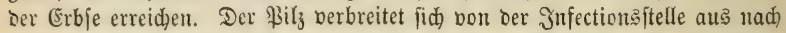
allen Seiten in Der Rinve weiter, bie franfe, nidht mebr fid) berbidente

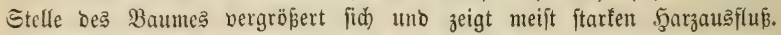
Die nod) gejunde Seite bes Baumes verbiat fid) um jo idneller, je weiter 
Die frebjige Etelle um fid) greift, uno fo entifteben an älteren 3 äumen, bei

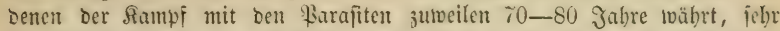
eigentbümlidje Stammourdjidnitte. Der über ber franten Stelle befindlide Theil bes S3aumes ftirbt ab, jobald Der Soljitamm an ber Sirebsiftelle fo verfient ift, Daj fein Nabrumgs̄aft mebr binourd) fann, uno es entiteht Daburd) Der betannte Sitenzopf. Sişen unterlyalb Der verpilzten Stelle nod)

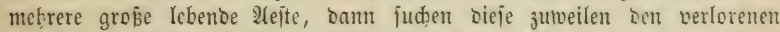
Bipfel zu erfeten, erbalten menigitens den Baum lebeno, im anoeren falle itirbt ber ganje Baum ab.

\section{Caeoma pinitorqum, Der $\Re$ iefernoteber,}

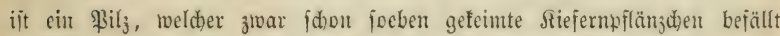
uno töbtet, in ser Regel aber erft an cin= bis zwanzigjährigen Siefern fid verberblid) crweișt uno bejonbers jüngere Bịlanjen fanell vernichtet. Enoe Mai erfemt mant an Der Rinbe ber neutn Iriebe gologelbe Sängştriche, Die fpäter aufplą̧en, un bas Sporenpulver auşuftrenen. 3eigt ein Trieb uur wenige jold)er frudjtlager, io übermindet berjelbe ben Edyaben burd

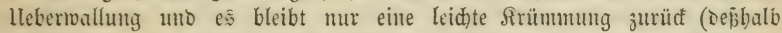
"Niiefernoreher"), fint Dagegen zahl(reide \$ilgitellen an einem Iriebe zur Entroidlung gelangt, wie biés befonbers bei feuchtem $2 B e t t e r$ ber Fall ift, Dann fitibt berfelbe völlig, coer bod) im oberen Theile ab. Im nädjiten Jahre entiteben an ber Iriebbafis zablreidje Echeioentriebe, bie aber, ba ser $\mathfrak{B i l}_{3}$ in Snneren ber Sieferntriebe peremirt, wieberum erfranfen. Şat

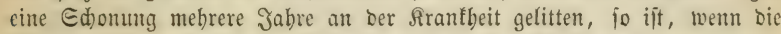
PFlanzen exit wenige Jabre alt waren, Der größte Theil Derjelben getöbtet,

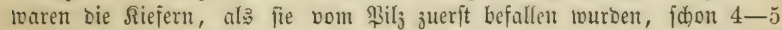
Jabre alt ober älter, bam erideint bic Єdyonung rie voun \$Milbe ftarf uno lange verbifien. Ireten mebrere trodene Jabre ein, io gelangt ber

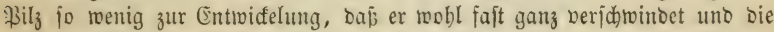
Sdhonung fid erbolen fann. Da bie frantheit an Feloränoern zuerft ent=

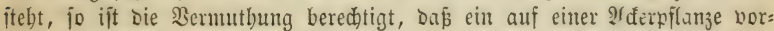
tommenter $\mathfrak{W i l}_{3}$ mit Dem Siefernoreber in genetifdem 3 ufammenhange iteht.

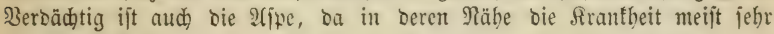
intenfiv auftritt.

\section{Der Budentrebs.}

Mit Der Bejeidnung "Bud)entreb" wiro eine gröpere $2(n j a b l$ ver: jdiebener Srantbeitserjdeinungen bejeidnet, bie nods nid)t genügent von einanoer unterjdieben werben. Eine biejer (Erid)einungen wiro ourd) einen $\mathbb{B i l}_{3}$, Sphaeria ditissima, erzengt uno fino bie von bieiem Parafiten

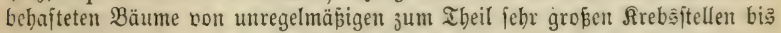

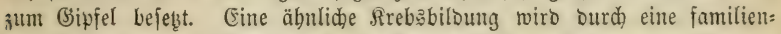
weije lebente groß̄e Rinbenlaus, Lachnus exsiceator, erzengt. Eine Dritte Rindentrebs[orm entjteht burd) Das Gaugen einer fleinen Molllaus, Chermes Fagi, bie juerft ein puitelförmiges $\mathfrak{A}$ (ufflaķen ber Rinte bers 


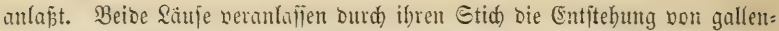
artigen Zellmuderungen in ber Rinte, Die zuerit eine ßerbifung, jobann

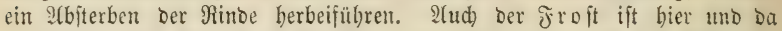

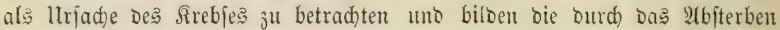

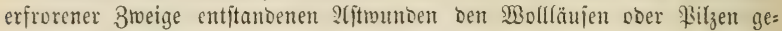
eignete 2 (ngriff

\section{Der \&ärdenfrebs doer die Särdentrantheit.}

Unter ber Bezeid)nung "Särdhenfrantbeit" berftebt man in Der ßrariį jebr berfdiebenartige Srantbeitảultänbe Der Särd)e. Sn ausgefprod)enen Jroftlagen, in benen jäbrlid) Die erfte Benabelung burd) Elätfröfte verloren

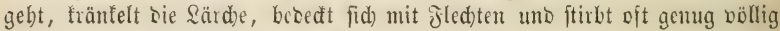
ab. Mo bie Qärdenmotte eine Reibe von Sabren hinourd) bie Benabelung im Jrübjabre vernid)tet, fann cbenfalle Rränteln uno 2lbfterben bie Folge jein. Son biejen beiden Erjotheinungen abjebeno leibet bie Särdhe aber nod) in größster 2(usbebnung an einer Rrantbeit, welde völlig verbeereno bie jüngeren Beftänoe heimgciud)t bat unb in ber Regel Durd) bie (Entftebung frebsartiger Etellen in ber Rinoe, imuner aber Durd) bas 2(uftreten cine? fleinen Pifzes d)arafterifirt wirb, welcher an Den abjterbenton 3tweigen und in ber Iäbe ber Rindentrebsiftllen zu fimben ift. Derielbe beipt Peziza Willkommii: befiz̧t meift etna bie bröpe cines Stednabeltnopfes, Die

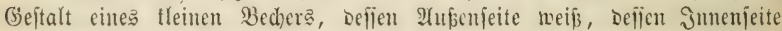
orangegelb gefärbt ift. Es id)eint, als ob biejer \$ilz als Parafit die Rrant: heit beranlafist habe, ood) jteht biefe 2(nfid)t nod) vielfad) angefod)ten Da.

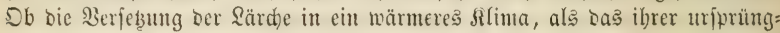
liden Şeimath), ferner bie (Erjichung aus idfedtem Samen ober andere

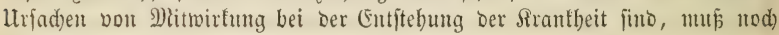
jeitgeitellt werbent.

\section{firaukljeiten ìr Blattorgant.}

Die Budenfeimliugatrantbeit, aud) Budencotyledoneu= oocr Budfenftengelfranflucit riro erzeugt Durd) einen Dem berüd)tigten fiar: toffelfrantbeitspilze nabe berwanten łarafiten, oen ičb Peronospora Fagi genaunt habe. In Bubenjaattämen ober Budbenbejamungşidlägen pertrodinen oft im Monnt Juni ober $\mathfrak{A}$ Mang Juli, befonders in naflen Jabren Die jungen Eamentflanzen, nad)bem Anfang Juni zuerit die Eamenlappen an Der Bajis fid) verfärbt baben uno Dam verfault fino. Diefi Berfaulent jeigt jid aud an Der Spitze Des Stengeldens, Defien Iod Das \$ertrodnen Der ganjen \$filanje nad) fich jieht. 2 n ben (d)einbar nod) ganj gejuben, aber vom Barafiten bebafteten \$flanzen treten aus dem Jumeren Der Gamen= lappen zablreiche \$ilzäben hervor, an Denen fid) mebrere Sporangien bilden. In Diejen entfteben jechs bis zebn 3oopporen, bie aus oer Epibe des fid) offnenoen Sporangiums ausfdhlüpfen, im $\mathbb{B a f f e r}$ fich bewegen uno wen

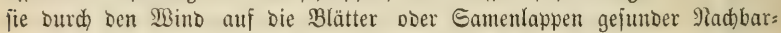
pflanzen gelangt fino, auf Diejen feimen. $\mathscr{A} u d$ in ben Sporangien felbjt feimen bie 3oojporen oft, die Sieimid)läudbe bobren jid) jlvijhen Den Epidermis: 


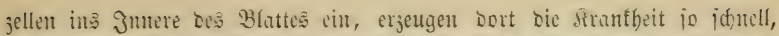

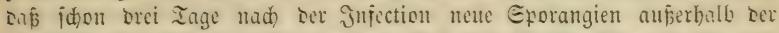

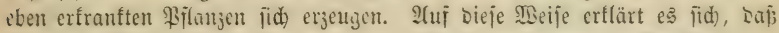

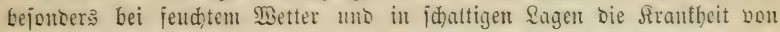
wenigen \$rlanjen jidh über grofe Gaatfämpe ober Edjläge verbreitet. Jm

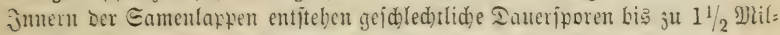
lionen in einem Budiempilänjden, bie mit ben verfaulten unt vertredneten Wiflanzentbeilen auf bie Eroe gelangen, Dajelbjt bis zum nädften Jrübjabre ruben uno bie sirantheit wicoer erjengen, wenn Dort abermals Buchedern jul Sieimung getangen. E: Dürfen mitbin ia, wo in cintm Jabre bicic Sirunflyeit fid gezeigt bat, im nädjitcn teine Budhedicrn gejät merben, Dagegen tönnen Eichen, Madollbölzer u. j. w. in erfranften Buchenfämpen jebr mobl erjogen merben. $\mathscr{A}$ (ud ijt es rathiam, sas ertrantte Saub unterzugraben ober žl berbrennen.

Der MBeidentopt, Melampsora salieina, ift bejonoers in Weitoutheegern ocr Salix acutifulia (pruinosa, caspica) verheerento auf= getrcten. Dft idjon im Juni, oit erjt jpäter inn Jahre zeigen fich auf bon

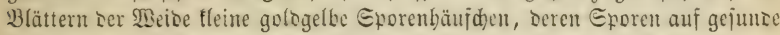

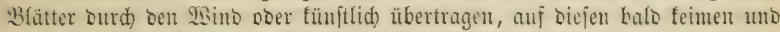
bimen circa acht Tagen bas (Erj)einen zahlreidur Eporenbäufden auj senjelben jur jolge baten. Die nom ßilze bifallenen Blätter werben balo jüwarjiflectig, rollen fid zujammen uno fallen $a b$, wäbreno an ber Epibe der Irieke die neu

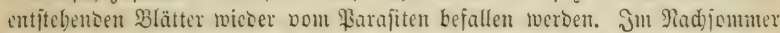
entitehen auf Den inficirten Blättern buntel gefärbte \$iljfrud)tlager, Die auf Den abfallenden Blättern überwintern, im nädjten Eommer bie Entjtehung Der Srantbeit aufs शene veranlafien. Bufammenbarten, Berbrennen ober Eingraben ies abgefallenen :aubes ift bringento erforberlid, ba bei inten:

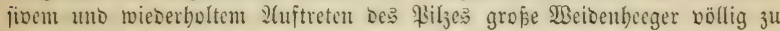

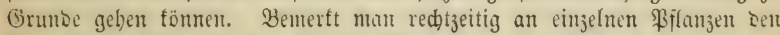

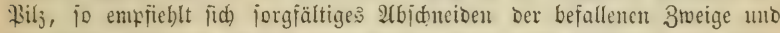
Eingraben Derfelben an Dit uno Etelle, wenn man genöthigt fein follte, Dic 3roeige Durdh Den bjeeger zu tragen, mobei zablreidte Eporen abfallen uno Daburdy die Rrantbeit nod) mebr berbreiten nüroen.

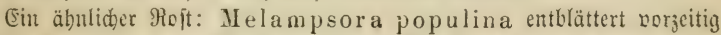

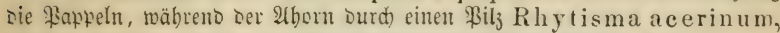
welcher idwarze flleden auf Den Blättern erzeugt, gejchäbigt wird.

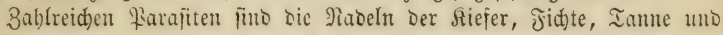
Särdhe auşgejețt.

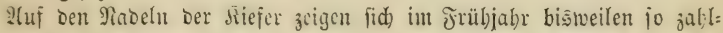
reide gologelbe Epormbläad)en dis Peridermium Pini, acicola

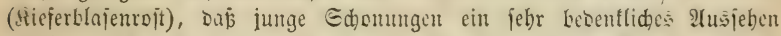

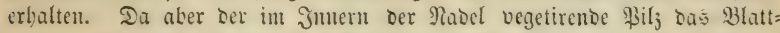
gemebe nidgt töbtet, io hat biefe Rrantbeit surd)aus feinen grofen Machtheil im Bepolge.

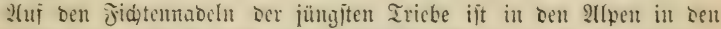

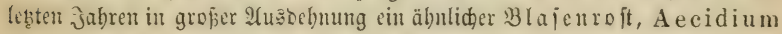
abietinum, aufgetreten, welder vielfad) mit ser Chrysomyxa Abietis 
verwechjelt wirb, von biefer aber baburd fid) unterfajeibet, bap bie Sporen in bellen, an ber Spiķe żerriffen aufplakenden Şautfätfen entbalten fino

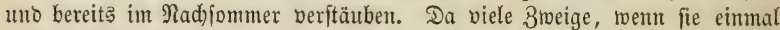
befallen finto, abjterben, fo finto bie Folgen biejer Srantbeit febr empfindlid). (Enolid) tritt aud) auf ber (Edeltame ein Blafenroft auf, Aecidium

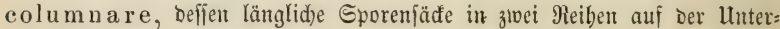
feite ber Nabeln fich fimben.

Der Fidtemadelroft, Chrysomyxa Abietis, gibt fich auf ben befallenen Rabeln ber jungen Triebe fhon Mitte Juni burd) Belbwerben

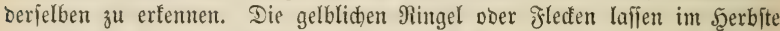
auf Der Unterfeite Duntlergologelbe Qängştriche erfentun, bie im nädbjten

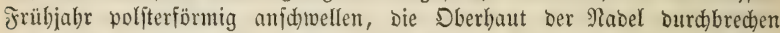
uno baun die Sporen abfdnüren. Die befallenen Rabeln fterben im Mai ab uno fallen zur Erde, wenn bie neuen Iriebe z̆ Entwidelung gelangen.

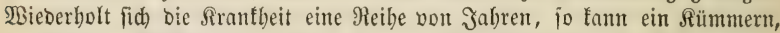
ja felbjt ein 2Xbiterben Des Baumes, reipeftive Beftandes, in Folge Dabon eintreten.

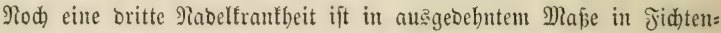
jurgorten aufgetretert, erzeugt burd) einen $\mathfrak{B i l}_{3}$, Den id Hypoderma

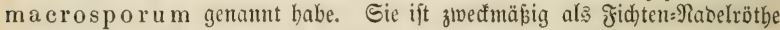

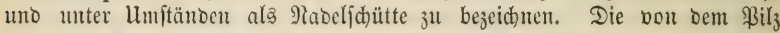

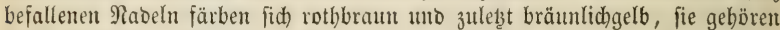
meif́t mur Den zmeijäbrigen Trieben an, wäbreno die lek̨ten Jabrestriebe

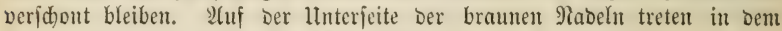

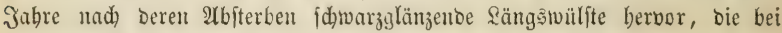
fench)tem Better im Frübjabre aufplakzen uno bie Eporen ausftreuen. Wieberholt fid) bie Rrutheit mehrere Jahre ober werben ausnabmsiveife alle

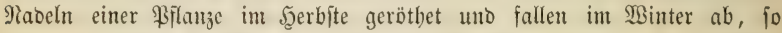

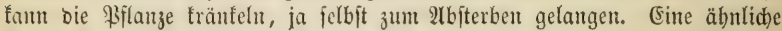
Sirantheit, erzengt Durd) Hy poderma nervisequium, veranlaft bie

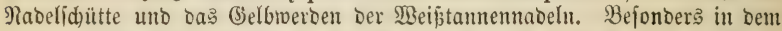
unteren uno mittleren Theile ber Baumfrone tritt baburd) eine fo itarfe Sid)tung uno (Entnabelung ein, oaj ber 3uwad) eine erhebliche Sdmmälerung erleibet.

\section{firankljeiten Der Japfen แแ\ friidjts.}

Die 3ahl ber auf ben 3apfen und Jrüdten beobad)teten fdjmarobentben Bilze ift zur Beit nod) eine fleine uno ibre Bebeutung in foritlid)er Beziehung Dürfte eine geringe fein.

3iemlid) bäufig fiebt man auf ber Jnnenfeite Der Sidjtenzapfenfdjuppen

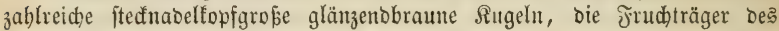
Aecidium strobilinum. 2noere \$ilzarten auf Jidhtenzapfen fino feltener. 2Uuf Dent Frücten des Bflaumenbaumes erzengt Exoascus Pruni bie fogenannten "Tajchen" ober "Narren." Die Ellernfrüd)te werben burd) Exoascus Alni, bie Samentapjeln uno Blätter ber Bappelnarten buch) Exoascus Populi umgeftaltet. 


\section{Earankljeiten Durd) แอd) mubekanute (Eiufliiffe.}

Boritebeno babe id) biejenigen Rrantheiten Der Walobäume $f_{u l z}$ bis frroden, Deren Entítebungäurjaden befannt fint. Zablloje franthafte Ers fdeinungen treten bem aufmerfjamen Beobsd)ter im SBalde citgegen, über Deren (Erjheinung wir zur 3eit nod) nid)t genügende ßlarbeit befibent. Dieje hier eingehender zu bejpreden, Dürfte bem 3wede bes $B$ ud)es nid)t cnt=

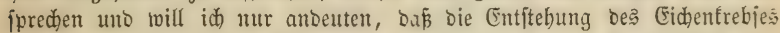
uno anberer frebsartiger: Biloungen, Der Şerenbejen ober Donnerbejen, ber

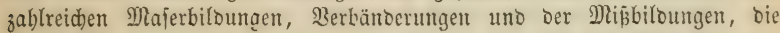
in ber Natur fo bäufig vorfommen, bisher nod nid)t aufgeflärt ijt.

\section{Siterafur für den Grorfffintt?.}

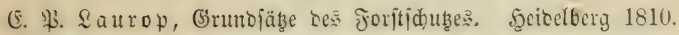

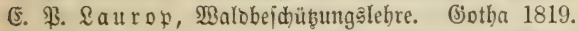

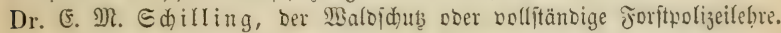
Seipjig 1816.

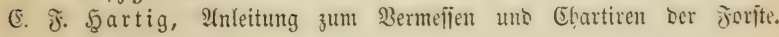
Giefen 1828.

B. Bfeil, 2(nleit. zur 2(blöjung ber W̉alberbitute. Berfin 1828.

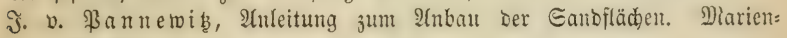
werber 1832.

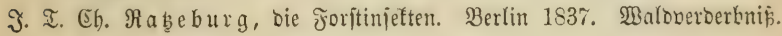
Berlin 1866.

Th. S2artig, die Hoerflügler Deutidlands. Erjter Bano; bie Blattmeipen uno Şolżmeipen. Berlin 1837.

Derfelbe, über die Jantilie ber Gallmeipen in Germar Beitid)rift für Entomologie. Bano II. III.

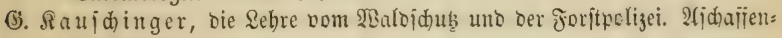
burg 1848.

Dr. (5. R̈̈nig, bie Balopflege. (Jotha 1849.

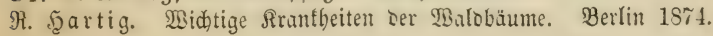




\section{Dூerzeidintis}

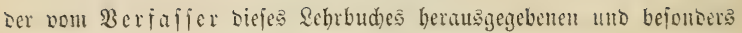
gebrudten Sdriften.

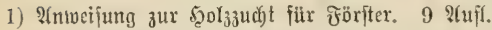

(Sit aud ins Franzöfitde iiberfebt worden.)

2) 2(ntveifung zur Iaration und Beja)reibung Der forftc. 4 I(ufi.

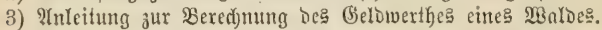

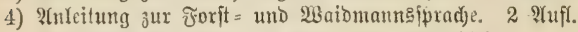

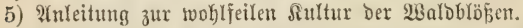

6) Inleitung zur \$rüfung Der Frorftandidaten. 2 ?(uff.

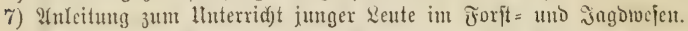

8) SAnleitung 3ur Dertilgung oder 3erminderung Der Riemraupen.

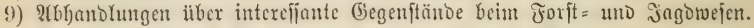

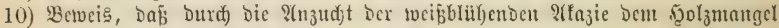
nidst abgeholfen werben fonn. 2 ?qufl.

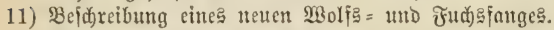

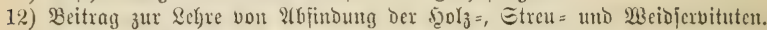

13) Jorft = unt JngDardjiv vont Den Jalyren $1816,181 \%, 1818,1819,1826$, $1822,1826$.

14) Forftrififenjd)aft in gebrängter Sïrze.

15) Grrunbiätze Der ซrorfitioireftion. 2 2(uff.

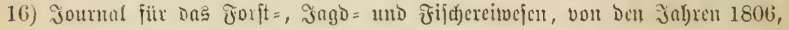
1807 unt 1808.

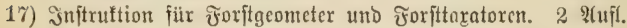

18) Subittabelfen, Geldtabelfen und Sotenztabeffen. 10 Tufl.

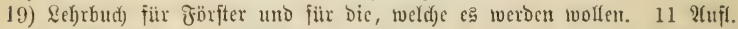

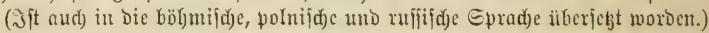

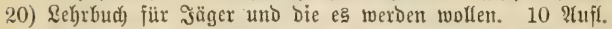

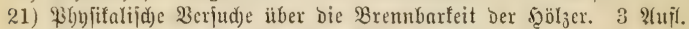
(aft aud) in bie franzöfifde Epradje iiberjest.)

22) פerfudje über die Dauer Der รૃölzer.

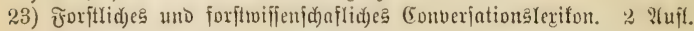

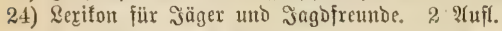

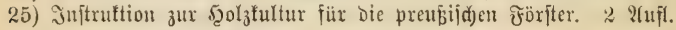

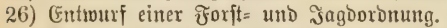

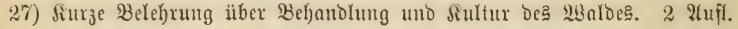
?uñer Den, im erften Bande verzeidyneten naturwifienfdaftlidjen Sdyriften jinto vom 5ุerauggeber biejes \&eljrbudes eridjienen:

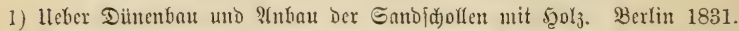

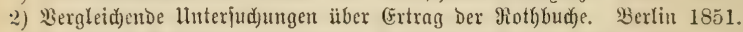

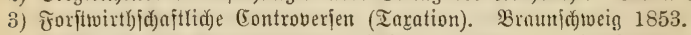

4) Berbältniई Dę Bremtwerthes veridiedener gcol $_{j}=$ uno Iorfarten. Braun= ¡diweig 1855.

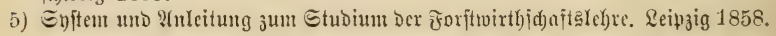


. 




\section{PLEASE DO NOT REMOVE CARDS OR SLIPS FROM THIS POCKET}

\section{UNIVERSITY OF TORONTO LIBRARY}

SD

371

H37

1877

BioMed
Hartig, Georg Ludwig Lehrbuch für Förster

11, vielfach verm. und verbesserte Aufl. 


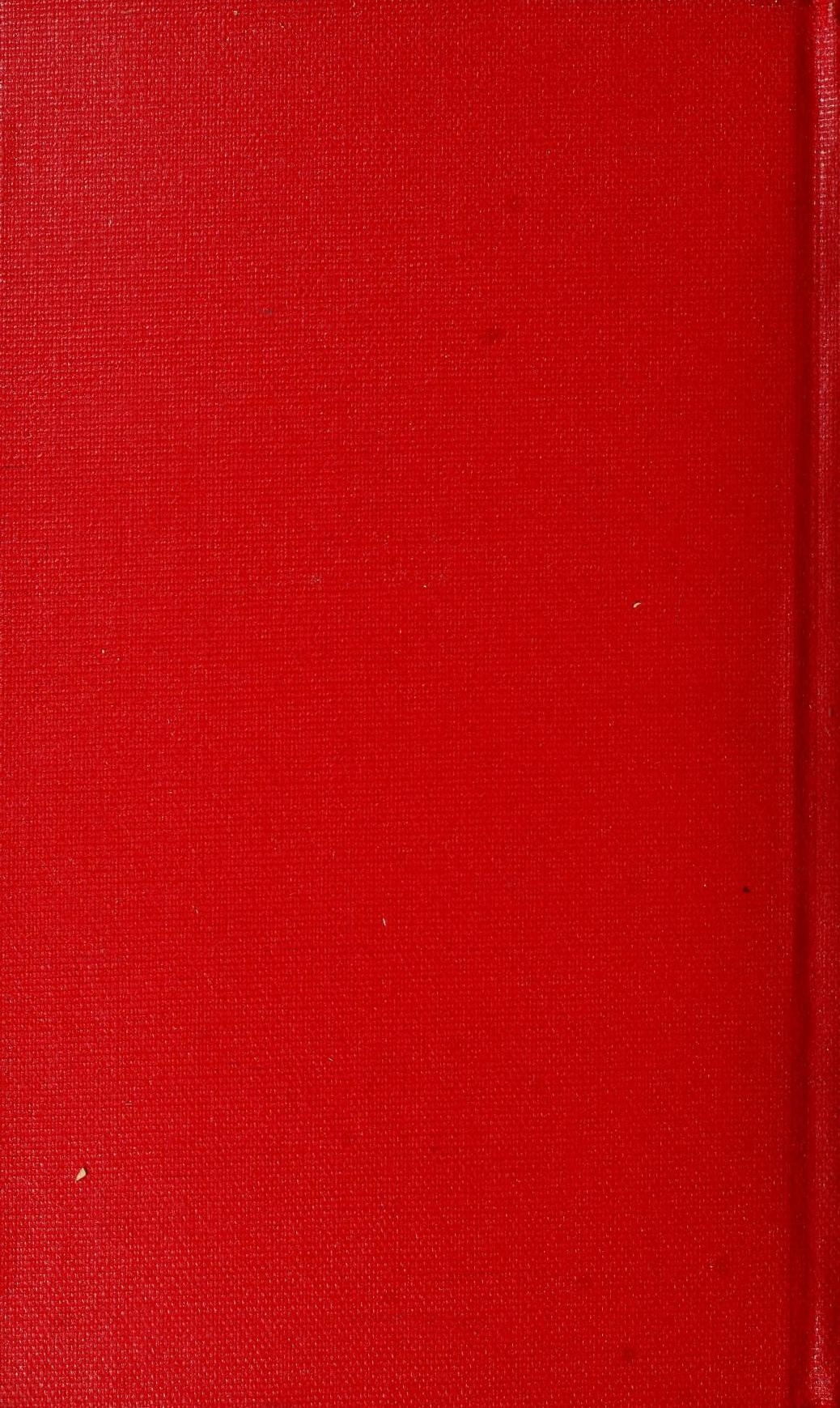

